a

11

3.

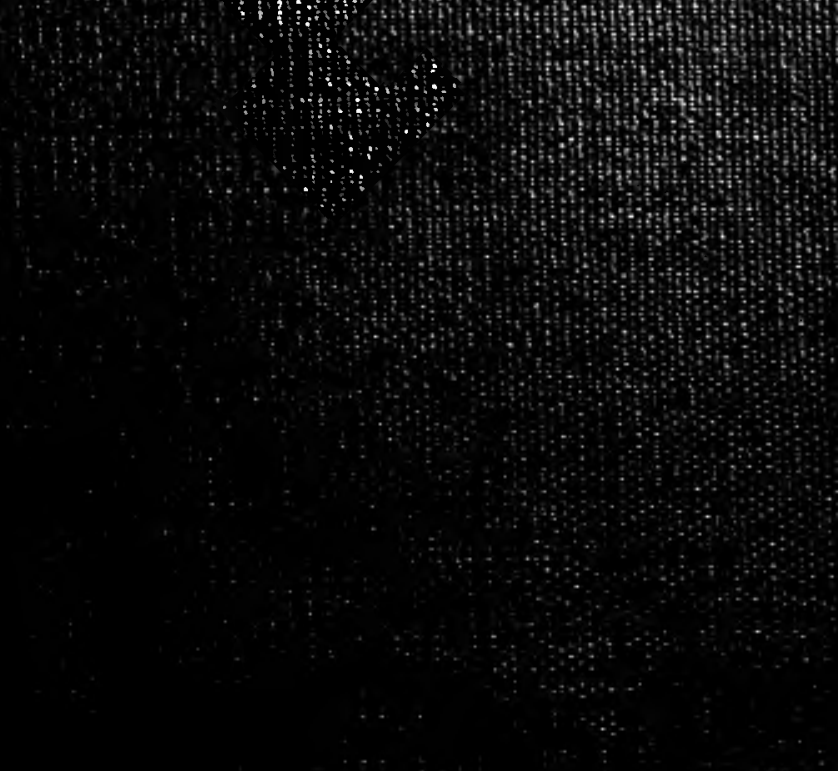







SMITHSONIAN INSTITUTION

UNITED STATES NATIONAL MUSEUM

Bulletin 106

,

\title{
NORTH AMERICAN EARLY TERTIARY BRYOZOA
}

\author{
BY \\ FERDINAND CANU \\ Versailles, France \\ AND \\ RAY S. BASSLER \\ Washington, District of Columbia
}

T E X T

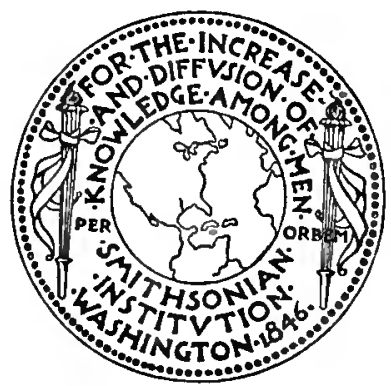

WASHINGTON

GOVERNMENT PRINTING OFFICE 
SMITHSONIAN INSTITUTION

UNITED SIATES NATIONAL MUSEUM

Bulletin 106

\title{
NORTH AMERICAN EARLY TERTIARY BRYOZOA
}

\author{
BY \\ FERIINAND CANU \\ $\mathrm{I}^{\prime}$ 'rsullles, France \\ AND \\ RAY' S. BASSLER \\ Ilashington, District of Columbia
}

T E X T

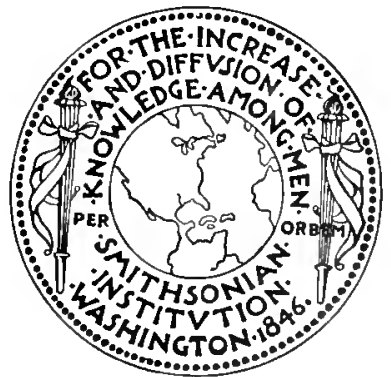

11. ASHINGTON

GOVIRNIENT HRINTING OFFICE 



\section{ADVERTISEMENT.}

The scientific publications of the Unitel States National Musenm consist of two series, the Procecdings and the Bulletins.

The Proceedings, the first rolume of which was issued in 1878, are intended primarily as a medium for the publication of original, and usually brief, paper's based on the collections of the National Mn ieum, presenting newly acquired facts in zoology, geology, and anthropology, including descriptions of new forms of animals and revisions of limited groups. One or two rolumes are issued annually and distributed to libraries and seientific organizations. A limited number of copies of each paper, in pamphlet form, is distribut ed to specialists and others interested in the different subjects as soon an printer. 'The date of publication is recorded in the tables of contents of the volumes.

The Bulletins, the first of wheh wat jested in 1875, consist of a series ofseparate publications comprising ehietly momograplas of large zoological groups and other general systematic treatises (occicionally in several rolumes), faunal works, reports of expeditions, and catalognes of type-specimens, special collections, etc. The majority of the volumes are oetaros. but a cularto size has been alopted in a few instances in which large plates were regarled as indispensable.

Since 1902 a series of oetar volumes containing papers relating to the botanical collections of the Musemm, and known as the rontributions from the . Kutionu Herburium, has been published as bulletins.

The present work forms No. 106 of the Rulletin series.

$$
\begin{aligned}
& \text { William deC. Ravenel, } \\
& \text { Administrative Assistent to the Secretury, }
\end{aligned}
$$

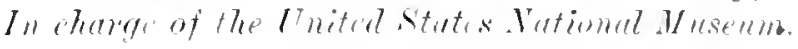

Washington, D. (., April 20, 1920. 


\section{(1) X TENS.}

Introndurion

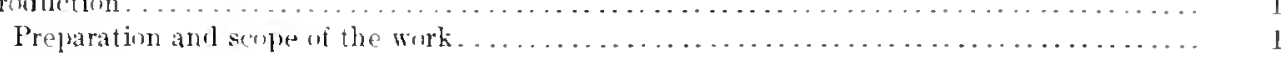

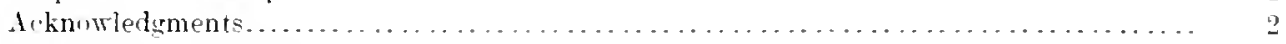

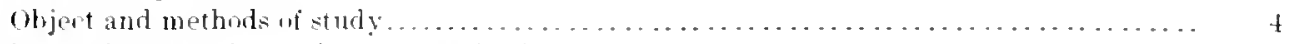

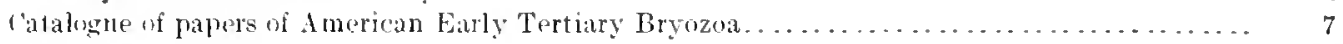

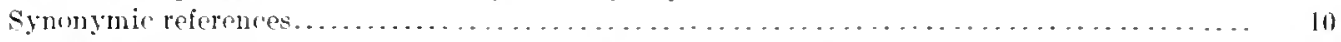

Reforence of previnusly described North American Early lertiary Bryozoa........... 10

Genlegic tables of Mesozoiv and Cemozoic formations . . . . . . . . . . . . . . . . . .

Sublivisions of European and somth American Mesozoic and Cenuzoic rocks..........

List of Mesozoiv and cenoznir formation names..........................

List of lualities with furmations and station numbers. . . . . . . . . . . . . . . . . .

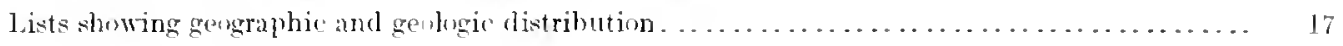

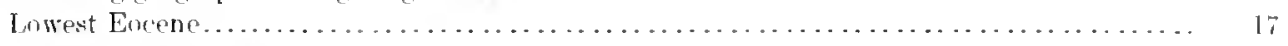

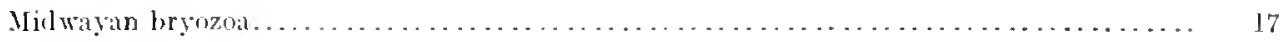

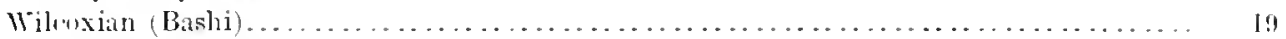

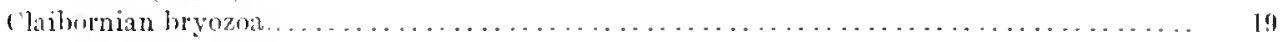

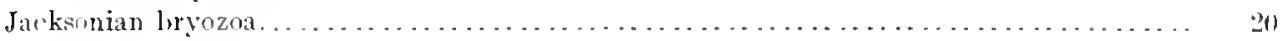

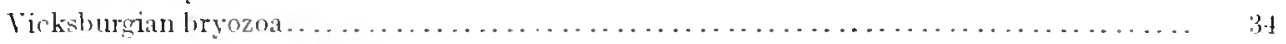

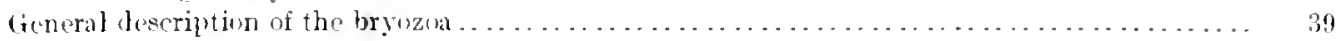

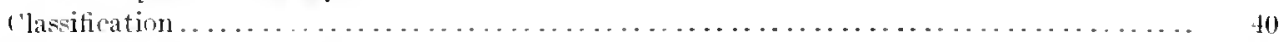

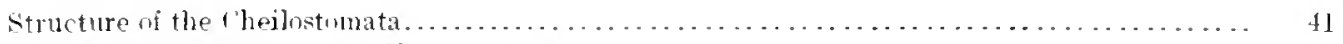

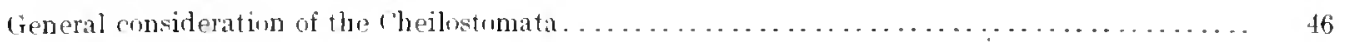

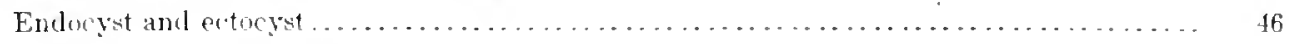

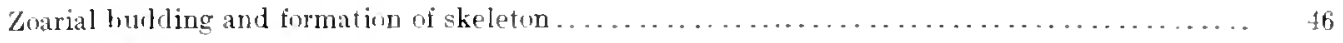

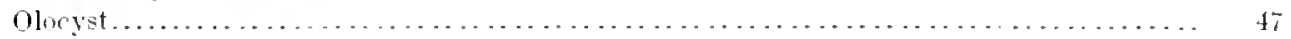

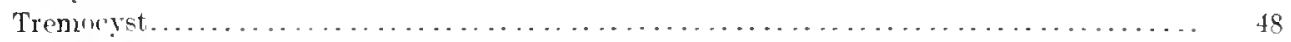

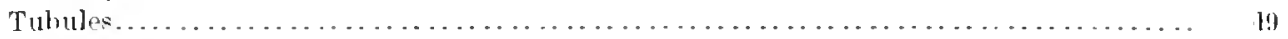

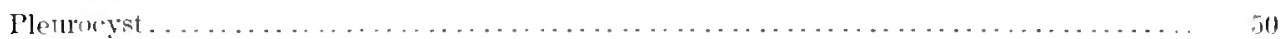

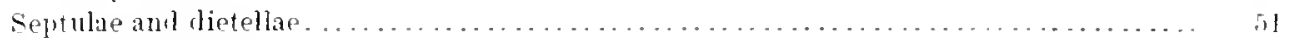

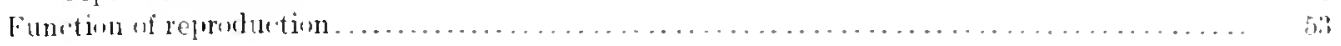

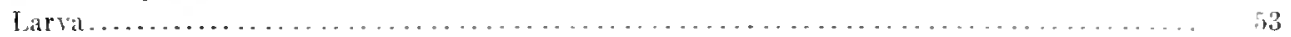

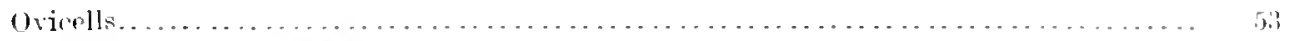

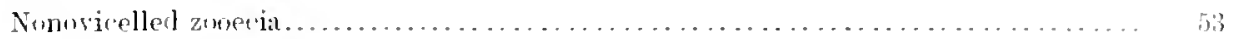

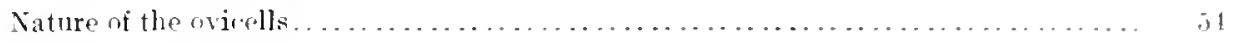

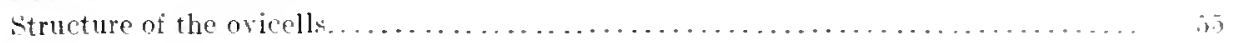

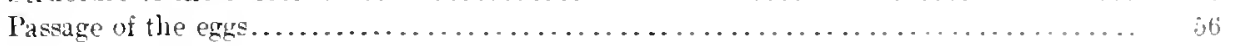

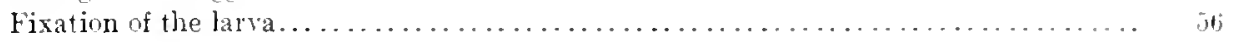

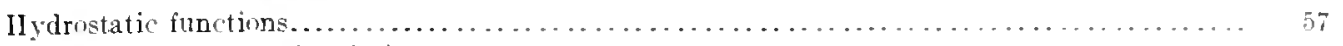

Znoecial hydrustatic relations. . . . . . . . . . . . . . . . . . . . . . . .

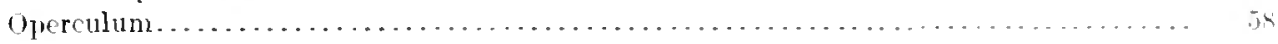

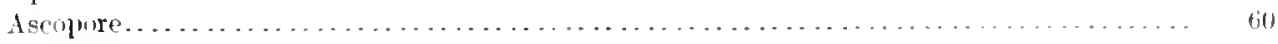

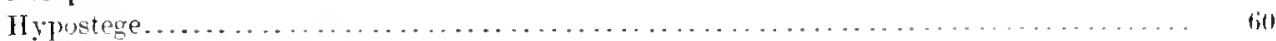

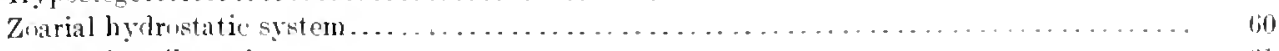

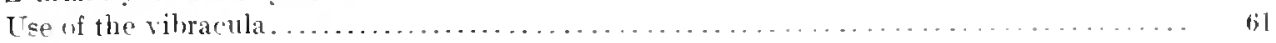

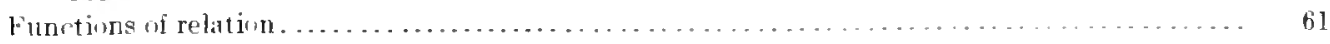

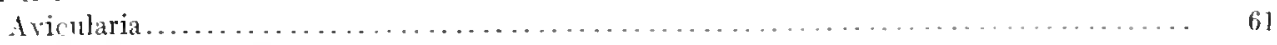

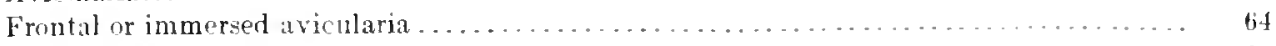

Interzooecral avicularia . . . . . . . . . . . . . . . . . . . . . . . . . . 


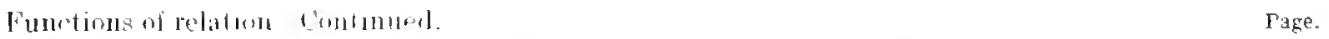

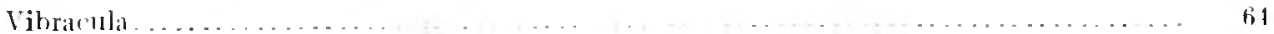

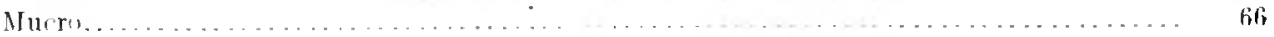

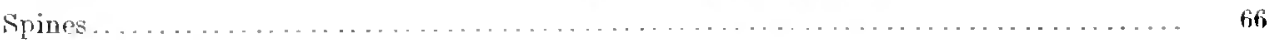

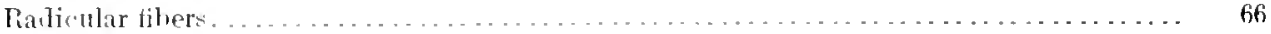

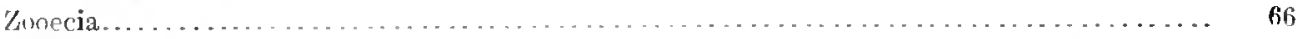

Form and size. . . . . .

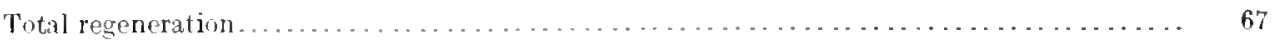

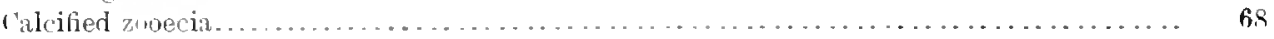

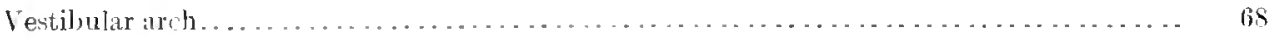

Zn

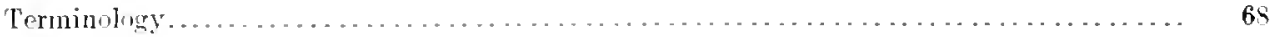

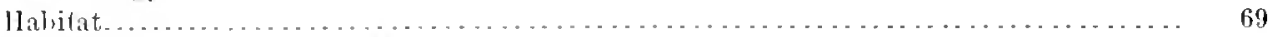

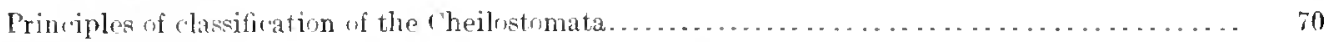

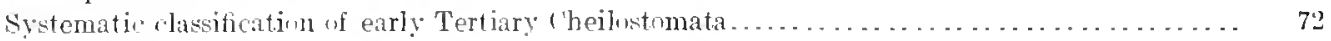

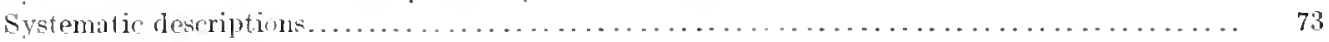

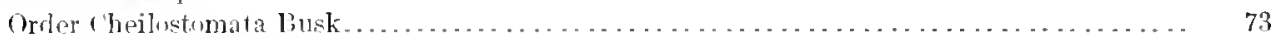

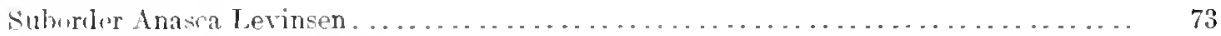

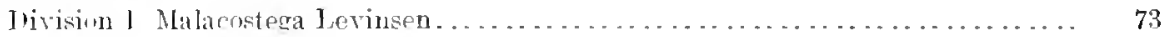

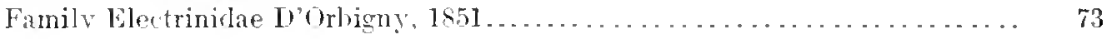

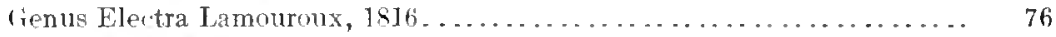

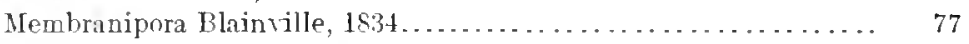

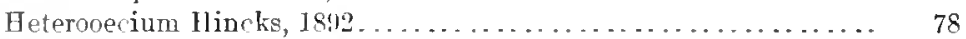

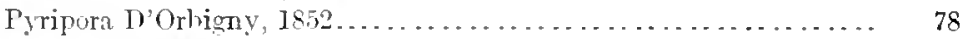

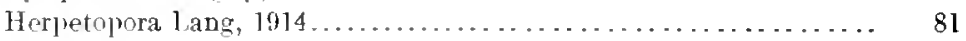

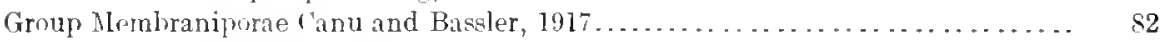

Section 1. Menbraniporae mithout ovicell ...................... 86

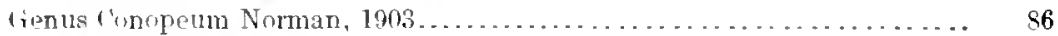

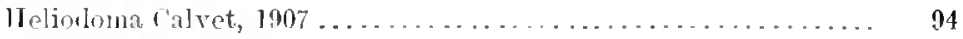

Membraniporina Levinsen, $1909 \ldots \ldots \ldots \ldots \ldots \ldots \ldots \ldots \ldots . . . \ldots \ldots$

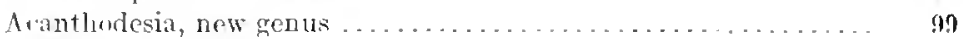

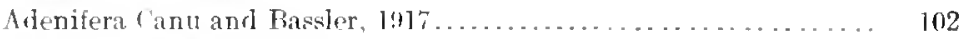

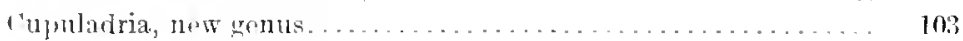

Trompona lo'orhipny, 185l....................... 10.3

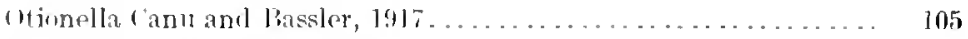

Secti u 11. Membranijorae with ondozreseial ovirell . . . . . . . . . . . . . 109

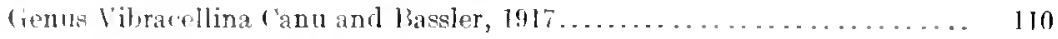

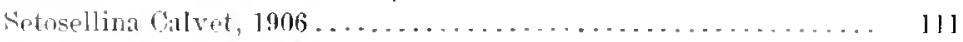

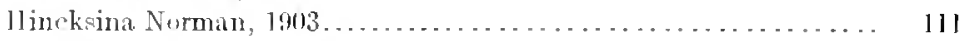

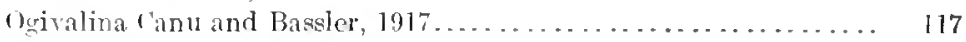

Membrendoecium 6 anu and Passler, $1917 \ldots \ldots \ldots \ldots \ldots \ldots \ldots \ldots \ldots . . \ldots \ldots$

Sertion III. Ovirell hyperstomial, always closed by the operculum ....... 123

Genus Periporosella ('anu and Fassler, 1917................... 124

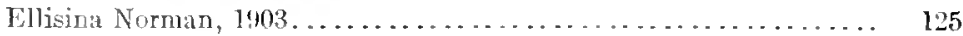

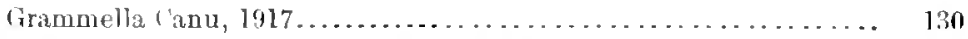

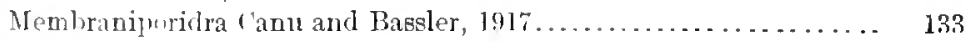

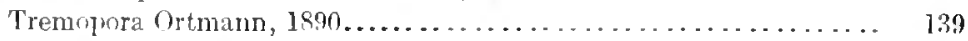

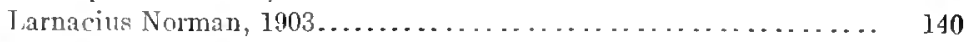

Section $1 \mathrm{~T}$, Oricell never clnsed by the operculum . . . . . . . . . . . . . . 140

Genus Alderina Noman, 1903........................... 140

Callopora Gray, $1848 \ldots \ldots \ldots \ldots \ldots \ldots \ldots \ldots \ldots \ldots \ldots \ldots \ldots \ldots \ldots . \ldots \ldots$

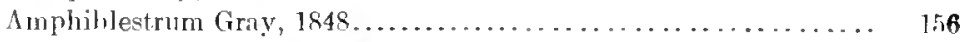

Ramphonotus Norman, $1891 \ldots \ldots \ldots \ldots \ldots \ldots \ldots \ldots \ldots \ldots \ldots . \ldots \ldots$

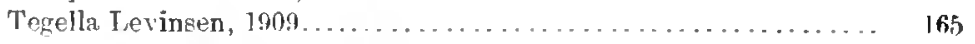

Stamenocella ('anu and Bassler, 1917................. 168 
Siystematic descriptions Gontinuced.

Oroler Ghoilostomata linsk-Continued.

Suburder Anaxcal Levinsen Continued

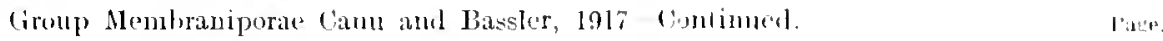

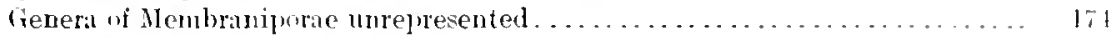

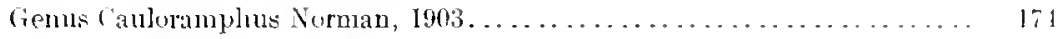

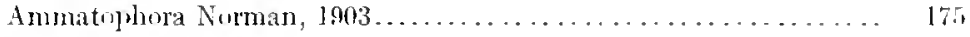

Marsinopora lang, $1914 \ldots \ldots \ldots \ldots \ldots \ldots \ldots \ldots \ldots \ldots \ldots \ldots$.

Antrojora Xurman, $1903 \ldots \ldots \ldots \ldots \ldots \ldots \ldots \ldots \ldots \ldots \ldots \ldots \ldots . \ldots \ldots$

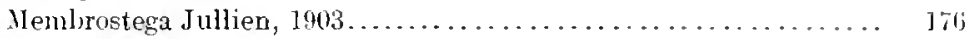

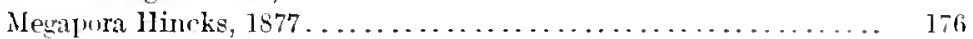

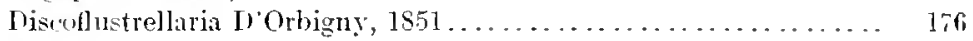

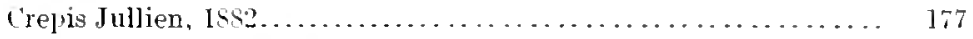

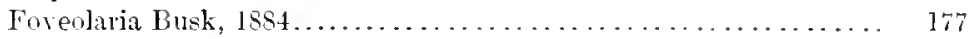

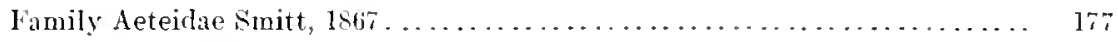

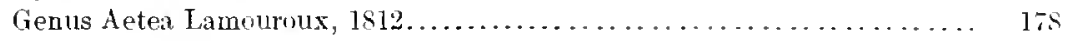

Family Scrupocellaridae Levinsen, $1909 \ldots \ldots \ldots \ldots \ldots \ldots \ldots \ldots \ldots \ldots \ldots \ldots$. . . . . . . . . . . . . .

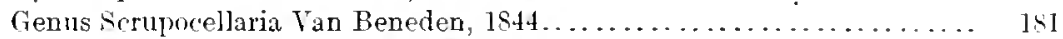

laberea Iamonroux, $1816 \ldots \ldots \ldots \ldots \ldots \ldots \ldots \ldots \ldots \ldots \ldots \ldots \ldots \ldots$

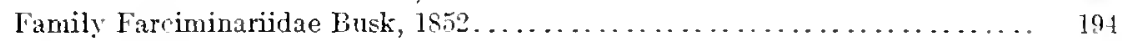

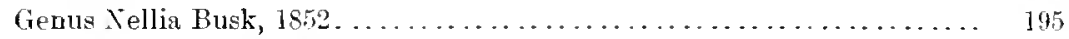

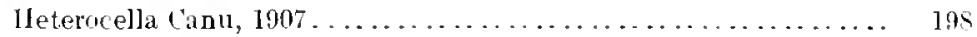

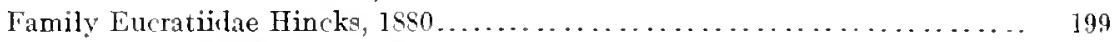

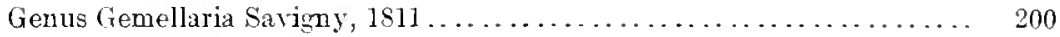

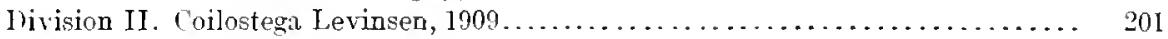

Family Opesiulidae Jullien, $18 s 8 \ldots \ldots \ldots \ldots \ldots \ldots \ldots \ldots \ldots \ldots \ldots \ldots \ldots \ldots \ldots$

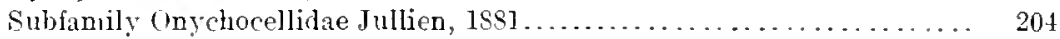

Gentis Onychocella Jullien, $1881 \ldots \ldots \ldots \ldots \ldots \ldots \ldots \ldots \ldots \ldots \ldots \ldots$

Rectonychocella (anu and Bassler, $1917 \ldots \ldots \ldots \ldots . \ldots . \ldots . . . .209$

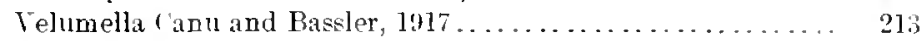

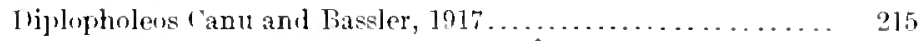

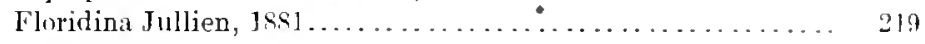

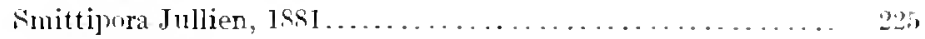

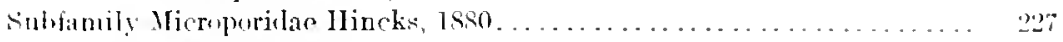

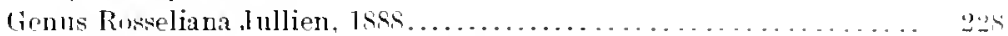

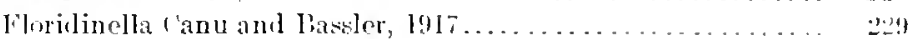

(iurgantua dullien, 1 sis. .........................

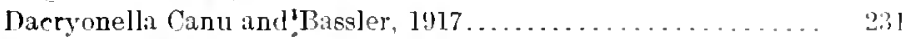

Aechmella Canu and bassler, 1917.......................

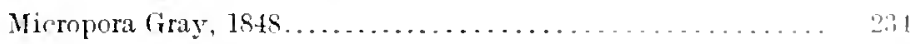

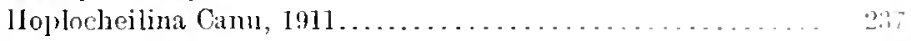

Sul,family Lunularidae Levinsen, $1909 \ldots \ldots \ldots \ldots \ldots \ldots \ldots \ldots \ldots \ldots \ldots$

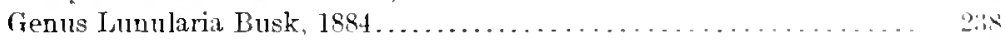

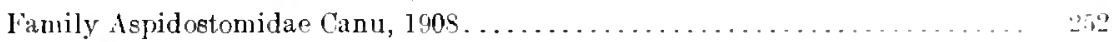

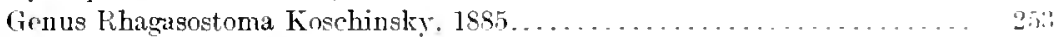

Odontionella Canu and Bassler, $1917 \ldots \ldots \ldots \ldots \ldots \ldots \ldots \ldots \ldots \ldots \ldots$

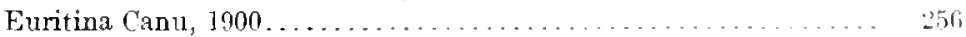

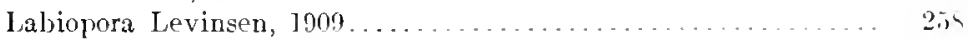

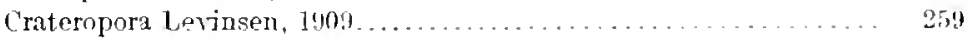


Systematio doseriptions contimual.

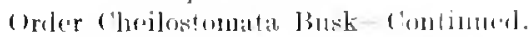

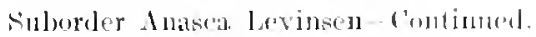

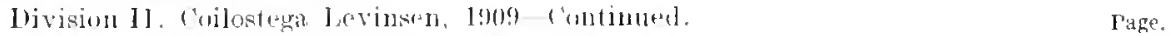

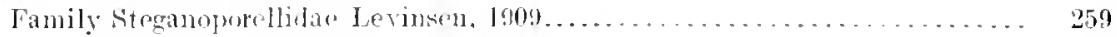

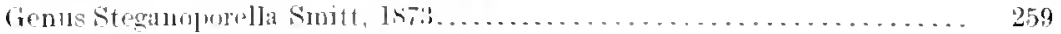

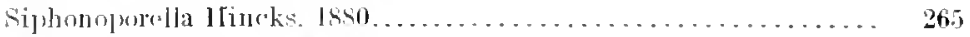

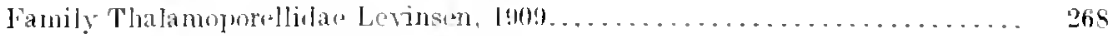

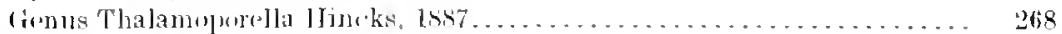

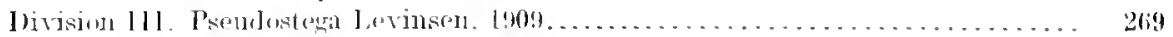

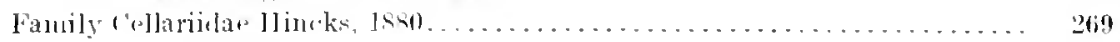

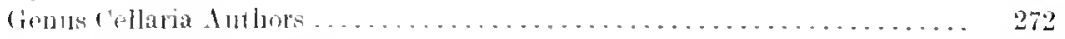

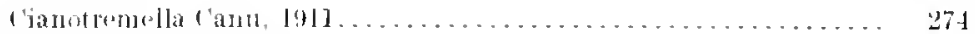

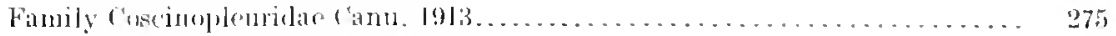

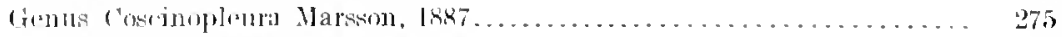

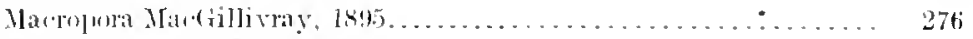

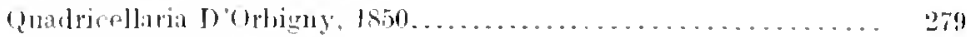

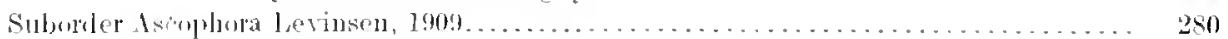

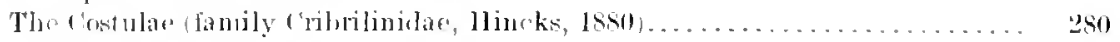

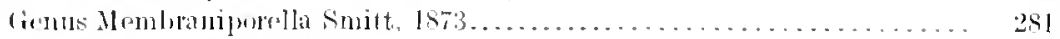

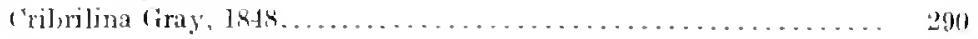

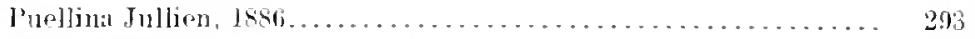

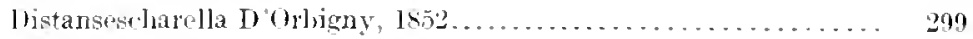

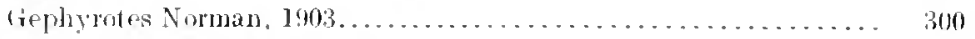

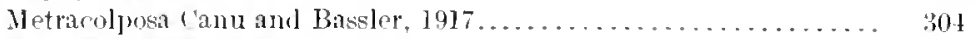

forbulipora Nacfillivray, $1895 \ldots \ldots \ldots \ldots \ldots \ldots \ldots \ldots \ldots \ldots . \ldots \ldots$

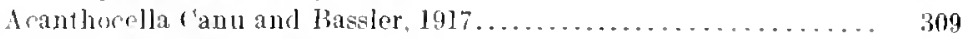

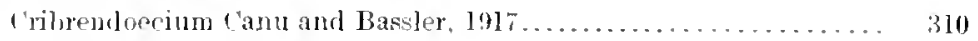

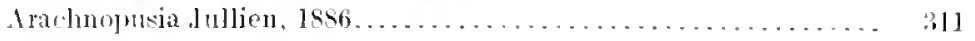

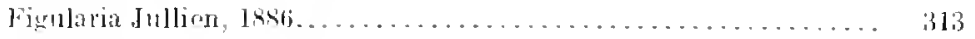

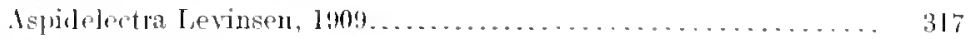

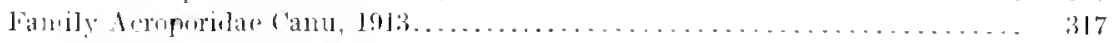

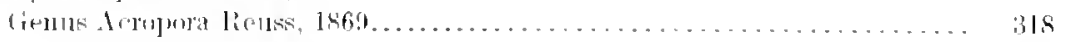

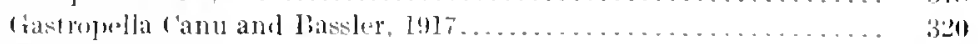

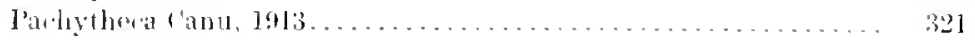

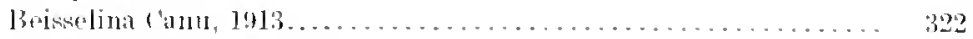

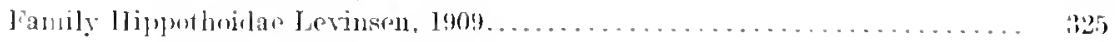

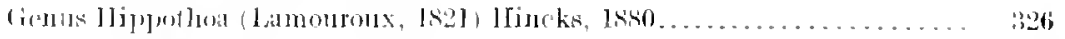

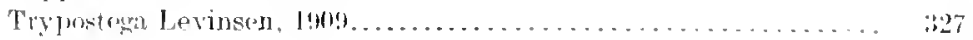

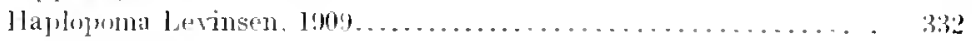

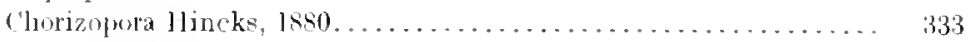

Dacryopora Lang, $1914 \ldots \ldots \ldots \ldots \ldots \ldots \ldots \ldots \ldots \ldots \ldots \ldots \ldots . \ldots \ldots$

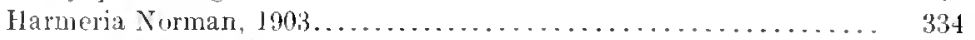

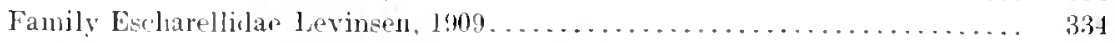

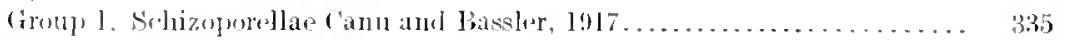

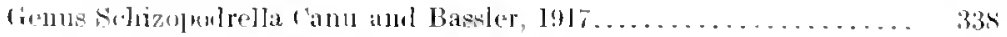

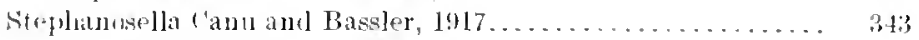

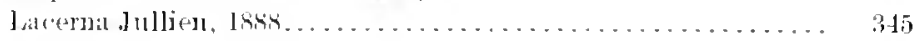

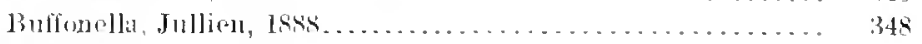

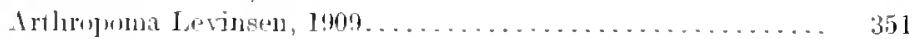

Phonicosia Jullien. $1888 \ldots \ldots \ldots \ldots \ldots \ldots \ldots \ldots \ldots \ldots \ldots . \ldots \ldots 2$

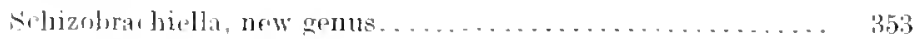

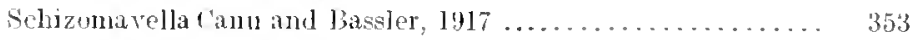




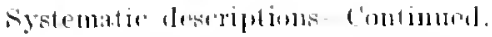

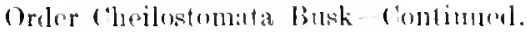

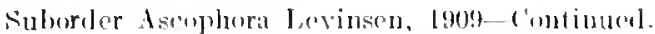

Family Escharolliclate Ievinsen, long continued.

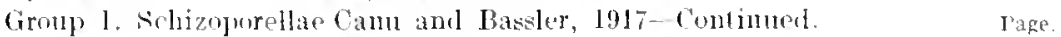

Genus Sehizolavella, new genus. . . . . . . . . . . . . . . . 358

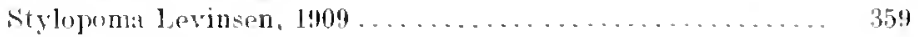

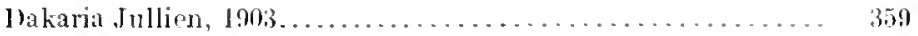

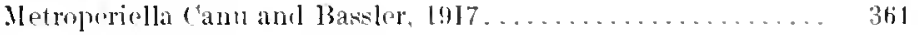

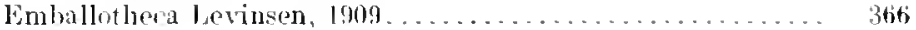

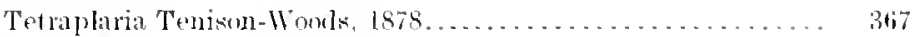

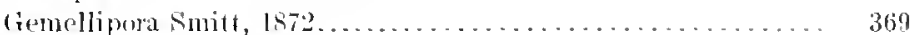

(iemollipurella, new genus . . . . . . . . . . . .

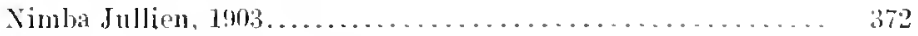

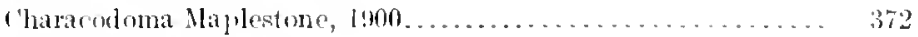

Group 11. Ilippoporae ('anuand Basster, 1917. (JepmolitdaeJullede, 1903). 372)

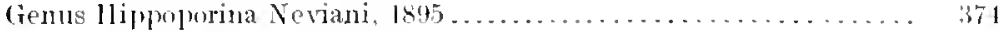

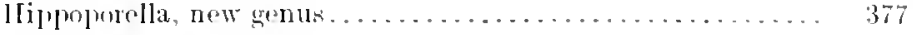

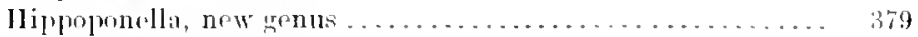

Hippomenella (anu and Basgler, 1917................ 379

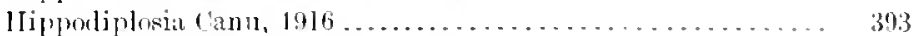

llippozengosella canu and Bassler, 1917.............. 395

Itipparlenella ('ant and Jassler, $1917 \ldots \ldots \ldots \ldots \ldots \ldots \ldots \ldots \ldots$

Group 111. Peristomellae ('anu and Bassler, $1917 \ldots \ldots \ldots \ldots \ldots \ldots \ldots \ldots \ldots$

Genus Batlosella ('anu and Bassler, $1917 \ldots \ldots \ldots \ldots \ldots \ldots \ldots \ldots \ldots . . .10 . \ldots \ldots$

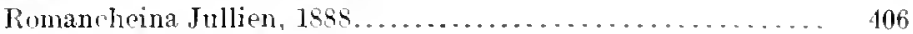

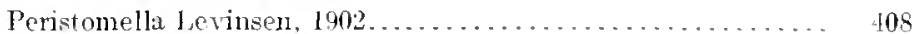

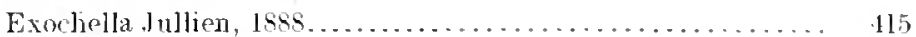

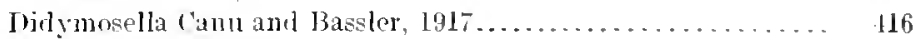

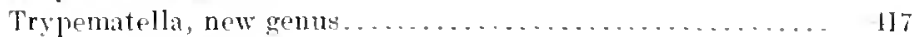

Group IT. Miroporellae . . . . . . . . . . . . . . . . . .

Grup 1 . livers gencra. . . . . . . . . . . . . . . . . . . . . 120

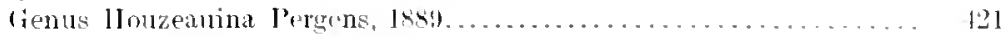

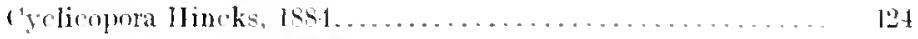

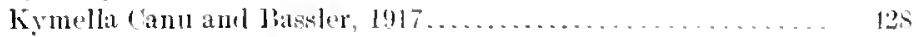

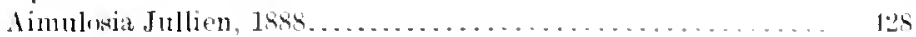

Anarthropora smitt, $1806 . \ldots \ldots \ldots \ldots \ldots \ldots \ldots \ldots \ldots \ldots \ldots . \ldots \ldots$

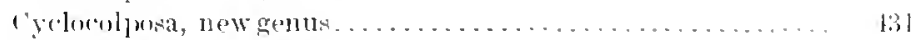

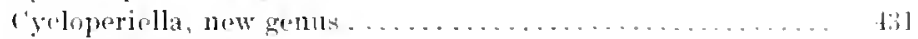

Family Stumacherosellidae Canu and liassler, $1917 \ldots \ldots \ldots \ldots \ldots \ldots \ldots \ldots \ldots$ ti:

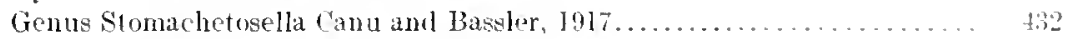

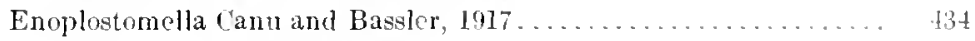

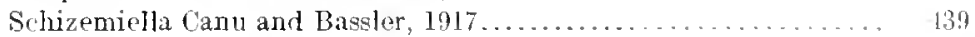

Metradulium Canu and Bassler, $1917 \ldots \ldots \ldots \ldots \ldots \ldots \ldots \ldots \ldots \ldots$ t

Leinsolla ('ann and Basslor, $1917 \ldots \ldots \ldots \ldots \ldots \ldots \ldots \ldots \ldots \ldots \ldots$ H

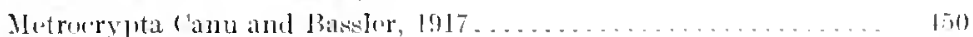

()hetosalla ('anu and Bassler. $1917 \ldots \ldots \ldots \ldots \ldots \ldots \ldots \ldots \ldots \ldots$ 151

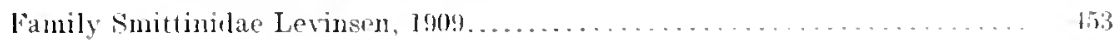

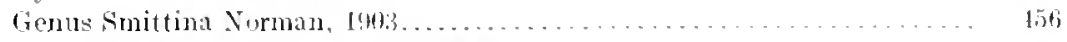

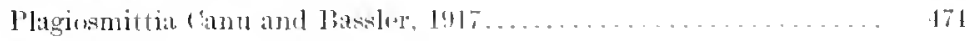

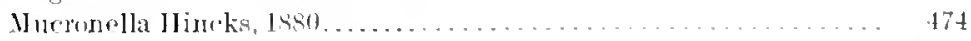

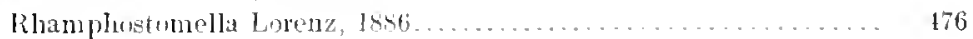


Systematic descriptions-Continum].

Order Cheilostomata Busk-Continuel.

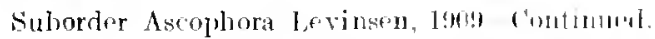

Family Smitinilae Levinen, ]!n! continucul. Fage.

Genus Cystisella Canu anil liassier, $1917 \ldots \ldots \ldots \ldots \ldots \ldots \ldots \ldots \ldots \ldots \ldots$

Porella (tray, $18.18 \ldots \ldots \ldots \ldots \ldots \ldots \ldots \ldots \ldots \ldots \ldots \ldots . \ldots \ldots \ldots$

Umbonula Ilincks, Is8n..................... 491

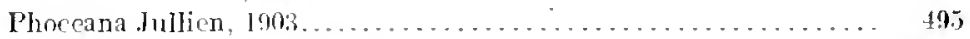

Bryocryptella Cossman, $1906 \ldots \ldots \ldots \ldots \ldots \ldots \ldots \ldots \ldots \ldots \ldots \ldots$

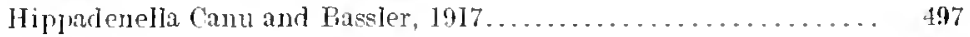

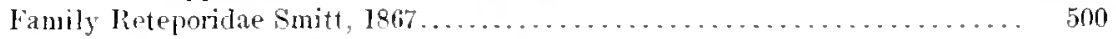

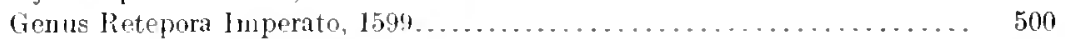

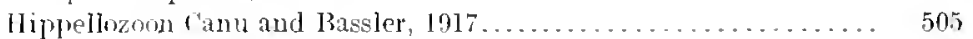

Schizellozom Canu and Bassier, 1917.................... 505

Triphyllozonn ranu and Bassler, $1917 \ldots \ldots \ldots \ldots \ldots \ldots \ldots \ldots \ldots . . . \ldots 6$

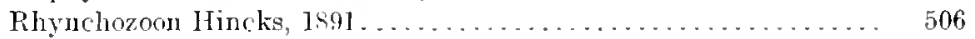

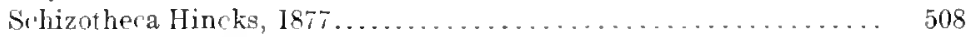

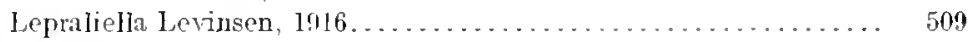

Family traleopsidae Jullien, $1903 \ldots \ldots \ldots \ldots \ldots \ldots \ldots \ldots \ldots \ldots \ldots \ldots \ldots$

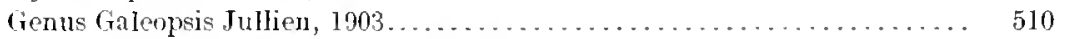

Srhizaropsis (anu and lassler, $1917 \ldots \ldots \ldots \ldots \ldots \ldots \ldots \ldots \ldots \ldots . \ldots \ldots$

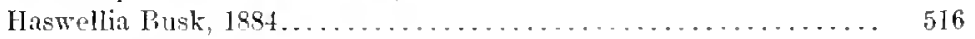

Semihaswellia Canu anci Bassler, $1917 \ldots \ldots \ldots \ldots \ldots \ldots \ldots \ldots .517$

Gigantopora Ridley, IssI........................ 519

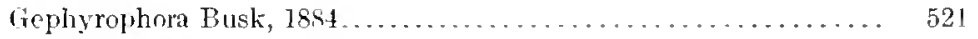

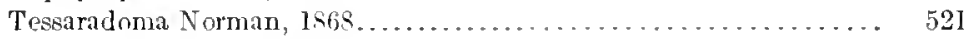

Tremotoichos Canu and Hassier, $1917 \ldots \ldots \ldots \ldots \ldots \ldots \ldots \ldots \ldots . \ldots 23$

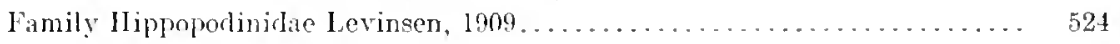

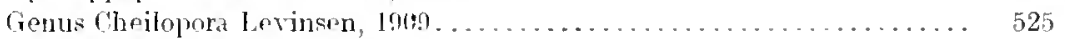

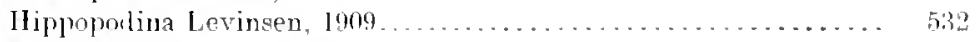

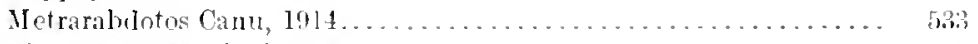

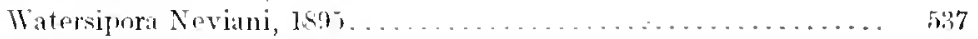

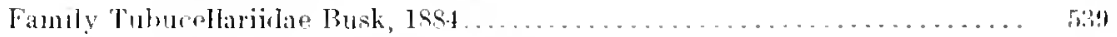

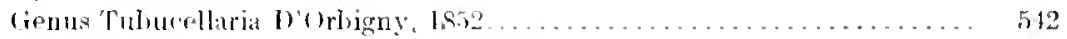

Subgenus Tubucellat tanil and Basslor, $1917 \ldots \ldots \ldots \ldots \ldots \ldots \ldots \ldots .516$

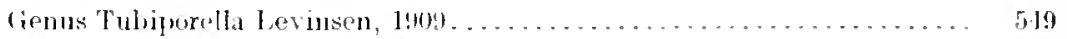

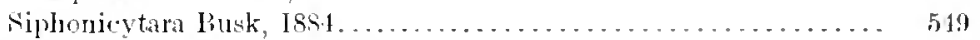

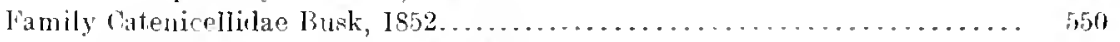

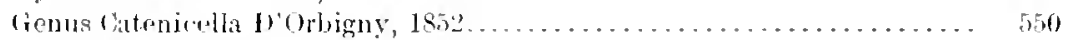

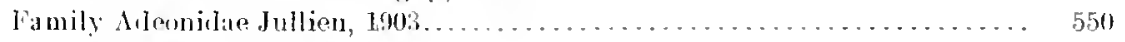

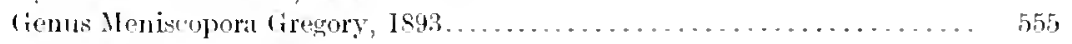

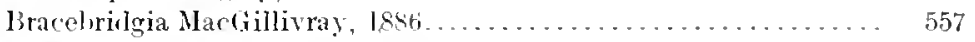

Allouna (Lamouroux, 1816 ) Levinsen, 1909 ................ . 560

Arleonella (Busk, Is84) Waters, 1889.................. 561

Mleonellopsis HacGillivrty, $1886 \ldots \ldots \ldots \ldots \ldots \ldots \ldots \ldots \ldots \ldots \ldots . . \ldots 63$

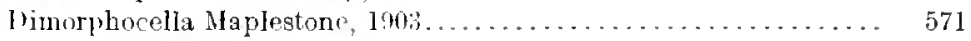

I.minopora Nicholin, $1842 \ldots \ldots \ldots \ldots \ldots \ldots \ldots \ldots \ldots \ldots \ldots$ 57

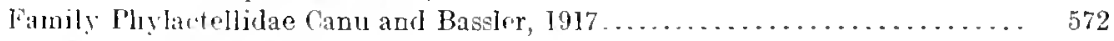

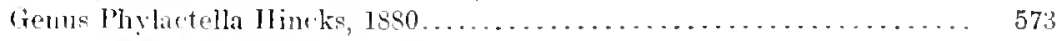

Prinastrella ranu and Passles, $1917 \ldots \ldots \ldots \ldots \ldots \ldots \ldots \ldots \ldots . . \ldots 76$

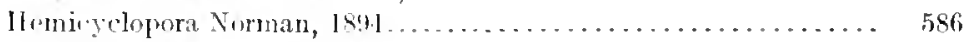

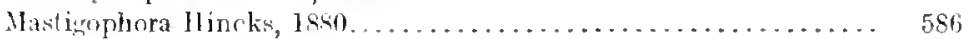

Schizobathysella Canu aud Bassier, $1917 \ldots \ldots \ldots \ldots \ldots \ldots \ldots \ldots \ldots .590$ 
Systematic: descriptions lontinumel.

Order Cheilostomata Busk-- Continued.

suborler Ascophora Levinsen, I!09-(inntinued

Fanily Phylactellidae Canu and Bassler, 1917-C'ontinuel. Pagf.

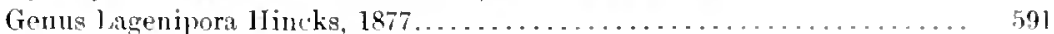

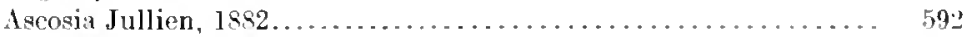

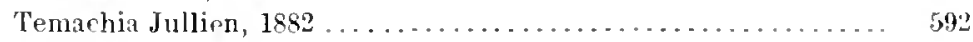

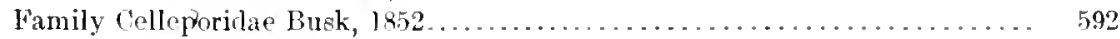

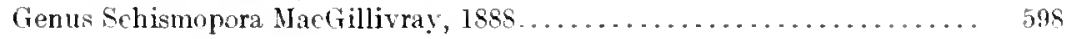

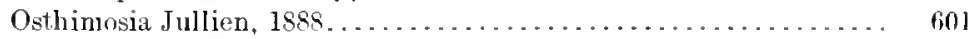

Costazzia Neviani, $1895 \ldots \ldots \ldots \ldots \ldots \ldots \ldots \ldots \ldots \ldots \ldots \ldots . \ldots \ldots . \ldots \ldots$

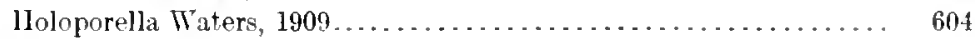

. Icanthionella Canu and Bassler, 1917................... 614

Kleidionella Canı and Bassler, 1917.................. 617

ramily Conescharellinidae Levinsen, $1909 \ldots \ldots \ldots \ldots \ldots \ldots \ldots \ldots \ldots \ldots \ldots . \ldots \ldots 22$

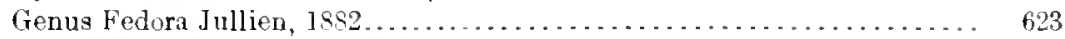

Stichoporina Stoliczka, $1861 \ldots \ldots \ldots \ldots \ldots \ldots \ldots \ldots \ldots \ldots . \ldots \ldots 24$

Schizorthosecos Canu and Bassler, $1917 \ldots \ldots \ldots \ldots \ldots \ldots \ldots \ldots \ldots . \ldots 26$

Orbitılipora Stoliczka, $1861 \ldots \ldots \ldots \ldots \ldots \ldots \ldots \ldots \ldots \ldots \ldots . \ldots \ldots$

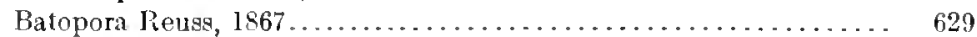

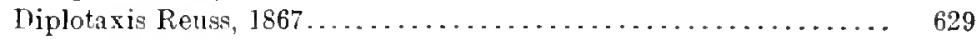

Conescharellina D'Orbigny, $1851 \ldots \ldots \ldots \ldots \ldots \ldots \ldots \ldots \ldots \ldots \ldots$

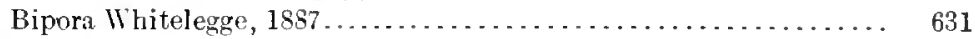

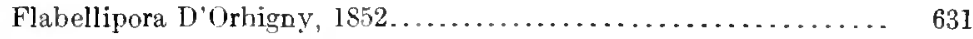

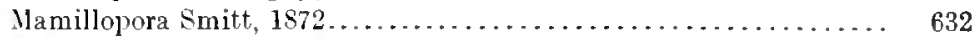

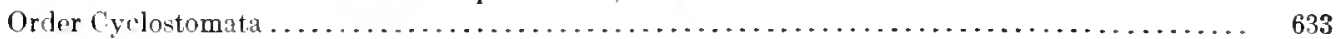

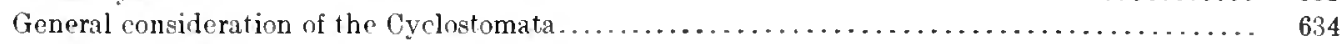

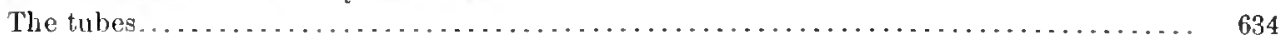

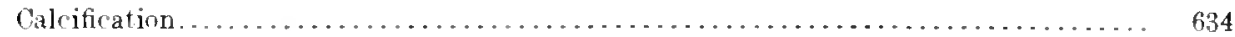

Gylindrical tubes or trepostomatous like Cyclostomata . . . . . . . . . . . . 636

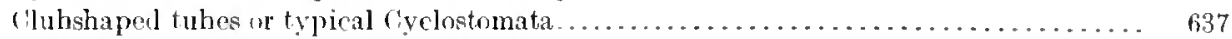

Tubes with facets. . . . . . . . . . . . .

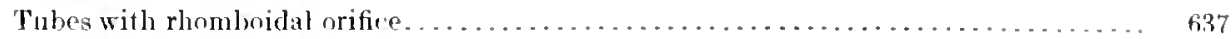

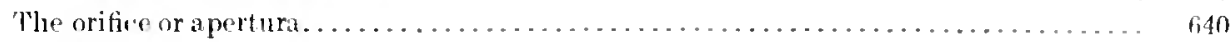

liaphrignıs. . . . . . . . . . . . . . . . . .

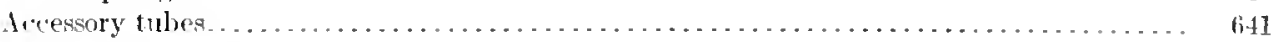

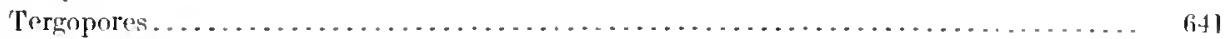

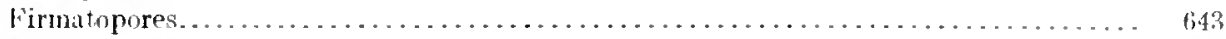

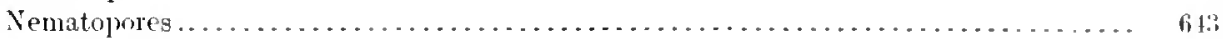

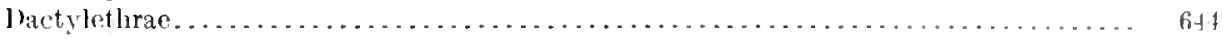

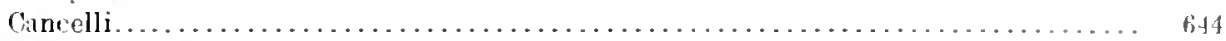

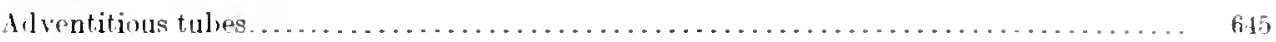

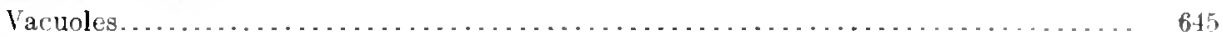

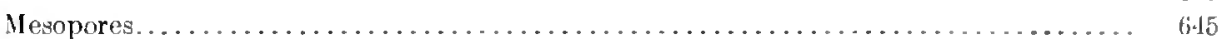

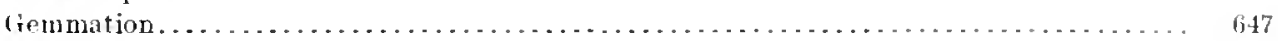

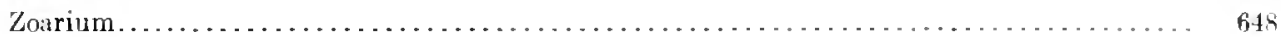

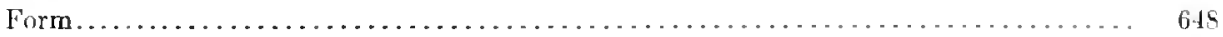

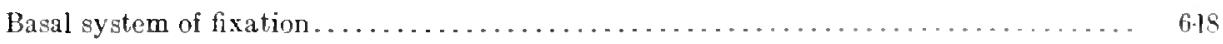

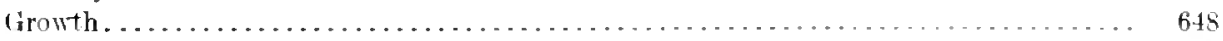

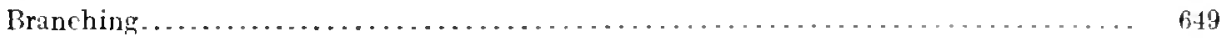

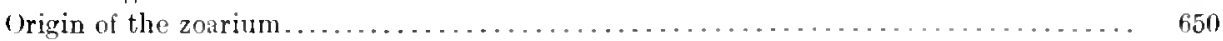

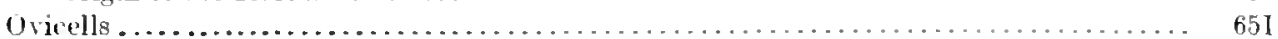




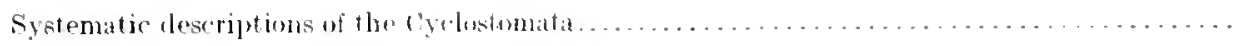

I. llivision hnovicellata . . . . . . . . . . . . . . . . . . . . . . . . . . .

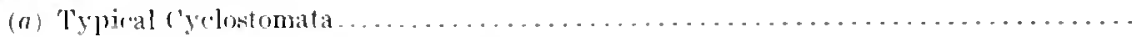

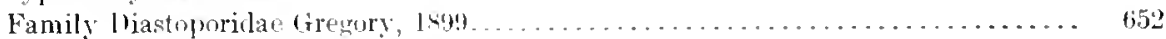

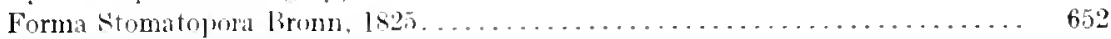

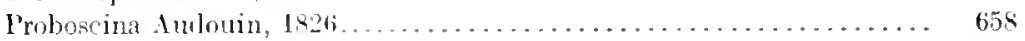

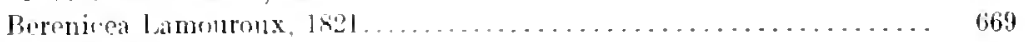

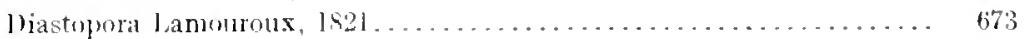

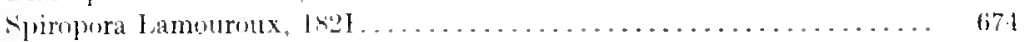

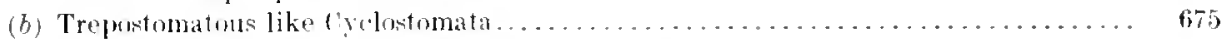

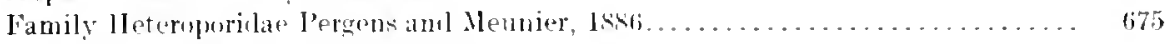

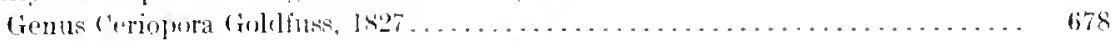

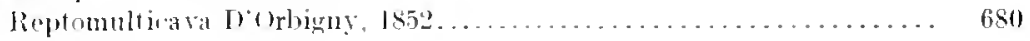

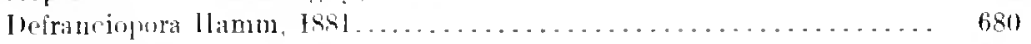

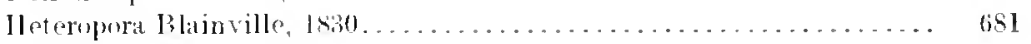

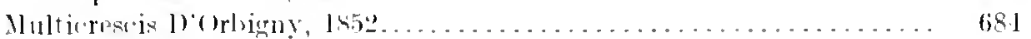

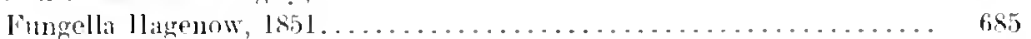

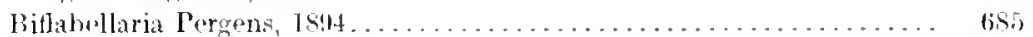

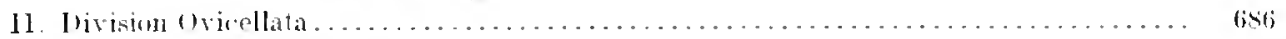

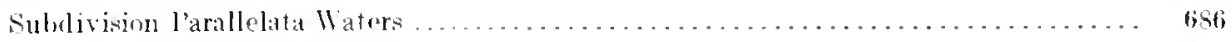

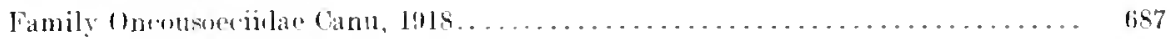

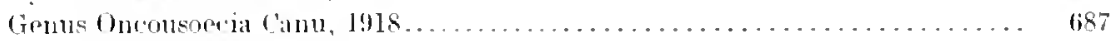

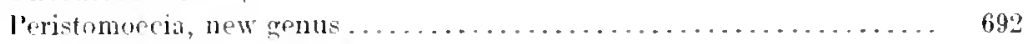

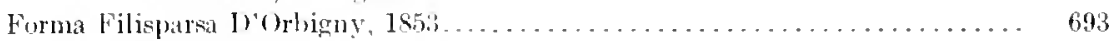

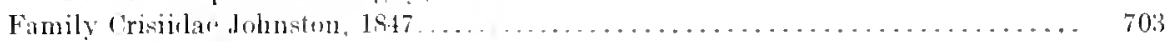

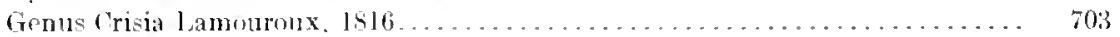

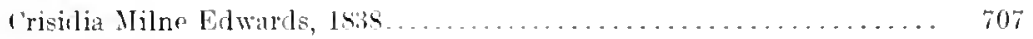

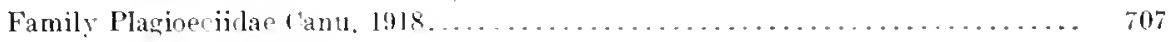

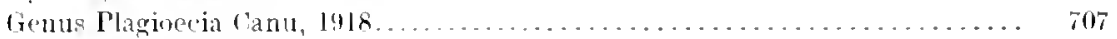

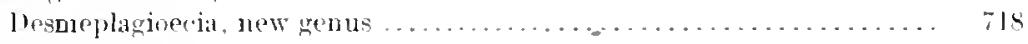

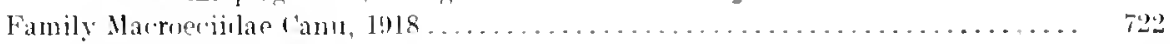

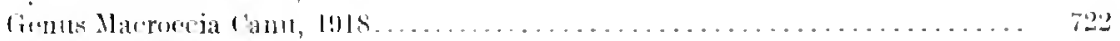

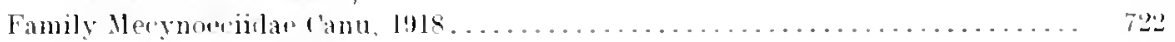

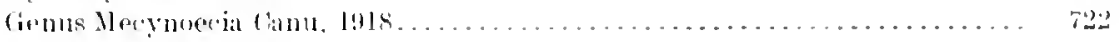

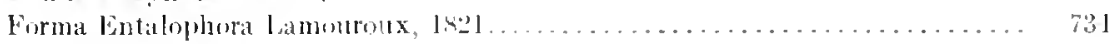

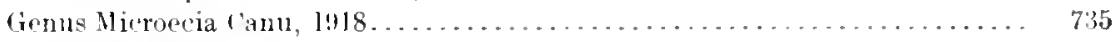

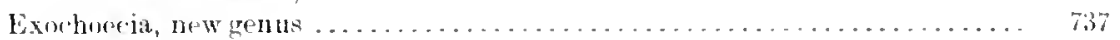

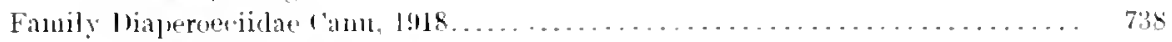

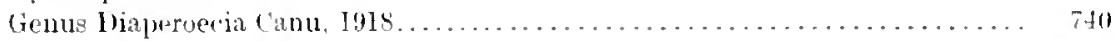

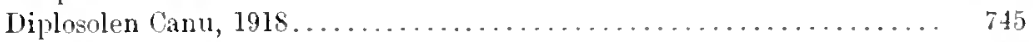

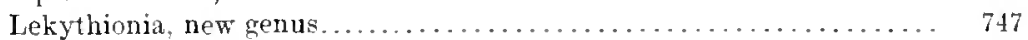

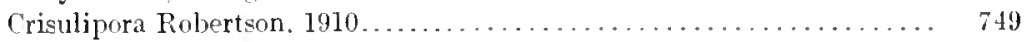

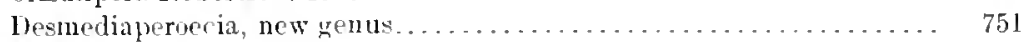

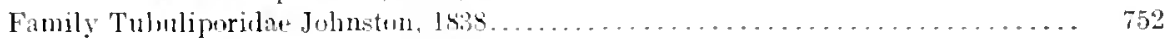

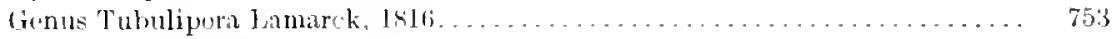

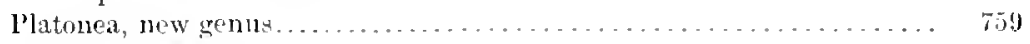

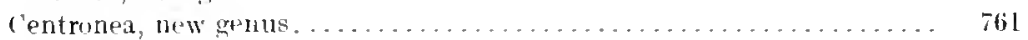

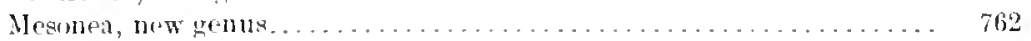

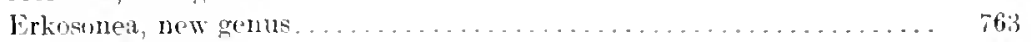

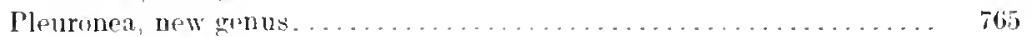

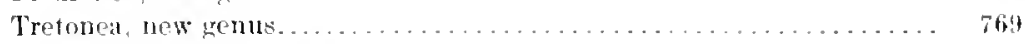

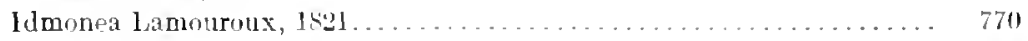

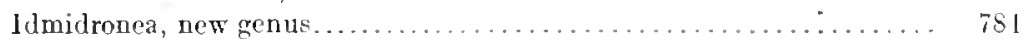


Systematic descriptions of the Gyclostomata-Continued.

II. Division Oríellata-continued

Suldivision Parallelata Waters-Continued.

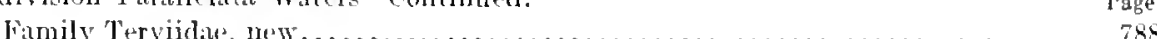

Gienus Tervia Jullien, $1882 \ldots \ldots \ldots \ldots \ldots \ldots \ldots \ldots \ldots \ldots \ldots \ldots \ldots \ldots \ldots \ldots \ldots \ldots . \ldots \ldots$

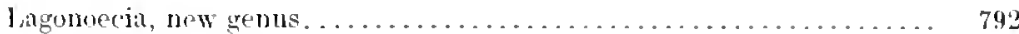

Prosthenoecia comu, $1918 \ldots \ldots \ldots \ldots \ldots \ldots \ldots \ldots \ldots \ldots \ldots \ldots$

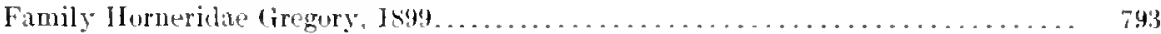

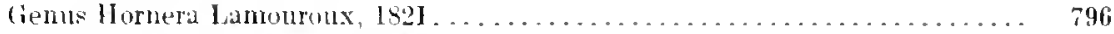

I'rassuhurnera Waters, $18 s 7 \ldots \ldots \ldots \ldots \ldots \ldots \ldots \ldots \ldots \ldots \ldots \ldots \ldots . \ldots \ldots$

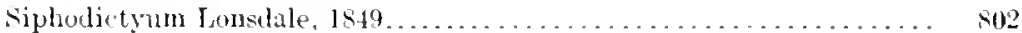

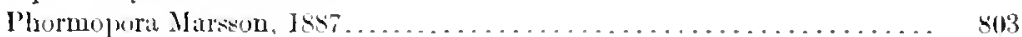

Family Frondiporidas linsk, $1875 \ldots \ldots \ldots \ldots \ldots \ldots \ldots \ldots \ldots \ldots \ldots \ldots \ldots \ldots \ldots$

Genus Frundiporal Imperato, $1599 \ldots \ldots \ldots \ldots \ldots \ldots \ldots \ldots \ldots \ldots \ldots \ldots . \ldots \ldots$

Telopora, new genus................................. 807

Forma Fasciculiporil D'Orbigny, $18+6 \ldots \ldots \ldots \ldots \ldots \ldots \ldots \ldots \ldots \ldots . \ldots \ldots$

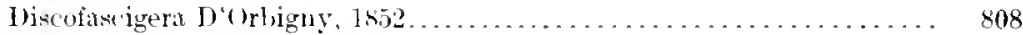

Apremelesia Lammonux, $1821 \ldots \ldots \ldots \ldots \ldots \ldots \ldots \ldots \ldots \ldots . \ldots \ldots$

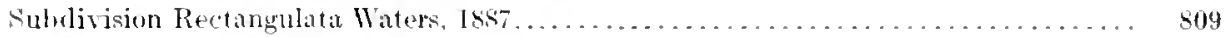

Family Lichemoridae smitt, 1 stiti. . . . . . . . . . . .

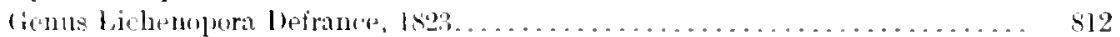

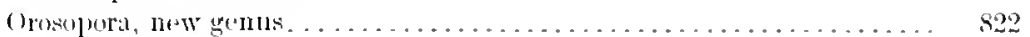

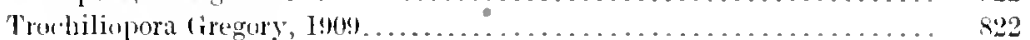

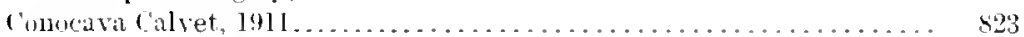

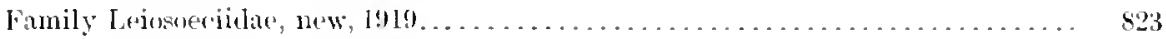

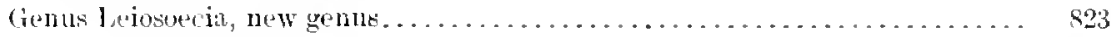

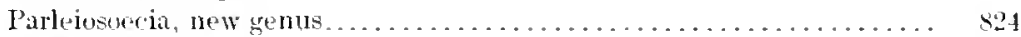

Family Treteryeloecidae Canu, $1919 \ldots \ldots \ldots \ldots \ldots \ldots \ldots \ldots \ldots \ldots \ldots \ldots \ldots \ldots \ldots .826$

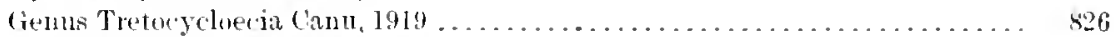

Partretocyolocia (anu, $1919 \ldots \ldots \ldots \ldots \ldots \ldots \ldots \ldots \ldots \ldots \ldots \ldots$

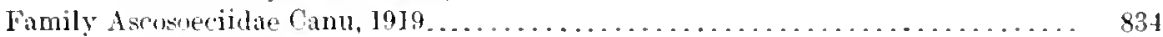

Genus Ascosvecia Canu, $1919 \ldots \ldots \ldots \ldots \ldots \ldots \ldots \ldots \ldots \ldots \ldots \ldots \ldots \ldots \ldots$

Polyascosnecia, new genus........................ 837

Parascoscecia Canu, $1919 \ldots \ldots \ldots \ldots \ldots \ldots \ldots \ldots \ldots \ldots \ldots \ldots \ldots . \ldots \ldots$

Order Ctenostomata lisk . ...............................

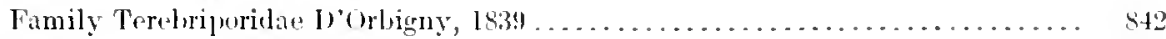

(ienus Terebripora l)'Orbigny, $1834 \ldots \ldots \ldots \ldots \ldots \ldots \ldots \ldots \ldots \ldots \ldots \ldots \ldots$

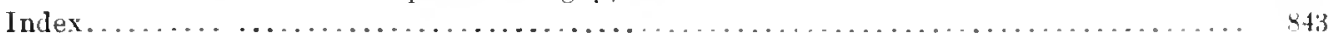





\section{ILLUSTRATIONS.'}

Text Fiaures.

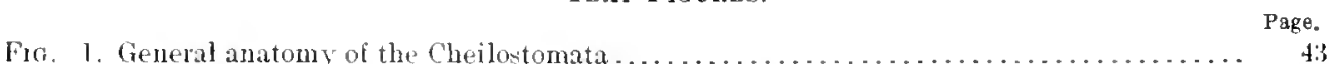

2. Earlystages in the levelopment of the (heilostomata...................... 44

3. Sketch showing proliferation of the endocyt in the Anasca (A) and in the Ascophora (B). 47

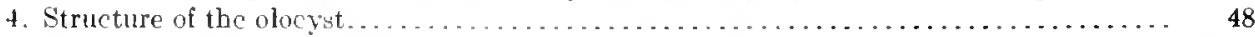

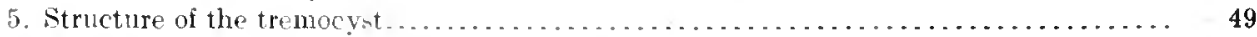

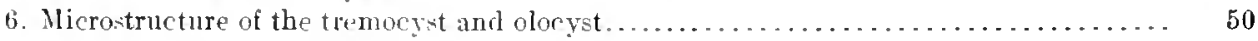

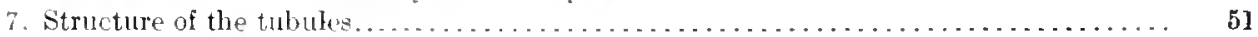

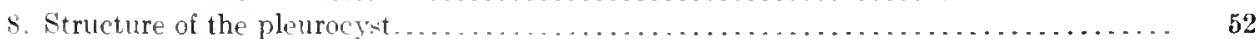

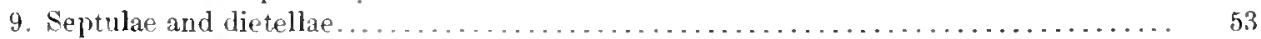

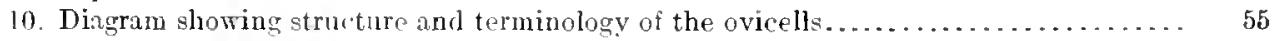

11. Parsuge of the

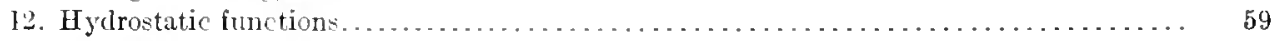

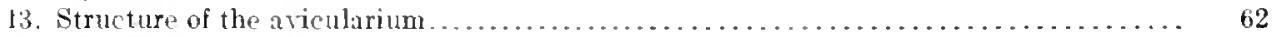

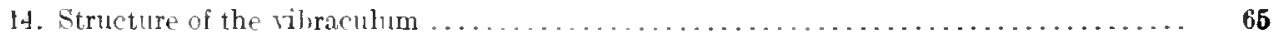

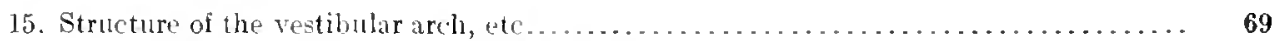

16. Sketch illustrating structure of the Malacostega . . . . . . . . . . . . . . . . . . .

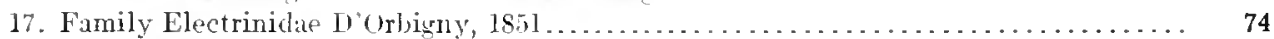

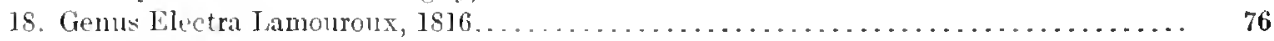

19. Genus Membranipora Blainville, $1834 \ldots \ldots \ldots \ldots \ldots \ldots \ldots \ldots \ldots \ldots \ldots \ldots \ldots \ldots \ldots \ldots . \ldots \ldots$

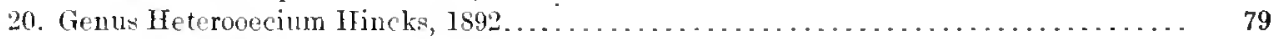

21. Genus Pyripora D'Orbigny, $1852 \ldots \ldots \ldots \ldots \ldots \ldots \ldots \ldots \ldots \ldots \ldots \ldots \ldots \ldots \ldots \ldots \ldots . . \ldots \ldots$

22. Genus Herpetopora Lang, $1914 \ldots \ldots \ldots \ldots \ldots \ldots \ldots \ldots \ldots \ldots \ldots \ldots \ldots \ldots \ldots \ldots \ldots \ldots . \ldots . \ldots \ldots$

23. Structure of the Membraniporas $\ldots \ldots \ldots \ldots \ldots \ldots \ldots \ldots \ldots \ldots \ldots \ldots \ldots \ldots \ldots \ldots \ldots \ldots . . . \ldots \ldots$

24. Genera of Membraniporae without ovicell . . . . . . . . . . . . . . . . . . . . 85

25. Genus Conopeun Norman, $1903 \ldots \ldots \ldots \ldots \ldots \ldots \ldots \ldots \ldots \ldots \ldots \ldots \ldots \ldots \ldots \ldots . \ldots . \ldots . \ldots \ldots$

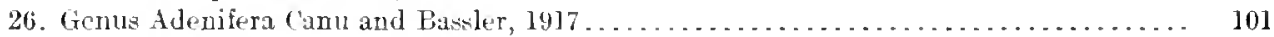

27 . Genera of Membraniporae with endozooecial ovicell. . . . . . . . . . . . . . . . . . 109

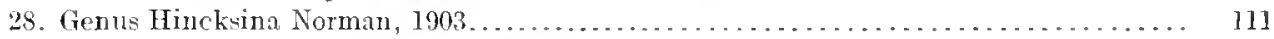

29. Genus Membrendoecium Cant and Bassler, 1917......................... 120

30. Membraniporae with hyp+rstomial ovicals, always closed by the opereular valve....... 124

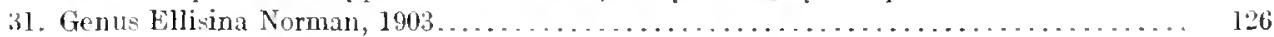

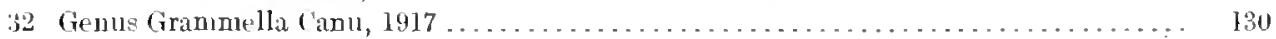

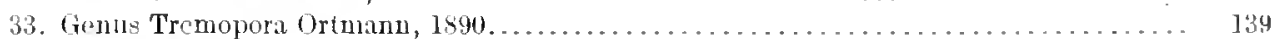

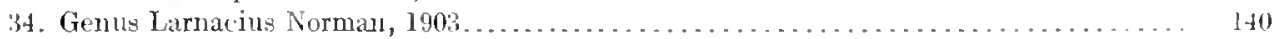

35. Genera of Membrauporat with ovicells never losed by the opereular valve......... 14]

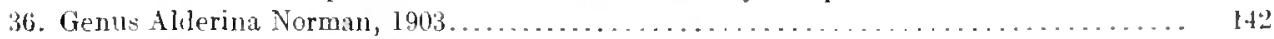

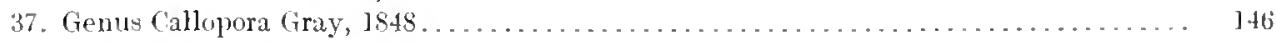

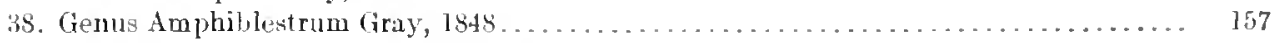

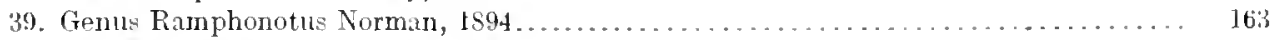

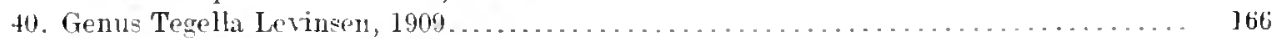

41. Miscellanente genera of Membraniporat . . . . . . . . . . . . . . . . . . . . 174

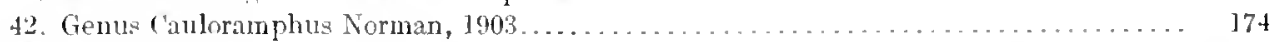

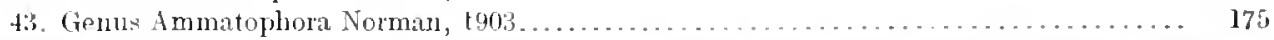

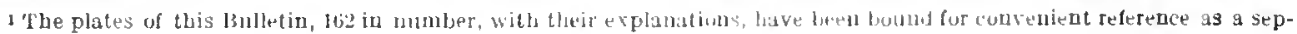
arato volume. 
Fig. 44. Geuns Antropora Nurman, 19013

45. (ienuk Mregapora Hincks, 1877

46. Genus Fuveolaria linsk, 1854.

47. Family Aeteidae Smitt, 1507

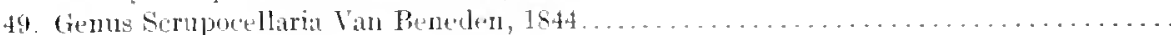

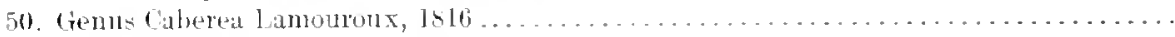

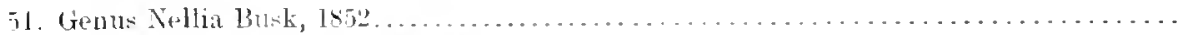

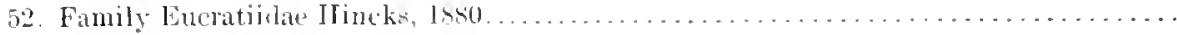

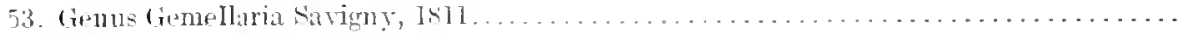

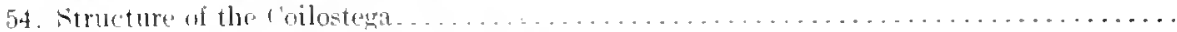

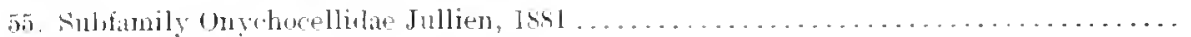

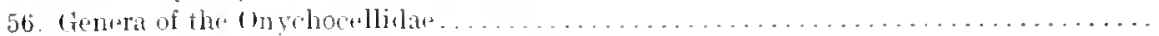

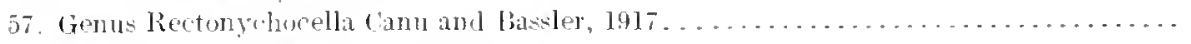

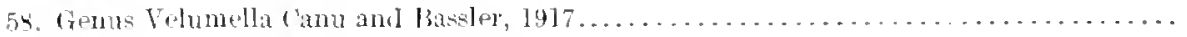

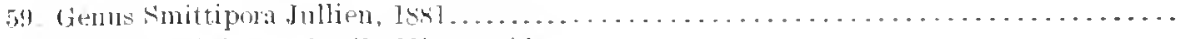

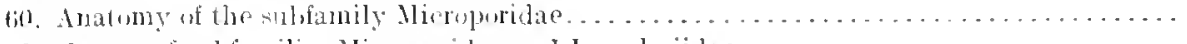

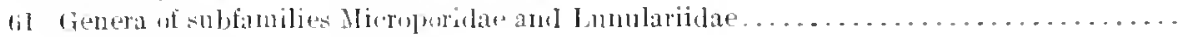

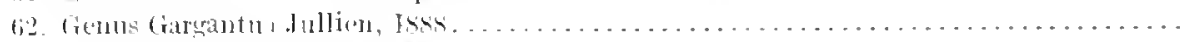

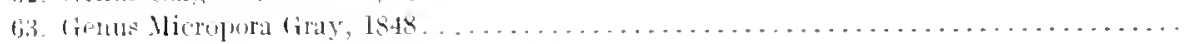

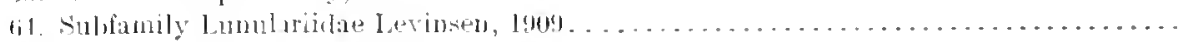

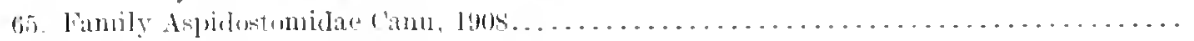

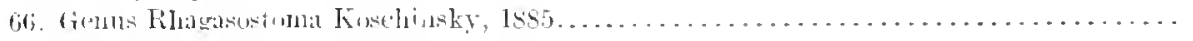

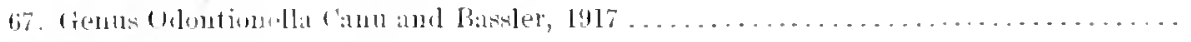

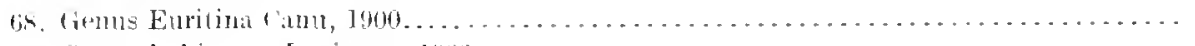

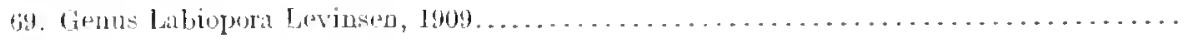

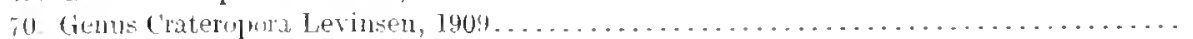

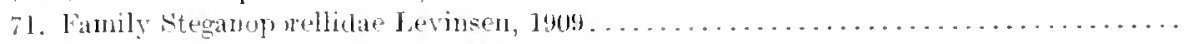

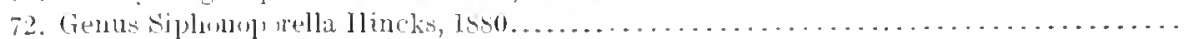

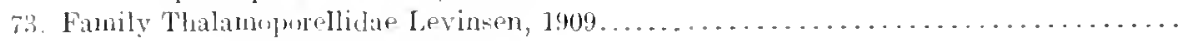

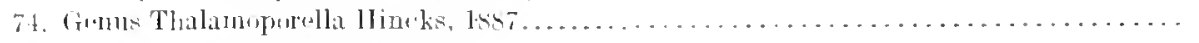

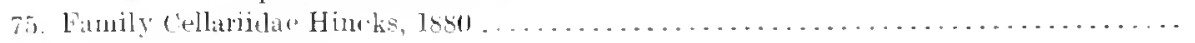

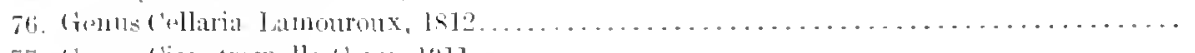

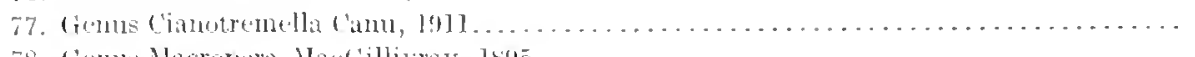

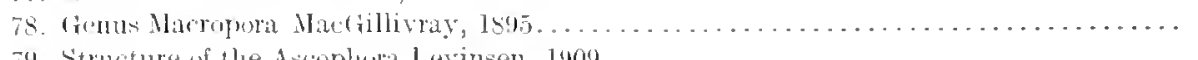

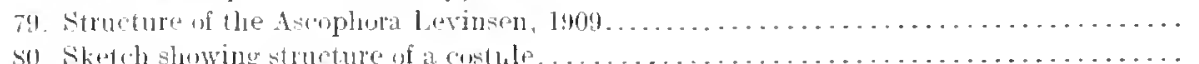

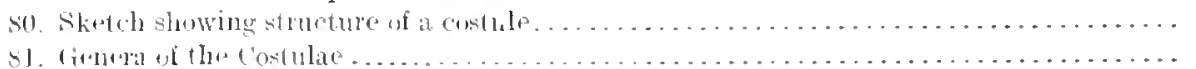

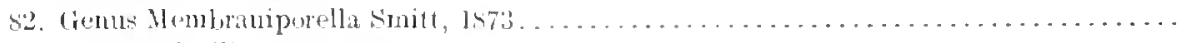

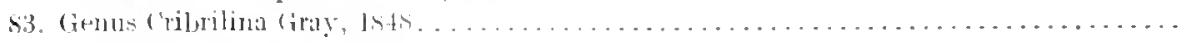

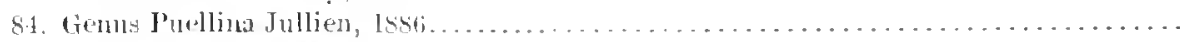

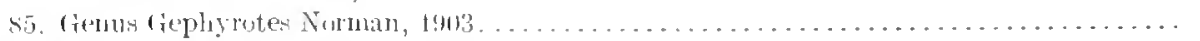

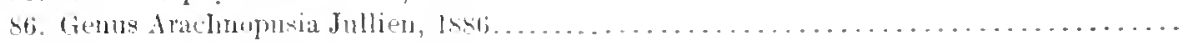

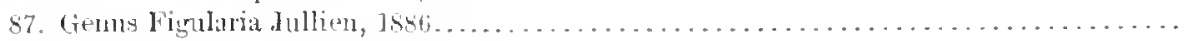

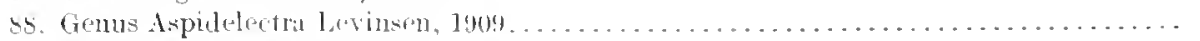

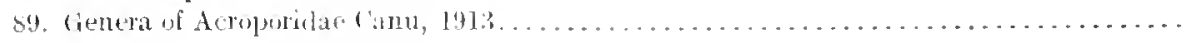

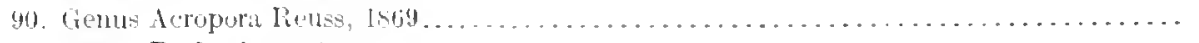

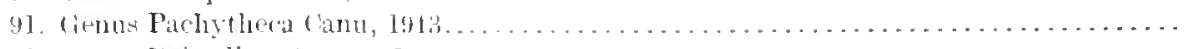

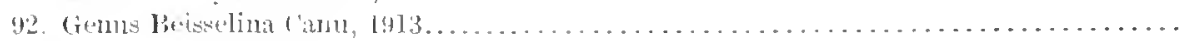

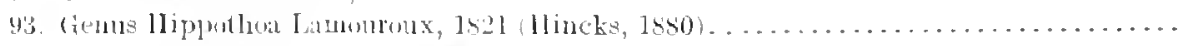

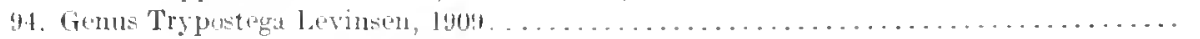

45. Genus 11 aplopuma Levinsen, long. . . . . . . . . . . . . . . . . . . . . 


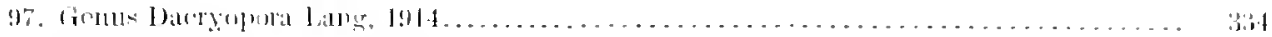

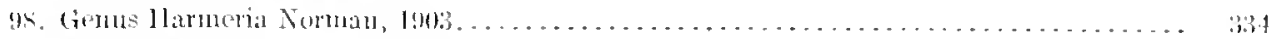

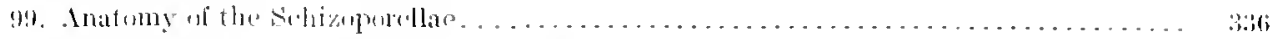

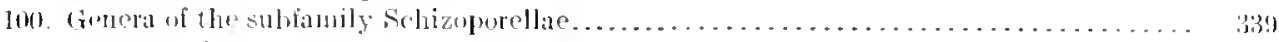

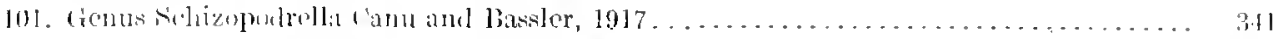

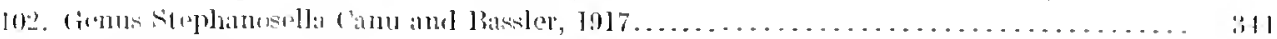

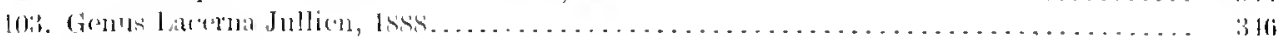

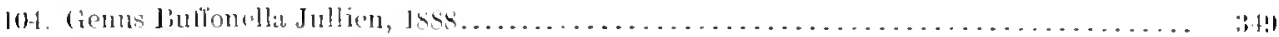

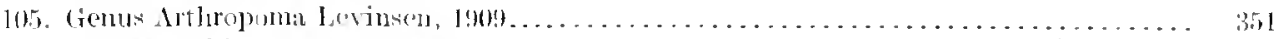

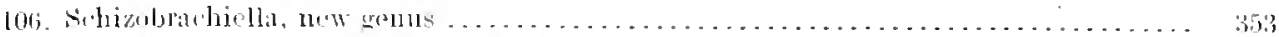

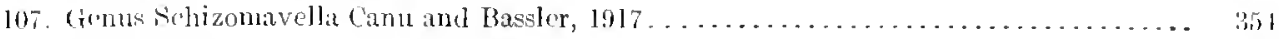

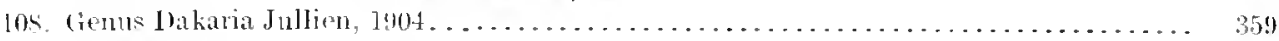

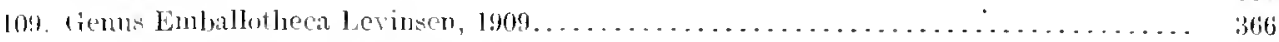

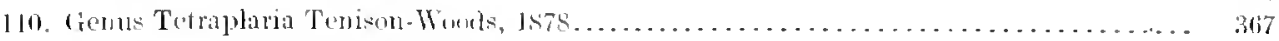

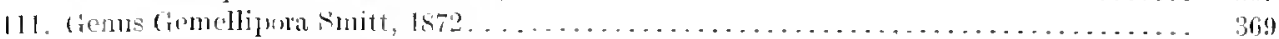

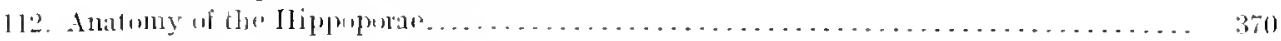

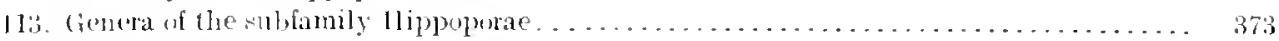

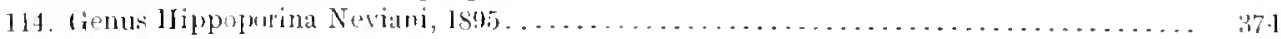

115.1 lippoponella. now

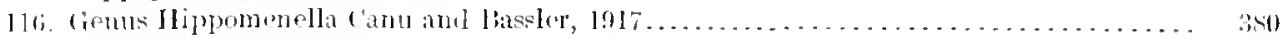

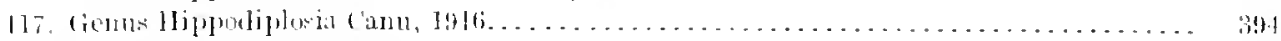

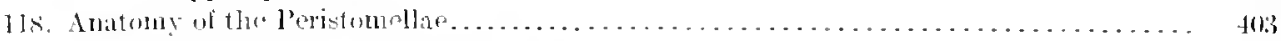

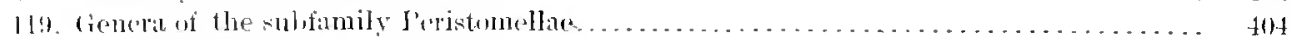

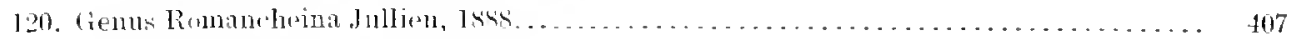

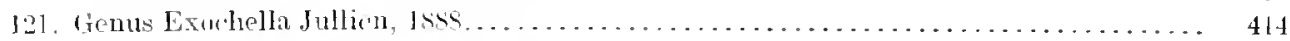

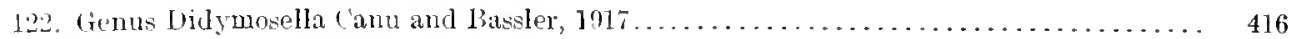

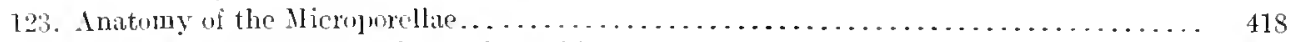

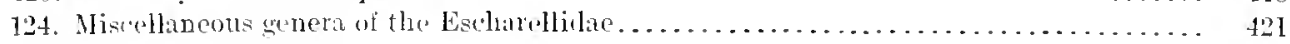

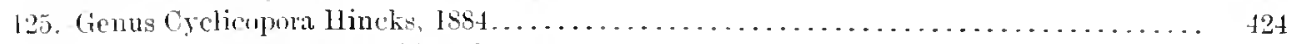

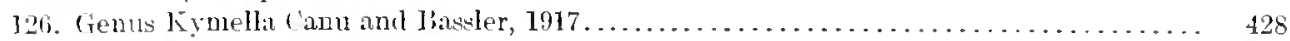

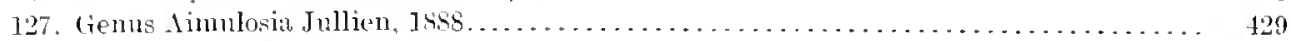

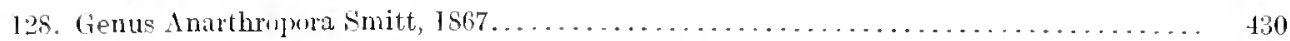

129. (ienera of the Stomachetosellidae Gann and Bassler, 1917................ 432

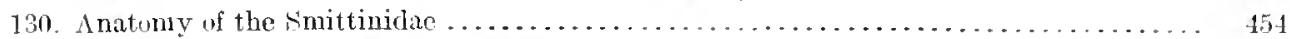

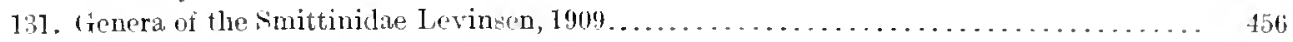

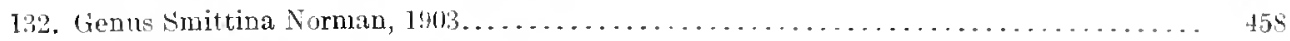

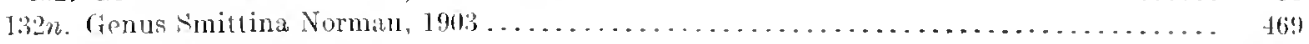

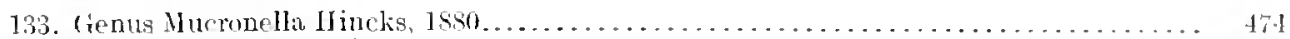

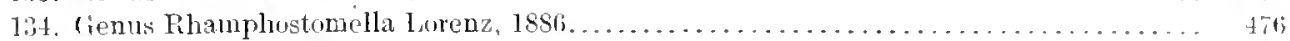

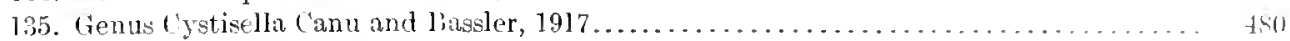

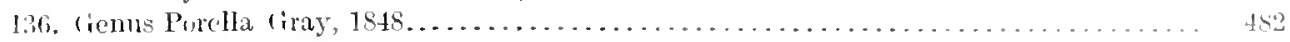

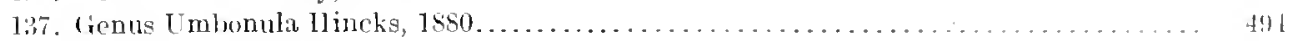

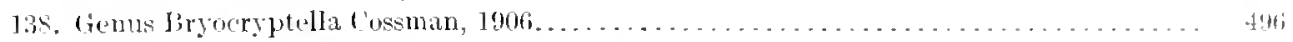

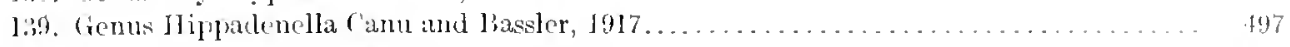

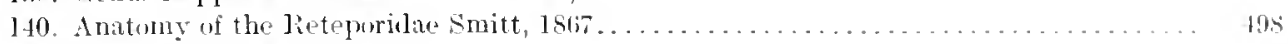

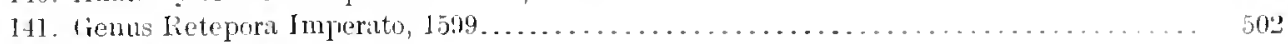

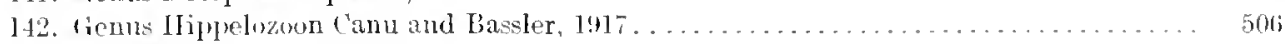

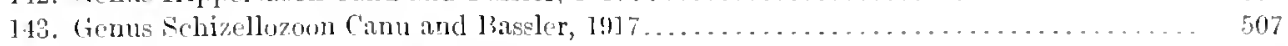

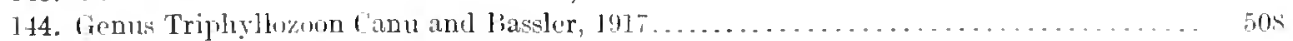

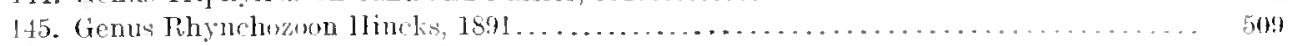

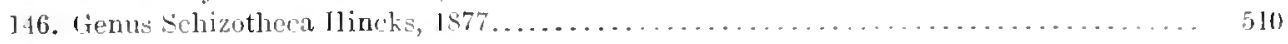

$$
55899-19-\text { Bu1l. } 106-\longrightarrow 11
$$


Page.

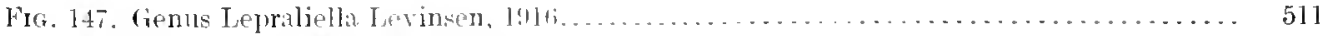

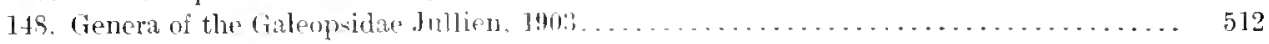

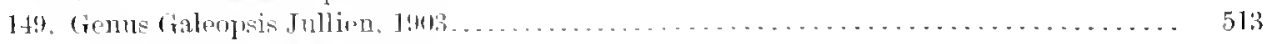

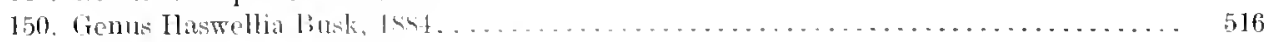

151. Cienus fomihaswellia lam and laksle $1917 \ldots \ldots \ldots \ldots \ldots \ldots \ldots \ldots \ldots \ldots \ldots \ldots \ldots .517$

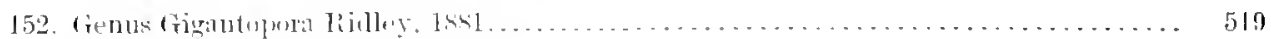

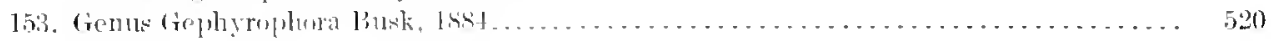

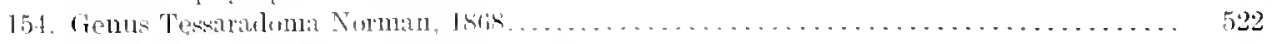

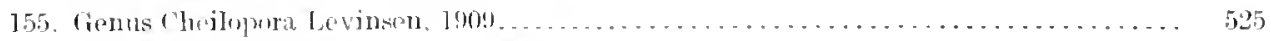

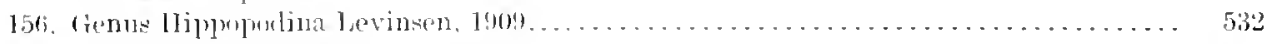

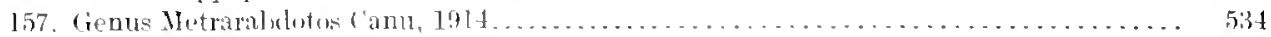

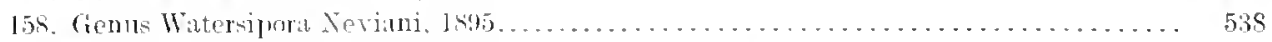

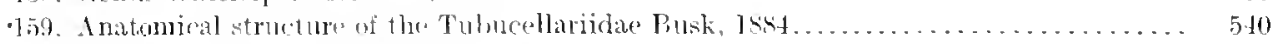

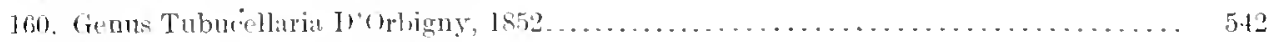

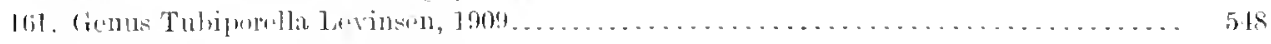

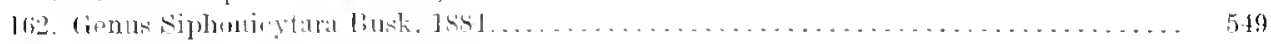

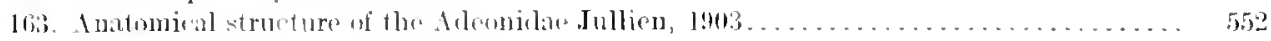

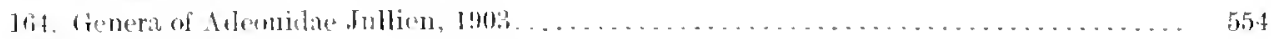

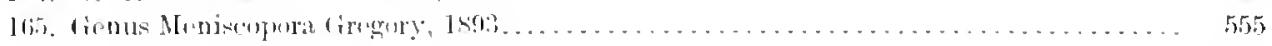

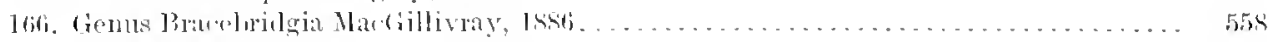

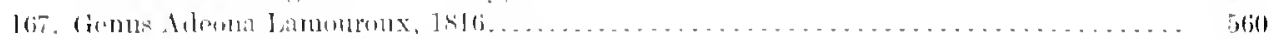

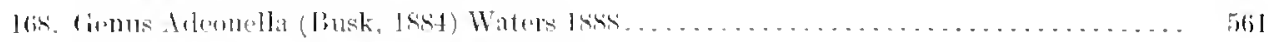

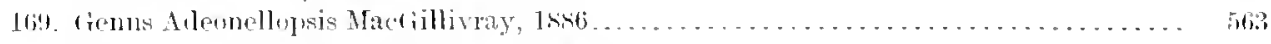

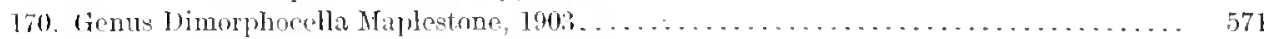

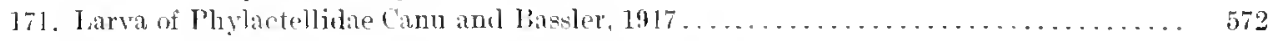

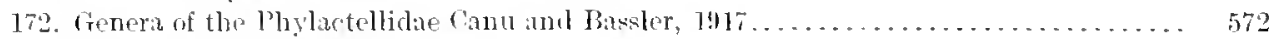

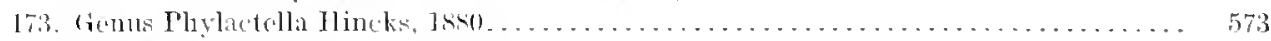

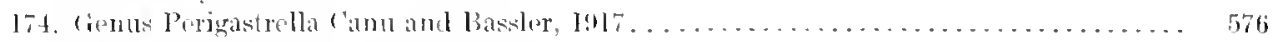

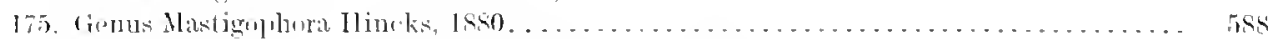

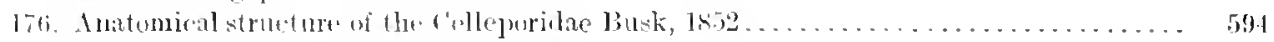

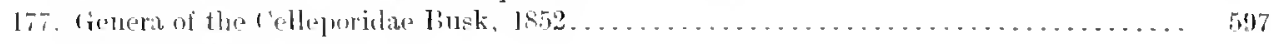

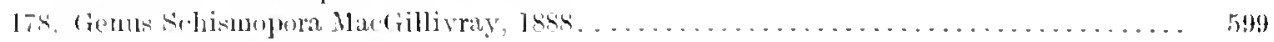

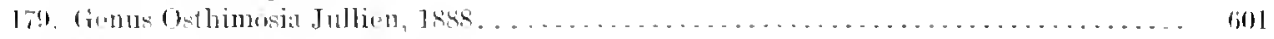

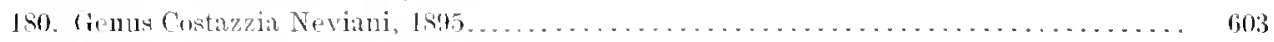

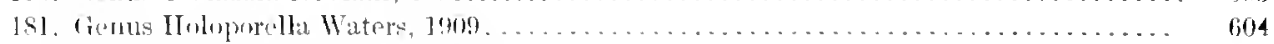

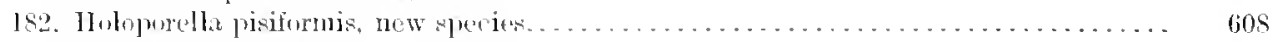

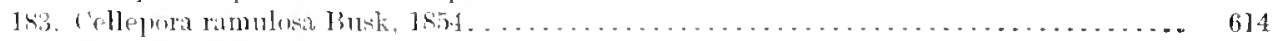

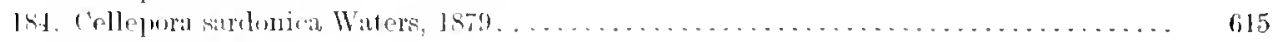

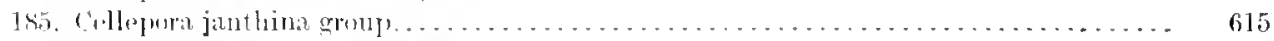

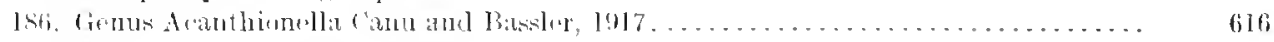

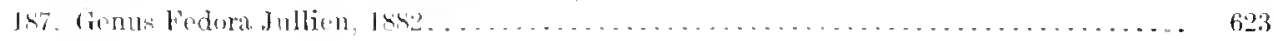

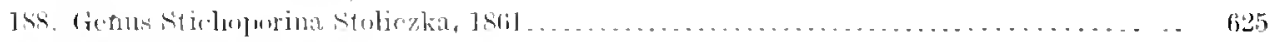

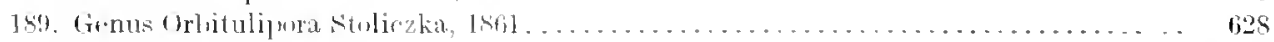

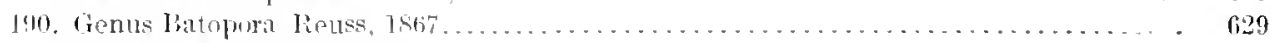

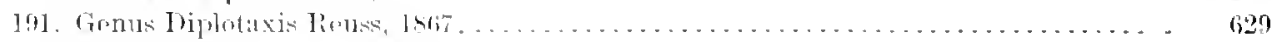

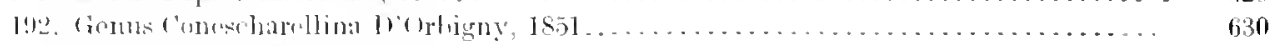

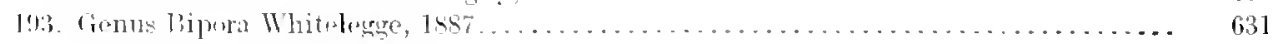

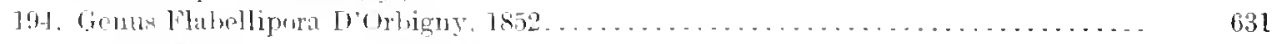

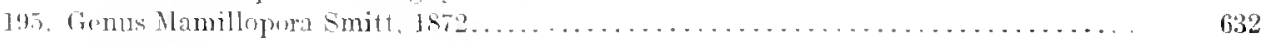

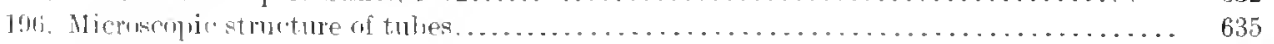

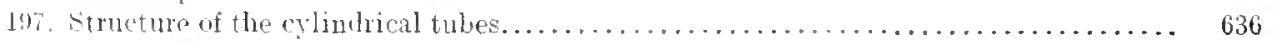




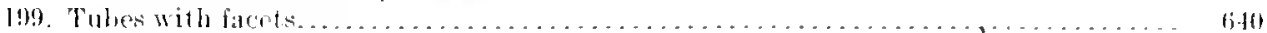

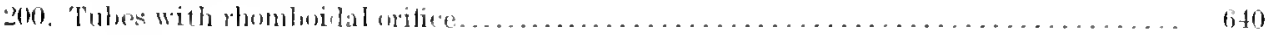

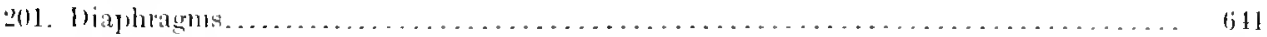

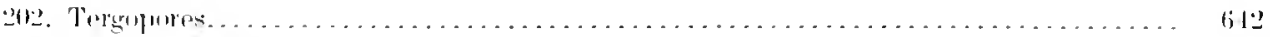

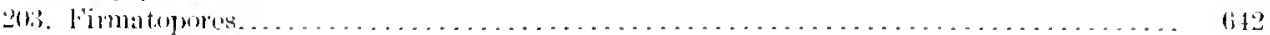

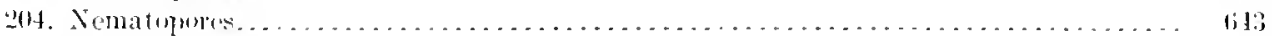

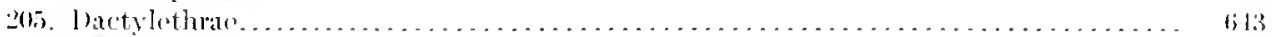

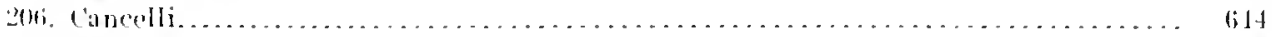

$207 . V_{10101}$

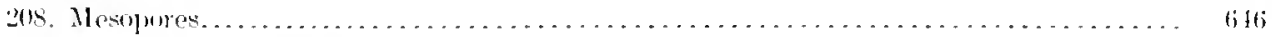

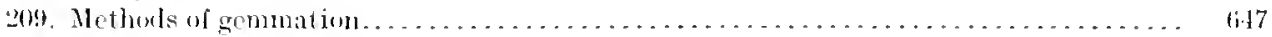

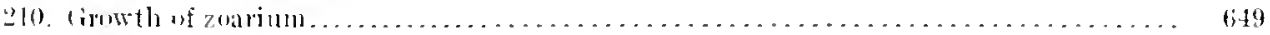

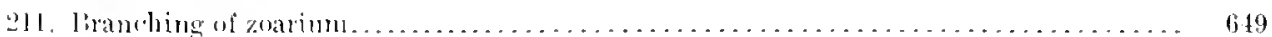

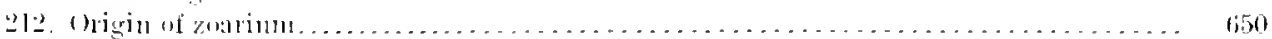

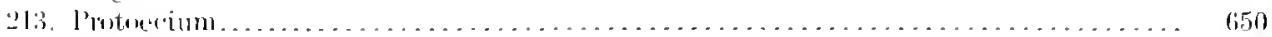

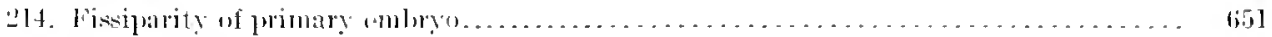

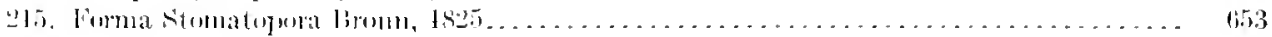

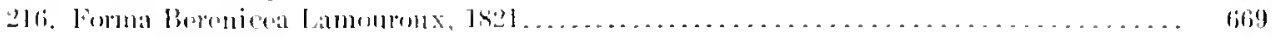

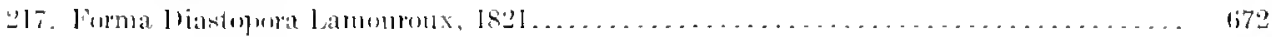

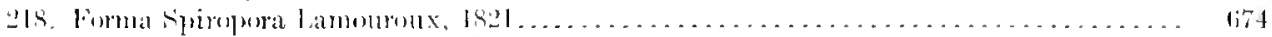

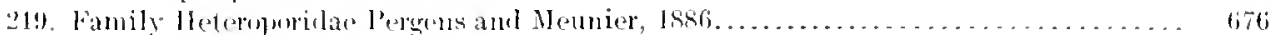

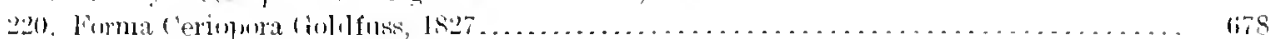

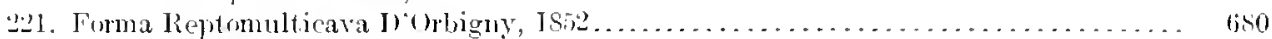

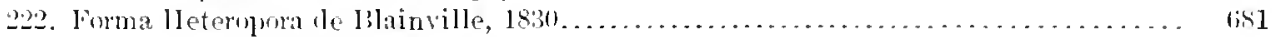

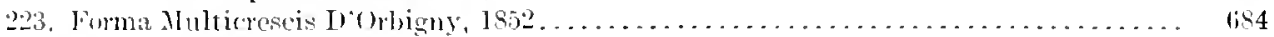

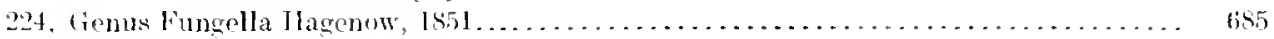

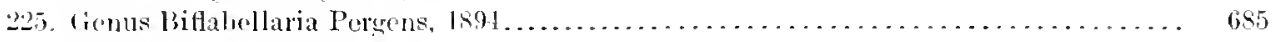

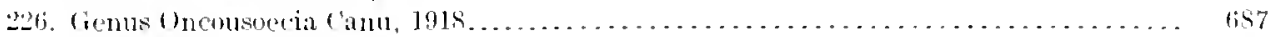

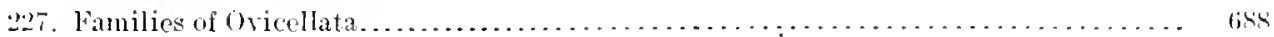



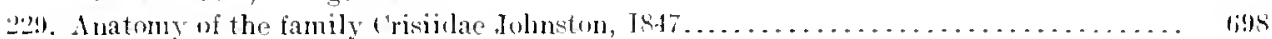

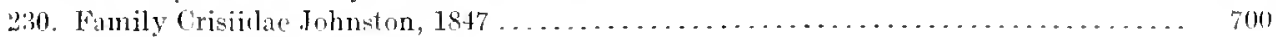

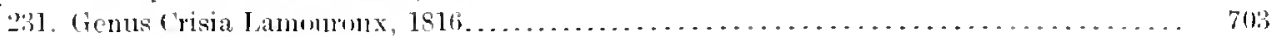

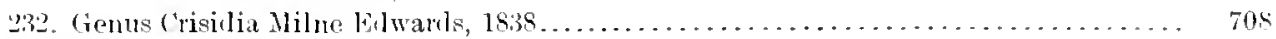

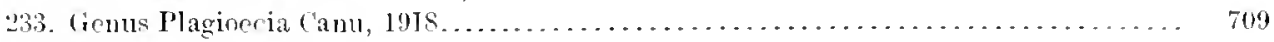

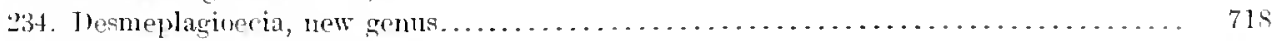

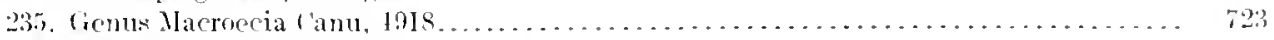

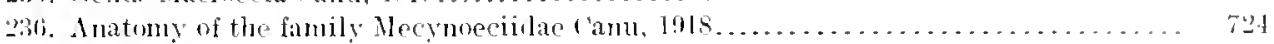

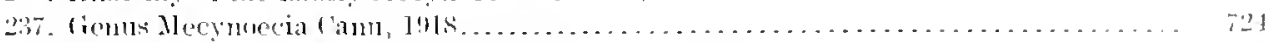

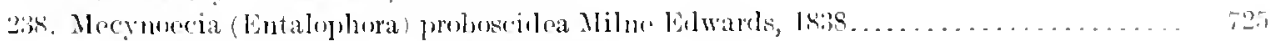

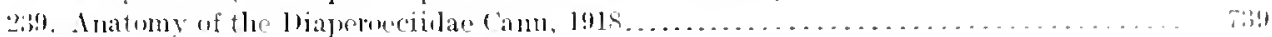

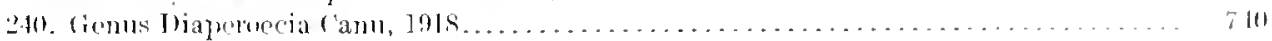

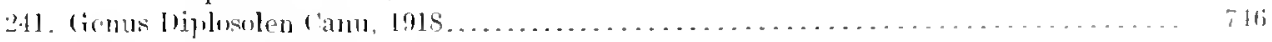

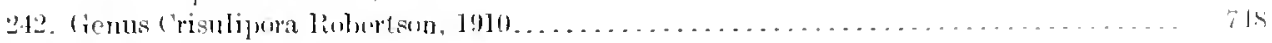

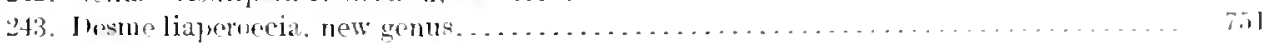

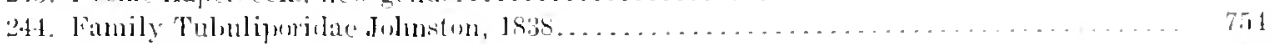

245. Cicmera of the lubliporislae. . .

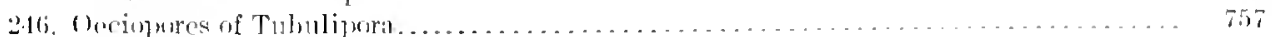

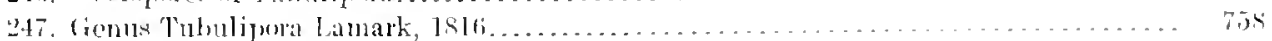

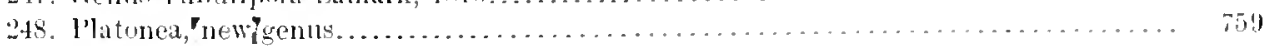

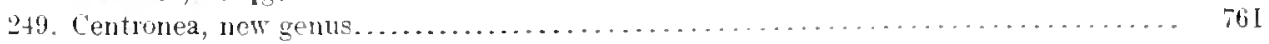




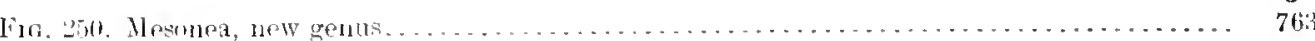

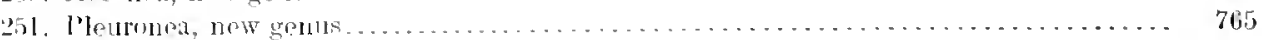

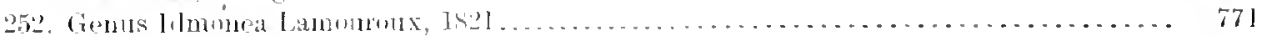

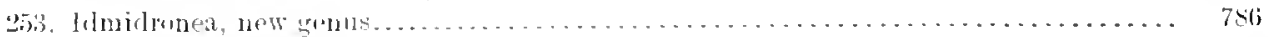

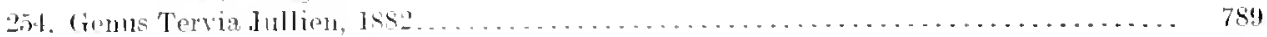

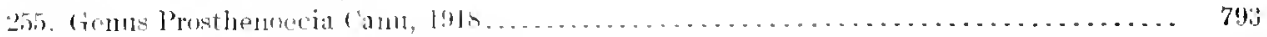

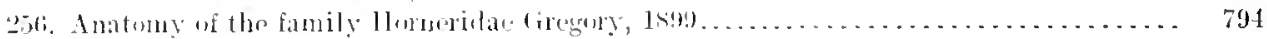

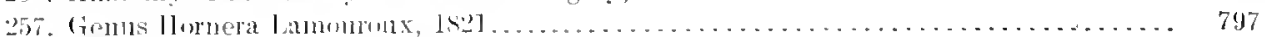

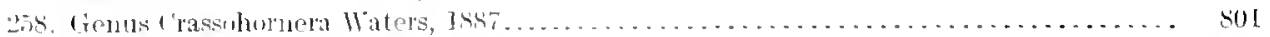

5.9. (ienus

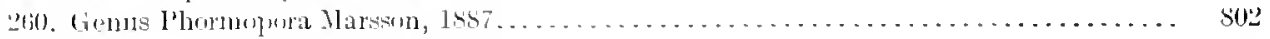

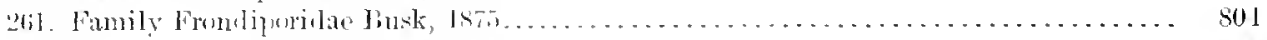

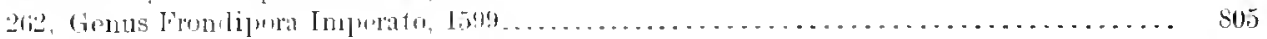

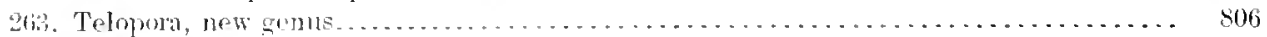

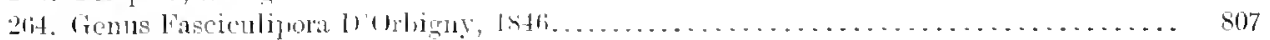

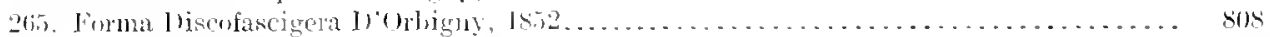

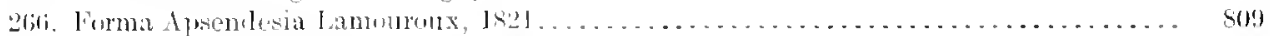

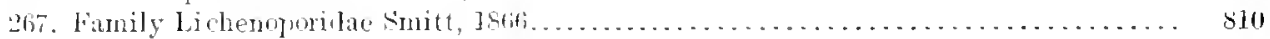

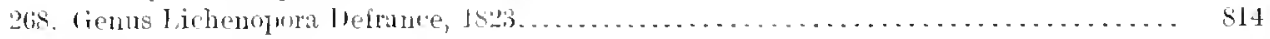

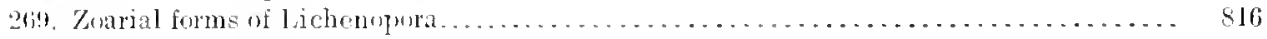

270. (1)

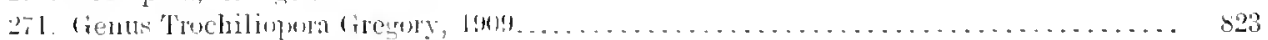

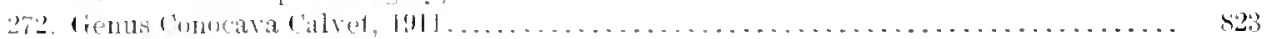

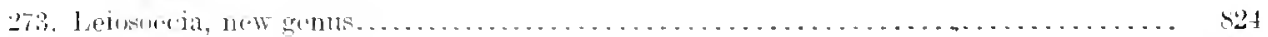

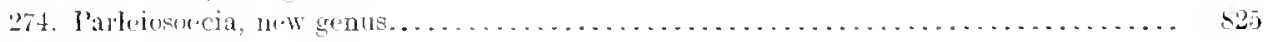

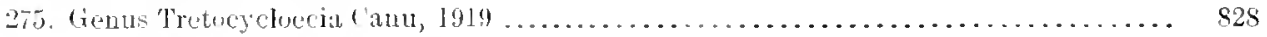

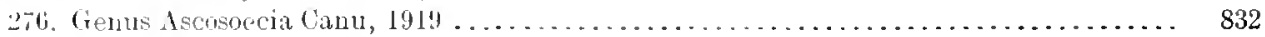

27 . Furna Multicarea $D^{\prime}$ (Hhigny; $1852 \ldots \ldots \ldots \ldots \ldots \ldots \ldots \ldots \ldots \ldots \ldots \ldots \ldots \ldots \ldots \ldots . . \ldots 35$

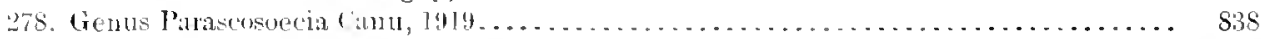

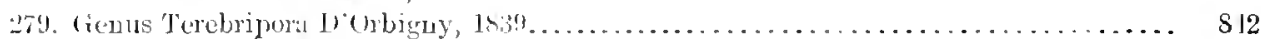




\title{
NORTH AMERICAN EARJI TERTIART BRTOZOA.
}

\author{
By Feludinad Caxu, \\ of Versailles, France. \\ AND \\ RAT S. BAssler, \\ of Washington, District of Columbia.
}

INTRODUCTION.

PRET.MLATIOX ANO SCOPE OF TIIE WORK.

Although the great abundance and splendid preservation of the bryozan in the Tertiary rocks of the Atlantic Coastal Plain and the Gulf region have been known to students since early in the last century, so little attention was paid to this class of organisms that the publications upon them number scarcely more than a dozen. Moreover these, with a very few exceptions, give so imperfect an idea of the comparatively few species described that the field of American Tertiary bryozoology may be considered as almost a virgin one.

Upon his appointment to the division of paleontology in the United States National Museum in 1901, the junior authol of this monograph began to accumulate collections of American Tertiary bryozon. In a fer years sufficient material had been assembled and studied in a preliminary way to prove the great value of these organisms in the most detailed stratigraphic correlation. When it is known that at many localities exposing Tertiary strata the bryozoa are practically the only fossils to be found, the need of this systematic study, if only for correlation purposes, is apparent.

In 1906 when the Coastal Plain Inrestigations of the United States Creological Survey were reorganized with Dr. T. Wayland Vaughan in charge, the active cooperation of Doctor Vanghan and his assistants was secured in furthering the collecting of hryozoa. By 1912 the collections resulting from these combined efforts had become so large and numerous that the Director of the Geological surver. upon the recommendation of Doctor Vanghan. proposed that the materials he made the suljject of a monograph. The junior author assented to the plan but snon formi that one person alone conld not hope to complete the necesiary work in a reasulable length of time. Besides, the intimate relationship of the Tertiary lyrozom with the living forms required a good knowledge of the taxomomy and anatomy of the recent species on the part of the stndent who attempted the leseription of the fossil forms. With the consent of the Geological survey anthurities the junior anthor thereupon proposed to Ferdinand Canu, of Versailles, France, whose stulies had been mainly on the Tertiary and Recent hryozon of Eirope and South America. to $5.599-19-$ I3ull. 306-_ 
join him as senior author in the work. Upon his consent, the study, description, and illustration of the numerous American species were energetically pursued and much progress had been made previons to the ontbreals of the great war. This was natmally lessened by the eivil mobilization of the senior author, but he was stil] enabled to spend a portion of his time upon the work. By the end of 1917 , in spite of other cxigencics arising from the war, the present monograph. comprising over 700 species of lower. Tertiary bryozon, had heen completed and the study of the upper 'Tertiary forms mucl adranced. In view of the necessarily slow publication of a largo palcontological work, the anthors early in 1917 issued preliminary descriptions of certain new gencra and families, published as Bulletin 96 of the United States National Muscum, under the title: A Symopsis of American Early Tertiary Cheilostome Bryozoa.

The Tertiary bryozoa belong almost entirely to the two orders Cyclostomata and Cheilostomata, the number of the latter being almost donble that of the former. In North Amcrica the Midwayan, Wilcoxian, Claibornian, Jacksonian, and Vicksburgian groups contain by far much larger faunas of this class than the succeeding rocks. Fol convonience only, the above-named groups have been designated as the Early Tertiary and their bryozoa are described in the present rolume. The study of the American Miocene; Pliocene, and Pleistocene species has been completed and it is hoped that their deccription can be published in the near future.

With a very few exceptions all of the type-specimens described and iłlustrated in the present volume are contained in the paleontologic collections of the United States Nationa] Museum. The Museum catalogue numbers are given in the plate descriptions. The station locality numbers of the Tnited States Geological Survey are cited on pages 15 and 16.

The illustrations were prepared by photography, an ordinary 3 -inch objective being used in a camera with a long bellows. The photographic prints were locally strengthened only enough to retain the scientific details when the illustrations are reproduced by half tonc. It has been found most satisfactory from an artistic standpoint to blacken the apertures in many cases: indeed. this is often the only retouching that the prints liave undergone.

The plates are arranged accorting to the five large geological divisions here treated-Midwayan, Wikoxian. Clabornian, Tacksonian, and Vicksburgian. Under each of thesc divisions the species are arranged as nearly in biologic order as possible. It should be noted, however, that any species which occurs in tro or more of thesc divisions is ilhstrated only under the oldest one. Thus, for eximple, the illustrations of a species ocemring in both the Claibornian and Jacksonian are to be found only on the Claibornian plates.

ACTNOWIEDGMENTS.

In the accmmlation of data and specimens for the preparation of this mumaraph the authors are inclebed particularly to the various geologists of the 
Eastern and Southern States where Tertiary strata outcrop, and to the Federal geologists who have encouraged their studies. To Dr. George Otis Smith, Director* of the United States Geological Survey, and to Mr. David White, Chief Geologist, obligations are due for their kind interest in the work and for the help of the Survey in the preparation of the work. Especial recognition is due Dr. T. Wayland Vaughan, Chief of Coastal Plain Investigations of the Federal Survey. It was at his urgest request that the study of the Amerion 'Tertinry bryozon was undertaken; he has spared no efforts to hetp the work along, not only by his own personal exertions in supplying both stratigraphic and palcontologic data. but also in having his assistants collect and prepare many lots of fossils for this special study: and his adrice and broad experience in all matters relating to the American Tertiary formations have been of inestimable value.

Dr. C. Wythe Cooke, of the Inited States Geological Surrey, has supplied many splendid faunas resulting from his stratigraphic work in Alabama and Georgia particularly. He is the discoverer of the celebrated Vicksburgian locality near Monroeville, Ilabama. and it is due to his intelligence and care in collecting fossils and recording stratigraphic data that it has been poscibte to rork out many of the bryozoan faunal zones of the American early Tertiary. Thanks are due to Mr. Wendell C. Mansfield. of the United States Geolngical Surver. for collections, and to Mr. I. B. Milner. of the same organization, for his care in the preparation and preservation of these hitherto neglected fossils.

Dr. Charles D. Walcott, Secretary of the Smithsonian Institution, and Dr. Richard Rathbun. late Assistant Secretary in charge of the United States National Iluseum, extended varions courtesin during the comrse of this work and furnished financial assistance for making special investigations and for the publication of the work. Under these auspices the junior author was enabled to make researches, particularly in North and Sonth Carolina. and to collect the rery large middle Jacksonian famns here described.

Dr. Charles E. Resser and Miss Idelaide C. Quisenberry of the division of paleontology of the United States National IItseum, have been of great aid to the junior author throughout the work. Doctor Rescer has assisted materially in the preparation of numerous text figures. and Miss Quisenberry has taken a most active interest in the translation and preparation of the manuseript. The retonehing of the photographs and the preparation of the drawings have been done by Miss Francesca Wieser, of the United States Cienlogical Survey, whose skill and faithful work is herein again attested.

Mr. Earle Sloan, of Charlenton. Sonth Carolina. Was most kiml in furninhine numerous specimens and in personally combeting the jumion anther during a trip throngh the Southern States to classic localitics. which, withont his hetaiken knowl-

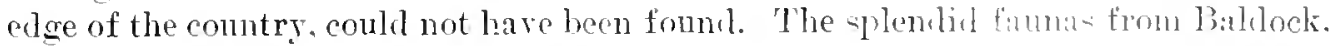
Entaw Springs. and Lenude Ferry, South carolina. are dne to Mr. Sloan's gen-

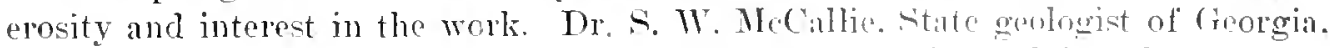
has also fumished collections which have hen of allu in -tulying the 'Tertiary 
stratigraphy of that State. Dr. Eugene A. Smith, the first to decipher the correct sequence of lower Tertiary formations in the Southerm States, supplied important collections from Alabanil particularly from the Midrayan group.

Ample collections of washing with hryozo: from the typical Jacksonian of Mississippi were secured by Mr. E. X. Lowe. State geologist, who has been ever ready to obtain material to alvance these stmlies. 'The lower Jaclisonian fauna lierein described is largely the resnit of Mr. Lowe's efforts. Mrr. John M. Nickles also has contributed specimens for study: particularly from the Midwayan of Arkansas.

The Ulrich collection, now the pronerty of the United States National Museum. has furnished some excellent materials of great use in the present monograph. 'The authors have also had the advantage of the advice and experience of Dr. E. O. Uhrich, who marle these particular collections in the hope that some day the subject would be monographically treated.

Professor H. Dourillé. member of the Inetitute of France, has verified our clins:fication. and he has been most generons to the senior author with his advice and encouragement. We are sincerely thankful for his help.

The anthors are deeply arateful to the National Acadeny of Sciences for financial assistance which made it posilue for then to prepare and include in this monowaph the important portion relating to the Cyclotomata. therely completing the stury of the North American early Tertiary species.

ORIECT ANI, IIFTIIODS OF STUDT.

There are many minute openings am almoit imperceptible protuberanres on a foril loreozan. Their emmeration. the reaceiption of their form, size, and position would be a work both tedious and perfectly nseless, unless, by the aid of zoology, a reason for their presence can be obtained. Here. more than anywhere else, the intimate union of zoology with paleontology is absolutely necessary.

The fossil bryozon are more than small perturnted stones. They are the remains of creatures of a former time, and the object of the palcontologist shonld he their resurrection. His riole is to animate them in order to classify them. and to classify them correctly in orier to use them.

This fertile method of constint comprisum with the living specimens is tending to prevail in Europe, but here in Anerica rircumstances, notably the predominance of the Paleozoic famas, have not permitter its application in bryozonlogy. The present authors have endeavored to inangurate this method of research in America by a stuly of the exuberant famis of the great Anericin Tertiary Gulf. They have endearored to describe the fantus an an to be molerstond by all maturalists and not by the specialist alone.

The lack of lare monographs now hryozonlogy canses the stuly of the frosil forms to be exceptionally difbeult. The mont recent monograple, that of IIincks. dates from 1580, and is eoncerned only with Great Britain. Since that time, it is true, important researches have leeen malle by many eminent naturalists of all comntries and publisled in a great 13 muber of ecientifie works. in all languages. All these works are assembled only in the librarie of the very few specialists who 
at present study these interesting animals. The paleontologist who has not followed closely the development of all theso researehes and who is not himself a trained zoologist is absolutely powerless to prepare a useful work. On the other hand, a large paleontologic work prepared ly a competent zoologist would be little comprehended by the realers, since they have not been able to study any comprohensive work embodying the more important progress in bryozoology.

The present writers were therefore in a quandary since hy preparing a strictly paleontologic monograph they ran the risk of publishing a nork incomprehensible and discomraging to students and collectors alike. In order to avoid such a result they alecibed to closely associate the paleontelogy and zoology of the lyryozoa by the introduction of numerous text figures. wherein the more recent work concerning each of the fanilies and genera considered is illustrated. Naturally this is not as comprehensive a zoologic rork as could be desired, but it is sufficient for the exact interpretation of the structure of the Tertiary hryozon of American stratia. This has been supplemented by liste of reent and fossil species under ench genus. No attempt has been made to classify all the known species, but the lists are simply complete enough to remain exact.

The terminology of the luyozon ha-becone somewhat specialized, althongh it is still far from being rery complicated. The reader will easily become familiar with it by the aid of the special drawings scattered among the text figmres.

Although the Tertiary bryozoma often occur literally hy the million in $\mathrm{a}$ stratum. they are usually so inconspicuous as to be munoticed by the average collector. When these fossils are present a careful examination of a weathered outcrop will almost invariah]y reveal a few minute twig-like stems or porous, flattenel fragments projecting from the surface. Futher searh along the outerop, especially along a seam in the rock. is rery liable to result in the discorery of many sucli fragments.

Is most of the Imerican Tertiary leyozon oceur in soft limestome or marls, the collection of the materia] for study consists simply in scooping up a large amount of the loose rock containing these frumentary remains. If the specimens are found in a hard, indurated rock. it is usully only a matter of search to find

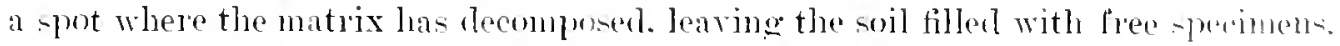
In any case it is not advisable to pick up the specimens one by one. not only un account of loss of time. but also of hreakage. On arriving at the laboratory the day or other rock holding the bryozoans shomld be allowed to soink in water for some hours. The material may then be agitated and the muddy water mum away. Continuing this process mtil the agitated water no bonger lurombe muldr, the resilual mass is set aide to bry. The debris when dry is then reaty for

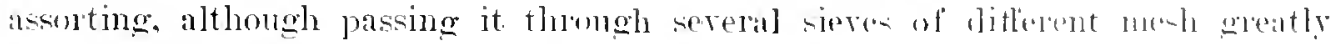
facilitates the assorting of the contained fossils.

Then bryozon are quite rave in any exposmpe it is wall to do most ot the

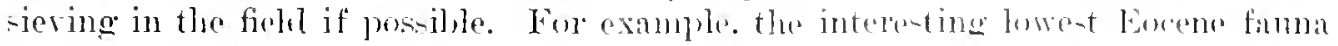

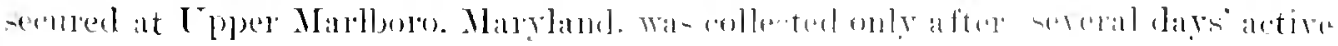


work of sieving the sand, and a small pill box was sufficient to hold the entire results.

In case these fossils can not be found in soft rock. it is often still possible to obtain good specimens for study. A comparatively bard fossiliferous rock when crushed in a sack with a wooden mallet will often afford fairly well-preserved fossils after the débris has been washed and sieved as mentioned above. In such a case the bryozoans, although likely to he broken into smaller fragments than usual, are generally well enough preserved for accurate determination. If the rock is calcareous and too hard to yield to such treatment, thin sections may he employed to determine the bryozoa. If the matrix be siliceous the fossils are almost invariably present as molds, in which ease gutta-percha squeezes afford excellent resuits.

The separation into species of the framentary specimens resulting from the washings can be made with an orlinary hand lens magnifying eight or ten diameters. The identification of these species can also be made under such a lens providing the species have already been well described and illustrated. In the identification and disenvery of the characters of new species. however, a higher mannification is necessary, and also some sperial sections must be preparer.

First thin sections of the walls. partienlarly the frontal, are needed to ilhstrate the characters of the three layers. oloryt. tremocyst. and pleurocyst. Second, the frontal must be abracled away to show the ocenrence of such structures as dietellac. This abrasion is effected by mounting the fossil. frontal side up, in Canada balsam on a slide and after heating to harlen the balsam. rubbing it gontly on a soft hone. Third. by the preparation of a similar section the interior of the frontal side can be studied. Calcification on the frontal flequently obseures the true form of the apertura and its accompanving struetures. These are all well preserved on the inmer side of the frontal. so by momnting the fragment in balsam. onter face down. and rubbing away the olposite silp. the structure of the interior is clearly revealed. Throughont the description in the present work this section is spoken of as "in the

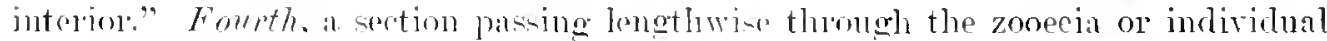
cells is necessary to determine the nature of the ovicell as well as the general structure. This section requires much atre an the specimen must be mounted on edge and the abrasion must follow a definits low of cells. By the use of small wire nippers it is easy to trim the specimen to just the right form. then by monnting it in hardened balsam between two small bits ol' wood (framents of a match serve exeellently) to hold it on elwe. the abrasion can lo continned until the desired section is obtainesl. Fifth, actual dissection of the fossil specimens with a fine needle under the microscope is often necesary. e-perially to determine the mature of the ovicell.

It will now he erident that the deseription of the small openings on a fossil bryozoan is the least part of their stmely and that as refined methods of research may be employer on these microsepic form- ar on any other elass of animals. 


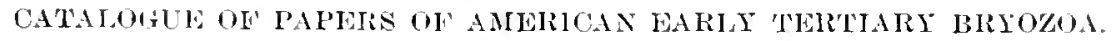

1833

LEA, Isac. Contributions to Geology. Philadelphia, 1833.227 lm., g pls. The bryozoa described are as follons; all are from the Eocene at Clabolne. Alabama: Lumulites bouri. 11. 189, 11. 6, 202.

Lunulitcs alurlosii, 1). 190, pl. 6, 203.

Orbitolites interstitia, P. 191, 11. 6, 204.

Orbitolites lisroillen, p. 192. pl. 6, 205.

1845.

Loxsdale, Wildan. Account of 26 species of Polyparia obtained from the Eurene Tertiary formations of Jorth America. (Quart. Journ. Feol. Soc. Iondon, vol. 1, pr. 509-533.)

Tubulipora probnscilea : (Milne-Edwards), 1. 522. Locene: Rocks Pridge.

Idmonca marillaris, new species, p. 523. Eocene: Wantoot, South Carolina.

Idmonea commiscens, new species, p. 524. Eocene: Rneks Bridge.

Hippothoa tuberculum, new species. 1). 52T. Encene: Rocks Bridge.

Eschara tubulata, new species. P. 52S. locene: Wilmington. North Carolini.

Eschara petiolus, new species, 1. 5s. Eocene: Eulaw, South Carolina.

Eschara incumbcns. new species, 1, 529. Eocene: Roclis Bridge. Sonth Carolina.

Eschara linen. new species, p. 530. Eocene: Eutaw, Soutb Carolina.

Eschara timinca, new species, 1. 330. Encene: Eutaw. Sonth Carolina.

Lumulites scrungulu, new species. p. 531. Eocene: Wilmington, Wantoot (?).

Lumulites contigur, new species. p. 533. Eocene: Wilmington.

$18+7$.

Coxrap, T. A. Observations on the Eocene formation, and descriptions of 105 new fossils of that periol from the vicinity of Vicksburs, Mississipri. with an appendix. (Iroc. Acad. Nat. Sci. Philadelphia, vol, 3, 1847, pp. 2s0 200.)

Lunulites ricksungensis, 1), 296

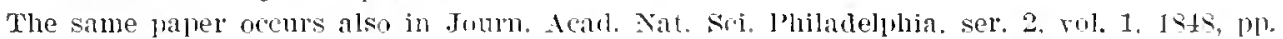

1]1-134, pls. xi-xiv.

Lumulites ricksungensis, 1). 12 .

185.

Emarows, Ebenzar. Report of the Forth Carolina Geological survey. Raleigh, 195s. Paleontologs. pp. $193-314$.

The only Eocene bryozon described is Lumblites contigua, 1) 311, figs. 2-0, 2.i]. Eocene: Tilmington. North Carolína.

1862.

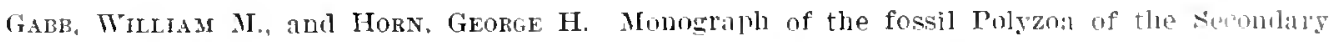
and Tertiary formations of North America. (Jomrn. Acad. Nat. Sci. Philaderhia. ser I vol. 5. 1662, 1小. 111-17s, pls. 19-21.)

Eschara tubulata Ionsdale, F. 115. Eocene: Wilmington, North Carolina.

Eschara pctiolus Lonsdake, p. 116. Eocene: Eutar. South Carolini.

Eschara incumbens Lonsdale, p. 116. Eocene: Rocks Bilige, Soutli Culolina.

Eschara ? viminca Ionsuale, p. 116. Eocene: Entaw, Sonth Calolina.

Eschara texta, new species, p. 117. pl. 19, fig. 1. Focene: Charleston. Sonth Carolina.

Eschara ovalis, new species, p. 115, pl. 19, fig. 2. Eocene: Clailurmu, Alabama.

Lumulites scrangula Jonsiale. D. 119. Eocene: Wilmingtun. North Carolina.

Lumulites distans I,onsdale, p. 11?. Incality not given. 
liabe. William M., and ITolin, George II. Continued.

In uliles interstitia (Lea). p. 120. Eocene: Claiborne, Alabama.

Lunulites contigua Lonsdale, p. 121. Eocene: Wilmington, North Carolina.

Scmicschara tubulata, new species, 1. 122, pl. 19, fig. 5. Eocene: Claiborne, Alabama.

Cellemra cycloris, new species, p. 12т. pl. 19, fig. 9. Eocene: Claiborne, Alabama.

Cellcpora inomata, new species, p. 127. pl. 19, fig. 10. Eocene: (?) Claiborne. Alabama.

Reptocellonoraria glomerata, new species, p. 134, pl. 19, fig. 15. Eocene: Ticksburg. llississippi.

Escharclla micropmo, new species, 1\% 136, 11. 19, fig. 17. Eocene: ? Anbama.

Rentesclarella carolinchsis, new species, p. 136. pl. 19, fig. 1S. Eacene: Charieston, South Calolina.

Oligotresium ricksturgensis (Conrad) p. 139, pl 19, fig. 22. Upper Eocene: Vicksburg. Mississippi.

Escharinclla ? linca (Lonsdile), p. 140. Eocene: Eutaw, South Carolina.

Discofustrellaria bonci (I.ea), p. 154. Eocene: Claiborne. Alabama.

Cupularia discoidca (Lea), p. 155. Eocene: Claiborne. Alabama.

Heleractis duclosii (Lea), p. 156, pl. 20, fis. 39. Eocene: Claborne, Alabama.

Itmonet maxillaris Lonsiale. I. 16it. Worene: Wantoot, Sonth Carolina.

Idmonca commisccns Lonsdale, p. 169. Eocene: Rocks Bridge, South Carolina.

Entalophor" moboscidcoirles (Lansdite), 11. 170, 11. 21, fig. 60. Eurene: " Alabams.

\section{2.}

Ulurch, E. O. American Paleozoic Bryozon. (Jomrn. Cincimmati Society Natural Histors, rol. 5. 1982).

Itroropom attenuata, new species, p. 111, pl. 6, fig. 12. Midwayan: Pulaski Comty, Arkansis.

Hetcropora consimitis, new species, 11. 145, ll. 6, fier. 11. Mlilwayan: Pnlaski Counts, Arkinsas.

1890.

Gregorio, ANToNio DE. Monographie de la Faune Encenique de l'Alabama et surtout de celle de Claiborne de l'Etage Pinisien. (Annales de Géologie et he Taléontologie. Livraisons 7 and s. Palermo, 1500. $316 \mathrm{pl}$., 40 pls.) The bromzon describel from the Eucene of Claiborne, Alabanit, are:

Crisia laeta De Gregorio, p. 239, pl. 39, figs. 10, 11.

Jyriosoum propepunctatum The Arregrio, p. 2s9, 1). 39. firs. 12-13.

Alyriosoum fervens te Gregnio, 1. 239, j1. 20, figs. 14-15.

Idmonea subdisticha be Gugario, p. 259. pl. 39, fig. 16-20.

Entalophora poboscidoides Gab and 1101n, 1). 240, pl. 39, figs. 26-27.

Entalophora amoena ]e Grogotio, 1). 240. 17. 39, fig. 21.

IInnera mivifica De Gregorio, p. 240, 11. 39, figs. 81-32,

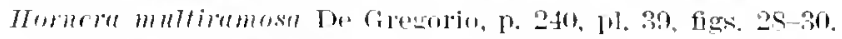

Hornera claibornensis De Gregorio, 1). 241, 1. 39, figs. 22-23, 33-34.

Hormera, speries (?) p. 241, pl. 39, figs. 24-25.

Eschara (?) spongiopsis the Grescorio. 1) 241, pl. 40. fies. 1-2.

Eschara ovalis Gabb and Horn, ]. 241, 11]. 40. figs. 3-5.

Escharclla sifra De Gregorio. 1). 242, ril. 40, fiess. 6-7.

Escharclla micropora Gabb and lIorn. 1. 242. pl. 40, figs. 8-22, 23.

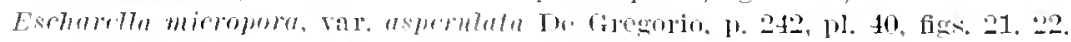

Semicschara tubnlata Gabb :tnd IIorn. 1). 242, pl. 40, figs. 24-28, 29-31.

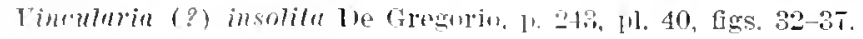


GRegonio, Axtonio ne-Continumed.

Lunutites (Discofustrellaria) bonci Lea. p. 243, pl. 41. figs. 1-4. j-6. 7-9: nl. 42. firs. 1-6.

var. concata De Gregorio, p. 244, pl. 41, figs. 10-14.

var. depressa De Gregorio. p. 244. 11. 41, figs. 15-19.

var. ellipsoiles De Gregorio. 11. 245, nl. 41. firs. 20-21, 23-25.

var. duclosii (Lea) De Gregorio, not Gabb and Horn, p. 245. 11. 41, 26-31, 32-33.

var. truncata De Gregorio. 1. 245, ni. 41, figs. 31-46.

var. almina De Gregorio, 11. 24t. pl. 42, figs. 7-10.

var, tiza De Gregorio, n. 246, pl. 42, figs. 11-12.

var. minuteccllulata De Gregolio, P. 246, pl. 42, figs. 13-15.

Batopora convirialis De Gregnio, p. 246, pl. 42, figs. 30-33.

Cellepora inornata Gabb ani Horn, 1) 247, 1). 43. figs. 2, 3-4.

Cellepora cycloris Gabb and Horn, p. 247, pl. 43, fig. 1 .

Celtcporaria figula De Gresorio, p. 247, pl. 43 , figs. 5-6.

Biflustra (?) supradubia De Gregorio, p. 245, pl. 43, figs. 11, 12.

ICmbranipora simplex De Gregorio, p. 245. pl. 43, figs. 7-S.

Membranipora contemplata De Gregorio, p. 24S, pl. 43, figs. 9-10.

Dimiclausa De Gregorio, new subgenus, r. 245.

Lunulites (Dimiclausa) fcncstrata De Gregorio, p. 249, pl. 42, figs. 23-27.

Lunulites (Cupulariu) interstitia (Lea) De Gregorio, 1). 2-19, pl. 42. figs. 16-21. 22.

Cupularia discoidea Lea. species, p. 249. pl. 42. fig. 29.

Lunulites distans Lousdale, species dubious, P. 250. pl. 42, fig. 29.

1901.

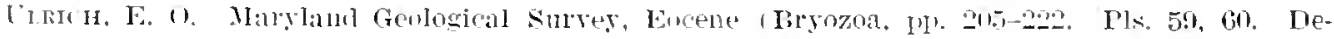
scribes the following species, all from the base of the Aquia formation at Upper Marlboro, Maryland:

Discosparsu rarians, new species. p. 205, pl. 61, ti̊. 3.

Fascipora subramosa, new species. p. 207, pi. 50, figs. 1, 2.

Reticulipom lichotoma Gabb and Hom, p. 20\%, pl. 59, figs. 9-12.

Cavaria dumosa, new species, p. 20s, pl. 50, figs. 4-s.

Ceriopola micropora Guldfuss, p. 210, pl. in. fics. 13, 14.

Heteropora? tccta, new species, p. 210, D. 59, figs. 15, 16.

Ucmbranipora rimulata, new species, p. 211, pl. 60. figs. 1, 2.

Membranipora spiculosa, net species, r. 212, pl. 60, figs. 3, 4 .

Yembranipola angusta, new species, p. 219 , pl. 60. fics. 5. 6.

Reptoflustrella heteropora Gahh and Iform. P. 2I?, pl. 60, ligs. S, 9.

Biflustra torta Gably and Horn, p. 214, pl. 60, fig. 7.

Eschura ?? digitatı Morton, 1. 216, 11. 60. figs. 10, 11.

Lunulites reversa, new species, p. 21T, pl. 60, figs. 19, 20.

Cribrilina modesta, new species, 17. 218, pl. 60, figs. 12. 13.

Critrilina crassula, new species. I. 21s, pl, 60, fig. 14.

Lemalia subplana, new species, p. 219. pl. 59, figs. 17, $1 \mathrm{~S}$.

Lcpralia labiosa, new species, p. 220, pl. 60, figs. 15, 16.

Jucronella aspera, new species, p. 221, pl. 60, fiss. 17. 1S. 
1917.

Canu, Ferdinand, and Bassler, Ray s. A Symonsis of American Early Tertiary Cheilostome Bryozoa. Bulletin 96 U. S. National Museum, $87 \mathrm{pp} .6 \mathrm{pls}$. Present a classification and lescribe the following nuw genera and the genotype of each whenever the species is new:

Acanthocella, Aeanthionella, Adenifer, Lerhmella, Bathosella, Cribrendoccium, Cystisclla, Dacryonella, Didymosella, Diplopholeus, Fnoplostomclla, Floridinclla, Gastropella, Hippadenella, Hippellozoon, Hippomenella, Hipposeugosella, Kleidionella, $\mathbf{y m}$,lla, Leiosella, Memuraniporidra, Mcmurendoccium, Jetracolposa, Metradolium, Metroerypta, Metroveriella, Ochelosclla, Odontioncllu, Ouiralima, otionclla, Perigastrella, Plagiosmittia,

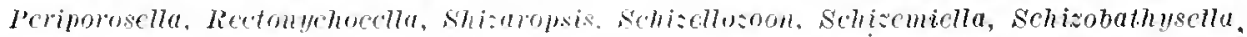

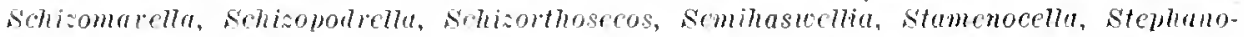
sella, Stomachctosclla, Tremotoichos, Triphyllozoon, Tubucella, Velumella, Vibracellina.

\section{SYTONYMIC IREFERENCLS.}

The following alphabetic list gives the present position of all the North American early Tertiary bryozoa described previously to 1917 . This list supplements the chronological catalogue of papers printed un pages $\tau$ to 10 . By comparison with this catalogue it will be noted that the larger part of the old species has becn identified, with the exception of those contained in the work of De Gregorio, 1890. This author's decriptions and illustrations are so poor and his localities so indefinite that in the majority of cases it has been impossible to consider his species as recognizable.

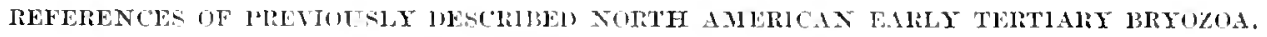

Batopora contilalis be Gregorio, 1890. Cot recognized.

Biflustra (:) suprudubia De (irearorio, 1sim. Not recognized.

Biflustra torta Gahb alul IInn, 1>82. See Euritina torta.

Cavaria alumosu U1rieb, 1:k1. See Partretocyctocin alumosa.

Cellcpora cycloris Gabb and Horn, 151;2. See Prriyustralla cycloris.

Cellepora inomuta Gabb and Iroun, 1stiz. See trybostegu inormatu.

Celleporaria figula De diregorio, 1s,o. Not recognized.

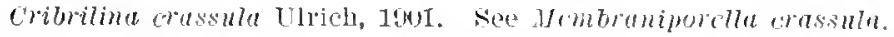

Cribrilina molesta llich, 1901. Ses Vembreniporella modesta.

Crisia lactu De cireurorio. Not recognizable.

Cupularia hiscondea Iea. Not recognized.

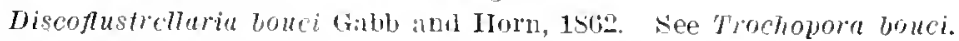

Discosparsu lariuns UTrich, 1001. See Diupcrocciu rarians.

Entalophora anocha lie Giecolio, 1590. See Heteropora amoena.

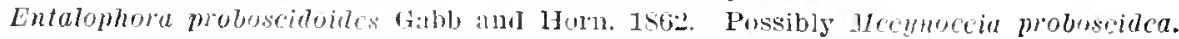

Eschara digitat, Norton, 1 s.3. See Coscinopleura digitatu.

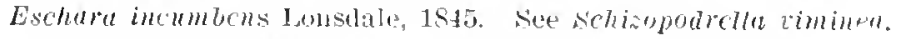

Eschara linca Ionstale, 1sta. see schisopodrella linca.

Eschara avalis Gably and Horn. 1sto. Not recognizad.

Eschara petiolus lousdile, 1515. See Himpoliplesclla petiolus.

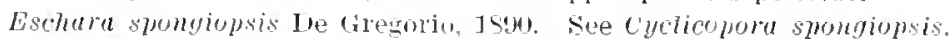

L'schure texta Gabb allu Horn, 1sti2. See schiropodrcha timince.

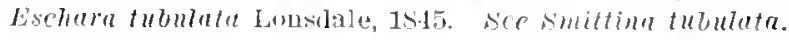

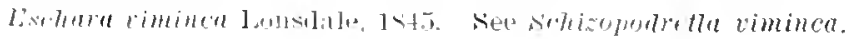




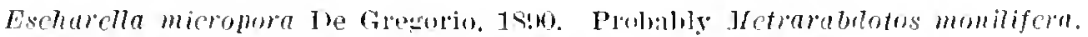
Escharella mirropom, var, asperulatu I Gregoriu, 1890. Sor recognizable. Escharella sifm De Gregorio. Not recoguizable.

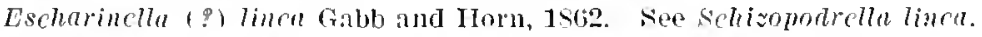

Fascipora subramosu Ulrich, 1901. See l'lagioccia subramosa.

IIctcractis duclosii Gabb and Itorn, 1862. See Trochopora bouci.

IIeteropora attcnuata Ulrich, 1852. See Tretocyeloccia aftenuata.

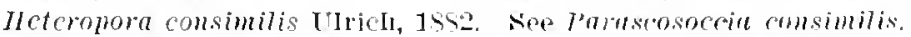

Hippothoa tubcrolum Lousdale. 1S15. See Pyripora tuberculum.

Hornera claiborncnsis De Gregorio. Not recognized.

Horncra mirifica De Gregorio. Not recognizable.

Hornera multiramosa De Gregorio. Not recognizable.

Irmonea eommisorns LoHsdale. 1St5. Not recognized.

Idmonca marillaris Ionstale, 1Sta. Sce Jlmidrunct matillaris.

Idmonca subdisticha We Gregorio. Not reconnizible.

Lepralia labiosa Ulich, 1901. See chcilopora labiosa.

Lepralia subplana Ulrieb, 1001. See Ircniscupora subplana.

cunulites bouci Iea. 1833. Sce Trochoporn buuci.

Lunulites (Discoflustrcllaria) bouci De Gregorio, 18no. See Trochopora bouei.

Lunulites (Discofustrcllaria) bouci, var. almima Te Gregorio, 1S90. See Trochopora buari.

Lunulites (Discofustrellaria) uouci, var. rmme De Gregorio, 1800 . See Truchopora busci.

Lunulites (Jixrofustrcllaria) bouci, var, dcpressa. De Gregorio, 1s90. See Trochupora bouci.

Lumulites (Disenflustrclluria) bouci, rar. duclusii De Gregorio, 1800. See Trochoporn bunci

Lumulites (Discofustrellaria) bouci. var. cllipsoides De Gregorio, 1890. See Trochopora bonci.

Lunulites (Discofustrellaria) bouri, rar. minutrcellulata De Gregorio. 1890. Not recugnized.

Lumulites (Discofustrellaria) bouci. rar. ti=a De liesorio, 1S00. See Trochopora bouci.

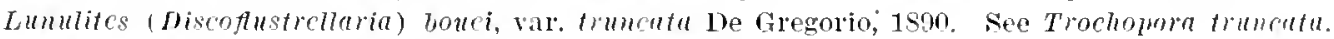

I.unulites contigua Lonsiale, 1Stes. See Lumularia contigua.

Lunulites distans Lonstale, 1845. Set Lunularia distans.

Lunuliles duclosii Iea, 1833. See Trachopma bnuci I ea, 1833.

Lumulites (Dimiclunsa) fcnestrata De Grugriu, 1s'm). See Lumularie fencstruta.

Lunulites interstitia Gabb and IIorn, 1s62. See Schi:prthosecos interstitia.

Lunulites (Cumularia) intcrstitia De (ipegurio, 1s!o. See Srhizorthosccos interstitin.

Lunulites reversa Urich, 100J. See Lunularin rerersu.

Lunulites sedangula Lousdale, 1S45. Not reagnized.

Lumulites ricksburgensis Conrad, 1547. See Lunularie (Oligotresium) vicksburgusix.

Hembranipora angusta Linich, 1901. See Lillisina angusta.

IL maranipora contemplata De Gregorio, 1s60. Not recognizable.

Membramipora rimulata Ulich, 1901. Sec Jembraniporima rimulatu.

Hembranipora simplex De Gragoriu, 1S!n. Not recognizable.

Lembranipora spiculosa Ulrich, 1901. See Ellisina spiculosa.

Myriosonm ferrens De Gregorio, 1890. Not rocuruizahle.

Vyriasoum propepunctatum le Gregorio, 1s90. Not recognizalble.

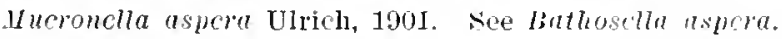

Oligotresium ricksburgensis Gabb and 1lorn, 1s62. See Lunularia 10ligntresilm, ricksulgensis.

Onychocella digitata Weller. Ṡee Coscinmplcum digituta.

Orbitolites discoillen Lea, 1S33. Not recusnizable.

Orbitolitcs interstitia Lea, 1833 . See Nothizorthosious interstiti.

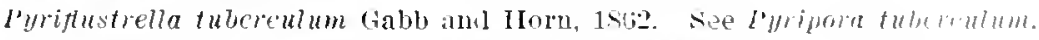

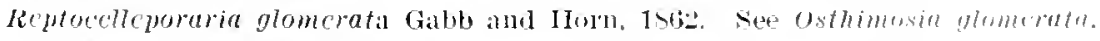

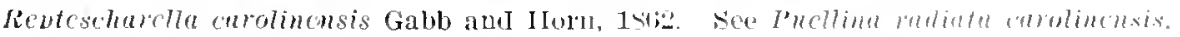

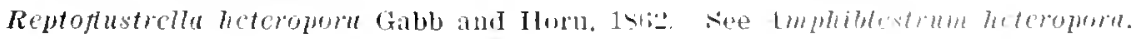


Reptescharellind disparilis Gubb and IIorn, 1stis. See licropora eoriacea. Reticulipora dirhotomn Gabb and Iorn, 180.2. See Lelibthionia dichotoma. Semieschart tubulata Gahb aui Iforn, 18ti2. See smittina tubulata.

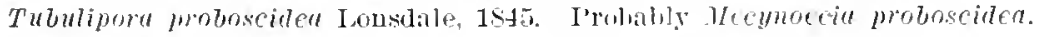
Tincularia (?) insolita De Gresnio, 1890. Nut recognizable.

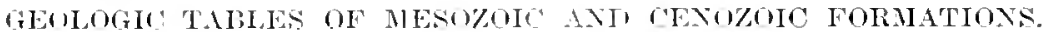

The following tables are introduced for comrenjence of reference in the locat ion of the rarious formational names employed in this monograph.

Table showing relations of Early Tertiary fumations of Athutic and Gulf states.

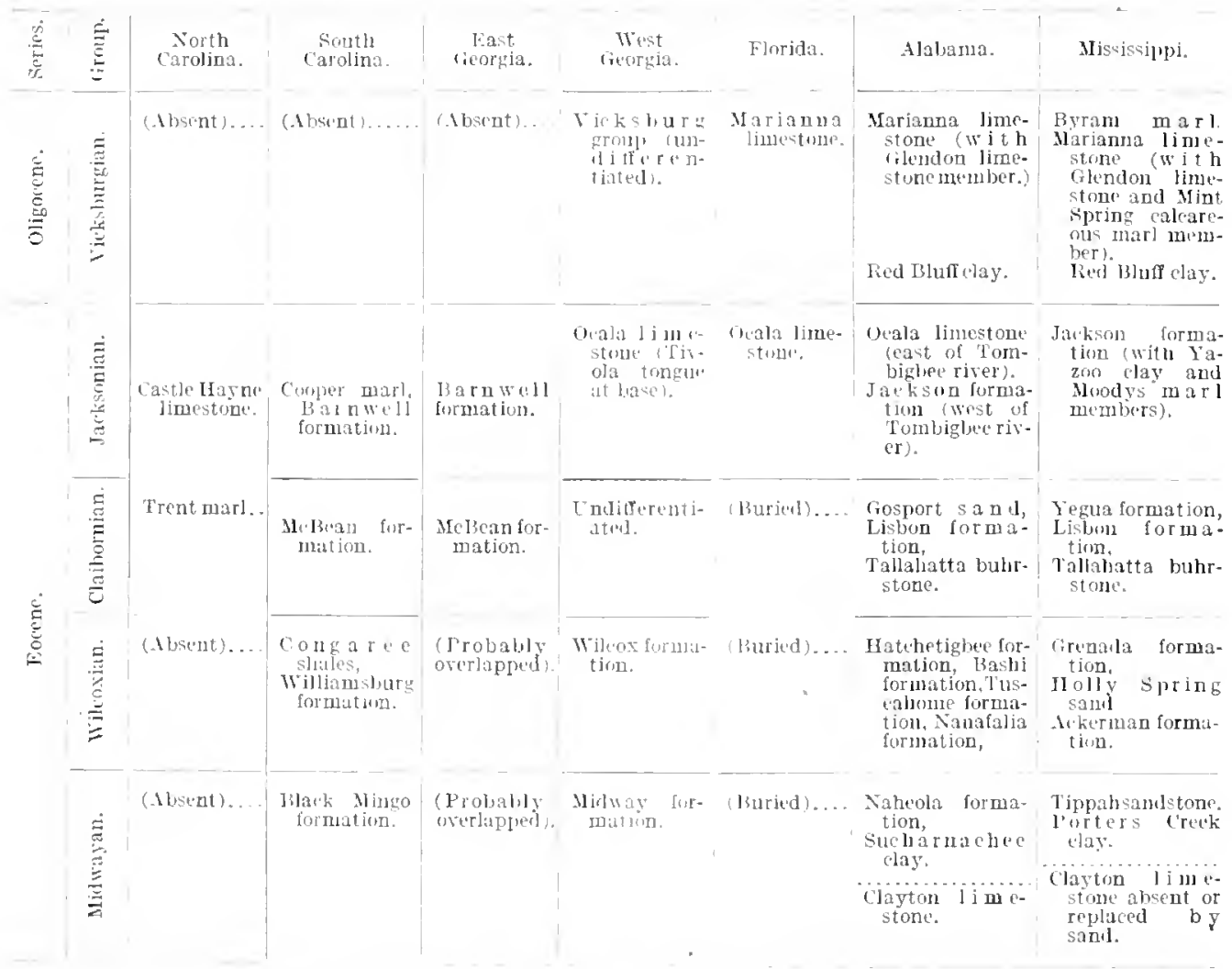

The alwre table shows the general relation- ot the eally Tertiary formations

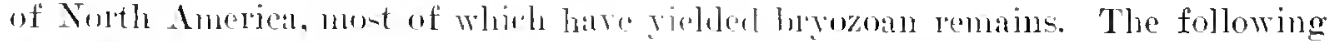

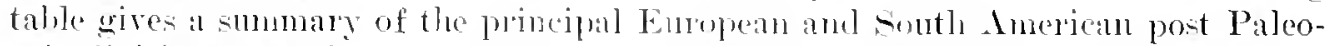

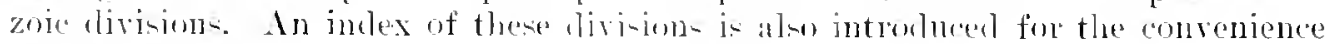
of the strelent. 


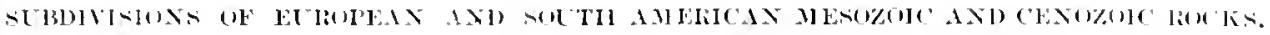

FUPOPE

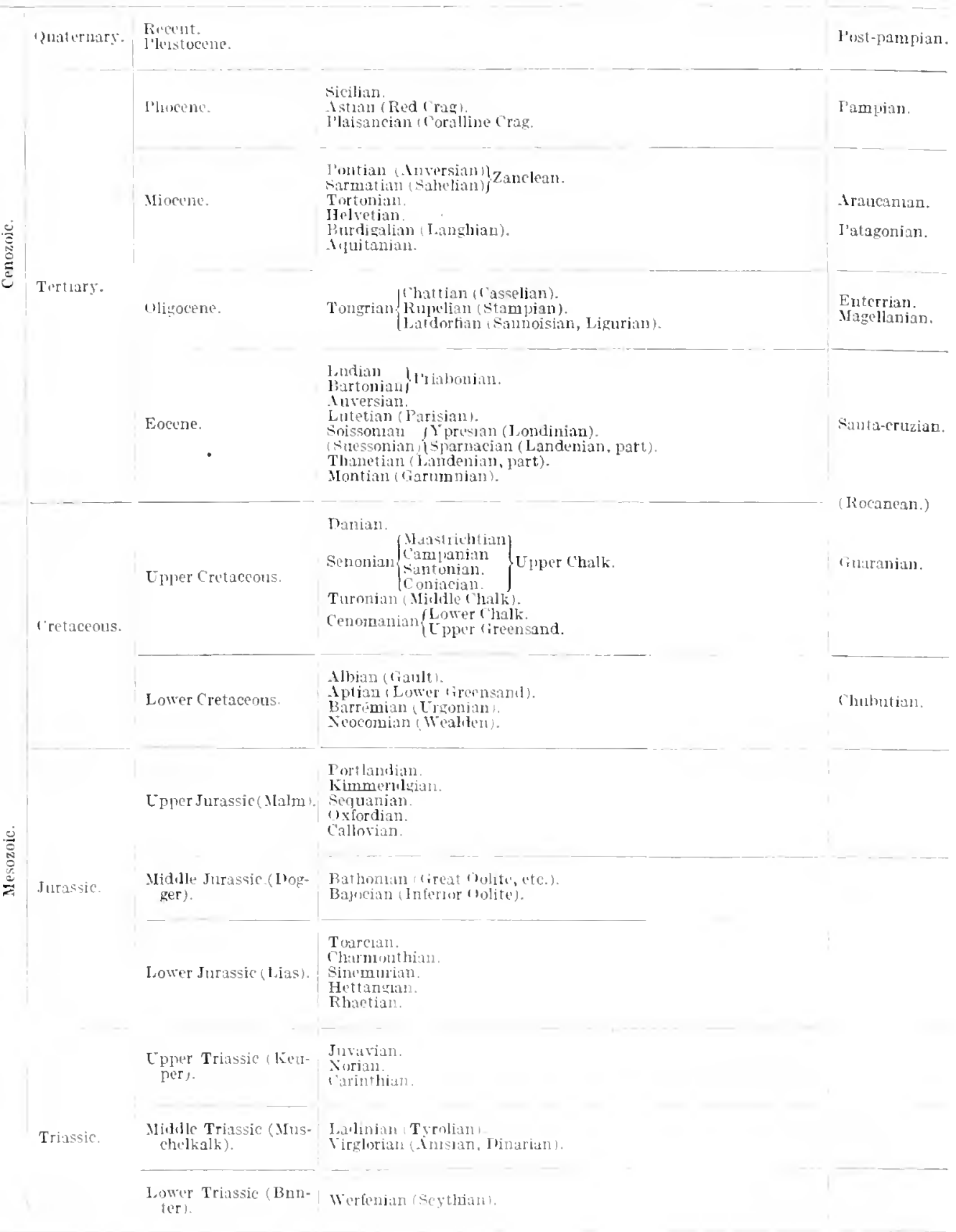




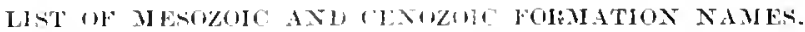

Ackerman formation. Wilcoxian.

Albian. Lower catacons.

Aurersian. Miocen.

Anisian. Mlalde Triasic.

Aptian. Lower Cretaceous.

Anuitupian. Minculle.

Arilucintan. Múneene.

Astiau (leed ('rilg), l'liocene.

Auvelsian. bocenc.

liajocian. Midule Juasic.

Laruwell fulmation. Ialcksenian

barrémian. Low cretaceons.

birtouian, Eocente.

bashi formation. Wilfuxian.

Bathonian. Niblle Jurasicic.

Istack IIngo formation. Minkayal.

fiurdigalian. Niocen.

Byrau marl. Vikksburgian

Callovian. L'pler arassic.

Campanian. Elmer cretaceons.

cariuthian. Copel Triassic.

tasselian. aligucene.

Cistl. Hayne imestonu. Jaclisunian

Cenonanian. Coure cretacens.

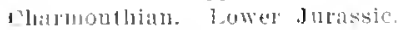

t'battiale. Uligureme.

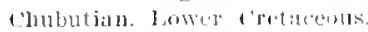

didyon liwastone. Muwayan

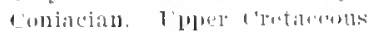

comsaree stades. Milusiall

Cooper marl. Jacksunian.

comalline craze. I'linene.

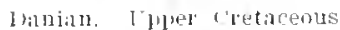

frinariatu, Vidhle Triassic

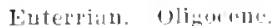

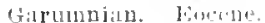

Gialt Lowel Ereticteous

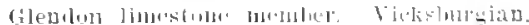

tiuspolt mand. Clabluruina.

tireat Gulite. Niddle Iurassic.

timalal formative. Wilcoxian.

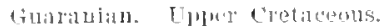

latchetiolwe formattan. Wilorian.

Ilelvetian. ylucene.

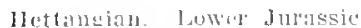

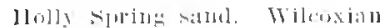

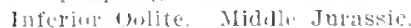

dackin formation. Tarclisonian.

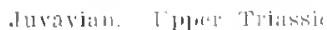

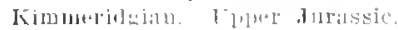

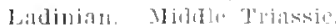

Landwita buerum

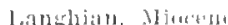

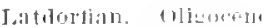

Liguriall (1)isurenu

lislun formatim. latilkatuian.

lendiuian lineme

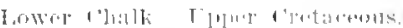

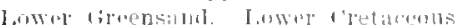

ludi:m. Fencent.

1.110.tian. Fisconu.

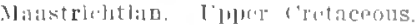

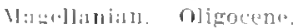

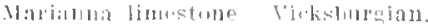

Ifchean formatiun. Claibruian.

Nidale Clatk. Luper Ch+taceous.

Milualy formation. Midrayan.

Miut Spriug calcareous marl menkst. Vickslurgian

llontian. Eocene.

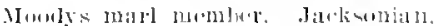

Nabeola formation. Midwayan.

Nanafalia formution. Wilcoxian.

Nexomian. Juwer Cretaceous.

Nonian. Lpher Triassic.

ncala limestone. Iacksonian.

Uxfor]ian. Tppor" Jurassic.

1"ampian. Flioceme

larisian. Evcene.

latagurian. Minceue.

Ililisancian. I'liocene.

Joutian. Hircene.

forters craek claly. Mirfwayn.

Jortlandino. Upuer Jurassic.

I'ost-uaurian. J'leistocene

I'liationian. Euceve.

IRed Lluff clay, Tirkslumeian.

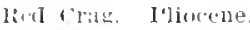

Ilbiatian. Loner Turassic.

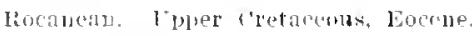

l'uplian. Olimwene.

Salielian. Hiocene.

Sanmuisian. Oligocene.

Santa-ruzian. Erocevi.

Santunian. lipuer Cretaceous.

Saruatian. Hiocene

scythion. Jower Triassic

senonian. lopler Cretrceons.

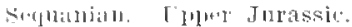

Sicilian, Inlinerene.

sinemurian. Lower Jurassic.

Suissunial (sumsonian). Encene.

strullualin. Eucene

stampian. oligocen.

sincbardactere clay. Midmayan.

suesumian. Focenn.

Tillinlatta lullestone. Clabminian.

Thandian. Eoveno

Tippall sikndstone. Mirhayan.

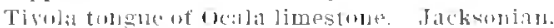

Tuarcian lower Jurassic.

Juncrian. oliugcene.

Tortonian. Miocene.

pront marl. Cinlournian.

L'uronian. I'purer cretaceons.

Thusalune fumation. Wiluxian.

Tyrolian Mible Triassic.

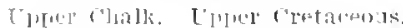

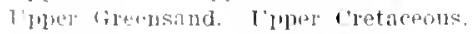

frembiall, lower eretaceons.

Tirglorian. Middle Tluassic.

Wralden. Lower retareous.

Worfunian. Inwer Triassic.

Wilus formation. Wilcorian

Witliamelure formation. Wilensian.

Yazace claly. Tacksnnian.

Yeztla formation. Ilatihornian.

Yuresian. Eocene.

yim+lar Mimene. 


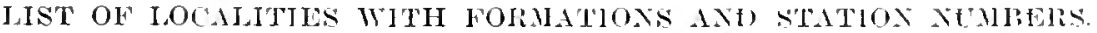

The following list includes all of the localities from which the bryozoa describer] in this volume have been obtained. Its purpose, in addition to showing the reologic and geographic distribution of the former, is to cite the station numbers of the collections under which, in the records of the United States Geological Survey. full stratigraphic data are given.

$$
\text { I.UWEST LOCENL. }
$$

Lpper Marlboro, Marpland. Dryozoin bed at base of Aquia formation.

$$
\text { MILWAXAN. }
$$

Well near depot at Brundidge. Alabama. Clayton limestone.

Old limekilu on south edge of Lurerne, Creushaw County, Alabaura. Clayton limestone. Station No. 6760, United states Geological survey.

Conochechebee Creck, 1 mile north of Fort Gaines, Georgia, Claytun limestone.

Three miles north of Scoohi, Femper Comty, Mississippi. Porters creek clay. Station No. Gigo. L'uited states Geological surver.

Bluff on south side ot Owl Creek. 23 miles northeast of Ripley, 'l'ipmaln Comnty. Mississipri. Clayton limestone. Station No. c497. Lnited States Geological Survey.

Mabelrale, near Little Rock. Arkinsas. Chyton limestone.

Woods Bluff, Alabama. Bashi furmation.

$$
\text { WiLCORHA: }
$$

CLAIEURNIAN.

Claiborne, Alabima. Gosport saud.

(Une mile southwest of Rockville, Clarke County, Alabima. Gusport sand. Station No. Gras. Lnited States Geological surver.

Wautubbee Hills, 4 miles south of Enterprise, Clarke County, Jississilui. Lisbon formation. Station No. 2616, United Stiltes Creolugicil surver.

Inseless Ferrs, Caldwell Cunuty, Texas. Cuok Mountain formation. Station No. J4ts, Lnited States Geological surrey.

Gopher Hill, Tombisbee liver', Alibama. Gosport saldi.

$$
\text { r.ME SOXIAX:。 }
$$

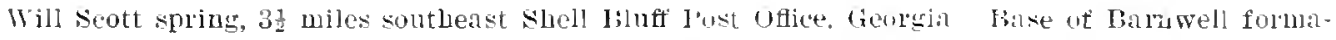
tion.

"I'wo and one-half miles north of Robert. Mississiplui. Moodys marl menuer of lower Jaclisoniau.

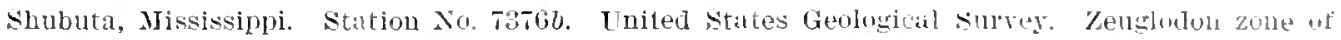
Moudys marl. Lower Jacksonian.

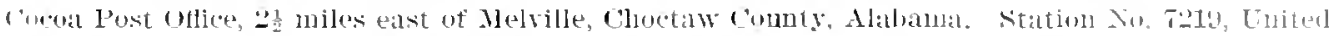

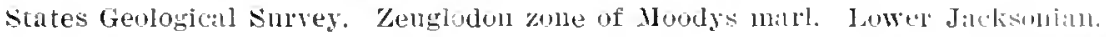

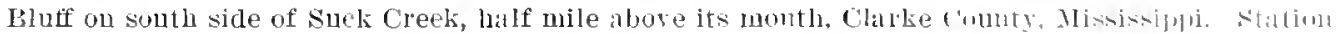

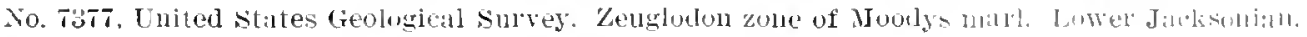
Jackisun, Mississippi. Joulys marl menber of luwer Jicksonian.

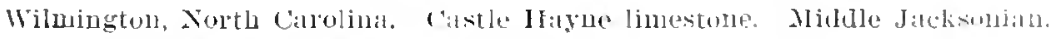

Eutaw sefrings, sunth Carulinal. Cogler marl. Midelle dildisunian.

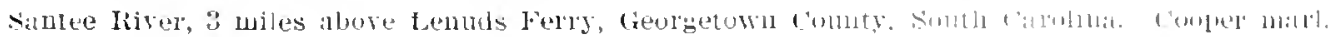
Iiddle Jackśsulian.

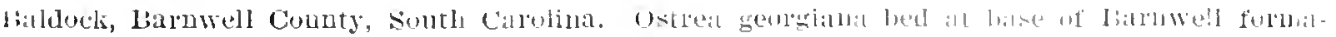
tient. Afidule Jackisoniatl. 
Rich Ilill, 5 miles southeast of Fuoxille. Clawford County, Georesia. Station No. 3604,

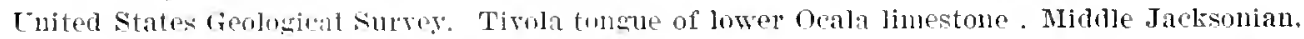

Penuehatchee creek, 1 miles northenst uf Jily, Dooly Comty, Georgia. Tivola tongue of lower Orala limestone. Mimhl. Tarksonian.

One-balf mile southeast Georgia kablin Compiny lline. Twiggs County, reotgia. 'Tirola tongue of lower Ocala limestone. Jialle dacksunian.

neese Plantation, 17 miles northeast of llawkinswille, Georgia. Station No. 2310. Lnited States Grolocical survey. Timbla tongus of Jomed Oeala limestone. Nidelle Jacksouian.

Three and one-fouth miles sonth of Perry, Georgia. Tivola tongue of lower Ocala limestone. Mirlalle Jacksonian.

Proots Farm. 12 milos southeast of Mil'slillyille, Georgia. Station No. 3996, United States Geoloxical survoy. Tirola tongue ot lower Ocala linestune. Midale Jacksonian.

Wing Jaw Pluff on Comee River, 1s miles west of Wrightsville. Joluson County, Georgia. Station No. 5539. Cinited States Geologion] Survey. Wivola tongue of lower Ocala limestome. Mrolle .Jacksunian.

Three and one-talf milw morth of Grovina, Fomgia. Tirota tongue of lower Ocala limestone. Middle Jacksonian.

Near Plant Srstem lablund Wharf, lainkidge, Georgia. Station No. 3300, Inited States Geological Survey. Toll of Ccala limestone. Timper Jacksonian.

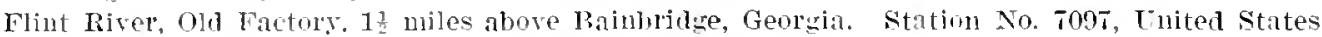
Geological Survey. Torl of Ocala limestome. Tpper Jarksonian.

Rej liluff on Flint River, 7 miles above Baimbrige, Georria, Station No. 33st, United States Geological survey. Tou of Ocala limestome. Truel Jacksnnian.

Flint River, 4 miles below Bainbrictge, Genrgia. 'Top of Ocala limestune. Upper Jacksonian.

Steamboat Point on West Bank Selulga River, Escambia Counts, Alabama. Station No. 6747, lniter states Genlogical survey. 'Top of Ocala limestone, Upper Jacksonian.

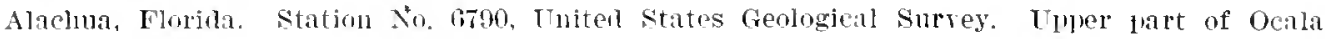
liwestone. Upper Jacksonian.

Ocala, Florida. Uptel part of Ocala limestone. Upper Jacksonian.

West rank of Chipola Fiver, east of Marianna, Jackson County, Florida. Station No. 676s,

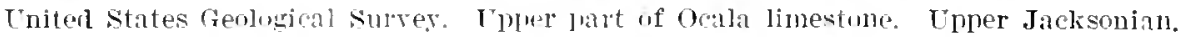

VITSELGIAN.

Rel Bluff, Wraye County, Mississippi. lied Bluff clay.

Seveu and one-balf miles suntluest of Liblon Springs, Nabama. Rea Fluff clas.

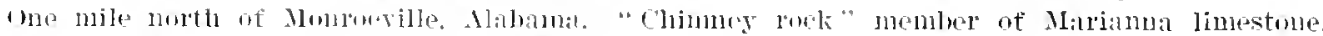

Station No. 6r1T, Tuited States Geological Survey.

Murder Creek, east of Castrobury, Coneenh County, Mabana, Marianna limestone.

MeGowims Bridge, West liank Conecub River, one mile below moutb of Sepulga River, Escambia

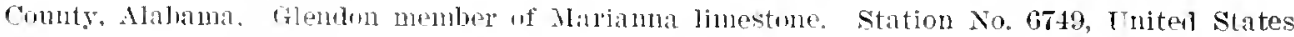
Geological surtey.

Silt Jountain. 5 miles sulth uf Jackson, Nabana. Marianma limestone.

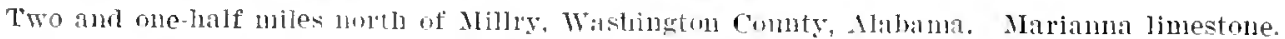

Near Claborne, IIon roe connty, Nabana. Malianua limestome.

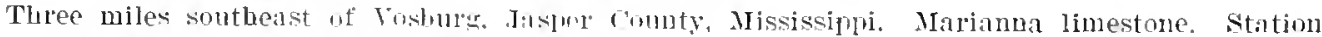

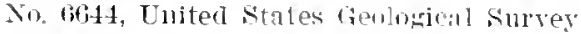

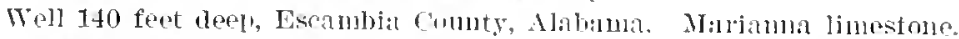

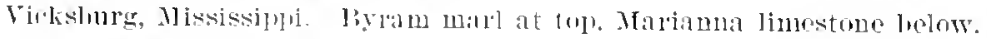

Вугіm, Mississippi. Trymam mall.

One-fourth mile west of Wombards, Warme Counts, Mississipui. Byram marl. Station No.

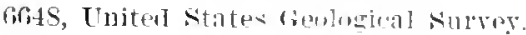




\title{
LISTS SHOWING GEOGRAPHIC AND GEOLOGIC DISTRIBUTION.
}

\author{
LOWEST EOCENE (BRYZOAN BED AT BASE OF AQUIA. FORMATION).
}

UPPER aIARLBORO, MARTLAND.

[r. r.=vers rare; $r=$ rare; v. c.=very common; $c .=c o m m o n$.

CEHELOSTOMATA.

Membraniporina rimulata Ulrich, 1901 (r. r.).

Ellisina spiculosa Ulrich, 1901 (r.).

Ellisina (?) angusta Ulrich, 1901 ( $\mathrm{r}$. c.).

Amphiblcstrum hetcropora Gabb and Horn, 1862 (r.).

Ramphonotus lacvis new species ( $r, \mathrm{r}$.).

stamenocella cylindrica, new species (r. r.).

Lunularia reversa Ulrich, 1901 (r.).

Euritina torta Gabb and Horn, 1862 (r.).

Coscinopleura digitata Morton, 1834 ( $\mathrm{r}$.).

Macropora aquiae, new species (c.).

Membraniporclla modesta Ulrich, 1901 (r.).

Membraniporella crassula Ulrich, 1901 (r.).

Bathosella aspera Ulrich. 1901 (r.).

Cheilopora (?) labiosa Ulrich 1901 (r.).

Meniscopora subplana Ulrich, 1901 (c.).

Acanthionella simplex, new species (r. r.).

CTCLOSTOMATA.

Hetcropora tecta Ulrich, 1901 (r.).

Plagioecia subramosa Ulrich, 1901 (r.).

Diaperoecia varians Ulrich, 1901 (r.).

Diplosolen compactum, new species (r.).

Lckythionia dichotoma Gabb and Horn, 1862 (r.).

Partrelocycloecia dumosa Ulrich, 1901 (r. c.).

MIDIVAYAN BRYOZOA.

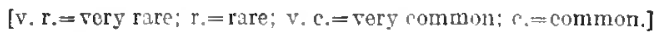

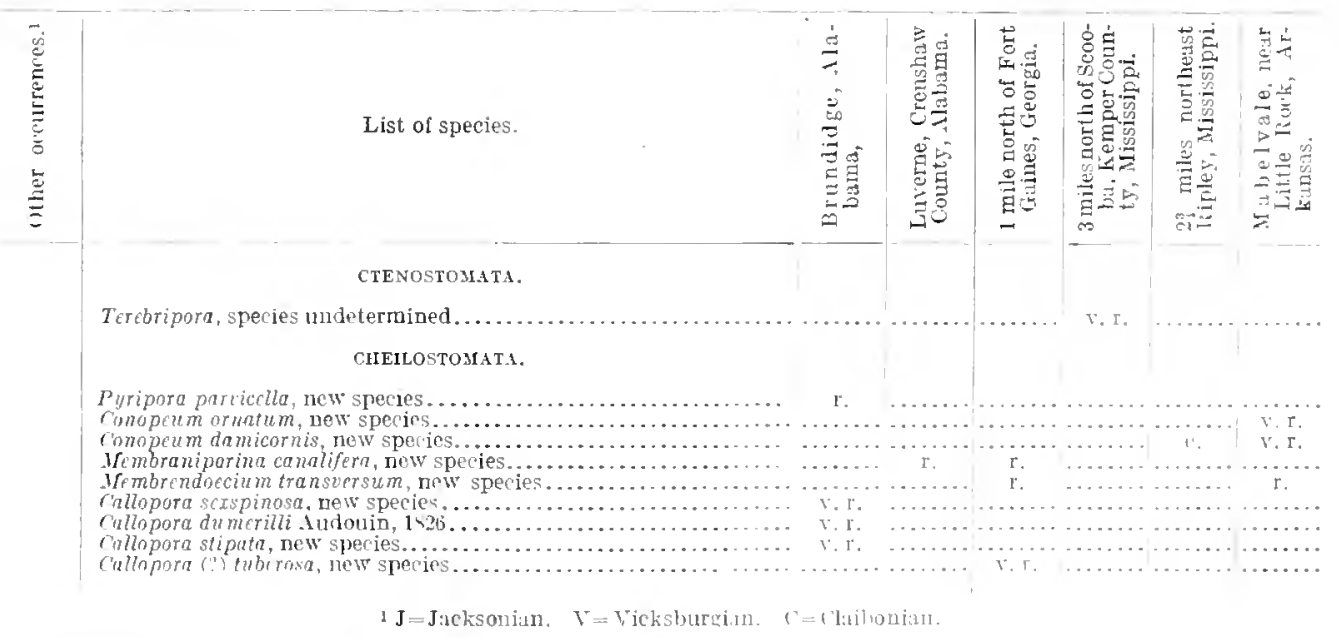

$59819-211-13011,106-2$ 


\begin{tabular}{|c|c|c|c|c|c|c|c|}
\hline 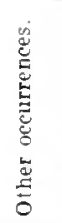 & List of specils. & 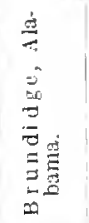 & 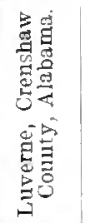 & 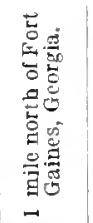 & 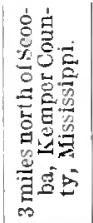 & 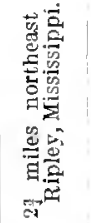 & 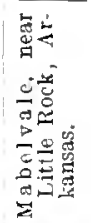 \\
\hline 3.1. & 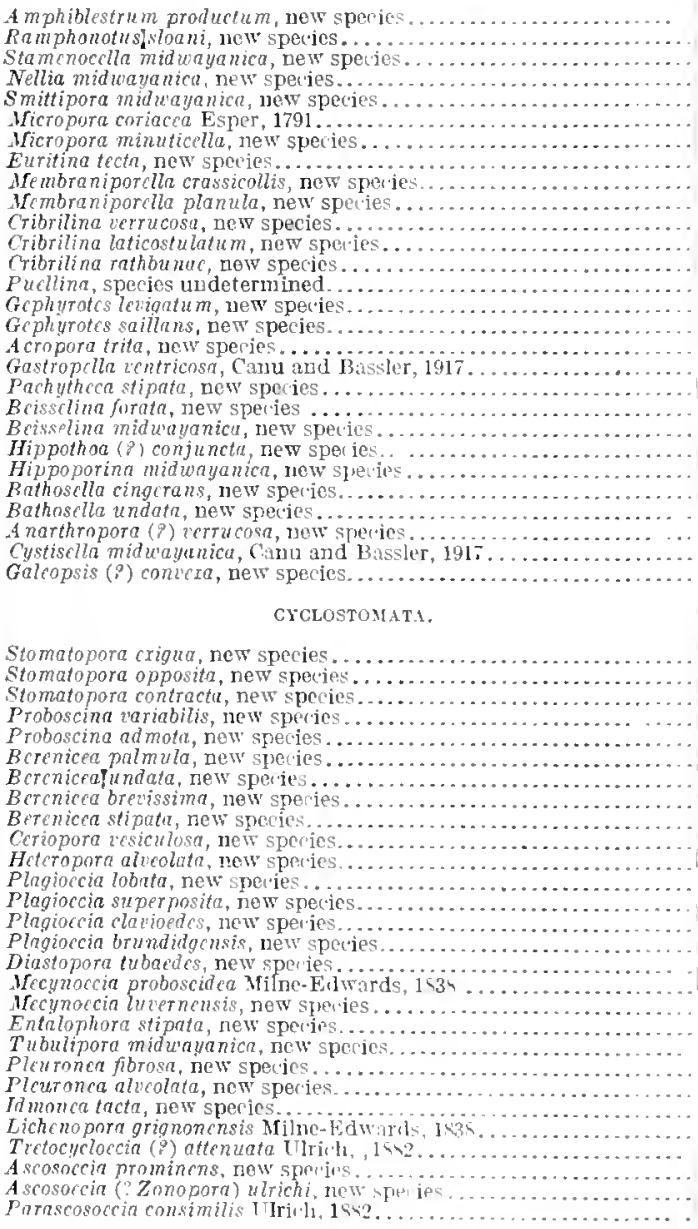 & 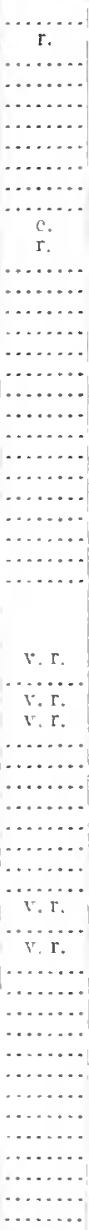 & 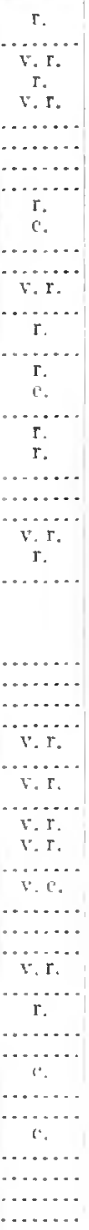 & 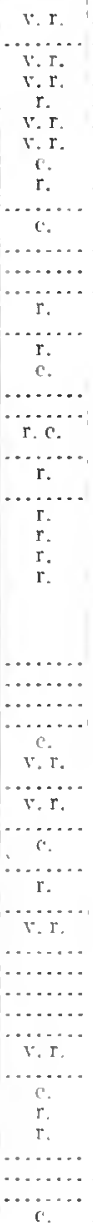 & 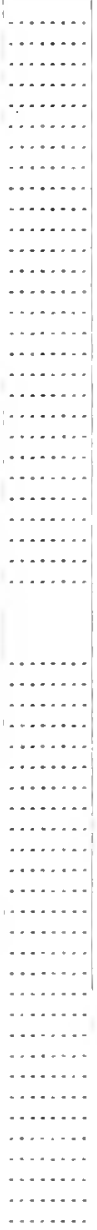 & 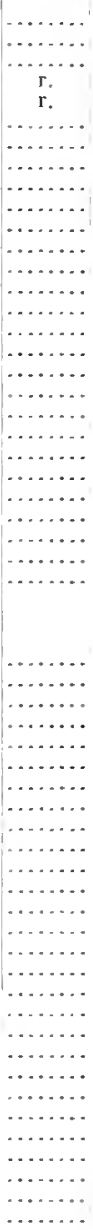 & 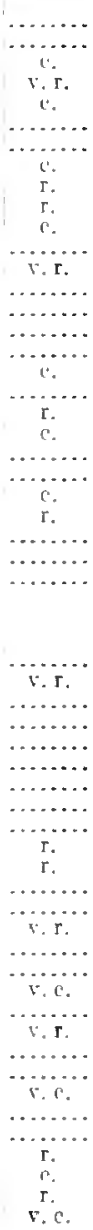 \\
\hline
\end{tabular}


WILONIAN (BASHI,, WOOHS BLUFF, ALADAMA.

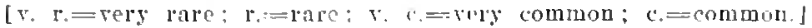

CHELLOSTUMATA.

Conopcum wilcoxianicum, new species (c.).

Conopcum (?) similior, new species ( $r$ ).

Aldcrina (?) nodulosa, new species (r, r.)

Lunularia ovala, new species (r.).

Trypostega clongata, new species (r.).

Plagioecia lubifer, new species $\left(\mathrm{r}^{\circ}\right.$ ).

Lagonocria lamellifera, new species ic.)
Aimulosia clavula, new species (r.).

Rhamphostomclla simplcx, new species (r.). Adeonellopsis porosa, new species (v. r.). Adeonellopsis magniporosa, new species (c.).

\section{CLAIBORNIAN BRYOZOA.}

[v, $r=$ very rare: $r=r a r: r, c=$ very common; $c, m$ common.]

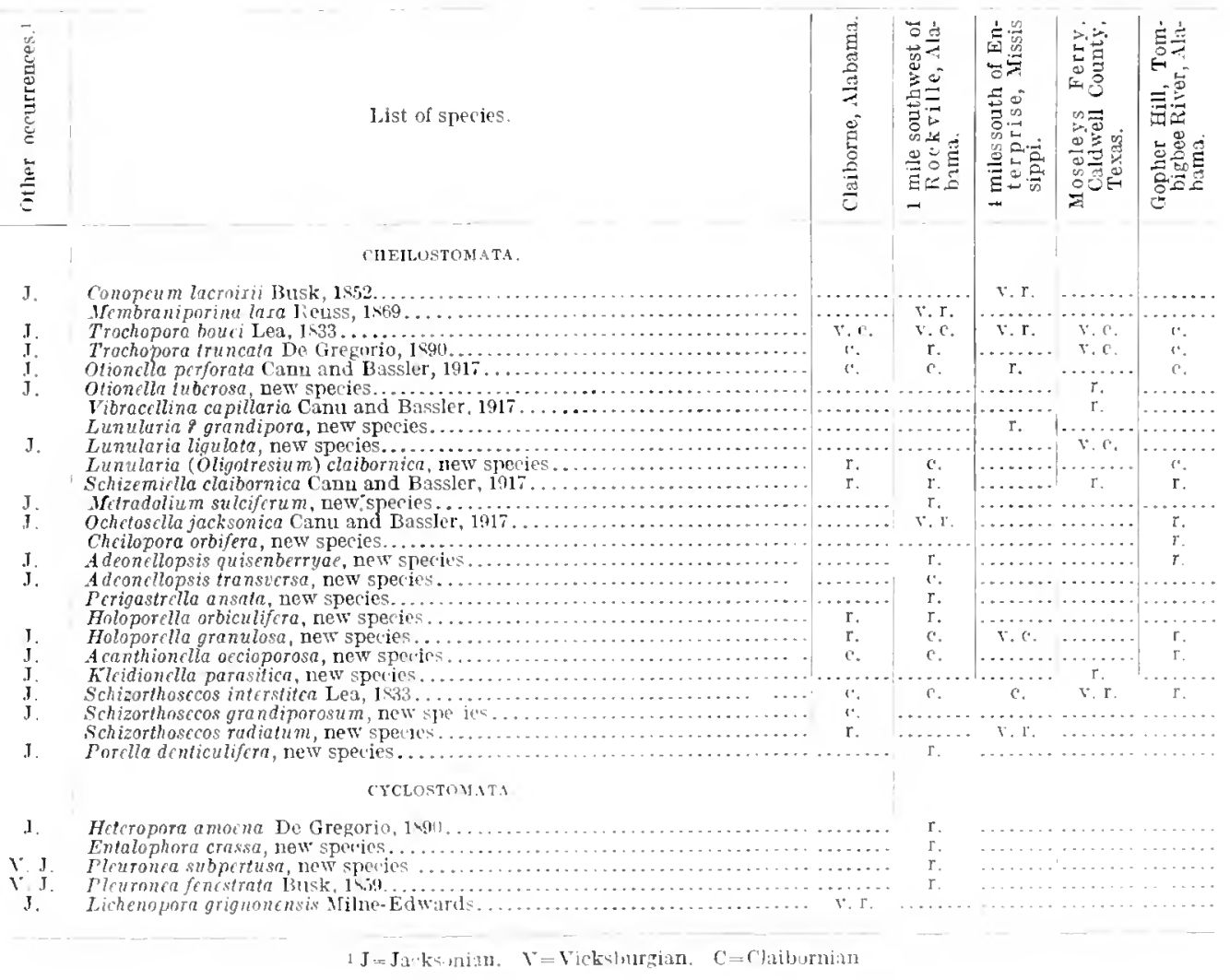


JAKSONIAX (HEILOSTOMATOUS BRYOZOA.

$[r, r=\operatorname{rer} 5$ rare; $r=$ rare; $c .=$ comminn; $v, c=\operatorname{ser} 5$ common $]$

Elcctra parimater, new sinecics.

Purinora luberculum Lonsilale, 1s

C. Conopeum lacrmain Busk, $1 ., 12$

Cononeum hooksn llitime, 14,50

Compeum inbrisum, new species.

cmopeum coneatum, near species.

Conoperm in millosum, new species

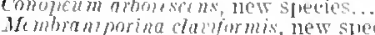

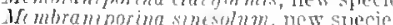

Jembramporzma benjumin tamu and Bassier, 191-

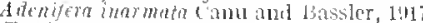

C. Trocherra hova lea, 1 \$83

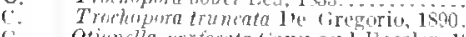

(C. Otionella prombin ( amm and Rassler, 1917

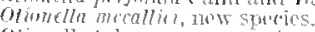

C. Otimella tubtrusa, new speris

Otimmlla vara, new species....

Mholisina replats, now specios.

Honcking smithl, new species.

IInckina jackanica, new specie

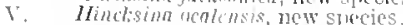

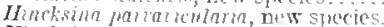

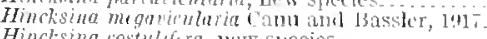

v. Hinclisima cosmlifera, nes suecios.

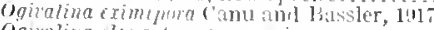

Ognalina anouta, now sinecins.

Opualina dombntr minor, new species.

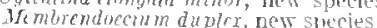

Membrendoevin reth $m$, new succios.

Ifombrenducium phriforme, new species.

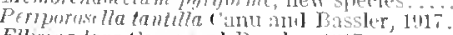

Ellowna lara ('anu and Basslor, $191 \%$

Ellwena brezs, new syeres.

Ellisma profunda Hichellivas ivis

Grammilla crassmaminata llinctis, lisen

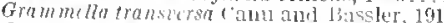

r. Grammilla pusilla, new species

Mr mbrawiportdra ofcuporona, new sjecies

lfombramporilla pachymurnlis, new spucies

Membramlundsa lrestmma, new specins.

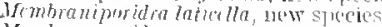

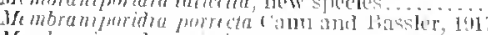

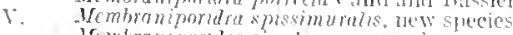

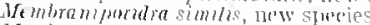

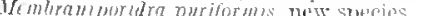

Aldrina pulcherranim, new sinedins

d lering lumato, new, species.

Alderina crassa, new suecits.

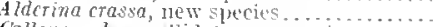

Ćallopora dumernlli lula, new variet $5 . . . . . .$.

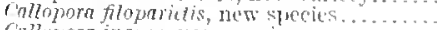

fallopora ingtns, new species.

C'allopore cucullata, nor silecies.

Callowora crassmpina, new suecies.

Callopera comera, new siecins.

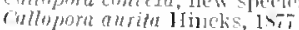

cellopera temairowtes llincks, 1 vio

rullepora mumbla, new spocies.

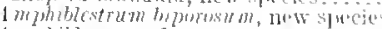

1 mplublestrum flamment, new specio

1 mphoblestram polins, new s]ecies....

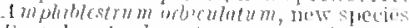

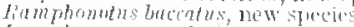

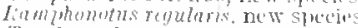

Triclla acmleato, new siecin.

Jignlla niklos, now spucis

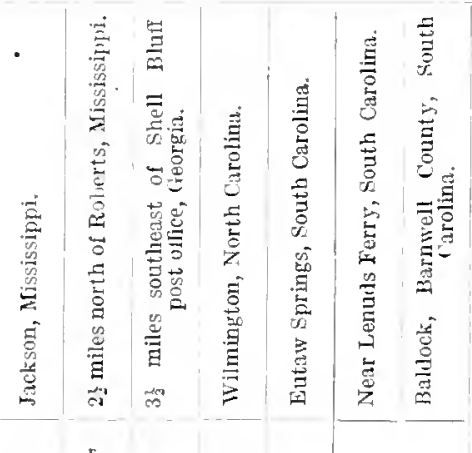
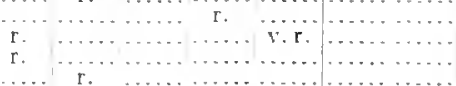

r. $r \ldots \ldots \ldots \ldots \ldots \ldots \ldots \ldots \ldots \ldots$
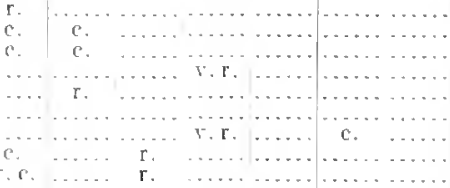

$\ldots \ldots, \mathbf{r}, \ldots \ldots \ldots$

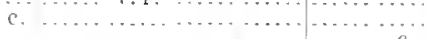

r.

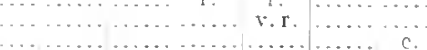

$\ldots \ldots$
$r_{r}$$\ldots \ldots \ldots$

$\ldots \ldots \ldots$ r.r. $\ldots \ldots$

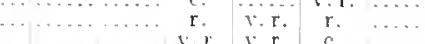

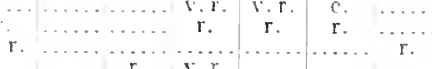

$\because \ldots r . r \ldots \ldots$

$\ldots+\ldots \ldots$ c. r. r. r.

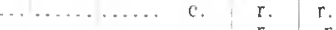

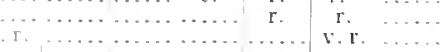

.

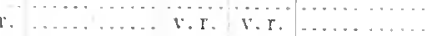

r. r. r.

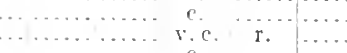

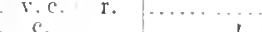

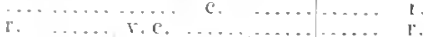

_. $\ldots \ldots \ldots$

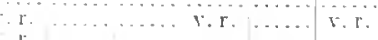

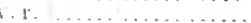

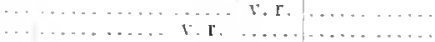

r. $\quad \ldots \ldots$

r.

\begin{tabular}{ll|l|l|} 
& $r$ & $\ldots$ & $\ldots$
\end{tabular}

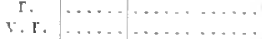

$r \quad \ldots \ldots \ldots \ldots \ldots$

…

r. $\quad \cdots \ldots \ldots \ldots \ldots$

(n.............

$r, \ldots \ldots \ldots$

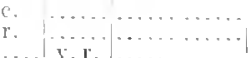

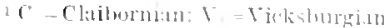


NORTH AMERICAN EARLY TERTIARY BRYOZOA.

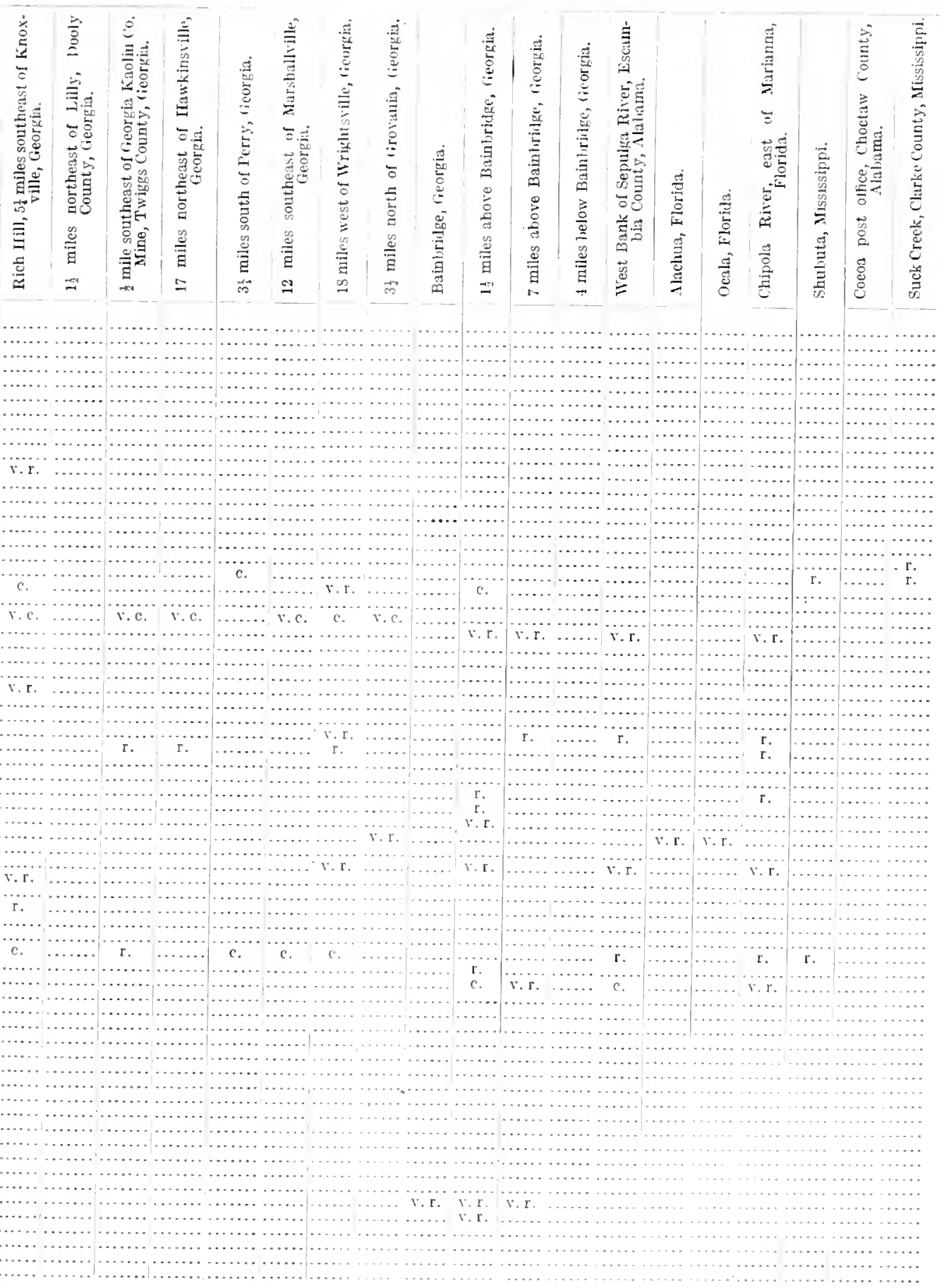


JACKSONAN CHEILOSTOMATOCS BRYOZOA.

[r. $r$. = very rare: $r_{0}=$ rare; $c_{0}=$ conmon; $v$. $c=$ very common.]

Stamenocella anatina, new species. .

Stamcnocella puriforme, new species.

.

I. Stamenocella inferniculifera, new species.

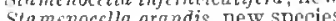

stamerocella grandis, new species......

Actca cf. truncata Ian ishorough, 185
Scrupocellaria lliptica Reuss, 1 .

Scrupoccllaria gracilis Reuss, 1869.

Sermpocrllaria dubia, new speeies.
Trllin bifaciala, new snecies.....

Nollia concalcnata Canu, 1907.

Gimcllaria prima Reuss, 1866.

Onychocilla anqulosa Renss, 184

onychocella colsa, new species

Onychncella gcorgiana, new specie

Onychocclla laciniosn, new species.

Onychocella duplienter, new species.

fictonychocella bilamellaria, new species

Fectomychocella semiluna, new species.

i. Rectonychocclla tenuis, new species.

fiectomychocella clliptica, new species.

Fectomychocella elliptica, new species
Vilumella ligata, new species.

lilumclia plicata, new species

Diplopholcos fusiformc Canu and Bassler, 1917

Wiplowholros sagutellarium, new specics.

Liplopholeos sagiltarium, new species...

I)iplopholos provuliporum, new speciss.

Florinina granulosa, new species.

Floridina bifuliata, new speries.

Floridina onydentata, uew species

$\therefore$ Floridinn antigua Smitt, 1 R. 3 .

Floridina laguncula, new species.

Floridina asymmelrica, new species.

Jucryondla octonariu, hew suecies.

Ineryonella minor, new speces...

d chmilla crassimargo, new species.

Acchnalla filimaron Canu and Bassler, 1 at

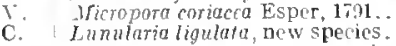

Lunularia verrucost, new slecies..

I mularia foncstrata De Gregorio, 1591

Lumaria tubifere, new species.

I. Innularia distans Lonstlale, 1815.

I unularia contigua Lomsdale, $18+5 \ldots$.

Lunularia jacksoni nsis, new species...

hhagrsastoma minusculum, new species.

hhagasostoma lerigalum, new species.

silegnnoporclla jacksuniara, nta species.

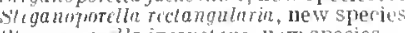

strgemporelin incrustuns, new species.

rillarma striclocdla, new species.

illarta dumprpha, new species

crllario bifacinta new specios.

Guctupora mullibnallusa, Hew specios

Guadracellara (o) lacinis str new specius

Quadricellara (p) bernsi, new species.

ifrmbraniporella alrichi, new specics.

Vimbranipmolla boculata, nu suecios.

Li mbraniporella conloressa, new specus.

Vemhraniportla mandafera, new specifs.

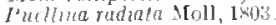

J'vellonu radiata analicula, acw species

I'uellina radiata carblinensis nulb and llorm, intig

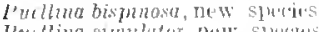

l'mellina somulutor, Dow sonen.

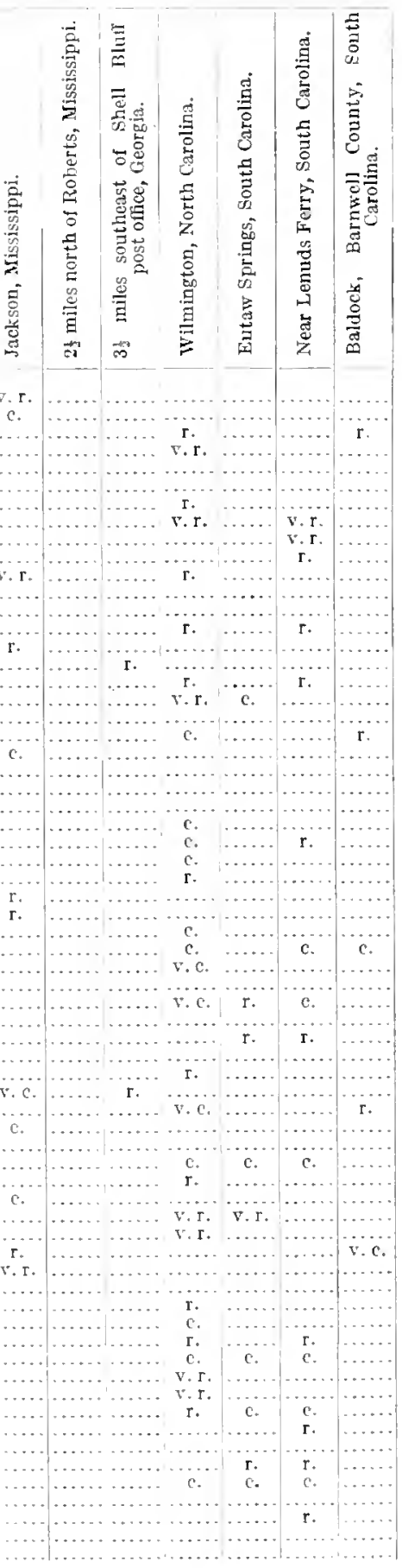


NORTH AMERICAN EARLY TERTIARY BRYOZOA.

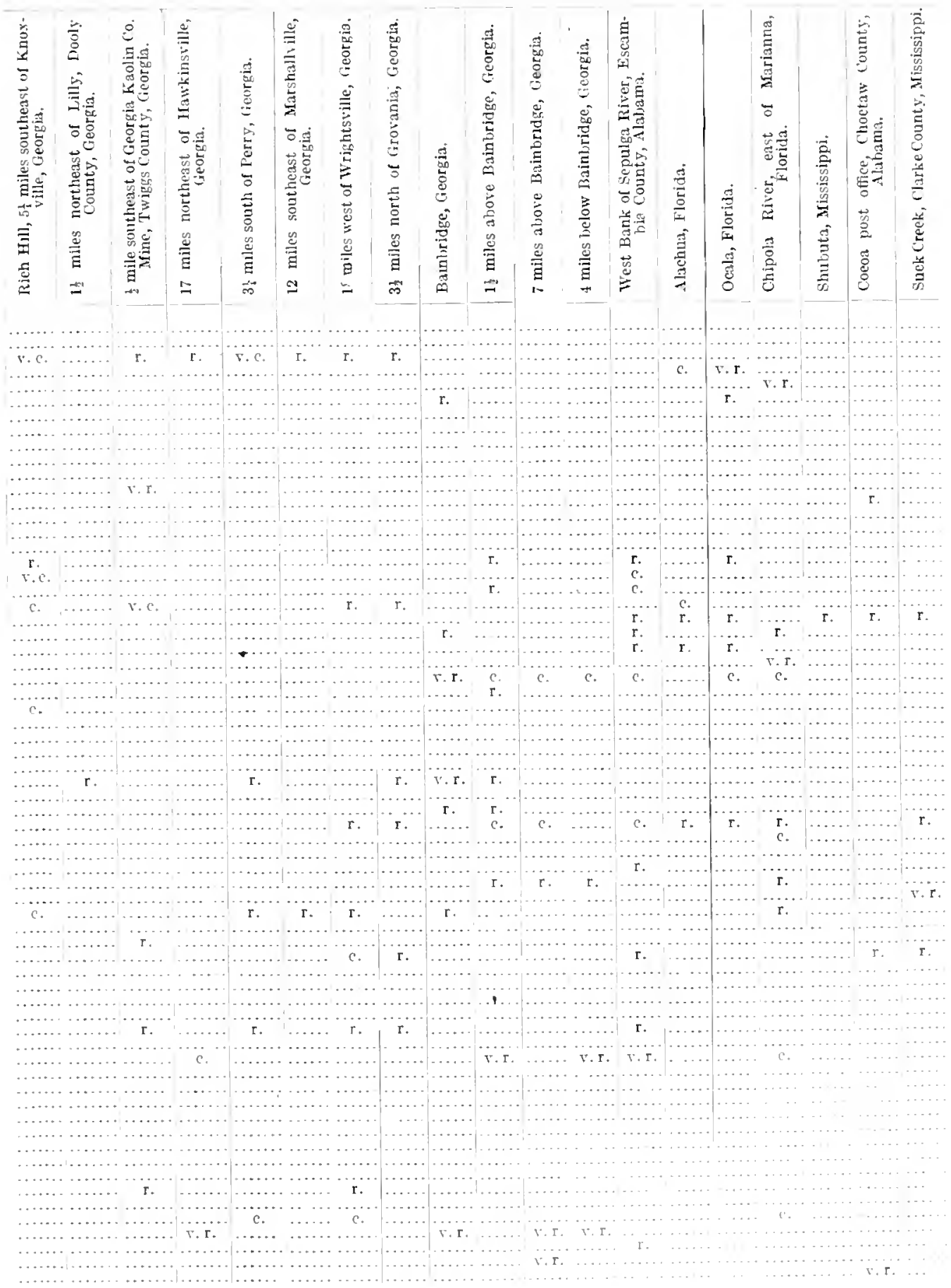




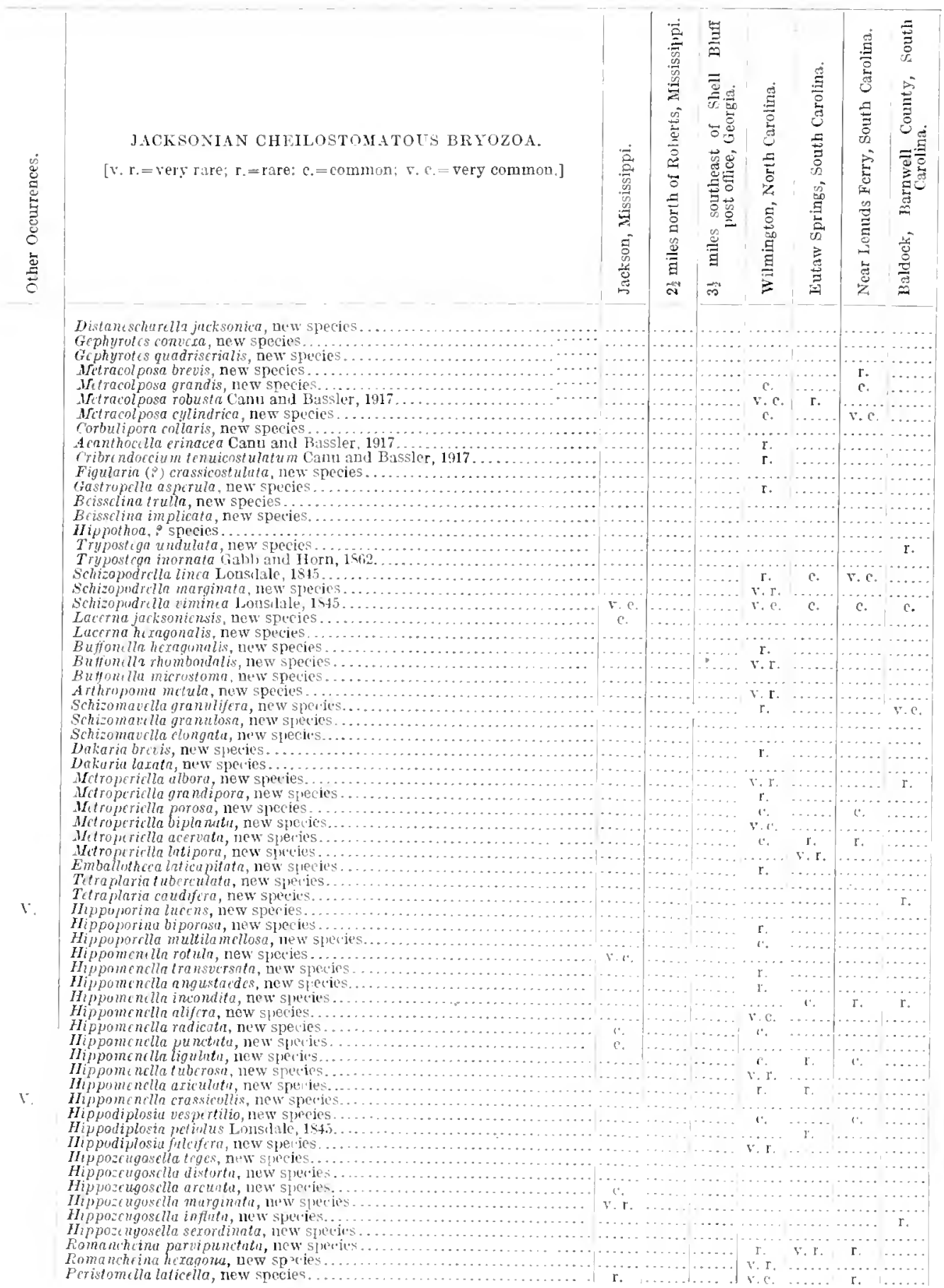




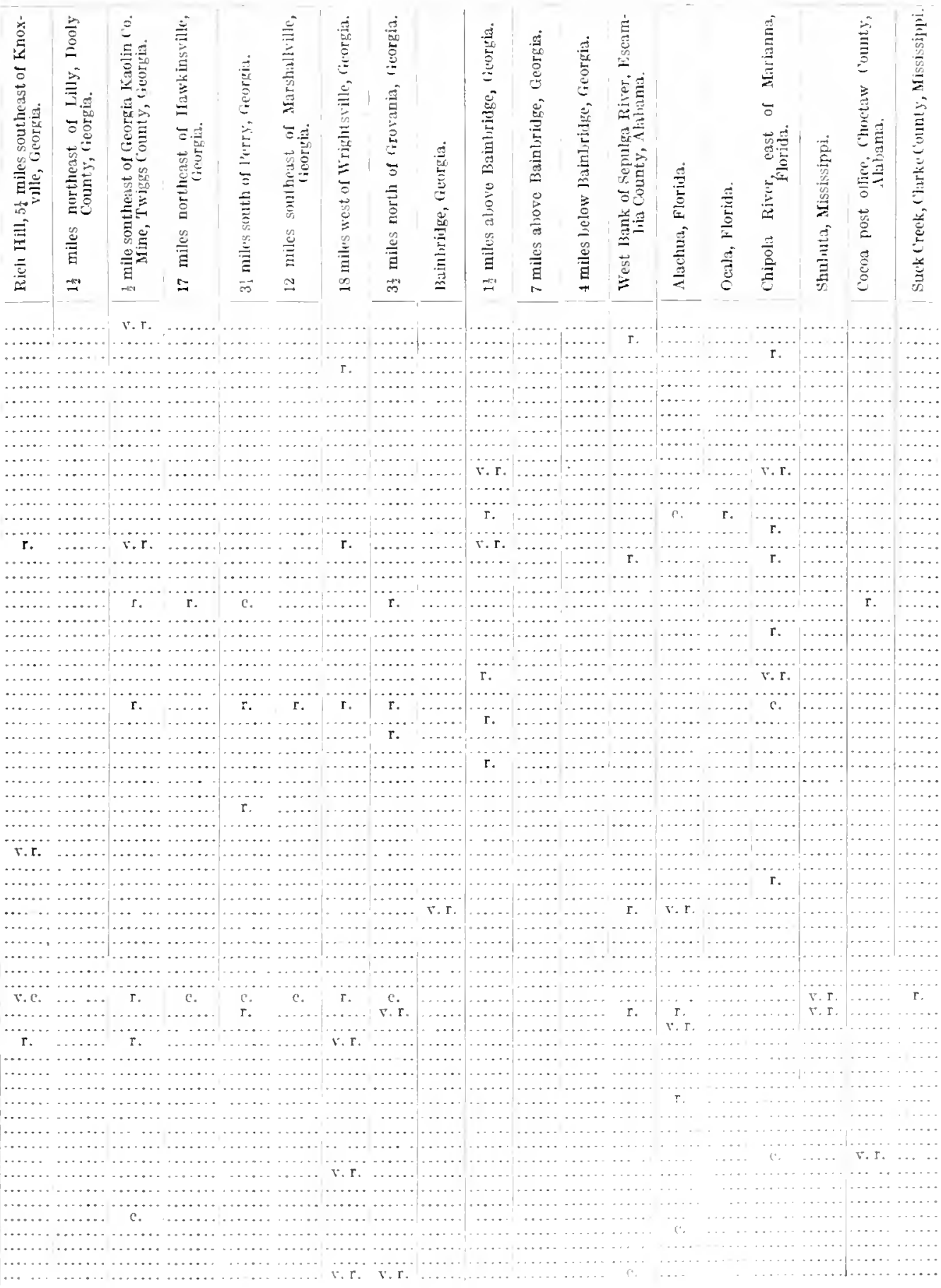


JACKSONIAN CHEILOSTOMATOUS BRYOZOA.

Peristomella fulcifora, new species.

Ilunzcauina ornata, new species

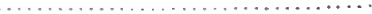

Houzcauina librata, new species.

Cyclicopora fissurata, new species

Cyclico pora laticella, new species.

Met radolium labratulum, new specie

Metradolium dissimile, new species....

Ifetradolium parvirimulatum, new spice
Metradolium transecrsum, new species

Alctradolium grande, new species.

Metradolium conecnicns, new species.

Mctradolium sulcifcrum, new spicties.

Mctradulium obliquum, new species.

Alctrocrypta bucculenta canu and Bassler, ial

Ochetosilla robusta, new species.

r. Ochetosclla jacksonica Canu and Bassier, 1917

Smi tina collum, new species.

Smittina labintula, new species.

Smittima grnalfossac, new species.

Smittina coronata, new species.

v. Smiltina angulata Reuss, 1865

Smitina erigua, new species.

Smittina strumbelit ricuss, 1865

Smittina puncturuta, new specie

Smiltina sordida, new species.

Smi tina orbuvicularia, new species.

Plogiosmittia rcgularis (anu and Bassler, iul

Plagiosmittza porclloides, new specic

Plagiosmittia virgula, new specie
Mucroaclla patcrs, new species.

Mucroaclla patcns, new species.
Mrucronclla granulosa, new suecies

hham phostomella brendole nsis a mericana, new vartety

tham phostumella contexa, new species.

Porella irregularis, new species.

Porclla granulosa, nuw species.

Porclla coronato new suecies.

C. Porella denticulifira, new speci

Porella jacksonica, net' species.

Porella pungens, new species.

Porella uzguiculata, new species.

Pordlla plarulata, new species.

Porella abdita, new species.

Porella obliqua, new species.....

Purella portcntosa, new species.

Phoccana (?) simulator, new species.

Retepora tamosa, new speties...
lietepora scutuluta, new species.

Galeopsis longicollts, new specins.

Galcupsis verrucosa, new species.

Galcopsis crinaceus, new species

ralenpsis cyclops, new species

Schizaropsis conterus Canu and Bassler, 1917

Thus elin grackis, new species.

Semihaswellia lriphra, new specie.
Scmihasterlin critis, new species

Siemihasunllia ( $($ ) clna, new species.

rigantopora filiformis, new species.

Tessaradoma ornata, new specios.

Tessaradoma grandipora, new specics.

T'remotoichos rectifurcatum Canil and Bassler, 191 .

rheilopora yrelacidoides, new species.

Theilntora sirictocilla, new species.

Cheilnpora grandls, new species...

Chcilopora saillans, new species.
f'hilupura transicrsa, new species

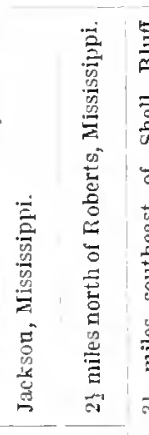

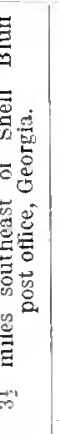

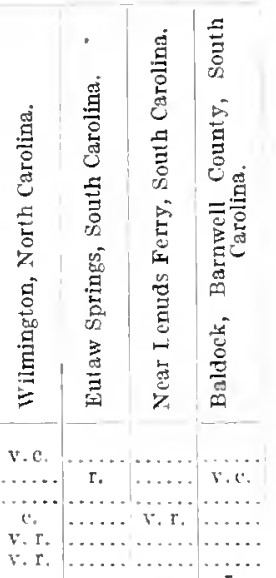

an.

\begin{tabular}{c|c|c|c} 
r.c. & r. & c. & $\ldots .$. \\
r. & v.c. & c. & c.
\end{tabular}

r.c. $\mid \cdots \ldots+\ldots \ldots$

r... r. $\quad$ r. $r, \ldots$

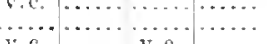

v.e. $\ldots \ldots$ v.e. $\ldots .$.

c. $\cdots \cdots$ r.

f.c. c. $\quad$ v.c.

c. $\cdots \cdots \cdot$ r. $\quad \cdots \cdots$

r. $\quad \cdots \cdots \cdots$

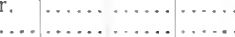

r $\ldots \ldots$

$\because \ldots \ldots \ldots \ldots$

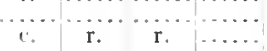

\begin{tabular}{c|cc|c|}
$\ddots$ & r. & r. & $\ldots \ldots$ \\
¿. & $\ldots$ & $\ldots$ & $\ldots$
\end{tabular}

ve. $\quad$ r. v. v. $\cdots$

v.c. $\ldots \ldots \ldots \ldots \ldots$

n............

r. $\quad$ r. $r . \ldots$.

$\ldots \ldots \ldots$

$\because \cdots \cdots \cdots \cdots$

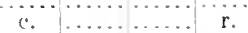

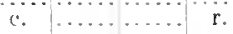

r. $\quad \ldots \ldots$ r.

r.

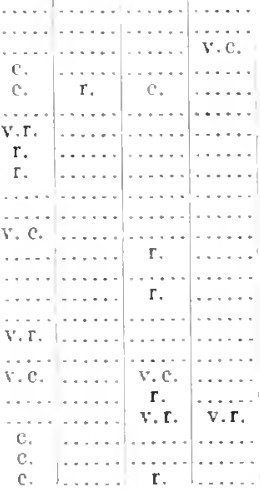


NORTH AMERICAN EARLY TERTIARY BRYOZOA.

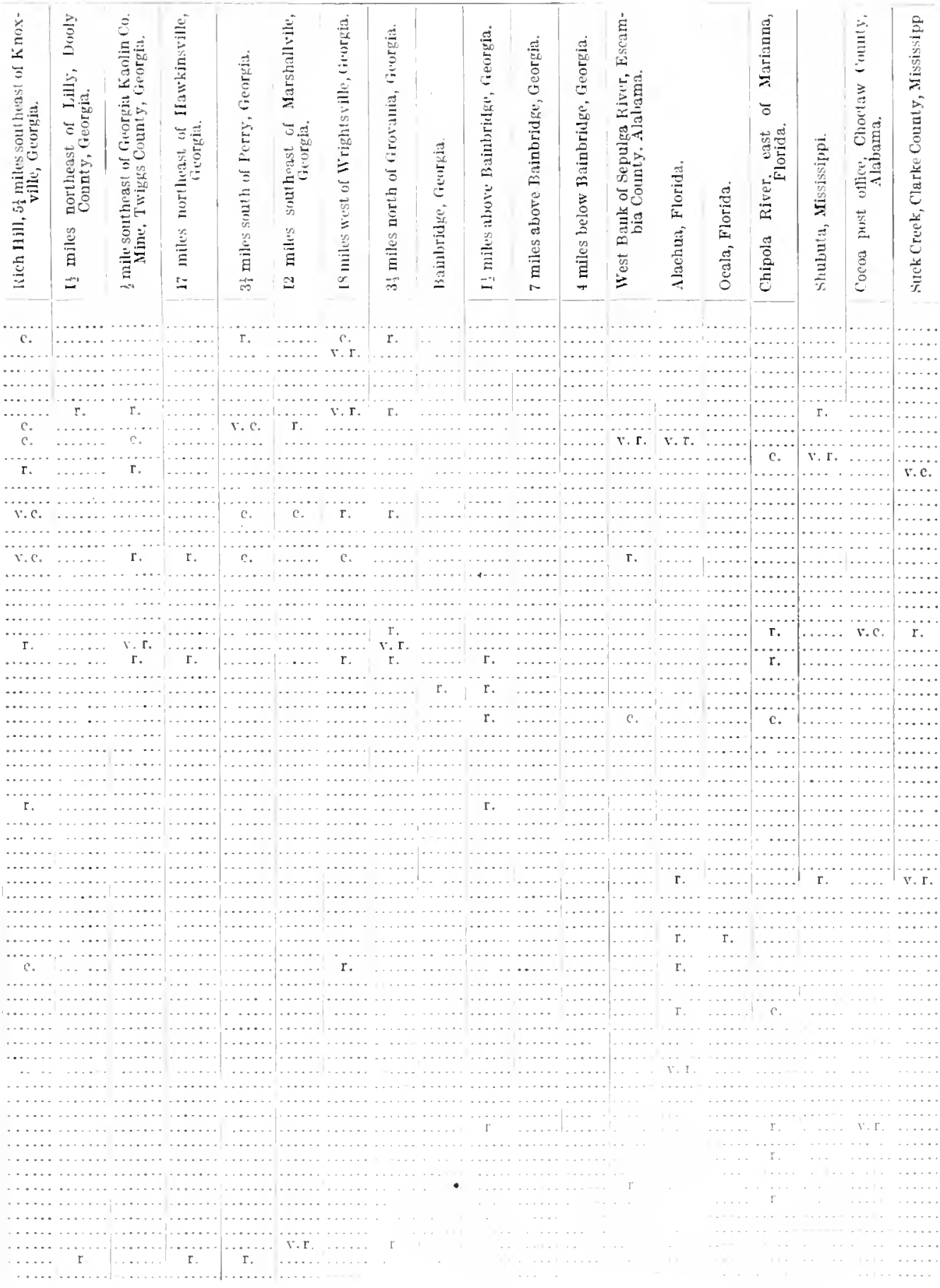


JACKSONIAN CHEILOSTOMATOCS BRYOZOA.

Cheilopora tratisersoides, new species.

Cheilopora specula, new species.

cheilopora sillcifeta, new species.

Hippopodina vibraculifera Canu and Bassler, 191:

ITatersipora (P) erceta, new species.

Tubucllaria partiparosa, new spect

Tubzcellaria nodifera, new species.

Tubucclia monilijera, new species

Tubucrllo gibbosa, new species....

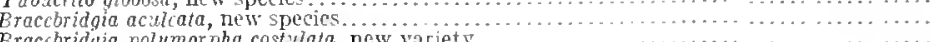

.

C. Adconellapsis quisenber yae, new species

C. Adeonellopsis transectsa, new species.

Phylactella parvicollum, new species.

Phylactella parnicilla, new species...

Prigastrella heragonalis, new species.

Perigastralla thomboidalis, new specin

Perigastrella cycloris Gabb and Horn, 18 is.

Perigastrella oscitans, new species.

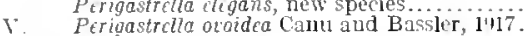

Perigastrella maxilla, new species.

Pcrigastrclla trapezoidfo, new speci

Perigastrclla depressa, new species.

V. Perigastralla rectilincala, nen species.

Pcrianstrella' tubulosa, new species

...

Hcmicyclapora parajuncta ( antu anit inssler, 191

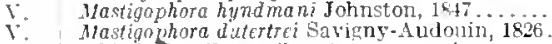

Schizobathysella semilunata, new species

Schizobathysclla saccifera ('anu and l3assler, 191

V. Lagchipora americana, new species

Schismopora globosa, new spccies.

Schismopora umbonata, new species.

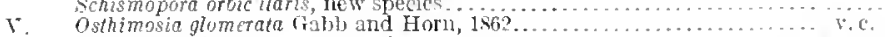

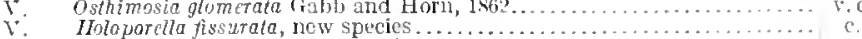

Holoporclla altirostris, new species.

C. Holoparclla gran'los, new species

Huloporilla crassicollis, new species.

Holoporellu pisiformis, new specie.

Holoporlla damicorms, hew spectes

Holaparlla micropora, new species.

Holoporellu hirostrata, new species.

C. A canthionellu ar cioporosa, new species

․ Ifcidionella grandis Canu and Bassler, 1917.

c. Kleidionella parasitica, new species

hicidionella lobata, new species.

K? idionclla cristala, new species...

Sitchaporina protecta lioschinslii, 18

C. Schizorthasccos interstitca lea, 1533 ........... Schizarthasces grandiporas r.

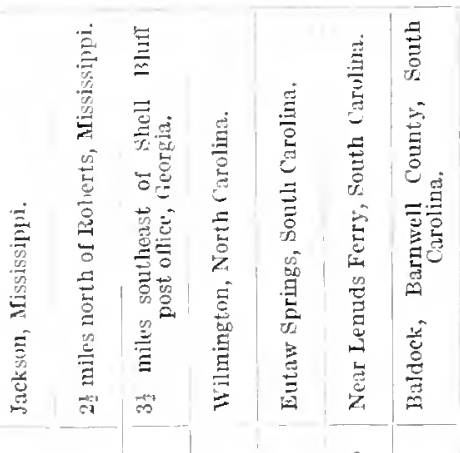

c.

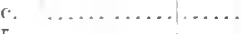

r.

(. $\quad$.........

(n)

r.

c. r. $\quad$ r.

c....... c.

(n)

c. $-\cdots, \ldots$

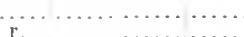

r. $\quad \cdots \cdots+\cdots \cdots$

. r.

$\mathrm{r}, \mathrm{\cdots} \cdot \ldots+\cdots \cdots$

e. $\cdots \cdots$ ห. c. r. $\quad \cdots+$ r.

.......

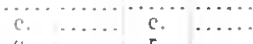
i. $\ldots$. r. ......
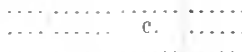

r. $\quad \cdots \cdots \cdots$

v. r. $\ldots \ldots \ldots \ldots$

.

...............

.......................

c. $\quad \ldots \ldots \ldots \ldots . . . . .$.

г. …

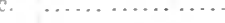

.

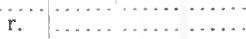

\begin{tabular}{l|l|l} 
c... & $\ldots \ldots$ \\
\end{tabular} ve r. re r,

......... v. c. ...

.................. 


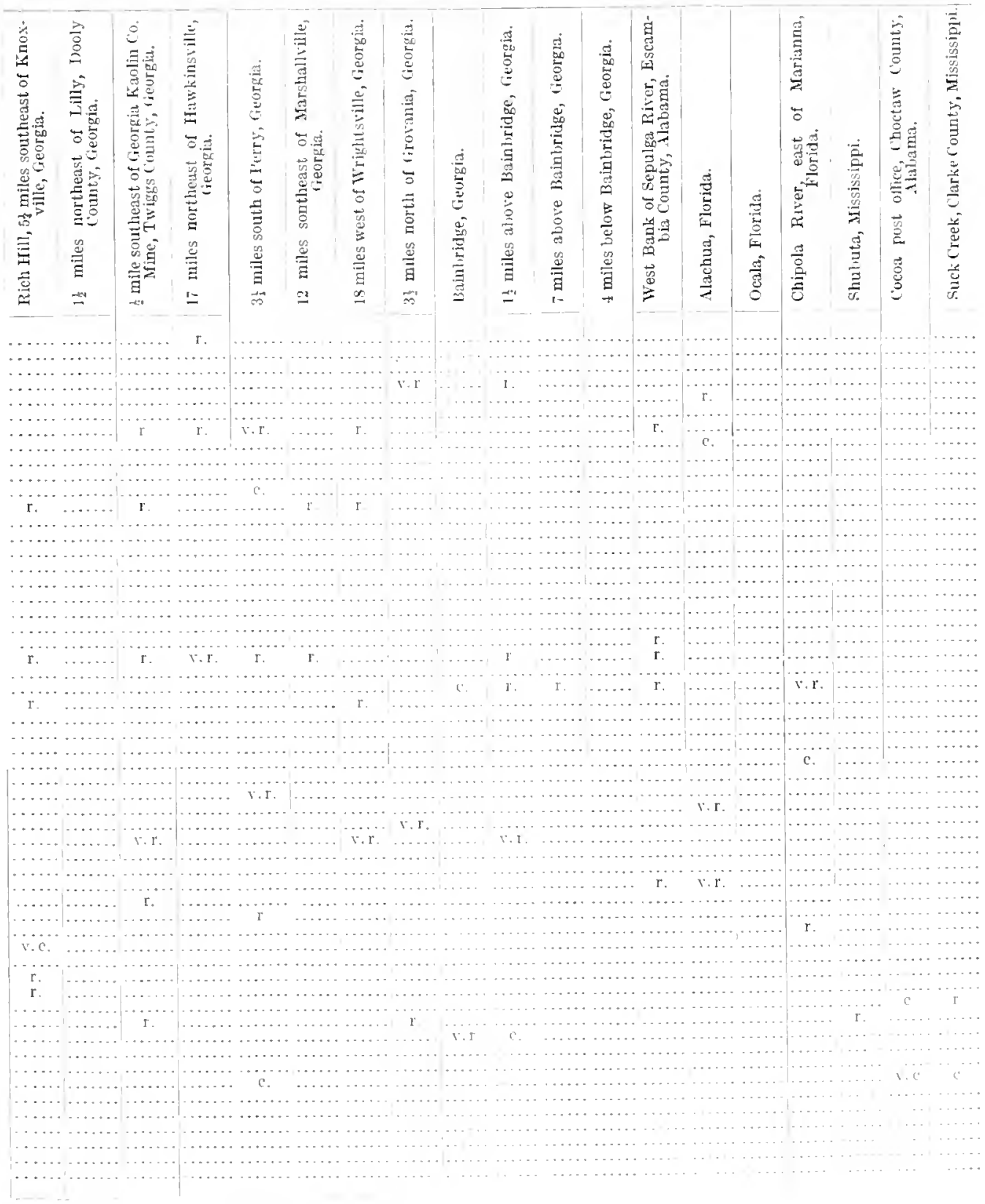


JACKSONIAN CYCLOSTOMLTOUS BRTOZOL.

[v $r=$ very rare; $r=\operatorname{rarc}: c=$ common; $\mathrm{v}, c=$ very conmon.]

Y. Stomatopora paripora, new suecies

Stomatopora polygona, new speeies.

Stomatopora exca vans, new snecies.

Stomatopota cormu, new species.

Stomatopora striatula, new snecies.

Stomatopora fasciolata, new species.

Proboscina rugosa, new snecies.

Probosrina projecta, new species.

Proboscina gcminata, new species.

Proboscina anceps, new species.

Proboscina crpatiata, new species:

Probnscina divergans, new specics.

Probuscina colubra, new species.

Proboscina claratuln, new species

Prohoscina stiatula, new spccies.

Proboscina mominens, new species.

Proboscina undulata, new species.

e'roboscina parbiangulau, new species

Proboscinu exigua, new species.

r. Proboscina latoluevis, new specirs.

Proboscina idmonoides, new species.

Proboscina magniramosa, new spccies..

Bercnicca inachs, new speeies.

Plaginecia divagills, new species

Bercnicca benjamini, new species.
Berenicra incondita, new species.

Bercnicca incondita, new species.
Diastopora tubiformis, new suecics

Diastopora striatisentota, new speci

spiropora majuscula, new species.

Criopora aldrichi, new speries.

Crriopora (7) proposita, new species.

Itcteropora oratis, new specics.

IIteropota a maena De Gregorio, $1 \backsim 90$.

‥ Filisparsa fallar, new species.

$\therefore \quad$ Filisparsa ingens, new specis

Crisio edwordsi Rouss, 187-

Crisia cribratia Stimpson, 1833 .

Crisia lowei, new species.

Plaqiocia concrta new species

Plagioccia globulosia, new species.

Plagiorcia la mellosa, new specics.

Plagiotcia botula, new species

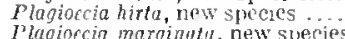

Desmeplaginecia dichotoma, new specio

i. Desmenlaginccia comptessa, new slectus

Desincplagwccir. plicata, new specles

Iesmenlagioceia lobata, new species

Desmeplagioccia (Actinopara) brevis, new sjecies.

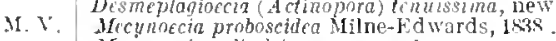

Mecynaccia cylindrica, new speeies.

Hecymocia pusilla, new species

Hectnacia brevis, new specics.

lfeclyrocia magnicellac, netv species.

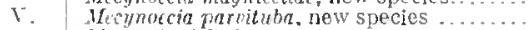

Micruecin frabrllata, new species.

Microecia vibrio, new specics.

Itiaperoceia longicauda, new speeies

IDinpernceia jacksoniensis, new species.

Inaperocrin lohulata, new species.

Hiapcroccin lobulata var partipora, new variet:

IDinlosalen planum, new specics.

T'ubulipora intertupta, new snecies.

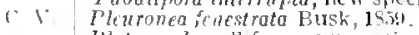

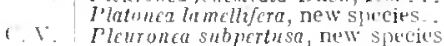

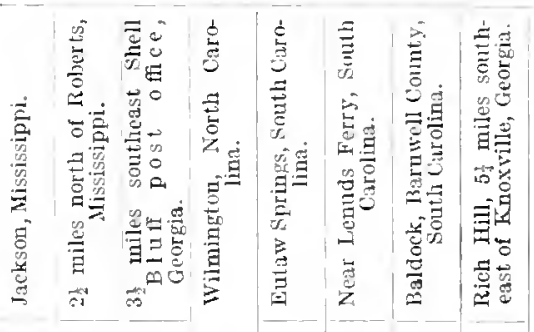


NORTH AMERICAN EARLY TLRTIARY BRYOZOA.

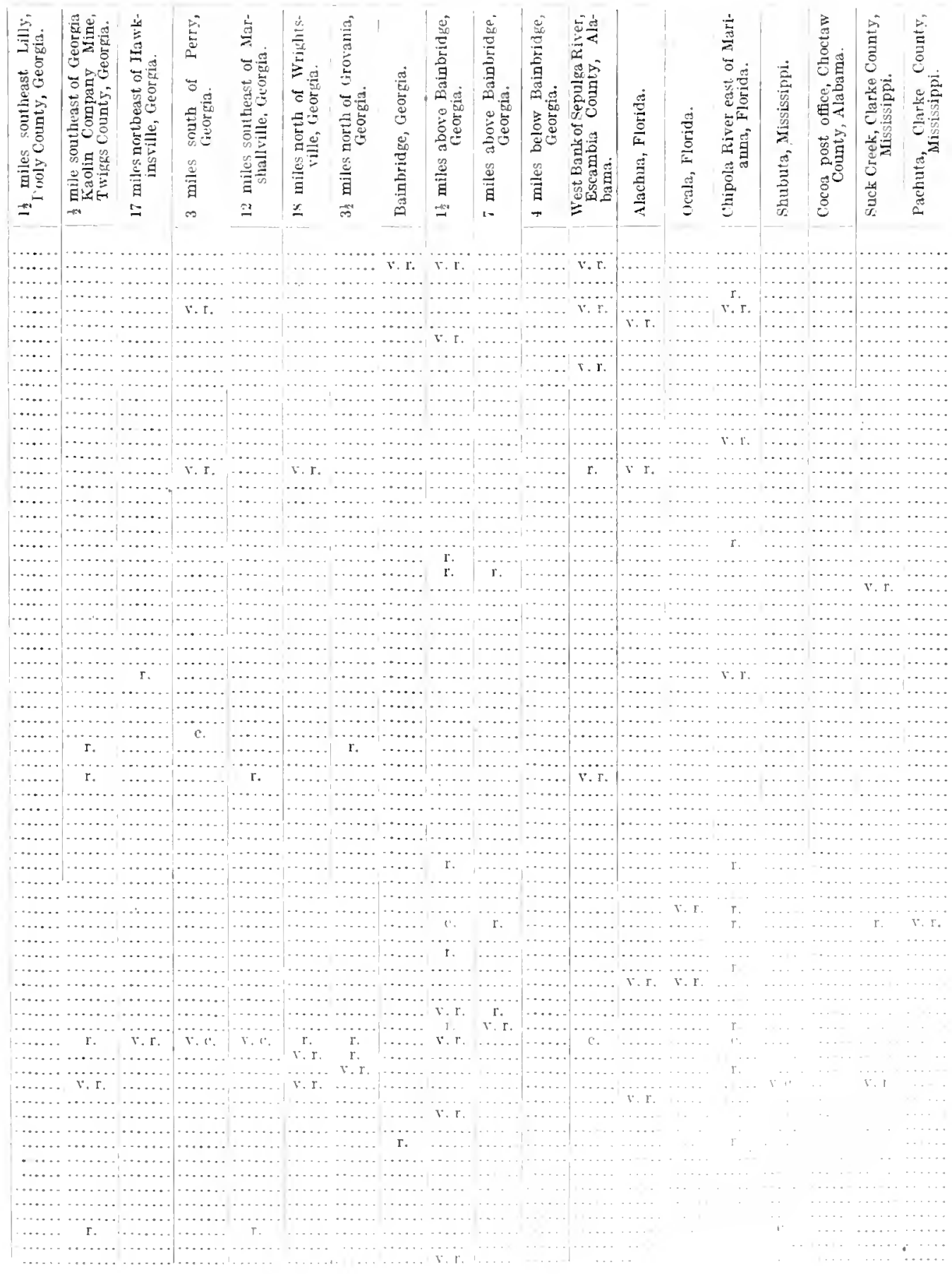




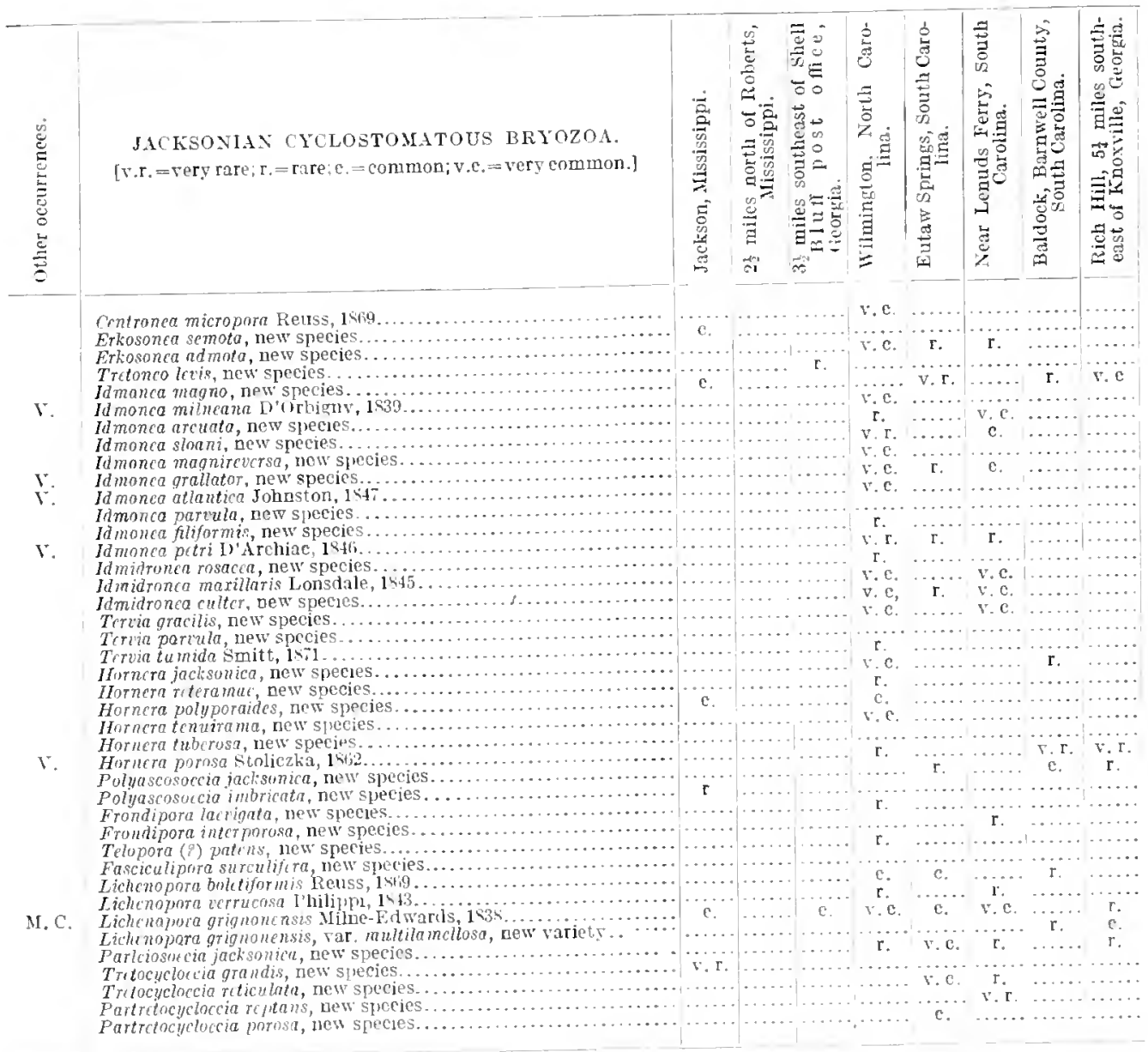


NORTH AMERIUAN EARLY TERTIARY BRYOZOA.

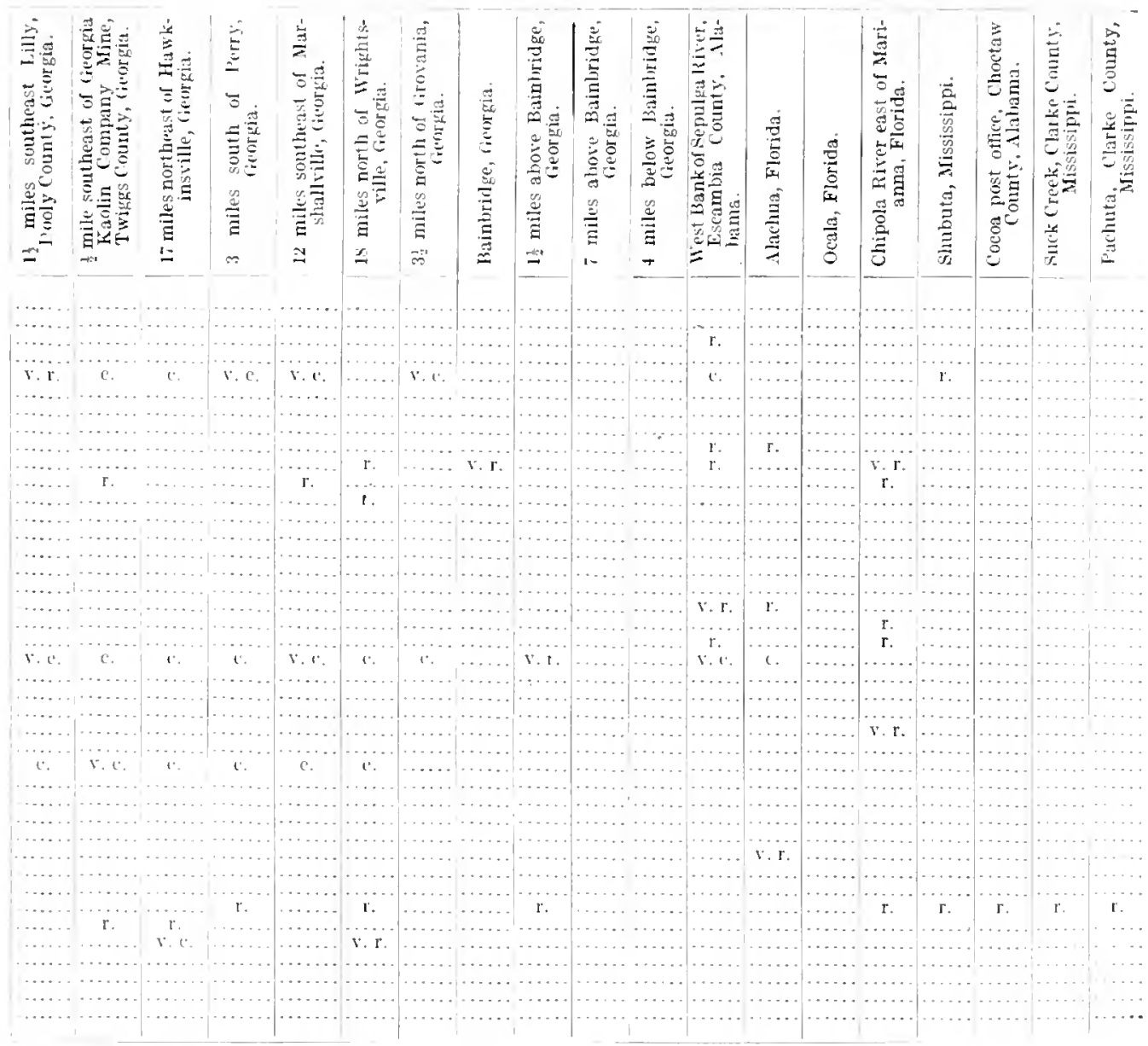

5is $990-21-$ Sill $100-3$ 


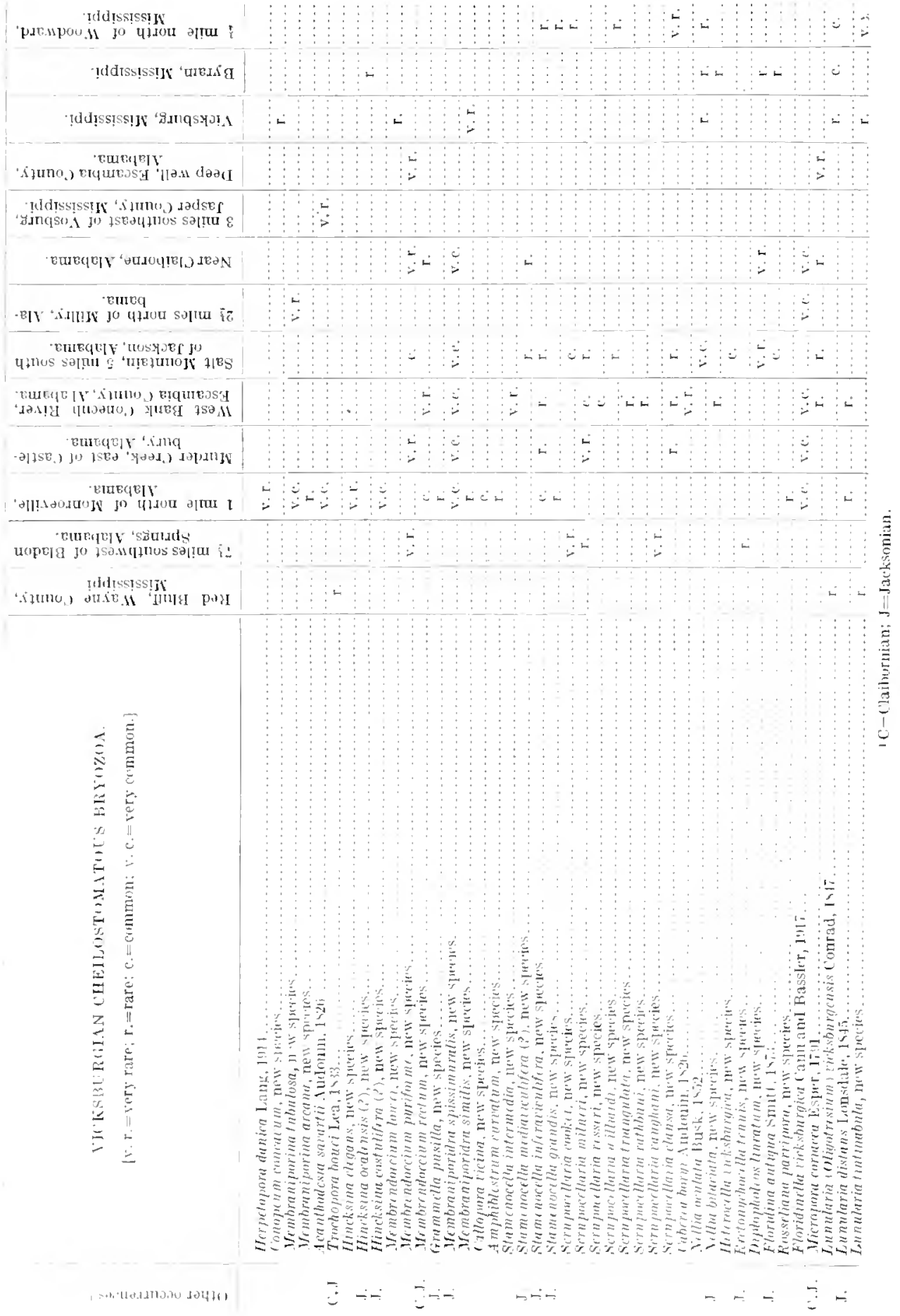




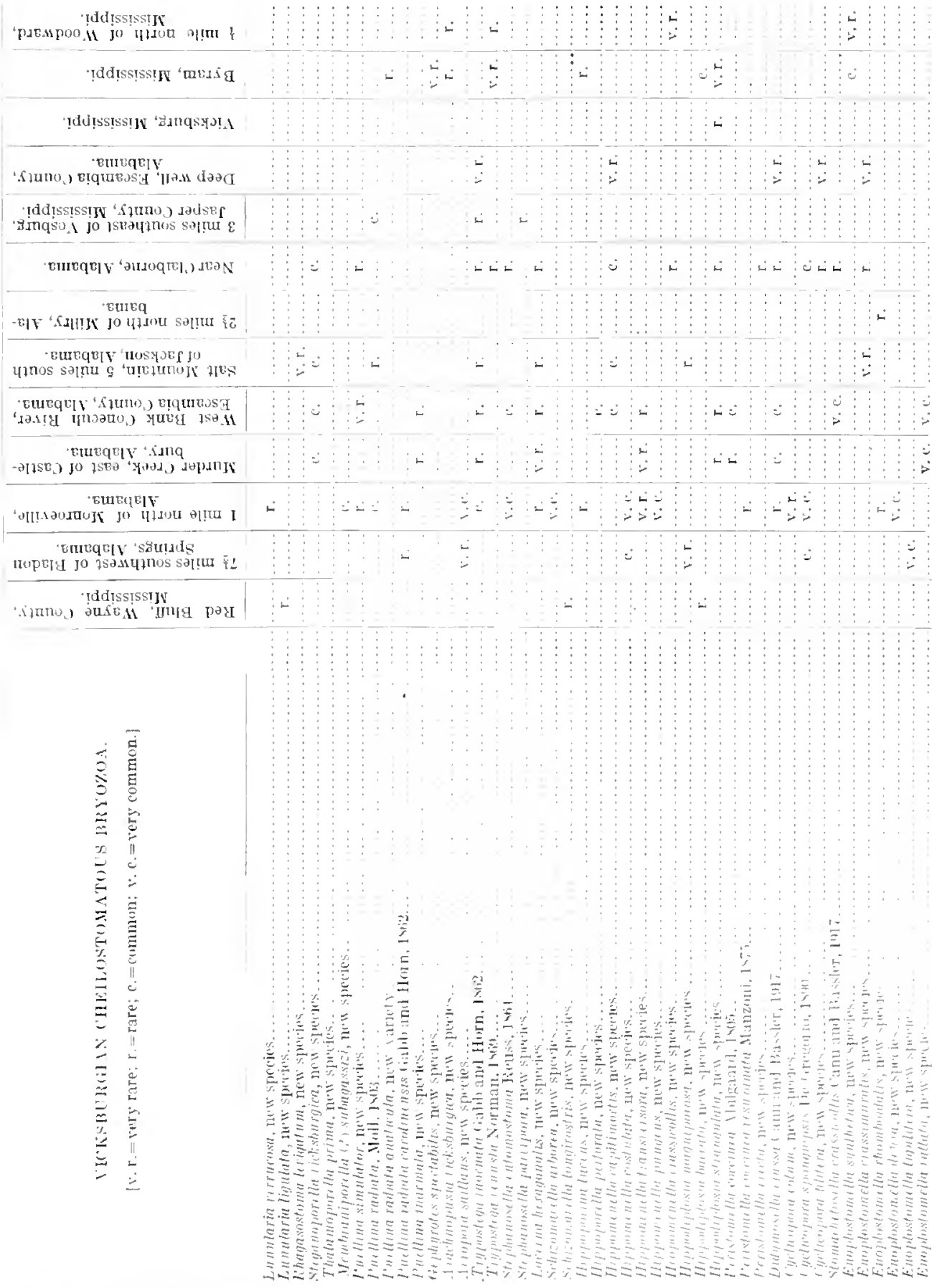




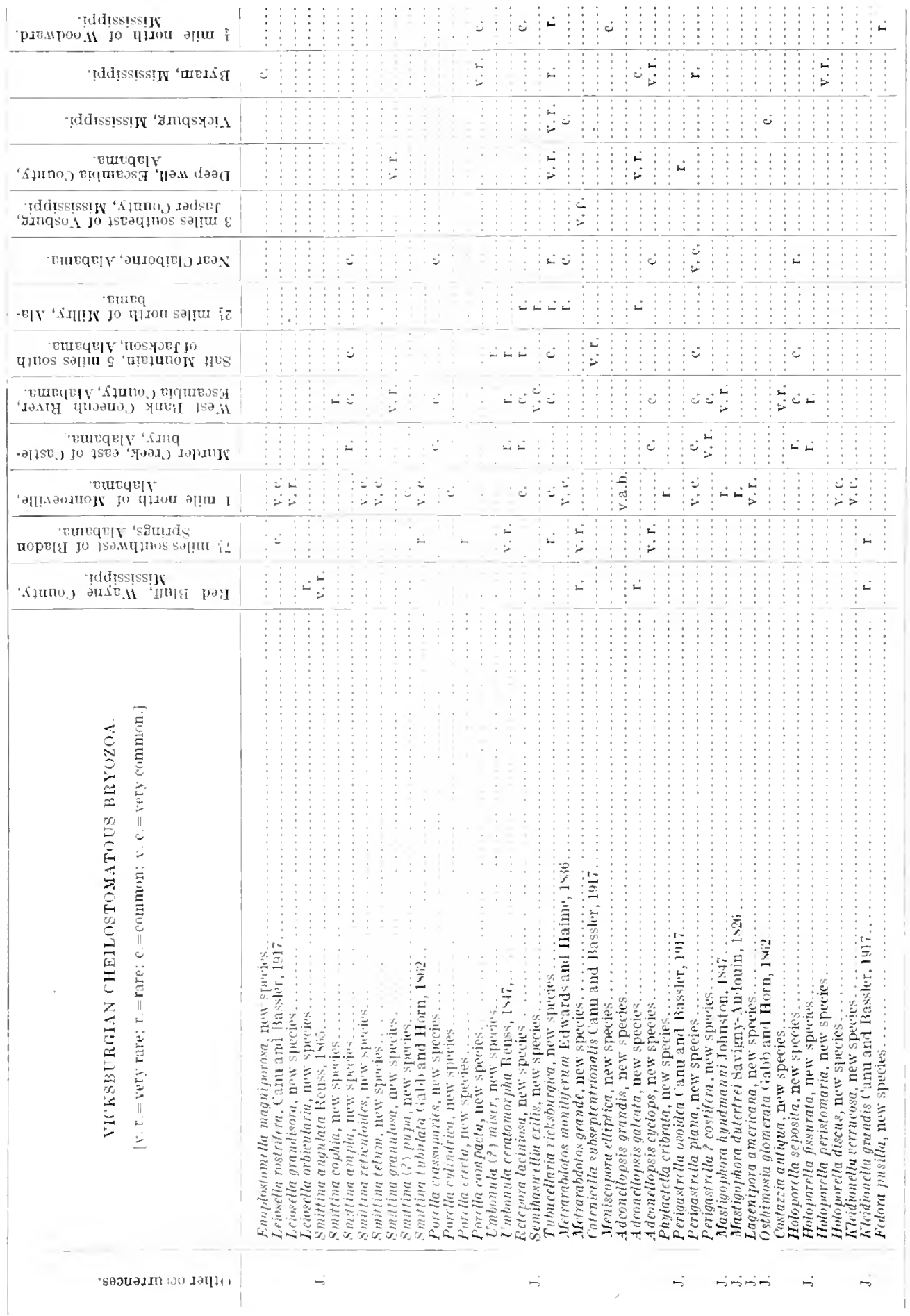




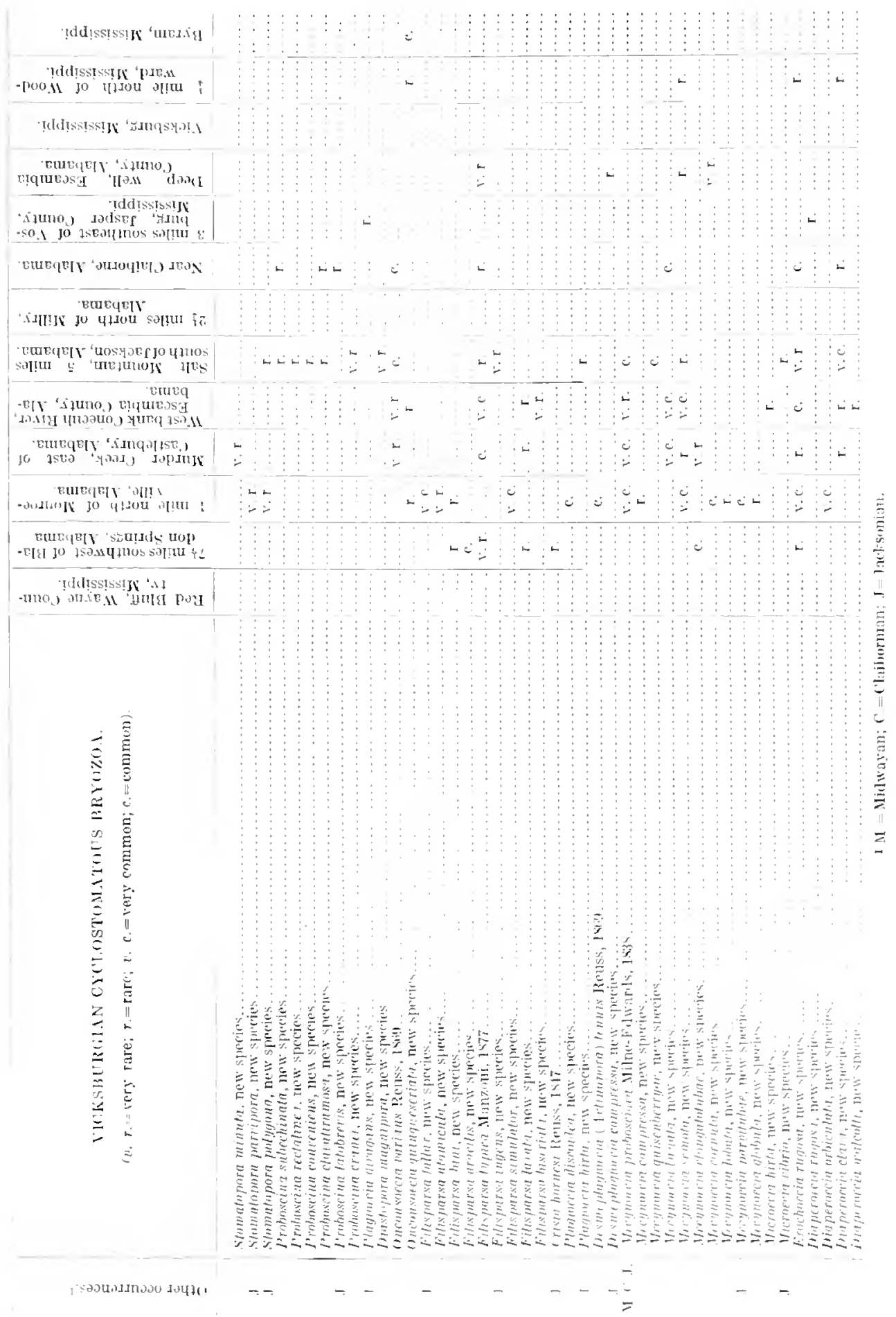




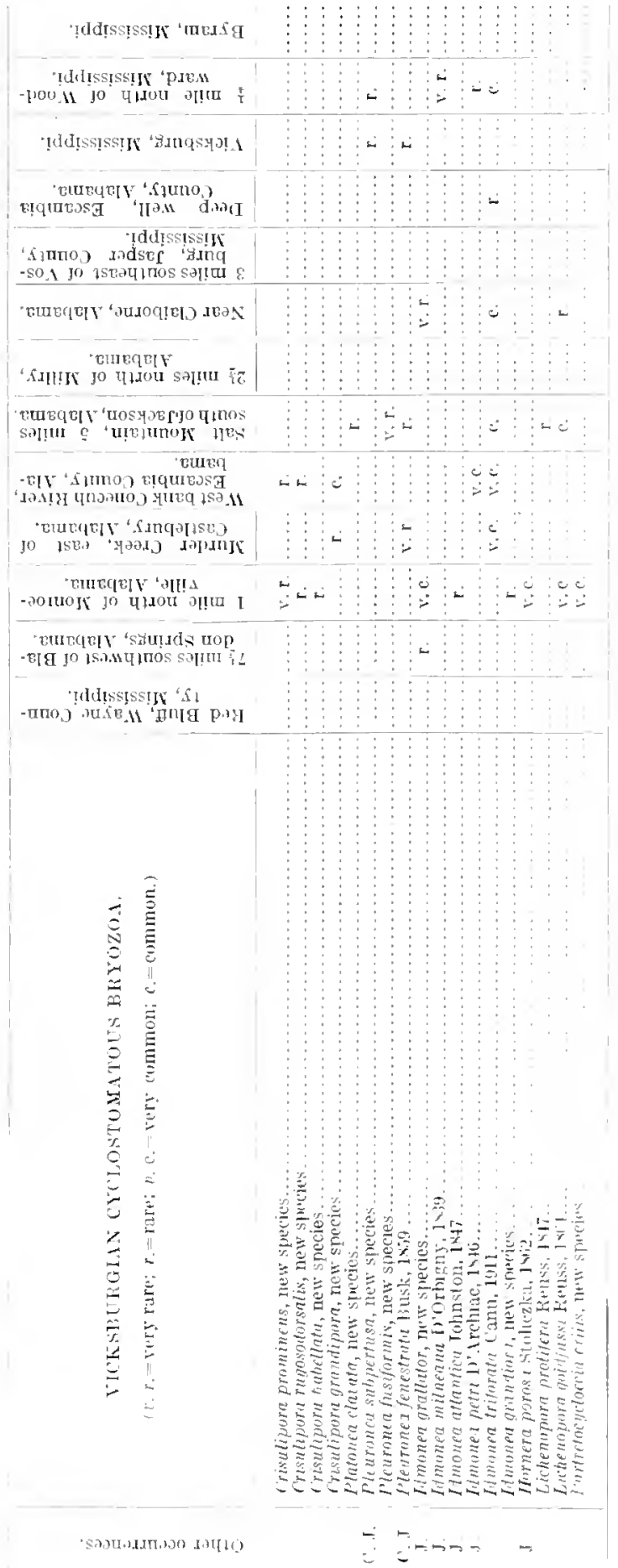


GENERAI, DESCRIPTION OF THE BIIYZOA.

The paper-like fronds called "sea mats" and the moss-like structures tossed up on our sea coasts to-day are not plants as they were long supposed to be. but are animal colonies consisting of a great number of small cells opening side by side. Before their true nature was learned, these organisms were termed aoophytes or corallines, hnt when it was discovered that each individual cell of the composite colony contained an animal witl a complete alimentury canal, the name Bryozoa, or moss-like animal, was coined for them. Another term, Polyzoa, was introduced for the same group and is prefered by many English naturalists, but all of the continental and American authors employ the designation Bryozoa.

In spite of the great abundance of bryozoa in the recent seas and their rery frequent occurrence as fossils. knowledge of their structure is unfortunately usually limited to the special student. For this reason the following remarks, deroid of scientific terms, so far as possible. have been introduced.

The bryozon are small, composite, usually marine, animals arising from a freeswimming larra which becomes attached to some foreign object and then develops int the primary individual or ancest ruli. By repeated budding from the ancestrula. colonies of various shapes and sometimes considerable size arise. Each individual animal or zooid is composed of a double-walled membranaceons or calcareous sac, the zooecium, within which is the visceral mass, the polypide, consisting of a freely suspended alimentary camal $U$ shaped so that the mouth and anus open close to each other. The mouth is surrounded by the lophophore bening a crown of hollow, slender, ciliated tentacles arranged in a circle or crescent. Both sexes are usually combined in the same zooid. It is a curious fact that the same zooecium may be inhabited at different times by different polypides.

The colony which the individual zooids form is known technically as the zoarium; it presents a great rariety of form and structure, although the form is quite constant in individual species. Terr frequentls the zoaria grow orer shells, stones, or other bodies, forming delicate incrustations of exquisite patterns. By the superposition of many such incrustations, hemispherical, globular, nodular, or irregular masses often of considerable size may result. Again the zoaria map arise in fronds or branching stems, and at other times they form open-meshed licework of the most regular and beautiful pattems. Most bryozon are attuhed either basally or by the greater part of their surface to extraneous objects, or are moored to the bottom by root-like appendages. In many forms the zoarium is regularly jointed to give greater mobility.

The indiridual zooids of the zoarium conform to a simple and definite type of structure throughout the class. The soft parts of the animal consist of an alimentary camal with three distinct regions discernible. esophagus, stomach, and intestine. The alimentary canal is inclosed in a se and bent upon itself so that the tro extremities are close to each other. The mouth or oral opening is either entirely or partially surrounded by a row of slendor. hollow. ciliated tentacles which serve for respiration and for sweepine foml towad the month. The two 
large divisions under which the Bryozoa are elassed (Entoprocta and Ectoprocta) are based upon the position of the anal opening. In most cases the anal opening is situated without the row of tentacles (Ectoprocta); rarely it is placed within this row (Entoprocta). A heart and rascular system are wanting, but there are numerous leucocytes floating in the greneral carity. A nerrous ganglion is present between the mouth and anus and sends delicate nerve filaments to the tentacles and esophagus. The upper part of the sac is generally flexible and can be invaginated through the action of mumerons longitudinal and transrerse muscles which traverse the fluid-filled risceral cavity.

The reproductive organs are developed in varions parts of the body earity, although the spematozoa occur nsually in the lower and the ova in the upper part. The ova may be developed in a special receptacle, in an inflation of the surface or in a modified zooecium. 'The grneral trm ooecium or ovicell is applied to all of these structures.

Many bryozoans exhibit, attached to the zooecinm, organs rescubling a bird's head. termed avicularia, and other bristle-like appendages named vibracula. The jaws of the avicularia open and close with a snapping motion which has given rise to the probably erroneous idea that they are organs of defense. The structure of these two organs is described in more detail in the consideration of the cheilostomatoms bryozoa. Both the avieularia and vibracula are incapable of preservation in the fossil state. but their former presence is indicated by the porelike excavations in which they lodged.

The extended polypide is withdrawn into the zooecimm by the contraction of letractor muscles attached to the tentacular crown. In the bryozon with flexible zooecia the contraction of the body walls by parietal muscles produces protrusion of the polypide. Hut in the rigid calcareons zoaria the means for protrusion are morecomplicated (ser proin).

('L.ASTIR]CATTOX.

The Bryozoa and the Brachiopoda are considered as constituting the phyllum Mollnscoidea, although some anthors helieve there is no relationship hetween them and regard the Bryozon as representing a distinct phyllum. The two large subdirisions of the Bryozoa, Ectoprocta, and Entoprocta. based upon the position of the anus with reference to the tentacles have been inentioned before. These subclasses differ widely from each other in many respects and here again some authors believe they are not even distantly related. Hovever, the great majority of these animals belong to the Fetopucta and under this to the superurder frymmolaemata. Five orders of Crymnolaemata are known. of which the Cheilostomata is perhaps the largest in number of species. The relations of these rarions classifieatory terms are expressed in the following table: 
NORTH AMEIIUAN EARLY TERTIAFY BRYOZOA.

\title{
Phyllum MOLLUSCOIDEA.
}

\section{Class BRYOZOA.}

\author{
Subclass Extoprocta.
}

The row of tentacles encloses both the oral and anal orifires.

$$
\text { Subelass Ectorrocta. }
$$

The tentacles surround the nonth only.

\section{Superorder PHYI,ACTOLAEMATA.}

Fresh-water Ectoprocta with the tentacles arranged in horse-shoe shape and the mouth protected by an overhanging lip.

\section{Superorder GYMNOLAEMATA.}

Almost exelusively min rine Ecloprocta with a circular row of tentacles surround. ing the mouth which is at their center.

\section{Order I. TREPOSTOMATA.}

Zonecia calcareous and superposed upon each other so as to form long tubes intersected by straight or curvel partitions. Monticules or maculae of larger or smaller cells distributed on the sulface at regular intervals. Range: Paleozoic only.

\section{Order 2. CRYPTOSTOMATA.}

Gymmolamata differing from the Trepostomata in that the plimitive part of the tube is usually much shorter and the passage to the mature region is more abrupt. Triparietal gemmation. Probably the Paleozoic representatives of the Cheilostomata.

\section{Order 3. C'TENOSTOMATA.}

Zooecia gelatinous or chitinons with tooth-like processe resembling a comb (c)osing the aperture when the tentacles are retracted. Range: Paleozoic to Recent.

\section{Order 4. CYCLOSTOMATA.}

Zooecia calcareous and tubular with a cireular aperture. Range: Jaleozoic to Recent.

$$
\text { Oreler 5. CHEILOSTOMATA. }
$$

Zooecia calcareons or chitinous with the aperture clond when the polypide is retracted, by a chitinous lip on "nereulum. Range: Mesozoic to Rerent.

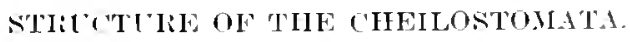

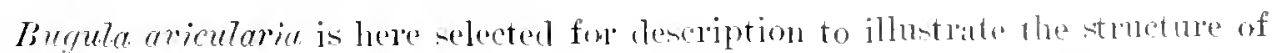
the Cheilostomata, becanse it is one of the most common recent bryozon fomm on the seashore in all parts of the world and is an eximple uf the chan fremently studied. It grows in brown or purple chitingus, bushy tufts soverul inches high, 
attached to rocks or other objects. Upon examination (fig. 1) the fluffy mass is seen to be made up of narrow branching stems with root-like filaments at the base. Under a lens each stem is noted to be made up of box-shaped, chitinous structures-the zooecia, arranged in four longitudinal rows. The zooecia have a wide crescentic aperture near the distal mid (mo.) on either sicle of which is a short, blunt spine. In front of some zooecia is a round structure-the ooecium (ooec), and on most of them is the bird's-head appendage-the avicularium (avic), supported on a short stalk. Beneath the wall of the zooccia, which is simply the liardened and thickened cuticle of the animal proper, is the soft body wall. This body wall is generally known as the endocyst, and some authors apply the term ectoryst to the hardened cuticle or zoarial skeleton. In this work, howerer, the term ectocyst designates the outer membrane covering the zoarial skeleton.

The anterior part of the polypide can be turned inside ont like the fingers of a glove, within the posterior wart. When this portion, the introvert, is extruded a circle of usully fourteen long slender tentacles (tent.) on a circular ridge or lophophore surrounding the mouth is secn at its anterior end. A pair of retractor muscles serves to retract the tentacles. Numerous cilin on the tentacles drive currents of water with their contained food particles toward the mouth $(m o)$. The tentacles are probably tactile and also may serve in respiration. 'The tentacle sheath is the enclosing wall of the introrert.

The coelome or body cavity occupies a considerable part of the zooecial interior. A large double strand of spindle-shaped cells known as the funiculus (funic) connects the aboral end of the alimentary canal with the aboral wall of the zooecium. The body carity contains a number of colorless corpiscles or lencocytes.

Alimentary canal. - The mouth (mo) at the base of the tentacles opens into the pharynx (ph) which by a slorter constricted tuhe leals to the stomach. The coecum is a long conical projection of the stomach directed toward the aboral end of the zooecium, to which it is attacher by the funiculus. The intestine is directed upward and ncarly parallels the esophagus; it opens outside the lophophore not far from the mouth in the anal aperture (an).

Nervous and cxcretory systems. - A small round ganglion located between the month and the anal aperture, giving off nerves to the rarious parts of the zooid, constitutes the nerrous system. No special seuse organs are developed.

Recognizable excretory organs are absent. It is probable that the leucocytes carry on the collection of the nit rogenous waste matter.

Reproductive organs.-Both sexes are mited in the same zooid as in most bryozoa. The ovary (ox.) occurs about the midrle palt of the hody carity and the testis in the lower portion. The latter gives rise to a spherical mass of cells, the spermatidia (sp.) which develop into sperns with long mobile tails. After. the sperms hecome free from each other they move about in the body carity where fertilization takes place. Only one mature orum at a time is developed from the ovary. After fertilization the orm passes into the ovicell or ooecium (ooec) where development takes place. 

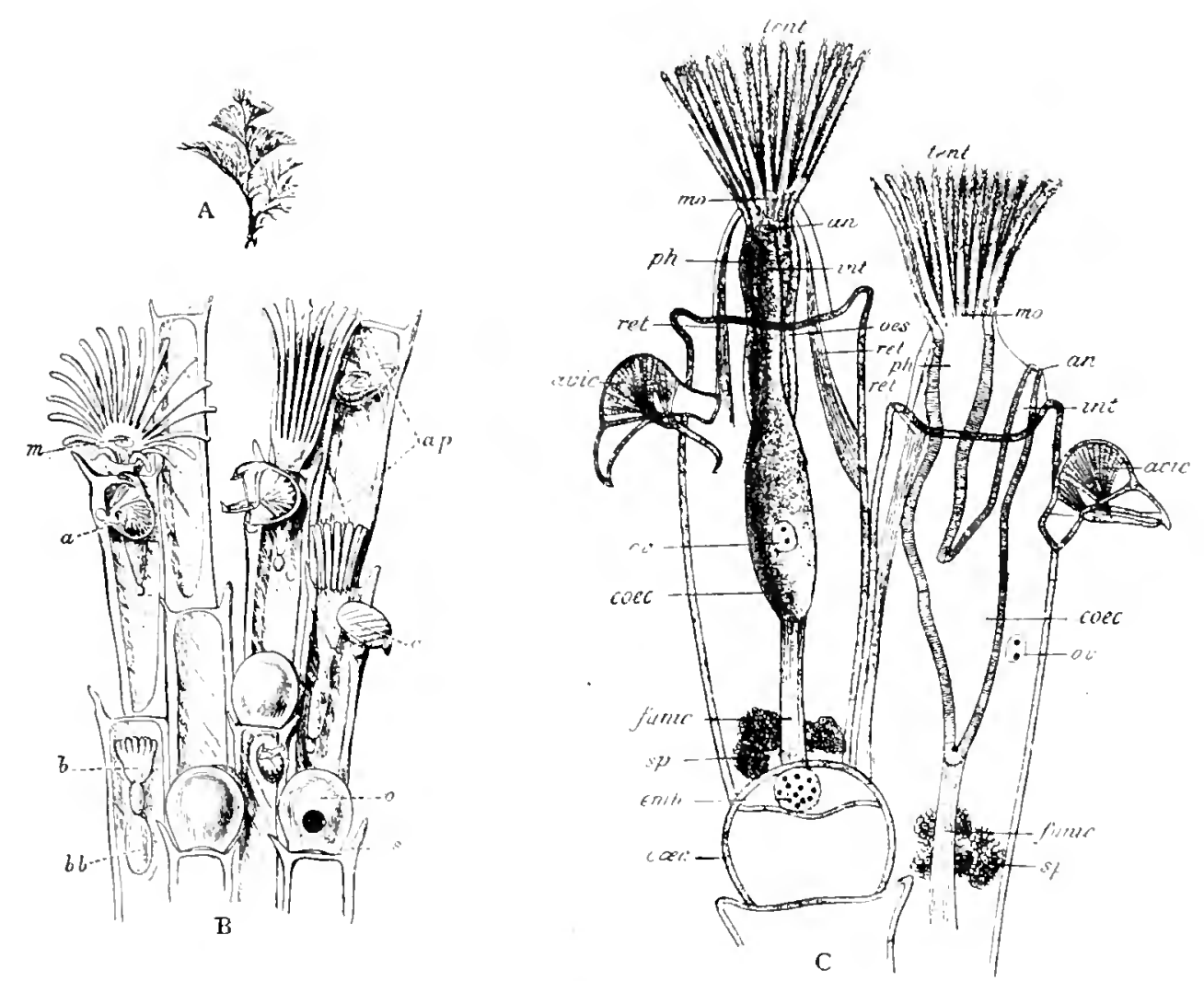

Fia. 1.-Cieneral Anatunty uf the Cheilostomata.

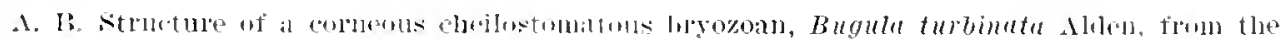
Itlantic at l'jymouth, England.

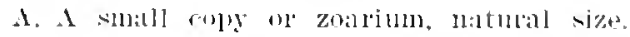

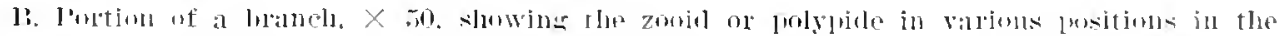

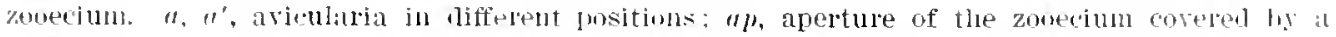

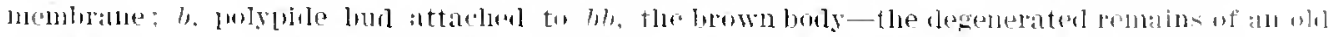

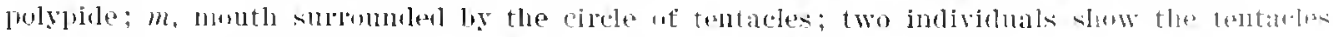

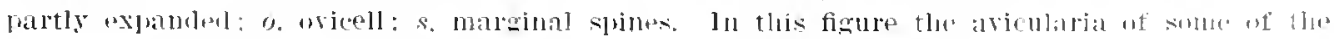

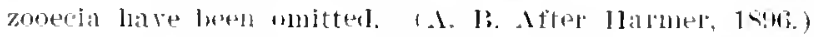

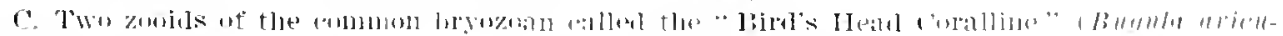

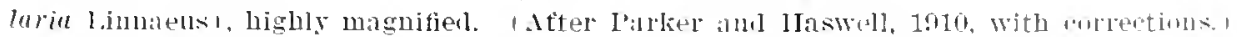

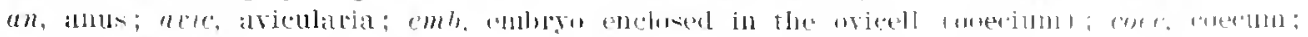

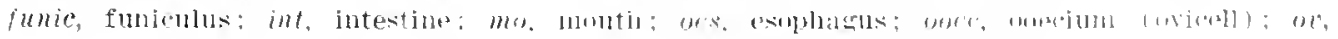

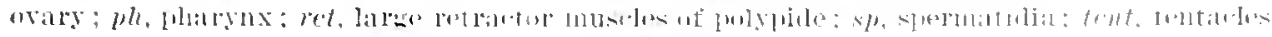

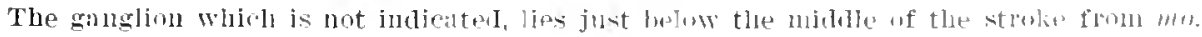


Derelopment of larea.-Segmentation of the fertilized orum is complete and nearly regular (see fig. 2). A blastula in the shape of a biconvex lens is formed and in its interior or blastoevele the primitive endoderm cells (end) become visible. These increase by division forming free cells which almost fill the blastocoele and represent probably both the endoderm and mesoderm. Small cavities necur in

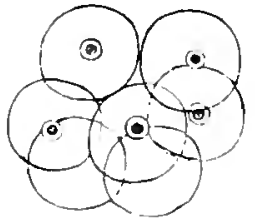

A
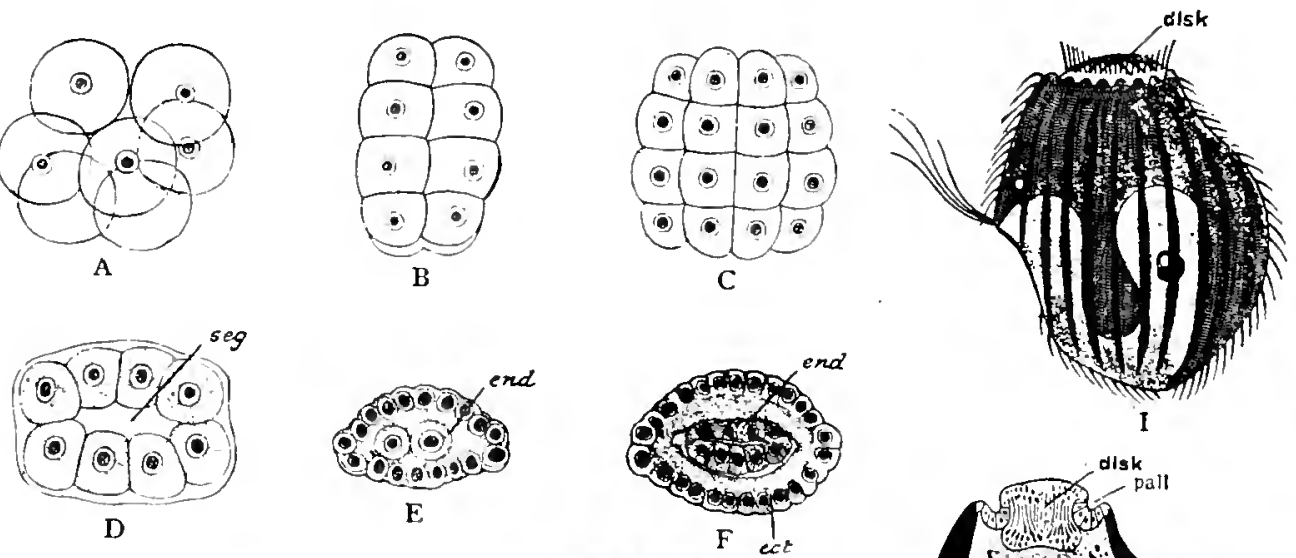

D E
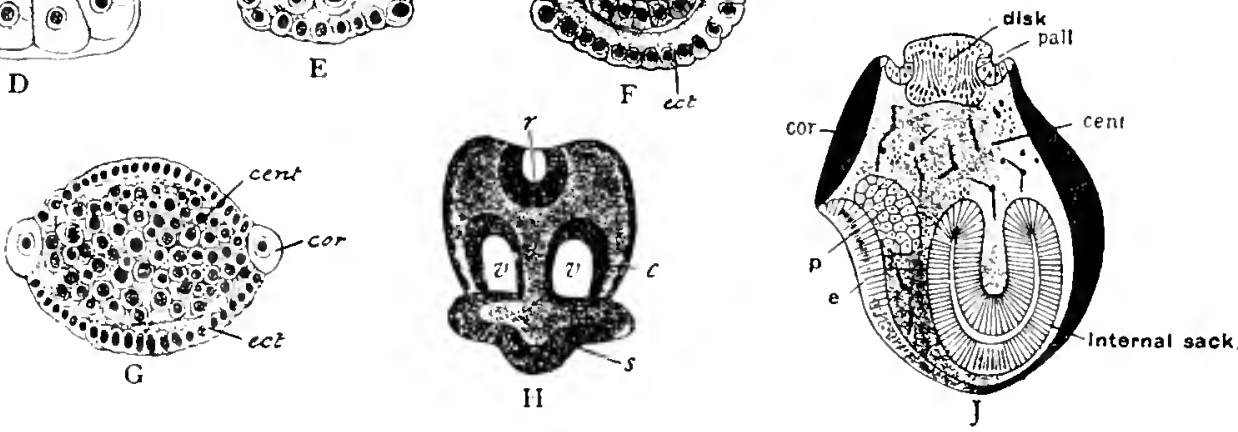

Fig. 2.-Early Stages in the Therelopument of the Cheilostomata.

See text for lescripition of the ligures.

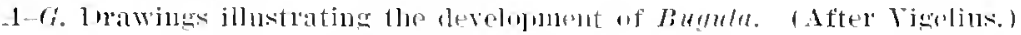

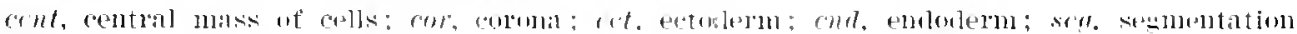
carity.

H. Lemgitudinal suetion of the attaclued larva of $B$ menlu.

c, culls of corona; $r$, rudiment uf the zooid in the furm of a sac; $s$, basal plate of everted suclier ; $v$, restibulus.

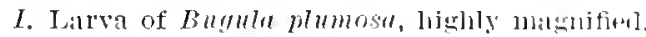

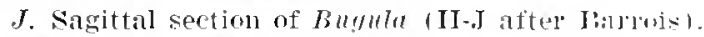

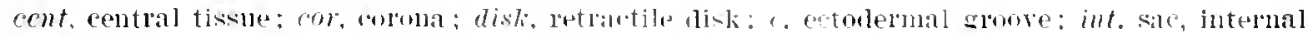

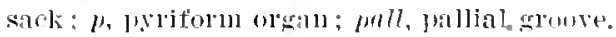

this mass of cells and form the prinitive coelome hy their union. Next the efruatorial region of the embryo becomes thickened and provided with cilia forming the roronn (fig. 2. ( $\mathrm{x}, \mathrm{cor}^{\mathrm{r}}$ ). On the oral side of the corona the cireular pallial groove arises. The sucker, a structure which afterwards serves to fix the larvi, then develops as a sac-like invagination of the ectoclerm or what later beeomes the oral side of the ciliated ridge. On the oral side noir the corona a second depression 
of the ectoderm results in the ectedermal gronve. Near by this groove a mass of cells, the myriform organ $(p$.$) . forms. Another larval structure, the catotto or$ metructite disk (dish) provided with motionless sensory cilia, develops at the opposite or alooral pole.

The larva now escapes from the wivell and commences a short period of free life. Tp to this time an alimentaly canal is absent, but now elnanges oceur which result in a complete metamorphosis of the larva. By a contraction of the body the sucker is turnel inside ont and aflixes the larva to some foreign objert. The aboral side, containing the retractile tisk and pallial groove, becomes expanded and is the source of the entire muter curering of the primary zooid. This expansion obliterates the pallial groove and at the same time the corona bents down toward the oral side. forming the umbrlla-shaped stage of the larva. The restibule (fig. $2 \mathrm{H}$, ) is then formed ly the bending down of the edge of the umbrella and fusion with the expanded lawe, forming thus a circular cavity. The walls of the restilule break up and the arity merges into the general carity of the larval interior. The retractile disk and the basal plate of the sucker are now the only remaining larval structures. The former gives orlgin to the basal part of the wall of the primixy zoosinm and the latter, after beeoming invaginated, develops the ectoderm and endoderm of the primary zooid. Besides this sac the interior of the larva now contains only a mass of undifferentiated tissue terived from the varions structures that have disintegrated. The outer wall of this tissue forms the wall of the primary zooecium and most of the internal mass forms a brown body, although a small part seems to form the mesoderm of the zooid. A pouch $o r^{\circ}$ diverticulum of the sic forms the rudimentary stomach and intestine and a second diverticulum, the esophagus. These fuse and result in the contimuons alimentary canil. In this proees of development the brown body remains close to the stomach and is eradually abouber. After the rudimentary alimentary canal has been formed. the walls of a space in the upper part of the primitive sac avity become changed into the tentacle sheath, on the base of which appear the tentacles and lophophore. The nerve ganglion is the result of an invaination of the ectoderm in the region hetween the mouth and anus.

The primary zooid resulting from the metamorphosis of a lan vis the andentor of the entire zoarium and is ilpropliately called the ancestrula. By a process of asexual reproduction (repeated bulding) the entire branching structure with its numerons zooecia results. Although the studies are still imperfect, it is undoubt-

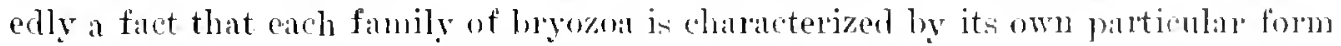
of larva. This process of bumling is di-tessed in more detal mulor the gemeral consiclerations of the Cheilostomata below.

Some zooecia of the adult colomy contain no polypicle, but in its place is a brown body similar to the one deseribed above in the primary zonorim. This brown body is the remains of a polypide that has molerene degenemation. In such cases the alimentary canal with the lophophore and toutacles have become completely absorbed. Such degenerater polypirles may become resenerated with a

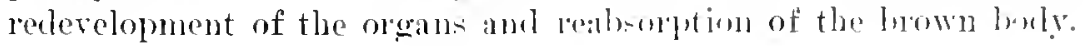


ENDOCY INT ECTOCYST.

The skeletal portion of the bryozoid is lined interiorly by a very fine epithelial nuembrane called the endocyst. This cndoryst is the essentially living part of the bryozoan. It grows without cessation ly the proliferation of its elements, and it secretes the different cuticles. It emits bud of like characteristics but which encencler by successive differentation the varion- ar gans of the bryozoid. ${ }^{1}$

The first differentation, almost immediate. incleerl. is the ectocyst ${ }^{2}$ (epitheea of Harmer, outer menbrane, frontal nembrane of Waters). This is generally thin, so thin sometimes that its presence is often doubtful: ${ }^{3}$ it has no secreting power.

The calcareous or chitinous secrotion forming the "zoarial skeleton" occurs between the ectocyst and the endocyst. This is the only part capable of fossilization. The study of the relations between the skeleton and the living olgans of the zoarium forms the essential object of tudy of paleontologic bryozoology.

The second differentiation of the enclocy-t is the formation of the mesenchyme and of its successive delivatives-polypirde. lencorytes. etc. ${ }^{*}$ This study is in the domain of zoology exclusively.

The difference of orientation in the prolifuration of the endocystal elements is most inportant. In the Anasea this proliferation oceurs only laterally. In correlation early on the budding parts of the zuarium, the endoerst dirirles in two and provokes a corresponding division of the entreyt. thus engenderine the hydrostatic apparatus called the hypostege ( fig. 3 ).

In the Ascophora the proliferation occur- in two wits-lateral and frontal. In correlation the endocyst derelops an both silles af the zondial skeleton. owing to the emission of frontal luels (fig. 3). Thum in the Mnasea the buth are alranged side by sicle, while in the Ascophoral they are liand oree each other.

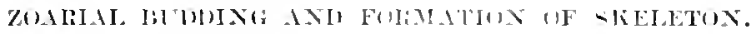

Tho buds of the endoeyst are as noted abrive. lateral or frontal. They eviclently secrete lime and occasion secondary calcitivaltinn.

'The lateral buds are:

1. Little dereloped and leave in focilization the lateral punctations (= parietal dietellae) of the diromidac.

2. Inre developed. they form the avionlarial the interzonecial vibracula (Adeonidae, Lumulariidae, Onpehocellidac).

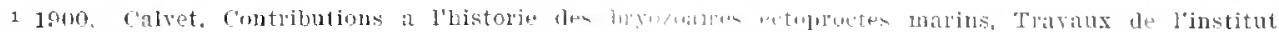

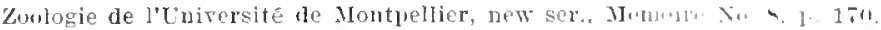

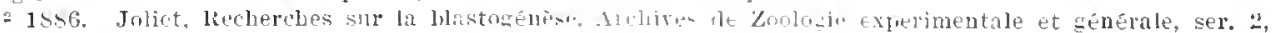
vil. 4. [. 6.5

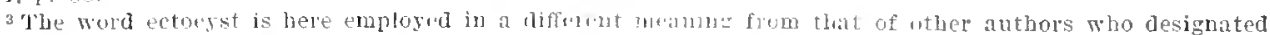
as the "ectocyst" that part of the hrozowis which wr wall the sheleton.

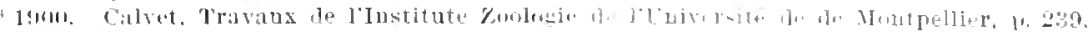

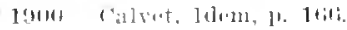




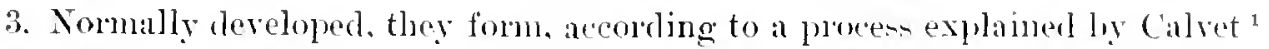
and by Waters; " one. two larely threc, distal zooecia. Moreover. the coalescence of many buds is often necessary for the formation of a zonecium or of an interzooceial heterozonceium. ${ }^{3}$

Similarly with the frontal buds:

1. Little developed, they form above the olocyst, a second deponit the tremoryst; their fossil remains are the tremopores.

2. Little dereloped and only laterally. they form the lateral punctations, the zoarial remains of which are the areolae of Harmer. visible in Smittinidac, Escharellidae, etc. They engender the superjor endocyst. "The latter deposits the pleurocyst above the olocyst and form the interareolar costules.
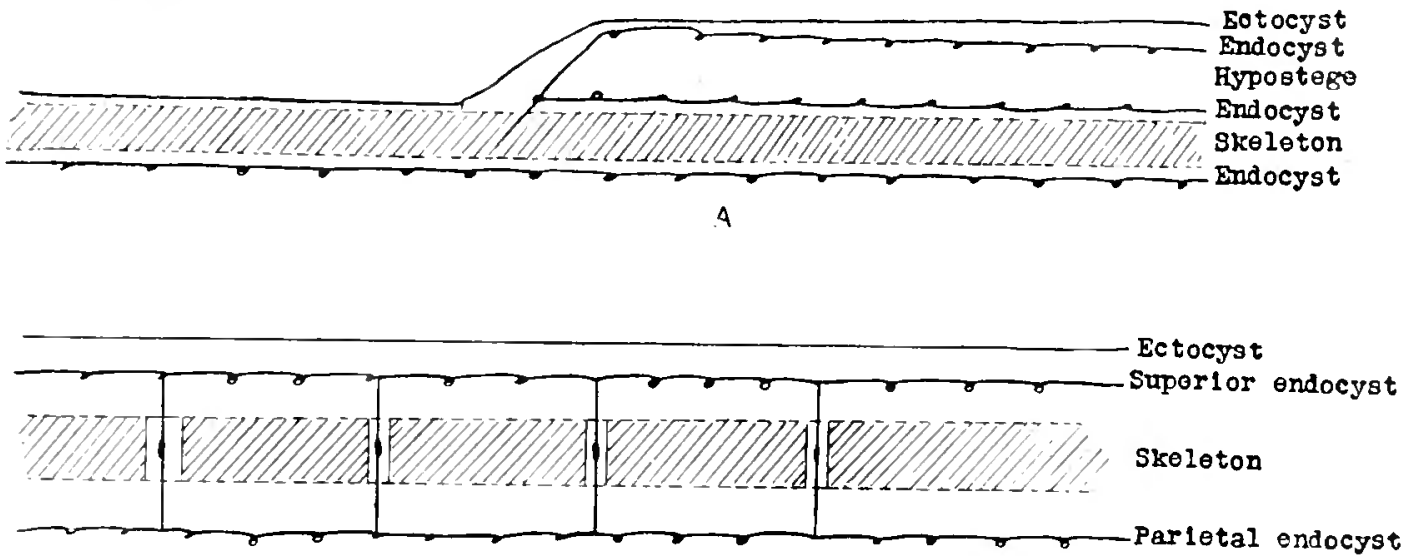

B

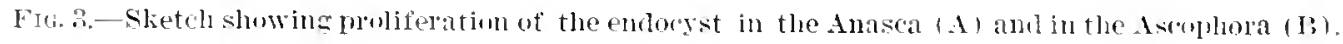

3. Somewhat more developed. they form and secrete the skeletal tubutes which make up the thick wal]s of the Acroporidae, Myriozomidae. Porella, etc.

4. More developed, they engender the fuontal avicularia and the radicels.

5. Normally developed. they give rise to the complete zooecia lueaped up un one another without apparent order as in the Celleporidae.

The gymnocyst of Levinsen and the cryptoeyst of Jullich are not special formations: these are special walls definer particularly by theil punition. The cloptoryt. -upports the hypostege in the Malacostegal the gymmoryt are not mpport it at all: these walls may be of olorystal or tremocytal fomation. Wh have preserved these two terms of nomenclature in the exact menning of thip atuthor.

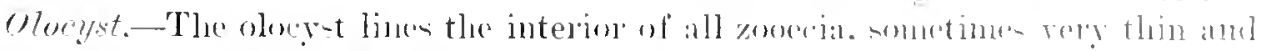
tuansparent and sometimes quite thick. It is formed of wontered clenents, quite

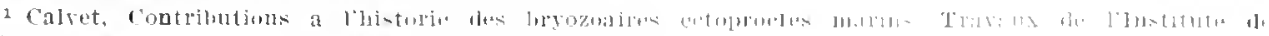

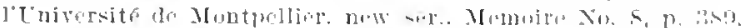

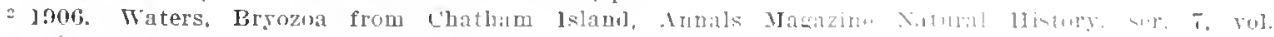
17. 1. 1. 15

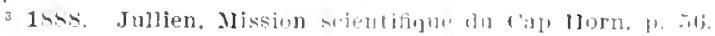


crowded on the large walls (fig. 4. A). When there is a mucro, the elements are grouper in radial rows (fig. 4. $B$ ). The walls of the mural rims in the Malacostega also have their elements grouped in rows perpendicular to the lines of the zooceial sutures (fig. $4, C^{\prime}$ ). The olocystal walls are always smooth (fig. $t, D$ ); they are perforated by very small pores when they are surmonnted by a tremocyst or a plenrocyst.

Tremocyst.-The frontal endoevstal buds deposit above the oloeyst a second calcareous deposit called the tremomst: the pores thus formed are the tremopores;

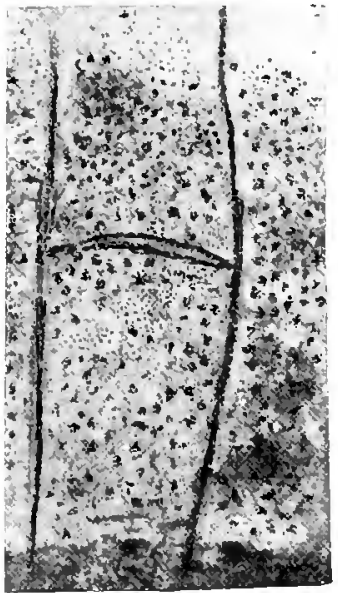

$A \times 100$

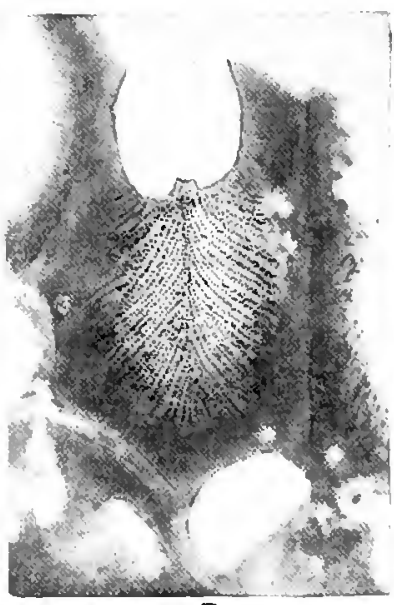

$\mathrm{B} \times 100$

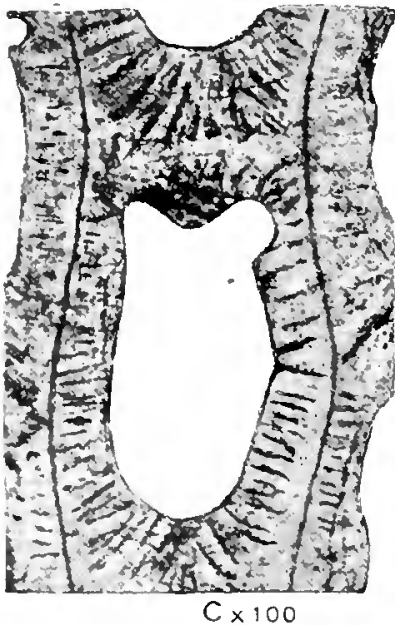

$\mathrm{C} \times 100$

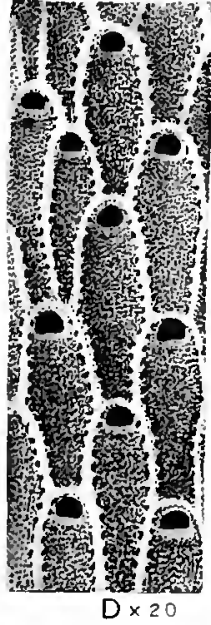

$\mathrm{D} \times 20$

Fig. 4.-Strunture of tles oloryst.

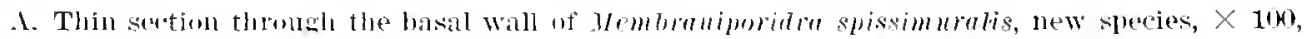
slwwingr olocyst with croweled elements.

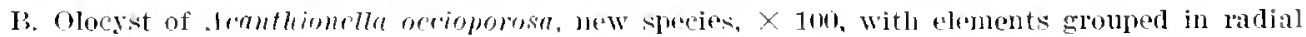
lines.

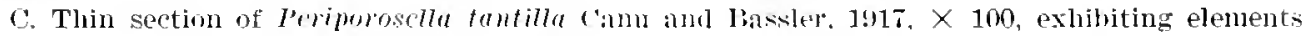
of olocyst gromper in series aromm the mural rim.

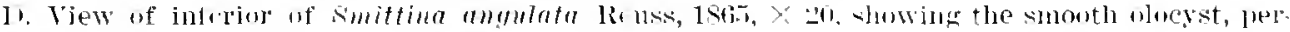
foriterl by areoline only.

the zonecia, which are provided with them. are tremogastres: the tremopores are fimnel shaped or tubular: they are always traversed by mesenchymatous elements.

The funnel-shaped tremopores arise from a rery small pore perforating the

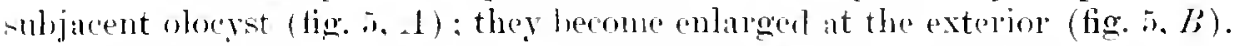

The tubular tremopores or tubutar also arise from a snall pore piercing the subjacent olocyst (fig. 5. ' '). but the latter is very thin and permits one to see through a circular. white area the base of the tubula itself. It the exterior the tubules have the same diameter (fig. 5. $I$ ) ).

Often the tubular pores are united among themselves and the number of the interior pures (fig. $\pi, E$ ) does not correspond to the number af exterior pores (fig. 
5, F), as in Porella contructa, new species, Enoplostomella syntheticu Canu and Bassler, 1917, etc.

The tremocyst is generally intimately united with the subjacent olocyt; in some cases it is clearly detached (figs. $5, G, I I$ ).

In tangential sections the size of the tremopores depends on the position of the plane of the section. In the vicinity of the oloeyst (fig. 6, $A$ ) the small per-

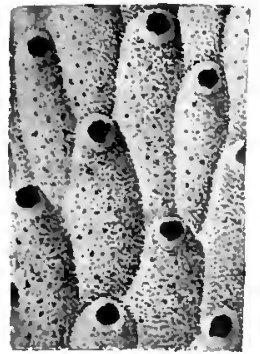

A $\times 20$

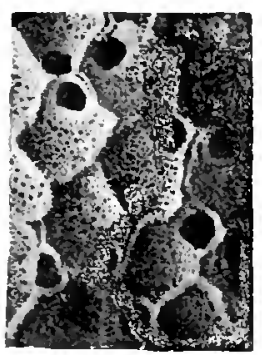

$E \times 20$

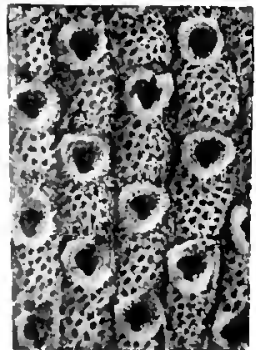

$\mathrm{B} \times 20$

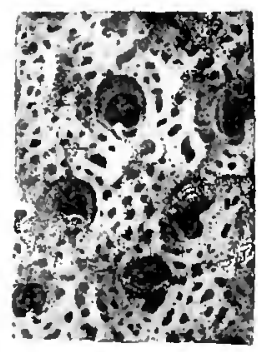

$F \times 20$

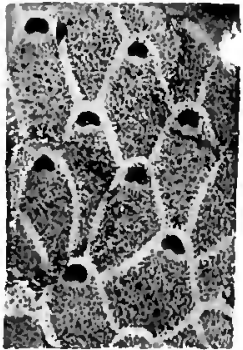

$\mathrm{C} \times 20$

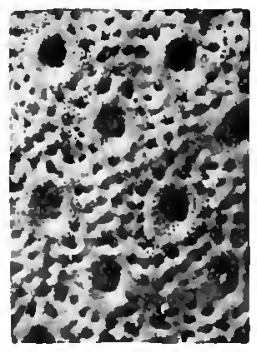

$\mathrm{G} \times 20$

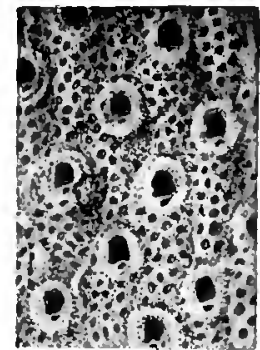

$\mathrm{D} \times 20$

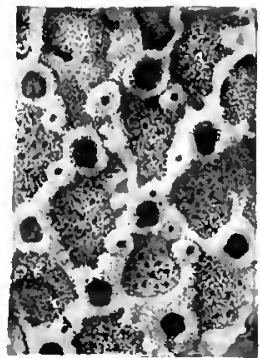

$\mathrm{H} \times 2 \mathrm{O}$

FIr. 5.-Structure of the tremocrst.

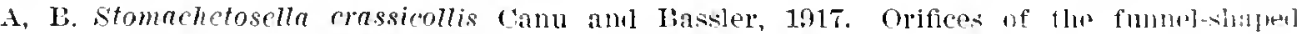
tremopores as seen in the interior $(A)$ int at the exterior $(B), \times 20$.

C, D. Porella rrussoparies, new yeries. Orifices of the tululat tremopores, $x$ :'l, in the interiol (C) and at the exterior (D).

E, F. Enoplostomella synthetiea, new species. Views, $\times 20$, showing contescence of the tremopores, the number of which in the interior ( $F$ ) does not correspond with the number at the exterior $(F)$.

$G, H$. Hippodiplosia magniporosa, new species, $\times 20$. Views showing that the tremocyst $(\xi)$ mas be detachen from the suhjaldent uluerst (II).

forations of the latter are alone visible. At the zorral surface (liw. (i. II) the tremopores have their normal diameter. It is ifuite frequent to find thes in che

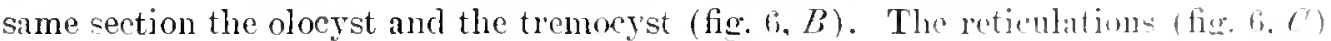

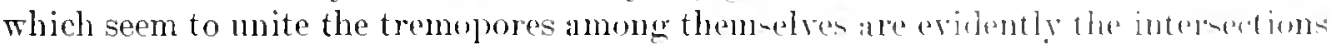
of the different calcifications.

Tubules.-The tubular tremopores, when ther are quite long, constitute the

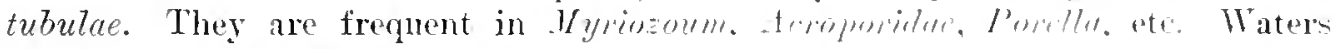
อัร599-19-Bull. 106-4 
and Levinsen have carefully studied these structures. "These tubes have a disk near the junction with the zonecinm. and in the middle of the axial tubes, which are often very long, there are similar disks (fig. $7, A$ ). The shell structure is terminated by a membrane $(b)$ (fig. $\tau, B$ ) perforated by these pores: but over this, as in the greater part of the cheilostonatous bryozoa, there is another fairly thick and somewhat chitinous membrane $(a)$ (fig. $7, B$ ) continnously covering the zoarium. The cell contents of the tubes attach themselves to this by delicate

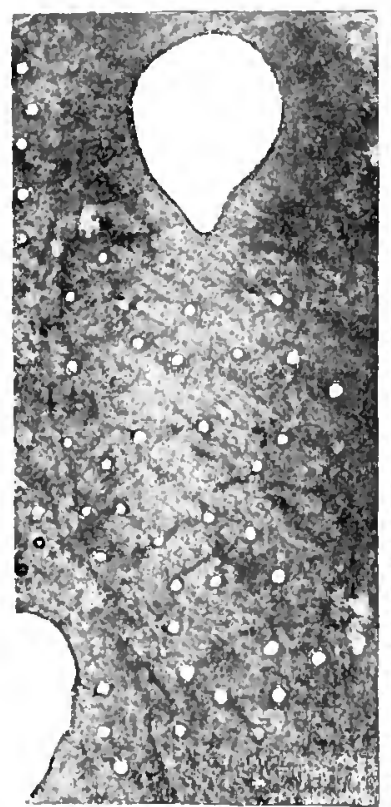

$A \times 100$

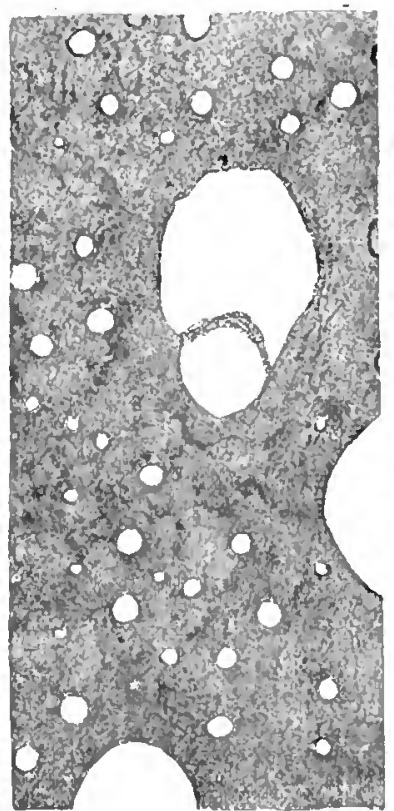

$B \times 100$

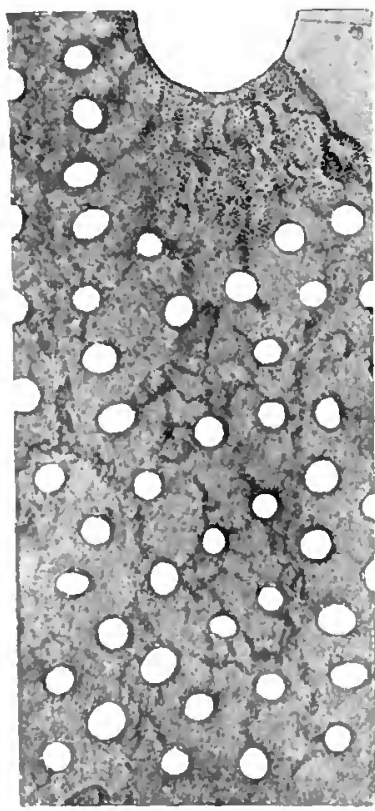

$\mathrm{C} \times 100$

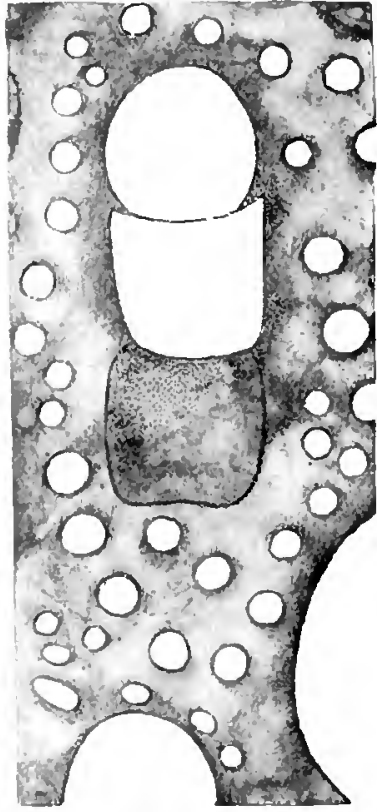

$\mathrm{D} \times 100$

Frg. 6.-Microstructure of the tremucyst anf olucyst.

A. Stomachctosella crassicollis Canu aml Bissler, 1917. Tamiential sectim, $X$ 100. at the level of the subjacent olocyst ; the inner urifice of the tremepores is visible.

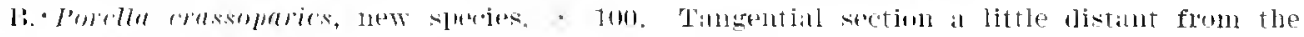
Heregt. blocyst and tremoegst are visible.

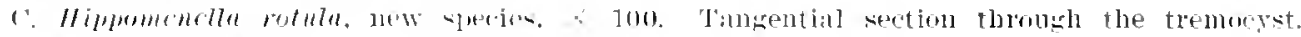
Areolie and tremolores are of the same nature.

D. Porella denticulifon, new speries, $\therefore$ 100. Tangential section throngh the orifices of the tremonoms.

threads" (fig. $7, C$ ) (Waters, 1900). Levinsen in 1909 demonstrated that these "delicate threads" were formed of mesenchymatous tissue.

Plemrocyst. - The arenlas are only lateral tremopores; they are the remains of endocystal buds and are traversed by mesenchymatous fibers. The superior endocyst continues its calcareons deposit as the phemocyt: ${ }^{1}$ the lateral arrancement is the cause of special manifestations quite different from those of the tremocrit.

\footnotetext{
"This deposit llarmer and Lerinsen attribute entires to the ectocyst.
} 
The calcareous secretion is first active alout the areola (fig. 8. A), but it extends rapidly over all the frontal.

The plenrocystal deposits are often granular (fig. $S, B$ ) but they generally form interareolar costules (fig. S. C) so frequent in Smittina, IIippomenella, etc.

The porous pleurocyst is more rare (fig. $8 . D, E$ ); the pores are unequal, irregular, and arise from the irregular union of the primitive granulations. Contrary to the tremopores they do not perforate the subjacent olocyst (fig. $8, D$ ).

The pleurocyst is easily detached from the olocyst (fig. S. F).

The areolae appear clearly in the tangential sections when made at the level of the olocyst (fig. 8, $G$ ). Made on the exterior plane the interareolar costules alone appear (fig. 8, $I I$ ).

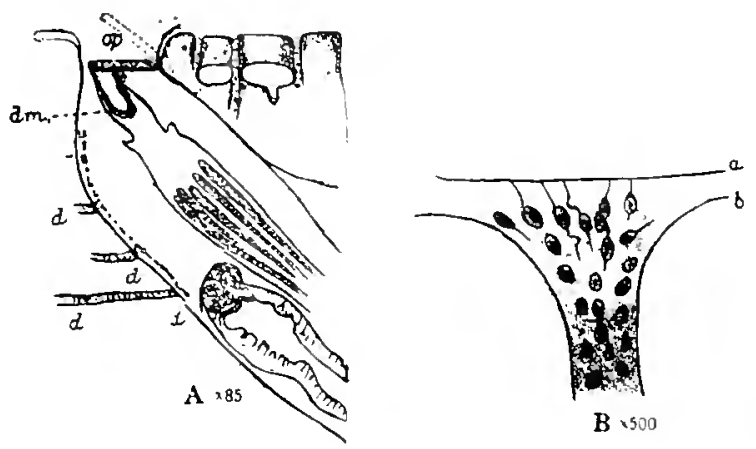

l'IG. T.-Silucture of the tubules.

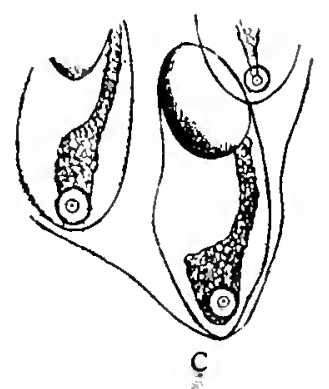

A-C. Alyriozoum subgracile D'orbigny, 1852. A. Section, $X$ 85, throngh polypide showing the disks ( $d$ ) in the pore tubes, diaphragm $(d m)$, and the operculum $(o p)$, with dotted lines to show the position when partly open. (After Waters, 1900.)

B. End of tubula, $X 500$, showing the covering interument a (ectorst) and the inner une, $b$. (After Waters.)

C. Each of the tubes contains a mesenchymatons tractus, and is, at its proximal prit, furmished with a uniporous septula. (After Levinsen. 19ub.)

Made in an intermediate plane they show some radial reticulations which are eridently the intersections of the different calcifications (fig.,.,$I$ ).

On recent bryozon these three fumelamental deposits are suligect to mme interesting variations, the study of which was only berun in 1909 ly Levinsen. ${ }^{2}$ Te refer the reader to his work, for on the fossils these variations are quite invisible.

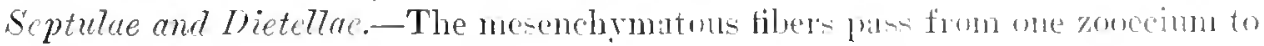
another by small pariatal pores called septutuc. The septulate alre miporons (fig. $9, A$ ) or multiporous (fig. $9, B)$ (=rosette-plates of authers). On the fossils the

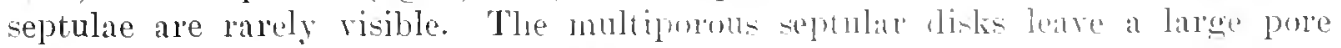
often visible exteriorly. as in the IIembraniporace Fur shortnes in this monograph we called these structures al-o septulae.

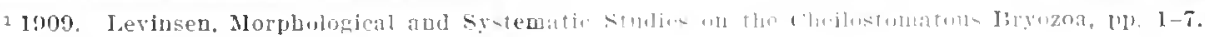


The mesenchymatous fibers before passing through the septulae traverse in the proximal part only of the zooecia small lateral chambers called dietellae (= pore

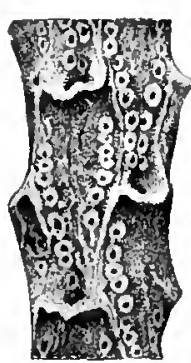

$A \times 20$

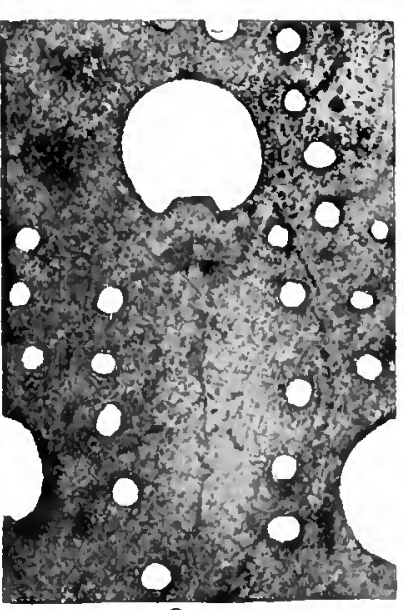

$G \times 100$

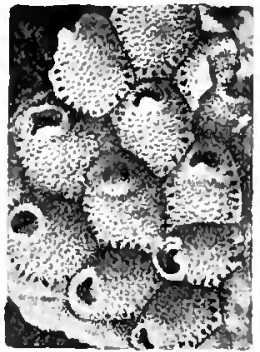

$B \times 20$

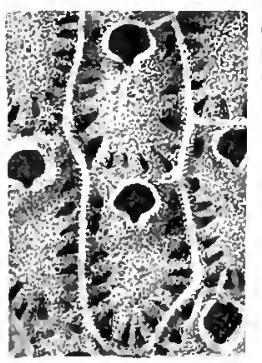

$\mathrm{C} \times 20$

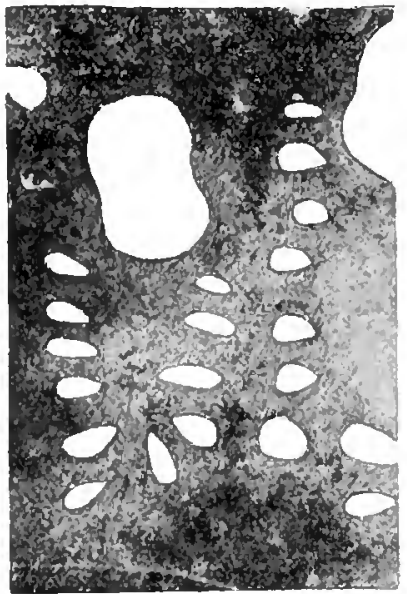

$\mathrm{H} \times 100$

$D \cdot 20$
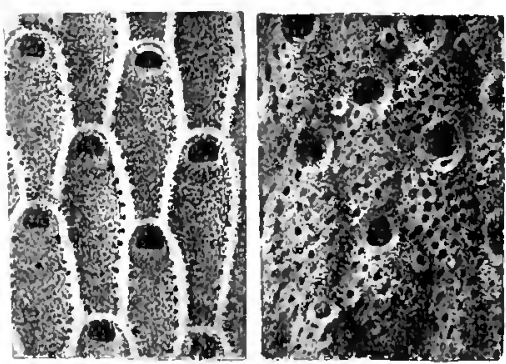

$E \times 20$

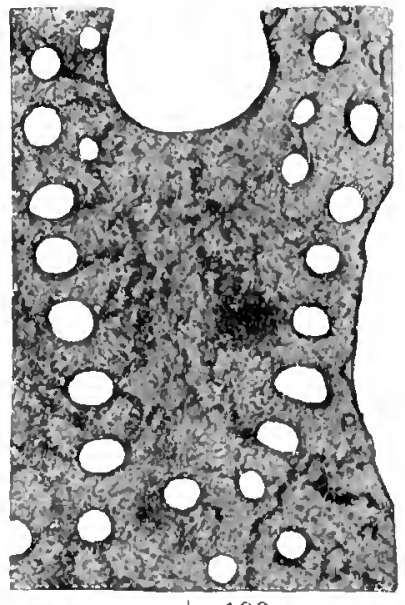

$1 \times 100$

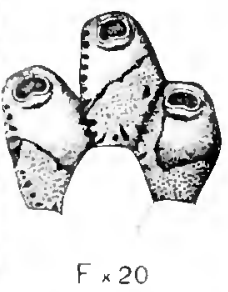

Fig. S.-Structure of the plenrocyst.

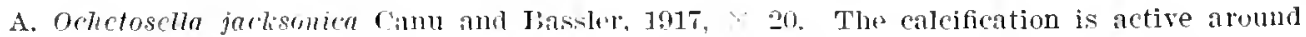
the : ireolae.

B. Mucronelfa gramulosa, new species, $\times$ so. Granulalr pleuroesst.

C. Smittina arandifossac, new slecies, $\times 20$. l'lemcrest with interareolar costules.

D, E. Smittina anqulata leuss, $1865 . \times 20$. Porons pleurocyst. In the interior the olocyst is perforated only by areoline (D).

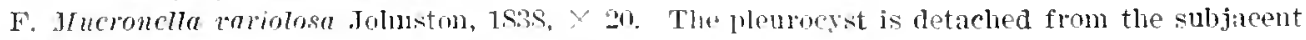
olocyst.

G. Smittina reticuloines, new speries, $X 11 m$. Timantinl thin section in the vicinity of the ilocyst.

If. Smittina reticuloides, new species, $\times 100$. Tangential thin section through the interarevlar costules.

I. Himmenella rotula, new species, $\times 100$. Tancential thin section through the pleurocyst.

chambers of English authors) (fig. 9, $C, D$ ). These structures persist in fossilization only if their walls are thick: they may be rlisenvered by abrasion of the frontal 
(fig. $9, E$ ). In certain speeies (see $M c m b$ rendoecium. duplex) some of the zooecia are without dietellae.

\section{FUNCTIONS OF REPRODTC'TION.}

LAISVA.

The great obstaele in bryozoology is the lack of knowledge of the larral srstem, for studies on this subject are really very incomplete. Moreover, any attempt at a general classification is impossible at present, because each family is undoubtedly characterized essentially by its larra. Nevertheless we are alle to ntilize with success the studies on this subjeet made by Smitt in 1865, Barrois in 187, and Calret in 1900. In our text figures we have reproluced illustrations of the larva wherever known.
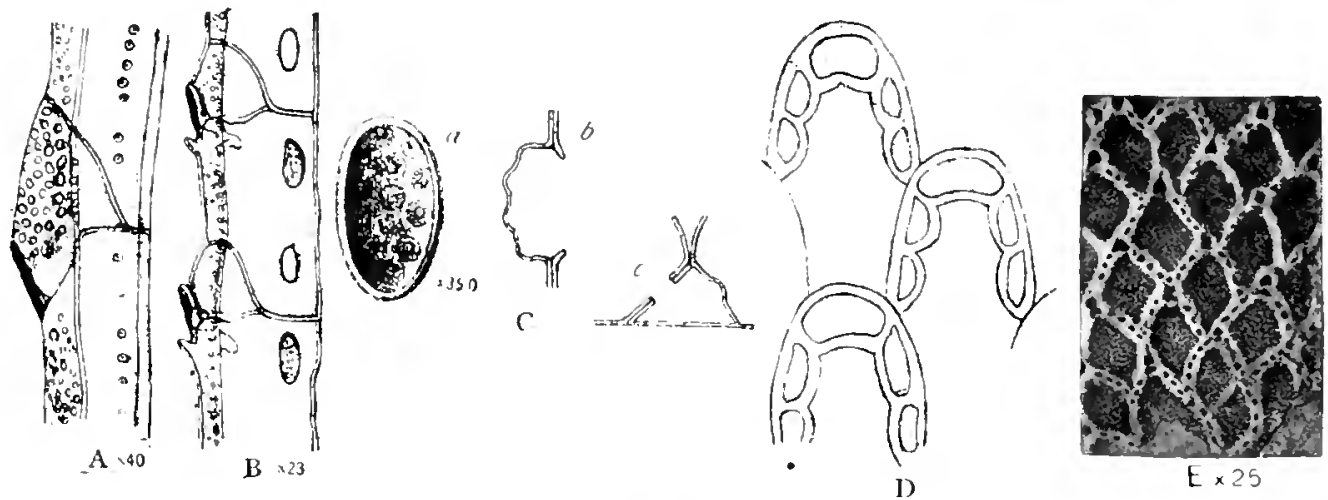

F's. 9 - Steptulae and dietellae.

1. Uniporous septulae of IFippopodina fereensis Busk. 1SS4, $\times 40$.

B. Multiporous septulae or disk septulae of Cheilopora sineera Snitt, 187t, X 25. (A, B, after Leviusen, 1909.)

C. Hippodiplosia pallasiana Moll. 1S03: 0 , multiporous septula. X 350: h, schematie lomgitudi mal section through a multiporous septula; $C$, schematic longitudinal section thrugh a dietella (.After Lerinsen, 1909.)

I. Iretellae of Callopora lincata Linnaeus, 176s. (After Nornan, 1903.)

E. Dietellae of Trypostega renusta Norman. 1864. olitained by abrasion of the fiontal uf a specimen from the Vicksburgian at Iyram. Missiscipri.

1)ICLIS.

The egers are transformen into embryos and into larva within carities of incubation. These eavities, when they are risible. are callel orict $7 t$.

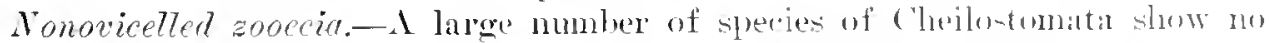
ovicalls and nothing on the exterion leveals their mole of repulution. Fume are

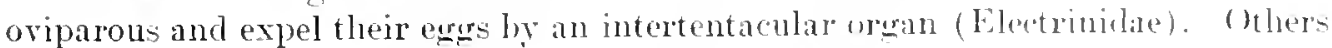
develop their embsyos in the tentacular sheath (Crchotomata). There in guite an

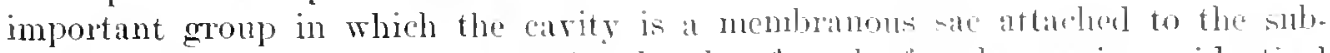

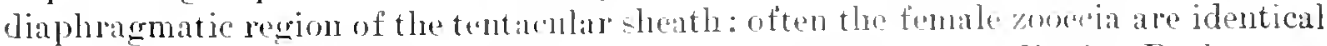

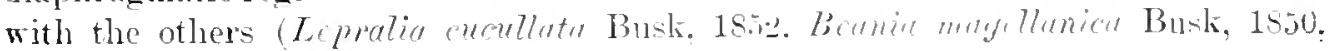


Diplodidymia Reuss, 1867); but often also the female zooecia have a special form suitable for their function (=gonoecia of the Adeonidae and Catenicellidae).

In actual experience it is necessary to have a very large number of specimens to establish that any fossil species entirely lacks ovicells, for these organs are very fragile.

Nature of the ovicells.--Most of the Cheilostomata have some visible ovicells. Their nature is not always peculiar to a particular larral system. Nevertheless the cndotoichal ovicell appears peculiar to the Cellaridae, the recumbent oricell to the larvae of the Phylactellidine and the Conescharellidae and the peristomial ovicell to the larvae of the Tubucellariidae. In all other cases many very different systems of larvae may be developed in ovicells apparently identical; these latter are endozooecial or hyperstomial.

The endozooecial ovicells are formed by the distal portion of the zooecium; in certain genera they are separated from the zooecium by a fold of the wall (Flustridae, Hippopodinidac, Farciminariidae, Onychocellidae, etc.).

The hyperstomial ovicells are placed on the distal zooecium. A rery important group among them has their orifices closed by a distinct operculum formed for the most part by the ectocyst itself; this is the group of the Aneucleithriens. In practice, on the fossil forms, such oricells are recognized by their frontal which does not hide the apertura; seen in profile, their orifice is perceptibly perpendicular to the apertura.

A second group has the orifice always closed by the operculum; this is the group of the Cleithricns (Micropora, ete.). Practically, on the fossils these are recognized as follows: First, their frontal partially covers the apertura; second, seen in profile, their orifice is oblique to the apertura; third, the common orifice is identical and of the same size in all the ovicelled zooecia.

The third group, that of the Subcleithriens, is intermediate between the two preceding; the operculum closes the ovicell only in opening. This opercular function is certainly intended to protect the passage of the eggs. On the specimens deprived of their opercula. the distinction is rery subtle, especially as the closing is not always perfect. Practically on the fossils, subcleithrien oricells are recognized by the following points: First, their frontal partially covers the apertura; second, seen in profile their orifice is oblique to the apertura; third, the common orifice is identical with the true orifice; fourth, the common orifice is identical with the apertura of the moricelled zooccia.

When the operculum is fragile the ovicell is more or less deeply imbedded in the distal zooecium: the apertura is oblique: the ovicell opens into a small, free space called the locella (Peristomellie).

Again, when the operculum is fragile the frontal becomes much thickened and the ovicell imbedded in the distal zooecimm opens into the peristomie thus formed. The apertura, more or less visible and oblique, is placed at the base of this peristomie (Smittinidae). The exterior orifice is therefore never closed by the operculum and it is rery irregular. 
Figure 10 gives a summary of the terminology now applied to the ovicells.

Stmeture of the avicells.-In 1886 Jullien discorered that the ovicell was formed by two walls; the internal wall or "sparganile" is thin, fragile, and hyaline; the external wall, or "coites," is thicker, often incomplete, proceeding from the peristome and sometimes intimately joined to the subjacent wall. In 1903 he described the peculiarities of these two walls for each species.

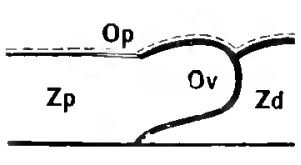

ENDOZOOECIAL OVICELL. The ovicell is within the zonecium itself. The operculum closes both zonecium and oricell.

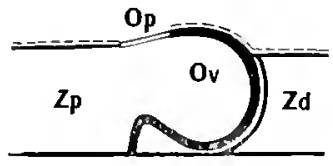

SEParated ENDOZOOECIAL OVICELL. A fold of the zooecial wall separatis the ovicell from the zooecium.

Cletthrian hyperstomial, ovicell. The ovi-

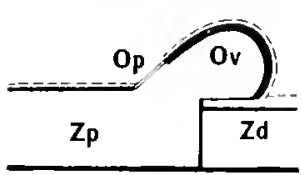
cell is placed on the distal zooeciumand opens below the operculum. The operculum always closes the ovicell and zooecinm.

There is only one aperture.
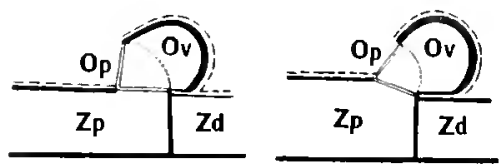

SUBCLEIT HRIA N H Y P E R STOMIAL OVICE L L. The operculum in opening closes the ovicell. There are two a pertures.

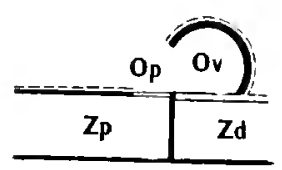

ANeucleithrian HYPERSTOMIAL ovicelu. The ovicell opens above the operculuni.

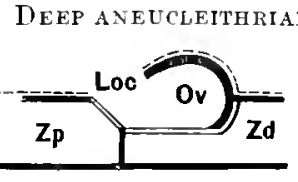

THPERSTOMIAL OVICELL.

The ovicell is placed in a deep cavity of the distal zooecium. The operculum is very oblique and operates in a chamber or locella.

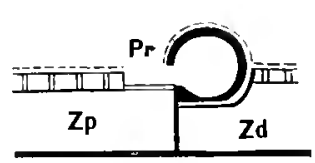

Peristomial aneucleITHRIAN IYYPERSTOMIAL OVICELL. The ovicell opens above the operculum in the peristomie.

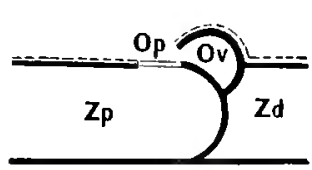

INDEPENDENT (RECUMBENT) ANEUCLEITHRIAN hyPERSTOMIAL OVICELL. The ovicell is placed on the distal wall of the zooecium itself.

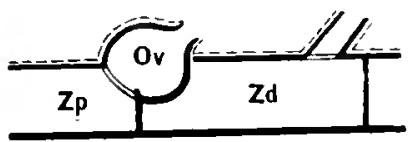

PERISTOMIAL OVICELL. The ovicell is formed by a great enlargement of the peristomie.

ENDOTOICHAL OVICELL.

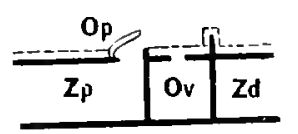
The ovicell is separated from the zooecium. Its orifice is removed from the aperture and placed on the same plane.

Fig. 10.-Diagrams showing structure and terminology of ovicells of Cheilostomatous liryman.

$L o c,=$ locella : $O p$, =operculum ; $O v,=$ ovicell ; $P r=$ peristomie; $Z d$, =distal zooecium: $Z p,=$ proximal zooecium. The thin broken line indieates the membramous ortomst, while the thin double line represents the operculum.

In 1909 Lerinsen maintained that the ovicell is formed of two membranesthe endooecium and the cetoocium. According to the family one or the other is calcified. Between them there often is an intermediate laypr which he called the cryptocyst; finally, in certain special cases the ovicell is covered by an onecent coner. independent of the two aforesaid membranes. 
The observations of Jullien appear to us more exact. In fact. almost always, the formation of the ovicell is identical with that of the frontal. There are, however, some exceptions (Smittina. Umbomula). Moreover, all the observa!ions of Levinsen are explained rather well by the manifestations of the three calcareous deposits previonsly noted-olocyst, tremocyst, and plemrocyst. In all of onr studies we have not once found it necessary to have recomrse to his theory.

Passage of the eggs. - The eggs are formed in the general cavity, but they do not develop there. They pass into the ovicell, where, by successive segmentation, they are transformed into embryos and into larrae. This passage is very delicate (fig. 11, A) ; it is assured by the tentacular sheatl or by a sacciform expansion of the endocyst (fig. $11, B$ ); it is plotected by some arrangements as varied as remarkable and of which the principal are the following:

1. The functioning of a special operculum to the ovicell (fig. 11, C).

2. The functioning of the zooecial operculum itself, which closes the orifice of the oricell either always or only during the passage and the incubation. The operculum is then strongly chitinized to serve for protection (fig. 11, $D$ ).

3. The development by thickening of the walls of a peristomie into which the orifice of the ovicell opens (fig. 11, E). The aperture is deep and closed by a fragile operculum. The exterior orifice of the peristomic is the peristomice; it is irregular and surrounded by the peristome.

4. The obliquity of the apertura and the imbedding of the ovicell in the distal zooecium forms a very small chamber or locella sufficiently protected; moreover, the mucro, the labial appendages, and spines complete this little cell (fig. 11, $F$ ).

Fixation of the larra; A neestrula.-The larra of the cheilostomatous bryozoa after some hours of life in liberty becomes fixed on a substratum and then grows into the zoarium. The first zooecium is the ancestruta. In the Malacostega this ancestruda is anilogous to the other zooccia, but smaller. In the Anasca there is more variety. More often the ancestrula is a small zooecium identical with the others. Frequently there are some interesting rariations which lav ve been stuclied by the zoologists.

On fossils the ancestrula is very fragile and is very often broken. We have been able nevertheless to figure a score of specimens almost always identical with the zooecia. Only Pueltina radiata Moll, 1803, Thamphostomella simplex. new species, and Smittina puncturata. new species, have given membraniporoid or modified ancestrulae.

The larve of the bryozon ale not fixed at hazard; they chose their own substratum. which is surprising. The Lmmlaridac choose a grain of sand; others. shells and stones; others, marine algae: and still others live only on a special species of mollusca or bryozon (symbiosis). The reader will find in the course of this monograpl many interesting cases that wo lave noted. When these obscrvations are sufficient they will pernit us to reconstruct the submarine depths and their biologic conditions. 
The transformation of the larva into the ancestrula has been the subject of the histological works of Barrois, 1877, and of Levinsen, 1900. The zoarial budding has been the subject of works of Haddon. 1883; Darenport. 1891; Calvet, 1900; Waters. 1906 , etc.
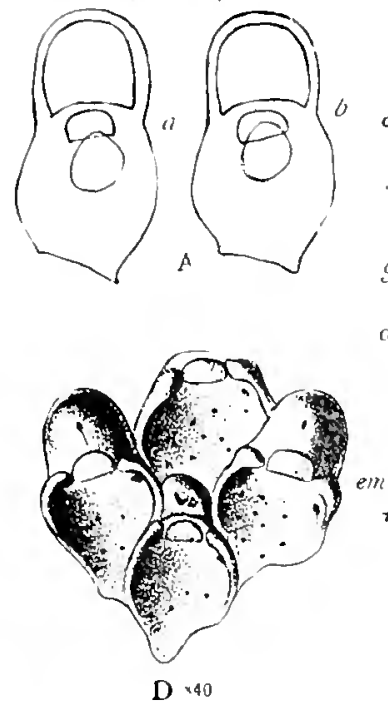

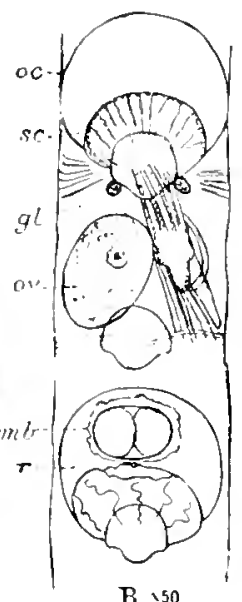

B 150

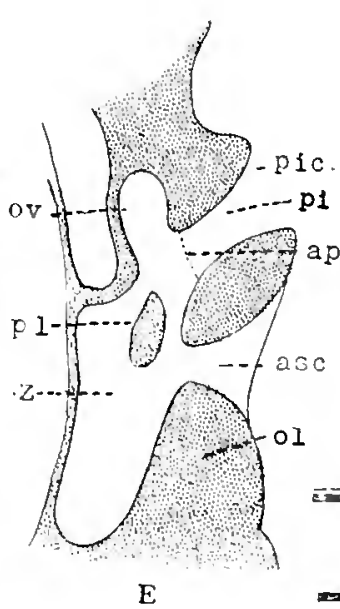

E

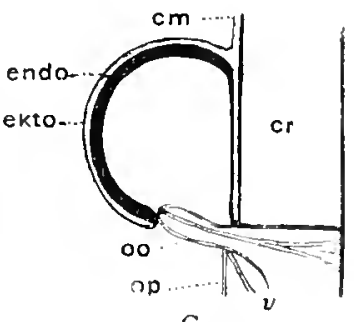

C

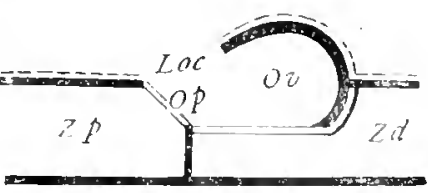

F

Fig. 11.-Passigge of the eggs:

A. Lepralia martyi Joliet, 1S7\%. a. Ego commencing to appoach the entrance of the ovicell. b. The same, some hours after and in which the ega ix already strongly engaged in the passage of the ovicell. (After Joliet, 1S7T.)

B. Schizopodrella (Schizoporella) nivea Busk, 18S4, $\times 50$. A sac-like structure (se) is shown at the base of each ovicell $(o c)$, but of the numerous muscles in this sac only about lialf of those in focus are drawn. It seems that the ovum (ov) passes into this sac which is then ruptmerl (r) and the ovum is pressed forwal into the ovicell, where it segments. The small oral glands ( $(l)$ are shown. Emb=embryo. (Alter Waters, 1013.)

C. Schizopodrella (Schizoporella) micornis Johnston, 1S47. Operculum of the ovicell. (After Levinsen, 1909.) It is probable that this figure is only a sihematic one after a longitudinal section on the orter of figure $\mathrm{B}$. cm, covering membinne: er. cryptocyst; clito, ectocyst: ende, endocyst ; oo, ooecinl opereuhum ; op, operculum ; r, restibulum.

D. Micropora coriacea Esper, 1797, $\times$ 40. The operculum closiug the ovicall protects the lassage of the eggs. (After Levinsen, 1009.)

E. Gastropclla renlricos Canu and Bassler, 1917. Sketch showing development of a veristomie above the oricell.

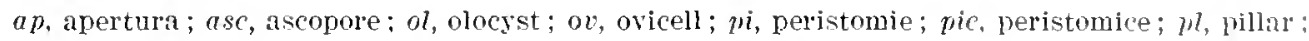
$\approx$ zooceium.

F. Section through ovicell showing the locella protecting the passage of the args.

loc, locella; op, operculum; ov, ovicell ; $\approx d$, flistal zonecium ; $\approx p$, proxinal zonecium.

\section{IYDROSTATIC FUNCTIONS.}

Zooecial hydrostatic relations. - The discovery of the zoocial hyrdrostatic system of the Cheilostomata was marde by . Tullien in $1 \mathrm{~s} s \mathrm{~s}$. It explained the arreater

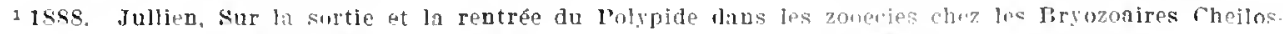
tomiens monodermies, Bulletin Societe Zoologique France, vol, 13, pp. fit. fis 
part of the opercular and muscular manifestations for a long time remaining absolutely enigmatical.

In the Ascophora the polypide can emerge from the zooecium only if an equal volume of water compensates this extrusion. For this purpose a sac called the compensatrix is placed under the dorsal. This sac communicates with the apertura and occupies a part of the zooecial lengtli; to it parietal muscles are attached. At the moment of extrusion of the polypide, the muscles contracting, enlarge the compensatrix, the operculum in opening frees its orifice and a minute drop of water penetrates into it, thus compensating for the polypide.

The entrance of the water into the compensatrix is a function which is exercised in many ways, indicated by the frontal and by the operculum.

Operculum.-The operculum is a quite small chitinized organ, closing at the same time the apertura and the compensatrix. It bears only a trace of occlusor muscles (=retractor), because the polypide itself in emerging pushes open the operculum.

The anterior part, or anter, closes the orifice of extrusion of the polypide, or porta; the posterior part, or poster, closes the orifice of the compensatrix; or vanna.

The principal cases of this function of the introduction of the water into the compensatrix are mentioned below.

If the orifice of the compensatrix be very small, the latter is closed by a small valve of the operculum, to which a small cleft or fissure of the apertura, the rimule, corresponds (Schizoporellae). This operculum is chitinized and rigid; it moves on two condyles and bears the marks of two feeble occlusor muscular bundles (figs. 12, $A-C$ ).

If the orifice of the compensatrix be large, it is closed by a large valve of the operculum, to which corresponds a large ranna, whose size is inversely proportional to the length of the compensatrix. The hydrostatic effort heing considerable, the operculum is chitinized and rigid and sways on two cardelles; it bears two lateral bands for the attachment of the powerful occlusor muscles (Hippoporina) (figs. 12, D-F).

When the compensatrix is attached to the operculum the latter is thin, fragile, semilunar, with a proximal border straight or convex. It does not always exactly cover the apertura, whose form is nevertheless alnost identical but with a proximal border always concare. The orifice not covered by the operculum is that of the compensatrix; it is protected by a lyrula or a mucro. and, according to the hydrostatic pressure, it moves on two condyles (Smittina) (figs. 12, G-I).

In order to diminish the arrival of the water there is often a small peristomial canal, or pseudorimule, or rimule-spiramen, or a spiramen opening into the peristomie.

The form of the operculum is therefore identical with that of the apertura; but the latter on the fossils is not always risible exteriorly, for it may be hidden by the

${ }^{1}$ Levinseu in 1909, in his Systematic and Morphological Studies ou the Cheilostomatous Bryozon. pp. $3 i-46$, published a very complete study on the operculum. 

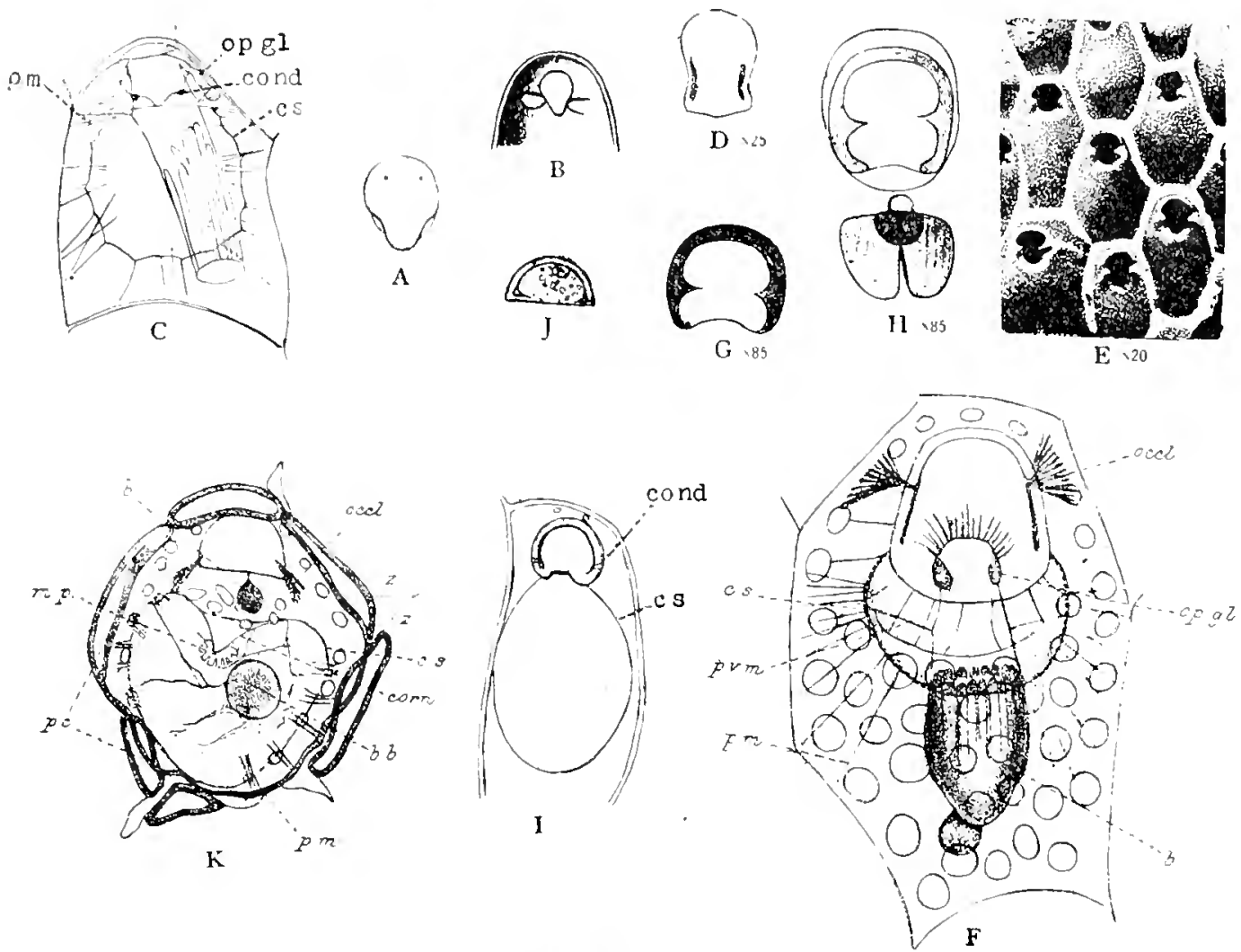

FIG, 12.--IIsdrostatic functions.

A. Operculum of Dakaria (schisoporclla) gcliala Waters, 1903.

1). Interior of Dalaria (Sintizoporclla) gclida Waters, 1903. (After Waters.)

C. Compensatrix of Phonicosia sanguinea Norman, 1S68. (After Harmer, 1902.)

D. Opereulum of Hippoponclla hippopus Smitt, 1967. (After Waters, 1900.)

E. Interior of Hippoporella multilamcllosa, new species, $\times 20$.

F. Compensatrix of Hippoliplosia mulusiana Moll, 1803. (After Harmer, 1902.)

G. Operculum of Smitina tripora Waters, 1903, $\times 85$.

H. Apertura of Smittina tripora. Waters, $1903, \times$ S5, with operculum and below it the arienlarian glands with the mandible above the glands.

I. Compensatrix of Smittima trispinosa Johnston. 1837. (After IIamer, 190\%.)

J. Operculum of Mieroporclla malusi Aulonin, 1526. (After Waters, 1S78.)

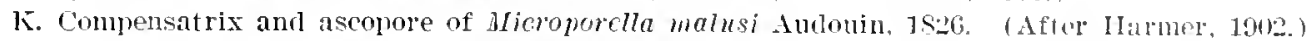

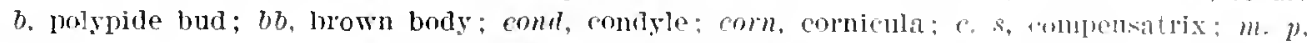

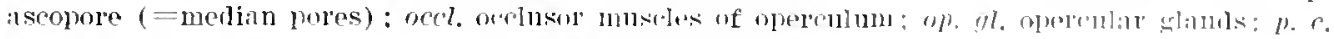

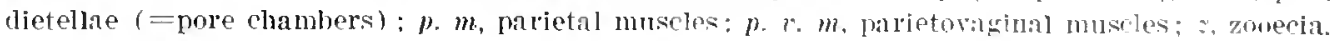


mucro. by the avicularia, or at the base of the peristomie. The only practical means of recognizing the apertura is the examination of the interior of the zooecinm, obtained by abrasion of the basal wall. Each time that it is possible one should not hesitate to make this preparation. It should be noted further that many of the apertures are oblique and that their true form can be observed or drawn only by a suitable tilting of the specimen, placing the plane of the apertura parallel to the objective. In some rare species the operculum does not correspond exactly to the apertura; in such cases it is erident that for the paleontologist the problem can not be solved.

According to Snitt, Hincks, and Jullien, the form of the operculum characterizes the families. Some results obtained by the study of embryology do not permit this theory to be held any longer. In the sane family characterized by the same larva the entrance of the water into the compensatrix may oceur in diverse manners. It is indubitable, however, that the form of the apertma is an excellent generic character.

Ascopore.-The compensatrix does not always open into the aperturn, but it may open exteriorly on the frontal by an ascopore (micropore). The operculum is then semilunar with a straight proximal border (figs. 12, $J, K^{r}$ ).

IIypostege.-In the Anasca the hydrostatic system is external, as it is formed of a cavity situated between the cryptocyst and the eetocyst. The cryptocyst is that part of the skeleton immediately in contact with the endocyst. The parictal muscles are attached to the cryptocyst when the latter is flexible (Flustridae); they are attached to the ectocyst when it is calcified (Onychocellidae, Steganoporellidae, etc.). Here the sea water can not penetrate into the hypostege. for there is no operculum, but a simple opercular valve intimately joined to the ectocyst. But. certainly there is a liquid in the hypostege: according as it is introdnced or expelled, it serves as a compensation to the polypicle.

All the zooecial hyposteges eridently communicate with each other and form a zoarial hydrostatic system. The simultaneous extrusion of all the polypides of the same zoarium is therefore impossible: this is a notable inferiority in the internal hydrostatic system of the Ascophora.

Zoarial hydrostatic system.-Calvet designated as the hypostege the space included between the ectocyst and the cryptocyst. We believe that it is necessary to make a distinction between this zoarial hypostege and the zooecial hypostege described by Jullien and quite visible on a rery large number of Anasca. It is evident that all the hyposteges communicate with each other under the ectocyst.

In many species (Lunulariidae) with a chitinized and thick ectocyst, this zourial hydrostatic system is quite important. ${ }^{1}$ It permits adaptation to diverse arpatic conditions and functions according to the principle of Archimedes.

The species which creep on algae have small tuberosities. The flexible and extensile ectocyst alone is fastened on the algae and the small tuberosities glide

1915. Canu, Ia systeme bydrostatique zoarial des liryozonires cheilostomes, Bulletin Societé Géo. logique irance, șer. 4, vol. 15, p. 21. 
orer this membrane. This arrangement aroids the disjunction of the zooecia with rigid skeleton in consequence of the inevitable growth of the substratum.

The species which creep (rer very delicate algae have some longer tuberosities. Ther have as their object the withdrawal of the ectoeyst from the eryptocyst, to angment the volume in order to dininish the weight and thus to bo able to grow on the algae, withont making it bend over, risking an overturn. The reader will find in the course of this monograph some very curions variations of the zoarial hydrostatic system which it is needless to mention here.

Use of the vibracula.-Either attached by some radicels or placed under the algae, the Lunulites, notably heea use of their turbinate form, are in a very unstable position; they upset at the least eurrent of rater. The animal maintains its normal position by the aid of Iong articulated filaments called vibracula. 'These are then objects for stabilization somewhat analogous to the balaneing rod of a rope daneer.

These vibracula have a like funetion in many articulated genera; Scrupocollaria, Bicellaria, Caberea, ete. parasites on algae, movements of which constantly compromise the equilibrium of their zoaria.

\section{FUNCTIONS OF RELATION.}

Aricularia.-The avieularia are heternzooceia formed of a small cell or arienlarian earity and of a molvile mandible.

The arieularian eavity is construeter like one of the adjacent normal zooecia. It contains an endoeyst, an ectocyst, a zoarial hypostege, leneoeytes, a mesenehymatous plexus, and mandibular muscles. The only difference is in the abortion of the polypide, which is reduced to the state of polypidian rudiment (= peculiar body, eiliated organ). The mandibular museles are powerful: therc is an elevator bundle (=abductor) of the mandible and an occlusor bundle (=depressor, adductor, retractor). The avicularian eavity is terminated by a beal.

"The mandibles of the avieularia are symmetrieal and have the elosing muscles attached by one or two long tendons. They all have a straight proximal edge. and wor'k from this straight base either against the ealcareous bal, or', in ease this is not complete, then from two teeth." (Waters, 1913.) Avicularian glands may ocrur.

The function of the avicularia is not ret known. It appears to be in relation with the hydrostatic system. (Smittinidae, Metradolium obliquum, new speeies, etc.) Many times the avieularia oeenr with the ovicell. They are alway placed in the vieinity of the apertura. and Canu considers them as being of service in alimentation. Waters thought that they were organs of oxygenation. "The polypide dies down from time to time, and a colony may be left with few or no active polypides. It remains in vigor, through the avicularian organs retaining vitality, and thus keeping the protoplasmic parenchyme in indirect eommunieation with the external surroundings. The arieularia have protoplasmic [mesenehyma-

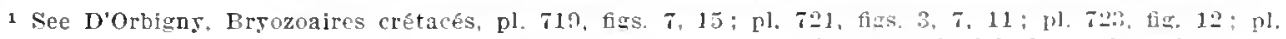
731, fig. $\pi$, etc. The presence of zoarial tulerositics Is not necessarily a proof of bydrostatism, for these bame tuberasities can exist in zoaria composed of many superposed lamelic. 

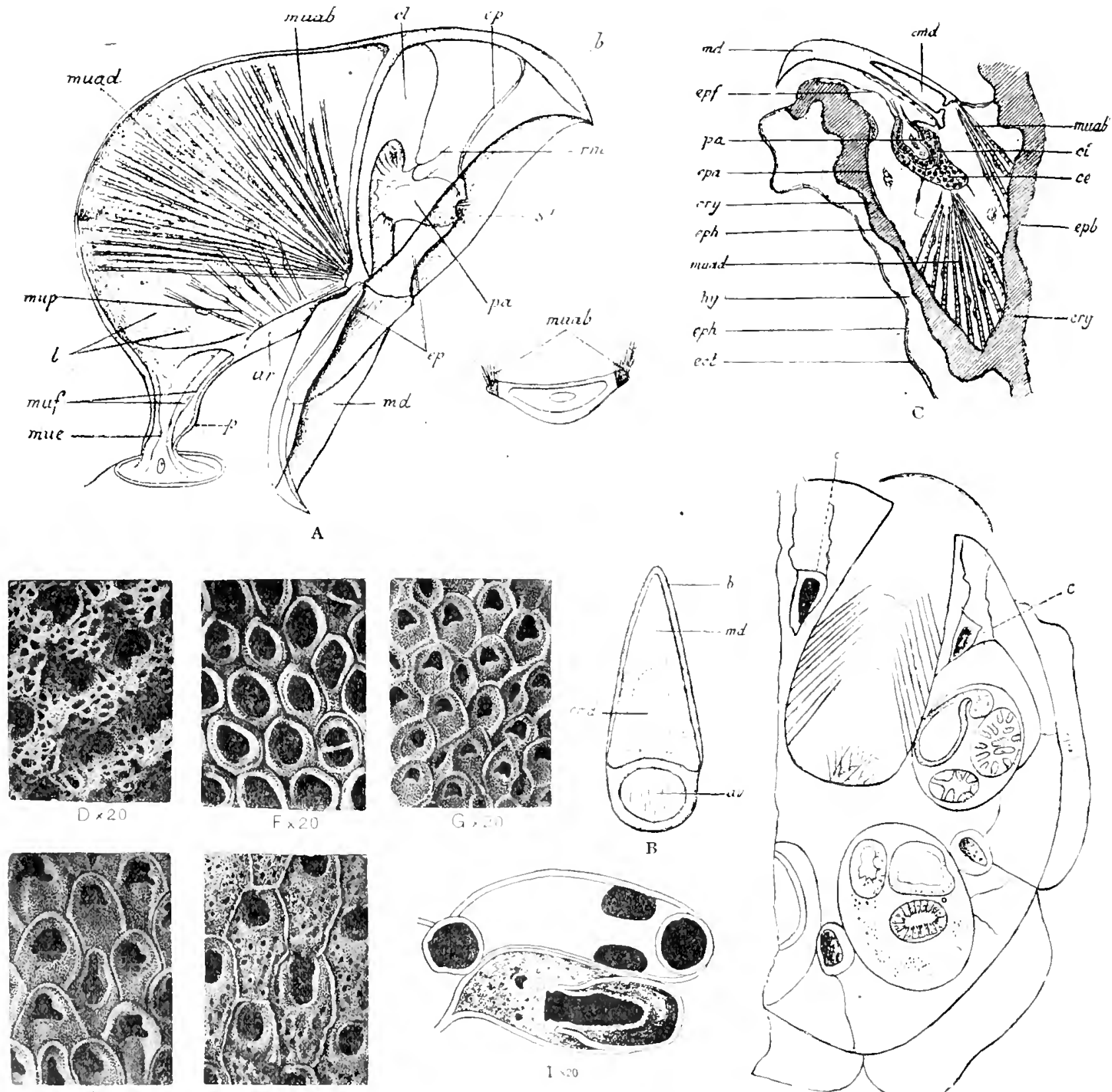

I's. 13.-Structure of the atricularimn.

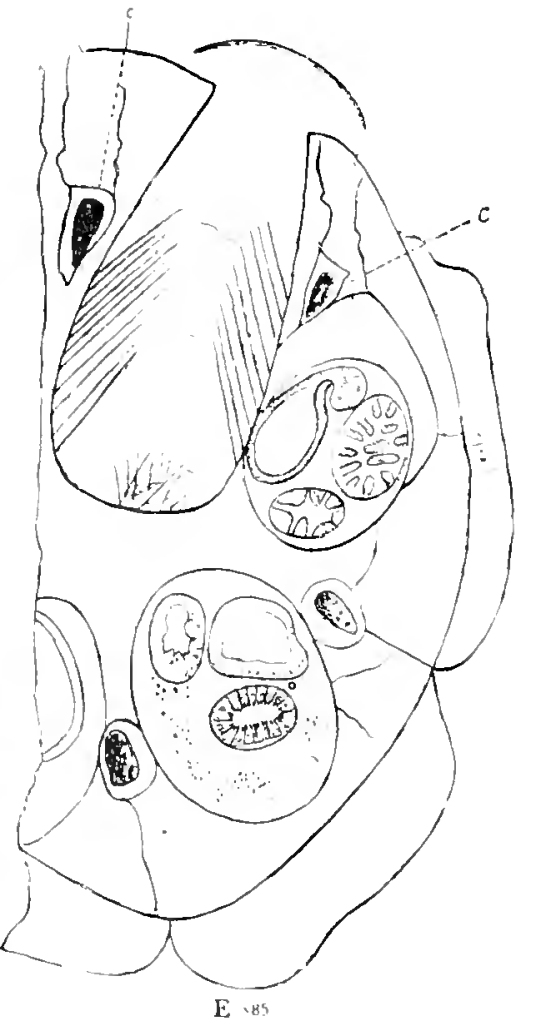


Fig. 13.--Structure of the avicularium.

A. Avicularium of Bugula sabaticri Calvet, 1900. (After Calvet.)

ar, area.

$b$, beak.

el, partition.

$e p$, epidermis.

$l$, leucocytes.

$m d$, mandible.

muab, mandibular abductor muscle.

muab', basal face of the mandible, where the

aricularium shows the insertion of two ab. muad, mandibular adductor muscle. mue, extensor muscle of the avicularium. muf, flexor muscle of the avicularium. mup, parietal muscles.

$p$, peduncle. $p a$, polypidian rudiment. $r m$, mesenchymatous network (or plexus). $s$, cilia of the polypidian rudiment. ductor nuuscles.

B. Exterior portion of an immersed avicularinm; ar, menbranums area; $b$, beals; emd, mandibular cavity; md, maudible.

C. Longitudinal section of the avicularium of Sehizopodrella (Schinoporclla) linearis val. hastata Hincks, 1880. (After Calvet, 1900.)

ee, external liser of the ciliated orrosul.

ci, internal layer.

emd, mandibukr cavity.

cy $y$. cryptocyst (skeleton).

ect, ectocyst.

epa, avicularian epidemis.

$c p h$, frontal epidermis of tle bryozoid. epf, facial epideruis.

cph, hypostegial epithelium.

lly, hypostege.

$m a$, mandible.

muab, mandibular abductor muscle.

muad, mandibular adductor muscle.

pa, polypidian rudiment (=ciliated organ).

D. Enoplostomella synthetica, new species, $\times 20$, showing tremopores tramsformed into avicularia.

E. Section of Cellaria demanti MacGillivray, 1SS7, showing the large avicularian chamher and the intermediate zooecia (c). (After Waters, 1004.)

F. Interzooecial avicularia, with pivot, of Grammella crassimarvinata Hincks, 1 sS1.

G. Curverl onychocellarium of unyehoeclla laciniosn, new species, $X 20$.

H. Straight and symmetrical onychocellarium of floridina antiqua smitt. $18-2 . \times 20$.

I. Reticulocellarim of Thalamoporella granulata Levinsen, 1909. (After Oslurn, 1914.)

J. Avicularian zooecium of Porella planulatu, new species, $\times 20$. 
tous] threads passing to the peculiar body, and the vitality of the colony will, both in times of full and diminished rigor, be increased by the avicularia; for the constant snapping of the mandibles often continues' when the polypides are not extending themselves ont the zooccia, and, as before said, even when there are few or no polypides. Sections often show the avicularia in unchanged conditions, when the zooecia only contain hystolysed remains of polypides." (Waters, 1904.)

The avicularia are not protective organs, as former authors believed; in fact, they are developed and much elongated in the most protected part of the zoarium. This phenomenon is of constant occurrence in the Cellepores.

The avicularia develop very often in the place of the tremopores and areolac; the zoologists have figured many examples of them; we ourselves have been able to observe such oceurrences on Schisopodrella Tined Lonsdale. 1845, and on Enoplostomella synthetica Canu and Bassler, 1917.

There are three principal kinds of a vicularia-articulated, frontal or immersed, and interzooceial.

The articulated avicularia exist on the articulated zoaria; they are often very complicated and quite perfecter nromisms (fig. 13. A).

Frontal or immersed aciculuria.-These are quite variable; it is always possible to distinguish the corneo-chitinous manlible, the calcified beak, the membranous frontal area, and a mandibular carity. (Fig. 13, B.) These are quite small and simple. without pivot or denticle, hardly distinct from the areolae. ${ }^{1}$ Others, on the contrary, are highly perfected. (Fig. 13, C.) The glands mentioned by Waters have unknown functions.

Interzoocciul arieuturia.- There are ordinary zooecia deprived of polypide and containing only museles. (Fig. 13,E.) Their variations are very important, for they express corresponding anatomical peculiarities. Their frontal is chitinous in the Malacostega (fig. 13. F), calcified in the Coilostega; in the latter case they constitute the onyehocellaria (figs. 13, $G, I I$ ) of Jullien, and in the group of the Tubifera they form the reticuloecllerio of Canu (fig. $13 \mathrm{I}$ ). They are straight and symmetrical if the polypide of the adjacent zooecium has its large retractor muscle placed at the midate of the lose (fig. 13. $I$ ) : they are unsymmetrical if the same muscle is attached laterally, as in the genus Onyehocella (fig. 13, $G$ ). In the Ascophora the interzooecial avicularia occur chicfly in the family Adeonidac. Nerertheless it is not rare to find some zooecia provided with a mandible (Porella planulata. new species, Metroperiella armdiporm. new species, ete.). (Fig. 13, J.)

Vibracula.-The vibracula are heterozooccia formed of a cavity with chitinous or ealcareous walls and of a long cilinm or seta. Their organization is identical with that of the avicularia: they differ only in the articulation of the seta (= whip or flagellum) and in the great length of the latter.

"The base of the asymmetrical seta of the ribracula is very complicated with a large number of curionsly shaped protuberances, to some of which the muscles

1 On the fossils it is often impossible to sag if an obsurred small pore is a tremopore, an avicularium, a vibraculum, or a radieular pore. 

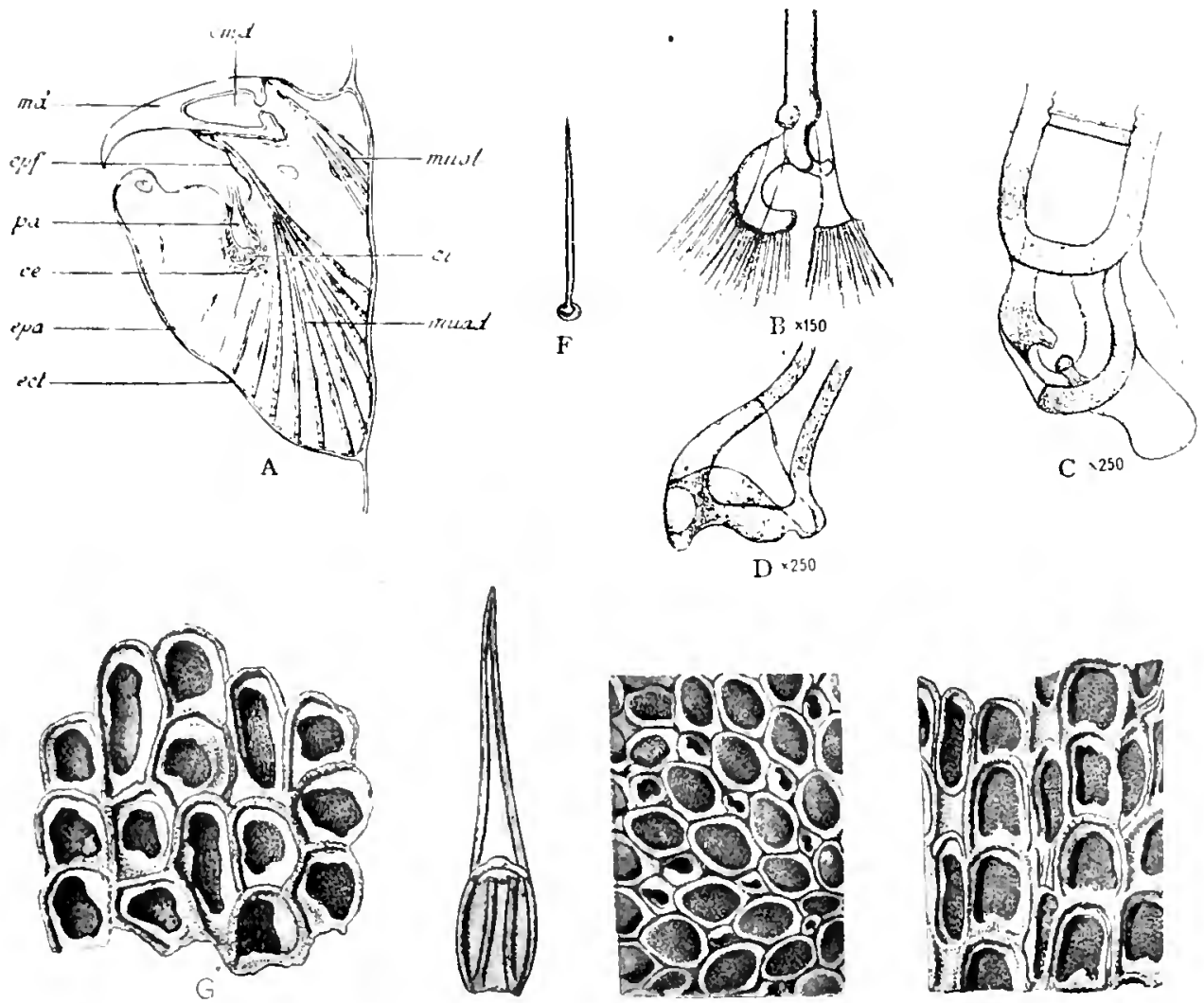

$\mathrm{H}$
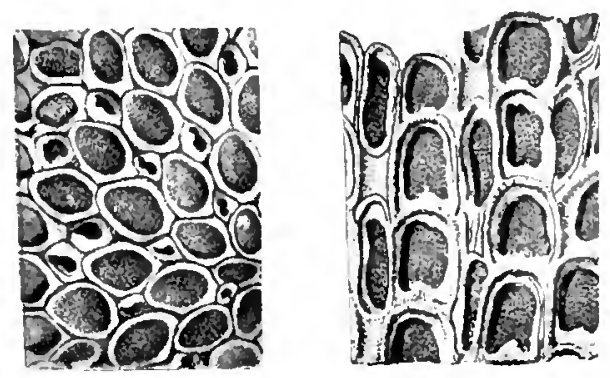

Fig. 14.-Sitructure of the ribraculum.

A. Longitulinal section of a vibraculum of Caberca boryi Audouin, 1826. (After Calvet, 1900.) cc, external layer of the polyphlian rudiment. ci, internal layer.

$m d$, viliaculoid mandible or seta. muab. manilibular abulactor muscle.

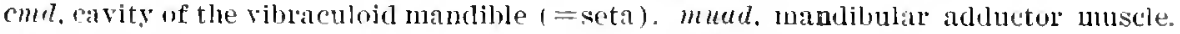
cet. ectocyst.

epr, viluracularian elinlermis. lol, pulypidian rudiment $(=$ abortive polypide $=$ ciliated organ $=$ peculiar boly).

cpf. fucial rpideruis.

B. Base ut vihratulum of Cribritina latimarqinata Fusk, 1884, $\times 150$.

C. Lnwer part of vibuculum of Sclcuaria maculata Busk. $1852, \times 250$.

D. Base of vibraculum of cupulatria cumarnsis Busk, 1552, X 250. ( $B-D$, after Waters, 1898.)

E. F. Vibracula and seta of Inmulites palelliformis Maplestone, 1904.

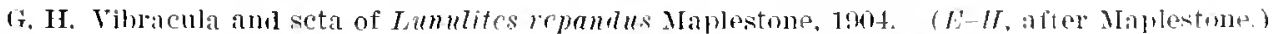

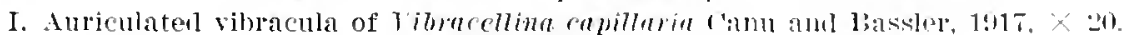

$$
\text { 5.590-10-Full. } 106 \text {-5 }
$$


are attached fascia, but withont any long tenclon; they are more attached by at short band to various parts of the base of the seta. The vibracular base is very small, so that it is difficult to follow the complicated mechanism; the reason for this complication is found in the seta being movable in all directions. Very minute glands occur." (Waters, 1913.)

There are two sorts of interzooecial ribracula, the symmetrical and the nonsymmetrical or auriculated (Fig. 1t).

Mucro.-The mncro is a skeletal appendix, more or less salient and placed before the apertura. Its function is not yet clearly known. It is elongated in the more protected parts of the zoarimm. jnst as the avicularia are. Moreover it appears to have the same use. Calvet in 1902 had already mentioned that in Schizoporella ambita. Waters, 1902, and in Emballotheed subimmersa, MacGillivray, the suboral arienlarim, is sometimes wanting and is replaced more often by a mucro becoming confused with the ealcareous thickenings which surround the inferior border of the zooecial orifice in the somewhat aged bryozooids. We have noticed the same thing in Metraclotium labratulum, new species. In the Cellopores the mucro of the deep zooccia. like the avicularia, sometimes projects to the level of the uppermost zooecia.

Spines.-The function of the spines is still not yet known. They become elongated ju the protected parts of the zon rimm. They do not exist on species pro. vided with a long peristomie.

Radicular fibers.-The radicular fibers attach the zoaria to submarine objects. They leave only small perforations on the zooecia or on the avicularia in most of the articulated species. On the tumbinated zoaria, in the Lumulites form of growtl, they energe from special, small zooecia without polypide perforated by a single pole.

$$
\text { ZOORCIA. }
$$

Form and size.-The internal form of the zooecium is evidently in rapport with the reciprocal arrangement of all the soft parts in the interior. Unfortinately no zoological study has been made along this line which may be fruitful from the riewpoint of classification.

The external form is stin more rarluibe decause of the intensity of calcification. It is in evident rappost with the surrounding medim and shows character's of adaptation. The influence of the medium on the zooecial form has never been the object of any zoological work.

"More generally the length of the tentacles is in rapport with that of the zooecia. In Actea anguina, Eucratea lafontii, Bugularia, Celluria fistulosu, Cellaria saticomoides, Flustra securifrons, Microporplla hectieli. Flustrell" hispida, Pherusia tubutosa. Cylindroccium ditutum and all the cyclostomes in which the zooccia are at least two times longer than wide, the tentacles are themselves long and often exceed half the length of the bryozooid. This rule is nevertheless not absolute and allows rather numerous exceptions. In Bowerbankia pustulosa, Tesicularia spinosa. Amathia lendigera, and $A$. semiconvoluta, for 
example, in which the zooccial cells are relatively very elongate, the tentacles are short and never exceed a third of the length of the bryozooid. Finally they are of a medium length in other species and have abont two-fifths of the length of the bryozooid. The dimensions in thickness are also quite variable. Yet it seems that they are proportional to the dimensions of the general cavity and inversely to the number of the tentacles." (Translated from Calvet, 1900.) ${ }^{1}$

We give for each species the exterior micrometric dimensions of the zooecia; our measurements only express the arerage or the most frequent measurements. We are not able to draw up any gencral law. Very frequently the length is double the width; the other relations are more rare. There must be some very interesting studies to be made along this line. but we have not had the time to do so. and, moreover, a zoological basis is wanting absolutely.

Total regeneration.-The regeneration of the polypide is a phenomenon well lnown in bryozoologs; it leares no trace in the Cheilostomata. Sometimes, for causes mblown, it is the entire individual which is regencrated. This total regeneration leaves some external traces. It was thoroughly studied by Levinsen in $190 \overline{7}{ }^{2}$ and he cited numerous examples. In the course of our work we have noted some interesting observations which confirm those of Levinsen. Following are some of the cases:

1. Replacement of a zooccium by an aricularium.

II inchsina megavicularia, new species (pl. 23, fig. 1).

Laccrna hexagonalis, new species (pl. 44, fig. 20).

2. Female polypide succeding a male polypje.

Hincksina elegans, new species (pl. 80, fig. 15).

3. Female zooecium in rerted and succeding a male polypide. Membraniporidra laticella, new species (pl. 26, fig. 5).

4. Replacement of a zooccium by a zooecinm.

Floridinella vicksb urgica, Canu and Bassler (pl. 82, fig. 26).

5. Replacement of an ordinary zooccium by an inverted zooecium.

Membraniporidra laticella, new species (pl. 26, fig. 4).

6. Replacement of a normal zooecium by a calcified zooccium.

Euritina tecta, new species (pl. 5, fig. 2).

Velumella plicata, new species (pl. 3t, fig. 4).

i. Replacement of an avicularian zooecimm by another avicularian zooeciums.

Schizomarella grunulosa, new species (pl. 46, fig. 15).

S. Triple regeneration.

Grammella crassimurginuta Hincks (pl. 24, fir. 13).

Alderina crassa, new species (pl. 29. fig. 7).

The effecting cause of total regencration is unkmown.

\footnotetext{
1 Contrlbutions a l'historie nature!le des Bryozoaires ectonroctes marius. 'Trataux d'Institut de Zoologle de l'Lnirersité de Montpelier, Memoire No. S, p. 183.

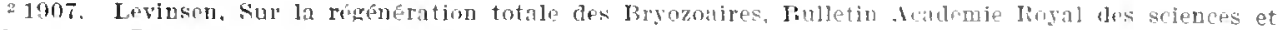
des lcttres de Danemark, pp. 151-160.
} 
Calcified zooecia.-Calcification of the frontal in the Anasca and of the apertura in the Ascophora is a phonomenon quite frequent and still inexplicalle. It is produced by the death of the polypirle by accident or disease. Generally the calcified lamella is perforated; rarely it remains entire; sometimes it disappears under the tremopores.

We have mentioned the calcified zooecia each time that we have observed them, but for want of material we have not been able to make a detailed study. Following are some examples:

Ramphonotus laevis, new species (pl. 1. fig. 14).

Rectomychorella bitam 7larive new species (pl. 33. fig. 3).

Floridinclla vichsburgico (anu and Bassler. 1916 (1)l. 82, fig. 26).

Metroperiella biplametu, new species (pl. 47. fig. 15).

Mctroperiella porosa, new species (pl. 47. tro. 8).

Smittina exig ta, new species (pl. 59. fig. 1i).

Smittina angulata Reuss (pl. 60. fig. S).

(ycticopora spongiopsis De Gregorio (pl. ss. fig. 10).

Porellu inverntaris, new specins (p]. 62. fig. 20).

Porella abdita, new species (pl. 65. fig. 3).

Porella portentosa, new species (pl. 61, fig. 17).

Adeonidae, Mippopodinidae.

Trstibular arch.-The superior portion of the tentacular sheath is called the restibnlum. The latter is calcified sometimes in the vicinity of the anter of the apertura; this calcified lamella is the restibuler arch. It is very delicate and is little resistant in fossilization. We have rinely found it on our American specimens. (Figs. 15, C, D.)

\section{ZOARIUN.}

Terminolog!- - For a aiven species. the form of the zoalinm is almost always identical: nevertheless it is not rale to find come species both incrusting and fiee. the latter form of erowth being only an arranced phase of the former. Some of the genera of bryozon, now entirely archaie. were hased on wrowth forms alone, and their names we now preserve in the hterature simply in describing the form of zoaria. Among such names are the following:

Eschara refers to any free form of Ascophora with two lamellae back to back.

Lunulites comprise all the free turbinate, conical forms.

Lepratia is an incrusting form.

Biflustru has reference to a free form of the Anasca with two lamellae back to back.

Timeularia has rol-like zoaria.

c'cltepormin is a creeping form of the Inasca.

Cellepora is any bryozoan made up of emmulate zonecia.

1 1913. Larger (René), Ia contre-érolution on lécénéresconce fan l'hérérlití pathologique causa natı relle de l'extinction des groupes animanx acturls "t fossilos. Essai de faltopathologie génerale compartér. l'aris. 
We have aroided the use of these archaic terms in om descriptions sare Eschara, Lmulites, and Tincularia.

The causes of zoarial rariations are unknown.

The free zoaria very sollom remain intact in fossilization and we most abways find them in the state of minute fragments. When the latter are very numerous it is always interesting to attempt their restoration. Those which we have made
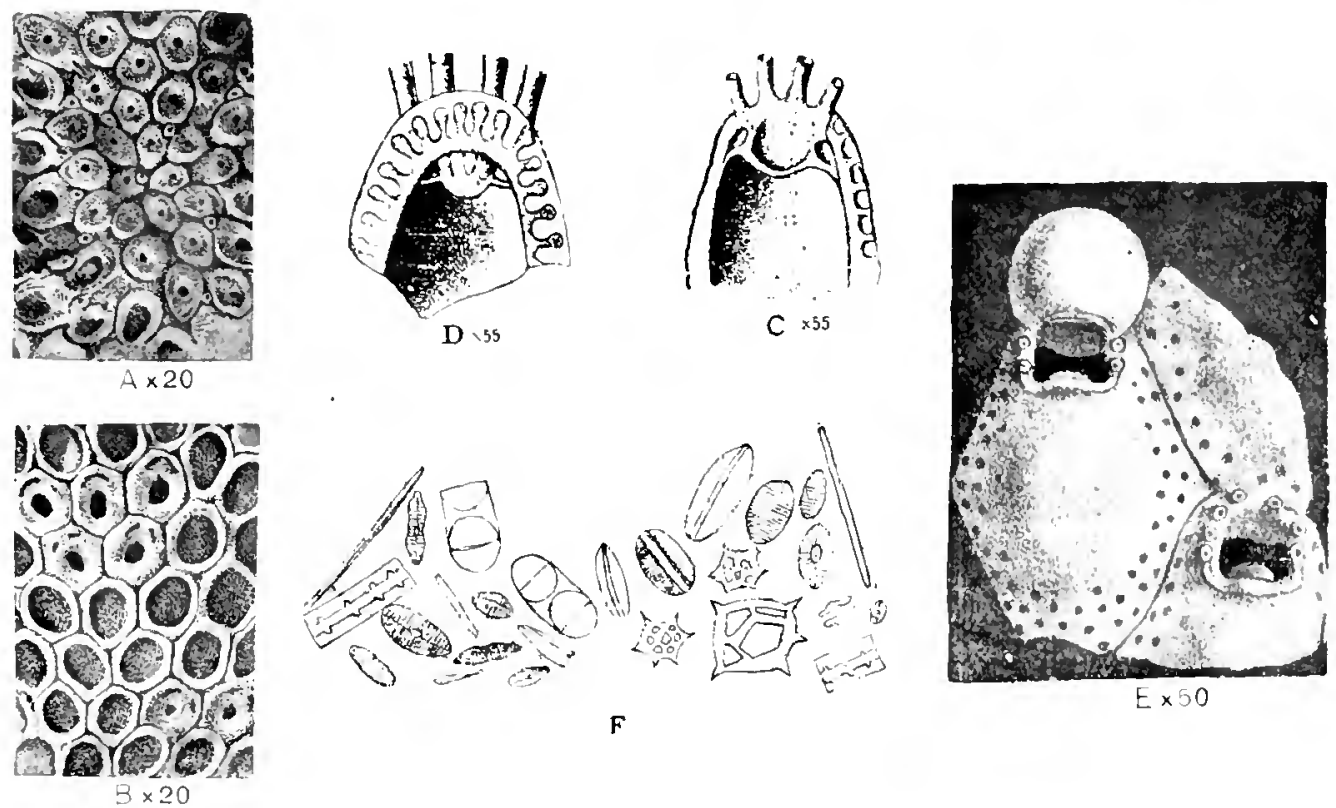

Fig. 15.-Structure of the restibular arch, etc.

1. Mcmbrendoecium rectum, new suecies. $\times 20$. Calcified zonecia.

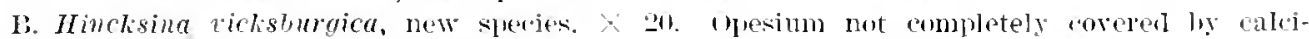
fication.

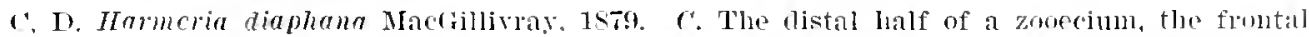
wall of which has been remured, so that the highly developed vestibular arell maly br sien and the rols by wheh it is connected with the latelal walls. $X 55.7$. The distal lalf of a zonecium. seen from the basal surface after lemeval uf the hasal wall. 'The hakil wall of the vestihulal' aroh is seen, $X$ is. (Aftor Leviusen, 19un.)

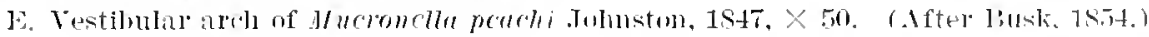

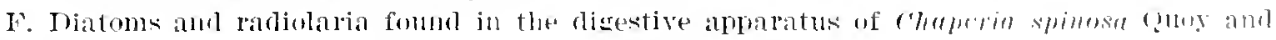
liamard, 1824. (After Jullien, 18sৎ.

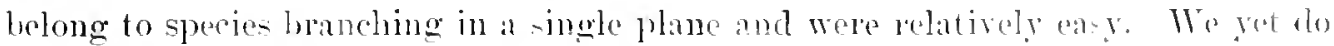
not know how to restore the hu-hy zoaria.

Habitat.-The bryozoa live-fir-t. in leep water: secomd. in watch always

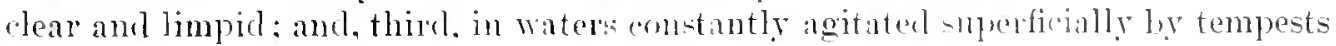
and reeply stirred by eurrents. (Diridigny. 15.00.) 
The bryozoa are reduced for food to planktonic organisms; it is probable that they thrive particularly in places where a brisk current exists. The straits and narrow passages are ordinarily rich in bryozoa. (Nordgaard, 1912.) They feed upon diatoms and radiolaria (fig. 15, F) .

The moring sands with large siliceous elements are not favorable for the habitat of bryozon and there one can scarcely encounter a single example. The rocky facies, on the contrary, lend thencelves rery well to the establishment of colonies of bryozoa which swarm there. The muddy bottoms are very poor in bryozoa (Guerin-Ganivet, 1912).

The bryozoa are rather numerous in the shell sands. They are numerous in the zone of the mud sands with microcusms (25-60 meters); the shells serve as substratum to the numerous incrusting bryozoa, whereas the erect bryozon more generally spread over the tunic of ascidians (Calvet, 1902).

The zoarial articulation is in rapport with the mobility of the habitat and with the zooecial fragility which requires some protection. All articulated species are then commensals of the great marine meadows.

PRINCIPTIS OF CLASSIFICATIOX OF THE CIUILOSTOMATA.

The principles of classification of this order are still imperfect in spite of the quite extended research of several students. Formerly the classification was hased on purely zoarial features, but in the latter half of the nineteenth century the zonecial characters were more closcly studied. especially by D'Orbigny, Smitt, and Hincks. The latter author considered especially the form of the aperture, in other words, only the hydrostatic system. In 1888. and again in 1903, Jullien established the systematic set of characters for consideration. These are as follows in diminishing order of importance:

Essential characters; general morphology (order); form of the frontal wall (sub-orter); form of the aperture anu of the opererulum (family); presence of cardelles, occurrence of lyrula, and finally ovicells and radicels.

Secondary characters or specific; frontal punctations, a vicularia, and vibracula.

In 1900 Canu wrote that every family ollght to be based on an anatomical peculiarity enmmon to all its members and fixer in an uninterrupted series of descendence. He established genera according to the rariations of this anatomical peculiarity and according to the divergence of its evolutionary charteters. This was the perfection of the ideas of . Iullien. hut the partial applieation made by Waters on the operculin and the a vicularian mandibles did not appear always to lead to universal results nor to the estajilishment of rery naturial genera.

We now blieve that other principles are bretter. In the bryozoa, as in other living beings, the form is only the result of functions: therefore in the study of the morphological variations of the organs we now substitute that of their plysiologic functions. Our studies are therefore always directed toward the discovery of functions which modify the skeletal form. 
Family-All the species which have the same larral form have the same lineage and belong to the same family; therefore the family is characterized by its larral system. The ovicell in which the larra develops is necessarily in rapport with it, and a knowledge of its structure gives the essential characters for readily interpreting the physiologieal utility of the morphological and skelotal variations.

cemus. - A really natural genus differs from another gents only in possessing a different function and not in the different form of any skeletal part. The essential functions common to all bryozoa without exception are:

1. Passage of egges and escapement of the larvac (= rapport of the operculum and the oricell).

2. Hydrostatic system and extrusion of the polypide (=form of the aperture and rapport of the operculum with the compensatrix).

3. Calcification and chitinization (= nature of the skelctal part and of the frontal considered as immediate deposits of the endocyst).

All of these functions are indispensable. We combine them in such a way that all the species of a genus have the same essential functions.

We have rigorously followed this principle in the establishment of our new genera; we have also modified the descriptions of the described natural genera which were often incomplete.

Evidently often the form indicates the function; for example, the form of the aperture reveals the hydrostatic function, the presence of the cardelles indicates the morements of the operculum, the presence of a lyrula indicates the nature of the operculum, etc. But there are some morphologic variations withont generic importance which may be common to nmmerous species; for example, nature, form, and attachment of the costules, granulations, and plenrocystal pores. form of the zooecium, presence of a rhamma, angle of divergence of zooecia, etc. These are the characters of adaption and are not the immediate result of essential functions.

A genus containing species combined only by the identity of characters of adaptation is not a natural one.

The function of the avicularia and onychocellaria is not known, but it can not be common to all bryozoa since many species are deprived of these structures; they therefore can not furnish good gencric character's. Nevertheless, there are some groups in which their presence appears to be absolutely inclispensable to the life of the zoarium and we hare therefore considered them sometimes in our generic diagnoses. We are not certain that we are in the right path, but in the actual state of nomenclature such hesitation is permissible; moreorer. the 1 mmber of the genera to be suppressed is not considerable if in the future we should not be justified.

Species.-All the morphological rariations and all of the chatracters of adaption are specific characters. They are always utilized without nethod becuse we are ignorant of the life of bryozon. 
BULLETIN 106, UNITED STATES NATIONAL MUSEUM.

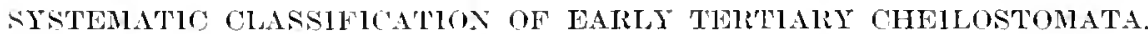

We have inserted the following table showing the classification of the bryozoa here described in order to have at arallhie aid in comprehending their position:

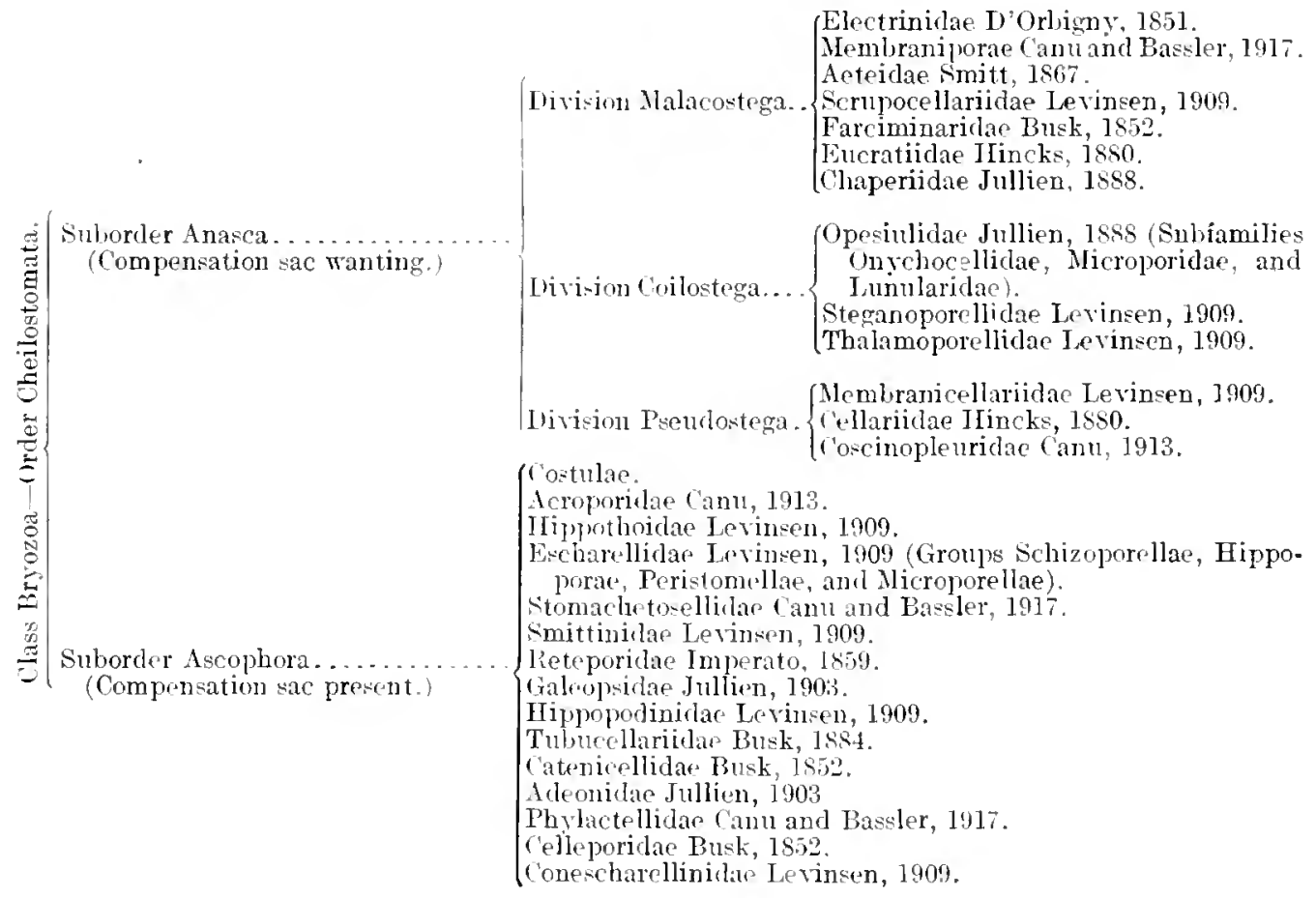




\section{SYSTEMATIC DESCRIPTIONS. \\ Order CHEILOSTOMATA Busk. Suborder ANASCA Levinsen.}

A zooecial hydrostatic system is absent, but a zoarial hydrostatic system is present, and is included between the cryptocyst and the ectocyst.

The Anasca are classified under the three divisions Malacostera. Coilostega, and Pseudostega.

\section{Division I. MALACOSTEGA Levinsen, 1909.}

The parietal muscles are attached to the cryptocrst, which i- alwars chitinons. The opereulum is a membranous ralve (fig. 16). In the fossil forms the frontal wall is quite or partially uncalicified.

The families of this division are as follows, those in the first column being represented in this work:

Electrinidae Dorbigny, 1S:1. Bicellaridare Smitt, 186,.

Membraniporae Cani and Flustridae Smitt, 1867. Bassler. 191\%. Notamiidae Hincks, 1880.

Leteidac Smitt, 1567 .

scrupocelláriidae Levinsen, 1909.

Farciminariidae Busk. 1884.

Eucratidac Hincks, 1850.

Family ELECTRINIDAE D'Orbigny, 1851.

Bibliography (Anatomical).-1S65. Sмsтt, Ow Hafs-Bryoznernas utreckling och fettinipar. Ofrersigt konsl. Vetenskaps-Aliade-

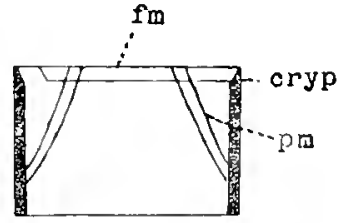

Fig. I6,--sketch illustrating structure of the Maliacostega.

Transverse section of a zenecium of a Flustrine form, slowing the membranous ectocyst ( $\mathrm{f} m$, frontal membrane), the membranous cryptoeyst (cryp), and the parietal muscles p. m.1. After Harmer, 1902.

miens Fürlandlingar, vol. 22, pl, 1, jiæs. 1-11); 11. 2, figs. 1-1.-186s. Sonneider, Teher die Entwickelung von Crulonantes compressus zu Membranipora pilosi, Sitzungsherichte der Gesellschaft der naturforschenilen Frounite, pl. 16-1Si1, Nitscine, Tipitrige zm henut-

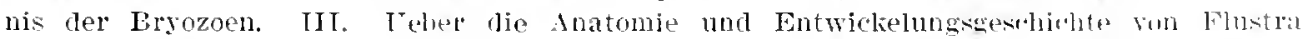

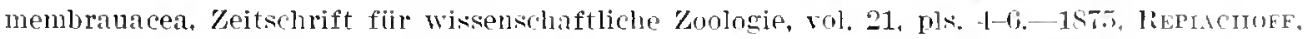
Zur Eutwickelungsceschirhte der 'Tencla zostericola, Leitschrift für wissensiaftliche Zuolo-

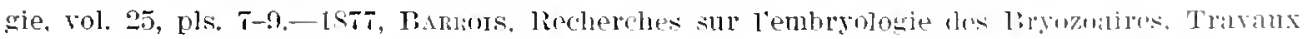

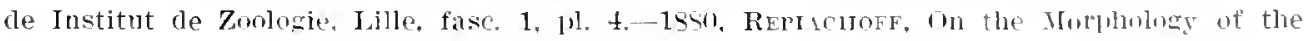

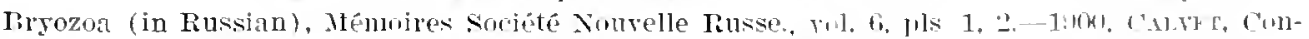

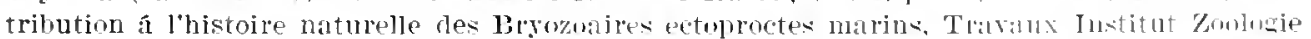

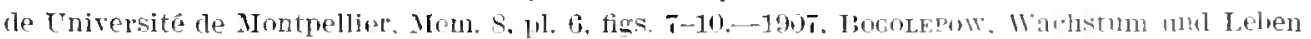

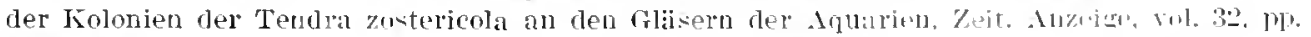

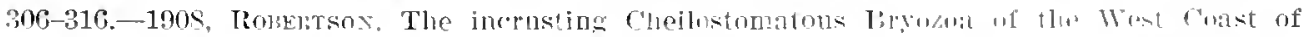

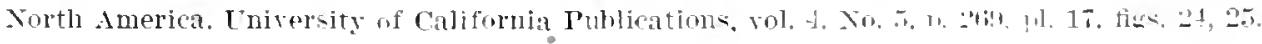



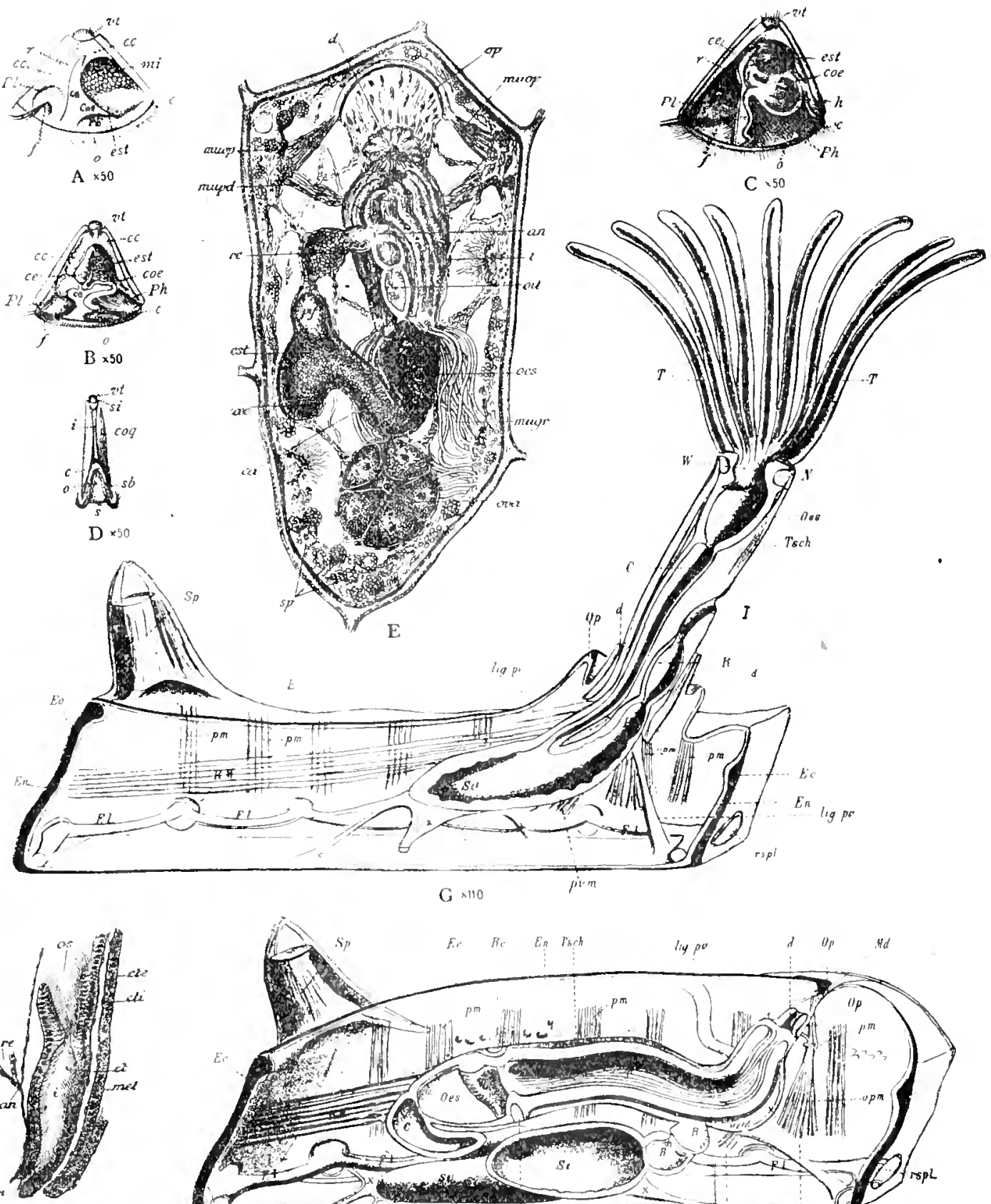

F

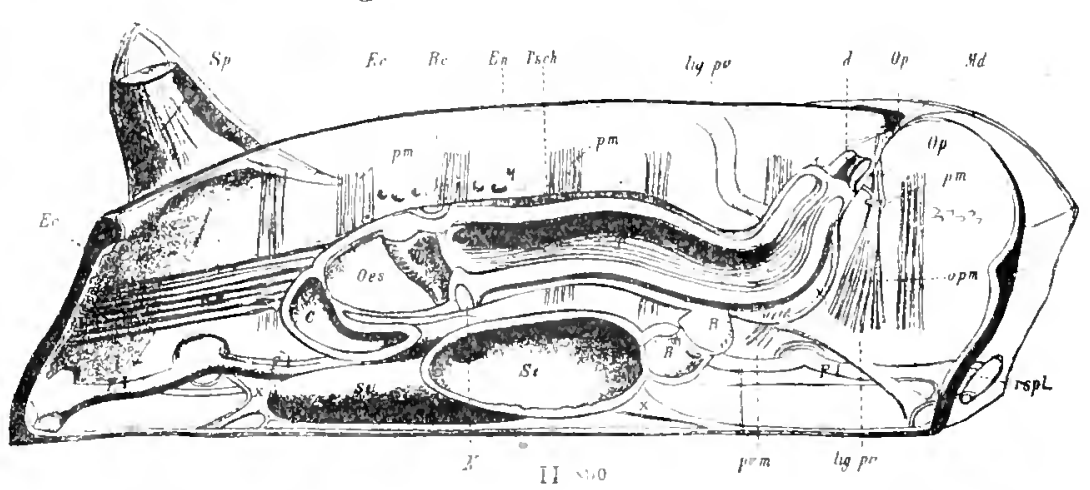

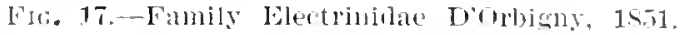


Fig. 17.-Fanily Electrinidate D'Orbigny, 1851.

A-F. Llectra pilosa Linmens, 175s. 1 lanval form=cyphonates compessus direnLeren, 1833.1

A. F. Lateral riews of larra, $x, \pi 0$, immediately after occhision.

C. Larra, $x 50$, a little before tixation.

D. View from front, $X$ 50. (1-I, After litrmois, 1SiT.)

c. corona.

(c) cavity of seguientation.

mi, aboral mass.

cc. rarity of the stomach.

0 , mouth of the gastrula.

coc, lateral diverticnlun of the stomald lavity.

I'l, pharsnx.

cor, sliell.

l'. ciliary plume

cst, stomach.

r. Jiarce retwacto! muscles.

$f$. fossette of the linme.

$\therefore$, olil face.

h. portion charged with elements (hepatir?) rt. terminal bur?. under the enimmatio orean of Schmpiler.

E. Slietch slowing anatomy of polypile. 1, (fiel Calvet, 1900.)

(m), allus.

" $u$, calcolia.

race, crecum.

a. Vaginal diaphragm.

cst, stomach.

muop, opereulal muscles.

muar, lanrar retractor muscles of the jolypila (or of the lophophore).

mupd, larictal or expulsor muscles of the pulypille.

F. Longitulinal section of the intertentarular uran. (After Calret, 1900,)

ct, tentacular canal.

etr, external tentacular epithelinm.

cti, internal tentacular epithelinm.

$i$ inferior envity. ucs, oesophagus.

nit, intertentacular argan,

op. opereulum.

werl, ovary.

m.l. lylorus.

re, rectum.

si. spermatoblast morulae. ni, superior olifice.

08 , superior carity.

re, rectum.

G. H. Mrmbranipora membranacen limnatus, 175s.

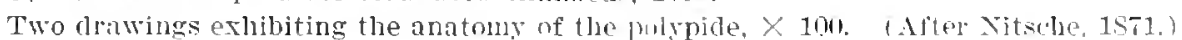

c. eardial inet of the stomach.

R. rectum.

d. interior diapling gen the tentamiar slizatli.

cr, ectneyst.

en, enuneyst.

met, anlistous menurane of the tentacles.

ors. esoplatgus.

op, foll of the opereular ralve.

apm, musiles of the operoulum.

$P$. provic part of the stomach.

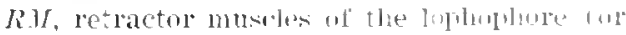
wit the polypiste).

rspl, septulir.

st. stumach.

T. tentacles.

isch, tentacular whouth.

ir. mesenchrme.

lim, matiotal or extensor muscles of the puly. linle. 
Zooecia having a chitinous frontal. Inteltentucular organ present. Larva a Cyplonantes. No avigularia. No dietellac. Opereulum with thickened border.

II istorical. -The family Electrinjtie was enablished in 1551 by Do Orbigny for species possessing "cellules en cornet," and was based on the genus Electra Lamour-

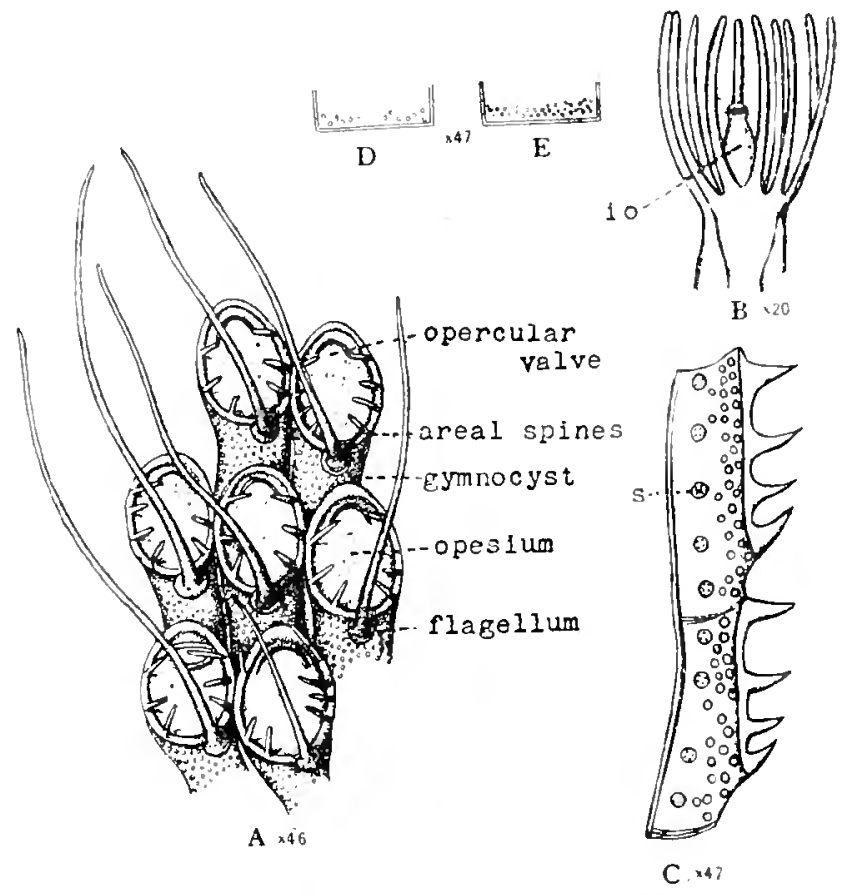

Fig. 18. Genus Electra Lamouroux, 181 i;.

A E. Elcetra pilosa Linnarus, 1758. A. Sevoral zoreceia, 46 , illustrating structure. (Aiter Jlineks, 1880.) l', I'rawing slowing intertentacular organ $(i, 0),. \therefore 20$. (. Lateral wall, rxhib-

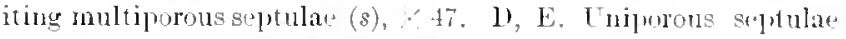

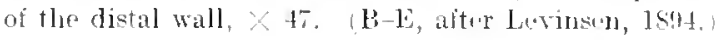
ollx, 1816. Two genera, Canda and Cabcrea, which D'Orbigny included in the family at that time, had to be withdrawn, because they dicl not have the same larval features. The Electra pilosa group has been the subject of numerous anatomical studies.

The Dembrenace gloup is also a natural division, and it is considered as containing typical Membranipora, which is the lasis of the family Membraniporidac Smitt, 1866. The untertentacular orean is known here also. In 1906 Miss Robertson discovered the Cyplonautes larva in $M \mathrm{~cm}$ tranipora villosa, which therefore belongs to the sane gloup.

Electra and Membranipora, having similar larval forms, belong to the same family, Electrinidae. This name, given by Dorbigny, has the right of priority.

C'Tussifertion.-The known genera of the Electrinidale are as follows:

Electra Lamouroux. 1816.

Membranipora Blainville, $183 \mathrm{t}$.

Ieterouccium Hincks. 1892.

Pyripore D'Orbigny, 1852.

II cructopore Lang, 1914.

'The two latter generia luve been pheed in the family on account of zooecial resemblance, and not from a study of their anatomy.

Genus ELECTRA Lamouroux, 1816.

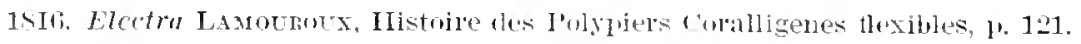

'The frontal is a gymnocyst. There is a cirole of spines around the frontal area. 'The distal septulac are miporous. The lateral walls halve 2 or 3 multiporous septulue. 
Genotype-Electra pilosi Linnaens. 17.5s. Rangr.-Eocene-Recent.

The recent species belonging to this aemus are according to Iserinsen and Watel's:

Elertic (Flustra) pitosa I immens. 17is.

Electra verticellata Lamnu1roux. 191 .

Electra (Nembranipora) bel7ula. Fincks, 1880.

Electra (Flustra) triacantha Lamonroux. 1816.

Electra (Membrenipore) distorfa Ilincks. 1880.

Electra (Tendre) ansterirola Nordman. 1839.

Electra (Membranipora) monostarhys Busk, 1852.

Electra (Mcmbranipora) bicotor Hincks, 1880.

Electra (.Membranipora) tenella Hincks, 1880.

ELECTRA PARVIMATER, new species.

Plate 19, figs. 1-3.

Jrescription.-The zoarium inclusts oysters; it is miserial around the ancestrula, but later it develops into multiserial branches. The zooecia are elongated. distinct, prriform; the gymmocyst is smooth and convex; the mural rim is enlared at the base, flat. and finely striated. The opesium is large. oral, very finely crenulated. The ancestrula is rery small.

$$
\text { Mensurments.-Opesium }\left\{\begin{array} { c } 
{ h _ { 0 } = 0 . 2 8 \mathrm { mm } ^ { 1 } } \\
{ l _ { 0 } = 0 . 1 5 \mathrm { mm } . }
\end{array} \quad \text { Zooecinm } \left\{\begin{array}{l}
L_{z}=0.10 \mathrm{~mm} . \\
l z=0.2+\mathrm{mm} .
\end{array}\right.\right.
$$

Atpinities. - This species belongs to the gromp of Electra monostarhys Busk. 1852. It differs from Busk's species in its smaller micrometric dimensions and in the oral form of the zooecia. Moreover the extreme smallness of the ancestrular zooecia has not been noted in this latter. species.

Oceurrener-Lower Jacksonian (Moolys marl) : 21 miles north of Robert. Newton Connty, Mississippi (rare).

Holotype.Cat. No. 65s65. U.S.N.M.

\section{Genus MEIBBRANIPORA Blainville, 1834.}

1S34, Membraniporn Buarvit.Le, Mamuel d'Actinolngie ou de Zoophytologie, p. 44.

No gymnocyst on the frontal. Two spines at least.

Genotype.-Membramipora me mbranacea Linnaeus, 175s. Miocene-Rerent.

The living species belonging to this genus are, according to 'Watels:

Membranipora membranaeea Limnaeus, 1758.

Membranipora danica Levinsen, 1894.

Membranipora (F7ustra) tubereutata Bosc, 180 .

Membraniporn (Flustra) inea D'Orbigny, 1839.

1 In the citation of measuremeuts, ho is the length and to the ridtl of the opesia, $L:$ and $l:$ similarly the length and width of the zonecia. Le and $l e$ the same for vibraculum. I.on and fon for the ourchocellaria, $h a$ and $l a$ for the apertura, etc. 
Membranipora villosa Hincks, 1880.

Membranipora (Flustra) isabchlean D'Orbigny. 1839.

Membranipora pura Ilincks, 1880.

Membranipora (Flustra) tehuetcha D'Orbigny, 1839.

Membranipora nitens Hincks, 1880.

Membranipora hyadlesi .Jullien, $18 s 8$.

GenIs HETEROOECIUM Hincks, 1892.

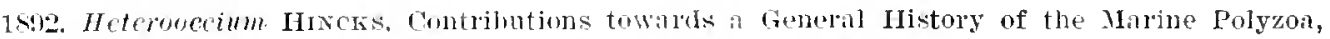
Appendix, Annals and Mingazine Naturill llistory, ser. 6, vol. 9, p. 312.

The ovicell is acanthostegous.

Genotype.-Heterooecium amplectens Hincks. 1881. Recent.
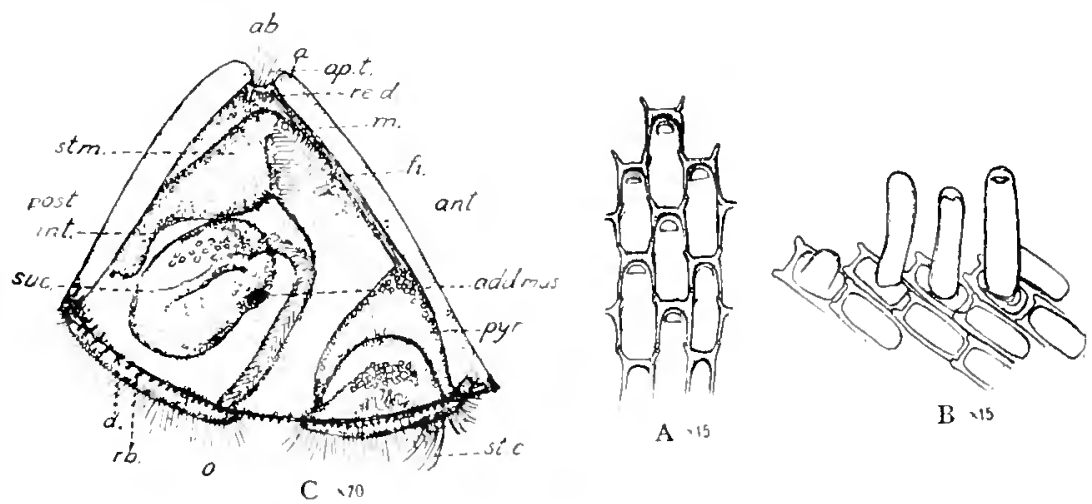

A -15

B $\times 15$

Fif, 19.-Genus ycmbrummer Blaimville, 1834.

A, B. Hembranipora membranece Linnaeus, 17ts. A. Orelinary zooecia, $\times 15$. P. Abuormal cells ("tower zooecia"), × 15. (After Hincks, 1sso.)

C. Cyphonautes orcidentalis robertson, 190s, the larval stage of Uembranipora viltosa Hincks, $1850, \times 70$, showing the organism in wllubll section as it appears while still living and lying on its side. $a$, apex; $u b$, aloral: atld, mus., adductor muscle; $a n t$, anterior; ap. $t$, apical tuft; $d$, denticle; $f$, flber; int, intestinal tract; m, mouth; 0 , oral ; post, posterior; pyr, pyriform hody; ru, rib; re. d, retractile disk; st. c. stiff cilia: stm. stomach; suc, sucher.

\section{Genus PYRIPORA I'Orligny, 1852.}

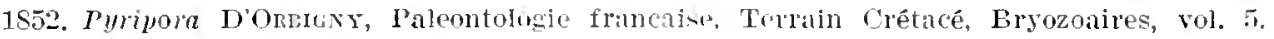
p. 53s.

Colony fixed, creeping over the surface of other bodies, formed of little regular, longitudinal and lateral lines of cells placed one after the other, not contiguous laterally, and disposed in a manner to represent creeping branches more or less extended. Cellules pyriform, narrow behind, and enlargel in front, open in dead or fossil individuals over the greater part of their anterior portion. No special pores, no accessory cells, nor ovarian resicles. (After D'Orbigny, 1852.) The opereulum is calcified. (Levinsen. 1009.) 
Genotype.-Nembranipora catenularia, Jameson, 1814.

Range.-Cretaceous-Recent.

The French author added that in ereating the genus Pyripora in the Prodrome of Stratigraphic Paleontology he had placed there all species with colonies formed of isolated cells, but that now in the restriction of families it was necessary to give more special characters, and that therefore he would restrict Pymipora solely to species with large open cells withont special pores.

History and discussion.-In 1847, when D'Orbigny published his Prodrone, it was the author's idea that this was only a provisional work which later researehes would modify. D'Orbigny's supplementary work classifying both fossil and recent bryozoa was publisher in the Paleontologie Française of 1850 to 1852 . This

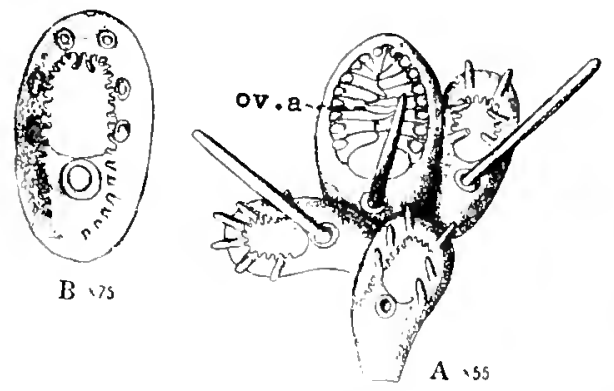

lig. 20.-Genus Heteroocizm Hincks, 1892.

A. B. Meterooecium amplectrus Hincks, 1892. A. Several zooecia, $\times 55$. The small dentieles are not only seen at the margin of the membranous area but are also visible through the calcified wall of the frontal surface. The aeanthostegous oricell (or. a.) has its eavity between the spines and the ectocyst. $B$. The frontal wall of a zooecium, $\times 75$, secn fron the internal surface. (After Levinsen, 1909.)

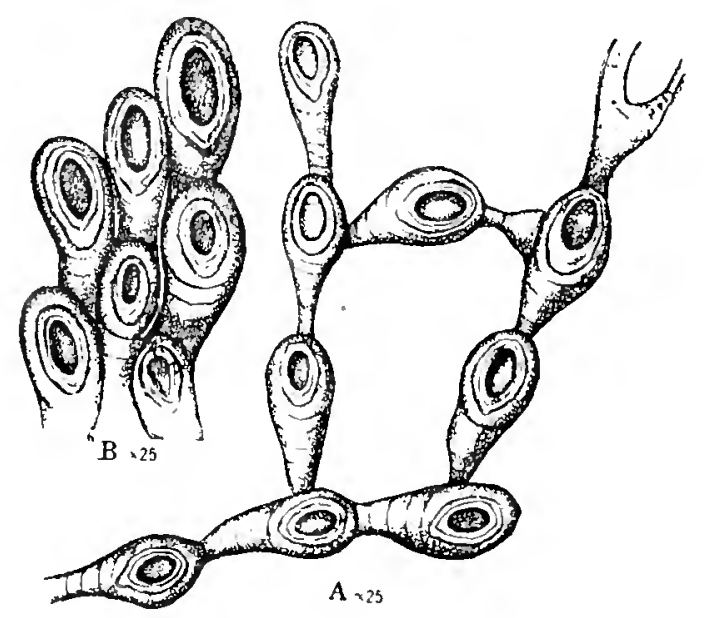

FIG. 21.-Genus Pyripora D'Orbigny, 1852.

A, B. Pyripora catenularia Jameson, 1814. A. Linear form, $\times 25$, witl regenerated zooecia. B. Expansion of zooecia, $X 25$, with all of them rregenerated. (After Ilincks, 1850.)

superseded the Prodrome, and of course is alone to be considered. In this special ease, priority has no significance and can not be invoked for the date of a genus $\cdots$. species.

Similarly, MacGillivray has given many definitions of his genus Ilientopori, and it becomes a question which one of them is to be recognized. Logirally it should be the last one which is the result of the most detailed and complete striclies of the author.

In 1852 D'Qrbigny cited four species of Pyripora-three fossil forms. E'scharina crenulata Reuss, Escharina perforata Renss, Criserpin Inpifomis Miche]in, and ore recent, Pyripora ramosa D'Orbigny; but as he did not cite a type, the clroice of one therefore becomes necessary. Common sense would indieate that his recent species, which lais always been considered as synonymous with Membruni- 
pora catenuluria . Tameson, should be selucted. Waters, ${ }^{1}$ howerer, decirled that the two were distinct species, but undoubtedly of the same group. We can thus logically select $M$ cmlraniporu catenutaria as a typical species of the genus Pyripora D'Orbigny, 185\%. This species is not rare, and the studies which it will receive will complete the definition of the genus and delimit the family characters.

Mr. Lang was kind enough to write us that Bromn and Roemer in 1851 had chosen Escharina cremutata as the type of Pyripora DOrbigny, $18+7$. We would Say that this species does not conform to the very vague definition of 1847 , and that as the definition of 1852 cancels that of $18+7$, the selection of Bronn and Roemer is therefore annulled.

Such an irrational application of the lav of priority has led Gregory into a paradoxical error. His gen Zonopor D'() rbigny does not contain a single species that D'Orbigny himself had classed in it. From this one would infer that the celebrated French paleontologist did not know what he was writing about.

PYRIPORA PARVICELLA, new species.

Plate 3, fig. 1.

Description.-The zoarium incrusts shells. The zooecia are arranged in isolated linear rows; they are smatl. quite elongated. pyriform, much narowed in the rear; the gymnocyst is smooth and convex: the opesinm is anterior, elliptical, very finely cremulated. with a length of a third of the zooceia.

$$
\text { Measurements.-Opesium }\left\{\begin{array} { l } 
{ h o = 0 . 1 6 \mathrm { mm } . } \\
{ l _ { 0 } = 0 . 1 0 \mathrm { mm } . }
\end{array} \text { Zooecia } \left\{\begin{array}{l}
L_{z}=0.45 \mathrm{~mm} . \\
l_{z}=0.20 \mathrm{~mm} .
\end{array}\right.\right.
$$

Affnitics.-This neat little species differs from Pyriporu tubercutum Isonsdale, $18 \mathbf{4}$, in its lesser zooecial length and in the more regular form of its zooecia. Several well-preserved specimens have heen found.

Ocmerence.-Mirwayan (Clayton linestone) : Brumilice, Alabama (rare). - Holotype.-Cat. No.637s7, U.N.N.M.

\section{PYRIPORA TUBERCULUM Lonsdale, 1845.}

I'late 19, fig. 4.

1845. Hippothou tubcrculum LonspdLe, Account of twenty-six species of lolyparia obtained from the Eocene Tertiary formations of North Aneriog. Quartery Journal Geological Society, Jondon, vol. 1, p. 527.

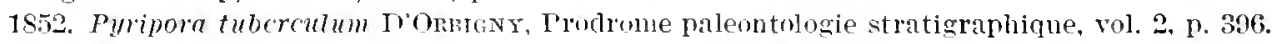
1862. Pyrifustrella tuberculum GABB and Hons, Nonograpli of the fossil Polyzoa of the Secondary and Tertiary formations of North Amprea. Jomrnal Acardemy Natural Sciences, Philadelphia, ser. 2, vol. 5. ․ 163.

Description.-The zooecia are rounded anteriorly and very unch constricted posteriorly; the gymnocyst is convex, more or less striated transrersely; the mural rim is broad, tuberculated, divided into two parts by a circular furrow; the

1 1907. Waters, Notes on some recent brrozoia in D'Orhigny's colletion, Annals and Magazine Natu. 1:al llistory, ser. 7 , vol. 15, 1, 11. 
opesum is stighty proform. the narrow end rased. 'The nornal mote of branching is bilateral.

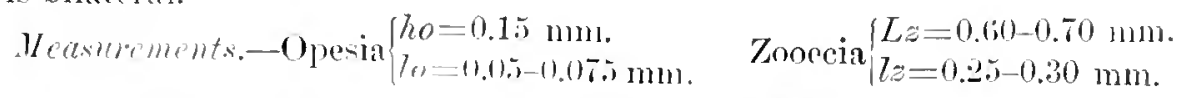

(ertain zoweria bear on the eymnocyt near the opesimm a little pore that is perhaps the place of a spine. The olocyst appeas to be formed of two calcarente siperposed layers.

The micrometric dimensions of this species ale identical with those of Pyriport

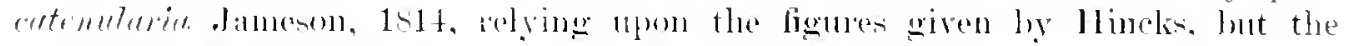

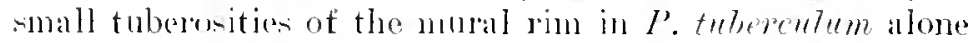
distinguish the two species. We hate been mable to make direst comparion with this living species, and therefore can not prononence on the ielentity of the two.

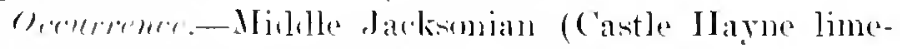

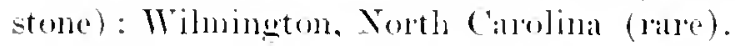

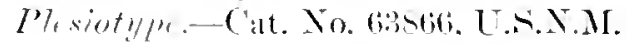

\section{Genus HERPETOPORA Lang, 1914.}

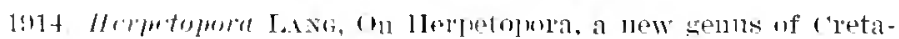

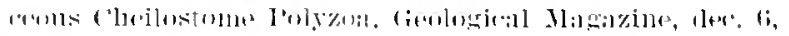
เᄈ1. 1. 11. ז.

Inclusting. minedial. 'The morle of lownehing is

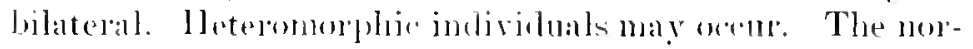

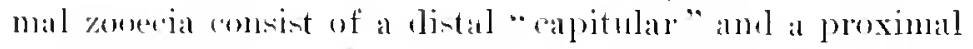
"camblal" portion. Sealed and reversed zonecial rery rommon. (After Isangr.)

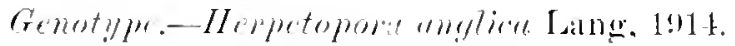

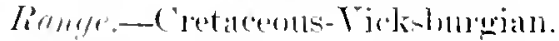

This permos has been confused in part with I'yriposel

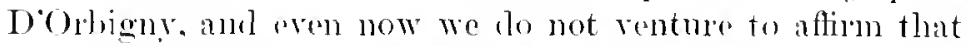
the Cretacente seceses figured by Lang are not the same

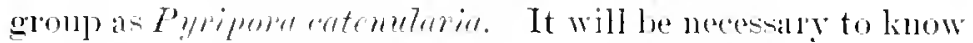
the significane of the heteromorphic zoneria noted ly the authol before the tull value of the wemus can be determined.

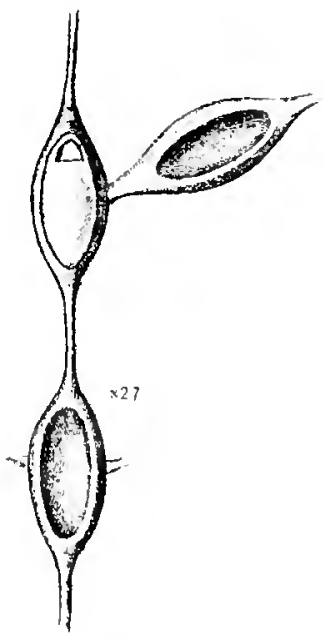

Her. 22.- Genus III inflofuru Lans, 1914.

Sereral zonecia of 71 irpetoprome anglire Lang. 1 bl t. X.27, two of which aw nurmal and the thirel sandal. (Altrer Isange, 1914.) (1ratacous (stomutian): ("hat lanu, Englant.

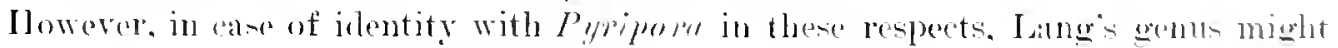
sill lee maintained for the species levoid of the camial portion.

HERPETOPORA DANICA Lang, 1914.

I'late so, fir. 1.

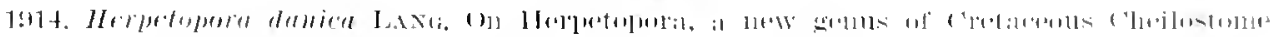

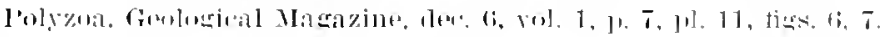

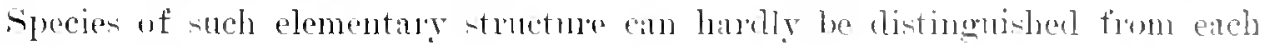

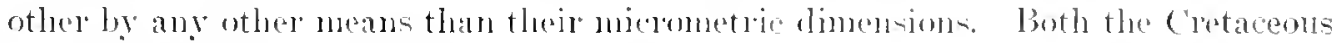

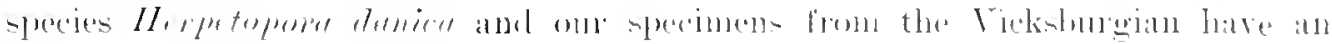


opesium measuring $0.72-0.80 \mathrm{~mm}$. ly $0.40 \mathrm{~mm}$. The Cretacens specimen- aliffer from those of the rickslurgian in having the operia finely cremulater. Moreover. some of on specimens branch unilaterally. However. these differences can be proved to exist in the same species. It should be noted that there is mo hasal

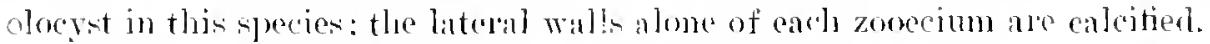

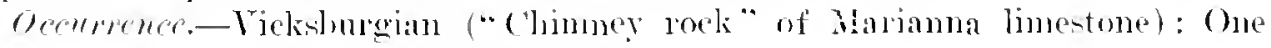
mile mortls of Momrocille. Alaluma (rare).

Geolorical distribution.-Semonian of England: Danian of Demmank (Tang. $191+)$.

Plexiotype.-Cat. No.6t2e?. T.N.X.M.

\section{Group MEMBRAN1PORAE Canu and Bassler, 1917.}

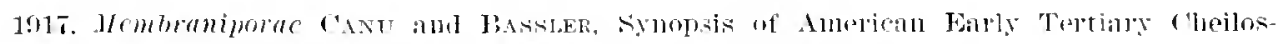

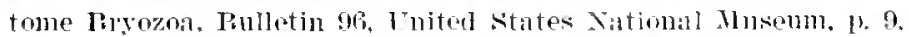

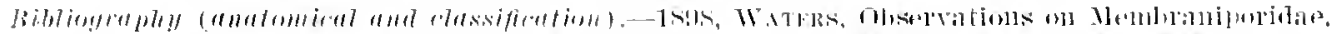

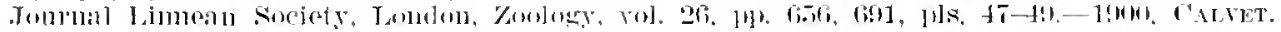

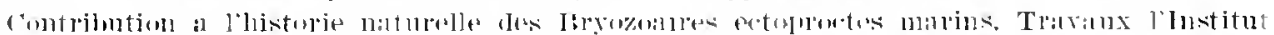

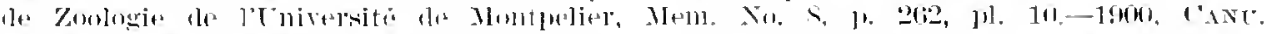

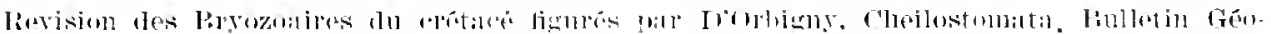

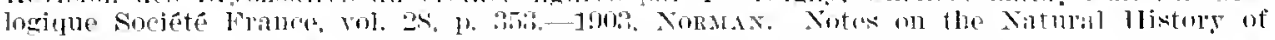

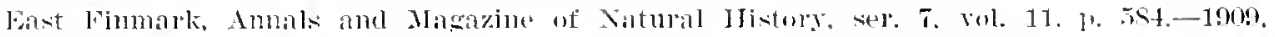

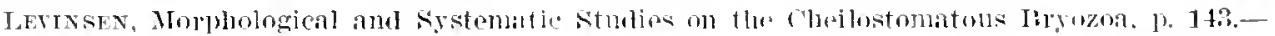

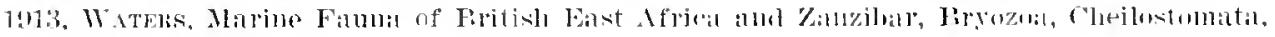
Procetelings Zoologian? Society, Lombun, 11]. 71, fig. 1.

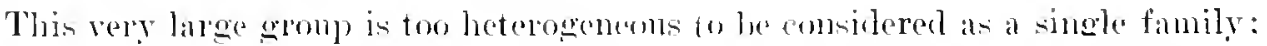
incleed it is certain that the genera classified here at present will witimately be assigued to many families. Infortumately we alde innorant of the larvac. and lesearehes upon the anatomy of these form- have not locou made.

The first attempt at elasification was made hy Watres in 1598 in his excellent

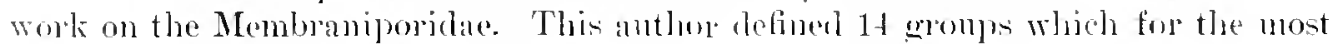

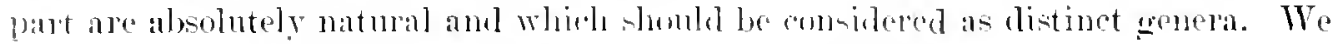
have had freguent occasion to refer to this puldivation.

Cants researches in 1900 were puite inemplate. as they were limited to the Cretacents spejes in which most ol the procimene were devold of aricells. This

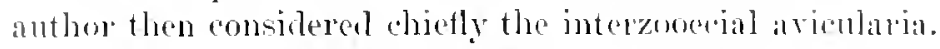

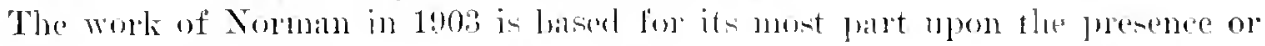

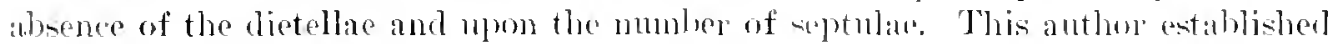
a numbles of natural genera.

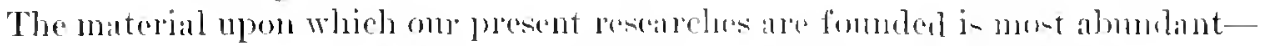
Jut as it is impossible to estalblish a satislactory nomeduature with for-ils alone.

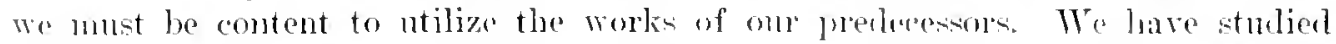

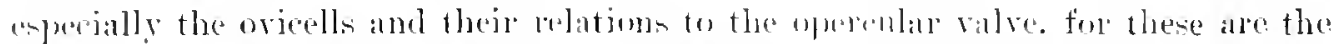
oreans in closest relation to the larval sytem. In the lobluwing table are listed

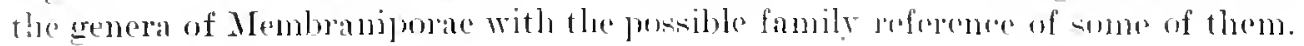




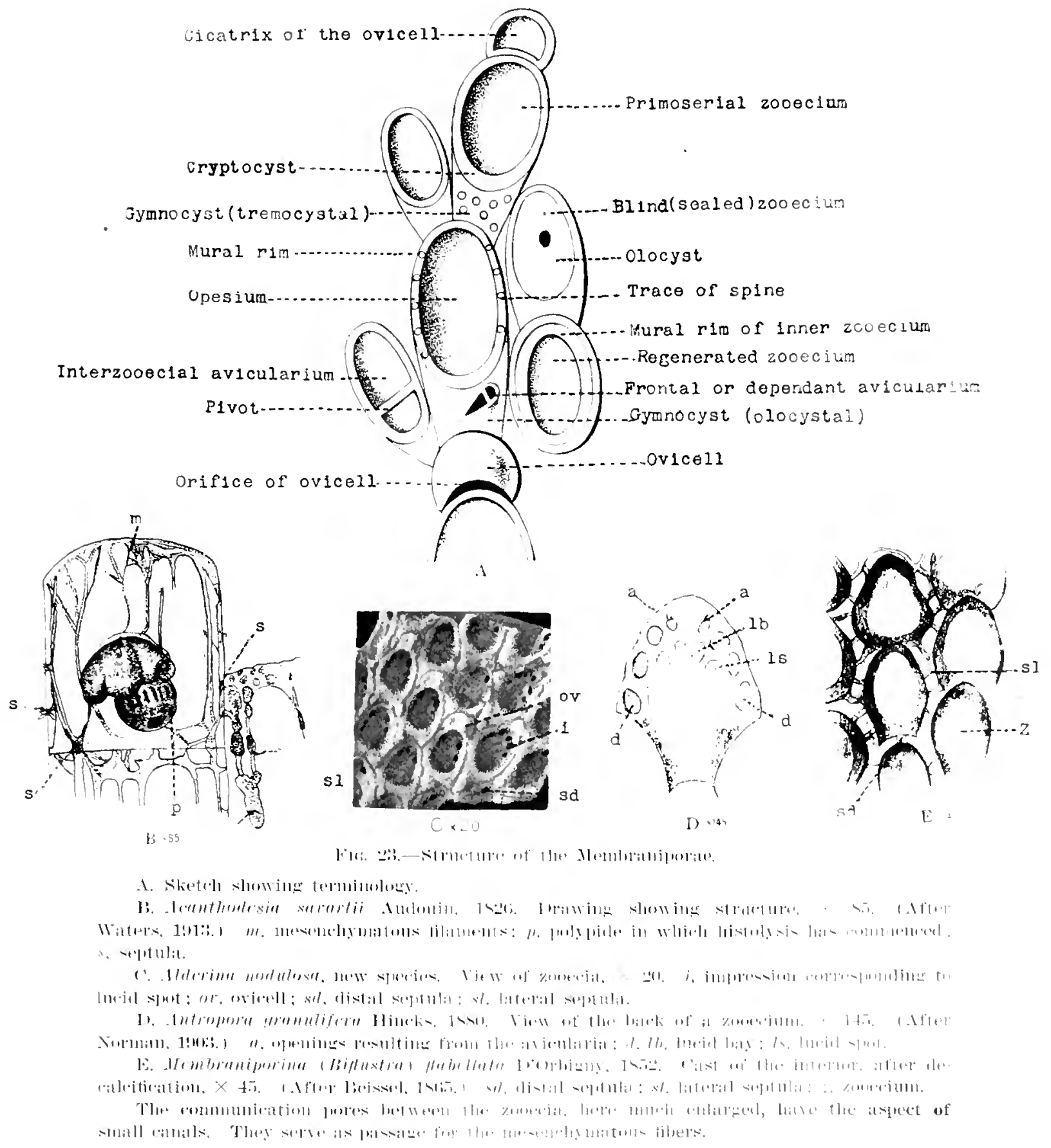


IILNERI TABLE HE MEMRR LNIPOR IE

Section I. No ovicell.

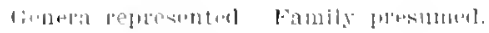

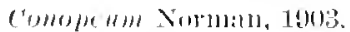

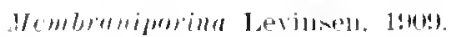

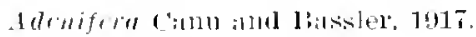

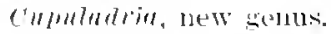

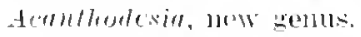

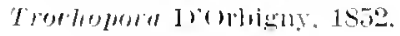

ofinclla cillu and Insslel. 1917.

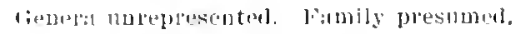

Hisenflastrelluria Irorbigng, 1851.

crepis .Jullien, 18s'2.

Heliodemule labret, $190 \mathrm{t}$.

Section II, Ovicoll andozooecial.

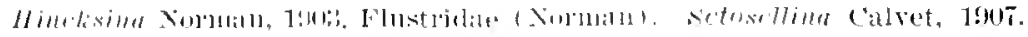

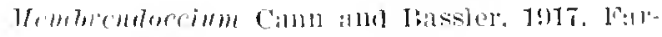

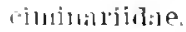

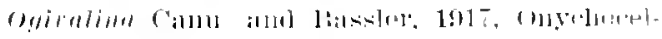

linlils.

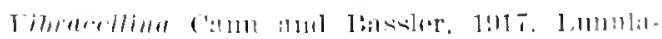

Iiinitu.

Section III. Ovicell hyperstomial, closed by the opercular valve.

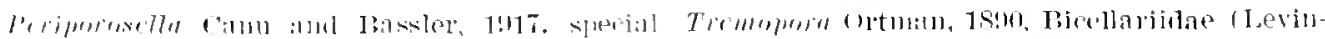
tilluily.

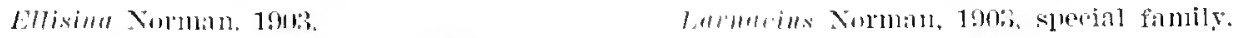

Gramm, lla ram, 1917.

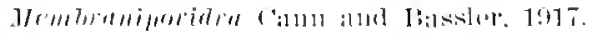

Section IV. Ovicell hyperstomial, not closed by the opercular valve.

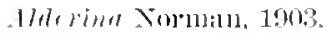

Cerloporm aray, 1S48.

4mmatablum Nolman, 1903.

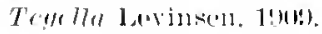

lowsomprera Lang, 1914.

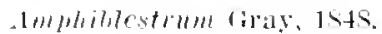

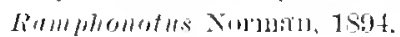

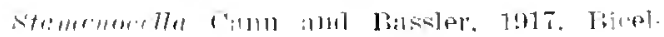

larijala.

Section V. Miscellaneous.

Fantoramplus Nolman, $190 \%$.

I'menterin linsk. 1SSS.

Wrmbresste , Jullion, 1003.

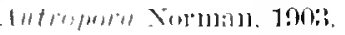

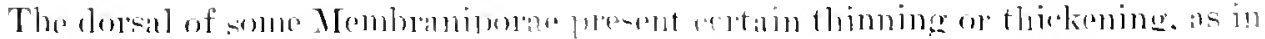

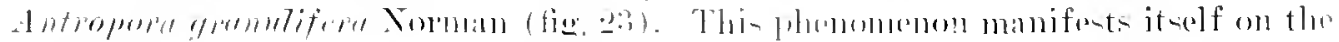

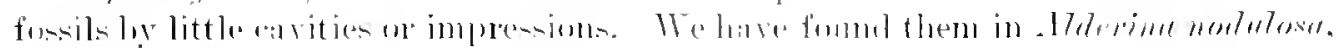

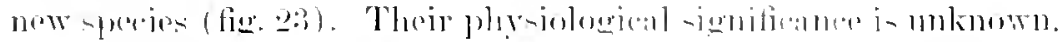

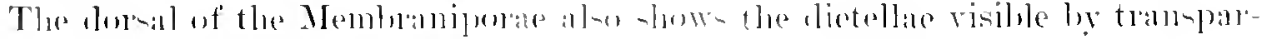

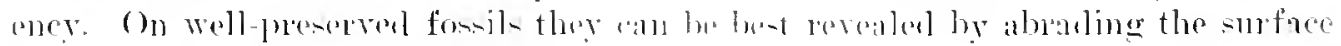

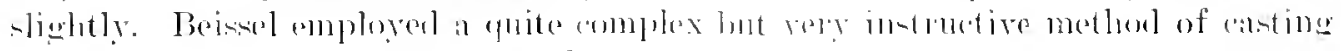

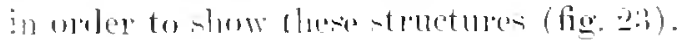




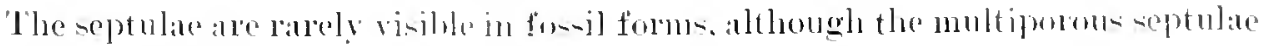

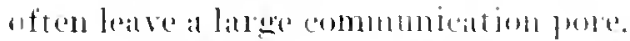

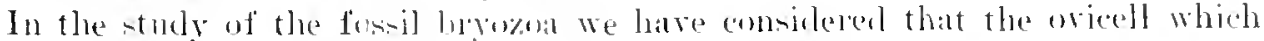

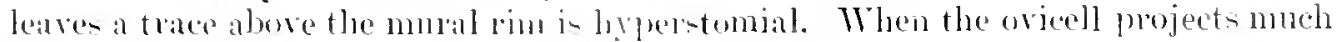

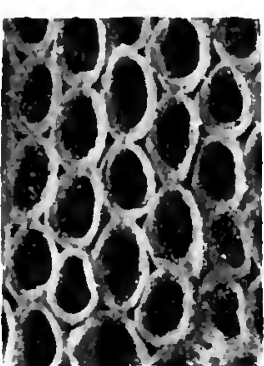

A. Conopeum

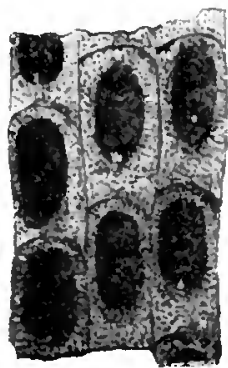

B. Acanthodesi.l

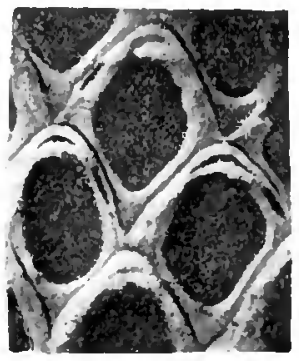

C. Adenifera

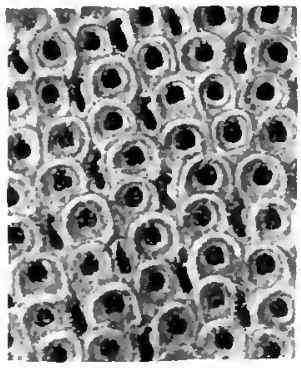

F Otionella

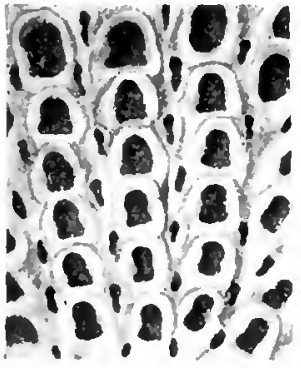

G Trochopora

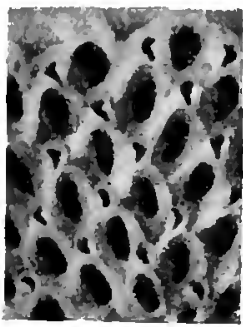

1) Cupuladria

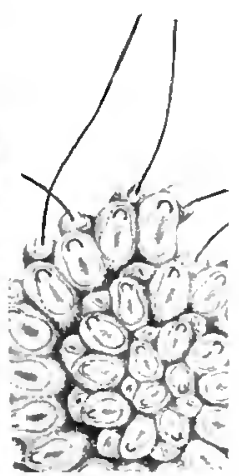

E. Heliodoma

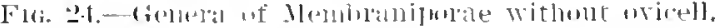

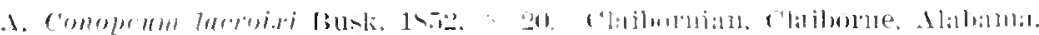

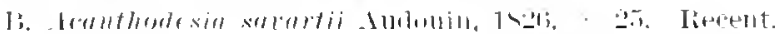

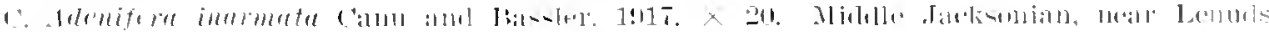
lorres south cilpolina.

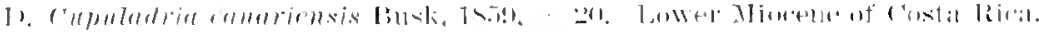

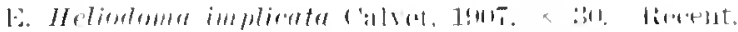

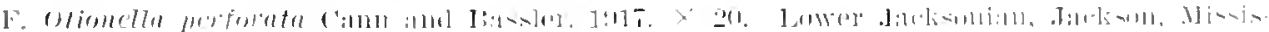
silit.

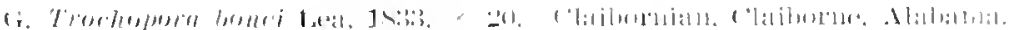

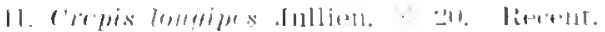

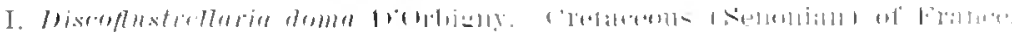

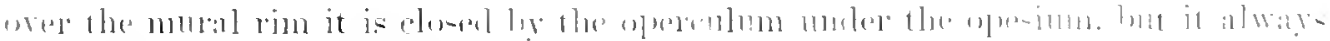

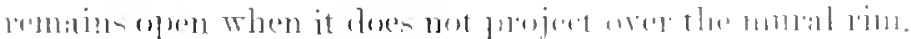

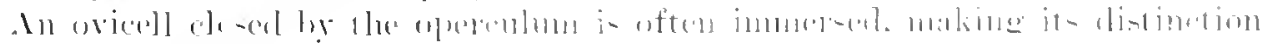

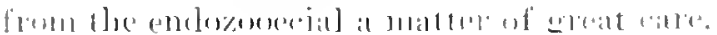




\section{SECTION 1. MEMBRANIPORAE WITHOUT OVICELL.}

Genus CONOPEIM Norman, 1903.

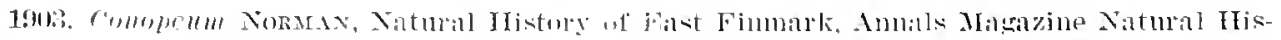

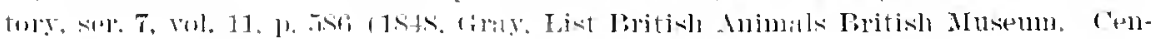
thenile. III. Jus. 14 li).

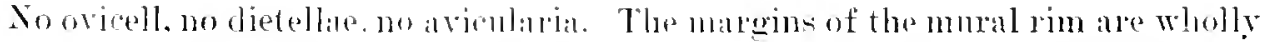

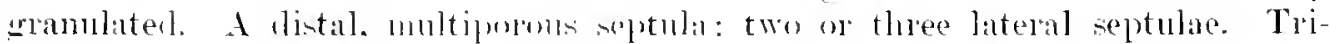
angular, intereresial hollow's having -pecial walls.

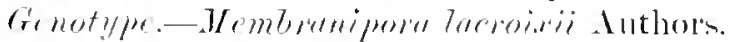

linu!r.-Cenominnian-Recent.

The wrantations of the mural rim are often rery fine and atcenuated on the fossil forms. In these also tho distal septulate often unite into a rery laree pore.

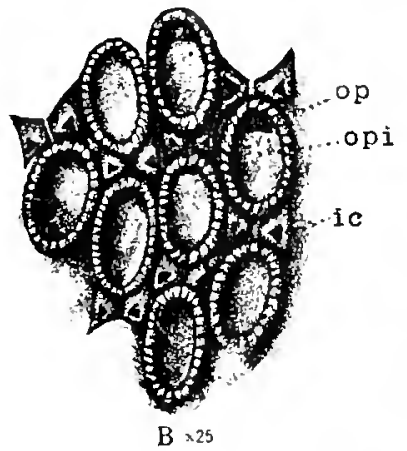

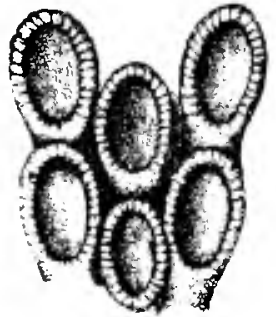

A $\times 25$

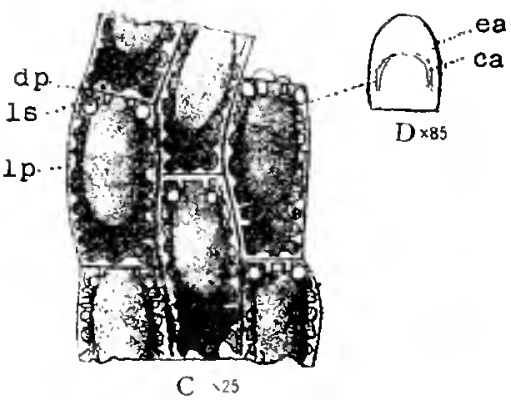

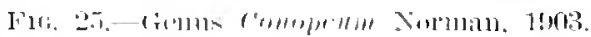

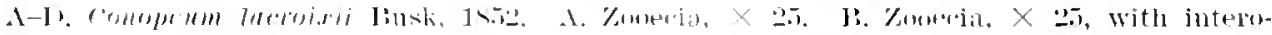

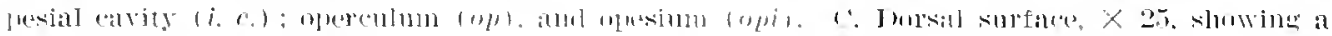

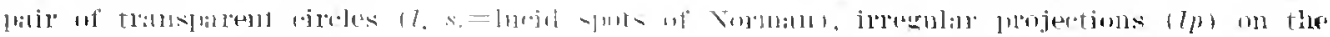

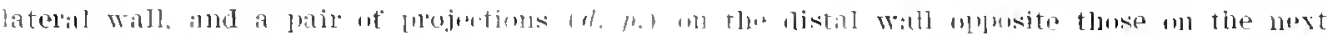

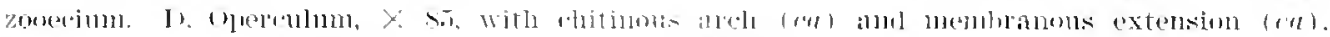

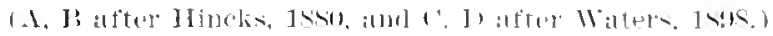

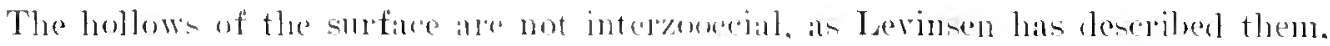

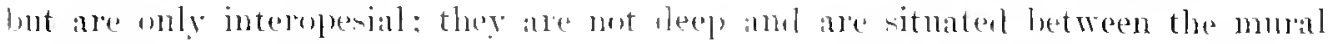

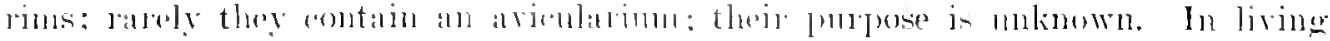

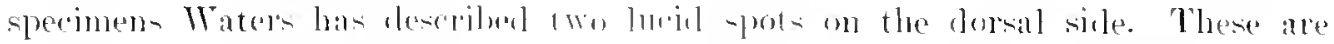

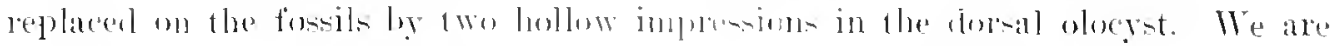

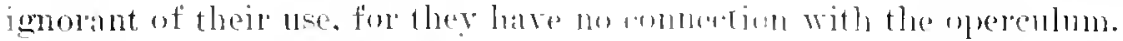

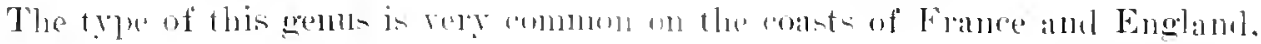

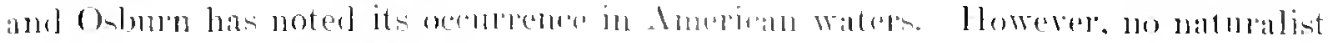

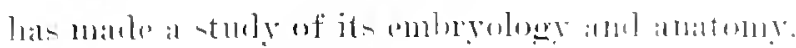

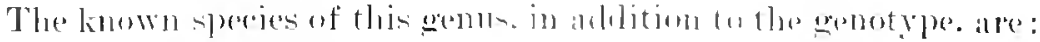

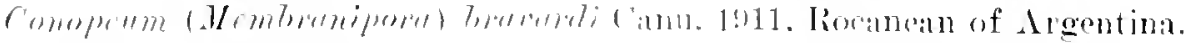

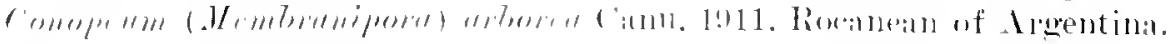

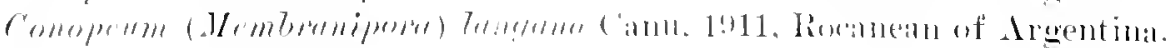

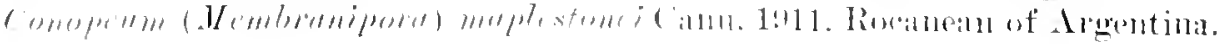


CONOPEUM ORNATUM, new specics.

l'litto 3, tim.

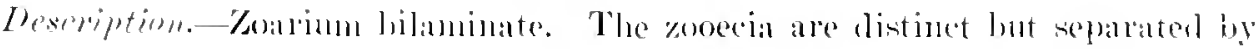

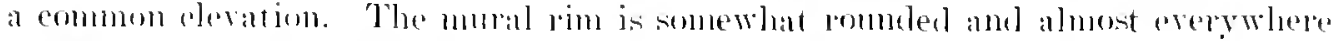

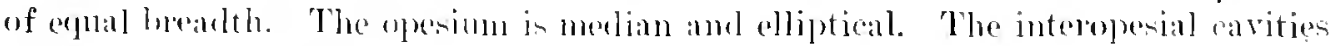
are dintinet and inregenlar.

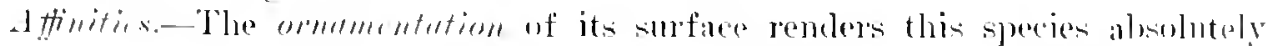
chatracteristie. althengh this feature is reproblued sometimes in other species. lout only arcidentally. Unfortmately we ponsess but a single fragment of thic interesting form.

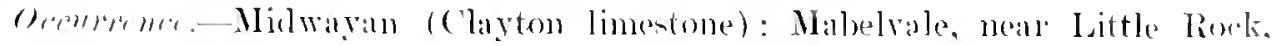

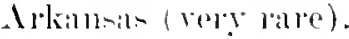

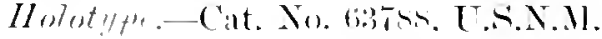

IONOPEUM DAMLCORNIS, new species.

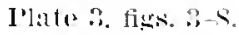

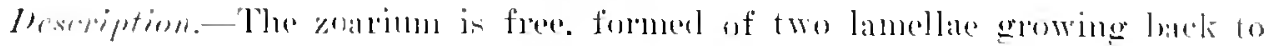

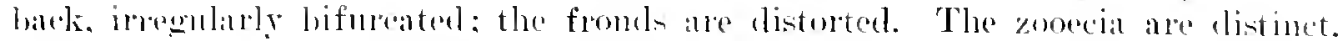
irregular, polyenal, or alliptical: the mural rim is very thin, regular. projerting

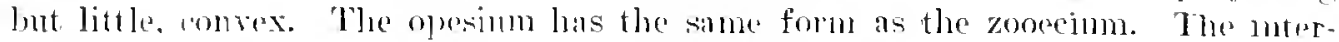

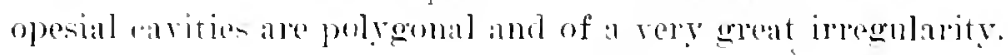

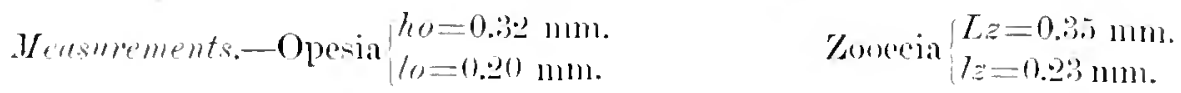

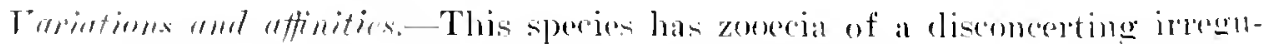

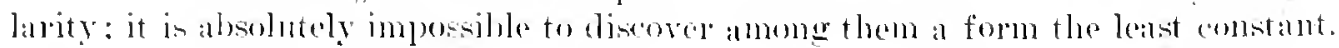
The sime holks troe with the interopesial avities which disappear followine the jrregulatitises af the zonlium.

The struture of the zonecial walls is quite remalkalule. In tangential spe-

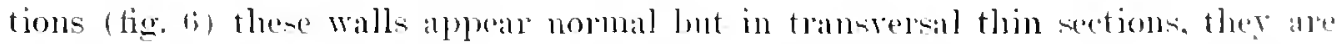

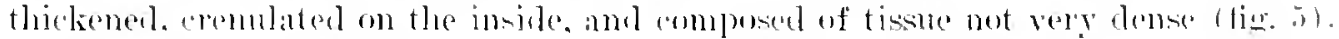

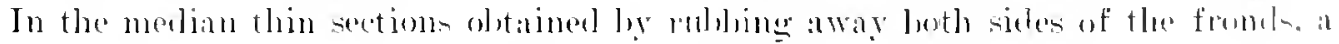

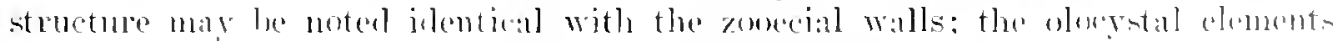

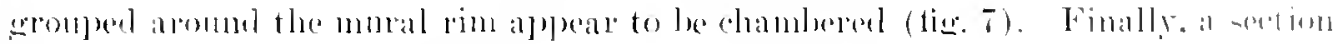

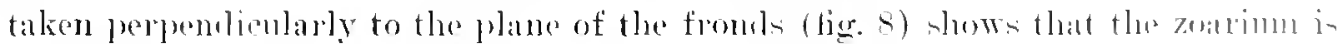

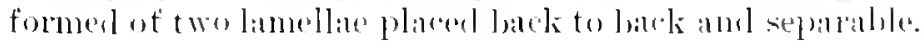

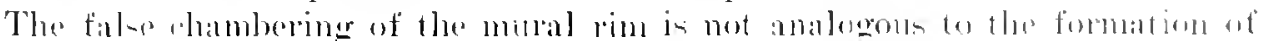

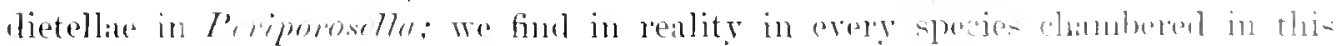

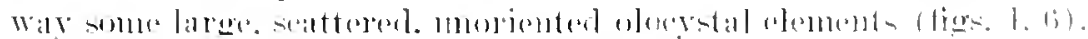

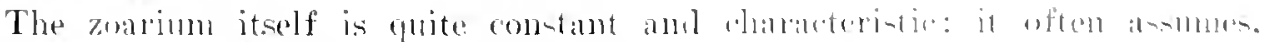

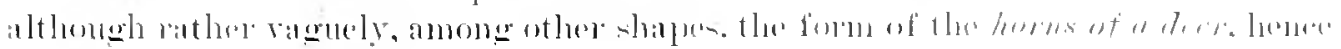

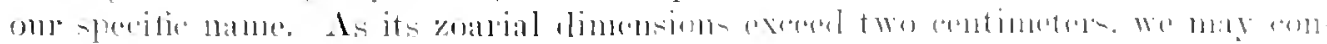


sicler this precies as an easily recomizul. characteristic fossil. Infortmately. the species lus not yet been discovered in many of the loealities of the Midwayan.

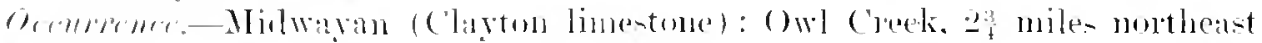

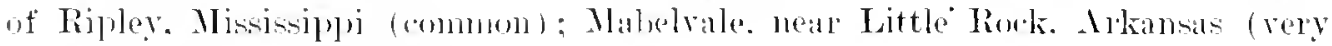
ratele).

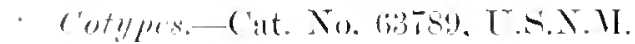

\section{CONOPEUM WILCOXIANICUM. new species.}

Plate 9, figs. 1-7.

Despription.-The zoarinm is incrusting, of ome or mole lamellace or free and bilaminate. The zoocoia are distinctly elomgated, elliptisal, or propiform: the mural rim is flat, finely erannlated. preximally wirlened. The operimm is anterior. ellip-

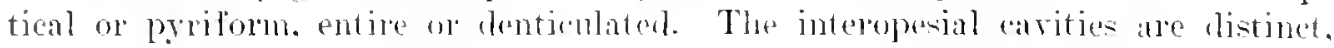
lozenge shaped. There are two thistal impressions.

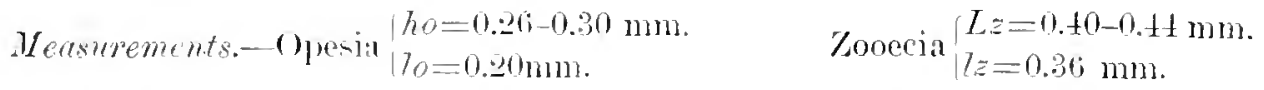

Aftinties.-This specias liffers from Conopenm hoockeri in the absence of the

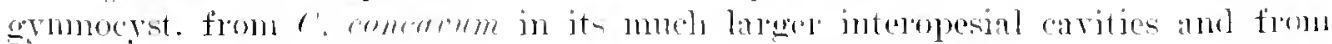
C. Tecroirei in the width of its mual rim. It is ralely incrusting. while the three

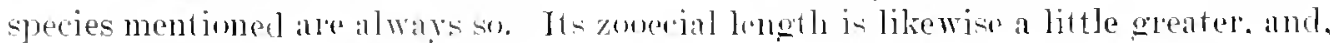

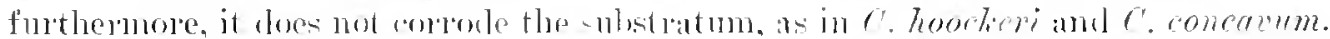

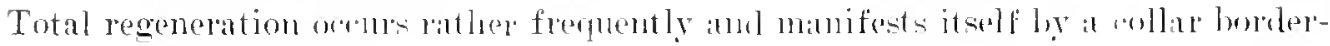
ing the opesia.

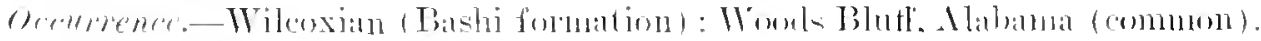

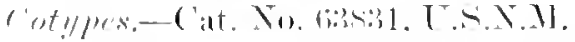

('ONOPELA (?) SIMLLOR, nen species.

Initu! g, tigs. S. !.

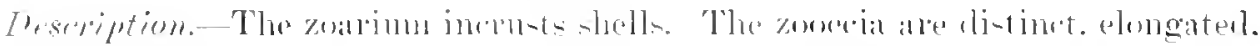

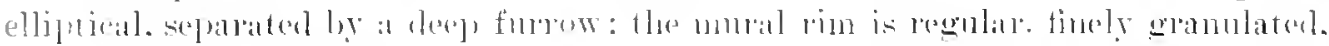

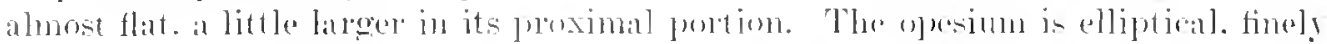

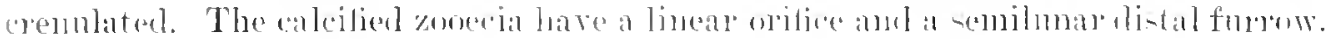

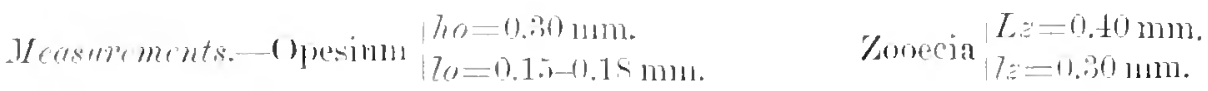

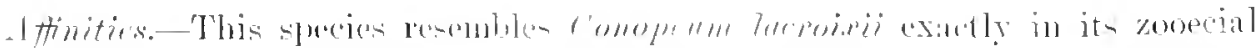

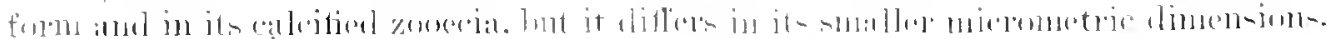

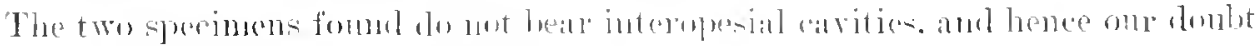

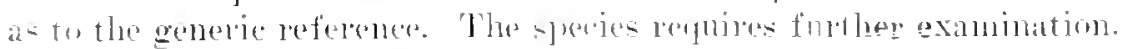

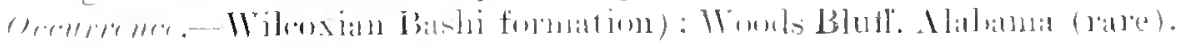

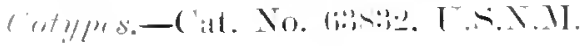


[ONOPELM LACROIAII Busk, 1852.

l'litio 1:3. ling. !

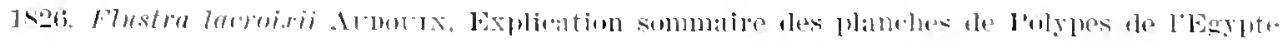

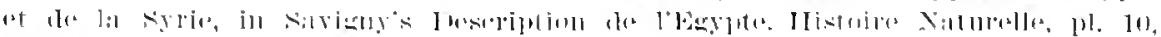
fị. 9 .

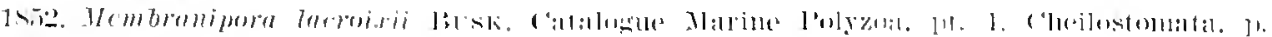
Bi, pl. 49 and pl. 114, tien. 1.

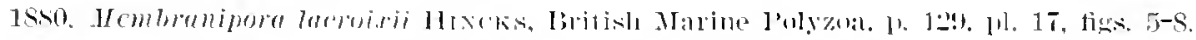

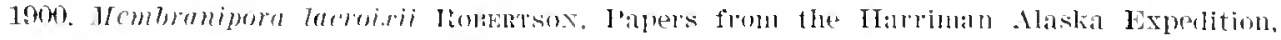

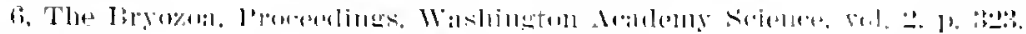

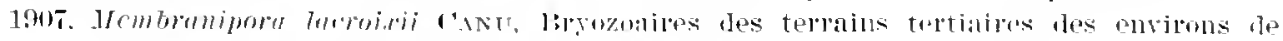

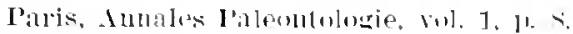

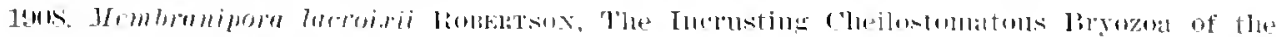

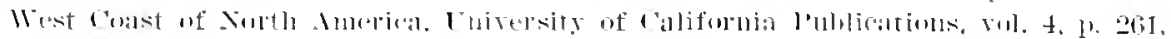
1) 14. fic. ì.

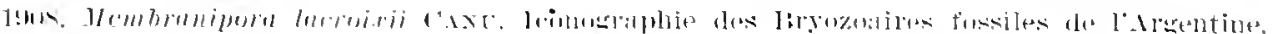

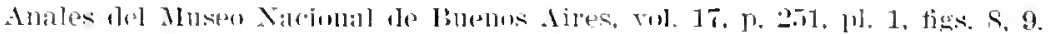

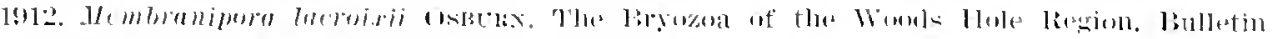

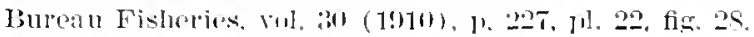

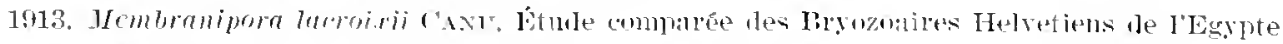

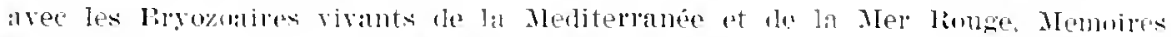

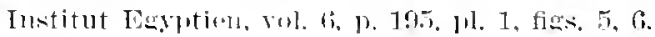

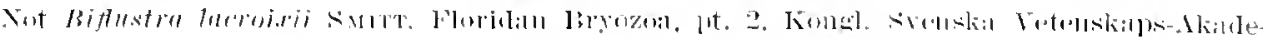

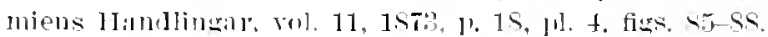

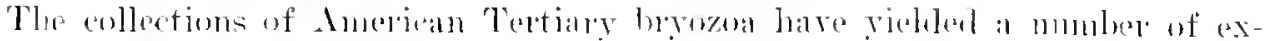
amples of this interesting speries whith is wilespreat in louth the recent and animt seas.

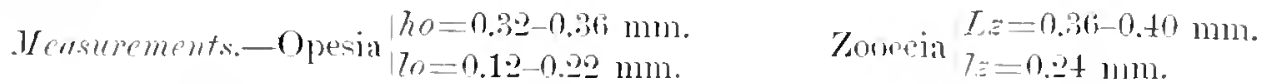

It is not certain that the species deseribed by Busk is that of Amburin. The

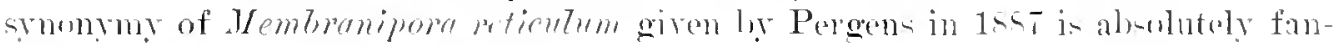
ta-tical. To aroid confu-ion. Canu in 190 - restrieted the symomomy to the species

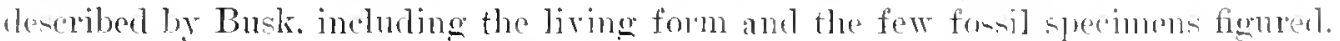

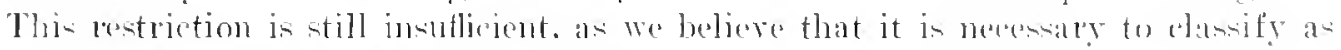

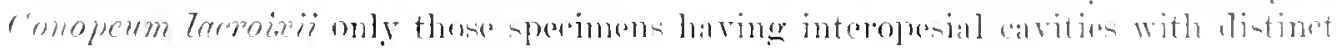

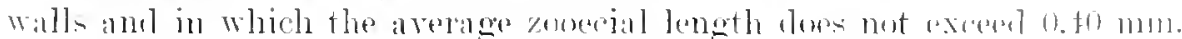

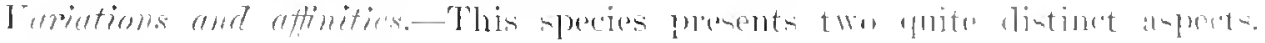

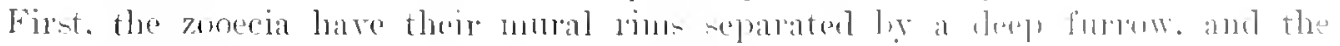

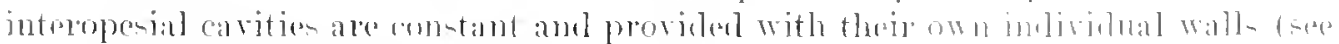

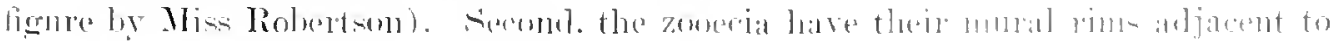

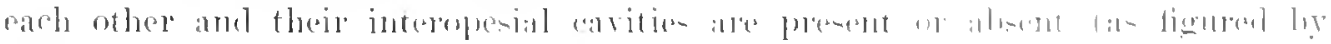
()-hurn).

In the living - she

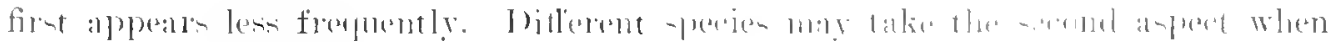

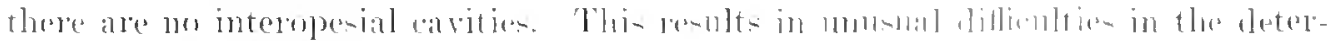

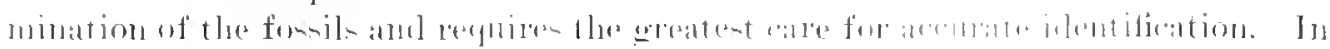


care of doubt the comscientions naturalist should remain silent or shombl figure the suecimens.

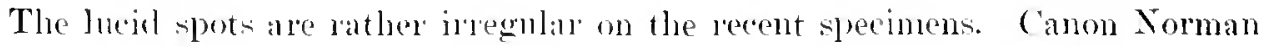
was mable to see them. but Osbum has figmed them. The have not ubserved them in all cases. On the fossils the correponding distal implessions are rery inconstant. They are risible on rertain -premens and bare disapeared entirely on others. The gramulations of the mural rim are rery inconstant, and we bave aberved but a single case of total regeneration.

This specien diflers from fonop"

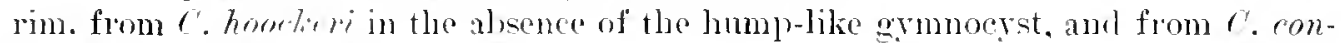
ravem in the ab-ence of the proximal concave cryptocyst. Its zooecia do not excarate the host like the two latter forms.

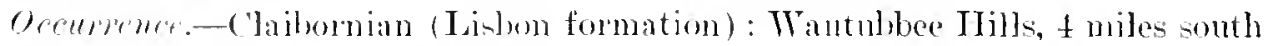
of Enterprise. ('larke Comty. Mississippi.

Lower Jackinnian (Momlys mall) : Jackison, Mismissippi.

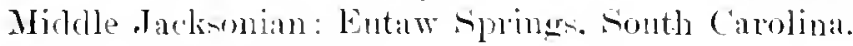

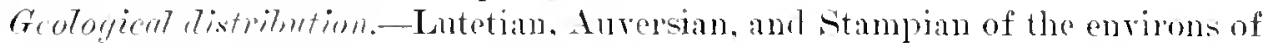

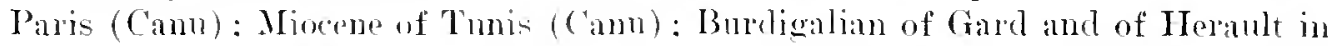
France (Canm): I Jelotian of Italy (Michedin, Seguenza), of Garel, of I Ieranlt, and of Tounane in France (Camu) : Tortonian of Austria-IJungary (Renss); Plaisancian of England (Hlinelss): Quaternary of England (Bell) and of Argentina (Camu).

Mabitut.-The luabitat of this species is still rery obscme on acemnt of the dillienlty of it detelmination. It certainly exists in the North Atlantice off the coasts of France. Eneland, Canala. and the Lnited States and in the Parific ofl Alaska and califormia. It has not yet luen observed with certainty in the Mediter-

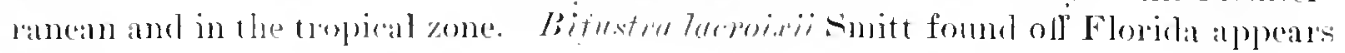

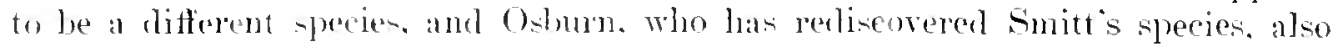
dombte its identity.

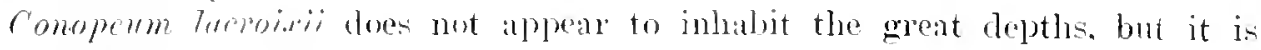
common neal the houres.

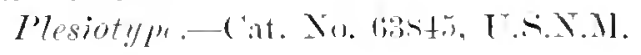

CONOPEUN TUBEROSUM, new species.

T'laito 10, fiess. (i, T.

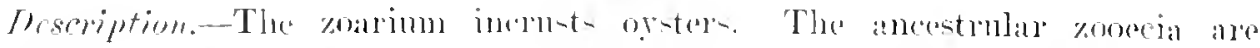

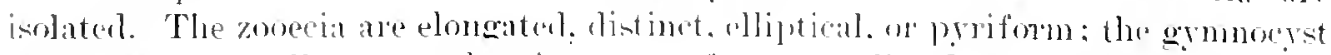

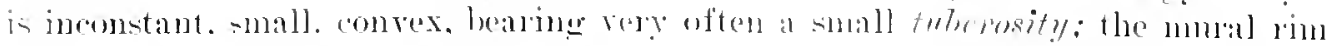

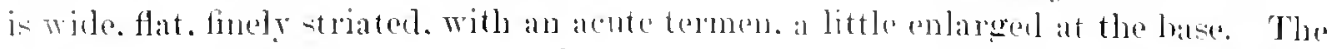

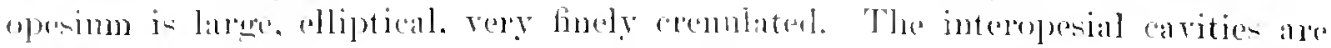

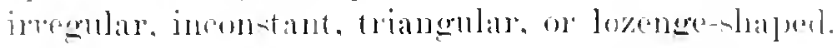

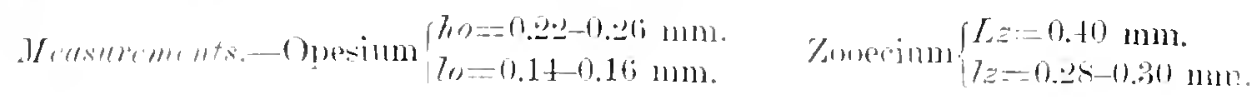




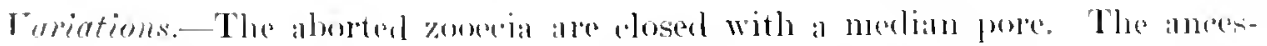

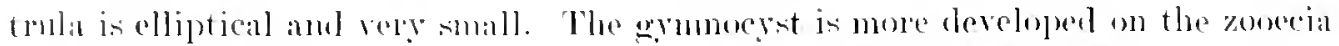
clase to the ancestrulal : here. the funtal tuberosity is absent and the ditlerence from

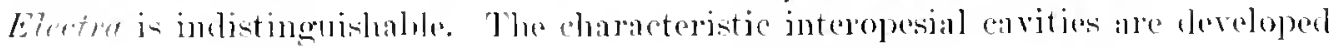
far from the ancestrula on the wiler parts of the zoarium.

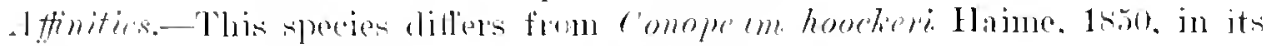
much smaller frostal tuberesity amel in it wider mural rim.

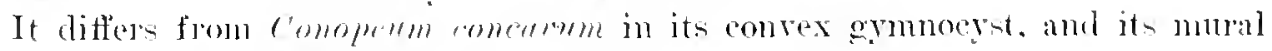
rim less enlarged at the halse amul not comeare.

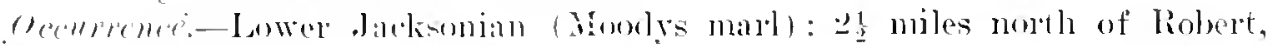
Xewton Comnty, Missisiplopi (late).

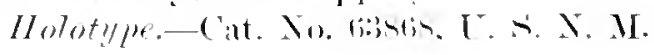

CONOPEUM HOOCIERI Haime, 1850.

I"latis ]!!, tissis, S-10.

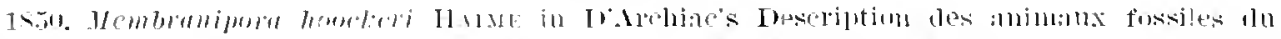

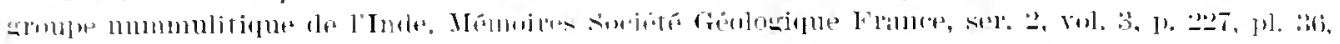
tid. $\pi$.

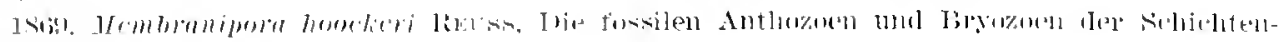

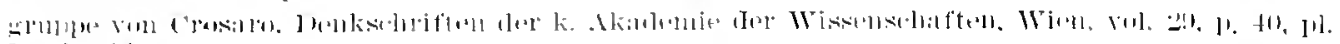
3i. ti:s. 14 .

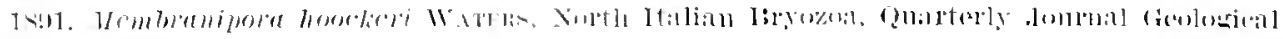

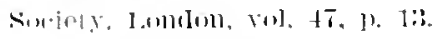

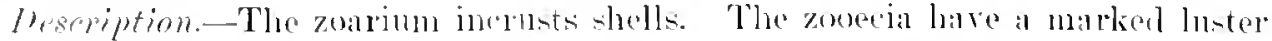
and alle distinct, dongate. elliptical. wmewhat narrowed posteriorly: the mural fim in rery thin, and sharply outlined. little enlarged at the base: the eymunerst is rery convex. The opesimm is rewalar in outline and elliptical. The interoperial

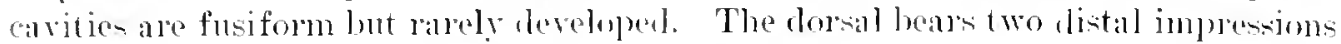
which are excavated in the sub-tratmo. There is a divtal septula and two septulate are on each lateral wall.

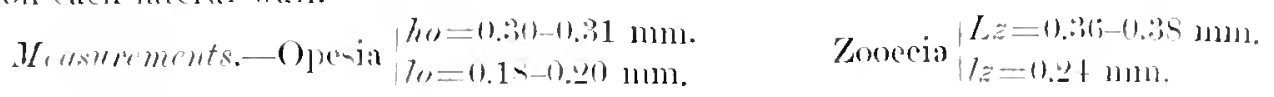

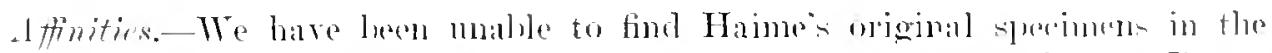

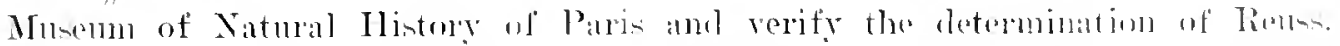

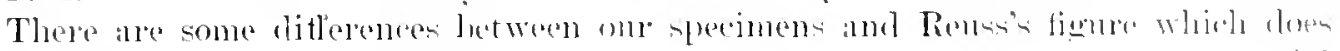

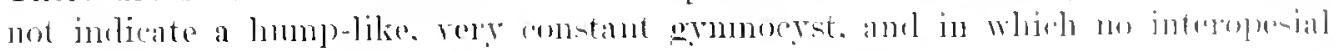

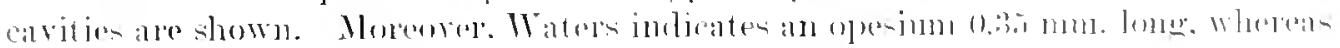

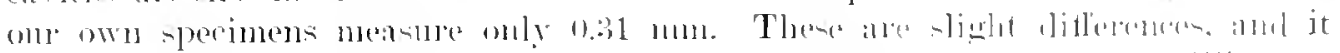

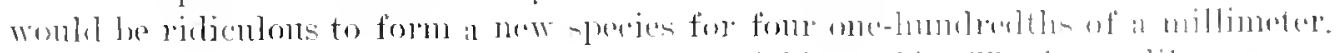

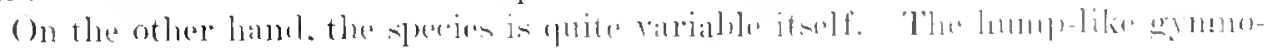

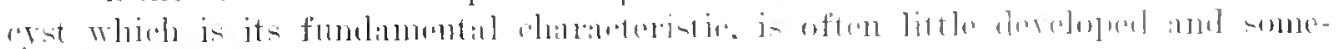

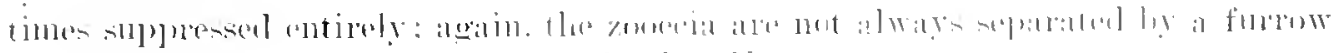

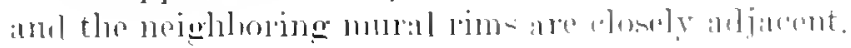




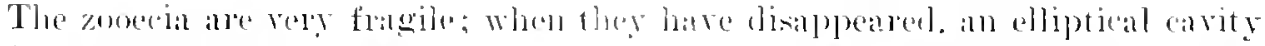

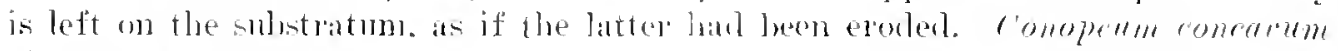

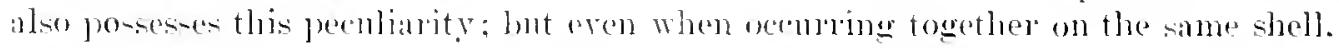

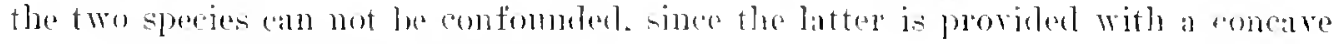

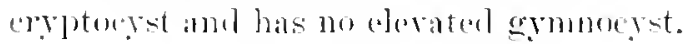

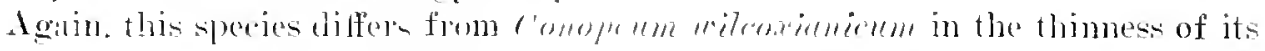

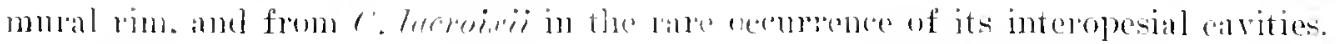

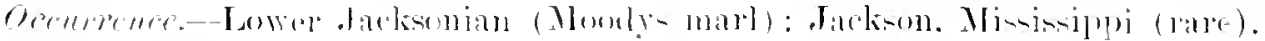

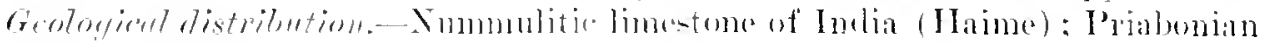
of Virention (Reuss. Iraters).

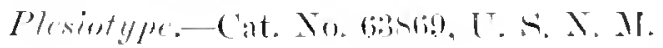

CONOPEUM CONCAVUM. new species.

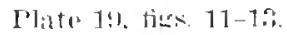

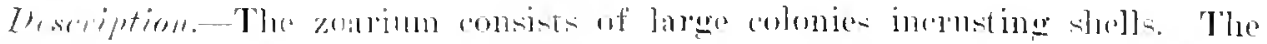

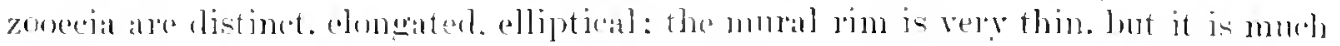

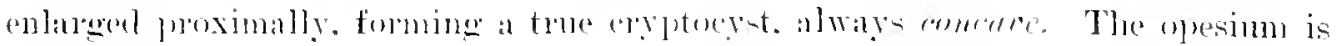

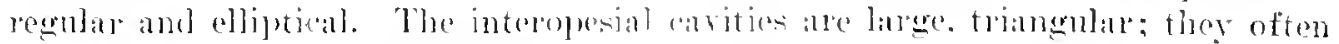

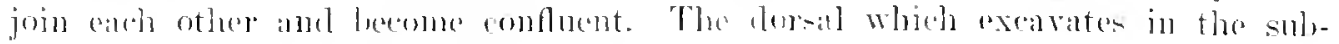

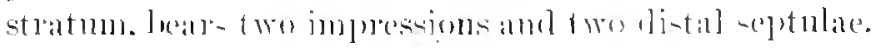

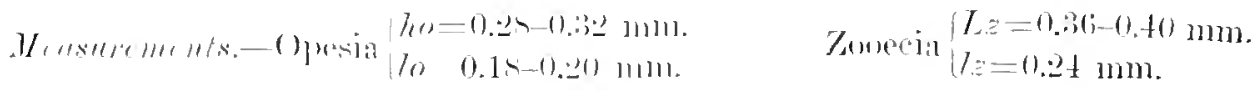

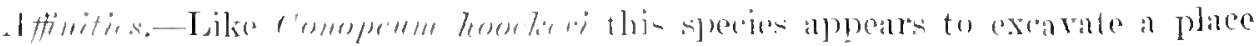

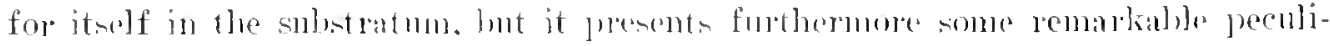

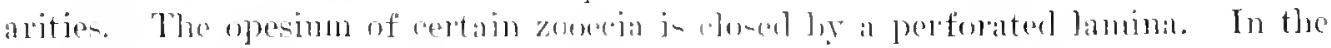

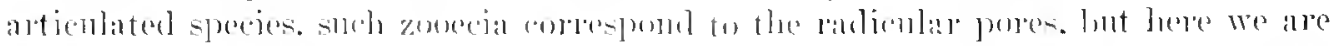

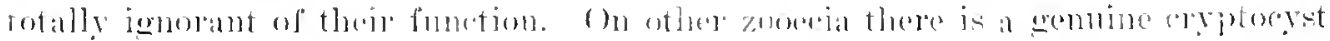

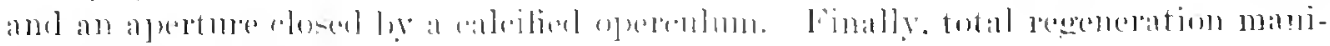

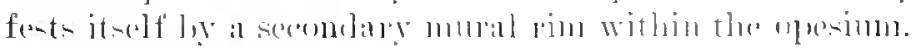

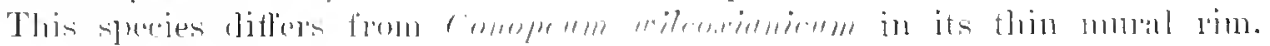

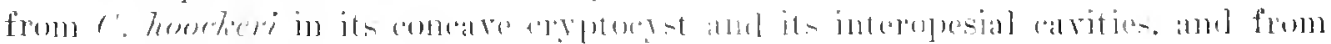

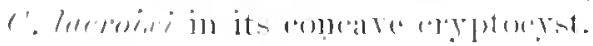

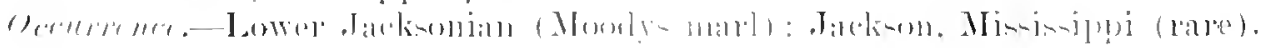

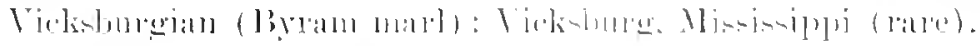

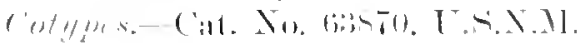

GOXOPEUM T.AWLLLOL[M. nen species.

l'late 20.11 .

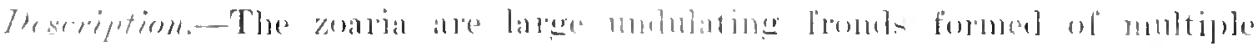

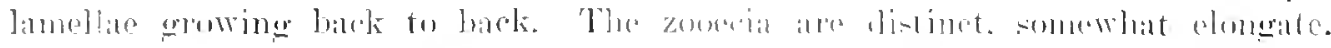

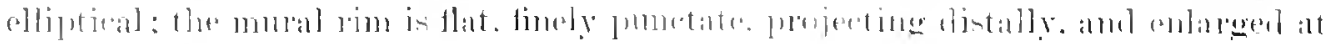

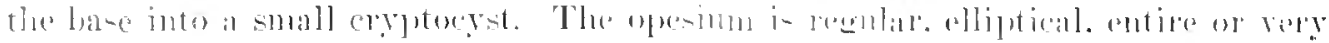




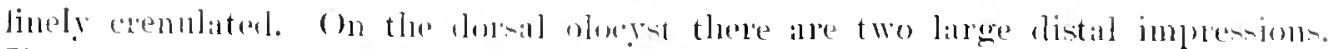

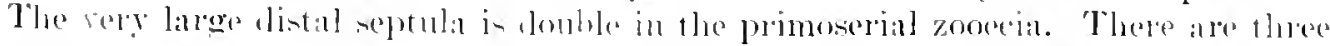

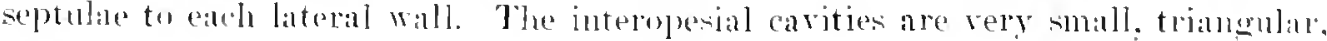
and r:ather eulntint.

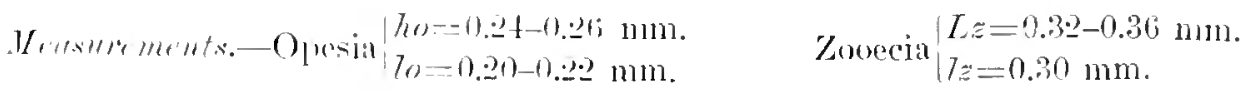

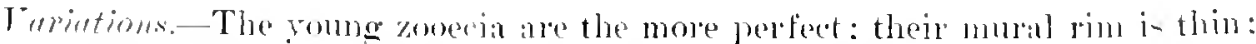

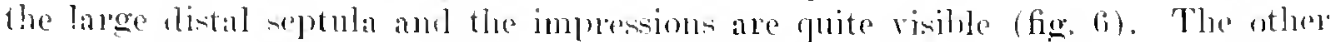

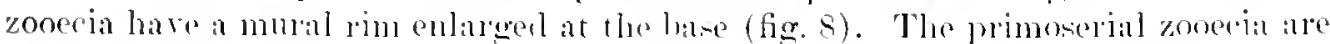

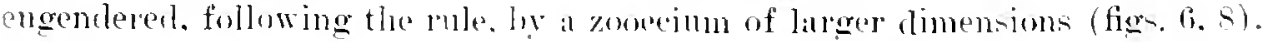

The origin of the multiplieity of the lamellae is quite remarkalole. On the zoarium may he percejeel a sut of -ubeolony, one superimposed upon the of her.

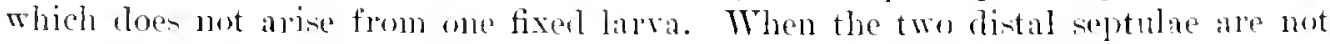

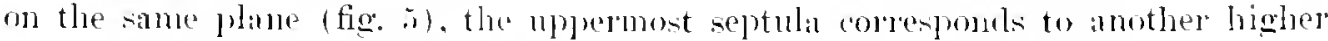
lamella of zooedia covering the mortial one and the firt of these zonoria is like an ancestrula of the suluenlony whele comes forth then as a spiral. This alisposition is clearly visible on figure is.

Deformerl zorecia ane common. They resilt quite often fiom the meeting of two subcolonios (figs. :3, t). Sometimes they alplear on the zoarium as zoocoia wanting in rigur and inealuble of engemplering a new zonecium (fig. 3) : then the two lateral lines are rejoined alme them. Their forms are very capriciom and escape all analysis.

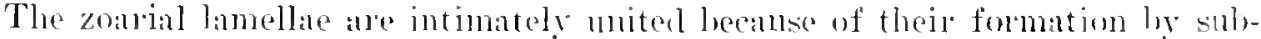
colonies. Sometimes, howerer, the lamellae back to lack are separable (lig. T). The dorsal then bear very remalkable. Iome, prismatic lines on which the zonecia are invisible.

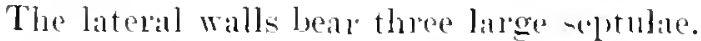

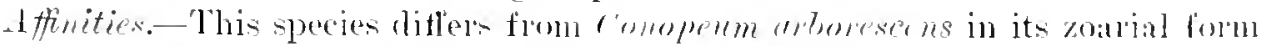
and its elliptical opesium. (Mn accomnt of its large zoarial dimensions it is a strik-

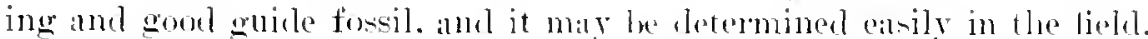

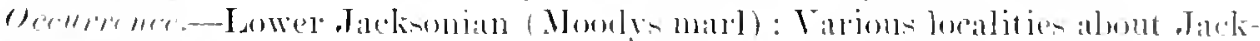

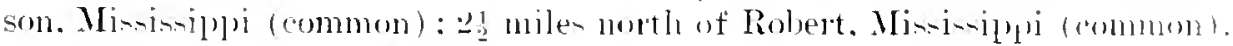

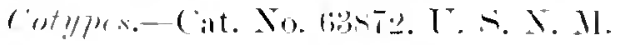

\section{CONOPEUM ABBORESCENS, new species.}

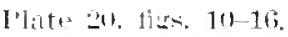

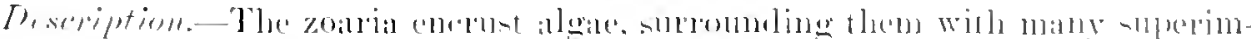

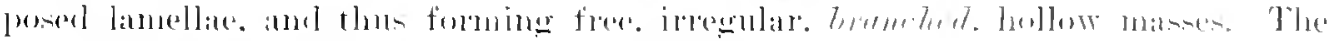

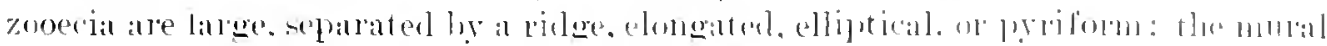

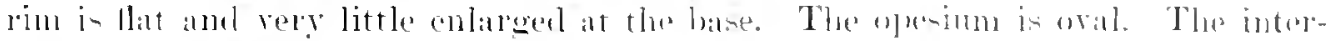

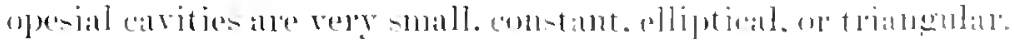

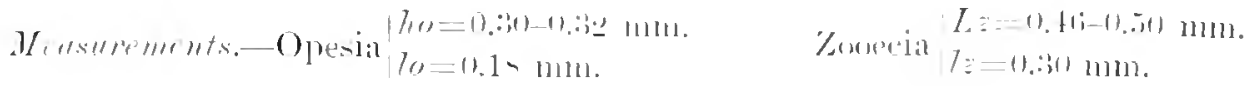




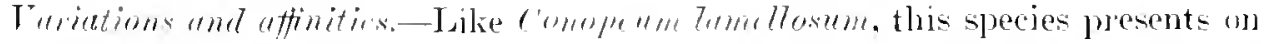

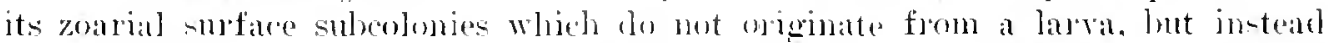
from the especial proliferation of a subjarent zuoecinm (fig. 12). 'These develop' "hietly at the hifureations of the algae. whill ale the parts most constant and least susceptible to growth which might risomange the zoarim. In tangential thin

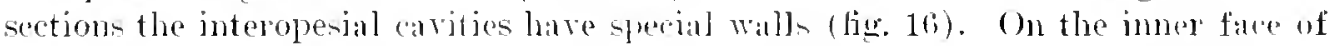
the zoarim the zooeciat are elliptical and prorjeded with a distal collan (fig. 1t).

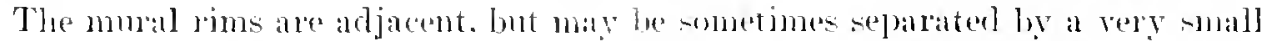

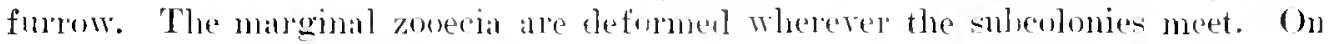

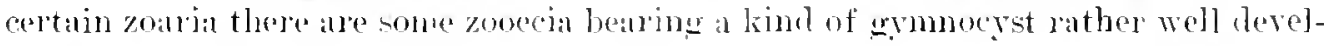

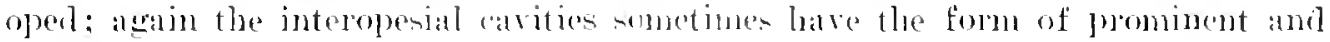
pointerl a vicularia.

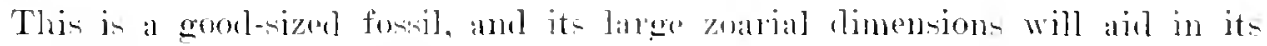
detemination eren in the firlal.

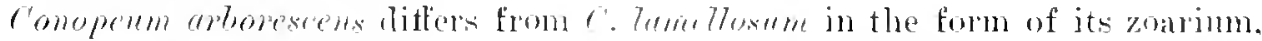
in the oral shape of the olesinm, in the rarity of furdow starating the zoneria. and in the greater thickness of the mumal rint.

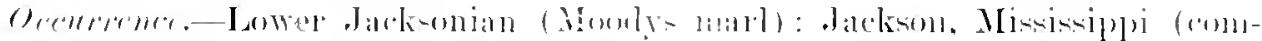

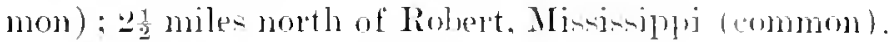

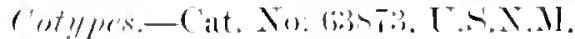

\section{Genus HELIOI)(1) Calvet. 1907.}

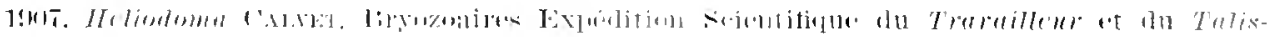
mim, 1 . 3919.

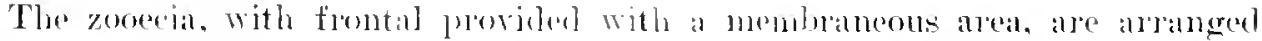

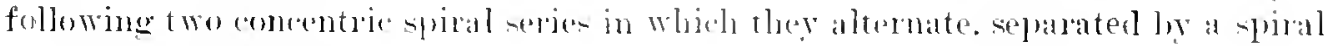

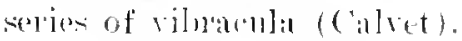

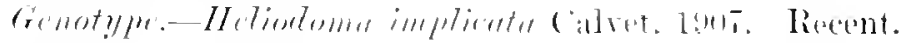

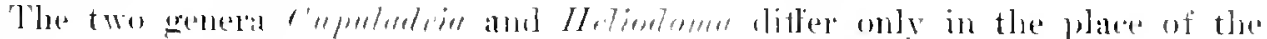

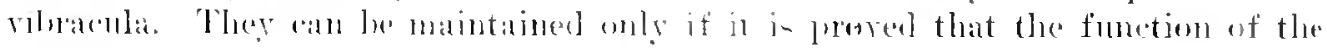

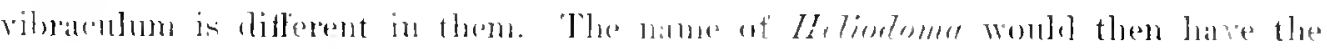
right of priority.

\section{Genus MEMIBRANIPORINA Levinsen, 1909.}

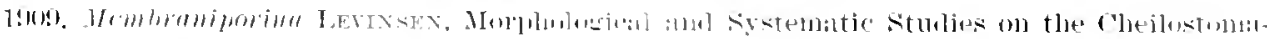

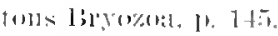

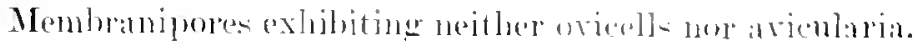

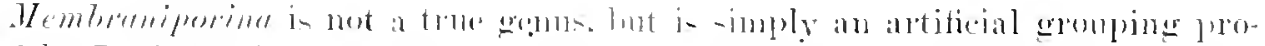

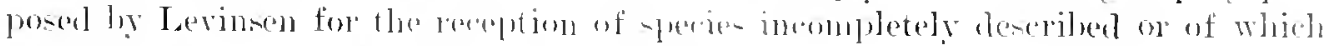
we have insufficient informat ion to glawe them mone hefinitely.

MEMBRANHORINA KIMULATA Ulrich. 1901.

$1 " 1: 11,1,112,1.2$.

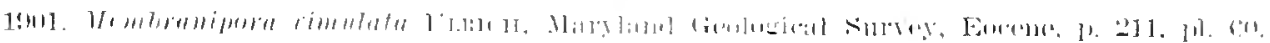
fị:- 1,2 .

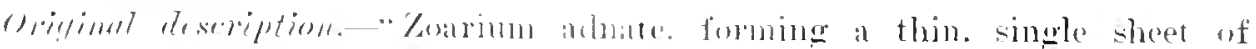

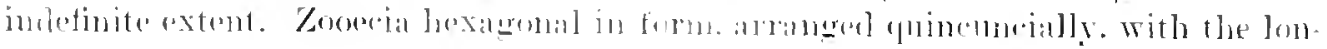


gritudinal rows generally very regular. Apertures oecupying the whole of the large opesimm, quite regularly ovate in shape. Rim or juterapertural epace narrower than the opesia, rounded, sometimes angular in the middle. but oftener with a depressed interzooecial suture line, marked with close transverse lines or wrinkles. 'laking the plare of an ordinary zooseimm, jsolated cells, or, more commonly, two or thee in longitulinal sepuence, occur which difler from the rest in having a convex cover. with a narow median slit. and above the slit a linerr crescentie impression. These cells may represent an mustal type of ooecia, but more probably are to be considered as a form of ricarions avionlaria or vibracula.

"The specimont 10 on which the species is fomder are livisible into twe varieties. one with smaller zoucedia and opesia and thicker wall than the other. Measuring lomgitudinally the former has four and one-half zooecia in 2 mm., the other only three and al halt. Diagomally one has six, the other tive in the same space. Thickness of zoarial sheet not exceeding $0.2 \mathrm{~mm} . "$

A restudy of the types show Elrich's description to le exact. Besides the alonormal zooecia pointed out hy this anthor we hate noted certain zonecia with clouble mural rim, these having undergone total regeneration. It is still impossible to place this species generically hecause neither ovicell. avicularia. nor interopesial "avities have been observect. The rarity of the specinsen- does not permit the determination of the occurrence of alietelae.

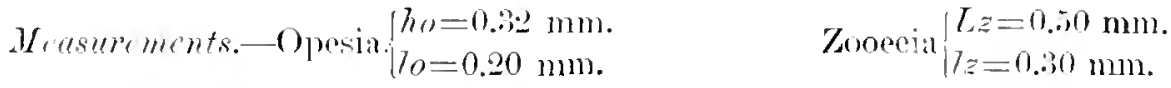

Occurpene. -Lowest Eocene (Bryozuan berl at base of Aquia formation): Tpper Marlhoro. Maryland (rery dare).

MENIBRANIPORINA CANALIFERA, new species.

Plite :3. tigs, 9. 10.

Ih seription. The zoarium is incusting shells. The zoneria are little distinet. the neighboring mural rims leing intimately joined together: the mural rim is hollowed and contains a cirenlan somel about the opesium. which is elliptical amel median.

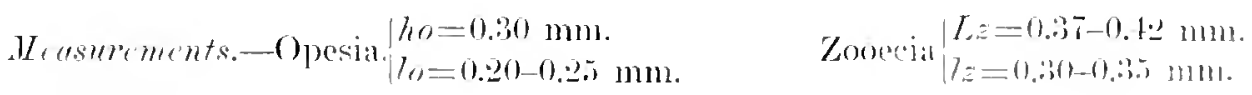

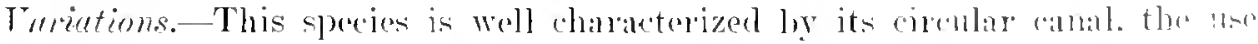

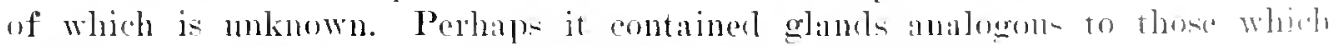

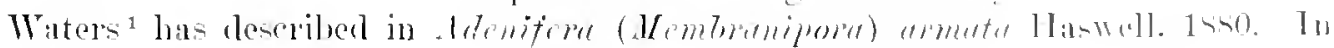

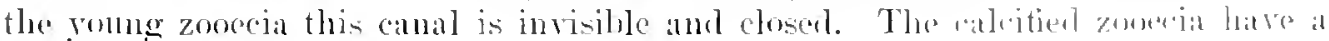
small linear orifice.

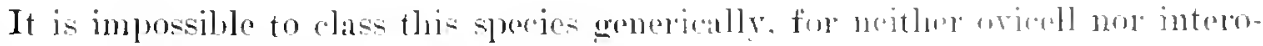
pesial eavities have heen ob-ereded.

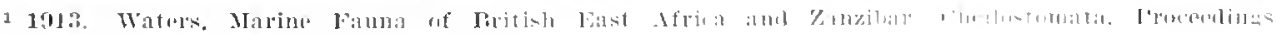

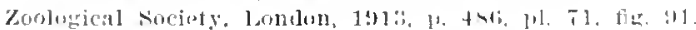




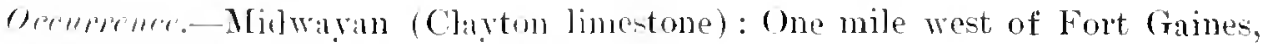

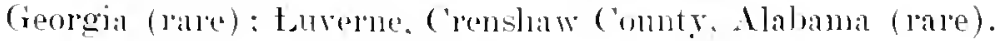

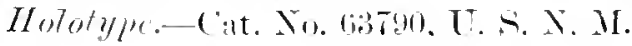

MENBRANIPORINA SINESOLUH, new species.

Plate 19. fig. 5.

Deseription.-The zoarium incrusts oysters: the zooecia are grouped in linear. axial series. emitting laterally zoneria arranged in quincunx. The zooccia are distinct. elongated. elliptical a oval. separated by a deep furrow: the gymmocyat is very suall. ineomstant. mooth. convex: the mural rim is very thin, flat, slightly enlarged at the base.

$$
\text { Mersumements.-Opesinm }\left\{\begin{array} { l } 
{ h \omega = 0 . 1 0 \mathrm { mm } . } \\
{ 7 \theta = 0 . 2 0 \mathrm { mm } . }
\end{array} \quad \text { Zooecia } \left\{\begin{array}{l}
L_{z}=0.44-0.50 \mathrm{~mm} . \\
z_{z}=0.30 \mathrm{~mm} .
\end{array}\right.\right.
$$

Aftinitios.-Thi- speeies has the -implicity of structure of $1 / \mathrm{cm}$ braniporima

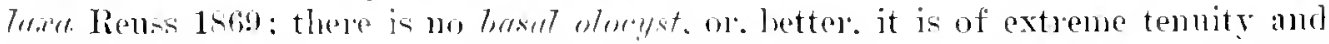
the substratum is entirely visible. $\%$ simsolum differs. however, in its smaller dimensions (ho=0.t0 $\mathrm{mlll}$. and not $0.50 \mathrm{~mm}$.) and in it more legular zonecia.

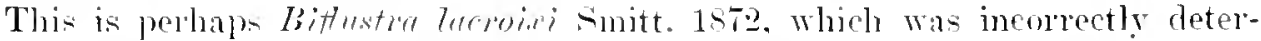
mined. Howerel. we are malule to make enmpariuns, as we have not diseovered the recent speries ol mea-merl the types.

Membraniporima simesolum ditlers foum Membromipora capillimaryo Canu, 1911. from the Rownean of Arentina, in its langer micrometric climensions (Lz=0.4t-0.50 mm. and not 0.8.5-0.42 num.). Memberniposing lape Reuss 1869:

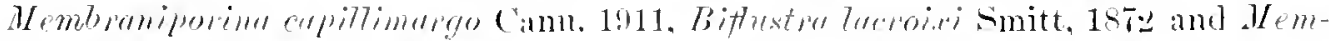

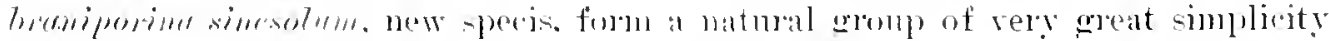
of structure. Cufortmately we lack recent ypecimen- for stmoly.

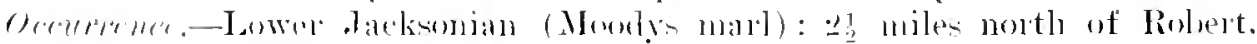
Newton County. Misi-ippi (rare).

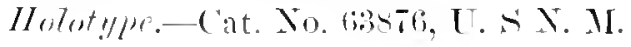

MEMBRANIPORINA LAXA ReUS, 1569.

I'late 1 is fig. 10 .

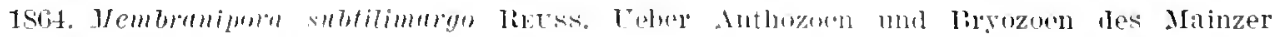

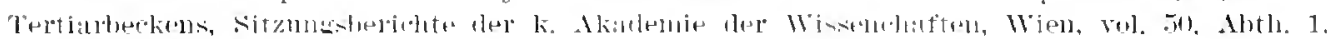
1. 6.3ก. 11. 9. fin. 万.

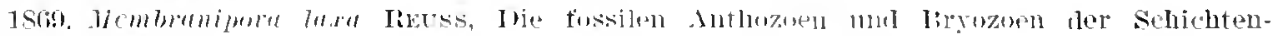

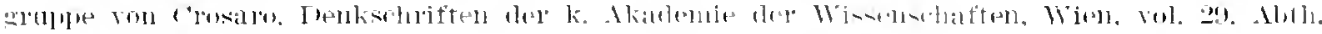

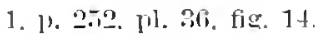

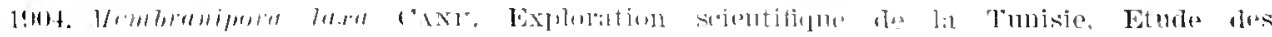

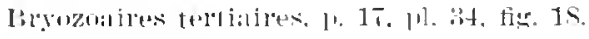

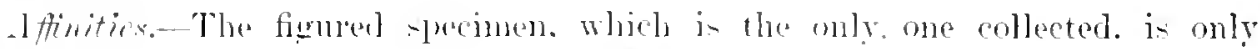

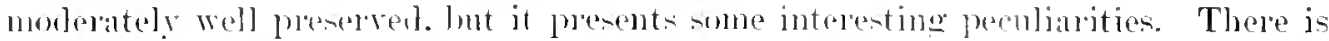

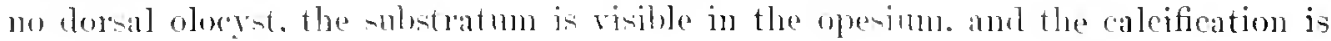


reducel entirely to the lateral walls. Total regeneration manifests itsolf in a very thin mural rim within the opesium.

The dimensions of the opesium are $0.50 \mathrm{~mm}$. to $0.55 \mathrm{~mm}$. by $0.40 \mathrm{~mm}$. measurements which are rely close to those of Mcmbranipora laxa from Tunis as figured by Canu. The granulations of the mural rim are much raver than in the specimens from Tunis; they must be very irregular in oecurrence, for Relss did not mention them at all. If our American specimen be correctly determined, it appears here in a lower geologic horizon than in Europe.

This species is rery close to Membranipora fitum. Jullien; but its dimen. sions are smaller and its zooecia are relatively more elongated in which it approaches the specimens cited by Calvet. It is evident that the great structural simplicity of such species makes their determination a matter of great care and of which one can not be exactly certain without the study of numerous specimens.

Occurrence-Claibornian (Gosport sand) : 1 mile southwest of Rockville. Clarke County, Alabama (very rare).

Geological distribution.-Priabonian of Vicentin (Reuss, Waters); Chatti:ul (= Casselian) of (Germany (Rems) ; Eocene of Tunis (Canu).

I'lesiotype.C.Cat. No. 688ts, U.S.N.M.

MEMBRANIPORINA CLAVIFORMIS, new species.

Plate 19, tìg. 14.

Description.-The zoarim is free and club shaped, quite slender in the lower part, composed of zooecia disposed about an imaginary axis. The zooecia are large. elongate, somewhat indistinct becanse their mural lims are often confluent; the mural rim is thick, round, smooth. The opesium is median and elliptical. Between the superior opesia there are small triangular cavities without special walls. The larger zooecia mealshre $0.70 \mathrm{~mm}$. hy $0.21 \mathrm{~mm}$.

Aftinities.-Only the singre specimen figured has been discovered. It bear a resemblance to Farcimia, but we have been able to observe neither articulation nor endozooecial ovicells; moreover, there are six longitudinal series of zooecia. It is

1 The billiography of this recent species is as follows:

1872. Biflustra lacroixi SMIT, Floridan Bryozoa, Kongl. Svenska Vetenskaps-Akademiens llandungal. rol. 10, No. 11, p. 1S, pl. 4, figs. S5-SS.

190:. Membranipora reticulum CaLreT, Bryozoaires des cotes de Corse. Travans de l'Instltut de Zovluni de Université de Montpeller, ser. 2, Mem. 12, Г. 14.

1003. Membranipora flum Jullev, dirgozories provenant des Campagres do lirondelle. 1. 11. pl. 5 , tig. 4 .

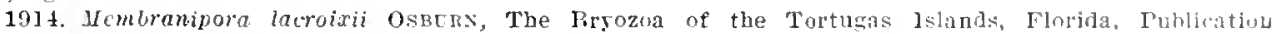
Carnegle Institution of Washington, No. 182, p. 193.

Smitt's figures, 8j-87, indieate clearly the presenes of triangular interograsial carities witl individual walls. Jullien thought this was an crror, and that the sumcies lore two spines placel un the distal triandu lar parts of the zooecium. Canu does not beliere that smitt could have committed surh an error in figuriup the form. Oshurn has collected from the Tortugas lslauds a specimen which lu stiles is similar to smitt figures, and which presents the usual characters of Connum lacruirit. Tut withut donbt the species figured by Smitt is provided with a mural rim muph natrwer than Buslis sprecles, and for this rason it will perhaps be convenient to consider it a distinct specis. The species of Jullien anil calret is also vet? probably another.

$$
5 \text { 5099-19-Bull. } 106-7
$$


necessary therefore to await more abundant material before the generic position can be determined.

Occurrence.-Middle Jacksonian (Castle Hayne limestone): Wilmington, North Carolina (very rare).

Holotype.-Cat. No. 63871, U. S N. M.

MEMBRANIPORINA BENJAMINI Canu and Bassler, 1917.

Flate 21, fig. 1.

1917. Alembraniporina benjamini CAxu and Bassuer, Synopsis of American Early Tertiary Cheilostome Bryozoa, Bulletin 96, United States National Museum, p. 11, pl. 1, fig. I.

Deseription.-The zoarium is incrusting. The zooecia are large, elongate, elliptical. and distinct; the mural rim is rounded, smooth, everywhere of equal - width. The opesium is median. elliptical. entire. In the vicinity of the septulae there is often an incomplete small canal.

$$
\text { Neasurements.-Opesia }\left\{\begin{array} { l } 
{ h o = 0 . 5 7 \mathrm { mm } . } \\
{ 7 0 = 0 . 3 0 \mathrm { mm } . }
\end{array} \quad \text { Zooecia } \left\{\begin{array}{l}
L_{z}=0.65-0.70 \mathrm{~mm} . \\
l z=0.40-0.45 \mathrm{~mm} .
\end{array}\right.\right.
$$

Affinitics.-Only the fragment figured, which is of considerable interest, has been found. In the proximal part of the zooecium in front of each septula there is a sort of incompletely calcified tubule, serving probably to protect the mesenchymatous filaments which pass from one zooecium to another.

This interesting species is named after Dr. Marcus Benjamin, the efficient editor of the United States National Museum, to whom we are indebted for many courtesies.

Occurence.-Middle Jacksnnian: Rich Hill, $5 \frac{1}{4}$ miles southeast of Kinoxville, Crawford County, Georgia (very rare).

Holotype.-Cat. No. 62567, U.S.X.M.

MEMBRANIPORINA TUBULOSA, new species.

Plate 80 , figs. $2-7$.

Tescription.-The zoarium is unilaminal. tubular, and inclusts very small algae. The zooecia are distinct. elongated. hexigonal; the mural rim is level, but little elevated. much enlarged at the base to form a concave cryptocyst. The opesium is anterior, elliptical, entire; the lateral walls bear two small septulae.

$$
\text { Nersurements. -Opesia }\left\{\begin{array}{l}
h 0=0.20-0.22 \mathrm{~mm} . \quad \text { Zooecia } \\
l_{0}=0.17 \mathrm{~mm}=0.40-0.45 \mathrm{~mm} .
\end{array}\right.
$$

Affinities.-The bifurcation of the zoarium corresponds to that of the alg: which served as a substratum. At this bifurcation there is often a giant zooecium. The ralcified zooecia have a concave cryptocyst perforated by a large round pore. It appear's to us that endozooecial ovicells may be present, but as we are not able to confirm the observation by a discection it is necessary to await better specimens before placing the species finally. 
In its exterior aspect this species is close to Acanthodesia (Membranipora) savartii Audouin, 1826, but it differs in its smaller micrometric dimensions, its tubular zoarium, and in the absence of an opesial denticle. In considering this form of zoarium it is necessary to admit that in order to attain such a shape there is necessary, first. an alga rery soft and incapable of breaking the armor formed about it by the bryozoan, and, second, either the base or the joint of the incrusted alga has reached its greatest resistant growth, is incapable of further growth, or is dead. We are without means of elucidating such problems, but one must admire the remarkable selective instinet of the larva which would always choose an iclentical substratum and could anticipate its nondevelopment. We will dwell many times on these marrelous larval activitics in the course of this work. It is greatly to be desired that their study will be undertaken by the young zoologists.

Occurrence.-Ticksburgian ("Chimney rock" of Marianna limestone) : 1 mile north of Monroeville, Alabama (very common); $2 \frac{1}{2}$ miles north of Millry, Washington County, Alabama (rare).

Cotypes.-Cat. No. 6ł230, U.S.X.M.

\section{MEMBRANIPORINA ARCANA, new species.}

Plate s0, figs. S-11.

Description.-The zoarium is a fragile, free network. The zooecia are ver! elongate, little distinet, nearly elliptical; the mural rim is very thin at the top, enlarged below, curred, almost smooth. The opesium is large: elliptical, entire. There is no calcified dorsal face.

$$
\text { I easurements. -Zooecia }\left\{\begin{array}{l}
L z=1.00 \mathrm{~mm} \text {. } \\
l z=0.40 \mathrm{~mm} .
\end{array}\right.
$$

Affinities.-This species is a true mystery. As it is very firagile and imperfectly caleified re would be justified in classifying it in Membranipora-that is to sar, in the Membranacea group. But we have discovered a sort of ovicell (!) situated in the lower part of the zooecium and deforming its proximal part. This problematic eavity has never been observed before. We are thus compelled to clase it in the genus Membraniporina, with species insnfficiently studied or poorly understood.

Uccurrence-Ticksburgian ("Chimney rock" of Marianna linestone): (1ne mile north of Monroeville, Alabama (1'are).

cotypes.-Cat. No. 64231, L.S.X.M.

\section{ACANTHODESIA, new genus.}

Greek: Acanthodes, full of bristles.

No ovicell. The opesium is garmished laterally by small spinoms processeand inferiorly by a serrate denticle. Fifteen tentacles.

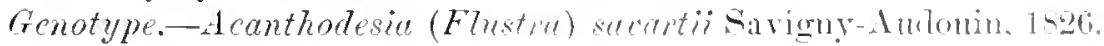

liange.-Lutetian-Recent.

Another species of this new genm: is Hembrunipora limosa Waters, 19us.

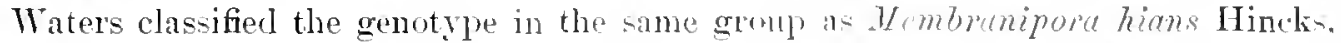

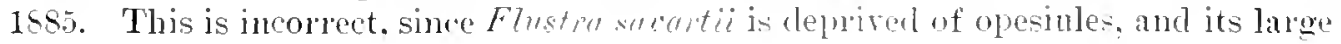


retractor muscle of the polypide inserted on the median axis of the zonecium assures the symmetry of the opesimm: moreover. there is no ocivell.

The spinous processes are of the same nature as those of the genera Hemiseptella Levinsen, 1009, and cupularia Defrance, 1821 . but they are rery inconstant; in fact, they have not been noted on the recent specimens, nor are they very frequent on the fossils. On the contrary, the serratc denticle is rarely found in the fossil examples.

\section{ACANTHODESIA SAVARTI Audouin, 1826.?}

Plate 21, figs. 2-4.

1826. Flustra sarartii Amours, Explication sommaire des planches de l'Egypte et de la Syrie, in Sarigny"s description de l'lsgyte, Histoire Naturelle, vol. 3, Puris, I. 240, pl. 10, fig. 10 .

1907. Mcmbraniporl savrtii Canu, Bryozoaires des terrains tertiaires des environs de Paris, Annales Paleontologie, rol. 2, p. 6, pl. 1, fir. 1.

1908. Mcmbraniporn saratii CANU. Iconographie des Bryozoires fossiles de l'Argentine, Anales del Museo Nacional de Buenos Aires, vol. 17, p. 252, pl. 2, figs. 5, 6.

1909. Mcmbramipora sncurtii Waters, Reports on the Marine Biology of the Sudanese Red Sen. XII, Tonnal Iinnean Society, London, vol. 21, p. 137, pt. 11, figs. 8-13.

1913. Jcmbramipora savartii WATERs, Miarine Fauna of British Dast Africa and Zanzibar. Lryozoa, Cheilostomata, l’ucenlings Zonlogical Society London, 1913, 1). 186.

1914. Membrnnipora sarartii Osburs. 'The Bryozon of the Tortugas Islands, Florida, Pubtication Carnegie lnstitution of Washington, No. 182, p. 1941.

$$
\text { Measurements.-Opesia }\left\{\begin{array} { l } 
{ h o = 0 . 2 6 - 0 . 3 2 \mathrm { mm } . } \\
{ l o = 0 . 2 0 - 0 . 2 6 \mathrm { mm } . }
\end{array} \text { Zooecia } \left\{\begin{array}{l}
L_{z}=0.36-0.44 \mathrm{~mm} . \\
l z=0.18-0.36 \mathrm{~mm} .
\end{array}\right.\right.
$$

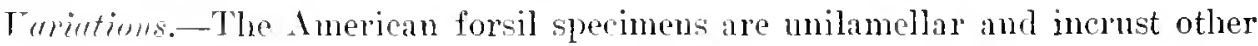
bryozoa, chiefly the Cellopores. After rubbing away the zoarial surface we have observed only one distal septula. The micrometric variations between one specimen and another are considerable. Our specimens correspond exactly to those from the environs of I'aris. and are almost the same as those from Egypt and from the English Crag, but they differ a little from examples dredged in the recent seas. We ha ve figured the extreme forms. but our fossils show all of the intermediate stages.

The opesial denticle is rarely observer on the fossils on account of its very great fragility. Nevertholess, these denticles are very clearly preserved on a specimen from the Vicksburgian of Jasper County, Mississippi (fig. t).

The rigor and resistance of this species is extraordinary. Quite cosmopolitan in the existing sens, it was present even in the Eocene seas. Unfortunately, we are still ignorant of its larval system. It appears sensitive to bathymetric variation, implying an elementary hydrostatic system. and the absence of powerful means of oxygenation.

Occurpence-Vicksburgian ("Chimney rock" of Marianna limestone): Three miles southeast of V'osburg, Jasper Connty, Mississippi (rare): 1 mile north of Monroeville, Alabama (very common).

1 Savigng laving become blind. the explanation of his plates was preparet by Audonin in 1936 sarigny's plates were published in 1812. 
Geological distribution.-The foreign oceurrences are as follows: Lutetian of the environs of Paris (Canu) : Latdorfian of Germany (Reuss, Stoliezka); Rupelian of Germany (Reuss, Schreiber); Chattian of Germany (Reuss, Philippi, Roemer): Miocene of Anstralial (Waters, Macrillivray); Helvetian of the Herault in France (Canu), of Italy (Neviani), of Egypt (Canu); Zanclean of Italy (Seguenza);

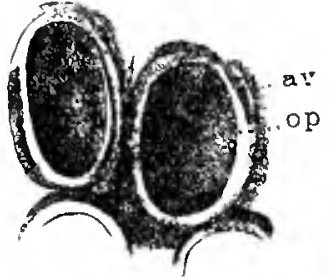

A $: 25$

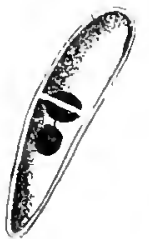

B .85
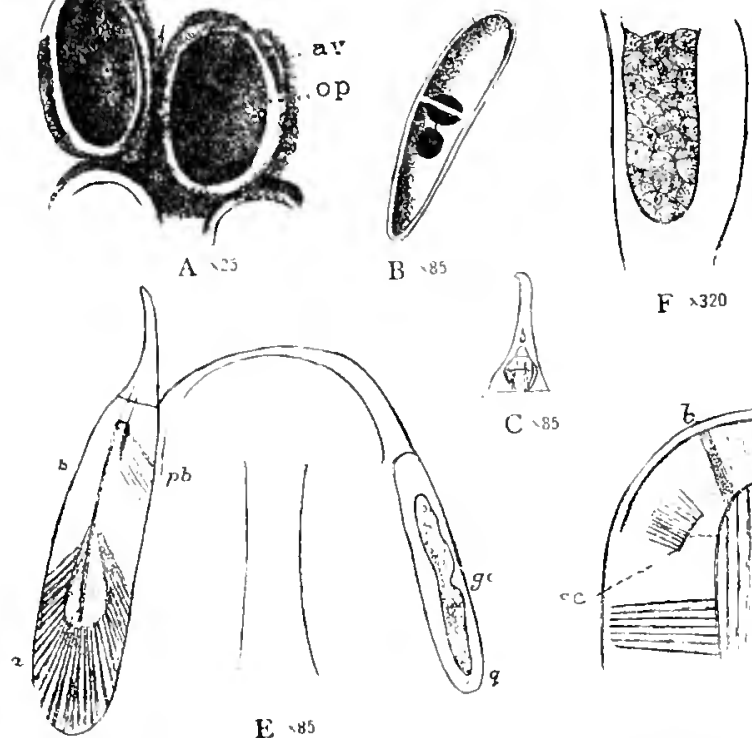

$\mathrm{F} \times \mathbf{3 2 0}$

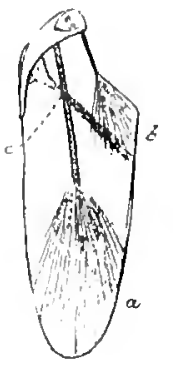

D .35

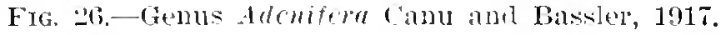

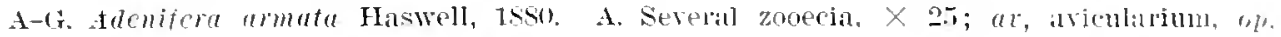

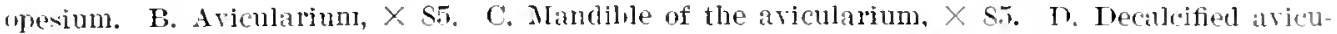
larium showing retractor muscles $(a)$, draricator (b). With tendou attached tu the mandible in the midule of the base, and the "peculial body" (c), $\times$ S.5.

E. Decalcified zoneciun slowing the avicularian elamber on the left witl muscles, as in fis. $D$, and the glandular cliamber (ac) on the riglut, $X 85$.

F. Lower portion of lateral sland, $\times 320$.

G. Opercular region, seen from the interiol, $X 50$. The opeleular muscle is attachel to at

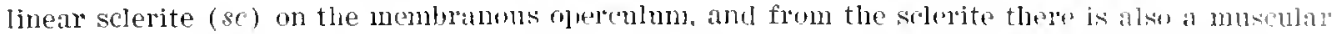
hand to the temtarular sheath (t. s.). Two protoplasmie bands piss to fle" distal septula. (A-G after Wraters, 1913.)

Plaisancian of England (Busk), of Belgimm (Lorie), of Italy (Manzoni); Astian

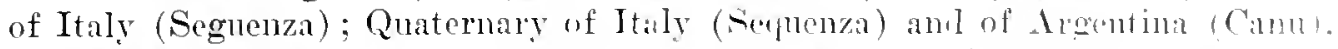
Habitat.-The living forms are found in the Allantic off Floridi, in the Pacifie off Australia, in the Indian Ocean at Zamzibar and Ceylon. ami in the Red Fea. where they have been brought up from depths of 18 to 54 meters. In the Gulf of Florida they hare been found at ileptlos of 16 to ti meters.

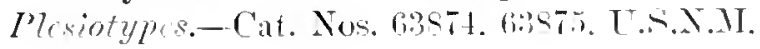




\section{Genus ADENIFERA Canu and Bassler, 1917.}

1917. Adenifera CANu and Bassler, Synopsis of American Early Tertiary Cheilostome Bryozoa, Bulletin 96, United States Natimal Museum, p. 12.

With a distal glandular penthouse.

Genotype.-Membranipora armata Haswell, 1880.

Range.-Jacksonian-Recent.

In 1914 Waters studied the genotype and wrote: "This form can not remain under Membranipora, though I am not snggesting that it is Petratia, but call attention to various similar characters in forms placed far asunder."

The hydrostatic zoarial system well known in the Petraliidae is not limited to this family, but occurs frequently in many other bryozoa. We have noted the fact that the life of bryozoa commensal upon alqae is in intimate relation with the substratum.

Waters noted 30 tentacles in Memeranipore armata, but this number occurs very rarely. We are in ignorance rcgarding the family to which this gemus should be referred.

The species which may be classed in this genus are as follows:

Adenifera (Membranipora) armata Haswell, 1880. Recent.

Adenifera (Membranipora) nigrans Hincks, 1882. Recent.

Adenifera (AL embranipora) marginella. Hincks. 1884. Recent.

Adenifera (Membranipora) striata MacGillivray, 190t. Tertiary of Anstralia.

ADENIFERA INARMATA Cann and Bassler, 19i7.

Plate 21, figs. $\pi-7$.

1917. Adenifera inarmate CANU and Iiasslek, Symo!nis of American Early Tertiary Cheilostome Bryozoa, Bulletin 96, United States National Museum, p. 12. pl. 1, fig. 2.

Description.-The zoarium is unilamellar. living upon algae; its lower side bears hydrostatic tuberosities. The zonecia are rery large, ogival in form, and distinct; the mural rim is very finely granulated, ronnded, enlarged at the base, where it sometimes bears callosities. The opesinm is entire. elliptical but somerhat irregillar. On the distal part of the mural rim there is an arched pad which is hollow, fragile, and symmetrical, the fore part containing two glands. No a vicularia.

$$
\text { Measurements. Opesia }\left\{\begin{array} { l } 
{ h _ { 0 } = 0 . 6 0 - 0 . 6 6 \mathrm { mm } . } \\
{ Z _ { 0 } = 0 . 5 0 \mathrm { mm } . }
\end{array} \quad \text { Zooecia } \left\{\begin{array}{l}
L z=0.80-0.90 \mathrm{~mm} . \\
l z=0.60-0.70 \mathrm{~mm} .
\end{array}\right.\right.
$$

Affinities.-This species differs from tdeniferd striata MacGillivray, 1904. from the Miocene of Australia, in its much snaller micrometric measurements and in the reduction of its cryptocyst. It differe from the recent Adenifera armata in the total absence of a lateral avicularimn on the listal arch. Here, again, it may be noted that the Membranipores have not always the simplicity of structure lescribed by the older anthor's.

Decurrence.-Middle Jacksonian: Xear Lenuls Forry, South Carolina (common); Wilmington, North Carolina (very rare).

Cotypes-Cat. No. 6250, U.S.X.M. 
CUPULADRIA, new genus.

No ovicell. The zonlium bears vibracula. No gymnocyst. Genotype.-Cupuladria (' "upuluria) cunariensis Busk, 1859. Range.-Miveene-Recent.

The genotype does not belong at all to the gemus Cupularia, as we now understand the genus, and as it is defined by its type species. 'There are neither opesiules nor eryptocyst. Previously Smitt, in 18\%, classified the genotype more correctly in Membranipora, as this genus was then understood. It can not, however, be maintained in this gemns, since its significance has been more restricted. We have therefore been obliged to create a new genus, characterized by the presence of vibracula. although these organs of zoarial adaptation may not logically furnish good generic characters. We on] y add a letter to the primitive term to modify the long synonymy of this species as little as possible.

This genus differ's from IIeliodoma Calvet, 1907, in the absence of a gymnocyst. The absence of an endozooecial ovicell does not permit it to be confused with either Vibracellina Canu and Bassler, 1917, or Setosellina Calret, 1907.

\section{Genus TROCHOPORA D'Orbigny, 1851.}

1S51. Trochopora D'Orbignr, Paleontologie française, Terrain Cretace, Bryozonires, vol. 5 , p. 506.

The zoarium has the Lunnlites form. The zooecia and the vibracula are arranged in distinct lows. The ancestrular zooecia are either bydrostatic or radicular. The growth of the zoarium is effected by superimposed (mizooecial) disks with the zooecia arranged in single rows. No ovicell. The vibracula are symmetrical.

Gcnotype.-Trochopora conica Defrance, 1833.

Range.-Lutetian-Helretian.

The lnown species of this genus are as follows:

Trochopora conica Defrance, 1833.

Trochopora ovalis D'Orbigny, 1851.

Trochopora subplena Reuss, 1855.

TROCHOPORA BOUEl Lea, 1833.

Plate 10, figs. 1-17.

1939. Lunulites bouei L.eA, Contlibutions to Geologr, 1. 199, H. 6.

1933. Lunulites duclosii Isa, Contributions to Geology, p. 190, IH. 6, fig. :203.

1862. Discofustrcllaria bouci Gabe and Hors, Monograph of the Fusil Folyzul of the Secondar and Tertiary formations of North America, Journal of the Auremy of Natural Sciences of Philadelphia, sel. 2, rol. 5, p. 154.

1962. Heteractis duclosii GABB and Hors, Monogralu of the Fusil Inolyou of the secondary and Tertiary formations of North Americis. Jumpul dudeny of Katural Sciences of Philadelplia, ser. 2, vol, 5, 1. 156, 11. 20, fig. 39.

1s90. Lumulites (Discoftustrellaria) bonci, ant vareties uncmla, acmessa, durlesii, fiza,

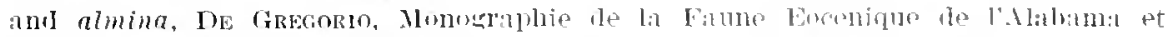

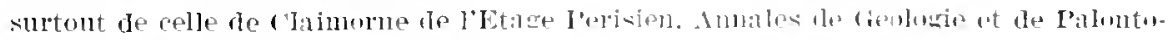
loute, livraisons, T. S, 1. 24?, 11\%. 11, 42. 
Description.-The zoarium is Lumulites in form, slightly convex, with the imer face concave. The zooccia are clongated, pyriform, distinct; the mural rim is regular, convex, projecting distally. The opesium is pyriform, entire. The ancestrular zooecia are normal or radicular. The ribracula are small, narrow, symmetrical, with neither condyle nor small canal. On the inner face the disks are thinner at the center; they are formed of radial costules with the zooccia in one row and perforated with a line of irregular pores. A large distal septula is present.

Variations.-This species is very constant in its zooccial form. The principal yariations are produced in the vicinity of the ancestrula, according to the conditions moler" which the larva becomes fixed. 'The larra aflixes itself as customary on a grain of sand (figs. 11, 13,14). There are four sorts of ancestrular zooccia. 1. The ancestrula gives rise to nolmal zooecia and a discoidal zoarium results (figs. 8, 11). 2. The ancestrula engenders a flabclliform zoarium of normal zooecia (variety durlosii) (fig. 2). The zoarium then becomes discoidal by the especial proliferation of the lateral rows. 3. The ancestrula gives rise to a discoidal zoarium commencing with radicular zooecia (var. almina) (fig. 5), this zone of radicular zooecia being more or less large. 4. The ancestrula gives origin to a flabelliform zoarium uniquely composed of vibracula (fig. 17). The ancestrula may he risible (fig. 8) or immersed (figs. 3, 5). The inner face is also quite variable; very often the primitive flabelliform zoarium is risible (figs. 9. 10); again, it is often corered by the accompanying disles (fig. 16).

The disks piled up to compose the zoalium are much thimer at the center (which preserves the cupuliform aspect of the zoarimm) (fig. 16). Frequently broken disks are found showing the construction of the gemus very well (figs. 12, 13, 15). In vertical fractures the fibrous texture of the zoarium is quite visible (fig. 14).

Occurrenec.-Claibornian (Gosport sand) : Claiborne, Alabama (very abundant); Gopher Hill, Tombigbee River, Alabama; 1 mile southwest of Rockville, Alabama (very abundant).

Claibornian (Cook Mountain formation): Moseleys Ferry, Caldwell County, Texas (abundant).

Claibornian (Lisbon formation): Wautublee Hills, 4 miles sonth of Enterprise, Mississippi (rare).

Lower Jacksonian: $3 \frac{1}{2}$ miles southwest of Shell Blufl post oflice, Genrgia (rave). Lower .Tacksonian (Moodys marl) : Tackon, Mississippi (abundant).

Vicksburgian (Red Bluff clay) : Red Bluff. Wayne County, Mississippi (rare). Plesiotypes.CCat. No. 63837. U.S.N.M.

TROCHOPORA TRUNCATA De Gregorio, 1890.

Plate 11, figs. 1- (;.

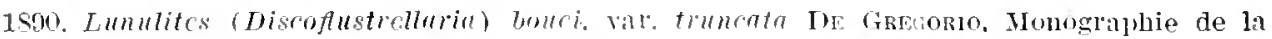
Faune Eocenique de l'Alabama et surtout le celle de Glaborne de l'Etage Parisien, Annales de Geologie et le I'aleontologie, Livraisuns 7, S, p. 245, pl. 41, figs. 3441.

Description.-The zoarium is a conical Lmmlites. solid. formed of successive disks. The zooecia are hexagonal, distinct. arranged in radial and circular rows; 
the mural rim is thin, sharp. irregular, and gashed. The opesium is irregular. The ancestrular zooecia never corer the grain of quartz to which the larra aftixes itself. The vibracula are not rery constant; they are at first very small, increasing in size toward the periphery and becoming primoserial. On the inner face the radial rows are flat, smooth at the center, very porous at the cirenmference.

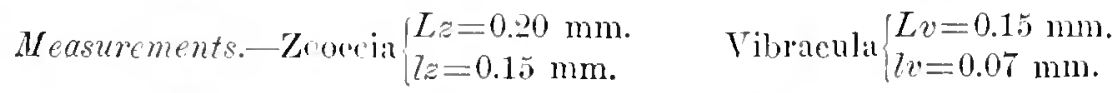

Affinities.-This is a very typical Trochopora and is the species corresponding to Trochopora subplena Reuss 1855, of the European Oligocene. It ditlers from it, howerer, in its smaller opesial dimensions $(7 z=0.15 \mathrm{~mm}$. instead of $0.20-0.24 \mathrm{~mm}$.).

When altered by fossilization Trochopora truncate is difficult to distinguish from badly preserved examples of Inmlarin ligulata, with which it rery often occurs. The specimens with a flat and perforated base may alone be considered as Trochopore truncute.

Vertical sections are not always necessary to discover the heaped-up disks, for' they are often visible in partial fractures.

De Gregorio's figures are rather mediocre, hut as his text apparently agrees with our specimens. we believe it necessary to adopt his name: "Testa superne truncata plus minusee discoidea. . . Le type de cette variété séloigne beancoup du type de l'espèce, de sorte qu'on pourrait le considerer comme une espèce differente . . figs. $34-37$ conche détachée de la face inférieure (disk)."

Occurrence-Claibornian (Gosport sand): Gopher Ilill, Tombigbee River, Alabama; 1 mile southeast of Rockrille, Alabama (rare); Claiborne, Alabama (very abundant).

Claibornian (Cook Momtain formation): Moseleys Ferry, Caldwell County, Texas (abundant).

Lower Jacksonian: $3 \frac{1}{2}$ miles sontheast of Shell Bluff post oflice, Georgia (rare). Lower Jacksonian (Joodys marl) : Jackson. Mississippi (abundant).

Plesiotypes.-Cat. No. 63838, U.S.X.M.

\section{Gemus OTIONELLA Canu and Bassler, 1917.}

1917. Otionclla Caxu and bassler, Synopsis of American Early 'Tertialy liryon, Ibulletin 96, United States National Museum, p. 13.

The zoarium is discoidal (Lunulites form), with neither oricell nol radiculin" and hydrostatic zooecia. The ribraculum is interzonecial, msymetrical, andiculated, one lip more prominent than the other. The zonecia are hexingonal and disposed in quinennx on the onter face and in radial lines on the inner sile. 'The ancestrula is as large as the other zonecia and of the same form.

Genotype.-Otionelle proforutu Canu and Bassler, 1917.

Range.-Campanian, Jaeksonian.

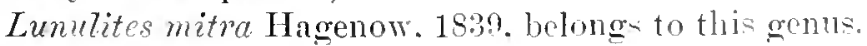

This genus is a Membranipore with the Lunulites form: that is to say, the colony is discoidal. It is a recugnized fact that these Lumulite furms of wrowth are 
only the adaptions to a particular mole of existence in sandy facies. We have not observed ovicells on any of our specimens, but we can not affirm their complete absence before sturying a much larger number of specimens and making more numerous thin sections.

OTIONELLA MCCALLIEI, new species.

Plate 12, figs. 1, 2.

Description.-The zoarium is chiscoidal, the inner side concave. The zooecia are hexagonal, distinct, separated by a furrow, disposed in irregular quincunx lines; the mural rim is thin at the top, enlarged into a cryptocyst below, smooth, sharp at the summit. The opesium is elongated, elliptical, bordered by a very small collar. The vibraculum is asymmetrical and auriculated, interzooecial, as large as the zooecia. On the inner face the zooecia are disposed in radial lines, perforated with large pores, communicating with the interior of the zooecia.

$$
\text { Heasurements.-Vibraculum }\left\{\begin{array}{l}
L v=0.25-0.30 \mathrm{~mm} . \\
z v=0.12-0.15 \mathrm{~mm} .
\end{array}\right.
$$

Affinities.--The only specimen found is the figured one, which is remarkable in that the ancestrula appears to be double and formed of two large zooecia; this is an illusion, for the true ancestrula is by no means placed in the geometric center of the zoarinm. The ribs of the inner face are ar'anged in radial lines and are independent of the zooecia of the outer face. Nevertheless they ought to communicate with the latter by the tubules, as is the habit in the genns.

This species differs from Otionella perforata in its much larger vibraculum and in the much smaller opesial collar.

The specific name is in honor of Dr. R. W. McCallie, State geologist of Georgia, who has taken an active interest in our work and has furnished numerous specimens from his State.

Occurpence.-Iower Jacksonian : $3 \frac{1}{2}$ miles sontheast of Shell Bluff post office, Georgia (very rare).

Holotype.-Cat. No. 63839. U.S.N.M.

Otionella Perforata Canu and Bassler, 1917.

Plate 11, figs. 7-19.

1017. Otionclln perforat" GaNU and Bussurs, Synopsis of American Tertiary Cheilostome Bryozon, Iblltin !ni, Lnited stales Tationa AInseum, 1\% 13, pl. 1. figs. 3, 4.

Description. - The zoarim is discoidal with a concave inner face. The zooecia are ogival in shape, broad, distinet, separated by a furrow, disposed in very irregular radial and transverse lines; the mural rim is broad on the sides and below with a projecting summit; the opesium is elliptical, little elongated, nearly orbicular, bordered by a projecting collar. The vibraculum is as large as the zooecium, unsymmetrical and auriculated. rather n:mow. On the inner face the radial ribs are perforated with numerous pores. There are at least two pairs of large lateral septulae to each zooccium, and only one pair in the vibraculum. 


$$
\begin{aligned}
& \text { Weasurements.-Opesium }\left\{\begin{array} { l } 
{ h _ { 0 } = 0 . 1 2 \mathrm { mm } . } \\
{ l _ { 0 } = 0 . 1 0 \mathrm { mm } . }
\end{array} \quad \text { Zooecimm } \left\{\begin{array}{l}
I_{z}=0.25 \mathrm{~mm} . \\
l_{z}=0.20-0.27 \mathrm{~mm} .
\end{array}\right.\right. \\
& \text { Vibraculnm } \mid \begin{array}{l}
L_{\ell}=0.25 \mathrm{~mm} \text {. } \\
\ell_{\ell}=0.10 \mathrm{~mm} .
\end{array}
\end{aligned}
$$

Variations.-The lines of zooccia ale easily detached from one another. Their edge (fig. 16) shows a minutely furrowed surface in which the furrows radiate from the same center of origin as the lines. As is indicated in figures 11, 12, 13 this center of origin is not necessarily the zoarial center. These furrows represent intercostal canals which are independent of the perforating tubules (fig. 19), the orifices of which are visible at $t$ in fig 16 . This same figure shows also the large multiporous lateral septulae.

In sections (fig. 19) the zonecia are urceolate, erect, separated by convex partitions. In the same radial line they communicate among themselves by means of a large distal septula $(s . d$.$) . The tubules (t)$, corresponding to the large pores of the inner face, probably serve for the passage of the mesenchymatous network.

In small zoaria the ribs of the inner face are hollow at their extremities (figs. $13,14,15)$. These hollow spaces were subsequently filled $u p$, for the sections do not indicate these carities (fig. 19).

The proliferation of the zooecia is not almays regular about the ancestrula (fig. 14). A flabelliform colony (fig. 13) is often formed and becomes discoidal by special budding at the ends and on the sicles of the lines of zooccia. The tangential section (fig. 17) is not very well oriented, but it is sufficient to show the constitutive elements of the olocyst grouped in radial lines abont the opesimm.

Affinities.-This species differs from Otionella tuberosa in the numerous pores which perforate its inmer face. The opesial collar is analogous to that which Lerinsen has noted in Membranicellaria; but we have never observed the endotoichal oricell of this genus.

Occurrence.-Claibornian (Gosport sand): Claiborne, Alabama (common); Gopher Hill, Tombigbee River, Alabama: 1 mile sontheast of Rockrille, Clarke County, Alabama (common).

Claibornian (Lisbon formation): Wantubbee Hills, 4 miles sonth of Enterprise, Mississippi (rare).

Lower Jacksonian (Moorlys minl) : Jackson, Mississippi (common).

botypes.-Cat. No.625\%1, T.S.N.M.

OTIONELLA TUBFROSA, new species.

Plate 12, figs. 5-15.

- Ineseription.-The zoarium is discoidal. with a concave inner face. The zooecia are hexagonal, somewhat indistinct, joined by their mural rims. disposed apparently in irregular quinemx; the mual rim is concare. broal, especislly at the base. The opesium is elliptical or nearly orbicular and bordered by a prominent collar. The vibraculum is interzooccial, aspmmetrical. aurieulated. lanere than the zonocium. 
'The immer face is but slightly concave: the radial ribs are smooth and perforated with some small seattered pores or ormamented with large tuberosities.

$$
\begin{gathered}
\text { Heasurements.-Opesium }\left\{\begin{array} { l } 
{ h _ { 0 } = 0 . 1 5 \mathrm { mm } . } \\
{ l _ { 0 } = 0 . 1 2 \mathrm { mm } . }
\end{array} \quad \text { Zonecinm } \left\{\begin{array}{l}
L_{z}=0.25 \mathrm{~mm} . \\
l z=0.25 \mathrm{~mm} .
\end{array}\right.\right. \\
\text { Vibraculum }
\end{gathered}
$$

Tariations.-The interzoocial sections show that the inner side is rery thick and fibrous. and that between the tuberosities there are sometimes very narrow tubules (fig. 9). The tuberosities on the rows of the noncelluliferous face (figs. 10, 12) are not constant ( lig. 14), and the same zoarinm (fig. 10) shows both smooth and tuberous conditions. Gemmation about the ancestrula is not regnlar. It is linear at first, and the zoarium becomes discoidal by the special budding along lateral lines (fig. 10).

In tangential section (figs. 7, 13) the mural rim is seen to be formed of olorystal elements grouped in radial lines aromel the opesium. A tangential section of the inner face (fig. 6) shows olocystal nuclei corresponding to the tuberosities. The libs are separated by a white line.

Affinitics.-The opesial collar is similar to that described by Levinsen in $14 \mathrm{~cm}$ branicellaria; but we have not observed ovicells.

'This species differs from Otionclla perforata in the tuberosities which ormament its noncelluliferous side and in its ribracula, which are larger than the zooecia.

Occurrenee.Claibornian (Cook Momntain formation) : Moseleys Ferry. Caldwell County, Texas (rare).

Lower . Tacksonian (Moodys marl) : Takson, Mi-sissippi (common).

Jacksonian (Zeuglodon zone) : South side of Suck Creek, Clarke County. Mississippi (rare).

Cotypes.-Cat. No.639t1, U.S.N.M.

OTIONELLA CAVA, new species.

Plate 21, 1iers. S-11.

Description. -The zoarium is orbicular. On the onter surface the zonecia are arranged in regular quincunx lines. They are hexagonal, a little elongated, somewhat indistinct, confluent though the union of their mural rims; the mural rim is quite uniformly developed. thick, somewhat enlared at the base. The opesium is elliptical, elongated, entire. The ribraculnm is very large, twice as long as the zooecia, and is interzooecial, unstmmetrical and amiculated; its projecting lip is small. On the immer side the radial ribs ale hollore and not calcified; the zonerial walls are piereed everywhere with small hydrostatic tuberosities.

$$
\begin{aligned}
& \text { Neasurements.-Opesium }\left\{\begin{array} { l } 
{ h o = 0 . 2 6 \mathrm { mm } . } \\
{ l _ { 0 } = 0 . 1 8 \mathrm { mm } . }
\end{array} \quad \text { Znoeciun } \left\{\begin{array}{l}
L_{z}=0.35 \mathrm{~mm} . \\
l_{z}=0.24 \mathrm{~mm} .
\end{array}\right.\right. \\
& \text { Vibraculum }\left\{\begin{array}{l}
L v=0.65 \mathrm{nmm} . \\
l e^{\prime}=0.26 \mathrm{~mm} .
\end{array}\right.
\end{aligned}
$$

Affinities. - The hydrostatic system of this speice is strongly developed and is quite analogous to that of Lmmerere distune Lonslale. 1545. The external surface 
of the ribs presents no sign of calcification. It is probable, however, that the ectocyst is not the only external memblane and that a chitinous eryptocyst replaced the calcified deposit which is wanting here. The zooecia appear thus to be both polypidian and hydrostatic.

On the inner side of the zarimu a line white mealy powder refills the ribs, but this species is easily distinguished from otionello tuberosu and from $O$. perforate by its gigantic vibracula and by the entire absence of the opesial collar.

Occurrence.-Middle Jacksonian : $3 \frac{1}{4}$ miles south of Perry, Georgia (common); Baldock. Barnwell County. South Carolina (common).

Jacksonian (Zenglodion zome): South side of Suck Creek, Charke County, Missiesippi (rare); Shubuta. Mississippi (rare).

Cotypes.-Cat. No. 6386r. U.S.N.M.

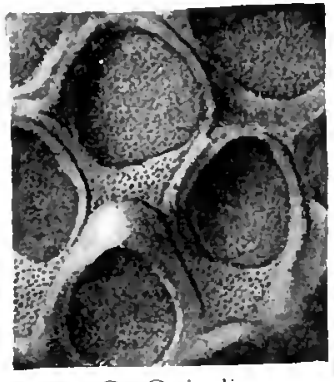

C. Ogivalina

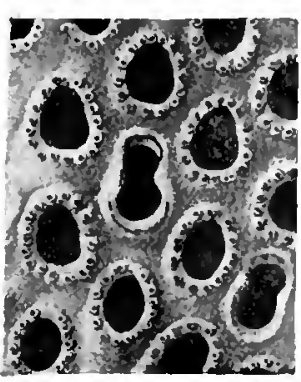

B. Hincksina

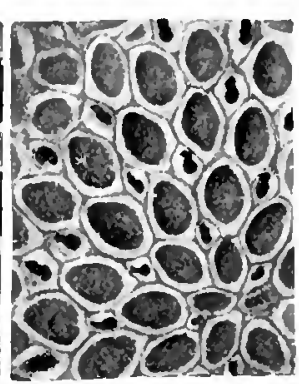

A. V'ibracellina

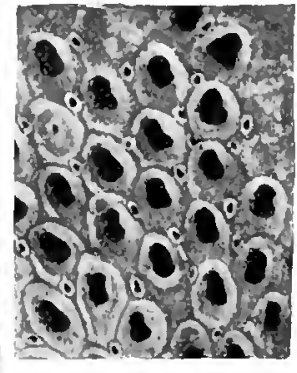

D Meinbrendoecium

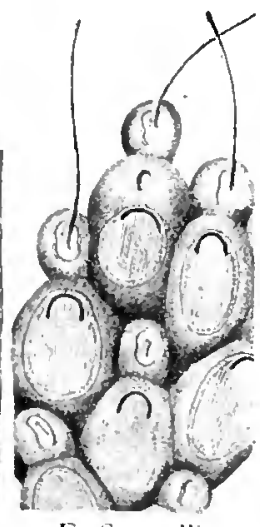

E. Setosellina

Fig. 27.-Genera of Membraniporae with endozooecial ovicell.

A. Tibracellina capillaria Cann and Bassler, 1917, $\times 20$. Clabornian, Calıwell county, Texas.

B. Hincksina megavicularia Canu and Eassler $.1917, \times 20$. Middle Jacksonian, Wilmington, North Carolina.

C. Ogicalina eximipora Canu and Bassler, 1917, $\times$ 20. Mlddle Jacksonian, Rich Hill, Crawford County, Georgia.

D. Mcmbrendoecium rectum, new speeies, Vicksburgian, Byram, Mississippi.

E. Sclosellina roulei Calvet, $190 \pi, \times 25$. Recent.

SECTION II. MEMBRANIPORAE WITH ENDOZOOECIAL OVICELL.

We have recognized four genera of Membranipores provided witl an endozonecial ovicell, a structure which distinguishes them from genera of the first section quite as clearly as from those which have a hyperstomial oricell. Furthermore, these four genera do not appear to belong even to the same family.

IInckisina according to Norman is a member of the Flustridas.

$\mathrm{I}^{2}$ tracellina may perhaps belong to the Lumblariclae.

Ogivatina may be referred to the Onychocellidae.

Membrendoecium may perhaps belong to the Farciminaridae. 
In the present state of bryozoology, generic grouping in distinct families quite frequently is necessarily artificial, arbitrary, and problematic, since we lack anatomical and larval data in most cases. It is better therefore to maintain these four genera in the present place rather than to introduce them doubtfully into the recent families mentioned above.

Genus VIBRACELLINA Canu and Bassler, 1917.

1917. Vibracellina CANo and BASSLER, Synopsis of American Early Tertiary Cheilostome Bryozoa, Bulletin 96, United States National Museum, p. 14.

Endozooccial ovicell. Auriform vibracula. No cryptocyst. No dietellae. Genotype-Tibracellina capillaria Canu and Bassler, 1917.

With the exception of Cupuladriu we know three species of Membranipores having auriform vibracula. These are Vibracella trapezoidea Reuss. 184t, very well described by Waters, ${ }^{1}$ who has created for it the genus Vibracella: Pyripora conAuens Canu, 1907 (not Reuss, 18t1), which is probably the type of a new genus and Vibracellina eapillaria, Canu and Bassler, 191\%.

In 1890 Kirkpatrick fignred an incrusting species Membranipora hastilis from the China Sea, of which he wrote: "Placed transversely at the head of each zooecium are ear-shaped vibracular cells, toothed on one margin, with a vibraculum shrped like a double-edged spear." Some months later he declared he was mistalken and that his Membranipora hastilis was the same as Membranipora coronata Hinclss. We think that he has been misled in the place occupied by the avicularium. That of Membranipora coronata is triangular and not auriform. The two species appear to us distinct and $M$. hastilis might be of the type of our genus Vibracellina.

vibracelliNa CAPLllaria Canu and Bassler, 1917.

Plate 16, fig. 16.

1917. Vibracellina copillariu CANU and BassLel, Synopsis of American Early Tertiary Bryozoa, Bulletin 96. United States National Mluseun, 1. 14, pl. 1, fig. 5 .

Deseription.-The zoarium incrusts small shells. The zooecia are elongate, distinct, oval, with a very small gymnocyst; the mural rim is convex, salient, very thin, almost cupillary. The opesium is oval, entire. The vibraculum is interzooecial, unsymmetrical; its opesium is oblique and bounded by two lips of which the upper one is convex and sinnous. The ovicell is a distal courexity.

Affinities.-At the center of the figured zoarium may be noted two smaller zooecia almost equal; which of these is the ancestrula can not be discerned. It is also to be noted that, excepting these, the zooecia assume their normal size almost inmediately. The absence of the cryptocyst and the almost complete absence of the gymnocyst will distinguish this species easily from Pyripora confluens Canu, 1907 (not Reuss, 18+4).

Occurrence.-Claibornian (Cook Mountain formation) : Moseleys Ferry, Caldwell County, Texas (rare).

Holotype.-Cat. No. 62572, U.S.N.M.

1 Waters, North Italian Inyozoa, Quarterly Journal Geological Society, London, vol. 47. p. 10. m. 1 äg. 23. 


\section{Genus SETOSELLINA Calvet, 1906.}

1906. Sctoscllina Calvet. Note préliminaire sur les Bryozoaires recueillis jrar les expelitions du Travaillew (1S\$1-S2) ot du Talisman (1SS3), Inlletin Museum IIistoire Naturelle, p. $15 \%$.

The original description is as follows:

Zooecies s'irradiant plus ou moins régulierèment autour de loozoide, séparées eutre elles, dans les séries radialies, par des viluachlatres. Frontale zocciale en grande partie mémbraneuse, de forme ovale, a orifice zoeciale semicirculaire. (lont le bord convexe correspond an bord supérieur de l'area, fermé par un opercule a bor convexe chitineux. Vibraculaires arrondis a area membraneuse oblongue, dirigée suivant laxe longitudinal de la zooecie.

Genotype.-Setosellina roulei Calvet, $100 \bar{T}$.

Range.-Priabonian-Recent.

This genus differs from Vibracellina Canu and Bassler, 1917, only in the arrangenent of the vibracula. Calvet says that the genotype did not have an oricell. Nevertheless there are two ovicells drawn on his figure.
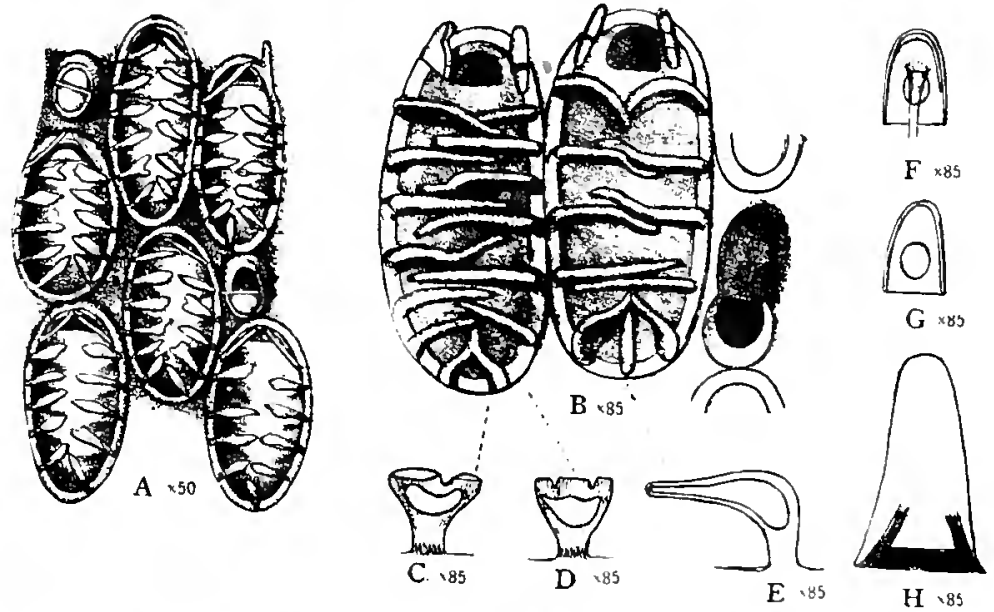

Fig. 28,-Genus IIinclisina Norman, 1903.

A. Hinclisina flustroides Hincks, 1S80. Zuoecia, $\times$ 50. (After Hincks, 1580.)

B-F. Hinclisina scelcios Busk, 1858. B. Zooccia, $X 85$. C, 1). Spinous plates by the side of the orat aperture, $X$ S5. E. Frontal spine seen from the side, $X 85$. 1\%. Mandible of the avicnlarium, $\times 85$.

G. II incksina flustroides llincks, 1880 . Avicularian mandible, $x$ s.

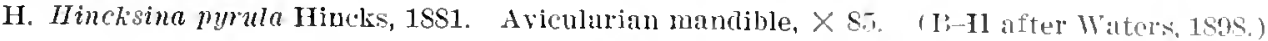

Genus HINCKSINA Norman, 1903.

1913. Ininclisina Noraxa, Natural History of East Finmark. Limals anl Magnzine Natulal History, ser. 7, vol. 11, 11. 585 .

Zooecia incrusting, having the entire area nemblanom- the mirgin surmonnted by numerous spines. Ovicell small, short, and little raised. Avicularia vecupving distinct cells sparingly scattered among the zooecia, oral. with semicircular mandible. No dietellae. (Norman.)

Genotype.-Membranipora flustroides IIncks, 1850.

Range.-.Tack-onian-Recent. 
This is in part the $M$ cmbranipora corbula group of Waters. The recent species belonging to the genus are as follons:

IInckina (Membranipora) flustroides Hincks, 1850.

IInclisina (Membranipora) pyrula Hincks, $18 \$ 1$.

II inckisina (Membramipora) maderensis Waters, 1898.

II inchisina (Mempranipora) sceletos Busk. 1558.

II inckisina (Membranipora) minuscula Hincks, 1882.

IInckina (Mcmbranipora) dcfensa Kirkpatrick, 1888.

IInclisina (Membranipora) corniculifera Hincks, 1SS2.

Hinchsina (Mcmbranipora) inarmata Hincks, $18 s 1$.

In this genus opposite spines may be able to unite and form a fronta] analogous to that in the Costulidae, but this is not a general phenomenon, as it occurs only in very rare zooecia.

The species of IIinclisina which we have distinguished may be separated into two groups. Those of the first section have small spines and avicularia little differentiated, while those of the second section are more typical.

\section{DIVISION I. AVICULARIA LITTLE DIFFERENTIATED.}

HINCKSINA REPTANS, new specics.

Plate 22, figs. 1-3.

1)escription.-The zoarium incrusts small pebbles and bryozoa. The zooecia are elongated. elliptical, distinet: the mural rim is thin, salient, rounded, almost equal throughout, bearing with some irregularity from six to eight lateral and two distal spines. The opesium is large. entire, elliptical or irregular. The ovicells are very small and are manifested unly as small distal convexities.

$$
\text { Mcasurements. Opesia }\left\{\begin{array} { l } 
{ h o = 0 . 3 0 - 0 . 3 2 \mathrm { mm } . } \\
{ 7 0 = 0 . 2 0 - 0 . 2 2 \mathrm { mm } . }
\end{array} \text { Zooecia } \left\{\begin{array}{l}
L z=0.45-0.50 \mathrm{~mm} \text {. } \\
l z=0.27-0.30 \mathrm{~mm} .
\end{array}\right.\right.
$$

Variations.-On all of our specimens the lateral spines are very imperfectly preserved, but the two distal spines are more constant. The mural rim is generally thin, but it may become a little broader (fig. 2 ). The gymnocyst is much reduced and generally absent. The primeserial zooecia are often modified avicularian zooecia little differentiated. Regenerated zooceia ale rare.

Affinitics.-This species differs from IInckina jacksonica in its incrusting zoarium and its more visible spines.

It differs from II inclisina smithi in its mural rim, which is never enlarged at the base, in its larger micrometric dimensions, its smaller ovicell and in its more inconstant spines.

It differs from Hinclesinu victisturgica in the absence of all proximal crenulation of the opesium.

Among the recent species it has the greatest aftinity with Mcmbranipora pymela as figured by Hincks ${ }^{1}$ in 1851 , but the ovicells are totally different.

\footnotetext{
1 Annals and Magazine Natural llistory, ser. 5. rol. S. 1851, p. 51.
} 


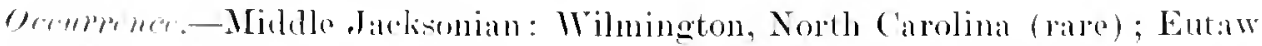

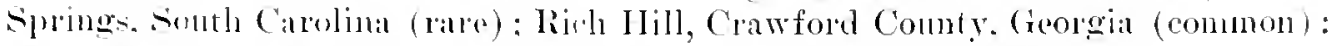
1s miles west of Wrightsville. .tackson ('omnty, (reorgia (very late).

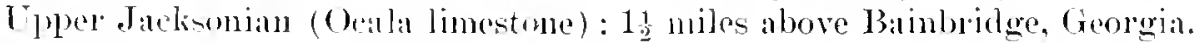

Cotype.s.C Cat. No. tiBsts. IT.S.N.M.

IINCLSINA SMITHI, new species.

Plinte 21 , firss. 15-17.

Description.-The zorrium incusts pebbles. The zooceia are elliptical distinct, and may or may not have a gymorgst the mural rim is thin. salient, convex, ornimented with s to 10 pines. The opesium is alliptical and rery slightly crenulatel. The entozonecial oricell is a quite visible convexity.

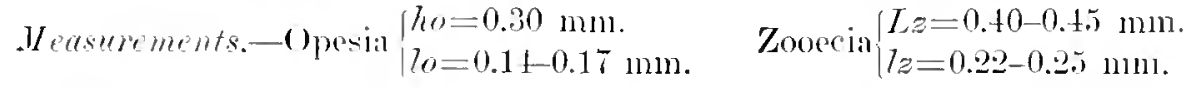

Iffinitis.-Tle mural rim is sometimes enlalged a little at the batee as in Ilimksime ocalensis, but the dinchsions are much smaller and the spines more numeroun. Tlese same small dimensions and its very slightly cremulated opesinm will distinguish it from II inelsine reptens.

II indsimu smithi ditlers from the recent $I I$. materonsis Water's. 189s. in the alsene of the fire peenlian distal spines and in its small ovicell.

We dedicate this elegant spocies to I)r. Eugene $\mathbf{L}$. Smith, State groologint of

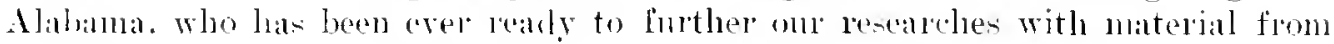
his stite.

Ceremence-Middle Jarkisonian: Entaw Springs, South Carolina (very rare). Hlototyl.-C at. No. 6.3567. U.S.N.MI.

HiNCKSINA JACKsonica Canu and Bassler, 1917.

Plate 202 , figs. $1-9$.

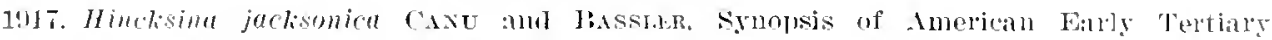

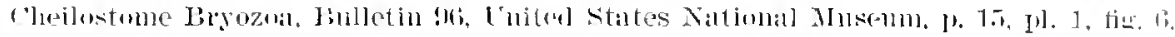

Description.--The zoarium is free, bilanellar, easily divisille into two layer.s.

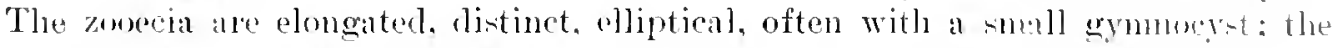

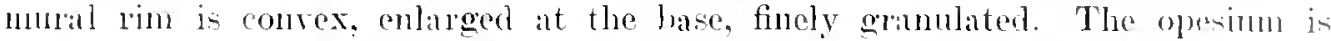
teminal. elliptical. regular. very finely denticulated. 'The wicall is onduzumetal and little apparent; it appear as a small distal convexity. Avicularian zomeda are rery late.

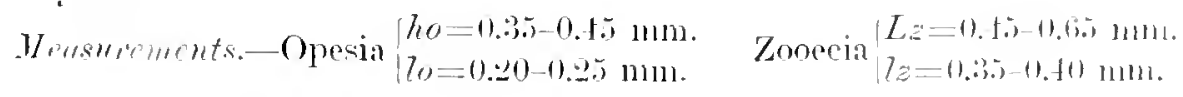

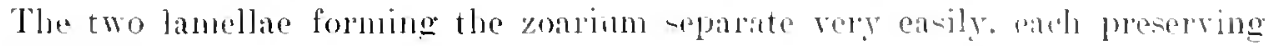
it own base.

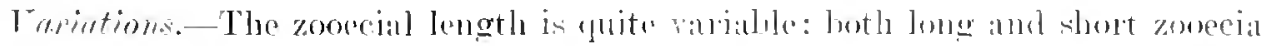

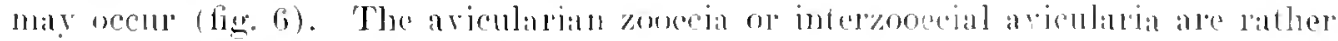


rare. They are renerally primoserial (fig. 7 ): their opesimm presents a lateral constriction but little accentuated.

This spreies is distinguished from the other species of IImclisina ly the absence of risible spines and by its free zoarium. It is rather common at many localities of the .Tacksonian, of which it appears to be a characteristic fossil.

Ceemenenes. Middle .Tacksonian: Rich Hill. ot miles southeast of Knoxville, Clawford County. Ceorwia (abumbant): 12 miles sontheas of Marshallville, Georgia (abundant): $3 \frac{1}{2}$ miles north of Grovania. Georogia (ahmolant): 18 miles west of Wrightsrille, Georgia (aloundant); 17 miles northeast of Ilawkinsrille, Geolgia (abmolant); noa (ieolgia Kablin Company Mine. Twigg County, Genroia (abundant): Balklock. Barnwell County, Gouth Carolina (common).

rotypes.—('at. No. 6.2573. T.S.X.XI.

HINCKSINA OCALENSIS, new species.

I'late 2-2, figs. 10-1?.

l'csription. - The zoarium inclusts pebhles and shells. The zonecia are romgated, elliptical, and distinct. 'The mural pim is salient, wamulose convex, rery thin at the top, enlarged and crembated at the lase. olnamented with spines of which the distal two are the more enstant. The opesinm is elliptical. almost entire laterally and crenulated proximally. The endozooecial ovicell is an indistinct convexity. The ancestrulat is an ordinnry zooecinm, but smaller and rery spinons.

$$
\text { Wrusurments.Opesia }\left\{\begin{array} { l } 
{ h o = 0 . 4 0 - 0 . 4 5 \mathrm { mm } } \\
{ 7 0 = 0 . 2 5 - 0 . 2 7 \mathrm { mm } . }
\end{array} \quad \text { zonecia } \left\{\begin{array}{l}
L_{z}=0.55 \mathrm{~mm} . \\
l z=0.32-0.35 \mathrm{~mm} .
\end{array}\right.\right.
$$

lariutions.-As always the zooccia are smaller in the vicinity of the ancestrula, so om measmements are invarially taken far from this zoocium. The mural rim is much enlarged (fig. 12), but it ahwys preserven its gramula unamentation and renulation. As shown in figure 19 , perforated zonecia with a large circular aperture have been noted.

1 tetuitios. - The cremulation of the proximal part of the opesimm in rery characteristic and clearly distinguishes this species from all the preceding ones, and notably from II indisina juclesomira. with which it might be confounder on account of its micrometric dimensions.

Hinelisine ocelensis is nearest the recent $I I$. molerensis Waters, 1s9s. but it has neithere the lane ovicell nor the tive distal spines of that species.

Tre have ohserved this form at numerous localitios in the Ocala limestone, and we halire it characteristic of this -tage.

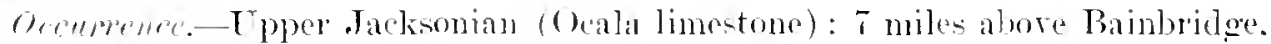

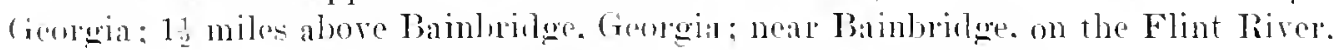

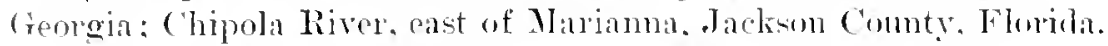

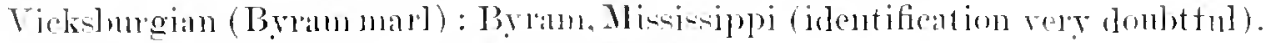

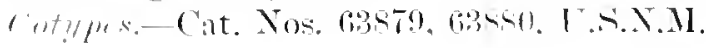


DIVISION II. WITH INTERZOOECIAL AVICULARIA DIFFERENTIATED.

The species of this section are an henutiful as they are well characterized. Their aricularial when present are similar in every respect to those of the recent sprectes,

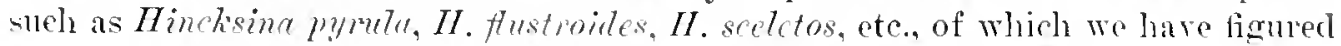
the mandibles. They are. howerer. withont a pivot. One must not confonnd the speeies of this genus with those of the genus Omatella Cann. 1900. in which the orieells are hyperstomial.

\section{HINCKSINA ELEGANS, new species.}

T']ite Ru, hiess. 12-1.i.

Description.-The zoaldum is milamellate creeping orer algae. The znoecia are elongate. distinct, elliptical. prorided with a gymnocrst: the mural rim is thicker in the proximal part below. fincly granulated. adorned on its summit with a crown of large granules or of hollow spines: the two distal spines are larger. eonstant. and symmetrical. The opecimm is ellptical and entire. The orieell is a small distal convexity. smooth am indi-tinct: the border of the opesimm is thick in the oricelled zooecia.

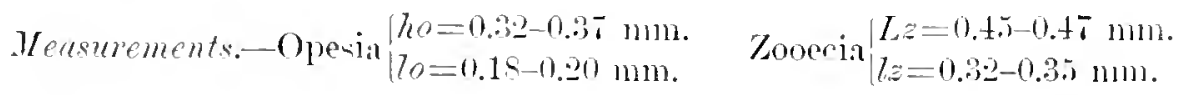

1finities.-Of this elegant speries we posess unfortunately only the three figured specimens. The aromment of it: mural rin is a small masterpiece of arnlpturing which could well serve as mortel for the decorator. The little gramule- must be the traces of small hollow spines attennated in the process of fossilization. The zooecia with ovicells have also the anpect of regenerated zooecia. It may he. therefore, that the female polypicle sncenest the male in total regeneration.

This species differs from II indisima rostulifera in the presenes of its two li-tal spines, which are larger than the areal spines. and in the opesial thirkeniug of the aricelled zooecia.

Oceurpence.-Ticksburgian ("Chimmer rock" of Marianna limustone) : 1 mile north of Monroeville. Alabama (very rare).

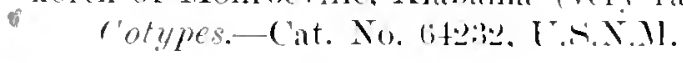

\section{HINCKSINA PARVAHICULARIA. new species.}

I'late 20. figs. 14. 15.

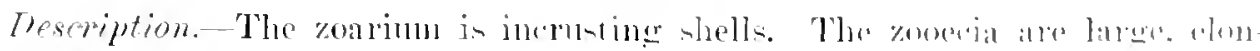

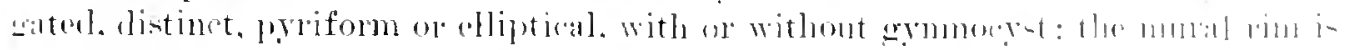
prominent. convex, ormanented with sixten lorge lollow spines. The ofu-imn is

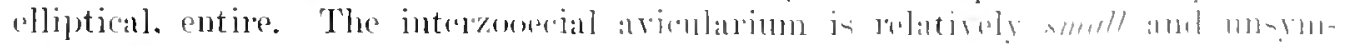
metrical.

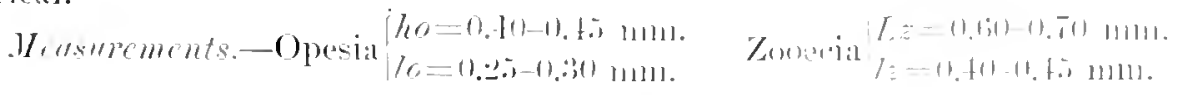

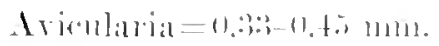

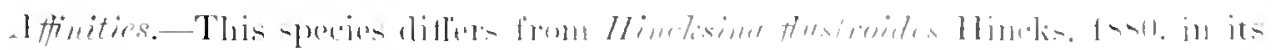

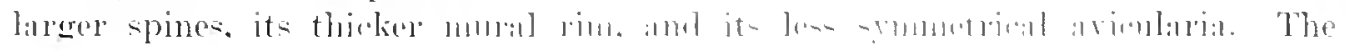


smaller size of these last distinguich it from $/ 1$. megavicularia in which the aricularia are as large as the zooecia proper.

Ocenmence.-Middle Jackonian (Castle Hạne limestone): Wilmington, North Carolina (rare).

totypes.CCat. No. 638s1, [.......II.

IINCKSINA MEGATICULARIA lanu and Bassler, I917.

llitte 23. 1in. 1 .

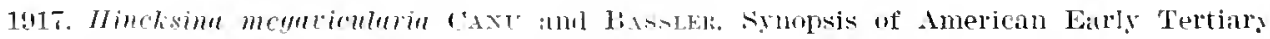

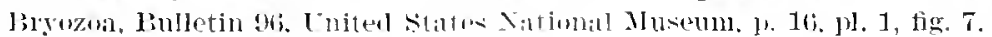

Ireseription.-.The zoarium incrus - wher bryozon. The zooecia are large.

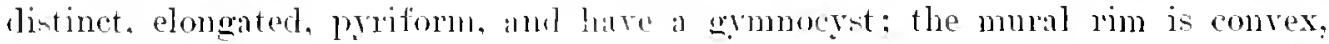
salient. provided with 14 to 20 lange: lollow plines. The opesium is terminal, elliptical. or somewhat priform. entire: the intergoecial avicularimm is large. symmetrical, and has a gymocyt : it - "periom is constricted laterally, probubly at the place where the pirot onght to be.

$$
\text { Measurements.-Opesia }\left\{\begin{array} { l } 
{ h o = 0 . 3 0 - 0 . 3 . 5 \mathrm { mm } . } \\
{ 7 0 = 0 . 2 . 5 \mathrm { mm } . }
\end{array} \text { Zonecial } \left\{\begin{array}{l}
L a=0.60-0.70 \mathrm{~mm} \text {. } \\
7 z=0.40 \mathrm{~mm} .
\end{array}\right.\right.
$$

Length of aricularlia=11.1ith-11.4i.5 $\mathrm{mm}$.

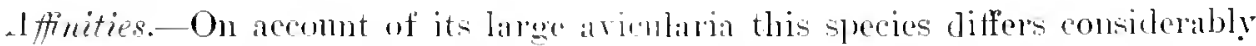

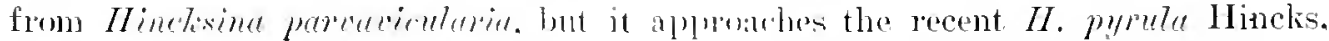
18s1. It diflers, nevertheles: in its lander number of pines: mufortmately we are mualse to comprare the ovicells.

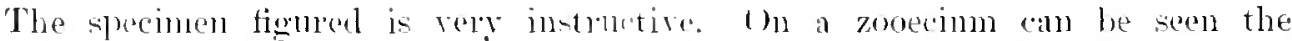
coalescing of oppusite spines. giving an a-pere like the fromtal of thembraniporethe.

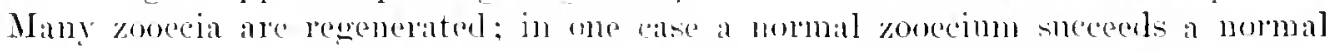

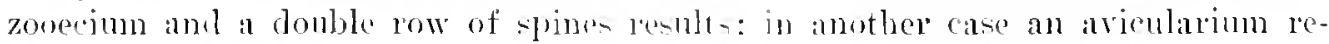
places a zooecium: in a thirel an ariculariun aluain replaces a zooeciom, but in a totally invered position.

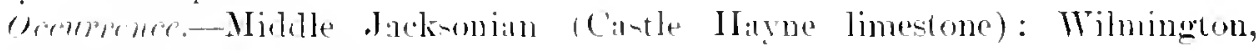
Nortlo ('arolina (very rare).

llolotyme-Cat. So. Gest. I.S.X.M.

HINCKSINA COSTULIFERA, nen species.

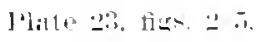

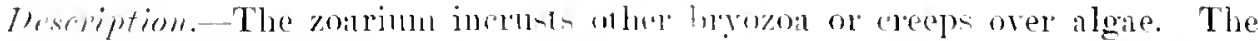
zooecia are elomeated, distinet. elliptical ul lyriform with or withont a gymm-

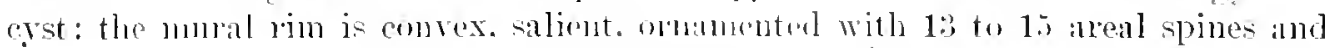
2 oral pines a little larere. The opmom in olliptical. entire. The endozooecial oricoll is a salient convexity. Xo interomerial aricularia. The ancestrula is a suall ordinary zonecium.

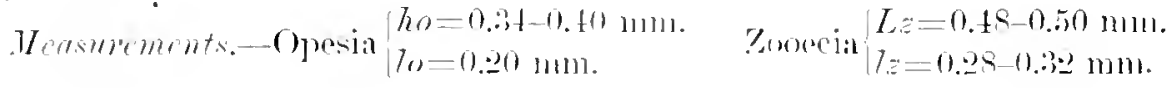


Tariation. - The distal part of the mural rim eomprised between the two oral spines presents thee important rariations. Sometimes it is a thin and spineless portion of the rim, again it supports two spines smaller than the others. and finally very olten it eontains a snall canal of unkmown function.

The conlescence of opposite spines is rery frectlent and there are small portons of the zoatiun bearing costulae which might be classitied as Membreniporelle. Typical Membraniporella, howerer. never presents when broken the aspect of the normal zooceia of this species. It would be rery interesting to compare the microstructure of these spines with thene of the costules of $\mathbf{M e m}$ truniporella. hut the very limited number of sperimens foumd has not permitted this.

The specimens fiom the Vickburgian near Monroeville, Alabama. which incrusted algae and in whieh the zomeia al'e hexagonal constitute perhaps a diflerent species or at least a variety; but we have fomm only two specimens thus far.

Affinities.-The small mieronetric climensions and the absence of interzooecial

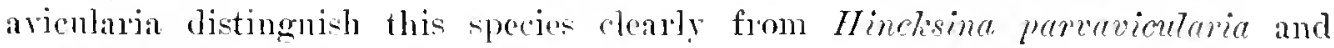
$H$. megaciomario. The oricell is extremely rare.

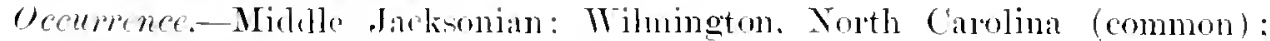
near Lenuds Ferry, South ('ilrolina (rale).

Vicksburgian ("Chimney rock" of Marianna limestone): One mile north of Momoeville, Alabama (a varjety or chacly relaterl new species).

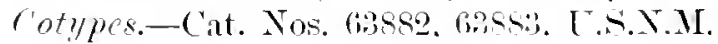

LEY TU SIECIES UF HIXCKSIXA.

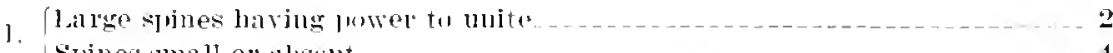

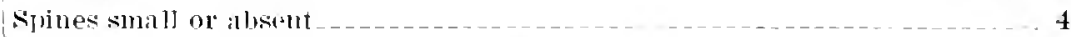

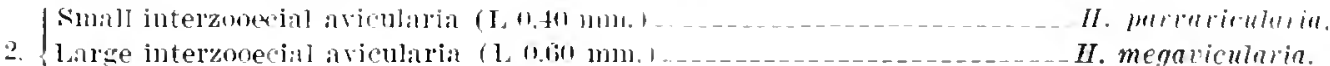

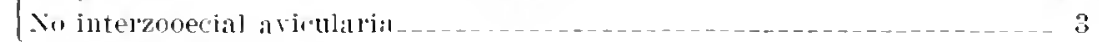

3. . 111 of the spines equal

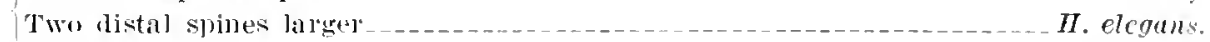

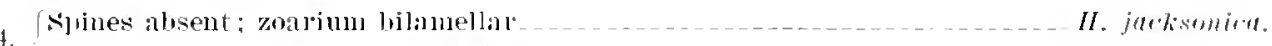

Spines jresent: zoarium inclusting

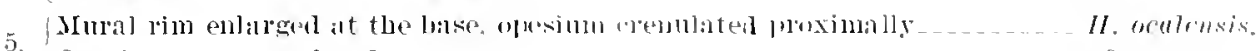

Oresinm not crenulated

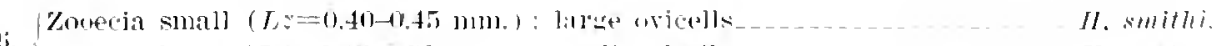

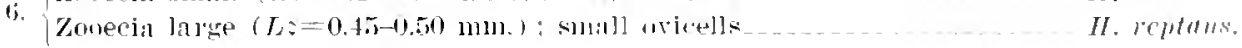

Genus OGIVALINA Canu and Bassler, 1917.

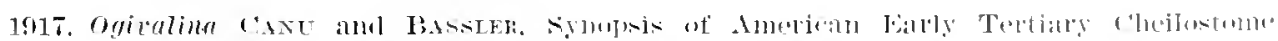

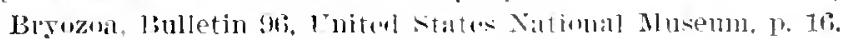

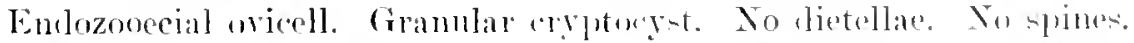

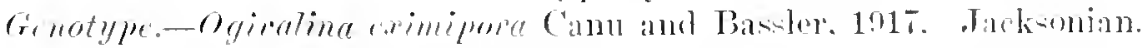

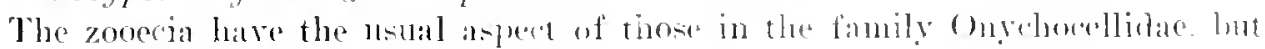

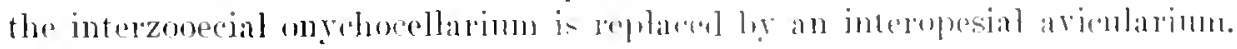




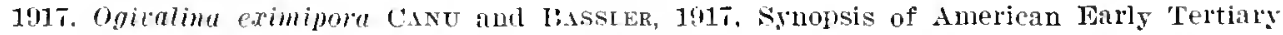
cheilostome Pryozon, Inuletin ai. Lniterl states Nitional Museum, p. 17, pl. 2, fig. 1.

Description.-The zoarium is composed of one or more lamellac and incrusts pebbles or creeps over algae. The zooecia are large, elongated, ogival, distinet. separated by a thread-like ridge; the mural rim is indistinet, thin, flat, smooth, enlarged at the base into a concave. gr:mululr. irregular cryptocyst. The opesium is oval, entire, unsymmetrical in its ploximal part. The endozooecial ovicell is a distal convexity, quite apparent. 'The avicularium is interopesial, triangular, relatively small, and without pivot.

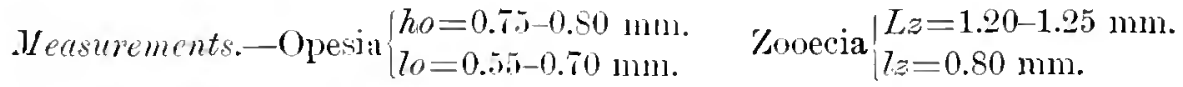

Iength of avieularium $=0.40 \mathrm{~mm}$.

Jariations.-CThe opesium lias little regularity of shape on account of the rery irregular development of the eryptocyst itcolf. Althongh the latter is generally plainly visible, there are nevertheless zooeria which are almost devoid of the cryptocyst. But the most important variation is the unsymmetrical shape of its distal border, a lack of symmetry chalacteitictic of the genus Onychocella. We know that this phenomenon is occasioned hy the olliquity of the polypide in the zooecium by reason of the attachment of the retractor museles in one of the proximal corners of the said zooecium. This anatomical feature appears to us to have more importance than the absence of the onychocellariun.

Oceurence.-Middle .Jacksonian: Wilmington, North Carolina (rure): near Jenuds Ferry, Soutl Carolina (rare): Eutaw Sintings South Camolina (very rare); Rich Hill, Craw ford County, Georgia (very rale).

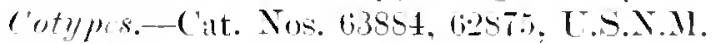

ogivalina Elongata, new species.

I'liate 29 , tien. 5 .

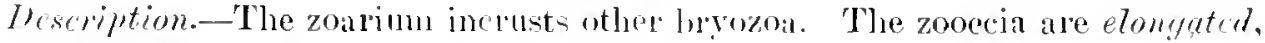
distinet, elliptical, slightly narowed in the rear: the mural rim is thin, smooth. convex, saljent, and encompasses the entire zooccimn. The opesimm is elliptical; the "ryptroyst is Hat. distinet from the mulat rim, gramular on the surface. and finely denticulated on its distal edge. The wirell is a anall distal swelling.

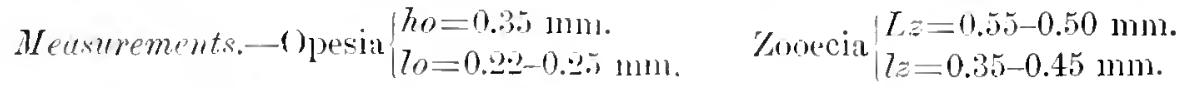

lurentions.-The feature which in rery characteristic in this speeies is the more distinct separation of the mural rim and erytocyst than in Gefiralind eximipure, where it is the mural rim itself which is enlared into the cryptocyst. Another important diflerence is in the symunetry of the opesimm. Which is one of the 
characters of the Membranipore gronp and not of the Onychocellitiae. The dorsal olocyst is very thin and ensily worn away, allowing the substratum to appear. We have observed some cases of total regeneration and deformed zooecia are not rale.

Affinities. - It may be that this species ought to be classed in IImelixime: howerer, the great development of the cryptocyst and the entire absence of avicularia will not allow us to place it there. This is a problem which can find its solution only in the study of an irlentical or closely allied recent speecies.

The zooecia resemble those of A mphiblestmm perfragile MacGillivray. 1868. figured by Ortman in 1890. The present species differs in its nonbilamellar zoarimm and in the absence of a large interzooccial avicularim. MacGillivray's species may belong to a new genus.

Occurrence.-Middle Jackonian: Near Lenuds Ferry, Sonth Carolina (common): Wilmington, North Carolina (very rare); Eutaw Springs, South Carolina (rare).

$$
\text { Holotype-Cat. No. 63885, U. S. N. M. }
$$

\section{OGIVALINA ELONGATA, var. MINOR, new variety.}

Plate 28, figs. 9. 10

This variety is well founded, for no intermediate specimens have been noticed. However, it can not be considered a smaller distinct species, for it occurs at the same localities as the species itself.

Ieusurements.-Opesia $\left\{\begin{array}{l}h o=0.25-0.50 \mathrm{~mm} . \\ l_{0}=0.17-0.20 \mathrm{~mm} .\end{array}\right.$ Zooecia $\left\{\begin{array}{l}L z=0.40-0.43 \mathrm{~mm} . \\ 7 z=0.22-0.26 \mathrm{~mm} .\end{array}\right.$

Oecurrence.-Middle Jacksonian: Wilmington, North Carolina (rare) : near I.nuds Ferry, South Carolina (rare); Eutaw Springs, South Carolina (rare).

Lower Jacksonian (Mootys marl) : Taclison. Mississippi (rare).

Cotypes.-Cat. No. 638s6. U.S.X.M.

\section{Genus MEMBRENDOECIUM Canu and Bassler, 1917.}

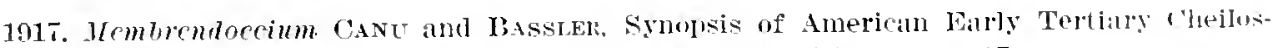
tome Bryozoa, Bulletin 96. Cnited States National MIusenm, p. 17.

Ovicell endozooecial. Small simple interopesial avienlaria. Dietellate present. No spines.

Genotype-L Impliblestrum pupillatum Busk, 1894.

Range.-Midwayan-Recent.

In Irembrendocium we have a very natural genus with exact chatracters. The recent species. Imphiblestrum papillatum is closely relaterl to onl fosil forms. but unfortunately this species is very rane and its strueture is imperfortly kmown. Itarienlaria have much the aspect of our species, and Bukk writes of it "Simall aringlaria having a triangular mandible on mall papillary eningenese seated in the angular interzooccial spares."

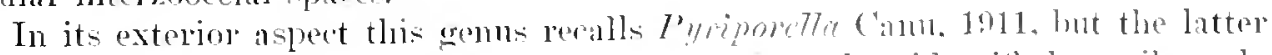

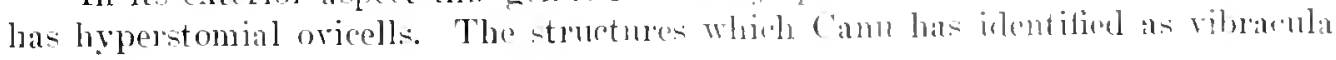


are, perhaps, small, simple aricularia withont pivot or axis analogons to those in Amphiblestrum papillatum. On the fossils on alccount of their -implicity it is sometimes almost impossible to distinguish an aricularium firom a riluaculum.

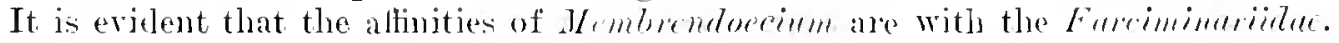

MEMBRENDOECIUM TRANSVERSUM, new species.

Plate 3, firs. 11-13.

Description.-The zoarium incrusts shells. The zooecia are elongated, di-tinct. oval: the mural rim is prominemt. flat, olslipne. wrinkled, enlarged at the barc. The opesinm is oval, the narrow end in frout, entire or cremlated. The entozosecial ovicell is a large. smooth, distal convexity. The aricularinm placed in front of each zooecium is small, triangular, pointed, with or without pirot. with its axis transzerse with respect to that of the zorecimm.

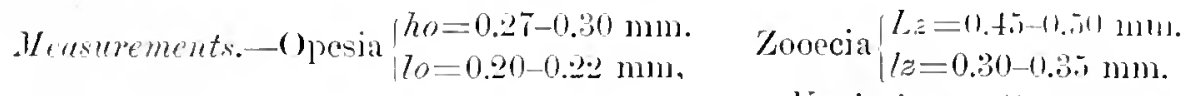

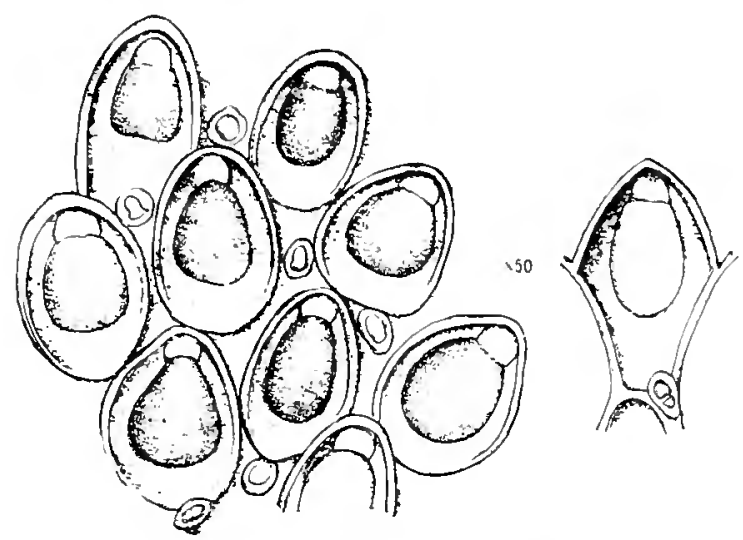

Fir. 29.-Genus Membrendoccium c'anu and Liassler, 1917.

The genotype Membernderciun prepilletum Busk, 1881 , 50. (Atter Busk.)

Dcempene.-Midwayan (Clayton limestone): Mabelvale, near Little Rock, Irkinsas (rale); 1 mile wert of Fort (raines, feorwia (rale).

rotypes.-Cat. No.63701. IT.S.N.M.

MEMBRENDOECIUM DUPIEX, new species.

Plate 24, fiess. 1-6;

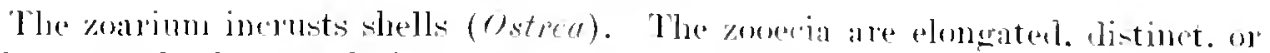
conthent. oral: the nural rims are distinct, thin, salient. corved. mamulaterl. not

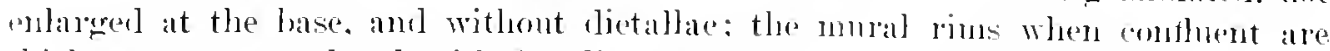
thick. comvex, grannlated. with tive distal dictellate. The opesimm is oval or ellipti"al. rery linely denticulated. The ovireall is a small, smooth, distal comrexity. The 
avicularia are interopesial, very small, elliptical, little rateed. The ancentrula is very small.

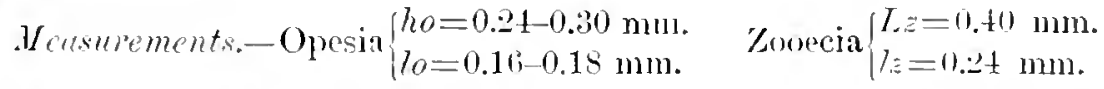

larintions.- I remarkable phemomenon in this species is the dimomplism of the mural rim. On the same zoarium, without any apparent reason, there are mural rims thin and distinet, and other's thick and confluent. The first are devoirl of dietellae while the second have five of them. These small pore-chambers are not therefore indispensable to the life of all the zooecia of the same zoarium, and not eren to the passagre of the mesenchymatous fibers. The ancestrula is very small. Iround it the zooecia have always a separate mural rim and are not always accompanied hy aricularia. The same holds true on the zon rial mancrins. We have not observed regenerated zoocia.

Affinities. - This species differs from Membremloceinm rectum in its conthuem mural rims not enlarged at the base and in its very inconspicuous aricularia. The specimen figured from Bainbridge. Georgia, is altered chemically. as are most of the specimens from this locality.

Uecurbence-OUper Jacksonian (Oeala limestone) : Bainbridge, Georgia : lied Blutt, on Flint River, 7 miles above Baubrislge, Georgia (rare): west bank of Sepulga River, Escambia ('omty, Alabama (rare) ; Chipola River, east of Mariamma. Jackson County, Floricla (rare).

Middle Jacksonian: Baldock. Barnwell County, South Carolina (rare): 18 miles mest of Wrightsville, Johnson County, Georgia (very rare).

Lower . Tacksonian (Moodys marl) : Jackson. Mississippi (very rare).

Cotypes-Cat. Nos. 638s9-63892, U.S.N.M.

MEMBRENDOECIUM LOWEI. new species.

Plate s1, tis. 1..

Deseription.--The zoarium incrusts small pebhles, from which it heacomen easily letaehed. The zooecia are elongated, elliptical, distinct, ol conthuent: the mullal

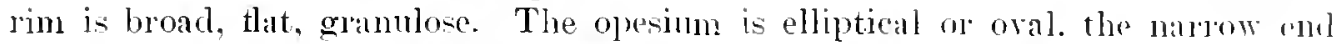
proximal. The oricell is a very small, distal convexity. The avicularia are very indistinct and not prominent.

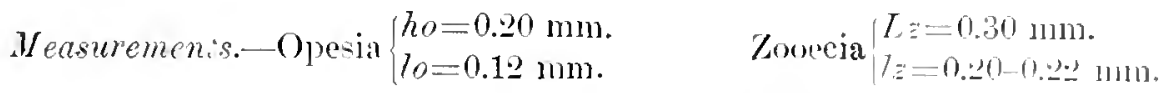

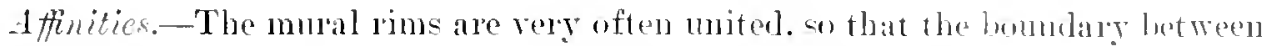
the zooecia is little visible. It is impossible to sy wherther the avicularia are incleed present or if these are only interopesial cavities. If, therefore. mu olserrattion of the endozonecisl ovicells should not be confirmed. it would be necersary to place this species under Conopeum.

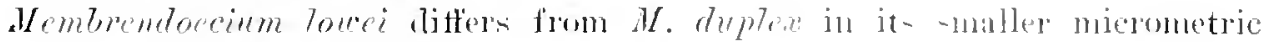
dimensions and in its inconspicuous arieularin. 
We take pleasure in dedicating this species to Mr. E. N. Lwwe, State geologist of Mississippi, who has spared no eflorts in supplying us with material for study.

Occurrence.-Ticksburgian (Bryam marl) : Vicksburg. Mississippi (rare). IIolotype.Cat. Yo. 4 ;2333, U.A.X.M.

MEMBRENDOECIUM RECTUM, nEw species.

Plate 13. figs, 1-8.

The zoarium incrusts other hryozol and pebbles. The zooecia are elongate, distinct, oval; the mural rim is salient, mooth, a little widened on the margins. very melh widened at the base, with tive distal dietellae. The opesimm is oral, entire. The ovicell is enrlozooecial and is a small, smooth, distal convexity. The a vicularia are small, straight, salient, and elliptical. The ancestrula is a very small, closed zooecium.

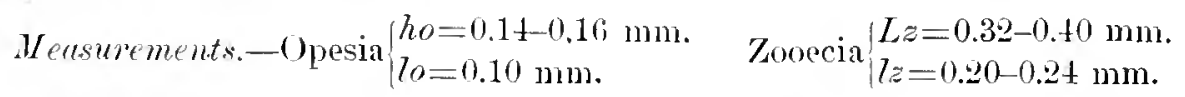

Variations.-Specimens of this species assume a little different aspect according to their geologic horizon. althongh not comgln to make it possible to establish true specific differences. Very frequently in the Claibornian and Jacksonian the zooecial length does not surpass $0.22-0.24 \mathrm{~mm}$. Howerer. these rariations depend chiefly on the presence or absence of a small gymnocyst.

Around the ancestrula there is an important group of closed zonecia perforated with a circular pore and bearing distally, as is usual the imprint of the opercular valve, which we must therefore suppose to have been thickened on its edges. We have observed some regenerated zoom ia with donble mural rims.

Affinities. - This species differs from Mcmbrondoceium duplex in the widening of the mural rim at the base and in that the zovecia do not become confluent. It differs from $M$. pyriforme in its smaller micrometer dimensions and the alnost general absence of a grmmocyst.

Occurrence-Lower Jacksonian: $3 \frac{1}{2}$ miles southeast of Shell Bluff post office. ( ieorgia (rare).

Middle Jacksonian: Wilmington, North Carolina (very rare): 18 miles west of Wrightsville, Hawkins ('omnty, (reorgia (rare): $\frac{1}{2}$ mile sontheast of Georgia Kaolin Compiny Mine. Twigrs ('omnty. Georgia (rave): 17 miles northeast of Iawkinsville, Georgia (rale).

Upper .Jacksonian (Ocala limestone). ('hipola River. east of Marianna, Jackson County, Floricla (rare).

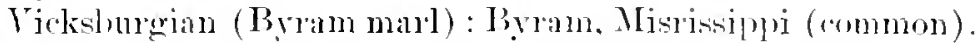

Vickshomrgian (" ('himney rock" of Mariamma limestone) : One mile north of Ifonroeville, Nabama (common) : near Claiborne. Momroe (onnty, Alabama (rare).

Vicksburgian (Glendon member of Mrorianna linnestone) : West bank of Cone"uh River, 1 mile helow month of Sepulga River. Esmanlia County, Alabania (rery rare).

fotypes.-Cat. Nos 635t2. (39965. U.S.X.M. 
MEMBRENDOECIUM PYRIFORME Canu and Bassler, 1917.

Ilite ㄴ.? tigs. 11-14.

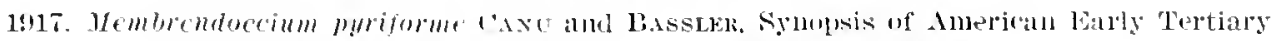

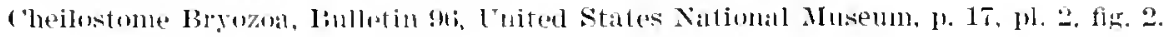

The zoarium incrusts bryozoa or snall shells. The zooecia are very elongate, oxal. distinct, and have a gromoryst the mural rim is prominent, smonth, somewhat conves, emlared on the nitroins. and much enlarged at the base. The opesium is oval. entire. The ovicell is endozooecial and is a small, smooth. distal convexity. The avicularia are very small. straight, salient, elliptical, often provided with a gymocyst. 'The ancestrula is surrounded by closed zooecia in which the frontal is perforated by an ubicular pore.

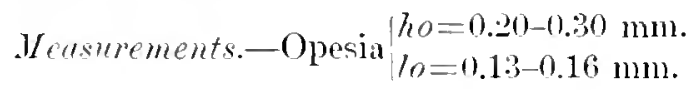

$$
\begin{aligned}
& \text { Zonecia } \mid \begin{array}{l}
L_{z}=0.40-0.50 \mathrm{~mm} . \quad \text { (Omitting the gymnocyst.) } \\
l z=0.21-0.30 \mathrm{~mm} .
\end{array}
\end{aligned}
$$

Juriations aml affinitics. - The length of the gymmocyst is quite rariable even on the same zoarium: therefore in the micrometric measmements it is preferalue not to comt the grmnocyst, for many of the zooecia are devoid of it. The reduction of the zooccial length is frefuent in this species and affects the entire zoarinm: it is rather a rare occurrence when some mechanical olstacle is not opposed to the free clevelopment of the zooecia.

This speeies is very closely related to 1 mphiblestrum pupillutum of Australisia, depending on Busk's figures. which we reproduce on page 120 . The micrometric measurements are identical. The avicularia appear a little larger and the oricell is unknown.

Membrendoesium pryifome differs from. W. rectum in its much larger micrometric measurements and in the presence of the gymnocyst.

cecurvence.-Ticksburgian ( Red Bhuft (lay) : T.t miles southwest from Blarlen splings. Alabama (verr rare).

Vicksburgian (Mariamna lintestone): Murder (creek, east of Cactlobury. Coneculh County, Mlabama (rery rane): Claiborne, Momroe Comnty. Alabama (rery rares): Salt Mountain, j miles south of .Tackson, Nlabama (common); reep well. Escambia ('omenty, Mlabama (rery liare).

Lower Jacksonian (Mondys marl) : Jackson, Mis-iniplpi (rery rame).

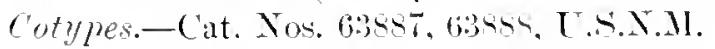

SECTION 3. OVICELL HYPERSTOMIAL, ALWAYS CLOSED BY THE OPERCULUM.

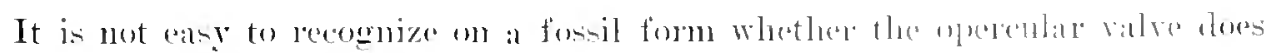
or does not close the hyerstomial ovicell. Ifter many discentions. whinh wo latre

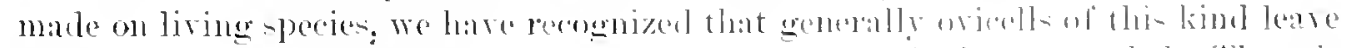

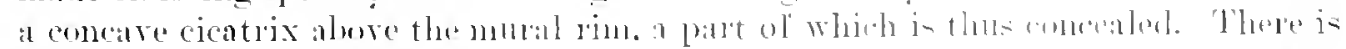

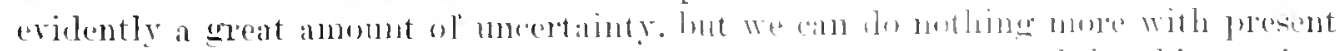

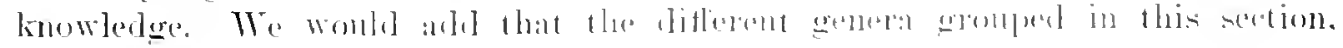


a]though very natural in themsolves. appen to ledong to different families which the zoologists alone can letermine.

Genus PERIPOROSEllA Canu and Bassler. 1917.

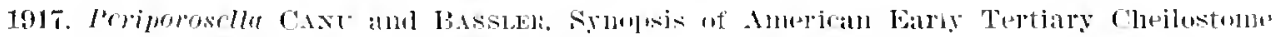

Bryozoa, linlletin 96, Vnited Status Nitional Muselm, 1. 18.

Each zooecium is surroumleal by a seccial series of dietellate (12 to 16) communicating with two large septulae.

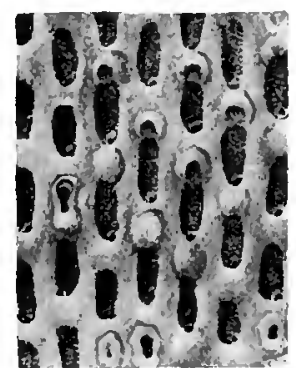

A. Periporosella

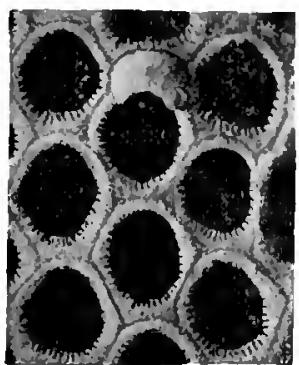

D. Membraninoridra

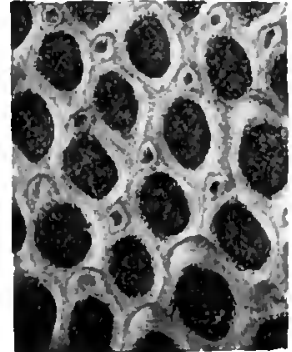

B. Ellisina

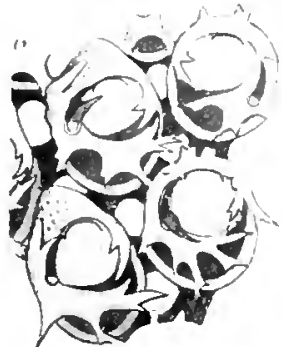

E. Tremopora

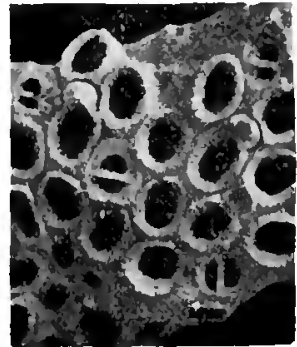

C. Grammella

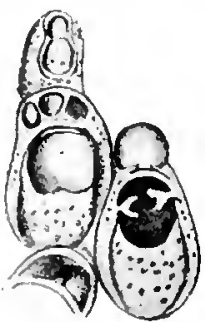

F. Larnacius

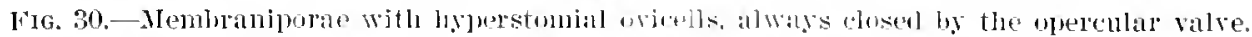

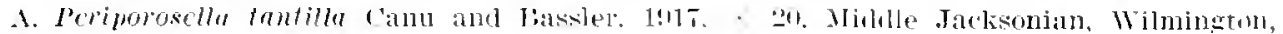
Nortlı Carolina.

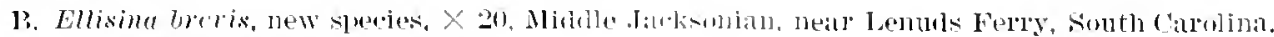

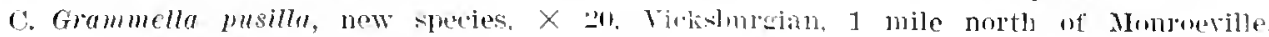
Alabauna.

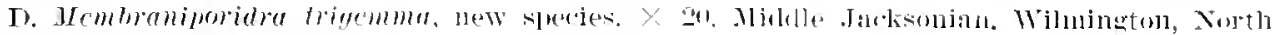
Carolina.

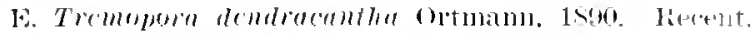

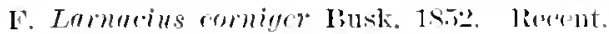

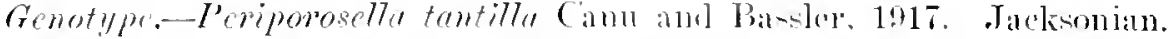

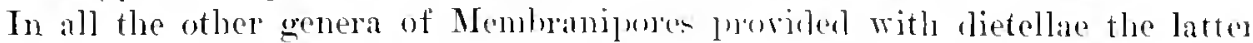

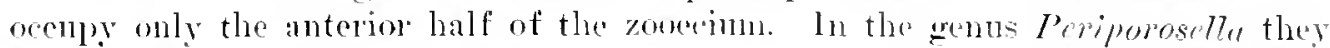

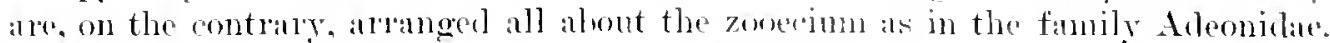

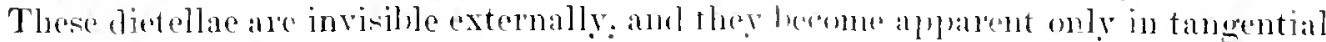
sections of some deptl. 
PERIPOROSBLLA TANTILLA Canu and Bassler, 1917.

1 'lilta 24, fiuss, $7-12$.

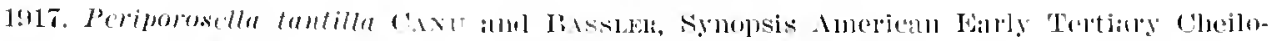

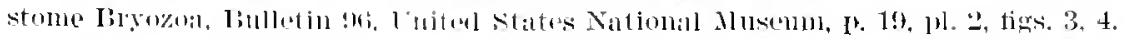

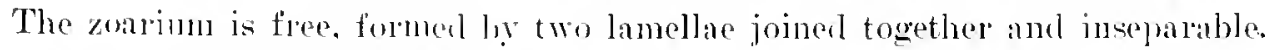
The zorecia are gemerally indistind. very elongated, rectangular; the mural rim is

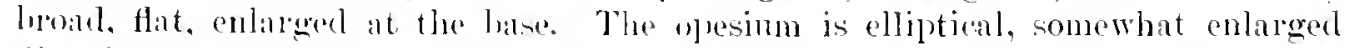

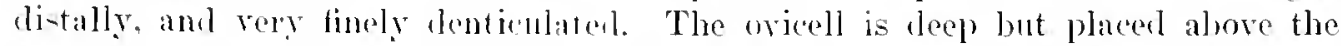
lalloge distal septula; it projert- lout little exterjorly. The avieularial are interzonerial, rare, elliptical. without pivot, lut with two literal denticles; numerons dietellae in each zooecinm.

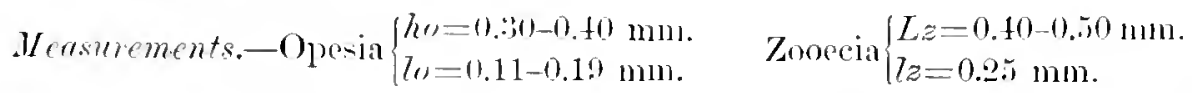

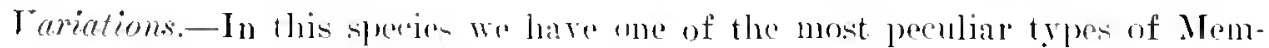

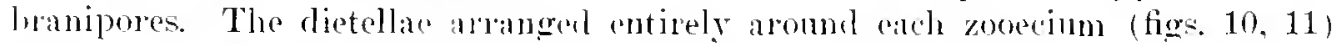
are covered by an epitheal alocyst analowous to the olocyst of the mulal rims in the Membranipores. Tluese eloment somp themselves in a radial manner about the opesium (fig. 1.丷) .

Another intelesting permliaruy is the mode of exmmation of the zonecin which are aranged in paralle] linder serien, and erery new row appeas invariably on one of the free edges of the zon rimum.

The large distal septula opens in a dietella, which establishes communication with the succosting zorecium, ame its opening is often visible in the latter.

This type of structure is diflepent from all others on aceount of its dietellae, its nerthos of gemmation. its ovirell. and even its avicularia. It certainly belongs to a fanily which our present zoolugial knuwledge will not yet permit us to suspeet.

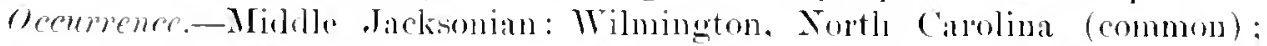
near Lenuds Ferry, Fonth Carolina (rane): Eutaw Springs, South Carolina (rare).

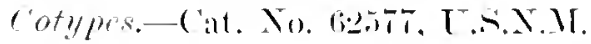

\section{Genus ELLISIXA Norman, 1903.}

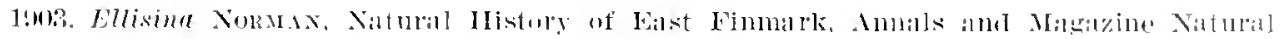
Ilistory, sel. T. vul, 11, l, s!mi.

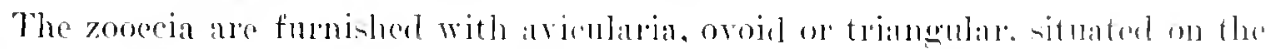
lineler portion of the zoureium. The ovicell is well developed. typhally with a

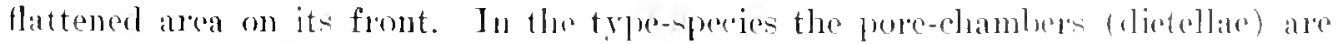

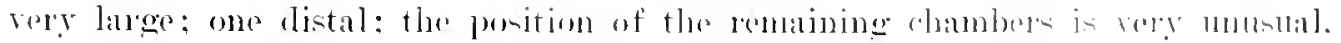
the two front lateral pairs poject onteide the side walls: and the two posterior

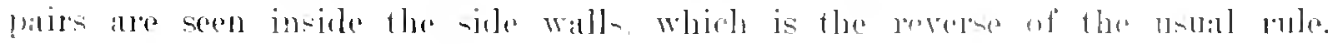
(Xorman).

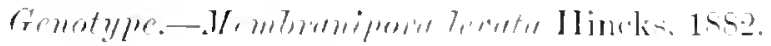

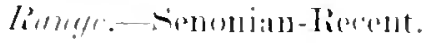


This is the Membranipora coromatu group of IVatels, which he defined as follows: "Small avicularium above the zooecinm: oricells small, globular, or chcullate."

The operenlar ralve always closes the ovicell. but may open it either by elevation or depression for the escape of the larvae.
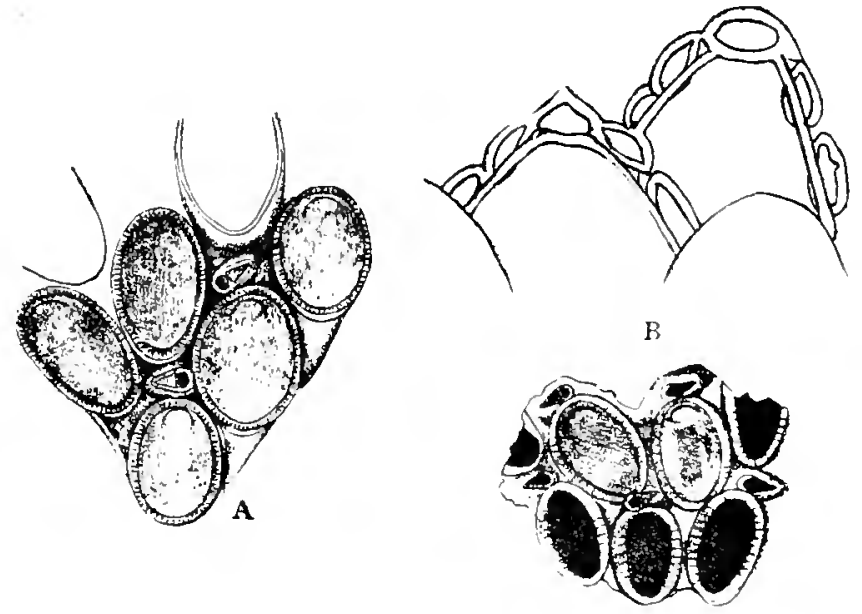

D.25

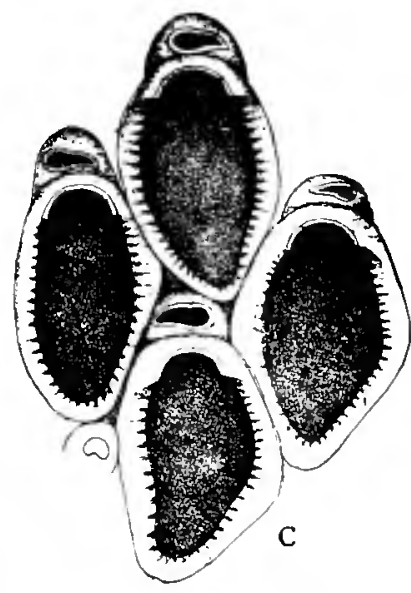

Fig. 31.-Gemus Ellisint Xmman, 190 .

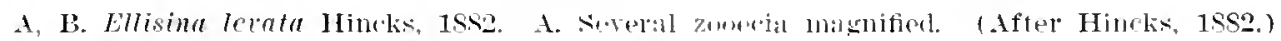
B. Sketch showing dietellate. (After Norman. 19013.)

C. Ellivina comonatn Hincks, 1s\$. Several zomeria. (Aftel Hincks, 1\$\$1.)

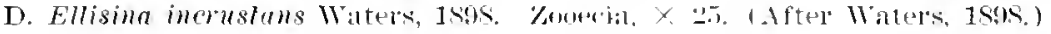

The recent species belonging to this grenus are as follows:

Ellisina (.1/emtranipora) Terata Hincks. 148..

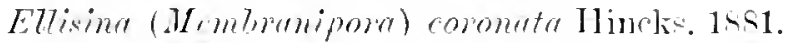

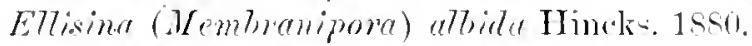

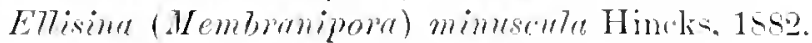

E7lisina (Membranipora) incrustans Water. 1 ses.

The fossil species are:

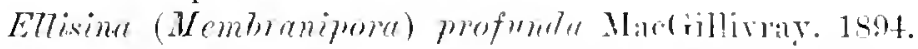

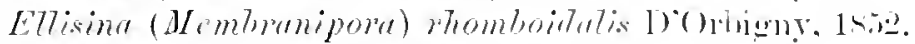

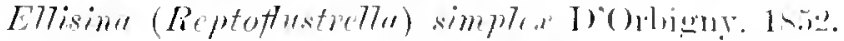

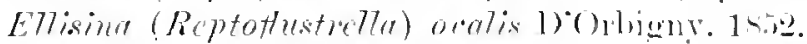

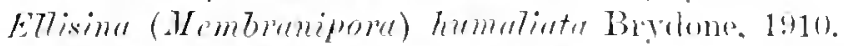

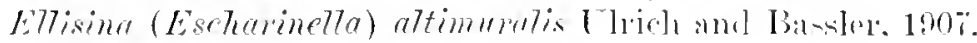

E7lisina? angusta. Thich, 1901.

E77isimer spromtosa lorich, 1901. 
ELLISINA SPICULOSA UIrich, 1901.

I'lite 1, tigs, :3-5.

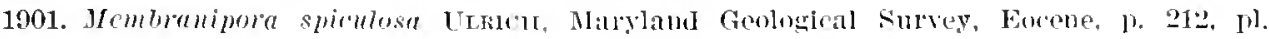
9, figs. $3,4$.

Description.-"Zoarinm adnate. Zoocia arranged in quincunx or irregularly. oblong, rom led and widest above, more or less produced below. Opesia large, normally orate, the upper edge nicely rounded, the lower varialle, taking up alout half of the length of the zonerium. Rim thin, highest alove. usually dying out before reaching lower extremity of zooerim. Front wall wrer lower half of zooecinm, slightly depressed, covered with small granulos or spines. those bordering the elge projecting sliarply into the opesial opening. Ooecia numerons, cuculate, strongly elevited. often with a tubercle or point forming the summit. When a zooecium is without an onecium its place is often occupied by an elevated avicularium of moderate size. The avicularial are very few in number, but when present similar to those found in Reptofustrella heteropore Gably and Horn. Length of zonecium $0.5 \mathrm{or} 0.6 \mathrm{~mm}$; width, 0.25 to $0.30 \mathrm{~mm}$. The specimen described shows a single cell differing from the rest in being closed, a convex cover, at the upper extremity of which a semi-circnlar impression is distinguishable. extendiug orer the whole." (Ifter Tlrich.)

The oricell is certainly closed by the operenlar valve.

Occurrence-Cowert Eocene (Bryozon bed at base of Aquia formation): Upper Narlboro, Maryland (rare).

ELLISINA (?) ANGUSTA Ulrich, 1901.

I'late 1, figs. $1 ;-10$.

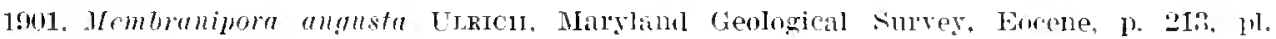
(ji). figs. 5,6 .

Originat deseription. - "Imong the material from Tlper Marllowo there are several specimens of a delicate. 14 embranipora that, on account of their imperfection and fragile nature, it may he risky to distinguish as a new species. However. as it is easily recognized and may prove useful in stratigraphic studie-, the writer has ventured to name it as above. The zonecia are shallow. elongate. (diptical. hexagonal, or rhomboidal, and separated except in young stages by a thin tuberculated wall common to aljoining colls (that is, there is nsmally no iteprescot dividing line between the zonecia). The inner portion of the wall $\mathrm{j}$ m muly thicker than the outer, so that the monthe of the comecting pores. of which there are at leat six on each side and one or two at each cull. are deatry. Slown in a viow of the front. Two specimens have cuenllate ooeria and on all an werational mall oral or

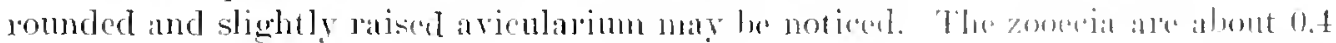

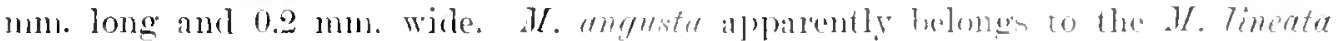
group of Waters."

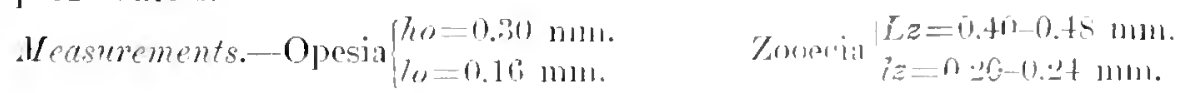


We have little to arld to the deceription given by Uhich. The specimens are rery fragile. much altered. and do not lend themselves readily to dissection necessary in study. The ovicell is transverse and appear's to be closed (?) by the opercular valve. The distal arjoularium oeeurs frefuently and is rather large. round, and without pivot.

The septular are laree plainly risilile. and do not appeal to correspond to the number of tietellate. They are also extremely fragile. After rublomg away the surface only a laroe distal and a lateral pair have come to riew. The lateral dietcllae are perhap rivicled into three portions corresponding to the three pairs of normal septulate. If this should be so, this species is incorrectly placed in the

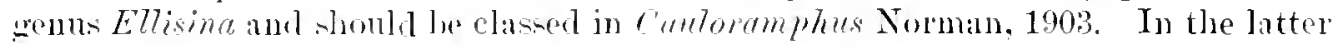
genus, howerer. acoorling to its anthor. the ovicells are "rery shallow and inconspicuous." which is not the case in the present species.

Ocemerener-Iowe-t Eocente (Bryozoan bed at base of Aquia formation): Upper Mardlooro. Marylind (abundant).

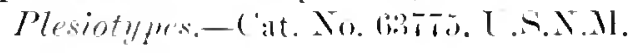

ELLISINA LAXA Canu and Bassler, 1917.

Plate 25, figs. $1,2$.

1917. Fllisma lay GAXU and Fisster. Synopsis of American Farly Tertiary Cheilostome

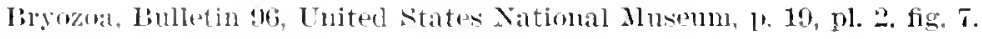

I'eseription.-The zoarinm incrust- pobbles and expecially shells. The zooccia

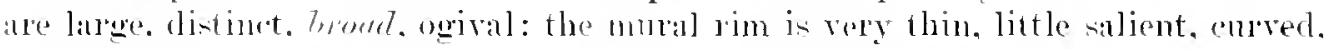
fincly striated. The opesimm is rely large and of the same form as the zooecium. The ariculatrum i- triangular. intryogedial. transverse, and without pirot.

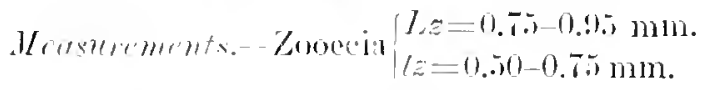

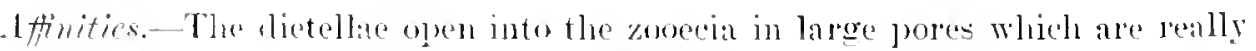
the remains of multiporoms septulate. The oricell is latre ame rery small.

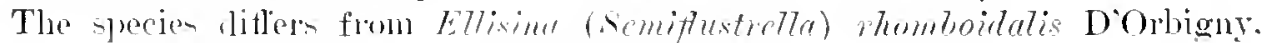

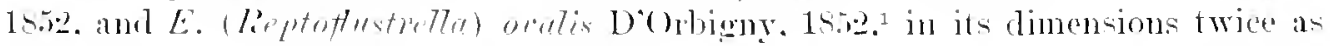
large and in the ogival and nomrombointal form of the zooceia. It is the largest known specius of E77isinu.

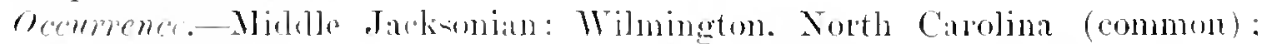

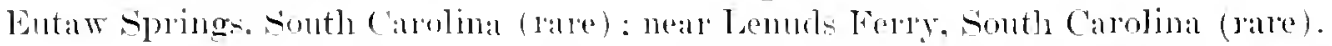

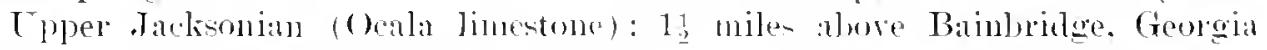

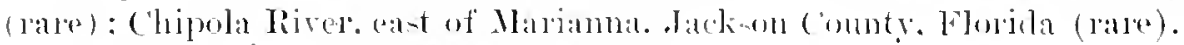

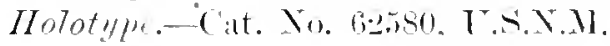

\section{ELLISINA BREVIS, new species.}

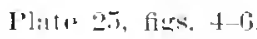

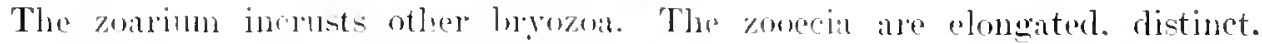

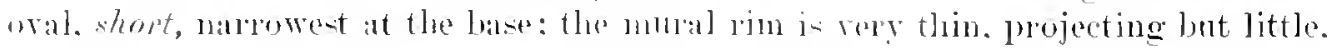


curved, finely striated. The opesium is of the same form as the zooecia. The avicularium is interzoocial, snall, oblique, rounded or pointed; two lateral denticles indicate the axis of rotation of the mandible. The ovicell is globular. indistinct, smooth. rarely earinated.

$$
\text { Measurement..-Znoecia }\left\{\begin{array}{l}
L_{z}=0.50 \mathrm{~mm} . \\
\tau z=0.25-0.30 \mathrm{~mm} \text {. }
\end{array}\right.
$$

Affinities.-The differences between this species and Etlisina (Reptoftustrella)

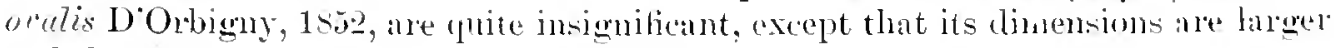
and the oricell is almost nerer carinated.

It ditiers from Ellisina (Semiftustrella) rhomboidalis D'Orbigny. 1852. in which the micrometric measurements are almost identical alt hough slightly smaller. in the much less lozenge slape of the zonecia.

Etlisina brevis differ's from E. Tare not only in its much smaller dimensions, but in its elongated zooecia which are less protuberant in aspect. In these rery simple forms, the micrometrie dimensions are the only constant characters of differentiation.

Occurrence.-Middle Jackonian: Near Lenuds Ferry, Soutl Carolina (rare); Eutaw Springs, South Carolina (rare).

Upper Jackintian (Ocali limestone): $1 \frac{1}{2}$ miles abore Bainbridge, Creorgia (rare).

Cotupex-Cat. Xos. 6359ti. 63897, U.S.N.M.

ELLISINA PROFUNDA MacGillivray, 1895.

Plate 25, fig. 3.

1595. dlembranimia profunda Machilentar, A Munogriph of the Tertiary Polyzon of Vie. toria. Transactions of the royal suciety of Victoria, vol, 4, p. 36, pl. 4 , tig. 14 ; pl. S, fig. 2.

190S. Hembranipora profund $\mathrm{CAxU}$, lconographie des Inyozoaires fussiles de l'Argentine, Antles del Mluseo Nícional de Buenos Aires, vol. 17, D. 258, pl. 2. fig. 11.

The external aspect, the position, the direction of the avicularia, and the micrometric measurements exactly alike, all indicate or appenr to indicate the inlentity of the American specimens with Membranipond mofunda MacGillirray. 1895. However. our uniplue specimen from near Lennds Ferry, sontlu Garolina. presents a remarkable peculiarity not described by the Australian anthor and which has not been observed on the specimen from Patagonia. In the interior of atch zuoecium there is a kind of double partial mural rim; distally two inerular pores separate the two mural rims. This arrangement greatly simmlates the structure in the interior of the zooceia of Cheperia. The study of this interesting feature remains to be made when more numerous specimens have been finund. The arionlalium is sometimes developed in the interion of the distal zooedinn.

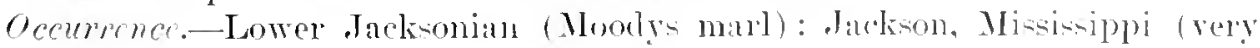
1:ne).

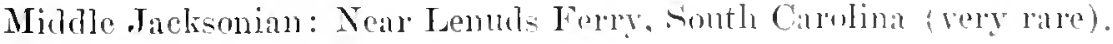
$5 \operatorname{son}-19-1 ;$ ull. $106-0$ 


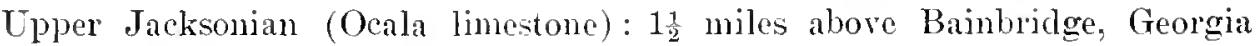
(very rare).

Geological distribution.-Miocene of Australia (MacGillirray) and Patagonian of Argentina (Canu).

Plesiotype.-Cat. No. 63895. U.X.X.M.

\section{Genus GRAMMELLA Canu, 1917.}

1917. Grammella Cand, Bulletin Societe Geolngique de France, ser. 4, vol. 16. p. 131.

The operculum closes the ovicell. 'The aricularium is interzocecia], large, with a solid pivot; its form recalls that of the Greek letter $\Theta$. No dictellae.

Genotype.-Membranipora crassimarginata IIincks, 1880.

Range--Santonian-Recent.

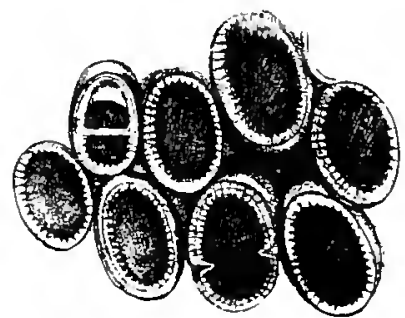

A
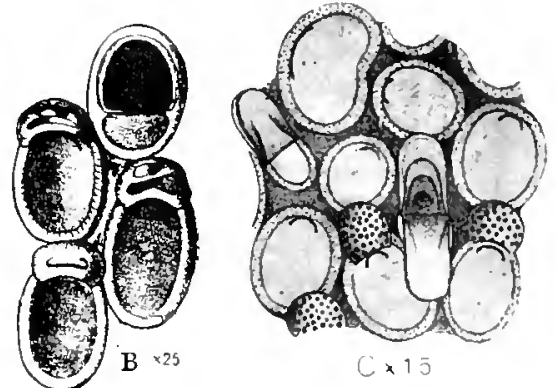

F1g. 32.-Genus Grammella Cunu, 1917.

A-C. Grammolla crassimarginatr Hincks. 1sso. A. Znoecia and avicularia. magnified. (Aftel Hincks, 1850,) B. Several zonecir with ovicell. $\times 25$. (Aftel Waters, 159S.) C. Titw of the rariety japonica Ortmann, $1890, \times 15$. (After Ortmann, 1890.)

The living species of this gemus are as follows:

Grammella (Membranipora) crassimarginata Hincks, 1880.

Grammella (Membranipora) crassimarginata juponica Ortmann. 1890.

Grammclla (Membrenipora) papulifera Mackillivray. 1s85.

Grammella (Membranipora) sculytre cumblata Waters, 1898.

The fostil forms are:

Grammella (Membranipora) smilpta Machillivray, 1894.

Grommella (Eschara) lesueuri Hagenow, $185 \mathrm{l}$.

Grammella (Flustrella) confust Do Orbigny, 1850.

Grammolla (Biflustra) megapora D'Orbigny. 1852.

This is the Nembranipora rassimarginate group of $1 V^{r}$ aters which he defines as follows: "Ovicell umbonate. witl partial rib: avicularia vicurions." He did not inclicate the presence of dietellae. lut he ealls attention to one distal and two Lateral septulae.

Waters introduced with doubt into this group (No. 11) the llemtranipora ratdemunta Hincks. 1885. Which Canu in 1900 made the type of his artificial sub- 
genus Taldemunitclla. The form of the large interzooecial arienlaria, the absence of the pirot, and the peenliar form of the mandibles are important arguments for the differentiation and the creation of a separate genus, but this is a study for the future.

GRAMMELLA CRASSIMARgiNata Hincks, 1880.

llate 24 , figs. 13-15.

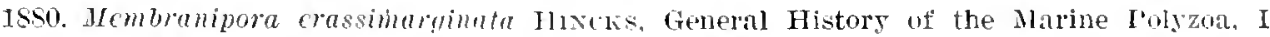
Madeiran Polszoa, Anmals Magazine Natural Mistory, ser. 5, vol. 6, p. 71. 11. 9, fig. 1.

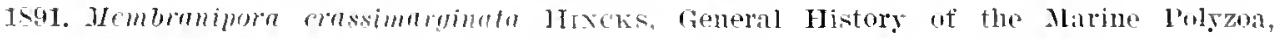
Appendix, Annals anu Migazine Jatural IIistory, ser. 6, vol. S, p. s6.

1S9S. Hembranipora crassimarginata W.Atess, Observations on Membraniporidae, Jurnal Linnean Society Lonion, Znology, vo]. 26, p. 655, pl. 47, fig. 4.

1900. Crassimarginatclla crassimarginata CAxt, Revision des bryozoniles du cretace figures par d'Orligns, Pt. 2. Cheilostonati, Bulletin Society Geologique de lrance, vol. 28, ก. 369 .

1903. Oochilina crassimarginato Xonuax, Notes on the Natural IYistory of East Iinmark. Polyzoa, Annals and Nagazine Xatural History, ser. 7, vol. 11. p. 595.

1909. Mcmbranipora crassimarginata sormax. The Polszon of Malein and neighboring Islands, Journal Linncin siciety Lomdon, vol. 30, 1. 287.

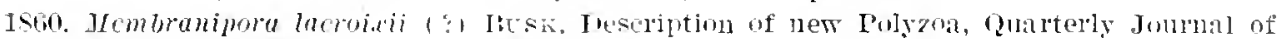
Ificroscopient science. vol. s. 1\%. 282.

1861. Dembranipora irregularis Jisss, Thesciption of new Iolyzoa, Quarterly Jounal of Microscopieal Science, vol. a in. s. vol, 1) p. 77, pl. 33, fig, 3 (not d'orhigny).

Thescription.-The zoarium incrusts pebles, shells, foraminifera, and other bryozoa. The zooecia are elongated, distinct, oval, or elliptical with fiequently a very small grmnocrst; the mural rim is very prominent, curved, thin at the top. enlarged at the base, finely granular. 'The opesium is elliptical. entire. 'The ovicell is globular, prominent, deeply exearated. and separated from the mural rim. 'The avicularium is interzooecial, as large as a zooccium; the mural rim is thick; the pirot is median and solid.

Leasurements.-Opesia $\left\{\begin{array}{l}h o=0.32-0.36 \mathrm{~mm} . \\ 70=0.20-0.2 .2 \mathrm{~mm} .\end{array} \quad\right.$ Zooecia $\left\{\begin{array}{l}L z=0.50 \mathrm{~mm} . \\ Z z=0.32-0.40 \mathrm{~mm} .\end{array}\right.$

Tariations.-Examples of total regeneration are numerons and manilest themselves by their donble mural rims. Figure 13 contrins even a case of triple rogeneration. The ancestrula is rather small and of normal form. Closed zoneria purforated by a small, round, medium pore. are located close to the ancestrula (fic. 1.j).

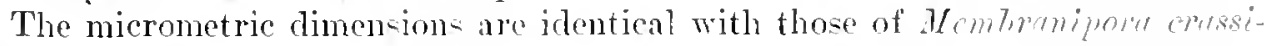
marginata relying upon the figure given by Waters. The only diflerence frum the recent species that we can cite is that in the latter the pirot of the arinlanim is placed jrregularly. On such a trifling diflerence wo can unt diutinguide another species.

Grammethe crassimargimate "xists tn-thy in the wators oft the Moulcira Islands. Its existence in the recent and ancient Gulf of Moxien is therofore rery probhle.

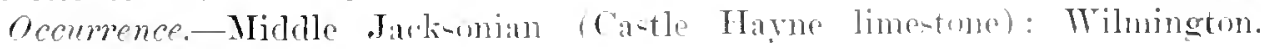
North Carolina (very rare). 
Upper Jacksonian (Ocala linestone): 31 miles north of Grovania, Georgia (very rare); Alachua, Florida (very uare): ? miles north of Ocala, Florida (very rare).

IIabitat.-Mediterranean : off Flance and Italy. Atlantic: the Madeira Islands and Tristan da Cunha. China Sea at Tizart. Pacific: Japan (var. japonica Ortmann, 1890).

Plesiotypes.Cat. Nos, 6389) 4, 6989.5. U.S.N.M.

GRAMMELla TRANSVERA Canu and Bassler, 1917.

Plate 25. figs, 7. S.

1917. Grammrlla transuersa CANt and Bassier, Symopsis of American Early Tertiary Cheilostome Bryozoa, Bulletin or, United States National Museum, p. 20, pl. 2, tig. 6.

Description.-The zoarium incrusts bryozoa. The zooccia are but little elongated, broad, distinct; the mural rim is thin. sharp edged, regular. The opesium is of the same form as the zooecium. The ovicell is salient, globular, smooth, and carimated. The avicularium is interzooceial small, elliptical, and the pirot is never median; its longitudinal axis is tronsererse with respect to the zooecial axis.

$$
\text { Mcasurements.-Opesia }\left\{\begin{array}{l}
h o=0.45 \mathrm{~mm} . \\
7.0=0.35-0.40 \mathrm{~mm} . \quad \text { Zooecia }
\end{array} \mid \begin{array}{l}
L_{z}=0.55-0.60 \mathrm{~mm} . \\
7 z=0.46-0.50 \mathrm{~mm} .
\end{array}\right.
$$

Affinities.-The avicularium is senerally elliptical, but it is sometimes triangular (fig. S). The mural rim exhibits a lare and interesting peculiarity. It is not provided with a side which merges into the zooecium so that the opesium is bounded by the termen itself of the mural rim.

The present form differs from other deseriber species of Grammella in its small avicularia transtersally orjented.

Occumence.-Niddle Jacksonian: Wilmington. North Carolina (rare) : Entaw Springs. South Carolina (very rare).

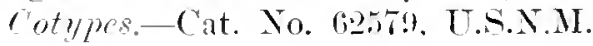

GRAMMELla PUSILla, new species.

Plate 25, figs. 9-13.

Description.-The zoajum incusts other bryozon and calnareous alorae. 'The zonecia are small, elongated, distinet. oral, or elliptical, with or without a very small gymmocyst; the mural rim is quite prominent, thin at the top. enlarged at the base, finely granulated. The opesimm is elliptiral. The ovicell is ghoular, granulose, deeply excarated. ormamented, with a callosity. and distinct flom the muril rim. The ancestrula is snall and its mural rim very thin. The aricularium is interzooecial, somewhat larger than an opesium; its pivot is placel a little below the transverse axis of the opesial ellipse.

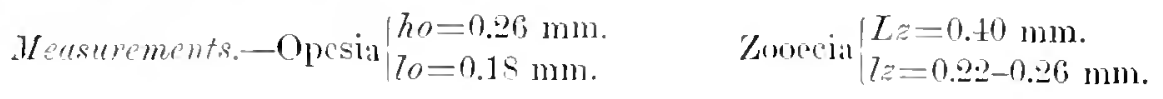


Examples of total regencration are very rare.

Affinities.-The termen of the mural rim sometimes becomes very sharp.and crenulated (fig. 10).

This species is quite similar to rretmmella crassimarqinata, differing only in its small dimensions. It is not a variety beanse it occurs at different localities.

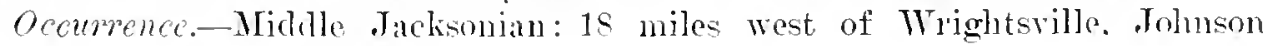
('ounty, Georoia (very rare).

Upper Jacksonian (Oeala limontone) : West bank of Sepulga River, Escambia Comnty, Alabama (rare); Clipola River. east of Mariama. Iackson County, Florida (rare) ; 11 miles alove Bainbridge, Georgia (rare).

Ticksburoian ("(himmey lock" of Mariama limestone) : One mile north of Monroeville. Alabama (rine).

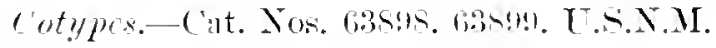

Genus MEMBRANIPORIDRA Canu and Bassler, 1917.

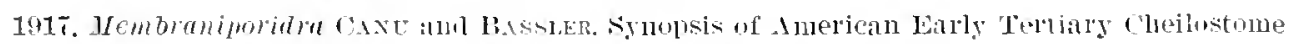
Bryozoa, Bulletin 96, Inited stites National Museum, p. 21.

The operculum always closes the wicell. To dietellae. So avicularia. One large distal septula; two pairs of lateral septulae.

Genotype.-Membraniporidru pormectu Canu and Bassler, 1917.

Range.-Tacksonian and Tirksburgian.

The ovicell is decply excavated in the distal zooecimm. It is unly by dissection that we are able to prove hy the continnity of the mural rim. although very thin listally, that the ovicell is indeed hyperstomial. The mural rim is always enlarged at the base and finely granular.

This genus differs from Alderine Xorman, 1508. not only in the closure of the ovicell by the opercular valve, but al-o in the absence of dietellae.

It is probable that many recent species naty be included in this genus. The most common form among them might woll serve as the true genotype.

\section{MEMBRANIPORIDRA OECIOPOROSA, new species.}

Plate 26, figs. 1, 2

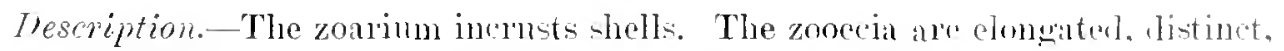
clliptical; the mural rim is slightly salient. curved, enlared at tho basc. where it has two lateral furrows, mumbinted with very small wranulations lanlially ar-

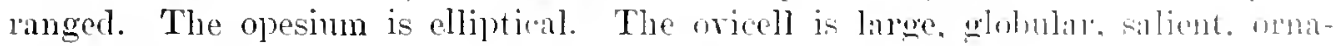
mented with a frontal callosity. the wall of which. lying on the dictal bilt of the zooecium, is finely porous.

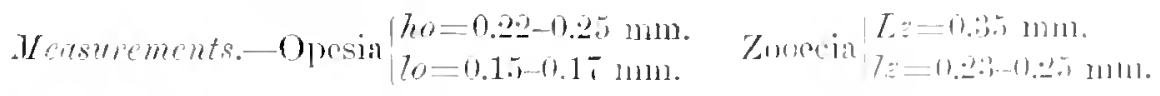

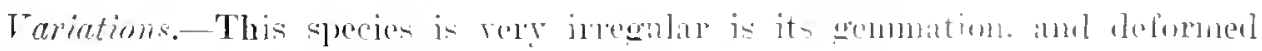

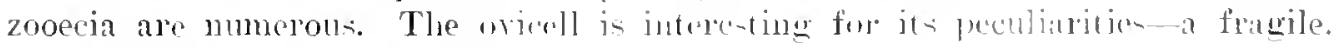

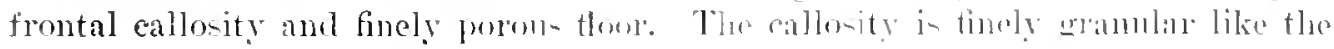


mural rim; it is an olocyst partially corered with a pleurocyst. The oricell borders the mural rim in a rery irregular fashion: we are not absolutely certain that the opercular valve always closes the zooecia. Moreover, as we possess only a rery small number of fragments. this species requires further examination.

Occumence.-Lower Jacksonian (Momlys mal) : Tackson, Mississippi (rery rare).

Middle Jacksonian: Eutaw Springs. South Carolina (very rare); Rich Hill, $5 \frac{1}{4}$ miles sontheast of Inoxville, Georgia (very rare) : Wilmington. North Carolina (very rare).

Cotypes.-Cat. Nos. 63902, 63903. C.S.X.MI.

MEMBRANIPORIDRA PACHYaCRALIS, new species.

Plate 28, figs. 14-17.

Description.-The zoarium incrusts shells. The zooecia are slightly elongated. distinct, hexagonal; the mural rim is vry ride on the magins and below, finely granular. The opesium is elongated, elliptical, fringed with a collar of grannles radially arranged. The ovicell is much sunken. but placed above the distal septula: it is closed above by a globular, salient convexity. separated from the mural rim and formed of two calcareous layers.

$$
\text { Measurements.-Opesia }\left\{\begin{array} { l } 
{ h _ { 0 } = 0 . 3 5 - 0 . 4 0 \mathrm { mm } . } \\
{ l _ { 0 } = 0 . 2 0 \mathrm { mm } . }
\end{array} \text { Zonecia } \left\{\begin{array}{l}
L z=0.55-0.60 \mathrm{~mm} \text {. } \\
l z=0.45-0.50 \mathrm{~mm} .
\end{array}\right.\right.
$$

Tariations.- The zooecia are generally separated by a furrow of slight depth and sometimes filled up. The mural rim on account of its thicliness is a true cryptocyst which renders this species rery easy of determination. We are ignorant of the use of the radially arranged aranulations which fringe the opesium. No regenerated zooecia have been observed. The rather large distal septula becomes multiporous.

Ocourrence.-Middle Jacksonian (Catle Hayne limestone): Wilmington. North Carolina (rare).

Holotype.C-Cat. No. 63917. T.S.X.M.

MEMBRANIPORIDRA TRIGEMIA, new species.

Plite :- figs. 14, 1\%

The zoarium is milamellar and creep orer algac. The zooceia are rather large. little elongated, ogival. distinct: the mural rin is thin, little prominent, cmred, much enlarged at the base, finely granular. The opesium is elliptical or subcircular, finely denticulated. The oricell is large. ghobular, salient, distinct from the mural rin. with a decply enbedderl floor.

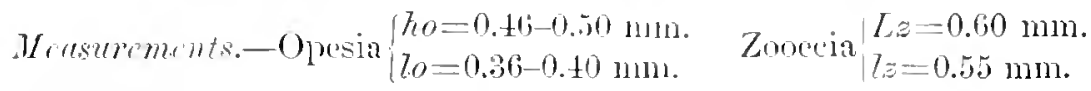

Affnities.-In general. in gemmation a zonecinn may engender only two, of which the one that is deformed hecomes primuncial. Here this gemmation is 
so vigorons that very frequently a zooccinm, in every respect la raer than the others. reproduces three undeformed primoserial zooecia. We have observed no regenerated zooccia.

This species differs from Mcmbraniporidra láicella in its larger micrometric dimensions and in the absence of a grmnocyst.

Occumence.-Middle Jacksonian: Wilmington, North Carolina (common); Rich Hill, $5 \frac{1}{t}$ miles southeast of Knoxville. Georgia (rare).

Cotypes.Cat. Nos. 63900, 63901, U.S.N.M.

MEMBRANIPORIDRA LATICELLA, new species.

Flate 26, figs. 3-5.

Zoarium incrusting other bryozoa. The zooecia are distinct, ogival, broul, with a small convex grmmocyst; the mural rim is salient, thin, curved, smooth, or shight? granular. The opesimm is entire, oral, the narrow end at the front. The ovicell is large, globular, salient, smooth, distinct from the mural rim; it is deeply embedded in the distal zooecium.

$$
\text { Measurements.-Opesial } \begin{aligned}
& h o=0.40-0.50 \mathrm{~mm} . \\
& 70=0.20-0.30 \mathrm{~mm} .
\end{aligned} \quad \text { Zunecia }\left\{\begin{array}{l}
7 z=0.60-0.80 \mathrm{~mm} . \\
7 z=0.40-0.50 \mathrm{~mm} .
\end{array}\right.
$$

Tariutions. - The mural rim is not always rount. It sometimes has a small sharp termen dividing it into two parts. The grmnocyst is rery irregular in form. but it is a constant feature. The regenerated zooecia with double mural rims are frequent. Figure 4 (zri) represents a special case where a regenerated zoocium roplaces a normal zooecium but reversed in direction. Figure 5 (zro) illustrates an inverted oricelled zooecium succeeling a normal zooecium.

This species differs from Membraniporidra trigemma in its smaller zoocial dimensions and in the presence of a grmnocyst.

Occurrence.-Middle Jacksonian: Wilmington, North Carolina (rery common) : Eutaw Springs, South Carolina (rare).

C'otypes.-Cat. No. 63901, U.S.N.M.

\section{MEMBRANIPORIDRA PORRECTA Canu and Bassler, 1917.}

Plite 26 , figs. (6-13.

1917. Membraniporidra porrecta CANu and BAsster. Synopsis uf Amprican Fary Teltiary Cheilostome Bryozoa, Bulletin 96, Unitel States National MIsemm, 1. 21, 11. 2. ti2. $\bar{~}$.

The zoarium is free, follicular, formed of two very thin learos growing back to back and easily separable. The zooceia are large, elongate, distinct. wal. with a proximal, convex gymmocyst; the mural rim is very thin, salicht. curver. The opesimm is large, elliptical. entire. The ovicell is globular, little elerated. ornamented with a frontal callosity: it is reeply emberled. I di-tal septula and two lateral septulae and tro distal imprescions are present.

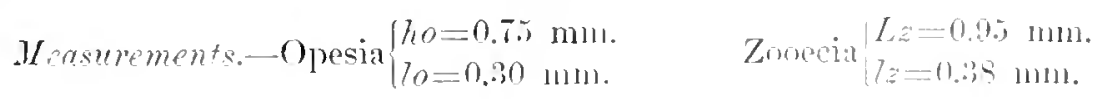


Tariations. - The micrometric rariations in this species are very great: there are long zooecia (figs. 7,8 ), wide zunecia (figs. 9. 10). and dwarfed zooceia (fig. 7). The furrom separating the zooccia is often fillerl and replaced by a thread-like projection. Some cases of total regeneration have been noticed. The ovicell is rare and fragile, its callosity is rery funcly granular like the mural rim. The mural rim aceording to the rule is an olocyst in which the elements group themselves. radiating from the opeinm. The gymuncyst is formed of scattered olocystal elements (fig. 13). These tissnes are very hard and it is very difficult to obtain them in thin sections. 'Two very faint listal innpessions exist on the dorsal oloerst at the bottom of each zooccinm.

occurrence--Middle Tacksonian: Wilmington. Tortl Carolina (common); Baldock. Barnwell Connty, South Carolina (rare).

Cotypes.C-Cat. No.6257s. U.S.N.Al.

\section{MEMBRANIPORIDRA SPISSIMURALIS, new species.}

Plate 27, tigs. 1-19; plate 2s, tigs. 1-7.

The zoarium is free, follienlar. formed of two lamellac growing back to back and easily separable. The zooecia are clongated. oral. distinet. separater by a furrow or by a raised thread-like line. The mural rim is that. ohlicune towarl the opesimm. thich, gradnally enlarging to form at the base a cryptocyst limited laterally by two grooves or furrows. The ope-imm is elliptical. entire, often partially ent off by the rectangular prominent denticles. The primoserial zooecia have an opesimm narrowed laterally. The ovicell is globular. salient. short, transrerse, and is deeply embedded in the distal zonecinm. There are two pairs of lateral septulae and a very large distal septula.

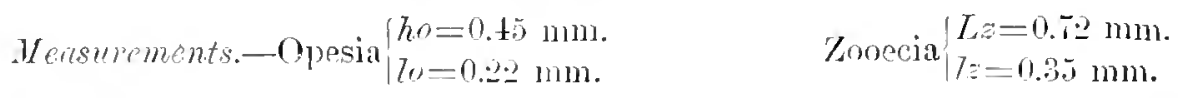

Tratiations. This species is rery common and as usual in such a case. the rariations are innuncrable. It is truly a protean form of the Membranipores. The imagination ean not conceive all the arjations: we will note only the prineipal ones. Certain of these rariations aflect not suly an entire zoarinm but often all of the zoaria from the saur locality.

Onr description is founder on the perfect but rare forms (figs. 1, 2, 3). The cryptoeyst may lack the lateril groores; again it is concalve (pl. 2i- figs. . . 5). and then it is convex (pl. 27. figs. 6i, 7 ). It may eren be wanting entirely either naturally (pl. 27 , fig. S) or by weathering (pl. 27. fig. 9). This latter variation aftects nearly all the specimens from Rich IIill, Georoir.

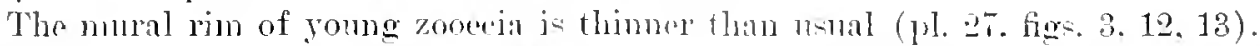
Rarely the primoserial zonecia do not have an opesimm laterally eontracted (pl. $\mathbf{T}$, figs. 1.2). This contraction is a rery important character. chicfly in the rolled and worn specimens.

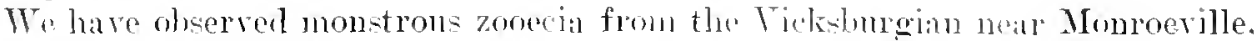
Alabana (pl. 27, fig. 14), and furthermore the extremely late ate of a zooecimm

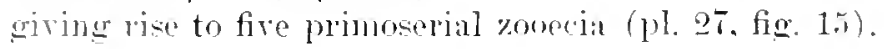


The gramulations of the mural rim are extremely fine: the granules beeome larger by ehemieal changes (pl. $2 \mathbf{-}$. fig. 16). The oricell is -mooth in the Jacksonian specimens (pl. 27 . ligs. 3.7 ). but it is ormamented with a frontal eallosity in those from the Vieksburgian (pl. 2. $\overline{7}$. figw, 16, 17). This structure is always placed abore the distal septula (pl. 28, fig. (i). The oricells on the same zoarim are rare. and their-ocenremee in grmps is rery infrequent (pl. 2-. fig. 9). Regenerated zooecia are rather rare (pl. 2 - . fig. 14). 'The opesial clentieles are alwalys irregular in form, size, and position: sonctimes they are quite large (pl. 르. fig. 18).

The zo:lrim is often unilanclar, cither by splitting in half or by growth on algae (pl. 27, fig. 19). This rariation atlects all the speeimen from the Vickshurgian along the west lank of Conecuh River, Escambia Comnty, Alabama. We have also some specimens incrusting shells from the Jarkomian at Wilmington. North Carolina.

The dorsal lamella of ench zooecium is an olocyst with scattered clements (pl. 25. fig. 3). The mural rim and the cryptocyst are of the -ame natmre and are formed by an olocyst in which the elements aro grouped in radial lines (pl. 28. fig. 2). The zooecial walls are rely thin (pl. 로. fig. 4) or rery thick (pl. 28, fig. 5). By rubbing away the surface it is easy to bring ont the two pairs of lateral septulate and the large distal septula (pl. 28. fig. i). On the same zoarinm the mieronetrie measurements are rather constant. but they vary much according to the loeality. They may be small (pl. 27. fig. 10) or large (pl. 27, figs. 5. 8. 14).

Occurrence.-Vieksburgian (Marianna limestone): Salt Momntain. five miles -onth of Jackson, Alabama (very common); near Claiborne. Momroe Connty, AlaLama (very conmon) : west bank of Conecuh River, Eseambia County, Alabma (rery common): Murder Creek. ast of Cantlebury, Coneenh County, Alabama (very common); 1 mile north of Monrot ville, Alabama (very common).

Upper Jacksonian (Ocalia limestone): Test bank of Sepulga River, Escambia County, Aabama (rare): Chipola River. cast of Mariama. Jackson Countr. Florida (very lare).

Jatksonian (Zeuglodon zome): Shulnta. Mississippi (rare).

Micldle Tacksonian: Wilmington. Xorth Carolina (rery common): 江 milusouth of Perry, Georgia (common): Rich Hill, 5: miles coutheast of Kinoxville. Crawford County, Georgia (common); 18 miles west of Wrighterille. Tohmom County, Georgia (common) : 12 niles southeast of Mar'salville, Georgiat (counmon); one-half mile sonthea-t of Georgia Kanlin Company Mine. Twigg Countr. Georgia (rare); Balılock. Barnwell Countr. Sonth Carolina (rare).

Lower Jacksonian (Moorlys matr) : Jackon, Misis-iplpi ranter.

totypes.-Cat. Noc. B390\%-63!11. T.X.X.M.

MEMBRANIFORIDRA SMILIS, new species.

I'lite 29, fies. \& 10 .

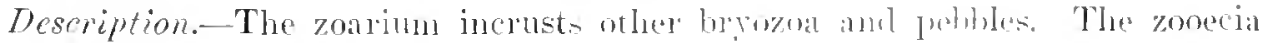
are elongated, little dintinct. -eparated or not by a very littl fonmw. elliptical:

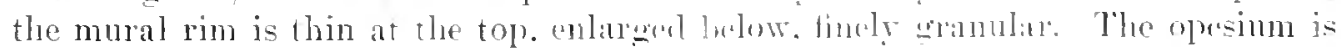


regularly elliptical. very finely crenulated. The primoscrial zooecia are modified. The ovicell is large. listinct from the mural rim, salient, globular, almost transverse, and is deeply embedded in the distal zooecimm.

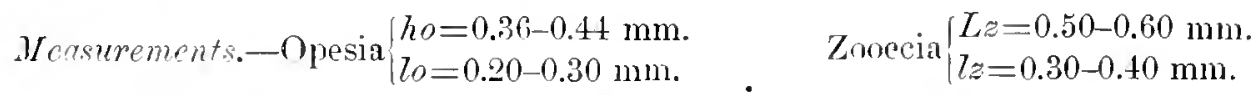

Affinities. - Te have chosen for illustration specimens showing the most contant features. but the rariations are numerous. The least ronghness of the substratum modifies the micrometric dimensions rerr mmeh.

The primoserial zooccia have no decided form and they sometimes assume the shape of large interzooccial avicularia. A zoarium from Old Factory near Bainhridge, Georgia, covers four square contimeters. The distal septula is rather large. but it is only easily risible after abrasion of the surfice.

This species resembles Membraniporidra spissimuralis very much, hut it differs in the absence of a cryptocyst with lateral grooves and in the smaller micrometric dimensions $(L z=0.60 \mathrm{~mm}$.$) ,$

Occurrence.-Middle Jacksonian: Tear Lenuls Ferry, South Carolina (common) ; Eutaw Springs, South Carolina (rery rare).

Upper Jacksonian (Ocala limestone) : Old Factory. $1 \frac{1}{2}$ miles above Bainbridge, Georgia (rare).

Vicksburgian ("Chimney rock" of Marianna limestone): One mile north of Monroeville, Alabama (rare); Vicksburg, Mississippi (very rare in the lower beds). Cotypes.-Cat. No.63912, U.S.N.M.

\section{MEMBRANIPORIDRA PYRIFORMIS, new species.}

Plate 2S, figs. 11-13.

Deseription.--The zonrium incrusts oyster shells and pebbles. The zooecia are elongate, distinct. myriform, with or without a small grmnocyst the mural rim is thick, curved, salient, broader below. The opesimm is entire pyriform and anterior. The ovicell is a little distal embedded niche corered by a slightly salient convexity.

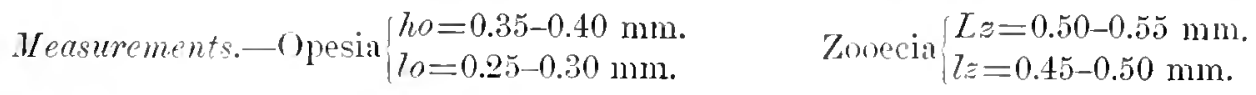

Affinitics.-The rery small oricell is often diflenlt to discover on specimens a little altered by fossilization. It is hyperstomial, that is to say. buried in the distal zooecinm, but it is so cmbedded that it can not be considered as endozooecial. Everywhere it opens into the interior of the zooecium befow the opercular valve.

This species has somewhat the aspect of Membranipom appenticulata Rellss, 1817 , but differs from it in the absence of a ricularia.

Occumence.-Upper Jacksonian (Ocala linestone): Old Factory, $1 \frac{1}{2}$ miles above Painbrilge. Georgia (common); Red Bhtl. T miles abore Bainbridge, Georgia (rery rare). Bainbridge, Georgia (rare); Chipola River, east of Mariama, Jackson Comnty, Florida (very rare): west bank of Fepulga River: Escambia Comnty, Alabama (common).

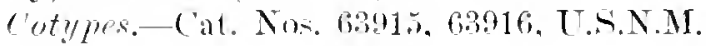


KFI TO AMERII IX SIEIES OF MEMBRANIPORINR.

1. Zoarim libamellar._..........

Zoarium inernstiug _-___.

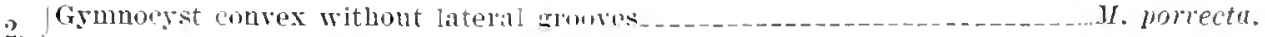

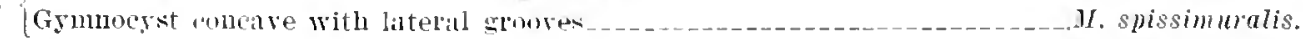

3. Oricell with porons flowr....... occioporosa.

3. Floor numprous___.

4. Oricell vely suall___

Oricell liarge, transrerse

5. Gymnocyst present__..... laticella.

No gymnocyst

6. Two primoserial nondeformed zorecia $(l z 0.351110.) \ldots \ldots \ldots \ldots$

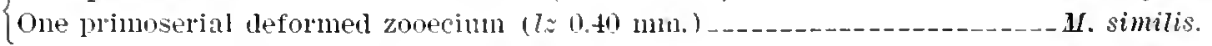

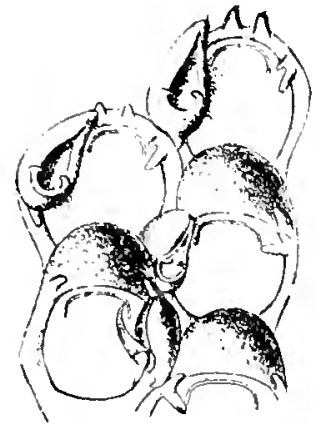

A $\times 23$

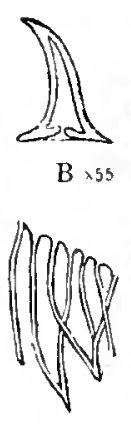

E

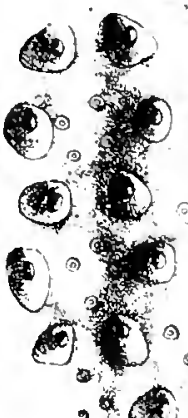

$\rightarrow$ Q

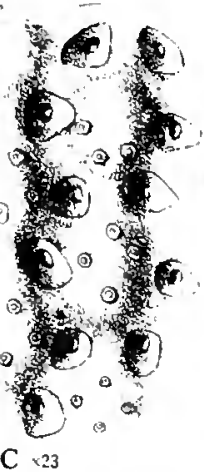

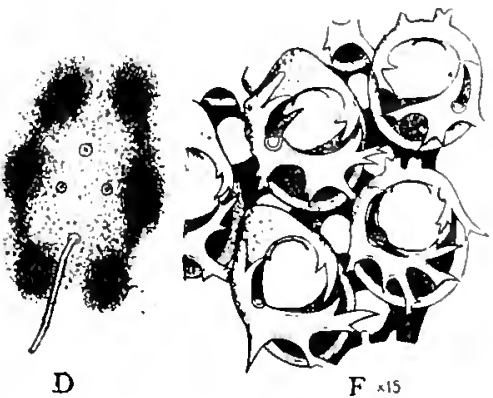

$F \times 15$

Fig. 33.--ienus Tremopora ortmann, 1890.

A-E. Trmoporn maicifera Hincks. 15s1. A. Sereval zooecia with ovicell, $X$ 23. B. Aricularian mandible, $X 55$. C. View of the basal sulface, $X 23$. (A-C after Levinsen, 1909.) D. View sluwing ralicular pores anl pure tubes. F. Ralical fibers. (D, E after Hincks, 1Ss1.)

F. Tremopora dendracantha ormann. 19oo. Several zonecin slowing the large bilureatel oral spines, $>$ 15. (After Ortmann. 159).

\section{Genns TREMOPORA Ortmann, 1890.}

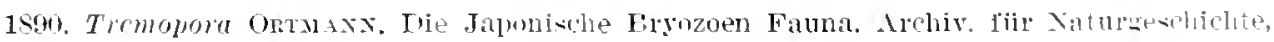
vol. 50, p. 29.

The opercular valve alway- clo-es the ovicell. The nural rim bear- one or two large bifurcated oral spines ant an aricularium more or less developerl.

crenotype.-Tremopord dembirmithe ()rtmann, 1890.

Rangr--Helvetian-Recent.

The zonecia are adjacent on -epalated and are joined amone thmedres by connecting tubes. The lower face often has radicels. Waters clatent thin genus

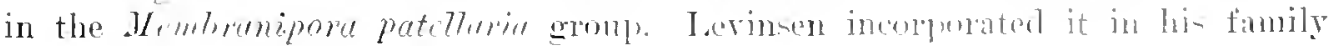
Bicellariidae. 
Genus LARNACIUS Norman, 1903.

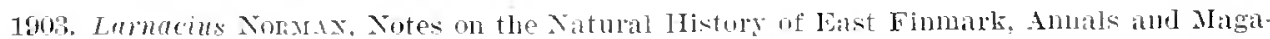
zine Natural llistory, ser. 7, wol. 12. 11. 5 .

This genus differs from a mphith stmm. Gray. 18ts. first in the interzooecial arieularim with pivot, second in the absence of djetellace, third in the distal end of the zonecinm, which is divided into chambers hy means of a transrerse and usnally

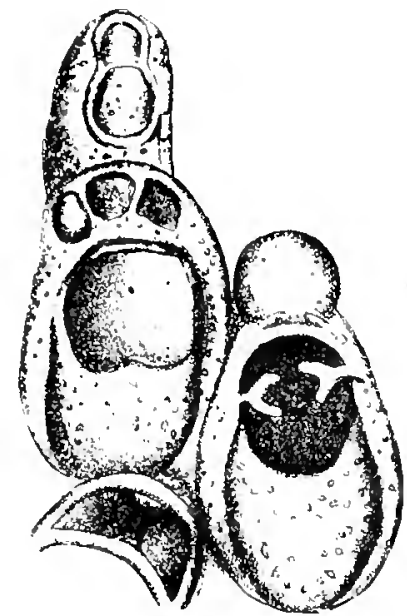

Fig. 3t, Genus Larmacius JorIll:1n, I903

Larnacius corniger 1;usk, 1552. Several zoneda, highly mannified, one with ovicull and the others with chambers in the place nsually orcupied by an ovicell. (Aiter Noman, T393.)

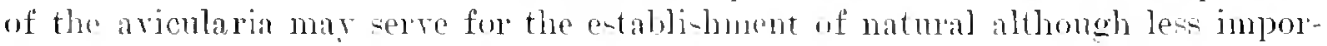
tint generic divisions.

\section{Genus ALDERINA Nolman, 1903.}

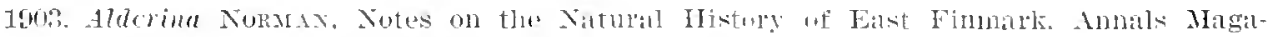
zine Natural IIistory, sel. 7, rol, 11. I. soo,

Front wall entirely membranums, side walls msully crenulated; no lateral spines. No avicularia. but nodulous processes sometimes developed in different positions on the side of the zovecium. Ovicell wnally berring (oither a rib or) a depressed area in front. I) jetellae in the type, two pairs of lateral and two distinctly marked and separated distal. Is in Fivime the two fount patis of dietellae unally extend outside the lateral wallu. and the two posterior insislo. CSoman. 190.5 ).

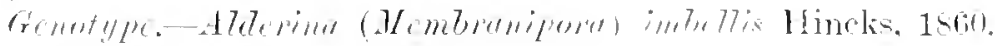

Tinuer--imonian-Recent. 
The following species are classed in this genus:

17drime (Membraniporn) imbellis Hincks. 1560. Recent.

Alderime (.1emtranipom) impalaris Smitt, 1572. Recent.

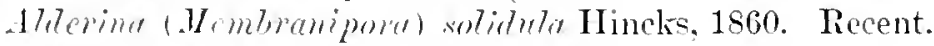

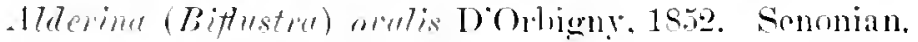

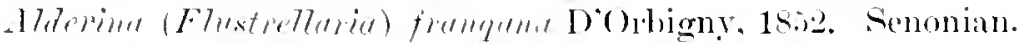

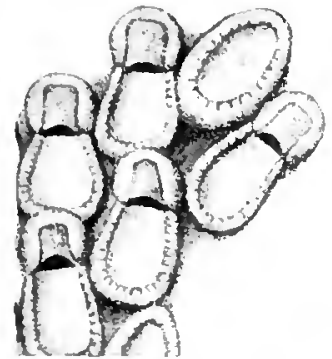

A. Alderina

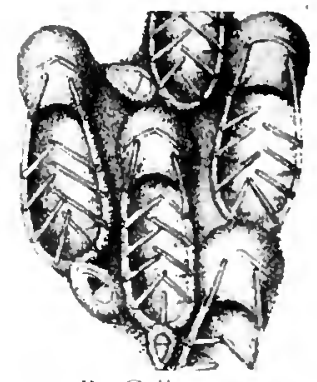

13 Cillopord

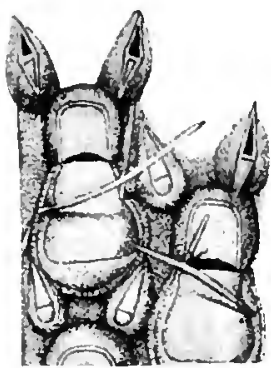

C. Amphiblestrum

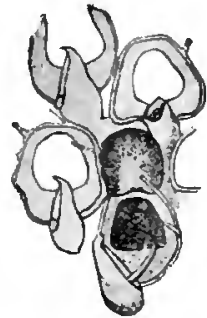

1). Ramphonotus

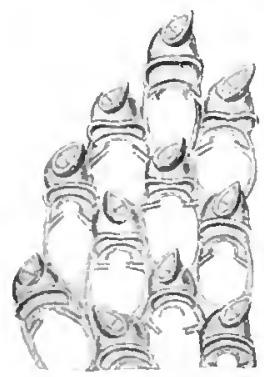

E. Tegella

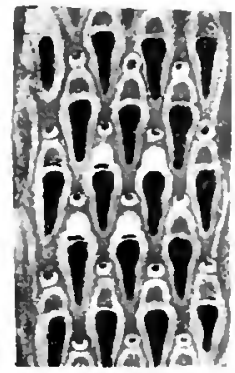

1. Stamenocella

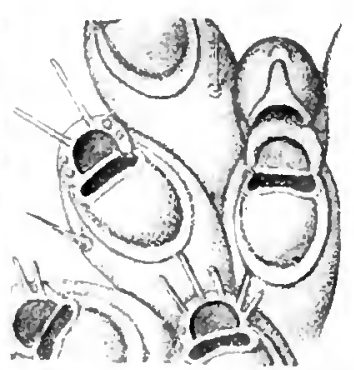

G. Meqapora

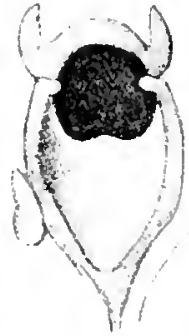

H. Ammatophoral I Massonopora

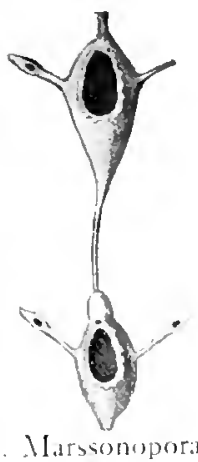

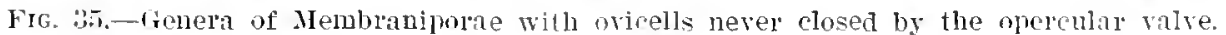

1. Hlicrina imucllis Hinclss, 1890. 25, recent.

P. Callopora lincata Linnileus, 17.5. $\times$ ji. Recent.

C. Amphiblestrum flominti lusk. 157., $x$ io. liecent.

I. Ramphonotus minux Fusk, 1890. $\because 2 \pi$. Recent.

E. Tegclla unicomis Fleming. 1828. 2\% 20. Recent.

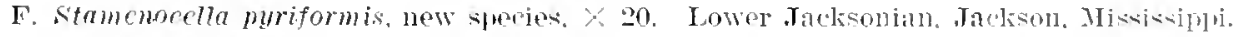

G. Megamra ringens Hincks, 1s80, $x$ n. Reeent.

II. Ammatophora nodulosa Hinckis. 1SSO. IRecent.

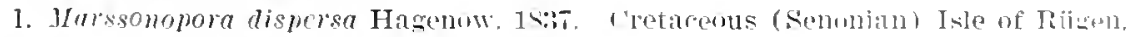

Alderina (Mombranipora) abortima Camu, 1911. Rocanean.

Aldrima (Membranipora) cummingsi (anm, 1911. Rivanean.

Alderima (Membranipora) perieporse Nowak. 197\%. Conomanian.

The recent species Alderind irregularis Smitt. 1952. is very important in the Imerican forms. and as it has been confused with other -pecies we helieved it useful to make known its symonymy and history. 


\section{ALDERINA IRREGCLARIS Smit, 1872.}

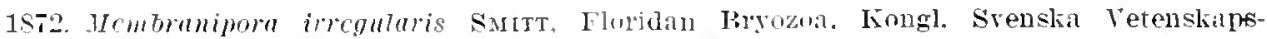
Akademiens IIandlingar. vol. 11. No. 11. 11. 5, 11. 11. fi世. 63.

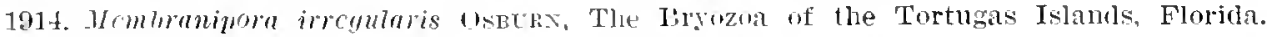
Publieation Carnegie lnstitution of Wasbington, No. 152, p. 194.

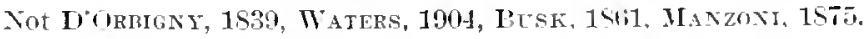

ouscreations. - We owe to the kinduess of Doctor Osburn a very complete. superb specimen of this interesting species. and we are able to supplement the observations which are indispensable for its chassification. The ovicell is transverse and formed of two caleified layers: the superior one is rery finely grannlated. incomplete. surrounding an area which is irregular and more or less linear. It is hyperstomial and opens by a large sperial orifice which the opereular valve never

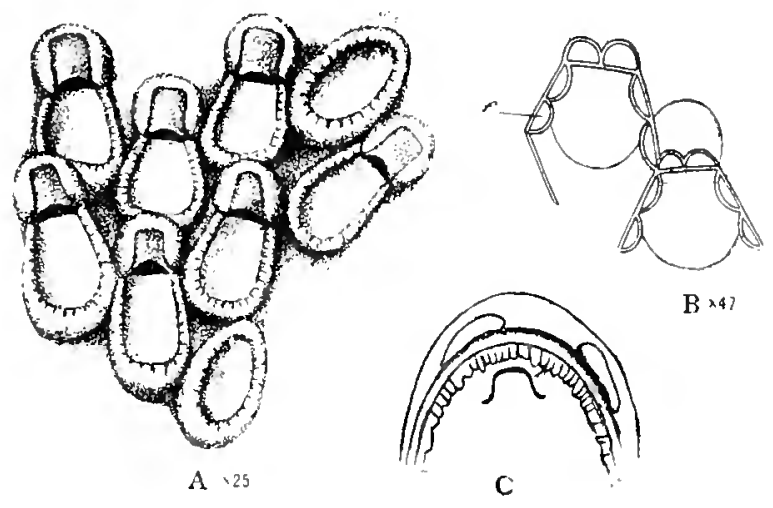

Fig. 36. Genus dlderint Norman, 190?.

A. B. Aldorinumbllis Flincks, 1860). A. Zoneria, 25. (Aitr llincks, 1880.) 13. Skoteh showing diotellas, $\because 4$. (Ater Levinsen, 1894.)

C. Aldrina solidula Hincks, 1860. A youngznowimmat the edure of a zoarium. (After Noman, 1903) closes. The latter is bordered by it very thick sclerite. The mural rim is grimular and enlarged at the balse. This is a very well rharacterized species of .17derina.

Iforsurements - $h o=0.34 \mathrm{~mm}$. Opesia $70=0.20 \mathrm{~mm}$.

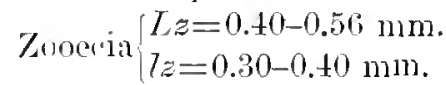

Aftritics.-This species is the cquatorial representative of the loreal A7derina imbellis Hinck. 1960. It differs from it in its transrerse and nonelongated orjcell and its irregularly linear and nonrectangular uricellarian area.

Smitt in 1872 identified it with Mcmbranipara ireguTeris D'Orbigny. 18:99. The

type is no longer to he found at the Mruemo of Natural History of Paris. The figure does not show an oricell; as the mural rim is snooth and is not enlarged at the base. it certainly represents a different specie- from that of Smitt. Waters in $1904^{2}$ found it almost. in the sane regions: ho fignrol its oricell but withont grivingr its nature; the mierometrie dimensions are much larger., to wit: ho=0.60 mm., $70=0.32 \mathrm{~mm} . . L_{\sigma}=0.80 \mathrm{~mm}$. $z_{\xi}=0.41 \mathrm{~mm}$. If it -hould be prored that this is an Alderina it would be necessary to rename suitt's epecice of much later date.

Busk in 1861" thought he han lomm Dorihiony's species in the Madeira Islands. The figure which he give in in effect very close to that of the French author: the mural rim is not enlargen at the bane: this is therefore. not the species

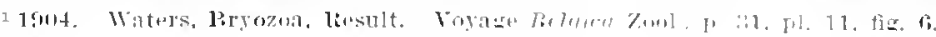

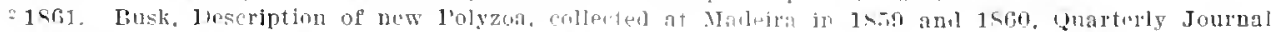

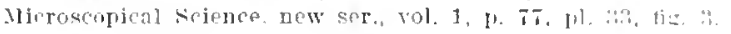


of Smitt. As the ovicell was not figured, we can not compare it with the species of Waters.

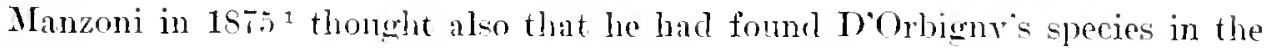
Plaisancian sands of Castrocaro. in Italy. His figure is rery similar to that of Smitt. 1872, although it will he diffieult to get an exact idea of the ovicell from it. In 1893. Neviani, ${ }^{2}$ revising the Manzoni collection, stated that Membranipore imerularis, $M$. catemutaria. and $M$. lineata of this author folm one and the same species, all appearing to hare interzooecial avicularia. Under these conditions it is evident that the Manzoni secies is different from that of DOOrbigny and also of Smitt. The paleontologist who rediscovers it will have to rename it.

Ilabitat.-Ponrtales has dredged this species off Floridla to a depth of 97 meters. Osbul'n has noted it off the Tortugas Islands from 13 to 15 meters.

It creeps over shells and Nullipores.

Alderina imbellis Hincks, 1860 , is a very rare species. It inhabits the deep waters off England (Hinck. 1s80), Demmark (Levinsen. 1894). and Norway (Norman, 1879).

ALDERINA? NODULOSA, new species.

Plate 9, fig. 10 .

Description.--The zoarium is free, milamellar, creeping over algae. The zooecia are elongated. distinct, oval, bearing inferiolly one to two projecting nod"les: the mural lin is thin at the top. much enlarged below. curved, delicately decorated with radially arranged granules. The opesiun is oral, finely crenulated. The ovicell is hyperstomial and never closed by the operculum, salient, globular', elongated. The distal septula may be replaced by three smaller septulae. The first pair of lateral septulae is very large; the two other pairs of lateral septulae are smaller and may each be replaced by two smaller ones. This arrangement of the septulae is risible exteriorly.

$$
\begin{aligned}
& \text { Neasurements. } \text { Opesia }\left\{\begin{array}{l}
h o=0.32-0.35 \mathrm{~mm} . \\
l_{o}=0.20-0.25 \mathrm{~mm} .
\end{array}\right. \\
& \text { Zooecia }\left\{\begin{array}{l}
L_{z}=0.45(2 \mathrm{nodules})-0.62 \mathrm{~mm} . \text { (1 nodule). } \\
l_{z}=0.30-0.35 \mathrm{~mm} .
\end{array}\right.
\end{aligned}
$$

Afrities.-This elegant species is quite remarkable on accomnt of its plainly. visible septular arrangement. A large septula is sometimes. without any apparent reason, replaced by two or three smaller ones closely arrangert. The long zooceim with a single inferior nodule appears to be primoserial.

On account of its nodules and its external aspect. thin species somewhat resembles Alderina solidula Hincks, 1860, in which. howerer. the septulat arrange-

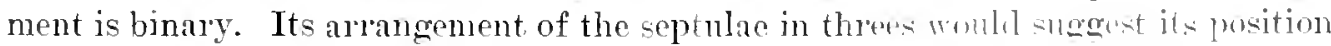
in the genus Cautoramphus Norman, 1003, but the oviculle of the promes of this genus are either unknown or endozooecial. 'The septulat arrangenent and the

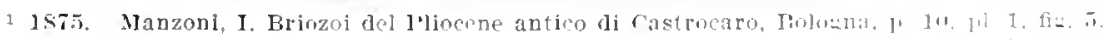

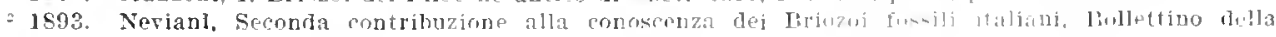

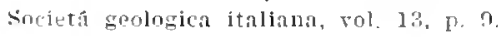


nature of its mural rim also are as in Antropora Norman. 1903 ; but speries of this genus are provided with aricularia. To be exact, it would be necessary to ereate a new genus, but as we possess only the single specimen figured, we think it prudent to await for more abundant material.

Occurrence-Wilcoxian (Bashi formation): Woods Bluff, Alabama (very rare).

Holotype-Cat. No. 63833, U.S.X.M.

ALDERINA PULChERRima, new specics.

Plate 29. fig. 1.

Description.-The zoarium is free. milamellar, creeping over algae. The zooeeia are large, elongated, elliptieal; the mural rim is broad, concave, smooth, enlarged below. The opesinm is elliptical, elongated, entire. The ovicell is hyperstomial and nerel closed by the opercular ralve, is globular, very salient, distinct from the mural rim, furrowed in front; it is formed of two calcareons lamellae of which the exterior one is of the same nature as the mural rim.

$$
\text { Mcasurements.-Opesia }\left\{\begin{array} { l } 
{ h o = 0 . 5 0 \mathrm { mm } . } \\
{ T _ { 0 } = 0 . 5 0 \mathrm { mm } . }
\end{array} \quad \text { Zooecia } \left\{\begin{array}{l}
L z=1.20 \mathrm{~mm} . \\
l_{z}=0.80 \mathrm{~mm} .
\end{array}\right.\right.
$$

This very beautiful species has no related form either fossil or living.

Occurrence--Middle Jacksonian: Wilmington, North Carolina (very rare); near Lenuds Ferry, South Carolina (very rare).

Lower Jacksonian (Moodys marl) : Jackson, Mississippi (very rare).

IIolotype-Cat. No. 63918, U.S.I.M.

\section{alderina lunata, new species.}

Plate 29, fig. 5.

Description.-The zoarinm inerusts bryozoa. The zooecia are distinct, separated by a deep, somewhat elongated, oval furrow: the munal rim is very thin distally, somewhat enlarged proximally, gramulated. The opesium is elongated, elliptical, or oral, and rery finely crenulated. 'The oricell is globular, salient, and transverse; the frontal area is in the form of a crescent and granulated like the mural rim.

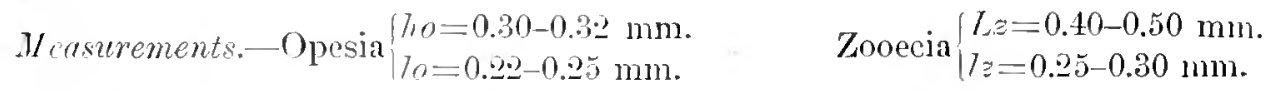

Affinities.-This speeies differs from the recent Alderina imbellis Hincks, 1860, in the less length of its oricell $(0.15$ instead of $0.20 \mathrm{~mm}$.) and its frontal area, which is in the form of a crescent instead of being rectangulan. 'These differences are insignifieant, for the micrometric measurements are jdentical, and they oceur almost within the possibilities of the habitual variations of a species. If we have created a distinct species it is because Aldering imbellis has never been found fossil, and beense such a sudden appearance in the Lower Eocene seems to us too imnsual.

A more closely related pecies is Alderina irregularis Smitt, 1872, in which the micrometric dimension a are also identical. It differs from it simply in its crescent 
form and the nonregnlarity of the area of the oricell. This is therefore an intermediate form between Alderind imbellis Hincks, 1560, and Alderina irregularis Snitt, 1Si2: perhaps it is an ancestral fossil form of those two recent species. one of which is boreal and the other equatorial.

From this example the reader may judge of the great difficulties which often aflict us in the determination of the Membranipores.

Occurenct-Lower Jacksoni:m (Mootys marl): Jackson, Mississippi (rery r'are).

Holotype-Cat. No. 63922. L.S.X.M.

ALDERINA CRASSA, new species.

Plate 29, fig. $i$.

Description.--The zoarium inclusts the radial plates of sea urehins. The zooccia are slightly elongated, di-tinct; the mural rim is very thick, convex. salient, granular. The opesium is elongated, elliptical, median. The oricell is hyperstomial.

Tariations.-We possess only the single figured specimen, which is incomplete. Many of the zooecia are regenerated. It is closely related to Membramipora perispar'sa Novak, 1877. On our specimen one zooecium with a triple mural rim has twice undergone total regeneration.

Occurrence.-Middle .Tacksonian: Eutaw Springs. South Carolina (very rare). IIolotype.-Cat. No. 63924, L.S.X.M.

\section{Genus CALlOPORA Gray, 1848.}

1S4S. Callopora Gist, List Pritish Animals IBritish Museum, Centroniae, pp. 109, 146.

1903. Callopora Norsax, Notes on Yatural History East Finmarli, Annals and Magazine Natural History, ser. 7 , rol. 11, p. 588.

Front wall entirely membranous. Marginal walls more or less thickened and crowned with spines, which may be many or ferw. Oricell globose'. of good size. commonly with a ril, across the front. Sessile avicularia with acute mandible at the bottom of the zooecium and above the ovicell or in a lateral position on one or both sides of the oral opening, or in both positions in the same species. Tsually two pairs of lateral dietellae and one distal. (Norman.)

Genotype.-C'allopora (Memeranipora) rinerta Limneus, 1 i.s.

Renge.-Santonian-Recent.

Nearly all the ovicells are provided in front with an area or more exartly with a callosity more or less granular, formed by the calcareons intelnal layer if the oricell.

This definition combines the Membremiporn Tineate group and the $1 \%$. tenurostris group of Waters, which he defined: "Ovicelle with rib: pore chambers usually one distal. four lateral ones: spines round the border. Ticarious aricularia."

$$
5.590-20-18011.1065-\ldots 11
$$


In order to separate the two groups generically one would have to be certain that the smaller aricularium of the .M. Cineata group is only interopesial. Unfortunately we have too fer specimens to make this sturly.
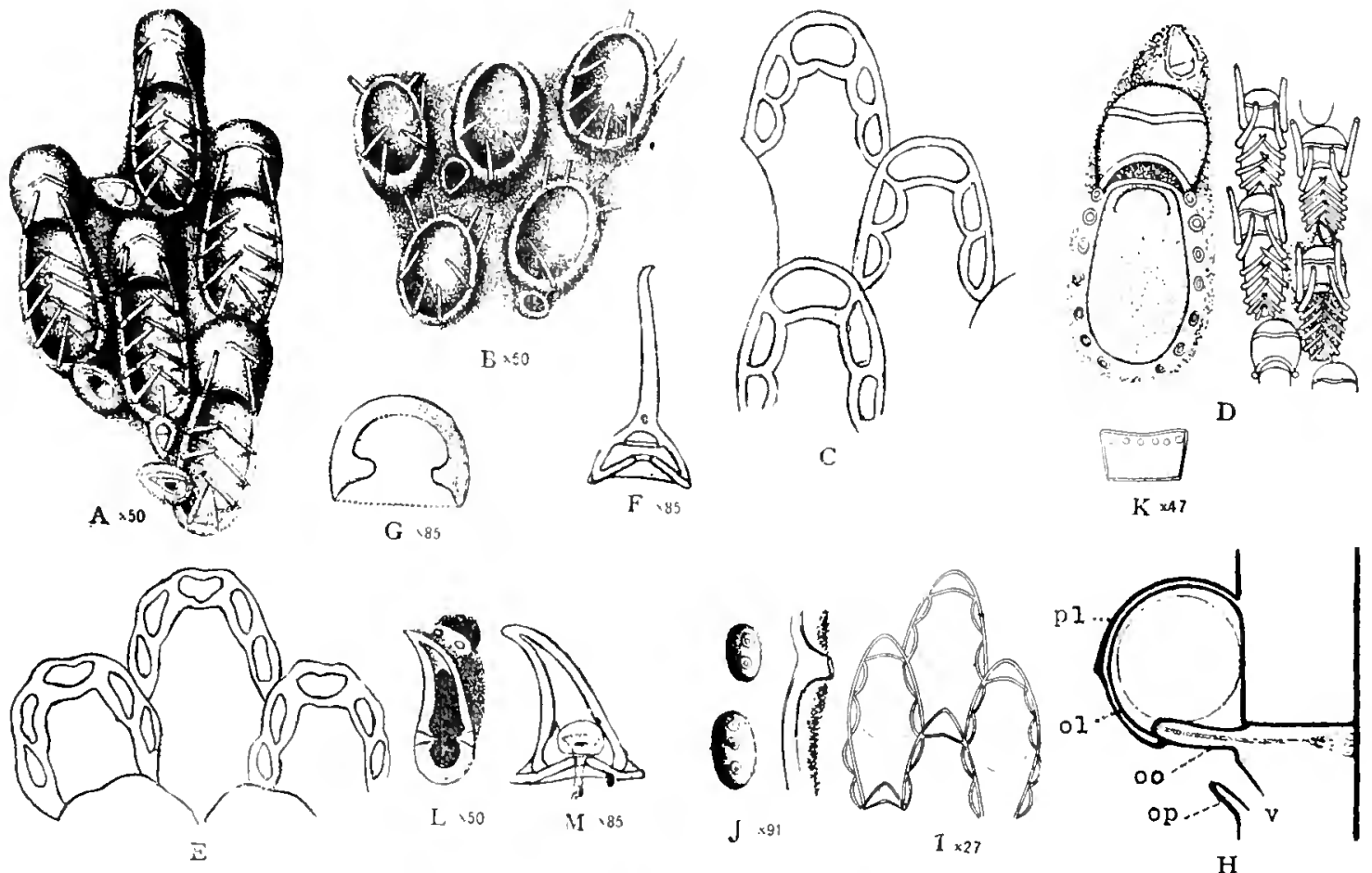

I'Ig. 3i.-Genus Callopora Griy, 1S4S.

A. Cullopora lineala Linnaens. 175. A. Zooecia with ovicells and aricularia $\times 50 . \quad B$. Ordinary zonecia, $X$ 50. (A. F. After IIneks, 1SSO).) C. Sketch showing dietellae. (Aftel Norman, 1908.)

I', E. Callopora craticula Alder, 1sī. D. Severnl zooecia with ovicells aud a siugle zonecinm furtber enlarged. (After Osburr, 1912.) E. Drawing showing occurrence of the dieteilas. Ifter Norman, 1903.)

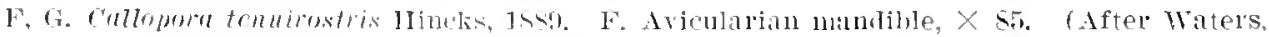
1585$.$) G. Opereulum X S5. (After V*iter's. 189S.)$

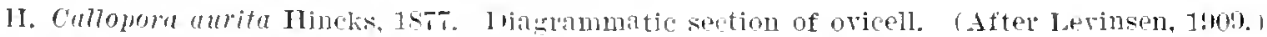

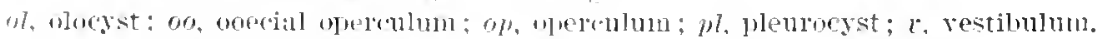

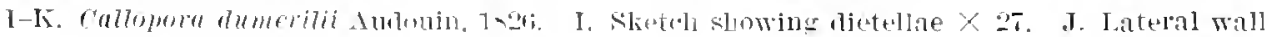

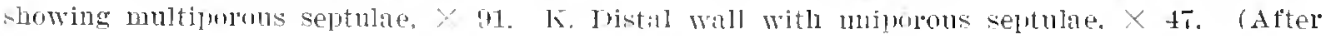
Levinseu, 1909.)

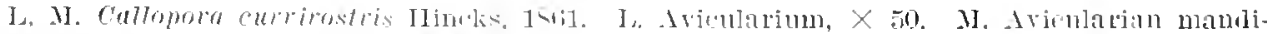

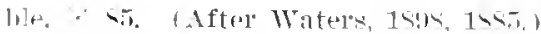

Callopora is not only one of the must important genera. but also was one of the earliest to be established. It shonld not be confused with the Paleozoic bryozom genus Callopme IIall. 1-in. for which Bassher has propused the name II altopore. 
The recent species are:

('allopora (14embranipora) Timutu Limnens, 1758.

Callopora (1/emlmanipore) eratimina Alder, 1854.

rallopora whiteavesü Norman. 1908.

callopore (Membranipora) nigmas. THinelss. 1S82.

Callopora (Membranipora) aninta Hincks. 1877.

Critopora (Membranipore) homila Mincks. 188 .

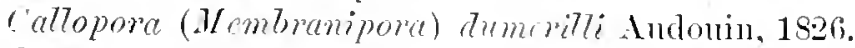

Callopora (Membranipora) catitomiensis Waters, 1898.

Callopora (Momtmanipora) temuirastris Minclss, 1880.

Callopora (Membranipora) murestris Hincks, 1861.

Callopora (Memtranipora) atrida IIincks. 1880.

Callopora (Membramipara) pluna Hincks. 1880.

The fossil forms are:

Callopora (Scmifustrina) monititcra D'Orbigny, 1852.

Callopora (Semiflustrina) inomata Dorbigny, 1852.

Callopora (11embranipora) invigitata Brydone, 1910.

Callopora (Membranipora) Tritamiea Brydone, 1906.

Callopora (Membranipora) wooderamil Brydone, 1906.

Callopora (Membranipora) conallifomis Brydone, 1910.

Callopora (Ifombranipora) callecti Camu, 1911.

Callopora (Membranipora) mordgaardiana. Canu, 1911.

Callopora (Pyriporella) amerthinoi Canu, 1911.

rallopora (Membranipora) tulicrosa Novak, 1877.

Callopora (bifustra) solca Novili. 18ti.

Callopora (Nembranipora) perieparsa Novak, 1877.

Callopora (Membranipora) jersryensis Ulrich and Bassler. 1907.

Group of CALLOPORA LINEATA.

CALLOPORA SEXSPINOSA, new species.

Plate 3. fin. 16 .

I'seription.-The zoarium incmses - Hells. The zooecia are di-tinct, sepalited by a deep furrow, elongated, oval, the pont above; the mural rim is salicut. rounded, ormamented by six large spines. somewhat wider in its proximal part. The opesium is regular, elliptical or oral. The oricell is hyperstomial. neren' closed by the opereular valve. small, globular. salient. Sometimes there is a sulll arieularium in the interzonecial angles.

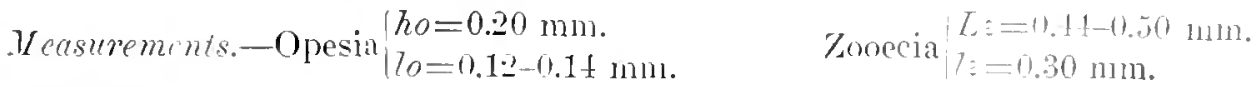

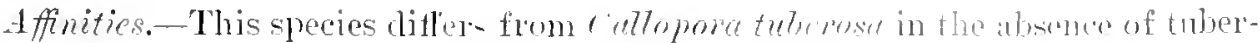
onities on the mural rim and in the prosenes of six spines.

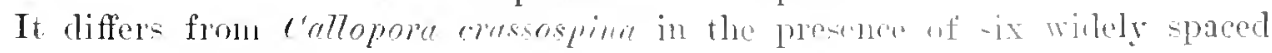
spines instead of twelve.

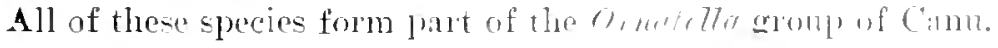


Occurance.-Midwayan (Clayton limestone): Brundidge. Alabama (very rare).

IJototype.-Cat. No. 63794, U.S.N.M.

CALlopora DUMERILII Audouin, 1826.

Flate 3. fis. 15.

Zoological bibliography.

1826. Flustra dumcrilii SAvign -Aunorid. Explication sommaire des planches de Polypes de l'Egrpte et de la Syrie pullibes par J. C. Savigny, Paris, pl. 10, fig. 12.

1559. Membranipora aumerilii Jesty. A Synonymie Catalogue of Marine Bryozoa, p. 148.

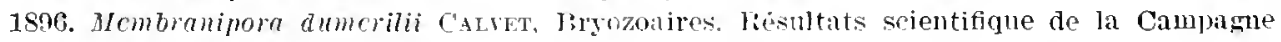
du " Caudan" dans le Golfe ite rascogne. Annales de l' Tniversite de Lyon, vol. 26. ก. 253.

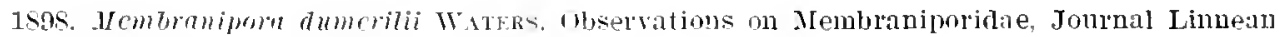
Society, London, Zoology, bul. 26, pl. 61;-6850.

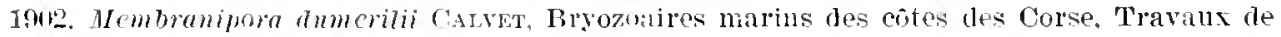
l'Institut de Znologie de l'trniversite de Nuntpellier, No. 2, Memoire No. 12, 1. 13.

1902. Mcmbranipora dumorilii Culver. Bryzonires marins de la region de Cette, Travilux re l'Institut de Zorlogie lle l'Universite rle Montpellier. Noo. 2, Memoire No. 11, p. 32.

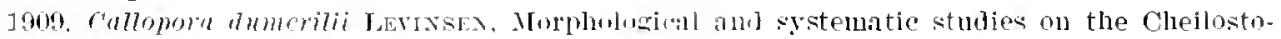
miaturs Bryozod, p. I5, pl. n, fig. 3.

Paleontological bibliography.

1559. Nembramipora ponilleti Busk, A Monuriaph of the Fossil Polyzoa of the Crag. Publications of the Paleontographical Soejety, Ionclon, vol. 14, 1. 32, pl. 3, figs. 4. 5, 6.

1S63. Rcptofustrina biauriculala IinEMER, Beschreibung ler norddeutschen tertiären Polx-

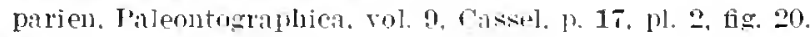

1866. Membranipora bianriculala Reuss, Die Bryozoen des deutschen Septarientlones, Denkschriften des laiserlichen Akgdemie ber Wissenschaften, Wien, vol 25, 1. IT1. (55), 11. 8, fig. 6 .

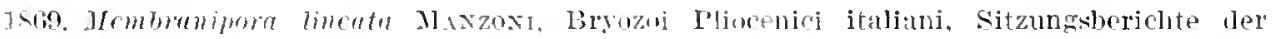
kaiserlichen Akarlemie der Wissenschaften, vol. 59, p. 10, p. 3, fig. 14 (not pl. 2. fig. 13$)$.

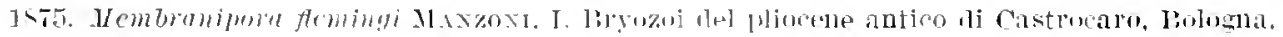
ค. 11, pl. 2, fig. 21 .

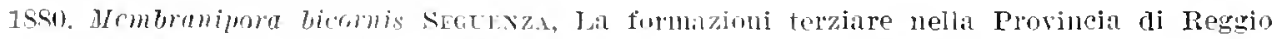
(Calabria), Mrmuires Reale Aradenia thei Lincoi, ser. 3 , vol. 6, p. 80, pl. S, fig. io. Roma.

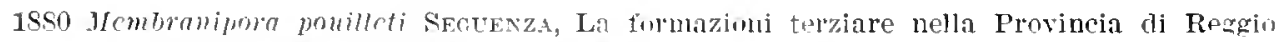

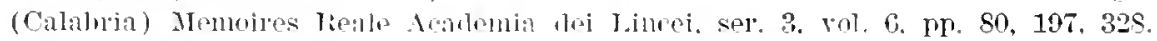

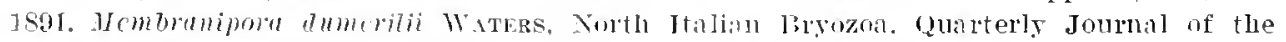
Geological Snciety of London, vol. 47, p. 12. 11. 2. fig. 4.

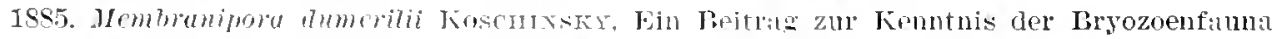

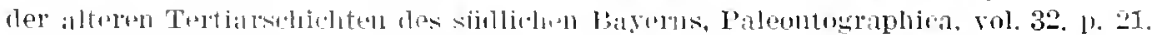

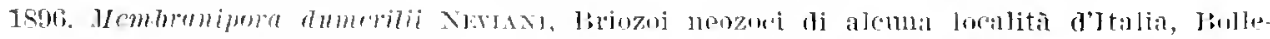

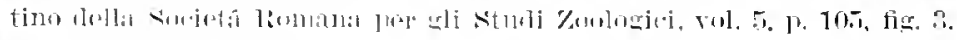

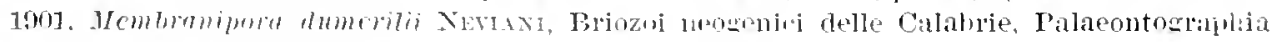

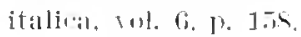

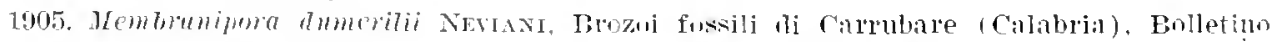

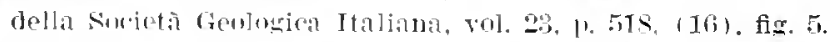

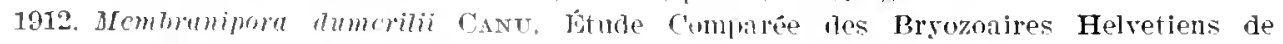

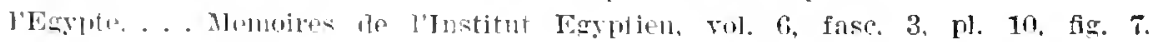


Description.-The zoarium incrusts pebbles. The zooecia are short, little distinct, separated by a narrow furrow; the mural rim is thin, projecting but little, convex, enlarged at the base; the opesium is of the same form as the zooccium, a little elliptical or nearly round. The lyperstomial ovicell, nerer closed by an opercular valve, is globular and projecting; it is ormamented with a frontal eallosity, finely granular. There are two small avicularia at the base of each zooecium; they are salient, triangular, and symmetrieal.

$$
\text { Mcasurements.-Opesia }\left\{\begin{array} { l } 
{ h o = 0 . 2 5 \mathrm { mm } . } \\
{ 1 0 = 0 . 1 5 \mathrm { mm } . }
\end{array} \quad \text { Zooecia } \left\{\begin{array}{l}
L_{z z}=0.35-0.40 \mathrm{~mm} . \\
l_{z}=0.25 \mathrm{~mm} .
\end{array}\right.\right.
$$

Occurrence-Midwayan (Clayton limestone) : Brundidge, Alabama (very rare).

Geological distribution.-Lutetian of Bararia (Koschinsky): Priabonian of Vicentin (Waters); Stampian of Germany (Roemer, Reuss); Burdigalian of (iard and of Herault in France (Collection Camu): Helvetian of Italy (Segnenza), of Frard and of Herault (Collection Canu); Zanclean of Italy (Seguenza); Plaisancian of England (Busk), of Italy (Manzoni); Sicilian of Italy (Sequenza, Neviani): Quaternary of Italy (Manzoni. Neviani) ; Miocene of New Zealand (Waters).

Habitat.-Eastern Atlantic from Madeira to Scandinaria. Mediterranean and Adriatic. Dredged at alhont 150 meters, it lives chiefly from 10 to 40 meters. It is to be noted that the recent finna of Madeira presents much relation hip to that of Florirla.

Mesiotype-Cat. No. 63718. C.S.N.M.

\section{CALLOPORA DUMERILII LATA, new variety.}

Plate 29, fig. 6.

Our determination of this recent species in a horizon so low is the more remurkable because in our large amount of material we have been able to disenver nnly a few specimens at Wilmington. much more distinct from the type and for which we are obliged to make a new rariety.

$$
\text { M. asurement. -Opesia }\left\{\begin{array} { l } 
{ h o = 0 . 2 4 \mathrm { mm } . } \\
{ 7 0 = 0 . 2 4 - 0 . 2 6 \mathrm { mm } . }
\end{array} \quad Z _ { a n e c i a } \left\{\begin{array}{l}
L_{z}=0.30 \mathrm{~mm} . \\
7 z=0.28 \mathrm{~mm} .
\end{array}\right.\right.
$$

A certain number of zurecia lave only a single aricularium placeel in front of the opesium as in the genus Ramphonotus. On our specimens there is not a single opesiun resembling its neighbor. In general the elongated zonecial are less rommon. Fol this reason we have believed that the American Jacksonian specinenonght to be separated as a variety. The differences from the recent type-species are slight, only the larger size of the opesia measuring 0.24 to 0.26 must. instracl of $0.20 \mathrm{~mm}$. being an insignificant diflerence. for which reason it is nese des to create a new species. Moreover, there is almost a complete intentity hetween our photo-

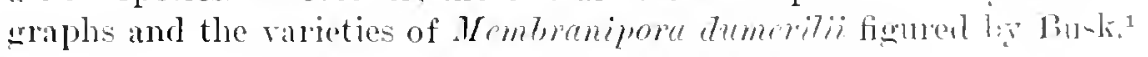

$$
\text { Crage I'olyzor, 1859, 11, a, fig. } 1 \text {. }
$$


Occurrence.-Middle Jacksonian (Castle Hayne limestone): Wilmington, North Carolina (very rare).

IIolotype.-C'at. No. 63928. U.S.X.MI.

CAILOPORA FILOPARIETIS, new species.

I'late 29 , nìg. 4.

Description.-The zoarium incrusts pebbles and Cellepores. The zooecia are elongater, distinct. elliptical, variable: the mural rim is very thin, filiform, salient, convex. The opesium is entire, medium. and of the same form as the zooccia. The ovicell is hyperstomial, never closed by the opercular valve, smooth, salient, transrerse. The avicularia are small, very pointed, nearly perpendicular to the zoarial plane appearing to be interjected between the opesia.

$$
\text { Measurements._Opesia }\left\{\begin{array} { l } 
{ h o = 0 . 4 0 - 0 . 4 5 \mathrm { mm } . } \\
{ 7 0 = 0 . 2 6 \mathrm { mm } . }
\end{array} \text { Ovicells } \left\{\begin{array}{l}
h o v=0.15 \mathrm{~mm} \text {. } \\
7 o v=0.20 \mathrm{~mm} .
\end{array}\right.\right.
$$

Affinities.-This species differ's from the recent Membranipora mucilenta . Jullien, 1882, in which the walls are very thin, by its much smaller micrometric dimensions and in the form of its mural rim.

The species having thin mural rims are not rare: they can be determined readily only if they bear ovicells and avicularia.

Occurrence.-Iower .Tacksonian (Mooul's marl) : Jackson, Mississippi (rare).

Holotype.-Cat. Yo. 63921. T.S.X.M.

CALLOPORA INGENS, new species.

Plate 29, tig. 3.

Description-The zoarim incrusts rocks. The zooecia are elongated, little distinct. separated by a very small furrow, nearly hexagonal; the mural rim is but little salient, convex, thin at the top, enlarged below. finely granulater ; the opesinm is elliptical and finely cremulated. The hyperstomial ovicell is small. globular and projects considerably. The avicularium is rery small, salient. oblicure. the point below.

$$
\text { Measurements.-Opesia }\left\{\begin{array} { l } 
{ h o = 0 . 4 0 - 1 ) . 4 4 \mathrm { mm } } \\
{ T _ { 0 } = 0 . 2 4 \mathrm { mm } . }
\end{array} \text { Znoecia } \left\{\begin{array}{l}
L z=0.56-0.60 \mathrm{~mm} . \\
7 z=0.40 \mathrm{~mm} .
\end{array}\right.\right.
$$

Afinitics.-The aricularium is placerl in a small triangular, interopesial carity. the walls of which are often distinct.

This species bears considerable resemblance to Callopora dumerili Andouin, 1826. differing from it only in its much laprer dimen-ions and the inconstancy of its small aricularia.

Occurrence-Lower . Tackonian (Mondy marl): Jackson, Mississippi (rery rare).

IIolutype-Cat. No. 639201). T.A.X.M. 
CALlOPORA CRASSOSPINA, new species.

Plate 29, fig. 9.

Description.-The zoarium incrusts rocks. The zooecia are elongated, distinct, regularly elliptical, provided with a small gymnocyst; the mural rim is convex, rery salient, ornamented with a line of large spines. The opesium is elliptical, entire. The hyperstomial ovicell, never closed by the opercular valve, is globular, projecting. and ornamented with a longitudinal carina. The avicularium is large, placed transrersally to the zooccial axis, very pointed, and has two denticles serving as a pirot.

$$
\text { Heusurements.-Opesia }\left\{\begin{array} { l } 
{ h o = 0 . 3 2 \mathrm { mm } . } \\
{ 7 o = 0 . 2 2 \mathrm { mm } . }
\end{array} \quad \text { Zooecia } \left\{\begin{array}{l}
L z=0.40 \mathrm{~mm} . \\
l z=0.30 \mathrm{~mm} .
\end{array}\right.\right.
$$

Atfinities.-The avicularia are so scattered orer the zoarium that most of the zooecia are not provided with them. At first riew this species strangely resembles Membranipora incmetans Waters, 1898. It differs from it, however, in its larger avicularium, its larger spines, and in its ovicell which is hyperstomial and not endozooecial. This is only another example in faror of the very great prudence which it is necessary to employ in the determination of the Membranipores.

Calloporr crassospina diflers from the recent Callopora craticula Hincks, 187 , in its transverse a vicularia and its greater zooecial length.

Occurrence.-Middle Jaclisonian(Castle Hayne limestone): Wilmington. North Carolina (rare).

Holotype.Cat. No. 63926, U.S.N.M.

CALLOPORA CONVEXA, new species.

I'late 29 , fig. \$.

Description.-The zoarium is unilamellar and creeps on algate. The zooecia are distinct. separated by an oral furrow, narrowed in their proximal portion; the lower part is a more or less dereloped gymnocyst, smooth and coneer; the mural rim is very thin with a slarp summit. The opesium is elongater, elliptical, or somewhat oral. The ovicell is hypertomial, small, globular. Sometine:there is an elongated aviculnrium with pointed beak.

$$
\text { Wrusurments.-Opesia }\left\{\begin{array} { l } 
{ h o = 0 . 3 0 - 0 . 3 \pm \mathrm { mm } . } \\
{ l o = 0 . 2 5 \mathrm { mm } . }
\end{array} \text { Zooecia } \left\{\begin{array}{l}
L z=0.50-0.55 \mathrm{~mm} \text {. } \\
l z=0.35-0.40 \mathrm{~mm} .
\end{array}\right.\right.
$$

Affnities.-Only a few specinens of this species have been found; nevertheless, they have appeared very interesting to us. We are not quite certain that the onercular ralre nerer closes the oricell. We are not able to classify the species in Membraniporidra in which the zooecial form is often analoguns. becaune of the presence of ariculariil.

The convex form of the zooccial and of the grinnory charanterizes this species quite well.

Occurrence-Mildle Iacksonian (Castler Hilyne linestone): Wihnington, North Carolina (rare).

Ilolotype.Cat. No. 6992-5. T.S.X.MI. 
I'lite 29, fig. 2 .

187т. Membranipra anrita Ilsces, on British Polgzon, Amnals and Magazine Natural Histoly, sel. 4, rol. 20, 1). 213.

1SS0. Jembranipora anitu Hncks, Jiritish Marine Polyzoa, p. 159, pl. 21, figs. $5,6$.

1894. Membranipora aurita Levissex, Mosdyr. Zoologica Danica, Hefte 9, p. 59, pl. 4, figs. $31-3 s$.

1902. Membranipora aurita Canet, Fryozoaires des côtes de Corse. Travaux de loInstitn de Zoologie de l'Universite de Nontpollier, ser. :-, Memoire 12, 1\% 34.

1909. Hombrawipora aurita I.Evissfx. Iorphological and systematic studies on the Cheilostomatous Iilsozoa, P. 150. [1. 9, fig. 4.

1912. Membranipora aurita Osburs, 'The Bryozon of the Woods Hole lierion, Bulletiu Bureau Fisheries, vol. 31. 1\%. 230 , 11. 223, fig. :37.

$$
\text { Mersurements.-Opesia }\left\{\begin{array} { l } 
{ h 0 = 0 . 2 0 - 0 . 2 5 \mathrm { mm } . } \\
{ 1 0 = 0 . 1 0 \mathrm { mm } . }
\end{array} \quad \text { Looecia } \left\{\begin{array}{l}
L_{L} z=0.25 \mathrm{~mm} . \\
1 \approx-0.17 \mathrm{~mm} .
\end{array}\right.\right.
$$

Aftinities.-Only the single figured specimen has been found and unfortunately it is incomplete. The frontal of the ovicells is destroyed and the avicularia are inconstant. The think. however. that our determination of the species is correct. Our specimen is tulmlar, as it grew about a small alga at a bifurcation. Conceming this method of growth, Osburn wrote: "Zoarium incrusting, usually on shell, but often on algae. . . on the stems of algae the zonecia are generally irregular and the cells sometimes crowded."

The zooecial micrometric dimensions correspond exactly with those in Levinsen"s finure. The opesial dimensions are very cloce to those which nay be measured on the figne given by Ilincls.

In the ricinity of the two areal spines thele is a contuction of the opesimm. The same characteristic may be observed in Osburn's figure.

On many zooceia we have observed mall ariculinia in the same position as shown in the published figures. but they are not constant. They appear a little larger in the lateral portions of the zoarium. It thus appears rery difficult to find any important differences beween this fossil form and the recent $1 /$ cmbranipora aurita Hincliss.

This species has hitherto nerer been found in the fossil state. and indeed. it was only recently discovered by Osburn in the Irest Atlantic.

Oecurreme.-Middle Jacksonian (C'atle Hayne limestone) : Wilmington. North Carolina (very rare).

Habitat.- Nortl, Sea: Ofl England and Denmark in the English Channel. Mediterrancan. Eastern Atlantie: Azore Ishands. West Atlantic off the coast of the United States.

It lives at depths from it to 34 meters. Howerer, at the lzores it has been dredged at a depth of 130 meters.

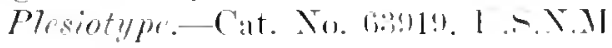


Group of C.ALLOPORA TENUIROSTRIS.

CALlOPORA CUCULLATA, new species.

l'late 1t, figr. 1 .

Description.-The zoarium incrusts a species of Idmomu. The zonecia are elongated, distinet, elliptical; the mural rim is salient, flat. granular, very thin at the top, enlarged below. The opesium is elliptical. The hyperstomial ovicell nerer' closed by the opercular valve, globular, and salient, exhibits a frontal triangular area of greater or less size. The aricularia are interzooecial. dispersed over the zoarium, large, without pivot. and quite acuminate.

$$
\begin{aligned}
& \text { Measurements.Opesia }\left\{\begin{array} { l } 
{ h o = 0 . 2 0 - 0 . 2 4 \mathrm { mm } . } \\
{ 7 \sigma = 0 . 1 6 \mathrm { mm } . }
\end{array} \quad \text { Zooecia } \left\{\begin{array}{l}
L=0.32-0.36 \mathrm{~mm} . \\
l z=0.20 \mathrm{~mm} .
\end{array}\right.\right. \\
& \text { Avicularia }\left\{\begin{array} { l } 
{ \text { Lav } = 0 . 3 0 - 0 . 3 6 \mathrm { mm } . } \\
{ \text { tax } = 0 . 1 6 \mathrm { mm } . }
\end{array} \quad \text { Ovicells } \left\{\begin{array}{l}
h o v=0.14 \mathrm{~mm} . \\
\text { tov }=0.08 \mathrm{~mm} .
\end{array}\right.\right.
\end{aligned}
$$

Affuities.-The ovicell is formed of two calcareous lamellae: the interior lamella is formed of an olocyst iclentical with the olocyst of the mural rim; the superior lamella is a cover like a hood but incomplete and leaves the triangular area referred to above. The size of this area is quite rariable.

In its ovicell this species resembles Callopora aurita Hincks, 1877, considerably, but it differs in its greater zooccial length, and its interzoecial avicularia are as long as the zooecia themselves.

Callopora cucullata differs from $r$. tenuirostris Hincks. 1880 . in the triangular area of its ovicell and in its smaller dimensions.

Occurrence.-Lower Jacksonian: $3 \frac{1}{2}$ miles southeast of Shell Bluff post office. (reorgia (very rare).

IIolotype.-Cat. No. 63849. U.S.N.M.

CALLOPORA STIPATA, new species.

Plate $t$, fig. 1.

Description.-The zoarium incrusts shells. The zooecia are elongated, distinct. separated by a deep furrow; the mural rim is flat, very finely striated, mule ealarged at the base; the gymnocyst is very small and inconstant; the opesium is oral, very finely denticulated. The ovicell is small. globular, smooth, saljent. The interzooecial avicularia are large, very elongated, fusiform or elliptieal with two lateral denticles.

$$
\begin{aligned}
& \text { Measurements.-Opesimm }\left\{\begin{array}{l}
h_{0}=0.18 \mathrm{~mm} . \\
l_{0}=0.13 \mathrm{~mm} .
\end{array} \quad \text { Zooecia }\left.\right|_{z=0.30-0.36 \mathrm{~mm} .}\right. \\
& \text { Arienlaria }\left\{\begin{array}{l}
\text { Lav }=0.24-0.36 \mathrm{~mm} . \\
\text { lave }=0.12 \mathrm{~mm} .
\end{array}\right.
\end{aligned}
$$

Affinities.-This species is very characteristic. The ariculinia arre grouped in distinct but irregular lines: they appear to safeguard the zonecin which they often entirely surround.

Occurrener.-Midwayan (Clayton limestone): Wroll at Brunclilge. Malama (very lare).

Holotype.-Cat. No. 6379.. T.S.N.M. 
CALLOPORA TENUIROSTRIS Hincks, 1880.

Plate 20. figs. 10. 11.

1879. Ncmbranipora Flomingi Waters, On the Bryzon of the Bay of Naples, Annals and Magazine of Nitural Ilistury, sel. 5, rol. 3, 1) 122. pl. 13, fig. 2.

1850. Membramipora tcmirostris, IInNcxis, Genelal History of the Marine Polyzoa. I. Madeinan Polyzon, Amuals and Magazicie of Natural History, ser. 5, rol. 6 , p. 70, 11. 9. fig. 3 .

1855. Membranipora tiluirostris Whass, On the nse of the avicularian mandible in the determiuation of Cheilostomatoms Brrozoa, Jommal Royal Microscopical Society, ser. 2, vol. 5, p. 14, fis. 41.

1957. Hcmbranimora frmimstris Inscks. Polyzoa of the Arliatic, Anuals and Magazine of Natural History, ser. 5, rol. 19, 1. 314.

1891. Ucmbranipma tcnuirastris WATlss, North Italian Bryozoa, Quarterly JournaJ of the Geological society of Jundon, vol. 47. n. 11.

1899. Jembremipora temirostris Waters, Observations on Membraniporidae, Jourual I innean Society. Lomion. Zoology. vol. 26, p. 695. pl. 47, fig. T.

1909. Crassimarginatella tenuirostris Nonuan, The Poiyzo: of Mladeira and neighboring islands. Journal Linnean Suciety. Inndon, Zoologr. vol. 30, P. 2SS.

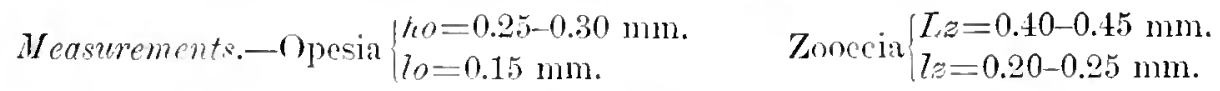

Noriuan has classified in the Crassimarginata group all of the Membranipores litving an interzooceial aricularium without consideration of the function of the opercular valve which closes the ovicell in frammolla crassimarginata Hincks. The Crassimarginath aroup and Tenuirostris group are therefore quite distinct as Waters has clearly shown in 1895.

The frontal callosity of the oricell is due to the incomplete development of the upper calcareous layer (probably a pleurocyst).

This species seems quite rariable. From dredgings at Oran (Algeria) two sorts of specinens hare been obtained which from all their characters may be classed as this species. The first is large and vigorons, the zooecial dimensions being $(1.40 \mathrm{~mm}$. by 0.60 mm. In analogons rariation exists in the classic Helvetian falums of Touraine. The others ale smaller and measure 0.40 by $0.30 \mathrm{~mm}$., dimensions which commpond to those in Waters's figule and which ought to be considered as normal. (Jur specinens are simply a little narrower.

The occurrence of this species as a fossil in America is entirely natural. It lives at the prescnt time at Macloisa where the famm is close to that of the Gulf of Mcxico. It has been fomm fossil in the Priabonian of Vicentin which is about the horizon of the Ameriean . Tacksonian.

I jonre 11 seems to lepresent the same species in the ricinity of the ancestrula, indeed only the avioularia are a little rifferent.

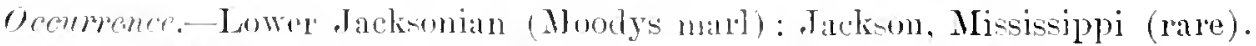

IJ abitat.-Moditerunean and deliatic. East Lthantic: Madeira Islands. East Pacific: Qunen Charlotte Istanch. It Naples, the species lives at depths langing flom 0 to tif neters. 
Geolonferel distribution.-Priabonian of Ticentin (Waters); Hehretian of Touraine (collection Camu).

Plesiotypes.-Cat. No.639-2. U.S.X.M.

CAllopora VICINA, new species.

Plitte S1, figs. 2, 3.

Description.-The zoarium incrusts bryozoa. The zooecia are elongated, distinct, elliptical, or oval; the mural rim is quite salient, flat, very finely granular. The opesium is of the same form as the zooecium. The avicularia are distributed irregularly over the zoarium between the opesia; they are oblique and their anterior part is embedded in the mural rim. whereas their point projects considerably above the latter.

$$
\text { Measurements.-Opesia }\left\{\begin{array} { l } 
{ \text { ho } = 0 . 3 0 \mathrm { mm } . } \\
{ 7 0 = 0 . 1 6 \mathrm { mm } . }
\end{array} \text { Zooecia } \left\{\begin{array}{l}
T_{z=0.40 \mathrm{~mm}} \mathrm{~m} . \\
7 z=0.26 \mathrm{~mm} .
\end{array}\right.\right.
$$

Tariations.-The mural rim is r:urely regular; more often it is a little enlarged at the base. The avicularia often exhibit two lateral denticles serving as a pirot for the mandible which can thus easily be placed between the mural rims, which are always separated by a deep furrow. On our specimens there are numerous zooccia with double mural rins. which have undergone total regeneration.

Affnities. - This species is really close to Callopora tenuirostris Hincks, 1880, but differs from it in its much smaller avicularia. It appears to be intermediate between the Callopora lineata group : ind the $C$. tenuirostris group.

Ocourrence.-Vicksburgian ("Chimney rock" of Marianna linestone): One mile north of Monroeville, Alabama (common).

Cotypes.Cat. No. 6t28t, U.S.N.MI.

CALLOPORA (?) TUBEROSA, new species.

Plate 8. fig. 14.

Deseription.-The zoarinu is free, nnilamellar. The zooccia are little distinct, subcircular; the mural rim is salient, rery thick, convex, and bears 6 to $S$ large tuberositis entire or hollow. The opesimin is oval, a little crenulated. The oricell is hyperstomial. On the gymnocyst there are one or two large, projecting a vicularia in which the orifice, turned toward the opesinm, is perpendicular to the zonecial plane and consequently hardly visille. Between the zooecia there are long. thin a ricularia without a pirot.

Affirities. - This species is quite an unusual form and we have been mullole to

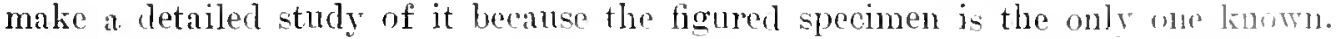

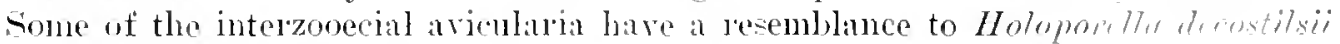
Audouin, 1826, but are provided witls a pirot.

Occurrence-Widwayan (Clayton limestone): One mile west of Fint riaines. Georgia (very rare).

Holotype.-Cat. No. 637\%?. T.S.X.Il. 
CALLOPORA MUNDULA, new species.

Plate 20, fig. 12.

Dceription.-The zorium is lilamellar. free. composed of large. Aat fronds; the two lamellae are back to back and inseparable. The zooecia ale large. elongated, distinct. separated by a deep furrow: the musal rim is thin distally, enlarged proximally, rounded or angular. The opesium is regular, elliptical. elongated. 'The ovicell is globular, salient, smooth; it is hyperstomial and opened in a special vrifice above the operenlum. The aricularium is frontal, large. elliptical with two lateral denticles.

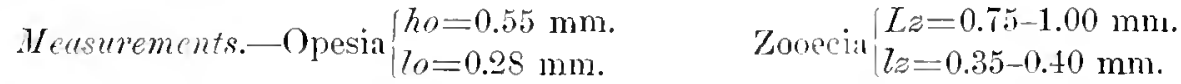

Affirities.-This neat and elegant species appears to be the largest species of r'allopora. In general aspect it approaches Grammella transereat: it differs from it. in the longitudinal and non-transverse orientation of its aricularium and its bifoliate and not incrusting zoarium.

Occurrence.-Lower .Tacksonian (Moolys marl) : Tackson. Misi--ippi (rare). Ilototype.-Cat. No. 63928, U.S.N.MI.

\section{Genus AMPHIBLESTRUM Gray, 1848.}

1848. Amphiblcstrum Gray, List Britisl Animals Firitish Museum, centroniae, pl. 110, 146. 1903. Amphiblestrum NondAN, Notes Natura History Gast Finmark, Annals and Magazine Satural IIistory. sel. 7, vol. 11, p. 5.,

Hinder portion of the area corered witle a culcareous crust. In front of this a considerable portion of the area. trically trifuliate. hut sometimes semielliptical or subrotund, is covered only hy a thin membrane, at the distal extremity of which is situated the simple oral opening. Marwin of zonecium thickened. often granulated. sometimes bearing a pair (or morc) of lateral spines found in young specimens. Reproduction by means of prominent hyperstomial ovicells never elosed by the opereulum. Sessile aricularia often present, sometimes one. sometimes two, on the hinder portion of the zooeciun. Dictellas, two pairs of lateral and one distal. (After Normuan.)

Genotype-Amphiblestrum. (Memtoranipora) fimingii Busk. 1852.

liange.-Senonian-Recent.

This is in part the Mcmlraniporaficmingai group of Waters which he defined as follows: "Ovicells with more or less arched area on the front: usually lamina over" considerable part of the front. Pore chambers."

The opesim often appears trifoliate. The distal part is ocempied by the opercular valve for which the opesial contraction scrves as a pirot. 'The proximal portion, which is the larger, is oceupied by the ehitinons part of the eryptreyst on which the parictal museles are inserted. The calcareous eryptocyst. the chitinons eryptocyst, and the opercular valve form a structure in dired contact with the ectocyst. The entire structure is covered hy a thin ectocyt united at the upercular vallye which is thus thickened and often bordered with a celerite. Between the chitinons 
eryptocyst ant the ectoryt is the hypostege or hydrostativ zooceial chamber. We do not yet know whether the hypostege contains sea water as in the compensation sack of other Cheilostomata ar was filled with the fluid of the general body carity.
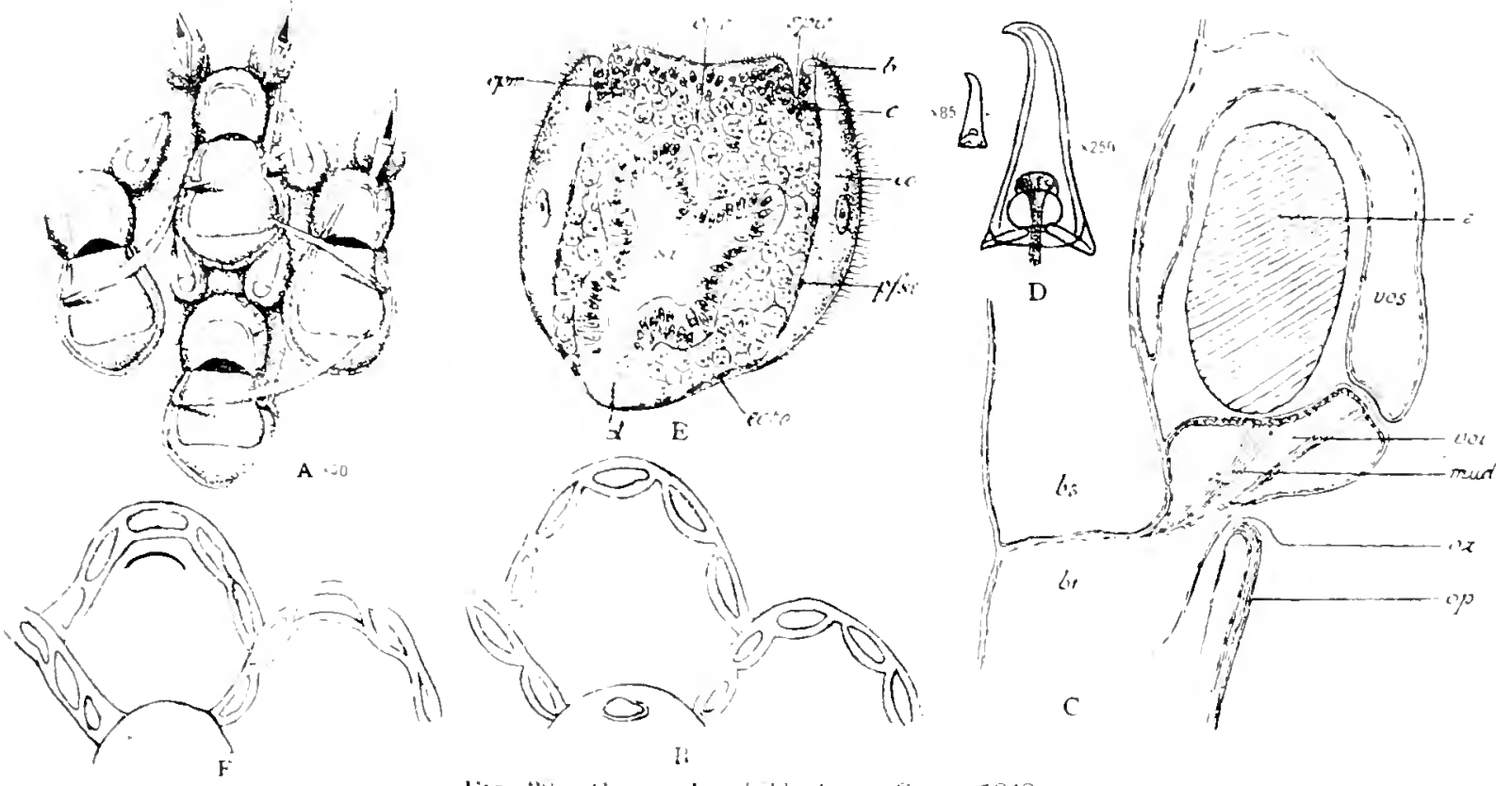

I:

Fic. :

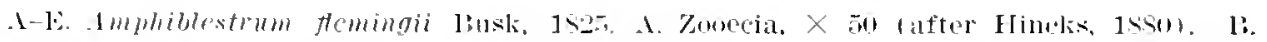

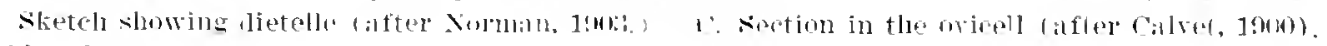
Ui. inferior brozooid.

bs, superiul hrozooid. "il: operculum.

co. coromma.

"), zooecial orifice.

c. embryo.

mud, dilator muscle of incubition colity.

si, internal sack.

-oi, inferior oricell resicle.

ivs. superior ovicell resicle.

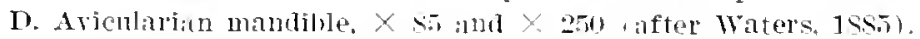

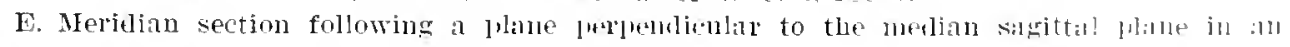

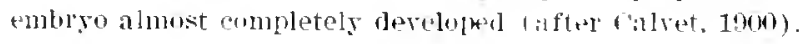

b. cellules of the npper resicular collar.

coto, ol'al ectoderin.

$c$, mintle.

d, tampen of the internal sais:

$\mathrm{rpm}$, mesoderm thickening.

onc, central nerroms wistn uf the enthryo.

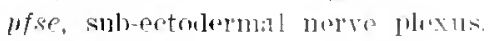

spa, palial furrom.

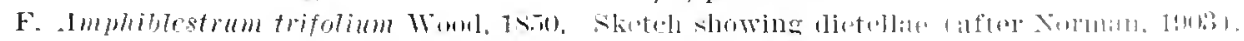

This organization is therefore ildentical with that of the Flectrinilate of the other Membraniporae. of the Flu-tritile, ate. The only ditlerence is that the

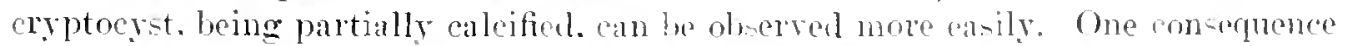

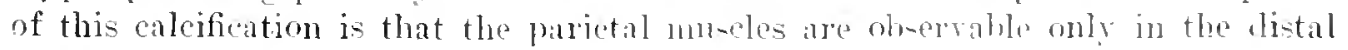
part of the zonecia. 
The oricell is widely open above the operculum. It is formed of two calcareous lamellae. the upper of which being incomplete, limits the frontal area or callosity as in the genus Callopora Gray. 18ts. But we insist it is also entirely covered by the mombrurous ectocyst, quite as in all the other Cheilostomata.

The relations of this genus with Callopom are very great. In the latter the aricularia are also interopesial or interzoocial. and they have the same form and arrangement. The rarity of the spines and the partial calcification of the cryptocyst are the only characters of differentiation.

The recent species belonging to the genns are:

A mpliblestrum (Membremipora) fiemingii Busk, 18.2.

Amphiblestrum. (Membranipora) trifotium Wood, 1850.

Amplibtestrum. (Membranipora) arfented MacGillivay, 1868.

Amphitzestrum (Membranipore) umbonate Busk. 155?.

The fosil species are:

Amphiblestrum (Reptoflustrelle) hetropram (iabb and Holn. 1sfie.

Amphiblestrum. (Membranipore) antepites Birdone. 1910.

Amphiblestmom hameri Cann. 1911.

Imphiblestrum coriense Machillivray. 1595.

A MPHIBLESTRUM HETEROPORA Gabb and Horn, 1862.

Plate 1, figs. 11-13.

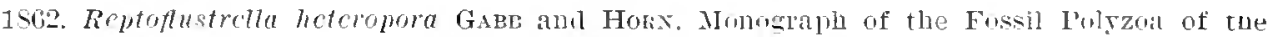
Secondary and Tertiary formations al Vorth tmelica. Iommal of the Acalemy of

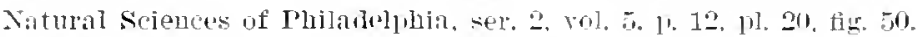

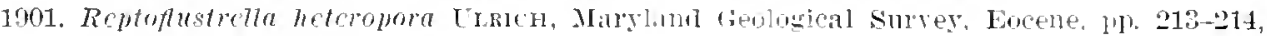
11. 60, figs. S. 9.

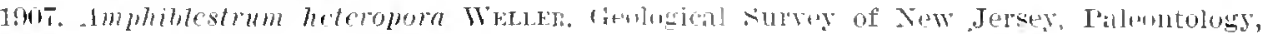
vol. 4, 1, 2393, pl. 29, figs. 1t-16.

Deseription.-Colony inerusting in imparular patches. Cellules in a single layer. placed with but little regularity. but with a tendeney to radiating lines; elongate, acuminate anteriorly, broadly truncate behind. Opening shbtriangular, with the sides convex, often approaching an oval in very long cellnles. Surface regularly convex, bordered anteriorly and daterally by a slightly elerated. romded edre. nsually becomine olsolete as it approaches the proximal end of the cellule. Special pore placed in advance of the opening. small and rume. To orarian resicles were observed. Old cellules are cloced over hy a continuation of the -urface wall totally obliterating the aperture. In this catse the "special pore" is also gen-

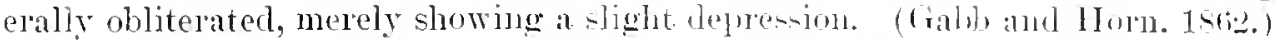

The Eocene specimens are contro in illpeatrance than the Cretaceons form of the snecies of which the writer has a mmber of excellent cxamples. They differ

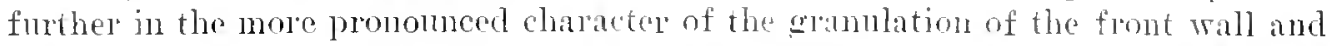
opesial margin. the Cretaceous form leing alnort smoth: in more frementy assuming a rhomboidal form of zoreciun: and in the relatively -naller size of the ope-inn and larger avicularia. Cucullate onecial ber prominent but otherwise 
similar to those of Membremipore spicutose, occur not infrectuently mpon the Cretalceous specimens but are wanting on the Eocene material in hand. When these occur they take the place of the avicularinu which otherwise ocenrs invariably on. or just above, the upper rim of the zonecimm. (Ulrich. 1901.)

Oceurence-Cretaceons (Vincentown): Mullica IIill and Vincentown, New Jersey (common).

Lowest Eocene (BrTozman bed at base of Aquia formation) : Upper Marlboro, Maryland (rare).

\section{AMPHIBLESTRUM PRODUCTUM, new species.}

Plate 4. figs. 2, 3 .

Description.-The zoarium incrusts rocks and shells. The zooecia are smill, very clongated, distinct, often with a small gymnocyst: the mural rim is salient. being enlarged below into a concave cryptocyst nearly as long as the opesium. The opesium is small, anterior, elliptical, entire. The hyperstonial ovicell, never closed by the operculum, is elongated, rery salient, and has a frontal carina. The aricularia are narrow, long, fusiform, pointed. and slightly projecting at the top, without pirot.

$$
\begin{aligned}
\text { If casurements.-Opesia } & h o=0.15 \mathrm{~mm} . \\
7 n=0.10-0.12 \mathrm{~mm} . & \text { Zooecia }
\end{aligned} \mid \begin{aligned}
& L_{z}=0.35 \mathrm{~mm} \\
& 7 z=0.20-0.25 \mathrm{~mm} .
\end{aligned}
$$

Tarintions. affinitio.-The length of the avicularia is rely variable: they are frequently primoserial: their mandible must be triangular. The ovicell has no callosity, but is ornamented with a longitudinal keel. This change in ornament has no generic importance.

The zooecia hare a little resemblance to Amphiblestrum curvatum, but the present species differs from the latter in its straight aricularia.

Oceurrence-Midwayan (Clayton limestone): One mile rest of Fort Gaines. Georgia (rare); Luverne. Crensham County. Alabama (rare).

Cotypes.-Cat. Nos. 63796.63797. T.S.X.M.

\section{AMPHIBLESTRUM BIPOROSUM, new species.}

\section{Plate 29, figs. 13, 14.}

The zoarim incruts shells. The zooecia are small, wile. prifornn, and liwtinct; the cryptocyst is enncave and as long as the opesium. The opecium is anteriol, somemhat trifoliate. The ovicell is hypertomial and nerer cleced by the operculum. Below earh zomerium there are two small imple aricularia. -lightly projecting, ronnd or elliptical. irregularly placed, learing two popes on the fowile.

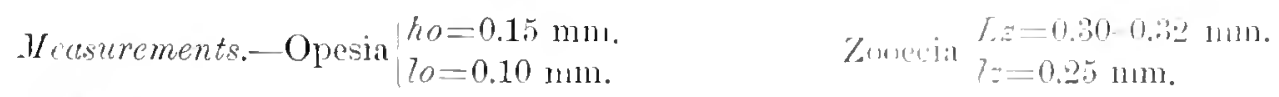

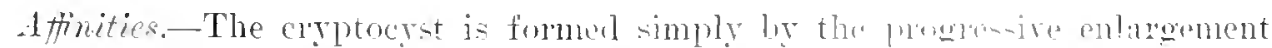

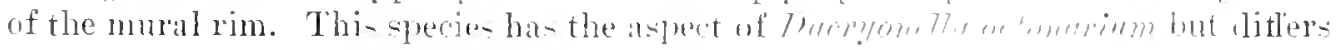


from it in its hyperstomial ovicell. It is the only species of Amphiblestrum prorided with round avicnlaria.

Ocourrence.-Middle .Tacksonian: Lemude Ferry, South Carolina (very rare). Holotype.-Cat. No. 63929, U.S.X.M.

AMPHIBLESTRUM FLAMIEUM, new species.

Plate 29, fig. 15.

The zoarium incrusts rocks. The zowecia are clongated. distinct. distended. and have a small narrow cryptocyst; the mural rim is thin, salient, complete, encompassing a concave cryptocyst shorter than the opesinm. The opesium is oval or elliptical. The ovicell is globular, salient, hyperstomial. nerer closed by the operculum. The a vicularia are interzooecial. much elongated, thin. and sinous in front like a fume, with a very small canal serring to lodge the mandible.

$$
\begin{aligned}
& \text { Heasuements.-Opresia }\left\{\begin{array} { l } 
{ h o = 0 . 2 0 - 0 . 2 5 \mathrm { mm } . } \\
{ 7 0 = 0 . 1 5 - 0 . 2 0 \mathrm { mm } . }
\end{array} \text { Zooecia } \left\{\begin{array}{l}
L z=0.50-0.60 \mathrm{~mm} . \\
I z=0.30-0.35 \mathrm{~mm} \text {. }
\end{array}\right.\right. \\
& \text { Arienlaria }\left\{\begin{array}{l}
\text { tav }=0.40 \mathrm{~mm} \text {. } \\
7 a v=0.15 \mathrm{~mm} .
\end{array}\right.
\end{aligned}
$$

Affinities.-The cryptocyst is rery valiable in this specics; some zonecia are mprovided with one and resemble those of Cullopore Gray. 1848. The relations between this genus and Amphillestrum Gray. 1848. are recognized as having been very close.

The ovicell on our specimens is onnamented with neither a keel nor a callosity. The affinities of this species with Calloport tenuirostris Hincks. 1880, a re very great, but it differs from the latter in the preence of a cryptneyst in the nuch smaller orifice of the avicularium and in the much larger zooecium.

It differs from lmphithestrum patens in the alisence of a gymnocyst, in the complete mural rim and in a long distal canal in the a ricularium.

Occuprence-Widdle Jacksonian(Castle Hayne lime-tone): Wilmington. North Carolina (rare).

Molotype.-Cat. No. 699930, T.R.X.M.

\section{AMPHIBLESTRUM PATENS, new species.}

Plate 3 . figs. 1-3.

The zoarium incrusts shells. The zorecia are distinct. lightly elongated, wide. often having a small eymnocyst the mural rim is enlarged haterally and incomplete proximally: the cryptocyst is a little concare. distinct from the mural rim. gramular. The opesium is terminal, elongated, oral. finely crenulated, with a straight proximal bordcr. The oricell is hyperstomial, never closed by the operculum. The avienlaria are interomerial, olongaterl. fusform, wite, with a short distal, small canal: the pirot is formed liy two lateral denticles. The ancestrula j= a small. ordinary zonecium. 


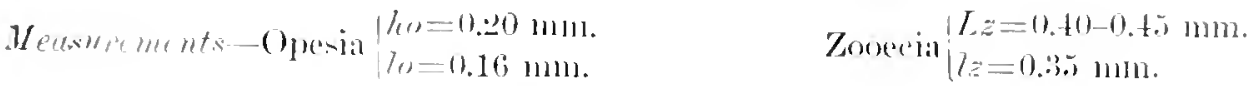

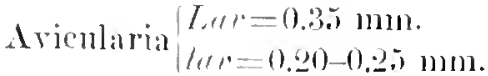

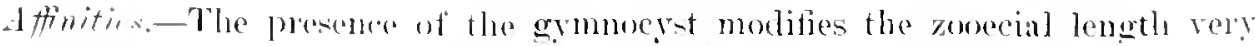

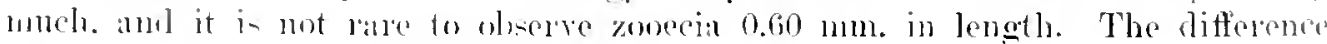

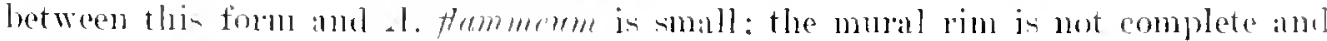

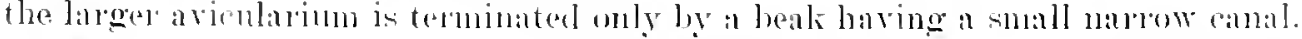

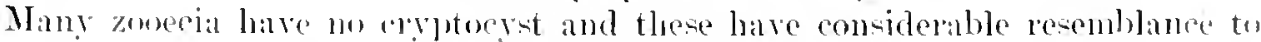

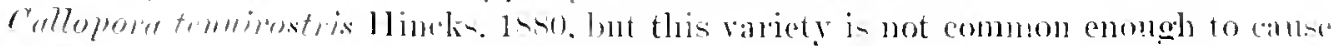

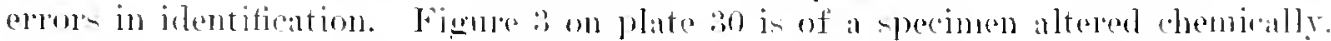

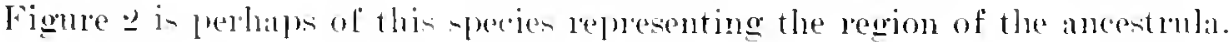

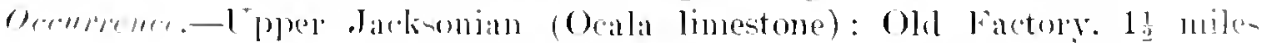

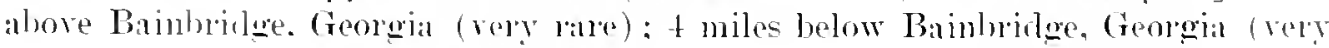

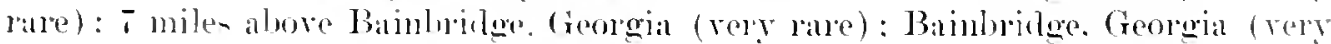
rave).

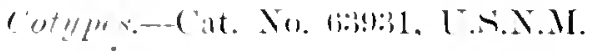

\section{AMPHIBLESTRUM ORBICULATUM, new species.}

I'lite: :B\%, fin. 4.

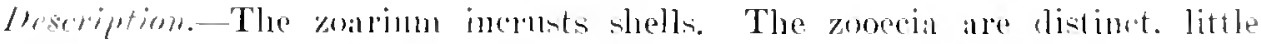

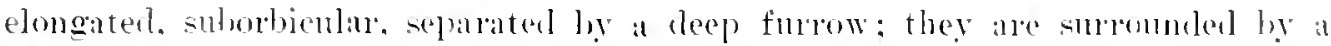

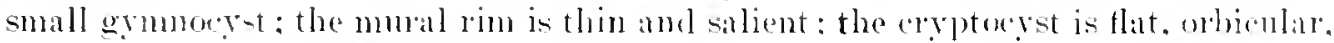

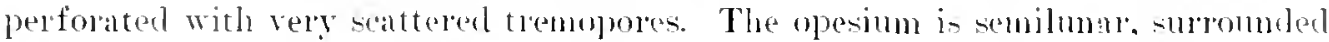
by a salient peristome, the ristal part of which bears from + to ti spines. The oricell is hyperstomial. globular and silient: it opens above the operenlum ly a special orifice. The small aricularia are lare, interzooecial. and triangulall. "Theres alle two pars of lateral dietellae.

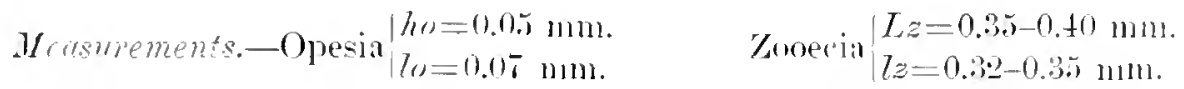

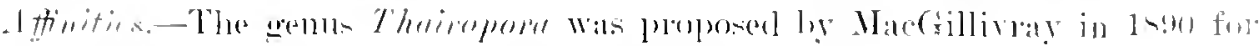

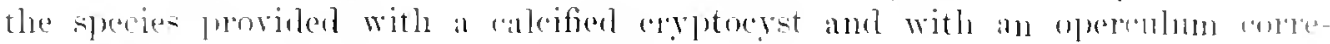

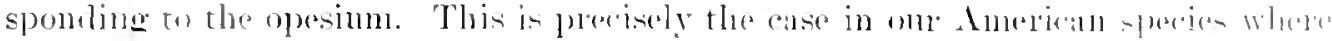

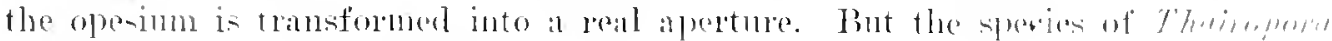

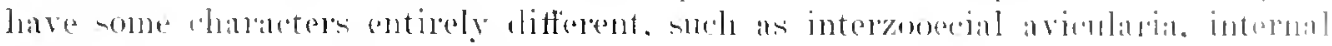

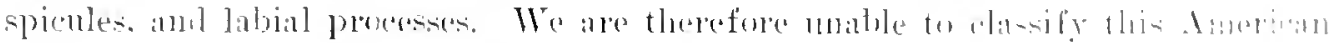
spures in that wentus.

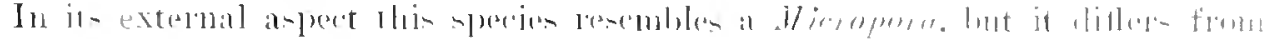

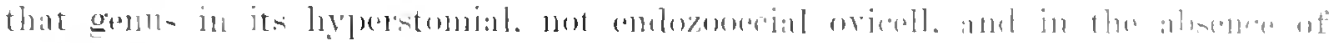
(1)p-inles.

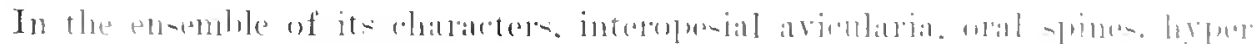

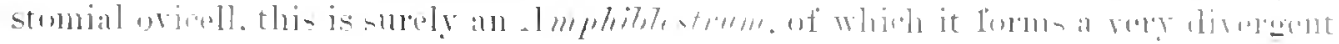


type on account of the transformation of the opesinm into an aperture ams of the opercular value into a true operominn.

Within the broken wicells there ane spines. This is an absolute imponibility. Gne must therefore suppose that the spines are reformed after the dentruction of the oricell. This destruction is frepuent evelywhere in the bryzon after the expulion of the latrae: the animal economizes its calrapace in this way.

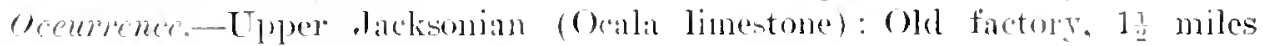
abore Painbrialge, Georgia (very riae).

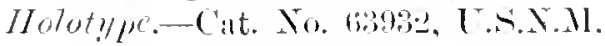

\section{AMPHIBLESTRUM CURVATUM, new species.}

Inlate -1. fim. 4.

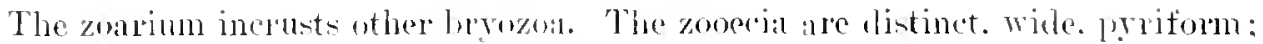
the cryptocy is comalve, finely granular. shorter than the opesimm. The operium is

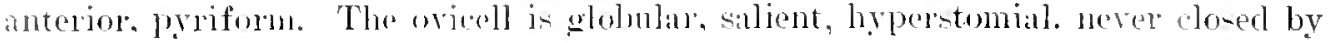
the operenlum, ormanented with a large frontal, gramular allosity. The avieu-

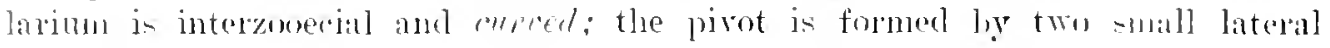
lenticlen.

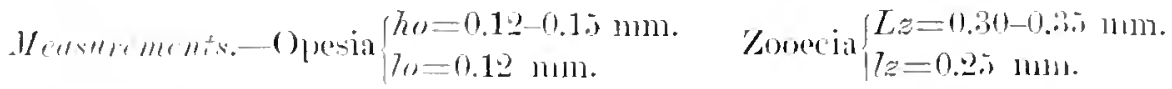

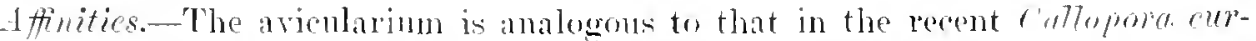

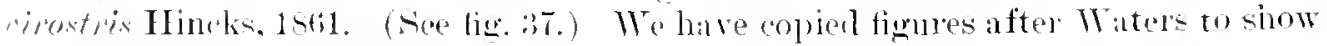

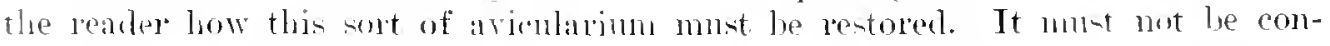
founderl with the onyehocellatium liaving a membranoms expansion. The paleontologist is always obliged to rompare the fossil vestiges with similat orwan of the recent spereise.

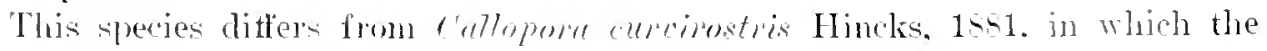

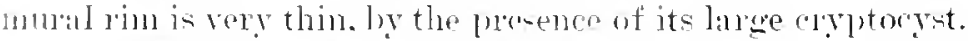

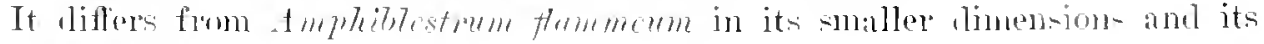
amperlaticulatia.

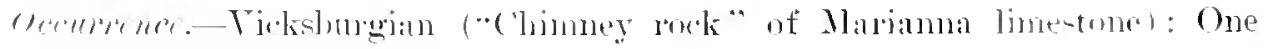

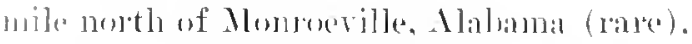

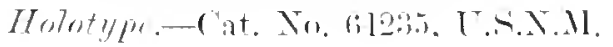

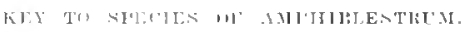

D?

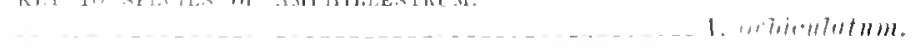

nowsinm aral are plliptio:al

$\because$

Avirulatia morvert -

$\therefore$ Irichlaria strilimbl

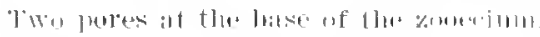

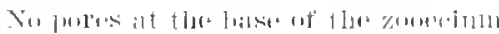

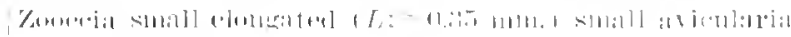

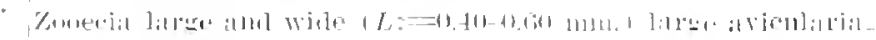

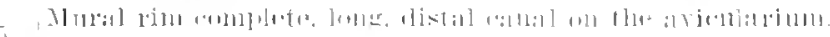

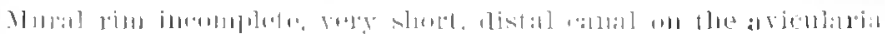

1. +111011mm.

$\therefore$

1. Mipmoxmm.

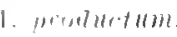

.

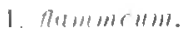

1. yitens. 


\section{Genus RAIIPHONOTLS Norman, 189.}

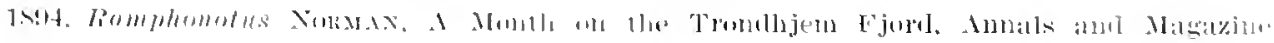

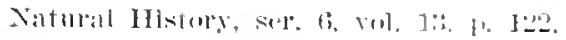

The zooecia, if developed freme in form. ale priform, widening upwall from the base. with a calcareous pution pusterion to and occupying a larger part of the front wall than that of the nuemblame portion; the membranons portion of the area is nolly as wite a long and often romewhat trifoliate in shape; the month opening is simple and, a nsul. close to its anterior margin; tha border.

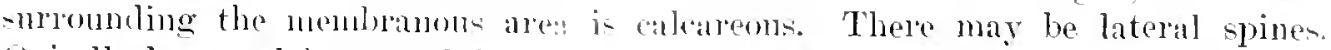
Ovicells large, glolose, and imperforate. hyperstomial, and never closed by the opereculum. An atcute birelsbeaklike aviculariun nounted on a pedicel, witl atute mandible of large size (often monstronsly so), would seem to be habitually developeri on the arlult zooceinm situited on the central portion of the zooecinm on or inmediately behind the hincler margin of the area. Dietellae: two pairs of lateral and one distal-the former rery nallow and ralely extemding beyoud the side walls; the latter small and apparently sometimes not present. (Nomiam. 1203.)

Genotype.-liamphonotus miner. Bukk, 1860.

Limme- Senonian-liecent.

In this genum the chyptoyst in mone ledued thin in $1 \mathrm{~m}$ fhiblestrum Gray 1ots; there ale erese species which are

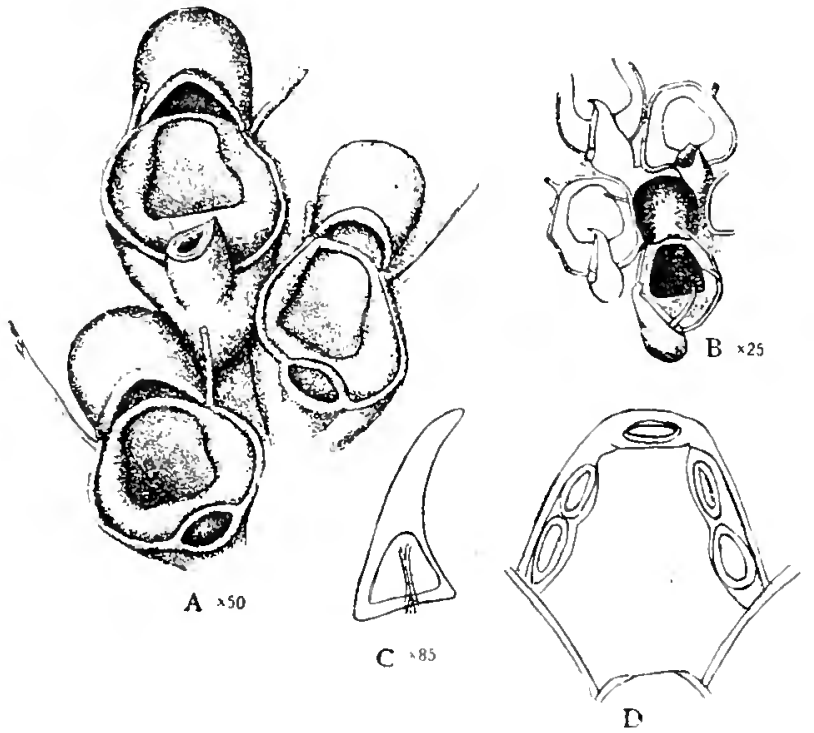

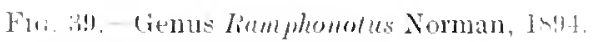

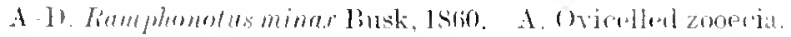
50. Is. Znwecia slwowing avicularium with mandil, e, 2.,

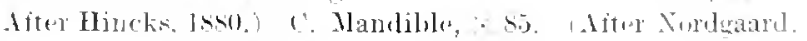

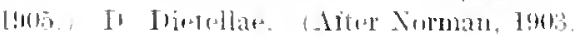

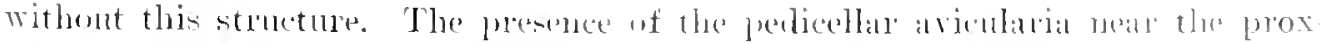

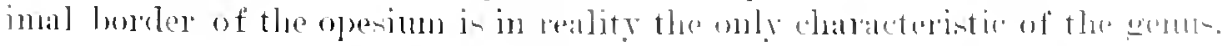

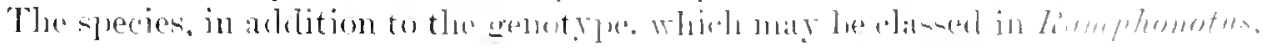
ar' ${ }^{2}$ :

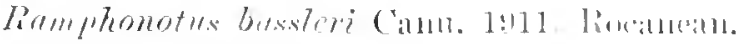

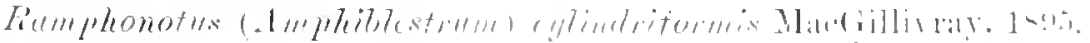

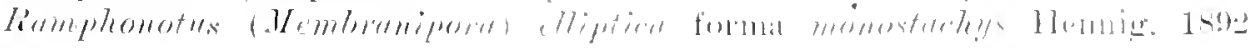
renomian.

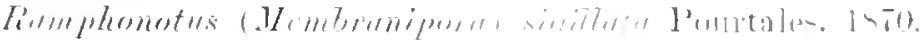




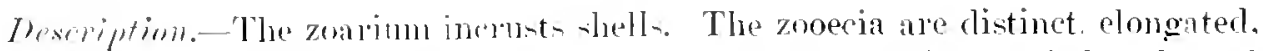

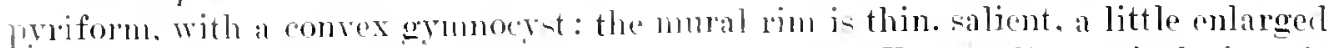

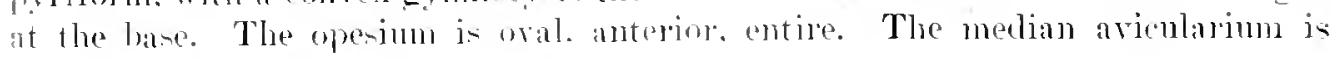
-mall and projects verey little.

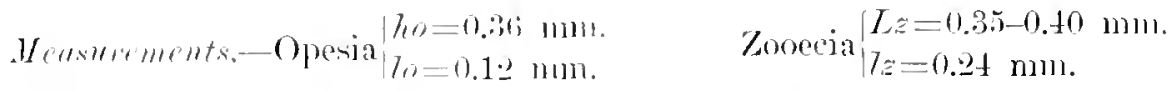

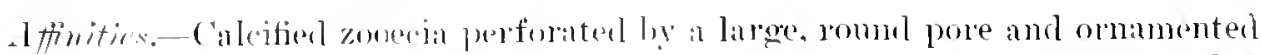
with a di-tal cresent maly be olservol. There are also imperforated ralcified zromerial.

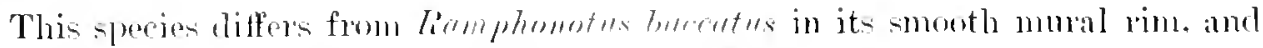

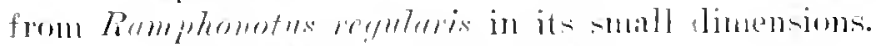

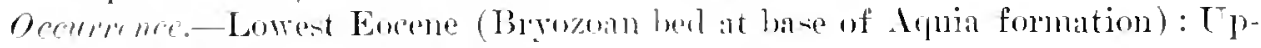

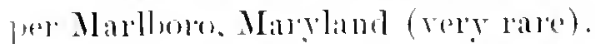

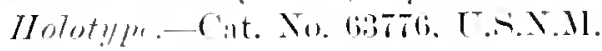

RAMPHONOTLS SLOANI. new species.

Plate 4. nis 4

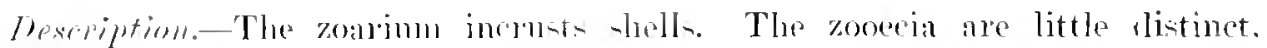

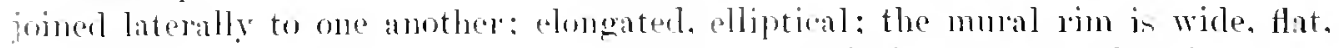

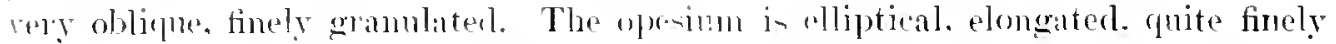

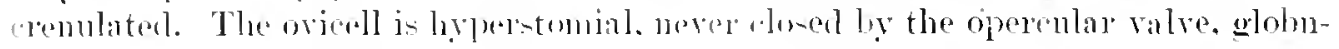

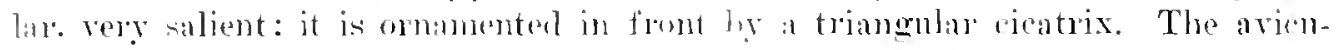

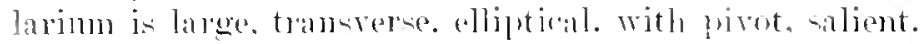

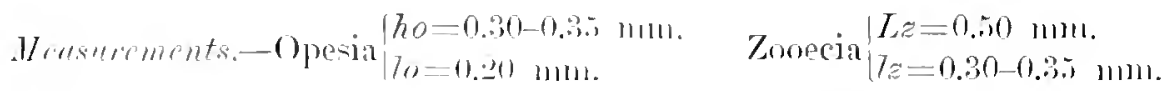

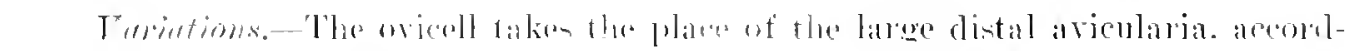

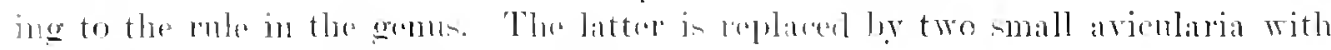

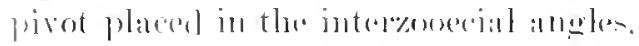

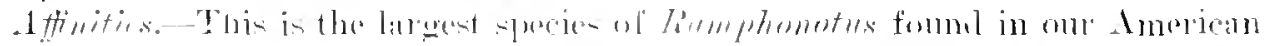

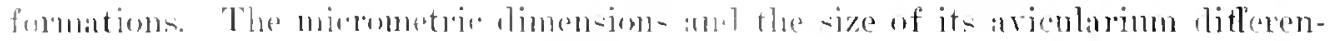

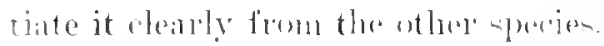

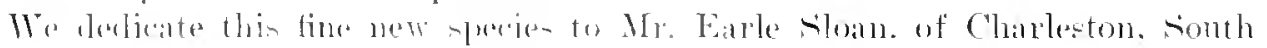

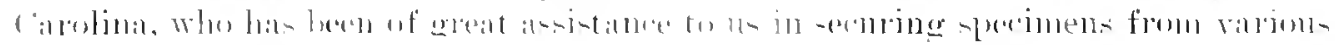
lualition in hi- state.

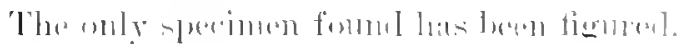

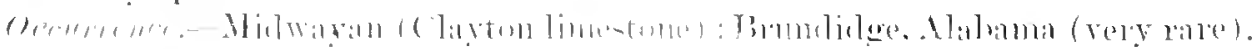

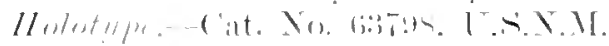


RAMPHONOTLS BACCATLS, new species.

llates : ill, fin.

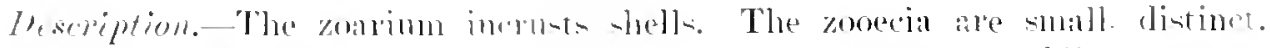

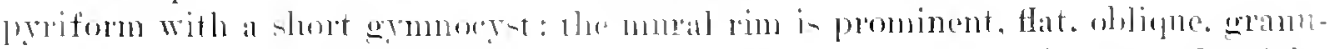

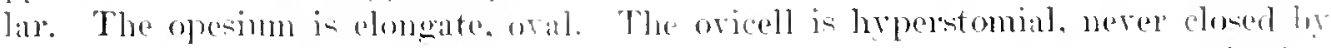
the opereular value. The small pelivellated arieulamm is sightly projectine ind roumderl.

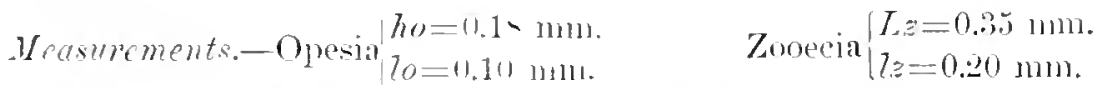

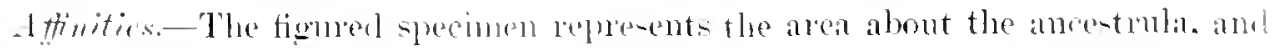
the matroinal zooecia are alone com-idereal as normal. We have observed some

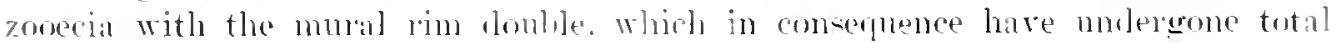
regeneration.

This species differs from Romplomolus fo in it granular mural rim which has - nomewhat the a-peet of a collar ut prials.

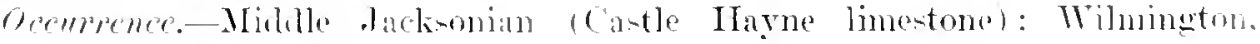
Sortlo ( arolina (very lare).

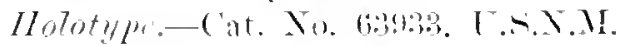

\section{RAMHIONOTIS REGLLARIS, new species.}

J'litr, :in, tigs, its.

The zoarium incrusts shels. The rooecia alde distinet. elongated. proviform:

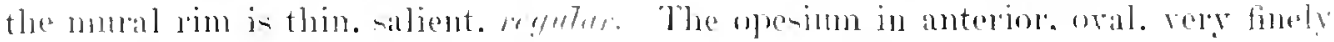

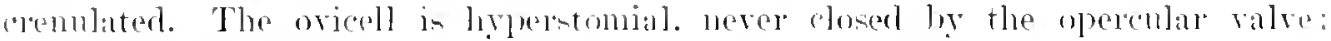
grlohose. projecting. with a large fremtal callusity, gramular. The merlian arion-

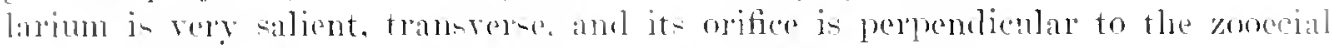

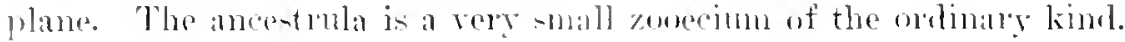

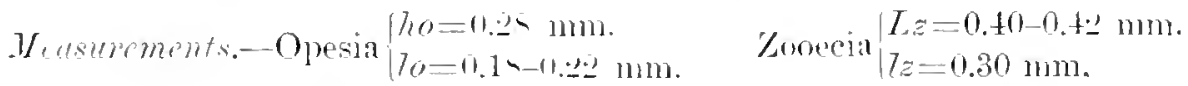

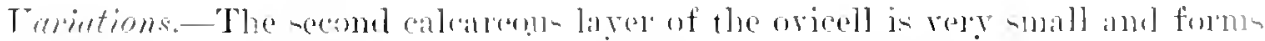

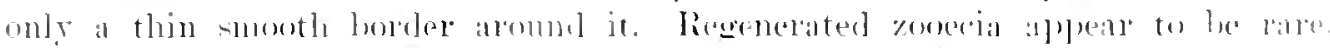

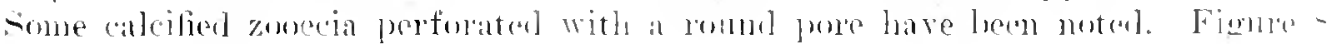

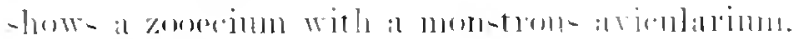

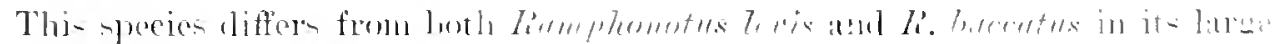

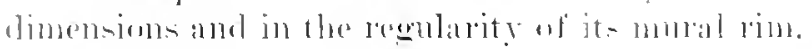

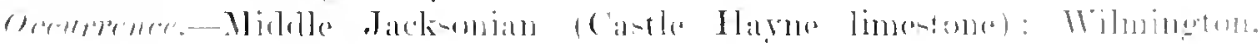
Xorth Carolina (commont).

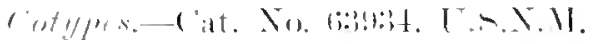

Gronus TEgELLA Levinsen, 1909.

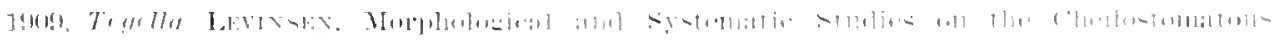
Introzinal. 11. 1, 1,

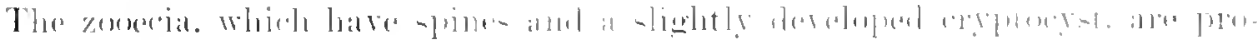

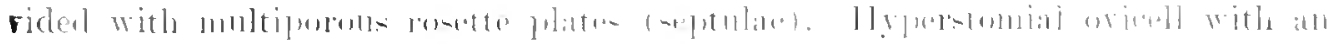




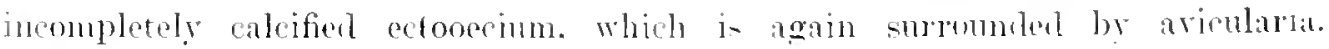
(Levinsen.)

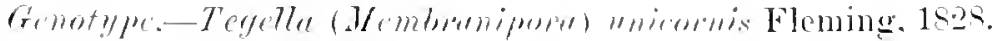

Ramle. - Rantonian-Recent.

Therent species of the gemus an:

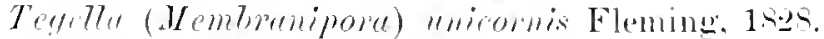

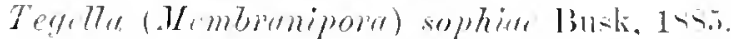

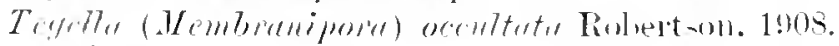

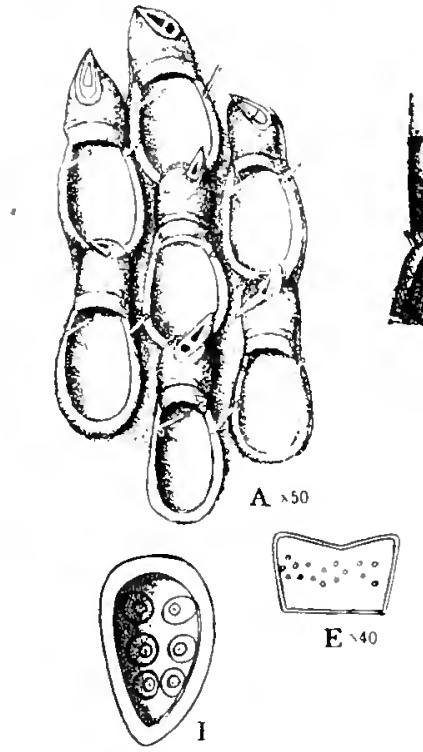

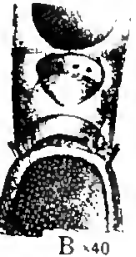

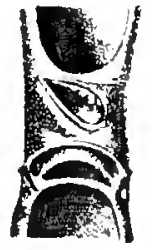

$C \times 40$

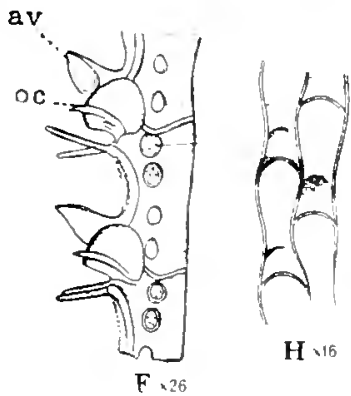

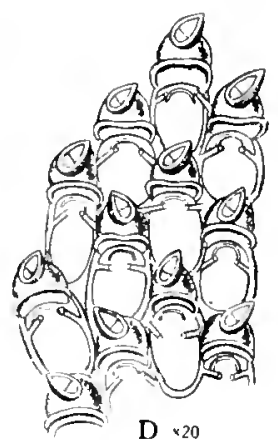

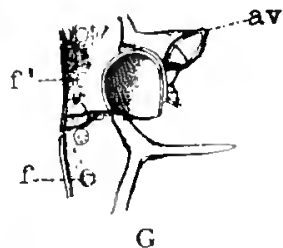

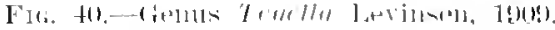

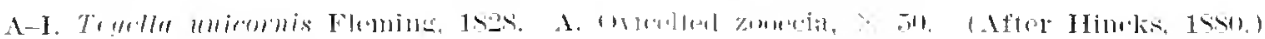

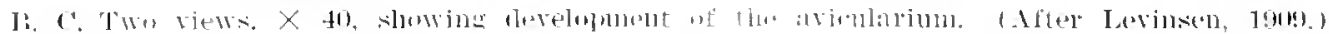

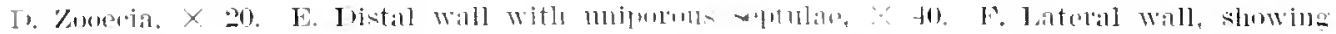

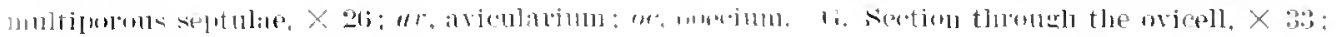

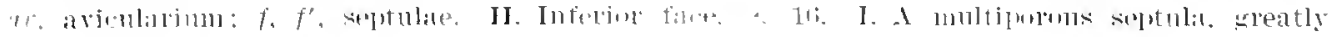

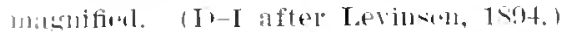

The fussil species ine:

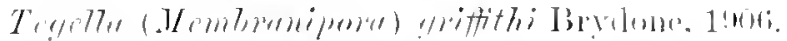

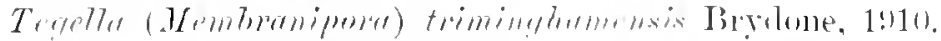

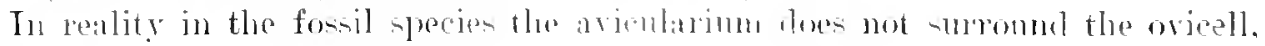

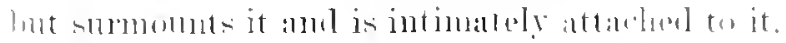

TEGELLA ACLLEATA, new species.

l'liltw. 119. 21 .

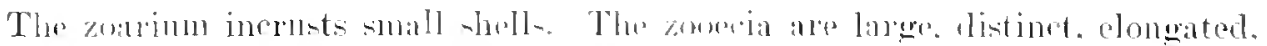

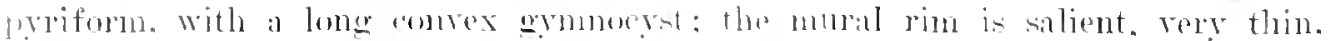

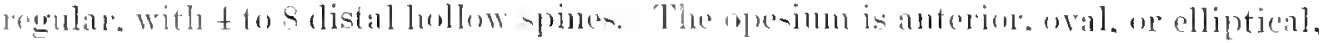


entire. The wivell is liyperstemial, never elosed by the opercular ralve. giolone. smooth. ornamenter with a mall frontal linear callosity. The median aviembinm is salient amb transverse. The interopesial arienlaria are long, very thin. and pointr.l.

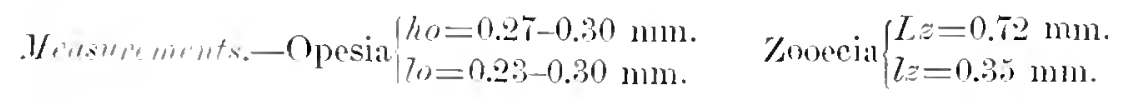

Funition.-The inter\%ooceial aricularium is always placed exactly in the axis of the proximal zooccimm with whicl it appears in immediate relation. $0_{12}$ the figured specimen an aricularim nay be seen devoloped on the distal zooedi. There are only two pairs of srmmetrical spines on the oricelled zooecia. The ovicell is formen of two calcareous lamellae. The external lamella (ectooecium of Jevinsen, enver- the lower lamella almost entirely and leaves only a thin linear portion of it risible. The presence of lares a ricularia gives the zoarimm the aspect of being amed with small sumals.

Whenerer an interopesial avicularium does not surmomt the ovicell. it imuch smaller.

Aftinitis.-The close connection of the ovicell with the distal aviculariun render it necessary to class this species in Tegella Levinsen, 1909, and its pedicellated aricularimm womld place it in Ramphonotus Noman, 1894. Such contralictions are inevitable when characters of alaptation like the avicularimm are employed in classification. It is easy to aroid this hy giving the genera broaler. limits precisely as Levinsen has done with the genns Callopora.

North (alrolinal (rare).

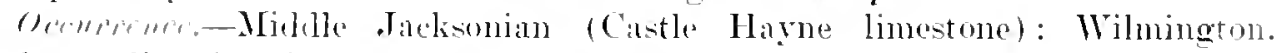

Hottoype-Cit. No.63936. T.S.X.M.

TEGELLA NICKLESI, new species.

PIate 30, tigs. I), 10.

The zuarimm incrusts pebloles. The zooecia are elongaterl, distinct, eiliptioal or oral, and provided with a rery small grmuncyst; the mural rim is thin, salient, convex. omanented with spines. The opesimn is regular and similar in form to the zooedia. The ovicell is hyperstomial, never closed by the operenlar valles. small. conver. It is smmounted by an elliptical, elongated avimulimm placel exactly in the axis itself of the proximal zerrecium.

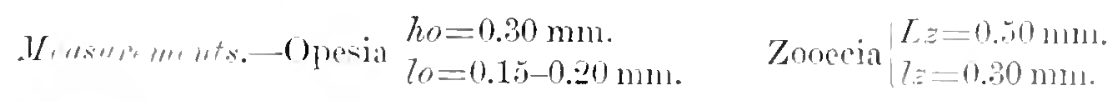

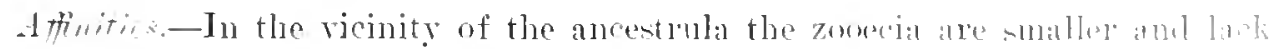
the distal arioularium: hele alon their mural rin hears larere spine-

The specien differs from Tigethe aculenta in its small dimensinne and in then

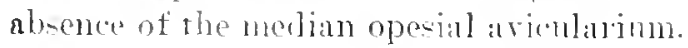

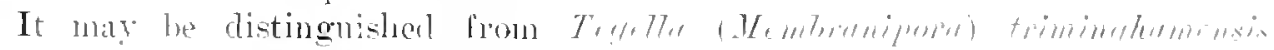

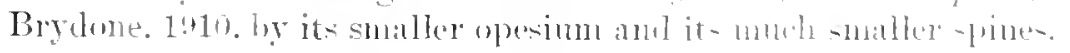


The specifie name is in Jonor of Mr. Tolm M. Ninkles. of the Tuited States

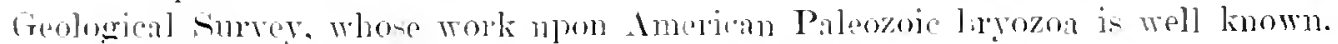

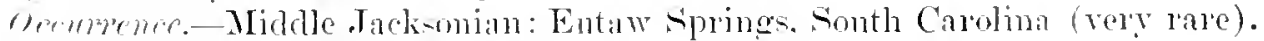

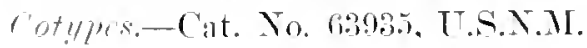

\section{Genus STAMENOCELLA Canu and Bassler, 1917.}

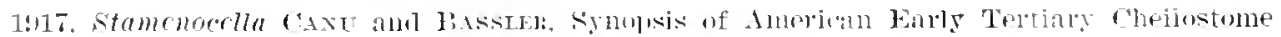

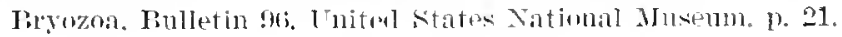

Oricell hyperstomial not elosed by the opereular valve. No dietellare Grmnocrst long and flat. supporting a small sessile. salient a rienlarimm.

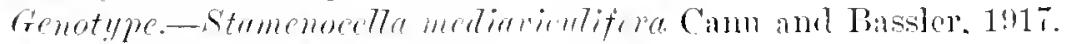

Range.-Senonian-Vicksburgian.

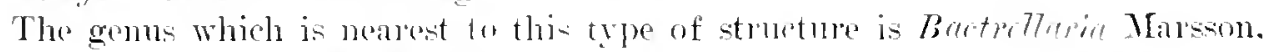

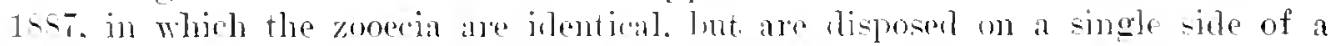
triserial zoarimu. The two enener molubledly belong to the same family.

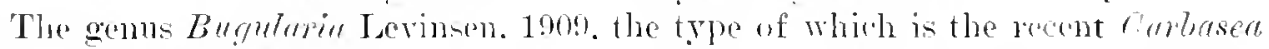

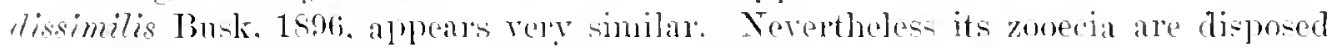

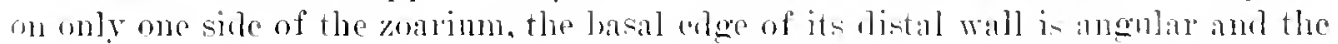

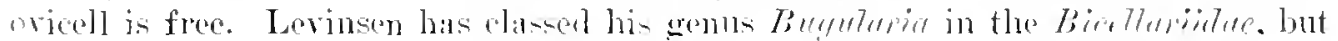
his family is not an entirely natural one. as it contanis thee cencra. Buguta.

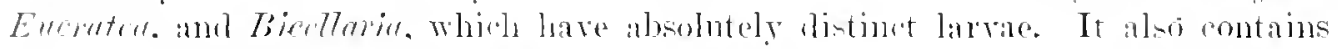

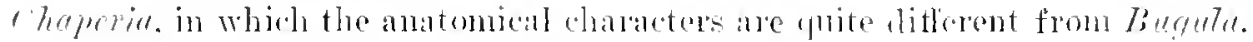

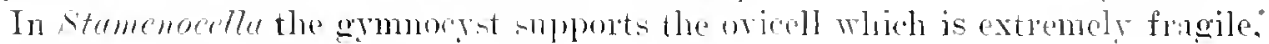

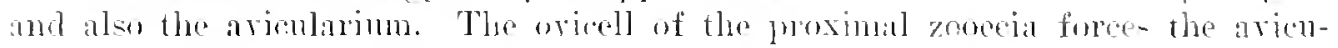

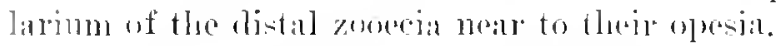

There may be rasised in this geme-

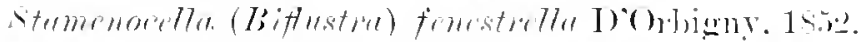

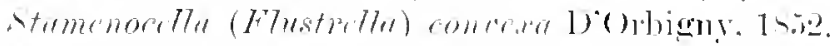

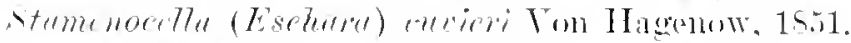

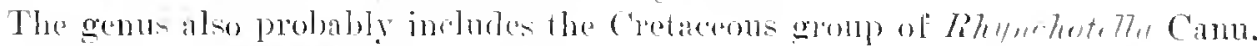

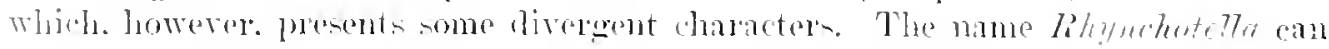

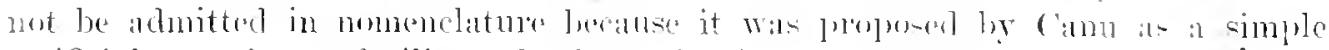

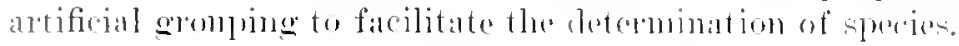

STAMENOCELLA CILINDRICA, new species.

l'late 1, tice. 15 .

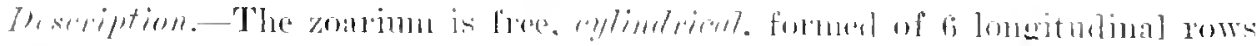

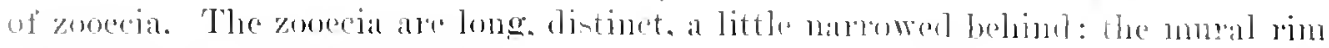

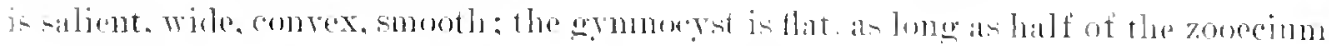

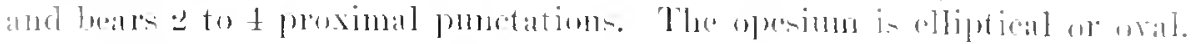

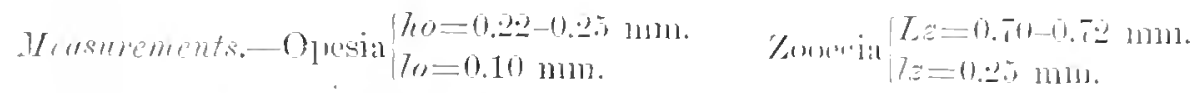

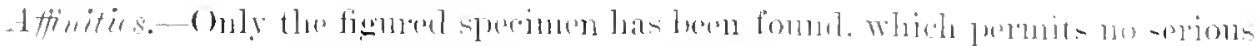

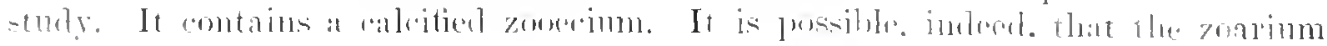




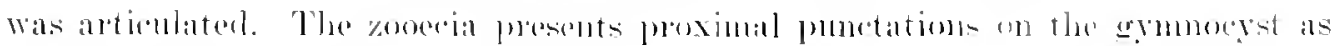

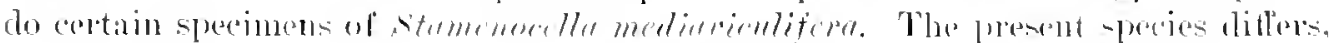

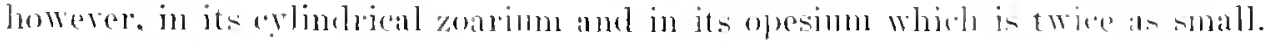

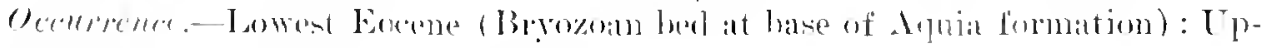

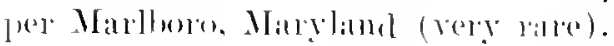

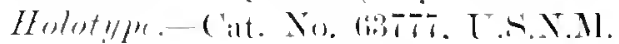

STAMENOCELLA MIDWAYANICA, new species.

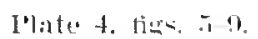

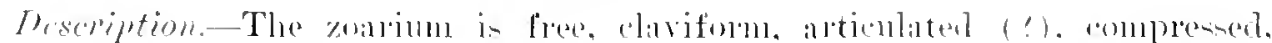

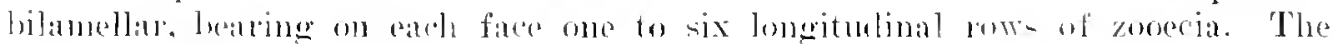

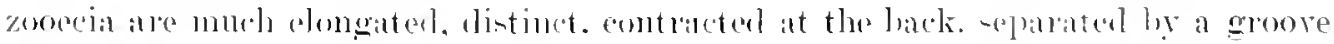

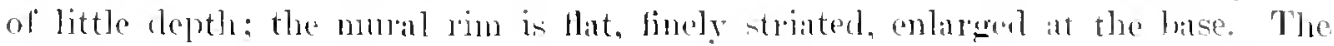

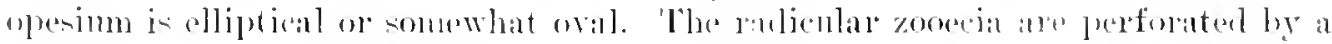

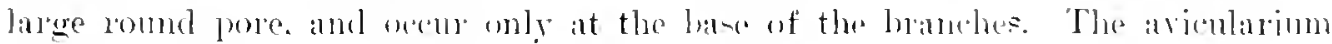

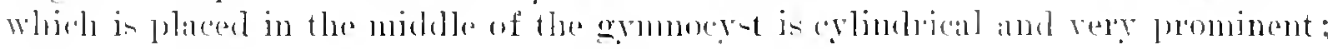

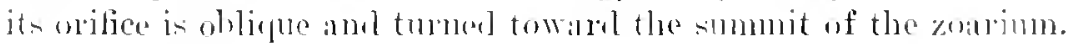

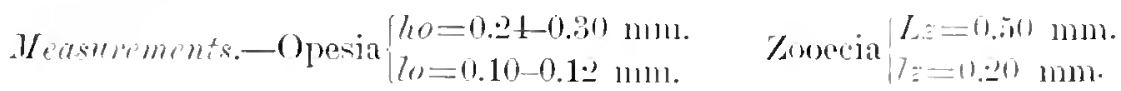

It

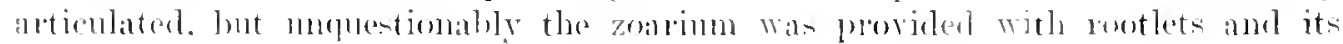

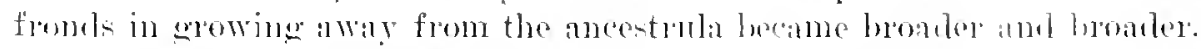

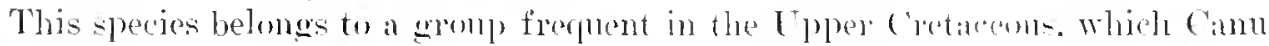

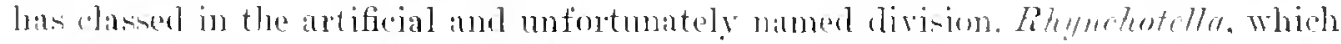

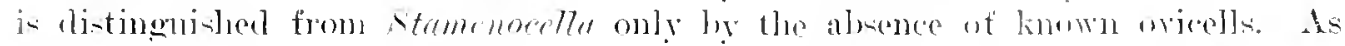

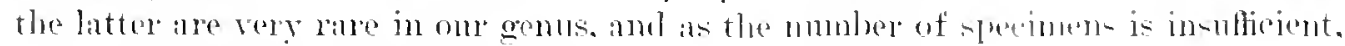
it is necessiry to hesitate before fonnding another wenoric tye.

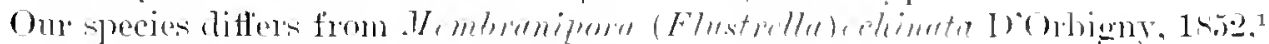

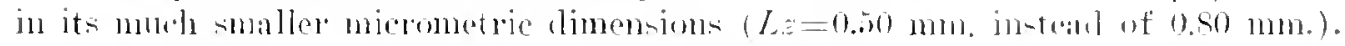

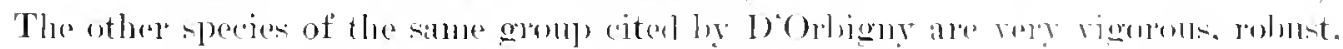

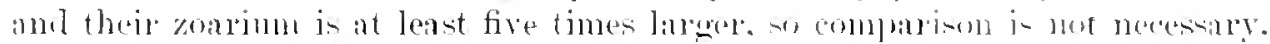

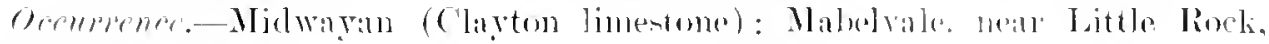

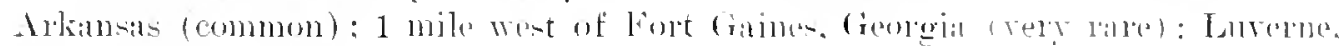

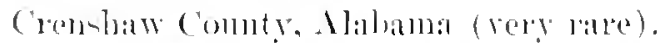

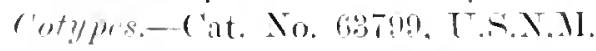

STAMENOCELLA ANATINA, new species.

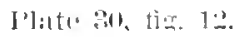

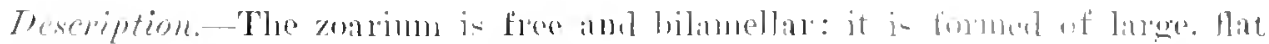

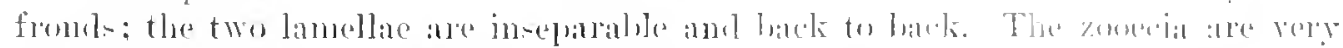

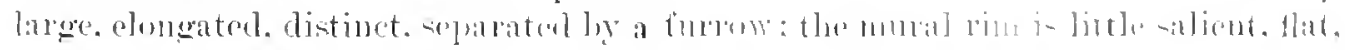




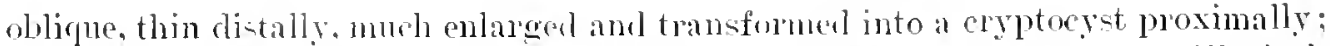
the grmnocyt in little comvex and smooth. The opesimm is anterior, elliptical. entire. The aricularinn occupies the surface of the ovmnocyst; it is large, salient. and teminated like the beak of a duali. with spatulat mandible.

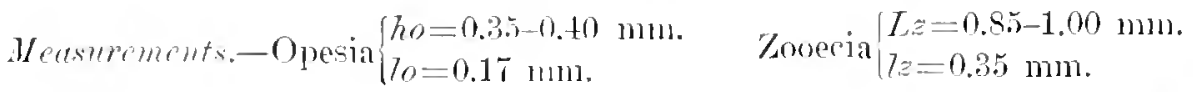

Affinities.-The figured specimen is the only une that has been found and it unfortmately ha- no ovicell. The lalge aricularimn is not constant, although many of the zoorcial ale unprovicled with them; their presence is therefore not necessary to each zonecinm. We think that the function of the avicularia, like that of the viluacula, in rather zoarial.

Among the sperien of the sane genus this is the only one in which the eryptocrst is much derolopel: its relationships with the genus Amphithestrum are therefore close: lnt in the latter there is no grmmocyt and the avicularia are lodged in the interzooscial angles.

The disposition of the zooecia is also much less regular than in the other species of Strmmmortla. It diflers from stamenorella grandipora in its small opesial leneth $(0.3 .5$ insteal of 0.50$)$, its crytoeyt. and chiefly in its large avicularium in the -hape of a duck's beak.

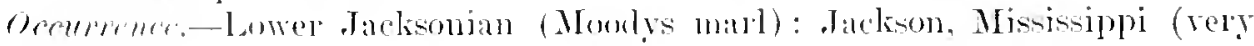
rare).

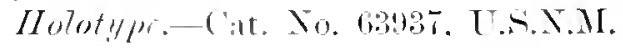

STANENOCELLA PYRIFORME, new species.

Plate 30, fins. 18-16.

Ireseription.-The zoarimm is hilamellar with natrow fronds: the two lamellae are back to back and rejarable. The zonerial are very long, narrow, distinat, sep-

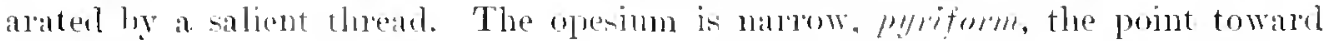
the lottom. Imalesed by a collar. The ryptocyt is smooth, developed laterally

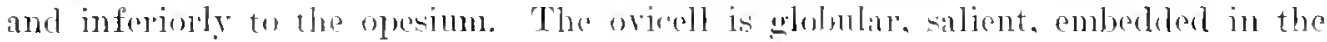

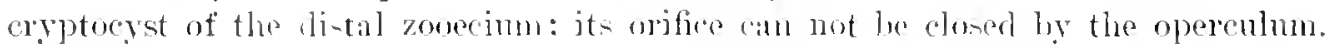

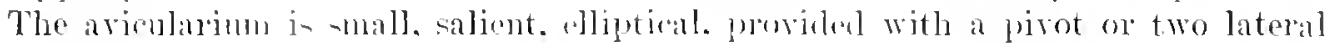
denticles.

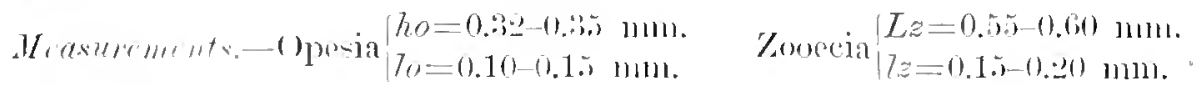

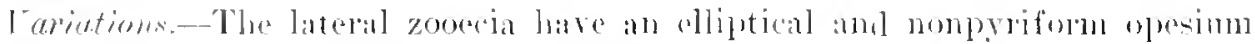
(figs. 13. 1t). On the rory wide fromls there are nany gows of these different

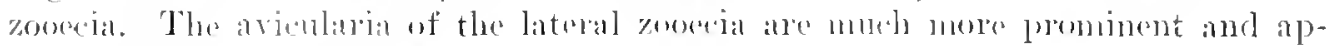

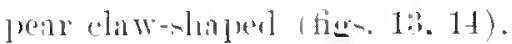

When it in puperly illuminater. the peonliar orithe of the oricell is quite

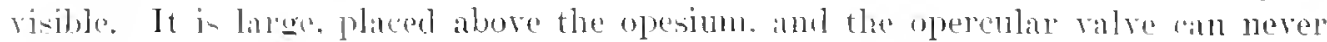
(olen it. 


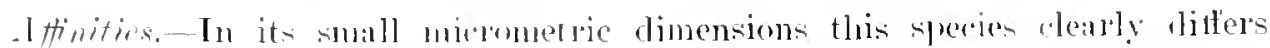

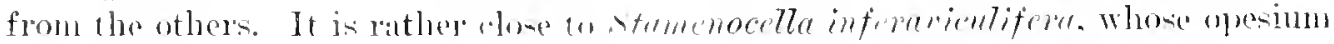

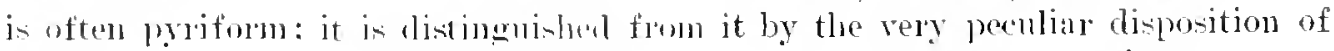

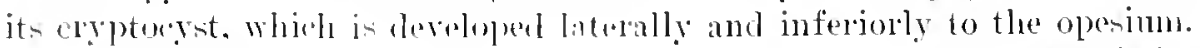

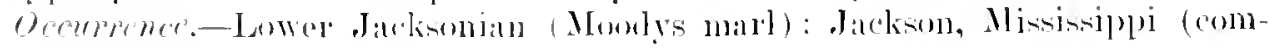
nion).

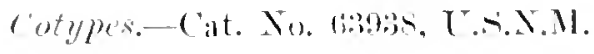

Stamenocella Mediaviculifera Canu and Bassler, 1917.

1 1:11.. : : figs. $1-\overline{5}$.

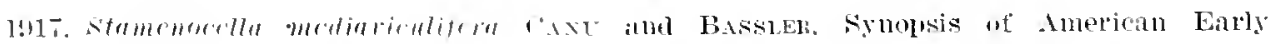

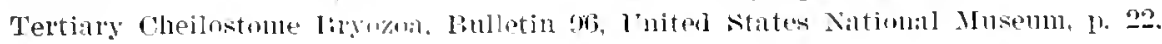
1.. 3. tị. 1 .

Irescription.--The zoarim is bilamellar. with the two lamellate back to back and inseparable. The zonecia are very elmgated. narrowed helhind dintinct or indistinet; the mural rim is thin. alient, somewlat enlarged and attemated, roumlet, smooth. The opesinm in elliptical or oval. entire; the grmmoeyst is flat or somewhat convex and nearly an long an the opesimm. The arienlarimu is salient and placed in the midlle of the gymnerst. 'The wicell is rarely intact.

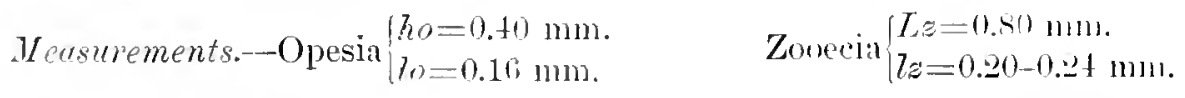

T'uriations and affinities. This preeden apparently lived in agitated waters. Although widely distributed. it is oflen rely rare, and specimens ale always more or les worn. In this commlition the mural rim is worn away ame invisilute the zorneria indistinct. and the arivllaria abent or replaces by a concave cieatrix (fig. 2). We have never found thr wicell intact: it is always more or less broken. but it place is cleary risible on the grmmocrst, notably in the specimens from near Perry, Georgia (fig. 3). The avinularim is of the simple type without denticles or pirot. The dintensioms in this species are much snaller than in S. arantis, and it i- rarely as well preservol. On certain specimens from Rich Hill, Creorgia, we have ohserved sometimes four puntations at the base of the grmnocyst. 'The rare precimens from the Tickshurgin are very medioce in preservation and have the abraterl aspect shown in figure is.

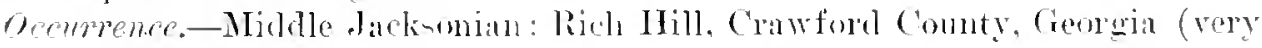

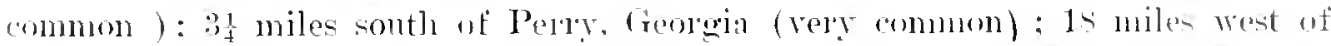

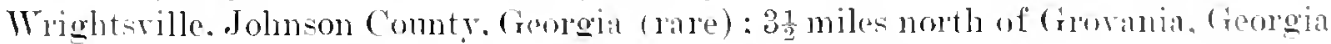

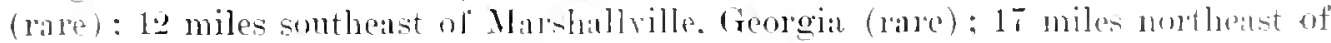

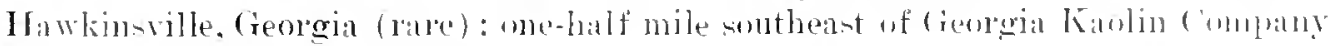

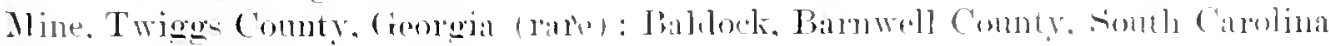
(rare): Wilmington. Nort! ('arolinal tratre).

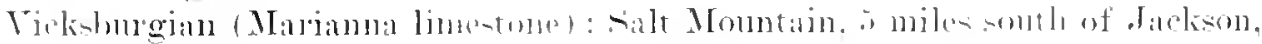

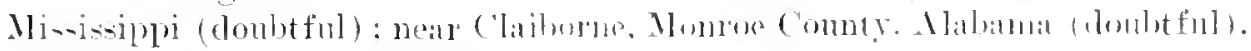

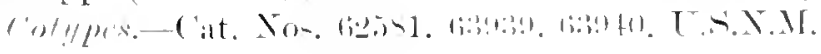




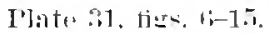

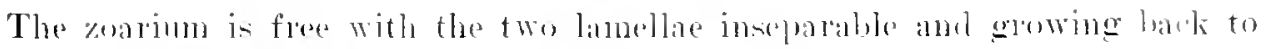

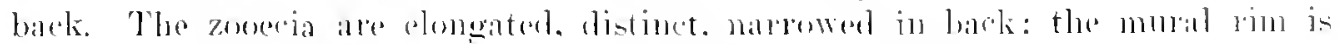
little salient. rely thin. attemute at it hase. The openimm is elliptical or wal,

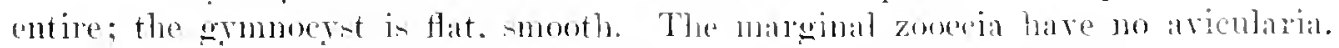

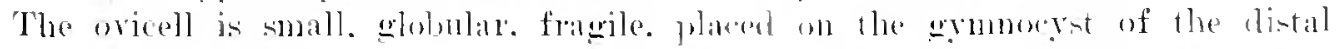

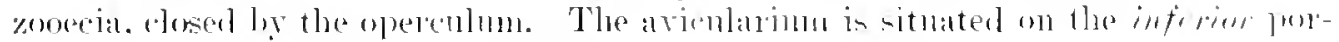
tion of the equmoerst in rese contact with the mumb rime of the proximal zooecintul.

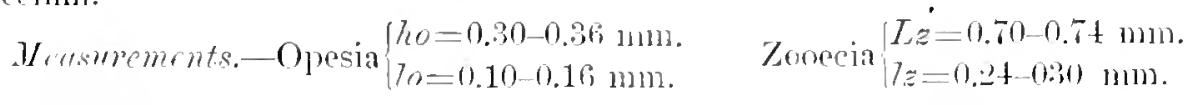

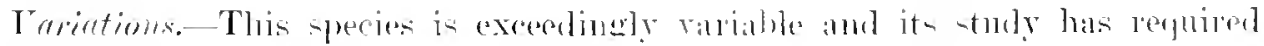

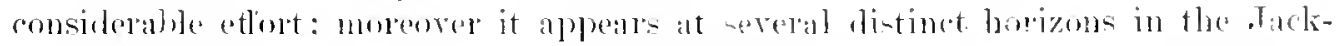

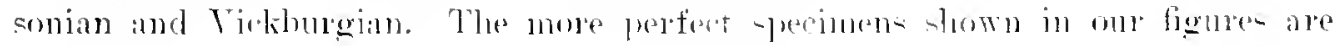

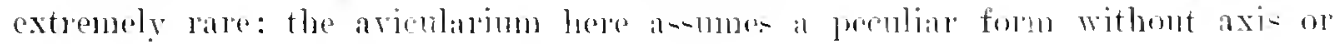
pivot, which makes its nature lombtful.

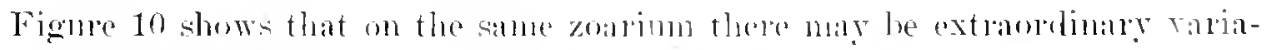

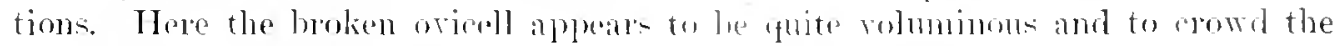

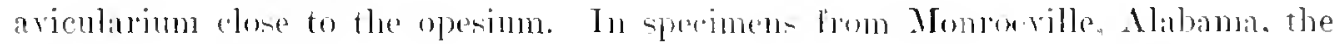

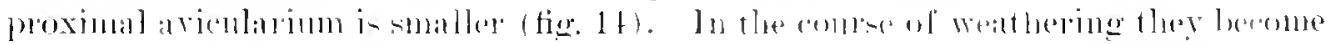
smaller and smaller (fig. 11). divide in two and aren may be peplaced lis a few punctations (fig. 13).

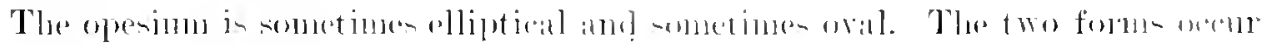
on the same yreetmen (lige. 5 ).

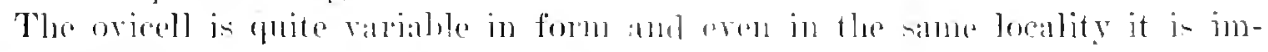

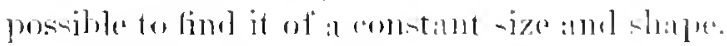

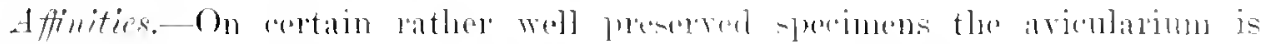

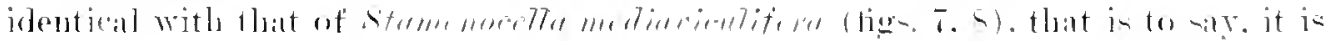

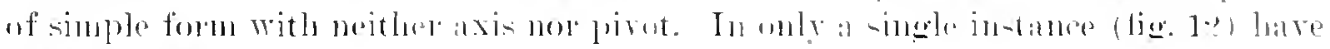

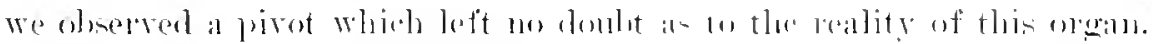

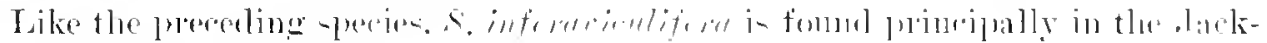

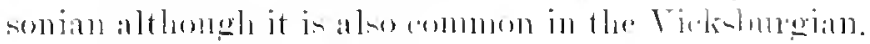

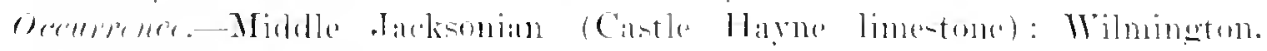
Nortla (arolinal (rory pare).

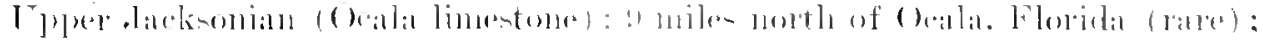
Marlina. Foloridia (anmmom).

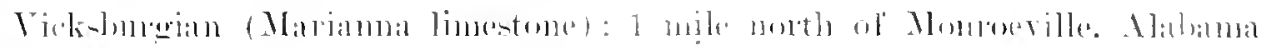

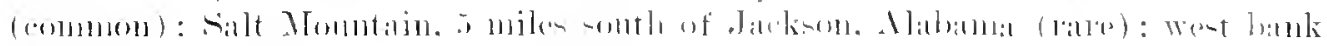

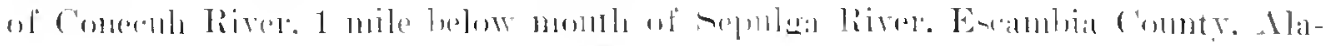

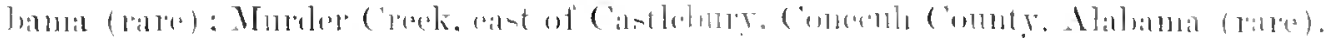

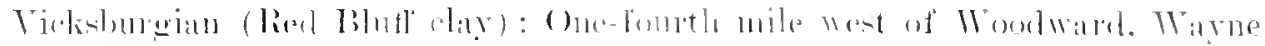

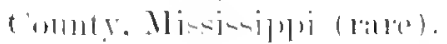

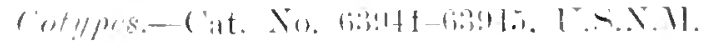


STAMENOCELLA GRANDIS, new species.

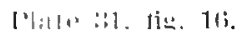

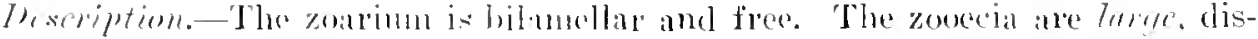

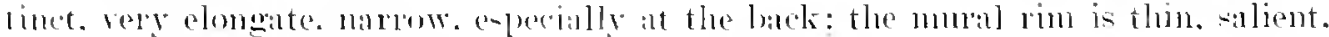

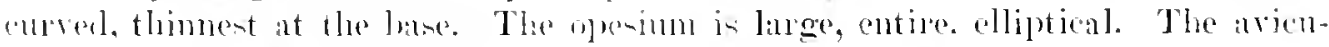

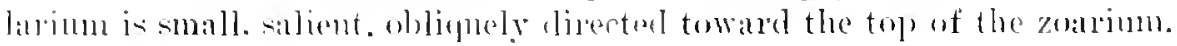

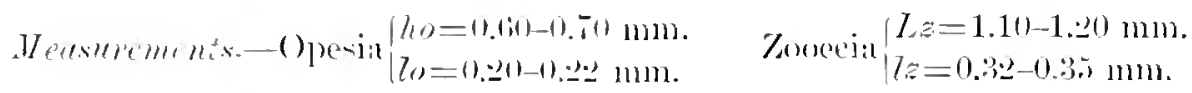

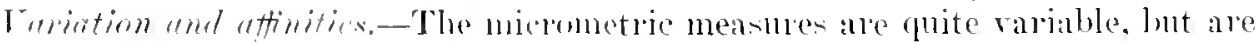

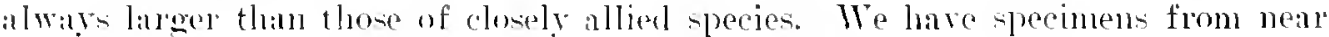
Mommeville, Alibama. and near Woolwall. Missisippi. where the zooecial length is $1 \mathrm{~mm}$. It the Chipola River bolity they vary between $0.8+\mathrm{mm}$. and $0.90 \mathrm{~mm}$.

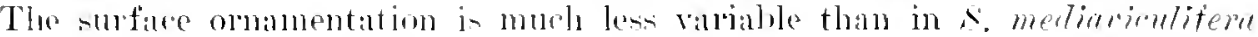
which prohaldy inhalsited area - with more rapid marine currents. The form of the

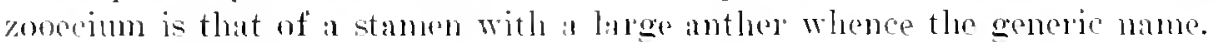

Ocoumence.- Vicksburaian (" Chimmer rok" of Mariama limestone): One

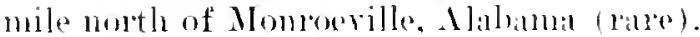

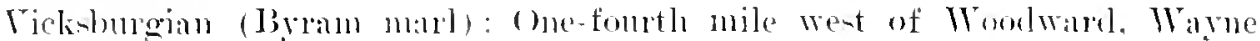
Comnty, Misissippi (ride).

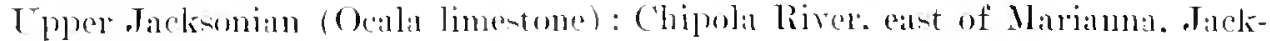
som ('omnty. Florida (very ranre).

Jototype-Cat. No. G3946. T .......I.

STAMENOCELLA INTERMEDIA. new species.

Plate $\mathbf{1}$, tig. 5 .

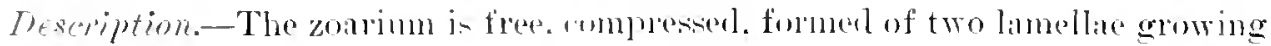
bark to back and inseparalile. The zonecia are listinct. elongated. with a concave

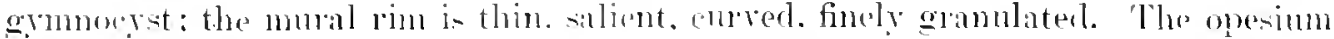

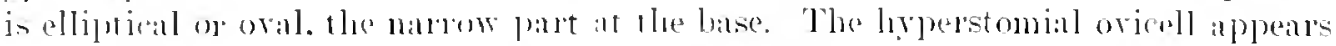

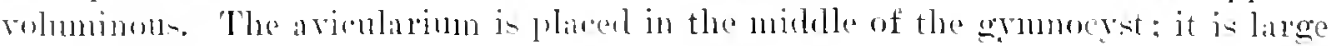

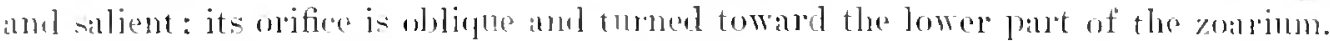

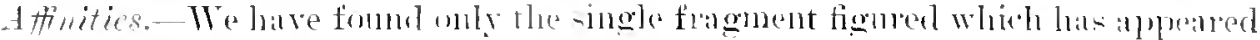

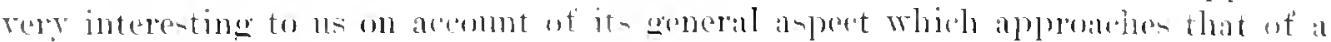
Buente witle a bilamellate zestrimm.

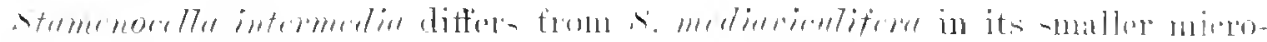

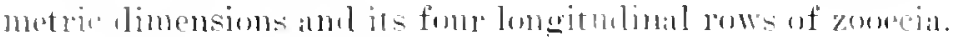

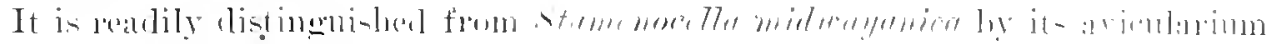

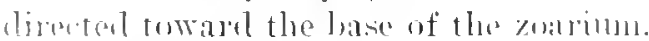

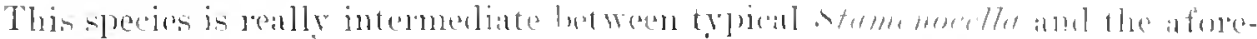

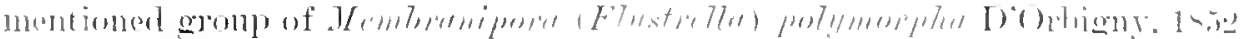

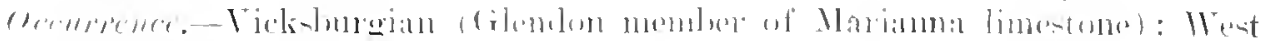

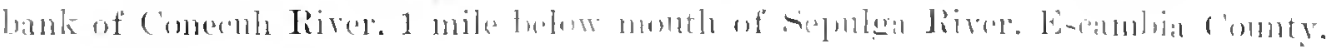

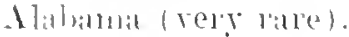

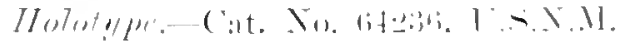


For the salse of completeness. definition- and illutrations of the remaining

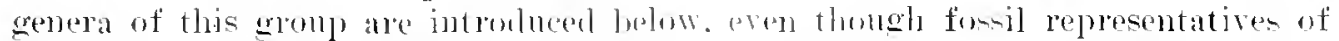
them have not ret been formol in the Aneriatn Tertiary.

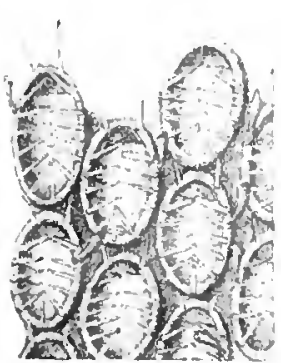

A. Cauloramphus

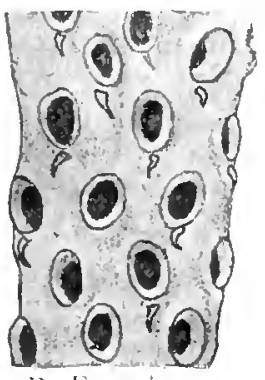

B Tistolatrat

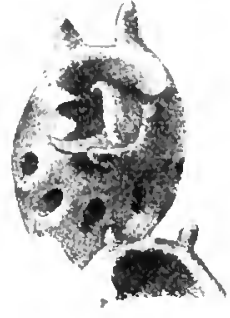

C. Membrostegat

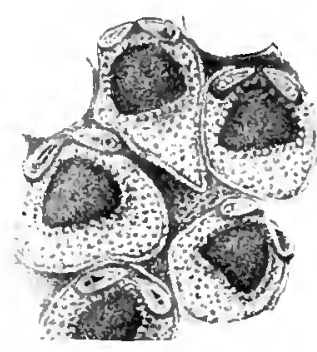

D. Antropora

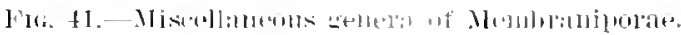

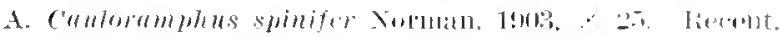

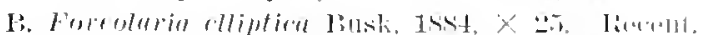

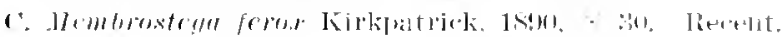

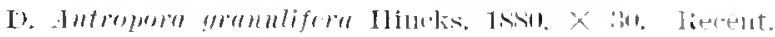

Genus CALLORAIIPHL'S Nornan, 1903.

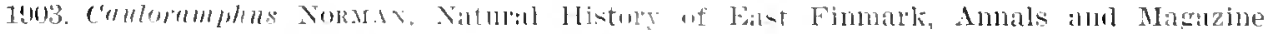

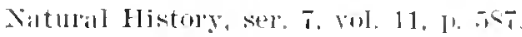

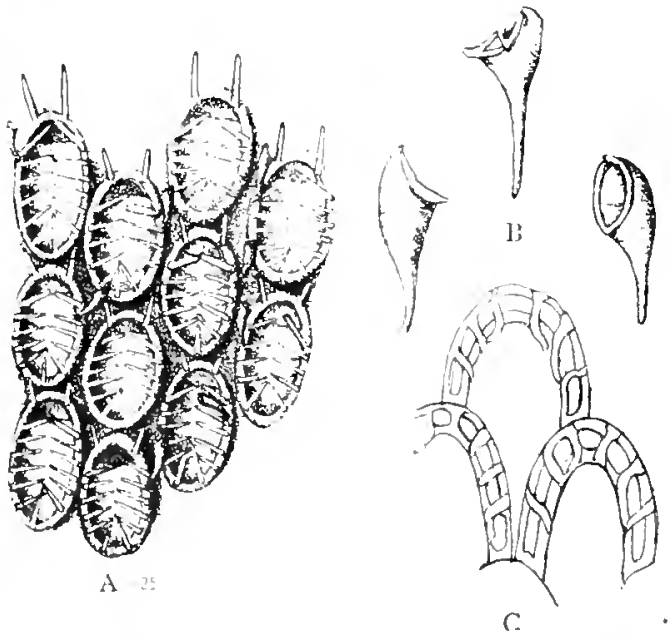

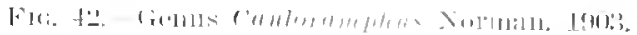

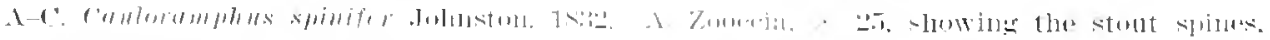

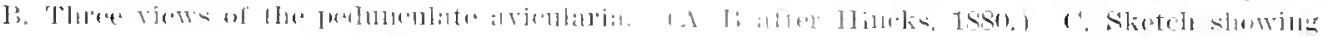

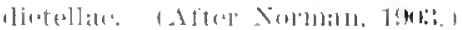

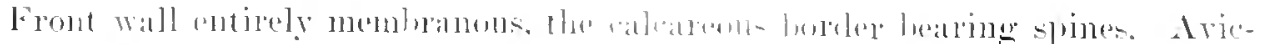

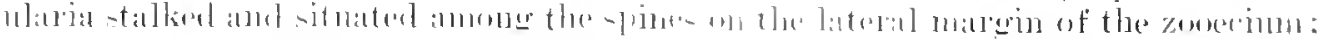

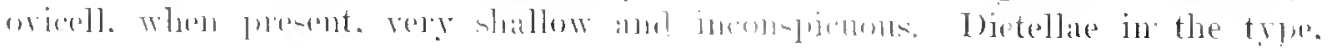


three patrs of lateral and one terminat; the latter is sometime- divided into two ar event theresmall chambers.

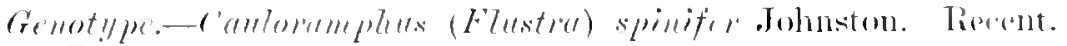

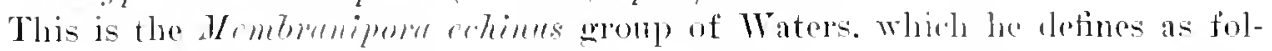

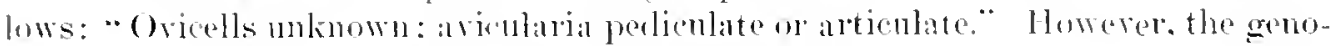

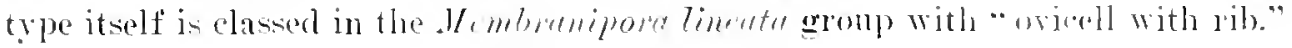

Genus AMIMATOPHORA Norman, 1903.

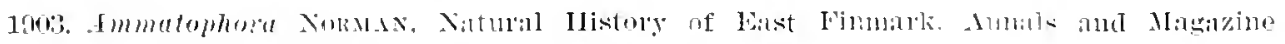
Natural Ilistery, ser. 7. rul. 12, 1. se.

Zooecia and oricell depresent and flattenerl. Zuoecia sulemite: a calcareons crest ocenpring about trothirds of the area. Olis orening ristil enel of the nembranow portion. W:ill thin. terminating at the ovicell in a knol. Ovicell entirely separable from the zooecium, resting on the knols ju-t mentioned: of musual and raried form. Surface of zondium with raisen nomulnus proceseres. No aricularia. No dietellae. (Norman.)

cienotype. - immatophor" (.Membranipora) nodntosa Hincks. 1580. Recent.

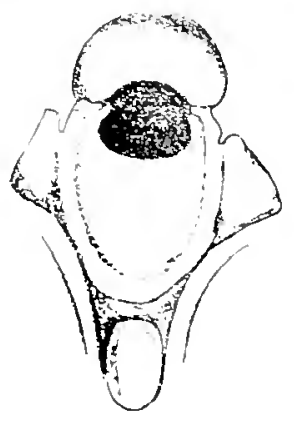

A
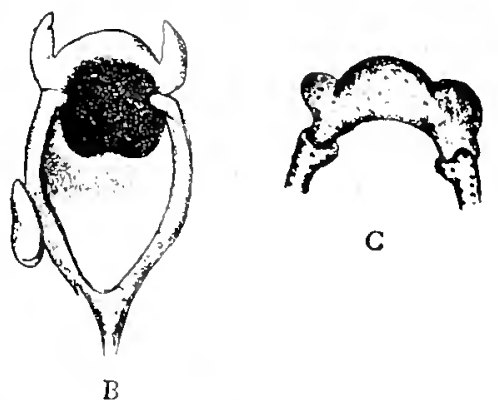

C

Fur. 43.-Genus Ammatophom Xirnam, 1903.

A-1'. Ammutophora nodulosn Ilincks, that. A. A zenoecium whibiting an mussul form of the ovioull. L. The younger andition of th* unore usual forms. The mature condition of the sames. (A ' after Norman, lens.)

The opercular valve never closes the ovicell.

Genus MARSSONOPORA Lang, 1914.

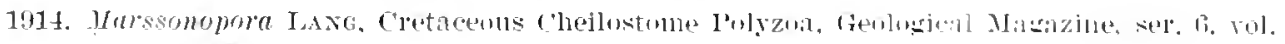
$1,1,4: 3$.

The zoalinm is miserial and incrusting. The zoopeia are proform: the sprunocyst is quite convex. It hears on its candal portion a mall aricularimm.

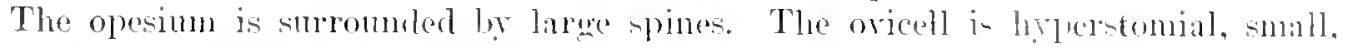

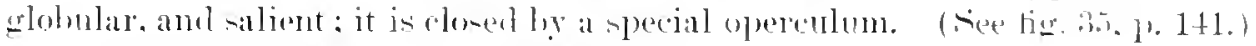

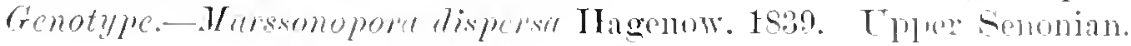

Genus ANTROPORA Norman, 1903.

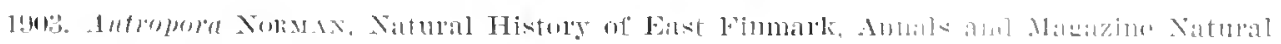

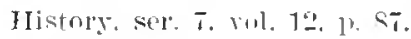

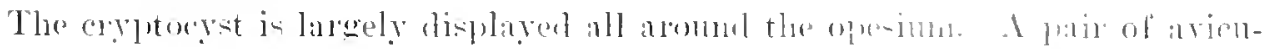

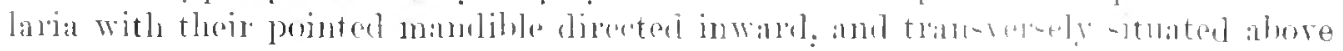


the oral opening. 'There are thres pairs of lateral atietelae and several (four nsually) luvil spots in the himel wall. (After Normin.)

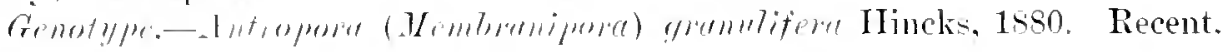

\section{Genus IIFMBRostegA Jullen, 1903.}

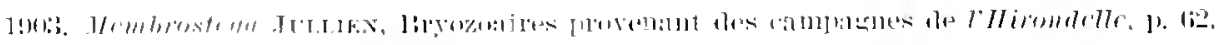

The mural rim in providerl with foul spines on the anterior lips of the orifice. The two outer ybine actuire such development that they form by their ramifica-

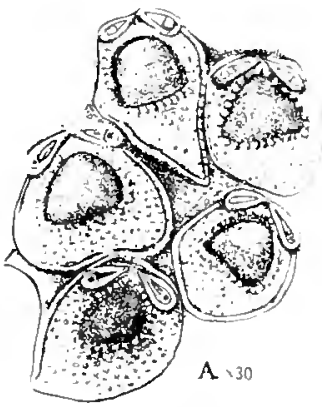

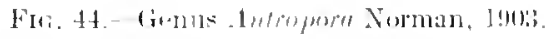

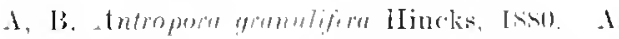

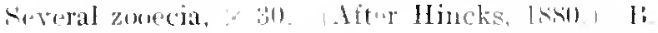

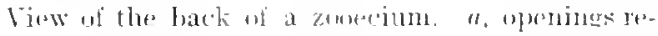
sulting from the arietularia: below these are seren

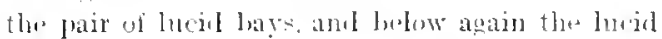
spots. (Atter Sorman, l!nt; porerl dietellate. Yoavienlaria. Hyperstomial oricell. not closed by the opereular value.

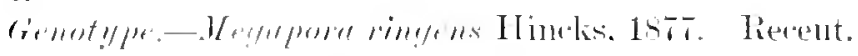

Geuas DISCOFLUTTREL],ARIA D’Orbigny, 1851.

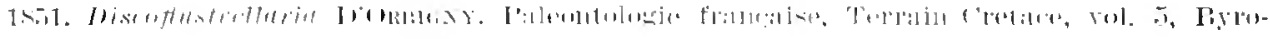

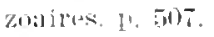

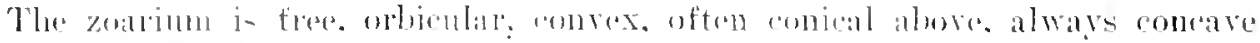

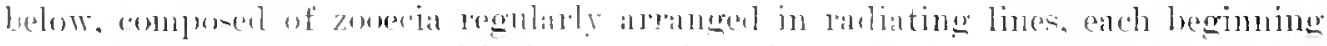
with a deformed zooecium with the formation of ammular transverse lines. Zooecia

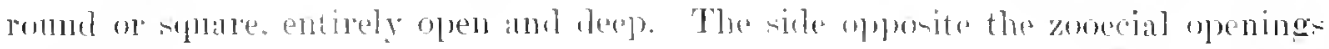

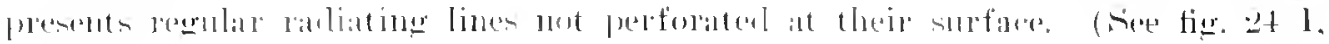
1.s.i)

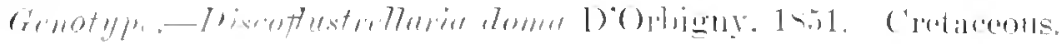


Genus CREPIS Jullien, 1882.

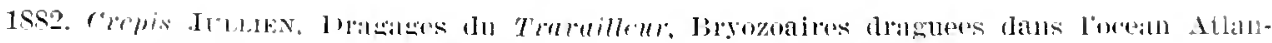
tiqne. Bulletin Soriete Zoologique France, rol. 7, p. 522.

Oral zonecia, with cryptocyt, not completely closing the area in front. where a large opening existed during all of its life. This semielliptical opesium has it: angles more " 1 less rounded; the elitinous ectocyst, brilliant when it is dry. is calcified on it: lateral walls. which are raised in front of the opesium and are prolonged at the Jack of the zooccium in a long thread, the end of which is united with the pariatil ectocyst of the preceding zooecium. (Sce fig. $24 \mathrm{H}, \mathrm{p}$. 85.)

Genotype-C'repis longipes .Tullicn, 1882. Recent.

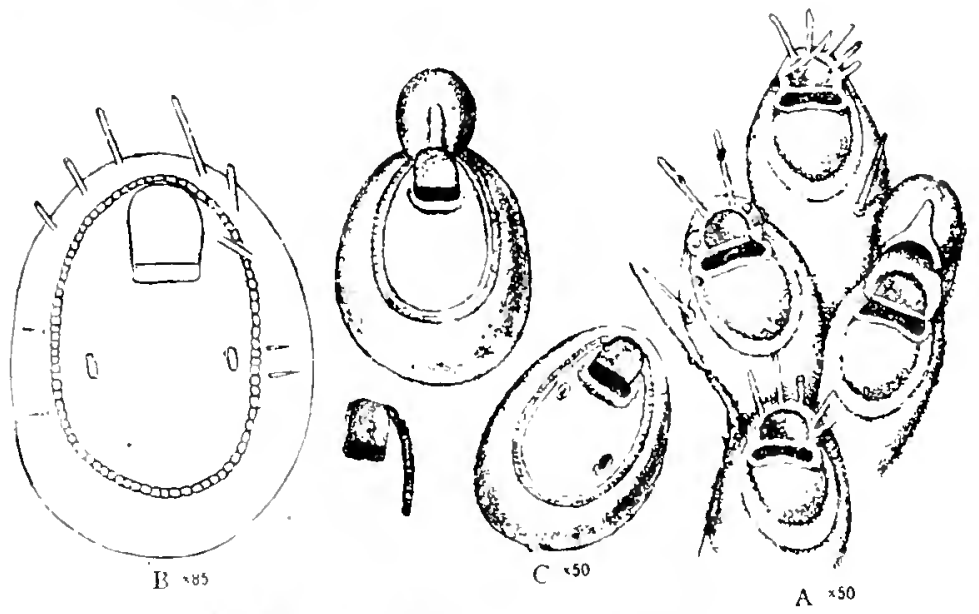

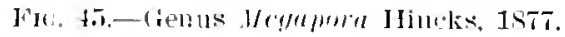

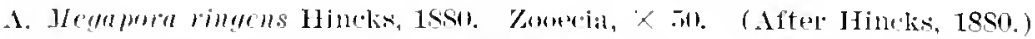

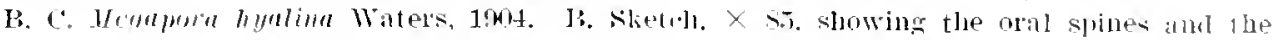

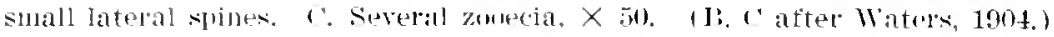

Genus FOVEOLARIA Busk, 1884.

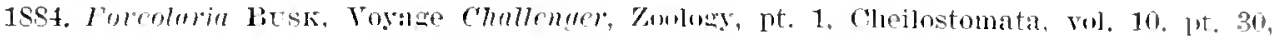
r. $6 \mathrm{~s}$.

Zoarimm erect, branched and cylindrical, or foliaceous and bilaminar. Front of zonecia with a thiek gramular border rery deeple emberded in a pit formes by the thickening of the eneneral ectocrst. I sesile arionlarium immediately below or in front of the lower bordes of the pit.

Genotype--Foveolaria elliptien Busk. 1sst. Recent.

\section{Family AETEIDAE Smitt, 1867.}

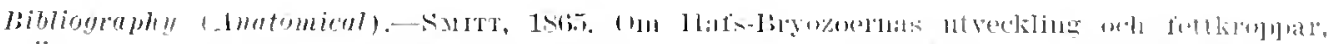

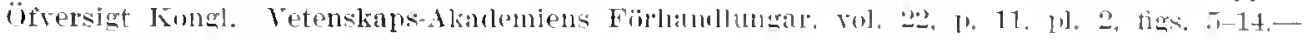

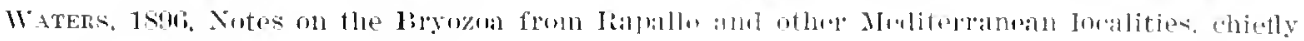


Cellularidae. Journal Linnean Societr. Lundon, Zoolury, rol, 26. p. 5, pl. 1.-IArixsex, 1909. Morpholngic and Systematic Stulies on the Cheilostomatons Bryozua. 1. 92.-WATERs, 1913, Marine Fauna of Pritish East Africa and Zanzibar, Bryozon, Cheilostomata. Frnceedings

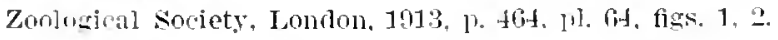

Zoarium composed of ereeping branches more or less adherent to the substratum. often growing in free tufts adhcrent only part of their length. Zooesia miserial. arising from each other in a tubular prolongation of greater or less length. Opesimm terumal, opercular ralve at its smmit. (After Robertson.)

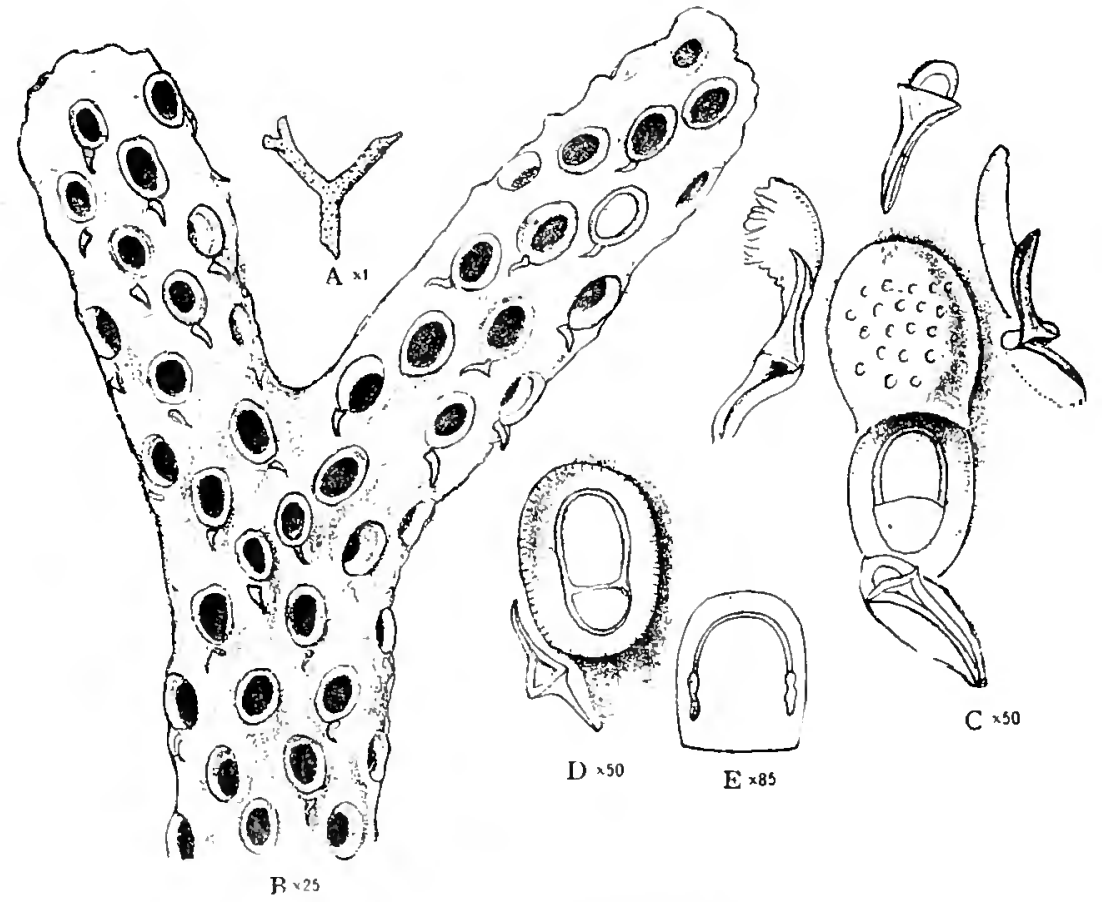

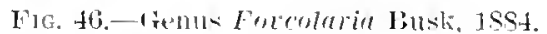

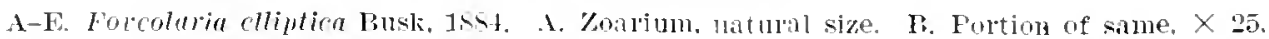

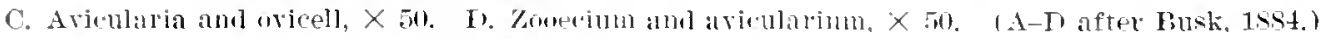
E. Gremom, X 85. (Aftel Water's. 1550.,

Genus AETEA Lamouroux, 1812.

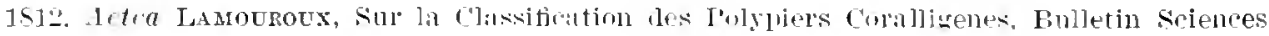
Sociéte Plilumatique.

Zoarimu adlecent to the -nhetratnun. Each zonecinum partially adherent, partially erect, the erect portion carrying at its distal extremity the membranous aperture with its operculum. (After Rohertson.) Twelve tontacles.

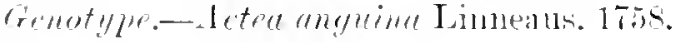

Reruge.-Eocene-Recent. 
AETEA ANGUINA ? Linnacus, 1758.

Flate 32. fiss. 2. 3.

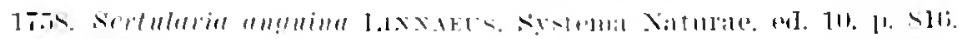

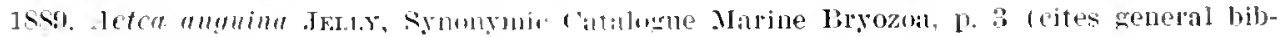
liogr:aply).

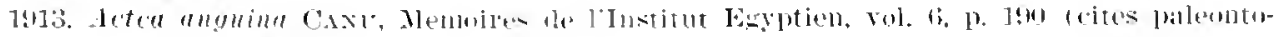
logic bibliuglallịy).

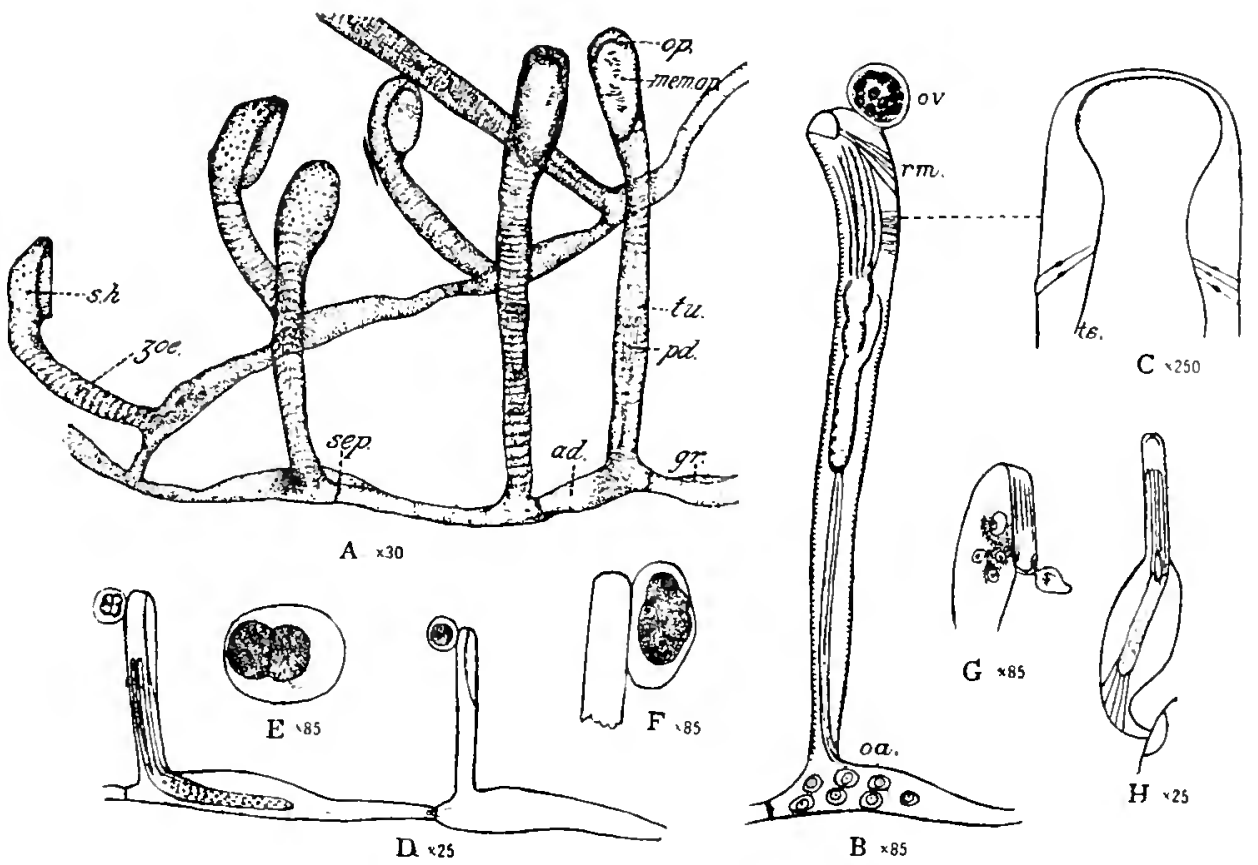

Fig. 17.-Family Aetrilate simitt, 1,stit.

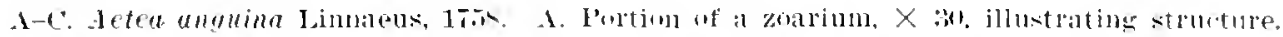

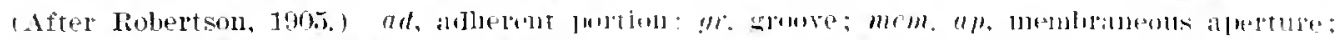

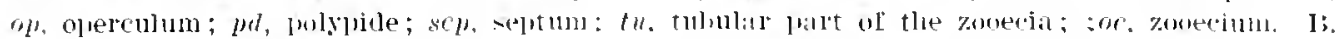

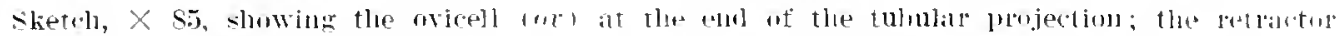

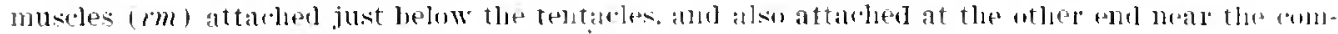

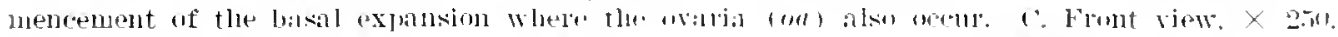

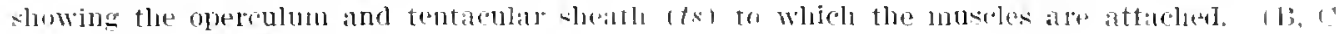
atter Watcris, 191:3.)

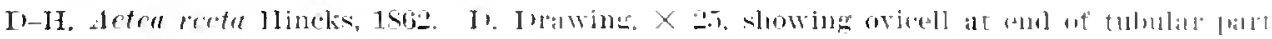

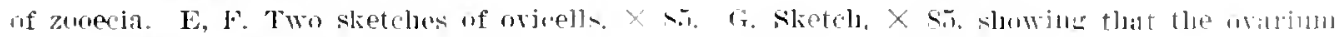

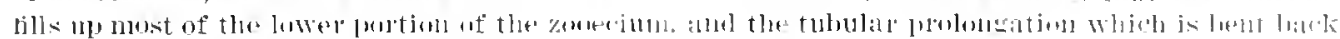

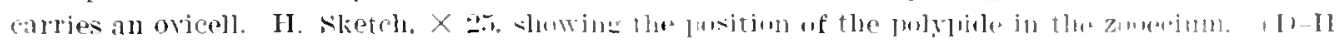
after. Waters, $15: 1$. I

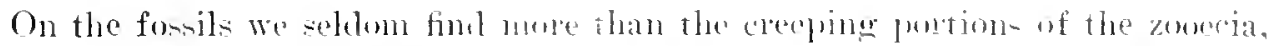

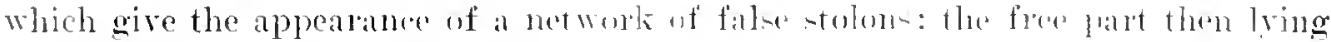

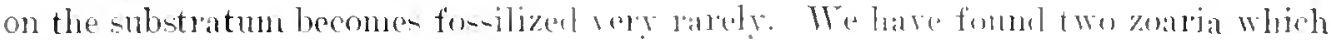

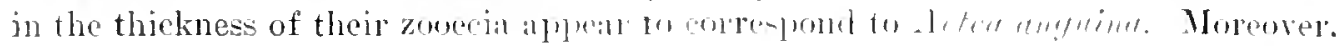


one of them retained an entire zonecinm whinh reoner to us to angere exactly with the figure of the species given by Water in 1913 in his wolk on the Marine Fauma of British East Africa and hanzibal. Inturtunately. in cleaning the specinen a stroke of the lumsh destroyed it. learing on detemination dontht ful.

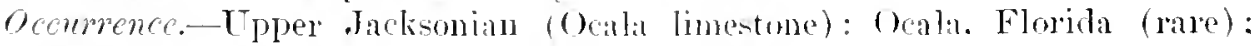
Bainbridge, Georgia (rare).

Geological distribution.-Helvetian of Egyt and Fiance (Canu); Zanclean of Italy (Seguenza); Plaisancian of Italy (Manzoni. Neviani) : Sicilian of Italy (Seguenza. Neviani): Quatemary of Italy ( Teviani).

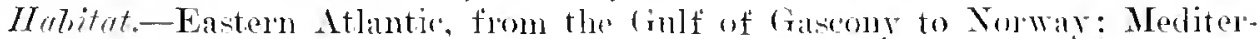
ranean. France. Italy, and the Arriatic: Parifir. Anstralia. Calitomia; Indian Ocean. Iflicall coast.

The species inhabits the regrion of the laminarian simweels. It seldom dives at a deptli greater than 30 meters.

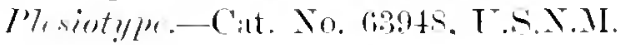

AETEA cfr. TRUNCATA Landsborough, 1852 .

I'late 32. กi:- 1 .

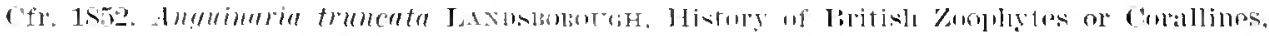
1). 2.es, pl. 16, fig. $5 \pi$.

The figure on plate 82 represents a srecimen firom Wilmington. Sortl Carolina, which in the thinness of its stolons is quite similar 10. Leton tromente Landsborongh. 18.5. However. it is impossilne to make a drifinte letemination withont an entire zonerium.

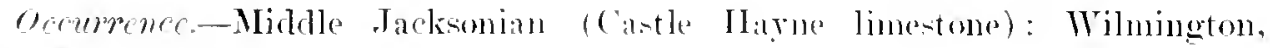
Surth ('arolina (rare).

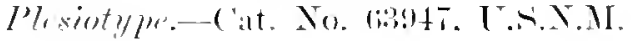

Family SCRUPOCELLARIIDAE Levinsen, 1909.

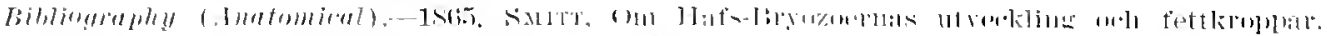

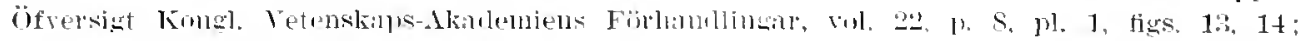

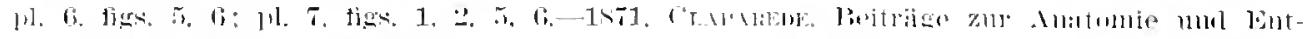

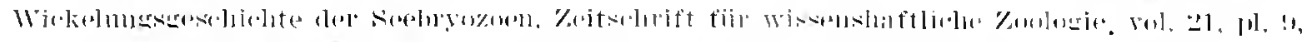

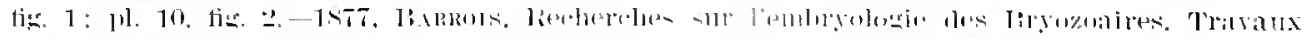

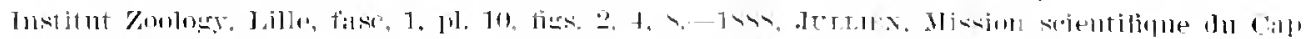

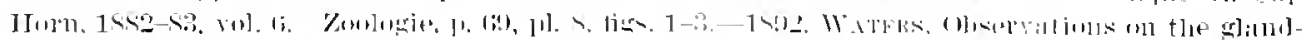

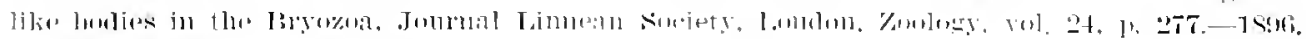

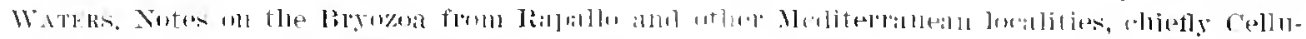

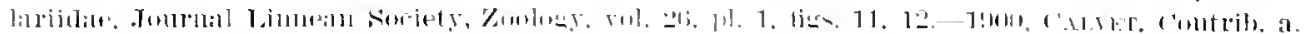

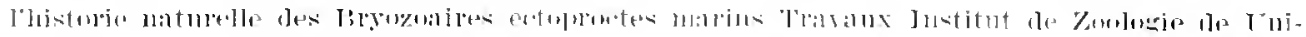

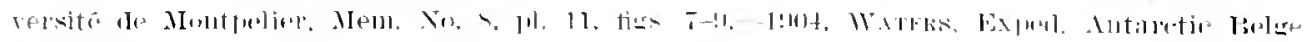

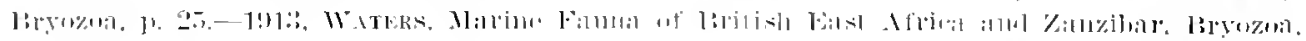

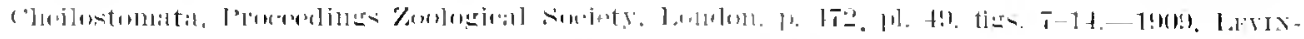

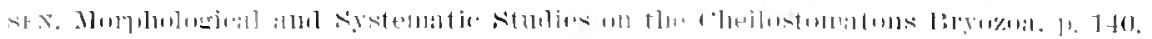


The zonecia have large operia. I gymmocyst and a cryoterest are more or less developer. The mural rim hear distally one or two palis of spines and laterally a membranens sentum. The di-tal wall. consisting of a horizontal. basal, and an oblifuely ascending frontal part. has nenally mumerous -matl. seattejed, uniporous septulae basally, while the distal half of each lateral wall has one multiporous septula. Besides dependent a vicularia, fomm in most peedes. vilmaenla may also occur on the basal surfiar of the zoarimm. and these ane comnecterl with the zoirium by an indepentent wall. The ovicells are generally hyperstomial. As a rule radicular fibel's erente sometimes springing from a scptula (or a dictella), sometines from a separate chamber commected with a viblaculum. The zoaria are always free, very branchet. mut frewpently with uni- or few-seried zovecial, generally consisting of a single layes and in most cases jointed by means of chitinous tran-rerse belts. (After Lerinsen. 1960).

Figure 49 grives a summary of the mest importint anatonical features in this family. No trace of the scutum is left on the fossil forms. lont its presence is revealed ly a small pore sitnitim on the mural rim. American Tertiary specimens are rare, mall. and very fragile. and as a result tre have been mable to make any detailed studies of the family.

The principal genera of this fanily are:

Caberea Lamomronx, 1816.

l'aberiella Levinsen, 1909.

C'(m)du Lamouroux, 1816.

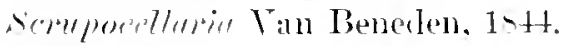

Bugulopisis Verril. 18 is.

Iloplitell, Levinsen, 1909.

Rhabdozomm IIneks. 188:-

Is mipee Lamonronx, 1816.

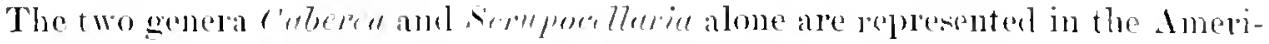

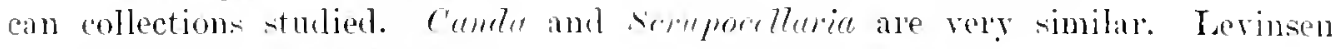

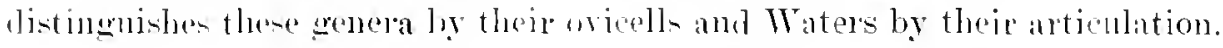

\section{Genus SCRUPOCELLARIA Van Beneden, 1844.}

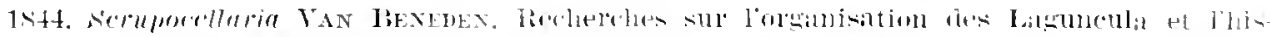

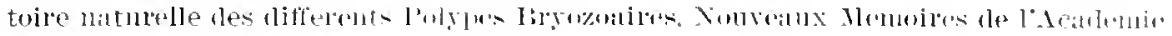

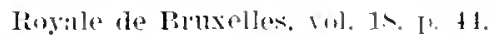

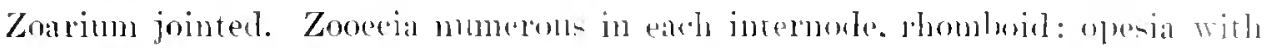

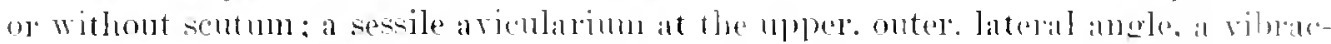

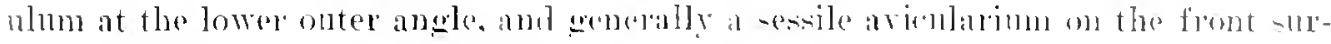
fince of each zonecium. (Roblest-om.)

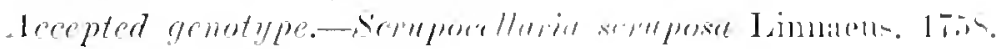

liange-Lututian-Recent. 


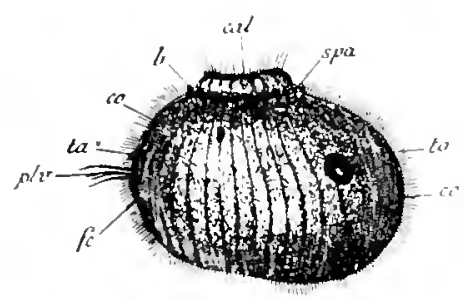

A

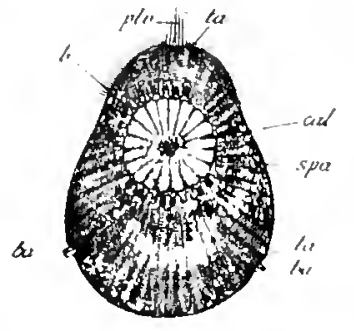

B
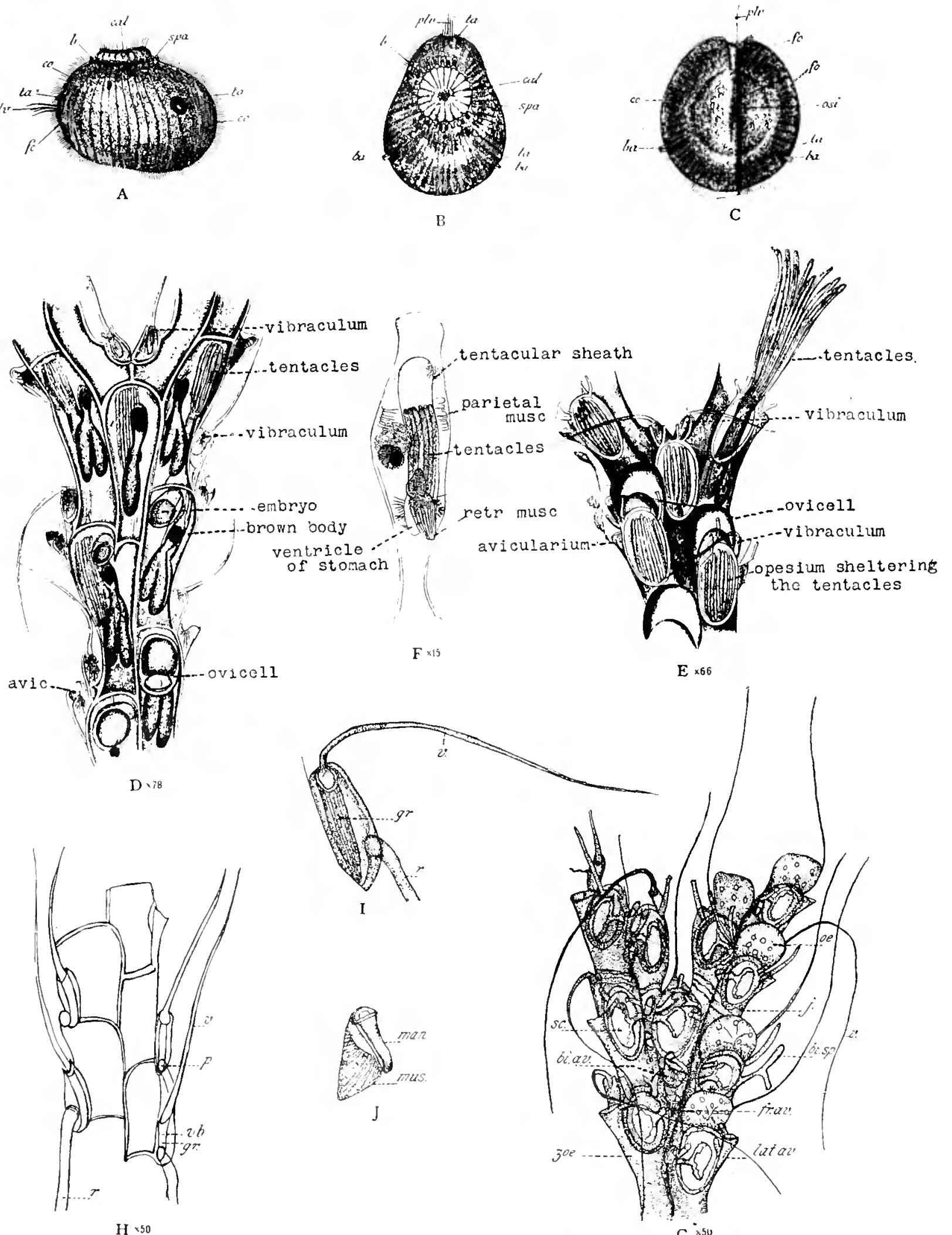

H $\times 50$

Cis $i 5$ 


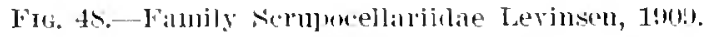

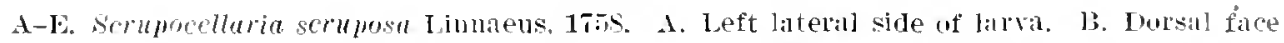

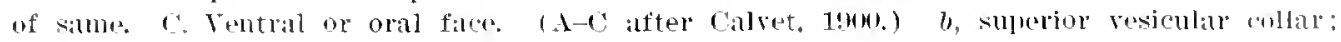

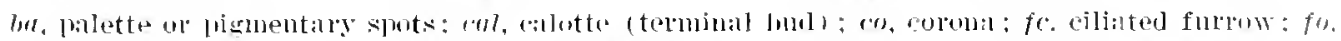
rentral or oral faces: ple, vibratilo plume: osi, uritice of the internal sack; spa, palleal furrom:

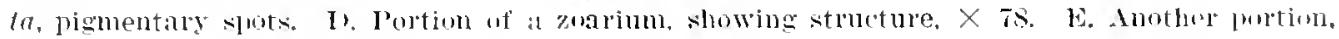
$\times$ 66. (D-E after Chaparede. 1570.)

F. Menipeq bentmumita Busk, 1884. Sketch showing anatomy. (Atter Jullien, 1888.)

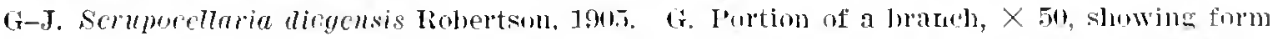

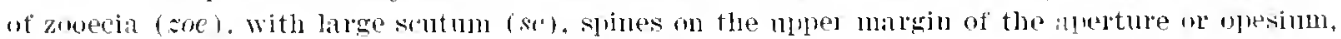

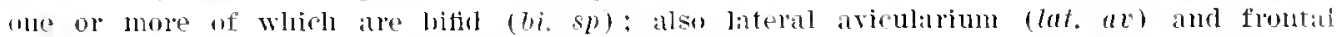
aricularium on the zonecinm at hifurcation $(b i, n i)$. On those zooecia not possessing onecia the

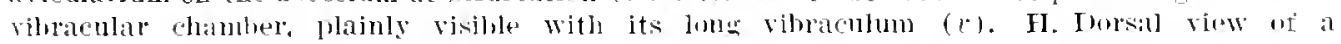

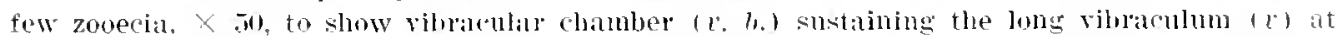
its summit. and showing the groove $1, \|$, extending in the direction of the length of the zoweria.

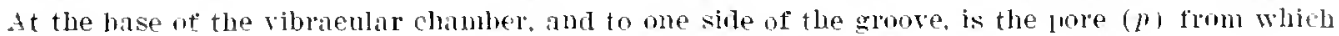

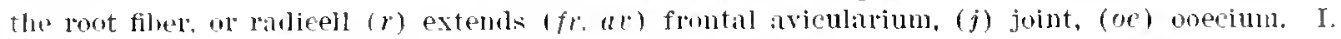
I viluracular enamber, enlarged, to slow detail, .I. The aviculariun on zooecium at bifuration.

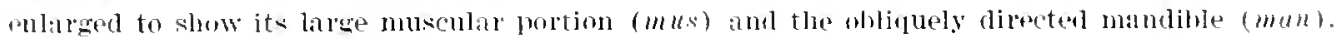
( G-J after Roluertson, 1905.) 
I']atte 32 , figs. $4-\overline{7}$.

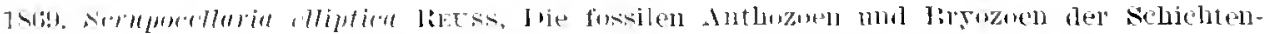

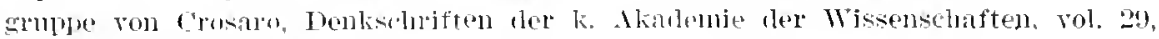

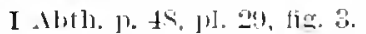

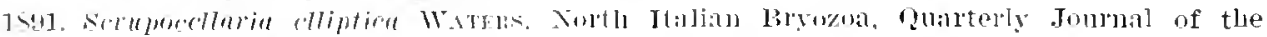

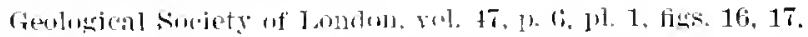

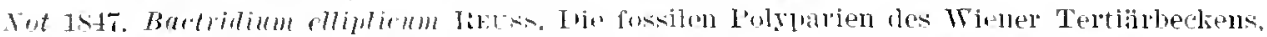

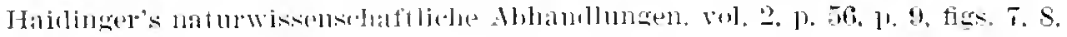

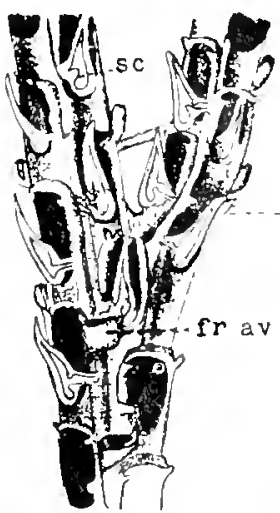

A, 25

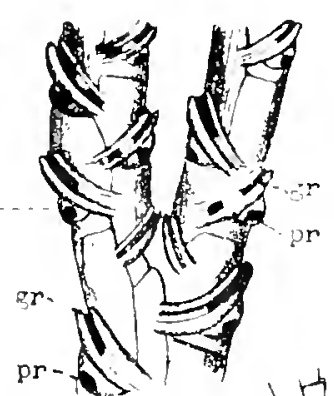

I -29
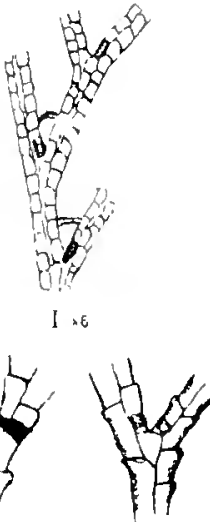

$\mathrm{H} \times \mathrm{O}$

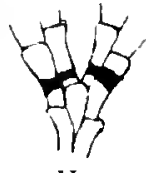

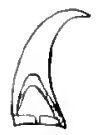

E. H' $^{4}$

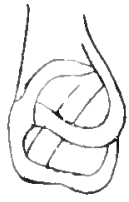

$F \times 250$

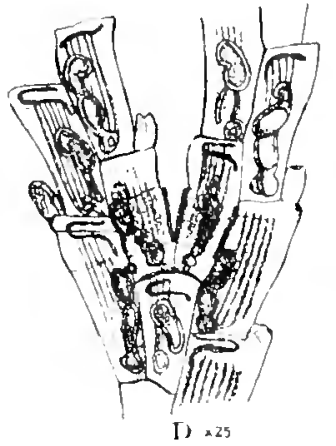

I) $\times 25$

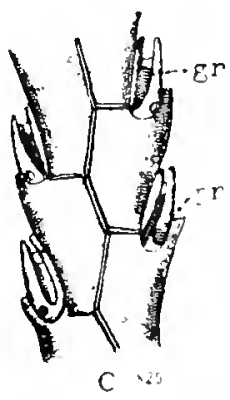

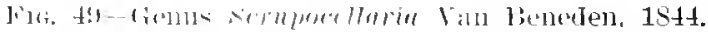

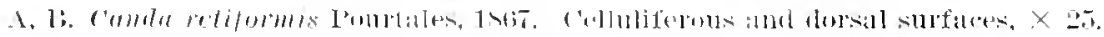

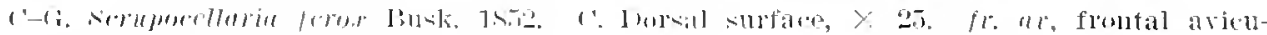

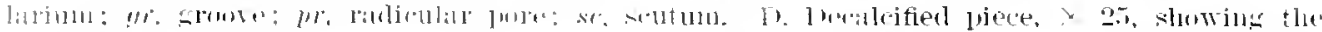

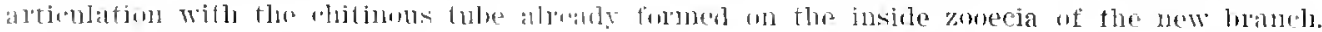

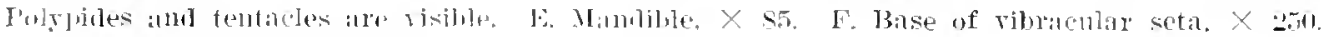

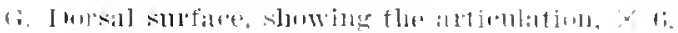

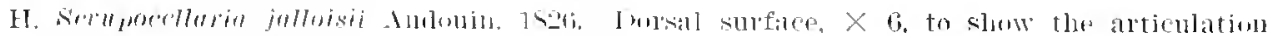
with two, hitinume tulws.

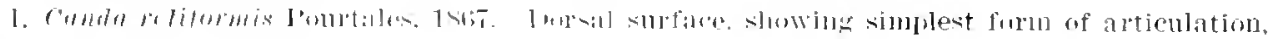
ii. (1- I iffer Itafers. 101:) 


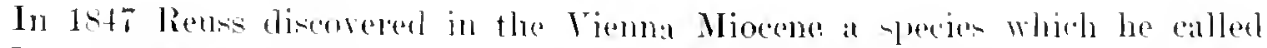

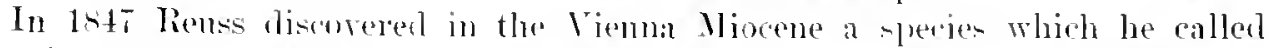
Vicentim, Italy, in 1ste. In amplaring the excellent figuree of Waters with the

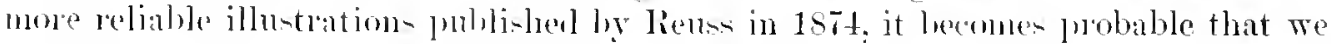
are dealing with two distinct - precies. In 187.5 Ianzoni betiever he had discovered

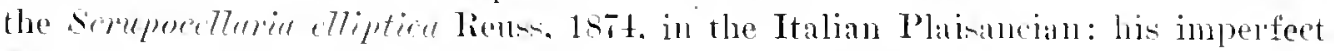
figure certainly led Sefuenzal and Teviani later into error. Finally the latter fingred in 1900, still unter this same name, a species muloubtedly tistinet. The

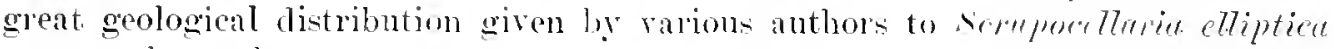
appears then to be erroneons.

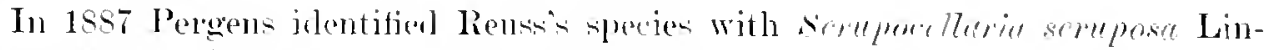
naeus, 17as. This was an elroneons irlentitication which. followed ly Miss Jelly,

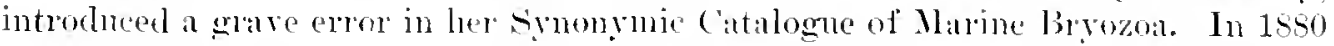
Hincks believed he hat fom the sane - peedes living in Engli-h water. but Waters thought that these specinene helonges to sempocellarin incrmis Norman.

Our specimens agree with the figures palblished ly Watro in 1891 . Under the circumstances we believe it leest to separate the Eocente preciev meler the name Scrupoedluria elliption Renss, 1869. Future tudies will be necessary before the status and name of the lliocene species san be eleterminet.

Description.-The small fromtal avicularim is rather comstant and is without a pirot. The same features hold for the distal a vicularimu. The dorsal vibraculum is transerse, conforming to the figme given by Waters. Immerliately below this is the radicular pore. The impression of the scutnum i- risible. The nicremetrie meaturements are as follows:

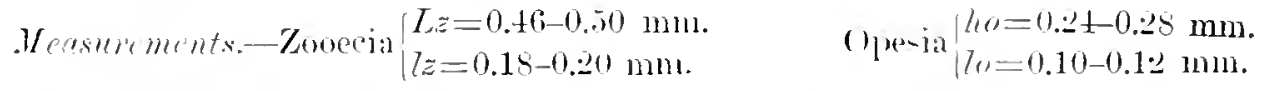

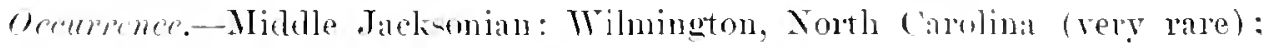
near Lenuds Ferry. South Carolina (very rart).

Geolegien thetribution.-Priabonian of Yicentin. Italy (liens. Waters), anet posibly in the liupelian of Gaas, Fance (Romss).

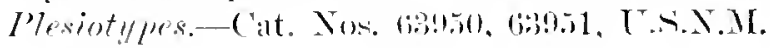

SCRUPOCELIARIA GRACILIS Reuss. 1869.

$$
\text { l'late } 32 \text {, figs. } 9,0 \text {. }
$$

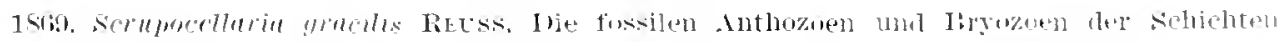

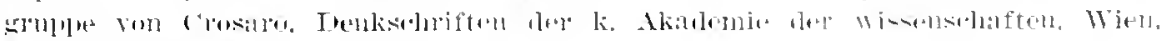
vol. 29. 11.200, 111. 24. fig., 4.

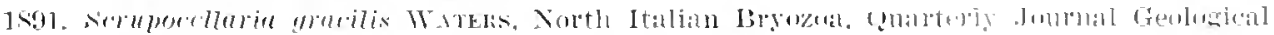

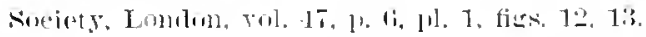

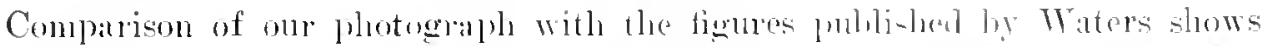

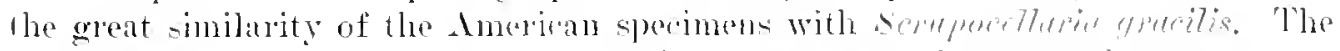

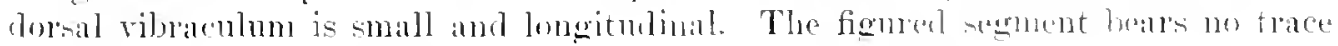

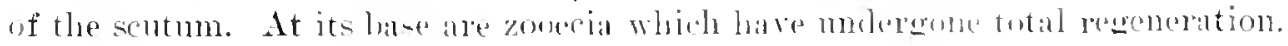


Ocempence-Mirlille . Tatisonian: Near Lemuls Ferry, South Carolina (very rare).

Geological distribution.-Priabonian of Vicentin. Italy (Reuss, Waters), and possibly in the Rupelian of Gats, France (Reuss).

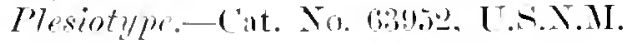

\section{SCRUPOCELLARIA COOKEI, new species.}

I'late 81 , figs. 6-S.

Description.-The segments of this new species carry at a maximum 10-12

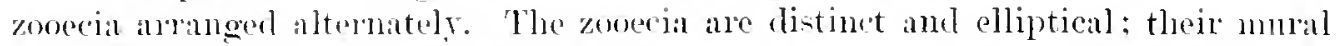
lim is rounderl, and beals a rely small distal pounded a vicularium, withont a pivot; the frontal arienlarim is larger and elliptical. On the dorsal side the zooccia are distinct and convex: the vibraculum is almost straight. pointed, and bears a sinall groove and a small rachicular pore.

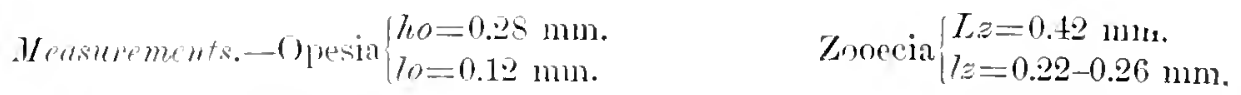

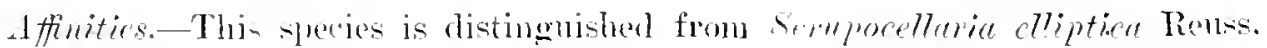
1869, by its greater brealth and its staight vihraculum. From s. mmilis it riffers in it areater micrometric dimensions. the constancy of the frontal arienbatrum and the latger ribraculum; from x. mitheri by its smaller limensions and -traighter and much smaller frontal aricularium. Tre have uot found the pore or the pit indicating the presence of the sentum on any of the specimens, nor can we explain the meaniug of the dintal lamella abserved in some opesia (fig. 6).

This fine species is ledicated to Dr. C. Wythe Cooke, of the United States (ieological Survey, to whose painstaking eftorts through several fiehl seasons we are indebted for mmly of om choicest material from the Tacksonian and Vicksburerian of the sumthern States.

Occurrence-Ticksbreian (Mariama limestome): Salt Momtain, 5 miles nouth of datekom. Alathanit (communon).

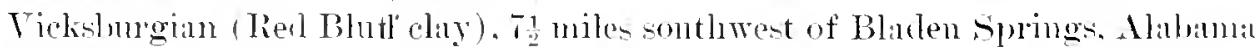
(very rare).

Vicksbugian (Byran mal): Near Woodwat. Wayne Comnty, Mississippi (rare).

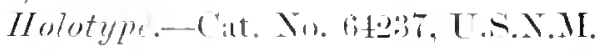

\section{SCRUPOCELLARIA MILNERI, new species.}

linte 81, figs. 9-16.

Description. -The segments in this species are linre and bear at a maximum 10-12 alternating zorecia. The zovecia listinct and elliptical; their mural rim romnded and bearing an inconspicuous distal aricularimm, without pivot. The froutal aviculanimm is very lare. oblique, acminate, withont pirot or denticle. On the dorsal the zonecia ale a little wonvex; the vibraculum is oblique, rather large, and bears a puite lintinet. prominent groove and a lare radicular pore situated on a 
small convex thamber. The hyperatomial ovicell is situated on the grmmocyst of the listal zooecimm.

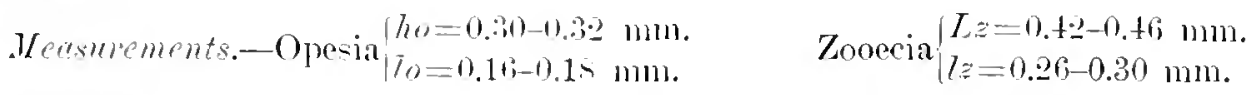

Athities. - The large size of its frontal aricularium and its greater micrometric dimensions clearly distinguish this species from somporellarid coolici, with which it is associated.

No trace of a sentum has been fomml, nol has a reason been obtained to explain the opesial lanella shown on some zonecia. One of om specimens is a branching segment showing. as detemined he Maters some time since, that the aticulations are calcified in such cases. The lomal is an olocyst with two separated layers (fig. 11).

This splendid species is nimed in homor of Mr. J. B. Milner, who has taken a keen interest in the lnyozoa in his preparatury work upon the Tertiary fonsils belonging to the [nited States Feofogianl Survey and the United States National Musemm, and who has found many specimens for onr study.

Ocomrence-Vicksburgian (Marianna limestone): Salt Mountain, 5 miles sonth of . Tackion, Mlabama (rame): Munder Creek, east of Castlebury. Conecul Comnty, Alabama (very rame): west hank of the Conecuh River, 1 mile below month of the Sepulga Rivel. Eacamtia (ommly, Alabama (common).

Tickshurgian (Red Bluft elay) : Ty miles southwest of Blarden sinrings, Alakama (lare).

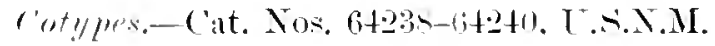

SCRUPOCELLARIA RESSERI, new species.

Plate s1. figs. 20-23.

Lescription.-The segment are formed of at least 10 alternating zooecia. The zooccia are distinct, with or without an elliptical grmmocyst; the opesium elliptical; mural rim is salient, thick, romberl, and bears two distal spines; the distal avienlarium is repry large and triangular: the frontal aricularim is smaller. projecting its pointed end above. On the dorsal the zooecia are distinct and convex; the vibraculum is straight. salient. and provided with a rectilinear croove. The ovicell is hyperstomial and situated on the distal zonerom.

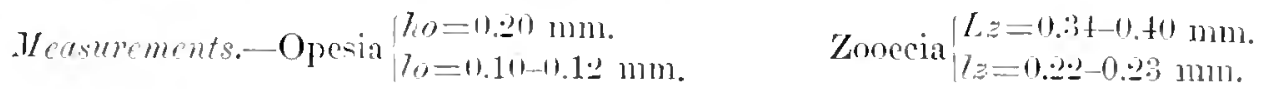

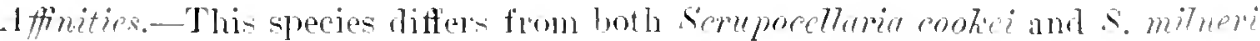
in the restilinear groore of its ribrambum which gives it a false rendulblance to Caberen. The specific name in in homol of Mr. Charlese E. Rascer, of the Tuiter States National Mnnemm, who has heen of asintance to us in the preparation of the illustrations for this work.

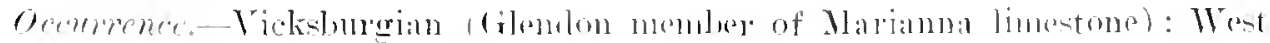

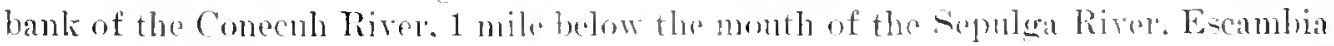
County. Alabinma (common).

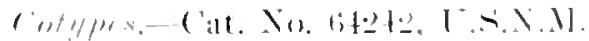


I'litu-1. ties: $24-2$ -

Thesriptim. The serments in this -pecies are thick and bear at least 10 zooecia aranged altermately. The zonewia are not distinetly separated from each other: are pyriform and proviled with a small proximal cryptocyst; their mural rim is rombled and with noither spines now sotum: the distal avieularium is very

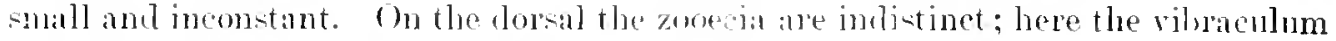
is puite large and bear-a broml groove anjarent to which is a radicular pore. projecting but little.

$$
\text { Mcasurements.-Opeeial } \mid \begin{aligned}
& h o=0.26 \mathrm{~mm} . \\
& 70=0.1 .2 \mathrm{~mm} .
\end{aligned} \quad \text { Znoecia }\left\{\begin{array}{l}
L_{z}=0 . \pm 0 \mathrm{~mm} . \\
7 z=0.28 \mathrm{~mm} .
\end{array}\right.
$$

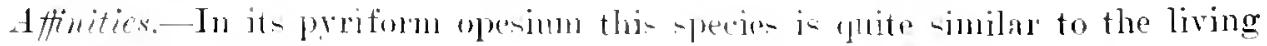

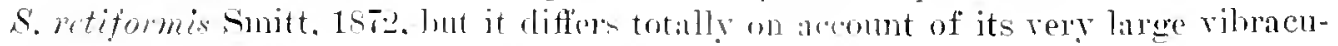
lum, which alove all is quite characteristic.

The secific mane is in honor of om fricme. Mr. Thomas F. Williard, of the United States Geologinl Survey, to whum wr are indehted for many contesies.

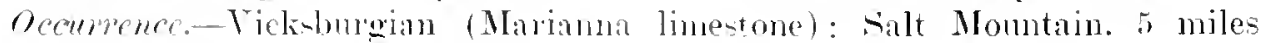
soutl of Jackson. Alabanal (eommon). (rare).

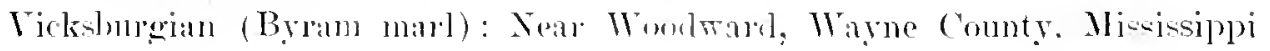

rotypes.-Cat. No. ritet:). IT.S.X.MI.

SCRUPOCELLARIA TRIANGLLATA, new species.

I'lite $\rightarrow 1$, tises. $1 \bar{i}-1$ !

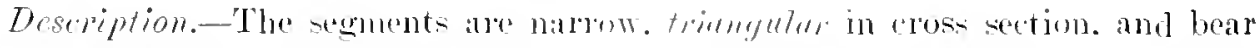

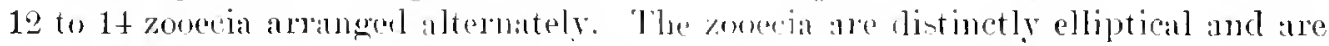
provided with a small poximal eryptocy : the npe-im is lyriform and narowest

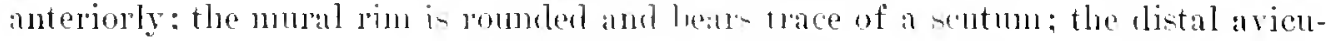
larimm is simple and vory small, while the trontal aricularim is quite rare. On the dorsal the zonecoia ars distinct and a little convex: the vibraculmu is lange.

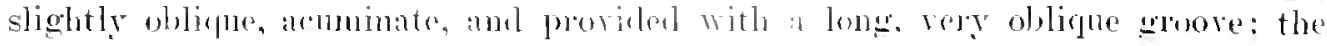
laticular pore is proninent.

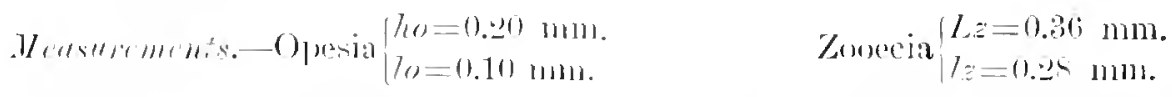

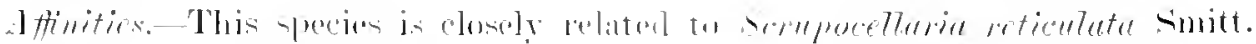

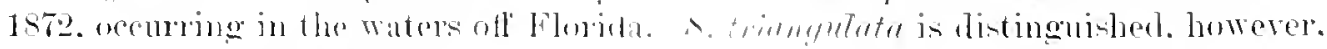

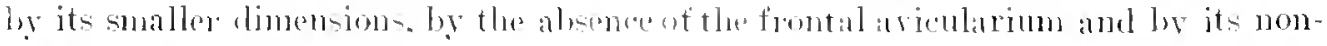
cremulated opesinm.

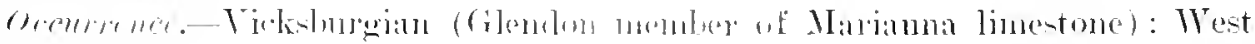

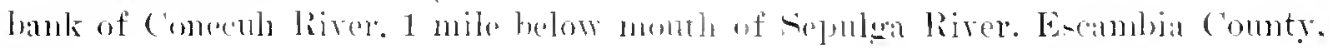
dabiana (raira).

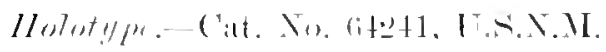


SCRUPOCELLARIA RATHBUNI, new species.

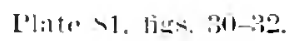

Deseription.-The regment are sarrow and bear 10 alternating zoocia : their

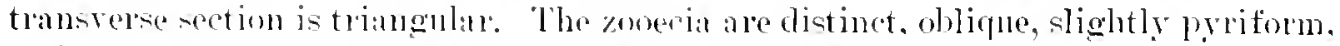
and are withont a cryptocrst : the ope-ium is pyriform and nalrowes proximally; the mural rim is thin, romblerl. and beals a short, hollow. projecting spine. which represents the schtmon: the distal aricularium is simple and very small, lut the frontal arienlarium is rery lare and projecting, slightly oblique. with the point abore and withont pirot. hut with two lateral denticles. On the dorsal. the zooecia are risible and convex: the aricularium is vely obligue and terminates in a long spatulate wroore: aljarent to it is a small projecting radicular pore.

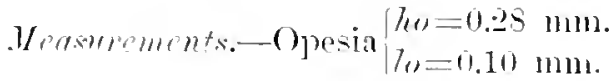

$$
\begin{aligned}
& \text { Zonecia } \mid L z=0.410 .45 \mathrm{~mm} \text {. } \\
& 17:=0.24 \mathrm{~mm} \text {. (Not counting projection of a vieularimm.) }
\end{aligned}
$$

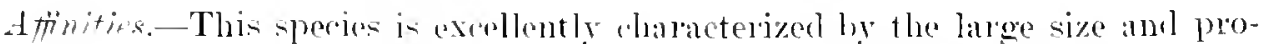
jection of its frontal aricularia. which wive to the zoarium a rery luistling aspect. Otherwise the species is rery close to the living se retiformis Sunit. 1870. It is remarkalble to observe the oecmereme of species of this trpe throughout the ages in the same waters of Florida.

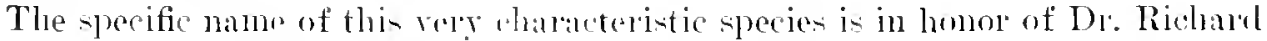
Rathlum, late asistant secretaly of the smithsonian Intitution, in dhatce of the

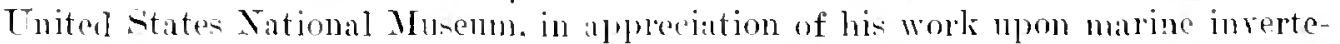
brates.

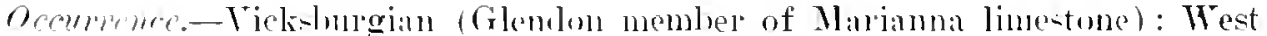

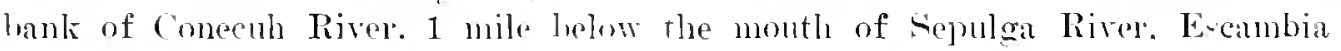
Co:metr, Alalsama (rare).

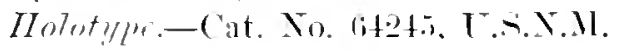

SCRUPOCELLARIA VALGHANI, new species.

Plate -1. ties. 29. 29.

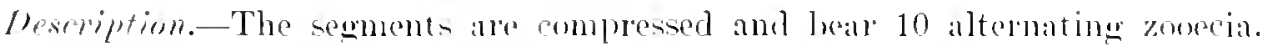
The zooecia are distinct, oblique. elliptiral. without cryptocest. but with a small gymuorst. The opesinm in elliptical: the mural pim. thin and romulerl. has a short. hellew. spine which is the traes of the articulation of the seutum. The

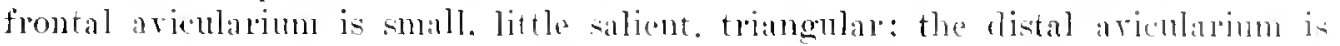

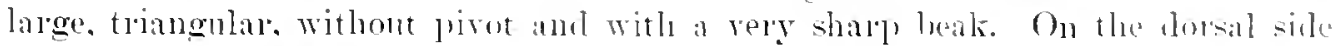

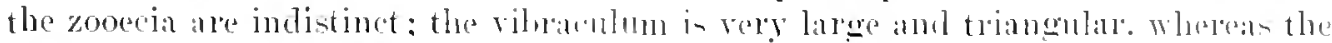
radicular pore is rery -mall.

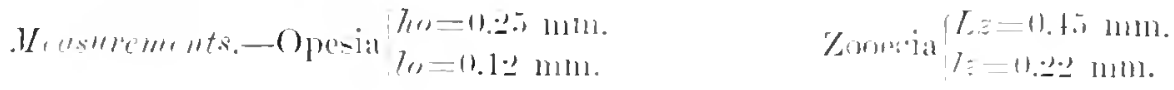




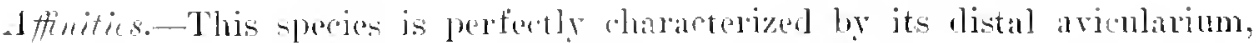

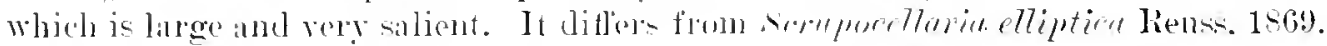
in which the dorsal sile is very imilar. exactly in the quite different form of the distal arieularium.

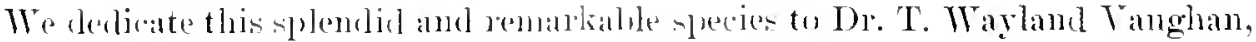
moler whose anspiese the present work has leen molertaken.

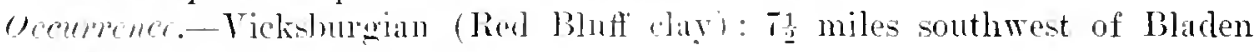
springs. Mlabama (very rare).

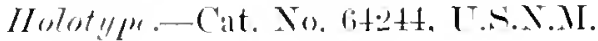

SCRUPOCELLARIA DUBIA, new species.

I'late 32, fiss. 16-14.

I'swription.-The little lraguents which we figure are hardly sulticient for the chanacterization of a species. The character-nef the clorsal are quite distinct. but on the frontal side all of the zooseia oherved apjeal to have undergone total legeneration. One of the segments seems to inclicate the vecurence of chitinous joints, a condition which is not habitual in scrupurdlurio. The species necessitates further examination based upon numerons and better lueserved specimens.

Occurene.-Middle Jacksonian: Neal Lemul- Ferry, Georgetown comnty, South Carolina (rare).

f'otypes.-Cat. No. (3is!sis, LA.N.X.M.

SCRUPOCELLARIA CLALSA, new species.

l'late 5. fïs. 1- 1 .

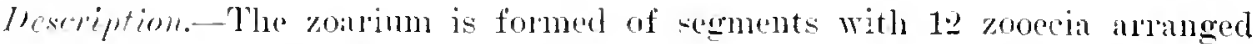
altemately. The zooecia are distinct. ellijtical. movided with a gymnocyst the

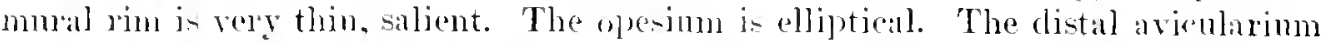

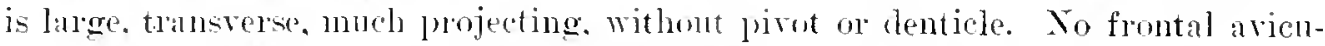
larimm. The opesinm is covered by a menturane with lateral libs; apertura semilnnate, with the proximal border concare. ()n the dorsal side the zooediat ale distinct and comrs: the vibraculum is straight and acmminate. and withont growe: adjacent to it is a small radicular pore.

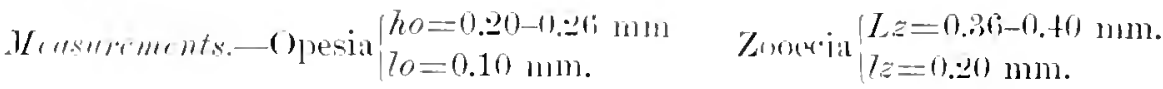

$$
\begin{aligned}
& \text { Iperture }\left\{\begin{array}{l}
h a=0.06 \mathrm{~mm} . \\
\text { /a }=0.08-0.0411111 .
\end{array}\right.
\end{aligned}
$$

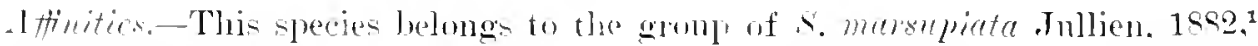

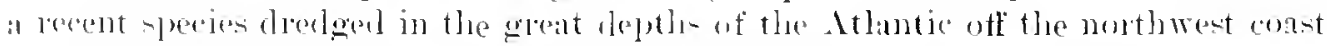

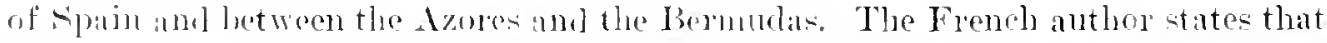

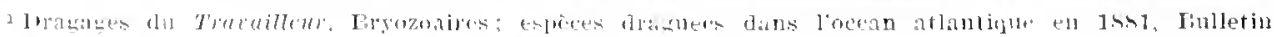

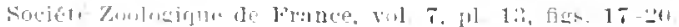


the membrane which clones the operium is a flabelliform spine jutting forward. Therefore, it replaces the soutmm. and its origin is the same. Is the ILenipede cleusu

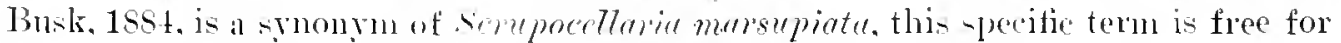
use for the present specien. The false costules observed are only remains of the ramifieations of the primitive pine. On. fossil speeies differ- from the reeent form

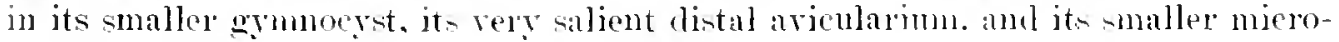
metric dimensions.

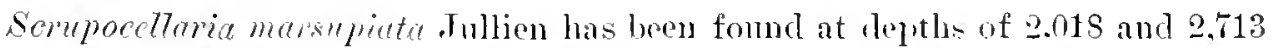
meters, but these fignres do not indicate the real habitat. Threr articnlated species live more often attached to algae at the smrace of the sea. and are deposited in the areat depths after their death. We can not therefore, consider these fignres in restoring the bathymetric lines of the Focene Gulf.

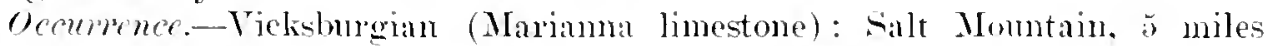
sonth of Jackson, Alabama (rare) : west bank of Conecuh River. 1 mile below month of Sepulga River, Eseambia Comty. Alabama (rave) ; Murder Creek, east of Castlebury, Conecuh Comnty, Alabama (rare).

Viekshrgian (Bryam marl) : West of Woolward. Waye Comnty, Mississippi (very rare).

rotypex.-Cit. Nos. 64:247. 64248, U.S.N.M.

Genus CABEREA Lamouroux, 1816.

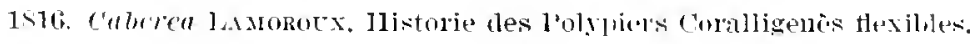

Zoarium not articulated. Zooecia in two or more series. -nlupuadrangular or ovate, with a very large aperture. Sessile frontal a vicularia on the sicle and front of zooecia: lateral aricularia mimte. Vibracular cells very large placed in two rows stretching oblichely downard across the back of the zooceda, which they almost cover, to the median line, notehed above and traversed thromgh a great portion of their length by a shallow groove. Vibracula mually torthed on one side. (Robertson.)

Genotype.-Cabcrea boryi Audonin, 18:6.

Range.-Viekshurgian-Recent.

CABEREA BORYI Audouin, 1826.

l'ate 81, firs. .3. :84.

1826. Crisia boryi (Siviguy) Audour, Fxplication sommaire des llinches le Polypes de

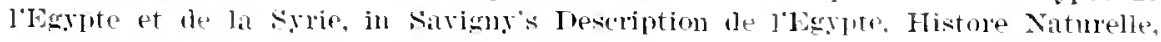
vol. 3, 11. 7., 11, 12. fig. 4 .

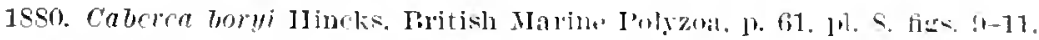

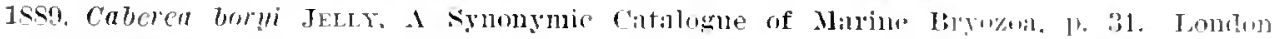
(sce for entier references).

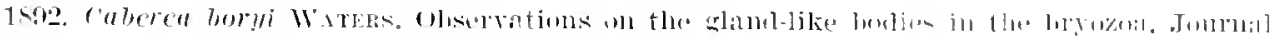

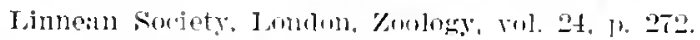

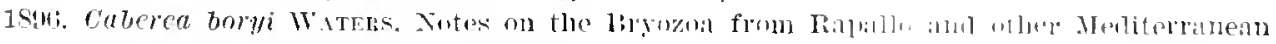

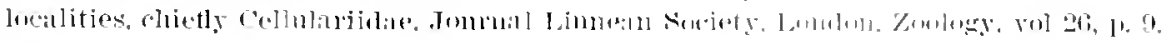



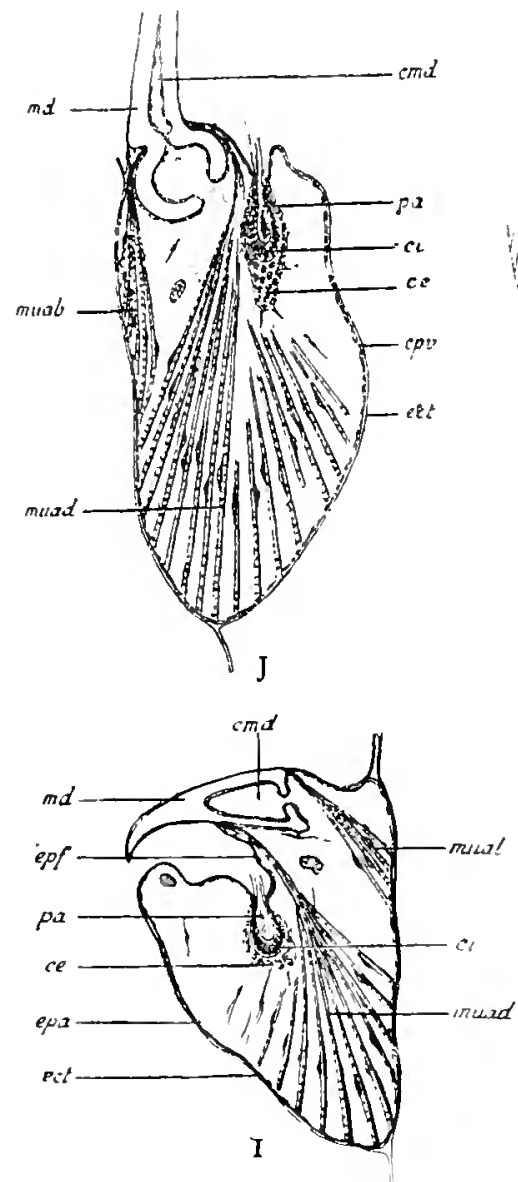
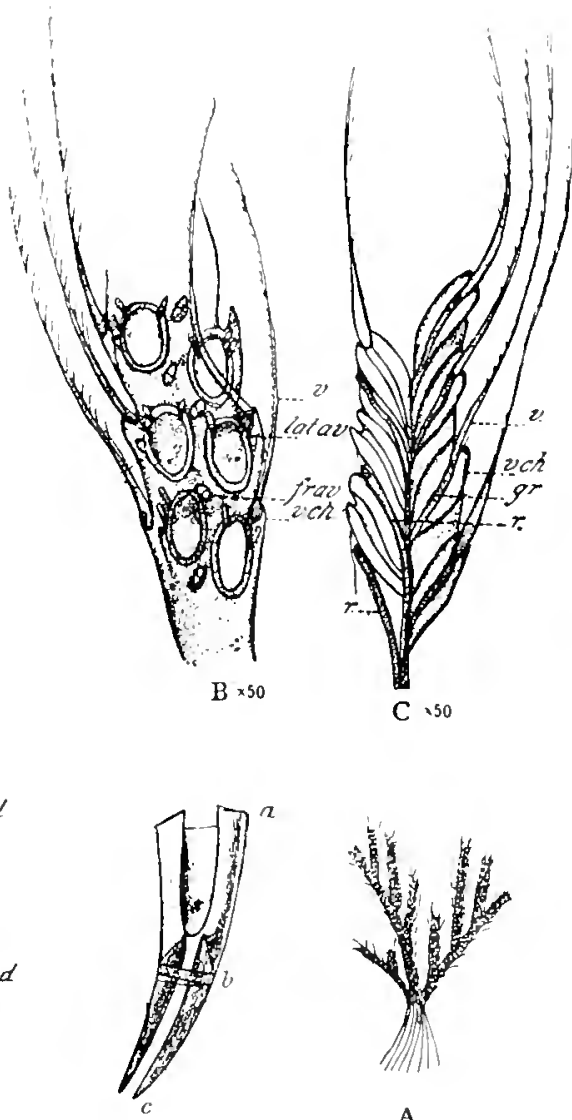

L
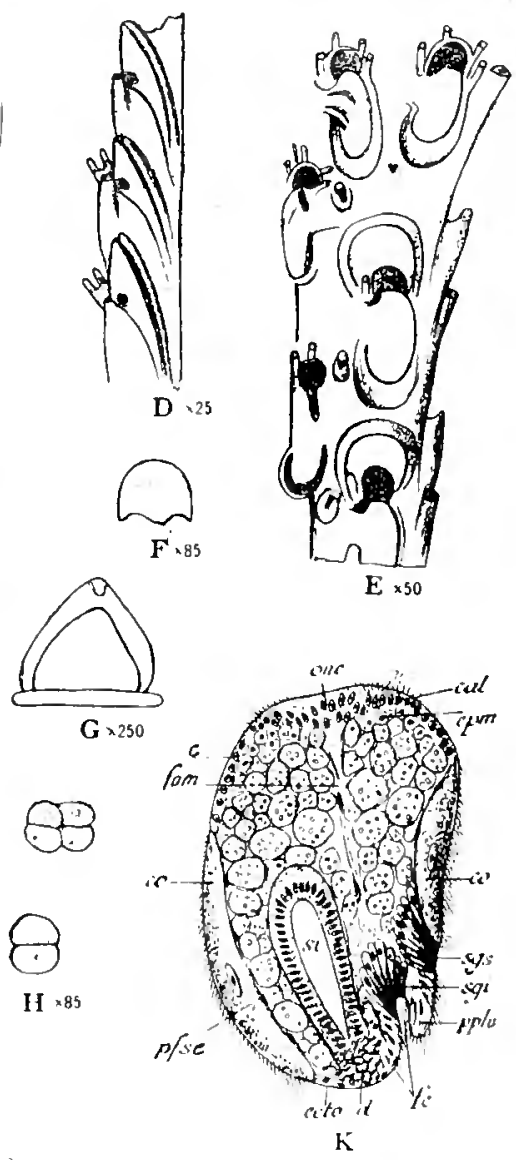

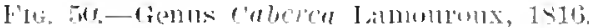




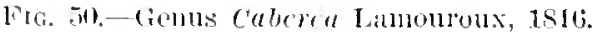

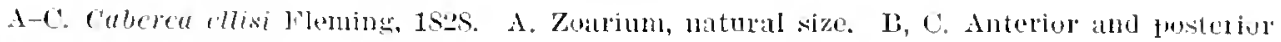

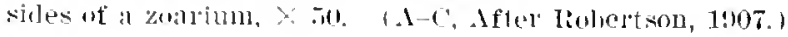

fr. ar., frontal avicularium.

Ifr, the sroove.

lat. at., the minnte lateral avicularial.

$r$, the roottets arising from ench vibracutar

chamber and proceding downwird through

the middle of the branch.

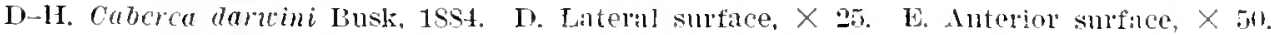

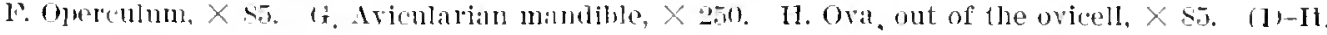
After Mallow.

I-K. Caberea boryi Aulouin, 1Sa. I. Longitulinat section of an avicularium, gleatly ellla rged.

re, external layer of tlo ciliated organ.

ei, interual layer of the same orgau.

('mal. mandibular cavity.

ret, ectocyst.

cha, aricularian efidern.

(l) focill eliderm.

J. Lungitudinat section of a vibaculum, sleatly enlarged.

('md, carity of the vibraculmm (=endocyst).

ect, ectucyst.

cpu, vibracular enidermis.

me, ribracutoid mandible.

muab, abductor mandibular muscle.

Ix. IIedian sagittal section of an embryo at one of the last stages of its develofment. It bresents almost the exact structme of the larva. (1-K. After Calvet, 1900.)

c. mautle.

('ul. calotte (terminal bud).

(०), coroun.

d. vacinal diaphram.

ccto, oral ectoderm.

rpm, mesorbrmic thickening.

fr. citiated cleft.

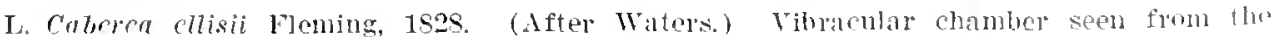
inside, $a, b$, vibracular chamber ; $b, r$, rontinuation of tho oronve beyond the dhamber. mo, mandilite (=endocyst).

muab, abdnctor musele of the mandilys.

muad, adductor or retractor muscle of the nutudible.

wa, aborted potyride=ciliated ol gan.

muad, adductor mandibutar muscle.

$p a$, abolted polypide=ciliated organ= peculin body witb ci, its internal layer and ce, its exterual layer.

fom, neuro musenlal bundles. onc, rentral nervous organ. pfse, subectoderm nerve plexus. lull, thapilla of the vibratile plume. syi, inferior ganolutar system. sgs. superior glandular system. si, internal sac. 


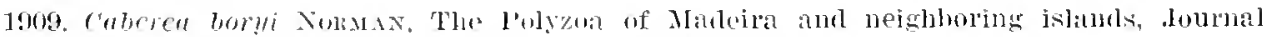
Limean Socisty, Lomblon, Zumlogy, vol. $80,11.285$.

1912. Caberen boryi CANu. Atude conplarée des Bryozoaires Helretiens de l'Egypte arec

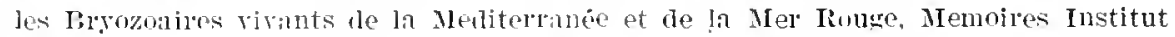
Errptien, vol. 6, [1, 198, 1)l. 10, fig. 17 (gives paleontolngical references).

Affinities.-Our unique specimen apjears to us correctly determined within the limits compatible with the extrome fragility of this small fossil. As in the fossil representative from Egypt, the opecium measures $0.20 \mathrm{~mm}$. hy $0.12 \mathrm{~mm}$. 'Traces of the scutum are risible on almost all of the zooccia, which prevents this specimen from being ilentified with Caterea ellisi Audonin. We have not noticed the occurrence of distal spines. 'Throfore this is not cabrea darwine Busk. Horrever, the small frontal avicularium placel near the zoarial axis appears more triangular.

Occurrenes.-Vicksburgian (Glendon number of Marianns limestone) : West bank of the Coneculı River, I mile below mouth of Sepulga River, Escambia County, Alabama (rery rare).

Mabitat.-Atlantic: Madeira Islands; English Channel, and British waters generally. Pacific: New Zealand and Australia. Mediterranesn and Adriatic.

Although floating and parasitic on marine algae this species has been found in the Mediterranean at depthe from 70 to 100 meters, but we are ignorant as to whether the specimens were living. 'The species luas never been observed off either the Atlantic of Pacific cont of America. where it is replaced by Caberea ellisi Audouin, 1896. (Roberton, () burn). Its presence in Madeira renders its discovery in Florida very probable.

Geolegient listribution.-Miocene of Australia (Waters): Helvetian of Egypt (Canu); Zanclean of Italy (Seguenza) ; Sicilian of Italy (Seguenza and Stefani); Quateluary of Italy (Seguenza, Neviani, Taters).

Plesiotype.Cat. No. 6424ti. U.S.X.Mr.

\section{Family FARCININARIIDAE Busk, 1852.}

The zooecia are fimbingel with an obliquely ascending distal wall and separated by common lateral walls, which ale furnished with a small number (2-4) of uniporous septulae: no trur spines. The a vieularia depentent, sometimes depressed, sometimes strongly projecting. 'The oriecls are emblozoocial. The zoria are dichotonouly Jranched tults. with slender, prismatic, sometimes jointed segments. on which the zooecia are allunged in longiturinal rows (generally 1-6) around an axis formed by the adjoining separating walls. (After Levinsen, 1909.)

There hive as yot been no anatumical researeles on the representatives of the family.

The known genela are as follows, the bat one alone beine represented in onr Imerican collections:

Cotumnaria Levinsen, 1909.

Faremimavia Busk. 18.42.

linir Busk. 18.5. 
We have added IIcterocelle Cam, 1907, to this family becane it is not yet advisable to create a distinct family for it.

Genus NELLIA Busk, 1852.

1552. Nellia ICsr. Catalogne Marine Polyzoa, British Museum, Cheilostomata, pt. 1, I. 18.

The zoaria are jointed. The zooecia are without spinous processes: the distal wall has at its inner corner a single septula: the oricells are in almost their whole
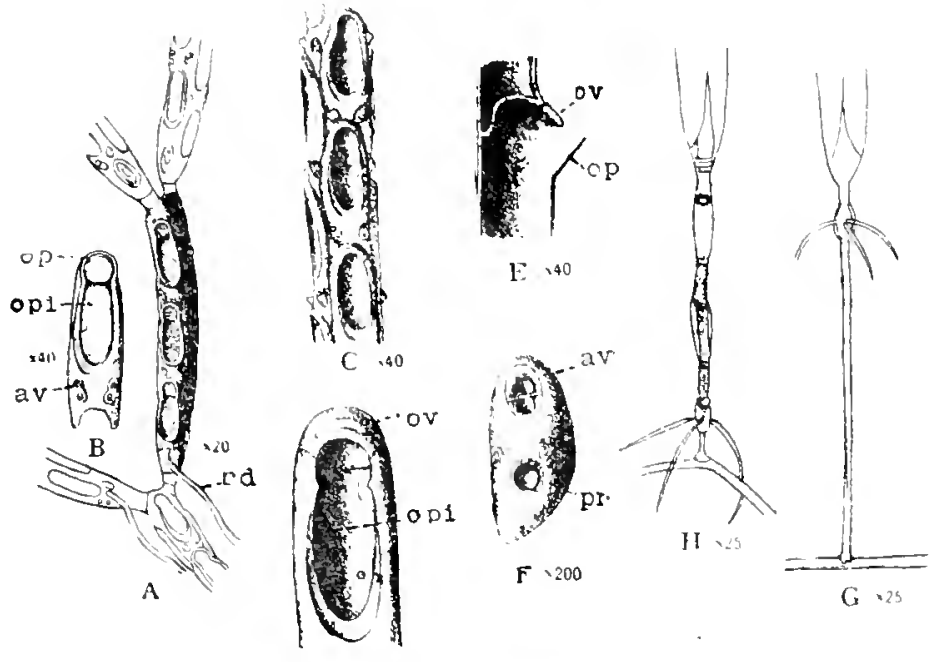

Fig. 51.-Genus Nellia Busk, 1S52.

1-II. Nellia oculata Busk, 1852. 1, P. Sesment, $X 20$ and a zonecium $\times 40$ (After Smitt, 1S72.) C. Fragment, $X 40$. The two proximal zooecia to the left withont ovicell. An aricularian chanber is seen through one of the literal walls of the middlemost zooecium. I. A zooecium with ovicell. $X 75$. An uncaleifiel trinsverse belt is present. F. A longitudinal section through an oricell, $X 40$. F. An avinnarium with pit for the insertion of the radical fiber, $X 200$. (C-F, Ifter Leviusen, 1909.) G, H. Stalk growing from stolon, $X$ 25. The growtl is from a spreading stolon from which. at intervals smb-colonies srow, commencins with short calcareous nodes joined lir chitinous tubes, $\times$ 25. (After Taters, 1913.) av, arieularia; or, ovicoll: op, opereulum: opi. opesia; $p r$, ralicular pore; rd, radical fiber.

extent inmersed into the proximal part of the ordinary zonecimm and project only very little on the surface of this. The avicularia are attached by a wide base or partially immersed with calcareous transverse pirot. (Aftel Levincen, 1909.) 12 tentacles.

Genotype.-Nellia oculata Busk. 185‥

Range.-Jaclisonian-Recent.

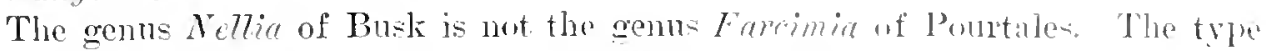
of the latter, Fareimia cercus Smitt. 1872. refuires further "xamination. 
NELLIA OCULATA Busk, 1852.

Pinte S2, figs. 6-10.

Bibliography of living forms.

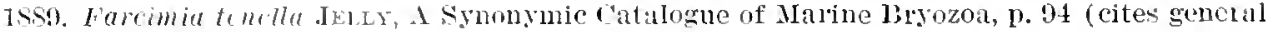
biluliography).

1909. Farcimil oculata WATERs, Reports on the Marine Biology of the Sulanese lied Sea. Joumal I,innein Society, London, Zoology, vol. 31, 1). 167.

1913. Farcimia oculata Waters, Marine Fauma of British East Africa and Zanzibar, Rrjozoa, Cheilostomata, Proceedings Zoological Society London, 1913, p. 489, pl. 67, figs. $8,9$.

1914. Nellia orulata (Isburs, The bryozoa of the Tortugas Islands, Florida, Publication Canegie lnstitution of Washington, No. 182, p. 191 (American bibliogr:iphy).

Biblingraphy of fossil formk.

18S3. Hembraniporl oculata Waters, Fossil Cheilostomitous Bryozoa from Mudidy Creek, Victoria, ete. Guirterly Journai Geological Societr, I.ondon, vol. 39, p. 434.

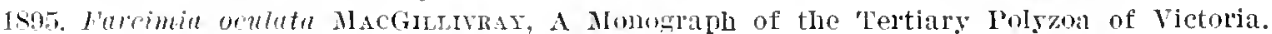
Transactions of the Royal Society of Victoria, vol. 4, p. 50, pl. 6, figs. 6, 7.

1007. Farcimia tenclla CANu, Liyozoares tes terrains tertiaires des enrirons de Paris, $\Delta \mathrm{n}$ nales de Palemtologie, vol. "2, p. 20, [1]. 11, figs. 36, 3\%.

1912. Farcimiu orulata Canu, Etude compare des Bryozonires Helretien de l'Egypte avec Ies Rryozuiles virants de la Mediterranée de la Mer Rouge, Memoires Institut Lgslutien, vol. 1, p. 191, pl, 10, figs. 16, 19.

The American fossil specimens have not the delicacy of the recent species, the segments being generally a little larger. The same is true of the examples found in the Lutetian of France. The measurements are quite variable on the same segment. We consider the upper zooecia of a segment as the more normal; the measmements for these are as follows:

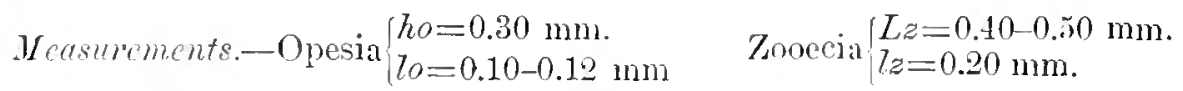

Below the opesimm there is sometimes a small isolated radicular pore. The lower zooecium is often incomplete and bears only a radicular pore. The ovicells are very diflicult to distinguisli.

Occurperee-Ficksbnrgian (Marianna linestone): Salt Momtain, 5 miles sonth of Jackson, Alabama (abundant); Vickshurg, Mississippi (rare in the lower beds).

Vicksburgian (Byram marl) : West of Wroodrard. Wayne Comty, Mississippi (rare); Byram, Mississippi (rare).

Geological distribution--Lutetian of the Paris l3asin (Canu); Helretian of Egypt (Canu); Miocene of Australia (MacGilliviay).

Habitat.-Pacific: Australia, Crozet Island and the Philippines. Indian Ocean: Off Ceylon. Mergui Archipelago, Zanzibar, and in the Red Sea. Atlantic: Off Florida, St. Thomas, and the Tortugas.

Specimens liave been dredged from a depth of 17 to 450 meters. Off the Tortugas Islands Osburn mentions that it is abunlant on sponges from 20 to 28 meters. The Tertiary Gulf was certainly decper than to-day and for this reason fissil examples are rare.

Plesiotypes-Cat. Nos.61249,64250, U.S.N.M. 
NELLIA BIFACIATA, new species.

late 32, figs. 15-19.

Deseription.-The seoments alre formed of four linear series, with five zooecia in each. The zooccia are distinct, constricted below, and provided with a muchdevcloped gymmocyst bearing two small avicularia. The mural rim is thin, salient, and without creptocyst. The opesium is somewhat oval, narrowest below; the two fiontal aricularia ale symmetrical, simple, and withont pivot.

$$
\text { Measurements.-Opesia }\left.\right|_{l o=0.08-0.10 \mathrm{~mm} .} ^{h o=0.20} \mathrm{~mm} . \quad \text { Zooecia }\left\{\begin{array}{l}
L z=0.50 \mathrm{~mm} . \\
\mid z=0.16-0.20 \mathrm{~mm} .
\end{array}\right.
$$

Afinities.-The four faces of the zourium are not identical. There are two rows of broad zooecia and two narrower ones. This character primarily, in addition to the great development of the gymnocrst, clearly distinguishes this species from lellia orulata Busk, 185.2. The micrometric measurements are also smaller.

The specimens from the Jacksonian are a little smaller than those of the Vicksburgian, but all the other characters are alsolutely similar.

The first of the lower zooecia of the segment is often radicular; the second is frequently regenerated. In figs. 15. 16 may be seen an ordinary zooecium transformed into a radicnlar zonecium; probably it contained no polypide. We have not had the opportunity to discorer the oricells.

Ocommence.-Tower Jacksonian (Moodys marl) : .Tackson, Missisippi (rery rime).

Middle Tacksonian (Castle Hayne limestone): Wilmington, North Carolina (rare).

Vicksburgian (Glendon member of Marianna limestone) : West bank of Conecuh River, 1 mile below mouth of Sepulga River, Conecul County, Alabana (rare).

Vicksburgian (Byram marl): Byram, Mississippi (rane).

Cotypes.-Cat. Nos. 63954, 03955 , U.S.N.M.

NELLIA CONCATENATA Canu, 1907.

Plate 32, tigs. 20, 21.

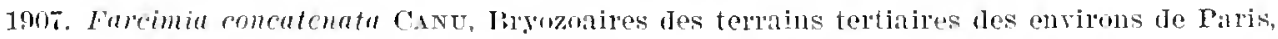
Annales de Paleontologie, rol. 2. p. 19, pl. 11. fiss, 1-4.

Of this species we have found only the two figured tragments which have been compared diretly with specimens from the ricinity of Paris, with the result that their identity can not be doubted.

The large rimensions of Nellin coneutenutu clearly distinguishes it firom the two preceding, Nellia omlata Busk and $N$. lifaciata.

Ocenrence.-Middle .Jacksonian: One-half mile sonthe:at of the Georgia Kaolin Company's mine, 'Twiggs County, Georgia (very rare).

Plesiotypes.-Cat. No. 63956 , U.S.N.M.

NELLIA MIBWAYANICA, new species.

I'lite 4, figs, 10-15.

Description.-The zoarium is artimbatod and lialiceliate. Each secment is quadrancular and formed of ctraight zooecia alranger in four series equal. two by 
two. The zooecia are lectangular; the opesinm is anterior, elliptical, and is surrounded by a thin mural lim projecting but little; the gymmocyst (?) is well. developed and beas's two symmetrical tuberosities, which represent small avicularia opening laterally in the same plane as the adjacent rows; the two distal avicularia visible in the neighborhood of the opereular valve also match those of adjacent rows. Ovicell endozooecial.

$$
\text { Measurements.-Large opesia }\left\{\left.\begin{array}{l}
h o=0.26-0.36 \mathrm{~mm} \text {. Large zooecia } \\
l_{0}=0.12-0.14 \mathrm{~mm} .
\end{array}\right|_{z=0.40} \mathrm{~mm} .\right.
$$

Affinities. This is a very curious species, which is diflicult to classify. We have placed it in Nellin because of its great resemblance to Vellia appendienlata Hinclis. 185?, a living species from Instralia. and to Farcimia articulata MacGillivray, 1895.

It is also close to puadriceltaria rentricosa Canu, 1913, of the Girondin Intetian of France: only the alosence of a little distal crescent distinguishes it from this European species.

When we know the chitinous appendages of these two species perhaps it will become necessary to place them in a new genus with $N$. appendiculata.

There are two rows of broad zooecia opposite each other. and two rows of similarly placed narrow zooecia. At the base of certain opesia, exteriorly or interiorly, there is sonctimes a rndicular pore: such zooccia. therefore, bear at the same time a polypide and a radicular fiber.

As re have found this species in the three Midway localities studied, it seems to be a characteristic form and is thrs deserving of the name applied to it.

Oecumenee.-Mirwiran (Clayton limetone): Mabelvale, near Little Rock. Arliansas (very ralle); 1 mile west of Folt Gaines, Georgia (very lare); Iurerne, Crenshaw County, Llabama (common).

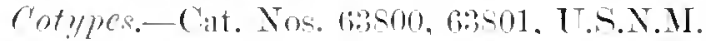

\section{Genus HeTEROCELLA Cami, 1907.}

1907. Hcterocella CANT, bryuznires des tel'rins tertiares des environs le I'aris. Annales de Iraleontologie. พ11. 2. 1. 14 .

The zoarium is articulated with each sement formed of four rows of zoocia. The opesia are always oblique; they are smatl on the converging zooecia and large on the diverging ones. On the olocyst at the bottom of the zooecia there are impressions of various forms.

Genotype.-Tincularia fratis Defince, 1830 .

In Europe this genus has been observed only in the French Lutetian. Its structure is still problematical. for no existing speces $\mathrm{i}$ comparable to these fossil forms. Some of the zooecia described ly Canu as regenerated are perhaps radicular.

HETEROCELIA VICKSBURGICA, new species.

I'lilte S2, tigs. 11-11.

Deseription.-The segments are quallangular, straight, or sliently curred. The zooccia are distinct and rectungulur" the mural rim is rounded, projecting dis- 
tally, and enlaned proximally: the opesinm is oval shaped and a little oblicue. The length of the zooecium is 0.60 to $0.70 \mathrm{~mm}$.

Aftinitirs.-This specios may be distinguished from IIctcrocella fragilix Defrance, 1820 , by its greater mirrometric dimensions, its straighter zooccia, and its smaller septulae.

Ocompenex-Vickburuian (Marianna limestone): Salt Momtain, jo miles south of Jackison, Alabama (common).

Cotypes-Cat. No. 642.)1, T.S.X.M.
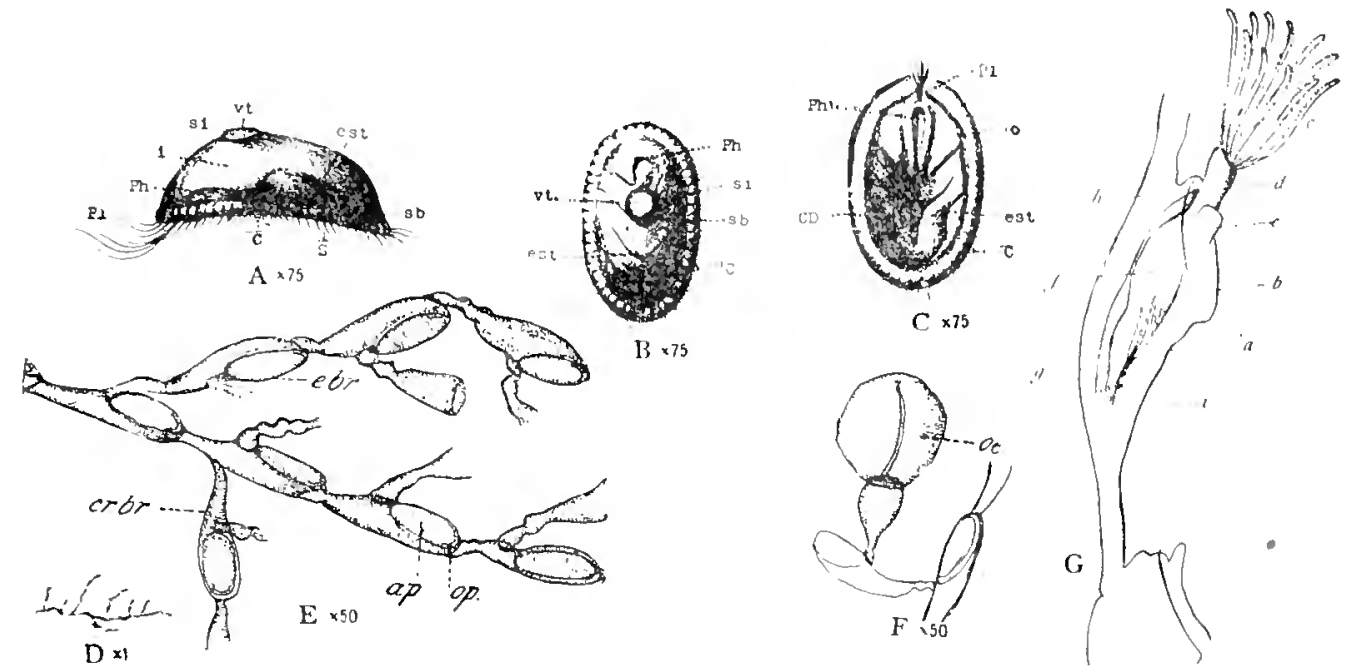

Fig 20-Wimly Euclatidae Hincks, 1850.

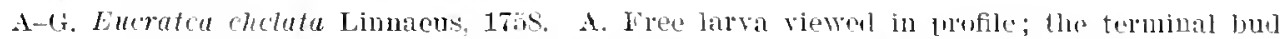

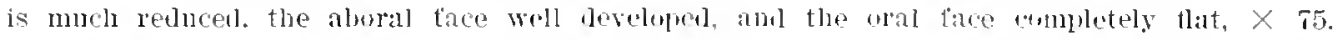

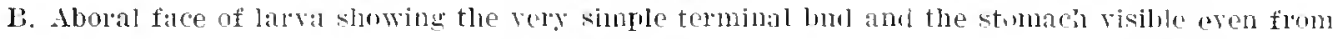
the side, $X$ 75. C. Larra, oral face, showing the trilobate form of the stomach. $X$ 75.

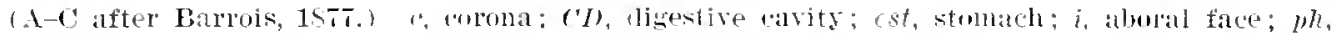

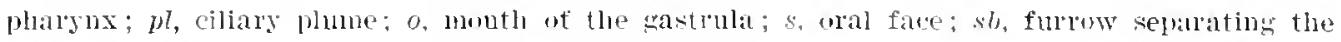

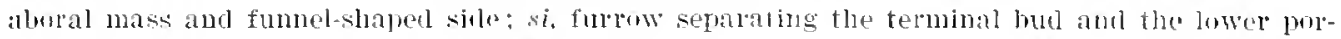
tion of the aboral face; $c t$, terminal bud. D. Zoarium, natural size. F. Fortion ot a zoalinu.

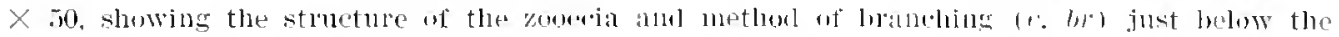

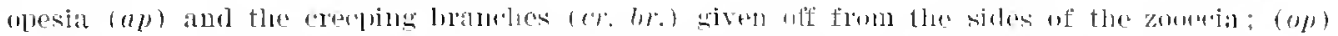

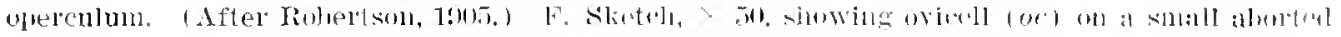

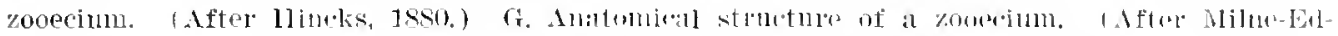

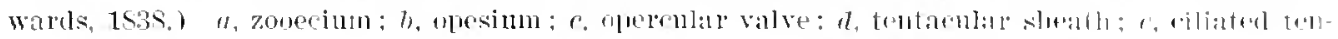

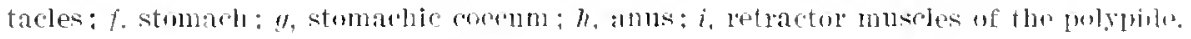

\section{Family EUCRATIDAE Hincks, 1880.}

Zoarium forming slender, iranching. phytoid tufts. Zomeria mniserial or in two series placed back to back; expanding from the base upwards, with a terminal or subterminal and usually oblique opesum. Teither avicul:urian nor vibracular appendages known. Oricell globuse. lypperstomial. (Robertson.) 
'The genera of this family are:

Everatce Lamonum: 181:.

Iuxleya Dyster, 1858.

Gemellaria Savigny, 1811.

Brettic Dyster, 15.58.

scrupuria Hincks, 1850.

\section{Genus GEMELLARIA Savigny, 1811.}

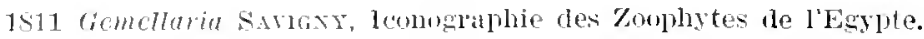

Zoarium erect, lunching dichotomously, each branch given off from the sides of the zooecia close to their upper extremity. Zooecia joined hack to back and

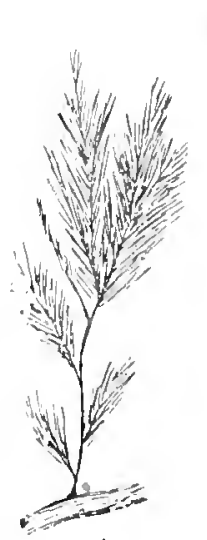

A 21

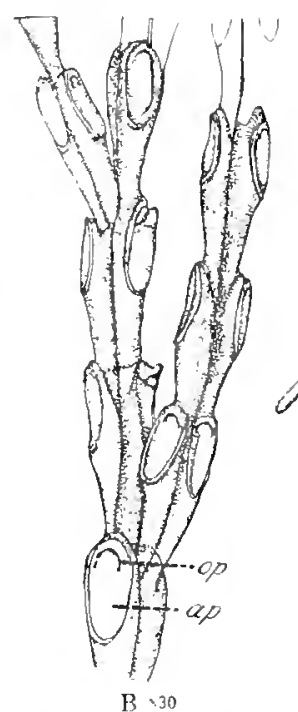

Fra. 53. - Henus Gemellaria Sarigny, 1811.

1. C. Crmelluria loricuta Linnaens, 1778. A, Skotch of growth labit, natural size. 13. Purtion of a branch, $x 30$, to show arrangenerent of zooecia and methol of hranching; ap, aperture; op, operculnm. (1, I) after Robertson, 1907.) C. Inatomical structure ol a zouecium. (Niter Tan boneden, 18 j5.) ", tentackes; b, pharynx; $c$ oesopharrus; $d$, stomach; $c$, intestine: $f$, froticlus contained in the stomach. m77 Busk. 1869. of the English Iontinian; it was figured anew in 1892 by Cregory under the name of Notamia wotheret7i. The figures of Busk and of (iregory do not at all coincirn. Howerer our American species differs from it in the absence of areolac.

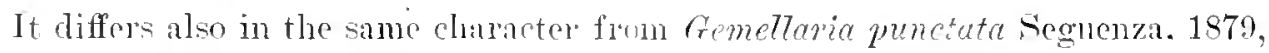
firom the Helvetian of Italy.

The eight fragments which we have fomd do not permit a detailed study. It

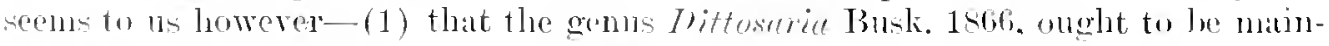
tains for the three linurn fossil species; (2) that their place in the Anasea is doubtful; (3) that this family, of which the larva is so near the Escharines, may be

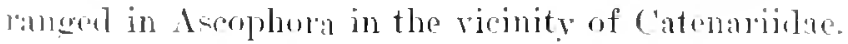




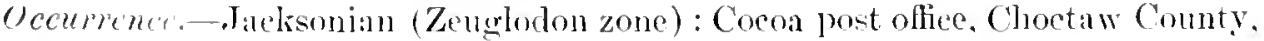
Alaballa (rage).

Geoloqieal dintribution.-Rupelian (=Stampian) of Germany.

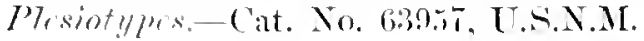

\section{Division II. COILOSTEGA Levinsen, 1909.}

The parietal muscles are attached to the ectocyst and raverse the chitinous or partially ealcified erypteyst by means of the opesiules. The hydrostatic system is zoarial but calch zonecinm in addition is provided with a hypostege with the cryptoeyst ealeified.

The families of this division are as follows, all exept the last three being represented in the present work:

Opesinlidae e Jullien. 1sss.

Sulofamily Microporidae Hineks. $18 \rightarrow 0$.

Onychocellidue Jullien, 1 ss1.

Lumularidae Levinsen, 190!).

A-pidostumidae Camm, 1908.

Steganoporellidae Lerinsen, 1909.

Thalamoporellidae Levinsen, 1009.

Setosellidae Levinsen, 1909.

Chlidoniitie Levinsen, 1909.

Alysidiidae Levinsen, 1909.

\section{Family OPESIULIDAE Jullien, 1888.}

The parietal muscles are attached to the crypto-

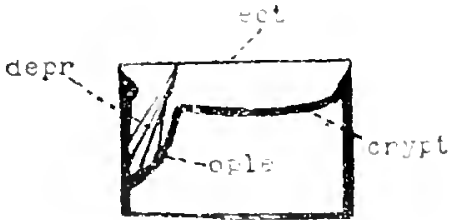

lic. 54.-Fincture of the Coilostega.

Diasrammatic transwersal section of a zooecium of the cisilostega. (. Ifter Harmer, 1902.) crypt, calcificd cryptocyst; col, membranous retocyst; ople, opesiule containing a depressor muscle (dep), or modified parietal muscle.

cyst; their place is indicated either by pores or loy lateral indentations called opesiules. The ovicell is endozooecial.

Historical.-In 1956 Jullien discovered that the parietal muscles in many genera of bryozon were attached to the eryptocyst; these he orouped in the elivision Opesiulae (Coilostega Levinsen). His incomplete studies leal him to coneeive but a single family, the Opesinlidae. Successively other anthors have erecter the following families:

Steganoporelliclae Levinsen, 1909. Stosellidae Levinsen, 1909.

Aspidostomitac Canu, 1908.

Thalamoporellidac Levinsen, 1909.

Microporiclae Hincks, 1880.

In 1909 Levinsen discovered that in Onyphoch 77 the parictal musches are atso attached to the ectocyst, and as the ovicell here is also emozonecial. it lrecame necessiry to group the Onychocellidae with the Micropridar. Previnus to this, Jullien lat remarked that his cenus lloofipom of the Opesiulintae had some incredible resemblances to the Onyohocellichar. Finally, haring observed the endo-

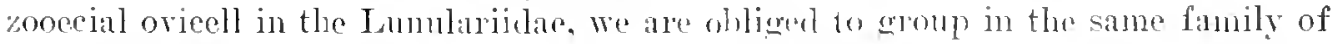

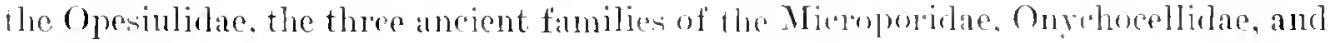




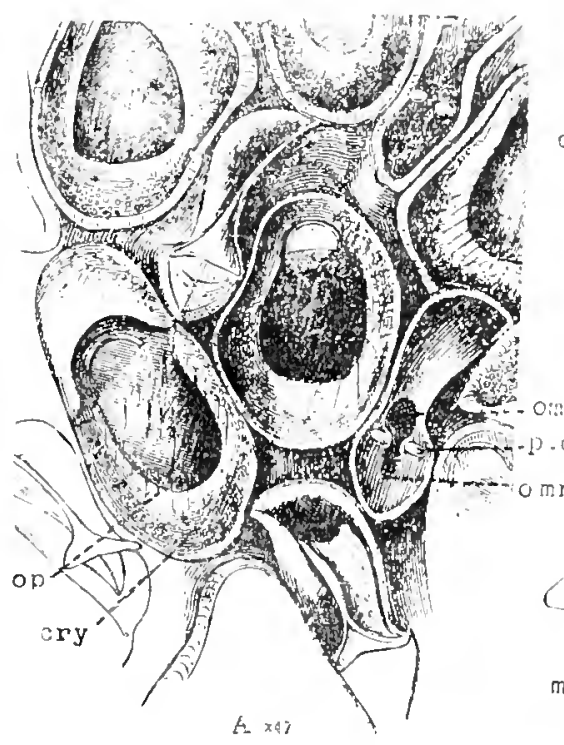

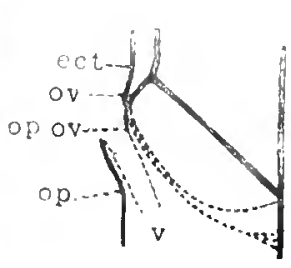

D

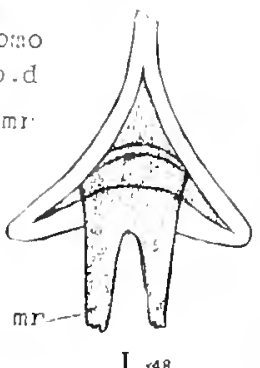

I 48

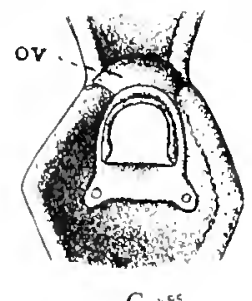

$C \times 55$
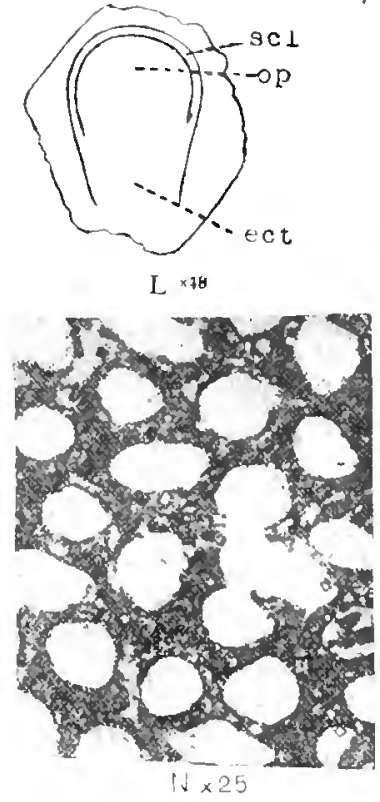

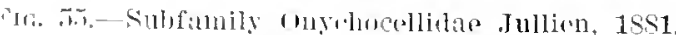
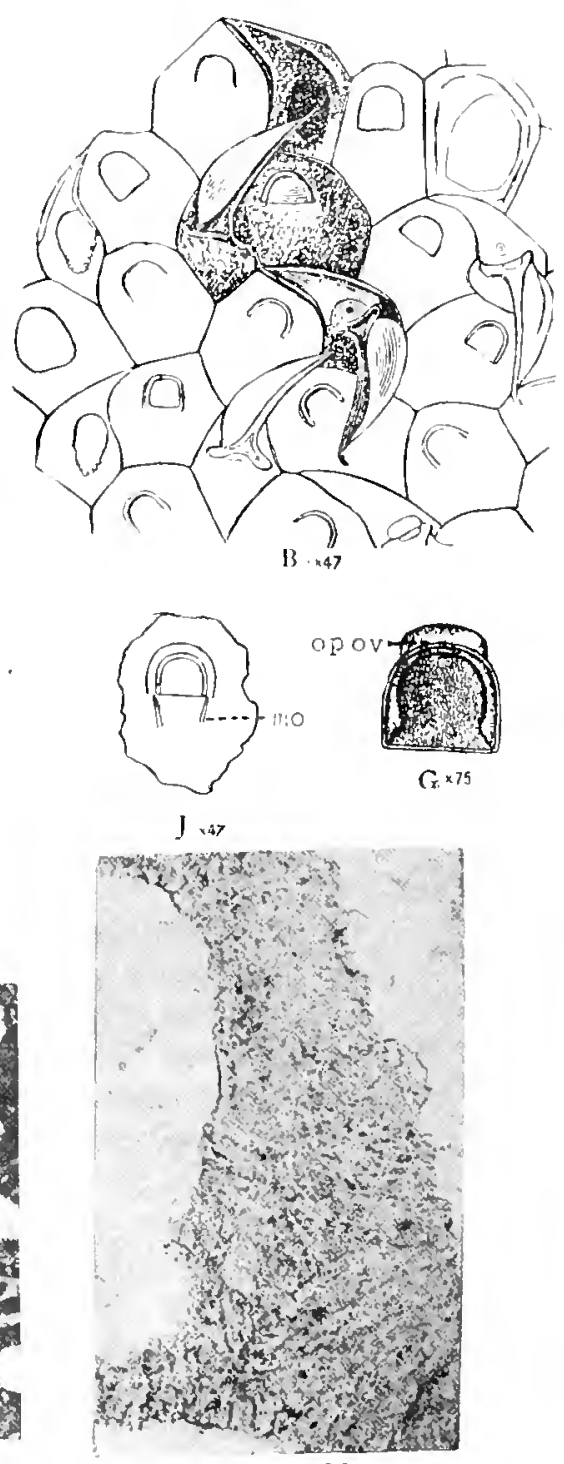

$M \times 100$ 


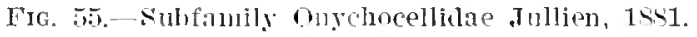

A. Onychocella laciae Jullin, 1Sxi. Portion of zoarium, $\times 4$. Is. Onychocella mavion Juliiell, 1Ss1. Zooecia and onychocellaria, $X 4 \pi$. (A, B after Jullieu.)

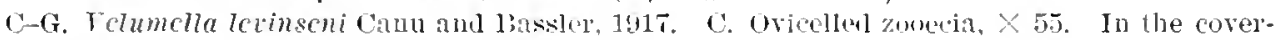
ing membrane of the aperture is sexu a simple chitinized operculum, and in each of the two sinuses of the aperture the end of a palietal muscle. 1). I.ongitudinal section through the endozonecial ovicell. E, F. Avicularium and manrible, $X$ fll. G. A znoecial olereulum, above which is an ooecial opereulum. (C-G after Levinsen, 1909.)

H, I. Rectonychoccla solira Nordmaird, 1907. Symmetrical mamcible on the aviculirium, $\times$ 45. (After Nordgnard, 1907.)

- J. Opercular valre of Onychocella luciae Jullien, 1S\$1, $\times 47$.

1i. Onychocclla angulosa Iieuss, 1847. Manulible, $X$ S5. (After Waters, 1855.)

L. Opercular ralve of Reclonychocella solida Nordgatrd. 190T.

M. II icrostructure of a zooecium of Diplopholcos lincatum, new species, $X \mathbf{1 0 0}$.

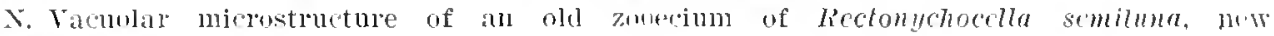
species, $\times 25$.

(v) pulyulian ronvexits.

cry, cryptocyst.

cet, ectocyst.

$l$, Iunate clitinous mass,

we, cormeous membrane.

mo, opercular muscles.

mr, elevator muscles of the mandible.

omo, passace of the occlusor muscles.

omr, fassage of the elevator muscles uf tho mandible. op, opesium.

$o p$, opercular valre.

op, opesiular inclentitions.

or, ovicell.

opor, operculum of the wirelt.

jul, livot with dentiolses.

i. liaclis.

xre. selelite.

r. ventilulum. 
Immulariulae. Our generic tables show that it is absolutely impossible to class these genera with an endozooecial ovicell in different families; that they constitute a perfectly homogeneous assemblage; and that the secondary characters of the aricularium (adaptation) are the only characters for generic differentiation.

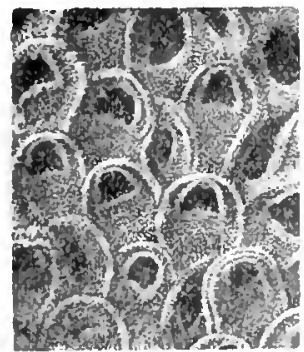

A Onychocella

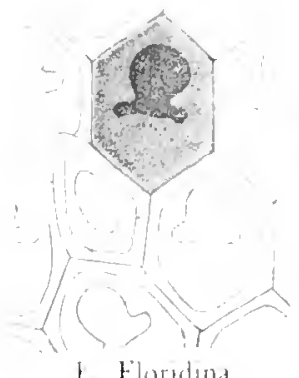

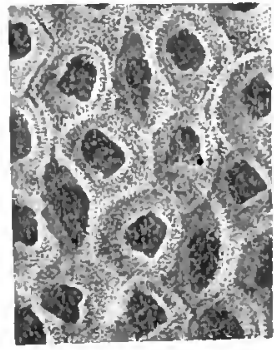

B Rectonychocelia

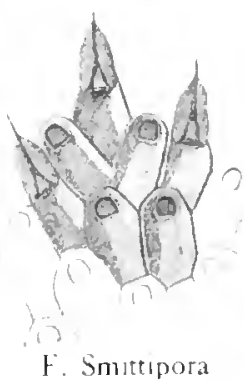

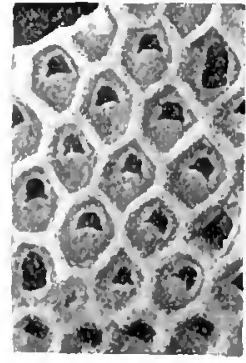

C. Velumella

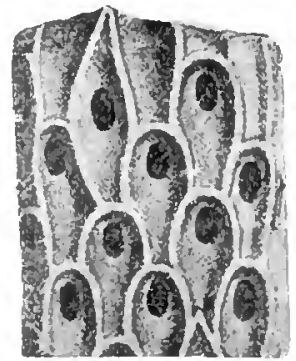

G. Oulva

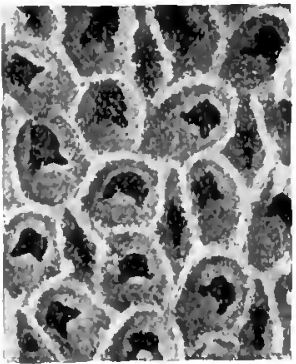

1) Diplophoteon

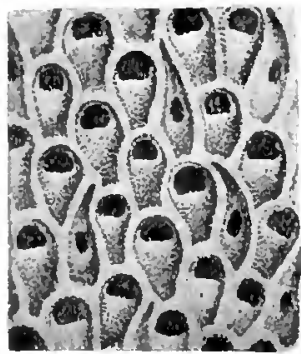

H () givala

FIG. 50.-Gruera of the subfamily Onychocellidae Jullien, 1985.

A. Onychorclla angulosa Reuss, $1847, x: 0$. Middle Jacksonian. Yumington, North Carolina.

13. Rectonnchocclla semiluna, new species, $X$ 20. Middle Jacksonian, Wimington, North Calolina.

C. Iclumclia levigatu, new specios, $\times$ 20. Ulper Jacksonian, West Bank of Sepulga River, Escambia Gunty, Alabama.

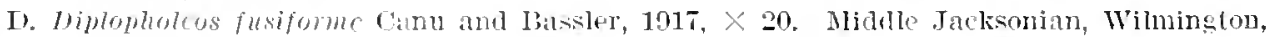
Nisth Carolina.

E. Foridina antiqua Sunit, 1st:- Recent.

F. Smittipura abyssicola smitt, 1S72. Recent.

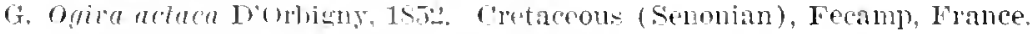

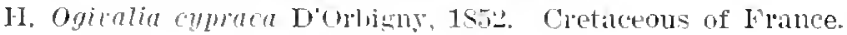

\section{Subfamily ONrchocellidae Jullien, 1881.}

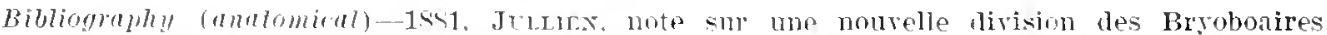

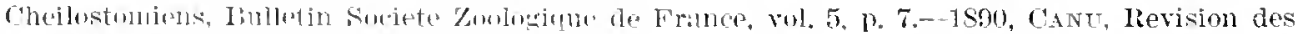

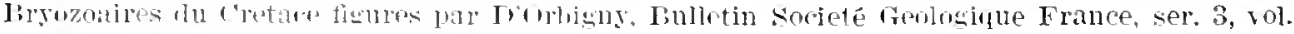

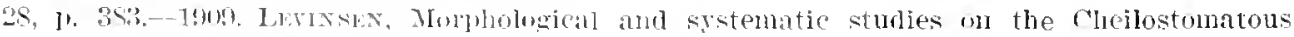

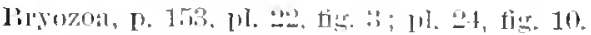

The ovicall is endwaneerial. The parietal muscles are attached to the ectocyst. 'The cryptocyst is calcifiel. The avicularia are interzonecial and transormed into onychocellaris. 
The cryptocyst is partially calcified. It bears laterally two opesiular indentations serving for the passage of the parjetal muscles. Between them a semitubular projection forms the polypidian convexity protecting the tentacular sheath of the polypide. This convexity is an incomplete polypide tube which is found nore perfected in the Thalamoporellidae am steganoporellirlas.

The onychocellarium which is always interzooecial, is a modified zoocium, and is also a complete aricularium. 'The axis of the mandible has one or two mentbranous expansions. All zooccial modifieations canse a corresponding modification of the onychocellarium. Thus, when the retractor muscles of the polvpide are attached in the inferior zooecial angles, the polypidian indentations are unsymmetrieal and the onychncellarium also beenues mingmnetrical, having only one membranous expansion.

The pivot of the onychocellarium is formed by two strong lateral teeth dividing the opesium into two parts. The inferior part serves for the passage of the elevator nuscles of the mandille; the superior part serves for the pasage of the ocelusor innscles of the mandible.

The operenlun is an operenlar valve surrounded by an arched. chitinous sclerite, which may or may not be distinct from the ectocyst.

The mural rim and the cryptoryst are both derived from the olocyst and formed of elements which group themselves in radiating series around the opesium (fig. 56M). The olocyst ceases in the old zooecia which become vacuolar (fig. $56 \mathrm{~N}$ ).

Genus ONYCHOCELLA Jullien, 1881.

1S81. Onychocella Jullien, Note sur une nurelle division des Fryozonires Cheilostumi'ss. Bulletin Sociêté Zoologique France, rol. 6, 1). 27i.

The retractor muectes of the polypide are attached in one of the inferior angles of the zooccia. The opesium is irregularly subtrifoliate. The opesiular indentations serve for the passage of the parietal museles. The onychocellarium is falciform with a single membranous expansion. A chitinous ring surrounds the end of the peculiar body; fourtecn tentacles.

Genotype.-Onychocella (Membranipora) angulosa Reuss, 1847. Range.Bathonian-Recent.

ONYCHOCELLA ANGULOSA Reuss, 1847.

Plate 32, tigs. 31, 32 .

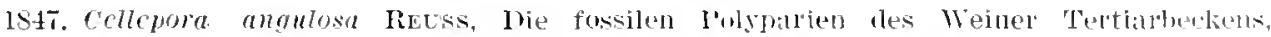
IInidinger's Niturwiss. Allandlungen, vol. "2, 1) 41, pl. 11, fig. 10.

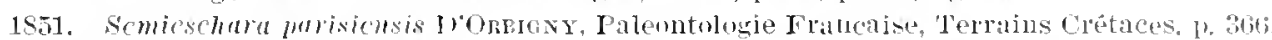

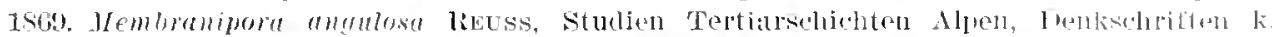

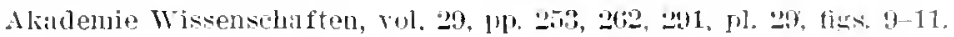

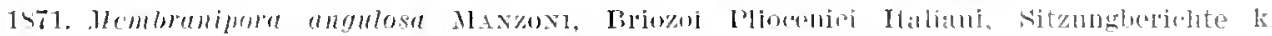
Akademie Wissenschaften, rols. 59 and 60, pl. 2, lis. 10.

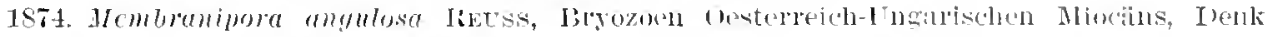

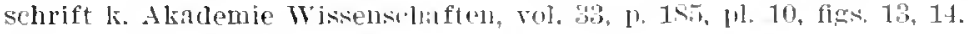

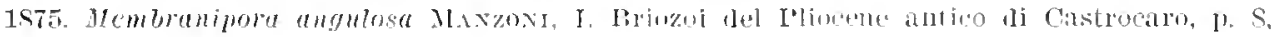
1)]. 1, fig. 11 . 
1891. Ombehochla angulosa Waters, Nurth Italian Fryuzoa, Quarterly Jourual of the Geological Societs, vol. $47,1 \%$. 9. (not synomymy).

1S95. Onychocella angmlosa NEvLNi, Bryozui fussili Farmesina, Paleontographica Italica, vol. 1, 1. 97, pl. 5, fig. 7 .

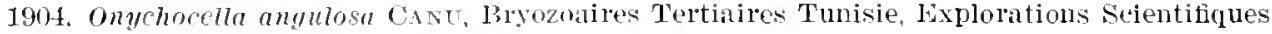
de la Tunisie, I. 18, pl. 34, fig. 2.

1907. Onychocella anyulosa CAxu, Bryozonires des Terrains tertiaires des environs de Paris, Annales de Paleontolurio, vol. 2, 1. 21, pl. 3, fig. 11.

1905. Onychocella amgulosa CANT, Pryozmires fossiles des Terrains du Sud-Ouest de la France, Bulletin Socièté geulosique de France, ser. 4, vol. 6, p. 513, pl. 12, fig. 13.

1909. Onychocella angmost Normas, The Folyzoa of Madeira, Journal Linnean Society Zoology, rol. 39 , p. 298 , pl. 37, fig. 1.

1912. Onychorclla anyulosu CANU, Hryomanes helvetiens de l'Egypte, Memoires de l'Institut egzitien, vol. 6,1 1. 201, 11.10 , fig. 10.

$$
\begin{gathered}
\text { Measurements.-Opesia }\left\{\begin{array}{l}
h o=0.16-0.20 \mathrm{~mm} . \\
7 y=0.18-0.20 \mathrm{~mm} .
\end{array}\right. \text { (Max. 0.26.) } \\
\text { Zonecia }\left\{\begin{array}{l}
L_{z}=0.40-0.60 \mathrm{~mm} . \\
l_{z=0.40-0.60 \mathrm{~mm} .}
\end{array}\right.
\end{gathered}
$$

Opesium of the $h$ hon $=0.20 \mathrm{~mm}$. onychocellarium $\int$ ton $=0.10 \mathrm{~mm}$.

Onychocellarium $\left\{\begin{array}{l}\text { Lon }=0.60 \mathrm{~mm} . \\ \text { lon }=0.28-0.30 \mathrm{~mm} .\end{array}\right.$

Affinitics and variotions. - The zooccia are hexagonal, but of an irregularity which defies all constant micrometric measurements. The polypedian convexity is hardly apparent and the opesinlar indentations are not symmetrical. The opesinm is sometimes transverse, but more often somewhat elongated.

The opecium of the onychocellatinm often has a small proximal sinns. larger in the interior than on the exterior as in the recent specimens.

The presenee of this species off the Madeira Islands and in the Priabonian of Europe rendered it probable that it would be found in America. However. it. is rare in the latter country.

Occurrence.-Niddle Tacksoninn: Wilnington. North Carolina (rare); near Lenuds Ferry, Gouth Carolina (rare).

Gcological distritution.-In France, this species makes its appearance in the Jutetian of the Paris Basin and the Pyreneean Basin (Camn). It exists abundantly in all the younger stages $\pi$ hich border the Mediterranean in France, Italy, Algeria, Tunis, and Egypt.

Mabitat.- Mediterranean (to a depth of 80 meters). Atlantic: Madeira Islands (50-70 fathoms). Pacific: ()ti (Mina. The species seems to be an inhabitant of the warm seas.

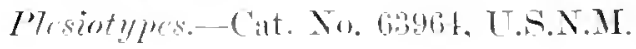

ONYCHOCELLA GEORGIANA, new species.

$$
\text { Plitte 17, figs. } 15,16
$$

Dexeription.-The zominm juclusts rocks. The zooecia are bexagonal. eloneated, distimet, but confluent among themselves. The cryptoeyst is finely granular. concare, smaller than the opesinn: the opesinm is elliptical or ovil with a conrex 
froxinul border. The onyeluocellarium is as large as the zooecia, falciform. acuminate, with an elliptical opesimm.

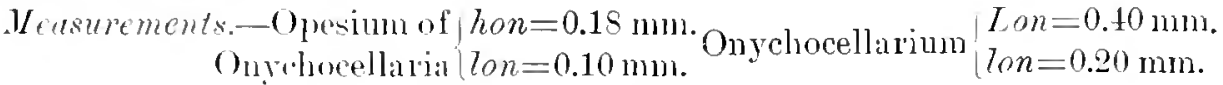

$$
\begin{aligned}
& \begin{array}{c}
\text { Opesia of } h o=0.20-0.24 \mathrm{~mm} . \quad \text { Zeoecia } \\
\text { zooecia } 7 z=0.10-0.14 \mathrm{~mm} .
\end{array}
\end{aligned}
$$

Aftinitirs and rriutions.-This species is much smaller than Onychocella angu7oxa Reuss, 186i. Its polppidian convexity is scarcely apparent and disappears totally in the marginal zooccia where the opesium is then elliptical.

Occurvence-Lower Taclisonian: Three and one-lialf miles southeast of Shell Bluff post office. Georgia (rare).

Cotypese-Cat. No.63812. I.A.N.M.

ONYCHOCELLA CELSA, new species.

Plate 32, fig. 25.

Description. - The zon rium incrusts Cellepores. The zoocia are distinct. elongated, ogival, separated by a furrow or by a salient threal. The cryptocyst is deep, snooth, a little longer than the opesimm; the opesiun is placed high, ogival; the opesiular indentations are rather deep and nearly symmetrical. The onychocellarium is as large as a zooecium. lozenge-shaped, sonewhat falciform; the opesium is large, elongated. median, oval, the point below.

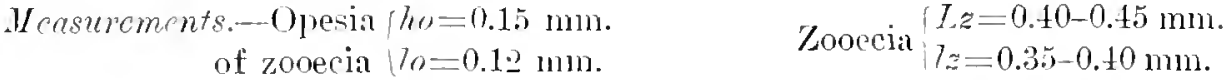

$$
\begin{aligned}
& \text { ()pesia thon }=0.2 .5 \mathrm{~mm} \text {. } \quad \text { Lon }=0.45-0.50 \mathrm{~mm} \text {. } \\
& \text { of onychocellaria } 170 n=0.10 \mathrm{~mm} \text {. Onychocellaria } / 70 \mathrm{n}=0.20-0.30 \mathrm{~mm} \text {. }
\end{aligned}
$$

Affinitics.-.This species differ's from Onychocelld georgiand in its salient polppidian convexity. It differ's from Onychocella angulosa Reuss, 18t5, in its smaller micrometric dimensions, its less falciform onvchocellaria. and its more stmmetrical and legular opesium. From Onychocella laciniosa it may be distinguished hy its elongated and nontransrerse opesim.

The only specimen found has been figured. It is a rely heautiful example of this genus.

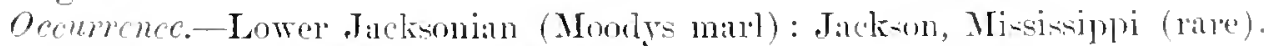
Ilototyle.-Cat. No. 63958. T.S.X.M.

ONYCHOCELLA LACINIOSA, new speeies.

Plates 32, figs. $20,2 \pi$.

Lescription.-The zoarimu incruats shells. The zonecia ale heximonal. confluent with one another by their mural rim. The cryporyt is flit. smoth,

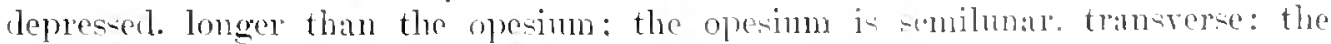
polypidian convexity is sightly projecting: the opesinlat indentations and small and unsymmetrical. The onvehocellarinu is faleiform. narmw. an long as the 
zooeciun; its opesium is oval, narlowest below, contracted below the pirot. The ovicell is little apparent.

$$
\begin{aligned}
& \text { ORDINARY ZOOFCLA, } \\
& \text { Mersurements.-Opesia }\left\{\begin{array} { l } 
{ h o = 0 . 0 8 \mathrm { mm } . } \\
{ 7 0 = 0 . 1 0 \mathrm { mm } . }
\end{array} \quad \text { Zooecia } \left\{\begin{array}{l}
L z=0.24-0.30 \mathrm{~mm} . \\
7 z=0.20-0.30 \mathrm{~mm} .
\end{array}\right.\right. \\
& \text { ORDINATY ONXCHOCELLARI.1. } \\
& \text { Opesial }\left\{\begin{array}{l}
\text { Tion }=0.10 \mathrm{~mm} . \\
\text { 7on }=0.10 \mathrm{~mm} .
\end{array} \quad \text { Onychocellaria } \begin{array}{l}
\text { Lon }=0.26 \mathrm{~mm} . \\
\text { lon }=0.14 \mathrm{~mm} .
\end{array}\right. \\
& \text { MARGTNAL ZOOECIA. } \\
& \text { Opesia }\left\{\begin{array} { l } 
{ h o = 0 . 1 8 - 0 . 2 0 \mathrm { mm } . } \\
{ l o = 0 . 1 6 \mathrm { mm } . }
\end{array} \quad \text { Zooecia } \left\{\begin{array}{l}
L_{z}=0.10 \mathrm{~mm} . \\
l_{z}=0.30-0.40 \mathrm{~mm} .
\end{array}\right.\right. \\
& \text { MARGINAL ONICHOIELIARIA } \\
& \text { Opesial hon=0.20 } \begin{array}{l}
\text { hm. } \\
\text { lon }=0.08 \mathrm{~mm} .
\end{array} \quad \text { Onychocellaria }\left\{\begin{array}{l}
\text { Lon }=0.16 \mathrm{~mm} . \\
\text { Ton }=0.24 \mathrm{~mm} .
\end{array}\right.
\end{aligned}
$$

Affinities and variations.--In its external aspect this species is only a small Onychocella angulosa: but one important and very characteristic difference is the size of the marginal zooecia of the zoarim. We have expressed these micrometric variations numerically alyove.

Although small, the lateral indintations are very constant, even in the margimal zooecia. In this respect the species differs from Onychoeclla georgiana.

The ovarian zooecia lave a somewhat larger opesimm.

Occurvence.-Middle Jacksonian: Wilnington, North Carolina (rare); near Lenuds Ferry, South Carolina (ratre); Rich Hill, ay miles sontheast of Kinoxville, Georgia (rare).

Lpper Jacksonian (Ocala limestone): Nine miles north of Ocala, Florida (rare); west bauk of Sepulga River, Escambia Comty, Alabama (rare); Old Factory, $1 \frac{1}{2}$ miles above Bainbridge, Georgia (rave).

Cotypes.-Cat. Nos. 68959, 63960 , U.S.X.M.

ONYCIOCELLA DUPLICITER, new species.

Ilate 32, figs, 25-30.

Lescription.-The zoarium incrusts other bryozoa. The zooecia are hexagonal, elongated, with their mural lims contuent, dimorphous. The eryptocyst is shallow and as long as the opesium; the opesium is oral. narrowest at the top; the polypidian convexity occurs only on the small zovecia a; the opesiular indentations are very small and nearly symmetrical. The onychocellarium is narrow, falciform, longer than the zooecia; its openimm is small. oral, narrowest below.

$$
\begin{aligned}
& \text { Mrasurements. Z Zoecia }(n) \text {. } \\
& \text { Opesia }\left\{\begin{array}{l}
h e=0.08 \mathrm{~mm} . \\
70=0.10-0.12 \mathrm{~mm} \text {. }
\end{array}\right. \\
& \text { Zonecia B. } \\
& \text { (ho }=0.1 \pm \mathrm{mm} \text {. } \\
& 70=0.12 \mathrm{~mm} \text {. } \\
& \text { ONXCHOCTLLARTA. } \\
& \text { Zoorcia }\left\{\begin{array}{l}
L: \vec{z}=0.36 \mathrm{~mm} . \\
7 z=0.30 \mathrm{~mm} .
\end{array}\right. \\
& L \approx=0.36-0.40 \mathrm{~mm} \text {. } \\
& 7 \%=0.28-0.32 \mathrm{~mm} \text {. } \\
& \begin{array}{l}
\left\{\begin{array}{l}
\text { Lon }=0.14 \mathrm{~mm} . \\
\text { Ton }=0.06 \mathrm{~mm} .
\end{array}\right. \\
\left\{\begin{array}{l}
\text { Lon }=0.50 \mathrm{~mm} . \\
7 o n=0.30 \mathrm{~mm} .
\end{array}\right.
\end{array}
\end{aligned}
$$


Affinitics and variations.-In reality the zooecia are not dimorphous, for their. micrometric dimensions are very similar; but there are actually two kinds of opesia. One is large, elongated, elliptical, with neither polypidian convexity, nor. opesinlar indentations; the other is small, transverse, with polypilian convexity and opesiular indentations (zooecia a). These two kinds of zooccia occur without apparent order, and we are in ignorance regarding the use of the large opesia.

Occurrence-Middle Jachoonian: Wilmington. North Carolina (verv rare); Rich Hill. Craw ford Comnty, Georgia (common); Eutaw Springs, South Carolina (common).

Upper Jacksonian (Ocala limestone): Along the rest bank of Sepulga River, Escambia County, Alabama (very lare).

Cotypes.-Cat. Jos. (63961-69963, U.S.Y.M.

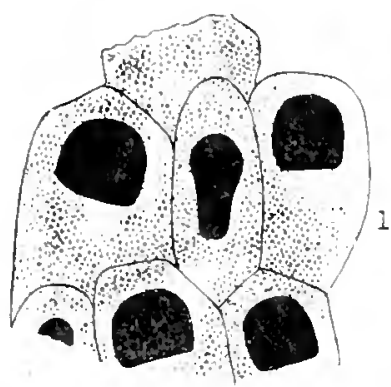

A $\times 24$

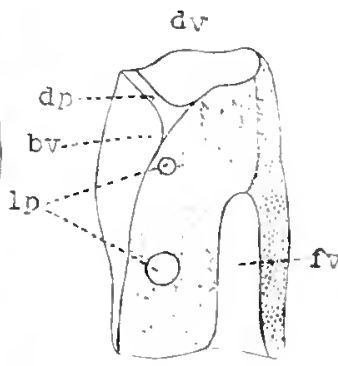

B $\times 3$ F

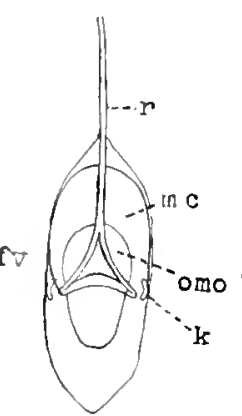

C $\times 24$

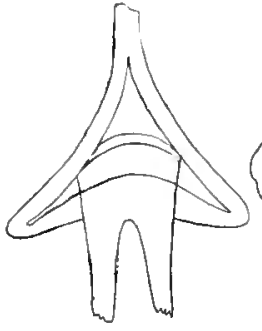

$D \times 70$

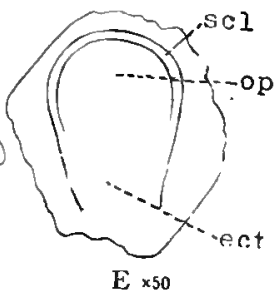

$\mathbf{E} \times 50$

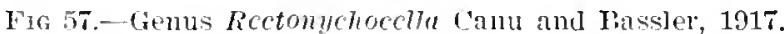

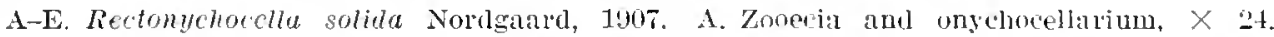
B. Longitulinal section of a zonecium, $X 34$. bi, basal wall; $d p$, distal dietella; $d v$, transrelsal

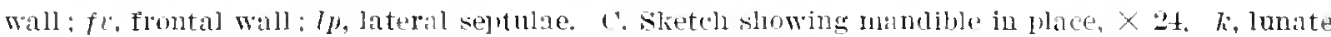

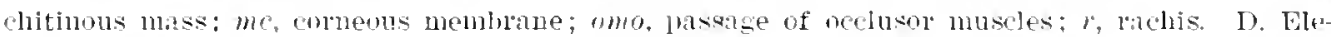

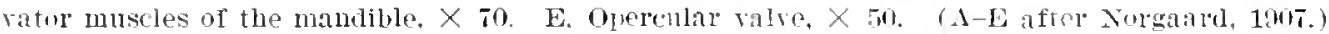
cet, ectorys ; op, onereular valve: sel, sclerite.

Genus RECTONYCHOCELLA Canu and Bassler, 1917.

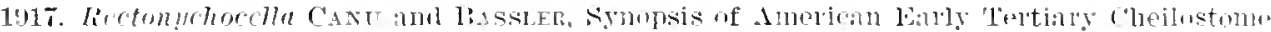
Bryozoa, Bulletin 96, United States Ňational Musenm, p. 25.

The retractor muscles of the polypide are attached in the median axis of the zooccia. The opesiular indentations are symmetrical. The onychocullatia are straight, and their opesium presents a posterior part, narow and lenticulated: the mandible is composed of two membranes. The zooecium is closed by an opercular valve. The mural rim is not separated from the criptocyst.

Genotype.-Onychocella solida Nordgiard, 1007.

Range-Jacksonian-Recent.

ธิธธด9-19-Full. 106 - 14 
This crenus differ from omychoedla only in the place of insertion of the retractor museles of the polypide. This simple change causes a general symmetry of the zoocium and the onychocellarium.

The opesia are often withont a polypiclian convexity. They occur on zooecia provided with miny hundles of parietal muscles as in the Mcmbraniporae.

RECTONYCHOClLLA BILAMELLARIA, new species.

Plate 33, figs. 1-3.

L)eseription.-The zorium is free and bitamellar. The zooecia are hexagonal, somewhat elongated. distinct or eonfluent through their mural rims. The cryptocyst is smooth, shallow, as long as the opesium; the opesium is oval, narrowest above; the polypidian convexity is small and inconstant; the opesiular indentations are symmetrical, small, and inconstant. The ovicell is endozooecial and is an indistinct distal convexity. The onychocellarium is straight, fusiform; its opesium is oral, the point below, with a contracted and rery finely crenulated posterior part.

$$
\begin{aligned}
& \text { Measurements.-Opesium of zooecia }\left\{\begin{array}{l}
h o=0.18-0.24 \mathrm{~mm} \text {. } \\
l_{0}=0.14-0.18 \mathrm{~mm} .
\end{array}\right. \\
& \text { Opesium of onychocellaria }\left\{\begin{array}{l}
\text { hon }=0.20 \mathrm{~mm} . \\
\text { lon }=0.10 \mathrm{~mm} .
\end{array}\right. \\
& \text { Zooecia }\left\{\begin{array} { l } 
{ T _ { z } = 0 . 4 8 - 0 . 5 0 \mathrm { mm } . } \\
{ 7 z = 0 . 3 6 \mathrm { mm } . }
\end{array} \text { Onychocellaria } \left\{\begin{array}{l}
\text { Lon }=0.40-0.50 \mathrm{~mm} . \\
\text { Zon }=0.16-0.20 \mathrm{~mm} .
\end{array}\right.\right.
\end{aligned}
$$

Affinities and variations.-The opesium is quite variable. The form with polypidian convexity is shorter and the darer, while the oval form with the proximal borrle concare is the longer $(=0.24 \mathrm{~mm})$ and sometimes oceurs solely orer an entire zoarium. Te have observed a calcified zooecium perforated by a circular orifice.

This species differs from Rectonyrhocella somituna in its bilamellar zoarium and in the opesinm of the onychocellin rium which is shorter than the zooecial opesium.

It is not dimorphous as in Diplopholeos fusiforme.

Occurrence.-Upper Tacksonian (Óala limestone): west bank of Sepulga

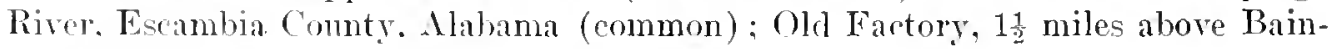
brislge, Georgia (rare).

Cotypes.-Cat. No. 63966. U.S.N.M.

RECTONYCHOCELLA SEMILUNA, new species.

Plate 3n, figs. $9-13$.

Description.-The zonrium is free. unilamellar, creeping over algae. The zooceia are slightly elongated, hexagonal, distinct, separated by a very small furrow. The cryptocyst is convex, smooth, shallow. a little shorter than the opesium; the opesimm is elongated, oval, alnost semilunar, entire; the polypidian convexity and the opesiular indentations are hardly visible. The ovicell is but little apparent. The onychocellarium is straight. lither larege. fusiform: its opesium is oral, the pointed end below, always longer than the zooecial opesium, with a finely denticu- 
lated poster; the small distal canal rarely fuses with the distal zooccia (on which consequently the rachis of the mandible is laid). Two or three septulae to the zooecial wall.

$$
\begin{aligned}
& \text { Measurements.-Opesinm of zovecia }\left\{\begin{array}{l}
h o=0.20-0.24 \mathrm{~mm} . \\
70=0.16 \mathrm{~mm} .
\end{array}\right. \\
& \text { Opesium of onvchocellarium hon }=0.34-0.36 \mathrm{~mm} \text {. } \\
& 7 o n=0.16 \mathrm{~mm} \text {. } \\
& \text { Zonerial } \begin{array}{l}
T z=0.40 \mathrm{~mm} \text {. } \\
7 z=0.30 \mathrm{~mm} .
\end{array} \\
& \text { Onychorellaria } \begin{array}{l}
\text { Ton }=0.50 \mathrm{~mm} . \\
\text { ton }=0.2 \pm-0.30 \mathrm{~mm} \text {. }
\end{array}
\end{aligned}
$$

Variations.-The important character of this species is the large opesium of the onychocellaria which is always longer than the zooceial opecium. This greater size is above all very apparent in tangential sections (fig. 12) or in views of the interior (fig: 10). At the exterior the hreadth of the opesium is reduced in the progress of ealcification (fig. 11). but the length always remains quite evident. On the same zoarium (fig. 13) one may thus observe both wide and narrow opesia.

In the underside of the zoarium the zonecia ale very irregularly convex; the olocyst is covered exteriorly by a thin calcareons pellicle. Finally, it is not rare to discover some zoaria incrusting other bryozoa.

Tangential thin sections (fig. 12) show that the olocyst constitutive of the zooccial walls is racuolar. Such checks in calcification are not rare in old zoaria of the Onychocellidae.

Afmitics. -This species differs from Rectonyshocella bitamentaria in its milanellar zoarium and in its large onychocellarian opesia.

It differs from Diptophotens fusiforme in the absence of the zooecial dimorbhism, in its milamellar zoarium, and in its onychocellarium, which does not fuse with the distal zooccium. To differentiate it from this last species is often very rifficult, and the inexperieneed student oryht to abstain from any determination which does not appear exact to him.

Occurrence.-Middle Jacksonian: Wilminaton. North Corolina (common); Baldock. Barnwell Comnty, Sonth Carolina (rare): Rich Hill. Crawford County, Georgia (common); 15 miles west of Wrightsrille, Johnson Connty. Georgia

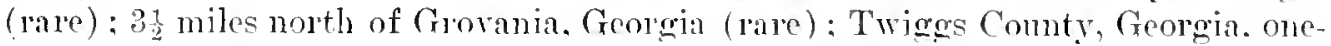
lalf mile sontheast of the Georgia Kaolin (o. Mine (rery abuntant).

Upper Jacksonian (Ocala limestone) : Mlachua, Florida (eommon).

Cotypes.-Cat. No. 63971, U.S.X.M.

RECTONYCIOCELLA TENUIS, new species.

Plate 33, figs. 4-1;

Description.-The zoarium incrusts shells. The zooceid alle alongated. with their mural rims confluent. The cryptocyst is rery slightly developer, much shorter than the opesimm, rery thin laterally; the opesimin is large. romgated, ontire, oval. or elliptical. The onychocellarimu is larger than the zoociun, fusiform; the lista] 
canal is very small; the opesinm of the onychocellarimn is longer than the zooecial opesium, oral, the point at the top.

$$
\begin{aligned}
& \text { Mersurcments. Opesium of } / 70=0.35 \mathrm{~mm} \text {. } \\
& \text { zonecimm } 10=0.25 \mathrm{~mm} \text {. } \\
& \text { Zooeciun }\left\{\begin{array}{l}
L_{z}=0.45-0.55 \mathrm{~mm} . \\
l z=0.40-0.45 \mathrm{~mm} .
\end{array}\right. \\
& \text { Opesium of } \quad h o n=0.45 \mathrm{~mm} \text {. } \\
& \text { onychocellarium lou }=0.17 \mathrm{~mm} \text {. } \\
& \text { 1) nychocellarium }\left\{\begin{array}{l}
\text { Lon }=0.75-0.901111 . \\
7 n n=0.30 \mathrm{~mm} .
\end{array}\right.
\end{aligned}
$$

Aftnitic.-This fine species does not exhibit a polypidian convexity; which characteristic clearly distinguisles it from Rectonychocella scmituna; moreover, the point of the onychocellarian opesium is more often at the top than at the bottom. In the vicinity of the ancestrula the onvehocellaria are much less in width than the zooccia (fig. 6).

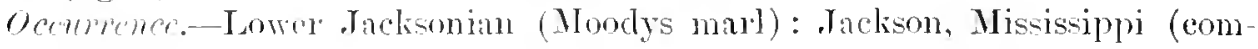
mon).

Tacksonian (Zenglodon zone) : Cocon Postoffice, Choctaw County, Alabama (rare): Shubuta. Miscissippi (rare): Bluff on south side of Suck Creek. Clarke Comty, Mississippi (very rare).

Upper Tacksonian (Ocala limestone), west banki Sepulga River: Escambia County, Alabana (rare): Alachus, Floricla (rare); nine miles north of Ocala, Floridia (rare).

Vicksburgian (Reil Bluff clay) : Seven and onc-half miles southwest of Bladen Springs. Llabama (rare).

Cotypes.-Cat. Nos. 63907 , 63969 , U.F.N.M.

\section{RECTONYCHOCELLA ELLIPTICA, new species.}

I'late 39. figs. 7,8 .

Description. -The zoarium incrust shells (Ostrac) or bryozoa. The zoocia are elongated, hexagonal, distinct, separated by a small furrow or thread. The rryptocyt is concave, deep, finely granulose, and as long as the opesium; the opesimm is clliptied, elongated, finely cremulated; the polypidian convexity is only risible in the vicinity of the ancestrula. The endozocecial ovicell is a barely risible convexity. The onychreelarinu is staight. lozenge-shaped, enlarged at the base; its cryptocyt is rery small, and itsopesium is oval, the point below, with a denticnlated posteriol: the surall distal canal often fuses with the cryptocyst of the distal zomerimn. The anerotella is small and exhibits a polypidian convexity.

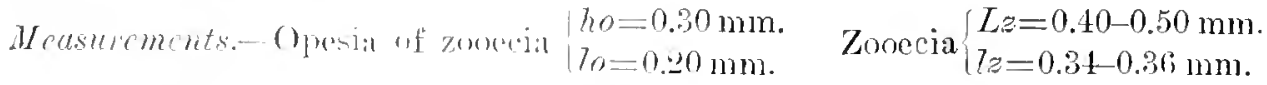

$$
\begin{aligned}
& \text { Opesia of onvehoceltariat } \begin{array}{l}
\text { hon }=0.34-0.36 \mathrm{~mm} \text {. } \\
70 n=0.16 \mathrm{~mm} \text {. }
\end{array}
\end{aligned}
$$

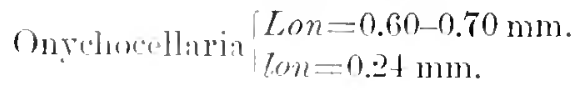


Tariations.-The specimens from . Jackson. Mississippi, have the zoorcia very distincty marked, because they are separated by a thin and salient thread, which gives them it particular aspect very difficult to define. In the other localities the zooecia are united among themselves and quite indistinct, giving these specimens a rery diflerent appearance. Nevertheless, the other characters are illentical.

The onychocellarian opesium is a little longer than that of the zoocinm, but the charicter is not evident at frst glance because of its slight width.

The fusion of the distant canal of the onyclocellarimm with the cryptocrst of the distal zooecium is not general and the extreme point of this organ is often distinet withont ever being prominent.

Affinitics.-The difference between this species and Rectonychocelle bitamellaria is almost entirely zoarial. Still, there are some slight zooecial differences; the opesium is elliptical, withont an enlared. - straight or convex proximal borler, and the length of the onychocellarian opesium is a little greater than the opesium of the zonecium.

The species differs from Rectonychocella temis in its smaller micrometric limensions ( $\mathrm{Lz}=0.45 \mathrm{~mm}$. instear of $0.55 \mathrm{~mm}$.) and in its onychocellarian opesium which is maller. and more tapering below.

Oceumenee-Upjer Jaclisonian (Ocala limestone) : Bainbridge, Georgia (rare): Chipola River east of

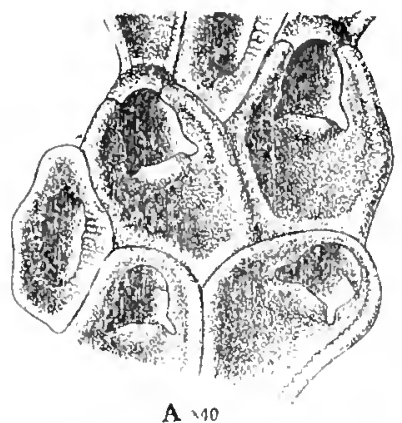

A $、 10$

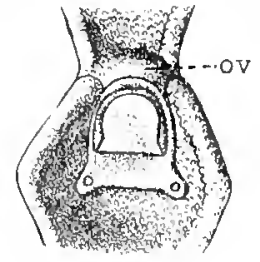

Is $x \leqslant 5$

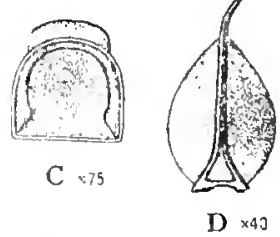

Fig, 58,- Genus Jizumulla Canu and Bassher, 1917.

A-I). Telumella (Onychocella) levinseni Canu and Bassler, 1917. A. A group of zooecia, the two uppernost with nvicell, $X$ 40. B. A zooecium with oricell(ow). In the covering uembrane of the aperture is seen a simple chitinized operculum, and in rach of the two sinuses of the aperture is the end of a parietal muscle, 55. C. A zooecial operculum above which there is an wocial operculum, 75. 1). Avicularian mandible, \& flo. Marianna, Florida (lare); West Binle Sepulga River, Eseambia County, Mlabluma (rare).

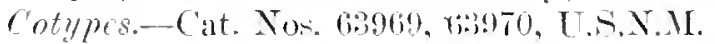

Genus VELUMELLA, Canu and Bassler, 1917.

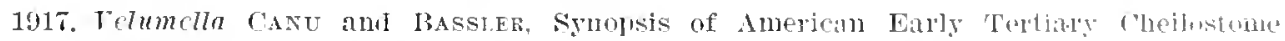
Bryozor, Imlletin 96, I'nitel Stites National Musemm, p. git.

The retractor museles of the polypide are attached in the molian axis of the zovecium; the opesiular indentations are symmetrical. The onychocellaria are straight, without distal canal; the rachis of the mantible hous two broad memliranes: the opesium of the onychoollarium is alliptial and entiraly rentivilated. 
The operculum is a wholly chitinized simple one, not separable from the ectocyst. Multiporous septnlae. The mural rim is distinct from the cryptocyst.

Genotype.-Vclumella (Onychocc77a) Tevinseni Canu and Bassler, 1917. ${ }^{1}$

The mural rim and the cryptocyst are formed from the same olocystal elements; they are not distinct from each other, and their separation is purely superficial. The operculum is revealed by the two small lateral teeth of the opesium which indicates its axis of rotation. The small size of the opesinlar indentations is indicative of very small parietal muscles.

\section{VELUMELLA LEVIGATA, new species.}

Plate 34 , figs. $1-3$.

Description. - The zoarium incrusts rocks. The zooecia are hexagonal, regular, with their mural rim confluent. The eryptocyst is deep, flat, smooth; the mural rim is thick, convex; the opesium is semilunar, transverse; the polypidian convexity is little apparent; the opesiular openings are small and round. The onychocellarium is hexagonal like the zooecium; its opesium is large, elongated, irregular, oval or elliptical.

$$
\text { Measurements.-Opesium }\left\{\begin{array} { l } 
{ h o = 0 . 0 7 - 0 . 1 0 \mathrm { mm } . } \\
{ l o = 0 . 1 0 - 0 . 1 2 \mathrm { mm } . }
\end{array} \quad \text { Zooecium } \left\{\begin{array}{l}
L_{z}=0.35 \mathrm{~mm} . \\
l z=0.32 \mathrm{~mm} .
\end{array}\right.\right.
$$

Opesium of $\mid \mathrm{hon}=0.22-0.30 \mathrm{~mm}$. onychocellarium $\mid 70 \mathrm{pn}=0.10 \mathrm{~mm}$.

Affinities. - This species differs from Telumella plicata in its transverse opesium. its smooth cryptocyst, and its round opesinlar openings.

Occurrenee.-Upper Jacksonian (Ocala limestone): Alachua, Florida (rare); 9 miles north of Ocala. Florida (rare); West bank of Sepulga River. Escambia County, Alabama (rare).

Cotypes-Cat. Nos. 63972-63974, U.S.N.M.

VELUMELLA PLICATA, new species.

Plate 34 , fig. 4.

Description.-The zourium forms broad incrustations on shells. The zooecia are hexagonal, elongated, their mural dims confluent. The cryptocyst is deep, flat, finely wranulated; the polypidiun convexity is salient and longitudinally wrinkled; the opesimm is semilmar, crenulated, elongated; the opesiular openings are small, oblique, linear. The onychocellarinm is larger than the zooecimm; its opesium is large, median and oral.

$$
\begin{aligned}
& \text { Measurements.-Opesiun }\left\{\begin{array} { l } 
{ h _ { 0 } = 0 . 1 0 - 0 . 1 2 \mathrm { mm } . } \\
{ 7 0 = 0 . 0 8 - 0 . 1 0 \mathrm { mm } . }
\end{array} \quad \text { Zooecium } \left\{\begin{array}{l}
I z=0.40 \mathrm{~mm} . \\
7 z=0.30 \mathrm{~mm} .
\end{array}\right.\right. \\
& \text { ( )pesium of } y m=0.25-0.30 \mathrm{~mm} \text {. } \\
& \text { onychocellarium } 70 \mathrm{pm}=0.18-0.20 \mathrm{~mm} \text {. }
\end{aligned}
$$

${ }^{3}$ This new hame was promsed for the recent species figured as onychocclla species by Levinsen in bis Alorphologienl and systematic studies on the cheilostomalous Bryozoa, 1009, pl. 22, figs. $3 a-d$. 
Affinities.-This species differs from Velumella plieata in its wrinkled polypidian convexity, in its non transverse opesium, and its linear opesinles. We have observed a normal zooecium replaced by a perforated calcified zoocium.

Occurrence-Upper Jacksonian (Ocala limestone) : along Chipola River, east of Mariamma, Florida (rery rare).

Molotype.-Cat. No. (i.9975. U.S.N.M.

\section{Genus DIPLOPHOLEOS Canu and Bassler, 1917.}

1917. Diplopholeos Cayu and Bassler, Sprnopsis of American Early Tertiary Cheilostome Bryozoa, Bulletin 96, Inited states National Museum, p. 20.

The retractor muscles of the polypide are attached in the median axis of the zocecium. The lateral indentations are symmetrical and almost transformed into true opesinles. The onychocellaria are straight, their opesium is oval, with a denticulated poster: the mandible is limembranous. The mural rim is not separated from the cryptocyst. The zooccium is closed by an operculum attached to the ectocyst. The axis of rotation of the operculum is indicated by two opesial denticles. The zooecial opesia are dimorphous; one kind is elongated and the other transverse.

Genotype.-Diplophoteos fusiformo Canu and Bassler. 1917.

Ranqe.-.Tacksonian, Vicksburgian.

This gemus differs from Rectonychorello in its dimorphons opesia and its polypidian convexity, which is constant. protruding, and acconpanied by two nearly complete opesiules. We are igmorant of the reason for the opesial dimorphism often accompanying zooecial dimorphism.

\section{DIPLOPHOLEOS FUSIFORME Canu and Bassler, 1917.}

Plate 34. figs. 11-14.

1917. Diphopholeos fusiforme Caxu and Fisscer. Synopsis of American Early Tertiary Cheilostome Bryozoa. Bulletin 96, United States National Museum, p. 26. pl. 3. fig. 2.

The zoarimm incrusts shells and pelbbles. The zooecia are hexagonal, a little elongated, separated by a narrow furrow or united among themselves by their mural rims: the cryptocyst is deep, concave, shorter than the opesium. finely granular: the polypidian convexity is protruding. wrinkled or grinnlated. denticulated in its opesial border: the lateral openings are deep, round, almost becoming true opesiules: the opesium is elongated. semilunate, finely crenulated. The ovicell in an inconspicuons distal convexity, sometimes limited by two lines of lateral suture. The onychocelhrinm is narrors. fusiform. onmewhat larger than the zonecia: the opesium is median, oval. the point below. with a narrow and denticulated posterine: the terminal point projects above the distal zonecium. lunt is rery fragile: the distal eanal through alteration in fossilization fuses nearly always with the eryptocyst of the distal zooecinm. The heteromorphic zooecia are a little maller: their cryptocyst is longer than the opesium which then appears nearly transterse. The ancestrula is of the same form as the zooceinm. 


$$
\begin{aligned}
& \text { Mcasurements. Opesiun of }\left\{\begin{array}{c}
h o=0.20 \mathrm{~mm} \text {. (measming only to the poly- } \\
\text { pidian convexity) } \\
10=0.15 \mathrm{~mm} \text {. (withont the opesintes) }
\end{array}\right. \\
& \text { inoecium }\left\{\begin{array}{l}
I_{z} z=0.40 \mathrm{~mm} . \\
l_{z}=0.30 \mathrm{~mm} .
\end{array}\right. \\
& \text { Opesium of } \quad \text { hon }=0.20 \mathrm{~mm} \text {. } \\
& \text { onychocellaria } 7 o p n=0.10 \mathrm{~mm} \text {. } \\
& \text { () nychocellaria }\left\{\begin{array}{l}
\text { Lon }=0.40-0.45 \mathrm{~mm} \text {. } \\
\text { lon }=0.20 \mathrm{~mm} \text {. }
\end{array}\right.
\end{aligned}
$$

rarictions.-The zooecia with the small opesimu ("1) are not regularly smaller than the other's; we can not therefore employ the nomenclature used by Harmer for the Steganoporellidae. The reduction of the opesium is due to the enlargement of the cryptocyst; we must therefore suppose that the parietal muscles are inserted there higher in consernence of the development of an organ of which we know nothing. This organ can be neither the orary nor the testicles, for we hare observed oricells in both forms of zooecia.

The fusion of the small distal canal of the fusiform onychocellarium with the cryptocyst of the distal zooccia is so general that we may now consider its character as distinctive upon first examination. The marginal zooecia are unprovided with polypidian convexity and lateral opesinles.

The zoarium sonetimes creeps orer algae. The unilamellar specimens often arise primarily from incrusting specimens which are detached from their substratum.

The mural rim and the eryptocyst are formed of the same elements secreted by the endocyst. These elements are grouped in radiating series around the opesinm (fig. 1t).

Affnities.-This species differs from Diplopholeos sagittellarium and from $D$. sagittarium by the form of its onyehocellarimm, by the fusion of the distal canal with the cryptocyst of the distal zonecimm, and by its larger zooccial dimensions.

When the zooecial dimorphism is not apparent, this species much resembles Rectonychocella semituna; but it is distingnished from it by its incrusting zoarimm and its rery distinct, nearly complete opesinles.

Occurrenec-Middle Jacksonian (Castle Hayne limestone): Wilmington, Torth Carolina (common).

Upper Tacksonian (Ocala limestone): (1) Factory 1] niles above Bainloridge.

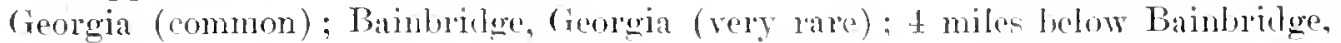

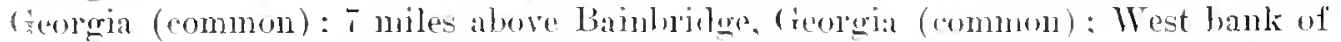
Sepulga River, Escambia (ounty, Mlabama (ommon): ('hipola liver, east of Marianna, Florida (common): a miles north of ()ala. Floridla (common) : Plant System Railroarl wharf at Bainbridge, Georgia (rare).

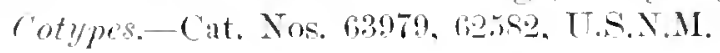


DIPLOIHOLEOS SAGITTELLARIUM, new species.

llite 34, figs, 5-7.

Dexeription.-Whe zoarinm incrustes shells and bryozoa. The zonecia are hexanonal, indistimet, with their mural lims conthent; the cryptoryst is shallnw, oblique towarl the opesimm, very finely gramuled, longer than the opesimu; the polypidian convexity projects but little, ocenrs below the opesial denticles, and is elevated almost rertically; the opesinlar openings are large, round; the opesinm is transverse in appearance (with the opesial openings), semilunar, narrowed anteriorly by two lateral tecth ahove the opesinles. The ovicell is an inconspicnons distal convexity. The onychncellarium is straight, muclı lạrger than the zooecium, with the form of a small leaf of the phant Sagitcaria, terminated by a large mandibular area; its opesium is oval. the point at the top, entire or crenulated. Dimorplism is manifested by large and small zooecia.

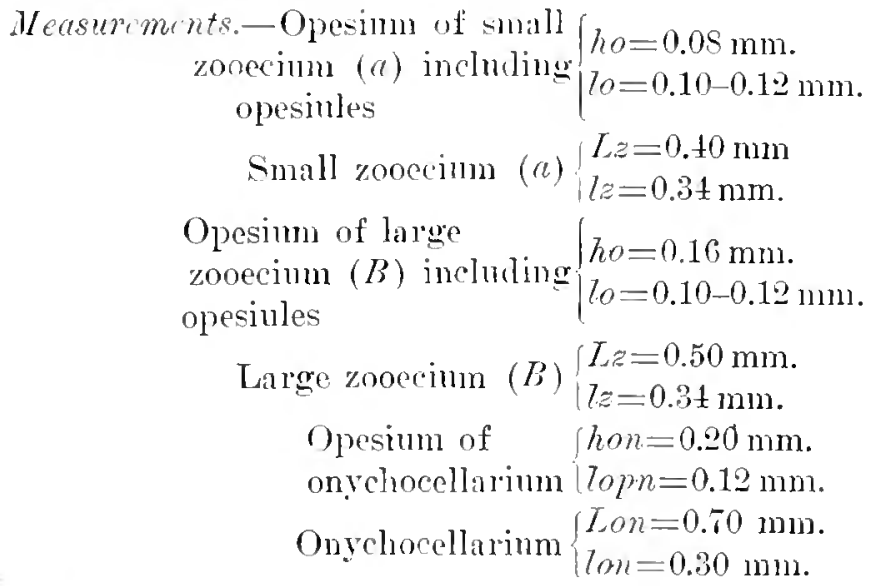

Tariations.- The lare zooccia occur less frequently. Well preserved specimens have the aspect of Steganoporella; but if the specimen is turned and the interior is examined, the internal dirisions characteristic of Steganoporella. limiting the polypidan tube. can not be seen (fig. $\tau$ ).

Good specimens also show that the polypidian convexity is elevated almost rertically as in Thalamoporella, and when the opesial denticles are united with the convexity, snch examples have then a constitution identical with that of this gemus. 'The ovicells however are very different (fix. 5 ).

Most often the polypidian convexity is broken or not developent. Wnt the npesiular openings are always ruite distinct (fig. 5 ).

The zooecial dimophism has to do perlaps with a loulle syiten of nutrition.

A finities.-Its zoocial dimorphism and the form of its onyelnoellarimm clearly

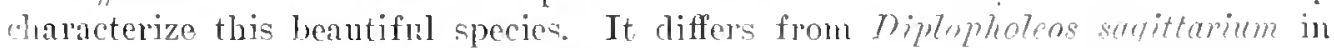
the smaller dimensions of it onychncellarim and in the absence of opmial denticles in this organ. 
Oeeurrance.-Middle Jacksonian: Wilmington, North Carolina (common); Near Lenuds Ferry, South Carolina (rare).

Upper Jacksonian (Ocala limestone) : Old Factory, 132 miles above Bainbridge. Georgia (rare).

Cotypes.Cat. No. 63976, U.S.N.M.

\section{DIPLOPHOLEOS SAGITTARIUM, new specics.}

Plate 34, fig. S.

Deseription.-The zoarium is incrusting. 'The zooceia are elongate, indistinct, confluent through their mural rims. The cryptocyst is very shallow; oblique torard the opesium, finely granular, much longer than the opesium; the polypidian ronvexity is elevated to the level of the opesial denticles; the opesiular openiugs are large, round, deep, and are almost true opesiules; the opesium is semilunar, narlowed below by two very prominent denticles bounding the upper part of the two opesinles. The onychocellarim is very large, having the form of a leaf of Sagittaria; the distal submandibular area is much developed. The opesium is oral, the point at the top with two long denticles inserted on the proximal margin. The ovicell is an indistinct, distal convexity.

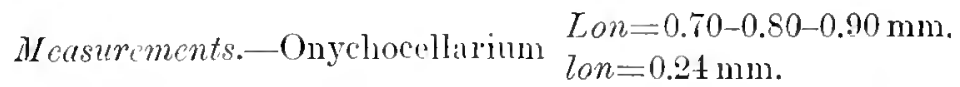

Iffnitics.-This species differs from Diplophoteos sagittellarum in the size of its onychocellania and in the two opesial denticles of this organ.

Oecumence.-Middle Tacksonian: Wilmington. North Carolina (common); Rich Hill, Crawford Connty, Georgia (common).

Ilolotype.-Cant. No. 63967. U.S.N.M.

DIPLOPHOLEOS PARUULIPORUM, new species.

Plate 31, figs. 9, 10 .

Description.-The zoarium incrusts bryozoa. The zooccia are small, elongated, ogival, distinct, or confluent through their mural rims. The cryptocyst is shallow, oblique to the opesimm; the polypidian convexity is elevated to the level of two very prominent denticles; the opesiules bounded by the polypidian convexity and by the denticles are almost complete. The ovicell is endozooecial and is a large distal convexity. The onychocellarium is larger than the zooecium; its opesium is elliptical, sometimes denticulated below, its submandibular area distally is very large and presents the form of a leaf of Sagittaria.

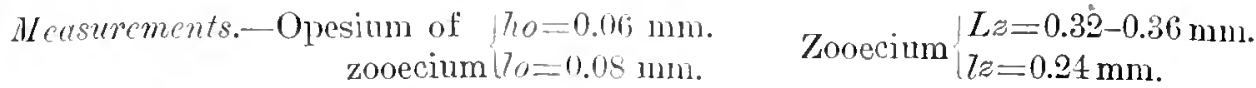

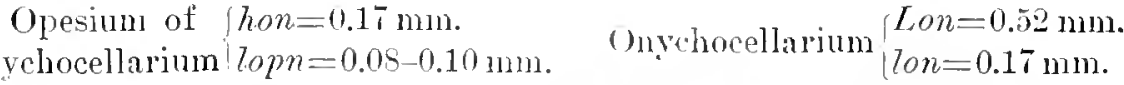

Affinitics.-This species is very doce to lliphopholeos sagittellarium and differs from it solely in its small dimensions. The dimorphism is little apparent on our specimens. 
Occurrener.-Middle Jacksonian (Castle Hayne limestone) : Wilmington, North Carolina (rare).

Cotypes.-Cat. No. 63978, U.S.N.M.

DIPLOPHOLEOS LINEATUM, new species.

Plate S2, fig. 15.

Description.-The zoarium incrusts shells. 'The zooecia are hexagonal, elongated, confluent by means of their mural rims. The cryptocyst is deep, glanular, longer than the opesium; the polypidian convexity is projecting, crentuted along its opesial border; the opesinlar indentations are deep; sometimes linear; the opesimm is elongated, semielliptical. narrowed above the opesiules by two prominent denticles. The onychocellarium is small, fusiform, without distal canal; its opesium is median, elliptical, cremulated.

$$
\begin{gathered}
\text { Measurements.-Opesium }\left\{\begin{array}{l}
7,0=0.20 \mathrm{~mm} . \\
70=0.12 \mathrm{~mm} .
\end{array}\right. \\
\text { Onychocellarium }\left\{\begin{array}{l}
\text { Lon=0.85 } \mathrm{nm} . \\
70 n=0.25 \mathrm{~mm} .
\end{array}\right.
\end{gathered}
$$

The long linear opesia are rather rare; there are some perfectly round. The opesial dimorphism is not apparent on the few specimens we possess and we classify the species only ly analogy.

Affinitics.-This species differs from Diplopholes fusiforme in its small onvehorellarium and its linear opesiules.

The opesial dimorphism is not very evident on the specimens found.

Oecurrence.-Vicksomgian (Mariamma limestone): Near Claiborne. Monroe County. Alabama (very rare); Salt Mountain. 5 miles south of Jackson, Alabama (very rare).

Ticksburgian (Byram marl): Byram. Mississippi (rare).

Holotype.-Cat. No. 6425\%, U.S.N.M.

\section{Genus FLORIDINA Jullien, 1881.}

1551. Floridina Jullex. Note sur une nowvelle divisinn des Bryozonires cheilostomes. Bulletin Societe 7oologique France, vol. 6, 1) 13.

The retractor muscles of the polypide are attached in the median axis of the zooecium. The opesinlar indentations are symmetrical, very large, limited abore by the two very salient opesial processes and placed on each side of a much produced. semitubular. polypidian convexity. 'The zooecium is closed by an opereulum attached to the ectucyst; the opercular axis of rotation is located above the two opesial processes. The onychocellaria are straight. without the small, llistal canal. rounded at their apex: the mamlible is himembranous. Oricell enduzoocial.

The cencral aspect of the opesium is trifoliate.

Genotype.-Floridina (Mollia) antiqua Snitt, 187 .

Range.- Semonian-Recent.

species of Frloritima for the most part are fomel incruting algae. 
The opesiular indentations serve as a passageway for both the parjetal and "percular muscles. Exteriorly the polypidian convexity quite resembles the polypide tube of strganoporntla: but in the interior it is incomplete (pl. 35. fig. 16). and it is rare even that the tuberosities $(t)$ bound it laterally.

Irregularity is the rule in this genus; all the characters of the opesium ale extraordinarily rariable. Determination of the species is often difientt and causes much perplexity for the numalist.

The opesial proceses often join the polypidian convexity. the opesiules thus beroming complete; in the interior the aspeet is identical with that of Thatamoprovella.

The known species of this genus are:

Floritina (Semieschara) cami Brydone, 1900.

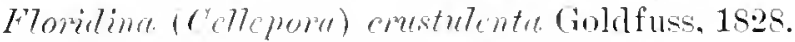

Floridina (Semirschame) bimarginata D'Orbigny, 15.2.

Floridina (Mo77in) antiqua Smitt. 1873.

F7oridina vendoma Canu, 1900.

There has as ret heen no rvilence of the genus in the Imerionn Cretaceous. If this observation be confinned we will be obliged to repeat that the beginning of the Eocene is the time when the change in direction of the Atlantic currents cccurred.

\section{FLORIDINA GRANULOSA, new epecies.}

I'late 35 , figs. 1-1.

Deseriflim. The zoarium is bilmellar with distortal fronds. The zooecia are distinct, hexagonal, separated by a deep furrow. The mural rim and cryptocyst are coredel with gramulions more or less large. The opesium is large, a little elongaterl. trifnliate; the opesiular portion is lange. orbieular and separated from the opereular portion hy two salient teeth. The oricell is endozooecial: this is a distal comvexity litide apparent. The onychocellarium is elongated. clliptical, as large as the zooecium: the opesium is oval. the point above and bears laterally two salient denicles.

$$
\begin{aligned}
& \text { Measurement...- Opesium }\left(h_{0}=0.2 .2 \mathrm{nmm}\right. \text {. } \\
& \text { of } z 00 \text { ecia } 170=0.15 \mathrm{llm} \text {. }
\end{aligned}
$$

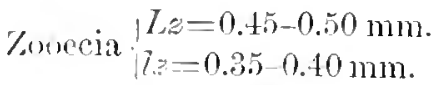

$$
\begin{aligned}
& \text { Opesium } / \text { hon }=0.25 \mathrm{~mm} \text {. } \\
& \text { of onrehocellarial } 70 n=0.15 \mathrm{~mm} \text {. } \\
& \text { Onychocellarium }\left\{\begin{array}{l}
\text { Ton }=0.45-0.50 \mathrm{~mm} \text {. } \\
7 \% \text { on }=0.8 .5-0.40 \mathrm{~mm} .
\end{array}\right.
\end{aligned}
$$

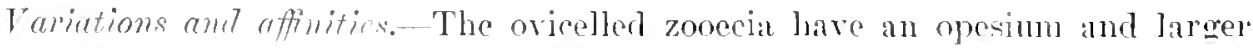
micrometrie dimensions (fig. 1). We have observed some caleified zorecial (fig. ?) bearing a larer central perforation.

This species is rery well characterizel by the absence (not contant) of the polypidiun convexity aml by its frontal granulations.

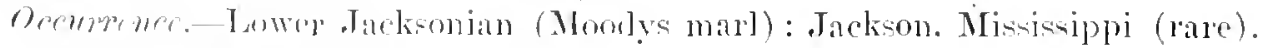

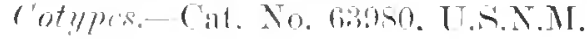


FLOKIDINA BIFOLIATA, new species.

I'late 35 . fier. 5 .

Dosciplion.--The zourium is bitamellar with curved founds. The zooecia are distinct, quite elongaterl, sepalated hy a leep furrow: the mural rim is smooth, wide. little salient: the cryptocrst is of little depth. of the same length as the opesium. The opesium is latre. trifoliats. elongate; the opercular portion is small and separated from the opesiular region by two, little prominent teeth: the polypidian convexity is little salient, non symmetrical. The onychocellarium is larger than the zooccia, quite elongated, fusifum, with spatulate beak; the opesimm is oral, the point alove.

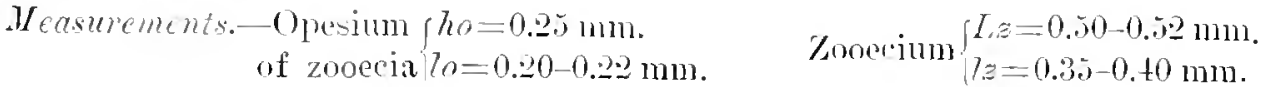

$$
\begin{aligned}
& \text { of onychocellaria tron }=0.40 \mathrm{~mm} \text {. Onychocellarium }\left\{\begin{array}{l}
\text { I. on }=0.50 \mathrm{~mm} \text {. } \\
\text { Zon }=0.30 \mathrm{~mm} \text {. }
\end{array}\right.
\end{aligned}
$$

Atinitiss.-This specios has a bilanellar zoarium like Floridinn grunuloxi: it differs from it in the abcolutely smooth frontal. and its onychocellarium much longer than the zooecia.

Occument.-Lowel . Jackonian (Mombs marl) : Tackson, Mississippi (lare).

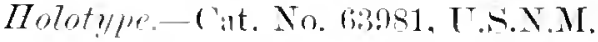

FLORIDINA ONYDENTATA, new species.

Plate 3.5., fig. 9.

Description.-The zontimn is milamellal, creeping orer algae. The zooecia are distinct. wide, ogival; the eryptocyst is shallow, concave, oblique to the opesium, finely granulated; the opesium is transverse or trifoliate. The opesiules are nearly complete and linear. The polypidian convexity is rery long and often mited with the opesial processes. The ony chocellarium is larger than the zouecium: its opesium is trimgular and toothed, with a lange spine on its proxinnl lorder.

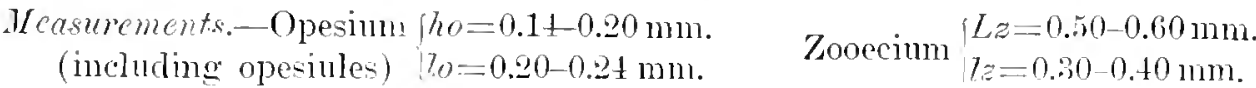

$$
\begin{aligned}
& \text { ()nychocellarium }\left\{\begin{array}{l}
\text { Lon }=0.90 \mathrm{~mm} \text {. } \\
\text { lon }=0.50 \mathrm{~mm} .
\end{array}\right.
\end{aligned}
$$

Tariations.-It is probable, that the pirot of the mandible was situated a little above the opesial tooth; this inclicates that there were on each side two himules of mandilular elevator museles.

The size of the opesiules is evidence of vigorons palietal muselen, nuecentry. moreover, for the zoarial hydrostatic system of this robut species.

We have observed a true zooecium having the form of an onvehuedlariun. More than once it has been proved that this orwan in omly a molified zooecimm. and that every variation of one oecasions a correpmuling rariation in the other. 
Affinitics.-This is the larest known species of Floridina. This character and the large teeth in the opesium of its onychocellarium distinguish it clearly from Floridina antinua and from $F$. lagunemla.

Ocenrrence-Middle Jachsonian (Castle Hayne limestone): Wilmington, North Carolina (common).

Ilolotype.-Cat. No. 63989, U.S.N.M.

FLORIDINA ANTIQUA Smitt, 1873.

Plite 35, figs. 10-1s.

1S73. Mollia antiqua Smitr. Floridan Fryozon, Kongl. Srenska Vetenskaps-Akademie Handlingar, vol. . 1. 12, 11. 2, fig. 73 (not Busk).

Description.-The zonrum is unilamellar, cleeping over algae. The zooecia are broad, distinct, ogival in shape; the cryptocyst is a little concave and rery finely granulated; the polypidian convexity is a continuation of the cryptocyst; the opesium is subtrifoliate and contracted by two large lateral teeth which separate the opercular part from the opesiular portion. The opesiular indentations are large and wide; they are often transformed into true, nearly complete linear opesiules by the mion of the opesial process with the polypidian convexity. The ovicell is a distal convexity little apparent, but clearly distinct from the cryptocyst of the distal zooecium. The onychocellarium is larger than the zooecium, elongated. with a submandibnlas area pounded but little developed; its opesium is oral, the pointed end at the top, much denticulated.

$$
\begin{aligned}
& \text { - Measurements. Opesinm ho }=0.20-0.2 \pm \mathrm{mm} \text {. } \\
& \text { (including opesiules) } 170=0.20-0.2 \pm \mathrm{mm} \text {. } \\
& \text { Zooccium }\left\{\begin{array}{l}
L_{z}=0.50 \mathrm{~mm} . \\
7 z=0.40 \mathrm{~mm} .
\end{array}\right. \\
& \text { Onychocellarium }\left\{\begin{array}{l}
\text { Lon }=0.60 \mathrm{~mm} . \\
7 o n=0.30 \mathrm{~mm} .
\end{array}\right.
\end{aligned}
$$

Tariations.-Interzooceial communication appears $t$ " be effected by a distal septula and t pairs of lateral septulae (fig. 1S). The eryptocyst is as usual, formed from elements of the olocyt (fig. 1s).

In the interior. (fig. 16). the form of the opesium is the same; we note further that there are two tuluerosities mongly ontining laterilly a polypide tule. The proximal margin of the opesimm of the onychocellarium is thickened.

The union of the opecial processes with a polypidian conrexity is frequent (fig. 18). (On the nome perfect specimens the length of the polypirian convexity is from 0.06 ; to $0.08 \mathrm{~mm}$.; its wilth is from $0.14-0.16 \mathrm{~mm}$. (fig. 11). It often diminishes in length without apparent reason and even disappears (fig. 12).

The size and aspect of the zooccia vary greatly. Figures $13,14,15$ are taken from the same zonium, where there may be noted broad zooecia with a rednced cryptocyst, smaller zooecia with the cryptoeyst much developed. and again resy narrow zooecia. Tsually most of the zoocia ane broal, and most of the opesiules : re large and incomplete.

The zoarimu sometimes inclu-te shells; the polypidian convexity is then little apparent, and the opesiules are quite large. 
Affinities.-This species differs from Floridina laguncula in its larger micrometric limensions ( $L_{\hat{z}}=0.50 \mathrm{~mm}$. and not $0.40 \mathrm{~mm}$ ), in its nealy always trifoliate opesimm, and in its large and rounded opesinlar openings. It is smaller than Floridina onydentata.

Occurrenee-Middle Jacksonian: Wilmington, North Carolina (common); near Lenuds Ferry, Sonth Carolina (common); Baldock, Barnwell County, South Carolina (common); $3 \frac{1}{4}$ miles south of Perry, Georgia (rare); $3 \frac{1}{2}$ miles north of Grovania, Georgia (rare); $1 \frac{1}{2}$ miles northeast of Lily. Dooly County, Georgia (rare).

Upper Jacksonian (Ocala limestone): Bainbridge, Georgia (rare); 1 miles above Bainbridge. Georgia (rare).

Vicksburoian (Mariama limestone) : Salt Mountain, 5 miles south of Jackson, Alabama.

Vicksburgian (Byram marl) : Brram. Mississippi (rare).

Habitat.-Smitt's original speeimens were obtained in the waters of Florida, where the species ranges in deptli from 2 st to $4 \pm$ fathoms.

Plesiotypes.-Cat. No. 68984, U.S.N.M.

FLORIDINA LAGLNCULA, new species.

Plate 36, 6gs. 1-6.

Description.--The zoarium is free, unilamellar, eleeping over algae, or inerusting stones, shells, or bryozoa. The zooecia are a little elongated, distinet, confluent through their mural rins; the eryptoeyst is shallow. oblique. direeted toward the opesium, very finely granular; the mural rim is projecting in front. convex, separated from the cryptocyst. The opesimm is limited to the elliptical. transverse opercular portion; the two opesial processes are quite salient and are situated nbove the polypidian convexity, which is thus little apparent. The onyehocellarimu is elliptical, elongated, larger than a zooecium; its opesium is oval, divided into two parts, a lower one large and nearly round, and a distal one narrow and linear.

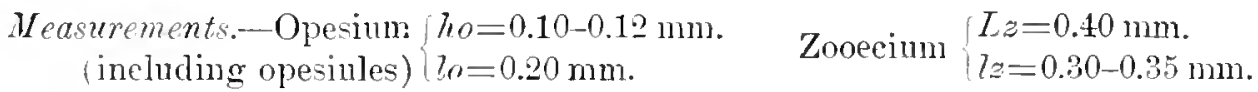

$$
\text { Onyehocellarium }\left\{\begin{array}{l}
\text { Lon }=0.55 \mathrm{~mm} \text {. } \\
7.0 n=0.33 \mathrm{~mm} \text {. }
\end{array}\right.
$$

Tariations.--In tangential sections the zooecial walls appear very thin (fig. 5). In the interior, the onesimm is trifoliate or has the aspect of Thitamoporelle or of Steganoporella (fig. 6). On the lower face of the zoarium. the zonecia are elongated. hexagonal, convex, and bear a projecting lyylrostatic tuberosity (fig. B).

The opesinles placed between the polypidian convexity and the opesial processe: are hardly visible because they are thus perpendicular to the zooceial plane. But with the reduction of the processes they become visille in the form of rounded lateral openings (fig. 4).

In some specimens from the Ticksburgian the proximal horder of the onychorellarian opesinm is straight and the opesium itself is oval. 
In its most usual aspect and when altered by fossilization, the opesium of the onychocellarium resembles a small botte, whence our specific name.

Aftinitics.-Floriatina lagunculu differs from F. antiqua Smitt, 1853, in its smaller micrometric measurements ( $L z 0.40 \mathrm{~mm}$.), in its more apparent mural rims, in its smaller opesiules rately visible exteriorly. and in its opesium which is reduced to the opercular region.

It differs from Floridina usymmetrice in the bottle shaped opesium of the onychocellarium, in its more olongated. regular zooecia, and in the symmetry of its opesimu.

Ocournence.-Middle Jacksonian (C'aste Hayne limestone): Wilmington, North Carolina (rely common).

Cotypes.-Cat. No. 6939s. L.S.X.M.

FLORIBINA ASYMMETRICA, new specics.

Plate :i, figs. 6-8.

Description.-The zourium is milanellar, tubular, growing over algae or incrusting their radicles. The zooecia are broad. distinct, hexagonal, somewhat ogival in shape; the eryptocyst is shallow, a little larger than the opesium, granular, without mural rim; the opesium is trifoliate and divided by two salient processes serving as upper limits to two incomplete and unsymmetricut opesiules; the polypidian convexity is deep, not prominent, and msymmetrical. The onychncellarium is larger than the zoocrimm, pentagonal, very elongated; its opesiun is triangular, denticulated.

$$
\begin{aligned}
& \text { Measuremonts.-Opesim | } h o=0.20 \mathrm{~mm} \text {. } \\
& \text { (inclucling opesiulos) } \mid 70=0.16-0.20 \mathrm{~mm} \text {. } \\
& \text { Onvehocellarium }\left\{\begin{array}{l}
\text { Ton }=0.50 \mathrm{~mm} \text {. } \\
70 n=0.25 \mathrm{~mm} .
\end{array}\right. \\
& Z_{\text {nuecium }}\left\{\begin{array}{l}
L z=0.36-0.40 \mathrm{~mm} . \\
l \approx=0.36-0.40 \mathrm{~mm} .
\end{array}\right.
\end{aligned}
$$

Tariations. - We have stated that inewnlarily is the rule in this genus. The symmetry of the zoocia is not absolute; on nearly all the zoaria there are asymmetrieal zooecia. In this species the phenomenon is mole general and symmetrical zooecia are raper. The opesiular indentations and the polypidian converity also lack symmetry. following the obliquity of the polypide in its lorging place occasioned by the eccentric altachment of the retrator muscles.

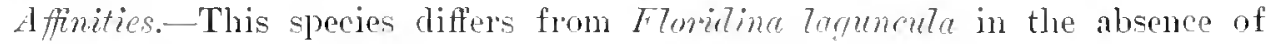
mural rim and in its irregular, although more visible, opesinles.

It diflers from Floritina antiqua Smitt in its smaller micrometric measurements $(L z=0.40 \mathrm{~mm})$. its less dereloped opesiules. and in its irrogular and less visible polypidian convexity.

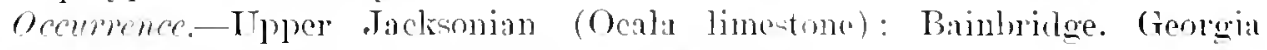

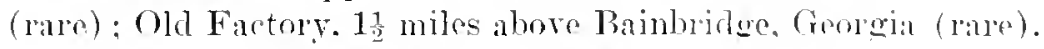

c'otypes-Cat. No. 08999. T.A.T.M. 
Genus SuITTIPORA Jullien, 1881.

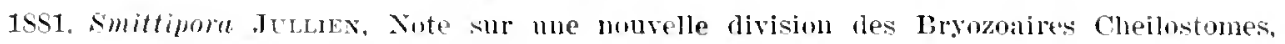
liulletin société \%onlogique de Frince. vol. (j. p. 14.

The cryptocyst which is deep and concave, exhilits three facets of which the two lateral ones are formed by the mural rim; the two lateral furmow which separate the mural rim from the elyptocyst are constiunt. The mandible of the onychocellarium is bimembranous; the onychocellarium and its opesium are little different from the zonecia.

Genotype.-Smitipora (Tincularia) abyssicola Smitt, 1853.

Range.-Senonian-Recent.

Mistorieal. -It is not certain that the Europen Cretaceous species classificd by . Inllien in this genus really belong to the group of Tincularia abyssicola Smitt. To the best of our knowledge the ovicells have nerer. been observed on the fossil forms, and Smitt's species has not yet been rediscovered. Tre have been unable to make any new observations on the specimens stuclied from the Millwayan which are of the type observed in the European Cretaceous. We are therefore obliged to follow Jullien's classifreation as Canu did in 1900. ${ }^{1}$

Neitluc Gabb and Horn in 1862
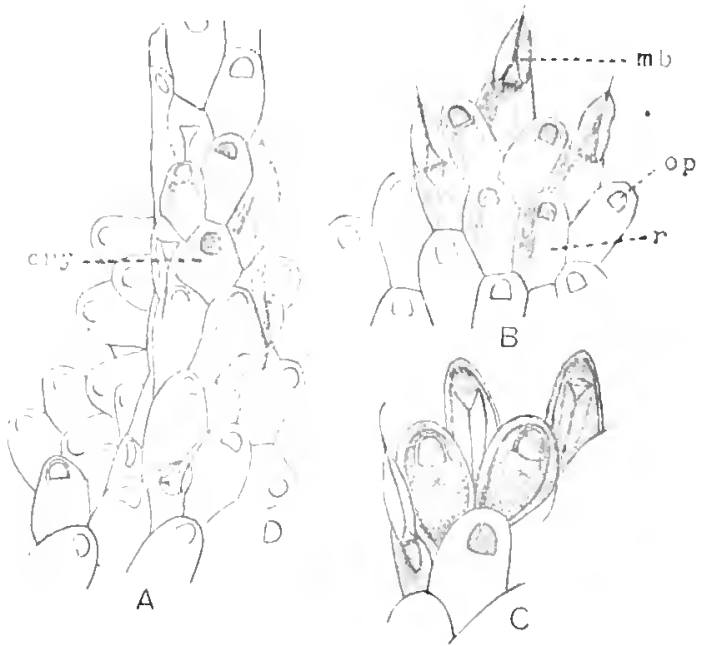

FIG, 5!.-G('nus smittipora Jullion, 1881.

1. (C. Smitlipora (Iincularin) abyssicoln Smitt, 1572. A. Zoarium in the vincularian method of growth. B, C. Incrusting zoaria. (Aiter smitt, 1872, and Hincks, 1881.) cr!l, cryptocyst; $m b$, mandible; op, opesium; $r$, channel of the cryptocyst. nor Ulrich and Bassler in 1907 have intimated the existence of Smittipora in the Anerican Cretaceous. If this be confirmed, it will be necessary to admit that at the beginning of the Eocene a change occurred in the direction of the Atlantic marine currents.

SMITTIPORA MIDWAYANICA, new species.

Plite 1, bigs, 16-1!!.

Deseription.-The zoarium is vincular, articulated (?), formed of cylindrical segments containing eight longitudinal series of zooecia. 'The zouecia are nuch elongated, hexigonal. confluent through their mural rims; the eryptueyst is deep. very narow, as long as the opesium, little distinet form the mural rin. The opesium is elliptical.

$$
\text { Measurements.-Opesium }\left\{\begin{array} { l } 
{ h n = 0 . 1 6 \mathrm { mm } . } \\
{ 7 n = 0 . 0 9 \mathrm { mm } . }
\end{array} \quad \text { Zooraium } \left\{\begin{array}{l}
L_{2}=0.34 \mathrm{~mm} . \\
l z=0.16 \mathrm{~mm} .
\end{array}\right.\right.
$$

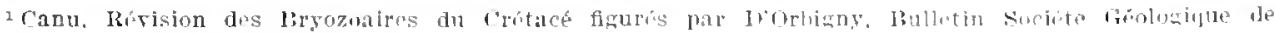
France, ser, 3, rol. 29, p. 407.

$$
\text { 5.599-19- Tiul, 10f - } 15
$$


Affinitics.-It is not certain that the zoarium was articulated. The only clariform segment (fig. 18) observed contained ladicular zooecia at its base; but this might well be consilered as the base itself of the zoarium. Nevertheless we have never observed branched segments.

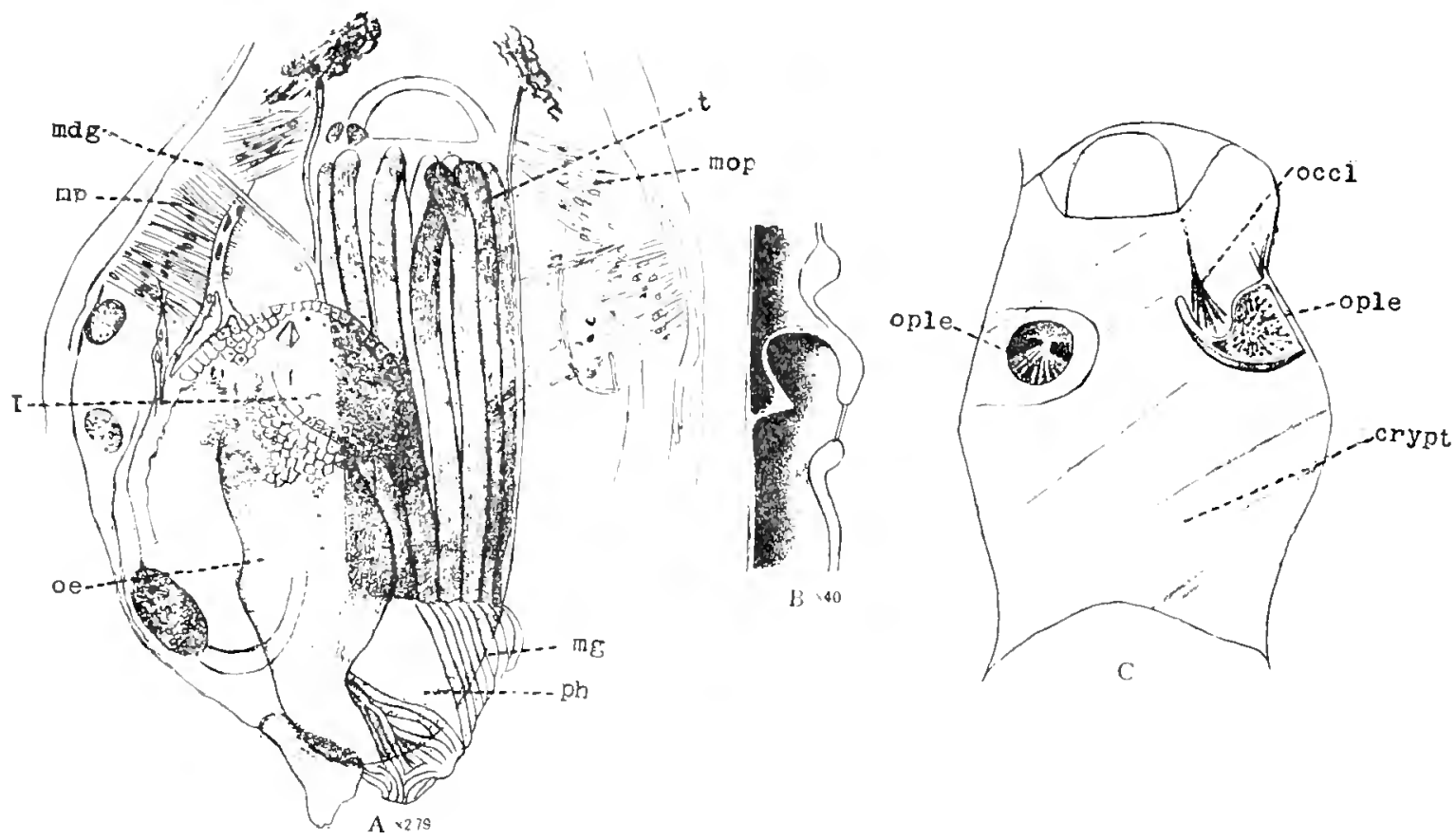

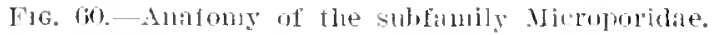

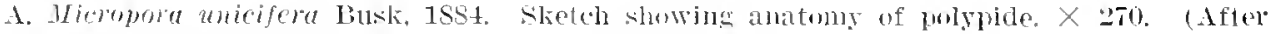
Jullien, 1sss.)

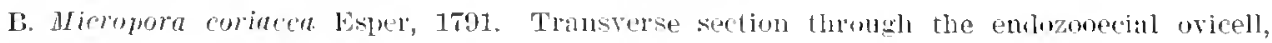
X 40. (After Levinsen, 19ug.)

C. Sketch combining fruntal (to the left, and lakal (to the right) views of Mioropora. (After Hilner, 190.)

(rint, cryptucyst.

$I$, jintestine.

ml!, dilntol muscles of the tentacular sheath. mon large retrictor muselos of the pulppids (of the sheath ame of the lophombore). mop, operular occlusur museles. mp, parletal museles.

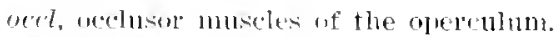
ox, esoplohasus.

onle, alusiule (fortal vinw).

tole, opesiale (basal view).

ph. pharyin.

$t$, tentacles (10 in number).

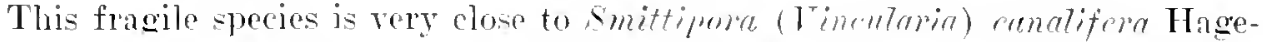
now. 15.1 of the Maestrichtian. from which it tiflers in its smaller micrometric measuremente (Lz $0.34 \mathrm{~mm}$ and not $0.4 \pm \mathrm{mm}$.) and in it elliptical insteal of subeirular opesimm. 


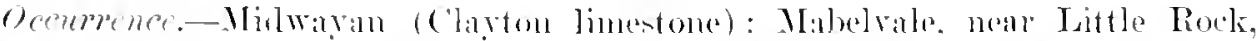

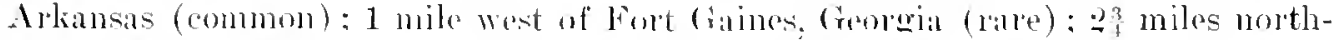

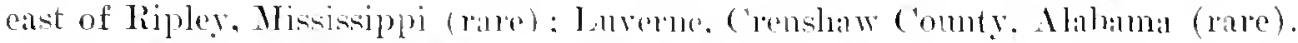

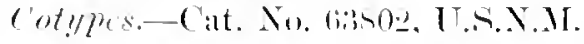

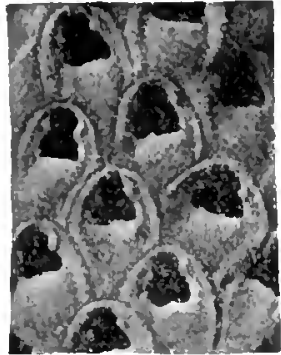

A. Floridinella

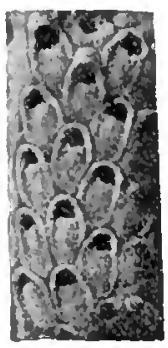

B. Rosseliana

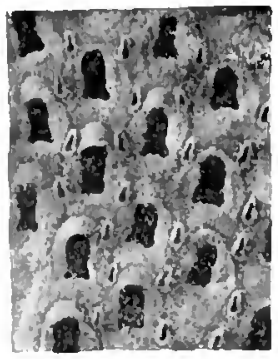

C. Dacryonella

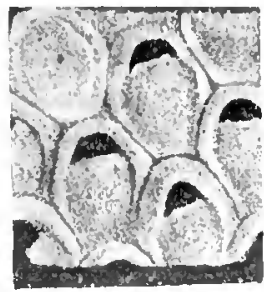

1). Gargantua

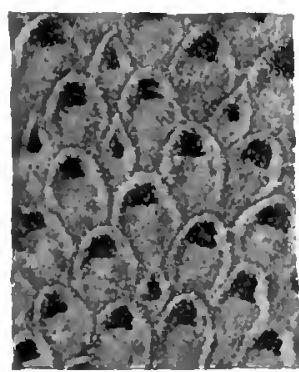

E. Aechmella

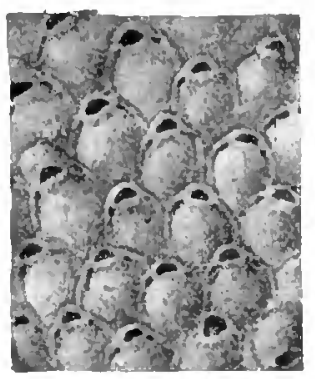

F. Micropora

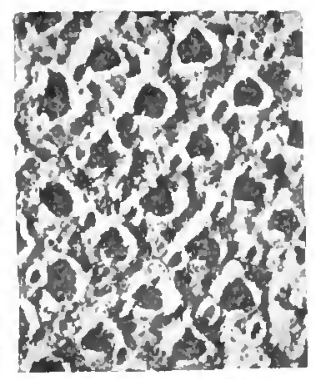

(j. Hoplucheilina

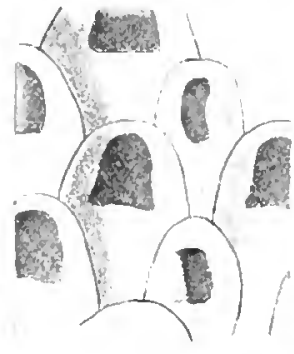

H. Vibracella

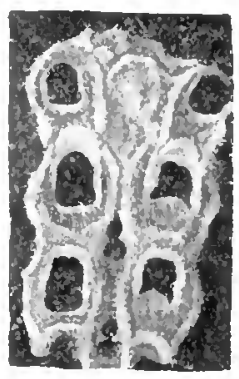

1. Lunularlat

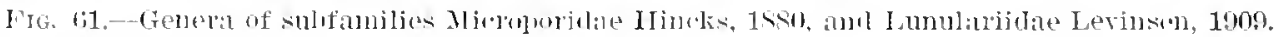

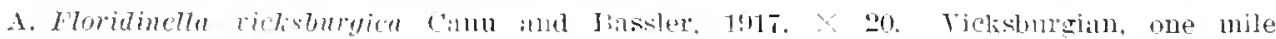

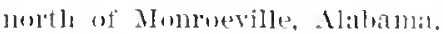

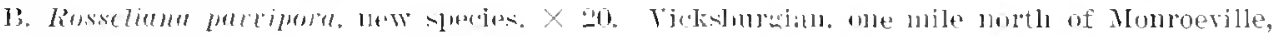
Alibama.

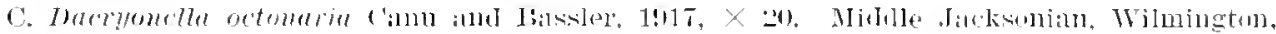
Nortle Carolina.

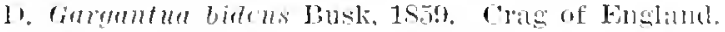

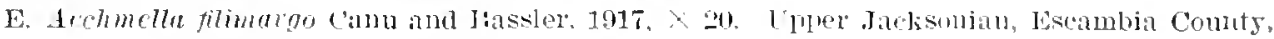
Alilliami.

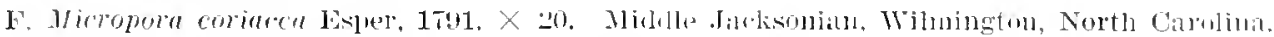

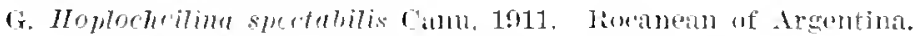

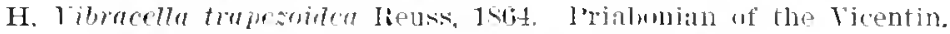

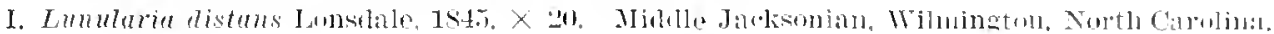

Subfamily Microporidae Hincks, Is80.

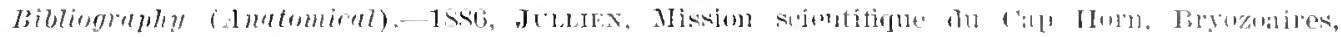

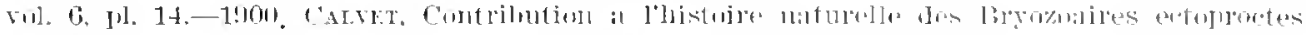

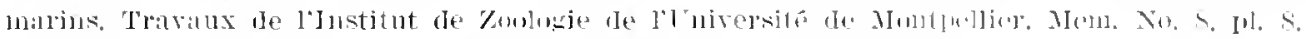

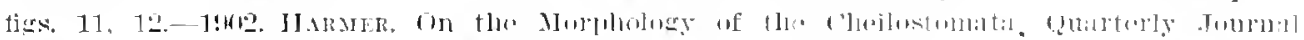

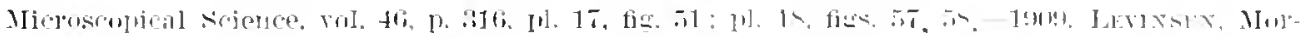

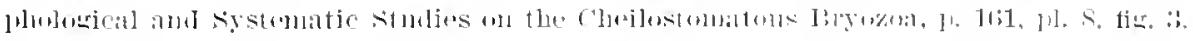

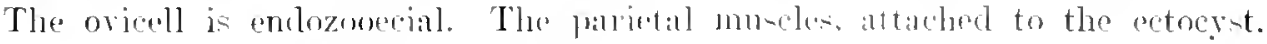

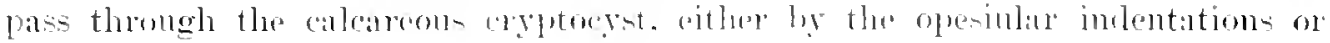


by true perforations called opesinles. The semi-circular apertme las generally a more or less strongly chitinized (or calcareous), simple operculum, more seldom an opercular valve. Avienlaria present.

Historicat.-The family Microporidae as delinited by Hincks and by .Jullien does not appear very natural because the ovicell system has not been considered; indeed Levinsen in 1909 made some modifications.

The family may be made more exact by including in it only those genera having an endozooecial oricell. There is no important difference between the Microporidae and the Onychocellidae; the onychocellaria simply disappear or are replaced by the avienlaria.

As Canu in 1900, ${ }^{1}$ has demonstrated, the replacement of the onychocellaria by avicularia is constant in the general line of descent. It is simply adaptation to new conditions of existence.

In our opinion, the Onychocellidac and Microporidae with the Lumularidae form one and the same family for which we have adopted Jullien's name Opesiulidae, but have retained the first three montioned as subfanilies.

\section{Genus ROSSELIANA Jullien, 1888.}

1888. Rosscliana Jutules, Mission scientifique du Cap Hom, Frozonires, rol. 6, p. TS.

The frontal of the zooecium is a cryptocyst of little depth. The opesium is somicircular. The oricell is endozooecial but prominent. Septulac miporous. No avienlaria.

Genotype.--Rosscliana (F7ustra) rosselii Audouin, 1820.

Canu, in 1900, has badly interpreted Jullien's genus, for the species which he considered as Rosseliana are more often typieal Onyehocella.

The fossil species are:

Rossctiana (Membranipora) incompta Reuss, 15it. Miocene.

Rossetiana (Membranipora) peussiuna M:mzoni. 187t. Miocene, Pliocene.

ROSSELIANA PARVIPORA, new species.

Plate 52, fig. 16 .

Description.--The zoarinm incrusts bryozoa. 'The zooecia arc elongated, distinct, separated by a deep furrow; the mural rim is thin, salient, complete, and distinct. The cryptocyst is flat. shallow, much larger than the opesium and very finely granulated; the opesim is semilunate, transrerse, with a proximal concare border. The ovicell is endozooecial, protruding, and smooth.

$$
\text { Measurements.-Opesium }\left\{\begin{array} { l } 
{ h o = 0 . 0 8 \mathrm { mm } . } \\
{ 1 0 = 0 . 1 0 \mathrm { mm } . }
\end{array} \text { Zonecium } \left\{\begin{array}{l}
L z=0.3 \leftarrow 0.36 \mathrm{~mm} . \\
7 z=0.16-0.20 \mathrm{~mm} .
\end{array}\right.\right.
$$

Affinities.--There is no polypilian conrexity in this species and the opesinlar indentations are only visille on rare zonceia. The oricelled zooecia have a little larger opesim, the breatth of which ranges from 0.12 to $0.1 \mathrm{tmm}$.

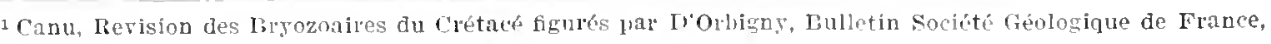
ser. 9, rol. 2S, p. 345 . 
This species resembler closely lasseliana rossetii Autouin, 1820 a a recent form, whicl. Jowerer, appears first in the Priahonian of Ticentin, Italy. Rosstiana pareipora ditlers, however, in its maller micrometric measurements ( $L:=0.36 \mathrm{~mm}$. instead of $0.44 \mathrm{~mm}$.) and principally in its small transrorse opesium.

Occumence.-Viclisburgian ("Chimmey rock" of Marianna limestone) : One mile north of Monroeville, Nabama (rare).

Holotype.-Cat. No.64253, U.S.N.M.

Genus Floridinella Canu and Bassler, 1917.

1917. Floridinella Cane and IBsssuer, Synopsis of American Early Tertiary Cheilostome Bryozon, Lulletin 96, Luited states National Museum, p. 2s.

The oricell is endozovecial and separited from the zooccia by a fold The polypidian convexity is not prominent. 'The opesiuka indentations are large and rounded. The opesium is constricted by two srmmetrical bateral tectl at the level of the opercular articulation.

Genotype-Flovidinclla vicksburgica Camu and Basster, 1917.

'This genus is a true Floridine withont onychocellarium. The following species must be classed in this genus:

Floridinella (Marginaria) destaycsi Hagenow, 1851.

Floridinella (Mcmbranipora) formosa Reuss, $187 t$.

FLORIDINELLA VICKSBURGICA Canu and Bassler, 1917.

Plate S2, figs. 17-20.

1917. Flaridinella ticksburgica Caxu and bassles, Synopsis of American Early Tertiny Cheilostome bryozoal. Lulletin United states Nitional Museum, p. 25, pl. 3. fig. 3.

Description.-The zoarium is milamelsar, hollow, cylindrical, and incrusts the stems ol' small roots of algae. The zovecia are elongated. distinct. separated by a deep furrow; the mural rim is incomplete. rather broat. distinct from the cryptocyst. The cryptocyst is shallow, smooth, or finely graluular, Jonger than the opesium; the polypielian conrexity is but slight y projecting; the opesiular indentations are large, symmetrically rounded; the opesiun is elongated. constricted smperiorly by two lateral teetle placed at the level of the operculum.

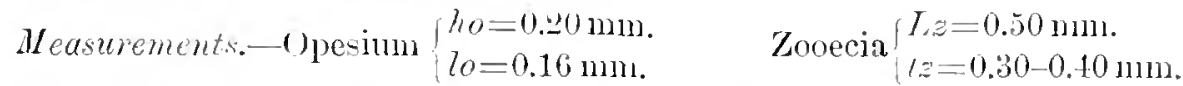

Tariations.-Species with tubular zoaria are quite polymorphic. for the zorecia are easiby deformed on accomt of irecularities in the substratm. In the present species there are wicte zooecia (fig. 21 ) and narow zooecia (fig. 12). The opesimm

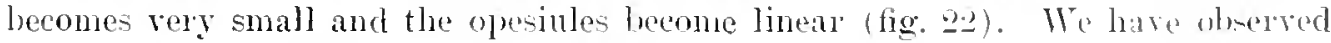
some cases of total regencration (fig. 26) and elosed zooecia perforated by al sit or by a pole (fig. 26 ).

The nonce] Juliferous face (figs. 23-25) always presents mall hrolrostatic tuberosities designed to detach the zoarium from the subtratmon, to deep on the ectocyet, and to increase the volume of the zoarinm. IIere the rooecia are dis- 
tinctly marked (figs. 2t. 25) or invisible (fig. 23). There are two pairs of lateral septules. The cryptocyst is a compact olocyst with the elements scattered.

Affinities.-This form should not be confounded with species of the genus Amphiblestmm because it is without aricularia and its oricell is endozooecial.

The ovicell unfortunately is very rare. On 100 specimens collected only two had ovicells. The great abundance of specimens in the Vicksburgian. to which it seems restricted. has given rise to the specific name.

Ocenremes.-Vickshurgian (Mariama limetone) : One mile not th of Mompeville, Alabama (abundant); Test bank of Conecull Rirer, Escambia Connty, Alabama (abundant); Murder Creek, east of Castlobury. Alabama (abundant): near Claiborne. Monroe County, Alabama (abmulant); "2: miles north of Millry, Washington County, Alabama (abundaut).

Cotypes.-Cat. No. 6.25t, U.S.N.M.

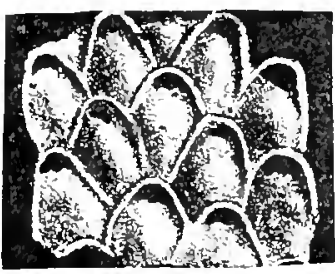

A $、 25$

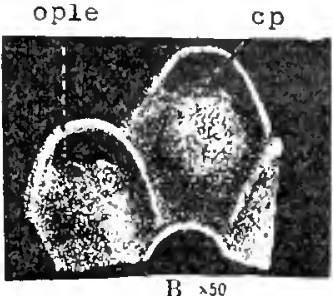

B $\times 50$

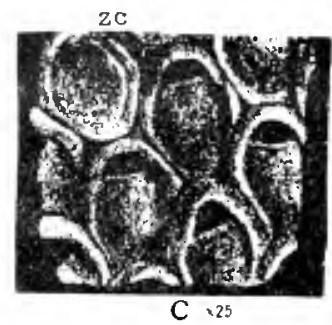

C $\times 25$

Fug. 62. rienus Gurgantut Jullien, 1SsS.

A-C. Gargantua bidens I usk, 1859. Thlee views showing zowecial structure. (After Busl. 1950.) cp, polypidian convexity : ople, opesiular indentations: ar. calcified zooecium.

Genus GARGANTUA Jullien, 1888.

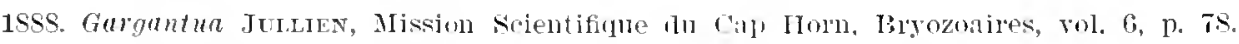

The polypiclian eonrexity projects lut little. The opresinles are incomplete and consist of two small symmetrical indentations. No aricularia.

Genotype.-Gargantua (Mombranipora) bidens Busk. 1859.

Range.-Miocene, Recent.

Jullien took for the type of this genus, Cetlopor (Maryinaria) bidens Hagenow, 1851. which was figured rely imperleetly, but he certainly had before him the beautiful figure given by Busk in 18.9. We are not certain of the identit! of the Cretaceous folm with the Pliocene species.

Furthermore, Water's in his work on Membraniporidae in $1898^{1}$ described and figured a Membranipore bietens living ofl Canri at a depth of 220 meters. This species certainly helongs to the same genus as that of lins: but it differs in its perforated ovicell, a character which we have nevis observel on the numerous specinens in our possession of typical Garguntua bidens from the Crag.

The recent species ought to be taken as typical of the gemus. and it is evident that a mole complete study of the whole subject ourht to be male. Garqantua is 
Rossetiana with clearly malked and constant opesinles. Membunimom onimis Seguenza 1579 is classed in this gemus.

Genus DiCRYONELLA Canu and Bassler, 1917.

1917. Darryonclle Cave and basschi, Synopsis of Ameriean Early Tertiary Cheilostome Bryozsia, lsulletin 96, Unitcl states National Museum, p. 28.

The polypidian comvexity potrules rely little and is ineonstant. The opesiules are large. lound, lateral indentations. The ovicell is endnzooecial. 'There are no opesial proceses (therefore an operenlar valve). The opesium is elongated (therefore the parietal muscles are much developed). The avicularia are very small, constant. placed in all the interzocecial angles, and have the form of small tear drops.

Genotype-Ducryonellu octonuria Cam and Bassler, 1917. .Tacksonian.

This is a Rossetiona ornamented with aricularia. As in this genns also, the opesinles are inconstant and placed very far from the aperture in consequence of the great development of the parietal museles.

DACRYONELLA OCTONARIA Canu and Bassler, 1917.

Ilate 36 , figs. 9-20.

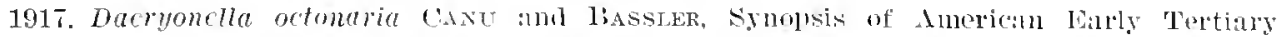
Cheilostome 13rozoa, Fulletin 90. Luited States Nutional Mustum, 1). 28, pl. 3, fig. 4.

Deseription.-The zoirimm incusts small shells or mole often creeps over algae; relre frequently it consists of many superposed limellae. The zooecia are somewhat elongated, confluent among themselves: raguely polygonal; the mural rim is broad, especially below, llat, smooth, oblique. The cryptocyst is terminated distally in a mall polypirtin convexity. The aricularia are straight, interopesial, riangular, projecting chiefly at the point.

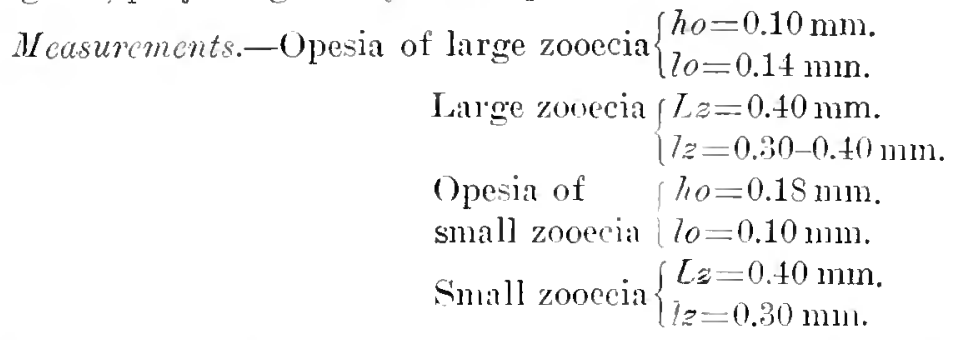

Trariations and affinitios.-The polymorphism of this species is rery remalkatle. On the same zoarium. Withont apparent reason, the zonecia are considerably increased in size. chiefly at the extremity of the fronds. The larger anoecia are always grouped together. none of them ling isolated: then their opesimm becomes transverse and almost triangular.

The polypidian convexity is here symmetrical. hut as menal is not conctant. Howerer the proxinul border of the opesimm is nearly always straight ne convex ind rery rarely coneare. We know that this phenomenon nay he observed in other enera of diflerent families and that it can not serve as a generic character. 
The zoarium is more often multilamellar. The lamellac consists of zooecia piled upon zooceia (figs. 11, 14). The outermost zooecia often experience some reduction (fig. 13) or deformations (fig. 17).

The small aricularia are interopesial. They appear almost circular in tanrential sections. These same sections also show the olocyst constitution of the zooecial wall (fig. 19).

The innel face of the zoarim exhibits convex hexagonal zooecia bearing the hydrostatic tuberosities. Many of these latter terminate in a small pore whose function is unknown to us (fig. 20).

Affinitics.-In Dacryonella minor the zoarium is bilamellar and free, and its dimensions much smaller. The rreat persistence of Dacryonella octonaria may be attributed to its perfected hydrostatic system.

Occurrence.-Middle .Tacksonian: Wilmington. North Carolina (abundant); Near Lenuds Ferry, South Carolina (common); Eutaw Springs, South Carolina (rare); $3 \frac{1}{2}$ miles north of Grovania, Georgia (rare); 18 miles west of Wriglitsville, Johnson County, Georgia (rare).

Upper" Jacksonian (Ocila limestone) : 7 miles above Baimbridge, Georgia (common); Old Factory, 11 miles above Bainbridge, Georgia (common); West bank of Sepulga River, Escambia County, Alabama (common); Chipola River. east of Marianna, Jackson County, Florida (rare); 9 miles north of Ocala, Florida (rare); Alachua, Florida (rare).

Jacksonian (Zeuglodon zone): South side of Suck Creek, Clarke County; Mississippi (rare).

Cotypes.Cat. Nos. 6258t. 6998-63990, U.S.N.M.

DACRYONELLA MHNOR, new species.

[']ate 36 , figs. $7, S$.

Description.-The zoarium is free, bifureated. and formed of two lamellac placed back to back. The zooecia are small, elongated, indistinct, confluent; the marginal rim is hroad, flat. cnlarged at the base into a concave cryptocyst. The opesium is entire. subelliptieal with a strajght or convex proximal border: the polypidian convexity is very inconstant. The ovicell is a rery suall distal convexity. The avicularia are triangular and project but slightly.

$$
\text { Measurements._Zooccia }\left\{\begin{array}{l}
l a-0.1+\mathrm{mm} \text {. } \\
7 s=0.091 \mathrm{~mm} \text {. }
\end{array}\right.
$$

Affnitics.- Although quite varialle the polypidian convexity is actually pres. ent as in Dacmyonella octonaria, but the mall dimensions and the free zoarium distinguish the two species rery well.

Occurrence.-Upper Jackonian (Ocala limestone): Chipola River, cast of Marramua, Jackson ('ounty. Florida (communom).

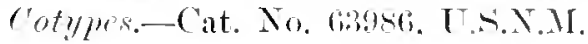




\section{Genus AECHMELLA Canu and Bassler, 1917.}

1!17. Aechmella Canu and Passler, Symopsis of Anerican Early Tertiary Cheilostome Iiryoza, liulletin 96, United states Nitional Museum, p. 29.

The polypidian convexity is little proninent. The opesinles are round, lateral indentations. The opesium is often contracted by two lateral teeth at the level of the opercular hinge. The ovicell is endozooecial. The avicularium is interzoeecial, smallesthan a zooecium, lozenge shiped, with the form of the liear of a lance.

Genotype.-Aechmella filimaryo Canu and Bassler, 1917.

Range.-Cenomanian-Miocene.

The gemus Aechmella is in effect Gargantua with avicularia. It may also be regarded as floridina with avicularia replacing the onychocellaria.

The species of the genus are:

Aechmella (Cellepore) michandirne D'Orbigny, 1850.

Aechmella (Cellepora) hippocrepis Hagenow, 1851.

Aechmella (Cellepore) rocmeri Lonsdale.

Acchmella (Cellepora) xiphie D'Orlbigny, 1852.

Aechmella (Ocllepora) xanthe D'Orbigny, 1852.

Acchmella (Collepora) urenia D'Orbigny, 185.

Aechmella (Membranipora) depressa MacGillivray, $190 t$.

Aechmelte (Memtranipora) concinne Macoxilliviay, 1904.

Aechmella (Membrenipora) ambigze MacGillivray, 1904.

It is probable that one part of Homalostega Marsson, 1SST, may be classed in this genns.

AECHMELLA CRASSIMARGO, new species.

Plate 37, figs. 1, 2.

Description.-The zoarium incrusts shells. The zooecia are small, slightly elongated, joined by their mural rims; the mural rim is incomplete, projecting in front, thick on the borders, distinct from the eryptocyst. The cryptocyst is shallow, a little convex, and smootb; the opesimm is almost transverse, trifoliate. contracted by two lateral tecth at the level of the opercular pivot: the polypidian eonvexity is scarcely visible; the opesinlar indentations are shallow and symmetrical. The ovicell is endozoocial. The ancestrula is a small zonecium of the same form as the normal ones. The aricularium ir interyoecial, smaller than the zooecia, lozengeshape, with a small distal canalicule and an elliptical opesium.

$$
\begin{aligned}
& \text { Measurements.-Opesim }\left\{\begin{array}{l}
\text { ho }=0.08-0.10 \mathrm{~mm} \text {. } \\
170=0.12-0.14 \mathrm{~mm} \text {. }
\end{array}\right. \\
& \begin{array}{r}
\text { Zooecium } \\
\text { (including the opesiular } \\
\text { indentations) }
\end{array} l_{z=0.3 \pm=0.2 \pm-0.30 \mathrm{~mm} .} \text {. }
\end{aligned}
$$

Affinitics.-We have observed mly a small number of -pecinems which were thought for a while to represent forms of ancestrular zoocia of trehmellu filimargo. Nevertheless, we now believe it mecesary to concicler this a distinet 
species on account of the thickness of the mural lim and the elliptical form of the avicularian opesinm.

Ocenprence-Middle Jacksonian: Near Lenuds Ferry, Sonth Carolina (rare):

Entaw Springs. Soutl Carolina (rare).

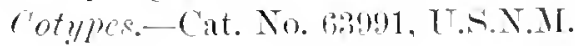

AFCIMELLA FILIMARGo Canu and Bassier, 1917.

Plate $: 7$, figs. $3-5$.

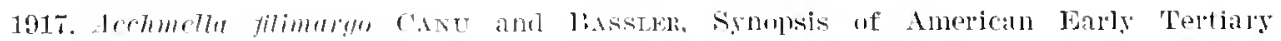
Cheibstome Pryozu, Pulletin m. Inited States Nitjonal Museum, P. 29 pl. 3, fig. $\pi$.

Desription.-The zondim inerusts Orbitoides. The zooceia are elongated. distinct. separated by a form or mited by their mulal rimi: the mural rim is thin, incomplete. convex. distinet from the cryptoryt. 'The eryptecyst is shallow. ohlipue towarl the opesinu. Hat. finely granulose: the opecium is transverse. monstricted by two lateral teeth at the level of the rotary axis of the opereulum; the polypidian convexity mojerts lut littlo: the operiular indentations are large, rount. and stmmetrical. The wicell is enflozooceial and small. The ancestrula is a small zooerinu, hut otherwiso irlentical with the others. The arjenlarium is inter-

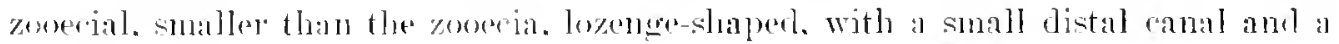
romend opeinim.

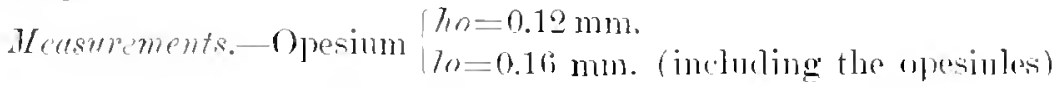

$$
\begin{aligned}
& \text { Marginal zooecia }\left\{\begin{array}{l}
T_{z}=0.50 \mathrm{~mm} \text {. } \\
?, z=0.30 \mathrm{~mm} .
\end{array}\right.
\end{aligned}
$$

Aftimitirs. This species differs from Iihagasostoma 7erigntum in having an enclozonecial weicell. It may be distinguished from A echmelta crassimargo by its filiform mural rim.

Tery often the proximal horeley of the opesium is simply undulated and the opesinles are visible only on account of the opesiular tectl. The opesia of the oricelled zooecia sesm a little larger than the othel's.

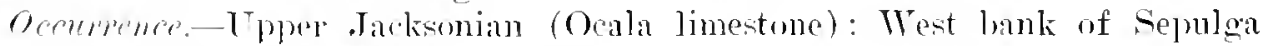
River, Escambia Comuty, Alabama (rate).

Cotypes. Cat. No. Gesis. T.S.X.MI.

\section{Genus MICROPORA Gray, 1848.}

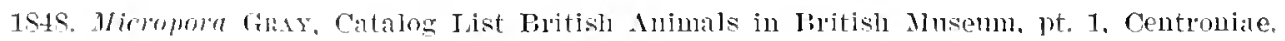
1. 115.

The two opesiules, which are more or less constant. lave the form of simple jwforations. Spines may appear. 'The ovicells are endozonecial, but very prominent. and the snall aricularia. which are situated proximally in the aperture. are furnisherl with a complete crosshar (after Levinen). Dietrlae with few pores.

Grnotypr.-Micropora. (Flustra) coriacea Esper. 1691.

I?"me-Midwayn.-Tecent. 
The species of the genus are:

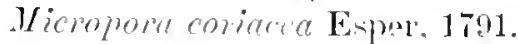

Micropore perforete Machilliviay. 18.5.

Meropore nomani Terinsen. 1909.

Nicropora brezisimer Waters. 1904.

Micropora minuta Reusi, $18 \mathrm{it}$.

\section{MICROPORA CORIACEA Esper, I791.}

Bibliography (Zoolonical).

I'late 4, figs. 20-20.

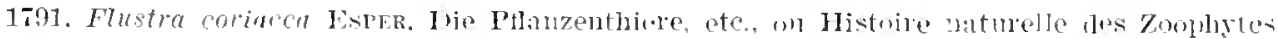
1). $\div$, fig. 2.

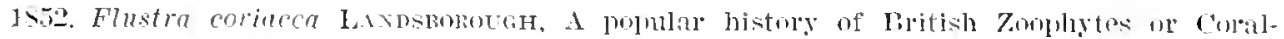
lines, 11. $3.5 \%$.

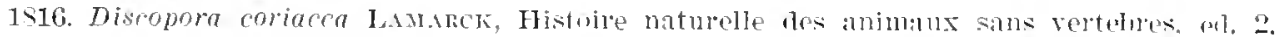
vol. 1, D. 16s: idlenl.

1424. Nisenpora morimen I.A

18.30. Discopom cowiarea

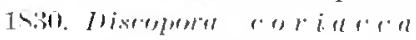
1834. พо1. 2, ए. 251.

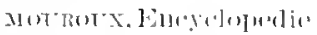
Methulinum, Ifistorire Natmelle des Zouplytesom Animanx Ii:lyonnes, vol. 14, 1. 2.5. Pitistilte, Dichionmelire los somanens Na. tmelles. vol. 60. p. 411.

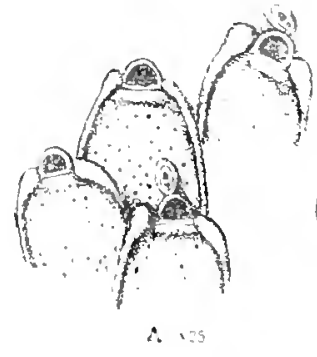

Fig. 133.-Genus Micrupora tiray, 1818.

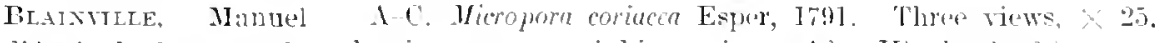

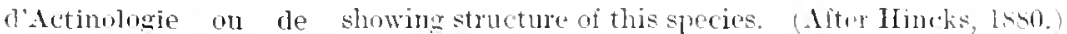

Zoom hytolucio, p. $4 \$ 6$.

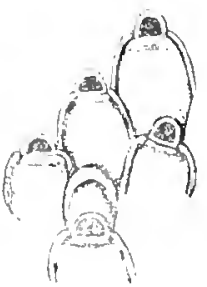

I. $x=3$

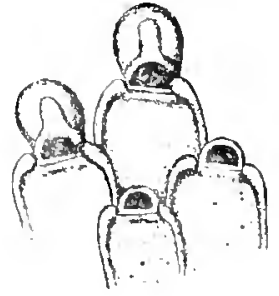

C. $\rightarrow 3$

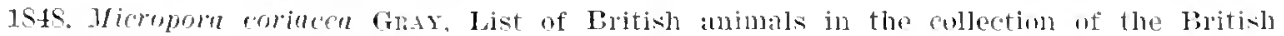
Musenim, 1) 11, s.

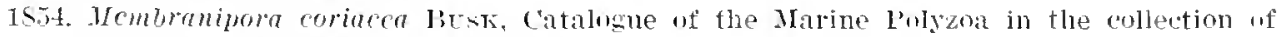
the Britisli Museum, pt. 2, 1). 5T.

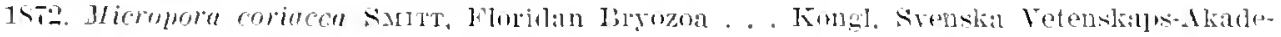
wiens Handlintwa, vol. 10, Xo. 11, p. 13.

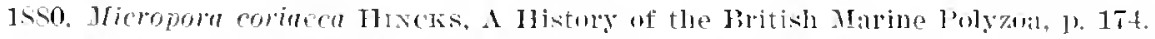

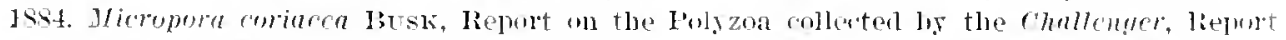

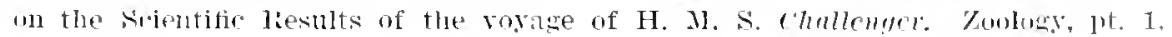
rol 10. 1,t. 31, 1) 71 .

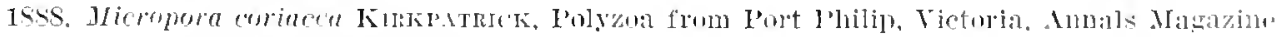
Natural History, ser. 6. rol. 2, 1). 75.

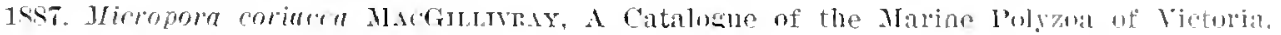

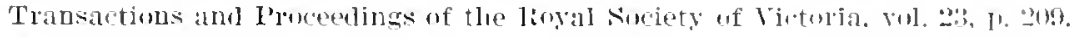

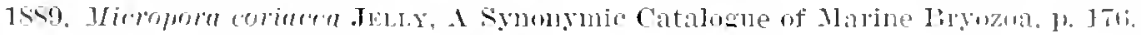

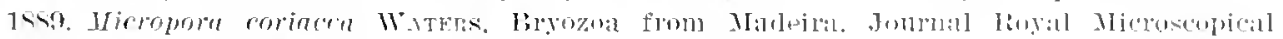
Society, I. 16.

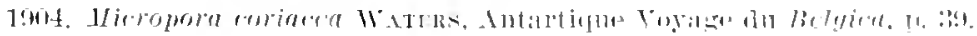


1908. Micropora coriaceu Ronertson. The incrusting cleilustomatous lirozoa of the west cuast of North Ameriar, University of Califurnia Publications, Zoology, vol. 4, 1. 275, pl. 17, fig. 26 (Bibliograplyy).

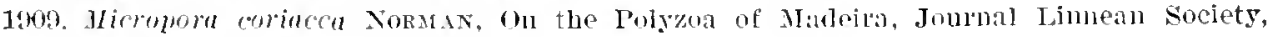
Zoologr. vol. 30. 1. 293.

Bibliography ('laleontulogirnl).

1862. Reptescharchina disjarilis Gabs and Ilowx, Journal Aradeny Natural Science, Philadelptial, ser. 2. vol. 5. 1) 147, pl. 20. tir. 20.

1869. Hcmbramipora gracilis Reuss, Die fossilen Anthoznen ma riromen der sibichtengruple von Crosino, Denkschriften del k. Aliademie der Wissenschaften. Wien, rol. 59, Alsth. 1, rol. 29, p. 291, pl. 20, his. 13.

1891. Micropora coriucen Watens. Nuth Italian Tryozua, Quarterly Joumal of the Geological Sociely of Jundon, vol. 47. p. 13, pl. 11, fig. 9.

1896. Mieropora coriacen Penfexs. Bryozonires des envinoms de Ibula. liuletin Societe Belge de Geologie, rol. 10. ค. $30 . \overline{3}$.

1890. Hicropora (l'encelansa) coriacea Nevisi, Rriozui postpliocenici di Spilinga (Calabrie), Atti Acarlemia Givenia di Scienze, Naturali in Cantania. ser. 4. vol. 9. p. 17, fig. 3 .

1900. Jieropor (Pencelunsa) coriaced Nenaxi. Rirozoi i neogenici delle Calabrie, Faleontographia italica. rol. 6. l). 166 (Italian bils]lograplup').

1904. Jicroport roviacea Canu, Les Brrozoalres du l'atagonien, Menoires Societé Geologique de France, vol. 12, No. 32. 1. 10. pl. 1. fig. 15.

1905. Micropore (Peneclausa) coriuccu Neviane, Friuzo fossile di Carrubare (Calabrie), Bollettino della Societá genlugiea italiana, sel. 2. vol. S. 1\%. 521.

1906. Mieropora macilis Cast. Bryozoires des Terrains du sul-ouest de la France. I. Aquitanion, Bulletin Société Geolugique de France, sel. 4, rol. 6, p. 513. pl. 12, fig. 10.

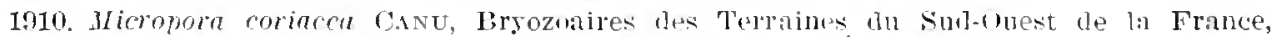
Bulletin Societe Genlogique de la France, ser. 4. vul. 10. p. St5.

This species has been known for a long time in America. Where Gablo and Horn described it under the name of liepteschomplimu disprmitis. More recently Camu has notel it in the Patagonian of Argentina. In Emope. Waters ajorved the species in the Priabonian. Is the living examples an found at Madeira and in the Gulf of Mexico, its presence in Imerican Focene strata was inevitable. Without erer being abundant it las been collected at a number of localities.

We have already called the attention of the reader to thic peculiarity of ocemrence. and we will later note still other examples. It is apparent that the course of the great Atlantic currents was at the end of the Eocene alwolutely ielentical with that prevailing today. Te lack bryozoan material from the middle Eocene in America and the lower Focene in Europe, so that this problem can not be studied for the beginning of Focene time.

Tariations.- The opesintes in the fossil forms of Micropome coriucca are often closed hy fossilization. The ancestrula is unforturately luroken on the beautiful specimen from Wilmington. North Carolina. figured. The oricell is endozonecial, but rery prominent and always visible. The creptoeyst is smooth or rery finely Eranulated.

$$
\text { Neasurement..-Opesium }\left\{\begin{array} { l } 
{ 7 , o = 0 . 0 8 \mathrm { mm } . } \\
{ 7 0 = 0 . 1 1 \mathrm { mm } . }
\end{array} \text { Zonecium } \left\{\begin{array}{l}
T_{z}=0.50-0.62 \mathrm{~mm} . \\
7 z=0.3 \mathrm{~mm} .
\end{array}\right.\right.
$$


These micrometric measurements differentiate it clearly from Wicropora minuticclla which is exceptionally small.

Occurrence-Nidwayin (Clayton limestone): One mile west of Fort Gaines, Georgia (very rare).

Middle Jacksonian (Castle II:yne limestone): Wilmington, North Carohina (rare).

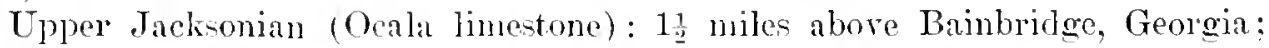
t miles below Bainbridge. Feorgia; 7 miles abore Bainbridge, Georgia; Chipola River, east of Marianna. Florida.

Vicksurgian (Mariamma limestone): West bank of Conecuh River, Escrmbia County, Alabama (rare); deep well. Escambia County, Alabama; near Claiborne. Alabama (rare): Salt Mountain, 5 miles south of .Jackson, Alabama (rare).

Postpliocene: Santa Barbara, California (Gabb) and Horn).

Patagonian: Argentina (Canu).

Gcological distribution.-Anversian of Frince (Canu); Priabonian of the Vicentin (Renss, Waters), of Hungary (Pergens) : Aquitanian of France (Canu); Burdigalian of France (collection Canu); Sicilian and Quaternary of Italy (Neviani).

Habitat.--Atlantic: Off France, England, Azore Islands, Madeira and Florida (36-136 fathoms,). Mexliterianean ( 80 meters). Antarctic (500 meters). Pacific: Off Queen ("harlotte Island and California ( 45 fathoms). In the Antarctic the species lives at a temperature of $9^{\circ}$ Centigrade.

Plesiotypex.-Cat. Tos. 63803, 6380t, T.S.N.MI.

MICROPORA MINUTICELLA, new species.

Plate 4, fig. 23.

Description.-The zoarium incrusts small shells. The zooecia are small, distinct, separated by a furrow, elongated; the crrptocyst is shallow, very finely granulated; the mural rim is thin, distinct, nearly complete; the aperture is semilunar, transterse, surrounded hy a peristome. The ovicell is smooth and endozooe“ial. A pair of very small lateral opesiules is present.

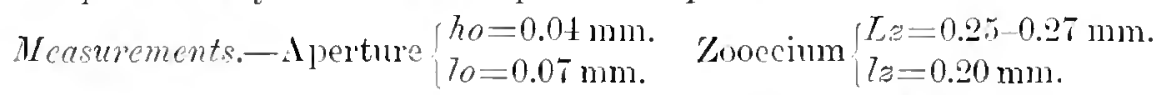

Affinitics. This is the smallest of the known species of Micropora. Its anoestrula, howerer, is not much smaller than the other zooecia.

Ocourence-Midwaym (Clayton limestone): One mile went of Folt Cirines. Georgia (very rare).

IIolotype.-Cat. No. 63505, C.S.N.MI.

Genus HOPLOCHEILINA Canu, 1911.

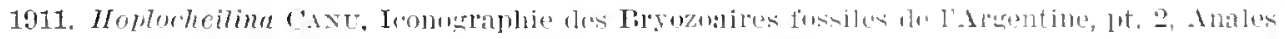
tel Museo Niatonal te linenes Ailes, ful. 21. p. 201.

The polypillian conrexity is little salient. The opesinles are round indentations of little deptll. The opesium is ogival. The aryetneyst is little rleep. The oricell is endozooccial. There are two large, oral arimlaria. 
Genotype.-Hoplocheitina spectubitis Camı. 1911.

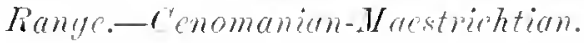

The species of this aenus are:

Hoplocheitind (Eschara) osentifere Rense, 187t. Cenomanian. Germany.

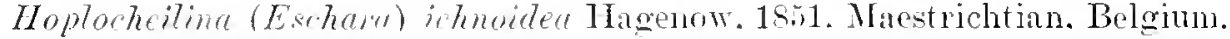

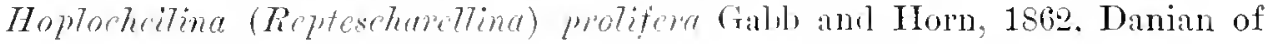

New Jersey.

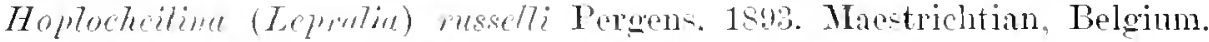

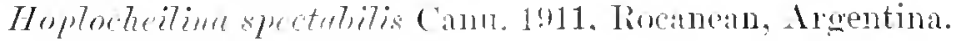

Sublamily Lunularinde Levinsen, 1909.

The zoarium is a Lunulites-that is a conical. cupuliform disk. Vibracula are mesent. The opesiular infentations are rery ineonstant.

The only known genus is Inmmlopiu, the structure of which is described below as a result of omr own stmlies.

Genus LUNLLARIA Busk, 188 .

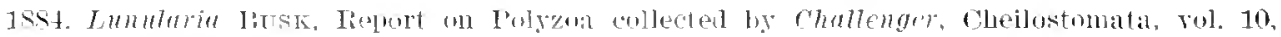
It. 30, 11. 20s.

The zoarium bas the Emmlites form. The aricularia are stmmetrical. Exteriorly and interiorly the zooceia are arranged in laclial rows. The eryptocyst is more or bes doreloped. Both radicular and lyydustatio zooecia are present. The ovicell is cullozooeciall.

Genotype.-Lmulites amplus Busk, $185 t$.

Ramge.-Cenomanian--Rerent.

Ilistopical.-Lumblite Lamarek 1812 is not a defmite generie type. but is merely a zorial form adonted for certain reasons. This style of growth obtains in many genera of cheilo-tomatoms bryozoa, as otionella and Trachopora in the

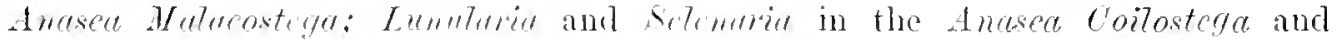
Stiehopore. Fedom, and Bipmin in the Aseophere.

All of the fossils litherto grouped muler the greneral name of Lunutites must now be classified according to their allinities. In 1900. (anu made the first and fimid attempt. In 1912. Waters bromght forth anatomical proof, which will be cited when the occasion demands.

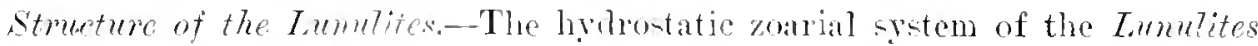
hryozoa is rery complicated and we are still igmorant of many of the details. The larva ordinarily attaclues itself firmly on a grain of sand. The ancestrula which is derived from it immediately gives lise to some clocel hrolrostatic zonecia which by their lightness permit the zoarim to conmence its glowth by ascending away from the sand dangerous to its development. (Abortinl zonecia of Dorbigny.) When in the vieinity of algae, the zoarinm remains fixed under their fronds. When they do not offer suflicient shelter, the clowel zouccia trinsform themselves into perforated, calcified zooecia which are radicular: the radicles then attach the zoarium to shells, stones. or mall algae. The zorium continnes to derelop in 
a mole or lesis widenod rono and alway with the apex ledow. It maintains its nomal position hy the abd of lone articulated filaments called vilorarula, which are thus organ for the maintemaner of stability.
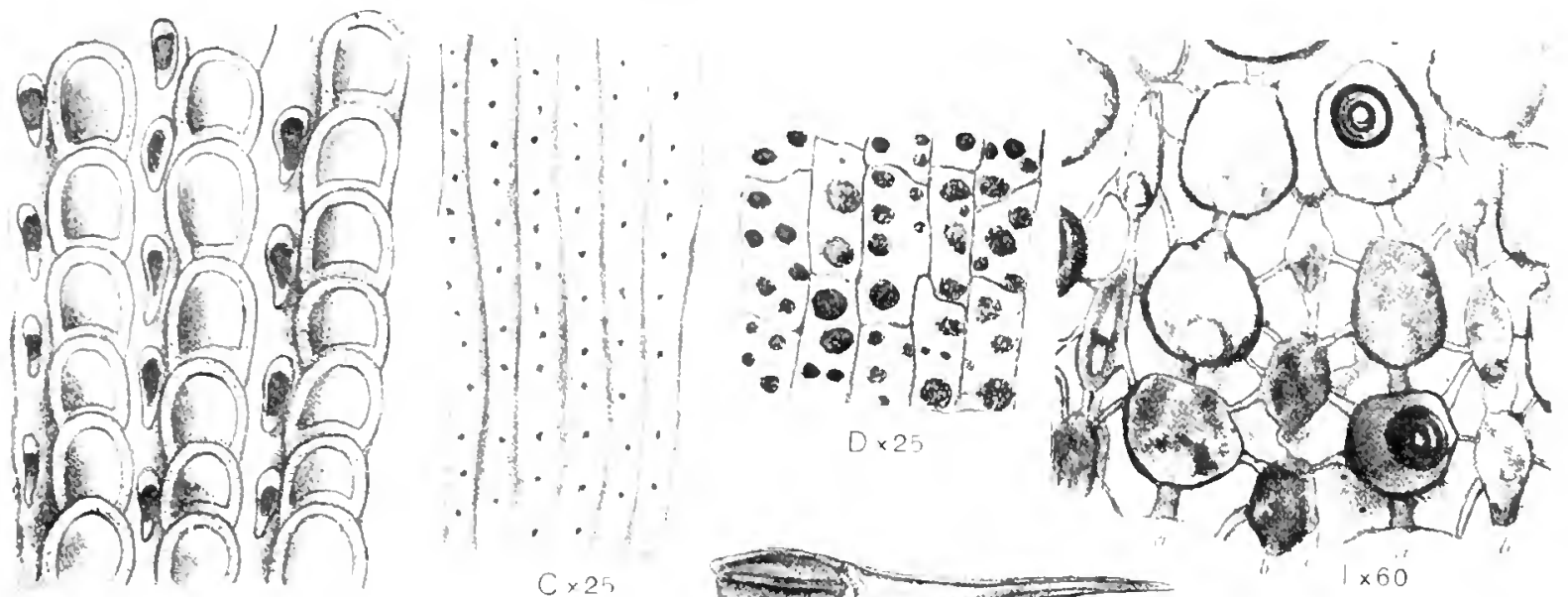

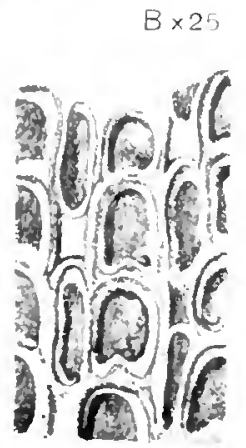

$E \times 25$
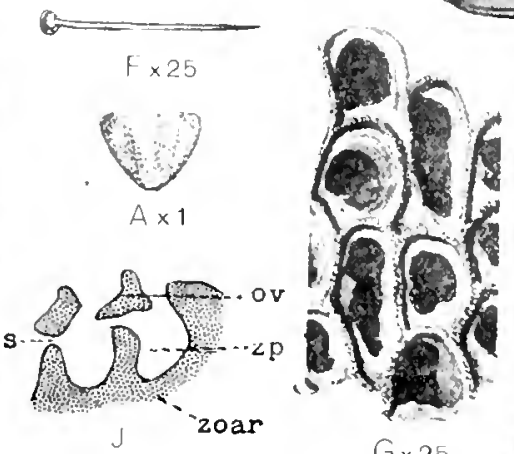

$G \times 25$

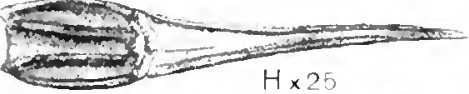

$\times 60$

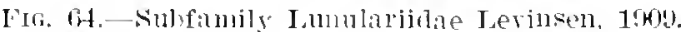

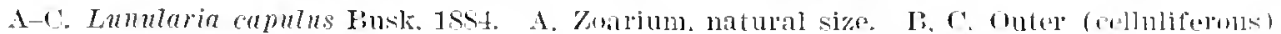
ancl inner faces of the zonlium, $\times 25$, (After linsk, 1S54,

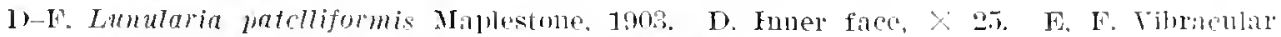

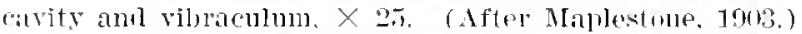

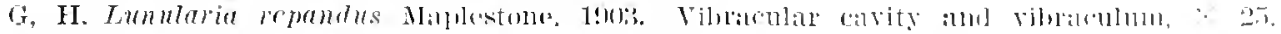
(After Maplestine, 1903, )

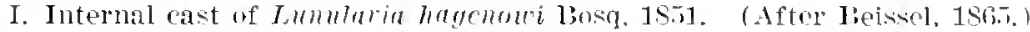

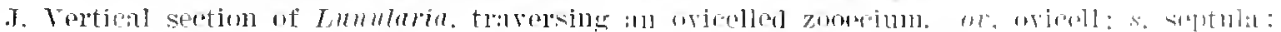
: whr, zoalium : :p, moximal zonesium.

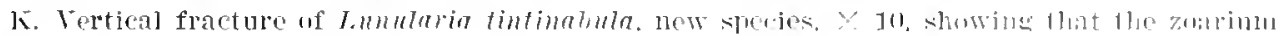

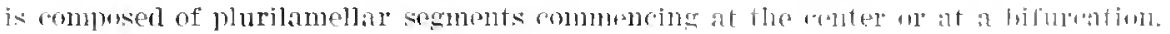

The choice of a substratum ly the lanve is instimetive but not infallinle. Often they aflix themselves on rely heary oljeets on which, merertheless. the zor -

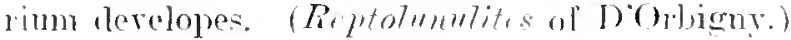


As they are a form of floating life, the Lumulites are subject to variations from hydrostatic pressure quite as much as the more mobile fish. To avoid this the zoarium increases or diminishes its rolume by the aid of parietal muscles attached to the ectocyst; it also increases its volume ly the development of tuberosities on its noncelluliferous face or by special tubules on the same face. This organization, infinitely raried in letails, permits the animal to be assured of its existence under a rather constant depth of water and to avoid the great strain of hydrostatic pressure.

Geological distribution.--Many (retaceous Lunulites are possessed of opesiular indentations and endozonecial ovicells and consequently ought to be classed in the genus Lunularia. The figures of the author's are often inaccurate and it is necessary to have recourse to direct observation. Iiy this neans we have established that the following species are true species of Lumularia:

Lunulites plana Dorbigny, 185:.

Pavolunulites degans D"Oljigny, 15:2.

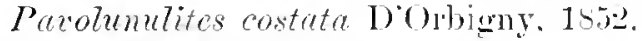

Lunulites munstepi Hagenuw, 1s.51 (=L. putellifomis Marson, 1877).

Lunulites ruliuta Lamatr. 1810.

Lunulites ureeolata Cuvier, 1520.

Lunulites beisseti Marsson, 1857.

Lunulites saldrose Marsson, 1587.

Lunulites golifussi Hagenow, 1 s.1.

Structure of the oiccll.--The oricell is truly enduzonecial and closed by the opercular valve. Becanse of the elevation of the zooecial axis it folms only a small distal cavity undemeath the pperculum and is situated on an culargement of the distal zooceimm (pl. 33, fig. - - ). On accomnt of its minuteness the ovicell has escaped observation, but with a little attention it is easy to discover it and to do so rather frequently.

Zoarial growth. - The zoalial growth in rely different from Trochopora, which increases in size by successive disks. It is mate by pluricellular segments racliating from the zoarial center (pl. 83 , fig. 8) wr from a bifureation (pl. 13, fig. 12). This is quite visible chicfly on the fractures (pl. $8 \%$. fig. 7 ), but it may also be seen on the sections (pl. 83, tig. 10).

\section{LUNULARIA REVERSA Ulrich, 1901.}

Inate 1, tigs. 17-19.

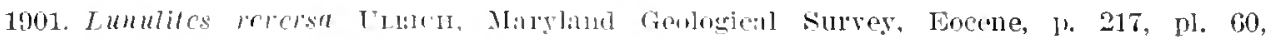
figs. $19,20$.

Deseription.-Zonrium flabliate (prhaps originaly discoid or depressed conial). Zooecia subquadrate or pentagonal, msually widest in the anterior half,

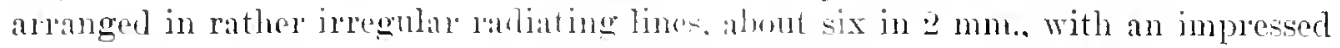

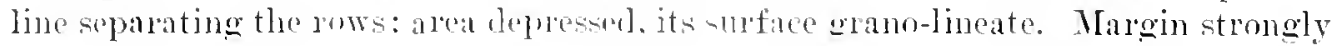

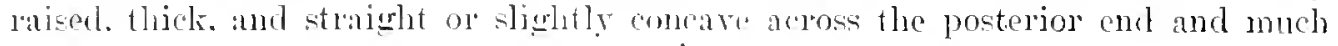


thimner along the sides, the antcrior end appearing to be overlapped by the pasterior ridge of the next succeeding zoocium. Aperture surrounded by a thickened rim, generally rounded in front and straighter behind, sometimes subquadrate, its anterior border close to the prominent end of the next cell, and the length and width areraging about half the corresponding dimensions of the entire zooecium.

Vibracular cells fusiform or clongate oval, rather large, one nsually at each angle of junction hetreen four zooecia. A constriction necurs near the center of each, sometimes on one side only, at other times on both. A narrow area may surround the opening. Under surfice marked by irregular depressed lines radiating from the narrow lower extrenity of the zoarium. Between these lines the surface is convex and rather coarsely pitted and granulate. (After Uhich.)

The vibraculum is symmetrical and has two lateral condyles. The figured specimen has no opesiular indentations. Ilowever. the presence of the calcified cryptocyst is an indication that the parietal museles are really attached to the ectocyst.

Occumener-Lowest Eocene (Bryozom hed at base of Aquia formation): Upper Marlboro, Maryland (rare).

Plesiotype.-Cat. No. 63799, U.S.N.M.

LUNULARIA OVATA, new species.

Plate 9, figs. 11, 12.

Description.-The zoarium is a slightly convex Lunulites, bearing at the center al large number of hydrostatic zooecia. The polypidian zooecia form the four or five exterior. circular rows; they are hexagonal, little distinct, elongated; the mural rim, smooth and thick, is distinct from the little developed cryptocyst; the opesium is elongated, oval, the narrow end in front, entire. The ovicell is a small, indistinct distal convexity. The vibracula are arranged in distinct and regular rows; they are interzooecial, symmetrical, fusiform, without lateral condyles. On the inner side the ribs are disposed in longitudinal series under the hydrostatic zooecia and in radial series under the polypidian zooecia. They are furnished with many roms of tuberositics.

$$
\begin{aligned}
& \text { Measurements.-Opesia }\left\{\begin{array} { l } 
{ h _ { 0 } = 0 . 1 5 \mathrm { mm } . } \\
{ l _ { 0 } = 0 . 1 2 \mathrm { mm } . }
\end{array} \quad \text { Zooecia } \left\{\begin{array}{l}
L z=0.25 \mathrm{~mm} . \\
l=0.23 \mathrm{~mm} .
\end{array}\right.\right. \\
& \text { Vibracula }\left\{\begin{array}{l}
I, v=0.25-0.30 \mathrm{~mm} . \\
l,=0.16 \mathrm{~mm} .
\end{array}\right.
\end{aligned}
$$

Affnitise.-This species is the American representative of Lumularin roulinter Lamarck 181S, a common species in the Parisian Lutetian, but it is much smaller in zooecial dimensions.

It differs from Lumularie veruense in its oval opesium and in the large tuberosities which ornament the sides of the inner face.

Occurrence-Wilcoxian (Bashi division): Wonds Blutf, Mlabama (rare).

Cotypes.-Cat. No. 63834, T.S.N.M.

$$
\text { 55s90-19-Isull. 106 - } 16
$$


LUNULARIA? GRANDIPORA, new species.

Plate 12. figs. 3, 4.

Trescriptim. - The zontimm is probably a slightly convex Lumulites. The zooecia are disposed in latial and cirrular rows; they are large, elongated, ristinct, separated by a furrow. and are withont eryptocyst; the mural rim is thin. complete, nearly level, with the summit sharp. The opesium is irregularly elliptieal, very finely erenulated. The oricell is typically endozooecial, very distinet. somewhat convex and separated from the mulsil rim. The viloracnla are arranged in distinet rows; ther are interzooecial, elliptical, symmetrieal, and bear in their distal half two lateral condyles. On the innes site the ribs are convex and bear large tuberosities.

Affinities.-Lunutaria grandiprora Aiflers from the other species of the genus Lumularia in certain essential characters which fact makes ns doubt its position in the genus; the large opesium in that of the Membranipores: the ovicell is not of the ordinnry type, but is the typical endozoocial oricell which we have observed in one group of Membranipores; finally, the ribraculum itself. although symmetrical, is elliptical and not luzenge-shaped and fusiform. We are mobably dealing with an especial genus which unst be classified near Vibracellina from which it diflers in its orlicular zoarim and its symmetrical nonauriculated vibracula.

Only three fragments of this interesting species have been collected, which is far too few mpon which to base a new genus.

Occurpener.-Claibornim (Lislon formation): Wautubbe Hill, $t$ miles south of Enterprise, Clarke County. Mississippi (rare).

Holotype.-Cat. No. 63840, U.S.N.M.

LUNULARIA VERRUCOSA, new specics.

Plate 37, figs. 6-9.

Description. The zourium is a convex Lumulites beang at the center a large number of dosed hydrostatic zonecia quite vermecose. The polypidian zooeria are distinet. separated by a furrow, rectangular, transverse; the mural rim is little distinct from the cryptocyst and is somewhat projecting; the cryptocyst is much larger than the opesimm, shallow, flat, and smooth; the opesium is elliptical and transverse with a proximal lorter sometimes convex. Its vibracula are arranged in sperial rows; they are sulatl. lozenge-shaped. and withont lateral condyles. On the inner side the ribs are flat, radial, and a little granulated on certain zoaria.

$$
\begin{gathered}
\text { Measurements. Oresia }\left\{\begin{array}{l}
h 0=0.10 \mathrm{~mm} . \\
70=0.07 \mathrm{~mm} .
\end{array}\right. \\
\text { Vibracula }\left\{\begin{array}{l}
L_{\eta}=0.15 \mathrm{~mm} . \\
7 v=0.07 \mathrm{~mm} .
\end{array}\right.
\end{gathered}
$$

Affinities. - This species also belones to the group of Lunularia rectiata Lamarek from which it differs in its rery small zonecial dimensions.

It differ's from Lumularia orata becanse its opesinm is transwerse and not oval. and by the sides of the inner ficce, which are flat and almost smooth. 
De Gregorio in his Monograph on the Eocene of Alabama has created for the group containing I. radiata Ianarck, 1816, L. fenestrata De Gregorio, 1590, and L. punctata Leymerie, 1545, a special geme Timiclausa, in which $L$. orata and L. vemueosa could be introluced. 'The essential character is the presence of hydrostatic cellules (cellulis medianis clansia). It is undeniable that the group of species just eited forms a rather hourogenons assemblage characterized chiefly by the great development of the calcareous cryptocyst. But, thongh the hydrostatic cellules may be constant, they are not peculiar to it, for not only to they exist on many other species of Lunularin, but they have the same constancy in the genus Trochopora, where the mode of growth is totally different. These species of Lumularir are perhaps identical or closely related forms, but they do not have different functions from other species, so that they can not be separated generically.

In the interior (fig. o) the zoocein exhibit a convexity, often supporting the oricell. This convexity is characteristic of the genus.

The larra always attached itself to a large grain of sand, which fact explains the large number of hydrostatic zooceia permitting the zoarium to lighten itself and thus escape the dangerons zone of the sand.

In the transverse sections the very thick zoarium is formed of many celled segments radiating from the center or from a bifuration.

Oecurrenee-Mieldle Jacksonian: Wilmington, North Carolina (common); Rich Hill, Crawford County, Georgia; 18 miles west of Wrightsrille. Johnson County, Georgia (rare) : 12 miles sontheast of Marshallville, Georgia (rare) : Baldock. Bammell County, Sonth Carolina (rare); $3 \frac{1}{4}$ miles south of Perry, Georgia (liale).

Tpper Jacksonian (Ocala limestone): Chipola River. east of Marianna. Florida (rare): Bainbridge, Georgia (rare).

Vicksburoian ("Chimney rock" of Marianma limestone) : One mile north of Monroeville. Alabama.

Cotypes.-Cat. Nos. 63992, 63993, U.S.N.M.

LUNULARIA LIGULATA, new species.

I'late 13, figs. 10-12.

Description.-The zoarium is a concave Lumulites, mueh expanded. The zonecia are rectangular, transverse, distinct; the mural rim is thick and distinet from tho cryptocyst. which is deep. smaller than the opesimm, and very fincly gramulaterl. The opesium. orbicular or elliptical, is surrounded by a prominent collar. The ovicell is a large distal convexity. The hydrostatic zooecia have a false opesimm partially olstructed by a wide calcareous tomgue. The vibracula are elongated. narrow fusiform. deeply embedded, disposed in distinct rows. The inner side has that or slightly convex radial ribs, perforaterl with small. seattered pores.

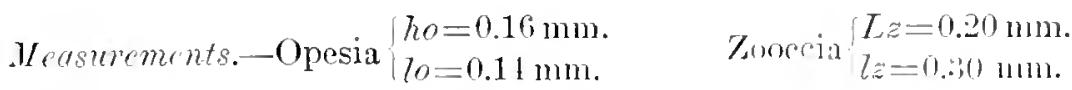

$$
\begin{aligned}
& \text { Vibracula }\left\{\begin{array}{l}
L r=0.20 \mathrm{~mm} . \\
7 r=0.10 \mathrm{~mm} .
\end{array}\right.
\end{aligned}
$$


Tariations.--The hydrostatic zooccia which suround the ancestrula are rery variable. The small tongue, which partially obstructs the false opesium, is more or less developed: it becomes transformed into a median column and it is then bordered by four small symmetrical pores. It is evident that the lateral fissures are opesiules through which the parietal muscles pass.

Affinities.-This species differs from Lumlaria verrucosa in its larger micrometric dimensions and in its hydrostatic zooecia. which are not wartlike, but are ornamented with a small tongue.

Although closer still to Lunularia radiata Lamarck 1816 , it differs from it in its smaller micrometric measurements ( $L z=0.20 \mathrm{~mm}$. insteal of $0.36 \mathrm{~mm}$.), and in its transverse, and not clongated zooccia, and in its hychostatic zooecia furnished with a tongue.

It belongs to the group Dimictause De Gregorio, 1890, for which we have as yet no constant characteristics.

Occumence.-Lower Jacknonian : 30 niles southeast of Shell Blutf post office, Georgia ( rare).

Claibornian (Cook Mountain formation): Moseleys Ferry, Caldrell County, Texas (very common).

Isower Tacksonian (Moodys mall): Tackson, Mississippi (abundant).

Jacksonian (Zeuglodon zone): Blutf on south side of Suck Creek, Clarke County, Mississippi.

Vicksburgian (Red Blufl clay) : Red Bluff. Wayne County, Mississippi (rare). Cotypes.-Cat. No. 638t6, U.S.N.M.

LUNULARIA FENESTRATA De Gregorio, 1890.

Plite 37, figs. 10-13.

1590. Dimiclausa fonestrata $\mathrm{DE}_{\mathrm{E}}$ Gregono, Monographie de la Fame Eocenique de Alabana. Annales de Geologie, et de Paleontolugie. Lirraisons 7,5 , p. 249, pl. 42, figs. 23-27.

Description.-The zoarium is a small, convex, expanded Lunulites with the zooecia and ribracula in distinct, altermating ratial rows. The zooecia are rectangular, somewhat transrerse, distinct, ogival; the mural rim is thick; the cryptocyst rery small; the opesimm large, elongated, elliptical. The oricell is a large distal convexity. The ancestrular zooccia are hydrostatic and calcified with four opesinlar openings like a window. 'The vibraculum is long, narrow, fusiform, decp, primoserial in the middle, but in distinct rows along the margins. The inner side is formed of large, radial, convex ribs with small pores far apart. A large, distal septula and two pairs of large, lateral septulae are present.

$$
\text { Measurcments.-Opesia }\left\{\begin{array} { l } 
{ h _ { 0 } = 0 . 2 0 \mathrm { mm } . } \\
{ l _ { 0 } = 0 . 1 4 \mathrm { mm } . }
\end{array} \quad \text { Zooccia } \left\{\begin{array}{l}
L_{z}=0.22-0.26 \mathrm{~mm} . \\
l_{z}=0.21-0.26 \mathrm{~mm} .
\end{array}\right.\right.
$$

Affinities and variations.--As we have not observed a polypidian convexity or an opesiule, we can not affirm that this species should be classed in the Coilostega: but on account of its resemblance to Lunularia Jistans Lomstale 18t5, we must 
provisionally place it in the same vicinity. It differs from $L$. distans, however, in its solid and not hollow zoarium and its smaller zooecia.

From Lunularia vicksburgensis Conrad it may be distinguished by the arrangement of its vibracula in all the interzooccial angles.

Its closest aflinities are with Lumularia ligulata from which it differs in its larger zooecial dimensions and its hydrostatic zooecia, which are always perforated by four rectangular pores which are really opesinles.

We hare seen some zoaria without hydrostatic zooecia.

Occurrence,-Iower Jacksonian (Moodys marl) : Jackison, Mistisippi (common).

Plesiotype-Cat. No. 63994, U.S.N.M.

LUNUlaRIA TUBIFERA, new species.

Plate 3i. figs. 14-1S.

Description.-The zoarium is a Lumnlites, small. irregular, little convex, without fibrous base. The zooccia are hexagonal, somewhat elongated; the mural rim is scarcely distinet from the cryptocyst, which is quite shallow. The opesium is oral, very finely crenulated. The ancestrular zooecia are ordinary zooecia transformed into radicular zooccia by total regeneration. The ribricula are small, symmetrical, without lateral condyles, cmbedded deeply when they are in distinet rows. On the inner side the zooecia are risible as hollow tubes, salient, closed or wide open.

Traviations. - Toward the center of the zoarim the vibracula are not in distinct rows. They are scattered among the zooecin and are very large (fig. 15).

The hydrostatic zooecia are radicular (fig. 15). We have observed (fig. 16) that the ordinary zooecia may be transformed in radicular zooecia by total regeneration. These zooccial transformations throngh regeneration according to the necessities of the zoarial life, demonstrate the vital unity of the zoarium and the importance of its special hydrostatic system.

On the inner face only the hydrostatic zonecia appear to be tubiferous. We can not explain the reason for this absence of the basal zooecial wall. Evidently the ectocyst corers all of the zoarium, but must be extremely fragile (fig. 18).

Affinitics.-Lumularia tubifera is close to $L$. ovata, but differs from it in its ancestrular zooecia, which are radicular, and in the complete absence of ribs on the inner face.

Occurrence.-Middle Jacksmian: One-half mile southenst of Georgia Kaolin Company mine. Twiggs County, Georgia (rale).

Cotypes.-Cat. No. 63995. U.S.N.M.

LUNULARIA DISTANS Lonsdale, 1815.

l'ate 38 , firs. 1-20.

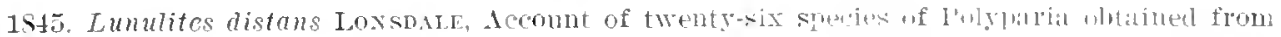

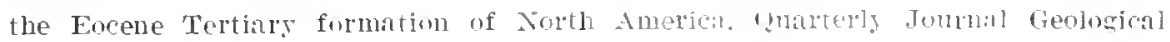
Societs London, vol. 1, p. 531 , fis. 
1562. Lamulites distans Gabe and Horx, Monograple of the Fossil Polyzoa of the Secondary and Tertiars formations of North America, Journal Academy Natural Sciences. Philatelphia, ser. 2, vol. 5., ए. 119.

1990. Lumulites distans DeGregonio. Monograplie de la Faune Focenique de l'Alabama et surtont de celle de Claborne de l'stage parisien, Amnales de Geologie et de Paleontologie, Liviaisons 7,8 , 11. 250, 11. 42, fig. 20.

1S5S. Lumulites contigua Empors, Geological survey North Carolina, Paleontology, p. 311 , figs. 250,251 (not $L$. contigua Lonsdale, 1815).

Description.-The zoarium is a large, convex Lumulites, on which the rows of zooecia alternate with rows of vibracula. The zooccia are disposed in radial and circular lows, and are distinct. elongate, hexagonal, or ogival. The cryptocyst is not distinct from the mural rim; it is decp, flat, very finely granulated; more dereloped in the small than in the large zooecia; the opesimm is elongate, ogital, with a slightly concave proximal bordel. The ovicell reposes on the distal wall; it is a small convexity, distinet from the mural rim. The vibraculum is elongated, narrow. lozenge-shaped, symmetrical, provided with two lateral condyles. The interior of the zoarium is hollow; the zooecia are devoid of basal walls and are wide open into the zoarial carity. The inner side is a thin calcareous or chitinous pellicule provided in the interior with numerous tuberosities. The ancestrula is a zoocinm identical with the others. The aneestrular zooecia are sometimes hydrostatic ol radicular.

$\mathbf{T}^{\mathrm{T}}$ ariations. - The zoarimm generally is of large dimensions (figs. 3, 4, 5). To insure the upright position it is necessary to lave an extensive hydrostatic system, because lime is much lreavier than the water. 'This is the reason for the absence of all hibrous tissue.

This exceedingly light apparatus is very fragile and breaks very easily. for entire zoaria are never found. In calcareous sediments the mud fills up the internal cavity and prescrves the fragile lamella which covers the zoarium. On these rather common fossils. it may le noted that the inner side (fig. 1s) of this lamella bears uumerous tuberosities. The radial rows of zooecia are separated by rertical partitions supporting the feontal cryptocyst which has been worn away on account of its fragility, althongh it is easy to reconstruct it in the mind's eye (figs. 1-5).

The inmer side of the zoarium is extremely fragile. Upon the supposition that one of our specimens is a mold of the exterior. an impression of it in wax (fig. 19) wives the external aspect of the inner side, but we have no confirmation of this structure from actual specimens. Quite frequently the zoaria are found with a large cavity representing the plare where some incrusting bryozoan or other organism has stengthened the fiagile imer side.

We lave found some zooecia with a polypilian conrexity (fig. 7 ); the parietal mucles are therefore attached to the cryptoryt.

The size of the zonecia is quite variable anrl must depend on the size of the ancestrula and the convexity of the zoarium. Figure 11 illustrates the rare case of a gigantic ancestrula surromded by large zonecia: generally the zoarium commences with radicular zooecia (fig. 8), a zone of small zooecia appears next (figs. 
14,20 ), and finally the normal zooecia are eleveloped (figs. $7,9,10,12$ ). The zone of small zooecia does not always develop (fig. 11), but fughments containing the two sorts of zovecia are rery common.

The entozooecial ovicell is clearly apparent on the splendidly preserved specimen shown in figure 9. Generally it has the more voluminous aspect shown in fignres 7 and 10 .

In the interior the fragile partitions limit the radial rows of zooceia (fig. 15), and the opesium and the eryptocyst have the same form. The zooecia lave no basal wall (fig. 16): the very oblique and much-eleveloped distal wall has an ovicell (ov., fig. 16). Certainly chitimons walls must have taken the place of the usual ealcareous walls here absent in order to limit the general carity which contains lencocrtes, orula. spernutozon, and the polypide, and separates it from the large partitioned zourial eavity which can only contain sea water.

The vibucula are as lare as the zorecia; they are present $j$ all the interzooecial angles. whereas in Lunularia ircholumensis and in $L$. contigua there is in one row only one vibraculnum to two zooecia.

The same large, partitioned zooecial cavity exists also in Lumularin rontigua: but the latter specjes has smaller zooecia and is provided with a complete basal wall.

Oecurrener-Widlle . Jacksonian: Wilmington, North Carolina (common), Lonsdale's type locality; near Lemds Ferry, South Carolina (common); Futaw springs, Sontl Carolina (common); 18 miles west of Wrightsville, Georgia (common) ; $3 \frac{1}{2}$ miles north of (rrovania, Georgia (rare).

Upper Jacksonim (Ocala limestone): Trest bank of the Sepnlga River. Escambia County, Alabama (rabe).

Jacksonian (Zuglodon zone) : IBluff soutl side of Suek C'reek, Clarke County, Mississippi (rare); Cocoa post ollice, Choctaw County, Alabama (rare).

Ticksburgian (Marianna limestome): One mile north of Monroeville, Alabama (rare) : west bank of Conecuh River, Eseambia County, Alabana (rare).

Plesintypes.Cat. Tos. 63997, 63998, U.S.N.M.

LUNULARIA CONTIGUA Lonsiale, 1815.

Plate 39 , figs. 1-5.

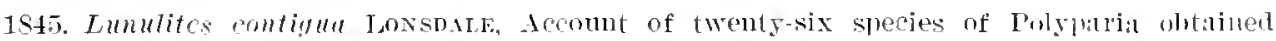
from the Eocole Tertiary formations of North America, Quarterly Junrnal Ger(-

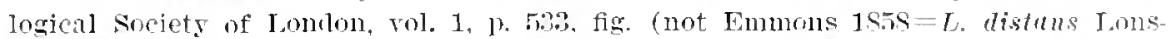
dale, 1S45).

Deseription.-The zoarium is a latge conical Lunulites in which the zooecia and avienlaria are disposed in distinct rows. The small zonecia are ocival. little distinct. transverse. The clyptocyst is of little depth and is as lone as the opesium: the opesium is semilunal with a nearly straight moximal horide. The large zooecia have no cryptocyst. Each zooeciom lias the form of an joulater clocel sac, situated in a linere. partitioned zourial cavity. The viluacula are lone and narow. with two lateral. improminent contyles, disposed in sperial rows. lut with 
two to every two zooecia. The inner side is chitinous or rery little calcified and bears small tuberosities.

Mecesurements:

Opesium tho=0.15 $\mathrm{mm}$.

of small zooecia $10=0.17 \mathrm{~mm}$.

Small zooecia $\left\{\begin{array}{l}T_{z}=0.3 .5 \mathrm{~mm} . \\ 7 z=0.3 \pm 0.40 \mathrm{~mm} \text {. }\end{array}\right.$

Opesium $\quad$ ho $=0.30 \mathrm{~mm}$. of large zooccia $170=0.26 \mathrm{~mm}$.

Jarations.-The zoarial organization of this species is analogons to that of Lumulites ristums Lonslale. 1845, with this difference, however, that the zooecia are quite calcified on their basal side (fie. 4). The concare molds (figs. 2. 4) show this remarkable character very well. The convex casts which have lost the frontal wall of the zooccia (fig. 1) show the internal side of the inner face of the zoarium; the rows between the partitions are ornamented with numerons tuberosities: in which character the species does not differ from L. distans Lonsdale.

Another charicteristic of this species is its zooecial dimorphism, which is unique in this genus. We are ignorant of the function of the large zooecium.

Vibracula are not placed in all of the intelzooccial angles, as in most of the species of Lunularia; there is only one for two zooccia in this way-namely. that the circular lows with ribracula alternate with circular rows withont ribracula. Gabb and IIoln have proposer the genus Otigotresium for this special character. We can not believe that the simple elongation of the small clistal canal in which the ribraculum may be lodged is a sufficient generic character.

Lunularia vichsturgensis Conrad 1847, presents the same arrangement of the ribracula, but $L$. contigua differs in its zooecial dimorphism.

Occumenee.-Middle Tacksonian (Castle Hayne limestone): Wilmington, North Carolina (rare).

Plesiotypes.-Cat. No. 63999, U.S.N.M.

LUNULARIA (OLIGOTRESIUM) CLAIBORNICA, new species.

Plate 13, figs. 13-15.

Deseription.-The zonrium is a convex, expanded Lumulites, formed of radial rows of zooecia and vibracula. The zooecia are ogival, transterse, distinet; the mural rin is very thick; the cryptocyst is small, finely granular. The opesium is semilumar and surrounded by a small collar; the proximal border is a little concave or convex. The ovicell is a distal convexity often covered by the external alcification. The ribracula are elongated, elliptical, disposed in radial rows in the interzorecial angle for two zooecia; joined between them by a small canal; its opesium is nurrowed in the lower part by a calcurcous lamella. which ends in two condyles. On the inner side the radial rows are convex and piereed by large closely "rranged pores.

$$
\begin{aligned}
& \text { Weasurentuts.-Opesinm }\left\{\begin{array} { l } 
{ h _ { 0 } = 0 . 1 7 \mathrm { mm } . } \\
{ 7 0 = 0 . 1 6 \mathrm { mm } . }
\end{array} \quad \text { Zooecium } \left\{\begin{array}{l}
T_{z}=0.30 \mathrm{~mm} . \\
\tau_{z}=0.40 \mathrm{~mm} .
\end{array}\right.\right. \\
& \text { Vibraculum }\left\{\begin{array}{l}
L_{r}=0.30 \mathrm{~mm} . \\
T_{r}=0.18 \mathrm{~mm} .
\end{array}\right.
\end{aligned}
$$


Affinities. - The vibucula are arranged two to every two zooecia (c)igotresium of Gabb and Horn) in which feature the species agrees with Lunularia contigne Lonsdale, 18t5, and $L$. vicksburgensis Conrad, 18ti.

It differs from Lumulariu contigue in its solid zoarium withont hydrostatic zoarial carity (fig. 13).

It may be distinguished from Lumuluria eicksburgensis Conrad, 18t7. by its ribracular condyles which are without depressions, by its opesial. proximal border nhich is often conrex, by the pores of the rows on the inner face which are much more numerous and eloser together, and hy its smaller zooecial dimensions.

Occurrence-Claibornian (Gosport sand): One mile southwest of Rockrihle, Clarke County. Alabima (common); Gopher IIill. Tombigbee River, Alabama (common); Claiborne, Alabama (rare).

Cotypes.-Cat. No. 63sti. U.S.M.M.

LUNULARIA (OLIGOTRESIUMI) VIChSBURGENSIS Conrad, 1847.

Plite S3, figs. 1-11.

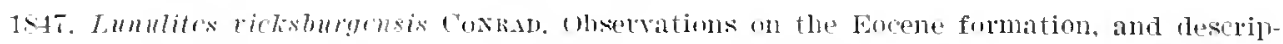
tions of one humbed and fire new fossils of that perion, fun the vicinitg of Vicks. burcr. Mississippi, with an appentix, Froceellings Academy Natural Sciences Philitdelphia, rol. 3. 1. 290; iden 1545, Journal Acadeny Nitural Sciences Philadelphia, ser. 2, rol. 1, n. 127 .

1962. Oligotresium richsburgensis GAss and Hurix. MIonograph of the fossil polyzoa of the Secondary and Tertiny formatims of North Amelica. Journal Academy Natmil Sciences Philadelphia, ser. 2, vol. 5, 1) 139, pl. 19, fig. 22.

Description. - The zoarium is a convex expanded Lunnlites, without hydrostatic zooecia. The zooecia ale distinct, ogival, somewhat transverse; the mural rim is rery thick; the eryptocrst is rery small and finely granulated. The opesium is oval, narrowest at the top, the proximal border quite concare; it is bortered by a small collar. The ovicell is a distal convexity hidden by the external calcification. The ribraculum is rery long: its opesimm is large and narrowed in the upper third by two large condyles with a small fossette. The vibracula are arranged in radial rots. but there is only one to crery two interzooecial ancles. On the inner sicle the radial lines are convex and garnished with large seattered pores. One pair of lateral septulae.

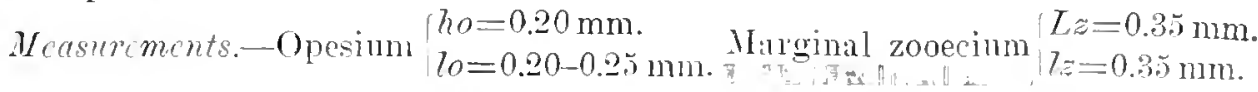

$$
\begin{aligned}
& \text { Vilsraculum }\left\{\begin{array}{l}
L v=0.35 \mathrm{~mm} . \\
\mid \ell^{\prime}=0.20 \mathrm{~mm} .
\end{array}\right.
\end{aligned}
$$

Faration.-The mieronetrie dimensions of the zonecia and onesia ane quite rariable and are notably larger on the zoarial marein-. The wetwrot whieh flont

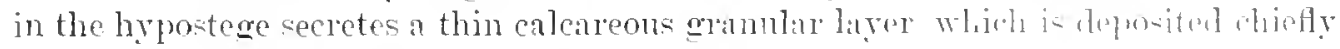
on the primitive olocy of the errytocrat and wricell (fig. - ) .

The riluaculum is not always olliptical: it has sometimes a distal eallosity in the form of the leaf of Sarittarin (fig. 3). 
As usnal in the genus. there is a pair of large, lateral septulae (fig. 7 ) and a large, distal septula (fig. 10).

Growth is accomplished by segments irradiating from the center or from a bifurcation (figs. 8, 9) : this is, moreorer, very irregular (fig. 5). The segments are inscrted the one into the other (fig. 10).

- The small interzoocial canals are very close together (fig. 7 ).

The ancestrula is a hydrostatic and radicular zonecium (fig. 4); indecd only the larra is attached to large objects (fig. 9). There are no other hydrostatic zooecia.

The pores of the inner face are at the extremity of the tubules which perforate the test even to the zooccia.

Iffinitics.- This species diflers from Lumbara ctaibomica in its larger micrometric dimensions, its shallow pit in each ribracular condyle, and in its proximal, opesial border, which is quite concave and never convex.

It difiers from $L$. contigua which has the same arrungement of ribracula, in the complete absence of the cutire zoarial cavity.

Ill the other Lmmlites forms observed have their vibracula placed in all the interzooccial angles and therefore can not be confounded.

As noted before, Gabh and Horn have created the genus Oligotresinm because of this especial disposition of the vilnaculum: but we do not believe it necesary to adopt this genms.

Occurrencr.-Tiekshurgian (Brram marl): Vicksburg, Mississippi (rare); 1 mile west of Woolmard. Wayne Comnty, Mississippi (common); Byram. Mississippi (common).

Ticksburgian (Red Bhufl clay) : Red Bhulf, Wayne County, Mississippi (rare). Plesiotypes.--('at. No. 6.t25. U.S.N.MI.

LUNULARIA JACKSONENSIS, new species.

Plate 37. tixs. 19-22.

Inescription.- The zoarium is a somewhat convex Lmulites. The zooecia are distinct, rectangular, disposed in radial and circular rows; the mural rim is salient. The cryptocyst is smooth, sunken, little developed; the opesimm is large. oral, enlarged at the base. The viblacula are placed in distinct radial rows in all of the interzoncial angles: they are symmetrical and bear two lateral condyles. 'The hydrostatic zooecia are numerous, closed hy an irregular, nomperforated olocyst. The inner side bears larea radial tuberose costules.

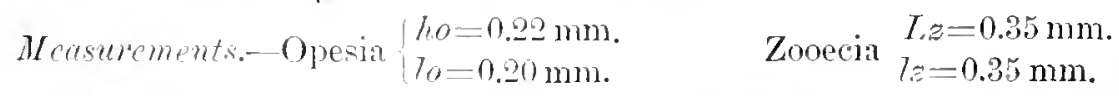

Affinities.- In the form of its zonecin this species is close to Lunulites fenestratn Freario 1s90: it litfers from it in the inner face. which is tubercnlose and nonperforated.

It ditfer's from Lummeria tintinatula in its flatter zoarimm and in its immer side. which is tuhero-e and not perforated. 
It diflers from Lummerier ovete in its much larger zooecial dimensions.

'This species bas only been found in the single Jocality at Jackson, where it appears abmolant in association with Lumberia fencstratu De Gregorio 1890.

Occurpenee.-Iower Incksonian (Moodys marl): Jackson, Missicsippi (conmon).

Cotypes.-Cat. No.63996, T.S.X.M.

LUNULARIA TINTINABULA, new species.

Plate 83, figs. 12-10.

Description.--The zoarimm is a Lunulites in the form of a little brll with hydrostatic zoocia. The zooecia are listinct, elougated. ogival: the mural rim is thin; the cryptocyst is quite concare, smooth, much shorter than the opesium. The opesium is oral, elongated, largely surommled by a salient peristome. The vibracula are arranged in radial rows; they are symmetrical, oral; their opesimm is narrowed laterally by two teeth; the anterior portion is nuch langer than the inferior portion. The bydrostatic zooecia bear a prominent thread, distal semilumar. On the inner side the radial rows are quite convex and garnished with large scattered pores. The zoarial surface is pelliculoid.

$$
\text { Measurements.-Opesium }\left\{\begin{array} { l } 
{ h o = 0 . 2 5 \mathrm { mm } . } \\
{ l _ { 0 } = 0 . 1 5 \mathrm { mm } . }
\end{array} \quad \text { Tibracula } \left\{\begin{array}{l}
L v=0.30 \mathrm{~mm} . \\
7 v=0.12 \mathrm{~mm} .
\end{array}\right.\right.
$$

$$
\text { Mirginal zooecia }\left\{\begin{array}{l}
L z=0.35-0.40 \mathrm{~mm} \text {. } \\
7 z=0.25-0.30 \mathrm{~mm} .
\end{array}\right.
$$

Tariations.-The oxterior surface of the zooceia is rery fracile; it is easily detached. The zooecia then appear under another aspect. There is no cryptocyst; the peristome of the opesium does not exist. There are un comlyles to the ribracula. These two aspects are quite visible on figure 14. An analogous phenomenon has been observed on Lumulwia conica Busk. 18n. as Cann luas noted it in 1216.

Only the distal lialf of the opesial peristome exists on the hydrostatic zonecia. This is a very important character. but it is not constant. It is sometimes replacel by a furow of the same form and limiting a long tongue as in Lunuloric ligulate (fig. 15).

- Affinitics.-This species differs from Lumlaria limmlata and from Lumularin fenestrata in which the opesimm is also borlered by a preristome in its much larero micrometric dimensious ( $L:=0.9 .5 \mathrm{~mm}$. instearl of $0.20 \mathrm{~mm}$.).

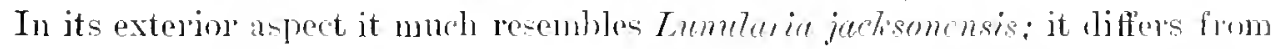
it in its much more conical zoarimu, in its lydrostatic zooedia providerl with a semielliptical. distal threat, and in its inner side which is poroms and not fulnerons.

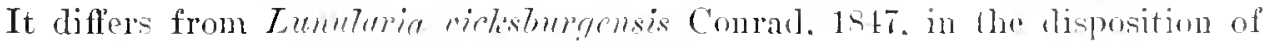
its vibracula placed in all the interzonecial angles; it is this fouture which does not permit it to be classilied in the origotresinm gloup.

Orecuremec.- Vicksburerian (Byram marl): One-fourth mile west of IToodward, Wạne County, Missiscippi (very common). 
Vicksburgian (Marianna limestone) : Vicksburg, Mississippi (rare in the lower beds).

Vicksburgian (Red Bluff clay) : Red Bluff, Wayne County, Mississippi (rare). Cotypes.-Cat. No. 61256, U.S.N.M.

liei to SPECIES OF LUNULARIA.

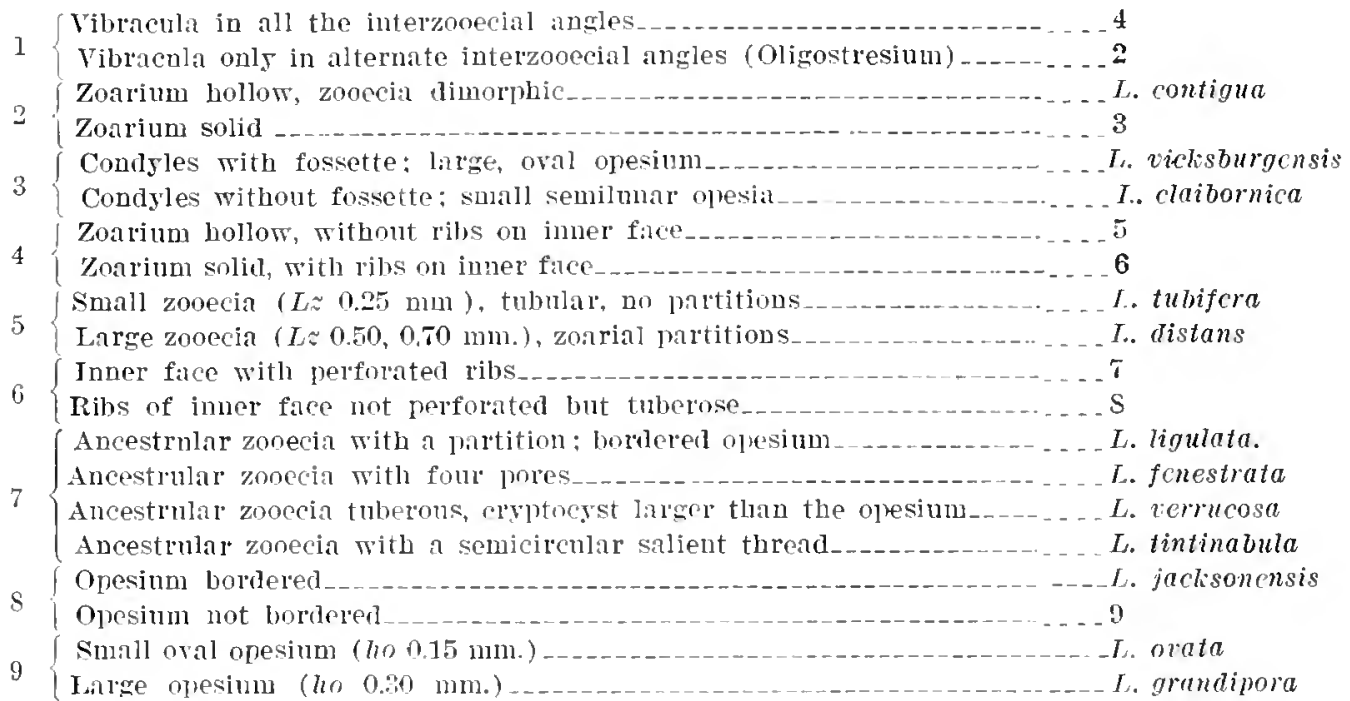

\section{Family ASPTDOSTOMIDAE Camu, 1908.}

Bibliography (Anatomical).-1S\$6. JuLtex, Mission Scientifique du Cap Holn, Bryozoaires vol. 6, p. T--1SS9. Waters, Scientific liesults Forage Challcnger, Suppl. Rep. 31. p. 28, pl. 1,

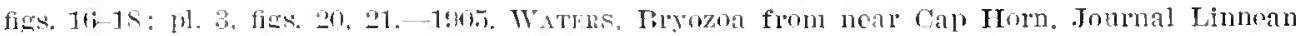

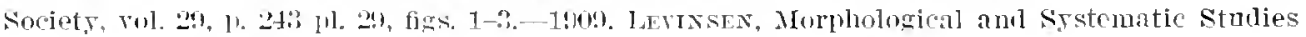
Cleilostomatis liryonon, 1). 171.

The zoocia have a raised margin, often indistinctly or incompletely developed. The two opesinles appear as narrow incisions, which join the zooecial aperture; the short polypide tube, which is not continued under the cryptocyst cover, is in most eases provided with marginal flanges. Avicularia are always present. Oricells are hyperstomial.

In 1856 . Jullien discoverel the relationship of Eschara (Aspidostoma) gigantea Busk, 1854, with the Onychocellitae. In 1859 Waters figured the operenlum and noted its resemblance to Thaugsostoma Koschinsky. 1885. In 1905 he confirmed the fact that the opesinlar indentations serve as a passagenay for the operenlar muscles. He established that in hhafusostoma the operculum is borne by the ectocyst. In 1909 Levinsen thouglit that the lateral indentations were opesiules and classified the family in the Coilostega tul,ifer, becanse he discovered a sort of polypidian tube. Moreover, he discovered in Cuteropore falcuta Levinsen an avicularium analogous to that of Eschara antiona D'(urhigny of the Cretaceous: finally, he noted the re- 
semblances of Eschura aegon D'Orbigny and E. atalantha D'Orbigny to Aspilostoma. Different species were described by Canu in 1904. 1908, and 1911.

'The known genera of this family are:-

Aspidostoma Hincks, 1881.

Rhagasostome Koschinsky, 1855.

Euritina Camu. 1900.

Odontionella Camu and Bassler. 1917.

Foraminella Levinsen, 1909.

Erateropora. Levinsen, 1909.

Labiopora Levinsen, 1909.
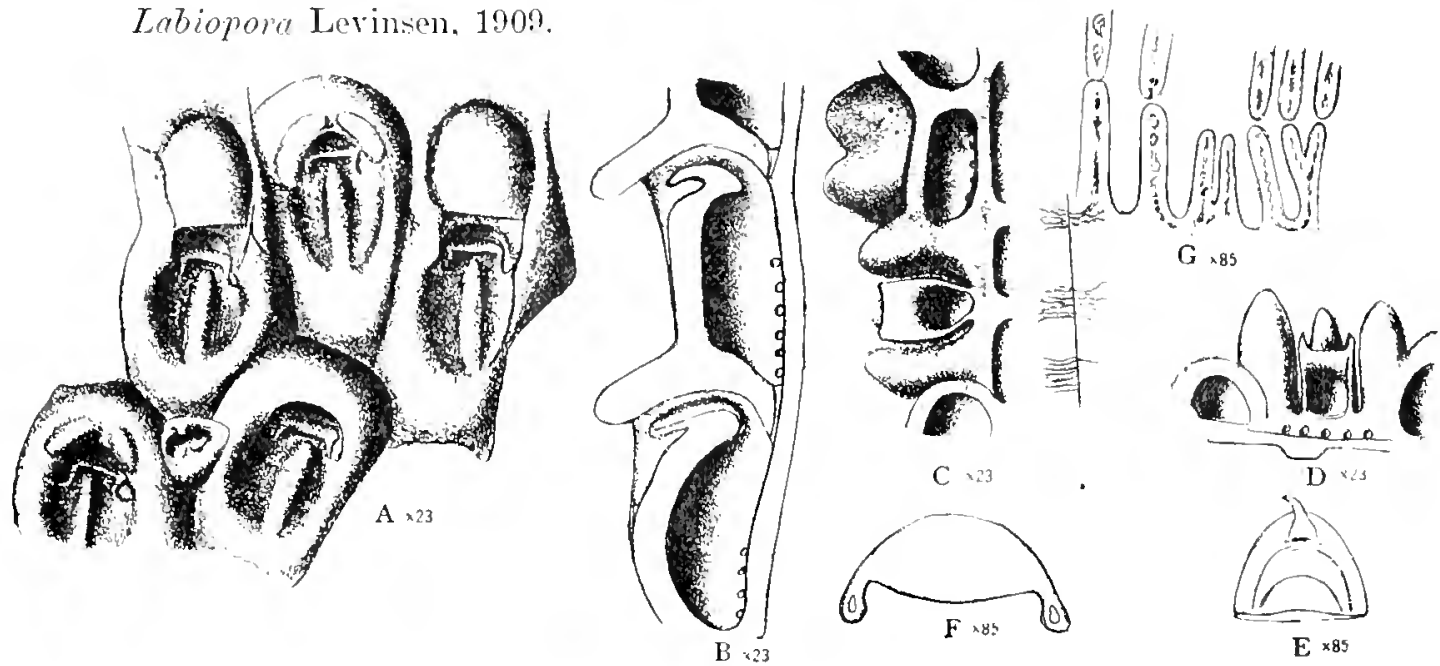

Fig. 65.-Family Aspirlostomitile Camm, 1!nos.

A-G. Aspilostoma gigantcum liusk, 18S4. A. Several zoopoia. two of them with ovicells

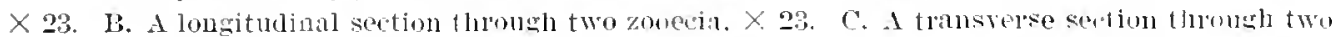
rooecia. $X 23$. Lppermost a distal wall is seen and to the left of this the arched distal end of the zooecium. Further lown an intresected polylide tube is seen and on enclu sille ut this a

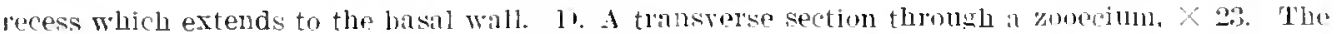
median frojection of the zooecimm is secn bencath the polypide tube. (A-D After Levinsen,

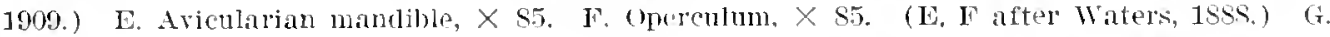

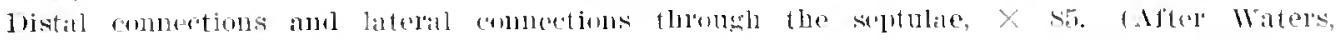
1905.)

\section{Genus RHAGASOSTOMA Koschinsky, 1885.}

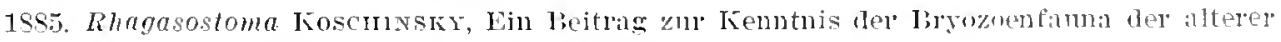
'Tertiäschichten Bayerns, Traleontograbhica, vol. 32, p. 29.

The ovieell is hyperstomial and opens above the opereular ralue; it has no lateral expansions (compressed process). The avicularia an intomocial.

Genotype.-Rhagasostoma haxagomem Koschinsky. 185.,.

Range.-Eocene-Mioecne.

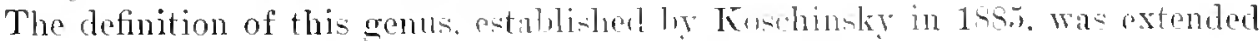
by Canu in 1900 to all the specios providerl with opesial incision. 'The number of 
the species is now therefore rather large, and it may become convenient perhaps to make some restrictions. The aricularia are quite raviable. Rhagasostoma cingens, R. hexagonum, and $R$. circmmzallutum Koschinsky. 1885. from the Lutetian of Bararia, have falciform onychocellaria. Rhequsostome dutempleanum D'Orbigny, 1852, and $R$. mugeti Camu. 1907, of the Parisian Lutetian, have an avicularim with double orifice. Rihagasostoma promincns, Cam, 1907. also from the Parisian Lntetian, possesses an aricularim witl two to four false opesinles. Many Cretaceous species of Rhagasostoma possess the delicate avicularia called reticulocellaria by Canu.

Such variations exist likenise in 1 spilostoma. Aspidostoma giganteum Busk, 1854, and 1 . globifemm Camu. 1911, have only small frontal or marginal avicularia. The other species have interzoocial avienlaria. Aspilostoma porifrum Canu, 1904,
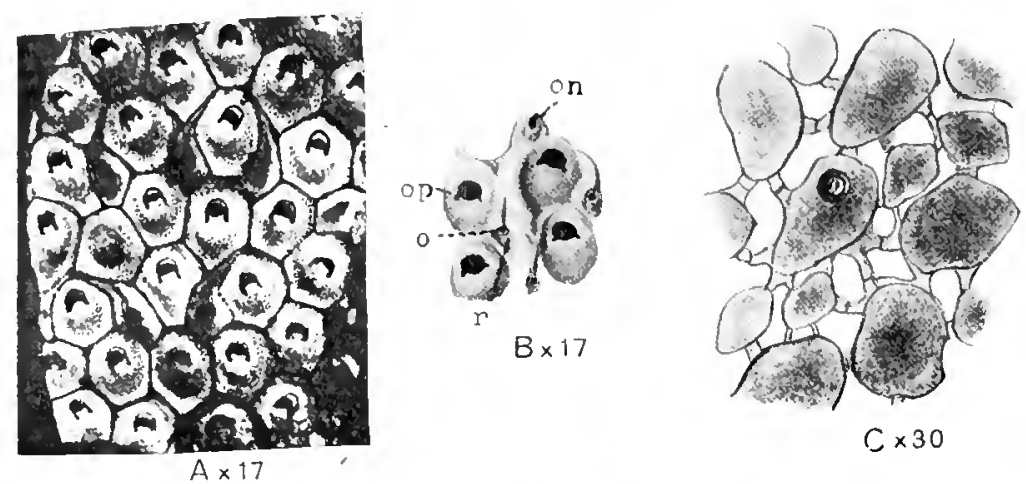

F1G. 60.-Gelus Rhagasostoma. Koschinsky, 1855.

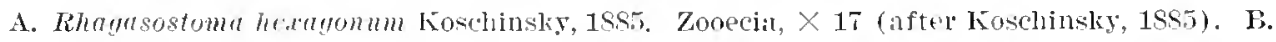

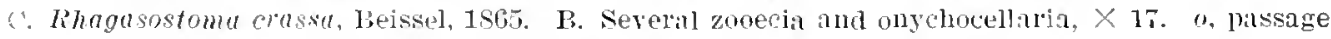

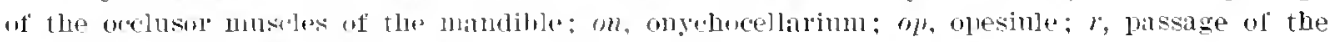
e]evator muscles of tle mandible.

C. Internal cast, $\times 30,1$ 13, C after IBeissel, 1S65.)

lias an uricularium with lateral teeth, as has also A. incrusture Cam, 1908. There is an avicularium with pivot in 1 spiclostoma flemmulum Canu, 1908. Finally, Aspidostome onyrhocellifemem Cann, 1911, has perlins a real onyehocellarim.

Rhagasostand is the depidastoma of the northem hemisphere. In Enrope the genus dies ont in the Lutetian. Here, in America, it survives into the Ticksburgian. In Australia it is fount in the Miocene.

Rhagasostoma dutempleanum D'Orbigny, 1852, and R. spiniferum Canu, 1913, appear to lorm a distinct genus on account of the nature of their oricells.

\section{RIIAGASOSTOMA LEVIGATUM, new species.}

Plate 39, figs. 6, т.

Deseription.-.The zoarim incusts shells. The zooecia are distinct, elongated, separated by a lurew; the mural rim is complete, salient, a little broader at the 
hase. The cryptocyst is deep. smooth, and somewhat conves: the polypidian conrexity is improminent and the opesinles somewhat lineal. The ovicell is globular, salient, smootlu, opening in a large orifice above the opereular valve. The a vicularim is interzooecial, smaller than the zooecium. fusiform, terminated by a small but wide canal; its opesium is median and rery small.

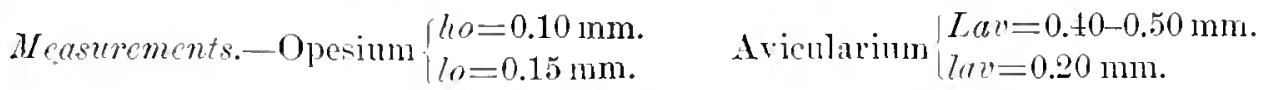

$$
\begin{aligned}
& \text { Zuoecium } \mid L z=0.55-0.60 \mathrm{~mm} \text {. } \\
& \text { (including opesiules) } / / z=0.35-0.40 \mathrm{~mm} \text {. }
\end{aligned}
$$

Affinitics.-This species diflers from Acchmella filimamo in its hyperstomial ovicell. It may be distinguished from lihagusostoma mineculum by its larger dimensions. Specimens from both the . Talisomian and Vicksburgian have been discovered. It appears to 11 that there were no essential diflerences between them. so we have united them under the same species.

Ocampenee.-Mirldle Jacksonian (Castle Hayne limestone) : Vilmingtom. North Carolina (very rare).

Vicksburgian (Marianna limestone) : Salt Momtain, 5 miles south of Jackson, Alabami (very rare).

Cotypes.-Cat. Nos. 64000, 64001, U.S.N.M.

RHAGAsostoma minusCULUm, new species.

Plate 39 , fig. 8 .

hespription.-The zoarium incrusts hryozoa. The zooecia are very small, oval, distinct. separated by a furrow the mural rim is prominent, slightly thickened, enlarged at the base, complete. The eryptocyst is deep. smooth, flat; the polypidian convexity is improminent; the opesiules are rounded incisions. The ovicell is globular and prominent. The avicularimm is inter'zooccial, clongated. fusiform, terminated by a very short but wide canal.

$$
\begin{aligned}
& \text { Mrasurements.-Opesium }\left\{\begin{array}{l}
h o=0.07 \mathrm{~mm} . \quad \text { Iricularium } \\
70=0.10 \mathrm{~mm} .
\end{array}\right. \\
& \text { Znoecium }(L z=0.30-0.35 \mathrm{~mm} \text {. } \\
& \text { (including opesinles) } 17 z=0.210 .25 \mathrm{~mm} \text {. }
\end{aligned}
$$

Affinities.-Tlis is one of the smallest lryozoans known. It is diflicnlt to conceive how such a small structure could contain tentacles, pharynx. stomach. intestines. muscles, and ovaries and lodge a creature much more perfecter than an orster or a Tridacne.

Orcumpme.-Middle Jacksonian: Wilmington, North Candinil (very raue): Eutaw Springs, South Carolina (rery rare).

Ilototype.-Cat. No. frto02. T.S.X.M. 
Genus ODONTIONELLA Canu and Bassler, 1917.

1917. Odontionella Caxu and Basser, Synopsis American Faly Tertiary Cheilostome Bryozon, Bulletin 96, U. S. National Museum. 1. 12.

Oricell hyperstomial. No condyle for the operenlar valve. The opesinm is not symmetrical. The proximal border of the opesinm hears irregular spinons processes, short, flat, more or less wide. The opesiular indentations are dissymmetrical. The operculum projects berond the ridec. Sixteen tentacles. The avicularium is placed on the gymnocyst.

Genotypes.-Odontionelle (Membrenipore) hiens Hincks, 1855, and Odontionella (Membranipora) ocoultata Waters. 1887.

Range.-Pliocenc-Recent.

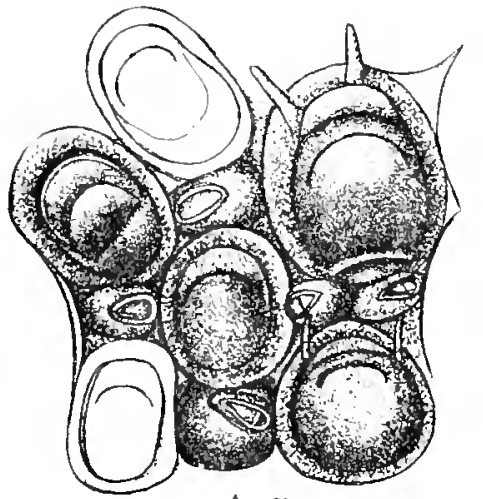

A $\times 75$
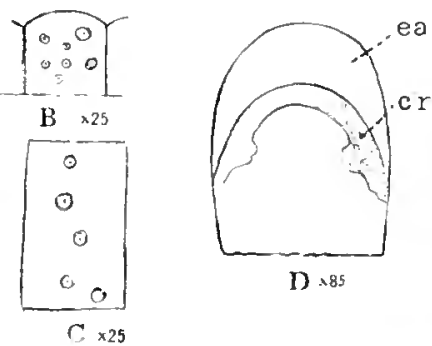

Fig. 6ĭ-Genus Odontionella Cann and Eissler, 1017.

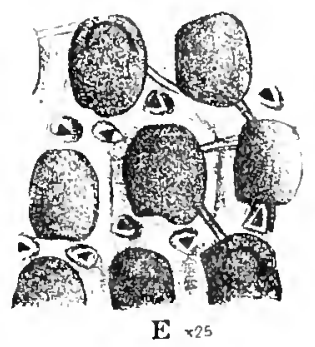

E $\times 25$

A-E. Odontionella (Membramipora) hians IIincks, 154., A. Zooecia, X 75. (After Hincks, 1855.) B. Distal wall with septulae, $X 225$. C. Latral wall with septulae, $X 25$. D. Operculum, $X$ S5, showing chitinous liuge (r) and expansion (eu). 14, Zooecia, $X$ 25. (Li-E after Waters, 1895.)

In 1917 we included in this genus species of A cunthodesin, new genus, but later researches hare shown that the type of Odontionelnd has opesinlar indentations. The latter genus thus really belong's to the Aspidostomidac Canu, 1908.

Genus EURITINA Canu, 1900.

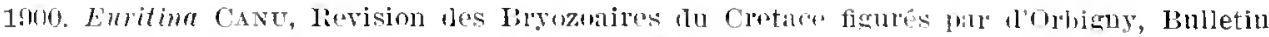
Societe Geologique, France, ser. 3, rol. 25, 1\% 411.

Oricell hyperstomial, never closed by the opereular valve; arieularium interzooccial; cryptocyst well developed, with three facets separated by two longitudinal grooves; no dietellac.

Genotype-Euritina (Eschara) curita D'Orbigny, 18.i-

Range.-Turonian-Eocene.

We are ignorant of the physiological function of the lateral grooves of the creptocyst, but as they are very contant in this group of species, they must be 
considered. We hatre stulied a number of species with a faceted cryptocyt not ably Membraniporidra spissimualis. It is not certain that the Cretaceous species are provided with onychocelliuria. for these structures are perhaps interzonecial avicularia, of a special type now extinct. In the interior the polypidian tube is an:logons to that in fspridestoma Ininclss, 1881 ; it is a thickening of the proximal border of the aperture.

The species of the genus are:

Euritina (Eschara) curita Dorbigny, 18.'-

Euritina welschi Cant, 1900.

Euritinu late Cann, 1911.

Euritina elongeter Canu, 1911.

Euritine intermedie Canu, 1911.

Euritiue (Biftustra) torte Gabb and Horn, 186?.

Euritinn (Tincularia) arecitis D'Orbigny. 185.2.

EURITINA TORTA Gabb and Ilorn, I862.

I'late 1. fig. 16.

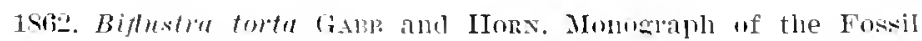
Polyzon of the Secundiry and Tertiny formations of Forth America, Journal Acadrmy of Natural Sciences,

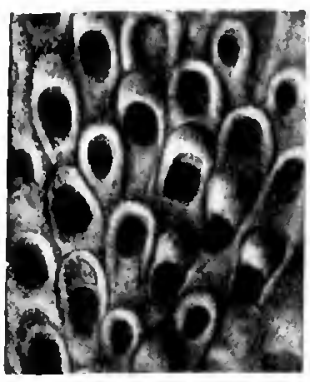

Fra, 6s:-Gienus Euritina Can11, 1900.

Euritina (Eschara) mritu D'Orbieny, IS52. Zooecia with ovicells, <20. I'hilathelphia, ser. 2, p. 152. pl. 20, fis. 36.

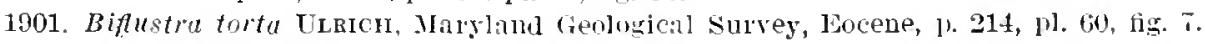

1909. Biflustra torta Weller, Cretaceous Faunas, Geological Survey of New Jersey, rol. 4 , p. 332 .

Neasurements.--Opesia $\left\{\begin{array}{l}h 0=0.25 \mathrm{~mm} . \\ l o=0.12-0.15 \mathrm{~mm} .\end{array} \quad\right.$ Jooccia $\left\{\begin{array}{l}L z=0.40-0.45 \mathrm{~mm} . \\ 7 z=0.25-0.30 \mathrm{~mm} .\end{array}\right.$

The zoarium is bilamellar; the two lamellae are back to back and may be separated. The cryptocyst is deep and the two grooves which separate it from the mural rim are quite visible.

The onychocellarium is straight, symmetrical, oral; the bealk is salient in front of the zooecial plane; there is no pivot.

At the base of our figure there is a regenerated zooecium.

"Although rather variable this is still to be counted as an easily renognized species. Ovirells occur but rarely, only fonr or five specimens out of fifty or more in my collection having any at all. They are cucullate often with a relicate longitudinal ridge across them and miformly convex." (Ulrich 1901.)

Decurrence--Lowest Encene (Bryozon hed at hase of Armia formation ): Eppur Marlboro, Iaryland (rare).

Geological distribution-C-Cpper Cretaceons (Vincentown limesand): Mntlica Hill, 'Timber Creek, and Vincentown, New Jer:er.

Plesiotype-Cat. No. 697T. U.S.X.M.

555.99-19-Bu11. $106-17$ 
EURITINA TECTA, new species.

Plate 5, figs. 1-7.

Description.-The zoarium is free and bilamellate. The zooecia are distinct, very elongate, vaguely oval; the mural rim is thin, thickened laterally, and forms the two lateral facets of the cryptocyst. The cryptocyst is smooth, flat, oblique toward the opesium. The opesium is elongate entire, elliptical, or it may have a proximal border more or less straight. The ovicell is hyperstomial, never closed by the opercular valve, globular, salient, smootl. The primoserial

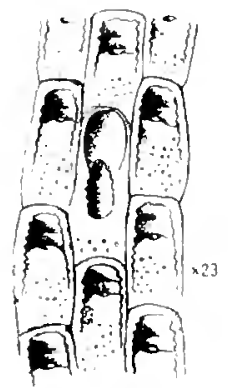

F1G. 69.-Genus Labiopora Levinsen, 1909.

Labiopora crenulata Levinsen, 1909. Zooecia, $x$ 23 (After Levinsะn, 1909). zooecia have special avicularia without pivot, marked with a distal convexity protrucling much above the zooecial plane.

$$
\begin{aligned}
\text { Me easurements.-Opesia }\left\{\begin{array}{l}
h o=0.22 \mathrm{~mm} . \\
l o=0.12 \mathrm{~mm} .
\end{array}\right. \\
\text { Zooecia }\left\{\begin{array}{l}
L z=0.45-0.50 \mathrm{~mm} . \\
l_{z}=0.25 \mathrm{~mm} .
\end{array}\right.
\end{aligned}
$$

Tariations.-The lateral grooves are very constant on the bilamellar zoaria, but on specimens which contain supplementary lamellae, the zoocia are devoid of them and appear to belong to another species (fig. 1). The cryptocyst and the mural rim are formed of very large but very compact olocystal elements (fig. 3). They are a little oriented on the mural rim according to the general rule. The cryptocyst is often divided into two symmetrical parts by a longitudinal linear junction (fig. 3). The bottom of the zooecia is the ordinary olocyst (fig. 4). The interior of the zooecia (figs. $5,6,7)$ does not correspond at all to the exterior. There is no trace of the grooves in the cryptocyst, and the lower opesial border is much thickened as in Aspidostoma Hincks, 1881.

The primoserial zonecil. yritc lifferent in form at the surface. have in the interior a shape exactly identical with the other zooccia, althongh plainly narrower. The exterior distal convesity of these zooecia is very constant and reminds one somewhat of a little roof. Figure 2 shows a regenerated zoocium of quite unusual character. Here a normal zooecium succeeds a "calcified" one.

Occurrence.-Midwayan (Clayton limestone) : One mile west of Fort Gaines, Georgia (common); Mabelvale, near Little Rock, Arkansas (common).

Cotypes.-Cat. No. 63807 , U.S.N.M.

\section{Genus LABIOPORA Levinsen, 1909.}

1909. Labiopora Levinsen, Morhological and systematic studies on the Cheilostomatous Bryozoa, p. 171.

No ovicell; distinct raised margins; frontal wall of polypide-tube not quadrangular and not surrounded by projecting flanges. Polypide-tube bilabiate, on 
either side connected with the lateral wall by a rertical calcareous lamina: multiporous septulae.

Genotype.-Labiopora crenulata Levinsen: 1909.

Genus CRATEROPORA Levinsen, 1909.

1909. Cratcropora LEVINSEN, Worlholngical and sistematic studies on the cheilustomatous Bryozoa, 1. 171.

No ovicell; distinct raised margins: frontal wall of polypide-tube not quadrangular and not surrounded by projecting flanges. Polypide-tube not bilabiate. with an expanded distal margin. not connected with the lateral walls by rertical calcareous laminae; uniporous septulat. (Levinsen, 1909.)

Genotype.-C'rateropora falcuta Levinsen. 1909.

Aspidostonia flammulum Canu. 1908, of the Patagonian of Argentina may perhaps belong to this genus, although it bear's oricells.

Family STEGANOPORELLIDAE Levinsen, 1909.

Bibliography (Anatomical).-1000. HARMER. A revision of the geluus Steganoporella, Quarterly Jommal Microscopical Science, rol. 43, pp. 225-295, pl. 12, 13.-1902. HARMER. On the Molphology of the Cheilostomata, Quarterly Journal of Microscopical Science, p. 317, pl. 15, figs. 64. 65, 66-1909. Levirsex, Morphological and systematic studies on the Cheilostomatous Bryozoa, p. 167, pl. 6, figs. 2-7.-1913. WaTEss, Bryozoa from Zanzibar, Proceedings of the Zoological Society of London, p. 498, pl. 72 , figs. 1220 .

The zooecium is divided into two chambers. The proximal chamber contains the polypide and the oraries; it is terminated by an ascending tube, the polypide

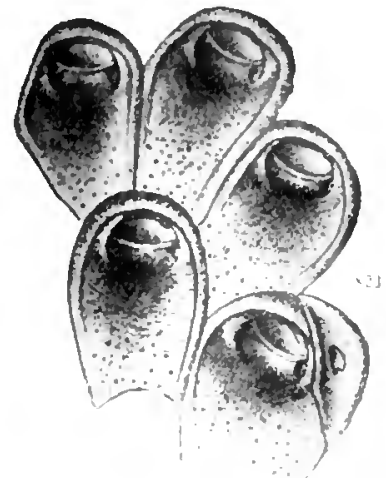

Fig. T0.-Genus Crateroprom Levinsen, Iso9.

Crateropora fulcata Levinsen, 1909. Zooccia, $\times 23$. (Ai. ter Levinsen, I90y).

tube, in which the tentacles are lodged when the polypide is retracted. The upper chamber contains the parietal and opercular muscles. The retractor muscles of the polypide are attached in one of the lower angles of the zooecium, which causes the general assymetry of the zooecium. No oricells, no avicularia. Generally two forms of zooecia: $\alpha$ and $B$. The two opesiules are generally not separated from the aperture of the zooecium. The operculum. which is sometimes bounded by at chitinous selerite proximally. sometimes continned immediately into the frontal membrane, is, as a rule, very large, and then suspended by strong hingo-teeth.

The structure in this family is remarkable and of great interest. The figures that are reproduced permit the rader to easily comprehend its details. despite the complexity of the terminology. The two known genera are Steganoporella Smitt. 15i3. and Siphonoporella Hincls $=1880$.

Genus STEGANOPORELlA Smitt, 1873.

1873. Steganoporella Surt, Floridan Inyozon. Kongl, svenska Vetinskals-Akademiens Fandlingar, rol. 11, Xu, t, 1., 1j.

The whole of the calcified part of the frontal area lying proximally to the aperture is a depressed cryptocyt: the aperture of the zooecium is surrounded 

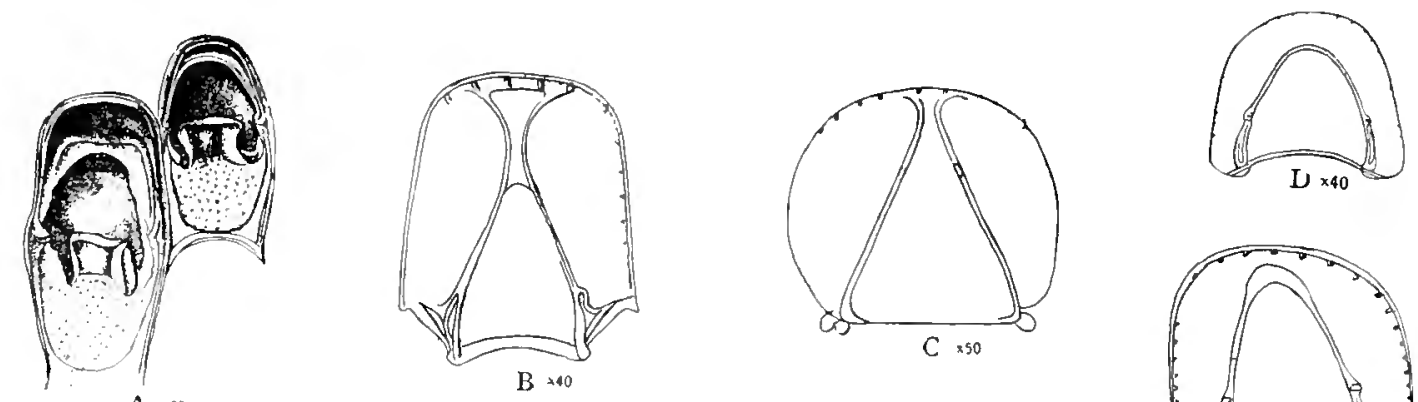

$A \times 20$
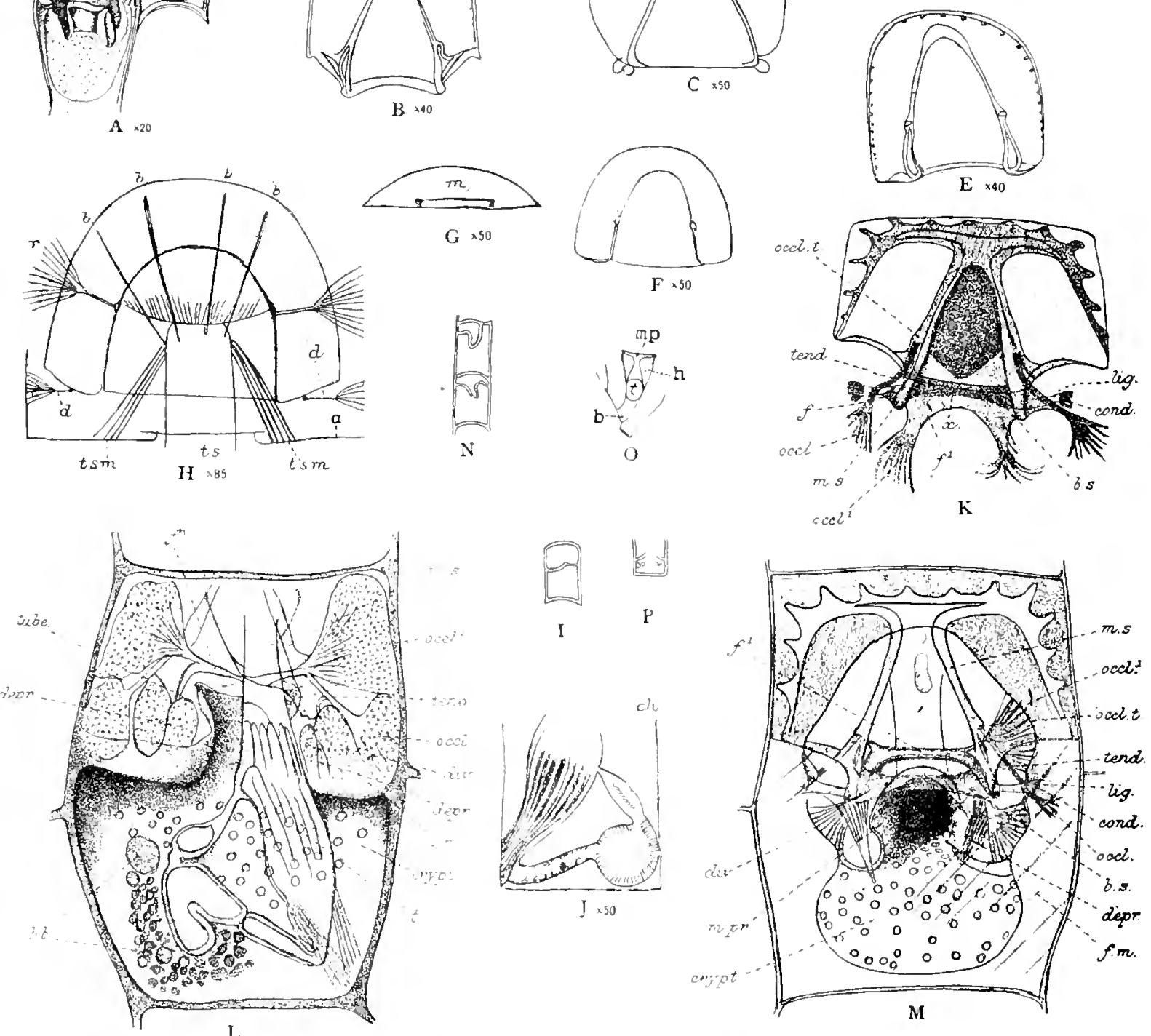

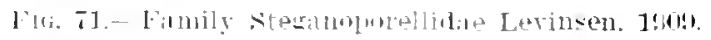




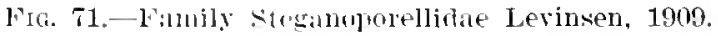

A-H. stegmoporella ma!milatris Inusk 15ia. A. View showing the a and $B$ zooecia, $X 20$.

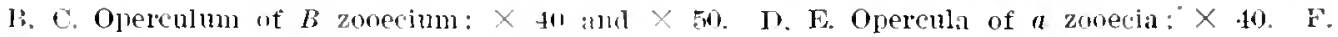
(1)erculum of a zooecia; $X$ 50. G. Sirtim ("it thrum an operculum showiug a membrane (m) letween the main sclerites, $X$ 50. H. Oleleulmu. $X$ ș. Decalcified distal ond seen from inside with the basal wall remover. The tentuculal slyeath ( 18 ) is held ly four bauds $(b)$ attached to the distal wall; also there are unseles $(t \mathrm{sm})$ from the distal end of the tentacular sheath to the wall $(a)$ which divides the zonecium. The large retrictor muscles $(r)$ are seeu attachel to a tendon, while below there is a smaller pair of muscles $(d)$ not attached areet to the operculum, but to the frontal wall guite close to the operculum.

I. Back of zooeciunr.

J. Yjew, $\times 50$. showing the tentacular liats attached to the side wall of the luximal colner, while the stomach, etc., is in the other cornel connected by a long, narow escolluacal tulue. i A, B, D, E, I : fter IIarmel, 1000 ; C. F. Il. J after Waters, 1915.)

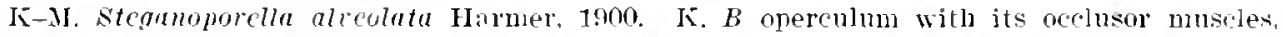
seen from the inner side, and somewhat distally so as to be considerably fureslurtened; cond, combles, united to the basal sclerite (bs) of the olverculum by the stlong lisaments lig; ofel, liroximal ocdusor muscle, the tendom itend, "f which is inserted into the occlusor tubetele

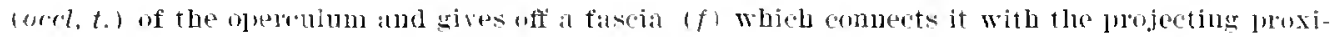
mal end of the main sclerite ( $m s$ ) ; acel distal acclusor inserted into the fascill $f^{\prime}$, $x$, line aloug which the operculum nasses into the roof of the restibule.

I. Basal vien of a $B$ zooecimu (lasal wall removed). The cryptocyst (crypt) is seen frum its basal surface; part of the flow of the latelal recesses $(l r)$ is broken away. Between rbe two recesses is the passage (lube) by which the t'utacle sheath passes to tho oritice: occl'. alistal

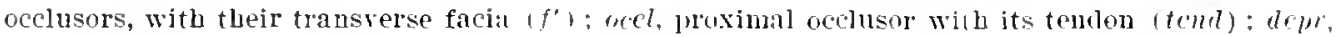
dopressor muscles of fruntal menulume; ar, divaricator muscles of operculum; ms, main sclerite of operculum. The novements of the tentare sleath are restrained by four delicate muscles, two of which originate from the wall of the tulie.

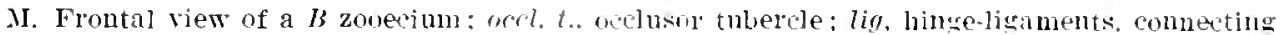
the condyles (cond) with the ends of the lossl sclelite $(b s) ; f m$, froutal memblane, into whi.h

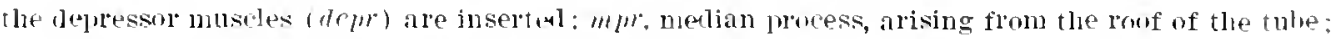
other letters as in fig. O. ( $K-M$ after Harmer, 1902.)

X. Steganoporclla lateralis Machillirrily. 1805. Back of zooecium.

O. Steganoporella neozolanica 1;usk. 146iI. Typical form. Part of transwerse section of the

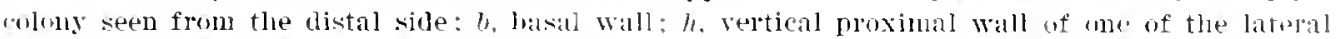
recesses; $m p$, distal wall of the task-sbiled cavity of the median frocess: $t$, olening intu the subarercular carity of the zroecium.

I'. Steganoporcla buslii Harmer, 19mo. I'roximal wall of a zooecinn slowins tlee insertinn

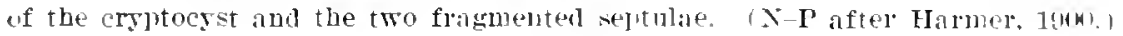


distally and laterally by a projecting margin; the zooecia frequently, occurring in two forms $a$ and $B$ and provided with a large operculum armed with teeth, which is suspended by strong hinge-teeth; the polypide-tube is never continued proximally beneath the cryptocyst cover. (After Levinsen, 1909.) 25 tentacles.

Genotype.-Steganoporella (Membranipora) magnilabris Hincks, 1881.

Range.-Lutetian-Recent.

The known fossil species of this genus are:

Steganoporella (Gaudryanella) asymetriow Canu, 1907, Lutetian of the Paris Basin.

Steganoporella (Gargantua) firma Canu, 1907, not Reuss, Lutetian of the Paris Basin.

Steganoporella similis Ḱoschincky. 1885, Lutetian of Bavaria.

Steganoporella (Tincularia) haidingeri Reuss, 1969. Priabonian of the Vicentin. Steganoporella (Leprulia)firma Reuss, 1867. Priabonian of the Vicentin. of France.

Steganoporella. (Eschara) elegans Mihne-Edwards, 1838, Aquitanian-Helvetian

Steganoporella elegans Smitt, 1873 (not Milne-Edwards, 1838), still lives off the coast of Florida at a depth of $15-37$ fathoms.

STEGANOPORELLA JACKSONICA, new species.

Plate 39, figs. 9-16,

Description.-The zoarium is bilamellar formed of two layers back to back and easily parted. The a zooecia are rely elongated, narrow, distinct; the mural rim is thin, salient; the cryptocyst is deep, granular, and porous; the opesium is semilunar and transverse; there is no polypide-tube. but a small polypidian convexity is present; the two opesinles are small. rounled. lateral incisions, quite indistinct: the inner partition is very oblique. The $B$ zoocia are twice as large, ogival, larger at the top than at the bottom; their polypide-tube is salient and complete; the two opesinles are two deep, rounded incisions; the opesium is bordered by a double collar (oral arch); the distal niche is large, mooth. deep; the $B$ zooecia always engender two new rows of a zooecia.

$$
\begin{aligned}
& \text { Measurements. - a zooecia } \begin{array}{l}
L z=0.46-0.50 \mathrm{~mm} . \\
l z=0.24 \mathrm{~mm} .
\end{array} \quad \text { Opesium }\left\{\begin{array}{l}
h o=0.12 \mathrm{~mm} . \\
l o=0.16-0.20 \mathrm{~mm} .
\end{array}\right. \\
& B \text { zooecia }\left\{\begin{array}{l}
L, z=1.20 \mathrm{~mm} \text {. } \\
l, z=0.50 \mathrm{~mm} \text {. }
\end{array}\right.
\end{aligned}
$$

Tariations.-It is rather remarkable that if the a zooccia become enlarged the $P$ zooecial are shorter.

The frontal is a direct tremocrst (fig. 1t) in which the granulations of the cryptocyst often fill up the perforations.

Only the $B$ zooecia have a distinct polypite tuhe (figs. 10, 16). After wearing away the frontal the a zooecia are ceen to have an oblique partition more elevated at the top than at the base (fig. 13). Similu abrasion on the dorsal side permits 
(fig. 12) one to ascertain how the polypide may project between the partition and the opesial collar.

Affnitics.-The a zooccia are much narromer than in Steganoporella rectangularia $(l z=0.2+\mathrm{mm}$. instead of $0.36 \mathrm{~mm}$.).

Steganoporella jacksonica differs from Steganoporella incrustans in its bilamellar zoarium and its perforated cryptocyst.

It differs from Steganopor lla vichsturgica in its much smaller micrometric dimensions. The widespread occurrence of this species in the Jacksonian has occasioned its specific name.

Occurrence.-Lower Jacksonian: Jackson, Mississippi (rare).

Middle Jacksonian: Baldock, Barnwell County, South Carolina (very abundant) ; 18 miles west of Wrightsville, Georgia (rare); $3 \frac{1}{4}$ miles south of Perry, Georgia (rare); 17 miles northeast of Hawkinsville, Georgia (rare); $3 \frac{1}{2}$ miles west of Grovania. Georgia (rare); $\frac{1}{2}$ mile southeast of the Georgia Kaolin Company Mine, Twiggs County, Georgia (rare).

Upper Jacksonian (Ocala limestone): West bank of Sepulga River, Escambia County. Alabama.

Cotypes.-Cat. Nos. 64003-64005, U.S.N.M.

STEGANOPORELLA RECTANGULARIA, new species.

Plate 40, fig. 1.

Description.-The zoarium is bilamellar. The a zooecia are short, wide, clistinct, ogival, with the distal walls sinuous; the mural rim is thin and salient; the cryptocyst is deep and porous; the polypide tube is somewhat salient and distinct; the tro opesiules are rounded, broad, and scarcely visible; the opesium is semilunar and transverse. The $B$ zooecia are much larger; their polypide tube is rery salient, and the tro opesiules are deep.

Neasurements.-Opesium $\left\{\begin{array}{l}l l o=0.12-0.14 \mathrm{~mm} . \\ l o=0.22-0.24 \mathrm{~mm} .\end{array} \quad\right.$ zooecium $\left\{\begin{array}{l}L z=0.44 \mathrm{~mm} . \\ 7 z=0.36 \mathrm{~mm} .\end{array}\right.$

$$
B \text { zooecium }\left\{\begin{array}{l}
l z=1.15 \mathrm{~mm} . \\
l z=0.55 \mathrm{~mm} .
\end{array}\right.
$$

Affinities.-Only two specimens have been found, but they appear distinct from Steganoporella jaclesonica because of their great zooecial width, and by the sinuosities of the distal walls of the mural rim. The species requires further examination.

occurvence.-Lower Jacksonian (Moodys marl): Jackson. Mississippi (very rare).

Holotypr.-Cat. No. 64006, U.S.N.M.

\section{STEGANOPORELLA INCRUSTANS, new species.}

Plate 40, figs. $2-6$.

Description.-The zoarium incrusts shells. sometimes forming broad expansions. The a zooecia are small, elongated. distinct: their mural rim prominent, thin; the cryptocyst is deep. smooth or finely oramulated: the opesium is semi- 
lunar, transvelse; there is not a complete polypide tube; the polypidian convexity is prominent; the two opesiules are rombled, asrmmetrical, rather distinct. The $B$ zooecia are of greater size and much enlarged in their distal part; the polypide tube is median, quite prominent, complete; the opesiules are large, rounded or linear nearly alike; the oral arch is single or double and salient; the distal niche is large. of slight depth, and smooth.

$$
\begin{gathered}
\text { Measurements._Opesium }\left\{\begin{array} { l } 
{ h o = 0 . 0 5 - 0 . 1 0 \mathrm { mm } . } \\
{ 7 n = 0 . 2 0 \mathrm { mm } . }
\end{array} \quad a \text { zooecium } \left\{\begin{array}{l}
L z=0.50 \mathrm{~mm} . \\
i z=0.30-0.36 \mathrm{~mm} .
\end{array}\right.\right. \\
B \text { zooecium }\left\{\begin{array}{l}
J_{z}=0.70-0.50 \mathrm{~mm} . \\
7 z=0.84 \mathrm{~mm} .
\end{array}\right.
\end{gathered}
$$

Tariations.-The micrometric dimensions are extraordinarily variable. The $B$ zooecia attain a length of $1.10 \mathrm{~mm}$. in the specimens from the ricinity of Bainhridge: Gcorgia; they always engender two new rows of zooecia.

The partition of the a zooecia is very oblique and begins at one of the upper distal angles (fig. 5). It becomes very visible after rubbing amay the zoarial surface. The polypide slips between this partition and the opesiule in order to emerge from the polypidian convexity.

The polypide tuhe of the $l$, zooscia is merlian. straight (see fig. $4, m$ ), or curved nearly at a right angle. The contortions of the polypicle in order to emerge from the zooecium (d), are really considerable (fig. 4 ); we are in ignorance regarding the use of this complicated structure; the embryos developed at the base of the distal chamber are not the cause of it.

One of the zoaria before us corers 5 square centimeters of surface.

Affnities.-This species differs from Steganoporplla jacksonica in it incrusting zoarium, in its a zooecia, which are shorter, and its nonperforated cryptocyst.

It is distinguished from Strganoporella (Lepratia) firma Reuss, 1867. by its $B$ zooecia, which are much larger.

Occurrence.--Upper Jacksonian (Ocala limestone): Chipola River, cast of Marianna, Jackson Connty, Florida (common): West bank of Sepulga River, Escambia County, Alabama (very rare) : 4 miles below Bainbridge. Georgia (rery rare); Old Factory, 11 miles above Bainbridge, Georgia (very rare).

Middle Jacksonian: 17 miles northeast of Hawkinsville, Georgia.

Cotypes.-Cat. Nos. 61007-61009, U.S.N.M.

STEGANOPORELLA VICKSBURGICA. new species.

I'late 84 , firs. 1-7.

Description.-The zoarium is formed of two lamellae placed back to back and easily separable. The $a$ zooecia are large, distinct. elongate, withont distal niche; the mural rim is thin and salient; the cryptocyst is deep and perforated with very small pores; the opesium semilnnar, transverse; the polypicle tube is complete but very little prominent, and the opesiules are hirdly visible. The $B$ zooecia are larger and have a deep, smooth distal niche; the polypide tube is large and rery promi- 
Iient: the opesiules are large. round, and dissimilar; the opesimm is surrounded by a small, improminent collar (oral arch).

$$
\begin{aligned}
& \text { Measurements._Opesinm }\left\{\begin{array}{l}
h o=0.30 \mathrm{~mm} . \\
l o=0.40 \mathrm{~mm} .
\end{array} \quad \text { a zooccia } \begin{array}{l}
L z=0.75-0.55 \mathrm{~mm} . \\
l z=0.65 \mathrm{~mm} .
\end{array}\right. \\
& \text { P zooecia }\left\{\begin{array}{l}
L z=1.25 \mathrm{~mm} . \\
l z=0.60 \mathrm{~mm} .
\end{array}\right.
\end{aligned}
$$

Tariations.-This species is rather constant in its characters. The partition which separates the two chambers is horizontal in the a and $B$ zooccia. so that both kinds of zooecia are provided with a polypide tube, a condition which does not exist in the preceding species studied (Stegmoporolla jacksonica. etc.) (figs. 3, 4). The tube is seen complete after very gently rubbing away the -urface of the zoarium (fig. 5).

The dissymmetry of the opesiules is comstant. but it is not very great, and certainly the retractor muscles of the polypide were not attached in one of the proximal angles of the zooecium.

In this section it appeared to us that the frontal was a tremocyst resting on an olocyst, but this is a point to be rerified. The zooecial mural rim is an olocyst whose elements are grouped in radial rows around the opesium (fig. 6).

The zoarium may attain a length of 2 centimeters; the size of the zooecia permits its determination with a simple hand lens. This is a good-sized fossit and can be readily employed in field determinations.
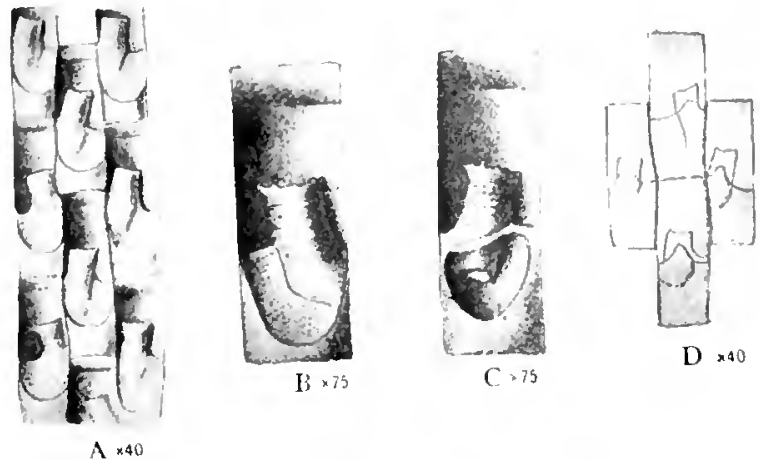

FIG. 72.-Genus Siphonoportlla Ilincks, 1880.

A-1). Siphonoporella delicatissima liusk, 1840. A. View of zoorcia, $\times 40$, with corering membrane removed. $B$. Zooecium of same, $X 75$. C. Zonecium, $\times 75$, showing proximally directed prart of polypide tube. 1). View from the hasal surtace, $x 40$. (A-I after Levinsen, 190\%.)

Occurrence.-Vicksburgian (Marianna limestone): West bank of Conecuh River, Escambia County, Alabama (common); Salt Mountain, j miles soutl of Jackson. Alabama (common) ; Murder Creek, east of Castlebury. Conecuh County, Alabama (common); Claiborne. Monroe County, Alabama (common).

Cotypes.-Cat. No. 6t25i, U.S.N.M.

\section{Genus SIPHONOPORELLA Hincks, 1880.}

1880. Siphonoporella Hixcks. General History of Marine I'olyzod, I. Ifuleiran Polyzon, Annals Magazine Xatural History, ser. 5, vol. 6, p. 22.

The proximal calcified pad of the frontal wall is formed by a larerer or smaller arched gymnocyst; the aperture is not surrounded by a projecting margin; the zooecia oceurring only in a single form and provided with a small. always marred 

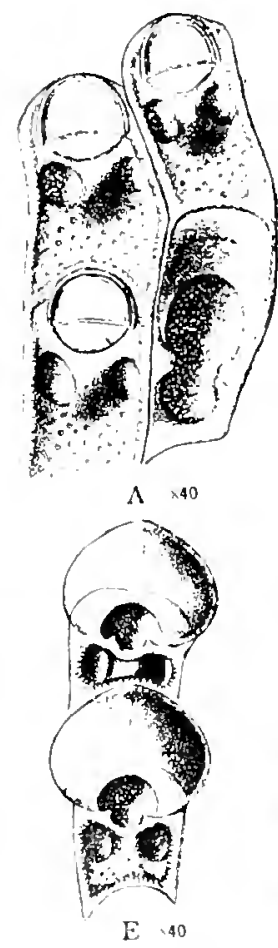

OPERCHIS.

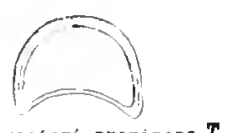

T. razleri prominens T. rozieri labula
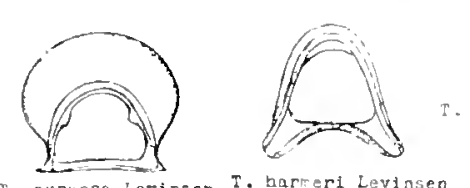<smiles>[CH]1CC1</smiles>
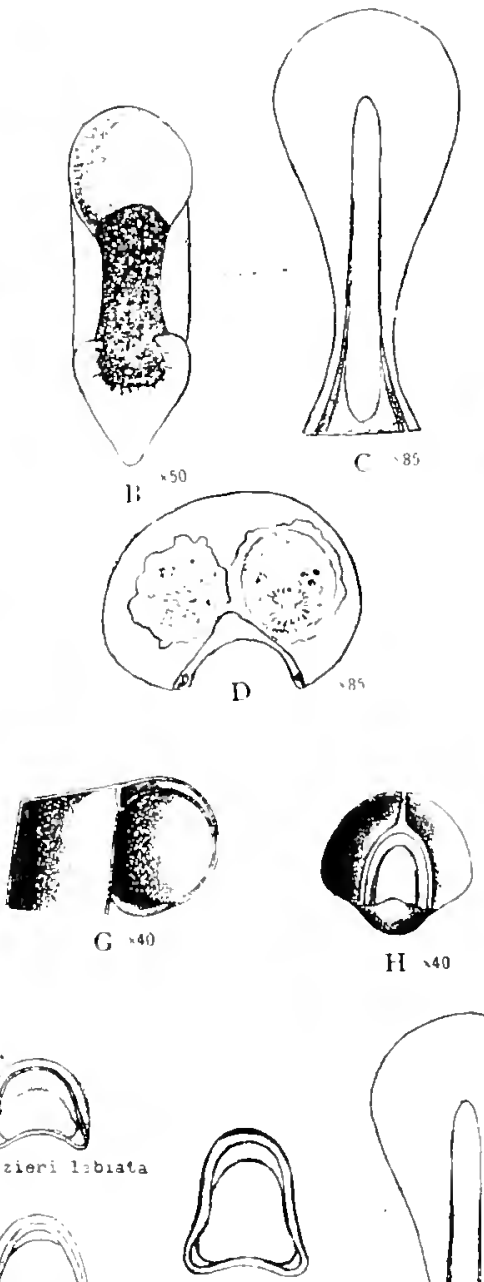

- Jervolsthincks

T. expunse Levinsen
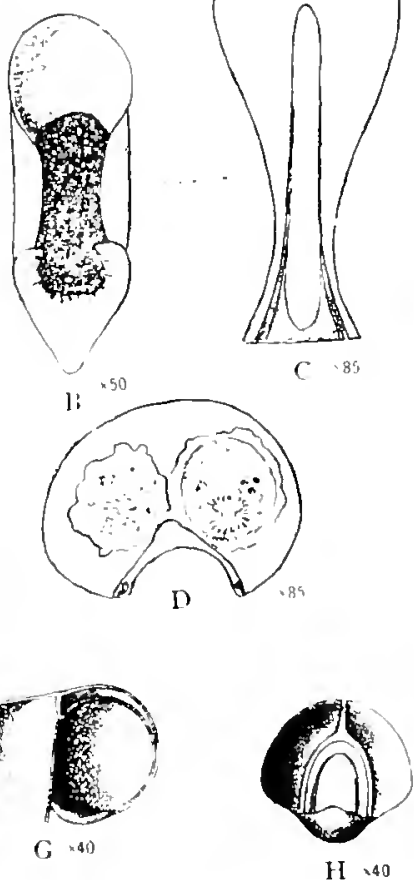
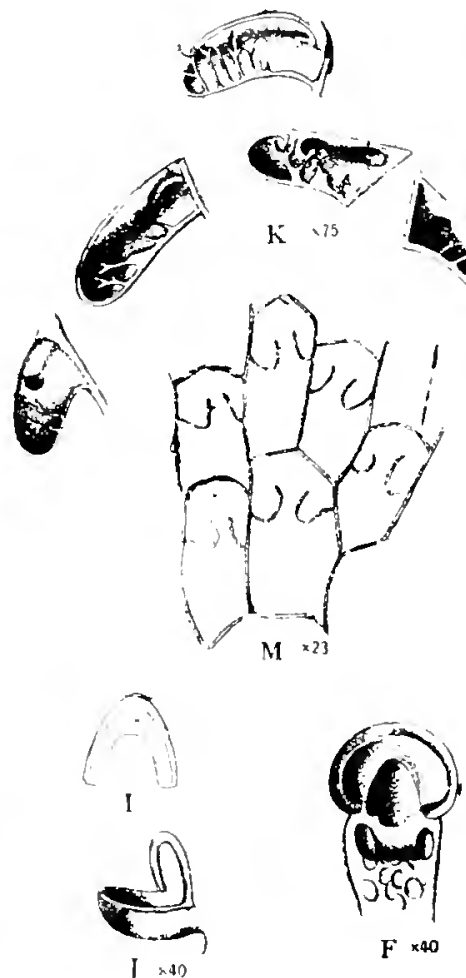

AVICULRIAI IAIDIBLES
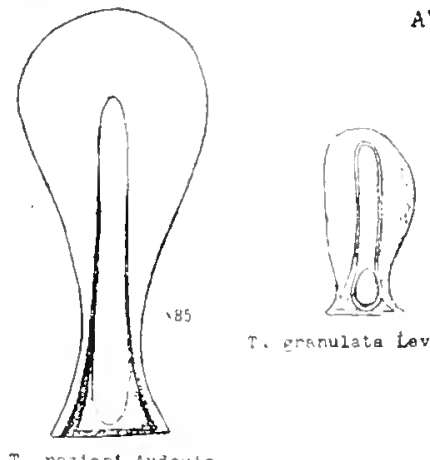

T. Epanulata Lovinsen
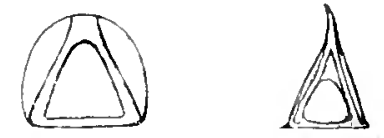

T. expanse Levlogen. T. namillaris Lam

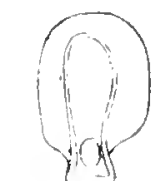

T. novae hollandiae

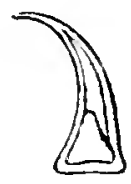

T. falcufara mincks

FIG. T3.-Family 'Lalamoporellidae Leviusen, 1009. 
Fig. 73.-Family Thalamolorellidae Levinsen, 1909.

A. Thalamoporella novae hollandia IIasnell, 1SS1. Three zooecia with their operculum anil an onychocellarium, $\times 40$. (After Levinsen, 1909.)

B-D. Thalamoporella rozieri Audouin. 1S26. B, C. Onychocellarium, $\times 50$, and mandible, $\times$ S5. D. Section of ovicell, $\times$ S5, showing two larvae, of which the right one is clearly older than the left. (I3-D after Waters, 1008.)

E. Thalamoporclla gramulata var. tubifcra Leviusen, 1909. Two gonozooecia. $X 40$. (After Levinsen, 1909.)

F-J. Thalamoporella lioticha Ortman. 1890. F. Median section of ovicell, $X 40$. G. Schematic longitudinal section through ovicell, $X 40$. H. Ovicell with frontal half cut away, showing the operculum, $\times 40$. I. Opercula. J. The distal end of a zooerium after the remoral of the basil surface; the independent basal wall of the polypirle tube is seen, $X 40$.

F. Thalamoporclla mamillaris Lamouroux, 1816. Five opesiules of different zooecia, showing the variation in shape of the opesiular outgrowths and in the mumber and structure of the protecting spinous processes; $\times 75$.

I. Spicula of Thalamoporella novae hollandine Haswell, 1881, X 200.

M. Basal surface of the Thalamoporella granulata Levinsen, $1909, \times 23$, where may be seen the polypidian tube and the opesiular climbers. (F-M after Levinsen, 1909.) 
operenlar valve: the polypide tube is continned. proximally beneath the cryptocyst corer. (After Levinsen, 1909.)

Genotype-Siphonoporella (1/emtrunipora) deticatissima Busk, 1861.

\section{Family THALAMOPORELLIDAE Levinsen, 1909.}

The tubifer zooecia have calcareous spicula in the shape of compasses and bows. The oricells are hyperstomial. with two calcareous layers, springing from
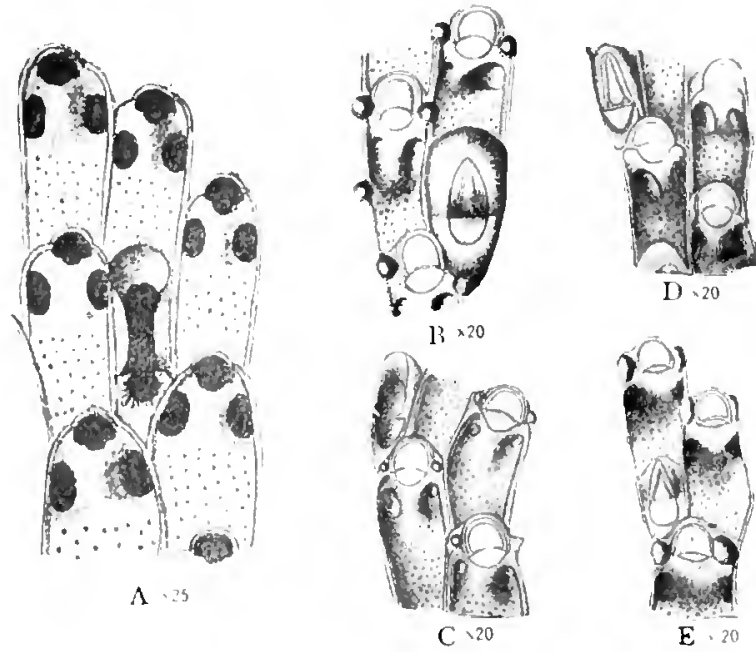

Fig. 74.-Gienus Thnlamoporella Hincks, 18s.

A E. Thelamopor lla roziri Audouin, 1826. A. View of the typical furm, $\times 25$. (After Waters, I908.) B. Zooucia, $\times$ 20, of var, prominens Levinsen, 1909. C. Zooecia, . 20, of var. enlifurniea Levinsen, 1909. 1). Zooecia, $>2$ 20 of var. sparsipunctuta Lerinson, 1900. E. Zooecia, $X 20$, of var. labintr Levins sn, 1909. (B-E aiter Levinsen, 1999.)

the whole anter of the apertura; they are closed hy a horizontal cup-shaped chitinized operenhum which is connected at its base with the operculum of the gonozooecium. The opesiulac are al. nays completely separated from the apertura. The opercular ralve is membranous or chitinized. and more or less completely separated from the ectocyst by a single or double chitinous sclerite. Interzooecial aricularia recur.

The principal characters of this family are shown in figure 73. Hitherto it has been considered as appearing first in the Miocene. The only specimens which we have found occur in the topmost beds of the Ticksburgian.

The known genera are Thatamoporella Hinclss, 1sst: Thairopore Madrilliway, 1887. Manzonchle. Jullien. 188s, and Woodipora Jullien, 1888.

\section{Genus THALAMOPORELLA Hincks, 1887.}

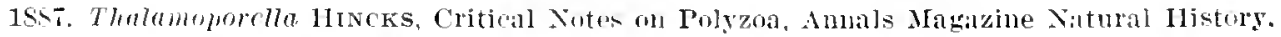
ser. 5 , rol. 19, p. 164 .

Characters same as for the family. 17-10 tentacles.

Genoty" -Thatamoportla (Flustra) razieri (Savigny) dubouin (1s12) 1820.

Ranur.-Ainitanian-Recent.

Fussil species of this genus: Thalamuporthe (Eschara) andegucensis Michelin. 1546. 
TIIALAOPORELLA PRIMA, new species.

liato to fig. 14 .

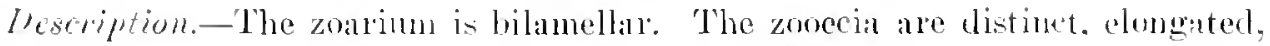
retangular, and their nural lims are intinately united among themselves; the cryptocyst is deep, that. with numerons temopores. The apertura is orlicular ol somewhat transverse, the puster is nalrower. than the anter; it las a linluge, distal, restibular areh; the polyphlian tube is invisible. The onvehocellarium is straght, oval, narrow, and perforated by a singhe elliptical orilice.

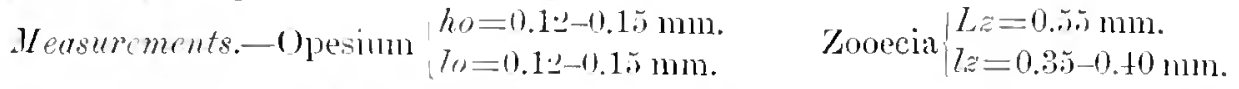

Aftinities. Only a few -peeimens of this species have been found. They are difficult to determine for all the speries of the genus are quite polymorphic. 'To us the present form appeared to differ from Thatemoportle rozioni Sarigny-

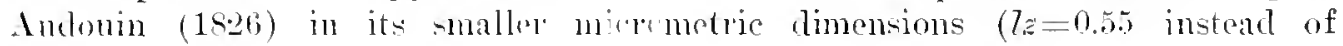
$0.7 \mathrm{~mm}$.$) .$

Gecurrenee-Uppermost Tielishmoin (Byam marl): Leaf River. Smith County, Mississippi (very rare).

Hotolype.-Cat. No. G4obir. T.A.X.M.

Division III. PSEUDOSTEGA Levinsen, 1909.

There are no parietal mucles. The hydrostatic system is external: there is a special hypostege on each zonceium.

The families of this division ale:

Membranicellaridae Levinien 1909.

('ellaridae Hincks 1880.

Cosimoplenridae C'ann 1913.

We are ignorant of the exact working of the hydrostatic system in the specics of this division. It is probable that the lateral incisions of the opesimm, otherwise rely constant, ale in intinate rektionship with the entrance or egress of the polypide. for they serve as lastage for the liquid of the general eavity in the hypostege ol vice rersa.

The endocyst covers il hypostegr. Its presence is often revealed by supplementary calcareous deposits which may alway be distingwished by their irregnlinity.

Other genera certainly belong to this divivion. lut it has not leen possible for us to class them in the families rited. It would he alsurd to crealte a special family for ach of them since we lack absolutely the necessary anatomical foutures.

Here the opesium being entirely abmer loy a constant operenlum of the sane form. becomes a real aperture, as in the $A$ romiliolat.

Family CELLARIIDAE Hincks, 1880.

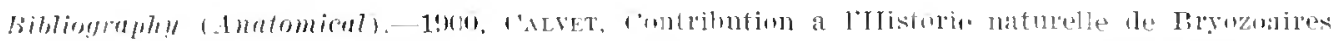

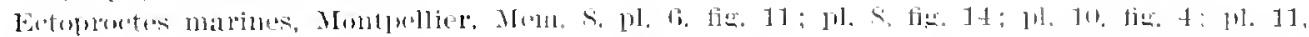

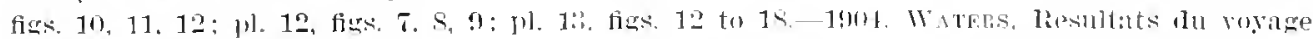

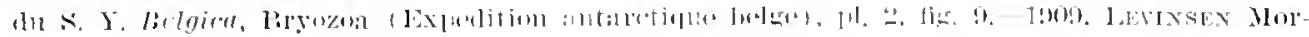

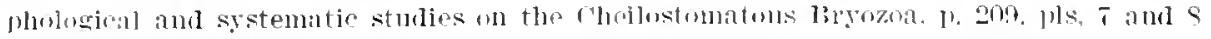



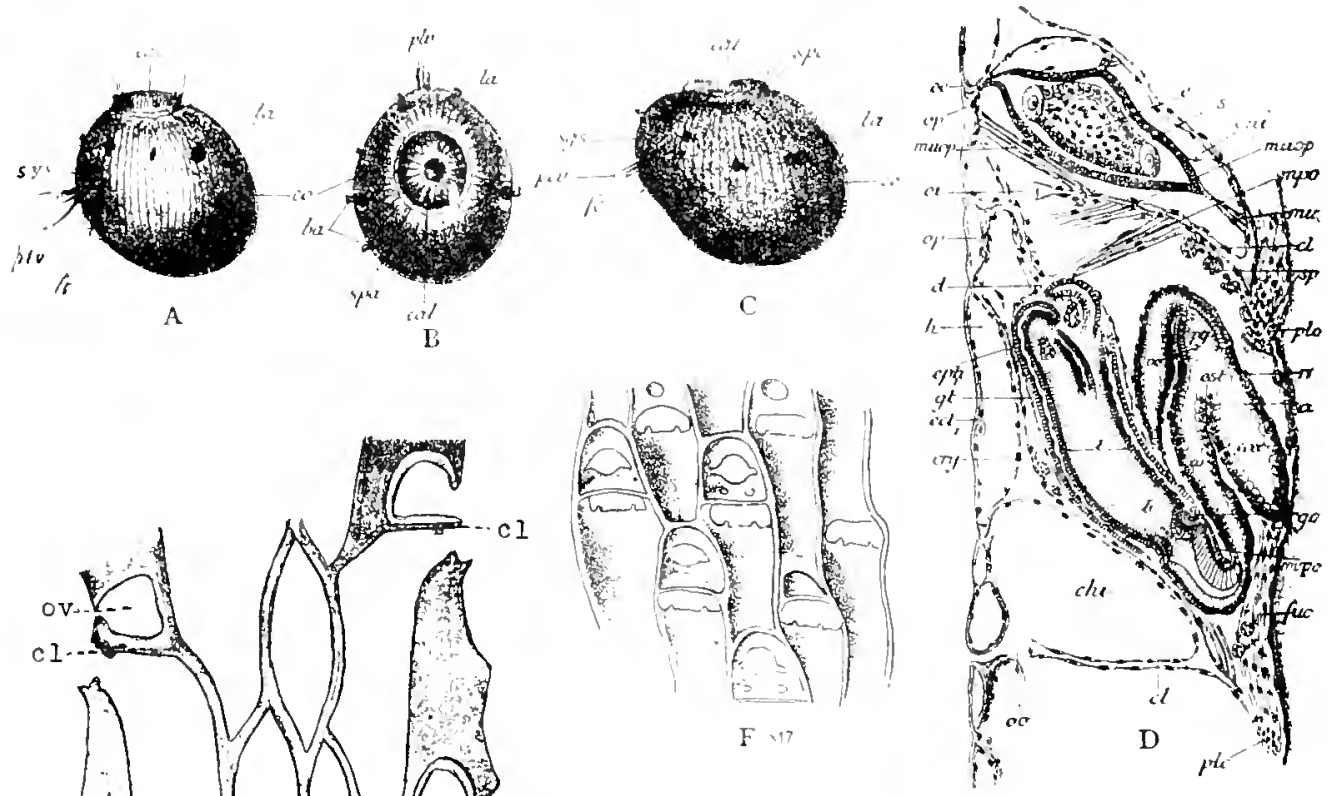

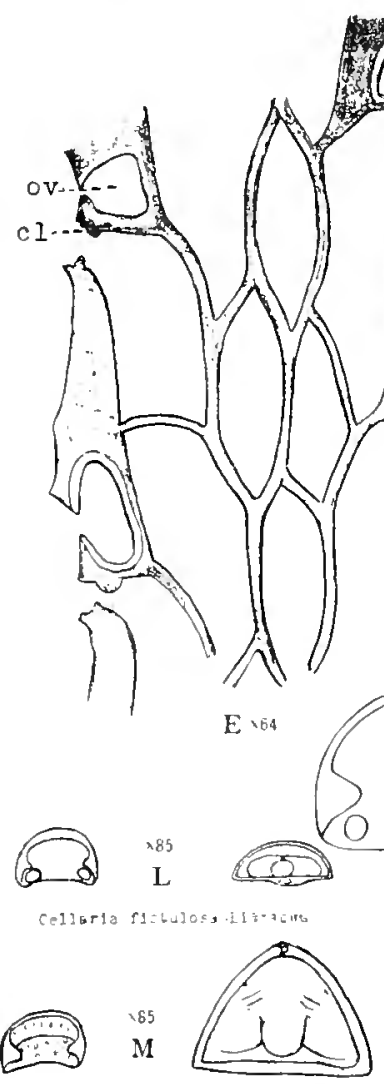

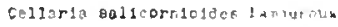

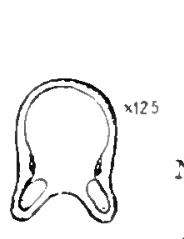

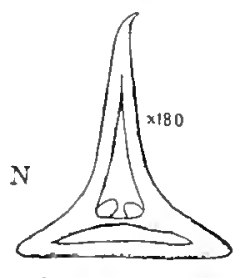

(25)

Cellarta dagolianifa Pusk
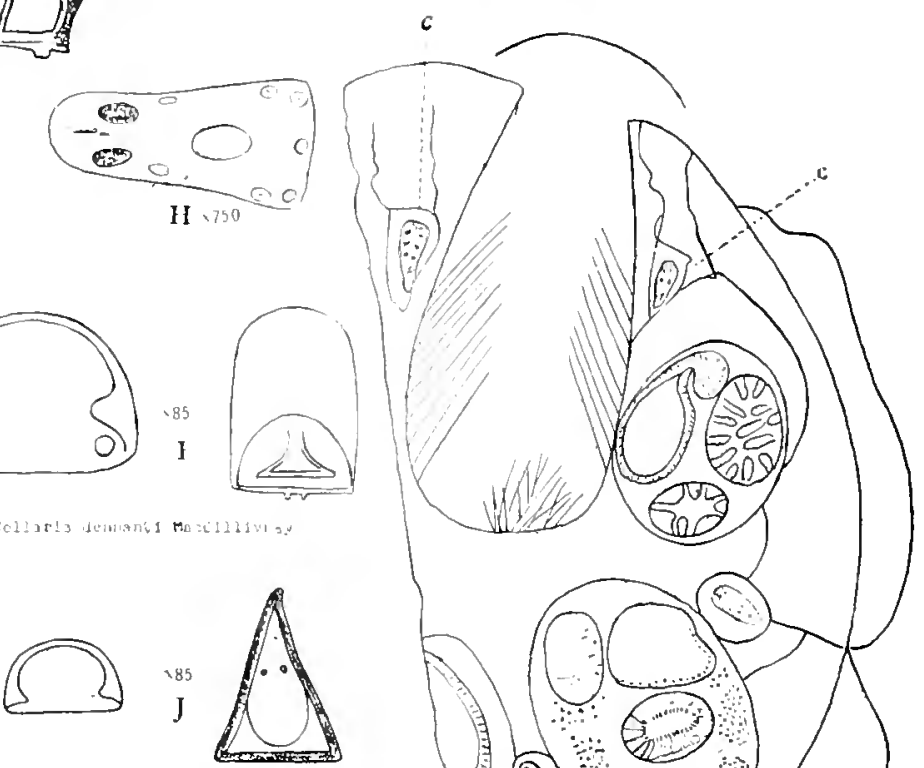

Fro, 75.-Family Cellariidne H1ncks, 1880. 
Fig. 75.-Falnily Cellaridae Hincks, 1980.

A-D. Cellaria fistulosa Linnaeus, 1768. A. Profile riem of larva. B. Aboral face. C. Lateral face. (A-C after Calvet, 1900.)

ba. palette of pigmentary spots of the larva. plv, vibratile plume.

cal, calotte (terminal bud).

(\%. colona.

fo, ciliated cleft.

spa, palleal furrow.

sgs, stupelior glindular $\leqslant 5$ stent.

$t a$, pigment spots.

D. Longitudinal frontodorsal sertion of a bryozoid. (After Calvet, 1900.)

(m) anus.

cal, cardiac region of the stomach.

cace, stomachic caecum.

chi, incubation cavits.

(r) cryptocsst.

d. vaginal diaphragm.

$\epsilon$, embryo.

ect, ectocsst.

$c$, interzooecial partition.

cpl, hrpostegial epiderm (endocyst).

c'st, stowach.

fic, central funicular cord.

gln. nerve ganglion. $y t$, tentacular sheath.

$l$, ligpostege.

mpd, parietal diaphragm muscles.

mupae, periesophagial muscular fibers.

muop, muscles of the operculum of the oricell.

oe, external orifice of the ovicell.

ai, internal oritice of the ovicell.

op, operculum.

plc, communication plates (septulae).

$r m$, mesenchyme corering of the polspide.

$s$, membraneous sac in which the embryo is erolved.

$t$, tentacles.

E. Cellaria rigida MacGillirray, 1s57. Longitudinal section through a zoarium, $\times 64$. (After Heunig, 1910.)

F. Cellaria atlantica Busk, 1584. Interior from the basal aspect after the remoral of the hasal surface. The cavities of the zooecia and the ovicells are risible and here and there external ridges which diride the frontal surface into areas. (After Levinsen, 1909.)

G, H. Cellaria dennanti MacGilliriay, 1S57. G. Section $\times$ S5, showing the large avicularian chamber, also the onter membranes nuited at certain points only, and between which there has been a calcareous deposit; the basal portions of the intelmediate zocecia are shown at $c$. In the lower zoceciun the full number of tentacles is not shown.

H. Section of tentacles, $\times 750$. (G, H after Waters, 1904.)

I-x. Opercnla (to the left) and aricularian mandibies (to the right) of Cellaria. (I, M after Waters, 1855 and 1904, and $N$ after Calvet, 1910.) 
The whole frontal wall of the zooecia is a cryptroyst and they have a well chitinized, bilaminar. simple operculum with a straight ol concave proximal margin. Within the proximal and sometimes also within the distal margin of the aperture is placed a pair of (or sometimes a single broad) supporting teeth. The subopereular area of the aricularia has an musually strongly developed. sometimes almost complete crytoryt. The ovicells are endotoichal. (1 fter Lerinsen. 1909.)

The genera known are Cellarin Authors, Cianotremellu Camu, 1911, Meticeritu

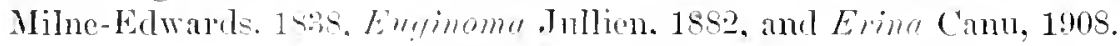

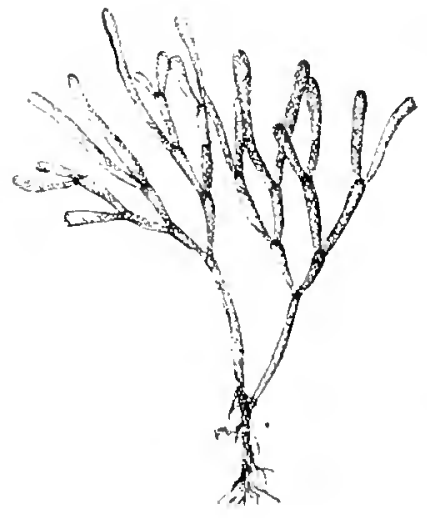

A $\times 1$

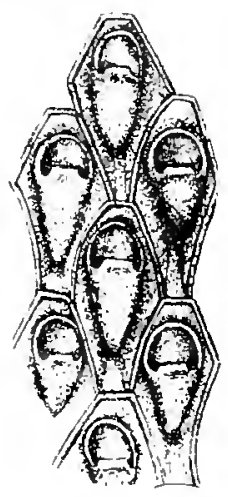

B $\times 50$
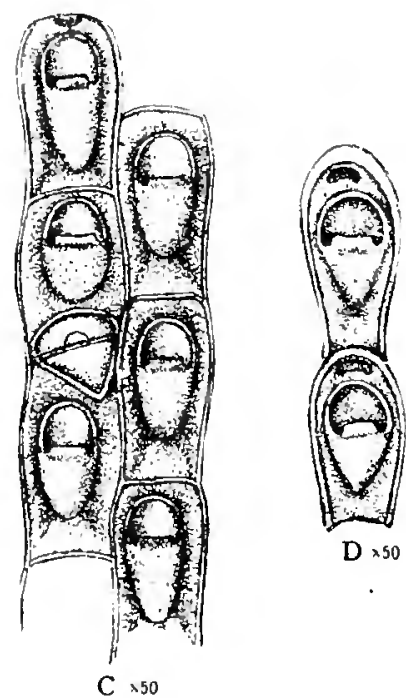

Fig. TG-Genus Cellaria Lamouroux, 1812.

A-I). Collaria simlosh Hassill, 1841. A. Zoarimu, natural size. B. Usual form of zooecia,

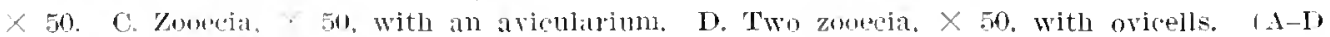
ifter Hincks, 1Ss!).

There are certainly generic divisions still to be made in the very important genus Celluric when we better understand the function of the oral armature and the working of the hyrlyostatic system.

\section{Genus CELLARIA Authors.?}

The zoarium is articulated, with cylindrical segments (internodes). The oricell is endotoichal and is closed by a peculiar. chitinous operculum moved by especial muscles. The operenlum is formed of a chitinized inner part. closing the aperture. corered ly the exterior ectoeyst. 13-15 tentales.

Genotype-f'pllarin fistulosa Linnaens, 1768.

\footnotetext{
1 The genus cellaria mas named hy lanouroux in 1s1:, but we cite it as "duthors" to show that we agree with th" creat majurily of the authors of the nineteenth century in reard to this genus. Recently

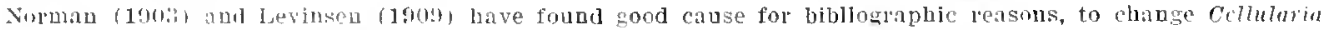

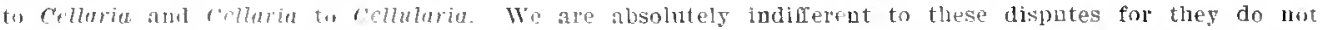

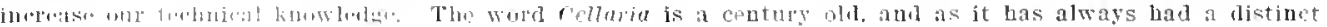
maning, why slupla wo change it?
} 
Range.-Tacksonian-Recent.

In the Eocene and the Oligocene we still recognize the single species Cellaridx reussi D'Orbigny, 18\%, of the Priabonian of Vicentim, Italy.

CELLARIA STRICTOCELLa, new species.

Plate 40, figs. $7-10$.

Description.-Zoarim articulated; the segments cylindrical and symmetrical. The zooecia are elongater, namou. confluent among themselves; the cryptocyst is of little depth. concave, smooth. The aperture is transverse, elliptical. without oral denticles. The ovicell is small, rectangular with an orifice of the same form.

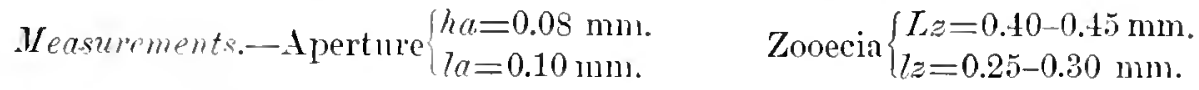

Affinitics.-Most of the time there is no oral armature; but sometimes deeply embedded lamellize are visible.

The micrometric dimensions are greater in the middle of the segments than at their extremities.

This species differs from Cellaria rassi D'Obigny, 185\%, in the form of its zooecia, which are not hexagonal and in their quincunx arrangement.

It differs from Cellaria dimorpha, new speeies, in the absence of all zooecial dimorphism.

Occurrence-Middle Jacksonian (Castle Hayne limestone): Wilmington, Sorth Carolina (uncommon).

Cotypes.-Cat. No. 64010, T.S.N.M.

CELLARIA DIMORPHA, new species.

Plate 40, figs. 11-19.

Description.-The zoarium is articulated: the segments are large, symmetrical. somewhat conical, formed of a dozen longitudinal rows of dimorphic zooecia. The small zooecia are rectangular, elongated, confluent through their mural rim: the cryptocyst is smooth. deep; the aperture is elliptical and transverse. Within the interior of the aperture there are two oblique symmetrically arranged lamellae. The ovicell is endotoichal; its orifice is circular and completed by a small canal the point of which is below and directed toward the proximal ovicell of the neighboring row. The large zooecia have the sane characters as the small.

Measurements.-A pertme of $\int h a=0.10 \mathrm{~mm}$. I pertmre of $/ \mathrm{h} a=0.20 \mathrm{~mm}$. small zooecia $l a=0.12 \mathrm{~mm}$. lar.ge zooecia $l a=0.2+\mathrm{mm}$.

Small zooecia $\left\{\begin{array}{l}L z=11.50 \mathrm{~mm} . \\ l z=0.20 \mathrm{~mm} .\end{array}\right.$ L sil re zooecia $\left\{\begin{array}{l}L z=0.45-0.5 \mathrm{~mm} . \\ z z=0.26 \mathrm{~mm} .\end{array}\right.$

Affinities. - This species is rery curious: and for the genus its charanters are quite divergent. Unfortunately the different oral organs of the living speries have not been thoromghly studied.

$55 \operatorname{sen}-19-$ Bull $106-18$ 
The oral lamellae are analogous to those in the genus Chaperia where they serve for the insertion of opercular muscles. They are not constant in the large zooecia, where they are sometimes replaced by two lateral clenticles.

The orifice of the ovicell has much resemblance to that of avicularia, for it is often constricted by two lateral denticles.

The frontal is an olocyst in which the elements are crowded and regularly disposed. The zoocial dimorphism is inexplicable.

Occurrence.-Middle Jacksonian (Castle Hayne limestone): Wilmington, North Carolina (common).

rotypes.-Cat. No. 64011. T.S.T.M.

CELLARIA BIFACIATA, new species.

Plate 40, figs. 14-17.

Description.-The zoarinm is articulated; the segments are cylindrical and nnsymmetrical. On the posterior face the zooecia are small, ogival, joined by their margins; the cryptocyst is smooth and shallow; the aperture is transverse and elliptical. The oricell is endotoichal; its orifice is large and circular. On the anterior face the zooecia are large. hexagonal, and united among themselves; the cryptocyst is deep, but much smaller than the aperture which is transverse and elliptical. Between the zooecia there are large falciform avicularia in which the pivot is indicated by tro large lateral teeth.

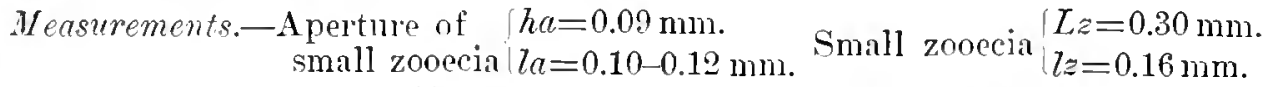

$$
\begin{aligned}
& \begin{array}{c}
\text { Aperture of } h a=0.12 \mathrm{~mm} . \\
\text { large zooecia } \\
l a=0.15-0.20 \mathrm{~mm} .
\end{array} \quad \text { Large zooecia } \begin{array}{l}
L z=0.35 \mathrm{~mm} . \\
l z=0.33-0.35 \mathrm{~mm} .
\end{array}
\end{aligned}
$$

Affinities.-This species is as remarkable as it is problematical. We know absolutely no other bryozoan with which it can be compared. There are only two rows of the large zooecia, which have considerable resemblance to those of Onychocella: the irregularity of the orifice is indicative of an opesium and not an aperture. The a vicularium is analogous to that in Callopora tenuirostris Hincks. The small zooecia are arranged in six rows. Their aperture is rather small and is without all internal armature. Its ovicell is endotoichal.

Cellaria bifaciata certainly belongs to a new genus, but unfortnnately the rarity of specimens has not allowed us to make a detailed study.

occurrence--Middle Jacksonian: Wilmington. North Carolina (rare); near Lenud's Ferry. South Carolina (rare).

Cotypes.-Cat. No. 64012. T.S.N.M.

\section{Genus Ciano'Tremella Canu, 1911.}

1!11. Cinnotremclla CaNt. Icomographie des Rryozoaires fossiles de l'Atrentine, nt. 2. Anales del Museo Nacional de Buenos Aires, vol. 21, p. 257.

Zooecia separated laterally by a thin mural rim. The opesinm is formed of a semicirenlar anter and of a convex poster. The ovicell is endotoichal and opens exteriorly by a salient and transverse pore.

fenotype-C'ianotremella gigantra Canu, 1911. Rocanean of Argentina. 


\section{Family COSCINOPLEURIDAE Canu, 1913.}

1913. Coscinopleuridae CANt, Etules morphologiques sur trois nouvelles fanilies de Bryozoniles, Bulletin Societé Geolocrique de France, ser. 4, vol. 13, p. 145.

The apertura is semilumar. marginated. anterior, never terminal. The oricell is hyperstomial, embedded in the distal zooecia, never closed by the operculum. The onychocellaria are straight but typical.

The known genera are:

Coscinopleura Marsson, $18 s$.

Escharipora. D’Orbigny, 1851.

Macropora MacGillvray, 1895.

Genus COSCiNopleuRA Marsson, 1887.

1ssi. Coscinonleura Marsson, Die Bryozoen der weissen Schreibkreide der Insel Riigen. Palaeontologische Abhandlungen, vol. $4, \mathrm{p} .71$.

The margins of the zoarium are bordered by large vibracula. The frontal is deprived of pores and avicularia.

Genotype-Coscinopleura (Eschara) eleyans Hagenow. 1840.

Range-Cenomanian-Thanetian.

This genus is quite remarkable: it realizes the type of special adaptation to the mobile substratum. Very certainly the zoaria were attached to algae in agitated waters. The zoarial equilibrium. constantly compromised, was assured by the vibracula and the hydrostatic zooccia.

The ribracula are powerful and their cilium must be very long; these are the zooceia whose frontal is perforated by large scattered pores; the upper lip of the apertura is quite salient. oblique, truncated, conical. They belong to the type of vibracula of the family of the Lumulariidae. They are placed laterally on the

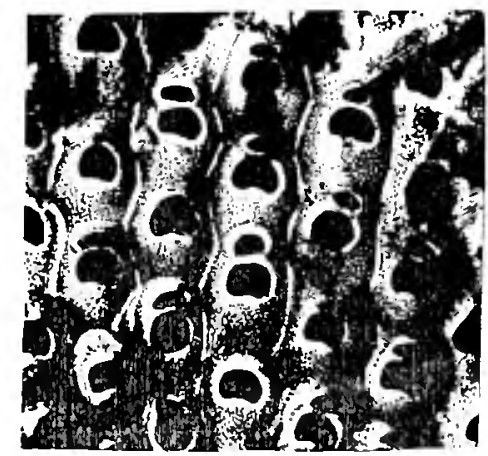

Fig. 77.-Genus Cianotremella Canu, 1911.

Ciunotremella gigantea Camu, 1911. View of zooecia showing salient transverse pore opening of ovicell. (Aiter Canu, 1911.) zoarial margins (fig. 13) and at the bifureations they are often accompanied by hyclrostatic zooecia (fig. 12).

The hydrostatic zooecia in onr opinion, contained the liquid destined for the zoarial hydrostatic system; they are therefore intended to augment the exterior rolume when they empty, and consegnently diminish the weight and assure the capacity to float. They are placed laterally (fig. 12) or they are grouped in litre number (fig. 21).

Canu, in 1913, cited the known fo-sil speeies of this genus.

Coscliopleura digitata Morton, 1831.

Plate 2. figs. 7-20.

1S34. Eschara digitata Mortox. Synopsis of the Or.tnie remains of the cretrcens Group

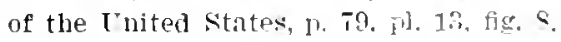


1845. Eschara aigitata Lonsdale, Account of six species of Polyparia obtained from Timber Creek, Now .Jersey. Unaterly Jummal reoloxical Society of London, vol. 1, p. 73, figs. $c, d, g$ ( $a$ and $b$ ? exchs, $e$ and $f)$.

1850. Escharn digitata D'Orbigny, Prodrome de paleontologie stratigraphique, vol. 2. p. 264. 1862. Eschart digitata GABB and IIorx, Mollograph of the fossil Polyzoa of the Secondary aul Tertiary formations of North America. Jourual Academy of Natural seiences of I'hiladelphis, ser. 2, vol. 5, 1). 114.

1901. Eschara? digitata Utrich, Haryland frolugical Surves, Eocene, 1, 216, pl. 60. figs. 11,12 .

1907. Onychocelli digitata Weller, Geological surves New Jersey, Paleontology. vol. 4. ก. 230, pl. 23 , figs. $7-10$.

Description.- "Zoarium bifoliate, branching dichotomously : br'anches flattened, acutely elliptical in cross section, usually 2.5 to $3.0 \mathrm{~mm}$. wide. Zooecia hexagonal. regularly ar'anged in quincmux, about $0.55 \operatorname{long}$ and 0.38 wide, bounded by a s]ightly impressed line: surface concave. especially tomard the aperture. which is sitnated usually just in front of the center. Aperture semielliptical, rounded in front, straight behind, 0.10 to $0.12 \mathrm{~mm}$. wide. Normally developed and perfect, the poterior border of the aperture is slight]y raised and hears a delicate lumarimlike curved plate. which extends into the a perture. Abortive cells. possibly of the soture of ricarious avicularia, are frequent but seem to be entirely restricted to the edges of the zoarimm and to those portions lying just beneath the axes of lifurcation. They are distinguished from the other cells by their subcircular and ucually smaller apertures. Ooecia unknown." (After Ulrich.)

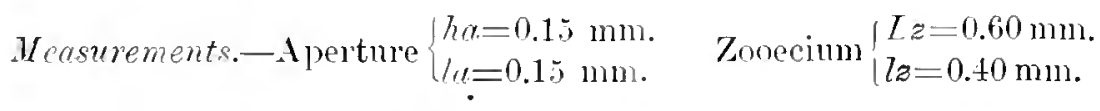

This species was discovered in the Enene by Thich in 1901. The descripfion which he arve is correct: nevertheless it " "ahortive cells" are the vibracula of a perfect and well known type.

The Eocene specimens are a little maluwol than those of the Cretaceons at incentown.

Occurrence.-Lomest Focene (Brrozoan lro at base of Aquia formation): T'pler Mirlboro, Maryland (rare).

Geologient distribution.-[Tpper Cretaleom (Vincentown marl= Danian): Tincentown and other localities in New .Jer-ey.

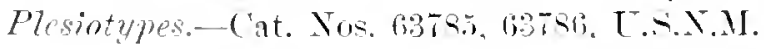

\section{Genus MACROPORA MacGillivray. 1895.}

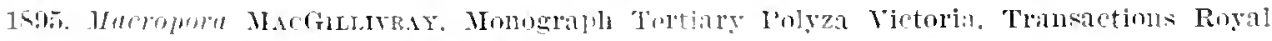
Suciety Tictoria, rol. 4, P. 54.

"The zoocia rery thick-walled. provirled with pouses. lnt without spines and witlont openinles. The zooecial structure in plovited with a well-dereloped vestibnlar arch. Ovicells and avicularia wanting. but among the zooecia we find -ome which have an aperture of a different form am whose distal margin is furnished with three nembrameou-feeler-like filament-. Dietellac." (Levinsen, 1909.) 
Genotype.-Mneropora entiatix. Mactrillivray. 1895.

Range.-Jacksonian-Recent.

Levinsen classed this genus in the Microporidae, but the absence of the opesiule and parietal muscles oblige ns to place it moder the Pseudostega. Perhaps it will be convenient to create a family of Macroporiclae: but wo ale absolutely without any. knowledge of its anatonical features.

MACROPORA AQUIAE, new species.

Plate 1, figs. 20, 21.

Irescription.-The zoarium incrust small shells. The zoocia are hexagonil. somewhat elongated, distinct. separated by a more or less salient thread; the crytocyst is very slightly concave and quite finely porous. The aperture is semilumar. transverse; its proximal border is straight with two small lateral characteristic indentations; the restibular arch is very small. There are two pairs of lateral dietellae.

Measurements. - $h a=0.04 \mathrm{~mm}$. Aperture $l a=0.08 \mathrm{~mm}$. Zooecia $\left\{\begin{array}{l}l z=0.10 \mathrm{~mm} . \\ l z=0.20 \mathrm{~mm} .\end{array}\right.$

Trriations and affinities.The micrometric measurements are quite rariable. The ancestrula is a zooecium identical with the others. The thread separating the zoocia often becomes quite attenuated. The vestibular arch is visible ouly when greatly magnifierl.
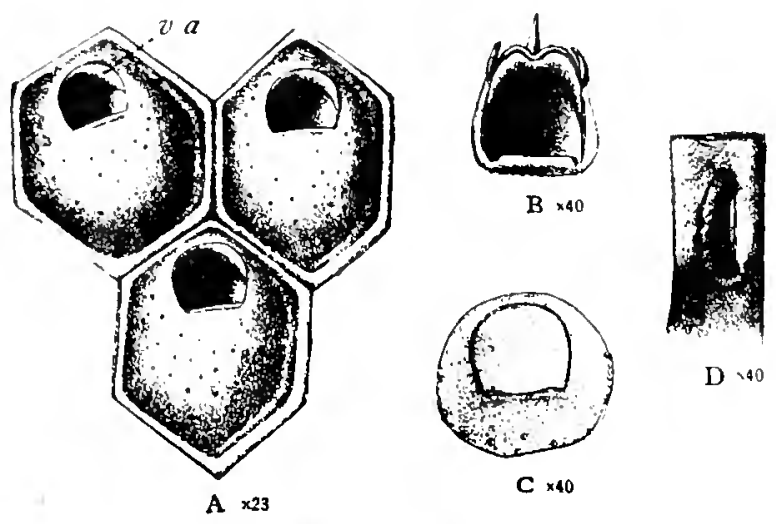

D $\ 40$

Fu. TS-Cienus Macropora Maceilliveray, 189.5.

A-11. Marropora centralis Maceillivery, 1595. 1. Thro zoomeria, 23.; re, vestibular arch. li. The aperture of a s[ecial form of zuoecium (avicularium?), 40. O. In operculum with its surroundings, $\times$ 40. I). A rlietella, 41. (A-T) after Levinsen, 1909.)

The frontal occasionally bear's some perforations which appean to be opesiules.

This small species is extremely fragile. It is not rare in the Aquia formation. to which it appears to be restricted.

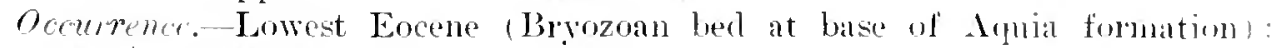
Epper Mariboro. Maryland (not uncommon).

Holotype.Cat. No. 637-0. I'.N.N.M.

MACROPORA MULTILAMELLOSA, nEW species.

I'linte 41. tigs. 1-:?.

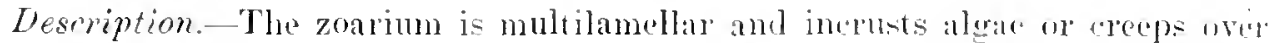
the sand: the zooecia of the upper and external lamella only are living. The external zooecia are hexigonal. elongated. distinct. separated by a frominent threat; 
the eryptocyst is smooth, slightly convex. The aperture is semilunar, transverse; the proximal border is straight with two small lateral slits. The zooecia of the internal lamellae have a granulated cryptocyst and their apertures are closed by a calcareous lamina. Fire dietellae are present.

$$
\text { Measurements._A perture }\left\{\begin{array} { l } 
{ h a = 0 . 1 2 \mathrm { mm } . } \\
{ l _ { a } = 0 . 1 7 \mathrm { mm } . }
\end{array} \quad \text { Zooecia } \left\{\begin{array}{l}
L z=0.85-0.90 \mathrm{~mm} \text {. } \\
7 z=0.65-0.75 \mathrm{~mm} .
\end{array}\right.\right.
$$

Tariations.-This species is a true Marmport: the aperture does not occupy all the distal extremity and is provided with a decided peristome and a small restibular arch: the zonecia are exactly hexagonal; there are five dietellae.

The granular constitution of the inner zooecia is quite remarkable. These gramles are equiralent to the "hydrostatic tuberosities;" their object is to keep the upper zooecial lamella at a distance to aroid an intimate contact analogous to that of other multilamellar bryozoa. They are secreted by the endocyst which floats in the lyypostege (Calvet) and forms a special pleurocyst. These zooecia wele without polypide, since their aperture was elosed by a calcareons lamina secreted by the endocyst; but they might liave continued to live, to be traversed by the mesenchymatous filaments of the endocyst, since the grannlations are formed only at the moment of the formation of the upper lamella.

The zoarial unity of the bryozon is incontestable since the larva is unique, but it often manifests itself in a rather obscure faslion in the incrusting species. In the present instance it appears as if a real intelligence presided over the vital manifestations at the moment of their necessity.

The utility of the frontal gramulation - is not evident at first glance, but it is easy to find their explanation by examining the whole of the zoarum. The granules are really hydrostatic and are also resigned to angment the volume and the lightness of the zoarium. The larra aftixes itself to saml grains, over which the zoarium spreads rapidly. This is a very clangerous habitat, as the sand is in danger from the least movement of the water. To aroid this the animal multiplies its lamellae. preparing for itself in this way its own foundation; by the specific lightness thus acquired it may have the power to elevate itself above the sand and aroid this dangerous zone. It is evident that the zoalium is entirely surrounded by the ectocyst and that the disruption of this mouls impecle the working of the hydrostatic system.

At the bottom of each zooeciun there are two oblique, projecting lamellae which serve as supports for the upper lamella.

Affinitics.- We have not found an ovicell, and in spite of its appearance this species is not a Coscinopleura. It difters from Mucropora contratis Machilliviay. 1895. and from Macropora clarkei Tenison Wools in its frontal tuberosities and in its multilamellar zoarium. These two species are from the Miocene of Australia.

The grenus Hacropora is unknown in Enrope. However, in the English Cretaceous there is IIomolostega cunifurmis Brydone, 1900, which may be either a Macropora or a Coscinopleura, but of which the ovicell is not yet known. 
Occurrence--Middle Jacksonian (Castle Hayne limestone): Wilmington, North Carolina (common); Eutaw Springs, South Carolina (eommon); near Lenuds Ferry, Soutl Carolina (common).

Cotypes.Cat. No. 6t015. I'.S.N.M.

\section{Genus QUADRICELIARIA D'Orbigny, 1850.}

1550. Quadricellaria D'Orbigns, I'aléontologie française, Terrain crétacé, Bryozonires, 1. 32.

Zonrium articulated; segments quarlangular; two opposite faces with large zooecia and the other two with small zooecia.

Genotype.-Quadricellariu elegans D'Orbigny.

Range.-Turonian-Senonian.

D'Orbigny's gemus is rather well delimited, hut it has been extended to include all forms with reetangular zoaria. Noreover. it is more of a zoarial form than a thoroughly established genus.

The two species which we doubtfully classify in Quadricellario have in effect quadrangular segments, but their aftinities are with Macropord. The specimens a re not oricelled and can not be positively classified generieally at the present time.

QUADRICELLARIA (?) LACINIOSA, new species.

Plate 40, figs. 1S-20.

Deseription.-The zoarium is articulated, with segments quadrangular; each face bears on each zooecium a large slit in the form of a crescent. The zooecia are quite elongate, distinet, formed of two parts. A shallow, very finely punctate cryptocyst and an inferior triangular gymnocyst. The aperture is semilunar and surrounded by a prominent peristome; the proximal border is straight with two small lateral slits. The ovicell is endotoichal.

$$
\text { Measur ments.-A perture }\left\{\begin{array} { l } 
{ h a = 0 . 0 8 \mathrm { mm } . } \\
{ l a = 0 . 0 6 \mathrm { mm } . }
\end{array} \quad \text { Zooecia } \left\{\begin{array}{l}
L z=0.50 \mathrm{~mm} . \\
l z=0.22 \mathrm{~mm} .
\end{array}\right.\right.
$$

Affnities.-The zooecia are joined back to back and arranged in alternating pairs at right angles, as in Dimetopia.

This species is not a Quadricellaric and certainly belongs to a new genus, although different fiom the genus represented in Quadricellaria burnsi. To create this genus one should know the ovieell and possess many specimens. We have only collected three segments.

Oecurrence--Niddle Jacksonian (Castle Hayne limestone) : Wilmington. North Carolina (very rare).

Cotypes.-Cat. No. 61013. U.S.N.M.

QUADRICELLARIA (?) BURNSI, new species.

I'late 40, tig. $2 I$.

Description.--The zoarium is articulated and radicellated; it contains a row of zooecia on each of the four faces. The zooecia are quite elongate, distinct, bordered by a rery slightly elevated mural rim; the cryptocy t is snooth and shallow. 
The aperture is semilunar or ogival and is surrounded by a prominent peristome; its proximal border is straight with two small lateral slits; there is a restibular arch.

$$
\text { Measurements.-Aperture } \begin{aligned}
& h a=0.08 \mathrm{~mm} . \\
& 7 a=0.06 \mathrm{~mm} .
\end{aligned} \quad \text { Zooecia }\left\{\begin{array}{l}
L z=0.41-0.46 \mathrm{~mm} . \\
7 z=0.20 \mathrm{~mm} .
\end{array}\right.
$$

Breadth of the segments $0.20-0.36 \mathrm{~mm}$.

Affinitios.-This species is articnlated as in Cellearia; but in its other characteristics it is nearer to Macropora. As in that genns, there is a peristome, an oral arch. and two oral slits. We have not seen an ovicell. It is impossible to establish a new genus on such insufficient material as we possess, since the fignred specimens are the only ones which have been found. We dedicate this species to

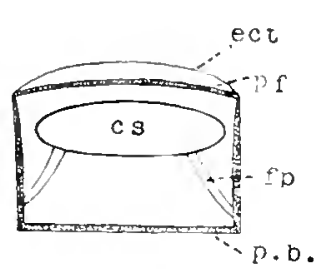

Fis. 79,-sitructuris of tlif Ascophora Levin$8+20,1909$.

Tramsinersesection of a zooceinun. rs, compensatrix: ect, ectocyst; $f_{P}$. pariptal fibers (musclus); pb, lasal skeleton wall; ff, frontal skelctal wall.
Dr. Frank Burns, who collected many species of Tertiary bryozoa for our study.

Occumence.-Middle Jacksonian (Castle Hayne limestone) : Wilmington, North Carolina (very rare).

Holotype.Cat. No. 64014, U.S.N.M.

\section{Suborder Ascophora Levinsen. 1909.}

The zooecial hydrostatic system is a sack or compensatrix placed uncler the frontal and in which the sea water is introduced. The parietal muscles are attached to this sack.

\section{The COSTULAE.}

(Family CRIBRILINIDAE Hincks, 1880.)

The zooecia have their frontal wall formed of flattened ribs ordinarily hollow, radiating from the onter border towarl the median line of the zooecia, where they are intimately joined together: these ribs are united to one another, sometimes by a more or less large number of transverse passages, and sometimes horder to borler. the ribs. however. always remaining apparent.

This family is not natural. for its essential characters are too much at variance. We indicate therefore, the anatomical bibliography for each of the genera studied. In the future, these genera will probably be distributed in the Malacostega and Ascophora. The anatomical researches published have shown the presence of a compensatrix, for which reason we classify the gronp in the Ascophora; but we recognize that certain genera are unprovided with this organ.

Tominolofy.-The internal structure of the ('ostnlize has been carefully studied lyy Norman. ${ }^{1}$ The costula (A) (bar of Norman) always has its proximal extremity rouncled (fig. 80), forming the loop of Norman or talon of Jullien (C). This itructure is hollow; the hollow part is the lumen line or more simply the lumen. There are often openings in the limen called lumen pores. The sides of the costules are the lateral lines (D); the pore-like openings generally developed between them 
are the lateml lacunac: the openings developed at the extremities are meatiun lacunac. A lateral lacuna consists then of two parts divisled horizontally (E). taking their origin in the lateral walls of two adjacent costules. I median lacuna consists of two rertical portion: formed by the distal extremities of two opposite costules $(\mathrm{F})$.

Classification.-For the reception of species of this family. D'Orbigny in $18 \% 2$ created the two families of Escharellidae (withont avicularia) and Eschariporidae (with avieularia). These names prevailed for 30 years.

In 1880 Hincks showed that C'ribritina Gray, 18 48 , has priority over Escharipora D'Orbigny, 1852, and made this genus the type of the C'ribrilinidae.

In 1856 .J. Jullien ${ }^{1}$ established that Membraniporella was not a true member of the Cribrilinidae. Thus regarding the family of Hincks in a different sense, especially since he added to it the Steginoporidac D Orbigny. he gave it another name-the Costulidae.

The elassification adopted by the French author is based chiefly on the form of the aperture and on the derelopment of the oral spines. Most of his genera may be preserved with some modifieation of diagnosis.

In 1909 Levinsen established that Hincks' family was not natural, that certain genera have aflinities with the Anasca and other's with the Ascophora.

Our studies of the Imerican bryozoa confirm Levinsen's riews, but we can not discover the true

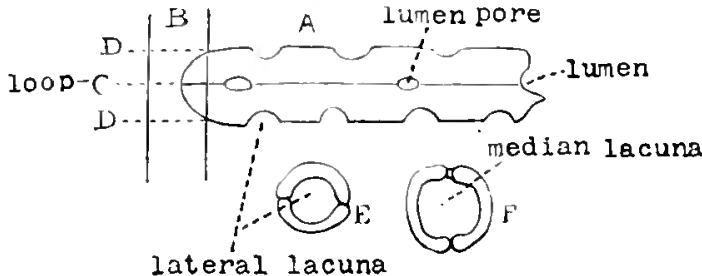

Fic. 80. - Sketch showing structure of a costule. (1ter. Norman, 1903.) aftinities of each genus. becanse it is from the larra alone that these can be demonstrated. The attention of the zoologists is called to this. as well as to the grreat number of other unsolved problems in the science of bryozoologr.

Spines more or less joined together occur in the genus scrupocellaria and in the family Catenicellidae. but the formation of the costules is the enigma of liryozoology.

The accompanying figures give a summary of the principal genera known in the so-ealled family.

\section{Genus MEMBRANIPORELLA Smitt, 1873.}

18i3. Membraniporella Susт, Floridan Bryozoa, Kongl. Svenska Vetenskaps-Akademienc Handlingar, vol. 10, No. 11, p. 10.

Bibliography (anatomicul).-157i. Rarkors, leecherches sur l' embryologic des liryozonires,

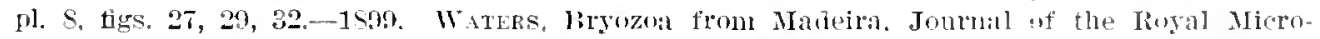
scopical Society. pl. 3, tigs, 18. 19.-1003. C. Nonuss, Notes on the Natural Ilistory of East

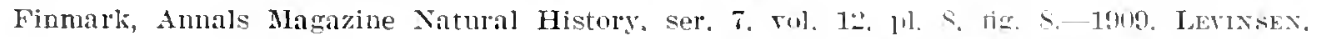
Morphological aud systematic Stulies on the Cheidostomatons Bryozoa. pl. 9. tig. 9.

The costules are provided with a large lumen of greater or hess size. without pores, and are completely joined or are separated by long tits: wambly no lumen

\footnotetext{
${ }^{1}$ The Costulidae, Bulletin de la Soclóté Zoologique de Franct. rul. 11. I'
} 


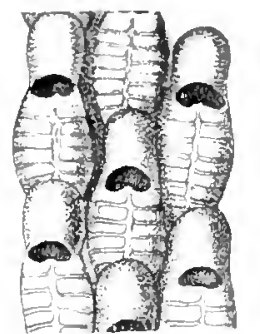

+ Nembraniporelia

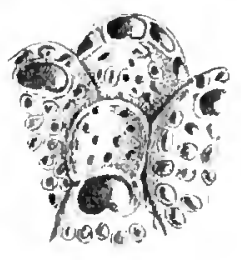

B. Cribrilina

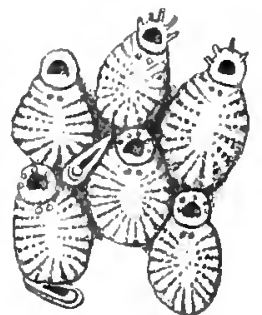

C. Puellina

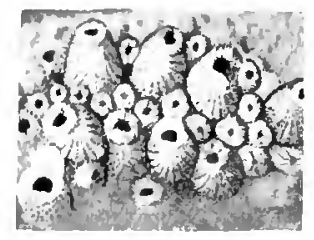

1). Distansescharelia

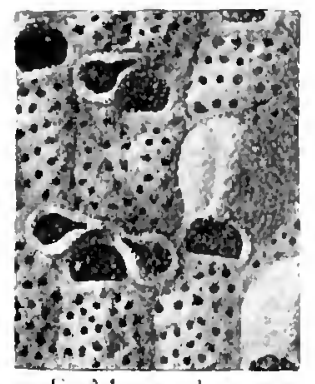

F. Metracolposa

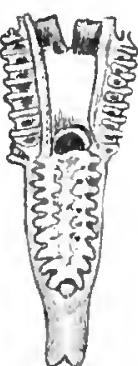

(j. Corhulpora

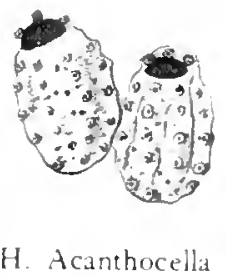

H. Acanthocellia

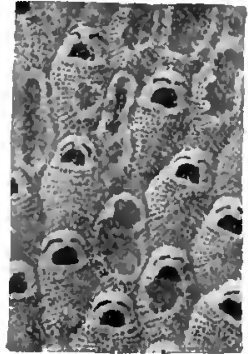

I. Cribrendoecium

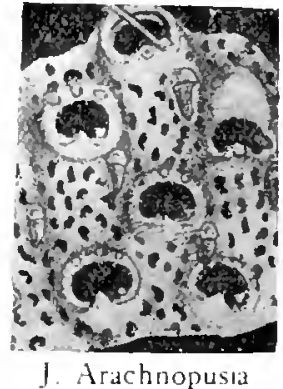

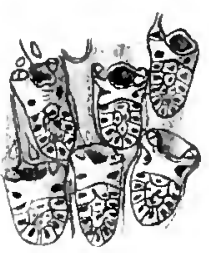

F. Gephyrote:

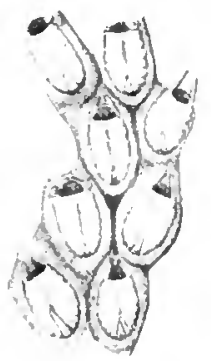

L. Aspidelectra

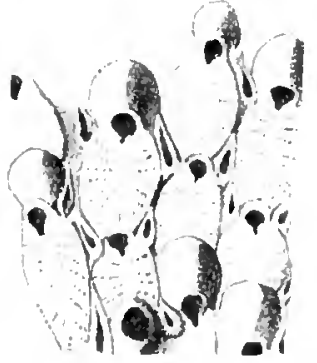

II. Barroingaza

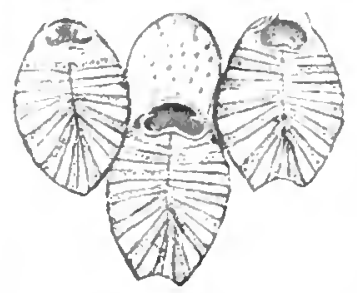

N. Regrinella

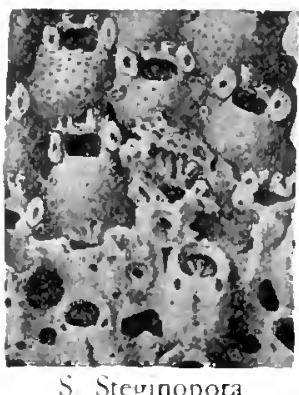

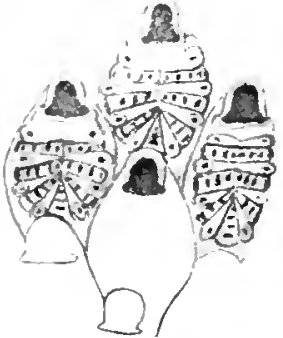

O. I,yrula

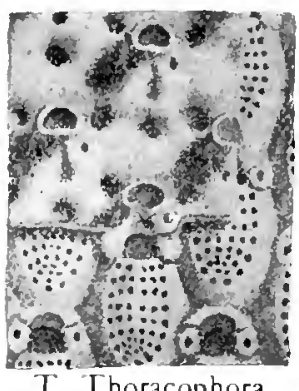

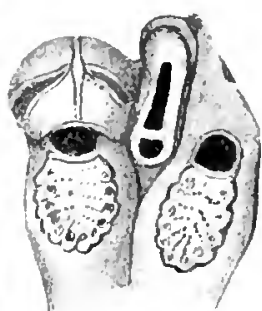

K. Figularia

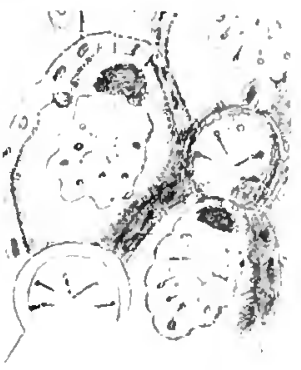

Q. Collarina

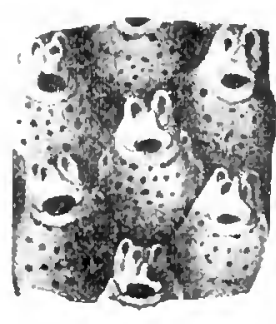

R. Murnopsia

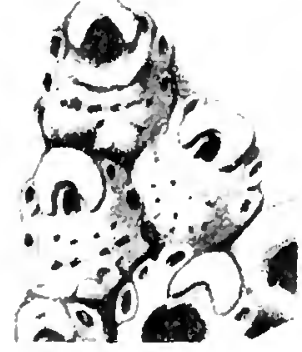

$P$ : Decurtaria

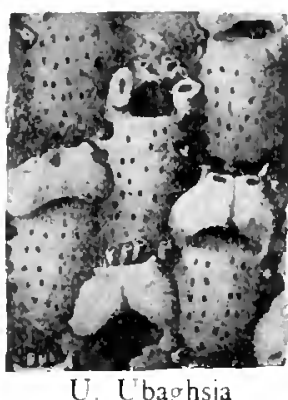

FIG. 81.-Genera of the Costulae. 
FIt. SI.-Generil of the Costulae.

A. Membiniporella nitian Julnston, 1538. Iiecent.

B. Cribrilina punctuta Hassel. IS4I. Iiennt.

C. Pucllina radiata MIOI, 1S03. Iiecent.

D. Distansescharella jacksonica. new species, $\times$ 30. Miclle Jacksonian of Georgia.

E. Gephyrotes nitida-pumetata smitt. ISGS. Recent.

F. Metracolposa grandis, new species, 20 . Midule Jacksonian, Wilmington, Nontlu Carolina.

G. Corbulipora ornata Matuillivily. 1895. Miocene of Australia.

H. Acanthocella tubulifera Hincks, I $\$ 81, \times 25$. IRecent.

I. Cribrendocelum tenuicostulatum ciun aul Bassler, 1917. Middle Jacksonian, Wilmington, North Carolina.

J. Arachnopusia monoceros Ijusk. 1S50, X 25. Recent.

I. Fifularia figlaris Johuston. IS47. $\times 30$. Recent.

L. Aspidelectra melolontha Busk. IS52. X 25. Recent.

M. Barroisina clegantula Fon Hagenow, 15.̄I. Cretaceous of Aachen.

N. Reginclla furcala Hincks, 18S2. Recent.

O. Lyrula hippoercpis Hincks, 1SS_. Recent.

P. Dccuraria cornutu Beissel, 186t. Cretaceous of Aachen.

Q. Collarina cribrosa Heller, 1867. Recent.

R. Murinopsis galeata Beissel, 1861. Cretaceous of Aachen.

S. Stcginopora ocellata Julfien, 1880. Cretaceous of France.

T. Thoracophora horrida D'Orbigny, 1S52. Cretaccous of France.

U. Lbaghsia arcifcra Jullien, 18s6. Cretacenus of France. 
pores. There are two pairs of lateral dietellae and a distal dietella. The ovicell is hyperstomial and is always closed by the operculum. The avicularia are always

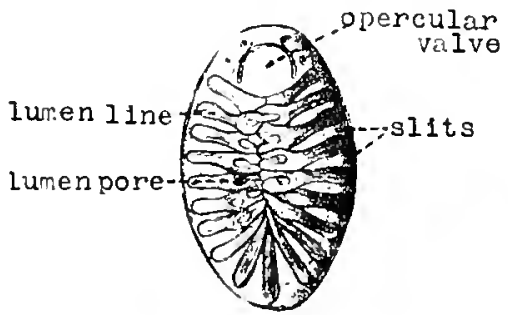

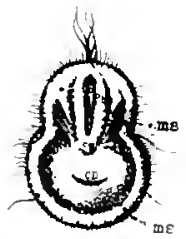

B $\times 75$

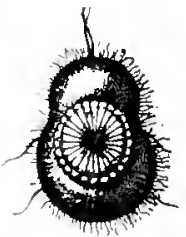

C $\times 7 \%$
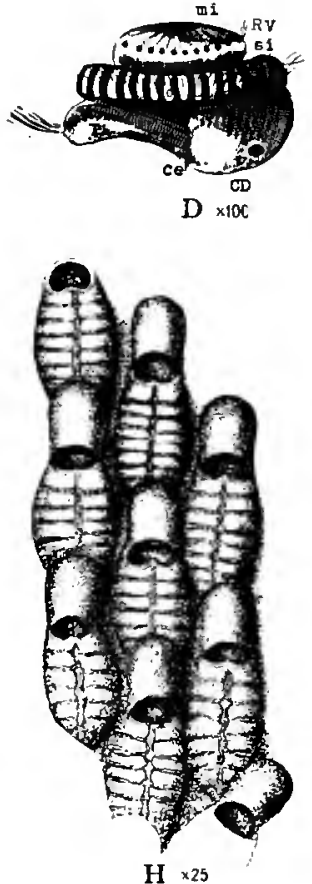

Fig. S2-Genus Membunimulla sintt, 1873.
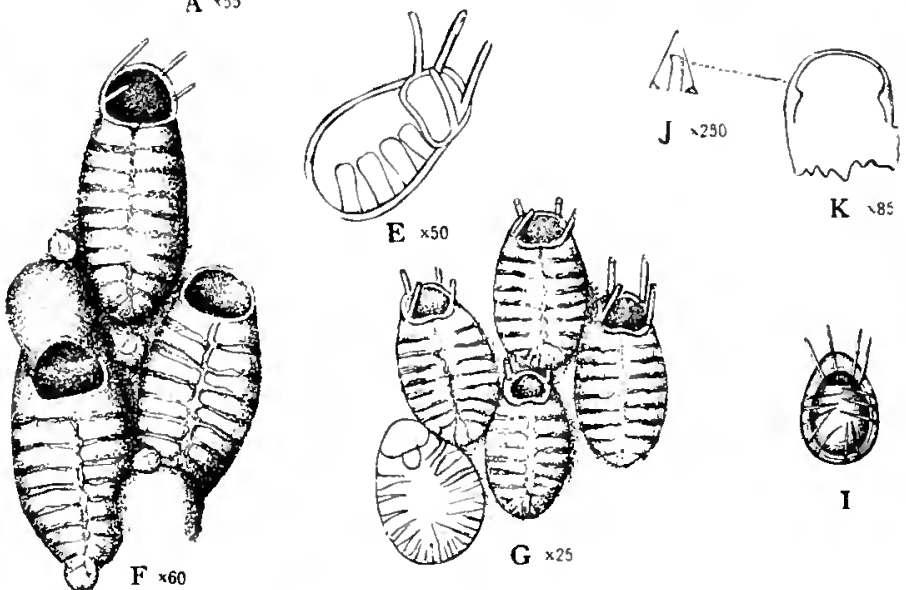

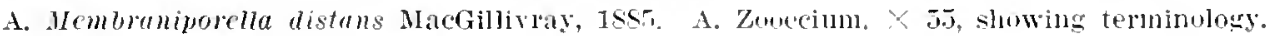
(After Levinsen, 1909.)

B-K. Membraniporella nitidt Johnston, 183s. Ir. Latrat, olal face, $x$ 7万. C. Ahoral vien of larva, $\times 75$. D. Free larva seen in profile. $X 100$. (B-I after Barrois, 1S7T.)

C. 1 ., digestive carity.

", month of the galstrula.

ce, obscure poltion of the cavity of the bouty

included between the two branches of the

stomach.

$l h$, pharynx.

$r$, border of the terminal but.

$m i$, aboral mesolerm.

*i. furrow keparatins the terminal but and the lower rurtion of the aboral face.

$m s$, oral mexoderm (labial).

E. Ontline showing the structure of the cell. $>50$. (After Hincks, 1880.)

F, G, H. Yarious forms of this species. I. Ancestrula. (F-I after Hincks, 18so.) J. IIanlible,

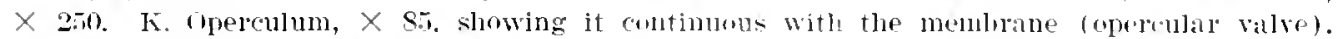
(J. $\mathrm{K}$ after Waters, 1S99.)

dependent. The aperture is closed by an oureular valve. The larva is that of the Escharines (Ascophora).

Crenotype.-Membraniporella (Lepratia) nitide Johnston, 1834.

liange-Cenomanian-Tireent. 
Levinsen believerl that this aenus wat rery close to Callopora Gray, 18ts, and that it could well be classified in the same family. But the larva is that of the Ascophora, although it is true that Barrois: determination of the larra has never been rerified. and that we have no information on the anatomy or larva of species of Callopom. Therefore, while awating more information, we must be content with a classification which, if it is not natural, is at least rery convenient.

The interening slits are often accompanied by lacumae, as in the other genera of this group. The presence of the latter is therefore not an exclusive character if the other important chalacters, absente of lumen pores, and the oricell alwas closed by the operculum, are present.

MEMBRANIPORELLA MODESTA UIrich, 1901.

I'late 1, tigs. $2: 2-25$.

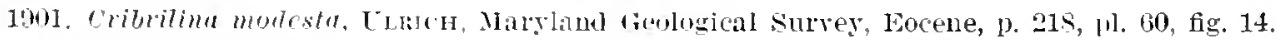

Original description.-." Zoarium forming a delicate parasitic patch upon foreign bodies. Zonecia orate. not very regularly arranged, about $0 . \pm \mathrm{mm}$. in length and $0.25 \mathrm{~mm}$. wide, bordered by a thin rim. Front wall gently convex, usually with six (five to seven) radiating and transverse furrows, or triangular space, incluling fire or six similar pores placed in obseme transverse furrows. Ipertures rounded, prominent. oblique, the posterior edge highest and often thickened in its central portion. Small aricularian cells oceur near or attached to one part or another of the apertural rim of most zonecia, generally one to each, rarely two. Ooecia cucullate, moderately arched."

This is a true Membruniporella; the slits are wide and complete. The lumen is often risible. The ovicell is embedded in the distal zooecia and its orifice is lower than the labial mucro.

Occurrence.-Lowest Eocene (Bryozon bed at base of Aquia formation): Upper Marlboro. Maryland (rame).

$$
\text { Pexiotypes.Cat. No. 63is1, U.S.N.M. }
$$

MEMBRANIPORELLA CRASSULA UIrich, 1901.

$$
\text { Plate 1, tir. } 20 \text {. }
$$

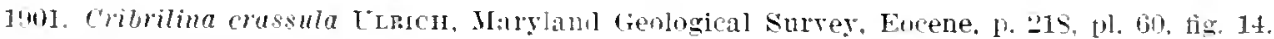

Mriginal deseription.-"Zoarium encrusting. Zooecia oblong, fladrate. or nexilgonal, irregularly arranged. with a heary. strongly elevated margin. clithridate in outline. Front wall with a narrow rased ridge puming down its center, and five or six transverse and radiating rows of minute punetures lying in furrows. Apertures romnled or subovate, the outline often less curved on the posterior side than olsewhere. Aricularian cells small, raised. varimsly distributerl. sometimes one or two and three to a zooccimm; or a cell may have nome at all. ()oecia unknown. Zooecia 0.5 to $0.6 \mathrm{~mm}$. in length. 0.25 to 0.30 11nu. wide: alont seven in 4 mm. measuring lengthwise."

Gecurener.-Lowest Eocene (Brinzonan bed at bats of Aquia formation): Upper Marlboro, Maryland (rare). 


\section{MEMBRANIPORELLA CRASSICOLLIS, new species.}

Plate 4, figs. 24, 25.

Description.-The zoarium is bilamellar and free. The zooecia are little distinct, being confluent by their mural rims. elongated, fusiform; the area is clibriform, contains three to five pairs of transrersal slits, and is deep and flat. The aperture is suborbicular, somewhat transverse. and is surrounded by a thick, prominent peristome. The ovicell is small. salient, convex, smooth; it is always closed by the operculum. There is often a large. simple. round avicularim placed on the mural rim to the right or the left.

$$
\text { Measurements.-A perture }\left\{\begin{array} { l } 
{ h a = 0 . 1 2 \mathrm { mm } . } \\
{ l _ { a } = 0 . 1 5 \mathrm { mm } . }
\end{array} \quad \text { Zooecium } \left\{\begin{array}{l}
l z=0.35 \mathrm{~mm} . \\
L_{z}=0.70 \mathrm{~mm} .
\end{array}\right.\right.
$$

Affmities.-The prominence of its peristome characterizes this species. It differs from Mem7ramiporella plamma in its costules. Which are not flat, and in the zooecial mural rims, which are joined to one another.

From Membraniporella bioculata it may be distinguished by its less numerous lits and by the entire absence of an oral mucro.

Occurrence.-Midwayan: One mile we-t of Fort Gaines. Georgia (rare); Mabelvale, near Little Rock. Arkansas (rare).

Cotypes.-Cat. No. 93806 . T.S.N.M.

MEMBRANIPORELLA PLANULA, new species.

Plate 5. figs. $8-10$.

Description.-The zoarium is free and bilamellax. The zooecia are distinct, separated by a furlow, elongated, fu-iform. bordered by a thin mural rim; the cribriform area is of little depth. former of flat costules. and contains five or six pairs of transverse slits. The apertme is semilmnar. The two small oral avicularia are symmetrically placed on the distal part of the mural rim; the pivot is indicated by two lateral clenticles.

$$
\text { Ieasurements. - Aperture }\left\{\begin{array} { l } 
{ h a = 0 . 1 0 - 0 . 1 2 \mathrm { mm } . } \\
{ 7 a = 0 . 1 2 \mathrm { mm } . }
\end{array} \quad \text { Zooecia } \left\{\begin{array}{l}
T_{.} z=0.85 \mathrm{~mm} . \\
7 z=0.36 \mathrm{~mm} .
\end{array}\right.\right.
$$

Affinties.-The micronetrical measurements are rather variable. Those given ahove correspond to figmre 9 . but in figure 8 the zooceia are smaller. In the interior (fig. 10) the measurements are from 0.9 i to $1.10 \mathrm{~mm}$. for the length and from 0.30 to $0.35 \mathrm{~mm}$. for the wirlth.

This species differs from Membraniporella crassicollis in its mone numerous, flat costules. in the absence of a prominent peristome. and in its zooecia. which are separated by a deep furrow.

Compared with Mcmbraniporella urichi it may be distinguished by its much smaller and less constant oral aricularia ( $L \cdot 0.15 \mathrm{~mm}$. and not $0.25 \mathrm{~mm}$.) and by the much larger slits of the cribriform area $(0.05 \mathrm{~mm}$. and not $0.01 \mathrm{~mm}$.).

Oceurence.-Midwayan (Clayton linestome): Mabelvale, near Iittle Rock, Alkansas (rare); Luverne. Crenslaw Comnty. Alabama (rare).

Cotypes.-Cat. Nos.63808, 63809. T'.N.N.M. 
MEMBRANIPORELLA ULRICHI, new species.

Plate 41, figs. 4, 5.

Description.-The zoarium is free, bilamellar, bush-like. The zooecia are little distinct, joined together by their mural rim, thin, rery elongated, lozengeshaped; the cribriform area is shallow, flat, and contains 10 to 12 very narow transrerse slits; the axis of the suture of the costules is salient. 'The aperture is elongrated, semilunar: its proximal border is provided with a quite salient thorn-like projection. The oricell is large, cmbedded in the distal zooccia, salient, globular, always closed by the operculum, and formed of two calcareons lamellae, of which the outer one is porous. 'The two oral avicularia are large. fusiform. and prominent; the pirot is indicated by two small, lateral tecth.

$$
\text { Measurements. A perture }\left\{\begin{array} { l } 
{ h a = 0 . 1 7 \mathrm { mm } . } \\
{ i a = 0 . 1 5 \mathrm { mm } . }
\end{array} \quad \text { Zooccia } \left\{\begin{array}{l}
L z=1.00 \mathrm{~mm} . \\
l z=0.35-0.40 \mathrm{~mm} .
\end{array}\right.\right.
$$

Affinities.-This fine species is very constant in all its characters. A tangential thin section (fig. 5) show's that the costules are formed of rather large, scattered olocystal elements, regularly placed.

Membraniporella ulrichi differs from Membraniporcllo planula in its mural liuns, which join each other; in its much larger avicularia ( $L v=0.25 \mathrm{~mm}$.) ; in the extreme thinness of the lumen $(0.01 \mathrm{~mm}$.), and in the sharpmess of the proximal border of the aperture.

It can be distinguished from Membraniporelta bioculata by its small and nonbifurcated oral promincuce, by its mnch smaller and more numerous costules, by its larger aricularia $(L v=0.25 \mathrm{~mm}$.) and by its much longer ovicells (hov $0.20 \mathrm{~mm}$. instead of $0.15 \mathrm{~mm}$.).

We dedicate this species to Dr. Edward O. Ulrich, whose brilliant work on the Paleozoic bryozoa has a world-wide reputation, and who was among the first to take up the serions study of the American Tertiary forms.

Occurrence.-Middle Jacksonian: near Lenuds Ferry. Sonth Carolina (abum(ant) ; Eutaw Springs, South Carolina (abundant); Wilmington. North Carolina (xare).

Cotypes.-Cat. No. 61016, U.S.N.M.

MEMBRANIPORELLA BIOCULATA, new species.

Plate 41, figs. 11-13.

Description.-The zoarium incrists bryozoa. The zooecia are distinct, separated by a furrow, elongate, elliptical; the cribriform area is rery convex, containing five or six pairs of radial slits. The costules have a lumen pore at the loop. 'The aperture is semilunar: the proximal edge has a large bifureated mucro. the branches of which frequently rejoin the oral avicularia. thus forming a new orifice above the aperture; distal spines are sometimes present. The ovicell is prominent, globular, smooth, little sunken in the distal zooceia, always clocer by the opereulum. The two oral avicularia are salient, oval, the point at the top: the pirot is calcareous or simply indicated by two lateral denticles. 
Measurements.-Aperture $\left\{\begin{array}{l}h a=0.10 \mathrm{~mm} . \\ 7 a=0.15 \mathrm{~mm} .\end{array} \quad\right.$ Zooecia $\left\{\begin{array}{l}L_{2}=0.60 \mathrm{~mm} . \\ l_{z}=0.35 \mathrm{~mm} .\end{array}\right.$

Affinities.-The development of the oral mnero is remarkable; it is well illustrated in fignre 12. The two nearly vertical arches situated under the two bifurcations of the mucro circumscrilue two large pores (or eycs), which may be distinguished clearly from the underlying radial lumen on the cribriform area. In the Cretaceous there are other spinose growths still more remarkable, as in the genus Steginopora D'Orbigny. 1852.

The secondary orjfice. which results from this development of the oral mucro. is smaller and more irregular than the primary one or apertura, which is only slightly risible.

The oral spines are rarely seen; when they exist, they are four in number and are never borne by zooecia with avicularia.

This species differs from Membreniporella ulvichi in its incrusting zoarium. its very convex cribriform area. its smaller oral aricularia $(L, 0.20 \mathrm{~mm}$. and not $0.25 \mathrm{~mm}$.), and in its smaller ovicell.

We have seen only three specimens of this remarkable species, so we are unable to make a more detailed study.

Occurrence.-Midkle .Jacksonian: near Lenuds Ferry, South Carolina (rare). Cotypes.-Cat. No. 6t021, U.S.N.M.

\section{MEMBRANIPORELLA COMPRESSA, new species.}

Plate 41 , fig. 6-S.

Description.-The zonlum is free. cylindrical, or compressed. The zooecia are distinct, elongatel. elliptical, separated by a furrow, and surrounded by a more or less developerl armnocyst. The frontal is quite convex; the costules are delicate without lumen pores, largely separated by a long initial slit following two lacunae. The ovicell is unknown. The aperture is transverse, semi-elliptical, and provided with a slightly salient and very thin border.

$$
\text { Measures.-I perture }\left\{\begin{array} { l } 
{ h a = 0 . 0 9 \mathrm { mm } . } \\
{ l a = 0 . 1 2 \mathrm { mm } . }
\end{array} \quad \text { Zooecia } \left\{\begin{array}{l}
L z=0.50 \mathrm{~mm} . \\
l z=0.30 \mathrm{~mm} .
\end{array}\right.\right.
$$

Affinities.-Norman " has shown that in the rariety intermedia of Membraniporella nitidu, the type of the cenus: "the rarliating ribs coalesce with each other by crossbars so as to form roundish openings, lateral lacmes:" and that, "in fact. this Madeiran form in its structure is in all respects a true rribrilina."

We have noted also that Membrumomella subagussizi with reference to the separating slits of the zooecia may or may not have such lacunae.

Here the lacumac are constant. But we can not classify the species in Cribritina because of the initial slit ant the absence of lumen pores, nor in Puellina becanse of the areat size of the lacmus and of the initial slit. Provisionally at least. the species may be retained in $M$ cmtraniporella Smitt.

\footnotetext{
190n. Norman On the Polyzon of Madeira and neighborina islands, Journal Linnean Society, vol, 34. p. 288 , pl. 36 , fig. 7 .
} 
The grmmocyst which surrounds the cribriform area is very inconstant and is developed chiefly in the lower part of the zooeria.

This speries difters from .1/ mbruniporetle subugassizi in its zoarial dimensions, its much smaller micrometric measurements, and its numerous frontal lacunae.

Oceurence-Middle Jacksonian: Fighteen miles west of Wrightsville. Johnsoln County, (Georgia (rare); one-lalf mile west of (reorgia Kaolin Company"s Wine, Twiggs County. Grorgial (rare).

$$
\text { Cotypes-Cat. Nos. 64017. filo18. U.S.X.M. }
$$

\section{MEMBRANIPOIRLLA MONILIFERA, new speeies.}

I'lite 41, ligs. !, 10.

Deseription.-The zoarium incrusts shells. The zooecia are distinct, separated by a furrow, clongated, elliptical, wide; the frontal is convex; the costules are radially arranged, mited near the zoarial axis. separated by long, rather wide slits, and oriamenterl witl two tuberesities of which one is a talon. The aperture in semi-elliptionl and is limited by a thin peristome which bears at least two. lalree. hollow spines ancl. in front, by a calcareons thickening in the form of a $T$. The oricell is closed by the operenlum. There is a restibular arele and four spines. of which the fir-t pair is the larger.

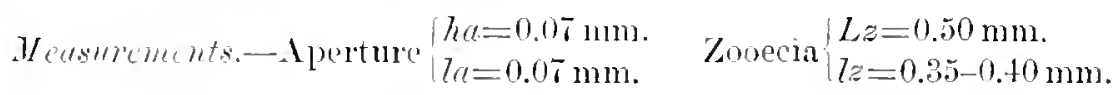

Turitions.-This species is characterized by its two costular tuberosities: one is at the aperture itself and the other is close to the zonecial axis. The general effect of these tuherosities is that of a double necleluec around the zooecia.

The part formed by the nuion of the costules forms in front of the zonceia a sort of shield of variable size.

Very often the costular tulerosities do not exist; the zooecia then lave the a-pect of a rer'y simple $\mathbf{M}$ cmbraniporctla.

There are no lumen pores.

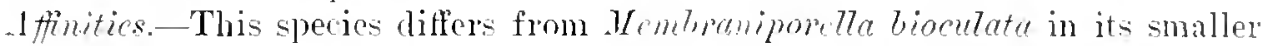
micrometric dimensions, the absence of oral aricularia, and the presene of tulbernsities on the enstules. In its incrusting zoarim it lifler's from all the other speries of $1 Y$ embrenipor 77 studied.

Oceureme-Widdle Jacksonian: near Lemuls Ferry, Sonth Carolina (rane): Eutaw Springs. South Carolinal (rare).

Cotyper-Cit. Xos. 64019. 61020, U.S.X.M.

MEMIRANIPORELLA (?) SUlBagasSIzI, new species.

I'late $s 4$, ligs. S- $-1:$.

Lescepition.-The zoarium is free eylindrical. formed of tive or six longitminal

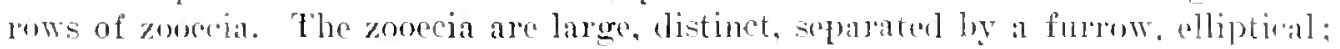
the frontal is rery convex and formed by a cribrifum allea surromded by a smootl gymnocyst the cribriform area contains 10 to 1.2 transwersal and ralial

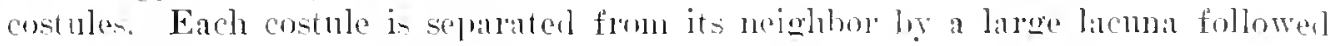

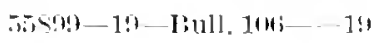


by a smaller circular lacuma. The aperture is suborbicular with a concave lower lip. The oricell is enomous, $\mathbf{g}$ lobular, very prominent, pierced with small pores widely spaced. The ovicelled zooccia bear at the right and left of the aperture two large, symmetrical lamellae formine a sort of peristomic. The operculum never closes the oricell. On each zooecium there are one or two large, oval aricularia rery prominent and triangular, with a pirot. the point turned toward the aperture.

$$
\text { Weasurements.-Aperture }\left\{\begin{array} { l } 
{ h a = 0 . 2 9 \mathrm { mm } . } \\
{ l _ { a = 0 . 2 5 \mathrm { mm } . } }
\end{array} \quad \text { Zooecia } \left\{\begin{array}{l}
I_{z}=1.00-1.10 \mathrm{~mm} . \\
7 z=0.45 \mathrm{~mm} .
\end{array}\right.\right.
$$

Tariations.-The more or less complete arch which is formed above the aperture of the ovicelled zooecia is evidently designed to facilitate the passage of the egas and is a psendo peristomie. The small lacma is not always present (figs. 11. 12); the aspect is then that of a true Membraniporclla. On the old zoaria (fig. 11) the grmmocyst is thickened and shows a mural rim around the cribriform area.

In this species the lateral clefts are the intercostal spaces. In figure 12 notably the lumen is clearly visible in the costules and in the broken zooecia. The costules appear to be hollow.

We note again that the operculum does not close the ovicell as in the other species of the genus.

In the future it may be necessary to classify this species in the genus Corbulipora Mackillivar, 1595, when we are better acquainted with the structure of that genus.

Affnitics.-This species is rely close to Membraniporella agassizi Smitt, 1873,1 which lives to-day in the Gulf of Mexico and in the waters off Florida. It is distinguished by the absence of a transverse rib on the ovicell, by the different form of the aricularia and the larger micrometric dimensions ( $l e=0.25 \mathrm{~mm}$. and not $0.16 \mathrm{~mm}$.).

The cremus corbutipora is a nember of the Cribrilinidae with a rincular zoarium, but quadriserial. In ont species the zooecia are in six series and appear to differ otherwise gencrically.

It is moreover quite remakable to find in the Eocene species almost identical with those now living off the coast of Florida. This is proof of the calm tectonic conditions in this region during all the Tertiary period.

Occurrence.-Ticksburgian ("Chimney rock" of Marianna limestone): One mile north of Monroeville, Alabama (common).

totype-Cat. No. 6toss. T.S.T.M.

\section{Genus CRIBRILINA Gray, 1848.}

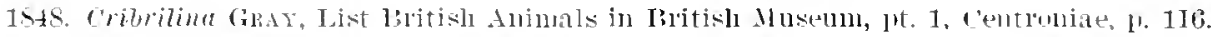
Bibliograph!l (Anatomical).--1894. Levissex, Zoologica danien, p. 61, pl. 5, tigs. 7-20.--1900.

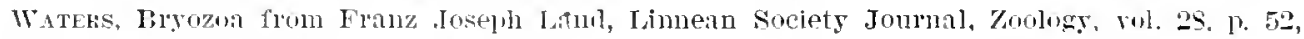
H. S. fiss. 21. 22.-1909. Norus, Nutes on the Natural History of East Finmark. Annals Iagrazine A'atural History, ser. 7 , rol. 12, p. 93, pl. S, fig. 10.-1909, Levixsex, IIor!lhological and Systematic Stmbies on the rheilostonatous Bryozoa, p. 15S, p], 9. fis. 11.

${ }^{1} 1575$, Smitt, Floridan Brpozoa, Longl. Srenska Vetenskaps-Akadeniens llandlingar, rul. 10, p. 11, pl. 5. figs. 103-106. 
The zoocium is closed by an operenlar valve. The costules are generally closely consolidated together: the lacumae are large and few in number; the limen $\mathrm{i}$ - more or less distinct. The dietellae are irregular in number (at least three lateral pairs). The ovicell is hyperstomial and is always closed by the opereulum. The orifice often has a mucro. The aricularia are dependent.

Genotype.-Cribritina punctata riray. 1848.

Range.-Midwayan-Recent.
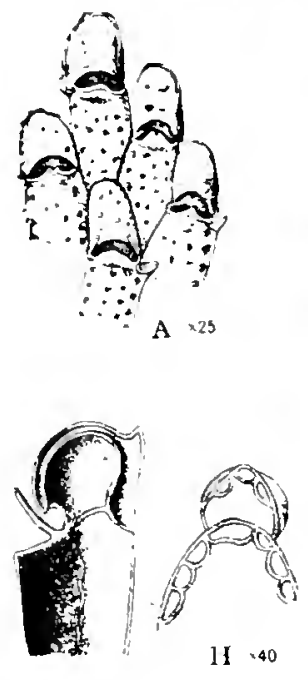

G. 55
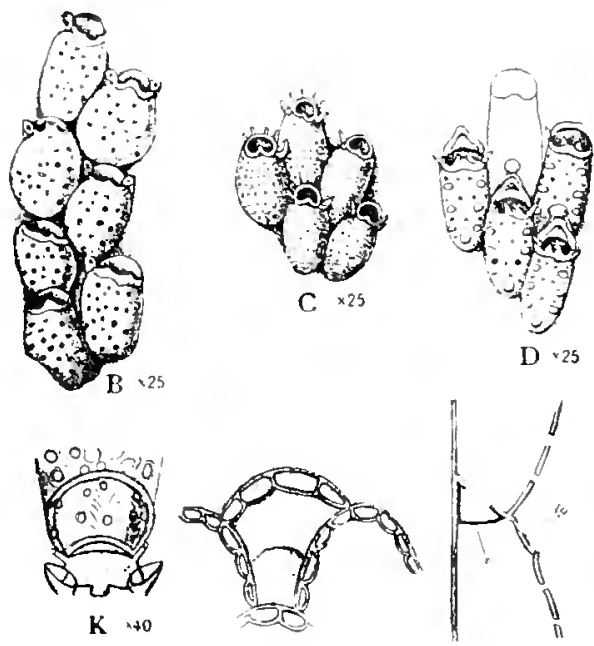

$1 \times 40$

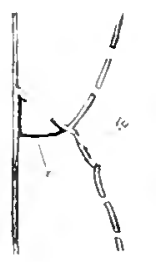

L $\ 35$

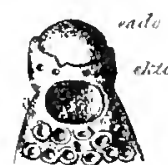

E 140
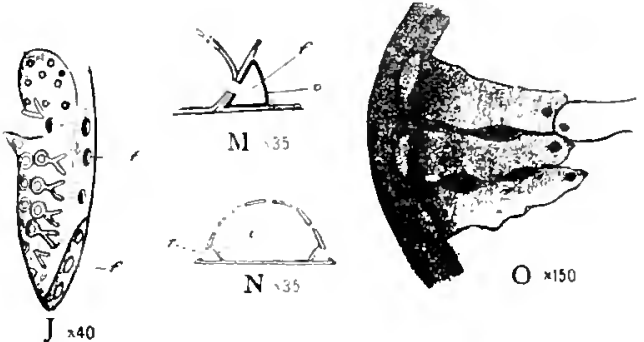

Fig. S:- Genus cribritina Gray, 1818.

A-X. Cribrilina punctata Hassal. 1541. A-D. Various forms of the species, $X 25$. (After

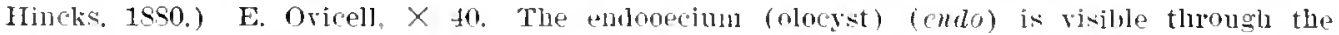
hroken ectooecium cho. F. Distellite ape seen on the three mirginal zooecia, of which the central alnormal one has no aperture, $X$ 5. G. Gagittal section through a zooecium with ovicell. T'he wricell is inclosed in a kenozonecium travity,. from the basal surface. The dietellae of the zroechun and kenozooecinm are seen, $X$ th). I. lietellae from the basal surface, $X 40$. (E-I after Levinsen, 1909.) J. Zonecium seen in protile,

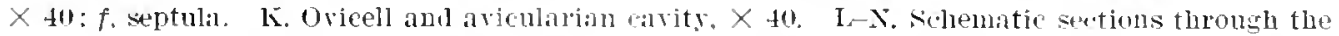

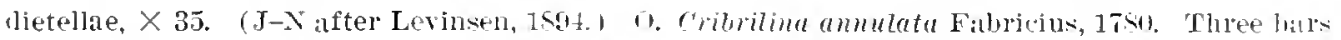
of the zooecium of a rery simple form. $x$ 1.50. (After Noman. 19m3.)

CRIBRILINA VERRUCOSA, new species.

Plate כ. fics. 12-14.

Deseription.-The zoarium incrusts other brtozoa. The zooedia are distinct, separated by a deep furrow. elongater. elliptical, crenulated on their borders. The cribriform area is convex and former of large. radial rostules; the lacunae are rery large, prominent, irregularly placed at the rate of 1 to 2 to each pair. of arjacent costules. The aperture i- enuilunal and is at the butom of a rery 
small restibule. The two small oral aricularia are peristomial, simple, and withont pirot.

$$
\text { Weasurements. I perture }\left\{\begin{array} { l } 
{ \text { ha } = 0 . 1 0 \mathrm { m } 1 1 1 . } \\
{ \text { la } a = 0 . 1 0 - 0 . 1 1 \mathrm { mm } . }
\end{array} \quad \text { Zooecia } \left\{\begin{array}{l}
7 z=0.40-0.45 \mathrm{~mm} . \\
7 z=0.30-0.35 \mathrm{~mm} .
\end{array}\right.\right.
$$

Tariations. - The general effect of the lacume gives to the zooceia a very characteristic uarty aspect. These small ormaments are very fracile: they are much attenuated by fossilization. which gives the species such a very variable aspect. It is likewise often diffienlt to perceive the costular radiations.

On the proximal lip of the aperture there $\mathrm{i}$ - often a convex sinuosity or a kind of indistinet muero.

The lumen line is rarely visible (fig. $1+$ ).

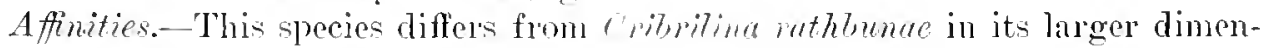
sions, its more prominent lacume, and its mere regular zoarinl maroins.

Occumanec- Midwayan (Clayton Jime-tone): Mabelvale, near Little Rock, Alkansas: Luverne. Crenshaw Comnty. Alabima (common): 1 mile west of Fort Gaines. Georgia (common); 13rundige. Nlabamal (common).

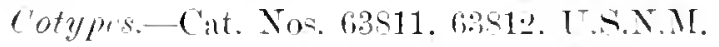

CRIBRILINA LATICOSTLLATA, new species.

\section{Plate $\bar{x}$. fix. 11 .}

Description. - The zoarium incrusts shells. The zooecia are distinct, separated by a deep furrow and are somewhat elongated and elliptical; the frontal is quite

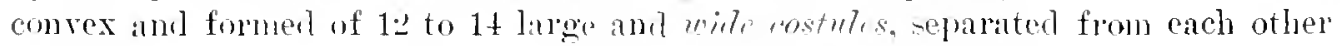
by at lacunae: and mited at their extremities. The apertura is semicircular. hordered by a salient peristone bearing two spine- on the distal part and a salient and thick muces on the proximal part. The ovioel is hypersomial placed on the distal zouccium, it is globular. salient and never clused by the operenlum. Above cach zooecium thore is a small, simple, orticular or elliptical aricularimn.

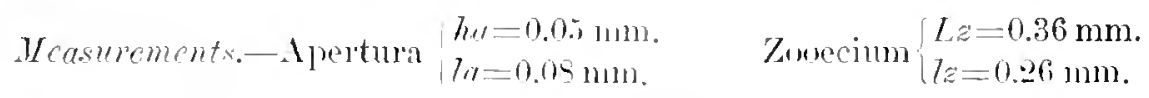

Tariations.--This species is quite fommled. which causes the lacunae to disalpear: The muero is quite alient and is lated in front of the orifice of the wicell; it manifestly protects the pasage of thr egers. The spines are extremely fragile and have been observed only in two adso.

The costules are intiuately joined on the median axis. We have never ol)served the proses of the papillate. For thens reasons we class this species provisionally in f'rituitina, but we believe that the opereulum does not elose the avicell. It is evident that the latter character is always problematic on the fossils.

Oremerener.-Midwayan (Clayton lime-tome): Brmolidge, llabama (rare). Hototype-cint. Yo.63810, L.N.X.M. 
CRIRRILINA RATHBLNAE, new species.

Plate 5. figs. 15-17.

Ineseription.-The zoarim inerut- other bryozoa. The zoneria are elongated. distinct, elliptical; the cribriform area is somewhat convex and formed of trinsrerse costules: the lacunae are large and prominent, 1 to 2 to each pair of aljacent costules. The aperture is semilunar. tram-rerse. bordered ly a thin, smooth. improminent peristome. The two small oral arjeularia are simple. peristomial, and without pivot.

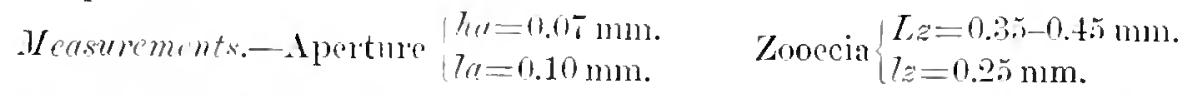

Jariations and affinitics.-The lacunate are variable in number on each zonerium: their prominence is much lessened ly fo-silization.

This species differs from ritwitinu errmensa in its smaller zouccial dimensions and its less convex eribriform area.

This interesting species is named in honor of Miss Mary r. Rathlum, of the United States National Musenu, as a slight appreciation of her valuable work upon marine invertebrates.

Occurrence.-Midwayan: Mabelvale. near Little Rock, Arkansas (very latre). Cotypes.-Cat. No. 63813, T.S.X.M.

\section{Genus PLELliNA Jullien, 1886.}

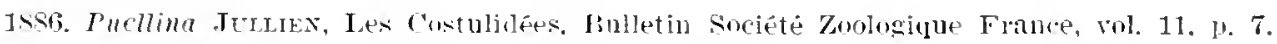
Bibliography (Anatomical).-1002. HARMer. On the Molphologs of the (heilostomital. Quar-

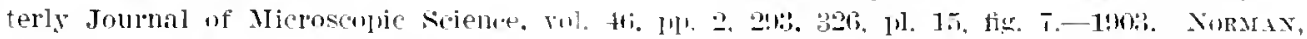
Notes on the Natural History of Fast Fimnark. Annals Magazine Natura! History. Ser. 7 ,

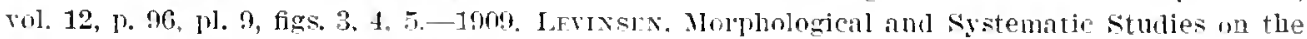
Cheilostomatous Pryozoa, 1) 159, 11. !1. fig. 12.

The lacunae between the costules are very small; the lumen, more or less risible, bears many pores, of which the first in the shield is larger than the others. The aperture is semicircular. The operenlum is simple and entirely chitinous. The oricell is hyperstomial and always closed lw the opereulum. Between the costular shields are papillae. The dietellae number at least three lateral pairs.

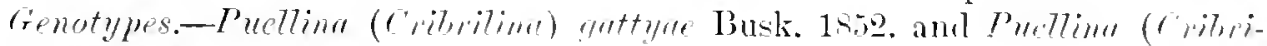
Tinc.) radiuta Moll, 1503.

Range.-Senonian-Recent.

The papillac are short, tentaculifom evaginations. The first pair, near the aperture, is always the larger by far. They have been consintered as true avienluria (.Jullien) as sensorial vibracula (Mmitt) or as simple appendages correspondine to the spines of the ancestrulia (IInmer'). Their place is almo-t invisible on the

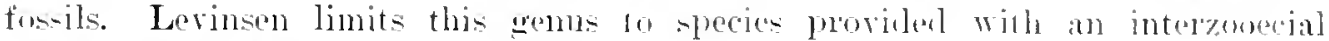

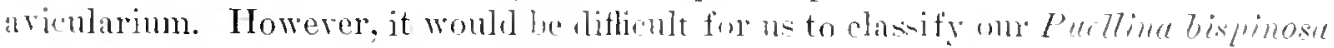
ant Pretlime simulator in another gemse. 


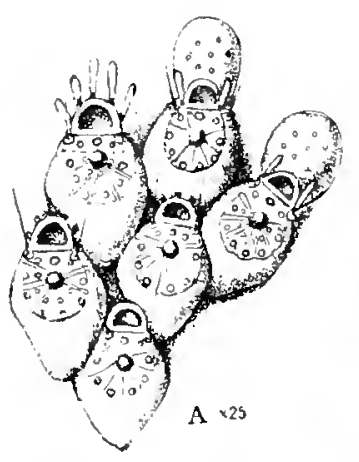

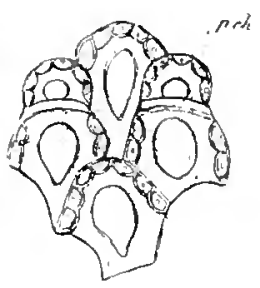

B $\times 40$

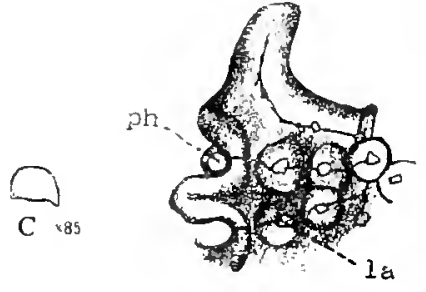

D

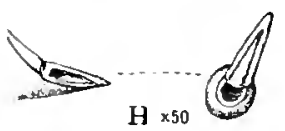

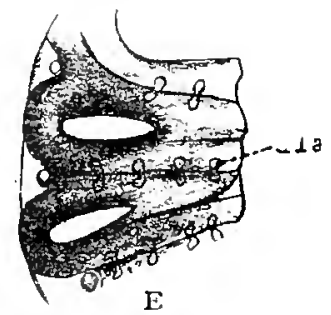
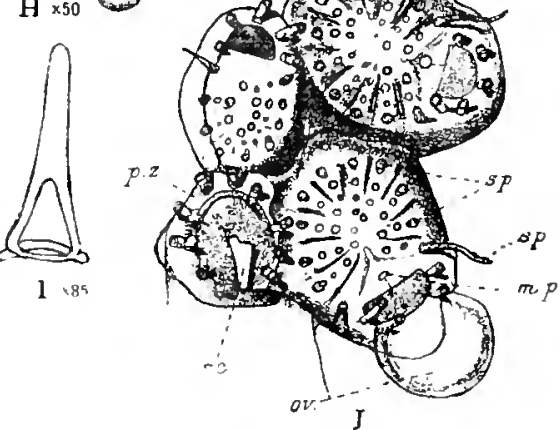

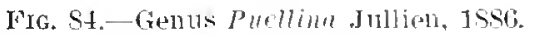

A-E. I'ucllina gattyae Busk, 1552. A. \%urecia anu uvicells. X 26. (Aftel Hincks, 1880.) P. Zouecia from the basal surface. The diefellaw purbl suldound the zonecia and their ovicells,

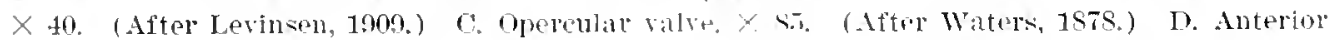
nortion of a zoosium of the orlinaly form. E. Variety. with interesting duplieated hateral

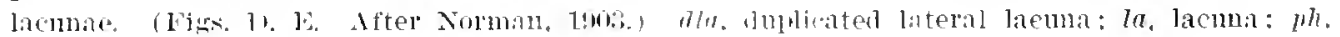
papillaf holes.

F. Puclima inmominata Couch, 1S44. Sk+th showing lerminology. Three costules of a zomecoum showing the lateral papillas and a small muming ontside the arch of the costule, into th" hody of the polyzoon. which a papilla his ononjed. I. Ifter Nolmitn, 1903.)

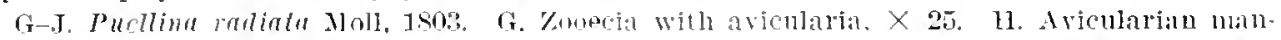

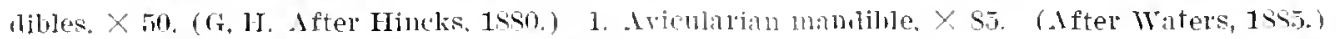

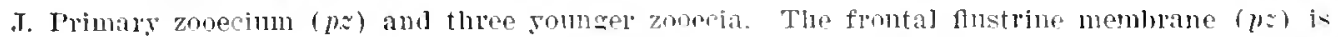

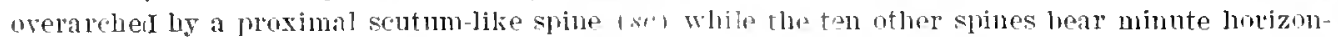
til ealcareous lobes which projert from thw innel shlw. The oral spiues of the zonecium hear

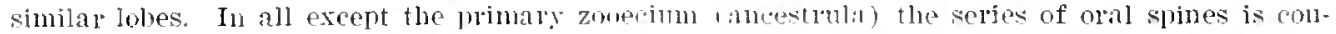

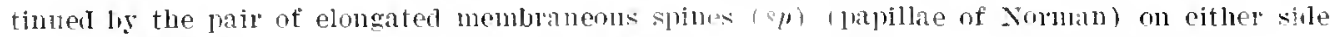

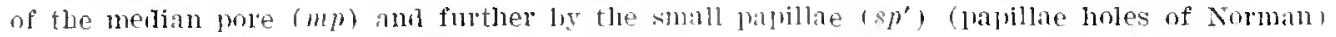
which corresponl with the marginal spines of the primaly zomedum. The sries of pores are in

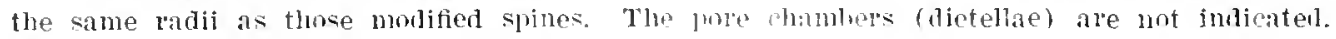
ifter liamer, 19m. ? 
PUELLINA, species undetermined.

Plate 5. fig. '21.

We have found a single specimen of a small Puellina in the Midwayan at Luverne, Alabama, which is figured on plate 5. We believe it is Puellina radiuta Moll, 1803, or one of its varieties, but unfortunately the specimen has no oricell and the avicularia are incomplete. It is preferable to wait for good material before making a definite identification.

Ocourrence.-Midwayan (Clayton limestone): Luverne, Crenshaw County, Alabama.

\section{PUEllina Radiata Moll, 1803.}

Plate 41 , figs, $14-1$ S.

Bibliography (:oological).

1503. Escharu mdiata MoLl, Die Seerinde, 1). 63. pl. 4. fig. 7.

1589. Cribritina radiata JeLLY, A synonynic catalogne. p. lis (I3ibljugraphy general).

1909. Cribritina rarliata Waters, lieport on the Bryozon of the sulinese lied Sea, Linnein Societs Journal, rol. 31, p. 143.

1909. Cribilinu ralinta Nokms, On the Polszon of Mateira and neighboring islands, Journal

Limean Society, rol. 30, p. 291 (zonlogical bibliography).

Bibliography (paleontologic refcrences uith illustrations).

1S47. Cellcpora scripta Reuss, Die fussilen Polsparien des Wiener Tertierbeckens, Haidingers" naturwissenschaftliche dbhandlungen, rol. 2. p. S2, pl. 9, fig. 2S.

1547. Cellepora mequcephala Iieuss, Die fossilen Folyprien des Wiener Tertierbeckens, Hai.I. inger's naturwissenschaftliche Abhandlungen, vol. 2, p. $\$ 3, \mathrm{pl} . \mathbf{1 0}$, fig. 5 .

1552. Scmieseharipora pulehclla D'Ormignr, Paleontologie francaise, Terrains crétacés, p. 450.

1564. Lepratia seripta Reuss, Zur Famma der dentschen Oberoligicins, Sitzungsbelichte der k. Akrdemie del Wissenschaften, rol. 50. 1. Pit1, (2S), pl. 15, fig. 3.

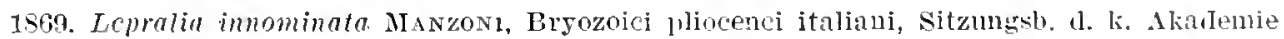
der Wissenschatten, ser. 1, rol. 59, [. 8. 1)T. 2. fig. 13.

1574. Icpralia seripta et rurceosta Reuss, Die fossilien Broyozoen des Usterleichisch-ungariseben Miocins, 1; Denliscriften der k. Akaidemie der Wissenseluaften, vol. 33, 1. 25. 11. 1, fig. $7:$ pl. 6, fig. 1.

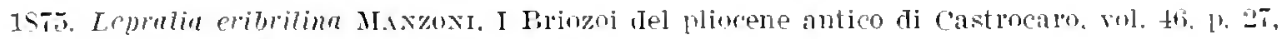
pl. 3, fig. 40 .

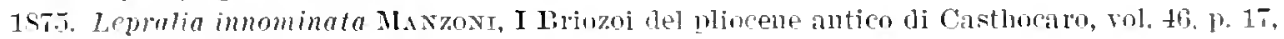
17. Т, fig. S5.

1855. Lepralia seriptn Manzoni, I Briozoi del pliocone antico di Castrocalo, vol, 4b, 1) 19, 13. 11. fig. 25.

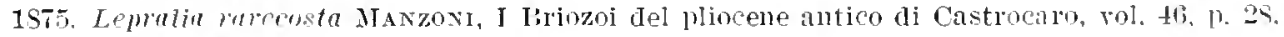
1). 13 , fig. 70 .

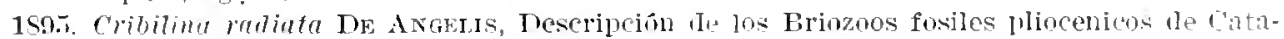
luก̃a, 1. 11, pl. B, fig. 10 .

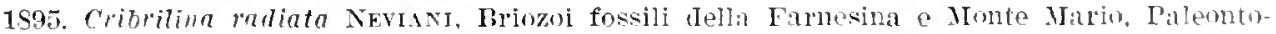
graphia italica, vol. 1. 1) 103 ( 27 ). 1) . 5. fig. 20 (not 21).

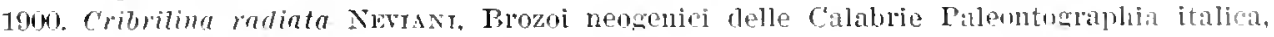
vol. 6, 1. 170 (56). Italian hibliography".

1591. Cribrilina maliata Waters, North Italian Frrozua, Quarterly Jomlual Genlogical sonciety, rol. 47, 1), 16.

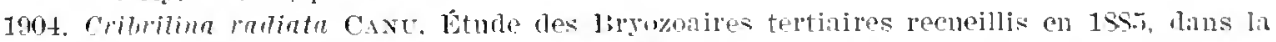

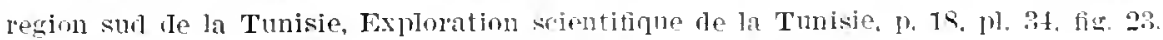

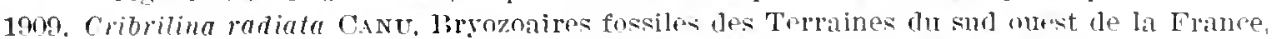

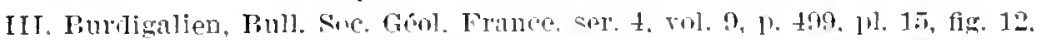

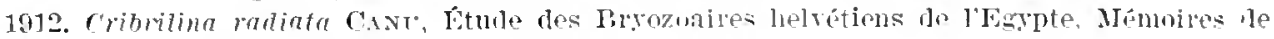
l'Institut Egrptien, rol. 6. p. 206. ji. 10. fig. 1\%. 
The biblioglaphy of this species is somerhat confused. Cribritina innominata Conch. 184t, is a distinct species. as was established by Neviani in 1900 and by Norman in 1909. TVe have done away with the old synonyms.

According to Neviani, Cribilina mareosta Reuss. 1874. is a good variety, recogpizahle by its very small dimensions.

There is one variety which has a frontal ascopore, namely. Lemralia innominata Bu-k. 1859. or Lepratia seripta Manzoni, 1870, which we have not included in the preceding bibliography. However, according to Nolman, it is subject to great variation. and. awaiting agreement among the zoologists, it has not been made a distinct variety.

To these varietics we add two others, anaticula and carolinensis.

The characteristics of the typical form of the species are: First. the apertare is semilunar and surromded by fom or fire large spines. Second. the ovicell is kecled in front and always closed by the opereulum. Third. the rery long, interzooecial a vicularium is terminated ly a very thin little canal.

The number of costules. in the recent specimens, is generally from 16 to 18 . In the fossil forms their number is from 10 to 12 . It is impossible to establish a valiety non this difference. for the costular variations in this species are extraordinary.

Certain specimens have very prominent custules; on others they are scarcely visible.

The ancestrula is a zooecium of the Membranipore type, surmunded with spines (figs. 16. 1T).

The micrometric measurements are nseless. for they are too variable.

Occumenee-Middle Jacksonian: Wilmington, North Carolina (common); near Lenuls Ferry. South Carolina (common): Eutaw Springs. South Carolina (common) ; 3.1 miles south of Perry. Creorgia (common); 18 miles west of Wrightsville. Jolunson Comty. Georeria (common).

Tpper Jacksumian (Ocala limentone) : Chipola River, east of Mariama, Jackson County, Florida (common).

Vicksburgian (Mariama limestone) : One mile north of Monjroville. Alalnuma (common); Salt Mountain. 5 miles sontl of Jackson. Alabama (rare) : 3 miles southeast of Vosbure, .Tasper Comty. Mississippi.

Geologieal distribution.-In Eurne I'nellina maliata is found in all the formations since the Lutetian.

Ilubitat.-The living form in comopolitan in the two hemispheres. It has been found in the Itlantic at Madeira. Florida. France, and the British Isles; in the Indian Ocean at Zanzibar: in the Parific at the Philippine Islands, Anstralia, and Tahiti: and in the Mediterranean. France. Algeria, Tumis. Italy, and the Adriatic.

Specimens have been dredged to a depth of 150 meters, but they live habitually near the slores in the shallower waters. Its ocemrence in the Priabonian of the Vicentin and in the waters of Madeira renders its presence inevitable in the Ameri(an Upper Eocene.

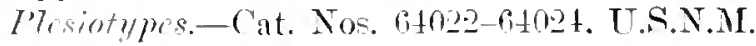


PUEllixa RAdita ANATiCUla, new variety.

Plite 41, fig. 19.

This variety is characterized by the little canal of the avicularium. which is enlarged like the beak of a duck. All the other characters are iclentical with the tripe form.

Occurvenee.-Middle Jakknnian: Serenteen miles northeant of Hawlinsrille, Georgia (very rare).

Upper Tacksonian (Ocala limestone) : Seren miles above Bainbridge, Georgia (very rare): Bainbridge, Georgia (very rare); 4 miles below Painbridge, Georgia (very rare).

Ticksburgian (Byram marl) : Brram. Mississippi (rather rare).

IIolotype-Cat. No. 64025. U.S.N.M.

PUEllina RAdita CARolinensis Gabb and Horn, 1862.

Plate 41. fig. 20.

1562. Reptcscharella curulinensis GaBB aud Horn, Monograph secondary and Tertiary I'olyzoa of North Anerica, Jumnal Academy Natural Science. Ehhladelphia, vol. 万. p. 136 , pl. 19, fig. 15.

This variety is characterized by its smooth peristome. without tuberosities, and by the small distal canal of the avicularium, which is larger than in the type.

In reality the spines have not disappeared; on the perfect specimens they are still risible: but they nerer luve the size and the importance of those which decorate the type. The zooecia are a little larger and have 16 costules.

Oceurrence.-Middle Jacksonian: Near Lenuds Ferry. South Carolina (rare).

Upper Jacksonian (Ocala limestone) : West bank of Sepulga River, Escambia Comnty, Alabana (lane).

Vicksburgian (Mariama limestone): One mile north of Momroeville. Alabama (l'ale).

Vicksburgian (Red Blutf clay) : Seven and one-half miles couthwest of Bladeu Springs, Alabama (rare).

Plesiotype.Cat. No. 6t026, U.S.N.MI.

PUELliNa BISPINOSA, new species.

Plate 41, tig. 22.

Deseription.-The zoalium incrusts shells (chiefly (1strea ichslumpensis) and other bryozoa. The zooecia are elongated, distinct, separated ly a furrow, elliptical; the frontal is convex and formed of from 16 to 18 thin costules sepranterl by very small lacumae and traversed by a line of lumen pores. The aperture is formed of a semilunar anterior and of a very convex posterior portion separater by two very small cardelles: the posterior portion is hidden by a small, prominent mucro. The ovicell is globular, salient, always closed by the uperculum. On each side of the aperture there are two small triangular aviculinia prointed, longitudinal. hetween which occur two large spines. 
Affinities.-This variety differ's from Puellina calamorpha Reuss, 1866, in that the avicularia are longitudinally disposed, the point toward the top. instead of being oblique and even transverse, in the two large oral spines instead of five small ones and especially in its elongated (not transrerse) and much larger ovicell.

The micrometric measurements are rery valiable.

$$
\begin{aligned}
& \text { Mcasurements.-Aperture }\left\{\begin{array}{l}
h a=0.01 \mathrm{~mm} \text {. } \\
l_{a}=0.06 \mathrm{~mm} \text {. }
\end{array}\right. \\
& \text { Zunecinm }\left\{\begin{array}{lll}
\text { Long. } & \text { Medium. } & \text { Short. } \\
L z=0.50 \mathrm{~mm} . & 0.40 \mathrm{~mm} . & 0.34 \mathrm{~mm} . \\
l z=0.24 \mathrm{~mm} . & 0.30 \mathrm{~mm} . & 0.24 \mathrm{~mm} .
\end{array}\right.
\end{aligned}
$$

This species differs from Puntlina ratiata Moll, 1803, only in the presence of two oral avicularia. However, Hincks calls attention to some small similar avicu. laria in Moll's species. In our opinion he discussed a distinct species, a fact which he had not noticerl. It conlil very well be, also, that Pucllina calamorpha Reuss. 1866. is also a living species.

This species differs from Pueltina simulator in the presence of an oral mncro and in the constancy of the two oral avicularia on all the zooecia and not on oricelled zooecia alone.

Occurrence.- Upper Tacksonian (Ocala limestone): Seven miles above Bainbridge, Georgia (rery lare).

Holotype-Cat. To. 64028, U.S.N.M.

PUELLINA SIMULATOR, new species.

Plate 41, fig. 21; plate St, fig. 14 .

Description.-The zoarium inerusts shells, bryozon, or Orbitoides. The zooecia are distinct. separated br a furrow. elongated, elliptical: the frontal is convex and formed of 20 to $2+$ thin costules separated by the relr small lacunae and traversed by a line of small lumen pores. The aperture is semilunar. bordered by a peristome bearing four indistinct distal spines. The ovicelled zooecia bear two thin oral avicularia, placed longitudinally, the point above; in the junction angles of the zooecia without avicularia there are some thin avicularia a little longer than nsual. The ovicell is imbedded in the distal zoocium, small. globular. improminent, and always closed by the opereulum.

$$
\text { Measurements.-Aperture }\left\{\begin{array}{l}
h a=0.0+\mathrm{mm} . \\
l a=0.06 \mathrm{~mm} .
\end{array} \text { Znoccial } \begin{array}{l}
L_{z}=0.36-0.40 \mathrm{~mm} . \\
l z=0.2 \mathrm{~mm} .
\end{array}\right.
$$

Affinitios.-This species simulates Pullina colmmorpha Reuss, 1866 , in its ovicelled zooecia ornamented with two avicularia. It diflers from it in its semilunar aperture with neither nucro nor proximal convexity. in the larger number of its costules, and in the long a vicularia placed in the junction angles of the nonovicelled zooccia. These latter are much smaller $(0.15 \mathrm{~mm}$. and not $0.30 \mathrm{~mm}$.) than the interzooccial aricularia of Pucllina ratiota Moll, 1803. 
It differs from Puellina lispinose in that the ordinary zooccia are deprived of aricularia and in the much smaller oricell.

Occurence.-Vicksburgian (Mariamma limestonc) : One mile north of Monroeville, Alabama (rare); near Claiborne. Monroe County, Alabama (rare); west bank of Coneeuh River, Escambia County, Alabama.

Jacksonian (Zeuglodon zone) : Cocoa Post Office, Choctaw County, Mabama. Cotypes.-Cat. Nos. 64027.61250. T.S.N.M.

PUELLINA INARMATA, new species.

Plate $8 t$, fig. 15.

Description.-The zoarium incrusts Orbitoides and bryozoa. The zooeeia are distinct, separated by a furrow, elongated, elliptical; the frontal is only slightly convex; the costules are fine. radial. separated by very small lacnuae. and omamented with a double row of rery fine granules; there are nine or ten pairs; in the shield there is a very visible lumen pore. The aperture is semilunar, transrerse. larger on the ovicelled zonecia. surrounded by a smooth peristome. The ovicell is imbedded in the distal zooecium. improminent, always elosed by the operculum : very rarely there is a small. simple avicularium in the zooecial junction angles.

$$
\text { Measurements.- Aperture } \begin{aligned}
& h a=0.03-0.0 t \mathrm{~mm} . \\
& l l a=0.06 \mathrm{~mm} .
\end{aligned} \quad \text { Zooccia }\left\{\begin{array}{l}
L z=0.36 \mathrm{~mm} . \\
l z=0.2 \pm 0.30 \mathrm{~mm} .
\end{array}\right.
$$

Affinities.-The total absence of avicularia characterizes this species. However, sometimes on the peristome a very small pore is visible and again, in some of the zooecial junction angles there is a small, round, and simple avienlarium.

The double row of small gramles which ormament the costules also characterize this species: however, this character is inconstant and many of the zooecia have some costules sculptured as in Puellina colamorpha Reuss. This last species has two very constant, oral avicularia.

Occurrence-Vieksburgian (Marianna limestone): Murder Creek. east of Castlebury, Coneculh County. Alabama (rare); west bank of Conecuh River, Escambia County, Alabama (rare).

IIolotype.-Cat. No. 61260, U.S.X.M.

\section{Genus DISTANSESCHARELLA D'Orbigny, 1852.}

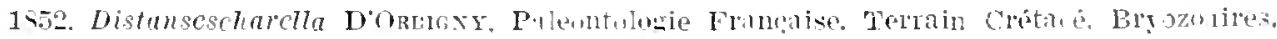
p. 451 .

In the interval which separates the zooecia there may be noted rery small aceessory cellules hardly a fourth the size of the others but of the same form. These smaller zooecia are alway's primoserial; there are always two or three of them following a preceding normal zooecinm.

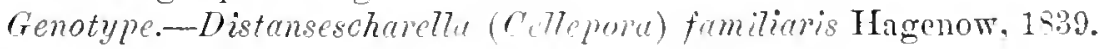

Ramge.-Senonian-.Tacksonian. 
DISTANSESCHARELLA JACKSONICA, new species.

Plite 42, fig. 1.

Only the figured specimen has been fomd, and it is unfortunately very incomplete. The function of the thick smalles zonecia is unknown. Smitt has cited something analogons to them in Memhnemipor 77 a agassizi Smitt. 1573. ${ }^{1}$ where they are rare.

The zoariun incrusts an Idmenen.

Cecurvence-Midrlie . Tacksonian: One-half mile southenst of Georgia Kaolin (ompany Mine, Twigge County, Georgia (very rare).

llotrotype. Cat. No. 19t02!. T.S.X.M.

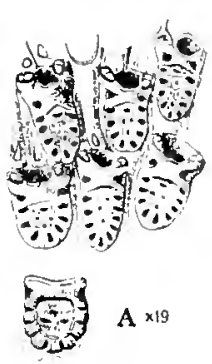

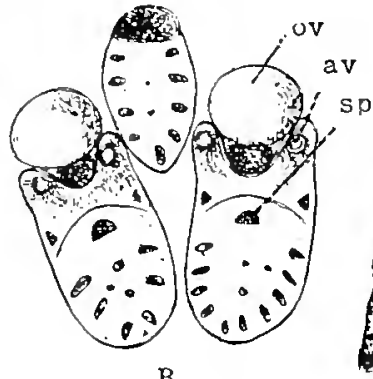

$\mathrm{B}$

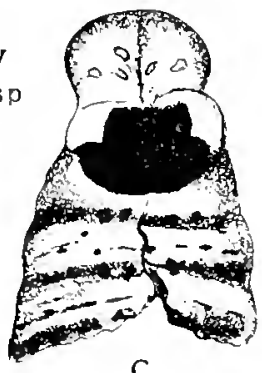

C

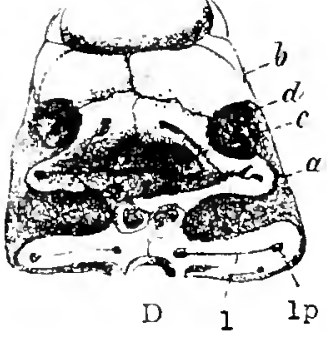

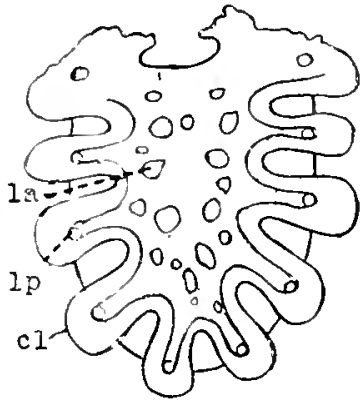

E $\times 83$

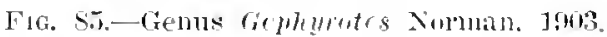

A-E. Gephyrotes nitido-puntala Smitt, 1S6s. A. Zoneria, $x$ 19. (After Smitt. 186S.)

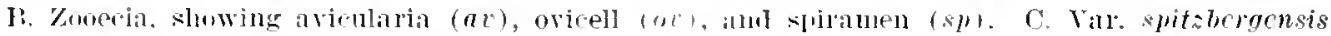
Norman. 1948. Anterior portion of an oricelled zonecium. (After Nornun. Ino3.) I). 'The anterior portion of a zoocinm, to show the structure of the bridge and orat opening. $a$, costula bifurated ; 7 , solid outsprear costula ; $c$, spiratuen: $d$. lateral foramen; $l$ lumen; $7 p$, lumen pore.

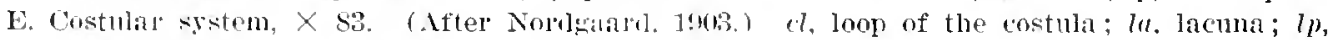
lumen pore.

\section{Genus GEPHYROTES Norman, 1903.}

1003. Gephyrotes Noradx, Nutes on Natum llistory of East Finmurk. Amals and Magazine Nitural History, ser. 7 .vol. 12, p. 100.

The contules are narrow. They are at first largely separated for half of their length: they are afterwards curved and join the adjacent costules, thus forming a complete arch; this arch is followed by large lateral lacmue. The two distal costules bifurcate to form a spiramen in the zooceial axis. I pair of avicularia "ith mandible pointing upwards is developer on the side walls of the aperture. The oricell is sil] glohose and imperforated. No dietellae.

Genotype.-Gepleyrotes (Cribilimu) nitito-punetata Smitt, 1sfs.

liemse.-. Tacksonian-Recent.

Te have classified in this genus all the Custulidae provided with a spiramen. But, under these conditions, all the costules are not identical. In their general 
aspect the rarions species of thi- genus have the aspect of the more typical Gateopsis. If the family Galenpsidae Canu. 1913, is matural, it may become necessary to inelude al loo the genil: Gephyrotes. althongh it present we do not think so.

GEPHYROTES LEVIGATUM, new species.

Plate h, figs. $1-1$.

Description.-The zoarium incru-ts slells. The zooecia are distinct. elongated, aliform; the frontal is a conrex gymueyst encireling a cribriform area formed of three or four prirs of costmles withont lateral median lacunae. All of the zonocia bear an oblique spiramen. The aperture is elliptieal, transverse, surrounded by a thin, sharp peristome. 'The oricell in embedded in the distal zoocia, rather large, smooth, and globular. The two oral aricularia are rather large; their point is directed toward the center of the aperture. One pair of lateral dietellae and a distal dietellin are present.

$$
\begin{aligned}
& \text { Ireasurements.-Aperture } h_{a}=0.06-0.05 \mathrm{~mm} \text {. } \\
& 17 a=0.10-0.12 \mathrm{~m} m 1 \mathrm{~m} \text {. }
\end{aligned}
$$

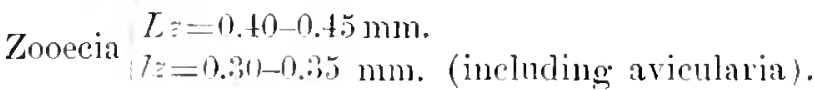

Tariations.-Our description agree- most with figure 1, which shows the general aspect of our specimens. We have illustrated two others (figs. 2 and 3) of a little different aspect. The gymment i- rery small in figmre $2:$ it is absent in figure 3: the costules are then linger. As the micrometric measurements, the arienlaria. and the ovicelli are itential. we have not created a new species for these less typical specimens.

There are no lateral lacunae. The costules seem to us to be those of $1 / \mathrm{cm}$ braniporefln. but we have not been able to discover their nature by a tangential thin section because of the lar ity of the specimens. The presence of the dictellac would still be a reason for classifying the -pecies in $1 /$ embroniporello. Howerer. the operculum appears to clowe the ovicell only when opening.

The patient eollector who will secure a score of specimens of this species and of the following. will be sure of making important discoveries on the structure of the Costuline.

Affmitis.-This species differ-from Gephypotes saltans in its less prominent peristome and in its oral aricularia. which are much smaller (Lav 0.15 mm. and not 0.2. $3 \mathrm{~mm}$.) and are lacking the aliarents pivot.

In its smooth ovicell. it lifler's fom Gephypotes convera and from Gephypotes spectatilitis.

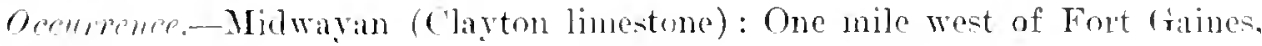
Georocia (rare).

Cotypes.-Cat. No. lins16. T.A.X.M.

GEPHYROTES SAILLANS, new species.

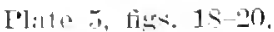

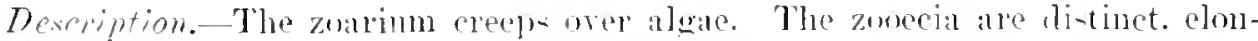

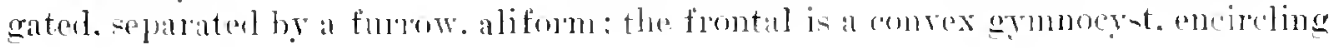


a small cribriform area formed of three on four pairs of costules, without lateral median lacunae. Many zooecia bear a spiramen. The aperture is elliptical. transrexse, provided with a restibular arch. and surrounded by a very satient peristome. The oricell, embedded in the distal zooecium, is large, globular, improminent; it opens into a false peristome in front of the spiranen: it is closed by the operculum when the latter is open. The oral aricularia are rely oblique, almot transrerse, large (Lac $0.25 \mathrm{~mm}$.), quite pointed, provided with a caleareons pirot, and directed toward the interior of the aperture.

$$
\begin{aligned}
& \text { Weasurements.-Aperture }\left\{\begin{array}{l}
h a=0.13 \mathrm{~mm} . \\
l a=0.15 \mathrm{~mm} .
\end{array}\right. \\
& \text { Zooecia }\left\{\begin{array}{l}
L_{z}=0.55-0.60 \mathrm{~mm} . \\
i_{z}=0.45 \mathrm{~mm} \text {. (inchuding avicularia). }
\end{array}\right.
\end{aligned}
$$

Tiriations and affinitics.- The spiramen is present on all the zooecia and is situated at the distal extremity of the cribriform area, nearly perpendicularly to the plane of the zooccia. It is necessary to incline the specimen preparation in order to see it clearly, and in om figures it luas disappeared because of perspective.

This species differs from Gephyrotes trigutum in its very prominent peristome and its large aricularia (Lav $0.25 \mathrm{~mm}$. and not $0.15 \mathrm{~mm}$.). Like that species, it shows such undoubted resemblances with Membruniporella that further examination of numerous specimens is required. On the other hand. the presence of a spiramen seems to indieate that there is a compensatrix buried under the costules, as in Figularil.

In its mooth ovicell it differs from Grphyrotes convera and from $G$. spectabitis. Occurncee.-Midwayn (Claytom limestone): Luverne. Crenchaw Connty. Alaliama (rave).

Cotypes.Cat. No. 63814, U.S.N.M.

GEPHYROTES CONVEXA, new species.

Plate 42, figs. 2. 3.

Description.-The zoarium incrusts Orbitoides. The zooceia are distinct, separated by a deep furrow, elongated, elliptical, di-tended; the flontal is very convex and eonsicts of a small grmnocyst suromnding a cribiform area; this area is formed of six or seven pairs of thick costules closely mited and decorated with at least two quite prominent lumen pores. The aperture is semilunar. transverse: the proximal border is somewhat concare, and the distal border bears four lollow spines. 'The orarian zooecia alone bear the ovicell, tle spiranell. and the oral aricularia. The ovicell is hyperstomial and little distinct. convex. transrerse. bordered in front; it opens into the peristomie formed by the avicularia and the lamella which bears the spiramen: it is closed by the opereulum at the moment the latter is opened. The two aricularia are very prominent. triangular. the point toward the proximal borter of the aperture. The spirames opens above the aperture. No dietellac.

$$
\text { Mensurments.-Aperture }\left\{\begin{array} { l } 
{ h a = 0 . 0 5 } \\
{ l a = 0 . 1 0 - 0 . 1 2 \mathrm { mms } . }
\end{array} \quad \text { Zooeria } \left\{\begin{array}{l}
T_{z} z=0.52-0.60 \mathrm{~mm} . \\
7 z=0.40-0.46 \mathrm{~mm} .
\end{array}\right.\right.
$$


Affinities.-This species is rery interesting in showing that the production of a peristomie and of a spiramen is a phenomenon in intimate comnection with the passage of the eggs and the eracuation of the larvac. Jullien ${ }^{1}$ believed that the spiramen was in relation with the opening of the operculum and consequently with the hydrostatic system. Here the operenlum of the ordinary zooecia operates withont a spiramen. The function of the latter therefore is problematical, indeed it may be only a psendo-spiramen.

The characters of the species are the thick confluent cu-tules and the fact that the ovicelled zooecia only are provided with a spiramen.

This species differ's from Gephypotes suitlans in its more numerous and uniter costules and in the points of the avicularia which are directed backward.

Occumence.-Upper Jackiconian (Oeala limestone): West bank of Sepulga River, Escambia County, Alabama (rare).

Cotypes.-Cat. No. 64030. U.S.N.M.

GEPHYROTES SPECTABILIS, new species.

L'late St, fig. 16.

Deseription.-The zoarim incrusts shells. The zooecia are distinct, elongated. elliptical, separated by rely long interzooccial cavities. The frontal is convex and is formed of six pairs of widely separated costules. Each intercostular slit is followed by a lacuna; each costule bears a small but prominent lumen pore on the loop and a larger one at the other extremity. The first pair of costules bifureates to surround the spiramen which opens obliquely above the aperture. The ovicell is embedded in the distal zooecia; it is globnlar, projecting. transrerse, and bears in front a hollow collar; it opens into the peristomie formed by the arieularia and the prominent lamella which bears the spiramen. The two oral avicularia are quite prominent, triangular. oblique, the point directed toward the upper extremity of the zooccial median axis; provided with a calcareous pirot.

$$
\begin{aligned}
& \text { Measurements.-External aperture }\left\{\begin{array}{l}
h p=0.05-0.10 \mathrm{~mm} . \\
h p=0.10-0.12 \mathrm{~mm} .
\end{array}\right. \\
& \text { Zooecia }\left\{\begin{array}{l}
I, z=0.50-0.60 \mathrm{~mm} . \\
l z=0.35-0.40 \mathrm{~mm} .
\end{array}\right. \text { (excluding avicularia). }
\end{aligned}
$$

ramiations.-This super species is perfectly characterized by its cribriform area. The lumen pore of the shield is frequently wanting. The two opposite lacunae are frequently joined to form a small trinsversal slit. The large interzooecial cavities are very irregular in form and size; it is imposeible to consider them as avicularia and their function is therefore problematical.

The marginal zooecia show in our figure appear to be of young zoocial they are withont spiramen and avicularia, and their aperture is transverse with a conare. proximal border. In the junction angles there i- a minute pore. probably a small, simple avicularium.

$$
1 \text { 1903. Jnllien, Bryuzoaires provenant de campasme drHimmen. It. Tt. }
$$


This species is somewhat like the C'vitritinu detys Koschinsky, 1885, of the liabonian of the Vicentin. The latter, howerel', is provided with interzooecial ariollaria.

We unfortunately posiess only the figured specimen.

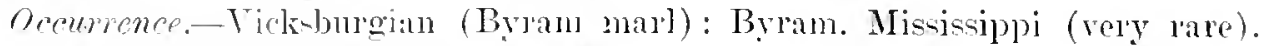
Ilototype-cat. No. ijtoli1. T.S.X.M.

GEPHYIRTES QUADRISERIALIS, new species.

I'late 42 , ficss. 4,5 .

Inseriptim. The zurium is free cylindrical, bifurcated, formed of four longitudinal rows of zonecia opposed to each other, two by two. The zooecia are distinct, clongated. separited by a furow. The frontal is rery convex and formed of nine pairs of clonely united costules. Each co-tule bears at least two lumen pores; the firt pair lifureates to form the spiramen and the peristomial lamella. The apertme in alliptinal and transverse and buried at the bottom of the peristomice.

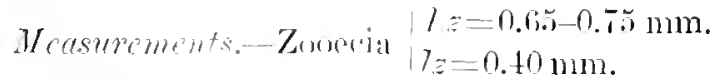

Iffnitis.-The spiranen is not constant and is sonetimes replaced by a psendorimule ent at the midrle of the lower lip of the peristomice.

As the pirimen is almost vertically placed, it is elearly visible only when the specimen is inclinml: then, viewing it transwersely, the proximal border of the apertule bencath it is quite visible. The lacunae are so small that they can not lu shown in the figure.

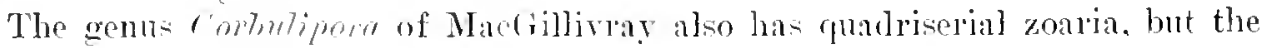
zonecia have no spiramen.

The structure of the costules is identical with that in Gephyrotes convera:

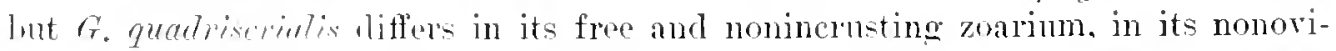
celled zooccia bealing a spirmen. and in the entire alsence of a zooceial gymnocyst.

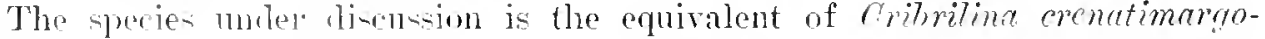
homeri Relss. 18ti. of th" Priabonian of the Ticentin. but differs form it in its guadriserial and not hilanellar zoalium and in the presence of the spiramen.

Gephypotes quatristriatis furthermore has no oral avicularia and is of such an aleerant type that it will he convenicnt perluaps to separate it generically when the ovicell has heen discovered.

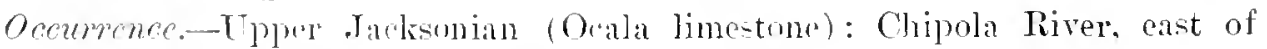
Marianna, Jackon Comntr. Florida (rare),

Cotypes.-Cat. No.64031, U.S.X.M.

Genus IIETRACOLPOSA Canu and Bassler, 1917.

1917. Metracolposa Caxt and Bissler. Sinopsis of American Earle Terting Cheilostome Pripozoa, Pulletin 96, Tnited States National Museum, 1. 34.

The costulus are sibalated hy numerous lacunae. The aperture is semilunar. Thr operentum in opening aloses the ovicell. The oricell is large and deply emherldel in the rintal zonecia. The oricelled zooecia have a large aperture. 
Genotype.-Metracolposa robusta Canu and Bassler, 1917. Jacksonian.

This genus ditlers from Cribritina Gray, 1848, in its opereular dimorphi im. Moreorer, the operculum probably closes the ovicell during the whole period of derelopment of the embryo, as this is the habit in those species where the operculuin closes the ovicell in opening. The ovicell occupies a large part of the distal zooecia, the eapacity of which is thus much reduced. The lumen pores are scareely risible, irregular, never prominent.

METRACOLPOSA BREVIS, new species.

Plate 42. figs. 6, 7 .

Description.-The zoarium is free, and bilamellar. The zooecia are large, elliptical, short. The frontal is little convex; the costules are triangular, radial, seven or eight pairs in number, separated by five or six lacmae coneentrically arranged; no lumen pores. The aperture is transverse, semielliptical, bordered distally by a rery thin incomplete peristome. The ovicell is enormous, globular. smooth, opening alove the operculum but able to be closed by it. No a vicularium.

$$
\text { Measurements.-A perture }\left\{\begin{array} { l } 
{ l u = 0 . 1 4 \mathrm { mm } . } \\
{ 7 a = 0 . 2 8 \mathrm { mm } . }
\end{array} \quad \text { Zooecia } \left\{\begin{array}{l}
L z=0.80-0.90 \mathrm{~mm} . \\
t z=0.60-0.70 \mathrm{~mm} .
\end{array}\right.\right.
$$

Affinities.-This very clegant species may be distinguished from ILetrucolposa grandis by its less length, greater width, the radial arrangement of the costules. and the absence of avicularia.

It differs from Metracolposa robusta in its greater width, its larger costules, and the absence of avicularia.

Occumence-Widdle Jacksonian: Near Lenuds Ferry, Sonth Carolina (rare); 1s miles west of Wrightsvile, Johnson County, Georgia (rare).

Holotype.C Cat. No. 64032, U.S.N.M.

METRACOLPOSA GRANDIS, new species.

Plate 42, figs. S-13.

Description.-The zoarimu is large, free, bilanellar. The zooecia are distinct. elongated, large, elliptical. The frontal is convex; the costules are thick, nearly transverse, little distinct, numbering from five to seven pairs and separated by large circular lacunae. The aperture is transrerse, semielliptical, bordered distally by a very thin, incomplete, improminent peristome. The ovicell is very large. elongated, proninent, globose, perforated by small irregular pores and decorated in front by al large deltoid earina. A very large transverse oral a vicularium abore ench aperture.

$$
\begin{aligned}
& \text { Measurements. A perture }(h a=0.11-0.24 \mathrm{~mm} \text {. Aperture }(h \alpha=0.16 \mathrm{~mm} \text {. } \\
& \text { (ordinary) }\{7 n=0.22-0.26 \mathrm{~mm} \text {. (wicelled) }\{7 n=0.30 \mathrm{~mm} \text {. } \\
& \text { Zooecia }\left\{\begin{array}{l}
L z=0.90-1.10 \mathrm{~mm} . \\
T_{z}=0.510 .56 \mathrm{~mm} .
\end{array}\right. \\
& \text { 50. } 1: 1-1 !)-1 \text { 3 } 411.106-20
\end{aligned}
$$


1 ariations.-The number of the costules is rather variable; they are arranged horizontally at the top and radially below. The lumen pores are sometimes visible (fig. 9); they are irregularly placed and never prominent.

There are sometimes two distal avicularia (fig. 9); their points touch above the aperture on the median zooccial axis; there are some zooecia mprovided with aricularia (fig. 9).

In the interior (fig. 10) the proximal border of the aperture is bordered by a thick collar. The avicularia are interzooecial.

The margins of the costules are invisible in tangential section (fig. 12); the lumen pores are visible, but not the lumen itself. In figure 12 the lacunae are seen to be surrounded by a polygonal network, which indicates the boundary of the primitive spines.

Affinities.-This species differs from Metracolposa brevis in the presence of large distal avicularia and in its greater zooecial length, and from Metracolposa robusta in its larger zooecia and its much larger and more mumerous avicularia. On account of the size of its zoarium this is an easily recognized fossil.

Occurrence.-Middle Jacksonian: Wilmington, North Carolina (common); near Lenuds Ferry, South Carolina (common).

Holotype.-Cat. No. 640s3, U.S.N.M.

METRACOLPOSA ROBUSTA Cann and Bassler, 1917.

Plate 43, figs. 1- 7 .

1917. Mctracolposa robusta CANU and BASSLER, Synopsis of American Early Tertiary Cheilostome Bryozoa, Bulletin 96, United States National II useum, p. 35, pl. 3, fig. 6 .

Description.-The zonium is free, bilamellar, large (1 to 2 centimeters in width), solid, robust. The zooccia are distinct, elongated, elliptical; the frontal is somewhat convex; the costules are transverse at the top, radial below; they number from seven to nine pairs and are separated by four or fire large lacunae; the lumen pores are small and irregular. The aperture is transverse, semielliptical with a straight or slightly convex proximal border; it is bordered distally by a very thin, incomplete peristome. The ovicell is large and deeply embedded in the distal zooecia, elongated, salient, convex, decorated in front with a deltoid carina; it opens above the aperture and probably was closed by the operculum when it opened. The aperture of the ovicelled zooecia is larger. A small, triangular distal avicularimn is placed either on the right or left of the aperture.

$$
\begin{array}{r}
\text { Mcasurements.-Aperture (ordinary) }\left\{\begin{array}{l}
h a=0.10 \mathrm{~mm} . \\
l a=0.20 \mathrm{~mm} .
\end{array}\right. \\
\text { Aperture (ovicelled) }\left\{\begin{array}{l}
h a=0.12-0.14 \mathrm{~mm} . \\
l a=0.28-0.30 \mathrm{~mm} .
\end{array}\right. \\
\text { Zooecia }\left\{\begin{array}{l}
L z=0.96-1.00 \mathrm{~mm} . \\
l z=0.44-0.46 \mathrm{~mm} .
\end{array}\right.
\end{array}
$$

Tariations.-The zooecial width is rather variable; there are some zooecia which measure $0.51 \mathrm{~mm}$, in which case the costules are radially arranged (fig. 2). 
The avicnlaria are rather rare; their point is directed townd the median axis of the zonecia above the aperture; sonetimes they are rertieal; when well preserved they have a calcareous pirot.

In the interior (fig. 7 ) the ovicell is seen to occupy the larger part of the cavity of the distal zooccia-a comlition which is better visible on the vertical section (fig. 5). This section also permits one to understand the movements of the operculum. This structure closes the oricell at the moment of the passage of the eggs and during the erolution of the emhryos. After the expulsion of the latter it closes only that zoocium in which the aperture has preserved its distal but deeply buried margin.

In thin section the zovecial walls are thin, and composed of scattered olocystal elements. The avicularia appear to be interzooecial.

It may be that the costnles are not hollow, for the lumen has never been observed.

The two lamellae forming the zoarium are inseparable.

There are four or five lateral septulae ( fig. 6).

Affinities.-Metracolposa roluste differs from Mctracolposa brezis in the presence of an avicularium and in its smaller zooecial width.

It differs from Metracolposa grantis in its smaller general dimensions and its much smaller and rare avicularia. and from Metracolposa cylindrica in its bilamellar zoarinm.

The zoarial dimensions are such that this is a good-sized fossil and casily recognized.

Occurrence.-Middle Jacksonian: Wilmington, North Carolina (very common): Entaw Springs, South Carolina (rare).

Cotypes-Cat. No. 62586, U.S.X.II.

\section{METRACOLPOSA CYLINDRICA, new species.}

Plate 42, figs. 14-20.

Description.-The zoarium is free, cylindrical, formed of six rows of zooecial. The zooecia are distinct, much elongated. elliptical; the frontal is convex; the costules are thick, numbering eleven or twetve pairs, separated by four or five rather large lacnnae, without lumen pores. The aperture is transverse, semielliptical, with a straight or slightly coneave proximal border. The ovicell is very large, embedded in the distal zooecinm, elongated, prominent, convex, decorated in front with a deltoid carina; the ovicell opens above the aperture and probably was closed by the operculum. The avicularia are triangular and are placed in the junction angles of the zooecia: their point is turned toward the median axis of the zooccia.

$$
\begin{aligned}
& \text { Measurcments.-A perture hat=0.10-0.14 } \mathrm{mm} \text {. Iperture } / \mathrm{h} a=0.1 \mathrm{imm} \text {. } \\
& \text { (ordinary) } \backslash 7 a=0.16-0.18 \mathrm{~mm} \text {. (ovirelled) } 7 a=0.35 \mathrm{~mm} \text {. } \\
& \text { Zoocia }\left\{\begin{array}{l}
L z=1.10-1.20 \mathrm{~mm} . \\
7 z=0.411-0.42 .2 \mathrm{~mm} .
\end{array}\right.
\end{aligned}
$$


Tariations.-The distal aricularia are inconstant; rhey are sometimes attenuated (fig. 16) and eren absent (fig. 1S).

The keel of the wiedl, very clear in figure 17 , is much attenuated in figure 15.

We have observed (fig. it) an aperture closed by a calcareous operculum. This phenomenon is frequent in all the Cheilostomes, but as yet zoologists have not learned its siguifieance.

Certain zoalia are nalrow at their lower extremity (fig. 18) as if they were formed of segunents for articulation. The base of such segments (fig. 20) bears three pores. which is not the case in articulated zoaria.

The zooceial walls (fig. 19) are very thin. The ovicell occupies a portion of the earity of the listal zoocia. As in the other species of the same genus the costnles are apparently not hollow.

Affinities.-This species is distinguished from all others of the genus by its cylindrical zoarium. but it is rery close to Metracolposa robusta of which it might be a varioty if we hat intermediate forms. It differs from the latter in having a larger number of costules, in the presence of two larger distal avicularia and in the smaller zooccial breadth, and from Metruentposa gruntis in its much smaller lacumae and its very different micrometrical dimensions.

Occurence-Widdle Jackinian: Wilmington. North Carolina (common); near Lenuds Iierry, south Carolina (very common).

Cotypes.-Cat. No.6t03t, U.S.N.M.

\section{Genus CORBULIPORA MacGillivray, 1895.}

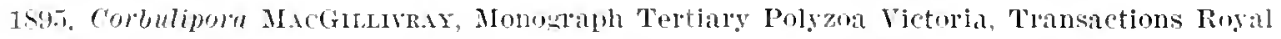
Society Victoria, vol. 4, p. 60 .

"Zoalium erect. zooecia quadriserial, facing to the four sides, much elongated, calcareons, rendily separating longitudinally. Anteriol part wider; a ised, formed by a ceries of vertical ribs on each side. turning abruptly inwards and uniting to form a flat plate; posterior part of zooceia narow, smooth, and entire; thyrostome with the upper lip arched, thickened and smooth." (Macrilliviay.)

fienotype.-- combulipora omata Machilliviay, 1995.

Range.-Eocene-Miocene.

This geuus is purely zoarial. The figures given by Machillivay are incomplete. Two specimens that have been sent to us by Mr. Maplestone are somewhat different from Macillivay's description. The costules have lumen pores; the initial slit separating two costules is very small. The genus has the costular structure of rephyrotex.

CORBULIPORA COLLARIS, new species.

Plite 43 , fig. 14

Deseription.-The zoarium is free, quadriserial, bifurated. The zooecia are ristinct. separated ly a proninent thread or a furrow: and are much elongated, elliptical: the frontal i-comrex: the contules are fine, numerour, ornamented with very small lumen pores; separated by a large, initial slit, followed by two lacuma: the superior costules are more or less united to form a solt of collar. The aperture 
is semilunar; the distal part is borkered by a very thin, incomplete peristome. There are one or two small, triangular. transverse, oral avienlaria tonching each other at their tips.

$$
\text { Measurements.-Aperture }\left\{\begin{array} { l } 
{ h a = 0 . 0 5 \mathrm { s } m \mathrm { m } . } \\
{ l _ { a } = 0 . 1 1 \mathrm { mm } . }
\end{array} \quad \text { Zooecia } \left\{\begin{array}{l}
T_{z}=0.60 \mathrm{~mm} . \\
l z=0.30 \mathrm{~mm} .
\end{array}\right.\right.
$$

Affinities. - All of the zooecia are not porided with the characteristic collu which arises from the more or less complete mion of the first three pairs of costules. The number of pairs of costules varies from 12 to 17.

Only a few specimens have been fomd. none of which shows an oricell. The (puadriserial zoarim and the costules with lumen pores are the only reasons we have for classifying this species in Coptuliporu, a genus which must be considered as inadequately described.

Oeeurmere-Middle Jacksonian (Castle Hayne limestone) : Wihmington, North Carolina (rare).

Holotype.Cat. No.64035. L.M.N.M.

Genus ACANTHOCELLA Canu and Bassler, 1917.

1917. Acanthocella Canu and Bassler, Srumpsis of American Early Teltiary Cheilostome Bryozoa, Bulletin 96, Lniterl States Nitimual Mnseum, p. 35.

The costules bear a row of rery prominent lumen pores and are separated hy lacumae of greater or less size. The aperture is semilunar. The ovicell is hyperstomial and it orifice is not in contact with the opereulmm.

Genotype.-Cribrilina tululife re Hincks. 1851, from Iustralian seas.

Range.-. Jacksonian-Recent.

ACANThoCella ERINACEA Canu and Bassler, 1917.

Plate 4 . figs. $1(1-19$.

1917. Acunthocella erinare Gax and Fassuse, Symepsis of American Early Tertialy

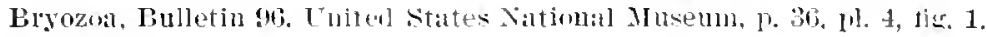

Description. - The zoarium incru-ts shells and bryozon or creeps orer algane. 'The zooecia are distinct, rer's sightly elongated. subcincular : the frontal is rely "onvex; the costules are thick. sepanated by the lacunate and ornamented by three very prominent, hollow spines corre-ponding to the lumen pores. The apertures is semilunar with a straight proximal boreler: the peristome is distal and bears four large, hollow spines. The ovicell i- hyper-tonial, buried in the distal zonecia. mlobose, not closed by the operculum. olnamented with small, remote punctations.

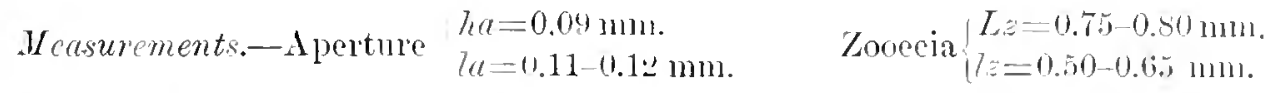

Tariations.-The sharp print- which decolate this specis wive it the spinous aspect of a hedgehoy. It is very variable in its micronuter limensions and its gemmation; the zooecia are oriented $i$ the most muexpected and divergent manner. The costules are separated hint ly an initial slit (fig. 13) hidrlen and almost ver- 
tical, and are followed by large (fig. 10) or smaller (figs. 11, 13) lacunae, which vary in number, although there are always at least two.

The tangential sections show very clearly the existence of a lumen and of large lumen pores (fig. 12).

Affinities.-This species differs from the recent Acanthocella tubulifera Hincks. 1881 , in its larger number of lumen pores ( 3 or 4 instead of 2 ).

It differs from Cribritina suggerens Waters, 1881, in its zoarium, which is not bilamellar and in its larger micrometric dimensions $(l \alpha=0.12 \mathrm{~mm}$. and not $0.06 \mathrm{mmm}$.$) .$

Oeeurrenee.-Middle Jacksonian (Castle Hayne limestone) : Wilmington, Nortl Carolina (rare).

Cotypes.-Cat. No. 62587 , U.S.N.M.

Genus CRIBRENDOECIUM Canu and Bassler, 1917.

1917. Cribrendoceium Canu and Bassler, Synopsis of American Early Tertiary Cheiln. stome Bryozoa, Bulletin 96. United States National Museum. p. 36.

The ovicell is endozooecial. The costules are separated by a small initial slit and some medium-sized lacunae; they have no lumen pores. The apertme is formed of a semilunar anterior portion and a larger and concave posterior part separated ly two cardelles. The aperture of the oricelled zooecia is larger. Large interzooecial a ricularia are present.

Genotype-Cribrendoecium tenuicostulatum Canu and Bassler, 1917.

This genus shows the closest resemblance to II ippopodina Levinsen, 1909, in the nature of its ovicell and its oral dimorphism. On the other hand, its interzooecial aricularia and the structure of its ovicell marked with two lateral cicatrices, relate it to Figularia. Jullien, 18s0. It is therefore very probable that the species of Cribrendoeeium are provided with a compensatrix. just as in the two genera cited and as the nature of its aperture would predict.

\section{CRIBRENDOECIUM TENUICOSTULATUM Canu and Bassler, 1917.}

Plate 43 , fis. 8 .

1917. Cribrendoecium temucostulatum GAve and BAsscen, Synopsis of American Eariy Tertiary Cheilostome Bryozon, Bulletin 96, United States National Museum, \}. 36, pl. 4, fig. 1.

Description.-The zoarium incrusts shells. The zooccia are distinct, elongated, separated by a furrow, elliptical, fusiform; the frontal is convex; the costules are very thin, numerous, without lumen pores, and separated by very small lacunae. 'The apertures of the ordinary zooecia are formed of a semilunar anterior and a very large, straight posterior part separated by two small cardelles; the aperture of the oricelled zooecia is larger and its posterior portion is convex. The ovicell is endozooccial and exteriorly is prominent and transverse; it is formed of two calcareous deposits; the onter one is incomplete and leaves two lateral cicatrices in the form of a cross. The avicularia are interzooecial and are elongated, spatulate. perforated by a long slit and generally without pirot. 


$$
\begin{array}{r}
\text { Measurements_-Ordinary aperture }\left\{\begin{array}{l}
h a=0.09 \mathrm{~mm} . \\
7 a=0.11 \mathrm{~mm} .
\end{array}\right. \\
\text { Oricelled aperture }\left\{\begin{array}{l}
h a=0.10 \mathrm{~mm} . \\
7 a=0.13 \mathrm{~mm} .
\end{array}\right. \\
\text { Zooecia }\left\{\begin{array}{l}
I_{z}=0.50-0.60 \mathrm{~mm} . \\
7 z=0.25-0.35 \mathrm{~mm} .
\end{array}\right.
\end{array}
$$

Affinities.-The discovery of a member of the Cribrilinidae provided with an endozooecial ovicell is very important, as it indicates clearly that the structure of the frontal has no connection with the varions organs (ovarian) of the polypide. At the same time the presence of the costules does not imply the muscular systen of the Anasca, since the form of the aperture indicates a characteristic compensatrix of the Ascophora; this frontal has no comnection with the hydrostatic system.

The costular structure has no special function, being only a decoration or, to be exact, an adaption for a particular purpose, and it can not be employed to characterize a natural family.

This species must not be confounded with any speeies of the gents Figularia Jullien, which is provided with a hyperstomial ovicell.

Oecurrence.-Middle Jacksonian (Castle Hayne limestone) : Wilmington, North Carolina (rare).

IIolotype.-Cat. No. 62588 , U.S.N.M.

\section{Genus ARACHNOPUSIA Jullien, 1886.}

Bibliography (Anatomical).-1S51. Hincks, Contribution toward a general Fistory of the Marine Polyzoa, Annals Magazine Natural History, ser. 5, vol. \$, p. 57, pl. 3, fig. 6.-1854. HrNcks, Contribution toward a general History of Marine ['olyzoa, Anuals Magazine Natural History. ser. 5, rol. 4. 11. 129. pl. S, fig. 5.-1854. Busk, Reprort on the Scientific liesults of the royage of the Challenger, it. 1. Cheilostomata, vol. 10, pt. 30. p. 133, pl. 19, tig. S.-1897. Watens, Bryozea from Yew Sonth Wales, North Australia. Annals Magazine Natural History, ser. 5, vol. 20, p. 187, pl. 6. fig. 7.-1SS\&. Julı.1Ex, Mlission scientific du Cal IIurn, vol, 6, Zoology, Bryozoaires, 1. 63, pl. 3, figs. 8, 9.-1906. WATERs, Bryozoa from Chatham Island, Aunals Magazine Nitural History, ser. 7 , vol. 17, p. 16, Il. 1, fig. 11.

The cribriform area is formed by the coalescence of hollow branched spines attached to the lateral walls. The lacunae are concentrically arranged and semilunate with an interior denticule. The opercular valve is membranous. The ovicell is hyperstomial and opens into a small peristomie above the operculum; it is closed by a special operculum and is formed by a domble calcareons deposit. The lateral walls have septular disks with 1 to 3 pores; the distal walls bear only septules; 17 tentacles.

Genotype.-Aruchnopusia (Lepralia) monoceros Busk, 1854.

Range.-Vicksburgian-Recent.

ARACHNOPUSIA VICKSBURGICA, new species.

I'late S5, figs. $1-3$.

Description.-The zoarium inerusts shells. The zooecia are distinet, separated by a furrow, at the bottom of which there are some small, elliptical, wide pores; 
the frontal is convex, formed of calcareous polygonal pieces perforated by a large pore; each pore is semilunate and has an interior denticle; the convex side of this fore is turned toward the exterior, but the denticle is directed toward the zooecial axis; the cribriform area is surrounded by a smooth collar, composed of adjacent polygonal pieces. The aperture is elongated and formed of a semilunar anter and

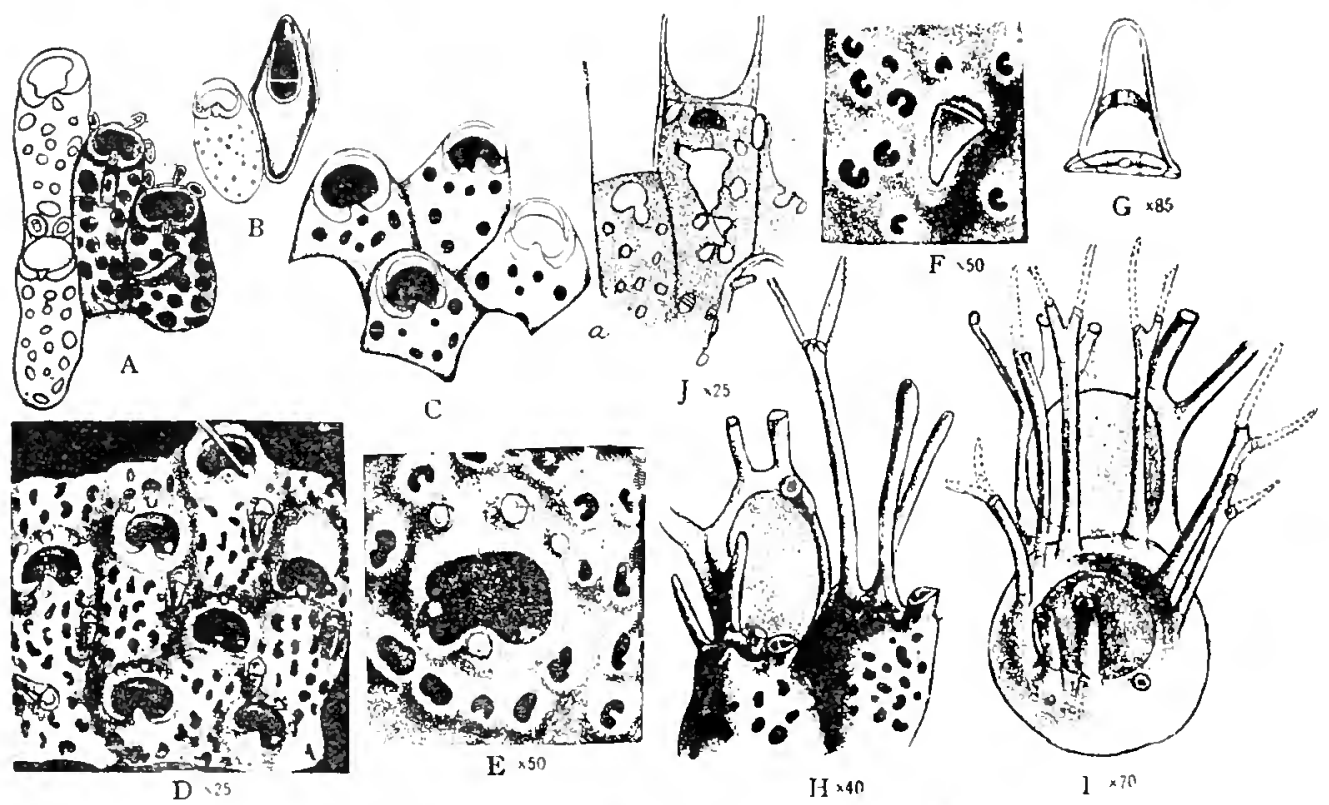

Fag. S6.-Cienus arachopusia Jullien, $18 s e$.

A-.. Arathmusiu monocoros Busk, 15it. A, B. Zovecium and one of the large marginal avivularia. (After Hincks, 18s1.) C. Young cells. (After Hinclis, 18s4.) D. Zooecia, X

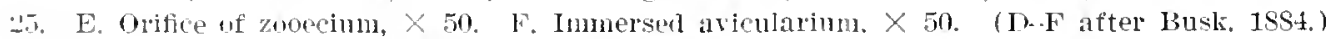
(1. Avicularian mandible, $x$ s.i. (After Waters, 18s7.)

H. Fung zomeria, $X 40$, bearing two or three marginal spines. There are other colonies of zoveria which lave four of them. These marginal stines disappear promptly, except that whe which is nearest the posterior lip of the rritice, and whose base alune jersists; it is from the hase of the spine that the species derives its name. The avieularian eavity forms here in great lelief, and its cirmuference must som increase on account of the caleareous deposit. After Jullien, 1856.) I. Ancestrnla. X 70 , with a young zoocium with five spines. (Aftel* Jullien. 18S6.) J. Growing ends, $X$ 25, showing the ealcareous projections arising from the sirle. thus folming pures. In the lett-land zorecium ( $a$ ) the lowel calcaleous wall below the "lal a jutture is nut complete. Above the zonecia (distally) the basal and latera] walls ale found butole thro is any wher sign of growth, and in the division thus formed above the right-hand zhrocum the alcalenus front wall is commencing and has male a semicireular growth. Ibetween the zurcium a and $b$ thele was anothel, but this has been omittel. (After Waters. 1900.)

a concare postel' without cardelles; the peristome is salient, smooth, and bears a distal lip, rery prominent and oblique, and an acute, proximal mucro. The ovicell is hyperstomial, opening in the peristomie above the operculum: it ooecial cover is formed of varions rectangular, calcareous pieces. A large elliptical avicularium is plared near the aperture. 
Weasurments.-Aperture $\left\{\begin{array}{l}h a=0.15 \mathrm{~mm} . \\ 7 a=0.15 \mathrm{~mm} .\end{array} \quad\right.$ Zooecia $\left\{\begin{array}{l}L z=0.65-0.72 \mathrm{~mm} . \\ l z=0.35 \mathrm{~mm} .\end{array}\right.$

Trariations.-The structure of this species is quite remarkable. The lacunae are transformed into true areolac serving for the passage of the mesenchyme fibers, and of the endocyst, which is situated under the ectocyst; the endocyst continues its calcareous secretion orer each areola and carres ont a great number of polygonal pieces on each zooccium.

The smooth collar which surrounds the cribriform area is formed of as many pieces as it has a reolac and covers the shich of the primitive costules.

The ooecial cover is composel of many calcareous pieces arising from as many pores of the distal zooecia and even the adjacent zooecia; nevertheless, the frontal arch terminated by two lateral appenclages seems to have an exterior origin. This activity of calcareous secretion about each areola is very remarkable and tangential sections of the living Arachnopusia monoceros would be of great interest.

The mucro is not at all constant; it is replaced in the nonoricelled zooccia by a calcareous thickening bearing a cicatrix. Its development appears therefore according to rule to be in connection with the formation of a peristomie and with the passage of the exgs in the ovicell.

Affuities.-This species differs from Arachnopusia (Cribritina) terminata Waters in its zoarium, which is incrusting and not free: in its much smaller oral dimensions $(0.15 \mathrm{~mm}$. and. not $0.25 \mathrm{~mm}$. by $0.14 \mathrm{~mm}$.) : and in the presence of larger avicularia.

The aftinities of the Tertiary fam of the American Gulf region are greatest with that of Europe, but in Arachnopusia we have a genus which has been observed in the fossil state only in the Southern hemisphere. chiefly in the Australian deposits. This single example is insuflicient to prove communication with the Pacific of the American Tertiary Gulf, for the study of the Eocene deposits of the Pacufic is still to be made. Irachnopusia monoccros Busk. 1854. was discovered recently in Florida waters at the Tortugas by Osburn.

Occurrence.-Vicksburgian (Byram marl): Byram. Missiscippi (rare); onefourth mile west of Woodward, Wayne County, Mississippi (rare).

IIolotype.-Cat. No. 64262, U.S.N.M.

Genus FIGULARIA Jullien, 1886.

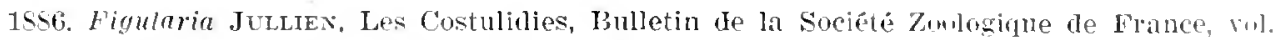
7t, p. Gos. (Fimulina I evinsen, 1909.)

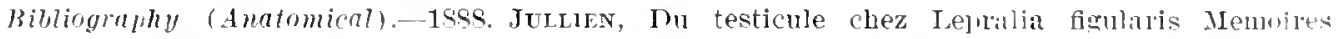
Societe Zwologique France, 1\%. 2. 11. 10, figs. 1, 2-1902. IAamer. On the Morplongeg of the

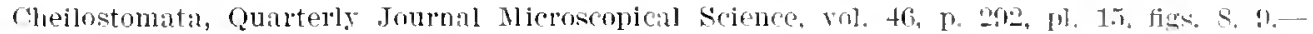
1903. Normas, Notes on the Natural History of East Finmark, Nunals Magarine Nitural

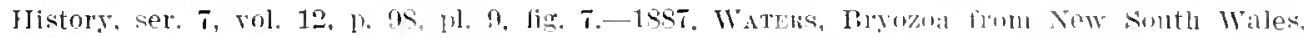
Annals Magazine Natumal History, ser. 5, rol. 20, p. 187, pl. 6. fie. 1.-1859. Waters, Pryozoa

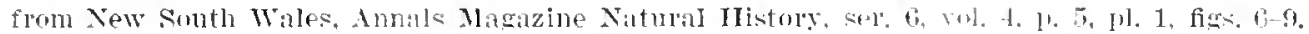




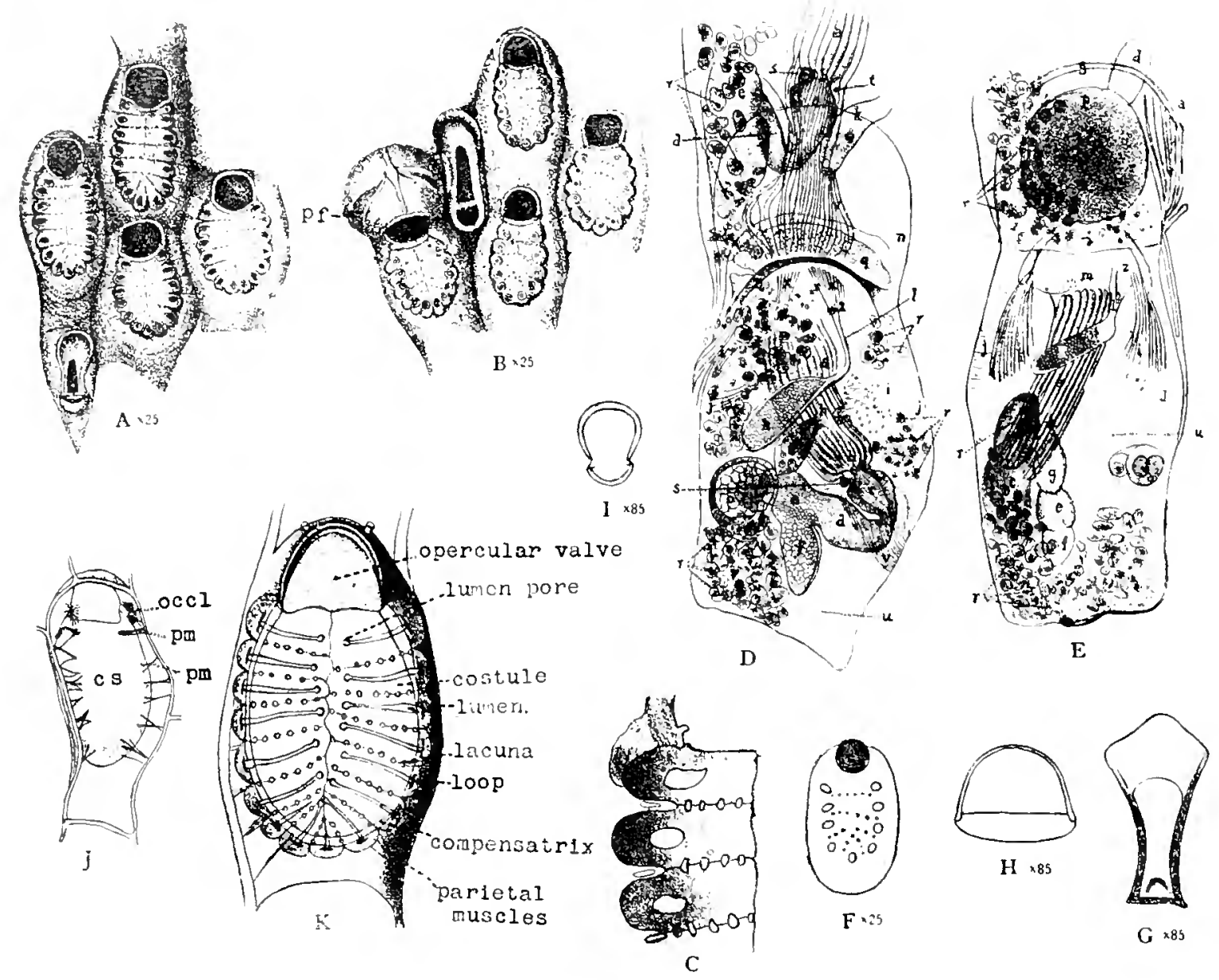

1'16. S7.-Genus Figularia Jullien, 1886. 
FIg. S7.- Genus Funlaria Jullien, 1886.

A-I. Figularia fimlaris Johuston. 1st7. A. 13. Zonecia and avicularia, $x$ 25. (After Hincks, 1S50.) $7 \%$, priform fossa ot Hinclss=wirle stigna uf Busk. C. Detail of costules. (After Nolman. 1903.1 D, E. Two zonecia smen the dorsal face, exhibiting the internal sincture of their contents. (After Jullicu, 1S\$6.) In fig. D the testicle is still witlont spermatozooids: the ovary possesses an exs alrealy in process of development: at the bast of the ovicell is seen an epithelial covering. In tia. E the testicle contains spelmatozooids, indicated by very fue lines; the ovary contains three nonfertile ovules, and the ovicell a larva or an egg in full development. $a$, lophophore in the tentacular shealh; $b$, moutli; $c$ pharyns; $d$, exophagus; $e$, stomach; $f$, gastric caetum; 9 . intestine; $h$, anus, $i$, retractor muscles of the ofrerculum; $j$, parietal muscles; $l$, testicle; 1 . deferent sanal; $m$, irisoja (obturator diaphragm of the tentacular sbeath): n. ovioll: o. orary: ?, egg in process of development (larva); $q$, epithelium of the base of the wirell; $r$, psendo-cellular debris of the brow body, sometimes containing diatoms aul radiolillia: s, buain (so-called esophagal gauslion); $t$, cervical nerve; $u$, cellular tissue, under the almoninal wall; $v$, rectractor muscles of the polpide; $x$, folds of the tentacular sheath; $\approx$ orifice of the ejaculitory canal on the irisoju. F. A zonecium decalcified, $\times 25$. (After Waters, 1559.)

G-I. Figularia clithridiatn Waters, 1s8. G. Avicularian nandible, $X$ Sā. If. Opeleu.

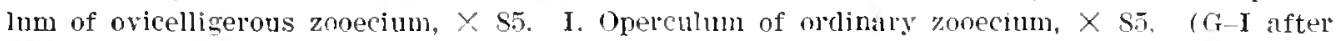
Waters, 1SST.)

J, K. Figularia plitomela Busk, 1S84. J. Basal riew of the zooecium. The distal parietal muscles $\mathrm{mm}^{\prime}$ a re stronger than the other sumps $p m$. cs. compensatrix; occl, oeclusur muscles. K. Zooecium illustrating terminologt. The funtal shield is composed of hollow calcareous costulae. alternately aranged on the two sirles of the zoopeium. The rows of pores correspond with the in. tervals between the costmae. The comprumirix and some of the pirietal wuscles are inclicated. (After Harmer, 1902.) 
The costules are bound together by the intercostal cross pieces, producing at the bottom of the intereostal spaces a line of lacuma: each costnle is provided at its talon with a lalge lmuen pore. The aperture is formed of an anterior part and posterior part separated by two cardelles; it is closed by a wholly chitinized rompound opereulum. The ovicell is hyperstomial: it is provided with a median suture and with at least two pear-shaped perforations. The avicularia are interzooccial. No dietellae.

Genotype.-Figularia (Lepratia) figularie Johnston, $18+7$.

Romge. Tacksonian-Recent.

The speries of this gemus are:

Figutaria (Lepratia) figularis .Tohnston. 1847.

Figularia (Hemeschara) phitomela Bnk. 1884.

Fignlarie (Cribritina) clithridiata Waters. $188 \mathrm{i}$.

In the last the aperture of the ovicelled zooecia is very large.

Levinsen believed that this genus had some relationahjp with the Membraniporel pymle aroup. Its operculum and its compensatrix approach moreover II ippoporina, which is a true menber of the dsrophora.

It is doubtful whether this genus is represented in the Eocene of the United States, but as it is the only one of which the amatomy has been stmdied, we have illustrated it in some detail.

The oral glands so often described by Waters are here the testicular glands (Jullien).

FIGULARIA (?) CRASSICOSTULATA. new species.

Plate 4., fig. 9.

Deseription.-The zourium incruts shell- The zooecia are little elongated, wide, elliptical, separated by a furrow; the frontal is convex; the costules are thich, trunsverse, separated by a small initial slit followed by two or three lacunae. in number from 8 to 10 pairs. The apertme of the ordinary zonecia is formed of an anter much arched and a poster a little wider and nearly straight. separated by two small cardelles; the peristome bears laterally two small tuberosities; the aperture of the ovicelled zooecia is larger and transrerse. The oricell is hyper-tonial and exteriorly very convex: it is formed of two calcareous deposits. of which the onter one is incomplete, and leares two cicatrices in the form of a crescent. 'The aricularium is interzooccial and large and wide.

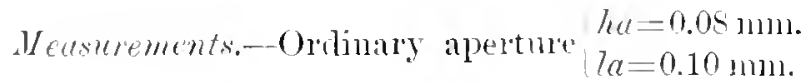

$$
\begin{aligned}
& \text { () vicelled aperture } \begin{array}{l}
h a=0.10 \mathrm{~mm} . \\
/ 1 t=0.15 \mathrm{~mm} .
\end{array} \\
& \text { Zooecia }\left\{\begin{array}{l}
L_{z}=0.73 \mathrm{~mm} . \\
l z=0.30-0.40 \mathrm{~mm} .
\end{array}\right.
\end{aligned}
$$

Athitirs.-This species differs from cribrendoreium temucostulatum in the wreater size of its costules and in its hyperstomial ovicell. There is no pore on the shicld of the costmles as in all the other species of this genus. 
Occurrence-Upper Jacksonian (Ccali limestone): Chipola River, east of Marianna, Jackson County, Florida (very lare): Old Factory, 1르 niles alove Bainbridge, Georgia (very lare).

IIolotype-Cat. No. 64036, L.S.X.Ml.

\section{Genus ASPIDELECTRA Levinsen, 1909.}

Bibliography (Zoological).-1903. Normax, Xotes on the Natural IIistory of East Finmalk,

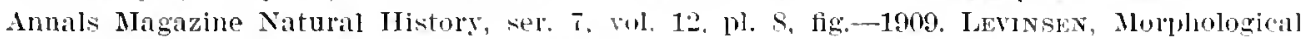
and systematie studies Cheilestoniltom riproil. pl. 160.

"The proximal part of the zoocciun with one or" two thick, projecting, hollow spines; the frontal shield nerforated by slits: ench distal wall with two multiporous septular disks, and the distal half of each lateral wall with a single septula, the aperture in the frontal shield with an opereular valve: no avicularia: no ovicell." (Levinsen.)
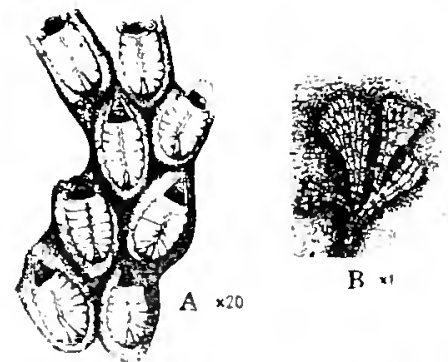

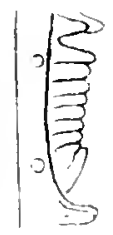

C.40

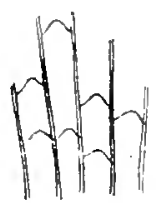

$\mathrm{D} \times 1 \%$

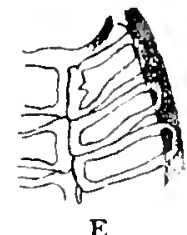

$\mathbf{E}$

Fik. SS.- ciontun Ispielvedra Levinsen, 1909.

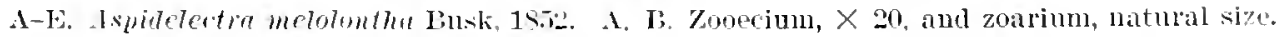
(After Hincks, 1S50.) C. Iatteral view of a zomcium, $X 40.5$. Lower side of the zoarium, 1:. (C. I aftel Levinsen, 1s!lf.) E. Structure of the costules. (After Norman, 1903.)

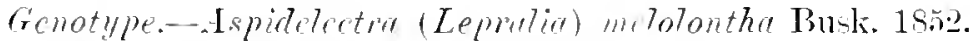

Levinsen thought that this genus helonged to the Electrinidae. It is nut repremented in the Ameriean Eocene. and wo cite it to show how hoterogenems the ('ribrilinidae are. and to sngest the importance of the ontogenetic works which might lee murlertaken on this suljed.

\section{Family ACROPORIDAE Canu, 1913.}

The zonecia are indistinct and their frontal is thickened. 'T'he asoonore, purforating the frontal, opens into the zooecia below the operenlum. The wivell is hyperstomial. deeply immersed and invisible exteriorly. The apertura is buried at the bottom of a long peristomie. There are some frontal avicularia an sume peristomial avicularial.

The characteristics of this family are not yet sulliciently studied; the recent specimens are rare and the sections marle of the fossil forms are often diflicult to interpret. 
We are able to distinguish the prineipal genera only by the nature of their frontal.

Following the Membraniporae, these are the most ancient Cheilostome fossils linown.

\section{Genus ACROPORA Reuss, 1869.}

1860. Acromora Reuss, Die fossilen Anthozoen und Bryozoen der Schichtengruppe ron Crosaro, Denkschriften der k. Akademie der Wissenschaften, Wien, vol. 29, p. $2 \pi 7$.

The zoarium is free and escharian. The frontal is a thick tremoerst with tubules. The avicularia are grouped on the peristome.

Genotypes-Acropora (Eschara) gracitis Milne Edwards, 1836, of the Australian seas and Acropora (Cellaria) coronate Reuss. 1847, a fossil of the Vicentin.

Range.-Jacksonian-Recent.

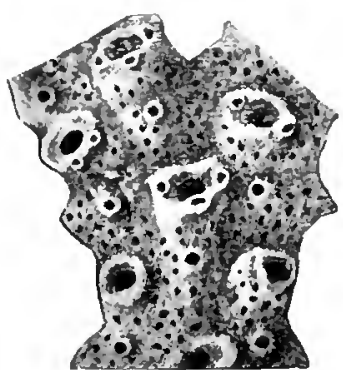

A. Acropora.

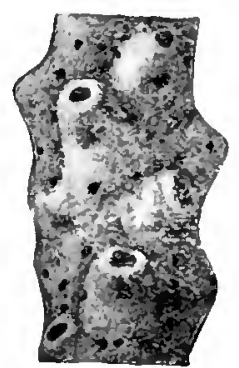

B. Gastropella.

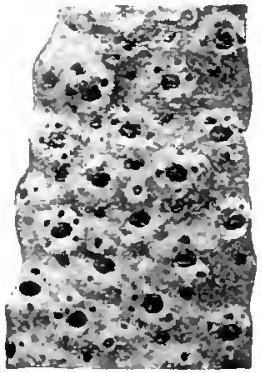

C. Pachytheca.

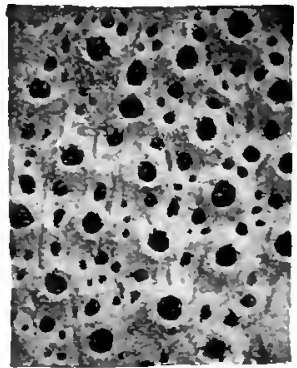

D. Beisselina.

Frg. S9.-Genera of the family Acroporidae Cann, 1913.

A. Acropora saillans, new species, $\times 20$. Vicksburginn. 1 mile north of Monroeville. Alabama.

I. Gastropella ventricosu Canu and Bassler. 1917, X 20. Midwaran of Arkinsas.

C. Pachytheca stipata, new species, $\times 20$, Midwayal, Crenshaw County, Alabama.

I. Bcisclina trulla, new species, $X$ 20. Inwer Jacksonian, Jackson, Mississipri.

The known species of this genus are:

Acropma (Eschara) coronata Von Hagenow, 1851 (not Reuss). Maestrichtian. Acropora (Cellaria) coronata Reuss, 184i. Priabonian.

A Cropora (Entalophora) grateloupi D'Orbigny, 1851. Lutetian.

Aropura (Porina) contorta Canu. 1910. Auversian.

Aropore (Pustulipora) mamillata D'Archiac, 18t6. Auversian.

Acopora (Eschara) gracitis Milne Edwards, 1836. Recent.

ACROPORA TRITA, new species.

Plate 6, figs. 5,6 .

Hestivion.-The zoarium is free, eylindrical, bifureated. The zonecia are indistinct; their frontal is confused with the zoarial surface and it is formed of a tremocyst with small scattered pores. It has no salient peristomes. The peristomice is oblique. elliptical, transverse.

$$
\text { Mentum mts.-Peristomice }\left\{\begin{array}{l}
h p e=0.10 \mathrm{mmn} . \\
7 p e=0.15 \mathrm{~mm} .
\end{array}\right.
$$


Affinities.-The aspect of this species is that of a wom zoarim, thus recalling Heteropora. The examination of the transverse section indicates clearly a Cheilos: tome despite this deceptive appearance. The ascopore is not regularly placed and it is often little disceruible as in Acropor'e mamillata D'Al'hiac, 1846 ; it differs from the latter species in the absence of a salient peristome.

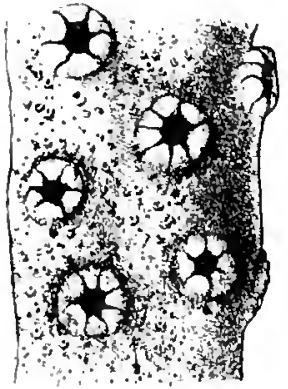

A

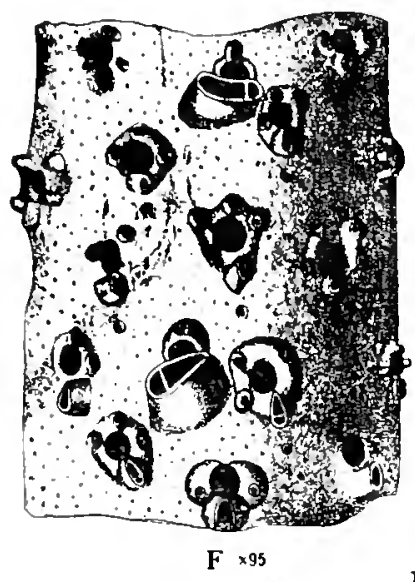

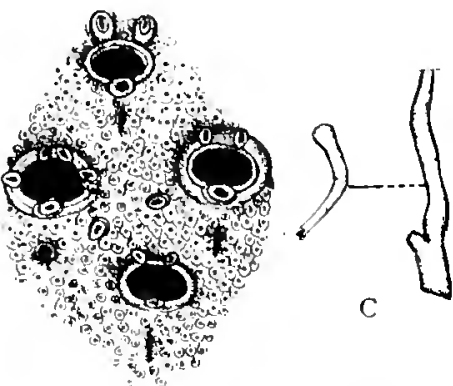

$\mathrm{B}$

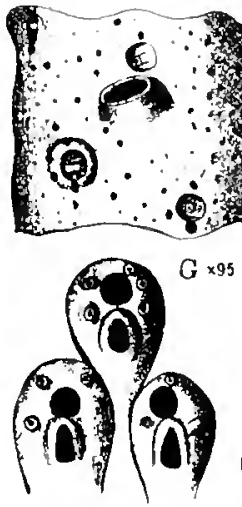

$\mathrm{H} \times 95$

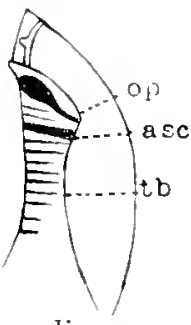

K
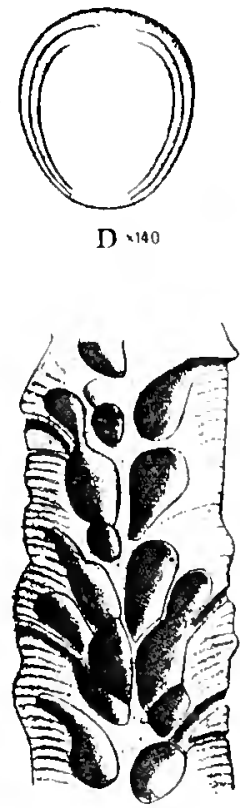

E $\times 17$

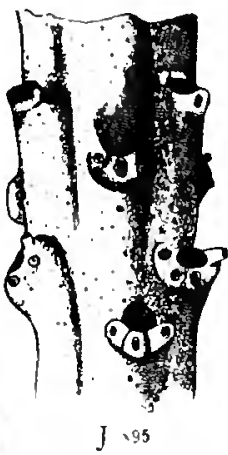

I $\times 12$

Fıg. 90.-Genus Acropora Reuss, 1869.

A-E. Acropora gracilis Milne-Edwards, 1836. A. Zooecia. (After Milne-Edwards, 1836.) B. Zooecia and avicularia. (After IIncks, 1Ss1.) C. Zoaria, natural size, D. Operculum, $X$ 140. E. Longitudinal section. (C-E after Levinsen, 1909.)

F-K. Acropora coronata Reuss, 1869 . F, G, H. Three views of zooecia, showing variations of the avicularia, $\times 95$. I. Termination of a branch, natural size, and $\times 12$ slowing openings for articular tubes. J. Small form (cf, Acropora labrosa Reuss). I. Diagrammatic section through a zooecium; asc, asconore; op, operculum; tb, tubules. ( $\mathrm{F}-\mathrm{K}$ after Waters, 1831.)

Occurrence.-Midwayan (Clayton limestone) : One mile rest of Fort Gaines. Georgia (rare).

Cotypes.-Cat. No. 63817. U.S.N.M.

ACROPORA SAILLANS, new species.

I'late S5̃. figs, 4-12.

Description.-The zoarium is free, cylindrical. bifurcated. formed of 5 or 6 longitudinal rows of zooeria. The zooecia are distinct, larece elliptical; the frontal 
is convex and formed of a tremocyst with small scattered pores; it is prolonged into a long peristomie, smooth or a little granular; the ascopore is large and salient. The peristome is salient and it supports 2 to 5 small avicularia with pivot; the peristomice is elliptical, transverse, oblique.

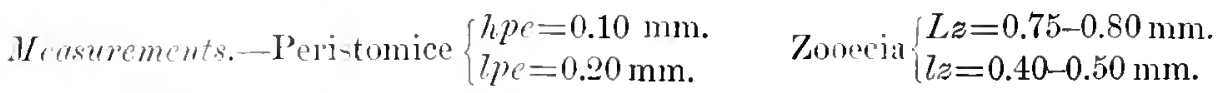

Tariations.-The diagrammatic section (fig. 6) illustrates the structure of this species; the small peristomial aricularia are visible as small cavities.

The ascopore is perfectly visible in the interior (fig. 10). It opens manifestly into the zonecium leaw the operculum. The frontal is formed of a tremocyst with tubules placed on a very thin perforated olocyst; these tubules have thick walls; " it is diflicult to see them on the transverse sections (fig. 9).

The longitudinal thin section is very curious (fig. 12). It shows on the median axis a series cf fusiform zooecia disposed in chaplet, the latter resulting fom the alternation of zooecia as seen in perspective.

Affnitics.-This species is much larger than Acropora coronata Reuss, 1847 ; the zooecia ale mole listinct; the peristomial avicularia are smaller.

It differs from Gastropella asperula in its frontal with numerous tremopores and in the absence of areolac.

Occurrenee-Vicksburgian ("Chimney rock" of Marianna limestone) : One mile north of Monurverille, Alabama (very common).

Vicksburgian (Red Bluff clay) : Seven and one-half miles sontheast of Bladon Springs, Alabana (very rare).

Cotypes.-Cat. No. 64263 , U.S.N.M.

\section{Genus GASTROPELLA Canu and Bassler, 1917.}

1917. Gastroprllu Caxu and Bassler, Synopsis of Amelican Early Tertiary Cheilostome Bryozoa, Iinlletin 9r, United States National Museum. 1), 37.

In Acropora having a smonth fronta] gamished laterally with areolae.

Genoilpe--Craviopella ventricosa Canm and Bassler, 1917.

Range.-Midwayan-Jacksonian.

GASTROPElla VENTRICOSA Canu and Bassler, 1917.

I'late 6 , figs, $7-12$.

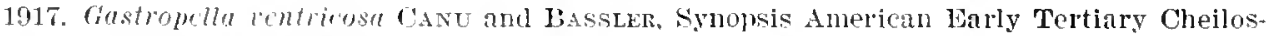
tome Bryozon, liulletin 96, United States National Museum, p. 35, pl. 4, fig. 3.

Description. - The zoarium is free, cylindrical. bifurcated. The zooccia are large, elliptical, suchlen; the frontal is smooth, convex, ganished laterally with some large areolae. The ascopore is very large, not salient, placed in the upper third of the zooecia. The peristome is salient and sluap; the peristomice is oblique, orbicular or elliptical. The ovicell is cntircly hirlden within the thickness of the frontal of the distal zonecium. 
Measurements-Peristomiee $\left\{\begin{array}{l}\text { hpe }=0.10-0.15 \mathrm{~mm} . \\ l p e=0.15 \mathrm{~mm} .\end{array} \quad\right.$ Zonecia $\left\{\begin{array}{l}L_{z}=0.5 .5 \mathrm{~mm} . \\ l z=0.40 \mathrm{~mm} .\end{array}\right.$

Aftinities. - There is frequently a rely small peristomial aricularium (fig. 10). On longitudinal sections the ascopore minnifestly opens below the apertura (fig. $12)$; it often appears like a lare funnel (fig. 1.2). On the ovicelled zooecia there is a sort of clamp ( $p l$ ) which is perhaps inteneled to fasten the operculun during the expulsion of the larva (fig. 11) ; but it is diflicult to comprehend the exact position of this operculum and perhaps we have located it bally if the ovicell is peristomial.

This species differs from Gaxtropella asporula in the more elevated position of the ascopore, in the absence of the numerous avicularia on the peristome, ant in the rery linge areolae.

Occurrence-Midwaran: Mabelrale, neal Little Rock, Mrkansas (common): one mile west of Fort Gaines, Georgia (common): Luverme. Crenshaw County, Dlabama (rare).

$$
\text { Cotylles.-Cilt. Yo. 6.25s9. U.S.X.MI. }
$$

GASTROPELLA ASPERULA. new species.

Plate 4 . figs. 1ei-1s.

Description.-The zontrinu is flee and cylindrical. The zooecia are large, elongated, little distinet: the frontal is smooth, convex, surrounded by small areolae. The ascopore is large, not salient, pliced at the middle of the frontal. The peristome is very salient and lears 2 to 6 small aricularia; the peristomice is elliptieal. transverse, oblicue toward the bottom of the zoarium: the apertura is semielliptical with a concare proximal horder.

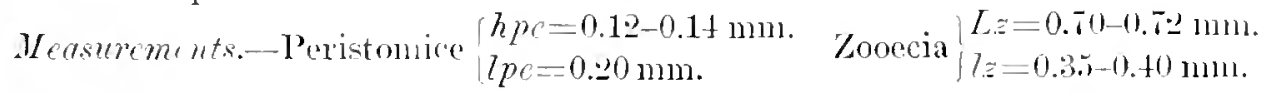

Aftinitics. - This heautiful species is rather constant in its characters. We have never been able to find an ovicell in oul sections.

It differs from Gastropellu centricosu in its smaller areolae. its smaller ascopore. and in the presence of many small aricularia on the peristome.

It differs from Phoccanu simulator with which it occurs and much resembles exteriorly in the presence of an ascopore.

Occurrence.-Middle Jacksonian (Caste IInye limestone): Wilnington. North Cirolina (rare).

Cotypes.-Cat. No. 6t037. U.S.N.M.

Genus PACHYTHECA Canu, 1913.

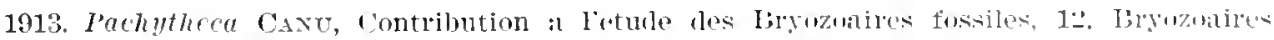

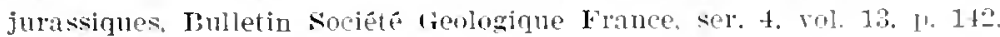

The froutal is a thick olocyst. 'The soarium in frees. and suberlimbical. The ascopore is large and opens exteriorly quite a distance from the perintone.

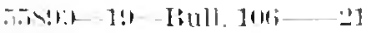


Genotype.-Pachytheca (Porina) filiformis D'Orbigny, 1852.

Range.-Campanian-Midwayan.

\section{PACHYTHECA STIPATA, new species.}

Plate 6, figs. 13-15.

Description.-The zoarium is free, cylindrical or escharian, bifurcated. 'The zooecia are little distinct, elongated; the frontal is somewhat convex, smooth. The ascopore is large, deeply imbedded, placed at the middle of the zooecia on the median line. 'The peristome is salient, wide, supporting four small aricularia; the peristomice is orbientar.

$$
\text { Weasurements.-Zooecia }\left\{\begin{array} { l } 
{ L _ { z } = 0 . 4 5 - 0 . 5 0 \mathrm { mm } . } \\
{ l _ { z = 0 . 3 0 } ( ? ) \mathrm { mm } . }
\end{array} \quad \text { Peristomice } \left\{\begin{array}{l}
h p e=0.10 \mathrm{~mm} . \\
l_{p}=0.10 \mathrm{~mm} .
\end{array}\right.\right.
$$

Affinitiss.-The peristomes are crouded quite close to one another as in Beisselina. The species diflers from Pachytheca (Eschara) defrancei Hagenow, 1851 , in the presence of avicularia on the peristome.

It differs from Parhytheca (Porina) filifomis D'Orbigny, 1852, in its rarely cylindrical zoarium and in the presence of many (and not of one alone) peristomial avicularia.

Occurrence.-Midwayan (Clayton limestone): Isurerne, Crenshaw County, Alabama (common).

Cotypes.-Cat. No.63819, U.S.N.M.

Genus BEISSELINA Canu, 1913.

1013. Beissclina Canv, Contributions a letude des Bryozonires fossiles, 13, Blyozoaires jurassiques, Bulletin Societé Geolosique, France, ser. 4, vol. 13, p. 138.

The tubules are large and often are replaced by some small aricularia; they lide the true zonecial form. The zoarium is free and escharian.

renotype.-Beissrlina (Eschara) striutu Goldfuss, 1826.

Range.-Cenomanian-.Jacksonian.

It is impossible to confuse the genera Lcropora Reuss, 1869 , and Beisselina. Cann, 1913. However. it is diflicult to find any physiologic character clearly fiflerent. It is true that we are atways ignorant of the function of the avicularia and of the tubular tremopores.

BEISSELINA FORATA, new species.

Plate 6, figs. 16-20.

Deseription.-The zoarium is free, escharian; the two lamellae, back to back are inseparable. The zooecia are indistinct. The peristome is thin, sharp, rery little salient: the peristomice is orbienlar. The frontal pores are large, orbicular. numbering 5 or 6 . The ascopore is large and in aspect little different from the otheremes.

$$
\text { Measurementr-Peristomice }\left\{\begin{array}{l}
h p e=0.09 \mathrm{~m} 11 \mathrm{~m} . \\
7 p e=0.09 \mathrm{~mm} .
\end{array}\right.
$$


Afinities.-The elements of the olocyst (fig. 20) are regularly disposed in guinucunx.

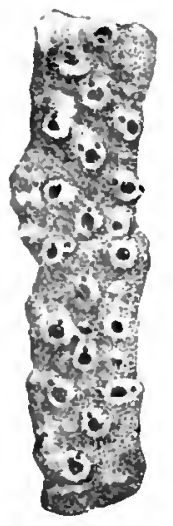

$A x<0$
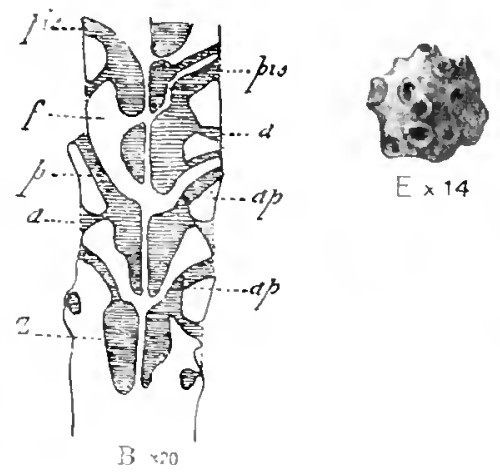

$E \times 14$

Fig. 91.-Genus Pachythcon Canu, 1913.

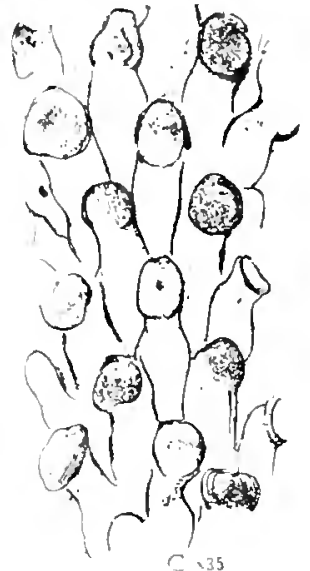

A. B. Inchythece filiformis DOrbigny, 1552. A. Zonaum, X 20. B. Lougitulinal section. $\times$ 20. (A, B after Canu, 1913.) a, ascopore: ap, apertura ; $f$, frontal thickening; $p$, peristomie: pis, peristomice; z, zooecium.

C, D. Pachytheca bosqueti Beissel, 1S63. C. Cast of the interior, $\times 35$. D. Extremity of a branch, profile view, $X$ 14. F. The same extremity seen from the top, $X$ 14. (C-F after Beissel, 1S63.)

This species differs from Beissetina miduayenica in its very large frontal pores, in the somewhat larger diameter of the peristomice $(0.09 \mathrm{~mm}$. instead of $0.06 \mathrm{~mm}$.). and in its somewhat prominent peristome.
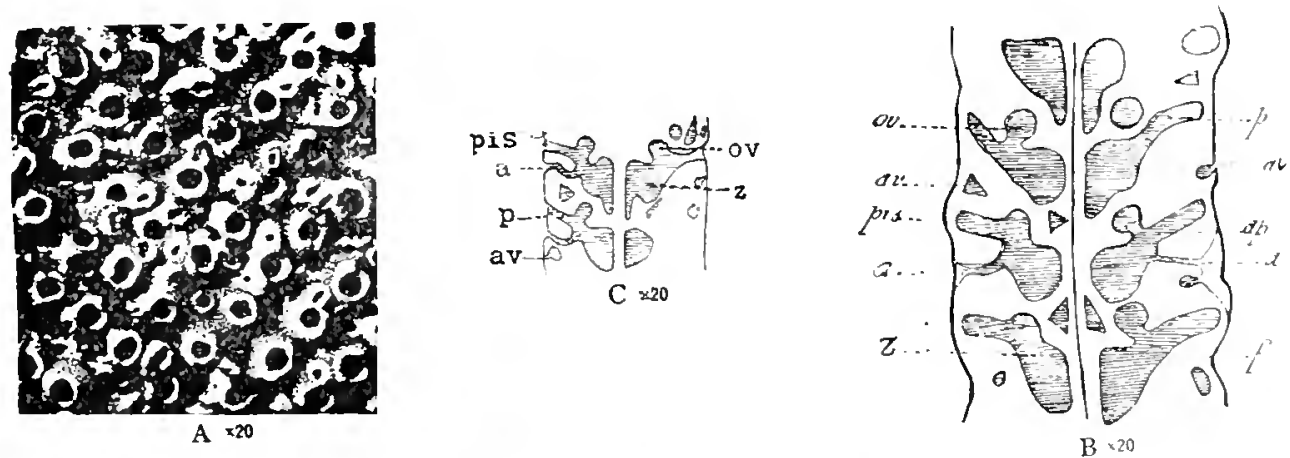

Frg. 92.-Genus Bcisselina Canu, 1913.

A, B. Beisselina boryana ron Hagenow, 1851. A. Surface of zuarium, X 20. 12. Lumsituli-

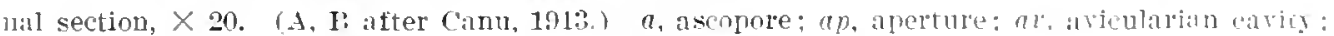

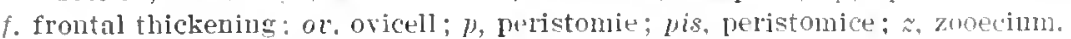

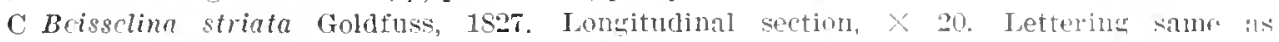
oll fig. B.

Occurrence-Midrayan (Clayton limestone): Mahelrale. near Little Rock. Arkansas (rare).

Cotypes.-Cat. No.63820, T.S.N.M. 
Deseription.-The zoarinm is a bifureated Escluara: the fronds are compressed, little thick; the two lamellae, back to back, are inseparable. The zooecia are indistinct; the frontal is perforated with some pores irregularly placed. There is no peristome; the peristomice is small and orbicular. The ascopore is large and placed on the median axis of the zooecia.

$$
\text { Measurements-Peristomice }\left\{\begin{array}{l}
7 l p e=0.06 \mathrm{~mm} \text {. } \\
l p e=0.06 \mathrm{~mm} \text {. }
\end{array}\right.
$$

Tumations. - The frontal pores are absent (fig. 3), rare (fig. 4), or abumdant (fig. 2). In the interior (fig. 5) the pores appear like perforations direct in the olocyst. 'The transverse sections (fig. 7 ) indicate some lateral walls, quite thin and intimately joined. On the transverse thin section the tro lamellae are distinct and the olocystal elements are gromped in a transversal line. These elements are very dense. furte crowded, and it is rlfhcult to obtain sections sufticiently transparent (fig. 11). The longitudinal soction (fig. 12) is diflicult to interporet; but our s hematic figure is perfectly exact.

Aftinitis. This species diflers from Dessetime forata in its smaller orifice (0.06 insteal of $0.09 \mathrm{~mm}$.), in its rarer ancl smaller frontal pores, and in the absence of the perintome.

Fonctimes there are some larow salient ariculalia with pirot as in Beisselinu Tabiata Gabh and Horn, 1862, of the Vincentown mall (see plate $\tau$, fig. 14). It differs from this Cretaceons species in the absence on the rarity of the lar we frontal aricularim, in the maller dianeter of its peristomice (0.06 $\mathrm{mm}$. and not $0.11 \mathrm{~mm}$.), in its smaller ascopore, and in the alsence of the peristome.

Oenmener.-Milwayan (Clayton limestone): One mile west of Fort Gaines. Georogia (very common): Mabelvale, near Litte Rock, Arkansas (common): Luverne. Crenslaw Comnty, Alabana (rare).

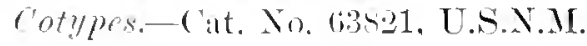

\section{BEISSELINA TRULLA, new species.}

Plate 4., fins. 19-21.

Ihespription.-The zoarimm is an Eschara with wille and rounded fronds; the two lamellate are inseparable. The zooecia are clongated, distinet; the frontal is ormanented with if or 7 laree pores of which one is an ascopore. The peristome is salient. thin. and sharp; the peristomice is orbienlar.

$$
\text { Mensurment. Peristomice }\left\{\begin{array} { l } 
{ h p e = 0 . 1 1 \mathrm { mm } . } \\
{ 7 p = 0 . 1 1 \mathrm { mm } . }
\end{array} \text { Zooecia } \left\{\begin{array}{l}
I_{z}=0.5 .5 \mathrm{~mm} . \\
7 z=0.24 \mathrm{~mm} .
\end{array}\right.\right.
$$

Iftinities. Thin species is easy to recognize by its distinct zooccia and its f'routal perforated like a colanter. It differs from bisselina implicata in the size of its fromtal pores which attain $0.04 \mathrm{~mm}$. in diameter and in its much larger peristomire (0.11 ant not $0.0 e^{3}$ mom.). 
It differs from Beisselina forato, which is also provicled with large frontal pores, in its larger zooecial and zoarial dimensions.

Occurronce.-Lower Jacksonian (M[oodys mar]) : Jackson, Mississippi (rare). IIolotype.-Cat. No. Gt038, U.S.N.M.

BEISSELINA IMPLICATA, new species.

Plate 44 , fins. $1-4$.

Description.-The zoarium is an Eschara with fronds linear and elongated. The zooecia are hardly distinct; the frontal bears 2 to 4 pores, an ascopore, and a small, salient a ricularium: the peristome is salient; the peristomice is orbicular.

$$
\text { Mcasurements.-Peristomice }\left\{\begin{array}{l}
h p e=0.06-0.07 \mathrm{~mm} . \\
\text { I } p e=0.06-0.07 \mathrm{~mm} .
\end{array}\right.
$$

Affnitics.-This species, complicated in appearance, differ's from Beisselina trulla in its little distinct zooecia, in its smaller frontal pores. and in the smaller diameter of its peristomice $(0.07 \mathrm{~mm}$. instead of $0.11 \mathrm{~mm}$.).

Fignre 3 perhaps represents a distinct species, but it is the only specimen fonnd.

In the geologic column this is the last Beissctina observed. We have no knowl. edge of the genus in the Miocene or Pliocene.

The small salient avicularium is far from being constant and many specimens are deprived of it.

Occurence-OUper Jacksonian (Ocala limestone) : Alachna. Florida (common ) : ? miles north of Ocala, Florida (rare) ; $1 \frac{1}{2}$ miles above Bainbridge, Georgia (rare).

Cotypes.C Cat. Nos. 64039, 64040. U.S.N.M.

Family IHPPOTIOOD.AE Levinsen. 1909.

The zooecia become calcified from belind in successive zones forward, leaving at the surface more or less salient lines, the lines of growth, and are furnished with a variable number of dietellae.

The genera of this family are as follows:

Hippothoc Lamouroux, 1821.

Chorizopora Hincls, 1880.

Trypostega Lerinsen, 1909.

It aplopoma Levinsen. 1909.

Dacryopora Lang, 1914.

This family. in spite of its exterior appearances, is not a natural one. The larva of Chorizopora is not identical with that of IIippothon and IIaplopoma. The ovicell of Trypostega is not like the gonoecia of other genera. We have therefore not given a general table for the family, but have indicated the zoological bibliography for eacl genus. 
Genus HIPPOTHOA (Lamouroux, 1821) Hincks, 1880.

Zoological biblography-1Sтт. Bankols, liecherches sur l'embryologie des Iryoznaires, 'Tritvaux de ]'Institut de zoologie, fasc. 1, p. 149, pl. 9. figs. 4, 16.-1,s6f. Jullen, Mission scientifque du Cap Holn. vol. 6, Zoology. p. 2S, pl. 4, 1igs, 1-4.-1900. Waters, Bryozna from Franz . Toseph Land. Tomrul limnean Society. Londun, vol. 29, p. 70, pl. S. figs. 16-18.-1900. LnVINSEN, Morphological and systematic studies on the Cheilostomatous Bryozoa, p. 276, pl. 18,

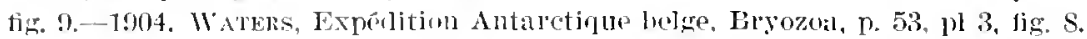

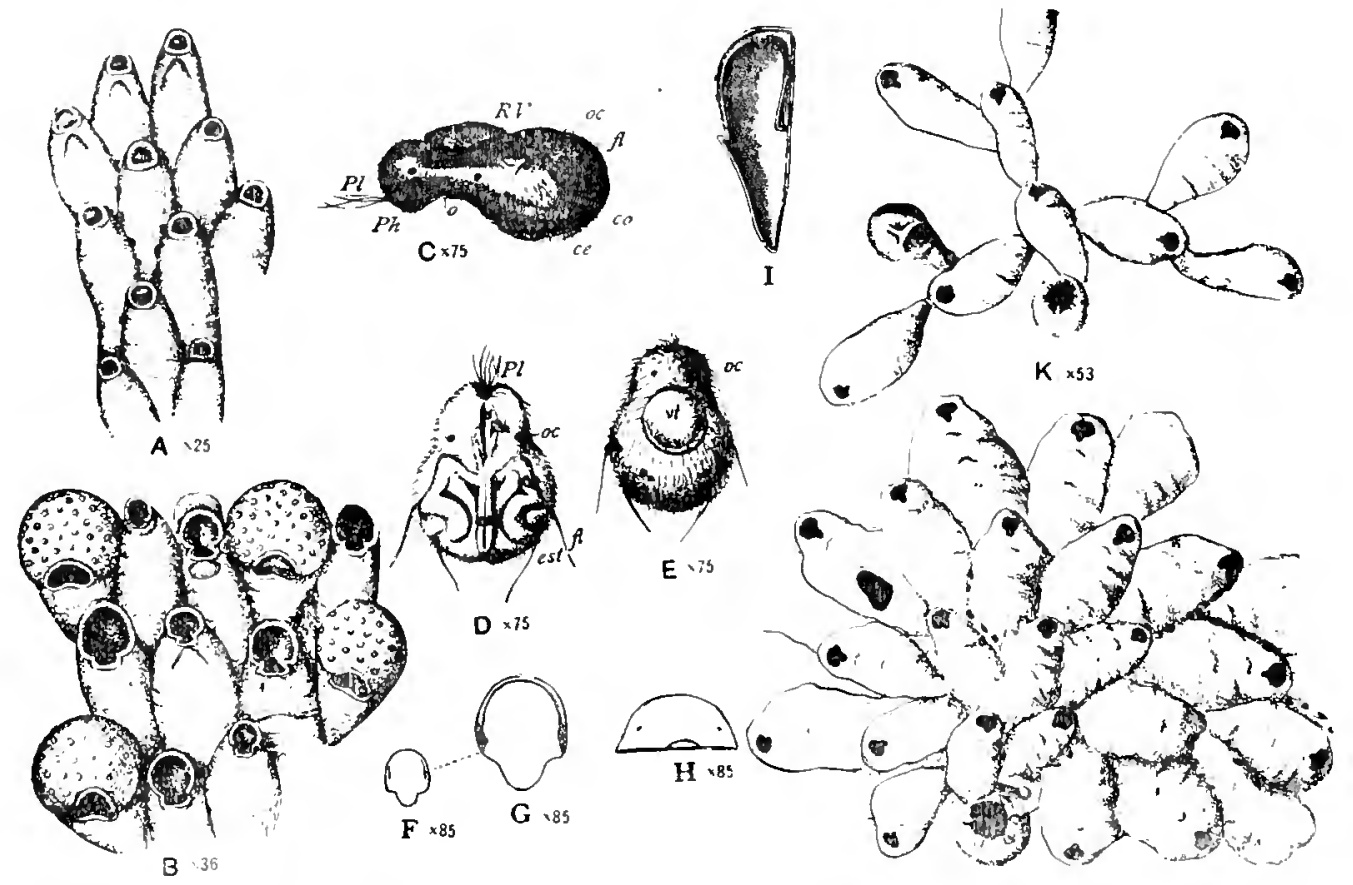

F1G. 93.-Genus Hippothoa Iamouroux, 1821 (Hincks, 1SS0).

1-1. Hippothoa hyalina Iinnaeus, 175s. A. Portion of zoarium, $\times$ 25. M. Zoarium with wicelled zooecia, $\times$ 36. (After Hincks, 1880.) C. Free larva, profile view, $\times 75$. D. Oral face of laria, slowing the singular structure of the stomach. $X 75$. L. Aboral face of larra, $\times 7 \%$, slowing the simplicity of the structure of the terminal bud. (G-E after Barrois, 1009.) rd, digestive cavity; $r$, obscure portion of the body eavity included between the two brauches of the stomach (=orifice of the external sack) : est, stomaclı; $f$, flagelluvı; $o$, mouth of the gastrula (=ciliated eloft): oc. oculiform points (=pigment spots): $p h$. plarpnx; $p l$, vibratile plume; rr, border of the telminal hud (=ealotte). F. Operculum of wale zooecium, $\times S 5 . \quad G$. Operculum of ordinary zooecium, $\times$ S5. H. Operculum of ovicelligerous zooecium, $\times$ 85. (F-H after Waters, 1900.) J. A sagittal section through a gonozooecium. The ovicell is surrounded by a kenozooccium. (Aftel Levinsen, 1909.) J、 K. Hippothoa bouguinvillei, DOrbjgny, 1839. J. Young, uniserial zoarium with a spinous ancestrula and with a gonoecium without polypide, $\times 53$. (J, K after Jullien, 1SSS.) K. Joung zoarium exhibiting spinous ancestrula with opesium, $\times 5 \%$.

The frontal of the zooceia is not porous. The operculum is compound. The sperture is provided with two much deroloped hinge-teeth and with a more or less 
angular rimule. The gonoecia are larger than the other zooecia and have a different form; they never contain a polypide; they contain an ovary and an incubation cavity which is a sort of endozooccial ovicell. There are male zooecia smaller than the normal zooecia.

Genotype.-IIppothoa divaricata Iamouroux, 1821.

Range.-Iutetian-Recent.

Historical.-Lamouroux created this genus for all uniscrial incrusting zoaria of Ascophora bearing generally zooecia very much narrowed hehind. The genas was hased entircly on zoarial features. By juggling the definition, it was transformed in 1880 by Hinclis into a genus based on zooecial features, and included only those species in which the aperture bears a small rimule. It is evident that we may observe hippothoiform zooecia provided with a different hydrostatic system and consequently with an aperture of a different form. ${ }^{1}$ Furthermore, Jullien in 1886 dismembered the old genus IIppothoa and applied the name of Diazeuxia to the group of the species with a small rimule. Waters, in 1900, and Levinsen, in 1909, preserved the definition of Hincks.

HIPPOTHOA (?) CONJUNCTA, new species.

Plite 7 , figs. 15. 16.

This species is certainly not a IIippothoa, for its aperture is elliptical and withont a small rimule. The fom specimens discorered are too fer for the study of characters sufficient to establish a new genus, especially as they bear no ovicell.

The zonecia are provided with a candal portion, which is very long, thin, and stoloniform. When such a portion encomter's another they join together and the gemmation of a branch is arrested. This is a peculiarity which we have never observed in Mippothor.

Occurrence.-Midwayan (Clayton limestone): Luverne, Crenshaw County, Alabama (rare).

Cotypes.-Cat. No. 63523, U.S.N.M.

HIPPOTHOA ? species undetermined.

Plate 44 , fig. 5 .

The specimen collected is very mediocre and bears only a single zooecium intact. In the form of its aperture it is neither II ippothoa nor Dacryopora. We have nentioned it simply to call attention to the occurrence.

Occurrence.-Upper .Tacksonian (Ocala limestone): (hipola River. east of Marianna. Jackson County, Florida (rare).

Genus TRYPOSTEGA Levinsen, 1909.

Tonlogial bibliography--1909. Levissen, Morphological and systematic studies on the Cheilostomatous Lryozna, p. 280, pl. 19, fig. 1; pl. 23, fig. 13.-1919. Writers, The Maline Fanmaf British East Africa and Zanzibar, Proceedings Zoological Society, London, P. 507.

This is notably so in the case of the genus Dacryopora Lang, 1914 (Geologica! Magazine, ser 6, vol. 1. p. 440 , pl. 34, figs. 4 and 5 ). 
The zooecia have a compound operenlum; they are surmounted by a small, elongated, constant zooecinle which is closed by a chitinous operculum. The female zooecia bear a hyperstomial oricell which is always closed by the operculum.

Genotype.-Trypostega (Schizoporella) venusta Norman, 1864.

Range.-. Tacksonian-Recent.

The organization of the female zooceia is very different from that of the gonoecia of II ippothou. There is certainly a polypide; the larrae derelop in an oricell embedded in the distal zooecia, but the ovicell is closed by the operculum. It is probable that the larve are different from those of the other genera. The zooeciules (= smprazoocial chambers of Waters and dwarf zooecia of Levinsen) we the organisms whose functions are unknown: they are unprovided with polypide.
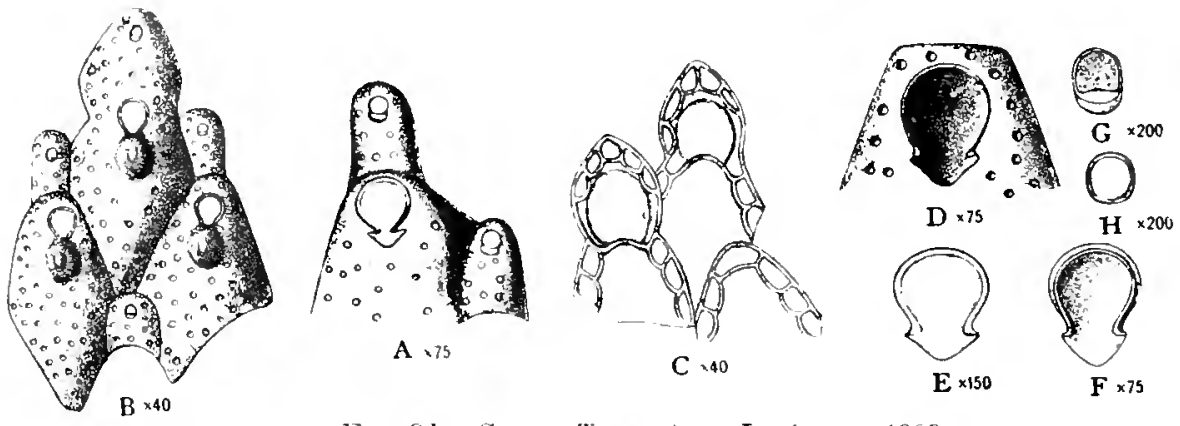

FIg. 91.- Genus Tryuosteya Levinsen, 1909.

A-II. Trypostrga venusta Norman, 1864. A. A zooecium and two zooecinles, $\times 75$. B. Jrawiug slowing three zoneciules and a larcel one surrounding an ovicell, $X 40$. C. View from the basal surface, $X$ 40. Two ovicells are seen surrounded bs zooeciules, which, lilie the ordinary zonecia, are furnished with dietellae, $X 40$. D. Ajertura, $X 75$. L. F. Opercula, $\times 150$ and 75. F. Apertura of zooecinle with opereulum, $\times$ 200. H. Operculum of a zooeciule, $\times 200$. (A-II. After Levinsen, 1909.)

TRYPOSTEGA ELONGATA, new species.

Plate 9, fig. 17.

Deseription.-The zoarium incrusts shells. The zooecia are distinet, elongated. fusiform; the frontal is convex and perforated with numerous pores scattered and disposed in quincmx. The apertura is formed of a large semicircular anter separated by two cardelles from a small, somewhat convex poster. 'The ovicell is large, salient, porous, elongated, carinated; it is hyperstomial and always closed by the nperculum. The zooccinles are elongated, fusiform; their small orifice is elliptical.

$$
\text { Wrasumements.-Apertura }\left\{\begin{array} { l } 
{ h a = 0 . 0 6 \mathrm { mm } . } \\
{ 7 a = 0 . 0 8 \mathrm { mm } . }
\end{array} \quad \text { Znoecia } \left\{\begin{array}{l}
L_{z}=0.40 \mathrm{~mm} . \\
l z=0.28 \mathrm{~mm} .
\end{array}\right.\right.
$$

1ffinitios.-This species differs from Trpostega venusta Norman, 1864, of the Ticksburgian, in the greater length of its zooeciules $(L z=0.20 \mathrm{~mm}$. instead of $0.10 \mathrm{~mm}$.), and in its slightly smaller apertura. 
In spite of the imperfections of the few specimens discovered it was interesting to note this species. for it completes the geologic series in the distribution of the semus. We are acquainter with Tryprosterg species from the Lutetian of sonthern France and Trypostega aquitanien C:mu, 1906, from the Stampian of southerm France.

Cecurenee.-Wilcoxian (Bashi formation): Woods Bluff, Alabama (rare). IIolotype.-Cat. No. 63836, U.A.N.M.

\section{TRYPOSTEGA UNDUIATA, sew species.}

Plite 44, figs. 6, 7 .

Deseription.-The zorrium incrusts shells and bryozoa. The zooecia are small, distinct. clongated, priform; the frontal is convex, ornamented with transverse undulations and often with an infra-oral gibbosity, and unprovided with risible pores. The ovicell is clongited, prominent, smonth, globular, hyperstomial, and always closed by the opereulum. 'The aperture is semilunar; the proximal border is straight and bears a large rectangular rimule. The zooceiules are small, elliptical. perforated by a very small circular orifice.

Weasurements. A perture $\left\{\begin{array}{l}h a=0.07 \mathrm{~mm} . \\ 7 a=0.05 \mathrm{~mm} .\end{array} \quad\right.$ Zooecia $\left\{\begin{array}{l}L_{z}=0.36-0.40 \mathrm{~mm} . \\ l z=0.24 \mathrm{~mm} .\end{array}\right.$

Affinitics. This species differs from Trypostega inornata Gabb and Horn, 1862. in its distinctly smaller dimensions $(L: z=0.40 \mathrm{~mm}$.), its frontal umdulations and its infra-oral aibbosity.

It differs from Trypostega vemestr. Norman. 186t, in its smooth, nonporous frontal and its smaller oral dimensions.

It differs from T'rypostega aquitaniea Cann, 1006, of the French Stampian, in the absence of a distally much developed peristome.

Occurrence.-Middle Jacksonian: Rich Hill $5 \frac{1}{4}$ miles southeast of Knoxrille, Georgia (rare); 1 miles west of Wrightsville, Georgia (rare); Baldock, Barnwell County, South Carolina (rare).

Upper Jacksonian (Ocala limestone) : Near Georocia Kaolin Companỵ's mine, Triggs County, Georgia (very rare); Old Factory, $1 \frac{1}{2}$ miles above Bainbridge. Georgia (very rare).

Cotypes-Cat. No. 64042, U.S.X.M.

TRYPOSTEGA INORNATA Gabb and Horn, 1862.

Plate 44, figs. S-10.

1562. Cellepora inornata Gabs atud Honx, Monomaph Polyzoi secondary and Tertiary North America, Journal Academy Natural Science, Philadelphia, ser. 2, roi. 56 p. 12\%, pl. 19 , fig. 10.

Deseription.-The zoarium incrusts shells. The zooecia are elongated, distinct, pyriform; the frontal is smooth and nearly flat. The aperture is formed of an 
anterior semilunar portion and of a wide rounded rimule. The ovicell is large, somewhat globular. smooth. The zooeciules are small, elliptical, smooth, perforated by a very small orifice.

$$
\text { Measurements.-Aperture }\left\{\begin{array} { l } 
{ h a = 0 . 0 8 - 0 . 1 0 \mathrm { mm } . } \\
{ l a = 0 . 0 6 - 0 . 0 8 \mathrm { mm } . }
\end{array} \quad \text { Zooecia } \left\{\begin{array}{l}
L z=0.44-0.50 \mathrm{~mm} . \\
l z=0.26-0.30 \mathrm{~mm} .
\end{array}\right.\right.
$$

Affinitics.-Smitt, in 1873, identified this species with Trypostega venusta Norman, 186t. We can not subscribe to this identification, for the American authors do not mention the frontal pores at all. Another part of their description corresponds much better to the present species than to Trypostega undulata in which the zooecia are rery convex. They write as follows: "Cellules slightly convex, oval ..." and "The oval plain, small cellules, with the mouth oroid to subtriangular. . .." They confound the zooeciules (figured) with the ovicells, yet they say in the text, that "the orarian resicle is something much broader than shown in the figure, sometimes attaining as great a width as the cellule itself."

This species differs from T'rypostega undulata in its less convex frontal, its large micrometric dimensions ( $L z, 0.44-0.50 \mathrm{~mm}$. instead of $0.40 \mathrm{~mm}$.), in the larger aperture, and in the absence of undulations and frontal gibbosities.

It differs from Trupostega venusta Norman, 186t, in its larger micrometric dimensions and its smooth frontal. which is not perforated by scattered pores.

Occurrence.-Upper Jacksonian (Ocala limestone): Chipola River, east of Marianna. Florida (lare); west bank of the Sepulga River, Escambia County, Alabama (rale).

Vicksburgian (Marianna limestone) : Salt Mountain, 5 miles south of Jackson, Alabama (rare); Murder Creek. east of Castlebury, Alabama (rare) ; near Claiborne, Monroe County. Alabama (lare); west bank of Conecuh River; Escambia County, Alabama (rare); one mile north of Monroeville, Alabama (common); three miles southeast of Vosburg, Jasper County, Mississippi (rare); deep well, Escambia County, Alabama (very lare).

Plesiotypes.-Cat. Nos. 64043-04045, U.S.N.M.

TRYPOSTEGA VENUSTA Norman, 1564.

I'late s5, figs. 15, 16

18.i1. Holliu tuberulatu Tonsigrs, Palentoloric Francaise, lescription des animaux in-

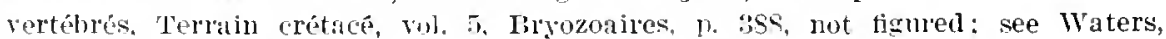
Annais Magaziue Natural History, ser. 7. vol. 15, p. 6.

1864. Lepralia venusta Noratan, On undescribed British Polyzoa, Annals Magazine Natural Ilistory, ser. 3. vol. 13, p. S4, pl. 10, figs. 2, 3.

1873. Gemellipora glabra. form striatula Sista, Floridan Bryozoa, pt. 2, Kongl. Srenska Yetenskaps-Akademiens Handlingar, vol. 11, No. 4, p.:37, pl. 11. p. 207.

1880. Schizoporella renusta Irxcks, British Marine Polyzoa, 1. 276. pl. 30, figs. 6. 7.

1852. Lepralia striatula MacGillivar, Descriptions of new or little known Polyzoa, Transactions of the Royal Society of Victoria, pt. 2. vol. 19, p. 124, pl. 3, fig. 17 .

18S5. Schinoporrlla striatula Waters, Clieilostomatous Bryozoa from Aldinga and the River Murray Cliffs, South Anstralia. Quarterly Journal of the Geological Society of Lon. don, vol. 41. P. 301. 
1S57. Gemclipora striatula IIAcilluvar. Rryozoa in McCoy's Prodromus of the Zoology of Victoria, vol. 2. lec. 14, N. 150, pl. 139, fig. 10.

1SSS. Schisoporella vemusta KinkPATnick, Polyzon of Mauritius, Annals Magazine Natural History, ser. 6, vol. 1, p. 76 .

1590. Schizoporella renustr Kinkpatrick, Mydroida and Polyzon from the China Sea, Aunals Mngazine Natumal IIistory, ser. 6, vol. 5. p. 17.

1590. Schizoporella renusta linkPatrick. Proceediugs Royal society Dublin, n. s. vol. 6. P. 612 .

1599. Schizoporella striatula I'mllups, Report on the Polyzui from Loyalty Isles, New Guinea and New Lritain. Zoologienl Results. A. Willes, pt. 4, p. 440.

1002. Trypostcga venusta Levissen, Studies on Bryozoa, Vidensk Medd. fra den Naturł. Foren. i Kjybenliaven, 1). 23.

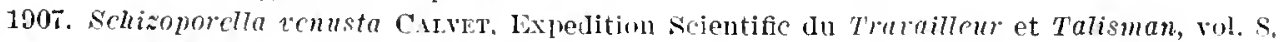
p. 416.

1909. Trypostega renusta Lrixsex, Morphological and Systematic Studies on Cheilostomatous Bryozon, 1). 2S1, pl. 19, figs. 1a-1 ; pl. 22, figs. $13 a-13 a$.

1909. Trypostrga venusta Norman. Poļ̣zoa from Madeim, Journal Limnean Society Zoology, vol. 30, p. 299.

1912. Gcmellipora glabra. form striatula Troknely, Marine Polyzoa Indian Ocean, Transactions Linnean Societ 5 Zoolog., rol. 15, p. 149.

1013. Trypostcga venusta Waters, The Marine Fauna of British East Africa and Zanzibar, Proceedings Zoologica] Society Iondon, 1). 506.

1914. Trypostega venusta Osburs, The Bryozoa of the Tortugas Islands, Florida, Publication Cannegie Institution Washington. No. 152, 1. 195.

Measurements.-A A pertme $\left\{\begin{array}{l}h a=0.08-0.10 \mathrm{~mm} . \\ l \alpha=0.06-0.08 \mathrm{~mm} .\end{array} \quad\right.$ Zooecia $\left\{\begin{array}{l}I_{z}=0.40-0.46 \mathrm{~mm} . \\ 7 z=0.26-0.30 \mathrm{~mm} .\end{array}\right.$

Affinitics.-Doctor Osburn has been kind enough to send us a recent specimen from Beaufort, and we have thus been able to make all the comparisons with great facility. Undoubtedly our specimens belong to the recent species, evervwhere rery cosmopolitan, although their mierometric dimensions are slightly smaller.

The frontal pores are rather large and scattered. The zooeciules are small and pyriform: their orifice is orbicular and quite variable in size.

This species differs from Trypostega undulate in which the dimensions are rery close. in its frontal perforated by a larger orifice $(h a=0.08-0.10 \mathrm{~mm}$. instead of $0.06-0.07 \mathrm{~mm}$.), and in the absence of a rectangular rimule at the aperture.

It differs from Trypostega inornata Gabb and Horn, 1862, in its perforated frontal and its smaller micrometric dimensions ( $L . z$ smaller than $0.45 \mathrm{~mm}$.).

It differs from Trypostega aquitonira Canm, 1906, in the absence of a distal thickening at the peristome. This character is unimportant, and it may be that the French species is only a variety of the recent form.

Abrasion of the surface of the zoocia permits of the ready discorely of dietellae (fig. 15); their number is variable; there are none around the zooeciules.

The frontal gibbosity is not constant on the recent species; the specimen received from Doctor Osburn notably; is deprived of it and otu fossil specimens resemble the recent one absolutely.

Oceurence-Ticksburgian (Byram marl): Byram, Mississippi (rare); onefourth mile west of Woodwad, Wayne County. Mississippi (rare). 
Ticksbulquan (Marianna limestone) : Near (laiborne, Monroe County, Alabama (race).

Geoloqient distribution.-Miocene, South Australia. (Waters.)

II abitat.-Atlantie: In the English Channel. off Madeira, Azores and Cape Verde Islands, Florida. Pacific: China seas $(45 \mathrm{~m}$.$) . Torres Strait. Amirante$ (36-140 m.), Saya de Malla (48-200m.), Mauritius, Wasin (16 m.), British East Africa.

Plesiotypes.-Cat. No. 64266. T.S.X.M.

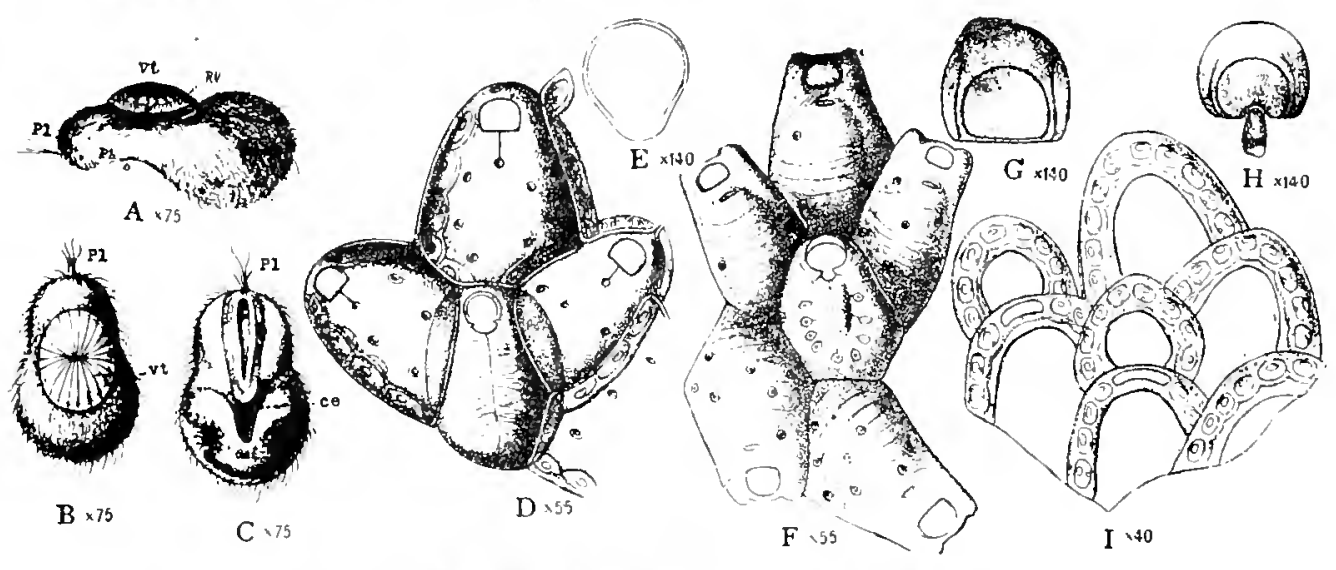

Fig. 9.5.-Ginus Haplopoma Ievinsen, 1909.

A-I. Haplopomm impressum Audouin, 1826. A. Free larva in profile, $X 75$. B. View of larra, abodal face, $\times 75$, showing the arrangement of the striations of the terminal bud. $C$. Oral face of larva, $\times \quad \mathrm{i}$, exhilviting the general form of the stomach. (A-C after Barrois, 1Sit.) ce, orifice of th. internal sac; $e$ st, stomach; $o$, month of the gastrula; phe pharynx; $p l$, ciliary plume; $R \boldsymbol{V}$, border of the terminal hul; $v t$, terminal bud. D. Group with primary zooecium (=ancestrula), $X 55$. In the margin of the zooecia internal dietellate are risible. E. The operculum of the ancestrulal of fig. I', $X 1+0$. F. Zoorcia with ancestrula, $X$ 55. G. operculum, $X 140$. H. Onerculum of the ancestrula of fig. $F, \times 140$. I. View from the basal surface. The zomecia and the kenoznoecia surrounding the ovicells are furnished with (lieteliae, $X$ t0. (D-l after Levinsen, 1909.)

Genus HAPLOPOIIA Levinsen, 1909.

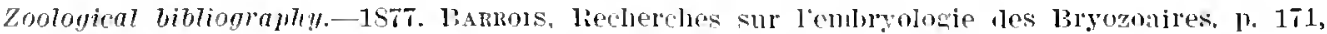
pl. 9. figs. 1-3.-1909. Lextrsen, Norphologiml aml sistematic Studies on the Cheilostomatous Bryozon, p. 280, pl. 18, fig. 11 ; pl. 22, figs. 9, 10.

The frontal of the zonecia is garnished with seattered pores; it is perforated by a median ascopore opening into the compensation sac. The operculum is simple. The ovicell is elosed by the opereulum. The ancestrula has no ascopore, but the aperture bears a limule which opens into the compensation sac. Fifteen tentacles.

Genotype.-IIaplopoma. (Flustra) impressa Savigny-Audouin, 1826.

Range.-Tortonian-Recent. 
NORTH AMEMICAN EARLY TERTIAR BRYOZOA.

Genus CHORIZOPORA Hincks, 1880.

Zoologicul bibliography.-1880. Inxeks, british IIarile Polyzoa, p. 222. pl. 32, figs. 1-4.-

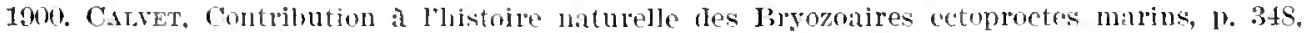
pl. 11, figs. 12-15,-1909. Levixsen, Norphological and systematic Studies on the Cheilo-

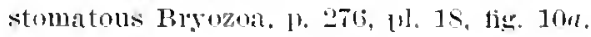

The zooecia are more or less distant. connected by a tubular network; the aperture is semicircular with the inferior margin entire. The orieclls are coverel by avicularia.

Genotype-Chorianore (Flustru) brongniarti Sarigny-Andonin, 1826. Recent.

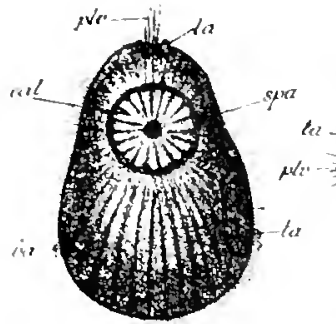

A

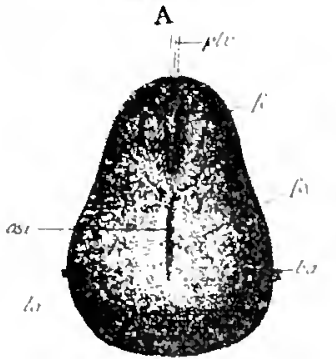

C

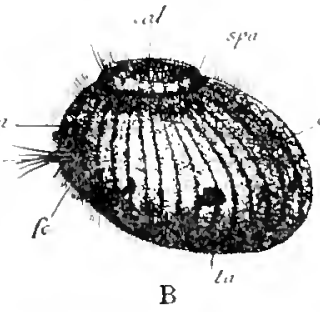

B

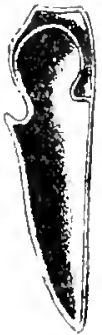

I $\times 55$

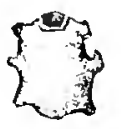

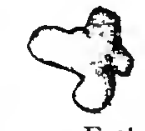

E $>1$

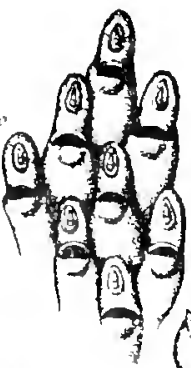

G

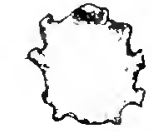

.25

I'IG. 96.-Genus Chorisonore IIIucks, ISSO.

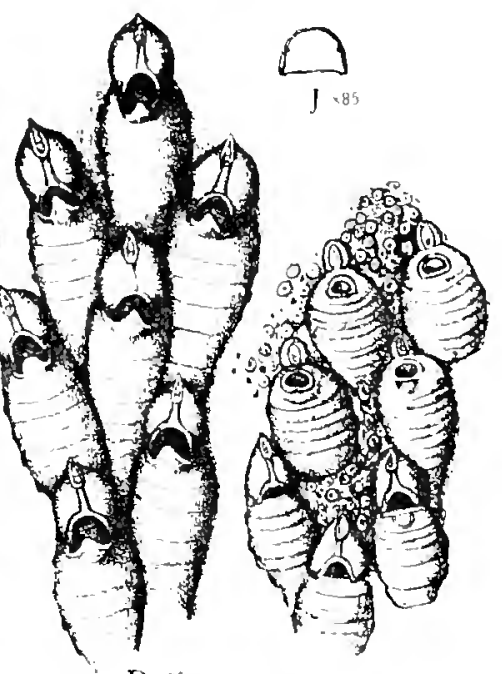

F 3

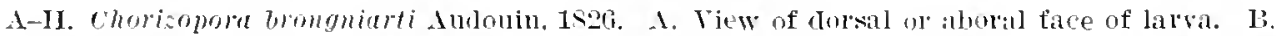
La ra seen laterally and trom its left face. C. Ventral (oral) face of larra. (A-C atter calvet. 1900.) ba, palette of the liguent sputs; col, calottr: co, coloma; fr, ciliated clutt; fo, oral face:

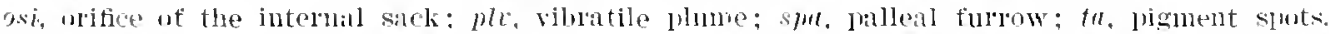

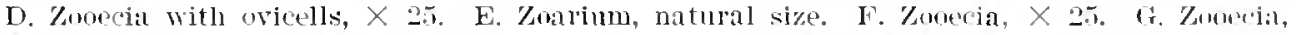

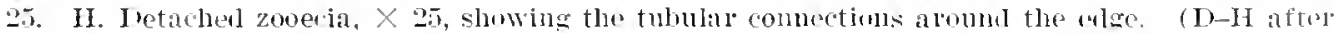

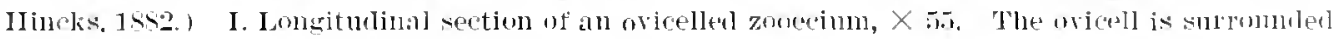
ly an avicularium. (Aftel Levinsell, 1909.)

\section{Genus DACRYOPORA Lang, $191 \mathrm{t}$.}

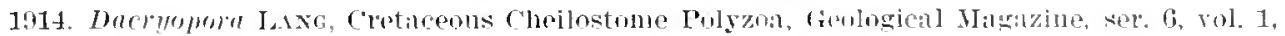
1. 440 .

Deserintion.-Inerusting, uniserial Cheilostome Polyzoi, normally with lilateral hranching: zooecia monomorphic, divicled into a proximal caulal amel a distal capitular portion: termen. except distally. indieated ly a contonr on the complete 
front wall at which the slope of the front wall changes; distally it coincicles with the lateral and distal edges of the orifice, and bears one or more pairs of spines; extraterminal front wall comparatively small and slightly arched: intraterminal

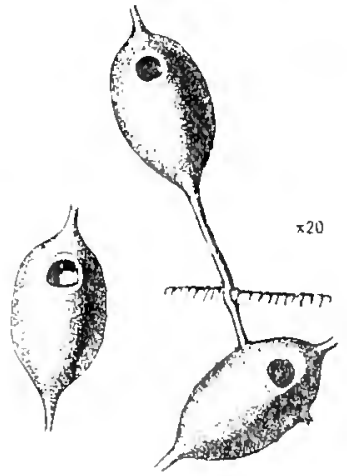

Fig. 97.-Genus Ducryourn Lang, 1914.

Dacryopora guttu Lang, 1914. (After Lang.) Two zooecia, $\times 20$. Senonian, chatham, Kent; England. frout wall entirely calcareous, highly arched, often bearing a median lidge; aperture semicirenlar or slightly cribrilinid. (After Lang.)

Gonotype.-Daryopora gutta Iang, 1914.

Range.-Cenonanian-Senonian.

Genus HARMERIA Norman, 1903.

1908. ILumuria Nonan, Notes un Natural IHistory of East Finmark, Anuals and Magazine Natural History, ser. $\mathbf{7}$, vol. $12, \mathrm{p} .107$.

"The zooccia lack a covering membrane; the calcaneous matter is very thin and brittle and there are no spines. 'They present a larger or smaller distinctly clefined frontal area, provirled with numerous pores. A compound operenlum, feebly clitinized. Rosette plates with few pores. No ovicell ant no aricularia. The disciform colony presents two different sizes of zooecia, lar'ger inner and small outer." (Levinsen, 1916.)

Grustype-LIImeria (Lepratia) scututatu Busk. Recent.

Family ESCHARELLIDAE Levinsen, 1909.

The oricell is hyperstomial. The opereulum is rigid and chitinous; it closes the aperture, the compensatrix and often the ovicell; its form is in rapport with the hydrostatic sytem and the passage of the egiss into the orjcell.

Historical.- This family is the reunion of the old families of Mieroporellidae, Myriozoidae and Escharidae (part) of Smitt and Hincks. Levinsen, in 1909, having proved the ident ity of the larvae former the family of Fscharellidoe, but the name is barlly closen, for it is baserl on an arrelate genus which the more recent work will not permit us to employ.

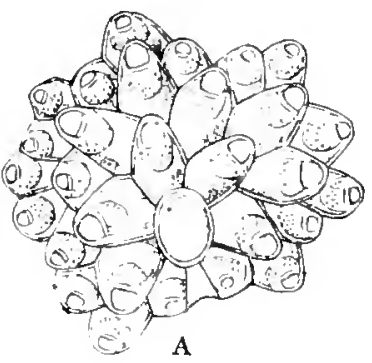

Fic. 98.-Genus Hameria Xoman, 1908. .

1. I. Itermerin scutulate Busk. (After Levinsen, 1916.) A. Colony with an crate membraniporoid ancestrula sur. rounded by five large and three smaller zonecia. B. Ancestrula with the fire surrounding larger zonecia.

Division - - Iceording to the form of the operculum we matass the numerous genera of thic fanily in the following four large groups, althougl there are some aberrant genera:

Schizoporellae. IFippoporac.
Micropolellae.

Peristomellae. 
Evidently the hydrostatic and reproductire functions are identical in each but they operate in a quite rariable manner. These variations added to those of calcification, which is also an important function, permits the establishment of a large number of genera almost all rather natural however, which facilitate the study of this very important family. The anatomical structure is given in detail for each group.

\section{Group I. SCHIZOPORELIAE Canu and Bassler, 1917.}

Bibliography (Anatomical).-1S7t. Parrors, Recherches sm l'embryologie des Pryozoaires, pls. 7. \&, figs. S, 10, 11, 21: pl. S, figs, 30, 33, 35.-15s8. Jullen. Mission scientifique du Cap IIorn, 1). 45.-1892. W.aters, Obstrvatisns on the Gland-like Bodies in the Bryozoa, Linnean

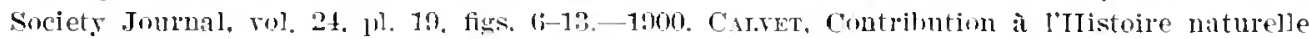

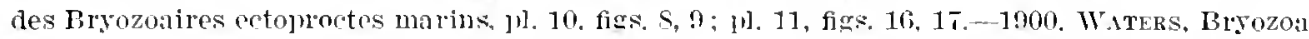
from Franz Josef Land, Limnean society Jommal, vol. 25, 11. 9, fig. 11; 1H. 12, fig. 5. - 1902. IIARMER, On the molphologr of the Cleibstomita, Quarterly Jommal of MIicrosenpical sience,

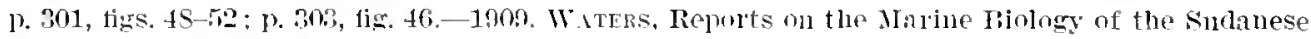
Red sea, The Rryozo: Iime:m societs Jommal, vol, 31, p]. 12, fir. 11.

The operculum is semilunar; the proximal border bears a slit or rimnle which opens the compensatrix. The muscular attachments are two small. symmetrical tuberosities more or less removed from the border. When the proximal border of the aperture is linear it serres as a pirot for the operculum: when it is arched and the rimule very large the pirot of the operculm is formed by two projecting interior condyles.

The text figure gives a presentation of the anatomical structure of the species of this group.

The classification was attempted successively in 1899. 1904. and 1913 by Waters in considering the muscular attachments of the operenlum. In 1888 and 1903 . Jullien formed many genera based on the natme of the frontal or on zoarial peculiarities. We will continue the work of these authors by considering the relationship of the opereulum to the ovicell (passage of the eggs and escape of the larvae).

After the elimination of the genera created by Jullien and Lerinsen, approved besides by Waters. a large number of very different species are still placed in the large genus Schizoporella Ilincks. 1880.

The group of Schiaporelle viridis forming a palt of the genus Tratersipore Neviani, 1895, is provide? with an endozoocial oricell, and belongs provicionally to the family Hippopodinidae.

The Schizoporella simese group. in which the operenlum does not correspond to the apertura and which is provided with a rimule spiramen. belonges to wur family Stomachetosellirlae.

The Schizoporella unicomis group is quite well characterizel: the orifice of

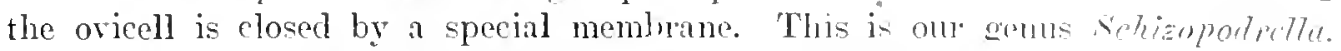
Hincks did not designate a type for his gemus schianperth: the firt species described is Schizoporella unicomis Johnoton. 14t. We conld thut it is not obligatory) preserve the name of Schisoporeme for this gronp, hut it seeme to 

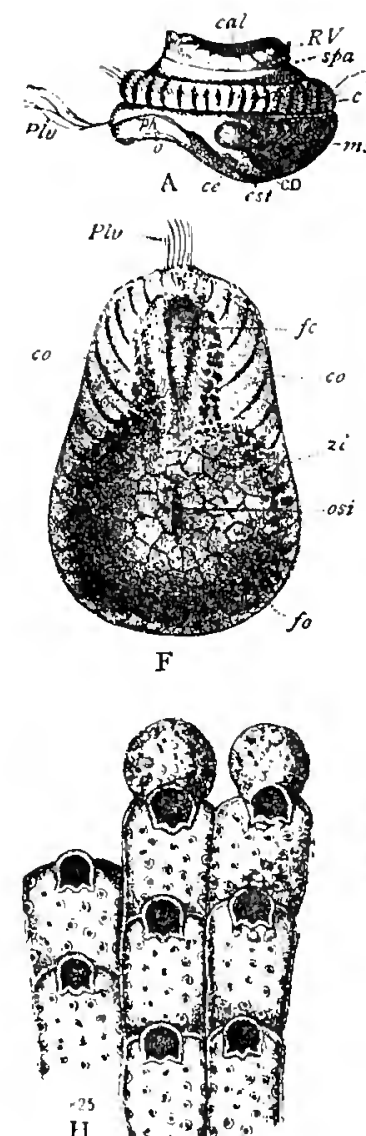

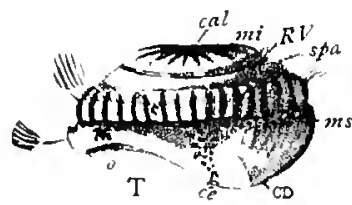
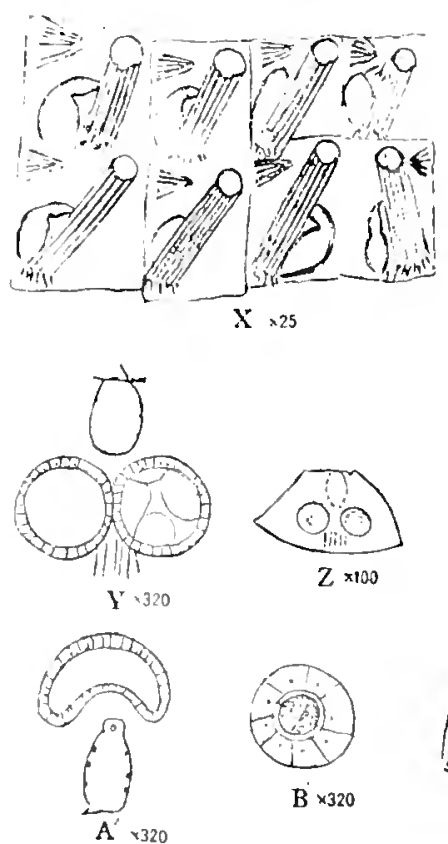
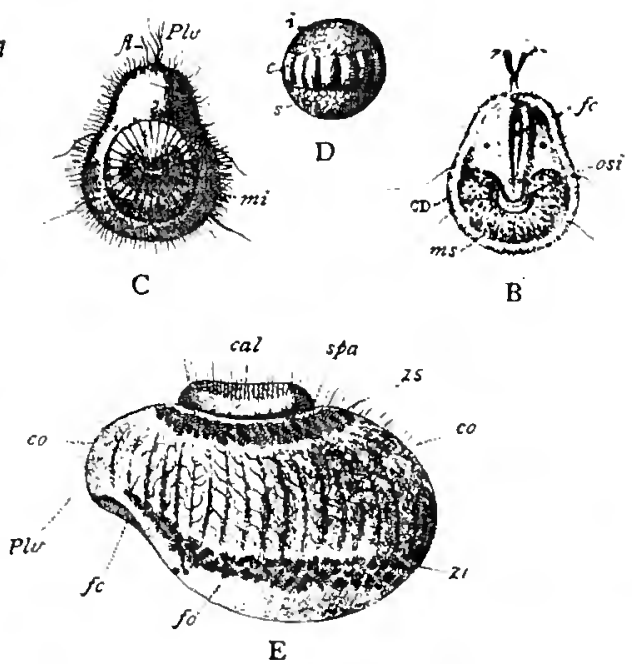

B
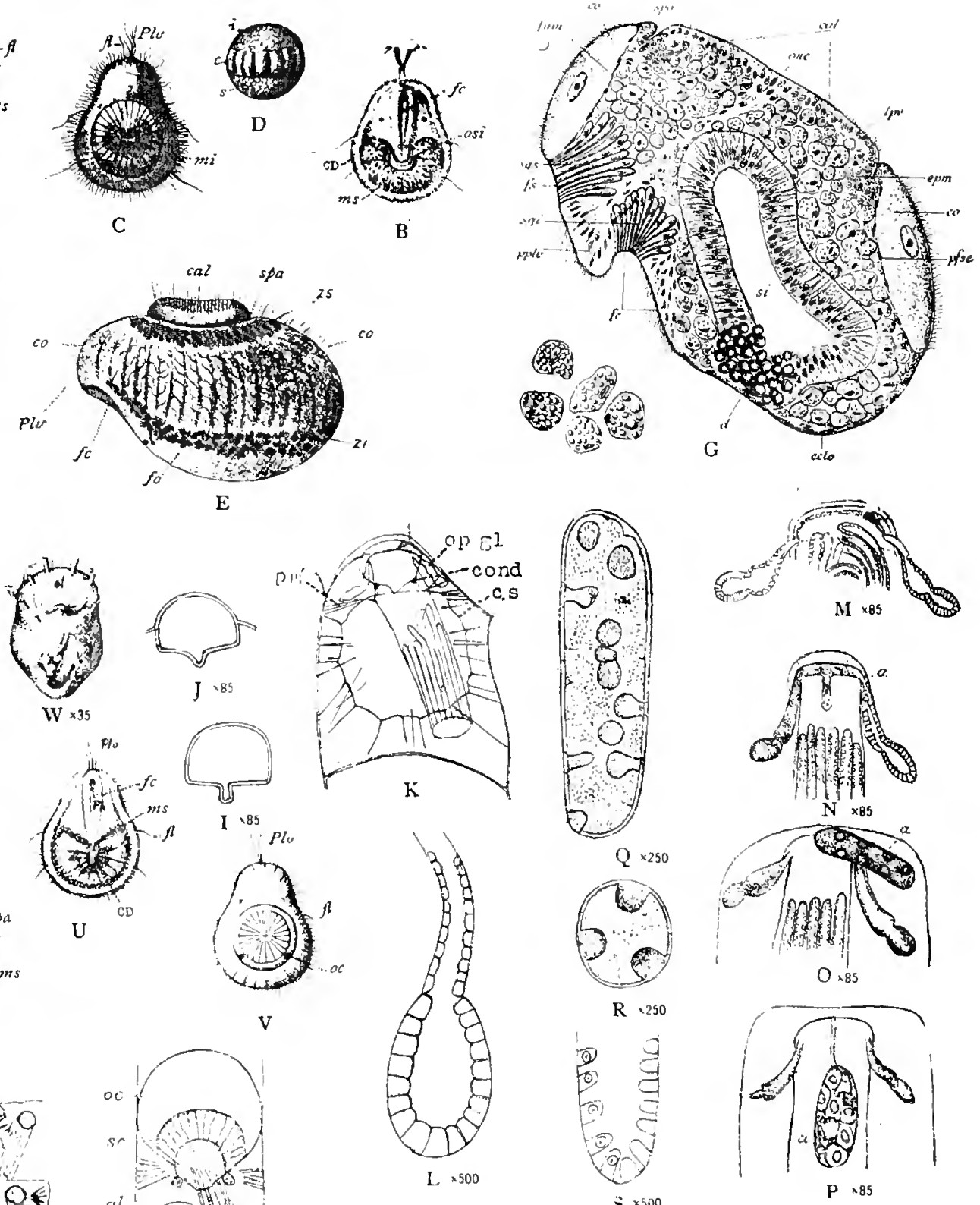

V
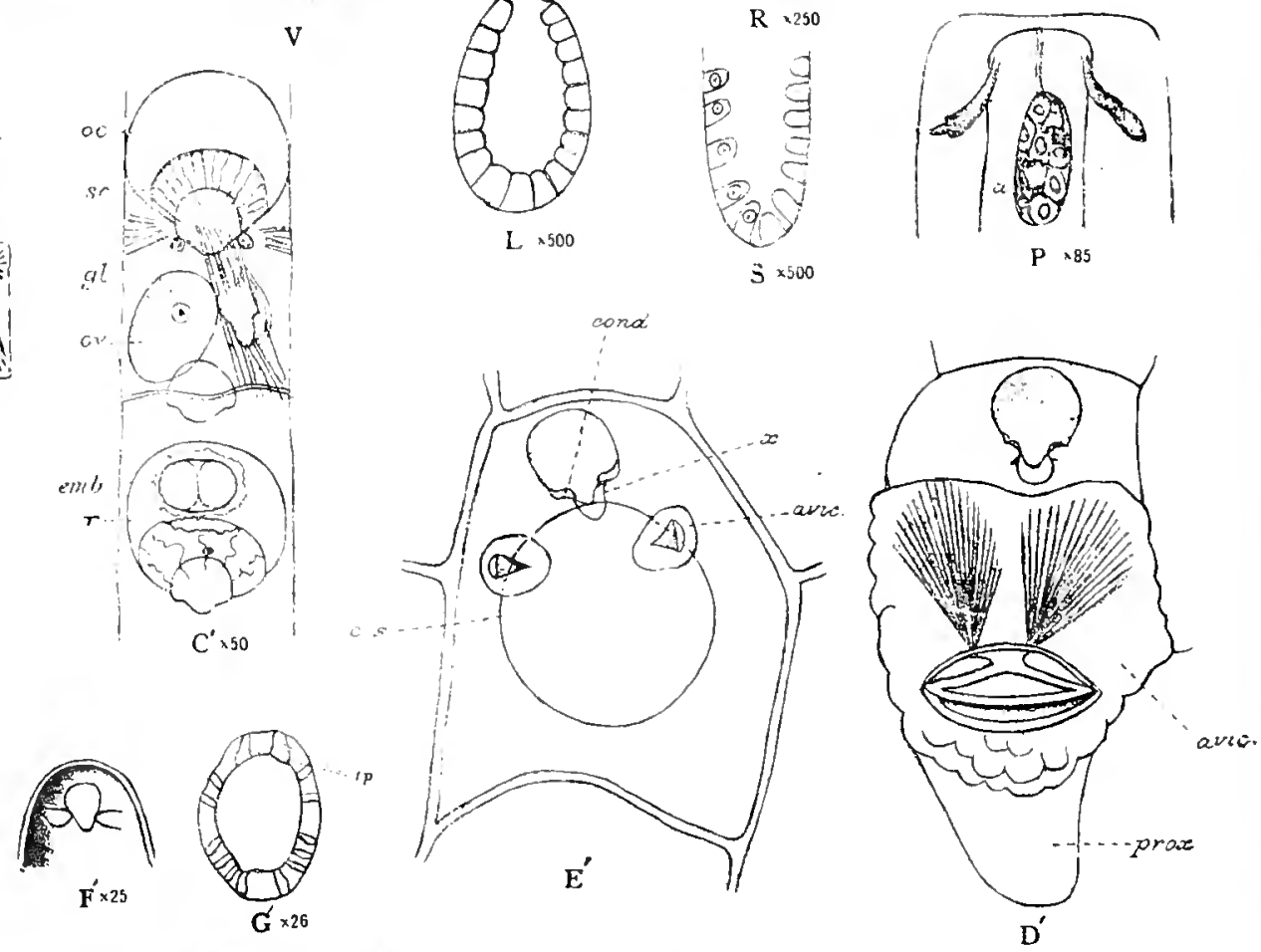

I'IG. 99.-Anatomy of the Schizoporellae. 
A-D. Schizoporella spinifera Johnston, 1847. A-C. Latel'il (A), or:al (B) and aboral (C) face of the larva. D. Embryo. (A- $\mathrm{N}$ after Larrois, 1S77.) cal, calotte (terminal bud); $c d$. digestive cavits: $c o$, corona ; $c s t$, stomach; $f c$, ciliated cleft; $f$, flagellum; fo, oral face: $I=i$ aboral face: $m i$, aboral mesolerm: $m s$, oral (lahial) mesoderm; osi, orifice of internal sac; $p h$. pharya; $p l l$. viblatile plume; $R l^{\top}$, teminal $b u d ; s=s$, oral (restibular) face; spa, palial furrow ; zc, inferior pigmented zone; $z$ s, superior pigmented zone.

E-S. Schizobrelliclla sanquinrt Norman. 1S6s. E, I. Iarva from the left lateral face (E) and from the ventral face $(F)$. G. Iedian s:igittal section of the embryo. (E. F aftel Calvet, 1900.) cal, calotte (terminal bud) ; co, coronil; $l$. vaginal diaphragn ; ccto, oral ectocyst: epm, mesodermal thickening: $f r$, ciliatel clett: fum. noun muscular inmeles: $f s$. superiol fosette: one, central nerrous organ of embryo; $p f s e$, neve plexus under ectodern: $p l v$, papilla of vibratile plume; sqa, superior wlandular system: si, internal sac:spa, palial furrow; sgi, inferior glandular system. H. Znneria and ovipells, $X$ 25. (After Hincls, 18so.) I, J. Opereula, X SJ. (After Waters, 1Sis.) K. Basal view of zooeciun from which the basal wall has heen remored. c. s., compensation sac; op. ol., opereular glands; $p$. m., parictal nuscles; $r$. vimule; $t$, tentacles. L-S. Glandular system. (After Waters, 1892.) L. Gland-like borly, X 500. M. Opereular and distal end: the slgnd-like bodies are shown in section, $X$ S5. $\aleph$. Same as MI, showing (a) growtl from tissue at the opercular end. The right gland-like body is shown in section and with an attacbment to the zooecial wall, $X$ s.j. O. The plolnngation of tissue shomn in fig. N. has now grown into the median body $(a)$ which lies diaxonally across the pruer part of the zooecium, $X$ S5. P. The same, hanging from the center, attached merely by a fine cord, $X$ s5. Q. Longitudinal section of a median body showing the refracting masses, $X 250$. R. Transverse section of the same, $\times 250$. S. Nucleated cells of slands, $\times 500$.

T-X. Schisopodrella (schisoporella) unicomis Johnston, 1S47. T. Free larva, lateral riew. U. Oral fave of same. V. Ahoral face of larva. W. Ancestrula with telminal bur and two lateral buds, $X$ 35. (T-W after Barrois. 1576.) X. Sketch slowing the diagonal position of the zooecia, X 25. (After Waters, 1905.)

I-B'. Schizopodrella (Schizoporella) nivea Busk 1SSt. Avicularian glands of the small avicularia. (After Waters, 1913.) The two crauls separated, $X 320$ (I) ; the same, $\times 100$ (7); glands united, $\times 320\left(\mathrm{~A}^{\prime}\right) ;$ gland, $\times 320\left(\mathrm{~B}^{\prime}\right)$.

$\mathrm{C}^{\prime}-\mathrm{E}^{\prime}$. Schisoporlella (Schisoporella) lincaris Hassall, 1841. C'. Two rooecia. $\times 50$, figured near together but not in the same row, and placed together 10 save space. A saclike structure $\left.(s)^{\prime}\right)$ is slown at the base of each ovicell (oc) but of the numernus muscles in this sac only about lualf of those in focus are drawn. It seems that the orum (r.n) passes into this sac which is then ruptured $(r)$, and the ovum is plessed forward into the ovicell, where it segments. The small oral galnds are shown ( $g l)$. After Waters, 1913.) $D^{\prime}$. Sketch showing a rigantic avicularium $\left(a v^{c}\right) ; p r o x^{2}$, proximal end of tle zooecium, into which the polypide extends, beneath the aviculirim. (After Harmer, 1902.) E'. Zooecium, showing the compensatrix (c.s.). The enargination of the frontal shield containing the sinus of the operculum enlarges as it lasses thronglh the thichness of the calcarenum wall, so that its outline on the inner side of the frontal shield is represented by the line $r$. (After Harmer, 1902.)

$\mathrm{F}^{\prime}$. Schizoporclla golida Waters, 1904. Interior, showing condyles (denticles), X 25. (After. Waters, 1904.)

G'. Schizoporella magniporata Nordgaard, 1906. Slietcle, $X 26$, slowing the llistal ( $f p$ ) ant lateral dietellae. (After Nordgaard, 1906.)

$$
\text { 55899-19-Bull. } 106 \text { - _-_ }
$$


us more useful to preserve it. at least provisionally, for all the species imperfectly studied and classerl.

All the other species have the oricell closed by the operculum and form a heterogeneous group).

The function of the avicularia is mknown, but it has certainly not the universality of the hydrostatic system. However, on many bryozoa, the avicularia appear to be indispensable. for they are constant in form and position. For cxample, the group of Schizoporclla auriculata (genus Schizomavella) is ornamented by a very constant median avicularium.

On other species the avicularia occupy a lateral or eccentric position. They belong to the still poorly defined groups of Schizoporella vulgaris, including the fossil forms, Eschara pliymatopora Reuss. 1869, and Lepratia schizostoma MacGillivray, 1898, of Schizoporello argented with the fossil representative Schizoporella terebrata Maplestone, 1901, and of Schizoporella spinifcra.

A number of Schizoporellae are absolutely deprived of avicularia; they have been divided into the genera Phonicosia, Arthropoma, and Dakiaria, according to the special function of the rimule.

A rather important group appears to lave a little chitinized operculum. The functions of this important organ are then assumed by the peristome specially developed; this is the curious genus Metroperietla. The group of Waters with large operculum does not appear a natural one to us.

\section{Genus SCHIZOPODRELLA Canu and Bassler, 1917.}

1917. Schizopodrelln CANU and Bassler, Synopsis of American Narly Tertiary Cheilostome Bryozon, Bulletin 96, Unitel States National Museum, p. 40.

The ovicell is hyperstomial. It opens alore the aperture by a special opening closed by a special membrane and without connection with the operculum; it surmounts this aperture without inclosing it. The inferior border of the aperture is somewhat concave and bears a narrow rimule. The frontal is a tremocyst direct or corering a rery thin olocyst finely perforated. The muscular attachments are generally at a distance from the borrer of the operculum. There are oral glands. 16-21 tentacles.

Genotype.-Schizopodrcllu (Lepretia) unicomis Johnston, 1847.

Range.-Lutetian-Recent.

Waters in 1913 (p. 505) differentiated this genus without naming it. Schizopodrella differs from Stephanosclla in the tremopores which ornament its frontal and ovicell. It differs from Laceme in the absence of areolae.

The recent species of this genus are:

Schizopodrella (Lepratiu) unicornis .Johnston, 1847.

Schizopodrella (Schizoporella) Tongirnstris IHincks, 1888.

Schizopodrella (Lcpratia) errata Waters, 1879.

Schizopodrella (Schizoporella) elmwoodiae Waters, 1900.

Schizopodrclla (Schizoporella) nivea Busk, 1884.

Schizopodrella (Lepratia) Tinearis Hassall, 1841. 


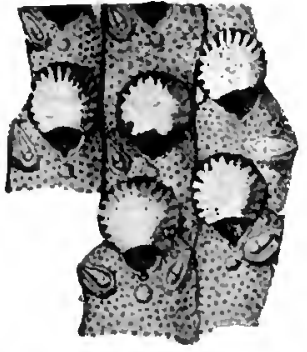

A. Schizopodrella

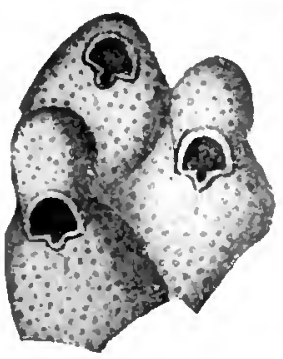

G. Arthropoma

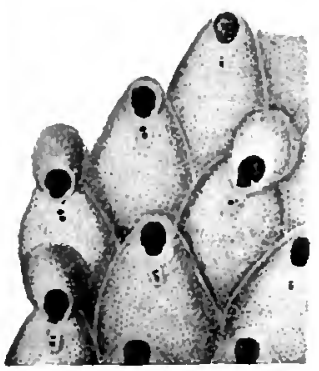

L. Metroperiella

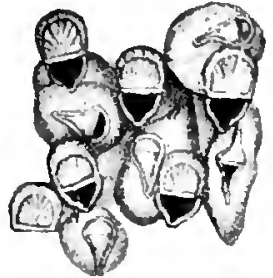

B. Stephanosella

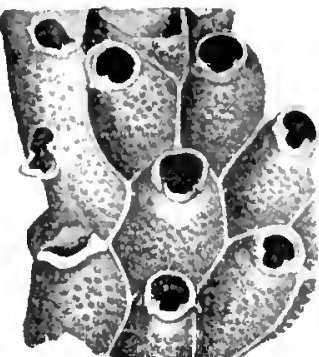

H. 1)akarı.1

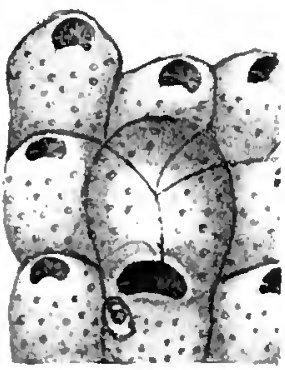

11. Emballotheca

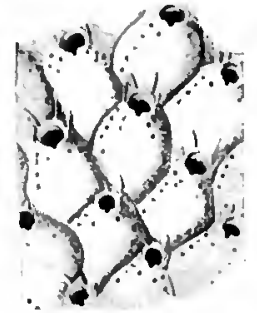

C. Lacerna

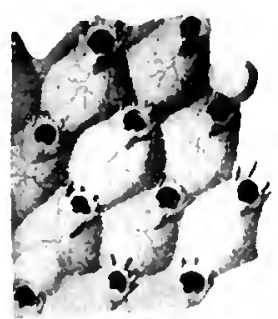

D. Buffonella

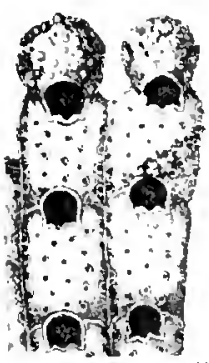

E. Schizobrachiella F. Schizomavella

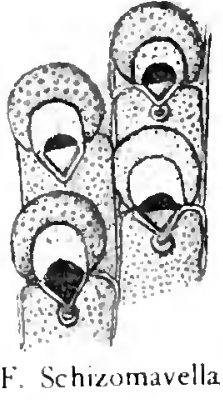

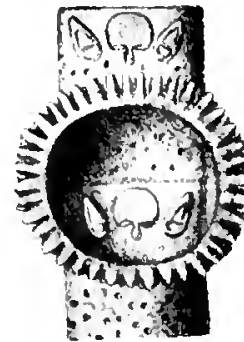

J. Sitopoma

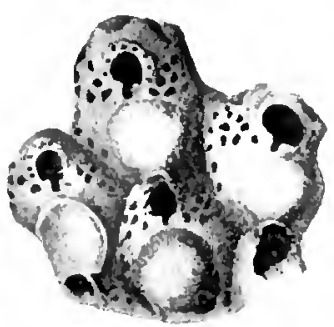

1. Phonicosia

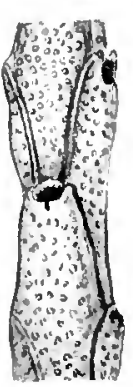

N. Tetraplaria

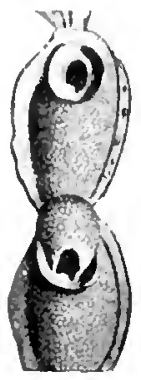

O. Ninba P. Characadona

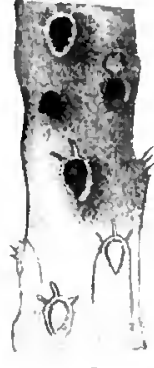

(). Gemel

lipora

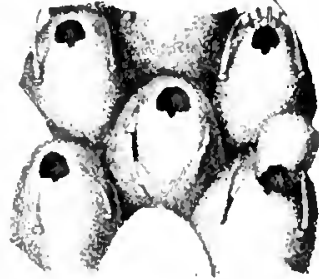

K. Schizolavella

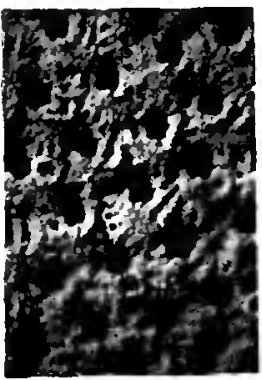

R. Gemelinporella

FIG. 100.-Genera of the subfamily Sehizoporellae Canu and Bassler, 1917.

A. Schizopodrella unicomis fohnston, 1847, $\times 30$. Recent.

B. Stephanosclla biayerta Michelin, 1845, $\times 30$. Recent.

C. Lacerna liostecnsis Jullien, 1SSs, $\times 25$. Recent.

D. Buffonclla ridleyi MacGillivray, 1S92, $\times 30$. Recent.

E. Schizobrachiella sanguinca Norman, $1885, \times 30$. Recent.

F. Schizomurclla auriculata Hassall, 1842. $\times 50$. Recent.

G. Arthropoma cecilii Audouin, $1526 \times 30$. Recent.

H. Dakaria chevreuxi Jullien, 1904, $\times 20$. Recent.

I. Phonicosia jonsseaumi Jullien, 18ss, $\times 25$. Recent.

.. Stylopoma spongitcs I'allas, 1766. Recent

K. Schizolavella vulgaris Moll, 1803, $\times 2$ 5. Recent.

L. Mctropcriella lepralioides Calvet, 1904, $\times 35$. Recent.

11. Emballotheea quadrata MacGillivray, 1850, $\times 23$. Recent.

N. Tetraplaria ausiralis Tenison-Woods, 1878. Tertiary of Austrilia.

O. Nimba pretexta Jullien, $1904, \times 25$. Recent.

P. Characodoma halli Haplestone, 1900. Miocene of Australis.

Q. Gemellipora glabra Smitt, 1872. Recent.

R. Gemelliporella vorax, new species, $\times 20$. Miocene of South Carolina 
SCHIZOPODRELLA LINEA Lonsdale, 1815.

Plate 45, figs. 10-18.

1S45. Eschara linea IoNsDAr.s, Account of twenty-six species of Polyparia obtained from the Eocene Tertiary formation of North America, Quarterly Journal Geological Society London, rol. 1, p. 530, fig.

1862. Escharinclla ? linea GAsB and Hors, Monograph of the fossil Polyzoa of the Secondary and Tertiary formations of North America, Joumal of the Academy of Natural Sciences of Philadelphia, ser. 2, vol. 5, p. 140.

Deseription.-The zoarium is fuee, bilamellar; the two lamellae are inseparable. The zooecia are large, elongated, distinct, elliptical; the frontal is convex and formed by a thick tremocyst closely united with a very thin inner olocyst, the interior of which is very finely perforated. The aperture is semilunar; the proximal border is a little concave and bears a narrow jimule. The hyperstomial ovicell is salient, globular and smooth. Two small avicularia are symmetrically disposed on each border of the aperture; they have a fragile pivot; the beak is rlirected toward the median zooecial axis.

$$
\begin{gathered}
\text { Measurements. - A perture }\left\{\begin{array}{l}
l a=0.15 \mathrm{~mm} . \\
7 a=0.12 \mathrm{~mm} .
\end{array}\right. \text { (including rimule). } \\
\text { Zoocia }\left\{\begin{array}{l}
I_{a}=0.75-0.90 \mathrm{~mm} . \\
7 z=0.45-0.65 \mathrm{~mm} .
\end{array}\right.
\end{gathered}
$$

Variations.-There are some zooecia which are narrow (fig. 12), some wide (fig. 13), and others rery irregular. Often the zooecia are surrounded by a prominent thread (fig. 14). The ovicell is always smooth. This is a peculiarity which is very rase in the bryozoa, as the ovicell and the frontal are generally of the same nature. The small oral avicularia are very constant; sometimes there is one of them which is abortive (figs. 13, 14); the pirot (fig. 14) is very fragile and often missing on the fossils.

The interior is furnished with a thin perforated olocyst (fig. 17). Upon rubbing away the interior it may be noted that the tremopores are bound together by a system of small canals radiating from the mediun axis of the zooccia. Their intersection with the calcareous deposit over the tremopores form reticulations visible in tangential sections (fig. 16). The tremopores are fumnel shaped and are much larger on the exterior than on the interior.

On account of the size of its fronds this is an easily recognized bryozoan.

Affinities.-This species is very close to Sehizopodrella unicornis Johnston, $\mathbf{1 8 4 7}$, but differs in its smaller, less prominent avicularia, which are turued toward the interior of the aperture and not toward the exterior of the zooecia.

It differs from Schizopodrella viminee Lonsdale, 18t5, in its wider zooecia, and its two symmetrical avicularia.

It differs from Schizopodrella marginata in its micrometric dimensions which are twice as large, and in the presence of the two oral avicularia.

Occurrence.-Middle Jacksonian: Type-locality, Eutaw Springs. South Carolina (very common); near Lenuds Ferry, Sonth Carolina (abundant); Wilmington, North Carolina (rare).

Plesiotypes.-Cat. No. 64052, U.S.N.M. 


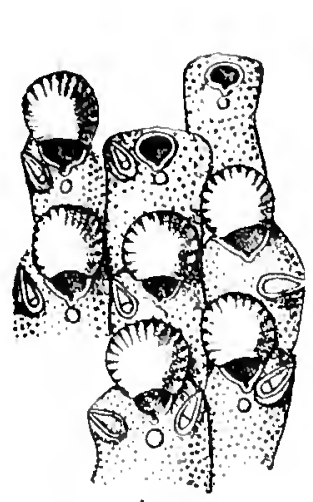

A $、 25$

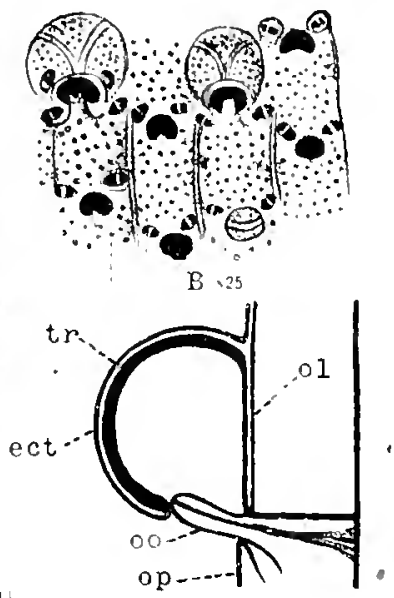

$\mathrm{C}$

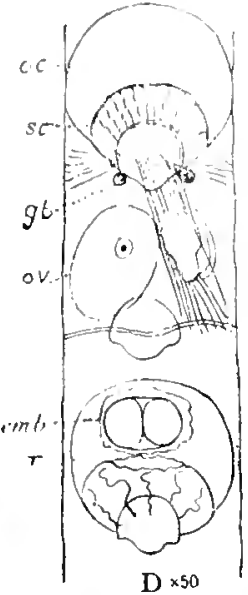

$D \times 50$

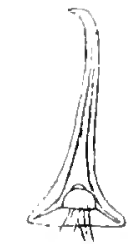

E 185

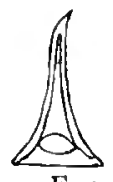

$\overrightarrow{F \times 85}$

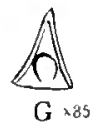

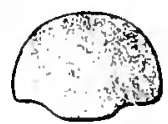

II

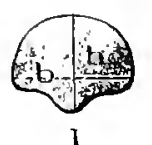

1

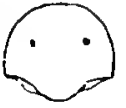

J $\times 85$.
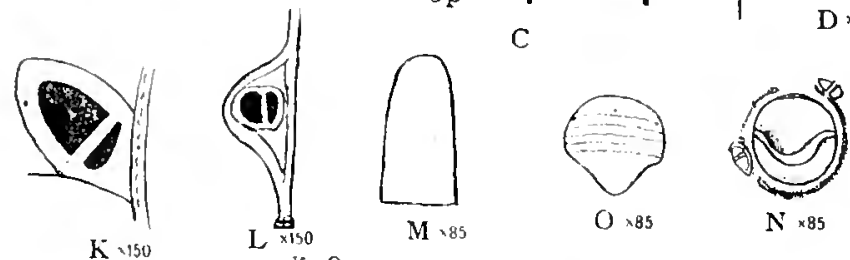

K-O, milzopodredin hlva Bu.te
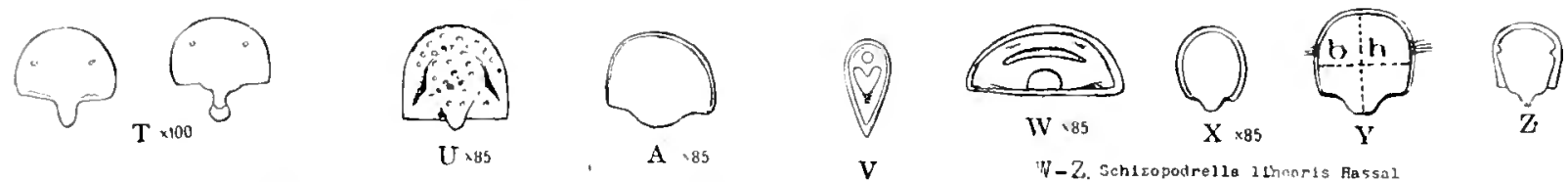

Fig. 101.-Genus schisopodrclla Canu and Bassler, 1917.

A. Schizopodrclla unicornis Johnston, 1S47. Zooecia with ovicells and avicularia, $X$ 25. (After Hincks, 1880.)

B. Schizopodrella nivea Busk, 18s4: Zooecia, $\times 25$. (After Waters, 1913.)

C. Schematic section throush the ovicell of Schisopodrella unicornis Johnston, 1847. (After Levinsen, 1909.) cct, ectoeyst; ol, olocyst ; on, ovicell operculum; op, opcreulum; $t r$, tremocyst ; $v$, restibulum.

D. Schizopodrella nivca Busk, 18st. The two zoocia figured $\times 50$, were near together, but not in the same row, and are placed logether to save sinace. A sale-like structure $\left(s c^{\prime}\right)$ is shown int the hase of each ovicell $(O C)$, but of the numerous muscles in this sae only about half of those in focus are drawn. It scems that the ovum $(o v)$ passes into this sac, which is then ruptureu $(r)$, and the ovum is pressed forward into the oricell, where it segments. Tlic small oral glands are shown $(g b)$.

E-J. Schizopodrclla unicomis Johnston, 1817. E, F, G. Iandibles, $X$ 85. II, I, J. Opercula, $\times$ 55. (After Waters, 1913, ảnd Nordgaard, 1905.)

K-O. Sehizopodrella nirca Bust., 18s4. K. Fasal avieularium, $\times$ 150. I. Lateral avien-

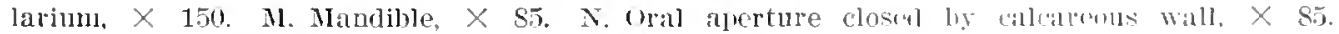
O. Onerculum, $\times$ \$5. (After Waters, 1913.)

P-S. Schizopodrella longirostris Hinclis, 1SSG. I'. Avienlarium,

R. Oral aperture $\times 75$. S. Operculum, $\times 100$. (P-S after Levinsen, 19010.)

T. Stylopoma spongites I'allas, 1766. (Iperculat, $X$ 100. (After Levinsen, 1909.) (Introduced by error.)

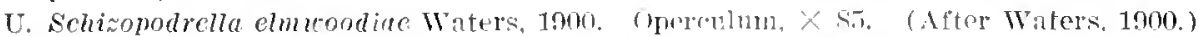

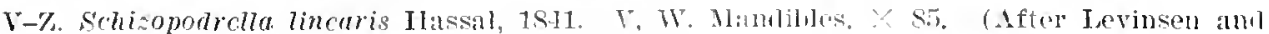
Waters.) $X, Y, Z$. Opercula, $X$ S5. (After Wators and Nordgnard.)

$\mathrm{A}^{\prime}$. Sehizopodrclla crratn (Waters, 1S75). Operenlun, X Sĭ. (Aftrir Waters, 1S79.) 
Plate 44, figs. 11, 12.

Description.-The zoarium is free, bilamellar, with much compressed fronds. The zooecia are distinct elongated, rhomboidal, separated by a prominent thread; the frontal is flat and formed by a tremocyst with small pores. The aperture is very small and semilunar, its proximal border is intersected by a small rimule relatively wide and of little depth. On the margins there are two or three very simple, small a vicularia.

$$
\text { Measurements.-Aperture } \begin{aligned}
& h a=0.09 \mathrm{~mm} . \\
& l_{a}=0.05 \mathrm{~mm} .
\end{aligned} \quad \text { Zooecia } \begin{aligned}
& L z=0.50 \mathrm{~mm} . \\
& l z=0.30 \mathrm{~mm} .
\end{aligned}
$$

Affinitics.-This species is characterized by its very small dimensions. It differs from Buffonella microstoma in the presence of the frontal tremocyst and in its free zoarium.

Occurrence.-Middle Jacksonian (Castle Hayne limestone): Wilmington, North Carolina (very rare).

Cotypes.-Cat. No. 64046, U.S.N.M.

SCHIzOPODRELLA VIMINEA Lonsdale, 1845.

Plate 45, figs. 1-9.

1S45. Eschara viminea Loxsdale, Report on the Corals from the Tertiary formations of Nortl America, Quarterly Journal Geological Society, London, vol. 1, p. 520, fig.

1S45. Eschara incumbens Lossdale, lieport on the Corals from the Tertiary formations of North America, Quarterly Journal Geological society, Iondon, vol. 1, p. 529.

1862. Esehara viminea GaBb and Horn, Monograph of the Fossil Pulyzoa of the Secondary and Tertiary formations of North America, Journal Academy Natural Sciences, Philadelphia, ser. 2, rol. 5, p. 116.

1862. Eschara incumbens GABB and HonN, Monograpl of the Fossil Polyzoa of the Secondary and Tertiary formations of North America, Journal Academy Natural Sciences, Philadelphia, ser. 2, vol. 5, p. 116.

1862. Eschara texta GABB and Horn, Monograph of the Fossil Polyzoa of the Secondary and Tertiary formations of North America. Journal Academy Natural Sciences, Philadelphia, ser. 2. rol. 5, I1]. 17, pl. 19, fig. 1.

Description.-The zoarium is free bilanellar, formed of two lamellae, back to back, and rarely separable; the fronds are wide, flat, or undulated. The zooecia are very long, fusiform, or cylindrical; the frontal is convex and formed of a tremocyst, with numerous pores in quincunx. The apertura is semilunar, transverse, with a straight proximal border, with a very small linear rimule; the peristome is very thin and hardly salient. The ovicell is hyperstomial, mucls embedded in the distal zooecia, quite large, globular, salient, 'smooth; its orifice, placed much above the apertura, is very large. Near the apertura, there is a triangular avicularium, the beak directed toward the exterior.

$$
\text { Measurements.-Apertura }\left\{\begin{array} { l } 
{ h a = 0 . 1 0 \mathrm { mm } . } \\
{ 7 a = 0 . 1 8 \mathrm { mm } . }
\end{array} \quad \text { Zooccia } \left\{\begin{array}{l}
L z=0.80-1.00 \mathrm{~mm} . \\
l z=0.30-0.45 \mathrm{~mm} .
\end{array}\right.\right.
$$


Variations.-The oral sinus disappears frequently on account of the considerable thickening of the frontal (fig. 2), but it persists at the base of the peristomie and is always visible in the interior (fig. 8).

Eschara incumbens Lonsdale, 1845 , is merely this same species provided with its ovicells. They_are very large; their frontal is thickencd considerably on the parietal olocyst-a very rare phenomenon in the Cheilostomes, where the ovicell is almost always of the same nature as the frontal. By dissecting the ovicell the apertura is always visible and very constant in form and size. The oral avicularium is not at all constant; it disappears over entire fronds when they have the aspect of Eschara texta Gabb and Horn, 1862. Amother character common to the two species is "The alternate elevations and depressions of the cellular surface of this remarkable species give it, to the naked eye, very much the appearince of a woven fabric," quite visible in our figure 3, and noted in 1862 by Gabb and Horn.

According to the tangential section (fig. 6) the tremocyst does not appear to repose on a calcified olocyst.

Affinities.-This species differs from Schizopodrella linca Ionsdale, 1845, in its less zooecial width $(l z=0.30-0.45 \mathrm{~mm}$. instead of $0.45 \mathrm{~mm} .0 .65 \mathrm{~mm}$.), and in a single avicularium placed below the apertura and not above it.

Occurrence,-Lower Jacksonian (Moodyrs marl) : Jackson, Mississippi, (rery common).

Middle Jacksonian: Wilmington, Nortlr Carolina (very common); Eutaw Springs, South Carolina (common, type locality); Baldock, Barnwell County, South Carolina (common) ; near Lenuds Ferry, South Carolina (common); $3 \frac{1}{2}$ miles north of Grovania, Georgia (rare); $3 \frac{1}{4}$ miles south of Perry, Georgia (common); 17 miles northeast of Hawkinsville, Georgia (rare); one-half mile sontheast of Georgia Kaolin Co. Mine, Twiggs County, Georgia (rare).

Jacksonian (Zeuglodon zone): Cocoa Post Office, Choctaw County, Alabama (rare).

Plesiotypes.-Cat. No. 61051. U.S.N.M.

Genus STEPHANOSELlA Canu and Bassler, 1917.

1917. Stephanosella Cañ and Bassler, Synopsis of American Early Tertinry Cheilostome Bryozoa, Bulletin 96, United States National Museum, p. 40.

The oricell is hyperstomial and embedded in the distal zooecia. It opens above the aperture by an especial orifice. 'The frontal is a smooth olocyst. No spines. The oricelled zooecia have a large aperture and their avicularium is frontal.

Genotype.-Schizoporella (Lepratia) biaperta Michelin, 1845.

Range.-Jacksonian-Recent.

Our genus does not exactly correspond to the Schizoporilla biaperta group of Waters, 1913. We prefer to take into consideration the nature of the frontal rather than the muscular attachments, which are impossible to verify on the fossils. If the areolae were more frequently observed in the species of this genus, it would be preferable to unite them with the genus Lacerna Jullien. 1888.

Stephanosella differs from Lacerna in its oral avicularia and in the absence of spines. 
The known fossil species of this genus are:

Stephanosella (Lepratia) entomostoma Reinss, 1847.

Stephanosella (Lepralia) seriate Reuss, 1874.

Stephanosella strictifissa MacGillivray, 1895.

The genotype Schizoporella biaparta Wiehelin, 1845, lives to-day off the Azores (Norman), in the waters of Florida (Smitt), and off the eastern const of the United States (OSburn). The eurrents have also carried the speeies along the western coasts of the United States (Roberston).

The simultaneous oceurrence in Europe and Ameriea of Stephanosella (Schizoporella) entomostoma Reuss, $184 \pi$, show's again that the equatorial currents were already in existence in the Vieksburgian age.

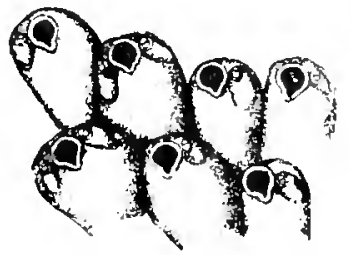

A $\cdot 30$

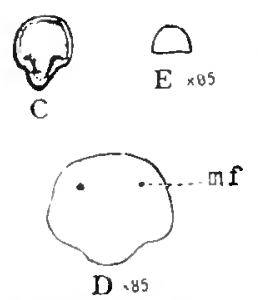

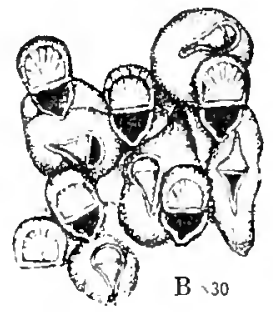

Frg. 103.-Cienus Strphanosella Canu and Bissler, 1917.

A-D. Stephanosella biaperta Michulin. 1845. A. Zooecia, X 30. B. Zooecia with ovicells and avicularia, $X$ 30. (After Hincks, 1ss0.) C. (rerculum of the rariety divergens. (After Norman, 1903.) D. Operculum, $\times$ S5. mf, muscular insertion.

E. Mandible, $\times$ S.5. (After Nordgrand, 1906.)

STEPHANOSELLA PARVIPORA, new species.

Plate S5, fig. 22.

Description.-The zoarium incrusts bryozoa. The zooecia are distinet, somewhat elongated, snbliexagonal, irregular; the frontal is smooth, little convex, bordered by widely spaced. rery small areolac. The aperture is very smath, transrerse. and is provided with a wide rimule. The ovicell is large, salient, snrrounded by a collar. One or two irregular, oral aricularia are placed at different heights and deform the zooecia.

$$
\text { Measurements. - I perture }\left\{\begin{array}{l}
h a=0.01-0.045 \mathrm{~mm} . \\
l_{a}=0.06-0.07 \mathrm{~mm} .
\end{array} \quad \text { Zooecia } \begin{array}{l}
T_{z}=0.35 \mathrm{~mm} . \\
7 z=0.25 \mathrm{~mm} .
\end{array}\right.
$$

Affinitiss.-The frontal of the oricell is very fragile and does not alwars exist on the fossils; only the outer eollar persists.

This species differs from stephonoselle pntomostoma Renss, 1817. in its much cmaller aperture $(7 a=0.06 \mathrm{~mm}$. instear of $0.12 \mathrm{~mm}$.). Its other micrometrie dimensions are also much smaller than thoee of Stephanosella (Schizoporella) bioperte Michelin. 1845.

Occurence.-Ticksburgian (Marianna limentonc): Three miles southeast of Vosburg. Jasper County, Mississippi (riure).

Hototype.-Cat. No. 6+270. T.S.N.M. 
STEPHANOSELLA ENTOMOSTOMA Reuss, 1817.

I'late 85, figs. 19-21.

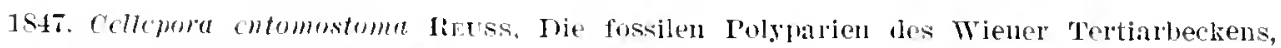
IIaidinger's naturwissenschaftliche Abbaudlungen, vol. 2, p. 92, pl. 11, fig. 7 .

1Scit. Lepralia cutomostomn licess Zur Fauna der deutschen Oleroligocäns, sitzungsberiehte der k. Akademie der Wissenschaften, vol. $50, \mathrm{p} .27$, pl. 13, fig. 6 .

1S74. Lepratia entomostoma Reuss. Die fossilen Bryozoen des Uester reichisch-Ungarischen Miocins, vol. 1, pl. 1T, p. 4. fig. 11.

Measurcments. A perture $\left\{\begin{array}{l}h_{h} \alpha=0.08 \mathrm{~mm} . \\ l_{\alpha}=0.05 \mathrm{~mm} .\end{array} \quad\right.$ Zooecia $\begin{array}{l}L_{z}=0.32-0.36 \mathrm{~mm} . \\ 7 z=0.20 \mathrm{~mm} .\end{array}$

Tariations.-The frontal is an olocyst absolutely smooth when there are no areolae (fig. 21 ); it is covered with small gramulations of pleurocystal origin when rery small, scattered areolac appear. More often there is only an oral aricularimn; it is small, elliptical, without pivot on the ordinary zooecia (figs. 19, 20) but elongated, thin, with pivot on the oricelled zooccia; moreover, on the latter it changes place, is remored from the aperture and becomes frontal (fig. 21).

The ovicell is globular, salient, and bears in front a fragile finely ribbed callosity of olocystal origin; it is bordered by a very thick circular collar. The aperture of the ovicelled zooecia is larger $(7 a=0.10 \mathrm{~mm}$. instean of $0.07 \mathrm{~mm}$.).

The aperture is oblique, which, on account of perspective, diminishes the lougth of the rimule.

Affinities.-This species differs from Stephanosella (Schizoporella) biaperta Michelin, $\mathbf{1 8} \pm 5$, living and fossil, in the position of the avicularium, which is always placed below the aperture, and in its smaller micrometric dimensions.

It differs from stcphanoselta parvipora in its larger aperture and in the avicularim, which is placed below the aperture.

Occurrence.-Vicksburgian (Marianna limestone) : Test bank Conecuh River, Escambia County, Alabama (common): Claiborne, Momroe County. Alabama (rare); 1 mile north of Monroeville, Alabama (very common).

Geological distribution.-Chattian of Germany (Reliss) and Tortonian of A ustria-Hungary (Reuss).

Plesiotyp (- Cat. No. 64269, U.S.N.M.

Genus LACERNA Jullien, 1888.

1SSS. Lacena Jullex, Mission Scientifique dn Cau IIorn, 1. 4 S.

The oricell is hyperstomial and is provided with a special orifice. which can be closed by the operenlun for the passage of the eggs. The aperture is archeel anteriorly; its proximal border is straight, with a small, rounded rimule. The aperture and the rimmle are surrounded by the same peristome, which is provided with spines. There is a vestibnlar arch. The frontal and the ovicell are fomerl of an olocyst surrounded with areolae. above which an incomplete and granular Heurocyst is deposited. 1t tentacles.

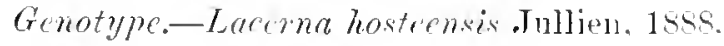

Ranre.- Iutetian-Recent. 
The recent species of this genus are:

Lacerna hostcensis $\mathbf{J} u l l i e n, 1888$.

Lacerna (Schizoporella) catoni Busk, 1879.

Lacerna (Schizoporella) ornata Calvet, 1909.

Lacerna (Schizoporella) insignis Hincks, 1881.

The fossil species are:

Lacerna (Lepratia) sequenzai Reuss, 1869.

Lacerna (Lepratia) süssi Reuss, 1869.

Lacerna (Schizoporella) fissa Koschinsky, 1885.

Lacerna (Lepralia) fuchsii Reuss, 1874.

Lacerna (Schizoporelle) convexa MacGillivray, 18!5.

Lacerna (Schizoporella) nitcns MacGillivray, 18!).

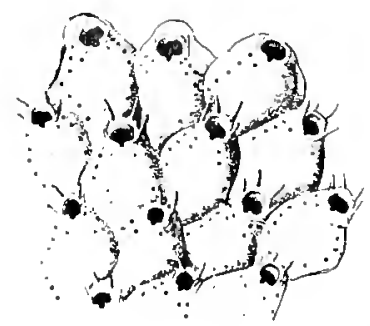

A

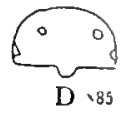

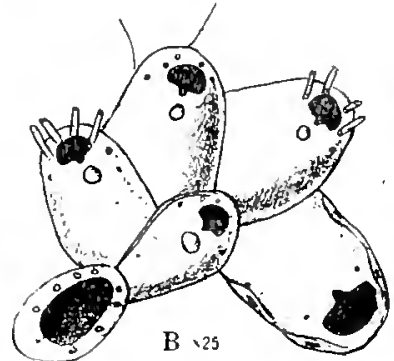

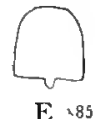

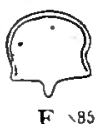

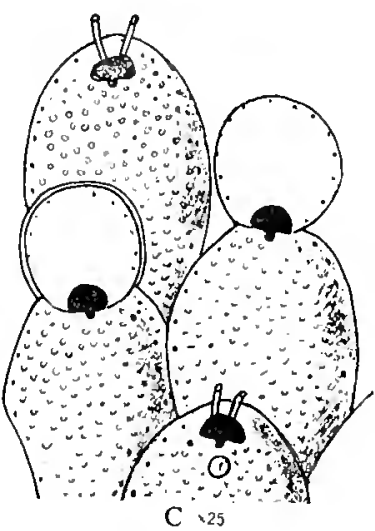

C.25

Fig. 103.-Genus Lacema Jullien, 1898.

A-D. Laccrna hostcensis Jullien, 18ss. A. Znoecia, $\times$ 25. (Aftel Jullien, 1S8s.) B. Zooecia with ancestrula, $\times 25$. C. Ovicelled zooccia, $\times$ 25. D. Operculum, $\times$ 85. (After Waters, 1904.)

E, F. Lacerna eatoni Busk, 1879. F. Operculum, X S5. (After Waters, 1904.) F. Operculum of the variety arcolata, $K$ S.5. (After Calvet, 1910.)

Lacerna (Schizoponella) nitidissima Maplestone, 1901.

Lacema (Schizoporclla) cavolini Neviani, 1895.

Lacerna (Schizoporella) ovalis Maplestone, 1901.

This genus is very closely related to Stephanosella. Laccrna differs in the larger and more numerous areolae, the presence of spines, and the place of the avicularium below the aperture.

\section{LACERNA JACKSONENSIS, new species.}

Plate 44, figs. 13-16.

Dcscription.--The zoarium incrusts other bryozoa. The zooecla are distinct, very little elongated, separated by a furrow; the frontal is somewhat convex, smooth, and burdered by a line of large closely arranged areolae; a pleurocyst 
more or less granular and complete is deposited on the frontal, chiefly in the vicinity of the areolac. The apcrture is semilunar; the proximal border is linear and bears a nirrew, linear rather long rimule; the peristome is salient; it surrounds the aperture and its rimule and it bears anteriorly six hollow spimes. The ovicell is large, salient, elongated, of the same nature as the frontal; it is formed of a smooth, orbicular callosity (olocyst) surmounted by a prominent collar, and by areolae; it is never closed by the operculum. The aricularium is triangular, long, salicnt, placed laterally below the aperture and deforming the zooccia; it is tralisterse or oblique; its point to the outside.

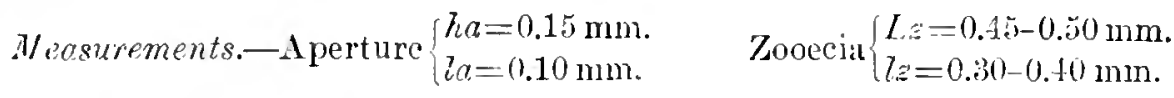

I'ariations.-The aricularinm is sometimes far ronoved from the aperture (fig. 13 ) ; it is transrerse (fig. 13) or oblique (fig. 14).

The part of the peristome which surrounds the rimule forms au clegant festoon above the aperture.

The plenrocyst and olocyst are closely united. The smooth zooecia are young zooecia in which the subjacent olocyst is still visible. The pleurocystal calcification operates according to rule, the arcolae toward the aperture with the formation of small, interareolar, incomplete costules.

On the ovicell the calcification is more regular and fincr; the physiological use of this structure is unknown; the length is $0.25 \mathrm{~mm}$.

Affinities.-This species differs from Lacrna hexagonalis in its small dimensions and the presence of the prominent festoon which surrounds the rimulc.

It differs from Lacerna seguenzai Reuss, 1869 , in the absence of the oral mucro, and from Lacerna süssi Reuss, 1869, in the place, the size, and the form of its a vicularia.

Occurrence.-Lower Jacksonian (Moodys marl) : Jackson, Mississippi (common).

Cotypcs.-Cat. No. 64047, U.S.N.M.

LACERNA HEXAGONALIS, new speeies.

Plate 44, figs. 17-20.

Description.-The zoarium incrusts Orbitoides, bryozoa, and shells. The zooecia are distinct, little elongated, hexagonal; the frontal is little convex, formed of an olocyst more or less covered by a pleurocyst and surrounded by a line of large areolae. The aperture is scmilunar; the proximal border is linear and notehed by a narrow, linear, rather long rimule; the peristome is salient, and surrounds at the same time the aperture and its rimule forming exteriorly an oval peristomice; the peristome bears six large, hollow spines. The ovicell is large. salient, elongated, of the same nature as the frontal; it is formed of a cireular callosity surrounded by rery small areolae and a thick, salient collar; it is often closed by the opereulum when the latter opens. The avicularium is long, thin, triangular, little salient, disposed in the same manner as the zooecial walls, withont pirot. 
Measurements.-Aperture $\left\{\begin{array}{l}h a=0.125-0.15 \mathrm{~mm} . \\ l a=0.15-0.20 \mathrm{~mm} .\end{array} \quad\right.$ Zooecia $\left\{\begin{array}{l}L_{z}=0.65-0.72 \mathrm{~mm} . \\ 7_{\tilde{z}}=0.50 \mathrm{~mm} .\end{array}\right.$

Tariations.-The calcification is here rather remarkable and more visible than in Lacema jacksonensis. The frontal is an olocyst, entire and smooth (fig. 17); on the young zooccia; the pleurocyst develops at first over the areolae (fig. 18), then spreads over all the zooccia (fig. 20). As usual, the pleurocyst is irregularly gramulated, quite variable in its texture and its deposits.

The calcification of the ovicell is absolutely identical. Originally the latter 'was formed by a thin olocyst thickened on its border into a circular crown; the frontal callosity is surrounded by very small areolae (fig. 17) and may be covered by a granular pleurocyst (fig. 20). On the young zooecia the operculum may never close the ovicell (fig. 17), but on the mucl calcified zooecia the operculum in opening may close the oricell (fig. 20). Figure 20 presents a remarkable zooecium; for in the total regencration an avicularium replaces a normal polypide.

The species appears to have some dictellae, variable in number (fig. 19).

Affinities.-This species differs from Arthropoma (Lematia) speyeri Reuss, 1864 , in which the aperture is identical in its nomporous frontal and its larger a vicularium.

It liffers from Lacema juchonensis in its larger micrometric dimensions and its oval and nonfestooned peristome.

It differs from Laeerna (Schizoporella) nitens MacGillivay, 1995, in its decper rimule and in the point of the avicularium turned toward the bottom and not toward the top.

Occurrence.-Vicksburgian (Marianna limestone): Salt Mountain, 5 miles south of Jackson, Alabama (rare); west bank of Coneculn River, Escambia County, Alabama (lare); near Claiborne, Monroe County, Alabama (rare); Nurder Creek, cast of Castlebury, Conecuh County, Alabama (rave); 1 milc north of Monrocville, Alabama (rare).

Upper Jacksonian (Ocala limestone): Chipola River, east of Marianna, Florida.

Cotypes.-Cat. Nos.64048, 64049, U.S.N.M.

\section{Genus BUFFONELLA Jullien, 1888.}

1S59. Buffonella Jullien, Mission scientifique du Cap Moln, vol. G, Zoologie, n. 47.

The opcrenlum in opening closes the oricell. The aperture is semilunar: its proximal border is straight and bears a rimule at its middle. The frontal and ovicell are absolutely smooth. The opereulum has a wide sinus and two muscular points distant from the border. In front of the aperture there is often a small avicularian chamber.

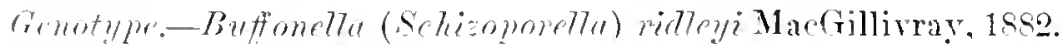

l'unge-Eenonian-Recent.

The recent species of this genus are according to Waters:

Puffomolla (Sekisoporella) ridleyi MacGillivray, 1882. 
Buffonella (Schizoporella) simplex D'Orbigny, 1833.

Buffonclla (Schizoporella) rimosa Jullien, 1888.

Buffonella (Schizoporella) mursupitera Busk, $188+$.

Buffonella (Schizoporella) rumida Ilineks, 1881.

Buffonella (Schizoporella) levata Iincks, 1882.

Buffonella (Schizoporella) laciigata Waters, 1859.

Buffonella (śchizoporella) cdwardsiana D'Orbigny, 1839.

Buffonella (Escharella) stylifera Levinsen, 1851 .

butfonella (schizoporella) hexugona Nordgand, 1905.
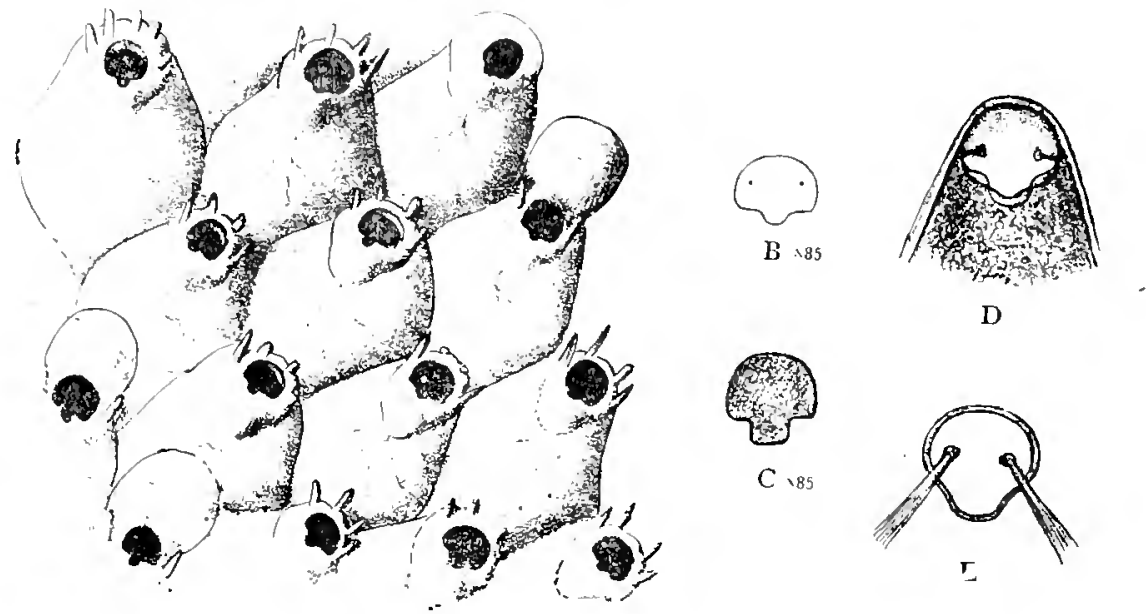

D

A $\times 50$
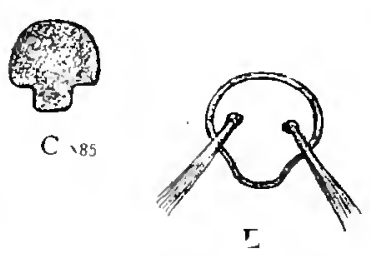

F1G. 104.-Genus Buffonella Jullien, $18 s 8$.

A, B. Ruffonella ridleyi MacGillivray, 1ss2. A. Zooecia, $\times 50$. (After Jullier, 18Ss.)

B. Operculum, $\times$ S5. (After Waters, 1904.)

C. Buffonella hexagona Nordgaard, 1905. Operculum, $\times$ S5. (After Nordgaard.)

D, E. Euffonella stylifera Levinsen, 1SS6. D. Aperture of zooecium. E. Operculum. (After Levinsen, 1SS6.)

The known fossil species of the genus are:

Buffonella (Lepralia) incisa Reuss, 1874.

Buffonella (Lepralia) pauper Reuss, 1874.

Buffonella (Schizoporella) muda Canu, 1908.

Buffonella (Schizoporella) crenulata MacGillivray, 1904.

Buffonella (Schizoporella) arachnoides MacGillivray. 18s2.

Buffonella (Schizoporella) clerici Neviani, 1895.

Buffonella (Schizoporella) carinata Hennig, 1892.

BUFFONELLA HEXAgONALIS, new species.

Plate 46, fig. 1.

Description.-The zoarium is formed of many superposed lamellae and incrusts stones. The zooecia are distinct, elongated, hexagonal, separated by a prominent 
thread; the frontal is convex, smooth, with the radial nerres visible by transparency. The aperture is small and bears on its proximal border a rather wide triangular rimule. Above the aperture there are two small, simple avieularia.

$$
\text { Measurements.-Aperture }\left\{\begin{array} { l } 
{ h a = 0 . 1 2 \mathrm { mm } . } \\
{ l _ { a } = 0 . 1 0 \mathrm { mm } . }
\end{array} \quad \text { Zooecia } \left\{\begin{array}{l}
L_{z} z=0.65-0.75 \mathrm{~mm} . \\
l z=0.45-0.50 \mathrm{~mm} .
\end{array}\right.\right.
$$

Affinities.-This species differs from Buffonelln rhomboidalis in its longer zooecia, in the salient separating thread, and the presence of two small supraoral a vicularia.

The same characters also differentiate it from Buffonella incisa Reuss, 1874.

Ocourence.-Middle Jacksonian (Castle Hayne limestone) : Wilmington, North Carolina (rare).

Holotypc.-Cat. No. $6 \pm 053$, U.S.N.M.

\section{BUFFONELLA RHOMBOIDALIS, new species.}

Plate 46, fig. 2.

Description.-The zoarium incrusts bryozoa. The zooecia are distinct, elongated womboidal, separated by a furrow; the frontal is convex and absolutely smooth. The aperture is small, withont peristome; the rimule is large and rectangular.

$$
\text { Measurements.-Aperture }\left\{\begin{array} { l } 
{ h a = 0 . 1 2 \mathrm { mm } . } \\
{ 7 a = 0 . 1 0 \mathrm { mm } . }
\end{array} \quad \text { Zooccia } \left\{\begin{array}{l}
L z=0.55-0.65 \mathrm{~mm} . \\
l z=0.40-0.50 \mathrm{~mm} .
\end{array}\right.\right.
$$

Affinities.-This species resembles Buffonella incisa Reuss, 187t, very much, in its extreme simplicity of structure. It differs from it only in its larger micrometric measurements $\left(L_{z}=0.55-0.65\right.$ mm. instead of $0.36-0.40 \mathrm{~mm}$.).

Occurrence.-Middle Jacksonian (Castle Hayne limestone): Wilmington, North Carolina (very rare).

Iolotype-Cat. No. 6405t, U.S.N.M.

BUFFONELLA MICROSTOMA, new species.

Plate 46, fig. 3 .

Description.-The zoarium incrusts shells. The zooecia are very smull, elongated. distinct; the frontal is smooth and convex. The aperture is very small; the rimule is wide and triangular. The ovicell is globular, salient, and smooth; it opens above the aperture by a small slit; it may be closed by the operculum.

$$
\text { Neasurements.-A perture }\left\{\begin{array} { l } 
{ h a = 0 . 0 6 \mathrm { mm } . } \\
{ l \alpha = 0 . 0 6 \mathrm { mm } . }
\end{array} \quad \text { Zooecia } \left\{\begin{array}{l}
L_{z}=0.35 \mathrm{~mm} . \\
l z=0.20 \mathrm{~mm} .
\end{array}\right.\right.
$$

Affinitics.-This species differs from Buffonella incisa Reuss, 1874, in its slightly smaller micrometric dimensions and in its, rimule, which is triangular and not rectangular. Moreover, the European fossil sometimes bears a small, lateral avicularium, which we have not observed on the American specimens. 
Occurrence.-Upper Jacksonian (Ocala limestone): Chipola River, east of Marianna, Florida (very rare); Old Factory, $1 \frac{1}{2}$ miles above Bainbridge, Georgia (rare).

Holotype.-Cat. No. 64055, U.S.N.M.

\section{Genus ARTHROPOMA Levinsen, 1909.}

1909. Arthropoma Levinsen, Morphologienl and systematic Studies on the Cheilostomatons Bryozoa, p. 332.

The ovicell is hyperstomial and always closed by the operculum. The frontal is a tremocyst with scattered pores. The operculum bears a mobile, small tongue in the middle of the straight. proximal border. The rimule of the aperture is straight and rectangular.

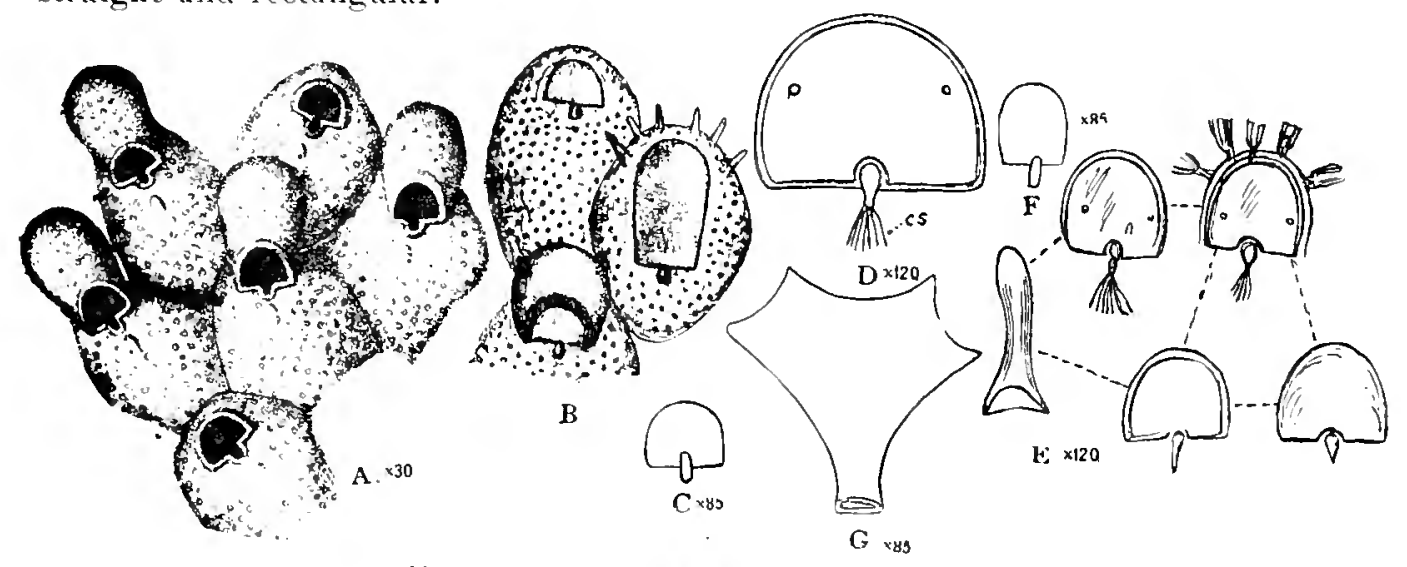

FIG. 105.-Genus Arthropoma Levinsen, 1909.

A, D. Arthropoma cccilii Audouin, 1S:6. A. Zooecia, $\times$ 30. (After Hinclis, 18so.) B. Avicularian zooecia. (After Kirkpatrick.) C. Operculum witl its mobile tougue, $X \quad 85$. (After Waters, 1904.) D. Operculum, $\times$ 120. (After Busk, 18s4.) cs., connected part of the compensatrix, which by foldings has assumed the longitudinally striated appearance.

E. Arthropoma circinata MacGillivray, 1s6s. Operculum and mandible, $\times 120$. (After Busk, 18S4.)

F, G. Arthropoma pcsanseris Smitt, 1879. Operculum and mandibles, $\times$ S5. (After Waters, 1S99.)

Genotype.-Arthropoma (Flustra) cecilii Savigny-Audouin (1812) 1826.

Range.-Jacksonian-Recent.

The little mobile tongue of the operculum is attached to the compensatrix. This is the only character which differentiates this genus from Phonicosin Jullien. 1888 , and if this be judged insufficient, it will be necessary to reunite the two genera under the latter name, which has the right of priority.

The mobility of the little tongue is evidently intended to protect from rupture the compensatrix, which is an extremely fragile organ.

Kirkpatrick has discovered a zooecium transformed into an interzooecial avicularium with special mandible. Such zooecia are not rare in other genera and we have sometimes noted them on the fossil forms. 
The recent species of this genus are according to Waters, 1904 , and Lerinsen, 1909 :

Arthropoma (Flustur) secitii Sarigny-Audouin (1812) 1826.

Arthropoma (IIiplothoa) pesanseris Smitt. 1872.

Arthropoma (Lepralia) circinata MacGillirray, 1868.

Among the fossil species re may doubtfully cite A thropoma (Lepralia) speyeri Reuss. 1865.

ARTHROPOMA METULA, new species.

Plate t6, fig. 18.

Ilexcription.-The zoarium is free. bilamellar. The zooecia are elongated, listinct, in the form of quills; the frontal is convex and is a tremocyst with very small pores. The aperture is transverse: the proximal border is linear and bears a small rectangular rimule. The ovicell is very large, salient, globular, smooth; its orifice is very regular and is closed by the operculum itself. The avicularimi is placed laterally below and close to the aperture; it is elliptical and salient; two lateral denticles serve as pirot.

$$
\begin{aligned}
& \text { Weasurements. I I perture }\left\{\begin{array} { l } 
{ h a = 0 . 2 0 \mathrm { mm } . } \\
{ l _ { a } = 0 . 2 0 \mathrm { mm } . }
\end{array} \quad \text { Zooceia } \left\{\begin{array}{l}
L_{z}=0.85 \mathrm{~mm} . \\
l_{z}=0.25 \mathrm{~mm} .
\end{array}\right.\right. \\
& \text { Ovicell } \begin{array}{l}
l o x=0.30 \mathrm{~mm} . \\
l o r=0.45 \mathrm{~mm} .
\end{array}
\end{aligned}
$$

Iffnities.-This species differs from Arthropoma speyeri Reuss, 1865, in its much larger and higher placed avicularium. This latter species is of Tongrian age (to be exact, from the Rupelian). It is remarkable to note that this genus appears almost simultaneouly in Europe and America. The figured specimen is the only one which has been found.

Arthropoma metula differs from the recent Schizoporella acuminata Hincks. 1881, in its transrerse and not straight aricularia and probably in the nature of the oricell.

Gecurache.-Middle Jacksonian (Castle Hayne limestone) : Wilmington. North Carolina (rery rare).

Ilolotype.-Cat. No.6t061, U.S.N.M.

\section{Genus PHONICOSIA Jullien, 1888.}

1888. I'honicosiu Jullien, Mission scientifique du Cap Horn, vol. 6, Zoology, p. 51.

Orifice with posterior lip, straight, and bearing an clongated notch at its midlle, with the extremity cut squarely. (Translation a fter. Jullien.)

Cenotype.-Phonicosia joussfaumi Jullien, 1888. Recent.

Waters, 1904, remarked that the gemms Phonicosia was described from one small dead specimen, without opereula. The published figure does not permit the oliselvation of the closing of the ovicell by the operculum, and we therefore leare. to the genus I'honicosia the limits established by its author. 
SCHIZOBRACHIELLA, new genus.

The ovicell is hyperstomial and closed by the opereulum. The frontal is a tremocyst. The operenlum bears a straight poster notched by a small, narrow, rounded rimule. The tongue of the operenlum is rigid and is not attaclied to the compensatrix: the muscular attachments are placed near the border. No a vicularia.

Grnotype.-Schizobrachiello (IIsmeschard) sanyuined Norman, 1865. Range: Ielveti:n-Rccent.

The recent species of this genus are:

Schizobrachienta (Hemesehara) sunguince Nomman, 1868.

Schizolmushiella (Lepralin) candida Stimpson, $185 \%$.

Schizobrachiclla (Schizoporella) Texinseni Nordgaard, 1905.

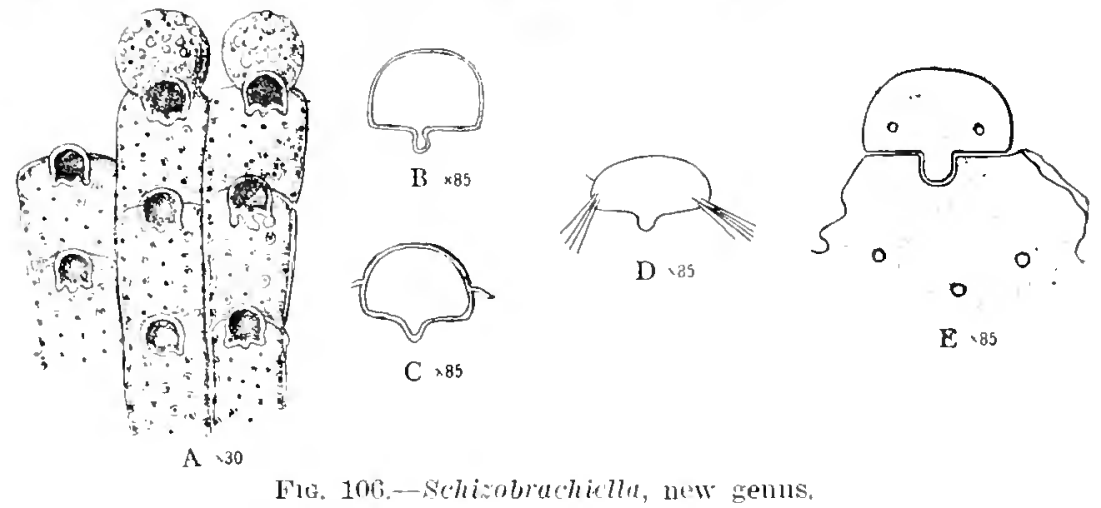

1-I). Schisubachicha san!minca Norman, 1S6s. A. Zonecia, X 30. (After Hincks, 1sSO.) R, C. Opereulum, $\times$ 85. (After Waters, 1579.) D. Operenlum, $\times$ S5. (Alter Norrgatiru, 1., (1). )

l:. Schizobrachicha levinschi Nontgand, 1905. Opereulum, X 85. (After Nortgaral. 1905.)

The known fossil species are:

Schizobrachiclla (Lepratia) goniostoma Reuss, 1847.

Schizabrachiclla. (Lepralia) granoso-porosa Reuss, 1874.

Sehizobrachiclla (Leprelia) erassipora Reuss, 18 it.

Sechizobrachielle (Schizoporella) ulate MacGillivray, 1895.

Schizobrachiclla (Schizoporella) subsinutu. NacGilliviay, 1895.

'This genus differs from Dataria. Jullien, 190t, in a much smaller rimule, in the muscular attachments rery near the border of the operculum, and in the atbsence of interior condyle.

This genus differs from Schizolucellin and Schizomavella in the absence of avicularia.

Genus SCHIZOMAVELLA Canu and Bassler, 1917.

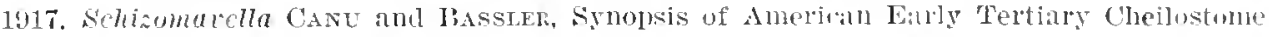
Bryozon. Pulletin 96. United States National Museun, p. 40.

The operenlum closes the oricell. 'The muscular' attachment is generilly in the immediate vicinity of the border of the opereulum. The rimule is wide and

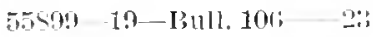


arched. The frontal is a tremocyst. A median avicularium oecurs on the front wall. There are small oral glands. 23 tentacles.

Genotype.-Schizomavella (Lepratia) auriculata Hassall, 1842.

Range.-Taclisonion-Recent.

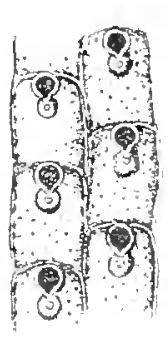

A $\times 30$

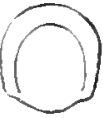

M. 85
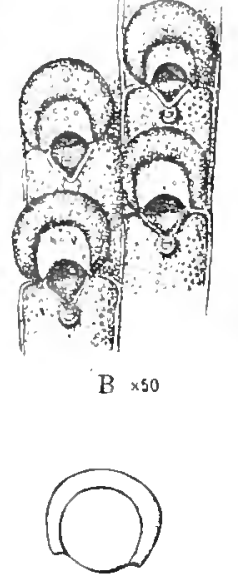

IT 185

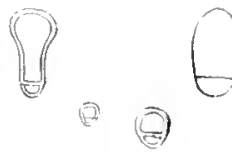

C

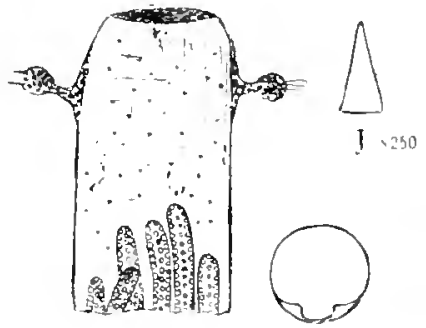

II $\times 195$

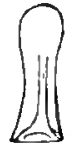

$\mathrm{D} \times 85$

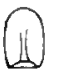

E $\times 85$
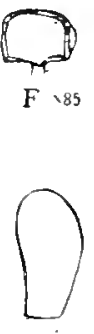

$\mathrm{K} \times 85$

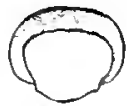

$P \cdot 85$
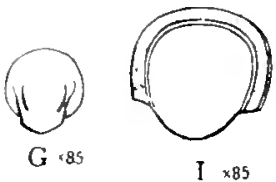

FIG. 107.-Genus Schinomarella Canu aud Bassler, 1917.

A-I1. Schisomarella ariculatu Hassal, 1842. A. Zomecia, X. 30. H. Zucecia witl ovicells, X 50. C. Avicularia. (After Hiucks, 18s0.) D, E. Avicularian manuibles, $X$ S5. F. Opr" culum, K S. (After Waters, 1579.) G Opereulum, X Si. (After Noman, 1903.)

H. I. Schisomarcla reticulalo punctala Hincks, 1877. H. Tentacular sheath with oral chands attached near the oral aperture and connected to the rateral walls, $\times 85$. (After Waters, 1900.) I. Operculum, X S5. (After Nordgard, 1906.)

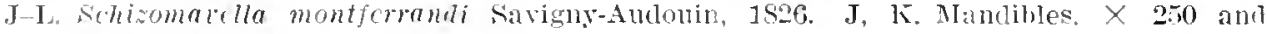
$\therefore$ S5. I. Operculum, X 8.5. (After Waters, 1908.)

1]. Schizomazclla porifere Smitt, 1S67. Mperculum, X S5. (After Nordgarm, 190.).)

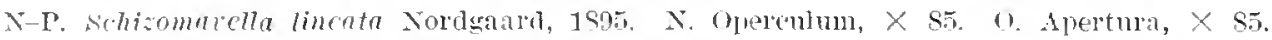
F. Operculum, $\times$ 85. (After Norlgaari, 1905.)

Q. I. Schizomarella ambila. Waters, 18s9. Q. Operculum, X S5. (After Waters, 1ss9.) I.. (nereulum, $\times$ 85. (After Galvet, 1904.)

The recent species are:

Schizomanlll (Schizoporella) harmsworthi Waters, 1900 (=Sehizoporiln reticulata menctata Hineks. 15ir).

Schizomarella (Lepratia) galeata Busk, 1859.

Schizomavelle (Flustra) montforransli Silvigny-Andouin. 1802h.

whizomacella (Schizoporella) Tineata Nordgarde. 1895.

selizomairlla (Escharella) porifere Smitt, 1897.

Schizomavelle (Schizoporella) ambita Waters, 1889.

Selizomarella (Schizoporella) scabra Waters.

Schisomavella (Schizoporella) fayatensis Calvet, 1903.

Sefizomarella (Lepratia) auriculata Hassall. 1842. 
The fossil species are:

Schizomavella (Schizoporella) Iata MacGillivray, 1895.

Schizomavella (Schizoporella) plagiostoma MaeGillivray, 1895.

Levinsen in 1909, thought that median avicularia elaraeterized the Smittinidae and that they might not exist in the Escharellidae. The Selnizoporellae provided with a median avicularium might be reunited with the Smittinidae under the name of Smittina. The work of Harmer in $1902^{1}$ showed that in Schizoporella Finecris. the compensatrix and the hydrostatic system are analogous to those of the other Schizoporella and are notably different from those of Smittina trispinosa. Tnder these eonditions we think we must maintain the primitive nomenclature. To facilitate the determination we have created the genus Schizomavella for the species provided with a very constant median a vieularium.

The distinetion between Schizometelle and certain species of Hippoporina is easy to make on the recent specimens by an examination of the museular attachments on the operculum. On the fossil forms. the interior may furnish some useful points, but very often the problem is insoluble, so re must content ourcelres with simple comparisons.

SCHIZOMAYELLA GRANULIFERA, new species.

Plate 46 , tigs. 4-12.

Irescription.-The zoarim is free. with flat or undulated fronds formed of two lamellae, back to baek, and inseparable. The zooecia are distinct, elongated, fusiform, separated by a furrow or a prominent thread; the frontal is convex, ornamented with small tremopores and small gramutations. The aperture is transverse, elliptical; the rimule is very wide and separated from the anter by two small cardelles. The aperture of the oricelled zooecia is larger. The oricell is globular, very salient, ornamented by the same tremocyst as the frontal; it is hyperstomial, but always elosed ly the operculum. The median arieularim is small, round or triangular. arjacent to the rimule.

$$
\text { Weasurements.-Aperture }\left\{\begin{array}{l}
h u=0.10-0.12 \mathrm{~mm} . \\
Z a=0.12-0.14 \mathrm{~mm} .
\end{array} \quad \text { Zooecia } \begin{array}{l}
L_{z}=0.5+0.70 \mathrm{~mm} . \\
l z=0.3 \pm 0.50 \mathrm{~mm} .
\end{array}\right.
$$

Tariations.-This species is rery rariable and its study has given us meh troulble. The numerons speeinens collected at many localities permit the recognition of the principal rariations. The micrometric dimensions rary in unusual proportions; the zooecial length varies from $0.50 \mathrm{~mm}$. to $0.80 \mathrm{~mm}$. and the wilth from 0.30 to $0.52 \mathrm{~mm}$. It is the same with the aperture, the dinensions of which. rather fixed on a single specimen, rary a sreat deal, according to loealities. The frontal granulations are attenuated (fig. 10) or rery salient (figs. 5. 8). The zooecial margins are sometimes very salient (fig. 10), but they are wanting most of the time (figs. 6. 8). The avicularium is generally round, but it may be mueh remored from the aperture and become trimgrlar (fig. 9). Thie oricell eovers

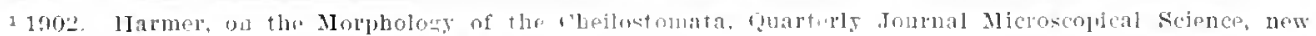
ser., rol. \pm 6, p. 301, pl. 17 , figs. 42,46, th. 
monch of the aperture (fig. $T$ ): it is therefore always closed by the operculum; mean while the orifice of the aperture persists in the interior (fig. 8); we have come to the conclusion that the operculum is lowered to allow the escape of the larrae.

The tangential scction (fig. 12) reveals clearly a tremocyst surmounting an olocyst closely united with it; the tremopores are very small and wide open. In the interior (fig. 11) the olocyst appears absolutely smooth, but when greatly magnified it is easy to distinguish the small pores corresponding to the tremopores.

Affinities.-This species differs from Dalaria laxata in its bilamellar zoarium and it surller zonecial width, always less than $0.50 \mathrm{~mm}$. instead of $0.60 \mathrm{~mm}$. It differs from schizomacella elongata in it leser zooecial length, which is $0.70 \mathrm{~mm}$. instead of $1.00 \mathrm{~mm}$.

Occurrencr.-Middle Jacksonian: Baldock, Barnwell County, South Carolina (very common); 12 miles southeast of Marshallville. Georgia (rare); 31 miles south of Perry, Georgia (rare): Rich IIill, Georgia (rare); $5 \frac{1}{4}$ miles soutlueast of Knoxrille, Georgia (rare); 18 miles east of Wrightsville, Georgia (rare); $\frac{1}{2}$ mile southcast of Georgia Kanlin Company Mine, Twiggs County, Georgia (rare); $3 \underline{2}$ miles north of Grovania. Georgia (rare): Wilmington, North Carolina (rare).

Upjer Tacksonian (Ocala limestone) : Chipola River, east of Marianna, Jackson County. Florida (common).

Cotypes.-Cat. No. 6405s, U.S.N.M.

SCHIZOMAVELLA GRANULOSA, new species.

Plate 46, figs. 13-16.

Inecription.-The zoarium incrusts bryozoa. 'The zooccia are elongated, distinct, fusiform; the frontal is little convex and formed of a gramular tremocyst with rery small pores. The aperture is formed of a semilumar anter and of a wide romuled rimule, separated by two imer condyles. The ovicell is very large, salient. formen of a large area surrounded by a small, salient collar; it cntirely surroumls the aperture. lont without forming a peristomie. The median avicularium is rnite snall, little prominent in the immediate ricinity of the aperture.

$$
\text { Wrisurements.-Aperture }\left\{\begin{array} { l } 
{ h _ { a } = 0 . 1 0 \mathrm { mm } . } \\
{ 7 a = 0 . 0 8 - 0 . 0 9 \mathrm { mm } . }
\end{array} \text { Zooecia } \left\{\begin{array}{l}
L z=0.60 \mathrm{~mm} . \\
7 z=0.40 \mathrm{~mm} .
\end{array}\right.\right.
$$

Affinitics.-The gramular frontal is characteristic of this species; it recembles strangely in its gramulations, in its bordered ovicell. and in its avicularium, pliced near the aperture, the recent Sehisoporenta mursupifera Busk, 18St. It differs from the latter only in its more elongated zooecia and its nontransverse apertme.

We have obsered (fig. 15) a regenerated avicularian zonecium in the interior of a primitive zooecium, where another one has succeeded it with a rery small mandible.

Occurrence-Upper Jacksonian (Oeala limestone): Old Factory, $1 \frac{1}{2}$ miles ahove Bainbridge, (reorgia (rare).

Cotypes-Cat. No.64059, U.S.N.M. 
SCHIZOMAVELLA ELONGATA, new species.

I'late 46 , fig. 17.

Deseription.-The zonriun is free. formed of two lamellac, back to back and inseparable; the zooecia are distinct. rery elongated, fusiform, separated by an improminent thread; the frontal is flat and ormamented with small, wide open tremopores. The aperture is subulvicular: the rimule is very wide, coneave, scarcely distinct from the anter. The oricoll is globular and salient, olmamented with a tremoeyst analugous to that of the frontal. The median aricularium is small. triangular, withont salient beak and imbedded in a eavity.

$$
\text { Measurements.-Aperture }\left\{\begin{array} { l } 
{ h a = 0 . 1 0 \mathrm { mm } . } \\
{ 7 a = 0 . 1 0 \mathrm { mm } . }
\end{array} \quad \text { Zooecium } \left\{\begin{array}{l}
l=1.10 \mathrm{~mm} . \\
l z=0.30 \mathrm{~mm} .
\end{array}\right.\right.
$$

Affinties. - This species is chancterized by its very great zooccial length. We have observed two calcified zooecia; the aperture is covered by the tremoeyst and replaced by a small pore. The plysiologie rôle of such zooecia is unknown to us.

Oecurrence.-Middle Jacksonian: Thuee and one-half' miles north of Grovania, Georgia (rare).

Ilototype,-Cat. No, 6t060. U.S.N.M.

SCHIZONAVELLA ARBOREA, new species.

Plate so, igs. $1-6$.

Deseription.-The zoarium is free, aboreseent, rectingular, or cylindrical. The zooceia are disposed in four longitudinal rows, altermating and placed back to back; they are hexagonal, very little elongated, separated by a prominent thread. The frontal is a direct tremocyst with large pores. The aperture is small, oblique and formed of a semilunar anter and of a very wide rimule of little depth. The ovicell is large, globular, salient. punctate; it is closed by the zooecial operculum which is larger on the ovicelled zooecia. The median avicularium is elliptical, salient, separated into two parts by a wide pirot.

$$
\text { Measurements. A perture }\left\{\begin{array} { l } 
{ h a = 0 . 1 0 \mathrm { mm } . } \\
{ l a = 0 . 1 0 \mathrm { mm } . }
\end{array} \quad \text { Zooecia } \left\{\begin{array}{l}
L z=0.80 \mathrm{~mm} . \\
l z=0.72 \mathrm{~mm} .
\end{array}\right.\right.
$$

Variations. - The median avicularium is rery viriable on the same fragment; it is quite small $(l=0.08 \mathrm{~mm}$.) or very long $(l=0.25 \mathrm{~mm}$.), but it always remains elliptical (figs. 2,5).

The zoarinm is square (figs. 2. (6) or quite pounded (figs. 4, 5).

The ovicell does not entirely surround the aperture and is quite different from the ovicell of other species of the same genus.

Affinitics.--This species is well characterized by the arboresent form of its zonrium. In its direct tremocyst and in the form of its aperture, it diflers furm species of the same genus.

It differs from Cellaria selereibrei Reuss. 1sig. in which the zoram is vin-

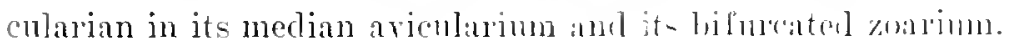


Occurrence.-Ticksburginn ("Chimmey rock" of Marianna limestone): One mile north of Monroeville. Alabima (abundant).

Vicksburgian (Red Bluff clay) : Seven and one-half miles southwest of Bladen Springs, Alabama (rare).

Cotypes.-Cat. No. 6+271, U.S.N.M.

SCIIZOMAVELLA LONGIROSTRIS, new species.

Plate 5. tig. 13.

Description.-The zonrium is free bilamellar, revy small; the two lamellae are easily separable. The zonecia are elongated, listinct, oval; the frontal is convex and formed of a tremocyst with large pores. The aperture is orbicular or transverse; the anter is large and semilunar: the rimule is wide and concave. The oricell is globular and salient; its orifice is always closed by the operenlum. The median avicularium is long, salient, provided witl a pirot and a long triangular beak.

$$
\text { Mecusurements.-Aperture }\left\{\begin{array} { l } 
{ 7 a = 0 . 1 0 \mathrm { mm } . } \\
{ 7 a = 0 . 1 2 \mathrm { mm } . }
\end{array} \quad \text { Zooecia } \left\{\begin{array}{l}
L z=0.65-0.80 \mathrm{~mm} . \\
7 z=0.40 \mathrm{~mm} .
\end{array}\right.\right.
$$

Affinities.- We possess only a lew small pecinens of this species, and it has therefore been impossible for us to make a careful study of it. It appears to present some interesting peculiarities in its ovicell and in the disposition of its large avicularium; but it is necessarr to a wait more material.

There is a sinnilar recent species. Schisoporelln longirostrata Hinchs, 1882. but its avicularium is not median.

Occumener.-Ticksbmeian (Red Rluff clay): Red Bluff, Wayne County, Mississippi (rare).

Holotype.-Cat. No.64:64, U. S. N. M.

\section{SCHIZOLAVELLA, new genus.}

The ovicell is closed by the operculum. The operculum bears a rariable rimule. The frontal is a tremoctst. There are two lateral avicularia.

Genotype.-Schizopormlla vulgaris Moll, 1803.

Rangr.-Rupelian-Recent.

'This genus differs from Schisomavella only in the latelal position of the avicularia and in the muscular attachments of the opereulum, which are more distant Irom the border.

The functions of the avicularia seem to be multiple: but they are not well known. The generic dirisions based on these urgans always present a relative macertainty which only further sturlies can elininate.

The fossil species of this same genus are:

Schizolavella (Eschara) phymatopor Reuss, 1809.

Schizolarella (Lepratire) schizostomo Mactillivay. 1895.

$$
{ }^{1} \text { lnt=abbreviation of "latelal aricularia." }
$$


Genus STYLOPOMA Levinsen, 1909.

1909. Stylopoma Lerinsen, Morphological and Systematic Sturlies on the Cheilostomatous Bryozon. pl. 18. (Name only.)

The ovicell is hyperstomial. It covers the apertura and the avicularia entirely. The frontal is a tremocyst. The apertura is provided with a small linear rimule.

Genotype.-Stylopoma (Eschara) spongites Pallas, 1766.

Range-Miocene-Recent.

Levinsen proposed this name for Eschara spongites and Schizoporella longirostris Hincks, 1886; but having recognized that the size of the rimule is not a generic character, he suppressed it. We reestablish the genus, basing it upon the function of the passage of the eggs, which operates in a very different manner from
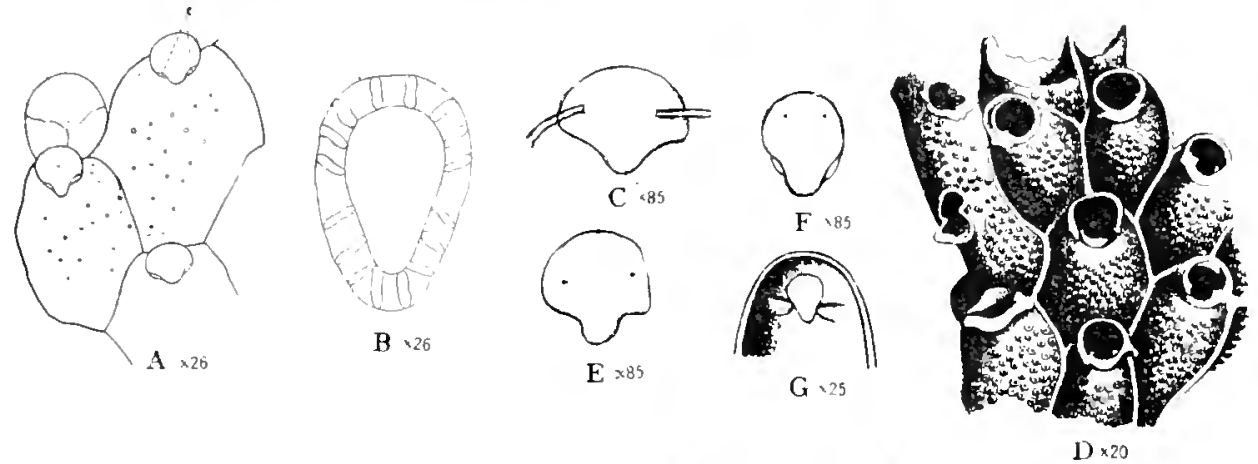

Fig. 108.-Genus Dakaria Jullien, 1904.

A-C. Dakaria condylata Nordganri, 1906. A. Sketch of zooecia, $\times 26$. B. Sketch showing dletellae, $\times 26$. C. Operculum, $\times$ \$5. (After Norlgaard, 1906.)

D. Dakaria cherreuri Jullien, 1904. Young zooecia, $\times 20$. (After Jullien, 1904.)

E. Dakaria magniporata Nordgarad, 1906. Operculum, $\times$ S5. (After Nordgaarl, 1906.)

F, G. Dakaria gelida Waters, 1904. F. Operculum, $X$ S5. G. Interior of zooecium showing the oral condyles, $\times 25$. (After Waters, 1904.)

that in Schizopodrella, where the species would otherwise have been placed. The great development of the ovicell above the apertura assures this function.

\section{Genus DAKARIA Jullien, 1903.}

1903. Dakaria Jullien, Resultants des Campagnes scientifiques du Prince de Monateo, filsc. 23, Pryozoaires provenant des Campagnos de l'Hironlchle (1SS6-SS), 1). 00

The ovicell is hyperstomial and closed by the operculuns. The frontal is a tremocyst. The operculum bears a wide rimule and articulates often on two condyles; its muscular attachments are elongated on the border. No avicularia.

Genotype.-Dakaria ehevreuxi Jullien, 1903.

Range.-Lutetian-Recent.

The recent species of this genus are:

Dakiaria cherrenxi Jullien, 1903. 
Dakaria (Schisoporella) condylata Nordgard, 1906.

Daliaria magniporata Nordgaard, 1906.

Dukaria yclitla Waters, 1901.

The known fossil species are:

Dakiaria (Lepratia) squamointer Rouss. 1864.

Dakiaria (Celluria) be?richi Stoliczka, 1862.

Duharia (Schizoporella) subsqummoidea Koschinsky, 1885.

This genus differs from Phonicosin in a wider sinus of the apertura. Perhaps it may be necessary to introduce here all the Schizoporellae, having the same form of operculum, the same frontal, and provided with lateral avieularia, as long as the special function of the latter is not clearly defined.

All the species of this gemus hare not the special form of apertura mentioned by Jullien for Dakaria chovreuxi. But as this species must enter normally into the new genus we have adopted Jullien's name so as not to eneumber the literature with a new term.

DAKARIA BREVIS, new species.

Plate 46, fig. 19.

Description.-The zoarium is uni to multilamellar and incrusts shells or bryozoa. The znoceia are distinet, fusiform, short; the frontal is convex and almost smooth, ornamented with very small granules. The aperture is small, transverse; the rimule very wide and little clistinct from the anter. The ovicell is salient, globular. elongated, of the same nature as the frontal. There is no median avieularium.

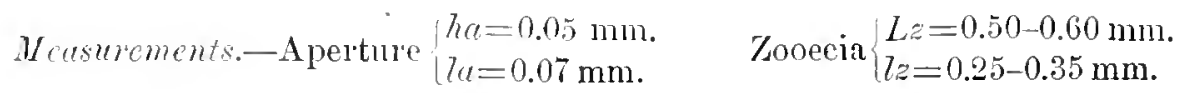

Affinitics.-The oricelled zooccia are somewhat larger than the others; their operenlum is also slightly larger. We have observed an ordinary calcified zooecinm and an ovieelled zooecium presenting the same phenomenon. We had supposed before that these zooceia corresponded to the diseased polypides.

Dakaria brevis differ' from $D$. laxata in its smaller zooecial dimensions $(L z=0.50 \mathrm{~mm}$. instead of $0.50 \mathrm{~mm}$.), in a smaller aperture, and in its elongated ovicell.

Qceurenec-Middle Jacksonian (Castle IIayne limestone): Wilmington, North Carolina (rare).

IIolotype-Cat. No. 64062. U.S.N.M.

DARARIA LAXATA, new species.

Plate 46, fig, 20 .

Description.-The zoarium incrusts shells. The zooecia are distinct, clongated, wide, fusiform; the frontal is convex and finely granulated. The aperture is suborbicular; the rimule is very wide and searcely distinct from the anter. The ovicell is globular, very salient; it is closed by the operculum, for it cover's much of the alereture: its surfare is gramulaterl like the frontal. No median a ricularium. 
Measurements. I I perture $\left\{\begin{array}{l}h a=0.12 \mathrm{~mm} . \\ 7 a=0.12 \mathrm{~mm} .\end{array} \quad\right.$ Zoocia $\left\{\begin{array}{l}L_{z}=0.20 \mathrm{~mm} . \\ L z=0.55-0.60 \mathrm{~mm} .\end{array}\right.$

Affinities.-This species diflers from Sehisomavellu granulifera and Schizomavella elongata in the absence of the median aviculariun and in its incrusting zoarium.

It differs from Dakavia brevis in its much larger zooecial dimensions.

It is probable that the gramulations hide rery small tremopores.

Occurrenee.-Upper Jacksonian (Ocala limestone): Old Factory, 11 miles above Bainbridge, Georgia (rare).

Holotype.-Cat. No. 6t063, U.S.N.M.

\section{Genus METROPERIELLA Canu and Bassler, 1917.}

1917. Jetroperiella Canu and Bassler. Synopsis of American Early Tertiary Cheilostome Bryoza, Ibulletin 96. United States National Museum, p. 40.

The ovicell is hyperstomial and completely surrounds the aperture. The rimule is a large rounded sinus. The frontal is a tremocyst bearing a medim avicularim.

Genotype.-Metroperiella (Schisoporella) Lepratioides Calvet. 1903.

Range.-Jacksonian-Recent.

The known fossil species of the genus are:

Metroperiella (Lepratia) trigonostoma Reuss, 181 .

Metropericlla (Schizoporella) lata MacGillivray, 188..

There are some aricularian zonecia with a large mandible in all the species of this grenus.

METROPERIELLA (?) ALBORA, new species.

Plate 4i, figs. 1,2 .

Description.-The zoarium is milamellar. The zooecia are elongated, distinct. nearly cylindrical; the frontal is a tremocyst with irregular pores, and is rery little convex. The aperture is oral; the rimule is semielliptical, rery wide and separated from the anter solely by two lateral denticles on which the transverse axis of the operculum is inserted; a wide, whitc, improminent peristome surrounds the aperture. The median avicularium is small, little salient. elliptical, the beak tulned toward the bottom.

$$
\text { Neasurements.-Aperture }\left\{\begin{array} { l } 
{ h a = 0 . 1 5 \mathrm { mm } . } \\
{ l a = 0 . 1 5 \mathrm { mm } . }
\end{array} \quad \text { Zooecia } \left\{\begin{array}{l}
l_{z}=0.75 \mathrm{~mm} . \\
7 z=0.35-0.40 \mathrm{~mm} .
\end{array}\right.\right.
$$

Affnities. - The frontal tremocyst reposes on a very thin and finely perforated olocyst. The tremopores are very short tubules with their section visible on the olocyst. Around each aperture there are four large tremopores: two placed on the dictal zooecia and each of the two others on adjacent zooccia.

This species differs from Metroperima arandipora in its much narrower zooccia $(0.35 \mathrm{~mm}$. instead of $0.45 \mathrm{~mm}$.), its wide white peristome and the four laree pores around the perictome. 
Ve have not diseorered the oricell.

It differs fron Metroperiella porosa in its larger aperture, less regular tremopores and much shorter median aricularium.

Ocemance-Middle Jacksonian: Wilmington, North Carolina (rare); Baldock. Barnwell C'ounty, South Carolina (rare).

Holotype.-Cat. No. 64064, U.S.N.M.

\section{METROPERIELLA GRANDIPORA, new species.}

Plate 47, figs. $3-6$.

Description.-The zoarium creeps over algae; it is formed of many lamellae superposed on the same side. The zooecia are distinct, rery little elongated, hexagonal; the frontal is convex; the tremocyst has wide-open pores sumounting a very thin, finely perforated olocyst. The ovicell is large, very prominent, completely surrounding the aperture. The aperture is large, oval, with a rery wide rimule separated from the anter by two condyles. The median avicularim is salient, triangular, small and provided with very small lateral denticles.

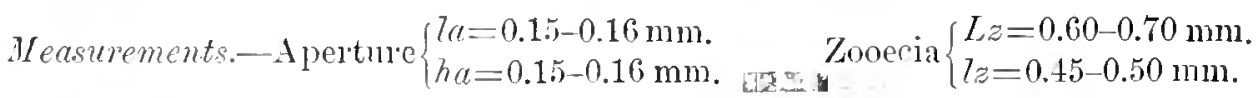

Tariation.-There are some wide zooecia (fig. 4) and some long zooecia (fig. 6), sometimes hoth kinds may be adjacent (fig. 3).

Certain regular zooecia are transformed into interzooecial avicularia (fig. 6): the aperture is closed by a large spatulate mandible and articulates on two lower condyles.

On the normal zooecia the condyles, on which the operculum articulates, are risible in the interior by turning the specimen.

The oricell has in front a large fragile area, which casily disappears in the process of fossilization (fig. 6).

Affinities. -This species differs from Metroperiella acervata, which is a!so pleurilamellar in a larger aperture $(2 a=0.15 \mathrm{~mm}$. instead of $0.12 \mathrm{~mm}$.), the much smaller avicularium, its large tremopores and the absence of a salient thread around the zooecia.

It differs from Metroperiella porosa in its nonbilamellar zoarium, its median avicularium much smaller $(0.15 \mathrm{~mm}$. instead of $0.35 \mathrm{~mm}$.), and in its somewlat larerer aperture ( $7 a=0.15 \mathrm{~mm}$. instead of $0.12 \mathrm{~mm}$.).

It diflers from Metroperiella albora in its wide zooecia $(l z=0.45 \mathrm{~mm}$. and not $0.35 \mathrm{~mm}$.$) , and in the absence of a ride peristome, which is white and nonsalient.$

Occuryenes.-Middle Jacksonian (Castle Hayne limestone) : Wilmington. North Carolina (rare).

Cotypes.-Cat. No. 64065, U.S.N.M.

METROPERIELLA POROSA, new species

Plate 47, figs. $7-11$.

Description.-The zoarium is free, formed of two lamellae, which are irregular, back to back, and separable. The zooecia are distinct, elongated, hexagonal; the 
frontal is little convex and formed by a tremocyst with numerons wide open pores. The aperture is oral, with a wile. romded rimule, separated from the anter by two condyles risible in the interior. The ovicell is large, globular, salient: it completely surrounds the aperture. forming around it a prominent peristomie: it is formed of a large frontal and smencinded by a salient collar. The median arienlarium is long, rery thin. remote from the aperture.

$$
\text { Measurements. - Ipertne }\left\{\begin{array} { l } 
{ h a = 0 . 1 2 - 0 . 1 + \mathrm { mm } . } \\
{ l a = 0 . 1 2 - 0 . 1 \pm \mathrm { mm } . }
\end{array} \quad \text { Zooecia } \left\{\begin{array}{l}
L z=0.60-0.70 \mathrm{~mm} \\
l z=0.50 \mathrm{~mm} .
\end{array}\right.\right.
$$

Tariations.-The beak of the aricularim is rery long, thin, and fragile; it is only visible on the best preserved specimens (fig. 11); on others it has the aspect of a suall triangular pore (fig. 8), but always remote from the apertme and not salient.

The zonecia with a thick tremocrst are sometimes bordered by a small salient thread (fig. 8).

The frontal area of the ovicell is fragile; it often disuppens in the process of fossilization.

The orifice of the oricelled zooecia is quite rariable. The operation of the operculnm appears to be complex. It must be lowered much externally to permit the extrusion of the tentacles, which onght. mereover, to be very thin. The operculum never closes the ovicell because the outer orifice does not exactly correspond to its form, but in opening it offer a shelter sufficient for the passage of the egos. It is probable also, as in many other schizoporellae that it remains closed during the escape of the larrae.

In figure $S$ the reader may note two zonecia which are transformed into interzooecial avicularia analogous to the zooccia of Arthropoma cecilii Savigny-Audouin, 1S12-1S26, figured in 1890 by Kirkpatrick and which we have reprodnced on text figure 105 .

We have observed (fig. 8) a calcified zooecium whose aperture is covered by the tremocyst.

The median aricularium is the result of the development of an inner bud, as it is easy to note on inner surfaces.

Affnities.-This species differ's from Metroperiella biplanata, in which zoarium is also bilamellar, in its much larger instead of rery minute tremopores.

It differs from Meiropericlla grandipora in its smaller aperture (la $=0.12 \mathrm{~mm}$. instead of $0.15 \mathrm{~mm}$ ), its median avicularium, which is very large and remote from the aperture, and its zoarium, which is bilamellar and not pleurilamellar.

Occurence.-Middle Jacksonian: Near Lenuds Ferry, South Carolina (common) ; Wilmington, North Carolina (common); $3 \frac{1}{4}$ miles south of Perry, Georgia (rare).

Cotypes.-Cat. No. 6t066, U.S.N.M. 
1917. Metroperiella biplanata CANU ant B.ssLer, Symopsis of American Early Tertiary Cleilostome Firgozon, Dulletin 96, United States National Museum, p. 41, pl. 4, fis. 1 .

Description.- The zoarim is free, formed of two flat lamellae, back to back, and inseparable. The zonecia are much clongated. distinct. fusiform; the frontal ja convex and formed of a tremocyst with numerous very fine pores. The aperture is oval, formed of a semilunar anter, and with a wide. rounded rimule, separated by two inner condyles. The ovicell is hyperstomial, large, globular, salient; it completely smrounds the apertme, forming about it a very pronounced peristomie, in mhich is placed its special orifice; the peristomie is rery irregular. The median arienlarim is small, little salient, in the immediate vicinity of the rimule.

$$
\text { Weusurements.-Aperture }\left\{\begin{array} { l } 
{ h a = 0 . 1 6 - 0 . 1 8 \mathrm { mm } . } \\
{ l _ { \alpha } = 0 . 1 4 \mathrm { mm } . }
\end{array} \quad \text { Zooccia } \left\{\begin{array}{l}
l_{z}=1.00-1.10 \mathrm{~mm} . \\
l_{z}=0.50-0.60 \mathrm{~mm} .
\end{array}\right.\right.
$$

Trariations.-As in the preceding species, the passage of the eggs into the ovicell is singularly aided by the development of the special peristomie, in which even the operculum itself is completely concealed when it opens. This operculum can not open withont allowing the water to get into the compensation sac. and in conseruence withont extending its tentacles; it is therefore rather probable. especially if the larvae are large. that the operculum remains closed during their escape and that the ovicell is indeed closed by a special operculum, as in Schizopodrelle (fig. 15).

We have observed some avicularian zooecia. as in Metropericlla porosa and Netroperietla grandinora.

There are some wide zooecia of $0.65 \mathrm{~mm}$. (fig. 12) and some narrow ones of $0.40 \mathrm{~mm}$ (fig. 16). Very frequently the zonecia are margined (figs. 12, 16): we know that this arrangement has for it: object the separation of the ectoryst of the zoarium for a purpose unknown for these rigirl species.

Above many of the zovecia (fie. 16) can be observed a crescent-shaped cicatrix, the morphologisal significance of which is unknown to us.

The median a vicularium disappears on the oricelled zooccia.

The clnsed zooecia (fig. 15) are perhaps zoneeia which have lost their polypide by aceident.

Affinitice.-This species differs from Metmperinlla porosa. in which the zoarinm is also bilamellar, in its tremocyst witl mmerous and rery small pores, its small avicularimm placed quite near the rimule and its larger zooccial dimensions.

It differ's from Netroperiella grandipora in its bilamellar zoarium, its tremocyst with small pores and its long zooceia.

Of all the species of Metroperiella this is the only one in which the zooecial length may be $1 \mathrm{~mm}$.

Decurrence.-Middle .Tacksonian (Castle IIayne limestone) : Wilmington, North Carolina (rery common).

Cotypes.-Cat. No.62590, U.S.N.MT. 
METROPERIELLA ACERVATA, new species.

I"lite 45 , figs. $1-5$.

lleseription.-The zorrium is formed of many lamellae pited up on one inother, all on the same silla; it probably ereeps over algae. The zooccia are distinct, clongated, hexagonal. bordered by a regular, salient thread. The frontal is little convex, nearly flat, smooth. The aperture is small suborbicular provideal with a vestibular areh, formed of a semilunar anter and of a wide, rounded rimule, separated by two internal condyles. The ovieell is globular, salient, completely surrounding the aperture to form around it a peristomie. The median avientarium is long, thin, much removed from the aperture.

$$
\text { Measurements.-Aperture }\left\{\begin{array} { l } 
{ h a = 0 . 1 4 \mathrm { mm } . } \\
{ l a = 0 . 1 2 \mathrm { mm } . }
\end{array} \quad \text { Zooecia } \left\{\begin{array}{l}
l z=0.56-0.65 \mathrm{~mm} . \\
L z=0.75 \mathrm{~mm} .
\end{array}\right.\right.
$$

Ifinitics.-The characteristic of thi species is its smooth and nomporous frontal: this is an exception in the genus.

It differs from Metropericlla arandipora, in which the zoarium is also multilamellar in its larger micrometric dimensions and its nonporous frontal.

It differs from Metropericlla porosa, in which the median avicularium is long and distant from the aperture, in its multilamellar zoarium. its smooth zooecia and its larger zooecial length $(0.75 \mathrm{~mm}$. instead of $0.65-0.70 \mathrm{~mm})$.

Occurrence.-Middle Jacksonian: Wilmington, North Calrolina (common); near Lenuds Ferry, South Carolina (rine): Entar Springs, South Carolina (rare).

'́otypes.-Cat. No. 6t06s, C.S.Y.M.

\section{METROPERIELLA LATIPORA, new species.}

I'late 4i, fir. 20 .

I) seniption.-The zoarium is free and formed of two lamellae. back to back, and separable. The zooceia are distinct. polygonal, surrounded by a prominent thread; the frontal is flat, formed of a tremocyst with small pores. The apertintil is lurge, transrerse, elliptical, provided with a rery wide rimule; it is larger and provided with an elevated peristome in the oricelled zooecia. 'The ovicell is latre. salient. globular, somewhat embedded in thr distal zooecia, smooth. completely surrombing the apertura. The median arienlarium is distant from the apertura. long. thin, triangular, rery little salient. grandished with a pirot.

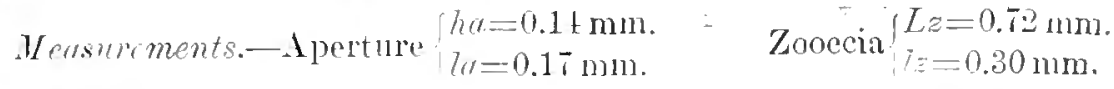

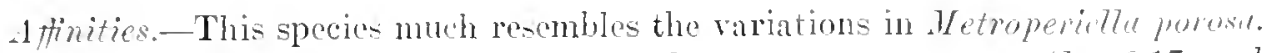
It differs from $M$. porosa in its larger and transvelse apeltura (lu=0.17 and not $0.1 \pm \mathrm{mm}$.) and in its nuch wider and not triangular rimule.

Occurrence.-Middle . acksonian: Rich IIill. Craw ford County. Georaia (rery rare) : Eutaw Springs. South Carolina (very rare).

Hototyp.-Cat. No.6t067. T.S.X.M. 
Genus EMBALLOTHECA Levinsen, 1909.

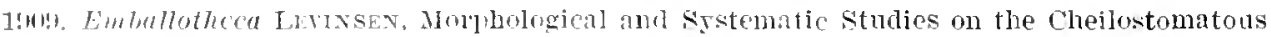
Bryozoa, 1). 333.

The ovicell is hyperstomial and opens above the aperture by a wide orifice which the operenlum may close when it opens the aperture. The aperture bear's a concave proximal border and a wide rounded rimule. The operenlum has muscular attachmerts near the borcler" that of the ovicelled zooecia is larger. The frontal and the ovicell are covered by the same tremocyst with large pores surmounting a verg finely perforited olocyst.

Genotype.-Emballotheca (Eschara) marlrata MacGillivray, 1880.
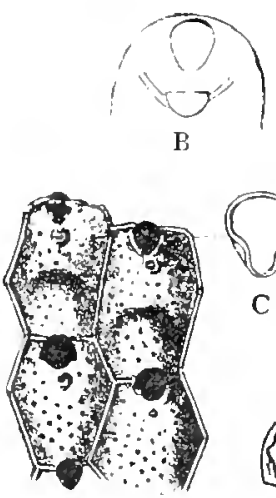

A $、 25$
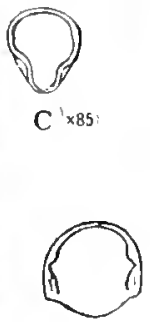

D

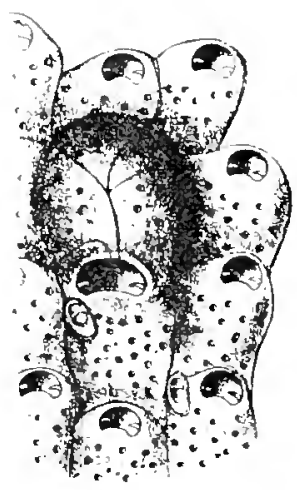

E $\times 23$
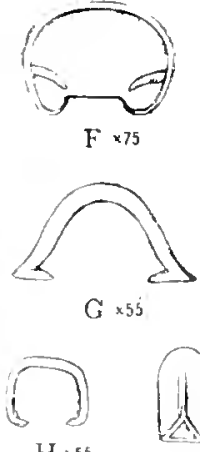

H、S5

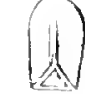

$1 \times 75$

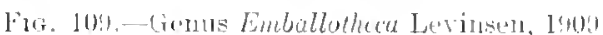

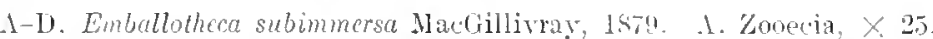
13. Decalcitied cell, slowing lateral tubular cumections of the avioularian rhamber. C. Cperculun of orlinary zuecium, $X 85$. [1. (9perculum of ovicellimerous zooecium, $x$ s5. (1-D after Waters, 1sso.)

L-I. Embullothece qualdata Machillivray, 1850. E. Zooecia, X 23. six difforent zooecia take part in the formation of the ovicell figured. F. Aperture of zovecium, $X$ is. 1\%. Cperculum of ovicelligerous zovecium, $K 55$. H. (y)erenhm of ordinary zovecium, $X 55$. I. Avicularian mandible, 75. (F-I after Levinsen, 1909.)

li a nye. - Jacksonian-Recent.

The known recent species of this genus are:

Emballotheca (Schizoporella) furcata Busk, 1884.

Emb a.7 lothooa (Eschara) quadrata Machillivay, 1880. Emballotheca (Leprutia) subimmeren Mackillivray, 1879.

EMBALLOTIECA LATICAPITATA, new species.

Plate 48 , tig. 6.

Ucseription.-The zoalium is free and bilamellar. The zooecia are large dis-

tinct, rery little elongated, polygonal, enlarged distally; the frontal is convex, formol of a tremoeyst closely umited to the subjacent, finely perforated olocyst; the tremoprores are wide and separited by small tuberosities. The aperture is laree, elongater, with a rery lange. semicimular rimule, with two salient denticles serving a pirot. The oricell is enormous, sonnowh emberted in the distal zooecia, ylobular and salient. 'Two las'ge, triangular avicularia are placed above the aperture: their beak is directed toward the medimm axis of the zooecia; they have a strongercilcareous pirot.

Measurements. - Iperture ol $\mathrm{h} a=0.25 \mathrm{~mm}$. ordinary zooceial $7 a=0.20 \mathrm{~mm}$.

Zuoecia $\left\{\begin{array}{l}L z=0.80 \mathrm{~mm} \text {. } \\ l_{z=0}=0.70 \mathrm{~mm} \text {. }\end{array}\right.$

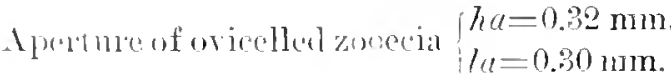


Affinities.-The distal part of the zooecin is often wider than the proximal part. which gives them the aspect of a broad head.

This species differs from the recent Emballotheca quadrate MacGillirray, 18s0, in its smaller micrometric dimensions and the entire absence of a mncro concealing the rimule.

This is a magnificent species. of which only two specimens have been found.

Occurvence.-Middle Jacksonian (Castle Inyne limestone) : Wilmington, North Carolina (rare).

Holotype.Cat. No.64060. U.S.X.M.
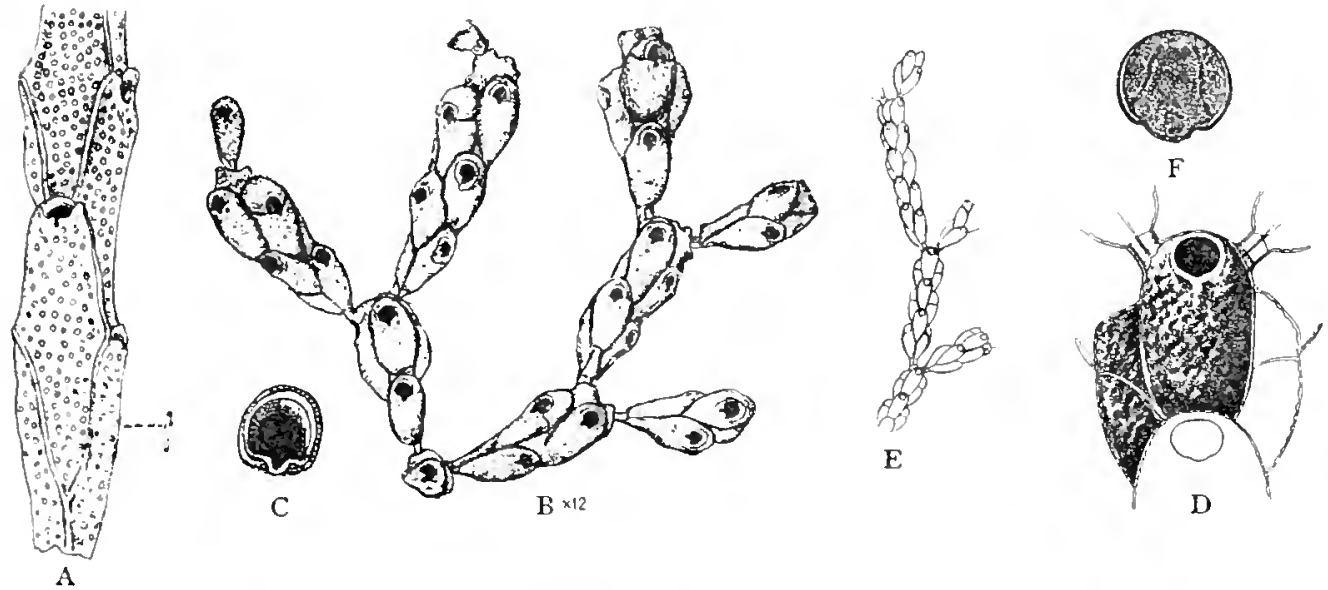

Fig. 110. Genus Totraplaria Tenison-Mooks. 187S.

A. Tetraplaria anstralis Tenison-Wools. 157s. Zooecia. (Aftel MacGillivay 1S95.)

B, (. Tetraplariu (Pollaploccium) gilbcrtonsis Maplestume, 1009. Zoariun, X 12, and aperture. (After Maplestone, 1909.)

D-F. Tetraplaria (Arborella) diehotoma Osburn, 1914. W. Kooecia. E. I'ortion of coluny. showing mode of growth. F. Operculum. (D-F after Oslum, 1914.)

Genus TETRAPLARIA Tenison-Woods, 1878.

187S. Tetraplaria Tenison-Woovs, On some Australian Tertialy fussil corals and Polyzos?,

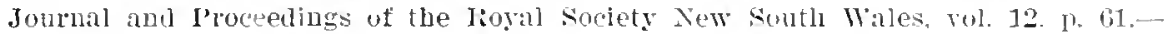

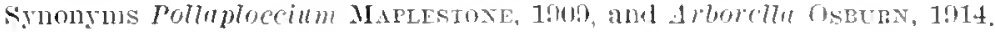

The zoarium is articulated. 'The zooecia are arranged in pair back to back. facing four ways: the opposite pairs of two sides alternating at light angles with the other two.

Genotype.-Tetraplaria australis Tenison-Woods, 18 is.

The known species of this gemus are:

Tetraplaria australis Tenison-Woods, 187s. Fosil.

Tetraplaria (Pollaploccium) gitbertensis Miplestone. 190!. Recent. Tetraplaria (Arborella) dichotoma Osburn, 191t. Recent. Floricla.

Tetraplaria (Cellaria) schreibersi Reuss, 1869. Fossil. 
This genus is purely zoarial. The articulation is only an adaptation to some special circumstances, particularly to life on large marine algae whose mobility is very great. It is therefore not astonishing to note some apertures of different form. On the other hand, the characters of adaptation can very well become fixed in general descent and transform themselves into essential eharacters One must not forget that the bryozoan individual is the zoarinm issned directly from the larva, and not the zooecium, which is only a bud of the aforesaid larva.

In the present ease our knowledge of the ovicells and the opereulum is of little importance. It is better, therefore, to admit the genus snch as Tenison-Woods has conceived it.

The genus still exists in the waters off the coast of Florida, which is still another proof in favor of the continnity of the famnas in the Gulf of Mesicu.

TETRAPLARIA TUBERCULATA, new species.

Plinte 48, figs. $7-10$.

Lescription.-The zoarium is articulated, the segments are composed of a dozen zooecia placed back to back, disposed in four series, placed two by two at right angles. The zooecia are little distinct, elongated, subcylindrical; the frontal is convex and formed of a tremocyst with small pores. The aperture is semilunar; the proximal border is somewhat concave and bears a triangular rimule. On each margin of the aperture there are two large symmetrical tubercles.

$$
\text { Measurements.-Zooecia }\left\{\begin{array}{l}
l, z=0.12 \mathrm{~mm} \text {. } \\
7 z=0.11 \mathrm{~mm} \text {. }
\end{array}\right.
$$

Iffinities.-In the distinctly schizoporelloid form of its aperture this speeies resembles very much Tetraplaria anstralis 'Tenicon-Woods, 1878. ${ }^{1}$ It differs in its nonoblique aperture and the prescnce of two oral tubereles.

Occurrence.-Upper Jacksonian (Ocala limestone): Chipola River, east of Marianna, Florida (rare).

Cotypes.-Cat. No. 64070, U.S.N.M.

TETRAPl,ARIA CAUDIFERA, new species.

Plite 45, figs. 11-14

Description.-The zoarium is articulated; the segments are formed of four longitudinal rows of alternate zooceia, placed at right angles. The zonecia are distinct. rery elongated, narrowed in the back in the form of a tril; the frontal is convex and formed of an inemplete tremocyst surroming a sort of smooth plastron. The apertme is elongated, elliptical, bearing two small, lateral denticles; there is a small vestilular arch. On ench sicle of the aperture there are two small, very simple aricularia without denticle or pirot.

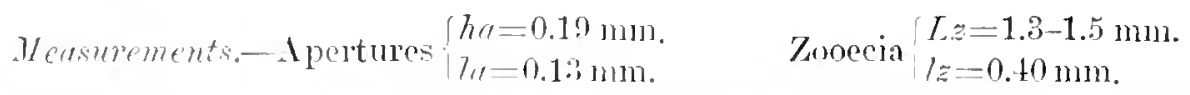

${ }^{1}$ It is to be noted that the figure given by Touison-Woods 1<TR, resembles but Jitue the fismre ne Machillibrar, 18\%. The first is smooth with a lepralioid aperturs; the second is punctate with a schizo.

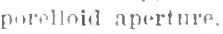


Affintiex-The form ol the aperture is rather indeterminate; it is impo-sible to say whether this species belones to the schizoposellae or to the IIppoporas.

It resembles for this reason Cellaria schribcrsi Reuss, 1869, of the Priabonian, but differs from it in the form of its zooecia, which are very thin in the posterior, in their great length, and in its incomplete tremocyst.

It differs from Tetraplaria tubermata, not only in the form of its oritice, but in the replacement of the two lateral tubercles by two small avicularia.

Ucenrence.-Midllle elacksonian: Baldock, Barmwell ('ounty. South Carolina (rare).

Cotypes.-Cat. No. (itorit. U.S.Y.M.

\section{Genus GEIELLIPORA Smitt, 187?.}

156: Gemelliport SurtT, Floridan Fryazoi, pt. 1, liongt. Srenska Vetenskaps-Akarlemiens 11 antlingar. vol. 10, No. 11, T. 3. .

The opercula are subtriangular with two small lateral projections, corresponding with two small latcral teeth in the aperturis; the muscular attachment is close to the side of the opereulum. The apertura of the ovicelligerous zooecla diflers in shape from that of the ordinary zorecia. in most species being wider with a flatter simus.

(After Waters. 1904.)

Genotype--Gemellipora glabra Smitt, 1872.

Rangc.-Mioceno-Recent.

This genus requires further examination.

The recent species are:

Gemellipore (Schizoporella)

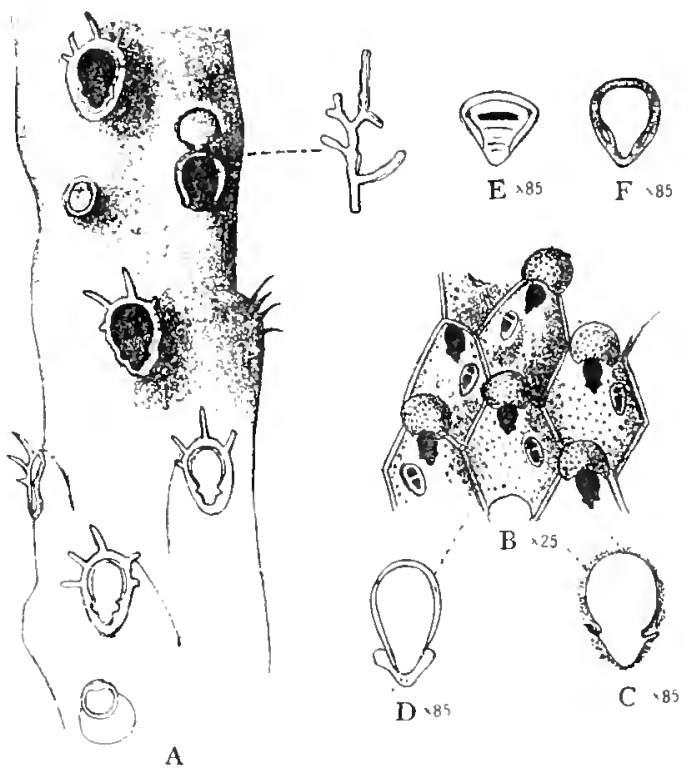

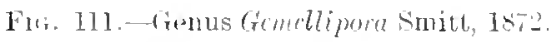

1. Gemellipmentule Suitt, 1S52. Zoarium, matmal size, and zunecia, enlarged. (After Smit, 15i2.,

B-D. Gemellipore protust Thondy, 1905. 1:. Orirelled zoorcia, $Y$ 25. C. Interior of a zooecium, showing the oral aperture, $\times 85$. T). (operculum, $\times$ t. (B-I) after Waters, 1913.)

E. Crmelliporu bianqula Hincks, 1881, Operoulun, × s.5. (After llaters, 1887.)

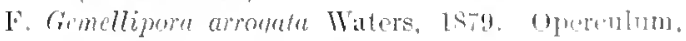
$\times 85 . \quad$ (Ifter Waters, 1904.) triangula IJincks, 1881.

Gemellipora (Lepratia) arrogata Waters, 1979.

remellipora (Schizoportla) lata MacGillivar, 1882.

Gemellipora glatsa Smitt, 1872.

Grmellipmen protuse Thounely, 1505.

The fossil species are:

Gomellipore elenentissime Machillivray, 1904. 


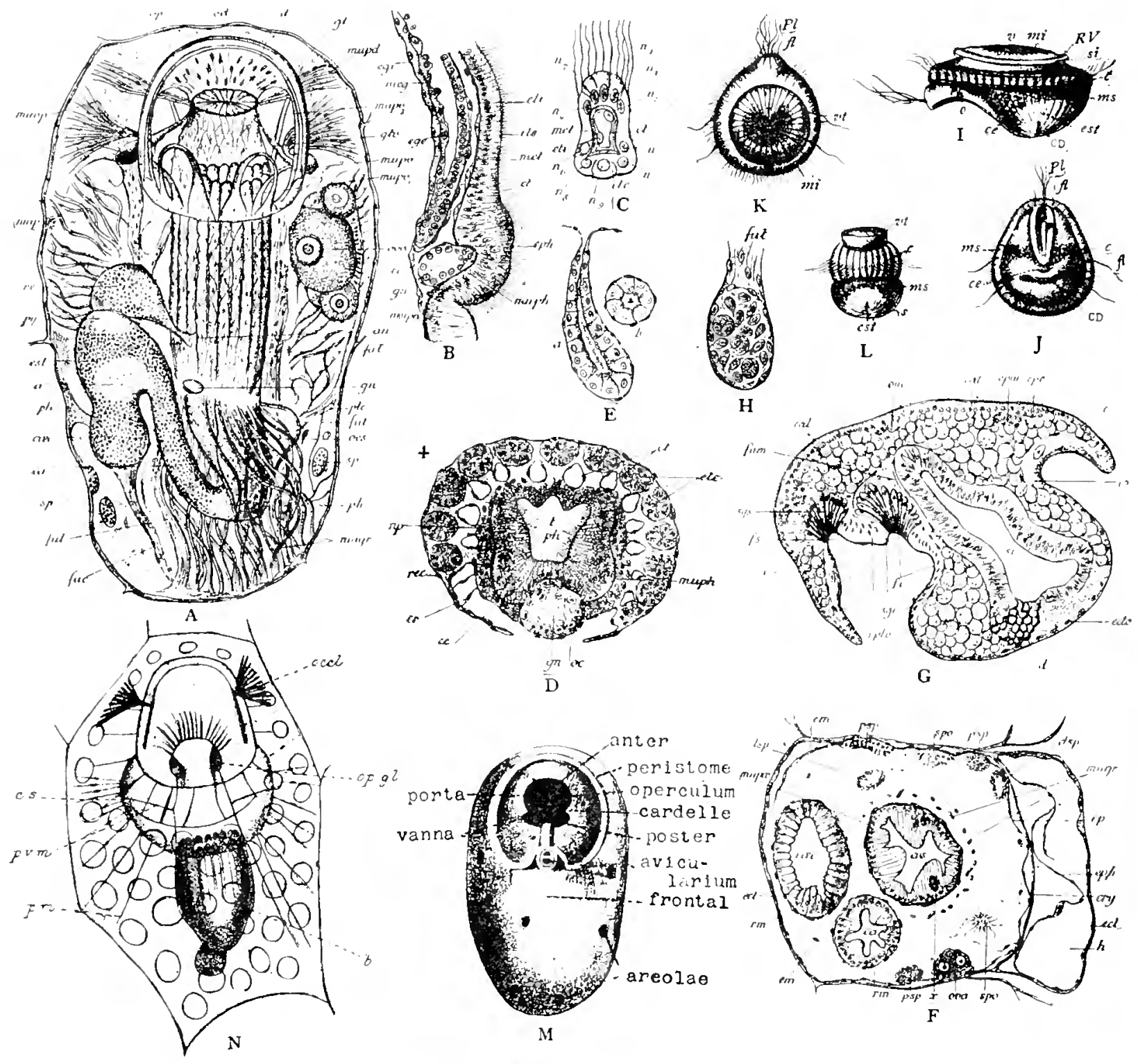

FIG. 112.--Anatomy of the Hippoporae. 
Fig. 112.- - Haltonit of the Ilippoporate.

A-1, N. Hippoliplosia pallasiana Mal, 1sis. A. Sketch showing anatoms. b. l'ortion of a longitudinal section in the region of the liarynx. C. Tumsverse section of al tentacle. L. Transverse section of the lophuphore lassing through the orifice of the cipeular canal. E. Longitulinal and transverse sections ol the vaginal glandular organ. F. Transverse section of a bryozooid. (A. Median wagital section of an embryo of this species. H. Tangential section of a multiporous septulal. (A-1I atter rislyet, 1000.)

(lill, anus ;

ca, carliac resion of the stomato

cal, calote (terminal bud);

race, caecum;

co. corollat

cry, crypteryst (skeleton);

cl, tentacular canal ;

d, vaginal diaphragm;

18p. cleutospermatoblast norula;

em, mesenchync elements;

epm, mesolerual thickening;

cpe, ectodermal thickening;

cst, stomacl ;

clc, external tentacular epithelium;

ep, epiderm of the lispostege;

glv. vagiual glands (=opercular glands of

Waters and Harmer).

muop, operculitr nuscles;

$m u p$, parietal muscles;

mupd, parictal-cliapluragm muscles;

muph, peripharyugeal nuscular fiber's;

mupo, periesophageal muscular fiburs: mupo, parleto-vaginal muscles;

up, peripluarngeal nerves;

or, orifices of the circular canal;

$o c s$, esophagnas ;

ole $\ell_{\text {, ovary ; }}$

pr, septule;

ph. platynx;

whe communication plates:

lle, vibratile plume;

lulv, mapilla of vibritile plume;

DSp, llotospermatublast morvlac;

ply. plylorus;

re, rectum;

l'm, mesenchyme covering of polypide;

stit. inferior g]andular system;

*IR, superior glandular system;

si, interual sac;

$\therefore p$, spermatoblast morulae;

spu, ciliated tritospermatoblast morulae;

$t m$. mesenchyne;

$t r$, transverse muscular fibers of the circular canal

I-1. Lateral face, (I) oral face, I.T) ahoral face, (K) dorsal face, (L) of the larval. (After Barrois, 1STt.)

c, corona ;

0, ciliated cleft.

$c c$, eavity between the two branches of the $P L$, ciliated plume;

stomach ;

ph, pharynx ;

cl, digestive cavity:

$R^{\prime} \mathrm{I}^{+}$borler of the terminal lud :

cst, stomacl ;

si, separatiug furrow ;

fl, flagellum ;

s. oral or vestibular face:

$m s$, oral (labial) mesoderm;

\%, ternima! bur] (=ealotte of calvet).

mi, aboral mesor]erm;

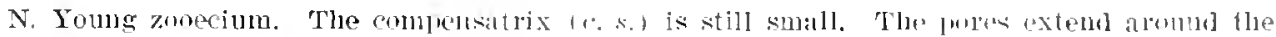
distal margin of the operculum. IAter Harmar. 1906.)

b [m] yisle bul :

occl, occlusor muscles of operculum;
opml, opercular glauds (= wasinal glands of s. r.. complomatrix.

p. m. pariatal musiles;

Calvet) :

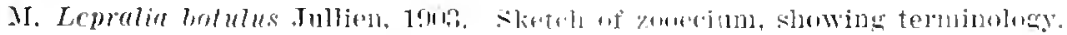


Gemrllipore politre MacGillivay, 1ont.

Gemellipore enericututa Maplontone. 1901.

Tnder the name of Gemellipure sumitt han dencribed two solts of apertures. The first species deseribed belong to the anu- Pasyther Lamomoux; 1812. The crifice of Gemellipora gletrre is the one which has been considered as typical. In 1904. Waters gare a list of species of this genus: but it will be necessary to redistribute them into th" genera Schisomorectla and Typostega.

\section{GEMEILIPORELLA, new genus.}

The ovicell is hyperstomial and deeply ambodded in the clistal zooecinm. Thine operenlum does not elose the ovicell and operates in a locella. The form of the aperture is like a keyhole. The frontal is armished with lateral areolar pores and with a granular plemoevst.

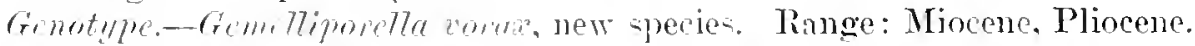

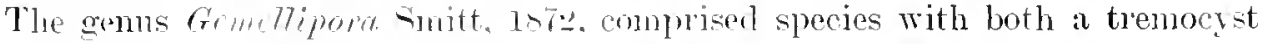
and a plemocyst: we group the lattru in thi- now genus. The type species will be described in a forthoming volune.

\section{Genus NIMBA Jullien, 1903.}

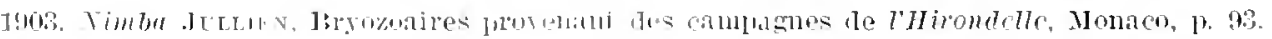

The frontal is smooth ar sranular. The orifice is semilmar. with a rinule on the poster which is almost entiruly fomel of two large cardelles, which the rimule separates; the anter is smooth; the perisome forms a sort of anreola around the orifice, and the glomlar ovicell oenpres the anterior region of the aureola. The ojening of the ovicell is always closed bi the upereulum, which must lower itself ru give passage to the larvae. (Translation iffer .Tullien.)

Geuntype.-Vimber prestexter Tullien, 1903. Recent (Azores).

Genus CHARACODOMA Vaplestone, 1900.

15no. Charamoluma Maplestone, Further Jescriptions of the Tertiary Polyzon of Victoria,

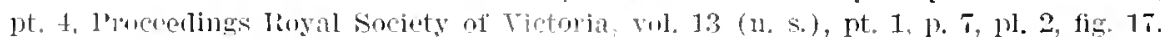

"Zoarium in elongated quadrate intunoules. Zooecia miserial on each face of the zoarimu. Ipertula ovate with a shan denticle on each side pointing downwar over the lower or clistal triangular portion." (Maplestone.)

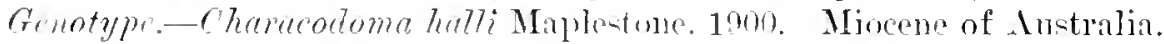

Group 2. HIPPOPORAE Canu and Bassler, 1917.

(LEPRALIIDAE Jullien, 1903.)

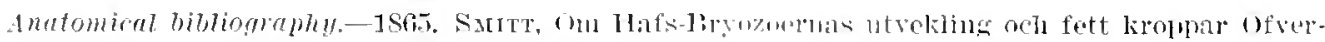

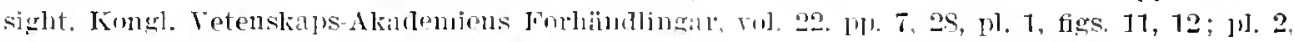

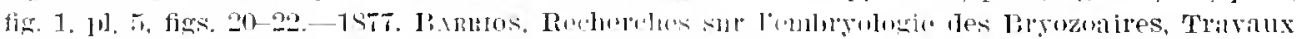

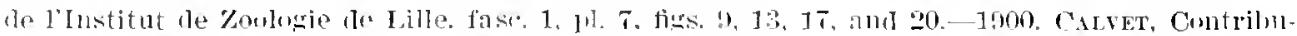

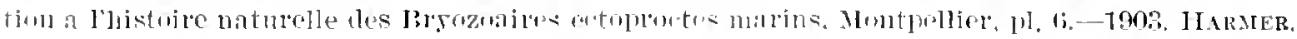


On the molphologs of the Choilostontata, Quarterly Journal of Mimoseopial seience, rol. 46. pl. 17.

The classification has been the whicet of study of Waters in 1898, 1909, and 1913.

The operen]mu has a projection on each side for muscular atachment; it is gencrally thick. The apertue bears two lateral denticles or cardelles serving as a pirot for the operentm. The oricel] is always hyperstomial.

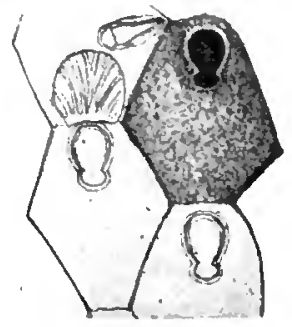

A Hippoporina

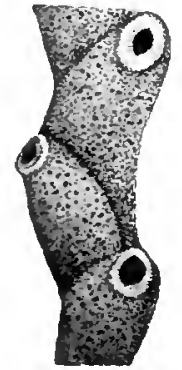

F. Hippozeug-

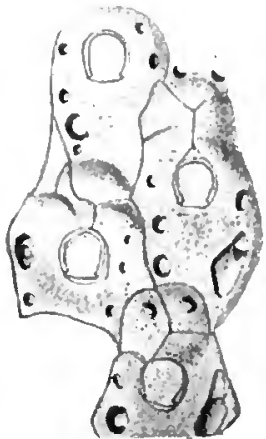

B. Hippoponella

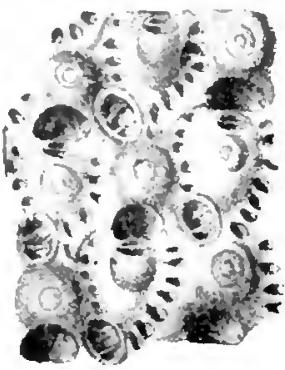

F. Hippadenella
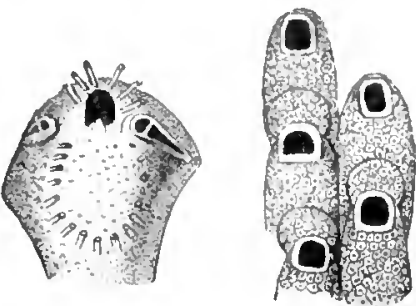

C. Hippomenella
1). Hippodiplosia

$$
\text { osella }
$$

FIt. 113.-Gentra of the subtimily Hipluporae Cann and Riakler. 1917.

1. Hippoporina porcellana linsk. 1890. Teecnt.

I. Hippoponclla hippopus simitt, 1Stit. liecent.

$\therefore$ Itippomenella mucroncllifurmis Watcrs, 1895, $\times 225$. Rocent.

[1. Mippodinlosia pullaximn Mloll, $1803, \times 20$. Rowent.

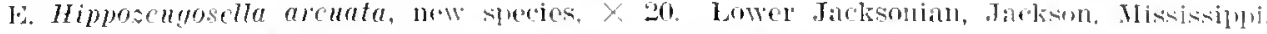

F. Hippadenella margaritifera Guny and Gaymard, $1833, x^{2} 5.5$. Recent.

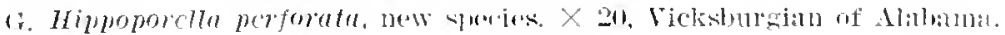

'The distal part of the apertmo is the anter'; the proximal part is the poster. The eardelles separate the porta from the vanna. The porta serves for the pasage of the tentacles. The ranna opens the compensation sac, which becomes filled during the extrusion of the polypide. Wre may suppose that the larere the vimna is the larger the compensation sar mut be and that concequently the polypide hears mole tentacles and that they are laterer. 


\section{Genus HIPPOIORINA Neviani, 1895.}

189- Hippoporina Neving, Bryozoi fossili della Farnesina Monte Mario presso Roma. l'aleontologia Italica, 1). 107.

The operculum is much contracted laterally. The cardelles are very large and always placed at the bottom of the aperture. The ranna is much smaller than the porta. The proximal border of the a perture is straight or somewhat concave. The ovicell is hyperstonial and closed ly a special membrane without any connection with the operculum. The frontal is an olocyst.

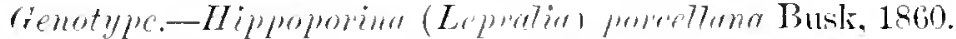

Rínefe-Danian-Recent.

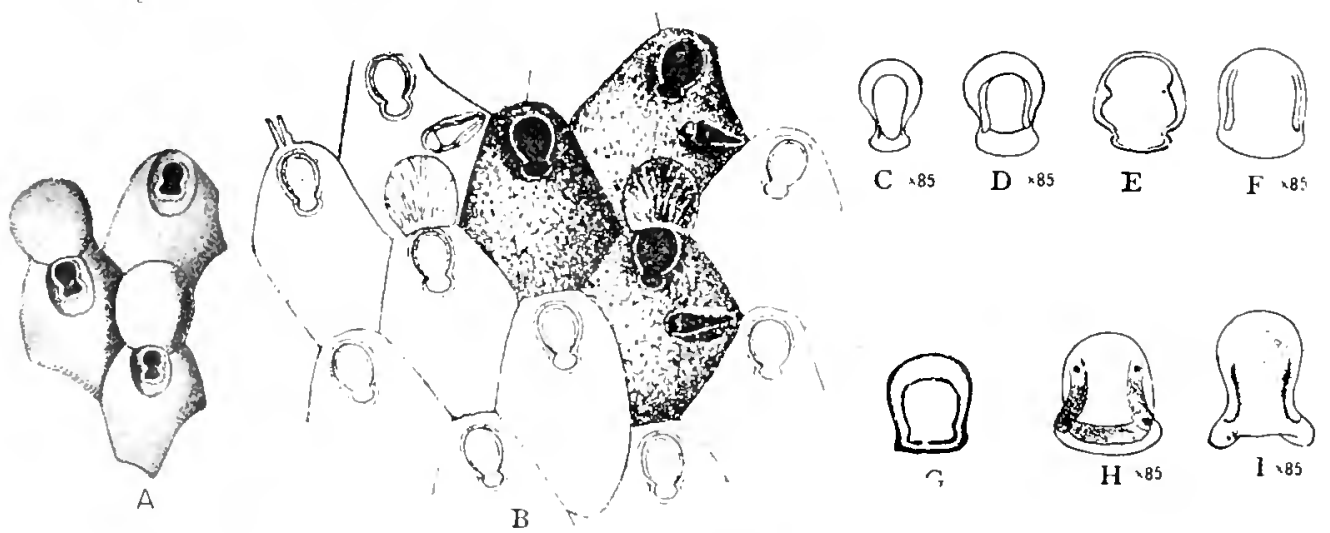

Fig. 114.-Genus Mippoparina Neriani, 1895.

A. Hippoporima integra Neviani, 18!5. A. Ovicelled and ordinary zooecia, $\times$ 25. (After Neviani, 1900.)

B-E. Hippopurina porcollma busk, 1860. 13. Zogecia. (After Smitt, 1872.) C, D. Opercula of same colony, $\times$ S.). (After Waters, 1ses.) E. 'Prelculum. (After Norman, 1909.)

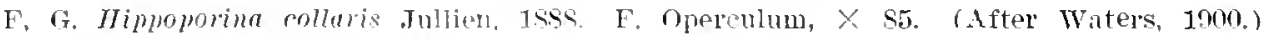
G. Operculum. (After Norman, 1!)(19.)

H. Mippoporine elimatu Waters, 18s7. Mperculum, $\chi$ S5. (After Waters, 18s5.)

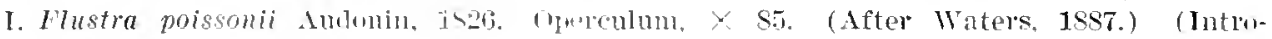
duced by eron.)

The recent species of this arens are:

IIippoporina (Lepretia) porcellana Busk, 1860.

Hippoporina (Lepretiet) colluris .Jullion. 1889.

IIiproporinu (Leprulia) climute Waters.

The fossil species are:

Hippoporina integra Neriani. 1900.

?Hiploporina (Lepretien) sutrifer Russ, 18 it.

!II ippoporina (Eschara) confortu Reuss, 1847.

?Hippoporina (Escharu) delicuta Manzoni. 1877.

Hippoporina parvula Canu, 1909.

Hippoporina hexagonalis Canu. 1916. 
Historical. - The genus Lepralia was created in 1838 by Johnston for all the incrusting species in which the frontal was ealcified. This conception was followed by the paleontologists until 1880. when, the zoarial elassification having been reeognized as poor. Hincks applied the name Lepralia to only those species having cardelles. It the time that he resurreeted this old name he should have followed the rules of nomenclature, but he did not do so, for under his disenssion of Lepratia he did not include a single one of the species originally placed there by Johnston. Norman in 1905 suggested that the name Lepralia conld be employed only for the species of which Lepralia (M mbreniporella) nitida Johnston is the type. ${ }^{1}$

The first species placed under Lepratia by Johnston was L. hyalina (Limnens) which belongs to the earlier described genus II ippothon Lamarck. Leprulia nitina, the second species, was therefore selected by Nomman as the genotype, but unfortunately this same form had been selected by smitt as the genotype of Membraniporella in 1873.

The paleontologists were much disturbed by the change in meaning attributed to the name Lepratia, for the number of fossil species published by Reuse, Busk. Manzoni, and others was considerable. Moreover, in 1895, Neviani changed the name of Lepralia to Hippoporina, employing it in the meaning given by Hincks. Canu, as a paleontologist, adopted IIippoporina immediately. Water's thought that it might be employed with restriction. In reality Neviani's genus was not yet precisely established. Of the three primitive species which he introduced, Eschar foliacea Solander, 1786, is of contested generic position, Lepratia pallasiana Moll. 1803, does not correspond exactly with the definition, and Lepralia adpressa Busk. 185 t, has endozonecial ovicells. It is impossible to characterize a genus by the examination of a single function (hydrostatic in this case). Fortunately he established in 1900 the true characters of the genus Hippoporina by the pulblication of a -uperh figure of Hippoporina integra. A fossil species should not be taken as a genotype if a recent equiralent species can be found. All the species of the first group of Waters correspond to it exactly, and in this group Lepretive porecllena may be chosen as type of the genus ILippoporina.

In 1898 Waters thought that the genus Lepralia Hiineks, 1880, might be separated according to the form of the operculum. His first group was provided with an operculum much contracted laterally. As mentioned before, it became the genus Hippoporina. The seeond group was provided with an opereulum with straight or nearly straight borders. It is not a natural group, and two of the specion which Waters included have been ehosen as genotypes by ourselves.

HIPPOPORINA MIDWAYANICA, new species.

Inte $\overrightarrow{\boldsymbol{i}}$, figs. $1 \overline{\mathbf{i}}-19$.

Description.-The zoarim incrusts other bryozoa. The zooecia are mall. distinct, oroid: the frontal is convex and smooth. The aperture bears a circular

1 Rut this is not an obligation as he clalms it is; rules are not laws. See Norman, 1905, Anuals and Magazine Natural Llistory, ser. T, rol. 12, p. n?. 
anter separated by two large cardelles from a convex rather large poster; it is surronnded by an incomplete peristome bearing 6 large spines. The ovicell is prominent, globular, smooth; it opens above the aperture. The avienlarian zooecia are provided with a long, thin beak rounded at the extremity.

$$
\text { Mcasurements.-Aperture }\left\{\begin{array} { l } 
{ h a = 0 . 1 0 \mathrm { mm } . } \\
{ l _ { a } = 0 . 0 7 \mathrm { mm } . }
\end{array} \quad \text { Zooccia } \left\{\begin{array}{l}
L_{z}=0.40 \mathrm{~mm} . \\
l_{z}=0.25-0.30 \mathrm{~mm} .
\end{array}\right.\right.
$$

Aftinitics.-The aricularian zooccia are very interesting; the beak develops around the aperture which does not preserve its form. The extensol muscle of the mandible passes by a sort of very narrow rimule (fig, 19) or by a wider one (fig. 18).

Such transformations exist in the Celleporidac. Waters noted very similar avicularian zooecia in Holopordla pigmentaria Waters, 1909. ${ }^{1}$

Another interesting peenliarity is the complete absence of dorsal olocyst, easy to sec on the broken zooecia of figure 19. This economy of calcification is rather frequent on the incrusting specics. This new species differs from IIppoporina lucens and Hippoporina porecllana Busk, 1860 (=Lepralia cleidostoma Smitt. 1872), in the plesence of avicularian znoceia and the absence of frontal avicularia.

Cotypes.-Cat. No. 63824. U.S.N.M.

Occurrence.-Midwayan (Clayton limestone): One mile west of Fort Caines. Georgia (rare).

HIPPOPORINA LUCENS, new species.

Plate 48, figs. 15-17.

Leseription.-The zoarium incrusts shells. The zooccia are small, distinct. oroid; the frontal is smooth, convex, polished. The aperture is elongated; the almost circular anter is separated by two large cardelles from a poster rather wide and straight. The ovicell is globular, salient, smooth; it is hyperstomial and opens above the aperture by an arched erescent shaped slit. The avicularium is very salient: its mandible is nearly perpendicular to the zooecial plane; it has a calcarcous pivot.

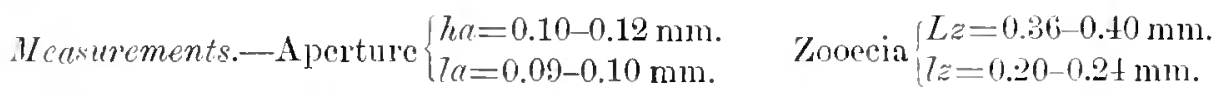

Tariations.-The avicularium is rery inconstant; it does not exist on all zooecia; its rupture causes the formation of an irranlar cavity (fig. 1. 1). The ovicell is formed of two calcareous lamellae perfectly distinct when broken (fig. 17). The frontal also becomes corered with a more or less granulated calureous deposit (figs. 15, 16) of the origin of which we are ignorant.

Affinities. - This species is very close to Hippoporina rle idostoma Smitt, 1972 (= H. porcellana Busk, 1860), which is still living in the jegions of Madeira and Florida. It diflers from it in the position and form of its avicularium and the much smaller width of its aperture $(0.09-0.10 \mathrm{~mm}$. instear of $0.10-0.13 \mathrm{~mm}$. men-

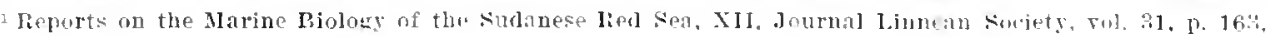
II) 17 , flg. 22 . 
tioned by simitt). This biologic persistence through the ages proves the constancy of the oceanic areas in the Tertialy period. Moreorer, the recent species having been discovered fossil in the European Miocene proves that the grut equatorial current already existed around the Saransso Sea.

'This species differs from Il ippoponind biporosa in a single ventral avicularium (instead of two oral avicularia), and in a longer aperture (ha=0.10 $\mathrm{mm}$. insteal of $0.08 \mathrm{~mm}$.).

Occurpene.-Upper Jacksonian (Ucala limestone) : West bank Sepulga River; Escambia Comnty, Alabama (rare); Alachma, Florida (very lare); Bainbrielge. Georgia (very rare).

Vicksburgian (Byram mall) : Byram, Mississippi (rare).

Ticksburgian ("Chimmey rock" of Marianma limestome): One mile north of Monroeville, Alabama (rare).

Cotypes.-Cat. Nos. 61073.64074, U.S.N.M.

HIPPOPOIINA BIPOROSA, new species.

I'late 49, tigs. $1-3$.

Description. The zoalium incrusts bryozon. The zovecia are small, distinct, woid; the frontal is convex and smooth. The aperture is small and elongated; the anter nearly circular, is separated by two large cardelles from a poster wide and straight. The ovicell is globular and salient; it is hyperstomial and opens above the aperture. There are one or two small, lateral avicularia placed on the side of the aperture.

$$
\text { Measurements. I Iperture }\left\{\begin{array} { l } 
{ h a = 0 . 1 0 \mathrm { mm } . } \\
{ l a = 0 . 0 5 \mathrm { mm } . }
\end{array} \quad \text { Zooecia } \left\{\begin{array}{l}
L z=0.10 \mathrm{~mm} . \\
l z=0.28-0.30 \mathrm{~mm} .
\end{array}\right.\right.
$$

Affinities.-This species differs from Hippoporina luans and IIippoporinu cleidostoma in the position of its small oral aricularia disposed on each side of the aperture.

- Occurrence.-Middle Jacksonian (Castle Havne limestone) : Vilmington, North Carolina.

Cotypes-Cat. No.64076. U.S.N.M.

\section{HIPPOPORELLA, new genus.}

'The opereulum is much contracted laterally. The cardelles are larege. The ramma is much smaller than the porta. The proximal borker of the apertur: is somewhat concave. The oricell is hyperstomial and never elosed by the operculum. The frontal is bordered by areolar pores.

Genotype.-Iippopormlla perforata. new species.

Range.-Jacksomian-Recent.

The presence of the areolar pores and of an almost smooth pleurocyst differ- entiates this genus from IIppoporina Neviani, 1895. The plenrocyst of the ovicell is formed of 3 pieces which are often visible on the fossils. 


\section{HiPPOPORELLA MULTILAMELLOSA. new species.}

Plate 48, figs. 18-22.

Deseription.-The zontium is free and formed of many lamellae superposed on the same sille; the base in contact witl the subjacent algae presents some hexaconal zooecia striated transwersely and sometimes perforated. The zooecia are distinct, hexagonal, separated by a very salient thread: the frontal is smootl, convex, ornamented with some lateral areolae. The aperture is elongated; the anter is almost circular and separated by two very salient cardelles from a postel lectilinear exteriorly and concave interiorly. The ovicell is large, globular, salient, imbedded in the distal zooecia; it opens above the aperture and can not be closed by the operculum. The aricularimu is large, transrerse, withont pirot; it is placed on the frontal irregularly.

$$
\text { Neasurements.-Apertine }\left\{\begin{array} { l } 
{ h a = 0 . 1 3 \mathrm { mm } . } \\
{ \text { (exterior) } } \\
{ l a = 0 . 1 0 - 0 . 1 1 \mathrm { mm } . }
\end{array} \quad \text { Zooecia } \left\{\begin{array}{l}
L z=0.50 \mathrm{~mm} . \\
l z=0.35-0.40 \mathrm{~mm} .
\end{array}\right.\right.
$$

Trariations. In the interjol' (fig. 21) the two cardelles are represented by two transverse condyles. somewhat salient. The aricnlarium is most characterized by its mandible lodged in a calcified sirea, spatulate in form and of little depth: the orifices which serve as passage for the retractor and extensor muscles of the mandible are separated or joined together. The frontal is a compact olocyst perforated simply by some lateral areolac.

Affinities.-In it exterior aspect and its multilamellar zoarium. this species may be confomder with Dataria birvis. It differs from the latter in its aperture, of which the anter is rectilinear. in its hexagonel and mnch larger zooecia and in its oricell imbedred in the distal zooecia.

It riffers from II ippoporfte perforata in its smaller miclometric measurements and in its inferior face, where all the zooecia are not regularly perforated.

Oceurenee-Middle .Tacksonian (Castle Hayne linestone): Wilmington, North Carolina (common).

$$
\text { Cotypes.Cat. No. ratoTó. T.S.N.M. }
$$

HIPPOPORELLA PERFORATA, new species.

$$
\text { I'late sf. figs. } 7-13 \text {. }
$$

Deseription.- The zonvium creppe on algae forming orbicular lamellae, free and irregular. The zonecia are hexagonal, very little elongated, distinct, separated by a furrow: the frontal is smooth and convex: it is an olocyst perforated laterally by some large arenlae. The aperture is semilunar, transverse; two deep cardelles separate a large anter from a small rectilinear poster. The ovicell is very large, imbedded in the distal zonecium and is hyperstomial. It opens above the aperture by a large opening without connection with the operculum. On the lower face of the zoarium the zooeria are convex. hexagonal. perforated in front of the " aperture by a round pore, and striated transrersely. The ancestrula is membrani- . poroid. 


$$
\text { Measurements. I perture } \mid \begin{aligned}
& h a=0.06 \mathrm{~mm} . \\
& l_{a}=0.09 \mathrm{~mm} .
\end{aligned} \quad \text { Zooecia }\left\{\begin{array}{r}
L z=0.48-0.50 \mathrm{~mm} . \\
l_{z}=0.35 \mathrm{~mm} . \text { (lower face) } \\
0.40 \mathrm{~mm} . \text { (upper face) }
\end{array}\right.
$$

Tarations.-The exterior - mfince of a zoarium çreeping on the roots of algae is naturally larger than the surfice in immediate contact with the substratum. When the calcification is intence and the walls thick, the micrometric difference for each zooecinm becomes perceptible. as we have establisher in this species. The number of lateral areolae is about six: they are frequently above the aperture; their place is inconstant, in no wise regular. The orbicular zoarium contains at the center some zooecia somewhat ditlerent; they are erect and ormamented with at large auriculated vibraculum; they arise flom the exaggerated derelopment of one of the areolae (fig. 11). The perforations of the lower face of the zoarium serve probably as a passage for rarlical fibers; they are often surrounded by hollow, hydrostatic tuberosities (fig. 13). The tangential section (fig. 10) shows that the olocystal elements of the frontal wall are grouped in lines radiating from the aperture toward the areolae; perhaps a rery compact pleurncyst covers the olocyat.

II ippomenclla radicata and Schisoporelle geminopora Renss, 18t7, have also some radicular pores on their lower face, but they belong to different genera easy to differentiate.

This species differs from 11 ippoperella multilamellosa in its unilamellar and orbicular zoarium, in the alyence of a separating salient thread, in the constant presence of the pores, and in its transverse aperture.

Oecurene.-Ficksburgian (Giendon member of Marianna limestone): TTest lank of Conecul River, Escambia County. Llabama (common).

Cotypes.Cat. No. 642 个.2. U.S.N.M.

\section{HIPPOPONELLA, new genus.}

The operculum' is contracted laterally. 'The ovicell is hyperstomial and always closed by the operculum. The frontal is bordered with areolar pores.

Genotype.-ILippoponella (Lipratia) hippopus Smitt, 1867. Recent.

\section{Genus HIPPOMENELLA Canu and Bassler, 1917.}

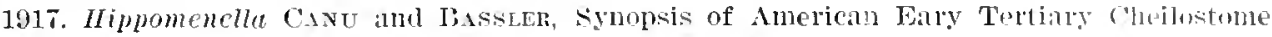
Bryozor, Bulletin 96, Tnited Stites Nitional Museum. P. 41.

The aperture hears two -mall cardelles placed rery low and separating a lange porta from a small ramat; it is always semielliptical (in the interion). The ovicell, byperstomial, is deeply imbeded in the distal zooecia; it opens by a large opening above the aperture, but it is nevel closed by the opereulmu. The fiontal is formed of an olocyst perforated laterally by some areolate and supporting a plenrocyst more or less developerl. 'The ovicell bears laterally two aria in the form of a lumar crescent and more or less perforated. 'There are nearly always some spines and some aricularia.

Genotype.-Iippomenolla (L protia) mucromelliformis Waters. 1899.

Ranar.-Lutetian-Recent. 
The species helonging to this gemus are:

Hippomenella (Mucromella) perforatu Maplestone, 1902. Recent, Australia.

?Himpomenclid (Lepmatia) peristomata Waters, 1899. Recent, Madeira.

IIipumenella (Lepmin) murmellifomis Waters, 1892. Recent. Madeira.

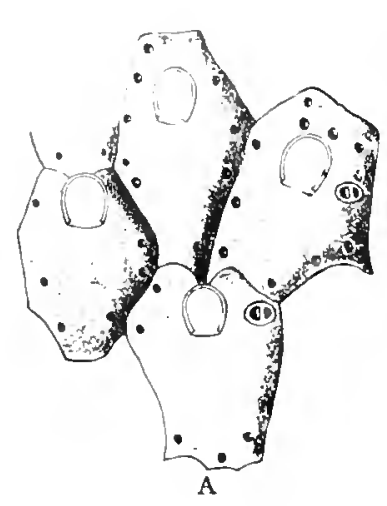

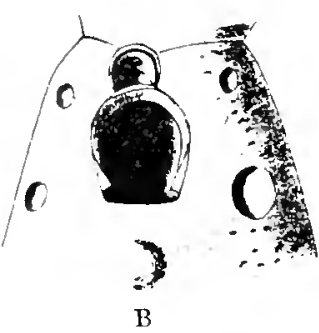
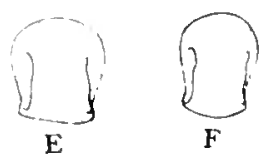
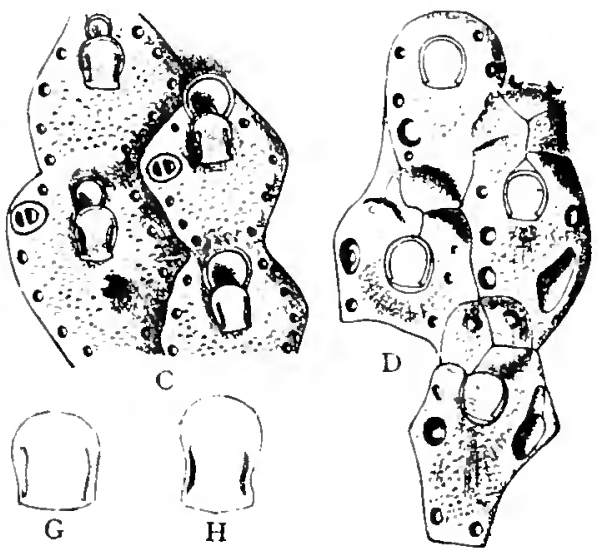

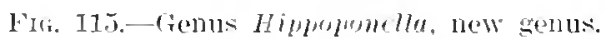

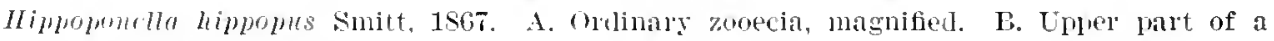
\%onecinm, slowing the aperture and two tringular hinge teeth. C. Zooecia with ovate avicu-

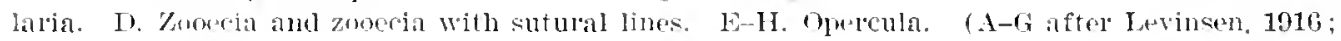
H aftel llaters.)

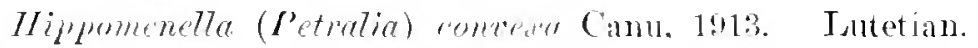

Hippomenelle (Petratia) mueronata Cinm. 1913. Lutetian.

llippomenella (Lemratia) semiler is Reuss. 1869. Priabonian.

This genus, of which we describe 15 new species, is a very natural one: the

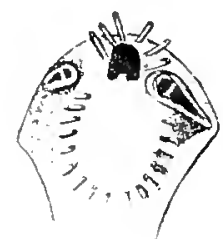

A $、 25$

Flg. 116 . - liemus Hippomenfla Canu and liassler, 1917.

1, B. Hipponemella mucromlliformis Waters, 1s.9s. 1 . knoecium with its avioularia and areolas, $\because 25$. P. (Iperculum, $<$ s. $\langle 1,1$, after Waters, Ists.)

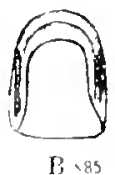

examination of our plates reveals no aberant type. Unfortunately, on account of an extraordinary polymorphism, the determinations are excedingly difficult, and the classification of these species has given us great trouble.

A singular anomaly is the disappearance of the genus in the recent waturs off Florida, where nu species has been cited by Smitt in 1872 , or by Osburn in 191t. In Europe the genus made its first appearance in the Lutetian in the vicinity of Bordenux; it occurs fossil in the Priabonian, and it till exists at Madeira. It is correct to say that it is extremely rare. for only the type of VTaters species exists in the Funchal Musemm.

This genus is intermediate between IIippoporina Neriani, 1895. and $I^{\prime}$ 'ristomella Levinsen. 1902; it contains sone sprecies which in their exterior aspect have exactly the appearance of species of the latter genus. but they are provided with cardelles. 
'Thin in truly an American: wentu- and it furmishes us with many important -tratigraphic data, as noted in the table below:

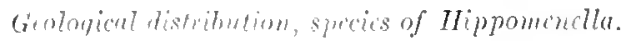

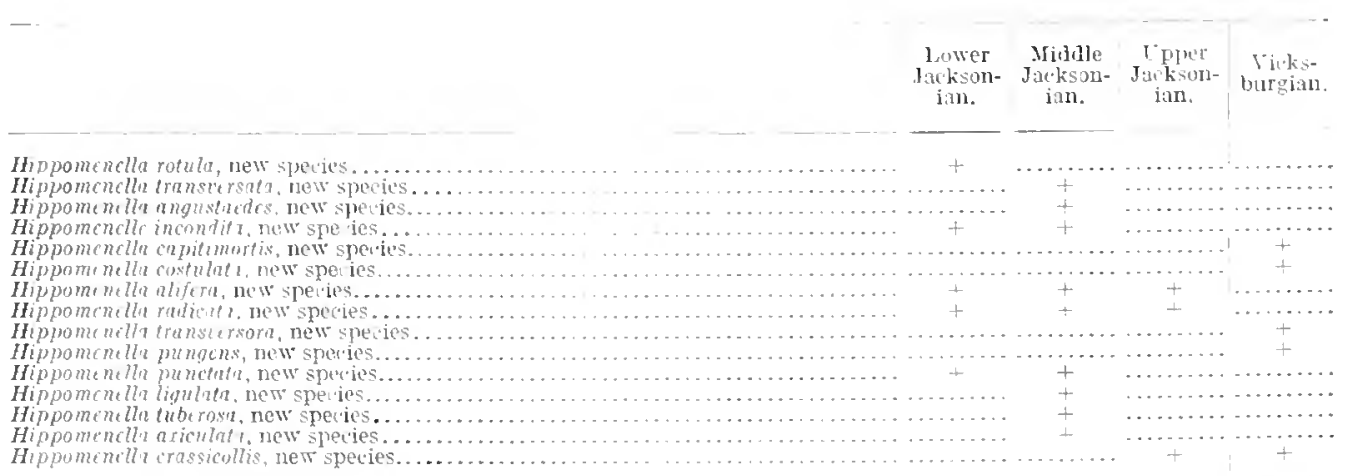

Thus the lower . Tacksonian is characterived by II ppomenella rotula alome: the

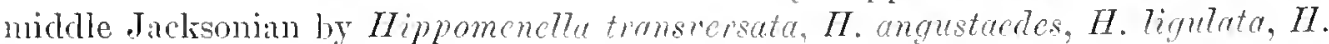
exientate, and II. tuberosa: the mpper . Jackonian by no species. The Tiekshurgian is characterized by $H$. capitimontis. $H$. costulata, $I I$. tomseresore and $H$. punquns. H. redicate. and II. alifend ringe through the entire Tacksmian.

Group 1. ZOARIUM BILAMELLAR.

HIPPONFNELLA ROTLLA, new species.

Plate 4?. fings. 4-14.

Wescription.-The zominum is free, formed by two lamellac, back to back and inseparable. The fromils are flat or undulating and mav musure 2 centimeters in lengtl. The zroecia are listinct. rery elonguted, fusifornt the froutal. little conrex and smooth. is andisled laterally with a lomble row of arenta much crowded. The aperture is elliptical (in the inturior): it presents exteriorly a muemoid convexity very salient on its proximal burler: thepe are two very small cardelles. The ovicell is laree. glubular. salient. much imbedded in the distal zonocia: the two lateral areas bear three of fom laree eavities separated by radial projections. The avicularia are small, ineonstant. placel laterally below the apertme, provided with a pirot, and with a triangular beak directed toward the base. No spines.

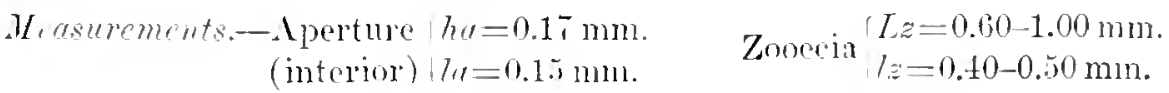

Tariutions. - The micometric variations are oxtranclinary; they vary from one to two times. There are sometimes narow zonecia (fig. i), again there are wille zonecia (fig. $f$ ). and often giant zoneria (fig. T). The avienlaria are ahsent (fig. . .) ol present (figs. $i-9)$. generally small. The mucomoid convexity is prominent (fig. 5) or absent (fig. 7 ). The carities and the pores of the oricell are rariable in size and in position (figs. 7.9 ). 
In the interior (fig. 10) the olocyst is in juxtaposition with a tremocyst with tubular pores; the areolac are therefore of the same nature as the tremopores. 'The olocyst in the upper part of the frontal is covered with a pleurocyst in which the elements are oriented toward the mucro arcording to rule (fig. 11).

Figure + represents a monstrosity in which an abuormal bud lias caused the formation of inverted zooccia; these monstrosities may moreover be perfectly oriented but superposed upon other zooecia. This kind of gemmation, which is hore only a monstrosity, is, on the contrary, the rule in the Celleporidae.

Affintis.-This species liffers from Ilippomenclla argustacles in its aperture. which is not elliptical extcriorly, in its zoarim of large spreading fronds, and in the absence of oral spines.

It differs from Ilippomenelle incondita in the pores of its ovicell, which are larger, less numerons, and more regularly disposed.

It differs from Ilippomenella capitimortis in its ovicell with many pores (instead of two diaphragmed pores).

It differs from Hippomencllu costulate in the absence of fire eostules on the ovicell and in its much smaller a vicularia.

It differs from all the other II ippomenellue save 11 . transersata in its broad bilamellar zoarium. In the latter species the avicularia are oriented transversally.

Occumence-Lower Jacksonian (Moorlys marl): Jackson, Mississippi (very common).

$$
\text { Cotypes.-Cat. No. 6t07т, U.S.N.M. }
$$

HIPPOMENELLA TRANSVERATA, new species.

Ilate 49. figs. 15-17.

Ih scription.-The zonrim is bilameliar. The zooecia are elongated, distinct, elliptical: the frontal is little convex and garnished laterally by a lonble or triple row of triangular areolae separated by very short costules. The apertura is somewhat clongated. elliptical; two very small cardelles separate a large anter from a somewhat smaller poster. The avieularia are placed symmetrically on each side of the apertura; they are small, triangular and oriented almost transversally.

$$
\text { Measuriments.-Apertura }\left\{\begin{array} { l } 
{ h a = 0 . 1 5 \mathrm { mm } . } \\
{ 7 a = 0 . 1 6 \mathrm { mm } . }
\end{array} \quad \text { Zooecia } \left\{\begin{array}{l}
L_{z}=0.80-1 \mathrm{~mm} . \\
7 z=0.60 \mathrm{~mm} .
\end{array}\right.\right.
$$

Affuitis.-Unfortmately we have no knowledge of the ovicell of this species. but the peculiar disposition of the aricularia is absolutely characteristic and almost mique in the remms.

The species differs from Uipromenclla trensicrsora, in which avicularia are in the same place, in the triangular form of the avicularia and in the absence of the large oral mnero.

Oemerence-Middle Jacksonian (Castle Hayne limestone) : Wilmington, North Carolina (rare).

Cotypes.-Cat. No. Gitors, U.S.N.M. 
HIPPOMENELLA ANGUSTAEDES, new species.

Plate 49, firs. 18, 19.

Description.-The zoarinm is free and formed of two lamellae. back to back, and inseparable; the fronds are of 7itt7e width, flabellate, and do not contain more than six longitudinal rows of zooecia. The zooecia are elongated, distinct, oral: the frontal is convex. smooth, and gamished with a donble lateral row of areolae, mumerous and small. The aperture is elliptical, elongated, divided into equal parts by two cardelles; the peristome very little salient, bears 4 to 6 large distal spines. 'The avicularia are placed laterally in the vicinity of and below the aperture: they have a pirot and their triangular beal is directed downward: they are never ecual in size.

$$
\text { Measurcments. I I perture }\left\{\begin{array} { l } 
{ h a = 0 . 1 6 \mathrm { mm } . } \\
{ 7 a = 0 . 1 2 \mathrm { mm } . }
\end{array} \quad \text { Zooecia } \left\{\begin{array}{l}
L_{z}=0.70-0.80 \mathrm{~mm} . \\
7=0.46 \mathrm{~mm} .
\end{array}\right.\right.
$$

Affnities.-This species differs from IIippomenella transversate in its smaller micrometric measurements $(L z<0.80 \mathrm{~mm}$.) and in its lower placed avicularia. which are larger and more oblique.

It differs from Mippomenella incondite in its much smaller aricularia and its orifice exteriorly elliptical and not semilmar.

It differs from Hippomenclla capitimortis in the size of its aricularia and in its aperture exteriorly elliptical (and not semilunar).

It differs from Ifippmnenella costulata in its avicularia placed lower and with a beak turned downward (and not laterally) and in the presence of oral spines.

It differs from IIippomenclla rotula in its narrow fronds and its elliptical aperture garnished with spines.

Occurrene.-Middle .Tacksonian (Castle Hayne limestone): Wilmington. Torth Carolina (rare).

IIolotype.-Cat. No. 64079. U.S.N.M.

HIPPOMENELLA INCONDITA, new species.

Plate 50, figs 1-S.

Description.-The zoarium is free. formed of two lamellae, back to back. ant inseparable; the fronds are wide, irregular, and undulated. The zooecia are distinct, somewhat elongated. elliptical, swollen: the frontal is convex and garnished laterally with a donble row of large areolae. The aperture is exteriorly semilunar; the proximal border has a very convex mucronoid protuberance. The ovicell is hyperstomial, salient. globular, much imbedded in the distal zooecia, never closed by the operculum, very irregularty punctate. The aricularia are placed laterally on the line of the arenlae. close to and somewhat below the aperture; they are small. little prominent. and their beak is directed downward. No spines.

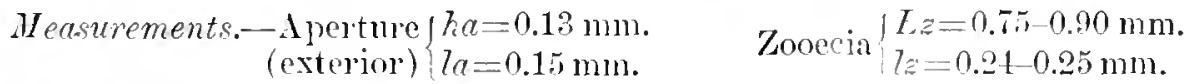

Trariations.-The zooecia are long (fig. 2) or short (fig. 3). The punctations of the oricell are very irregular (figs. $5-\tau$ ) and rarely (fig. 6) it is possible to 
see two latelnl primitive areas. The lateral aricularia are rarely wanting (fig. 2): we have obselved (fig. A) an incxplicable case of an avicularian monstrosity. The znoecia apparently never have spines: however, our figme 3 presents some traces of them.

Affnitics. - This species difters from Hippomenclls anqustucdes and from Hippomene 7 a transersate in its aperture exteriorly semilmmar (and not elliptical) with mucromoid convexity.

It diflers from Ilippomenclla rotula, from Himpomenolla capitimortis, and from Hippomene7ln erstulutre in the extremely irregular punctations of its ovicell.

It differs from all other Mippomencllae in its bilamellar zoariun.

Occurrence-Middle Jacksonian: Rich IIill, $5 \frac{1}{4}$ miles south of Kinoxville. Georgia (rery enmmon) : 3 miles sulth of Pelry, Geolati (common); 18 miles west of Wrightsville, Georgia (rare) ; 17 miles northeast of IIawliusville. Georgia (com. mon); 32 miles north of Grovania, Feorgia (common); Twiggs County, Georgia (several localities) : 12 miles sontheast of Marshallville. Freorgia (common) : neal Lenuds Ferry, South Carolina (rare) : Baldock, Baluwell Comnty. South Carolinit (rare); Eutaw Spungs, South Carolina (common).

.Tarksonian (Zeuglorlon hed) : Suck Creek. Clarke County, Mississippi (rare); Shributa, Mississippi (very rare).

Cotypes.-Cat. Nos. litoso-64082. U.S.X.M.

IIPPONENELLA CAPITIMORTIS, new species.

Plate 55 , figs. 17,18 .

Description.-The zoarium is free. lamellar. formed of two lamellae. back to back, and inseparable. The zooecia are large, elongated, elliptical. or oral: the frontal is convex. smooth, garnisherl laterally with a double row of numerous areolae. The orbicular aperture (in the interior) is exteriorly formed of a semilunir antel :und of a rery convex and mucronoid postel. The oricell is hypes -tomial, cmbedded in the distal zoecia: the two lateral areas are perforaterl by a rely large pore in part occupied by a denticle shaped like the head of a lanee. The avicularia are absent of rel'y small.

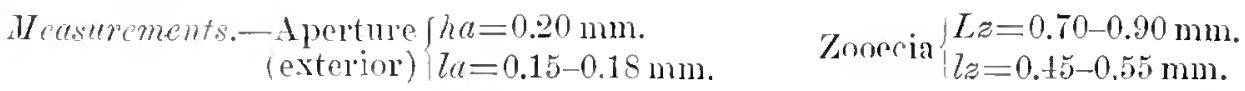

Jamintions.-The rows of areolae are often three in number; on certain parts of the zooecia they have thus the aspect of tremopores. The small avicularia derelop in the place of an areola; they are placed at a distance from the aperture; they have a pirot and there is only one to each zonecium. The ovicell is vely characteristic: it wives the zooecium the vane aspect of a trath's head. We are absolutely iumorant of the physiolngic use of the larae perforations and of the little tongue in the form of a head of a lance which they contain.

Affinities.-This species much resembles IIppomenella semitevis Reuss, 1869. of the Priabonian. It tiflers from it in the presene of the little tongue in the pores 
of the ovicell, in its convex anter and in the absence of the large vibracnlum which according to Waters develops at the side of the apertwre in the European species.

The ovicell of this species is very characteristic, but mufortunately it is very rare; in its absence the determination offers some difticulties. It resembles considerably II ippomenella rotula, but diflers in the larger aperture (ha $=0.20 \mathrm{~mm}$. instead of $0.15 \mathrm{~mm}$. exteriorly) and in the small avicularim placerl much lower.

Oecurrence.-Vicksburgian (Marianna limestone): West bank of Conecuh River, Escambia County. Alabama (common); Salt Momntain, 5 miles south of Jackson, Alabama (common); Murder (reek, east of Castlebury, Coneculn County, Alabama (common); near Claiborne, Ionroe Connty, Alabama (common); deep well, Escambia Connty, Alabama.

C'otypes.-Cat. Nos. 612067,64268 , U.S.N.M.

hippomenella costulata, new species.

I'late 86 , figs. 14-19.

Description.-The zoarium is free, more or less cylindrical, most often composed of six longitudinal rows of zooecia. The zooecia are elongated, distinct, oral. separated by a furrow; the frontal is rery convex. finely granulated, sumounded by a single line of small triangular areolae, separated by some short, interareolar. costules. The aperture is little elongated and suborbicular in the interior; on the exterior it shows a proximal lip more or less convex and salient; the peristome bears $t$ to 6 spines. The ovicell is hyperstomial, much imbedded in the distal zooecia, garnished with two perforated areas with a large pore and radial costules. The avicularia placed on each side of the aperture are disposed obliquely or transversally; they are prominent, subtriangular, and are provided with a pivot.

$$
\begin{aligned}
\text { Measurements. - Aperture }(h a=0.15 \mathrm{~mm} . \\
\text { (exterior) } \mid 7 a=0.15 \mathrm{~mm} .
\end{aligned}
$$

Variations.-The two large pores of the ovicell are often divided into two parts by a small tongue or by an internal crossbar (fig. 17): the costules are sometimes altered (figs. 18.19). The proximal lip of the aperture becomes sometimes a velitable mucro (fig. 19). The interareolar costules are attenuated (figs. 15. 16) or very complete (fig. 18). The aricularia are constant and symmetrical. The zoarium may have more than six rows of zooecia (fig. 19) and even he incrusting.

Affinities. - In its oricell this species approaches Hippomenella capitimortis; it differs from it in the presence of the costules on the oricell, the greater length of the avicularia and their lateral place on the side of the aperture, and the presence of a single row of areolae (instead of two).

It differs from IIippomenolla rotula in its nonlamelliform zoarium. its sonewhat larger oral dimensions, the finer costules of its oricell, and the presence of spines.

It differs from IIippomenclla angustaedes in its transversal or very oblique aricularia (and not almost longitudinal), in their symmetry and a single row of areolae.

$$
\therefore 5 \varsigma 99-19--131111.106-25
$$


Occurrence.-Vicksburgian ("Chimney rock" of Marianna limestone): One mile north of Monroeville, Alabama (very common).

Vicksburgian (Red Bluff clay): Seven and one-half miles southwest from Bladen Springs, Alabama (common).

Cotypes.-Cat. No. 64273, U.S.N.M.

\section{Group 2. ZOARIUM UNILAMELLAR (Semieschara). HIPPOMENELLA ALIFERA, new species.}

Plate 50, figs. 2-18.

Description.-The zoarium is unilamellar and creeps ovcr algae. On the inner face in contact with the substratum the zooecia are convex, hexigonal, formed of an olocyst covered by a pleurocyst and often ornamented by hydrostatic tuberosities. The zooecia are elongated, distinct, hexagonal or oval; the frontal is conver, smooth, surrounded by two or three rows of small and numerous areolae. The aperture is elliptical, elongated; the peristome rery little salient, bears six large spines; two small cardelles separate a large anter from a smaller poster. The ovicell very large, very prominent, globular, and smooth, is hyperstomial and little embedded in the distal zooecia; a small median nerve separates the two areas. The avicularia are very large and salient; they are placed below and close to the aperture; thcir beak is triangular and directed obliquely toward the bottom; they have a calcareous pirot.

$$
\text { Measurements.-A perture }\left\{\begin{array} { l } 
{ h _ { a } = 0 . 1 8 - 0 . 2 0 \mathrm { mm } . } \\
{ 7 _ { a } = 0 . 1 4 - 0 . 1 6 \mathrm { mm } . }
\end{array} \quad \text { Zooccia } \left\{\begin{array}{l}
T_{z}=0.70-0.80 \mathrm{~mm} . \\
l_{z}=0.40-0.60 \mathrm{~mm} .
\end{array}\right.\right.
$$

Variations.-This species represents the height of polymorphism; there is not a single spccimen comparable with another and not a single zooecium resembles its neighbor.

The arcolae are often disposed in two or three rows (figs. 10, 13). sometimes spreading over all the frontal (fig. 11) and becoming true tremopores. The avicuJaria may be short and unsymmetrically disposed (fig. 10), but are generally very large and very salient, like extended uings (figs. 11,14). The ovicells, globular (fig. 13) or pyriform (fig. 11), are almost always smooth.

The lower face of the zoarium is smooth (fig. 15); each dorsal is formed of two separable calcareous layers (fig. 16), a plenrocyst on an integral olocyst; the hydrostatic tuberosities are rare but ma become very large (fig. 17). The zoarium may be incrusting.

In the interior the apertura shows a porta larger than the vanna, separated by two cardelles (fig. S).

Affinities.-Its smooth ovicells and large avicularia characterize this species rather well. It differs from IIippomenella radicata in its larger aperture, its smooth oricell, it avicularia symmetrically disposed, and in its dorsal not regularly perforated.

It differs from II ippomenella transversata in its elongated aperture (and not transrerse), in its more salient a vicularia and more than two lows of lateral areolae. 
Oecurrence.-Middle Jacksonian: Wilmington, North Carolina (very common) ; $3 \frac{1}{4}$ miles south of Perry, Georgia (r'are) ; $3 \frac{1}{2}$ miles north of Grovania, Georgia (very rare).

Upper Jacksonian (Ocala limestone) : Alachua, Florida (rare); West bank of Sepulga River, Eseambia County, Alabama (rare).

Jacksoni:un (Zengloclon zone): Shubuta, Mississippi (rare).

Cotypes.-Cat. No. 64083, U.S.N.M.

HIPPOMENELLA RADICATA, new species.

Flate 50, firs. 19-24.

Description.-The zoarim is milamellar and creeps over algae; the lower face presents some elongated zooecia, smooth or striated transversally and regularly perforated by a radicular (?) pore. The zooecia are elongated, distinct, oral, separated by a furrow; the frontal is smooth, convex, garnished laterally by a double row of triangular areolae often separated by short pleurocystal costules. The aperture is elongated, elliptical, provided with two very small cardelles; it is surrounded by a peristome little salient, garnished with 6 large spines; there is a vestibular arch. The ovicell is globular, salient, hyperstomial, embedded in the distal zooecia, never closed by the operculum; the two areas are smooth or punctate. The avicularia are placed below the aperture; they are salient, triangular, the beak pointed toward the bottom, rarely symmetrical.

Measurements.-A perture $\left\{\begin{array}{l}h \alpha=0.16 \mathrm{~mm} . \\ 7 \alpha=0.14 \mathrm{~mm} .\end{array} \quad\right.$ Zooecia $\left\{\begin{array}{l}L z=0.50 \mathrm{~mm} . \\ 7 z=0.36-0.40 \mathrm{~mm} \text {. }\end{array}\right.$

T'ariations.-The areas of the ovicell are not always visible and are replaced by punctations (fig. 20). Of the two avicularia there is one almost always larger than the other; nevertheless symmetry is possible (fig. 22). The dorsal perforation is placed just below the aperture; it corresponds perhaps to some radicells as in the genus Petralia MacGillivray, 1881, it is rather constant; nevertheless we have some specimens which are deprived of it. The interareolar costules are absent or accentuated (fig. 21).

Schizoporella geminipora Reuss, 1867 , and IIippoporina perforata are also provided with pores on the nnder side as in the genus Petralia MacGillivray. 1881. But the nature of their ovicell, never elosed by the opereulum. does not permit their arrangement in this genus.

Affinitics.-This species differs from IIippomenella alifera in its less prominent and nonsymmetrically placed avicularia, in its larger interareolar costules. its smaller micrometric dimensions, and in its dorsal radicular pores.

It differs from Hippomenella transwersora in its elongated aperture (and not transverse) and in the absence of a labial convexity at the aperture.

It differs from Ilippomenella punctuta in which the oricell is porous in its smaller mierometric dimensions $(=0.70 \mathrm{~mm}$. and not $1.00 \mathrm{~mm}$.) and in its free and monincrusting zoarium. 
Occurrence-Lower Jacksonian (Moodys marl) : Jackson, Mississippi (common).

Midhle Jackonian (Castle Iayne limestone): Wilmington, North Carolina (common).

Upper Jacksonian (Ocala limestone): Alachua, Florida (very rare).

Cotypes.-Cat. Nos. 64084, 64085, U.S.N.M.

HIPPOMENELLA TRANSVERSORA, new species.

Plate S6, figs. 20-24.

Description.-.The zoarium is unilamellar and creeps over algae or incrusts Orbitoides. The zooecia are elongated, distinct, ovoid; the frontal is convex, surrounded by a double row of triangular areolae separated by short costules. The aperture is transerese exteriorly; the peristome is complete and bears six distal spines and a salient, proximal mucro. The ovicell is globular, prominent, hyperstomial, embedded in the distal zooecia, never closed by the operculum; the two lateral areas are small and each is perforated with a large pore. The avicularia are small, transverse, triangular, placed below the aperture on the line of areolae. The ancestrula is a small zooecium. Thiree large lateral septules.

$$
\text { Mcasurments. Aperture }\left\{\begin{array} { l } 
{ h a = 0 . 1 2 \mathrm { mm } . } \\
{ L _ { a } = 0 . 1 1 - 0 . 1 6 \mathrm { mm } . }
\end{array} \text { Zooecia } \left\{\begin{array}{l}
L z=0.80-0.90 \mathrm{~mm} . \\
l z=0.40-0.44 \mathrm{~mm} .
\end{array}\right.\right.
$$

Affinitis.-This species differs from IIippomenclla alifera and IIippomenella radicata in its transverse aperture and in the presence of an oral mucro. Its greater aflinities are with IIippomenclla costulata, from which it differs in its transverse aperture, its much-developed mucro, the more constant presence of the spines, and in its lamellar zoarium.

Occurrence--Vicksburgian (Marianna limestone): West bank of Conecuh River, Escambia County, Alabama (rare); 1 mile north of Monroeville, Alabama (very rare); Murder Creek, east of Castlobury, Coneeulu County, Alibama (very rare).

$$
\begin{aligned}
& \text { Cotypes-Cat. Nos. } 6427 t \text {, 6t27o, U.S.N.M. } \\
& \text { Hippomenella PUNGens, new specics. }
\end{aligned}
$$

l'late 57 , figs. $1-4$.

Description.-The zuarium is free. milamellar, creeping over algae. The zooecia are regular, hexagonal, very little elongated, separated by a furrow. The frontal is finely grannlated, conrex, surrounded by a double row of numerons very small areolae. The aperture is in the form of a horseshoe and is provided very inferiorly with two small cardelles; the anter is very large and the poster is small and slightly coneave; the peristome is thin and bears four small distal spines. The oricell is hyperstomial, globular, salient, embedded in the distal zooecia; it bears superiorly some costules more or less prominent and inferiorly two areas perforated by a large pore. The avicularia are small, triangular. symmetrically 
disposed below the aperture. On the lower face, the zooecia are smooth, convex and ornamented with numerous small hydrostatic pricleles.

$$
\text { Weasurements. A perture }\left\{\begin{array} { l } 
{ h a = 0 . 2 3 \mathrm { mm } . } \\
{ 7 a = 0 . 1 7 \mathrm { mm } . }
\end{array} \quad \text { Zooecia } \left\{\begin{array}{l}
L z=0.75-0.85 \mathrm{~mm} . \\
l_{z}=0.65-0.80 \mathrm{~mm} .
\end{array}\right.\right.
$$

Affinities.-This is the species which has the most resemblance to the type of the genus Hippomme7la mucronelliformis Waters, 1899. from Madeira as much in its frontal as in the form of its aperture. It differ's from it in its much larger sperture ( $h a=0.23$ and not $0.16 \mathrm{~mm}$.), in its avicularia of the same size; in the absence of a small oral mucro, and in its hydrostatic prickles.

It differs clearly from the other species of Mippomenella in the hexagonal form of the zooccia.

The frontal is formed of a very thin plemrocyst (fig. 4), very distinct from the subjacent olocyst, from which it may be separated.

Oocurrence.-Vicksburgian ("Chimney rock" of Marianna limestone): One mile north of Monroeville, Mlabama (very common).

Cotypes.-Cat. No. 64278 , U.S.N.M.

Group 3. ZOARIUM INCRUSTING.

hiPPOMENElla PUNCTATA, new species.

Plate 51, figs. 1-3.

Description.-The zoarinm incrusts shells and bryozoa, especially the Cellepores. The zooecia are distinct. very elongated. fusiform, separated by a furrow; the frontal is convex, smooth in the middle, surrounded by a double row of small areolae and formed of an olncyst surmounted by a distinct pleurocyst. The aperture is elliptical, elongated, provided with two small cardelles placed very low; the peristome is thin and gamished with six distal spines. The ovicell is globular, salient, little imbedded in the distal zooccia, never closed by the operculnm; the lateral areas almost disappear under a tremocyst, which has numerons small pores in quincunx. The avicularium is small, salient, triangular, placed eccentrically before the aperture; it is provided with a pirot and its beak is pointed downward.

$$
\text { Measurcments.-A perture }\left\{\begin{array} { l } 
{ h a = 0 . 1 8 - 0 . 2 0 \mathrm { mm } . } \\
{ l a = 0 . 1 4 - 0 . 1 5 \mathrm { mm } . }
\end{array} \quad \text { Zooecia } \left\{\begin{array}{l}
L_{z}=0.80-0.90 \mathrm{~mm} . \\
l z=0.35-0.45 \mathrm{~mm} .
\end{array}\right.\right.
$$

Affinities.-It is easy to mnderstand in this species the deposit of the pleuroeyst, the elements of which begin to be deposited around the areolae. The buds of the internal endocyst of which the areolae are the traces, reunite by coalescence to form a superior endocyst and continne therefore to be able to secrete and deposit the pleurocyst.

This species differs from Hippomenella rotula in the presence of its spines, its ovicell with small pores and not with large costules, and its zoarium incrusting and not bilamellar.

It differs from Hippomenclla radicata in its larger dimensions, its ovicell with pores more numerous and smaller, its unique avicularia and its zoarium incrusting and not unilamellar. 
It differs from the other incrusting species in the entire absence of oral mucro.

Oecumence.-Lower Jacksonian (Moodys marl) : Jackson, Mississippi (common).

Middle Jacksonian : Eighteen miles west of Wrightsville, Georgia (very rare); Rich Hill. 51 miles southeast of Knoxville, Georgia (rare); one-half mile sontheast of Georgia Kaolin Co. Mine, Twiggs Connty, Georgia (rare).

Cotypes-Cat. No. 64086 , U.S.N.M.

hipPOMENELLA LIGULATA, new species.

Plate 51, figs, 6-9.

Deseription.-The zoarium inerusts bryozoa, Orbitoides, or ereeps over algae. The zooceia are short, distinct. oral; the frontal is very convex, smooth, surrounded by a double row of very small triangular areolae separated by some small interareolar costules. The aperture is somewhat elongated, semielliptical; a mucro strap shaped, very salient, oblique or erect, hides the aperture nore or less; the peristome is ornamented with six large distal spines. The ovicell is globular, salient, imbedded in the distal zooceia, elongated, with two very large lateral areas. The two avieularia are placed below the aperture, they are of the same size and very projecting.

$$
\begin{aligned}
& \text { Weasurements.- Aperture } h a=0.14 \mathrm{~mm} . \\
& \text { (exterior) } 7 a=0.14 \mathrm{~mm} .
\end{aligned} \quad \text { Zooecia }\left\{\begin{array}{l}
L z=0.60-0.70 \mathrm{~mm} . \\
l z=0.40-0.44 \mathrm{~mm} .
\end{array}\right.
$$

Taritions.-Most of the time the zon rium is incrusting, but free zoaria are not rare; the lower face is smooth and. according to eircumstances, garnished by the hydrostatic apophyses (fig. 7 ). When the muero is erect the aperture is quite visible and without the peristomial thickening the species may be confonnded with IIippomenella alifera (fig. 6). When it is oblique it hides the aperture more or less (fig. S). In fossilization the small areolae are easily filled up and disappear (figs. 6, 8, which are the most habitual aspects); but superb specimens with areolae are not rare (fig. 9). 'Then they are triangular and the funtal is covered by rery fine interareolar costules coalescent at the mucro.

Figure 9 perhaps represents a variety, for the two avieularia are much smaller and arjiacent to the aperture.

Iffinities.-This species differs from Ilippomenclla alifera in the salient mucro which ormaments its aperture and which in perspective completes the large peristome.

It is again in this same mucro that it differs from Hippomenella radicata. and in the absence of perforated base.

It diflers from Hippomenella tuberosa in its smaller micrometric dimensions ( $L_{2}=0.70$ and not $\left.0.8 \pm \mathrm{mm}.\right)$ and in its nontuberose frontal.

Occurrenee-Middle Jaeksonian: Wilmington, North Carolina (common): near Lenuds Ferry, Sonth Carolina (common); Eutaw Springs, Sonth Carolina (1'ate).

Cotypes.-Cat. Nos. 6408s, 64089, U.S.N.M. 
HIPPOMENELLA TUBEROSA, new species.

Plate 51, figs. 4, 5 .

Description.-The zoarimm incrusts bryozoa. The zooecia are large, elongated, elliptical, or hexagonal, separated by a deep furrow; the frontal is rery convex, surrounded by a double row of areolite and decorated with tuberosities grouped in lines radiating from the mucro. The aperture is senielliptical in the interior with two cardelles placed very low; on the exterior it is surrounded distally by a peristome garnished with six latrge spines and proximally by a salient mucro. The ovicell is large, elongated, salient, hyperstomial, little imbedded in the distal zooecia, never closed by the operculum; the two areas are garnished laterally with an arched slit. The two avicularial are of equal dimensions; they are small. little salient, triangular, provided with a pirot, placed at some distance below the aperture; their beak is pointed downward and toward a neighboring aperture.

$$
\text { Measurements.-Aperture }\left\{\begin{array} { l } 
{ h a = 0 . 1 4 - 0 . 1 6 \mathrm { mm } . } \\
{ l a = 0 . 1 4 \mathrm { mm } . }
\end{array} \quad \text { Zooecia } \left\{\begin{array}{l}
L z=0.8+\mathrm{mm} . \\
l z=0.70 \mathrm{~mm} .
\end{array}\right.\right.
$$

Affinitis.-This is a splendid species. The frontal tuberosities are of pleurocystal origin and the olocyst is easily visible below.

The species differs from IIippomenella ligulata, which shows some radial granulations, in its larger micrometric dimensions ( $L_{z}=0.84$ and not $0.70 \mathrm{~mm}$.) and in its much less salient avicularia.

Occurrence-Mildle Jacksonian (Castle Hayne limestone): Wihmington. North Carolina (very rare).

Holotype.Cat. No. 64087, U.S.N.M.

\section{HIPPOMENELLA AXICULATA, new species.}

Plate 51, figs. 10-13.

Description.-The zoarium incrusts bryozoa. The zooccia are distinct. wile, irregular in position; the frontal is little convex, smooth, surrounded by three lines of small and triangular areolac. The aperture is semielliptical with two cardelles, placed quite low; the peristome supports six to eight distal spines; an enormous, salient mucro, oblique or ereet, lobate, hides the aperture more or less. The ovicell is large, salient, imbedded in the distal zooecium, is hyperstomial and is never closed by the opereulum; it frontal area is perforated with an arehed clit. The avicularial placed near the aperture are small and irregular.

$$
\text { Measurements.-A perture }\left\{\begin{array} { l } 
{ h a = 0 . 1 6 \mathrm { mm } . } \\
{ l a = 0 . 1 + \mathrm { mm } . }
\end{array} \text { Zooecia } \left\{\begin{array}{l}
L z=0.68-0.70 \mathrm{~mm} . \\
l z=0.50 \mathrm{~mm} .
\end{array}\right.\right.
$$

Variations.-The mucro forms in front of the aperture a small pullet, quite rariable in form and dimensions. We are ignorant of the physiologic use of this organ, but it appears essential and analogous to that of the spines. If it be true that their existence is for the purpose of capturing the diatoms, our species must have been excessively voracious. What is strange is the absolute irregularity of the nucro; no one of them has any resemblance to the other and they are of all dimensions. 
Affinitics.--The zooccia with a small mucro resemble Hippomenella ligulata, lut the present species difler's in its wicler zooecia ( $l z=0.50$ and not $0.44 \mathrm{~mm}$.), in the presence of three rows of areolae and in the occurrence of a single avicularium.

Occurrence.-Middle Jacksonian: Wilmington, Nortlı Carolina (rarc) ; Entaw Spriligs, South Carolina (rare).

Cotypes.-Cat. No. 64090, U.S.N.M.

\section{HIPPOMENELLA CRASSICOLLIS, new species.}

Plate 51, figs. 14-19.

Mescription.-The zoarium incrusts bryozoa or shells. The zooecia are little distinct, clongated; the frontal is convex, surrounded with a double row of areolae, covered by a very thick and finely granulated pleurocyst. The aperture is semieliptical in the interior, with two cardelles placed verv low; on the exterior it is surrounded with a peristome, salient, very thiek, supporting two to six large distal spines. The ovicell is globular, salient, hyperstomial, embedded in the distal zooecia and ornamented with large radial costules. On the frontal there are two or three small triangular avicularia with pivots.

$$
\text { Mcasurements.-Aperture }\left\{\begin{array} { l } 
{ h a = 0 . 1 8 \mathrm { mm } . } \\
{ l a = 0 . 1 2 \mathrm { mm } . }
\end{array} \quad \text { Zooecia } \left\{\begin{array}{l}
L z=0.60 \mathrm{~mm} . \\
l z=0.50 \mathrm{~mm} .
\end{array}\right.\right.
$$

Variations.--The variable aspect of this species depends on the active intensity of the pleurocystal calcification, which may be found shown in figures 16-19. The small avicularia are irregularly placed (fig. 19); nevertheless they may be svmmetrical (fig. 16): they are elongated in proportion to the deposition of the plenrocyst with the result that they are always salient. The large costules of the ovicell are placel above the two lateral areas, sometimes perforated.

Oecurrenee.-Upper Jacksonian (Ocala limestone): Alachua, Florida (rare).

Vicksburgian (Byram marl): One-fourth mile west of WVodward, Wayne County, Mississippi (very rare).

Vicksburgian (Marianna limestone) : Near Claiborne, Monroe County, Alabama (liare).

rotypes.-Cat. Nos. 6t091-64093, U.S.N.M.

KEY TO SIETES OI IIIPOMENELLA.

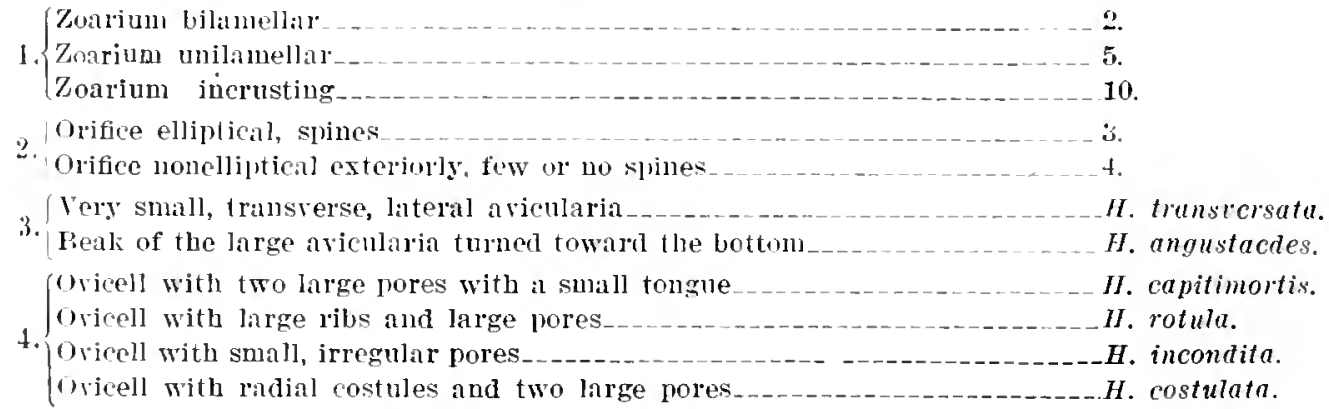


5. lixterjor alperture transworse and nucronate

5). Aperture elliptical

(i. Two small lateral aviculalia _

li. $\{$ Two large avicularia below the aperture

- Iricularia very small; zooecia bexagonal

7. Ial re a vicularia _._.

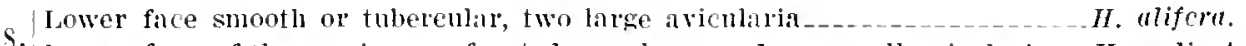

S. lower fice of the zoidrium lerforited: one large and one small avicularium H. radicuta.

j) No nucro

9. $\left\{\begin{array}{l}\text { Nucro present } \\ \text { Inuco }\end{array}\right.$

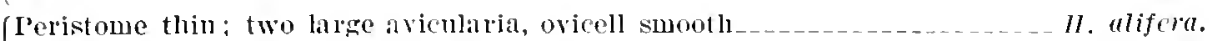

10. I'eristome thin: one smbmedian avicularium. ovicell with small pores___H. punctala.

leristome very thiek; two or three small avicula ria ; ovicell smootb___._._.II. crassicollis.

Two large avienlaria _

11. Two small a vieularia

1. Fnormous mucro with pallet; three rows of areolae ____._._._._. $H$. axiculata.

12. Small muclo; tuberosities radial on the frontal___

\section{Genus HIPPODIPI,OSIA Canu, 1916.}

1916. Hippodiplosia Canu. Les Bryozoaires du Sud Ouest de la France. Bulletin Soeiété Geologitue France, ser. 4, vol, 14, 1). 326.

The poster is nearly as lare as the anter. The opereulum is somewhat narrowed laterally at the site of the cardelles. The opereulum always closes the ovicell, which is hyperstomial. The frontal is a tremocyst. There are some spines and some avicularia. 16-18 tentacles.

Crnotype.-Mippodiplosia (Eschara) pallasiana Moll, 1803.

Tange.- Tacksonian-Recent.

In this genus the vamna is very large: it is the opening of a compensation sac. probably larger than in Ilippoporina Neviani, 1595. Consequently the tentacles ought to be more numerons or lareer. Calret reports 16 to 17 tentacles in the genotype. On the other hand, one can suppose that a larger vanna permits simply more rapid egress of the tentacles as an immediate compenation, since the conpensatrix is smaller in this group than in Schizoporella.

The Eocene species of the genus are rather different from those of the Miocene. It is probable that when the physiology of the aricularia is better known some restrictions will be mecessary.

The living species of this genus are:

IIippodiplosia (Eschara) pallasiana Moll, 1803.

Hipportiplosia (Lepralia) vestita IIincks, 1885.

The fossil species are:

II ippodiplosia (Lepratia) rarepuneta Reuss, 18ti. 'Tortonian.

IIippodiplosia (Lepratiu) planiceps Renss, 1847. 'Jortonian.

IIippodiplosia (Lepratire) semieristatu Reuss, 184\%. Tortonian.

IIippodiplosia (Lepralia) clavata Manzoni, 1874. Tortonian.

II ippodiplosia (Leprlia) auingeri Reuss, 1847. Tontonian. 
II ippodiptosia (Lepratia) asperrima Renss, 1847. Tortonian.

Itipporliplosio (Lepratia) aperta Manzoni, 1874. Tortonian.

Hippodiplosia (Leprolia) megalota Reuss, 1847. Tortonian.

Hipporliplosia (Esehara) ampla Reuss, 1847. Tortonian.

Hippodiplosia (Eschura) biauriculata Reuss, 18t7. Tortonian.

Hippodiplosia (Eschara) oculata Manzoni, 1871. Tortonian.

Hipporiplosia granulosa Canu, 1915. Aquitanian.

II ippodiplosia remucosa Canu, 1915. Aquitanian.

IIIPPODIPLOSIA VESPERTILIO, new species.

I'late 52, figs. 5-12.

Description.-The zoarium is free, formed of two lamellae fused together ant inseparable: the fronds are narrow and bear 4 to 6 longitudinal rows of zooccia.

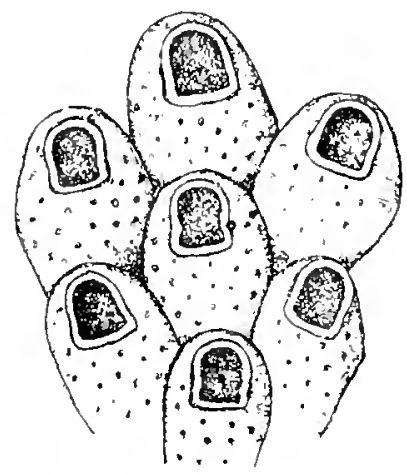

A .30

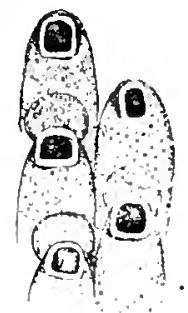

B $\times 20$

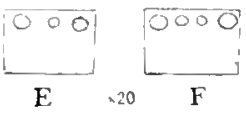

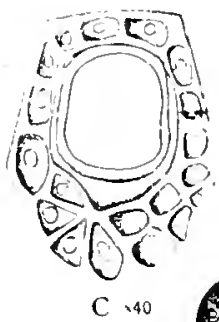

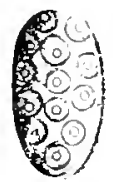

D
F1G. 117.-Genus IIiporiplosia Canu, 1916.

A-F, Hippodiplosia pallasiona Moll, 1803. A. Ordinary zooecia, $\times 30$. 1. Ovicellel zooecia, $\times 20 .(\Lambda, 13$ after Hincks, 1880. $)$ C. Young zooecium, $\lambda 40$. D. Multiporous septula. E. Distal wall, $\times 20$. $F$. Lateral wall, $\times 20 . \quad$ (C-F after Levinsen, 1894.)

The zooecia are long. distinct, sinuous, claviform; the frontal is convex; it is a thick tremocyst with tubules resting on a very thin, perforated olocyst. The aperture is elliptical, elongated, provided with two very small, inconstant cardelles. The oricell is globular, little salient, little imbedcled in the distal zovecia, closed by the opereulum when it opens; it is surrounded by areolae. Two tubulal symmetrical avicularia open on each side of the aperture.

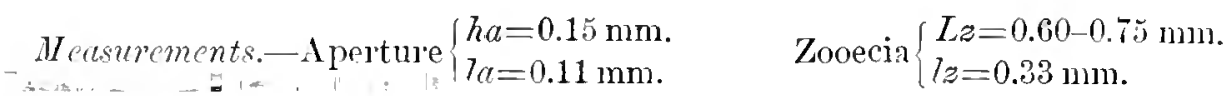

Tariations.-In the interior (fig. 9) the aperture is oblique; the tubules are visible by transparency through the very thin olocyst. The longitudinal section (fig. 7) shows zooecial alternation due to the closeness of the border of the zoarium; there is a large distal septula and we are able to verify five or six lateral septulae. The longituclinal section (fig. 10) indicates that the operculum onght to close the ovicell in opening, although we camnot be rigorously certain of this. It is evident rhat if the oricell was closed by a special membrane. it would be necessary to create 
a new gemus to receive this species. The ovicelled specimens are very rare and we were not able to prepare many sections.

The last tubules of the distal zooccia form on the ovicell a circle of areolae; it appears to be formed by a thickening of the olocyst. The two avienlaria are rery constant; they give to the zooecia a vague aspect of a bat's head.

Affinities.-The zooecia much resemble those of the genus Iippozengosella; they differ from it in the absence of a small, distal tongue; their mode of gemmation is also different.

This species differs from IIippodiptosia petiulus Ionsdale, 1845, and from Hippodiplosia falcifera in the very constant presence of two oral symmetrical aricularia and in its very narrow zoarium.

Oceurrence-Midale Jacksonian: Wilmington, North Carolina (common); near Tenuls Ferry, South Carolina (common).

cotypes.-Cat. No. 64095, U.S.N.M.

HIPPODIPLOSIA PETIOLUS Lonstale, 1945.

I'late ï, figs, $1-1$.

15t5. Eschara retiolus Lonsuane, Account of twenty-six species of Polyparia obtained from the Eocene Tertiary formation of North America, Quarterly Journal Geological Society, London, vol. 1, p. 52s, text figure.

Measurements. - Iperture $\left\{\begin{array}{l}h a=0.15 \mathrm{~mm} . \\ 7 a=0.10 \mathrm{~mm} .\end{array} \quad\right.$ Zooecia $\left\{\begin{array}{l}L z=0.80-0.90 \mathrm{~mm} \text {. } \\ 7 z=0.30-0.32 \mathrm{~mm} .\end{array}\right.$

We have had the good fortune to find some specimens of this species which no observer has noted since 1845 . There are no cardelles present. The ovicell is little salient; it is bordered by areolae and ganished with short radiating costules; it is open above the aperture. but lower than the poster; it may therefore be closed by the operculum, for its exterior orifice is identical with the interior aperture and with the neighboring apertures (fig. 4). The frontal is a tremocyst with tubules supported by a very thin olocyst (fig. 3), with which it is closely joined. These tubules are rather large; they are developed irregularly and give to the zooecia this "increased convexity." noted by Lonsdale (fig. 2). There is sometimes a sulall avicularium to the right or left of the aperture. The tremopores are easily filled up in fossilization.

Affinities.-Its zoarium is formed of large bilamellar fronds like Itippodiplosin falcifera, but the present species differs in the practical absenee of avicularia and in its smaller tremopores.

The species diflers from IIpporliplosia vespertitio in the absence of avicul:1ria and in its large. expanded fronds.

Oceurence.-Middle Jacksonian: Eutaw Springs, South Carolina (rare).

Plesiotypes.-Cat. No. 64094, U.S.N.M.

hip PODLlosia FAlCifera, new species.

Plate 52, figs. 13-16.

Deseription.-The zoarium is free, formel of two lamellae, back to back, and inseparable; the fronds are wide. large, and flabellate. The young zooecia are 
distinct, elongated, elliptical; the frontal is convex and formed of a thick tremocyst with large tubules resting on a very thin perforated olocyst. The aperture is elliptical. somewhat elongated; the anter is separated by two very small cardelles from a poster somewhat smaller. The avicularium is long, thin, provided with a pivot; it is placed laterally moler the apertme; the beak is falciform. The old zooecia are indistinct.

$$
\text { Measurements.-Aperture }\left\{\begin{array} { l } 
{ h a = 0 . 1 5 \mathrm { mm } . } \\
{ l _ { a = 0 } = 0 . 1 2 \mathrm { mm } . }
\end{array} \quad \text { Zooecia } \left\{\begin{array}{l}
L_{z}=0.60-0.70 \mathrm{~mm} . \\
l_{z}=0.30-0.35 \mathrm{~mm} .
\end{array}\right.\right.
$$

Affinitics.-Only the two figured specimens have been found; apparently the proliferation of this species does not correspond to the zoarial vigor. In the old zooecia the tubules are very long; the avicularia immersed between them are hardly visible.

The species differs from Ilippodiplosia vespertilio in the presence of its large falciform avicularim, which attains a length of $0.35 \mathrm{~mm}$.

Occurrence.-Middle .Jacksonian (Castle Hayme limestone) : Wilmington, North Carolina (very rare).

Cotypes.-Cat. No. 64096, U.S.N.M.

HIPPODIPLOSIA MAGNTPOROSA, new species.

Plate 87, figs. 7-9.

Description. - The zoarium is hollow, erlindrical, branched, unilamellar, rarely phrilamellar: it inerusts small algae. The zovecia are little distinct, elongated, almost cylindrical; the frontal is a tremocyst with large fumel-shaped pores resting on an olocyst perforated by small corresponding pores. The aperture is almost orbicular and formed of a large anter separated from a small concave poster by two very salient, triangular cardelles; the peristome is often very wide. smooth, and rery little salient. The oricell is embedded in the distal zooecium, it is hyperstomial and opens above the aperture by a thin slit; it is of the same nature as the frontal. Often the coalescence of two tremopores determines the formation of a small lateral avicularim with pirot.

Measurements.-Aperture $\left\{\begin{array}{l}h a=0.20 \mathrm{~mm} . \\ l_{a}=0.15 \mathrm{~mm} .\end{array} \quad\right.$ Zooecia $\left\{\begin{array}{l}I_{z}=0.75 \mathrm{~mm} . \\ l z=0.40 \mathrm{~mm} .\end{array}\right.$

Tariations.-The lateral aricularim is rery inconstant. The young zooecia (fig. $\boldsymbol{\tau}$ ) have a thin peristome, somewhat prominent in front. Sometimes the tremocyst is detacher from the molerlying olocyst (fig. 9).

Affinities.-This species differ's from IIippodiplosia petiolus Lonsdale, $\mathbf{1 8 4 5}$ in its hollow zoarium and its shorter zooecia.

It differs from II ipporliplosia strangulata in its shorter apertme and in the absence of a peristomial avicularium.

Occurrence.-Vicksburgian (Mariamma limestone): Salt Momtain, 5 miles sonth of Tackson, Alabama (rare).

Vicksburgian (Red Bluff clay): Seven and one-half miles southwest from Blaclen Springs, Alabama (rare).

rotypes.-Cat. Nos. 64278, 64279. U.S.N.M. 
FIPPODIPI.OSIA BACCATA, new species.

Plate $5 \mathfrak{\imath}$, figs. $\mathfrak{5}, 6$.

Description.-The zoarium incrusts shells. 'The zooecia are short, little distinct : the frontal is somewhat convex; it is formed of a tremocyst with widened pores surmounting an olocyst with very small pores; between the tremopores there are some very small peart-like tuberosities. The aperture is somewhat oval, the point below; the peristome is wide, smootl, a little salient, complete. The ovicell is hyperstomial and very fragile. On the same peristome, and placed laterally, there is a small avicularium (?).

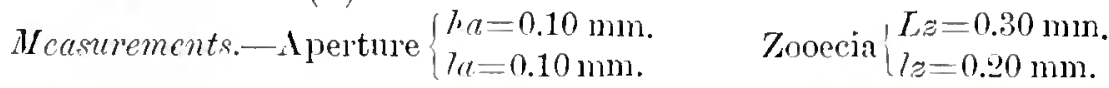

Occurrence-Vicksburgian (Byram mall) : Byram. Mississippi (common).

Vicksburgian (Red Bluff clay): Red Bluff, Wayne County. Mississippi (rare).

rotypes.-Cat. No. 6t27T. U.S.N.MI.

hipPODIPLOSIA STRANGULATA, new species.

Plate ST, firs. 10-13.

Description.-The zoarium is unilamellar; it incrusts algae or shells. The zooecia are elongated, distinct, fusiform; the frontal is convex and formed of a thick tremocyst with large pores. The apertura is elliptical, quite elougated, a little constricted in its lower parts, and formed of a large anter, separated from a smaller poster by two salient cardelles; it is buried by the derelopment of a suall peristomie; the peristome is thin, salient, without spines. The ovicell is large, globular, salient, ornamented with pores somewhat smaller than those of the frontal; it is lyperstomial, imbedded in the distal zooecium; it opens into the peristomie. In the peristomie itself or on the peristome there is a quite small orbicular avienlarium.

$$
\text { Measurcmonts. - Apertura }\left\{\begin{array} { l } 
{ h a = 0 . 2 0 - 0 . 2 2 \mathrm { mm } . } \\
{ l a = 0 . 1 4 0 . 1 5 \mathrm { mm } . }
\end{array} \quad \text { Zooecium } \left\{\begin{array}{l}
l z=0.70-0.77 \mathrm{~mm} . \\
7 z=0.30-0.35 \mathrm{~mm} .
\end{array}\right.\right.
$$

Variations.-The micrometric dimensions of this species vary much and are of little use; this is the habitual rule of species growing upon varions kinds of $51 \mathrm{~b}-$ strata; there are some wide zooecia (fig. 11), some narrow zooeria (fị. 10) and some bordered zooecia (fig. 12).

Exteriorly this species has the aspect of Porelle; it has all the escential characters; tremocyst, peristomial avicularium and ovicell opening into the peristomic. The two cardelles alone reveal to us a different hydrostatic system. The reader may be convinced of this by consulting our anatomical talles of the llippoponina and Smittinidae and in comparing their compensatrices. Noreover, species of this sort have a chitinous operculum very different from the opercula of Smittinidae, as it is easy to observe, notably in Eschara lamellosa. The absence of the chitinons appendages and of the polypide is often very unfortmnate for the paleontologist. 
because he must draw on his personal experience for the positive elements of appreciation.

Affinities.-The species differs from Hippodiplosia magniporosa, in which the zoarium is also unilamellar, in the greater length of its apertura and zooecium, chiefly in the presence of the median peristomial avicularium.

Occurrence-Vicksburgian (Marianna limestone): West bank of Conecuh River, Escambia County, Alabama (very rare) ; Murder Creek, east of Castlebury, Conecnh County, Alabama (rare); near Cla iborne. Monroe County, Alabama (rare). Vicksburgian (Byram marl): Byram, Mississippi (very rare); Vicksburg, Mississippi (rare in the upper beds).

Cotypes.-Cat. Nos. 642s0, 64281, U.S.N.M.

Genus HIPPOZEUgosella Canu and Bassler, 1917.

1917. Iippozcugosella CANu and Bassuer, Synopsis of American Early Tertiary Cheilostome Bryozoa, Bulletin 96, United States National Museum, p. 42.

The ovicell is hyperstomial, its orifice is large, without rapport with the operculum, and is closed by a special membrane. The aperture is elliptical; two small cardelles separate the anter from the somewhat smaller poster. The frontal is a tremocyst with small pores. The zoarium is free; the zooccia are joined two by two. No spines. Avicularia present.

Genotype.-Hippozeugosella (Bactridium) hagenowi Reuss, $18+7$.

Range.-Priabonian-Miocene.

The only species known are Bactridium hagenowi Reiss, 18ti, of the Priabonian and Cucullipora tetrasticha MacGillivray, 1895, from the Miocene.

This genus embraces the two ancient genera Bactridium Reuss. 1869, and Cucullipora MacGillirray, 1895, with limits still more extended.

Bactridium was created in 1847 by Reuss with unilamellar and biserial species. The first three species belong to Scrupocellaria. A gain, in 1869, he maintained his genus, but with Bactridium hagenowi Reuss, $184 \bar{t}$, as a type and with a definition based upon the zoarium. In 1891, Waters in stulying this species discovered that it had a schizoporellidan aperture. It is very diflicult to establish the limits between the schizoporellidan and hippoporinan apertures in the fossil forms.

The genus Cucullipora MacGillivray, 1895, embraces the bilamellar and biserial species in which the orifice is prorided with labial processes. The inconstance of the latter does not permit them to be considered as generic characters. They occur in other genera, such as Wratersipora, Lagenipora, etc.

In the American Tertiary we have one unilamellar, biserial species. Five other species are bilamellar and biserial; the edge of the two lamellae is visible laterally with a very characteristic aspect. This edge is lidden in a single species (Hippozeugosella scxordinata) ly the addition of two supplementary lows. In all these species the mode of ramification is identical. Each new branch is formed by the union of two zooecia arising from two consecutive zooecia (pl. 53. fig. 4). Finally, the mode of gemmation and of the pairing of zooecia reminds one of ratenicclla Audouin, 1826, Ichthyaria Busk. 1884. and Urecolipora Machillivray, 
1880 , but it is impossible to confuse them, as these genera lave quite different characters. Catenicella possesses gonoccia; Urceolipora is provided with an endozooccial ovicell and Ichthyaria has no avicularia.

\section{HIPPOZEUgosella TEges Canu and Bassler, 1917.}

I'late 53 , figs. $1-6$.

1917. Hippozengosella téges CaNu and Bassler, Synopsis of American Early Tertiary Cheilostome Liyozoa, Bulletin 96. United States National Museum, p. 42, pl. 4, fig. 5.

Description.-The zoarium is free, erect, unilamellar, formed of two longitudinal rows of zooecia; on the dorsal the zooccia are convex, altemate, and they have the aspect of a mat. The zooecia are distinct, elongated, hexagonal; the frontal is convex and formed of a tremocyst with very small pores. The aperture is orbicular and formed of a large anter and with a smaller poster separated by two very small cardelles; the peristome is complete, broad, and infundibuliform. On the peristome itself and near the zoarial axis, there is a small round avicularium provided with a pirot. Ovicell?

$$
\text { Measurements.-A perture }\left\{\begin{array} { l } 
{ h a = 0 . 1 1 \mathrm { mm } . } \\
{ l a = 0 . 1 1 \mathrm { mm } . }
\end{array} \quad \text { Zooecia } \left\{\begin{array}{l}
L z=0.70-0.75 \mathrm{~mm} . \\
l z=0.45 \mathrm{~mm} .
\end{array}\right.\right.
$$

Affinitics.-The frontal pores are very small and are easily filled up. The frontal and the dorsal are covered with very small granulations. The formation of the branches is effected by the union of two zooecia arising from two superposed zooecia (fig. 4).

This species differs from Bactridium hagenowi Reuss, 1847, in the absence of a frontal avicularimm, in the absence of two peristomial tubereles, and in the absence of areolae on the dorsal.

Waters, ${ }^{1}$ in 1821 , when studying the species from the Vicentin described the aperture as schizoporellidan. We have not exactly verified this form in our American species. We have discovered two triserial specimens (figs. 5, 6) which are perhaps the bases of the zoaria.

Oceurrence.-Jacksonian (Zenglodon zone) : Coroa post office, Choctaw County, Alabama (very rare).

Upper Jacksonian (Ocala limestone) : Chipola River, east of Mariamna. Jackson County, Florida (common).

Cotypes.-Citt. Yos. 6:2591, B4099. U.S.X.M.

\section{HiPPOZEUGOSELLA DISTORTA, new specics.}

I'late $5 \%$, tigs. 19-21.

Deseription.-The zoarium is free. subcylindrical; it is formed of two lamellae, back to back with two zooecial rows not united by the lateral zooecia. The zonecia are elongated, distinet, fusiform; the frontal is rery convex and formed of a tremocyst with small pores. The aperture is elliptical, elongated, imbedded; the peristome is irregular and formed of three distorted lamellae leaving between them

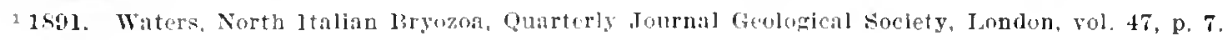


a double rounded indentation. The ovicell is globular, salient, ornamented with small pores. as the frontal; its orifice is very large and placed above the aperture. In the peristomie itself there is a small aricularium.

$$
\text { Ieasurments. I perture }\left\{\begin{array} { l } 
{ h a = 0 . 1 3 \mathrm { mm } . } \\
{ l _ { a } = 0 . 0 9 \mathrm { mm } . }
\end{array} \quad \text { Zooecia } \left\{\begin{array}{l}
L z=0.75 \mathrm{~mm} . \\
l z=0.40 \mathrm{~mm} .
\end{array}\right.\right.
$$

Variations. - The labial processes which form the peristomie give to the species a deformed and curious aspect; they are rery fragile and break very easily in fossilization. The broken portion shows the small peristomial avicularium.

The mode of gemmation is interesting. It occur's on the edge; the risible zooeciules form the base of the distal zooecia of the other face.

A finities.-This species differs from IIippozeugosnlla (Cuenllipora) tetrasticha MacGillivray, 1895, in its smaller dimensions and its avieularium much smaller and never frontal.

It differs from II ippozengosella areuata in the absence of the peristomial tongue and in the larger development of its labial processes.

The only specimen found in here figured.

Oecurrence-Middle Jacksonian: Eighteen miles west of Wrightsville, Johnson County, Georgia (very r'are).

IIolotype.-Cat. No. 6t098, U.SN.M.

HippozeUgosella ARCUATA, new species.

Plate 53 , figs $21-25$.

Inscription.-The zoarium is free, bilamellar; each lamella is biserial. The zooecia are distinct, elongated, arehed; the frontal is very convex; it is formed of a lirect tremocyst with rither large pores. The aperture is oblique, elliptical or orbicular, imberlded. The peristome is somewhat salient, and its distal part is a little isolated tongue. The oricell is hyperstomial, globular, salient, covered with tremopores like the frontal; it is opened by a large orifice above the aperture. No aviculariı.

Measurements:-Aperture $\left\{\begin{array}{l}h_{a}=0.13-0.14 \mathrm{~mm} . \\ Z_{\ell}=0.11-0.12 \mathrm{~mm} .\end{array} \quad\right.$ Zooccia $\left\{\begin{array}{l}L_{z}=1.10-1.20 \mathrm{~mm} . \\ 7 z=0.30 \mathrm{~mm} .\end{array}\right.$

Affinitics.-This species is very well characterized by its much arched zooecia. Certain fragments are narrowed toward the bottom as if the zoarium might have been articulated. We have also found a triserial fragment (fig. 25) growing from a single zooecium. The zooecia and the little tongue are quite visible on the edge of the zoarim (fig. 21, 23); between the zooccia there al'e no rooeciules as in the other species of the same genus.

This species differs from Ilippoarngosente distorta in its much less developed labial processes and in its arehed and much longer zooecia ( $L z=1.10$ instead of $0.75 \mathrm{nmm}$.).

It differ's from II ippozeugosella marginata in its nommarginated zooecia, its smaller tremopores, and its zooecial length greater than $1 \mathrm{~mm}$.

Oeeurrence.-Lower Jacksonian (Moodys marl) : .Tackson, Mississippi (common).

Cotypes.-Cat. No. 6 1103 , U.S.N.M. 
NORTH AMERICAN LARL, TERTIARY BRYOZOA.

HIPPOZEUGOSELla margiNata, new species.

I'late 5is. firs. 9-11.

Description.- The zonrium is free, bilamellar; the two lamellate are separated by some zoneciules; they are hiserial. The zooecia are little elongated, distinct, rhomboidal. separated by a salient thread: the frontal is convex and formed by a tremocyst with large polygonal pores. 'The aperture is elliptical, oblique; the peristome is thin, little salient, interrupted toward the back by a small. inconstant tongue. 'The ovicell is hyperstomial, globular. salient. covered with tremopores like the frontal.

Measurements.-A perture $\left\{\begin{array}{l}h a=0.15 \mathrm{~mm} . \\ l_{a}=0.10 \mathrm{~mm} .\end{array} \quad\right.$ Jorecia $\left\{\begin{array}{l}L_{2}=0.85-0.95 \mathrm{~mm} . \\ \tau_{z=0}=0.45-0.55 \mathrm{~mm} .\end{array}\right.$

Affinitich.-This new species differs from Ilippozengosella areuate in the \%ooeciules which separate the lanellae (fig. 11) and in its zooecial length smaller and less than $1 \mathrm{~mm}$.

It differs from Ilippoapugosella inflata in the absence of peristomial avicularia and in the size of its tremopores.

Occurrenee.LLwer Jacksonian (Moorlys marl) : Jackson, Mississippi (rape). C'otypes.-Cat. No. 6t100.T.S.N.M.

HPPOZEUGOSELLA INFLATA, new species.

Ilate 5i, figs. 12-20.

Description.-The zon ritum is free, bilamellar: each lamella is biserial. The zooecia are elongated, distinet; the frontal is rery conver and formed of a tremocyst with rely small pores. The aperture is somewhat elliptical or orbicular: two very small cardelles separate the anter from the smaller poster: the peristome is little salient and is interrupted by a small. distal tongue. Two larece tubular avicularia are placed symmetrically on ach side of the aperture.

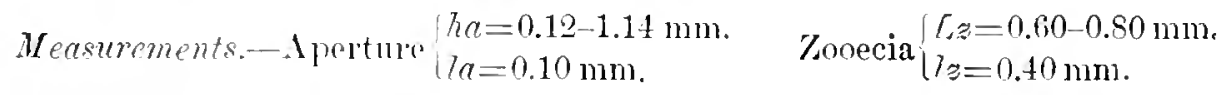

Tariations.-The young zooncia are provided with a small distal tongue (fig. 12) and the avicularia there are replaced by some tuberosities. 'The edge of the zoarium sometimes presents some intercalated zoneciules (figs. 17, 19), although sometimes they are wanting (fig. 18). Under the influence of calcification the zonecia are flat or very convex (fig. 14) ol very wide (fig. 16).

Affnitics.-This species differs from Mipposcugosella marginata and II ippozengosella areutate in the spesence of the two avicularia.

In its general aspect and its avicularia it has much resemblance to IIipposeugosella serom rinata: but it differ's in the disposition of its zoarium, which possesses only four longitudinal rows of zooecia.

Occurrence.-Middle Jacksonian: One-half mile sontheast of Georgia Kaolin Co. Mine, 'Twiggs County, Georgia; Balclock, Barnwell County, South Carolina.

rotypes.-Cat. Nos. 64101, 61102. IT.S.N.M.

$$
\text { 5.899-19 Th111. 101;- -20; }
$$


I'late 53, figs. 7,8 .

Description.-The zoarium is free, cylindrical, or foliaceous, formed of six longitudinal rows of zooecia. The zooecia are distinct, elongated, elliptical or fusiform; the frontal is very convex and formed of a tremocyst with very small pores. The apertme is suborbicular, somewlat imbedded; the peristome is wide, little salient, interrupted by a small distal tongue. The ovicell is globular, salient, hyperstomial, corered with tremopores like the frontal. On the peristome of ench side of the aperture there are two small tubular avicularia with a pivot, the beak of which is turned toward the interior of the apertme.

$$
\text { Measurements.-Aperture }\left\{\begin{array} { l } 
{ h a = 0 . 1 2 \mathrm { mm } . } \\
{ l a = 0 . 1 0 \mathrm { mm } . }
\end{array} \quad \text { Zooecia } \left\{\begin{array}{l}
L_{z}=0.85 \mathrm{~mm} . \\
l z=0.35-0.40 \mathrm{~mm} .
\end{array}\right.\right.
$$

Affinities.-In its exterior aspect, its conver zooecia. and the smallness of its tremopores, this species much resembles Hippozcugosella inflata. It differs from it in the somewhat larger zooecial dimensious, and especially in the disposition of its zoarium, parts of which are occupied by two supplementary rows of zooecia.

It therefore approaches close to Hippodiplosella vespertilio, but it differs in its mode of bifurcation, which is identical with that of the other species of the same genus. It may be verified by the examination of the interiol of the zooecia. Moreover, its ovicell is closed by a special membrane and not by the opereulum.

Occurrence-Upper .Tacksonian (Ocala limestone) : Alachua, Florida.

Cotypes.-Cat. No. 6t100, U.S.N.M.

Gemus HipPADENElla Canu and Bassler, 1917.

This new gemus is based upon Porella (Flustra) margaritifera Quoy and Gaymard, 18s3, and is described on page 497 under the Smittinidae. We believe the gemus to be more naturally placed under the Hippoporae, and for that reason have mentioned it at this point.

\section{Group 3, PERISTOMELLAE Canu and Bassler, 1917.}

Anatomical bibliography.-1577. Bargols, liecherches sur l'embryologie dies Bryozoaires, pl. 8, figs. 22, 31,40.-1885. Waters, On the nse of the aricularian mandible in the determination of the Cheilostomatous Bryozoa, Jonrnal of the Royal Microscopical Society, ser. 3, vol. 5, pl. 14, fig. 25.-JSSS. Jurlien, Mission scientifique du Cap Horn, 11. 9, fig. 2.-1909. IJEvinsen, Morphological and systematic studies on the Cheilostomatous Bryozon, p. 317, pl. 17.

The aperture is oblique without lyrula, cardelles, or rimule. The ovicell is Inyperstomial and embedded in the distal zooecia. It opens above (and nearly opposite) the oblique aperture and below the frontal mucro in a locella, where the operculum operates.

The disposition of the ovicell in respect to the operculum is close to that of the Smittinidae. Nevertheless the family differs from the Smittinidae in the absence of a peristomie. Between the aperture and the orifice of the ovicell there is, as it were, a sort of chamber or locella in which the operculum moves and takes 
shelter from extraneons influences. The orifice of this chamber is irregular; it is not a peristomice, since it has no peristome. The tentacles must necessarily be long and flexible.

The locella is the equivalent of the peristomie; it assumes the same functions with great economy of calcification.

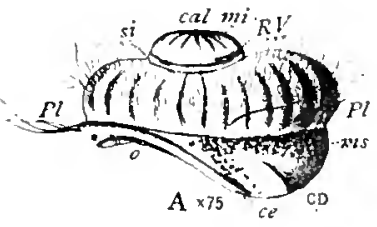

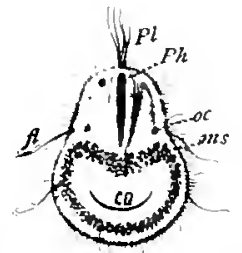

B $\times 50$

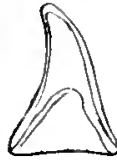

$\mathbf{F} \times 85$

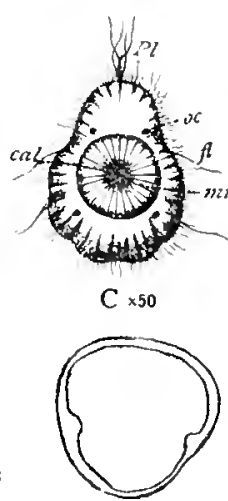

E $>85$

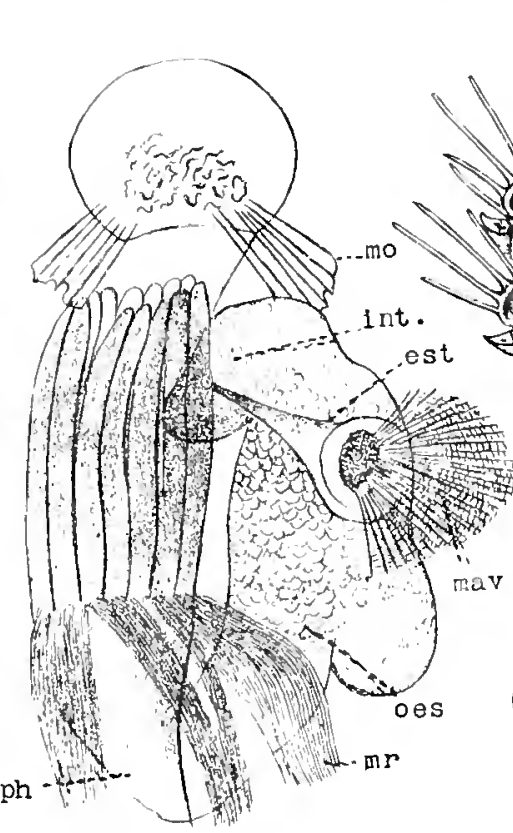

$1 \times 210$
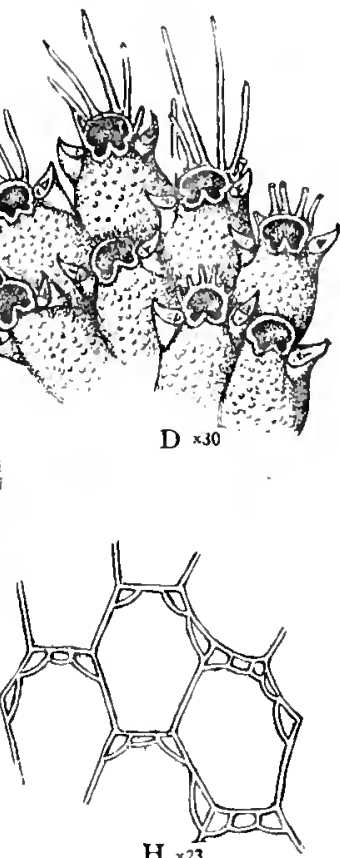

Fig. 118.- Matomy uf the leristomellat Canu and Bassler, 1917.

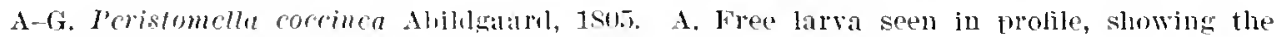
slighty exposer dispusition of the erroma and the relatively small size of the terminal but. $\times$ 75. B. Free larva, oral face, $X 50$. C. Frese lava, aboral face, $X 50$. (A-C after Barois,

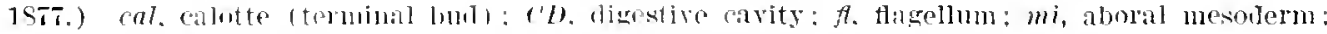

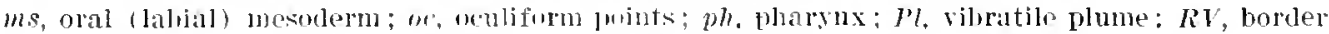

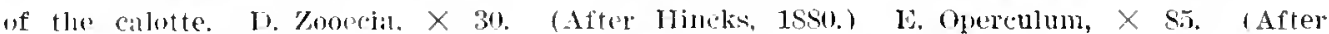

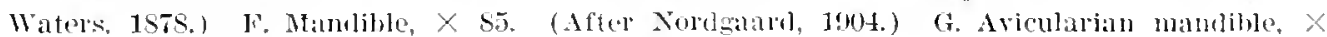
23. (Aftry Watus, 1585,)

11. Peristomella mestans Hincks, 185: Tiew from the basal surface showing dietellae, $X$ ․) (After levinsen, 1909.)

1. Exochella longirostris Jullien, 18ss. Polviule seen anteriorly, $\times 210$; the avicularium has leen drawn at its place ; its muscular fibers are erect. The feeble development of the? stomach is to be noted. (After Jullicr. 1Sss.) cst. stmmall: int, intestine (?) : mat, elevator

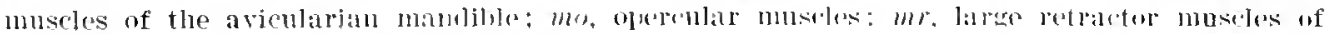
the tolypicle; ocs, esophagus; $p h$, pharyux.

'The principal genera of this group are:

Bathoset7. Canu and Bassler, 1917.

Romancheina .Jlllien, 1888.

l'reristomella Lerincen. 1902. 
Eachella Jullien, 1888.

Didymosella Camm and Bassler, 1917.

Trypematella, new genus.

They are differentiated from one another in their functions of calcification and their avicularia.

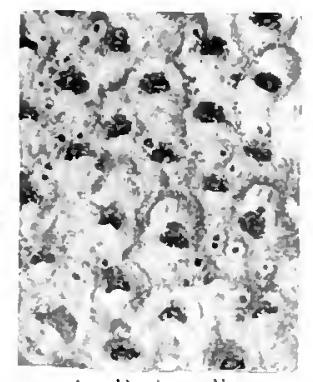

A. Buthosella

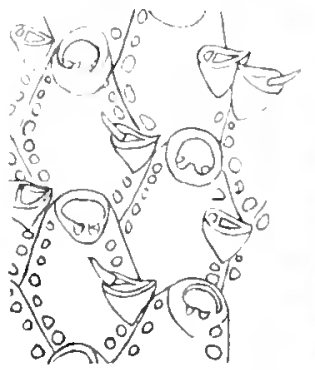

D. Exochella

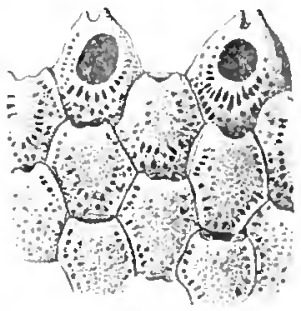

13. Romancherna

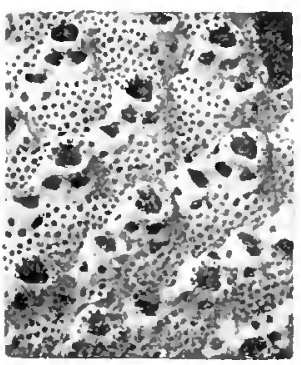

E. Didymosella

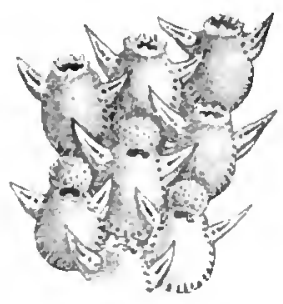

C. Peristermella

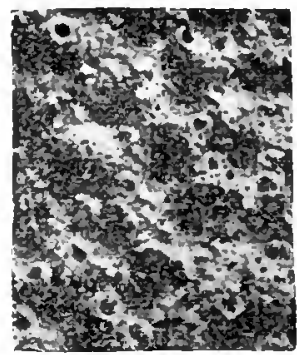

F. Trupematella

Fig. 119.-Genera of the subfanily I'eristomellae Camu and Bassler, 1917.

A. Bathosclla aspera Uhieh, $1901, \times 20$. Iowest Eurene of 1linrliand.

13. Romanchcina martinli Jullien, 1sSs, $\times \cong \%$. Recent.

C. Ieristomella cuccinca Abilingari, 1805. Hecent.

D. Exuchclla longirostris Jullien, 1sss. $\times 31$. Recent.

E. Didymosclla crussit Canu and liassler, 1917. $\times 20$. Vicksburgian of Alabama.

F. Trypcmatclla papulifera, new slecies, $\times \mathbf{2 0}$. l"loistocene of California.

\section{Genus BATHOSELLA Canu and Bassler, 1917.}

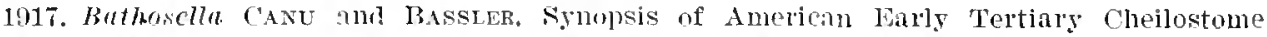
liryozoa, Bulletin :\%, Tnited States National MInsenm, p. 43.

The aperture is oblique withont lyrula, carclelles, or rimule. The ovicell is embedded in the distal zooecia. It opens above the aperture and below the frontal mucro in the locella. The frontal is a thick olocyst more or less covered by a pleurocyst. The zooecia are indistinct. The avicularia are simple and irregularly placed. The areolae are very rave. No spines.

Genotype.-Bathosella (Nucromella) repere Uluich, 1901.

Ranar.-Eppor cretaceous-Midwiyatl. 
BATHOSELLA ASPERA UIrich, 1901.

l'late 1. tigs. $27-31$.

1901. Mucronclla aspera ULricr. Maryland Geological Survey, Eucene, 1). 221, 17. 60. figs. 17,18 .

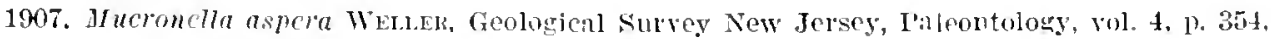
pl. 26, figs. 14, 15.

"Zoarimm inerusting, consisting of one or more layers; surface under a low power of magnification, presenting a decidedly rough aspect. Zooccia varying from orate-hexagonal to suluhomboidal, indistinct externally, arranged more or less irregularly, though the rows are more regular than they may appear at first sight; about six in $2 \mathrm{~mm}$. Apertures rounded or subquadrate, $0.13 \mathrm{~mm}$. in diameter, rendered oblique by the eleration of the more or less strongly swollen posterior margin and the depression of the anterior part. The central portion of the raised lip forms a "mucro' of greater or less thickness and prominence, the same hiding a minute centril tooth bencath it and forming, with the rest of the thickened portion of the lip, a more or less obscure rescmblance to the figure W. Behind the lip the surface slopes ritpidly and in the most nearly perfect example is gramulose. In the depressed space in front of the apertme there are. normally, three small raised avieularia (vibracula?) while a few langer avicularia, differing further from the others in being divided into two unequal parts by a crossbar, are scattered withont order among the zooecia. Ooccia are not often seen. When present, they occupy the depressed space in front of the aperture, are cucullate, about as large as the zooecial apeltur'. and usually bear a furrow ruming from the summit to the concave edge."

$$
\text { Measurements. Aperture } h a=0.12 \mathrm{~mm} . \quad \text { Zonecia }\left\{\begin{array}{l}
L z=0.40-0.50 \mathrm{~mm} \text {. } \\
7 z=0.30-0.3 \mathrm{~mm} .
\end{array}\right.
$$

There is very little to add to Ulrich's exedlent description quoted above. The wall of the ovicell is formed of two calcareons layers. but the upper layer is incomplete and often forms a very narrow collar around the lower one. 'The avicularia symmetrically disposed on each side of the aperture are not rare. The zoarimm is incrusting small shells.

Ocmerence.-Lowest Eocene. (Bryozon hed at base of Aquia formation): Upper Marlboro, Maryland (ride).

Geological distribution.-Cretaceons (Vincentown limesand): Tincentown. etc. New Jersey and Delaware.

Plesiatype.-Cat. No. 6:3782, U.S.N.M.

BATHOSELAA CINGERANS, new species.

Plate 8 , figs. $7-10$.

Description.-The zoarium is milamollar, hollow, cylintrical; it creeps on the stems of the small algae which it often cotirely smmounds. The zonecia are very little distinct. elongated; the frontal is convex and surronnded hy a line of rather large areolae. The apertur is oblique. semilunar: and its proximal border. 
is concave. The ovicell is little salient. The avicularium replaces an areola; it is elongated and inconstant.

$$
\text { Heasurements.-Zooecia }\left\{\begin{array}{l}
L z=0.65-0.70 \mathrm{~mm} . \\
l z=0.35-0.40 \mathrm{~mm} .
\end{array}\right.
$$

Affinities.-The abnormal zooecia (fig. 10) are probably hydrostatic zooecia which are intended to bioy up the zoarium when the subtratum is very feeble. The apertures do not appear to be of equal size (fig. 8); but as it is very difficult in drawing under the camera lucida to discover their true plane, it is very probable that the great differences result from deformations due to perspective.

This species differs from Bathosella aspera Ulrich, 1901, in its line of areolae and its free and not incrusting zoarium.

It differs from Bathosella undata in the presence of a continuous line of areolae around the zooecia and in its unilamellar and not bilamellar zoarium.

Occurrence.-Midwayan (Clayton limestone): Mabelvale, near Little Rock, Arkansas (common).

IIolotype.-('at. No. 6352s, U.S.N.M.

BATHOSELLA UNDATA, new species.

Plate 8, figs. 3,4 .

Description.-The zoarium is free, bilanellar, the two lamellae, back to back, and inseparable. The fronds are undulated. The zooecia are indistinct, elongated; the frontal is smooth, vcry little convex; it bears laterally 3 to 5 areolae. The aperture is very oblique and buried in the locella by a convex mucro and very finely denticulated. The oricell is scarcely salient; it is deeply imbedded in the distal zooecia and it opens into the locella by a transverse slit.

$$
\text { M casurements.-Zoocia }\left\{\begin{array}{l}
L z=0.50-0.60 \mathrm{~mm} . \\
l z=0.35 \mathrm{~mm} .
\end{array}\right.
$$

Affinities.-This species much resembles Bathosclla aspera Ulrich. 1901, when the latter is deprived of its avicularia with pivot. It differs from it in its bilamellar and not incrusting zoarium, in its much smaller and more buried ovicell, and in the absence of all frontal al vicularia.

Occurrence--Midwayan (Clayton limestone): Mabelvale, near Little Rock, Arkansas (very rare); 1 mile west of Fort Gaines, Georgia (rare).

IIolotypc.-Cat. No. 63827, U.S.N.M.

Genus ROMANCHEINA Jullien, 1888.

1859. Romancheina Julliev, Mission Scientifique du Cap Ilorn, vol. 6, Zoologie, Bryozoaires, p. 62 .

The aperture is oblique without lyrula, cardelles or rimule. The ovicell is imbedded in the distal zooecia. It opens above the aperture and below the frontal mucro in a locella. The frontal is a tremocyst with pores more or less large. The ovicell is much smaller than the zooecia; the mucro is wide and convex. The 
avicularia are triangular, thin, transverse, rarely disposed symmetrically. Four spines. Back of the apertura there is a distal armature bearing laterally two large condyles; these condyles limit the orifice of the compensatrix.

Genotype.-Romaneheina martiali Jullien, $18 s 8$.

Range.-Jacksonian-Recent.

ROMANCHEINA HEXAGONA, new species.

Plate 53, fig. 26.

Description.-The zoarium incrusts free bryozoa. The zooecia are large, somewhat elongated, hexagonal, enlarged in the median part; the frontal is convex and formed of a tremocyst with numerous small pores in quincuin. The apertura is semilunar somewhat elongated, removed from the distal border of the zooecinm;

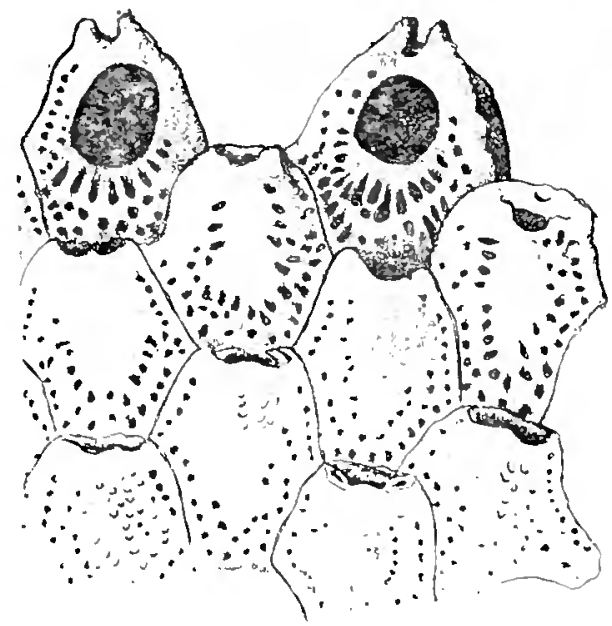

A $\times 20$
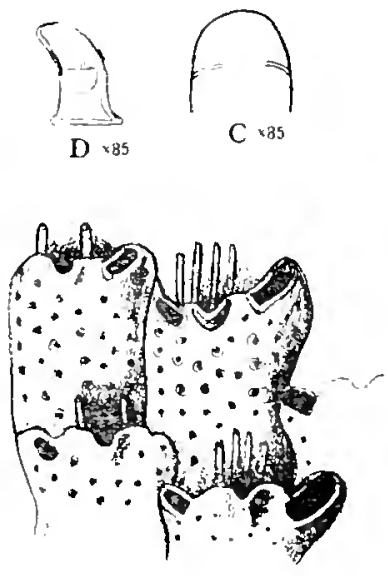

$\mathrm{B} 、 25$

FIg. 120.-Genus Romanchcina Jullien, 1888.

A. Romancheina martiali Jullien, 18s8. \%ovecia, $\times 20$. (After Jullien, 1Sss.)

B-D. Romancheina prestans, var. Waters, 1889 (not Hincks). B. Zooecia with cleft mucro, $\times 25$. C. Operculum $\times$ 8.5. D. Avicularian mandible, $\times$ 85. (After Waters, 1859.)

the peristome is little salient, very thick, ornamented with 4 distal, hollow spines with a proximal mucro little salient. The ovicell is large, little convex, of the same nature as the frontal; it is hyperstomial, deeply imbedded in the distal zooecium and it opens into the peristomie. The two symmetrical avicularia are thin, very long, disposed transversally, and with very pointed beak.

$$
\text { Measurements.-Zooecia }\left\{\begin{array} { l } 
{ L z = 0 . 6 0 - 0 . 8 0 \mathrm { mm } . } \\
{ l z = 0 . 6 0 - 0 . 7 0 \mathrm { mm } . }
\end{array} \quad \text { I pertura } \left\{\begin{array}{l}
l a=0.10 \mathrm{~mm} . \\
h a=0.12 \mathrm{~mm} .
\end{array}\right.\right.
$$

Affinitis.-This species differs from Romancheina parvipunctata in its nonterminal and nonoblique apertura, the distal part of the peristome being on the same level as the proximal portion, in its less salient mucro and in its greater zooecial midth. 
'The only specimen found has been figured.

Cccurrence.-Middle Jaclisonian (Castle Hayne limestone) : Vilmington, North Carolina (very rare).

Holotype.-Cat. No. 64104, U.S.N.M.

ROMANCHEINA PARVIPUNCTATA, new specics.

Plate 54, figs. 1-4.

Description.-The zoarium is incrusting. The zooecia are distinct, irregular, very wide; the frontal is convex and formed of a tremocyst with small pores placed on a perforated olocyst; the mucro is distinct, salient. tubular. The aperture is very oblique and hidden in the locella by a muero. 'The ovicell is small, little salient, of the same nature as the frontal; it opens well below the mucro. The avicularia are transverse, triangular, with a pirot. placed on each side of the aperture.

$$
M \text { casurements.- Iperture } h u=0.1+\mathrm{mm} . \quad \text { Zooecia }\left\{\begin{array}{l}
L z=0.56-0.60 \mathrm{~mm} . \\
l z=0.50-0.60 \mathrm{~mm} .
\end{array}\right.
$$

Teriations.-The two avicularia are small and rarely placed symmetrically; more often one of them is of much lar rer dimensions. Their disconcerting irregularity is inexplicable, for utility takes precerlence of fantasy in the animal kingdom. 'The ancestrula is a quite small zooecium with a frontal much reduced (fig. 4 ). The number of spines varies from two (figs. 1. 2) to four (fig. 4). The ovicell is always less wide than the zooecia (figs. 1,2). The tremopores are so small that they are easily filled up; the frontal appears more or less smooth. In the interior the aperture is bordered laterally by two linne condyles (fig. 3).

Occurvenen--Middle Jacksonian: Wilmington, North Carolina "(rare); near Jenuds Ferry, South Carolina (rare) : Entaw Springs, South Carolina (very rare). Cotypes.-Cat. No. 6t10z, T.S.N.M.

Genus PERISTONEILA Levinsen, 1902.

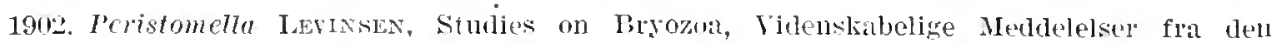
naturhistoriske Forening Kjobenharn, r. 20.

The aperture is oblique without lyula, cardelles, or rimule. The ovicell is hyperstomial and embedded in the distal zooecia. It opens above the aperture and below the frontal mucro in a locella. The frontal is an olocyst perforated by some areolae and covered by a plemocyst; the moro is very salient, generally snall and triangular. The aricularia are large and transverse; four distal spines. Dietellae. Neither armature nor condyles back of the apertur.a.

Genotype.-P'eristomella (Cellepora) coceinea Abildgard. 1805.

Range.-Lutetian-Recent.

The fossil species of this genus are:

Peristomella (Lepralia) peregrina Manzoni, 1859.

I'eristomella (Lepratia) fulgurans Mauzoni, 1870.

Peristomella (Lepratir) mamillata Wood, 1557.

Pristomella (Eschara) alifera Reuss, 1869. 
l'eristomella (Averomella) inhabitis Iioschinsky. 1885.

Peristomella (Lepratia) stremix Manzoni, 1869.

Peristomella (Lepralia) lariniuta Seguenza, 1 si9.

The recent specics are:

Peristomella (Smitia) jacksoni Waters, 1896.

Peristomella (Mucromella) pracstans Hincks, 1882 (not Waters, 190t).

Peristomella (Mueronella) contorta Busk, 1854.

Peristomella (Mucronella) labiuta Busk, 1876.

Peristomella (Escharella) enstifera Osburn, 1914.

PERTSTOMELA Coccinea Abildgaard, 1805.

Plate 87 , fig. 18 .

General bibliograph!!.

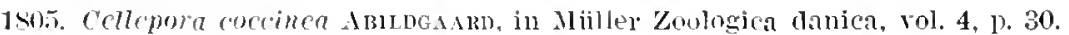

1S10. Cellepora coecinca Lamourotx, Histuile des polypiers corralligenes flexibles, p. 92.

1824. Cellepora coceinco LAmodmoux. Encyclopelic Méthorique, Ilistoire naturelle dex Zooplytes ou animaux rayounés, vol. 1t, p. 183.

1529. Berenicen coceinca Flearing, llistory of Eritish Animils, p. 5.38.

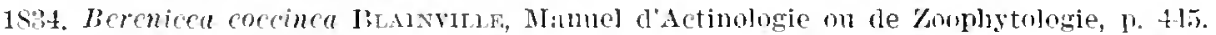

1S36. Collepora coccinea 1amarek. Histoire naturelle des animaux sans vertèbres, ed. 2. vol. 2, P. 259.

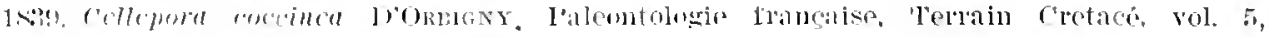
pt. 4. p. 399.

1840. Lepratia corrine Thompsox, Adilitions to the fauma of Irelami. Ammals Macrazine Natural IIjstuly. ser. 1, rol. 5, p. 25\%.

1S41. Lepralia appense Ilassadi, Supplement to a catalogue of Irish Zooplytes, Aunals Jaunzine Natural II istory, vol. T. 1\%. $30 \mathrm{~T}$.

1S41. Lepralia corcincu Ilassits, Supplement to a catalogue of Irisli Zoophytes, Annals Magaziue Natural Ilistory, vol. 7, D. 367.

1842. Lemralia appensa IlAssalx, Remarlss on the gems Lepralia of Dr. Johnston, with descriptions of six mulescriber species and notices of two other Zooplytes, Annals Magazine Natural History, vol. 9, p. 408.

1S44. Lepralia cocciner Couch, A Curmisl linua. pt. 3, p. 115.

1S44. Lepralia tridendate Coter, A Cornish Famna, pt. 3, p. 155.

18ti. Lemalia ballii Johnstus, A llistoly of the British Zoophytes, ed. 2, p. 321.

1847. Lepralia cocrinch Jon Nistox, A History of the British Zoophytes, ed. 2, 1. 322.

1StS. Escharina ballii Gisy. List of the specimens of the British animals in the collection uf the Iiritis Nuseum, nt. 1, Centroniae or Radiated Animals, wh. 1, 1. 124.

1S1S. Escharina coccinca Gror. List of the specimens of british animals in the collectiuns

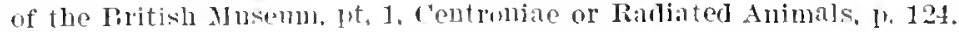

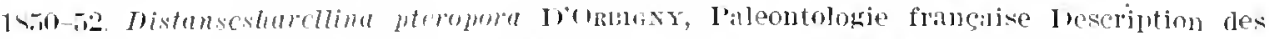
animaux invertélnès, 'l'errain crétacé, vol. 15, p. 451, liryozoaires.

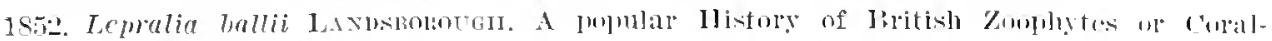
lines, p. 323.

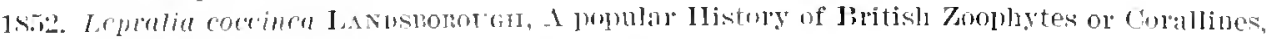
1. 8 ind.

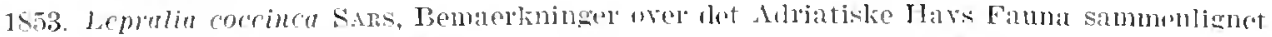
mer] Nordlavets, Nyt Magazin for Natulvidurskab, wol. T, p. 379.

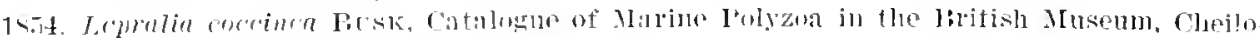
stomata. nt. 2. 1). 70.

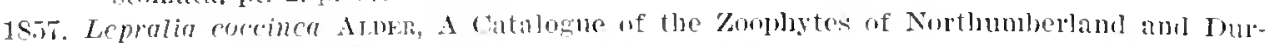

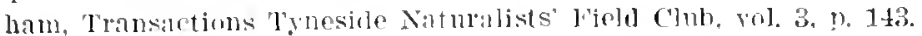


1861. Lepralia coccinca ErAuy, Notes of Algae, etc, found in the Isle of Man and on the coasts of Nortlumberlind and Durham, Annals Magazine Natural History, ser. 3 , vol. 7, p. 70 .

186:. Lepralia coccinen Hincks, A catalogue of Koophytes of South Devon and South Cornwall, Annals Magazine Natural History, ser. 3, vol. 9, p. 202.

1564. Lepralia bicornigra Jieuss, Jie Foraminiteren, Anthozoen und Bryozoen des Deutschen Septarienthones, Denlischriften der k. Akademie der Wissenschatten. Wien, vol. 25, Abtlı. 1, p. 37, pl. 12, fig. 9.

1Sti. Iiscopora appensa sMTt, Kritisk förteckning ofver Sliandinaviens-flafsbryozoer, ifrelsigt af kongl. Vetenskals-Alialemiens Förhandlingal, rol. 24, Bihang, p. 27 .

1567. Discopora coccincu Surte, Bryozon Maliua in regionibus articis et borealibus viventia. . Ofrersigt afk. Vetenslia ps-dkatemiens Firhamtlingar, 24 Agr., 1. t5i.

IStis-9. Cellepora pteropora IEuss, Die fossilien inthozoen und Bryozoen der Schichtengruppe von Crosaro. Denkschriftel del k. Alademie der Wissenschaften, Wien. vol. 29, Abtl. I, 1). 260.

1869. Lcpralia pleropora Manzoni, Bryozoi fossili italiani, 3d contribution, Sitzungsberichte der kiaserlichten A sademie der Wissenschaften, Wien, vol. 60, Abth. I, p. 934.

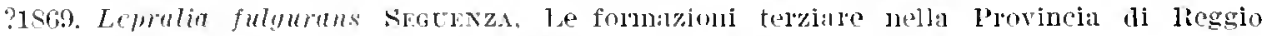
(Calabria), Reale Accademia dei Lincei Nemorie della classe di Scienze Fisiche, Matematiche e Naturali, Roma., ser. 3, vol. 6, 13ryozon, p. 200.

1869. Lepralia peregrina Manzovi, Briozoi fossili italiani, 3 d contribution, Sitzungsbericlite der kiliserdichen Akadenic der Wissenshaften, Wien, vol. 60, Abth. 1, p. 946.

1869. Lcpralia pteropora lievss, Die fossilen Folyparien des Wienel Tertiirbeckens, Haidinger's Naturwiss. Abhandlung, vol, 2, Wien, p. 263, pl. 30, fig. 4.

1S69. Lcpralia pteropor Mavzoni, Isriozoi pliocenici Italiani, Sitzungsb. der k. Akademie Wissenslaften, vol. Go, Wien, pl. 1, fig. 1 .

1570. Discopore cocrincu FIscher, Bryozoaires, Jìhinudermes et Foraminifères Marins du Dejartement de la Gironde et des côtes du sud-onest de la Frauce, Actes de la Sociêté Linnécne de Bordeaux, wul. 27 ( 3 ser, vol. 7 ), p. 24.

1874. Lemalia uncinca RuUss, Ijie fossilien Pryozoen des üsterreichisclı Ungarischen Mï̈cins, Donkschriften ler k. Akatemie der Wissensclust, rol. 33, Wien (see Manzoni ), p. 155 , ser. 15, pl. 6, fig. 11 .

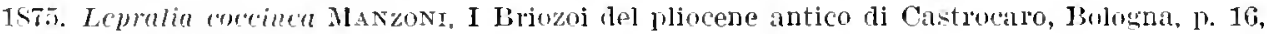
pl. 2, fig. 19 ?

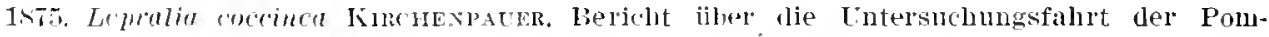

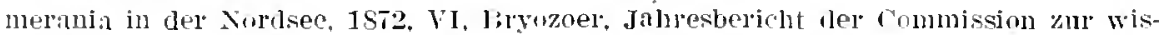
sensellafulichen Untersuchnug der deutellen Meere in Kiel, vols. a and 3, p. 187.

1875. Lcpralia fulgurans MANzon,. I Lyyuzoi del bliocene antico di Castrocajo, p. 16, Bologna.

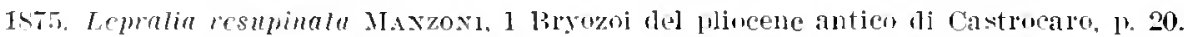

187S. Lemalia coccinea Waters, Ibyozoa (Polyzoa) from the Plincene of Isuccoli (Sicily), Transactions Mancluester Geological Society. rol. 14, p. 470.

1S7S. repralia resupinala Watens. Bryuzoa (1'olyzoa) from the Pliocenc of Bruccoli (Sicily), Transactions Manchester Geological Society, rol 14, p. 474.

1974. Ifpralia coceince Waters, On the Bryozon (Polyzor) of the Bay of Naples, Annals Masazine Natural History, ser. $\overline{1}$, vol. 3, 1. 40.

1879. Lepralia coccinea Segtenza, Le formazioni terziarie nella provincia di Regraio (Calabria), Reale Acendemia dei Incei Memorie della classe di Scienze, Fisiche, Matematicle e Naturali lioma, ser. 3, vol. 6, pp. 81, 199, 294, 328, 369.

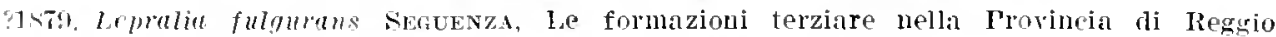
(Calabria), Ruale Aroatemia Iei Lincei Memorie della Classe di Scienze Fisiche. Matematicle "Naturali, Roma, ser. 3, vol. 6, Bryozoa, p. 200. 
1879. Lepralia resupinata SbuUenza, Ia formazioni terziarie nella Provincea di Regrio (Calabria), Reale Aceadenia dei Lincei Memoire della Classe di Scienze, Fisiche, Matenuatiche e Naturali, ser. 3 , vol, 6, p. \$1, 201.

1880. Mucronclla coccinca lincks, Eritish Marine Lolyzoa, p. 371.

1SS2. Mucronella cocinca Waters, On fossil Cheilostomatous Brrozon from Mt. Gambiel, South Australia, Quilterly Jumrual Geological Society, London, vol. 38, p. 266.

1555. Mucronella loricata Loschnskr, lieitrag zur Lenntniss der Bryozoan-fauna del alterer Tertiaschichten des sidlichen Tayerns, I, Cheilostomata, Paleontographia, vol. $32, \mathrm{p} .56, \mathrm{pl} .3, \mathrm{tix} . \mathrm{s}$.

18s6. Icpralia pteropora Gutw.um, Iryozoi Fossili di Montechio Maggiore, Atti della Societ Veneta Trentina di Scienze Naturiali, rol. 9, p. 302.

1880. Lepralia coreinea Cotrund, Iniozoi Fossili di Montechio Magglore, Atti delle Societa Veneta Trentina di Scienze Naturali, rol. 9, p. 302.

1SS6. Mucroncla coccinca IEvinsen, Bryozoer fral Kara-Haret Dijmplna-Togtets Zool. bot. Udbștte, p. 19.

1887. Mucronclla coccinca Pergexs, Les Iryozonires du Tasmadluan a Belgrade, Fulletiu des Séances Societé Royale Malacologique de Belgxique, rol. 22, p. 22.

1889. Afucranella coccinca PlGgens, Notes succinctes sur les Bryozoaires III. Bryozoailes dragués par M. Lennier aux environs de Cherbourg (Brest in error), Bulletin lies Séances Societé Royal Malacologique de Belgique, vol. 24, p. 61.

18S9. Hucronclla coccinca JeLLY, A syonynic catalogue of the recent marine Bryozoa, p. 191.

1591. Smittia coccinca Waters, North Italian Bryozoa, pt. 1, Cheilostomata, Quarterly Journal Gcological Society, vol. 41, p. 21, pl. 3, fig. S.

1895. Smittia (Mucranella) coccinca Neviaxt, Briozoi fossili della Farnesina e Monte Marino presso Roma, l'aleuntologica Italica, vol. 1, I'isa.

1596. Smillia (Ancronclla) coccinea NEvani, Briozoi postpliocenel di Spilinga (Calabria) Atti . Cadenia Givenia Scienze Naturalli, vol. 9, ser. 4, j. 43.

1897. Ducronclla coccinca CALIET, Resultats scientifiques de la Canpagne du Culan dans le golfe de Gascogne, Annales de Université de Ixyon, vol. 26, p. 262.

1599. Smittia coccinca Waters, Bryozoa from Madeira, Joulnal Royal Microscopical siciety, p. 16 .

1900. Smittia (Mucronclla) coccinca Neriavi. Eriozoi neogenici delle Calabrie, Paleontographia Italica, vol. 6, p. 209 , ser. 95, pl. 15, ser. 3, fig. 9.

1900. Mucronella coccinca Nondgard, Den Norske Nordhar's expedition, p. 14.

1902. Ducronella coccinca Calvet, IByozonires mains des cotes de Corse, Travaux de l'Instituté de Zoologie de l'Université de Montpellier, ser. 2, Memoire 12. p. 33.

1902. Hucronclla coccinca Calvet, Rryozoaires marins de la region de Montpellier, Travaux de l'Institut de Zoolorie de l'Université de Moutpellier, ser. 2, Memoire 11, p. 60.

1905. Escharoides coccinca Noraras, on the Polyzon of Madeira, Innean Soeipty Journal, vol, 30, p. 304.

1906. Peristomella coccinca Nordgatld, Die Iryozoen des westlichen nolwegens, Bergens MIuseum Meers fauna von kergen, p. 94.

1905. Peristomella coccinca Canu, Bryozoaires des Terrains tertiares des environs do Pallis, Anmales de Palcontologie, vol. 3, 1). 87 , pl. 10, fig. 12.

1900. Fscharoides coccinea Ifwinses, Morpholorical and Systematic Studies on the Cheilostomatous Bryozoa. P. 218.

1912. Mucronella coccinca Grenis-Givivet, Contributions a l'etude des Bryozoailes des

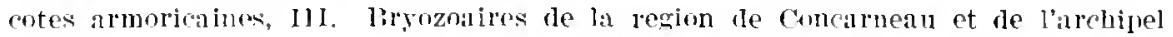

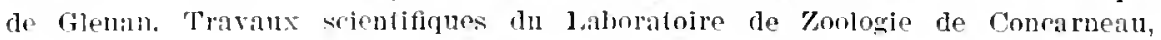
rol. 4. I. 16. 
'This cosmopolitan species is rery widespread in Europe since the Lutetian. in its normal form. Here in Amerien it does not begin until the Vicksburgian and it is not abundant.

The characteristics of this species are: (1) A peristome complete in front and with 6 spines behind; (2) a small mucro placed in a groove of the peristome; (3) two large oblique avicularia. The orifice is an orbicnlar extermal aperture withont any connection with the real aperture which is invisible and buried below the mucro.

Occurrene.-Tickshurgian (Mariama limestone): West bank of Conecuh River, Escambia County, Mabama (common) ; Murder Creek, east of Castlebury, Conceuh County, Alabama (1'are).

Geotogical Distribution.--Lutetian of Bararia (Koschinisky) and of Paris (Canu); Priabonian of the Vicentin (Reuss. Gottardi: Waters), of Transylvania (Pergens); Chattian of Germany (Reuss); Burdigalian of the Gard (Pergens); Helretian of Servia (Pergens), of Italy (Seguenza, Neviani), of the Gard and the Herault (Cam), of Touraine (Camu) ; Tortonian of Austria-Iungary (Reuss); Zanclean of Italy (Seguenza); Sahelian of Algeria (Canu); Plaisancian of Italy (Manzoni. Neriani); Astian of Italy (Seguenza); Sicilian of Italy (Seguenza, Neviani): Quaternary of Italy (Seguenza, Neviani); Miocerie of Australia (Waters).

This species is chiefly littoral. It has been observed in the eastern Atlantic from Marleira to Spitabelg, and in the western Mediterranean from 0 to 100 meters of depth. Nerertheles it has been dredged from 180 meters in the Gulf of Gascony and from 34 meters north of Norway. In this last station the temperature of the depths was $+3.5^{\circ} \mathrm{C}$.

l'7esiotypes.-Cat. No. 642S.'. U.S.N.M.

Peristomella Coccinea resupinata Manzoni, 1875.

Plate 87 , fig. 14 .

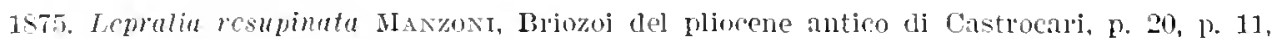
fig. 26.

1900. Jucronellt eoccince, var. resupinata Neviasi, Bryozon neogenica delle Calabrie Paleontographia Italica, vol, 6, p. 216 (96) (Bibliograplyy legional).

This variety is characterized by the length of the false peristone. Below the externul aperture there is an elongated tubular part which is not a true peristomie. but a simple modification of the frontal. This modification probably aims to give a tubular form to the locella and to thus facilitate the extrusion of the tentacles. 'The interireolar costules are also much aceentuated. On the proximal part of the peristome there is a small overhanging mucro.

In France we have never observed this variety. In Italy, according to Segu(nza, it is not rare to find some specimens marking the intermediate stages from the type. Ifere in Anerica the zoarium is incrusting sometimes; more often it is free and more or less vinculariform; it is probable that the axis of such zoaria is formel by a tios of thin filaments of alwa alomnd which the zooecia are gromped. 
Ocenrrenee.-Vicksburgian ("Chimney rock" of Marianna limestone): One mile north of Monroeville, Alibama (rare).

In Europe this variety has been observed since the Helretian in the same countries as the type species itself, but it has never been mentioned as recent.

It is remarkable that Peristometle roccinea Abildgaard, 1805, has disappeared from the western Atlantic and from the Gulf of Mexico since the commencement of the Miocene.

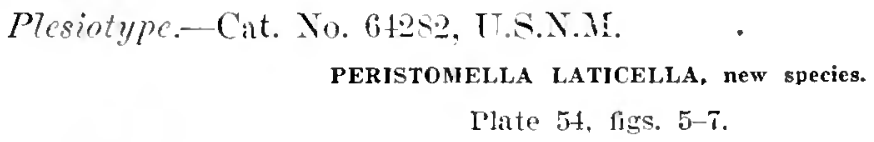

Description.-The zoarium incrusts shells and bryozoa or creeps over algace The zooecia are distinct, wide, aliform; the frontal is convex, smooth, surrounderl by a line of crowded areolae: it is formed of an olocyst corered orer and intimately united with a plemrocyst. The aperture is rery oblique (about $45^{\circ}$ ) semilunar, transverse, hidden under a salient and wide mucro; the proximal part of the peristome bears four large spines. The oricell is hyperstomial, but embedded in the distal zooecia; it is salient, wide, trinsrerse, globular, smooth, surrounded by rery small areolae, identical with the frontal. The two avicularia are large, triangular, with pivot, transverse, symmetrically placed. The ancestrula is small.

Measurements.-Exterual aperture tpri=0.15 mm.

$$
\text { Zooecia }\left\{\begin{array}{l}
L_{z}=0.55-0.60 \mathrm{~mm} \\
7, z=0.50-0.60 \mathrm{~mm} .
\end{array}\right.
$$

Affinities.-The analogy of the oricellarian walls with the frontal is easy to observe on this species (fig. 6) : the pleurocyst is more or less thick. The ancestrula is a small ordinary zooecium.

In its form and general aspect this species is close to Peristomello alifera Renss, 1869. from the Vicentin. It differs from it in its incrusting and non-bilamellar zoarium and in its wide zooecia.

It differs from Peristomella coecinea Abildgaard, 1505, in its transverse ovicell, the entire absence of a false peristomie. its much wider zooccia $(l \&=0.50-0.60 \mathrm{~mm}$. and not $0.30 \mathrm{~mm}$.). and the presence of six spines (and not four).

It differs from Peristomelle sperta aurl P. futgurans Manzoni, 1870: in its avieularia disposed trausversely and not longitidinally.

Oceurence.-Lower Jacksonian (Mondys marl) : Jackson, Mississippi (rare). Middle Jacksonian: Wilmington. North Carolina (very common); near Lenuds Ferry, South Carolina (rare); 18 miles west of Wrightsville. Jolmson County, Georgia (very rare) : 31 miles north of Grovimia. Georgia (very vire).

Upper Jacksonian (Ocala limestone) : West bank of Sepulgal Rirer, Eccambia County, Alabama (common).

Cotypes.-Cat. No. 6t107. U.S.N.M.

\section{PERISTOMELLA ERECTA, new species.}

Plate Si, fiss. 16,17 .

Description.-The zonrium incrusts shells. The zoocia are distinct. elongated. elliptical; the frontal is convex, smooth. bordered by areolae and covered by a thick 
pleurocyst filling up the interareolar costules. The aperture is very oblique, invisible, hidden by the mucro; the peristome is little salient, elongated, elliptical; it bears proximally a small mucro triangular and salient; it bears laterally and distally 6 to 8 spines. The lyyperstomial ovicell is imbedded in the distal zooecia; it is globular, salient, orbicular, of the same nature as the frontal. The avicularia
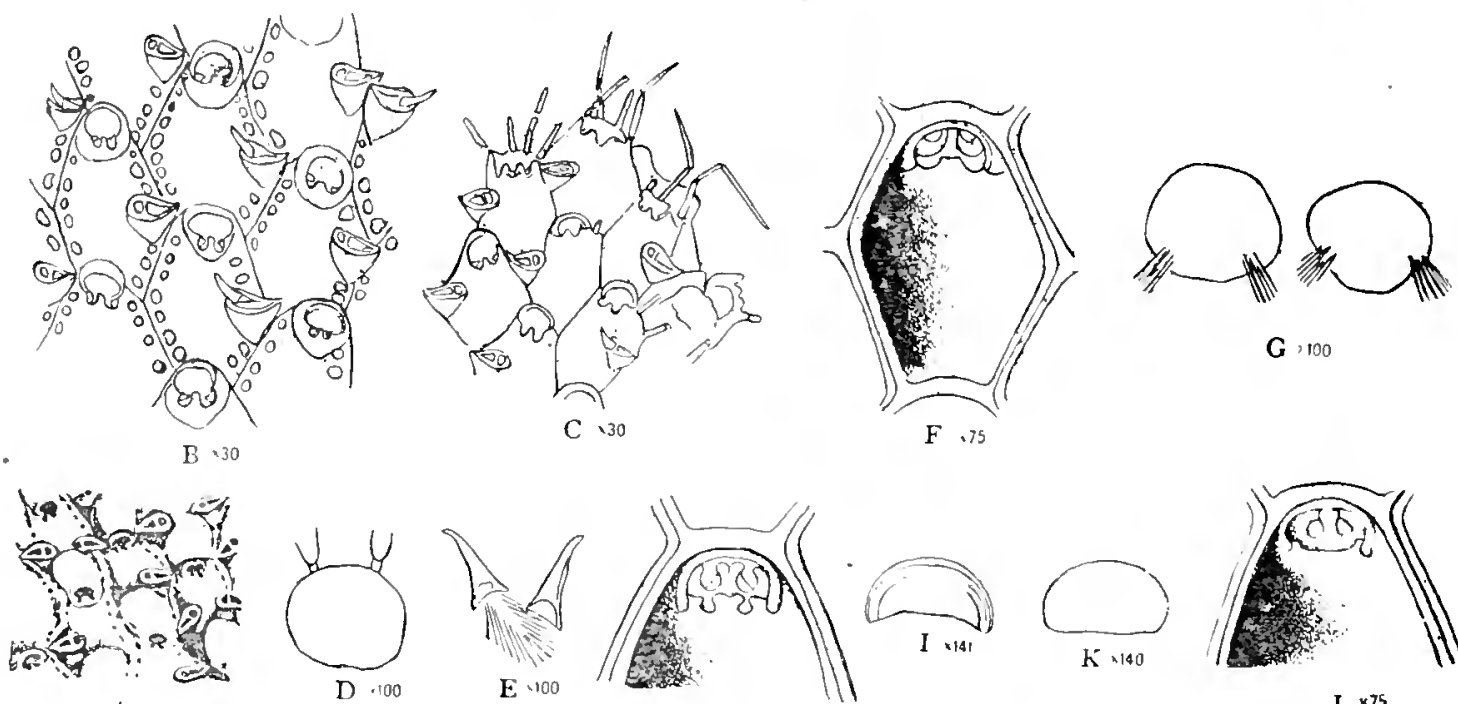

A.20
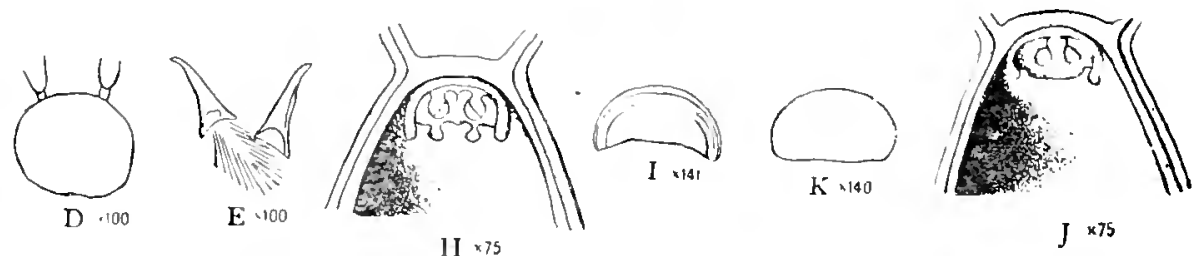

Fig. 121.-Genus Frochella Jullien, $18 s 8$.

A-G. Exochella longirostris Jullien, 1Sss. A. Ovicelled zooecia, $\times 20$. B. Young unovicelled zooecia, $\times$ 30. C. Young zooecia, $\times 30$, proviled with marginal artieulated spines, $3 \mathrm{or}^{4} \mathrm{in}$ number. In this singular species the peristome in growing has an abnormal tendency to bear either to the rigbt or to the left, abandoning some of the marginal spines of the orifice. The latter are then isolated ontside of the orifice, elose to the line of selration of the zooecia. This curious oceurrence is observed chiefly on the zooecia bearing cnly a single avicularium. The appearance of the avicularium seems, therefore, to be the cause of the change of direction of the peristomes of such zooecia. D. Orifice bearing two spines, $\times$. 100 . F. Aricularia, $\times$ 100, one of which is provided with the retractor muscle. (After Jullien, 18ss.) F. Interior, showing the aperture and the locella, $\times 75 . \quad$ G. Opereula, $\times 100$. (After Levinsen, 1909.)

H, I. Exochella lobata Levinsen, 1909. H. Interior, showing the apertura, locella, and the vestibular arch, $\times$ 75. I. Opereulum, $\times$ 140. (After Levinsen, 1909.)

J, K. Fxochella tricuspis Hinclss, 1881. J. Intelior, $\times 75$, showing the vestibular arch, the apertura, the locelli, and three coalesced teeth. K. Operculum, $X$ 140. (After Levinsen, 1909.)

are straight, very long triangular, with pirot, placed symmetrically and longitudinally.

Measurements.-External aperture $7 p i=0.1+\mathrm{mm} . \quad$ Zooecia $\left\{\begin{array}{l}T_{z=0}=0.60 \mathrm{~mm} \\ 7 z=0.35 \mathrm{~mm} .\end{array}\right.$

T'ariations.-The exterior aspect is quite variable, as in all the species with a pleurocyst; this is not deposited on the young zooecia. The interareolar costules are formed first (fig. 1); their intervals become filled up and the zooecia are then corered by this finely granulated deposit which is characteristic of the pleurocyst. 
The texture of the frontal of the ovicell is iclentical, but the areolae are much smaller. In front of the ovicell 2 or 4 spines often persist. The direction of the a vienlaria is not very constant; they are sometimes somewhat oblique.

Affinities.-This is the Ameriean representative of Peristomella fulgurane Manzoni, 1sio, of the Italian Pliocene. Onr species differs from it in a lesser convexity of the frontal and in the avicularia, which are straight (and not somewhat arched) and which nerer touch the peristome.

This species diflers from Peristomella laciniata Seguenza, 1579. in the absence of a false peristomie and in the elliptical, elongated form of its external aperture.

It differs from Peristomella luticella and $P$. coccinea Abildgaard, 1905, in its avicularia placed longitudinally (and not transversally).

Occurrence--Vicksburgian (Marianma limestone): Near Claiborne, Monroe County, Alabama.

Cotypes.-Cat. No. 642s4, U.S.N.M.

PERISTOMELLA FALCIFERA, new species.

Plate 5t, figs. S-10.

Description.--The zoarium incrusts shells. The zooecia are large, elliptical, erect; the froutal is very convex, smooth, surrounded by a clouble line of rery small areolae, quite crowded; it is terminated distally by a salient mucro, bifid, oblique. The peristome is quite prominent, thick, garnished with six spines; the locella is rery large; the apertura (in the interior) is suborbicular, oblique, entirely hidden by the mucro. The ovicell is very large, globular, quite salient, smooth; it is hyperstomial, placed on the distal zooecium; it opens into the locella by a large orifice, facing the mucro. On each side of the apertura there are two long falciform avicularia, parallel to the zooccial axis. the beak above.

$$
\text { Measurements.-Zooecia }\left\{\begin{array}{l}
I_{z}=0.75 \mathrm{~mm} \text {. } \\
l_{z}=0.60 \mathrm{~mm} .
\end{array}\right.
$$

Affinities.-In the disposition of the avicularia, this species is near to Peristometla fulgurums, but differs in the form of the straightened a vicularia and its larger micrometric dimensions.

It differs from Lepralia complicatu Reuss, $181 \bar{i}$, in its much larger bifid muero hiding the apertura.

The convexity of the zooccia gives to the interior of the zoocia a rery peculiar geometric aspect; the locella appears as a simple slit between the zooecia and the ovicell (fig. 10).

Occurrence.-Middle Jacksonian (Castle Hayne limestone): Wilmington, North Carolina (very common).

Cotypes.-Cat. No. (it10s. U.S.N.M.

Genus EXOCHELLA Jullien, 1888.

1Sss. Exochella Jvit.JEx, Mission seientifique du Cap Hom, vol. 6, Zoologie Bryozoaires, p. 55.

The aperture is oblique without lyrula, cardelles or rimule. The ovicell is hyperstomial and imberled in the distal zooecia. It opens above the aperture and 
below the frontal mucro in a locella. The operculum is slightly chitinized and not distinetly marked off from the compensatrix. The peristome has three, sometimes coalesced teeth, a median and two lateral. Normally there is an avicularium on each side. Three dietellae. Spines. The frontal is surrounded by areolae.

Genotype.-Exochella Tongirostris Jullien, 1888.

Rangr.-Rocanean-Recent.

Genus DIDYMOSELLA Canu and Bassler, 1917.

1917. Jinymosclla CAN $\mathrm{U}^{+}$and Bassier, Synopsis of American barly Tertiary Cheilostoue Bryozoa, Bulletin 96, United States National Museum, p. 43.

The frontal is a tremocyst. Below the aperture there are two large pores which open into the zooecial, under the operculum. Spines. There is a large marginal avicnlarium, triangular, with pivot, arranged transversally.

Genotype-Clidymosella (Porina) larealis MacGilliway, 1868.

Range.-Vicksburgian-Recent.

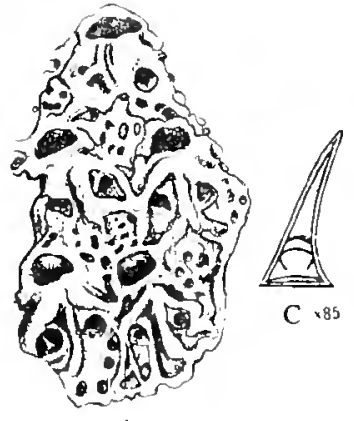

A

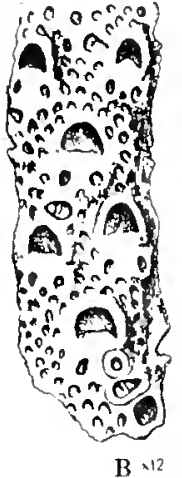

B .12

Fin. 12:- - Genus Iridymoscllu Canu aml Bassler, 1917.

1-1. Inidymostlle larralis Marcillivray, 1868. A. Koveria. (.Ifter MacGillivray, 15.5.) I3. Zooecia, $\times 12$. (After Waters, 1882.1 ('. Avicularian nandilsle, $\times 8.5$. (After Witers, 1887. The zooecia are elongated, distinct, in the form of a bottle; the frontal is convex and formed of a tremocyst with large, crowded, tubular pores. The aperture is elliptical and transverse; the salient peristome bears the traces of very small spines; two enormons pores are adjacent to the peristome. The avicularium is marginal, triangular, very large, with pivot, and arlanged transversally. The lower face is smooth and presents some large, scattered concarities.

$$
M \text { casurements. }- \text { D perture }\left\{\begin{array} { l } 
{ h a = 0 . 1 0 \mathrm { mm } . } \\
{ 7 a = 0 . 1 1 - 0 . 1 2 \mathrm { mm } . }
\end{array} \quad \text { Zooecia } \left\{\begin{array}{l}
L z=0.60-0.70 \mathrm{~mm} . \\
7 z=0.40 \mathrm{~mm} .
\end{array}\right.\right.
$$

Fariations.-In bongitudinal section we are better able to comprehend the organization of this species. In particular the dorsal wall is a very thick olocyst, 
the carities observed on the exiterior do not perforate it; they limit the zenecia betreen which they are hollowed ont. The large frontal pores open into the same zooecia (fig. t) : the tremopores are tulules: finally the avicularimm is a very large chamber bollowed in the thickness of the frontal wall.

The tangential section (fig. 5) reveals the renarkible size of the aricularium. a size which must correspond to a powerful musculature; the frontal is a tremocyst with large pores in the form of tubules; the olocyst which surround the large frontal pores show mall vacuoles.

Affinities.-This is the Imerican representative of Didymosella bioculate Waters of the Priabmian. It differs from thic European species in its frontal which is a tremoeyst and not ammished with lateral areolac.

It diflex from Didymosella (Porina) Zarealis MacGillivary, 1868, in its much more mumeroms tremopores and in its two pores placed lower.

"In recent specimens there is usually a thick epitheca (cetocyst) covering the front of the zooecia, but not chosing the peristomial pores. It may possiluy be a II iantopore." (Malu(rillivar.)

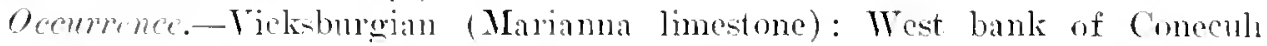
River, Escambia Comnty. Ilabana (eommom); Mureler Creek, east of Castlobury, Conecuh Comnty. Alabama (common): near Claborne. Monroe County. Mlabama (rare): 1 mile north of Momoerille, Mlabaua (rare); deep well, Escambia ('ounty. Mlabama (rely rare).

Cotypex-Cat. No. (i2.)92. T.S.T.M.

\section{TRYPEIATELLA, new genus.}

Trypemos, in allusion to the numerous perforations of the zoarium.

The oricell is hyperstminal and closed by the operoulm for the passage of the eggs. The apertma is semilumar, with proximal borker a little enneare. The fiontal bears some lateral arealar pores (plemorest on olocyst). Two large lateral areularia are placed below the apertural.

Genotype.-Trypematella papulifera, new species. Pleistocene of californial. 'The type of this gents will be descrihed in a forthcoming publication.

Group 4, MICROPOREILAE.

The orifie of the compensutrix (ascopore) is distinct and at some distance firm the apertura. The ovicell is hypersomial and closed ly the opereulum.

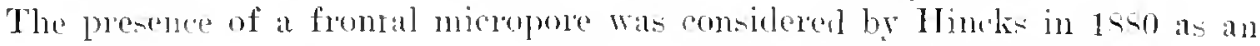

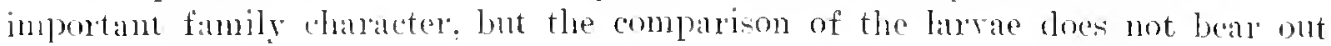
this conchu-iom.

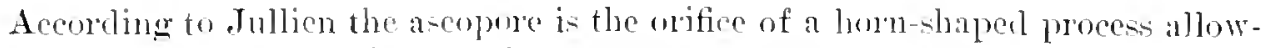
ing the exterior to commmicate with the tentacnal sheath. Il:umer and Levinsen

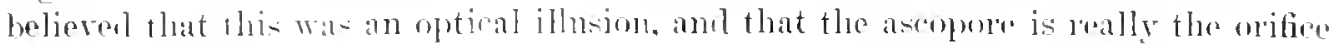
of the compensatrix.

$$
\text { 5.ง }
$$



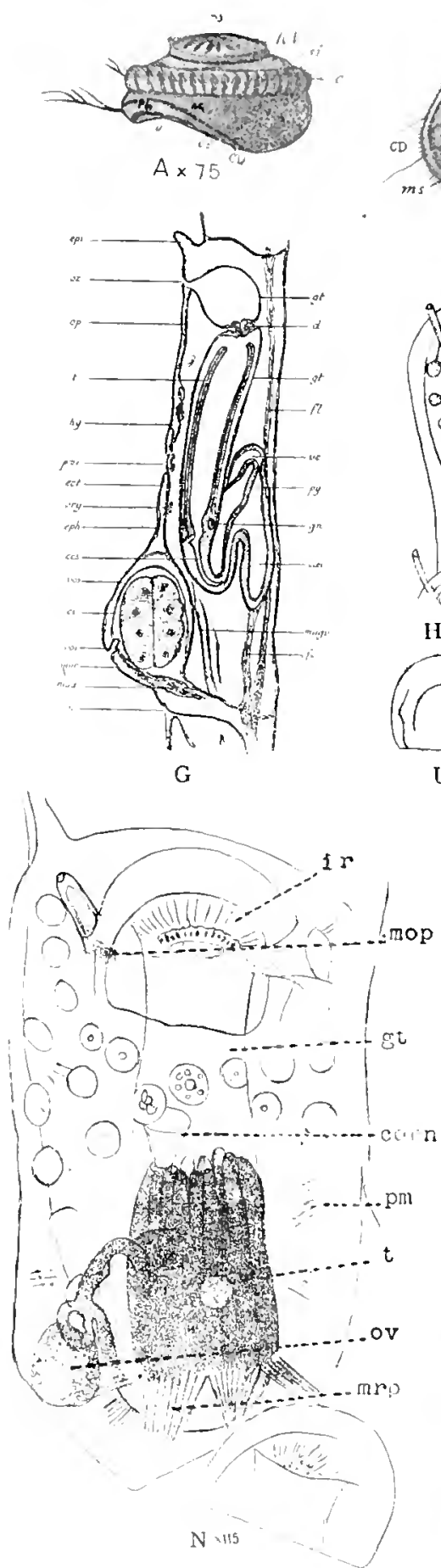

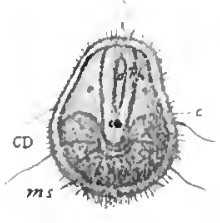

$B \times 50$
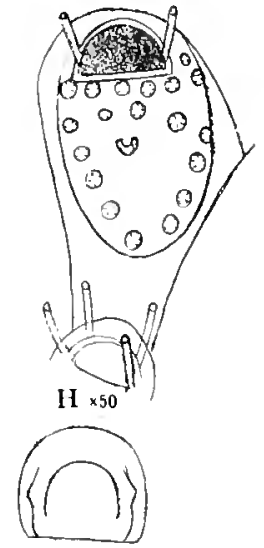

$U \times 100$

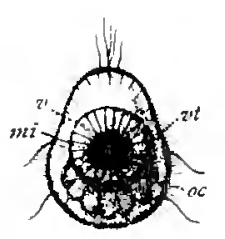

C $\times 50$

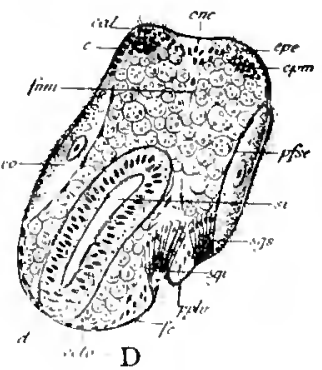

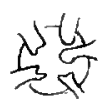
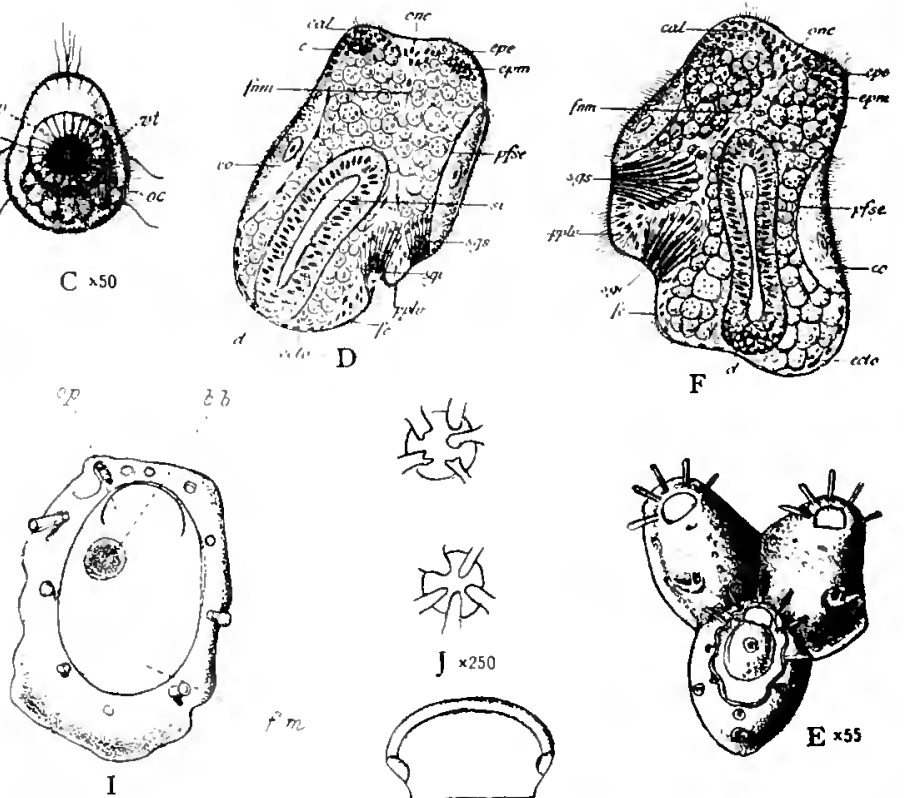

5ys
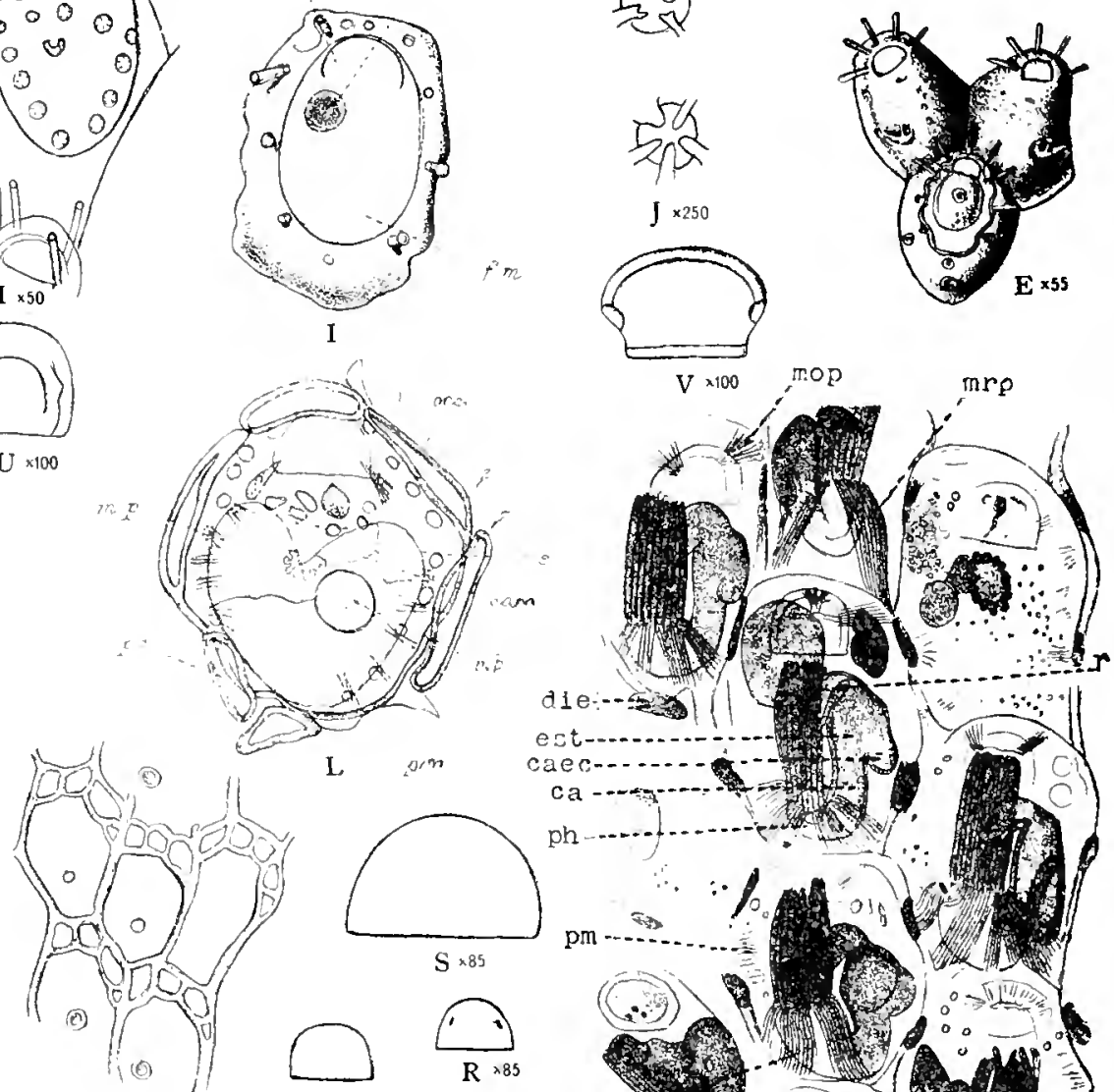

L
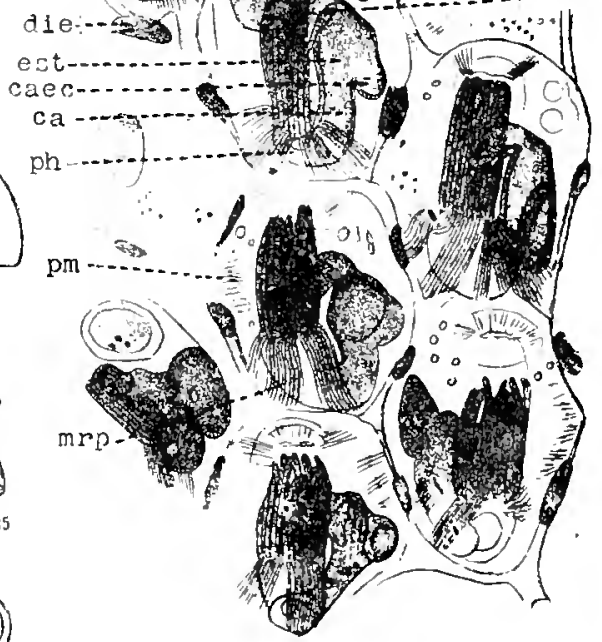

$\mathbf{M} \times 45$

$\mathrm{K} \times 100$
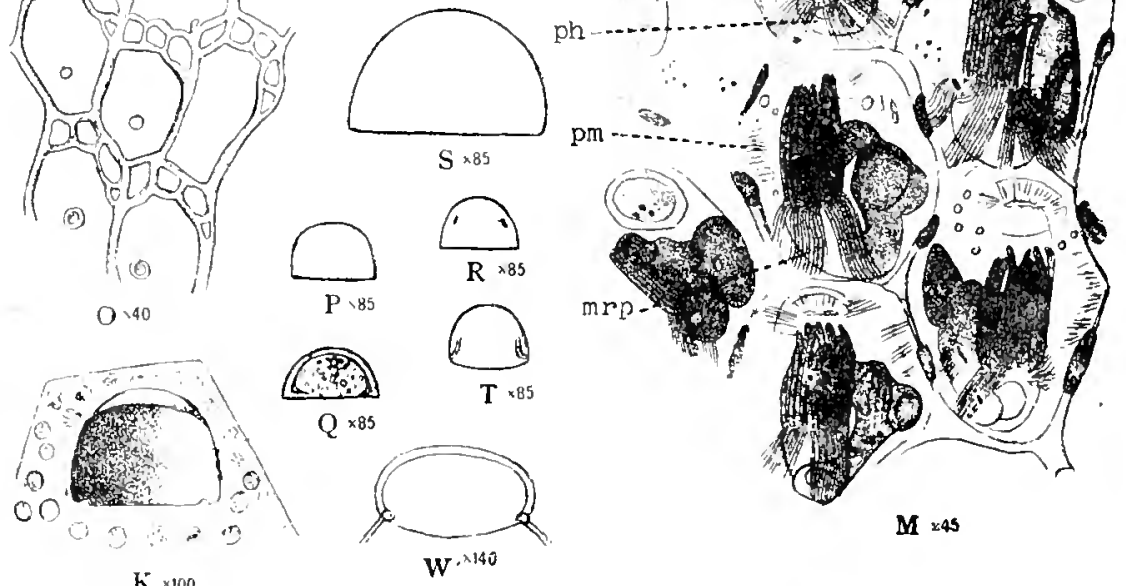

Fif. 123.-Anatony of the Microporellae. 


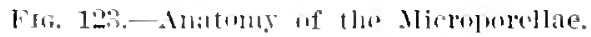

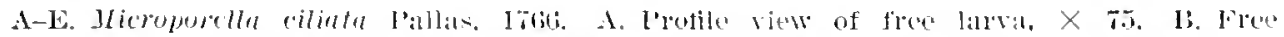

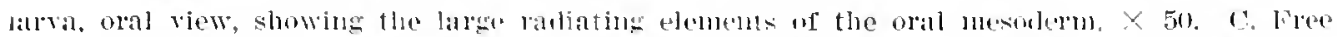

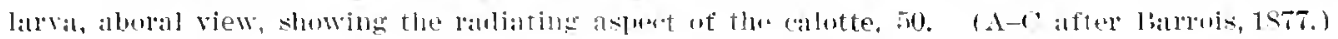

c. (colonal:

ral, calutte (terminal buld);

CD, digentive carrity;

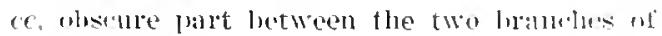

the stomach ;

mi. ahural mesoderm;

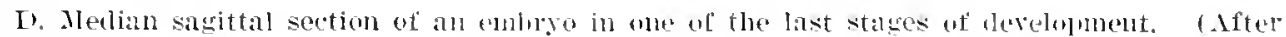

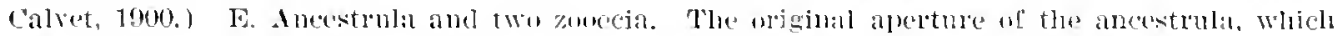

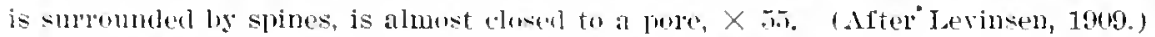

F-X. Microporclla molusi Audouin, 1926. F. Median sagital section of an embryo just hefore it emerges. (After Calret, 1:kn.) In the course ol the neuro-musculal bumles passins

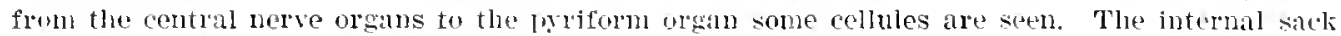
has a simple form almost regularly rymolical.

(c) $1: 1,11]$ le:

cal, callute (1erminal bual);

co. contontal ;

d, tampon or inner sac;

cet. ertoulerm;

cpr. ectolerm thickening:

- $7 m$. mesolerm flickening;

fc. cilialed cleft;

C. Longitudinal scetion of a myuzuit. (After Calret, 1900.)

frec, stomachic caecum ;

ri. inculation carity;

ril. erytucyst, or skeleton;

d. diaphragm ;

thh. ligpostegal epitheliam;

ir. sulne;

11. routral funiculal rorel;

7l. lateral funicular cord;

(1i). Herrous ganglion;

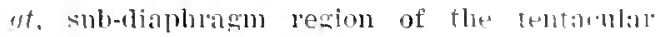
sheath ;

at', subulaphratsuregion :

lil. hypestrese:

II. Znoevia, $x$ 50. (After Waturs, 1911\%, fum, nemo-nustular bundle;

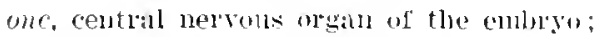

Ifse, sub-ectoderm nerve plexus;

ble, fapilla of the vilsatile plume;

si. internal sac;

sqs, superior glandular system;

sui. inferior glandula system. murl, dilator muscles of the ineubation cavity; mmer. lasce jetractor muscle:

mm: retractor muscles of the frontal walls of the lower ovicellarian resicle:

ors, esopluagus:

"1). aporeulum;

as zooprial oritive;

mor molian frontal pore:

lin. polonis:

ir. loctum:

t. tentacles:

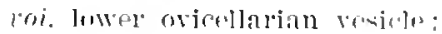

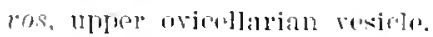

I.

ur. aculiturn points;

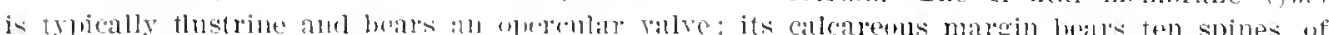

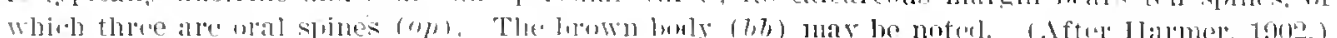

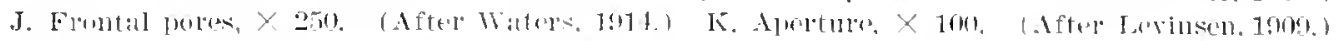

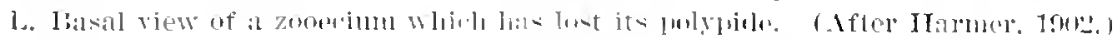

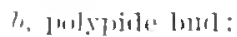

bl, brawn lumb:

ond cornitula:

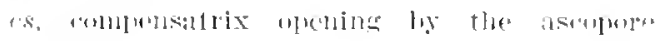

$(m . p):$. 


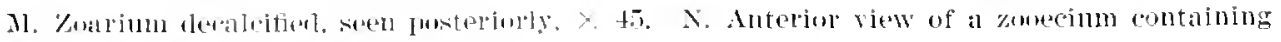

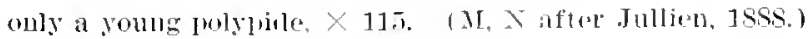

(a) corliate region of the stmmatr:

race, ruevum of the stomiall:

com, conturenla :

aic, dietcllal :

ost. stomach :

al, tentalcular slutatla:

ir. irisoid:

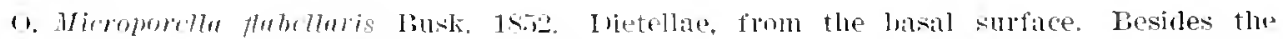

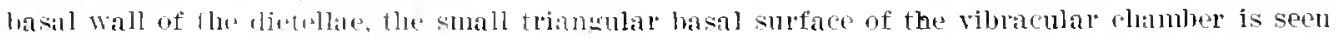

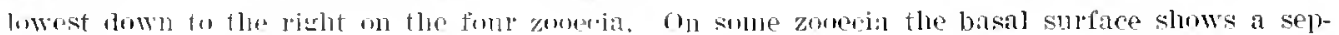

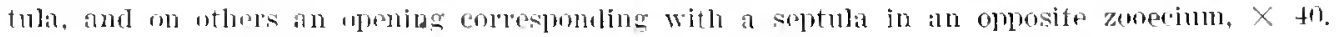
Aftel luevinken, 1!m, )

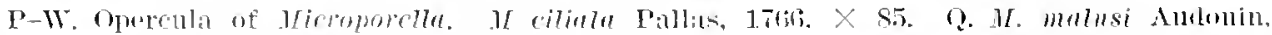

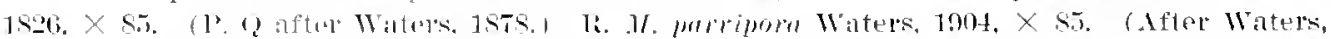

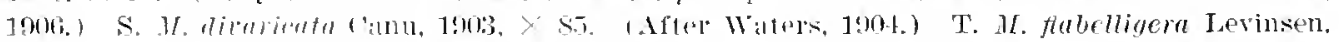

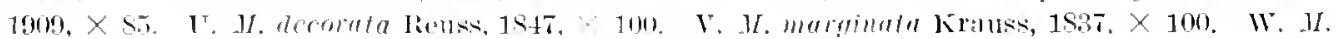

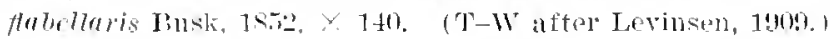

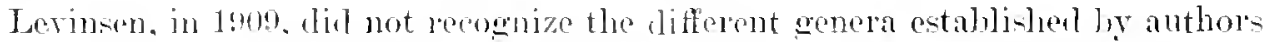
according to the form of the aperture. Wo have been able to adopt a number of these eneras mptoring the primeiple of the great variations in the function of calcification.

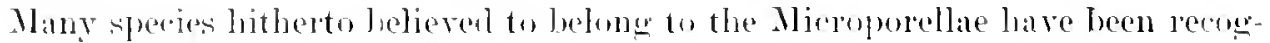
nized to belong in reslity to the delesuldae.

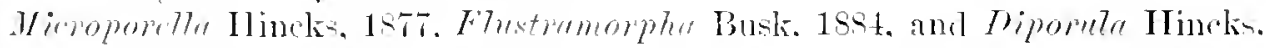
187!, ale refored to this gromp. the general anatomy of which is illustrated in figure 12:?. I discusion of the wroup will be lefpred until the pullication of our

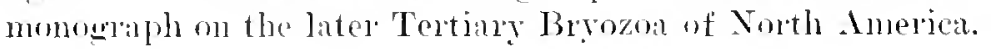

\section{Group 5. DIVERS GENERA.}

The genera of this section have some peculiar duaracters which do not permit of their classification in any of the latere coup cited; but they appear really to helomer to thr same enent family. The principal of these genera are:

Monzranimu P'arens, 1889 .

t'yetiempore Ilincks. 185 t.

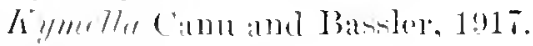

r'yctucolposa, new genus.

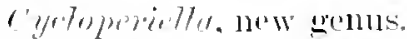

Limmlexin .Jullian. 1858.

Anurthropore sinitt.

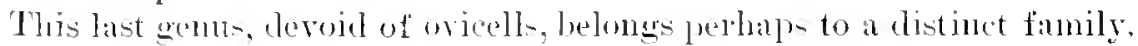


Genus HOLZEALINA Pergens, 1889.

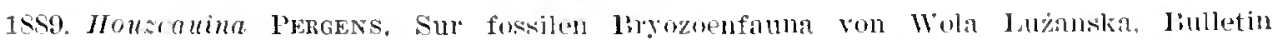

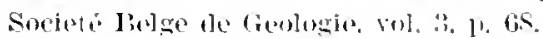

The ovicell is hyperstomial and imberled in the distal zeroecia ; in elosed by the operculum. The frental i- an oloryt perforated laterally by some areolae. The aricularinm is derived from a lateral arenta, but it develops at the midetle of the frontal.

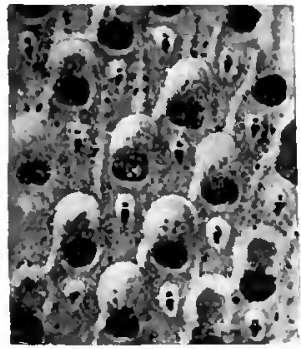

A. Houzeauina

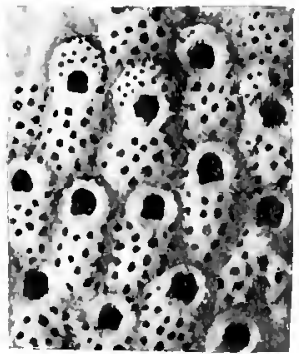

13. Cyclicopora

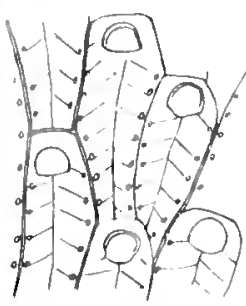

C. Kymella

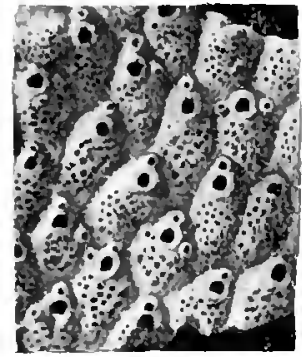

1). Anarthroporas

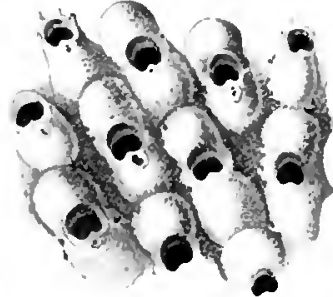

E. Aimulosia

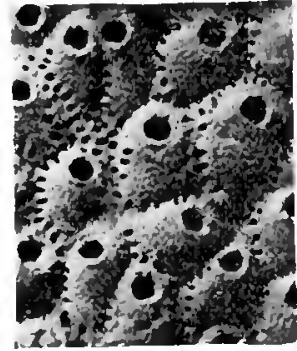

F. Cy'clucolposa

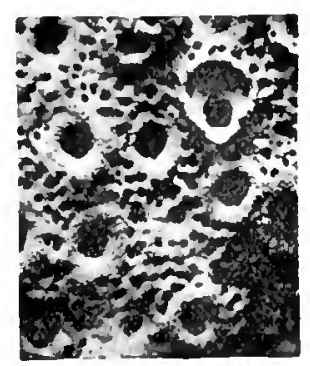

G. Cyclopertella

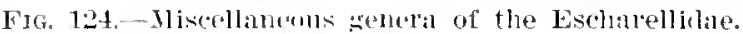

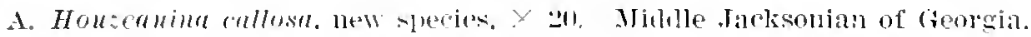

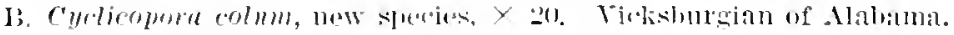

(. Kumblla polmis Waters, 1914. $\times$ 16. Hecent.

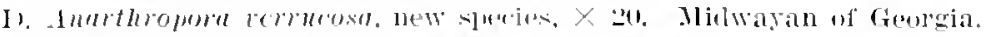

E. Aimmlesin australis Jullien, ]its,

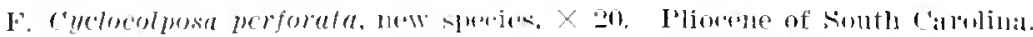

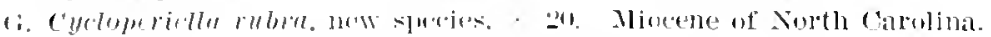

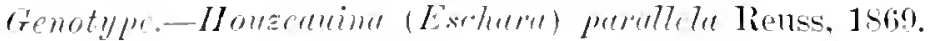

liange.-. Jacksonian-P'riabonian.

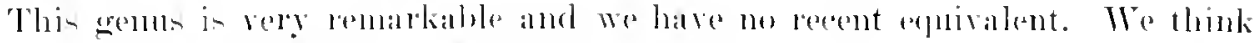

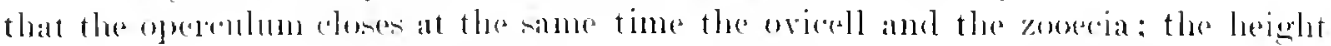
of the real anerture is, in effect. somewhat lingere than that of the external anereture. This common operembur is of different form from the opereulum of the nonovicelled zonceia.

The mole ol formation and the migin of the median aricularim is as remarkable as mexpected. It was in -turlying the intriol of the zonecia that we made this 
discovery. The aricularimm develops on a lateral areola slipping under the frontal in the form of a triangle and developed longitulinaly at the middle of this frontal (pl. 5t, fig. 17).

HOUZEALINA ORNATA, new species.

Pliate $\overline{74}$, ligs 12-17.

Irescription.-The zoarium is an Eschan the flonds of which reach frequently more than a centimeter. The zooecia are quite elongated, distinct, rectangular. separated by a salient thread; the frontal is Hat. smooth, omamented laterally with munerons areolne often rery large. The aperture is subcircular. The ovicell is buried in the distal zooecia. globular and salient and has a very fragile olocystal frontal. The aricularim is median, somewhat salient. triangular, the beak tuned toward the bottom and provided with a pirot.

$$
\begin{aligned}
& \text { Veasurements. - Ipertuse }\{h a=0.15 \mathrm{~mm} \text {. Aperture of } / h a=0.10 \mathrm{~mm} \text {. } \\
& 17 a=0.1+0.16 \\
& \text { oricelled zooecia } \mid l a=0.14 \mathrm{~mm} \text {. } \\
& \text { Zooecia } \mid \begin{array}{l}
L z=0.50-0.90 \mathrm{~mm} \text {. } \\
l z=0.2 \pm 0.30 \mathrm{~mm} \text {. }
\end{array}
\end{aligned}
$$

Tariations.-The dimensions of the aperture which we mention are the marimum; most of the time they rary aromm $0.12-0.14 \mathrm{~mm}$. by $0.12 \mathrm{~mm}$. The aperture of the ovicelled zooecia is transrese: nerertheless in looking at the base of the locella the zooecial aperture is perfectly visible with a greater height $(0.12-0.15 \mathrm{~mm}$. and not $0.10 \mathrm{~mm}$.). If this aperture were elusel by an ortinary operculum it would not be able to open exteriorly to allow the passage of the tentacles. It is this which makes us suppose that the oviculles zonecia have a special operculum. The areolac are small (fig. 14) n large (lig. 13).

The active formation of the pleurocys wives to the zooccia a remarkable ornamentation (fig. 16) inpossible to desolibe. In the interior (fig. 17) we see a thick olocyst perforater laterally by some very small areolace am the triangular cavity which is the lodging of the ariculatum ly which the mesenchymatous elements pars through one of the lateral aleola. When the aricularium does not exist (fig. 1:i) the areolice ale larerer.

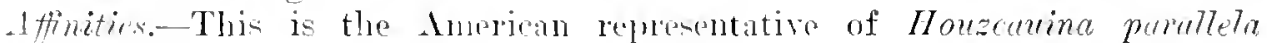
Renss. 1869. It differs from it in it orlbicular orifice (and not semilunar) without a straight proximal borkler.

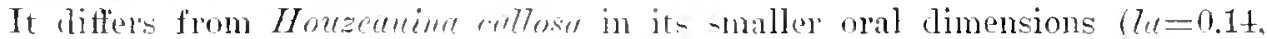
and not $0.18 \mathrm{~mm}$.) in its larger areolac and the much larere frontal callosity.

Crenerence.-Middle Jacksonian: Rich Hill. Craw ford Comty, Georgia foom-

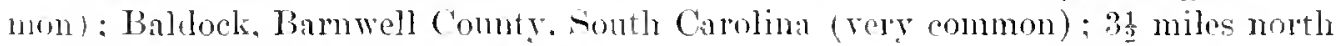
of Grorania, Georgia (rare); ${ }_{1}$ miles sunth of Perry, Georgia (rare); 18 miles west of Wrightsrille. Georgia (common): Enta Springs. South Curolina (rare).

rotypes.-Cilt. No. 6t111. T.S.X.M. 
HOUZEAUINA CALlosa, new species.

Plate 54, tig. 11.

Description. - The zoarium is an Eschara; the partition which separates the two lamellate, back to back, is mique. The zooedia are much elongated. distinct, rectangular. separated by a very prominent thread; the frontal is smooth, that. garnished laterally with small areolae, of which the two lower are larger thin the others. The hyperstomial ovicell is imberded in the distal zooccia; it is salient and globular and bears in front a perforated callosity. The median avicularium is small, triangukn, the beak turned toward the bottom, salient, without pivot, but with an opening for the passige of the extensor muscles of the mandible.

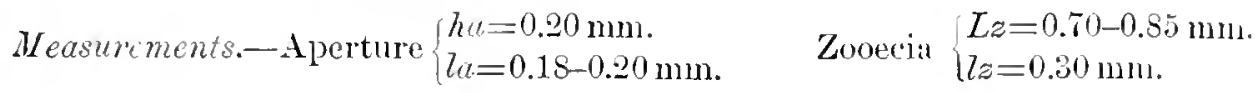

Aperture of $h a=0.15 \mathrm{~mm}$.

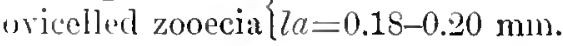

Afmitis. - This species differs from Houzcauina ornata in the small perforated frontal callosity of the ovicell. in its smaller areolae and its larger oral rimensions.

Only the firured specimen has been found.

Occurrence.-Niddle Jacksonian: Eighteen miles mest of Wrightsrille. Johnson Countr. Groroia (very rare).

II olotype.-Cat. No. G+109, T.S.X.MI.

HOUZEAUINA LIBRATA, new species.

Ilite 52, figs. 17, 18; Plate 55, figs. 14.

Deseription.-The zoarium is bilamellar, its fronds often clariform. The zooecia are indistinct, elongated; the frontal is conrex, smooth, gamished laterally with some rery widely spaced areolae, the lower two of which are the larger'a finely granulated plenrocyst is closely mited with a thick subjacent olocyst. The aperture is imberded, semilumar, with a proximal borler nearly straight: there are two bery small cardelles placed quite low. The avicularim is median, little sillient. elliptical: it does not exist on the zooccia provided with two large lower areolae.

$$
\begin{aligned}
& \text { Measurem nts.-Aperture }\left\{\begin{array}{l}
h a=0.10-0.14 \mathrm{~mm} . \\
7 a=0.10-0.14 \mathrm{~mm} .
\end{array}\right. \\
& \text { Zooecia }\left\{\begin{array}{l}
I_{z}=0.60(\mathrm{max} .0 .7+\mathrm{mm}) . \\
{ }_{7 z=0.30-0.40 \mathrm{~mm} .}
\end{array}\right.
\end{aligned}
$$

Turintions.- The dimensions of the aperture vary very little and oscillate around 0.12 mm.. nevertheless it is sometimes slightly transverse $(0.10 \mathrm{by} 0.1+\mathrm{mm}$.) and sometimes a little elongated $(0.14$ by $0.10 \mathrm{~mm}$.). Py rublung away one face we are able to -tudy the interior of the zooscia; the avicularium is indert that of Houzcuring as it renilts from a development of the lateral areolae. through which pass the me-enchymatous fihers which mite it to the zoorcin. It establishes a phenomentm of hethere, of equilibrium between this aricularium and the other areolate chintly the lower ones. which do not exist on the zooecia deprived of the 
median avicularium. Caun ${ }^{1}$ has alleady cited an analogons cane of equilibrium in Exochlla mutubtis Canu, 1911. from the Rocanean of Argentina. The olocyst is very thick (pl. 5i, fig. 5). Finally we have olserved two monstrous zooecia (pl. 55. fig. 3).

Aftinities. -This species is rery leceiving, and, without the study of the zooccial interior, it would be inpossible to classify it properly. The absence of prominent threals separating the zooecia will suffice to differentiate it from all the other's.

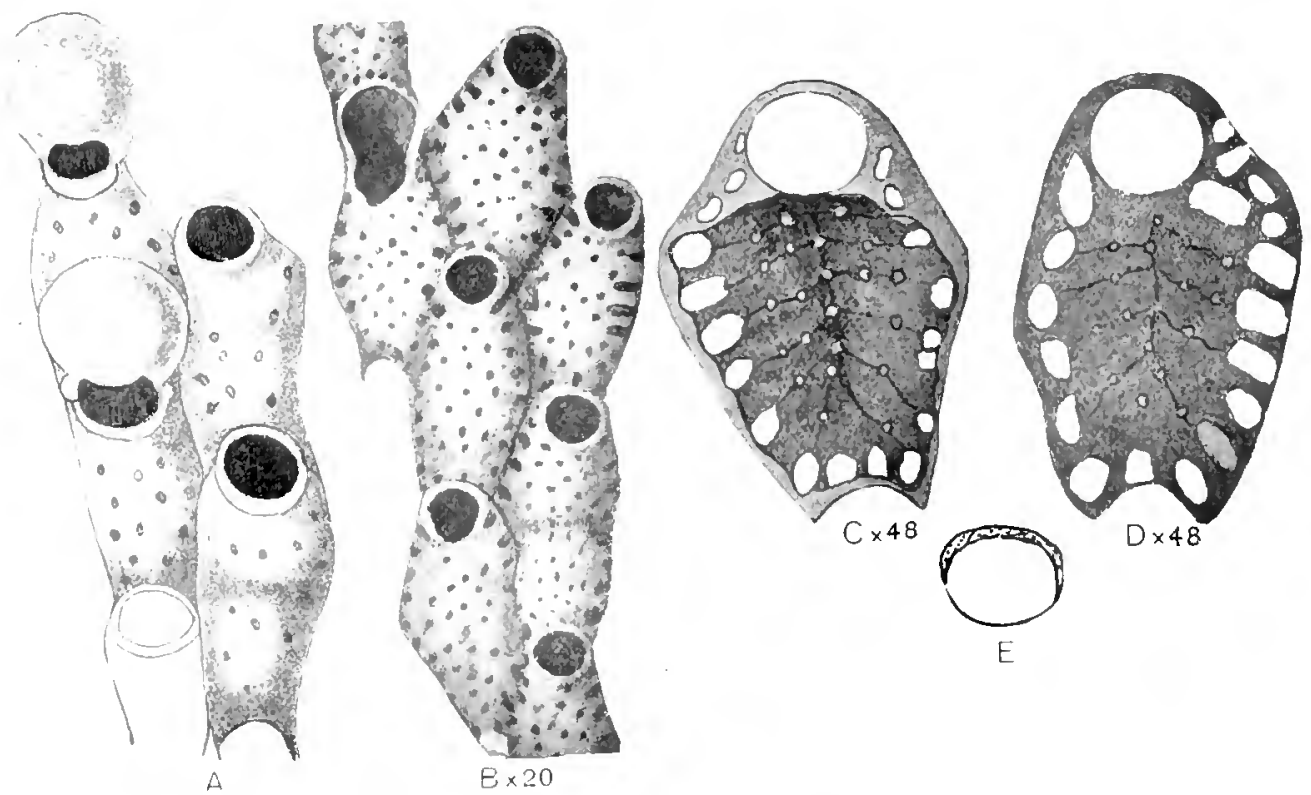

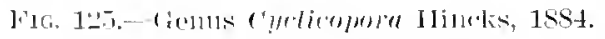

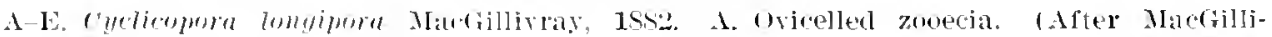

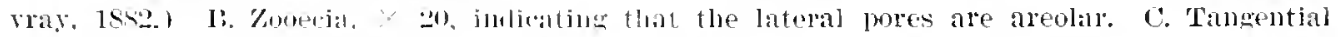
section of the inmor faro of the fromill wall, $X 48$, showing the tremopros along the suture

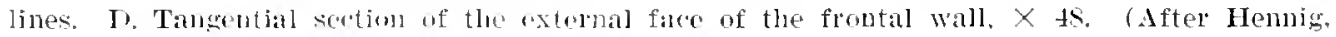

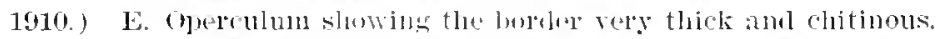

Occumenee-Middle . Tacksonian: Wilmington, North Carolina (common); near Lenuds Ferry, Sonth Carolina (very rare).

Cotypes.-Cat. No. 6t097. TT.N.X.M.

\section{Genus CYCLICOPORA Hincks, I884.}

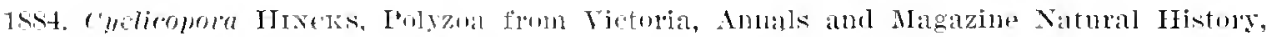

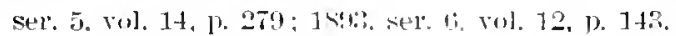

The ovicell is hyperstomial and atways closel by the opeleulum. The frontal is a tremocyst with pores in quincmux. There are no carlelles, but the operculum

${ }^{2}$ lconographie Brsozoaires fossiles de lidentine, pt. 2. Anales del lluseu varional de Buenos

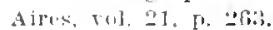


functions as if they axister (as in the genus llippodiplosict). The proximal border of the apertura is straight or somewhat concare. No spines.

Genotypc.-Cyclicopora (Lepratia) Tongipora MacGillivay. 1882.

Rangc.-Jacksonian-Recent.

The simplicity of the structure of this aenus has heen much exagrerated on account of an incomplete olservation of the operculum, the ovicell, and the frontal. The axis of rotation of the opereulum is at the midlle of the aperture; its anterior part is reenforced by a band much more chitinized.

Cycticopora polaris Waters, $190+$. belongs to a closely related genus; the operculum bears indeed the same distal selerite, but its form is different, the frontal is a pleurocyst proceeding frem lateral areolae, and there are some spines; this is the genus irymella describul on page 428 .

Hincks has introduced Cycticopom into a special family. the Cyclicoporidae. This family is perhaps really a good one: the frontal of the two known genera appear to be formed hy the consolidation of the primitive costules. as the figures of Hennig and of Waters, which we reproduce, seem to prove. Finally, the operculum has a broad, thickened border, reminding us of the opercula of some Membranipora, such as Mombranipore tenuirustris Hinclss. 1850.

CYCLICOPORA FISSURATA, new species.

Plate $5 \pi$. fie. $\tau$.

leseription.-The zonimu is unilamellar and creeps on algate. The zooecia we elongated, distinct. elliptical; the frontal is conres and covered by rery large tremopores. The apertura is semilumar with a proximal border somewhat concare; the peristome is wide. complete, hardly salient. On each side of the apertura there are two arjeularia, elongated. thin. adjacent to the peristome. the beak directed towaril the top.

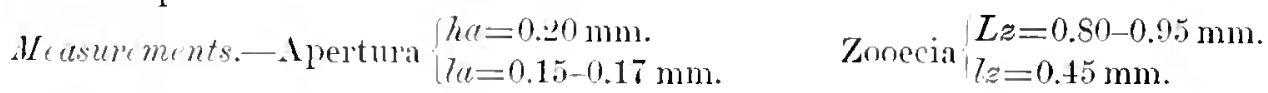

Affinities.-The ariendaria are seen in perspective; they have the aspect of two fisures in the zooecin.

This species ditlers flon C'ycticoporu longipond MacGillivray, 1892, in its enormons tremopores and it two large oral aricularia.

It diflers from (y yclicopore cotum in its much larger dimensions.

Oerumence-Midulle Tacksonian (Castle Hayne limestone): Wilnington, North Carolina (very rare).

Ilolotyp.-Cat. No. B1113, T.S.N.M.

CTClCOPORA COLUM, new species.

I'lite St, fig. 15.

Description.-The zoalum incrusts bryozoa. The zonerian ane elongated, distinct, separated by a deep furrow, the frontal is conves ami covered with large tremopores, widely sacel. The aperture is semielhiptical or semilunar; the proxi- 
mal border is straight or somewhat concave. The oricell is globular, salient, coreled with smaller tremopores than those of the frontal; it is hyperstomial and always closed by the opereulum. One of the lateral tremopores, near the aperture, transforms itself into a suall aricularium, simple, somewhat salient, and elliptical.

$$
\text { Mrasurements.-Aperture }\left\{\begin{array} { l } 
{ h a = 0 . 1 2 - 0 . 1 \pm \mathrm { mm } . } \\
{ 7 a = 0 . 1 + 0 . 1 6 \mathrm { mm } . }
\end{array} \quad \text { Zovecia } \left\{\begin{array}{l}
L z=0.55-0.60 \mathrm{~mm} . \\
7 z=0.40 \mathrm{~mm} .
\end{array}\right.\right.
$$

Afinitirs.-This species liffers from Cyetiropora Tongipora MacGillivay, 1882. in its large tremopnres which give it the aspect of a colander.

It differs from C'yeticopora fissurate in its much smaller dimensions and the absence of elongater. lateral avicularia.

Oceurene.--Ticksurgian ("Chimmey rock" member of Mariamma limestone): One mile north of Monroeville, Alabama (very rare).

Ilototyle-Cat. No. 64283. U.S.N.Mr.

\section{CYCLICOPORA SPONGIOPSIS De Gregorio, 1890.}

Plate 8 , figs. S-16.

1890. Escham sumatopsis Do Gregono. Mnnographie de la Fame Focenique de Alabana, Ambtes Geologin et de Paloontologie, Livr. 7, 8, p. 241, pl. 40, fig. 2.

Description.-The zoarium is unilamellar. crlindrieal. hollow; it surrounds the radicells of small algae. The zonecia are very little distinct, elongated, fusiform; the frontal is little convex, very thick and formed of a tremocrst with large tubular pores lesting on a very thin olocyst. The apertura is oval, at the base of a deep peristomie: the peristome is smooth, not salient, and bears from 1 to 4 simple avicularia. The ovicell is hrperstomial. buried in the distal zooecia; it opens into the peristomie, it is ormamented with large pores analogons to those of the frontal.

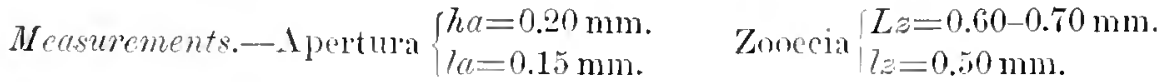

Turiations.--There are occasionally some zooecia bordered by a prominent thread (fig. 14). The number of small simple. peristomial aricularia is quite variable: sometimes one (fig. 15) sometimes $;$ or $t$ (fig. 10). The frontal walls are rery thick and the tubules themselves have thick walls. In the transversal sections (fig. 9) this same phenomenon is quite visible. The tangential section (fig. 13) shows the linge frontal tremopores and the black. sinmous lines of intersection with the olocrst.

Affities.-This species recembles mnch the romg zon ria of Porellu crassoparies which suremen aloo the small algae and their distinction is often quite difficult: it ditler's from the latter in the complete absence of the median avicularium.

It seems to us that this species resembles the figure given by De Gregorio of lis Eschera spongiopsis. but we have not been able to check this observation with his type.

Ocenrence.-Ticksburgian (Marianna limestone): One mile north of Monroeville, Alabama (very common) ; near Claiborne, Momroe County, Alabama (common). 


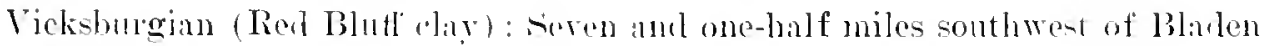
Springs. Mabama (common).

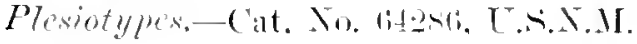

CYCLICOPORA FILIFERA, new species.

I'l:1tas, tiss. 17-1!).

Desmiption.-The zondum incusts shells. The zooecia are large. elougateel, elliptical, distinct. separated lor a prominent threal, often quite thick: the flontal is somewhat convex and porols: it in formed of an olocyst with small scattered pores surmounting a tremougs with larger' corresponcling pores. 'The apertura is orbicular and placed at the base of a lingre, oblique peristumie; the peristome is thin, salient, shap, learing on its proximal boleler a very small avicularium: in the peristomie, there is often a rery small muero. The ovicell is hyperstomial, placed on the distal zonecimm. globulats. salient; it opens in the peristonie by at small nrifice.

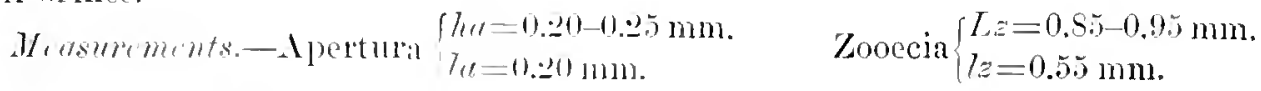

Afmitis.-We are not quite artain of the gemus of this species. The tremocyst in fact, is visible only on the rery well lneserved zooecia; usually it does not exist and is replaced by in thick plourocyt alomited between the threads which become rery silient (fig. 18); finally there is a peristomice which does not correspond to the aperturia.

In this last character, in its wion! which opens into the peristomie. in its sumall peristomial avienlarim this -perion is not without analogy with the genus

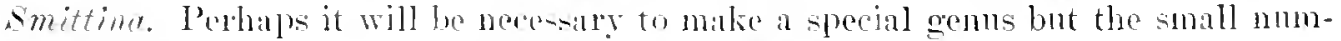
ber of perimens collected dow not permit us to do so.

Oecurpence-Vicksburgian (Mariama limestone): Well at depth of 1 to feet, Escamlia Comnty, Alabama (vely lab); near Claibolne, Monroe Comnty Alabama

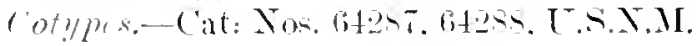

CYCLICOPORA LATICELLA, new species.

$$
\text { Inlate in. fir. } 0 .
$$

lhorription.-The zorium inerusts shells. The zooecia are distinct. some-

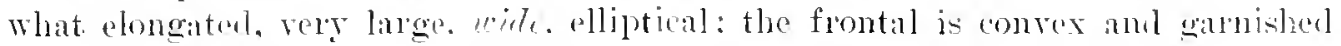

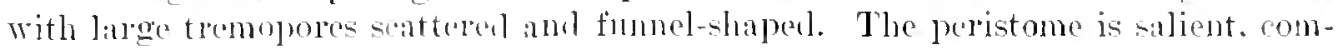
plete: the aperturia and the peristomice are subrrbicular. On one of the sides of

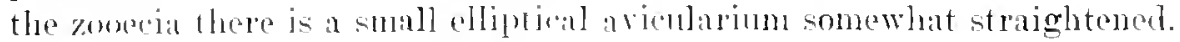

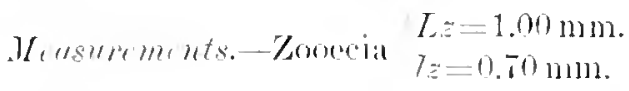

Iffinitix-The only sperimen collowed has been figurerl. Tt bears no oricell. We dissify it here from its aperturat and its frontal. But it is evilent that these characters are insullicient and that thi-species comld also belong to the IIippopodinirtine. 
Orentreme-Middle .Tacksonian (Castle Hayne limestone): Wilnington, North Carolina (very rare).

Hototype-Cat. No. (it112. U.S.X.M.

Genus KYMELLA Canu and Bassler, 1917.

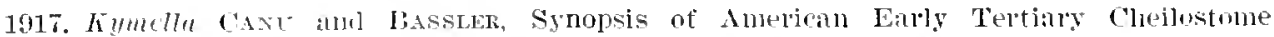
Irryzon, Bulletin 90, Cuited states Xatiomal yusemn, p. 44.

The hyperstomial ovicell is always closed hy the operculum. The funtal is bondererl laterally by areolac. 'The apertura bears a very thin wide rimule.

Genotype. - Irymotla (rycticopora) polaris Waters. 1904. Recent.

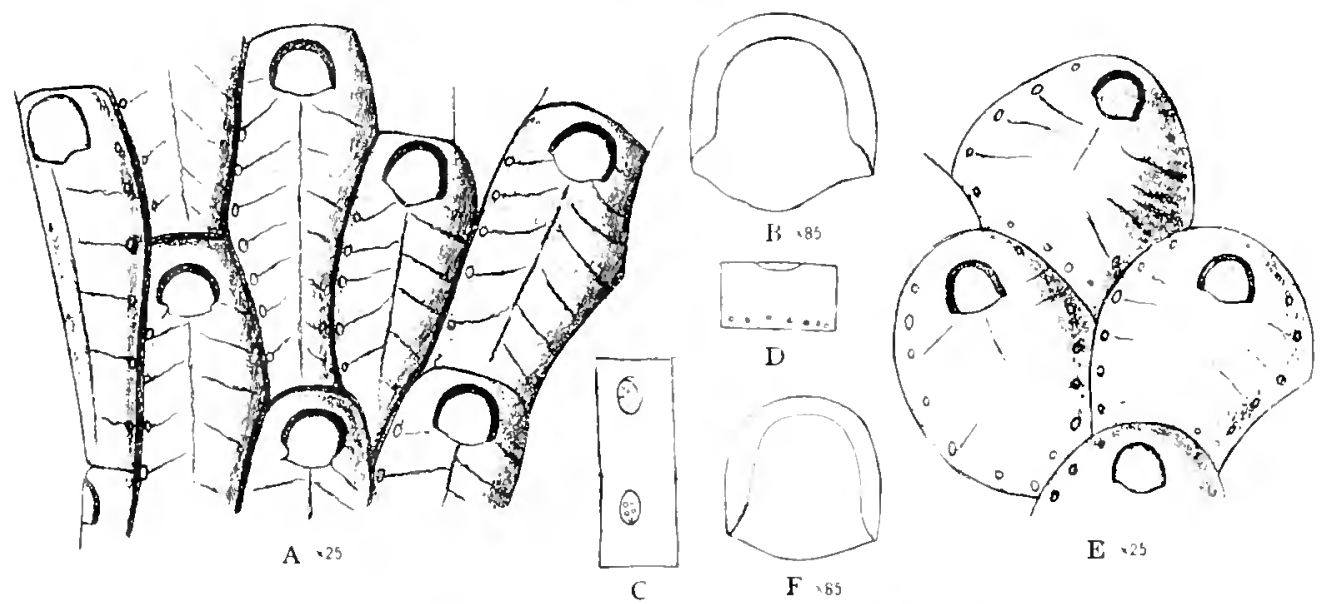

FTf. 120.-Genus himbllu Canu and Bassler. 1917.

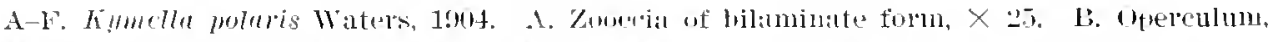

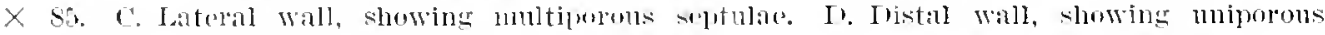

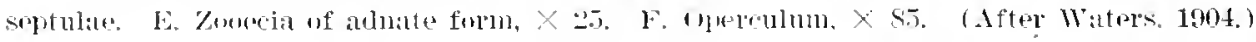

\section{Genus AInUlosia Jullien, 1888.}

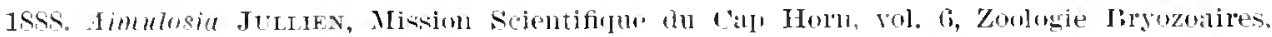
1. 51.

The ovicell is hyperstomial and never closed hy the operculum. The apertura is semilunar; the poster is somewhat concave. The frontal is an olocyst bordered with areolac. A small round or elliptical avicularium is adjacent to the apertura.

Genotype-Aimulosia australis .Jullien. $18 s 8$.

Range.-Wileoxian-Recent.

Is in the genur Erorfente, the stomach is rudinentary: it is replaced by the ewphagns. which .Jullien calls a gastroid esopliagus.

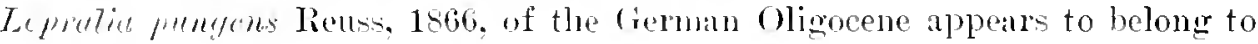
t]2is genus. 
AMIULOSIA CLAVULA, new species.

llato !) tiers. 1:-16.

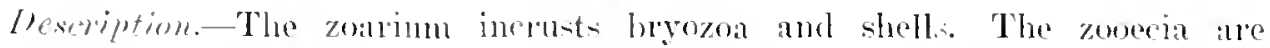
distinct. shurt, a little elongaterl: the fuontal is smootl. comvex, sumponded with lare. triangular areolac. 'The apertula is somilumal with a concave poster. The ovicell is lange. olobular. hyperstomial: it is opened langely above the apertula.

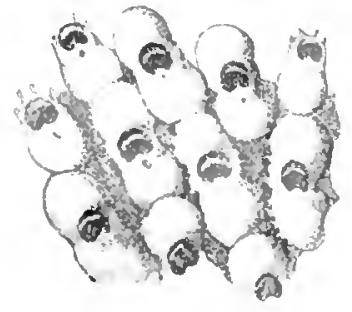

$A$

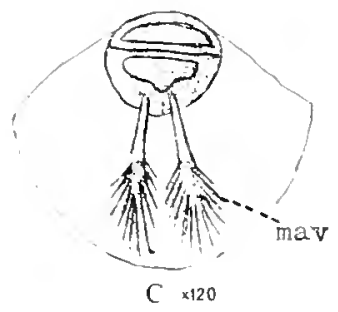

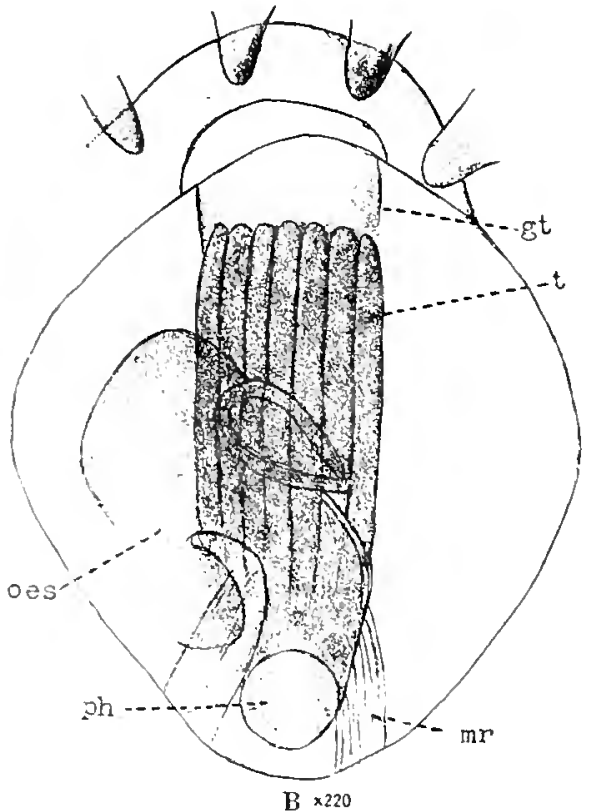

B $\times 220$

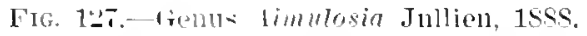

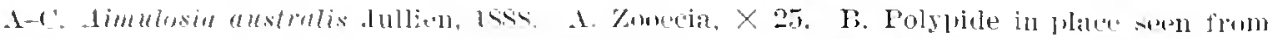

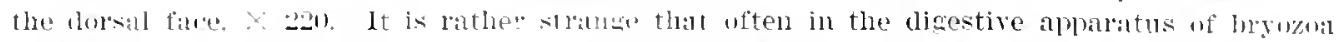

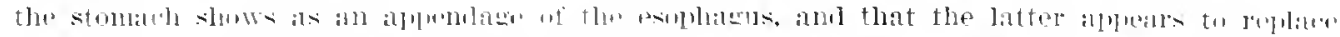

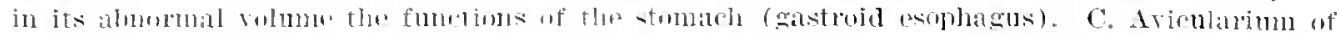

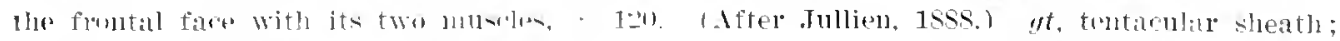

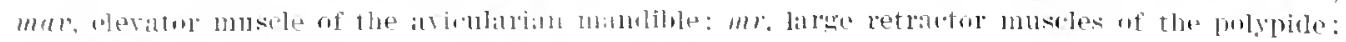

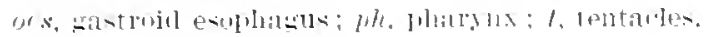

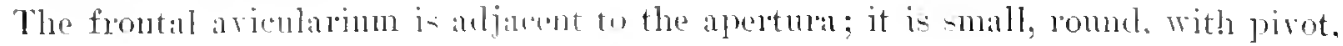
and it opens extermally.

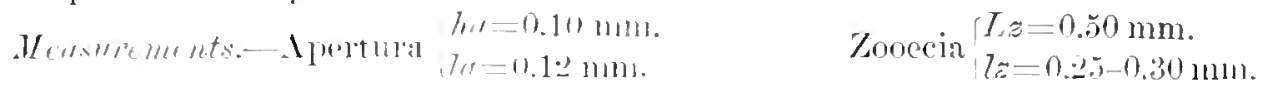

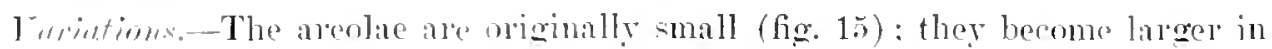

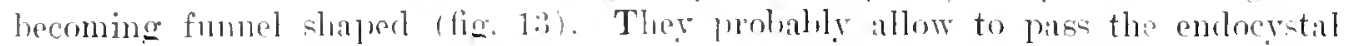
hads. which are levelopel abow the frontal and which deposited an irregular plemoeret (fig. 1.i). Very frepuently the oricell is wikler than the zonecium. whith thus assumes the form of it mit. 
On the young zooceia (fig. 14) the oricell is more salient and the frontal aricularium is farther removel from the apertura. Thus the rariations of the pleurocyst extrandinarily deform the primitive character.

Ocempnee.-Vilcoxian (Bashi formation): Woorls Bluff, Alabama (rare).

C'otype-cat. No. 19385 s. U.S.N.M.

Genus ANARTHROPORA Smitt, 1867.

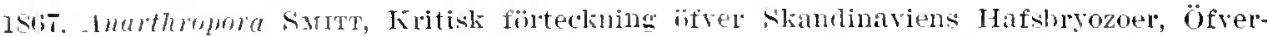
sigt Kongl, Vetenskaps-Akademiens Formamtinglar, vol. 2t, Bihang, p. T.

"Zovecia with the oral extremity slightly produced and free, subtuhular; orifice terminal. semieircular: an aricularian pole on the elerated portion of the cell in front: special pore wanting." (After llimeks. 1860.)

Genotype.-Anarthropore (Ispratia) monoden. Busk. 1860.
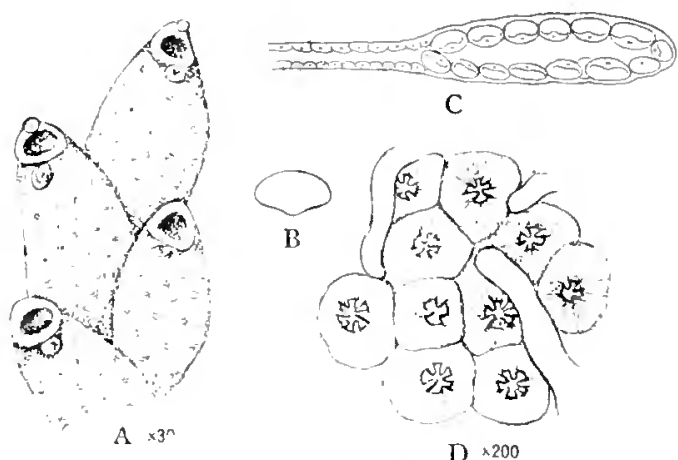

B

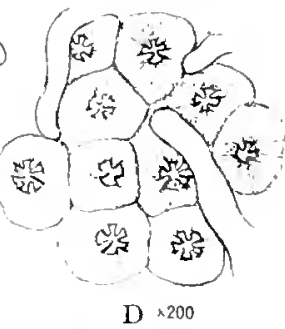

F1ri. 124. - ienus Anarthorpora Smitt, 16iti.

1-Il. Lmathropera manolon Lusk, 1S60. I

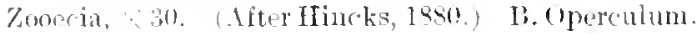
('. Sertion of tentacle, seen in profile, areatly mannifiest. (l: ('atter Jullien, 1903.) D. Stellate pores of the trontal, 200. (Ifter Levinsen, 1909.)

linnge.-Latdorfian-Recent.

The anatomy was deseribed by Jullien in 1904.

This gents, deprived of ovicell. maly perhaps be better chassed in the family Ademidae.

\section{ANARTHIROPORA (?) VERRL'COSA, new Specie क}

Plate 7 , fig. 20.

Lescription.-The zorrium inerust bryozoa and shells. The zorecia are alongated. listinct, fusiform; the fiontal is ronvex and remeose. The aperture is semilumar ; the proximal lunder is somewhat concave: the peristome is eomplete, salient, warnished with some distal spines. No ovicell. The avicularia are small. salient. simple, orbicular; there are three of them. one above the aperture and two laterill ones.

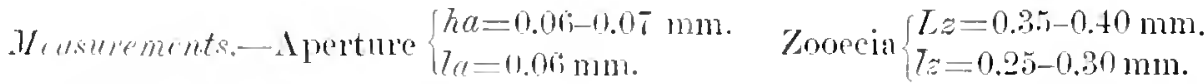

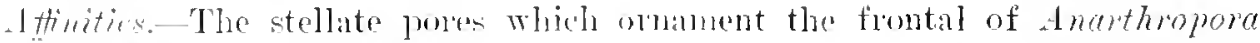
monoton Busk, 1sfo, are only visihle on the young zooecia. On onr specinens we lave never olstreal them; we ade not wen very certain that the rerruensities obscrved are hollow. Nevertbeless the very -pecial armangenent of the arienlaria

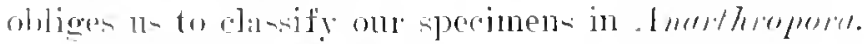

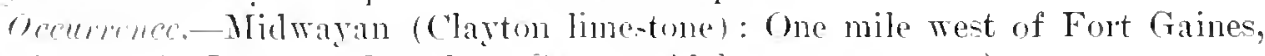

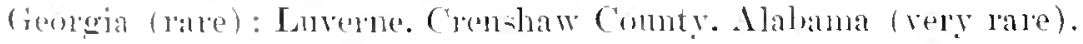

Holutyme-Cat. No. 638.5. T.S.X.M! 


\section{CYCLOCOLPOSA, new genus.}

The apertura is suhorbienlar. ol elliptical, without ardelles. The fromtal is an olocyst. perforated ly a doulle row of areolar pores and covered by a granular detachable pleurocyst. The oricell is hyperstomial, never cloced by the opereulum, embedded in the distal zooecinm.

Genotype-Cyclocolposa purforuta, new species.

Range.-Miocene-Plincene.

In spite of appearances this genus is very different from Gycticopora Hinclis. 188t. The frontal pores are really areolar pores, and not tremopores, for they are separated by short costnles: the granulations reveal also the detachable pleurocyst, moreover, and are often visible on the altered zooceia. In Cyclicopora the opercuhum always closes the ovicell to assine the passage of the eggs. Here this function is assured by the embedding of the ovicell in the distal zooecium, and in the great thickness of the frontal. The orifice is thns arranged in the locella in front of the tentacular sheath.

The description of the trpe species is reserved for a later publication.

CYCLOPERIELLA, new genus.

Greek: Peri, around. In allusion to the form of the oricell.

The oricell is hyperstomial, globular, not embedded in the distal zooecium, and entirely covers the aperturia. The apertura is formed of a semilunar anter and of a very concave poster. The frontal is formed of a very thin olocyst supporting a tremocyst with large widened pores.

Genotype-Cyclopericlla mbra, new species.

Range.-Mincene-Pliocene.

This genus offers the same frontal and apertural characters as Cycticopore Hincks. 185t. It differs from it in its oricell, nerer closed by the operculum. The parsige of the egg- is assured by the form of the ovicell itself. which entirely cover's the aperturia.

The type species will be described in our rolume on the later Tertiary Bryozoa of North America.

\section{nily STOMACHETOSELLIDAE Canu and Bassler, 1917.}

The frontal is thick and occusions the formation of a peristonie. The apertura is generally orbicular or semilunar with a very concare proximal border. The peristomice is always different in form; it is noteled below hy al rimule-spiramen designel to ennduct the water into the compensatrix. The oricell is hypertomial, imbedded in the distal zooecia: it opens above the apertura in the peristomie. No peristomie, lyrula, or carlelles.

This family differs from the Reteporidae in the almence of ribices, racuoles and reticulated zoarinm, in the cleft on the ovicell and in the presence of a peristomie. It resembles this family in its imbedded ovicell and it rimule-spiramen.

It diflers from the smittinidar in the absence of lyrula. cardelles, median aricularium, and of a peri-tome with spines. It possesses the same imberled ori- 
cell opening into the perintomie. In the Suntinidae the peristomie is formed by the development of a peristome with spines; in the Stomachetosellidae it is formed by the thickening of the frontal.

We have founded our generje clissification on the aspect of the ovicell and on the variations of the escape of the larvac, an important function. All the other

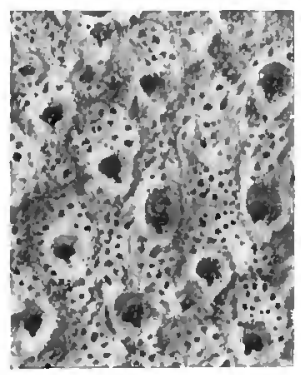

A. Stomachetosella

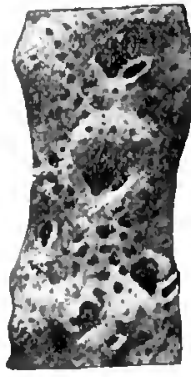

B. Enophoseomella

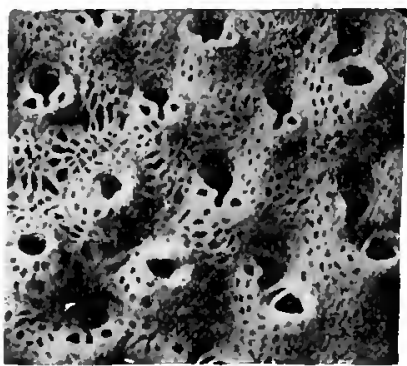

C. Metradolium

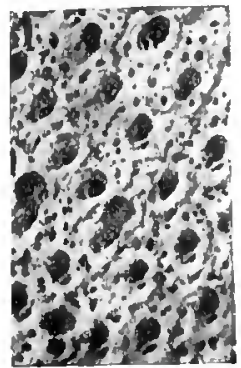

D. Schizemiella

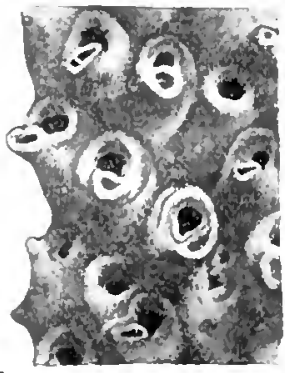

E. l.eiosella

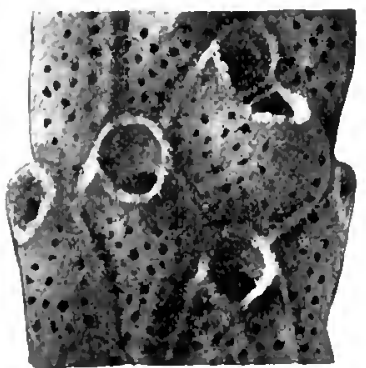

F. Metrocrypta

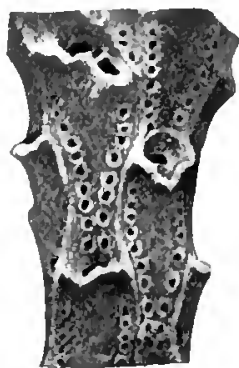

G. Ochetosella

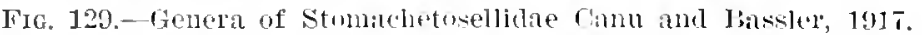

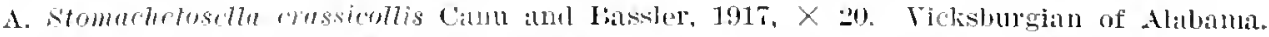

13. Enoplostemelle defixu canu aur 13assinr, 1017, $\times$ 211. Vickshurgian of Alahama.

c. Urtradolium obliqum, new species, $\times 20$. Jacksonian uf North Carolina.

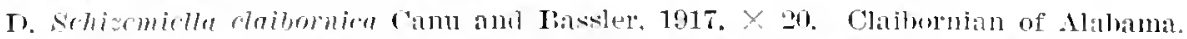

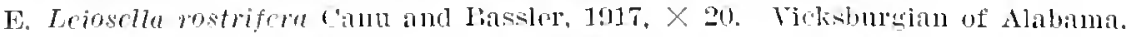

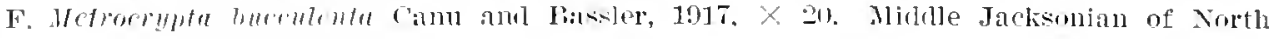
('ilolina.

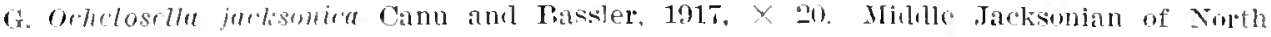
Garolina.

functions, reproduction. liydrostatic. ralification. and pa-sage of the eggs: remain axactly the sane.

Genus STOMACIFtosella Canu and Bassler, 1917.

1937. Stomuchetoxelle Canu aud Bassuer. Synopsis American Early Tertiary Cheilo-

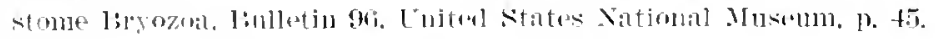

The ovicell entirely surrounds the apertura. The frontal is a tremocyst with winlemouthed tumber. Su aricularia. The peristomice of the ovicelled zonecia posecsies a tratighter rimule-spiramen.

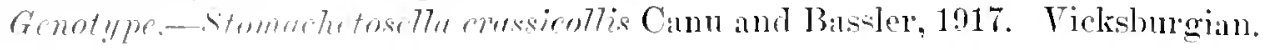


STOMACHETOSELLA CRASSICOLLIS Canu and Bassler, 1917.

Plate S?, ligs, 1-1.].

191: Stomachetosella crassicollis Cate and Pisster, Symopsis American Early Tertialy Cheilostume Iirgoran. Bulletin 96, Cmitell States National Museum, p. 45, p]. 4, fin. 7.

Inescription. -The zoarium is free, bilamellar. formed of broad, mndulated branching fronds. more or less flabelliform. The zooecia are elongated, little distinct; the frontal is convex. mooth. thick and saljent aromol the alpertura and formed by a tremoeyst with large tubules resting on a thin oloeyst. The apertura (interior) is orbicular; the peristonice is provided with a triangular rimule-spiramen; the false peristome is thick and smooth. The oricell is hyperstomial, butied, globular; salient, ornamented with tubular tremopores; it opens into the peristomie; it is possibly closed by the operculnm (?); the vimule-spiramen of the ovicelled zooecia is longer and linear. Laterally, near the apertura there is often a triangular, improminent avicularium, the beak directed above, with pivot.

$$
\begin{aligned}
& \text { Measurements.-Peristomice }\left\{\begin{array} { l } 
{ h p = 0 . 1 0 - 0 . 1 5 \mathrm { mm } . } \\
{ \text { (exterior) } } \\
{ 7 p e = 0 . 1 5 - 0 . 2 0 \mathrm { mm } . }
\end{array} \quad \text { Zooecia } \left\{\begin{array}{l}
L z=0.90 \mathrm{~mm} . \\
7 z=0.30-0.40 \mathrm{~mm} .
\end{array}\right.\right. \\
& \text { A pertura } \mid h a=0.12-0.15 \mathrm{~mm} \text {. } \\
& \text { (interior) } \backslash 7 a=0.12-0.15 \mathrm{~mm} \text {. }
\end{aligned}
$$

Tariations.-The variations are very important and apply to all the organs. The smooth peritome is altered in the old zooecia: it loses its anterior projection (figs. 5,6 ); it is not always salient (figs. 6,7,9). The tubules are rather constant in size (figs. 2. 3, 6,9); they are obliterated, however, by the fossilization (fig. 8). The zoocia are sometimes separated by a prominent thread (fig. 5). The walls are very thick (figs. 12. 13, 14) and there is a special one for each zooecinm (fig. 14); all the walls are united among themselves but perfeetly distinet; there are no walls in common.

In the interior the apertures are orbieular: they appear elliptical and transversal in perspeetive beeause they are oblique. The wall is an olocyst with small perforations on which the tubules of the tremocyst are visible on account of its thimness.

The tangential seetion (fig. 10) made at the level of the olocyst shows quite well the superposition of the two secretions.

In vertical section it is easy to see that the passage of the ova is assured. It is not the same. however. for the eraenation of the larvae. However the constaney of the forms of the peristomice and ovicelled zooceia seems to indicate that the opereulum coulu alwars cluse the oricell; but it is necessury to suppose some very lonur. speeial opereular museles.

This species with its enomons, solid walls. appears robust and resistant. Nerertheless this is not the cace. It was rapidly exterminated and never had a large geographie distribution. This is frequent in the bryozoa where plianey is a better sign of longevity and resistance.

$$
5.5899-19-\text { Rull. } 106-.25
$$


Occurrnee.- Ticksburaian (Mariama limestone): West bank of Conceulı River, Escambia County, Alabama (very common); near Clajborne, Momroe County. Alabama (lare).

Cotypes.-Cat. No.62593, U.S.N.M.

Genus ENOPLOSTONELLA Canu and Bassler, 1917.

1917. Enoplostomella CaNu and Fassife, Srnopsis of American Earls Tertiary Clleilostome Bryozoa bulletin 96, Uniter States National Museum, p. 46.

The apertur and peristomice of the oricelled zooecia are identical with the apertura and with the peristomice of the ordinary zooecia. The frontal is a tremocyst with wide-mouthed tubules. The ovicell does not entirely surround the peristomice. There is an aricnlarium in the peristomie in the immediate vicinity of the peristomice.

Genotype.-Enoplostomella defixa Canu and Bassler. 1917.

Pange.-.Jacksonian, Ticksburgian.

ENOPLOSTOMELLA SYNTHETICA, new species.

Plite !10. figes. 1-9.

Description.-The zoarimm is free, formed of from 2 to \pm lamellae, back to back, and separable. The zooecia are indistinct and irregular (exteriorly); the frontal is formed of a tremocyst with very large wide-mouthed tubules superposed on a thin olocyst perforated with small pores. The apertura (in the interior) is semilunar with a concave proximal border; the peristomie is rery deep; the peristomice is orbicular, imbedded, with a wide and short rimule-spiramen limited by the peristomial avicularium. The ovicell is hyperstomial, much imbedded, little salient covered also with large tremocystal pores; it opens into the peristomie. In each peristomie there is a small triangular avicularium, little visible externally. On the frontal, laterally a small or very large avicularium is formed by the coalescence of the tubules.

$$
\text { Drcasurements.- Apertula }\left\{\begin{array} { l } 
{ h a = 0 . 1 5 - 0 . 1 7 \mathrm { mm } . } \\
{ \text { (ivterior) } } \\
{ l a = 0 . 1 6 \mathrm { mm } . }
\end{array} \quad \text { Zooecia } \left\{\begin{array}{l}
L z=0.80-0.90 \mathrm{~mm} . \\
(7 z=0.35-0.50 \mathrm{~mm} .
\end{array}\right.\right.
$$

Tariations.-The function and transformation of the tubules give to this species a disconcerting aspect of irregularity, augmented still more by the orientation of the zooecia. which is not constant (figs. 2, 3). The interior aspect (figs. $4,5,8)$ shows, on the contrary, a mole simple olganization. Through the thimmess of the olocyst, perforated with small pores, the tubules regularly placed in quincunx can be seen; the frontal avicularium is visible only if it is very large.

The derelopment of the buds of the endocyst and the result of their coalescence form here a very remarkable synthesis. The buds. revealed by the very similar openings of the olucyst become transformed into adventitions or anans more or less complicated, which engender small simple avicularia with pirot. some avicularian arities and large avicularia with or without pirot, in which the mandibles ought 
to be quite variable. The proliferation of the tubules obstructs eren the apertura (fig. i) which is nevertheless visible in the interiol (fig. S) as in Myrosonm.

Affnitics.-This species differs from Enoplostomclla crassmuratis, ju its large zonecial dimensions. its external irerewarity and its many layered zoarim which is nerer vincularoid.

Oecumence.-Vickburgian (By̧am marl): Byram. Mississippi (eommon); one-half mile west of Woodwards. Wayne County, Mississippi (very rare).

Cotypes.C Cat. No. 6tono. T.S.X.II.

ENOPLOSTO.MELLA ERASSIMURALIS, new specics.

l'late 01. figs $1-11$.

Jeseription.-The zoarium is milamellar. cylindrical. hollow; it inerusts small radicles of algac. The zooecia are little distinct, elongated, separated from each other by a thick, smooth projection: the frontal is thick, concare; it is formed of a tremocyst with very large tubules superposed on a very thin oloevst with minute pores. The apertura (in the interior) is formed of a scmilumar anter and of a concare poster; it is transverse and oblique; the peristomice is triangular, buried; the rimule-spiramen is wide and bordered laterally by the peristomial aricularium. The avicularium is adjacent to the peristomice; it is triangular provided with a pirot and its beak is direeted toward the top.

$$
\begin{aligned}
& \text { Mcasurements.-Apertur: }(h a=0.12 \mathrm{~mm} \text {. Peristomice } / h p=0.20 \mathrm{~mm} \text {. } \\
& \text { (interior) } l a=0.16 \mathrm{~mm} \text {. (exterion) } \mid l p_{c}=0.20 \mathrm{~mm} \text {. }
\end{aligned}
$$

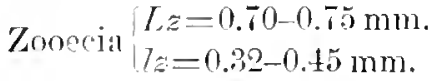

Tariations.-On acconnt of the thickness of the walls, the rariations of the frontal are extradinary (figs. ․-.) : the exterior aspect does not correspond at all with the view of the interior (figs. 6. 7) which is fortmately more regular. The zooecia have no special walls (firs. 8, 10): they are invisible in thin sections: an energetic consolidation must take place on the very young zoocia; the latter moreover do not bear any kind of prominent separating mural rim. The tubules are seen with difliculty on the transverse sections (fics. ?. 10).

In the interior the aricularium appears as a triangular chamber adjacent to the apertura. The olocyst is rely thin: the tubules are visinle as round white spots by transparency. 'Their pores ale all very small (figs. 6. 7 ); this is the reason that in tancential scetinn the tremopores are laree. round, and obscure spots feebly lighted by a luminous point.

The zoarim is formel smmetimes by two smperpowal lameliac. Tery larely it is bifurcated.

Affuitics.-In the external aspect of the zoarium, thic species resembles Enoplostomella rhomboilulis. Wut it diffres from it in its hollow zoarium and the much thiclier, separating mural rim. 
Occurrenef-Wicksburaian (Marianna limestone): Salt Mountain, 5 miles south of Jackson, Alabama (very rare); near Claiborne, Monro County, Alabama (rare); (leep rell in Escambia Connty, Alabama (very rare).

Cotypes.-Cat. No. (42293. U.S.N.ML.

\section{ENOPLOSTOMELLA RHOMBOIDALIS, new species.}

\section{Plate 90. firs. 10-1i;}

Ireseription.-The zoarium is free, cylindrical, or somewhat compressed, bifurcated. formed of two lamellae, back to back, and inseparable. The zooecia are little distinct, clongated, rhomboidn?. separated by a plominent thread; the frontal is somewhat convex and formed by a thick tremocyst with very lare tubules resting on a thin oloeyst irregularly perforated. The apertura is rery oblique semilunar. with a proximally concave border; the peristonice is elongated. mnch buried. with a triangular rimule-spiramen. The ovicell is hyperstomial, opening into the peristomie. little salient, globular, onnmented with large tremopores. In the peristomie there is a small triangular avicularium with pirot, placed transrersely.

$$
\begin{aligned}
& \text { Ueasurements.-Peristomice hpe=0.16 mm } \\
& \text { (exterior) } 17 p e=0.12 \mathrm{~mm} \text {. } \\
& \text { Zooecia } \mid \begin{array}{l}
L_{z}=0.05-0.75 \mathrm{~mm} . \\
l_{z}=0.45-0.60 \mathrm{~mm} .
\end{array}
\end{aligned}
$$

Trariations.- The thread separating the zooecin is quite valriable and changes the external aspect considerably: it in thickened laterally (fig. 12) or only near the apertura (fig. 14). It gives to the zooecia a groater wilth (fig. 13) or less (fig. 15).

In the interior. the structure is mole regular. but it may be noted that the small perforations of the olocyst are not regulary arranged in quincunx. an occurrence which is very rare.

Affmitios.-This species differs from Enoplostomelle crassimuratis, in which the zoarium has some lesemblance, in its rhomboinal form. its solid and not hollow zuarium and its peristomice still more imbedder.

It differs flom Euoplostomella defira, also with a cylindrical zoarium. in its smaller and mole hidden peristomial aricularium. its much less salient ovicell and in its less zonecial width.

Oeempenee-Ticksburgian (Marianna limestone): One mile north of Monroeville, Alabima (rare); $2 \frac{1}{2}$ miles north of Millyy. Washington County, Alabama (1'are).

cotypes.-ciat. No. 64391. U.A.N.Mr.

ENOPlostonella DEFiXA Canu and Bassler, 1917.

liate !1, hisw. 12-21.

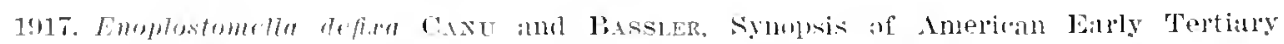

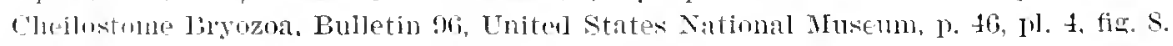

Irspription.-The zoarium is free, cylindrical, vinculariform. formed of six 11) seren lomertulinal rows of zooecia. The zooecia are indistinct; the frontal is little thickened. conrex. formed of a tremoryst with large pores placed abore an 
olocyst with tubules. The apertura (interior) is formed of a semilunar anter and of a coneare poster'; the peristonice (exterior) is elongated. imbedded, provideut with a triangular rimule-spiramen. The ovicell is hyperstomial, buried in the distal zooceial. globular. salient, deconterl with large tremopores; it opens largely into the peristomie. The oral avicularium is adjacent to the peristomice and placed somewhat obliquely: it is triangular. lather long, and provided with a pirot; the beak is turned outward.

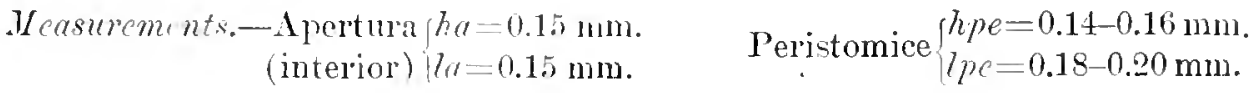

$$
\begin{aligned}
& \text { Zooecia }\left\{\begin{array}{l}
L_{z}=0.90-1.00 \mathrm{~mm} \\
\mid t_{z}=0.40 \mathrm{~mm} .
\end{array}\right.
\end{aligned}
$$

I ariation.-The zooecial walls are relatively little thickened (figs. 19. 20. 21): also the exterior aspect is rather ennstant. The variations observed are principally those of the a ricularium: it is often long and salient (figs. 1t, 15), often short (fig. 13), often worn (figs. 17.18). The tremopores are large, but they are smaller. when they are more numerous (fig $\div .16 .18$ ). The zooecia are sometimes bordered by a thread (fig. 14) which may becone very prominent.

The tangential section shows the frontal tremopores. Bcenuce of the general convexity of the zoarium it is impossible to obtain a preparation which shows all of them. In figure 21 the lateral tremopores occur alone and in the middle, the subjacent olocyst appears.

Affinities.-This species differs from Enoplostomella rhomboidalis, in its zoarial form, in the absence of large separating threads betreen the zooecia, and in the much more slobular oricell.

It differs from Enoplostomella Tigulifera, which is also vinculariform in the absence of lateral tongues to the peristomice and in its oral avicularium of much less strength. (Lav=0.25 mm. and not $0.40 \mathrm{~mm}$.)

Occurrence.-Vicksburgian ("Chimney rock" of Marianna limestone): One mile north of Monroeville, Alabana (very common).

Cotypes.-Cat. No. 62594 , U.S.N.M.

ENOPLOSTONELLA LIGULIFERA, new species.

Plate 90, figs. 17-22.

Description.-.The zoarium is free, cylindrical, sometines bifureated. The zooecia are distinct, elongated. fun form; the frontal is convex. thick. formed of a tremocyst with tubules smmonnting a thin olocyst with small scattered pores. The apertura is very oblique and orbicular; the peristomice is large, elongated. provided with a wide, triangular. short rimule-spiramen, garnished laterally with two salient, widespread tongues. The wirell is hyperstomial, globular, salicnt, garnished with tremopores; it opens largely into the peristomie. The avieularium is very long, transversal, provided with a pirot; the beals is directed outward. 


$$
\begin{aligned}
& \text { Measurements.-Aperturafhu=0.15 mm. Peristomice } / \text { he }=0.20 \mathrm{~mm} \text {. } \\
& \text { (interior) } 17 \%=0.15 \mathrm{~mm} \text {. (exterior) } 17 \text { pe }=0.15 \mathrm{~mm} \text {. } \\
& \text { Zooecia }\left\{\begin{array}{l}
T_{s}=0.75-0.85 \mathrm{~mm} . \\
7 z=0.45 \mathrm{~mm} .
\end{array}\right.
\end{aligned}
$$

Tariations.-The peristomice is somewhat romd with the avicularium adjacent. When the rimule-spiramen is muet developed. there are no aricularia. The two occurlences may be ohserved on the same zoarial fragment. The lateral tongues are quite variahle in form and size.

Affinitics.- This species differs from Enoplastomella defixa in its rery long aricularium $(0.40$ and not $0.25 \mathrm{~mm}$. $)$ anl in the tongue-like processes of the peristomice.

It differs from Enoplostomella rhomboinatis in its zooecia separated by furrows and not by prominences, and in its much more globular and salient ovicells.

Oecurrence.-Vickshumpian (Red Blufi clay): Seven and one-half miles southwest of Bladon Springs, Alibama (very common).

Cotypes.-Cat. No. 64292, U.S.N.M.

ENOPLOSTOMLLLA VAllata. new species.

Plate 02, tigs. 1-10.

I)eseription.-The zoarium is free, bifurcated. compresser, formed of three or four longitudinal rows of zooecia arranged on one side; on the dorsal face the zooecia are separated by projections or stockudes and ornamented with tremopores. The zooecia are elongated, rectangular, separated by projections; the frontal is convex, thick. formed of a tremoryst with tubules surmounting a perforated olocyst. The apertura is very oblique and semiluna with a straight proximal borler; the peristomice is somewhat elongated and is provided with a wide and triangular rimule-spiramen. The arieularium is placed on the border itself of the rimulespiramen, which it bounds laterally; it is triangular and provided with a pivot: the beak is turned outrard.

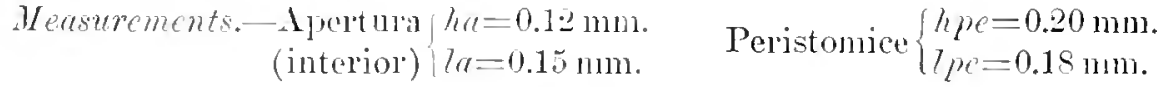

$$
\begin{aligned}
& \text { Zooccia } \begin{array}{l}
L_{z}=0.85-0.95 \mathrm{~mm} . \\
7 z=0.45 \mathrm{~mm} .
\end{array} \\
& \text { Width of branclese }=0.55-1.00 \mathrm{~mm} \text {. }
\end{aligned}
$$

I"uriations. - The plojections which hound the zouecia on the two fiaces of the zoarimu are not constant: certain branches are deprived of them (figs. 5, 6). Juwerer, on the donal fice, the two lateral lows are alone visible; on account of their alternate arrangement they appear irregular on the transverse section (figs. 7. S) and only ane nua be visible (fig. 9). The tubules are longer on the dorsal of the zoarium (fig. 10). We have nevel heen ahle to discover the ovicell on any wit our numerous specimens.

Iftimitis.-This species is nut rinuluniturm. as are the other species of the same gemus previously drecribed. 'The zonecial ale arranged on but one side of the 
zoarim. We do not think that it would be of any adrantage to create a special gemus for this particular arrangement as the functions are exactly the same as those of the other Enoplostomella. We can not logically separate it without a complete stuely of the ovicell.

The species difler from Enoplostomclla magniporosa in its much smaller tremopores. and its less wide zooecia.

Occurrence.-Vicksburgim (Mariama limestone): West bank of the Conecuh River, Escambia County, Alabama (very common); Murder Creek, east of Castlebury, Conecul County, Alabama (very common).

Cotypes.-Cat. No. Gtene, U.S.T.M.

ENOPLOSTOMELLA MAGNIPOROSA, new species.

Plate S9, figs. 15-20.

Description.-The zoarium is free, bifurcated, compressed, formed of four longitudinal rows of zooecia arranged on one side only; on the dorsal face the zooecia are separated by projections and ormamented with large tremopores. The zooecia are distinct, elongated, hexagonal; the frontal is flat or convex and formed of a tremocyst with very large pores. The apertura is suborbicular; the peristomice is elongated and is provided with a wide and rounded rimule-spiramen. The ovicell is hyperstomial, small, salient, ornamented with tremopores. The avicularim is placed amost within the peristomie; it is oval, provided with a pirot; the beak is directed outward.

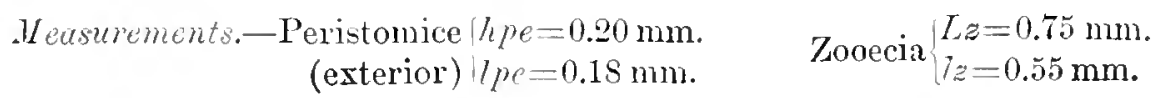

Tarintions.-On the young branches (fig. 19) the avicularium is not placed in the peristomie and the zonecia are more convex and are separated by furrows. We have found only the single oricell figured, and on a young branch (fig. 19). The tremopores, ly their conlescence, give to certain zooecia a fantastic aspect (fig. 16).

Affinities.-The zoarium has the aspect of that of Enoplostomella vallata: it diflers from it in the size of its tremopores and in its avicularium placed within the peristomie.

Occurenre-Ticksburgian (Byram marl): Byram, Mississippi (common).

cotmpr.c-Cat. No. 6.t289. U.S.N.M.

Genus SCIIZEMIELIA Canu and Bassler, 1917.

1917. Schizemirlln CANT ant Basster, Symosis American Larly Tertiary Cheilustome Irguzo, Bulletin 96, Unitel States National Museum. 1\%. 47.

The frontal of the oricell is rery fragile. The aperturn is schizoporellidan with wile rimule. The rimule-spirmon is inconstant. The tubules are romited on their commonage.

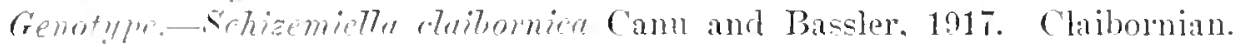




\section{SCHIZEMIELLA CLAiBorNiCA Canu and Bassler, 1917.}

Plate 14, figs. 2-4.

1917. Schizcmiella claibornica CaNy and Basster. Synopsis American Early Tertialy Cheilostome Bryozoa, Bulletin 96, United States National Museum, p. 47, pl. 4, fig. 9.

Description.-The zonrim is free, bilamellar, with inseparable lamellae. The zooecia are indistinct; the frontal is thickened, little convex, formed of a tremocyst with large, irregular tubules placed on a thin olocyst with rery small pores in quincumx. The apertura is formed of an ogival anter and a concare poster with a very wide rimule; the peristomice is elongated. embedded, with a very wide, irregular rimule-spiramen. The ovicell is hyperstomial and opens largely into the peristomie; it is little globular, hardly salient; covered by a smooth or perforated, very fragile wall; the peristomice is elliptical and transverse. The aricularium is uriangular, the point directed above. adjacent to the peristomice which it deforms, provided with a pirot.

$$
\begin{aligned}
& \text { Measurements.-Peristomice thpe }=0.20 \mathrm{~mm} \text {. Apertura } / \text {. } a=0.12 \mathrm{~mm} \text {. } \\
& \text { (exterior) } l p e=0.11-0.16 \mathrm{~mm} \text {. (interior) } / 7 \alpha=0.11 \mathrm{~mm} \text {. } \\
& \text { Zooecia } L z=0.54 \mathrm{~mm} \text {. }
\end{aligned}
$$

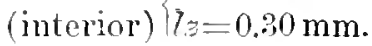

Turiations.-In the interior the tremopores are regularly placed in quincunx; on the exterior they are very irregularly disposed, larger and less mumerons.

The frontal of the ovicell is so fragile that we are unable to get an exact idea of it from our few specimens. This organ requires further examination.

The rimule of the peristomice is very inregular. In reality the form of the apertura belongs (fig. 4) to the group) of rery typical Schizoporella. and the operculum onght to be chitinized enough to sufficiently insure the opening of the compensatrix by itself.

Occurrence-Claibornian (Gosport sand) : Claiborne, Alabama (rare); 1 mile southwest of Rockille. ('larke County. Alabama (rare); Gopher Hill. Tombigbee River, llabama (rare).

Claibornian (Cook Mountain formation): Moseleys Ferry. Caldrell Comty. Texas (riare).

Cotypes.-Cat. No. 62595, TT.S.N.M.

\section{Genus METRADOLIUM Canu and Bassler, 1917.}

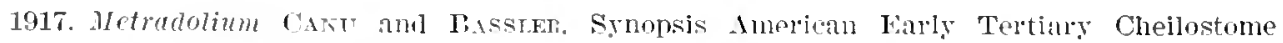
IBrozoa, Fulletin N. L'uited States Nationa Nuseum, p. 47.

The nricelled zooecia, different in form from the others, have a peristomice in the form of a lunar crescent without rimule-spiramen. The frontal is a tremoeyst with tubules.

Genotype.-Metredotium dissimile Canu and Bassler. 1917. .Tacksonian.

Eschara tubsrosa Renss. 186if. of the Stampian of Germany. helongs withont doubt to this genus. 
The oricells have the aspect of the gonoeein of the Areonidate. Employing sections it may he seen (pl. 57 . fig. 10) that this anect is deceptive and that the ovicells are hyperstonial and open in the peristomic; only the form of the peristomice is changed. This change is in certain relationship with the physiologie peculiarity which is difficult of analysis and of precise description. We believe that the oricelled zooccia exist only for the larva. After the passage of the eggs, the polypide and the compensatrix disappear by histolysis, so that the peristomice lunar-crescent in shape, serves only for the escape of the larvae. It is, in fact. very diflieult to suppose the persistence of a polypide, in the absence of liydrostatic apparatus (rimule) and in a peristomial system so long and so complicated. Moreorer, these same zooecia are provided with a much reduced avicularium; this organ was useful in mutrition: its reduction proves its inutility and consecuently the disappearance of the polypide. There is nothing analogous in the recent species.

The species of this genus are quite polymorphic. Their classification has reanired much time, much patience, and much trouble. The alterations due to fossilization often occasion problems diflicult of solution.

The individuals were rery rolacious; they therefore did not persist in the successive stages of a region.

These oricells are not without analogy with thoce of the Tubucellariifine (text fig. $159 \mathrm{E}$ ) and the histological phenomena onght to be somewhat analogous. The Tubucellaridae are always provicled with an ascopore and not with a spiramen. that is to say, a pore which opens into the compensatrix itself and not into at peristomic.

METRADOLIUM LABRATULUM, new species.

I'late $5 \overline{5}$, figs. s'-11.

Description.-The zoarinm is free, bilamellar. with rounded and bifurcated fronds. The zooccia are little distinct, elongated, elliptical; the frontal is a tremocyst with tubules placed on a rery thin olocyst in which very thin perforations correspond to the tubules. The apertura (interior) is orbicular; the peristomice bears a rimule-spiramen on the zooceia with an oral avicularium; the peristomice is orbicular on the zooceia provided with an enormous proximal mucro at the base of which is the spiramen. The avicularium is very much projecting. oval. furnished with a pirot: its beak is directed towart the exterior.

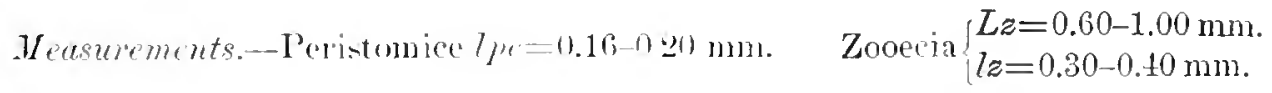

Tariations.-This species is curions and instructive. (h) the same zoarimn we mar note the existence of a rimule and of a spuramen. both of which must have the same function. namely, of conducting the water below the apertirn to sway the opereulum and to open the compensatix. One must not confound thispiramen with the ascopore of the Microporellae; the latter is the same opening as that of the compensatrix.

Here the large oral muero peplaces exactly the avicularium; it therefore has the same nutritive use. This is why in many mueronated species we see the mucru 
much elongated in the buried parts of the zoarium. This spccies then permits us. according to Calvet, to determine the physiologic equiralence of the two organs.

The size of the aricularian mandible indicates a rorncious species. which did not live long.

The mucro is quite variable in form and it is sometimes a sort of very irregular salient lip.

()ecurene-Middle Jacksonian: One-half mile southeast of Georgia Kaolin Co. Mine. Twiggs County, Georgia (rare); $3 \frac{1}{2}$ miles north of Grovania. Georgia (rare); Baldock, Buruwell County, South Carolina (rare); 18 miles west of Wrightsville, Johnson County, Georgia (very rare); $1 \frac{1}{2}$ miles southeast of Lily, Dooly County, Georgia (rale).

.Tacksonian (Zenglorlon bels) : Shubuta, Mississippi (rare).

Cotypes.-Cat. No. 6 $111 \pm$, U.S.N.MI.

METRADOLIUM DISSIMILE Canu and Bassler, I917.

Plate 56 , figs. 1-15.

1917. Metradolium dissimile Caxu and Bassler, Synopsis American Early Tertiary Cheilostome Bryozoa. I;ulletin 96, United States National Museum, p. 45, pl. 4, fig. 10.

Description.-The zoarium is free, bilamellar, branching; the fronds are wide. thick, distorted. or mululated, dichotomons. The zoocia are distinct, elongated, elliptical. The frontal is a tremocyst with tubules resting on an olocyst with rery small pores corresponding to the tubules. 'The peristomie is deep and rery oblique: the apertura is small and suborbicnlar; the peristomice is orbicular; the spiramen is median, more or less distant from the peristomice. There are two oral avicularia symetrically placed but dissimilar in form and size; the smaller is round, simple, nonsalient; the larger is enormous, oval, salient, with pivot. The oricell is enornous, buried in the distal zooecia, hyperstomial but opening largely into the peristomie, salient and globular; its peristomice has the form of a lumar crescent; the ovicelled zooecia bear only a small aricularium with pivot.

Mcusurements.-Peristumice hpe $=0.14-0.16 \mathrm{~mm} . \quad$ Zooecia $[z z=0.74-0.76 \mathrm{~mm}$. (exterior) $\mid z p e=0.15-0.20 \mathrm{~mm}$. (exterior) $l z=0.40-0.50 \mathrm{~mm}$.

Trmations.-The two aricularia are often symmetrical and tubular (fig. 9). cspecially on young zouria (figs. 10, 11); there are some entire branches constituted in this way. but presenting here and there some normal avicularia. The external micrometric dimensions ale evidently smaller on the young zonria (figs. 10. 11): the more the froutal beromes thickened the more the peristomice becomes werter and the more robust the large arienlaria become.

The spiramen is often replaced by a rimule-spiramen (fig. 7 ), a phenomenon vi-ible in the interior (fig. 12) on accomt of the areat obliquity of the peristomie. When the spiramen is yute large (figs. 2. 3). the oril aricularia disappear or are mincle reducel: the fronds with this structure do not belong to a distinct variety for it is a common ocempence to find fronds containing a mixture of such zonecia aml normal zonoria. 
'The ovienll is globmlan. salient, with tremopores analogons to those of the frontal (fig. 5): the zooecia which heal them have also an aricularim and a spiramen, hut the latter invarials? beomes closed and it does not appear in rertical sections (fig. 1.i). The oricell in enolmons. almost as large as the zooecia (fig. 1.5). If it contains only larvae. as is probuble, their expulsion through a peristomice so small would plesent some dilliculty.

Iangential soctions (fies. 13, 1t) show mumerons tremopores; the reticulations are not visible on accomnt of the distance of the olocyst.

Iffinities.-This species ditlors from Metradotium labratulum in the absence of the laripe oral labrimn.

It diflers from Metratolinm previmututum in the ravity of the zooecia with rimule-spiramen, in the much smaller dimensinns of the peristomice (0.12 instorl of $0.1+\mathrm{mm}$.). and in the constant presenee of the large oral avicularimm.

occurener--Middle .Jackonian: Wilmington, North Carolina (very conmon): Eutaw Springs. South Carolina (rarc) ; noar Lenuds Ferry, South Carolina (common): Rich Hill. Cravforl County, Georgia (common) : 12 miles southeast of Marshallville. Georgia (rare): $3 \frac{1}{t}$ miles south of Perry, Georgia (rery common).

Cotypes.-Cat. No.62596. T.N.X.M.

\section{METRADOLIUM PARTIRIMUlatUM, new species.}

Plate 55, figs. 15-20.

Thesmiption.-The zoarium is free. compressed, bilamellar; the fronds are flat, narow, bifurated; the lamellae are inseparable. The zooecia are little distinct; the frontal is convex, thick. formed of a tremocyst with numerous tubules. The apertura (interior) is semilmal: the peri-tomice is small, transverse; it bears a suall mnsymetrical rimule-spiramen. one side bcing higher than the other; the peristomice of the zoocis with spiramen is wide. elliptical, transverse. There are two symmetrical, oral avienlaria. of which one is much larger than the other; the latter is alient, elliptical, the hati tmod toward the exterior.

$$
\begin{array}{r}
\text { Measurements-D'Pristumice } \\
\text { (exteriol) }
\end{array}
$$

- Torbetions.-The principal avicularium is very small (fig. 1T), medium sized or very large (fig. 19). The zoodia with spiramen ale rave; they are arranged in crompe in the midst of the others. We are mable to learn what influcnce causes their formation. The ovicell is mnknown.

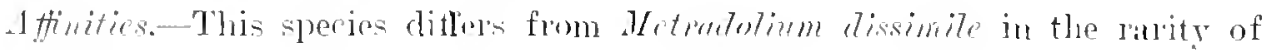
its zooecia with spiramen ant it much smaller micemetric diumsions

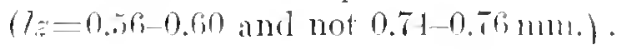

The sperimens mprovided with zoneera with spiramen are difficult to dislinguish from . Metrudolizm oblinum. It differs from it in its smaller micrometric

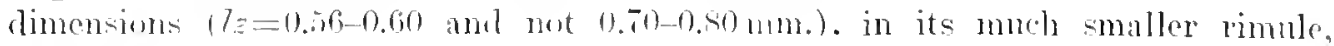
nearly symmetrieal and not olingur. 
Occumence-Middle .Tacksonian: Wilmington. North Carolina (rare): near Lenuds Ferry. South Carolina (common); Entaw Springs. South Carolina (very common): Rich Hill. Crawford Comnty, Genrgia (common); Baldock, Baruwell County, South Carolina (common): one-half mile southeast of Georgia Kaolin Company Nine. Twiggs County. (Heorgia (common).

Tpper Jacksonian (Ocala limestone): Alachua. Florida (very rare); west bank of Sepulga River, Escambia Countr, Alabama (rery rare).

Cotypes-Cat. No. G.t11s, T.S.N.M.

METRADOLIUM TRANSVERSUM, new species.

Plate 5 T, figs. $1-3$.

Incsoription. The zonsium is flee. bilamellas. erect; the fuonds are foliaceous or nearly cylindrical; the two lamellae, back to back. are inseparable. The zooecia are indistinct, elongated, and large; the fromtal is convex, thick, and formed of a tremocyst resting on an olocyst, with small correponding pores in quincuns. The apertme is elongated. semilunar, with a concare proxinal border ; the peristomice is oblique, wirle, tronsecrse; the rimule-spiranen is wide but little deep: its form and its position are iregular. The oral avicularium is small, rare. and inconstant.

$$
\begin{aligned}
& \text { Measurements - I pertura }(h a=0.20 \mathrm{~mm} \text {. } \\
& \text { (interior) } l a=0.17 \mathrm{~mm} \text {. } \\
& \text { Zooecia }\left\{\begin{array}{l}
I z=0.80 \mathrm{~mm} . \\
l_{z}=0.40 \mathrm{~mm} .
\end{array}\right. \\
& \text { Peristomice } \int \text { l } p e=0.15 \mathrm{~mm} \text {. } \\
& \text { (extrior) } / 7 p e=0.18-0.20 \mathrm{~nm} 1 .
\end{aligned}
$$

Tomiations. - On well-preserved specimens the tremopores are placed at the botton of small sulci. These tremopores are snall, numerone, regularly arranged in quinemx: they are easily altered by fossilization. The peristomice is rery irregnlar; the rimule is often placed quite laterally (fig. 2). and it is replaced on the proximal border by a salient convexity. which angments still more the transverse aspect of the peristomice. In old zonecia the rimule disappears. the peristomice becomes orbicular and leep: the species is then unrecognizable.

Affinities.-This species differs flom . Yetrutotium pareirimulatum in the inconstance of its rimule-spiramen, its lare micrometric dimencions ( $L: z=0.80$ and not $0.60 \mathrm{~mm}$.), and in the absence of zooecia with spiramen. It differs from Metradolim gronde in its much smaller rimule. its smaller peristomice (lpc=0.20 and not $0.25 \mathrm{~mm}$.), and it more numerolis and snaller tremopores.

It differs from Metratotinm sulcifem in its less deep and more transitory snlei, in its rery small rimule-spiramen. and the absence of the larece oral aricularimm.

Oecumenee.-Mirldle . Tacksonian (Cartle Hayne limestone): Wilmington, North (arolina (very common).

Upper Tacksonian (Oeala limestone) : Chipola River, east of Mariamna. Tackson County, Florida (common).

Tackimian (Zenglodon zone) : Shubuta. Mississippi (very rare).

C'otypes.-Cat. No. $6+1$ 20. U.S.N.M. 
HETRADOLIIM GRANDE, new species.

Plate 5.5, fiss. 12-14.

Despription.-The zoarium is free. bilamellar; erect; the foonds are dicho-

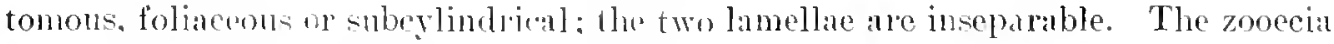
are very lirye, elongated, indistinct laterally; the frontal is convex, thick. formed of a tremocyst with large pores. The peristomice is large, elongated; the rimulespiramen is lange, rombled. The oral aricularium is large, transverse adjacent to the peristomice or placed in the peristomie.

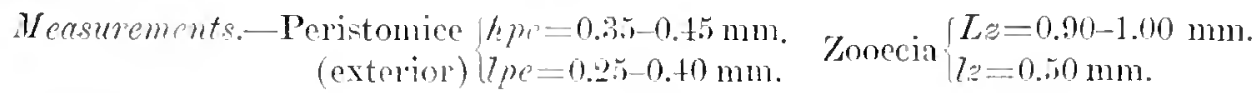

Affinitics.-When the aricularium is exterior the rimule-spiramen is quite well formed (fig. 13): when it is hirdrn in the peristomie the rimule becomes rery irregular and deeper. It is the lengthening of the tubules of the tremocyst which increase ambl deform the peristomice and augment the external dimensions of the zooecia.

This species differs from Mctudotium transerersum in its large rimule. its elongated and nontransverse peristomice (hpe=0.35 and not $0.15 \mathrm{~mm}$.) and its large tremopoles.

It differs from Metratolizm sulcifem in the absence of frontal sulci and its smaller general micrometric dimensions.

Occurpence-Middle Jacksonian: Noar Lenuds Ferry, South Carolina (very rave); Rich Hill. Crawford Comnty, Creorga (race); Entaw Springs, Sonth Caro-

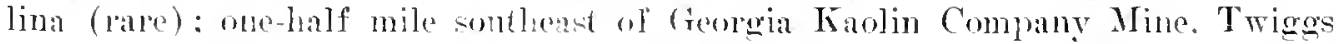
County, Geoloria (rare).

Jacksonian (Zenglodon zone) : Blufl on sonth side of Suck Creek. Clarke Connty. Mississippi (very rare).

Cotypes.-Cat. Nos. 6t116, 6t117, U.S.N.M.

METRADOLUM CONVENIENS, new species.

Plate 5li, figs. 16-21.

Description.-The zoarim is free. bilamellar, erect; the fronds ale foliaceous. fiat, or undulated, branching; the two lamellae, back to back, are inseparable. The zooecia are elongated, little distinct laterally; the frontal is convex, thick; it is formed of a remoeyst with small tubules arranged in quincunx, placed on a very thin olocyst with small corresponding pores. The apertura is subround; the peristomice is rery rlongaterl. elliptical; the rimule-spiramen is more or less risible and always symmetrical. The oricell is globular, little salient, ormamented with tremopores similar to those of the frontal: its peristome is transrerse in the form of a lumar-erescent; it is hyperstomial, very large, and opens largely into the peristomie. Near the peristomice there are two elliptical avicularia, replacel often by a single lorger and more salient one. 


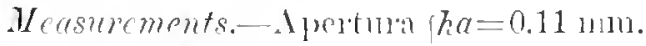

$$
\begin{aligned}
& \text { (interior) } / 7 q=0.11 \mathrm{~mm} \text {. } \\
& \text { Peristomice } / h p p=0.19 \mathrm{~mm} \text {. }
\end{aligned}
$$

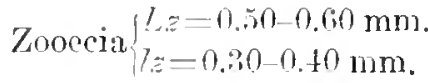

$$
\begin{aligned}
& \text { (interior) } 7 p e=0.12 \mathrm{~mm} \text {. }
\end{aligned}
$$

Tariations.-The perictomice is quite varible in its general form; it is often l)ovided with a rimule-spiramen (figs. 17. 18). but there are some entire fronds which are entirely without it (fig. 20). The ovicells are quite variable in form and size, (figs. 1 $1-19$ ). The two oral a vicularia are symmetrical (fig. 20). but very often there is only one large oval avicularinm with pirot. having its beak turned outward (fig. 19).

The longitudinal section (fig. 21) shows that the ovicell is almost as large as the zooceimm itself, and that the apertur: of the ovicelled zooecium is smaller than that of the other zooccia.

Affinities.-The symmetry of the rimule-hiramen is very characteristic and permits one to easily distinguish this species.

It differs from Metradolium arands. in which the limule-spiramen is often strmmetrical, in its smallex micrometric rimensions ( $L: z=0.60$ and not $0.90 \mathrm{~mm}$.) and its smaller and more numerous tremopores.

It differs from Metralotium dissmile. in which the rimule-spiramen is vaguely symmetrical, in the absence of zooccia with spiramen, and in the somewhat smaller dimensions $\left(L_{z}=0.60\right.$ and not $\left.0.76 \mathrm{~mm}.\right)$.

Occurpence.-Middle Jacksonian (Castle Hayne limestone) : Wilmington. North Carolina (very common).

$$
\text { Cotypes.-Cat. No. G } 4119 \text {, U.S.N.M. }
$$

METRADOLIUM OBLIQUUM, new species.

$$
\text { l'ate } 5 \text {, tigs. } 4-10 \text {. }
$$

L'xription.-The zoalium is free. Vilanellat, erect: the fronds are flat, bifurcaterl the two lamellice are back to back and inseparable. The zooccia are elongited, very littlo distinet; the frontal is thick. convex; it is formed of a tremoevst with tubules smmonnting an olocyst, which $i=$ rery thin and finely perforated with corresponding pores. The apertura is ohlique. suborbicular; the peristomice is former of a subcireular anter with poorly definet outlines and of an unsymmetrical rimule-spinamen oblique with respect to the zoowial axis. The ovicell is globulan, salient, hyperstomial. Iargely open into the perintonic. cleeply embedded in the dista] zooveriun: it is covered with tremoporos like the frontal: the peri-tonice is large, transrerse. in the form of a lunar crecent. of which the convexity is proximal. Two aviculatia ale symmetrically placer on each side of the rimule: the larger is salient. transverse, oral. provided witl a pirot. its beak turned outward.

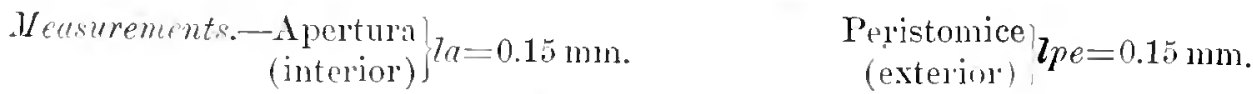

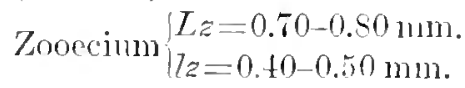


Variations.-The rimule-spiramen is unsymmetrical and oblique; it is formed of two lateral lips not al'ranged on the same plane; one is always higher than the other; the lower is always adjacent to the litge aricularium. When the two oral aricularia are symmetrical the rimule is symmetrical. There is, therefore a certain relation between the functions of the avicularia and the hydrostatic system. The longitudinal section shows a rery large ovicell opening into the peristomie above the operculum, and a large septula (multiporous) at the base of the zooecia (fig. 10).

The tangential section (fig. S) shows the structure of the frontal, which is a tremocyst with tubnles. The conrexity of the zooecia allows one to note the subjacent olocyst at the elge of the tremocyst (fig. 9).

Affinities.-In the interior the apertura bears a proximal spine forming a sort of lyrula (fig. i) which disappears easily in fossilization. This species differs from Metradolium sulciforum in its smaller tremopores not arranged at the buse of the sulci.

It differs from Metrarlolium rissimile in the general absence of zooecia with a spiramen and in the lesser width of the peristomice ( $p e=0.15$ and not $0.20 \mathrm{~mm}$.).

Occurrence-Middle Jacksonian: Wilmington, North Carolina (rery common) ; $3 \frac{1}{2}$ miles north of Grorania, Georgia (rare); 12 miles southeast of Marshallville. Georgia (common); Rich Hill, Crawford County, Georgia (very common); 18 miles west of Wrightsrille, Georgia (rare); 3. miles sonth of Perry, Georgia (common) : near Lenuds Ferry, Sonth Carolina (very common).

C'otypes.-Cat. No. $6 \pm 121$, U.S.N.M.

METRADOLIUMI SULCIFERUM, new species.

Plate 14, figs. 5-15.

Description.-The zoarium is free, bilamellar, erect: the fronds are compressed, narrow, bifurcated. The zooecia are large, elongated, indistinct; the frontal is convex. thick, formed of a tremocyst with tubules. supported by a very thin olocyst, finely perforated with corresponding pores and closely joined. The apertura is formed of a semilunar anter and of a coneave poster supporting a very short median lyrula: the peristomice is oblique and is formed of an anter with undefined outlines and an unsmmetrical rimule-spiramen. There are two avicularia symmetricaliy placed on each sicle of the rimule; the larger is provided with a pirot and witl a rery large manulible.

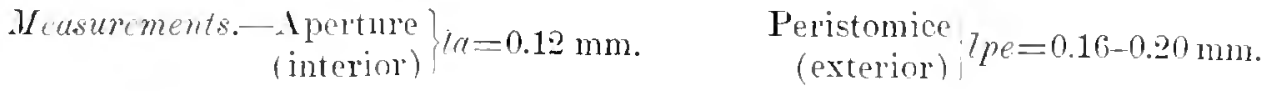

$$
\begin{aligned}
& \text { Zonecia }\left(\begin{array}{l}
l_{z} z=1.00-1.25 \mathrm{~mm} \text {. } \\
7 z=0.30-0.40 \mathrm{~mm} \text {. }
\end{array}\right.
\end{aligned}
$$

Tarutions.-On the roung fromds (tigs. 6,12 ) the metian zooecia are mpro. vided with oral aricularia: the lateral zonecia bear only large avicularia. In the normal zooecia, there are two avicularia; the larger $i$ adjacent to the lomer lip of the rimule (fig. 8). In the old zooecia the large aricularimm is lost among the tubules and opens then into the peristomie (figs.9.10.11). The more the tubules 
are elongated the more the peristomice is enlarged and the more the micrometric measurements are increasel. These are, therefore, often inferior to those which we give above; it is not rare to olsserve; $L z=0.80-1.00$ by $7 z=0.40-0.45 \mathrm{~mm}$. (fig. 8) Tery rarely a thin separating threal linits the zooecia (fig. 6).

One of the distinctive characters of this species is a sort of small lyrula which is visible on the proximal borter of the apertura in the interior of the zooecia (fig. 13).

The specific character of the species is the presence of the frontal sulci at the base of which the tubules open: they give to the tangential sections an especial and strange aspect (figr 15).

Aftnitis. -The species differs from Metradolium obliquum in which the rimule-spiramen is identical, in its frontal sulci and in its larger dimensions $(L z>0.80 \mathrm{~mm})$.

It diflers from Metratolum transuersum also provided with sulei in its very large and unstmmetrical rimule-spiramen and in the almost constant presence of two oral aricularia.

Ocrumene.-Claibornian (Gosport sand): One mile sonthwest of Rockville, Clarke Comty, Alabama (rare).

Lower Jacksonian (Moodys marl) : Tackson. Missicsippi (very common). Cotypes.Cat. No. 63850 , U.S.N.M.

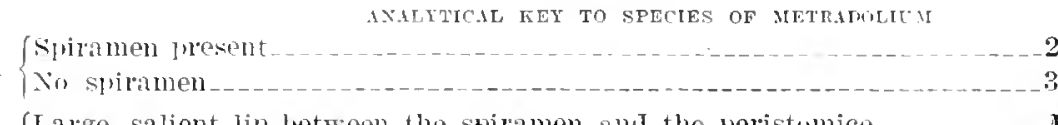

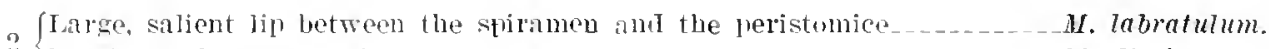

$2\left\{x_{n}\right.$ lip to the peristomice

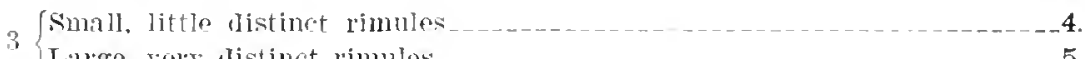

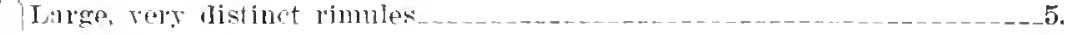

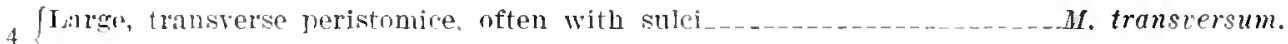

Sunall fielistomice (lpe $=0.10-0.12 \mathrm{~mm}$.)

5 flare, symmetrical rimule. straight, rommled $\ldots \ldots \ldots$. convoniens.

Iarge, unssmmetrical rimule, one jip being much lower than the other 6 .

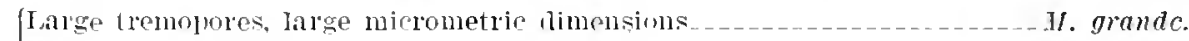

6 small tremolnres, oblique rimule___.

Tremopores at the hase of the sulci

\section{Genis LEIOSELLA Canu and Bassler, 1917.}

1917. Lciosella CANU and Bassler, Symopsis American Early Tertiary Cheilostome Pryozu, Bulletin 96, Unitel States National MInsenm, P. 4.

The frontal is an olocyst. The peristomice of the ovicelled zooecia is of different form from that of the other zoocia; it is a lunar erescent and deprived of rimulespiramen.

Genotype.-Lriosella rostrifera Camm and Baseler. 1917. Vicksburgian.

'This cenus differs from Metradotium only in the nature of the frontal which is here a very thick olncyst.

Of the three species mentioned, one only bears ovicells. Further researches are necessary. 
I'late 92. tigs. 11-17.

1917. Lciosella rostrifon CANU and IAssler, symolsis American Lirly Tertiary cheilustome Bryozoa, Bulletin 96, United States National Museum, p. 18, pl. 5, fig. 1.

Description.-The zoarinm is free, bilamellar; the fronds are narrow, flat, claviform, bifurcated. The zooecia are elongated, distinct, oroid; the frontal is smooth, convex, formed by a thick olucyst. The peristomice is irregrular; the rimule-spiramen is bordered laterally by the oral avicularium. The apertura is elongated, ovoid, very oblique. The oral avicularium is large, transverse, salient, witl the beak strong and curred; it is provided with a pirot and a large mandible, more or less spatulate. On the firontal, there are two small, elliptical avicularia with round mandible.

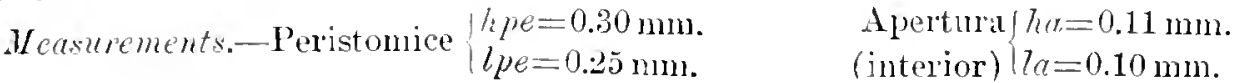

$$
\begin{aligned}
& \text { Zoocisis } L z=0.90-1.00 \mathrm{~mm} \text {. } \\
& \text { (interior) } l / z=0.25-0.30 \mathrm{~mm} \text {. }
\end{aligned}
$$

Tariations. - It the exterior the measurements are quite variable because of irregularity in calcification and the mequal development of the avicularinm. The apertura is very oblique and elongated; in perspective in the interior (lig. 16) it appear's transverse and elliptical. The oral avicularium on account of its great prominence is very fragile and easily broken (fig. 13); it is more or less lost in the thickness of the olocyst (figs. 1t, 15). The small frontal avicularia are not always visible (fig. 15).

Occurvenee.-Ticlisburgian ("Chimney rock" of Marianna limestone) : One mile north of Monroeville, Alabama (very common).

Vicksburgian (Red Bluff clay) : Seven and one-half miles southeast of Bladeu Springs. Alabama (common).

Cotypes.Cat. No. (i.25y U.S.N.M.

LEIOSELLA GFANDISORA, new species.

Plate 12, fig. 1S.

Lescription.-The zonrium is free, subeylindrical. The zooecia are indistinct, somewhat elongated; the frontal is sniall, hardly convex, and is formed of a thick olocyst. The peristomice is rery large, fumel-shaped, provided with a linge rimule-spiramen, little distinct; the apertura is large, elongated, somewhat oral. The ovicell is large, prominent, transverse; the peristomice of the ovicelled zooecia is elliptical and transrelse. In the peristomie there is a large thin, triangular avicularimn.

$$
\begin{aligned}
& \text { Weasurements.-Peristomice f hpe }=0.40-0.4511 m \text {. Apertura } / h a=0.30 \mathrm{~mm} \text {. } \\
& \text { (exterior) } 17 \text { pe }=0.30 \mathrm{~mm} \text {. } \\
& \text { Zooecia }\left\{\begin{array}{l}
T_{z}=0.70 \mathrm{~mm} . \\
l z=0.40-0.45 \mathrm{~mm} .
\end{array}\right. \\
& \text { (interior) }\{? a=0.25 \mathrm{~mm} \text {. } \\
& \text { 5. ร. } 99-20-\text { Bull. } 106-29
\end{aligned}
$$


Affinitics.-As the figured specimen is the only one found we are able to get only an imperfect idea of this very remarkable species. The attennation of the rimule-spiramen in this species and in some other species of the same family is always an indication of a reinforcement of the operculum more chitinized and more rigid.

The species differs from Leinse7ta omicularia in its larger micrometric dimensions and the absence of small frontal avicularia.

Occurrener.- Vicksburgian (" ('himney rock" of Marianna limestone): One mile north of Monroeville. Alabama (very rare).

IIototype.-Cat. No. 642!6, T.S.N.M.

LEIOSELLA ORBICULARIA, new species.

Plate 01, firs. 22, 23.

Description.-The zourinu is free, cylindrical, formed of two separable lamellae. The zooecia are distinct, almost orbicular; the frontal is smooth and conrex, formed of a rery thick olocyst. The peristomice is large, orbicular, placed in the nidille of the zooecia; the rimule-spiramen is formed on one side by the oral avicularium; the aperture is elongated, very oblique, somewhat oral, the point below. On the border of the peristomie there is a large oral arieularium triangular, not salient, with thin wall, provided with a pirot. There are some small frontal a vicularia, simple and orloicular, seattered among the peristonices.

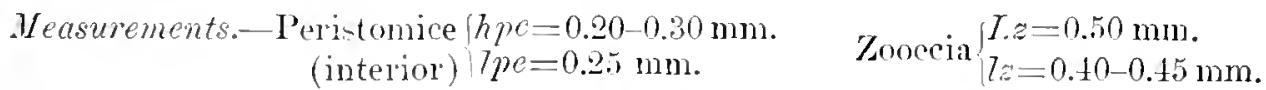

Affinities.-Only two specimens have been found. The great difference in form and position between the peristomice and the apertura is rery remarkable. We are ignorant of the ovicell.

The species differs from I ciosplla grantixom in its smaller micrometric dimensions and the presence of small frontal arieularia.

Occurener.- Vickshurgian (Red Bluff clay) : Red Bluff, Wayne County, Mississipipi (lare).

Hototype-Cat. No. 6te94. T.S.X.M.

Genus METROCR YPTA Canu and Bassler, 1917.

1917. Metrocmpte CANU and BAsster. Synopsis American Farly Tertiary Cheilostome Bryozoa, Eulletin 96, United States National Muscum, p. 49.

The frontal is a trenocyst with tubules. The rimule-spiramen is wide and of very little depth. Ovicell unknown.

Genotype.-Netrocrypte bucculenta. Cann and Bassler, 191\%. Tacksonian.

The oricell of this genus is unknown and it is therefore rery doubtful that it should tre introlued into this family. The oral avicularim is rerg rate; however. its presence seems to us the lext rharater for colasification. 


\section{METROCRYPTA BUCCULENTA Canu and Bassler, 1917.}

Plate 5S. figs. 1-10.

1917. Metrocrypta bucculenta Canu and Bassler, Synopsis American Early Tertiary Cheilostome Bryozar, Bulletin 96, United States National Museum, 1. 49, pl. 5, fig. 2.

Deseription.-The zourium is free, cylindrical, bifurcated. The zooecia are elongated, large, little distinct; the frontal is convex, porous, formed of a tremocyst placed on a thick olocyst. The peristomice is somewhat elongated, oval, its lower point formed of a wide rimule-spiramen; the peristomie is somewhat salient; the apertura (interior) is much smaller, orbicular, very oblique. The oral avicularium is rery rare; it is quite large, prominent, triangular, adjacent to the peristomice, provided with a pirot placed very low.

$$
\begin{aligned}
& \text { Measurements.-Peristonice thpe }=0.30-0.35 \mathrm{~mm} \text {. I Apertura } h a=0.15 \mathrm{~mm} \text {. } \\
& \text { (exterior) } l p e=0.30 \mathrm{~mm} \text {. | (interior) } l a=0.15 \mathrm{~mm} \text {. } \\
& \text { Zooecia }\left\{\begin{array}{l}
L_{z}=1.00 \mathrm{~mm} . \\
l_{z=1.23 \mathrm{~mm} .} .
\end{array}\right.
\end{aligned}
$$

Tariations.-The zooecia are sometimes distinct and separated by a prominent thread (fig. 3). The peristomie (fig. 6) is very wide and in proportion $\pi$ ith the size of the peristomice; the apertura being small. we are ignorant of the use of the exaggerated development of this tube. The exterior and frontal walls are very thick (figs. $6, \tau$ ): but the interior walls are thin and rery fragile (fig. 10). In the interior the apertura is almost invisible, because it is almost perpendicular to the plane of the frontal (fig. 10).

We have observed some interzooecial swellings; they are globular, porous, prorided with an orbicular orifice (fig. 9). They are superposed on the tremocyst and always appear in connection with a peristomie (figs. 2, 8). Can this be the oricell?

Occurrence.-Middle .Tacksonian (Castle Hayne limestone) : Wilmington, North Carolina (common).

C'otypes.-Cat. No. 62598 , U.S.X.M.

Genus oCHETosella Canu and Bassler, 1917.

1917. Ochetesclla caxt and Hassrer, Synonsis American Lally Tertiary Cheilostome Bryozoa, Bulletin 96, Uniter States National IInsenm, p. 49.

The ovicell is hyperstomial and deeply imbedded in the distal zooecium. The rimule-spiramen is reptaced by a small canal supported by a peristomial projection. The frontal is an olorgest perforaterl laterally ly some areolate and covered by a iniform pleurocyst.

Gcnotyp.-Ochetosellu jucksonicu Canu and Bansler, 1917.

Rande.-Claibornian. Jacksonian.

At first glance, this genus apperal's close to Palmicelluriu. but this is an error. The large avicularian nutere of that $\underline{g}$ enus is replaced here by a small canal which is evidently the equivalent of the rimule-spiramen of the other genera of the family 
Stomachetosellidae. When it exists, the oral avicularim is indeed in its place in the immediate ricinity of the peristomice and of the rimule-spiramen.

oChetosella JACKSONICA Canu and Bassler, 1917.

Plate 15, figs. 1-10.

1917. Ochctosclla jarlisonica Cand and Bassler, Synopsis American Early Tertiary Cheilostome Bryozoa, Bulletin 96, United States National Museum, p. 50, pl. 5, fig. 3.

Description.-The zonrium is free, erect, cylindrical, bifurcated, often anastomosing. The zooecia are elongated, distinct, hexagonal, separated by a salient thread; the frontal is concave, bordered by large areolae, formed of a thin olocyst and covered by a uniform and finely granulated plenrocyst. The apertura is semi. lunar and invisible externilly; the peristomice is rery oblique, with undefined outlines, raguely triangular. The ovicell is globular and deeply imbedded in the distal zoocia. The oral aricularium is rare.

$$
\text { Measurements.-Zooecia }\left\{\begin{array}{l}
L z=1.10-\mathbf{1} .20 \mathrm{~mm} \\
\{z=0.50 \mathrm{~mm} .
\end{array}\right.
$$

Fariations.-The young zooecia have no separating thread (figs. 3-6); they have a mucro much developed and quite prominent (figs. 4,5) which bears the characteristic small canal. The zooccia are thicliened by the development of the pleurocyst which is deposited at first around the areolne (fig. 9) and afterwards over all the frontal (fig. 8). In these conditions, the mucro is of less and less prominence, but the small canal-like spiramen always persists. This same pleurocyst covers the ovicell (figs. 3. 10).

At the bifurcation of the branches, there is a large zooecium which bears a large special aricularium whose purpose is still to be learned.

Affnities.-This species is very easy to determine. It differs from Ochetosella robusta in its smaller zoarium, in its large, lateral areolae and in the absence of the zooecial peristomie.

Occurrence-Clper (laibornian (Gosport sand): One mile southwest of Rockrille, Clarke County. Alabama (very rare); Gopher Ilill. Tombigbee River: Alabama (rare).

Lower .Jacksonian (Moodys marl) : Jackson, Mississippi (very common).

Middle Tacksonian: Wilmington, North Carolina (rery common); near Lenuds Ferry, South Carolina (common); Entaw Springs. South Carolina (common); $3 \frac{1}{\frac{1}{4}}$ miles south of Perry, Georgia (common); 18 miles west of Wrightsville, Georgia (common) : Rich Hill, Crawford Comnty, Georeria (very common); Baldock, Barnwell County, South Carolina (rery common); 17 miles northeast of Hawkinsville, Georgia (rare); one-half mile southeast of Georgia Kaolin Company mine. Twiggs County, Georgia (rare).

Upper . Tacksonian (Ocala limestone): West hank Sepulga River. Escambia County, Alabama (rare).

Cotypes.-Cat No. 62509. T'.S.N.M. 
OCHETOSELLA ROBUSTA, new species.

Plate 57, figs. 11-17.

Description.-The zoariun is free, cylindrical, branching. The zooecia are large, elongated, cylindrical; the frontal is very convex; it is terminated distally by a salient and almost complete peristomie; it is formed of a tremocyst with very small pores. 'The oral mucro bears a trenched spiramen and avicularium; the peristomice is very oblique; its ontlines are undefined. The oral avicularium is round, simple and without pivot.

$$
\text { Measurements.-Zooecia }\left\{\begin{array}{l}
L z=1.20-1.30 \mathrm{~mm} \text {. } \\
7 z=0.65 \mathrm{~mm} .
\end{array}\right.
$$

Tariations.-The development of the calcification gives to the zonecia some quite variable aspects which it is impossible to analyze, but which figures 14 to 17 represent sufficiently. Figure 12 represents a very curious case of an inversion of zooecia on the same branch.

Affinities.-This species is always easy to distinguish from Ochetosella jacksonica by its large branches and the absence of arealac.

Occurrence--Middle Jacksonian: Wilmington, North Carolina (common); near Lenuds Ferry, South Carolina (rare).

Cotypes.-Cat. No. $6+122$, U.S.N.M.

Family SMITTINIDAE Levinsen, 1909.

Allutomical bibliography.-1865, Smrt, Skandinaviens Hafs-bryozoel, Ofrersigt Kongl. Vetenskaps-Akàdemiens Förbandlinger, vol. 22, pl. 3, figs. 9, 10, 11; pl. 5. fig. 4.-1S92. IVATErs, Observations on the Gland-like Bodies in the Bryozoa, Joumal Linnean Society, London, Znologs, rol. 24, pl. 19, figs. 15, 16.-1900. Waters, Bryozoa from Franz Joseph Ianu, [1, 10, figs. 8-17; pl. 12, figs. 3, 4.-1904. Waters. Expedition Antaretic Belge, Bryozoa, pl. 4, figs. 1, 2.-1909. Waters. Reports on the Marine Biology of the Sudanese Red Sea. XIII. The Fryozon, Journal Linnean Society, London, vol. 31, pl. 14, tigr. 14; pl. 15. fig. 11.

The ovicell which is hyperstomial and imbedded in the distal zooecia opens into the peristomie. The peristome is produced and channeled in front. The operculum is (not universally) very thin; the lower edge is straight or slightly curved inward and hardly separated from the ectocyst; the muscular attachments are usually a ridge on the border. There are very small oral glands ofter partly attached to the tentacular sheath. Spines.

This family is a very important one. but unfortumately our knowledge of the anatomy and embryology is too little to allow ns to fix its exact limits. The development of the peristome is one of the essential characters; we continue to follow the same terminology as for the preceding families. The orifice of the peristome is the peristomice (secondary orifice of Hincks); it is irregular and its ontlines are vague and undefined. The apertura is the zooecial orifice closed by the operculum; it is not alvays visible externally. The internal tube formed by the development of the peristome is the peristomie.

The calcification functions as in other gener:i. Nevertheless, the pleurocyst is a frequent occurrence, and the greater part of the time the two calcareous layers are separable. 


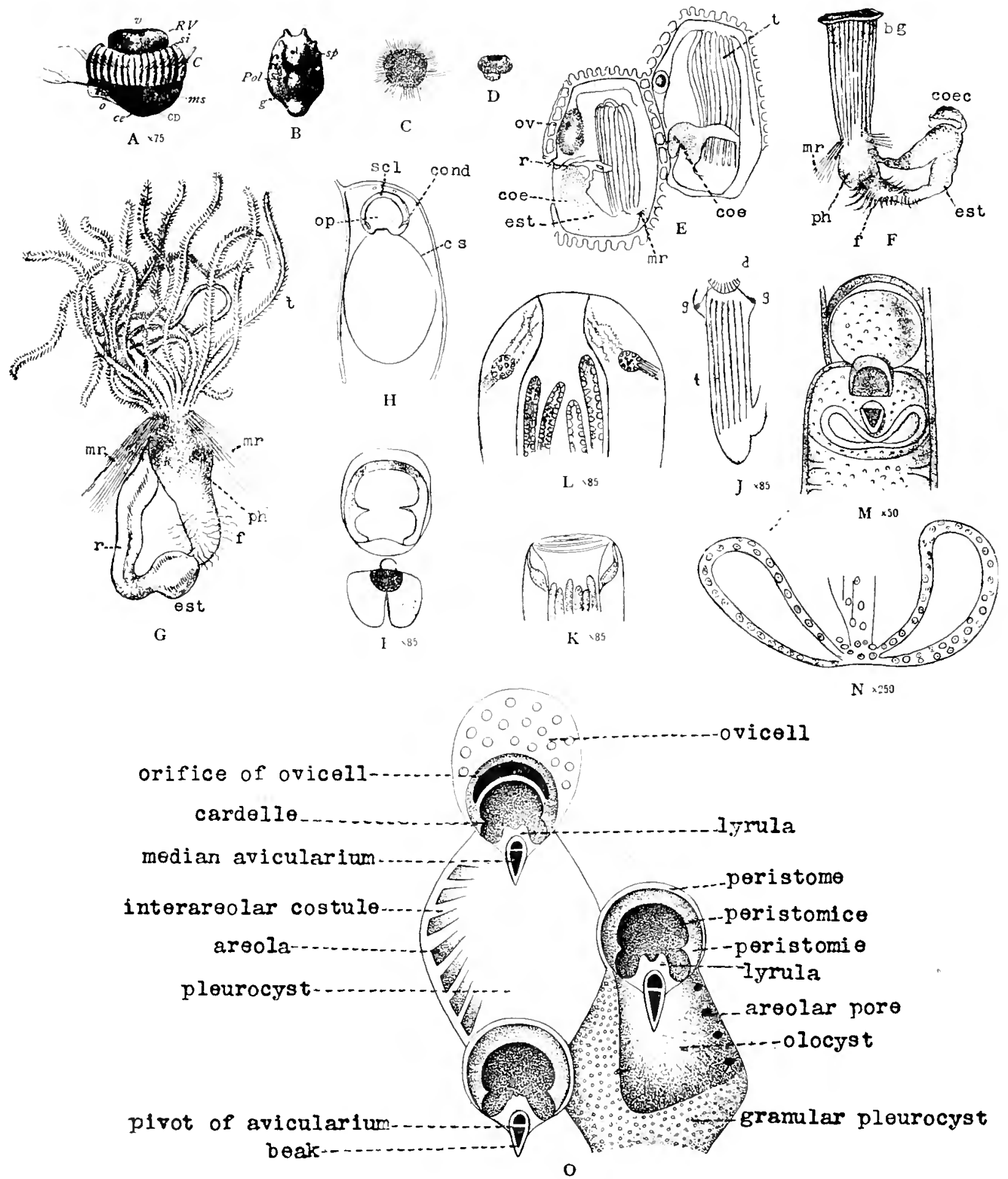

Fı. 130.-Anatomy of the Smittinilae. 
Frg. 130.- Anatumy of the smittinidale Levinsen, 1909.

A, B. Porella levis Fleming, 1S28. A. Free larva, $x$ 65. B. Ancestrula. (A, B after Barrois, 1S7T.)

ca, calotte (terminal bud) ;

$C D$, digestive cavity ;

ce, portion of the body between the two branches of the stomach;

est, stomach ;

mi, aboral mesodern;

$m s$, oral mesoderm;

C-E. IIucronella peachi Johnston, 1848, C, D. Ciliated embryoes. E. Zooecial anatoms. The place of the rectum does not appear to be exact. Letters as in figure G. (C-E after Smitt, 1865.)

F, G. Porclla cervicornis Pallas, 1760. F. Polypide with the tentacles arranged in the tentacular sheath. G. The same with the tentacles extended. ( $F, G$ after Milne-Idwards, 1S3S.)

bg, edge of the tenticular sheath;

coce, caceum of the stomach;

cst, stomach ;

$m r$, retractor muscles of the polypide;

H. Smittina trispinosa Johnston, 1S3S, var, arborea Levinsell, 1SS6. The compensatrix (cs) is attached to the operculum (op). Its orifice is overluug by a median lobe of the frontal shield. The contyles (cond) are at a mnch deeper level and are long recurved denticles, which are crossed by the submarginal lateral sclerites (scl) of the onerculum. The author has not figured the parietal nuscles. (After Harmer, 1902.)

I. Smittina tripora Waters, 1904. Section showing aperture with operculum, and helow it the avicularian glands, with the mandible above the glands, X S5. (After Watel's, 1904.)

I. Smittina protecta Thoruely, 1907. Polybirle removed from the zooecium, showing the small oral (vaginal of Calvet) glanls ( $l)$, the liaphragm $(d)$, and the tentacles $(t), \times 8.5$. (After Waters, 190S.)

I. Smittina ophiliam Waters, 1S78. Distal extremity showing the oral glands. $X 85$. (After Waters, 1892.)

I. Smitina trispinosa. Johnston, 1838. Mistal encl, showing oral glands, X S.). (After Waters, 1892.)

M, N. Porella acutirostris Smitt, 1867. M. Piece monnted in halsam, showing the avicu larian glanels through the semitransparent shell, $X 50$. N. Section of avicularian gland, $\lambda$ 250. (N, N after Waters, 1900.)

O. Sketch of several zooecia, showing terminology. 


\section{Genus SIIITTINA Norman, 1903.}

18s0. smittin Hixcrs, British Marine IPolyzon, p. 340 (preoccupied).

1903. Smittina Noran, Nutes on the Natural History of East I'immark, Annals and IIagazine Natural Ilistory, ser. 7 , vol. 12, p. 120.

In the apertura there is a lyrula and two cardelles. The frontal is an olocyst, perforated laterally with areolae and supporting a grannlar or costulate pleurocyst.

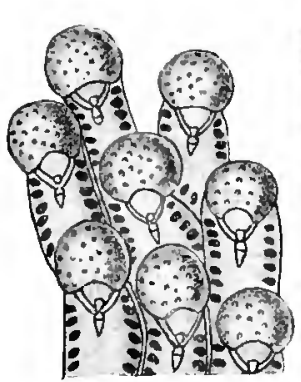

A. Smittına

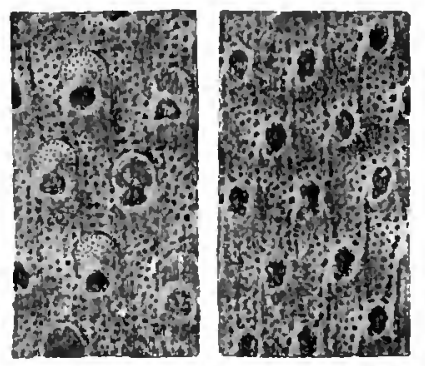

B. Plagiosmittia

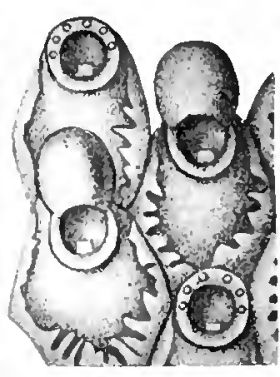

C. Mucronella

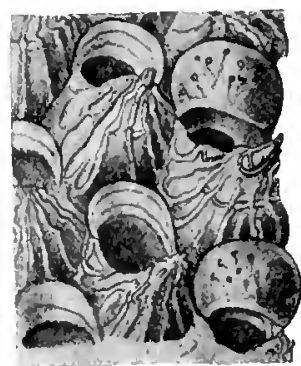

D. Ramphostomella

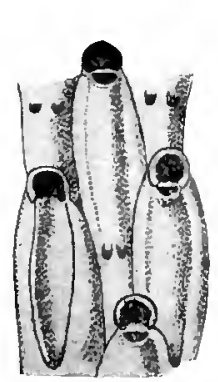

E. Cystisella

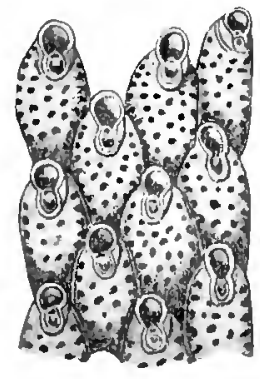

F. Porella

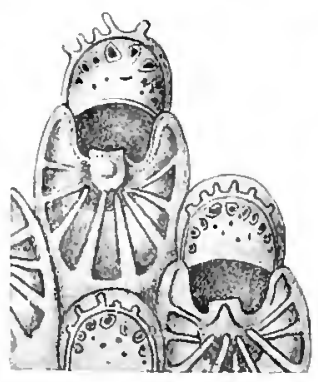

G. Umbonula

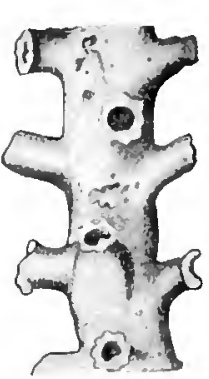

H. Phoceana

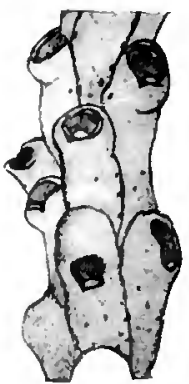

I. Bryocryptella

Fin. 121.- Gicher:a of the fimily suittinidie, Levinsen, 1909.

A. Smittina reticulata Macillimay, 1842.

B. Plagiasmittia regularis Canu and Bassler, 1917, $\times, 20$. Jacksonian of North Carolina.

C. Mucronclla peachi Johnston, $18+\bar{T}, \times 50$. Recent.

D. Ramphostomolla costuta Lorenz, 18\$6. Recent.

E. Cystisclla saccata Busk $15.0, \times 25$. Recent.

F. Forclla corticomis I'allas, $1700, \times 20$. Recent.

G. Umbonula verrucosa Esper, $\times 2$. . Recent.

H. Phoccana columnaris Jullien, $1912, \times 10$. Tecent.

I. Bryocryptclla torquata Jullien, 1903. Recent.

The anterior indentation of the peristome contains an a vicularium rery often triangular. 13-19 tentacles.

Genotype. - Smittina (Lepraliu) reticulutu MacGillivray, 184\%.

Range.-Lutetian-Recent.

The difference between Smittina and Porella appeared very difficult in the old days, and the form of the avicularium was alone taken into consideration. A form 
is not a good generic eharacter, for semieircular aricularian mandibles of the Porella type are observed in three genera on the following species:

Smittina (Lepralia) concinna Busk, 1854.

Smittina (Smittia) unispinosa Waters, $18 s 9$.

Umbonula (Cellepora) rerrucosa Esper, 1791.

Ramphostomella (Esehara) seabra Fabriejus, 1780.

We prefer to consider the function of calcifieation clearly distinct on the genotypes of the two genera. It is for this reason that Smittina majuscula Nordgaard, 1905, seems to be a Porella even though a lylula is present. Likewise Porella glaciata Waters, 1900, Porella laevis Fleming. 1828, and Porella plana Hincks are true Smittina on account of their frontal with pleuroeyst, in spite of the presence of semicireular mandibles and the absence of lyrula.

Certain Smittina are ornamented witl false tremopores, but in the interior areolar pores alone are visible.

Historical.-Hincks did not indicate a genotype. The first species described in his work is smittin landsborori Johnson. $18 t \overline{7}$, but unfortunately this is a quite rariable species, very difficult to determine and whose synonymy is not yct exactly fixed. We prefer to adopt the seeond speeies Smittia reticutata MaeGillivray which has been found fossil in the Miocene.

In 1903, Norman changed the name of Smittia to Smittina because the former was preoceupied in the Diptera. In 1909. Levinsen extended the meaning of the genus Smittina to inacceptable limits. Tnder the same name he has combined two absolutely different genera.

With Waters we can accept Tomman's term but in the exact sense fixed by Hincks. for Smittina is one of the most natural genera of the family.

SMITTINA COLLUM, new species.

Plate 5S, figs. 11-17.

Deseription.-The zoarium is plnrilamellar; it inerusts shells or algae over large surfinces. The zooecia are large, somewhat elongated, distinct, limited by a furrow or by a salient thread; the frontal is smooth, convex. bordered by a row of triangular areolac; it is formed of a smooth pleuroeyst, placed on an olocyst perforated laterally, often separable. The peristomice is semilunar and bears a short rimule-spiramen; the peristomie visible externally is satient and bears laterally an avicularium; the peristome is thin and sharp; the lyrula is much imbedded. little visible, wide and flat. The ovicell is hyperstomial, placed on the distal zooecia, opening largely into the peristomie. 'The avicularium is straight, triangular, with pirot, the beak direeted abore.

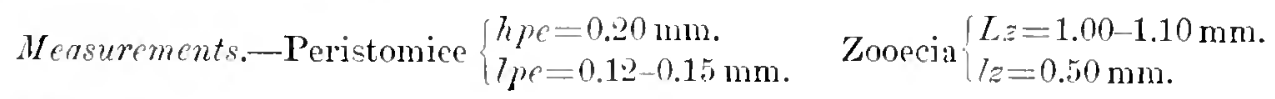

Tariations.--On one zoarium the zoocia are not regularly arranged; they radiate from false ancestrulae forming thus nuany subeolonies. This phenomenon is frequent in the multilamellar zoaria. 

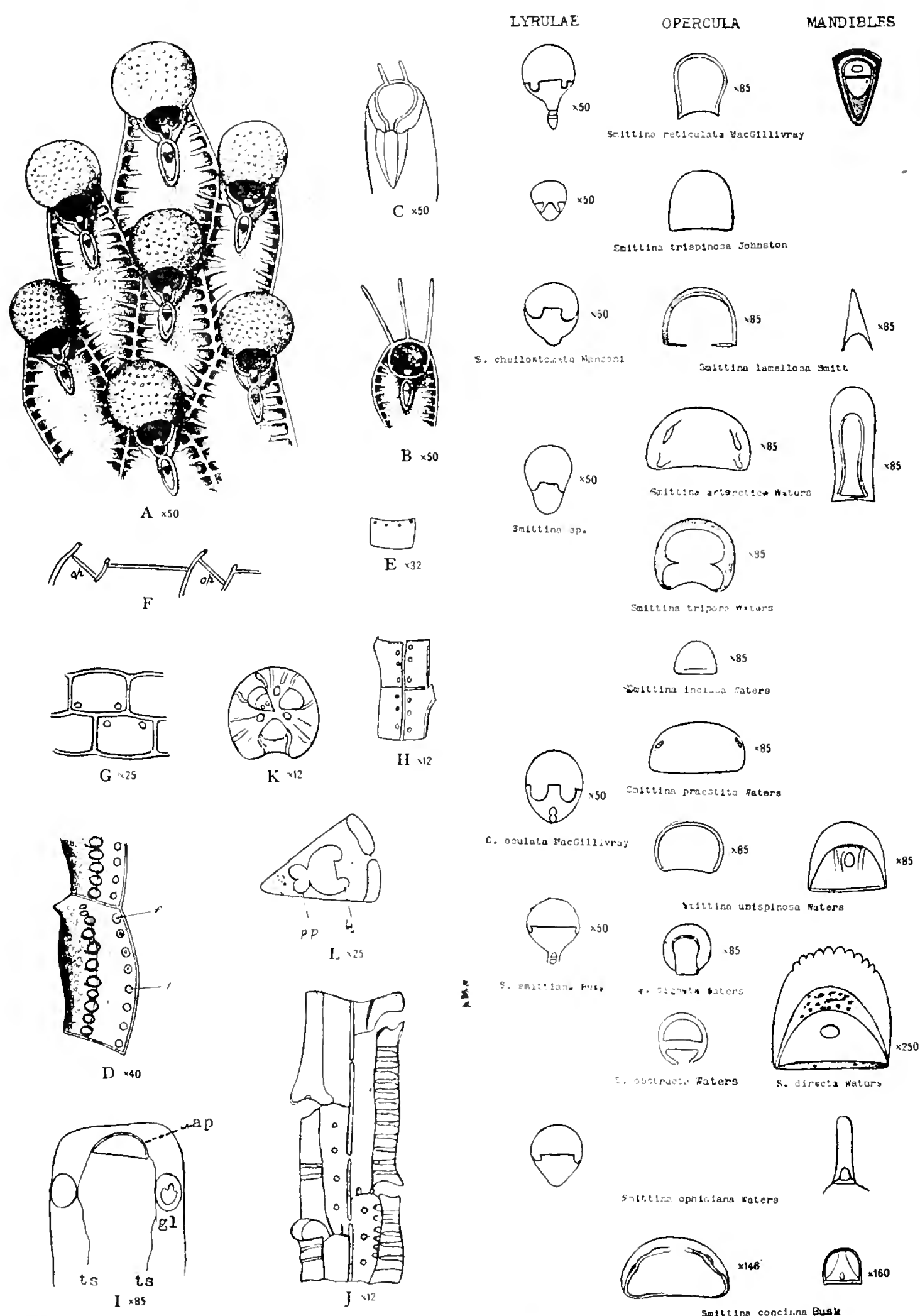

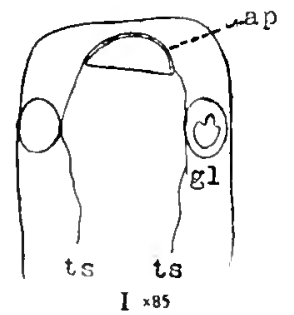

45

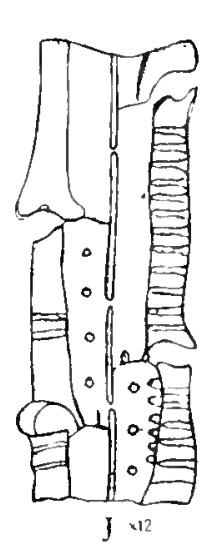

Fig. 132.-Genus Smittina Norman, 1903. 
FIg. 132-CGenus Smittina Norman, 1903.

A-E. Smittina reticulata MacGillivray, 1852. A. Zooecia with ovicels, $\times$ 50. B. Ioung cell, $\times$ 50. C. Outline of a single adult zooecinm, $\times 50$. (A-C after Hincks, 18s0.) T. Iateral view of a zooecium, $X 40$. E. Encl view of same, $X 32$. ( $D$, F after Levinsen, 1894.)

F. Smittina trispinosa, var, munita Hincks, 18s0. Section showing denticles, op, operculum, ard spines. (After Waters, 18s9.)

G-I. Smittina antarctica Waters, 1909. G. Transverse section showing lateral septulae, $\times$ 25. II. Section showing lateral septulae, $X$ 12. I. Section showing aperture ( $a p)$, tentacular sheath $(t s)$, and gland-like bodies $(g l), \times$ s.. (After Waters, 1904.)

J, K. Smittina inctusa Vaters, 1904. Longitudinal section, $\times$ 12. K. Transversal section, $\times$ 12. (After Waters, 1901 and 1904.)

L. Smittina rirecta Waters, 1904. Transwerse section of a zooecium showing ( $r p)$ septulae, (ly) lytula, $\times$ 25. (After Waters, 1900.) M (right half of page). Lytulae, opereula. and mantjbles of Smittina. (After Waters, 1889, 1900, 1904, and Nordgard, 1905.) 
The line of areolae is often double or triple (fig. 11); they are generally small but they may become larger (fig. 12) when there is a formation of interareolar costules. In the interior the olocyst is smooth (fig. 15); the wide lyrula is quite risible.

Affinitics.-This species is quite well characterized by its avicularium placed on the peristome which forms a sort of collar about the zooecium. In this character it differs clearly from Smittina grandifossa and from Smittina coronata.

Occurrence.-Middle Tacksonian: Wilmington, North Carolina (common); near Lenuds Ferry, South Carolina (rare).

Cotypes.-Cat. No. 6t123. U.S.N.M.

\section{SMITTINA LABIATULA, new species.}

P'alte 59, figs. $7-10$.

Description.-The zoarium is free, cylindrical, formed of from 4 to 6 longitudinal rows of zooecia. The zooecia are distinct, a little elongated, elliptical; the frontal is somerhat convex and surrounded by a row of irregular areolae. The apertura is much imbedded; it is hardly risible. The peristomice is limited laterally by two salient lips, between which is a large sinus terminated by a median avicularium. The ovicell is hyperstomial and is imbedded in the distal zooecia; it opens into the peristomie above the apertura.

Variations.-This species is remarkable in its plemrocystal variations, according to which the areolae are large (fig. 9) or small (fig. $\tau$ ). The coalescence of the peristomie and the aricularium occasions in the vertical sections (fig. 10) an armature quite variable and difficult to comprehend. The oral, median avicularium sometimes becomes frontal: it is distant from the peristomice and triangular.

Occurrence.-Middle Jacksonian (Castle Hayne limestone) : Wilmington, North Carolina (rare).

$$
\text { C'otypes.-Cat. No. } 64125 \text {, U.S.N.M. }
$$

SMITTINA GRANDIFOSSA, new species.

Plate 50, figs. 1-6.

Description.-The zoarium is plurilamellar. and incrusts shells or algae over l:rre surfaces. The zooecia are large. somewhat elongated, distinct, hexagonal, scparated by a thread more or less prominent; the frontal is smooth, little convex, lordered by a row of large. triangular areoler; it is formed of an olocyst perforated laterally, in which the elements are oriented toward the lyrula and which supports a smooth or costulate pleurocyst. The peristome is little salient, somewhat thick; it bears inferiorly a pseudo-rimule; the lyrula is salient and triangular; often there are two wide rimules. The oricell is hyperstomial, globular. little salient, imbedded in the distal zooecia ; it hears a porous area surrounded by a prominent collar; it opens largely into the peristomie.

$$
\text { Mcasurements.-Peristomice }\left\{\begin{array} { l } 
{ h p e = 0 . 2 0 \mathrm { mm } . } \\
{ 7 p e = 0 . 2 0 \mathrm { mm } . }
\end{array} \quad \text { Zooecia } \left\{\begin{array}{l}
{[z z=1.00-1.20 \mathrm{~mm} .} \\
\{z=0.70 \mathrm{~mm} .
\end{array}\right.\right.
$$


Variations.-On the same zoarium the zooecia are not regularly arranged; they radiate from false ancestrulae, forming thus so many subcolonies that they result in zooecial deformation. The line of areolae is often donble or triple in the loner part of the zooecia (fig. 3). The separating thread is little salient (fig. 1) or very thick (fig. 4). In the latter case of great pleurocystal calcification the areolae are quite large.

The area of the oricell is formed of a thin olocystal layer covered by a plenrocystal layer'; it is very fragile and is very easily broken.

Affinities.-This species differs from Smittina coll:ım in the absence of an avicularium on the peristome.

Smittina grandifossa differs from Smittina coronata in its larger dimensions $(L z=1.00 \mathrm{~mm}$. and not $0.50 \mathrm{~mm}$.) and in its smooth and not granular pleurocyst. Occurronce.-Middle Jacksonian (Castle Hayne limestone) : Wilmington, North Carolina (common).

Cotypes-Cat. No. 6412t. U.S.N.M.

SMITTINA CORONATA, new species.

Plate 50, fig. 11.

Description.-The zoarim is unilamellar and creeps over algae. The zooccia are somewhat elongated, distinct, hexagonal, separated by a salient thread; the frontal is little convex and bordered laterally by a row of triangular areolae; the olocyst perforated laterally supports the gramular plenrocyst, bordered with short interareolar costules. The peristome is thin and little prominent; the peristomice bears a psendo-rimule, at the base of which is the lyrula. The ovicell is hyperstomial, placed on the distal zooecia. completely surrounding the apertura; it is formed of a porons area surroumled by al collar or crown, salient and smooth.

$$
\text { Measurements.-Peristomice } \begin{aligned}
& \mid h p e=0.15 \mathrm{~mm} . \\
& l l p e=0.15 \mathrm{~mm} .
\end{aligned} \quad \text { Zooecia }\left\{\begin{array}{l}
L z=0.55-0.65 \mathrm{~mm} . \\
l z=0.45 \mathrm{~mm} .
\end{array}\right.
$$

Affinities.-This species differ's from Smittina grandifossa in its smaller micrumetric dimensions $(L z=0.55 \mathrm{~mm}$. and not $1.00 \mathrm{~mm}$.) and in the granulations of the pleurocyst.

It differs from Smittina collum in its smaller dimensions, in the absence of an oral a vicularium, and in the presence of the pleurocystal granulations.

Occurrence.-Middle Tacksonian (Castle Hayne limestone) : Wilmington. North Carolina (rare).

Holotype.-Cat. No. 6+126. U.S.N.M.

SMITTINA ANgULATA Reuss, 1865.

l']ite 60, figs. 1-16.

1865. Cumulipora angulata Iircss, loie loraminiferen, Anthozoen und Bryozoen des

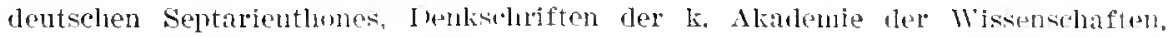
Wien. vol. 25, Abth. 1, pl. S, tier. 12.

Deseription.-The zoarimm is linge, massire, irregular. witl lobed branches. multilamellar. hollow: it incrusts large algae or shells. The zooecia (in the more 
common form) are elongated, distinct, claviform; the frontal is convex, bordered by a line of round or triangular areolie; it is formed of a smooth olocyst, perforated laterally, supporting a porous pleurocyst. The apertura is semilumar with a convex proximal border; the peristomice is semilumar; the peristome is little salient; there is no lyrulit. The ovicell is rare, placed on the distal zooecia, somewhat convex, completely surrounding the apertura, of the same nature as the frontal area. The median aricularium is peristomial and little elliptical, with pirot. On the line of the areolic there is another small elliptical avicularium, with pirot.

Tariations.-The zonecial variations are extraordinary; they are occasioned by the plemrocystal calcification. The plemrocyst is developed above the olocyst (fig. 6) and may be detached from it: the calcareous deposit, at first irregular (fig. 5 ), is spread around the special pores (fig. 4): this is the most habitual aspect of the zooccia. The calcification increasing still more. the zooccia surround themselves by a salient thread and with interareolar costules (fig. 8) and when the thickness is great there is no trace of the zooecial divisions (figs. 12. 13). It is casy to distinguish a porous plenrocyst from a tremocyst by the inspection of the zooccial interior: here (fig. 1t) the interior is smonth and only perforated laterally by small pores corresponding to the areolae.

The transversal section (fig. 10) shows the znoecial lamellae regularly superposed: the very thick walls (fic. 9) are perforated by tubules allowing the zooecia to communicate among themselves. The oldest lamellae of the zoarium are filled up with calcite (fig. 11) and thus form a more rigicl substratum for the later lamellae: we do not know whother this calcification is of chemical or physinlogical origin.

The absence of the iyrula might permit this species to be separated in a special genus, but its mode of calcification is the same as all the other species of the genus Smittina.

Its large zoarial dimensions render this species rery easy to determine: it is a good sized and characteristic fossil. Nevertheless small zoaria are not rare and there are eren some bilamellar ones.

Oecurvene-Lower .Tacksonian (Moodys marl) : Jackson. Mississippi (common).

Middle Tardsonian: Three and one-half miles north of Grovania. Georgia (rare).

. Tacksmian (Zenglodon zone): Blutt on south side Suck (reek. Clarke County, Mississippi (rare); Cocoa post office. Choctaw County. Alabana (very common).

Upper Jacksonian (Oeala limestone): Chipola River. east of Marianna, Florida; $1 \frac{1}{2}$ miles above Bainbridge. Feorgia (rare).

Vicksburgian (Red Blutf) : Red Bluff. Wayne Countr. Alabama.

freological distribution.-Rupclian (Stampian) of (rermany (Reuss).

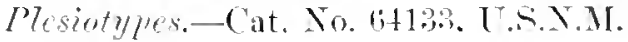


SMITTINA EXIGUA, new species.

I'late 59, figs. $17-19$.

Description.-The zoarium is free, bilamellar with flat or undulated fronds; the lamellae, back to back, are separable. The zooecia are elongated, distinct, elliptical; the frontal is convex bordered by a line of areolar pores; the pleurocrst is porous with short interareolar costules. The apertura (interior) is transverse. semilunar with a proximal border very little convex; the peristomice is elongated, deformed inferionly by the oral avicularim; the lyrula is very small and pointed. The ovicell is small, much imbedded in the distal zooecia; the frontal area is quite fragile. The median avicularium is very small, elliptical with pivot.

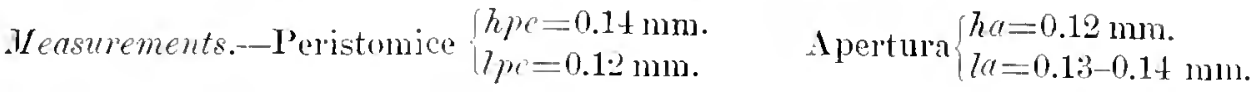

$$
\begin{aligned}
& \text { Zooecia } \mid l_{z} z=0.60-0.80 \mathrm{~mm} \text {. }
\end{aligned}
$$

Tariations.-Like all the species with porous pleurocyst, this one has some zooecia of quite variable aspect; even in fossilization the pores are closed and the zooccia appear absolutely smooth.

Some closed zooecia, in which the apertura is replaced by a simple pore, appear quite frequently; they never have an avienlarinm. Their physiologic rôle is unknown.

1ffinitic.-This species diflers from Smittina stromberli; Renss, 186.), in its larger micrometric dimensions ( $L_{z}=0.60 \mathrm{~mm}$. and not $0.4 t \mathrm{~mm}$.), its porous am not costular plenrocyst. and in its smaller ovicell.

It differs from smittina sordidn in its pleurocyst, which is porous and not granular. and in the absence of all frontal avicularia.

Certain variations of Porella portentosa assume somewhat the aspect of this species, which differs, horrever. in the plenrocyst and nontremocrstal frontal and in the nonbeaded peristome.

Occurrence.-Middle Jacksonian: Eutaw Springs, South Carolina (rare): Baldock. Barnmell County, South Carolina (rare); $3 \frac{1}{2}$ miles west of Grovania. Georgia (very rare); Rich Hill, Crawford County, Georgia (rare): 1 mile south east of Georgia Kaolin Company Mine. Twiggs County, Georgia (very rare).

Cotypes.-Cat No. 6t122, 6ti31, U.R.N.M.

\section{SIITTINA STROMBECKI Reuss, 1865.}

\section{Ilate 59, figs, 12-14.}

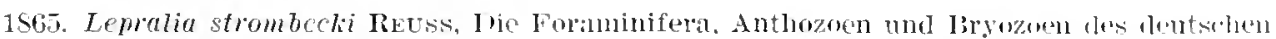
Septarienthomes, Jenksehriften det k. Akad. der Wissmseluafun Wien, wol. 25, Alith. 1. pl. S, fig. 12.

Deseription.-The zourium incrusts shells and bryozoa. The zorecia are small, clongated, fusiform, separated by a furror or by a salient thread; the frontal is somewhat convex and bordered laterally hy a line of small aveolate: the plenucyst is costular on the borders, appancutly smoth in the middle. but actually porous 
under great magnification. The peristome is very little salient; the peristomice is semilunar and deformed inferiorly by the avicularium; the apertura is semilunar, with a proximal border slightly eomrex. The ovieell is hyperstomial placed on the distal zooecia; it opens above the apertura in the peristomie. The median avieularium is small, a little salient, oblique, nearly round.

$$
\text { Measurements.-Peristomice }\left\{\begin{array} { l } 
{ h p e = 0 . 0 6 - 0 . 0 8 \mathrm { mm } . } \\
{ 7 p e = 0 . 1 0 \mathrm { mm } . }
\end{array} \quad \text { Zooeeia } \left\{\begin{array}{l}
l_{z}=0.40-0.50 \mathrm{~mm} . \\
l z=0.20-0.30 \mathrm{~mm} .
\end{array}\right.\right.
$$

Affinities.-This small speeies is remarkable on account of the great facility with which the zooecia are more or less bortered on the same zoarium. We have not seen an appreeiable difference from Reuss' species, and we believe our identification is good.

It differs from Smittina exigua in its much smaller micrometric dimensions ( $L z=0.50 \mathrm{~mm}$. and not $0.60 \mathrm{~mm}$.), in its costular plenrocyst not porous in appearance, and in its inerusting zoarium.

It differs from smittina sordida in the absence of lyrula, and of frontal avienlarium and in the presence of interareolar costules.

Occurrence.-Middle Jacksonian: Eighteen miles west of Wrightsville, Johnson County, Georgia (rare); $3 \frac{1}{2}$ miles morth of Grovania, Georgia (rare); one-half mile southeast of Georgia Kaolin Company Mine, Twiggs County, Georgia (rare); 17 miles northeast of Hawkinsville, Georgia (rare).

Upper Jacksonian (Ocala limestone) : Old Factory, $1 \frac{1}{2}$ miles above Bainbridge, Georria (rare); Chipola River, east of Marianna, Jackson County, Florida (rare).

Geological distribution.-Rupelian (Stampian) of Germany (Reuss).

Plesiotypes.-Cat. Nos. 61127-64129. U.S.N.M.

\section{SMITTINA PUNCTURATA, new species.}

Plate 61 , figs. $5-S$.

Description.-The zoarium inerusts bryozoa or shells. The zooccia are large, swollen, utrienlar, distinet, elongated; the frontal is very convex, bordered by a line of small scattered areolae; it is formed of a plemroeyst very fincly porous; the much developed peristomie bears an avicularium. The peristomice bears in front a short, false rimule; the peristome is thiek and sharp; the lyrule is wide and bifurcated. The ovicell is small, globular, hyperstomial, of the same nature as the frontal. The aricularium is median, elongated, with pirot, its beak direeted toward the top. The aneestrula is small, bordered by a mural rim and provided with a semilumar apertura.

$$
\text { Measurements.-Perist omice }\left\{\begin{array} { l } 
{ h p c = 0 . 1 6 \mathrm { mm } . } \\
{ 7 p e = 0 . 1 5 \mathrm { mm } . }
\end{array} \quad \text { Zooecia } \left\{\begin{array}{l}
T_{z}=0.75-0.80 \mathrm{~mm} . \\
7 z=0.60-0.70 \mathrm{~mm} .
\end{array}\right.\right.
$$

Affuities.-In the external aspeet and its large dimensions this speeies is elose to Smittina collum. It differ's from it in the median position (and not lateral) of its avicularium and in its porous and never costular pleurocyst.

Ocerrence-Middle Jacksonian (Castle Hayne limestone) : Wilmington, North ("alolina (eommon).

rotymes.-Cat. No.64135. U.S.N.M. 


\section{SMITTINA SORDIDA, new species.}

Plate 59, figs. $15,16$.

Description.-The zoarium incrusts shells. The zooecia are elongated. distinct, separated by a furrow or a very thin salient thread, vaguely elliptical: the frontal is convex and formed by a thick pleurocyst, smooth or finely granulated. The peristome is salient and often bears two quite prominent lateral lips; the peristomice is elongated, irregular; the lyrula is little salient, acute, accompanied sometimes by two cardclles. The oricell is large, salient, placed on the distal zooecia; it is hyperstomial and opens largely into the peristomie above the apertura; it is formed of a large area bordered by a salient collar. The small oral avicularium is triangular, the beak directed above. Quite frequently, a small frontal avicularium, salient and round, is placed laterally.

$$
\text { Measurements.-Peristomice }\left\{\begin{array} { l } 
{ h p e = 0 . 1 5 \mathrm { mm } . } \\
{ / p e = 0 . 1 1 \mathrm { mm } . }
\end{array} \quad \text { Zooecia } \left\{\begin{array}{l}
L z=0.5 .5-0.70 \mathrm{~mm} . \\
7:=0.35-0.40 \mathrm{~m} m .
\end{array}\right.\right.
$$

Variations.-This species is not beantiful; its aspect is sordid; the zooecia have neither regularity nor symmetry. On the same fragment there are some zooecia with notched peristomes and other zooecia with perfect peristomes. At the same time there are some fragments entirely deprived of frontal a vicularium.

This species is deprived of areolae; this is the reason that we suppose its frontal to be a pleurocyst; an olocyst would never have this irregularity and would be absolutely smootl. The presence of cardelles and of the lyrula is as usual for. the genus. The very small mumber of specimens collected has not permitterl us to study the interior to clear up the mrstery of the constitution of its frontal.

Occurrence-Upper Jacksonian (Ocala limestone): One and one-half miles above Bainbridge, Georgia (rare); below the Plant System railroad wharf, Bainbridge, Georgia (rare).

Holotype.-Cat. No. 6+130, U.S.N.M.

SMITTINA COPHIA, new species.

Plate 92. fixs. 21-23.

Description-The zoarium is hollow, mnilamell:ur, cylindrical; it incrusts very small algae. The zooecia are distinct, elongated, claviform, separated by an especially thick mural rim; the frontal is almost flat and formed of a plenrocyst with interareolar costules. The peristome is wide, salient, thick; the peristumice is elongated, elliptical; a very small lyrula is visible at the base of the peristomie. The ovicell is globular, quite salient, hyperstomial, placed on the distal zooecia ; it is formed of a rery large area quite finely porous, surrounded by a smootl, salient collar which surrounds it like a cap; it orens into the peristomie 'There is sonetimes a small median avicularium on the proximal lip of the peristome.

$$
\text { Measurements.-Peristomice }\left\{\begin{array} { l } 
{ h p c = 0 . 2 0 \mathrm { mm } . } \\
{ / p c = 0 . 1 5 - 0 . 2 0 \mathrm { mm } . }
\end{array} \quad \text { Zooecia } \left\{\begin{array}{l}
L_{z}=0.80-0.90 \mathrm{~mm} . \\
l_{z}=0.30 \mathrm{~nm} .
\end{array}\right.\right.
$$


Variations and affimitics.-The young zooecia (fig. 21) have thin margins and the ovicell is quite salient. The old zooecia are eovered by the pleurocyst; the areolac are larger and the ovicell is immersed in the eap (fig. 23).

The present species diflers from simittina telum in which the zoarium is identieal. in the alsenee of a large frontal avicularim and in the presence of a lyurula.

It differs from smittima reticuloides, which is also provided with large costules, in its much larger micrometric dimensions and in the absence of the oral avienlarinm.

Oecurrence.-Yielisburgian (Glenton member of Marianna limestone) : West bank Conecuh River. Escambia ('ounty. Alabama (rare).

Cotypes-Cat. No. Gitegr, L.S.N.II.

SMITTINA AMPLA, new species.

Plate 03, figs, 10-16.

Deseription.-The zoarium is an Eschara in which the two lamellae. back to back. are inseparable. The zooceia are large. distinet, elongated. elliptical; the frontal is very convex and bordered with a line of Jarge triangular areolae; it is formed of an olocyst partially perforated with large lateral pores, surmomnted by a pleurocyst with large interareolar costules. The apertura (interior) is elliptical, transverse and bears a small lyrula, cylindical and salient; the peristome is thin, sharp, little salient, ganished with 4 thin spines; the peristonice is elongated elliptieal or oval. 'The ovicell is large, globular, salient. carinated; it is formed of a smooth area surrounded by a salient collar; it covers much of the peristomice which it deforms; it is hyperstomial and opens largely into the peristomic. The oral avieularim is small. elliptical, very alient, deforming inferiorly the peristomice. At the side of the apertura there is often a large lateral avicularinm, with pirot and a spatulate leak directed towards the top.

$$
\begin{aligned}
& \text { Measurements.-Apertura }\left\{\begin{array} { l } 
{ h a = 0 . 1 8 \mathrm { mm } . } \\
{ 7 a = 0 . 2 0 \mathrm { mm } . }
\end{array} \quad \text { Peristomice } \left\{\begin{array}{l}
h_{p e}=0.30 \mathrm{~mm} \text {. } \\
\text { lpe }=0.22 \mathrm{~mm} .
\end{array}\right.\right. \\
& \text { Zooecia }\left\{\begin{array}{l}
L_{z}=0.90-1.00 \mathrm{~mm} . \\
7_{\tilde{z}=0.22 \mathrm{~mm} .} \text {. }
\end{array}\right.
\end{aligned}
$$

Travitions.-The lyrula. seen from the interior (fig. 14) appears short and cylindrical; on the exterior (fig. 11) it appears flat and broar. But the interest of this species is in its ealcification (fig. 14): there is here as it were a juxtaposition of the olocyst and of a tremocyt: the litter only exists at the base of the zooecia; on the sides the line of the arealae become unique. This algmentation of the number of the areolae appears to corlespond with a more intense pleurocystal ealcification. There appears therefure to he a relationship between the tremopores and the areolae, hoth allowing the buds of the endocyst and the mescnchymatous fibers to pass at the same time.

The vertical section (fig. 16) shows how the apertura is oblique on the zooecial plane. 
Affinities.-The presence of the very salient avicularian muero characterizes quite well this species and permits us to differentiate it from the other large costulate species such as Smittina colum, S. grandifossa, and S. coronata.

Oceurrenec.-Vicksburgian (Mariama limestone): Salt Mountain 5 miles south of Jackson, Alabama (common): west bank of Conecuh River, Escambia County, Alabama (common); Murder Creek east of Castlebury, Conecuh County, Alabama (rare); near Claiborne, Nomroe County; Alabama (common).

Cotypes.-Cat. No. 64300, T.S.N.MI.

SMITTINA RETICULOIDES, new spccies.

Plate 96, figs. 1-9.

Description.-The zoarium is free and bilamellar; the fronds are narrow or wide. flat or undulated; the two lamellae back to back are inseparable. The zooecia are elongated, distinct, narrow. fusiform, separated by a thread more or less salient; the frontal is flat surrounded by a line of triangular areolar pores numerous and quite large. The apertura is semilunar with a proximal border somewhat convex; the peristomice is oral and irregular; the peristome is little salient quite wide, smooth. enlarged at the base to bear the median avicularium. The ovicell is globular, salient; it is formed of a small circular area perforated by some large pores and with a large smooth collar; it is hyperstomial, placed on the distal zooecia and it opens into the peristomice. The median avicularium is small, triangular, with pivot. the beak above; it is placed on a thickening of the peristome.

$$
\text { Mcasurements.-Zooecia }\left\{\begin{array}{l}
L z=0.70 \mathrm{~mm} . \\
l z=0.30 \mathrm{~mm} .
\end{array}\right.
$$

Tariations.-The plenrocystal calcification is very intense and gives to the zooecia the most fantastic aspect sufficiently represented by figures 4, 5. 6. We have been successful with two tangential sections. The first (fig. 9) is taken at the level of the olocyst where one sees the elements irregularly grouped around the median axis; the areolae are large and round. The second seetion wats made a little nearer the surface (fig. S); it gives the construction of the interareolar costules. the elements of which are grouped transrersely.

Affinitics.-This species is very close to the recent smittina reticutata MacGillivray, 18t2; it differs from it in the area of the ovicell which is much smaller. ormamented only with some large pores and in the median avieularium which is much smaller and always placed on a thickening of the peristome and not on the - frontal itself.

It differs from the variations of Smittina telum with very small avienlaria in the much larger number of areolae $(10)$ and in a less zooecial wilth $(0.30$ and not $0.40 \mathrm{~mm}$.).

Occurrence.-Ticksburgian ("Chimney rock" of Mariamna limestone): One mile north of Monroeville, Alabama (very common).

$$
\text { Cotypes.Cat. No. 64309. U.S.N.II. }
$$




\section{SMITTINA TELUM, new species.}

Plate 93, figs. 1-9.

Description.-.The zoarium is free, cylindrical, hollow, unilamellar; it incrusts the small roots of algae. The zooecia are distinct, elongated rectangular; separated by a salient thread; the frontal is convex, bordered by a line of large areolac and almost entirely occupied by an enormous avicularinm. The apertura is semilunar, somewhat transverse with a very little convex, proximal border; the peristomice is not deformed by the avicularium; there is no lyrula apparent; the peristome little salient in its distal part, is ornamented laterally with two large, smooth, salient lips. The ovicell is globular, salient; it is formed of a fragile and porous area surounded by a little prominent collar; it is hyperstomial and opens into the peristomie. The arieularium is gigantic, salient, triangnlar like a dart, with pivot, the beak directed toward the bottom.

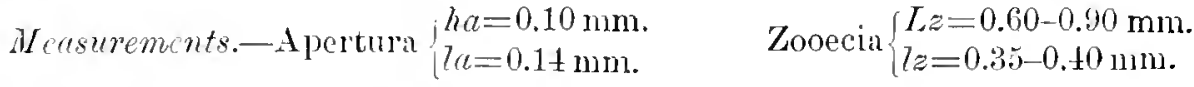

Tariations.- The median aricularia are not always constant in size; one may follow their successive development on figures 2 to $\tau$. The lateral lips of the peristome are small (fig. 2) or very large (fig. 1); they may even be wanting (fig. 5) or be joined with the avicularium (fig. 4 ). The ovicells are smooth (fig. 6) or granular (figr. 7 ), according to the fineness of the grains of the plemrocyst. In the interior (fig. S) the olocyst is perforated by very small areolar pores which are nevertheless very large exteriorly. A lyrula does not appear to be present.

The tangential section (fig. 9) indicates that the avicularian chamber is rather small and that it is the same as the one which covers the frontal of the zooccinm. The white line which surrounds the zooecinm and the size of the areolac indicate that this section has been made smperficially at the level of the interareolar costules.

Affinitics.-This species with its giant avicularium is very close to Smittina canavarii Neviani, 1900, of the Sicilian of Italy. It differs from it in the absence of lyrula, in the narrower zooccia, and in the larger number of areolac.

In its zoarial form of a hollow cylinder it approaches somewhat Smittina cophin, but $S$. tetum differs in the presence of the gigantic avicularium.

Occurrence.-Ticksburgian ("Chimney rock" of Marianna limestone) : One mile north of Monroevile, Alabama (very common).

Cotypes.-Cat. No. lit299, T.S.X.M.

SMITTINA GRANULOSA, new species.

Plate 92, figs. 19, 20

Description.-The zonrium is cylintrical and hollow. The zooccia ale elongated, distinct, fusiform; the frontal is convex and formed of a very finely granmlase pleurocyst The peristome is salient, thin, sharp; its anterior cleft con:tains a small elliptical avicularium; the apertura (interior) is semilunar. The ovicell is globular, salient: it is formed of a finely granular area, surrounded by a small improminent collar: it is hyperstomial, placed on the distal zooecium and 
opens largely into the peristomie. The median avicularium is elliptical, without pirot.

$$
\text { Measurements._Peristomice }\left\{\begin{array} { l } 
{ h p e = 0 . 1 0 \mathrm { mm } . } \\
{ l p e = 0 . 1 0 \mathrm { mm } . }
\end{array} \quad \text { Zooecia } \left\{\begin{array}{l}
L_{z}=0.55-0.60 \mathrm{~mm} . \\
7 z=0.25 \mathrm{~mm} .
\end{array}\right.\right.
$$

Affinities.-The areolae lisappear very easily through alteration in fossilization. Their absence on the fossils is therefore not a proof of a difference in structure. We do not hesitate to classify this species in Smittina, for the frontal is deceptive in this genus. Moreover the few specimens figured are the only ones fomd. It is probable that when better ones are discovered they will be found provided with areolue as llsulal in the genus.

Oecurrence. - Ticksburgian (Marianna limestone): West Bank Conecuh River. Escambia County, Alabama (very rare); well in Eseamlia County. Alabama (very rare).

Cotypes.-Cat. No. 64297, U.S.T.M.

SMITTINA ORBAVICULARIA, new species.

Plate 61, tigs. 1-4.

Description.-The zoarium is milamellar and creeps over algae. The zooecia are lirge, elongated, distinct, wide. claviform or turbinate. The trontal is little convex, surrounded by large crowded areolae and short interareolar costules. The peristome is thick and little salient; the peristomice is orbicular; the apertura (in the interior) is semilunar, transverse with a straight or somerhat concave proximal border; the lyrula is visible only in the interior: it is short and rectangular. The ovicell is small, little salient; it is formed of a very fiagile area surrounded by a colla which is little visible: the ovicell is hyperstomial and opens into the peristomie. The avicularium is orbieutar, with pjot; it is

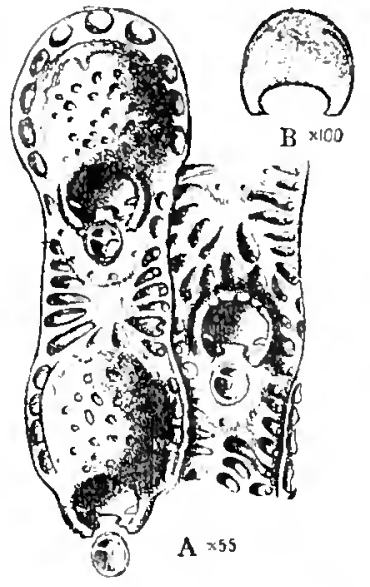

FIG. 132n.-Genus Snittina Norman, 1903.

A, B. Smittina okarocnsis Levinsen, 1909. 1. Several zooecia, $X 55$, showing vibracula provided with trabecular pivot. 13. Operculum, $\times 100$, with form different from the ordinary. (After Levinsen, I909.) large. placed eccentrically with at least two orifices for the passate of the muccles which raise the semicircular mandible.

$$
\begin{aligned}
& \text { Wcusurements.Peristomice } / h p=0.12 \mathrm{~mm} . \quad \text { Apertura } / h a=0.10 \mathrm{~mm} \text {. } \\
& \text { (exterion) } l p c=0.12 \mathrm{~mm} \text {. (interior) } l a=0.15 \mathrm{~mm} \text {. } \\
& \text { Zooecia }\left\{\begin{array}{l}
l=0.90-1.00 \mathrm{~mm} . \\
7 z=0.40-0.50 \mathrm{~mm} .
\end{array}\right.
\end{aligned}
$$

Affinitics. The avicularium ol this species resembles that of smittimu okuroensis Levinsen, 1909 (fig. 132k), dredged off New Zaland. "Its chanber" which is separated from the zooecium by a broad, arehed line. is provided at the margin with $3-5$ pores, and the transverse bar (pivot) which rlivides the frontal 
area into two parts, is provided with a short, proximally direeted proeess. The subopereular area, which is turmed toward the aperture. has a transversally oval opening." 1

This is a rery unsual type of aricularium which well characterizes this fossil species.

Occurrence.-Middle Tacksonian: Wilmington, North Carolina (eommon); Eutaw Springrs. South Carolina (rare) : Near Lemuls Ferry, South Carolina (rare). Cotypes.-Cat. No. 64154, U.S.N.M.

SMITTINA (?) PUPA, new species.

Plate 95, figs. 1--9.

Description.-The zoarium is subcylindrical, hollow, bifurcated, milamellar, or plurilamellar. The zooecia are long. distinct, fusiform, or elliptical; the frontal is convex, smooth, bordered by a line of large rather widely spaced areolae. The peristome is thick. salient: the peristomice is suborbicular; the apertulat is oblique and semilunar. The ovicell is orbicular, little salient, ormamented by some large irregulat pores. On the line of the areolie, there are two small, salient ariculiria, with pirot, orbicular more or less symmetrically disposed.

$$
\text { Measurements.-Peristomice }\left\{\begin{array} { l } 
{ h p e = 0 . 1 5 \mathrm { mm } . } \\
{ l l _ { c } = 0 . 1 2 - 0 . 1 5 \mathrm { mm } . }
\end{array} \quad \text { Zooecia } \left\{\begin{array}{l}
L_{z}=0.65-0.85 \mathrm{~mm} . \\
l z=0.35 \mathrm{~mm} .
\end{array}\right.\right.
$$

Affinitics.-This species is mprovided with lypula and the median avicularium is rarely visible; we must doubt its place in the genus Smittina. Nerertheless the other functions, orarian and calcification are identical. It is remarkable to note that the larger the areolae are, the less numerons they are. The lateril avienlaria always replace one of these areolac.

This species differs from. Smittina tubulatu Gabb and Horn, 1862, in the presence of two lateral avicularia and in the absence of median avicularium. In practice, the distinction hetween the two species is often difficult; there are many specinens of Smittina tubulata which resemble Smittina mpa.

On accomt of the size of the zoarium, this is a well eharacterized fossil.

Occurpene.- Tickbulnian ("Chimney rock" of Marianna limestone): One mile north of Monroeville. Alabama (very common).

Cotypes.-Cat. No. 64307. U.S.N.M.

SMITTINA TUBULATA Gabb and Horn, 1862.

Plate 94, fiss. 1-11.

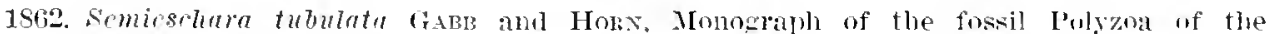
Seomury and Tortiary formations of North America, Jomrnal Academs Natural

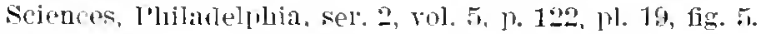

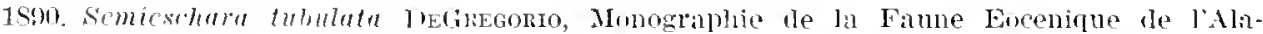

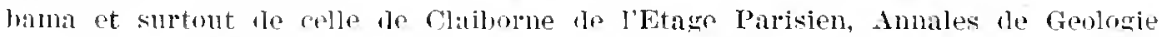

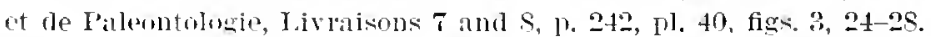

llescription.-The zoarium is eylindrical. hollow, tubular, uni or plurilamellar : it incrusts small aluae. The zooecia are laree, long; elliptical. or tubular; the

\footnotetext{
1.erlusen, Morpholog\}al and systematic Studies on the Cheilostomatous Pryozoa, p. 342, pl, 18, fig. 12.
} 
frontal is convex and surrounded by a line of areolae; it is formed of a smooth olocyst, perforated laterally, surmounted by a smooth or porous pleurocyst. The peristome is salient, thin, sharp; the peristomice is elongated and elliptical; the apertura is semilunar with a very concave proximal border; the lyrula is quite small and very fragile. The ovicell is hyperstomial and placed on the distal zooecia but is little salient; it is widely open in the peristomie. 'The median avicularimu is small, orbicular, with a fragile pirot.

$$
\begin{aligned}
& \text { Weasurements.-Peristomice }\left\{\begin{array} { l } 
{ h p e = 0 . 2 0 \mathrm { mm } . } \\
{ 7 p e = 0 . 1 5 \mathrm { mm } . }
\end{array} \quad \text { Apertura } \left\{\begin{array}{l}
h a=0.20 \mathrm{~mm} . \\
l_{a}=0.15 \mathrm{~mm} .
\end{array}\right.\right. \\
& \text { Zooecia }\left\{\begin{array}{l}
L z=0.80-0.90 \mathrm{~mm} . \\
7 z=0.35 \mathrm{~mm} .
\end{array}\right.
\end{aligned}
$$

Trariations.-The aspect of this species is quite rariable; the most labitual (figs. 2, 3) shows a pleurocyst with much scattered pores. But on the younger zooecia (fig. 4) the pleurocyst is smooth and there is a line of areolae around each zonecium. The zooecia are sometimes separated by a salient thread on specimens strongly calcified (fig. 6).

On the plurilamellar zoaria the zooecia are irregularly oriented and often wider (fig. $\tau$ ). The transversal sections show that the zooecia are provided with a rery thick frontal (figs. 9, 11).

Affinities.-This species differs from Smittina pupa in the presence of a small median aricularium and the absence of lateral avicularia. Under the microseope the distinction is often rery difticult.

Certain small specimens of Smittina angulata Reuss, 1866, resemble this species and their differentiation is difficult for the two species are quite variable. Smittina tubulata is deprived of lateral a vicularia and the zooecia are longer.

The size of the zoarium makes this an easily recognized fossil.

Occurrencc.-Vicksburgian ("Chimney rock" of Marianna limestone): One mile north of Monroeville, Alabama (very common).

Vicksburgian (Red Bluff clay): Seven and one-half miles southwest of Bladen Springs, Alabama (rare).

Plesiotypes.-('at. No. 6t302, T.S.X.M.

\section{Genus PLAgiosmittia Canu and Bassler, 1917.}

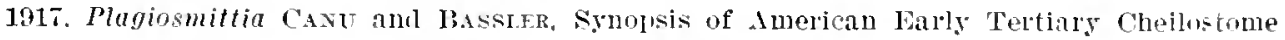
Pryozoil, Fulletin 96, United Stites National IIuseum, p. 51.

The ovicell opens into the peristonie. The frontal is a tremocyst. The avicularium is placed in the peristomic. The zooecia are oriented transversally to the zoarial fronds. Two large condyles are placed in the interior back of the apertura; they limit a small canal leading to the orifice of the compenatrix.

Genotype.-Plagiosmittiu Perneluris Cann and Bassler, 1!11.

Range.-Jacksonian-Vicksburgian.

This genus differs little from Porllt Gray, 18t8, in the nature of its functions. The difference lies in the inregularity of the place of the median aricularium 
and in the disposition of the zooccia on the fronds. Possibly it should be considered as only a subgenus.

Plagiosmittia Regularis Canu and Bassier, 1917.

I'late 61, figs. 9-13.

1917. Plagiosmittia regularis CANU and BAsst.r. Synopsis of American Early Tertiary Cheilostome Bryozod, Bulletin 96, United States National Museum, p. 51, pl. 5, fig. 4.

Description.-The zoarium is lilamellar; the fronds are flat, narrow bifurcated. The zooecia are much elongated, distinet, separated by a thread or a furrow and are much narrowed proximally. The frontal is flat or little convex aud formed of a tremocyst with numerous crowded pores. The peristome is thin, salient; the apertura is semilunar with a very concare proximal border; the peristomice is irregular, but it often contains a false rimule limited by the avicularium. The ovicell is globular, little prominent; it is formed of a large circular area with small numerous pores, surrounded by a smooth collar, little salient; it is imbedded in the distal zooecia and opens into the peristomie. The aricularium is peristomial, placed more or less laterally: the mandible mores in the peristomie.

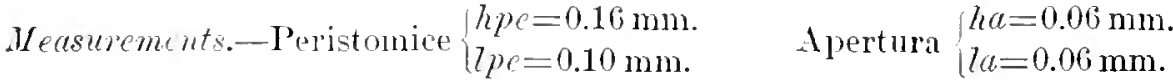

$$
\begin{aligned}
& \text { Zooecia }\left\{\begin{array}{l}
L z=0.75-1.00 \mathrm{~mm} . \\
l z=0.20 \mathrm{mmm} .
\end{array}\right.
\end{aligned}
$$

Affnitics.-This species is quite constant on the whole; many zooecia, however, are marginated.

It differs from Plagiosmittic porclloidts in its larger dimensions ( $L z=0.75$ and not $0.60 \mathrm{~mm}$ ) and in its avicularium always placed laterally in the peristomie.

It differs from Plagiosmittia virgula in its larger micrometric dimensions ( $L z=0.75$ and not $0.56 \mathrm{~mm}$.) and in the absence of the large median a vicularium.

Occurrence.-Middle Jacksonian: Wilmington, North Carolina (common).

Upper Jacksonian (()eala limestone) : Old Factory one-half mile above Bainbridge, Geororia (rare); west hank Sepulga River. Escambia County. Alabama (common); Chipola River, east of Marianna. Tackson County, Florida (common). rotypes.-Cat. No. 02600 . U.A.X.M.

\section{PLAGIOSMITTIA PORELLOIDES, new species.}

Plate til, firs. 14-1S.

Description.-The zonrium is lilamellar: the fronts are flat, narrow. bifurcaterl. The zooecia ale much elongated, distinct, separated by a furrow or a silient thread, much narrowed inferiorly: the frontal is flat or a little convex and formed of a tremocyst with numerous and crowded pores. The peristome is thin. salient; the peristomice is oral; the apertura is semilumar with a concave lower border. The wicell is little salient, intuedder in the distal zooecium: it is formed of a large area with very fine pores. surrounted by a small, rery thin collar; it opens into 
the peristomie. The small median avicularim is placed in the peristomie or in the peristomial sinus.

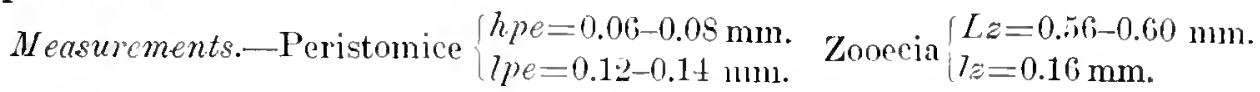

Affinities.-This species differs from Plagiosmittia regularis in its smaller micrometric dimensions $(L z=0.60$ and not $0.75 \mathrm{~mm}$.) and in its aricularium which is median.

It differs from Plagiosmittia virgula in the absence of the large median avieularium, and in its smaller dimensions ( $L z=0.50$ and not $0.56 \mathrm{~mm}$.).

Occurrence.-Middle Jacksonian: Wilmington, North Carolina (very common); Eutaw Springs, South Carolina (common); near Lenuds Ferry, South Carolina (very common).

Cotypes.-Cat. No. 64136, U.S.N.M.

plagiosmititia Virgula, new species.

Plate 62, figs. 1-7.

Description.-The zoarium is free. lilamellar; the fronds are narrow and bifureated. The zooecia are elongatel, elliptical, distinct, separated by a furrow; the frontal is little convex and formed of a tremocyst with much crowded pores. The peristome is thin, salient, sharp; the peristomice is oral; the apertura is semiJunar with a straight proximal border. The ovicell is large, little salient; it is hyperstomial, imbedded in the distal zooecia, and opens largely into the peristomie; it is formed by a very finely porous circular area surrounded by a thin, little salient collar. The avicularium is melian, placed in the peristomie; it is often developed and transformed into large unguiculate avicularia assuming the form of a comma.

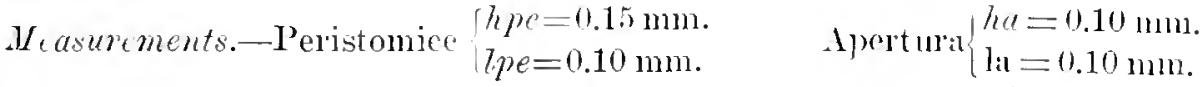

$$
\begin{aligned}
& \text { Zooecia }\left\{\begin{array}{l}
L z=0.45-0.50 \mathrm{~mm} . \\
I_{z}=0.20-0.25 \mathrm{~mm} .
\end{array}\right.
\end{aligned}
$$

Affinitics.-The large frontal avicularinm is not always developed; it is replaced by a small peristomial avienlarimn. The difference between this speeies and Plagiosmittia porelloides is then very small; only the mieronetric dimensions are smaller $(L z=0.50$ and not $0.60 \mathrm{~mm}$.). The tangential section shows (fig. 4) that the median avienlarim is often replaced by two peristomial avicularia.

The three species of Plagiosmittin are distinguished quite well from each other by their zooecial length:

Plagiosmittia regutaris=0.

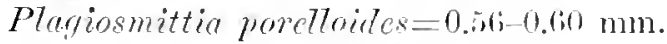

Plargiosmittie virgulu $=0.45-0.50 \mathrm{~mm}$.

Occurrence.-Middle Jacksonian (Castle IIarne limestone) : Wilnington, Nortl Carolina (rer'y common).

Cotypes-Cit. No. 641:37. I.S.X.M. 


\section{Genus IIUCRONELLA Hincks, 1880.}

1S80. Afucronclla Hrixcks, British Marine Polyzoa, p. 360.

The frontal is surrounded by areolae and covered by a plemrocyst, costnlate or granular. There is a lyula and often some cardelles in the peristomice inferiorly.
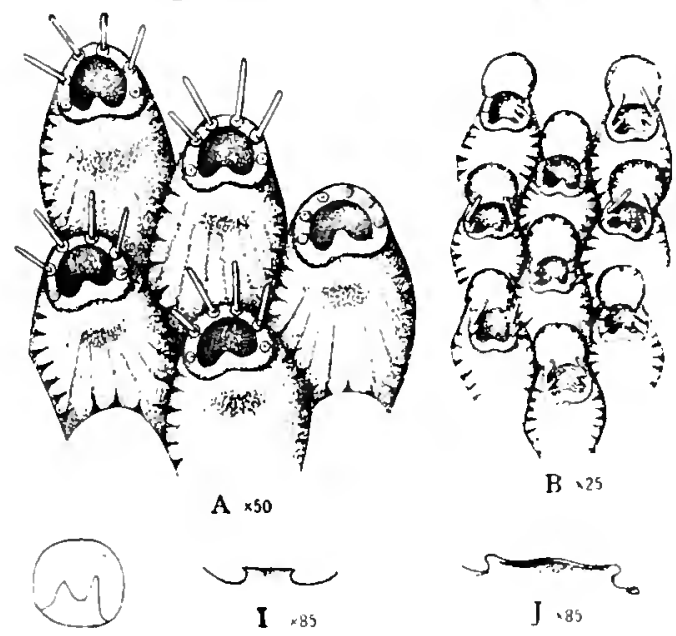

$11 \times 50$

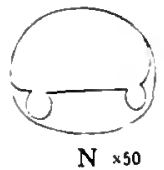

$B \cdot 25$

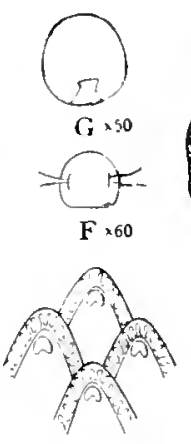

$E \times 18$
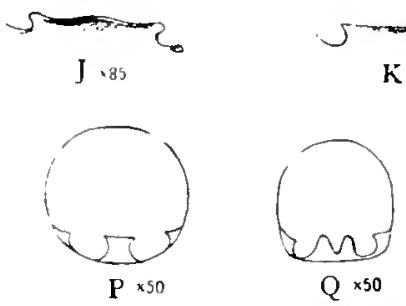

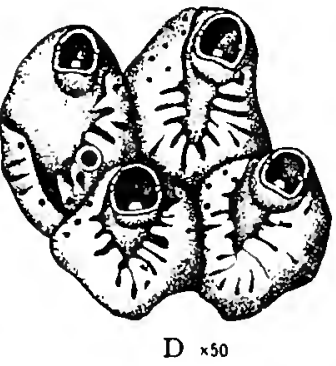

D $\times 50$
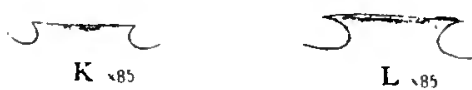

L 、 85

$\mathrm{R} \times 50$

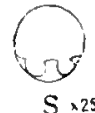

$S \times 25$

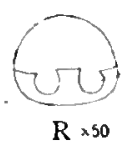

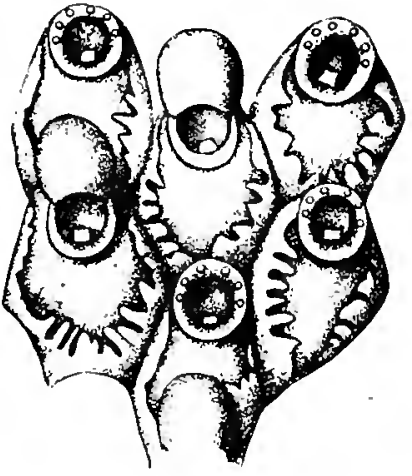

C $\times 50$

$\sin$

M $、 25$
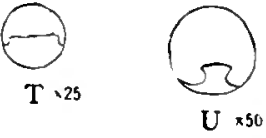

Fig. 133.-Ginus Murvonella Hincks, 1880.

A-G. Murronclla perthi Johnston 1S47. A. Zooecia, $X$ 50. B. Zooecia with ovicells, $X$ 25. C, D. Old conditions, $X 50$, showing the growth of the plenrocyst over the surface $E$. Septulae, $X$ 1S. (A-1. after Hincks, 1SS0.) F. Opereulum, $X$ 60. (After Levinsen, 1894.) G. Lyrula, $\times 50$. (After Waters, 18s9.)

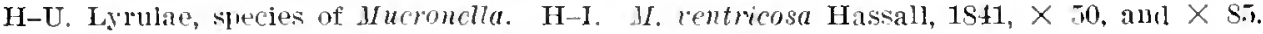

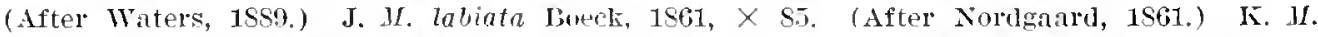

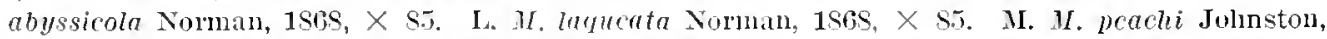

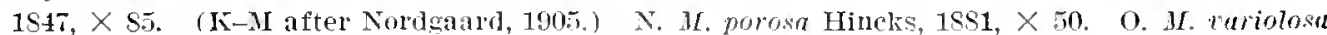

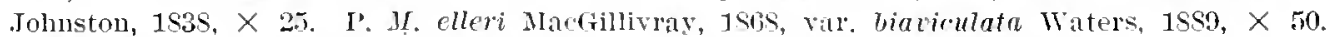
Q. M. biincisa Waters, $1892, \times 50$. R. M. rostrata Hincks, $1880, \times 50$. S. M. lovis MaeGillivay, 1852, $\times 25$. T. 1\%. spinosissima MacGillivray, 1879, $\times$ 25. U. M. diaphana MacGillivray, 1879. $\times 50 . \quad(\mathrm{N}-\mathrm{U}$ after Waters, 18S9.)

Genotype.-Mucronella (Lemmin) perehi Johnston. 1847.

Range.-Jacksomian-Recent.

The limits of this genus were rigorously estalihsed in 1904, by Waters. It differs from Smittina in the replacement of the avicularinm by a mnero, that is to say, by an organ which we know to be almost erfuivalent. 
The recent species of this genus are:

Mucronella (Lepralix) perachi Johnston, 1847.

Mueronella (Lepralia) ventricosa IIassall, $18+1$.

Mucronella (Lepratia) veriolosi Johnston, 18t7.

Mucronella teres Hincks, 1881.

Mucronclla crozctensis Water. 1904.

The known fossil species are:

Mucronella (Lepralia) hörnesi Reuss, 1865. Oligocene of Germany.

Mucronella (Lepralia) grotrimi Reuss, 1865. Oligocene of Germany.

MUCRonella PATENS, new species.

l'late 62. fig. 10.

Description.-The zoarium incrusts shells. The zonecia are distinct, winle. hexagonal; the frontal is convex, and surrounded by a double row of small areolae, mueh crowded. The peristome is salient, wide, its proximal portion is a very salient and erect mucro; the lyrula is small and triangular. The ovicell is hyperstomial and is placed on the distal zooecimn; it is small, globular, salient, smooth; its orifice is placed just at the level of the muero.

$$
\text { Mcasurements._Peristomice } \begin{aligned}
& h_{l} p e=0.10 \mathrm{~mm} . \\
& 7 p_{c}=0.15 \mathrm{~mm} .
\end{aligned} \quad \text { Zooecia }\left\{\begin{array}{l}
T_{z}=0.60-0.70 \mathrm{~mm} . \\
l_{z}=0.75 \mathrm{~mm} .
\end{array}\right.
$$

Affinities.-This species is quite well eharacterized by its great zooccial width: all the known species have some elongated zooecia.

Occurrence.-Middle Jacksonian (Castle Hayne limestone) : Wilmington, North Carolina (rare).

Holotype.Cat. No. 6t139, U.A.N.II.

\section{MUCRONELLA GRANULOSA, new species.}

Plate 62, ligs. $8,9$.

Description.-The zoarium incrusts bryozoa. The zooecia are distinct, little elongated, hexagonal; the frontal is convex, surrounded by a line of small areolae and formed by a regularly grumulur pleurocyst. The peristome is thin, sharp, little salient; it bears on the anter $t$ to 6 spines and on the poster a lamellar mucro, oblique. very prominent and partially liding the apertura; a small lyrula and two ver'y small cardelles are risible at the base of the peristomie.

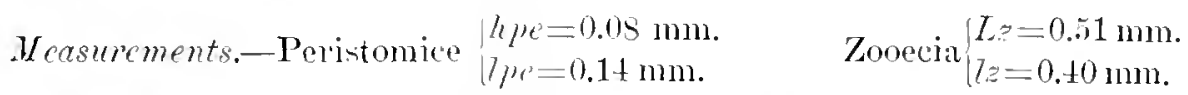

Affinitiex-This species is very elegant; it is rather rare that the elements of the plenrocyst are deposited with such regularity; howerer, this phemomenon exists in Mucronella variolosa. Johnston, 1847. A single speeimen has been found, incomplete, for the ovicell is wanting. hut it appears interesting to us on account of its elegince alone.

Occurrence-Lower Jacksonian (Moodys nar]) : Jackson, Mississippi (very l'are).

$$
\text { Holotype.-Cat. No, tit13๖. T.S.X.M. }
$$


Genus RHAMPHOSTOMELLA Lorenz, 1886.

1Ss6. Thamphostomella Ionenz, Inyozoen von Jin Mayen, Die Oesterreichische Polarstation Jan Matyen, vol, 3, p. 11.

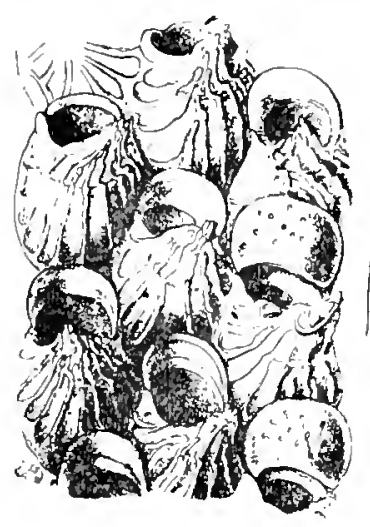

A $\times 30$

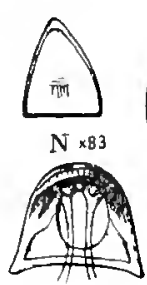

$P \times 250$

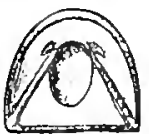

$0 \times 83$

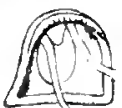

Q 250
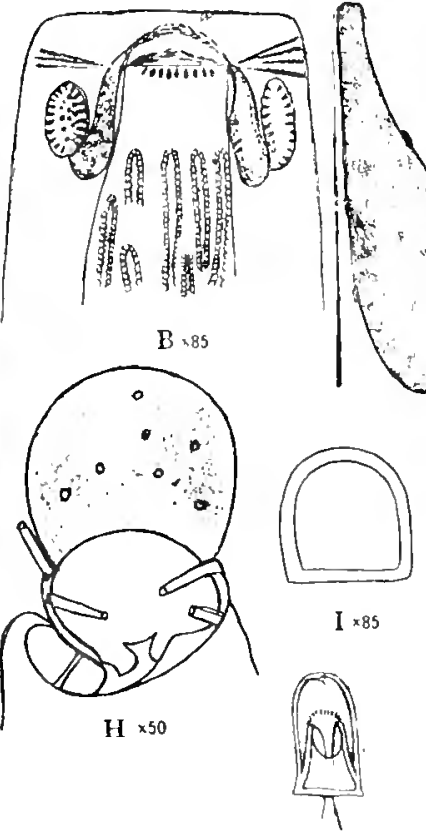

$\mathrm{R} \times 190$

$\mathrm{H} \times 50$

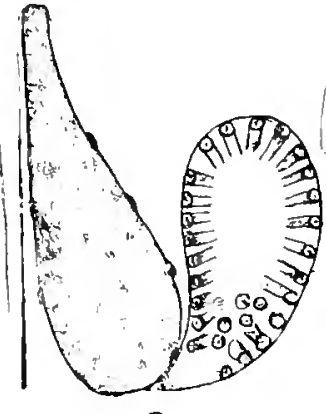

C、 250

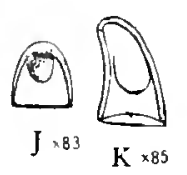

$\mathrm{K} \times 85$

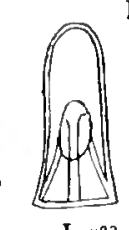

F $\times 60$
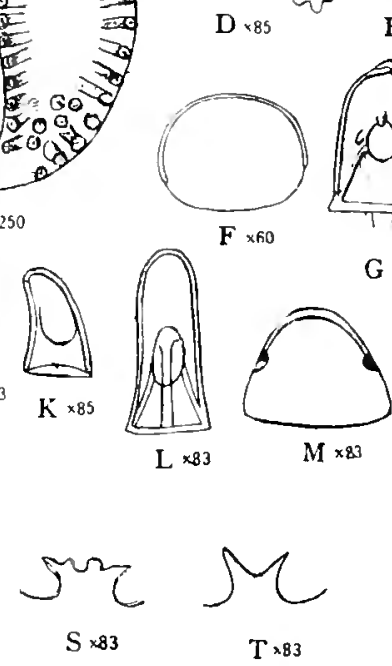

Fis. 134.-Genus Rhamphostomelln Lorenz, 1486.

A-r. Rhamphostomella rostuta Lorenz, 1ss6. A. Zooceia, $X$ 30. (After Lorenz, 1856.) b. Section showing the oral glands terminating near the tliapluram, $\times$ S5. C. Gland, $\times 250$. D, E Opcreulum and avicularian manlible, $X$ 8.5. (F-E after Waters, 1900.) F, G. Operculum and avicularian mantille, $x$ (6). (After Lorenz, 1880.)

HI-L. Rhamphostomelln plicafa smitt, 1S6. II. Wvicell and the anterior nart of the zooecium, $\times$ 50. (After Nordsaard, 1906.) I. K. Glereulum and avicularian mandible, $X$ 85. (After Waters, 1900.) J. Avicularian mandible, $\times 83$.

L. Avicularian mandible, $X 85$.

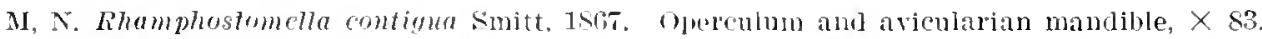

o. Rhamphosiomella scubre smitt, 18ist. Avicularian manlible, $\times$ 83. (J-O after Norilganarl, 1905.)

P, Q. Rhamphostameln radiatula Itincks, 187t. Arienlarian mandibles, $\times 250$. (After Lorenz, 18sG.)

I. Rhamphostomella bilaminata Lirenz, 1850. Avicularian mandible, $\times 150$. (After Lorenz, 18s6,)

S, T. Thamphostomella spinigera Lirenz, 1kst. Irifferent forms of lyula, $\times$ S3. (After Nordraard, 1906.)

The operculum closes the oricell. which is hyperstomial; it is thin and delicate. but there is a raised circular lidge. There is a rery narow lyrula. before an aspumetrical sinus. The frontal is a pleurocyt with costules. Before the orifice of the oricell and at the sume height, there is a rery large arjenlarim. oblique. 
salient and placed eccentrically; 18 tentacles. The oral glands are much developed.

Genotype.-Rhamphostomelle costata Lorenz, 1886.

Range.-Priabonian-Recent.

The only known fossil species is lhhamphostomclla brendolensis Waters. 1891, from the Priabonian of Vicentin.

RHAMPIIOSTOMELLA SIMPLEX, new species.

Plate S, figs. 11, 12.

Description.-The zoarium incrusts shells. The zooecia are little distinct; the frontal is convex and formed of a pleurocyst very finely granulated. The apertura is oblique, imbedded, hidden; it hears a very small lyrula. The peristome bears two spines. The oricell is hyperstomial, placed on the distal zooecia; it opens largely above the apertura and in front of the avicularium; it is formed of an area with very fine pores surrounded by a searcely distinct collar. The avicularium is enormous, quite salient above the apertura ; it is always placed obliquely and opens at the side of the apertura. The ancestrula is a small membraniporoid zooecium.

$$
\text { Measurcments.-Zooecia }\left\{\begin{array}{l}
L_{z}=0.30 \mathrm{~mm} \text {. } \\
7 .=0.20 \mathrm{~mm} .
\end{array}\right.
$$

Affinities.-This species is rather difficult to study because of its small dimensions. Our specimens are well preserred, and at an enlargement of 40 diameters they show very clearly the essential characters of Rhamphostomella in their more simple and more regular manifestations. The areolae are very rarely visible because of their rery small dimensions.

Rhamphostomella simplex differs from Rhamphostomella convere in its indistinct zooecia and in the opening of the avicularium which is invisible exteriorly and turned toward the apertura.

It differs from Rhamphostomolle limetolensis in the absence of the large frontal a vicularium.

Occurrence.-Wilcoxian (Bashi formation): Woods Bluff, Alabama (rare).

Cotypes.-Cat. No. 63829, U.S.N.M.

RHAMPHOSTOMELLA BRENDOLENSIS Waters, 1391, var. AMERICANA, new variety.

$$
\text { I'late 62, fig. } 11 .
$$

1S91. Rhamphostomella brendulensis Watris, North Italian Bryozoa, Quarterly . .ournal Geological Society Iondon, vol. 47, 1, 23, 1). 3, figs. 10, 11.

Description.-The zonrium incrusts shells. The zooecia are little distinct. elongated; the frontal is convex and formed of an irregularly and finely granulated pleurocyst. It has no peristome; the peristomice bears an asymmetrical sinus placed between two very salient aricularia of which one is always larger than the other; the apertura is ohlique. deep. hirrlen; the lyrula is flat and rather long. The ovicell is imbedded in the distal zooecia; it is little salient and smooth. On the 
frontal and placed in all directions there is a very large aricularium with small opesium and of which the mandible is rounded like the beak of a duck.

$$
\text { Mcasurements.-Zooecia }\left\{\begin{array}{l}
L_{z}=0.35 \mathrm{~mm} \text {. } \\
T_{z}=0.25 \mathrm{~mm} \text {. }
\end{array}\right.
$$

Affinities.-The European type has distinct and malginated zooccia; the large frontal avicularium appears to us as placed nearer the apertura. These insignificant differences do not permit us to make a distinct species out of our American specimens.

The presence of the large frontal avicularium differentiates clearly this species from Rhamphostomella simplex and Rhamphostomella convexa.

Occurrenee-Middle Jacksonian: Wilmington, North Carolina (rare) ; Eutaw Springs, South Carolina (very rare).

Geological distribution.-Priabonian of the Vicentin (Waters).

Hototype.-Cat. No. 64140, T.S.N.M.

RHAMPHOSTOMELLA CONVEXA, new species.

Plate 62, fig. 12.

Description.-The zoarium incrusts bryozoa. The zooecia are distinct, elliptical, a little elongated. separated by a furrow; the frontal is very concex and is formed of a pleurocyst very finely and very irregularly granulated. The peristome is little salient and bears two symmetrical spines; the peristomice bears an asymmetrical sinus formed by a quite salient oral avicularium with pirot and opening exteriorly; the aperture is oljlique, imhedded. hidden by the oral avicularium. The ovicell is sulall, salient, placed on the distal zooecium; it is rery widely open above the apertura and faces the aricularium.

$$
\text { Mrasurements.-Zooceia }\left\{\begin{array}{l}
L z=0.35-0.45 \mathrm{~mm} \text {. } \\
1 z=0.2 .5-0.30 \mathrm{~mm} \text {. }
\end{array}\right.
$$

Aftinities.-In this species it is absolutely impossible that the operculum could close the ovicell; it is closed loy the ectocyst itself or by a special membrane. We can only form an hypothesis. for we are totally ignorant of the larral system of the Smittinidae in general.

This species differs from Rhamphostomelle $x \mathrm{imple}$ in its zooecia distinct and convex, and in its oral arienlarium, which opens exteriorly and not in the peristomie.

It differs from Rhamphostomella brentolensis Waters, 1891, in the absence of the large frontal avicularium.

Ocmerrenee-Middle Jacksonian: Rich Hill, Crawford County, Georgia (rare); near Lenuds Ferry, Sonth Carolina (rare).

Upper .Tacksonian (Ocala limestone): Old Finctory, $1 \frac{1}{2}$ miles above Bainbridge, Georgia (rare).

Uolotype.-Cat. No, 6t141, U.S.N.M. 


\section{Genus CYSTISELla Canu and Bassler, 1917.}

1917. Cystisclla Cand and Basster, Syoprsis American Early Tertiary ('heilostome Bryuzon, Bulletin 96, United States National Iruseum, p. 53.

The frontal is an olocyst. It bears a very wide avicularian chamber in which there is a pair of large glands. The mandibles have a lucida in the middle. (Waters).

Genotype.-Cystisella. (Porella) saccata Busk, 1856.

Range.-Midwayan-Recent.

"In Porella saccata it [the ovicell] is many layered, as thin calcareous layers, presumably gymmocrst [ou olocyst] layers, continually grow over the ooecium, not only from the distal zooccium but also from the two reighboring zooceia, and we can sec as a rule three, distinctly separated, thin covering plates on their surface." (Levinsen, 1909, p. 336.)

CYSTISElla midifayica Canu and Bassler, 1917.

l'late 8 , figs. 5,6 .

1917. Cystisclla miduayanica CANU and BAsster. Synopsis American Early Tertiary Cheilostome Bryozon, Bulletin 96, Cinited States National Museum, 1). 53. 11. 5, fis. 6.

Description.-The zoarimm incrust shells. The zooecia are distinct, somewhat elongated, hexagomal, separated by a furrow or a thin salient thread; the frontal is very convex and very finely granulated. The peristome is thin, little salient in its distal part; it bears some spines; the peristomice is clliptical and deformed inferiorly by the avicularium. The aricularium forms a long chamber, median and conical; its orifice is little circular and turned toward the apertura.

$$
\text { Weasurements._Peristomice }\left\{\begin{array} { l } 
{ h p e = 0 . 1 0 \mathrm { mm } . } \\
{ 7 . p e = 0 . 1 4 \mathrm { mm } . }
\end{array} \quad \text { Zooecia } \left\{\begin{array}{l}
L_{z}=0.40 \mathrm{~mm} . \\
7 z=0.30 \mathrm{~mm} .
\end{array}\right.\right.
$$

Occurrence.-Midwayan (Clayton limestone): Luverne, Crenshaw Comnty, Alabama (very rare); one mile west of Fort Gaincs, Gcorgia (rare).

C'otypes.-Cat. No. 62606, U.S.N.M.

\section{Genus PORELLA Gray, 1818.}

1StS. Porclla Glis, List of liritish Animas in collection pritish Iuscum. Centroniae, P). 12T, 148 .

The ovicell opens into the peristomie; it is porous, imbedded in the distal zooecium. The apertura is semilunar. Neither lyrula nor carlelles. The operrolum is almost straight in its proximal part, with rouncled corners: there is a muscular prominence a little distance from the edire. In front of the apertura there is an aricularium: the mandible is semicin'mlar and has well marked thickenings formed of cliacronal bars. The frontal is a tremocyst with tulules. 20 tentacles.

Genotype.-Porelle (.Mill pora) cervicomis Pallas, 1666.

Range.-Tutetian-Recont. 


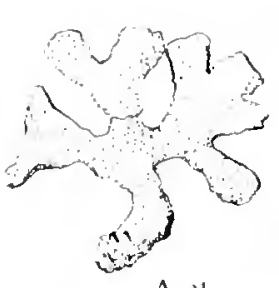

A 11

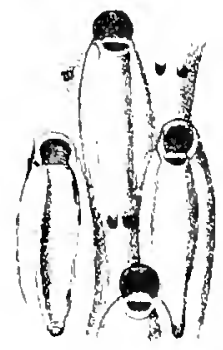

B $、 25$

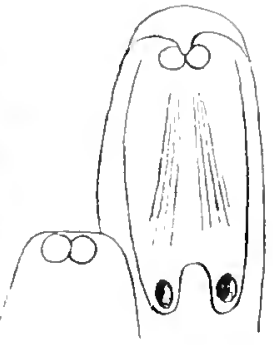

C $\times 85$

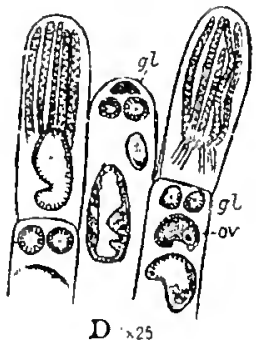

D $\times 25$

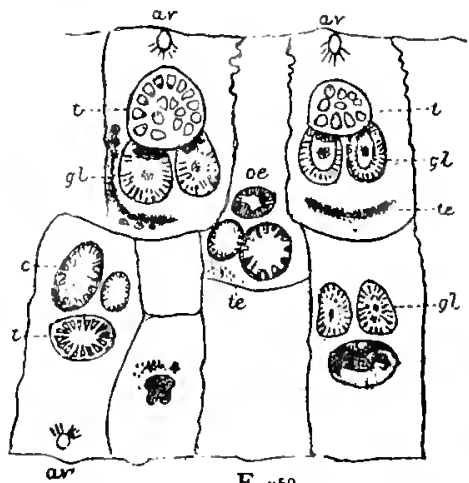

E $\times 50$
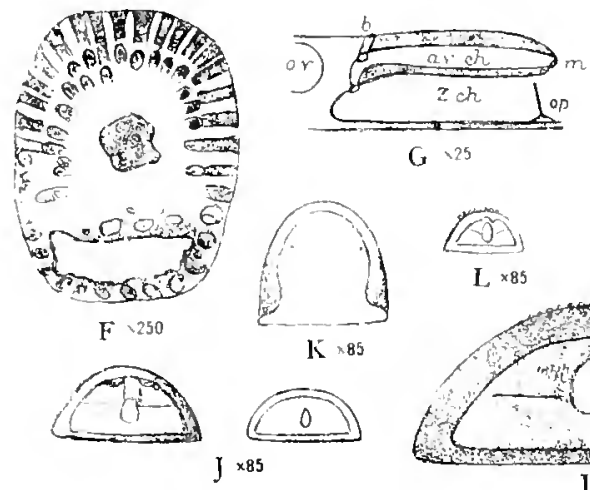

G \25

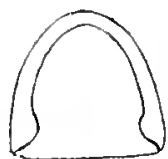

I1 $\times 85$

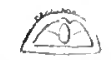

$\mathrm{L} \times 85$
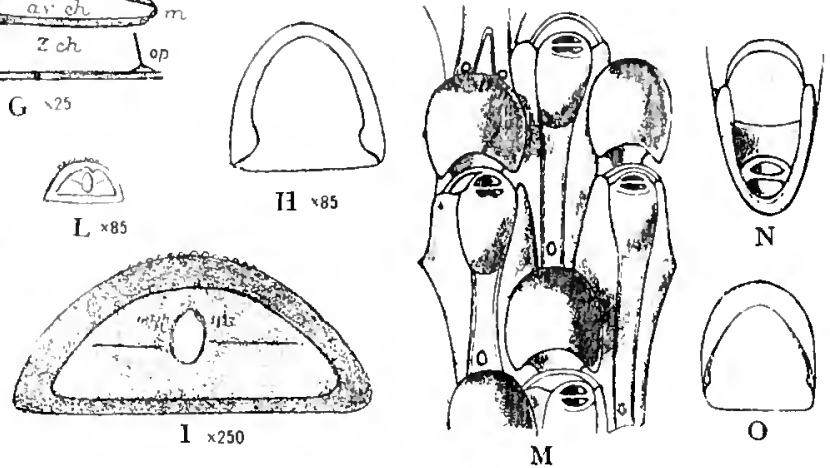

o
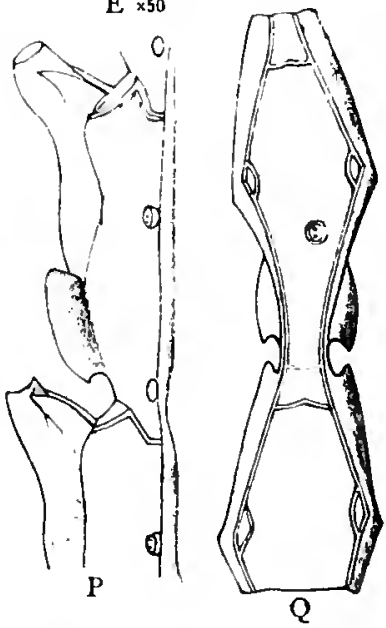

Fia. 135-Gems Cystisclla Canu and liassler, 1917.

A-J. Cystisclla sacenta Busk, 15.6. A. Zoarium, natural size. (After Yortgatard, 1905.) 13. Specimen boiled in caustic putash showing the large avicularian chamber, that of the left zooecium broken away; also showing the pores at the base of the avicularian rhamber, $X .7$. $\therefore$ The interior of a furtion, $X$ 8.5, in which there are no polynides showing the glands reducer to two small globes attacher to the fleshy tissue. In the avicularian chamber there ale two very long muscles, and at the lase there are the two characteristic pores. D. Section showing the position of the oral glands $(g l)$, which are behind the tentacles so that they are not seen in the zovecia cut through near the frontal surface, $(o v)$, ovum, $\times 25$. E. Transverse section showing the large oral glands ( $g l)$, the avicularian sheath $(a v)$, the tentacles $(t)$ in their sheatl, esophagus (oc), carcum $(c)$, testes (te), $\times 50$. F. Oral gland, $\times 250$. In the upper mart the cells are partly absorbed. Cr. Diarammatic section, $x$ 25, showing the frontal pore connerted through a rosette plate with the avicularian chamber, which farther down is similaxly connertel with the zonecium. av. $c h .$, avicularian chamber; $m$, mandible; op, operculum; ov, uvicell; srh, zooecial chamber: H. Olerculum, $X$ s.5. I, J. Avicularian mandible, $\times$ 250 and $\times 85$.

K, J. Cystisella clegntula D'Orbigny, 185.2. Operculum, X 85, and avicularian manaible, $\times$ Si.

M-Q. Cystisella frughis Levinsen, 1916. M. Zooecia and ooecia, frontal surface. N. Aperture, much enlarged. O. Operculum. P. Zonecia in lateral view. Q. Basal wall of the zooecia. (After Lovinsen, 3016.) 
Thi- geme differs from simitfine only in the calcification: the tremongt replaces the plenrocyst. There are. however. some other secondany ditlerences. The mantible of the avieulariun in semicircular: it is generally (but not miver-ally)

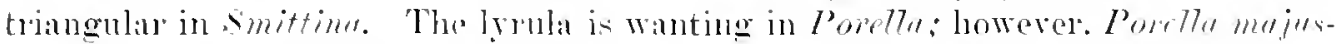

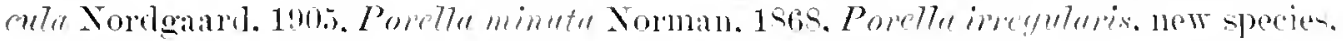
and Porella coronota. new speecics, have an apparent lyrula.

The median arienlarim is puite varialle. In the same species it may les quite salient or buried in the peristomie, acending to the thickness of the trenowet; these rariations make the determination of the species rery difficult. Some speries have the aricularium always salient: other's. on the contrary. have an invisible aricularium. and only aluasion of the surface will reveal it.

II istorient.-The genera Smittina and Pombll are two ruite natmal genera which have been armirably described ly IIncks, lut of which he has not given the exact limits occasioning thus some hesitation among collectors. Waters, in 1900. recognized the necesity of making two gromps in the genus Porella, according to the nature of the mindible. The firt group is very homogeneous and is the genns Porella as Lerinsen limited it in 1909, and as we now understand it. The second gronp is less homogeneous, for the presence of a lucida on the mandible thes not appear to correspond to an important physiologic function. In 1009 Levinsen

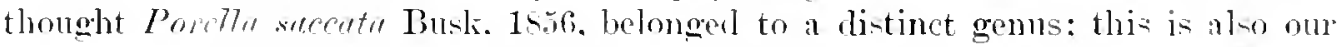
opinion and we have created the genus 'ystivelln. Likewise he thought that P'orell" emetirostris might erve as genotype for another genus. On the other hame. we

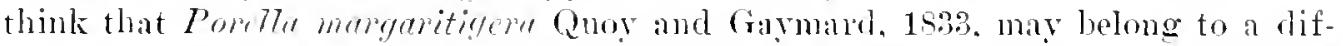

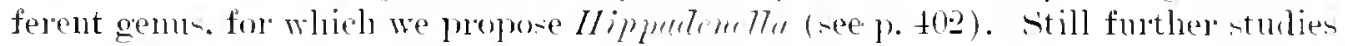
are necestary. P'atmirellario in a zoarial suldgemus which may be conveniently preserverl.

PORELLA OBLIQUA, new species.

['lite 14, fir. 17 .

Ineseription.--The zondium incrusts -hells. The zooecin are small, a little clongated, little distinct; the frontal is little convex and formed by a tremocret with iarge pore. The apertura is semilunar: the periatome is smootl, thin. more of les salient. The wriell is hyperstomial and opens into the peristomie: it is formen of

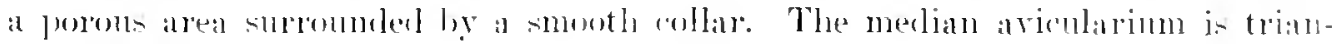

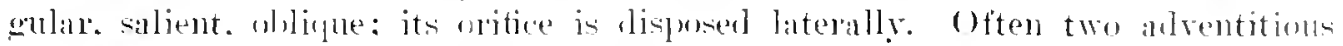
aricularia hite the frontal mole or les.

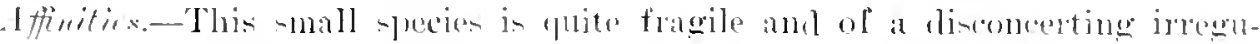

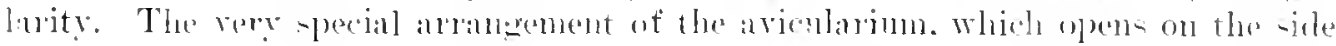

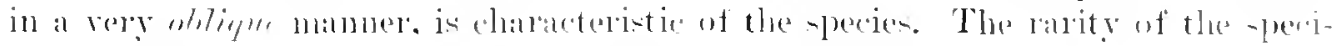
mens hat mot permitterl us to malke a caldeful -tudy. but we have thomght it worth while to "all the - precies to the attrition of collectors.

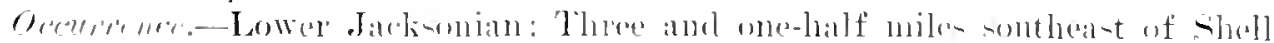

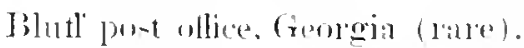

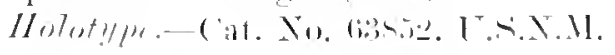

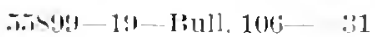



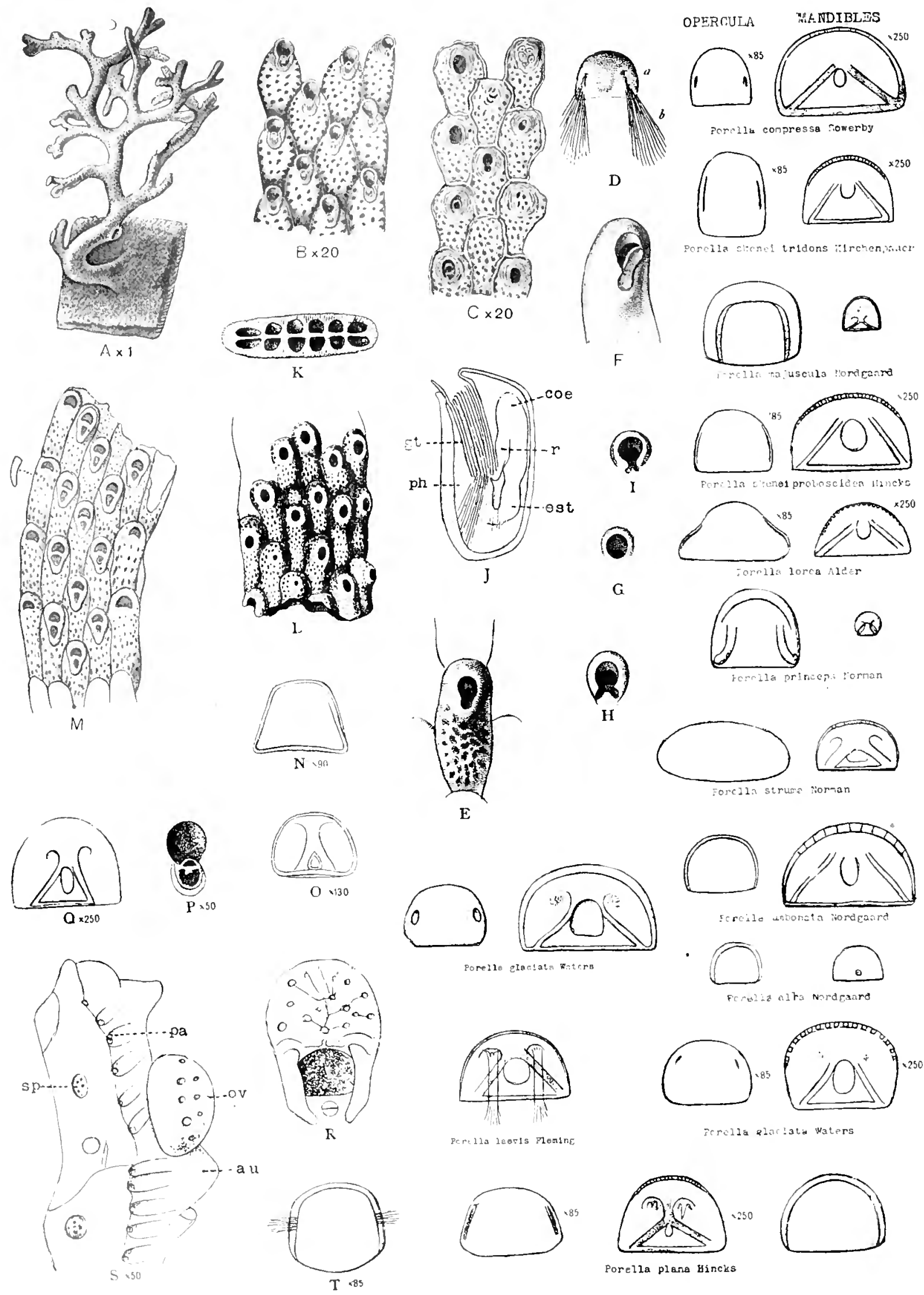
Fis. $1: 26$ -

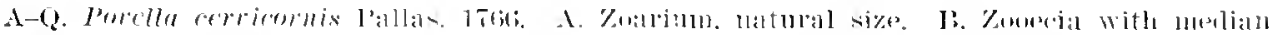

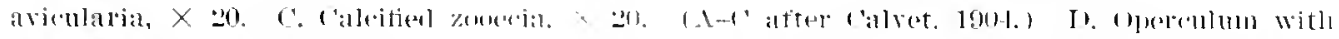

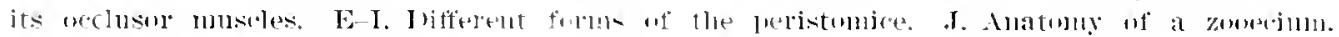

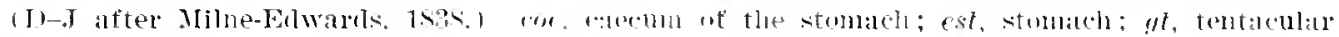

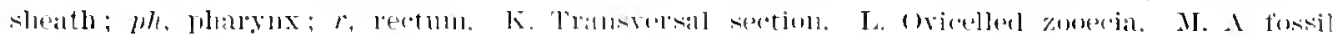

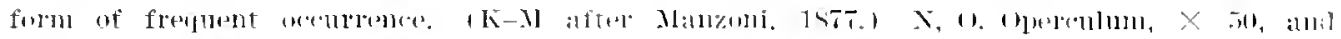

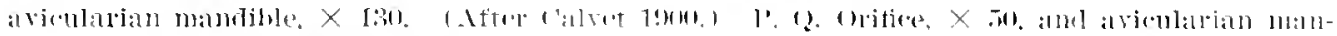

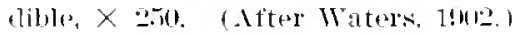

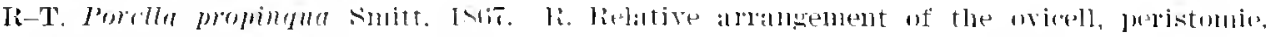

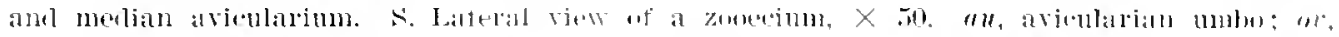

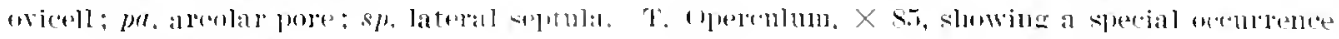

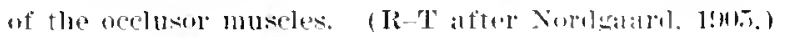


PORELLA IRREGULARIS. new species.

Plite fid. fizs. 1S-21.

Itexription.-The zonrin incrunt shell and bryozoa. The zooecia are dis-

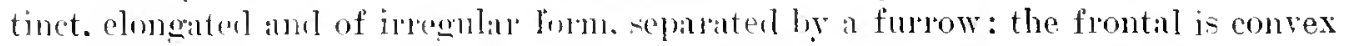
and formerl of a tremoryst with numeroms intwular pores. The apertura is visible at the lase of the peristomie: the prestome in thin. oral, salient. The ovicell is globular. somewhat alient. little imberleles in the distal zooecia; it is hyperstomial and opens inte the peristomie alowe the aperturas: it is formed of a large area rery

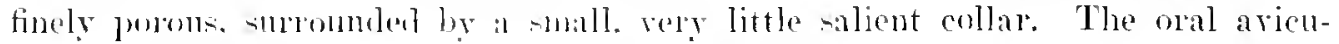
latrimm is median, placed in the sinu of the perintome, little salient, smooth.

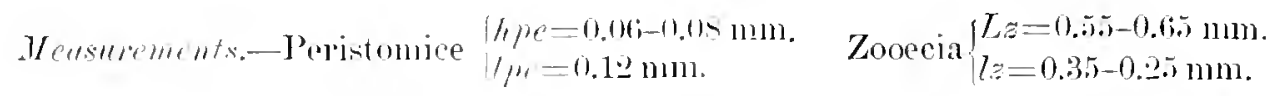

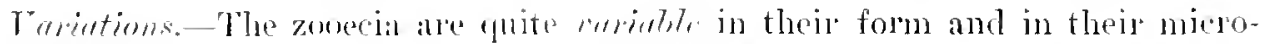
metric dimonsions eren in the zo:lrial regiom distant from the ancestrula (figs. 19. 20). In the interiol (fig. 21) the sllall lyrula is visible. Figure 18 shows nmmerous traces of incompletely dereloperl ovicelln: there are some semicircular olorystal traces on the distal zoneria. The formation of the ovicell is therefore much ponterior to that of the zooecia : it probaly yount to coinciule with the maturity of the orary as . Jolliet thomght in $14-T^{.}$But what in the origin of the endocytal bud which serperes the ovicellanian olocrent?

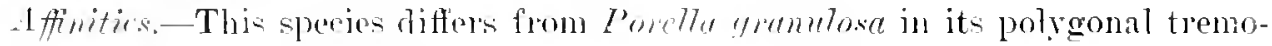
yore- and it irromlan zoweria.

It diflese from Porethe comemet in the aluene of all adventitious aricularia.

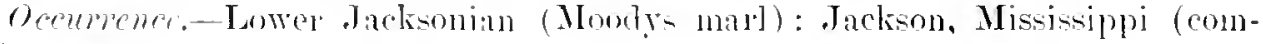
mon).

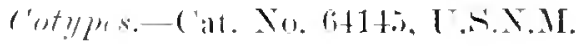

$$
\begin{aligned}
& \text { PORELla GRANULOSA, new species. }
\end{aligned}
$$

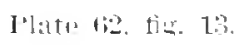

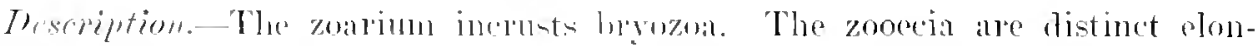

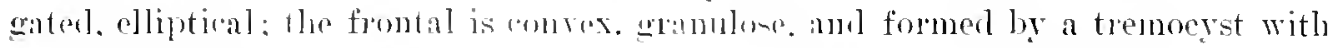

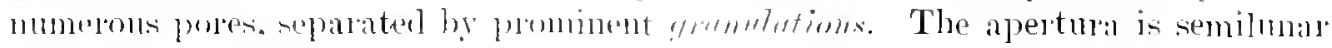

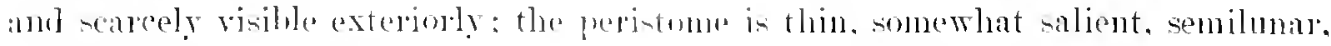
deformen helow by the aricularime. The wionl is elobular. little salient, some-

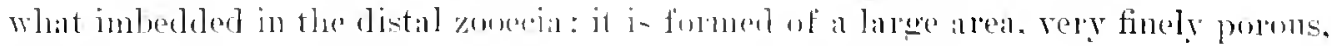

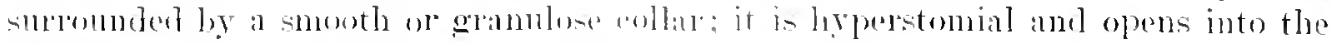

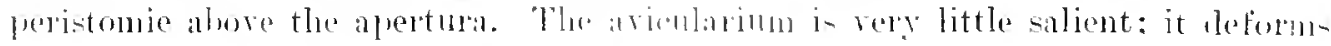
the peristome ant opens into the preistomin.

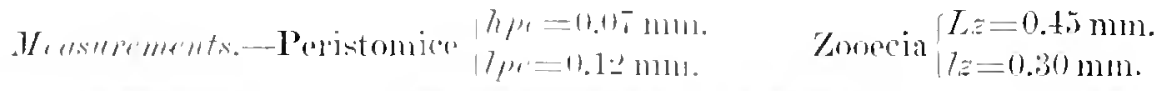

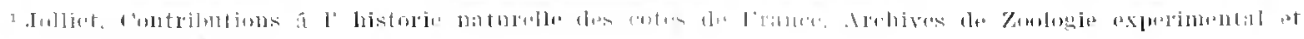

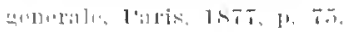


Afmitics. One mal follow. flom the zoarial extremity. the formation of the aricularimn. In the peristomial sinus first formed there devolops a small avieulatrom which increases ant is transformer in small. somewhat salient chambers.

This species differs from lownll inguteris in the frontal gramulations and the regular form of the zooceia.

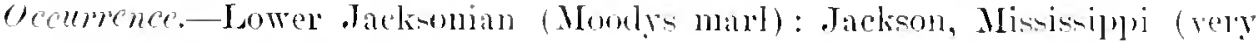
rare).

llolotype.-Cat. No. (it1t?. T.S.X.M.

PORELLA CORONATA, new species.

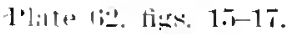

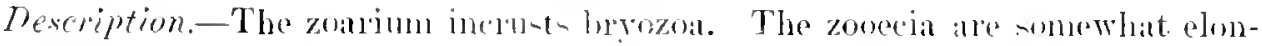
gated. little distinct, rather irlegular: the frontal is emrex and formed of a tremocyst with large pores in quindunx. The apertura is little visible at the liase of a leep peristomie; the pexi-tonte is thin. salient, gamisher with 1 to 5 small, round avieularia; the lymla is rery sulall and supports a median aricularium. The ovicell is large, transverse but little salient; it is formed of a larea area fimely porous and rery fragile, surommled hy a little salient collatr. The median ariculanimm is very little salient, opening motwarl and borme on a small lyrula. Sometimes there are some small alventitious later:al arieularia.

$$
\text { Measurements.-Peristomice }\left\{\begin{array} { l } 
{ h \mu = 0 . 1 0 \mathrm { mm } . } \\
{ 7 \mu = 0 . 1 4 \mathrm { mm } . }
\end{array} \quad \text { Zooecia } \left\{\begin{array}{l}
L z=0.60 \mathrm{~mm} . \\
l z=0.30 \mathrm{~mm} .
\end{array}\right.\right.
$$

Trubtions.-The romg zoodia (fig. 15) or maroinal zonecia are separated by a prominent thread: their arombrim is buried in the peristomie, and the arienlaria of the peristome are rery - mall. On the adult zonecia the aricularia of the peristome form a solt of cromen anomel the apertura: but their mumber is quite variable and the formation of the oricell camses them to disappear (fig. 16): they have a pirot. The fromtal of the wricell is very fragile: its alsenere complieates still more the rexy imegular is prect ot this species.

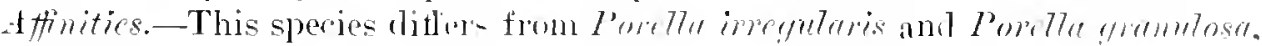
which also have incrusting zaldi!. in the presence of the avicularia on the peristome.

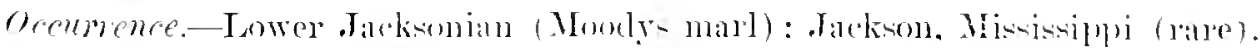

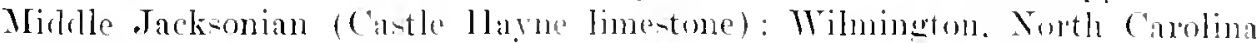
(rery rare).

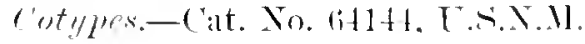

PORELLA DENTICLLIFERA, new species.

I'lilth lin, figs: 1-i.

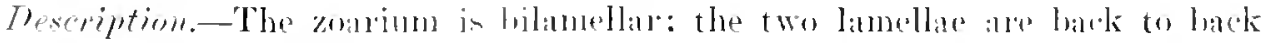

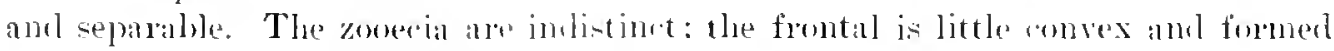
of a tremocyst. With pores mermous and litte numerous. The atpertura (in the

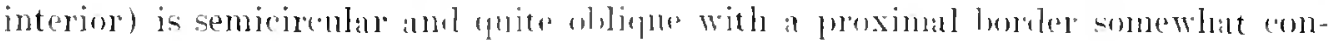


care: the peristming has the form of a traperoinl the peristome is absent. The ovieell is small. entirely imbeldes in the clistal zooecimm, not salient; its frontal is perforated with numeroms small pures. The motian avicularimm is sather large, sumoth: it makes a prominence in the peristomie in the form of a renticutered tube with its listal pillt.

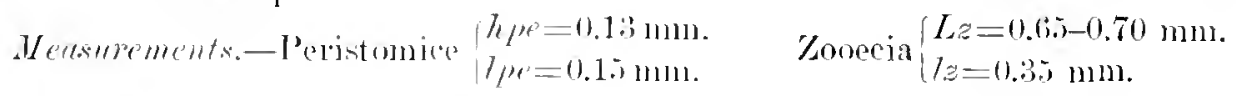

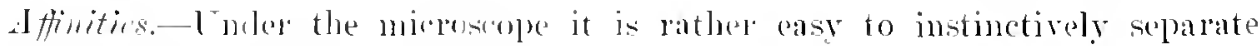

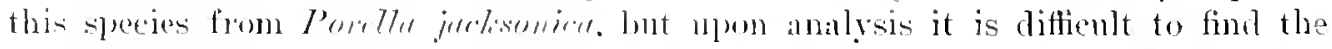
clearly separating clasaters. It alperalrs to differ form it in the small denticles which often teminate the malian arvenlintum ame in the size and rarity of the tremopores.

The tangential section (fig. 5 ) is that of a tremoerst resting on an olocyst; the ovirell is here confoumber naturally with the peristomie.

The tremopores are mbular and as long as the thickness of the zooecium.

Ocrumence.-Ciabormian (Gosport saml): One mile sonthwest of Rockville, Alabama.

Luwer .Jacksonian (Momlys mal) : Talckson, Mississippi (common).

Cotypes.- ('it. No. 6t14li, ['........

PORELLA JACKSONICA, new species.

I'lilter lins, tiors, bi-1T.

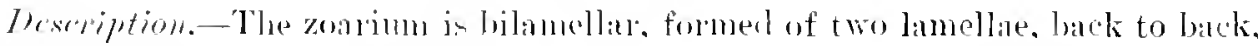

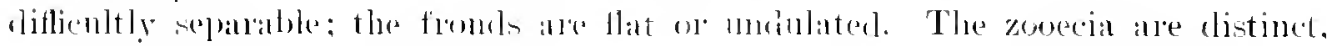
very alongated. fusiform: the fromtal is comrex and teminated distally by an enommons, oblique avicularian muce making a projection at $4.5^{\circ}$ and corering

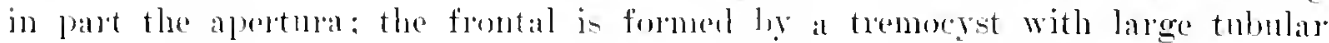
pores lesting on a thin perforaterl oherst. The apertulat is transrersesemilmar. olilique, buried at the base of the peristomie. The peristone is not salient. The wreell is entirely imberleled in the walls of the distal zooceia and is not salient: it: frontal area is piered with pures and rery frogile. The median avicularium is

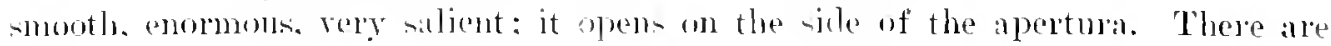

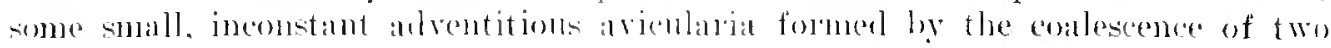
tremoporess.

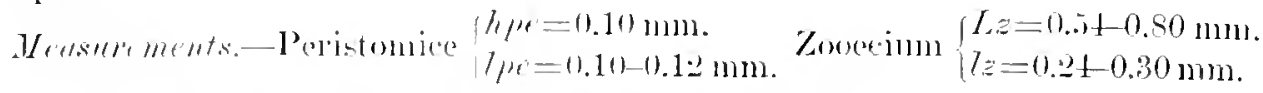

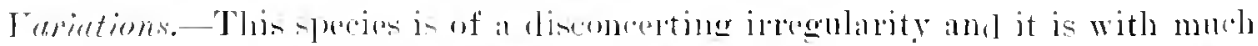

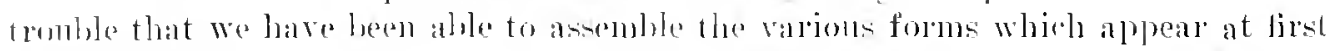

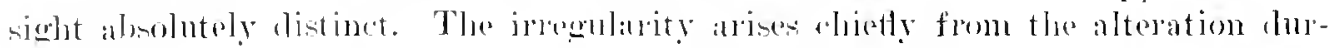
ing fosilization, as is the haloit in the speres with eleat relief: the breaking of ilse merlian ariollarium, the obliteration of the tremopores, and the rupture of the

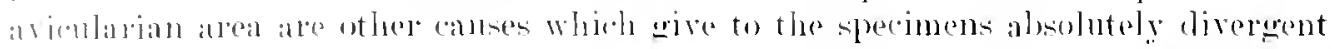
asperts. Thein illmuination eren under the minowope changes their aspect; the 
illumination from betow is preforable. The aust usual aspects ale those of the

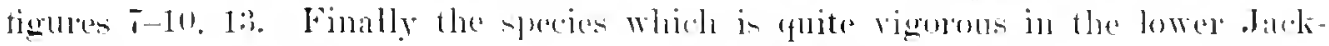

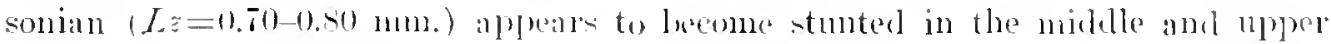

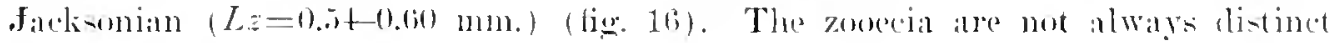
(figs. 10. 16i).

In the intorior (fig. 15) the tubules are well marked by the white cirele which

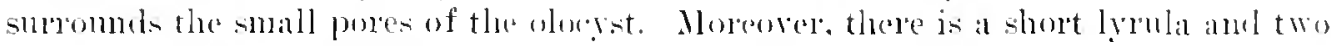
small carlelles (fig. 1.i).

This species has been fomml in many localities of the Jacksomian. which fiat orcasions jts name.

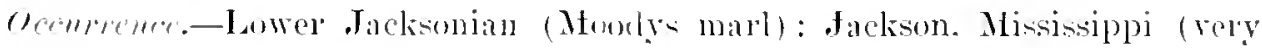
common).

Micklle Jacksonian: Wilningtom. North ('al'olina (common); Balklock. Ban'nwell comty. South Carolina (rare).

Jacksonian (Zenglodon zone) : Somth side of Suck (reek, Clurke ('onnty. Mjisisippi (very lare): Shulunta, Missisippi (rape).

Clyer Jacksonian (Ocala limestome) : Machua. Floricla (rare).

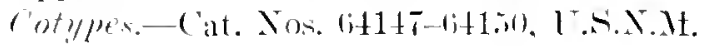

Porella PUNGeNs, new species.

Ilitte 152 , tim. 14 .

Harription.-The zoarium incults oysters. The zonecia are distinct: quite elongated. fusiform. separited ly a deep furmow the frontal is convex. formed of a tremocyst. with four rows of large scattered pores. The apertura is hidilen at the base of the peristomie by the menlian arienlarime the peristome is rery thin and somewhat salient. Tlue oricell is large. violmar. salient. formed of an area with mmmerous small pores surromeriect by a smooth collar. The morian avicularium is enomous, rery salient: elevated oblinuely at $4.5^{\circ}$ : it eorers in part the apertura and opens on its sicle.

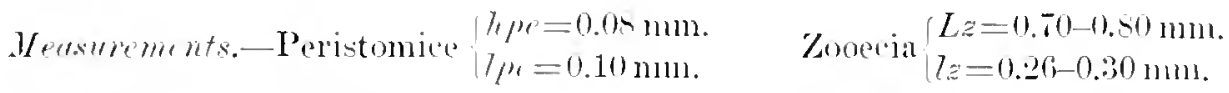

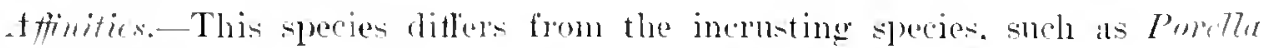

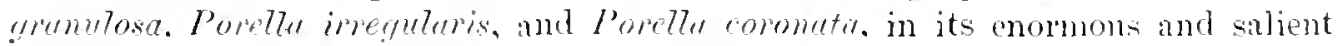
median avienlarimus.

It aspect is sinilar to l'omlle juelisomicen, of which it is perluaps only the incrusting form. It difles from it nerertheles in its aviculirimm still more

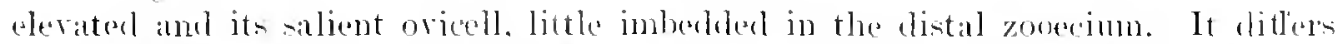

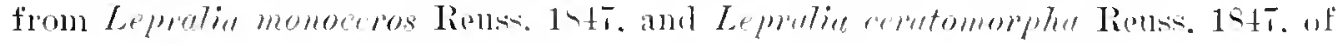
the Enropean Ifiocene, in the presence of tremopores and not of aroolic. The \%orrimm appears to be bristling with slan proints.

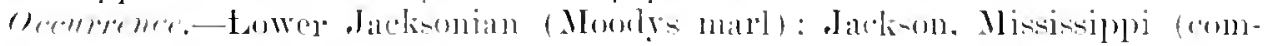
mull).

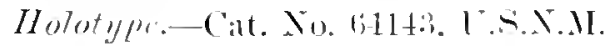


Deseription.-The zonrium is milamellal and reeps on algae. The zooecia are distinct. elongaterl. fusiform: the frontal is convex and is terminated distally by a lone ungulate mucro arering the apertura: it is formed of a tremorst with sentlered pores. disposed in quincmx. The apertura is invisible exteriorly; the peristome is wanting. The oricell is had dly salient; the pores of the area are much -maller than those of the frontil: it is hyperstomial and opens into the peristonie. The median avienlanimm is larege, ollique, smooth, totally burying the apertura.

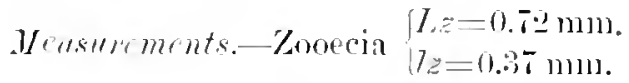

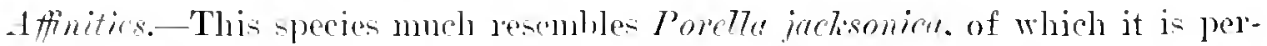
latp the creeping form. It difler flom it in its smaller tremopores, the exagerated leneth of its median avioularium. which always covers the apertura on the well prespred specinens. and in the alsence of all adventitions avieularia.

In the intelior (fig. 5) the oloryst is thick; the proximal horder of the apertura is comvex: the mucro is vicible.

On the zoarial matgins the avicularium is more fragile and more eavily broken ( fị..: $:$ )

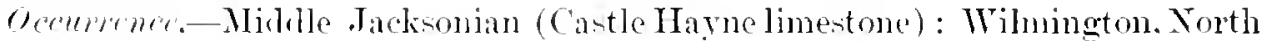
Cirolina (commom).

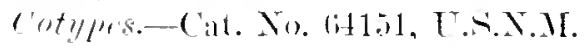

PORELla PLANULATA, new species.

Plate lit, tiss. G-9.

Iheseription.-The zoaldum is lilamellar and formed of two lamellae. back to batck and insepuable. The zooccia are distinct, elongated, roumled in front. nar-

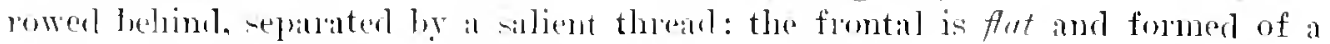
tremoryt with large tubules resting an an olocrst with small pores. The apertura (in the interior) is formed of a sinulumar anter ame of a very concave puster; at the exteron the peristonice is elliptionl and the peristome very thin. The median arientamm is very small. buried in the thickness of the tremeyst and opens into the peristomie: it is visible only ly aluanom of the sulface. Sometimes avicularian zorrecia are interealated anong the nomml zonecia.

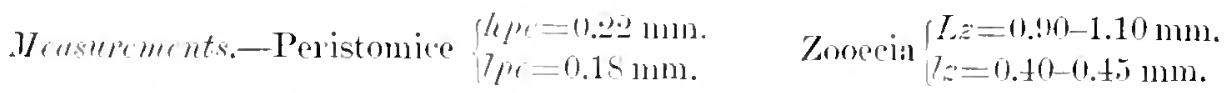

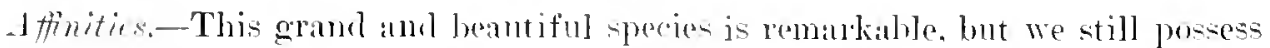

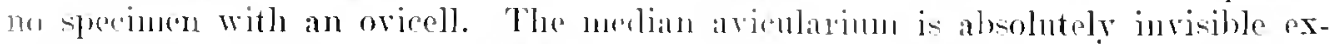
teriorly: ly properly inclining the preparation its orifice is visible: upon abrasion of the sulfice it alpears like a small carity in the thickness of the tremoryst (fig. a).

In the interion certain zooecia are divided in two palds by a partition. of whore nowe alle alsolutely ignorant (fig. s). 


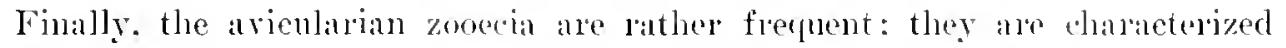
by a very large opening. narmower in its nedian part. We know that the operulum in replaced there by a mandible and that the polypicle has disapreared by histolysis.

oceurenee.-Middle Jackionian (Castle Hayne limestone) : Wihningoton, Nonth Carolina (rare); near Lenteds Forry, Fonth Carolina (rare).

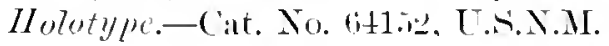

PORElla ABDita, new species.

Plate 65, figs. 1-3.

Iheseription.-The zoarimu is large, bilamellar, and formerl of two lancllace, hack to back, and inseparable. The zooecia are indistinct: the frontal is convex and formed of a tremocyst with irregrular pores. The peri-tonice is orbicular or elliptical. The median aricularim is very small. buried in the thickness of the trenocyst, opening in the peristomie, herdly visible exteriorly. Often al suall adrentitions avienlarim is placed in the vicmity of the peristomice.

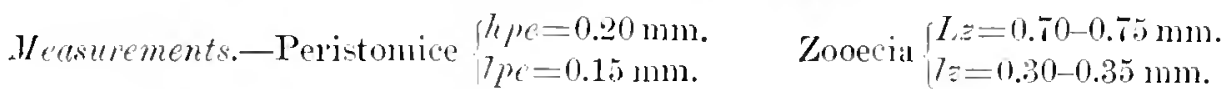

Affinitics.-TVe have collected only a small number of specimens and it is possible, therefore, that they are relited to another species of which they nay be the strongly calcified representatives. This is, in fact the habitual variation in Porella denticulifere and Portlu jucksonicu. To be certain of the identification with the Jatter species it will be necessary to fund a greater number of specimens in the same localities.

Oecurpence.-Tpper Iack-rmian (Ocala limestone) : Alachua. Florida (rare); 9 miles north of Ocala, Floridal (rare).

Cotyles.-Cat. Nos. 6t1st. Git15., U.N.X.M.

PORELla PORTENTOSA, new speeies.

I'Iite 6it, firs. 10-23.

Deseription.-The zontum is bilamellat; the fromels are flat or a little undulated. The zoodcia are distinct, quite elongated, tulmlan: the fiontal is convex and formed of a tremocy-t with bare tubular peres. slpported ly a rey thin, perforated olocyst; the tulules have thick walls and are reparited finom one. another. The apertura is semiluman, with the poxinal horler convex; the peristome is very thin, harelly salient. The ovicell is mon embedeled in the distal zooecium, harelly prominent; it fromtal is a perforated aldea: the oricoll is hypepstomial and opens into the peristemie. The aromlarimu is placed entirely within the peristomie.

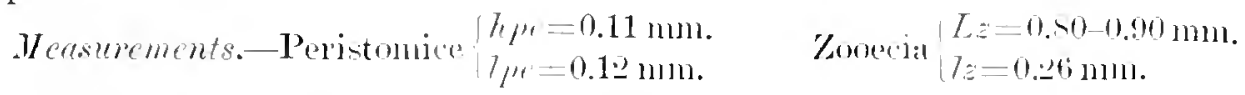

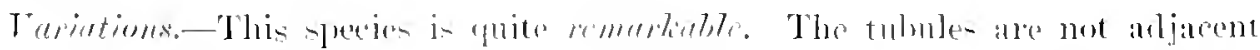
and are separated from anch othere: this results in the fromtal having a fantastic

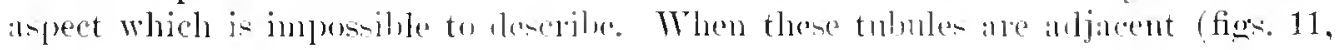


12) the retermination remains rather diffentt. and it is necessary to assemble a (omsicleralole mumber ot suecimens to make it. The thickness of the walls of the tubnles jo quite vishle on the tangential sections (fig. 23). 'Their length is visible on the transweral sextions. which are always difheult to make on account of the irregularity of the fontal network. The olocyt is perforated with resy small

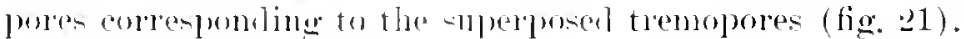

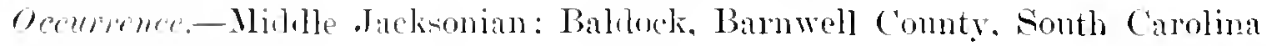
(rerg common): Rich Ilill. ('awford Connty, Georgia (common); 18 miles west

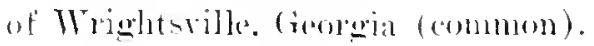

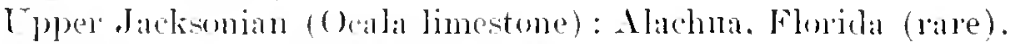

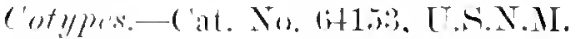

PORELLA CRASSOPARIES, new species.

Ilate !). fies. 10-21.

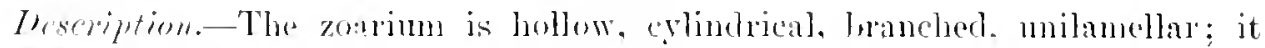
incrusts mall algale. The zorecia are distinct. elongated. tubnlaj; the frontal is convex and fomed of a thire taemocyst with large tubules placed on a very thin perforated oloryst. The aperoma is semihmar, very obligue, situated at the base "ft a leep peristomie: the peristome is thin or thick. hardly silient, interrupted in front. The ovirel] is salient. orolmbar, of the same nature as the frontal it is hyperstomial and opens into the peristomie. The merlian arienlarimm ic sunk in the thickness of the tremoryt: it opens intu the peristomie where it often forms a tublat plominemer.

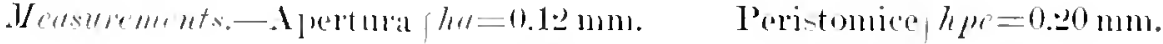

$$
\begin{aligned}
& \text { (interior) } \mid / \mu=0.15 m m \text { s } \quad \text { (exterior) } \mid 7 / \mu e=0.14 \mathrm{~mm} \text {. }
\end{aligned}
$$

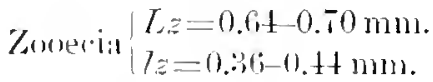

Inviutions.-The wat variations of this specion evidently depend on the thirliness of the trumocyst. The young zonecia (fig. 12) ale hordered and appear smaller. 'The old zomedia (figs. 13, 14) appear larger': the ariculajmm is there little vi-ible (fig. 19). and aren invisible (fig. 14): the arat thickness of the

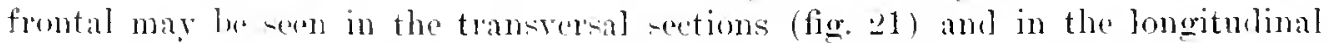

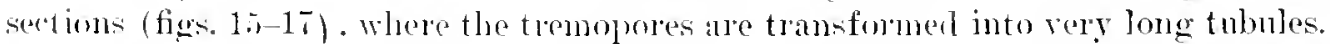

In the intrion the lateral walls are rery thin (lig. 1s): the avienlarium is only visibu there a a mall comvexity helow the apertura. The aluasion of the ulocyst (fie. 19) -lown that it is very small.

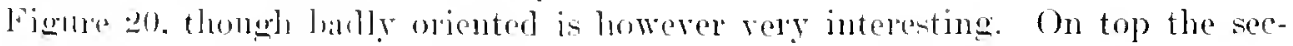
tion is in the tremourst and the pores are white. Below the section is in the olorent for the puren alle closed. The black ringe indicate the section: on some prove we sere the smill pore which perforates the olocyst in the middle of the lallew ring formol by the tremopore.

The zontum mat he formed of many superposed lamellae (fig. 1.i). 


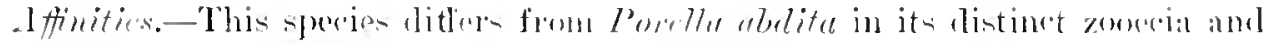

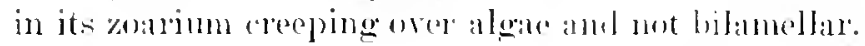

In its exterior aspect and in the natme of its zoarinm it maly he eanily am-

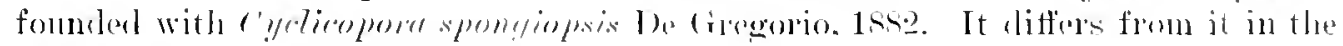

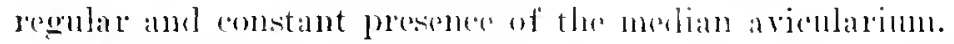

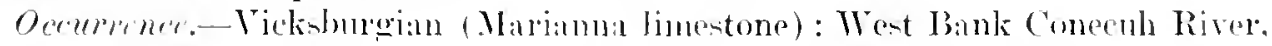

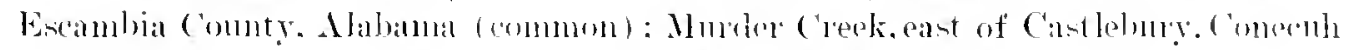
County, Alabama (commons): Clabibune, Monaroe County, Mlabama (common):

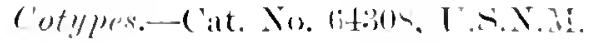

\section{PORELla CYLINDRICA, new speeies.}

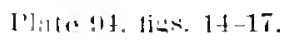

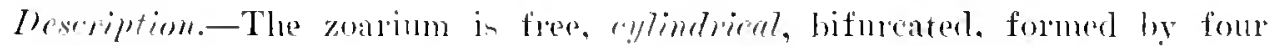
to six longitudinat rows of zoureia. The zoroeria ale distinct elongated, separated by a salient thread: the frontal in -rmewhat convex and is formed of a thick tremocyst with large tubules. The apretura is lexp and partially hidden by the median aricularimo: it has no peri-tome. The median avicularimm is enormons. very salient, rery straght with an wities tmonel towad the sirle of the apertura.

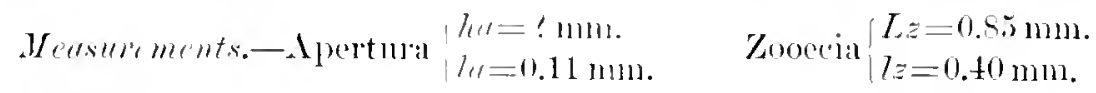

Affinitis.-The vincularian form of its zoarium clearly distinguinles this species from the species with large mexlian avicularium, swoh as Popella deuti-

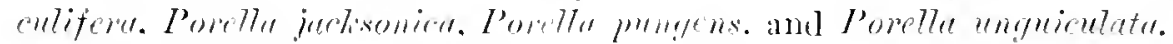

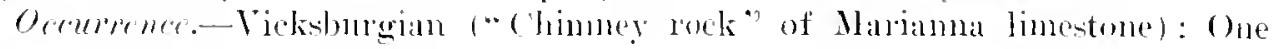
mile north of Momoeville. Alatmana (omminom).

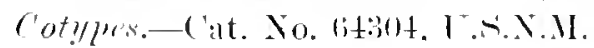

PORELLA FRETTA. new species.

I"l:1to !r. ties: 17-20.

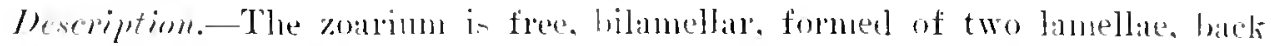
to back, and inseparable: the faum are nalow and bifmeated.

The zooecia are distince. long. tubutar; the frontal is comves and formed of a tubular tremerest plareal an a thin olocyst with small pores. The apertura is semilunar, oblique. buriexl. hy the mubu when the latter is entive: it has no

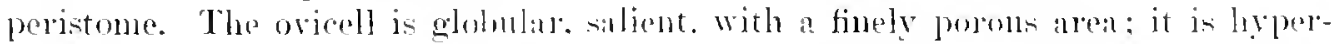
stomial and ppens into the peristomise. The median ariculanim forms a very salint

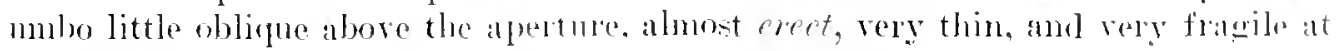
the extremity.

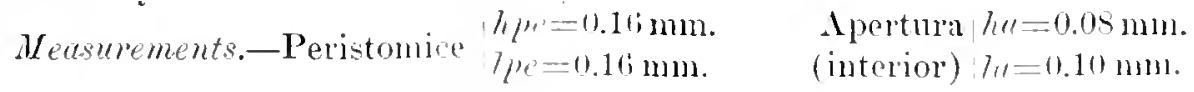

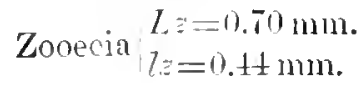


laniotions.-This speries is not very variable in itself. but the frontal arienlarium in so fragile that the fosils are ocenerally deprived of it: it is replaced hy a larege irrexular cicatrix.

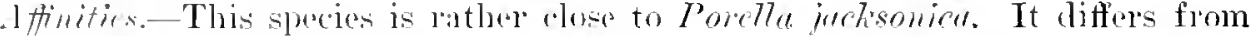
it in its much less ollieque avicularimo its smaller tremopores, and its zoarial fromls muth less wille and containing only from five to six longitudinal rows of zooecia al most.

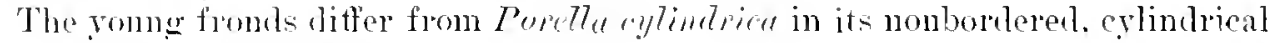
zooevia and in its smaller tremopores.

It differs from Portla rompurta, in which the zuarial fronds are identical, in the thinmess of the arienlarium and in its more numerous and much smaller tremopores.

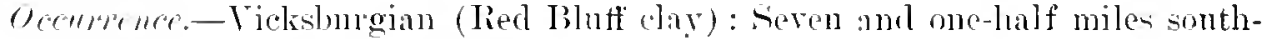
west from Blaten springs. Alabama (rare).

Cotypes.Cat. No. 6+301, T.N.X.M.

PORELLA COMPACTA, new species.

I'late! It. firs. 1:, $1: 3$.

Ilescription.-The zoarium is free. libamellar. formed of two lamellate back to bark. and easily separable; the foucls are very narow and bifureated. The zonecia are distinct, somewhat elongaterl, wile; the frontal is eonves and formed of a tremocyst with tubules coalesced into rery large tremopores, placed on an olocyst with numerous small pores. The apertura (interior) is elongated, semilumar. obligue: it has mo salient peristonte. The ovicell is rery small. not salient, ormanented also with lange tremopores. The avieularium forms an enormous

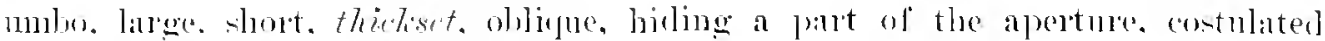
longituliually.

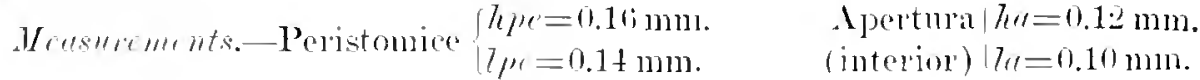

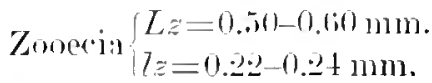

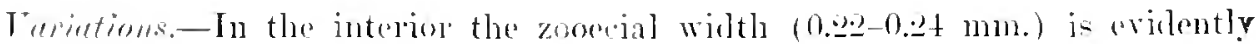
smaller than the exterior $(0.30 \mathrm{~mm}$.).

There is ne correpondance hetween the mumlues of perforations of the olerest

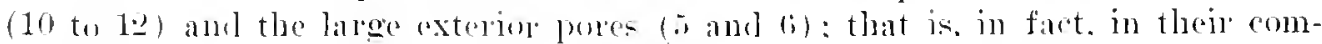
monalge. the tulumber berome conlluent and lennite amomg themselves.

'The mandible of the meelian avinlasinu is small. semiciremlar; it is placed

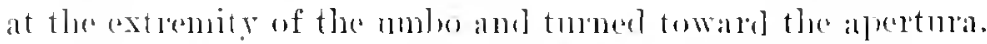

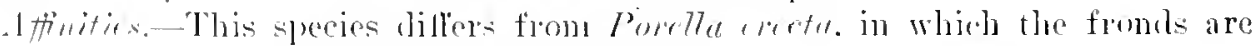

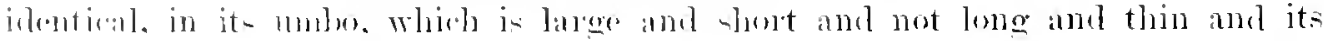

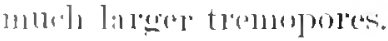




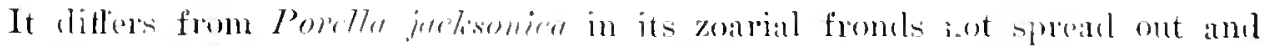
very namow. in its nuch wiler mulu ame in it still larger tremoporen.

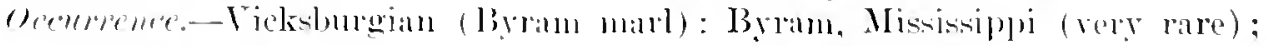

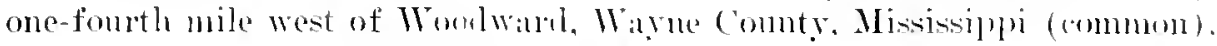

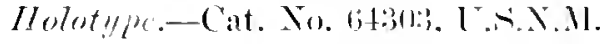

Golouncal distibution af tumiem species of l'orella.

\begin{tabular}{|c|c|c|c|c|c|c|}
\hline \multirow{3}{*}{ Niane. } & \multirow{3}{*}{$\begin{array}{l}\text { ('laphorn- } \\
\text { ian. }\end{array}$} & \multicolumn{4}{|c|}{ Jacksonian. } & \multirow{3}{*}{$\begin{array}{l}\text { Vilks- } \\
\text { burgian. }\end{array}$} \\
\hline & & \multirow{2}{*}{$\begin{array}{l}\text { Lower } \\
\text { Jackson- } \\
\text { ian. }\end{array}$} & \multicolumn{2}{|c|}{ Middle Jacksonian. } & \multirow{2}{*}{$\begin{array}{l}\text { T'ples } \\
\text { Jackson- } \\
\text { lan. }\end{array}$} & \\
\hline & & & $\begin{array}{l}\text { Wilming } \\
\text { 1on zone. }\end{array}$ & $\begin{array}{c}\text { Rich llill } \\
\text { zonle. }\end{array}$ & & \\
\hline Porella nbliqun, new species...................... & & + & & & & \\
\hline 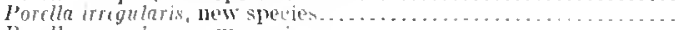 & $\ldots \ldots \ldots$ & + & $\cdots$ & . & . & s. \\
\hline 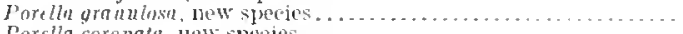 & $\ldots \ldots \ldots$ & + & $\ldots \ldots$ & ...... & • & . \\
\hline & $\cdots \cdots \cdots$ & + & + & $\ldots$ & & r \\
\hline 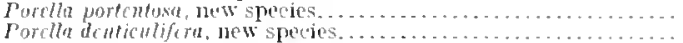 & $\cdots$ & $\because$ & $\cdots$ & + & . & $\cdot$ \\
\hline & $\ldots . .$. & + & $\ddot{+}$ & + & $\ddot{t}$ & \\
\hline 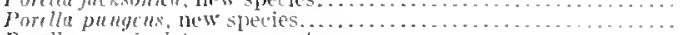 & $\ldots \ldots \ldots$ & + & & & & $\ldots . .$. \\
\hline 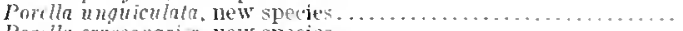 & $\ldots \ldots$ & $\ldots$ & + & & & : \\
\hline 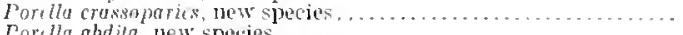 & $\cdots \ldots \ldots$ & . & $\ldots \ldots$ & ... & $\cdots$ & + \\
\hline & & & $\cdots \cdots$ & & + & $\cdots \cdots \cdots$ \\
\hline 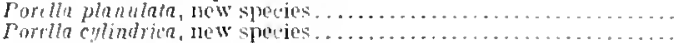 & & & t & $\ldots \ldots \ldots$ & 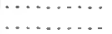 & $\begin{array}{c}\cdots \cdots \cdots \\
+\end{array}$ \\
\hline 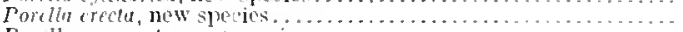 & & & $\cdots \cdots$ & ....... & ........ & + \\
\hline Pordla compacta, new speries... & & & $\cdots \cdots$ & & & + \\
\hline
\end{tabular}

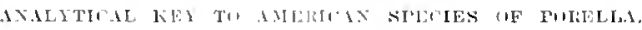

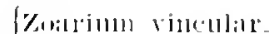

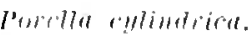

Zon rium incrosting 2

Joilrium exidlarian 5

Zotrimu cunibluleltar 10

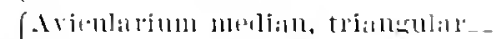

I'merllin olmiruar.

2 Aricularimu quite salient on numlu. Prinlla phumeles. Avitulallinm little sillient : 3

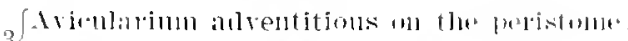
lorella rorimalata.

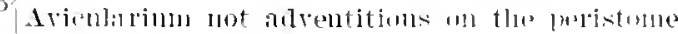
$+$

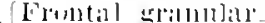

Porrlla! !rambrose.

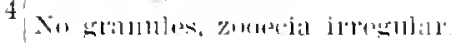

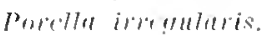

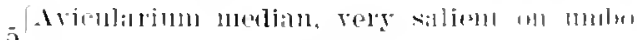

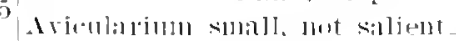
()

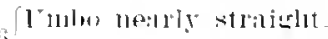

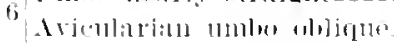
8 lincllar rerceflu. $\overline{1}$

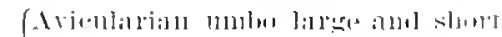

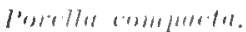

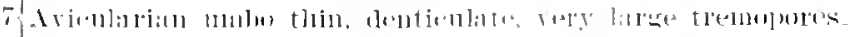

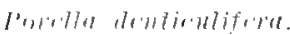

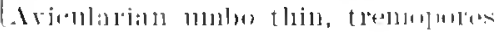

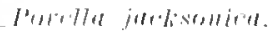

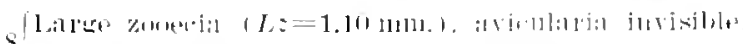

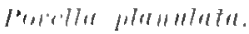

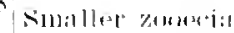
$\therefore 1$

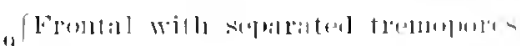

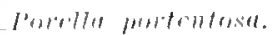

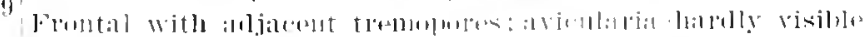

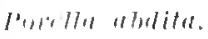

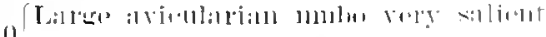
lentlla unduiculatu.

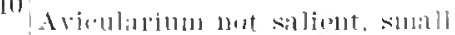

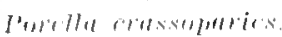




\section{Genus UDBONULA Hincks, 1880.}

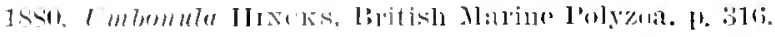

'There is neitlea lyula nor cardelles. The apertura is mborbicular. 'The ovicell is hyper-tomial and opens largely above the apertura. The frontal is a pleurocyst with costules smomoler ly areolae. A prominent mbo immediately below the month supporting an ariolarium. $20-30$ tentarlen.

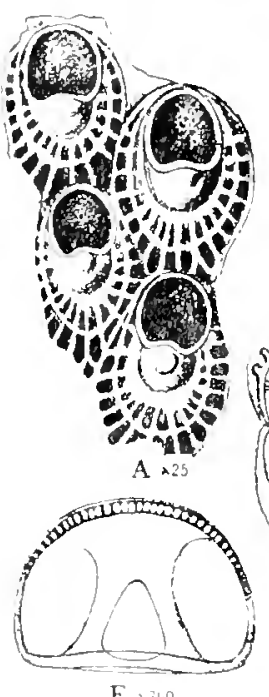

I. 1260

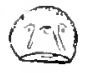

C $\times 35$
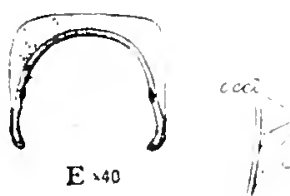

$E \times 40$
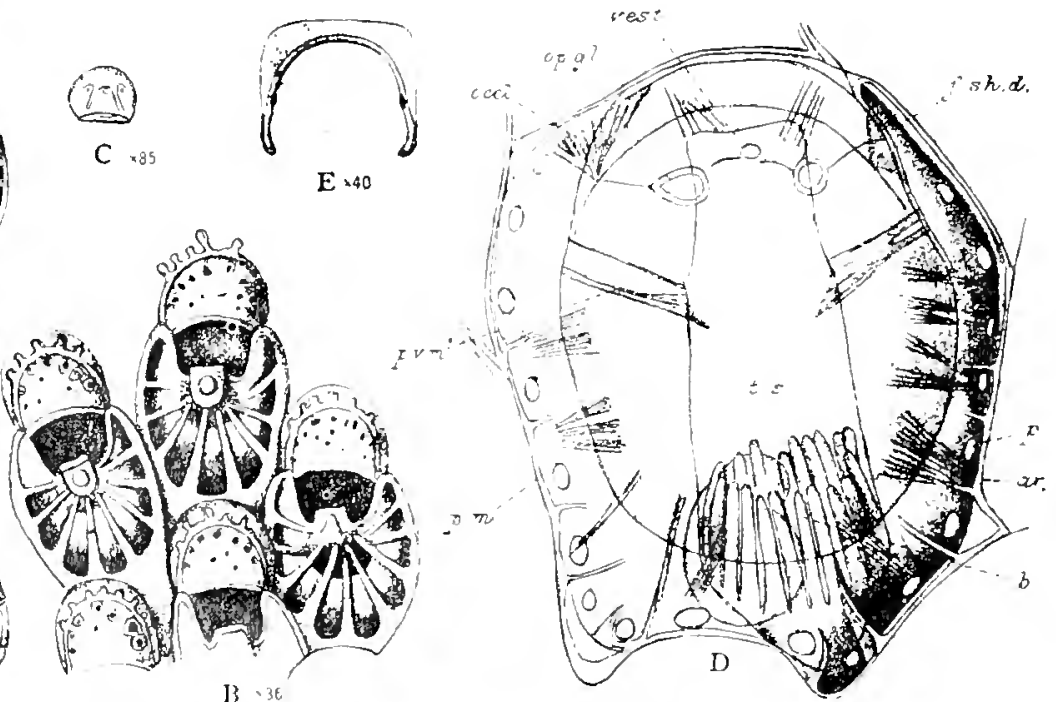

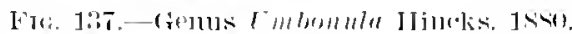

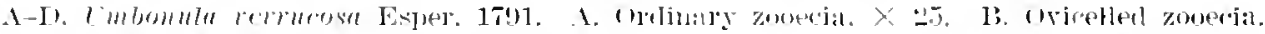

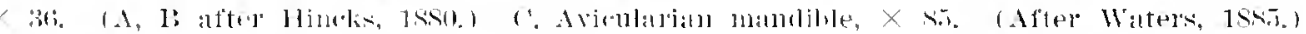

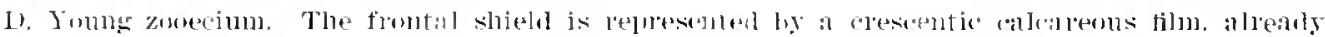

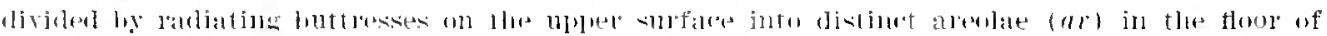

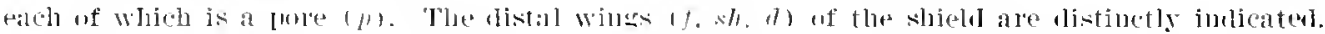

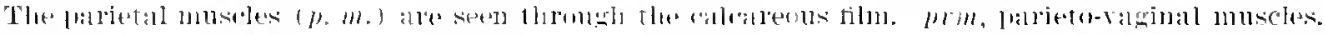

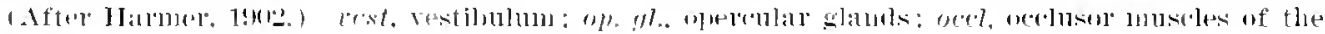

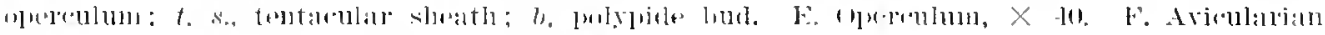

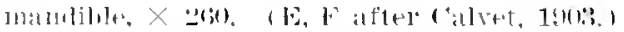

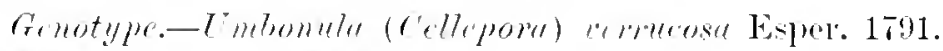

Remere--Iutetian-Riecent.

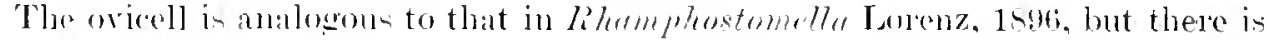

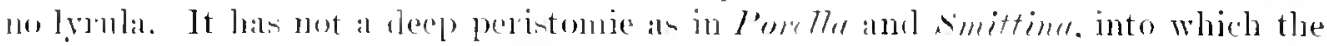

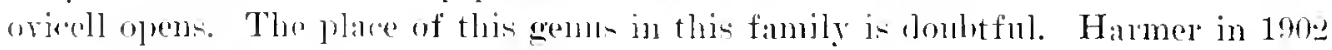

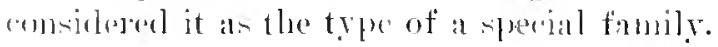

UMBONULA (?) MISER. new species.

I'late (-t. tín, 19.

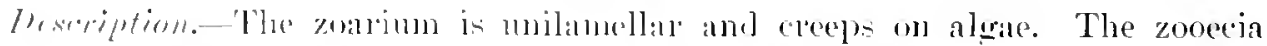

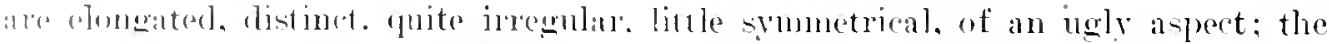

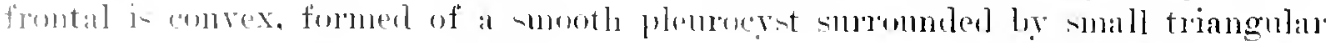

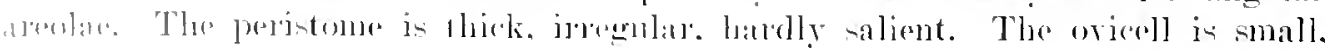


little prominent: it is hyperstomial and opens into the prei-tomie. The mexlian aricularium is small. little salient: it deforms the peristomien inferionly.

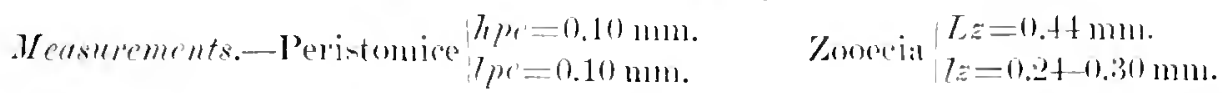

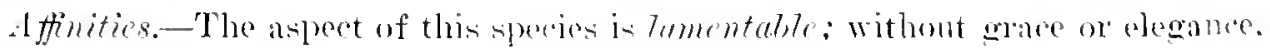
it can not compare with any of the negant ricksburgian -pecies.

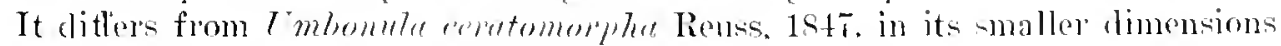
(Lz=0.4t and not $0.60 \mathrm{~mm}$. ) and in it.s muld smaller areolac.

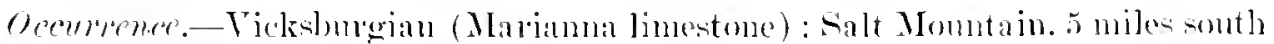
of . Jackson, Mlabana (rare).

Holotype.-Cat. No. lit3or, I'.N.X.M.

UMBONULA CERATOMORPHA Reuss, 1847.

I'late ?4, tign. 19 .

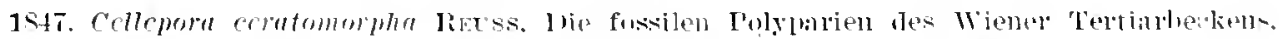

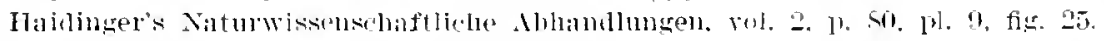

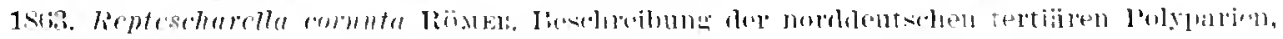

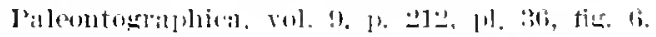

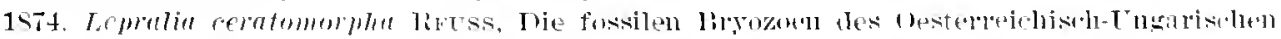

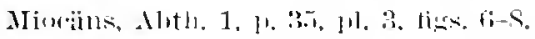

The hiblingraplyy of this specien is rathere confused. and as we have not at hamb the lata for a serions discoscion. We can consirler therefore omly the published fignres. Even in these narrow limits its eomopolitaniom ju quite manifest.

()m Imerican specimerns are excharian. Whereas the Europrean specimen are ineruting. Acomeling to present irleas this rharacter is not upecific.

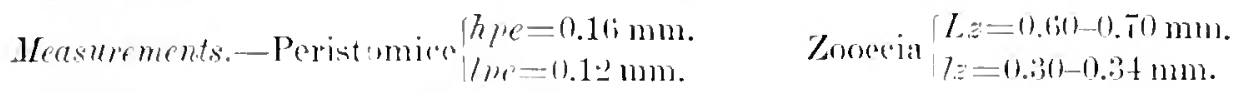

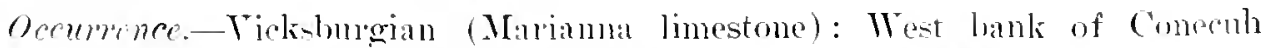

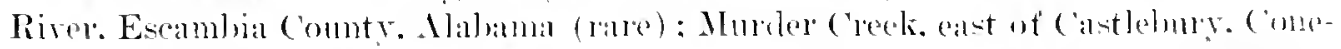

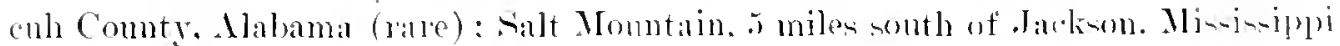
(rare).

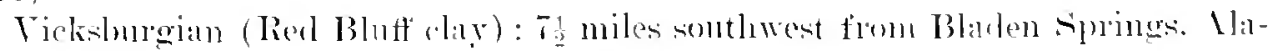
loma (very lare).

Geologieal distribution.-('hattian (I"pper Tongrian) of (ielmany (Remene) : Tortonian of Austria Itungary (liensis).

Plesiotypes.-Cat. No. (it30.t. I'N.X.M.

Genus PHOCEANA Jullien, 1903.

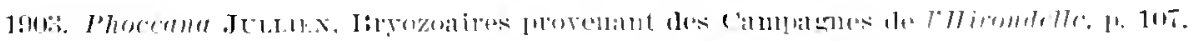

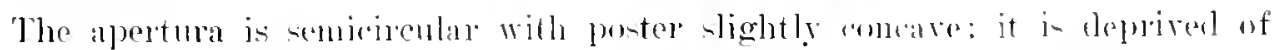

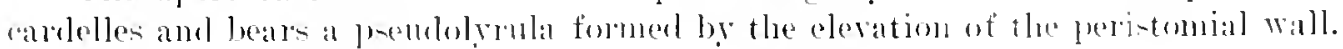
The operenlum bears a chitinoms mumal rim incumplete at the lewe of the converity

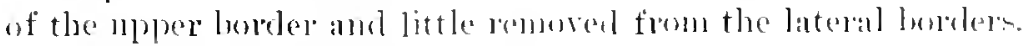

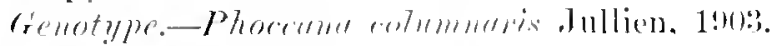

Ronnge-. Tacksonian--liecent. 
Thesmiption.-The zorlimu ic free. cylindrical. nerer loranched, and formed of four to five longitudinal rows of zoocela. The zooeria are indistinet: the frontal is little convex and mooth. The peristone is salient, entire or irregularly perforated; the peristonice in iregular. orlicular or elliptical. and transverse; the peristomie is deep, and the apertula is invisible.

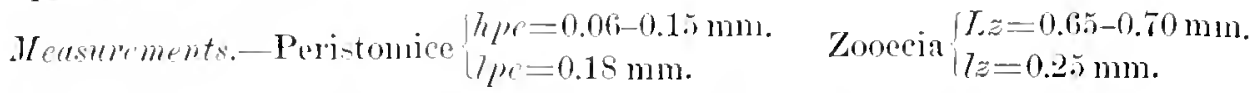

Affinitiv:-The pemblolyula is visible only on the specinens with feesble peristomie (fig. (i). The longratudinal section of i zonerium (fig. 8) shows that the peristome ofter bears a small arienlarium.

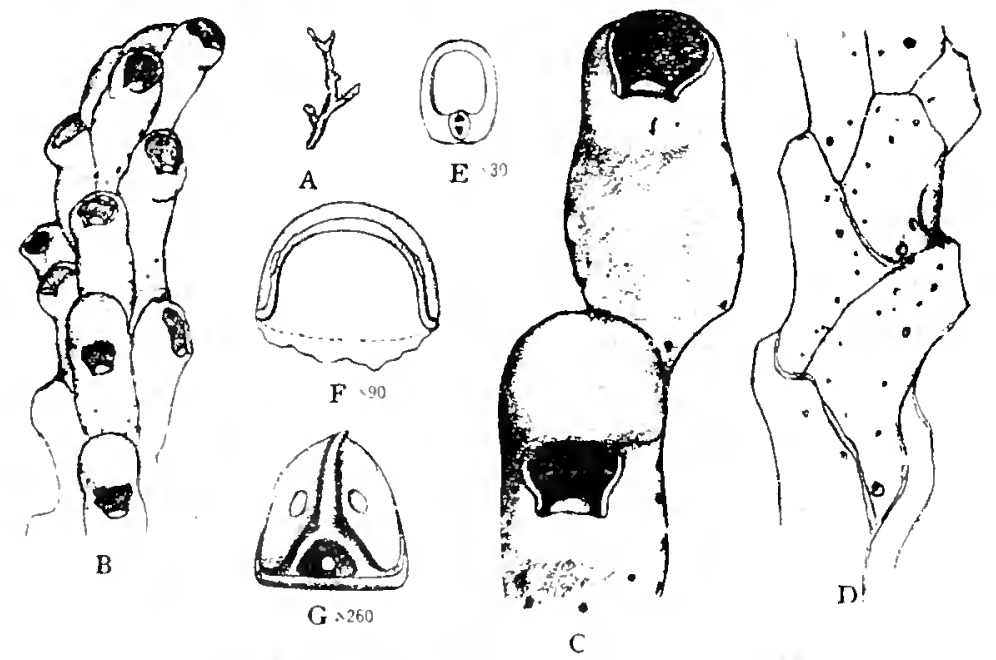

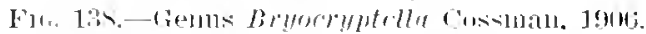

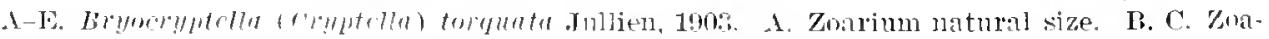

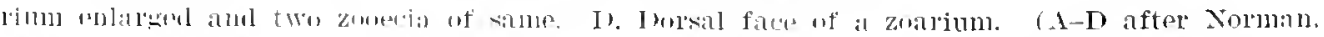

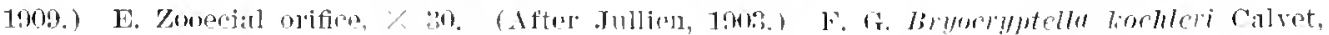

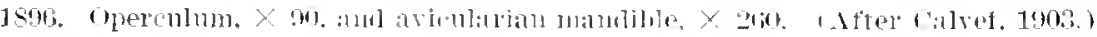

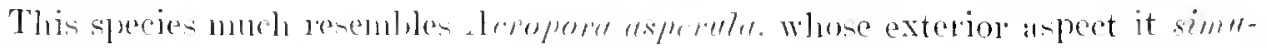
Zutes alsolutely. It liflers fiom it. howerer. in its maller micumetrie dimensions, in the absence of an arepore, and in the presenee of the preristomial psemblyrula.

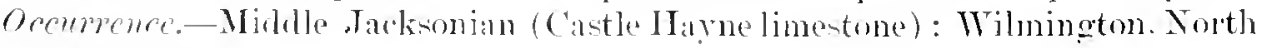
C'arolina (common).

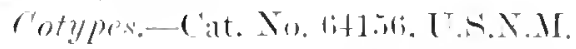

Genus BRYOCRY'TELLA Cossman, 1906.

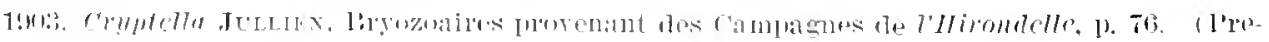

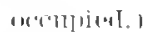

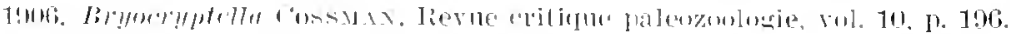

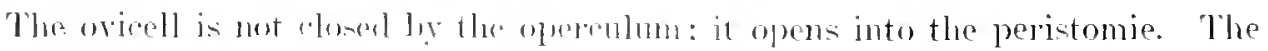

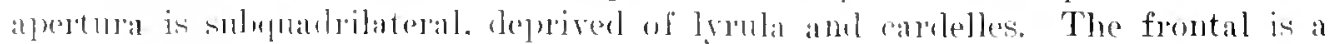

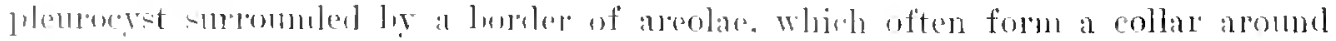


the orifice. There is a median avicularim developed on the poster. The zoarium is escharoid, flattened and branched, formed of a single layer of zooecia.

Genotype.Cryptella torquata Jullien, 1903. Recent.

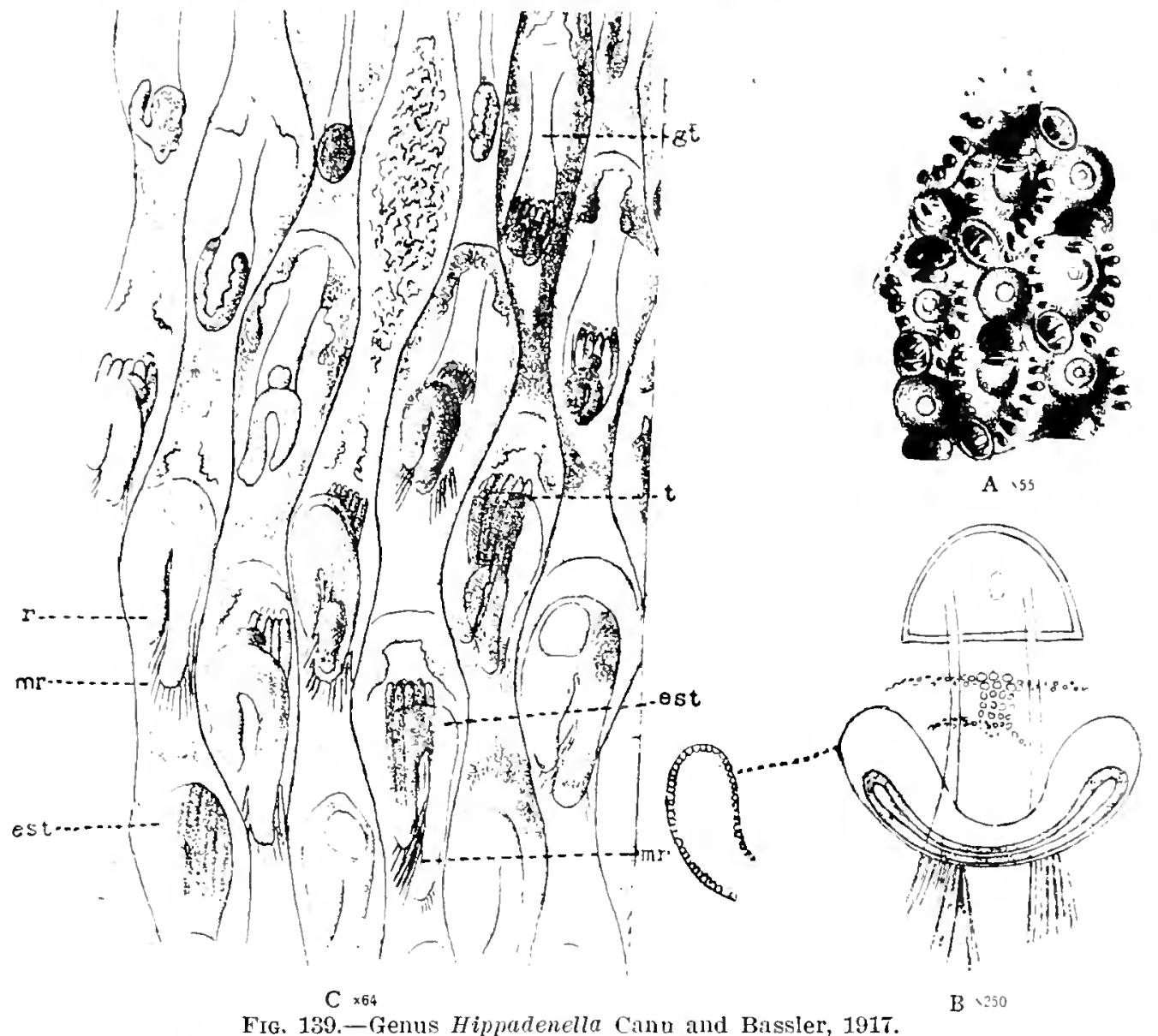

A-C. Hippadenella margaritifera Quoy and Garmard, 1\$33. A. Zooecia, $\times$ 55. The primary ribs of the froutal wall are seen at the bottom of the aricularia. Both the ovicelis and the avicularian chambers show concentric depmits af lime. $X$ 55. (Atter Levinsen, 1940.) B. Sertion exhibiting contents of avicularian chambers with double gland-like bodies and the protoplasmic mass and a section of the larger body, $\times$ 250. (After Waters, 18ss.) C. Flarwent of decalcified zoarium, $X 61$, seen from the dorsal face. The growth of the polypile flom the roung stage, figured in the upper part of the figure to the more advanced stages in the lower part, is exbibited. The stomach is enormus. (After Jullien, 1Sss.)

est, stomach; $y t$, tentacular sheatlı; $m r$, retractor muscles of jolypide; $r$, rectum ; $t$, tentacles.

Genus HIPPADENELLA Canu and Bassler, 1917.

1917. Hippadenella CANU and Bassler, Smopsis Americin Early Tertiary Cheilostome Bryozon, Nulletin 96, Linited states Nitional Mrnseum, p. 54.

The frontal is a plemrocyst surrounded by areolae. The apertura bears two cardelles. The mandibles have a lucida in the middle. The avicularian chamber shows a double gland-like body and the protoplasmic mass. 

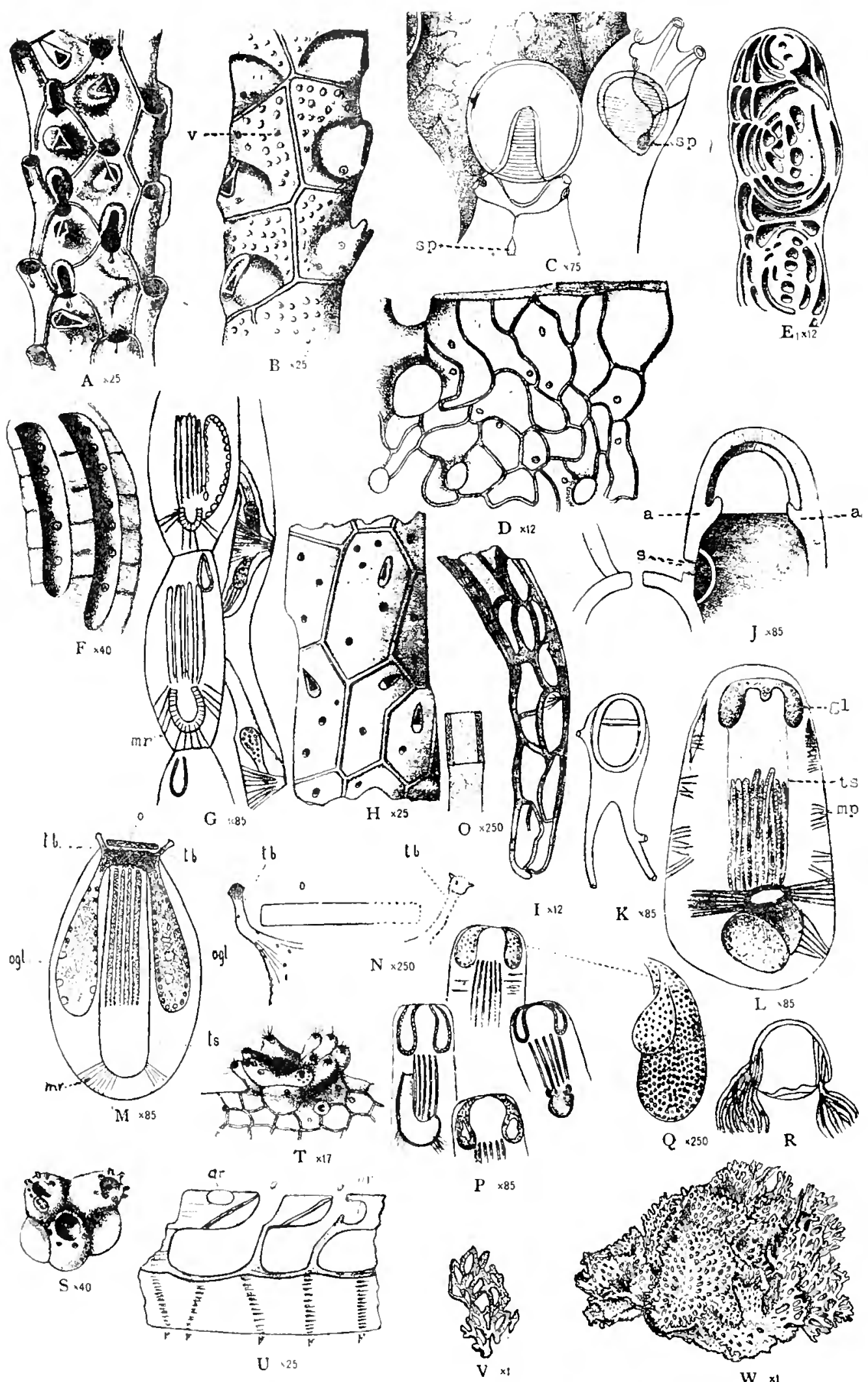

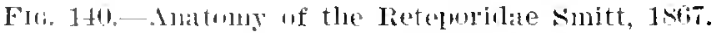




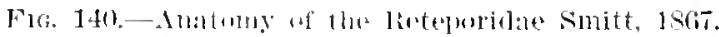

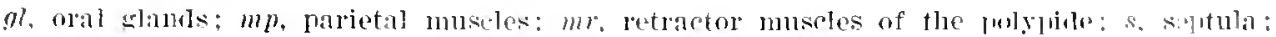
sn. spirimen: ts, tentacular slesath: $r$, ribrarlula

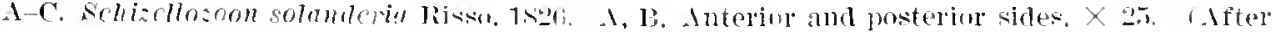

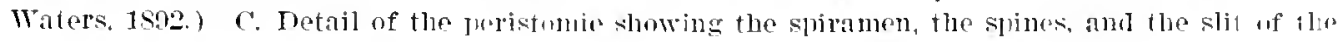
oricelt, $\times$ 75. (After Calvet, 1902.)

D-G. Retepora cellulosa Snitt, 1sit. D. The proximal part uf an oli colouy cut across

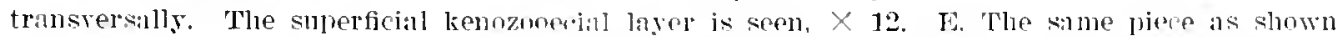

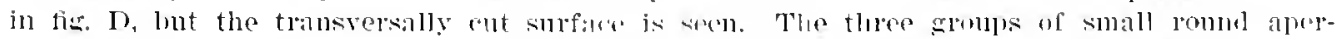

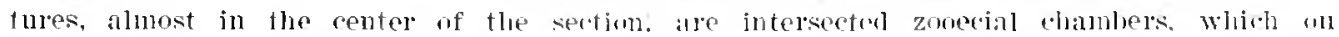

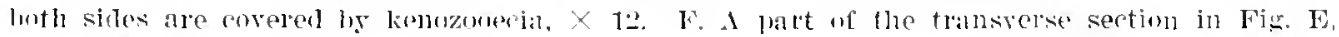
more hights mignified. The sepinatime walls furmished with mimmous septulale are sem

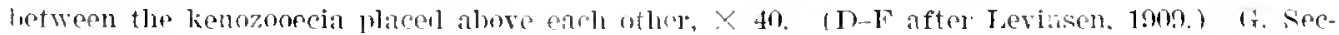
tion shuwing viearious avieularia with gland-like hodies. Fach arienlarium is comerotod throngh

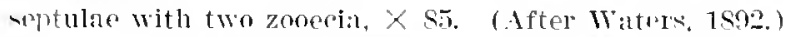

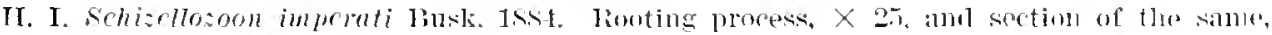
$\times$ 12. (After Waters, 1sss.)

J-I. Retepror antarctira Witers, 1not. J. Caleareous section sluwing the internal ran) conirles (teeth) ment the base of the urerolum; also the hateral septula with "watch-ulass" curer, $X$ S. K. Aricularian chanler with handhes learling th the proximal end of the zooecinul. $\times$ S5. T. Zooecimm showing the aral (vasinil) slanis $(g l)$, and also the parietal musples $(m p) . \times$ s.t.

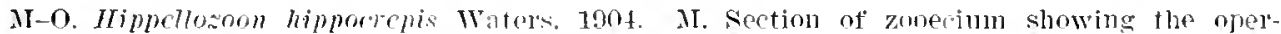
culum (o), below which is the fleshy mass, with a tubular process from each siale. To this

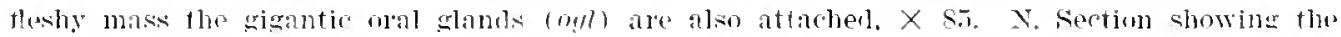

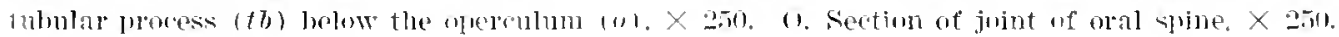
( J-O after Watel's, 1004.)

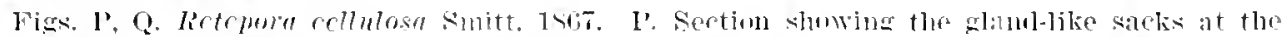

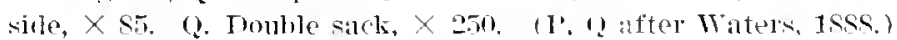

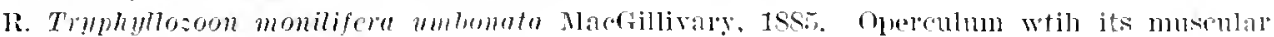
attacliments. (After Machillivray, 1Ss5.)

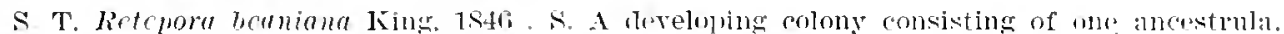

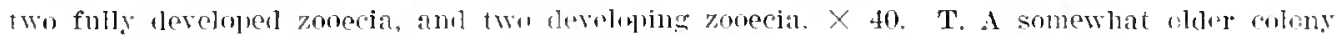

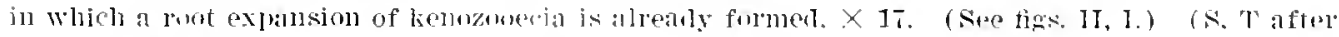
Levinsen, 1909.)

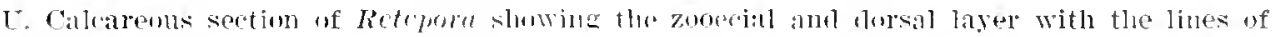

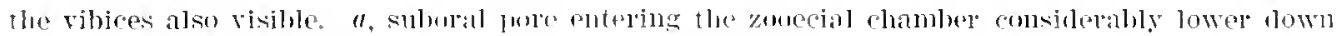

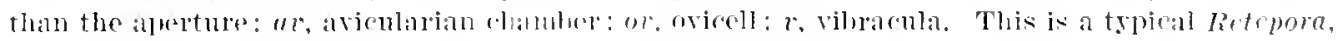

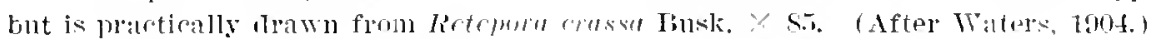

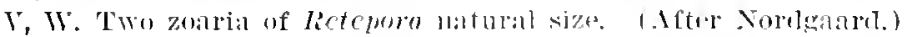


Genotype.-Mimpadenella (Flustra) margarififera Quoy and Gaymard, 1833. Recent.

It seems to ns that it wonld he hetter to classify this gemus in the Hippoporae. although all other authors are agreed in comsiclering the genotype as belonging to the genus Porella; we can not maintain it there. the frontal being a pleurocyst and the apertura bearing cardelles.

\section{Family RETEPORIDAE Smitt, 1867.}

Anatomical bibliography-1S7s. Hincks. Notes on the Genus Retepora, Anmals and Magazine Niatural History, ser. 5, rol. 1, pl. 19-18s9. W.ters, Suplementary Report on the Polyzoa collected by H. M. S. Challenger, pl. 3, figs. 5 to 13,39, f1-_1892. Waters, Obserrations on the Gland-like Bodies in the Bryozoa, Iinnean Suetet Jommal, Zoolugy, rol, 24, pl. 19, fig. 14.1S94. Waters, On Mediteranean and Now Zoaland Reteporidae and a fenestrate Bryozoan, Linnean Society Jommal. Zoology, rnl. 25, 11. 7.-1002. Jullies, Pryozonires provenant des

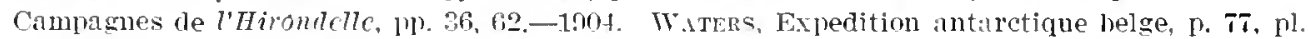
6.-1909. Levinsen, Morphological and systematic studies on the Cheilostomatous Bryozoa. p. 290, pl. 10, pl. 23, firs. 1, 2, 3.-1909. Waters, Reports on the Marine Biology of the Sulamese lied sian. 'The Bryozon, Limmenn Suciety .Jumnal, Zoology, vol. 31, p. 175, pl, 19.1913. W'Aters, Figozon from Zanzibar, Procedines Zoological Society, Iondon, pl. 72, fics. 1 to 11, P. 52 (classification).

The ovicell is hyperstomial, much immersed in the distal zooecium; it is largely open into the peristomie. The zoarium is generally reticulate; the dorsal face presents some projections or vibices withont connection with the zooecia and contains interiorly some kenozooecia (lacmae of Waters) more or less numerous and elongated. The reteporidan pore placed in front of the apertura is according to its situation an ascopore or a spiramen: 11 to 16 tentacles.

Figure 140 sums up our anatomical knowledge of this family. We are ignorant of the larva and the generic classification is necessarily impossible to be stated with exactitude.

The classification has been given in 1592 and 1914 by Waters. We have given names to the principal gromps which lhe formed. Levinsen introduced into this family the genera Sehizothere Hincks, 1890, and Rhynchosoon Hincks, 1891. It is evident that the forr genera formed by Waters are in rapport with the hydrostatic system. It is now necessary for the zoologint to study the function of calcification with all the care possible.

\section{Genus RETEPORA Imperato, 1599.}

1509. Retchor Imperato, Dell' historia naturale, libre X゙xriti.

"This group has a fissure in the orieell. The proximal edge of the opercultum is nearly straight, and very similar througlout this groul : labial avicularia recur in some but not in all. The oral glands are rery well reveloped." (Waters.) The reteporiclan pore is a spiramen.

Genotype-Retepora eellulosa Iinnaeus-Smitt, $186 \pi$.

Lienge.-Tackonian-Recent. 
Historical. - It is in this grouly as defined by Waters that the two genera Retepora and Sertella created by .Jullien in 1903 may be classified. Following are their descriptions:

"Retepora Smitt 186i. Orifice transversely oval, deprived of denticules, an internal border to the oricell and a spiramen on the frontal. Cenotype: Retepora cellulosa Linnaens-Smitt, 186r."

If the form of the operculum corresponded to this form of the apertura, the genus Retepora might be admitter into these limits, but the operculum of the genotype published by Waters in 1900 (see fig. 1+1) is identical with the other operenl:1 of the same group and not at all elliptical.

"Sertella Jullien, 1903. Orifice elliptical with large transversal di:meter, of which the anterior lip or anter is fentooned and the posterior or poster is smooth and curvilinear; these two lips are separated from each side of the orifice by a very delicate and fragile cardelle. The frontal is here smooth and with some origells (=areolar pores). Genotype: Retepora Beaniana Kring, 1846."

We are ignorant regarding to what functions the festoons of the anter correspond exactly and it does not scem possible to us to accept a genus based on a character so insignifieant. On the other hand. the presence of areolae indicates a special mode of ealcification. a perfectly distinet function. Jullien's genus may therefore be maintained, but $\pi$ ith this essential character. The study of the frontal of the Retepores has not yet been made with much care, and it is prudent to amait it.

We are not certain that the reteporidan pore may really always be a spiramen, for Waters indicated an ascopore fur lictepora rrassa Busk, 18st. Our American species belong to this group. as defined by Waters.

RETEPORA RAMOSA, new species.

Plate 65, figs. 15-25.

Description.-The zoulium is free. somewhat compressed. Wranched, dichotomous: it contains only three or four longitudinal rows of zonecia. The dorsal is smooth or very finely granular: the ribices are transverse. irregular, very little salient; some pores are disceminated between them. The zooecia are indistinct: the frontal is smooth and convex. The apertula is deeply imbedded, hardly risible: its anter is finely denticulated: the peristomice is ogival with a coneave lower lij): the spiramen is an elongated slit. often united to the peristomice. The oricell is hyperstomial, rery deeply imbedderl in the distal zooecia. hiurlly salient. smooth: it is perforated by an upper slit.

$$
\text { Measurments.-Peristonice }{ }_{17 p e}^{h}=0.12 \mathrm{~mm} \text {. }
$$

Tariations.-On each sicle of the apertura there are unally some rery salient tuberosities (fig. 18). The vilices are often replaced ly furrows (fig. 20) on the same zoarium; then the small forsal pores disappear. The ovicell is rory fragile; the rupture of its frontal lining : alont the formation of a talse slit (figs. 19, 21): its orifice is absolutely buried : it i- never closed by the operenlum (fig. .-t). 


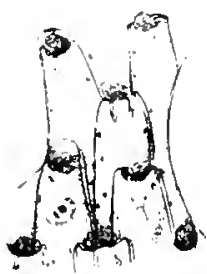

A $\times 25$
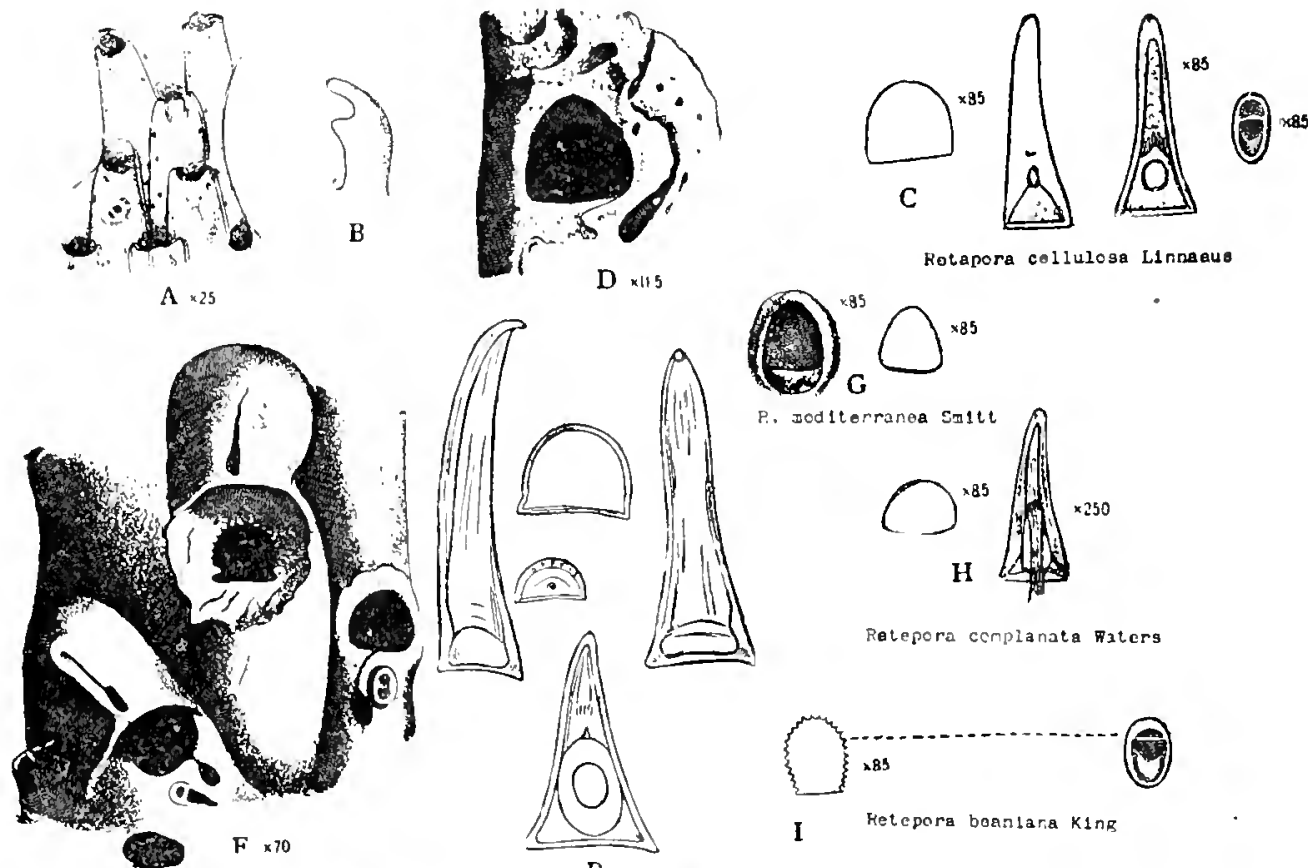

$\times 115$
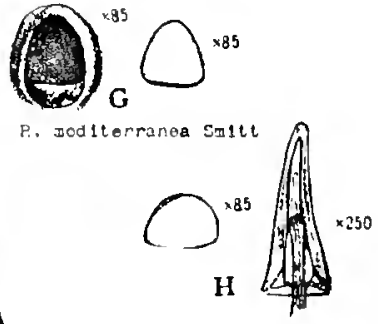

Retepora complanata Futers

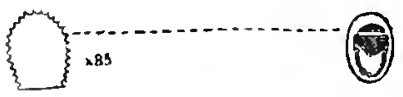

$\mathbf{I}$

Hetepera boanlara Klng

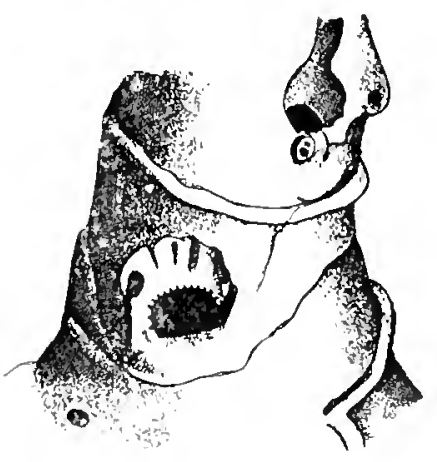

fetapiza atldilloe Pusis
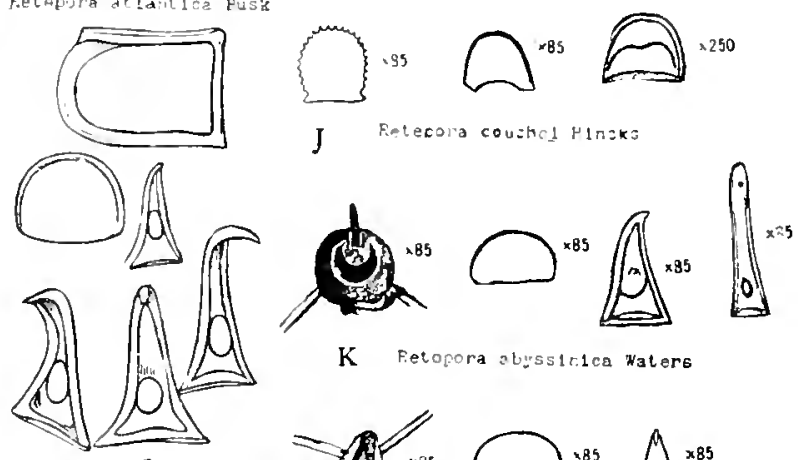

K Fetopora abssicica Natere
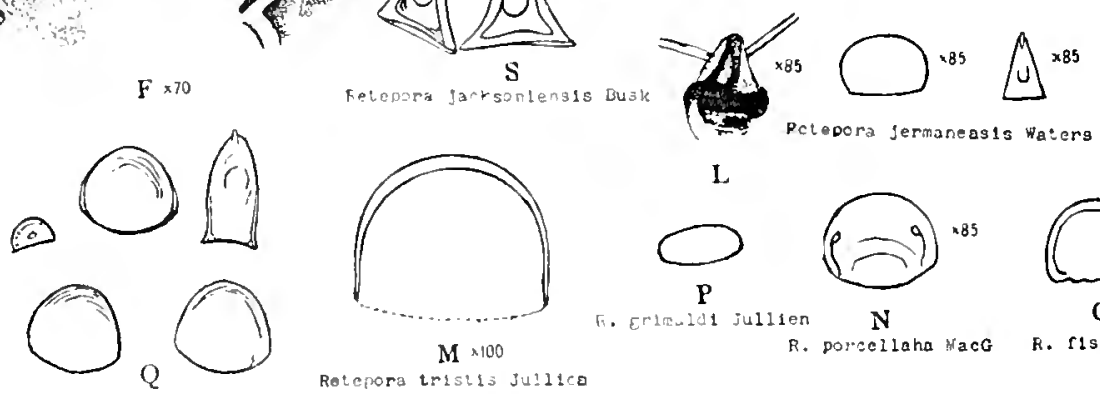

L
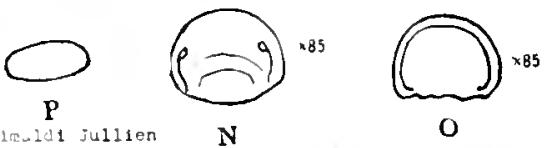

M $\times 100$

R. porecilaha wack

R. R1saa Riaca

Retcrora trisita Jullico

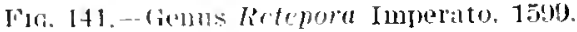


F16, 141.- -ienus Retemora Imperato, 1599.

A. B. C. Retepora celluloga (linnaens) Smitt, 1867. A. Several zoneria, X 25. B. Arieu-

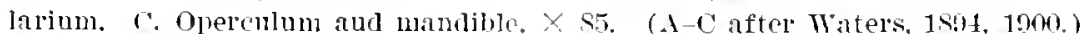

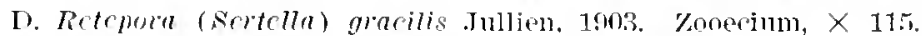

E. Retepora (Sertella) acquitanica Jullicu, 1003. Several gooecia, $\times 70$.

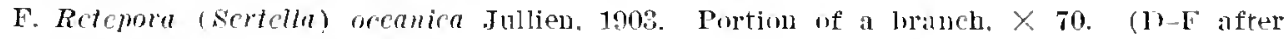
Jullien, 1903.)

G. Retepora mediteranea Smitt, 1S67. Oral alenture aud cherculum. X S5. (After Waturs, 18.4.)

II. Retcpora complanata. Waters, 1894. Opereulum, $\times$ S5. and maudible, $\times 250$ (After Waters, 1894.)

I. Retcpora (Serlella) braniana King, 1St6. \%ooecial orifice and reteporilan aricularium. $\times$ S.T. (After Jullien, 1903, and Watels, 1994.)

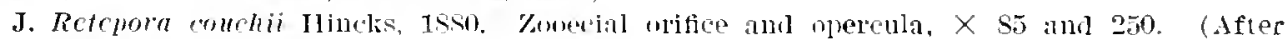
Jullien. 100:3. and Waters, 1578, 1805,

K. Retrpora abyssinica Waters, 1009. Zooecial orifice, operculum, and mandibles, $X$ s. (After Waters. 1900.)

L. Reteport jermanensis Tratel's. 1909. Zooecial orifice. operculum, and mandibles, $X 85$. (After Waters, 1909.$)$

II. Retcpora (scrtclla) tristis Jullien. 1009. Onercnlum, X 1S0. (After Jullien, 1003)

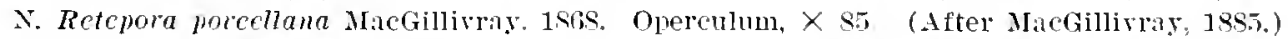

O. Retcpora fissa MacGilllvia, 1S6S. Operculum, $\times$ S5. (After MacGillivray, 1595.)

P. Retcpora grimalai Jullieu, 1903. Zooccial orifice. (After Jullien, 1903.)

Q. Retcpora producta Busk, 1881. Opercula ind mandibles. (After Busk, 18s4.)

R. Retepora allantica Busk, 1SS1. Opercula and mandibles. (After Busk. 1SSt.)

S. Retepora jarkonirnsis Eusk, 18st. Operenla and manables. (After lusk, 1ss4.) 
Affinitics.-Busk, in 1854, created the gemus Reteporella for the Retepores not reticulated: Inllien. in 1903. appears to have admitted this genus, but we can not recognize a genus based purely upon a zonrium, unless its zooecial characters are at the same time perfectly delimited.

This species differs from Retepora simplex (Busk) Renss. 1869, in the absence of a labial mucro on the peristomice and of two oral avicularia.

Occurrence.-Middle Jacksonian : Wilmington. North Carolina (common); near Lenuds Ferry. South Carolina (common): Eutaw Springs, South Carolina (rare). Cotypes.-Cat. Nos.6t158, 6t1\%9. U.S.N.M.

RETEPORA SCUTULATA, new species.

Plite 65, figs. 9-14.

I'seription.-The zoalinm is free, reticulate; with narrow and elongate meshes or fenestrae: the dorsal is smooth or very finely aramlated; the vibices are rare and hardly salient. The zonecia are indistinct; the frontal is smooth and convex. The apertura is decp, buried, transrerse; the peristomice is oblique ogival; its anterior lip bears on one side a small avicularium, thin and elongated. The oricell is little salient, smooth; it bears an upper; almost round cleft; its orifice is not visible.

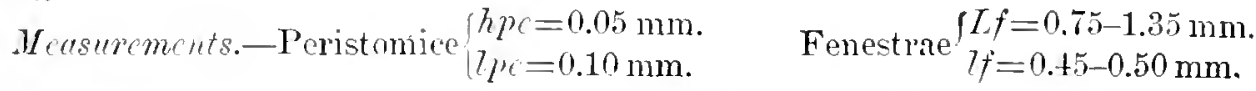

Affinities.-This species differ from Retepora ramosa and Retepora laciniosa in its invariably reticnlated zoarium.

It differs from Retepora murginata Renss, in its indistinct and nonborderer zooccia. and from Retepora viticata Goldfuss, 1827, in the absence of lateral averlar pores.

Occurrence-Upper Iacksonian (Ocala limestone): Chipola River, cast of Marianna, Tackson Comnty. Florida (common); Alachua. Florida (rare).

Cotypes.Cat. No. 6t15i. U.S.N.M.

RETEPORA LACINIOSA, new species.

Plate 96, figs, 12-22.

I'eseription.-The zoarium is free, branched, not reticulaterl. bifureated, somewhat compresserl, formed of three longitudinal rows of zooecia. The dorsal is smootls or gramlar; the vibices are very little salient, and circumscribe some irregular lozenge-shapen areas. The zooecia are indistinct; the frontal is smooth and comvex. The apertura is semilunar (interior) and bears a minute proximal rimule inregularly placed; the peristomice is very oblique; it bears on its proximal lip a small tuberosity and a small oral avicularium separated by a stit or rimutespiramen. The ovicell is hyperstomial but very deeply imbedderl in the distal zooccia: its orifice is not visible: it bears superiorly a small slit, somewhat elonwated. The small labial avicularium is frequently transformed into a large frontal alinlalinum.

Heasuments. - I'eristomice. $7 \mathrm{~m}=0.11 \mathrm{~mm}$. 
Iariations.-The dorsal is sometimes smooth (fig. 16) and sometimes gramular (figs. 15. 17); in the latter case the lozenge-shaped areas contain a round aricularium and an elliptical aricularium. In the young zonecia (fig. 1t) when the small labial aricularimm is not yet formed the rimnle-spiramen is lateral and a median mucro separates it from another symmetrical slit. The aspect of the frontal changes completely when the labial avicularinm is much developed (fig. 20); it is elongated. triangular with a somewhat rounded beak and it occupies then a part of the frontal.

Affinities.-This species differs from Retepora ramosa in which the zoarim is not reticulate, in the presence of a labial a ricularium.

The rimule spiramen is the exact equivalent of the spiramen itself. I generie dirision may not be serionsly established on their differentiation. They are moreover often observed together on the same zoarinm.

Occurrence.-Ticksburgian (Marianna limestone) : West bank Conecuh River. Escambia County, Alabana (common); Salt Mountain. 5 miles sonth of Jackon, Alabama (rare); $2 \frac{1}{2}$ miles north of Milly. Washington Connty. Alallama (rare); 1 mile north of Monroerille, Alahama (common).

Ticksburgian (Byram marl): One-fourth mile west of Woodward. Warne County Mississippi (common).

Cotypes.-Cat. Nos. 64311-61313, U.S.N.M.

\section{Genus HiPPELLOzoON Canu and Bassler, 1917.}

1917. Hippellozoon CANU and BassLfr, Synopsis of American Early Tertiary Cheilostome Bryozon, Bulletiu 96, Luited states National Musenm. 13. $5 \pi$.

The ovicell is widely open. There is neither labial avicularium nor reteporidan pore. The operculum is contracted in the middle, having long bands at the sides for the muscular attachments: the proximal edge is not straight. The aperture has two cardelles.

Genotype.-Hippellozoon (Retepora) novaezelandiue Waters, 1894 . Recent.

Levinsen having introduced the genus Rhynchozoon Hincks, 1891. in the Reteporidae, we have decided to adopt the suffix "zoon" as characteristic of the family. It is erident that if the study of the larvae does not confirm the observation of Levinsen the names which we have given should not be preserved. There should be no law of priority in these attempts at synthetic nomenclature.

Genus SCHIZELlozoON Canu and Bassler, 1917.

1917. Schizclloiam Caxt and Rassler, Synopsis American Farly Tertiary Cheilostome Pryozon, Bulletiu 06. United States National Museum, 1. 5.

The oricell is widely open and provided with a semicircular - lit. It has neither Jabial aricularium. nor reteporidan pore. The operculum has a broad thickened borter: the proximal edge is not straight. The poster of the apertura bears a wirle. little deep sinns.

Genotype.-Schizellozomn (Retepore) imperati Bukk. 1s\&t. Recent.

The spiramen (reteporidan pore of Waters) is replaced by a pendo-spiramen. which is a groove in the prosimal lip of the peristomice. 
Genus TRIPHYLl_ozoON Canu and Bassler, 1917.

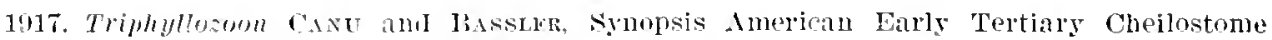

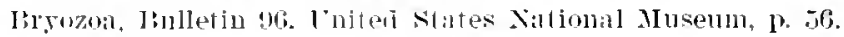

"The ovicell has a 'trifoliate stigma.' There is generally a minute aricularium on the lip to one side. The operenla generally are fairly similar with a nearly straght proximal ellae. and in shape rither wider than long, with the mescular attachments rather high ul and near the border. Apparently all have the labial

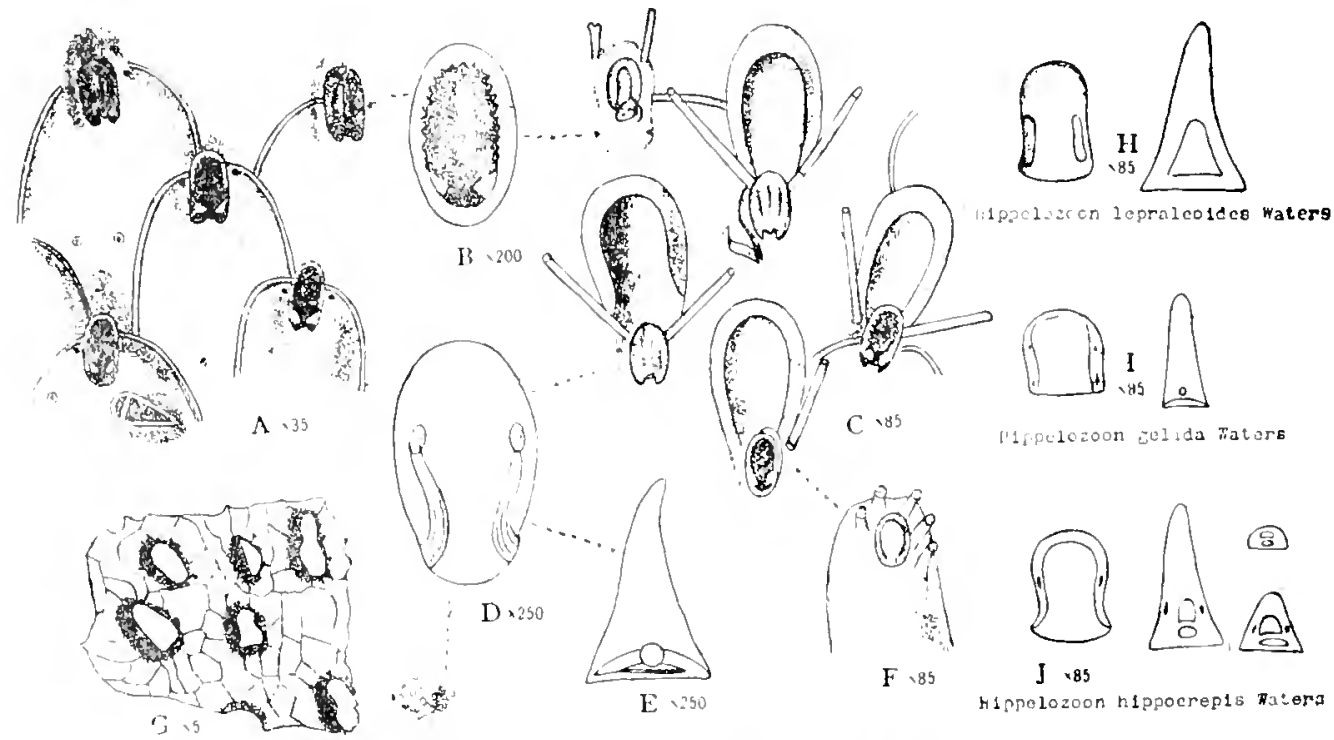

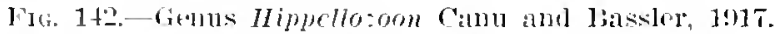

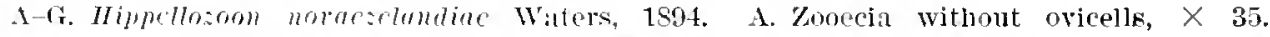

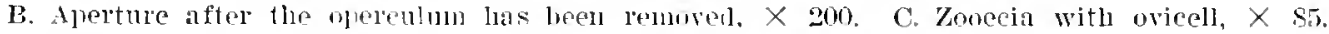

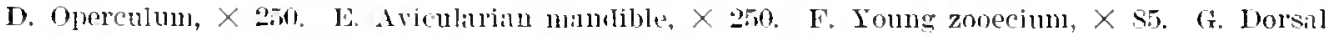
surfice, $X 5$. (at-6 after Wilters, 1,904.)

II-J. Opercula and mandibles. HI. Hippellozoon lepralioides Waters, 1894. I H. aclida Waters, 1304. J. 11. himporrerpis Walles, 1904. (II-J after Walers.)

pore which is often the end of a long tube opening into the zooceinm (=ascopore), proximally to the operculum." (Waters.)

(renotype.-T'miphyllozoon (Retepore) moniliferum MacGillivay, 1S60. Recent.

Genus RHYNCHOZOON Hincks, 1891.

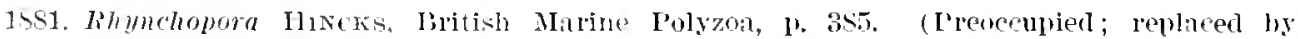
Inhmohrozon in 1s:11.

"This genus seems to be characterized by the possession of a more or less welldeveloped sinus on the aperturi, ly its ovicell, which has an entire frontal surface 

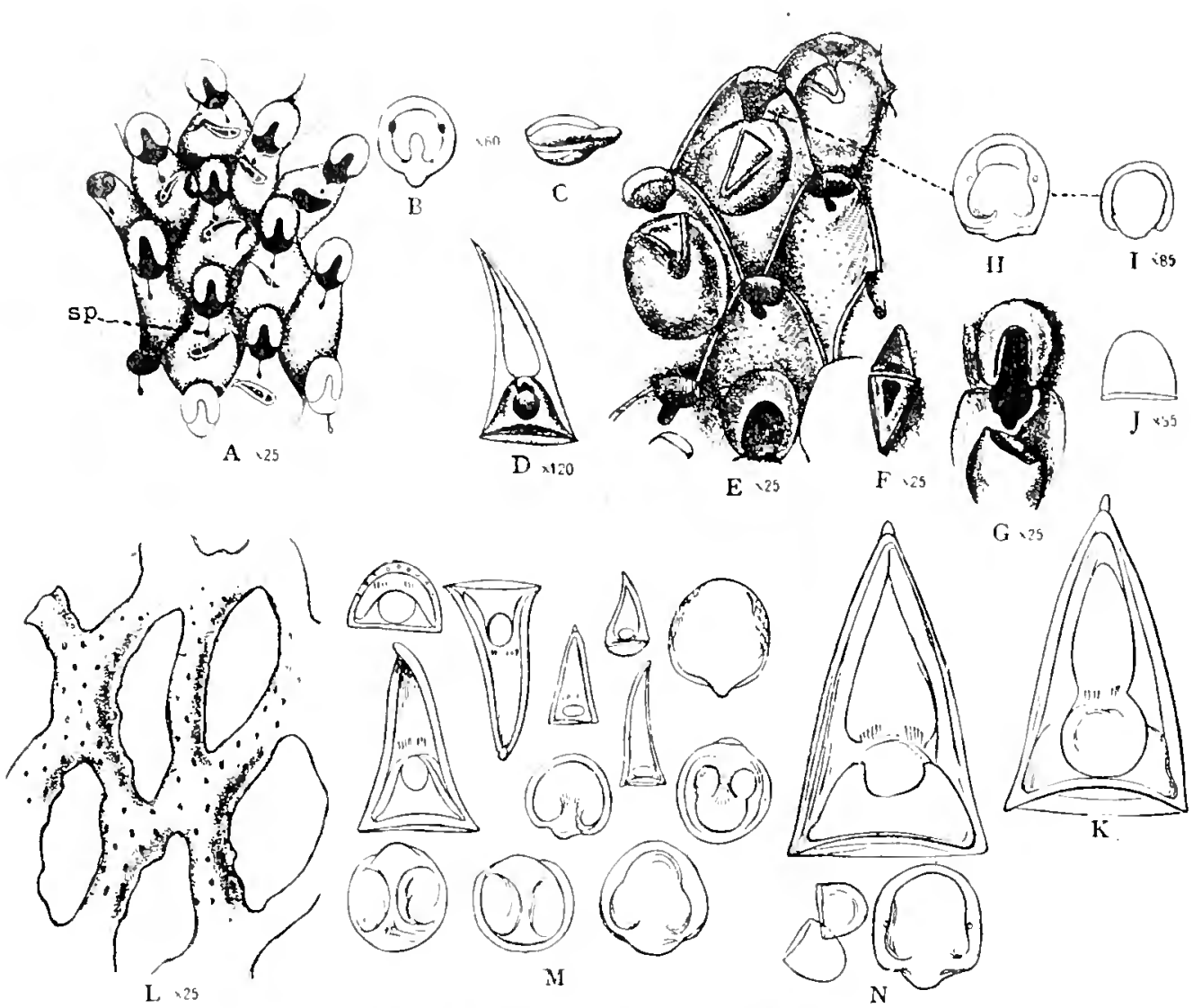

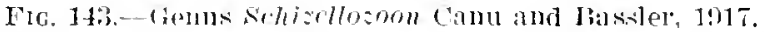

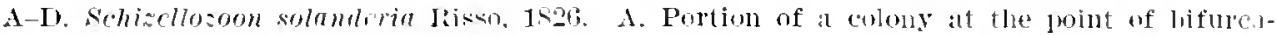

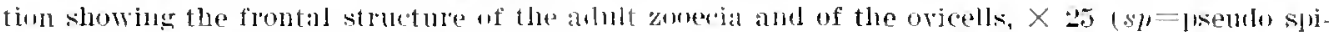

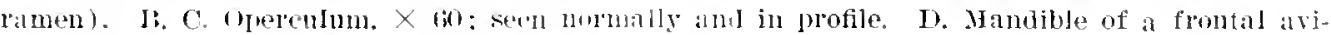
rularium, $\times$ 120. (A-1) alfer Calvet, 10012.)

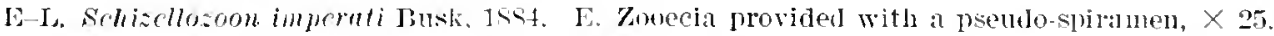

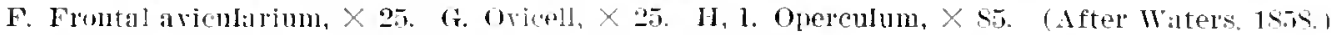

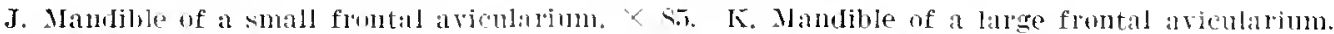

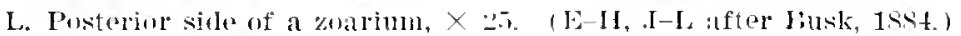

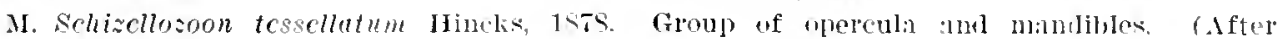
Busk, 1894.)

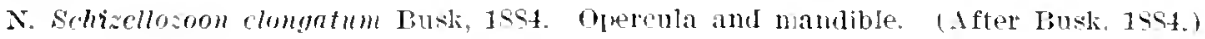


and is provided with an incomplete ooecial cover and by the possession of porechambers (dietellae)." (Levinen.)

Genotype-Rlymchozoon (Lepratie) bispinos .Johnston, 1949. Recent.

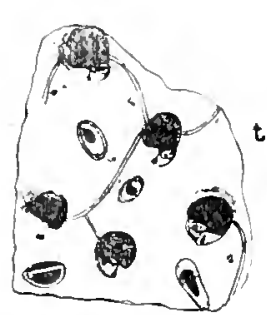

A $\times 40$

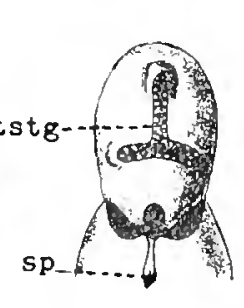

B $\times 85$
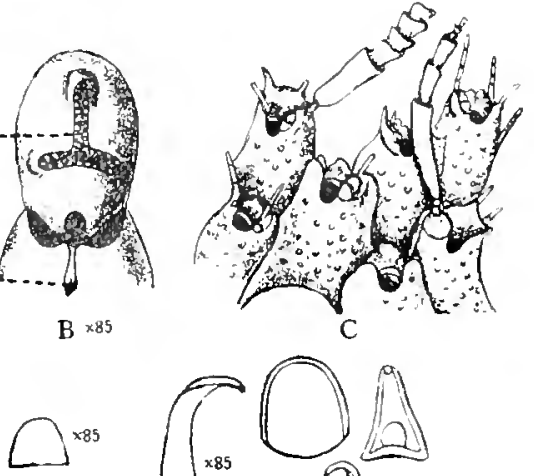

E

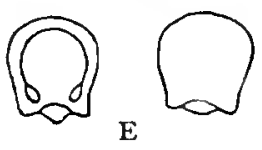

I. formosur :arilisvraj
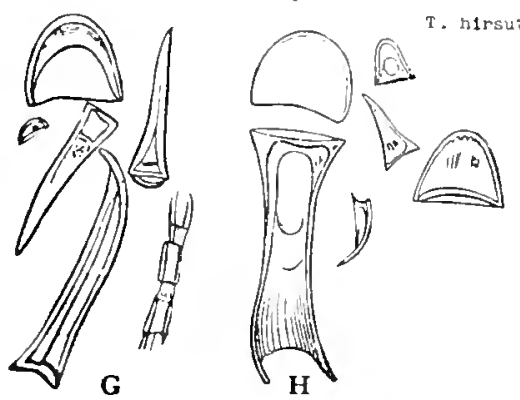

T. donalculatum Eust:

FIg. 144.CGenus Triphyllo:oon Cann am Bassler. 1917.

A-D. Triphyllowoon moniliferum IIacGilliray, 1860. A. Zooecia of var. munita IIincks, 1550: $\times$ 40. B. Oricelled zooeciun of rar. munita Hincks. 1580. $\times$ S., shuwing the trifoliate stigma ( $t * t g)$ of the ovicell and the spiramen $(s p)$ of the peristomie. (A, B after Waters, 1s94.) C. Zuoecia showing articulited spines. D. Operculum of the principal rarieties. (C, D after MacGilliv'ay, 1855.)

E-L. Gpercula and mandibles. E. Triphylosom formosum IJacGillirras. (After Nac. Gillivity, Iss5.) F. T. hirsutum Busk, 1ss4. (After Waters, I900.) G. T. hirsutm Busk. 1SS4. H. T. denticulatum Busk, 18St. I. T. tubulntum Pusk, 1SS4. J. T. colummiferum Isusk, 1SS4. K. T. contortoplicatum Lusk, ISSt. J. T. rictriensis Busk. 1SSt. (G-I. after Eusk, 1SSt.)

Genns SCHIZOTHECA Hincks, 1877.

Isti. Srhizothece IIncks, On British Polyzua. I't. II, Classification. Annils Magazine Natural History, ser. 4, rol. 20. 11. 52s: 1SS0. British Marine ['olyzoa, p. 283.

"Zooecia with a suborbicular plinar"y orjice. the lower margin sinuated; the -econdary orifice raised, tubular, notched in front. Oricell terminal, with a fissure in the front wall. never closed by the opereulum."

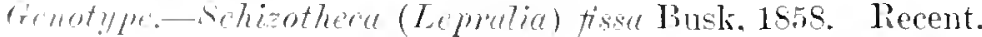

Tevinsen classified this genus in the Reteporidae, whele we also believe it better illared. 
Genus LEPRALIELLA Levinsen, 1916.

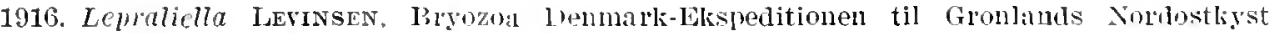
1906-1908, vol. 3, No. 16. 1) 4466 .

"The zooecia are provided with a distinct, not beaded or faintly so, vestibular" arch, and with two well-developed hinge-teeth. A well chitinized opereulum. Avicularia of different size and position. The oricells, the proximal portion of which is not pedicel-shaped or shaft-like. hare no pores and are not prorided with an inwards directed tongue." (Levinsen.)

Genotype.-Lepraliella (Cellepora) contigua Smitt, 186\%. Recent.

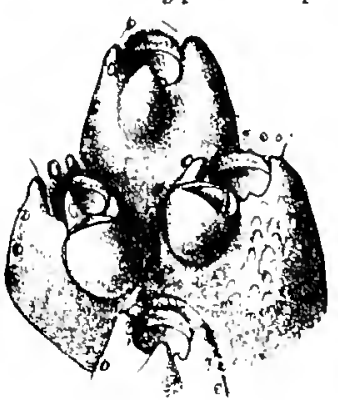

A 155

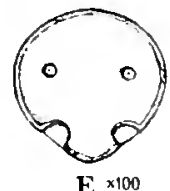

E $\times 100$

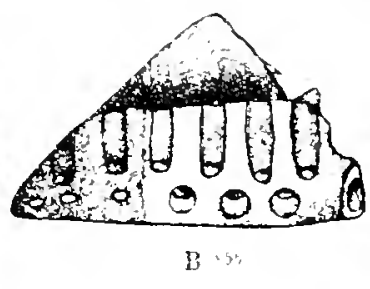

$B \cdot 5 r$

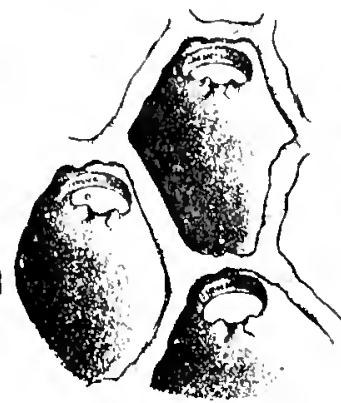

C .55
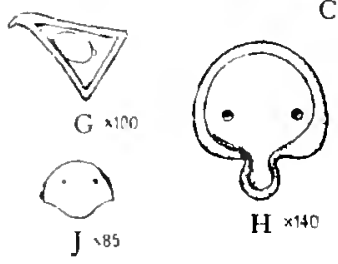
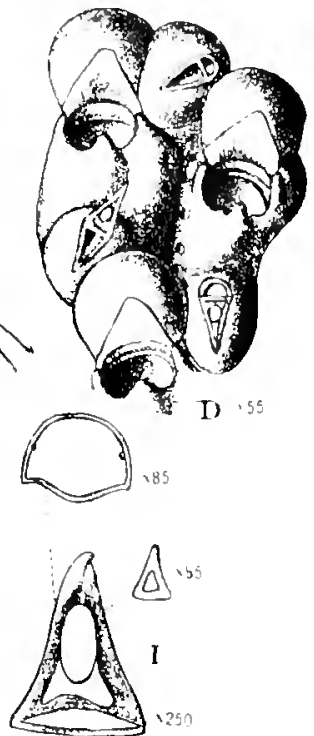

Frg. 145.-Genus Rlymchosoon Hinels, 1991.

A-G. Rhynchosoon angulatum Levinsen, 190\%. A. Zooecia, X 55. P. A zooecium. seen flom the left side wall. On the left side is seen an aricularium, $X$ 55. C. Zooecia seen from the hasal side after removal of the hasal wall, $\times$ 5. D. Dricelled zooecia, $\times 55$. E. Operenlum. $X$ 100. F. The ajerture with the oleloulum in situ. The beaded restibular arch is seen shining through the opereulum, $\times 100$. F, Aricularian mamible, $\times$ 100. (A-G after I,evinsen. 1909.)

II-J. Opercula and mandibles. H. Rhynchozoon scintillans Hiucks, 1895. X 140 . Ifter I.evinsen, 1909.) I. R. profundum MacGilliviay, 1s91. (After Waters, 1s\$7.) J. R. corugatum Thornel., 1905, $\times$. S5. (After Waters, 1909.)

Family GALEOPSIDAE Jullien, 1903.

1903. Jullew, Bryozon provenant des Cimplanes de l'Hirondelle, pl. 14.

The ovicell is hyperstomial and opens into the peristomie above the operenlum. A spiramen introduces into the peristomie the water destined afterwards for the compensitrix.

In the family of the Adeonidare, at in that of the Reteporidae, this spiramen also exists: it is in evident relation with the hydrostatie system, as is proved hy the 
cxamination of the yomm zorecia. In most of the species of Galeopsidae the spiramen. if it le in lapport with the hydustatio system, might have another nse, another finction, unfortunately till unknown. It is not possible, for example. to compare the size of the piramen of Gatropsis with the smallness of the orifice of the compensatrix simply closed ly a rimule or by a poter of an operculum. On the ot her hand, it is quite freument to find on the same zoarim some zooecia deprived of epiramen and which nevertheles are still living and contain a polypicle.

In the fanily of the Tessaritomidae. Inllien. 1903, the spiramen opens into the peristomie juit at the level of the operculum; exteriorly it is placed much lower.

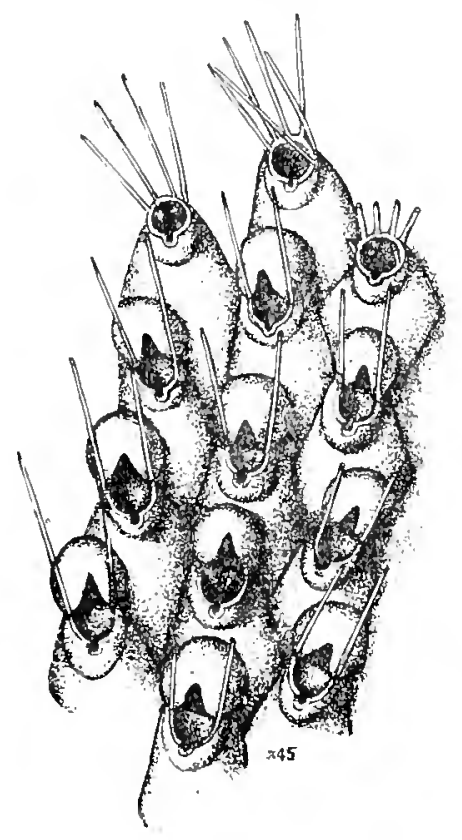

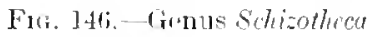
Hincks, $157 \%$.

Sichisotheor fiss liusk, 1858. Zooecia, $\times 4$. with and withrut ovicell. (liter lliurks, 1s50.) always eccentrically and may be confused with the aseopore of the Acroporidae.

We have no knowledge of the larra of the Galeopsidac and Tessaralomidae, and we think that it is preferalile to mite them provisionally in a single family: the distance of the spinamen from the operenlunis does not seem to us a character sufficient to influence the larval system.

In the speries witl thick frontal the tubules covel the oricell, which becomes invisible exteriorly; the sections permit of their aliseovery in the vicinity of the zonrial axis.

\section{Genus GALEOPSIS Jullien, 1903.}

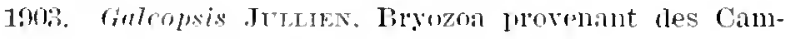
latunes de l'mirantello, p. 94

The spilamen is rery large and salient. The apertura has two cardelles. The frontal is a tremocyst a an oloryst.

Gemotypr-Galcopsis rebidus. Jullien, 1903.

Ranegr.-Mare-trichitian-Recont.

The mature of the frontal is not always evident in this gemus. Is we have not heen sumessful with ont tangential sections, we have accepted the grems as it was defined by its anthor.

The kuown frosil species of this genus are:

Finteopsis, new species. Cretarents (Vimentown). New Jersey and Delawade.

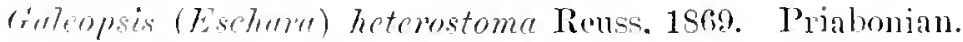

Gutropsis (Eschum) Allpticata Reuss, 1869. Priabonian.

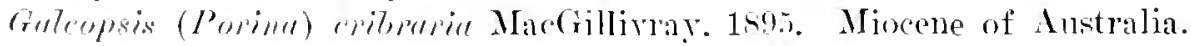

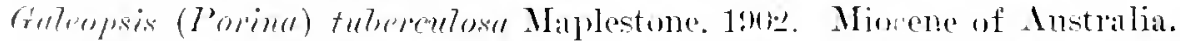

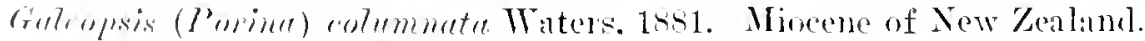
fretropsis, new sprecies, Plaisancian of England (Collection. ('amm). 
The recent species are:

Galeopsis rabidus . Jullien, 1903. Atlantic (Azore Islands).

Gulcopsis mun Jullion, 1903. Pacific (Gamlier Islinds).

Gatcopsis (IIiprothoa) fonestrate Smitt. 15\%.2. Atlantic (Florida).
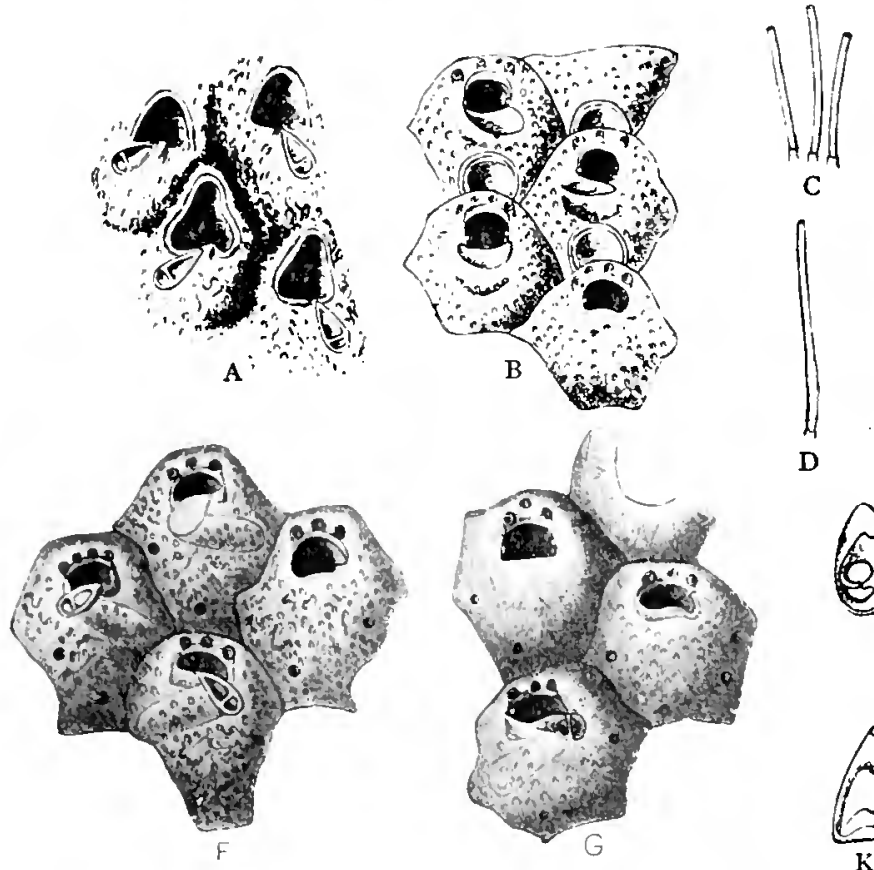

D
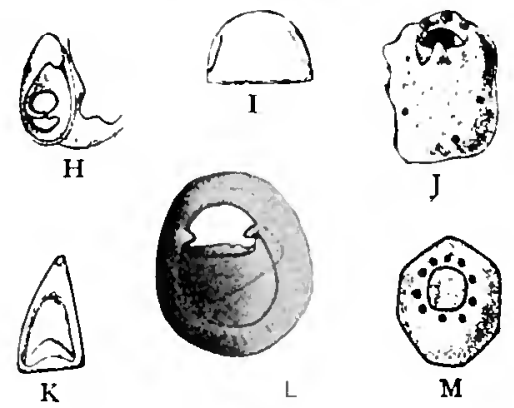

FIG, 147.-Genns Lemaliella revinsen, 1914;.

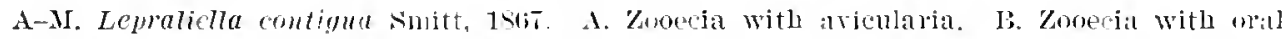
spines. C, D. Spines. E. Gueciferons zuneria. F. Zooecia provided with pores. (;. Zonecia with apertures of lifferent forms. Il. Aviculalium. I. Operenlum showing the marginal riblses. J. Zooecium with a mucronate peristome. I. Triangular mantible. I. Aperture with oril teeth. II. Ancestrula. (Atter Leriuksl, 1916.)

\section{GALEOPSIS (?) CONVEXA, new species.}

I'late 5, igs. 1, 2.

Description.-The zoarium is an Eschara with claviform fronds: the two lamellae are inseparable. The zooecia ale distinct, elongater, elliptical; the frontal is smooth, quite conece. The peristomice is orbieular; the peristone is thin, shilp, and bears laterally a very lare triangulal ariculariun with pirot. "The ovicell is large, salient, imbedrled in the distal zooecium, and opens into the peristomie. On the frontal there is a larege semicircular ascopore surmomnted by two small pores.

$$
\text { Measurements.-Peristomice }\left\{\begin{array}{l}
h p=0.14 \mathrm{~mm} . \quad \text { Zooecia } \\
l p=0.11 \mathrm{~mm} . \\
l z=0.40 \mathrm{~mm} .
\end{array}\right.
$$


Aftnitics.-The few specimens found have not permitted a detailed study of this species. We are ignorant of the exact nature of the frontal pore. It is by analogy simply that we hare classified the species in Galeopsis.

Occurrence-Milwayan (Clayton limestone): One mile wost of Fort Gaines, Georgia (rare).

Cotypes.-Cat. No. 68826, U.S.N.M.

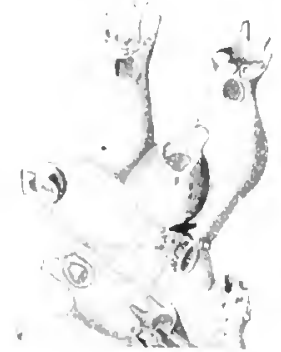

A. Galeopsis

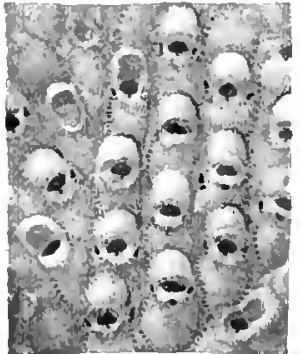

B. Schizaropsis

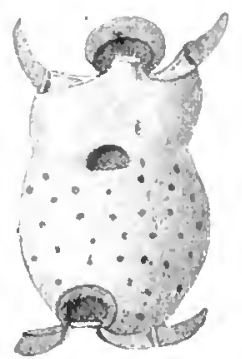

F. Gephyrophora

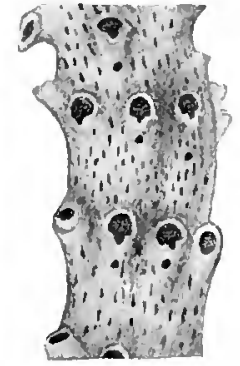

C. Hasweilia

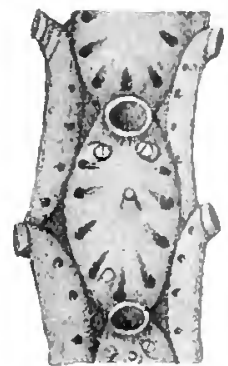

G. Tessarodoma

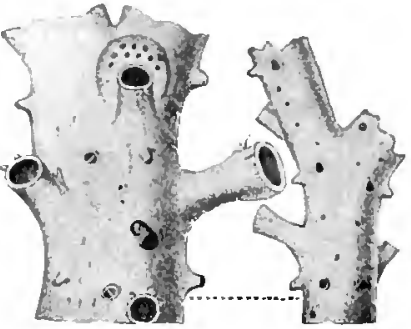

D. Semihaswellia

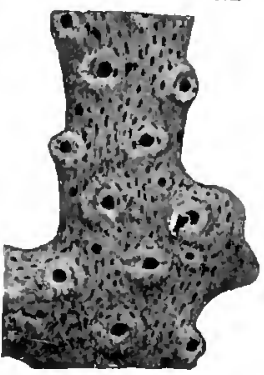

H. Tremotoichos

E. Gigantopora Fig. 14. - C Genera of the family Galeopsidae Jullien, 1903.

A. Galeopsis rubidus Jullien, $1908, \times 25$. Recent.

B. Schizuropsis rontern Cann and Bissler, 1917, $\times 20$. Jacksonian of Mississippi.

C. Haswellia anstraliensis Busk, 18st, $\times 25$. Recent.

D. Semihaswellia proboscilea Waters. $1890, \times 12$. Recent.

E. Gigantopora lyncoides Ridley, 1SS1. Recent.

F. Gephyrophora polymorpha Busk, 1Ss4, $\times 25$. Recent.

G. Tessarodoma gracile Sar's, $1850, \times 60$. Recent.

H. Tremotoichos rectifureatum Canu and Bassler, 1917, $\times 20$. Jacksonian of North Carolina.

\section{GALEOPSIS LONGICOLLIS, new species.}

Plate 66, fig. 1 .

Description.-The zoarium inclusts bryozoa. The zooecia are distinct, elongated, convex; the frontal bristles with hollow spines; the peristomie is very long, cylindrical, smooth. The spiramen is salient, transverse. elliptical, placed at the base of the peristomie; the peristomice is irregular, very oblique, suborbicular; the peristome is thin and sometimes bears a quite small avicularium.

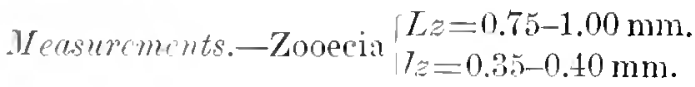


This species differs from Galcopsis vermeosa in its meh smaller spiramen and in its narrower zooecia.

It differs from Galeopsis erinceeus in its spiranen much smaller than the peristomice and in the greater lengtli of the peristomie $(=0.45 \mathrm{~mm}$. $)$.

Oecurrence.-Middle Jacksonian (Castle Hayne limestone): Wilmington, North Carolina (very rare).

IIolotype.-Cat. No. 64160, U.S.N.M.
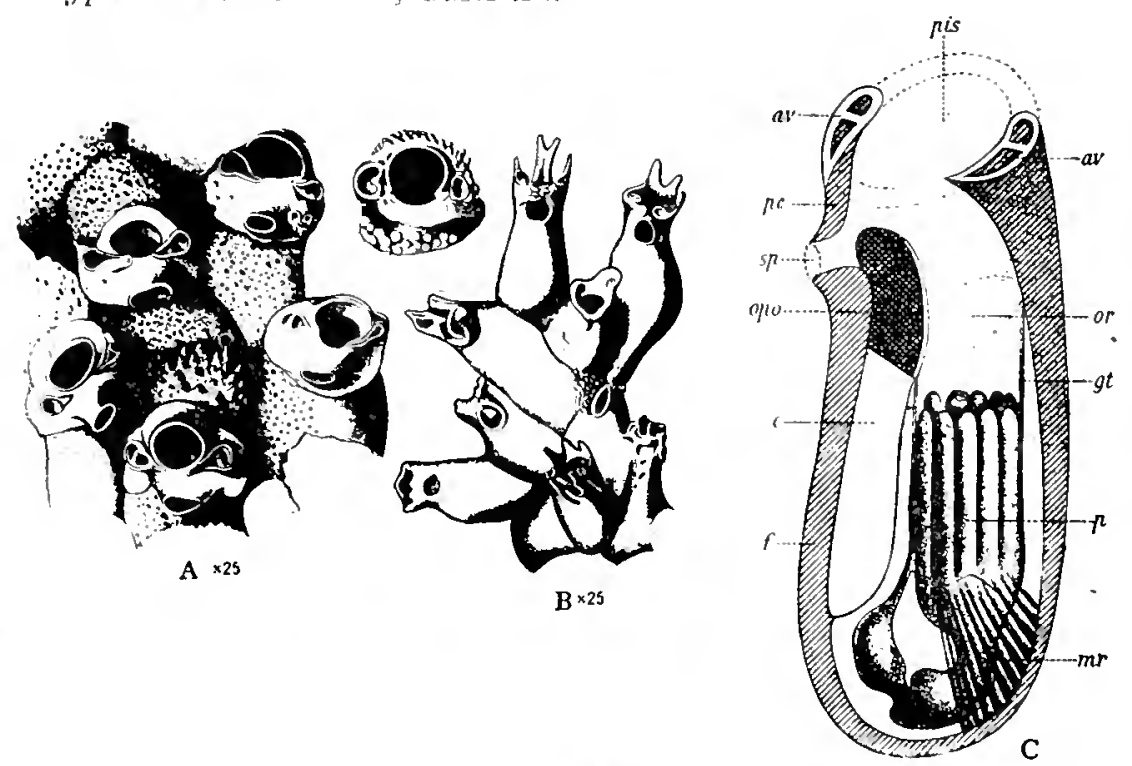

FIG. 149.-Genus Galeopsis Julleu, 1903.

A. Galcopsis pupa Jullien, 1903. Zooecin, $\times$. $\mathbf{5}$.

B. Galeopsis rabidus Jullien, 1903. Zooecia, $\times 25$.

C. Schematic view showiug the general olganization of a zooecium. (A-C after. Julliell.)

av, aricularium; $c$, compensatrix; $f$, frontal wall; $g t$, tentacular sheath; $m r$, 1 etractor luuscles of polypide; opo, operculum; or, true urifice or apertura; $p$, polypide; pe, peristone; lis, perjstomice; sp. spiramen.

GALEOPSIS VERRUCOSA, new species.

Plate 66, fig. 3̈.

Deseription.-The zourim is milamellar, incrusting algae or shells. The zooecia are elongated, distinct, elliptical. or oval; the frontal is very convex and ornamented with numerous salient and pointed wartlike nodes. The aperturit, inidden at the base of the peristomie, is formed of a large anter and of a somewhat smaller poster separated by two cardelles; the peristomice is orbicular; the peristomie is recumbent on the distal zooecia; the peristome is thin. sharp, and often bears a small, triangular aricularium with pivot. The ovicell is lyperstomial; it opens largely into the peristomie. The spiramen is immense, salient, elliptical and transrerse.

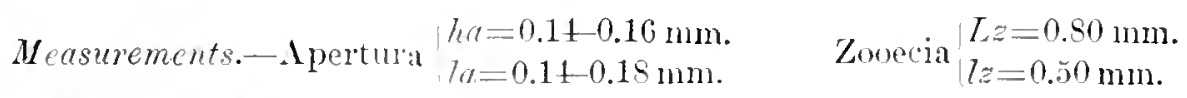


Affinities.-This species mucl resembles Gatcopsis crinaceus. It differs from it in its greater zonecial length (greater than $0.60 \mathrm{~mm}$.) and in its spiramen which has not the form of a transversal slit.

Occurrence-Widdle Jacksonian (Castle Hayne limestone): Wilmington, North Carolina (rare).

Hototype-Cat. No. 64102. T.S.N.M.

GALEOPSIS ERINACEUS, new species.

Plite 60, fig. 2 .

Description.-The zoarium incrusts shells. The zooecia are elongated, distinct, elliptical, little regular; the frontal is convex and tristles with small points. The apertura hidden at the bottom of the peristomie has two cardelles placed a little low; the peristomice is orbicular: the peristome is thin. salient, irregular, notched; the peristomie is recumbent on the distal zooecia. The spiramen is very large. 11ansverse, elliptical, salient. much wider than the peristomice.

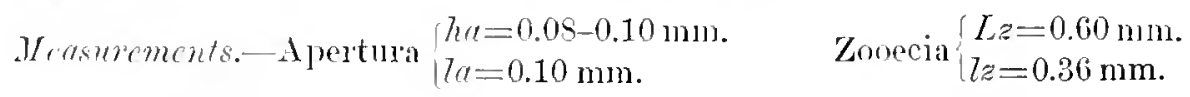

Aftinitics.-This species is quite well characterized by its spiramen in the form of an elongated and narrow slit. It differs in addition from Gateopsis vermeose in its smaller micrometric dimensions.

ricrumence-Middle Jacksonian (Castle Harne limestone): Wilnington, North Carolina (rare).

Holotype-Cat. No. 6it161, U.S.N.M.

GALEOPSIS CYCLOPS, new species.

']ate 66 , figs, $4,5$.

In seription.-The zoarium incrusts shells. The zooecia are elongated. distinct, fuviform, or cylindrical: the frontal is a little convex and formed of a tremocyst with mulch scattered pores. The peristome is salient, thin; it bears distally a small round avicuturium withont pirot; the peristomice is orbicular; the peristomie is quite oblinge and is recumbent on the distal zooedium. 'The spiramen is large. orlinular, not salient, smaller then the peristomice.

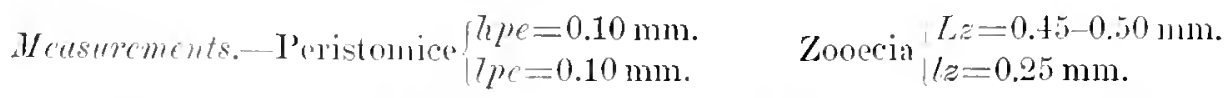

Tountions.-The young zooccia have no spirancon; it is replaced by a deep vimns of the peristome as in the Stomachetosellidae (fig 4 ). The ancestrula (fig. $5)$ is an cordinary zuoecium.

Afthition. 'This species much resembles Eschara heterostoma Reuss, 1869, of the Priabonian from the Vicentin. It differs from it in its inerusting and not escharian zoarim and in the presence of the small distal arieularia. 
It differs from Crateopsis erinacus and ratropsis vermeosa in its much smaller and not salient spiramen.

Occurrence.-Upper Jacksonian (()ala limestone) : Alachun, Florida (very l'are).

IIolotype.-Cat. No. 64163. U.S.N.M.

Genus SCHIZAROPSIS Canu and Bassier, 1917.

1917. Schisaropsis Caxe and Basster. Synousis American Early Tertiary Cheilustome Bryozoa, Bulletin 96. United States National Mruseum, p. 57.

The apertura bears a straight proximal border notched by a small rectilinear rimule. The froutal is gamished laterally with areolae; it is formel of a rery finely granulated plenrocyst placel on a thick olocyst. The spiramen is almost as large as the peristomice.

Genotype.-Schizaropsis comered Canu and Bassler, 1917. .Tacksonian.

SCHIZAROPSIS CONVEXA Canu and Bassler, 1917.

I'late lai fiss. 6,

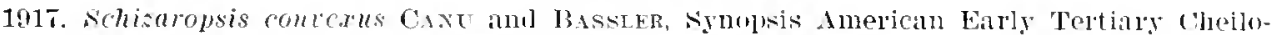

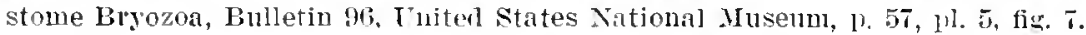

Description.-The zoarium incrusts oysters; the zooecia are grouped in linear longitudinal lines. The zooecia are clistinct, a little elongated, elliptical, or rectangular; the frontal is very convex, smooth, or very finely granular. bordered laterally with six large, widely spaced areolac. 'The apertura is formed of a semilumar anter and of a straight proximal border noteled by a small rectilinear rimule. The spiramen is elliptical, transverse. placed on the exterior peristomie. almost as wide as the peristomice. The ovicell is globular, salient, smooth: it is hyperstomial and opens by a very large orifice above the apertura and opposite the spirmen. 'Two small triangular avicularia are placed stmmetrically on each sicle of the apertura.

$$
\begin{gathered}
\text { Measurements.-A pertura }\left\{\begin{array}{l}
h a=0.05 \mathrm{~mm} \text {. (without rimule). } \\
7 q=0.07 \mathrm{~mm} .
\end{array}\right. \\
\text { Zooecia }\left\{\begin{array}{l}
T_{z=0.35-0.50 \mathrm{~mm} .} \\
\tau_{z=0.30 \mathrm{~mm}} .
\end{array}\right.
\end{gathered}
$$

Variations.-The roung zooecia have no superior arch and are deprived of spiramen. On the adult zonecia when the superior areh is not former the lateral lips of the peristomie limit a rimule-spiramen. The lateral areolae are little visible hecause of the rery large convexity of the frontal: they are quite apparent when the preparation is properly inclinerl.

The spiramen is little rivible ly perspective because it is in a plane almost perpendicular to the zooecial plane.

Oecurrenee.-Iower Jacksonian (Mendys marl) : Jackeon, Missiscippi (rare).

Cotypes.Cat. No.6260s. T.S.X.M. 
Genus HASWELlia Busk, 1884.

18S4. Ifaswocllia Busk, Report ou the Polyzoa collected by H. M. S. Challenger, pt. 1, p. 1i1.

The apertura has its proximal border notched by a very wide rimule not separated from the anter. The frontal is a very thick tremocyst. 'The spiramen is a small salient tube. The zoarium is cylindrical.

Genotype.-IIasuellia (IIyriozoum) australiensis Haswell, $18 \mathrm{~s} 0$.

Range.-Jacksonian-Recent.

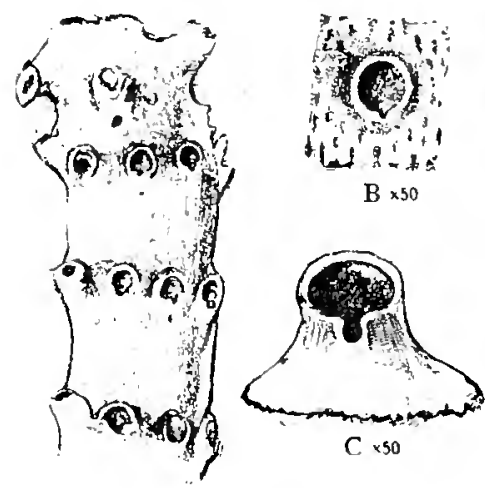

A 125

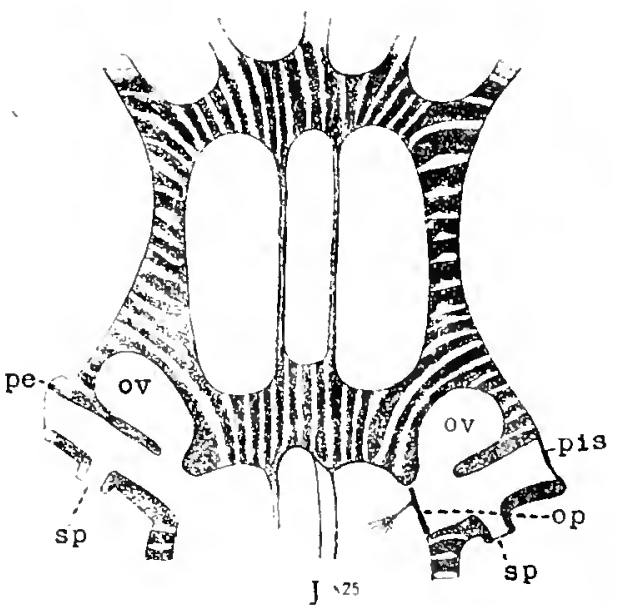

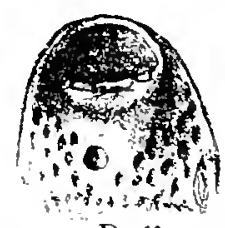

D, $>50$

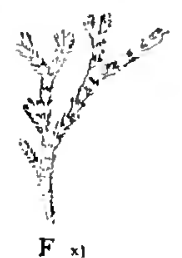

$F_{x]}$
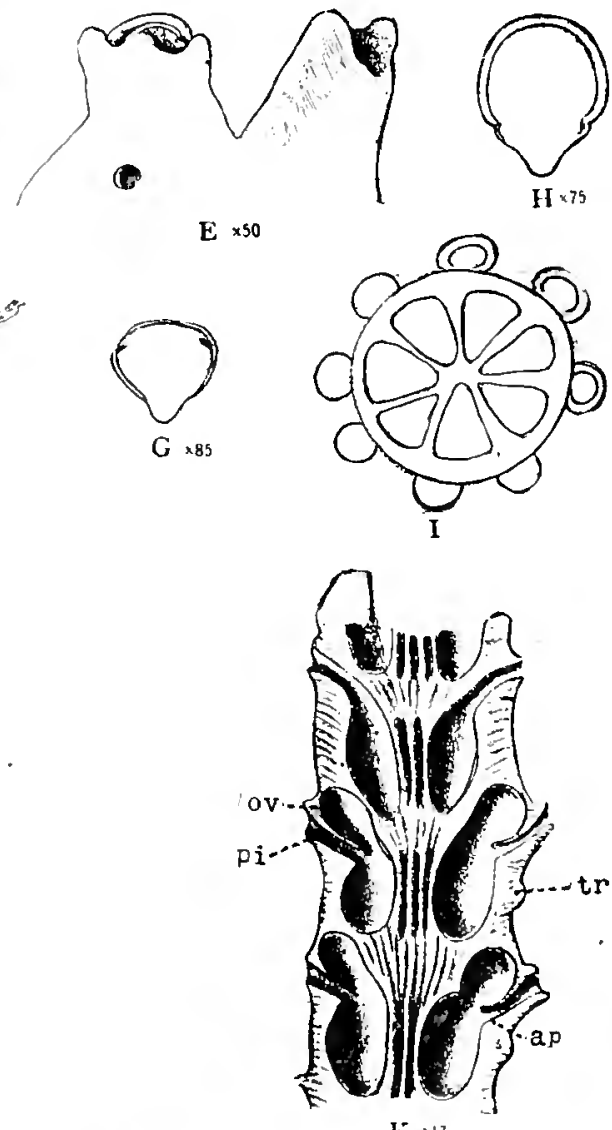

K 17
E $\times 50$

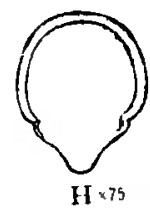

$1 \times 7$

E $\times$

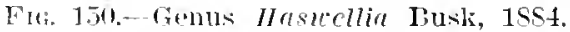

A-K. Insucllia austruliensis Haswell, 1859. A. Zooecia, X 25. B, C, D, E. Successive asperts of the visible orifica, $X$ no, showing development of the peristomie. F. Zoarium natural size. (A-F after Busk, 1S\$4) G. Operculum, $\times$ S5. (After Waters, 1s81.) H. Operculum, X 75. (After Levinsen, 190.) I. Transverse section. (After Busk, 1954.) J. Longitudinal section, $X$ 25. (After Witers, 1900.) K. Iongitudinal section, $\times$ 17. (After Levinsen, 1909.)

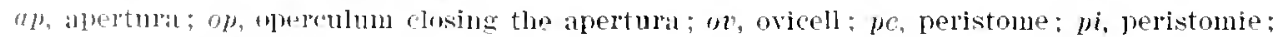
pis, peristonice; sp, sliramen; $t r$, frontal tremocyst. 
HASWELlia GRACILIS, new species.

Plate 60, figs. S-10.

Description.-The zoarium is free, cylindrical, slender. The zooeeil are disposed all around the zoarimm; they are quite long and indistinct; the frontal is a thick tremocyst with small, numerous pores. The peristome is salient. almost perpendicular to the zoarium; the peristomice is orbieular; the peristomie is invisible exteriorly, but it is as long as the zooecia. The spiramen is a small, salient, oblique tube placed on the median zoocial axis just below the peristome.

$$
\text { Measurements.-A pertura }\left\{\begin{array}{l}
h a=0.09 \mathrm{~mm} . \\
l_{\alpha}=0.09 \mathrm{~mm} .
\end{array} \text { Zooecia. }-L_{z}=0.55-1.50 \mathrm{~mm}\right. \text {. }
$$

Affinities. - In spite of its rery simple structure this species has necessitated long study. Success with the longitudinal seetions (fig. 9) has permitted us to classify it generically. The spiramen is higher than the peristomie and quite distant from the apertura.

This species much resembles the recent Porina proboscidea Waters, 18s8. It differs from it in its much smaller micrometric dimensions and in its zooecia disposed all round the zoarium and not on one side alone. It cometimes has a small avicularium placed in the ricinity of the apertura.

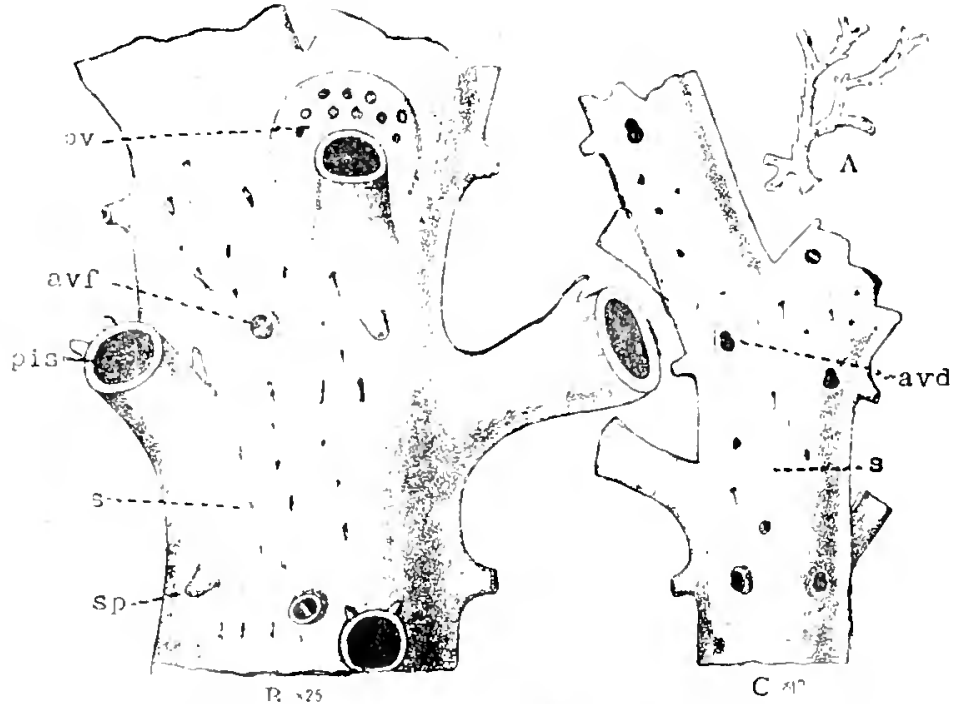

Fig. 151.-Genus Semihasuellia Canu and Bassler, 1917.

A-C. Semihasuellia proboscidea Waters, 1859. A. Zoarium natural size B. Fragment of branch with ordinary and ovicelled zooecia, $\times 25$. C. Posterior face without zooccia, $\times 12$. (A-C after Waters, 1859.)

ard, dorsal ariculariun; arf, frontal aricularium; ov, ovicell; pis, exterior oritien or peristomice, never closed by the operculum; s, sulci; sp, spiramen.

Occurrence.-Middle Jacksonian (Castle Hayne limestone) : Wilmington, North Carolina (very common).

$$
\text { Holotype.-Cat. No. 6410t. U.S.N.M. }
$$

\section{Genus SEMIHASWELLIA Canu and Bassler, 1917.}

1917. Semihrsuellia CAxu and Bussler, Synopsis of Americau Early Tertiary Cheilostome Brrozoa, Bulletin 96, United States National Museum, p. 59.

The zooecia are disposed only on one side of the zoarium; the dorsal bears only avicularia. The frontal and the dorsal are of the same nature and are formed of a tremocyst with sulci. 
Genotype--Popinu poluswidte Waters, 1889.

Range.-Tacksonian-Recent.

This gemus is zoarial; mo pecial distiuct zooecial function separates it from Haswellia. Nevertheless, it has some important zoarial functions susceptible of riving generic characters; the rery constant presence of small dorsal avicularia seems to be a very gool character. The recent specimens are extremely rare and it is still not possible to study them in detail.

SEMIHASWELLIA TRIPORA, new species.

I'lite 66, figs. $24-27$.

Deseniption.-The zoarium is free, somewhat compressed, not branched, bearing laterally large apophyses quite salient; there are three longitudinal rows of zooecia indicated on the dorsal by as many rows of small round avicularia. The zooecia are small. indistinct: the frontal is a tremocyst with sulei. The peristome is quite salient, perpendicular to the zooecial plane, thin and garnished with two small distal aricularia, almost symmetrical; the peristomice is orbicular. The spiramen is a small pore placed just below the peristome, not salient.

Measuments.-Peristomice $\left\{\begin{array}{l}h p e=0.05 \mathrm{~mm} . \\ l p c=0.05 \mathrm{~mm} .\end{array} \quad\right.$ Zooecia.-Lz=0.35-0.40 $\mathrm{mm}$.

Affuities.-This species differ's from Semihasueflice exilis in its very salient peristome and in its much shorter zooecia, less than $0.50 \mathrm{~mm}$.

Oecuranee.-Middle Jacksonian: Near Lenuds Ferry, Sonth Carolina (rare).

Cotypes.-Cat. No. (it167, U.S.N.M.

SEMIHASWELLIA EXILIS, new species.

Plate 6in, fins. 11-23.

Description.--The zourum is free, cylindrical, thin, formed of three loneritudinal rows of zooecia opening on only one sille; it often bears laterally some cylindrical hollow appendages. The zooecia are indistinct; the frontal is confused with the zoarial surface; it is formed of a thick tremocyst with tubules. placed on a perforated olocyst; the dorsal is of the same construction and bears a small round salient avicularim without pivot. The peristome is salient, thin, almost perpendicular to the zooccial plane; the peristomice is orbicular. The spiramen is small, not salient, and placed on the median axis of the zooecium immediately below the peristome.

$$
\text { Measmements.-Peristonice }\left\{\begin{array}{l}
h p e=0.05 \mathrm{~mm} . \\
l_{p}=0.05-0.07 \mathrm{~mm} .
\end{array} \text { Zonecia-Lz=0.45-0.50 } \mathrm{mm}\right. \text {. }
$$

Tariations.--'The peristome quite often bears two small avicularia symmetrically placed (fig. 15). The sulci (figs. 15, 16) do not always appear with clearness on our fossils (figs. 12, 1 1 ) ; these are the very fragile ornaments which fossilization much attenuates.

We have made numerous longitudinal sections without ever discovering the aricell: the 50 specimens observed have shown none of them visible exteriorly as 
in the genotype. Howerer we have not yet concluded that they are absent. as in such small zoaria they are fratrile. One of the sections taken through the zoarial apophyses shows that these are hollow; we are absolutely ignorant of theil use, for we have no analogous case in the recent species.

Affnities. - This species is easy to differentiate from Semikasmellia tripora; its small peristomial pores are much smaller and hardly visible; its zooecial length is larger (more than $0.40 \mathrm{~mm}$.) ; the zoarial apophyses are smaller.

Occurrence.- Tacksonian (Zeuglodon zone) : Cocoa post office, Choctaw County, Alabama (very rare).

Upper Jacksonian (Ocala limestone): Chipola River, east of Mariama, Florida (rare); Old Factory, about 1 miles above Bainbridge, Georgia (rare).

Vicksburgian (Mariamna limestone): West bank of Coneculh River, Fscambia County, Alabama (very common); $2 \frac{1}{2}$ miles north of Millry, Washington County, Alabama.

Cotypes.-Cat. No. 64166, U.S.N.M.

SEMIHASWELLIA (?) CLARA, new species.

Plate 66, figs. 2S, 29.

Description.-The zoarium is fiec, a little compressed, formed of three rows of zooecia disposed on only one side; the dorsal is granular and bears two lateral rows of alternate salient avicularia with pivot. 'The zooecia are distinct, oval, a little elongated: the frontal is convex and ornamented

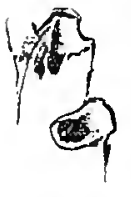

B.

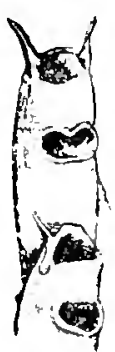

A

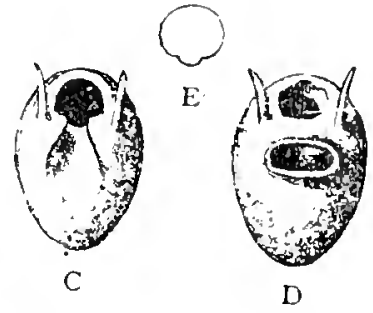

D

Fig. 152.-Genus Gigantopora Ridley, 1881.

A-E. Gigantopora lyncoides Ridley, 1881. I, B. Zooecia, seen from the tront and in profile. (liter Ridley, 1881.) C. Young zooecium. D. Normal zooecium. E. Operculum. (C-E after Kirkpatrick, 18s8.)

with some tremopores irregularly disseminater. The peristome is salient, thin. bearing one or two very small avicularia; the peristomice is orbicular. The spiramen is placed on the median axis of the zoneeium in the vicinity of the peristomice.

$$
\text { Measurements.-Peristomice }\left\{\begin{array} { l } 
{ h p e = 0 . 0 5 \mathrm { mm } . } \\
{ l p e = 0 . 0 5 \mathrm { mm } . }
\end{array} \quad \text { Zooecia } \left\{\begin{array}{l}
l_{z}=0.40 \mathrm{~mm} . \\
l z=0.30 \mathrm{~mm} .
\end{array}\right.\right.
$$

Affinities.- We have only fouml the two specimens figured. They form a rather divergent type in this genus in the ristinct form of the zooceia and in the nature of the walls. Some further study is necessary to properly classify this species.

Occurrenec.-Middle .Jacksonian: Near Lenuds Ferry, South Carolina (rare). Cotypes.-Cat. No. 6t16s, U.S.N.M.

\section{Genus GIG.1 NTOPORA Ridley, 1881.}

1SS1. Gigantopora Ridrer. Zoological collections made during surveg of 1I. M. S. .17rt. Proceedings Zoological Suciety London, p. 47.

The apertura bears a rimule. The frontal is an olocyt. 'The spiramen is inconstant; it is almost as large as the apertura. 
Genotype.-Gigantopora lyncoides Ridley, $18 s 1$.

Range.-Tacksonian-Recent.

GIGANTOPORA FILIFORMIS, new species.

Plate 66, figs. 30-35.

Description.--The zoarium is free, filiform, somewhat compressed, bifurcated, with two rows of altermate zooecia on the anterior face; the dorsal is smooth and convex. The zooecia are indistinct; the frontal is smooth and little convex. The apertura is formed of a semilunar anter and of a straight proximal border notched by a small linear rimule; the peristomie is formed by two large lateral peristomial aricularia, which can be transformed into bifurcated spines. An arch which unites

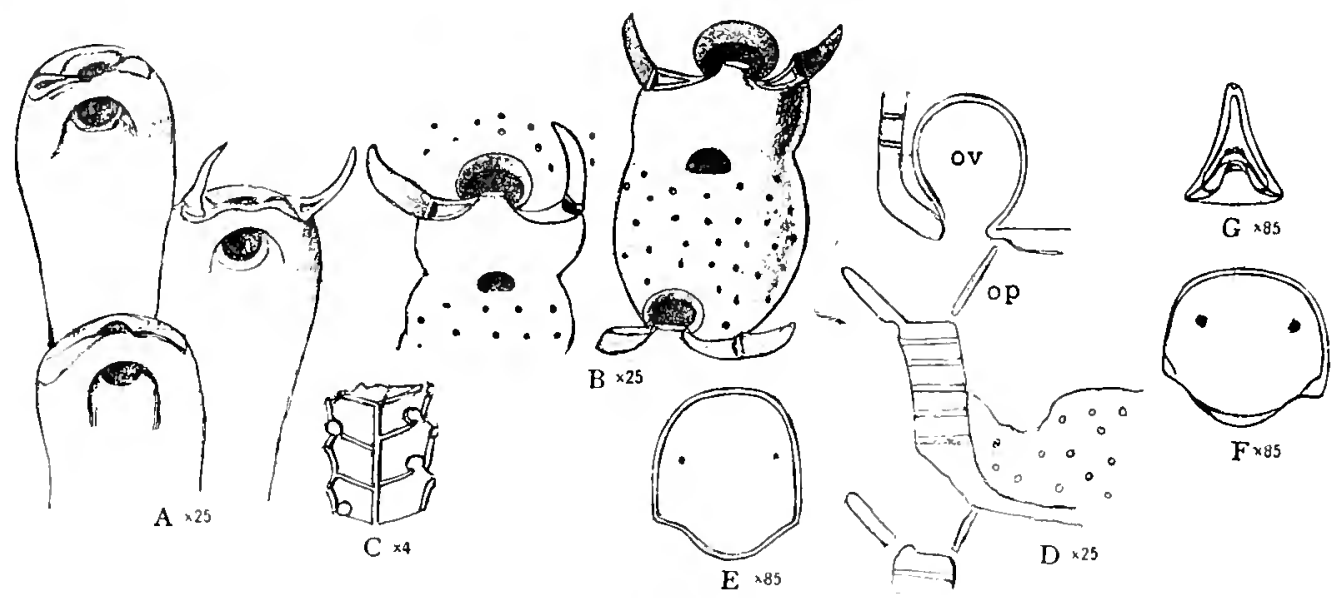

FIG. 15\%. Goums Gephyrophore Busk, 1884.

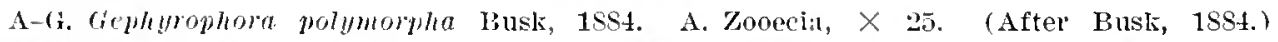
B. Kowecis, $X$ :5. 1, D. Isongitudinal section, $X 4$ and $\times 25$, showing the ovicell (ov) opening in the furistrmie above the urercumm $(o p)$. E. Operculum, $\times$ 85. (B-W after Waters, 1889.) $\mathrm{F}, \mathrm{G}$. Operculum and aricularian mandible, $\times$ S.̄. (After Waters, 1S8๘.)

these two avicularia separates the peristomice from the spiramen. The hyperstomial oricell is small, globular, smooth.

$$
\text { Neasurements.-A Dertura }\left\{\begin{array} { l } 
{ h a = 0 . 0 4 \mathrm { mm } . } \\
{ l _ { a } = 0 . 0 4 \mathrm { mm } . }
\end{array} \quad \text { Zooecia } \left\{\begin{array}{l}
L_{z}=0.40-0.45 \mathrm{~mm} . \\
l_{z=0}=0.30 \mathrm{~mm} .
\end{array}\right.\right.
$$

Vuriations.-The spiramen is rare on onr specimens; some zooecia only are furmished with it (fig. 35). The dorsal (fig. 34) is smooth; nevertheless it is porous on one of our specimens. The avicularia have no pirot, but they have two lateral denticles; they are quite salient.

Affinities. - The mode of formation of the spiramen is identical with that of Gigantopore lynooides Rilley, 1881. It differs from it in its peristomial avicularia, which are not vibraculoid and which are much larger, and in its spiramen, which is not much larger than the apertura. 
Occurrence-Upper Jacksonian (Ocala limestone): Chipola River. east of Mariamna, Jackson County, Florida (rare).

Cotypes.-Cat. No. $6+169$, U.S.N.M.

\section{Genus GEPHYROPHORA Busk, 1884.}

1SS4. Gephyrophora Busk, liepurt on the Polyzoil collected by 1). 67 .

The apertura bears a proximal rimule. The frontal is a tremocyst.

Genotype.-Gephyrophora polymorpha Busk, 1854.

Range.-Tongrian-Recent.

The known speeies of this genus are:

Gephyrophora polymorpha Busk, 1884. Recent.

Gephyrophora (II ippothoa) fencstrata Smitt, 1872. Recent (Florida).

Gephyrophora (Schizoporella) biturrita Hineks, 18st. Recent.

Gephyrophora (Eschara) tuberosa Reuss, 1865. Rupelian.

Gephyrophora (Schizoporella) tuberosa, var. angustata, Waters, 1ssi. Miocene.

Levinsen thought that the ovicell was endozooecial. If this obserration be confirmed the genus must be removed from this family.

Genus TESSARADOMA Norman, 1868.

1S68. Tessaradoma Norman, Report 3Sth Meetiug British Association Adrancement of Science, p. 309.

The apertura is prorided with eardelles. The frontal is surrounded by areolae and eorered by a pleurocyst. The spiramen opens at the level of the opereulum. The operculum in opening eloses the spiramen.

Genotype.-Tessaradoma (Pustulopork) gracile Sars. 1550.

Range.-Jacksonian-Recent.

In spite of Jullien's observations, the exact nature of the spiramen is still doubtful; its place and its function are not yet elucidated.

TESSARADOMA ORNATA, new species.

Plate $6 \bar{T}$, fig. 1 .

Description.-The zoarium is free, compressed, formed of three longitudinal rows of zooecia and on one side only; the dorsal is a tremocyst with sulci and garnished with a row of salient avieularia with semicircular mandihle. The zooecia are distinct, elongated, gibbose: the frontal is convex, smooth, surrounded by areolae and ornamented with one or two simple, salient arieularia. The peristome is salient and bears two small lateral arieularia; the peristomice is orbicular; the peristomie is visible exteriorly, long and rery oblique. The spiramen is a large pore placed quite distant from the peristomice.

$$
\text { Veasurements.-Peristomice }\left\{\begin{array} { l } 
{ h p e = 0 . 0 9 \mathrm { mm } . } \\
{ 7 p e = 0 . 0 9 \mathrm { mm } . }
\end{array} \quad \text { Zooecia } \left\{\begin{array}{l}
L z=0.60-0.75 \mathrm{~mm} . \\
7 z=0.25 \mathrm{~mm} .
\end{array}\right.\right.
$$


Afinitics. - The only specimen found has been figured. It is very pretty, but it has no oricell. It much resembles Semihaswellia clara, but is distinguished from it in the place of the spiramen, which is much more distant from the peristomice.

It differs from Tessaradoma grandipora in the much smaller diameter of the peristomice $(0.09$ and not $0.11 \mathrm{~mm}$.) and in its thin peristome, measuring 0.10 and not $0.15 \mathrm{~mm}$.

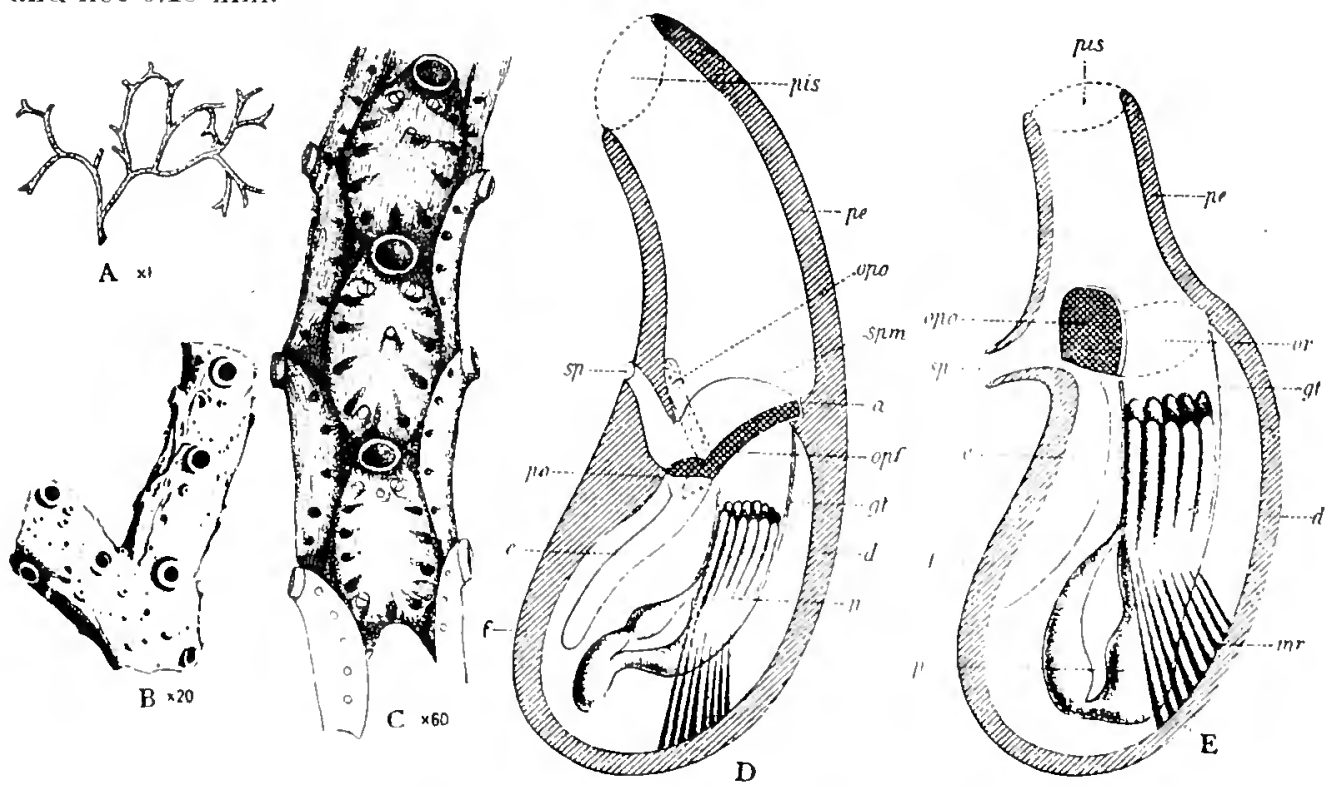

Fig. 154.-Genus Tessaradoma Norman, 186S.

A-G. Tessaraloma gratile Sars, 1S50. A. Zoarium, natural size. B. Portion of zoarinm, $\times 20$. C. Zonecia, $\times 60$. (After Hincks, 1Sso.) D. Schematic drawing of a lougitudinal section through the zooecium. L. Drawing showing the introduction of the water by the spiramen in the peristomial tube just at the level of the operculum and abore it. (B, D, E after Jullien, 1903.)

$u$, anter; $c$, compensatrix; $u$, dorsal zooecial wall; $f$, frontal zooecial wall; $g t$, tentacular sheatl; $m r$, retractor muscles of the nolvpide; opf, closed opereulum; opo, open operculum; or, zooecial oritice or aperture; $p$, polypide; $p e$, peristome; $p i s$, peristonice; po, poster ; $s p$, spiramen; smm, membraneuts portion of the spiramen.

(iccurrence.-Middle Jacksoniau (Castle Hayne limestone): Wilmington, North Carolina (very rare). IIolotype.-Cat. No. $6 \pm 170$, U.S.N.M.

TESSARADOMA GRANDIPORA, new species.

Plate $6 \vec{i}$, figs. $2,3$.

Description.-The zoarium is free, compressed, branched, formed of 3 longitudinal rows of znoecia; the dorsal is a trenocyst with sulci bearing a median row 
of avientaria with semicireular mandibles. The rooecia are distinet, elongated, separated by a furrow of little itepth: the fromtal is smooth, convex, ormamented with some lateral areolae. The peristome is large, salient, very thick, and brars two small lateral avicularia; the peristomice is orbienlar: it has no peristomie. visible exteriorly. The spiramen is little distant from the peristomice; it is elongated into the form of a buttonhole.

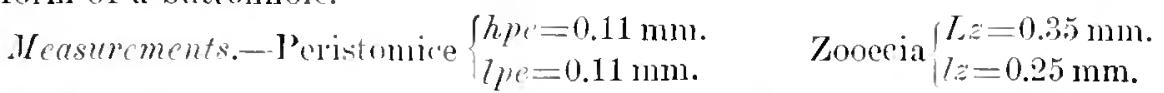

Afinities.-Only the tro specimens figured have been found, and we, therefore, have not been able to make a cletailed study of the species.

This species differs fron Trescratome ornata in its spiramen which is median and close to the peristomice and in its wide peristome which may attain $0.15 \mathrm{~mm}$. in diameter.

Occurrence.-Upper Jackonian (Oeala limestone) : West bank Sepulga River. Eseambia County. Alabama (rare).

Cotypes.-Cat. No. 6+171. U.S.N.M.

\section{Genus TREMO'TOICHOS Canu and Bassler, 1917.}

191i. Tremotoichos Canu and Bassler, symopsis of American Early Tertiary Cheilostome Bryozon, Bulletin 96, Lnitel stites Xitional Museum, p. 59.

The frontal and the dorsal are tremoersts with sulei. The spiramen opens interiorly at the level of the operenlum; exteriorly it is distant from the peristomice and almost never placel on the median axis of the zooecia.

Genotype.-T'remotoichos rectifuretum Canu and Bassler, 1917.

Range.-Jacksonian.

This gems possesses all the chrracters of Scmihaswellia, the difference heing little perceptible and consisting solely in the place of the spiramen. Is the latter does not appear to exereise the same physiological function (according to . Jullien) as in Semihasuclliu we believe it necessary to erente a new genus.

TREMOTOICHOS RECTIFURCATUM Canu and Bassler, 1917.

Plate 0 T. figs. $4 \geq 3$.

1917. Tremotoichos rectifurentum GANu and BAssler, Synopsis of American Eilrly Tertiury Cheilostome Iryozoa, Fulletin 96, United States Natioual Museum, p. 59, 13l. 6. 1ig. 1.

Jeseription.-The zoalium is free, subeylindrical, branched almost at a right angle. The dorsal is very thick: deprivel of avicularia and formed of a tremoeyst witl tubules and with sulci. The zooecia are indistinet; the froutal is a tremoryst with sulei placed on an olocyst with very small perforations. The peristome is salient, perpendicular to the zoarial plane. thick, and provided with a small proximal avienlarium; the peristomice is orbienlar. The spiramen is a pole of the frontal placed on the right or left of the median axis and distant fion the peristomice.

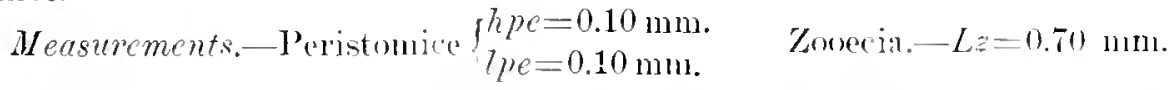

Turiations.-The spiramen is not always apparent (fig. 7 ) ; it is eonfused with the tremopores. The peristone of the roung zonecia (fig. 5) is thin. The sulei 
are not always apparent on the dorsal. The peristome may bear two small avieularia (fig. 7). The branches are somelimes quite close together.

The transversal section (figs. 14, 15) shows some very thick, external walls; the tremopores are tubular and thin. The frontal abrasion (fig. 18) often makes apparent a median axis $(\mathrm{am})$ by no means analogous to that which results from the union of the dorsal walls of the two lamellae of the Eschara; it is due to the prolonged wall of the zooecia that they are disposed as in figure 15 and that the zoarium is ent according to axis $(c, a m, d)$.

It is almost impossible to be successful with a longitudinal seetion showing the spiramen because of its eccentric position.

In a schematic one we obtain figure 16 , in which it is very difficult to place the operenlum. However, it is necessary to remark that the examination of the interior (fig. 20) reveals no corresponding frontal perforations. The zooecia communicate between themselves by some very apparent septules on figure 19. In thin section (fig. 17) the tubules of the tremocyst are always confused.

Occurrence.-Middle Jacksonian: Wilmington, North Carolina (very common) ; near Lemuds Ferry, South Carolina (very common).

Upper Jaeksonian (Ocala limestone): Chipola River, east of Marianna, Jackson County, Floricla (rare).

Cotypes.-Cat. Nos. 62606, 61172, U.S.N.M.

Family HIPPOPODINIDAE Levinsen, 1909.

The frontal is ealcified. The ovicell is endozooecial.

We have extended the meaning of Levinsen's definition, since we inelude in this family all species provided with an endozooecial ovicell. Evidently, we can not affirm that they all have the same larva, but the identity of the ovicell implies that the larrae are at least closely related.

The known genera of this family are listed below:

Cheilopora Levinsen. 1909.

Hippopodina Levinsen. 1909.

Mctrarabdotos Canm, 1914.

Watersipora Neviani, 1895.

There are certainly other genera which will be referred to this family.

1. The specimens which we possess of Escharopsis sarsi Smitt, 1867, have endozooccial ovicells; therefore the genus Escharopsis Verrill, 1879, may belong to this fitmily.

2. Levinsen ${ }^{1}$ thought that Flustramorpha fabelligera Krauss, 1837, had endozooecial ovicells; therefore the genus Flustramorpha Busk, 1884. may be maintained and introduced into this family.

3. Levinsen ${ }^{2}$ thought that IIarmeria diaphana MaeGillivray, 1879, was provided with endozoocial ovicells; Harmeria Norman may then belong to this family. 'The type of the genus, II armeria scutulata Busk, 1855, has no known ovicell.

1 Morpholngical and Systematic Studies on the Cheilostomatous Bryozoa, p. 328. 2 Idem, Г. 316. 
4. Lerinsen ${ }^{1}$ also believed firmly that Eischarina pesanseris smitt, 1575, had endozooecial oricells. If this observation be confirmed, this species is the type of a new genus of this family. Waters in 1909, thought, on the contrary, that it could be placed in Phonicosiu Jullien, 1888.

5. Nyriozoum marionise Busk, 188t, could perhaps also belong to the same family.

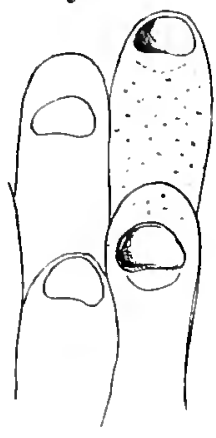

A $\times 30$

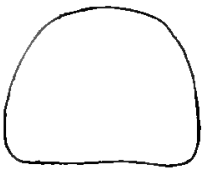

$\mathrm{D} \times 85$

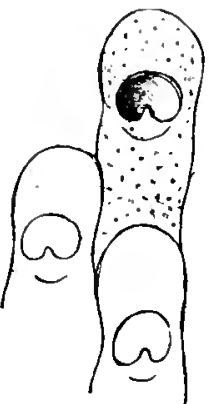

$\mathrm{B} \times 30$

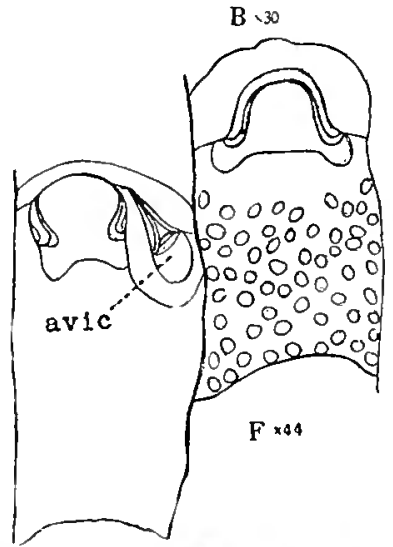

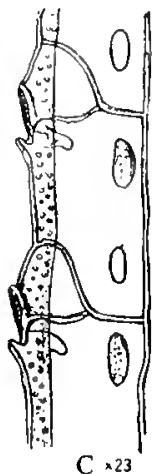

$\mathrm{C} \times 23$

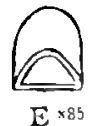

I'Ig. 155.-Genus Chrflopora IJevinsen, 1005.

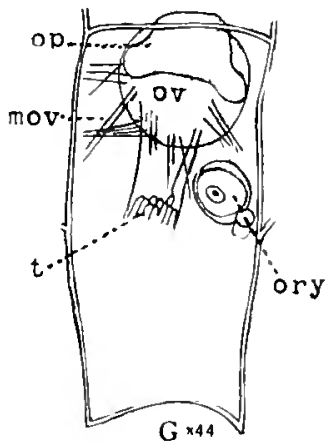

A-D. Cheilopora sincera sinitt, 1S67. A, B. Ovicelled zooecia, X 30. (. Ifter Nordgaril, 1900.) C. Lateral view of two zooecia showing the septulae, $X 23$. (After Ievinsen, 19u9.) D. E. Operculum and avicularian mandible, $\times$ 85. (After Nordgaard, 1905.)

F, G. Cheilopora haddoni II rmer, 1902. F. Showing an avicularium and the two kinds of opelcula, $\times 44$. G. Basal views of a zoecium with trifoliate operculum, from the same slide. $\times 44$. $(\mathrm{F}, \mathrm{G}$ after Harmer, 1902.)

alic, avicularium; mor. musles of the orisac; op, operculum; ory, ovary; or, orisac; tontacies.

All these species require further examination and we can not yet introduce them into a regular nomenclature.

Genus CIHEILOPORA Levinsen, 1909.

1909. Cheilopora LFynsex, Mrmphological and Systematic Studies on the Cheilostonitums lityozoa, 1. 353.

The frontal is a tremocyst with pores in quincunx, not separable from the olocyst. subjacent and perforated with rery small corresponding pores. Two 
dietellae. "The distal wall has no expansion, partly separating the ovicell from the zooecimm; multiporous septulae; peristome present in the form of a lip-like projection." (Lerinsen, 1909.)

Genotype.-Theilopora (Lemalia) sineera Smitt, 1867.

Range.-Aquia-Recent.

The genotype is mprovicled with cardelles. We think that the species provided with cardelles and a different operculum might be introduced into a new genus.

CHElLOPORA (?) LABIOSA Ủirich, 1901.

Plate 2, figs. 1-3.

1!M1. Lomalin labiosa Lurtch, Maryland Geological survey, Eocene, 1. 220, pl. 60, figs. 15, 16.

Description.-."Zoarium forming thin crusts over shells and other foreign bodies. Zooecia thomboidal, hexagonal, or subovate arranged more or less irregulinly in curved series, five or six in $2 \mathrm{~mm}$., often separated by a depressed line. Front wall punctate, slightly convex, flat, or deplessed, the last when the margin on one or both sides is thickened and elevated. Aperture subquadrate or semielliptical, sometimes contracted near the middle, always enclosed by a more or less strongly thickened rim. Aricularia ocenr on the raised apertural border, usually one to each zooecium, or two, as shown in the figures. Ooecia unknown."

The figure published by Tlrich is somewhat theoretical; notably the area as drawn is scarcely risible and only on a single zooecium of the type. We reprodnce two rely frequent variations. None of the specimens examined bears ovicells; our generic determination, made by analogy, necessarily remains somewhat doubtful.

The zooecia are convex, elliptical, rather little distinct. The peristome is incomplete in its proximal part; it bears laterally one or two very salient avicularia of the nore simple type.

Ocemrener.-I Lowest Eucene (Brgozon bed at base of Aquia formation): Tpper Marlboro, Maryland.

$$
\begin{aligned}
& \text { Plesiotype.-Cat. No. } 63753 \text {, T.N.N.M. } \\
& \text { CHEMopora (?) ORBIFERA, new species. }
\end{aligned}
$$

I'late 14, fig. 16.

l'cremiftion.-The zoarium is unilamellar. The zooccia are distinet, a little dongated, lozenge-shaped; the frontal is somewhat convex and formed of a tremocyst, each pore of which is surromnded by a special orticntar collar quite distinct from the neighboring ones. The apertura is transverse, semielliptical; the distal half is sumomted by a peristomie with a border thin and sharp. The aricularium in lateral. provided with a pirot; its beak is turned toward the bottom.

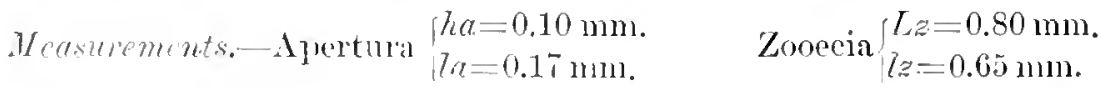

1 finitics.- In the form of its ronecia and in the nature of its frontal this species

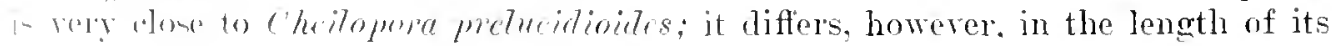


peristomie, in its much larger and more numcrous tremopores. and in its lateral avicularium.

The fignred specimen bears no ovicell and its generic determination remains therefore somewhat doubtful.

Occurrence-Claibornian (Gosport sand) : Bhuff on Tombighee River, Gopher Hill. Alabama (very rare).

IIolotype.Cat. No. (i3s.s1. U.S.N.M.

CHEILOPORA PRELUCIDIOIDES, new species.

Plate 69 , figs. 1, 2

Description.-The zoarim is free, formed of two lamellae, back to back. sepalrating with difficulty. The zooecia are distinct, somewhat elongated, regular. elliptical. separated by a thread; the frontal is convex: the tremopores are large and are placed at the bottom of small hexagonal cavities. The apertura is large. ogival, with a proximal border, rigorously straight; the proximal border of the peristomice is somewhat convex; the peristome is complete, but salient only in its lateral and distal parts. Frequently near the apertura there are two small. simple aricularia disposed symmetrically.

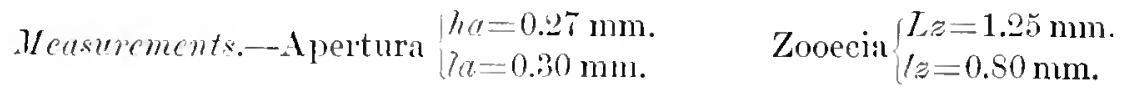

Tariations.-In the interior the zooecia are lozenge-shaped, as is usual in this genus (fig. 2). They bear on their latcral walls two large, fusiform dietellae, as in the other species of Chcilopora with cardelles. We have not yet discorered the ovicell.

Affinitics.-This species much rescmbles the recent Cheilopara pretucidio Hinek, 1853. living still in American waters; it differs from it only in its bilamellar goarimm and in its peristome, which is not salient in its proximal portion.

It differs from the other fossil Chcilopora in the absence of cardelles. Occurience-Dliddle Jacksonian: Near Lenuds Ferry, South Carolina (rare). Ilolotype.-Cat. No. 6t1it, U.S.N.MI.

CHEILOPORA STRICTOCELLA, new species.

Plate 68, fig. 12.

De seription.-The zoarimu is free, phuriamellar, former of lamellace lack to hack, and inseparahle. The zonecia are distinct, narrow, fusiform, separated laterally by a salient thread; the frontal is somewhat convex and perforated with lange tremopores in quinemx. The apertura is elongate; the anter is large and semielliptical: it is separated liy two cardelles from a very small poster. of which the prosimal border is convex; the peristome is incomplete. salient, and sharp. The a ricularian zooecia hare al rely elongatted orifice.

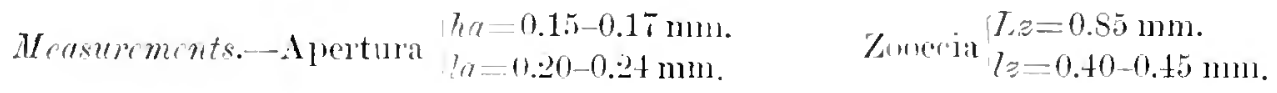


Affnitics.-We have not found the ovicell of this extremely rare species and its generic determination naturally remains somewhat doubtful.

We have already mentioned the presence of analogons aricularian zooecia in Porella planulata and in Metroperiella grandipora.

The great narrowness of its zooecia absolutely characterizes this species and does not permit it to be confused with any other.

Oceurpence.-Middle Jicksonian: Near Lennds Ferry, South Carolina (very rare): Baldnck, Barnwell County, South Carolina (very rare).

Ilototype-Cat. No.64177, U.S.N.M.

\section{CHEILOPORA GRANDIS, new species.}

Plate 68, figs. 3-5.

Description.-The zoarium is milamellar and creeps over algae. The zooecia are very large, ogival, separated by a salient thread; the frontal is somewhat convex and perforated with nmmerons tremopores. The apertura is oval, elongated; two triangular cardelles separate a large semilumar anter from a smaller convex poster. On each side of the apertura are two salient avicularia with pirot, symmetrically placed.

$$
\text { Measurements.-A pertura }\left\{\begin{array} { l } 
{ h \alpha = 0 . 3 0 \mathrm { mm } . } \\
{ l _ { \alpha } = 0 . 2 7 \mathrm { mm } . }
\end{array} \quad \text { Zooecia } \left\{\begin{array}{l}
L_{z}=1.00-1.25 \mathrm{~mm} . \\
7 z=0.70-1.25 \mathrm{~mm} .
\end{array}\right.\right.
$$

$T^{\prime}$ ariations.-Is in all the species which are attacked by gigantism, a disease which the bryozoa as well as other organisms suffer, as shown by Larger, this also is quite rariable in its micrometric measurements. Very often the zooecia are elongated, and the width oscillates between 0.70 and $0.80 \mathrm{~mm}$. The length. somewhat more constant, is never lower than $1 \mathrm{~mm}$. On the dorsal face of the zoarium the zooccia hare exactly the form of a more or less elongated lozenge.

We are ignorant of the ovicell, but the generic determination does not offer any doubt.

Affnities.-This species differs from Cheilopora saillans in its much larger micrometric dimensions and in its milamellar zoarimm.

It differs from Cheitopora transversa in its elongated and nontransverse apertura.

Oecurrenee.-Middle Jacksonian: Wilmington, North Carolina (common); $3 \frac{1}{2}$ miles north of Grovania, Georgia (rare); $4 \frac{1}{2}$ miles southeast of Marshallville, Georgia (very rare).

Cotypes.-Cat. No. $6+17 t$, U.S.N.M.

CHEILOPORA SAILLANS, new species.

Plate 68, figs. 9-11.

Desmiption.--The zoarium is free, bilamellar, formed of two lamellae, back to back, and more or less separable. The zooecia are distinct, elongated. lozengeshaped, separated from each other by a thick, rery salient thread; the frontal is somrewhat convex and formed of a tremocyst on a thin perforated olocyst. The 
apertura is somewhat elongaterl, suluorbirular, and formerl of a large semilumar anter and of a rery convex, somewhat maller poster: the two cardelles are prolonged in the interior as fin as the lateral zooecial walls. The ovicell is endozooecial, small. little salient, transverse, of the same nature as the frontal. 'The two oral avicularia are orbicular, withont pivot, very sillent.

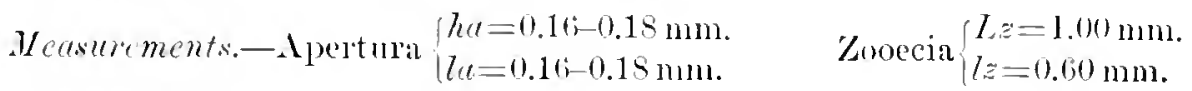

Fariutions.-Evidently the oral aricularia are not always equally salient, but their presence is rery constant.

The cardelles are very chanarteristix. They are prolonged as a prominence in the interior of the zooccia as far as lateral walls and thus form two powerful condyles.

That which we take for dietellae are perhaps only the cavities of the aricularia (fig. 11). We do not believe this for the following reasons:

1. In Cheitopore prelueilioides these eavities are visible on the specimens which have no exterior avieularium apparent.

2. In Cheilopora sailluns, if we illuminate strongly from below the preparation showing the zooecial interior, we note that the apertnra becomes naturilly brilliant, but that the cavities remain dark, and that they have therefore no orifice in common with the aricularia.

Nevertheless a relationship betwean these dietellae and the avicularia is

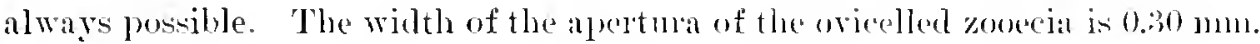

Affinities. - It is rather difficult to separate this species from Cheilopor transwersa and Cheilopora transwersoides in which the exterior aspect is similar. but it differs from them in its more salient avicularia and in its apertura nerel transwerse, but always jound ol prifin'm.

Oecurrenee.-Middle Jacksonian: Wilunington. North Carolina (common): $3 \frac{1}{4}$ miles sonth of Perry, (reoloria (1:are); 17 miles noptleast of II awkinsville, Georgia (rare) ; one-lalf mile southeast of Lily, Georgia (rare).

C'otypes. - at. No. Gt176, T.S.X.M.

CHELLOPORA TRANSIERSA, new species.

I'litu tin, fiers. 6 .

Thseription.-The zonrimm is free, bilamellar, formen of two lamellac, back to back. The zooceia are distinet. lozenge-shaped, entirely suromnded ly a sedalrating, salient thead; the frontal is somewhat convex and perforated hy numerous small tremopores, disposed in quincunx. The apertura is transeverse, subelliptic, and provided with two large cardelles; the anter is less convex than the poster, but it is vider. The peristome is complete and somewhat salient. The wricel! is endozooccial, little salient, convex, transverse, of the same nature as the frontal. The two oral aricularia are a little salient, orbicular, withont pirot.

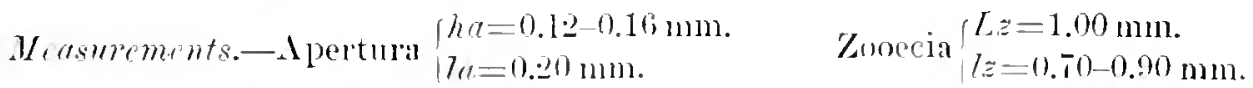


Tariations.-The apertur:a of the oricelled zooecia is twice as large ( $l a=0.40 \mathrm{~mm}$.$) .$

In this species. as in the preceding rheilopord, many of the apertures are (losed by a smootl. calcareous lamella. We have examined this lamella in the interior: it is there cuite distinctly risible. placel at the middle of the peristomie; it is not in direct continnity with the oloegst. We do not think that it represents at calcarcous opereulum. but it is probally the closure of the diseased zooecia which have lost their polypide. This is evidently only a hypothesis.

We can not aflirm that the oral avicularia are true avicularia. for certain ones among them have much resemblance to the andiculate ribracula.

Affinitirs.-This epecies num resembles rheitopora saillans, but differs from it in its quite manifestly transterse apertura.

It differs from theilopore transersoides in its nonsymmetrical apertura. in its larer micrometric dimensions, and in the very large apertura of its ovicelled zooccia.

Oecurpener.-Widele .Tacksonian: Wilnington, North Carolina (common); near Lemuds Ferry. South Carolina (rare).

IIolot?lye.-C 'itt. No. 64179, IT.S.X.MI.

CHEILOPORA TRANSVERSOLDES, new species.

Plate B., figs, 6-S.

Deseription.-The zoarium is free. bilamellar, formed of two lamellac. back to back, and inseparable. The zooecia are distinct, elongated, lozenge-shaped, or ogival. separated ly a salient thread. wide and rariable; the frontal is convex and formed of a trenocyst with numerous pores placed on an olocyst fincly perforated with pores corresponding to the tremopores. The apertura is transerse, elliptical, stmmetrieal: the anter is perceptilly equal to the poster; there are two strong median warlelles. The oricell is endozooecial, small, little salient, convex, smooth. The two oral aricularia are small. subortiendar. little sallient.

$$
\text { Measurement..-Apertura } \begin{aligned}
& \text { tha } a=0.1+0.18 \mathrm{~mm} . \\
& 7_{a}=0.1 \mathrm{~S}-0.24 \mathrm{~mm} .
\end{aligned} . \quad \text { Zoocia }\left\{\begin{array}{l}
L_{z}=0.90-1.00 \mathrm{~mm} \text {. } \\
7 z=0.60-0.10 \mathrm{~mm} .
\end{array}\right.
$$

Trariotions.-.-The apertura of the ovicelled zooecia is identical with the apertura of the ordinary zosecia.

In the interior we have observed that the two cardelles are only the extremities of two comlyles, supported on the zonecial walls. The two dietellac are also very constant. The zooccial walls are very thin.

Affinitis.-This species ditlers from Cheiloporatranswersa in its symmetrical apertura, in its smootl and much smaller ovicell. and in its smaller micrometric dimensions.

It difters from cheitoporte saitlens in its transrerse and not snborbicular apertura. and ir its oricells with small orifice. 
Orcurenec.-Midale . Talkonian: Wilmington. North (arolina (rare): near Lenuds Ferry, South (anolina (eommon): 1i miles northeast of Hawkinsville, Georgia (rare).

Cotypes.-Cat. No. (i+17.5. T'..N.M.

CHEILOPORA SPECULA, new species.

Hate tig, tigs, 1-5.

Deseription.-.The zoarium inerusts bryozon and shells. The zooecia are large, elongated, distinet, utricular: the fromtal is convex, with numerous tremopores. The apertura is elliptical. transverce: the poster is as large as the anter: there are two salient eardelles: the peristome is incomplete in front: the distal part is extraordinarily developed, very long. semicylintlical. The ovicell is endozooecial, convex, globular. somewhat salient, covered with trenopores like the frontal. The two frontal aricularia are small. spmmetrical, tubular.

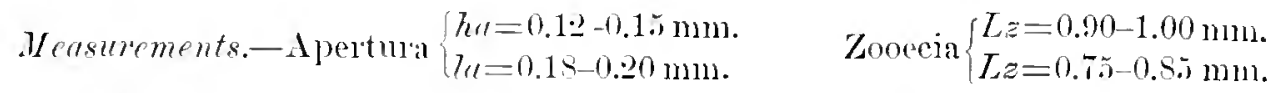

Tirriations.-This species is quite remarkable in the great levelopment of a part of its peristome. which forms a sort of utchtower above the apertura. This appendage is often lobed or hifurated. It is very often broken on our fossils and it assumes the most raried and incolnerent forms. It does not exist on the ovicelled zooecia, which bear only two long. lateral, very salient palettes. It is erident that this peristome is not in rapport with the passage of the egos. It appears to us to be simply like an apparatus (or more exactly like a tap) destined to retain the diatons serving as the habitul nourishment for the bryozoa. The funnel-shaped gullet which terminates it superiorly confirms this hypothesis. for it facilitates the issue of the strams of water. It is a perfect adaptation to the principle of the flow of the liquids and of their decantation. For a long time the bryozon have invented suel "spouts."

Occurrener.-Middle .Tacksonian (Castle Hayne limestone): Vilnington, Nortls Carolina (eommon).

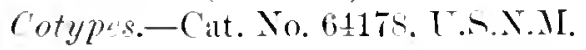

CHEILOPORA SULCIFERA, new species.

Plitte 169, figes. 7, 8 .

Deseription.-The zoarimu is unilanellar and cleeps on algae. 'The zonecia are distinct. lozenge-shaped. ntricular: the frontal is conrex: it is covereel with tremopores often transformed into sulei. The apertura is oval. transerse: it is formed of a semilunar anter, separated by two combles from a wirle. concave and triangular limule. The ovicell is enclozooedial, small. transrerse. little salient. porous. The two frontal avicularia (!) are oblique. tulular, symuetrically placel.

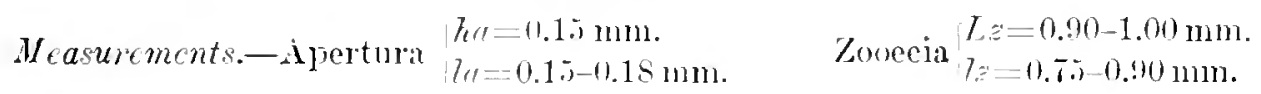


Tariations.-The four sperimens which we have found of this species have not permitted an attentive and detailed stuly. We think that it may serve as type of a special genus. In fact the apertura has not the "Hippo" form of the other species of the gemm, for it appears to be more "Schizo"- that is to say, with rimule: the two lateral arienlaria ale rather vihianda, analogous to those of schisoporella rulgaris . Tohnston, $18+7$.

The zooecia are elongater (fig. 8) or transverse (fig. $\bar{\jmath}$ ).

Occureme.-Middle Jacksonian (Castle Hayne limestone) : Wilmington, North Carolina (rare).

Cotypes.-Cat. No. 6t1S0, IT.S.N.M.

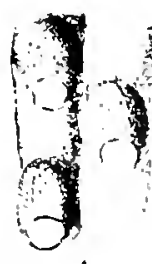

$A \times 20$

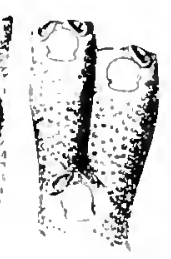

$B \times 20$

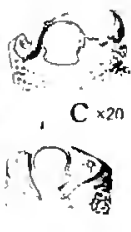

$\mathrm{D} \times 20$

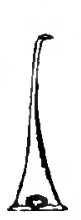

E $\times 25$

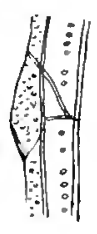

$\mathrm{F} \times 20$
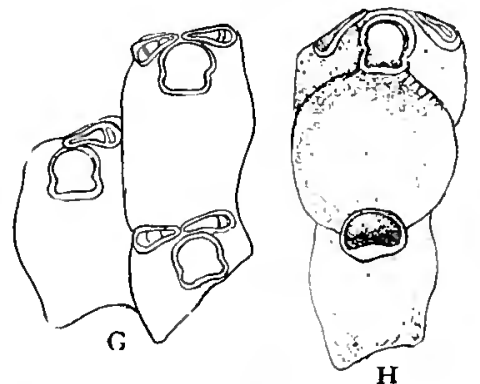

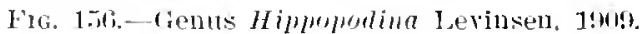

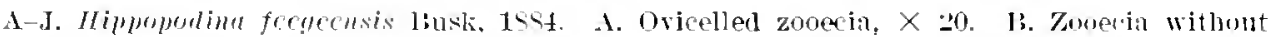
ovicell and with avicularia, $X 20$. C. Zuoecium with auther form of avicularia, $X 20$. D. Avi-

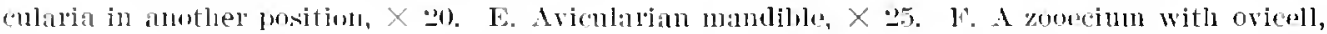

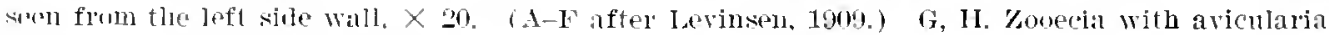

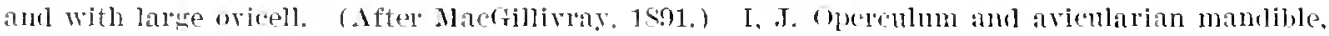
$\times$ S. . (After. Waters, 1!19.)

\section{Genus HIPPOPODINA Levinsen, 1909.}

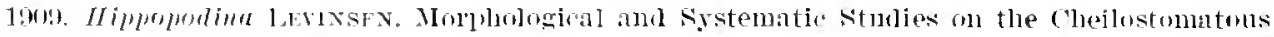
Plyorzat. [1. 8-i:3.

The apertura is poovided with two cartelles.' The frontal is a tremocyst placed on an funcry perforated and rery thin olocyst. The oricell is endozooecial. "The horizontal fart of the distal wall is continued into an expansion which forms a partial partition between the ovicell and the zooecium; miporous septulac: no peristome." (Levinsen, 1900.)

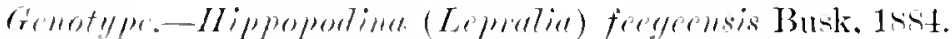

Range.-Jacksonian-Recent.

\section{HIPPOPODINA VIBRACULIFERA Canu and Bassler, 1917.}

Plate 60. tiss. 9-14.

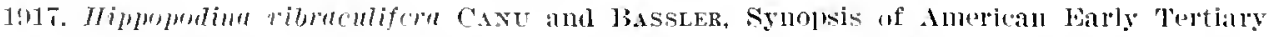

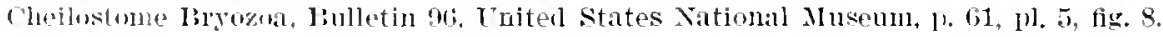

Theseription.-The zonrium is free, bilamellar; the two lamellae, back to back. are easily semalatel. The zooecia are elongated. large, hexagonal; the frontal is 
convex and formed of a tremocyst with rely numerous pores placed on a very finely perforated olocyst. from which it is separable. The apertura is formed of a rery large orbieular anter and of a narower poster with proximal lip straiglt and denticulated; the restibular arch is clarly visible. The endozooeeial oricell is immense and takes the place of a zonecium; it is convex and perforated with tremopores; the apertura of the orimian zooeeia is much larger. Two anriculate vibracula are placed symmetrically on the distal part of the zooccia.

$$
\begin{aligned}
\text { Measurements.-Apertura } & h u=0.25 \mathrm{~nm} . \\
\text { of ordinary zooecia } & l a=0.28 \mathrm{~mm} .
\end{aligned} \quad \text { Zonecia }\left\{\begin{array}{l}
L z=0.00-1.10 \mathrm{~mm} . \\
l z=0.80-1.00 \mathrm{~mm} .
\end{array}\right.
$$

Apertura of $/ h a=0.25 \mathrm{~mm}$.

ovarian zonecia $/ \%=0.35 \mathrm{~mm}$.

Tariations.-Numerons zonecia are elosed at the level of the restibular arch by a sort of finely perforated operculum. They probably do not eontain a polypide. which perhaps died of disease. ${ }^{1}$ 'The phenomenon is freruent in the family. The two superposed frontals are clearly visible in figme 12; the tremopores are tulular (fig. 11).

The vibracula are quite comstant. We think that the zoarium was not fixed at the bottom of the seas, that it was attached to the algae. and that the vibracula assure stabilization. There were fire septulae.

Occurence-Middle Jacksomian: Wilmington, North Carolina (common); $3 \frac{1}{3}$ miles north of Grorania. Georgia (rery rare).

Upper Jacksonian (Ocala limestone) : Old Faetory, $1 \frac{1}{2}$ miles above Bainbridge. Genrgia (rare).

$$
\text { C'otypes.-Cat. No. (ig604, T.R.N.M. }
$$

\section{Genus METRARABDoTOS Cam, 1914.}

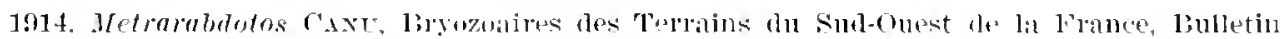
Sociêté Géologique, France, vol. 14, p. tĩ.

The ovicell is endozooceial. Tho apertura is semilumar. with a rimule and lyrula. The frontal is smrommert with Jateral areolate and formed of an oloryt surmounted by a pleuroyst.

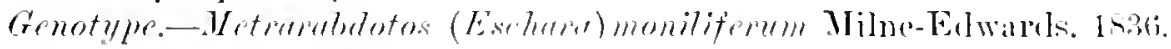

Range.-Priabonian-Astian.

METRARABDotos MoNilifERUM Milne-Edwards, 1836.

I'lite !h, liess. $1-10$.

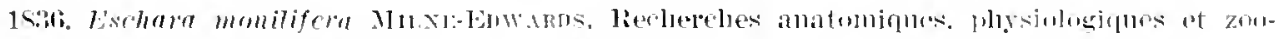

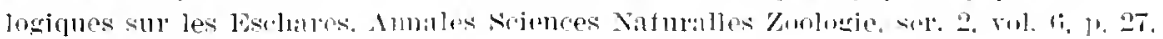
pl. 9. fis. 1 .

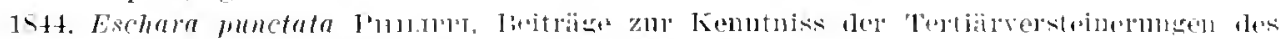

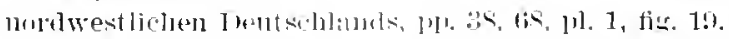

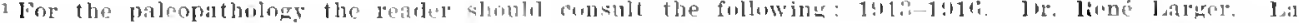

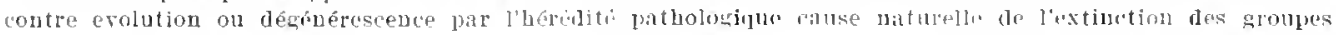

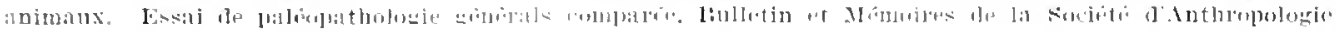
dis lasis, 1913.
} 
1845. Eschara monilifera Mucurın, lomographie zoophytologique: Description par localités

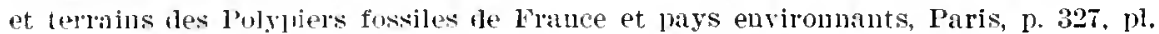
7S. fing. 111.

1Sti. Eschara muctata Jieuss, bie fossilen l'olyparien des Wiener 'Tertiabbeckens, Haid-

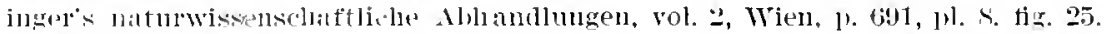

1951. Eschara muctata lisuss, Ein lieitrag zur Paleontologie der Tertiäschichten Oberselulesiens, Zeitschrift Ineutselen Geologisehen Gesellschaft, vol. 3, 1. 164.

1859. Eschara monilifcra liusk, A Monograph of the Fossil Bryozoa of the Crag, I'ublicatims of the latleontological suciety of Loudon. 13. 69, pl, 11, tiss. 1-3.

1s61. Eschara momilifera śtor.sezא, Oligocane Bryoznen von Litelorf en Bernburg, Sitzumgsheriehte der k. Akidenie der Wissenseluaften. Wien. rol. 45. Abth. 1, 1) 88.

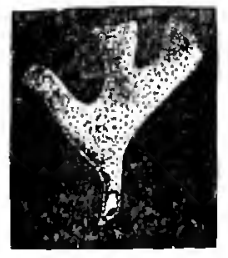

A $\times 1$

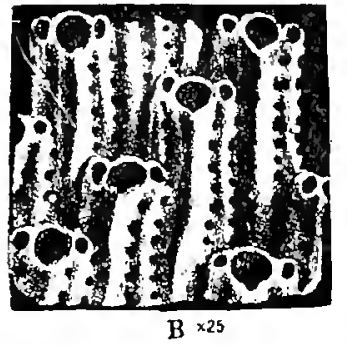

HIG. 15T.-Genus Jetiarabrotos Cimu, 1914.
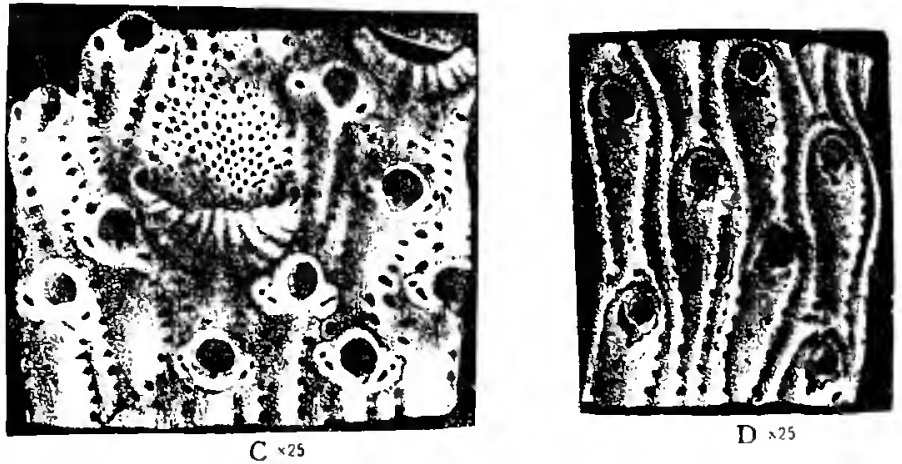

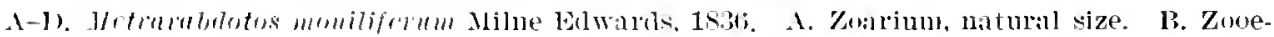

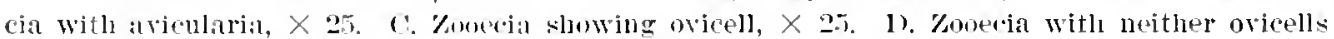
nor aricularia, $X 2 . \overline{2}$ ( $1-\mathrm{D}$ after Busk, 1S59.)

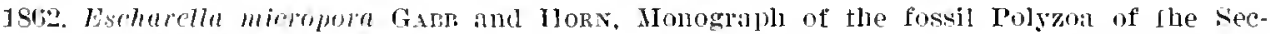
wulary and Tertiary Formations of North Amelica, Journal Aeademy Natural Sciences, 1'hilillelplia, ser. 2, vol. 5, p. 136, pl. 19, fig. 17.

1s64. Eschan monilifen śtoliczka, Fossile Bryozoen ans dem tertiaien Grülsandsteine ler Orake-Bay bei Ankland, mit Betrachtungen ibel neue oner weniger bekannte bryozn-Siplen und deren Classitication, heise der Oest. Fregatle Novara, sen. Theil, vol. 1, Ahtlı. 2. Pil leontologie, p. 32, pl. 19, figs. 15, 10.

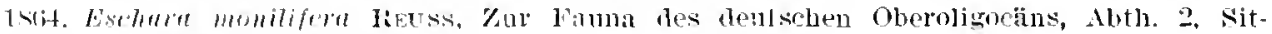
zungsuerichte der k. Akademie der Wissenschaften, Wien, rol. 50, 1) 35.

1sio. Eschar monilifora licuss, Vebel die Foraminiferen. Anthozoen mnd Bryozoen des

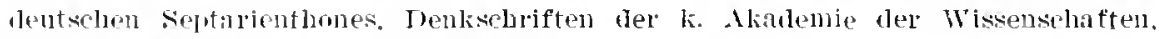

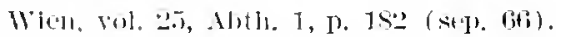

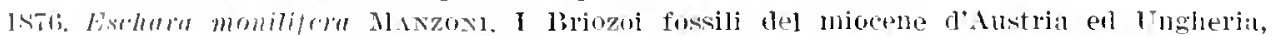
Denksch. mall.-natur. Chasse tel k. Akatemie ter Wissenschaften, Wien. vol. sit.

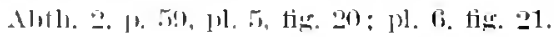




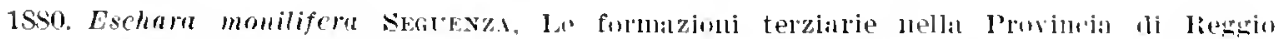

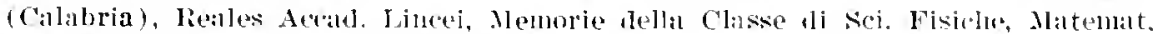

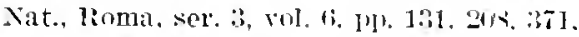

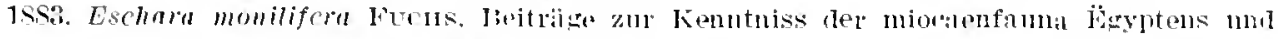

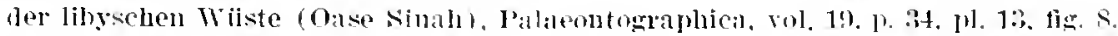

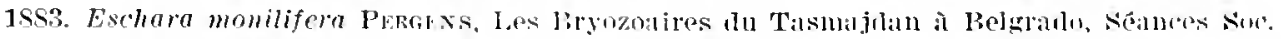
Roy. Malacolngique de Belgique, vol. 22. p. 9.

1Ss7. Eschara monilifera Pergess, Note préliminaire sur les Bryozonires fossilus los

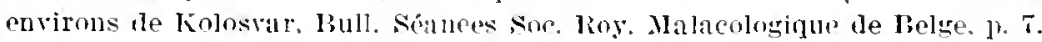

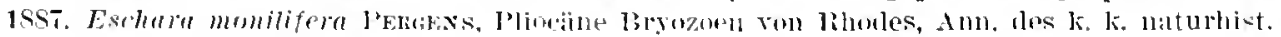
Hofmusemus, Wien, rol. 2, p. 2T.

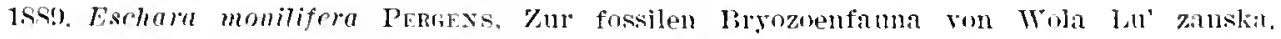
bulletin Societi Relge Grolorie, val. 3. Nimoires, p. 70.

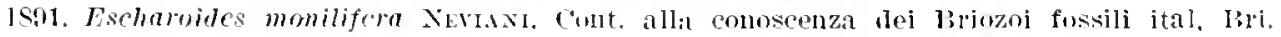

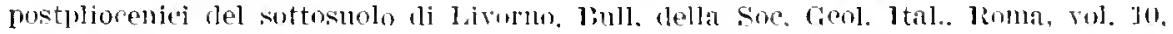
p. 125 (sep, 29).

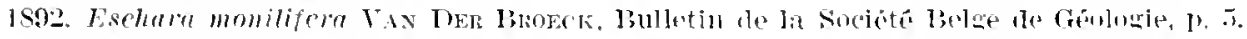

1894. Escharoiles monilifora Nevuxi. Terga Cont. alla connseona dei Briozni fossili it:1l.

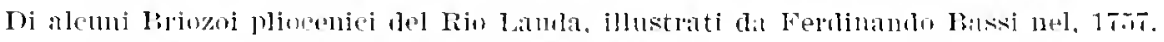

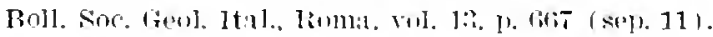

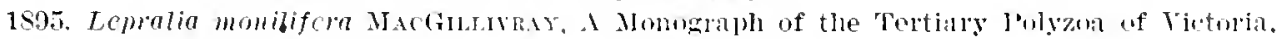
Transatiens Royal Suciety Victoria. rol. 4. 1). 76, 16]. 14, tig. 2S.

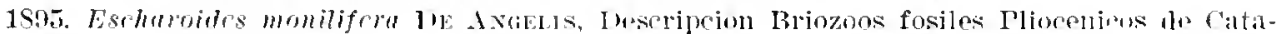

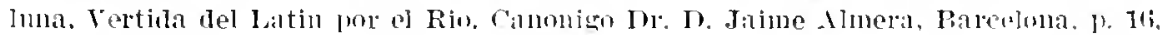
1). B. fig. 13.

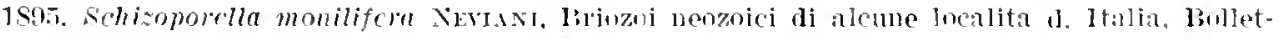
tina Societá Romana per gli studi zool., vol. 2. p. 298 (14).

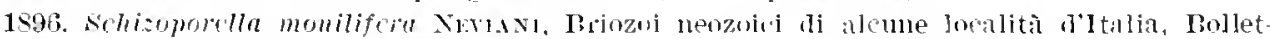

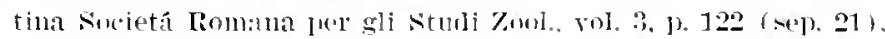

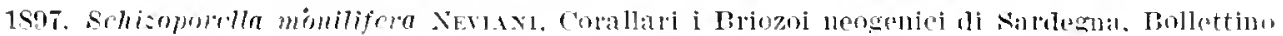
Societí Creologica Italia, Rolna, vol 1.i, 1) הs.

1S9S. Escharoides momiliferl J) ANGLLS, L, primeros antuzons y Rriozoos miocenieos

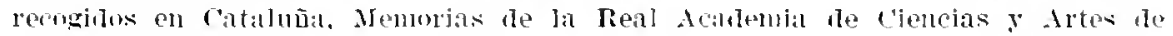
[3:1'celoni:1, 11. 24.

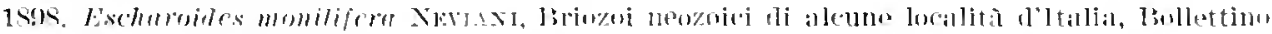

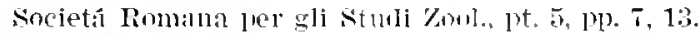

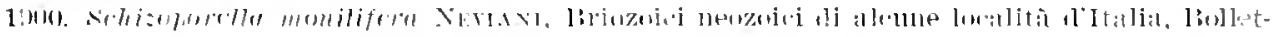

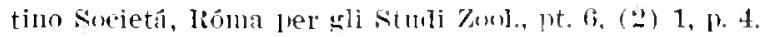

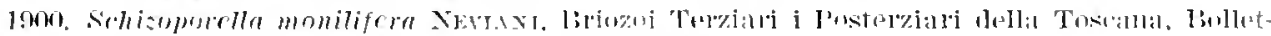
tinn soleta Geologien Italia, rul. 1!) 11. 20.

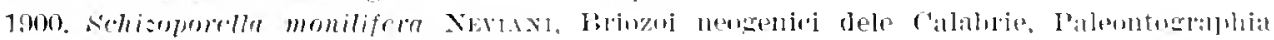
italiant, vol. 6, p. 197 (sepl. (:3).

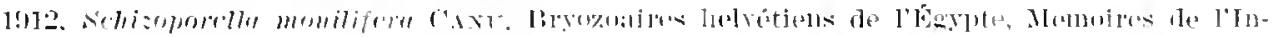
stitut entiptien, vol. 6. 1. 210.

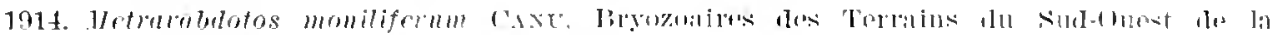

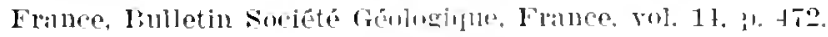

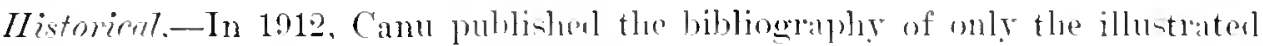
forms, but now we publish a eomplete hiblioglaphy. The generis determination has raried little and corresponts to the ereneral ideas of each time. Before 1s9., the species was known as Eschom. the chasification being zoarial. The inflence of

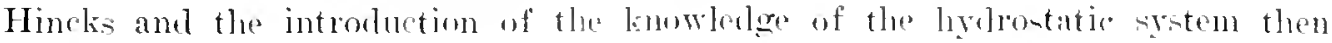


cansed it to be rlassified in schisoporm?ll. In 1914, the recognition of the ovicell sritem obliged Canu to create a new gemus in which he classed in addition Metrapablotos (Eschera) potymophem Reuss, 1869.

This species marle its appearance in Europe in the uppermost beds of the Priabonian; it does not exist in the bryozoan marl of the Priabonian. Its ocenrrence is therefore valuable for the sruchonism of the American formations. and it confirms the equivalence of the Vickshurgian witl the Tongrian. It appears to be exterminated in the I'pper Pliocene.

I'arintions.--This suecies has not remained exictly identical. throughout its long geologic persistence. The ovicell of the specimens from the English Cang (Plincene) is hambly costulate: the costules are quite visible and very clear in the French Miocene: they are finally rery salient and quite rigorous in mo imerican specimens. These variations do not seem to us of specific order. for the caleification of the zonria depends much on the richness of the waters in lime.

The restoration which we have attempted (fig. 1) indicates a ramose zoarium branching dichotomously in the same phane; its total length seldom exceeds 3 or $t$ rentimeters.

The sinus of the apertur: shows a small, very fragile lyola whose function is unkuown for it does not apjear jelentical with the lyrula of smittina.

The zonecia are convex (fig. 3) or marginate (fig. 2); but always borkered witl numerous and triaugular. large areolae generally visible in the interior (fig. 6 ).

The froutal of the ovicell (fig. 5) is vely fragile and moreover often wanting on the fossils. The longitudinal section (fig. 10) is the habitual section of the endozonecial ovicells: the larvae onght to be very large. Tho orifice of the ovicelled zooecia is three times larger (7te=0.30 insteal of 0.10 mun.) than the apertura of the ordinary zooecia. 'Tlue tangential section (fig. s) shows by its lateral retienlafions and its sinous mertian line. the presence of a plemocrst reposing on the olocyst but this appears very thin and is never seen exteriorly.

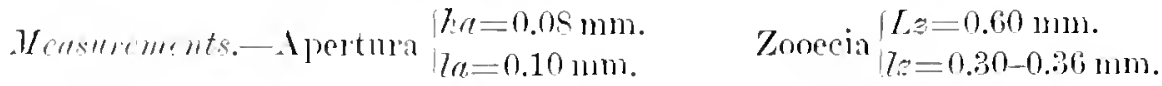

Maximum width of the fromts $=2 \mathrm{~mm}$.

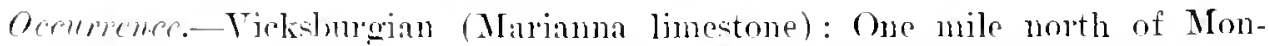

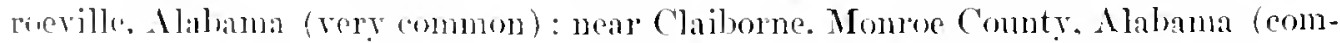
men ) : 21 miles north of Millry. Washington Countr. Mlahama (rare) : Ticksburer. Miscissippi (commom in the ]ower beds).

Grotogiral distribution.-Priabonian of Transplyamia and Galieia (Pelgems). I atrloufian of Germany (Rouse. Stoliczka). Rupelian of Germany (Rellsi). Chatrian of Germany (Remss). Burligalian of Spain (Do. Ingelis). of the Garel (Canu). Ifolvetian of Tombine (Michedin), of Spain (Desogelis). Tortonian of Servia

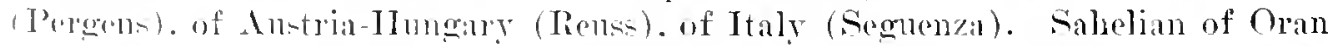

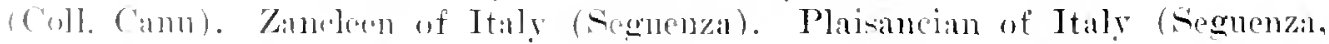

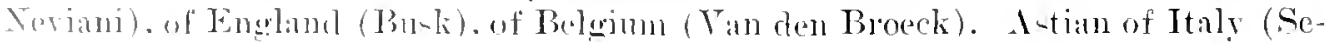


guen\%a). of Belgimm (Tan den Broetk). Miocene of Amtralia (Machilliviay) and of New Zealand (Machillivay).

Plesiotypes.-C'at. No. 64316. L.A.N.MI.

MFTRARABDOTOS GRANDE, new species.

I']ate (4), figs. 11-15.

Iheseription.-The zoirinu is free. arboresent. branehed thehotomously in the same plane. The fromls are namow, compressed. often twistel. The zonecia are clongated, distinct, fusiform. the frontal is convex, smrounded by areolac, and formed of a granular plenoeyst mited to the olocyst. The apertura is oval and formed of a semilunar anter and of a loroad. triangular rimule. in which a very small lyula is placed. The peristome is hardy salient. The oricell is endozooucial. enormons, with a frontal ormanented with larger: radial costules.

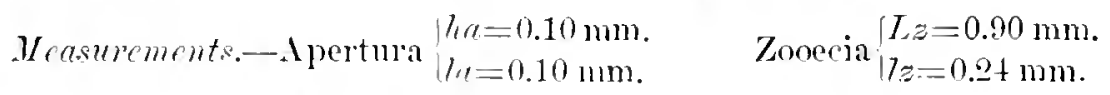

Wietlle of branclese $=3$ to $5 \mathrm{~mm}$.

Tariations.-The zoarium bears some tuberositics (fig. 1.i), partitioned in the interior, which serve perhaps as zoarial hydrostatic apparat 11 .

The frontal walls of the zouccium are very thick (fig. 15), whereas the lateral walls are quite thin (fig. $1 t$ ).

This species is rely abuntint in the locality in .Tasper County. Mississippi. It alone numbers many more specimens than all the others combined and constitutes almost alone the Cheilostome fanna of this locality. It oceurs here in clay. which halitat it seems to prefer. This is also the case in the lestramblotos potymorphum Reuss, 1869, which lived in France in the clay of Gaas.

We have attempted a restoration of this remarkalile species: the zoarium must attain fiom $i$ to 10 centimeters in length.

Affinitiss.-This species difters from Metrabulotos momilifinm Milne-Edrards. 1836, in its longer zonecia ( $I z=0.90 \mathrm{instead}$ of $0.60 \mathrm{~mm}$.). in the absence of small oral a vicularia. and in a much langer zoarium. and with wirler frouds $(3-5 \mathrm{~mm}$. instead of $2 \mathrm{~mm}$.).

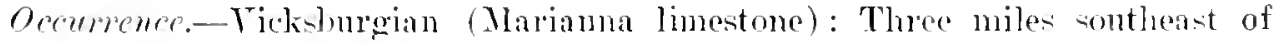
Voshmer. Tasper Comnty. Misissippi (rery common).

Tiekshmogian (Red Bhull eliy ) : Soven aud one-half miles conthwest of Blarlen

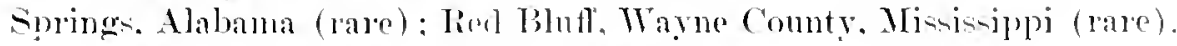

Cotypes.-Cat. No. litint. T.M.X.M.

Genus WATERSIPORA Neviani, 189. .

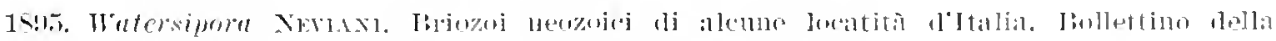

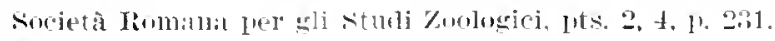

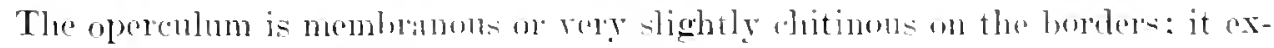
libirs a chitimons axial hamb of a hown color. manking ont from the rest of the operenlum two lateral -paces. which are clearer and which rorrespond to the two 
powerful cardelles borne ly the zooccial orifice. The frontal is a tremocyst. 23-24 tentacles.

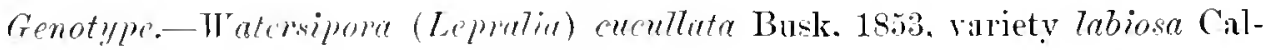
vet, 1903.

Range.-Helvetian-Recent.

The genotype is quite variable; the published figures resemble it but little because of the very irpegular development of the two labial appendages of the aperture. In 189.5 Neviani. ignoring the operculum, created for it a subgenus of

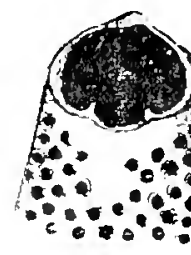

A $、 50$

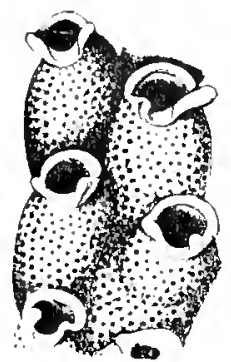

$\mathrm{G} \times 35$
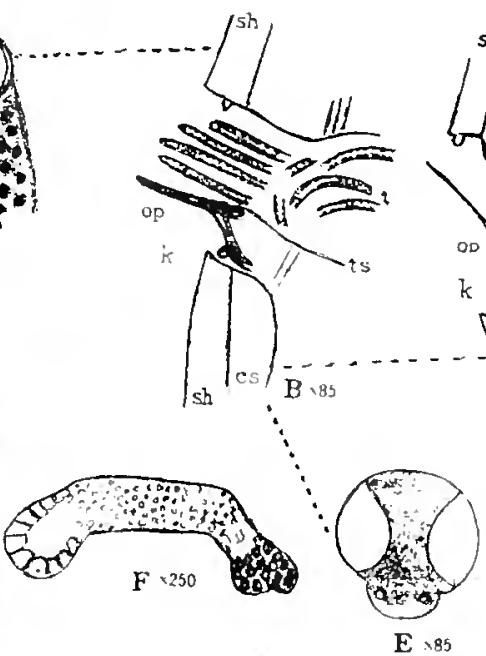

$\mathbf{E} \times 85$
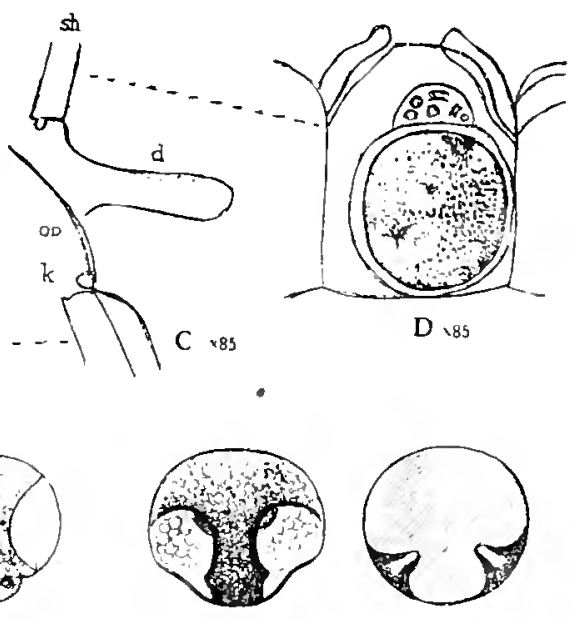

Il 90

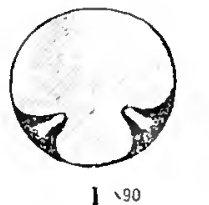

F1G. 158. Genus Itatcrsiporn Neviani, 1895.

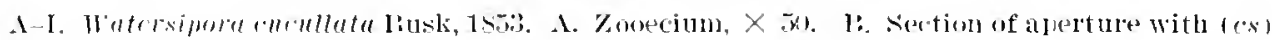
(omplemsatrix, (k) knols of operculum. fop) operculum open, (sh) frontal walls of zowecium, (t) tentacles, $(t s$ tentacular sheath: $\times$ sis. C. Aperture wilh operculum nearly elnsed: (d) diapluragm, $X 85$, $D$. Transverse section of a zonecium near the clistal end, sluowing the larva near the base of the zorecium, $X 85$. W. Operenlum membraneous or somewhut chitineuts. $\times$ 85. F. Commencement of glands growing on the (1)erculum. $\times 20$. (1-F a cter Waters,

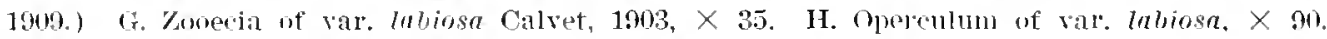
I. Aluertulas of rar: labiosm, $\times$ so. (G-I after Calvet, 1903.)

Smittic muder the name of thatersipom. The great difterence of the opereulnu by its rigos ma justify the existence of a new genus. although the function remains idntical. Noremer, in order to preserve the genus, it will be necessary to complete the aecoription by fiutler sturlies.

WATERSIPORA (?) ERECTA, new species.

Plate 6!U, fig. 15 .

Deseription.-The zoarinm is flee, crect, with two lamellae. back to back. The zoonela are alongated. little distinet: the frontal is smootle and little convex. The 
aperture is buried at the bottom of a peristomie; it is irregular and formed by the derelopment of two lateral lips. separated by a psendorimule. No avicularia.

$$
\text { Measurements.-Zooecia }\left\{\begin{array}{l}
T_{z}=0.50 \mathrm{~mm} \text {. } \\
(7 z=0.25 \mathrm{~mm} \text {. }
\end{array}\right.
$$

Affinities.-Only the figured specimen has been found; it bears no oricell. It differs from the type of the genus in its smooth and nomporous frontal and in its zoarium. which is free and loes not incrust algae.

(Jecurence.- Tpper. Jackisonian (Oeala limestone): Nlachua, Floricla (rare). Ilototype.-Cat. No. 6\$1S1, T.N.X.M.

\section{Family TUBUCELLARIIDAE Busk, 1884.}

Bibliugraphy (Anutomical).-1907. WArers. 'Tubucellaria: its Species mul Oviculls, Jomrnal

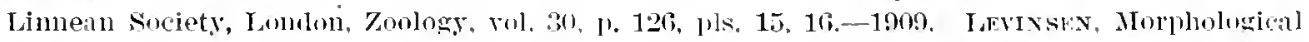
and systematic stuclies on the Cheilostomatous Bryozon, 1\%. 304. pl. 16. figs. 3. 4. 5.

The zonecia have no spines; theil frontal is formed of long tremocystal tulules sumounting a thin perforater olocyst. The septulae are numerons, scattered, and multiporous. The ovieell is restibular, being formed by a great expansion of the peristomie. which is always very long. The frontal bears an ascopore opening into the compensation sac.

Teminotog!.-The very considerable thickening of the frontal derelops a very long peristomic, the lower orifice of which is elosed by the operenlum and forms the true apertura: its onter orifice is the peristomice, which is more irlegular in form. The latter is surounded ly a more or less thickened and salient peristome. Exterioly, the upper part of the zooecia, which eorresponds to the peristomie, is the peristomiale.

Anatomical strueture. - The zonecia are provided with elosely placerl pits or areas separated by ridges, each surromming a pore. This disposition is the rule when the tremoeyst corres a perforated oloevst. These pits or areas are the extremities of well developed tubnles. as in the family Myriozonmidie.

The oricelled zooecia have a particular form like the gonoecia of the deleonidae: but they have not at all the same structure. The larvae develop in a large expansion of the peristonic, forming a peristomial ovicell. In its interior. there is at first a normal polypide. This disappoars ly listolyis and a diminutive and rely vigorons polypide succeeds it. in which the circular canal and the gangion may he observed. This communicates with the opening of the oricell and is accompratied by a rolmminous oratry.

The cliaphragm (ivisoill) is attached to the operculum and to the wall.

There is a large number of delicate muscles attached to the compan-ation sac, and the latter communicates with the exterior ly the ascopore.

The zoarinm is free, mnilamellar, hilamellar. or cylindsical. It is often articn-

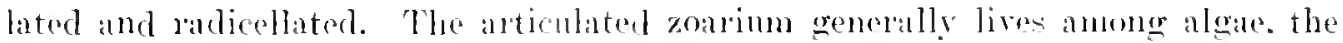
mobility and flexibility of whirh it mut whare. 


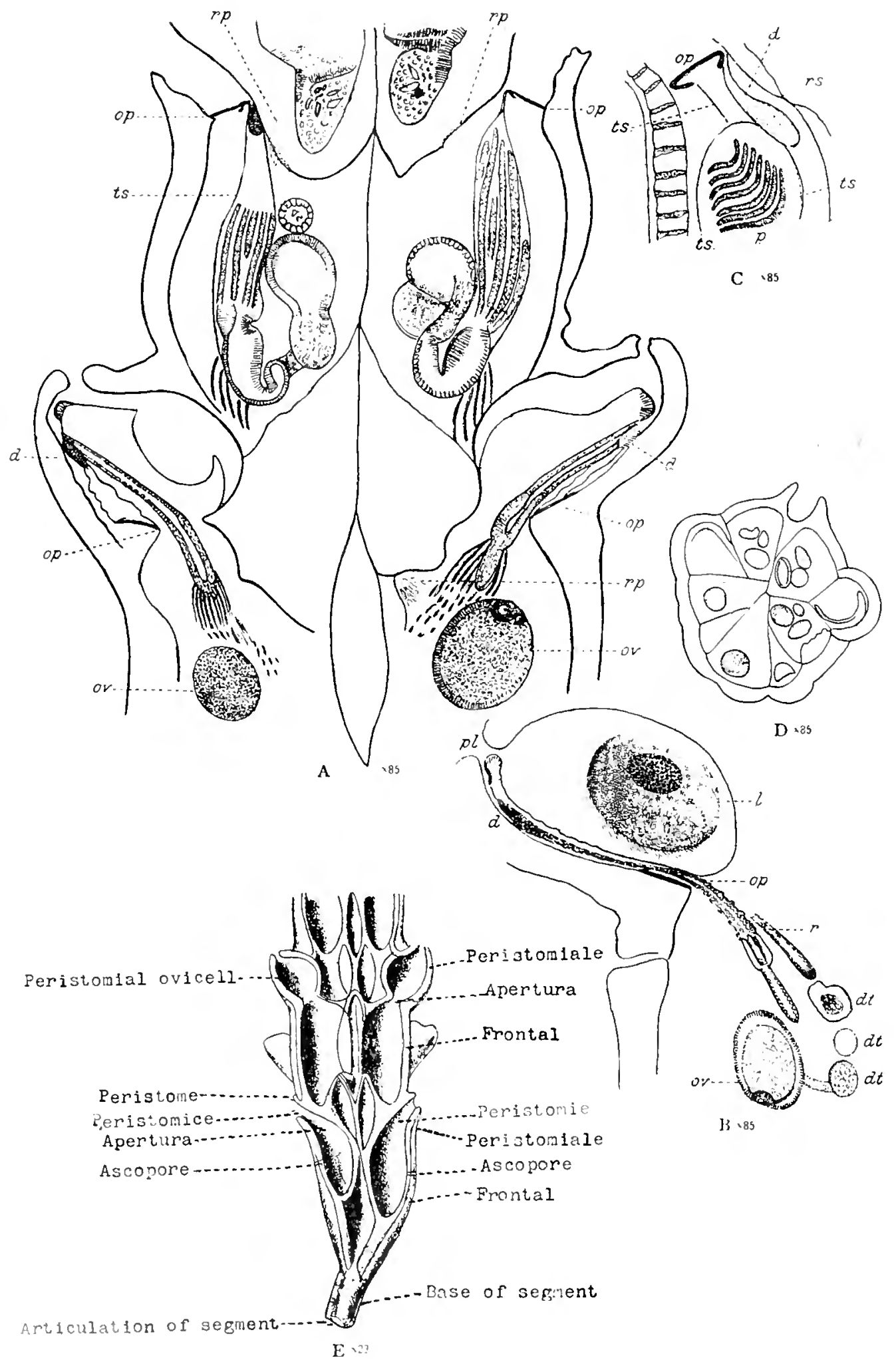

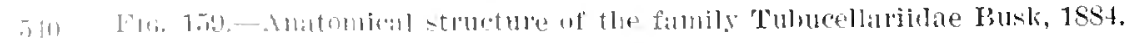




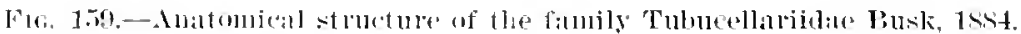

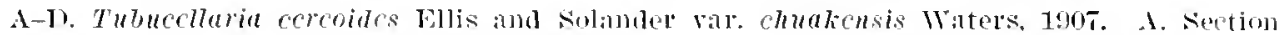
through two ordinary polypiles and two peristomial ovicells. This is all absolute culy of ome section, though in two or three cases where the operculum had not been well cut through that cetal hal to be taken from the following sectim. In the peristomial ovicell the plus is seen

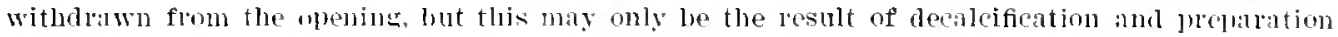

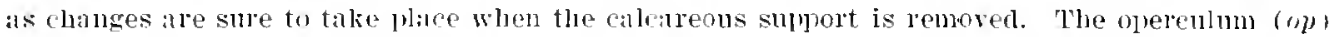
has opened the peristomial oriecll ful the fassage of the diminutive polphide. and the pusition

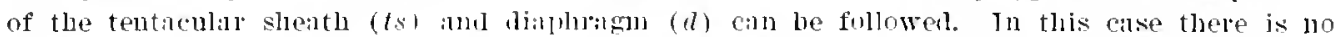

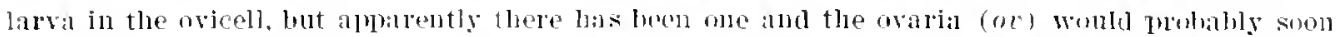
furnish others. The parenchru passing through the rosetle plate is secn at rn; $\times$ s. T. B. Sec-

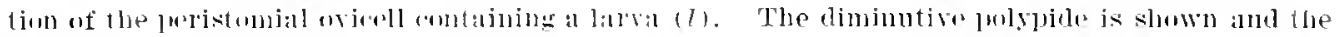

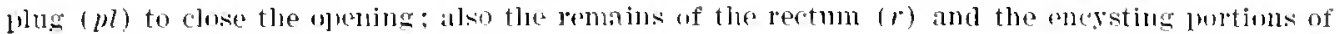

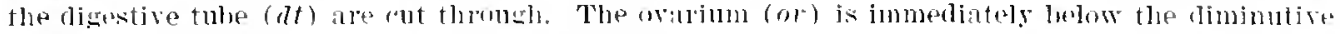
polypide, and there ale parenohym lureals (mesenchyme) from it to one of the cysts. This

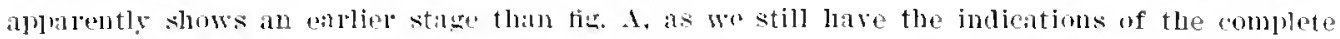

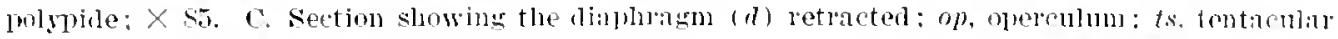

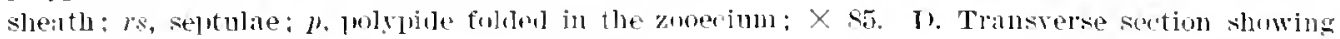
compensatrix, $\times$ s5. ( $1-1)$ after Witters, 1907.)

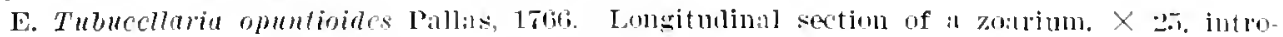
duced tu show terminolusy. (Aftel Levinsen. 1imn.) 


\section{Gencric Table.}

Zoarium alticulater. No arirularia Tubucellaria.

Zoarium fixml, bilamellar. Aviculatia rery ralle

Tubucella.

Zoarium unilamellat. Aricularia on each zonecium

Tubiporclla.

The prefix "tub" might well remain the characteristic of the family in the creation of new genera.

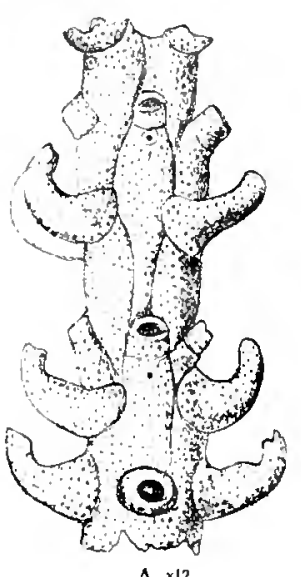

A $\times 12$

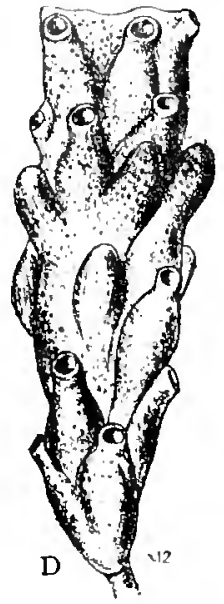

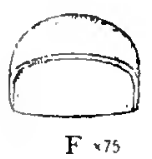

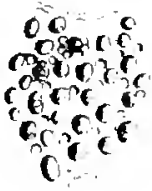

E
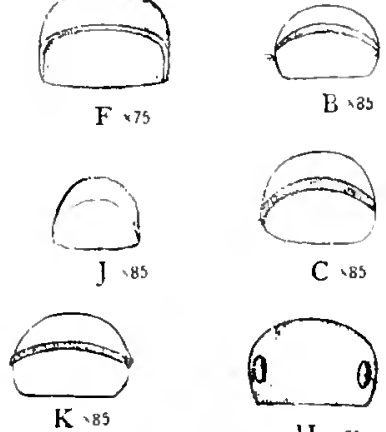

11.75

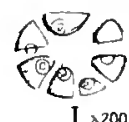

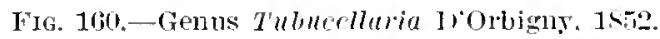

A-C. Thunecllaria ceroides Ellis and Solander, 1786. A. Iortion of a zoarium, $\times 12$.

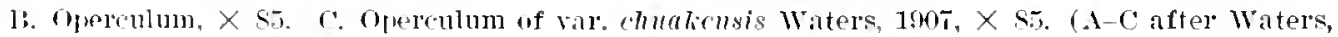
1907$.

I-F. Tubucllaria opuntioides Pallas, 1766. D. I'oltion of a zoarium, $\times 12$. F. Aspect of the surface of a zocecium. The ascopore is seen distally. F. Opereulum, $\times \quad 75$. ( ए-F after Levinsen. 1909.)

G-I. Tutucrllaria hirsut Limournux, 1516. G. A part of the surface of the zooecium. The ascoune is seen ristally. I1. Opelenlum, $X$ 75. I. A separating wall with septulate, the pusition of which is at the proximal end of each of the threat-shaped appendages: $X$ 2on. $1(\mathrm{x}-I$ after Levinsen, 1909.)

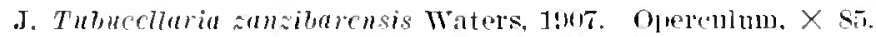

K. Tulucellaria fusifomis lorbigny, 15,2. Uperulum, X S5. (J, K after Waters, 1907.)

\section{Genus TUBUCELLARIA D'Orbigny, 1852.}

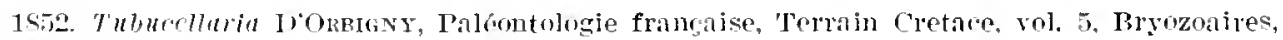
ก. 395 .

The zoarium is articulated and radicellated. The operoulum is simple and separable. No vestibular arch. no a vicularia. 22-27 tentacles.

Genetype.-Tubueflerien (Cellaria) cereoidtes Ellis and Solander. 1786.

Rang.-Isutetian-Recent.

The oldest species is Tuluerellaria fragilis Michelin. 1845, from the French Iutotian. In Europe the known Oligocene species are rather confused and do not permit nseful comparisons with the American forms; their ocenrence. moreover, is very rale. 
TUBUCELLARIA PARYiporosa, new species.

Plate 70, figs $1-4$.

Deseriptzon.-The zoarium is articulated the segments are cylinclrical and rery long. The zooecia are much elongated. distinct, fusiform: the frontal is convex and covered with small closely arranged pores: the peristomiale oecupies tlye npuel fourth of the zooecia and is separated from the frontal by a small furrow. The peristome is round, little thickened. salient. arlanged obliquely or normally on the segment. The ascopore is situated on the frontal below the peristomiale. The ovicelled zonecia have a much larecr external aperture.

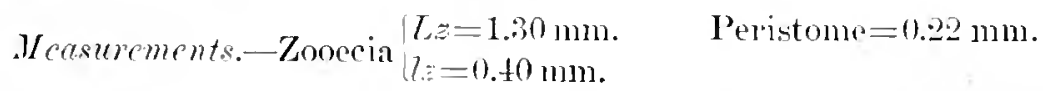

Affinitics.-The system of branching is the same as in Tuluerellaria fallax; lut T. pareiporosa is distinguished from that species by it much smaller frontal pores and by its greater zooecial length $(1.30 \mathrm{~mm}$. instead of $1.10 \mathrm{~mm}$.).

It differ's flom T'mburellurin richaburgica in its smaller pores, its less zooceia? length $(1.30 \mathrm{~mm}$. and not $1.40 \mathrm{~mm}$. $)$. and in its system of branching not borne on a large calcareous process.

We have observed a closed zooceium in which only the ascopore persists. What could be it physiologic nse in the absence of the polypide?

Occumence.-Midule Jacksonian: Baldock. Barnwell County. South Carolina (common).

Cotypes.Cait. No. 6+18.2. T......M.

TUBUCELLARIA FALLAX, new species.

Plite 70. figs. 5-10.

Description.-The zoarimm is articulated; the segments are cylindrical and short. The zooecia are elongated. distinct, fusiform; the frontal is convex and covered with polygonal pores: the peristomiale ocenpies the upper fouth of the zooccia and is not separated from the frontal. The peristome is round, thin. salient, and arranged rery obliquely to the segment. The ascopore is situated on the frontal below the vestibular area. The ovicelled zooecia have a much lal'orer external aperture.

$$
\begin{aligned}
& \text { Weasurements.Zonecia }\left\{\begin{array}{l}
T_{z} z=1.10 \mathrm{~mm} \text {. } \\
l z=0.35 \mathrm{~mm} \text {. }
\end{array}\right. \\
& \text { Peristome }=0.20-0.25 \mathrm{~mm} \text {. } \\
& \text { Peristomice / fricellod zooecia }=0.20 \mathrm{~mm} \text {. }
\end{aligned}
$$

Tariations.--The articulation in the American species is rather different from that which we have observed on the recent forms. On the latter. in the immediate neighborhood of the peristome, there in a large pore or sort of chitinous joint which maintains the upper segment. On Tuburellaria fullar aud $T$. parriporose there are two pores in the vicinity of the external aperture, and the zooevia which bear 
them are not provided with an ascopore. We have as yet collected no segnent preserving the base, and we are therefore ignorant of the signification of these pores. It may le presumed that one pore is intended for the chitinous joint and the other for a radicell (figs. 6. 7 ).

The tubules in becoming elongated also increase the diameter of the segments ond the width of the zooecia (figs. 8. 9): but this is a very rare variation. The peristomiale presents pores a little larger and arranged at the hase of longitudinal cimals.

The oricells are lare convexities, of which the external apertures $(0.20 \mathrm{~mm}$. are nuch larger than those of the ordinary zooecia $(0.12 \mathrm{~mm}$.).

At the locality near Pery, Georgia, a segment was found with burge pores and with rely thick peristomes. which we think belongs to this species (fig. 10). but of this we are not absolutely certain.

Affinitics.-This species differs from Tubucellaria parviporosa in having somewhat larger pores and much shorter zooecia (lz=1.10 $\mathrm{mm}$. instead of $1.30 \mathrm{~mm}$.). It may be distingnished from Tubucellaria vicksbugien by its smaller frontal pores, its shorter zooeria $(1.10 \mathrm{~mm}$. instead of $1.40 \mathrm{~mm}$.). and by its system of articulation, which does not liave a rery salient process.

This species is rather decrieing in its quite variable extermal aspect. It may ouly he determined with certainty by the aid of micrometric measurements; it is the smallest of the Imerican Tubucetlaria.

Occurpenee.-Middle Jacksonian: 18 miles west of Wrightsville. Johnson Comnty, Georgia (rare): $3 \frac{1}{4}$ miles soutl of Perry, Georgia (rare); one-half mile sontheast of Georgia Kaolin Co. mine. Twiggs Comty, Georgia (rare); 17 miles northeast of thakinsville, Georgia (very rare).

Tpper Tacksonian (Ocala limestone): West bank Sepulga River. Escambia County, Alabama (rare).

Cotypes.-Cat. Nos. 6-1183-6it18.). T.A.N.XI.

TUBUCELLARIA VICKSBURGICA, new species.

Plate 9 $\overrightarrow{\mathbf{\imath}}$, firs. 1-16.

Thescription.--The zoarium is articnlated, composed of large, long. cylindrical segments: the younger sements have only one hasal pore. but the older ones have two of them. The zooecia are much elongated, distinct, swollen; the frontal is covered with lare, polygonal pores: the peristomiale is not distinct from the frontal. The peristome is rery salient, olsique, thin in the young zonecia, rery thick in the old ones. The ascopore is litge $(0.02 \mathrm{~mm}$.). The ovicelled zooecia have a larger' external aperture.

$$
\begin{aligned}
& \text { Old zouncias } \\
& \text { Vimne zororeist. }
\end{aligned}
$$

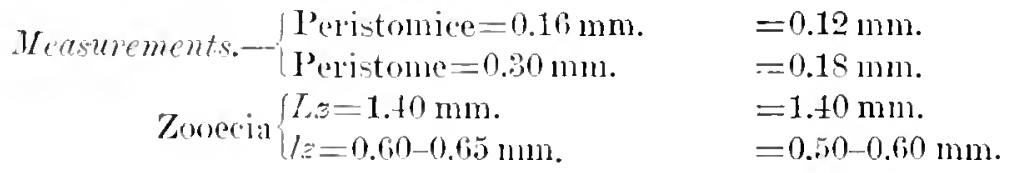


Tariations.-In the recent species of this genus calcifieation is lather reoular,

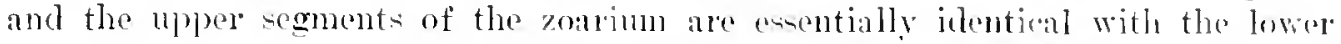

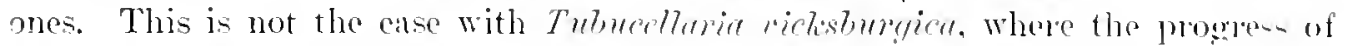
calcification is not equal in either one w the other. 'This has resulted in rerv clifferent external aspects. but it is easy to lind good intermediate stages. for, fortunately, the speeies is not rave.

On the roung zonceia the peristome is rery salient (figs. 2. 8) or slientity salient (fig. 4 ): the poses are then elisposed at the base of the small longitminal anals. The peristome is thicker on the intermediate specinens (fig. 1.i), and on the segments of the lase of the zoarimm it is very lade and hides all of the peri-trimiale (fig. S).

The system of ramification is res rematkalule. The zomecimm luals in place of the usual peristomie an enopmons. very prominent apophrsis perforated by two (fig. 15) or fom (fig. 8) very large pores. The base of the branched segments mesents the same di-position of two (fig. 11) pores. We must therefore artmit that the segments are thus unitud to each other hy means of a corneous double joint : the apophysis with four pores bears perhaps two segments of lamification. It the end of the segments the branching takes place in the same mamer. lint without prominent processes (fig. s). The zooecia which branch and articulate in this way are unprovided with an aseopore. We have attempted a restoration (fig. 1) of the base of the zoarium: the numher of specimens did not permit us to complete it with young segments. The latter bear only a single pore at their base and are joined to the other segments only hy a single chitinoms joint, according to the aeneral rulu.

The tubules are not crlindrical; their diameter is augmented withont cessation: consequently the frontal pores are smallev on the poung segments (figs. 3. t) than on the old segments (figs. 8. 15). The progress of this calcification deforms the zooecia and the peristomiale is sepratated from the frontal by a small furow.

There are -ix longitulinal rows of zooccia to each segment.

The longitudinal section (fị. 19) unfortunately does not inchele an oricell.

The tangential thin section (fig. 16) shows a tremoryst. of which the pures are separated by a complex and rery chalucteristic network.

In the interior (fig. 13) we note ar rery thin olocyt, of which each mill poyforation engenders a funnel-shaped tubule. This same armanement moy be easily studied on the liring specimens. This solt of tubule mar not le limified an in Myrozonm, since its snccessive widening ofl'-ets the increase of rolume.

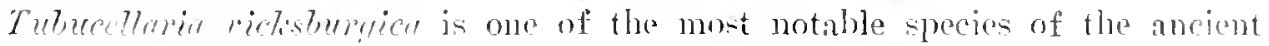
early Trutiary rult.

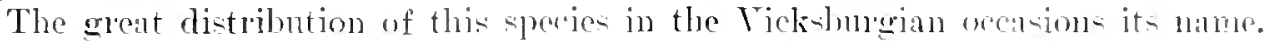

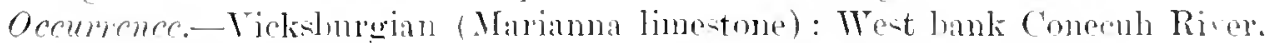

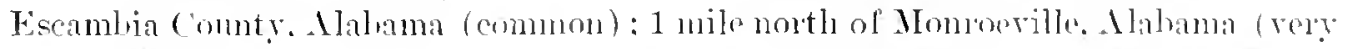

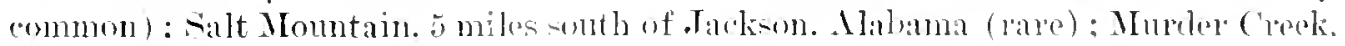
eat of (antlebury. Mlabimal (l'are). 
Vichsburgian (Byram marl): Byram, Mississippi (rare); Woodward, Mississippi (very rare).

V'icksburgian (Red Bluff clay) : Seven and one-half miles from Bladon Springs, Alabama (lare) ; near Claiborne. Momoe County, Alabama (rare); $2 \frac{1}{2}$ miles north of Milhy, Washington County, Alabama (rare); Vicksburg, Mississippi (rery rare in the lower beds); deep well. Escambia County, Alabama.

Cotypes.-Cat. No.64314. U.S.X.M.

TUBUCELLARIA NODIFERA, new species.

Plate 70, figs. 11-17.

Deseription.-The zoarim is articulated and formed of rather long cylindrical segments. The zooecia are rery elongated, distinct, fusiform; their frontal is convex and ornamented with polygonal pores; the peristomiale is not separated from the frontal. The peristome is salient, thin, disposed obliquely on the segment. The ascopore is large and placed on the frontal; it opens into the zooecia. Certain verticells of zooecia present a very salient, extremely noclose frontal, which characterizes the species.

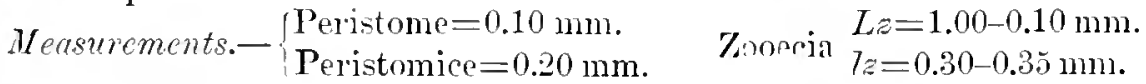

Affinitics.-The nodosities which ornament the segments of this species are quite original; they result from the considerable growth of the tubules orer the ascopore (fig. 16). Probably on accomnt of equilibrimm there are always tro series of nodose verticells to each segment (fig. 14); the three thick upper zooecia are placed in quinemx with the three thick lower' zooecia. 'These verticells have not always exactly the same rolume (fig. 12). We can hardly conceive what particular adaptation could correspond to this special arrangement.

No fossil or living species presents the peculiar character of this species and comparisons are therefore not necessary.

Occumence.-Upper Jacksonian (Ocala limestone) : Alachua, Florida (common ).

Cotypes.-Cat. No. (5t186, U.S.N.M.

\section{Subgenus Tubucella Canu and Bassler, 1917.}

1917. Tubucellu CANo and PAssier. Symopsis of American Early Tertialy Cheilostome Pryozoa, Bullotin 90. Thited States National Musenm. 1. 62.

The zoarium is free, bilamellar, firmly attached, rigid. The avicularia are very rare. The peristomiale is equal to the frontal.

Genotype.-Tubucella (Eschara) mammillaris Milne-Erlwards. 1836. ${ }^{1}$

Renge.-Lntetian-.Tacksonian.

The articulation is not a function; it is a mode of adaptation on a mobile substratum. We are, therefore, not able to consider the nonarticulated species as

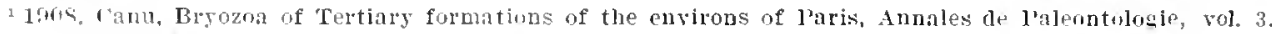

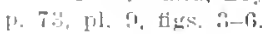


forning a special genus. An artificial subgenus appears to us nseful for classification.

The only known described species of this gemus are Tutucella mammillaris Mi]ne-Edwards, 1836, of the Lutetian-sannoisian of Europe and Tubucelle pupitlosa Reuss, 18t7, of the Priabonian of the Ticentin. We have discovered two species in the American deposits.

TUBUCELla MONiliferA Canu and Bassler, 1917.

Ilate 70, figs, $18-25$.

1917. Tubucella monilifera Caxu and B.ssler, synopsis of American Early Tertiary Cheilostome Bryozoa, Bulletin m;. L'nited States National Musemu. P. 63. ]ll. 5. fig. 9.

Description.-The zoarium is free: the two lamellae are placed back to back and intimately joined; the from ts are broad, compressed, distorted, and branching. The zooecia are much elongated. fusiform. little distinct. surrounded by a coller of large pores; the frontal amd the peristomiale are of equal length, sepalrated by the ascopore and perforated with small hexagonal pores. The peristome is salient, thick, oblique. The aricularia are very rare, large, transverse, elliptical. usually with two denticles for a pivot.

$$
\text { ILeasurements.-Zooecia }\left\{\begin{array}{l}
L=0.90-1.00 \mathrm{~mm} \text {. } \\
l_{z=0.92} \mathrm{~mm} .
\end{array}\right.
$$

Tariations.-The zooecia are rery constant in their exterior aspect. The larger pores surround the peristomiale and are three times larger than the others.

Certain fronds bear some zoocia (fig. 20) closed not by the olocyst, but by the tremocyst, the tubules of which have encroached upon the peristome. The plypsiological function of these zonecia is unknown.

The aricularia are scattered. are very large, and form a very large frontal (fig. 21), the origin of which is one of the lateral pores of the periatomiale.

We hare often noted before the faculty of the trenocystal buds to transform themselves into a ricularia.

Oricelled zooecia have lieen ohererverl and are illustrated in figure 22. where. also, an aricularium with pivot may he noted.

In the interior (fig. 21) we have noted a very thin perforated olocyst surmounted by a tremocyst with tulules. The ascopore opens very far from the aperture and the peristomie. In compsing the extreme simplicity of this internal structure with the beauty and regularity of the exterior ornamentation. We nunst admire the splendor of the work of the buds of the endocyst. Whose calcarents deposits so successfully modify the anect of the rooccial.

Affinities.-This species differs from Tubucelle mommiluris Mihne-Edwards, 1836. in its nonprominent ascopore and the absence of large globular ovicells.

It differs from Tubueflin pepitlese Reus. 18ti. in the alsence of the arehed ovicelled zooecia and its much -traighter fronds. 
It differs from Tutumetln githose in the absence of large zoarial gibbosities around certain peristomies.

On aceount of the size of the framents this is an easily recognized fossil.

Occumence--Nildle Jacksmian: Wilnington. North Carolina (common): Eutaw Springs south Carolina (rery rare).

Cotypes.Cat. No, fiegos. T.S.X.IT.

TUBUCELIA GBBBOSA, new species.

Plate 71, figs. 1-9.

Thaspiption. - The zoarium is free, bilamellar. dichotomously branched: the fromels are wide and compressed. The rooecia are indistinet; the peristomiale is

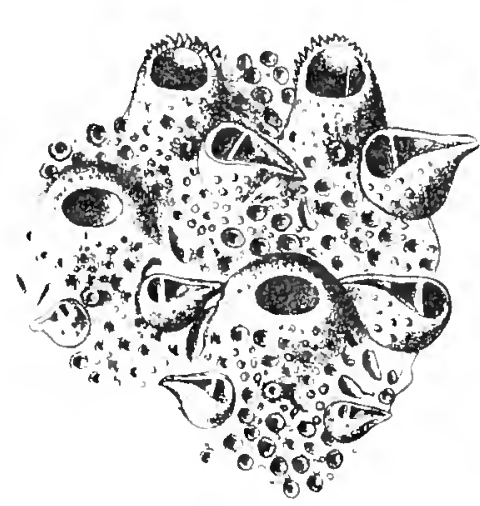

A $\times 23$
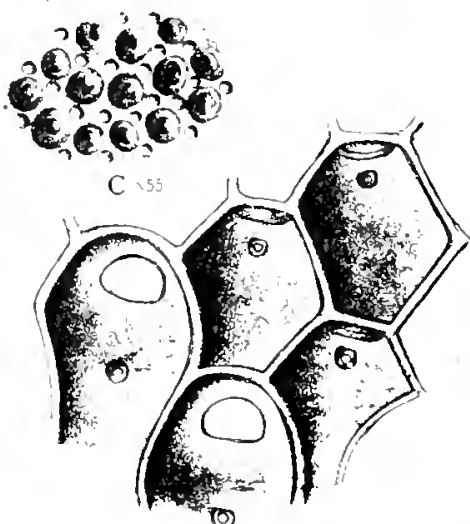

$\mathrm{B} \times 23$

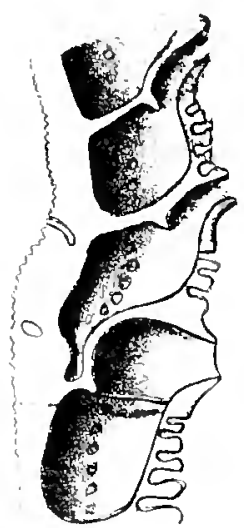

$\mathrm{D} \times 17$

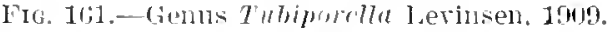

1-1\%. Tubiportla matghostris Mactilivay. 1452. A. Goup of zonecia showing two peristomial wicells, $\lambda 23$. F. View after lemoval of thr hasal sulface. Two ovicells ale seen and

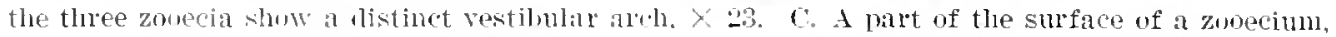

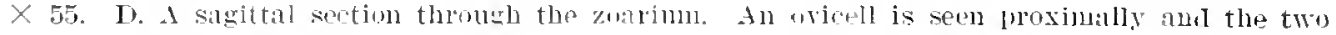
zoowia show a restibular arch at the beginuing of the pelistomial tube, $X 17$. (A-D aftel Levillsell, 10(!).) ,

a little smaller than the frontal and they are separated from cach other by a small ascopore; the pores of the frontal are al little smaller than those of the peristomiale. The peritomie is salient. little thirlened: the peristomie is rel'y long and arehed. Around the peristomie of certain zooecia the tubules are much dereloper, forming on the zoarim very prominent gibtositis.

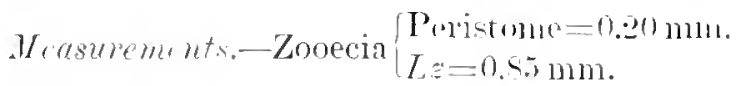

Iffuitis.-The eriblowities which characterize this species are quite original. 'The section whing we have prepared (figs. 8, 9) show that they result from the extrandinary development of the tulule aromit certain peristomies. The zonecia which bear them are without oricells. In Tubucellarie notose it is. on the eor. 
11:4ry. the fiontal tubules which are much cleveloped about the ascopore: this is a fundamental difference. We are alu ignorant of the physiological purpose of the development of the peristomial tulumes.

The length of the tubulec is al way rery variable, as can he noted on the figmed sections (figs, 6,7 ).

We have been rather fortunate in reconstructing a part of the zonrium, the dimensions of which oneht to attuin about foul or five centimeters in Jength.

It ia vely easy to distingui-h this species from all known fornt

We have not had the chance to diseorer the oricell in the eight sections which have heen stirlied.

nemenener--Middle otak-mian: Lemuls Ferry, soutl Carolina (common).

Cotypes.-Cat. No. (it1it, I.S.X.M.

\section{Genus TUBIPORELLA Levinsen, 1909.}

1909. Tubipor lla IevTxsex. Hurphological and stytematic Stulies on Cheilustu. matous Bryozon, p. 80.5
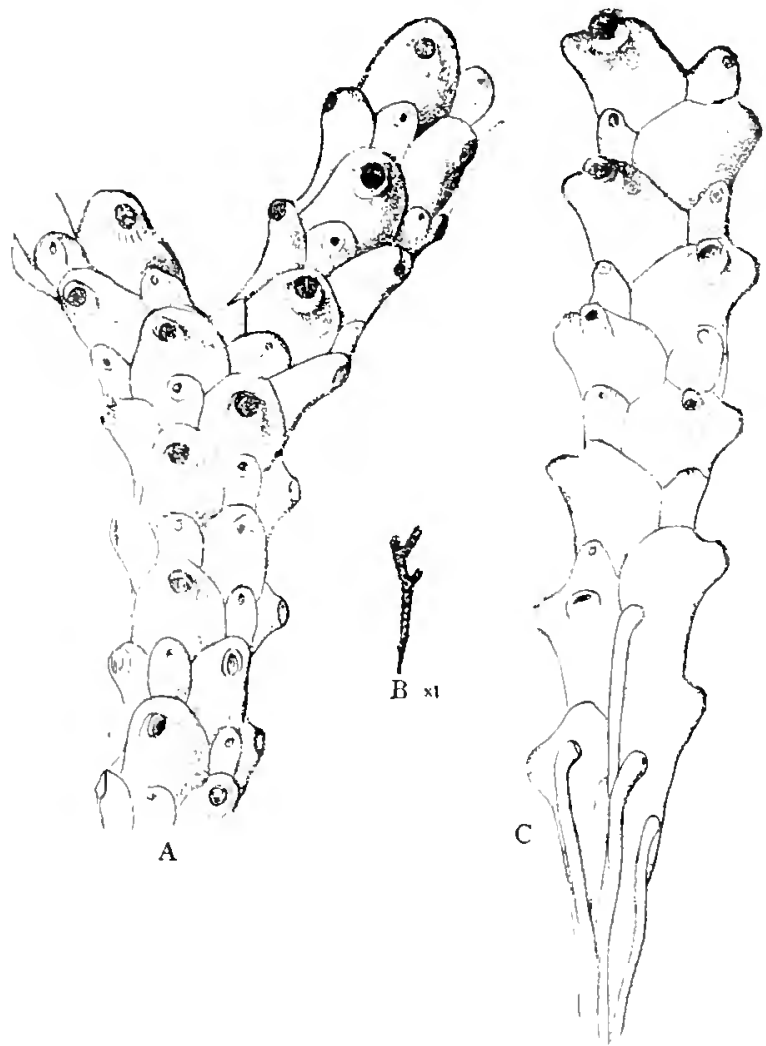

A membraneous opercular valve. I restibular arch. varh zooccium with one or two arielularia at the height of the as(u)jore. The colony occurs as a flee. foliaceous expansion with a -ingle layer of zooecia (Levin-('n).

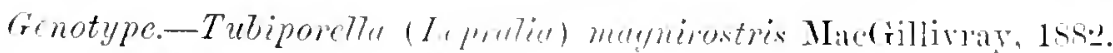

Range.-Miocene-Recent.

\section{Genus SIPHONICYTARA Busk, 188.}

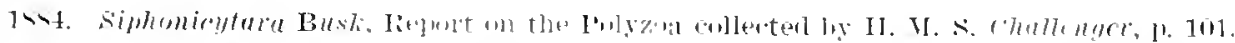

Busk, in 18st, placed in this fimily his new genus siplumicytart. speciunens of which have never been fomm -ince and fon which reanon it has not heen posible

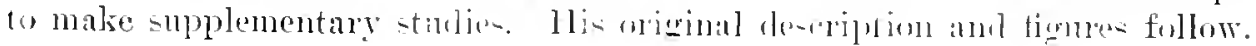


"Zoariun continuous. rarlicate. brancherl. branches alternate, subcylindrical ruadriserial. subsecund. Zooecia completely immersed below, flattened in front. Peristome tubular, extended. A circular median pore below the middle of the front. A large circular orifice (aricularian?) near the top of most of the lateral zooecia hehind." Indies.

Genotype and onty species.- Siphonimytara scrmuta Busk, 1881. Recent. East Family CATENICELLIDAE Busk, 1852.

Genus CATENICELLA D'Orbigny, 1852.

\section{CATENICELLA SUBSEPTENTRIONALIS Canu and Bassler, 1917.}

Plate 913. 6ig. 11.

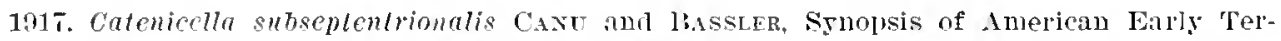
tiars Cheilostome Bryozon. Bulletin 94, Initell states Xational Iruseum, p. 63, [1. 5. fig. 5 .

The Catenicellidae are bryozoa peculing to the southern hemisphere. They abound in the recent seas off Australia, and their fossil forms are frequent in the same region. Howerer. Water's ${ }^{1}$ discovered in the Priabonian of the Vicentin two species haring some affinities with this fanily: namely, Catenicella septentrionatis Waters, 1S91. and Catsnicella continua Waters, 1891. According to Waters ${ }^{2}$ the latter species is a Tittaticella and the first belongs to a new genus.

The single and unique fragment found in America is very close to Catenicella septentrionatis Waters, 1891. It differs from it in its somewhat larger micrometric dimensions. more closely arranged frontal pores and in the presence of a small. oral a vicularium.

Occumence.-Ticksburgian: Salt Inuntain, five miles south of Jackson, Alahima (very rare).

Hototype.-Cat. No. 62601, T.S.N.M.

\section{Family ADEONIDAE Jullien, 1903.}

Biblingraph!" (Anatomical).-1S59. Watrks. Bryozoi from New South Wales, Annals Magazine

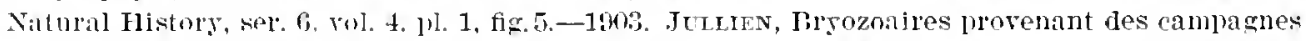
de l'Jirondelle, pl. 14, fig. 4.-1912. WATERs, A strueture in Arlesnella (Iaminopora) cuntortia Michelin, with renarls on the Adennidae, Annals Migizine Naturil History, set. S, rol. 9.

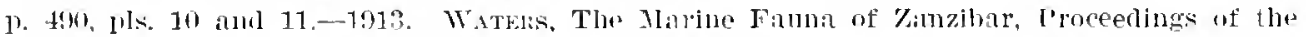
Zoological Soclety of Loniom, pl. 73, figs. 1-S.-100. Levisex, Morphological and sestematic Stulies of the Clusilostonutous Pryozma. 1\%. 252. pl. 14, fies, 1-5; pl. 23. fig. 9.

The zooecia are provided with a compensatrix, but are deroid of spines and oral crands. The areolae are always elosed and excarated out of the wall substance itcelf. The frontal is composed of an olocyst covered hy a rery thick plemrocst. The opereulum opens at the bottom of a peristomie. The female zooecia are of the line termed gonnecia and are often larger than the others: they contain an ovicell

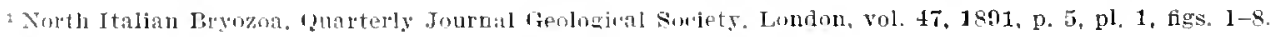

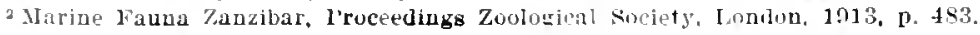


sac. in which the embryo is developed. The septules are numerous, placed in linear rows, arranged to correspond to the areolac. The avicularia are frontal or interzooccial: the latter have no pirot. 13-16 tentacles.

History.-The history of this group has been given by Gregory ${ }^{1}$ in some detail. Primarily the name of Alleona Lamouronx. 1810, was applied to species which hat a fenestrated zoarimm provided with radienlar fiber's. It was created simply for a form of zoarial growth and it should never have changed in meaning. In 189t Busk created the family and characterized it ly the trimorphic zooecia and the presence of an ascopore. In 1907 Cann discovered in the French Lutetian a group of species deroid of ascopores, and formed for them the family Meniscoporidac. In 1909 Lerinsen confirmed the fact that Bractridgia was indeed a member of the Adeonidae. whence Canu's family Meniscoporidae became superfunous. The family Adeonidae is now well established on ovarian characters and important anatomical features.

Stmecture and terminology.-It is always easy to recognize a species of the Arteonidae by rubbing away one face of the zoarimm so as to reveal the areolar carities of the walls (parictal areolae). This eharacter is a general one and has no exception. In all the other families of the sub-order Ascoploora, the areolar pores commmicate directly with the interior itself of the zooceium. hut in the Adeonidae the areolar cavities do so by means of the septules. These carities serve for the passage and protection of the endocrstal elements which must serrete and deposit the pleurocyst.

The gonoecia are often larger than the other zooecia: their aperture is rlifferent and their frontal pores are more numerous. They develop first a normal polypide. which soon disappear's by histolysis and is replaced by a small polypide placed at the distal extremity and a large ovicell sac occupying the greater part of the gonoecium: here the embryo is dereloped. The form of the gonoecia is rather rariable. as noted by Canu, who has made a special study of this subject.

The great thickness of the plenrocyst cances the formation of a peristomie, at the bottom of which is the aperture (primary orifice of Hincks) closed by the operculum and of which the form is constant. The external orifice of this peristomie is the peristomice (secondary orifice of Hincks): its form is irregular and it is surrounded by a more or less salient peristome. The form of the aperture is often hidden, and in order to discorer it, it is necessary to rub away the posterior face of the zoarium to examine the interior of the zooecia.

The hydrostatic system is quite variable. We have found all the variations noted in the other families of Ascophora. The genera, which are without frontal ascopores, have an opereulum like Schizoporella, Hippoporina, etc., of which the anterior part serves to close or to open its compensatrix. The operenlum of the genera provided with frontal ascopores is semilmnar and water penetrates into the compensatrix by means of the ascopores. Finally, as in Gateopsis, the water panes first into the restibule by a spiramen before penetrating into the compensatrix.

I Rritish 1'alneogene Bryozoa. Transactions Zoological society, London, vol, 13, 1s93, p. 2.t1.

= Bryozon kinrirons Paris, Annales te l'alemtologie, 1:nr, 1r. 4i. 


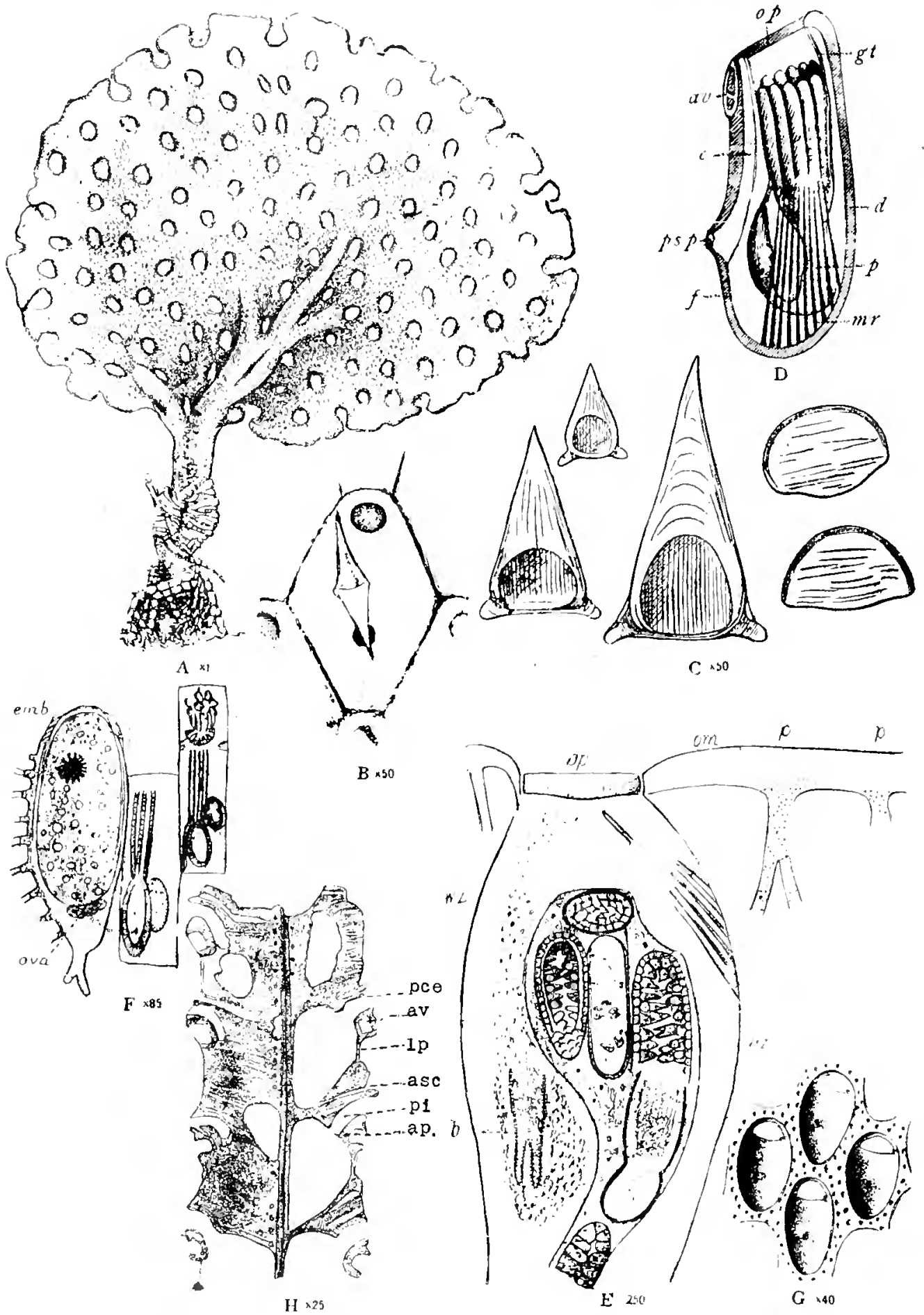

For, 1ti,--Anatoniral structure of the family Adeonidae Jullien, 1903. 
F1g. 163.- Inatomiall structule of the fimily Adeonilate Jullien, $100 \%$.

A. Alcona grisca Lamourax, 1,16. Specimen natural size, with radicles and fenestrie. (After MacGillivias, 18s0.)

B, C. Adeona appcndiculutu Lisks, 1sSt. T. A zooecinm with ascopore and avicularium, $\times$ 50. C. Operculum and mandibles. $\times$ 50. (13, C after Busk, 1854.)

D. Structure of zooecium and mlylicle of Aleona. (After Jullien, Isss.)

$a v$. ariculariun; $c$ compensitlix; $d$, dorsal ; frontal; $f t$, tentacular sbeath; mr, retractor museles of the polypide; op. olurenlum ; $l$, polypite; $p s p$, ascopore.

E, F. Adconclla platalca Tiusk, 1552. E. Section of a zooecium, $\times 250$. slowing a mass with several bodies and a part of a bul $(b)$ hy the sille, but not inclosed in the mass: pore tubes ( $p)$

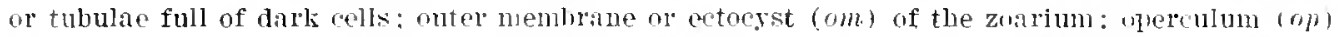
walls of the zoocium ( $u$. $z$ ). 'llis slecimen is somewhat difficult to understam?, as it has the alyearance of being leversed. i.ffter Waters, 1912.) F. Section. $X$. s. showing the ovicellular

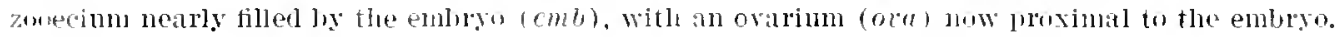
(After Waters, 1913.)

G, H. Adconcllopsis cosinumbra Reuss, 1st7. G. Interior, $\times$ 40, showing the ascoprire,

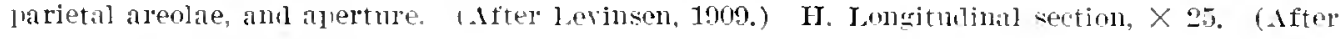
Waters, 1ss9.)

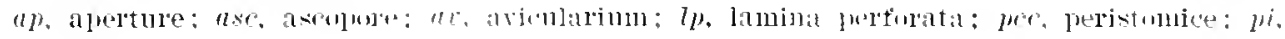
peristomie. 


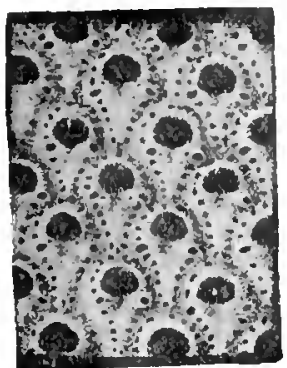

A. Meniscopora

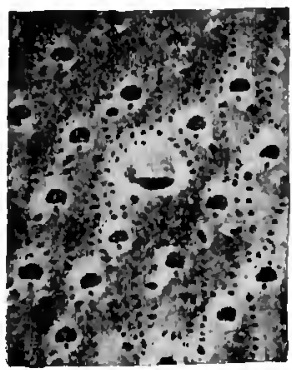

D. Sinitustoma

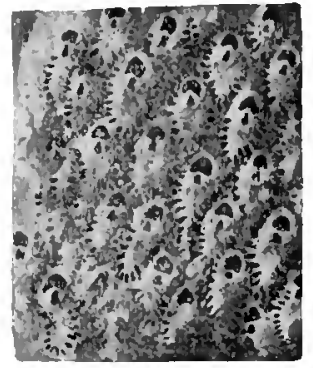

B. Bracebridgia

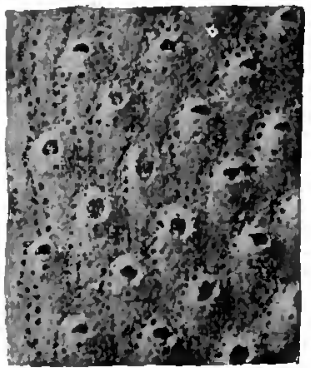

E. Adeonella

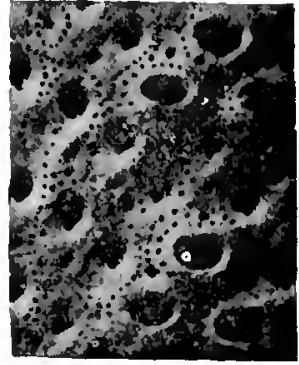

C. Schizostoma

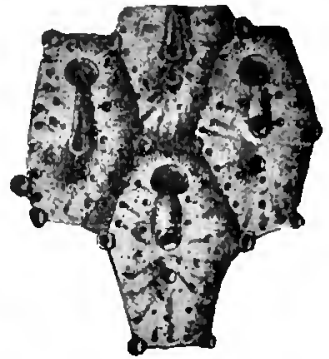

F. Adeona

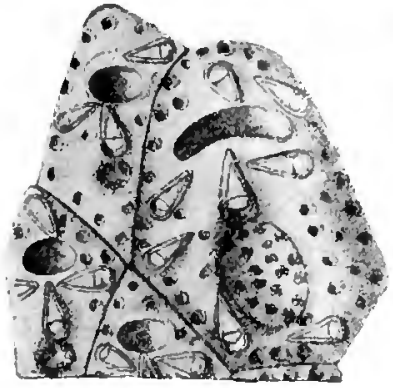

G. Adeonellopsis

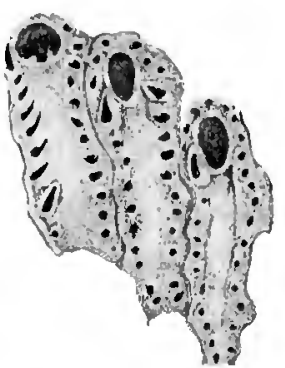

H. Dimorphocella
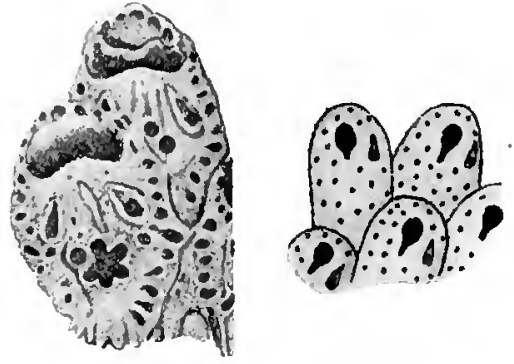

I. Tremadeona

F1G. 161.-Genera of family Adeonidae Jullien, 1903.

A. Jenisconorn bigibbera Gregory, 1893, $\times 55$.

B. Bracebridgia aculcata, new species, $\times 20$. Mlddle Jacksonian of Georgia.

C. Schinostoma crassa Cann, 1902, $\times 20$. Lutetian of France.

D. Smittistoma mortisaga stoliczlsa, $\times 20$. Intetian of France.

13. Adconella folliculata Canu and Bassler, 1917, $\times$ 20. Nliddle Jacksonian of Nurth Carolina.

F. Alcona violuceu Johnston, $\times 40$. Tiecent.

G. Afroncllopsis foliacea MacGillivray, $1805, \times 40$. Recent.

II. Dimorphocelln triton MacGillirray, 1so5. Niocene of Australia, (Ordinars zooecia without ascolore aud gonoecia with ascopore.)

1. Luminoporn rontoita Michelin, 1842, $\times$ 25. Recent. (Tremalonn in error.) 
The mode of ealcification of the Aleonidae is more complicated. The prim tive olocyst secreted by the endocy-t in lather thin. It is covered by a plenocyst secreted by the endocrstal element which pass through the parictal areolac and deposit over all of them more or less comirlerable quantities of lime. When the leposit is somewhat thick the parietal areolae are transformed into true tubules (pl. 15. fig. 14, and text fig. 16i3ll). In trinsverse thin sections the plenocrstal elements smperimposed and oriented in ratial fibers (pl. 99, fig. 16) can be clearly seen.

The frontal aricularium is never vi-ible in the interior; it early has mo commmication with the zooecia, and it is therefore nourished exteriorly by the endocyst proceeding from the areolac and corering the skeleton.

In tangential thin section theae pleurocystal elements are rery irregular and are grouped in still more irregular filaments (pl. 15, fig. 15). This is the characteristic of this secretion, which is very rane in the Anasca, but which develops frequently in the other Ascophoda, and attains its maximmm of alevelopment in the Adeonidae.

Classitication.-The essential characters of classification of the dreonidae have been given hy Waters and Levinsen. There are three principal groups. The first comprises the species which are withont frontal ascopores. This is the family Meniscoporiclae Canu, 1907, composed of simittistoma. Meniscoporu. Schisostoms, Calectina, and Biruebridgin. The second group is composer
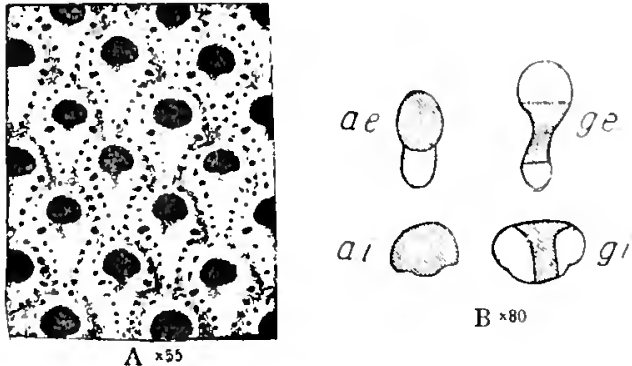

$\mathrm{B} \times 80$
Fig. 165.-Genus Meniscopora Gregory, 1893.

A. UCniscopora bigibbera Gregory, 1893. Zooe(iil, $\times 55$. (After Gregory, 1893.)

B. Meniscopora simehi Canu, 1907. Views of peristomice and apertura, $X$ so. (After (anu, 1907.)

ae, peristomice of zooecium; ai, apertura of a zonerium; $g e$, peristomice of a gonoecium; $g i$, apertura of a gonoecium. of the species which are provided with a spiramen and contains the single genus Adeonella. The thira group contains the species which are proviled with frontal ascopores and embraces the genus ldeoma if the ascopore is simple and tine grenus deonethopsis if the arcopore is stellate.

Genus IENISCOPORA Gregory, 1893.

189:. Meniscoporn Guegon:. British Palaengene liryozon, Transactions Zooncionl society, London, vol. 13. [. 2.0.

The zooecia are trimorplic. The nomal axial zooecia have an external aperture straghter than that of the matrinal zooceia the aperture is formed of a semilunar anterior and of a rery concare posterior part. 'The gonoecia are larger than the ordinary zooecia and their aperture is of diflerent form. The peristomie is of slight depth. Interzomerial avioularia are rare. Certain lateral areolac are transformed into small frontal arienlaria. 
Genotype--1Yeniseopora bigibtera Gregory, 1698.

Rimbr.-Tlanetian-Helretian.

MENISCOPORA SUBPLANA Ulrich, 1901.

Plate 2, firs t, $\pi$.

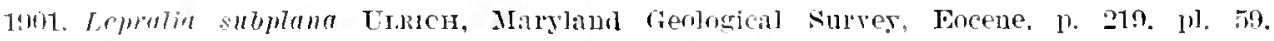
firs. $17,18$.

")inimel drsepiption.- "Zoarium, as seen in three specimens, forming a hollow cylinder. composed of numerous layers. each 0.8 to $0.3 .5 \mathrm{~mm}$. in thickness. and rarying in diameter according to the mmber of layers from 7 to $13 \mathrm{~mm}$. Zooecia not. very regularly arranged, sometimes subovate. at other times hexigenal or subeuadrate. longer than wide, the length averaging about $0.45 \mathrm{~mm}$. Tiper surfare nearly flat, the outline of the zooecia, in aned conditions especially, scareely distinguishable and mainly hy a double row of pores which. as show by fractures, are the months of small tubes trancresing the wall in a vertical direction. Front wall slightly convex, perforated. the pores mually smaller than those outhining the zooecia, distinctly visible on the imer surface. sometimes wanting orer a varing space just behind the aperture. The latter is rouncled in frout. nearly traight behind, with the angles romblet. generally semielliptical, the width and length averaging, respectively. 0.1.5 and $0.13 \mathrm{~mm}$. Small lound or oral aricularia generally present. Their position is rariable, though wanly close to the lim of the aperture. While an ocratomal zonecimm may oceur. having no avieularia. as many or more will he fomnl having une on each side of the aperture. Ooecia mknown.

Fractures dividing the zooecia rertically (fig. 4) show that the walls (side and front) are travelsed by minute. way, restical tubuli, and that the zonecial caritics are comnected by two series of pores. the larger set near the bottom and a rom of smaller pores above the midheight. The openings of the larger set are often irregularly distributed orer the concare floors of the zooceia."

Tlrich's description is quite exact. The zoarium is multilanellar and inerusts alerae: the lower face, in contact with the subtratum is smooth or ornamented with numerous small hydrostatic tubero-ities

In the interior, the areolar cavitios are quite visible.

The gunueria ale irlentical in form with the other zooreia. but they are somewhat larewer.

Ocrumence--Lowest Encene (Bryozoan berl at base of Aquia formation): F frer Marlboro. Maryland (not nucommon).

MENISCOPORA ELLIPTICA, new species.

I'late oi, fiss $17-21$.

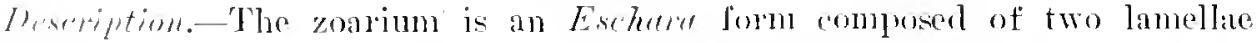
plarel burk to hack and easily separable. The zonecia are little distinct. elonaterl. trateht: the fontal somewhat cunvex hatrs some pores which are little 


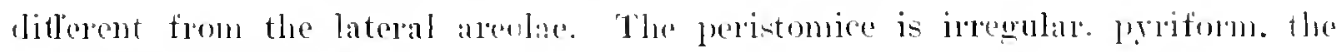
narrowest part below: the peristome is thick and complete; the peristomie is shallow, but it hisles the jeal form of the aperture which (sech from the interior) is: elongated and elliptical. On the line of the areolae, in the vicinity ol the peristomice, there is a snall, simple, Miptim a ricularim somewhat puinterl.

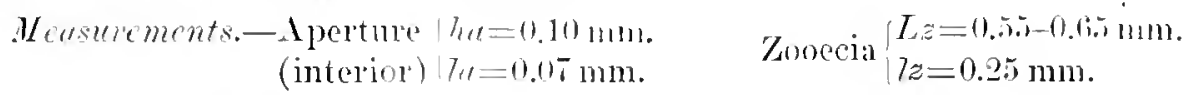

A thinities.-The frontal pures and the avicularia are quite variable.

'This species is very close to 17 misenpone (Eschara) semitubulosa Roms. 1s69, of the Prialonian of the Ticentin. Tnfortunately the latter las not ret leen found again and no direct comparison is therefore posible.

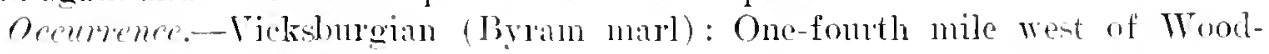
ward. Wayne Comnty Missi-siplui (eommml).

C'otypes-Cat. No. Gitis. I.S.X.M.

\section{Genus BRA('EBRIDGIA MacGillivray, $18 s 6$.}

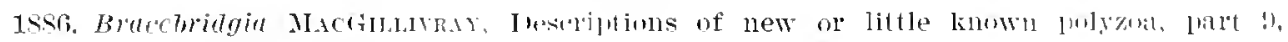
Transactions lingal suciedy of Vioturial. 1). S.

(syu. Pornstoma i caxu, 1!nit.)

"Znarium hilaninate. erect. Apertura subcirenlas" staighter below, with an internal denticle; peristomu thiokered. smooth or with a small alpionlate muclo: frepuently in the fousil- but rarely in recent specimens, a triangular avicularium immediately below the lower lip: lateral aricularia on the lree eclow of the zonrium" (MacGillivery). The womoecia are larger than the usual zoouria.

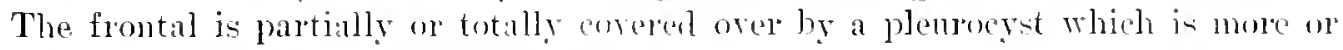
less confluent with the suljarment uloryt.

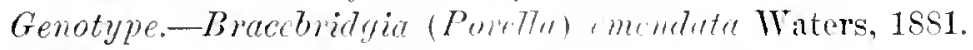

limme-.Tacksonian-Rerent.

The gems Porostoma Canlt. 19ut. diflese from Bracebridgin only in the place of the oral aricularium, which is placed entirely within the puristomie. It:

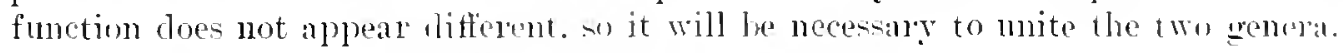

The known species of limetriblin ale as follows:

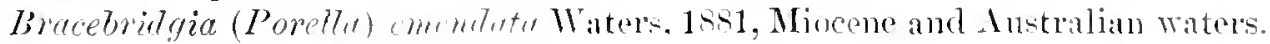

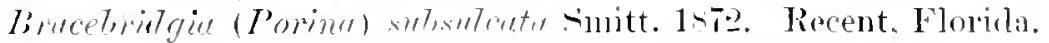

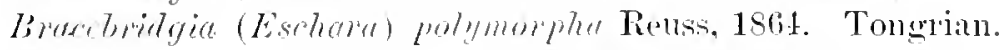

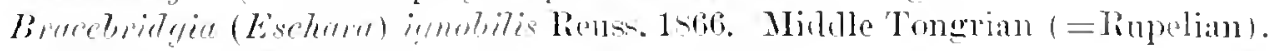

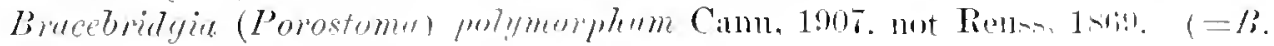
tentifermm, name new) I presian.

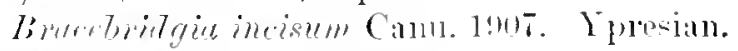

Bracebridgia (Porostomen), 7nontum Cregory. Lutctian.

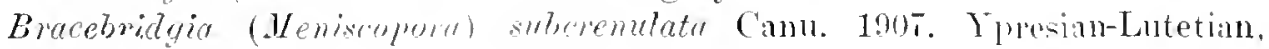
Bartonian. 
Bractividgia (Porina) subsulcata Suntt. 157.2. has been dredged at depths from 10 to 48 fathoms. Osbun found it again off the Tortugas from 16 to 19 meters. He was kind enough to send us some speemens. The examination of their interior has proved to us that the speeies has no ascopore nor spiramen.

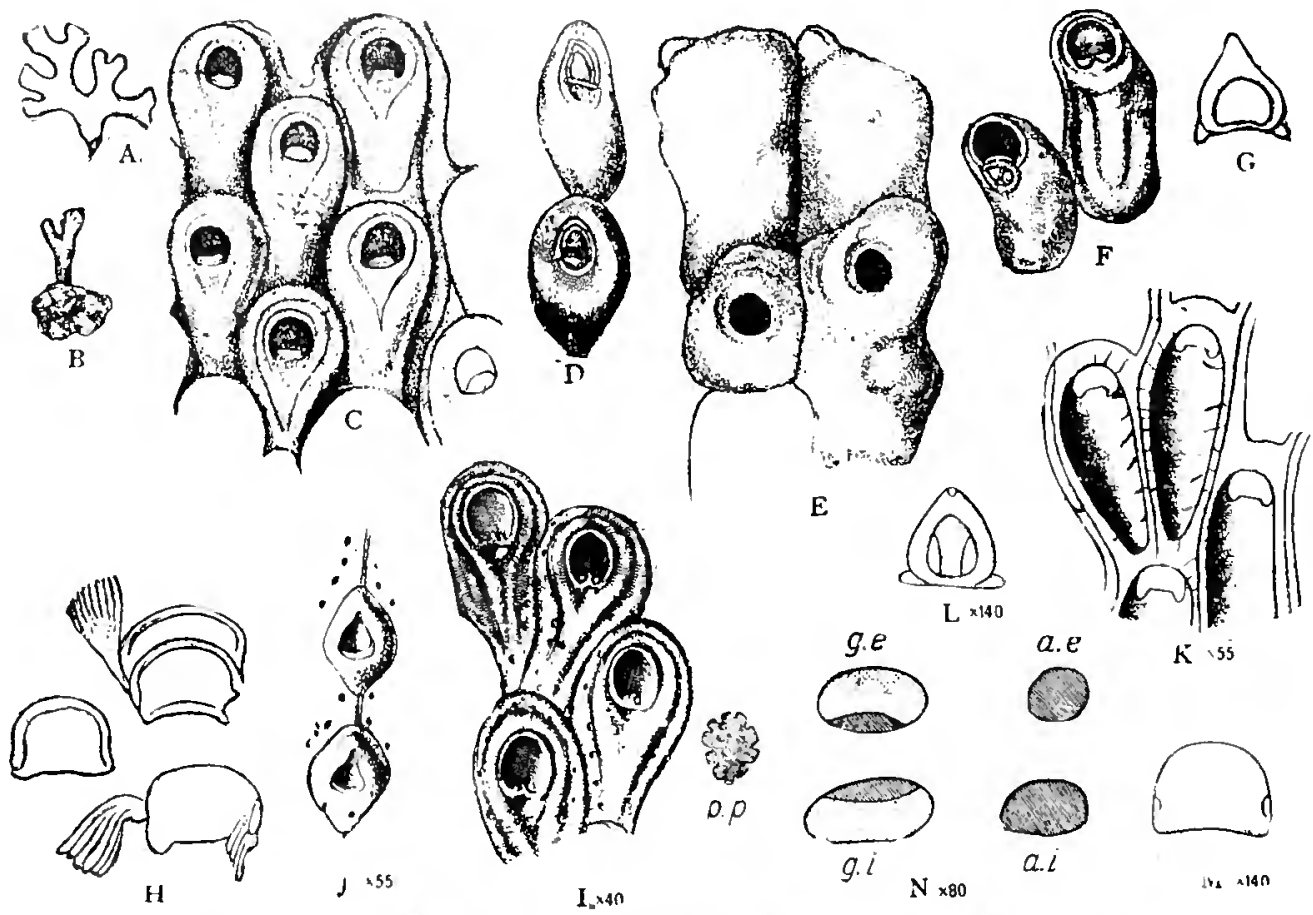

Fig. 166.-Genus Bracebrituin diacGillirray, 1886.

A-M. Bracebridgia pyriform is lusk, 1ss4. A. specimen, natural size. B. Young specimen growing from an incrusting base; natural size. C. Portion toward the periphers, showing normal zooecia. D. Two a ricularian cells from the margin of a lohe. E. Older zooecia toward the base of the specimen, two completely closerl. F. Two zooedia from incrusting part. showing apiculate mocess and oral avicularim. G. Mamlible of avicularinm. H. Opercula from elge of a lobe. (A-H after Macrillivray, 18ss.) 1. Zocecia with parietal areolae. $X 40$. J. A portion of the margin of a zoram with two avicularia, $X 55.5$ K. Four zooecia from the basal anvect ufter remoral of the basal surface, $X$ 5.. L. An aricularian mandible, $X$ 140. Mr. Opelculum. $\times 140 .($ I-MI after Levensen, 1909.)

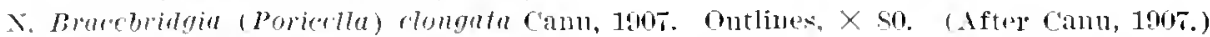

we. peristome of a zorecium: $n i$, alerture of a zurecium: ac. peristome of a gonoecium:

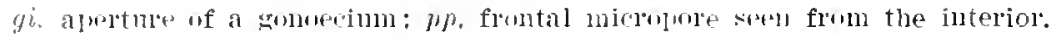

BRACEBRIDGIA ACULEATA, new species.

Plite 71 , figs. 10-12.

Thespiption.-The zoarium is free. bilaminar, composed of two lamellae placed back to lack and separable. The zooecia are elongated. fusiform, distinct. separated by a furrow and surrounded by an especial line of areolae; the frontal is 
formed of thin, prominent interareolar costules, and of a false area due to incomplete pleurocystal calcification. The peristomie is of little depth: the peristone is thin, prominent, dereloped distally only; the aperture (as seen from the interior) is semilunar with an almost straight proximal border. The ariculariun is median, simple, triangular; its point projecting, like a spur.

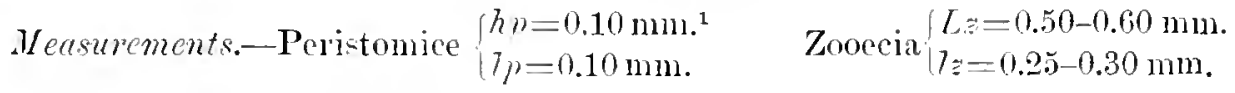

Observation.-Photography does not give exactly the aspect of this species: it does not show sufficiently the very great projection of the avicularium abore the plane of the figure.

Bracebnidgia aculeate differs from the other known species by its straight and median aricularimm. which is never oblique, or stblateral.

In the interior the arienlarium is invisible, and it is therefore of exterior or pleurocystal origin.

Occurrence.-Middle Tacksonian: Three and one-fourth miles south of Perry. Georgia (common).

Cotypes.-Cat. No. 64188 , U.S.N.MI.

BRACEbridgia POLYhorpha Reuss, 1864, var. COSTUlatA, new variety.

Plate 71 . figs. 13-23.

1S64. Eschara polymorpha Reuss, Fauna ientsehen Oberoligocan, sitzungberichte der b. Alsactemie der Wissensehaften, Wien, vol. 50, D. 651, pl. 12, fig. 6.

1S6s. Eschara polymorpha Russ. Bryozoa deutschen Septarienthones. Sitzungberichte der k. Alademie der Wissenschaften, Wien, rol. 52, p. 61, pl. \&, figs. 8-10.

1S67. Eschara polymorpha Reuss. Fanma Steinsalzablagerung, Sitzungherichte der k. Akalemie der Wissenschaften, Wien, vol. 5. P. $\mathbf{3 4 4 .}$

Measurements.-A perture $\left\{\begin{array}{l}h a=0.08 \mathrm{~mm} 1 \\ 7 a=0.10 \mathrm{~mm} .\end{array}\right.$

Tariations.-The areolae form a line of small pores around eacl zonecinm (figss. 15, 20). Between them short costules often develop) (figs. 17.,20).

The plenrocyst is not rery regular; it forms a prominent collar around each zonecium. in the form of an interrogation point. Below the a vicularimm there is an irregular, triangular area, the depth and size of which depends upon the pleurocystal activity, which is always very irregilar.

The aricularimm. when it is well preserved. deforms the external aperture (figs. 15. 18, 21); it is oblique (figs. 15. 18) or transversal (fig. 1i): the two poxitions may be observed on the same zoarial frament (fig. 21 ).

The gonoceia (figs. 14,22 ) are larger than the nenal zonecia.

All these characters are lesened by fossilization (fig. 203) and the zonecia appear very polymorphic.

In the doenidae we grife the dimen-inds of the nerjstomice or external alueture when this is sonewhat

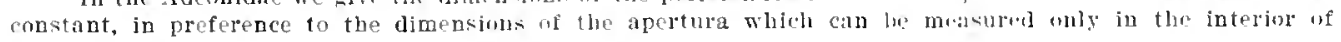
tho zoorecia. 
In the interior the aperture is semilumar and transrerse with a slightly concare proximal border.

In cxanining the fiwure of Reuss we can note only a few differences of little importance: the interareolar costules appear less salient and the avicularim there appears smaller and more romoved from the extermal aperture. At the most. our specimens form a rarjety.

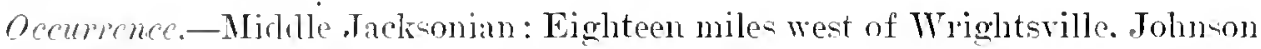
(omuty, Georgia (rare) : Rich Hill, st miles sontheast of Knoxville. Georgia (rare) : 1.2 miles southeat of Marshallville. Georgia (rare): one-half mile southeast of Georgia Kaolin Company Mine, Twiggs Comnty, Georgia (rare).

Geologicat distribution.-In Enrope the species ocens in the Latulorfian of 3, atrlorf (Teuss). Rupelian of Germany (Reuss), Chattian of Germany (Reuss).

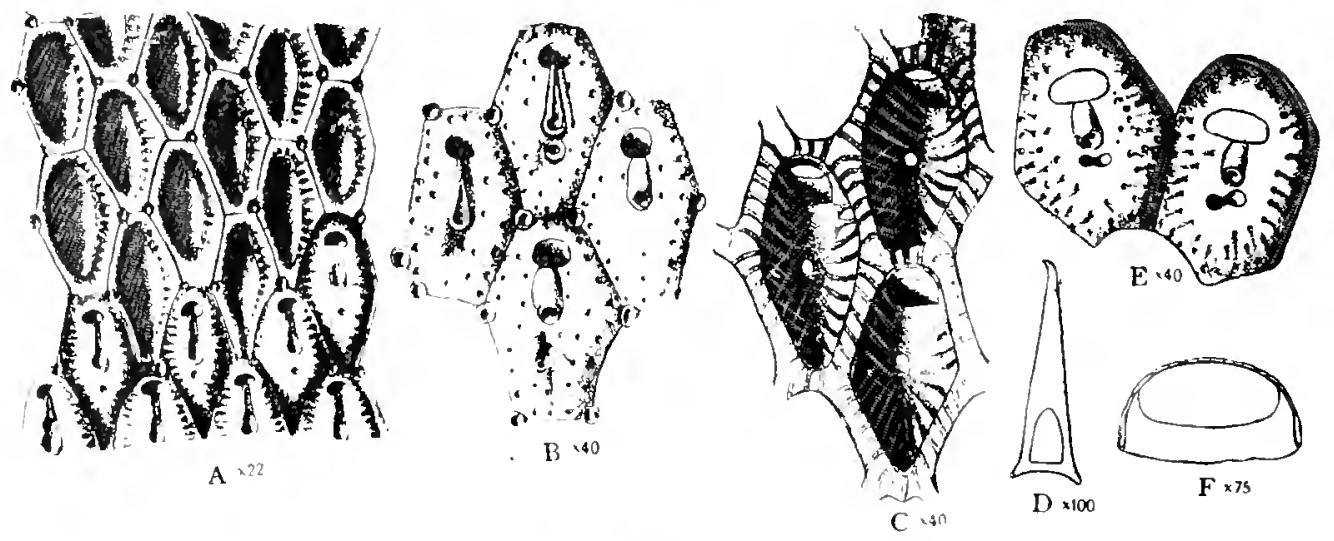

Fig. 107.-Genus dilcomt Lamouroux, 1816

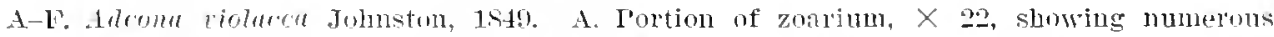
magrual zooecia with formtal wall still unaleified. P. Four zoneria, $X 40$, two of which latre the aricularium replaced by an elongated cavity which opens by means of a round pore. C. Three moreja. $X$ 40, viemel from the has side after lemoval of the basal surface. The primary alverture and the luoximal margin of the secondary are visible. L. Aricularian mandible, $x$

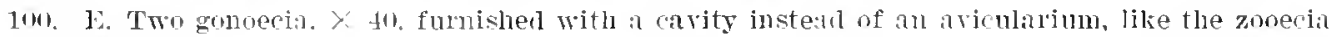

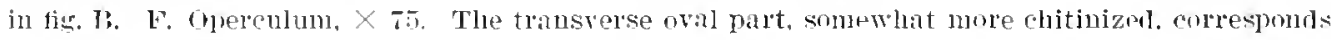
with the secondaly allelture. (1-l"after Jerinsen, 1909.)

These three are the -ubatages of the Tongrian. Finally. Reus cited it from the Tortonian of Wieliezka in Pologue, but he did not give a figure.

Gotypes.-Cat. No. lit1!n. T.S.N.M.

Genus ADEONA (Lamouroux, 1816) Levinsen, 1909.

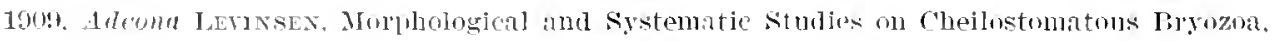
1. 250.3 .

The frontal is perforited by an ascopore opening into the compensatrix. "The opeculum is semilunar. The gonoecia are distinct and larger than the ordinary zurneviat.

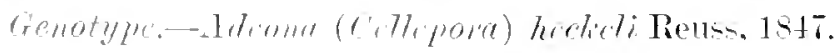


Genus ADEONELLA (Busk, 1884) Waters, 1888.

1854. Adconclla Busk, Report on the Polyzoa collected by H. M. S. Challenger, 1873-76, vol. 10, pt. 30, [3. 183.

"Zoarium erect, very variously branched or lobate, attached by a contracted base or pedicle, often containing ladical fibers and aflixed usually on a more or less flexible support (Busk)." "The zooccia without such median ascopores; the proxi-

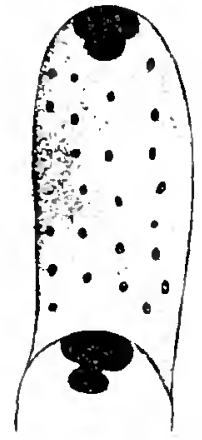

A 185

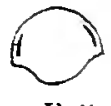

F $\backslash 85$

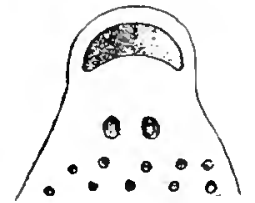

$\mathrm{B} \vee 85$

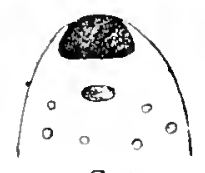

C. .85

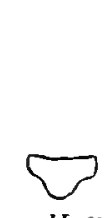

G .85
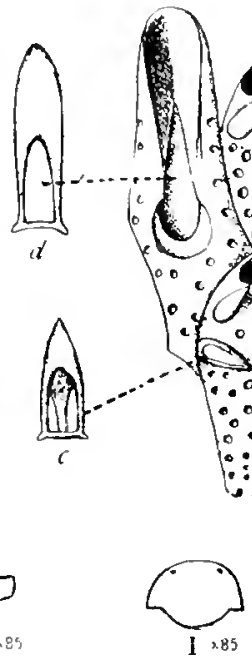
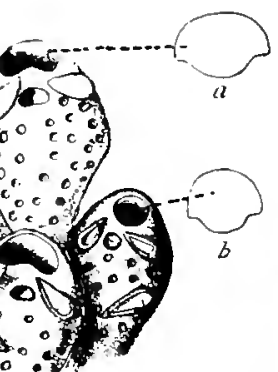

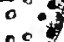

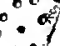

D $\times 55$

D $\times 55$

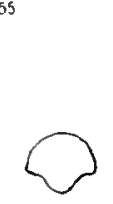

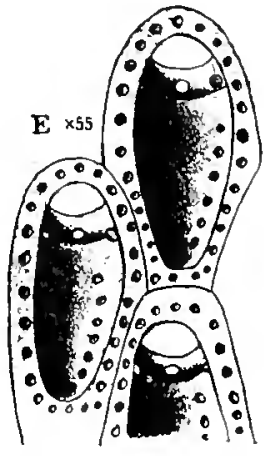

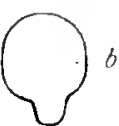

$\mathrm{k} \times 100$

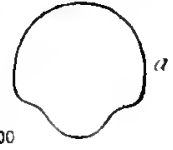

A. Jelleyae Levingen

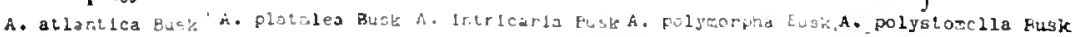

Fig. 168.-Genus Adconclla (Busk, 1884) Waters, 1888.

A-C. Adconella polymorpha Busk, 18s4. A. Toung cells, the lower one showing the collumencenent of the bridge, $\times 85$. F. Ovicelligerous cell with double pore, $\times$ 85. C. Cell with bridge forming a peristomial pore or spiramen, $X$ S5. (A-C after Waters, 1Sss.)

D-E. Adeonclla serrata Lerinsen, 1909. D. Tro gonozovecix, an independent (interzooerial) avicularium and an ordinary zooecium, $\times 55$.

$a$, operculum of a govozooecinm, $\times 55 ; b$, operculum of a zooecium, $\times 85 ; c$, the mantihle of a dependent (frontal) a ricularium, $\times 55$; $d$, the mandible of an independent (interzooecial) avicularium, $\times 55$.

E. The zooecia, from the basal aspect, after the lemoral of the basal sulface, showing the interior, $\times 55$. (D-E after tevinsen, 1909.)

F-J. Opercula, $X$ 85. (After Waters.) F. Adconella atlantica Busk, 18s4. G. A. platalea Busk, 1S52. H. A. intricaria Busk, 18S1. I. A. polymorpha Busk, 1S\$4. J. A. polystomella Reuss, 1847 .

K. Operculum of Adconella jellcyae Levinsen, 1909. a, gonozonecium ; $b$, ordinary zovecium. (After Levinsen, 1909.)

mal part of the secondary aperture, which appears sooner or later, is transformed. by a coalescence of two calcareous processes into a pore. which leads into the space between the primary and secondary aperture." (Lerinsen, Waters.)

The peristomie is perforated by a spiramen. The aperture bears a concave lower lip. which is the opening of the compensatrix. The operculum is at the bottom of the peristomie and below the spiramen. 13-16 tentacles.

$$
55899-19-B 111.106-36
$$


Genotypes.-Adeonella polymorpha Busk, 1884, and Adeonella (Eschara) polystomella Reuss, $18+7$.

Range.-Jacksonian-Recent.

Adeonella folliculata Canu and Bassler, 1917.

Plate 72, figs. 1-S.

1917. Adronella folliculata CANu and Bassler, Synopsis of American Early Tertiary Cheilostome Bryozoa, Bulletin 96. United States National Museum, p. 66, pl. 6, fig. 3.

Description.-The zoarium bilamellar with two lamellae, back to back. and separable. The fronds are lobed, very thin, and fragile. The zooecia are very long, distinet, separated by a furrow, little convex, bordered with numerous parietal areolae (10-12 pairs). The peristomie is short, somewhat projecting exteriorly and is perforated by a spiramen; the peristomice is semilunar with a convex lower lip; the aperture (interior) presents a proximal concare border. The gonoecia are $(0.30 \mathrm{~mm}$.) larger than the other zooecia; their external aperture is greater $\left(l_{\alpha}=0.10 \mathrm{~mm}.\right)$ and the spiramen is more remored from the aperture. There is a very small, simple avienlarium on the peristome.

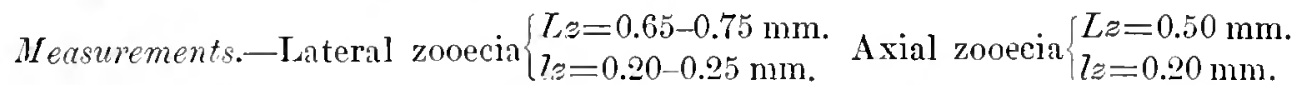
Gonoecia $\left\{\begin{array}{lr}L z=0.50 \mathrm{~mm} . & \text { Peristomice of }\{h p=0.04 \mathrm{~mm} . \\ 7 z=0.30 \mathrm{~mm} . & \text { zooecia }\{p=0.07 \mathrm{~mm} .\end{array}\right.$

Peristomice of $h p=0.04 \mathrm{~mm}$. gonorcia $l p=0.10 \mathrm{~mm}$.

Tariations.-The zoocial walls are so thin and fragile that it is difficult to obtain a good interior presenting all the characters of the species, and it is necessary to study this feature by successive rubbing away of the substance.

The axial zooecia are shorter than the lateral ones (figs. 3, 6), nevertheless there are fronds composed miquely of long zooecia alone (fig. 4).

Often one of the parietal areolae is transformed into a small, simple avicularium, slightly pointed (fig. 2) and of inconstant position. Just as the zooecial areolae may be transformed into a vicularia, the parietal pores resulting from a growth of the ectocyst are susceptible to continuation of evolution, according to the needs of the zoarium.

The small peristomial avicularium is round; its place is rery variable, but always on the distal border.

The gonoecia are somewhat larger $(0.30 \mathrm{~mm}$.) and their external aperture also larger $(0.10 \mathrm{~mm}$. $)$; the spiramen is placed farther from the external aperture and perhaps it opened exactly at the level of the operculum, instead of being above it (fig. 6).

Figure 5 represents a rery common alteration by fossilization.

The fronds have the thinness of a leaf and are very fragile.

Occurvence.-Micldle .Jacksonian (Castle Hayne limestone) : Wilmington, North C:rrolina (common).

Cotypes.-Cat. No. 62008, U.S.N.M. 
Genus ADEONELloPsis MacGillivray, 1886.

1856. Adconellopsis MacGilluray, Description of New Polyzoa, pt. 9. Transactions Royal Society Victoria. p. 7 .

"The zooecia provided in the central line with one or sereral ascopores" (Ievinsen). The ascopores are grouped at the base of a cribriform area. Interzooecial avicularia and gonoecia are present. 13-16 tentacles.
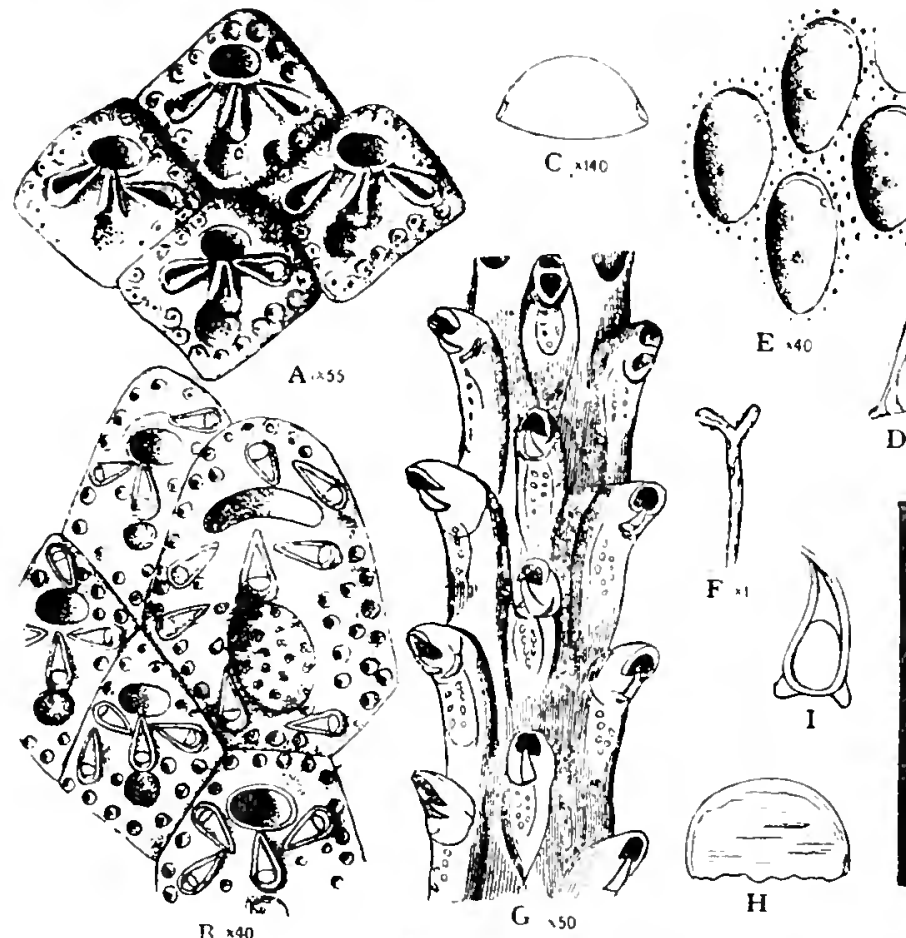

E.40
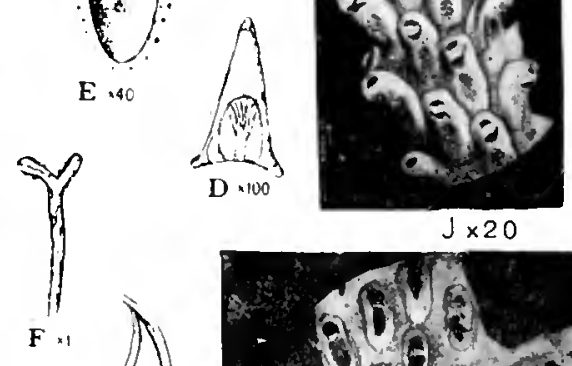

Fig. 169.-Genus deoncllopsis IIacGillivay, 1880.

A-E. Aleonellopsis foliaece IIachilliving, 1SSt, A. Four zonecia, $x$ 5.5. R. Group of zonecia, including a gonozooecium, $\times 40$. C. Opereulum, $\times 140$. D. Aricularian minible, $\times 100$.

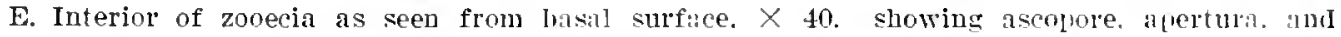
parietal areolae. (A-E after Levinsen. 1909.)

F-K. Adconellopsis (Cribricella) distomm Fusk. 1S5S. F, G. Fragment of zoarium, nitural size and $\times 50$. H. Operculum. I. Mimmilile. (F-I after Bnsk, 18s4.) J. Yumg zuneci: $X \geq 0$. K. Old zonecia, $\times 20$. (J, Ii after Minle, Gunerin ranivet, 1911.)

Genotype.-Adeonellonsis foliewen MacGillivray, $18 s$.

Range.-Wilcoxian-Recent.

We are entirely ignorant of the physiological rese of the stellate pores. and also of the true mechaniom of the hydrostatic system in the majority of the species.

The gonoecia are not alwar apparent: certain species are leprived of them; on others they are distinct hut little liflerent from the of luer zonecia.

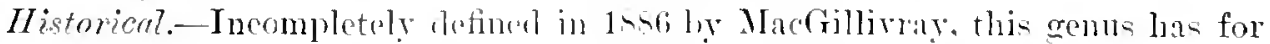
a long time remained unrecognizal. In 1 son Maplestone ceated a renus Oraticella 
based on a badly preserved example provided with a cribriform area. In 1902 Levinsen formed a genus Lobopora for the species having Eschara coscinophora Reuss, 1547, for type. In $190+$ Canu. not vet having learned of Levinsen's work, formed the genus Cribricella, with the same genotype. He added a genus Poricella for a similar species, but mithout median avicularium. In 1909 Levinsen abandoned his genus Lobopora and classed in the genus Adeonellopsis MacGillivray, 1886. all the species provided with stellate ascopoles. We adopt his classification because all the preceding genera have no different furctions and therefore can not be accepted.

Homever, Cribricella and Poricell $\alpha$ may be admitted as artificial subgenera in order to facilitate the classification.

The first subgenus, the group of $A$. distoma-coscinophora, ought to be the subject of special reseaz"ch, for it is much involved.

Tnder the name Eschara coscinophora Reuss. 1st\%, authors have united several different species.

First. Cribricella (Eschara) distomr Busk, 187s. This species is found living in the Atlantic from Madeira to the coasts of Brittany, where Madame GuerinGanivet recently found it. ${ }^{1}$

Second. Cribricella (Eschara) coscinophora Rellss, 18t7, lefigured by Manzoni in 1877. This is a Miocene fossil adorned with a small aricularium, small cribriform area, and very small parietal areolae.

Third. Crithicella (Eschara) coscimophord Reuss. 1864. 1866. This is an Oligocene species which Canu believed he had rediscovered in the Parisian Lutetian and to which he gave the new name of Cribricella punctata.

Fourth. Cribricelle (Eschara) coscinophory. Stoliczka, 1862. According to the excellent figure of the author, this is not Reuss's species, but is the Cribricella (Adeonellopsis) wetherelli Gregory, 1892. and probably also Cribricella (Lobopora) coscinophora Canu. 1907. However, this latter is provided with an adventitious aricularium on the old zonecia-a peculiarity not nentioned by Gregory or Stoliczka.

The differences betwen these various species are rather small; in effect they depend principally upon the micrometric dimensions. Hotever, they are of real value upon serious analysis. As always, the German Oligocene species are the most problematic because for a long time we have been unable to obtain any specimens. either by purchase or exchange. It may be possible that the Oligocene species are identical with the Miocene, as Reuss himself believed, but this is not clearly apparent from the published figures.

The known species of this genus, in aldition to the genotype, are:

Adconellopsis (Porichlla)maromira Cinu. 1004. Upper Eocene of Tunis.

Adeoncllopsis (Poricella) clongatu Canu, 1907. Lutetian of Paris.

Arconellopsis obtipua MacGillivray, 1895. Miocene of Australia.

1 Contrihutions a leitud des Firyogaires des cotws armoricaines, I. lbryozoaires provenant du Haut

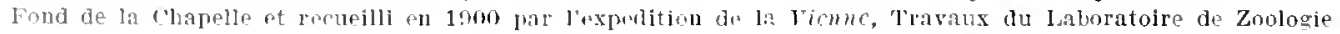
de Concarneau, vol. 3, 1911, p. . pl. 2. figs. 1. . 
Adeonellopsis distoma Busk. 1858. Atlantic.

Adeonellopsis (Eschara) coscinophora Reuss, 18t7. Oligocene of Germany. Adeonellopsis wetherelli Gregory, 1892.

ADEONELLOPSIS POROSA, new species.

Flate 8, fig. 13.

The specimen figured is the only one which has bcen found. It incrusts a shell. It is characterized by its large cribriform area, perforated by a dozen pores. It is possibly the base of a bilamellar zoarium.

Occurrence.-Wilcoxian (Bashi formation): Woods Blutf, Alabama (very rare).

Holotype-Cat. No.63813, U.S.N.M.

ADEONELLOPSIS MAGNiPOROSA, new species.

Plate 8 , figs. 11-20.

Description.-The zoarium is bilamellar; the fronds are wide and lobed. The zooecia are distinct, elongated, elliptical, much narrowed toward the hack, separated by a deep furrow. The peristomice is transrerse and semielliptic. The cribriform area is deep and perforated by large stellate pores. The median avicularim is triangular or orbicular, without pirot or denticle.

$$
\begin{aligned}
& \text { Measurements.-Zooecia } \mid L z=0.45-0.55 \mathrm{~mm} \text {. Zooecia } L z=0.50 \mathrm{~mm} \text {. } \\
& \text { (exterior) } l z=0.25-0.30 \mathrm{~mm} \text {. (interior) } l z=0.20 \mathrm{~mm} \text {. } \\
& \text { Total area : } L=0.95 \mathrm{~mm} \text {. } \\
& \text { Wirlth of apertula }=0.09 \mathrm{~mm} \text {. }
\end{aligned}
$$

Tariations.-The normal. adnlt zoocia have a transverse, semilunar, external apertura below which is a rather large. elliptical and oblique avicularium. The cribriform area is deep and contains from fire to seren stellate pores (figs. 16, 20).

On old zooccia there is produced a strong pleurocystal incrustation in consequence of which the aricularium and the cribriform area become buried. Then the apertura, the avicularium. and the area are only risible in a single total area; the aricularinm becomes triangular and pointed (fig. 15). Sometimes on the old zooecia there is an adrentitious. round aricularium (?) below the total area (fig. 17).

In spite of the considerable variations of the exterior, the internal aspect (fig. 18) is, on the contrary, very constant, and in it are revealed the true characters of the species.

Affinitics.-The new species differs from Adconellopsis wetherelli Gregory, 1892, which it much resembles in the large size of the pores of the cribriform areat. As this character is very constant we are obliged to give it specific importance.

This is also the American species which has the largest ascopores.

Occurrence.-Wilcoxian (Bashi formation): Woorl Bhuff, Alabama (common).

Cotypes.-Cat. No. 63530. T.S.N.MI. 


\section{ADEONELLOPSIS QUISENBERRYAE, new speeies.}

Plate 15, figs. 20-26.

Description.-The zoarium is free, bilamellar, formed of widened fronds branching dichotomously; the two lamellae are placed back to back and are separable. The zooccia are elongated, distinct, separated by a furrow, surrounded by an especial line of numerous parietal areolae. The total area contains the aperture, the aricularium, and the cribriform area; the apertura in the interior is semilunar and transverse: the avicularium is very large. triangular, pointed and placed obliquely, its point touching one of the lateral walls; the cribriform area, little visible exteriorly, bears from five to seven small stellate pores or the interior. A salient. alliptical, adventitious avicularium is located at the base of each zooecium.

$$
\begin{aligned}
& \text { Measurements.-Zooecia }\left\{\begin{array}{l}
L_{z}=0.52-0.56 \mathrm{~mm} . \\
7 z=0.30-0.36 \mathrm{~mm} \text {. } \\
\text { and } 0.20 \mathrm{~mm} \text {. (in the interior) }
\end{array}\right. \\
& \text { Length of the total area }=0.16-0.30 \mathrm{~mm} \text {. } \\
& \text { Length of the avicularim }=0.20 \mathrm{~mm} \text {. }
\end{aligned}
$$

Treriations.-. On the young zooecia the cribriform area is small, exterior and externally entirely uniporons (fig. 21). The old specimens have a total area: the aricularium and the aperture are surrounded by a thick pleurocystal covering (figs. 22, 23, 25). This latter is so active on the undulating lamellae that the exterior zooecial measurements are larger than the interior measurements.

The zooecial walls are very thick; they are striated and show clearly the deposit of the pleurocyst, which is formed hy the addition of successive liners on the exterior (fig. 2t).

The basal zooecia (fig. 23) are covered with a calcareous deposit and lose their polypide. The parietal areolae and the arienlarium alone persist.

Affinities.-This species is characterized by its avicularium, which is so oblique that its point tonches one of the parietal walls of the total area. In Adeonellopsis marmiporosa and Adeonellopsis coscinophora Reuss, 1847, the avicularium is st l'aigliter and in the total areal never touches the walls.

It accompanies Adconellopsis transeres in the same localities and in which the a vicularium is also very oblique; it differs from it in its larger dimensions and in its cribriform area uniporons exteriorly and multiporous interiorly.

We dedicate this species to Adelaide C. Quisenberry in appreciation of the interest she has taken in this work and of her help in its preparation.

Occumprene-Claibornian (Gosport sand): One mile southwest of Rockville, Clarke (ounty Alahma (rare): Gopher Hill, Tombighee River, Alabama (rare).

Iower Jacksonian (Moodys marl) : Jackon, Mississippi (rare).

Cotypes.-Cit. Nos. 63856.63857, T.S.N.M.

ADEONELLOPSIS TRANSVERSA, new speeies.

Plate 15, figs. 11-19.

Itescription.-The zoarium is free and bilamellar, the two lamellae being scp. arable. The ordiniry zooecia are elongated. little distinct. separated by a furrow. 
elliptical in the interior, and surrounded by a score of areolae. The peristome is complete, somewhat projecting and rather thick. The peristomice is oval and clongated; the peristonie is shallow; it contains proximally a small pointed triangular avicularium almost transecrse, and distally the aperture, which in the interior is semilunar with a slight convex proximal border. The stcllate ascopore is placcd on the median part of the zooccia close to the peristome. One of the areolac is transformed into a round, rather large, irregularly placed a vicularium. giving to the zooecia a strange and undefinable aspect. The gonoecia are larger than the ordinary zooecia and bear three ascopores arranged in a triangle and placel in a carity of the frontal.

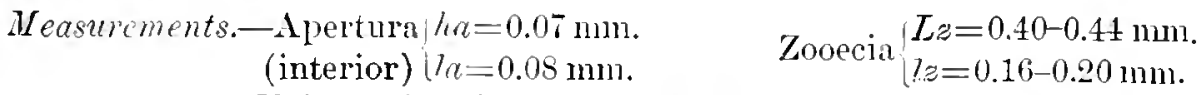

$$
\begin{aligned}
& \text { Tieight of peristomie }=0.1+-0.16 \mathrm{~mm} \text {. } \\
& \text { Gonoecia }\left\{\begin{array}{l}
L z g=0.40-0.50 \mathrm{~mm} . \\
l z g=0.30 \mathrm{~mm} .
\end{array}\right.
\end{aligned}
$$

Tariations.-The rariations are very numerons and the species is quite irregular, but onls the plenrocyst is affected externally, for in the interior the zoneria and the apcrtura are rery constant in their form and their micrometric dimensions.

The peristomial avicularia, which arc salient and visible (figs. 16, 19). are often more or less decply imbedded and then become invisible (figs. 17. 18).

The ascopore, more or less removed from the peristomice (figs. 16, 17). approaches it (fig. 18), and eren rather frequently opens into the peristomic itself (fig. 19).

The species may have two adventitious arieularia on a zonecimm (fig. 17). which still more complicates the zooecial irregularitics. Their occurrence appear much less constant on the ovarian zooecia (fig. 12).

In the interior (fig. 13) the ascopore is stellate and of rather variable form.

In tangential section (fig. 14) it will be noted that the adrentitions aricularia result often from the coalescence of many areolae. Above many of the zooecia there is a pore hardly visible exteriorly but which is much more constant in the other species. The pleurocrstal elements are rather large. scattered. without manifest orientation. Finally, the line of juncture of the zooccia is finely undulating, a feature which is rery rare. The zooecial walls are very thick and the arcolar carities are true pore-tubes.

Affinitics.- This species diflers from Adconellopsis (Poricella) elongata Canm. 1907, from the French Lutetian, in its somethat larger micrometric dimensions, in its prominent adventitions a vicularia. its ascopore smaller extermally, and in the proximal lip of the aperture, which is convex and not concave. It ditfers from Adeonellopsis grandis in its vely small zoulium and in the absenee of a cribriform area on the gonoecia.

Occurpene.-Chabornian (Gosport sand): One mile sonthwest of Rockrille, Clarke County. Alabama (common).

Lower Jacksonian (Mondys marl) : Jackson, Mississippi (rane). Cotypes.Cat. No. 639.5. T.A.X.M. 
ADEONELLOPSIS GRANDIS, new species.

Plate 99, figs. 11-18.

Description.-The zoarium is free, bilamellar, dichotomously branched. often attaining more than 2 centimeters in length; the two lamellae are placed back to back and are separated with diffieulty. The ordinary zooecia are elongated, distinct, lozenge-shaped, and separated by a furrow. The peristome is almost complete and bears a large distal pore; the peristomie, which is rather deep, contains a small, straight aricularium, triangular on the old zooecia and round on the young, and a well-hidden aperture; the peristomice is in the form of a crescent on the young zooecia and rather regularly elliptical on the old ones. The ascopore is stellate, vely small, and close to the peristomial avicularia. On the line of the areolae there are one or two round, simple, and little salient avicularia. The gonoecia are larger than the ordinary zooecia; their ascopore is replaced by a deep cribriform area perforited by four to six pores.

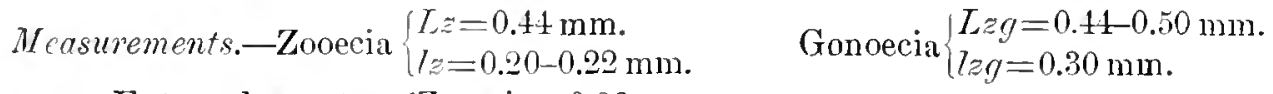

Externa] aperture $(Z$ ooecia $=0.06 \mathrm{~mm}$.

(width) $\mid$ Gonoecia $=0.10 \mathrm{~mm}$.

Tariations.-The peristomial aricularium is round when it is prominent (figs. $12,15)$, but on the old zooecia with very thick walls it becomes triangular and pointed; this transformation is quite remarkable, but it still does not permit one to discover the function of the organ itself. The ascopore is visible only on the young zooecia (fig. 14). On the others it is placed in the peristomice below the avicularium but always quite visible.

In thin transverse sections (fig. 16) the zooecia are rery thick. The pleurocystal elements, piled one on the other are grouped in transversal filaments.

In tangential section, the ascopore is rarely distinct from the avicularium (figs. 17, 18) because they are rery close to one another.

Afinities. - This species differ's from Adconcllopsis transwersa in its peristomial avicularium, which is straight and not oblique, and in the size of the zoarium. The zoarial dimensions permit the species to be classified among the good-sized fossils useful in field determination.

In its distal pore it resembles Adconellopsis oyclops, but differs from it in the absence of the cribriform area on the ordinary zooecia.

Occurrence.-Vicksburgian ("Chimmey rock" of Mariamma limestone) : One mile north of Mourceville. Alabama (very abundant).

Cotypes.-Cat. No. 64319, U.S.N.M.

ADEONELLOPSIS GALEATA, new species.

Plite 99, figs. $1-10$.

Ibecription.-The zoarium is free, bilamellar, erect, formed of short, dichotomomsly divided fronds; the trio lamellae, placed back to back, are inseparable. 
The zooecia are elongated. distinct, elliptical, surrounded by numerous prietal areolae. The cribriform area is wile. perforated by at least seren stellate pores. The peristome is much dereloped above the aperture and caps the zooecia with a large convexity, supporting a small, round aricularimm. The aperture is transrerse and semielliptical; the peristonic is quite decp. At the base of each zooecium there is a small, simple. adventitions, very salient a ricularium.

$$
\begin{aligned}
& \text { Measurements. - Zooecia } L z=0.45-0.52 \mathrm{~mm} . \\
& \text { Width of the peristomice }=0.14 \mathrm{~mm} . \\
& \text { Length of the total area }=0.15-0.20 \mathrm{~mm} .
\end{aligned}
$$

Variations.-Our description is based on young zooccia (fig. 2). Quite frequently the development of the pleurocyst remites in a single total area the aperture, median a vicularium, and the cribriform area.

The median avicularium normally round, is more elongated and pointed if it be deeply imbedded (figs. 3,4 ). The small distal avicularium is not rery constant on the old zooecia (fig. 6). The adventitious a vicularium is less prominent on the old zooecia, but it remains visible (fig. 7 ). The distal thickening of the peristome which caps most of the zooccia disappear's at the base of the old fronds (figs. 4,6).

The older zooecia as usual lose their polypide and consequently their hrdrostatic system. They contain only parictal areolae and aricularia (fig. 6). The latter persist even after regeneration.

There are sometimes two and three pores on the distal part of the prominence above the zooecia (figs. 2,3).

The longitudinal section (fig. 10) shows very well the identity in structure of this fossil form with that of the recent species so well figured by Waters. The depth of the vestibule accounts for the invisibility of the aperture.

The tangential thin section (fig. S) indicates that the pleurocystal elements n'e rather large.

Affinities.-The old zooecia are exactly like those of Alleonellopsis cyolop., but the young zooecia differ from that species in their zooecial cap and in the fact that they lack a thin peristome.

Adeonellopsis galeata differs from A. quisenbermyae in its median aricularikm, which is straight and which never touches the walls of the total area.

It differs from Adeoneltopsis magniporosa in the distal thickening of its peristome and the presence of a small distal avicularium.

Occurrence-Vicksburgian (Byram marl) : Byram. Mississippi (common).

Vicksburgian (Marianna limestone): Two and one-half miles north of Millry, Tashington County, Alabama (rare); Deep well, Escamlia County. Alabama.

Vicksburgian (Red Blufl cliy): Red Bluff, Wayne County, Mississippi (rare). Cotypes.-Cat. No. Gt31s, T.S.X.M. 


\section{ADEONELLOPSIS CYCLOPS, new species.}

Plate 100, figs. 1-11.

Description.-The zonrum is free, erect, bilamellar, formed of small dichotomonsly branching fronds; the two lamellae, placed back to back, are inseparable. The zooecia are distinct, elongated, elliptical. bordered by numerous parietal a reolae. 'The marginal zooecia are rery long, and without distal aricularia on the peristome or median avicularium and with a very small cribriform area. The median zooecia are wide; their cribriform area is large and of little depth, and the median avicularium is round and prominent. The peristomice is crescent shaped; the peristome thin and sharp, bears a small, round avicularium. The zooecia bear in their inferior part one or two small adventitions avicularia. The old zooecia have thick walls and their aperture, cribriform area and avicularia are arranged at the bottom of a total area.

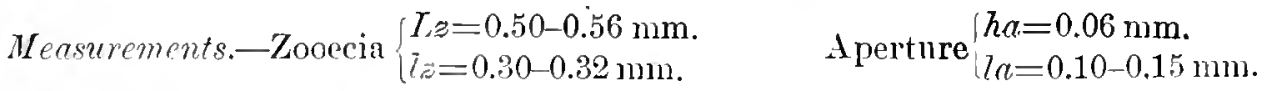

Tariations.-On very young zoocia the parietal areolae are quite large (fig. 6) but they are somewhat smaller on the other's (fig. 3).

The thickening of the plenrocyst is visible on figures $3,4,6,8$. When the znoecia are old the total area occurs constantly. But in this species. this condition is retarded and the normal zooecia are much greater in number than the old zooecia.

At the base of the zonlia the zooecia, no longer having a polypide. have closed apertures; only the aricularimm and the areolae persist (fig. 7 ). The small peristomal pore is absent in the marginal zooccia (fix. 3 ) and rery small at the ends of the fronds (fig. 6 ): but it is constant and rather large in the axial zooccia.

On the old zooecia. which are much thickened (fig. 9). it disappears or is irregularly placed. This pore, situated on the thin peristome and the rarity of the old zonecia provided with a total area, characterize this species.

The adrentitions aricularia result from the coalescence of two or three areolar cavities: they never have a pivot and are of the most simple type.

Affinities. -Tlis species differs from Adeonellopsis galeata in the occurrence of the mareinal zonecia different from the others and in its thin peristome. It may he distinguished from Alteonellopsis magniporosa and from $A$. quisenberryae by the presence of a small distal peristomial avicularium.

Occurrener.-Vicksburgian (Mariamna limestone): West bank Conecuh River. Escambia Connty, Mlabama (abundant) ; Murder Creck. east of Castlebury, AlaHama (abmulant) : near Claiborne. Alabama (abundant).

Ticksbuentan (Red Bhuff clay) : Seven and one-half miles southwest of Blarlon Springs, Mlabama (very lare).

Tickshurgian (Byran marl) : Byram, Mississippi (very rare).

Cotypes-Cat. No. 6.13:1, U.S.N.M. 
Genus DIMORPHOCELLA Maplestone, 1903.

1903. Dimorphneclla Maplestonf. Furtlel descriptions of the Tertiary Polyzoa of rictorit, Article IX. Transictions Is rall suciety Victoria, p. 140.

"Two distinct forms of cells. Zooecial cells elongated or rhomloidal, distinct. Thyrostome [aperture] arehed abore, with a simus in the lower lip. Ooecial cells [gonoecia] much larger than the zonecia. elongate. pyriform or oral, with a loroul aperture and a perforated area in front." (Maplestone.)

Genotype-Dimorphocella. (Adermella) triton MacGillivray, 1895. Miocene.

The other known species of this gents are:

Dimorphocella pyrifomis Maplestone, 1903. Miocene.

Dimorphocella portmarina Maplestone, 1903. Recent.
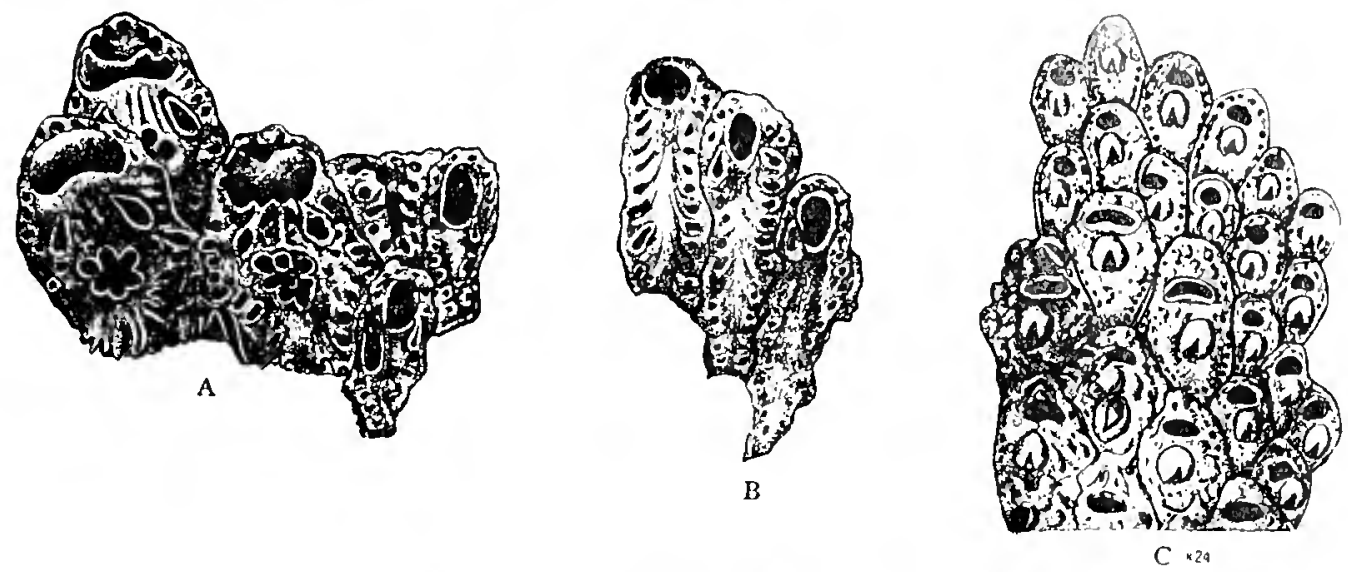

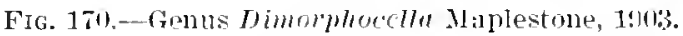

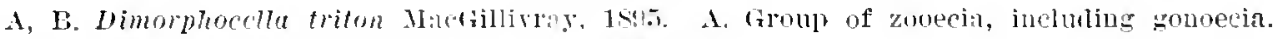
B. Normal zooecia. (A, B after Mincillivaly, 1595.)

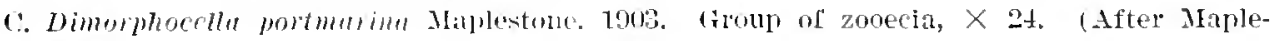
stone, 1903.)

According to the definition and examination of the figures the ordinary zoocia have no aseopores, whereas the womoecia are provided with them. On the recent species Dimorphocella postmarima there are some ascopores on the two kinds of zooecia. Further study is therefore necessary to establish the ralidity of this gemu..

Genus LAMINOPORA Michelin, 1842.

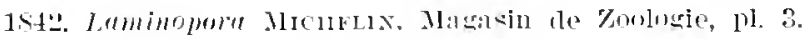

The apertura is very elongate: the anter is semielliptical; the poster hears a long, rounded rimule; two small rardelles separate the two latter parts; the operculum bears two lateral denticles articulating on the cardelles. The frontal is a tremoeyst with pores not stellate. The gomoecia have no special form. 13-15 tentacles.

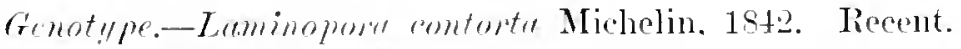

Gemelliporce arbusculn Calvet, 1906 . belongs to this genns. 


\title{
Family PHYLACTELLIDAE Canu and Bassler, 1917.
}

The aricell is recumbent; its orifice is rery large and closect by a special

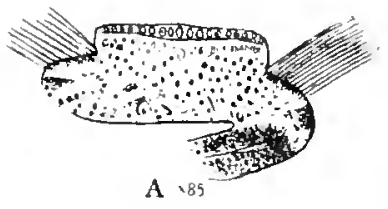

A 185

\begin{abstract}
Fir. 171. - Tarva of Phylactellidae.
\end{abstract}
1, R. I'lulactlla linbiata smitt, 1867. Two views of the large larva in the ovieell, $X 85$, showing the larva to be more fully developed than in other bryozoa.

Hincks, but he has not completely defined it.

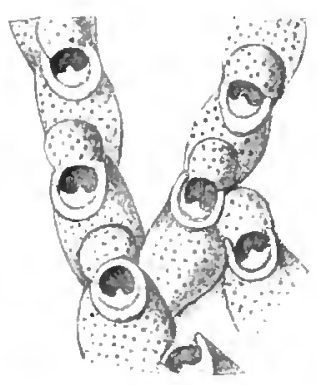

A. Phylactella

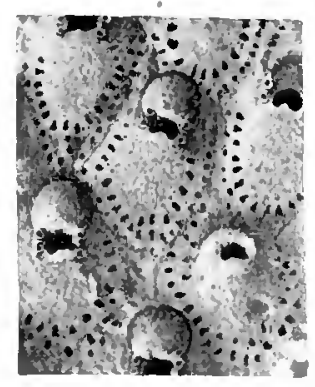

B. Perigastrella

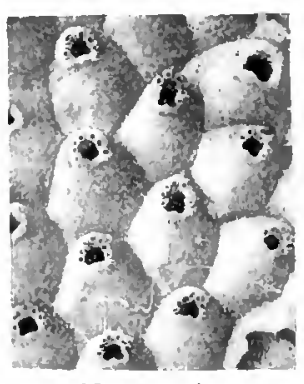

(' Hemicycloporat opereulum. "The larvae are large and more fully developed within the ovicell than is usual; the corona and cilia are very distinct."

In 1900 Waters $^{1}$ discovered the larva of Phylactella. It is quite distinct from all others in its form and its lar.ge dimensions, and evidently it characterizes a special family. The principal genus was outlined by

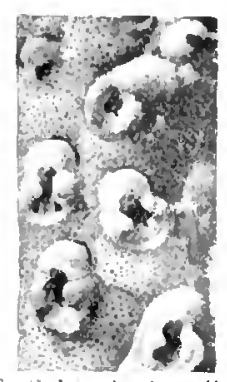

E Schirobathyella

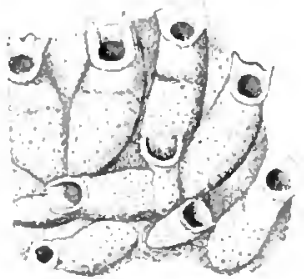

F l,ilcempora

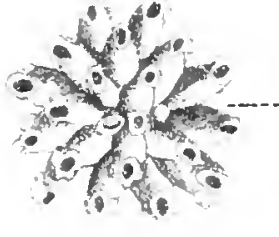

G. Ascosia

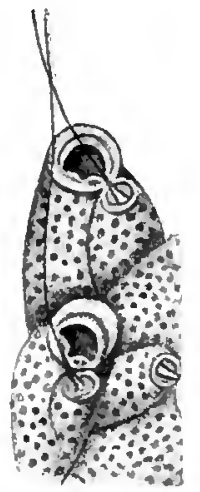

1). Mastigrophora

Fig. 172. Genera of the family Phylactellide Citun and Bassler, 1917.

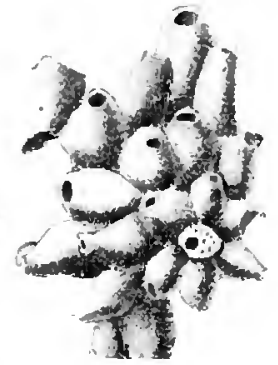

H. Temachı

A. Plumlactella labrosa Busk, $1552, \times 30$. liecent.

B. I'erigastrella hexagonalis, uew species, $x " 1$. Jacksonian of North Carolina.

C. Hemicycopora parajunelu Canu and Bassler, 1917, X 20. Jaeksonian of South Carolina.

1. Hasligophora. hyndmanni Johustou, 1S47, $\times 30$. Iiecent.

E. Schizobuthysella suceifera Canu aud Bassler, 1917, X 20. Jacksonian of North Carolina.

F. Lagenipora socialis Hincks, 1577, $\times 25$. Recent.

G. Asronsil pandora Jullien, 1882. $\times 10$. Recent.

H. Temachia opulenta Jullien, 1SS1, $\times$ S.5. Recent.

19um, Taters, Rrgozoa from lranz Josef Land, Journal Linnean Society London. Zoologs, rol. 28, p. 90, [1]. 12, figs 3,4 
The special oricell which Water called recumbent is placed on the distal part of the zooecium itself between the apertula and the distal zooecimm. Fiewed laterally it appears attached like a sack on the back of a porter. Evidently it is also more or less supported on the listal zooecium, but frerpuently it is completely separated from it. In its form, position. and large opening it is eminently adapted to the size of the larrae.

We know but little of the opercular system. The three opercula which we know have been figured by Waters.

The determination of the species presents some difficulties. The tremopores and the areolae are very small; they become obliterated quite easily and the true nature of the frontal is difficulty dişcernible.

For the classification of the genera we apply always the sane principal functions. working of the operculum. compensatrix, calcification. This elassification may not always be definite, nor complete for we have only fossil forms at our disposition.

Generally the ancestrula is a rely small zooecium provided with a very large elliptical aperture.

Genus PHYLACTELLA Hincks, 1880.

1590. Phyluctella H I N C E S , British Mitrine Polyzoa, 1. $35 \%$.

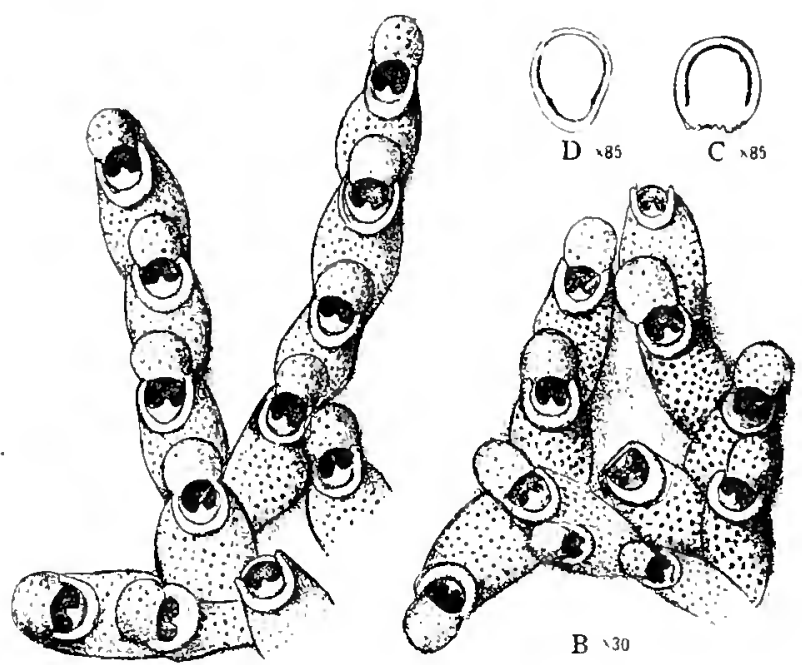

A $\cdot 30$

F1r. 173.-Genus Phylactellu Uincks, 1850.

A, B. Plylactella labrosa Busk, 1852. Two groups of zooe.

The apertura is more or less circular; it bears either al lyrule or some cardelles. 'The thick band of the opereulum is cia, . 30. (After Hincks, 1850.)

C. Opereulum, $\times 85$.

1. Phyluctlla menctigera Waters, 1899. Operculum, $\dot{x} 85$. (1, D after Waters, 1899.)

at a small distance from the erlege. The apertura is surrounded by a peristomic more or less funnel-shaperl; the peristome is interrupted distally and replaced by a small tongule. The frontal in a tremecrst with very fine pores. To spines.

Genotype-Phylactella labrosa Busk. 1552.

Range.-.Tacksonian-Recent.

The fossil species of this genus are:

Phylactella (Lepratia) tuliceps Rens. 1865, Chattian of Germany.

Phylactella porosa Machillivay. 189.. Miocene of Australia.

The recent species are:

Phylactella (Le pratia) Fithrosa Busk. 18.re. 
Phylactella (Lepratia) collaris Norman, 1866.

Phylactella (Lepratia) eximia Hincks, 1877.

Phylactella punctigera Waters. 1899.

Phylactelle columnaris Kirkpatrick, 1888.

PIILACTELLA INFUNDIBULUM Canu and Bassler. 1917.

Plate 71, figs. 24-26.

1917. Phylactella infundibulum CANU and BAsscer, Synopsis of American Early Tertiary Cheilostome Bryozoa, Bulletin 96, United States National MIuseum, p. 67. pl. 6, fig. 2.

Description.-The zoarium incrusts other bryozoa. The zooecia are large, distinct, elongated, oral; the frontal is quite convex; it is formed of a tremocyst with very small pores separated from each other by fine granules. The apertura is formed of a large semicircular anter, separated by two cardelles from a very concare poster; the peristome is long, tubular. depressed in front, and interrupted behind by a wide distal tongue; the peristomje forms a sort of finnet around the apertura. The ovicell is large, salient, globular, finely porous and granular; it is hyperstomial, recumbent, and it opens into the peristomie.

$$
\text { Measurements.- Ipertura }\left\{\begin{array} { l } 
{ 7 h a = 0 . 1 6 \mathrm { mm } . } \\
{ 7 a = 0 . 1 6 - 0 . 1 7 \mathrm { mm } . }
\end{array} \quad \text { Zooecia } \left\{\begin{array}{l}
L z=1.25 \mathrm{~mm} . \\
7:=0.72 \mathrm{~mm} .
\end{array}\right.\right.
$$

This superb species is unfortunately quite rare.

(1ecurrence.-Middle Jacksonian (Castle Hayne limestone): Wilmington, North Carolina (rare).

Cotypes.-Cat. No. 62607, U.S.N.M.

PhylaCtella PARVicollum, new species.

Plate 72 , fig. 9

Deseription.-The zoarium incrusts shells. The zooecia are distinet, clongated. elliptical or oval; the frontal is convex and formed of a tremocyst with very small pores separated by small salient gramulations. The apertura is orbicular; it is formed of a large anter separated by two small cardeles from a mall concave and finely denticulated poster; the peristome is small, little salient, often interrupted distally by a small salient tongue.

$$
\text { Wheasurements. A pertura }\left\{\begin{array} { l } 
{ h a = 0 . 1 5 \mathrm { mm } . } \\
{ 7 a = 0 . 1 5 \mathrm { mm } . }
\end{array} \quad \text { Zooecia } \left\{\begin{array}{l}
L \approx=0.60 \mathrm{~mm} . \\
7 \approx=0.45-0.50 \mathrm{~mm} .
\end{array}\right.\right.
$$

Affinities.-This charming species is unfortunately rare and we hare not had the good fortune to discover the ovicell.

It differs from Phylactella infundibutum in its micrometric dimensions, which are twice as small. On the other hand, its zooecial length, $0.60 \mathrm{~mm}$.. is mueh greater than that of Phylnctella paricella ( $L z=0.40 \mathrm{~mm}$.).

Occumener.-Middle Jacksonian (Castle Hayne limestone) : Wilmington, Nor'th Carolina (rare).

IIototype.-Cat. No. 61192. U.S.N.M. 
PHYLACTElla PARVicella, new species.

Plite $\mathbf{7 1}$, fig. $\mathbf{2 7}$.

Deseription.-The zoarium incrusts bryozoa. The zooecia are relatively smalt, short, distinct, elliptical ; the frontal is convex and formed of a tremocyst with very small pores separated by very minute granules. The apertura is elliptical; the neristome is thin, salient, complete.

$$
\text { Measurements.-A pertura }\left\{\begin{array} { l } 
{ h r = 0 . 1 0 \mathrm { mm } . } \\
{ 7 . \alpha = 0 . 1 0 \mathrm { mm } . }
\end{array} \quad \text { Zooecia } \left\{\begin{array}{l}
L_{z}=0.40 \mathrm{~mm} . \\
7 z=0.30 \mathrm{~mm} .
\end{array}\right.\right.
$$

Affinities.-This is the smallest of our Phylactella; it is therefore easy to determine. Unhappily, only the figured specimen has been found so we are ignorant of the oviccll.

Occurrence--Middle .Jacksonian: Baldock, Barnwell County, South Carolina (very rare).

Holotype.-Cat. No. 6t191, U.S.N.M.

PHYLACTELLA CRIBRATA, néw species.

Plate 96, fig. 10.

Description.-The zoarium incrusts bryozoa. The zooecia are elongated, distinct, ovoid; the frontal is convex and formed of a tremocyst with numerous pores in quincunx. The apertura is suborbicular, oblique, little visible exteriorly; the peristome is thin, complete. salient, bearing on its proximal border a wide salient mucro, placed facing the orifice of the ovicell. The ovicell is small, transverse. smooth; it is hyperstomial and recumbent. A triangular aricularium somewhat salient, the point directed toward the top, is placed laterally on a single extremity of the transrersal axis of the zooecia.

$$
\text { Measurements.-A pertura }\left\{\begin{array} { l } 
{ h a = 0 . 1 6 \mathrm { mm } . } \\
{ 7 _ { a } = 0 . 1 9 \mathrm { mm } . }
\end{array} \quad \text { Zooecia } \left\{\begin{array}{l}
Z_{z}=0.65-0.55 \mathrm{~mm} . \\
7 z=0.40-0.45 \mathrm{~mm} .
\end{array}\right.\right.
$$

Affnities.-This species is very well characterized by its sieve-like frontal of tremopores, larger than ordinary. and by its lateral avicularium.

It is to be noted that most of the known Phylactelle have an aperture whose diameter is close to $0.15-0.17 \mathrm{~mm}$. The genus is a perfectly natural one.

Phylactella (Lepralia) tubiceps Reuss, 1865, of the German Rupelian, is quito close on account of the size of its tremopores and in the prescnce of an aricularium: it differs from it solely in the absence of a peristomie, an exterior which has given the name to the European species.

Upon examination of more numerous specimens it may he that the two species will be recognized as identical.

Occurrence-Wicksburgian ("Chimney rock" of Marianna limestone) : One mile north of Monroeville, Alabama (rare).

Holotype-Cat. No. 64310. T.S.N.M. 
Genus PERIGASTRELla Canu and Bassler, 1917.

1917. Perigastrella CANu and Bassler, Sjnopsis of American Early Tertiary Cheilostome Bryozoa, Bulletin 96, United States National Museum, p. 69.

The apertura is semicircular. The band of the opereulum is on the border. The frontal is surrounded by one or two rows of small areolae; it is formed of an olocyst supporting a smooth or finely granular pleurocyst. Spines.

Genotype-Perigastrella (Lepralia) Tabiata Boeck. 1861.

Range.-Iutetian-Recent.

The recent species are:

Perigastrella (Lepralia) labiata Boeck, 1861.

Perigastrella (Lepratia) contracta Waters, 1899.

$\Lambda \quad 25$

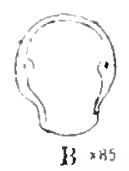

C. .85
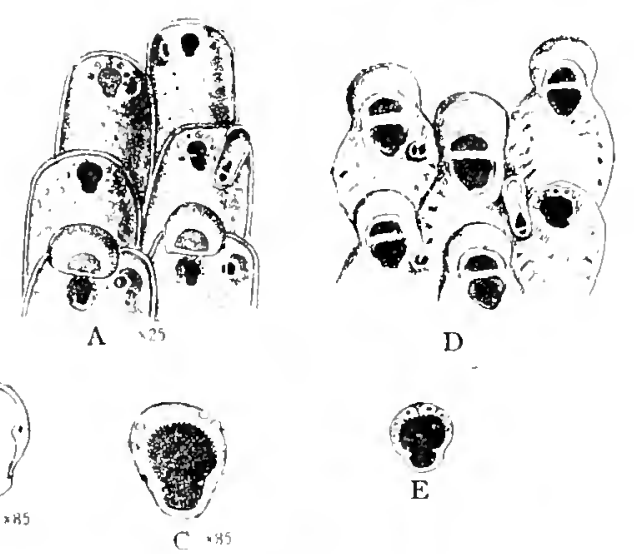

D

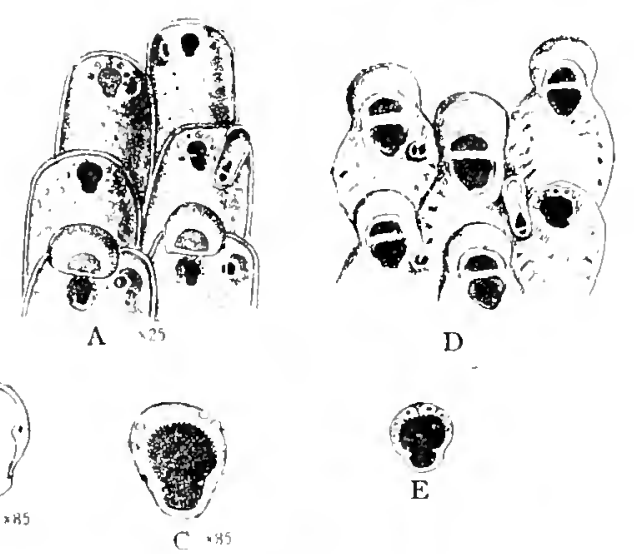

Fir. 174. Genus Perigustrelle Canu and Bassler, 1917

A-E. Perigastrella contractn Waters, 1899. A. Zooecia, $\times 25 . \mathrm{B}, \mathrm{C}$. Operculum and apertura, $\times 85$. (A-Cafter Waters, 1899.) D, E. Zooecia and apertura. (Aiter Norman, 1909.

presser on the frontal. The ovicell is small, lecumbent, little salient and hyperstomial. On the peristome itself there are sometimes two small, round avicularia.

$$
\text { Measurements.-Apertura }\left\{\begin{array} { l } 
{ h a = 0 . 1 4 - 0 . 1 6 \mathrm { mm } . } \\
{ 7 a = 0 . 1 2 - 0 . 1 4 \mathrm { mm } . }
\end{array} \quad \text { Zooecia } \left\{\begin{array}{l}
l_{z}=0.40 \mathrm{~mm} . \\
l z=0.30-0.34 \mathrm{~mm} .
\end{array}\right.\right.
$$

The form of the apertura, like the handle of a basket, is rather characteristic. Widely spaced areolae have not been observed in any other species. The olocyst and the detachable pleurocvst are clearly visible on figure 19.

Occurrence.-Claibornian (Gosport sand): One mile southwest of Rockrille, Clarke County, Alabama (rare).

Cotypes.-Cat. No. 63853 , U.S.N.M.

Perigastrellu (Mueronella) semierecta Koschinsky, 1885.

Perigastrella. (Lepratia) grotmani Stoliczka, 1862.

Perigastrella ansata, new species.

liate 14, figs. $18,19$.

Deseription.-The zoarium incrusts shells. The zooecia are distinct, short, little elongated: the frontal is conrex and formed of an olocyst perforated laterally by widely spaced areolae and surmounted by a finely granular plenrocyst. The apertura is formed of a large ogival anter and of a concave poster; the peristome is little salient. very thin, with an inferior lip salient or somewhat deferior lip salient or somewhat de-

The fossil species are: 


\section{PERigastrella hexagonalis, new species.}

Plate T2, fir. 10.

Description.-The zonrimm inernsts bryozoa. The zooecia are large, distinct. hexagonal; the frontal is little concave and surrounded by a louble row of quite crowded areolae; it is formed of a gramular pleurocyst. The apertura is transverse, oblique, trapezoid, little visible exteriorly: the peristome is little salient. oblique with an inferior lip in the form of a mucro, which is elevated and prominent. The ovicell is small, transverse, globular. gramular; it is hyperstomial and recumbent.

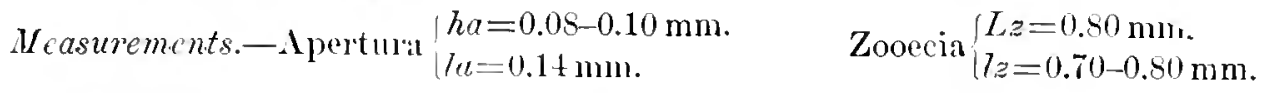

Gemerrence--Míidle Jacksonian (Castle Hayne limestone): Wilmington, North Carolina (rare).

Ilolotype.—Cat. No. 6+193, I.N.X.M.

\section{PERIGASTRELLA RHOMBOIDALIS, new species.}

Ilate 72 , fig. 11 .

Description.-The zoarium is bilamellar; the two lamellae, back to back. are inseparable. The zooccia are distinct, large, elongated, rhomboilal; the frontal is convex, surrounded by a double line of small triangular areolae and formed of a finely gramular pleurocyst. 'The peristomice is semilunar, transverse, complete, with a concave proximal border; the peristome is thin, sharp, little salient. 'The ovicell is small, transrerse. little alient, finely gramular; it is always closed by the operculum.

$$
\text { Weasurments. A pertura }\left\{\begin{array} { l } 
{ h a = 0 . 1 6 \mathrm { mm } . } \\
{ 7 a = 0 . 2 . 2 - 0 . 2 + \mathrm { mm } . }
\end{array} \quad \text { Zooecia } \left\{\begin{array}{l}
L z=1.00-1.20 \mathrm{~mm} . \\
l z=0.60-0.50 \mathrm{~mm} .
\end{array}\right.\right.
$$

Aftinitics.-The figured specimen only has been found. It appears to repre. sent a type rather divergent in the genus. We believe in making a new genns only when the material is sufficient.

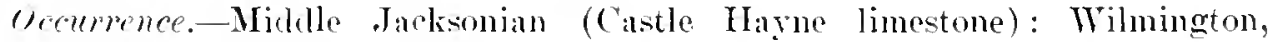
North Carolina (very rare).

IIolotype.Cat. No. G+194. I'A.X.M.

\section{PERIGASTRELLA CYCLORIS Gabb and Horn, 1862.}

Ilate 72. fiers. 12-14.

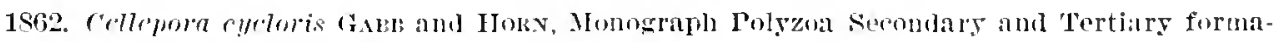
tims of North Amrrica, Jotmial Acalemy Naturil Sclmees, Philatelphia. ser. Z.

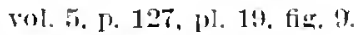

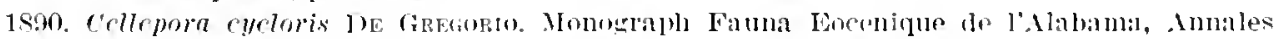

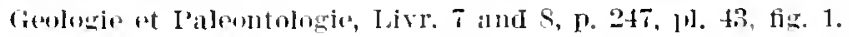

Ileseription.-The zoarium inerusts shells and bryozoa. The zooecia are listinct, large, hexagronal: the frontal is very convex and surroumded by a triple row of very small areolae: it is formel of a smooth or very finely granular plen- 
royst. The apertura is hidlen at the base of a large peristomie; it is transverse (interior) and formed of a semichliptical anter separated by two small cardelles from a somewhat concave poster; the pristome is very salient. thin; its distal part supports eight spinea; its proximal part hoars a wide, very salient mucro perpendicular to the zoocrial plane or depressed on the frontal. The ovicell is small, salient, glohnlar, smooth; it is liyperstumial and recumbent.

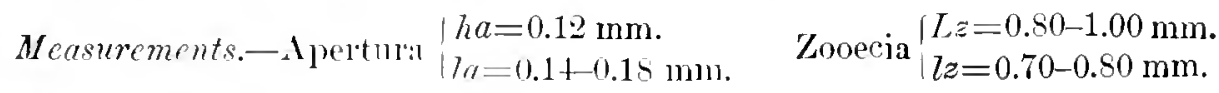

Aftuities. - This lange and leantiful species has been known for a long time. The transversal schenatic section of a zuoecium given by Gabb and Horn is perfectly exact. The labial muen is placed in such a position that our photographs can not show their important saliency.

The operentum may never close the wicell.

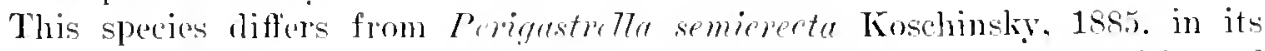
larger dimensions ( $L, z=0.80$ and not $0.70 \mathrm{~mm}$.) and the different disposition of the labial mucro.

Occurrence.-Midale . Tacksmian: Wilmington, North Carolina (common): near Isomes Ferry. South (arolina (very rare).

Upper Jacksonian (c)ala limestone) : Test bank Sepulga River, Escambia County. Alabama (rare).

Plesiotypes-( at. No. (it19., T.N.X.M.

\section{PERIGASTRElla OSCITANS, new species.}

I'late T2. figs. 15-18.

Description.-The zondum incrusts shells, often over a very larege surface. The zooccia are distinct, clongated, elliptical; the frontal is convex and surrounded by a lime of round or triangular areolae; it is formed of a gramular pleuroeyst. The apertura (interior) is ablique, transverse. trapezoid; the peristomie, rather deep, often bears two or thres rery prominent denticles; the peristome is thin, salient, complete; it hears six spines on its distal part and the proximal part is a wide silient mucro. erect, and partially hiding the apertura. The ovicell is small, transrerse, salient, very wide]y open; it plenrocyst does not entirely cover the oloeyst, thus leaving a very appalent frontal area.

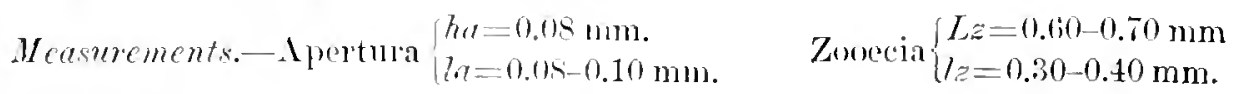

rariutions.-It is difficult to find and speimens of this species, for they are easily altered ly fossilization: the apertura in always more or less closed by the calcareons deposit. We have suceedod. huwerer, in preparing a superb specimen (figr. 15) in the ricinity of the ancestrula: the arenlas are there quite small and the labial mucro jo much attenuated. The mure halitual aspect of the species is that of our figure 16 . 
On the well-preserved specinens (not:ably those from Wilmington), ly inclining the preparation, we ean sere in the preistomie two ol thee salient denticles of whose physiologic significance we are ignomat.

The frontal is often smooth (fig. 17).

The orifice of the ovicelled zooecia has somewhat the aspert of a human mouth opened to yawn.

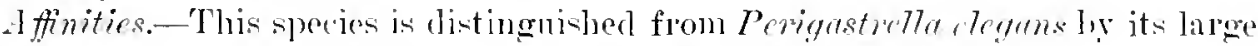
general dimensions and the aherence of three rows of areolar pores.

It is distinguished from Proigastrentre oroidea in the elliptieal form of its zooecia, its lesser zooecial longth ( $L_{z=0}=0.70$ and not $0.80 \mathrm{~mm}$.). its les anvex frontal, its wider and la1ger ovicell with two quite visible limellac.

It is distinguished from Prevarstrolla planu in it smaller micrometrie dimensions ( $7 z=0.40$ and not $0.50-0.60 \mathrm{~mm}.)^{\prime}$ and in its pleurocyst. which is complete instear of being lateral only.

Occumenee.-Lower Jacksonian (Moodys mar]): Jackson, Missiscippi (rare).

Middle Jacksonian: Wilnington. North Carolina (common) : $3 \frac{1}{1}$ miles suth of Pery. Georgia (rare) : 12 miles sontheast of Marshallville. Georgia (ralos): Rich

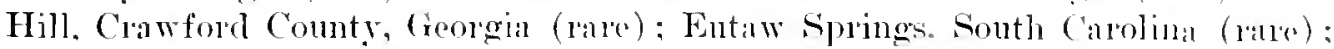
one-lualf mile sontheast of Georgia Kaolin Company Mine. Twigus Comnty. Cicororia (rare): 17 miles northeast of IIawinsville. Georgia.

Epper .Tacksonian (Ocala limestone): West bank of Sepulga River, Escambia

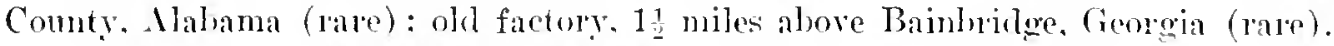
Cotypes.-Cat. No. rit106. I.N.N.M.

PERIGASTRLLLA ELEGans, new species.

$$
\text { Platir in. fig. } 1 .
$$

Theseription.-The zondinm incrusts shells. The zosecia are distinet. a little clongated, small, elliptical: the frontal is convex and surromrled by two of three rows of round or triangular areolar pores; it is formed of a rery finely granular plenrocyst. The apertura is depe trapezoid; the peristome is emplete, thin. salient: its inferior lip is a very salient muero, hilling somewhat the apertula or depressed on the frontal. The ovicell is very small. little salient. and formed of a plenrocyst and an olocyst which are distinct from each other.

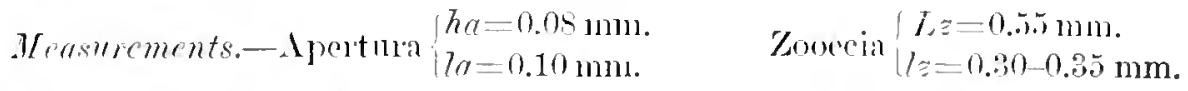

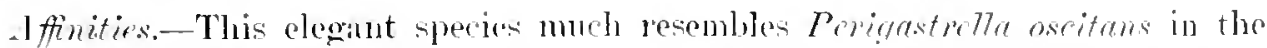
absence of decided characters and apjeas's to be a minor variety of it. It differs flom it in its much smaller miclometric dimensions. less than 0.5. mm., in its smonther oricell. and its thee rows of arentar pores.

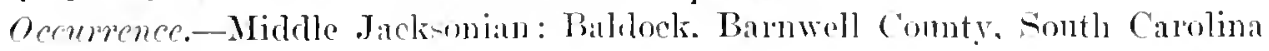
(rare).

Holotype.C-Cat. No. lit1!T. T'A.X.M. 
Plite 73 , figs. $2-1$.

1917. Perigastrella oroidea Canu and Bassler, Symojsis of American Early Tertiary Cheilostome Rryozoa, Bulletin 96, Lnited States National IInseum, p. 69, pl. 6, fig. 8.

Description.-The zoarium incrusts shells. The zooecia are distinct, elongated, large, ovoid: the frontal is very convex, bordered hy very small areolar pores and formed of a very finely granular pleurocyst almost smooth. The apertura, almost invisible exteriorly, is trapezoidal and oblique; the peristomie is deep; the peristone is very oblique and bears six to eight spines: it is sometimes interrupted in front, but more often it bears a salient mucro, oblique or erect, liding more or less the apertura; there is a small lyrula in the apertura. The ovicell is small, salient, glolular, almost entirely detached from the distal zooecinm; it is hyperstomial and recumbent: its frontal is finely granular like the zooecja. The ancestrula is rery small, but identical in form with the other zooecia.

$$
\text { Meamurements. - A pertura }\left\{\begin{array} { l } 
{ h a = 0 . 0 5 \mathrm { mm } . } \\
{ 7 a = 0 . 0 8 - 0 . 1 0 \mathrm { mm } . }
\end{array} \text { Zonecia } \left\{\begin{array}{l}
L z=0.55-0.80 \mathrm{~mm} \text {. } \\
7 z=0.50 \mathrm{~mm} .
\end{array}\right.\right.
$$

Affinitis.-This beautiful species is quite recognizable by its very large zooecial convexity. It differs from Perigastrella semiereete Koschinsky, 1885, in the presence of spines and in its somewhat larger dimensions.

It rlifters from Perigustrella oxcitans in its very small and nearly invisible areolice. its large frontal conrexity, and its peristomice, three times smaller, and in its oral lyrula.

It also resembles the ancestrular zonecia of Prrigastrellu rycloris Gabl and Horn, 1869. Jut differs in the apertma, which bears a lyirula and no cardelles.

Ocenrence-Middle Jacksonian: Eutaw Springs, South Carolina (common). Upper Jacksonian (Ocala limestone) : Plant System Railroad wharf at Bain-

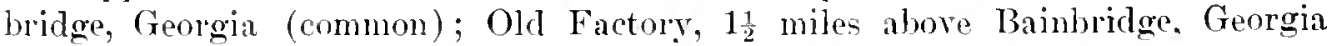

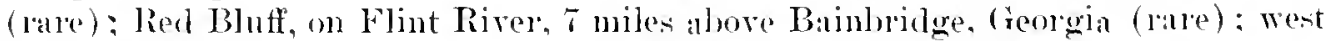
bank Sepulga River. Escambia County, A]abama (rare); Chipola River, east of Mariamna .Jackson County, Florida (very rare).

Tickshmrian (Marianna limestone): Well, Escambia County, Alalama.

Cotypes-Cat. No. 62613. U.S.X.M.

\section{perigastrella maxilla, new species.}

I'late" 7i, fiess, 5 .

Thexription.-The zoarium incrusts shells and other bryozon. The zooecia are distinct, short, ovoid, erect; the frontal is rery convex. almost smooth, surrounded by minute areolate, revealed only by some seareely visible ronghnesses. The apertura is deep. oblique, trapezoid. with a straight or somewhat convex proximal

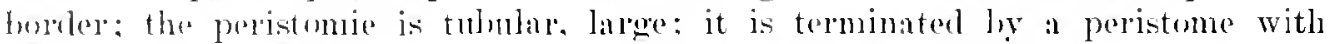
usually eiglat spines and by a very large, rounded, salient, erect mucro, exposing to view the apertura and almost invariably depressed on the frontal. The oricell 
is transverse. globular, salient. and formed of a plemrerst on an oluegt: it is hyperstomial, recumbent, and somewhat supported on the distal zooecium.

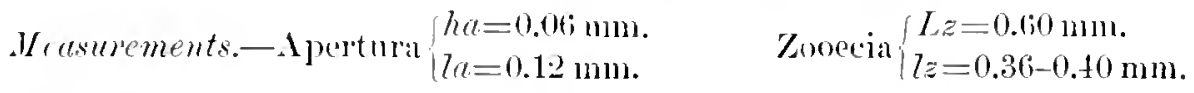

Tariations.-The mucro arises just in front of the orifice of the ovicell; its size depends strangely enough on the developnent of the ovicell. IBut its aspect is rery irregular; sometimes it is erent (fig. 5). Sometimes it appears as alepressed on the frontal (fig. 6). The greater part of the time the frontal appear's smooth and the areolac are discernible only on perfect and very well cleaned specimens.

Affinities. -This species diflers from Perigastrella oroulea in its small dimensions $\left(L_{2}=0.60\right.$ and not $0.80 \mathrm{~mm}$.), in the absence of lyrula, in the apertur:a, and in its larger ovicell.

It differs from Perigustrella trapezuider, $P$. depressa, and $P$. metilineata, whose aspect is equally smooth, in its more convex frontal. and esperially in the great development of its peristomie and its labial muero.

Oecurrence.-Miskle Jacksonian : Rich Hill. Craw ford County, (Georwia (ratre); 18 miles west of Wriglitsrille, Johnson ('ounty, Georgia (rare).

c'otypes._Cat. Nos. lit19s, (it199, T.S.S.M.

PERIGASTRELLA TRAPEZOIDEA, new species.

l'late 7:3. tigks, s. 1.

Description.-The zoarium incrusts hryozoa and shels. The zooecia ale distinct, somewhat elongated, irregularly hexagonal; the frontal is little convex, without distinct exterior peristomie. smromeded by a double line of very small areolae and formed of a finely gramular plenrocyst. The apertura is trapezoidul, visible exteriorly, sometimes a little deformed by the mucro; the peristome is little salient; it bears six to cight spines on its distal part and a wide mucro arect. projecting in the form of a proximal lip. The ovicell is globular, salient, transverse. somewhat smpportech on the distal zooecimm, finely grannlated; it is hyperstomial and recumbent.

$$
\text { Measurmentw.-Aperturat }\left\{\begin{array} { l } 
{ h a = 0 . 0 6 \mathrm { mm } . } \\
{ 7 a = 0 . 1 0 \mathrm { mm } . }
\end{array} \quad \text { Zoneria } \left\{\begin{array}{l}
L_{z}=0.50 \mathrm{~mm} . \\
l z=0.40-0.50 \mathrm{~mm} .
\end{array}\right.\right.
$$

Sariutions.-The areolate and the fromtal gramulations are so -mall that the zooecia often seem nearly smooth. 'The tongue. which serves as a mmero, is generally erect and very prominent just in front of the orifice of the oricell, but often it is somewhat oblique and partialy hides the aperturat.

Affinities. - This species differs from Perigustm the osrituns in its less elongated zooecia, its much smaller granulations. its ovicell with no distinct and visible olocyst, and in its very small, scarcely visible areolac.

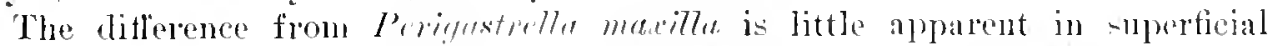
observation. It differs frou it in its less elevated zooccia. its flatter frontal, its mucro never depressed on the lrontal. and ehiefly in the absence of an exteriorly visible peristomie. 
It differs from Perigustrelle depressa, of which it has the zooecial form and general appearance, in the presence of its spines, in its frontal granulations. and in its labial muero.

The difference between it and II micyclopora prejuncta is quite small; it differs from it. however, in its visible areolae; its much larger labial mucro, and in its frontal oramlations.

It differs from Perigustre7la oroble in its smaller dimensions. ( $L z=0.50$ and not $0.75 \mathrm{~mm}$.) and in its transversal and trapezoidal apertura.

Occurpenee.-Midule Jacksonian: Wilmington. Torth Carolina (common); near Lenuds Ferry, Sonth (arolina (common).

Cotypes.-Cit. No. 6iton. T.S.X.M.

perigastrella depkEsSa, new species.

l'late i:s, firs. 10-13.

Description. -The zoalimm incrusts bryozoa and shells. The zuoecia are very little elongated. distinet. inregularly lexagonal; the frontal is little convex, bordered by very small aroolae. and formed of a neary mooth pleneoyst detachable from the subjacent olocyst. The apertma is semilunar, transverse, with a straight or shohtly convex proximal border; the peristome is seareely salient; its proximal border is depressed. never salient, sometimes inclined toward the apertura. The oricell is large. smouth. partially fixed to the distal zooeeium: its orifice is little visible exteriorly.

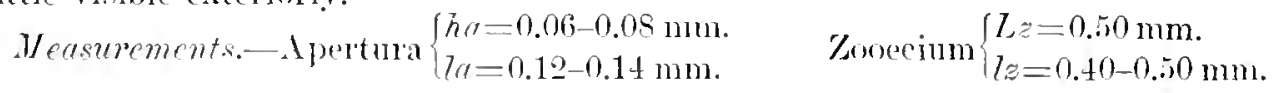

$T^{r}$ ariations.-The zooceial form of this species is rather variable and can not serve for determination. The areolae are invisible most of the time; only the perfect specimens are provided with them. But the essential characters of this -pecies are easy to recognize: orifice of the ovicell invisible, entire absence of salient l:1 lial muclo.

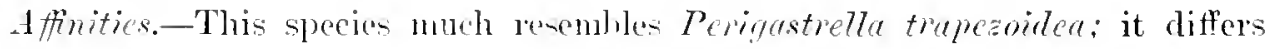
from it in its still flatter fromtal, in the al kence of a salient labial mucro. and in its il most smooth zooecia.

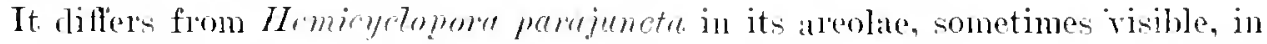
the absence of latial mucro, and in its wivell, which is betton attached, more fixed to the distal zorecinm.

Orentreme.-Middle Jacksonian: Wilmington, Sorth (arolina (common) : near Temurds Ferry, south (arolina (rare).

rotyle-Cat. No. 6t201, T.S.X.M.

PERIGASTRELLA RECTILINEATA, new species.

I'late 78, figs. $14-19$.

Iheseription.-The zonlum incrusts shells and bryozoa : the zooecia are disposed in 7iner roms. The zooedin are distinct, elongaterl, elliptical; the frontal is smooth, 
surrounded by a line of minnte areolate it is convex transveresely and concave longitudinally. The apertura is little visible exteriorly transrerse. semielliptical with a proxinal borter slightly convex: the peristome is very little sallent and bears six distal spines: its proximal lip is a little salient palette more on less oblique; partially hiding the apertuia, and whome lateral borders are straight. The wicell is globular. smooth. salient. fixes in part on the distal zoociun : it is hyperstomial and recumbent: its orifice is ratrely vicillde exteriorly.

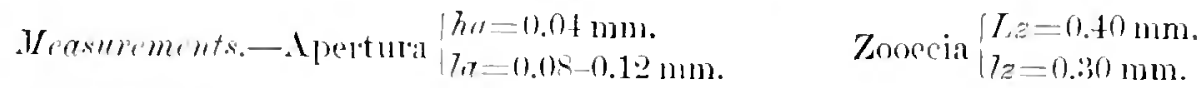

Taviutions.--The zooceia grumper in long. linear, adjacent series, characterize quite well this species (fig. 19); howerer, many zoaria have their zonecial regularly disposed in ruincunx (figs. 16, 17).

The areolac are rarely visilole; the aspect of the frontal is then absolutely smooth. Howerer, after brushing and washing with patiesce some specimens. we have been able to discover the areolac: they are extremely small. but their reality is not to be doubted. At the catremity of the large zoaria the zoneeria are rather large.

This species may easily be reengnizerl at first glane by the peenliar disposition of its lallial mucro: it has straight borkers and is clearly detached on the wide. apertura, which appears thus ornamenter laterally with two sorts of linear or circular opesiules.

In the interior the olocyst presents some kinds of fibers radiating from the apertura (fig. 18).

On one specimen we have olserved a membranipornid ancestrula.

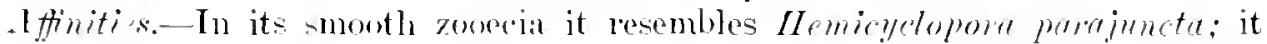
differs from it in its smaller zoorecia $(L z=0.30$ and not $0.50 \mathrm{~mm}$.), never Jougitulinally coneave, in larger lalial mucro, and in being bordered by false opeciules.

It differ's from Perigastrelle depresse in its smaller zooecia $\left(L_{z} z=0.40\right.$ and not $0.50 \mathrm{~mm}$.). in the presence of a labial mucro. and in its much more convex frontal.

Ocmerenec-Lower Jacksonian (Moodys marl): Jackson, Mississippi (rare).

Mieldle olacksonian: Wilmington, Nortli Carolina (common).

Ticksburgian (Marianna linestene): Salt Monntain, 5 miles south of .Tackson, Alabama (rare): 1 mile nortl of Monrocrille. Alabama (rare).

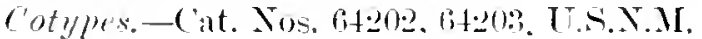

\section{PERIGASTRFLla PLANA, new species.}

Ilate 100 , figs. $18-21$.

Inesription.-The zoarium incrusts shells. The zooecia are distinct. elongated. rather large, oval: the frontal is almost flut, bordered loy a double row of small prominent areolae and formed of a smooth or granular pleurocyst. The apertura is semielliptical, transverse. with a straight, finely cienuliated proximal borter: the peristome is eomplete, salient. thick: it bears six distal spines and a wille. convex. salient, oblique labial muero. The ovicell is salient. transverse; its orifice is quite 
risible exteriorly and placel just in front of the labial mucro; it is hyperstomial, recumbent, somewhat supported on the distal zooecium: it is smooth and formed like the frontal of an olocyst under a pleurocyst.

\section{SIIORT IIEXAGONAL ZOOECIA.}

$$
\begin{aligned}
& \text { Mecrupcments.-A pertur:a }\left\{\begin{array}{l}
h a=0.08 \mathrm{~mm} . \\
7 a=0.1+\mathrm{mm} .
\end{array}\right. \\
& \text { Ioxe zooecra. }
\end{aligned}
$$

Tariations.-The exteriol peristomie is little visible by the illumination from ahove in our figures; it is more accentuated under the microscope by illumination from below. The young zonecia have a complete peristome (figs. 20. 21) and the areolae are quite visible. On old zonecia the plenroeystal calcification is intense in the vicinity of the areoline, so that the zonecia appear to be suromuded by a wide collar (figs. 15. 19). Sometimes in the interior of the peristomie there are two or three denticles: their fragility is perhaps the cause of their rarity.

Affnities.-CThe greater affinities of this species are with Perigastrella oscitans, and near the ancestrula confusion is possible. I'crigastrella plana differs from it in its creater width $(7 z=0.40-0.60$ and not $0.30-0.40 \mathrm{~mm}$. $)$ : in the oval. nonelliptical form of the zooecia. and in the proximal horder of the crenulated apertura.

Oceurenee-Ticksburgian (Mariama limestone) : West bank Conecul River, Escambia County, Alabama (rure): Murler Creek, east of Castlebury. Conecuh County, Alabama (common) ; near Claborne Monroe County, Alabama (very common); one mile north of Monroeville. Alabama (very common) : Salt Mountain, five miles south of .Tackson, Mlabama (common).

Vickshrgian (Byram marl) : Bram, Mississippi (rare).

Cotypes.-Cat. Nos. 63918, (3432) $\frac{1}{2}$, T.S.N.M.

Perigastrella ? COStifera, new species.

I'late 100. figs. 12-17.

Deseription.--The zorinn is incrusting cylostome lryozoa. The zooecia ale distinet, elongated, fusiform. providerl at their extremity with a long exterior neristomie; the frontal is amewhat convex and bordered latelally with widely spaced areolae; it is formed of a plemreyst with interareolin costmes more or less lons. The apertura, invisible exterioly, apprars orbienlar and oblique. The peristomice is irregular, ollique, with four distal spines. The ovicell is small, lypperstomial, recumbent, opening into the peristome.

$$
\text { Measurments.-Zooecia }\left\{\begin{array}{l}
r_{z}=0.35-0.45 \mathrm{~mm} \text {. } \\
7 z=0.20-0.25 \mathrm{~mm} \text {. }
\end{array}\right.
$$

Afenitix.-(1)n account of its orbicular orifice and its large peristomic. this

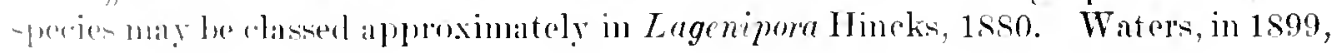


limited this grenns to only those species whose oricell is provided with a cribriform area. We are ignorant of the physiologic signifieance of this areat, ant we are unable to discuss the subject from a study of more ov less well-preserved fossil forms.

This species differs from Perigastrella tubulose. which is also provided with a long peristomic, in its interareolar costules, and in its smaller micrometric dimensions $(L \dot{z}=0.45$ and not $0.65 \mathrm{~mm}$.).

Perigastrolla grotiuni Rinss, 1865 , is also provided with an exterior tubular peristomie, hut our species ditlers in its more seattered areolat and in the presence of interareolar costules.

It is to be noted that this species does not spread out into flahelliform zoaria. We have observed it only on very narrow substrata, such as would he oflered by the cyclostome bryozoa. It is not possible to comprehend how a wide subutratum is eapable of destroying larvac: we must therefore admit that a larva is capable of choosing its substratum, which is marvelous in the olscure depthe of the sea. Such srmbiosis is frecuent ererywhere in the bryozoa.

Oerumenes.-Vickshurgian (Marianna limestone): West hank of (oneeuh River. Escambia County, Alabama (common) : Murder Creek. east of Castlebury. Alabama (very rare).

C'otypes.-('at. No. (64:3)'s, U.S.I.M.

PERigastrelia? TLBULOSA, new species.

Plate it. fig. 1.

7)scription.-The zonium incriste shells. The zooecia are distinct. Iong. lingeniform: the frontal is very convex, smooth, surrounded by very fine areolac. The apertura is deep. suborbicular. and formed of a large semilnuar anter separated by two small cardelles from a very concare poster; the peristome hears six distal spines. The oricell is smooth. globular, salient: it is hyperstomial. recumbent, opening largely in the peristonie; it is surrounded by a rery little salient collar.

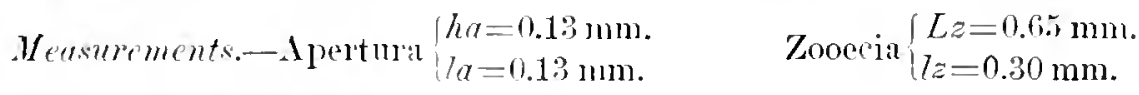

Aftinities.-This species presents all the characters which would permit its classification in Lagowipor IIncks, 1868. However, its ovicell is not placed as in Lagenipore socialis IIncks. 15i $\bar{c}$. and does not bear the cribriform area noted by Waters. On the other hand, the apertura with cardelles is a little different from the semielliptical apertura of the other species of I'rrigustrelle. Finally the preristomiale is not free, which was a fundamental character according to IIincks. The generic place of this species is therefore doubtful.

It differs from Perigastrelle! costifore of the same lageniform group in its zooecial size $(L z=0.6 .5$ and not $0.45 \mathrm{~mm}$.) and in its smooth frontal.

Occurrence-Upper .Jacksonian (Ocula limestome): Chipola River, east of Marianna, Jackson County, Florila (conmon).

Holotype.Cat. No. 6.204. I.S.X.M. 


\section{Genus HEIICICLOPORA Norman, 1894.}

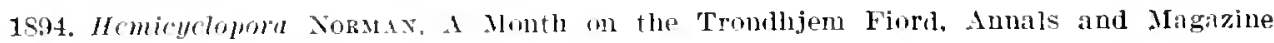
Nitural Hlistory, set. li, vol, 1:i, [1. 12t.

The ovieell is recumbent. The apertura is provided with rery low cardelles and formed of a large anter and of a small concave poster. The frontal is smooth and formed of an oloxyt. sipines.

Genotype.-Hemieycloporn (Jepratia) politu. Hineks, 1880.

limere-Helvetian-Recent.

Another known recent species is II miryclopora (Lemalia) Tabiosa .ullien, 190:3.

The only known fossil spereies is Hemiegrolopord obelisens Manzoni, 1865.

\section{HEMICYCLOPORA PARAJUNCTA Canu and Bassler, 1917.}

$$
\text { I'late TH, ijus. 2., : }
$$

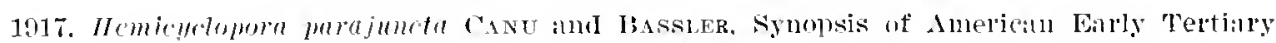

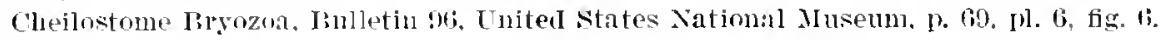

Tescription.-The zon rinm incrusts shells. The zooecia are distinct, somewhat elomgated, ogival: the frontil is somewhat convex and absolutely smonth. The apertura is olligue. sububicular: the peristome hears $s$ flistal spines and a proximal small mucronoid lip. The ovicell is globular, very salient, smooth, very

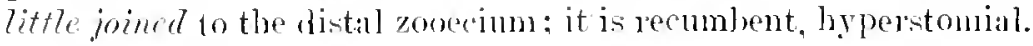

$$
\text { Metsurments.-Ipertura }\left\{\begin{array} { l } 
{ h a = 0 . 1 0 \mathrm { mm } . } \\
{ 7 a = 0 . 0 9 \mathrm { mm } . }
\end{array} \quad \text { Zooecia } \left\{\begin{array}{l}
L z=0.50-0.55 \mathrm{~mm} . \\
l_{z}=0.40-0.55 \mathrm{~mm} .
\end{array}\right.\right.
$$

Iftivities.-This species offers the exterior aspect of Perifusterlla with very small aroulate which gemerally appear smontl.

It differs from Perigastrella alemese in the plesence of the small labial mulero and in its ovicell almust completely detached from the distal zooecium.

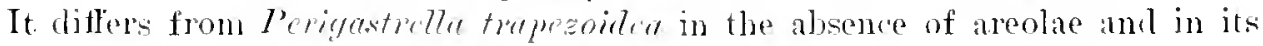
much smaller wicell more detached fiom the distal zonecium.

acmerpere.-Niklule. Jackonian: Near Lennels Ferry, Sonth Carolina (commonl).

r'otypes-Cit. No. rigkin. IT.S.X.M.

\section{Genus MISTIGOPHORA Hincks, 1880.}

1580. Mastignhora IIncks. Tiritish Marine I'olyzoil, p. 278.

The ovicell is small and recumbent. The apertura is semilunar: its proximal hurlor is straiglat and bears a rimule elongated ame rommlet. The frontal is a trenocyst with small pores placed on an oloeyst. Vibracula.

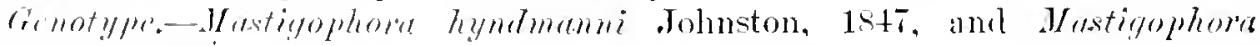

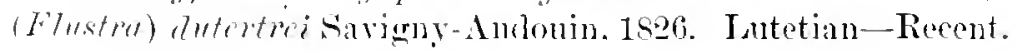

'The fossil speroses of this penus are:

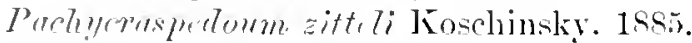

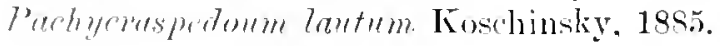


MASTIGOPHORA HYNDMANNI Johnston, 1847.

Zoological libliography.

\author{
I'later $T$-I, fị.. 10 .
}

1947. Lepmlia hymlmanni Jouxsmox. JIstory of Rritish Zoophrtes, ed. 2. 1. 301.

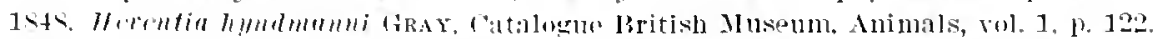

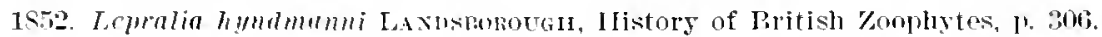

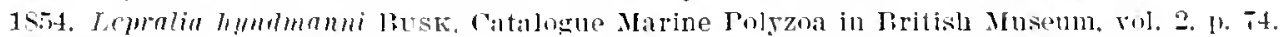

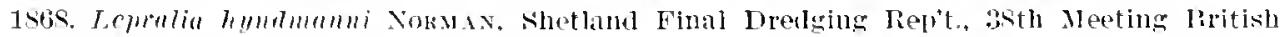
Association. I1. 30T.

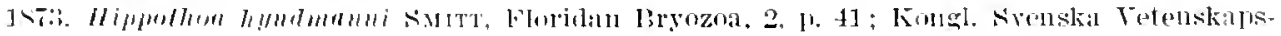
Akild. Ilindll.. vol, 11. Niı, 4.

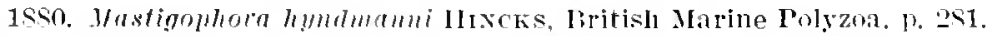

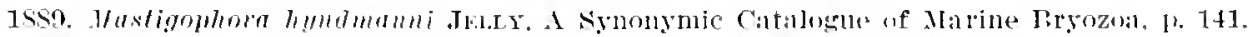

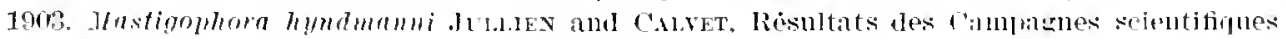

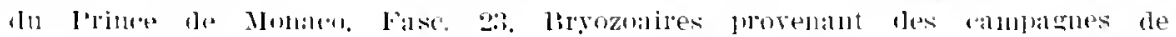

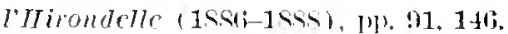

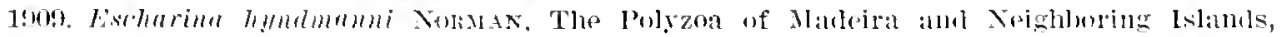

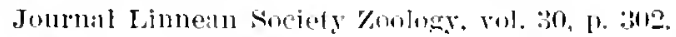

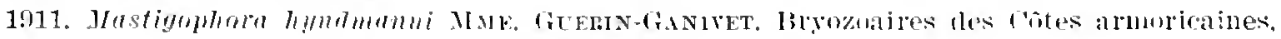

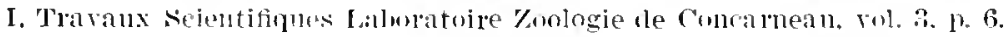

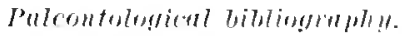

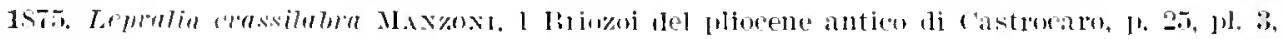
fig. 38 .

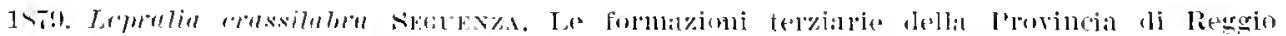

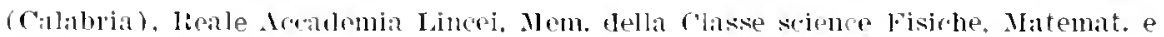
Nilt. IP. 81, 2012.

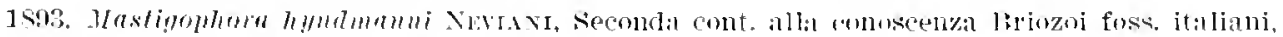
Bolletino Sociotà Geolouria ltaliana, vol, 12. p. 25.

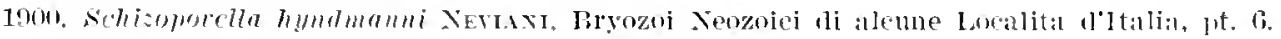

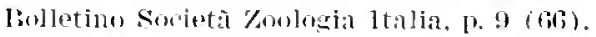

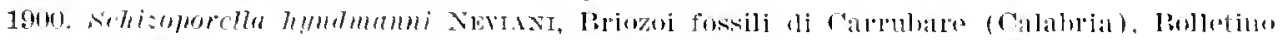

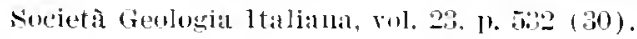

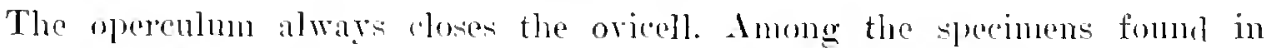
America. We have disonvered a variation a little more elongated, which we have figurexl.

It is remarkable that this speceses which existerl on hoth shores of the Atlantic

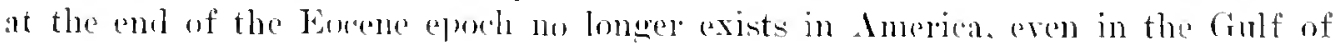
Mexico.

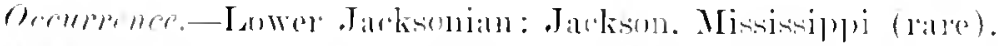

Misldle Jacksonian : ä miles somth of Perry, Georeria (very rare).

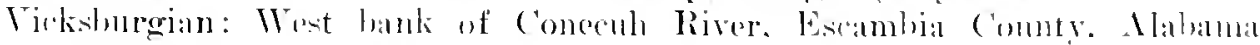

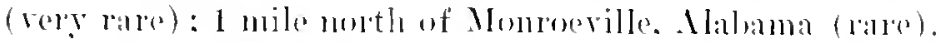

Geological distribution.-I Inetian of Italy (Negnenza. Neviani) of Tonraine

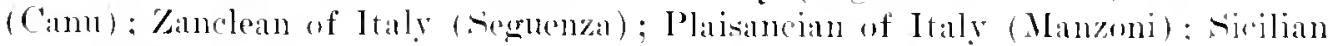
of Italy (Neviani).

Mabitat.-Atlantic in 13ritish waters. (is) 170 meters; in the Iritish Channel;

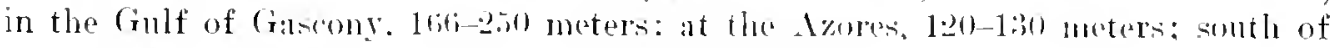
Africa. Mecliterrancan, aloner the French sloness. 
'This is a deep-water species for it has never been dredged at less than a depth of 65 meters.

Plesiotypes.-Cat. No. 6t207. T.S.N.M.

MASTIGOPHORA DUTERTREI Savigny-Audouin, 1826.

Plate 74 . fis. 11.

Zunlugical bibliograthil.

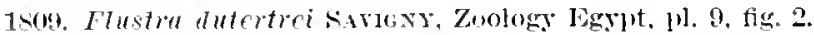

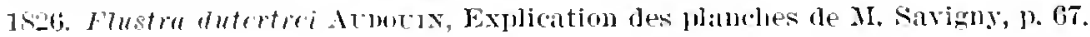

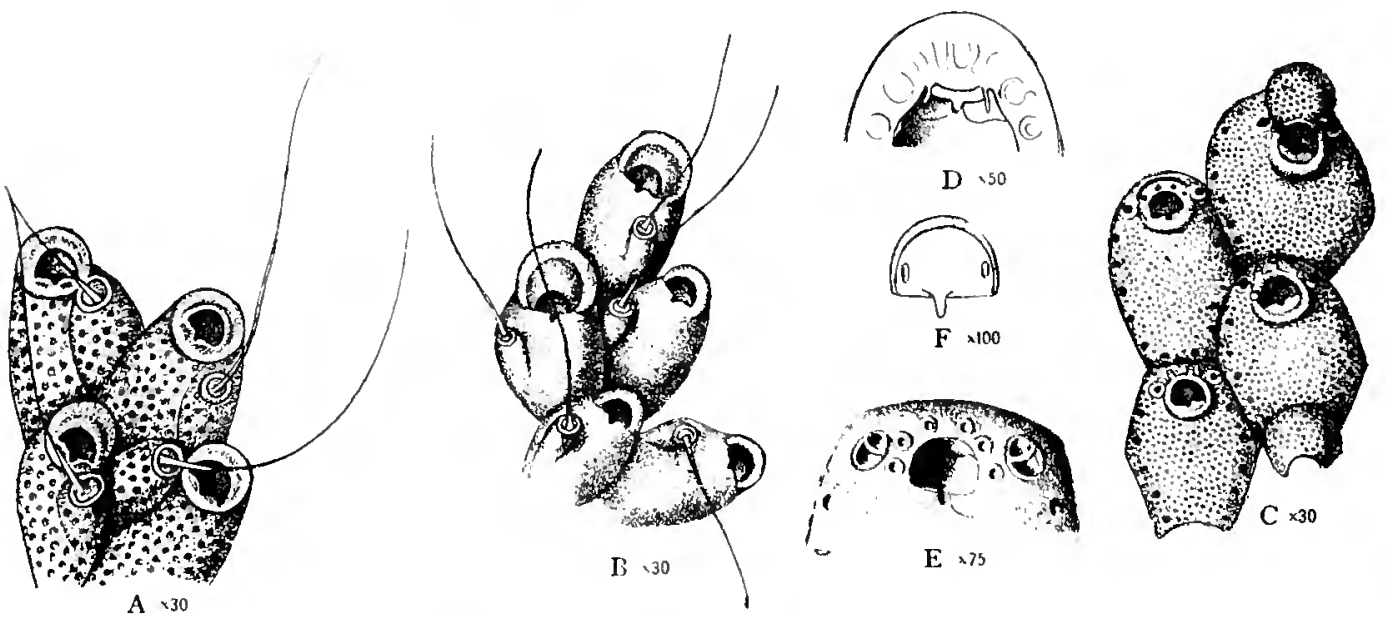

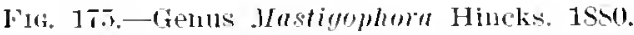

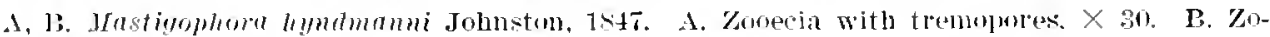
cesilil with oricells, $\times 30$.

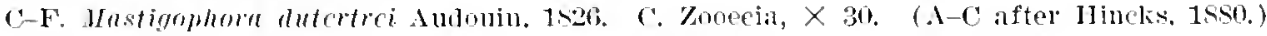
1). The distal end of a zooejum, $X 50$, from the basal aspect after the basil surfice has been fally remover. The high hinge teeth are seen, and also the restibular arch and the processes suringing from the litter. E. View slowing the vestibular arch and also the distal markin of the hinge teeth. Which fur the most part are internal, $X$ 75. Is. operemlum, X 100 . (D-F after Levinsen, 19ur.)

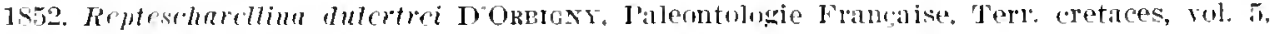
11. 453.

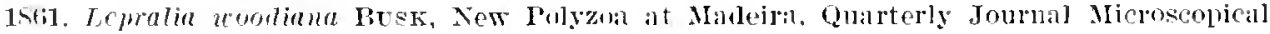
society, vol. S. 1. 284.

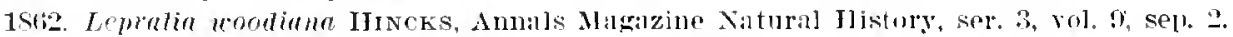

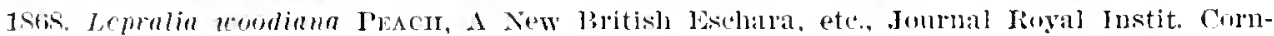
wall, rol. 19, sill. 2.

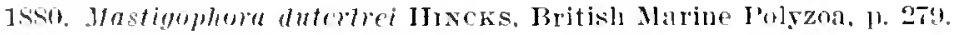

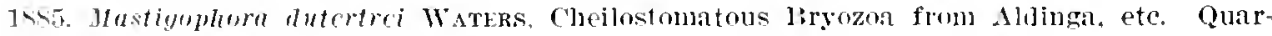
terly Jomrnal Geologica] Society London, rol. 41, p. 301.

1589. Mastignhorn dutertrei JeLrs, A Synongmic Catalogue of Marine Jryozod. P. 141. 
1590. Maxligophora dulerlvei linkp.trick, Rejort upon the llydrozoa and Polyzoa collected ly P. W. latssett-smith, during survey of the Tizat and Macelosfeld hanlis. in the China Sea, Annils Ilagazine Nitnral Histors, ser, (i, rol. T. 1) 17.

1S90. Mastigophora dutertrei Ontass, Die japanische Bryozoan-Fanna, .lichiv fïr Naturg.. rol. 50, pt. 1. P. 51, [1]. -1, fig. 5.

1903. Mastignphora dulerfici Julins and Calvet, Résultats des campasnes sei. du l'rinee

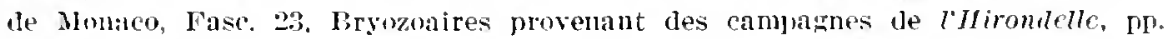
$91,146$.

1908. Schizoporclla duteitrci W.ArEss, Report on the Marine Biologt of the Snlinese Rel Sea. Journal Limnean Society Loman, rol. 31, p. 128.

Palcontologiral biblingtaphly.

1844. Hillepora punctat' l'mllup, Beitrige Kenntuiss Tertiïrersteinerungen des nordwestlichen Deutschlands, 1). 67, 11. 1, fig. 13.

1550. Lepralia wondiana I3usk, A Monograph of the Fossil Polyzon of the Crag, Publieations Paleontographiea society Londun. 1). 42, pl. 7 , firs. 1, 3.

19fi. Lepralia aurita Reuss. Velier die Foramin., Anthozoen und Bryozoen des dentschen

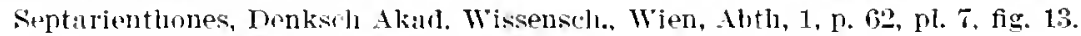

1875. Lepralia ofophora Maxzoxi (not Reliss), T briozoi del plincene antico di Castrocaro, P. 23, 11. 3, fig. 30 .

18S0. Lemalia brachyrephala SEgtwas, Le formazioni terziarie nelle Provincia di Regain (Calabrai), lieale Acar. Iincei, Mem. Classe, Sci. Fisiche, Matema, e Naturali. गए. $82,129$.

1855. Mastigophora dutrotrci Waters. Cheilustomatous Bryozon from Mldiuga and the River Murray Cliffs, South Australia, Quarterts Jumnal Roval Microscopical Socioty, 1). 301 .

180S. Schizoporella dutcrtrci Neviaxi. Briozoi fossili della Farnesina e Monte Mario presso Tomil. latenntograplica Italica. Piza, vol. 1. 1. 113, sep. 37.

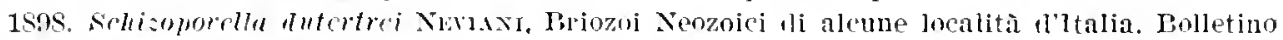
Societa liomana ler sli Studi Zool., p. 14.

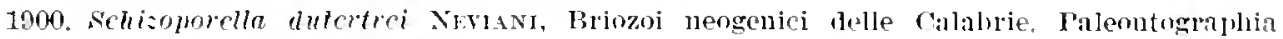
it:llivil. vil. 6, I. 1!) (S:3).

The geopraphical distribution of this species is considerable. but. like the preceding, it no longer exi-ts on the American shore. However, at the end of the Eocene, it existed on the two sides of the North Atlantic. This phenomenon is inexplicalle. all the more as the same gems is actually represented in the waters of Florida by two species. Is in the preceding. we are quite certain that the ovicell is recumbent. placed on the dintal part of the zooecium itself and that it does not rest on the distal zooerinm.

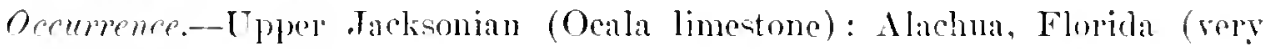
rare).

Vicksburgian ("('himmey rock" member of Marianna limestone): One mile north of Monroeville. Mlabima (raro).

Groblogical distribution.-Rupelian and Chattian of Germany (Reuss): IIelvetian of Italy (Seguenza): Tortonian of Italy (Seguenza) : Plajsancian of Funland (Busk), of Italy (Manzoni) : Sicilian of Italy (Neriani).

IIabitut.-Pacific, off . Iapan. 163 meters, and off Chili, 14 meters. Itlantic:

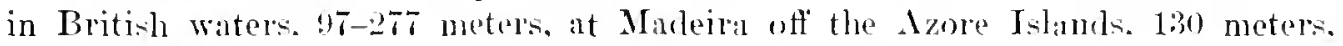
and in the British Chamel. Mediterranean, and the Red Sea.

Plesiotype-Cat. No. fit:-204. I'.A.N.M. 
Genus SCHIZOBATHYSELLA Canu and Bassler, 1917.

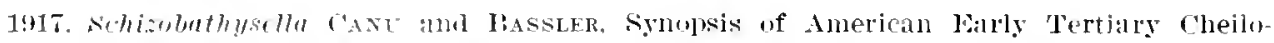

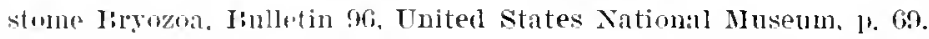

The a]ertura presents on its straight proximal border a small linear limule. The oricell is reeumbent and opens widely above the aportura. The frontal is a tremocyst. The peristomie is greatly expanded and is interrupted in front by an immense incouplete spirauen. The avienlarim is viluaculoid.

Grnotype.- Prhizoluthysolla saccifere Camu and Bassler. 1917. Tackomian.

This anos differs from Mrastigophera only in the nature of the peristome, which is much more salient and interrupted in front by a psendo-spiramen.

It differs from Ginantoporn Ridley, provided also with a spiramen, in the different form of the opereulmm, and in the smooth frontal of the latter.

To Jullion the spiramen seemed part of the hydrostatic apparatus. Here it appears to ws as in rapport with the extrusion of the lavar.

\section{SCHIOBATHYSELLA SEMILUNATA, new species.}

Plate 74 , figs, 4-1i.

lhereiption.-The zorliun jucrusts shells. The zonecia ane elongated distinct, swollen, elliptical; the flontal is rery convex and formed of a tremocyst with mumerous pores in puincums. The poristome is thin, irregular, distally latciniate; the peristomie is long and recumbent on the distal zooecia: the apertura is semilunaly; the anter is orival and the poster straght: there are two small cardelles quite low. The spiramen is elliptical, transverse, much barger than the peristomice.

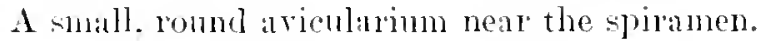

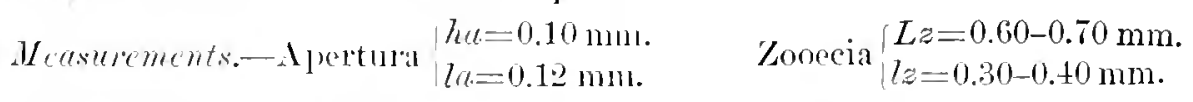

Trumtime.-The spilmuen is not always complete: the transversal arch which separtated it fon the peristomice is not ahays formed. but the lateral walls of the peristomic are always salient. 'Tle appenclages which olnament superiorly

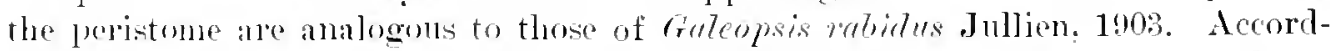
ing to the French anthor these are the spines wore or less united among themselves.

Affinities.-This species differs from Gotropsis momeost and Goleopsis erinaeces in the replacement of the fountal tuberosities by tremopores and in the sanilunar and not elliptical form of the apertura.

()erurgene.-Mirdle Jacksonian: Wilmington, North Carolina (rare); $3 \frac{1}{2}$ miles mortls of Grovania. Georgia (rery pare).

Cotype-Cat. No. Gtens. T.R.X.II.

SCHIZOBATHYSELLA SACCIFERA Canu and Bassler, 1917.

l'late 74. tign, 7.

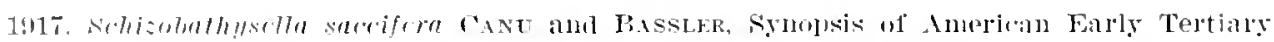

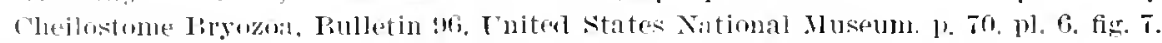

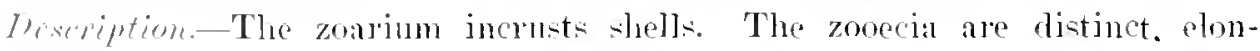

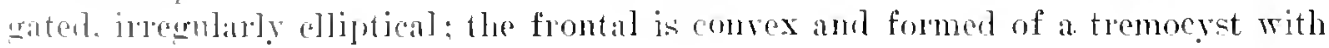


sumall pores. The apertura is semilmar; it beass on its straight poximal boreler a small linear rimule; the peristome is much eleveloped into two lare lateral lips

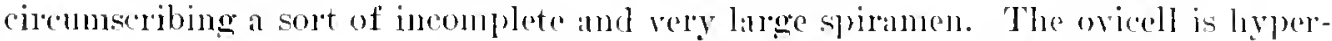
stomial ant recumbent: it forms a solt of small. punctured sacti placed on the bottom of the zooceimm. A small vibraculoid ariculatim is developed laterally near the aperture.

$$
\text { Weasurements. A Aperturar }\left\{\begin{array} { l } 
{ h a = 0 . 0 8 \mathrm { mm } . } \\
{ 7 a = 0 . 1 0 \mathrm { mm } . }
\end{array} \quad \text { Zooecia } \left\{\begin{array}{l}
L z=0.60-0.50 \mathrm{~mm} . \\
7 z=0.30-0.40 \mathrm{~mm} .
\end{array}\right.\right.
$$

Iariations.-The peristome is quite varialde. The tremopenes are olten olliterated hy fossilization. The ovieell is truly recumbent or partially supported on the distal zonecium (fig. S). To aceommodate so great a peristomial complexity it is probable that the tentacles were very long and fine.

Ocemrenec-Middle Jacksonian: Wilmington. Yorth Carolina (rare): onehalf mile southeast of Geororia Kaolin Co. mine. Twigess County. Georgia: 18 miles mest of Trightsville. Frorgia.

Cotypes.Cat. No. fietil1. IT.S.X.M.

Genus LAGENIPORA Hincks, 1877.

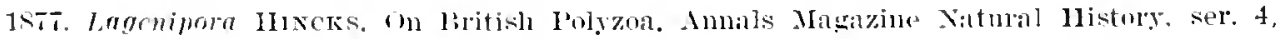
vol. 20, 17. 215.

- Colonies consisting of a number of cells immersed in a common calcarenus crust. Zonecia recumbent. contigunus, lageniform: oral extremity free, tubular, with a terminal orbienlar orifiee." (Hincks.)

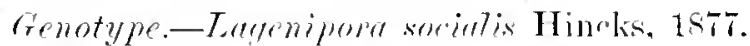

Range.-Jacksonian-Recent.

Waters and Tullien did not almit that a long. free. peristomie could characterize a genus.

The first of these anthors has preservet Hincks's name for all the species more or less erect and provided with a cribriform area om the ovicell. Ievinsen, in 1909. called simiopelta the gromp of the species of Waters in which the growth is that of the Collepores.

We have not the data for a riscussion, and we preserve Hincks's genlss in his exact meaning. It is indisput alde that the genotype is one of the Phylactellictae on account of the nature of its ovicell. and that the specimens discovered in our Eocene are well elassified in this family.

IAGENIPORA AMERICANA, new species.

I'liter T4, figs, 0 .

Mesriptim.-The zonrium incrusts shells. The zoneria are distinct. long. laseniform, composed of two parts: the frontal is onvex and ramished witl tremopores: the peristomiale is very long, oblique. smooth. teminated by an expanded peristome. Oricell unkmown. 
Occurrence-Middle Jacksonian (Castle Hayne limestone): Wilmington, North Carolina (rare).

Upper Iacksoni:m (Oeala limestone): Oid Factory, $1 \frac{1}{2}$ miles above Bainbridge, Georgial (very rare).

Tieksburgian (" Chimney rock" member of Mariamna limestone): One mile north of Monroeville. Alahama (very rare).

Holotype-Cat. No. 64206, U.S.N.M.

\section{Genus ASCOSIA Jullien, 1882.}

1882. A sersin Jitldes, Dragages du Tratailleur, Sryozoaires, Bulletin Société Zoologique de Frause, rol. T, p. 9.

Zonecia erect joined together only at the base; orifice oral from the front backward, beveled on the top of the zooecia and looking forward, surrounded by a flat border; oricell globular sunken in a hood on the back of the zooecia which bear it; one or two viluracula placed on the sides of the orifice. Dorsal face of the zoarium formel by the convex base of the zooecia which are separated by furrows.

Genotype-.-Ascosia pantora Jullien, 1882. Recent.

\section{Genus TEMACHIA Jullien, 1882.}

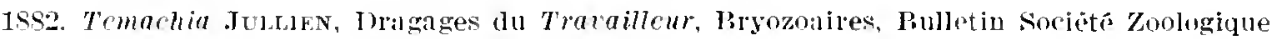
France, rol. 7. 1). 509 .

The zooecia are suberect. dilated at the base, and narrowed like the neck of a hottle toward the top; the peristome is cleft anteriorly and deprived of spines; the ovicell is globular, and its opening corresponds to the eleft of the peristome. The ancestrula has a frontal wall entire and covered with lattice work. with two strong lateral spines at the level of the orifice. (Translation after Jullien.)

Genotype.-Temachir opulenta Iullien, 18s2. Recent.

\section{Family CELLEPORIDAE Busk, 1852.}

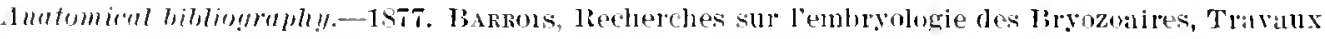

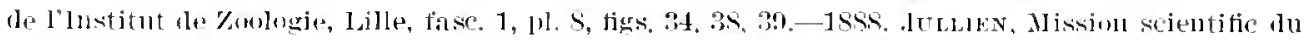

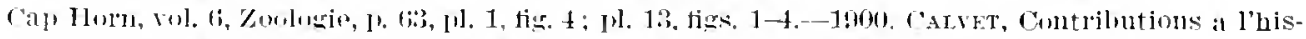

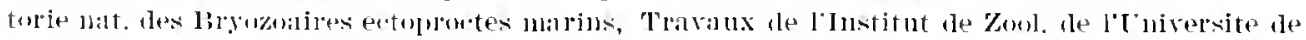

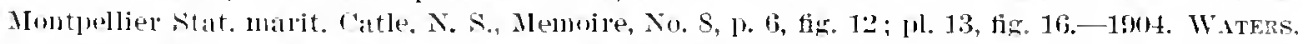

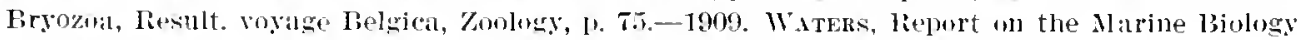
of the sudanese Red sea, from colledions mate by Cyil Crussland, tatc, XlI, Journal Lin-

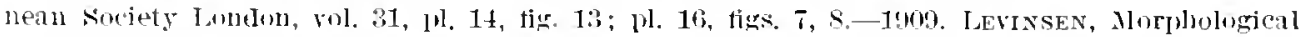

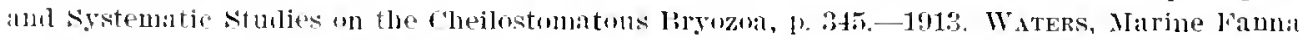

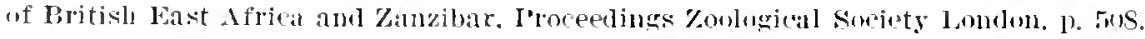


The oricell is recumbent. The budding is double, terminal and superficial. The zooceia are more or less erect and cumnlate.

Fignre 176 illustrates the anatomical knowledge of this important family.

The only known larra is of the sehizostomatous group. Levinsen in 190 ? created a special family for the holostomatous group, which is perhaps a valid one, but as we are ignorant of the larva we have not recognized it. Our elithridiate group is perhaps also a distinct family.

The budding is superficial: it nceurs on all the zooecial walls. Certain frontal pores are therefore not areolae but veritalle septules. The consequence is the piling up or accumulation of the zooccia. In the distal budding the zooecia a re always oriented: in the superficial budding they are arranged in all directions. However, the zooccia issuing from the larra and those which are in contact with the substratum are always oriented. In some rare fossil species the cumulate zonecia are rare. The power of superficial budding is then apparently not spontaneons, but it is generalized gradually.

Among the Cheilostomes the Cellepores have appeared last (about the Lutetian) and in the tropical seas. They are multiplied to excess in the Miocene. At present they have overrnn the seas, where often they multiplied in immense numbers; they dominate the recent fauna by their extraordinary numbers. In the size of their zoarium, the extreme rapidity of their budding, the infinite pliancy of their aptitude for adiptation. and in their astonishing fertility, they show an orerwhelming vitality. They accommodate themselves to all areas, to all depths. to all temperatures, and to all kinds of foorls. These are the most vigorous and the most perfected of all the hirozon.

II istorical. - An anthoritative history of the genus Cellepora was given in 1852 by D'Orbigny. ${ }^{1}$ He attributed it to Fabricins, 1780 ; this it appears was an error that Hincks repeated later: Icrinsen, in 1909. noted that its founder was Limneus himself, in $176 \bar{i}$. In 1913 Traters rewrote the history with a serupulous exactitude; his conclusion was that the interpretation of the poor figures of the early anthors lus caused most vexatious confusion and that it is more scientific to adopt the types of Busk and Hincks, who recognized the true nature of the bryozoa.

It was in 1836 that Milne-Edwards, in the second edition of "Animaux sans rertebres" of Lamark, gave the name of Cellepores to the species with cumulate zooecia. Whether wrong or right, this opinion has prevailed in the science. There has been nothing of scientific interest added to the discussion after three-quarters of a century. Moreorer, the word indicating only a special and complex mode of budding. onght necessarily to disappear from the generic nomenclature, since by definition even, a genus is a union of creatures having the same functions, the budding being only one of these functions.

We have preserved the word Cellepord as an invalid senus only for the species requiring further study, as me are often forced to do in paleontology.

$$
\text { I'aleuntolugir française, Terlains cletaces, p. ano. }
$$

$55 \$ 99-19-$ Bull. 106-3S 

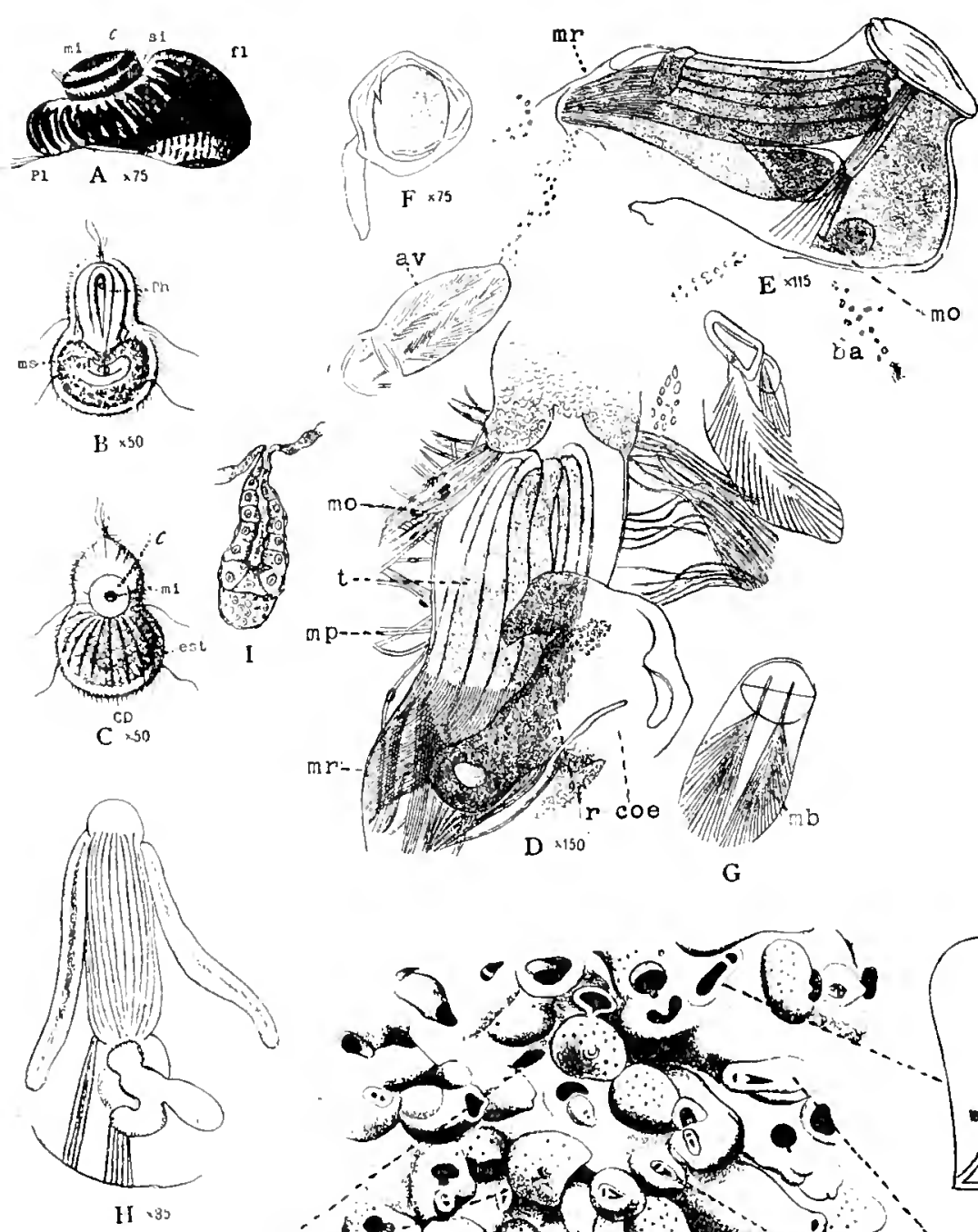

G

Deep zoocciumovicell...-

superficial $2000 \mathrm{cium}$
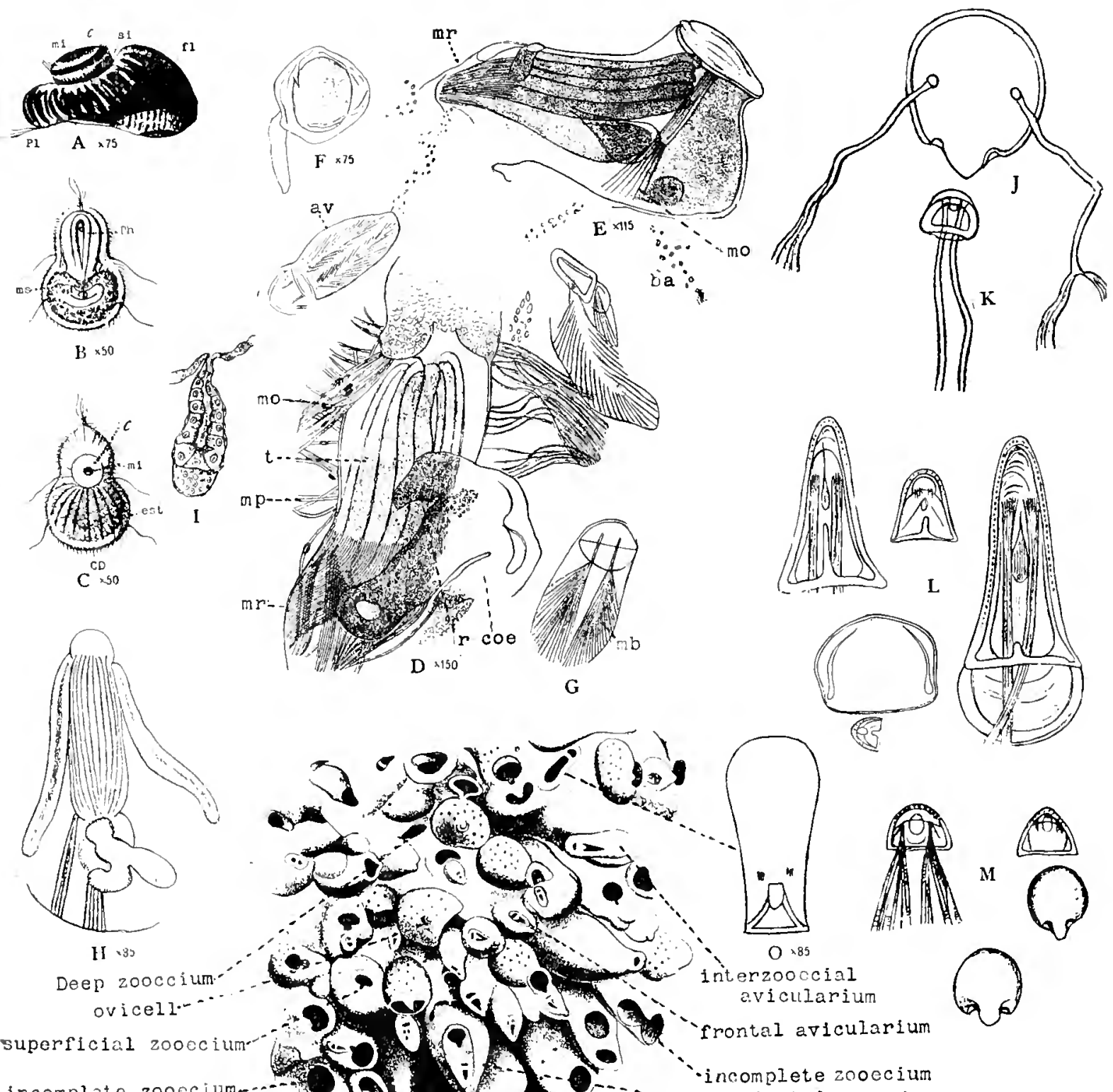
evicharium avicllarium

incomplete zooccium..

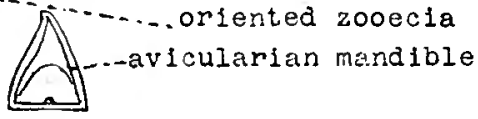

[No. 176.-Anatomical structure of the family Celleporidae Busk, 1852. 
Fig. 176.-Anatomical strueture of the fimily Celleporidae Fusk, 185.2.

A-C. Free larva of schismopora pumionsa Busk, 1854. A. Tateral view, $X$ 7.5. showing the ruluction of the alotte, the extension of the cornm with the disapluearance of the cilia leplaced bs a general covering of shorter cilia and, finally, the flattening of the oral face. B. Vien of the oral face showing the thick band of the oral mesoderm and in the midle a small portion of the stomach, $\times 50$. C. Tiew of the aboral face slowing the aspect of the calotte and the epithelial structure of the stomack, $\times 50$. (A-C atter Barrois, 1sit.) r, colona; ed, ligestive cavity; est, stomach; $f$, flagellum : mi, abolal mesoderm; $m s$, oral (labial) mtsolerm: o. ciliated cleft: ph, pharyx: $p$, vibutile plume; si, furrow of separation.

D-G. Anatomical structure of Osthimosia erexa Jullien, 1sss. D. Znoecium viewed posteriorly. The funiculus seems to exist after the stomaclic caecum, $\times 150$. F. An isolated zonedum. The buds of the endocyst lave developed to produce an avicularian avity and to lodge in the areolar pores of the fromtal face, $\times 115$. F. A larvin its oricell, after decalcification of the zoarimm, $X$ 75. G. Alrangement of the muscles in the avicularian cavity. (D-G after Jullien, 1SSS.) ar, aviculirium; ba, buds of the areolar pores: cor, stomachic raecum; mb, muscular bundles; mo, acclusor muscles of operculum; mp, parietal muscles; mr, lare retractor muscles of the polypine: $r$, rectum: $t$, tentacles.

H. Holoporella albirostris Smitt. 1867. Iolypide showing the long oral (vaginal) slands, $X$ S5. (After Taters, 1913.)

1. Schismopora pumiosa Busk. 1554. Glantular vaginal organ (oral glands of Waters). Longitudinal section. (After Calvet, 1900.)

J, K. Costa zia costata MacGilliviar, 1868. The muscles are attuclued to the ajerculum and the aviculalian mandible. (After MacGillivras, 1SSS.)

L. Holoporella apiculata Busk, 1sst. Chitinous appendages.

II. Sehismopora bidcnticulata, rar. subacqualis Busk, 18st. Chitinus appendages, (I, M aftel Fusk. 18st.)

X-1: Sehismopora coronopus Woot, 1850. N. Portion of a zoarium, X 24, slowing terninologs. (After Jullien, 1903.) O. Nandible of the intelzonecial avicularium, $X \quad s \overline{.}$ l'. 'The

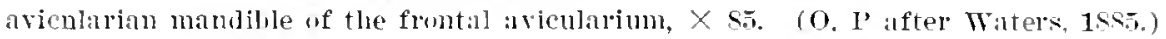


Terminotory.-The zorecia parallet to each other are called oriented. They are generally axial or marginal.

The nonparallel zooecia, erect in every meaning of the word, are the cumulate zooecia. Sections through such zoaria are very complicated and very difficult to comprehend.

The complete zonecia, the more exterior ones, are the superficial zooecia; they give the better characters for classification, but they are often broken on the fossils.

The deep zooecia separate the superficial zooecia, but at a lower level; their frontal is huried; their apertura and their avicularia are alone visible. Often their aricularia are more salient than those of the superficial zooecia because they endearor to reach the level of the latter.

The zoarial surface is in perpetual growth; the formation of the zooecia is not simmltaneons; there are therefore some incomplete zooccia. These are cavities of greater or less size. which must not be confused with the aricularia.

The interzooecial avicularia are very large. Their mandible is symmetrical and articulates on a pirot or on two lateral denticles. These aricularia bear some powerful muscles and they are adjacent to the superficial zooecia.

The frontal aricularia of the deep zooecia appear interzooecinl when they are very salient: but they remain always attached to the deep zooecia, and they are completely isolated from the superficial zooecia.

Waters has best studied the classification of the Cellepores. In 1913 he gave a first wrouping. which certainly will be perfected in the future. The table below sulus up his opinion.

Schizostomatous division (=Schismopora Macrillivar. 1SSS) :

C. coromopus-pumicosa sroup (Ccllcpora Waters, 1915; Cellcpora Levinsen, 1909; Osthimosia Wiltels, ]1:1:3).

C. cutoncrisis 4roul, (Osthimosia Jullien. 1555; Waters, 1904, not 1913).

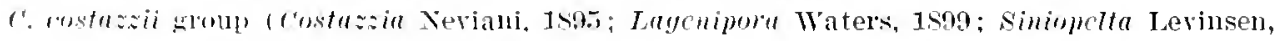
$1909)$.

Holostomatous division (= Molostoma, Macrillivray. 1sss):

C. diseostilsii geroun (Holoporella Waters, 100.i).

C. sardonien group.

C. ramulosu group.

To this we add a third dirision:

Clithrisliate division :

Acanthionclla Canu and Bassler, 1917.

klleitionclla Canu and Bassler, 1917.

We will adopt provisionally this classification and will discuss the names adopted for each gents. But the natural classification may only be made by the application of our system of physiological functions and in considering before all the comnection of the opereulum with the ovicell. It will be necessary to commence this work on the recent speeies. 
The Cellepores are rery difficult to study. Good specimens are rare. for the erect zooecia are very fragile and are assily broken. The technicue of their study is quite difficult and still prorly established; the tangential sections are almost impossible; the obliquity of the apertura renders the interpretation of the interior difficult; the trinsverse sections give little information for their orientation is dillicult. The illustration by photograpley is quite deceiving and by drawing it is rery delicate. The preparation of the truc illustration of a group of zooccia of Cellepores has not yet been realized.

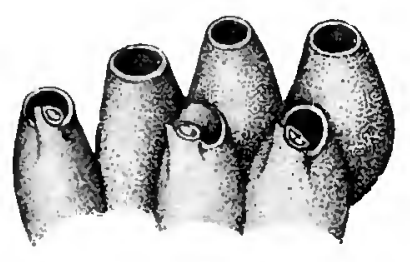

A. Schismopora

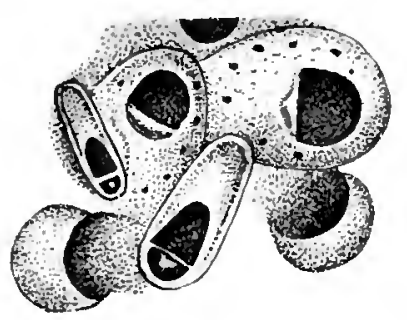

D. Holıporella
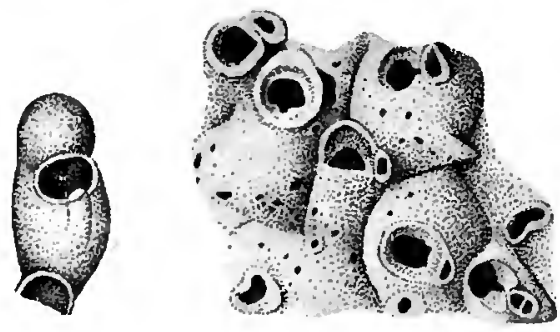

B. Osthimosia

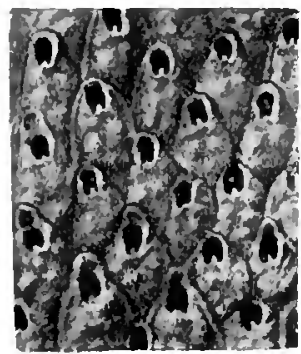

E. Acanthionella

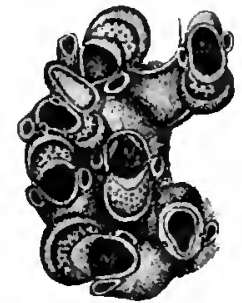

C. Costazzia

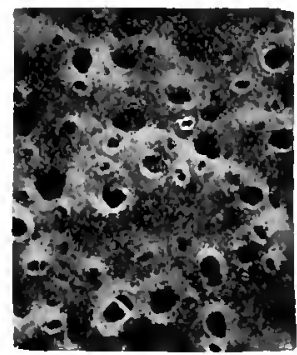

F. Kleidionella

Fig. 17T.-Cienter of the fimily Celleporiale Busk, 1sio.

A. schismopora pumicosa Isusk, 1s94, $\times 30$. Recent.

B. Osthimosia evexa Jullien, 1858, $\times$ 35. Fecent.

C. Costazia costazii Sa rigny-1udouin, 152s, $\times 30$. Recent.

D. Holoporella descostilsii Savigny-Autouin, 1828, $\times 25$. Recent.

F. Acanthionclla ofcioporosa, new species, $x 20$. Clabornim of Alabinul.

F. Fleidionclla grandis Canu and Pussler. 1917, X 20. Jacksonian of Nolth Carolina.

The recent specimens are more easily determinable; their chitinons appendages give excellent characters. Bu-k. MacGillivay, Waters, and Nordgaard have arranged excellent comparative tables; but they are still only of secondary importance to paleontologists.

We are stulying at this moment diflerent processes of techintue which certainly will give us excellent results in the future but the exsential condition is that our collectors should prowre it large number of sperimens in perfect preservation. 


\section{Genus SCHISIIOPORA MacGillivray, 1888.}

1SSS. Schismopora MacGmelver. Bryozoa in McCoy's Prodromus of the Zoology of Victoria, vol. 2. live. 17, p. 253.

The oricell is perforated. The frontal is smooth. The apertura bears a proximal rimule. No spines. 1.5-20 tentacles.

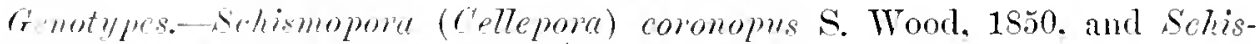
mopore (relleposa) pumirose Busk, 1854.

lieme.-Jarksonian-Recent.

II istoricul.-This is the Pumicosa group of Waters, for which he has always preserved the name of Cellepord until 1913 , when certainly it was by error that he ("illed it cothimosiu. The latter genus of Jullien is perfectly limited as he described it in 1904 and 1909. The genus Schismopore MacGilliviay, 1888, has a much more general meaning. since he applied it to all the Cellepores with proximal rimule. We preserve it, however, witl a more restricted meaning so as not to create a new name.

Certain recent species classified in this genus are provided with tremopores; it will be necessiry to create a special genns for them.

SCHISMOPORA GLOBOSA, new species.

I'late 75 , figs. $7-1 \overline{5}$.

Description.-The zoarium is massive, glotutur, measuring as much as 18 millimeters in dimeter. The superficial zooecia are distinct, little erect, irregularly oroid; the frontal is smooth and convex and bears an avicularium as large as the apertura. The apertura is oral and garmished with a wide triangular rimule. The deep zooecia are visible only through their apertura. The ineomplete zooecia are rare. To interzooecial avicularium.

$$
\text { Measurements.-Apertura }\left\{\begin{array}{l}
\text { hat }=0.15 \mathrm{~mm} \text {. } \\
\text { /a }=0.10 \mathrm{~mm} \text {. }
\end{array}\right.
$$

ruriutions.-The frontal avicularium is ahmost alwars broken: it leaves a wide cicatrix of little depth (fig. 11.).

The transversal section (lig. 13) perfectly oriented is very instructive: it is the perfect type of the Celleporid accumulation. Lbore each zooecimm there is a small triangular chamber which appears to correspond to the frontal avieularimm: the plites of these small chambers mite two by two, outlining the zooecial contom. The skeletil tissue is an elocyst whose elements are scattered or piled together (fig. 14).

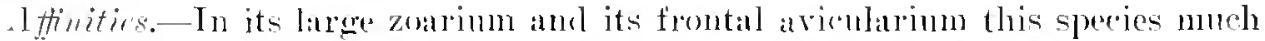

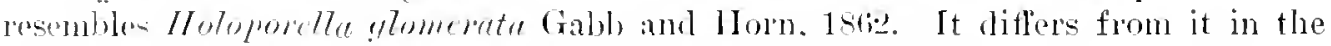
diflerent form of its apertura, in the absence of areolare, and its very little elevated zorecial.

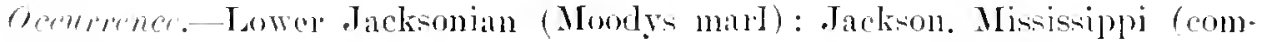
m(n) 11 ).

Gotypess-Cat. No, fit:213, I.A.A, I. 

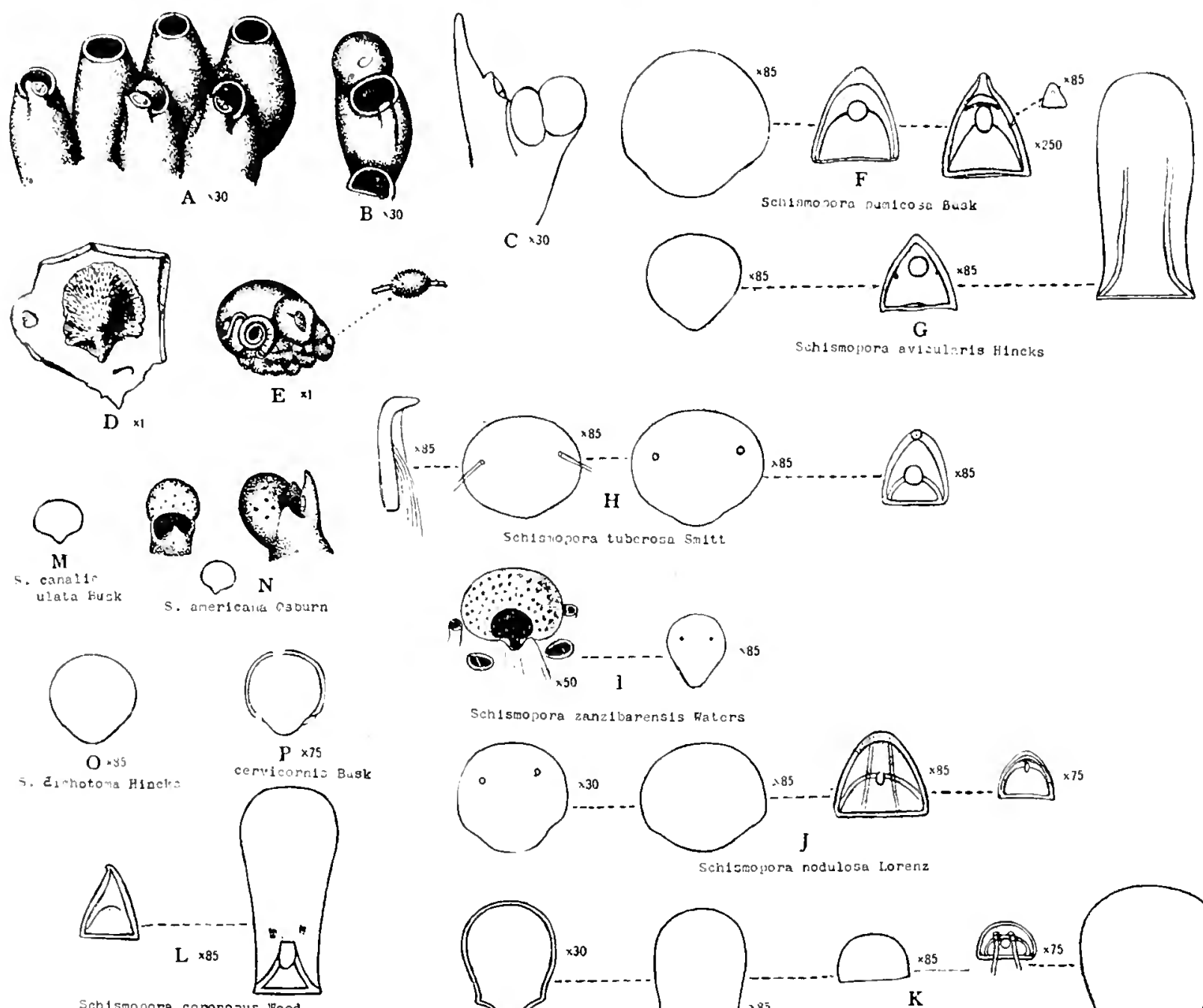

Schlsuopora coronopus mood

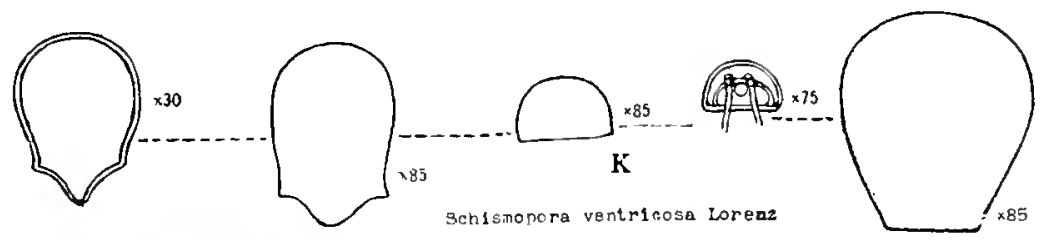

Fig. 17s-CGenus Schismopora MacGillivay, $18 s 8$.

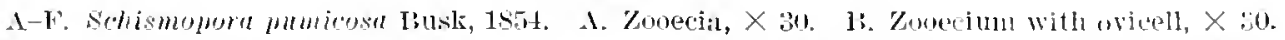

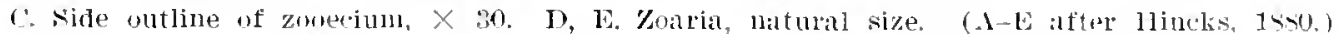

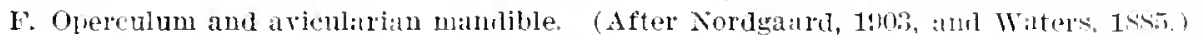

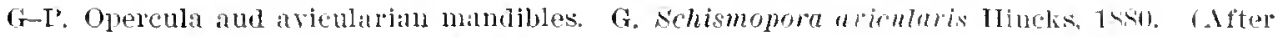

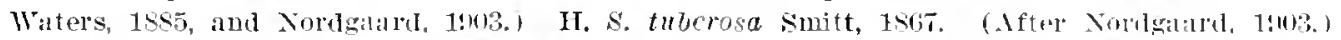
I. S. zanzibarensis Waters, 1913. (After Waters, 1913.) J. S, molutusu Lorenz, 18sti. (After

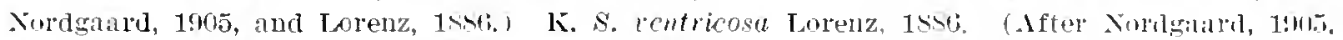
and Lorenz, 1886.) I. S. cormonus Wood, 1850. (After Waters, 1S55.) M. S. cunaliculuta Busk, 18S4. (After Osburn, 1912, X. S. americana Osburn, 1912. (M, X after 1)shuln, 1912.1

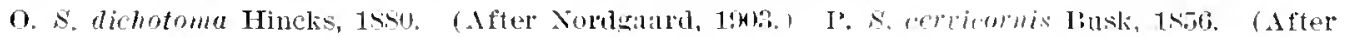
Lorenz, 18s6.) 
Ifscription.-The zon rimm is discoidal. convex, incrusting; the marginal zooecia are oriented; the central zooecia are heaped up. The siperficial zonecia are erect. salient. very oblique, orbicular; the frontal is smooth and prolonged into a strong umbo, deforming or hiding the apertura. The apertura bears a wide, triangular. proximal rimule; it is little visible exteriorly. The deep zooecia are little visil, and are revealed only by their apertura; they hare no mmbo. The marginal zooecia are oriented: their frontal is very convex and terminated by a large nmbo completely hiding the apertura. The incomplete zooecia are rare.

$$
\text { Mcrsumements - Ipertill:a }\left\{\begin{array}{l}
h a=0.07 \mathrm{~mm} . \\
7 a=0.06 \mathrm{~mm} .
\end{array}\right.
$$

Affinitirs.-In its large umbo and its oriented marginal zoneria this species resembles rellepore pumicos Bu-k. 185\%. It differs from it in the absence of a visible avientarimm on the $110 \mathrm{mb}$.

It differs from Hotoporolle fissurate. which is also surromuled hy oriented zonecia. in a latrer umbo. in smaller dimensions, and the absence of areolace.

Oceurenec-CTper Jacksonian (Ocala limestone): Alachua, Florida (very lare): West hank Sepulga River. Escambia Comnty, Alabama (rare).

Holotype-Cat. No. 61211, U.S.N.M.

\section{SCHISMOPORA ORBICULARIS, new species.}

Plite 75 , figs. 4-6.

Description.-The zoalium is unilanellar. little convex, incrusting algae. orbicmer. crarnished inferiorly with an epitheca smooth or slightly striated concentrically. The superficial zoocia are buried, distinct, elliptical, almost always oriented: the frontal is smooth and little convex; the apertura is oral, oblique witl a wide triangular simus. and often accompanied by a small avicularium. The ovicel! reclines on the listal zooecia : its rrifice is at the level of the proximal border of the peristomice. The deep zonecia have only their apertura risible.

$$
\text { Measurements.-A pertura }\left\{\begin{array}{l}
h=0.11-0.12 \mathrm{~mm} . \\
7 n=0.10 \mathrm{~mm} .
\end{array}\right.
$$

Affinitics.-The simplicity of structure of this species is remarkable. The cummlate zonecia are rare and are at the vely center of the zoarium. The zoarim is manifestly orlicular and can attain $i$ millimeters in diameter: unfortunately, we possess only the figurerl specimen.

This species differe fronn IIotoporella dixcus in its rery numerons oriented zonecia. in its apertura. which is smaller and of clifferent form. and the absence of perforations on the basal epitheca.

In the deternination of the (ellepores it is necessary to distrust the zoarial resemblanees. 
Oceurenec.-Middle Macksonian: One and one-half miles sontheast of Georgia Kaolin Company Mine, Twiggs (Comly, Georgia (very rare).

Holotype.-Cat. No. 64212, U.S.N.M.

Genus OSTHIMOSIA Jullien, 1888.

1Sss. Osthimosia Jurbiex, Mission scientific du Cap Hol'n, vol. 6. Zoologite, p. 64.

The ovicell is not perforated. The frontal is surrounded by areolae. The apertura bears a proximal rimule. 'Ihere are no spines.

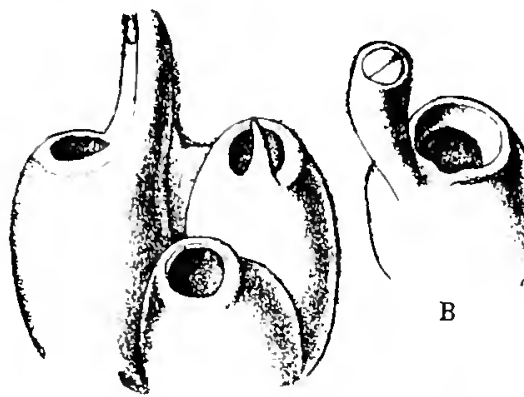

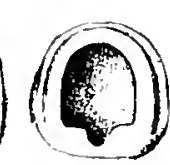

A

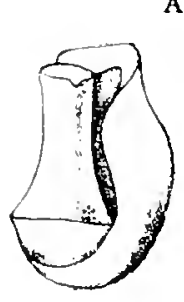

C

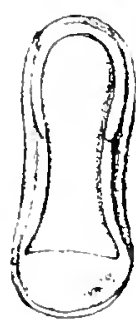

$\mathrm{D}$

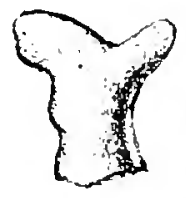

E

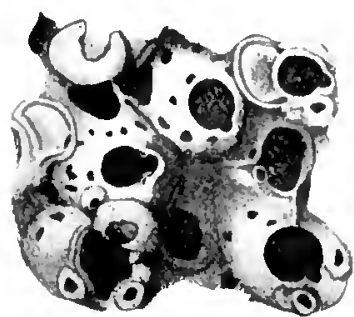

$\mathrm{G} \times 35$
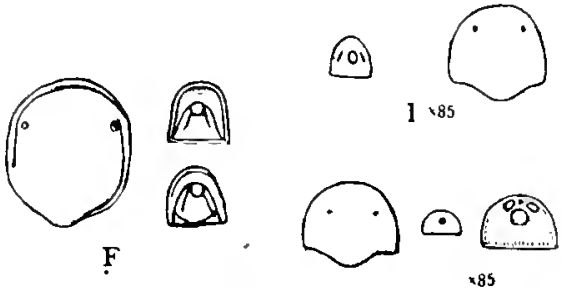

$\times 85$

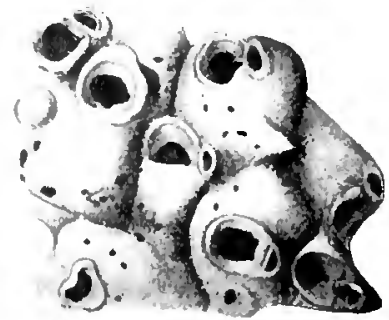

$\mathrm{H} \times 35$

F1g. 17\%.-Genus Osthimosia Jullien, 1888.

A-F. Osthimosia catonensis Busk, 18s4. A. Zooecia seen in protile. F. Funtal view of zonecinm. C, D. Two riews of the interzooecial avicularium closed by the mandible. E. Kuarinm natural size. F. Aperture, opereulum, and avicularian mandible. (A-F aftel' Busk, 15s4.)

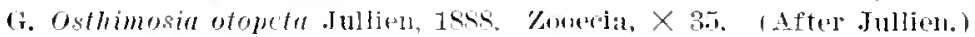

H, I. Osthimosia cexa Jullien, 1s8s. H. Zooecia, $X$ 35. (After Jullien, 18ss, 1 J. Operculum and avicularian mandible, $X$ si. (After Waters, 1904.)

J. Osthimosin cletuta Water's 1ss4. Geeculum and avicnlarian mandibles, $\times$ 55. (After Water's, 1904.)

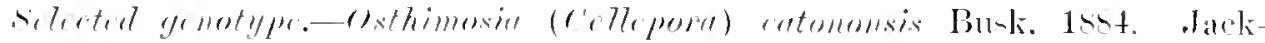
sonian-Recent. The genotype of Jullien was Osthimosia excer Jullien. 1888.

The recent species of this grenus are:

Tsthimosin ('ellepone) retumensis Inusk. 1894.

Osthimosia otopete .Jullien. 18se.

Osthimoside ravetut Malurs. 1sist.

Osthimosia (Cellepora) signata Busk, 1884.

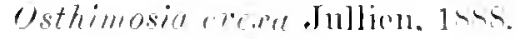


Osthimosia evera .Tullien, 1888.

The known fossil species are:

Osthimosia tubifere ('anu, 1908, Patagonian of Mrgentina.

Osthimosia crassatina (anu, 1908, Patagonian of Argentina.

Osthimosia parvicella Cant, 1908, Patagonian of Argentina.

OSTHIMOSJA GLONERATA Gabb and Horn, 1862.

Plate 7t, figs. 12-19.

1862. Cellemraria glomeratn Gabis and IIORs, Monoglaph of the fossil Polyzoa of the Seeoudary and Tertiary formations of North America, Journal Acalemy of Natur:al Sciences, Philadelphia, ser. 2, rol. 5, [1. 134, p]. 19. fig. 15.

Description.-The zoarium is massive, globular, measuring as much as $2 \frac{1}{2}$ "entimeters in diameter. The superficial zooecia are scattered, distinct, oval, quite erect: the frontal is smooth and surrounded by some large areolar pores; it benrs a median avicularium, with pivot, oval, with the point directed toward the base. The apertura is orbicular ant is provided with a repy wide and rounded rimule. 'The ovicell is laree, smooth, transverse. recumbent; its orifice is very large and plinced above the apertura. The deep zocecia have a reduced frontal; the apertura and the much enlarged avicularium are alone visible. The ineomplete zooecia are quite numerous and irregular. There are some interzooecial arjeularia, suall and withnut pirot.

Mecusurements. I pertura $\left\{\begin{array}{l}h a=0.10 \mathrm{~mm} . \\ l a=0.10 \mathrm{~mm} .\end{array}\right.$

Tariations.-The superficial zooecia are generally quite ereet (figs. 15, 17, 19), but they are sometimes simply oblique (fig. 16). When the frontal arienlatium is broken we have then the aspect of the figure given by Gabb and Horn. In reality the specimens of Schismopora globosa more often rescmble this same figure. The American anthors cite their specimen as from Vicksburg. In this locality we have only discovered the present speries. We think, therefore, that nur specimens really represent the species described by Gabb and Horn, from a specimen which appears, moreover, quite mediocre.

The considerable enlargenent of the frontal aviculariun in the deep zooecia is a useful phenomenon to note, for it occurs quite frequently.

Specimens of this species are often covered with incomplete zooecia, which do not allow serious determinations. Often, in fact, the zoarium of the Cellepores dies suldenly without apparent reason before the complete formation of the zooecia. In this species, as in all the massive or brancled species. there are zooccia of all sizes and forms.

Ocempnce.-Lower Jacksomian (Moorlys nual) : Tackson, Mississippi (very commints).

Mikhle Tacksonian: Wihmington, North (arolina (common) : $3 \frac{1}{4}$ miles soutl of Perry. Georgia (rare).

Ticksburgian (Byram marl) : Vicksburg, Missiscippi (common).

Plesotypes.Cat. No. 6t20\%, T.S.N.M. 
Genus Cost AZZIA Neviani, 1895.

189i. Costazia Nevini. Brinzui nenzoici di alcune localita d'Itallia, Bolletino Sucietá

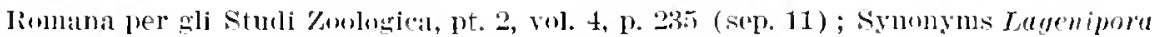
Waturs, 1899-1919: Siniopelta Levinsen, $190 \%$.

"The oricell at the side of the peristome has a flat area and pores round the borter" (Waters). "I zoeci, acervulati. hamo la frontal molto rigonfia, variamente jerforata ed ornata da leggere en-tule; l'apertura zoeciale sulbtrigona con labbro calloso: grandi aviculari scafoidi sono sparsi fra i zocej." (Neviani.) 14 tentacles.

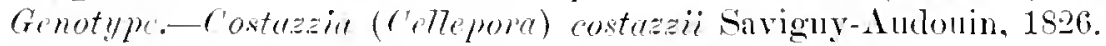

Rumge.- Ticksburgian-Recent.

II istorimt.-Waters, under the name of Lagenipore, and Levinsen, under the name of siniopeltu, designated an assemblage of jdentical forms appearing to con-

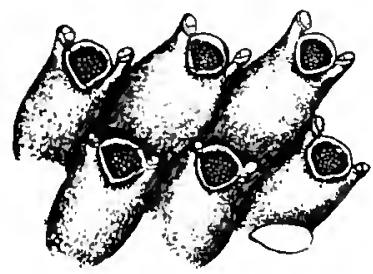

A $\times 30$

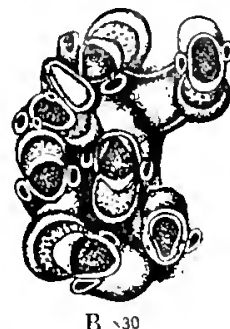

B $\times 30$
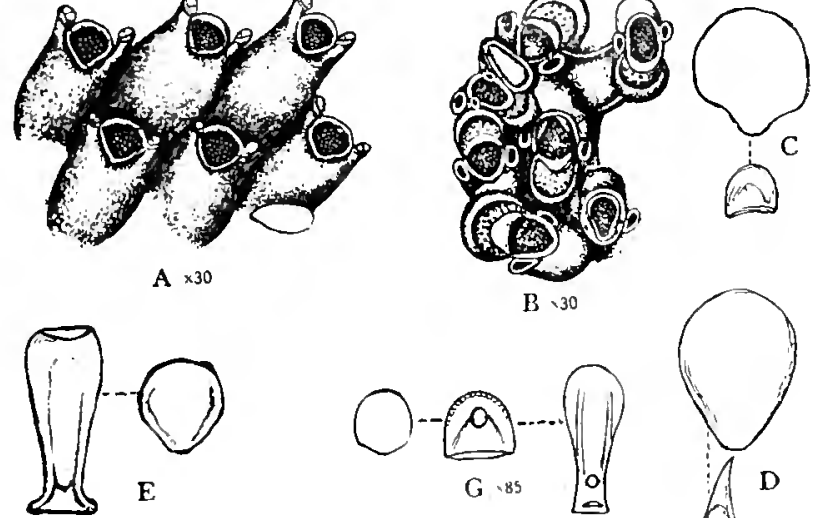

Costa 221 isnote Noman

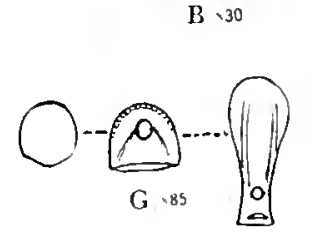

Costazzla lucida E1ncko

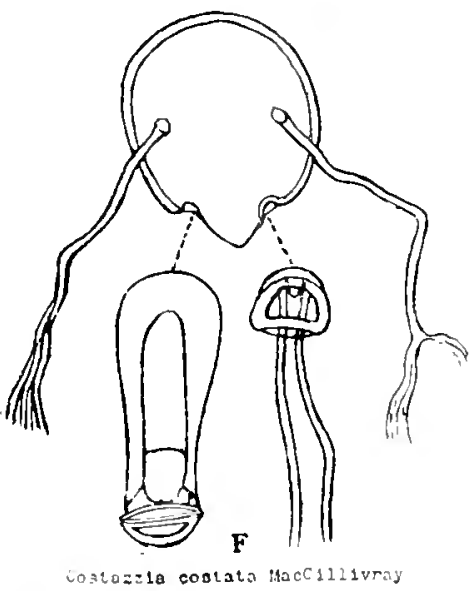

costazzlo costata MacC1121vray

F1g. 150.-Cienus Castaria Neviani, 1505.

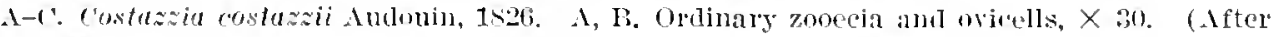
Fincks, 1850.) C. Operculum and avicularian mandible. (After 13usk, 1skt.)

I)-G. Operula and aviculitian mandib]es. D. Costasia tubulosa IIncks, 1880. (Aftej*

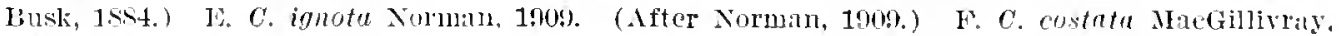
1S6S. (Atter IlacGillivar, 1SGs, and Waters, 1SS5.) G. C. lucida Ifincks, 1sst. (After Waters. 18(2)

stitute a rather natural gemus. However, the type itsclf of Lagenipora socitlis Iincks. 1880, is not comprised in the list given by Levinsen. and he himself eliswed it in Schismoport. Considering that the zooecia of Lageniprom socintis are oriented and by no means cumulate, wo have ma intained the gemus of Ilineks with its primitive definition in the family of Phylactellidae. For the genus simiopetta Levinsen, 1909, we substituted the genus ('ostazzia Neviani, 1895. which has priority. Nerertheless, the definition given ly the Italian anthor is inconplete and the acceptanee of this gentis is questional)le. The frontal area of the oricell cloes not correspond to a distinct function. Under our system of classilication we can not armit this genus. Most of the species must lo put in sichizmoperen. The following species is described under costezziat to call attention to this tyee of structure in American strata. 


\section{Costazzla ANTIQUA, new species.}

liate 100 , fig. 22.

Description.-The only specimen found has been figured; its state of presel'vation is mediocre and does not permit of a serious study and a complete description. The zoarimu is hollow and appears to incrust the radicells of an alga. The apertura is large and appears to have a large and wide proximal rimule. The oricell is deeply imbedded in the distal zooccia. and probably may be always closed by the operculum; its area is large and fragile. There are small interzooecial aricularia provided with a pirot and a pointed beak.
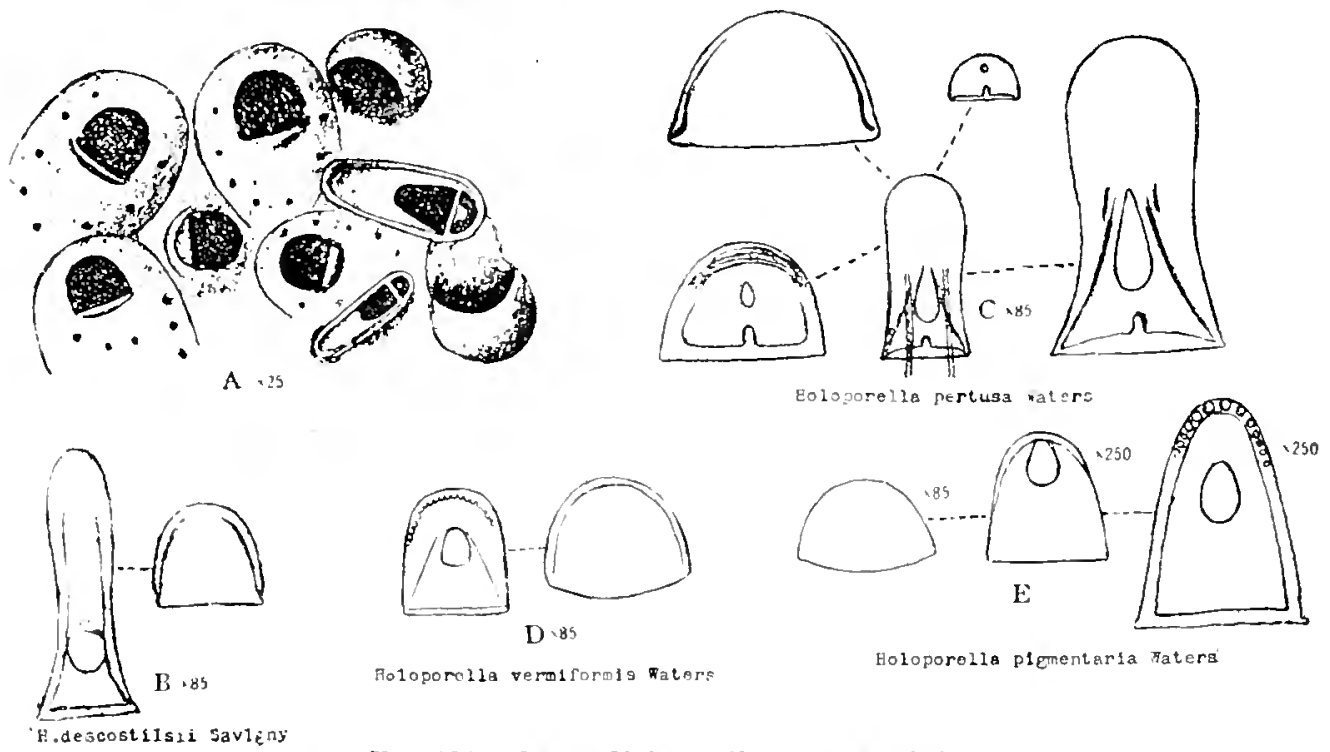

Holoporolla plementarla jaters

Fig. 1S1.-Genus IIoloporenla Waters, 19ma.

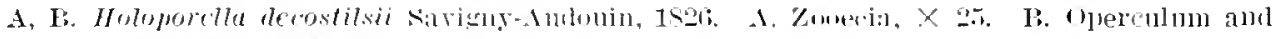
a vicularian mandible, $X$ si.

C-E. Operenla and miandilles. C. Holopunclla mertusn smitt, 1572. D. H. rermiformis Waters, 1909. E. H. pigmenturin Waters, 19m. (A-E after Waters, 19km.)

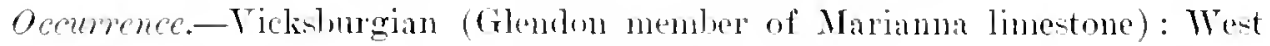
bank of Conecuh River, Escambia County, Alabama (rory rare).

Hototype-Cat. No.64326, T.M.X.M.

\section{Genus HOLOPORELLA Waters, 1909.}

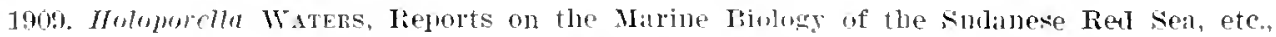
XJI. The Pryozas, Jomrnal Limmean Sucjety London, vol. 31, 1. 159.

"The lower lip of the aperture is more or lese straierht: the operculum has the mulceles attached near the horder, sometimes with a ridere (for the attachment of the tentacular sheath) running inward. The ovicell is a willely open cap. There are w-mally oral and vicarious (interzooccial) aviculatia. and the mandible of one 
of the two usually has a small projection from the base or columella" (Waters, 1909). Spines. 16-1s tentacles.

Genotype.-Holoporme (Cellepora) descostilsii siavigny-Audouin, 18:96. Ranye.-Claibornian-Recent.

HOLOPORELLA ORBICULIFERA, new species.

I'late 16. figs. 10-15.

Deseription.-The zoarimm is small, massive, convex, incrusting shells. The superficial zooecia are prominent, orbicular, separated; the frontal is smooth garnished with a very few areolae; it is terminated by a very fragile aviculiferous beak. The apertura is somewhat elongated, finely crenulated; the anter is semilunar and is separated from a concave poster by two small carlelles placed rery low; the peristome is very thin and bears two large spines. The ovicell is recumbent. hyperstomial, transverse. The deep zooecia have a deep peristomic; they have neither spines nor aricularia. The incomplete zooecia are accompanied by a small elliptical or round a riculallium with pirot.

$$
\text { Measurements.-Apertura }\left\{\begin{array}{l}
h a=0.09 \mathrm{~mm} \text {. } \\
l a=0.06 \mathrm{~mm} \text {. }
\end{array}\right.
$$

Variations.- Usually the beak is broken and leaves a broad cicatrix on the frontal. The very small zoarium does not permit of good plotography of the characters. The thin section shows some more or less large pores between the zooecia; they are irregular and do not appear to correspond to a definite organ. Some zooccia have a small, triangular upper chamber; this is the eavity of the ariculiferous beak (fig. 15 ). 'The walls are formed of scattered olocystal elements (fig. 1t).

Aftinities.-In the smallness of the zoarim and in its zooecial aspect this species approaches somewhat IIoloporelle separate. It differs from it in its imbedded zooecia withont pedunculate avicularia.

Occurence.-Claibornian (Gosport.sand) : Claiborne, Alabama (rare); 1 mile west of Rockville, Clarke Comnty, Alahama (rare).

Cotypes-Cat. No. 63859, U.S.X.M.

\section{HOLOPORELLA FISSURATA, new species.}

Plate $\boldsymbol{i}$ (j, tigs. $1-6$.

Iescription.-The zoarimu forms small, convex masses on shells or on the radicells of algae; on oysters it is surrounded by a large zone of oriented zooecia. The superficial zooecia ane silient, round, erect; the frontal is smooth, surrounded by four to seven large areolae; it is terminated by a pointed muero deforming the apertura and bearing an oral aricularim, rather large and with a bar. The apertura is semilunar: the anter is large and the poster is concave: the peristome is very thin and very little salient and beal's two large, symmetrical spines. The ovicell is salient, transverse. recumbent; it opens by a very large opening above the apertura; it bears a long arched fissure. The oriented zooecia are marginal: they are 
long, surrounded by areolie; the oril mucro bears no avicularia. The deep zooecia are visible only by their apertura. The incomplete zooecia are rare.

$$
\text { Wcrsurements. - Ipertur: }\left\{\begin{array}{l}
h a=0.10-0.12 \mathrm{~mm} . \\
7 a=0.10-0.12 \mathrm{~mm} .
\end{array}\right.
$$

Tariations. - This species is well characterized by its large, oral aricularium and by the fissure of its ovicell. The marginal zooecia exist only on the solid substratum (shells or bryozoa) (fig. 4). They evidently do not exist on the hollow tubular zoaria, which surromul the radicells of algie. Likewise the incomplete zooecia exist only on the latter (fig. 5). In the interior the operculum articulates on two small condyles.

Aftinities.-This species much lesembles IIoloporella altirostris. It diffel's from it in its larger apertura and in the absence of pedunculate avicularia on the deep zooccia.

It differs from IIotoporetla albirostris Smitt, 1572, of the waters of Florida, in the absence of the interzooccial avicularia, but it is very closely related.

Occumener.-Lower .Jackionian (Moodys marl) : .Tackson. Mississippi (common ).

Jacksonian (Zeuglodon zone) : Shubuta, Mississippi (rare).

Vicksburgian (Marianna limestone) : West bank of Conecull River. Escambia County, Alabama (rare); Murder Creek, east of Castlebury, Conecul County, Alabama (rare).

Cotypes.-Cat. Nos. 64216, 64217, U.S.N.M.

HOLOPORELLA ALTiRostris, new species.

Plate $7 \overline{0}$, figs. $16-20$

Description.-The zoarium forms small globular masses attached to other bryozoa, shells, or algae. The superficial zooecia are very salient, erect, irregular; the frontal is smooth and terminated by a prominent beak, bearing an enormous oral arieulariun with pirot; the terminal portion of the beak is fringed and partially hides the apertura. The apertura is oblique. semilumar and formed of a lar.ge. finely renulated anter, separated by two small cardelles placed very low from a concave poster; the peristome, thin and little silient, bears two srmmetrical spines. The ovicell is reeumbent, hyperstomial, transverse, smooth, globular. widely open above the apertura and at the level of the large oral avicularium; it bears in front either a small, fragile, cicatrix or a fissure. The deep zonecia have no frontal; their apertura is risible and the oral aricularium is quite salient and pedunculate. The incomplete zooecia are rare.

$$
\text { Weasurements.-Apertura }\left\{\begin{array}{l}
h a=0.09 \mathrm{~mm} \text {. } \\
l a=0.10 \mathrm{~mm} \text {. }
\end{array}\right.
$$

Ifinities. - In its zoarium and in its ovicell. sometimes fissured, this species much rescmbles IIotoporella fissurata. It differs from it in its much larger oral avicularium becoming pedunculate on the deep zooecia. 
This fossil species bears the largest oral arieularium (0.18 by $0.15 \mathrm{~mm}$ ).

Oceurence--Middle Jacksonian: Wilnington. North Carolina (common); Rich Hill, Crawford County, Georgia (very common).

Cotypes.-Cat. Nos. 64214. 64215. T.S.X.M.

HOLOPORELLA GRANULOSA. new species.

Plate 16, figs. 1-9.

Inescription.-The zoarium is massive and formed of small globular masses fixed to bryozoa or to shells, which it surrounds completely. The superfieial zooecia are little erect, oblique, large. elliptical; the frontal is convex, surrounded by widely spaced areolae and formed of a granular pleurocyst placed on the olocyst. The apertura is large, semilunar, with a concave, proximal border: the peristome bears laterally one to two lateral avienlaria. The ovicell is hyperstomial, reemmhent, transverse, small, somewhat salient. gramular, widely open above the apertura. The deep zooecia have a normal apertura and a very salient. peristomial arienlarium. The incomplete zooecia are rare. The interzooecial avicularia are rather large, oral, little salient, without pirot.

$$
\text { Ihersurements.-Apertura }\left\{\begin{array}{l}
h a=0.15 \mathrm{~mm} \text {. } \\
7_{n}=0.17 \mathrm{~mm} \text {. }
\end{array}\right.
$$

Fariations.-The zooecia in contaet with the substratum (fir. 5) are oriented; on the lower face of the zoarimm the zooceia are visible, irregular: their walls have two or three calcareons layers. The granular pleurocyst is detachable from the subjacent olocyst (fig. S) and the two calcareous formations are often visible. In the interior (fig. 6) the apertura is oblique and without cardelles. The oricell is of the same nature as the frontal (fig. 4). The interzooecial arieularia (figs. 3, 7) are quite remarkable in the absence of pirot.

Affinities.-By its zonecial aspect this species much resembles Holoporella desenstitsii Savigny-Audonin. 1826 , of recent seas. It differs simply in the presence of peristomial avicularia.

Occurpenee-Claibornian (Gosport sand) : Claiborne, Alabama (rare); Gopher Hill, Tombigbee River, Alabama (rare): 1 mile sonthwest of Rockrille. Clarke County, Alabama (very common).

Claibornian (Cook Mountain formation): Moseleys Ferry, Caldwell Connty. Texas (rare).

Claibomian (Lisbon formation): Wautubbe Hill. Clanke Comty Misissippi (very common).

Lower Tacksonian (Moodys mal) : Jackson, Miscissippi (common).

Cotypes.-Cat. Yo. 1938 s, U.S.N.M.

hOLOPORELLA CRASSicollis, new sjecies.

Plate 76, figs. 11, 12.

Deseription. - The zoarium is milanellat and incrust shells. The zooecia are little erect, almost always oriented: the fromtil is mooth and convex. The apertura 
is small, elongated, and formed of a large circular anter separated by two small triangular cardelles from an almost straight poster: the peristome is very thick, salient; it bounds an infundibuliform peristomie and bears eight spines. The ovicell is hyperstomial, recumbent. very small, little salient, smooth; it is widely open in the peristomic. Laterally and near the apertura there is a small, oblique, little salient avicularium.

$$
\text { If casurements. I pertura }\left\{\begin{array}{l}
h a=0.15 \mathrm{~mm} . \\
l a=0.10 \mathrm{mmm} .
\end{array}\right.
$$

Occurence-Middle Jacksonian: Wilmington, North Carolina (rare): Rich IHill, Crawford County, Georgia (rare).

ILolotype-Cat. No. 64219, U.S.X.M.

\section{HOLOPORELLA PISIFORMIS, new species}

Plate $\mathbf{7}$, figs. $8-11$.

Description.-The zoarium is formed of small, globular masses, of the size of a pea. The superficial zooecia are small, raised, and entirely smooth. The apertura
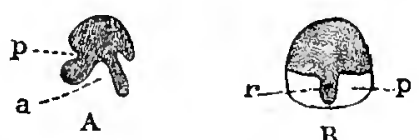

B

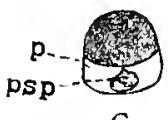

C

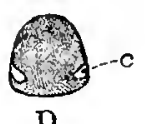
is semilunar and provided with two large carrelles; the peristomice is very irregular; its proximal edge bears two lips more or less coalescent and sometimes a small oral, elliptical avicularium. 'The ovicell is lyperstomial, recumbent, globular, smooth, wiclely open above the apertura. The deep zooecia are visible only by their apertura.

$$
\text { Measurements.-i pertura } \begin{aligned}
& h a=0.08 \mathrm{~mm} . \\
& l_{a}=0.07 \mathrm{~mm} .
\end{aligned}
$$

Fin, 182.-IItoloprelle pisiformis, new species.

A-1. Sketches showing variations in the form of the peristomice. D. Sketch of apertura. a, nucro; $r$, cardelles; $p$, lateral apophysis; $p s p$. psendospiramen; $r$, rimule.

Tariations.-This small species is remarkable in the diseoneerting irregularity of its peristomice hiding the apertura. Certain zooecia have a salient mucro (fig. 11); then the two cardelles are replaced by two peristomial apophyses separated from the mucro by two psendorimules. Other zooceia bear two apophyses separated ly a rimule (fig. 9); the latter may be joined (fig. 10), surrommling thus a sort of spiramen. All these details lave the most minute dimensions.

Afinitis.-This species is well characterized by its small dimensions and its peristonial variations. It differs from IIotoporella separata in its smaller zooecia and in the absence of pedunculate avicularia issuing from the deep zooceia.

It liffers from lloloporelle mirpopore with small zooecial dimensions, in its more elevated zovecia, its smaller zoarium and in its much larger apertura ( $h a=$ 0.08 and not $0.05 \mathrm{~mm}$.).

Oecurence-Middle Jacksonian: Wilmington, North Carolina (common); Ricle Fill. Crawford (ounty, Georgia (rare).

Cotype-Cat. No.64223. U.S.N.M. 
HOLOPORELLA DAMJCORNIS, new species.

Plate 7 , figs. $1-i$.

Iescription.-The zonium inerusts, first. the radicels of an alga to form an astachment for suspension; it then derelops freely into a small irregular mass ornamented with homs of greater or less length. The superficial zooecia are little ereet, simply oblique; the frontal is smooth and quite eonvex; it is terminated by an aviculiferous umbo more or less developed; the avieularium is open under the umbo toward the apertura. The apertura is semilunar, very finely crenulated the anter is separated from the poster, which is smaller and concave, by two minute eardelles. The ovicell is hyperstomial, very salient, globular, smooth, provided with a large opening. The deep zooeeia are rare; they have no frontal: their umbo forms an interzooecial prominence. The interzooecial avieularia are large, elliptical, with pirot. The incomplete zooecia are suborbieular and not rare.

Measurements.-Apertura $\left\{\begin{array}{l}h a=0.15 \mathrm{~mm} . \\ l a=0.13 \mathrm{~mm} .\end{array}\right.$

Variations.--The zoarium with its eccentric shape is very eurious; no one specimen resembles another and yet all have a general indefinable facies which permits their immediate cletermination. Evidently this is not altogether a phenomenon of symbiosis in its entirety, but it is very close to it. It is even probable that the alga chosen by the larva was always the same and that its disappearance has caused at the same time the death of the Cellepore.

The umbo is rather fragile and is easily broken (fig. 6); often it is even not developed at all (fig. 5).

Figure 7 shows the ordinary cumulation of the zooecia. Such seetions indieate the complieated structure of the zooecial walls, which sometimes appeutr to contain dietellae. The interpretation of the sections of the Cellepores are really problems of descriptive geometry.

Affinities. - In its zooecia this species somewhat resembles Holoporella albirostris Smitt, 1872, which still lives in the Floridan waters. It differs from it however in its symmetrieal umbo and the absence of areolice.

Occurrence.-Jacksonian (Zenglodon zone) : Snck Creek, Clarke County, Mississippi (rare); Cocoa post office, Choctaw County, Alabama (common); Jackson, Mississippi (very rare).

Cotypes.-Cat. No. 61222, U.S.N.M.

HOLOFORELLA SEPARATA, new species.

I'late 76 , ligs. 13-19.

Deseription.-.'The zoarium is massive and is formed of small irregular masses fixed to bryozoa, to the convexity of slells, or to the radieells of algale. The superficial zooeciil are ereet, suborlicular, separated one from the other; the fiontal is smooth. The apertura is orbicular and formed of a linge, semilumar anter sepat 5is!) $19-13$ ull. 10ti-_- $3: 1$ 
rated from a convex poster by two small cardelles. On the frontal is an oral avicularium with pirot and pointed beak and placed obliquely with respect to the apertura. The oricell is hypestomial, salient, globular, smootl. The deep zooecia luave an analogous apertura and an oral pedunculate avicularium quite salient, just to the level of the superficial zooecia. 'The incomplete zooecia are abundant; they are formed either by simple cavities or by zooecia deprived of frontal.

$$
\text { Mcasurements. Apertura }\left\{\begin{array}{l}
h a=0.06 \mathrm{~mm} \text {. } \\
7 a=0.06 \mathrm{~mm} .
\end{array}\right.
$$

Atmities.-This species resembles absolutely 11 oloporclla altirostris in all its general characters. It differs from it only in its smaller micrometric dimensions. the smaller oral aricularium, and the absence of the two spines of the peristome. It appears like a minor variety. The true diflerence is in the appearance of the zoarium which particularly affects the convexity of shells.

Ocenrence.-Middle Jacksonian: Baldock, Barnwell County, South Carolina (vely common); one-half mile sontheast of Georgia Kaolin Co. mine, Twiggs County, Georgia (rare) : $3 \frac{1}{2}$ miles north of Grovania, Georgia (rare).

Jarksonian (Zenglolon zone) : Slnuluta, Mississippi (mare).

Cotypes.-Cat. No. 64220, U.S.N.M.

\section{HOLOPORELLA MICROPORA, nEw species.}

Plate 76 , figs. $7-10$.

I'cseription.-The zoarinm is free, massive. and globular. The superficial zooecia are small, little erect, simple, oblique; the frontal is smooth and convex; it is terminated by an aviculiferous salient jeak. The apertura is quite small aud semilunar; two small cardelles separate the concare poster from a larger anter. 'The deep zooceia have their umbo completely developed. The interzooecial aricularia are rather large, elliptical, rare.

$$
\text { Measurements.-Apertura }\left\{\begin{array}{l}
h a=0.04 \mathrm{~mm} . \\
7 a=0.06 \mathrm{~mm} .
\end{array}\right.
$$

Affinitics.-Whis species is characterized by the extreme smallness of its spertura. It liflers from IIolopornlla pisiformis in its larger zoarimm, which may attain 13 cm. in dianeter. in its oblique and not erect zooecia. and in its -till smallel* apertura.

Cecurpence- - Tpper Jacksonian (Ocala limestone) : Below Plant Fystem Rajlroal wharf, Bainbridge, Geolgia (very rare); Old Factory, $1 \frac{1}{2}$ miles above Bain.. briclge. Georuria (common).

Eotypes.-Cat. No.64218, U.S.N.M.

HOLOHORELLA SEPOSITA, new speeies.

Plate 102, figs. $7-9$.

Leseriftion.-The zoarium is free, massive, globular, and of the size of a pea or fastened on the bryozoa in small, very conrex masses. The superficial 
zooecia are completely erect, orbiculal, quite seattered from each other; the frontal is smooth and surrounded by from $t$ to 6 large, widely spaced areolac. The apertura is ogival very finely crenulated with two minute cardelles placed fuite low; the peristome is fummel slaped and leats four spines. The ovieell is lyperstomial. recumbent, salient, transverse. smooth; it opens very wilely above the apertura. Very often the frontal bears a sulbmedian triangular avicularium, with pivot. The deep zooecia are almost entirely visible. The incomplete zooecia and the oral, incomplete avicularia are rery abundant.

$$
\text { Measurements.-Apertura }\left\{\begin{array}{l}
h a=0.09 \mathrm{~mm} \text {. } \\
7 a=0.08 \mathrm{~mm}
\end{array}\right.
$$

Tariations. - It is quite lare that a zoarimu dies when its superficial zonecia are completely formed (fig. 9). The most habitual aspect is that of figure 8 ; the oral aricularium is reduced to the state of a ciratrix of more or less depth: the pines are almost always alsent and the incomplete zooetia are rery abundant. The Cellepores are not always marred by fossilization: they are often incompletely developed.

Aftnitics.-This species liffers from IIoloporella orbiculiferc in its larger and more scattered zooecia and in having four spines instead of two.

It differs from Holoportle pisiformis in its larger micrometric dimensions and in the absence of a peristonice with simple or double apophysis.

It differs from IIoloporella separate in the absence of a larese pexlumculate avicularim between the superficial zooecia and in the presence of four spines and some areolae.

Oreurpence.-Tieksburgim (Mariamna limestone): West bank Conecul River, Escambia County, Alabama (common) : Murder Creek, east of Castlebury, Conecul, Comnty, Alabama (rare); near Claibome, Monroe County, Alabama (rare); Salt Mountain, 5 miles south of .Iackson. Alabima (common).

Cotypes.-Cat. No. 64329, U.S.N.M.

\section{HOLOPORELLA PERISTONARIA, new species.}

F'late 102, fiss. 5, 6 .

Description.-The zoarium is a small. irregular mass. The superficial zooecia are erect, tubular; the frontal is convex, surrounded by some large areolae. The apertura is oval, the poster being rery concare: it is surounded by a very lone peristomic, sometimes fissured in front: the peristome is more or less thick, accorting to its proximity of the apertura. The deep zooecia have a small avicularimu on their peristome. The marginal zooecia are recumbent, somewhat clongated, very convex; their frontal is terminated by an aviculiferous beak. salient and not rmmetrical.

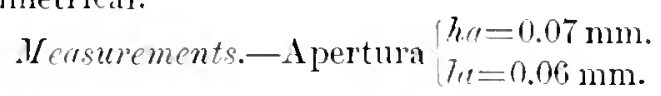

Iffinitis.-The only specimen collected has been figured: although it hears no ovicell. it appears to us to lw sufficiontly characterized to he describer. Mani- 
festly the front:l is formed of a pleurocyst with extremely fine granules superposed on the olocyst. The considerable development, attaining $0.15 \mathrm{~mm}$. in length, of the peristomic is very characteristic: it secms to us that it was miquely of pleurocystal origin.

Occumence.-Ticksburgian (Byram marl) : Byram, Mississippi (very rare). Ilolotype.-Cat. No. 64328, U.S.N.M.

HOLOPORELLA DISCUS, new speeies.

Plate 102, figs. 10-13.

Description.-The zoarium is free and discoidal, of 8 millimeters in diameter at the most. On the lower face the zooecia are oriented, irregularly hexagonal, perforated by a small submedian pore (corresponding perhaps to the radicles). 'The superficial zooccia are erect or quite oblique, distant from one another; the frontal is convex and gramular, surrounded by seven or eight widely spaced areolar yores. 'The apertura is formed of an anter almost circular and of a small, somewhat concave poster, separated by two very small cardelles; the peristome is wide clenulated; it limits an infundibuliform peristomie. The deep zooecia are deprived of frontal. The incomplete zooccia are large and rare.

$$
\text { Measurements.-A pertura }\left\{\begin{array}{l}
h a=0.11 \mathrm{~mm} \text {. } \\
l a=0.13 \mathrm{~mm} \text {. }
\end{array}\right.
$$

Tariations. - We have supposed that the pores of the inner face are the radicles which permit the zoarium to attach itself to stones or shells. The larva is fastened on a minute fragment of bryozoa or shells and never on a large surface. The absence of vibracula, that is to say, of all system of stabilization, does not allow us to believe that the zoarium could attach itself to the algae or float freely below their fronds in the manner of the Lmnulites.

Affnities.-The aflinitios of this species are chiefly with Holoporella crassicollis. in which the peristomic is also infundibuliform and the dimensions very close. Hotoporella discus differs from it in the presence of areolae. in the absence of multiple spines, and in its free, discoidal, nonincrusting zoarium.

It differ's from Schismopora orbiculata, in which the zoarium is also discoidal, in the form of its apertura deprived of rimule. in its rery erect zooecia and in the presence of perforations on the lower face.

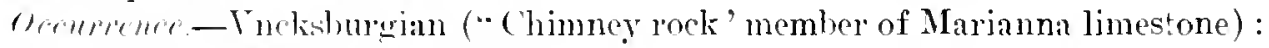
One mile north of Monroeville, Alabama (very common).

Cotypes.-Cat. No. 6.3330, U.S.N.M.

\section{HOLOPORELLA BIROSTRATA, new species.}

$$
\text { I'late } 76 \text {, figs. } 20-24 \text {. }
$$

Description.-The zoarium forms a small convex mass, incrusting stones. The superficial zonecia are erect and salient; the frontal is convex, smooth. and bears two or three wnall salient avieularia, with pirot; it is prolonged into a bifid bedi: which partially masks the apertura. The ovieell is hyperstomial, recumbent, salient, 
globular, transrerse, smooth. The deep zooecia are entirely hidden: their apertura is alone visible. The submarginal zooecia are oblique, oriented; the frontal is rery eonvex, smooth, and terminated by a touble beak, of which one at least is a riculiferous; there are three small elliptical avicularia with pivot on the frontal; the oral avienlarium is curved and opens into the locella. The marginal zooecia are oriented; the frontal is terminated by two aviculiferons beaks entirely hiding the apertura ; there is only one avicularinu in the vicinity of the apertura; the apertura is very oblique, and disposed at the base of the locella. The interzooecial aricularia are elongated like the beak of a duck; the pirot separates a small pore in crossing the subtriangular orifice: the mandible was lodged in two-thirds of a enlcified area.

Affinities.-In the interior on the apertura there are two small cardelles separating a large anter from a smaller, very concave and broader poster (fig. 24). The a pertura is rery finely dentienlated.

Some zooecia are perforated in their median portion by a longitudinal tube. the external relations of which have not been discovered because of the lack of specimens.

The marginal zooceia much resemble the Cellepord vernecos Reuss. 1847 . The present species differs from it in the presence of two oral a vicularia opening into the locella.

Occurrence.-Middle Jacksonian (Castle Hayne limestone) : Wilmington. North (arolina (very rare).

Cotypes.-Cat. No. 64221, U.S.N.M.

AXILYTICAL, FEY TO HOLOPORELLA.

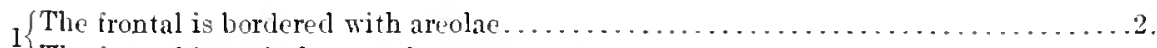

The frontal is entirely smooth (new gents) . . . . . . . . . . . .

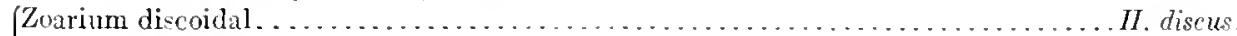

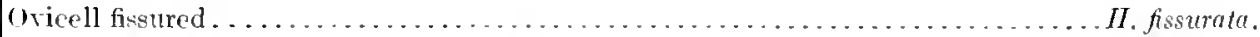

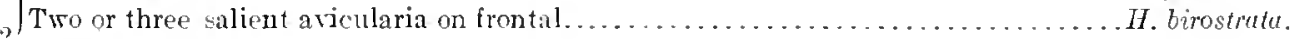

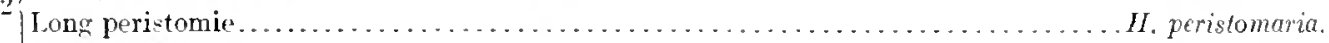

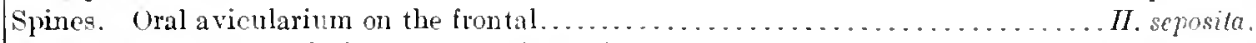

No spines. Oral aricularium disposed laterally on the peri-tome ............. II. gramulosa.

${ }_{3}$ No oral avicularium or aviculiferous beak on the frontal. . . . . . . . . . . .I. crassicollis.

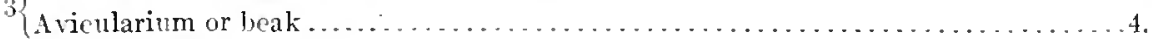

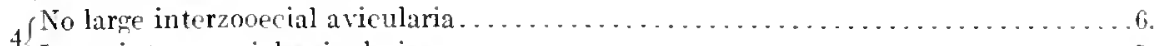

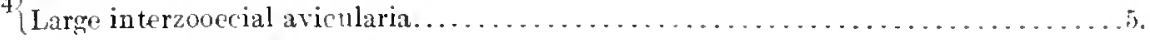

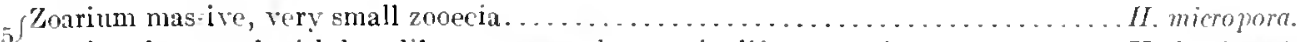

$5\{$ Zoarium large and with hornlike proceses; large aviculiforous $t . m b$............ II. dumicomis.

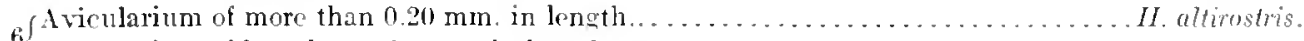

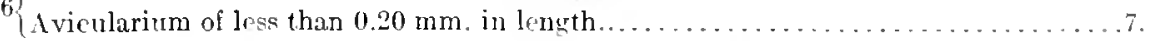

${ }_{7}$ Pedunculated avicularium between the supurficial zootcia................ . separatu.

7 No salient aricularium. . . . . . . . . . . . . . . . . . .

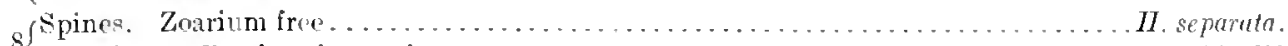

S No spines. Zoarium incrusting . . . . . . . . . . . . orbiculifera.

According to the nature of the frontal there are really two cistinet genera. We have not formed them, because on the focsils not only are the arcolae not always

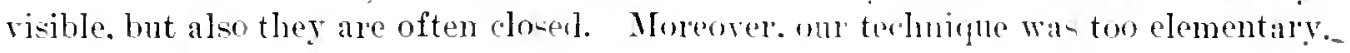




\section{CLITHRIDIATE GROUP.}

The oriflee is oval. The funtal is a rery thick olocyst perforated by some scattered avicularia. The ovicell is hyperstomial and lodged in the thickening of the olocyst.

It would be convenient. perhaps, to make a special family for this group; but we are ignorant of the larva. and it is necesary to search first and find the analogous or closely relater recent species.

Some species have very little of cumulate zooecia.

\section{Genus ACANTHIONELLA Camu and Bassler, 1917.}

1917. Acanthionella Caru aud Rassler, Sruogsis of American Early Tertiary Cheilostome IBryozoa, Bulletin 96, rnited States Vational ifusenm, P. 72 .

The apertura is oral and bears a long lyrula. The frontal is a rery thick olocyst, in which are lodged some avicularia. The oricell is hyperstomial: it js

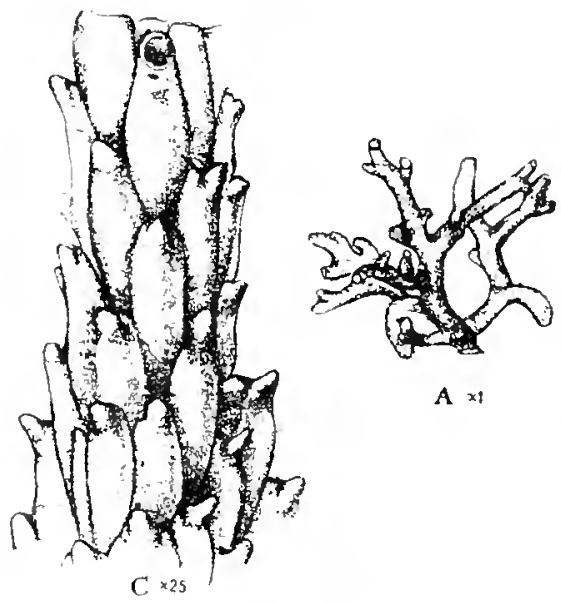

Fis. 189.-Collepora ramulosa Busk, $18 j 4$.

A. Zuarium, natural size. B. Zooecium, $\times 50$. C. Portion of zoarium, X 25. (1-C after Pusk, 1854.)

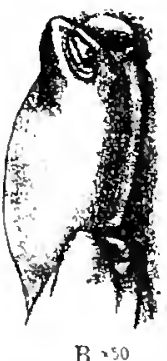

$B=0$ lodged in the thickening of the frontal of the distal zooecia: it opens into the peristomie.

Genotype-4eanthionella (Escharifora) typica Gabb and Horn, 1862.

Range.-MastrichtianTaclisonian.

This genus differs from $T i c^{i-}$ dionella in the presence of a lyrula and the rarity of cumulate zooecia.

ACANTHIUNELLA OECIOPOROSA, new species.

Plate 17. fixs. 1-14.

Description. - The zoarium is free, bilamellar, with fronds mole or less rounded. The orientar zonecia are indistinct; the frontal is a rel'y thick olocyst perforiter by tro to five small avicularia. The apertura (interior) is oval and garnished by a long proximal lyula; the peristomice (csterior) is orlicular; the peristomie is rery deep and contains sometimes an avicularium bearing the lyrula. The oricell is buried in the distal zooccia: it opens into the peristomie; it bears a frontal area closed hy a mucl hranched spine. The young zonecia and the cumulate zovecia are distinct, elongated, giblose. The interzooecial avicularia are rare, of the size of the zoosedi: elliptical. and previsled with a pivot.

$$
\begin{aligned}
& \text { Masurements. I pertur: | ha }=0.10 \mathrm{~mm} \text {. } \\
& \text { (interior) } l_{t}=0.1+m m \text {. } \\
& \text { Zooeria } L z=0.35 \mathrm{~mm} \text {. } \\
& \text { (interior) } 17 z=0.26 \mathrm{~mm} \text {. }
\end{aligned}
$$


I'ariations.-Most of the time the zooecia are oriented; nevertheless the species is qutite variable. The roung zooecia (fig. 7 ) and the cumulate zooecia (fig. 10) on the same zoarium (fig. 6) have a thin and gibbose frontal wall. These gibbowities are much smaller on the zooecia with thick frontal (fig. 2) and are placerl

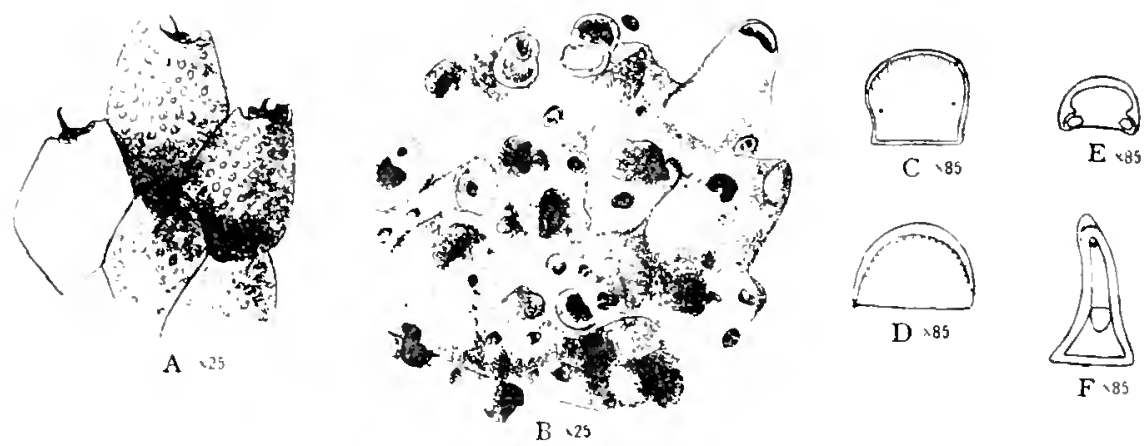

Fig. 184.-Cellepora sardonica Waters, 1570.

A. Oriented zooecia, $\times 25$. B. Cumulate zooecia, $\times \mathbf{2 5}$. C. Operculum, $\times$ S5. D. Aperturi, $X$ s5. F, F. Aricularian mandibles, $X 85 . \quad\left(A-F^{*}\right.$ after Waters, 1879 and 1855̄.)

between the aricularia. We have nothing to prove that the perforations of the frontal are really avicularia and contain neither denticle nor pirot; but on the genotype there are some true avicularia with pirot. The peristomial avicularium is rery curious: it is placed obliquely (fig. 5) and is little risible exteriorly; it bears
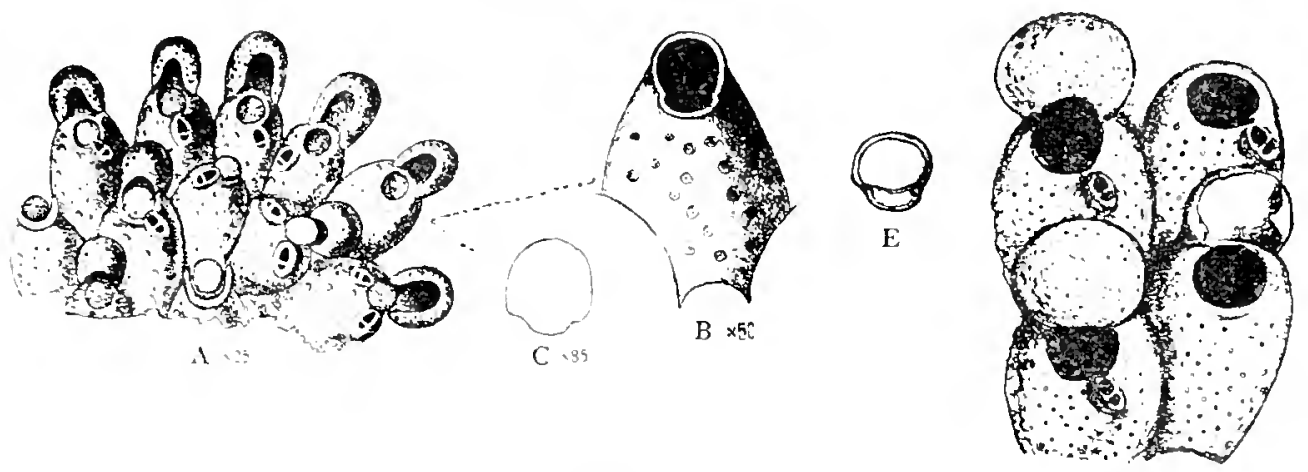

Fig. 185.-Cellepora ianthinn group.

$D$

A-E. Cellepora junthina Smitt, 1567. A. Group of zooecia, $X$ 25. 13. A single zovecium, $X$ 50. C. Operculum, $X$ S5. ( $A-C$ after Waters, 18\%.) D. Group of oricelled zonecial. E. Operculum. (D, E after Norman, 1909, as Cellepora rotumbra.)

the habitual lyrula. The porous area of the oricell is of a unique type; it is formed by a much branched spine forming a sort of filtering apparatus and breaking very easily (fig. 4).

In the tangential sections (figs. $11,12,14$ ) the zonecia are separated by white lines caused by the frontal convexity. 'The olocystal elements (figs. 12. 1t) are 
oriented in radial fibers around the lyrula. These fibers are visible even on the internal walls (fig. 6). When the section is deeper (fig. 13) the zooecia are separated by the habitual black line; the olocystal elements of the walls are grouped in more or less diffused links. The transversal fracture of the zoarium (fig. 9) indicates a concentrie lamellar structure, the use of which is yet to be clemonstrated.

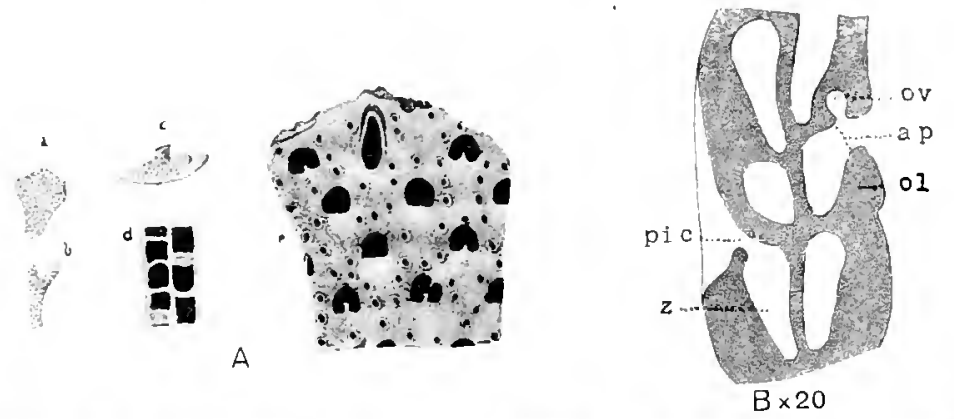

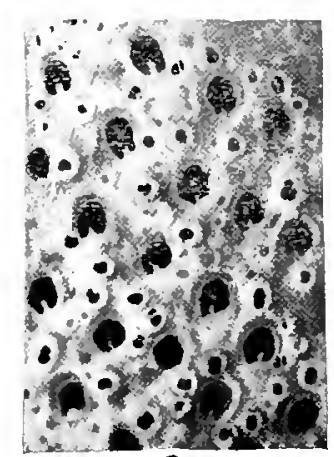

$\mathrm{C} \times 20$

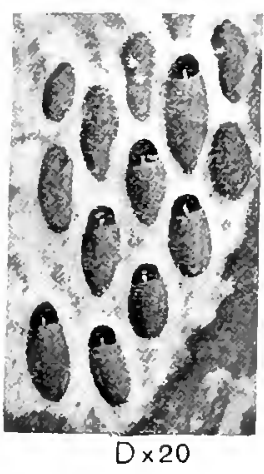

$0 \times 20$

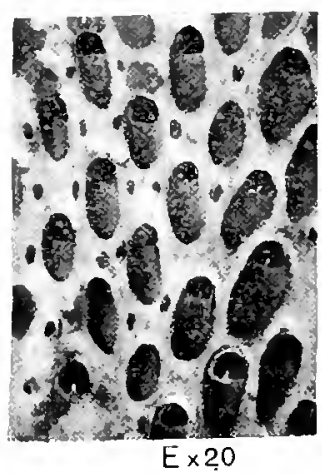

$E \times 20$

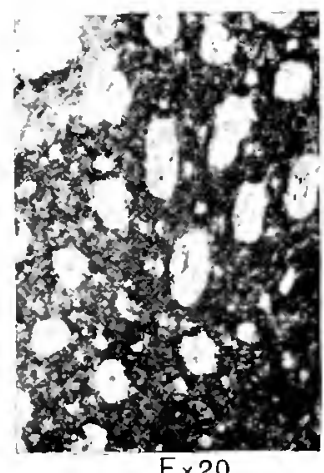

$\mathrm{F} \times 20$

FIG. 186.-Genus Acunthionella Canu and Bassler, 1917.

A-F. Acanthionella typica Gibb and Iforn, 1862. A. View of the bifoliate zoarium $(a, b)$, the incrustiug base, natural slze $(c)$, the two lamellae $(d)$, and the surface $(e)$, enlarged, showing the lyrula and the pores. (After Gabb and Horn, IS62.) B. Schematic draning of a vertical section, $\times 20$. ap, apertura; ol, olocyst; ov, ovicell; pic, peristomice; $z$, zooecium. C. Photogralph of the surface, $\times 20$. The lyrula and the olocyst frontal with avicularia are sbown. I. Interior of the zooecia, $\times 20$, illustrating occurrence of $]_{\text {sruli. }}$ E. Another interior, $\times 20$. with the oricell showing in three of the zociecia (at the tor). F. Tangential thin section through the frontal of the zooecia, $X 2 \pi$. The olocsstal structure of the frontal is sbown. Cretaceous (Vincentown), Vincentown, New Jersy.

Attmitin.-This species differs from Acanthionella typica Gabb and Horn. 1862. in its frontal gibbosities and in the presence of a porous area on the ovicell.

recurence-Claibornian (Gosport sand): Claiborne, Alabama (common); 1 mil soutl of Rockville, ('latke ('ounty, Alabama (very common) : Copher Inill, 'Tounhigbee River, Alabana (rare).

Lower Macksonian (Moodys marl) : Jacksor Mississippi (i Imon).

Cotyps.-Cat. No.63561. U.S.N.M. 
ACANTHIONELLA SIMPLEX, new species.

Plate 2, fig. 6.

Description.-The zoarium is free, bilamellar, bifurcated. The zooecia are indistinctly oriented; the frontal is formed of a thick olocyst bearing a large suborbicular and salient avicularium. The peristome is very deep; the peristomice is oral and bears on its proximal lip a sort of flat and rery prominent lyrula. The ovicell is hardly visible exteriorly; it is hyperstomial and opens widely into the peristomie.

Affinitics. - The only specimen found has been figured. We have not been able to study this species in detail; but it was urgent to mention the occurrence of the genus in this stage.

It differs from Acanthionclla typice Gabb and Horn, 1862, in the presence of a single frontal avicularium (and not 3 or 4 ) and in its lyrula attached to the peristomice (and not to the apertura).

It differs from Acanthionella occioporosa in the absence of frontal gibbosities and in the rarity of its frontal avicularia.

Occurrence.-Lowest Eocene (Bryozoan bed at base of Aquia formation): Tpper Marlboro. Maryland (very rare).

Holotype.-Cat. No. 637st. U.S.N.M.

$\cdot$

\section{Genus KLEIDionella Canu and Bassler, 1917.}

1917. Flcidionellu Cane and Basster, Sympsis of American Filrly Tortiary Cheilostume Bryozoa, Bulletin 96, United States National IIusenm, 1. i2.

The apertura is oval. The frontal is a very thick olocyst. The ovicell is hyperstomial and lodged in the olocyst of the distal zooecia; it opens into the peristomie. There are some small and some large interzooecial avicularia. No lyrula.

Genotype.-Fileidionclla grandis Canu and Bassler, 191i.

Range.-Claibornian-Viclisburgian.

The abundance of cumnlate zooecia and the absence of lyrula distinguishes this genus from the preceding one, Acanthionclla.

\section{KLEIDIONELLA GRANDIS Canu and Bassler, 1917.}

Plate 78 , figs. 1-17; plate 70, fig. 1.

1917. Kleidionella grantis CAxU and BASSLER, Synopsis of Amerian Farly Tertiary Cheilostome Bryozoa, Bulletin 96, United States National Nuseum, 1. 72. 11. a. figs $0,10$.

Description.-The zoarium is very large, compressed, formed of bifureatel fronds almost in the same plane, attaining toward the base 2 cu. 5 m. in width. The zooecia are disposed in two gromps, back to back, and insepalable. The axial zooecia, back to back, are oriented; all the other zooecia are cumulate. The superficial zooecia are distinct, urceolate, little rased, very oblique: the frontal is quite convex. smooth. bearing 0 to 3 improminent avicularia with pirot; the 
frontal is formed of a very thick olocyst. The apertura is oral, deeply imbedded at the base of a peristomie: the peristomice is irregular, suborbicular. The decp zooccia have a flat frontal. their avicularia are prominent between the superficial zonecia. The interzooccial avicularia are distinct. elliptical, of the size of zooecia: they have a pivot; their orifice is like the beak of a dnck; the passage of the reflexor muscles of the operculum is indicated by the very small perforations on the inferior cavity; the beak is salient above the zoarium. The incomlete zooecia are quite numerous. On many zoaria there are some distinct groups of large zooecia and of small zooecia.

$$
\begin{aligned}
& \text { Measurements. - Apertura }(h a=0.15 \mathrm{~mm} \text {. Zooecia }(L z=0.60 \mathrm{~mm} \text {. } \\
& \text { (interior) } l^{\prime} a=0.15 \mathrm{~mm} \text {. (interior) } l l_{z}=0.30-0.35 \mathrm{~mm} \text {. }
\end{aligned}
$$

Tariations.-Following the rule, the variations of these Cellepores are quite great, but the species is always rather easy to determine by its zoarial size.

The two pimitive lamellae of the Eschara are back to back and their zooecia are oriented. It is easy to verify this phenomenon in the longitudinal sections (pl. is. fig. 14). in the transversal section (pl. 78, fig. 15), in the interior (pl. 78 , fig. 17). The Cellepores are therefore Cheilostomes perfected by the superficia] budding which does not exist in other families. The exterior zoocia are cumulate but never very much raised. Many zoaria (pl. 78. fig. 11) have some groups of large zooecia (pl. 78. fig. 9) perfectly distinet from the gronps of smaller, flat zooecia (pl. 78 , figs. 10, 12, 13). The reason for the dimorphisn is absolutely unknown to us; to determine it, it would be necessary to examine a very large number of specimens as complete and perfect as possible. The total regeneration appears to have affected many of the interzooccial av:cularia and some small frontal aricularia, as in figure 7 of plate 78 .

The tangential sections are very difficult to interpret, but they are very instructive. We there note above all the disorder characteristic of the Celleporidac: no regularity, no simmetry. Figure 1, plate 79 , shows a section nearest the surface; the structure of the frontal walls appears in place or is only manifested by the black circles, for the olocyst is very compact; the white marks which surround these walls result from the conrexity of the zooecia. which are only adjacent at their base. Figure 16 of plate 78 shows a deeper section at the level where the zooecial walls are adjacent; the zooccial convexity is raised and the zooecia are white.

Occurrence-Tower Jacksonian (Moodys mall) : .Tackson. Mississippi (common ) : 21 miles nortl of Roberts. Mississippi (common).

Midlle Jacksonian: Wilmington, North Carolina (common) : $3 \frac{1}{2}$ miles soutl of Perry, (reorgia (common).

Tacksonian (Zeuglodon zone) : Cocoa post office. Choctaw County; Alabama (very common) : Pachuta. Clarke Comty, Mississippi (very common); sontl side of Suck Creek. Clarke County, Mississippi (common). 
Vicksburgian (Red Bluff clay) : Seren and one-half miles from Bladen Springrs, Alabama (rare): Red Blıff. Wayne Comnty, Mississippi (rare).

Cotypes.-Cat. Nos. 62613, 642.25, (it2.26, U.S.N.M.

KLEIDIONELLA PARASITICA, new species.

Plate 11i. 1ìns. 17-22.

Description.-The zonrium is masive, niginally spread ont over the ratieles of algae: it afterrards emits bilamellar and eschariform fronds, in which the axial zooecia are oriented. The superfieial zooecia are salient, globular, oblique; their frontal is very convex. smooth and formed of a very thick oloeyst; it bears 0 to 3 small, elliptical avicularia. somewhat salient. with pivot. The apertura is oval. rery deep: the peristomice is elliptical. The avicularia of the deep zooecia are more salient. The interzonecial aricularia are as large as the zooecia, elliptical, provided with a pirot and with a romder beak. On the bilamellar brinehes the zooecia are oriented; they are elongated. somewhat distinct; the frontal is smooth, convex and garnished with three elliptical avicularia, little salient, with pivot. The rery roung zooecia have a large peristomice.

$$
\begin{aligned}
& \text { Weasurments. Apertura (interior) }\left\{\begin{array}{l}
h a=0.12 \mathrm{~mm} \text {. } \\
/ / \mu=0.08 \mathrm{~mm} .
\end{array}\right. \\
& \text { Peristomice (exterior) }\left\{\begin{array}{l}
7 p e=0.20 \mathrm{~mm} . \\
7 / p e=0.14 \mathrm{~mm} .
\end{array}\right. \\
& \text { Zooecia (interior) }\left\{\begin{array}{l}
L z=0.44 \mathrm{~mm} \text {. } \\
7 z=0.30-0.36 \mathrm{~mm} \text {. }
\end{array}\right.
\end{aligned}
$$

Tariations.-The fronds with oriented zooecia and with two limellae, back to lack, are not rare (figs. 1s, 20, 21); at their base they bear some cumulate zooecia. The latter (fig. 22) are abundant on the incrusting zoaria. They have a distinet but little salient peristome. The lower fice (fig. 19) of the incrusting zoaria presents nothing particularly remarkable.

Affnities.-This species dillers from Treintionclla grandis in its rery small zoarium and in its smaller zocecia.

It differs from Iileidionellu lots:ta in the constint presence of the cumulate zonecia, the rarity of the oriented zooecia and the presence of the large interzooecial avicularia.

Ocemperec-Tower Ticksonian: Three and one-half miles southeat of shell Bluff Post Office. Georgia (common).

Cotype. -Cat. No. 63860 . T.S.N.M.

KLEIDIONELLA LOBATA, new species.

Plate 7!. fies. $2-14$.

Mescription.-The zoarium is free, compressed, formed of lobed lifureated fronds borne on an expander base: it is formed of two lamellae, back to back. and it bears some zooecia almost always oriented and rery rarely cmmlate. The oriented zooecia are indistinet: their fromtal is thick, little convex, and bears one to 
five small elliptical aricularia, little salient, with pivot. The apertura is oval, deeply imbedded at the base of the peristomie; the peristomice is elliptical, elongated, not garnished with a peristome. The ovicell is hyperstomial, little salient, envex. transverse, smootll; it opens into the peristomie by a very large opening. The interzonecial avienlaria are of the size of the zooecia; they have a pivot placed quite low; their beak is round and not salient. The cumulate zonecia are very rare; they are globular, oblique, very convex and bear one or two frontal aricularia.

$$
\begin{gathered}
\text { Measurements.-Peristomice (exterior) }\left\{\begin{array}{l}
h p e=0.14 \mathrm{~mm} . \\
l p e=0.10 \mathrm{~mm} .
\end{array}\right. \\
\text { Zoocecian }\left\{\begin{array}{l}
L_{z}=0.40-0.48 \mathrm{~mm} . \\
l_{z}=0.30 \mathrm{~mm} .
\end{array}\right.
\end{gathered}
$$

Tariations.-The peristomice may be mistaken for the apertura in the very young zooecia (fig. 4) at the extremities of the fronds. The ovicell is formed rather slowly (fig. 4) and is easily broken (figs. 5. 8). The cumulate znoecia are extremely rare; they sometimes appear isolated (figs. 5, 9); but at other times they are grouped (figs. 10, 11). Their presence, even accidental, proves that this species is well classed in its true genus and that it is a Celleporid.

The olocyst is so compact that it is impossible to obtain its microstructure (fig. 12) in tangential section; as in the other Celleporidae the zooecial limits are not visible in such sections.

The longitudinal section shows (fig. 13) short zooecia with thick walls and an oblique apertura.

Affinities. - This species differs from KT citiomella paresitica and Kleidionella grandis in the almost complete absence of cumulate zooecia and in its very characteristic zorarium.

It differs from Kleidionella cristata in the fronds of the zoarimm, which are wider and deprived of median crest.

Its zoarium often exceeds one centimeter in length. and we may consider it is a goorl-sized fossil.

Oecurence-Diddle Jacksonian: Wilmington. North Carolina (very common); near Lemuds Ferry. South Carolina (common); Eutaw Springs, South Carolina (rare): Ballock, Barnwell County, Georgia (rare).

Cotypes-Cat. No. 64227, U.S.N.M.

KLEIDIONELLA CRISTATA, new species.

$$
\text { l'lite } 7 \text {. figs. 12-21. }
$$

Ilescription.-The zoarium is formed of elongated, bilamellar fronds, composerl of two lamellae. back to back; the cumulate zooecia are grouped on the zoarial axis, thus thickening it and forming a characteristic longitudinal crest. The oriented zoocia are elongaterl, little distinet, rhomboidal; the frontal is thick, little convex. formed of a little compact olocyst; it bears one or two elliptical aricularia. little salient with pirot. The peristomice is elongated. elliptical; the ipertura is oval, very fincly clenticulated. The ovicell is hyperstomial, transverse, salient, convex. smooth; it opens wilely into the peristomie. The cumulate zooecia 
occupy the median part of the young fronds, but they totally orerspread the fronds at the base of the zoarium: they are globular, rery salient. and bear a frontal avicularium. The interzooecial aricularia are as large as the zooecia; they have a pirot; they are elliptical and their beak is round and little salient; they are chiefly disposed on the elge of the frouds.

$$
\text { Measurements.-Peristomice }\left\{\begin{array} { l } 
{ h p e = 0 . 2 0 \mathrm { mm } . } \\
{ 7 p e = 0 . 1 5 \mathrm { mm } . }
\end{array} \quad \text { Zooecia } \left\{\begin{array}{l}
T_{z}=0.60 \mathrm{~mm} . \\
l z=0.35-0.40 \mathrm{~mm} .
\end{array}\right.\right.
$$

Tariations.-There are tluree sorts of branches. The younger ones are formed entirely of oriented zooecia (fig. 14): the median crest exists, however. and the zooecia are there distinct. The older ones have some cumblate zooecia on the median crest (figs. 15, 16, 19). Finally, the fragments of the base are uniquely covered with cumulate zooecia (fig. 1i), among which are found some interzoocial aricularia. The presence of the interzooecial a vicularia on the edge of the zoarim (fig. 18) is inexplicable. The phenomenon is rather frequent in many Cretaceous Cheilostomes with olocystal frontal.

The tangential section (fig. 20 ) is interesting becanse it shows the structure at different depths; the olocystal elenents (fig. 21) are scattered.

Affinities.-This species differs from Kleidionella lobata in the almost constant presence of the cumulate zooecia and in its narrower and more elongated fronds.

It differs from Iileidianclla parasitica in its smaller zooecial dimensions and in the very peculiar nature of the frouds. common).

Oceurrence-Middle Jacksonian: Near Lenuds Ferry, South Carolina (very Cotypes.-Cat. No. 61224. T.S.N.M.

KLEIDIONELLA VERRUCOSA, new species.

Plate 101, figs. 1-11; plate 102, figs. 1-4.

Description.-The zoarium is free, formed of two layers, back to back, of cumulate zooecia, bilamellar at the summit, multilamellar at the base: the fronds are thick, compressed, elongated, bifurcated. 'The young zooecia are oriented, distinct, elongated; the frontal is smooth, very convex, bears an elliptical aricnlarium, salient, with median pivot. The apertura is oval and deep; the peristomice is elliptical. The ovicell is hyperstomial, salient, convex, smooth; it opens willely into the peristomie. The enmulate zooecia are salient, ovoid, smooth, often deprived of frontal aricularium. The interzooecial aricularia are salient, somewhat larger than the zooecia : they have a pirot and their beak is rery round.

$$
\begin{gathered}
\text { Heasuriments.-I pertura }\left\{\begin{array}{l}
h a=0.12 \mathrm{~mm} . \\
l_{a}=0.06 \mathrm{~mm} .
\end{array}\right. \\
\text { Zooecia } \begin{array}{l}
L_{z}=0.50-0.60 \mathrm{~mm} . \\
l . z=0.30 \mathrm{~mm} .
\end{array}
\end{gathered}
$$

Tariations.-The cumulate zoocia ale often grouped together as wartike projections among the oriented zooecia (pl. 101. fig. 6). The latter are risible 
only on the hilamellar zoaria (pl. 101, fig. 3). they are risible in transverse sections (pl. 102, fig. 2) or longitudinal sections (pl. 10.2 fig. 4) of the other zoaria. There are all solts of transitions between the frontal avieularia (pl. 101, fig. $t$ ) and the interzonecial aricularia. The zoarium may attain $1 \frac{1}{2}$ eentimeters in length and may be comsidered as a cood-sized fossil. easy of determination in the field.

In tangential sections (pl. 102, fig. 3) the zooecial walls are seen to be formed of rery dense olocystal elements.

Affinities.-This species differs from liteilionella eristata, in which the fronds have almost the same form, in its larger cumulate zooecia, never grouped especially in the middle of the fronds, and in the rarity of the oriented zooecia miquely arranged at the extremity of the branches.

It differs from tileidionella lobata in the presence of its mmerous cumulate zooecia.

Oecurence.-Vicksburgian ("Climner rock" member of Marianna limestone): One mile nortl of Monroeville. Alabama (extremely common).

Cotypes.-Cat. No. 6t32i, U.S.N.MI.

\section{Family CONESCHARELLINIDAE Levinsen, 1909.}

The zooecia are erect; the apertura is terminal. The gemmation is always and uniquely lateral. The ovicell is byperstomial and recumbent. There is both a zooecial and a zoarial hydrostatic system.

Historical.-The first specimens discovered were confused with Selenaria Busk, 1852, and Lunulites. In 1857 Whitelegre formed the genus Bipora for the pecies whose apertura were provided with a rimule. In 1910 Maplestone created the family Biporae. Irior to that, in 1900. Seviani grouped the genera Batoporu

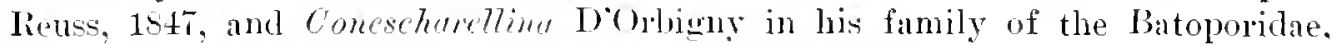
Whereas Stichoporina Stoliczka, 1S61, and Crbitulipora Stoliczka, 1S61, remained in Tepraliidae. Bipora Whitelegge, 1S57. was classed in 1895 in Selizoporellidae by MacGillirray. In 1009 Levinsen made a somewhat serious study on the recent gencra Bipora Whitelegge, 1Sst, Concscharellina O'Dibigny, 1S51, and Flabellipora $\mathrm{D}^{\circ} \mathrm{Orbig} \mathrm{yy}, 1551$, and all of the gromp with rimule of the Biporae; he omitted the recent genus Fedora. Iullien, 185. . No author has regarded the family in its entirety and the right of priority does not exist.

This is a very mysterions gromp. which hat grven the zoologists unch trouble until, in 1910, when Maplestone ${ }^{1}$ prexented some details on the zondial life.

Almost all our specimens belong to a new American genus. Schizorthosecos.

The zonecial hyduostatic system is analogous to that which we have deseribed for Lumularia Busk, 18st, but with some rariations still very imperfeetly studied. Arounl the ancestrula there are some hydrutatie and radicular zooecia and often between the zoocia thele are some hylpostatic zooeciules and some zooeeiules of renforement or compensation. The inner surface of the zonrium heing smaller than the external surface, the latter have for their object the making up the difference.

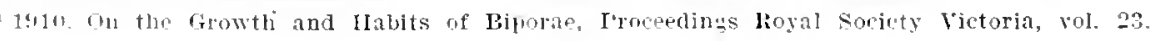


Genus FEDORA Jullien, 1882.

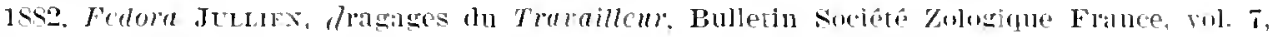
1. 17. (Kionidrlla Koschinsky. 19S5.)

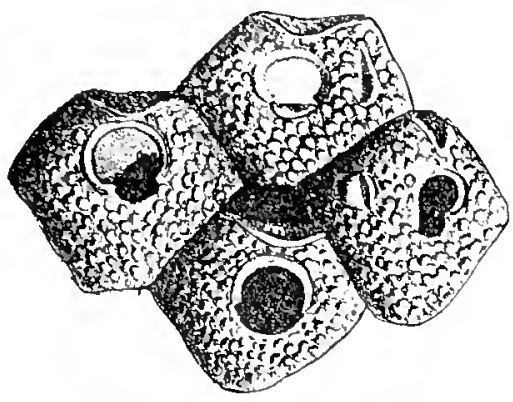

A $\times 44$
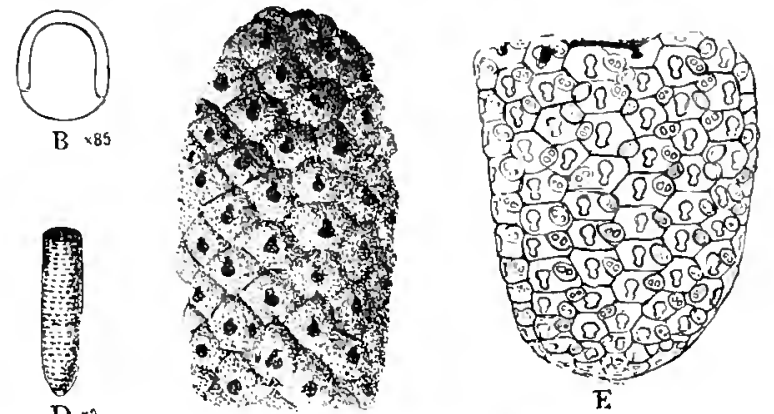

$\mathrm{D} \times 2$
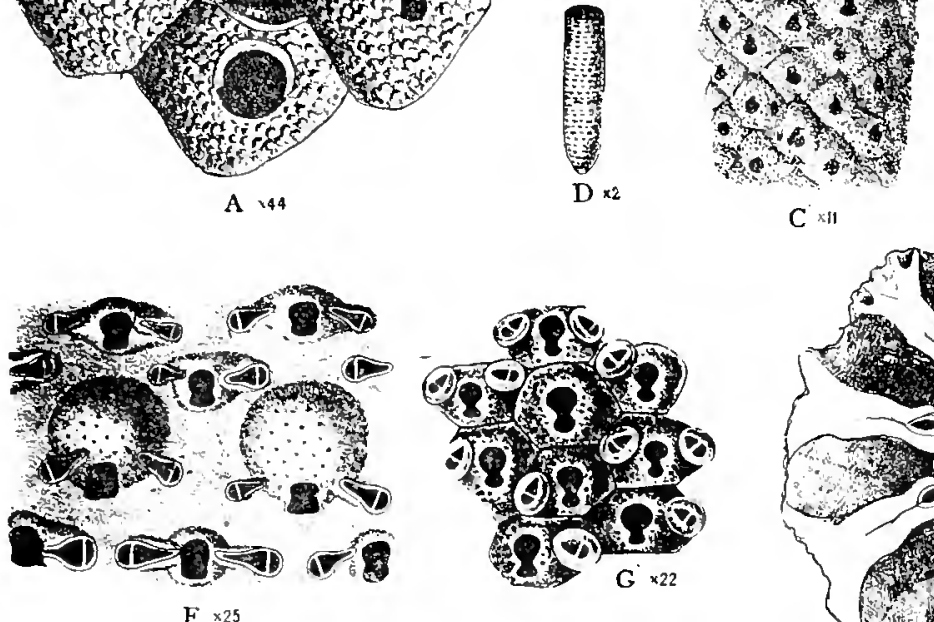

$\mathrm{C} \times \mathrm{in}$
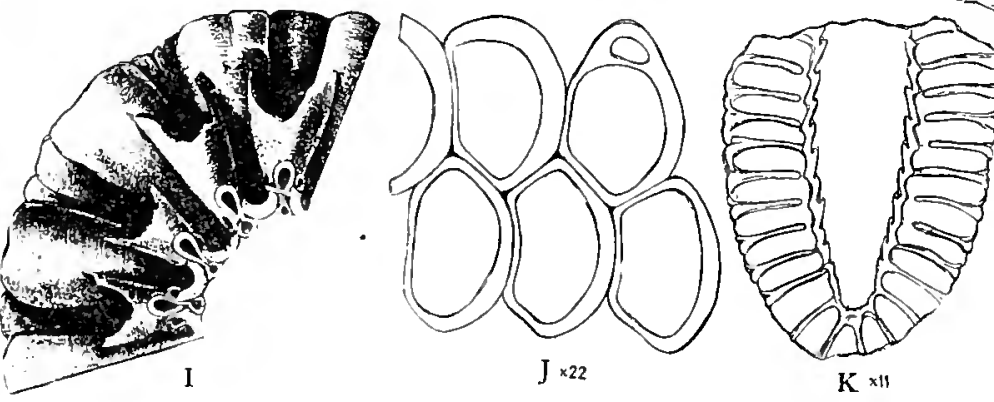

$\mathrm{H} \times 22$

Fir. 157.-Cienus Fedora Jullien, 158\%.

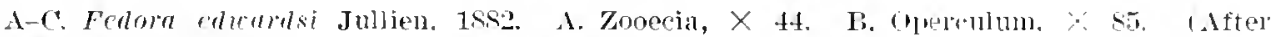

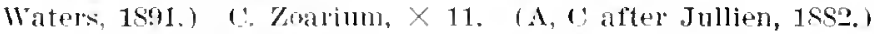

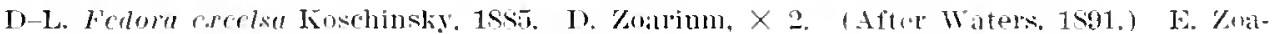
rim, magnified. F. Ovicelled zooecia, $X$ 25. (After Watels, 1s!1.1 1;. Mrdinaly zooecia,

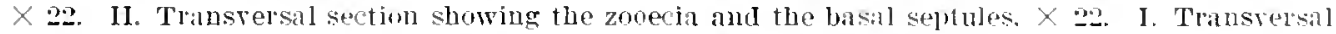
hreak showing that the zonecia arise ou the internal walls of the zurimm. .1. Taugential sec-

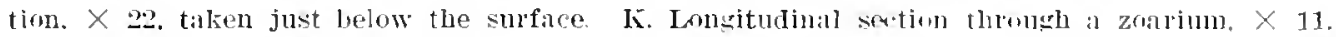
I. Enlaggenent of a longitudinal soction, $x 22$, slowing the basal sentules ipl, parietal septules

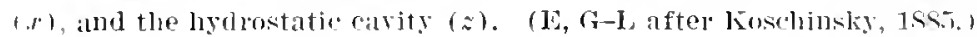

"Zooecia sublexagonal with circular orifice, thick but not silient, noteled on its posterior fomth where it is thin: finally placed a little ahove the center of the 
zooecium. of which it occupies about a third of the diameter; the ovicell nonsalient, indicated exteriorly by a smooth stripe forming an obtuse angle, of which the summit is turned toward the orifice. Avicularia not constant, situated on the sides and outside of the orifice." (Jullien, 1882.)

Genotype.-Fclora edwardsi Jullien, 1882.

liange.-Lutetian-Recent.

The known species of this genus are:

Fedorc edwardsi Jullien, 18s2. Recent.

Fedora (Tionidella) obliqueseriata Koschinsky, 1855. Lutetian.

Fedora (Tionidllla) exeelsa. Tíoschinsky, 1885. Iutetian.

Fedora (Discofustrellaria) dactylus D'Orbigny, 1881. Lntetian.

'The recent species has been dredged at a depth of 2,018 meters.

FEDORA PUSILLA, new species.

Plate 102, figs. 14-17.

Description.-The zoarium is small, rery conical, hollow. The zooecia are tubular, indistinct, separated exteriorly by some hydrostatic zoocciules. The apertura is subnbicular and formed of a large anter separated by two small cardelles froll a smaller postel. The ovicell is hyperstomial, very little salient; it is opened by a rery thin slit abore the operenlum; it is borne by a larger zooecium. Six inferior septules.

Occurrence-Vicksburgian (Byram marl): One-fourth mile west of Woodwards. Wayne County, Mississippi (rare).

Cotypes.-Cat. No. 64331, U.S.N.M.

Genus STICHOPORINA Stoliczka, 1861.

1S61. Stichoporina Stoticzkx, Oligocäne Bryozoen von Iatrotf in Bernburg Sitzungsberichte der k. Akatemie der Wissenschaften, Wien, vol. 45. Ahth. 1, 1862, pp. 71-74. [ls. 1-3.

The zoarium is eupuliform. The apertura is orbicular or elliptical with two cardelles; the apertura of the ovarian zooccia is larger and transrerse. The avicularia have some vibraculoid mandibles.

Genotype.-Stichoporima reussi. Stoliczka, 1861.

Range.-Lutetian-Recent.

The known species of this genus are:

Stichoporina renssi Stoliczka, 1861. Lutetian. Latulorfian, Recent. (=Stirnoporimu simpler Koschinsky. 1885.)

Stichoporina motecta Kóschinskr. 1885. Lutetian. Priabonian.

Stichoporina crassitabris. Koschinsky, 18s5. Intetian.

Stichoporina (Lrmatin) minutissima Seguenza. 1880. IIelretian.

Stichoponina prsimplen Neviani, 1895. Plaisancian. 
STICHOPORINA PROTECTA Koschinsky, 1885.

Plite 79. figs. 15-1S.

1885. Stichoporina protecla Koscunsky, Ein Beitrag zur Bryozoenfauna der älteren Tertiarschichten des siddichen Bayerns, Abth. 1, Cheilostomata, Paleontographia. vol. 32,1 . 65, pl. 6, figs. $8-11$.

1891. Stichoporina simplex Watens, North Italian Eryozoa, Quarterly Jourmal Feological Society, London, vol. 47 , p. 31, pl. 4, figs. 16-18.

1909. Stichoporina protecta Canu, Bryozoaires des terrains tertiaires des envirous de l'aris, Amales de Paleontologie, vol. 4, p. 101, pl. 11, fig. 8.

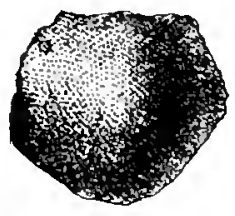

A $\times \mathbf{~}$

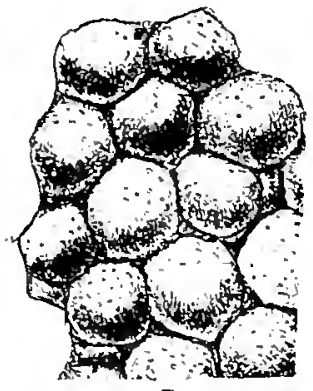

$\mathrm{G} \times 15$
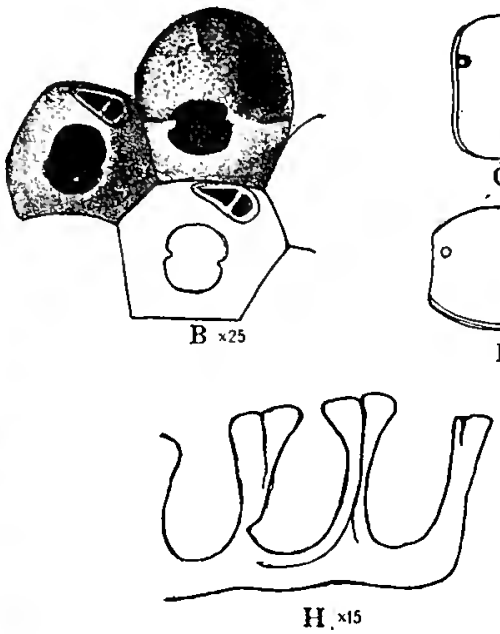
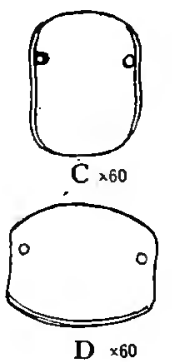

D $\times 60$

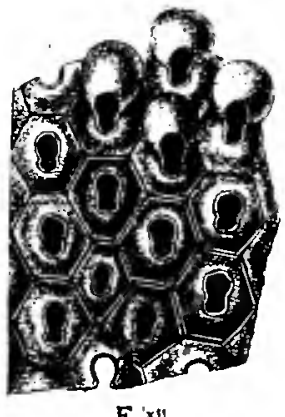

F $x \|$

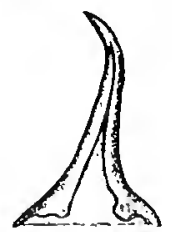

E $\times 100$

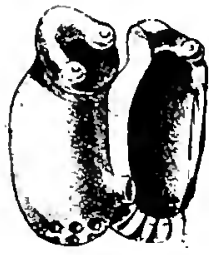

$1 . \times 22$

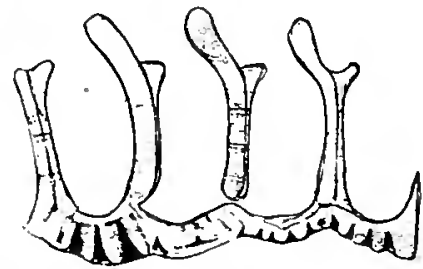

$\mathrm{J} \times 22$

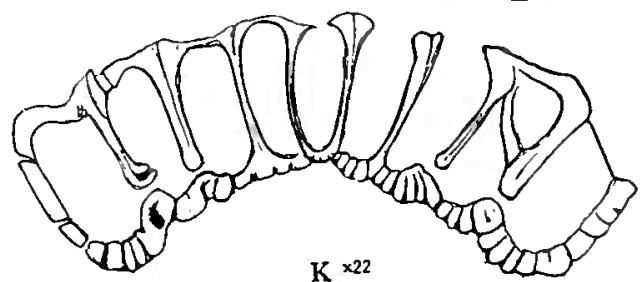

$\mathrm{K} \times 22$

FTa. 18S.-Genus stichoporina Stolicgka, 1861.

A-II. Stichoporina simplex Koschinsky, 1S85. A. Zoarium, natural size. B. Zooecia, $\times 25$. C. Operculum of an ordinary zooecium, $\times 60$. D. Operculum of an oricelled zooecium, $\times 6 n$. E. Aricularian mandible, $\times 100$. (A-E a fter Kirkpatrick, 1S90.) F. Zooecia, $\times 11$. G. Internal face. $\times 15$. II. I fongitudinal section. $X 15$. (F-H after Koschinsky, 18s5.)

1, .T. Stichoporina cranilabris Koschinsky, 1S55. I. Isolated zooecia, $\times 22$. J. Longitulinal section, $\times 22$, showing the lateral septulae. (I, J after Koschinsky, 1S85.)

K. Stihoporina protecta Koshchinsky, 1Ss5. Longitudinal section showing the prietat septulae, $\times 22$. (After Koschinsky, 1855.)

Tariations.-Our specimens very well resemble the specimens previonsly described by other authors. The apertura of the ovicelled zooecia is larger than

$$
\text { 5.5 } \$ 99-19-B \text { ull. 106- } 40
$$


the others and transverse (fig. 15): its operculum probably closes the ovicell in opening, in order to facilitate the passage of the eggs. On the lower face (fig. 16) there are often some circular imblications difficult to explain. In transverse section the zooccia (fig. 18) are tubular: their peristomic forms a narrow gullet.

Occurrence.-Mildle . Macksonian (Castle Hayne limestone) : Wilmington, North Carolina (common).

Geological distribution.-Tutetian of Bararia (Koschinsky) and of the Paris Basin (Canu). Prialmonan of the Vicentin (Waters).

Plesiotypes.-Cat. No. 61228, U.S.X.M.

Genus SCHIZORTHOSECOS Canu and Bassler, 1917.

1917. Schinorthosccos CanU and Basslek, Synopsis of American Larly Tertiary Cleilostome Bryozon, Bulletin 96. United States National Museum, p. 74.

The zoarium is cupuliform. 'The apertura is oval with a proximal romded rimule. There are numerous interzooccial zooeciules capable of being transformed into aricularia, into radicular zoocciules, and into compensation zooecinles. The oricell is hyperstomial, placed on the distal zooecium and never closed by the operculum.

Grnotype-Schizorthosecos (Orbitolites) interstitia Lea. 1833.

Remge.-Claibornian-Jacksonian.

This gemus is exclusively Ameriean; it characterizes the Clabornian and the base of the Tacksonian, where it is exterminated unexpectedly.

It differs from Conescharcllina D'Orbigny, 1851, and Bipora Thitelegge. 1887. in its distinct zooecia and in the absence of lunoccia.

SCHIZORTHOSECOS INTERSTITIA Lea, 1833.

Plate 1S, figs. 1-9.

1533. Orbitolites interstitin Lfa, Contribution to Geologs, Philadelphia, p. 191. 1h. 6. fig. 204. 1562. Lumulites interstitia GabB and IIORN, Monograph fossil Polyzoa Secondary and Tertiary formations North America, Joumal Academy Natural Sciences, Fhiladelphia, ser. 2. rol. 5, p. 120.

1S90. Lumulites (Cupularia) interstitin DE GREgoro, Monographic Fauna Eocenique de Alabama, Annales de Geolosie ot de I'aleontologie, Livr. 7 and \&, p. 249. pl. 42, figs. $16-22$.

1517. Schisorthosecos interstitin C.Ixt and BASSIER, Synopsis of American Early Tertiary Cheilostome Bryozoa, Bulletin 96, United States National Mluseum, p. 75, pl. 6, figs. $4,5$.

I'escription.-The zoarium is cupuliform, little deep. The zooccia are listinct. tublar. erect. terminated by a narower peristomie. The apertura is placed at the base of the peristomie; in it rimule, it often has a flat lyrula: the peristonice is of the same form as the apertura. Between the peristomes, on the external surface. there are numerous zooeciules, which are transformed according to their position into radicular znoecinles. into aricularia with pirot, or into compensation zonecinles. On the inmer face each zooceim is indicated by a hexagon perforated with six to ten large tremopores. which are the orifices of long tubules: some large avicularia with pivot surround the ancestrula. 
The aricell is hyperstomial, plated on the distal zooecimm: it is never cloced by the opereulum; its orifice is large; it is former of two ealcareous layers, of which the external one is frequently incomplete and circumserihes a more or less large frontal area.

Tariations.-In the interior of certain apertures there is a caleareous arehed lamella or indeed a tooth when this lamella is incomplete.

In the interior (fig. 2) the ancestrula is an ordinary zonecium: viewed from the inner face it has the aspect of a circle perforated by three pores (fig. 5) surrouncled by a calcareous ring and by six hexagons perforated by three, four or five pores. On the exterior it is surromind by radicular zooeciules, as is the habit of all the species attached to submarine bodies (figs. 7,5 ).

The zooecia are regulurly cylinclrical; the internal surface is smaller than the external surface; the discrepancy is filled by the zooeciules, which we call compensation zooeciules; they are more or less numerous (fig. 3).

On their inner face, near the ancestrula, there are some large avienlaria with bar; their mandible was semiclliptical and transverse (figs. 4, 5).

On the external face (fig. 6) there are large membraniporoid zooccia superposed on the others and always situated near the center. Their function is unknown.

The base of the zooecia is perforated; these pores are the extremities of the long tubules which open also on the extemal fice. These tubules must be intended to give lightness to the zoarium.

Occurrence.-Claibornian (Gosport sand): Claiborne, Alabama (very common); Gopher Hill, Tombigbee River, Alabama (eommon): one mile sonthwest of Rockville, Clarke County, Alabama.

Claibornian (Lisbon formation) : Wautubbe Hills, forr miles sonth of Enterprise, Clarke County, Mississippi (common).

Claibornian (Cook Mountain formation): Moseleys Ferry. Caldrell County. Texas (very rare).

Lower Jacksonian: Three and one-half miles southeast of Shell Blnff post office, Georgia (rare).

Lower Jacksonian: Jackson, Misissippi (very common).

Plesiotypes.-Cat. No. 62809. U.S.X.M.

SCHIZORTHOSECOS GRAXDIYOROSUM, new species.

Plate 1s, figs. 10-1:.

Description.-The zoarium is cupuliform and little concave. The zooecia me distinct exteriorly, tubular, terminated ly a contracted peristomie. The apertura is placed at the base of the peristomic: it bears a romded rimule: the peristomice is oral. The peristomes are separated by some eompensation zooeciules with irreguJar orifices. On thejr inner face the zooecia are indistinct: they each contain one large and one small pore. At the base of each zooecium there are a dozen very small pores. 
Affinitics.-This species differs from Schizorthosecos interstitia Lea, 1833, in the totally different nature of its inner face. which does not bear very numerous small pores of tubules.

Bipora cburnea, Mapleston, 1909 , is a recent species bearing pores somewhat analogons, hut the author has not explained their use.

Occurrence.CClaibornian (Gosport sand) : Claiborne, Alabama (common).

Lower Jacksonian (Moodys marl) : Jackson, Mississippi (rare).

Cotypes.-Cat. No.63863, U.S.N.M.

\section{SCHIZORTHOSECOS RADIATUM, new species.}

Plate 1s. figs. 16-19.

I)escription.-The zoarium is cumliform. very little concave. The zooecia are indistinct exteriorly. tubular. terminated by a contracted peristomie; before each

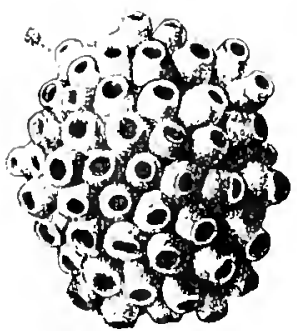

A

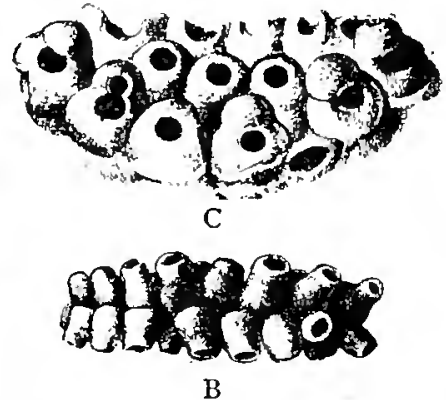

$\mathrm{B}$ peristomice there are four to six small radial costules; above, in the interzooecial angles there are two small compensation zooeciules or avicularia. The apertura is placed at the base of the peristomie and has a r o unded, distal rimule; the peristomice has also a very wide and quite variable lower indentation. On the inner face, the radial series are separated by lateral mural rims, very thick

appear between them in hexagons. smowth. much elongated, little distinct, terA-c. Orbitulipora petiolus Lonsdale, 1850. Natural size and magnified views of a zoarium. (After Reuss, 1867.) minated by an enomous perforation.

Affinitics. - This spccies is extremely rare; it is rery easily confused with the very abundant specimens of the Schianthesecos interstitia Isea, 1833. To discover specimens of it one must study under the microscope the inner face of all the specimens found. The enormous salient collars, as well as the small frontal radiations. well characterize this species.

")enzpenee-Claibornian (Gosport sand): Claiborne, Alabama (rare).

Claibornian (Lishon formation): Wautubbee IIils, four miles south of Fnterpriso. Clarke County. Mississippi (very rare).

Cotypes.-Cat. No.63561, U.S.N.M.

Genus ORBITULIPORA Stoliczka, 1861.

1861. Orbituliporl Stoliczka, Olizocine Bryzoen von I,atdorf in Bernburg Sitzungsberichte der k. Akalemie der W'issenselaften, Wien, vol. 45, Abth. 1, p. 90.

'The aprertura is orbicular. The frontal is a tremocyst. The zoarium is orbienlar and formed of two lamellae with zooceia back to back. 
Genotypc.-Orbitulipore haidingeri Stoliezka, 1861.

hange.-Aurersian-Tortonian.

Orbitulipora petiolus Ionsdale. 1850. Orlitulipora lenticularis Reuss. 1867, and Orbitulipora cxcentrica Seguenza, 1880, are the only known species in addition to the genotype.

Genus BATOPORA Reuss, 1867.

1s67. Butopora lieuss, Ceber. einige Bryozoen au: dem deutschen I'nteroligocan $\mathrm{S}$ i t zungsberichte der k. Akademie der Wissensch a $f$ te $n$, Wien, Abth. 1, p. 16.

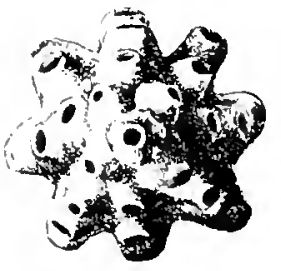

A

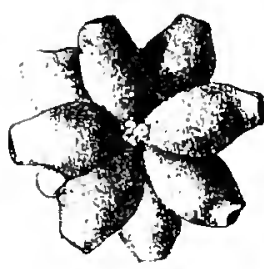

$\mathrm{B}$

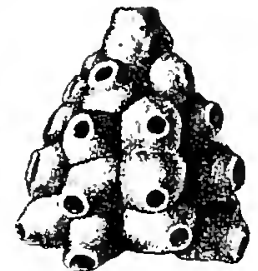

$\mathrm{C}$

F1G. 190.-Genus Batopora Reuss, 1867.

A-c. Batopora rosula Reuss, 1867. Frontal, dorsal, and lateral rietts of a zoarium, magnified. (After Renss, 1867.)

The apertura is orbicular. The frontal is a granular olocyst. The zoarium is
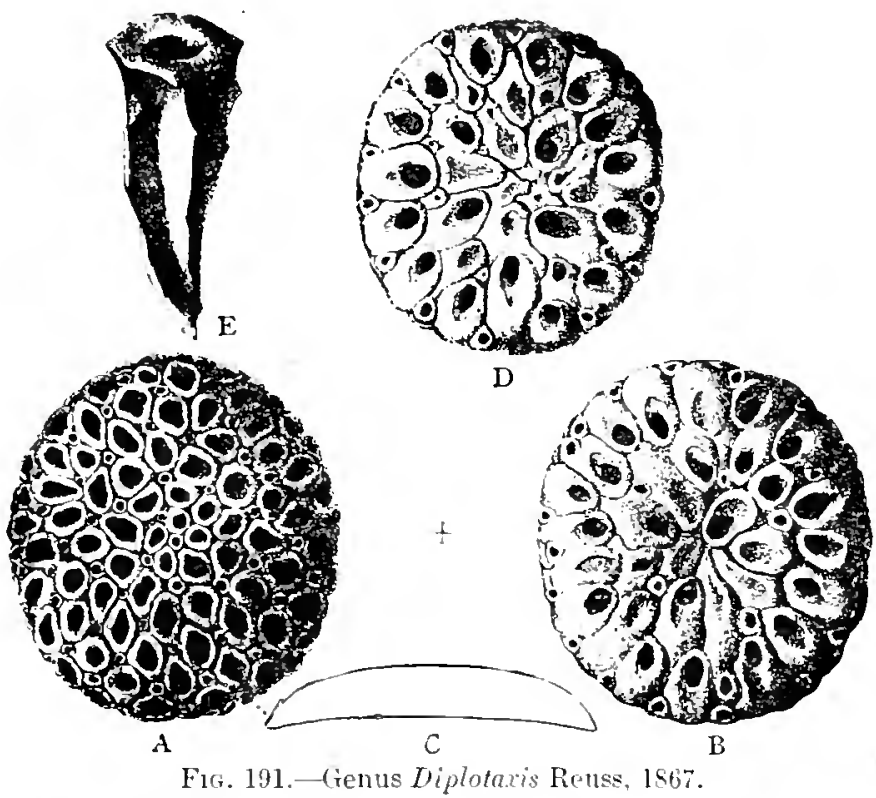

1-E. Diplotaris placentula Reuss, 1867. Varinus views of the zoarium magnified. (After Reuss, 1S67.) conical, never hollow. 'The ancestrular zooecium is ornamented with radicnlar pores.

$$
\text { Genotype.-Batopora }
$$

stoliczkai Reuss, 1867.

liange. - Iutetian, Tortonian.

The species of this genus are:

Butopora stoliczlai Reuss, 1S67. Latdorfian. Batoporascrobimuta Kóoschinsky, 1985. Iutetian.

Batopora conica Seguenza, 1850. Tongrian. Batopora conire Inantien (according to l'ergens. 1887). Priabonian.

Batopore multimaliata Reuss, 1869. Tortonian.

Genus DIPLOTAXIS Reuss, 1867.

1stii. Diplotaris IReuss. Cether ainige Bryounen ans dem deutschen Unteroligacan, Sitzungsberichte der k. Akademie der Wissenschaften. W'ien, Abth. 1, p. 16.

The zoarium is discoidal and formed of two lamellae. back to back. The zooecia of the external face are oriented toward the zoarial margins; the zooecia of the inner face are orienterl toward the center. The apertura has a distal rimule. renotype.-Diplotaris plecentula Reuss. 1867. Isatrlorfian. 


\section{Genus CONESCHARELLINA D'Orbigny, 1851.}

1S51. Concscharchina DOORngsy, Paleontologie francaise. Terrain Cretace, vol. 5, p. $\mathbf{4 4 6 .}$

The zoarium with lunoecia. The zoaria, which have the form of a low cone or an arched disk, only show a single layer of zooecia, while their inner carity is

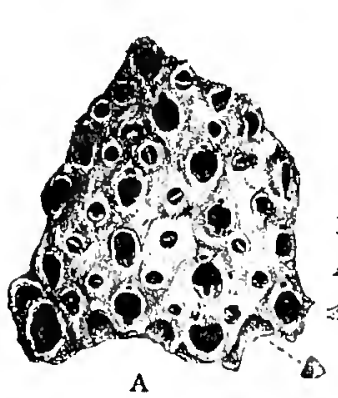

A
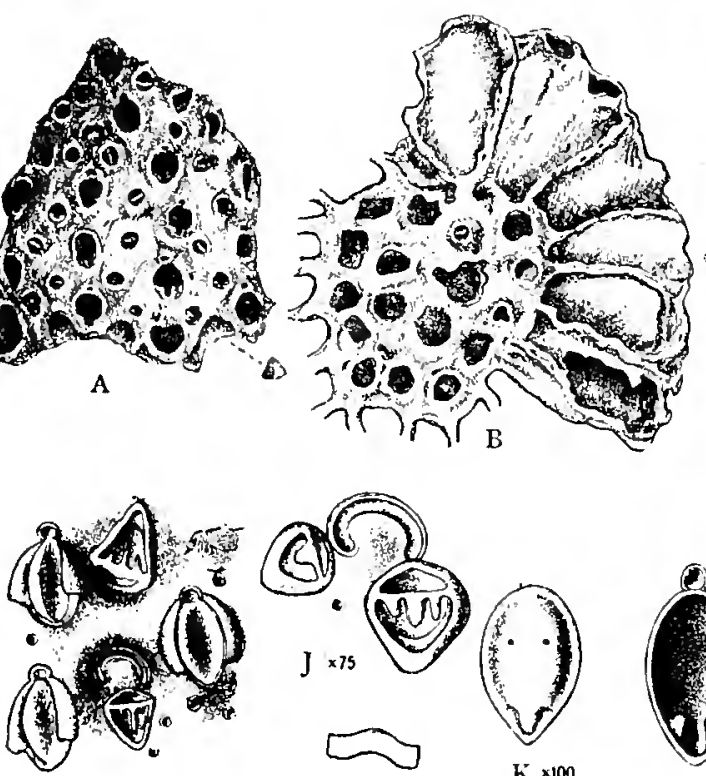

$1 \times 75$

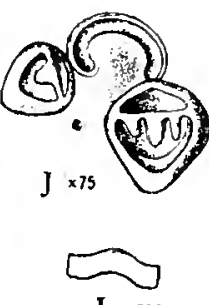

L $\times 200$

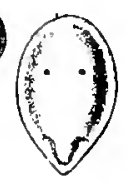

$\mathrm{K} \times 100$

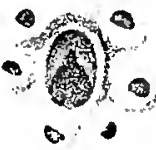

$D: 50$
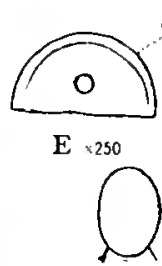

F $>85$
(ㅇ) $\times 85$

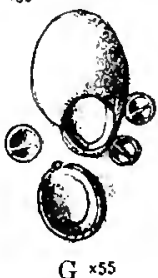

Fıg. 192.-Genus Conescharcllina Dorbigny, 1851.

A-H. Conescharchina cancellata Busk, 1852. A. Zoarium, natural size and magnifiel. 13. Internal face magnified. (A, B after MacGilliviay, 1895.) C. Zooecia, X 25. D. Aperture, $\times$ 50. (C, D after Waters, 1882.) E. Avicularian mandible, $X 85$ and $X 250$. I. Operculun, $\times$ 85. (E, F after Waters, 1857.) G. Oricell, $\times$ 55. IH. Ovicell from the side, $\times$ 55. (G, H after Levinsen, 1909.)

1-X. Conescharellina angulopora Tenison-Woods, 1Ss0. I. Between the two avicularia is seen one of the peculiar crescentic apertures belonging to certain kenozooecia (zooecia of compensation), $X$ 75. J. A crescentic aperture and two avicularia, $X 75$. K. Operculum, $\times 100$. L. A transrerse section of the operculum, $\times 200$. II. Aperture, $X 75$. N. Avicularian mandible. $\times 2(K)$. (I-N after Levinsen, 1909.)

O-I. Conescharellina incisa 1Hincks, 15s1. O. Aviculariau aperture, $\times 25$. P. Oral aperture, $\times 25 . \quad(0, P$ after Waters, 18s7.)

9. Concschurellina phitippinensis Busk, 1S52. Five zooecia are seen from the basal side (after removal of the frontal wall), showing a number of avicularian chambers, which are connected jartly with the zonecial surface and partly with each other through septules and pore chambers. There is also seen one of the peculiar kenozooecia, which are provided with a narrow semilunate aperture, $\times$ 75. (After Levinsen, 1909.)

occupied by munerous avicularia placed in horizontal lavers; ovicells may occur. (After Isevinsen, 1909.) The apertura has a distal rimule. 
Genotype.-Conescharellina cancellata Busk, 18.5.

Range.-Miocene-Recent.

The lunoccia are the openings of spccial compensation zooeciules.

All the unilamellar Bipora of Whitelegge, 1557, are classified in this genus by Levinsen.

Genus BIPORA Whitelegge, 1887.

1857. Bipora Whitelegge, Notes on some Australian Polyzoa, Proceedings Linnean sonipty Tew South Wales, ser. 2. vol. 11, 1: 383 .

The zoarium with lunoecia. The zoaria are plate-like or fan-shaped with two layers of zooecia; ovicells are not foumd. (After Lerinsen, 1909.) The apertura has a proxima] rimule.

Genotype.-Bipora umbonata Haswell, 18s0. Recent.

Genus FLABELLIPORA D'Orbigny, 1852.

15.92. Flabclinora Dorligny, Paleontologie Francaise Terrain Cretacé, rol. 5, p. 432.

'The zoaria, which have no lunoe-
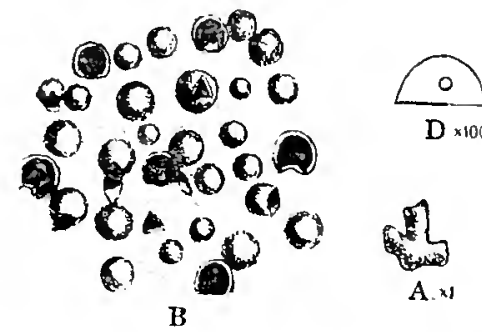

Fig. 193.-Genus Bipora Whitelegge. Issi.

A-D. Bipora umbonata Haswell, 1880. A. Zoarium, natural size. B. Zooecia and lunoecia magnified. (After Haswell, 1880.) C, D. Bipora crassa Tenison-Woods, 1880. Opereulum and avicularian mandible, $\times 100$. (Aiter Kirkpatrick, 1590.)

cia. are plate-like, two layered; no ovicells. (After Lerinsen, 1909.) The apcltura has a proximal rimule.

Frnotype.-Flabellipora elegans D'Orbigny, 1552. Recent.
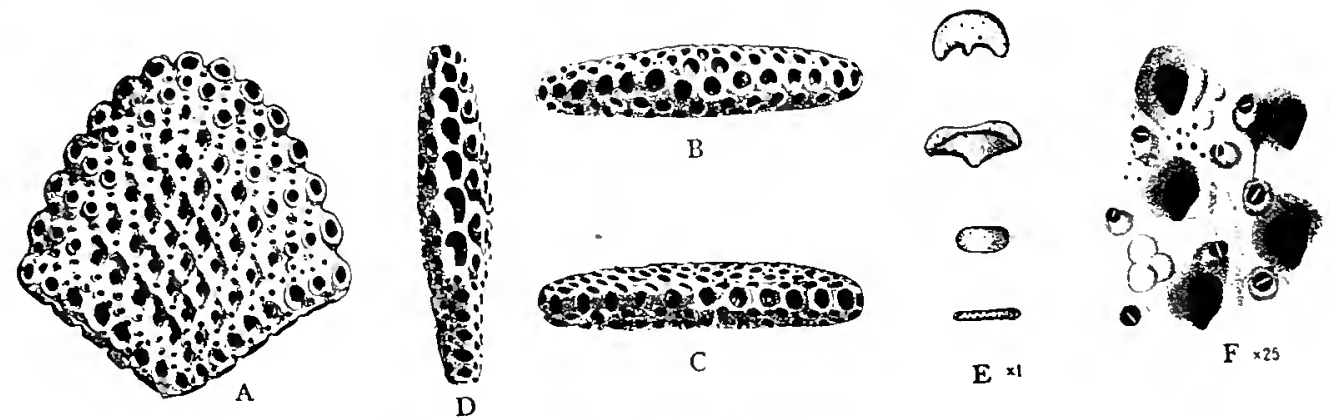

F'z. 194.-Genus F'labellipora D'Orbigny, 1852.

A-F. Flabellipora clegans D'Orbigny, 1S52. A-D. Four views of the enlarged zoarium. (After 1) Orbigny, 1S52.) E. Various aspects of a zoarium natural size. F. Zooecia and a vicularia, $\times$ 25. (E, F after Waters, 1Ss7.) 


\section{Genis MAMILLOPORA Smitt, 1872.}

1872. Mamillopora Smitt, Floridan Bryozoat, 1't. 1. Kong. Svenska Vetenskaps Akademiens Handlingar, vol. 10, No. 11, p. 33.

The zoarium is cupuliform. The apertura is elliptical with two submedian cardelles. There are some avicularia betreen the zooecia. The ovicelled zooecia are much larger"; their apertura is not transverse.

Genotype.-Mamillopora mupula Smitt, 1872. Recent (Florida).

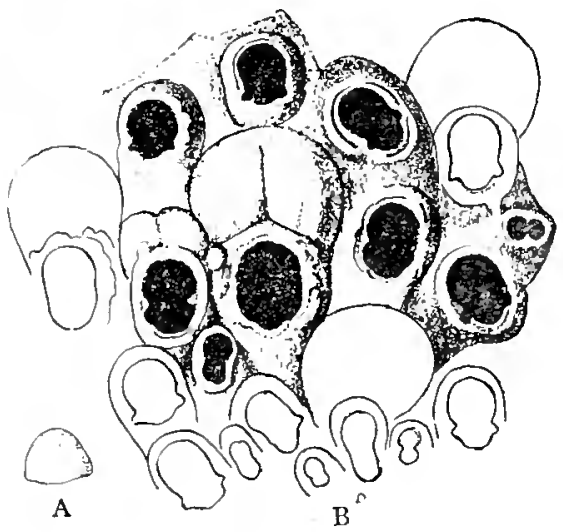

FIa. 195.--Genus Mamillopora Smitt, 1872.

A, B. Mamillopora cupula Smitt, 1S72. Zoarium, natural size, and zooecia, enlargel. (After Smitt, 1S72.) 


\section{Order CYCLOSTOMATA Busk.}

Zooecia very simple, cylindrical, calcareous tubes arising from a proximal tube by some special morle of gemmation, usually without transverse partitions; orifice plain, inoperculate, not contracted; walls thin, minutely porous; apertural portion of zooecial tubes more or less raised, bent ontwards, free or in bundles. Marsupia and appendieular organs wanting. Ovicell an enlurged zooecium or an inflation of the zoarial surface.

Hitherto the families and genera of Cyclostomata have been founded almost entirely upon the form of the zoarimm and the arrangement of the zooecia. Various classifications have been proposed, but it is needless to review them here because Gregory in $1909^{1}$ gave a good account of them and discussed the general problem of classification at some length.

The distinction between the families of Cyclostomata, like the other orders. of Bryozoa, is or should be based on their larval forms, each family being charaterized by a special larra. The larvae of the Cyclostomata are very similar to each other and difficult to discriminate, but fortmnately they show their differences by the evolution of the embryos in oricells of very different size. form, and position.

We believe that the same principles of classification as are applied to the apparently more complicated Cheilostomata (see pp. 70,71 ) can be employed in the study of the Cyclostomatis, indeed, that a natural classification can be built up by a study of the physiologic functions of the organs. In the Cheilostomata it will be noted that the form of the aperture and of the operculum, the presence of the cardelles, occurrence of lyrula and the ovicell were the essential characters of greneric and family classification. In the Cyelostomata the aperture is always more or less cireular, the operculum, cardelles, and lyrula are wanting, leaving the ovicell as the single remaining essential character showing on the zooecium. The value of the ovicell in the elassification of the Cyclostomata is therefore of utmost importance, but unfortunately until very recently its study has been much neglected.

The most important work on the oricells of recent species is that of Waters. published in $1894^{2}$ and $1914^{3}$. In $1893^{1}$ the remarkable phenomenon wherely a single egg can engender a considerable number of larrae was discovered by Harmer. This discovery of the fissiparity of the primary embryo explains the rarity of ovicells.

\footnotetext{
'Catalogue lossil Prjozoa in lepartment of Geology, British Museum, vol. :- pp. xxiv-xli.

21594. Waters, Ovicells of Cyclostomatous Bryozoa, Jinncan Society Journal, vol. 20. pp. 275-285. [11, 14. 15 .

${ }^{3}$ 1914. Waters, The marine fauna of British East-Africa, l'roceedings of the Zuological Societ $y$, pp. 83̈4-836.

1598. Ilarmer, Embryonir Fission in Cyclostomatous Fryozoa, Quarterly Journal of Miscroscopical sirence (n. 8.), vol, 34, pp. 199-241, pls. 21-24.
} 
The oricellis on the fosil forms have not escaped observation as D'Orbigny, Hagenow, Renss. and Poncta have figured them, although these students did not recognize their great value in classification. In $1897^{-1}$ Canu discovered the ovicell of the Melicerititidae. and in $1899^{2}$ that of the Ceidae. In $1898^{3}$ he published some special rariations and indicated the great necessity for the study of the ovicell. In $1915^{*}$ he published a summary of his new ideas on the classification of the Cyclostomata with descriptions of a number of new genera, a work which was preliminary to the present one where these ideas are more fully developed.

GENERAL CONSIDLRATION OF THE CYCLOSTOMATA.

TIIE TUBES.

The zooecia of the cyclostoniatous bryozoa are tubular.. Whatever may be the zoarial form, each tube grows from a proximal tube by a special mode of gemmation (fig. $196 \mathrm{~A}, \mathrm{~B}$ ).

Considering the form of the tubes there are:

(a) Club-shaped tubes or typical Cyclostomata.

(b) Cylindrical tubes or Cyclostomata resembling the trepostomatous bryozoa

(c) Tubes with facets.

(d) Tubes with rhomboidal orifice.

This division, however, is not an absolute one. Hollow zoaria (in the Cavaria form of growth) often have shortened tubes the exact nature of which it is inlpossible to determine. In the zoarium of Lichcnopor . the polypidian tubes are chub-shaped and the accessory tubes cylindrical.

Considering their functions the tubes are classed as follows:

(a) Polypidian tubes.

(b) Accesory tubes (=aborted tubes of author's).

(c) Adventitions tubes.

The tubes are often grouped in longitudinal, transversal, or radial bundles (fascicles) which may be monoserial or pluriserial.

Calcification.-The ectocyst is formed of two thin, flexilule membranes between which the calcareous skeleton is located (fig. $196 \mathrm{C})^{5}$; the tubes are therefore not strictly adjacent. The disappearance of the exterual membrane leaves a space which, in thin sections. appears as a clear line. This intercellular space is quite variable in size and is linear or vesicular. At the center of the agglomerate zuaria the tubes are often adjacent by reduction, reabsorption or filling up; rarely they are so in the entire zoarium (see Exochoecia).

\footnotetext{
1597. Canu, liryozonires du Turonicn des Janieres, Bulletín Societé Géologique de France, ser. 3, vol. -5. ค. $15 \overline{5}$

21s.9. Canu, Ies Ovicẹlles des Céidées, Bulletin Société Géologique de France, ser. 3, vol. 27, p. 326.

${ }^{3} 1898$. Canu, Étude sur les Oricelleg des Bryozontres du Pathonien d'occalgnes, Bulletln Société Géolonglupe de France, str. 3, wol, 26, p. 259.

- 1918. Canu, Les Ovicelles des Pryozoalres Cyclostomes, Bulletin Société Géologique de France, ser, 4, vol, 16, pp. 324-335.

1900. Calret. Contributions a l'histolre naturelle des bryozoalres eetoproctes marins, Travaux in. stitut Zoologiıue Universite IIontpelller Mém., No. s, p. 16f.
} 
The calcareous skeleton is exteriorly porous (fig. $196 \mathrm{\Lambda}, \mathrm{D}$ ). It each pore in the gremeral earity there are corresponding spherular lencocytes (fig. 196 E).
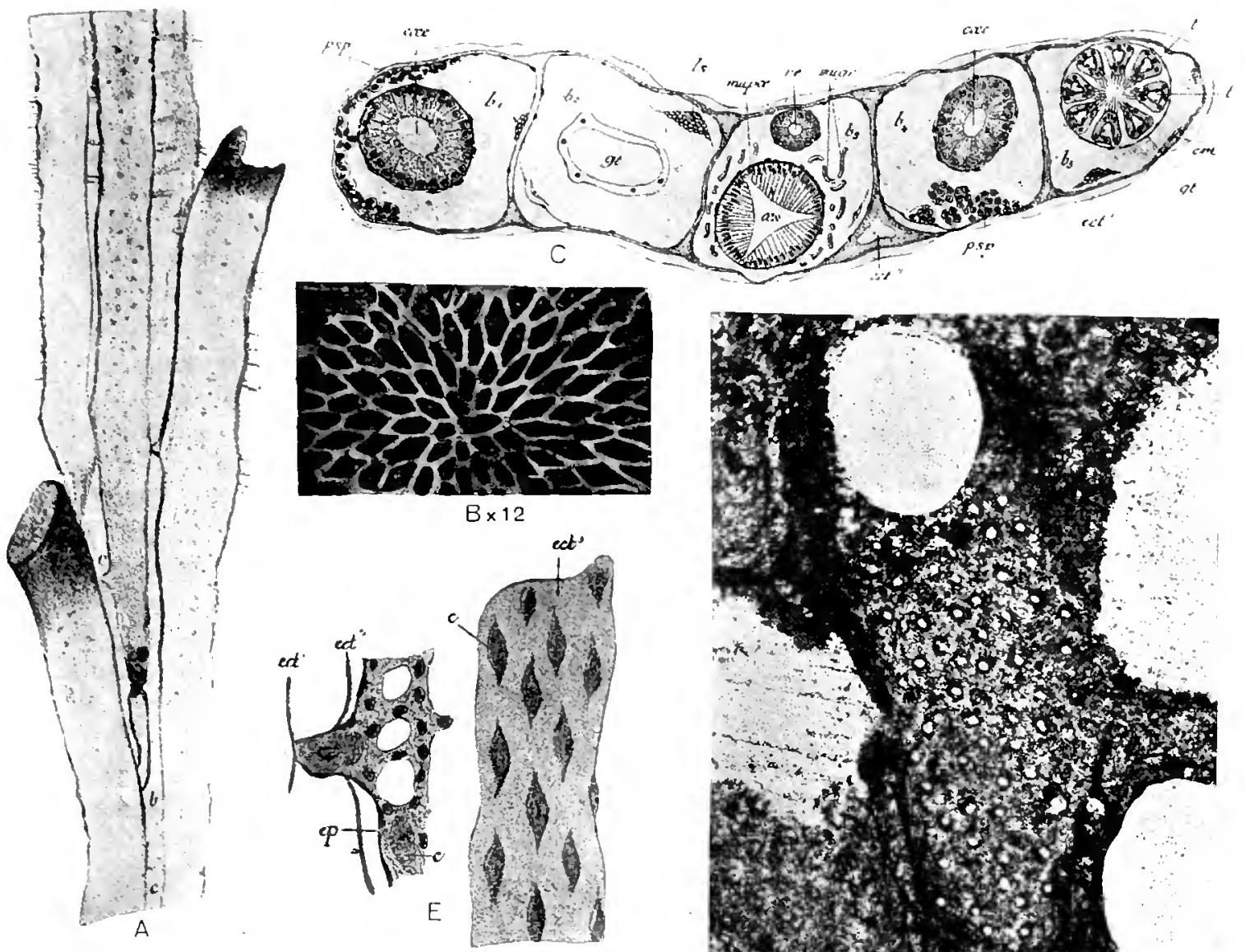
These septulae serve as in the Cheilostomata, for the passage of the mesenchymatons fibers.
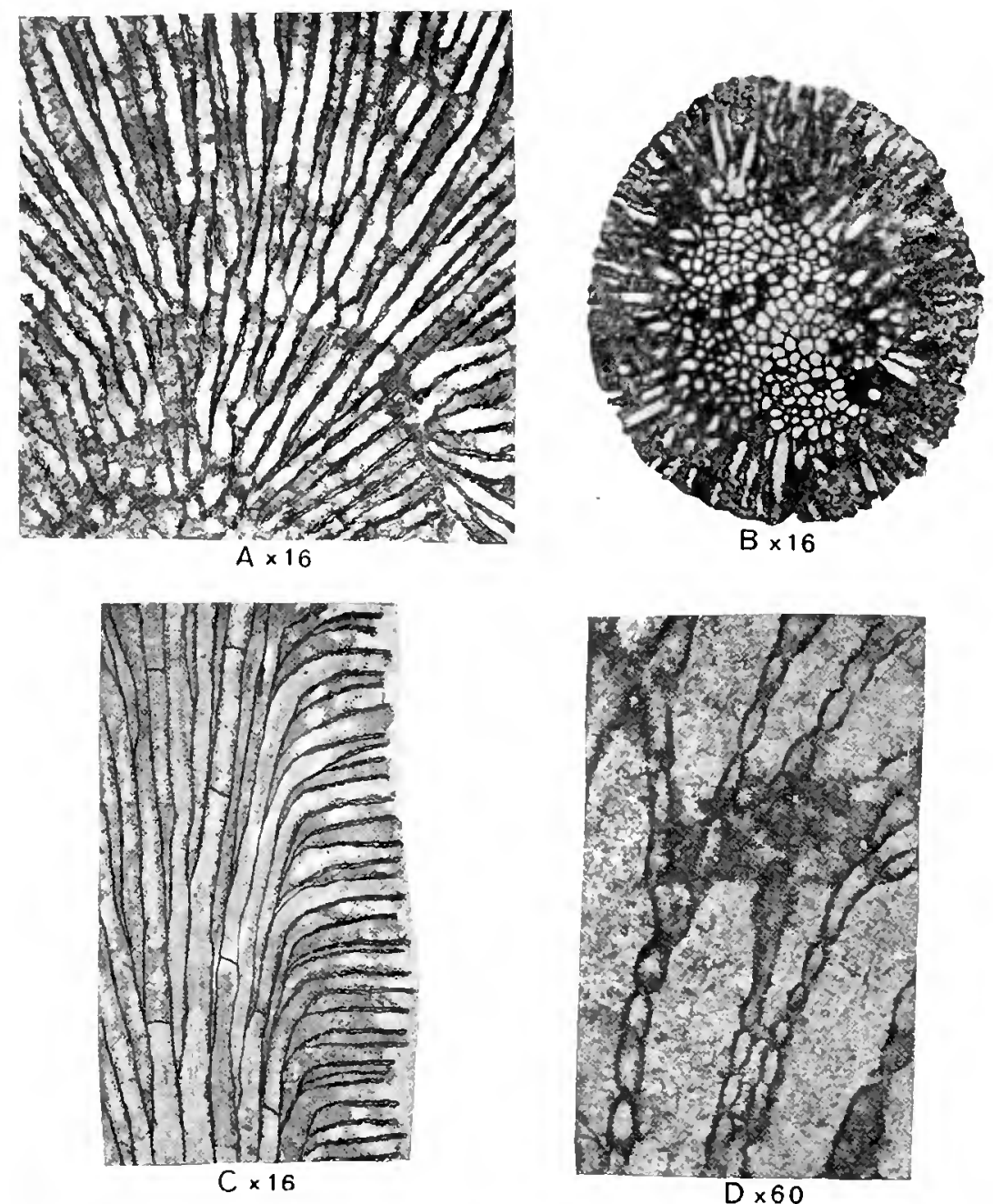

ITG. 197. - Structure of the cylindrical tubes.

1. Longitudinal thin section, $X 16$, of a massive species Ceriopora vesiculost new species. 'Tles walls are vesicular throughout their conrse. B. Transerse thin section, $\times 16$, of Tretoryclucria dirhotoma lituss from the Helvetian of France. The tubes are of the sime size at both the center and circumference. C. Longitudinal thin section of a ramose species Tretocyclocciu whiculntu new slecies, $\times 16$. The interzooecial spaces are vesicular only at the extremity of the tuhes. I . Portion of longitudinal thin section, $x$ 60, of Hetcropora constanti Irorbigny, showing the great size sometimes attained by the vesicles.

Cylimbiral tubes or trepostomatous-like Cyclostomata-In this division the inferior part of the tube is developed, but this part is rery short. These tubes 
are parallel to each other and their length is unlimited. They give rise easily to adventitions tubes.

In transverse section all such tubes appear of the same size at the center as at the periphery; the smaller tubes dispersed irregulary between the large ones are the young tubes (fig. $197 \mathrm{~B}$ ).

In longitulinal section the interzonecial spaces are generally vesicular througly. ont their course in the massire forms (fig. $197 \mathrm{~A}$ ), but only at their extremity in the ramose forms (fig. $197 \mathrm{C}$ ). However there are numerous exceptions to this. These resicles are sometimes quite large (Fig. 197 D); we are ignorant of their function. There is no zone of growth risible, since the tubes have the same cliameter.

The ancestrular tubes are short and not strictly parallel to each other. They rise more or less in a spiral around the ancestrula and form the nuclear region, with nonoriented tubes (=immature region of the Trepostomata) (fig. 197 i).

Club-shaped tubes or typical ('yclostomata.-These increase regnlarly in dianneter during the greater part of their length. They are slightly ollique to each other and always have a part at the exterior of the zoarium. Their length is limited. They rarely give rise to arlentitions tubes. They become cylindrical when near the zone of growth or when they bend toward the exterior, or finally when they curve at a right angle with production of adventitious tubes. The last case is without exception.

In transverse section these tule- appear smaller at the center than at the circumference (fig. $198 \mathrm{~A}, \mathrm{~B}$ ). In longiturlinal section they are separated generally by a linear space, rarely resicular (fig. $198 \mathrm{C}$ ).

The zone of growth is the ensemble of the small orifices of the incompletely developed tubes; it is quite variable in for'm and size (fig. 198 D. F). The lamella on which the new tubes are developed is called the basal damella (=gemininal lamella of $\mathrm{D}^{\circ}$ (Orbigny).

Tubes with faccts (Motopopminu).-These are expanded tubes in which the peristome is closed by a facet (DOrligny) or zooccial a rea (Lerinsen). This area (fig. 199) is perforated by an orlicular or semilunar orifice destined for the passage of the tentacles. The orifice is often closed by a sort of calcareons operculun. The zonecial walls are thickened at their extremity.

This form of tubes has completely disappeared from the recent seas; they correspond therefore to some anatomical features rather dificult to reestablish. such a form exists in many families: Melicerititidae, Lobosoeciidae, Placioeciidae. and other families.

Tubes with rhomboidal orifice.-These are cylindrical or funnel-shaped. Theiraperture is oblique to the zooedial axi-; it is not orbicular. but is elongated and rhouboidal (fig. 200). The bundles are caused by the remion of many tubes and form zoarial and lateral expansions symmetrieally arranged, called pinnules. They comprise many genera of the family Cytisidae. This form of tules has disippeared from the recent seas. 


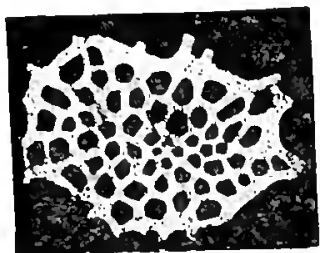

A $\times 25$
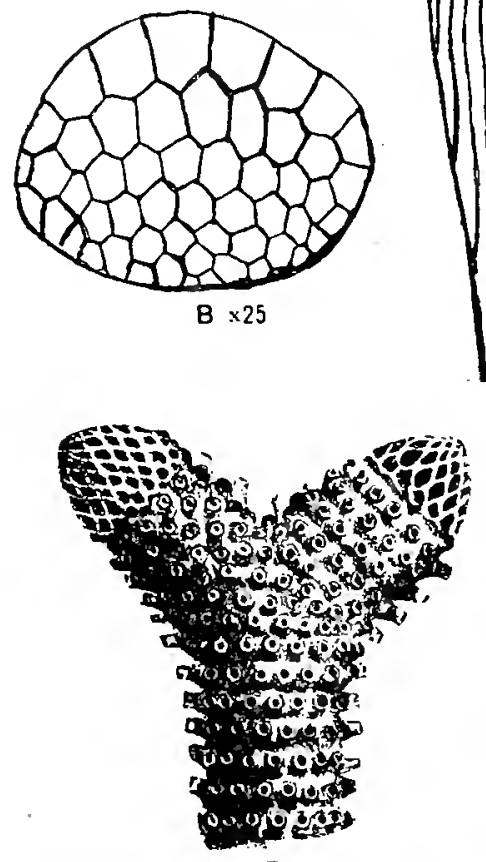

D

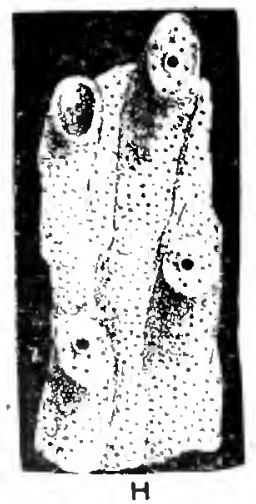

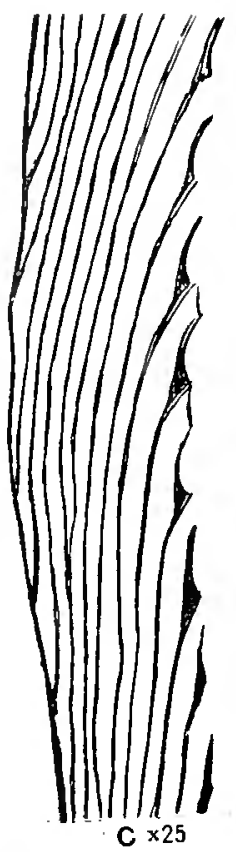
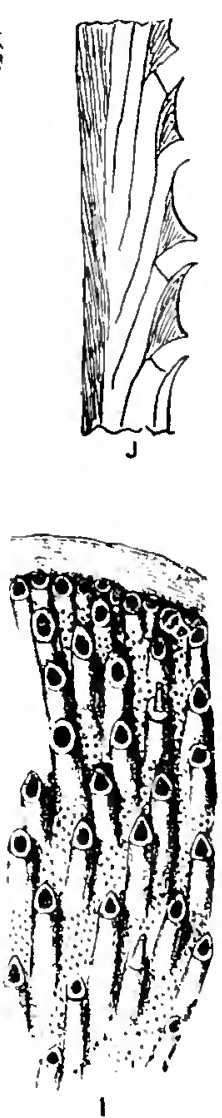
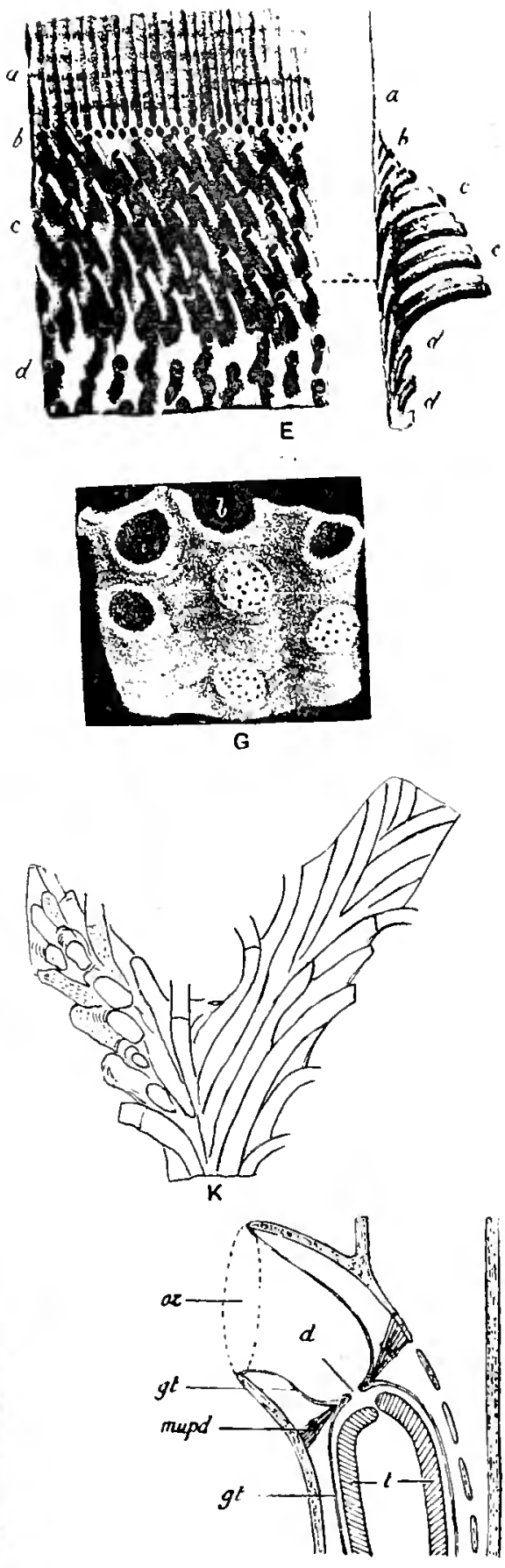

F

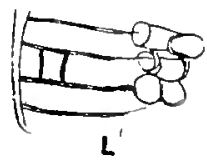


Fig. 19S.-Structure of the tubes and apertura.

1. Transverse section, $\times 25$, of $\mathbf{H}$ ccymorcia cormuta, new species, a species with club-shapen tubes. These appear smaller at the center. F. Transrerse sectim, $\times$ 25. of Immonea magna, new species, with the tubes smaller at the center of growth, here laterally placed. C. I.ongitudinal thin section of Irmonca magnircecrsa, new species, $\times 25$, showing linear space separating tubes. D. A branch of Entalophora conomana D'Orbigny, enlarged, showing zone of growth. F. Th» zane of growth and hasal ]amella of Plagioccia (Diastopora)latomaryinata Dorbigny. F. sketch showing relations of tentacular sheath and zonecial walls in a cyolustomatous brisuzan

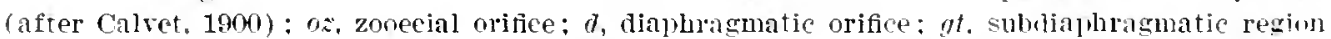
of the tentacular sheath; $g t^{\prime}$, super diaphragmatic region of the tentanlar sleath: mupl, paris. tal diaphramatic uuscles: $t$, tentacles. G. Surface of Plagioceia prolifera. Busk, with orifices

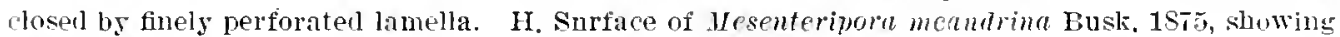
lamella perforated at the middle. I. Plagioecia samicnsis Hincks. 19so, illustrating lamella surmuruted by a projecting tubule. (Figs. H-J after Busk.) J. Lunsitulinal thin section, $X 12$, of Horneru concatenata Reuss showing deeply placed lamella. L. Section of Mccunoecia rugasu Waters, 1577, illustrating that the lamella is placed where the tulye rises free from the zoarium. L. Section of Ascosoccin lateralis D'Orbigny preserving a double lamela. (J-I, after Waters.) 
The orifice or apertura.-The orifice of the zooecial tubes is always open. Figure 198 F represents the relations of the tentacular sheath and of the walls of the zooecia in their superior or distal region. ${ }^{1}$ It is therefore by turgescence that the polypide may extrude or retract its tentacles.

When the polypirle dies from disense or accident, a calcareous lamella $\mathrm{lm}$ mediately closes the tube. This lamella is smperficial and finely perforated (fig.

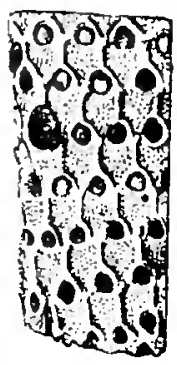

F1g. 199.-Tubeswith ficets.

Loboscoccia (Melieeritites, semiclansa Michelin from the Cenomanian at lie Mans, France, $\times 14$. Surface of lrauch showing zooecia with facets.

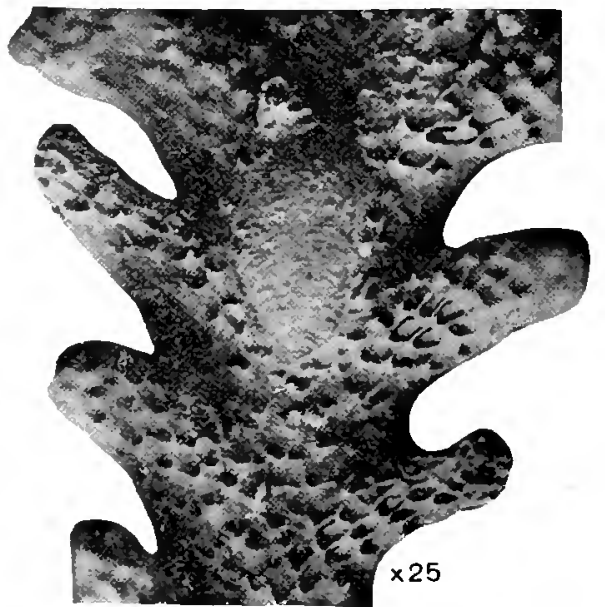

FjG. 200.-Tubes with Homboidal orifice.

All ovicelled specimen of Homocosolen gamblei Gregory, 1909, $\times \mathbf{2 5}$, from the Turonian at St. Calais, France, illustratiug rhomboidal form of apertures.

$198 \mathrm{G}$ ) and varies much in form and position. It is sometimes perforated at the middle (fig. $198 \mathrm{H}$ ) or surmounted by a projecting tubule (fig. $198 \mathrm{I}$ ). Again it may be deep and invisible; it is formed then about the point where the zoarial tube rises free from the zoarium (fig. $198 \mathrm{~J}, \mathbf{K}$ ). It is sometimes double (fig. $199 \mathrm{I}_{4}$ ). ${ }^{2}$

liaphragms.-'The diaphragms are rare and acciclental in the club-shaped tules, but are abundant and specific in the cylindrical; they are sometimes formed in both the accessory and the adventitious tubes. Their physiologic function is unknown.

Like the lamellae of closure they are entire or perforated; the perforation is central or excentric. Figure $201 \mathrm{~A}, \mathrm{~B}$ will be useful in the interpretation of thin sections. In our American Tertiary formations species with diaphragms are rare.

${ }^{1}$ 1900. Calvet, llistoire naturelle des Bryozoaires ectoproctes, v. 180, fig. 24.

2 1s4t. Waters, Closule on the Cyclostomatous Bryozon, Journal Linnean Society, p. 400, 404, pl. 17 


\section{ACCLNSOLIY 'TERES}

These are the zooecia closed or open which appear deprived of polypide. They may occur on the dorsal (tergopores, firmatopores, mematopores) or on the frontal (Ciactrlethrae, cancelli).
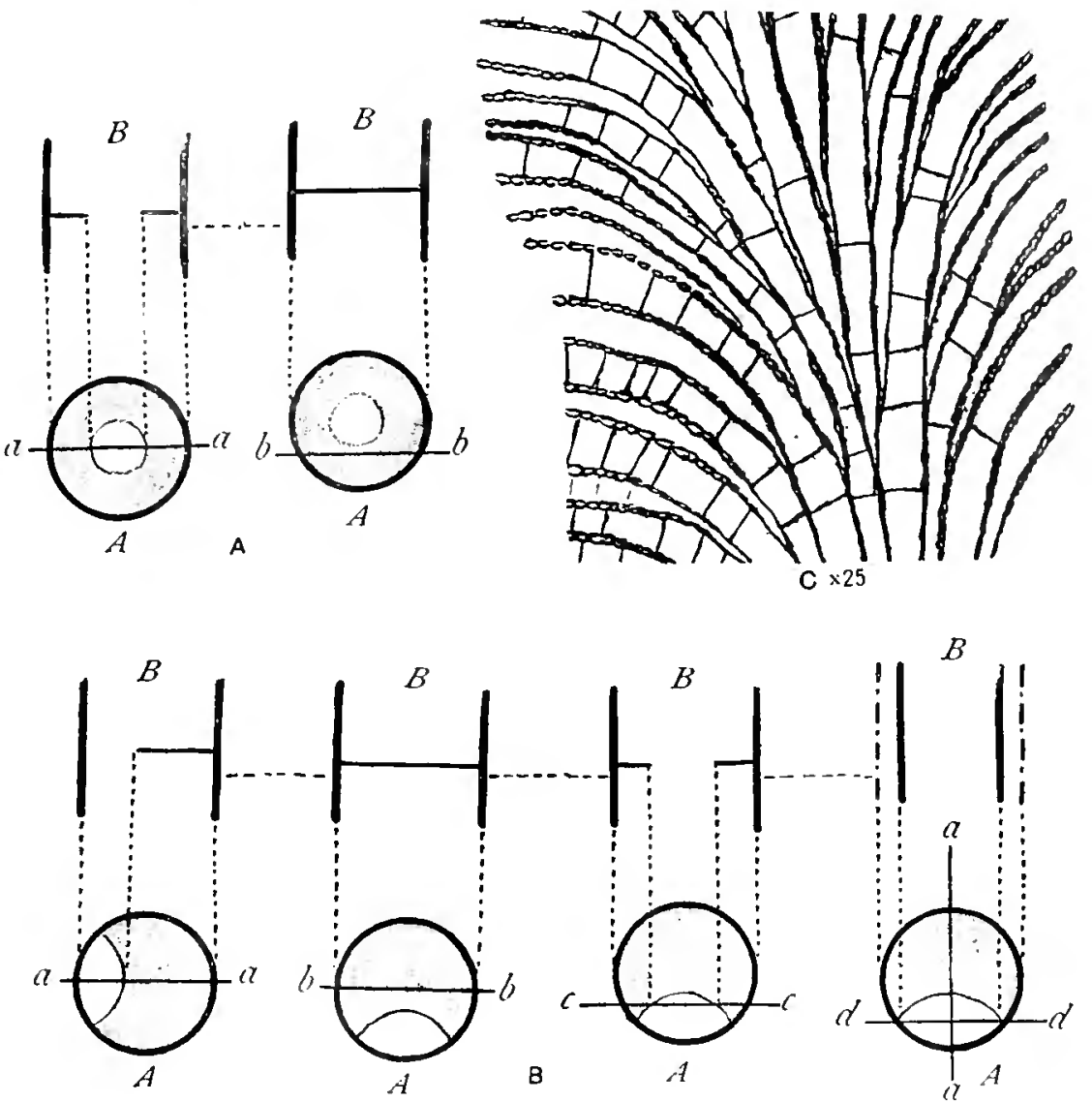

Fig. 201.-Diapliragms.

A. Sketches showing aspect where a zooecium with a centrally perforited diaphrigm is cut longitudinally $(B)$ and transversely $(A)$; $a a$ and $b b$, intersection of the two longitudinal sections. I. Sketches showing aspect where zooecium with a laterally pelforated hiplurigun is cut lonsiturlinully (B) and transversely (A). C. Longitudinal thin section of II ctcropora alveoluta now species, $\times 2 \mathbf{2}$, with more numerous diapluragus than usual in the genus.

Tergopores.-The tergopores are ascending, transverse, accessory pores or. the dorsal which are parallel to each other and as large as the polypidian tubes. They emanate from each other by sucressive bifurcations of their walls which are never adjacent; the new tergopores therefore always commence by the spreading of two neighboring walls. They are formed. first. of a longituclinal end portion sone- 
what oblique, and club-shaped, and as short as it is distant from the polypidian tubes; second, of a large, transverse, and cylindrical part. The orifice on the rlorsal of the zoarium is polygonal and on fossils always open.

When a tergopore is aborted (fig. $202 \mathrm{~A}$ ), it is immediately replaced by two others, formed by the simultaneous bifurcation of the distal and proximal tergopores.

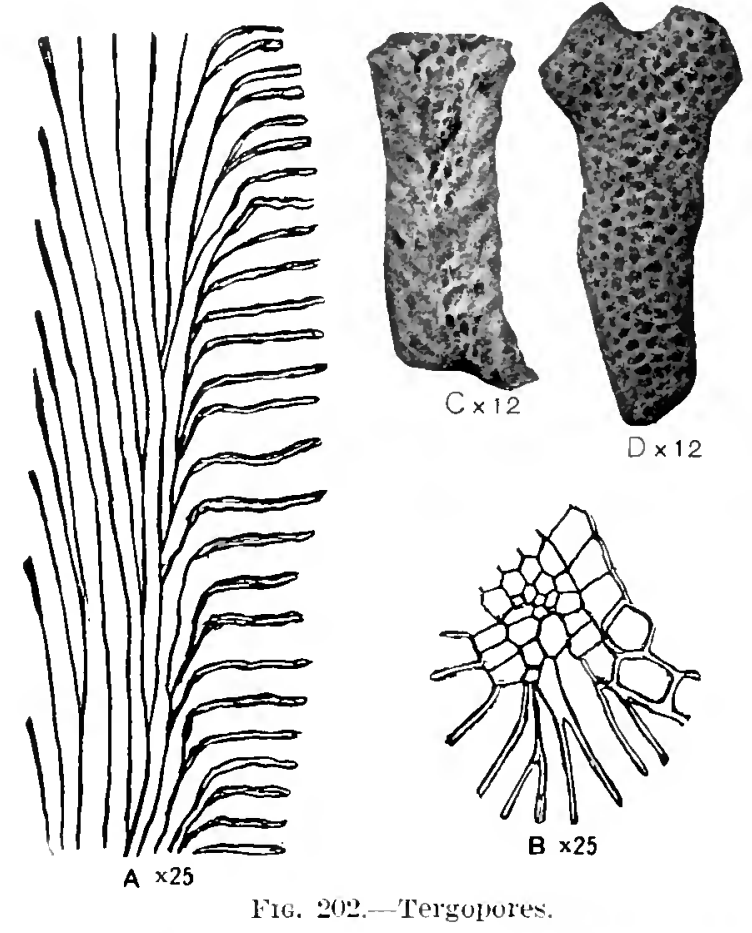

A. Longitudinal thin section of Alesonea subpertusa, new species, $\times 25$, illustrating structure of tergopores (to right) and zooecial tubes. B. Transvelse section, $X 25$, of the same species showing the zooecial tubes in the upper lialf and the tergopores below. G. IBroken branch of same, $\times 12$, with tlye layer of the tergolores separated from the zooecial tubes. D. Dorsal of sume, $\times 12$, exhibiting large tergopores.

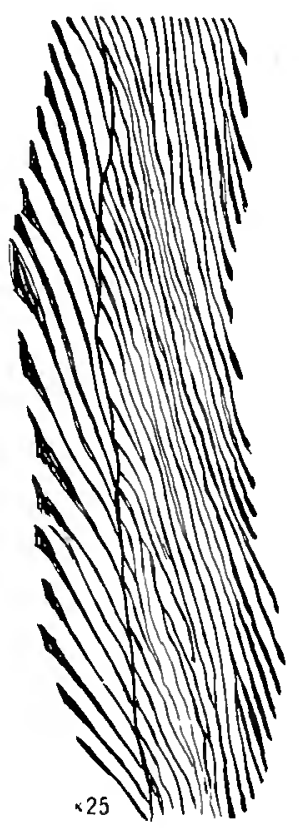

Fig. 203.-Firmatopores.

Longitudinal thin section of Idmidronca coronopus Milne Edwards, 1S38, illustrating structure of firmatopores (to right).

The ectocyst of the tergopores was much thicker than that of the polypidian tubes, for its disappenrance shows a much larger, interzooecial space (fig. 202 A).

As the tergopores give rise to one another independently of the polypidian tubes, their ensemble is easily separated from the frontal of the zoarium (fig. $202 \mathrm{C})$. They evidently form part of the system of basal fixation of the zoarium. Iu sections, they have the appearance of mesopores but they differ in their formation for these are tubes and not ramifications. 
The tergopores have so far been observed only in the genera Mesonea and Pleuronea.

Firmatopores.-The firmatopores (=eanal of reenforcement of Pergens) are longitudinal, cylindrical, capillary tubes on the dorsal of the zoarium. They arise on the basal lamella at all heiglits and are directed toward the base in the opposite direction to the zooccia which are ascending; they form by their opening on the substratum, the basal system of fixation of the zoarium (fig. 203).

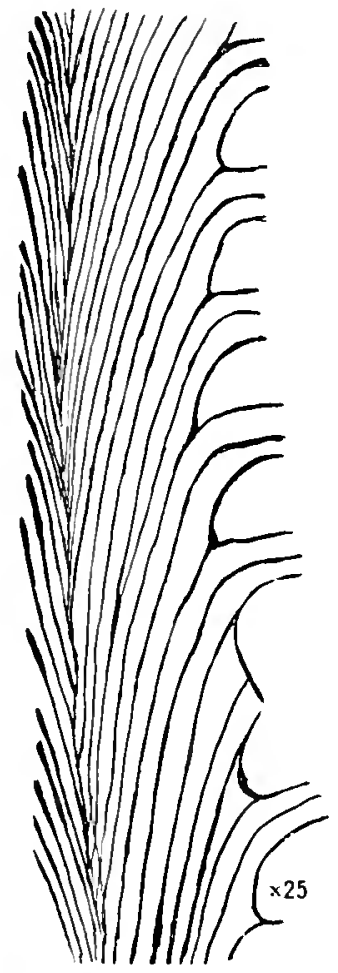

F'Ig. 204.-Nematopores.

Iongitudinal thin section, $X$ 25, of Diplodesmopora oppo. sita new genus and species from the Coniacian at Tours, France, showing zooecial tubes to jiglut and nematopores to left.
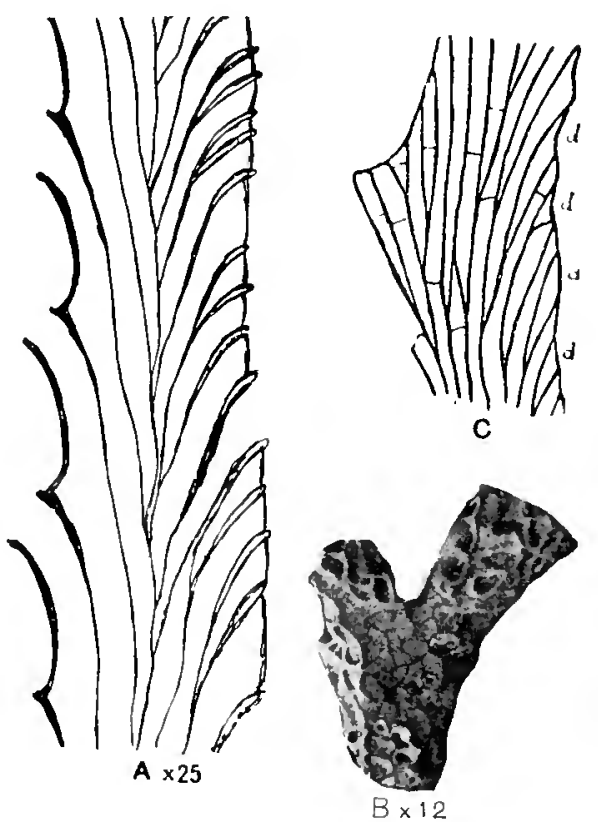

FIG. 205.-Dacty lethraite.

A. Isongitudinal thin section of Erkosonca scmola new species, $\times 25$, showing dactylethrae (to right) and zooecial tubes. B. Dorsal of the same species, $\times 12$, illustrating dactylethrae closed by a lamella. C. Longitudinal thin section of Clansa hetcropora Dorbigny, showing dactylethrae (to right) and zoocial tubes.

Nematopores.-The nematopores are inferior and opposite ramifications of the oriented tubes; they are always rectilinear and their orifice is oblique. 'Their walls are thin or thick, but always adjacent. They are sometimes closed by a calcareous epitheca (fig. 204). They are distinguished from firmatopores, which have the same threadlike aspect. in their ascending and not descending arrange. ment. 
Dactylethrac.-The dictylethrae are club-shaped tubes without polypide, with the same diameter as the polypidian tubes; their orifice is polygonal and closed by a calcareous lamella very finely perforated (fig. 205). They resemble the tergopores in longitudinal sections but they differ in their calcareous closure. Exteriorly the dactylethria resemble cancelli but differ from them in longitudinal
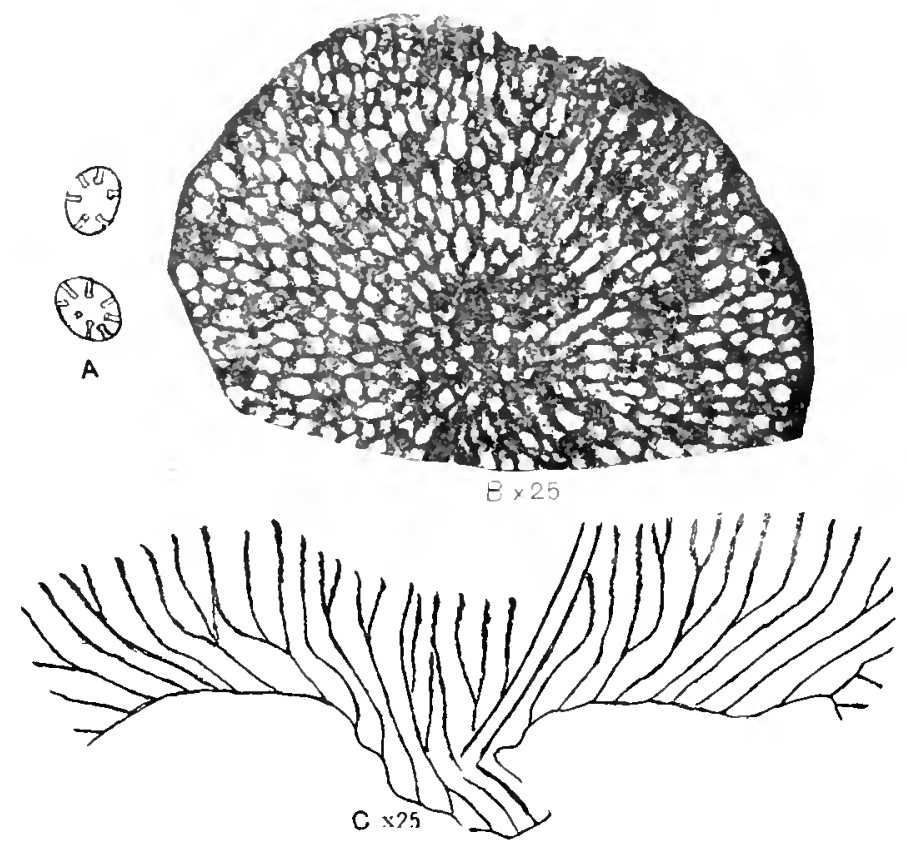

F'r a ofi-Concelli.

1. Thanswerse thin sectims, $X 35$, of two cuncelli of tichenopora holdsucorthi Isusk, 1875, showing spinules of the interior. (After Waters, 1S94.) I. 'I'mgential thin section of the dursal,

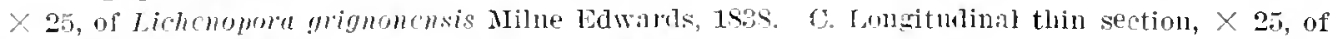
Lichenopora goldfussi reuss, 1s6t. The cancelli are superpused and ramified.

section, in their club-shaped cylindrical form, and in the absence of internal spinules. They differ from the tergopores in their aspect which is oblique and not at right angles, and in their calcareous closure.

The physiological function of the dactylethrae is unknown.

Cancelli.--The eancelli have been interpreted in many different ways, ${ }^{1}$ but following the principle of least change we have adopted the meaning held by the coologists. They are the cylindrical tubes closed by a finely perforated calcareons ranella, which are garnished in the interior with numerous spinules. At the center of the zoaria the cancelli are completely cylindrical; on the margins their lower part is elub-shaped (fig. 206).

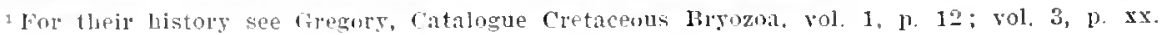




\section{IDTENTITIOIS' 'IUIES.}

These are ramifieations of the polypidian tubes and arise only on the frontal part of the latter. This diflerence is fundamental and permits no confusion. The adventitions tubes are clissed as racuoles and mesopores.

Taeroles.-The vacnoles are parietal perforations with nonadjacent walls ],etween them. They open at the base of longitudinal furrows ealled sute $i$ and bend ontwarel at a right angle. Vacnoles seem to eharacterize the family Horneridno (fig. 207), although they have been noterl in at least one other family (Ascosoecijlae).

Mesoporis.-The mesopores are -uperior and eylindrical ramifications of the bent tubes: they are without polypide and are always parallel to the superior part of the tubes. In the chub-shaped zooecia their walls are generally simple (= maculae cancelli. of Gregory) (fig. $208 \mathrm{C}$ ), but on (ylindrical zooceia their walls are usually vesicular (fig. 208 1). IIowerer, there are numerous exceptions to this. Iesopores are almost always of smaller diameter than the generative tubes; they seem to be almost always closed by a very fragile calcareous lanella little resistant to forsilization. and finally they may branch among themselves (fig. $208 \mathrm{D}$ ).

Ulrich. the anthor of the word mesopores, defined them in 1890 ats "angular or irregular cells occupying interzooecial spaces in certain Paleozoic genera." The accesson'y tubes, like

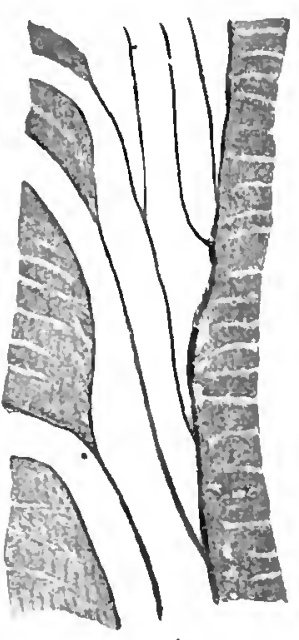

A

Fig. 207.-Vacuoles.

A. Longitudinal thin section, $x \mathbf{2 5}$, of Hornert anturetion Waters, 1304, showing vacule's on both the frontal (to the left) and dorsill (to the light). IB. Lonuitulinal thin section, $\times 2 \pi$, of

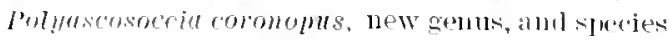
showing difference bow worn the vacueles (on the left) and the mesolures $(m)$ (to the right).

the arlventitions tubes, are inchded in this definition in spite of their diflerence in origin and probally function. In 1890 rregory defined them more precisoly as "almorted zonecia, whieh are smaller in diameter than the nornal zonecia," and in 1599 as "rudimentary zooccia."

Aborted or monalorted, a zooecium is a zooecium; it should have the same origin as a polypidian zooecium and should grow from another zooecium by a special mode of gemmation and before its complete calcification. Any collular cavity not having this origin is not a zonecium (=tube) but is only a ramification. This consideration of origin obliges us therefore to change the nomenclature somewhat. Two solutions are possible, first, to preserve Ulrieh's definition aud apply the term "mesopore" to all structures which are not polypilian tubes in conformity with the ideas of the author, or secmel, to restrict it to the zonecial ramifications only. 
In the first alternative we would be obliged to create a new work for the zooecial ramifications which would change the description of most of Ulrich's genera
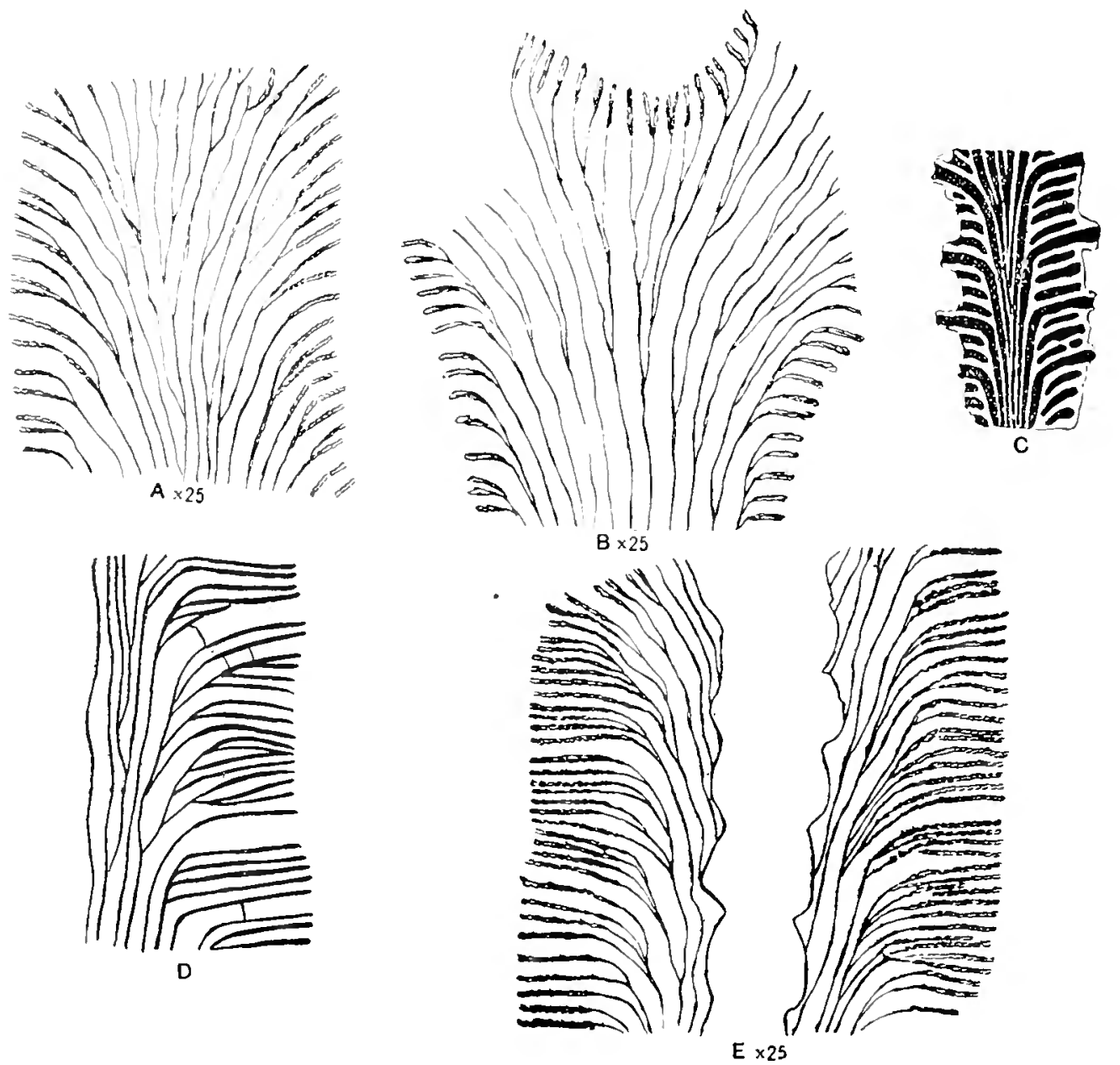

Fig. 208.-Mesopores.

A. Longitudinal thin section, $\times 25$, of Trctocycloccia ? attenuata Ulrich, 1582 . The mesopores alre short and few. I3. I,ongitudinal thin section, $X 25$, of Hctcropora ovatis new species, The mesopores are very short. C. Longitudinal section of Sparsicavea carantina D'Orbigny. (After Gregory.) The zooecia are chub-sliaped and the walls are simple. D. Longitudinal section of Ascosoccia (Zonopora) arborca Koch and Dunker, 1837. (After Pergens, 1S99.) The mesopores are ramified. E. Longitudinal section of p'arteiosoccia jacksonica, new species, $\times \mathbf{2 5}$, showing branching mesopores with resicular walts.

and species. In the second, on the contrary, very few descriptions would have to be changed. By application of the principle of least change we have thought that the restriction of the term "mesopore" to zooecial ramifications would be preferable 
GLIMIATION.

In principle, gemmation is independent of the form of the tubes and their reunion in bundles. Gemmation may be divided into juxt:posed, peripheral, or oriented.

In juxtaposed gemmation the tubes are parallel and open at their two extremities. In transverse section, they are larger at the center of the zoarium. Such gemmation exists only in the family Corymboporidac, which became extinct in the Cretaceons (fig. $209 \mathrm{~A}$ ).

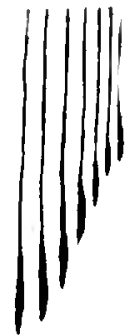

A

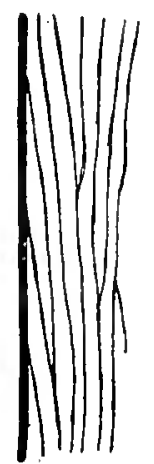

$\mathrm{D}$

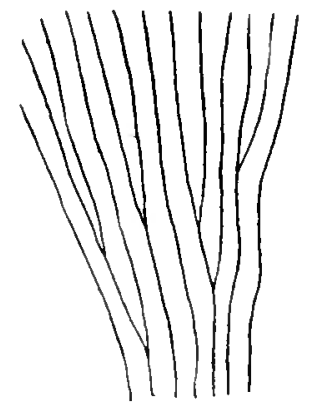

B

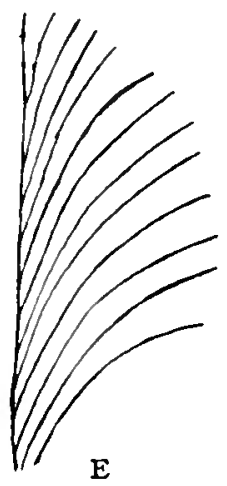

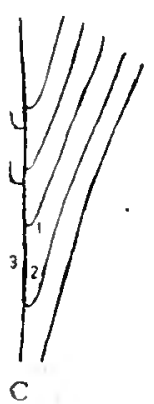

c 
mation characterizes the Cryptostomata, but it has also been noted in many different families of the Cyclostomata and with raried forms of tubes, cylindrical (Cyrtopora, Grammascosoccia, Crisina) or funnel-shaped (Cea).

In biparietal gemmation the tubes in longitudinal section are, at their base, adjacent to two other tubes. It is dorsal, axial, or intrazoarial.

Dorsal gemmation occurs on the basal lamella. The tubes grow on the dorsal, one from the other, carly, before the formation of the polypide; the zone of growth is risible and regular. The expanded tubes adopt chiefly this mode of gemmation (zorial forms called Entalophora, Bereniced, ete.) in a large number of families.

Axial gemmation occurs by bifurcation in the vicinity of the zoarial axis. The zone of growth is visible but irregular. It has no basal lamella, but there is almost always an opposite plane formed of adventitions zooecia (Retrporidea, Desmeoport. Oscutiporat).

Intrazoarial gemmation occuls at all heights and at all places in the interior of the zoariunil. The dor'sal of the zoarium is not a basal lamella; it is formed by the remion of the tubes coming from the interior of the zoarim (Frondipora). There are all stages between axial gemmation and intrazoarial genmation. In rabular form gemmation is therefore as follows:

By juxtaposition.

Peripheral.

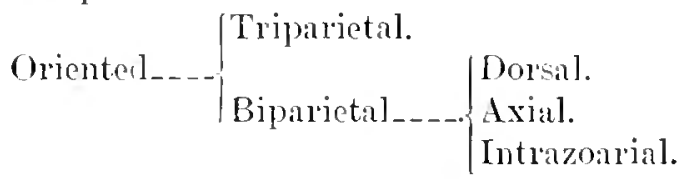

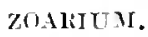

Form.--The form of growth in the Crclostomatil is quite variable and the numlier of zoarial forms known is quite large. Generally the same species always assumes the same zoarial form. Eacl form of growth has a particular name, and in the old classification they constituted many distinct generit. The reader will find these zoarial forms described in great detail in Gregory's Catalngue of the Cretaceous Bryozon.

Busul system of fixution.- The basal system of fixation of the free zoaria is little known. This is an abolutely new study to be undertaken when suflicient. material has been collected. The scarcity of such specinens has prevented us from attempting this study. Certain accessory dorsal tubes undoubtedly form part of the system of fixation and it will be useful to know their reciprocal relationships.

Grouth.-The growth of the zoaria when there are no mesopores occurs:

1. By zooecial superposition, if the tulbes are cylindrical.

2. By indefinte zuoceial multiplication if the tubes are club-shaped.

3. By superposition or agglomeration of subcolonies.

The growth of the zonria with mesopores is diflicult to understand; the section of a small zoarium is identical with that of a large one. It is necessary therefore to suppose that the animal constantly recommences its tuhe. This consideration 
had induced Lee ${ }^{1}$ to formulate his theory of reabsorption which is summarized in figure 210.

Branching.-Branching of a zoarium is not a spontaneous accidental or rapid phenomenon in close relationship with the mechanical movements of the water, but is a true physiological phenomenon. Its object is the increase of the zoarial surface, that is in reality, the surface of oxygenation. Moreover, as seen in

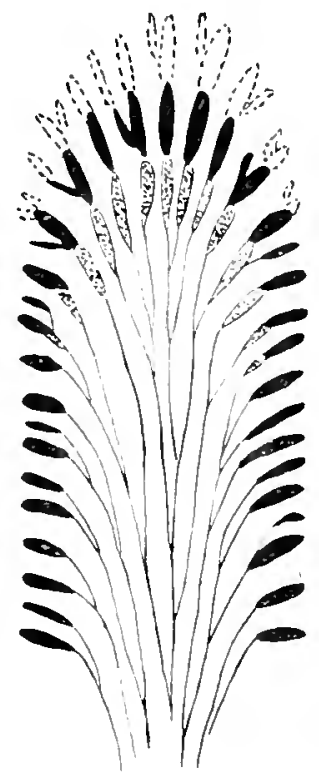

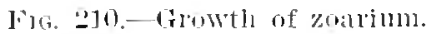

Triagram of a branching trepostomatous bryozoan showing in black the colony as seepe in longiturlinal section, in stippling the terminal portion of tho salle turing an earliot. peyiul and supposted to have lreen resurhed, and in broterl lines, the teminal portion as it minlit lable been had srowth ('intinued, (After Isee, 1912.)

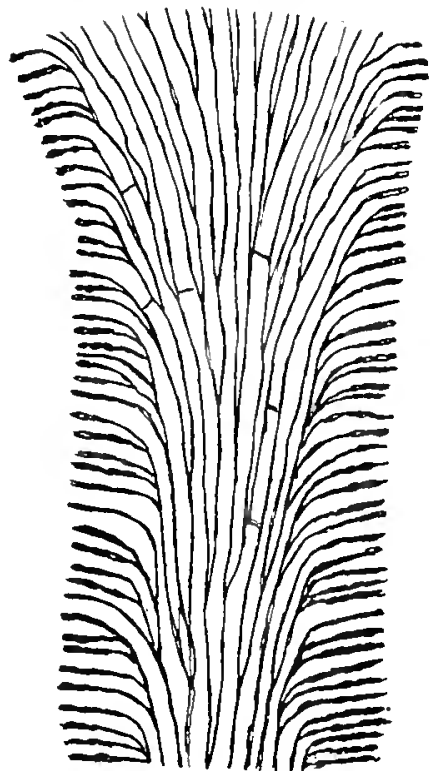

lig. 211.-Blanchines of zoarium.

Iongitudinal thin section of Tretocycloceia retiruluta new species, $\times 12$, slowiug that the sularation letween the two axial tubes of lamification occurred near the base of the cylinclucal branc]us.

sections (fig. 211), the divergence of the axial tulses of ramification begins early. almost at the base of the primitive branch.

The necessity of the dichotomous, arborescent, or bushy architecture requires the formation of accessory tubes of padding and of consolidation; they often oppose the free development of the poorly placed zooecia, the degenerate polypide of which and the orifice are closed by lamellae.

During the Paleozoic era the atmospleric pressure may have been greater and consequently the quantity of oxyen di-solved in the sea water was greater. In the following eras the rarification of the oxygen has caused an increase in the 
number of the ramified species, the symmetry of the zoaria, and the diminution of the arventitious tubes.

Origin of the zoarium.-The first tube of a zoarinm is the ancestrula and its lower part is a dilated blisterlike form ealled the protoecium. It is in this dilation that (1) the histolysis of the fixed larva and (2) its replacement by the first normal polypide living in the ancestrula occurs.

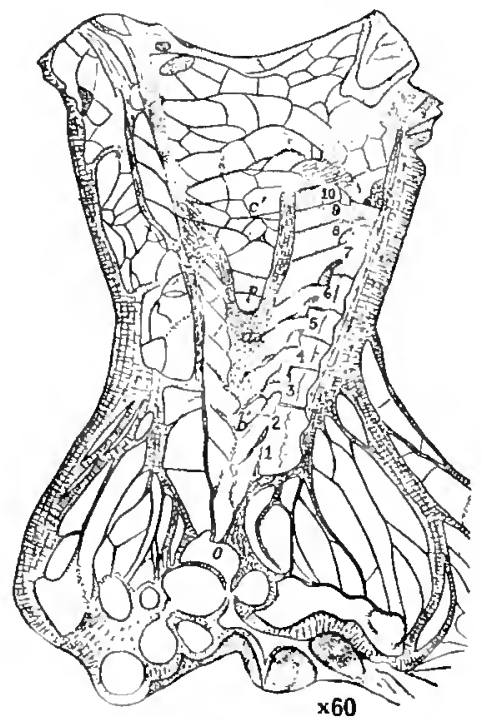

FIG. 212.-Origin of zoarium.

Section of a Fenestella, $\times 60$, cutting exactly in the plane of the axis and of the zooecial apertures to the right (1-10). The initial zooecium (protoecium) is at $o$; the thickening of the axis $(a x)$ commences at $b^{\prime} ;$ the apex of the cone of exmansion of the colony is at $p$; the vesicular tissue $\left(c^{\prime}\right)$ above $p$ is of secondary origin forming during the mature and senile life of the colony. (After Cumings, 1904.)

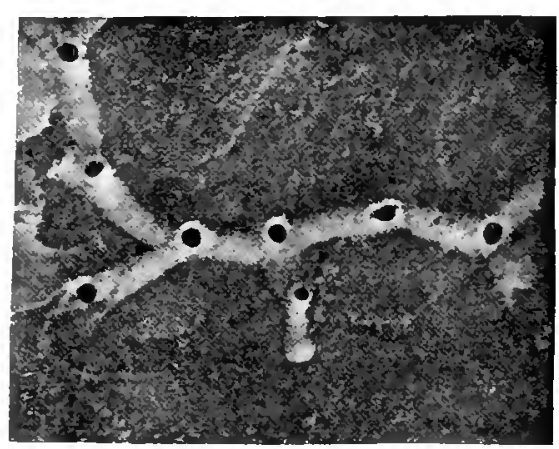

Fig. 213.-I'rotoecium.

Znarium, $\times 25$, of stomatopora parriporu new species, showing the orbicular protoecium.

The protoceium is visible on all incrusting species in which the zoarial form . is that of Proboscina or Berenicea (fig. 213). In the free species it is visible only in the section properly made in the base of the zoarium (fig. 212). The scarcity of specimens has not allowed us to make a special study, of this feature.

1 The reader will find excellent models in the studies of Cummings.

1904. Defelopment of some Pajeozoic Bryozon, American Journal of Sclence, pp. 49-78, with 83 figures. 1305. Development of Fenestella, American Journal of Sclence, pp. 169-178, 3 pls.

1005. Derelopment and Systematic Position of the Monticuliporoids, Proceedings of the Paleontological Soclety, rol. 29, pp. 357-366, with plates. 
OVICELLS.

The oricells of the cyclostomatous bryozoa are nsually rare. Moreover, they are very fragile and resist fossilization very poorly. 'Their form and nature give the essential character's of an entirely natural classification. This new conception has obliged us to greatly modify and correct the zoarial classification hitherto generally recognized.

The oricells allow the larrat to eseape by an orifice called the oeciopore, which is surrounded by a more or less salient collar called the oeciostome. In another group the escape of the larra occurs by the rupture of the walls and there is no oeciostome.

The studies concerning the ovicells of the fossil bryozon are still very incomplete; it is often impossible to discover the oeciostome on a single specimen and consequently to find a good generic character immediately. The special mode of formation of the larva is the cause of this rarity of the oricells. The fertile egg is developed by successive segmentation into a large primary embryo occupying almost all the ovicell. In the latter. by fissiparity secondary embryoes are detached which are erolved in the ordinary manner and escape by the oeciostome. In this manner 150 larrae may be sent out from a simgle ovicell (fir. 214).

Figure 226 gives the form of the oricell in cach family discussed in this rolume.

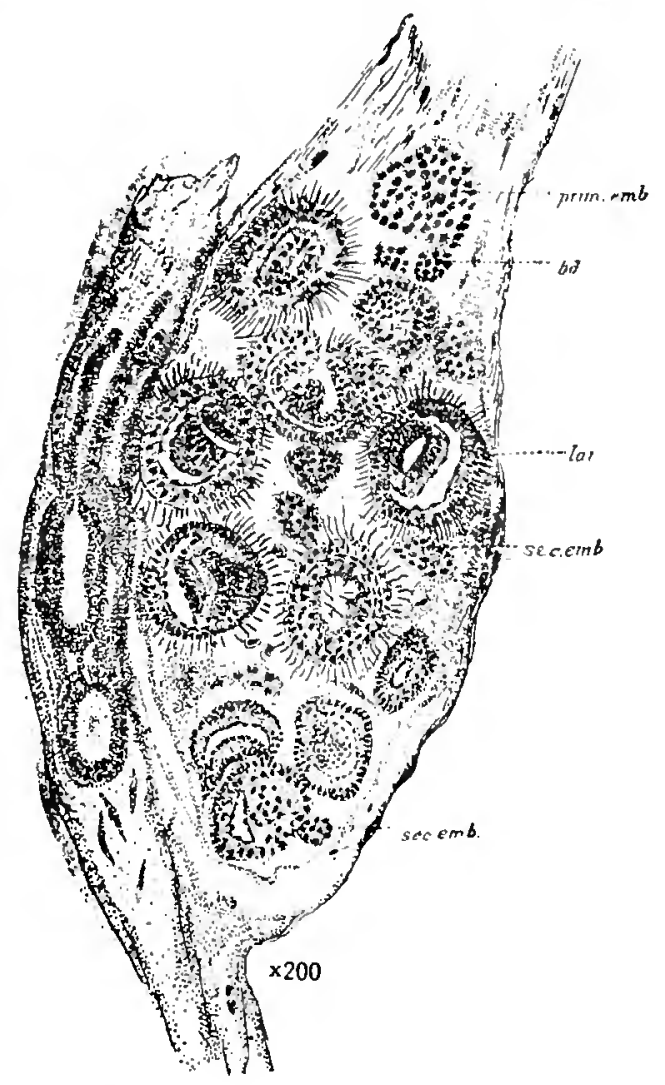

FIG. 214.-Fissiparity of primary embryo.

Section of a mature ovicell of Crisia cburnca Linnaeus, $1758, \times 200$, showing the primary embryo (prim. $\mathrm{cmb}$ ) giving off buds (sec. $\mathrm{emb}$ ) and also larvae (lar). (After Robertson.)

\section{STSTEUATIC DESCRIPION OF THE CYCLOSTOMATA.}

Our studics have caused us to reject for the present all of the former major classifications of the Cyclostomata and to retain simply for convenience the two larger divisions of the Inovicellata and Oricellata. Under the first of these terms we recognize two subdivisions $(a)$ the typical Cyclostomata, or those with clubshaped tubes and (b) trepostomatous-like Cyclostomata, or those with cylindrical tubes. 


\title{
Division INOVICELLATA
}

\author{
(a) TYPICAL CYCLOSTOMATA \\ Family DIASTOPORIDAE Gregory, 1899.
}

Crclostonata tubulata in which the zooecia are simple, open tubes, which either" grow as linear series or as inerusting or erect sheets. The sheets may be coiler into hollow tubes. The zoarium is exceptionally massive. The zooecia may be wholly immersed or partly free. Appendages absent. (After Gregory, 1899.)

\section{Forma STOMATOPORA Bronn, 1825.}

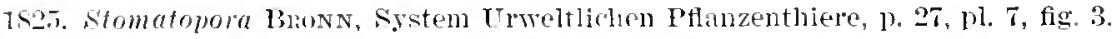

18.ri. Gibgory, ratalogue of the Jurassic bryoua in the British Mrusenm, p. 42.-1904. LANG, The Jurassic Forms of the Genera Stomatolorit and Proboscina, Geological Magazine, ser. 5, vol. 1, pp. 315-322-1905. Stomatopora antiqua Haime and its related Jiassic folms, Grological Magamine, ser. 5, rol. 2, p1. 255-268.-1907. The evolution of Stomatopora dichotomoides, Geological Mlagazine, ser. 5, vol. 4, pp. $20-24$.

Zorrimm flat, adnate. branching dichotomously, composed of miserial subtulum:ur zooecia.

Genotype.-Stomatoporu dichotoma Isanouroux, 1821.

Runge.-Ordovician-Recent.

The tubes are oral when the peristome is of less width than the width of the tubes. They are cylindrical when the diameter of the peristome and of the true is practically equal. Again there are some fusiform tubes and others having a elub shape. The peristomie is the free part of the tubes forming a prominence above the gemeral zonrial surface: in the fossil forms it is never very large. The peristome is always round; it remains so when the peristomie is perpendienlar to the zooecial plane. Most of the time the peristomie is olshique and by rupture the peristome beromes elliptical.

In our descliptions we never give the size of the aperture. 'This is a measurement which is absolutely inconstant on the same zorriun and the consideration of the dianeter of the peristome appears to us sufheient. The determination of species of Stomatopore and of Probosrinu is extrenely diffienlt. A knowledge of the ancestrula would probably make the work less diflieult, but unfortunately no stuly of this part of the subject has yet been made.

The genus stometopora has been the subject of much study by Lang, who has e-tablished the following points:

The doveloment of a zoarium is conparable with and follows the same laws as the develimment of the znoecinum.

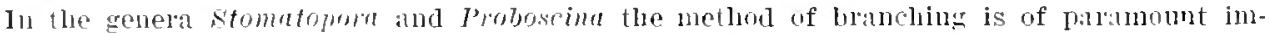
jurtinter.

Twe ways of branching may be noticed, namely, lateral branching (ramification) and dichotomy (dichotonisation).

In latera] blanding a new zoverim arises from any moint in a chain of ald zouecia,

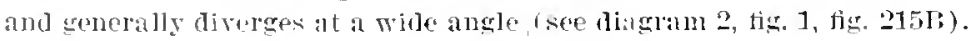


In dichotony, two new zooeeia allise fron the end of an older zooecinm; the angle at which they diverge varyiug from $180^{\circ}$ to $20^{\circ}$ or $30^{\circ}$, and varying in al definite manner (see (iagr'au 2, tigs. 2-9).

Dichotomy in the forms under consideration ocems in three types, one of which is intermediate between the otler two. In that termed type I the two new zooeeia are separate
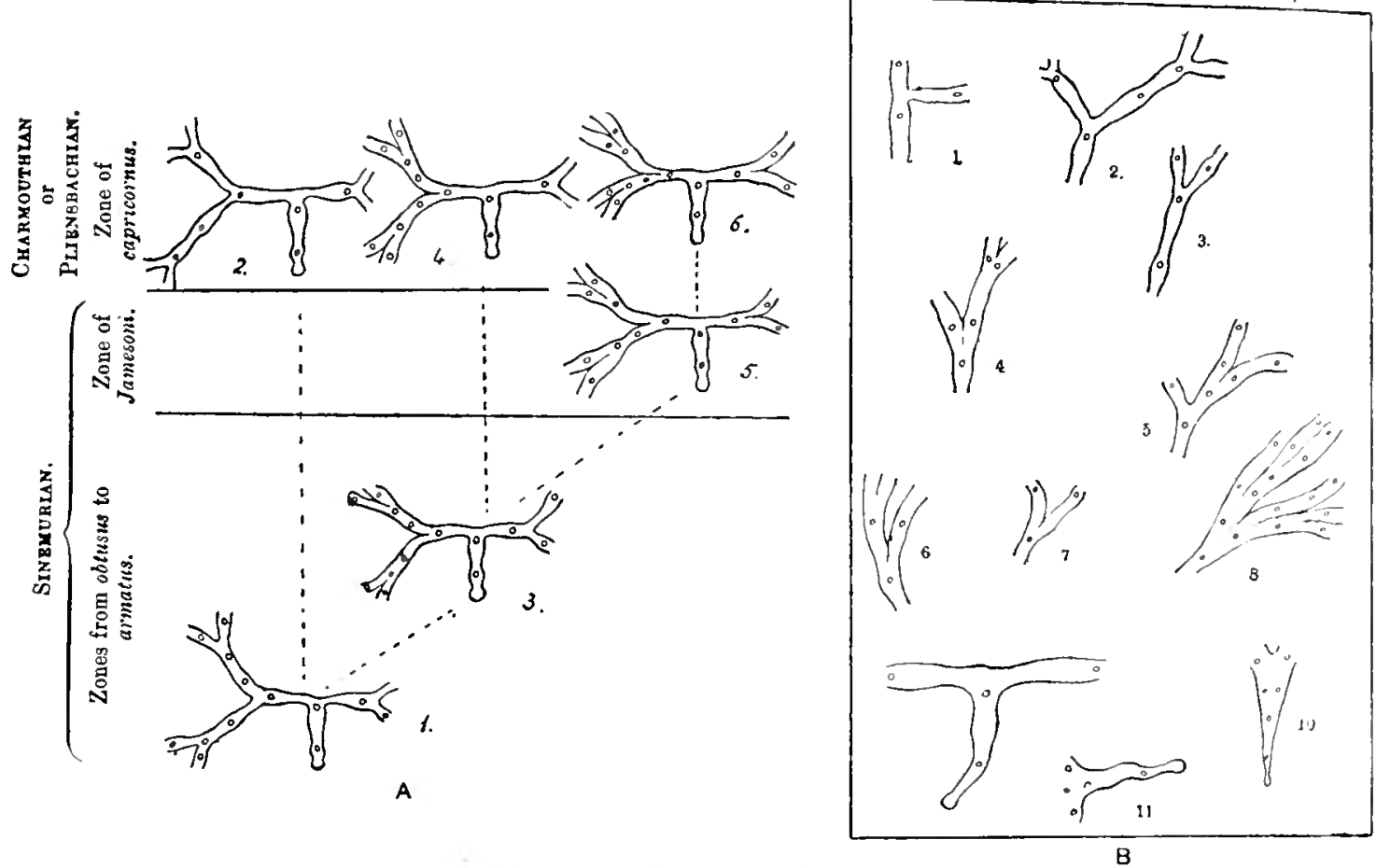

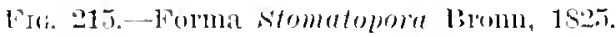

A. Tiacrand to show the changes in the method of branching and in the slinpe of the zooceitum

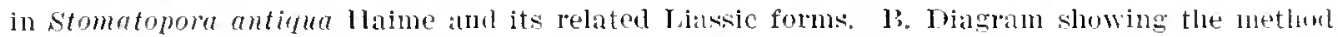
of branching in Jurassic forms of stomatopora and l'robseinu. 1, lateral branching; 2, type 1 with lalge angle; 3 , type 1 with small angle; 4 , trie Il with small angle; 5 , tye Il with large angle preceled by intermexliate ty with large angle; 6 , intermediate t5pe with small ansle; 7 , intermediate tyres with large angle: 8 , type $1 \mathrm{l}$ with an angle of $0^{\circ}$; 9 , type 1 with an angle of $180^{\circ} ; 10$, the tilst dichotomy is after type $1 \mathrm{I}$ with an angle of $0^{\circ} ; 11$, the alrangement of the peristomes is ilregular flom the first.

from one another tlingughont their whole length (diagram 2, figs. 2, 3, 9), ouly touchiug at their bases. In tyle 2 they are contiguous throughout their length (figs. 4, 5, S); anu they are contiguons for patt of their length in the intermediale fyje (1igs. 5, 6, 7 ). The angle of divergence of the two new lomehes tends to diminisli distally.

'The frequency of branching is measured by the number of peristoues between two dichotomies. The number of pelistumes between the first two or three dichotomies is sunll (nearly always one or two), then suddenty jucrenses lingely (anagenesis) and finally becomes small agalin (liatagenesis).

The ratio of length of zomerium to brealth is monressive (anagenetio at first and reaches its acme at the third dichotomy, after which it is relogressive (katagenetic). 
Generally the zooecia are either cylindrical or pyriform. In many of those forms which have cylindrical zooecia thronghont the greater part of the zoarium, the zooecia between the first and third dichotomies tend to be slightly pyriform; while in those forms with Iyriform zooecia, the zooecia between the first and third dichotomies are generally more pyriform than the rest.

Ribbing, when present, is usually faint at its first appearance, becoming stronger later on, and in some enses becoming fainter again finally. The point at which the acme is reached varies a great deal.

Finally, Lang has demonstrated that the method of branching and the shape of the zooecia varies sensibly in time and according to the successive geologic stages (fig. 215A).

In the application of these observations Lang, in order to characterize a species of Stomatopora, made a large tal,le, ${ }^{+}$which is an excellent example of booklkeeping. We are unfortunately not able to adopt this method in our work as we do not possess a sufficient number of specimens of our various species.

Before Lang's studies, Gregory, in 1896, had also devised a system of description. which, however, was given up in the succeeding volumes of the Catalogne of the British Museun. In order to make the species collected in our American Tertiary formations of stratigraphic ralue we have no other method than that of good illustrations always on the same scale $(\times 12$ and $\times 25)$.

The branches of the same zoarium of Stomatopora or of Proboscina nerer grow over each other (see pl. 105, fig. 1); a branch is arrested in growth when it encounters another. What is the mysterious force which permits the minute luanches of the same colony to be cognizant of each other in the eternal night of the oceanic depths? Evidently this is a manifestation of a kind of cerebral activity of which the nerve ganglion of the bryozon is the organ. But how does the transmission of the sympathetic vibrations occur and by what magic do they become synchronized? Althongh microscopic the biologic mechanism of a zoarium is sublime.

STOMATOPORA OPPOSITA, new species.

I'late 10\%, fig. 25.

Description.-The zonrium is not dichotonous; the branches are opposed and are emitted symmetrically at the distal extremity of a tube. The tubes are short, finely punctate, elliptical. The peristome is orbicular, thick, little salient.

Necurements.- $\left\{\begin{array}{l}\text { Diameter of tube } \\ \text { Iength of tube } \\ \text { Diameter of peristome }\end{array}\right.$

Occumence.-Midwayan (Clayton limestone): Mabelvale, near Little Rock, Arkansas (rery rare).

II olotype.-Cat. No. 65247, U.S.N.M.

"Jang. Teological Magazine, vol. 2, 1905, p. 262; vol. 4, 19007, p. 23, ete. 
STOMATOPORA CONTRACTA, new species.

I'late ]05, tigs. $1,2$.

Deseription.-The zoarium creeps orer shells (Terebrutula) forming irregular polygons; the dichotomization occurs almost at jight angles. The tubes are oval, contracted at their extremity, finely striated transversely. The peristome is orbicular, thick, little salient.
Measurements.
Dianeter of tube
$0.36 \mathrm{~mm}$.
Length of tube
$0.50-0.60 \mathrm{~mm}$.
$0.16 \mathrm{~mm}$.

In the specimen shown in our figure, three tubes appear tu have undergone total regeneration.

Oreurcnee.-Midwayan (Clayton limestone): Well at Brundidge, Alabama (very rare).

Holotype.Cat. No. 6524?, U.S.X.M.

STOMATOPORA EXIGUA, new species.

I'late 107 , tig. 26.

Description.-The zoarium incrusts shells. 'The tubes are fusiform, narrou, striated transversally. The peristome is thin, oblique, round, or cllipticad; the peristomie is very oblique.

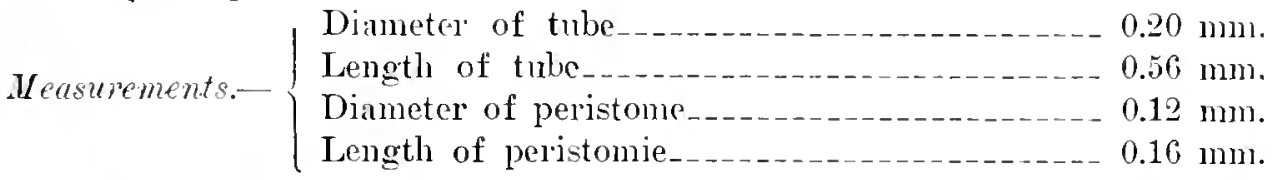

Occurrence.-Midrayan (Clayton limestone): Well at Brundidge, Alabama (rery rare).

IIototype.-Cat. No. 65248. U.S.N.M.

STOMATOPORA PARVIPORA, new species.

I'late 131, figs. S, 0.

Description.-The zoarium incrusts oysters and other shells. The tubes are cylindrical, very small. striated transversally; the protoecium is orbicular. The peristome is thin. salient, oblique, round, or elliptical; the peristomie is short.

Measurements- $\left\{\begin{array}{l}\text { Diameter of tube } \\ \text { Length of tube }-14-0.18 \mathrm{~mm} . \\ \text { Dianeter of peristome }\end{array}\right.$

Occurrenee.-Lower Jacksonian (Moodys mal) : Jackson, Mississippi (very rare).

Middle Jackonian (Castle IIạne limestone): Wilmington. North Carolina (rare).

Vicksburcian ("Chimney rock" member of Mariama limestone): One mile north of Monroeville. Alabama (very rare).

Cotypes.Cat. Nos. 6.3361, 65362. U.S.N.M. 
Plite 115, figs. 9-11.

I)ecription.-CThe zoarium incrusts shells and orbitoid foraminifera on which it forms more or less regular polyyons: the angle of diehotonization is very obtuse and close to $120^{\circ}$. The tubes are thin. eylindrical. 'The peristome is thick, romn. little salient.

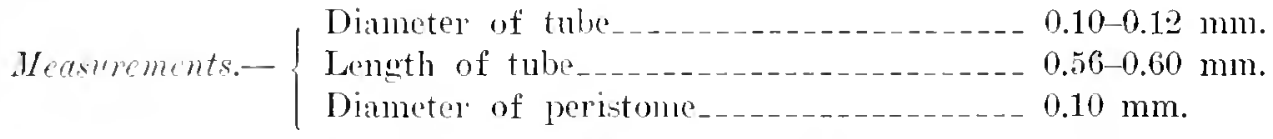

'This very interesting species is easily recognized by its small polygonal zoaria.

Ocenpenre-Lower Jacksonian (Moodys marl) : Jackson, Mississippi (rare). Niddle Tackonian: Wilmington. Tortl Cirolina (very common), Eutaw Springs (rare), and near Lemuls Fel'ry, South ("alolina (very rale).

Tpper Tacksonian (Ocala linestone) : West bank Sepulga River, Escambia

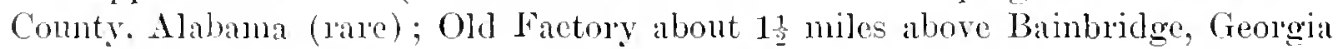
(rare); and below Plant System Railroad Wharf, Banbridge, Georgia (very rare).

Vicksburgian (Mariamna limestone): One mile north of Monroeville, Alabam? (rery rare); and Salt Monntain, 5 miles sonth of Jaekson, Alabama (rare). Cotypes.Cat. No. 6.277, U.S.N.M.

\section{STOMATOPORA MINU'TA, new species.}

I'late 162, fis. 21.

Deseription.-The zoarium inerusts oubitoid formminifera. The tubes are cylindrieal, small, sumoth. The peristome is thin, salient, elliptieal.

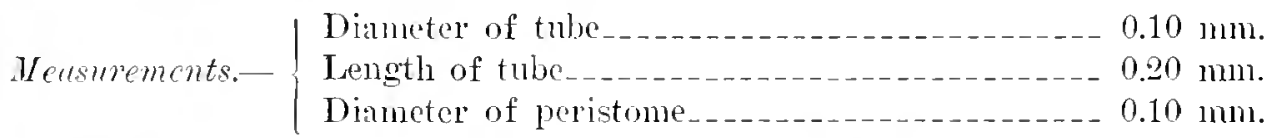

Ocentrence.-Vicksburgian (Mariama limestone) : Murder Creek east of Castlebury, Conecuh County, Alabama (very lare).

İ́lotyp.-Cat. No. 65475 , U.S.N.M.

STOMATOPORA EXCAVANS, new species.

Plate 115, fig. 1.

Tescription.-The zoarium incrusts shells, in which it appears to ercurate furrows. 'The tubes are elub-shaped, rery narlow belind and rised almost vertically at their extrmity. The peristome is thin, ohique, orbieular, or elliptical.

Wersurements.-. $\left\{\begin{array}{l}\text { Iength of tubes } \\ \text { Diameter of peristome }\end{array}\right.$

Affuities.-This species diflers from Stomatopore comu, in which the tubes are also club-shaped, by its smaller micrometrie dimensions. 
Occurrence-Middle Jacksonian (Castle Hayme limestone): Wilmington, North Carolina (very rare).

Holotype.-Cat. No. 6527t, U.S.N.M.

STOMATOPORA CORNU, new species.

Plate 130, fig. 14.

Description.--The zoarium incrusts shells. The tules are long, in the folm of a horn. The peristome is thick, salient, round.

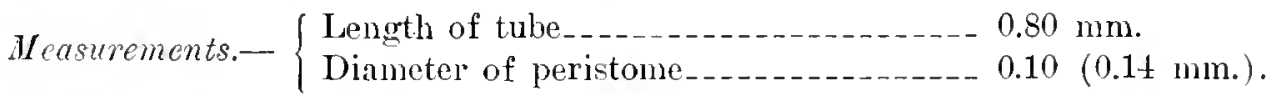

Occurrence.-Upper Jacksonian (Ocala limestone) : Chipola River, east of Marianna, Jackson County, Florida (rare).

Holotype.Cat. No. 65455, U.S.N.M.

STOMATOPORA PRATTI, new species.

Plate 116, figs. 1-3.

Description.-The zoarium incrists bryozoa and shells, forming very irreginlar polygons. The tubes are oval, wide, wrinkled transversally, of quite rariable width. The peristome is thin, salient, orbicular.

Yeasurements.- $\left\{\begin{array}{l}\text { Diameter of tube } \\ \text { Lengtls of tube } \\ \text { Dianeter of peristome }\end{array}\right.$

This species is well characterized by its great zooecial widtlı. The specific name is in honor of Dr. J. H. Pratt, State geologist of North Carolina.

Occurrence.-Widdle Jacksonian: Wilnington, North Carolina (common); near Lenuds Ferry, South Carolina (rare); $3 \frac{1}{4}$ miles south of Perry; Georgia (very rare).

Upper Jacksonian (Ocala limestone): West bank of Sepulga River, Escambia County, Alabama (very rare); Chipola River, east of Marianna. Jackson County, Florida (very rare).

Cotypes.-Cilt. No. 65268, U.S.N.M.

STOMATOPORA STRIATULA, new species.

Plate 116 , tigs. 4,5 .

Description.--'The zoarium inerusts shells, orbitoid foraminiferal and bryozoa; the angle of dichotomization is very acute and about $60^{\circ}$ at the most. The tubes are oval, wide, striated transversally. The peristome is thin, salient, orbicular, The peristomie is short. The angle of divergence is sometimes so sulall that two primoserial tubes are adjacent and the zoarium partially assumes the aspect of a Proboscina.

$55899-200-1$ Bull. $106-12$ 


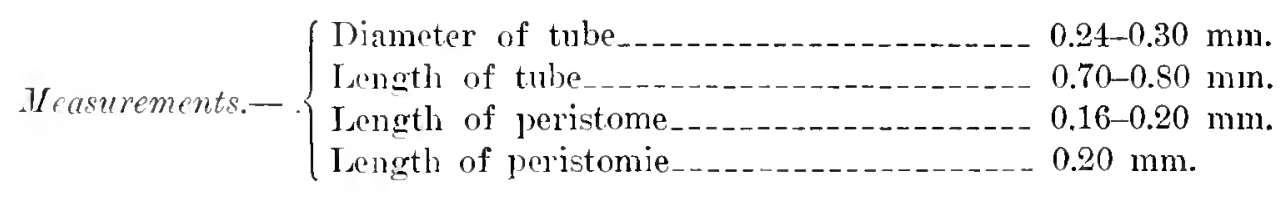

Affinities.-This species may be confused with Stomatopora pratti in its general size. It differs from it in the smallness of the angle of divergence of the branches and in its zooecial width which is never more that $0.30 \mathrm{~mm}$.

Occurrence--Middle Jacksonian: Near Lenuds Ferry, South Carolina (rare) ; Wilmington, North Carolina (rare).

Upper Jacksonian (Ocala limestone): Alachua, Florida (very rare).

Cotypes.-Cat. Nos. 65269, 65270, U.S.N.M.

\section{STOMATOPORA FASCIOLATA, new species.}

Plate 116, figs. 10,11 .

Description.-The zoarium incrusts bryozoa, forming irregular rectangles. The tubes are oval, very wide, often ornamented with salient, transverse bands. The peristome is thin, round, somewhat oblique, salient.

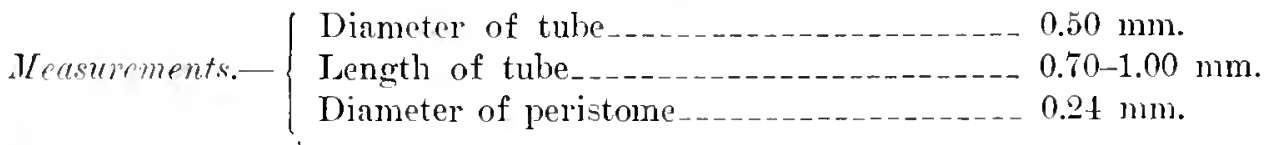

Affinitics.-The large species is clearly characterized by its zooecial width, which is much greater than that of Stomatopora mratti. The transverse bands are, moreover, ver'y inconstant.

Oceurence.-Upper Jacksonian (Ocala limestone): Old Factory, about $1 \frac{1}{2}$ miles above Bainbridge, Georgia (very rare).

Hototype.-Cat. No. 65273 , U.S.N.M.

\section{Forma PROBOSCINA Audouin, 1826.}

1826. I'roboscina Aubour, Explication sommaire des planches de Polypes de l'Egypte et de la syrie. . . . In Savigny's Description de l'Egspte. Histoire Naturelle, vol. 3 , p. 236 .

The zoarium consists of multiserial elongate bands, which may be simple or branched, and are always flat and adnate. The zooecia are cylindrical and narrow. The peristomes are flush with the surface of the zoarium, or slightly raised; and they are usually distributed irregularly, but are occasionally quincuncial or in transrerse linear series.

Range.-Ordovician-Recent.

Historical.-Proboscina horyi Audoum, 1826, was the first species of this genus ancl has been quoted as the genotype, although the genus Proboscina has never been considered as more than a multiserial Stomatopora. Numerous species ranging from the Middle Ordovician to the Recent have been referred to the genus and 
for almost a hundred years it has been recognized by all authors in a zoarial sense. However, the original figures of Proboscina boryi showed the presence of an ovicell formed by an enlargement of the peristomie, a character which we believe of more importance that the form of growth, hitherto depended upon for the recognition of the genus. On the principle of least change we believe it best to retain the name Proboscina for the many multiserial incrusting species in which the ovicell is unknown and to refer the few ovicelled species elsewhere. In this case Proboscina bom $i$ becomes a member of the new genus Peristomoccia described on page 692.

The bi- and tri-serial species of Proboscina have a family likeness, which renders them ensily discernible. A single ovicell was figured by Waters in 1904 and it is known in another Cretaceous species in the Canu collection.

The multiserial species of Proboscina are quite variable in their development. Many oricelled species are known, and, as indicated elsewhere in this work, they belong to different genera and even different families.

Terminology.-This is the same as that of Stomatopora. We add only the maximum width of the zoarium, and sometimes the separation of the tubes. The latter is measured by the distance between two tubes placed at the same height, their peristome being included in the measurement (see text figure 216).

PRobosclNa VARIABILIS, new species.

Plate 105, figs. 3, 4.

Description.-The zonrium is biserial and incrusts shells. The tubes are oval, smooth, alternatcly arranged. The peristome is thick, round, salient; the peristomic is short, almost perpendicular.

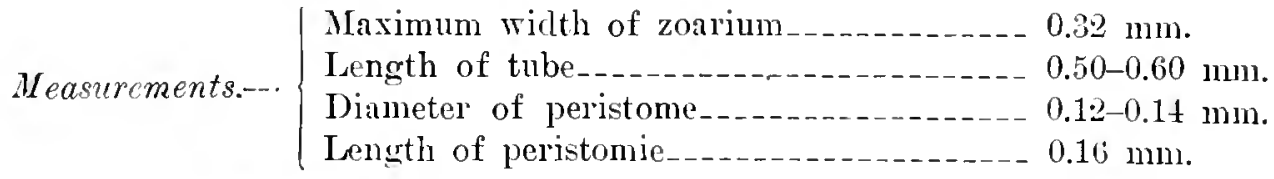

Occurrence-Midwayan: (Claxton limestone). Well at Brundidge, Mlabama (very rare).

IIolotype.Cat. No. 65250 , U.S.N.M.

PRoBoscina ADMota, new species.

Plate $\mathbf{1 0 5}$, figs. $\boldsymbol{\tau}-\mathbf{1 1}$.

Deseription.-The zoarium is multiserial and incrusts shells or algae; it is formed of thick, claviform fronds, bifurcated and not ramified, more or less symmetrically arranged on each side of the ancestrula. The tubes are indistinct and arranged in transverse series. The peristomie is thin, salient, orbicnlar. The peristomes are very close to each other.

$$
\text { Jeasurments. }-\left\{\begin{array}{l}
\text { Maximum width of zoarium } \\
\text { Dianeter of peristome }
\end{array}\right.
$$


I'ariations.- We have figured some zonrial variations, one of which has a very remarkable triangular pahn tree shape. The zoarium is quite often free and the basal lamella is smooth. The peristomie disappears sonetimes; in which case the zoarium offers the aspect of Cellulipora.

Occurrence.-Midwayan (Clayton limestone) : One mile west of Fort Gaines, Georgia (common); Luverne, Crenshaw County, Alabama (very rare).

'otypes.-Cat. No. 65252, U.S.N.M.

Proboscina RUgosa, new specics.

PIate 116, figs. 8-9.

Description.-The zoarium is biserial and incrusts shells and bryozoa. The cubes are cylindrical, arranged alternately and covered with large trinsverse and very salient wrinkles. The peristome is orloicular, thick, little salient. The branclies commence with a single zooecinm and terminate in two, three, or four nonalternated ones. There are some secondary iranches which commence with two zooccia.

Weasurements.- $\left\{\begin{array}{l}\text { Maximum width of zoarium } \\ \text { Length of tubes } \\ \text { Diameter of peristome }\end{array}\right.$

Oecurpence.-Middle Jacksonian: Eutaw Springs, South Carolna (rare). Molotype.-Cat. No. 65272 , U.S.N.M.

proboscina projecta, new species.

Plates 116, figs. 6-T.

Description.-The zoarium is biserial and incrusts bryozoa, emitting branches at the principal points of curvature. The tubes are indistinct, arranged alternately, striated transversally. The peristome is thin, orbicular, ollique. The peristomie is very sulient and oblique. The branches commence always with an isolated tube.

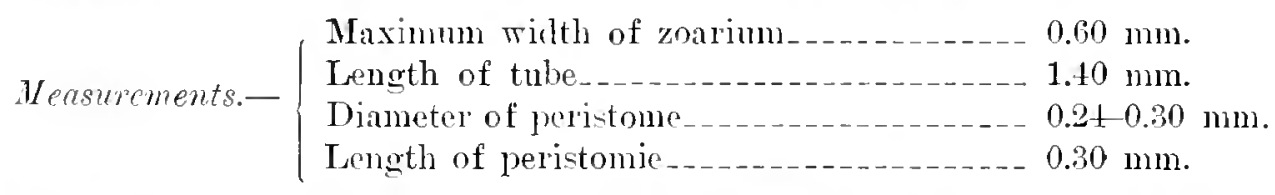

Ittinitis. - This species difters from Prosboscina grminete in its larger peristome (nnere than $0.20 \mathrm{~mm}$.) and in its larger peristomic.

Occurrence.-Middle Jacksonian (Castle Hayne limestone) : Wilmington, North Carolina (rare).

Upper Jacksonian (Ocala limestone): West bank Sepulga River, Escambia ('ounty, Alabama (very rare).

Holotype.-Cat. No. 0.5e71, U.S.N.M. 
PROBOSCINA geninata, new species.

Plate 120, figs. $1-3$.

Description.-The zonrium is biscrial, and incrusts cyclostonatous bryozon. 'The tubes are cylindrical, rarely distinct, arranged altermately, striated transversally. 'The peristome is round, horizontal, little oblique, vely thick; the peristomie is very long, scarcely oblique. In the short branches, the tmbes are not alternated; the peristomes are at the same height and appear geminate, but this phenomenon is rather rare.

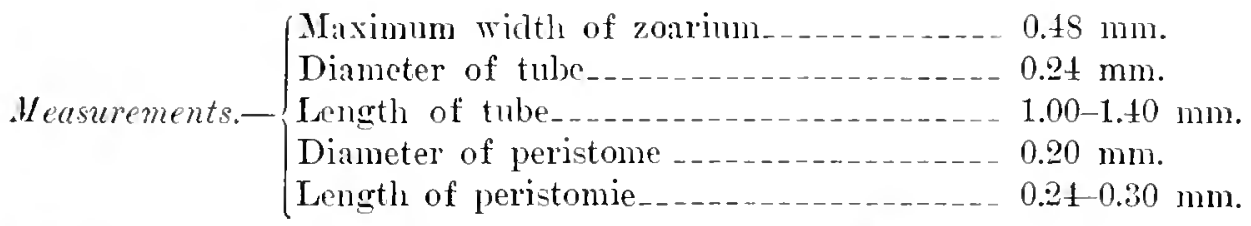

Affinities.-This large species is quite close to Proboscina projecta, but diffcrs from it in its peristome of smaller diameter $(0.20 \mathrm{~mm}$. instead of $0.24 \mathrm{~mm}$.) and its peristomic a little shorter and much more crect.

Occurrence.-Tower Jacksonian (Moodys marl) : Jackson, Mississippi (rare).

Middle Jacksoniar (Castle Hayne, limestone): Wilmington, North Carolina (rare).

Cotypes.-Cat. No. 6527s, U.S.N.M.

PROBOSCINA ANCEPS, new species.

I'late 120 , tigs. $\mathbf{4}, \mathbf{6}$.

Description.-The zoarium is biserial and incrusts shells emitting sublinear branches. The tubes are indistinct, geminate, striated transversely. The peristome is orbicular, thick, little salient, irregularly fringed. The branches are often uniscrial. '1'his species is provided with the largest peristome of all the American species.

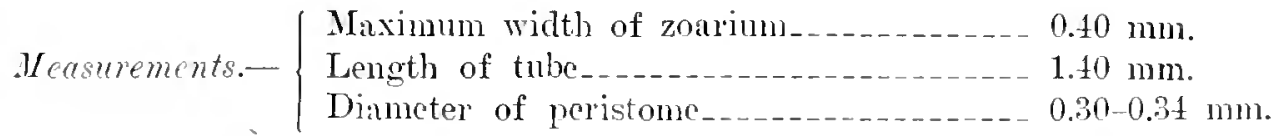

Occurence.-Middle Jacksonian (Castle Hayne limestone): Wilmington, Torth Carolina (rare).

Cotypes.-Cat. No. 65279, U.S.N.M.

PRoboscina exPATiata, new species.

I'lite 120, figs, ?. 1n.

Deseription.-The zoarim is biserial and incrusts shells enitting wide branches which are not all dichotomous. The tubes are very wicle, little convex, depresuret. irregular, as if cxpanded, short. The peristome is thick. orticular, or elliptical, rery little salient. 


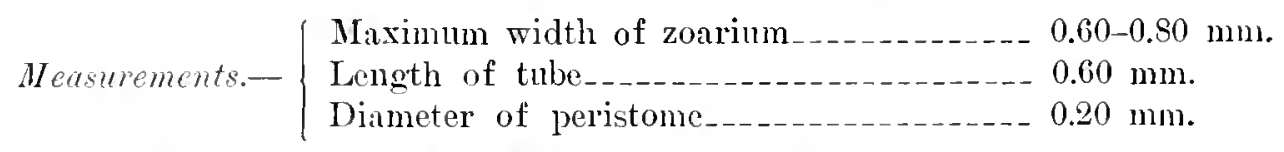

This very curious species with a flaccid aspect is easy to determine.

Occurrence-Middle Jacksonian (Castle Hayne limestone): IVilmington, Sorth Carolina (rare).

IIolotype-Cat. No. 65281, U.S.N.M.

proboscina alternata, new species.

Plate 120, figs. 11, 12.

Description.-The zoarium is biserial and incrusts shells in narrow branches. The tubes are distinct, cylindrical, arranged alternately, striated transversely. The peristome is thin, obliquely orbicular; the peristomie is very salient, oblique, directed toward the exterior and alternately on each side of the median axis. The branches commence with an isolated zooecium.

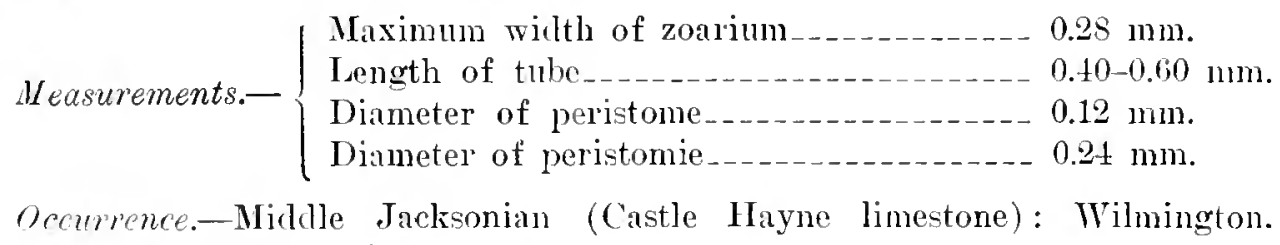
North Carolina (very rare).

IIototype.-Cat. No.65282, U.S.N.M.

PROBOSCINA DIVERGENS, new species.

Plate 120, fig. 13.

Description.-The zoarium is biserial and incrusts shells, and bryozon in rectilinear blanches. The tubes are cylindrical, alternated or opposite, finely striated transversally, short. The peristome is thin, elliptical; the peristomie is rather large and diverges from the median axis of the zoarium.

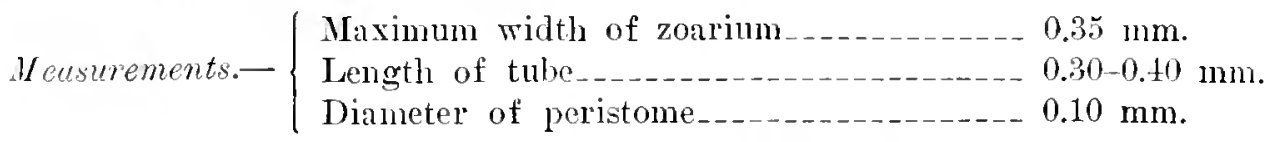

Lftinitics.-This species differs from Proboscina altemate in its smaller tubes (less than $0.40 \mathrm{~mm}$.) and in its peristomes opposite and not alternated.

Oecurrence.-Mikllle Jacksonian: Near Lenuds Ferry, South Carolina (very rare).

[pper Jacksonian (Ocala limestone) : Chipola River, cast of Marianna, Jackson County, Florida (very rare).

II olotype.-Cat. No. 65283, U.S.N.M. 
PROBOSCINA COLUBRA, new species.

Plate 120 , figs. 7,8 .

Description.-The zoarium is triserial and incrusts shells and branched, linear or massive bryozoa. The tubes are little distinet, cylindrical, arranged in transverse irregnlar rows and with adjacent peristomes. The peristome is thin, orbienlar, hittle salient. The zoaria with branches widened like the head of a snake are rather rare; generally they are linear. The peristomes of a transverse series are never all adjacent; there is always one isolated. At the base of the branch, the peristomes are arranged in quincunx.

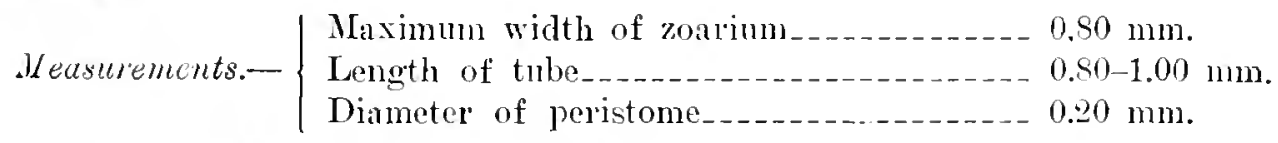

Oecurrence.-Middle Jacksonian, Wilmington, North Carolina (very ratre): Entaw Springs (rare), and near Lenuds Ferry, South Carolina (rare).

IIolotype.-Cat. No. 65ㅛ8, U.S.N.M.

Proboscina Clavatula, new species.

Plate 119, figs. 1, 2.

Description.-The zoarium is multiserial, symmetrical on each side of the ancestrula, incrusting shells; the branches are widened at their extremity in the form of a peg and commence with an isolated zooecinm. The tubes are distinct, cylindrical. rather long. The peristome is round, oblique, salient, thin.

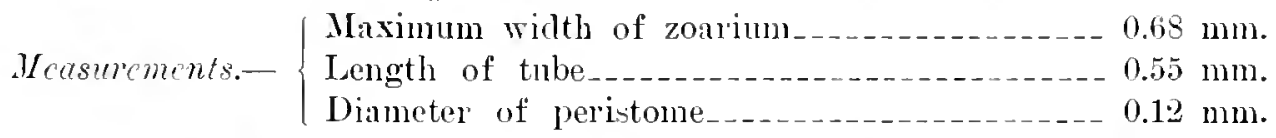

Occurrence.-Middle Jacksonian: Wilmington, North Carolina (rare); 18 miles west of Wrightsville, Johnson County, Georgia (very rare); $3 \frac{1}{2}$ miles south of Perry, Georgia (very rare); Entaw Springs (very rare); and near Lennds Ferry, South Carolina (very rare).

Upper Jacksonian: (Ocala limestone). Alachua, Florida (very rare); west bank Sepulga River, Escambia County, Alabama (rare).

IIototype.-Cat. No. 6528t, U.S.N.M. .

\section{PROBOSCINA STRIATULA, new spccies.}

Plate 119, figs. 5-8.

Mescription.-The zomium is triserial and incrusts shells and cheilostomatous bryozoa in short branches enlarging at each bifureation. The tubes are distinct. arranged in quincminx, regular, finely striated transversally. The peristome is thin. round or elliptical, little salient.

Measurements.- $\left\{\begin{array}{l}\text { Maximum width of zoarium } \\ \text { Length of tibe- } \\ \text { Diameter of peristome }\end{array}\right.$ 
Occurrence-Middle Jacksonian: Eutaw Springs, South Carolina (rare); Wilmington, North Carolina (very rare).

Cotypes.-Cat. Nos. 65286, 65287, U.S.N.M.

PROBOSCINA PROMINENS, new species.

Plate 119. figs. 9-11.

Inceription.-The zoarium is triserial and incrusts bryozoa in long and undulated branches. The tubes are distinct, cylindrical, punctate, arranged in quincunx. The peristome is thin, orbicular, oblique; the peristomie is very salient ohlique. and often elevated to the vertical.

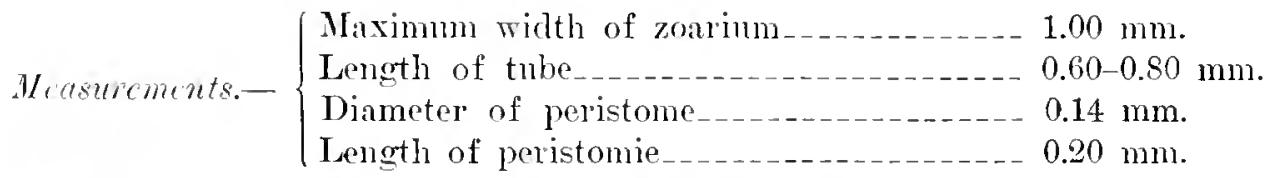

Affinities.-This species differs from Proboscina undulata in its triserial zoarium (and not quadriserial) and in its much longer tubes $(0.60 \mathrm{~mm}$. and not (). $40 \mathrm{~mm})$.

Occurrence-Widdle Jacksonian (Castle Hayne limestone): Wilmington, Nortl Carolina (common).

Cotypes.-Cat. No. 6528s, U.S.M.M.

PROBOSCINA UNDULATA, new spccies.

I'late 119 , figs. 3,4 .

1) scription.-The zoarium is quadriserial and incrusts shells in unduluted branches. The tulbes are little distinct, arranged in quincumx. slightly striated transversally. The peristome is thin, orbicular, oblique; the peristomie is rather large and oblique.

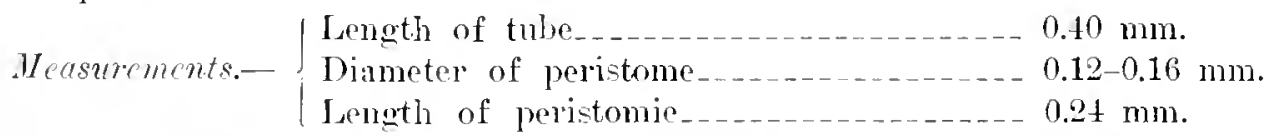

Occurrence-Middle .Tacksonian (Castle IIayne limestone): Wilmington, Sorth Carolina (very rave).

Ilolotype.-Cat. No. 6.5285, U.S.N.M.

proboscina Parviangulata, new specics.

Plate 11S, figs. 1-li.

Iteseription. - The zoarinm is bi- or tri-serial and incrusts bryozoa. orbitoid forminifera. and shells in curved branches, diverging at the dichotonization at a very small angle. The tubes are distinet, cylindrical. a little wrinkled transversally. The peristome is thin, oblique, orbicular, or clliptical; the peristomie is oblique, cometimes elevated until it is rertical, curved, and rather long. 


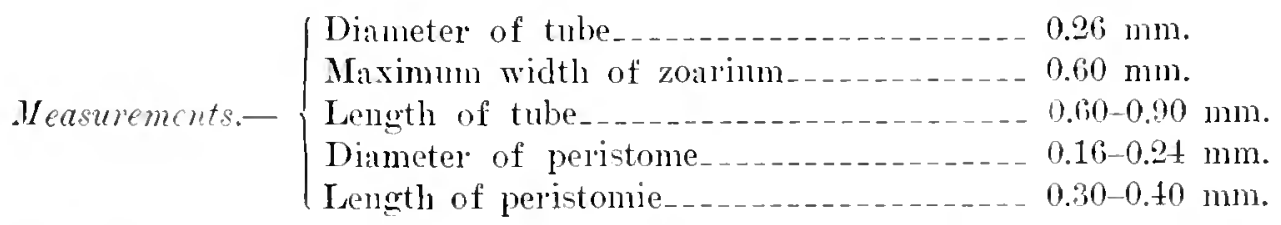

Tariations.-This species is very peculiar and easy to determine by its small angle of divergence. The branches begin always with an isolated zooecium and each recommences a series analogous to that which issues from the ancestrula itself. TVe have thus successively: Zooecia 1. 2, 2, separated, bifucation; 1, 2, 3, bifurcation; $1,2,3 . \pm$ (in transverse roms), bifulcation. The variations of this species are considerable, but invariably the angle of dichotomization remains very small.

Occurrence.-Middle Jacksonian: Near Ienuds Ferry, South Carolina (common) ; Eutaw Springs. South Carolina (rare); Wilmington, North Carolina (comninon).

Cotypes.-Cat. No. 65289. U.S.N.M.

I'ROBOSCINA SUBECHINATA, new species.

Plate 15ig. figs. 1-2.

Description. - The zoarium incusts shells in claviform and triserial branches. The tubes are distinct, cylindrical, arched, wrinkled transversally, in quinemx or in transverse series. The peristome is thin, orbicular, obliqne; the peristomie is rather long and elevated to $45^{\circ}$.

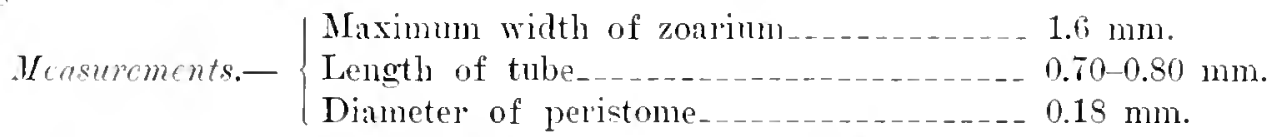

Affinities.-The angle of divergence appears to be small. The zooecia arranged in transverse series are frequent; the peristomies are always free and isolated.

In zondial aspect this species much resembles Proboscina echinata Reuss. 156. Unfortumately we are ignorant of the micrometric measurements of this species and no specimen is known in the Enropean museums. Canu in 1909 believed it ought to be compared with Proboscina major Johnston, 184i, but this was only a sugraestion. The specimens of Proboscina major Johnston, 18t7, collected in the Mediterranean. have a peristome somewhat wider than that of om Imerican specimens of the present species.

Occurronce. Tirksburgian (Marianma limestone) : Near Clabolne, Monroe County, Alabana (rare); Salt Mountaiu 5 miles south of Jarlison. Alabama (rane). IIototype-Cat. No. 65375, U.S.N.M.

PRoboscina ExIGUA, new species.

Plate 11S, tigs. $7-\fallingdotseq$.

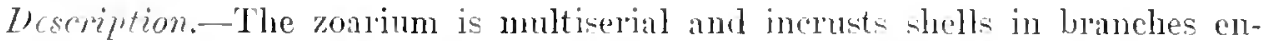
larged distally. The tubes are smatl. distinct. cylindrical, arranged in fuincunx or in transverse series. The peristome is thin orbicular. alient. The branehes are 
sometimes regularly rectilinear; they never commence with an isolated zooccium. The distance apart of the zooecia in quincunx is from 0.40 to $0.50 \mathrm{~mm}$.
Meusuriments.-
$\left\{\begin{array}{l}\text { Maxinum width of zoarium } \\ \text { Length of tube- } \\ \text { Dianeter of peristome....... }\end{array}\right.$ $1.6 \mathrm{~mm}$. $0.40-0.50 \mathrm{~mm}$. $0.10-0.12 \mathrm{~mm}$.

Affinities.-In the arrangement of its tubes and in the aspect of the zoarium, this species much resembles Proboseina colubra; it differs from it in its much smaller micrometric measurements.

Occurrence.-Upper Jacksonian (Ocala limestone): Chipola River east of Marianna, Jackson County, Florida (rare).

rotypes.-Cat. No. 65290, U.S.N.M.

PROBOSCINA RECTALINEA, new species.

Plate 152, figs. 3-7.

leseription.-The zoarium is multiserial and incrusts shells in linear branches. The tubes are little distinet, cylindrical, arrunged in quincunx, feebly striated transrersally. The peristome is thin, salient, orbicular, somewhat oblique.

$$
\text { Measurements.- }\left\{\begin{array}{l}
\text { Maximum width of zoarimm } \\
\text { Length of tube } \\
\text { Diameter of peristome }
\end{array}\right.
$$

Tariations. - The first branches are triserial; they never start with an isolated zooecium. The branches are directed in a straight line with remarkable regularity. The protoccium is orbicular and very small; its dianeter is $0.12 \mathrm{~mm}$.

Affinities.-The tubes are of the size of those of Proboscina exigua, but the present species differ's from it in its much more silient peristome, and in its zooecia arranged in more crowdel quincuns.

Occurrence.-Vicksburgian (Mariamma limestone): Salt Mountain, 5 miles south of Jackson, Alabama (rare).

Cotypes.-Cat. No. 65376 , U.S.N.M.

PROBOSCINA CONVENIENS, new spccies.

Plate 152, figs. $10-12$.

Description.-The zourum is multiscrial and incrusts shells; the branclues are irranged symmetrically on each side of the ancestrula; they have the form of an elongate palm leaf. The tubes are indistinet, arranged in regular quincunx. The peristonc in thick, salient, orbieular.

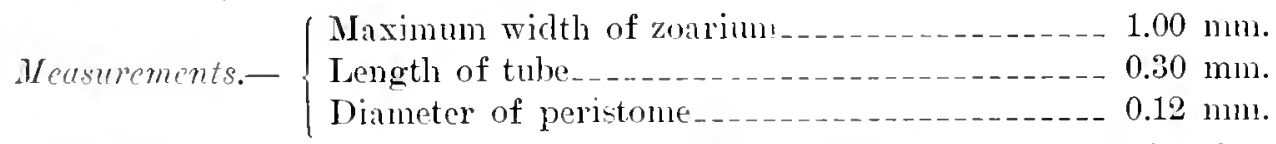

Affinities. -This species much resembles Diaperoecia clava, new species, but differ's in its much thicker peristome and in its micrometric measurements. We believe that the discovery of the ovicell of this species would classify it in Diaperoecia. 
Occurrence-Vicksburgian (Marianna limestone): Salt Mountain, j miles south of Jackson, Alabama (rare).

Cotypes.-Cat. No.65378, T.S.N.M.

proboscina Clavatiramosa, new species.

Ilate 153, figs. 1,2 .

Description.-The zoarium incrusts shells in multiserial clariform branches. The tubes are scarcely distinct, cylindrical, arranged in quincunx $0.36 \mathrm{~mm}$. apart. The peristome is thin, salient, orbicular.

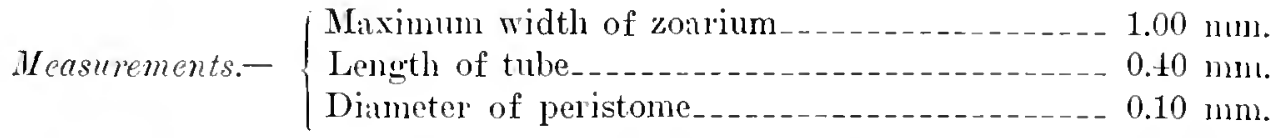

Affinities.-This species differs from Proboscina conveniens in its clariform branches, much narrowed at their base, and in the much more seattered arrangement of the peristomes.

Occurrence-Vicksburgian (Marianna limestone): Salt Momntain, 5 miles south of Jackson, Alabama (rare); near Claiborne, Monroe County, Alabama (rare).

IIolotype-Cat. No. 653379, U.S.N.M.

Proboscina LATOBREVIS, new species.

I'late 118 , figs. 10-12.

Description-The zoarium is biserial and incrusts shells and orbitoid foraminifer" in short and undulated branches. The tubes are distinct, wide and short, punctate, arranged alternately. The peristome is thin, salient orbicular, oblique. The branches conmence witls a very large zooecium.

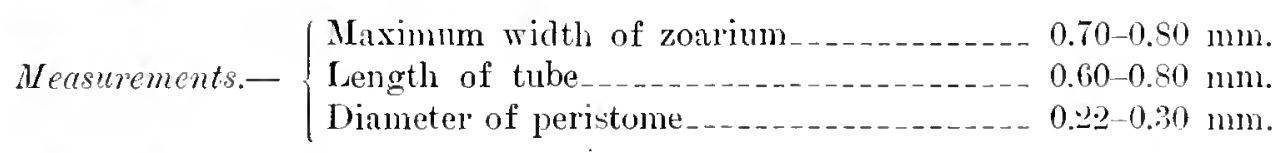

1 ariutions.-The tubes in the vicinity of the ancestrula have no constant micrometric measurements; the peristome increases gradually from $0.1 \pm$ to $0.22 \mathrm{~mm}$.; the length of the tubes grows from 0.50 to $0.70 \mathrm{~mm}$. Somotimes the branches are triserial; when two zooecia are adjacent their peristomes remain free.

The phenomenon of rejuvenation is rather rare. Here the branches connuence indeed in a single zooecium, but it is enormous when the ancestrula is very small.

Occurrence.-Upper Jacksonian (Ocala limestone): Old Fictory about 1 1, miles above Bainbridge, Georgia (rare).

Vicksburgian (II riamia limestone): Near Claiborne, Mouroe County, Mlabama (rare).

C'otypes-Cat. Nos. 65291, 65292, U.S.N.M. 
Plate 152, figs. 8, 9.

Description.-The zoarium incrusts shells in large, short, triserial claviform branches. The tubes are indistinct, lasge, short, arranged in quincuns or in transrerse rows. 'The peristome is very thick, orbicular, somewhat oblique. The zooecia are generally adjacent, two by two, but they are sometimes isolated.

We declicate this vigorous species to om friend. Mr. IV. E. Crane, who has collected many hryozon for us both in Europe and America.

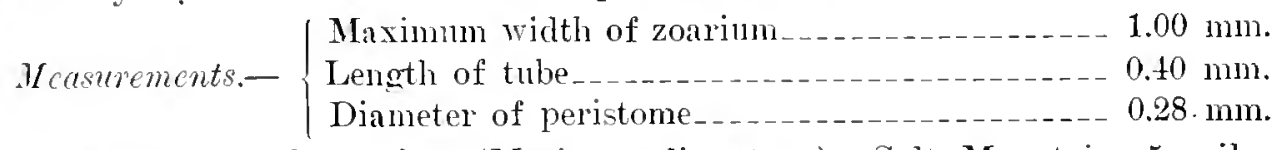

Occumence.-Vicksburgian (Mariamna limestonc): Salt Mountain, 5 miles sonth of Jackson, Alabama (very rare).

IIolotype.-Cat. No. 6537\%, U.S.N.M.

PROBOSCINA IDMONEOIDES, new species.

Plate 117, figs. 1-4.

Description. - The zoarium inclusts shells in rectilinear, multiserial branches. The tubes are distinct, cylindrical, arranged in divergent rows on each side of the zoarial axis. The peristome is thin, salient, elliptical, with a distal extremity often pointed; the peristomic is short, bent upward, oblique, directed toward the lateral margins of the zoarium. All the branches are not clearly idmoneiform. but the zooecia are always arranged in oblique rows. Evidently the peristomes are always free and wide spread.

1/easurements.- $\left\{\begin{array}{l}\text { Maximum width of zoarium_- } \\ \text { Length of tube } \\ \text { Diameter of peristone }\end{array}\right.$

Occurrence.-Upper Jacksonian (Ocala limestone): Old Factory about $1 \frac{1}{2}$ miles above Bainbridge, Georgia (rare); Red Bluff on Flint River, 7 miles above Bainbridge, Georgia (rare).

Cotypes.-Cat. No. 65293, U.S.X.M.

PROBOSCINA MAGNIRAMOSA, new speeies.

Flate $11^{\circ}$, firs. 6.7 .

Description.-The zoarium is multiscrial and incrusts Cellepores in undulated large branches. The tubes are little distinct, cylindrical, arranged in quincunx, rather regular and crowded. The peristome is orbicular. very oblique, thin: the peristomie is long and oblique.

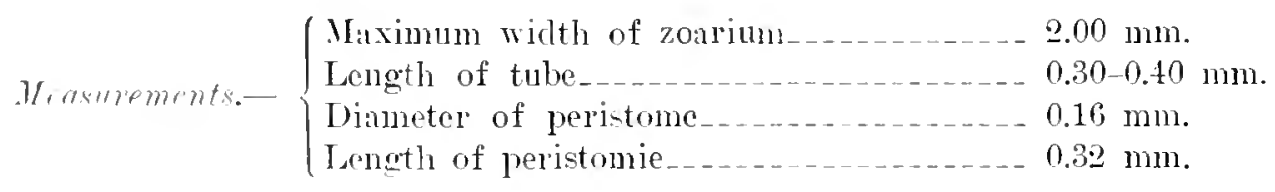


Fariations.-Our zourim is unfortunately incomplete. We can note, however. the great irregularity in the arrangement of the tubes; they are more seattered on one branch than on another; the length of their peristomie is quite variable; the separation of the peristones varies from one to two times. It is impossible to clearly characterize this species.

Occurrence.-Jacksonian (Zeuglodon zone): B]uff on soutl side of Suck Creek, Clarke County. Mississippi (very rare).

IIototype.Cat. No. 65295, U.S.N.M.

\section{Forma BERENICEA Lamouroux, 1821.}

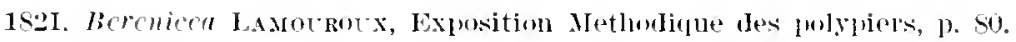

The zoarium is a thin, unilamellar, incrusting shect. It is generally orbicular. suborlicilar, or flabelliform.

Genotype.-Bereniced prominens Iamouronx, 1821.

liunge.-Ordovician-Recent.

Like Proboscina the ancient name Iierenicea is retained in a zoarial sense to include those species of lamellar incrusting Cyclostomata, showing no ovicell. As

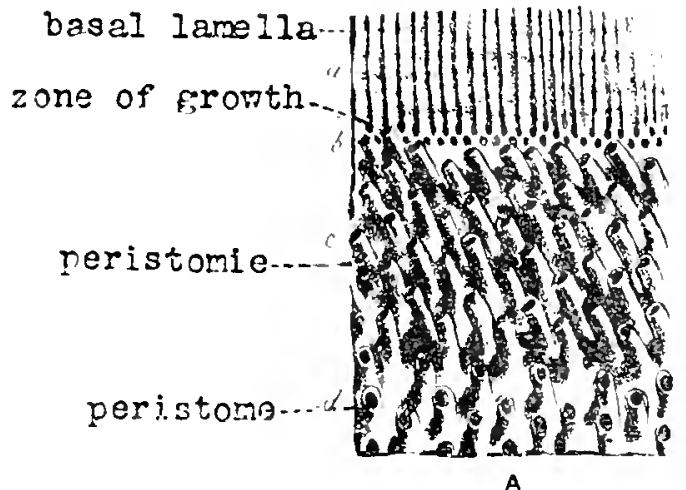

FIg. 216.-Forma Berenice I:amouronx, 1821.

A-C. Two species of Derenier showing the terminology employed in this and similar Cyclostomiati.

noted on subsequent pages, species of Bercnicea preserving ovicell are referred to several listinct genera and inleed families. A large number of species have the ovicell of Plagioecia, but other's belong to Oncousoccia, Mecynoccia, Microcciu, Diaperoecia, and Diplosolen.

BERENICEA PALMULA, new species.

Plate 105, figs. 5. 6.

I' seription.-The zoarium incrusts shells and is formed of flubelliform, bifurcated, short, pluriserial branches. The zone of growth is much reduced. The tubes are little distinct, oval, smooth, arranged in quincunx. The peristomie is short, 
oblique, or raised vertically. The peristome is thick, orbicular, somewhat oblique. The ancestrula is very small, with an orbicular protoecium.
Mcasurements.-
Diameter of the peristomes $0.12 \mathrm{~mm}$.
Distance between the peristomes $0.50 \mathrm{~mm}$. Scparation of the peristomes $0.44 \mathrm{~mm}$. Diameter of the zooccia $0.24-0.30 \mathrm{~mm}$.

The length of the tubes is extremely variable; it is even very difficult to find a place where the tubes are arranged in quincunx, permitting the exact measurement of their separation.

Occurrence-Midwayan (Clayton limestone): One mile west of Fort Gaines, Georgia (very rare).

Holotype.-Cat. No. 65251, U.S.N.M.

BERENICEA UNDATA, new species.

Ilate 105, fig, 12.

Description.-The zoarium is orbieular and incrusts shells; the zone of growth is thick, but very narrow. The tubes are cylindrical, little distinct, little crect at the extremity; ornamented witl small, overlapping wrinkles. The peristome is salient, thin, elliptical, elongate.

Measurements.- $\left\{\begin{array}{l}\text { Diameter of the peristome } \\ \text { Distance between the peristomes_-_-_-_- } 0.08-0.10 \mathrm{~mm} \text {. } \\ \text { Separation of the peristomes_-_- } 0.50 \mathrm{~mm} .\end{array}\right.$

Affinitics.-This species differs from Iiaperoecia rugosa, new species, in its much smaller and less salient overlapping undulations.

Occurrenee--Midwayan (Clayton limestone): Luverne, Crenshaw County, Alabaina (very rare).

Holotype.-Cat. No. 65253, U.S.N.M.

BERENICEA STIPATA, new species.

Plate 106, figs. 1-2.

Deseription.-The zoarium is irregularly orbieular; the zone of growth is very narrow and thick. The tubes are cylindrical, indistinet, erect at the extremity, much crowded against each other. The peristome is thin, orbicular, very oblique.

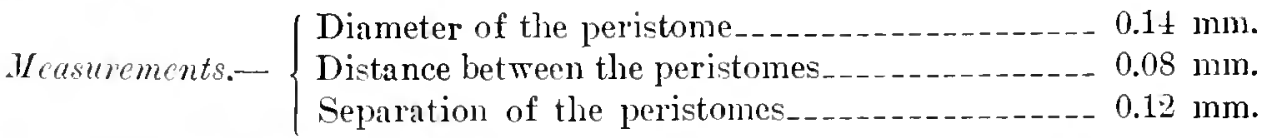

Ocmerches-Midwayan (Clayton limestone): Luverne, Crenshaw County, Alabama (very rare).

Holotype-Cat. No. 65419, U.S.N.M. 
BERENICEA BREVISSIMA, new species.

Plate 106, fig. 3.

Description.-The zoarium is orbicular and incrusts shells; the zone of growth is very narrow. The tubes are indistinct, very erect, quite short, pressed against each other. The peristome is thin, orbicular, oblique.

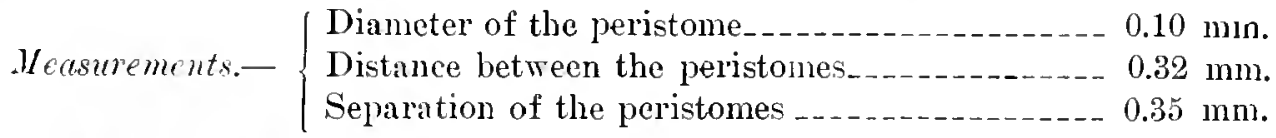

Occurrence-Midwayan (Clayton limestone): One mile west of Fort Gaines, Georgia (very rare).

Holotype.-Cat. No. 65420, U.S.N.M.

BERENICEA INGENS, new species.

Plate 11T, fig. 5 .

Icscription.--The zoarium is flabelliform and incrusts bryozoa. The tubes are very large, punctate and horn-shaped. The peristome is thin, orbicular or elliptical, salient.

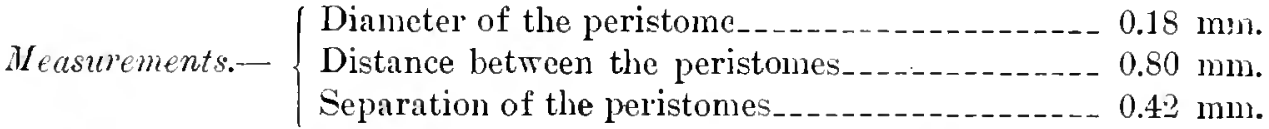

Occurence.-Lower Jacksonian: Three and one-half miles southeast of Shell Bluff post office, Georgia (very rare).

Ilolotype.-Cat. No. 65294, U.S.N.M.

BERENICEA BENJAMINI, new species.

Plite 117, figs. $\mathrm{S}, \boldsymbol{y}$.

Description.-The zoarium incrusts shells; it is orbicular or ir'regular; the zone of glowth is rery small. The tubes are distinet, cylindrical, scattered, striated transversally. The peristome is thin, salient, orbicular; the peristomic is much bent upward and erect.

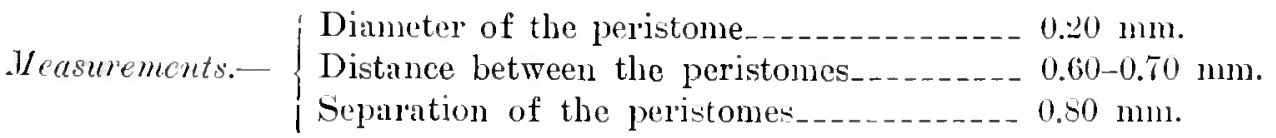

The specitic name is in honor of Dr. Marcus Benjaming of the United States Sational Museum, who has taken an interest in our work since its inception, and to whom we are indebted for many courtesies.

Uccurrenec.-Middle Jacksonian: Eutaw Springs, South Carolina (rare).

IIolotype.-C'at. No. 65296, U.S.N.M. 
Plate 121, figs. 10, 11.

Description.-The zoarium incrusts bryozoa; it is developed in wide dichotomons, irregular lokes. The tubes are distinct, cylindrical, arranged in quinemn. smooth. The peristome is thick, orbicular, or elliptical, little salient.

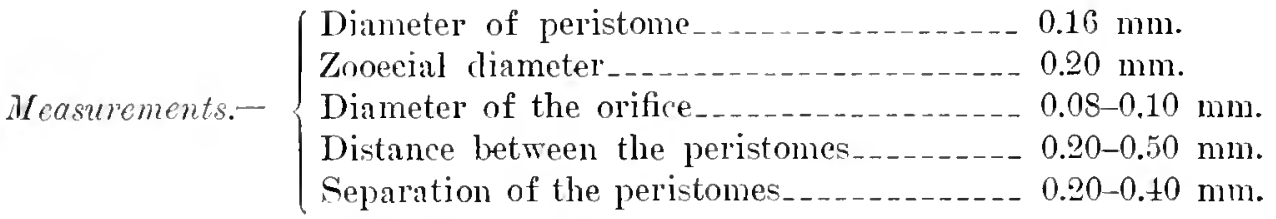

This species is possibly a Proboscina.

Occumence.-Middle Jacksonian: Rich Hill, $5 \frac{1}{2}$ miles southeast of Knoxville, Cram ford Comty, Georgia (rare).

IIolotype.Cat. No. 05301, U.S.N.M.
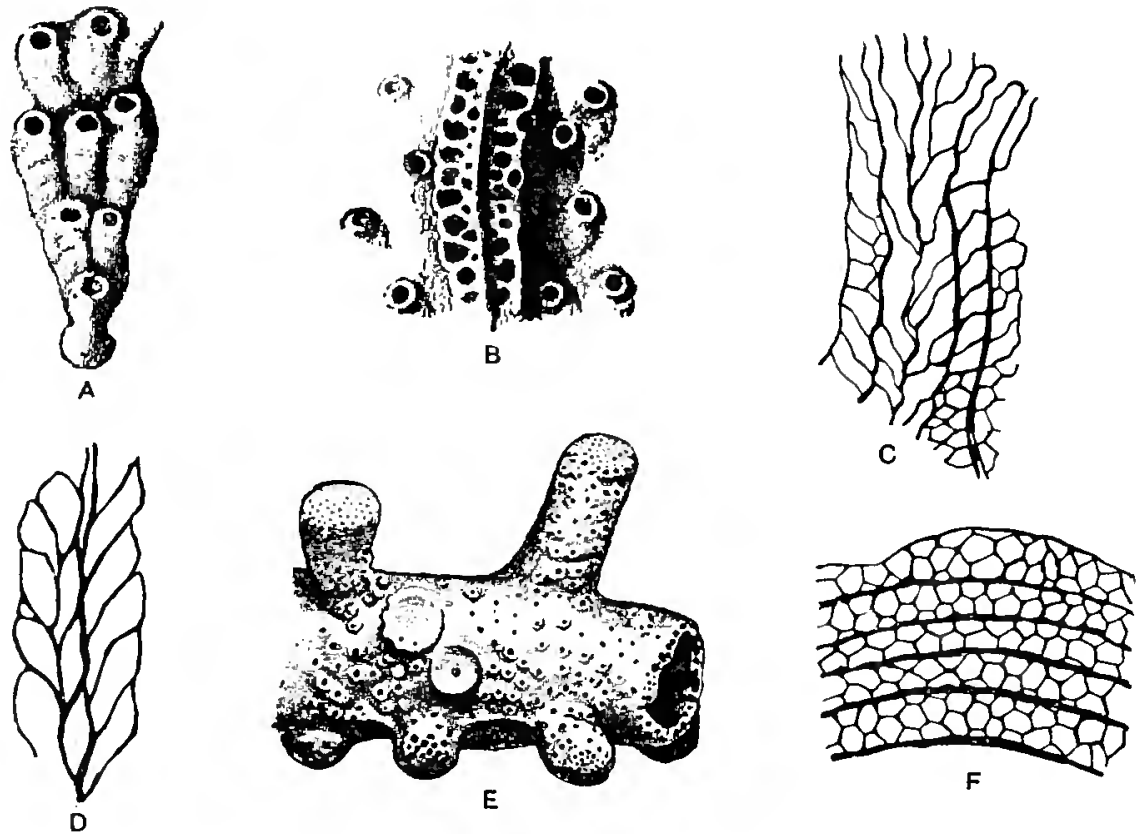

Fig. 217.--Forma Dirstopora Lamouroux, 1821.

A. 'The initial stomatoporoid cell of Diustopora davidsoni Haime, 1854, showing expansion to berenicoid condition. 3. Base of Diastopora datidsoni Ifaime, 185t, slowing basal berenicoid encrustation and erect frond. C. Section through frond of Diastopura lametlosa cervicomis Michelin, 1S46, to show multiple growth. D. Longitudinal section through a frond of Diastopora showing zoarial laminis. E. A Diastopora giving off shoots in the condition of Entalophora. F. Transverse section across part of a zoarium of Reptomultisparsa showing concentric layers. (Figs. A-F after Gregory, 1896.) 
Forma DIASTOPORA Lamouroux, 1821.

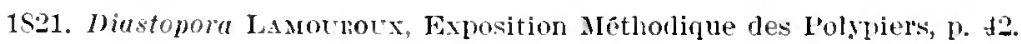

The zoarium is milaminar.

IIistorical.-Gregory, 1899 (p. 127), included in the genus Diastopora all the free forms, uni- or bi-laminar, branched or bushy. Even thus understood, this is not a natural gemus, because the ovicell is of a quite varied form and nature. Under these conditions we believe it necessary to recognize the zoarial forms in the exact sense of their anthors. The discovery of their ovicells will later permit the classification of the species. According to D'Orbigny, Diastopora is unilamellar, Bidiastopora is bilamellar and branched, and Mesentiripora is lobate, bushy, and meandriform.

DIASTOPORA TUBAEDES, new species.

Plate 106, figs. 4, 5.

Description.-The zoarium incrusts small branched algae; it is cylindrical, tubular, branched; the zone of growth is very small. The tubes are cylindrical, arranged in regular quincunx, straight, and never bent upward. The peristome is thin, orbicular, oblique; the peristomie is salient, rectilinear.

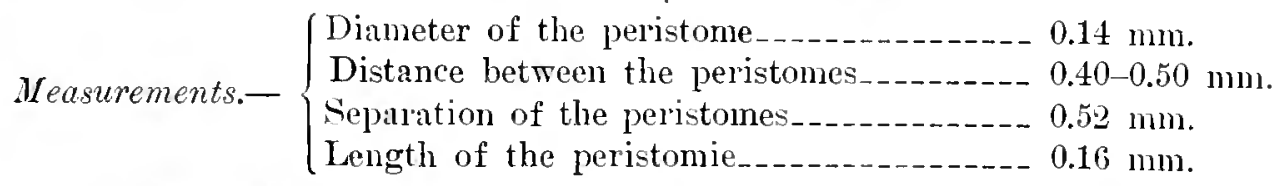

Occurrence.-Midwayan (Clayton limestone): Luverne, Crenshaw County, Alabama (very raje).

IIolotype.-Cat. No. 65421, U.S.N.M.

DIASTOPORA TUBIFORMIS, new species.

Plate 121, fig. S.

Description.-The zoarium incrusts the delicate branched radicells of aldae; it is hollow, cylindrical, branched; the zone of growth is rather wide. 'Ilhe tubes are distinct, crlindrical, somewhat bent llpward, striated transversally. The peris. tome is elliptical, thin, a little salient, often closed by an entire smooth lamella. There is no peristomie.

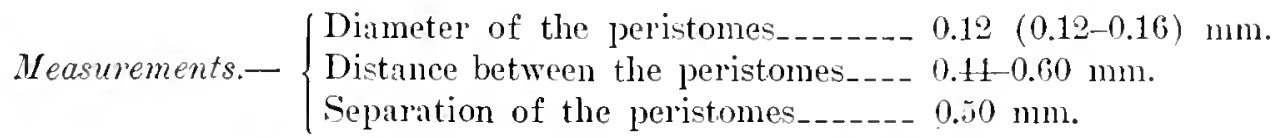

Occurrence.-Middle Jacksonian: Near Lenuds Ferry, South Carolina (rare).

IIolotype.-Cat. No. 65299, U.S.N.M.

$55899-20-$ Bull. $106-43$ 
Plate 121, fig. 9.

Description.- The zoarium is formed of wide, expanded fronds. The tubes are indistinct at their base, cylindrical at their extremity, arranged in widespread quincmux, garnished with small thin and scattered striations. The peristome is thin, orbicular, oblique, or elliptical when it is horizontal; the peristomie is salient. oblique, erect. The basal lamella is smooth.

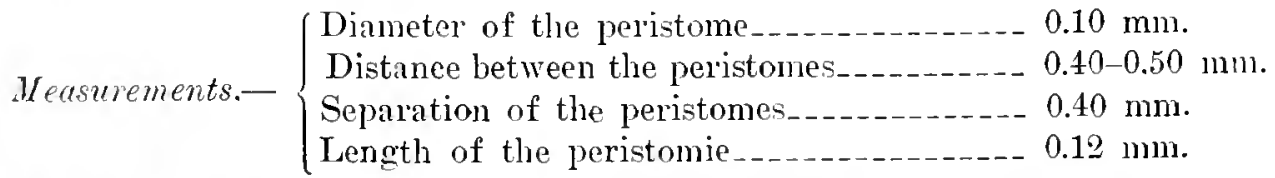

Affinitics. - This species differs from Diaperoeria moga, new species, by the
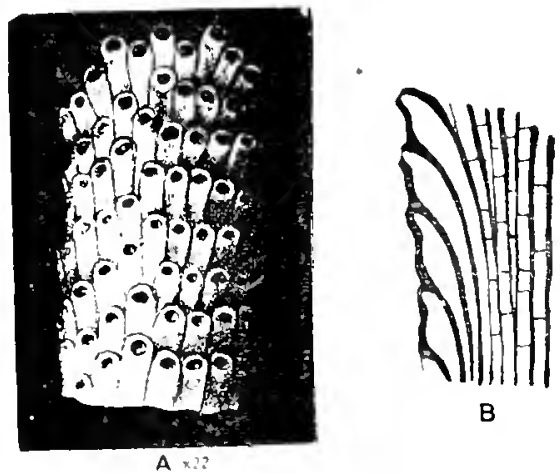

Fia. 218.--Forma Spiropora Lamouroux, 1821.

A. Zoarium, of Spiropora tetregone Lamouroux, 1821. B. Iongitudinal sectiou, through half of zoarium of spropore richmondensis vine, 1 sst. (Aftel Gregory, 1896.) transver'se, little salient wrinkles and a lesser zooecial length.

Occurrence.--Upper Jacksonian (Ocala limestone) : Chipola River, east of Marianna, Jackson County, Florida (very rare).

Middle Jacksonian: Seventeen miles northeast of IIawkinsville, Georgia (rare).

Holotype-Cat. No. 65300, U.S.N.M.

DIASTOPORA MAGNIPORA, new species.

Plate 153, figs. 3, 4.

Description.-The zoarium is formed of a unilamellar and flabellate frond. The tubes are enormous, ride. oval. distinet at their base, somewhat uprard bent. The peristome is rely thick, orbicular, or elliptical, very salient; the peristomie is short, raised to $45^{\circ}$.

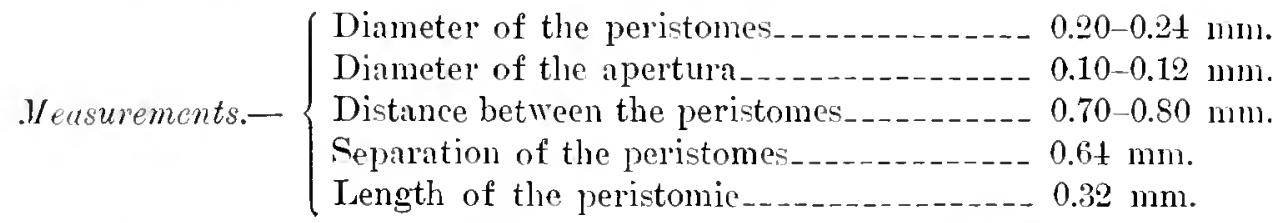

Oreumener.-Vicksburgian (Marianna limestone): Salt Momntain. 5 miles south of . Tackon, Alabama (very lave).

Hototype.Cat. No. 6.3380. U.S.N.M.

Forma SPIROPORA Lamouroux, 1821.

1821. Spiropora Lxmotrotx, Exposition Nethodique des Polypiers, p. 47.

The apertures of the zooecia open in regular annular or spiral lines. 'The zooecin are regularly cylindrical. 
Genotype.-Spiropora elegans Lamouroux, 1821.

The ovicell of spiropore has never been found, in spite of the large number of specimens collected. It is probable that it does not exist and that the larra is developed in a small distal sack of an ordinary tube. An important character is the presence of diaphragns in the tubes at different heights.

SPIROPORA MAJUSCULA, new species.

Plate 128, figs. S-13.

Description.-The zoarim is formed of very large, cylindrical and dichotomous branches. The tubes are distinct. flat, separated by a salient threacl. The fascicles form annular, salient. regular verticells, broken and incomplete at the bifurcations.

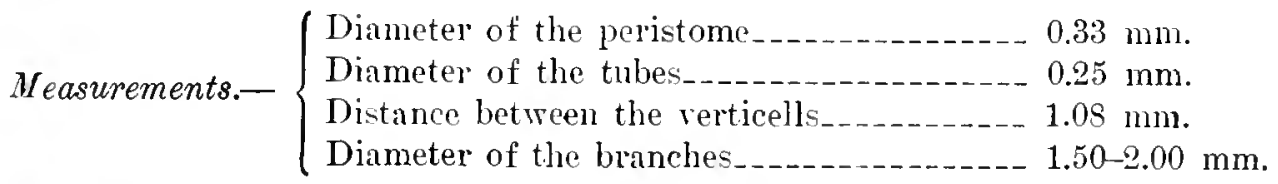

Affinities. - This is the largest species of spiropore known. Its regularity is rather remarkable. In longitudinal section the diaplinagms appear not only at the base of the tubes, but at different heights; they are scattered or close together. In transversal section the zooecia are separated by a clear line, the calcification of the tubes being more intense in the interior.

Occurrence.-Middle Jacksonian: Nealr Lenuds Ferry, South Carolina (very common): Eutaw Springs. South Carolina (common).

Cotypes.Cat. No. 6582.2. U.S.X.M.

(b) TREPOSTOMATOUS LIKE CYCLOSTOMATA.

Family HETEROPORIDAE Pergens and Meunier, 1886.

1856. P'Ergexs and Meunier, La faune des Iirgozoaires garumniens de Fare, Annales de lat Société Rursale malacolngique de Relqique, vol. 21, 1. 223.

No oricell. The tubes are cylindrical.

Historicul.- We here reunite in the sime family the species grouped formerly under the two rell-known families-Heteroporidae and Cerioporidae. We now know that the presence of mesopores is not a family character. The family Cerioporidae not having been created until 1594 by Ilemnig. priority is secured by the family of I'ergens and Meunier.

Onganization. - All the known anatonical features have been summarized in figure 219 ; they are of little importance. They show us, however, that the parietal resicles do not contain any special organ and do not constitute a character of classification of great value. We know (see General Consideration. on page 63t) that the tubes are not exactly adjacent: they are separated (according to ('alvet) by the 


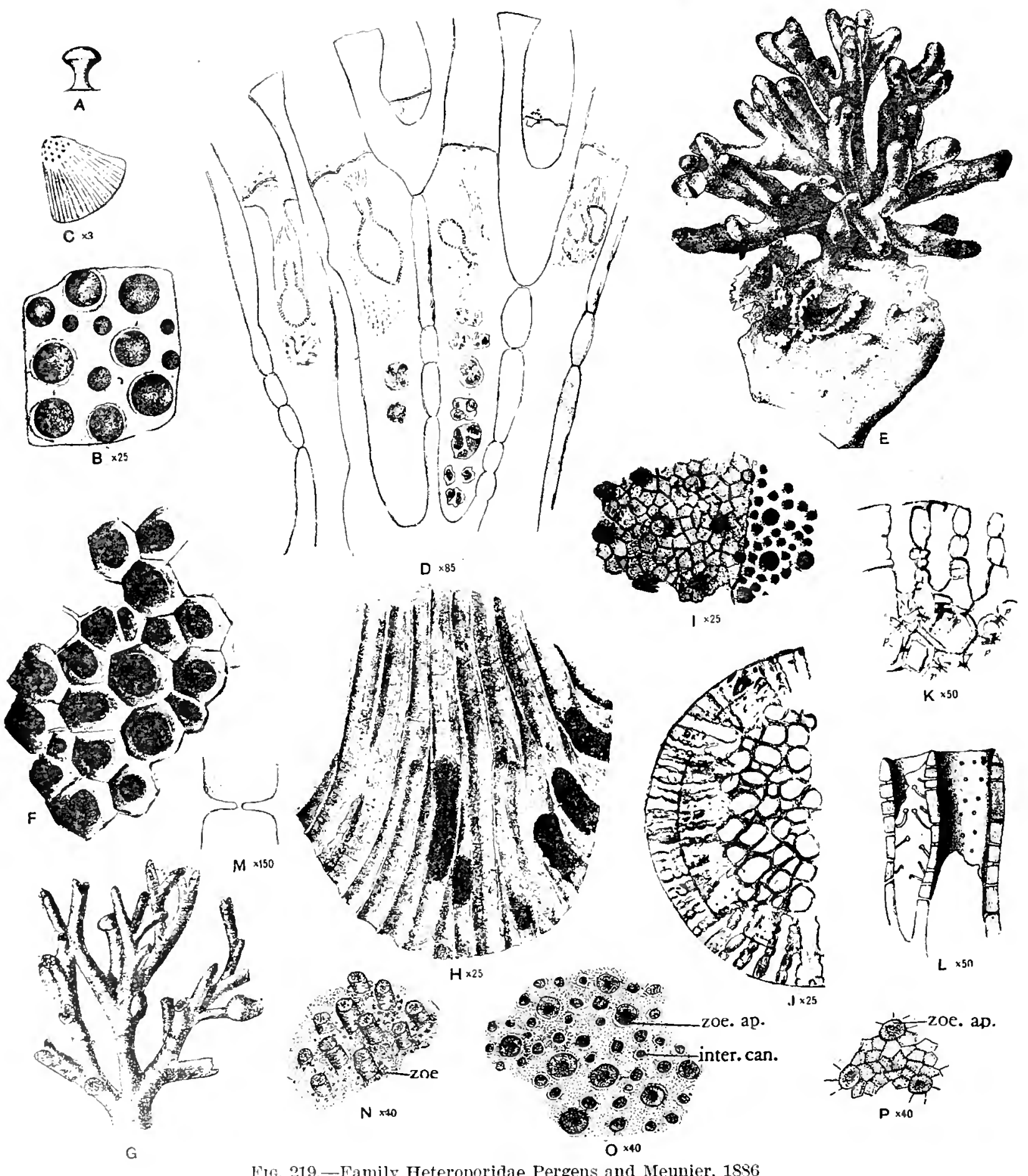

Frg. 219.-Family Heteroporidae Pergens and Meunier, 1886 
Fio. 219.-Family Heteroporidac Pergens and Ieunier, 188 ;

A-D. Heteropora claviformis Waters, 1904. A. Zoarium, natural size. F. Portion of a surface, $\times 25$. C. A broken colony, $\times 3$, showing the transverse section. $D$. Longitudinal decalcified section, $X 85$, showing closures traversed by the mesenchyme and the vesicular wall. Histolysis had commenced. (After Waters, 1904.)

E-F. Heteropora neozelanica Busk, 1879. E. Zoarium, natural size. F. Portion of the sirface, enlarged. (After Busk, 1879.)

G-P. Hetcropora pelliculata Waters, 1879. G. Zoarium, natural size. H. Longitudinal section, $\times 25$, drawn with the growing end downward. I. Surface, $\times 25$, with portion to right showing thin covering removed. J. Transverse section, $X 25$. $K$. Portion of the transverse section, $\times$ 50. (G-K after Waters, 1879.) L. Section showing the interzooecial pores and the hairlike spines, $\times 50$. M. Interzooecial pores, $\times 150$. (L, M after Waters, 1Ss4.) N. Portion of the surface of a colony, $X 40$, showing the projection of the zooecial tubes beyond the surface ( $z o e)$ when in a sheltered positiun. O. Fortion of the surface of a branch $\times 40$, showing the zooecial apertures (zoc. ap.) and the apertures of the interstitial canals (mesopores) (inter. can.). P. Portion of the surface of a colony, $X 40$, in which the interstitial canals are covered by a delicate calcareous layor. The zooecial apertures only are visible (zoc. ap.). (N-P after Robertson, 1910.) 
membraneous ectocrst, the disappearance of which leaves a clear line as seen in thin sections. The vesicles are formed by contractions of this ectocyst in front of the communieation pores. We know also, according to Calvet, that in the general carity of each polypide a large group of leucocytes are placed in proximity to each of these pores.

Classification.-We have adopted the classification of Gregory, 1909, because at present it is impossible to do otherwise. It is evident that many of our species will have to be changed to other families, if, as we suppose, the discovery of their oricell is possible.

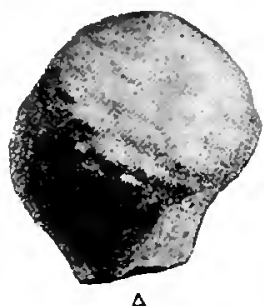

A

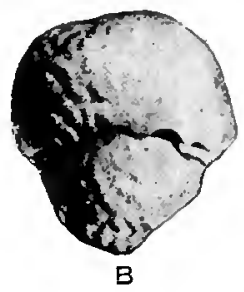

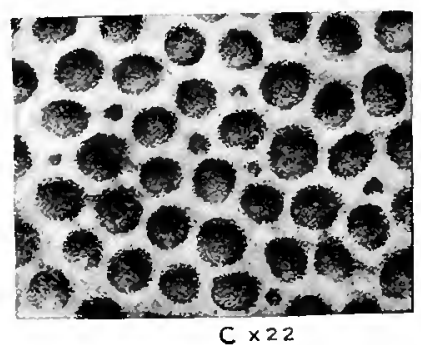

C $\times 22$

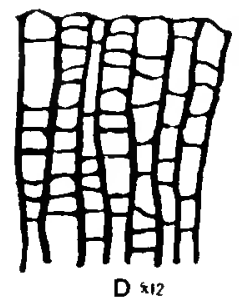

D $\$ 12$

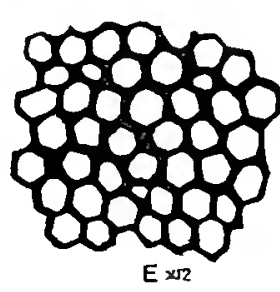

FIg. 220.-Furma Ceriopora Golufuss, 1827.

A-I. Ceriopora globosa Michelin, 1816. A, r. Zoarium natura size. (After Michelin, 1S46.) G. Iortion of the surface, $\times 22$. D. Iongitudinal section through marginal zonecia, showing diaphrasms, $\times$ 12. W. Transverse section through central zooceia, $X$ 12. (C-E after Gregory, 1S90.)

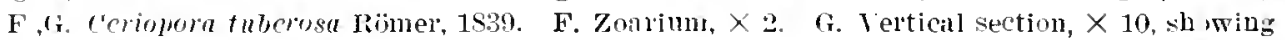
vesiculal wall. (After Gregory, 1909.)

Genus CERIOPORA Goldfuss, 1827.

1827. Cerioporn Gobntss, Petrefacta Germaniale, Abbildungen und Feschreibungen del' Petrefacten Deutschlands und der angrenzenden Länder, Diisseldorf, vol, 1, p. 33.

The tubes are prismatic or subcylindrical. No mesopores. The diaphragms are numerous and horizontal. The zoarium is massive or branched.

Genotype.-Ceriopore micropora Goldfuss, 1827.

Runge.-Triassic-Miocene.

The tubes are brancher at all heights. Externally they are not all of the sime diameter" the smaller are not mesopores, but are rudimentary zooecia, which are developel superiorly. Many successive polypides occupy, in fact, the same tube. 
Ceriopora micropora Goldfuss, 1827, has been identified by Ulrich in the Eocene of Maryland, but the single specimen found is not sufficient for a detailed study.

CERIOPORA VESICULOSA, new species.

Plate 111, figs. 5-10.

The zoarium is massive and subelliptical. The orifices are polygonal ond are $0.10 \mathrm{~mm}$. in width at the maximum. The walls of the tubes are resicular. Diaphragms are rare. There are many concentric lines of large vesicles.

Affinities. - The concentric lines of large vesicles give this species, in longitudinal sections, the aspect of Reptomulticava. However, there is no real separation between the successive layers apparent and there are no superposed subcolonies.

Occurvence.--Midwayan (Clayton limestone): Mabelvale, near Isittle Rock, Arkansas (rare): Luverne, Crenshaw County, Alabama (rery rare); 1 mile west of Fort Gaines, Georgia (common).

Holotype.-Cat. No. 65255, U.S.N.M.

CERIOPORA ALDRICHI, new species.

Plate 151, figs. 11-17.

Description.-The zoarium incrusts small cylindrical bodies, rootlets, small algae or branching bryozoa; it is hollow or solid. The walls of the cylindrical tubes are vesicular only at their extremity. The orifices are polygonal and measure $0.14-0.16 \mathrm{~mm}$. in width.

This interesting and abundant species is named in honor of $\mathrm{Mr}$. T. H. Aldrich, of Birmingham, Alabama, in recognition of his work upon the Tertiary paleon. tology of the United States.

Occurrence.-Middle Jacksonian (Castle Hayne limestone): IVilmington North Carolina (common).

- Cotypes.-Cat. No. 65370, U.S.N.M.

CERIOPORA (?) PROPOSITA, new species.

Plate 151, figs. $7-10$.

Description.-The zoarium is spread out in irregular masses, much compressed, nonglobular, with the lower face covered by a striated epitheca. The orifices are polygonal and measure $0.12 \mathrm{~mm}$. at the maximum. The walls of the tubes are irregularly resicular. There are many concentric lines of large vesicles.

Affinities.--The species, in longitudinal sections, somewhat resembles Ceriopora v'ericulosa in its concentric lines of large vesicles, but differs from it in its expanderl. nonmassive, and nonglobular zoarium.

Occurrence.-Middle Jacksonian: Three and one-fourth miles south of Perry, Georgia (common).

IIolotype-Cat. No. 65369, U.S.N.M. 
Genus REPTOMULTICAVA D'Orbigny, 1852.

1852. Reptomulticava. DORbians, Paléntologie frangaise, descriptions des animaux invertébìs, Terrain crétacé, vol. 5, p. 1032.

The zoarium is multilamellar, branched or massive. The zooecia are short and expand rapidly.

Genotype.-Reptomulticava heteropora Römer, 1839.

liange.-Neacomian, Miocene.
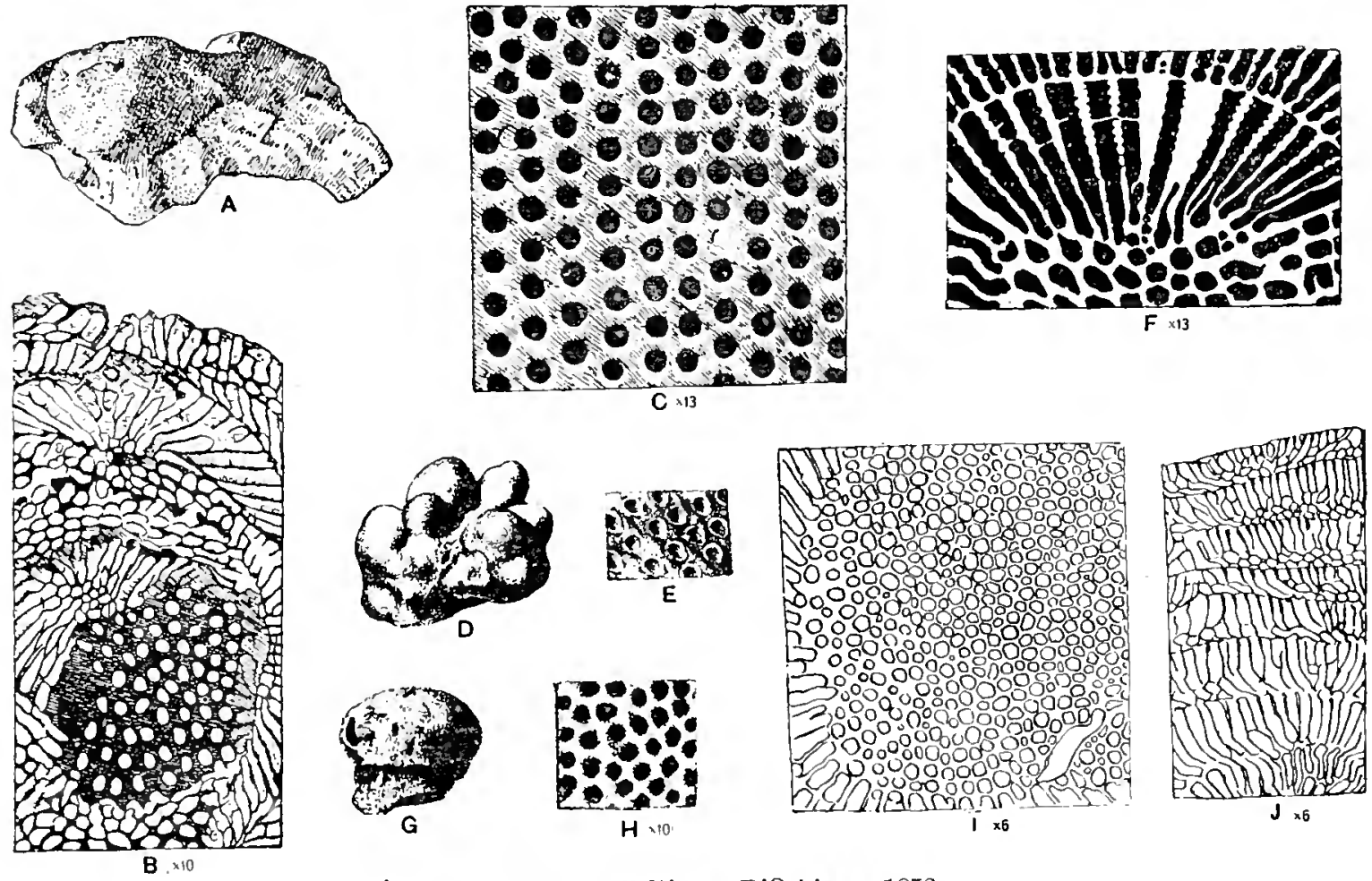

FIG. 221.-Folma Reptomulticava D'Orbigny, 1952.

A-C. Rcptomulticava hetcropora Römer, 1899. A. Zoarium, natural size, from the Neocomian of Germany. B. Section showing the multilamellar structure, $\times 10$. C. Fortion of the surface, $\times 13$.

D, E, F. Rcptomulticava lobosa Keeping, 1Ss3. D, F. Zoarium, natural size, and portion of the surface enlarged, from the Lower Greensand of England. (After Keeping, 1Ss3.) F. A vertical section across part of a zoarjum, $\times 13$.

(i-J. Reptomulticava fungiformis Gregory, 1909. G. Zoarium, natural size, from the Lower Greensand of England. H. Portion of the surface, $X$ 10. I. Transverse section across a zon rium, $\times 6$. J. Vertical section across the same zoarium, $X 6$. (A-C, F-J, after Gregory, 1909.)

Genus DEFRANCIOPORA Hamm, 1881.

18s1. Defranciopora HAMM, Die Bryozoen des Maastrichter Ober-Senon. Part 1, Die Cyelnstomen Bryozocn, Berlin, p. 39.

"The zoarium is formed of sereral saucer-shaped or discoid subcolonies in a rertical series. The apertures cover the upper, outer rim of the subcolonies; the lower exposed surface of each subcolony is covered by a calcareous layer (epizo- 
arium). The zooecia on the upper surface are radially arranged around a central area of crowded apertures." (Gregory, 1909.)

Genotype.-Defianciopora (Defrancia) cochloidea Hagenow, 1851. Maastrichtian.

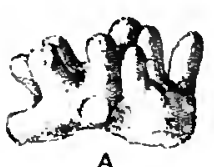

A

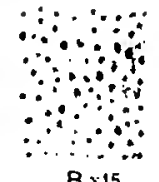

$8 \times 15$

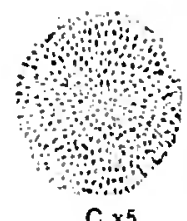

C $\times 5$

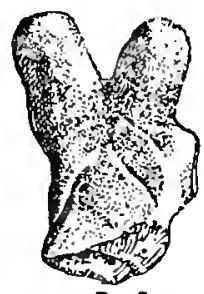

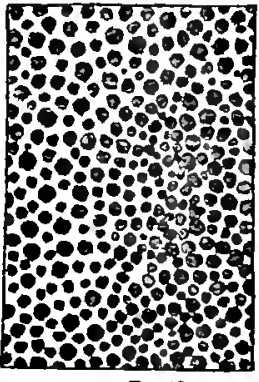

$\mathrm{E} \times 13$

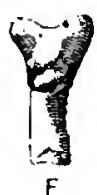

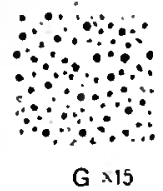

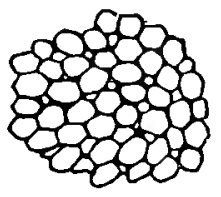

$\mathrm{H} \times 12$

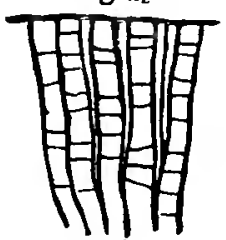

$1 \times 12$

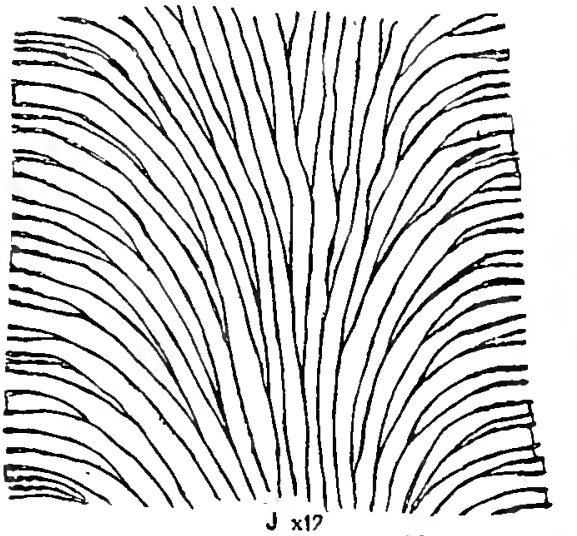

Hic. 222.-Forma Heteropora de Blainville, 1830.

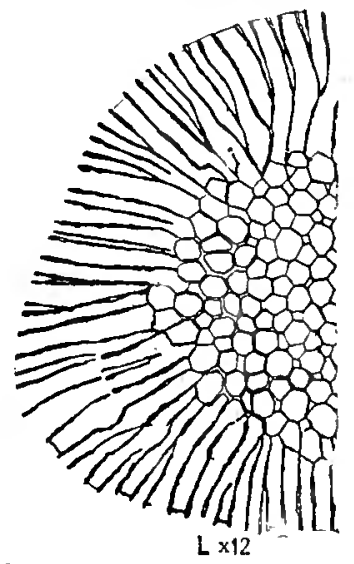

A-(i. Iletcropora cryptopora Goldfuss, 1827. A. Zoarium, natural size. B, C. Portion of

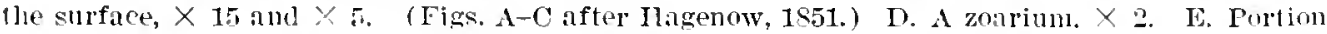
of the surface of the same zan rium, $X 13$. (Figs. D, E after Gregory, 1909.)

F. G. Zoarium of Heteropora cryptopora var. tenera Hagenow, 1851, and surface, $X 15$. (After Hagrenow, 1851.)

H, I. Hcteropora conifera Lamouroux, 1821. H. Transierse section through central zooccia, $\times$ 12. I. Longitudinal section through marginal zooecia, $X$ 12, showing diaphragnes and mesopores. (After Gregory, 1SO6.)

J. K. L. Heteropora pelliculata Waters, 1879. Longitudinal, tangential, and transverse thin section.

Genus HETEROPORA Blainville, 1830.

1930. Heteropora DE Butwillte, Dictionnaire des Sciences naturilles, rol. 60, p. 391.

The tubes are cylindrical and long. Mesopores are present. 'The zoarium is massive or branched.

Genotype.-IIcteropura (Ceriopora) cryptopora, Goldfuss, 1827.

Range.--Neocomian-Rerent. 
Plate 104, figs. 14-20.

1901. Ineteropora ? tedu Lumicr, Maryland Geological survey, Eocene, p. 210, pl. 69, tixs. 15,16 .

Inescription.-The zoarium is subcylindrical, solid or hollow. The orifices are orbicular and measule $0.10 \mathrm{~mm}$. in diameter. The mesopores are polygonal, wide open, as large as the tubes. The tubes have vesicular walls at their extremity.

The small number of specimens found does not permit a more complete study. The various aspects of this species are shown in Ulrich's figures, which we produce, and in our new illustrations.

Occurrener-Iowest Eocene (Bryozoan bed at base of Aquia formation): Tpper Marlboro, Maryland (rare).

Plesiotype.-Cat. No. $65+58$, U.S.N.M.

HETEROPORA ALVEOLATA, new species.

Plate 111, figs. 1-4.

Description.-The zoarium is massive and gives forth eylindrical branches. The apertura is large, hexagonal, and measures $0.16 \mathrm{~mm}$. in diameter. The mesopores are irregular, polygonal, and are often closed by a calcareous pelliele. In sections, the tubes are cylindrical, traversed by diaplurams which become very numerous at their extremity in the region of the mesopores; the walls are quite thick and are formed of a continuous series of rely large vesieles. The mesopores are long and have diaphragms.

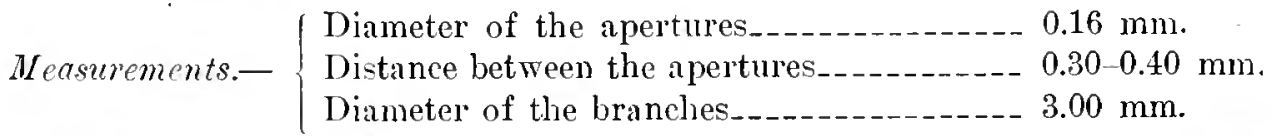

Affinities.-The diapluragms are so numerous that they give to the longitudinal section an alseolil aspect absolutely characteristic and very peculiar. Howerer, such a structure is not rare in the Paleozoic formations. The section does not al ways cut exactly across the mesopore; when it cuts only through the wall it rereals a complicated structure resulting from the coalescence of the sectioned resicles.

- This species differs from Meteropora oratis in the form of its aperture and in the great number of its diaphragms.

Occurrence.-Midwayan (Clayton limestone): Mabelvale, near Little Rock, Arkansas (rare).

IIototype.Cat. No. 65254, U.S.N.M.

HETEROPORA OVALIS, new species.

Plate 150, figs. 1-6.

Description.-The zuarium is free, branched, arborescent or dichotomous; the branches are eylindrical. The apertures are somewhat ocal, slightly salient, and 
measure $0.10 \mathrm{~mm}$. in diameter. The mesopores are numerous and polygonal. In sections the tubes are eylindrical. the walls are not resicular. The mesopores are short. regular and parietal.

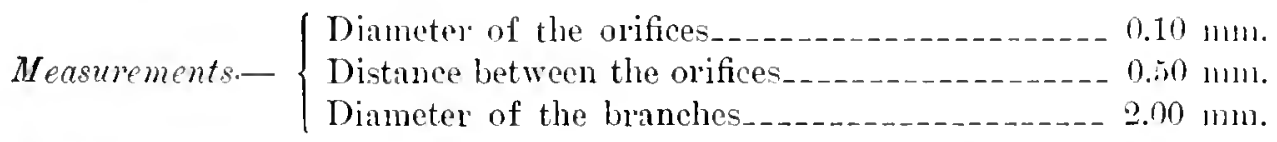

Aftinitirs. - This is a rery disconcerting species. The tubes are cylindrical and yet the walls are not vesicular; they are simply separated by a sort of small canal resulting from the disappearance of the ectocyst; this is the habitual arrangement of the club-shaped tubes. The zoarial walls are regular as in the zoarial form Petalopora, and sometimes lamellar (in transverse section) as in IIomera. The mesopores are regular, parictal as in the forms Petalopora and sparsicarea. which also have the club-shaped tubes.

This mingling of peculiar characters of the different families appears to indicate that this species must be ovicelled. [ufortmutely we have not found many specimens of it.

This species differs from Parascosoncin consimitis Ulrich, 1882, in a greater diameter of the orifice $(0.10$ and not $0.08 \mathrm{~mm}$.) in its solid and never hollow branches, in its much less numerous and shorter mesopores, and in its cylindrical tubes.

It differs from Parlciosoecia jachsomica, in which the extcrior aspect is ilentical, in its solid branches, its much shorter mesopores, and its cylindrical tubes.

Although very close to Heteropora subreticulata Reuss, 1869 , it differs from it in the exterior aspect of the mesopores, which, howerer. do not conform to the published figures.

Occurrence.-Lower Jacksonian (Moodys marl) : Jackson, Mississippi (rare).

Middle Jacksonian: Three and one-half miles north of Grovania, Georgia. (rare) ; one-half mile southeast of Georgia Koalin Company's Mine, Twiggs Connty, Georgia (rare).

Cotypes.-Cat. No. 6537 I, U.S.N.M.

Heteropora AMOENA De Gregorio, 1890.

Plate 113, figs. 16-1S.

1890. Entalophora amoena DE Gregorio, Monographie de la Faune Eocenique de l'Alabama et surtout de celle de Claiborne de l'étage Parisien, Amales de Géologie et de Paléontologie, livr. 8, 1). 240, 1). 39, fig. 21.

Description.-The zoarium is free, subcylindrical, hollow, ornamented with large lateral and alternate apophyses, forming pseudobranches. 'The orifices are orbicular, widely spaced, and measure $0.10 \mathrm{~mm}$. in diameter. The mesopores are numerous, irregular, polygonal. The tubes are cylindrical.

Affinities. - We believe that this species is Entalophora amoena de Gregorio. 1890, for it has the same lateral apophyses and the same cellular surface. To be 
certain of the determination the originals should be examined, but this has not been possible.

This species differs from Heteropora ovalis in its orbicular orifices and in its zoarial apophyses.

Occumence.-Clabornian (Gosport sand): One mile southrest of Rockville, Clarlie County, Alabama (rare).

Lower Jacksonian (Moodys marl) : Jackson, Mississippi (very rare).

Plesiotype.-Cat. No. 65433, U.S.N.M.
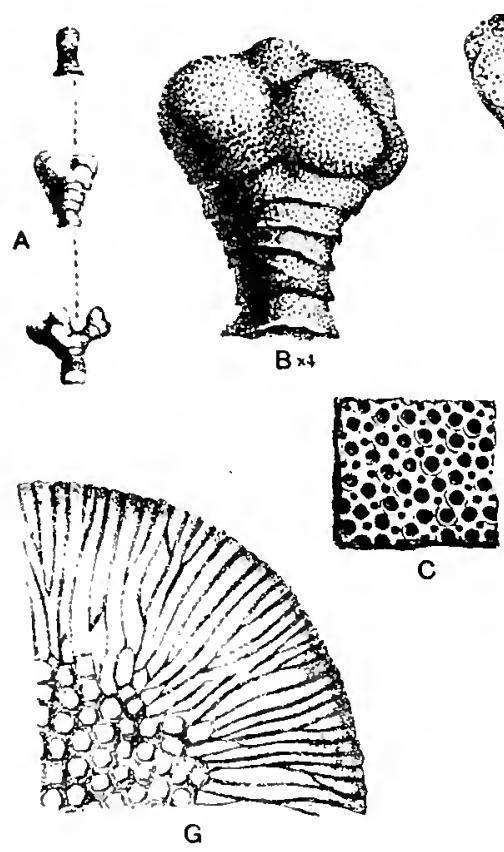

Fig. 223.-Forna Wulticrescis J'Orbigny, 1852.
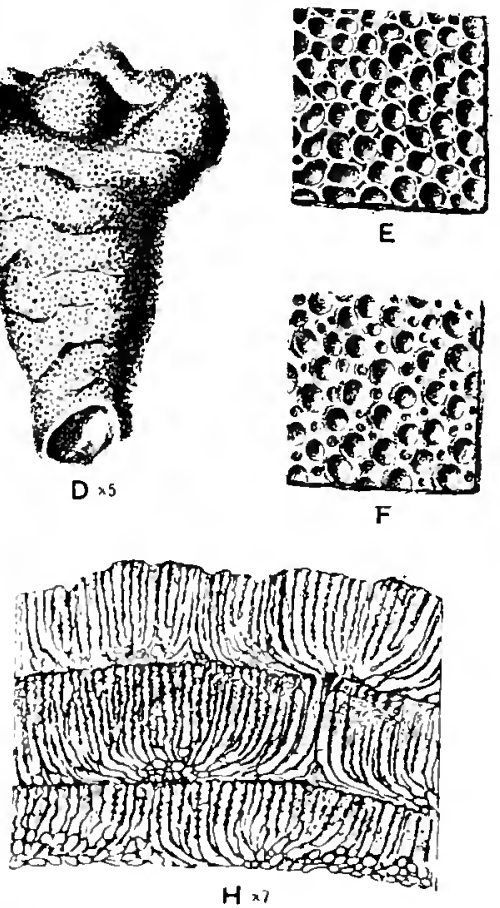

$H \times 7$

A-G. Multicrescis variabilis Dorbigny, 1852. A. Different forms of the zoarium, natural size. B. A zoarimu, $X 4$, showing the superposed layers of tubes, C. Portion of the surface much enlarserl. (A-C after Novak, 1S77.) D. A claviform zoalium, $\times 5$. E, F. Two aspects of the surface enlarged, showing the zooecia varying in size according to that of the mesopores. G. Portion of transverse section through a zonrium. (D-c after D'Orbigny, 1552.)

H. Multicreseis tubcrosa Römer, 1839. Part of vertical section, $X 7$, showing the beginning "of an upler layer. (After Gregory, 1909.)

\section{Genus MULTICRESCIS D’Orbigny, 1852.}

1952. Multicrescis DORBgny, Paléontologie frägraise, Description des animaux invertébrés, Terrain Crétacé, vol. 5, p. 1073.

The zoarinm is massive or branched and composed of snecessive thin layers of zonecia.

Genotype.-Multicrescis variabilis D'Orbigny, 185.9.

Range.-Neocomian-IJelvetian. 
Genus FUNGELLA Hagenow, 1851.

1S51. Fungella Hagenow, Die Bryozoen der Maastrichter Kreidebildung Cassel, p. 37.

The zoarium is simple and capitate. The peduncle is narrow, the head usually club-sha ped.

Genotype.-Fungella dujardini Hagenow; 1851. Maastrichtian.
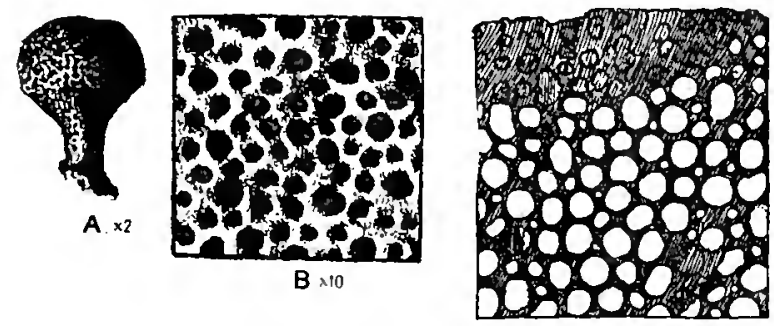

C

Fig. 224.- (ienus I'ungella Hagenow, 1851.

A-C. Fungella dnjardini Hagenow, 1851. A. Side view of zoarium, $X 2$, from the Cretaceous at Maastricht, Holland. B. Upper surface, $\times 10$. C. Horizontal section, $X 10$.

Genus Biflabellaria Pergens, 1894.

1594. Biflabellaria Pergens, Noureaux Bryozoaires du Crétacé du Limbourg, Bulletin de la société Lelge de Geologie, vol. 7, p. 172.

The zoarium is flabelliform, and consists of two layers on a median lamella. Genotype.-Biflabelleric apathyi Pergens, 1894. Maastrichtian.
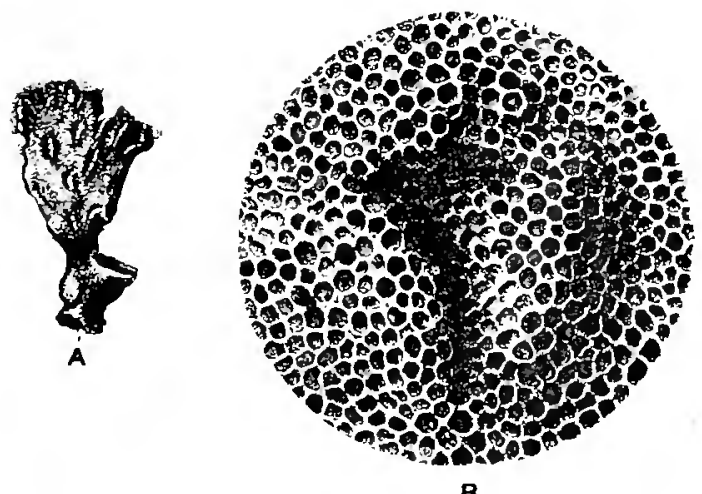

FIG. 225.-Genus Biflubcllaria Pergens, 1894.

The llabelliform \%orium nalural size and surface, $\times 17$, of Biflubcllaria aluthli ['elgens, 1894, from the Mastrichtian of IIoland. (After Pelrens, 1s!4.) 


\section{Division OVICELLATA.}

The majority of species of American Tejtiary Cyclostomata are provided with oricells and therefore belong to the division of the Oricellata. Waters has proposed the two subdivisions Parallelata and Rectangulata, which we have found valuable in classification. The following key is introduced for the determination of the families considered in this rolume:

KEY FOR THE DETERHINATION OF THE FAMIIIES OF OVICLLLATA.

1. The axis of the ovicell is perpendicular to the zooecial axis__._....... lo (Rectangulata).

[The axis of the ovicell is parille] to the zooecial axis. 2 (Parallelata).

l'ine tules adjacent to the ovicell are not disarranged

3.

2 . The tubes adjcent to the ovicell a de disadranged. The ovicell is formed

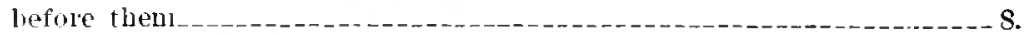

(The oricell is formed during the calcitication of the adjacent tubes;

3. it is isolated

The ovicell is tormeal after the calcification of the adjacent tubes and is

supported upon them

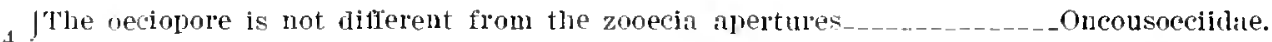

4. 'The oeciopore is of different form _. Crisiidae.

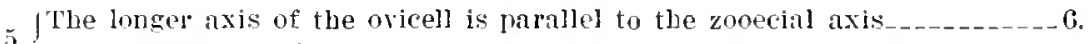

The louger axis of the ovicell is not parallel to the zooecial axis....... 7 .

f. The oeciostome is teruinal or subterminal _..._._.

6. The oeciostome is lateral__...._... IIorneridae.

- The ovicell is lohed (or lobate) .

7. The ovicell is not lobed

(The longer axis of the ovicell is jerlendicula to the zooccial axis

(Orthogonal development) _._._.

The longer axis of the ovicell is lan rallel to the zorceial axis___._._._..9.

9. A very large oecionole is present (Jarva enormous) _._._............. Macroeciidae.

\% J small oeciopore (ordinary lavia) _._._. Mecynoeciidae.

10 Oricell Jobate (or lobed)

10. \{ovicel] nonlobite (or not lobed)

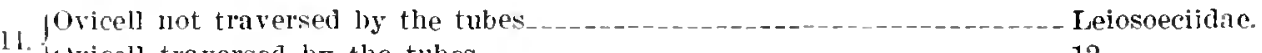

1. Wvicell traversed by the tubes_.

Oricell flat _._.

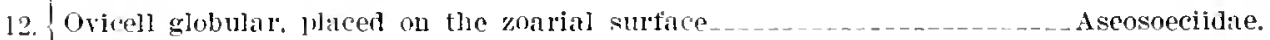

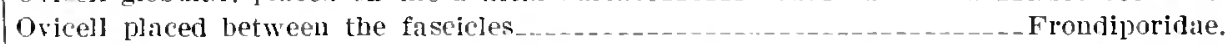

The order of description of the varions species is that of the geologic appearance as known at present.

Subdivision PARALLELATA Waters, 1887.

The ovicell is developed parallel to the zooecial axis between the tubes (and not between the peristomies). 


\section{Family ONCOUSOECIIDAE Canu, 1918.}

The axis of the ovicell is parallel to that of the tubes. The ovicell is developed at the same time as the adjacent tubes. which are not disarrangerl in their respective position.

We have been able to recognize two genera, Oncousoccin Canu, 191s, in which the ovicell is a dilation of the entire exterior part of the tubc. and Peristomorcia when the peristomie alone forms the ovicell.
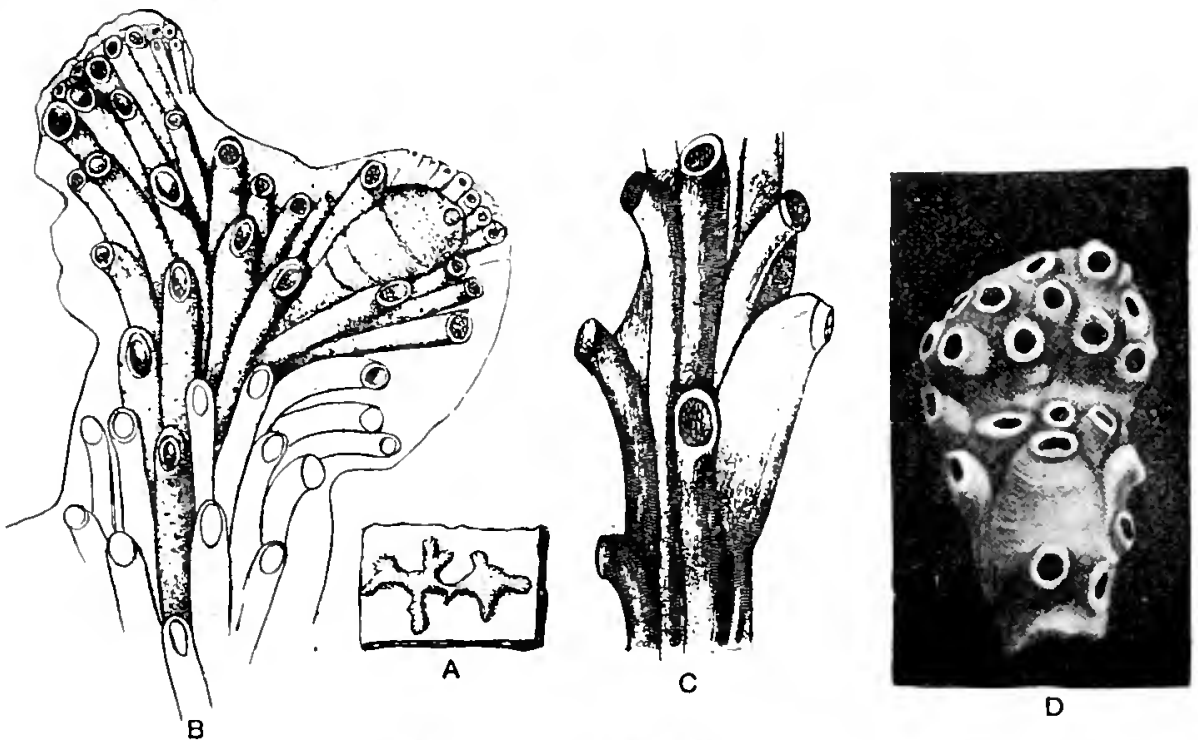

FIG. 226.-Genus Oncousocciu Canu, 1919.

A, B. Ovicelled zoarium natural size and enlarged of oncousoccia (Tubulipore) lobulutu Hincks, 1880. Recent.

C. Ovicelled zoarium of Onconsnecia (Crisia) schmit $\approx i$ Pergens, 1890. Cenomanian.

D. Ovicelled zoarium, $\times 12$, of Oncousoccia (Filisparsa) bifurcata Llrich and Bassler, 1907. (retaceous (V'incentown) of New Jersey.

\section{Genus ONCOUSOECLA Canu, 1918.}

1918. Oncousoccia Canv, Les oricelles des brrozoaires cyclustomes, Bulletin Sociêtê Géologique de France, ser. 4, vol. 16, p. 325.

The ovicell is a dilation of the entire cxterior risible part of the tube. The oeeiostome is not turned toward the base. Fourteen tentacles.

Genotype.-Tubulipora, lobulata Hincks, 1880.

Rangc.-Mastriehtian-Recent.

The exact limit between this genus and Mecynoccia is rather difficult to determine when one can not verify the abortion or the derangement of the adjacent tubes by dissection.

The ovicells are gencrally pyliform, but they are differently arranged; some have the point above and others have it below. This distinction does not appear 


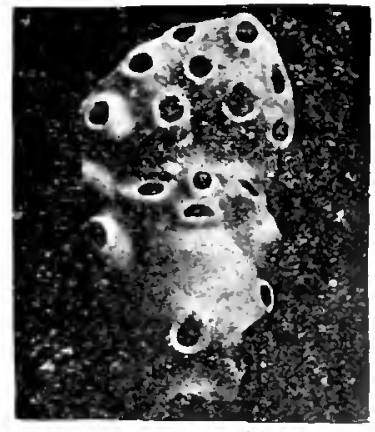

Oncousoecildae

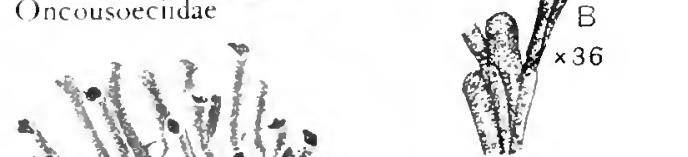

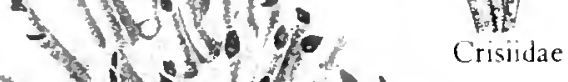
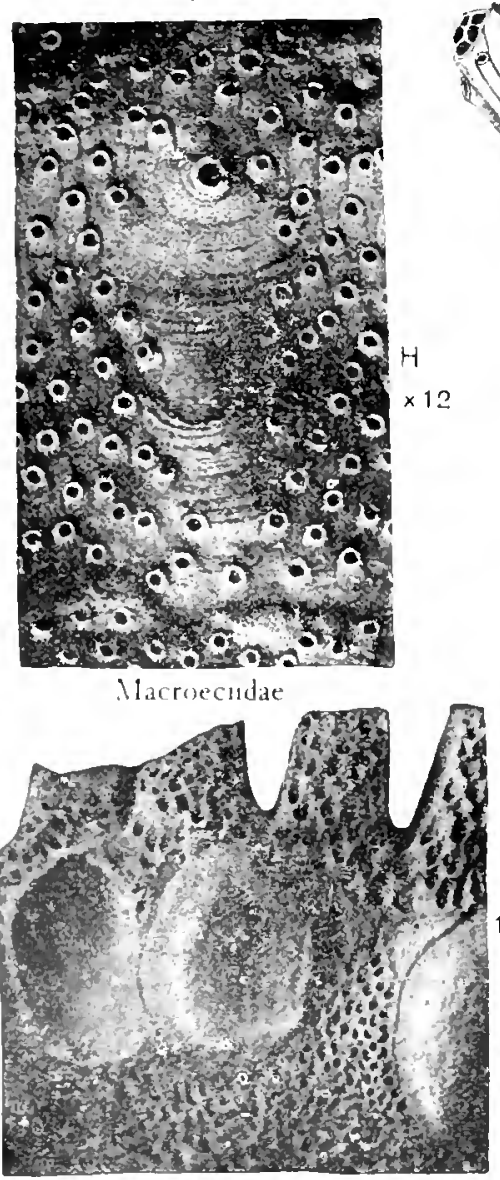

Cyturdate
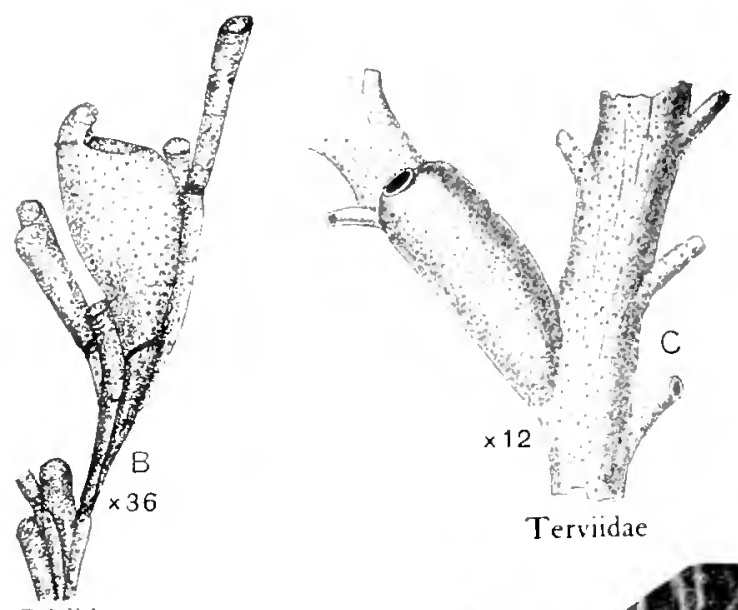

Terviidae

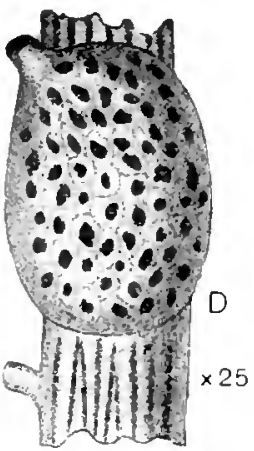

Horneridae

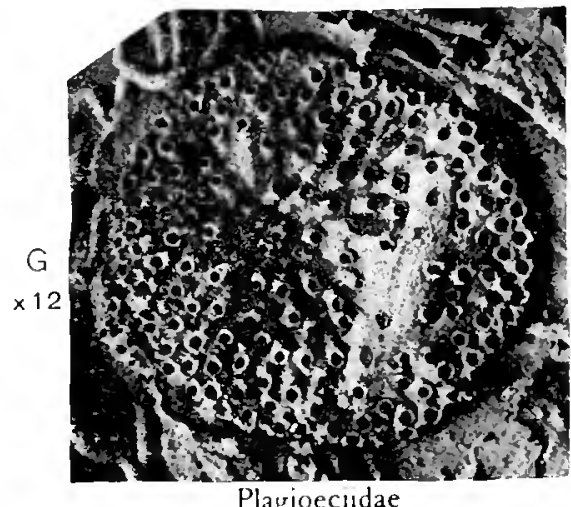

Placrioecudae

Diaperoeciidae

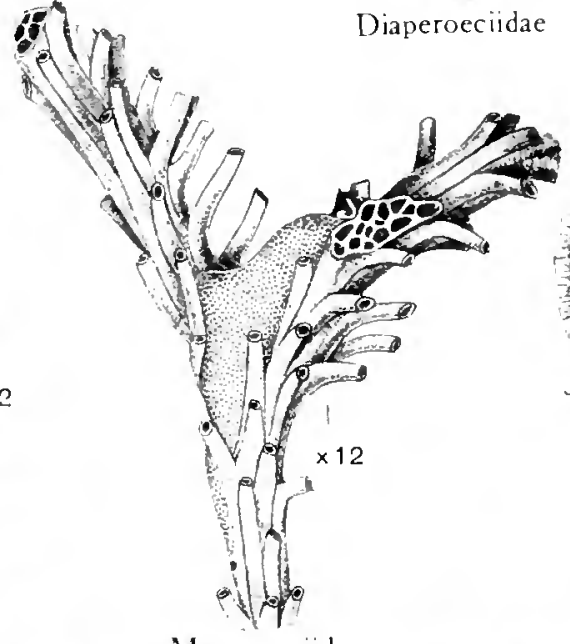

Mecynoeciidae
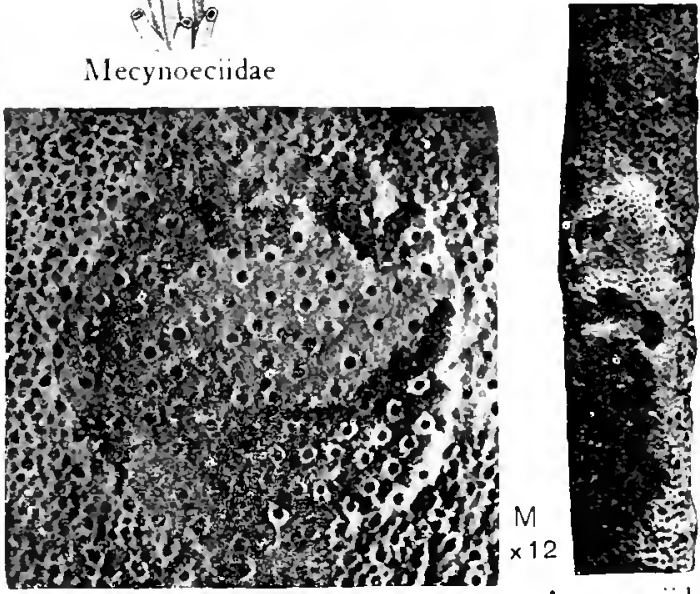

Ascosoeciidae

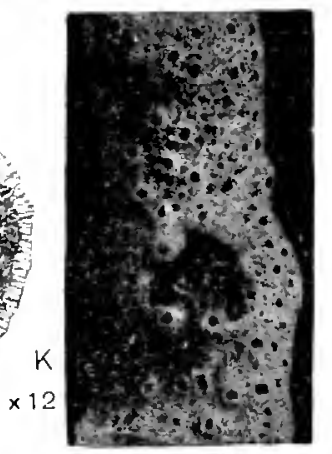

Lejosoeciıdae

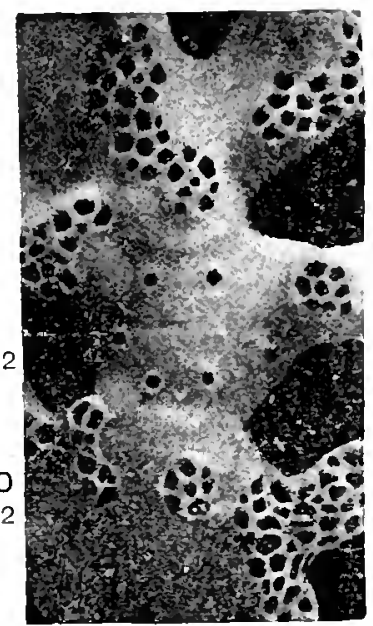

Frondiporidae 
Fig. 226.-Families of Ovicellata.

A. Oncousoecillae Canu, 1918. Onconsoccia (Filisparsa) bifurcata Ulrich and Bassler, 1907, $\times 12$; Upper Cretaceous of New Jersey.

B. Crisidae Johnston, 1847. Crisidia (Crisia) franciscana Robertson, 1910. (After Robertson.) Recent.

C. Tervildae, new family. Tervia irregularis Meneghini, 1844, X 12. (After Waters. 1sss.) Recent.

D. Horneridae Gregory, 1S09. Hornera antarcica Waters, 1904, $\times$ 2.5. (After Waters.) Recent.

E. Tubuliporidae Jolnston, 1838. Tubulipora fabellaris Fabricius, 17S0. (After Smitt, 1S67.) Recent.

F. Diaperoeciidae Canu, 1918. Diaperoecia intricaria Busk, 1875. (After Harmer, 1915.) Recent.

G. Plaginecidae Canu, 1918. Plagioccia palina Janırck, 1S16, X 12. Recent.

II. Macroecidae Canu, 1918. Jarroccia (Diastopora) lamellosa Michelin, 1s45, Jurassic.

I. Mecynoecidae Canu, 1918. Jlecynoecia (Eulalophora) probosciden Milne-Fdwards, 1838. (After Harner, 1915.) Recent.

J. Llchenoporidae Smitt, 1S66. Iichenopora radiata Audouin. 1S26. (After Hincks, 1SSt.) Recent.

K. Leiosousidate new family. Leiosoccia (Multicrescis) parricella Gabb and IIoln, 1 s60. $\times$ 12. Upper Cretaceous of New Jersey.

L. Cytisidae D'Orbigny, 1854. Is iscocytis (Pelagia) cudesi Michelin, 1844, X 12. Cenomanian of France.

1. Tretocycloeidae, new family. Parlretocycloccia porosa new species, $X 12$. Eucene of South Carolina.

N. Ascosoeciidae, new famils. Parascosoccia (Carea) costata Dorbigns, 1851, X 12 . Cretaceous of France.

O. Frondiporidae Fusk, 1S75. Frondipora vermeosa Lamouroux, 1821, $\times 12$. Recent. $55809-20-$ Eull. $106-44$ 
to us of generic value, for we are ignorant as to what difference in function it corresponds.

The zoarial form Fitisparsa D'Orbigny, 1852, contains species showing several sorts of ovicells, particularly those pertaining to Tervia and Oncousoecia, but the great majority of the species show no ovicells. The two American species of Oncousocia are precisely like Fitisparsa in zoarial growth. To facilitate the determination we place this old genus at the end of this family and maintain it for the species slowing no oricells.

\section{ONCOUSOECIA VARIANS Reuss, 1869.}

Plate 15T, figs. 17-24.

1847. Hornera biloba Reuss, Die fossilen Polyparien des Wiener Tertiarbeckens. Haidinger's naturwissenchaftliche, Abh. 2, p. 43, pl. 6, fig. 24 (fide Renss).

1847. Pustulopora anomola Reuss, Idem. (p. parte), p. 41, pl. 6, figs. 19, 20, (fide Reuss).

1562. Filisparsa tenella SroLiezisa, Oliogocäne Bryozoen von Latdorf in Sternhurg, Sitzungsberichte der k. Akademie der Wissenschaften, Wien, vol. 45, p. S0, pl. 1, fig. 5.

1869. Filisparsa varians lieuss, Die fossilen Polyparien des Wiener Tertiärbeckens, Haldinger's naturwiss. Alhand, vol. 2, pp. 286,291 , pl. 35, tigs. 14-15.

1869. Filisparsa varians IiEUss, Zur fossilen Fanna der Oligocïnschichten von Giias, Sitzungsherichte der k. Akademie der Wissensehaften, Wien, vol. 59, p. 479 (34).

1877. Filisparsa varians Maxzoxi, I Briozoi fossili del Miocene d'Austria ed Ungheria. Denkselurifte der mathematisch-naturwissensehaftliche Kilasse der k. Akademie der Wissenschaften, Wien, pt. 2, vol. 37, p. 9, pl. 7 , fig. 27.

1877. Hornera biloba Reuss-MIAnzoni, I Briozoi fossili del Miocene d'Austria ed Ungheria, Denkschriften der mathematische-naturwissenschaftliche kilasse der k. Akademie. der Wissenschaften, Wien, vol. 3S, p. 9, pl. 7, fig. 25.

1877. L'ilisparsa, species IIanzoxi, Bryozoaires du jliocène supérieur de l'île de Rhodes, Mémoires Société géologique de France, ser. 3, vol. 1, p. 69, pl. 3, fig. 18.

1877. Filisvarsa delvanxi l'ergens, Pliocïne Bryozoen von Rlodes, Annales des k. k. Naturhistoriscben Hofmuseums, Wien, vol. 2, p. 6 .

1877. Filisparsa varians Tergens, Note preliminaire sur les Bryozonires fossiles des environs de Kolosvar. Annales Soclété royale malacologique Belgique, vol. 22, p. 6.

1859. I'ilisparsa delvanxi Pergens. Note suceincte sur les Bryozoaires du Miocène de la Russie méridionale, Bulletin Société myale malacologique I3edgique, vo. 24, p. 2.

1891. Filisparsa varians Neriani, Contribuzione alla conoscenza dei briozoi fossili italiani, Briozoi postplioceniei del sottosuolo di Livorun. Bolletino Societa geologica italiana, vol. 10 , p. 139 (43), pl. 4, fig. 21.

1892. Filisparsa varians Waters, North Italian Bryozoa, Pt. 2, Cyclostomata, Quarterly Jommal Geological Society, rol. 47, p. 157.

1896. l'ilisparsa varians Pergens, Bryozoailes des environs de Buda, Bulletin Société belge de géologie, paleontolugie et d'hydrologie, vol. 10, p. 3ti2, fig. included.

1900. T'ubulipora (Filisparsa) rarians Nevian, Briozoi neogenici delle Calabrie, Paleontographial italica, vol. 6, p. 234 (regional bibliograplyy) .

1904. Tubulipora (Filisparsa) rarians Neviani, Briozoi fossili di Calrubare, Bolletino Societai geologica 1taliana, vol. 23, p. 54 S (sep. 46).

1908. Filisparsa varians Canv, Les Bryozoaires fossiles des Terrains du Sud-Ouest de la France, Bulletin de la société geologique de France, ser. 4, vol. 8, p. S84. 
100S. Filisparsa varians Beutler. Feitrag zur kenntuis des Iryozoenfunna der alterel Tertiaschichten des sullichen Biyern, 1I, Palentographica, vol. 54, 1. 238. 11. 24, tigs: 14-16.

1909. Filisparsa varians CANU, Les bryozoaires tertiares des environs de Paris, Annales de Paleontologie, vol. 4, p. 115, pl. 14, tigs. 6, 7, S.

1913. F'ilisparsa rarians Canu, Contributions a l'étude des Bryozoaires fossiles, pt. 5, Bulletin de la Société géologique de France, ser. 4, vol. 13, p. 125.

1911 Filisparsa varians CaNu, Les bryozonires fossiles des Terrains du Sud-Ouest de la France, Bulletin de la Société géologique de France, ser. 4 , vol. 14, p. 473.

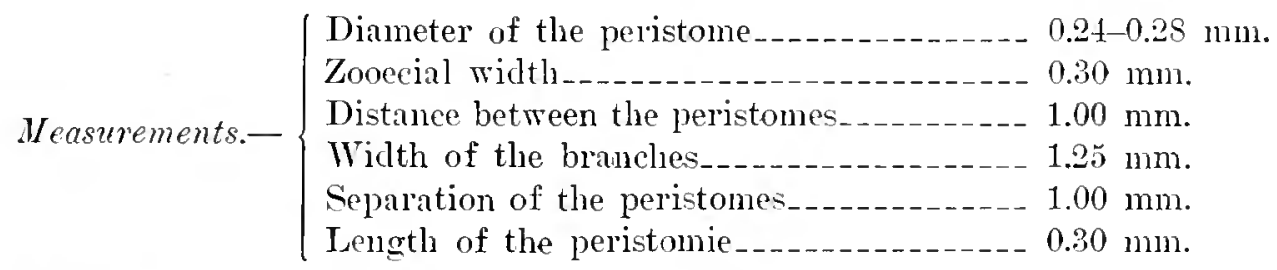

Tariations. - The ovicell of this species was long ago discovered by Cam in a specimen from the Priabonian strata of the Vicentin, but a figure of it was not published until 1916. It is pyriform, the point below; the oeciostome is transrerse and of the same diameter as that of an ordinary tube. This oricell must be extremely rare, as we have not observed it on our large number of American Vicksburgian specimens.

The tubes are porous; the length of the peristomie very inconstant. In longitudinal or transversal section, the thickness of the exterior wall is rery great.

Affinities.-The micrometric measurements are rather close to Fitisparsu ingens, but the present species differ's from it in a greater zooceial length and especially in its branches, which are only half as large.

Occurrenee.-Vicksburgian (Marianna limestone) : West bank Coneculh River, Escambia County, Alabama (very common); Salt mountain, 5 miles sonth of Jackson, Alabama (common); near Claiborne, Monroe County, Alabana (common); Murder Creek, east of Castlebury, Conecuh County, Alabama (rery common ).

Gcological distribution.-Lutetian of Paris, the Pyrenees. Bavaria (Camu): Priabonian of the Vicentin (Reuss. Waters), of Transylvania (Pergens) : Latdorfian of Germany (Stoliczka); Rupelian (=Stampian) of the soutluwest of France; Burdigalian of Gard (Collection of Cinu); Helvetian of Gard (Collection of Canu) and of Italy (Seguenza); Tortonian of Italy (Seguenza), of Austria-Hungary (Reuss), of Russia (Pergens); Zanclean of Italy (Segtenza); Plai-ancian of Italy (Seguenza); Astian of Italy (Seguenza). of southern France (Canu) : Sicilian of Italy (Neviani); Quaternary of Italy (Neviani).

IIabitat.-Mediterranean (Waters).

Plesiotypes.-Cat. No. 6.3402. T.S.X.M. 
Descriptions.-The zoarium has the Filisparsa growtl, thin, bifurcated with short branches; the dorsal is smooth and the tubes are there visible longitudinally. The tubes are long, distinct, convex, arranged in five longitudinal rows, curved upward into a long, very oblique peristomie; the peristome is thin and orbicular. The ovicell is large, salient, pyriform, the point below, placed at the extremity of a branch; the oeciostome is elliptical, transrerse. salient, of the same diameter as the tubes.

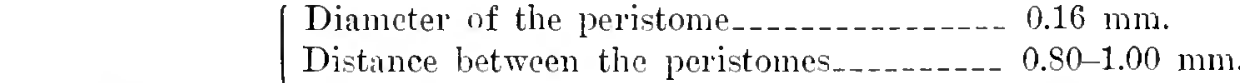

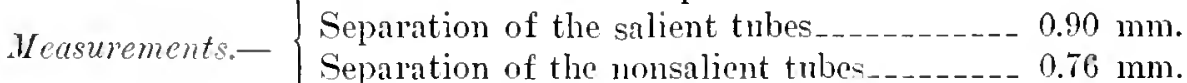

$$
\begin{aligned}
& \text { Length of the peristonie-_._._. } 0.30 \mathrm{~mm} \text {. } \\
& \text { Width of the branches______._._._._. } 0.50 \mathrm{~mm} \text {. }
\end{aligned}
$$

Tariations.-The two series of lateral tubes open on the side and they are sometimes even completely turned around so that they open in the plane of the dor'sal.

The peristomies opening nearly at the same height form very irregular kinds of verticells. On other branches, they are arranged in quincunx.

Affinities.-This species is very characteristic and very casy to determine. Some branches are similar to Filisparsa bini, but the present species differ's in the presence of its five longitudinal rows of tubes and in the greater diameter of the peristomes ( 0.16 and not $0.12 \mathrm{~mm}$.).

Oecurrenee.-Vicksburgian (Marianna limestone) : One mile north of Monroeville. Alabama (rare); west bank Conecrh River. Escambia County, Alabama (rare).

Vicksburgian (Byram marl): Byram, Mississippi (common).

Vicksburgian (Red Bhff clay): One-fourth mile west of Woodward, Wayne County, Mississippi (rery rare).

Cotypes._Cat. Nos. 6rot00, 6r̃t01. U.S.N.M.

\section{PERISTONOECIA, new genus.}

The peristomic alone is enlarged to form the ovicell. Genotype.-Stomatopora divergens Waters, 1904.

Range.-Recent.

Other species of this genus are:

Proboscina lamourouxi Savigny-Audonin, 1826.

Proboscina boryi Savigny-Audouin, 1820. 
Forma FILISPARSA D'Orbigny, 1853.

1853. Fitisparsa D'Orbigry, Déscription des animax invertébrés Terlanin Crétacé Palléontologie française, rol. 5, I. S14.

The zoarium consists of linear, riblonlike branches, which are erect. The branches dichotomize and may anastomose. The base is expanded. Zooecia open in one face only. The apertures are irregularly distriluted. (After Gregory. 1599.)
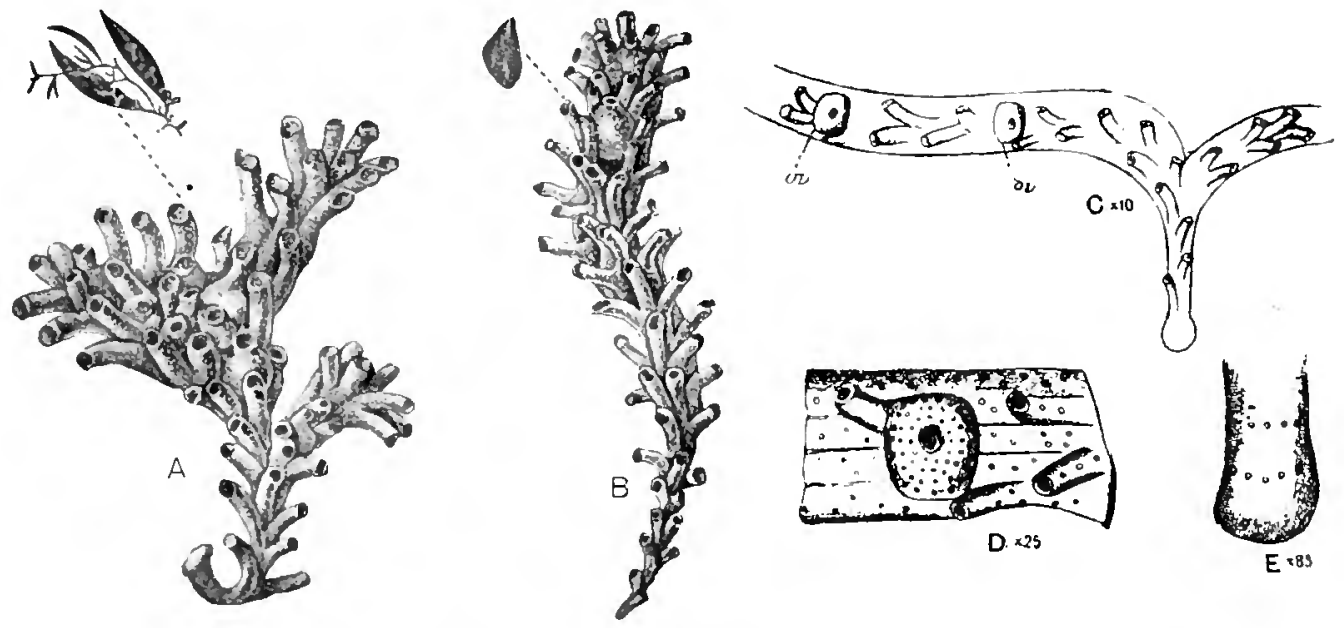

Hit. 2-2.-Peristomucial, new genus.

A. Ovicelled zoarium natural size ind enlared of Peristomoeciu (Proboscina) boryii Savigny Audouin, 1826. Recent.

B. Ovicelled zoarium of I'eristomoccia (I'roboscina) lamourouxi Savigny-Audouin, 1826. Iiecent.

C-1. Peristomocia (Stomatopora) diveruens Waters, 1904. C. Ovicelled zoarium (ov, ovjcell), $\times 10$. D. View, $\times 25$, showing ovicell developed all around the free peristomie. E. Protoecium, $\times$ S5. Rerent.

Genotype.Filisparsa neornmiensis D'Orbigny. 1893.

Zoarial forms of the type described as Fitisparse occur in several distinct fanilies, but unfortumately ovicells on species with this method of growtl are still rare. When the ovicell appears on the noncellular posterior face the species belonge to Terevia Jullien, 1883 , but if on the anterior fice it occurs as an elongated median sack formed by the dilition of the terminal part of a tube. Species of the latter type form the gems Oncousoecia Canu, 1919. The species withont ovicells much resemble those of Oncousoecia and for that reason we placed the zourial form Filispursa in the Oncousoeciidae.

FILISPARSA FALLAX, new species.

l'late 142, figs. 1-11.

Description.-The zoarium is filiform, slightly compressed, formed of two to three longitudinal rows of tules. The tubes are little visiJjle, convex, very finely striated transversally, cylindrical. The peristonne is thin, orbjenlar or elliptical. 


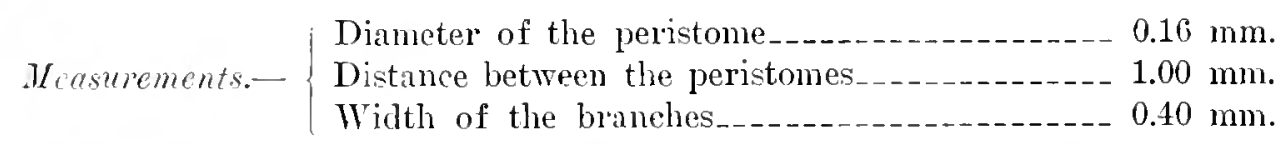

$\mathrm{T}^{\mathrm{a}}$ ariations.-This species is quite deeciving, as it closely simulates the abundant and widespread Wecynoceia proboscidea Milne-Edwards, 1838; but it has only a single celluliferous face. At Jackson, Mississippi, the specimens are more often biserial: at the locality near Monroevlle, Alabama, they are triserial. The tubes are ravely verticellate.

Affinitics. - This species differs from Filisparsa laxata which has the same peristomial diameter. in its much smaller branches and in the number of its longitudinal rows of tubes which are only two to three.

Oceurrence.-Lower Jacksonian (Moodys marl): Jackson, Mississippi (very common).

Middle Jacksonian: One-half mile southeast of Georgia Kaolin Company's Mine, Twiggs County, Georgia (rare); 12 miles sontheast of Marshallville, Georgia (rare).

Upper Jacksonian (Ocala limestone): West bank Sepulga River, Escambia Comnty, Alabama (very rare).

Vieksburgian (Marianna limestone): One mile north of Monroeville, Alabama (very common).

Cotypes.-Cat. Nos. 65325, 65326, U.S.N.M.

\section{FILISPARSA INGENS, new species.}

Plate 142, figs. 12-21.

Description.-The zoarium is formed of large dichotomous branches, pluriserial and compressed; the dorsal is ornamented with large, transverse wrinkles. The tubes are distinct, very convex, arranged in very regular quincunx; the peristome is thick, orbicular, oblique.

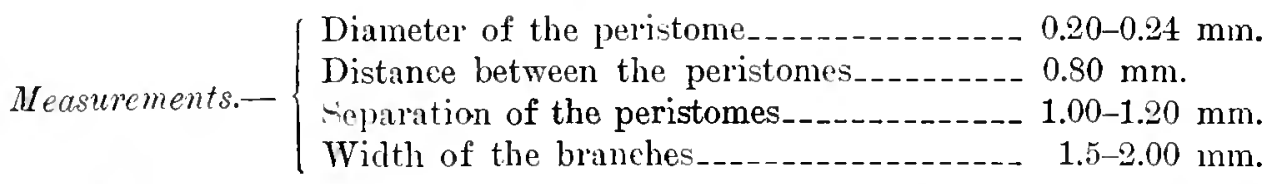

Tariations.-The great number of specimens collected, and chiefly their large size, has permitted us to make numerous sections for study. In transversal section the great thickness of the frontal walls is to be observed. In longitudinal section the tubes are short and issue on the dorsal at different heights; a short peristomie is often dereloped. The ablation of the dorsal shows the habitual lozenge-shaped areas formed by the projection of the tubes on the plane of the dorsal. The tangential section of the frontal shows the usual tremoeysts of the Cyclostomata. The tangential section of the dorsal shows the same structure. 
Occurrence-Middle Jacksonian: Wilmington, North Carolina (very common; near Lemuds Ferry, South Carolina (eommon); Eutaw Springs South Carolina (common).

Vicksburgian (Marianna limestone): Silt Mountain, 5 miles sonth of Jackson, Alabama (very rare).

Cotypes.-Cat. No. 65327 , U.S.N.M.

\section{FILISPARSA BIN1, new species.}

Plate 159, figs. 1-7

Deseription.-The zoarium is formed of filiform, sinnous, dichotomous, very little compressed branches, whose dorsal is very finely striated transversally. The tubes are distinct, convex, much elongated, arranged alternately in pairs on each side of the longitndinal axis. terminated by a narrowed peristomie, bent upward and salient; the peristome is thin and orbienlar.

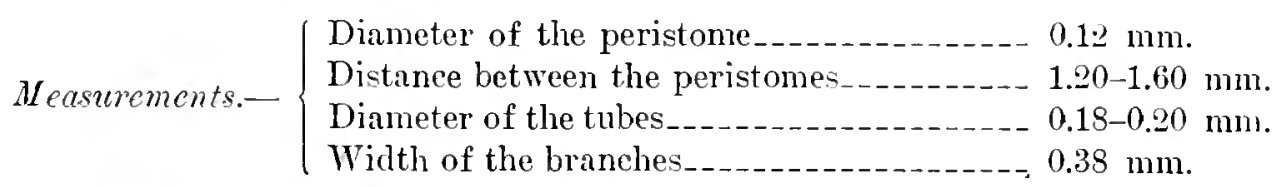

Affinities... The tubes which form each pair have their peristomes close together but not adjoining; they do not therefore form lines as in Idmonea bialternata Gregory, 1893. The present species differs from Filisparsa fallax not only in this very important character, but also in its smaller peristomial diameter (0.12 and not $0.16 \mathrm{~mm}$.).

Occurrence.-Vicksburgian (Red Bluff clay) : Seren and one-half miles southwest of Bladen Springs, Alabama (rare). (rare).

Vicksburgian (Marianna limestone): One mile north Monroeville, Alabama

Cotypes.-Cat. Nos. 65406, 65107, U.S.N.M.

FILISPARSA GRACILIS, new species.

Plate 159, figs. S-11.

Description.-The zoarium is formed of slender, rectilinear branches bifurcated at a very acute angle, compressed, formed of three longitudinal rows of tubes. The tubes are distinct, eylindrical, hardly curved at their extremity, finely striated transrersally and irregularly placed; the peristome is thin, orbicular or elliptical.

Measurements. $\left\{\begin{array}{l}\text { Diameter of the peristome____-_- } 0.16(0.11-0.18 \mathrm{~mm} .) \text {. } \\ \text { Distance between the peristomes_-- } 0.60-0.80 \mathrm{~mm} . \\ \text { Width of the branches_-_-_-_-_-_ } 0.40 \mathrm{~mm} .\end{array}\right.$

Affnities.-This species differs from Fitisparsa bini in its reetilinear, not sinuolis, branches and in its shorter peristomial distance $(0.80$ and not $1.20 \mathrm{~mm}$.). In the number of longitudinal rows, its affinities are chiefly with Filisparsa fallax; 
but it differs from it in its very acute bifurcations and in a smaller distance between the peristomes $(0.80$ and not $1.00 \mathrm{~mm}$.).

Occumence.-Vicksburgian (Red Bluff clay) : Seven and one-half miles sonthwest from Bladen Springs, Alabama (common).

Cotypes.-Cat. No. 65408 , T.S.N.M.

FILISPARSA TYPICA Manzoni, 1877.

I'late 159 firs. 12-18.

1S21. IInnera opuntia Defrance, Dictionnaire des Sciences naturalles, vol. 21, p. 432.

1877. Filisparsa typica Manzoni, I Briozoi fossili del Miocene d'Anstria ed Ungheria, Denkschriften der mathematische-naturwissenschaften klasse der k. Alademie der Wissenschaften, Wien, pt. 3 , vol. 38, p. 10 , pl. 8 , fig. 30 .

1895. Tubulipora (Filisparsa) typica Neviasi, Briozoi fossili della Farnesina e Monte Mario presso Roma, Palaeontographia Italica, rol. 1, p. 132 (56).

1909. Filisparsa typic Canu, Bryozoaires tertiaires des environs de Paris, Annales de Paleontologie, rol. 4, p. 115, pl. 14, figs. 25, 26.

1913. Filisparsa typica Canu, Contributions à l'étude des Bryozoaires fussiles, Bulletin de la Sociêté Geologique de France, ser. 4, vol. 13, p. 127.

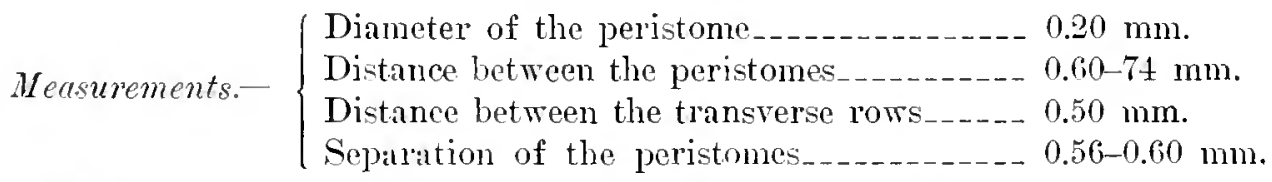

Tariations.--Usually the peristomes are grouped in transverse rows to the number of three to six; they are not adjacent when the peristomie is developed. 'This peristomic is rather short, moreover, and where it is a little reduced the peristomes are adjacent and the tubes show as psendo fascicles, whose sejaration is $0.50 \mathrm{~mm}$. The peristomes al'anged in quincunx are a little more widely spaced, their distances being from 0.60 to $0.74 \mathrm{~mm}$.; this arrangement is always very irregular. The zone of growth is large and triangular.

There are in the Cann collection more than 200 specimens of this species from the faluns of Touraine, none of which shows an ovicell. However. according to certain indications, it is possible that the ovicell, if it exists. is of the type of Jiaperoecia. It is also possible that in this and similar species the larra is developed in an ordinary tube in the vicinity of the tentacular sheath.

Occurrence.-Vicksburgian (Marianna limestone): Salt Mountain. 5 miles south of Jackson, Alabama, (rare); rest bank of Conecuh River, Escambia Connty; Alabama (very common); deep well, Eseambia County, Alabama (very rare); near ('laiborne, Monroe Comnty. Mlabama (rare); Murder Creek. east of Castlebury, Conecuh County, Alabama (common).

Yicksburgian (Red Bluff elay): Seven and one-half miles sonthwest from Bladen Springs, Alabama (very rare).

Goologic distrilution.-Intetian of the Paris Basin (Canu); Burdigalian of (rarrl (Canu); Helvetian of Tomrane (Canu) and of the Rlone valley (Cann): "Tortonian of Austria-Hungary (Manzoni); Sicilian of Italy (Neriani).

Plesiotypes.-Cat. Nos. 6.545, 65409, U.S.N.M. 
FILISPARSA SIMULATOR. new species.

Plate 159, figs. 19-2S. .

Description.-The zoarium is formed of rectilinear branches much compressed and pluriserial. The tubes are distinct, arranged in irregular quincunx or in transverse or oblique rows: they are terminated by a short upward bent peristomie; the peristome is thin, orbicular or elliptical. The dorsal is transversally striated.

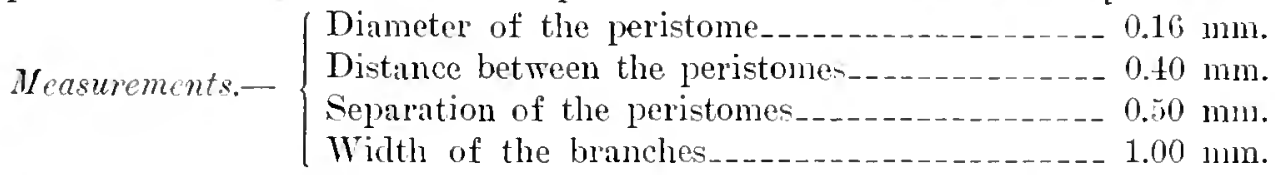

Tariations.-The arrangement of the peristomes is quite variable, heing sometimes in quineumx, and occasionally in oblique rows, when the species simulutes Idmonea. Nore often, they are grouped in transverse rows and the specimens resemble Filispersa typica Manzoni 1877 but $F$. simulator differs in its smaller micrometric dimensions $(\mathrm{D}=0.16$ and not $0.20 \mathrm{~mm}$.).

Occurrenee.-Vicksburgian (Marianna limestone) : One mile north of Monroeville. Alabama (very common).

Cotypes.-Cat. No. 65+10, U.S.N.M.

FILISPARSA ATOMICULA, new species.

Plate 157, figs. 25, 26.

Description.--The zoarium is very small and formed of rectilinear hairlike, triserial branches. The tubes are rery small, distinct, wrinkled transversally, arranged in irregular quincunx, terminated by an upward bent peristomie; the peristome is thiek and orbicular, salient.
Diameter of the peristome
Diameter of the apertura
Measurements.- Distance between the peristomes_-_._-_. $0.30-0.50 \mathrm{~mm}$. Separation of the peristomes_......... $0.30-0.36 \mathrm{~mm}$. Width of the branches _____... $0.30 \mathrm{~mm}$. larely.

This is the smallest of the American species of Fitisparsa and occurs very

Occurrence.-Ticksburgian (Marianma limestone): One mile north of Monroeville, Alabama (very rare).

\section{IIolotype.-Cat. No. $65+03$, U.S.N.M. \\ FILISPARSA LAXATA, new species. \\ Plate 160, firs. 1-4}

Description.-'The zomium is fomed of much compressed branches enlurgal at the bifurcations, pluriserial. The tubes are distinct, cylindrical, finely striated transversally, arunged in regulau quincunx, terminated by a peristomic up rilled bent and salient. The peristome is thin and orbienlar.

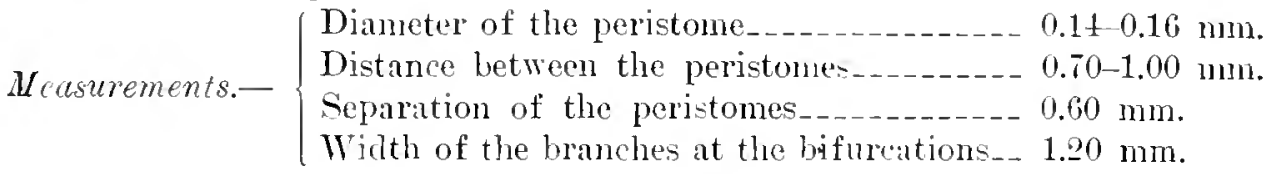




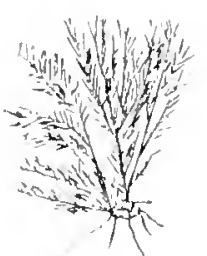

A

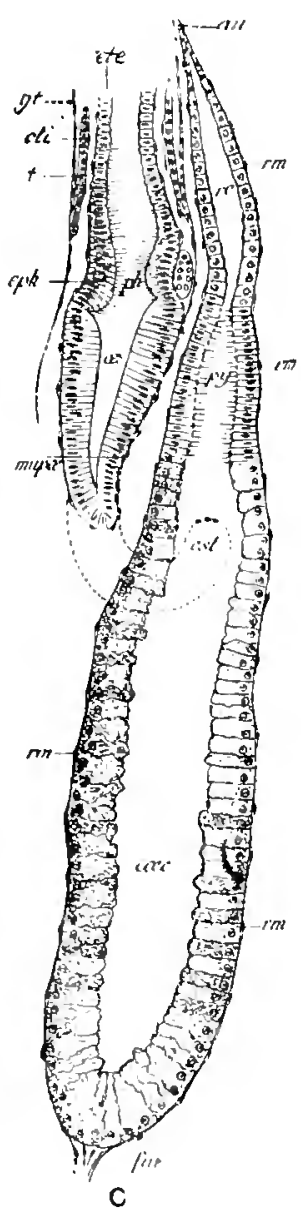

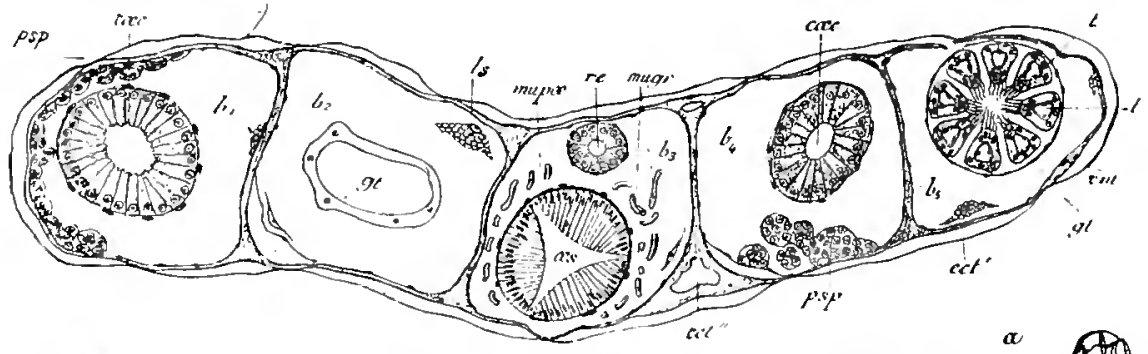
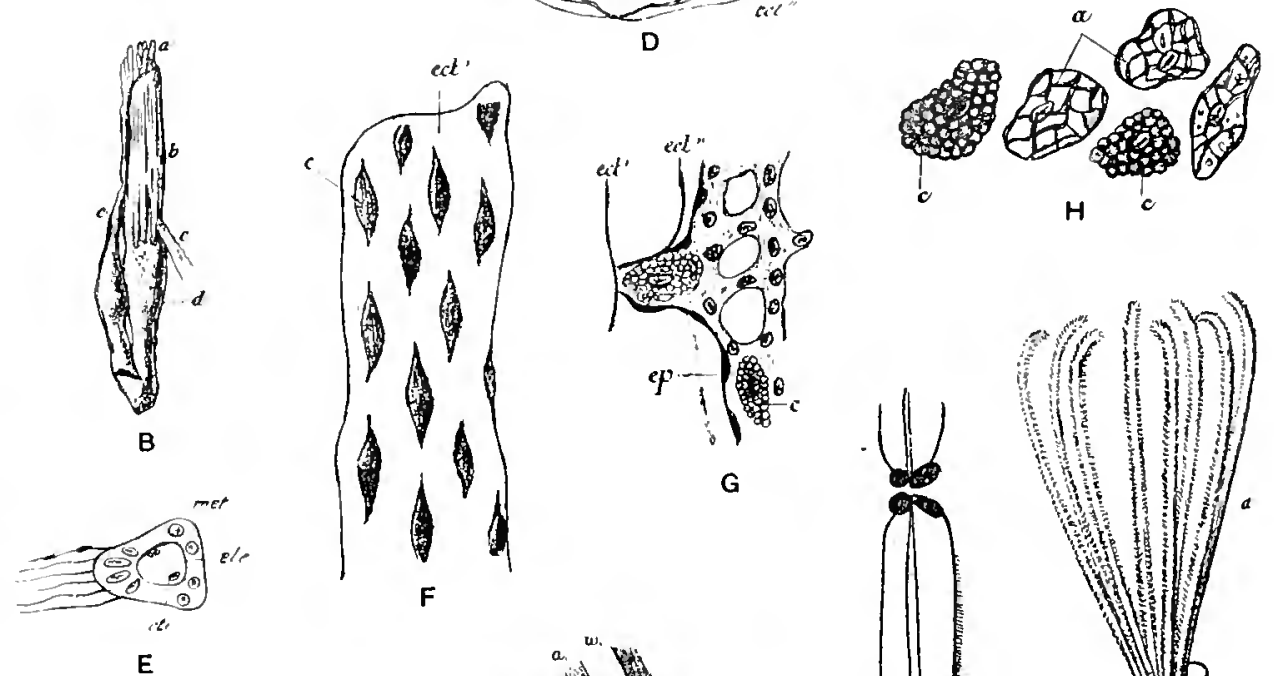

G
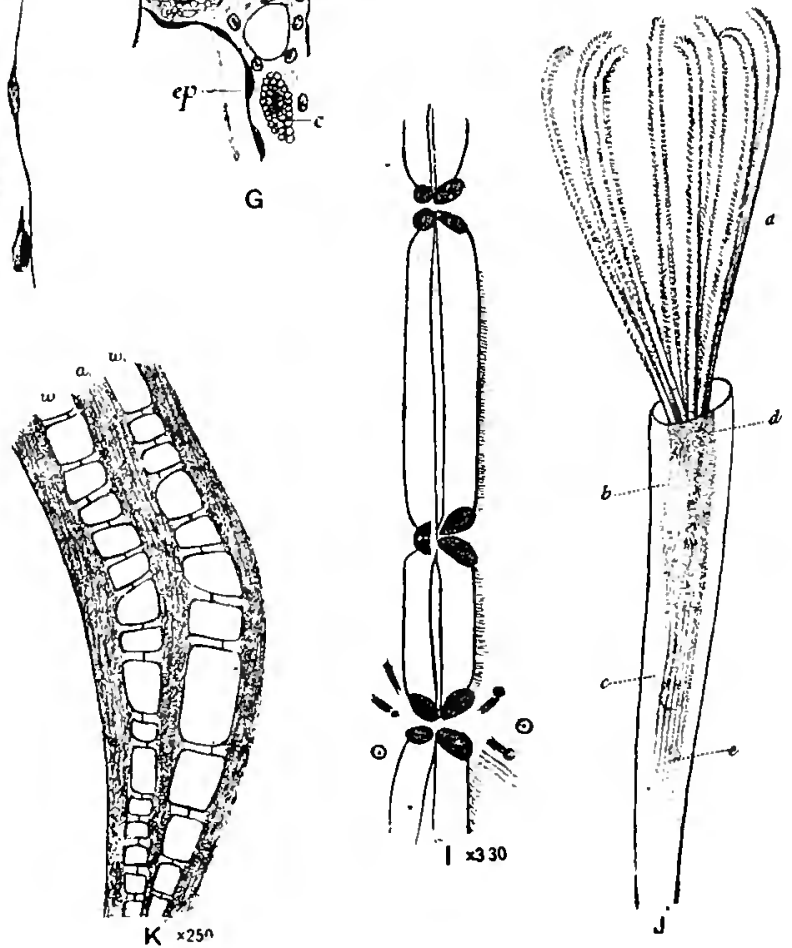

WJg, 209.-Anatomy of the family Crisidae Johnston, 1847. 
Jig. 229.-Anatomy of the finuily Crisiidae Jolnston, 1S4T.

A-1. Crisia denticulata Lamarck, 1536. A. Zoarium, natural size. B. Polypide isolated from the tube. (After Milne-Fdwards, 1S3S.) a, tentacles; $b$, tentacular sheath; $c$, retractor muscle of the polypide; $d$, alimentary tube; $\varepsilon$, anus. C. Portion of longitudinal section tingough the polspide. The contour of the cardiac region which has not been covered by the section is represented by stippling. D. Transverse section of a branch of the colony. H. Tentacle, transverse section. F. Strip of a tangential section of the ectocyst. Each of the pores corresponds to a spherular leucocyte. G. Portion of a Iongitudinal section of the wall of the ovicell. The spherular leucocytes are always abundant in the vicinity of the pores. H. Lencocytes of the general cavity of a zooecium. (C-H after Calvet, 1900.) cocc, stomachic coecum; $c l$, interzooecial paltition; cct, ectocyst; ect', ect', the two cuticular lcaves of the ectocyst; $c m$, mesenchyme; $c p$, endocyst : $c h$, epilerm of the philynx; est, stomach; cte, external tentacular cpithelium; cti, internal tentacular epithelium; $g$, tentacular sheath; mupoe, muscular perioesophagial fibers; mugr, great retractor muscle; met, anhistous membrane of the tentacles; oes, oesophagus; $p h$, pharynx; $p !$, pxlorus; $p s p$, protospermatoblast morules; re, rectum ; sm, mesenchymatous lining of the polypide; $t$, tentacles. I. Section through the inner wall of a zooecium showing the connectons from zooecum to zooecum (c) $\times 330$. (After Waters, 1914.)

J. Crisia geniculata Mime-Edwards, 1S7S. Folypide witl the tentacles evaginated. (After Milne-Edwards, 1S3S.) $a$, tentacles garnished with vibratile cilia; $b$, stomach; $c$, iutestine; $d$, anus; $e$, retractor muscle of the polypide.

K. Crisia ctongata Milne-Edwards, 183S. Proximal end of zooecium, showing connection $(a)$ to the two neighboring zooecia, through numerous tubes in which there is a septum in the middle of the zooecial walts (w) $\times \mathbf{2 5 0 .}$ (After Waters, 1914.)

L. Crisidia cormuta Ellis, 1755. Decalcified segment. (After Pergens, 1899.) a. $j$., link of juncture; est, stomach; $c p$, ectocyst ; $p$, parenchyme. 


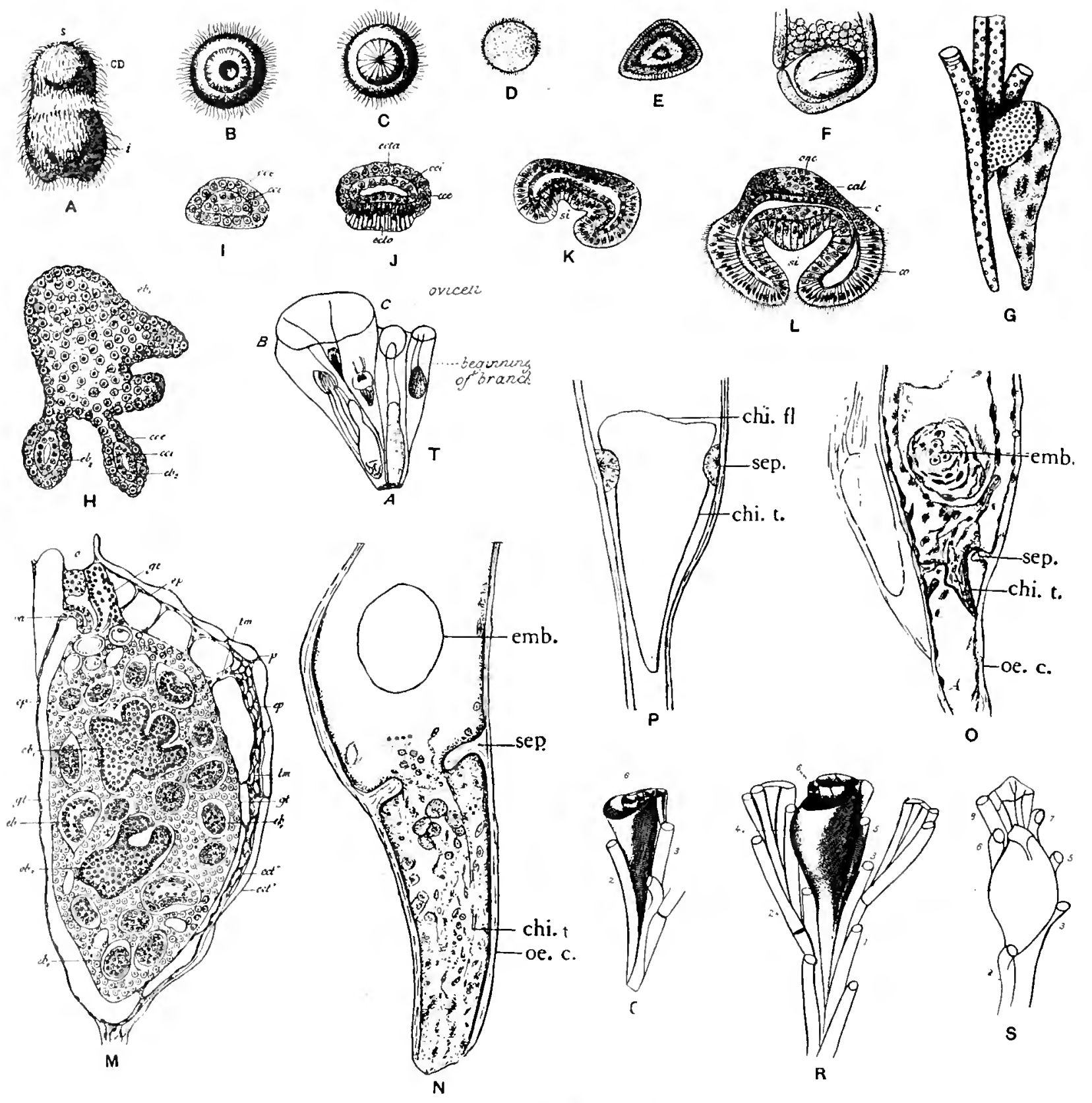

FIg, 230.-Fanily Crisidae Johnstun, 1847. 
FIG. 230.-Family Crisidae Johuston, 1847.

A-G. Crisin eburnca Ellis, 1755. A. Larra seen in profile. B. Aboral pole of larvi. C. Ora! pole. (A-C after Parrois, 1S77.) CD, digestive cavity; $s$, oral face or from the restibule. D. E, F. Embryos (after Smitt, 1S65). G. Ovicell showing internal sac containing the prinary entbryos (after Smitt. 1S65).

H-M. Crisia denticulata Milne-Edwards, 18.3S. H. Section of a primary enbryo. Two of the lobes of tlis embryo are provided with a central cavity and the two cellular distinct layers. The constriction which must cause the separation of the rest of the embrgos is rather market. I, J, K, L. Meridian sections showing different stages in the derelopment of the secondary embrro. MI. Sagittal section of an ovicell inclosing two primary embryos and a rather large number of secondary embryos. cal, calotte : ccc, extemal cellular laser of the secondary enbryos; cci, internal cellular layer of the secondary embryn; $c 0$, coroma: $c b$, prinary embryo; $c b_{2}$, secondary enbryo: cet' ect", the two cuticular leaves of the ectocyst ; cct $a$, aboral ectocyst ; ecto, oral ectocsst; $c p$. endocys; $g t$, tentacular sheath; onc, central nervous organ of the embryo; o, orifice; $p$, pores; si, internal sac; $t m$, mesenchymatous tissue; $v a$, valvule.

N. Crisidia (Crisia) franciscana Robertson, 1910. Cross section of an ovicell in an older stage of growtl showing a relatively large embryo (cmb.) and a septum (sep) whose growth is about completed. The chitinous tube (chi.t) growing down into the ooecial cone (oc. c) shows only at intervals in this section.

o. A cross section of an oricell containing a developing embryo on a young stage (cmb) and showing, also, an early stage in the growth of the septum (sep).

P. Crisia caluardsiana Dorbigny, 1839. Diasrammatic representation of a cross-section of the ovicell showing the cellular seftum (sop) with the chitinous tube (chi. $t$ ) and chitinous tlone (chi. $f)$. (O, P. After Robertson, 1910.)

Q-S. Crisia ramosa Harmer, 1891. Sketches showing development of ovicell. The ovicelt has in each case heen numbered 4 in order to admit of ready comparison between the three stages.

T. Crisia cburnca Ellis, 17.5., A young internode decalcified, with a developing ovicell. (Q-T after Harmer, 1893.) A. F, C. Summits of an imaginary triangle. 
Ittnitirs. - This species differs from Fitisparsa gracitis in the greater distance of the peristomes (more than $0.70 \mathrm{~mm}$.) and in the presence of multiserial and claviform branches. The young branches are triserial.

Oemmenef.-Vicksburgian (Marianna limestone): Murder Creek, east of Castlebury. Concul County, Alabama (rare); west bank Coneeuh River, Escambia County, Alabama (rare).

Vicksburgian (Red Blıff clay): Seven and one-half miles soutluwest from Blacken Springs. Alabama (rare).

c'otypes.-Cat. Nos. 65411, 65 112, U.S.N.M.

\section{FILISPARSA BISERIATA, new species.}

Plate 157, fig. 27.

Description.-The zoarium is formed of thin, rectilinear, fiscriat branches. The tubes are little distinct, alternate, terminated by a short peristomie; the peristome is thin and orbicular.

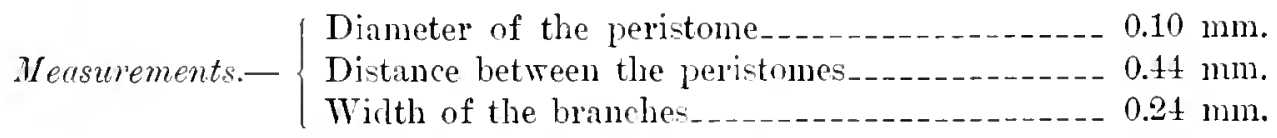

Affnities.-This species greatly resembles Crisia: but the zoarim does not appear articulated. D'Orbigny called zoarial forms of this kind Unicrisia. The species differs from Filisparsa fallax. which is often biserial, in its smaller peristomial diameter $(0.10$ and not $0.16 \mathrm{~mm}$.).

Occurrence.-Vicksburgian (Marianna limestone) : West bank Conecuh River, Escambia County, Alabama (very rare).

Ilolotype.-Cat. No. 65404, U.S.N.M.

KEY TO THE DE'EFMINATION OF AMERICAN SPFCHF OF TIR ONCOC SOECIDAF

I. $\{$ Zoullium liserial_____.

$\{$ Zoarium pluriserial__..._.

2 Peristome of $0.10 \mathrm{~mm}$

reristome of $0.16 \mathrm{~mm}$

Tuhes arranged in alternate series, branches sinuous..._......rilisparsa bini.

3. Tubs arranged in transverse series._........

Tules arringed in quincunx

4. I'eristome of $0.20 \mathrm{~mm}$._...... Filisparsa typica.

$\{$ Peristome of $0.16 \mathrm{~mm}$

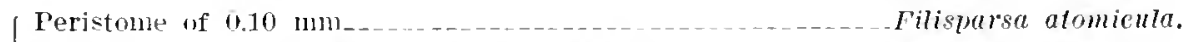

5.

Peristone of $0.20-0.24 \mathrm{~mm}$. . large branches_._.____. Filisparsa ingens.

l'eristome of $0.24-0.25$ mm-_oncousoccia rurions.

Ieristone of 0.16 mm $\mathrm{mm}_{-}$

6. Branches always triserial____.

( liranches pluriserial

- | The peristomes are distant, $1.00 \mathrm{~mm} \ldots \ldots$...._._._._._._. Filisparsa fallax.

The freristomes are distant from 0.60 to $0.00 \mathrm{~mm}$

S. Litcral tules turned toward the dorsal_..___._._._. Oncousoccia quinquescriata.

[ Zoarimn wu:h compressed with claviform liranches_____. Filisparsa larata. 


\section{Family CRISIIDAE Johnston, 1847.}

Anatomical bibliography.-1S7т. Barkols, Recherches sur l'embryologie des Bryozoaires, Travaux de l'Institut de \%oologie, Lille, fasc. 1, pl. 3, figs. 22, 23, 24.-183S. MiLne-Edwarns, Memoire sur les Crisies, les Hörneres et plusieurs antres Polypes, Annales des Sciences Niturelles, Zoologie, ser. 2, vol. 9, pp. 1-11. pl. 6. fïg. 1; pl. 7 , fig. 1.-1891. Harmer, On the Fitish species of Crisia, Quarter? Jourual of the Microscojical Society, new ser., vol. 32, pl. 12.-1893. HARMER, On the occurrence of embryonic fis. sion in Cyclostomatous Polyzoa, Quarterly Journal of Microscopical Science, new ser., vol. 34, pls. 1-3.-1900. Calver, Contributions a l'histoire naturelle des Bryozonires ectopoctes marins, Travax Institut zoologie Univelsite Montpellier Niat Marit, Catle, new ser., Memoire No. S, pl. 7, fig. 15 ; pl. S, fig. 22 ; pl. 10, figs. 15-20.1914. WAtens, The Marine fauna of Britisl East Africa and Zanzibar, Proceedings of the Zoological Society of London, p. 834, pls. 55, figs. 5, 6.-1916. WATErs, Some Species of Crisia, Annals and Magazine of Natural History, ser. S, vol. 1S, $\Gamma$. 470 , pl. 16 .

The ovicell is regular, symmetrieal, sacciform, isolated. 'The oeciopore is terminal, as large as the aperture of the tubes. The zoarium is articulated and radicated.

This family is often erroneously attributed to Busk, 1859, but it was established in $18+7$ by Johnston under the name of Crisiadae. The terminology adopted has no importance from the standpoint of priority, since scientific observation alone ought to be considered.

The best known genus of this family is Crisia. Perhaps it will be necessary to erect a distinet genus for the Crisia denticulata group which is withont a salient oeciostome. It is evident that here the function of the eseape of the liurvae has become different.

We possess rather good anatomical material of this family but unfortunately the determination of the specimens is alrays laborious and often doubtful.

The bathymetric distribution of the Crisidae is deceiving. They live in fact on marine algae and after death fall to greater depths often very far from their place of origin.

Genus CRISIA Lamouroux, 1816.

1S16. Crisia LAMor:Roux, Historie des Polyuiers Coralligines flexibles, p. 136.

The zooecia are biserial.

Genotype.-Crisin (Sertularia) eburnea Linnaeus, 1758.

$R$ ange.-Lutetian. Recent.

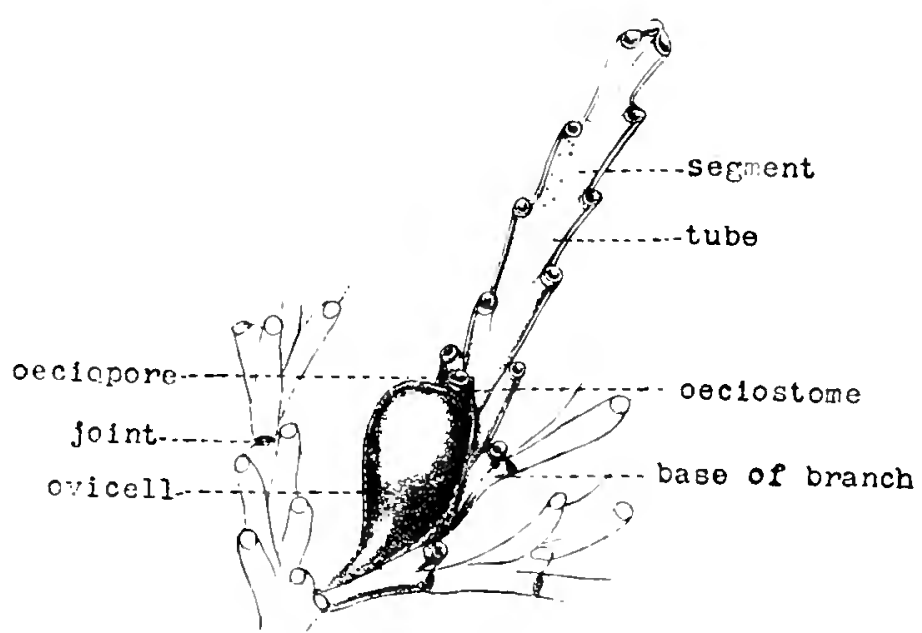

Fig. 231.-Genus Crisia Lamouroux, 1816.

A branch slowing the terminulugy in this genus. 
CRISIA HÖRNESI Reuss, 1847.

Flate 141 , figs. $1-4$.

1947. Crisia härncsi IEecss, Die fossilen Folyparien des Wiener 'Tertiärbeckens, Haidinger's naturwissenschaftliche Abhandlungen, nt. 2, Wien, p. 54, pl. 7, fig. 21 ; pl. 11, fig. 29.

1547. Coclophyma glabrum Reuss, Die fossilen Polyparien des Wiener Tertiäbeckens, Haidinger's natur'wissenschaftliche Abhandlungen, pt. 2, p. 99, pl. 11, fig. 28.

1860. Crisia hörnesi Reuss, Die Foraminiferen, Anthozoen und Bryozoen des Deutschen Septarienthones, Ein Beitrag zur fauna der mitteloligocänen Tertiärschichten. Denkschriften der k. Akad. der Wissensch., Wien, vol. 25, p. 191 (75), pl. 11, fig. 12.

1867. Crisia hörnesi Revss, Die fossile Fauna der Steinsalzablagerung von Wieliczlia in Galizien, Sitzungsberichte der k. Alademie der Wissenschaften, Wien. vol. 55. Abtheil. 4, 1) 121, no. 30.

1S77. Crisia hörnesi (Reuss) MANzoNr, I Briozoi fossili del Miocene d'Austria ed Ungheria. Denkscluriften del k. Aliad. der Wissensch., Wien, rol. 25, p. 191 (75), pl. 11, fig. 12: pt. 2. vol. 3i, p. 4, pl, 1, fig. 3.

18S9. Crisia hörnesi Terrigi, I Mlacco di Palo, p. 104, pl. 2, fig. 5 (fide Neviani).

1900. Crisin hörnesi Nevini, Bryozoi Terziari e Posterziari della Toscana, Bolletino d. Societá Geologica italiana, vol. 19, p. $2 \vec{\imath}$.

1900. Crisin hömesi Nevrani, Briozoi neogenici della Calabrie, Paleontographa italiana, vol. 6. 1. 224 (110) (local bibliography).

1891. Crisia härncsi Nerran, Contribuzione alla conoscenza dei briozoi fossili italiani, Briozoi postpliocenici del sottosuolo di Fivorno, Bolletino dellal Societá geologica italiana. rol. 10, n. 131 (35) pl. 4, fig. 3.

1S96. Crisia höruesi Nevian, Briozoi neoznici di alcune localita d'italia, Polletino della Societí Romana per gli Studi Zoologici, pt. 3, vol. 5, p. 123 (22).

1009. Crisia hömesi Cand, Bryozoaire des terrains tertiaires des environs de Paris, Annales Paleontologie, vol. 4, p. 103, pl. 12, fig. 12.

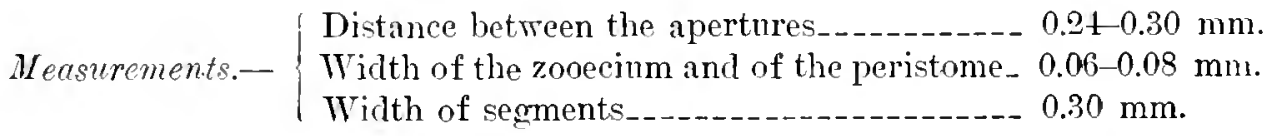

The ovjeell is rery salient, somewhat pyriform. The oeciopore is placed in the vicinity of the zoarim and the oeciostome is not salient. It is similar to that of Crisin denticulata Lamarck, 1812, ${ }^{1}$ in which the measurements are also almost identical.

Affinities.-This species differs from Crisia denticulata Lamarck, 1812, in having 16 or 17 tubes to the segments (in place of 11) and in the interapertural distance less or equal to the zoarial width, but nerer greater.

It differs from ('risia cribraria Stimpson, 1853, in a lesser number (17 or 18) of tubes on the segments.

It differs from Crisia lowei in its larger zooecial dimensions (0.09 and never $0.06 \mathrm{~mm}$. ).

${ }^{1}$ Crisia elongata Harmer, 1915. to which that author adds Crisia denticulata Waters. 1910, is not the Crisin clongatn Jamarck, 1812. The micrometric measurements given are slightly less than those of Crisia denticulata as Milne-Edwards who figured Lamarck's type wrote in 1838: "Elle ressemble beaucoup a la Crisie dentelcé, mais s'en distingue par ses brancbes plus greles, ses cellules tubuleuses beaucoup plus petites et flar la longueur considérable des espaces comprises entre deux etranglements ou articulatlons (=segments); le nombre des indivldees dont se compose une de ces portions du polypler s'éleve lci à environ ringt. . . . The figure of Milne-Edwards, magnifed 24 diameters, is excellent and gives rise to no confusion. The species of IIarmer Waters must therefore be determined anew. 
Occurrence-Lower Jacksonian (Moodys marl): Jackson. Mississippi (commen).

Vicksburgian (Red Blutt clay) : Seren and one-half miles sonthwest of Bladen Springs, Alabima (rare).

Geological distribution.-Tutetian of Paris (Cann); Stampian of Germany (Reuss): Burligalian of Gard (Canu); Helvetian of Herault (Canu). of Italy (Seguenza): Zanclean of Italy (Seguenza, Neviani): Tortonian of Italy, (Secruenzal), of (iemany (Renss): Astian of Italy (Negnenza); Sicilian of Italy (Neviani); Quaternary of Italy (Neviani).

Plesiotypes.-Cat, No. 6.3336, U.S.X.M.

\section{CRISIA EDWARDSI Reuss, 184:.}

l'lite 141, figs. 5-7.

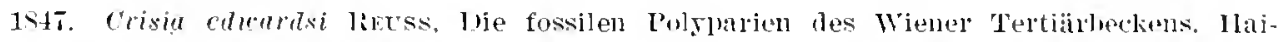
dingero naturvissels

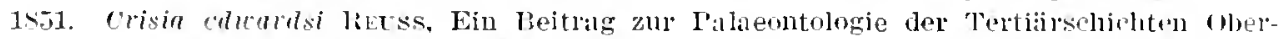
schlesiens, Zeitschrift der Lentschen Gologischen Gesellschaft, Berlin, vol. 3. p. 171.

1869. Crisia edicardsi IEcss, Dite loraminiferan, Inthozoen und Bryozoen des lentsehen

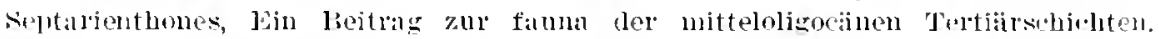
Denk. der k. Akademie der Wiscenschaften, Wien, vol. 25, p. 191 (75), pl. 11, fig. 10.

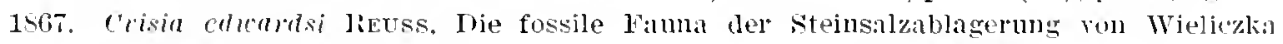
in talizien, sitzmesherichte der k. Akademie der Wissensehaften, Wien, rol. 5ั, Alitheil. 1, 1. 122.

1806. Crisia duardsi leuss, Zur fossilen Fauna der Oligocäschiehten von Gass, Sitz-

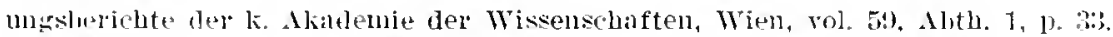

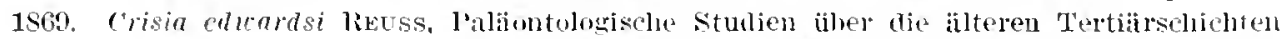
der Alpen, Abth 2 Die fossilen Anthozmen und bryozen der Sehichtengruppe von crosaro, sitzungsherichte der k. Akademie del Wissenschaften, Wien, rol. is, Abth. 1, R. 6i.

197. Crisia cluarlsi Maxzovi, 1 Brinzoi fossili del Miocene d'Austria ell Ungheria, Dinli sebriften der Math. natur. Classe ter k. Akademie der Wissenschaften, Wien pt. 3, vol. 3S, 1) 111, pl. 1, fig. 2.

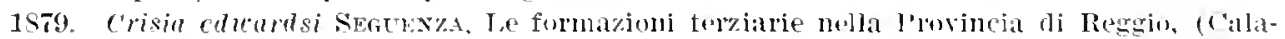

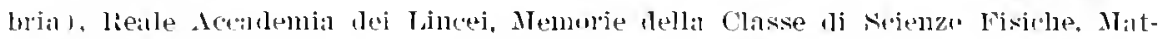
ematiche e Natulali, ser. 3, vol. 6, pp. S4, 1922, 20S, 296.

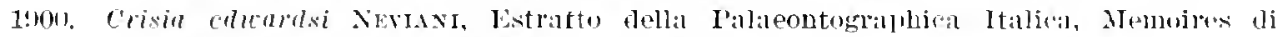

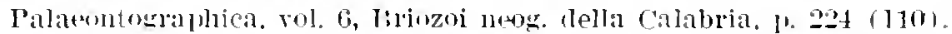

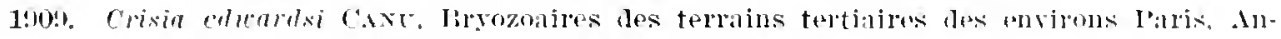

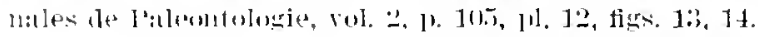
Measmements.-
Distance between the apertures- (1.:30 11111 .
Widtl of zooecia inclucling peristome_... $0.09 \mathrm{~mm}$.
Zoirial wilth $0.26-0.2811111$.

Our measurements are smaller than those of the specimens from the Tertiary formations of the envirom of Paris.

The charateristic of this speeies is that the distance between the apertures is wreater than the wilth of the segments. Put to be certain of the determinition it is necessaly to know the micrometric dimensions of the type and the nature of its ovicell, two features of which we are ignorant. 5.899?-2)-Iinll. $114 ;-4.5$ 
The peristomes are more salient laterally than in Crisia hömesi Reuss, 1847, with which it is scarcely possible to confuse it.

Occurrence.-Middle Jacksonian: Near Lenuds Ferry, South Carolina (rare).

Geological distribution.-Lutetian of Paris (Canu) ; Priabonian of the Vicentin (Reuss) ; Rupelian (=Stampian) of Germany (Reuss) and of Gaas (Reuss); Burdigalian of Gard (Canu) ; Helvetian of Italy (Seguenza) and of Gard (Canu); Tortonian of Austria Hungary (Reuss) and of Italy (Segnenza); Zanclean of Italy (Seguenza); Astian of Italy (Seguenza).

Neviani in 1900 affirmed that this species lived in the Mediterranean. This is possible, but we have not yet sufficient proof of this fact.

Plesiotypes.-Cat. No. 65337, U.S.N.M.

CRISIA CRIBRARIA Stimpson, I853.

Plate 141, figs. 9-11.

1553. Crivia cribraria STMPson, Synopses of the marine Invertebrata of Grand Manan or the region about the mouth of the Bay of Fundy, New Brunswick, Smithsonian Contributious to Knowledge, vol. 6, no. 5, p. 18.

1910. Crisia cribraria Osburs, The Bryozon of Woods Hole Region, Bulletin of the Bureau of Fisheries, vol. 30 , p. 215 , pl. 18, fig. 7 .

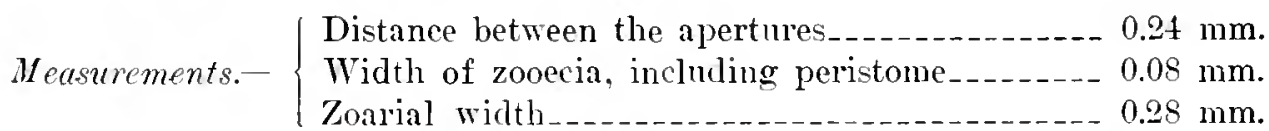

In the separation of the apertures, which is less than the zoarial width, this species is close to Crisia homesi Reuss, 1847. It differs from it in its micrometric dimensions, and especially in a larger number of tubes on the segments (27 in place of 18).

We have based our determination on Osburn's figure.

The ovicell is pyriforns, salient; its oeciopore is terminal and placed against the zoarial wall; it has no salient oeciostome.

Occurrence.-Iower Jacksonian (Moodys marl) : Jackson, Mississippi (rare).

IIabitat-Consts of the United States (28 meters) at Crab-Ledge on Cape Cod, and of Canada.

Plesiotypes.—Cat. No. 65339, U.S.N.M.

CRISIA LOWEI, new species.

Plate 141 fig. S.

I) seription.-The segments are short and are formed of 14 to 15 lateral and alternate tubes. The peristomes are orbicular, somewhat salient laterally to onehalf of their diameter; their separation is less than the zoarial width. The ovicell is pyriform.

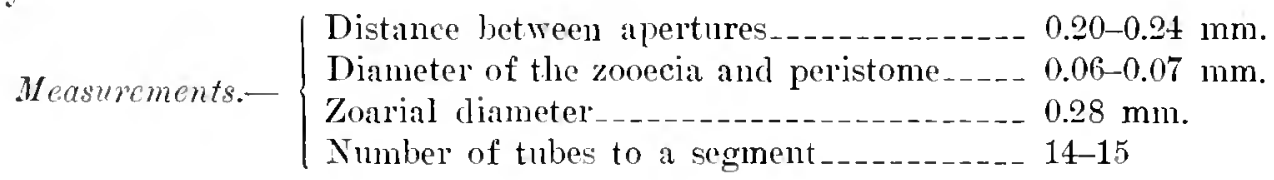


Affinities.-This species is vely close to Crisia hörnesi Renss. 1847 , in the distance between its tubes, which is less than the zoarial width. It differs from it simply in the smaller micrometric measurements.

We dedicate this species to Mr. E. N. Lowe, State geologist of Mississippi, to whom we are indebted for many courtesies.

Occurrenee.--Lower Jacksonian (Moodys marl) : Jackson, Mississippi (very rare). ${ }^{1}$

Hototype.-Cat. No. 65338, U.S.N.M.

Genus CRISIDIA Milne-Edwards, 1838.

1S3S. Crisidia Milne-Edwafds, Mémoire sur les Crisies, les Hornéres et plusieurs autres Polyes, Amiales des Sciences Naturelles, Zoologie, ser. 2, vol. 9, p. 11.

The zooecia are uniserial.

Genotype.-Crisia (Sertularia) cornuta Ellis, 1755.

Range.-Miocene-Recent.

This genus has not been recognized, but we are ignorant of the reasons. We have recognized it in the application of our fundamental principle: the genus is a natural one when any function operates in a different manner. Here the gemmation is different and more simple than in the genus Crisia Lamouroux, 1816.

\section{Family PLAGIOECIIDAE Canu, 1918.}

The longitudinal axis of the ovicell is perpendicular to the zooecial axis. The ovicell is formed before the calcification of the neighboring tubes, the formation of which it hinders. The oeciostome is small.

This family is quite well characterized by the orthogonal development of the oricell. In all the other fimilies this development is directed parallel to the zooecial tubes. The generic divisions are hard to determine becausc of the variations of the oeciostome which is always difficult to discover as it is so small or so much like a tube. Often it is only by dissection of the ovicell that the oeciostome may be found with certainty; unfortunately the ovicclled specimens are still too rare in collections.

The principal known genera are Plagioecia Canu, 1918, and Desmeplagioecia, new genus. However, it is certain that the first of these genera will be dismembered later according to the function of evacuation of the larvae.

\section{Genus PLAGiOecia Canu, 1918.}

191S. Plaqioccia CaNu, I,es ovicelles des bryozoaires cyclostomes, Bulletin de la Sociête Geologique, France, ser. 4, vol. 16, p. 327.

The ovicell is transversal. The oeciostome is small, equal to or less than the zooecial diameter. The tubes are isolated from each other. No adventitious tubes.

3 We have fouud segments of Crisia in the Clabornian at Claborne, Alabama, whlch are close to Crisia subacqualis Reuss, 1869 , but which are, however, very poorly preservel. We hare also found very beautlful specimens in the Vicksburgian, but unfortunately they mere broken in transit through the malts. 
Genotype.-Plagiorcia (Diastopora) patina Lamarck, 1816. Range.-Jurassic-Recent.
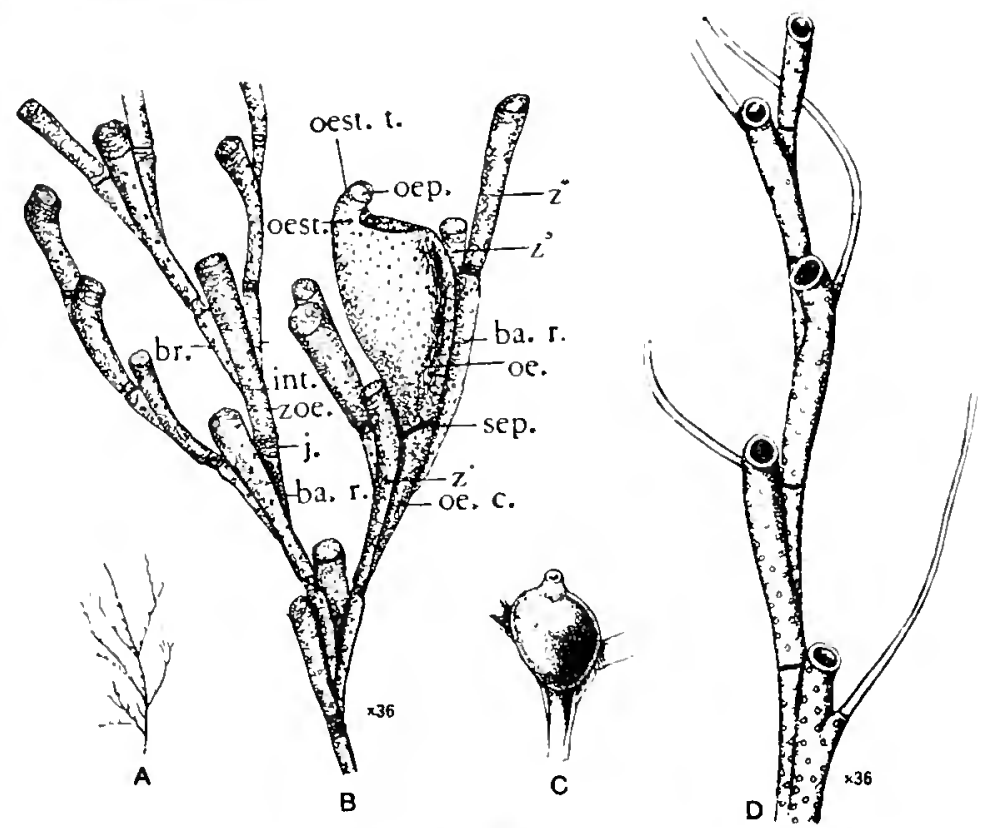

Fle. 232.-Genus Crisilia Milne-1dwatrols, 1838.

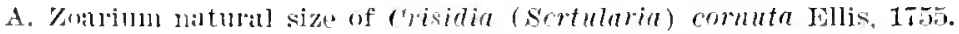

B. Portion of a colony, $\times 36$, of Crisidia (Crisia) franciscana Rohertson, 1910, sluwing method of branching, and formation of ordinesy and of ooccial internodes. The ordinary uniserial intermde consisting of a zooecinm (zoc) gribug orisin to two other zooecia (br). The (oe) the second memher, the zcoecium $\approx^{3}$, a third member. Alising from a basal ramus (ba. $r$ ) on the third zoocium is a fourth zooecium $\left(z^{6}\right)$, which serves to continue the branch njwald. The prominent oorciun (or) llating a well develunel tube (acst. $t$.) at its summit, bent slightly backwarl. (After Rubertion, 1910.

C. Ovicell of erisidin comuta Ellss. (Aftel Harmer, 1891.)

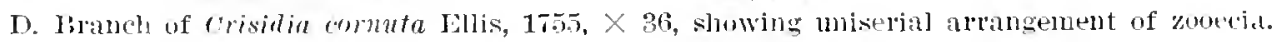
(.) $\rightarrow$ Il ater llincks, 1880.)

The other" known species belonging to this genus are:

Berenirea latomaryinuta D*Orbigny, 18.2. Piocene-Recent.

Diastoporu lacter Jullien, $188 \pm$. Recent.

P'roboscim sarthacensis Pergens, 1890. Cenomanian.

Mesenteripore compressa Goldfuss, 1827. Cretaceous.

Retimlipote oblinua D'Orbigny, 1850. Cretaceous.

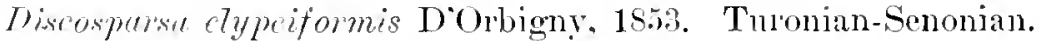

Entalophore remosissima D'Orbigny. 1850. Cenomanian-Coniaçian.

Thisstopored rehinate Pocta. 1892. Cenomanian.

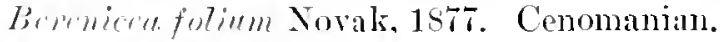

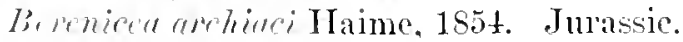

Benmicen Rilurinut Lamouronx, 1821. Bathonian.

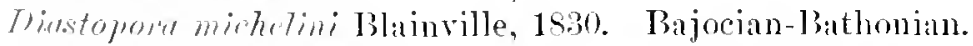

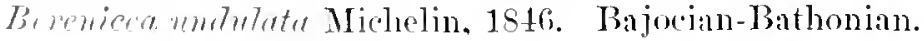


NORTH AMERICAN EARLY TERTIARY BRYOZOA.

Plagloecla SUBRAmosa Ulrich, 1901.

Plate 104, figs. 5, 6.

1901. Fascipora subramosa Ut.rich, Maryland Geological Surves, Eocene, p. 207, pl. 19. tiers. 1,2 .

Description.-Zoarium consisting of small flattened branches, varying from subeylindrical to flabellate, nsually about $1.5 \mathrm{~mm}$. in thickness. Fnds of branches convex, oceupied by the months of numerous subequal, thin-walled, angular tubes, usually about $0.12 \mathrm{~mm}$. in diameter. Sides of branches with rather obseure transrerse wrinkles and the apertures of the true or fully developed zooecia. The latter are somewhat seattered, though a tendency to arrangement in series-chiefly longi-
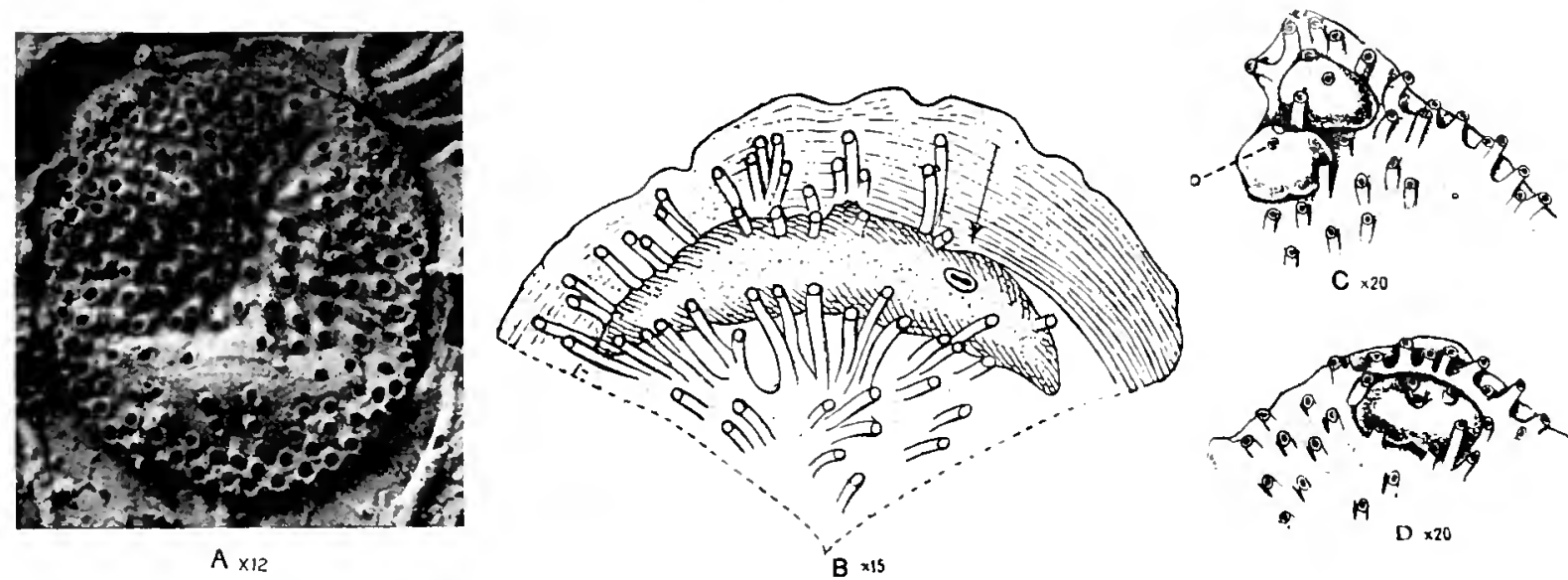

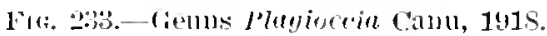

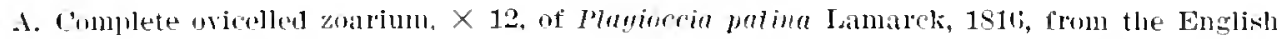
chamet.

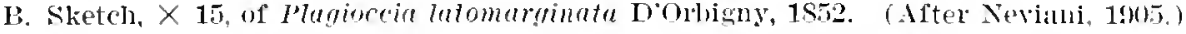

C. Two views, $\times 20$, of ovicelled poltions of Plagiorrin stmiensis Noman, 1864 . (Atter Harmer, 1915.)

tudinal-is commonly apparent. Zooecial apertures orate, ahout $0.1+$ by $0.18 \mathrm{~mm}$., with about five in $2 \mathrm{~mm}$. Interapertural space as well as apertural corers. minutely punctate. In rertical fractures the tubes are shown to be very long and that they approach the surface rery gradually. Oocium. a mere inflation of the surface througl which one or more of the zooecial tubes pass. In the general form of its zoarium this species agrees rery well with $F$. paconing (Michelin), DOObigny's type of the genms, but its zooecia are much smaller and not nearly so prominent.

The above deseription by Trich is excellent, but Fasciporu, to which he referred the species, is only a zoarial form and not a natural genus. Judging by the oricell, this is a rery typical Plugioccia.

Occurpence-Lowest Focene (Bryomon bed at hase of Aquia formation): Upper Marboro, Maryland (rare). 
Plate 106, figs. 6-14.

Description.-The zoarium is formed of bilamellar, rounded and flabellate lobes, branched in the same plane. The tubes are indistinct, arranged in regular quincmx, ornamented with salient, widely spaced, and overlapping wrinkles. The peristome is little salient, thin, elliptical, often acuminate distally. The ovicell is large, ghobular, very convex, arranged transrersely in the upper part of the lobe. The zone of growth is thiek, but not very wide.

Measurements._Diameter of the peristome___________ $0.10-0.12 \mathrm{~mm}$.

rariations.-The lobes are very irregular in dimension; their base is more or less narrowedl.

In tangential section we note that the tubes are perforated with the usual tremopores. Their arrangement in fusiform, elongate, lozenge-shape areas proves that their system of branehing offers no peculiarity.

The irregularity of the transverse sections is oceasioned by the unequal divergenee of the tubes.

Occurrence.-Midwayan (Clayton limestone). Luverne, Crenshaw County, Alabama (very eommon); one mile west of Fort Gaines, Georgia (rare).

Cotypes.-Cat. Nos. 65422, 65423, U.S.N.M.

Plagloecia Clavioedes, new species.

Plate 106, figs. 15, 16.

Description.-The zoarium is flaballiform and inerusts shells. The tubes are distinct, regularly clariform arranged in regular quincunx, the peristome is little salient, elliptical, horizontal. The ovicell is large, globular, little distant from the zoarial margin. The zone of growth is quite visible, but of little width and thickness.

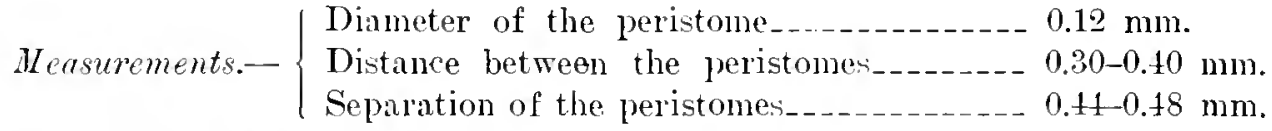

Occurrener.-Midwayan (Clayton limestone) : One mile west of Fort Gaines, (reorgia (very rare); Mabelvale, near Little Rock, Arkansas (rare).

IIolotype.Calt. No. 6ttet, U.S.N.M.

PLAGIOECIA SUPERPOSITA, new species.

Plate 106, figs. 17, 18.

Description.-The zo:rium incrusts terebratuloid brachiopods; it is formed of orlicular subcolonies adjacent and superposed. The tubes are little distinet, cylindrical, short, arranged in quincunx at the center ant in radial rows on the milgins, never hent upward t the peristome is thin, elliptical or orbicular, according to its obliquity. The ovicell is long, convex, parallel to the zoarial margins. The zome of growth is thiek and is supported by the projecting basal lamella. 
Mcasurments.-Diameter of the peristomes $0.13 \mathrm{~mm}$.

Affinities.-In its zooecial arrangement this species is very close to Plagioecia concreta, but differs from it in its incrusting habit of growth, and in its somewhat smaller micrometric measurements.

The only specimen so far discovered has been figured and comparisons with other species are evidently provisional.

Occurrence.-Midwayan (Clayton limestone): Well at Brundidge, Nabama . (very rare).

Holotype-Cat. No. 65425 , U.S.N.M.

Plagioncia BRUNDIDGENSIS, new species.

Ilate 109, figs. $13,14$.

Description. - The zoarium inerusts terebratuloid brachiopods, in irregular lobes. The tubes are small, distinet, exlindrical, somewhat bent upward at their extremity; the peristome is thin. little salient, elliptical. The oricell is very convex, transverse, short. The zone of growth is invisible.

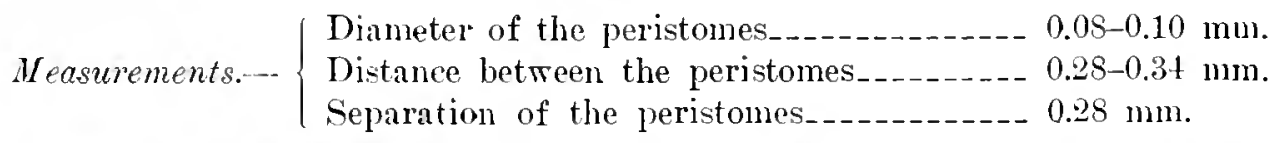

Occurrence.-Midwayan (Clayton limestone): Well at Brundidge, Alabama (very rare).

Plagioecia TUbifer, new species.

Plate 112, figs. 9-12.

Description. - The zoarium creeps over shells or on algae and emits tubular hollow expansions. The tubes are indistinct, with porous surface, arranged in very irregular quincunx; the peristome is large, salient, very thin, orbicular. The ovicell is short, little convex, transverse, elliptical. The zone of growth is searcely visible.

Mcusurements-Diameter of the peristome__......... $0.1+0.16 \mathrm{~mm}$. Occurrence-Wileoxian (Bashie formation): Woods Blutt, Alabama (rare). Cotypes.-Cat. No. 65265, U.S.N.M.

Plagioecia CONCRETA, new species.

Plate 123, figs. 1-14.

Description.-The zoarinm is free, unilamellar, formed of uggreguted subcolonies, orbicular, adjacent, and superposed. The tubes are distinct. cylindrical, terminated by a short, oblique, peristome, slightly striated transversally, arranged in quincunx. The peristome is round and oblique. or horizontal and elliptical. The ovicell is large, arehed, parallel to the zoarial margins, very convex. The zone of growth is narrow and somewhat thick on the agrgregated zoaria; it is very wide on the simple zoaria. 


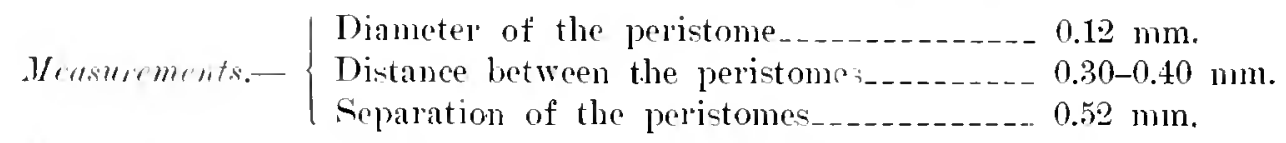

Trrintions.-The zonral variations are rery great. The simple zoaria are typical Jisosporsa with large zoarial malgins and wide zone of growth. The lasal lamella is striated concentrically (fig. 4), sometimes pedunculate. Sometimes the zoarja ale superposed in the form of Domopora (figs. 7, 14); but more often they are agregated in a manner to form large colonies (Muttisporsa) having a measurement of a centineters in diameter. This zoarial proliferation aceurs hy rejurescence; each zoarim is emitted from a vigorous tube of another zoarium which thus serves as a psendoancestrula. It is remarkable to note how an identical phenomenon is the cause of numerous zonrial forms as varied as they are absolutely mexpected.

(In the zoarial margins, the tubes are close togrether and are grouped in radial row and even in short fascicles (fig. 13) an arrangement similar to that in Actinopora.

The tubes are often elosed by smooth diaphrams. Aecording to Waters, this alrangement reveals a long peristomie, of which the diaphragm is the hase. The aspect of our fossils is not therefore the real one.

The ablation of the basal lamella reveals the labitual lozenge-shaped areas, showing that the tubes grow one mon another from their lower dorsal (fig. 9).

The plenomenon of rejurenescence begins always in a central zooecium (figs. 5, 6) prolonged more or less directly from the primitive zoarial ancestrula. In this kind of Domopora, the peristomie. well visilule (figs. 10) in the median sections of the isolated zoartia, risappear's completely (fig. 1t).

Finally, it is not unusual to enconnter incompletely developed orjeells (fig. 12).

This species is especially well developed at Wilmington, North Carolina, and Lenurls Ferry. Sontl, Carolina. The specimens from other localities are small and dombtful.

Aftritirs. - The simple and tree forms differ from Placioceid discoidea in which the tubes have the same dianeter in that the tubes are grouped in radial rows on the zoarial margins and in the greater separation of the peristomes $(0.52$ and not 0.82 111m.).

Gemerenee-Middle .Tarksonian: Near Lemuds Felry, South Carolina (common): Wihmetom, Nortl Carolina (very common).

Tper. Jacksonian (Ocala limestone): Chipola River, east of Mariamna, . Tackson comnty, Florida: Old Factory, about one and one-half miles above bianhrielere, Georgia (rare).

cotyly.s.-('at. No. 6is303. T.S.N.M.

Plagloecia bivagans, new species.

I'late 121, tigs. 1-7.

Ihseription.-The zoarium inclusts shells, bryozoa, and algae on their flat surfares: it is orbicalar or excentric: the zone of growth is thick lint rather nal'ow, 
with numerous incomplete tulnes. The tubes are cylindrical. very elect and wide apart at the center, recumbent and very close together on the zoarial margins. The peristome is orbicular at the center, elliptical on the margins. The ovicell is linge, transrerse, smooth, quite convex.
Mcasurements.-
Dianeter of the peristome
$0.10 \mathrm{~mm}$.
Measuremint.-
Distance between the peristomes
$0.30-0.40 \mathrm{~mm}$.
Separation of the peristomes
$0.10 \mathrm{~mm}$.

Tariations. -This speries sometimes emits subcolonies. The lan'rat is alfixed somewhat at hazard and the zoalia are then rleformed ly the irregularities of the substratum, which gives them the most varied aspects. Fignre 5. plate 121, represents a muliple zoarium fixed on the radicell of an alga and which thus assumes a rery aberant form. The tubes are frequently closed by a calcareous compact. smooth lamella.

This species is well characterized, first, by the thickness of the zone of growth; second, by its tules, which are more erect and more salient at the conter than at the circumference: and, third, by its peristomes, which are very close to each other in the vicinity of the zoarial malrins.

Occurence.-Inwer Jacksonian (Moodys marl) : Tackson, Mississippi (rare). Mishlle Jacksonian: Wilmington, North Carolina (rare); near Isenuds Ferry, Sonth Carolina (rare) ; Eutaw Springs, South Carolina (rale) : Rich IIill, $5 \frac{1}{2}$ miles southeast of Kinoxville, Crawford Comnty. Genrqia (very rare).

Vicksburgian (Marianna limestone): Three miles sonthrest of Vosburg. Jasper County, Misissippi (rare).

f'otypes.CCat. Nos. 6.i.97, 0.2.298, U.S.N.M.

Plagiogcia globulosa, new species.

I'late 115, tixs. 2-6i.

Lescription.-The zoanm is a cylindrical, hollow Entalophora ; it incrusts rery fine ralicells at their ramifications. The tubes are little visible, somewhat conrex, bordered by a very narow threal; the peristome is oblipue, elliptical, reaular, little salient, thin. 'The ovicell is very lange, globmlum, transverse. very salient, smootl.

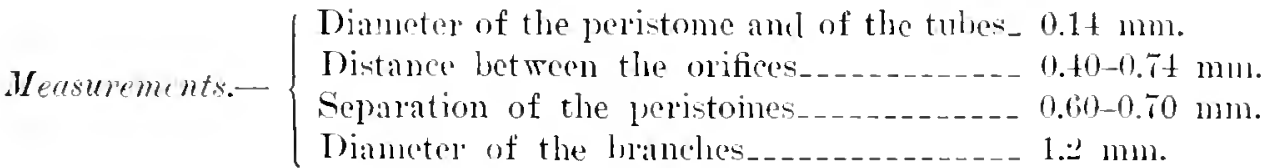

Almust all the tubes of om specimens are closed ly a calcareons lamella. As the lamella of growth is very small, we must suppose that there is a long peristomie.

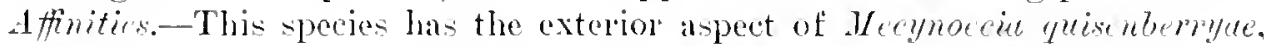
but differs from it in its hollow zonrium with a threadlike cavity in its interion, in the absence of orerhaping winkles mon the tubes, and in it oricell which is larger and of a different form. 
It differs from Diastopora tubiformis in which the zoarinm is almost identical, in the absence of overlapping wrinkles on the tubes, and in the presence of a separating thread between the tubes.

Occurrence.-Middle Jacksonian (Castle Hayne limestone): Wilmington, Nortl Carolina (rare).

('otypes.-Cat. No. 65275, U.S.N.M.

Plagioecia Lamellosa, new species.

Plate 122, figs. 10-13.

Deseription.-The zoarium is unilamellar. The tubes are indistinct at their base, cylindrical, rectilinear, striated, terminated by a very oblique peristomie, arranged in quincunx; the peristome is orbicular and oblique or more often elliptical and horizontal. The ovicell is convex, transverse, in the form of a crescent whose convexity is proximal and not parallel to the zoarial margins. No zone of growth is visible.

Weasurements.- $\left\{\begin{array}{l}\text { Diameter of the peristome } \\ \text { Distance between the peristomes-a- } 0.12 \mathrm{~mm} . \\ \text { Separation of the peristomes }\end{array}\right.$

Affinities.-The difference between this species and Diastopora striatisemota is very slight; they perhaps represent the same species. The present species differs from it in its larger zooecial diameter $(0.12$ and not $0.10 \mathrm{~mm}$.) and chiefly in the great separation of the peristomes $(0.58$ and not $0.40 \mathrm{~mm}$.). This has the same ovicell as Plagioecia botula, but it differs from it in its peristome of 0.12 and not $0.16 \mathrm{~mm}$. More numerous specimens will permit us perhaps to reunite these three species.

Oceurrence-Middle Jacksonian (Castle Hayne limestone): Wilmington, North Carolina (rare).

Cotypes.-Cat. No. 65t29. U.S.M.M.

PLAGIOECIA BOTULA, new species.

I'late 124, figs. 1, 2.

Inescription.-The zoarium is discoidal, incrusting shells, and emits flabelliform expansions. The tules are distinet, long, cylindrical, or somewhat in the shape of a horn, bent upward at their extremity, arranged in regular quincunx, slightly striated, terminated by a short rery oblique peristomie; the peristome is orbicular or elliptical when the peristomie is incomplete. The ovicell is rectilinear, convex in the form of a sansage. The zone of growth is invisible.

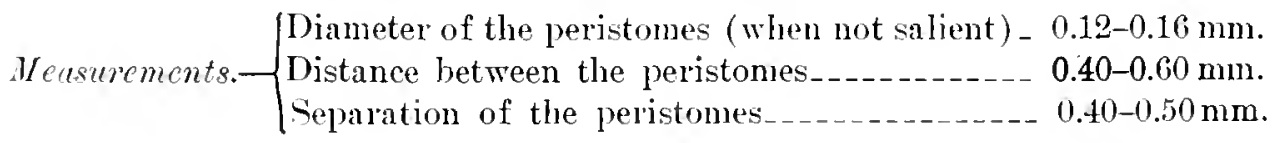


Tariations.-A large number of specimens present in their inferior part two inexplicable fractures, always almost identically arranged and of the same size. We have figured them on plate 124 .

Affinities. - The aspect of this species is similar to that of Plagioccia hirta, but differs from it in its tubes bent up a little (and not rectilinear), and more widely spaced in every sense.

Oecurvence-Miclde Jacksonian (Castle Hayne limestone): Wihnington. North Carolina (rare).

Upper. Jacksonian (Ocala limestone): Nine miles north of Ocala, Florida (very rare); Chipola River, east of Marianna, Jackson County, Florida (rare).

Ilolotype.-Cat. No. 6.530t, U.S.N.M.

Plagioecia hirta, new species.

Plate 124, figs. 3-11.

Description.-The zoarinm incrusts shells and bryozon; it is flabelliform, orbicular, sarely linear. The tubes are distinct, rectilinear, hornshraped, narrowed at the back, very slightly striated, arranged in regular quincunx, prolonged into a very oblique peristomie; the peristome is elliptical, horizontal, very thin, often sharply pointed distally. The ovicell is short, elliptical, not arched, placed near the zoarial margins. There is no visible zone of growth.

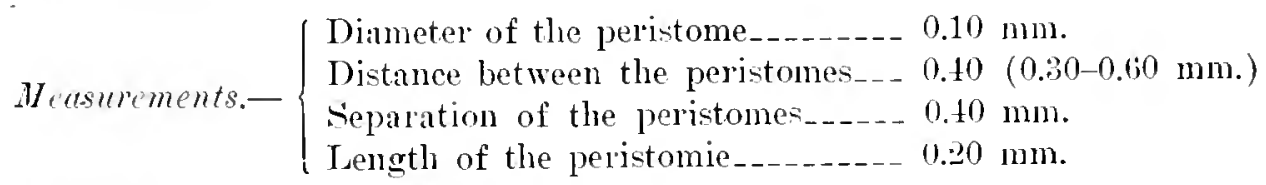

Turiations.-This species is rery well characterized by its rectilinear, salient tubes which give a bristling aspect to the zoarim. The zoarinm, howerer, is rather variable, but it remains quite orbicular when the substratum is flat. We figure (fig. 3) a curions case of the influcnce of the substratum on the ovicell; in consequence of the zoarial envelopment ahout a thin bryozoan, the ovicell appears clongate by perspective and not transverse. It is not rare to encomter many zoaria side by side, but each is provided with a distinct ancestr'tla. Following observations already made, these zoaria do not grow over each other.

We have seen that in the Stomatoporoids the branches of the same zoarium never grow over each other; the same phenomenon oceurs also in the Berenieed forms. In the latter the zoarial superpositions are produced by rejurenescence. How can these animals, growing on the same substratum but proceeding from different larvae, reengnize each other in order not to overlap? The life of these small beings is as mysterious as marvelous.

Affinities. In its zoarial aspect and the bristling arrangement of the tubes, this species has given resemblance to Berenicen nemurosu Milne-Edwards, 1838; it differs from it in its smaller peristone ( 0.10 and not $0.16 \mathrm{~mm}$.), its smaller zooecial 
distance $(0.40$ and not $0.70 \mathrm{~mm}$.) : Jesides, aceording to the figures given by Canu in 1898, the oricell is much more elongated. ${ }^{1}$

This species is also close to Plugioecia suborbiculuris Hincks, 1880 , as it was figured by Canu in 1909, based upon specimens from the Intetian; but the micrometric dimensions of the species are smaller than those of the American species.

It differs from Microerio ritrio in its rectilinear (and not serpentiform) zooecia : in its peristomial diameter of $0.10 \mathrm{~mm}$. (and not $0.08 \mathrm{~mm}$.), in its incrustinge zoarium (and not milamellar) and finally in its larger ovicell.

Occurrence.-Iower .Tacksonian (Moodys marl): Jackson. Mississippi (common).

Middle .Jacksonian: Wilmington, North Carolina (rare) : near Lenuds Ferry, Sonth Carolina (rare); Rich Hill, 51 miles sontheast of Knoxrille, Crawford Comnty. Georgia (rare).

Upper Jackonian (Ocala limestone) : Red Bluff on Flint River. 7 miles above Bainbridge, Georgia (rare): Chipola River, east of Marianna. Jackson County, Florila (rare); Pachuta, Clarke County, Mississippi (very raue); Old Factory

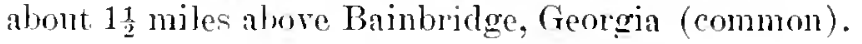

.Tacksonian (Zeuglodon bed): Bluff on south side of Suck Creek, Clarke County, Mississippi (rare).

Vicksburgian (Marianna limestone) : Salt Mountain, 5 miles south of Jackson. Alabama (rare).

rotypes.-C'at. Nos. 65305-6530s. C.S.X.M.

\section{Plagioecia MaRginata, new species}

Plate 125, figs. 1-S.

llscription.-The zourium is free, bilamellar, bushy. formed of undulated loles branching in every direction. The tules are distinct, elongated, flat. bordered hy a salient threal, oval, arranged in irregular cuincunx, striated transversally: the peristome is orbicular or elliptical frequently closed by a smooth calcareous lamella, thin and little salient. The ovicell is comrex, little transverse. sulmolienlar. The zone of guwth is laully visible.

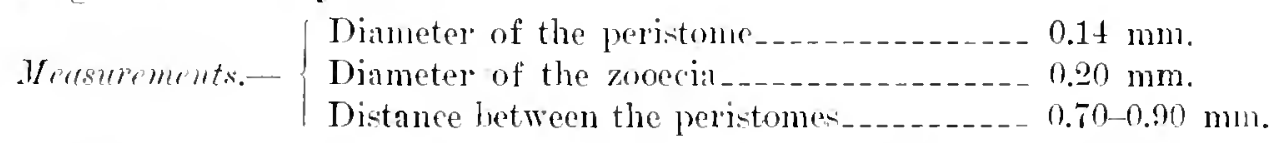

Turiutions.- The peristomie of the tubes was much longer than usually found in these species; a good specimen incrusted by a species of Floridina shows that it may he more than 1 millimeter in length. The nnilamellar forms are not rare.

Attivitis.-This species much resenbles Dinstopora foliace Isamouroux. 1921, of the Bajocian and Bathonian of Europe, but differs from it in its smaller micrometric dimensions.

Cemponre.-Middle Jacksonian: Near Lenuls Ferry, Sonth Carolina (common) : Entaw Eprings, South Carolina (raue).

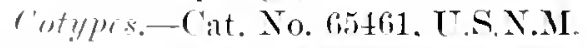

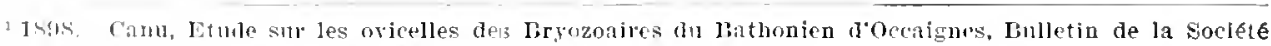

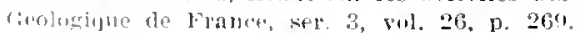


Plagioecia discoideA, new species.

liate 15i5, tigs. 12-17.

Ireseription.-The zourim is free, orbicular, with the form of true I iscosparset. The tubes are distinct, cylinelical, smooth, bent upward at their extremity, arranged in regular quincunx; the peristome is elliptical, horizontal, thin. The zone of growth is hindly risible.

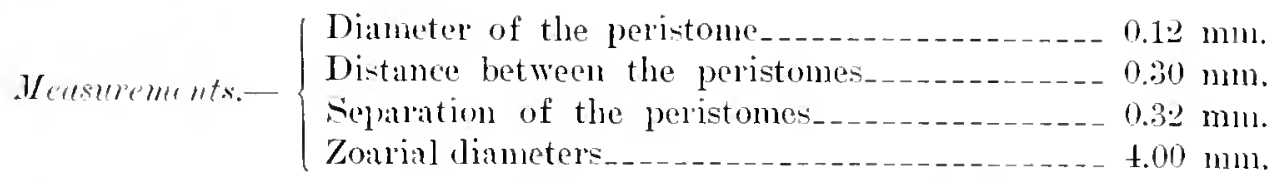

We have not found an ovicell well enough preserved to figure.

Affinitics. -This species differs from the free forms of Plunioneid concretu in its zooceia regrnlarly arranged in quincunx on the zoarial margin-

Occurpence-Cicksburgian (Manianna linestone): One mile north of Monroeville, Alabama (common).

C'otypes.-Cat. No. 65tti1, U.S.N.M.

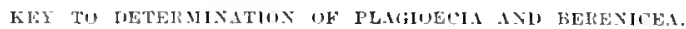

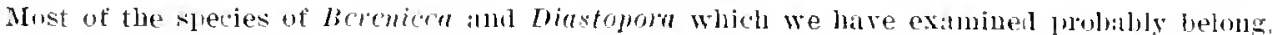
accorling to their exterior resenblances, to Plagiocrin. We lave therefore thuught it necssary to combine them in the sime ley for determination. 'Jluis will facilitate the identitication ot slecinens coming from localities which hare been studiel. It is evident that such keys alle Imrely artificial ant that they can not serve as a basis for a natural classitication. Horeover they are necessarily unly iluroximations.

Zourium bilamellar.

1 Zontium milamellat_....

Kairium incrustiug

Zo: rium composite

, Yoillum in thick, regular flomds.

$2\{$ Zanrium in thin lamellate_.

Tubes mareinate

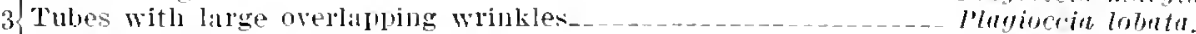

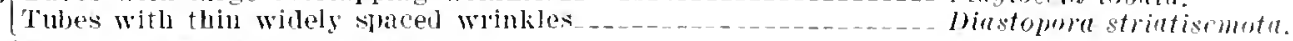

$4\{$ Zatrium disenictal (Discosparsa)

YKoarim not discoidal (Diastoprora)

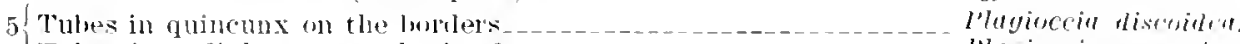

Tules in radial rows on the boldel's.

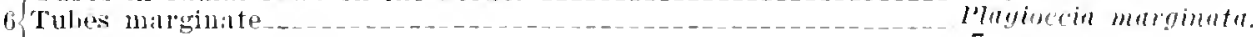

Tubes not marerinati.

(I'eristume of $11.20-1,2+$ num.

I'eristome of $11.14-11.16$ mml., znoteial indistinct

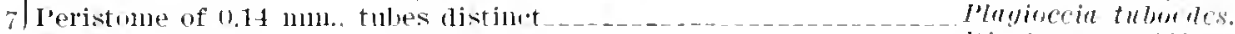

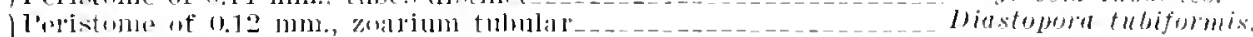

Peristome of 0.12 mum, zoarim lamellar.

leristome of 0.10 mII].

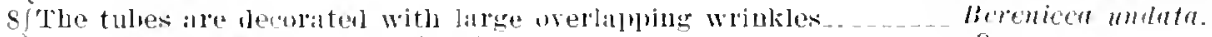

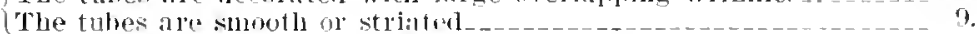

f'The tuhes ale vely close together nearly adjalcent _ _

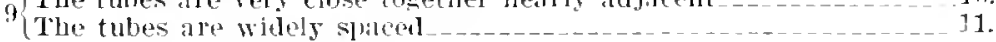

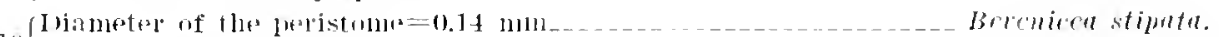

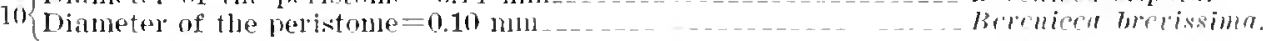




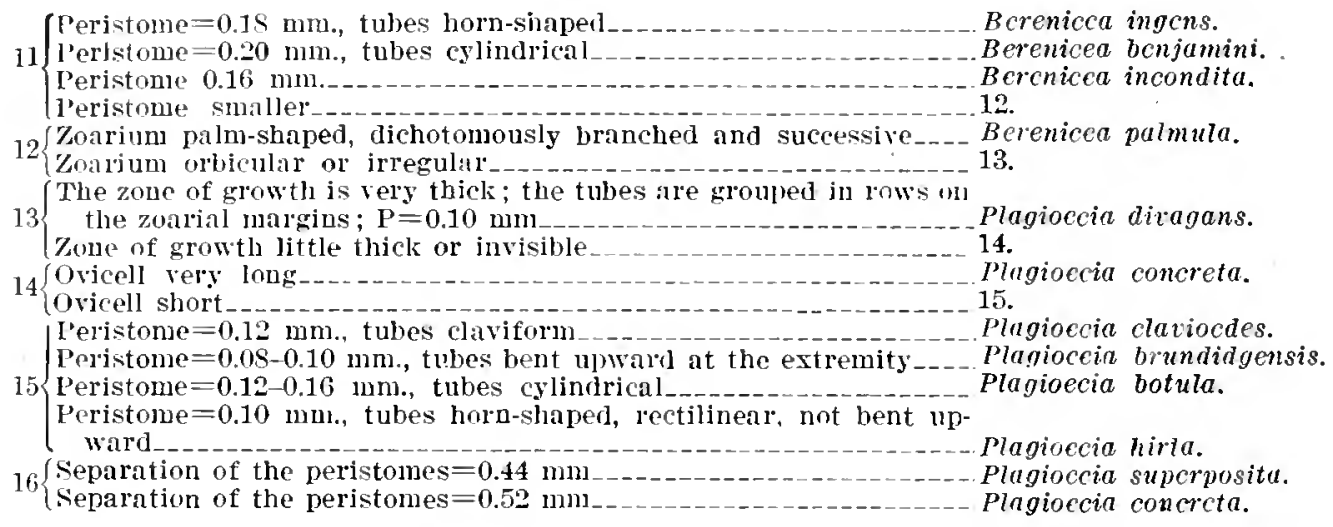

DESMEPLAGIOECIA, new genus.

Plagioecia in which the tubes are grouper in fascicles. Genotype.-Berenicea lineata MacGillivray, 1885. Range.-Turonian-Recent.

This genus includes the genus Actinopora D'Orbigny, 1852, that is to sav, the assemblage of species with orbicular zoarium. It is necessary to classify in it also

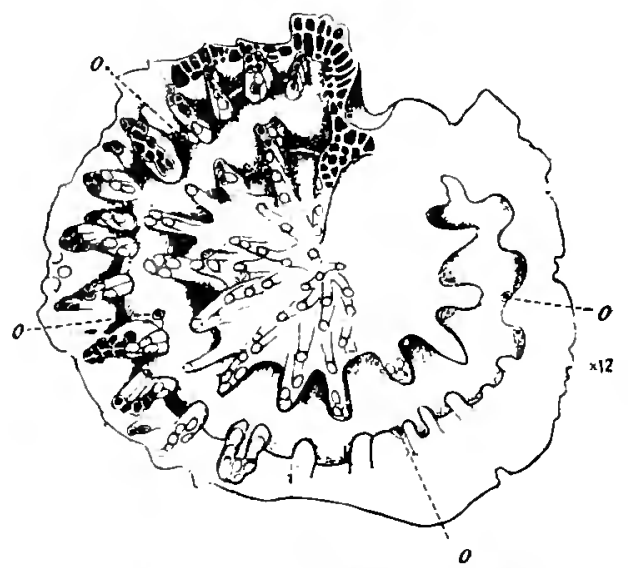

Fig. 234.-Desneplativeci:ı, new renus.

A colony of Desmeplagioecia (Actinopora) lincata MacGillivray, $1885, \times 12$, in whlch the ovicells form an almost complete ring. $o$, oerinstome. (After Harmer, 1915.) certain species of Reticulipora of the group Reticutipora olliqua D'Orbigny, 1852. We include in it also some species of the old group of Reptotubigera; these are the incrusting dichotomons forms. We do not think that the zoarial dichotomization corresponds to a special function. In spite of the very great exterior difference between the zoarial forms Actinopora and Reptotubigera, we class in the same genus all the species in which the ovicell is identical and which are provided with fascicles. This ovicell is transverse and it interrupts or deforms the fascicles just as in Plagioecia it obstructs, separates, or deforms the isolated tubes. The oricell is evidently formed before the calcification of the ncighboring tubes.

The principal species hitherto described are;

Desmeplarinecin (Berenicea) lineata MacGillivray, 1885. Recent.

Desmeplagioecia (Pavotubigera) gambierensis Waters, 1884. Miocene.

Desmeplagioccia (Pavotubigere) dimidiata Waters, 1884 (not Reuss, 1847).

Mincene.

Desmeplagioecia (Semitubigera) dollfusi Canu, 1909. Lutetian.

Desmeplagioecia (Actinopora) organisans D’Orbigny, 1851. Cretaceous. 
DESMEPLAGIOECIA DICHOTOMA, new species.

Plate 125, figs. 9-11.

Description.-The zourium incrusts shells mpon which it forms claviform, dichotomously branched lobes. The fascicles are crowded and arranged alternately on ench side of the zooceial axis; they are formed of three to six zooecia. The tubes are short, distinct, little convex; the peristome is thin. The ovicell is convex, short, transrerse; it interrupts five fascicles. The protoecium is rery small in rapport with the ancestrula.

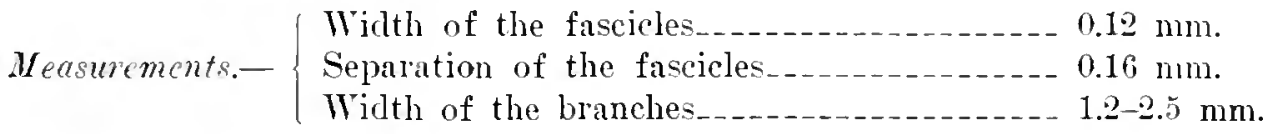

$$
\begin{aligned}
& \text { Occurrence.-Upper Jacksonian (Ocala limestone): Old Factory abont } 1 \frac{1}{2}
\end{aligned}
$$

DESMEPLAGIOECIA COMPRESSA, new species.

Plate 125, tigs. 16-19.

Description.-The zoarium has the Reticulipora form of growth with compressed fronds. The fascicles are incomplete, irregular, perpendicular to the zone of growth. The tubes are distinct, little convex. The peristome is orbicular. thin, salient. The zone of growth is very broad.

Tariations.-According to fragments observed, the ovicell appears to be that of Desmeplagioecia; but this must be confirmed.

The fascicles are rery irregular in length; they are often eren replaced by cellular rows, in which the peristomes are not adjacent.

The Reticulipora form appears to develop chiefly in very calcareous waters.

Occurrence-Upper Jacksonian (Ocala limestone): Chipola River. east of Marianua. Jackson County, Florida (rare).

Cotypes.-Cat. No. 6.3315, U.S.N.M.

\section{DESMEPLAGIOECIA LOBATA, new species.}

Plate 126, figs. 4-i.

Description.-The zoarium is free, bilamellar, composed of lobes which are rounded, irregular, undulated, ranified. The fascicles are very short, formed of four or five tubes, scarcely salient, arranged on each side of the axis of folding or undulation of the lobes. The tubes are indistinct, isolated at the center and seattered on the margins. The zone of growth is thick and rather wide.

It is at hazard that we classify this species in the genus Iscomeplugioccia as we possess only two nonoricelled specimens.

Occurience.-Middle Jacksonian: Eutaw Springs. South Carolina (rare).

Cotypes.-Calt. No. 65317, U.S.N.M. 
Description.-The zourim is bilamellar. formed of folded, irregular, undulated. flabellate or linear lobes. The fascieles are inconstant. irregular, little salient. long, perpendienlar to the zoarial margins; the tubes are little distinct, isolated on the axis of mndulation of flabelliform branches.

The zone of growth is wide and very fragile.

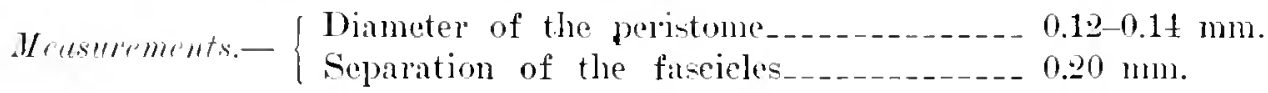

Truirtions.-This species is ruite remarkable, but unfortmately we know only a small number of specimens of which we have been mable to make a detailerl study.

The species has the zoarial form of Reticulipord. but rery irregular: the lobes are folded on themselves, but they are not elongated and linear. The flabelliform specimen is nnilamellar.

Occurpence-Widdle Jack-onian: Wilmington, Forth Carolina (rare) : near Lenuds Ferry, Soutl Carolina (rare).

Upper Jacksonian (Oeala limestone): Nine miles north of Oeala. Florida (very rare); Alacha, Florida (very rare).

Cotypres.CCit. Nos. (55313, 65314, U.S.N.M.

DESMEPLAGIOECIA (ACTINOPORA) BREVIS, new species.

Plate 120, figs. $1-3$.

Description.-The zorium is orbicular and incrusts oysters. The fascicles are short, irregular, discontimons, formed of three or four tubes, very salient, quite close together, arranged radially. The tubes are invisible; the peristome is thin, orbicular or quadrangular. 'The zome of growth is invisible, or much reeluced.

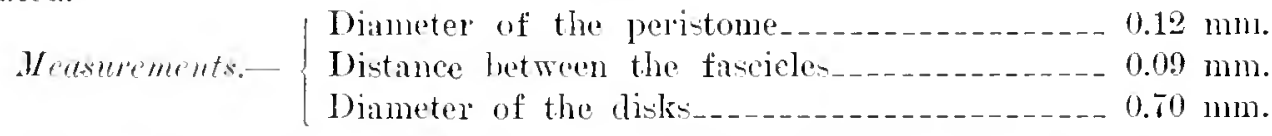

Affinitic.- This species dithers from Desmeplarioceta temissima and I'. tenuis lieuss. 1869, in its greater peristonial diameter (0.1.2 and not $0.05 \mathrm{~mm}$.) and in the much sualler zone of growth.

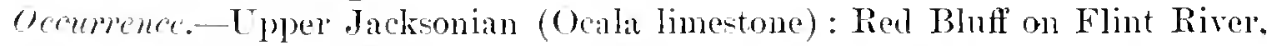
7 miles above Bainlnidge, (reorgia (lane); Old Factory about $1 \frac{1}{2}$ miles above Bainbridge. Georgia (very rare).

Cotypes.CCat. No. 65316, U.S.N.M. 
DESMEPLAgIOECIA (ACTINOPORA) TENUIS Reuss, 1869.

T'late 15\%, figs. 1-6.

38Bt. Infrancia monosticha Rerss, Teber Anthozoen mo liryozon der Mainzor Tertiarbeckens, Sitzungsberithte der k. Akademie der Wissenschaften, Wein, vol. 5n, 1. 11, pl. 3, fig. 1.

1S69. Discosparsa tenuis Reuss, Palionfologische Studien ibbr die alteren Tertiälschichten der Alpen. Crosaro, Denkschriften der k. Alatemie der Wissenschaften, Wien, vol. 29, p. 290 , pl. 34, 1ìgs. 9, 10.

1869. Discosparsa reqularis Reuss, Idem, p. 280. pl. 34, fig. 11.

1SST. Disensparsa tenuis PERgens, Note preliminaire sur les Bryozoaires fossiles de environs de Kólesvar, Bulletin de la Société rogale Malacologique de Belgique, vol. $2,2,0.37$.

1S92. Diastopor tenuis WATER, North Italian Bryozoa, Cyclostomata, Quarterly Journal of the Geological Society of Inndon. vol. 47, p. 154.

Description.-'The zoarium is free, discoidal, pedunculate or not. The fascicles are salient, very close together, arranged radially, almost continuous. The tubes are indistinct; the peristome is orbicular or quadrangular. The ovicell is very long, convex. parallel to the zoarial margin. The zone of growth is narrow. The lower face is concive, striated concentrically.
Mersurements-
Diameter of the peristonle $0.13 \mathrm{~mm}$.
Separation of the fascicles $0.13 \mathrm{~mm}$.
Diameter of the zoaria $3.00-0.00 \mathrm{~mm}$.

Afrnities.-Our determination has been based on the figures and not upon German specimens. In aspect our figures are similar to those of Defrancia monosticha Reuss, 1864, but the American zoaria are larger. We see no difference from Discosparsa tenuis Renss, $\mathbf{1 8 6 9}$.

This species differs from Desmeplagioecia breris in its fascicles, which are contimuous and not interrupted, and in its free zoarium. It differs from Dcsmeplagioecia tenuissima in its larger zoarial diameter.

Ocomrence.-Vicksburgian (Marianna limestone): One mile north of Monroeville, Alabama (common).

Geological distribution.-Priabonian of Vicentin (Reuss, Waters) and of Kolosvar (Pergens); Rupelian of Germany (Reuss).

Plesiotypes.-Cat. No. 65459 , U.S.N.M.

DESMEPLAGIOECIA (ACTINOPORA) TENUISSIMA, new species.

Plate 126, figs. S-10.

Description.-The zoarium is discoidal, free or incrusting shells, eccentric. The fascicles are very thin, arranged rulially, very salient, discontinuous. 'The tubes are invicible; the peristome is thin, orbicular, or rectangular. The ovicell is rery long, thin, little convex. The zone of growth is thick and rather wide.

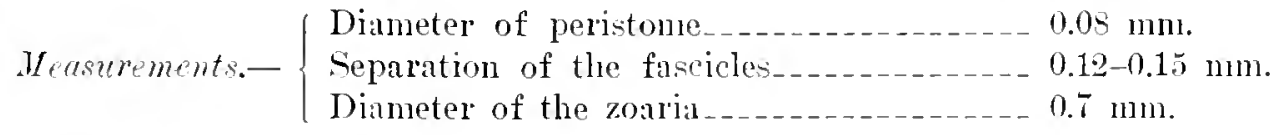
5.5501-20-Bull. 106- 46 
This species is well characterized by its small peristomial diameter and its very little convex ovicell. Desmeplagioecia brevis and Desmeplagioecia tenuis Reiss, 1869 , have a larger zooccial diameter $(0.12 \mathrm{~mm}$.).

Oceurence-Upper Jacksonian (Ocala limestone): Chipola River, east of Marianna, Jackson County, Florida (rare); Red Bluff on Flint River, $\tau$ miles above Bainbridge, Georgia (very rare); Old Factory, about $1 \frac{1}{2}$ miles above Bainbridge, Georgia (rare).

Cotypes.-Cat. Nos. 65318, 65319, U.S.N.M.

\section{Family MACROECIIDAE Canu, 1918.}

1918. Macrocciadac CANu, hes ovicelles des bryozoaires cyclostones, Bulletin Sociêté Geologique de France, ser. 4, vol. 16, p. 325.

The longitudinal axis of the ovicell is parallel to the axis of the tubes. The ovicell is formed before the calcification of the neighboring tubes whose order and ar'angement are disarranged. The oeciostome is immense and terminal.

This family is characterized by the size of its larva established by that of the oeciostome. No American species have so far been discovered.

Genus MACROECIA Canu, 1918.

1918. Macroceia CANu, Les ovicelles des liryozonires cyclostomes, Bulletin Société Geologique de France, ser. 4, vol. 10̉, p. 328.

The oricell is elongate, elliptical, rery salient. The oeciostome is not turned toward the bottom.

Genotype.-Mucrorcin (Diastopora) lamellosa Michelin, 1845. Jurassic.

Family MECYNOECIIDAE Canu, 1918.

Anatomical biblography.-1914, Waters, Pryozon from 7anzibar, Proceedings of the 7oological Societs of London, p. 840, 11. 2, figs. 1-49-1018. CaNu, Les ovicelles des bryozoaires cyclostomes, Bulletin de la Société Geologique de France, ser. 4, vol, 16, 1. 326.

The ovicell is developed parallel to the tubes. It is formed before them and disarranges their respective position. The oeciostome is anterior and nonterminal.

The principal genera of this family are: Mecynoecia Cann, 1918, Microecia Canu, 1918, and Exochoecia, new gemus.

\section{Genus MECYNOECIA Canu, 1918.}

191S. Mecynoccia CANu, Les ovicelles des hryozoaires cyclostones, Bulletin de la sociêté Géologique de France, ser. 4, vol. 16, 1). 326.

The oricell is symmetrical with indefinite contours. The oeciostome is elliptical. transierse, turned towarl the base, generally supported by a tube. 
Genotype--Mecynoecia (Entalophora) proboscidea Milne-Edwards, 1838.

The principal known species of this genus are:

Entalophora australis Busk, 1875. Recent.

Entalophora deliectulu Busk, 1875. Recent.

Entalophora deftexa Smitt, 1872. Recent.

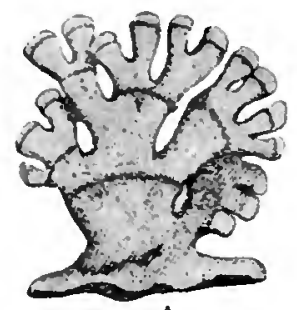

A

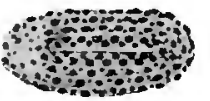

C

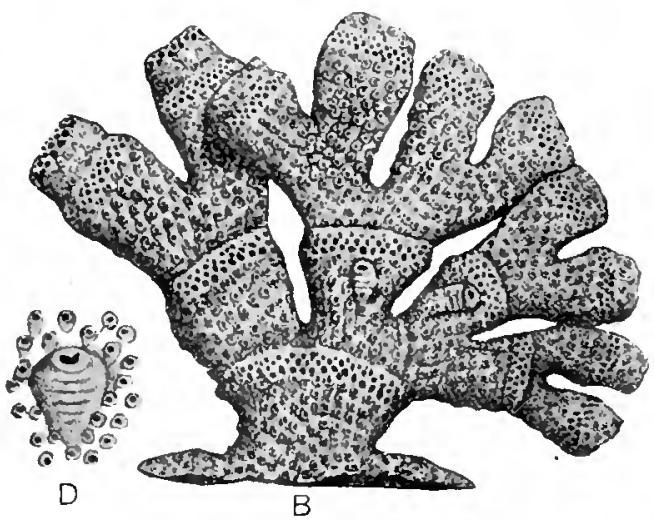

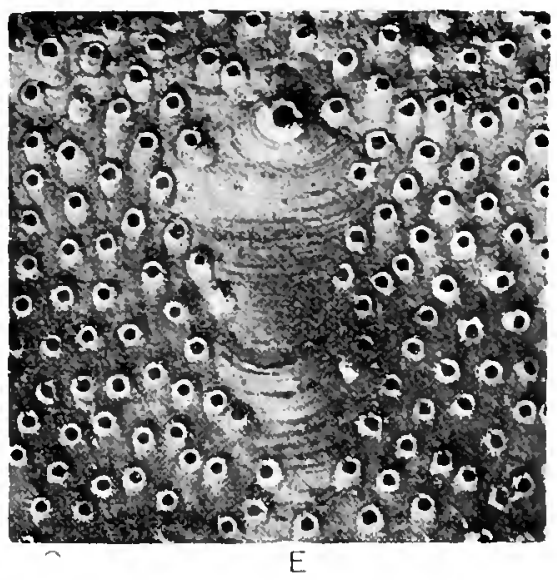

E

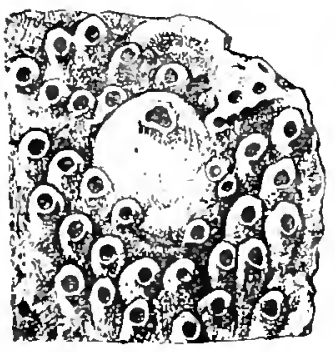

$\mathrm{F}$

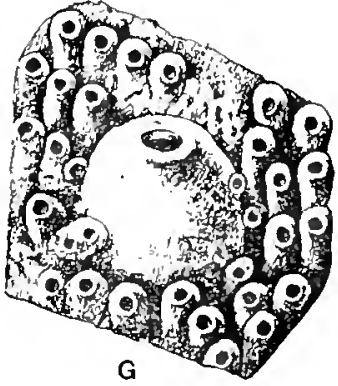

G

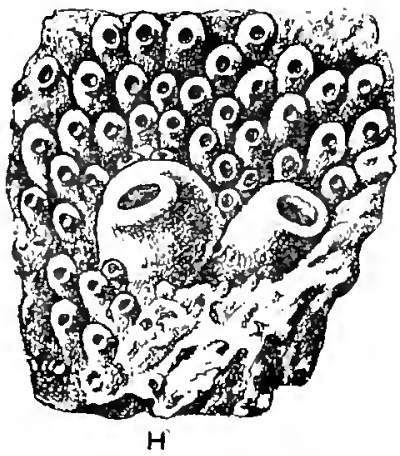

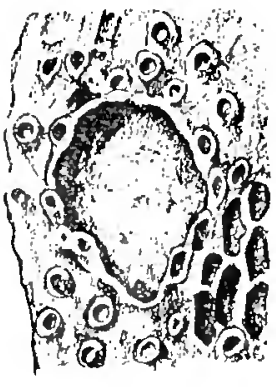

1

Fig. 235.-Vienus Macroccia Canu, 1918.

A-I. Macroccia (Diastopora) lamcllosa Michelin, 1St5. A, B. Zoarium, natulal size and enlargel. C. cross section of branch, enlarged. D. Sulface with ovicell, enlarget. (A-I). After

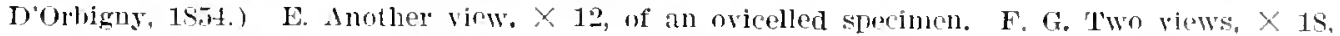
showing the ovicell well develuped. H. Axample with two adjacent ovicells, $X 18$. I. A broken ovicell, $X 18$, showing the oluning of the inferine tube of which it is anly tle dilaterl lart. (F-r, after (anu.)

Entulophora pulchella Reuss, 184T. Priabonian.

Entalophora madreporacea Goldfuss, 1827. Cretaceous.

Entalopora sretrece Dorbigny, 18.0. Turonian-Senonian.

Proboscina radiolitomem D'Orbigny, 185̆1. Cenomanian.

Entulophom cellerioides Lamouroux, 1821. Juracic.

Proboseine angustatu D’Orbigny, 1851. Cretaccous.

Laterotubigera femosu DoOrbigny. Coniacian. 

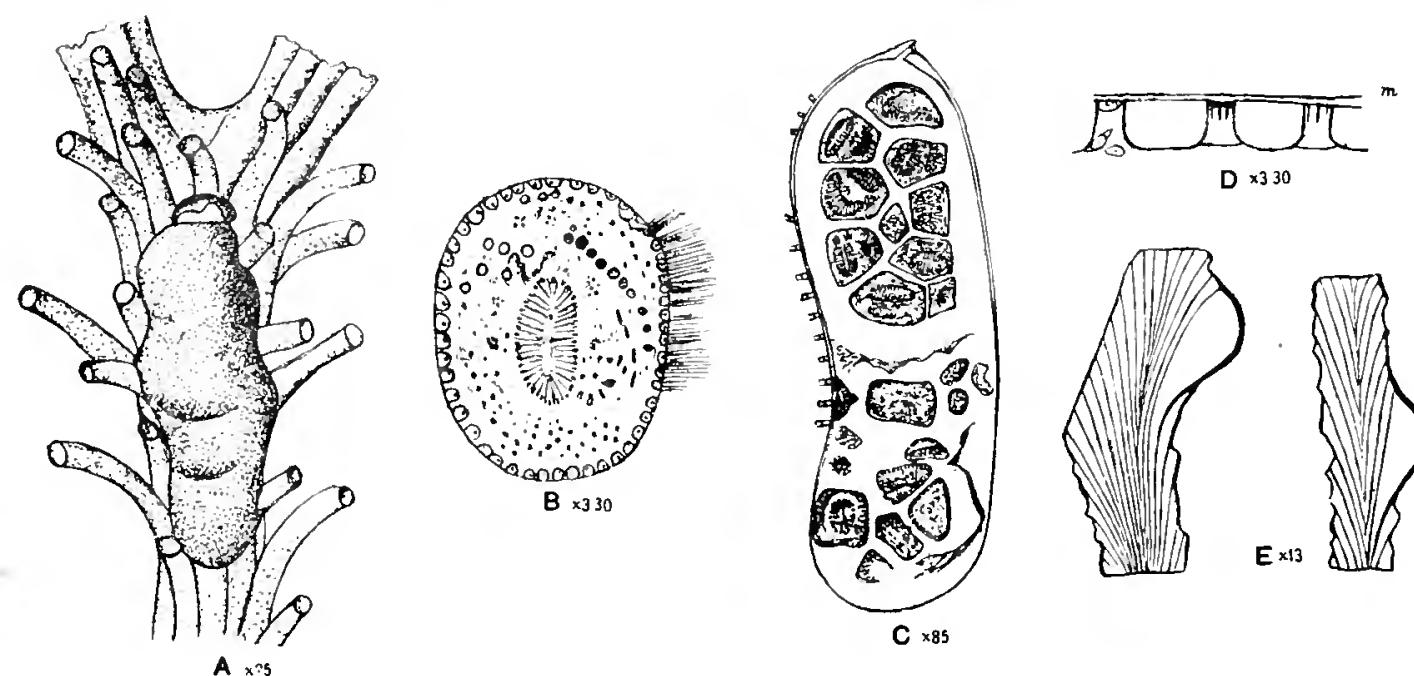

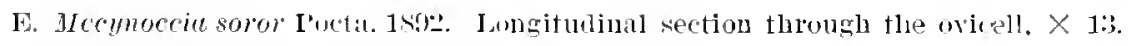

A-D. Mecynoecia dclicatula Busk, 15i.j. A. Frament of zoarium, $\times 25$, showing the elungated aricell with transierse oeciostome. B. View of the enbryo, $\times 270$. C. Soction of the ovicell containing embryos, $\times$ S5. D. Section of the surface pore tubes, $\times 330$. The exterior membraue ( $m$ ) is the ectocyst. (A-D after Waters, 1914.)

E. Mecynoccia soror Pucta, 1892. I.ongitudinal section through the ovicelli, $\times 13$.
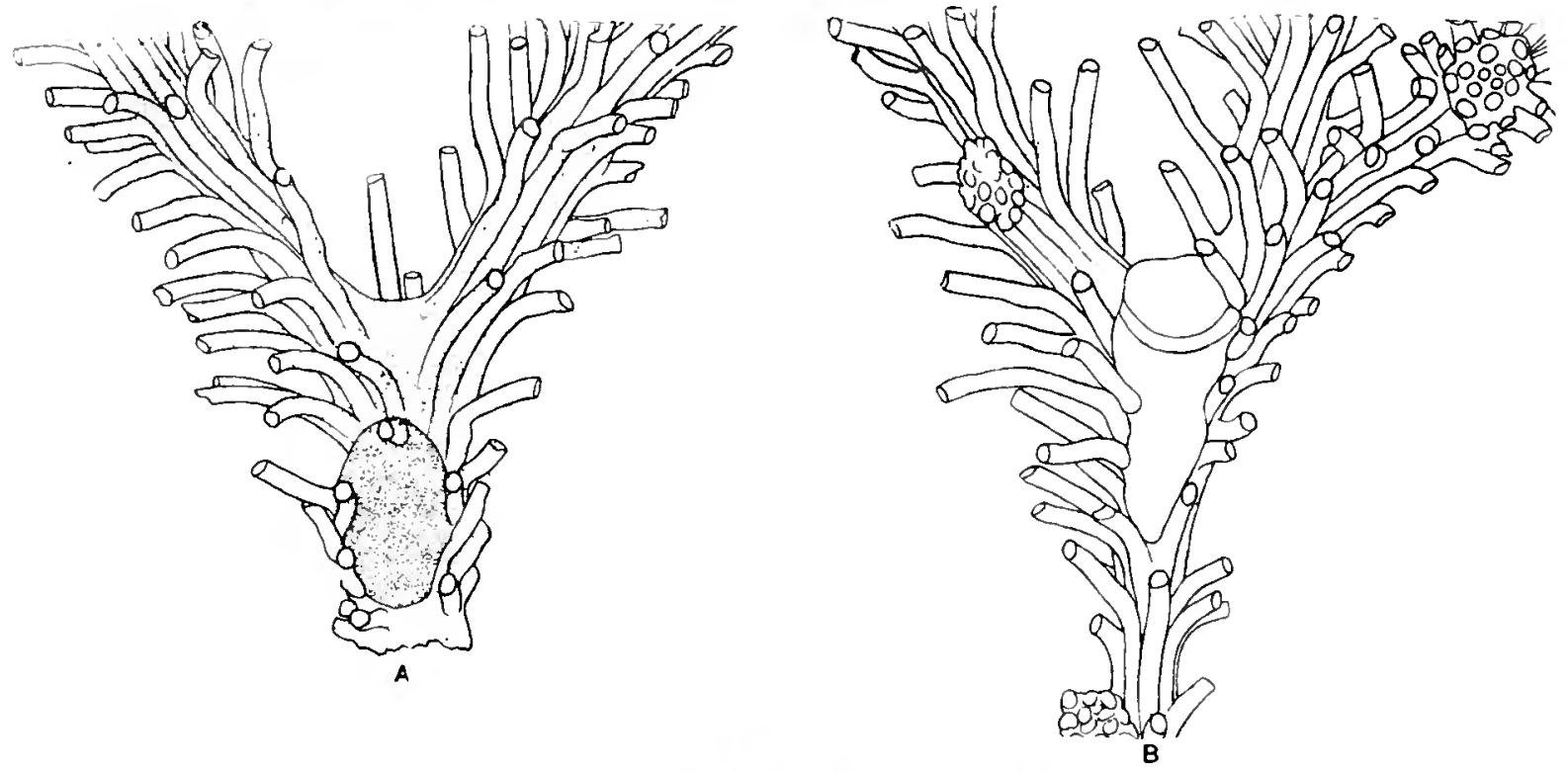

Fig. 237.-Genus Hecynoccia Canm, 1918.

A, I;. Two oricelled specimens of Ifecmoecia delicatula Busk, 1875. (After Smitt, 1872.) 


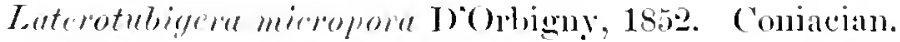

Entalophora vendinnensis D'Orbigny, 1850. Cenomanian.

Berenicea tenuis D'Orbigny, 1850. Oxfordian.
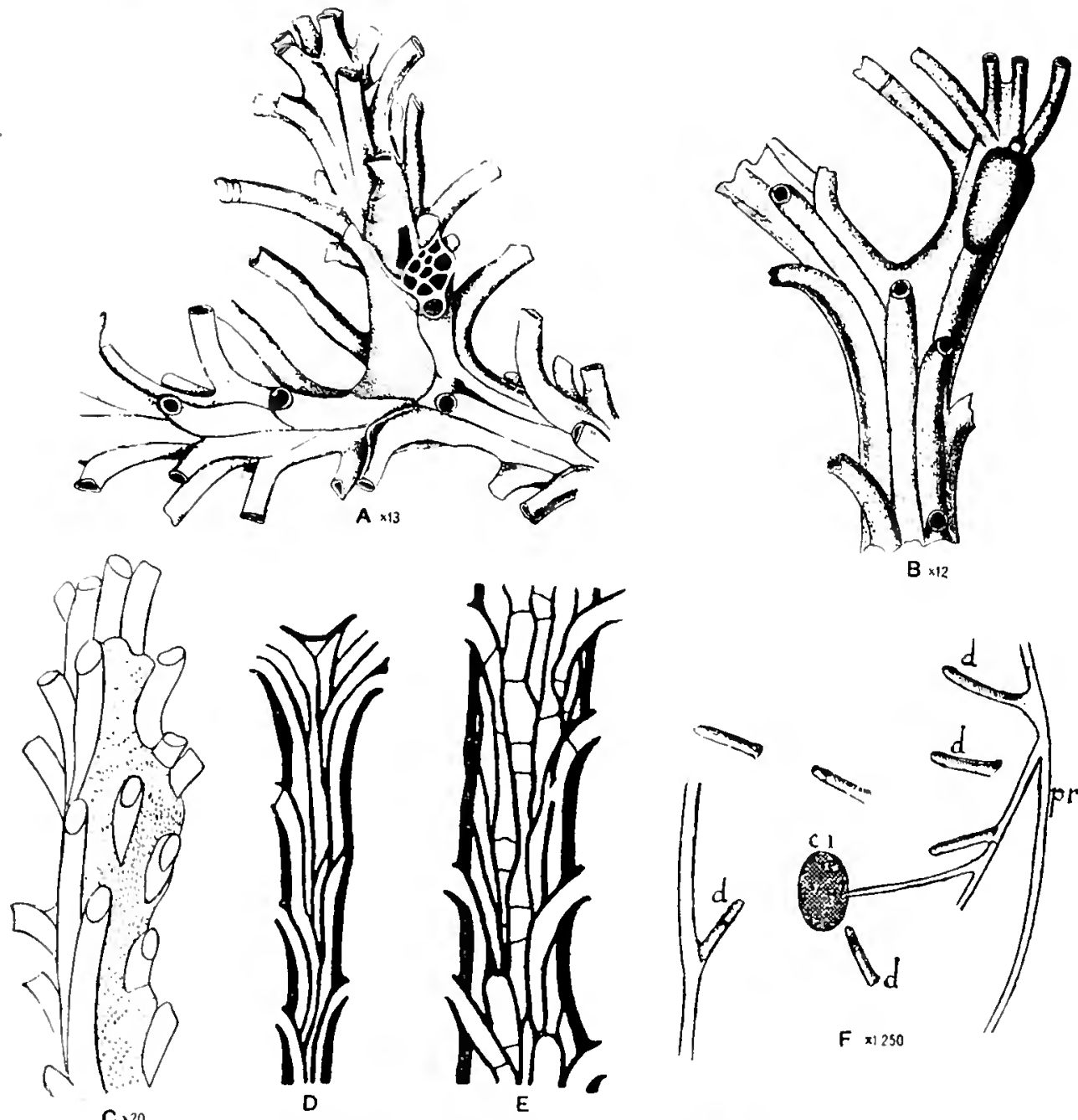

. 20

Fig. "ws.-Mecynoceia (Entalophora) probosciden Milue-Luwards, 1538.

1. Ovicelled brinch enlarged. (After IIarmer, 1915.) P. Another ovicelled specinen, $X 12$. (After Waters.) C. A third illustration of the ovicell, $\times 20$. (After Neviani. 195.) D. Longitudinal section of a slenter colnny. E. Longitudinal section of a thick, old branch of variety rustica Higenow, 1550, with a central elongated citrity and with numerous septil. F. Lengituli-

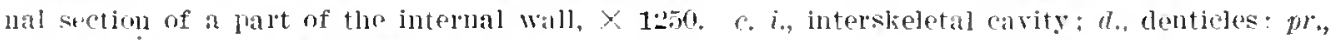
prolonsation. (I-F' after I'ergens, 18sa.)

Diastopora eschuroides Michelin, 1817. Cenomanian.

Proboscina parvitubulate Gregory, 1896. Bathonian.

Lienstopora dneidsoni Jaine. 1554. Jajocian-Bathonian. 
The known species of the zonrial form known as Entalophora are classified whon the oricell is known in the three genera Diaperoecia, Mecynoecia, and Plagionetu. Those which belong to Plagioecia have compact fronds of hollow zoaria, incrusting roots of algae, and in which the primitive berenicoid form is thus molified by the substratum. The species bolonging to the genus Diaperoccia are relatively rare and have an aspect of regularity unknown in the other genus. The species belonging to the genus Mecynoceia are the most common. For the forms without ovicell we maintain as heretofore the zoarial genus Entalophora.

\section{MECYNOECIA PROBOSCIDEA Milne-Edwards, 1838.}

I'late 108, figs. 1-15.

1900. Entalophora proboscidea Neriavi, Briozoi neogenici clelle Calabrie, Paleontographia italica, vol. 6, J. 2-42 (128) (regional bibliograplry').

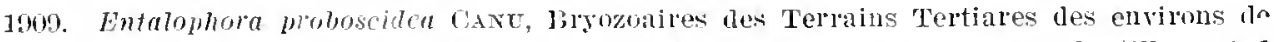
Pilis, Aumales de Paleontologie, rol. $\bar{i}, 1$ 1. 11S. pl. 15, figs. 11, 12. (illustrated bileontulogic bibliography).

1415. Entulophora proboscidca Caxu, Pryozonires fosiles des terrains du Sud-Ouest de la France, Bulletin de la Société genfogique de France, sel. 4, vol. 15, p. 331 (regiona) bibliograpliy).

1915. Entalophora proboscidca Harsrer. The lolyzoa of the siboga expedition, p. $10 S$, pl. 10, fig. 12 irecent bibliography).

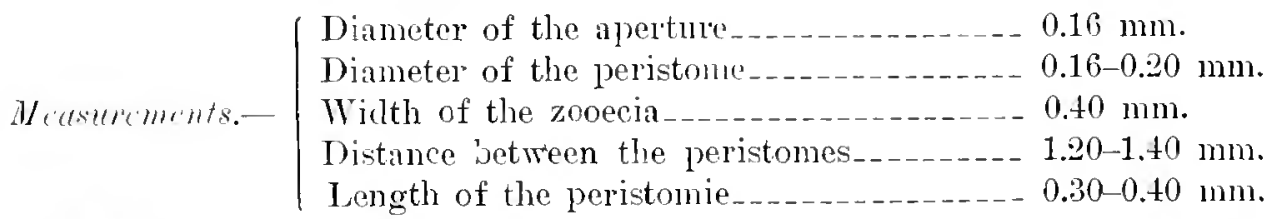

Tariations.-This species is quite variable like all the common species, but its micrometric measurements are rather constant and it is very difficult to discorel important varieties. The ovicell is not very constant in its form as may be noted from the published figures (fig. 225). Probably under the name of Entalophora proboscidea, there are many species of which it will be necessary to discover the constant characters.

Occurrence.-Midwaynan (Clayton limestone): Mabelvale, near Little Rock, Arkansas (very common).

Miclelle Jacksonian: Wilmington, Nortll Carolina (rery common); near Lenuds Ferry, South Carolina (very common); $3 \frac{1}{ \pm}$ miles of Perry, Georgia (very conmon) ; Rich Hill, $5 \frac{1}{4}$ miles sontheast of Knoxville, Craw ford County, Georgia (very common); one-half mile sontheast of Georgia Iraolin Co. mine, Twiggs County (xeoroia (rare); 12 miles sontheast of Marshallville, Georgia (very common); Baldock, Barnwell County, Sonth Carolina (very rare); 18 miles west of Wrightsville, Johnson County, Georgia (rarc) ; "st miles north of Grovania, Georria (rare); 17 miles northeast of Hawkinsville, Georgia (very rare).

Upper Jacksonian (Ocala limestone): West bank Sepulga River, Escambia County, Nlaloma (common); Chipola River, east of Marianna, Jackson County, 
Florida (common) : Old Factory, about 1 $\frac{1}{2}$ miles above Bainbridge, Georgia (rery rale).

Vicksburgian (Mariamna limestone) : Salt Mountain, 5 miles south of .Tackson, Alabama (common); West bank Conecuh River, Escambia Comty, Alabama (very rare); One mile nortls of Monroeville, Mabama (very common); Murder Creek, east of Castlebury, Conecul County, Alabama (rery common).

Gcolorical distribution.-Cretaceous-Recent. Cosmopolitan in Europe and America.

IIabitat.-Cosmopolitan in both hemispheres and in the wam and temperate zones. This is a species of the depths; it appears first at 10 meters: attains its maximum of abundance towarl 100 meters, and may descend almost to 330 meters. It affords, therefore, a resy useful measure of depth.

Plesiotypes.-Cat. Nos. 6rt37, 65438 , U.S.N.M.

\section{MECTNOECIA LUVERNENSIS, new species.}

Plate 109, figs. 10-12.

Description.-The zoarium is an unbranched Fitisparsa in which the noncelluliferous dorsal fice is trinsversally wrinkled. The tubes are short. little visible. elevated at their extrenity and terminated by a very short peristomie elevated almost rertically; the peristome is thick, orbicular. The ovicell is large, salient, globular; the oeciostone is elliptical. salient, transverse. supported on another tube.
Wecusurements.--
biameter of the peristome $0.20-0.22 \mathrm{~mm}$.

\section{Liameter of the apertulia}
Diancer between the peristome
$0.16 \mathrm{~mm}$.
$0.25 \mathrm{~mm}$.

Occurrence.-Midwayan (Clayton limestone): Inverne, Crenshaw County. Alabama (rare).

Cotypes.-Cat. No. 6.257. U.S.N.M.

\section{MECYNOECIA CYLINDRICA, new species.}

Ilate 12 $\vec{\imath}$, figs. $1-\overline{\mathbf{t}}$.

Jescription.-The zonrium is an Entatophora, legularly mplimbirul. lifurated. The tubes are cylindrical, visible, separated by a rery thin, salient threal; the peristomes are salient, orbicular, regularly arranged in quincunx. The ovicell is a large priform sack whose oeciostome is isolated.
Weasurments.- $\left\{\begin{array}{l}\text { Di } \\ \text { Di }\end{array}\right.$
Diameter of the peristome $0.10-0.12 \mathrm{~mm}$
Distance between the peristomes. $0.42-0.46 \mathrm{~mm}$. Separation of the peristomes $0.89 \mathrm{~mm}$.
Diameter of the branches $1.00 \mathrm{~mm}$.

Affinitics. -This species is very well characterized by its pyrilorm ovicell, its cylindrical and regular branches, and by its zooccial margins. It is much smaller 
(peristome $=0.10$ and not $0.16 \mathrm{~mm}$.) than Mecynoecia 7unata, in which the branches are also quite ylindrical.

Occumence-Mikdle Jacksonian: Wilmington, North Carolina (very common) ; near Lemds Ferry. South Carolina (rare); 18 miles west of Wrightsville, Johnson County. Georgial (very rare); $3 \frac{1}{2}$ miles north of Grovania, Georgia (rare). Cotyly s.-Cat. No. 65465 , U.S.N.M.

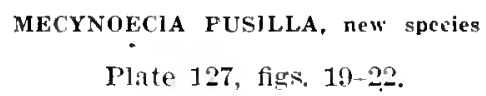

Descriptiun. - The zoarim is a smal7. hifureated Entulophora. 'The tubes are distinct, cylindrical. convex; the peristomes are salient, thin, oblique, orbicular, aranged in irregular quincunx. The ovicell is elliptioal, very long. striated transrerally: the oeciostome is elliptical, large. salient.

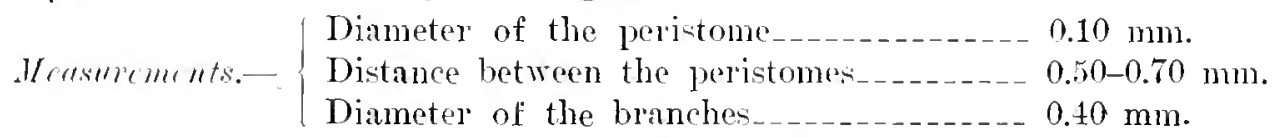

This is a small species provided with rely large ovicell. We might suppose that it was very prolific and coarse, but this is not so, as it is very delicate and its life was ephemeral. This is within the domain of the pathologist who must search for the canses of these unexpected ocenrences. It is the smallest species of the genus.

Decurrence.-Middle Tacksonian: Near Lenurls Ferry, Sonth Carolina (very rale) : 3 is miles north of Grovania. Georgia (very late).

Upper Tacksonian (Ocala limestome) : Chipola River, east of Marianna, Jackson Connty. Florida.

Cotypes.Cat. Nos. 6.5470. 65t71. 65484. T.S.N.M.

MECYNOECIA BREVIS, nCw species.

Plate 127, figs. S-1.

Description.-The zourium is an Entalophore with hanches claviform. compressed. and bifureated. The tubes are cylindrical. distinct. little convex, termimated at their extremity by a long peristomie upwarl bent; the peristomes are orbibular, thick, and arranged in irregular quincunx. The ovicell is large, short, very hinely porons; the oeriostome is elliptical. transverse, attached to the peristome of a tube. The zone of wrowth is very short and rounded.

ruriutions.-The zonrim is formed of claviform branches sometimes terminated by irregular lanifications: cylindrical branches are rare. The length of 
the peristomie depends upon how well the fossils are prescrved. The quinemx arrangement of the peristomes is not very regular and we figure a specimen where they ale alranged in transversal rows.

Aftnities. This species difters from Mecynoecia compressa in its much shorter oricell. its zonrium less lanellar, and its shorter distance between the peristomes. It differs from Entulophora subempressa. Reuss, 1566, of which it is the American representative, in the length of its peristomie.

Occurrence.-Middle Jacksonian: Eighteen miles west of Wrightsville,

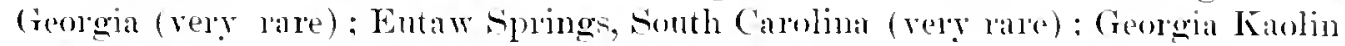
Company's mine. Twiggs County, Georgia (very rare): Rich Hill, five and onefourth miles sonth of Knoxville, Crawford County, Georgia (rare).

Jacksonian (Zeuglodon zone): Shmbuta. Mississippi (rery lane) sonth side of siuck Creek, Clarke County, Mississippi (very mare).

Cotypes.-Cat. Nos. 65 $466-65469$ U.S.N.M.

MeCrNoEgia MagNiCELla, new species.

I'late 12s, figs. 1,2 .

Description.-The zonium is an Entalophora with eylinclical branches. The tuhes are cylindrical, distinct, clisposed in irlegular quincunx, striated transversally, very large: bent upward at their extrenity and terminated by an oblique. little salient peristomie; the peristome is thick, orbicular, oblique.

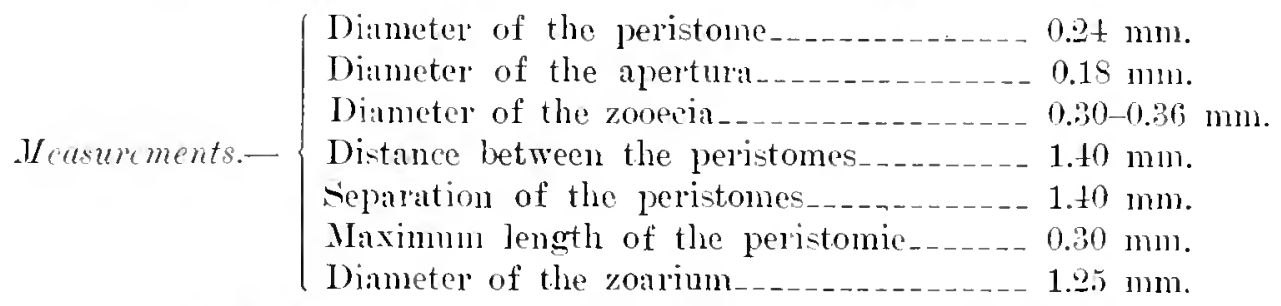

This species is the largest of the American fossils described in the present memoin. Its determination is therefore rely easy. The ovicell is mknown. Only the figured specimen has heen collected.

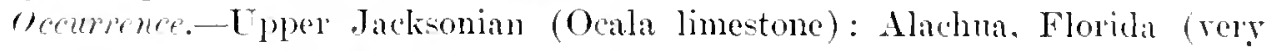
l'ate).

\section{MECYNOECIA COMPRESSA, new spcies.}

I'litte 1テ̃, figs. $15-22$.

Description.-The zonlum is formed of lamellar, eylindrical or slightly compressed fronds. The tubes are distinct, convex, striated transversally: the peri-tomes are little salient, thin, orbicular or elliptical. arranged in rery inpegular. ynincuns. The oricell is elliptical, very elongate, subymmetrical; the reciostome in transwerse and placed on the peristomic of a tube.

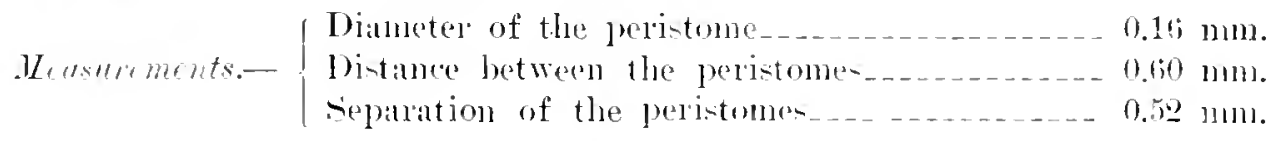


Jariations.-The quinemx arrangenent of the pelistomes is very irregular and it is not rire to find them adjacent to each other. The oeciostome appears to open into the peristomie of the tube to which it is attached, but this is only an illusion, for by scraping it with a scalpel we were able to verify that it really opens into the ovicell.

Aftinities.-This species is easy to determine on account of its much compressed branches. It differs from Mecynoccia brevis, in which this character appears, in the absence of the long peristomies and in its much elongate ovicell.

Ocempenee--Vicksburgian (Mariamna limestone) : One mile north of Momroeville, Alabama (rare).

Cotypes.-Cat. No. 65 462 , U.S.N.M.

MECYNOECIA QUISENBERRYAE, new species.

Flate 156 , figs. $26-30$.

I'scription. - The zoarimm is an Entalophora with cylindical and bifurcated branches. The tubes are little risible, gamished with transverse, overlapping winkles, aranged in quincmx or in oblique verticells; the peristome is thick, orbicular, little salient. The oricell is very elongate, symmetrieal, smooth; the oeciostome is supported on the tube and has the form of a lumar crescent.

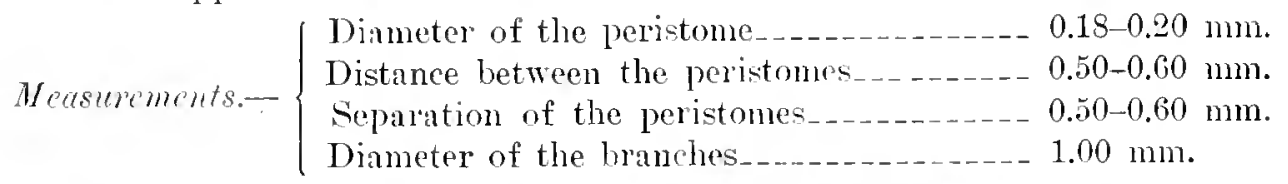

Affinitiv. - This species is very close to Merynocin lunate in the general anrangement of the tulues. It differs from it in its larger peristome (more than 0.16 mm.) and in its tubes which are closer together.

Ire dedicate this species to Miss Adelaide C. Quisenberry, of the United States National Musem, in appreciation of her help and interest in the preparation of this work.

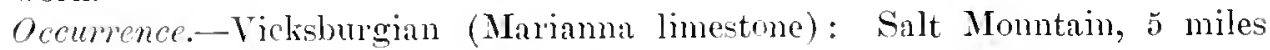
sonth of Jackson, Mlabama (common).

Cotypes.-Cat. No. 65396 , U.S.N.M.

MECYNOECIA LUNATA, new species.

Plate 156, figs. 1-S.

W'scription.-The zoarium is an Entalophora, regularly cylindrical and bifurcated. The tubes are distinet, eylindrical, separated by a little salient thread; the peristomes are thick, orbicular, arranged in quincunx or in Peripora. The ovicell is very elongate, very finely punctate; the oeciostome is very large, transrerse, attached to a tube and has the form of a hunar crescent. 

Measurements.-
Dianeter of the peristome
$0.1+0.16 \mathrm{~mm}$.
Diameter of the apertura $0.08 \mathrm{~mm}$.
Distance between the peristones
$0.70 \mathrm{~mm}$.
Separation of the peristomes
$0.50 \mathrm{~mm}$.
Diancter of the branches
$1.00 \mathrm{~mm}$.

Turiations.-The young zooecia are convex and are not bordered by a salient thread. The peristomie is not constant and is never very salient. The peristomes are often grouped in oblique verticells, an arrangement which characterizes the form Peripora of $\mathrm{D}^{\circ} \mathrm{Or}$ bigny.

Affinities.-This species differs from Mecynoecia cylindrica in its larger peristome $(0.16$ and not $0.10 \mathrm{~mm}$.). It differs from Mecynoecia quisenticrmyae in the absence of overlapping wrinkles and in its smaller peristome $(0.16$ and not 0.20

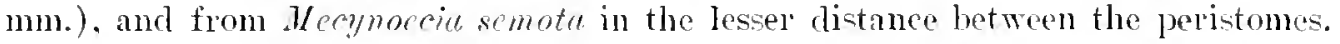
in the less salient peristomies. and in its never claviform zoarinm.

The immense oeciostome chatracterizes this species very well.

Occurrence.-Vicksburgian (Marianna limestone) : Vest bank Conecuh River, Escambia County, Alabama (rery common); near Claiborne, Nonroe Connty, Alabama (common); Murder ('reek. east of Castlebury, Conecuh County, Llabama (rery common).

Cotypes.-Cat. No. 6.1391-6.5983, U.S.N.M.

\section{MECYNOECIA SEMOTA, new species.}

Plate 156, fỉrs. 9-25.

Description.-The zoarium is a cylindrical or claviform Entalophora never containing more than eight longitutlinal rows of zooccia. The tubes are hornshaped, narrowed at the loack, cnlarged in the vicinity of the peristome, distinct, convex. striated transrersally. Jent mpward at their extremity and terminated by a free peristomie; very ohlirue and salient; their peristomes are urdely scpurated from each other, orbicular or elliptical. The ovicell is i n elongate and symmetrical sack.

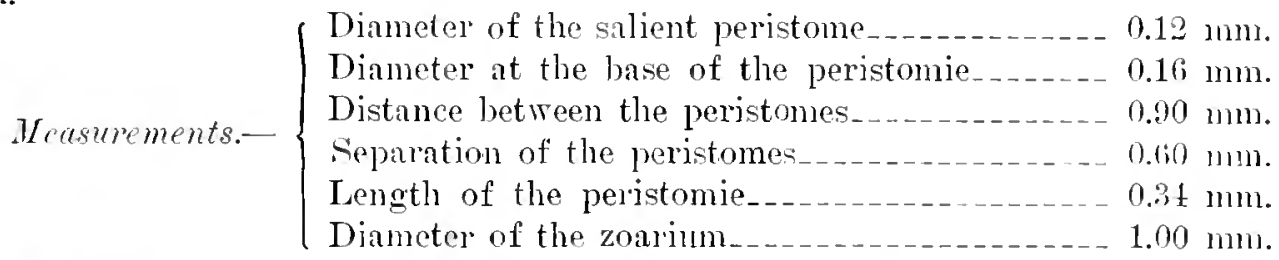

Tariations.-The micrometric dimensions of this species are quite variable and one should not attempt to determine isolated specimens. Onr measurements (exeept the first) are only the mot frecluent arerages. On certain specimens the distance is only $0.50 \mathrm{~mm}$. and abruptly on others it attains $1.00 \mathrm{~mm}$; in the latter case its distinction from Mreynocria clongatotube is very slight. The separation of the peristomes is a little less variahle; it varies. however. between 0.50 and $0.60 \mathrm{~mm}$. 
The zoarinm is never exactly cylindrical and claviform fronds are not rare. The zoarial base is a little hook and not a calcareous basal expansion.

Aftinitips. - This species differs from Mecynoecia lunata in its thinner branches with 8 rows of tubes instead of 12, and in its smaller peristome $(0.12$ and not $0.16 \mathrm{~mm}$.$) . It diflers from Mecynoecia clongatotuba in 8$ rows of tubes instead of 6, and in its generally much smaller distance between the peristomes $(0.90$ and not $1.20 \mathrm{~mm}$.), and from Entalophora pulchella Reuss, 1847. in its longer peristomie.

vccurrence-Vicksburgian (Marianna limestone): West bank of Conecul River, Escambia County, Alahama (very common): Salt Mountain, 5 miles south of Jackson, Alabama (rare): Murder Creek, enst of Castlebury, Conecul County, Alabama (rare): deep well, Escambia County, Alabama (rare); 1 mile north of Monroeville, Alabama (very common).

Tickslurerian (Red Bhuff clay): One-fourth of a mile of Woodwards, Wayne County, Mississippi (rare).

cotypes.-Cat. Nos. 15394, 65395, U.S.N.M.

MECYNOECIA ELONGATOTUBA, new species.

Plate 155, figs. 23-90.

Ineseription.-The zoalium is a cylindrical and lifurcated Entalophora with ix longitudinal rows of zooeeia. 'The tules are distinct, convex, very long, striated transversally, bent upward at their extremity and terminated by a short rery oblique peristomie: the peristome is thin, orbicular. ohlipue.

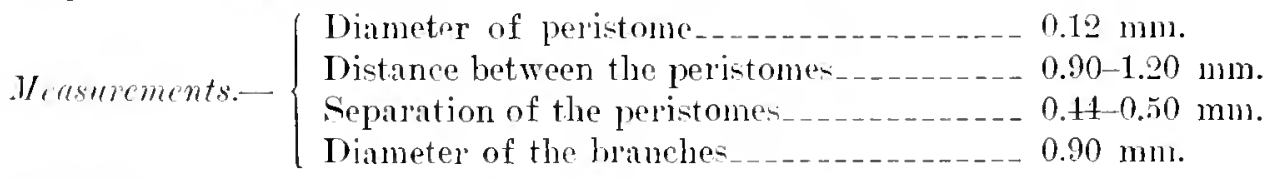

Tariations.-The length of the tubes is rery chanacteristic hut it is not constant: on certain branches it is only $0.80 \mathrm{~mm}$.; it is never more than $1.20 \mathrm{~mm}$. The banches are never exactly cylindrical: theil hase is often narowed.

The ovicell and the base are unknown.

Affirties. -This species differ's from Mecynoced semota, of which the diameter of the peristone is identical in its thinner branthes with six rows of zooccia instear of eight and in the long distance hetween the peristomes-almost always gleater than $0.90 \mathrm{nmm}$.

It cliflers from Necznoceia parvetuba, of which it has a little the general aspect, in its laner peristomial diameter (0.12 and never $0.10 \mathrm{~nm}$.).

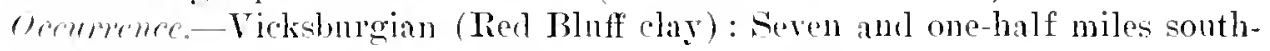
west of Blaclen Springs, Dlabama (common).

Vickishreian (Marianna limestone): Murler (reok. eat of Castlebury, Concenh (onnty. Alahama (very mare).

rotyper. Cat. No. 65t6?. U.A.X.M. 
MECYNOEC1A CORNUTA, new species.

Plate 155, figs. $30-36$.

Description.-The zoarium is a cylindrical and bifureated Entalophora. The tubes are little distinct, convex, widened at their extremity, horn-shaped, little narrowed at the base, slightly striated transversally; the peristome is thin, elliptical. very little salient. 'The oricell is quite elongate, smooth, globular, salient: the oeciostome is elliptical transverse, supported on a peristome.

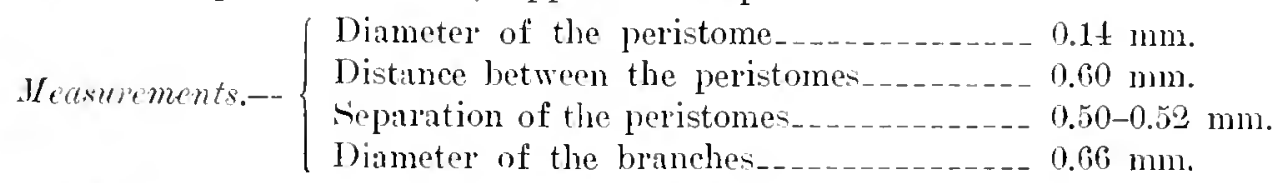

Affinities.-This species differs from Mecynoecia semota, in which the tubes are also borll-shaped, in its peristome of 0.14 and not $0.12 \mathrm{~mm}$., and in its lesser peristomial distance $(0.60 \mathrm{and}$ not $0.90 \mathrm{~mm}$.).

It differs from Mccynoecic lunatu in which the separation of the peristomes is very similar in the thinner branches, never containing more than eight longitudinal rows of zooceia, and in the absence of a salient thread between the tubes. Occurrence.-Vicksburgian (Marianna limestone) : One mile north of Monroeville, North Carolina (common); deep well, Escambia County, Alabama (very rare).

C'otypes.-Cat. No. 65t6t, U.S.N.M.

\section{MECYNoecla PARVITUba, new species.}

Plate 12s, figs. $3-\overline{7}$.

Description.-The zoarium is a thin Entalophora, with six longitudinal rows of zooecia. 'The tubes are small, little distinct, slightly striated transversally. bent upward at their extremity, and terminated by a salient peristomie: the peristome is thin, orbicular, oblique.

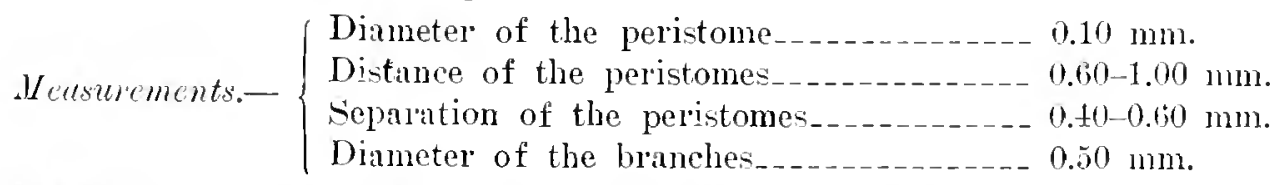

Affinitics.-This small species is quite well characterized by its small peristomial dimensions. It diflers from Mecynoecia pusilla in which the diameter is identical in its zooecial lengtl, much more than $0.70 \mathrm{~mm}$. It differs from Mecynoecir elongatotuba in its still thinner branches and in its peristomial diameter of 0.10 mm. (never $0.12 \mathrm{~mm}$.).

Occurrence.-Vicksburgian (Marianna limestone) : One mile north of Monroeville, Alabama (common).

Upper Jacksonian (Ocala limestone) : Old Factory, about $1 \frac{1}{2}$ miles above Bainbridge, Georgial (very rare).

Cotypes.-Cat. No. 65321, U.S.N.M. 
Plate 15t, figs. 1, 2.

Description.-The zoarium is a Proboscina, creeping on shells; it is formed of pluricellular branches, bifurcated, and irregularly lobed. The tubes are indistinct and rery short; the peristomes are thin, very near one another and arranged in quincunx. The oricell is small, little salient, little elongate; the oeciostome is as larere as a tube, transrerse, placed on the peristomic of a tube.

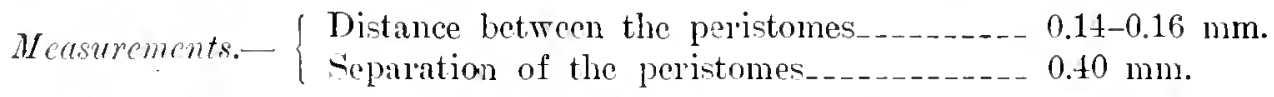

Oecumenes-Vicksburgian (Marianna limestone): Near Claiboruc, Mouroe County. Alabama (rare).

Holotype.-Cat. No. 65397 U.S.N.M.

MECTNOECIA GLOBULA, new species.

Plate 157, figs. 3, 4.

Description.-The zoarium incrusts bryozoa; it is a Proboscina with clubshaped branches. The tubes are short, little distinct, somewhat striated transrersally, bent upward at their extremity and terminated by a short peristomic elevated rertically; the peristome is thin and orbienlar. The oricell is little clongate, globular, smooth. symmetrical; the ocriostome is clliptical, transverse, as wide as the tube by which it is supported.
Diameter of the peristome $0.10 \mathrm{~mm}$.
Meusurements.-
Distance between the peristomes $0.40 \mathrm{~mm}$.
Separation of the pelistomes. $0.46-0.50 \mathrm{~mm}$.

Occurrenee.-Vicksonruian (Marianna limestone) : One mile north of Monrocville, Alabama (lare).

Cotypes.-Cat. No.6539s, L.S.X.MI.

Forma ENTALOPHORA Lamouroux, 1821.

We introduce in this zoarial genus or forma the species with the tubes opening on all sides of the cylindrical blanches, but in which no oricells have been discovererl. Nost of the species hitherto referred to Eutalophora, have the elongated ovicell of Mecynocia.

ENTALOPHORA STIPATA, new species.

I'late $\mathbf{1 0 8}$, fiur. 16.

Deseription.-The zoarum is cylindrical. club-shaped; the tubes are indistinct, all'anged in regular quincunx and transrersal relticells; the peristones are ynite close, thin, little salient, orbicular.

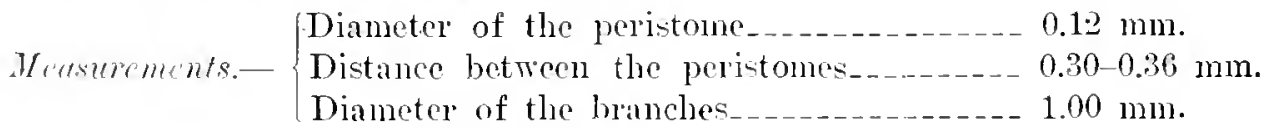

The figuren specinen only has been found, but it is quite characteristic. 
Occurrenec--Milwayan (Clayton limestone): Mabelvale, near Little Rock, Arkansas (very rare).

Molotype.Cat. No. 65439, U.S.N.M.

ENTALOPHORA CRASSA, new species.

I'late 113, figs. 1-5.

Description.-The zoarim is free, cylindrical, very large. The tubes are cylindrical, very little distinct, often wrinkled transversally; the peristomes are thick, very salient, orbicular, clnse to one another, sometimes adjacent two by two.

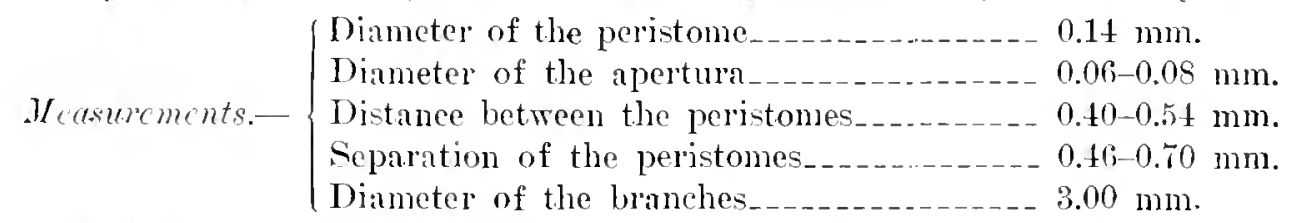

Tariations.-In longitudinal section the tubes are rery long, rarely branched. In transversal section they are polygonal.

Oceurrence-Claibornian (Gosport sand) : One mile southwest of Rockrille, Clarke County, Alabama (rare).

Ilolotype.-Cat. No. (int31, U.S.N.M.

Genus MIICROECIA Canu, 1918.

1918. Microccia Cave, Les ovicelles des Bryozoaires cyclostomes, Bulletin société Geologinue France, ser. 4, vol. 1ti, 1. 325.

The ovieell is rery small and is spread between only four tubes: the occiostome is small and hardly salient.

Genotype.-Bernicea saminsis Norman, 1864.

Rumge.-Senonian-Recent.

The previously known species belonging to this genus are:

Bcienicca sarniensis Norman, 1864. Recent.

Diastopora tubulus D'Orbigny, 1851. Senonian.

Berenicea suborbicularis Hincks, 1880. Recent.

In the absence of the neciostome the differentiation of this gemus from Oncousoccia is rery difficult.

MiCRoEcia Flabellata, new species.

Plate 12s, figs, $19,20$.

Deseription.-The zoarium incruts shells and bryozoa: it is fubellete. cceentric. The tubes are little distinet, flat, smooth, horm-shaped, very narow proximally, grouped on the zonrial margins in false radial rows; the peristome is elliptical, thin. sharp. The ovicell is small. globular, salient; the oeciostome is isolated and hardly salient. The zone of grovth is thick but little wide.
Measurments.-
Diameter of the peristome $0.14 \mathrm{~mm}$.
Distance between the peristomes $0.60-0.70 \mathrm{~mm}$. 
Some zovecia are closed by a calcareous septum. We know that the latter is always placed at the base of the peristomie. Most certainly this species was provided with tubes with long peristomies, as the elliptical form of the apertura proves.

Affinties. -This species differs from Berenicen regularis D'Orbigny, 185̃.2, of the Cenomanian, and from Diastopora suborbicularis (Hincks, 1880), Canu, 1909, of the Lutetian in its wider peristome $(0.1 t$ and not $0.06-0.10 \mathrm{~mm}$.), and in the arrangement of its peristomes in false radial series.

Occurrence--Middle Jacksonian (Castle Hayne limestone): Wilmington, Sorth Carolina (rare).

Mototype.--Cat. No. 65324. U.S.N.MI.

MICROECIA VIBRIO, new species.

Plite 129, firs. 14-1S.

Description.-.The zoarium creeps on algae or more often on Orbitaid foraminifera and shells; it is orbicular or elliptical, almost almays eccentric. The tubes are indistinct at the center. distinct and serpentiform on the zoarial margins; arranged in quincunx; the peristome is elliptical or triangular, thin, salient, or placed at the extremity of a short peristomie. The ovicell is globular and small. The zone of growth is vely little visible.

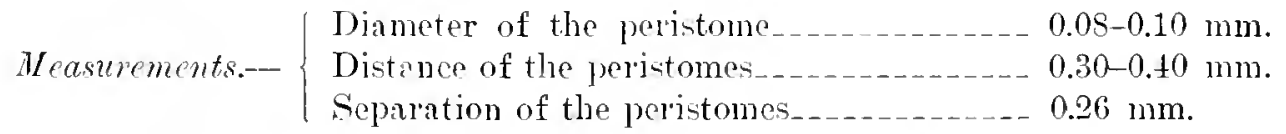

The central part of the large zoaria and the young zoaria do not bave distinct tubes; they are only visible in their peristomie more or less salient and elevated. The serpentiform tubes are only visible on the completely developed zoaria; often even the separating furrow disappears in fossilization. The presence of closed zooecia indicates a mole salient peristomie than that persisting on the fossils.

Affinities.--This species differs from Microccia hirta in the somewhat larger diameter of the peristome (often more than $0.08 \mathrm{~mm}$.) and in the form of its zooecia.

Occurence.-Upper Jacksonian (Ocala limestone): Chipola River, east of Marianna, Jackson County, Florida (rare) : below Plant System railroad wharf. l3ainbridge, Georgia (rare).

Ticksburgian (Mariama limestone): Salt Momtain, 5 miles south of Jackson, dlabama.

Cotypes.-Cat. Nos. 65323, 65 486 , U.S.N.M.

MICROECIA HIRTA, new species.

Plate 157, figs. 5-8.

Theription.-The zoarium is free, milamellar, suborbicular. The tubes are harrlly distinct, bent up at their extremity and terminated by a long, very oblique 
peristomie; the peristome is thin, elliptical. The ovicell is small, glohular, little salient: the oeciostome is not salient. It has no zone of growth.

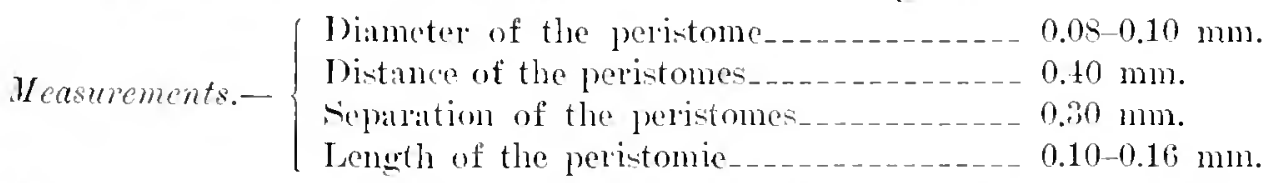

Afinities.-The zoalum appears as a disk garnished with points: but we bave not had the fortune to collect a single complete disk, for it seems extremely fragile.

This species differs from Microrcid vitrio in its free, orbicular zonium and in its rectilinear, never serpentiform, zooecia. It differ's from Plaqioecia 7amellosa not only in the nature of the ovicell. hut also in its smaller peristome $(0.08$ and not $0.12 \mathrm{~mm}$.) and in its other dinensions. which are always smaller. 'The zorria are absolutely iilentical.

Occurenee.-Tickshmegian (Marianna limestone) : West bank Conecuh River, Escambia County, Llabama (rare).

Cotypes.-Cat. No. 6.is39e, U.S.X.M.

\section{EXOCHOECIA, new genus.}

Greek: Eroche, prominence; in allusion to the position of the ovicell.

The oricell is large, symmetrical; it is placed on the zone of growth which it grows beyond, forming a large extering saliency; the occiostome is small, anterior, elliptical, tmined toward the base.

Genotyp.-Erochocia mugen, new species. Vicksburgian.

FXOCHOECIA RUGOSA, new species.

Plate 1.is, figs. 1-16.

Thesription-The zoandum is a reticulate Mesenteripora; it is folmed of irregular lamellae, presenting a rounded foll opposite the zone of growth. 'The tubes are arranged in quincunx in the vicinity of the fold and in radial rows perpendicular to the zone of growth on the rest of the zoarium; they are indistinct and ornamented with large overapping urintes. The peristoncs are on lieular or elliptical, amost arljacent in the lines. The ovicell is large, pyriform, sllepented on the zoarial margins, ornamented with large. transverse, widely spaced winkles: the oeciostone is small, elliptical, transverse, turned toward the base.

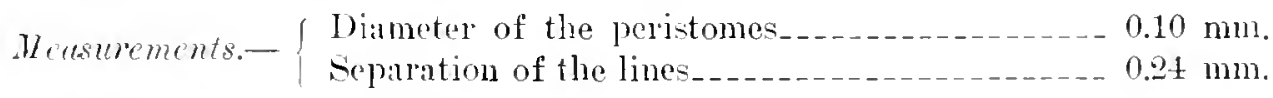

Trmintion. - Tre know that these reticulate zoulia result from the folding of a primitive berenicoid zoanim and from the bending back of the folded fronds at the top. One of the consecuences of this hending back is that the axis of the peristones no longer coincides with the axis of the median tubes which develop on the basal lamella and which appear at the zone of growth. The tubes opening laterally on the fronds are from preceding lanifications; the axis of the peristome is indeed that of their rooecium, but the lines of the peristome are oriented per- 
pendicularly to the zoarial margins and their traces are indicated in thin sections by their peculiar undulations (fig. 16) regularly spaced. The reader will better comprehent this peculiar arrangement by consulting figure 12 which shows the interior of the tubes abtained by the ablation of one of the two lamellae of the zoarimum.

The oeciostome is smaller than a tube as in the genus Mieroceia, but it is turned toward the base: it is isolated and is never supported on the peristome of a tube.

Tn spite of the large transverse wrinkles which ornament the tubes, the tangential section indicates that their walls are absolutely ilentical with these of all the other Crelostomata (fig. 11).

When the transverse section is indeed perpendicular at the time of the folding and at the zone of alowth (fig. 1t). the tubes adjacent to the basal lamella are alone risible. In the other case the tubes appen formed on the basal lamella and above their ranifications form the peristomial lines (for. 16).

Affinitis.-This species diflers from Reticutipore nummulitom Doorbigny,

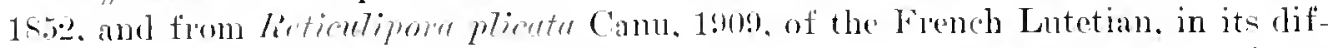
ferent micrometric measmements and in its larger wrinkles. Moreorer, the ovicells of the two latter species are not known.

This species is quite characteristic of the Tickshurgian.

Orpumenre.- Tickshumian (Red Bhtl clay) : Seven and one-half miles sonthwest of Blaten Springs. Alabama (rare); one-fourth mile west of Wondwaid, Wayne county, Mississippi.

Virksburaian (Mariamna limestone): Murfle Creek. east of Castlebury, Conceuh Comty, Alabama (common): wet lank Concemh River, Fseambia Comty. Alaliama (common); Salt Momtain, ob miles sonth of . Tackson, Alabama (rely late) : near (taiborne. Momoe Comnty. Alabama frommon); one mile north of Monoerille. Alabima (rely common).

$$
\text { rotypes.-Cat. No. 6.5105. T.S.N.M. }
$$

Family DIAPEROECIIDAE Canu, 1918.

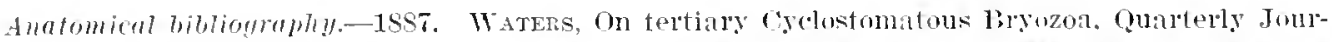

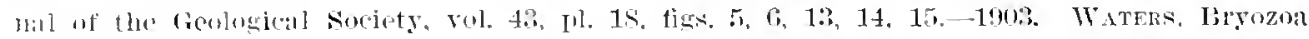

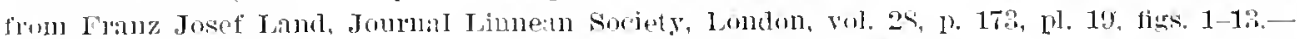

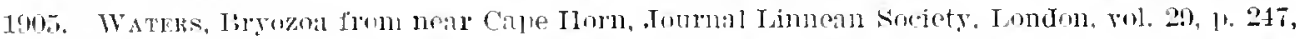

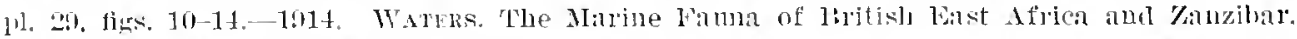

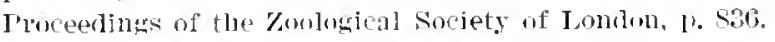

Theoricell is formed after the calcification of the distal tubes. It is an ireregular', sulugholular alevation, phaced among many tubes which project on the ovicell itself. The oeciostome is sumedian. transrelce. salient, often isolated, generally proximally directol.

We do not know the larva, but this family alpears difforent from the Tulnuliporicas in its oncontome which is often isolated and in its expansion hy which it completely sumoumals the tubes or the fascicles. 
When the ovicell is rery thick the tubes appear displaced and more scattered. This is only an illusion provolied by the elongation of the tubes and theje divergence; at their base they have the normal distance. (See Diraperoccir ctava.)

The tubes which traverse the oricell are often chosed by a finely porous calcalleous lamella.

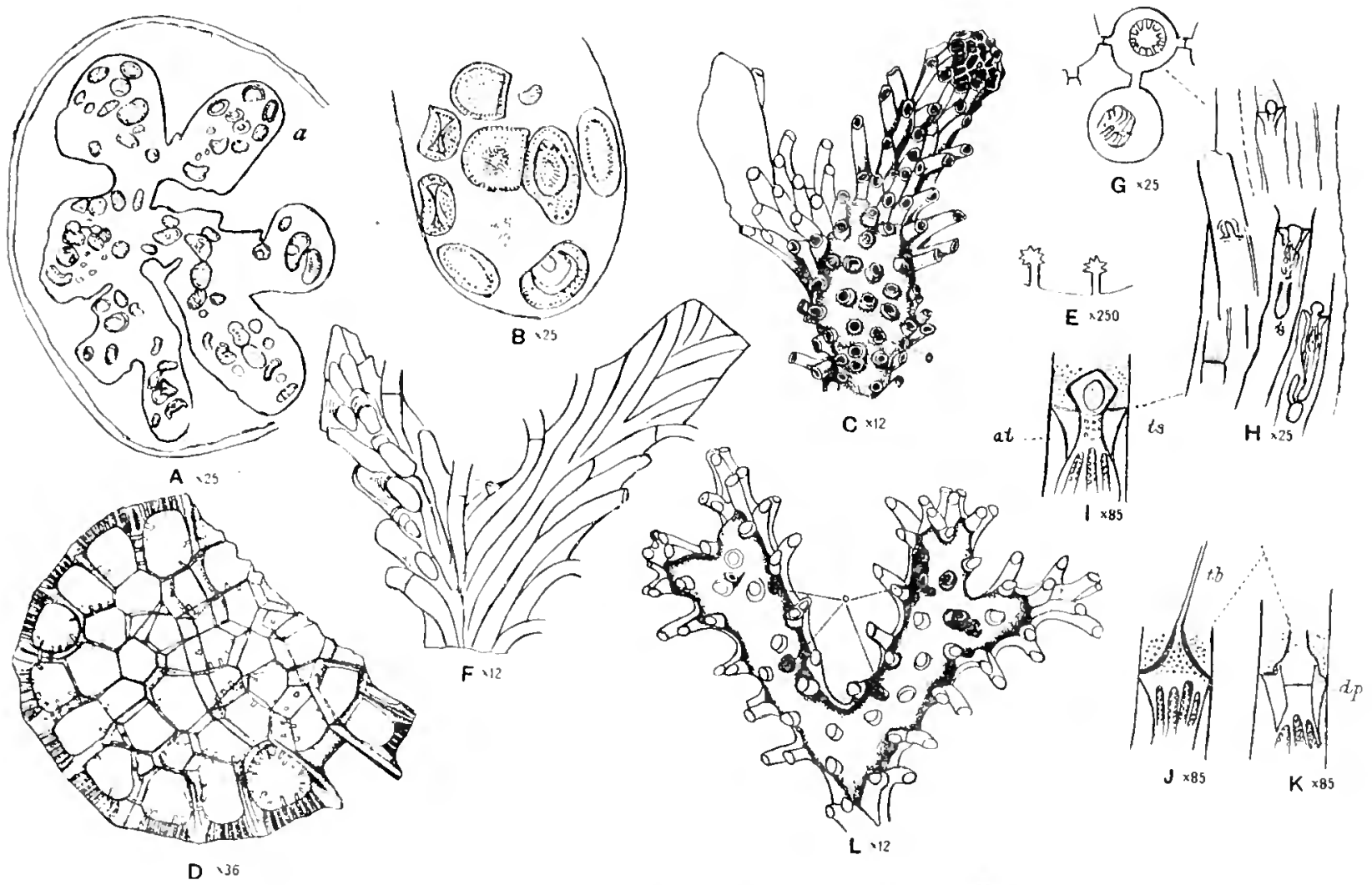

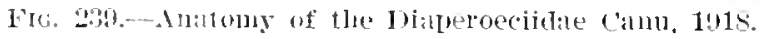

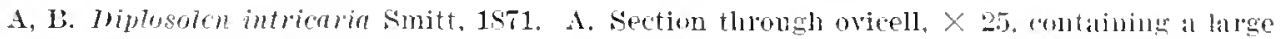
number of smatl embryos. 13. Section of lobe $a$ of the sime ovicell. (After Watris, 19m).

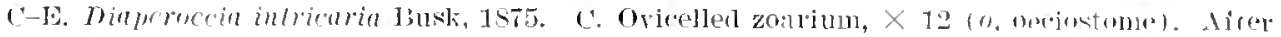

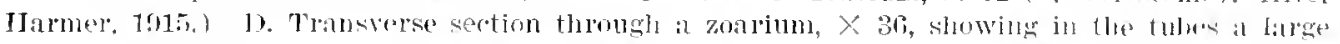

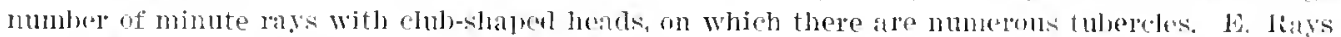
includerl in the tubes, $X$ ․ㅔ).

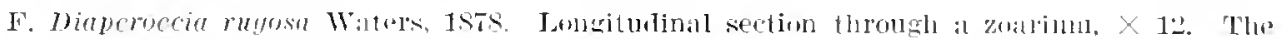

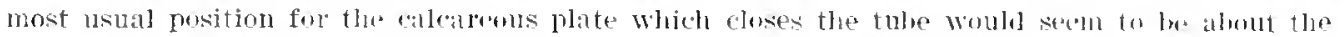

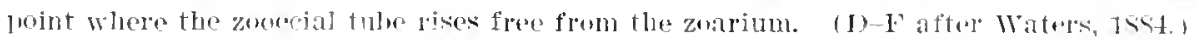

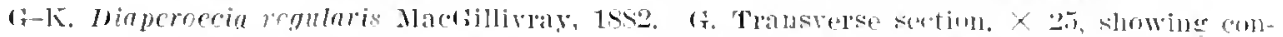

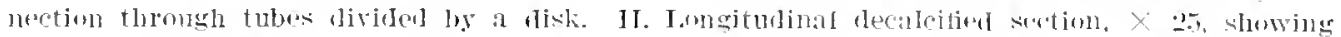
thisk memblanous transwelse wall. J. The thick membrane projerets in the mirleles, lout is mot

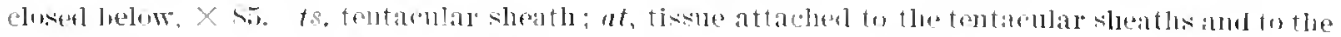

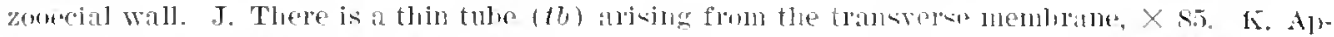

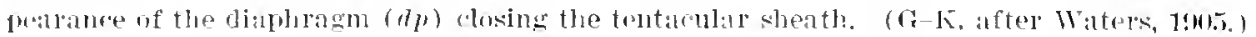

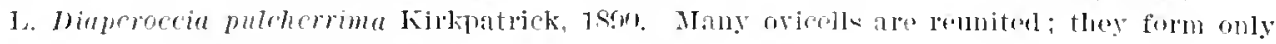

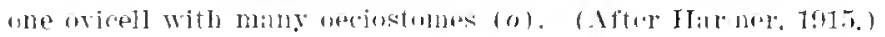


Genus DIAPEROECIA Canu, 1918.

1918. Dinprocia Cand, Les ovicelles des bryozonires cyclostomes, Lulletin de la société Geologique, France, ser. 4, rol. 16, p. 329 .

No arlventitions tubes; 10 to 12 tentacles.

Genotype-Diaperoecia (Entulophoru) intricaria Busk, 1875.

Range-Cretacous-Recent.

Waters in 1914 preserved the term "Diastopore". for this genus as we now understand it. The new ideas necessitate a new nomenclature to avoid all con-

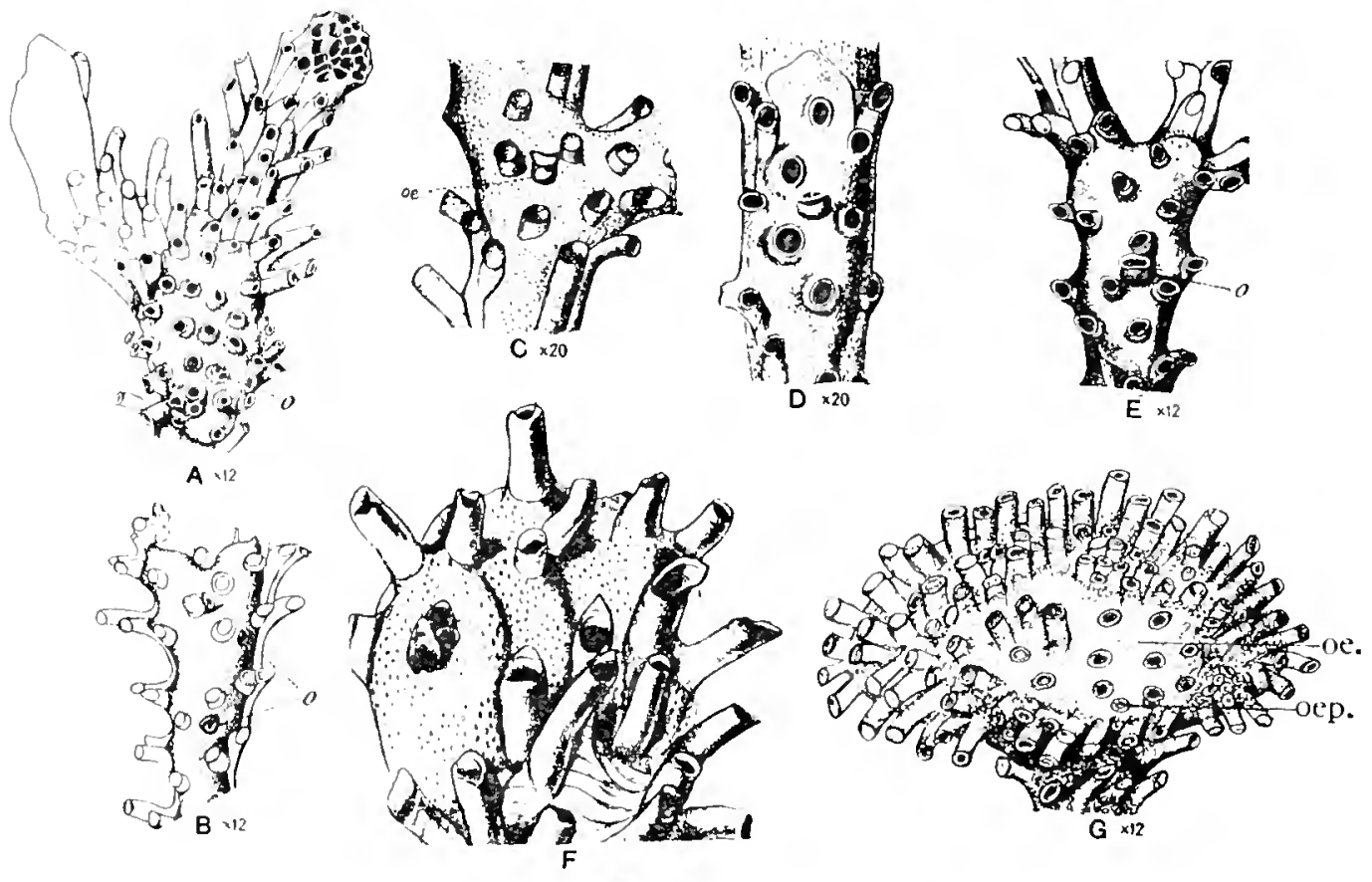

FIG. 240.-Genus Dimperocein Canu, 19IS.

A-G. Views of ovicelled zoaria showing the oeciostome. A. Diaperoccid intricaria Busk, 185. B. Dinperocein putenerima Kirlspatrick, 1590. (A, 13. After IIarmer, 1015.) C-E. Diaperoecia interjunct M MacGillivray, 18s5. (After Waters, 1914, 18s7, and Harmer, 1915.) F. Diaprocciu ecutricosu lisk, 1S75. G. Diaperoccia cupitata liobertson, 1910.

fusion, but the insufficiency of the present studies oblige us to preserve provisionally the old nomenclature; it is necessary, therefore, to consider the ancient genera muler their best known significance. It is probable that this genus will be disnumbered according to the form of the oeciostome. Thus the Cretaceous forms appear to have a very small, oeciostome scurcely salient; if this observation be confirmed, it will be necessary to create a new genus for them.

The previously known species belonging to this genus are:

Entulophora regularis MacGillivray. Recent.

Entulophora capitata Robertson, 1910. Recent.

Entulophora interjuncta MacGillivray, 1S85. Recent. 
Entalophora megosa Waters, 1879. Recent.

Idmonea radicata Kirkpatrick, 1888. Recent.

Tubulipora pulchemima Kirkpatrick, 1890. Recent.

Tubulipora cassiformis IIarmer, 1915. Recent.

Proboscina expansa IIncks, 1880. Recent.

Diastopora cristata MacGillivray, 18s6. Recent.

Proboscina johnstoni Hincks, 18s0. Recent.

Alecto dilatans, Busk, 1850. Pliocene-Recent.

Entalophora palmata Busk, 1852. Miocene-Pliocene.

Diastopora fabellum Reuss, 18t7. Helvetian-Tortonia.

Borenicca papillosa Reuss, 1847. Cretaceous.

Bercnicea congcsta Reuss, 1846. Cretaceous.

Entalophora echinata Römer, 1\$40. Cretaceous.

Berenicea polystoma Römer, 1839. Cretaceons.

Discosparsa varians Ulrich, 1901. Upper Cretaceous-Eocene.

All our American species form a perfectly homogeneous group; their oeciostome is always transversely elliptical, adjacent to a tube and directed downward. This function of the escapement of the larva appears most inportant and sufficient to justify the formation of different genera.

\section{DIAPEROECIA VARIANS Ulrich, 1901}

Plate 104, figs. 1-4.

1901. Discosparsa rarians Unicu, Maryland Geological Survey, Eocene, p. 205, pl. 59, fig. 3.

Description.-The zoarium is liscoidal or tubular; it incrusts algate or surrounds their small fronds. The tubes are indistinct, arranged in quincunx; the peristomes are salient, orbicular, very close to one another. The ovicell is smooth, nonglobular. traversed by the tubes; the oeciostome is transverse, elliptical, placed in the ricinity of a tube.

Atmities.-This species appears to lave some relations with the group of Cellutipora DOOrbigny, 15.5. Unfortunately, that genus is still insufliciently studied. On the other hand, on account of the form and arrangement of its oeciostome, this species will serve later as genotype for a new genus whrn analogous species have been discovered.

Occurrence.-Lowest Eocene (Bryozonn bed at base of the Aquia formation): Upper Marlboro. Maryland (rare).

Geological distribution.-Cretaceons (Vincentown [Dimian]) Vincentown, New Jersey (Ulrich).

Plesiotypes.-Cat. No. 65456, T.S.X.M.

DIAPEROECIA LONGICAUDA, new species.

Plate 115, figs. $7, S$.

Description.-The zoarium incrusts bryozoa; it spreads out flabelliform at the extremity of uniserial, long branches. The tubes are risible, convex, cylindrical, 
or elavate, striated transversally, bent upward at their extremity and terminated by a more or less salient peristome; the peristome is orbieular and thick. The ovieell is large, transverse, globular, traversed by the tubes which conserve their reciprocal positions.
Metsurements. Zooecial diameter._._.
Distance between the orifices _....... $0.40 \mathrm{~mm}$.
Separation of the peristomes_. .
| Diameter of the peristome_-_.
Mersurements of Diameter" of the peristome_._.

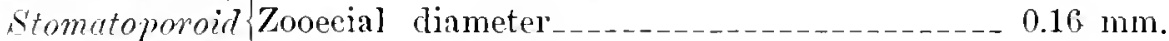
portion.- Distance between the orifices_______ $0.50-0.60 \mathrm{~mm}$.

The micrometric measurements of this speeies are quite variable; those which we give are quite approximative.

Iffnitics.-The species is very remarkable in its zoarial aspect which appears more often like a palm leaf at the end of a long stem. In the old zoarial elassifieation it would be impossible to give this species a generic name, since it affects successively the forms of Stomatopora, Proboscinu, and Berenieea. This phenomenon has been noted, moreover, rather frequently in the literature, and a most convincing example was figured by Hincks as long ago as 1880 in Stomatopord johnstoni.

Occurrence-Mirdlle Jacksonian (Castle Hayne limestone) : Wilmington, North Carolina (very rare).

IIolotype.-Cat. No. 65276 , U.S.N.M.

DIAPEROECIA JACKSONIENSIS, new species.

Plate 121, figs. 12-13.

Deseription.-The zoarium incrusts shells in claviform branches. The tubes are distinct, cylindrical, arranged in quincunx, finely punctate, with the peristomie salient, oblique, and elevated to $60^{\circ}$; the peristome is orbieular, oblique. The ovicell is salient, globular, inclosing a dozen tubes; the oeciostome is elliptical, little salient, joined to a tube.

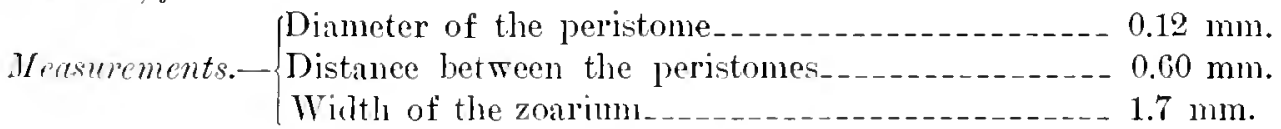

The figured specimen is the only one that has been discovered.

Oceurrence.-I Lower Jacksonian (Moodys marl): .Tackson, Mississippi (very rare.)

IIolotype.-Cat. No. 65302 , U.S.N.M.

DIAPEROECIA LOBULATA, new species.

Plate 122, firs. $1-\overrightarrow{7}$.

Mexription.-C'lhe zoarium is free and tubular or inerusts shells; it is formed "ff sucressive, thatellate lotules more or less symmetrically arranged on each side 
of the ancestrula. The tubes are distinct, cylindrical or hom-shaped, nearly rectilinear, arranged in quincumx, very slightly striated; the peristomie is very salient, raised at the center, quite oblique on the zoural margins; the peristome is elliptical, horizontal. The oricell is globular. sillient, transverse. elliptieal, locater on the zoarial margin. No zone of growtls.

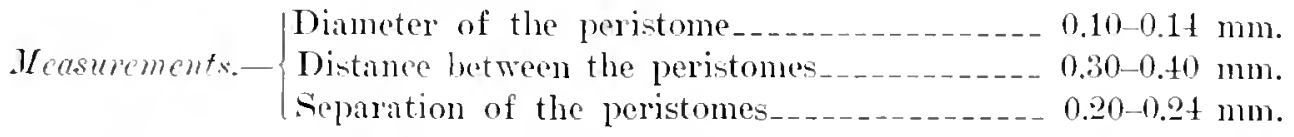

Furintions - The ovieell is almost always placed on the zoarial maroin; however. when the lobe is large and developed, it may be placed in the midtle. and is oriented more or less longitudinally.

The secondary loles do not originate from the preceding one ly dichotomization as in Proboscinu; they are produced by rejurenescence-that is to saly, ly the derelopment around a single marginal tube of the preceding lobe, serving thus as a pseudo-ancestrula.

The zone of growth is rery narrow and scarcely visible.

This specics is rery prolific: one of our specimens shows three successive and parallel ovicells on the same tube.

The tubes are very often loorn-shaped and consequently narrowed in their proximal portion.

Affinities. - In its micrometric measurements this species is quite close to Plagioceia botula, but it differs in its zoarial form of successive lobules and in the rery different nature of its ovicell.

Oceurrence--Middle Jacksonian: Wilmington, North Carolina (rare): Rich Hill, five and onc-half miles southeast of Knoxville, Crawford County. Freorgia (common).

$$
\text { Cotypes.Cat. Nos.65t26, 65+27. U.S.N.M. }
$$

DIAPEROECl LOBUlata, var. PARVIPORA, new variety.

Plate 122, figs. 8, 9.

This rariety presents the essential characters of the species-marginal oricell and successive lobules produccd by rejuvenescence. The only difference is in the diameter of the peristone, which neasures only $0.06-0.08 \mathrm{~mm}$.

Oecurrenee-Widdle Jacksonian: Near Lenuds Ferry. South Carolina (rery rare): Eutaw Springs, South Carolina (very rare).

Hototype.-Cat. No. 65128 U.S.N.M.

DIAPEROECIA RUGOSA, new species.

Plate 153, figs. 5-S.

Ineseription.-The zoarium incrusts shells and especially cheilotomatous bryozoa ; it emits short, foliaceous, bilamellar expansions. The tubes are indistinct, arranged in regular quincunx, garuished with large transverse, overlapping, widely spaced wrinkles, and are terminated ly a rery short, oblique peristomie. The 
peristome is elliptical. thin, horizontal. The ovicell is globular, placed around some tubes, orlamented with wrinkles like the tubes.

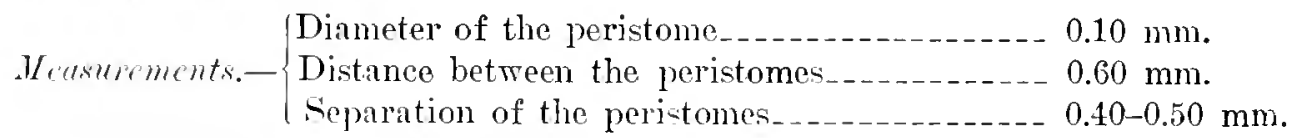

This superb species is well characterized.

Occurrencr.-Vickshurgian (Marianna limestone): Three miles sontheast of Tosburc. Tasper County, Mississippi (rare).

Ilototype.-Cat. No. 65381, U.S.N.M.

\section{DIAPEROECIA ORBICULATA, new species.}

Plate 153, figs. 9-15.

Description.-The zorium is free, large, orbicular: the basal lamella is striated concentrically. The tubes are distinct, cylindrical, rectilinear, arranged in quincunx or more often in irregular radial rows; the peristome is thin, orbicular, very oblique. The ovicell is large, trausversely elliptical. mole or less distant from the zoarial margins.

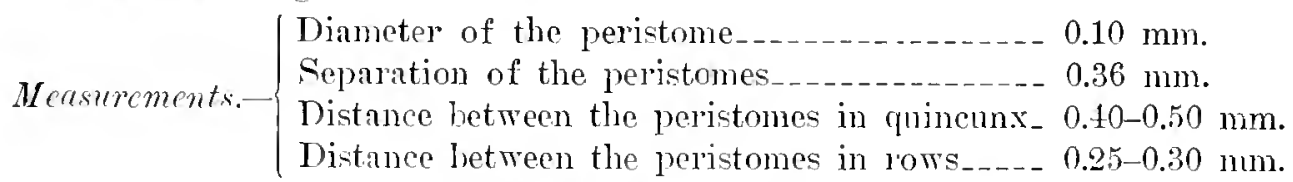

This beantiful species is admirably characterized by its zoarium in the Discoparsa form and ly its zooccia aranged in raclial rows. We have discovered one specinen with an absolutely smooth oricell.

Ocempenee.-Ticksburcian (Marianna limestone) : One mile north of Monroeville. Alalama (very common).

rotypes.-Cat. No. 65382, U.S.N.M.

\section{DIAPEROECIA CLAVA, new species.}

Plate 15t, figs. 1-9.

Description.-The zoarium is a multiscrial, thick Proboscina form in which the bramehes are short or elongated and are in the form of a $c 7 u b$; it incrusts shells, bryozoa, Orbitoil foraminifera, and algae. When the zoarium is free, the basal lamella is striated transrersally. The tubes are indistinct, arranged in regular quincuns, terminated by a very salient peristomie and elevated almost vertically. The peristome is orbicular, thick, sharp. The ovicell is rery large, very globular, irregularly elliptical: the oeciostome is elliptical, transverse, directed proximally, aljacent to a tube. The zone of growth is very thick.

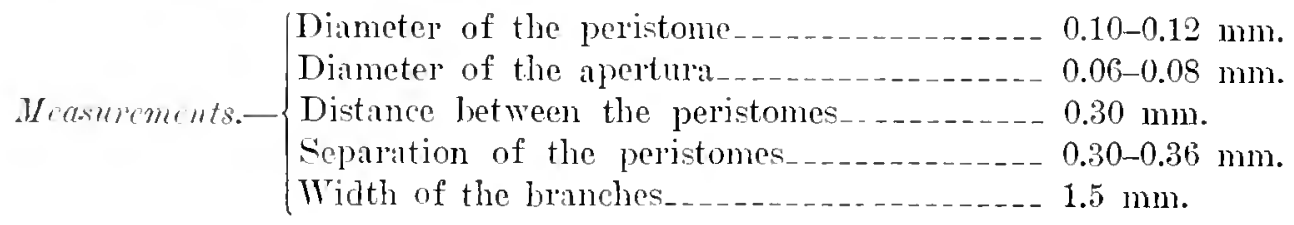


Variations.-The zoarial rariations are in rapport with the substratum. On the shells, the branches are always longer and the zoaria more complete; on the algae the branches are broken and detached from one another in fossilization.

The aspect of the oricell varies with the width of the branches and the number of the tubes surrounded.

Occurrence.-Vicksburgian (Marianna limestone): Salt Mountain, 5 miles south of Jackson, Alabana (very common); near Claiborne, Monroe County, Alabama (rare); Murder Creek, east of Castlebury, Conecuh County, Alabama, (rare); west bank Conecuh River, Escambia County, Alabama (rare).

Vicksburgian (Red Bluff clay): One-fourth of a mile west of Woodwards, Wayne County, Mississippi (rare).

Cotypes.-Cat. Nos.65383, 65384, U.S.N.M.

\section{DIAPEROECIA WALCOTTI, new species.}

Plate 154, figs. 10, 11.

Description.-The zoarium has the form of a multiserial Proboscina; it incrusts orbitoid foraminifera in clavate branches. The tubes are distinct, cylindrical, very irregularly arranged, slightly striated, terminated by a peristonie little salient and bent upward; the peristome is thin, orbicular, horizontal. The oricell is little salient; the oeciostome is adjacent to a normal tube.

Mensurement.-Dianeter of the peristome___________- 0.10-0.12 num.

We dedicate this species to Dr. Charles D. Walcot, Secretary of the Smithsonian Institution.

Occurrencc.-Vicksburgian (Marianna limestone): West bank, Conecul River, Escambia County, Alabama (rare).

Ilototype.Ciat. No. 65385, U.S.N.M.

\section{Genus DiPlosoleN Canu, 1918.}

1919. Diptosolen Cant. Les oricelles des bryozon ires ercolostomes. Bulletin Société Cenlogique de France, sel. 4. vol. 16. p. 320 . (Troposed for Diplopora Jul.Jen, 1Sef, preocenpied.)

Adrentitious tubules are present. The oeriostome is isolated. 12 tentacles. Genotype.-Dip7osolen (Berenicea) obelium .Johnston, 18-17.

Romge.-Senonian-Recent.

According to Waters the tubules are developer at the same time that a second calcareous layer is superposed on the normal skeleton.

The previously described species belonging to this genus are:

Brreniee obetiu .Johnston. 1828. Helvetian-Recent.

Reticulipora intricata Smitt. 1866. Recent.

Retimulipora tuensernmato Waters. 1894. Priabonian.

Diastopora compacta Canu, 1909. Lutetian.

Dicestopora 7inerta Gabb and Horn, 1865. Cretaceous (Vincentown).

Diastopora obetioides Pergens. 1889. Coniacian.

The term "Diplopora" of Jullien has been preoccupied two or three times. 
DIPLOSOLEN COMPACTUM, new species.

Plate 103 , figs. 1.テ-17.

Description.--The zoarium incrusts stones; it emits tubular unilamellar expamions. The tubes are distinct, eylindrical, lat; the peristome is elliptical. horizontal. often closer ly a finely punctate calcareous lamella. The adventitous
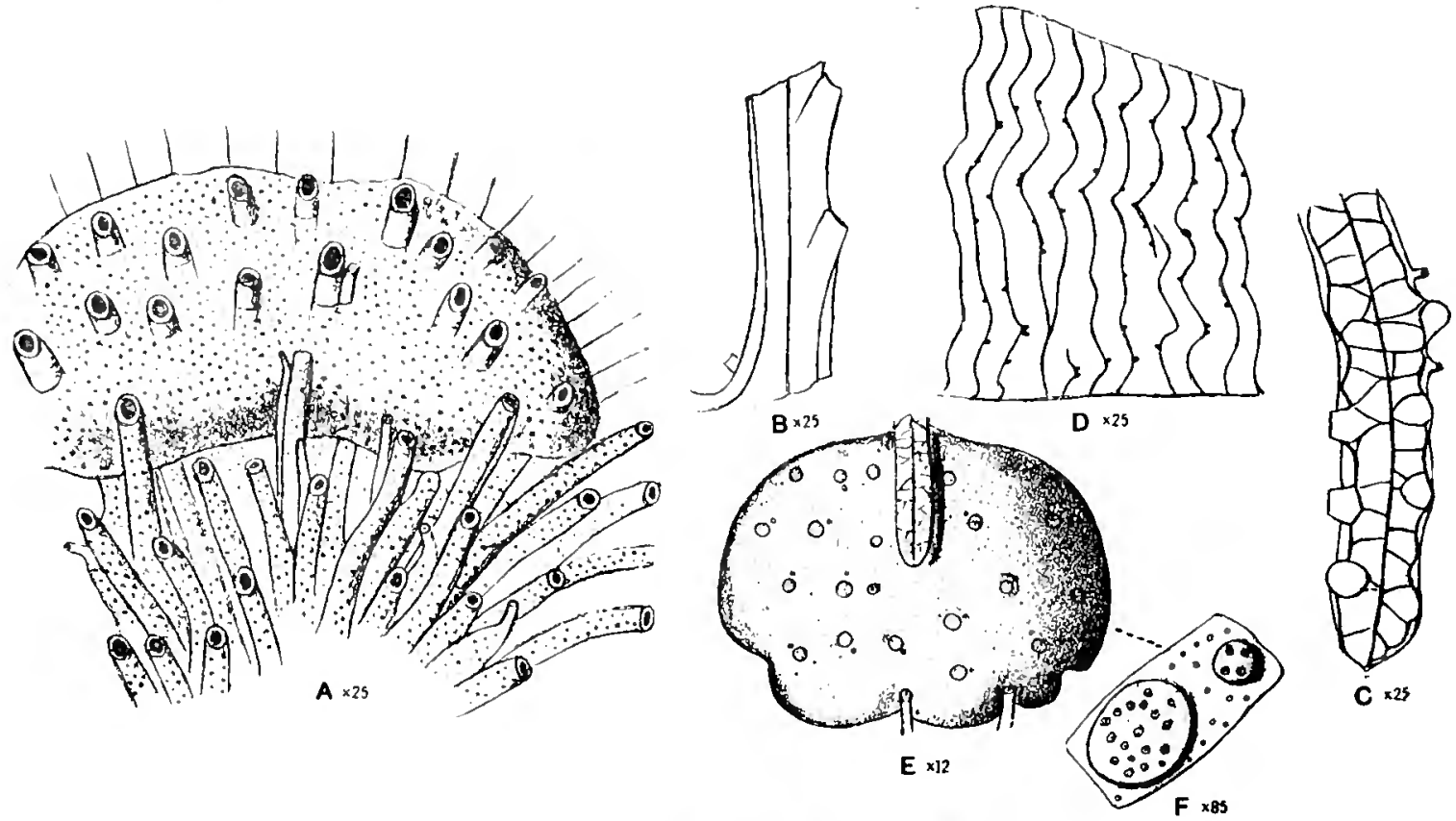

FIg. 241. Genus Diplosolen Canu, 1919.

A-F. Miplosolen obclin var. arcticn Waters. A. Zondium showing the adrentitious tubules and the ovicell, $X 25$. I?. Calcareous longitulinal section, showing the outer calcareous wall beyond the zovecia, $X: 5$. C. Transverse section, $X$ 25. D. Calcareous section, $X 25$, showing the irregular way position of the zonecial tubes and also showing small internal projections. ic. Ovicell with one oeciostume, $\times 12$. At the upper palt of the ovicell the base of a lateral branch is encosed. I'. 'lhe ent of a zoveciom and of an adventitious tubule, $X$ S5, both with closures. From the ovicell of Fig. I. (A- ister Waters, 1900.)

tubules are primoserial. The ovicell is large, spread over a score of tubes, little globular, punctate; the oeciostome is small, isolated, little salient; each tube perforating the ovicell is accompanied by its zooecinle.

$$
\text { Meusurements- }\left\{\begin{array}{l}
\text { Diameter of the peristome } \\
\text { Distance between the peristomes_- } \\
\text { Separation of the peristomes_. }
\end{array}\right.
$$

This species is quite well characterized by the nearness of its peristomes and by its primoserial zooeciules.

Orcumberme-Cowest Eocene (Bryozoan bed at the base of the Aquia formation). (Tpper Marlboro, Maryland (rare).

Holotype.--Cat. No. 65̃40, U.S.X.M. 
Diplosolen PLANUM, new specics.

plate 122, figs. $14-16$.

Description. The zonrium is free and bilamellar. The tubes are little distinct, flat, oval, arranged in irregular quincumx, much scattered; the peristone is elliptical, thin, horizontal, often closed by a porous calcareous lamella. The adrentitous tubules are indistinct, terminated by an elliptical aperture, arranged above each tubular peristome. The ovicell is convex, sulorbicular, spread orer" a dozen tubes.
Necsurements.-
Diameter of the peristome
$0.08-0.10 \mathrm{~mm}$.
Dimmeter of the tubes
$0.1+-0.16 \mathrm{inm}$.
Distance between the peristome:
$0.70-0.80 \mathrm{~mm}$.
Separation of the peristones
$0.50-0.55 \mathrm{~mm}$.

Affinitics.-This species resembles Diplosolen obctium Johnston, 18ti: it differs from it in its flat tubes, bilamellar zoarium, and scarcely visible zooeciules.

Occurrence.-Middle Jacksonian: Near Lenuds Ferry, South Carolina (rare). Holotype.Cat. No. Ge 430 . U.S.N.M.

\section{LEKYTHIONIA, new genus.}

Greek: Lekythion, small flask; in allusion to the form of the oeciostome.

The ovicell is not perforaterl by the adventitions tubules. The oeciostome is isolated. oral. in the form of a lottle or flask.

Genotype.-Lekythionia (Reticulipora) dichotoma Gabb and Holn, 1862.

Runge.-Cpper Cretaceous, Lower Eocene.

\section{LEKYTHIONIA DICHOTOMA Gabb and Horn, 1862.}

Plate 104, figs. $7-13$.

1S(i2. Riticulipura dichotoma GabB and Hons, Monograph Fossil Polyzoa Secondary and Tertiary Formations of North America, Journal Acaclemy Natural science. ['hilatelphia, ser. 2, vol. J., [. 173, p]. 21, tig. 64.

1901. Reticulipora dichotoma TLatcr, Maryland Geological Survey, Encene, j. 207, pl. 59, figs. $9-12$.

19uT. Reticulipora dichotoma Werles, Cretaceous Faunas, Geological Survey New Jersey, I'ileontology, rol. 4, r. 318, pl. 21, figs. 5-14.

Description.-The zoarium incrusts shells and stones; it emits bilamellar expansion-profucer by a folding of the primitive lobes; these expansions, with the large zone of growth develop rery irregularly and anastomose in a rery complicated network. The tubes are indistinct, arranged in quincunx or in little constant rows. The tubules are irregularly arranged on the zondinn. The ovicell is orbicular or elliptical, not convex, spread among a dozen tubes, not perforater by the adventitious tubules; the oeciostome is isolated, ovil, provided with an oeciostone more or less large.

Mensuremont.-Maximum diameter of the peristome $0.12 \mathrm{~mm}$.

We have little to add to the excellent description given in $1901 \mathrm{by}$ Ulrich, but the progress of science permits us to understand the structure of the species better. 
The tubules are more interstitial than adrentitious. for they do not perforate the ovicell.

Occurrence--Lowest Eocene (Bryozoan bed at base of the Aquia formation) : Upper Marlboro, Maryland (rare).

Geologicul distribution.-Cretaceous (Vincentown): Vincentown, New Jersey. Plesintypes.CCat, No. 65457, U.S.N.M.

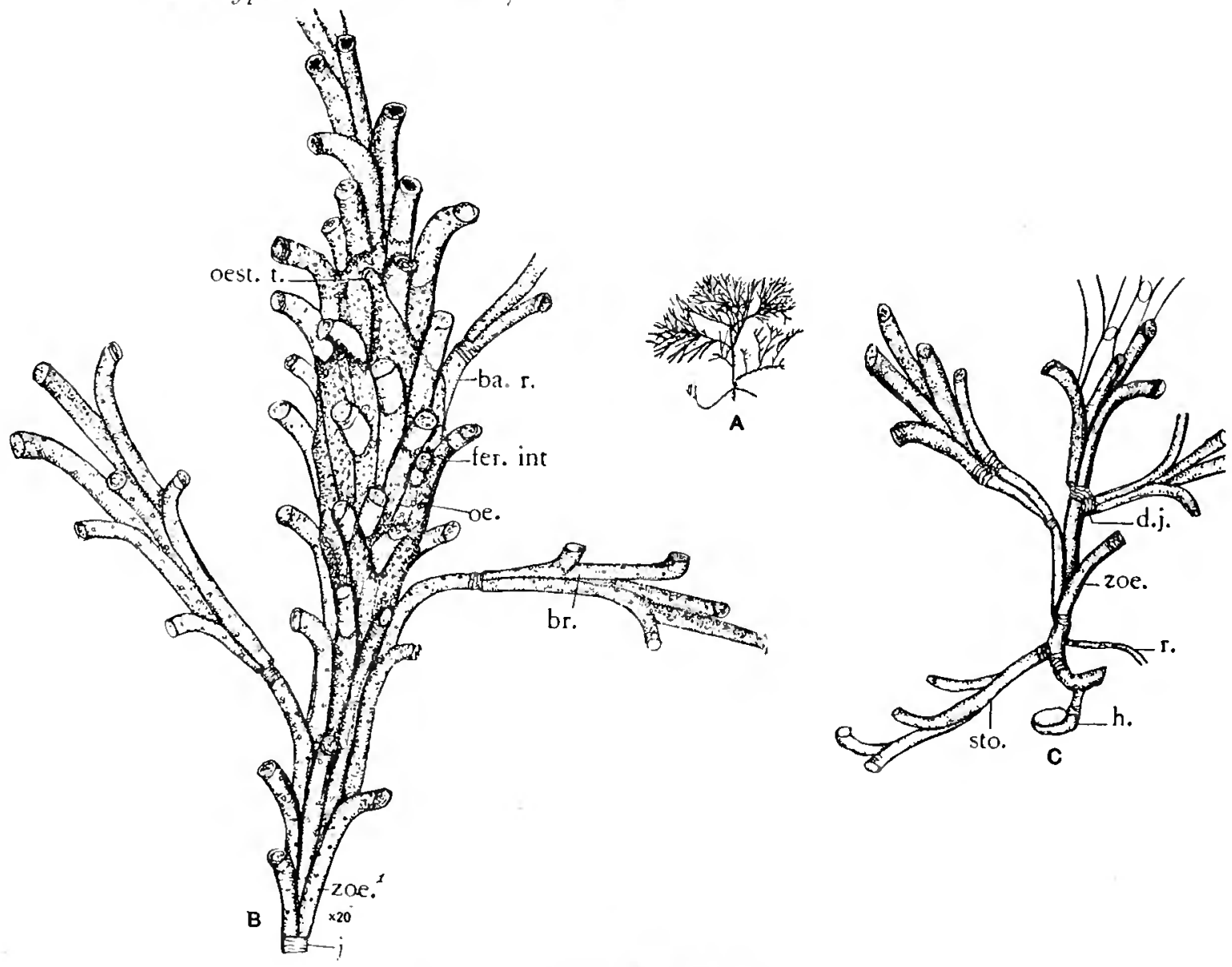

FIG. 242.-Cienus rrisulinora liobertson, 1910.

A-C. Crisuliuora ocrilmatis Rohestson, 1910. A. Zoarium, natural size. B. An ooecial internole, $\times 20$, shrnwing its origin in two zooecia in whose walls the first chitinous joint $(j)$ occurs, and the monle of furmation of three branches; also, the ooecium (or) distinguished ly its coarsely Inuctate wall, with the tubular aperture (ocst. t.) and circular oeciopore. The tubes at the distal extrunity of the internode, the proximal portions of which only are sluwn, gre rise to another interuote. C. A portion of the lower part of a colung showing a rootlet $(r)$ which grows long, renetrating masses of other material; another which is shorter and possesses a hook (h) ar lumes which has lail bohl of a grain of sand ur a pebble; and a stolonlike process (sto) whirh grows borizontally sending up zooecia at interals which produced new branches. From the first zooecium (zon) there arise two tubes one of which gives rise to a double joint (dj.) giving off manches at an angle to each other and hence in different directions. (A-C, after labertson, 1910.) 


\section{Genus CRISULIPORA Robertson, 1910.}

1910. Crisuliporn Robertson, The Cyelostomatous Bryozoa of the West Coast of North Ameriea, University of California Publications Zoology, rol. 6, p. 254.

Zoarium clendroid, calcureous, composed of segments or internodes united by chitinous joints. Zooceia tubular, disposed in sereral alteruate rows. Ooeeium an inflation of the surface of an internode. (Robertson) Oeciostome tube narrower than the zooecial tube, without any terminal expansion. 'Ten tentacles (Waters).

Genotype.-Crisulipora oceilintulis Robertson, 1910.

Runue.-Ticksburnian-Recent.

CRISULIPORA PROMINENS, new species.

I'late 154, figs. 12-20.

Tleseription.--The segments are thin, elongated, somewhat claviform, triserial. The tubes are distinct, eylindrical, bent upward. terminated by a sulent peristomie elevated to $45^{\circ}$; the peristome is thin, salient, orbicular, oblifue. The ovicell is sacciform, globular, striated transversally, the oeciostome is a tube smaller and less salient than an ordinary tube, directed upward. The basal lanella is ornamented with transverse, much scatered wrinkles.

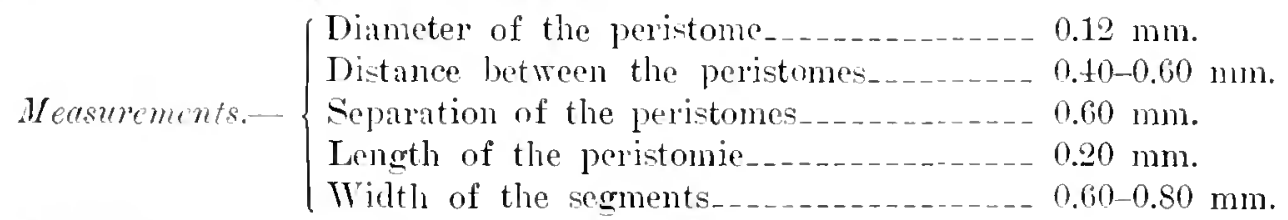

Tariations.-The segments of the base of the zoarinm are not similar to the others; they are more simple and biserial. The length and width of the segments are quite valiable just as is their general aspect; we have figured some of them.

This species differs from Crisutiporn mugosororsatis in its segments which are triserial and not pluriserial, and in the dimensions of its much smaller ovicell.

Occurpence.-Ticksburgian (Mari:mna limestone): One mile north of Monroeville. Alabama (rery rare); West bunk Conecuh River, Escambia Comnty, Alilliama (rare).

C'ntypes.-Calt. Nos. 65.396, 65387. U.S.M.M.

CRISULIPORA RUGOSODORSALIS, new species.

l'late 154, tigs. 25-29.

Deseription.-The serments are pluriserial, fusiform, swollen. 'The tubes are distinct. cylindrical, curved, arranged in regular quinemux, terminated by an oblique salient peristomie; the peristome is thick, orbicular, little oblique. The oricell is rery convex, roluminous, punctate and striated transversally, surrounding almot all the tubes of a segment; the oeciostome is a smaller tube adjacent to another. The dorsal fare is ormamented with large, transverse. seattered wintess; it is very often concive. 


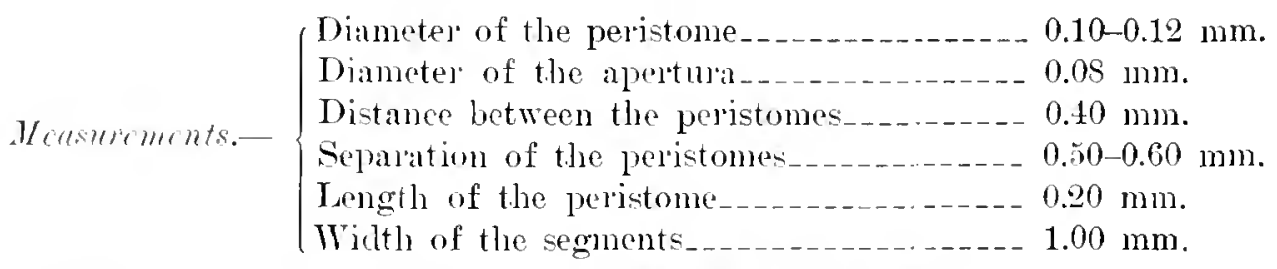

Atenities.-This species differs from Crisulipora prominens in its pluriserial zoarium. It differ's funn Crisutipora flabelluta in its dorsal surface, which is much more rugose. and in its nonflabelliform but fusiform and never bifurcated segments.

Oceurence. - Vielisburgian (Mariama limetone): One mile north of Momroevillo. Alabama (rare); west bank Conecul River, Escambia Comity, Alabama (rare).

Cot?lpe--Cat. Nos, 6.5389.6.53!n. T.S.X.M.

CRISULIPORA FLABELLATA, new species.

I'late 1,it. figs. 21-24.

Mescription.-The segments are pluriserial, flabellate. bifurcated. The tubes are distinet, cylindrical, arrunged in irvegular quincmx, striated; the peristome is thin, orbicnlar" the peristomic is well developed only on the lower tubes. The orjeell is enormous, globular, enveloping all the tubes of a segment; the occiostome is rery small. The dorsal face (batal lamelia) is mmanented with transwere, very widely scattered striae.

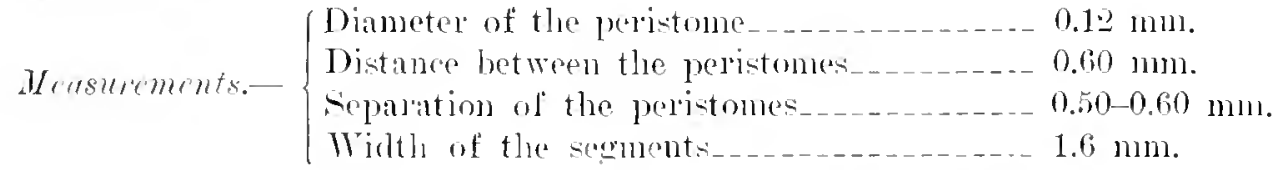

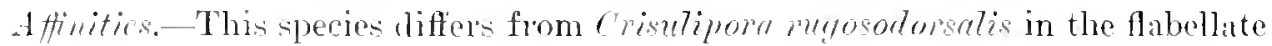
(and not fusiform) form of its segments. and in its dousal face ounamented with much smaller wrinkles. We learn from Mise Rohertson s wolk that the number of the enbryos is rery great in the ovicell of crisutipare. On the other hand. if we note the great size of the ovicell of this species we are surprised at the ruity of the specimens fomme. Theid extreme fareility and theil sperial mode of habitat on floating algate must he the mallice of this.

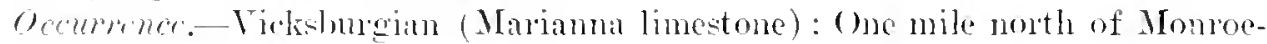
ville. ilaluama (rille).

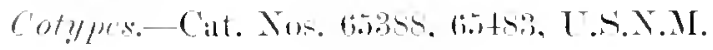

CRISULIPORA GRANDIPOLA. new species.

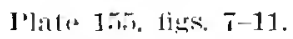

l'eseriftion. - Me know only the binerial seuments of the base of this species.

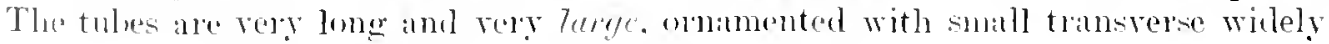
-pincul whinklas: the peristone is thick. orhicular. saljent. 


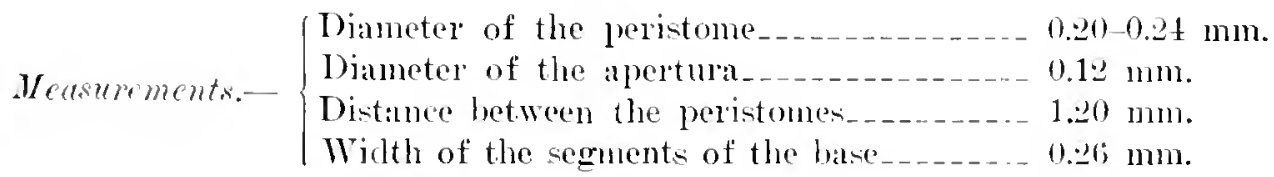

This species is not as ratre as the precerling one, for we possess a score of fragments which has permitted us to make longitudinal sections. The tubes are arranged as in Filispars. We have supposed that these are the branches of the base of a Crisulipora, but the discorery of other segments is necessary.

D'Orbigny named this special arrangement of the biserial zoaria, Unierisin.

Gemerence-Cickshurgian (Marianna linestone) : Mrurder Creek east of Castlebury, Conecuh Connty, Alabama (are); west lank (onecuh River, Escambia County, Alabinna (common).

C'otypes.-Cat. No. 65 t60. U.S.N.II.

DESMEDIAPEROECIA, new genus.

The oricell surrounds the fascicles. The surface of the tubes is ormanented with Jarge pores closed by a calcareons linnella.
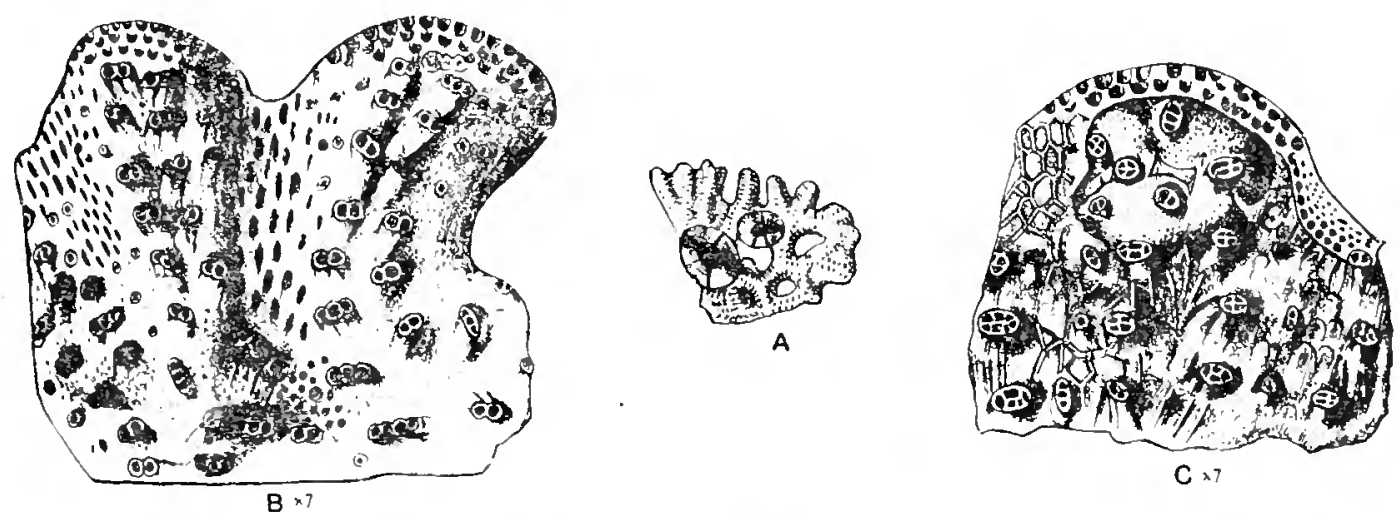

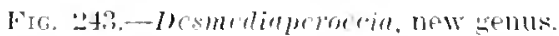

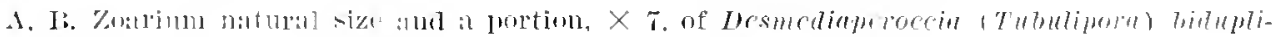

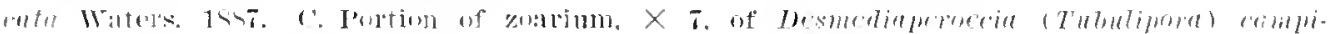
rherinn Waters. 155 inot IrOrbigny).

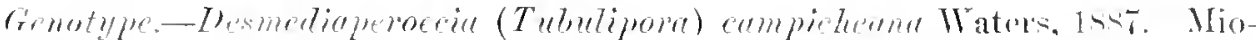
cene. Inother species refored to this genus is Lesmediamenesin (Tubutipma) bidnplienle Watcis. 1585.

We have not olserved the species mentioned by Waters. 1sst, in the Tertiary

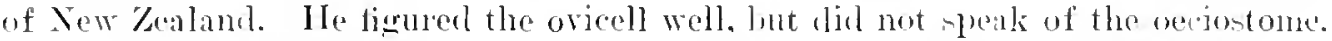

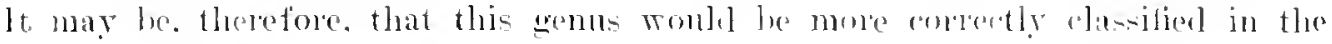
Tululiporielne. 


\section{Family TUBULIPORIDAE Johnston, 1838.}

Anatomical bibliography-183s. Mrene-EDwands, Mémoire sur les I’olypes du genre des Tubulipores. Inuales des sciences naturelle, ser. 2, vol. 8, p. 3, pl. 12.-1S77. Barrois, Recherhes sn l'embryologie des Bryozonires, Travax de l'Institut de \%oologie, fasc. 1, pl. 3. fir. 2n.-1sos. Harmer, on the develojment of Tubulipora, Qunterly Journal Microscopical science, vol. 41, pp. 73-117, pls. S. 9, 10.-1899. Watras, On some Ovicells of Cyclostomatons iryozoa, Journal Iinnean Society, London, rol. 20, p. 275, pl. 14, figs. 2, 5, 6. S.-1914. Waters. Bryozoa from Zanzibar, Proceedings of the Zoological Society. London,

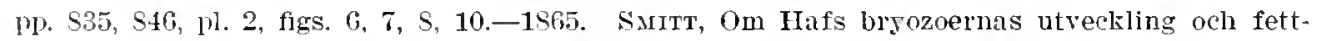
liropper, Oversight Kongl. Vetenskaps Akademiens, Forhandlungen, p. 20, pl. 4, figs. 9-14.

The ovicell is irregular and located on the zoarium. The oeciopore is subcentral. The tubes are very salient at their proximal extremity; they are isolated or fasciculate.

In studying the anatomy of Tubulipora organisans D'Orbigny, 1839, Jullien ${ }^{1}$ wrote:

J'a i vu que l'ovicelle constituait une rrale génésie fenclle depourvue de polypide, contenant me très grande quantité d'orules qui $\mathrm{y}$ sont fécondées et en sortent a l'útat de larves deji très developpées.

The limits of this family have never been very precise; all of the old authors understood it in a different sense, adding or eliminating genera according to their personal opinion. The zoarial form and the mode of aggregation of the tubes were the only characters studied. A disenssion of priority is therefore useless, since we now regiard the oricell as the essential and most important character.

In the establishment of the new genera we must consider the form and position of the occiopore, which is in rapport with the function of the escape of the larra. Unfortunately, very often sufficient material for a complete study is lacking. As in the Cheilostomata, we must also regard the function of calcification.

We consider the genus Tubulipore Lamarck, 1816, as quite a natural one and we accept the word "Tubuliporidlae" for" the family, although the genus Idmoned is the more important in time and in space.

\section{Classificatiom of ucurra.}

\begin{tabular}{|c|c|c|c|}
\hline & Notibules. & $\begin{array}{l}\text { Tubules on } \\
1 \text { sile. }\end{array}$ & $\begin{array}{l}\text { Tuhules on } \\
\text { :2 sides. }\end{array}$ \\
\hline 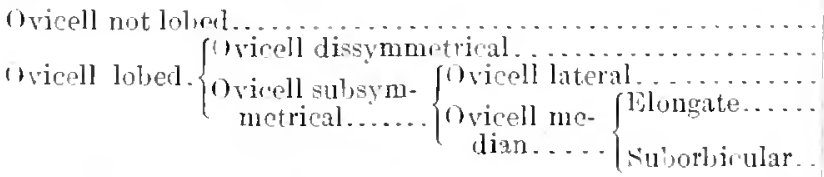 & $\begin{array}{l}\text { Ilmonera. } \\
\text { Tubuliporn. } \\
\text { I'latonca. } \\
\text { Centrones. }\end{array}$ & $\begin{array}{l}\text { Idmilronea. } \\
\text { Pliuronea. } \\
\text { Mesonea. } \\
\text { Erkosonea. }\end{array}$ & Trelonea. \\
\hline
\end{tabular}

Many of the Tululiporidne are provided with "pores" which are the orifices of the special tubes of whose function we are absolutely ignorant. We give them different names according to the case and to their nature. but we can consider them only as variations determined by the function of calcification. They appear to furnish secondary generic characters and nothing more. 
Genus TUBULIPORA Lamarck, 1816.

1816. Tubulipora Lamasck, Flistorie naturelle des animaux sans vertébres, vol. 2.

'The ovicell is irregular, lobed, spread ont letween the fascicles. The tubes are quite salient. isolated or joined in fascicles, miserial and irregular. The occiostome is adjacent to a tule and the oeciopore is directed in a direetion contray to that of an apertura. Eleven or 12 tentaeles. Gemmation genelally peripheral.

Genotype.-Tubulipora Aabcllaris Fabricius, 1780.

Rimge.-Midwayan-Recent.

Harmer. defines the genus as follows:

Zoarium with a distinct basal lamina. adnate or erect, beginning as a jyrlorm or flabellifolm colony, which may become lohed by the division of the terminal memnrane. Iolves short and adherent, or longer and dichotomously divided once or more often, sometimes becoming erect. Zooecia with a free, cylindrical, terminal fortion; or connate in obliquely transverse series, in which they are sepniated by flat septa corresponding with the intersection of two cylindrical zooecia. The series are aranged alternately on oplosite sides of the axial line of the lobe, but the trinsverse arrangement usually becomes radial iu the distal part of the fertile lobes. Ovirell, an enlarged zooecium, which extends into the intervals hetween the parallel or radial series.

Genotype.-Tubulipora liliarea Pallas, 1766. (= Tubulipora serpens authors).

Canu in 1916 explained why the ehange of Tubulipord serpens to Tubulipora litiucea is not acceptable. Moreover, this species is badly chosen as genotype of the genus, for it is the only one which has an idmoneiform zoarium; all the other species are more or less flabellate. We would rather prefer the Tubulipora fabellaris Fabricins, 1780, very well fignred later, as the true genotype. It is indeed true that Tubulipora serpens is a Tubulipora. The genus Idmonea Lamouroux. 1821, is also quite distinet and is characterized by the form and position of its oeciopore.

TUBULIPORA MIDWAYANICA, new species.

Plate 107, fig. 1.

Description.-The zoarium is flabellate, small, free, living on algae. The fascicles are salient, crowded, uniserial, complete, radiating from the ancestrula. The tubes are invisible; the peristome is thin, round or polgonal.

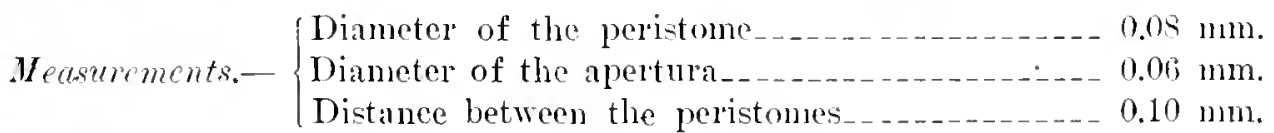

Affinitics.-The only specimen found has been fignred. The necesities of the generic elassification oblige us to describe it, but it is difficult to establish its relations with the other known species, especially since it has no oricell.

It differs from Tubulipora fabellaris Fabricins, 1780 , in its complete and noninterrupted lines and in its much shorter tubes.

Oecurrence.-Midwayan (Clayton limentone): One mile west of Fort Gaines. Georgia (ver'y lale).

IIolotype.Cat. No. 65243, U.S.N.M.

${ }^{2}$ 1898. Harmer, On the development of Tubulipora, Quarterly Journal Microscopical Society, n. $\mathbf{s}_{4}$ vol, 41, p. 99.

$5.509-20-B u 11.106-49$ 


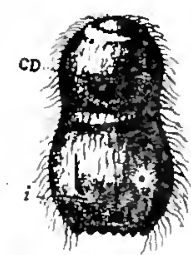

A

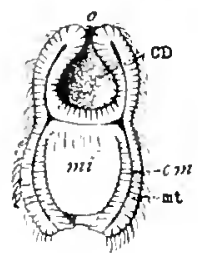

B

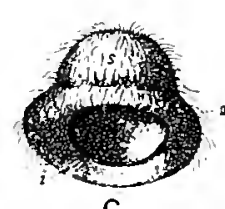

C
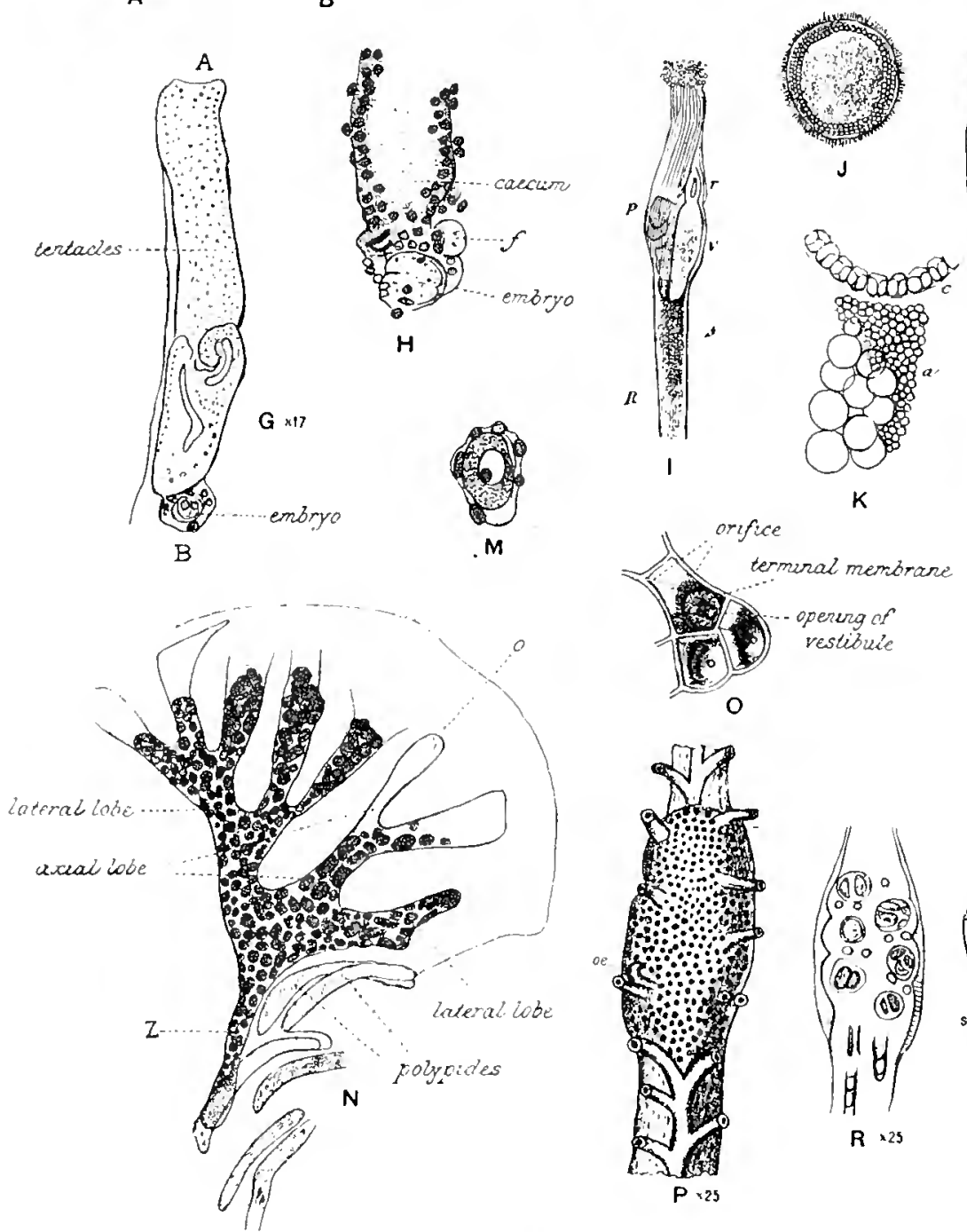

K
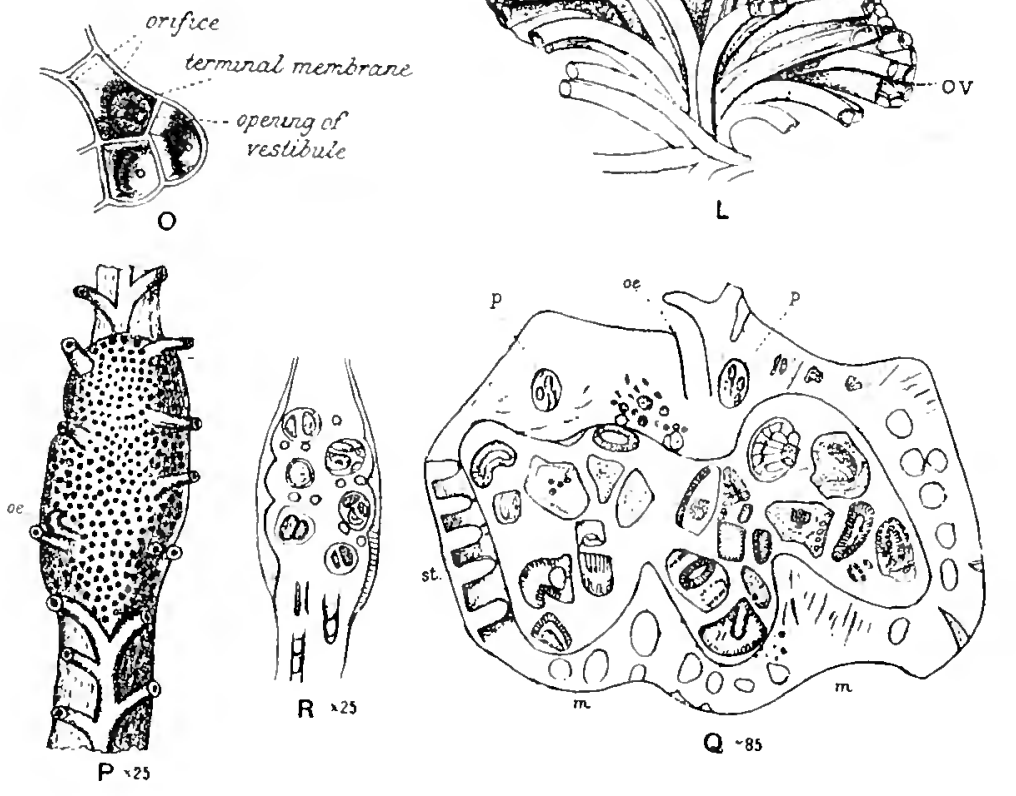

Fia. 244.-Family Tubuliporidae Johnston, 1838.
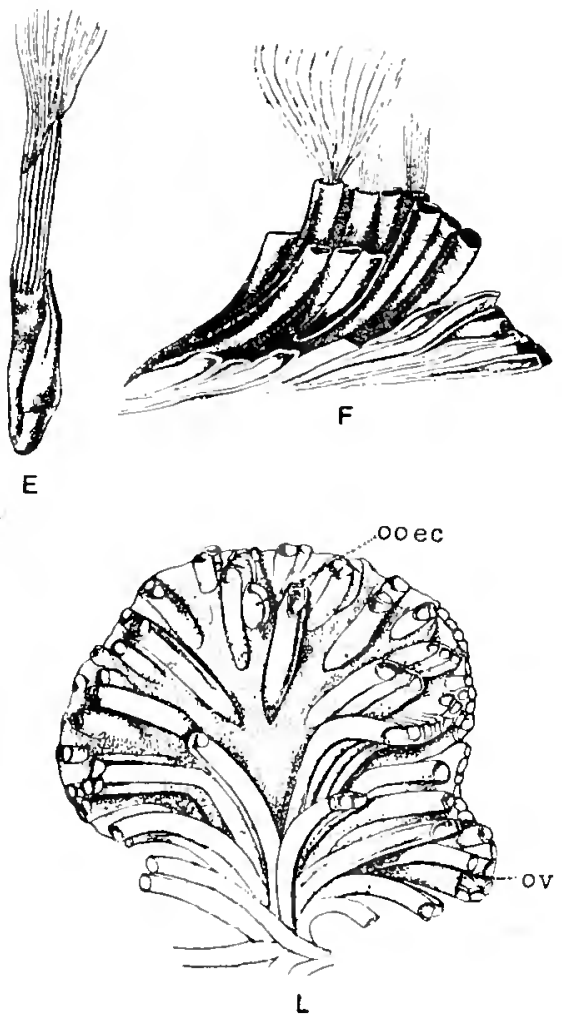


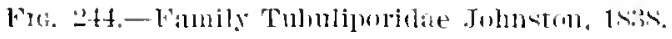

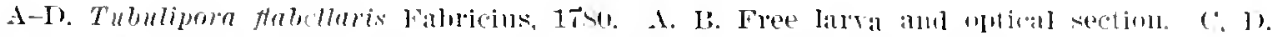

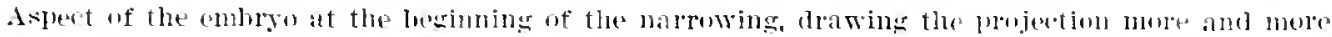

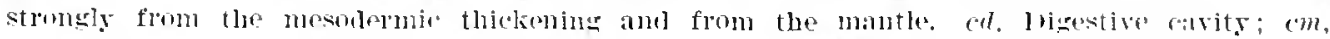

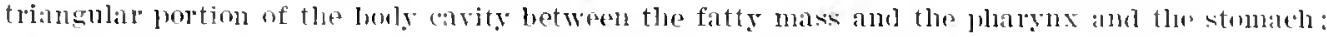

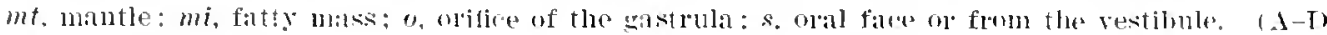
attro Parrois. JsT.)

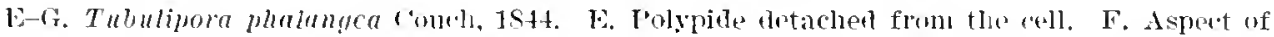

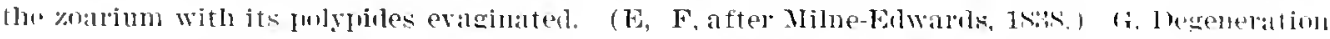

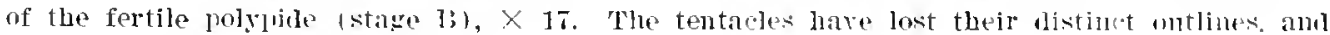
are oloviously legenerating.

1f. Stage B of Tubulipora plumosn Thompson, 1847, the embrya consisting uf two blastomeres.

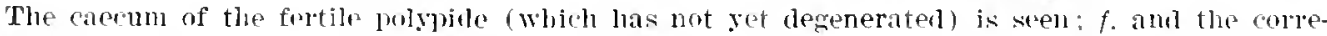
sponding strueture to the loft are probably the degenerating follicles of exgs which ale not leveloping. (After Harmer, 1898.)

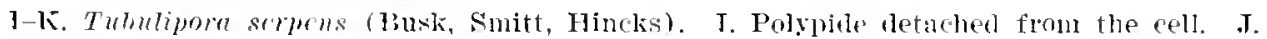

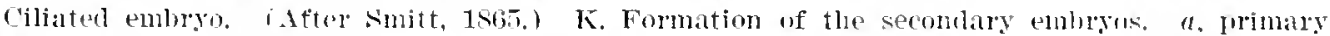

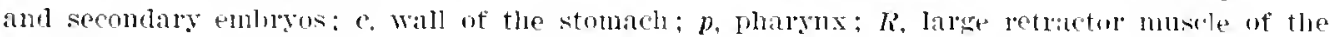
polypicle: $r$, anus; $t$, tentacles; $r$ stomach.

L-1). Tubulipora plumosa l'hompson, 1S4t. L. Fertile Inbe, with one ovicell and the besin-

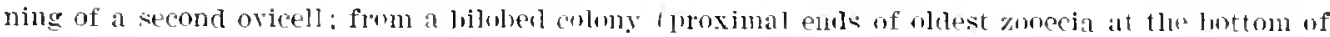
the figme, obscured ly foreigm substance. M. Ovarian exg. in fullicle (stage A). X. Decaldified preparation of an old wicell fstage G) witl nearly solid embryophore containing numerous sere

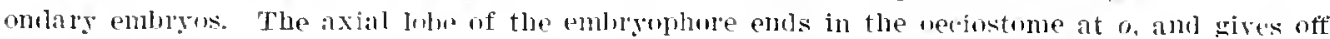
another lohe to the right. The min lateral bohe of the lisht sible is only olscurely bifulcated; that of its left sicle is dividen into tive lohes. Z, proximal part of the ovicell, corresuonuling with a zoofium. Greatest length of sulid part of embroplore to tip of most projerting lulu. 2... mm.

o. Orifices (apertures) of living zonocia. The terminal membrame las bern sumewhat re. tracted. (1,-0 after 11armer. 1sas.)

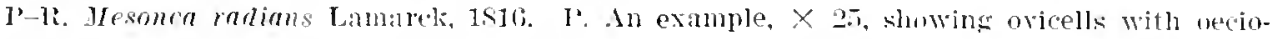

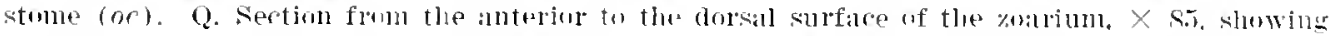

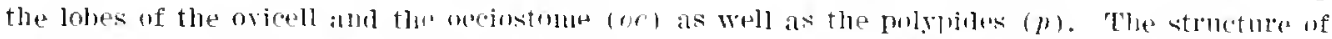
the wall of the wicell is seren at the lett $($ st) with one ol two rosette plates at the bise af the broad pore tulue. 'There is an outer mombune $(m)$. R. Longiturlinal sesetion af the orjowl, cut parallel to the anteriur and dorsal surfintes. (After Waters, 1914.) 


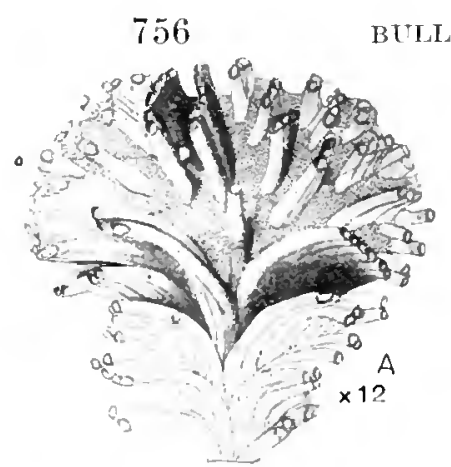

BULLETIN 106, UNITED STATES NATIONAT, NUSEUN.

Tubulipora
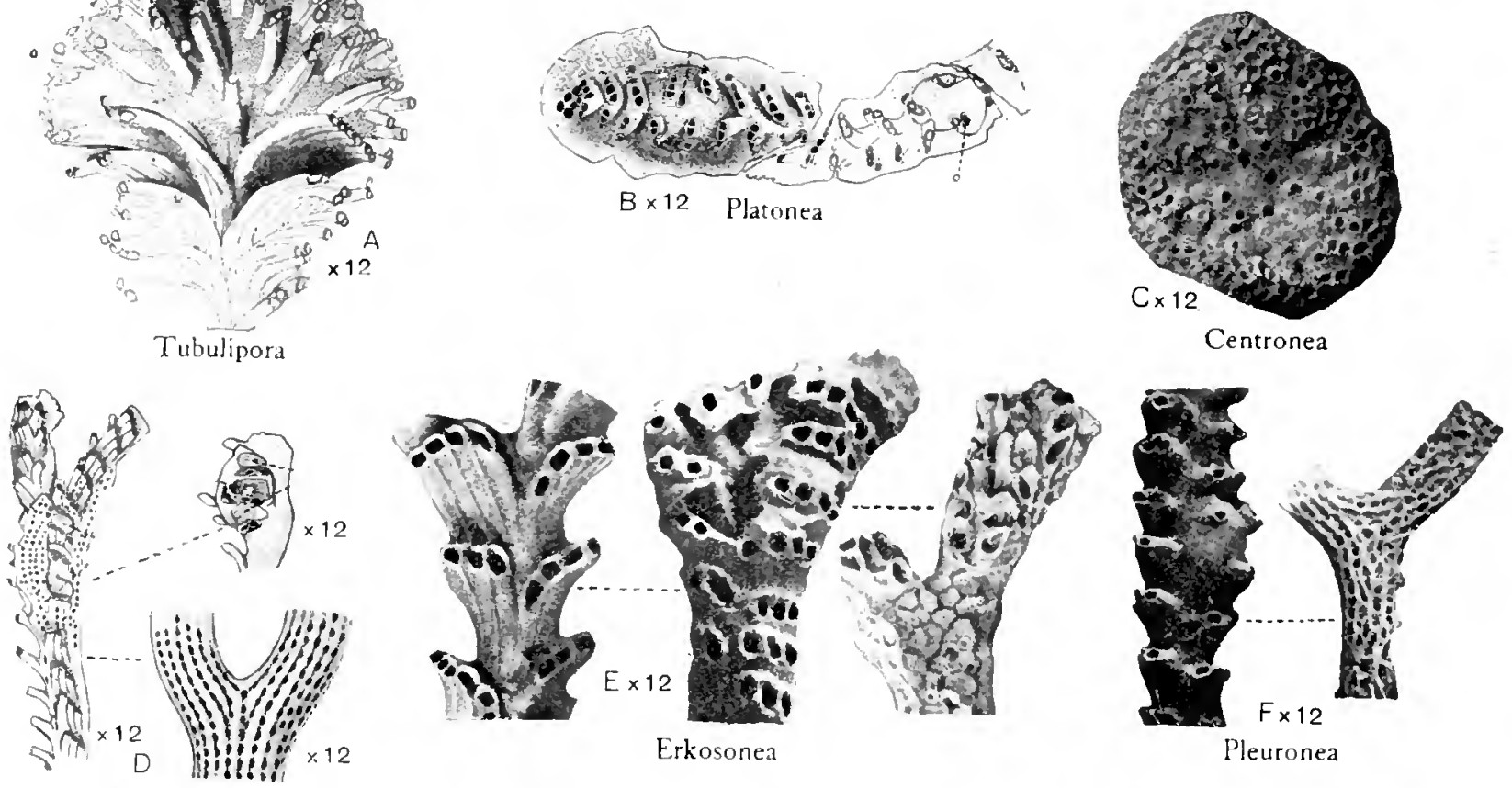

Mesonea
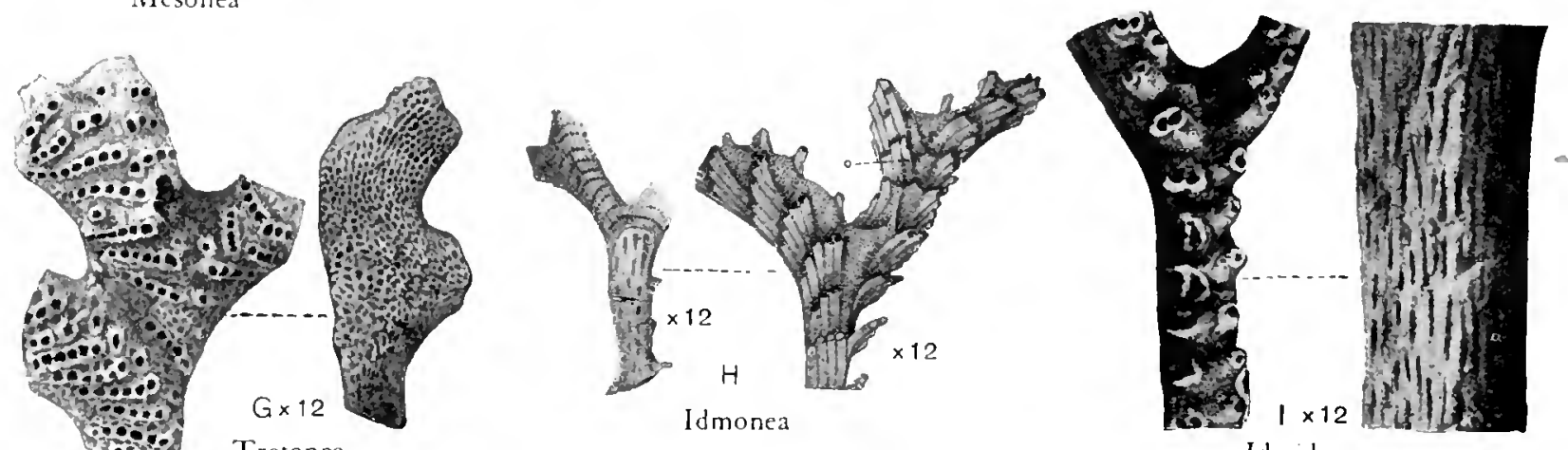

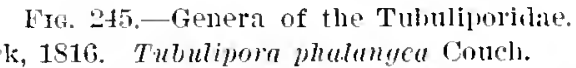

Idmidronea

Tretonea

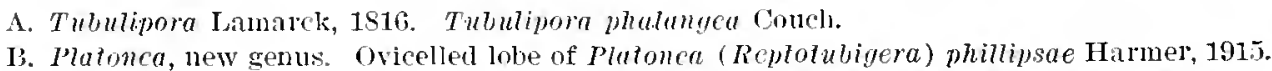

G. Centronca, new genus. ovicelled specimen of Centronca (sfultitubigera) mieropora Renss, $1860, \times 12$.

I. Mesonen, new senus. Frontal with ovicell and dorsal of Ifesonea (Relepora) raditms Iamarck, 1810.

E. Erlosonca, new genus. Frontal and dorsal sides, $X$ 12, of Erlosonca scmota, new species from the Eucene of Mississippi.

F. Ilfurmea, new genus. Frontal with ovicell and dorsal of Plcuronca (Idmonca) fonestrata. Iinsk, 1859.

G. Tretomer, new genus, Frontal with ovicell and dorsal of Trelonea lcris, new species from the Jackinnian of Georgia.

II. Itmoncu Iamouroux, 1S21. Dorsal and frontal with ovicell of Idmonca allantica Forbes, 18.6. (After IIarmer, 1915.)

I. Idmitrmen, new genus. Frontal, $\times 12$, and dorsal, $\times 25$, of Idmidronca (Idmonea) maxilluris Lunsiate, 1sti, from the Eoceve of North Carolina. 


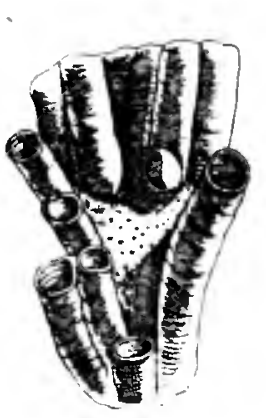

A
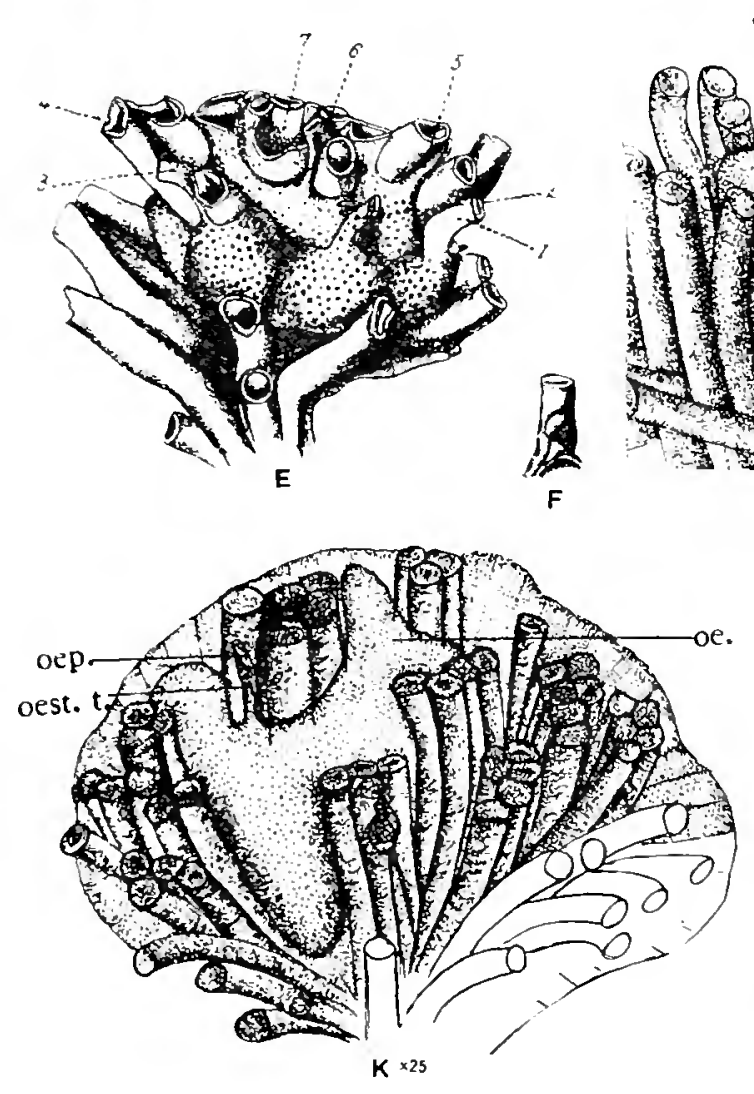

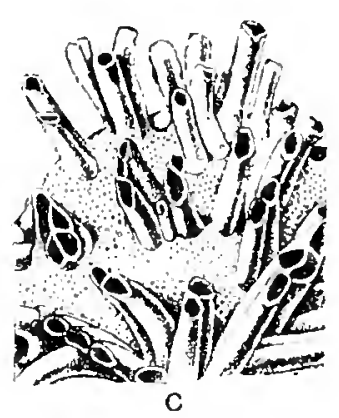

C
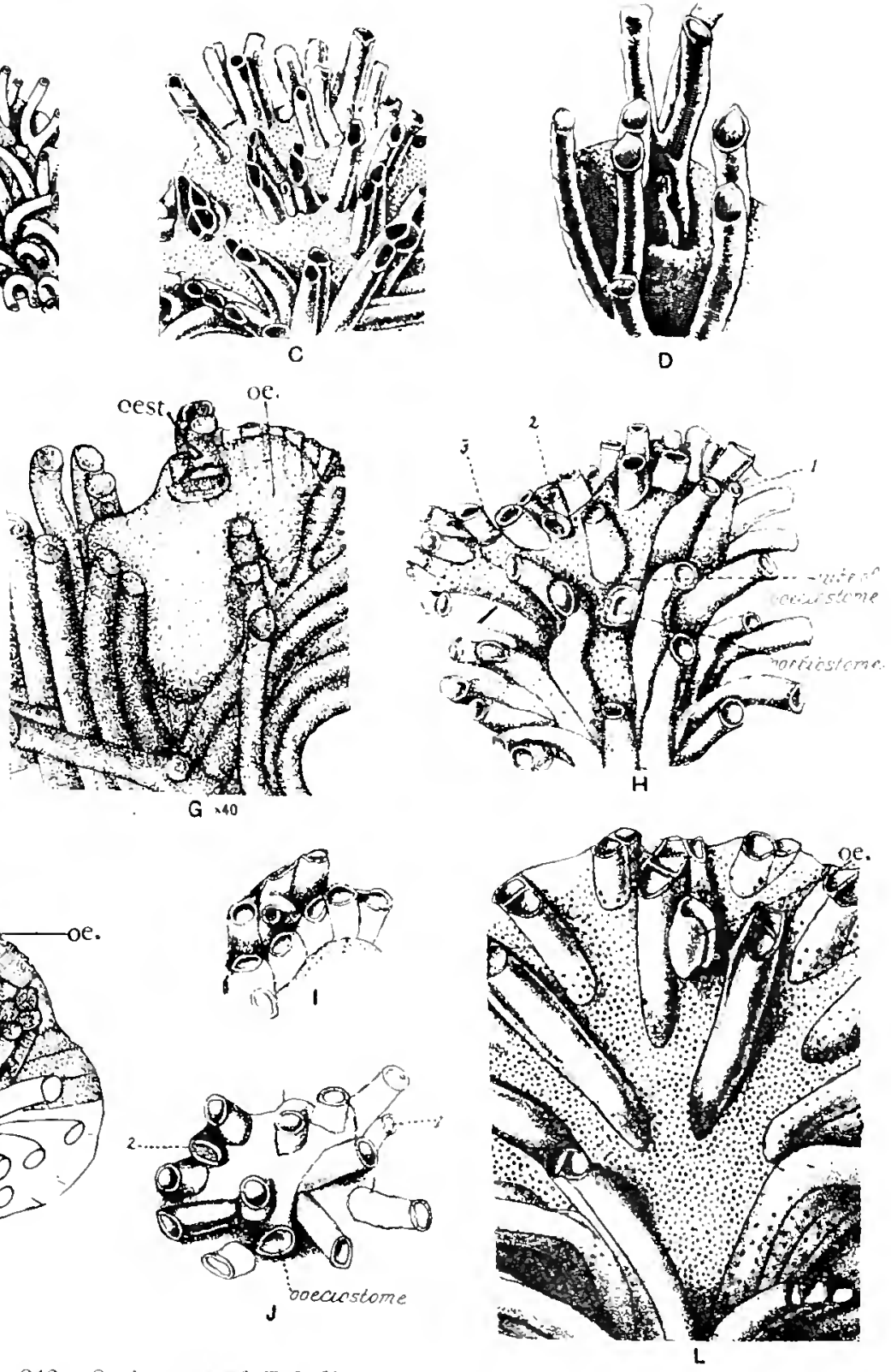

F1G. 246.-Oeciopoles af Tubutiport. 
TUBULIPORA INTERRUPTA, new species.

Plate 134. figr. 22 .

Decription.-The zoarium is flabellate and incrusts bryozoa. The fascicles are little salient, irregular, interrupted by isolated tubes or by other incomplete
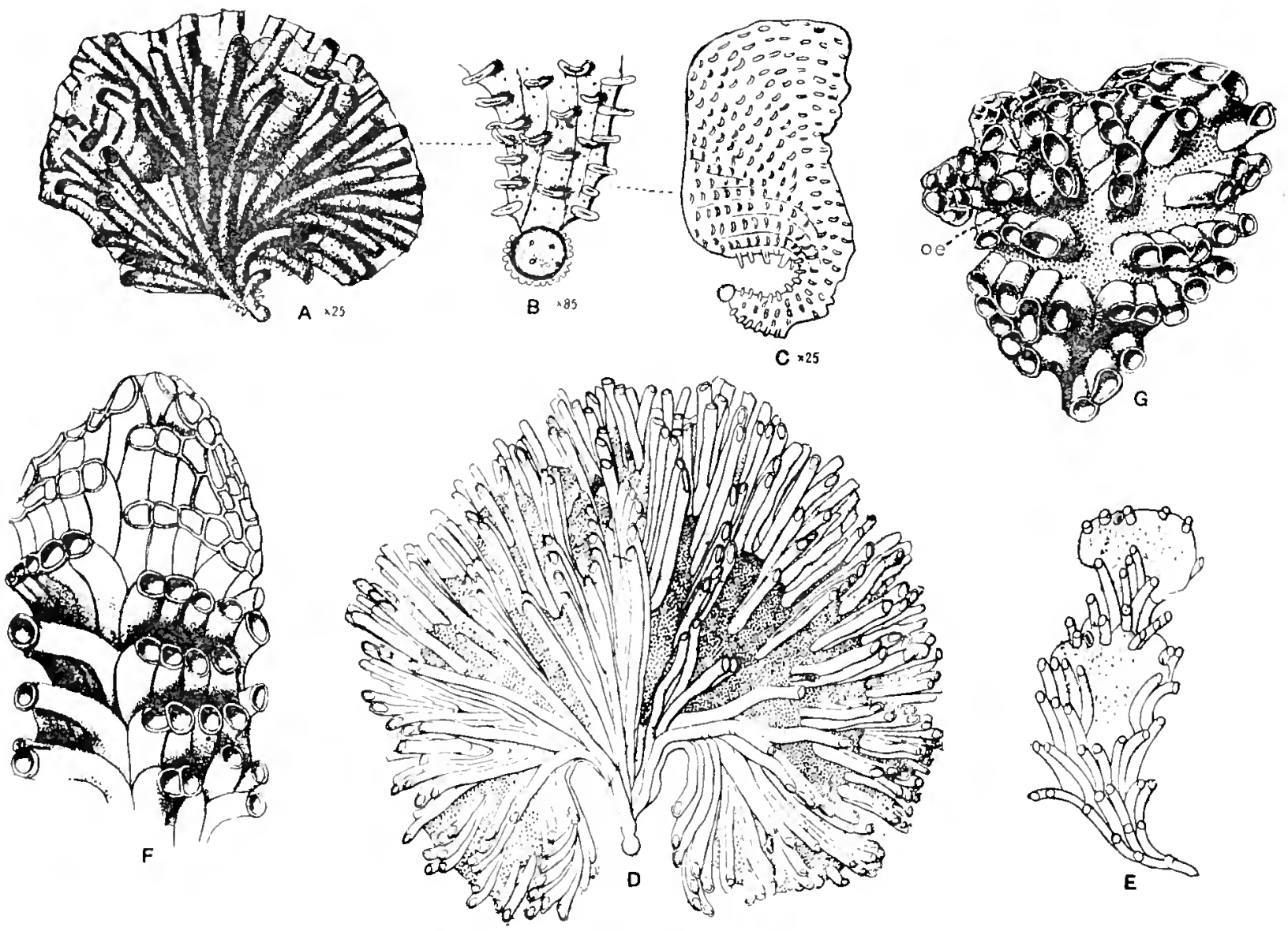

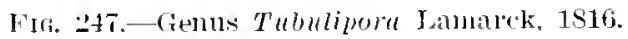

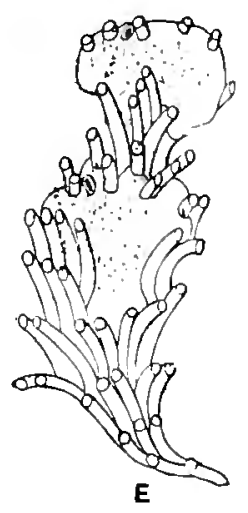

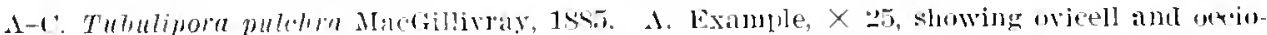

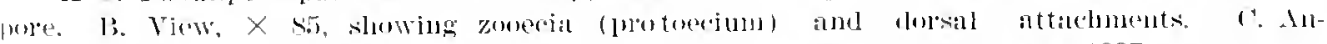

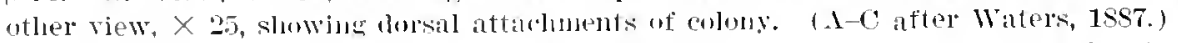

D. Tubulipora flabellaris Fabricius, 1780. An entire zoarium, magnitied. (After Sunte. 1567.)

E-G. Tubulipora serpors (smitt, Hincks, Busk). E. Ovicelled fossil rontimm. (After

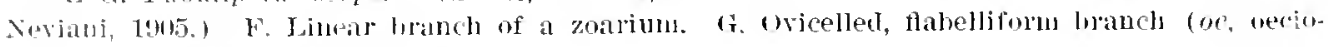
stomes). , F-C after Harmer, 189S.)

series. The tulnes are small, with a long but very oblique peristomie; the peristome is thin; the apertura is rounel or oral.
Mecasurements.-
Diameter of the peristome
$0.07 \mathrm{~mm}$.
Distance between the peristones
$0.12 \mathrm{~mm}$. 
Affinities.-Thi species differs from Tubulipora miduraynicu in its less projecting, irregular, and incomplete fascicles. In its general aspeet it much resembles Tubulipora Zucide MacGillivray, 18st, from the Anstralian coasts. It differ's from it in its less salient tubes and its more oblique peristomes. These are insignificant diflerences which a linowledgre of the micrometrie measurements of the Australian species might overome.

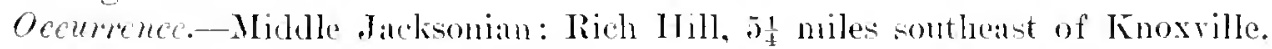
Craw ford Connty, Georgia (rery rare).

IIolotype-Cat. No. (i.333.5. U.S.N.M.

\section{PLATONEA, new genus.}

Greek: phetus, in allusion to the ovicell occupying the entire zoocecial wilth.

The ovicell is sulswmmetrical, lobate, median, elongate. spread out hetween the fascicles over the entire zoarial width. The gemmation is linear. "Oeciontome a
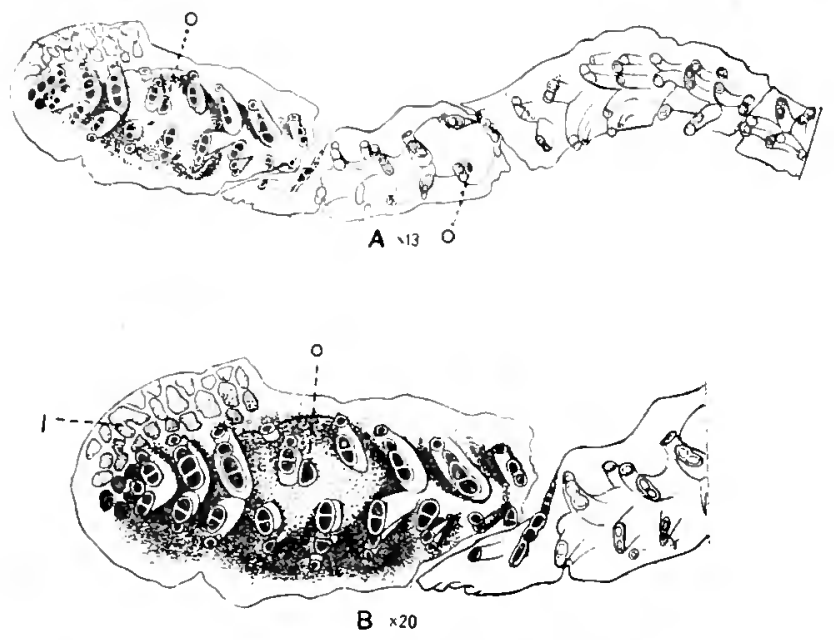

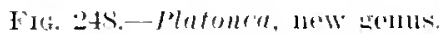

A, B. Ovicelletl lobe of Platonca (Reptolubigera) phitlipsac Harmer, 3915 o, eeciopore. short tube, dereloped on the proximal side of one of the series of zorecia, near its median end. Oexiopore directed frontally, elongited transvelsely and mor's or less oval." (Ilarmer, 1915.)

Genotype. - Reptotubigera philippare Harmer. 1915.

Range. - VicksburgianRecent.

II istoricul.--The form of the zoarium is that of an incrusting Irtmomer. Noting the gleat diflerence between this ovicell and that of $T u-$ bulipore. Ilaruer in 1915 believed that the old genus Reptotubigera of D'Orbigny might be restorer lut unfortunately all the species of Reptotubigere have not the same ovicell ant to our great regret we can recognize the genus of the French paleontologist only for those species deprived of ovicell. in conformity with his definition and figures.

Aftinities.-This genus diflers from Idmonea, which has the same fascicular arrangement. in its lobate ovicell spreading between all the faccicles and not limited to a single median part of the zourium. It differs from Tutulipore in its subsymunetrical orjeell. in its tubes little projecting above the wicell, and in its linear gemmation.

Tubutipore serpens is provided with a zoarium like an incrusting Idmonea. It is not a Plutoma lecause its ovicell is irregularly lobate, mot subymmetrical and hecause its small veciostome is adjacent to any tuhe whatsorerer. We repratedly have to remark that the zoarial form is of no value for generic clasification. 
Plate 161, figs. 1, 2.

Inscription.-The zoarimm incrusts shells and Orbitoid foraminifera; it is clongate, branching, with lobes in the form of a $c l u b$. The fascicles are symmetrically aruanged, alternate or opposite, miserial, salient, little oblique. The tubes are little visible, very little convex; the peristome is thick, round or polygonal, elevated almost vertically. The ovicell is quite large, globular, spread ont between the fiscicles over the whole zoarial width.
Mecasurements.-
Diameter of the peristome $0.10-0.14 \mathrm{~mm}$.

Our ovicelled specimen is not an excellent one and the oeciopore is not visible.

Atfinities.-Most of the described lieptotubigeru have no known oricell. Their comparison with our species is therefore absolntely useless.

Oecurvence-Vicksburgian (Marianna limestone): Salt Mountain, 5 miles south of Jackson, Alabama (rare).

Cotypes.Cat. No. $654+1$, U.S.N.M.

Platonea lamellifera, new species.

l'late 1.11, fiss. 12-19.

Description.-The fragments of the zoarinm are free, idmoneiform, very wide, short, irregular with subelliptical transverse section. The fascicles are quite salient, very close together, regular, alternated on each side of the median axis; they are formed of three to eight zooecia. The zooccia are little visible, somewhat convex; the orifice is rectangular and transverse. The basal lamella is smooth; it bears salient lamellac as wide as the zoarium, the purpose of which is to remove the latter from the substratum. The ovicell is lobate; it surrounds the fascicles more or less completely and spreads orer the whole surface of the zoarium; the oeciostome is little salient and is adjacent to the first zooccium of a fascicle.

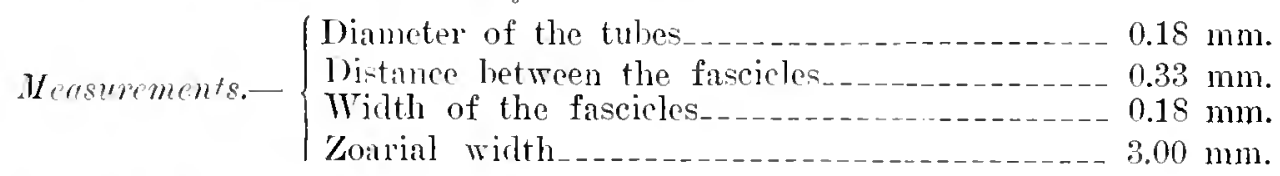

Voriutions.-This species is idmoneiform, but the lobes are very short; they are very thick at their extremity where the incompletely calcified zooccia are visible in great number (fig. 14). Onr specimens are somewhat altered; the basal lamella is theoretically smooth (fig. 18), but the tubes are often visible (figs. 17, 19) by chenical alteration.

The dorsal lamellae rested on the substratum and strengthened the zoarium which was spread out but very fragile and easily broken; their length is quite varialle (fig. 18).

${ }_{1}$ This is the distance between the peristones and mosured on the zontial margins. To calculate the visilue zonecini length it is necessary to add the diameter of the peristome. 
The ovicell which we have discorered is not complete, but it indicates suffieiently (fig. 15) that this species is a Platoned and not an Idmoned because of the presence of the interfaseicular lobes and the special position of the oeciopore.

Affinities.-This species differs from the recent Tubulipora serpens in its free and lamelliferous zoarum.

It differs from Idmone areuta, new species and Idmoneet petri D'Arehiae, 1846, in its much larger micrometric dimensions.

Dccurrence-Lower Jacksonian: Three and one-half miles southeast of Shell Bhuff post office, Georgia (common).

Cotypes.-Cat. No. 6.540 , U.S.N.M.

\section{CENTRONEA, new genus.}

Greek: Rentron, center, referring to the position of the ovicell.

The oricell is lobate, subsymmetrical, median, suborbicular. The fascieles are

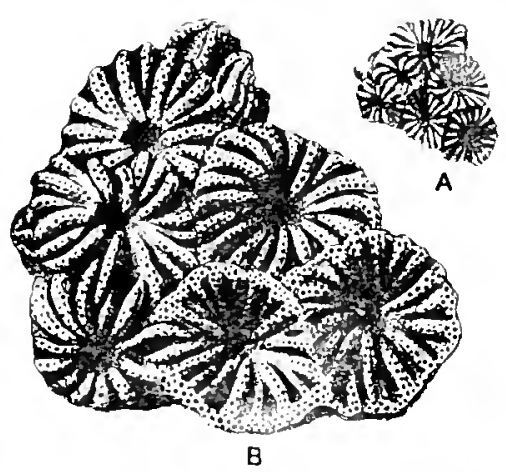

Fig. 249.-C'entroned, new genus.

A. 13. Views natural size and enlalrged of a compusite zurrium of centronca (.ultitubigera) micropora, Reuss, 1869. projeeting very little above the ovicell.

Genotype.-Centronea (Multitubigera) micropora lieuss, 1569. Priabonian.

As we do not linow the occiopore, the difference between this genus and Platonea is little important, but Centronea differs in the form of the ovicell, which is perhaps only in consequence of the orbicular form of the zoarium. As a contrary argument is also reasonable we prefer to recognize this genus.

Our specimens correspond exactly to the genus Multitubigera D'Orbigny, 1850, in their zoarial form. Following our enstom we reserve this old name for the nonovicelled species. On the other hancl, Mnuttitubigere is formed of agglonerate subcolonies of Actinopora. All the known ovicelled species of Actinopora belong to a different family and we are therefore unahle to longer enploy this old tem of nomenclature.

CENTRONEA MICROPORA Reuss, 1869, variety.

I'late 135 , figs. 1-15.

1869. Mullitubigera micropora Retss, Paläontologische Stulien ïber die älteron Tertiarschichten der Alpen, II Abthrifung, hie fossilen Anthozoen nut livozoen der Schichtengrupe ron Crosaro, Denkschriften dor k. Akalenuie der Wisconschaften, Wien, vol. 29, Abth. 1, 1). 34, fig. 15.

Description.-The zoarium is formed by the agglomeration of discoidal subcolonies superposed and joined by their germinal layer. The fascicles are salient, radiating, pluriserial, arranged around a more or less lirge center. The tubes are invisible; the peristomie is elevated vertically; the peristome is thin and orbicular. 
Turiations.-The zoarium is often simple and isolated (figs. 5,6 ); it is a much enlargerl cone, the lower part of which is ornamented with an epitheca corrugated concentrically. The germinal layer is quite large (fig. 11); it is wanting more often on the fossils, for it is very fragile. It disappears also and probably by fossilization at the junction of adjacent subcolonies (fig. 3).

When the zoarium is a agregated (fig. 3) the lower side bears as many peduncles as there are subcolonies (fig. 4 ). The germination of the subcolonies appers laterally (fig. 8) or almost centrally.

The fiscicles bear two or three series of tubes, rarely more (fig. 12) and only on the zuarial margins.

The ovicell (fig. 1t) is little salient; it is visible on account of the great reduction which it occasions in the projection of the fascicles.

The merlinn section (fig. 15) is very instrnctive. In the center there are some closed zovecia $\left(z . \rho_{.}\right)$. The gemmation is habitual and the tubes grow one from another from their dorsal acrording to the msual law (right side of fig. 15). The young subcolonies appear to come from the superior ramification and not the clorsal of a tube (left of fig. 15).

Attinities.-Our s]ecimens are not exactly identical with the Reuss figures. The fascicles appear shorter and more irregular, and we believe it useful to consiter them as a rariety until conparisons can be marle with typical specimens of each. Neither Waters nor ourselves have yet lieen fortunate enough to discover Reuss's species in the material from Vicentin.

Occurrence-Dicldle .Tacksonian (Castle Ifayne limestone): Wilnington, North Carolina (very common).

Geological distrilution.-Priabonian of the Vicentin (Reuss).

I'lesiotypes. C Cat. No. 65.?.?, U.S.N.M.

\section{MESONEA, new genus.}

Greek: mesos, merlian.

The ovicell is lobate, median, aubsymmetrical. The oeciostome curves orel and turns downward. There are curious, lateral, porous windows. The basal stirfice is ornamented with tergopores. The fascicles are arranged s'mmetrically on each side of the zoarial axis. Eight tentacles.

Genotype.-Mesomen (liptepore) rediuns Lamarek, 1816.

Range-Priabonian-Recent.

Iatruer in 1915 held that hetepara rudians was the type of the genus rrisime DOrbigny, 1850. The French paleontologist applied this term to species of I dmone haring a porous, basal lamella, but Crisina nomaniana D'Orbigny, 181?. the first described species of the genus, shows the ovicell and we have adopted it as the genotype. For Lamarcli's species we create the genus Mesonea, which differs from Itmone in the presence of tergopores, in the ovicell which spreads entively between the fascicles, and in the lateral porous windows. 
ERKOSONEA, new genus.

Greek: rmos, partition in allusion to the ornamentation of the dorsal.

The zoarium is ilmoneiform. 'The dorsal bears dactylethae, which appear also on the frontal at the bifureations. The ovicell is globular, spreal ont between three fascicles over the wilth of the zoarium.
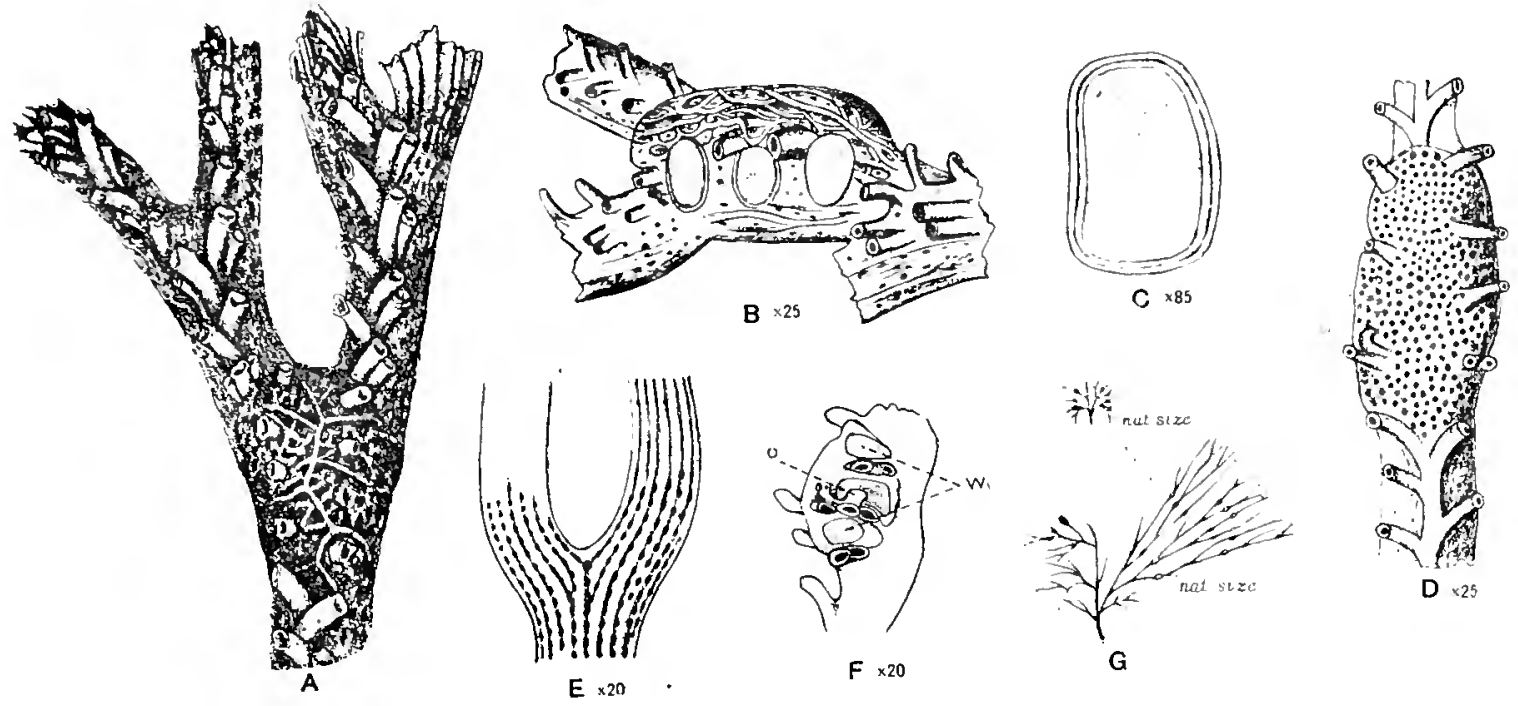

Fit. 250.-Hesthea, new genus.

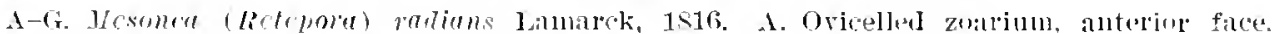

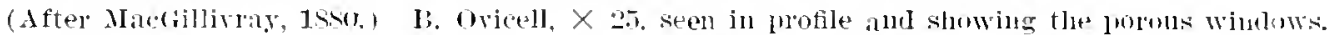
C. Transwrse section of the ovicell, $X$ s.5. (After Waters, 15si.) 1,. Ovicell witl the

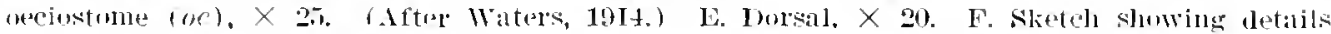

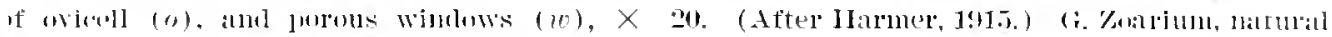
size. (After Witers, 1914.)

Genotype-Ertiosome semota, new speeies, Jacksonian.

The dactylethrae are the aborted tubes, since they are closed hy a caldureus membrane and do not eontain a polypide. They have the same diancter as the ordiniry tubes and grow in the ricinity of the base of the lower tubes fand not at different heights as the tergopores); they become branched but ralrely.

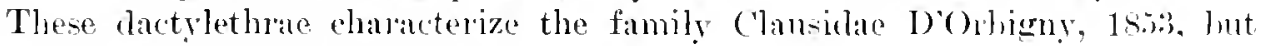
(negry noted no idmoneiforn genus.

Tubulipora cumpirhemu. Waters. 1887, of which the ovicell is known. must he put in a gemus close to Errosonea. The ovicell is very close to that of lyesonea.

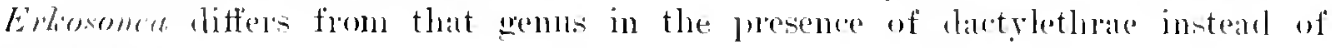
tergopmes.

\section{ERKOSONEA SEMOTA, new species.}

I'linte 1:in, lites, 1-1:3.

Discription.-The zourim is idmmeiform, linear, bifurated, with oval trans-

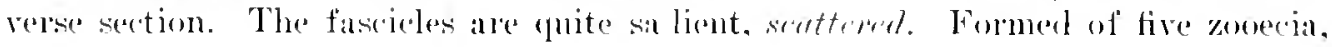


they border the zoarial margins and are almost opposite on each side of the median crest. The tubes are visible convex, separated by a slight salient thread; the peristome is thin, round or rectangular. The dorsal is hardly convex; it is formed by a thick layer of dactylethrae closed by a thin calcareous lamella. The daetylethrie appear on the frontal at the bifurcations.

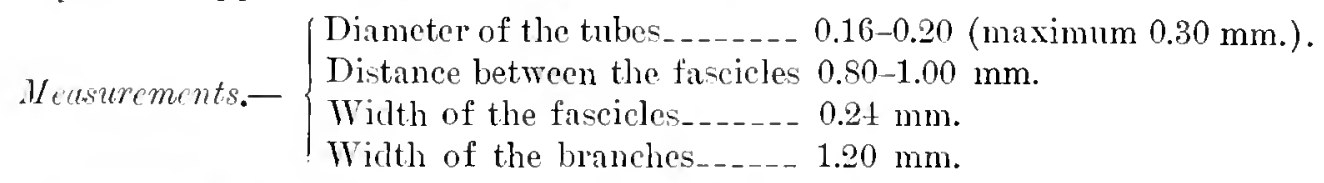

Turiations. - This species is quite fragile; the fascicles are very often broken and the dactylethrac have lost their covering pellicle. Specimens like figure 6 are much mole frequent than the good specimens (figs. 2, 3).

In longitudinal section the walls of the dactylethrae (fig. 9) often appear hollow: the intercellular tissue is therefore incomplete. The nature of dactylethrae is easy to see on onl figures, but their function is unknown to us. We have not had the fortune to find the growing extremity of a branch near the zoarial base.

The tangential section of the tubes is analogous to that of all other Cyclostomata.

Affinitics.-The species differs from Emosonea admota in the great distance between the fascicles and in the absence of radicular lamellae on the dorsal.

Ocourence.-Lower Jacksonian (Moodys marl) : Jackson, Mississippi (common).

Cotypes.-Cat. No. 65364 , U.S.N.M.

ERKOSONEA ADMOTA, new species.

Plate 139, figs. $14-2$; plate 133 , fig. S.

Desmintion.-The branches of the zoarium are large, linear, bifurcated with oval transverse section. The fascicles are salient, close together, oblique, divergent, formed of five zooecia; they are arranged alternately on each side of the median crest and do not spread beyond the zoarial margins. The tubes are visible, very little convex; the peristome is thin and rectangular. On the dorsal the dactylethrae have very salient margins; there are wide radicular lamellac.

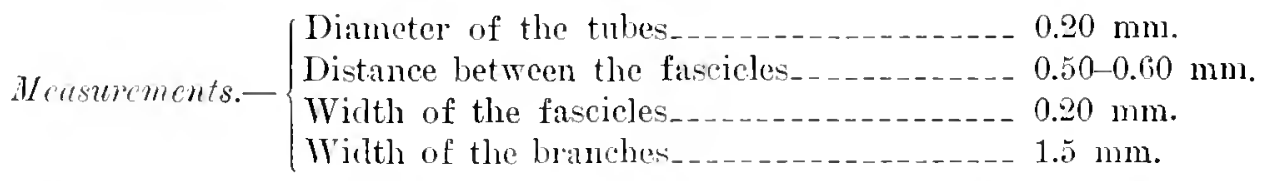

The dorsal is hardly convex; it frequently bears rery wide radicular lamellae. 'These are formed of two rows of dactylethrae which bend around at right angles. In Idmoneu grullator there are the habitual branchings of the tubes which form the radicells. The remarkable facility with which the Cyclostomata modify their tubes for aliptation proves that the zoarium is not only an animal colony but a veritable real individuality. The vital unity is assured in the interior of the zooecia by the mesenchymatous tissue. 
Affinities.-This species differs from Erkosonea semota in the lesser distanee of the fiscicles from each other and in the presenee of the radicular lamellae.

Occurrence-Middle Jaeksonian: Wilmington, North Carolina (very common); near Lenuls Ferry, South Carolina (rare); Eutaw Springs, South Carolina (rare).

Upper Jacksonian (Oeala limestone): West bank Sepulga River, Escambia County, Alabama (rare).

Cotypes.-Cat. No. 6535\%, U.S.N.M.

\section{PLEURONEA, new genus.}

Greek: pleuron, side, referring to the position of the ovicell.

The ovicell is situated laterally on one-half of the basal lamella and between

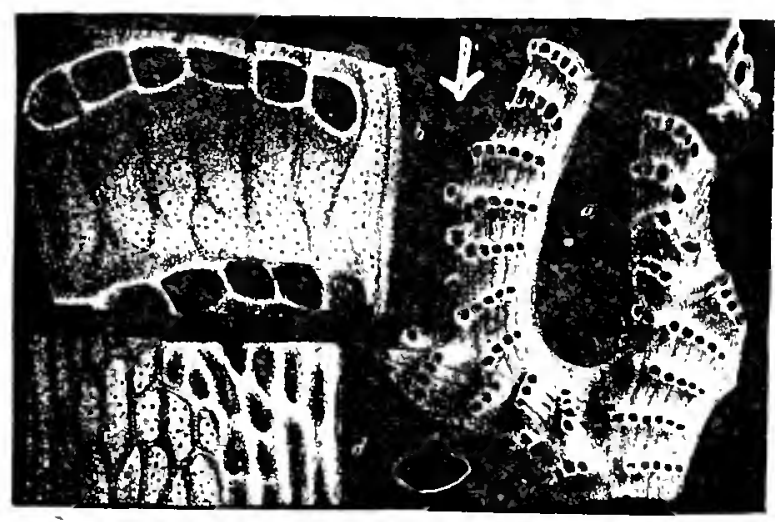

Fia. 251.-Plsuronea, new genus.

Views of Plcuronca (Idmonea) fonestrala Bnsk, 1559, from the Crag of England, showing the zoa rimm natural size, the frontal side enlarged, cross section of a branch and the frontal and dorsal sides much enlarged. (After Iusk, 1859.)

1850 , these ennals would be closed at their extron by a lamella extremely fine and fragile.

PLEURONEA FIBROSA, new species.

I'late 107 , figs. $2-9$.

Ilescription.-The zoarinm is free, idmoneiform, bifureated, with oral erose seetion. The fascieles are salient, uniserial, erowded and formed of five tubes at the maximmm. The tubes have a visible peristomie; the peristome is round or reetangular. The basal lamella bears a thick layer of tergopores, the orifices of which are irregular but arranged longitudinally and give a fibrous aspect to the zoarium. The ovieell is globular, salient, porous.

$$
\text { Weasurements.- }\left\{\begin{array}{l}
\text { Peristome-_. } \\
\text { Distance between the fascicles_-10 }
\end{array}\right.
$$


Affnities.-The ovicelled specimen (fig. 4) bears two ovicells symmetrically placeel to the right and left of the zoarium.

This species differs from Pleuromea atreolata in the fibrous aspect of the hasal lamella and in the different position of the ovicell.

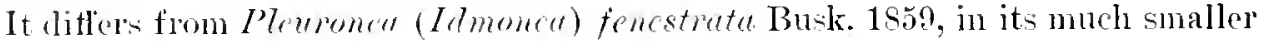
tergopores and its smaller micrometric measurements.

Occurrene.-Midwayan (Clayton limestone): Luverne. Crenshaw County, Maliama (common).

r'otypes.-Cat. No. 6524t, U.S.M.M.

PLEURONEA FENESTRATA Busk, 1859.

I'latle 114, figs. 1-1S.

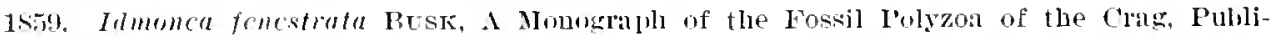
cations of the Palamentograllhical Society of I nndon, rol. 14, 1. 105, pl. 15, fig. 6.

1877. Immonca foncstrata Mlanzoni, I Briozoi fossili del Miocene d'Austria eil Thgheria; Part 3, Denkischriften der math. natur. Classe der k. Lsidemie der Wissenschaften

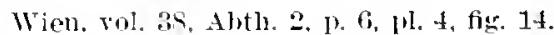

1sso. Idmonea fencstrate Seguesza, Le formazioni teriarie nella I'rovineia ri Reggio (Cabria), lieale Acorlemie dej lincei, Memoire della Classe di Scitume Fisiclue matematiche e Natmili, Romi, ser, 3, vol. 6, p. 132.

1s97. Idmonca foncstrata Narivi, Corallari e Briozoi neogenici di Sardegna, Bolletino alell societa Geologici 1talinna, Roma. vol. 15, p. 595 (27).

Inescription.-The zourum is free, arborescent, bifurcated or reticulated witl oval section, idmoneiform. The fiscicles are quite salient, miserial, scattered, alternate, arljacent to the median crest. They bear at the maximum five tubes. The tubes are silient, visible exteriorly. flat, separated hy a salient thread; the peristome is thin and rectangular. The basal lamella bears a thick layer of tergopor's almost as large as the tubes; their orifice forms regular, longiturlinal lines or a complicated network. The ovicell is large, conrex. porous; it bears tuberosities arranged in quincumx.

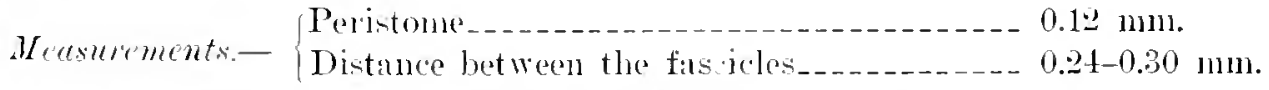

Iarintions.-The basal side of this species is quite varialule: there is not a single specimen exactly like the others. The orifices of the tergopores are large (fig. 4) or small (figs. 5. 7. 13) in quincunx or in lines; they even overturn the frontal on the old zonria (figs. 12, 16); those which are arranged in longitudinal series are the most frequent. The tergopores sometines occur at the lase of psendosulci.

Fortunately the frontal is more regular (figs. 3, 14) and permits the deternination more easily.

'The oricell of this species is quite variable in its form, dimensions, and position. In our studies on the cyclostomatous bryozon we figme some interesting variations which show that the ovicell is as polymorplic as in the gemus Tubulipore itself. 
The longitudinal section (fig. 18) shows us larger aml less entangled tergopores than in Plewroned alveolata; they are also longer and more ollique.

Affinities.-When the tergopores are arranged in longitulinal series this species presents the aspect of l'lempoma filmose; but it is distinguished from it lyy its much larger orifice and the greater separation of the fascicles.

It differs from Plemronen aleenlata in the greater separation of the fascicles and in the different position of the ovicell, and from Idmoned potimlute Reus, 1869, in the very different form of the orifice of the tergopores.

Cecurrenee-Claihornian (Crosport sand): One mile south of Rockrille. (Carke County, Alabama (lane).

Lower Jacksonian (Monlys mal) : Tackon. Mississippi (very eommon).

Midrlle .Tacksonian: One-lialf mile southeast of Georgia Kaolin Company's mine, Twiggs County. Georgia (rare): 12 miles sontheast of Marshallville, Georgia (ram): Ballock. Bamwell Comty, South Carolina (very lare).

Jackomian (Zengloelon zone): Bluft on south side of Suck Creek. Clarke Comnty. Mississippi: Shubuta, Mississippi (common).

Vicksburgian (Marianna limestone): Salt Mountain. o miles south of . ackson. Alabama (rare) : Vickshuro. Mississippi (rare); Murder Circek, east of Castlebury, Conecul County, Alabama (very rare).

Geological distribution.-Helvetian of Italy (Neviani) ; Tortonian of AustriaIungury (Manzoni) and Italy (Neviani): Astian of England (Busk).

Plesiotypes.-Cat. Nos. 65266. 65267. U.S.N.M.

PLEURONEA SUBPERTUSA. new species.

Ilate 113, tigrs. 6-15.

Description.-The zominn is free. branched, with suborbienlar rection, irmoneiform. The lascicles are quite oblique, opposite, and reunite on the zuarial axis. The tubes are salient, with the maxinum number of six to a fascicle; they are flat and are separated by a salient thread. The hasal lamella hears tergopores, the cliameter of which is pereeptilly equal to that of the tules.

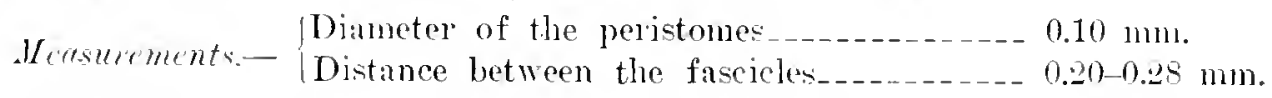

Varitions.-The speeies is rarely well preserved; it must have frepluented violent enrrents or agitated waters. The basal lamella with its tergopoles is easily detachel from the anterior portion of the zoarium (fig 10).

The tergopores are depriver of polypicle: their diameter is that of the tubes. They grow on the dorsal of the tubes in variable number: they diveroe at first superinly and then curve abruptly perpendienlarly to the zuarial axis, thus forming a right angle (fig. 15). Their walls are thickened, a fart which is perfectly visible in tangential sections (fig. 12); they are orbicular in the interior and polygomal at the exterior.

Each tergopore has only one point of tangeney with each of the other tergopores which surround it. The interstices between the nonarljacent walls are rarely 
calcifiel ( fig. 12); they are generally empty and appear white in tangential (fig. 11) and longitudinal sections (fig. 1.5). The interstices disappear when the section passes rigorously through the point of tangency (fig. 15).

The function of the tergopores is eviclently zoarial. Jut we are totally ignorant of their nature.

Afinities.-This species much resembles Idmonea pertusa Reuss, 1847, in its basal lamella, and in the fossils, it is difficult to separate them. It differs from it in its frontal, the fascicles of which are close together and not spread out from the median line.

It cliffer's from Idmonea reticnlata Reuss, 1869 , in the very different nature of its tergopores, and from Pleuroner fusiformis in the exterior polygonal form of its tergopores and in their larger diameter.

Oecurrence.-Claibonian (Gosport sand): One mile sonthrest of Rockrille, Clarke County, Alabama (rare).

Lower Jacksonian (Moodys marl): Tackson, Mississippi (common).

Nirlle Jacksonian: Rich Hill a miles southeast of Kinoxville. Crawford County, Georgia (very rare).

Upper .Jacksonian (Ocala limestone): Old Factory, about $1 \frac{1}{2}$ miles above Bainbliclge, Georwia (very rare).

Vicksburgian (Red Bluff clay) : One-quarter mile west of Woodwards, Wayne County, Mississippi (rare).

Vicksburgian (Mariamna limestone): Vicksburg, Mississippi (lower bed, lare).

Cotypes.-Cat. No. 65432 . U.S.N.M.

PLEURONEA FUSIFORMIS, new species.

Plate 161, tigs. 3,4.

Deseription.-The zoarim is free, bifureated, idmoneifolm. The bundles are salient, transverse, alternate on each side of the median axis, and formed of four to fire zooecia. 'The tubes are little visible; the orifice is rectangular and the peristome is thin. The basal lamella is convex and bears fusiform tergopores. The oricell is large, globular, salient; the oeciostome is arjacent to a bundle and subterninal.

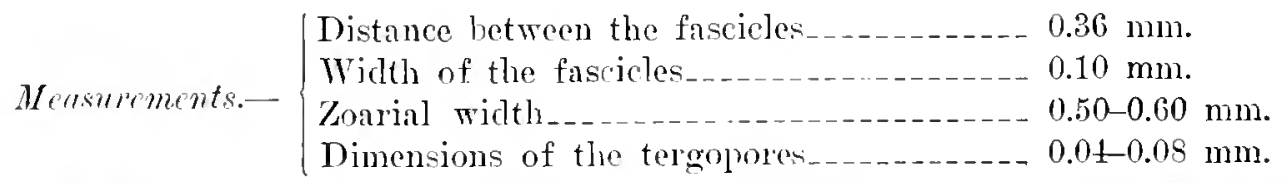

Affirtics.-This species is the American representative of Idmonea reticulata Rellss, 1869, of the Priabonian of the Vicentin. It diflers from it, however, in the more elongated form of the tergopores.

()ecurrene.-Ticlisburgian (Mariamna limestone): Salt Monntain, 5 miles south of Jackson, Alabama (very rare).

Inolotype.-Cat. No. 65442, U.S.N.M. 
PLEURONeA Alveolata, new species.

Plate 107, tigs. 10-1S.

Description.-The zoarium is frec, arborescent, bifurcated, idmoneiform with subcircular section. The fascicles are silient. opposite, crowded, and formed of five or six tubes at the maximum. The tubes have their upper portion risible and are separated by an salient line; the peristome is thin and rectangular. The basal lamella is ornamented with lange tergopores with orifices more or less funnelshaped, giving them the aspect of atreolue.

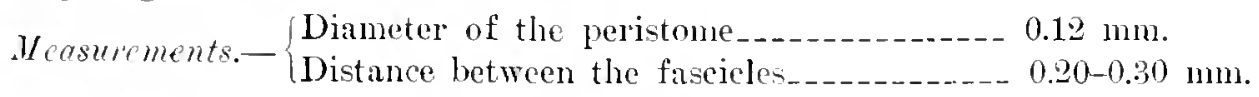

The tergopores are confused in every sense of the word; no section can cut through their whole length, and they appear as an irregular network with large meshes (fig. 16). They are polygonal exteriorly (figs. 12, 17). Their walls are not thick (fig. 16) and the interstices left between them are filled with a compant calcareous deposit. They are attached to the lamella and appear to be dorsal ramifications of the zooecia.

Affinities.-The species differs from Plenronea fibrosu and Pleuronea fenestratu in the very special funnel-shaped form of the orifice of the tergopores.

Occurrence-Midwayan (Clayton limestone): Mabelville near Little Rock, Arkansas (very common); 1 mile west of Fort Gaines, Georgia (common).

C'otypes.-Cat. No. 65245, U.S.N.M.

\section{TRETONEA, new genus.}

Greek: treton, opening, in allusion to the ovicells which are picrced by the fascicles.

The ovicell is lobate, subsymmetrical, median, elongated between the fascicles. There are pores on both faces of the zoarinm. The fascicles are arranged symmetrically on each side of the median axis. The oeciostome is placed at the beginning of a fascicle.

Genotype-Tretonea Tevis, new species. Lower Jacksonian.

The nature of the pores is not known for the specimens were silicified and it has not been possible to make sections.

TRETONEA LEVIS, new species.

Plate 141, figs. 20-27.

Description.-The zoarium is free, branched, with triangular sections; it Jears special pores on both sides. The fascicles are salient, quite close together, formed of six to eight zooeeia. The tubes are invisible and hidden under the pores; the peritome is rectangular, thin and salient. The ovicell is smooth; the oeciostome commences the second fascicle; it is a little larger than the apertures and turned in the direction of the median axis.

$55899-20-$ Bull. $106 \quad 19$ 


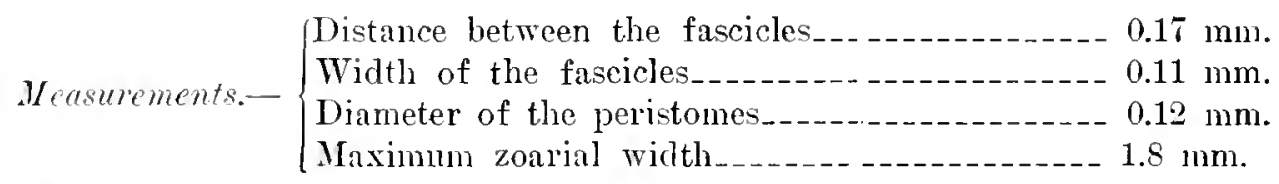

Afnities. This species much resembles Retecara, in the arrangement of its pore:- but differ's in the nature of its ovicell, which is entirely frontal and not located on a single side of the zoarium.

The knowledge of the nature of the pores and of better ovicells will perthaps permit of the discovery some day of the true position of this species.

This species differs from Idmonew subcancellate Manzoni, 1877, in its fascicles, which are much more salient and formed of more than three to four tubes.

Occurrence.-Lower Jacksonian: Three and one-half miles southeast of Shell Bluff post office, Georgia (rare.)

Cotypes.-Cat. No. 65341, U.S.N.M.

\section{Genus IDMONEA Lamouroux, 1821.}

1821. Idmonca Lamouroux, Exposition Methodique des Polypiers, $\mathrm{p}$. So.

The ovicell is irregular, little lobed or not at all, subsymmetrical, placed on the median clest of the zoarium. The fascieles are not entirely enreloped by the oricell. The oeciostome is excentric, nonterminal, and replaces the first or the second tube of a fascicle. The basal lamella is simple and bears no pores.

Accepted genotype.-Idmonea atlantica. Johnson. 1847.

Range.-Senonian-Recent.

This genus differs from Tubulipora Lamarck, 1816, in the absence of welldeveloped lobes, and in its oeciostome nonsubentral, and occupying a fixed place among the fascicles.

Historical.-The genus Irmonea was founded by Lamonronx upon I. triqueter, an incrusting form found in the Bathonian at Ranville, Flance. The history of the genus has been giren many times. but the greatest confusion has existed among palcontologists as to its interpretation. Among the zoologists. howerer. the name Ilmonca has always been applied to the well-known zoarial form bearing an anterior ovicell. Former authors were ignorant of the importance of the ovicell and eren of its existence. All speculation on their work is absolutely useless and idle. Usage and the principle of least change seems to us the only considerations to be regarded, and we have therefore followed the zoologict in regarding Idmonea attrinticu. Johnston, 1847, as the accepted genotype.

Tetermination. - The detemination of species of Idmonea is rery difficult in spite of the introduction, due to Pergens, of the micrometric dimensions; this is in reality because we have only isolated fragments for study. If the ovicell in rapport with the number of larvae and the fissiparity of the primary embryo is quite vilriable in form and position, the occiostome is more constant, for it is ouly in rapport with the form and size of the larve. But the larve of the different fimilies of Cyclostomata are much alike. It is necessary, therefore, to seek another 
character which would permit us to complete our knowledge of their biological tendencies. 'This claracter is furmished us precisely in the study of the base of the zoarimm and in its mode of attachnent to the substratum. This manifestation of the ancestrular zooeeia issued directly from the larvae is most important and it will be necessary in the future to introduce it in descriptions.

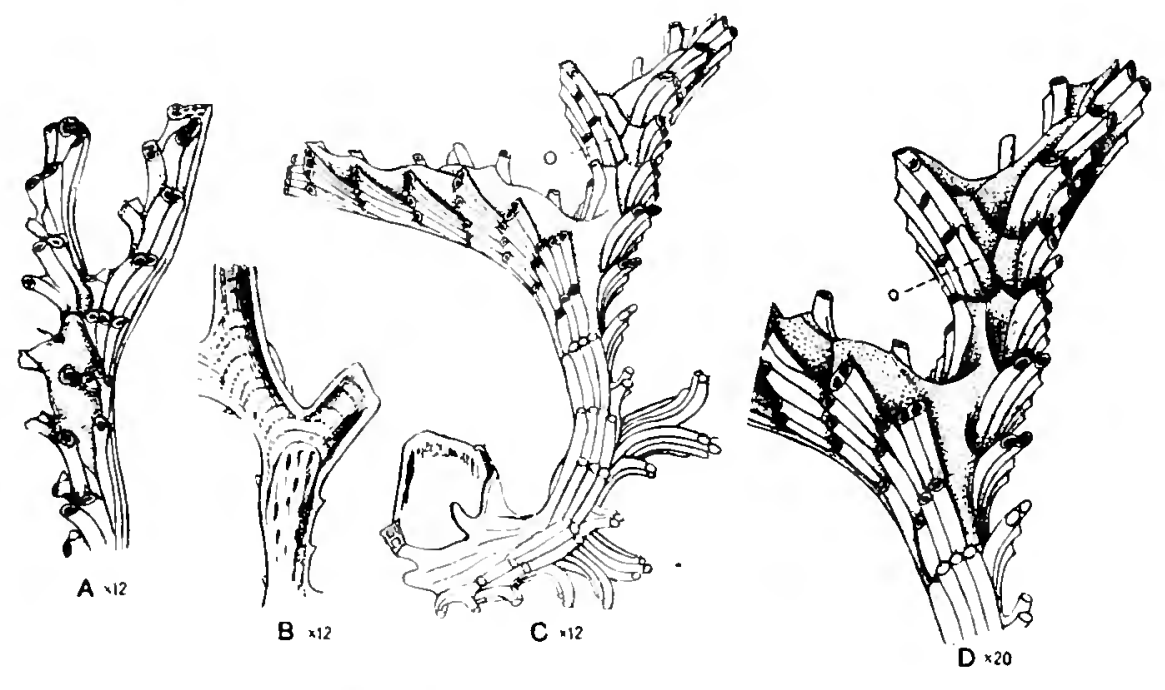

Fig. 2-D.-Genus Idmonea Iamourunx, 1821.

A-D. Idmonea allantica Forbes. A. Anterior face of the zoarium, $\times 12.13$. Posterior face busal lamella). $\times 12$. C. Base of the zoriun, $X 12$. I). Oricell and its veciostome (o), $\times 20$. (After Harmer, 1915.)

Species of Idmone a are often attached by an expanded base. The bramehes are bushy with their dorsal turned towild the exterior. Very often the branches are horizontal and parallel to the substratum, but this is a dangerous situation on aceount of their fragility and liability to facture. Certain species remedy this by the addition of canals of reinforcement or firmatopores. Other species develop on their dorsal, appendages of more or less length of a kind of caleareous radicell, more numerous on the branches of the base, which strengthen the whole zoarial system. Although the word "raticell" is not very appropriate, we have not thought it necessary to coin a new name in order to designate these structures.

The same species of Idmoner often presents very different and mexpected aspects which would lead one to helieve in the existence of many species. The micrometric measurements are in themselves insufficient. We hare recourse to two methods of identification and comparison-the transverse sertion and the comparison of photographs enlarged upon the same seale.

IDMONEA TACTA, new species.

I'lite 107. firs. 10-24.

Description.-The zoarium is somewhat claviform. bifurcated, and much compressed. The fascicles are salient, croudded. and formed of two to seven zooecia; 
they are alternated on each side of the median line and adjacent to each other on this line. 'Ihe tubes are visible, flat, separated by a scarcely salient thread. The basal lamella is striated transversally; the zoarial margins are thick and distinct.

A Afnitics.-In the number of the tubes to the fascieles this species approncies Idmonea arcuata; it differs from it in the separation of the fascicles which is less than $0.20 \mathrm{~mm}$. and in the rectilinear form of its zoarium.

In the zondial margins of the basal lamellae the species resembles Idmonea petri D'Arehiac, 1846, but differs from it in the ensemble of its mueh smaller mierometrie dimensions and in its claviform zoarimm.

Oceurence.-Midwayan (Clayton limestone): One mile west of Fort Gaines. Georgia (rare).

Cotypes.-Cat. No. 65246, U.S.N.M.

IDMONEA MAGNA, new spccies.

Plate 137. figs. 1-1s.

Description.-The zourium is large, dichotomons $\mathrm{y}_{\mathrm{y}}$ branched, sometimes reticulated, enlarged at the bifureations. triangular, higher than wide in transverse section. The fiscicles are quite sahent, oblique, alternated on each side of the median crest and quite distant from it; they bear four to eight zooecia. The tubes are visible, convex, almost all equal. The basal lamella is striated transversally, flat, somewhat convex or a little coneave: the tulses are often visible; the zoarial margins ale very narrow and somewhat thickened.

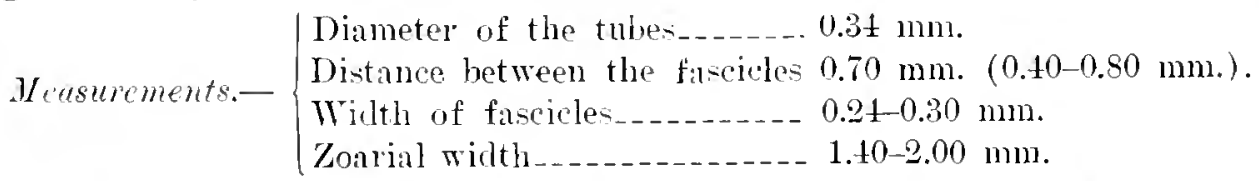

Trariations. - The number of the tubes to the fascicle is mole often four or five (figs. 2, 3) ; at the bifurcations it is larger (eight) (fig. 9). The basal lamella is convex (fig. 5) or concave (fig. 10); the two forms are visible on the same fragment (fig. 8). The fascieles of the reticulated branches are eloser (fig. 4). At the bifureations the faseieles are transverse (fig. 2), if the branches rest in the. same plane; when the branches are twisted and are opposite, the faseicles remain distinct and alternate (fig. 9). On well-preserved sperimens the tubes are visible on the bisal lamella (fig. 6). 'The incomplete zoocein in the process of formation are quite numerous (fig. 10) and give a vory clowded appearance.

In transverse section (fig. 1S) the zoarinm is triangular and the zooeeia are polygronal: hut seen from the interion, by abrasion of the basal lamella, they are round (fig. 15). The longitudinal section (fig. 11) is normal; the tubes grow 
from the basal lamella and branch almost immediately (fig. 12). The zooecial walls appear hollow (fig. 13); there are small diaphragms risible here and there.

On account of its size this speries is easy to determine. It characterizes the Jacksonian in America.

Occurvence-Midlle .Jacksonian: Rich Hiłl, $5 \frac{1}{2}$ miles southeast of Knoxrille, Crawford County, Georgia (very common): one-half mile sontheast of Georgia Kaolin Co. mine, Twiggs County, (Georgia (common) : 12 miles sontheast of Marshallville, Georgia (very common): Eutaw Springs, South Carolina (very rare); Baldock, Barnwell County, Sonth Carolina (rare); 16 miles northeast of Hawkinsville, Georgia (common) : 31 miles south of Perry, Georgia (very common); $3 \frac{1}{2}$ miles nortl of Grovania, Georgia (very common); $1 \frac{1}{2}$ miles southeast of Lily, Dooly County, Georgia (rery rare).

Jacksonian (Zeuglodon zone): Shubuta, Mississippi (rare).

Upper Jacksonian (Ocala limetone): West bank Sepulga River, Escambia County, Alabama (common).

Lower Jacksonian (Moodys marl) : Jackson, Mississippi (common).

Cotypes.-Cat. Nos. 65846-6.5850. U.S.N.MI.

IDMONEA MILNEANA D'Orbigny, I\$39.

Plate 136, figs, 1-12.

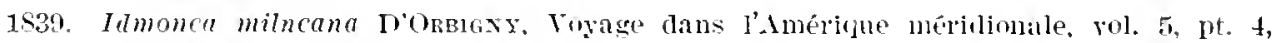
p. 20 , il. 9 , figs. 17-21.

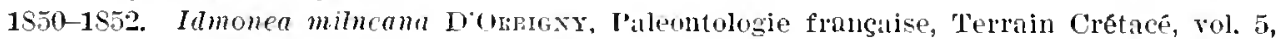
Bryozonires, p. 732 .

1560. Lamonca milncana Busk, Note on the fossil Polyzon collected near Monnt Gambier. South Australia, Quarterly Jomrnal Geological Society, London, vol, 16, 1. 261.

1S64. Idmonen milncana Stouczkis. Fossile Bryozoen aus dem Tertiären Grïsindsteine der Orakei-Ray bei Ankland. Reise der Oest. Fregatte Touara, geologischer Theil, vol. 1. Abth. 2. Paleontologie, p. 114.

1872. Idmonea milncana sast, Floridan Bryozoa, Kongl. Svenska Vetenskips-ikad. Handl., p. 8, pl. 3, figs. $1 t-17$.

1855. Idmonca milncana lusk, Catalogue of marine Polyzon in the collection of the British Museum, pt. 3, Gyclostomata, p. 12 .

1S77. Idmonca milncana EtIErudge, Synopisis of the known species of Iustrilian Tertiary Polyzoa, Jourmal Royal Societs New South Wales, rol. 11, p. 13.

1851. Idmonca milncana lifdry. Accomt of the zoological collections male during the Survey of II. M. S. Alcrt in the straits of Jagellan and on the coast of l'atagonia, Polyzoa, F'roceedings of Znological Siociety of I donchom, 1). 50 .

ISS2 Ilmonca milncana JISWELL, On the Cyclustomatous Folyzon of Port Jackson and neighborlood, Irocendings of Limean Society, New South Waler, vol. 4, 1) 3.51.

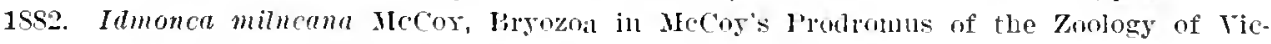
toria, vol. 1. des. T, p. 20, fl, 6. ti... 1.

18S4. Idmonca milncana WaTers, On fossil Cyclostomatous Pryona from Australia, Quar terly Jomrnal of the Gethigical sinciety, fondon, wi. 40, 1\%. Gist.

1sst. Idmonca milncana Busr, lieport on the Polyzon collected hy HI. M. S. Challcngcr, lit. 1, P. 13.

1SS7. Ifmonca milncana Machiluvray, Catalunte of the IIarine I'olyzoa of Victorla,

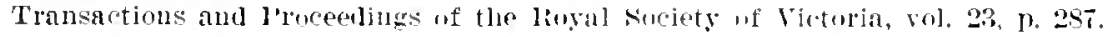


1SS7. Irmonca mitheuna Waters, Bryozoa from New South Wales, Annals Magazine Nituril IIistory, ser. 5, vol. 20, p. 256.

1sss. Idmonca milneuna Waters, On some ovicells of Cyclostomatous Bryozoa, Journal Linnean Society, London, Zoology, vol. 20 , p. 279, pl. 14, fig. S.

18s9. Idmonen milneana Jechy, A Synonymie Gatalogue of the Recent Marine Bryozoa, p. 118.

1890. Idmonea milneana OrTmann, Die Japaniscle Bryozoen-Fauna, Archiv. fur Naturgeschichte, vol. 1, Heft 1, p. 59, pl. 4, fig. 21.

1005. Itmonch milncana Waters, Bryozoa from near Cape Hom, Journal Linnean Society. London. vol. 29. p. 249 (habitat).

1008. Idmonca milncana CaNu, Bryozoaries fossiles du Sud-Ouest de la France. Bulletin Société géolngique France, ser. 4, vol. S, p. 356. pl. 7, fig. 16.

1909. Idmonea milneana Cano, Bryozoaires tertiares des envirous de Paris, Annals de Paleontologie, 11. 125 (53), pl. 14, figs. 11, 12. 13. (Paleontologic bibliograpluy).

1910. Idmonea milneana Canu, Bryozoaires fossiles du Sud-Ouest de la France, Bulletin Société géologique de France, ser. 0, vol. 10. pl. S40.

1911. Idmonca milncana CANU. Brrozoaires fossiles de sud-Ouest de la France, Bulletin de la Société géologique, ser. 4. vol. 11. p. 451, text. fig. 6. (ind.).

1014. Idmonca milnrand Waters, The marine fami of East Africa and Zanzibar, Proceelings of the Zoological Society of London, 1. S4t.

Description.-The zoarinm is bifureated. compressed with elliptical transverse section broader than high. The fascicles are scattered, little salient, arranged alternately on each side of the median axis; they are formed of three zooecia, the first of which is isolated. The tubes are visible, convex, with thin peristome. The basal lamella is convex, more or less striated transversally; the tubes are visible longitudinally.

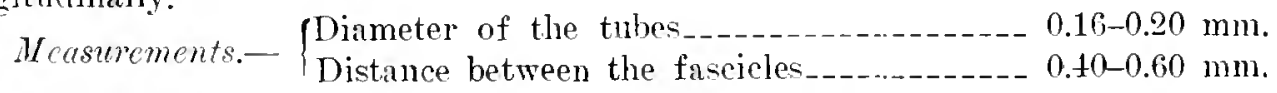

Tariations.-This species is rather constant in its characters and its determination is easy. We have not had the chance to discover its ovicell, but this has been figured by Waters and Smitt; it must probably oecur rery rarely.

The width of the zoarium varies between $0.80 \mathrm{~mm}$. (fig. 4) and $1.33 \mathrm{~mm}$. (fig. 3). The striations of the basal lamella are generally little deep; rarely they are accentuated (fig. 5).

The dorsal tangential section reveals the spindles characteristic of all the crclostomatous bryozoa in which the basal lamella is not reinforced (fig. 12). The microscopic structure of the tubes is identical on the basal lamella (fig. 9) and on the frontal face (fig. 8). The basal lamella has therefore no particular reality; it results simply from the agglomeration of the tubes which are closely mited together.

Occurrence.-Middle Jacksonian (Castle Hayne limestone): Wilmington, North Carolina (iery common).

Vicksburgian (Red Bluff clay): One-fourth mile west of Woodwards, Wayne Colntit, Mississippi (very rare).

Geological distribution.- Ypresian of England (Gregory); Lutetian of the Paris Basin (Gregory, Canu), of the Bordeaux Basin (Camu), of the French Pyrenees 
(Canu) ; Auversian of the Pyrenees (Canu) ; Latdorfian of Germany (Stoliezka); Rupelian (=Stampian) of (iermany (Schreiber); Tortonian of Anstria-Inngury (Manzoni) ; Sicilian of Italy (Seguenza, Neviani) ; Quaternary of Italy (SeguenzaNeviani) ; Miocene of New Zealand (Stoliczka) and of Australia (Waters, MacGillivray).

II abitat.-Mediterranean. Indian Ocean: Zanzibar (16 meters). Antarctic Ocean: Terre del Fuego, Patagonia (13-18 meters), Kerguelen Island (122-244 meters. Atlantic Ocean: Azores (733 meters), Chonos Archipelago, Florida (36-609 meters). Pacifie Ocean: Fiji Islands, Queen Charlotte Islands, Australia.

Plesiotypes.-Cat. No. 65351, U.S.N.M.

IDMONEA ARCUATA, new species.

Plate 135, figs. 16-20.

Description.-The zoarium is short, free, arched, lobate, with transrerse section wide and elliptical. The fascicles are quite salient, regular, arrangerl alternately on each side of the median axis; they are formed of six to eiglit zooecia. The tubes are little visible, small, nearly equal on the same fascicles; the peristome is rectangular. The basal lamella is smooth with the convex striations rather widely spaced.

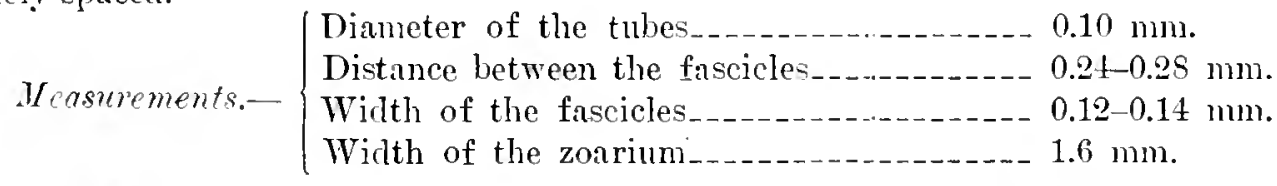

We have not discovered the ovicell of this charming species; we are therefore not certain of its generic classification other than certain lobes are clariform. a condition which does not exist in the typical Idmonea. Moreover, our specimen from Lenuds Ferry is incrusting a bryozoan.

Affinities.-This species differs from Idmoned petri D'Archiac, 1846, in the lesser distance between the fascicles $(0.28$ and not $0.40 \mathrm{~mm}$.) in its smaller tubes and the absence of the rectilinear form of the zoarium, and in a larger number of tubes (eight) to the fascicle.

It much resembles Idmonea tacta in its micrometric measurements, but differs from it in a greater interfascicular distance $(0.24$ and not $0.20 \mathrm{~mm}$.), in a greater number of tubes to the fascicles (eight and not six), and in its nonlinear zoarium.

occurrence.-Middle Jacksonian: Wilmington, North Carolina (rare) : near Lenuds Ferry, South Carolina (very rare).

Cotypes.-Cat. No. 65344, U.S.N.M.

IDMONEA SLOANI, new species.

Plate 135, figs. 21-26.

Description.-The zoarium is free, linear, bifurcated, with triangular transverse section which is higher than wide. The fascicles are salient, close together. arranged alternately on each side of a median erest; they contain four or five 
zonecia. the first of which is adjacent to the neighboring fascicles and placed on the median axis. The tubes are small, distinet, separated by a salient thread. The basal lamella is slightly omamented with convex striations; it is flat or concave and bordered by a more or less wide and thickened margin.

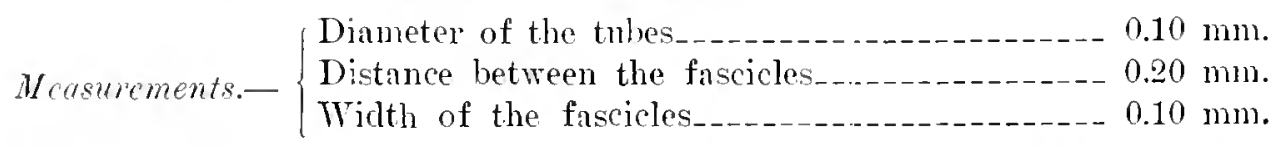

Aftinities.-This species contains sometimes on the dorsal traces of firmatopures. It is very close to Idmonea tacta in its small dimensions and the union of the fascicles on the median crest. but it differs in that the number of tubes is always greater than five. It differs from Idmoned petri D'Archiac. $18+6$, in its smaller zoarial dimensions and the much smaller distance $(0.20$ and not $0.40 \mathrm{~mm}$.) between the fascicles.

We dedicate this charming and delicate species to Mr. Earle Sloan of Charleston. South Carolina, in appreciation of his excellent work upon the geology of his State.

Occurrence.-Middle Jacksonian: Wilmington, North Carolima (very rare); near Lenuds Ferry, South Carolina (common).

Cotypes.-Cat. Nos.65345. 65480, U.S.N.M.

IDMONEA MAGNIREVERSA, new species.

Plate 136, figs. 13-23.

Inescription.-'The zoarium is long, thin, linear, bifurcated, with oral transrerse section much higher than wide. The fiscicles are salient, close together, adjacent to the median crest. and arranged alternately on each side of it: they contain three or four zooecia. The tubes are visible, convex, with square or crbicnlar peristome. The dorsal is semicylindrical, very large, mnch larger and thicker than the frontal, striated longitudinally by the tubes.

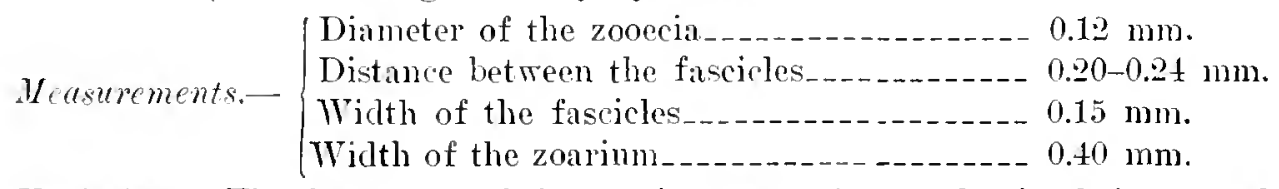

Tariations.-The fragments of the zoarimm are quite regular in their general aspect, just as is also the number of the zooecia to the fascicles (figs. 15. 16). The only variation is in the size of the dorsal, which is in rapport with the proximity of the base. The great number of the incomplete zooecia at the extremity of the branches (fig. 16) and the extraordinary development of the dorsal indicates a very long zoarium and of a relatively rather great solidity.

The longitudinal section (fig. 21) indicates tubes of an extraordinary length. The halitual small pores are rather difficult to see on the tangential sections (fig. 20). where the length of the lozenge-shaped spindles confirm the early origin of the tubes and their length (fig. 19). 
Atjnities. - This species is easily confused with Idmidroma maxillaris Lonsdale, $18 \pm 5$, in which the dor $>$ al presents the same great development. It differs from it in the complete absence of firmatopores which are risible either by abrasion, or in longitudinal sections.

It diflers from Idmoneu tumida Smitt, 1866, in the much less separation of the fascicles $(0.20$ and not $0.50 \mathrm{~mm}$.).

Occurnence-Middle Jacksonian (Castle Hayne linestone): Wilmington, Torth Carolina (very common).

Upper Jacksonian (Ocala limestone): Alachua, Floricla (rare); west bank Sepulga River, Escambia County, Alabuma (rave).

Cotypes.-Cat. No. 65352. U.S.N.M.

\section{IDMONEA GRALLATOR, new species.}

Plate 138, figs. 1-20.

Description.-The zoarium is small, filiform, linear. bifureated. horizontal. with oral transrerse section which is a little higher than wide. The fascicles are salient, little oblique. arranged alternately on each side of the median axis and quite distant from it. They are formed by four or five zooecia. the last of which is quite small. The tubes are visible, flat, separated by a salient thread. The basal lamella is convex. flat, or somewhat concave; it is striated longitudinally by the tubes and transrersally by the convex zones of growth; it bears radicelis of consolidation. 'The oricell is quite elongated between six or seven fascicles.

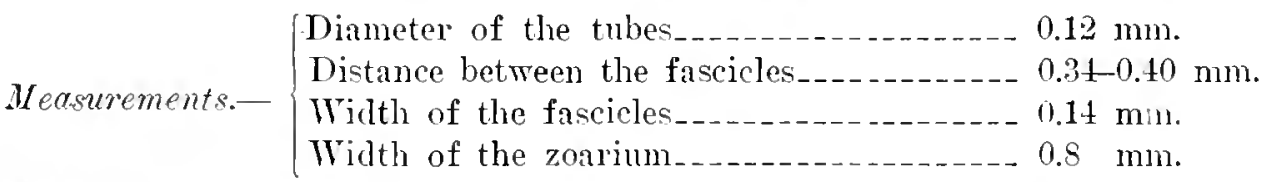

Tariations.-The fascicles are quite salient and quite divergent from the median crest (fig:. 2, 3) ; abrasion lessens this character (fig. fi). The dorsal is quite variable: it is flat on the young branches (fig. 8): but the older branches are convex (fig. 9).

The base of the zoarium is quite wide; the branches are arranger horizontally (fig. 19); the first bear radicells of consoliclation, like small stites (fig. 20) which separate all the branches from the substratum. A section (fig. 15) taken through these radicells shors that they are formed of ordinary zooecia curved as ustral and which were probably deprived of ordinary polypides.

We are not certain that the ovicell shown in figure 1:2 really belongs to this species; it is the only fragment found at this locality and the oeciostome is quite clearly preserved on it.

Aftinities.-The calcareous radicells are not rare. They have alrealy been noted by Smitt, 1872. in Idmonea milneana D'Orbigny. 1839. by Kirkpatrick. 188s, in Idmonea radicata. and by Norman, 1909, in Idmoned pedater.

This species differs from Idmonea pedate Norman in its le- salient fascicles and in having five zooccia (and not three) to a fascicle. 
It liffers fiom Idmone radioata in the nature of its ovicells; Kirkpatrick's species belongs to another family.

The difference hetween the fossil framents and Idmonea atlantica Johnston. 1847 , is guite difficult to determine most of the time. It is preferable not to determine the specimens which are not very well preserved. They differ from it in a lesser divergence of the fascicles on the median line and chictly in the interfascicular. (listance which is less than 0.40 (and very rarely more than $0.40 \mathrm{~mm}$.).

In its dorsal it resembles Idmonea sloani, but differs from it in its much greater interfascicular distance $(0.40$ and not $0.20 \mathrm{~mm}$.).

The dorsal of this species corresponds well to Ionsdale's description of Itmonea commiscens; but we have never observed "the interming]ing of mouths" mentioned and figured by that author. On the contrury. his Idmonea 14 of Rock Bridge conforms moie to the present species.

Occmpener.-Middle .Tacksonian: Wilmington, North Carolina (very common): Eutaw Springs, Sonth Carolina (rare): 18 miles west of Wrightsville, Johnston County, Georgia (rare); near Lenuds Ferry, Soutl Carolina (common).

Tpper Jacksonian (Ocala limestone) : Chipola River east of Marianna. Jackson County, Florida (rery rare); west bank Sepulga River, Escambia County, Alabama (rare): below Plant System railroad wharf, Bainbridge, Georgia (very rare).

Ticksburgian (Red Bluff clay) : Seven and one-half miles southrest of B]aden Springs, Alabama (rare).

Vicksburgian (Marianna ]imestone) : One mile north of Monroeville. Alabama (very common) : near Claiborne. Monroe County, Alabama (very rare).

Cotypes.-Cat. Nos. 65414-65416, U.S.N.M.

\section{IDMONEA ATLANTICA Johnsion, 1847.}

Plate 140, figs, 1-13.

1S47. Idmonca atlantica (Forbes Mss.) Johnston, A Histury of the British Zoophtyes, 2 ed., p. 278, pl. 4 S, figs. 3, 3.

1556. Idmonca atlantica Busk, Polyzon collected by Mr. IIcturlrew on the consts of Norway and Finland in 1856, Annals and Magazine Natural History, ser, 2, vol, 18. [1. 34, pl. 1, figs. $6 n-e$.

1859. Itmonca atlantica BUsk, Zoophytology, On some Maderian Polyzoa, Quarterly Jourual Microscopical Science, vol. 6, p. 128, pl. 18, fig. 5.

1875. Idmonca atlantica (part) Busk, Catalogue of Marine Polyzoa in the collection of the British Museum, pt. 3, Cyclostomata, p. 11.

1950. Itmonea atlantira IINCKs, History of British Marine Polyzoa, p. 451, pl. 65, figs. 1-4. 18S6. Idmonca atlantica (part) BUsk, lieport on the Polyzon collected by H. M. S. Challcnged during the years 1S73-1576, vol. 50, p. 10.

1sio. Ifmonea atlantiea Ortann, Archiv, für Natmgeschichte, vol. 1, Heft 1, p. 5S, pl. 4. figs. $20 a, b$ (val. disticha Ortmann).

1S94. Idmonca allantica Levinsen, Mosdyr. Zoologica Danica (Danske Dyr.), vol. 4.

1895. Ilmonca atlantica (det. R. Kirkpatrick) Thurstos, Ráméstaram Island and Fauna G. Manaar. Madras Goverument Museum, Bull. 3, p. 131. 


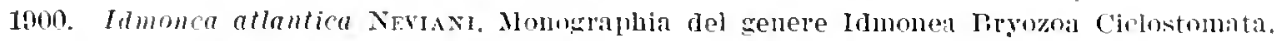

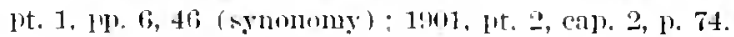

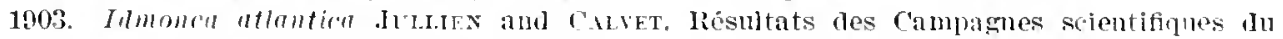
Prince du Monaco, Waseicule 23, p. 113.

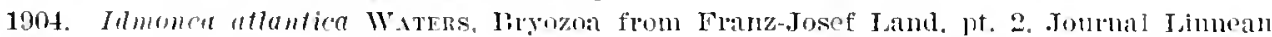
Society, 7oolngy, vol. 29, pl. 16t; pl. 21, tigs. 2, 3 (the ovicell here figured is unusually short).

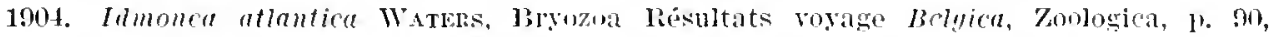
1). 9. lig. 5 .

1906. Idmoned atlantien NonbGand. Bryozon flom the 2al Fram Fxpedition, 1898-1902, Report Second Norwegian Aletic Expedition 1S9S-1902. No. 8, p. 38.

1907. Idmonen atlanticn Calvet, Note par les expeditions du Traraillour et Talisman, vol. S, p. 469.

1009. Idmomea allantica Normax. The Polyzoa nf lladeira and neighboring Islands, Journal Iinnean Society. Zoology, rol. 30, 1). 2is, pl. 33, figs. 1. 2.

1912. Idmonen atlantica THorxecr. Marine Polyzoa of the Indian Ocean, Transactions Limnean Societs, Zoology, ser. 2, vol. 15, 1) 156.

1912. Tubulipora allantica Osrurs, The Prrozoa of the Woods Hole Region, Fulletiu of the Rureau of Fisheries, vol. 30,1910, p. 217, p. 19, figs. $0,9 a$.

1856. Tubulipora atlantica. folma crecta sutт, Kritisk förteckning öfver Skandinaivens Hafsbryozoer, Öfversigt af. Kongl. Vetenskips-Akademiens Fördhandlingar, rol, 23. PT. 390, 434, pl. 3, figs. (i-7. pl. 4, figs. 3-13 (ovicell tigured).

1540. Idmonra radinns VAx Fexpos, Recherches sur les Bryozoaires de la mer du nord (suite) et projet dune classitication des Bryozoaires, Bulletin l'Academie Royale ge Belgique, rol. 16. p, fit6. 1). I, figs. 4-6.

1916. Tubulipora atlantica Harmer. The Polyzoa of the Siboga expedition, vol. 1, p. 124, 1). 10 . tigs. $4-5$.

Deseription.-The zoarium is free lineal, bifurcated. with subcircular transverse section. The fascicles are salient, quite removed from the median crest. arranged alternately on each side of it. nuch protruding heyond the zoarial margins: they are formed of three to five zooceia the first of which is the longer and hickes the others more or less. The basal lamella is somewhat striated longitudinally by the tubes, striated transversally by quite separated convex wrinkles; it is round or flat and more or less bordered laterally. The oricell is much elongated, convex. searcely lobed. placed on the median crest among five or six fascicles.

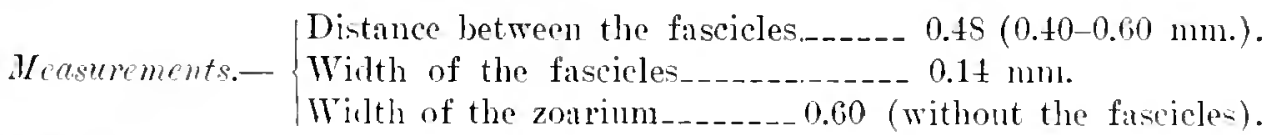

Variations. - The dorsal is round at the base of the branches (fig. 9) and flat on the younger branches (figs. 7,5 ): the two forms are often visible on the same branch (fig. 4). The fascicles are quite fragile and breals casily (fig. 6) : but the fossils thus altered are excedingly difficult of determination and are almost identical with the linear branches of Itmomea petri D'Archiac, 1847.

In a single instance only have we olserved a very short radicell (fig. 10).

The tangential (fig. 12) anil longitudinal sections (figs. 11) offer no special features; but the transverse section has a rery special form. for it is almost circular or semicircular aceoring to the form of the dorsal. 
Affinitics. Our fossil specimens have the aspect of the figures by Smitt, 1866: Hincks, 1880; Manzoni, 1877; and Busk, 1875. However, the micrometric measurements are gencrally smaller, although they are, on the contrary, essentially the same as those of specimens dredged in the Mediterranean.

In general aspect our specimens are quite different from the figures by Osburn. 1914, and Harmer, 1916, but the micrometric dimensions are closer.

In 1909, Canu, deceived by an excellent figure by Milne-Edmards, 1838, identified Idmonea atlantica with Idmonea coronopus Defrance, 1921. He is not now so sure, for he has been unable to find in the musenm Milne-Edwards's type and the micrometric measurements of the French specimens (interfascicular distance= $0.30-0.40 \mathrm{~mm}$.) are still less than those of our American specimens.

This species differs from Tervia tumida. Smitt. 1871, in an interfascicular distance somewhat smaller and in its fascicles which are much more protruding beyond the zoarium.

The difference from Idmonea grallator in the absence of the radicells is quite difficult to note at sight. It can be made ont only uncler the microccope. the interfascircular distance being always greater than $0.40 \mathrm{~mm}$.

Ocrumence-Middle Jacksonian: Wilmington. North Carolina (very common): one-half mile southeast of Georgia Kaolin Co. mine. Twiggs County, Georgia (rare); 12 miles southeast of Irashallville, Georgia (rare).

Upper Jacksonian (Ocala limestone) : Chipola River, east of Marianna, Jackson County, Florida.

Vicksburgian (Marjanna limestone): One mile north of Momroerille, Alabama (rare).

Plesiotypes.-Cat. No. 65353, U.S.X.M.

\section{idMONEA PARVUla, new species.}

Plate 13s, figs. 21-23.

Thescription.-The zoarim is free. ery smull, linear, bifurcated with triangular transverse section. The fascicles are little salient, much scattered, arranged alternately on each side of the median crest. extending very little orer the zoarial marmins; they are formed of two or three small, equal zooecia. The tubes are small, visilhle, convex. The dorsal lanella is rery convex, smooth.

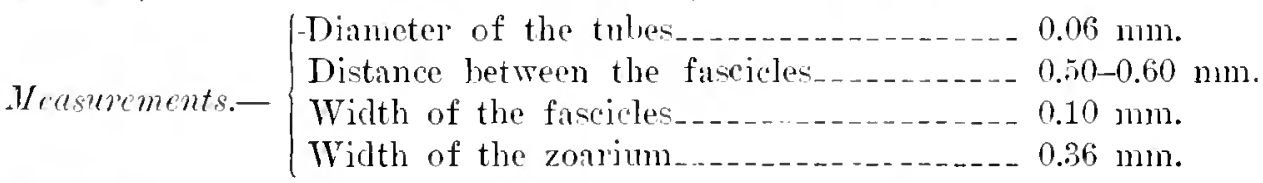

Aftinitics. - This is the smallest of our American species. It resembles somewhat Itmonea fliformis in the narrowness of the zoarinn: but it riffers from it in the frequent bifurcation of the zoarium and in a lesser interfascicular distance $(0.50 \mathrm{ancl}$ not $0.90 \mathrm{~mm}$.$) .$

Ocentence-Middle Jacksonian: Eighteen miles west of Wrightsville. Johnton Comnty, Georgia (rare). II olotypt.-Cat. No. 6.5t17. U.S.Y.M. 
JDNONEA FILIFORMIS, new species.

Plate $13 \mathrm{~s}$, tigs. 24-27.

Description.-The zonrium is linear, very long, very thin, filiform. The fascieles are little salient, arranged alternately on each side of the merlian line and extending rery little beyond the zoarial margins; they are formed by two zooecia only. The tubes are visible and convex. The dorsal lamella is romet and smooth.

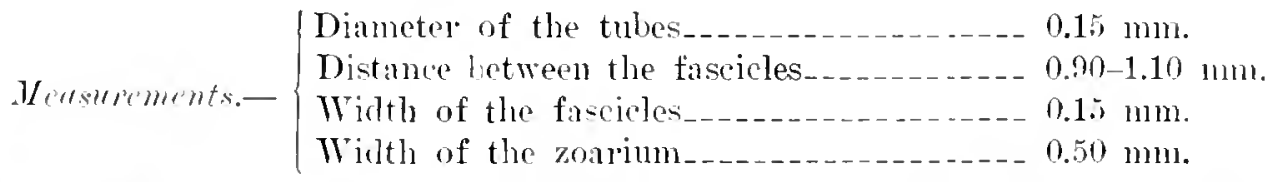

Atinitics. - This species presents the aspect of Idmonca unipom DoOrbigny. 185.2. figured ly Beissel. 1865, with two zooecia to the faseiele; but the interfascieudar separation is much greater.

Occurrence.-Middle Tacksonian (Castle Hayne limestone): Wilmington. Sorth (arolina (r'are).

Cotypes.-Cat. No. $65 \pm 18$, U.S.N.M.

IDMONEA PETRI D'Archiac, 1846.

Plate 139, tirs. 1-13.

1946. Idmonca petri Thachuc. Tescription des fossiles recueillis par M. 'Thorent dans les conches nummuliques les environs de Basonne, Mémoires de la sociẻté gräologique te France, ser. 2, vol. 2, p. 195. pl. 5, fig. 11.

190S. Idmonca non reticula lietcter. Ijeitrag zur Kenntnis der Bryozoenfauma der ilteren Tertiarscliclıten des suidlichen Bayern, Cyclostomata, Paleontographica, vol. 59, 1. $226,11.29$, tigs. 17,15 .

1911. Idmonea petri Caxu, Bryozoaires des sind-Ouest de la France. Bulletiu de la suciét géologique de rrance, ser. 4, vol. 11, 1. 45.2. pl. \&, figs. 1-2 et 10-11.

llesciption.-The zoarium is large, linear. or somewhat elaviform. compresecl. with triangular transverse section. The fascicles are very salient, elose together, not extending berond the zonlial malorins, opposite on each side of the median axis: they are formed of four to six equal zooceia. The tubes are visilule, flat, often reparated by a salient thead. The basal lamella is somethat concave, excavated, and bordered by a margin of little thickness: it is smooth. slightly striated transrersely and longitudinally.

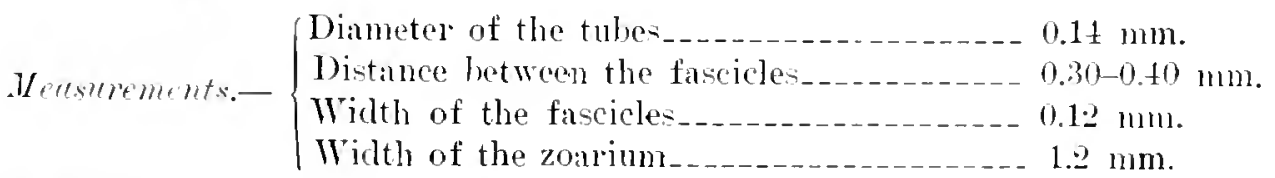

Affinities.-The determination has been made speeimen by secomen with the French material, hut it may be posible that this species has been described nnder another name ly the paleontologists. Idmoner disticha Reusi, figured by Manzoni in $18 \pi$. is exteriorly rery close. but the fascicles are clearly alternated. which is 
not the case in all our specimens. Moreover. the micrometric neasurements do not appen identical, if the small drawing of Manzoni is exact. It is to be noted that figure 6 represents a branch with alternated fascicles.

A species, also rery close, is Idmonea marginata D'Orbigny, 1853, of the European Senonian. If we consider, for example, figure 8 , with its eight tubes to the fascicle, the identity is perfect. The zooecial and zourial dimensions are also identical. The only appreciable difference is that the number of the tubes to the fascicle is frequently larger than in the Tertial'y species. The study of bases and oricells will perhaps permit us some day to make better comparisons.

This species differs from Idmonea arcuate in the linear form of its zoarium and in the distance between the fascicles being double. It differs from Idmonea sloani in its larger dimensions and in its transverse section wider than high.

Occurrence.-Middle Jacksonian: Wilnington, Nortl Carolina (very rare); near Lenuds Ferry, South Carolina (rare): Eutaw Springs, South Carolina (rare).

Vicksburgian (Marianna limestone): West bank Conecuh River, Escambia County, Alabama (very common).

Vicksburgian (Byram marl): One-fourth mile west of Woodwards, Wayne County, Ilabama (rare).

Gcological distribution.-Lutetian of Bavaria (Beutler); Auversian at Biarritz (C'anis).

Plesiotypes.-Cat. Nos. 65355, 65356. U.S.X.M.

IDMONEA TRIFORATA Canu, 1911.

Plate 161, figs. 5-24.

1911. Idmonca triforata CaNu, Les Bryozonires du Sudonest de la France, Bulletin de la Société géologique de France, ser. 4, vol. 11, p. 452, pl. 8, figs. 13-14.

Lescription.-The zoarium is free, linear, bifurcated, with triangular transverse section wider than high. The fascicles are rery salient, irregularly spaced, arranged alternately on each side of the median crest and distant from it, projecting beyond the zoarial margins; they are formed of three or four zoecia, the last of which is turned and opens on the dorsal face and the first is isolated on the young branches. The tubes are risible. long, convex; the peristome is quadrangular. The basal lamella is smooth and somewhat convex.

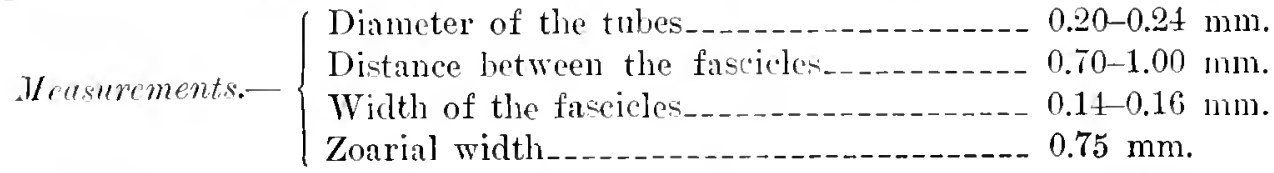

Tariations.-This species is exceelingly irregular; the distance between the fascicles has no constancy and varies from 1 to 2 times $(0.60$ to 1.20$)$. On the terminal branches the first zooecimm of each fascicle is icolated on the median axis of the zoarium (figs. $7,8,14,15$ ) and measures $0.30 \mathrm{~mm}$. in diameter. On the intunches of the base or lower branches the fascicles are regular and complete (firs. 12. 13). This double disposition is often visible on the same specimen. 
Some branches (figs. 1t, 15) are beyond all description on account of their great irregularity. The fascicles are quite salient (figs. 7, 8, 14). but they are fragile and break easily (fig. 16).

The fascicles are quite distant from the median crest; also on the longitudinal sections there are no zooecia with the apertura visible (fig. 22). In order to see the apertura of the zooccia it is necessary to make a meridian section by the prolonged abrasion of the frontal (fig. 23).

The miscroscopic structure of the zoocial walls (fig. 24) is rather difficult to comprehend.

Affinitics.-This species is quite odd and easy to determine; it is impossible t. confuse it with the others. One can not determine the isolated brinches. for the reader can believe in the existence of many species of which internediate stages appear in large numbers of speciniens.

The comparison with the French species has been made specimen with specimen and the identification is absolutely certain.

Occurrence.-Vicksburgian (Marianna limestome): Salt Mountain, 5 miles south of Jackson, Alabama (conmon); near Claiborne, Monroe County, Alabama (common); Murder Creek, east of Castlebury, Conecuh County, Alabama (very common); west bank Conecuh River, Escambia County, Alabama (very common) ; Escambia County, Alabama (deep rell) (rare).

Vicksburgian (Byram marl): One-fourth mile west of Woodwards, Wayne County, Mississippi (common).

Geological distribution.-Auversian of Biarritz (C'anu).

Plesiotypes.-Cat. Nos. 65441-65445, U.S.N.M.

\section{IDMONEA GRANDIORA, new species.}

Plate 162, figs. 1-3.

Description.-The zoarium is free, linear, fixed by an expanded base, compressed. The fascicles are somewhat salient, close together. arranged altemately on each side of the median line and formed of three equal zooecia. The tubes are invisible; the peristome is thin; the apertura is large.

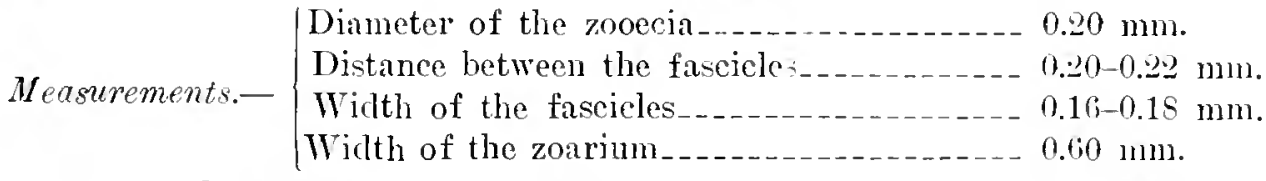

Affinitics.-Only the three specimens figured have been fotml. They are of interest merely on account of their great apertura and becallee this species exists in the strata of Vicentin where Canu his recently discovered it.

Oecurrence.- Ticksburgian (Marianna limestone) : One mile north of Mnnroeville, Alabama (rare).

Geological distritution.-Priabonian of the ricentin.

Holotype.Cat. No. 6.5472. T.S.N.M. 


\section{IDMIDRONEA, new genus.}

The zoarium is idmoneiform. The dorsal bears firmatopores or canals of reinforcement.

Genotype.-Iimidronea coronopus Defrance, 1820.

riangr.-Intet ian-.Jacksonian.

The firmatopores are small canals, very thin and numerous, which develop on the rorsal of the zoarium in great thickness. They are parallel and rery long, for we have followed then throughout the length of a branch. In a longitudinal section they appear somemhat intermingled, for it is absolutely impossible to prepare a section in a position exactly parallel to their general direction. On the dorsal they appear as very small, longitudinal striations extremely mumerous and quite close together. In Idmonea, on the contrary. the longitudinal striations are much more scattered and limit the tubes themselves which are entirely visible. The tergopores are much larger. The firmatopores are evidently intended to reinforce the consolidation of the branches. It is almost certain that they indicate a zoarim which is horizontal or arranged in a much expandert hush-like shape. All of the manches are not provided with firmatopores and the generic classification is then rery difficult.

We have not found the oricell, so the place of this genus in the family of the Tubuliporiclae is naturally hypothetical.

\section{IDMIDRONEA ROSACEA, new species.}

Plate 132, firs. 11-15.

Trescription.-The zourium is supported on a more or less expanded base which forms a trunk of greater or less size; the branches ale directed horizontally in all directions from the center like the petals of a rose. They are bifurcated and thoil section is triangular. The faseicles are very little salient and bear only two or three zooecia; they are alternated on each side of the median line. The tubes are iurisible; the pristomes are thin, round, or rectangular. On the dorsal the firmatopores are arranged longitudinally; they are rather large and their visible orifice, which results from abrasion, is polygonal.

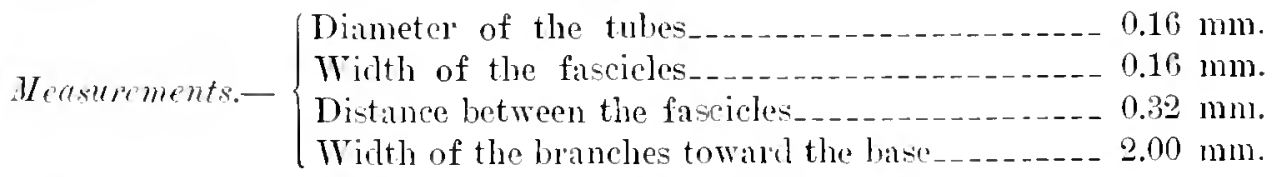

Afinitics.-This superb species is rather rare. It is remarkable because it appears to be formed of two symmetrical zoaria arringed horizontally on each sirle of the ancestrular center.

It diflers from Idmirlronea maxillaris Lonsdale. 1847, in the rotate form of its zuarium and in its nonsalient fascicles, and from $I$. multio in its fascicles. which ane mole scattered, nore distinct. never adjacent on the median line.

(Cenrerne.-Midclle Tacksonian (Castle Hayne limestone): Wilmington. North Curolina (rare).

$$
\text { Cotypes. Cat. No.653.59. U.S.X.M. }
$$


IDMIDRONEA MAXILLARIS Lonsdale, 1845 .

Plate 131, figs. $1-\bar{\tau}$.

1945. Idmonca maxillaris LoNsDale, Account of 26 species of Polyparia obtained from the Fucene-Tertiary formation of North America, Quarterly Journal Geological Society, London, vol. 1, 1. 523, fig.

1962. Ldmonce marillaris GABB aud IIonN, Jonograph fossil Polyzon of the SecomIary and Tertiary formations of North America. Journal Academy Natural Sciences, Pliladelphia, ser. 2, vol. 5, 1'. 167.

Description,-The zoarium is formed of triangular, linear, irregular branches more or less distorted and cervicorn. The fascicles are rery salient, quite close together, arranged alternately on each side of the median crest; they are formed of three zooecia. The tubes are invisible; the peristomes are thin and round. The dorsil is striated by numerons parallel firmatopores.

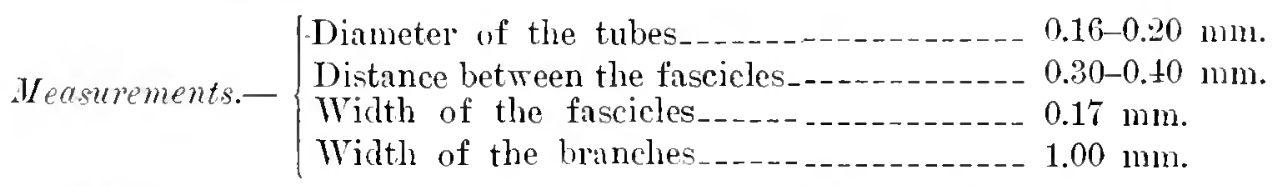

Affinities. - The species is remarkable for the extraordinary development of the dorsal formed of a great number of firmatopores. They form a very thick collar on which the fascicles appear to incrust. In this respect the species much resembles Idmonea magnireversa, but differs from it in its totally different longitudinal section, owing to the presence of inmumerable firmatopores.

It differs from Idmidronea rosacea and Idmidronea culter, which have an identical transrerse section, in the great saliency of the fascicles.

Occurrence.-Middle Jacksonian: Wilmington, North Carolina (very common) ; near Lenuds Ferry, South Carolina (very common); Wantoot, Sonth Carolina (type locality).

Plesiotypes.-Cat. No. 65360, U.S.N.M.

IDMIDRONEA CULTER, new species.

Plate 182. figs. 1-10.

Description.-The zoarium is formed of long, linear branches brfurcated with triangular transverse section. The fascicles are little distinct, not salient, quite close together, and formed of three, four, or five zonecia; they are alternated on each side of the median crest, but they are adjacent to each other with the least abrasion. The tubes are invisible; the peristome is small, thin, round. The dorsal is semicylindrical, very thick, striated longitudinally by its large firmatopores.

The transverse section is triangular; it has the form of a very thick linife, round at the back. This is always higher than wide. but the relation of the two dimensions is not constant.

Aftinities. - We have hesitated much to separate this species from Idmonea maxilluris Lonsdale, 18t5, of which it appears to be a condition of weathering. $5.5+20-20-1$ iull, $106-50$ 
BLLLETIN 106, UNITED STATES NATIONAL MUSECM.
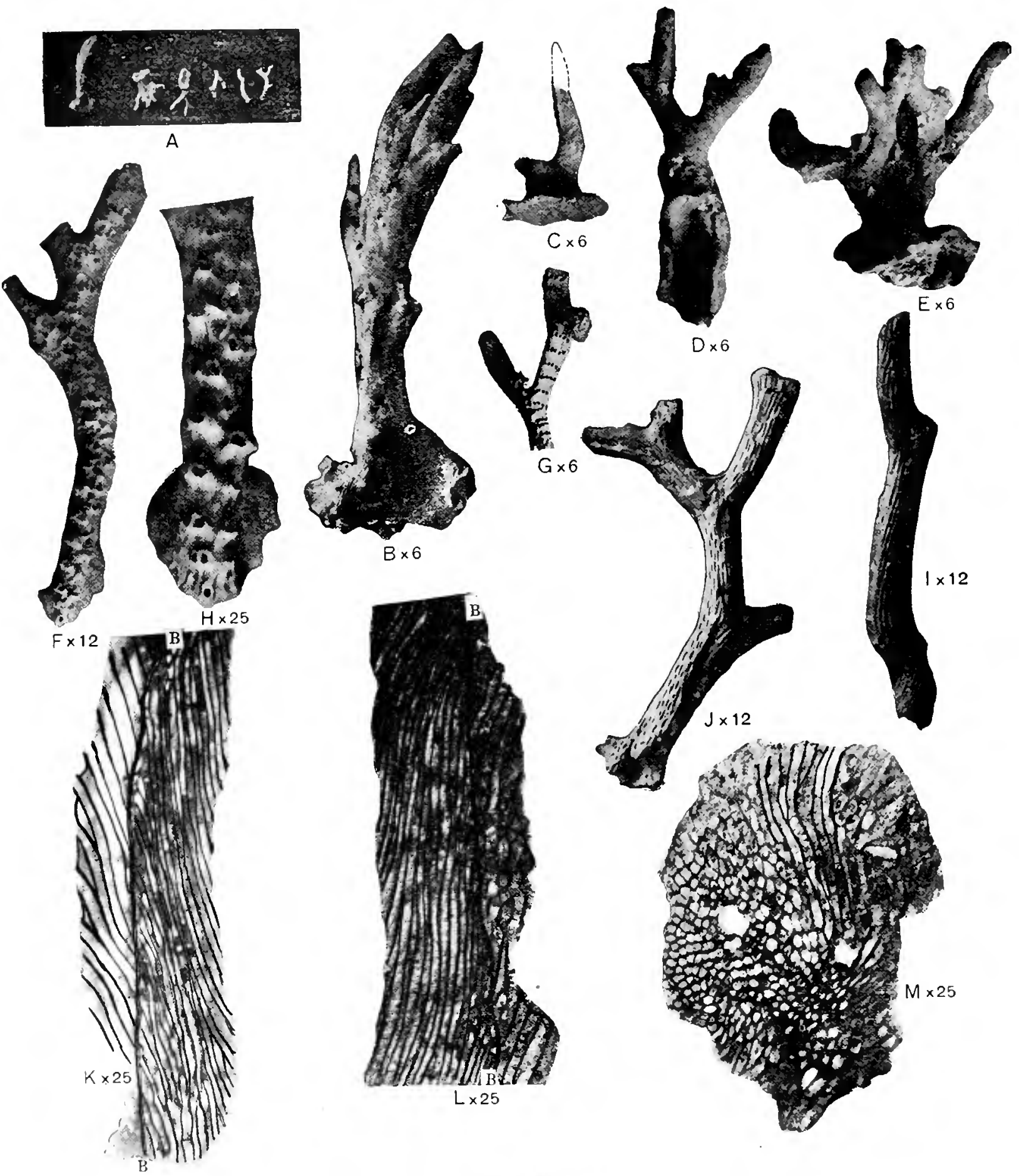

$1 \times 12$
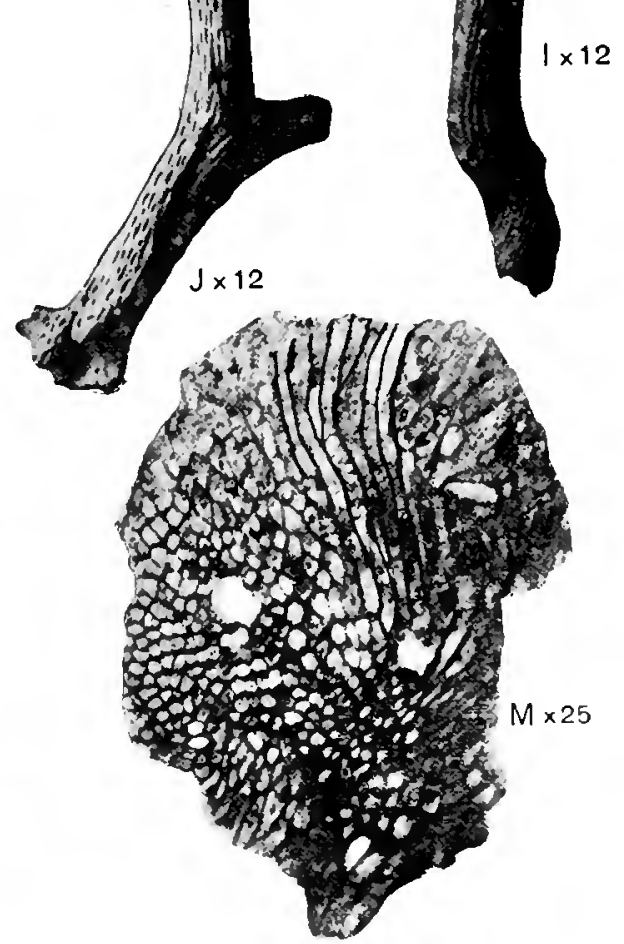

Fic. 258.-Idmidronca, new genus. 
Fig. :-5:-I - Imidnoner, new genus.

A-I. Idmidronca (Idmonca) coronopus Defrance, 1822. A. Zoaria, naturil size, from various localities in the Iutetian of France. 5 . Zoarium, $\times 6$, with layer of fimatopores forming many columns (on rocks). C. Specimen, $\times 6$, with a small basal plate of firmatopoles (incrusting shells), bearing a brancl without firmatopores. D. A concave base of firmatopores, $X 6$, attached to an alga. F. A large hase, $X$ 12. wit hout firmatopores. The ancestrublr zovecinm is visible. F. A small base, $X 12$, without firmatopores. The ancestrular zooecium is visible. G. The same specimen, $X 25$, showing absenco of firmatopores. H. An example, $X$, showing that the laser of firmatopores is separable. I. Specimen, $X$ 12, showing that there are many layers of firmatopores. J. The firmatopores occur at the bottom of sulci, $\times 12$. K. Longitudinal section in a thick zoarium through the axis of the fascicles, $X$ 25. The hasal lamella $(B B)$ is visible. The fimatopores are the cylindrical tubes growing on the basal lamella but directed toward the hase while the polypidian tubes are ascenting. L. Longitutinal soction, $\times 25$, in the thick zoarinm taken between tlie fascicles and in the axis of a bifurcation. The hasal lamella $(B B)$ is visible. 11 . Thin section in the base of a zoarium, $\times 25$. 
In our very numerons materials we have not heen able to discover the transition forms necessary for the union of the two species. Moreover, the branches with distinct fascicles are rery rare; the branch represented in figme 2 is the usual occurrence.

The size of the firmatopores is risible on the tangential section, where they appear under the form of short, rather wide spindles.

This species much resembles Idmonea commiscens Lonsdale. 18t5. It differ's from it absolutely only in its dorsal, which is never flat, contrary to what the author thought (p. 525). It is possible that Lonstale was considering two species among his specimens.

Oecurrence.-Niddle Jacksonian: Wilmington, North Carolina (very common) ; near Lenuds Ferry, South Carolina (very common); Eutur Springs, South Carolina (rare).

C'otypes.-Cat. No. 65358, U.S.X.M.

TERVIIDAE, new family.

The longitudinal axis of the ovicell is parallel to that of the tubes. The ovicell is formed after the calcification of the neighboring tubes. The oeciostome is directed toward the top.

We recognize three genera in this family. Temia . Tullien, 1882, Prosthenoecin Canu, 1918, and Lagonoecia, new genus.

\section{Genus TERVIA Jullien, 1882.}

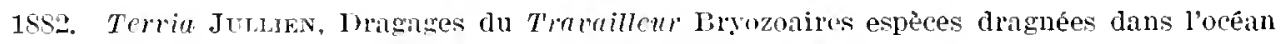
Atlintique en 1S\$1, Bulletin Sociête Zoulugique France, rol. 7, p. 4.

The ovicell is developed on the posterior and noncelluliferous (dorsal) face of the zoarium.

Genotype.-Treria (T'ubutipora) irregularis Meneghini, 1845.

Range.-Istetian-Recent.

The genus Tereia is characterized not only by it ovicell, but also by the aspect of its dorsal, for the tubes here are flat and separated by a salient thread. Moreover, on the frontal the fascicles are never parallel to each other as in Itmonea.

TERVIA GRACILIS, new species.

I'late 147, figs. 1-11.

Description.-The zoarium is free, bifurcated, sender, compressed. The tubes are distinct, separated by a salient thread, arranged in nonparallel fascicles; the peristome is thin, elliptical. The ovicell is very long and curves around almost all the dorsal. The dorsal is convex; the tubes are flat and separated by a salient thread. 

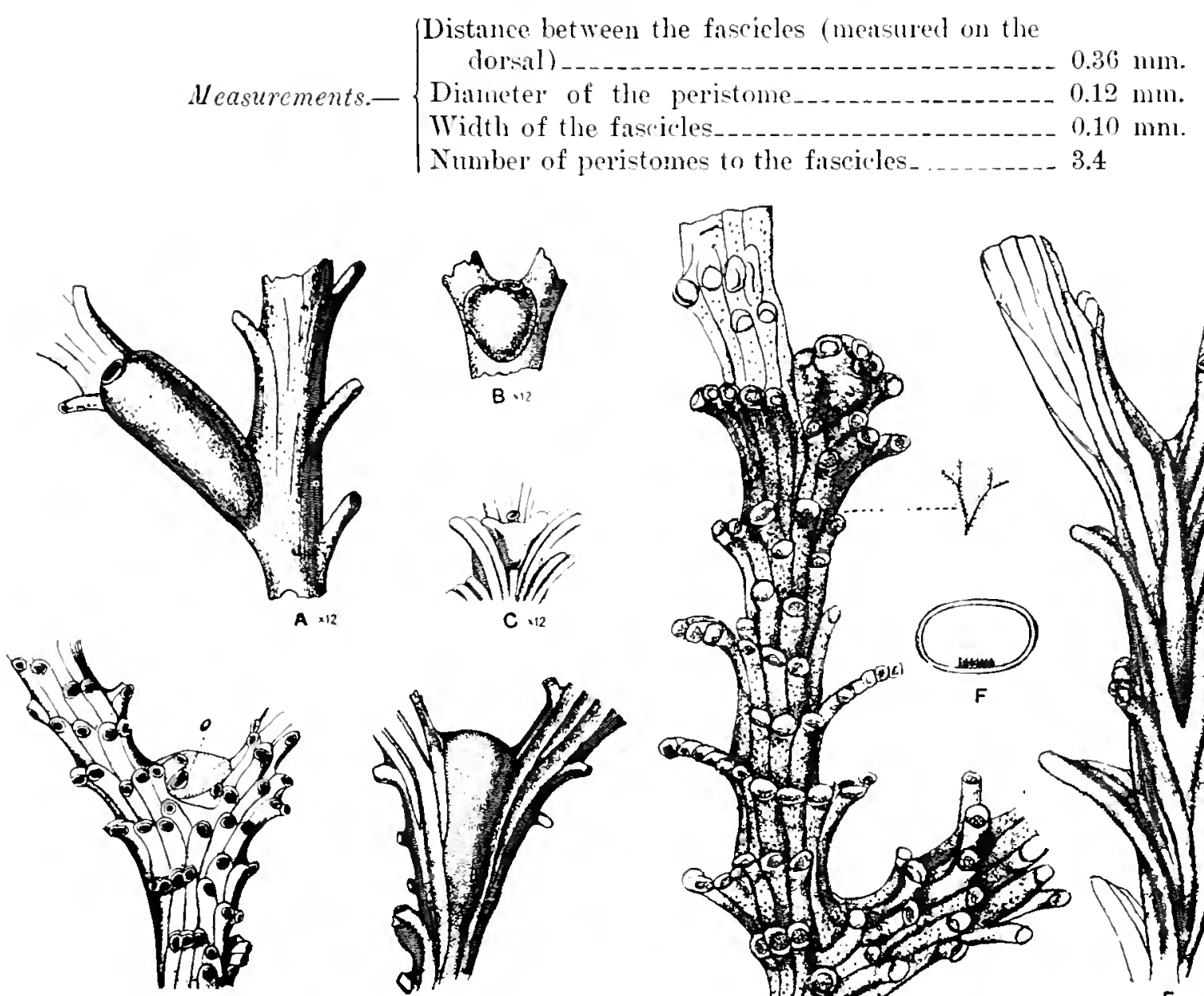

$\mathrm{G} \times 12$
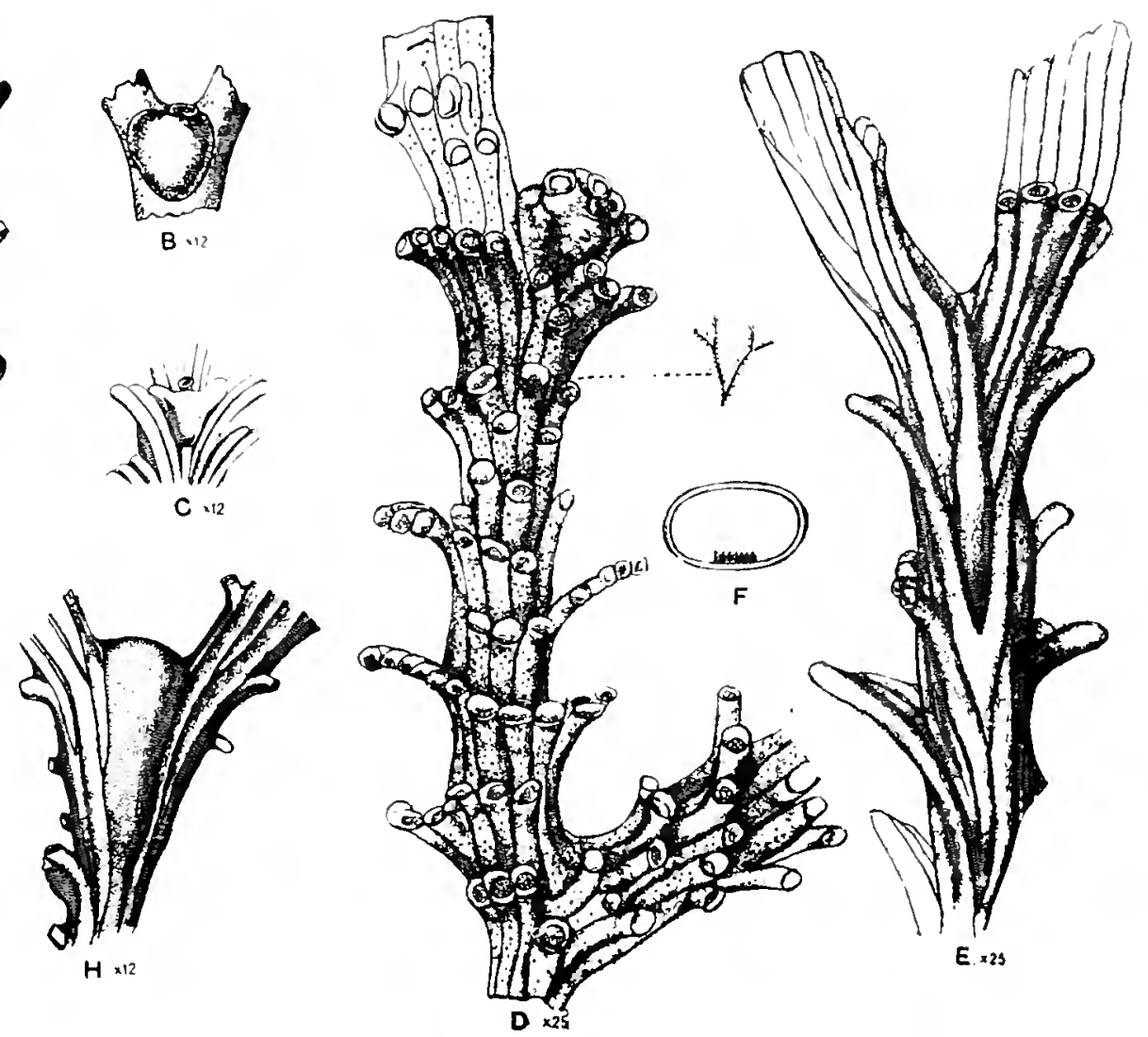

FIe. 25t.-Genus Tertia Jullien, 1\$ৎ2.

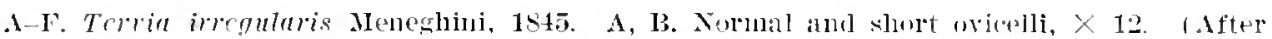
Waters, 1Sss.) C. Cordiform ovicell, $\times 12$. (After Jullien, 1903.) $\Gamma$, E. The two faces of the zoarium. (After Harmer, 1915.) F. Comb-like process in the zooecial tuhe near where it hecomes erect. (After Waters, 1914.)

G. II. Tervia jellyae Llarmer. 1915. The two faces, $\times 12$, o, oecintome. (After IIarmer, 1915.)

Tariations.-The tubes are arranged sometimes in quincunx, sometimes in verticells, and sometimes in fascicles: the last arrangement is more frequent. The comvexity of the dorsal is quite variable.

In longitudinal section the tuthe are very long.

The fascicles are salient on each side of the zoarium riewed from the dorsal.

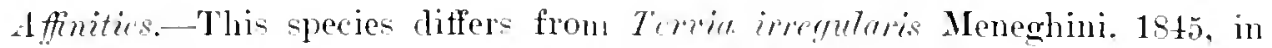
its smaller interfascicular distance $(0.36$ and not $0.60 \mathrm{~mm}$.) and in its more narrow and slender lorinches. 
It differs from Terria bialtemata Gregory. 1892, and from Tervia filiformis D'Orbigny. 1852, in its large micrometric measurements.

Occumence.-Middle Jacksonian: Wilmington, North Carolina (very common) ; near Ienuls Ferry, Sonth Carolina (very common).

Upper Jacksonian (Ocala limestone): West bank Sepulga River Escambia County, Alabama (very rare); Alachua, Florida (rare).

Cotypes.-Cat .No. 65.431, U.S.N.M.

TERVia ParVula, new species.

Plate 147, figs. 12-14.

Description.-The zoarium is formed of small compressed branches. The tubes are distinct, separated by a salient thread, aranged in quincunx or in irregular rows; the peristome is thin, small, orbicular, salient. On the dorsal the tubes are separated by a salient thead and superposed in lozenge-shaped areas.

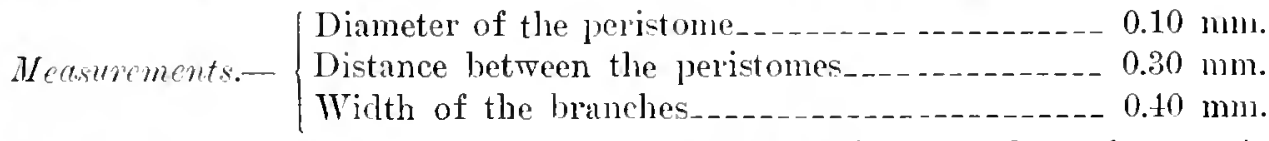

Affinities.-This species differs from Tonvia gracilis in its smaller micrometric dimensions. 'The few specimens collected bear no ovicells.

Occurrence.-Upper .Jacksonian (Ocala limestone): Chipola River, east of Marianna, Jackson County, Florida (rare).

Cotypes.-Cat. No. 65435, U.S.N.M.

TERVIA TUMIDA Smitt, 1871 .

Plate 140, figs. 14-21.

1571. Tubulipora (Idmonea) tumida sumt, Fíritiske förteckning öfer Skandinaviens Hafshryozoer, Of versigt af Kongl. Vetenskapsi-Akademiens Förhandlingar, rol. 29. p. 1116, pl. 20 , figs. $5,6,7$.

1903. Idmonce tumida WATFrS, Bryozoa from Franz-Joseph Land, Journal Linnean Society, London, rol. 29, p. 168 , pl. 21 , figs 4,5 .

Description.-The zoarium, is free, linear, bifurcated, provided with radicells at the bifurcations, with subcircular transverse section. The fascicles are salient, ynite far al)art from each other and also from the melian line, alternately arranged and extending beyond the zoarial margins; they are formed of three or four equal zooccia. The tubes are visible, flat, separnted by a salient thread. The dorsal lamella is very convex and striated longitudinally by the tubes. The ovicell is glohular. elliptionl, rery salient: the oeciostome is small, transverse, biaced neat the dorsal of the zoarium.
Merisurements-
biameter of the tubes
- $0.10 \mathrm{~mm}$.
Distance between the fircicles_._.
Wielth of the fascicles.
$0.10 \mathrm{~mm}$.
Width of the zoarimm
$0.70 \mathrm{~mm}$. 
Attinities.-This speeies constitutes a strong divergent type in the grenus. It exterior aspect is absolutely that of Idmonea, its oricell is exactly that of T'emin. It is quite easy to determine in its interfascicular distance greater than in I/momert. atlantica Johnston, $184 \bar{i}$, and all the other small American species.

It ofters much the same aspect as Idmonea hörnesi Stoliczka, but differs from it in the rery salient thread separating the zooecia and in the alternation of the fascicles (and not their opposite arrangement) on each side of the median crest.

Our specimens are in agreement with the figure given by Waters, 190\%, but resemble less that of Smitt, 1871. On the latter the first zooccium of each fascicle is isolated. a feature that does not exist on Waters's figure nor on onr specimen.

Idmone tumida bing an Arctic species, it is curious to find it fossil in an ecinatorial seal. IIowerer, the bryozoa appear much more sensible to the temperalthire of the bottom than to geographic position.

Uecurrenec-Middle Jacksonian (Castle Hayne limestone): Wilmington. North Carolina (rare).

Upper Jacksonian (Ocala limestone): Chipola River, east of Marianna, Tarkson Countr, F"loridia.

Habitat.-Aretic Ocean.

Plesiotypes.-Cat. No. 65854, U.S.N.M.

TERVIA GLOBULIFERA, new species.

Plate 146, figs. 1-s.

Deseription.-The zoarimm is free, bifureated almost at right angles: the branches are elliptical in section and short, clariform in length; the posterior face is round. smooth, or slightly wrinkled transversally. The fascieles are formed of seven tubes; they are little salient, close together, invisible on the dorsal. The tubes are tlat, risible, separated by a shallow furrow. The ovicell is globular, spherical, quite salient, pliced at the bifureations: the oeciostome is salient, transrerse. a large lunar crescent in shape.

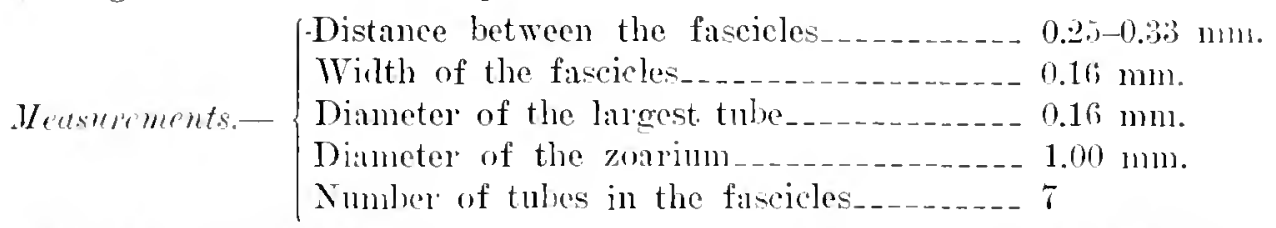

Trariations and Afinitirs. - This species belongs to the Tervin tumidu wrouls. and without the presence of the ovicell placed dorsally it is impossible to chasify pecimens generically. It rliffers from Tevria pyrifera, with which it is associated in globular form of its oricell, the smaller interfascicular distance (less than 0.35 mm.). larger tubes, fascicles which do not border the zooccial margins, and short (.lariform branches.

The zone of growth is short and thick.

The oeciostome is turned from the side of the dorsal contrary to the direction observed in the Temia imeguleris group where the occiostome is turned from the side of the cellular face. 
rex, elongated, elliptical, srmmetrieal, suspended on the lateral edge of the zo:rium: the oeciostome is terminal, very large, transverse, fastened to a small isolated tulue, and separated fiom the fascicles.

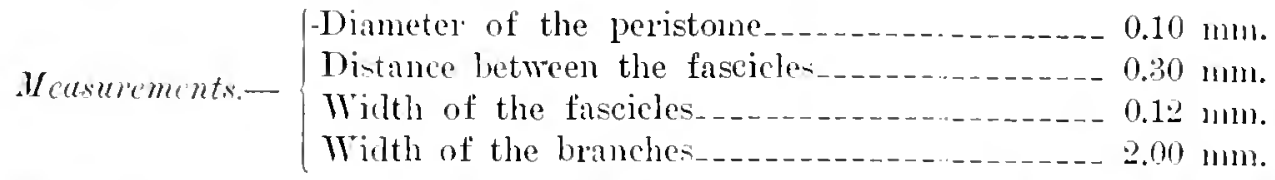

Variutions.- The lamellar fascicles are often oblique (fig. 3): the sixth tube, which composes them and which is placed in the ricinity of the lateral edge, is often isolated.

The ovicell is always placed laterilly (fig. 1); its position is hardly disarranged at the bifureations (fig. 2), even though this takes place at a very acute angle. It is remarkable that the oeciostome should be joined to a tube, but this tube does not belong to a fascicke, for it is always isolated.

The variation of the nature of the oricells in species with the Idmoneu form of growth is rery great. This is a proof of the poor method followed eren to this day by the naturalists is the dassification of the cyclostomatous bryozoa. Idmonea murestricted is only a zonrial form common to a great many fimilies.

Occurrence.-Wilcoxian (Bashi formation): Woods Bluff, Alabana (common).

Cotypes.-Cat. No. 6526t, U.S.N.M.

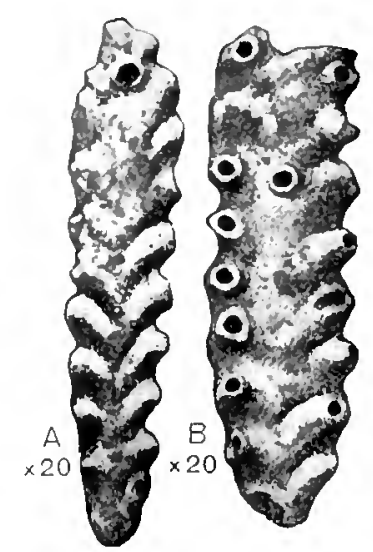

F1G. 255-Genus I'rostlenoceia) Canu, 1918.

Two uricelled zoaria of I'rosthenoecia (Reptotubig(ra) latcralis, DOOrhigny, 185., from the Lutetian of France.

1918. Prosthonoccia Caxu, Les oricelles des bryozoaires eyclostomes, Bulletin societé géolugique de France, ser. 4, vol. 16, 1) 327.

The ovicell is placed on the celluliferous fice; the oeciostome is large and transverse.

Genotype.-Prosthenoecia (Reptotubigera) luteratis DOrbigny, $18 \%$. Lutetian.

Family HORNERIDAE Gregory, 1899.

Anatomical bibliography.-1sss. Waters, On some Ovicells of Cyclustomitons Pipozoa, Jumrnat

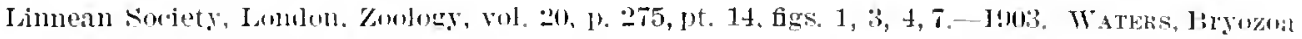
from Franz-Josejh Land, pt. 2, Jonrnal 1innean Societs, London, Zoology, vol. 29, p. 16S. 11. 20, figs. 1-6.-1904. Waters, Expedition anturctic Ijelge, Fryozoa, 1\% 98, 11. 9. fig. 1.-1911. IIENIG, I.e conglomérat pleistocene a I'ecten de l'ile de Cockburn. W'issenshaftliche ergebnisse

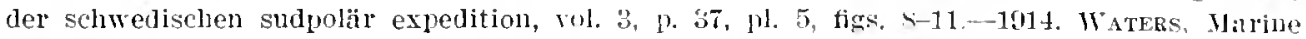
Fauna British East Africa and Zanzibar Bryozoa, Crelostomita, I'roceedings Zoological Society, Jonlon, $\Gamma .830$.

The ovicell is symmetrical, sacciform, subghobular. The oeciostome is lateral and opens on the fromtal. The zoarial walls are limellowe and squamons. They are travered by vacuoles. 

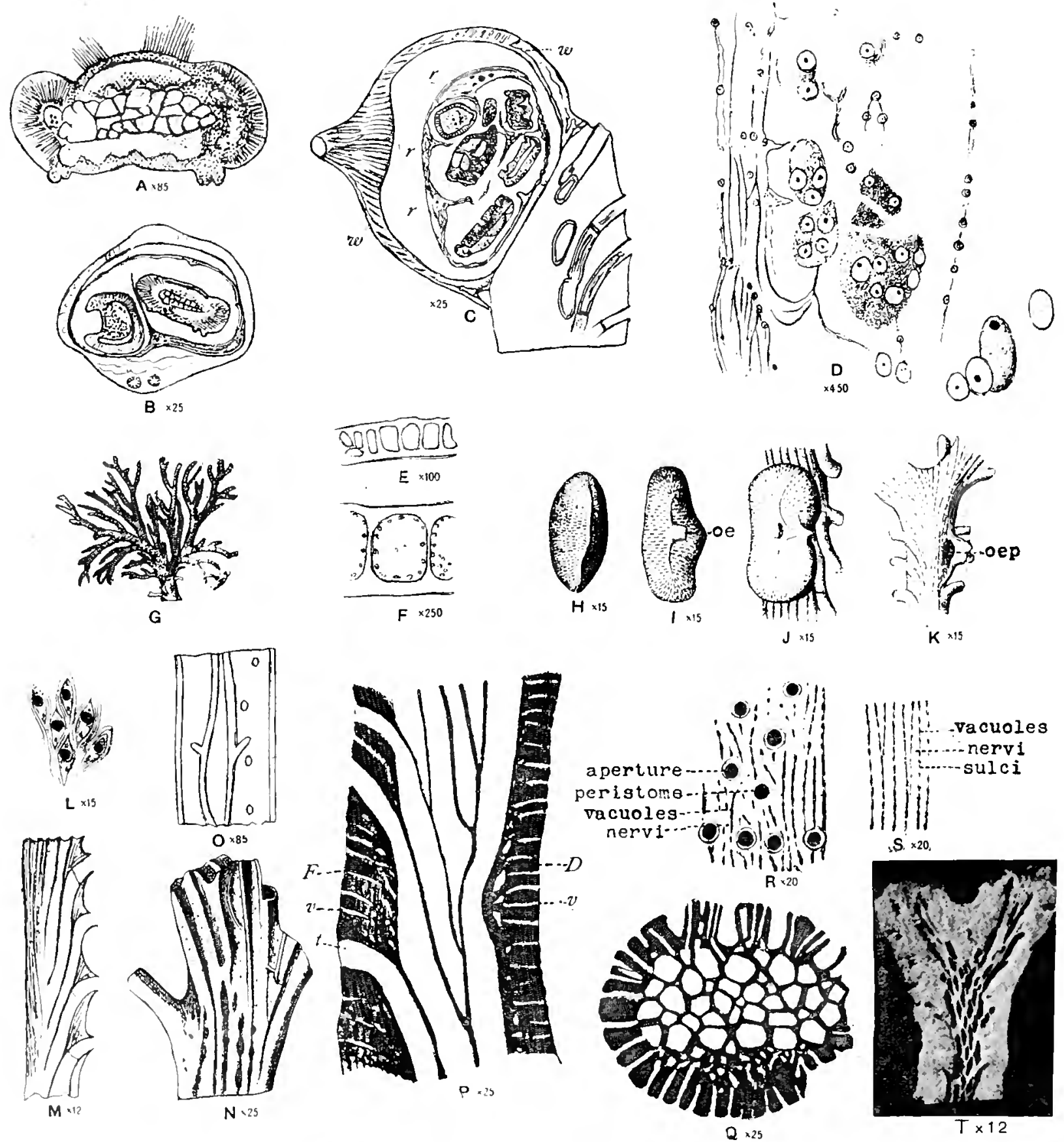

Fis. 2.ith-Anatomy of the family Horneridae Gregury, 189. 
Fig. 256.-Anatumy of the fimily Horneridate Gregory, 1899.

A-I. Horncra lichenoides I'ontoplidam, 1752. A. Section of embryo, $\times$ s5. Whether the cilia on the mper part are in two tufts or are entinuous is not clear. B. Transverse section of uvicell, $\times 25$. C. Iongitudinal section, $X 25$, showing the polypide and the ovicell, snrrounded ly the wall $(u)$, from which the reticulum $(r)$ has separated, no doubt in conseruence of the processes of preservation and preparation. In the reticulnm, on the left-hand side, some ovarian masses are seen. Six cubryos are seen in the section. D. Section of protoplasmic reticulum containing ovarian masses, $X 450$. This reticulmu is shown slightly magnified in fig. $\mathbf{U}$. I: Section of the wall of the ovicell, $X 100$. F. Section of the wall of the ovicell, $X 250$. G. Zoarium, natural size. H-J. Ovieelis, $X 15$, with latral oeciostome (oe). K. Dorsal of a zoariun, $\times 15$. 'The uricell is broken and shows the interior of the oeciopore (ocp). L. Frontal, $\times 15$. (After' Watel's, 1903, aud Smitt, 1867.)

M. Homcra concatenata Reuss, 1869 . Longitudinal section, $\times 12$, showing terminal closure. (After Waters, 1SS4.)

N, O. Homera fissurata Busk, 1sst. N. Dorsal surface (growing end), $\times 25$. O. Section of zooecial tubes, $\times 85$, showing interiur projections. (After Waters, 1SSS.)

I'. Hornora anturctica Waters, 1904. Longiturinal section, $\times 25$. ( F', frontal and D, dorsal.) The scals and Inmellar structure is quite visible. The vacnoles (r) perforate the zoarium. The tubes $(t)$ grow and bud as in the other Cyclostomata; they do not issue from a central canal as Hennig luas ineorrectly represented.

Q. Trausversal section, $\times 2 \%$. All the phygonal tubes are approximately equal.

li, S. Frontal and dorsil, $\times 20$, indicating the terminology peeuliar to this family. (Attel' Holnig, 1910.)

T. Homera jaclisonica, new species. Interior, $\times 12$, showing that there Is no sagittal canal. 
The racuoles ${ }^{1}$ are the small, oblique, recurved tubules which irregularly perforate the zoarium. They open at the base of the sulci and they are separated ly nervi or threadlike ridges which are longitulinal on the dorsal and often oblique on the frontal. The racuoles apparently are not connected with the ravities of the zooecia.

The squamous composition of the zoarium seems to indicate an external an irin somewhat analogous to the plenrocyst of the Cheilostomata, but the corresponding division into two of the ectocrst has not yet been observed, although it may be quite probable.

Ilemnig (fig. 256P) thought that the polypiclian tubes were inserted on a jongitudinal dorsal tube. Our longitudinal sections lave not confirmed this obserration. The successive ramification of the tuhes is identical with that of other families. The removal of the dorsal show- the ordinary lozenge-shaped areas.

In lorizontal section the tubes are perceptibly equal. They do not diminish from the circumference to the center as in the zoarial form Entutophora, therefore they are cylindrical.

The zoarium is often bushy: the frontal bearing the apertures is turned to the interior of the colony toward the median axis; the dorsal. on the contrary, is exterior. There are some flabelliform zonria. but very rarely on the same plane.

The Ilormeridae are attached to rocks or al gae by an expanded base.

'The larrat is the largest of the Cyclostomati. There are only a dozen embryos in the oricell.

\section{Genus HORNERA Lamouroux, 1821.}

1S21. Homer LAmouroux, Exposition metholique des genres de l'ordre des Polypiers, p. 41.

The ovicell is large, dorsal; its punctations or reticulations are large. The tubes are cylindrical with dorsal gemmation. The alpertures are disposed only on the frontal. The racuoles are arranged all over the zoarium at the base of longitudinal sulci. There are nine tentacles.

Genotype.- Homera frondiculate Lamouroux. 1821.

Ranae-Lutetian-Recent.

Hornere is quite well known and is a very natural genus. It is very common anong the Tertiary fossils. Certain Cretaceous specics have been cited, but we believe that it is necessary to await the description of their ovicells and of their sections lofore assigning them definitely to this genus.

The variations in this genus are extraordinary and it is often useless to attempt to determine an isolated specimen.

Species of II omera are bryozoms of deep water. All the recent species live at rariable but always very great depths. At 30 to 100 meters one may hope to fincl some examples. ]ut it is at greater depths. from 100 to 300 meters these animals find the nost favorable conditions for their development.

The thermal conditions of their habitat vary evidently with the depth. but in the rather restricted limits from $-9^{\circ} \mathrm{C}$. to $+6^{\circ} \mathrm{C}$.

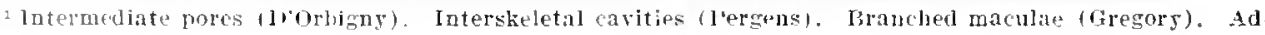
wations pores (Waters). 
MORNERA JACKSONICA, new species.

Plate 148, figs. 1-26.

Description.-The zoarium is elliptical, ramified in the strict sense at a very acute angle. The tubes are invisible exterion'ly; they hear flom two to foul vacuoles, two of which are adjacent to the apertura and are arranged at the hase of
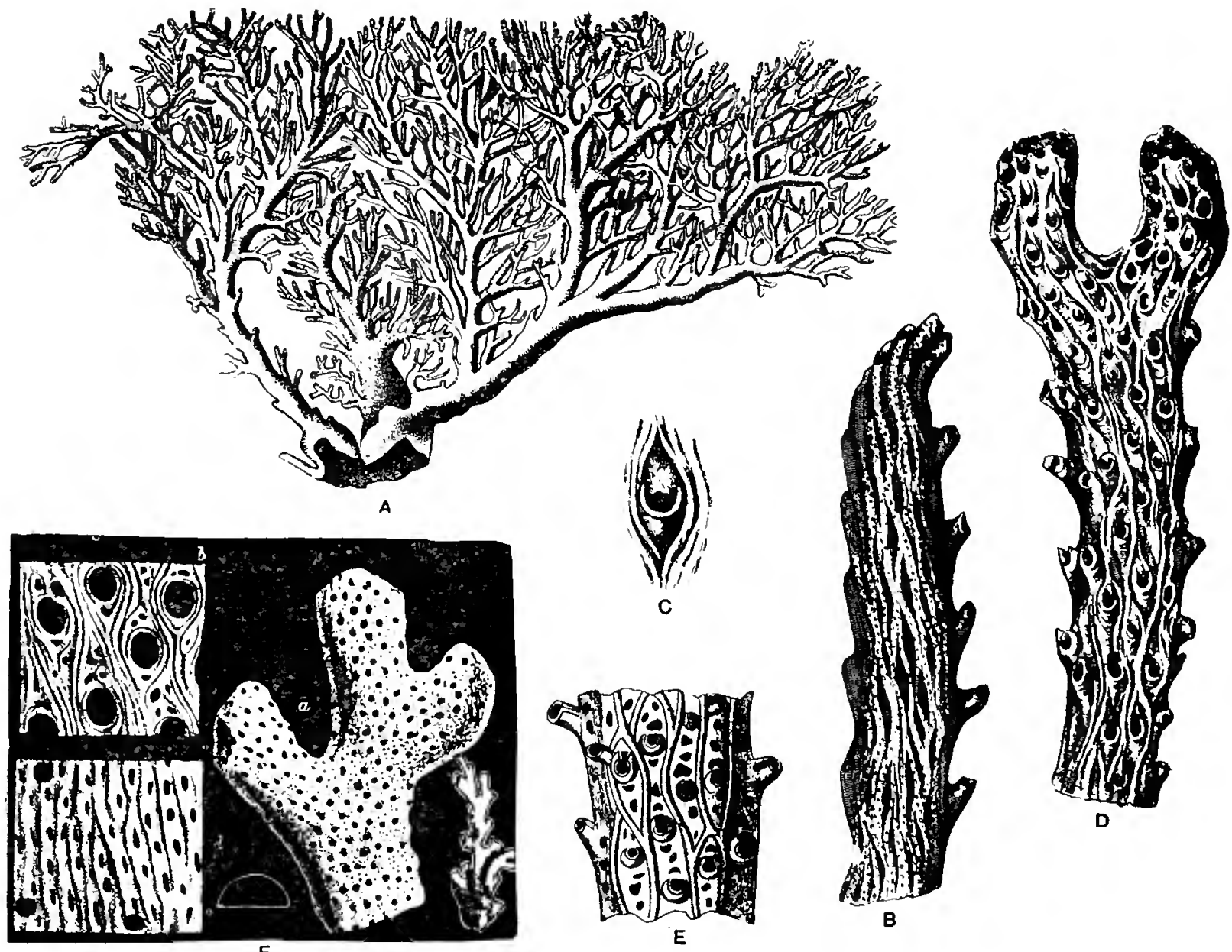

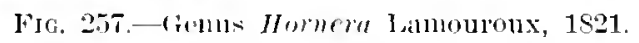

A-E. Homera frondiculati latumuroux, 1821. A. Complete zoalium, natural sizts. (After

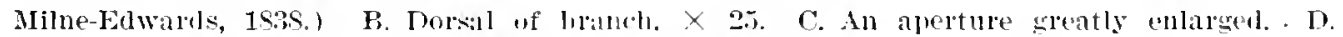

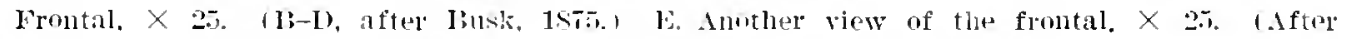
Waters.) F. Viens of the fossil form referml the speeies hy Rusk. 15 is.

one or two oblique sulci. The peristone is orbicular and little salient. The dorsal bears longitudinal snlei narrower than the nervi, and rather large vacuoles. The ovicell is elongated. elliptical, vely glohmlar, and quite punctate. 


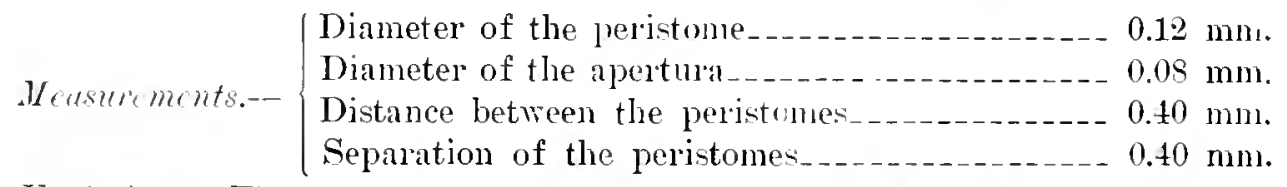

Tariations.- The peristome is not always salient (figs. 4,5 ), which reduces the diameter of the apertura (fig. $\tau$ ). The frontal nerri disappear easily in fossilization (figs. 6, $\tau$ ). The two large vacuoles adjacent to the apertura are very constant, lut some others may appear. Generally the more vacnoles there are, the smaller they are. The apertures are grouped quite rarely in transversal lines (fig. 9).

The dorsal face is quite rariable. Figure 10 illustrates the most frequent occurrence. The nervi become sometimes smaller and more numerous (fig. 11); rarely they become wider at the expense of the attemuated sulci (fig. 12).

The tangential section of the frontal always shows three or four vacuoles perforating the zoarium (fig. 13) the structure of which is composed of much crowded elements (fig. 14).

On the dorsal the vacuoles are maller (fig. 15) and their obliquity is easily risible (fig. 16). The removal of the dorsal fice by prolonged abrasion shows the usual lozenge-shaped interior: the carity mentioned by Hennig, 1910, therefore, does not exist (fig. 17).

The vacuoles radiate in every direction and are rarely parallel. Many successive longitudinal sections are necessary, then, in order to comprehend the zoarial structure. Figure 23 shows the great complexity of the dorsal plexus, figure 24 , the frontal vacuoles; figure 25 , the dorsal vacuoles; while figure 26 illustrates the lamellar and squamous structure of the walle.

Aftinities.-In the number of frontal vacuoles this species is close to Hornera frondiculatr Lamouroux, 1821, but it differs from this recent species in its orbicular and nonelliptical orifice and in its ovicell not provided with reticulations.

It differs from Hornera striate IIine-Edwards, 1836, in having more than two frontal racuoles and in its dorsal racuoles heing often lirger.

It differs from Hornera porosu Stoliczla. 1862. in its much smaller dorsal vacuoles and in its orbicular and nonelliptical orifice.

This species is found in all Jackonian deep-water localities.

Occurrence-Middle Jacksonian: Wilmington, North Carolina, (very common): $3 \frac{1}{4}$ miles sollth of Perry, Georgi (common); Baldock, Bammell County, Sonth Carolina (rare); 18 miles west of Wrightsrille, Johnson Connty, Georgia (common) : 12 miles southeast of Marshallville, feorgia (very common); 17 miles northeast of Hawkinsville, Georgia (common): 11 miles southeast of Lilly, IDooly ('onuty. (reorgia (very common); $? \frac{1}{2}$ miles north of Grovania, (ieorgia: one-half mile sontheast of Georgia Kaolin ('o. mine. 'Twiggs (ounty. (ieorgia (common).

Lpper Jacksonian (Ocala limestone): (Hd firctory, abent $1 \frac{1}{2}$ miles above Bain-

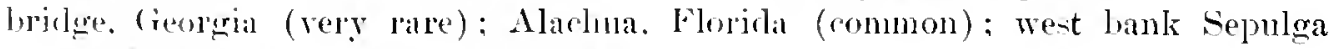
River, Escambia County, Alabama (very common).

Fotypes.Cat. Nos. 652.2, 65312. T.S.X.M. 
horNera RETERAMAE, new species.

Plate 114, figs. 1-8.

Deseription.-The zourium is laree, with retimated braneles, the fenetrae of which are elongated and fusiform. The tubes are invisible exteriorly: they hear two vacuoles adjacent to the peristome and a single suleus of little depth. The peristome is little salient and orbicular. The dorsal bears longitudinal sulci of little depth and rery litre vacuoles; the nervi are wide.

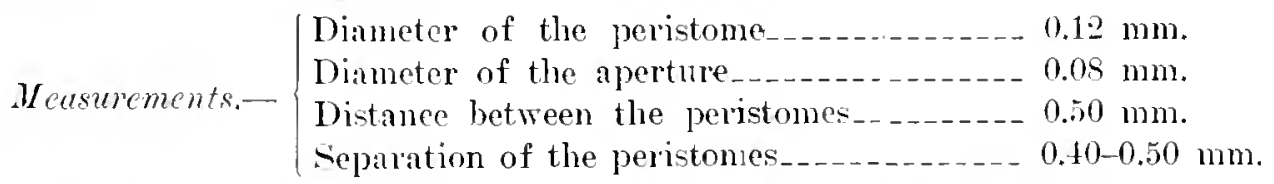

Affinities.-This speries is quite constant on the whole, and we have observed only the habitual alterations due to fossilization. It differs from IIomera reteporacea Milne-Edwards, 1835, in the speeial arrangement of the zonrial netrorli deprived of trabeculae and in which the branches are all of the same size.

It differs from Ilornera polyporoides in the absence of trabeculac and in the larger, zooecial dimensions.

Oceumence-Middle Jacksonian (Castle Hayne linestone): WVilmington. Sorth Carolina (rare).

Cotypes.-Cat. No. 6.3:2, U.S.N.M.

HORNERA POLYPOLOIDES, new species.

Plate 144, figs. 9-13.

Description.-The zoarium is reticulate and formed of compressed branches joined by short and thin transverse trabeculae. The tubes anc invisible exteriorly: they bear a single wide longitudinal suleus, at the base of which are three. fomr. or five large vaenoles. The peristome is wide, little salient, orbieular. On the dorsal the nervi are marrow, the sulei wide and deep. and the vacuoles large.

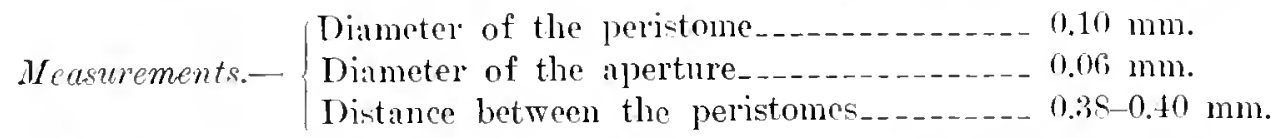

Tariations. - The number of frontal vacuoles is quite varialle according to the form of the branches. The dorsal vacuoles are often smaller when the sulei are more numerous (fig. 12).

Affinitics.-In its zoarium, this speeies resembles IIorm metcporucen MilneEnwards, 1838. Wut the Imerican species differs in its nore numerous frontal vacmoles. in its smaller dorsal vacuoles, and in the absence of two hape triangular vacnoles adjacent to the peristome.

It differs from IIorm ie peramac in its zoarimm formen of hianches joined by narrow traheculae and in the rery great irregularity of the fenestrae.

Occurrence-Lower Jaclisonian (Moodys marl): Jack-om. Mississippi (eommon). 
Middle .Tacksonian (Castle Hayne limestone): Wilmington. North Carolina (coimmon).

rotypes.-Cat. No. 65829, U.S.N.M.

\section{HORNERA TENUIRAMA, new speciss.}

Plate 144, figs. 14-23.

Description.--The zoarium is formed of small rami, round, and much branched, on which the zooecia leave little place for the dorsal. The tubes are invisible exteriorly: they hear two or three longitudinal sulci, at the hase of which there are two or three vacuoles. The peristome is somewhat salient, thick, orbicular. The dorsal is very narrow: it bears some longitudinal sulei with vacuoles of the sane size as the frontal racuoles.

Measurements.- $\left\{\begin{array}{l}\text { Diameter of the peristome_- } \\ \text { Diameter of the aperture } \\ \text { Distance between the peristomes- }\end{array}\right.$

Tariations and affinities.-In the frequent annular arrangement of the peristomes, this species much resembles IIomera subannulata Philippi, 1843, and $H$. hippolyta. Defrance. 1831. It differs from them in the considerable reduction of the dorsal, which is extremely narrow and which is not always easy to discem.

Occurrence-Middle Jacksonian (Castle Hayne limestone): Wilmington, North Carolina (very common).

Cotypes.-Cat. Nंo. 65330, U.S.N.M.

HORNERA TUBEROSA, new species.

Plate 145, figs. 1-3.

Description. - The zoarium is erect. of compressed and bifurcated branches. The tubes are invisible exteriorly; they bear a very wide, longitudinal sulcus with a single vacuole. 'The peristome is salient, thin, orbicular. The dorsal is convex; the longitudinal sulci are rather cleep; the vacuoles are very small; the nervi are wide, convex, and bear numerous salient tuberositics.

Affnitics.-This species is very well characterized by its dorsal tuberosities, this character never having been observed in any other known species. The only specimen found has been figured, but it is rery characteristic.

Occurrence.-Upper Jacksonian (Ocala limestone): Chipola River, east of Mariama, Jackson County, Florida (very rare).

IIolotype.-Cat. No. 65331, U.S.N.M.

HORNERA POROSA Stoliczka, 1862.

Plate 145, figs. 4-19.

1862. Horncra prosa Stoliczka, Oligocene Bryozoen von Tatdorf in Bernburg, Sitzungsherichte der li. Alsademie der Wissenschaften Wien, vol, 45, Abth. 1, p. 79, pl. 1, fig. 3.

Description.-The zoarium is formed of compressed branches bearing rami almost opposite. The tubes are invisible exteriorly; they bear two oblique sulci 
ornamented with large vacnoles. The peristome is salient, thin, elliptical, or oval. The dorsal is rery porous; the longitudinal sulci are of little depth, the nervi are wicle but little convex; the racuoles are lare but of lesser dinensions than the firontal racuoles.

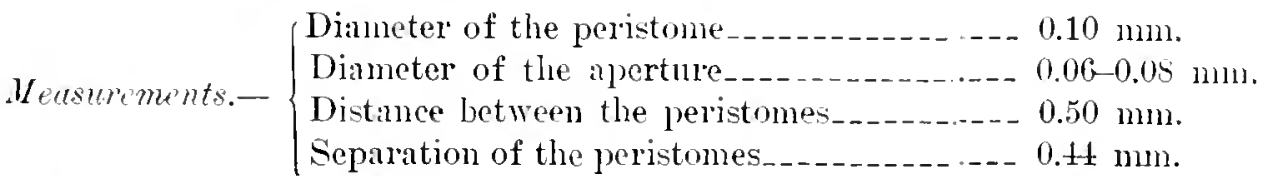

Truntions, - The peristome is very salient (fig: S) or scarcely projecting (fig. 10). When the frontal vacnoles are smaller (fig. 10) they are more numerous. The dorsal is exceedingly variable and it is impossible to discover the rule of variation. However. on the young branches the sulei are very narrow and the nervi very wide (fig. 14). Somewhat later the vacnoles are more visible (figs. 13, 15). Normally (fig. 12) the racuoles are large and the nervi little salient.
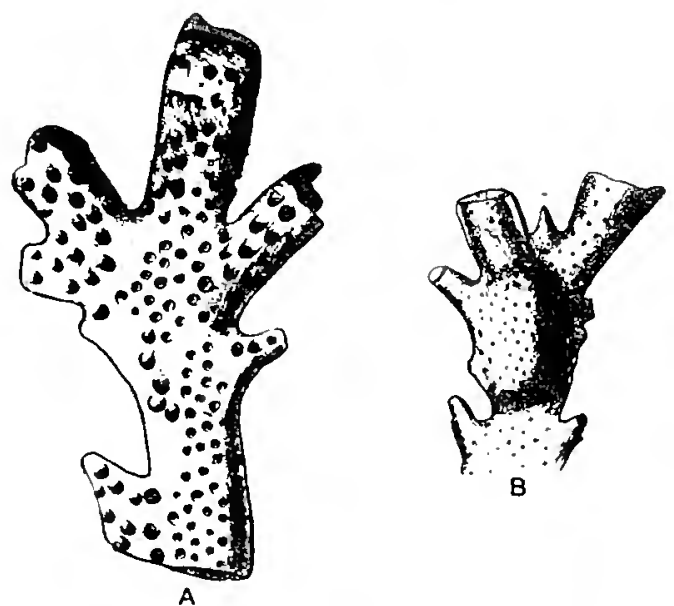
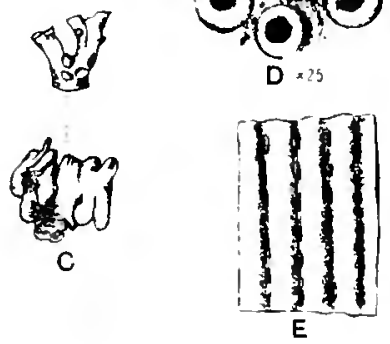

Frg. 258.-Genus Crassohomera Waters, 1857.

A. B. Frontal, $\times 12$, and dorsal, $\times 8$, of Crassohornera (Ceriopora) urbuscula Reuss, the latter showing the ovicell.

C-E. Viens of the zontium, natural size, and the frontal and dorsal, $\times 25$, of Crussohumera naipukurensis Waters, $158 \pi$.

The dorwal vacuoles are enlarged at their extremity, for in tangential seetions they appear smaller (fig. 17). As in all the species of the genus the elements are thick and crowded which makes it very difficult to obtain good thin sections (fig. 19).

The squamous and lamellar structure of the walls appear to result from the linear union of the primitive elements (fig. 18).

Atrinities.-The species singularly resembles Homera frondicalata Lamonronx. 1821. in the number of frontal vacnoles and in the elliptical form of the peristomes. It differs from it, however, in a smaller number of longitudinal sulei 
on the dorsal, and in the larger racuoles. We unfortunately have not yet dis. covered the ovicell, so that we are not able to confirm the identity of this species

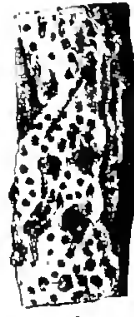

A

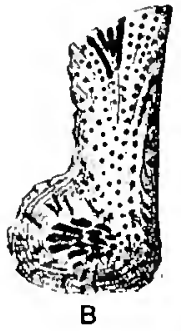

B

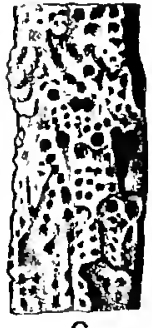

C

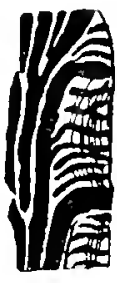

D with that of Lamouroux, as noted by Jelly in 1889.

Ocourenee.- Middle Jacksonian: Wilmington, North Carolina (rare) ; Baldock, Barnwell County, South Carolina (very rare); Rich Hill, $5 \frac{1}{4}$ miles southeast of Ińnoxille, Crawford County, Georgia (very rare).

Vicksburgian (Marianna limestore) : One mile north of Momroeville, Alabama (very abundant).

branch, $\times 8$, from the Cretaceous of England. B. A thin slice from a liranch, $\times$ 12, showing longitudinal and trausrerse sections. C. Dorsal of a well preserved specimen, $\times 10$. D. Longiturinal section, enlarged.

Geologieal distribution.-Iower Oligocene (Latdorfian) of Germany. Plesiotypes.-Cat. Nos. 65932, 6547s, 65479, U.S.N.M.

\section{Genus CRASSOHORNERA Waters, 1887.}

1587. Crassohornera Waters, Tertiary, Cyclostonatous Bryozoa from New Zealand, Quarterly Jourmal Geological Sucjety, London, vol. 43, p. 349.

Horneridae in which there are no frontal sulci. Genotype.-Crassohomera wapuhurensis Thaters, 1857 .

Range.-Priabonian-Miocene.

Genus SIPHODICTYUM Lonsdale, 1849.

1819. Siphodictym Joxspale, Notes on fossil /unlluytes, Quarterly Jommal Geological Society, Lomion, vol. 5, ก. 94.

" Horneridae in which the epitheca on the reverse sule is thick. The apertures are in irregular, transverse series. The maculae (=vacuoles) oc-

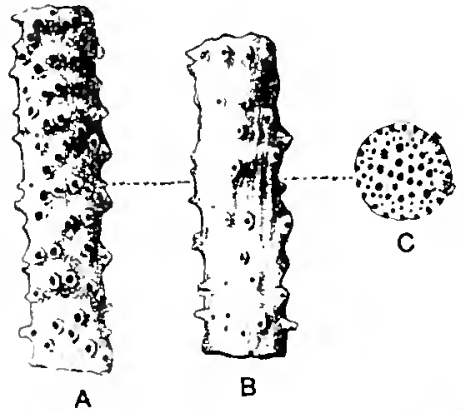

H1a. 260.-Genus Phormopora Miarsson, 1SST.

Frontal and dorsil aud end views, $X 16$, of a branch of lhormopora irregularis Marsson, 18s7. from the Cretaceous of the Island of Iiügen. (After MIarsion, 1Sst.) cur in single or double longitudinal series below the aperture. The reverse side is urnamented by rilges (= meri). which may be reticular." (After Gregory 1899.)

rruotype.-Siphodictyum gracite Lonsdale, 1849. Aptian.

The ovicell is unknown, but the zoarial structure is certainly that of the Horneridae. 
Genus PHORMOPORA Marsson, 1887.

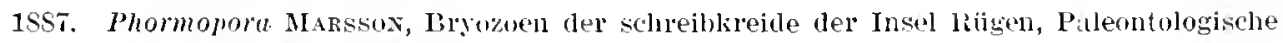
Abhandlungen, vol. 4. 1. 32.

Horneridae with evlindrical, dichotomous branehes. The apertures are seattered irregularly over the obverse face and not in regular transrerse rows. The reverse face is marked by small or well-developer tubuli.

Genotype.-Phormopora irregularis Marsson, 1857. Senonian. (After Gregory. 1899.)

The section published by Marsson appears to indicate the lamellar and squamous strueture of the Horneridae. but the ovicell is unknown.

\section{Family FRONDIPORIDAE Busk, 1875.}

187.5. Frondiporidae Busr. Catalogue of Marine Polyzon in the collection of the British Museum, pt. 3, Cyclostomata, rol. S. 1) 137.

The larva is elongated; the orifice of the palleal eavity and the orifice of the sack do not occupy exactly the two poles of the enbryo. The ovicell is arranged between the fascieles and is traversed by isolated tubes. The tubes are cylindrical.

The genera belonging to this family are: Frondipora Imperato, 1599. Teloporte, new genus, and perhaps the following forms: Fascieuliport D'Orbigny, 18t6, Discofascigera D'Orbigny, 1853, and A psendesia Lamonroux. 1821.

The zoarium is formed of tubes arranged in fiscicles. All the tubes have the same diameter throughout; they are not thinner at the base as in the zoarial forms Entalopora, Idmonen, ete. In transrerse section the tubes of the eenter have therefore the same diameter as those of the periphery, as in the zoarial forms, Heteropora and Cerioporu. There are therefore eylindrical tubes arranged in bundles. They put forth new tubes by ramification. The basal lamella is very thick and is formed by the exterior wall of long basal tubes withont polypide which ramify at nearly the half of their length. Each basal tube takes its origin on the interior of the zoarium which is just the contrary to what is observed on the basal lamella of forms with conieal tubes.

The Frondiporidae are extremely rare in our American Tertiary formations. They appear to have disappened from our recent American water's; neither Smitt. Robertson, nor Osborn eites a single species of the fimily. On the contrary, the specimens of this family swarm in the Mediterranean.

\section{Genus FRONDIPORA Imperato, 1599.}

1590. Frontipora Imperato. Dell IIistoria naturale, p. 631.

"Frondipora has the ovicell across the anterior surface of a branch, not much raiced, and the oeciostome, about $0.12 \mathrm{~mm}$. wide, with the lower edge straight, also is but little raised, and is not attached to a group of zooecia." (Waters.) The fircicles are arranged only on the anterior face of the zoarium. 

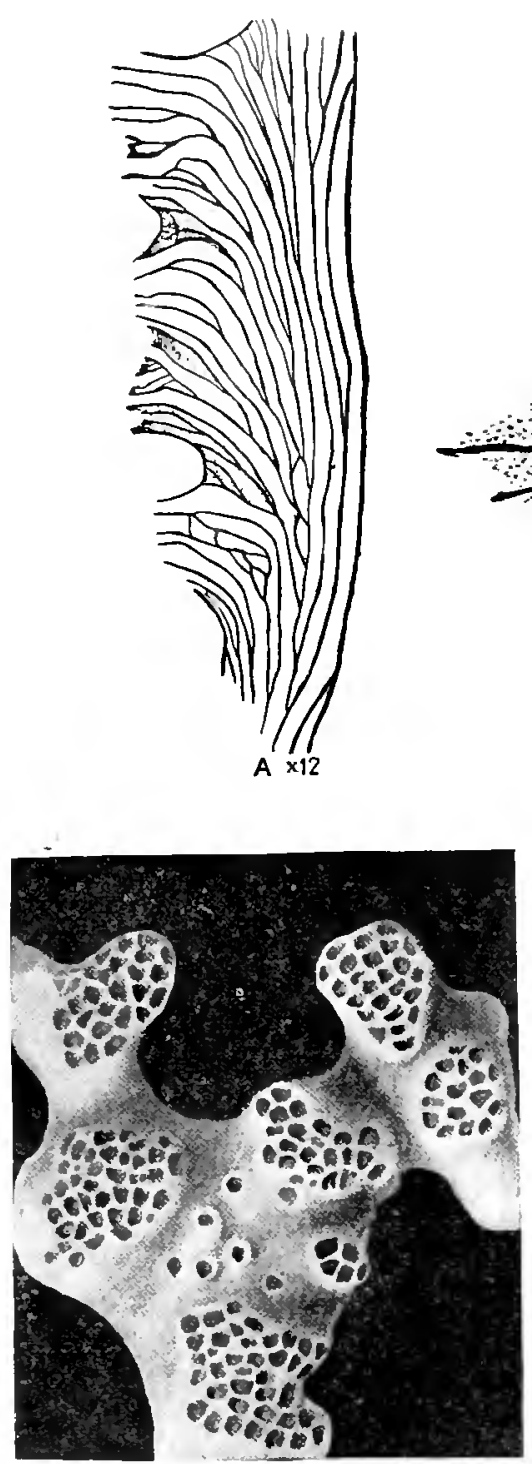

$\mathrm{F} \times 12$
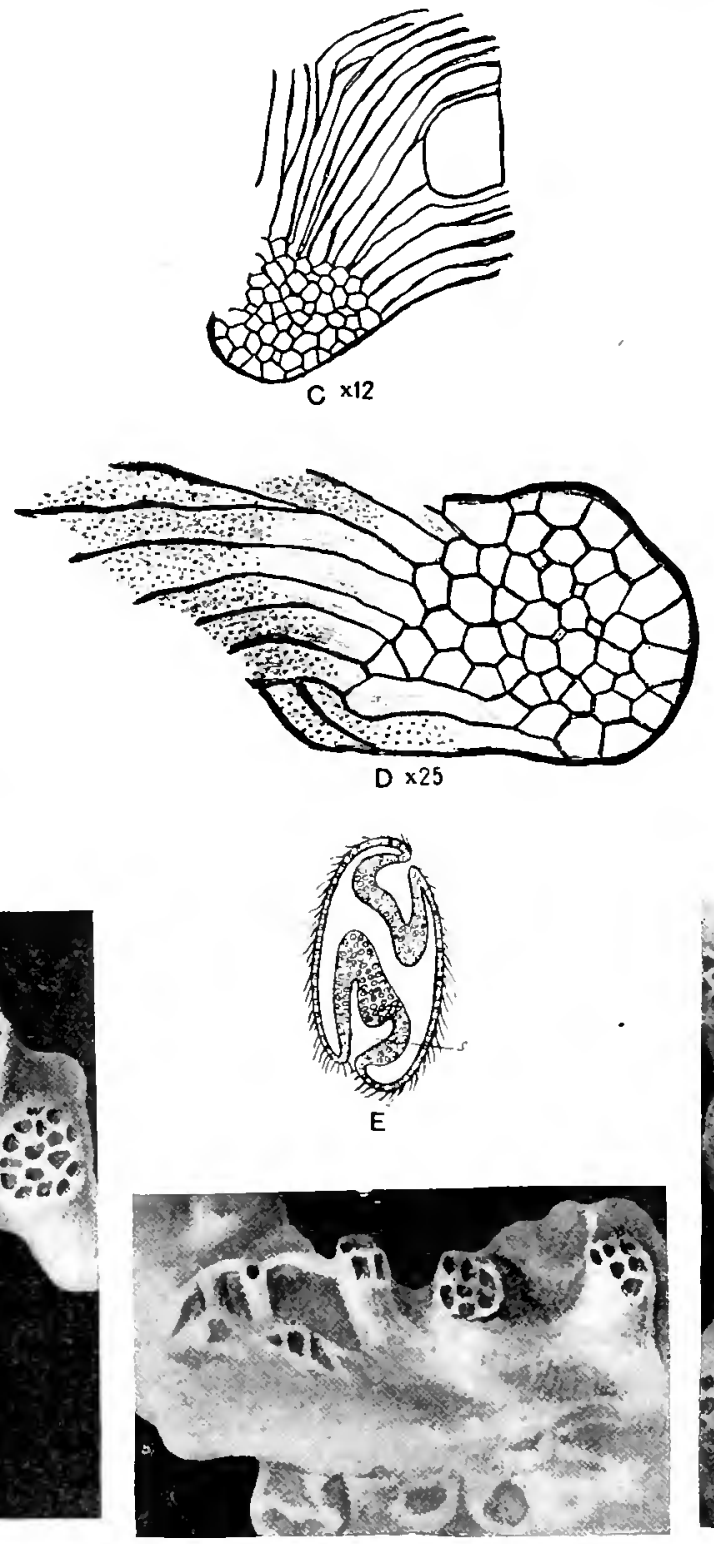

$\mathrm{H} \times 12$
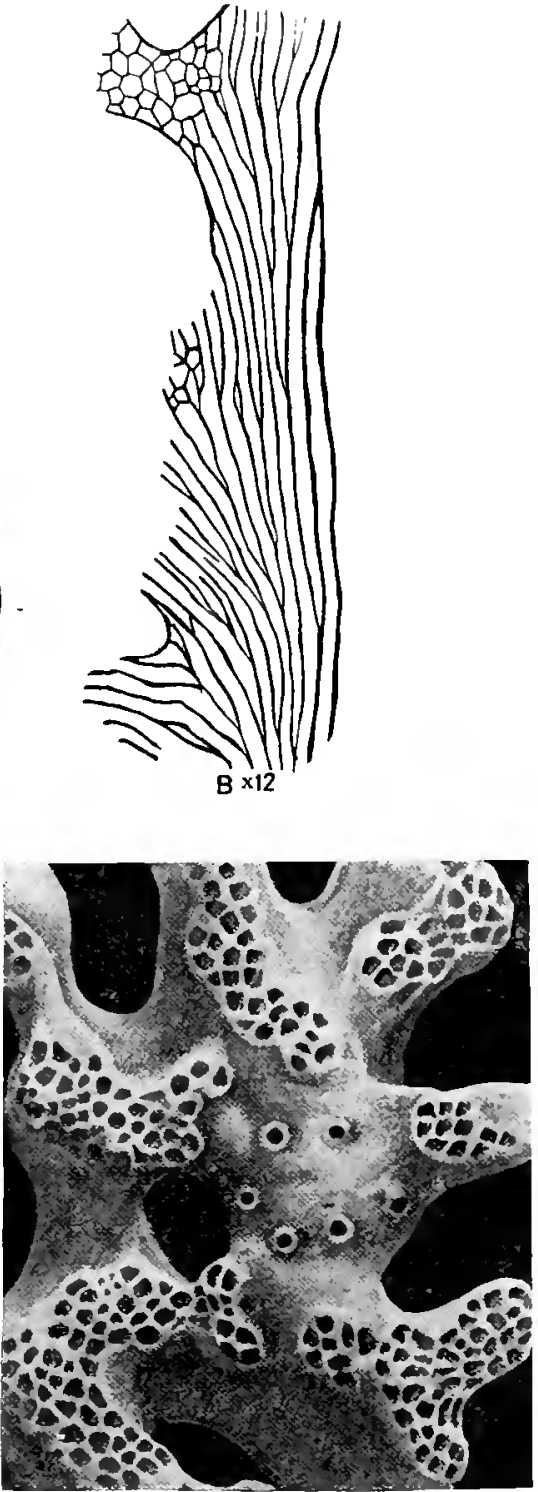

$\mathrm{G} \times 12$

Fig. 261.-Family Froudiporidae Eusk, 1875.

1-H. Frondipora terrusa Lamouroux, 1821. A, I. Two longitudinal thin sections of a branch, $\times$ 12. C. Transwerse section, $\times 12$, through an ovivelled branch showing the position of the ovicell hetween the fascicles. D. Transverse section through a branch, $X \mathbf{2 5}$, and cutting a fasciolo lonsitulinally. E. Larva of Frondipora showing internal sac (s). (After Barrois, 1952.)

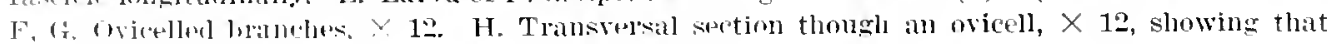

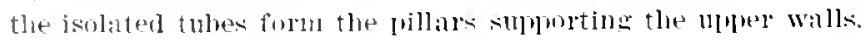


Genotype.-Frondipoia verrurosu Lamonronx, 1821.

Rangc.-Priabonian-Recent.

The zoarial variations are very great. Generally the zoarium forms true bushy masses which assume the most fantastic and elegant forms. Our fossil specimens are only the insignificant remains of such zoaria.
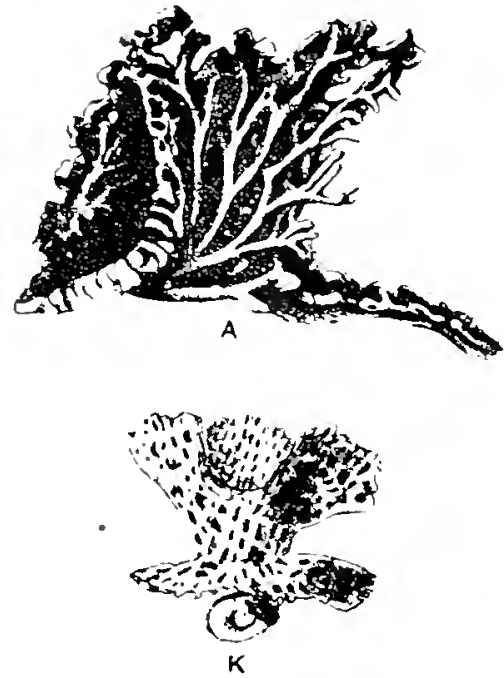
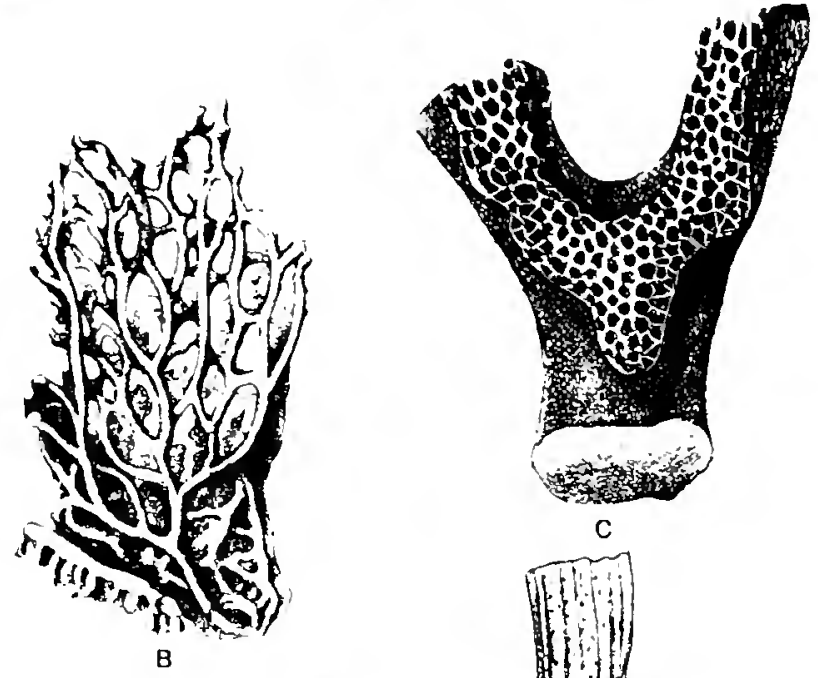

C
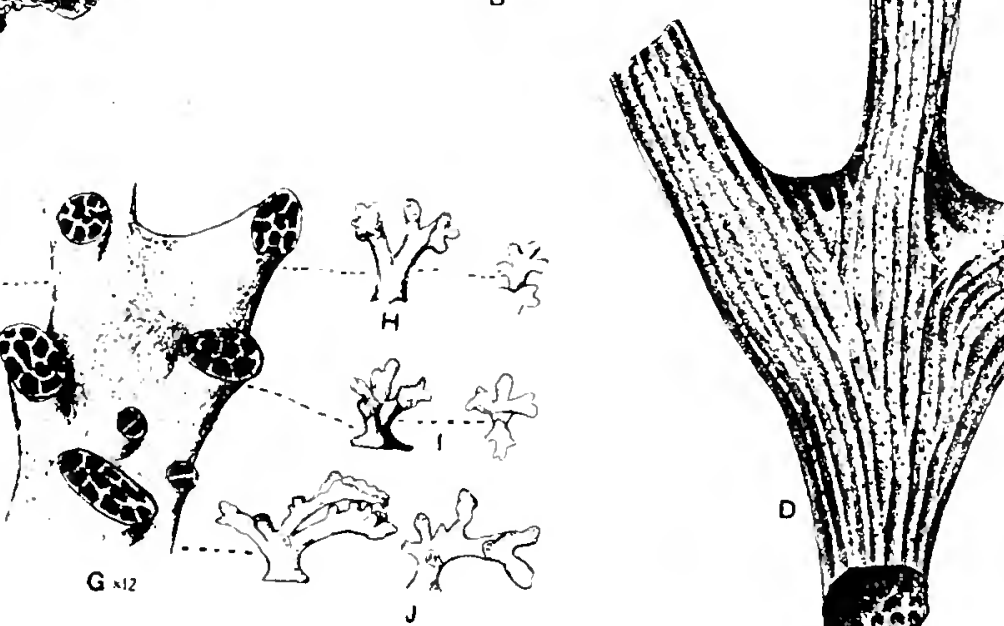

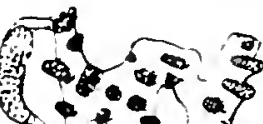

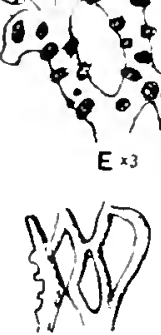

$\mathbf{F}$

ta.
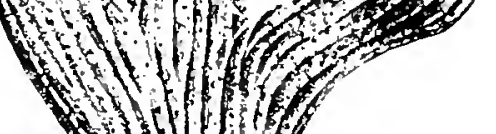

(1)

Mt 15

○

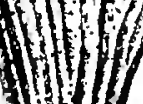

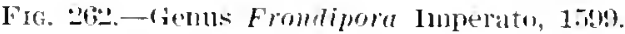

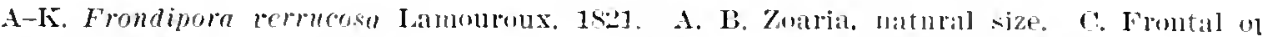
lranch, $X$ 25, showing fascicles confluent. D. Dursal, $\times$ 25. (A-I', after I;usk, 1975.) E.

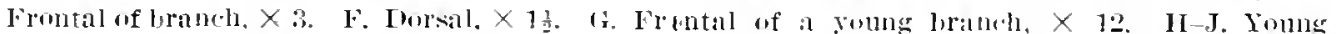
specimens, natural size. K. Colony, natural size. frowing on a slebll. (E-K. after Waters, 1ST9.) 


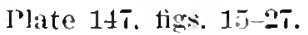

Description.-The zoarium is formed of compressed and dichotomons branches. The fascicles are formed of two to five tubes; they are little salient and arranged in compact groups or ju linear series. The tuhes are distinct, separated by a furrow; the peristome is thin, orbicnlar, or polygonal. The posterior face is convex, striater longitudinally by the tubes. The interfascicular spaces are smooth.

Variations.- The arrangement of the fascicles is quite variable; there is not one which resembles another. They are scattered or in alternate lateral, pluriserial, or monoserial series, very salient or hardly salient. There are never any isolated tubes between the fascicles, as in Frondipora interporosa.
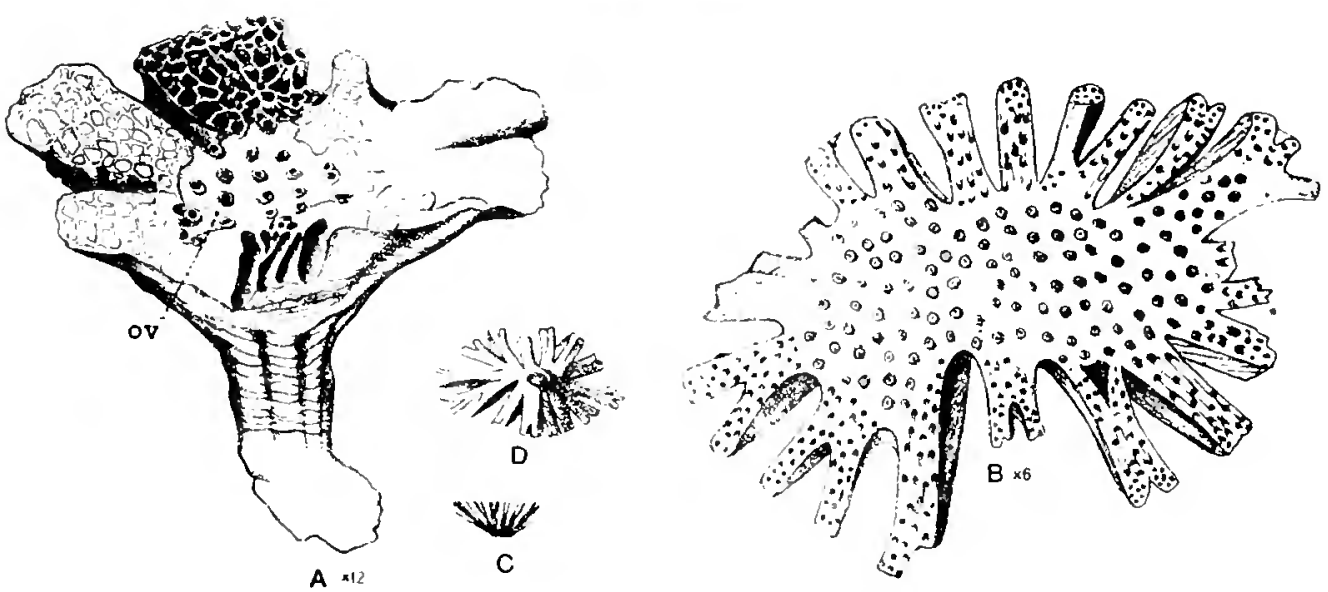

FIG. 263.-Telopora, new genus.

A. Telopora (supereytis) zatersi Harmer. 1915. Vinw of ovicelled zoarium, $\times 12$.

B-D. Telopora (supercytis) digitata Waters, 1ss4. I3. Top of view of zoarium, $\times 6 . \quad C$. Side view, natural size. D. Basal view, $\times 2$.

In transverse section (fig. 26) all the tubes are of the same diameter. Between them there are some small pores which appear to be new tubes. The latter. promptly attain their normal diameter, as can he seen in longitudinal section (figs. 24, 25). The peristonie of the tubes makes a more or less acute angle with their longitulinal axis (figs. 24. 25). There are sometimes diaphragns in the tubes.

Occurrence.-Mirllle Jacksonian (Castle Hayne limestone): Wilmington, North Cinrolina (riare).

Cotypes-Cat. No.65.t36, C.S.X.M.

FRONDIPORA INTERPOROSA, new species.

Plate 148, figs. 20-29.

We have only collected five specimens of this species. It differs from Frondipora laevigata in the presence of isolated tubes between the fascicles.

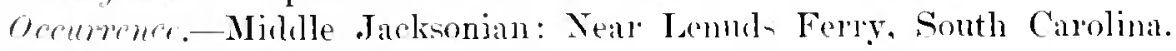

Cotypes.-Cat. No. 6.̃̆t.1. T.R.X.M. 
TELOPORA, new genus.

Greek: telos, end, in allusion to the position of the ovicell.

Oricell at the end of the erect colony spreading over the whole width.

Genotype.-Thopore (Supercytis) watersi Hamer, 1915.

Rangr.-Miocene-Recent.

Telopora (Supereytig) digitata Waters, 188t, belongs to this genus.

This genus presents the greatest zoarial analogy with supereytis Dorbigny, 15.2. but the ovicell is totally different.

TELOPORA ? PATENS, ner species.

I'late 14 , figs. 2t-2i.

Leseription.-The zoarinm is supported on a spreading base attachecl to algae: it is formed of wide divergent branches, little erect. irregularly branched. The anterior or cellular face is covered by the oblique orifices of the tubes. The posterior face bears sulci with large pores at the base.

Aftinitics. - This species is not a Telopord, for this gcuus does not present snlei on the dorsal. The figured specimen only has been discovered. We have thought that it was useless to form a new genus for a nonovicelled specimen of which we are unable to make a section.

Occurrence. - Middle Jacksonian (Castle Hayne limestone): Wilmington, North Carolina (rare).

IIolotype.-Cat. No. 65452. T.S.X.M.

\section{Forma FASCICULIPORA D'Orbigny, 1816.}

1846. Fasciculipora D'ORBIGXY, Voyage dans l'Amerique - Mérillionale, vol. 5 , pt. 4 , p. 20.

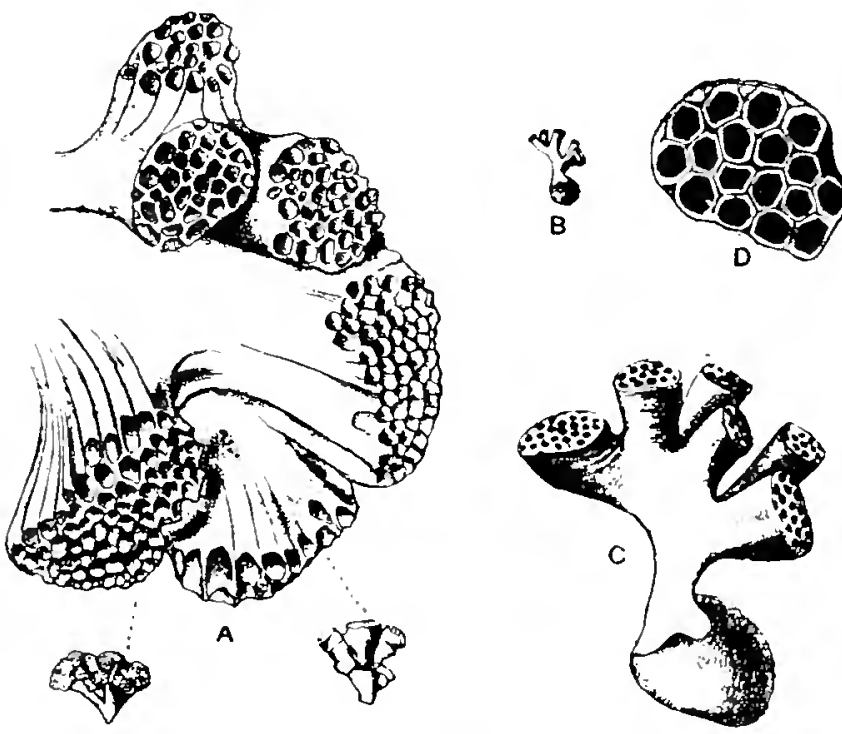

Fig 264.-Genus Fasciculipora D'orbigny, 3841.

A-D. Fasciculipora ramosa Dorhigny, 1s46. A. The funciform zoarium, natural size and enlarged (after Busk, JS75).

-Zoarium with long $\mathrm{P}-\mathrm{D}$. D'Orbigny's original figures of the species, representing branches, which may be sim- the zoarium, natural side and enlarged, and the zomecial surface ple or branch into a dendroid enlarged. Recent. South Patagonia.

stipitate zoarinm. The capitulum is simple or lobed. The branches are cylindrical and may be clarate. The sides may be covered by a thick epizoarium, or marked by interzooecial striae or grooves." (After Gregory.) 
Genotype.-Fasciculipora ramosa D'Orbigny, $18+6$.

Range.-Neocomian-Recent.

This grenus differs from Frondipore in its long fascicles not arranged on a single side of the zoarium. The ovicell has never been discovered. It is therefore convenient to consider it only as a zoarial form.

\section{FASCICULIPORA SURCULIFERA, new spccies.}

Plate 14S, figs. 14-19.

We have cliscovered only the two small specimens figured; these are two small branches of which we have not been able to make a section.

Occurrenec.-Upper Jacksonian (Ocala limestone): Alachua. Florida (very rare).

rotypes.-Cat. No. 65450, U.S.N.M.
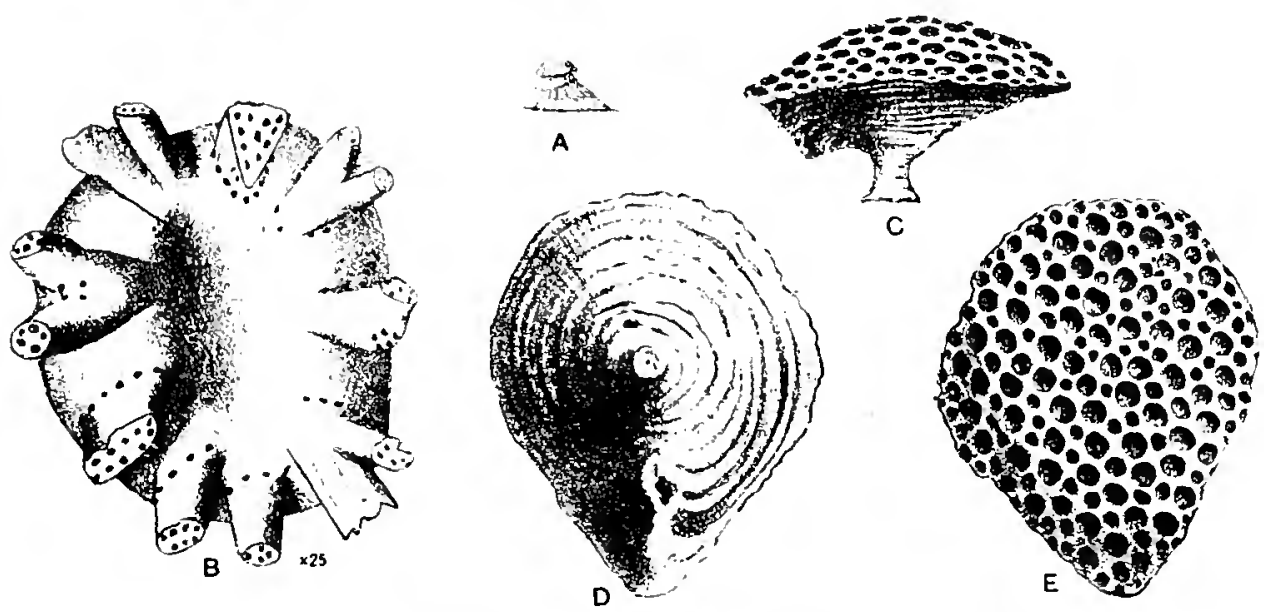

FIG. 265.-Furma Iniscofascigera Dorbigny, 1852.

A, B. Views of Discofascigera (Defrancia) exaltata Waters, 1884, natural size and $\times \mathbf{2 5}$. C, D, L. Various aspects enlarged of a zoarium of Discofascigera ligcricusis D Orbigns, 1852.

Forma DISCOFASCIGERA D'Orbigny, 1852.

1552. Discofascigera D’orbigny, Paleontologie française Terrain Crétacé, Bryozoaires, rol. 5, p. 674 .

The zoarium consists of a single, unbranched bundle of zooecia: the zooecia are short, and the zoarium is fungiform, consisting of a short stalk which rapidly expands above into a circular or subcircular disk, with a convex upper surface. A pertures crowded and all on the upper surface of the zoarium: they are either irregular or subquincuncial in arrangement. (After Gregory. 1909).

Genotype.-Discofascigera ligeriensis D'Orbigny, 1852.

Range.-Albian-Miocene.

The Tertiary species cited by Gregory are: 
Discofascigcra (Defrancia) cxaltata Waters, 1854. Miocene of Australia.

Discofascigcra (Defrancia) brendotensis Waters, 189.2. Priabonian.

I)iscofascigra (Discotubigera) actinoides Manzoni, 1878. Miocene of Europe.

Discofasciger (Supereytis) digitata MacGillivray, 1895. (=Telopora.)

All these species are extremely rare. Their ovicells have never been observed. We therefore consider D'Orligny's genus as amended by Gregory, as a zoarial form and twe describe it here for convenience in determination. There is no evidence to show that it is a member of the Frondiporidae.
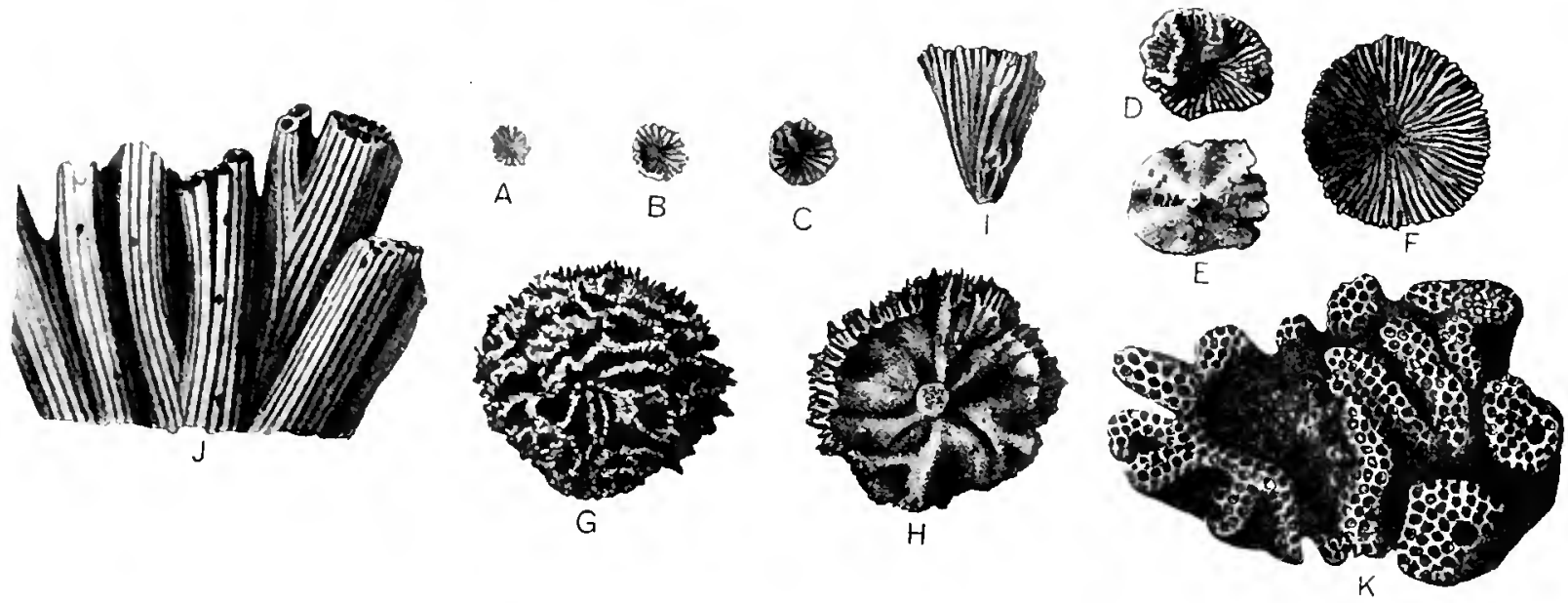

Fig. 26i.-Forma Apsendesia Lamouroux, 1s:21.

A-K. Apsendesia eristata Lamouroux, 1821. A-D. Top views of four zoria, natural size. E. IBasal view of speeimen I'. F'. Young zourium, natural size. G. H. Top and batsal viens of a well-dereloped example, natural size. I, J. Elerated branches, natural size, and $\times \subseteq$. The summit of the same branches. $\times 8$.

Forma APSENDESIA Lamouroux, 1821.

1821. Apsendesia I Amovrovx. Exposition méthodique des genres de l'ordre des Polspiers, arec leur description et celle des principales especes, p. $\$ 1$.

"Fascigeridae with a massive zoarium, which derelops from a small cupshaped disk. The zooecial groups in the adult are long, and form irregularly sinuous series, which may be so cromcled that the zoarium becones massive. Apertures all on the ends of the zooecial bundles." (After Gregory. 1909.)

Genotype.-A pendesia cristata Lamouroux, 1821.

Range.-Jurassic-Cretaceous.

This is a zoarial form in which the ovicell has not yet been discorered.

Subdivision RECTANGULATA Waters, 1887.

The ovicell is developed perpendiculary to the terminal zooecial axis between the peristomes and not between the tubes. 


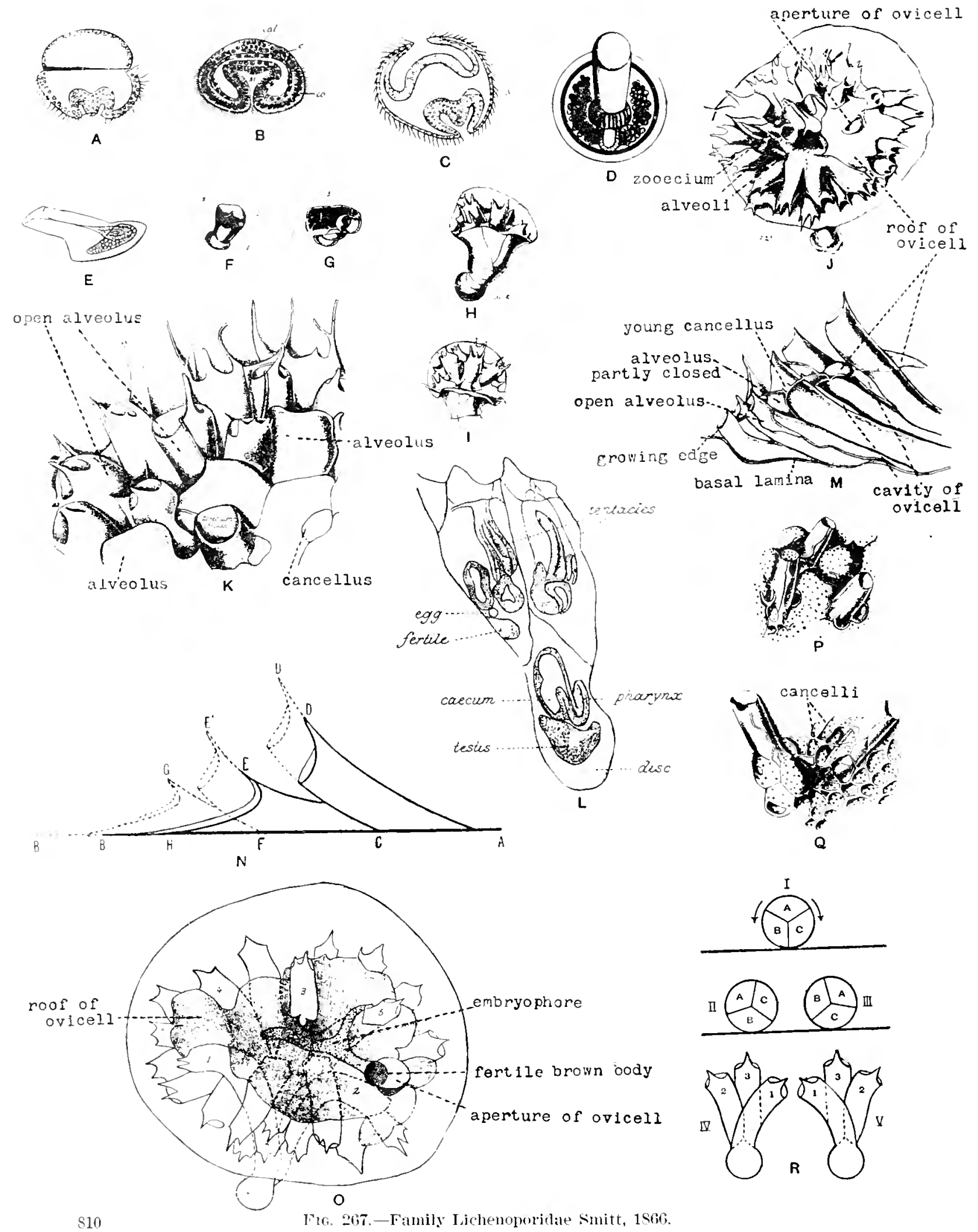




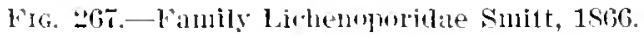

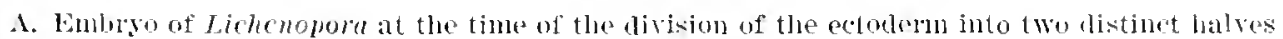
of which one is destined to be recovered.

B. Enbryo of Lichenoporn hispida Fleming. 150S. Meridian seetion of an embryo more anvanced in its develoment than the precoling one. The internal sac (si) the (womal low the thickness of the calnte (cal) and the palleal epithelum (c) are diflerentiated at the cust of the external cellular layer. The interml celular liyer forms a liniug which continues to the earity of the emhryo. (After Calvet, 19k).)

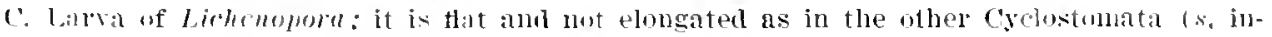
terual sae). The calotte is covered by the mantle, a feature which does not exist in the larva of the Cheilostomata. (After Barrois, 18s6.)

D, F. Protoecium of Lichenopma sen from the frout and in protile. (After liarois, 1SS6.)

F-R. Lichenopora remensa Fabricius. F-I. Drawings showing development of the ancestrula and formation of the zoirium.

J. Colony in which the roof of the ovicell is develoning. The aperture of the wicell is not yet completely formet. The proximal elge of the basal lamina has nearly reached the protoecillum.

K. Palt of the growing elge of an alult colomy, showing the way in which new zovecia are formed and representing varions stages in the development of the alveoli.

I. Horizontal section of a colong cunsisting of three complete zooecia only and showing the anatomical structure.

M. Thick radial section of part uf an old colony showing the relations of the wicell to the zooecia.

X. Diagram of the growth of the milrin uf the colony. The thick lines represent two young zonecia and part of the hasal limina as they would be seen in the radial section, and the lotted lines represent the condition of the corresunding parts after a certain amount of rrowth has

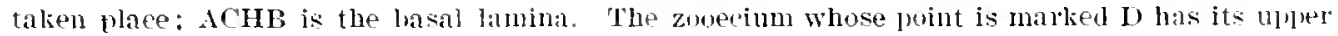
end free, even in the earlier conditin, while that marked $E$ is still incomplete on its distal side (fig. Ii).

O. Futire colony stainel and mounter in canada balsam. The shaded part shows how much of the ovicell is completely roofed. The al reoli which are still unroofed are not slecially indicated. The ovicell has an aperture, at the base of which is the fertile brown body (trimary embryo). Parts of the zooecia which a re sem either through other zooccia or throush -the lout of the ovicell are indicated hy duted lines. The colony is left-handed. Ziz is oceludul and was whiously fertile and would harly have heen visible at all in a dry propation. The embryophore is that part of the oricell in which the secombary embryos are develned.

I'. Zoofcia from an old culony. The alveoli ale sill elistinctly visible and the cancelli are commencing in the interalveolar grooves or at the base of the zonecial. The left land zunecium is closed by a poruus catcareous cap.

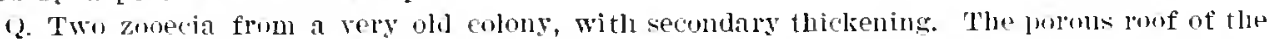
oricell is seen at the bottom of a sel of honey cmmb-like suaces, the so-called "eancelli" : somte of these are coverine the bases of the zoue-iat, and in the left hand zoocium these are entirely or

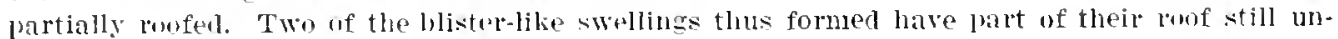
cincifierl.

I. Diagram to explain the difference between "right-handed" (dextral) and "heft-handerl" (sinistral, colonjes. (F-li, after llamer. 1896.) 


\section{Family LICHENOPORIDAE Smitt, 1866.}

Inatomical biblionraphy.-1854. Waters, Closnre of the Cyclostomatous Bryozoa, Journal Limean Sucirty, Zuolugg, vol. 17, p. 403, pl. 17, figs. 1. 6, 7, S.-1986. Parrors Mémoire sur la Meta-

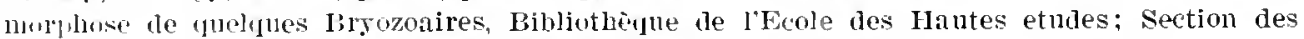

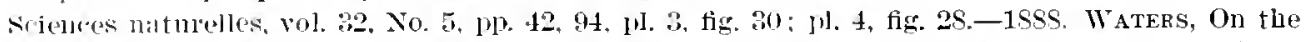
"vichlls uf some Liclenoporidae, Journal Linnean Society, Znology, vol. 20. pp. 280-285, p]. 15.150N; H.immer, On the development of Lichenunrit verucaria Fabricins, Quarterly Journal Mirlusopical Science, new ser., vol. 39, pl. 71-144, pls. 7-10.-1914. Waters, The Marine Fanna of Zanzibar and British East Africa, Zooluxicul suriety of London, n. S36.

The larra is very large and flattened. It is not elongated as in the other cyelostomes. The ovicell is lobate; it covers the zon rial center or it is placed betreen the farcicles. The oeciostome is rery large. The zonecia are joined in radiating facicles. The cancelli are placed at the zorial center and hetween the fascicles.

The cancelli are adventitious tubes which reem peculiar to the Lichenoporidae. They are garnished with spinules and are closed by a finely perforated calcareous lamella. Their structure is constant for each species and characterizes the species. Their function is muknown.

Generally the tubes are terminated by a long. very fragile point called the gate (=visor) by Jullien. The part which it protects forms a trap for diatoms.

The first tubes issned from the ancestrula are not parallel to it. This obliquity explains their peculiar spindle arrangement in the median sections where their projection on the flat section is alone visible. This arrangement does not exist in the Tubuliporidae.

The ovicells often cover the cancelli; but in the sane species the contrary may oceur and the cancelli may cover the ovicell.

The tubes never creep on the basal lamclla. They bend upward immediately after their formation. The abrasion of the lower face of the zoaria offer's, therefore, the aspect of a transverse section in the tuhes.

Genus LICHENOPORA Defrance, 1823.

1823. Lichcnopora Defraxce, Dictionnaire des sciences naturelles, vol. 26, 1. 250.

The zoarium is orbienlar, simple or composite. The faseicles are mono- or p]uri-serial. The oricell is placed in the center of the zoariunn. Its oeciostome is larger than the tuljes.

Genotype.-Lichenopora (Discopore) hispida Fleming. 18⒏

Range.-Neoconian-Recent.

This genus has been dismembered by the paleontologists into many other genera according to the zoarial rariations. Text figure 269 gives a summary of the genera as recognized by Gregory, 1899 . The zorlogists hilve never recognized them because the same species is capable of taking a number of zonrial forms and because these zerarial forms elo not correspond to special functions.

The Lichenoporidae are very fragile. They ane easily broken. On the fossils the visurs are rarely preserved in their entirety. The determination of the species, 
eren the recent ones, presents therefore nuch difficulty. Is the oeciostomes and the cancelli can only give constant chanders, we have given a smmmary in figure 256 of our knowledge of these impontant organs. On the fossils we have not ret discovered the complete oeciustome and this absence of eharacter much weaken the determinations.

The first two zooceia issued from the ancestrula determines the direction ol the tubes in a given section. Wo call them directrices and they are always of a smaller diameter than the other twhes.

LICHENOPORA BOLETIFORMIS ReUss, 1869.

Plate 180, figs. $1-11$.

1569. Ralionora boletiformis Reuss. Palliontologische Studien iber die ïlteren Tertiïrschichten der Alpen, Denkschriften der k. Akademie der Wissenschaften, Wien, wol. 29, p. S1, pl. 2S, fix. T (1) (not Tecticavea boletiformis Dorbisny, 1Sät, nor Lichenopora boletiformis Waters, 18s4.)

Description.-The zonrinm is free and reposes on the substratum only by a thin peduncle. It is formed of many limellae superposed. Each lamella contains many confluent subcolonies. The basal lamella is thick and striated concentrically. The subcolonies are orbienlar or elliptical with a large central area. The fascicles are little salient. short, biserial or triserial. The tubes are small and deprived of visor. The cancelli are larger than the tubes: they are polygonal and their walls are thin.

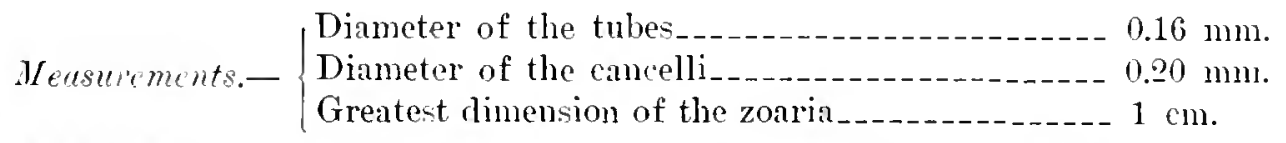

Tariations.-The fascicles become much attenuated and the zoaria have then much resemblance to Ceriopora (fig. 6). The zoarium has no fixed form, but a very convex ensemble is the most frequent. Each subcolony has no special basal lamella. The tubes are polygonal (figs. 7.8 ) in the sections but they are romd in the broken portion. The spinules of the cancelli (fig. S) a re small, mumerons, and arranged in longitudinal series.

The median sections vily acording to place where they are made. In a section (fig. 10) perpendicular to the fascieles the tubes are seen from the front. In section (fig. 11) practically within a fascicle the tubes appear in their lenirth and parallel to each other.

Affinities.-On accomt of its multiserial fascicles this species is rery cluse to Lichcnopore mediteranea Michelin, 1815, and to Lichcnopore ermucose Philipipi, 1St3. It is distinguished from them by the greater micrometric and zoarial dimensions.

Oecurstnet-Middle Jacksonian: Wilmington, North Carolina (common): Eutaw Springs. Sonth Carolina (very common) : Ballock. Barnwell County. South (arolina (rare).

Grological distribution--Priabonian of the Ticentin (Renss).

Plesiotypes.-Cat. No. 65t.s. I.S.N.M. 

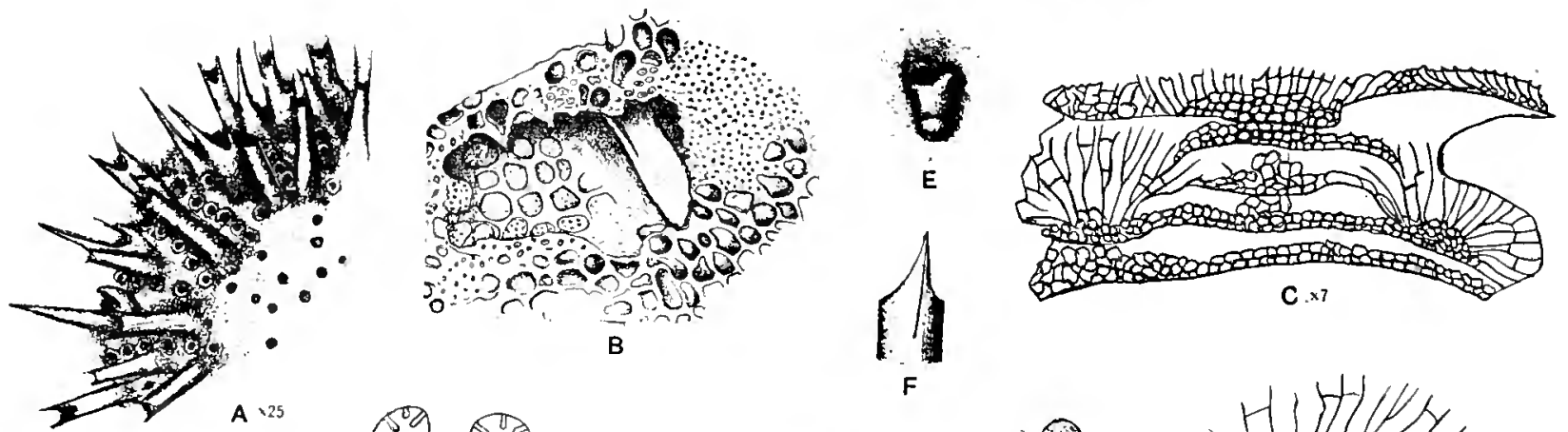

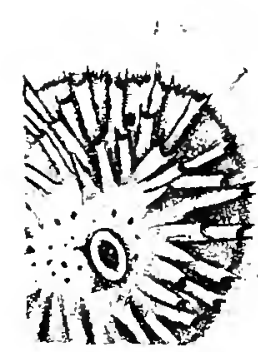

G $\times 25$

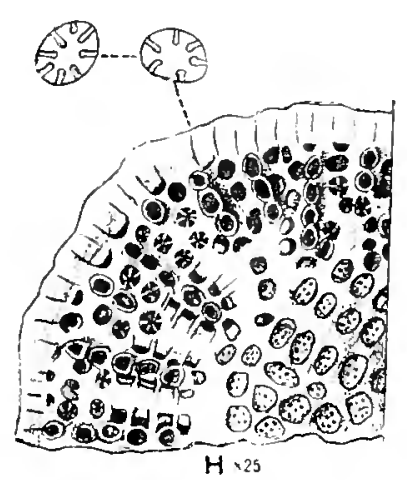

H $\times 25$
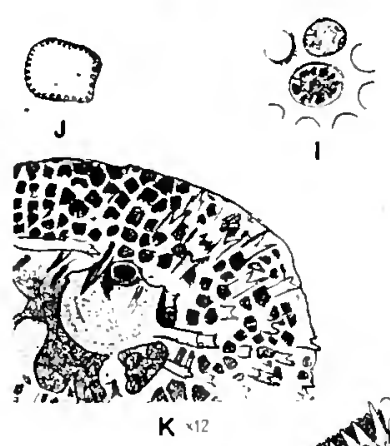

$K \times 12$

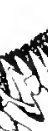

- 1 -
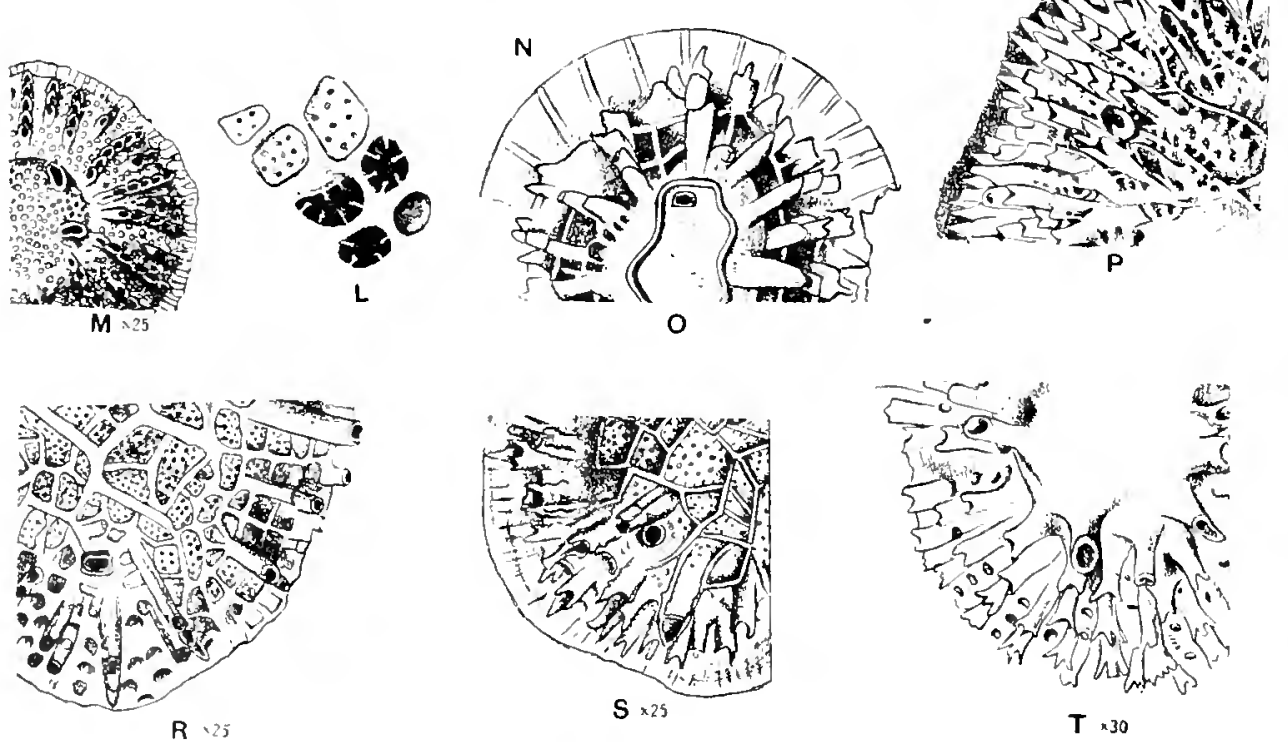
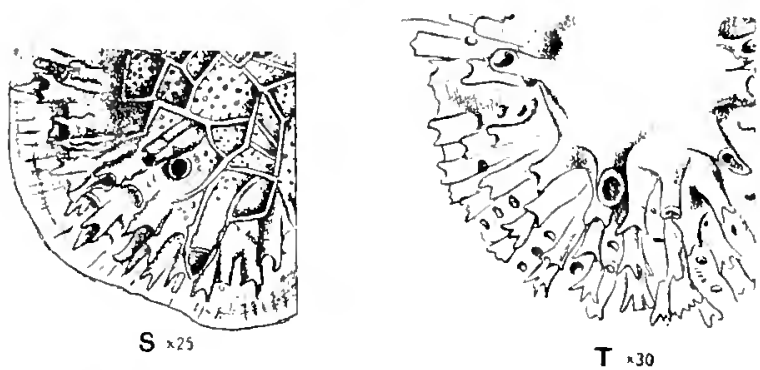

Fig. 268, - Genus Lichcnomora Jefrance, 1523.
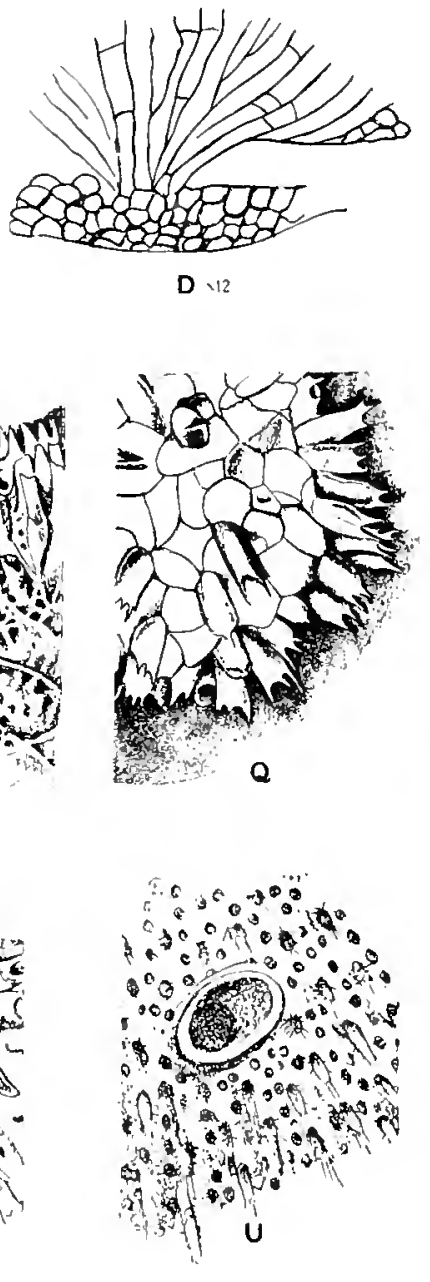
Fig. 265.-Genus Lichenopora Defrance, 1823 .

A. Fragment of the zoarium, $\times 25$, of richenopora hispida. Fleming, 1S2S, showing the cancelli and the tubes provided with the visor. (After Hincks, 1Sso.)

B. Ovicell of Lichenopora bullatn MacGillivas, 1SS6, superposed upon cancelli. (After MacGillivray, 1SS9.)

C, $D$. Longitudinal section, $\times \mathbf{7}$, and $\times 12$ of Lichcnoport bolctiformis Reuss, 1869 , it fossil from Aldinga, Australia, showing tabulae irregularly placed. (After Waters, 1SSt.)

E. Protoecium of Lichcnopora hispida Flening, 1S2S.

F. A single cell of Lichcnopora rermcaria Fabricius, 17S0, showing the acuminate matrin. (F, F, after Hincks, 1SSO.)

G-U. Figures showing oeciostonies and spinules of the cancelli. G. Lichonopora hispidu Fleming, 182S. (After Fincks, 1S50.) H. Lichenopora holdsworhi Iisk, 1S5. (After Waters, 1SSS.) I. Lichenopora mediferanca Blainville, 1S34. (After Harmer, 1915.) .J, I. Licheno-

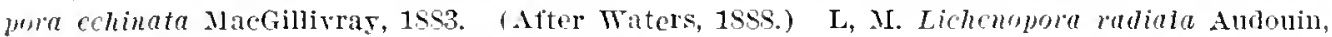
1526. (After Hincks, 1SS0, and Waters, 1579.) In $L$ the cancelli to the left are closed by a Jelicate calcareous cover perforated with about two to ten holes and to the right they slow spines with globular terminations. $\mathrm{X}$, O. Lichenopora novae-sclandine Isusk, 1S55. (After Harmer, 1915.) I', Q. Lichcnopora remararin Fibricius. 1780. (After Smitt, 1S69, and Harmer, 1S95.) 1i. Lichcnopora reticulata MacGillivray, 1SS3. (After Waters, 1S94.) S. Lichenopora lonabulum Jujlien, 1SSS. (After Waters, 1Ss7.) T. Lichenopora fimbriala Busk, 1S75. (Aftel Busk.) U. Lichenopora capillalu kirknatrick. 1S90. (After Kirkpatrick.) 

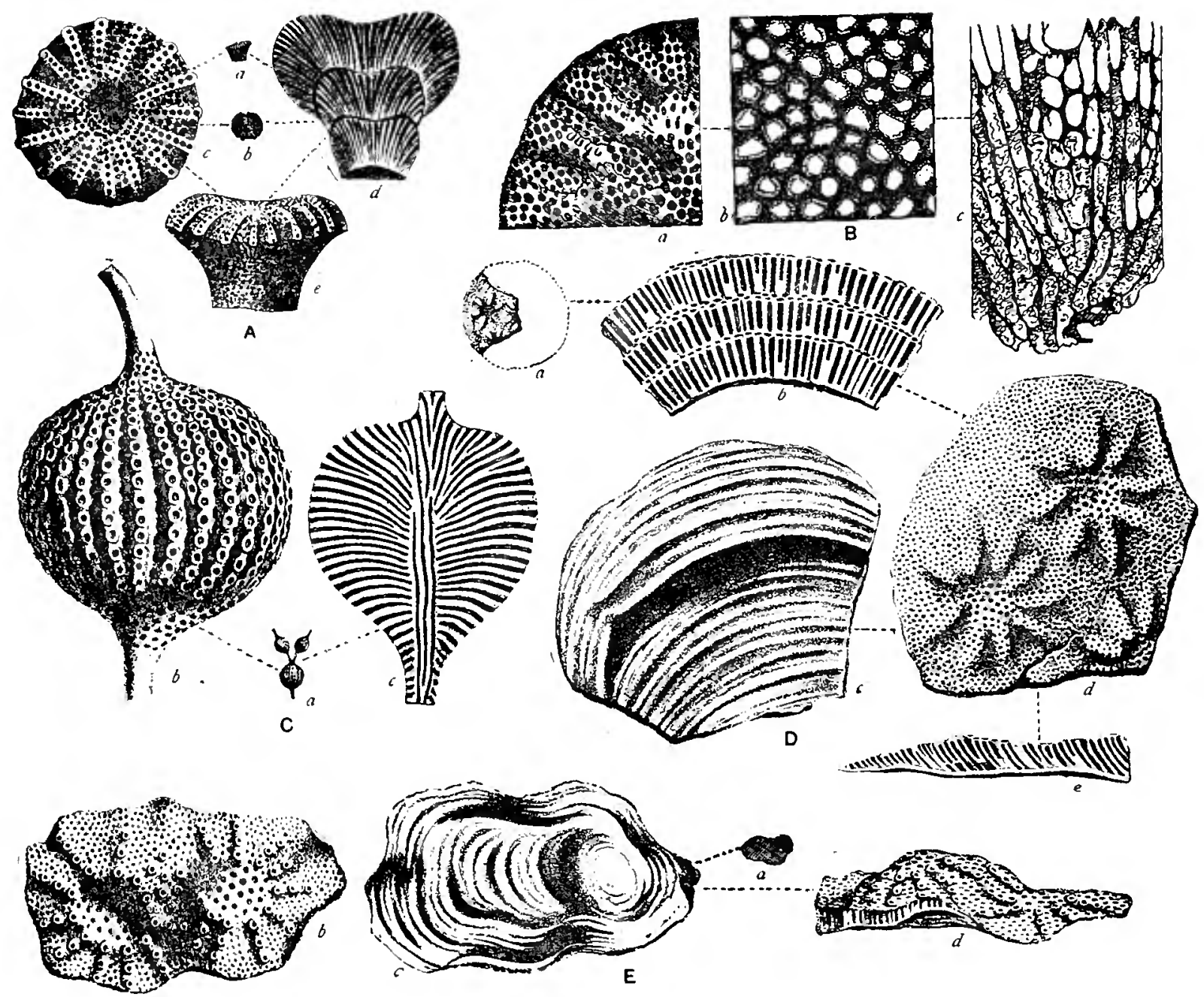

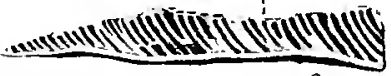
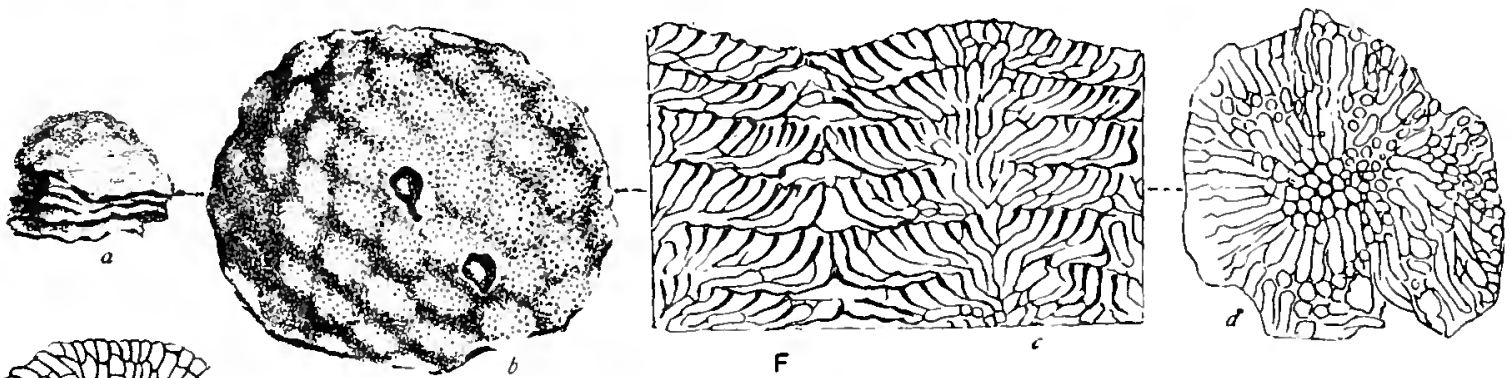

sintumbs

Ston

zisu-1065
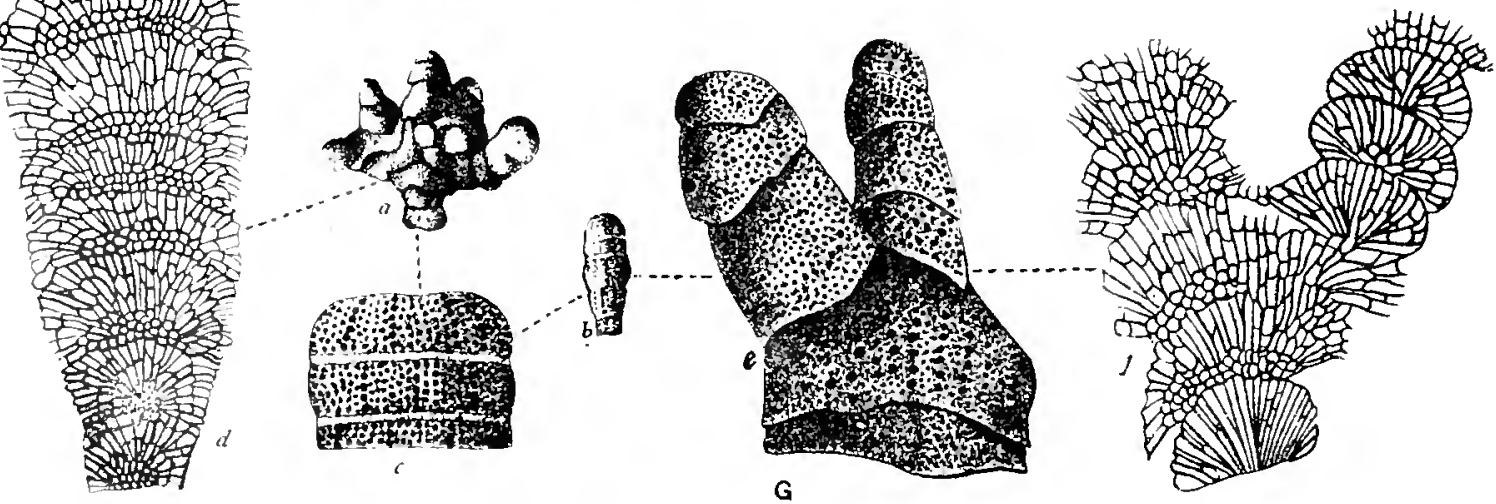
Fig. 269.-Zoarial forms of Lichcnopora.

A. a-e. Discocarca D'Orbigny, 1853. Genotype. Discocarea irreyularis D'Orbigny, 18.33. Various riews of Discocalca degans Simonowitch, 18.1. (After simonowitch.)

B. a-c. Lichenopora Defrance, 1823. Genotype Lichcnopora turbinata Deflance, 1823. Liclicnopora stcllata Goldfuss, 1S27. (After Gregory, 1909.) a. Portion of frontal; b. tangential thin section, $X 20$; $c$, vertical thin section, $\times 131$.

C. a-c. Pyricatca Dorhigny, 1S53. Views of the genotype Pyricatca franqana Donbigny, 185.?. (After D'orbigny.)

D, a-c. Bimulticatea D'Orbigny, 1853. Views of the genotype Bimulticarca variabilis $\mathrm{D}^{\circ} \mathrm{O} \mathrm{r}$ bigny, 1853. (After Dorbigny.)

F, a-l. Scmimulticatea D'Orbigny, 1853. Semimulticarea landrioli D'Orbigny, 1s.i3. ( After D. (Irligny.)

F, "t-d. Radiouma D'Orbigny, 1849. Zaarium, natural size and enlared, of the cenotyle Radiopora mendonensis D'Orbigny, 1553. (After D'Orbigny.) $r$, dongitudinal and transrerse sections of Radiopora ncocomiensis D'Orbigny, 1550. (Aftel Gregory, 1909.)

G, $a-f$. Tholopora Gregory. 1909. (Domopora D'Orbigny. 1S49.) G. b, c, d. Zoariun natural size, the extremity enlarged and a longitudinal thin section of the genotype Domopora clarata Goldfuss. IS:T. G, a. c. f. Similar views of Domopora virgulosa Gregors. 1909 . (After Simunowitch, 1ST1.)

$55999--20-$ Bull, 106--52 
LICHENOPORA VERRUCOSA Philippi, 1843.

Plate 131, figs. 10-13, and plate 130, figs. 12, 13.

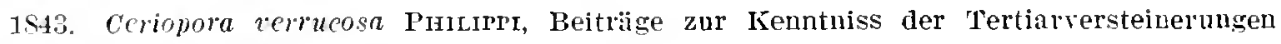
des nordwestliehen Dentsehlands, p. 67, pl. 1, fig. 12.

1S04. Heteroporclla verrueosa ReUss, Zur Fauna des deutsehen oberoligocans, Sitzungsberichte der k. Acatlemie dev Wissenschaften, Wien, rol. 50, pt. 2, p. 6s, p]. 7 , tigs, 1,2 .

1865. Incteroporella verrucosa Recss, Die bryozoen des dentsehen Septarienthones, Denkseluriften der k. Akadenie der Wissensehaften, Wien, vol. 25, p. 201 (see. 85 ).

1S69. Heteroporella vermeosa Reuss, Zur Fossilen der Oligociuschiehten von Gaas, Sitzungsberiehte der k. Alkademie der Wissenschaften, vol. 59, p. 34.

18s4. Heteroporella verrucosa Schreiber, Beiträge zur Fauna des mitteloligocänen Grunsandes aus dem Untergrunde Magdeburgs, vol. 2, p. 11, pl. 2, fig. 16.

Description.-The zoarimm is simple or composite. When it is simple it is discoidal. very convex; the lower face is convex, pedunculate and the basal lamella is striated concentrically. The central area is large and is occupied by the ovicell. The fascicles are salient bi- or tri-serial, not contimed as far as the zoarial border. The shorter ones are the more exterior. The tubes are polygonal and smaller than the cancelli. They have no visor. The cancelli are larger in the central area and smaller between the fascicles. The spinules are quite long, scattered, and rery fragile. The ovicell is placed under the central area.
Width of the fascicles $0.20 \mathrm{~mm}$. Diameter of the central cancelli__._._.... $0.16 \mathrm{~mm}$.
Measurements.- Zoarial diameter-_......... $6.00 \mathrm{~mm}$. Diameter of the interfascicular cancelli_... $0.12 \mathrm{~mm}$. Diameter of the tube-_...

Affinities. - The zoaria observed are simple and discoidal; sometimes they are superposed (as in Domopora).

This species much resembles Lichenopora defranciana Michclin, 1848, of the Paris Lutetian. It differs from it in its zoarium, which is not supported by a large peduncle and not turbinate, and in its convex and hollow lower face.

The comparison with German Oligocene fossils is alrays a little doubtful, these fossils never having been distributed to the principal museums of the world. Occumence.-Middle .Tacksonian: Wilmington, North Carolina (rare); near Lenuds Ferry, South Carolina (rare).

Geologic distribution.-Middle and Upper Oligocene of Germany (Reuss); Stampian of Gaas in France (Reuss).

Plesiotypes.-Cat. Nos. 65363. 65454. U.S.N.M.

LICHENOPORA GRIGNONENSIS Milne-Edwards, 1838.

Plate 129, figs. 1-11.

1523. Lichenopora crispa Defraxice, Dietionnaire des Sciences naturalles, vol. 26. p. 257.

158. T'ubulipor grignonensis Juxe-EDwaros, Memoire sur les Tubulipores, Annales des Ściences naturalles, Paris, vol. 9, p. 13. p]. 13, fig. 2.

14t5. Tubulipora grignonensis Incheliv, IConographie Zoophytologique. Paris, I. 169, pl. 46 , fig. 7 . 


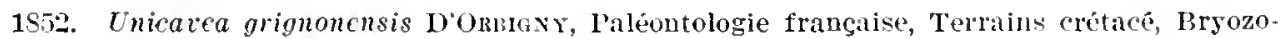
aires, p. 971.

1552. Discocavca parmensis D'Onduxgr, Paléontologie française, Iiryozoaires, p. 958.

1852. Radiotubigera grignoncnsis DOMnger. Paléontologie française, p. 756.

1S52. Discocavea crispa D'Orbigns, I'aleontologie franģaise, p. $95 \mathrm{~s}$.

18s6. Discoporclla grignonchsis I'ergens and Mednier, Les Bryozoaires du Système Montien, Louvain, p. 14.

19M. Lichenopora grignoncnsis Cand, Bryozoaires tertiares des enviruns de Paris, Annales de Paleontologie, vol. 5. p. 134, pl. 1T, figss, 3-7.

Deseription.-The zoarim is simple, free, and discoidal or composite incrusting, formed of a lamella with adjacent subcolonies. The basal lamella is thick and striated concentrically. The central area is large and concave. The fascicles are salient, solely in the vicinity of the central area; they are uniserial, short, and never reach the zoarial margins. The tubes are small, recumbent, provided with a visor; they are arranged in quincunx in the vicinity of the zoarial margins. The cancelli are polygonal and small. The ovicell placed in the central area covers over the cancelli.

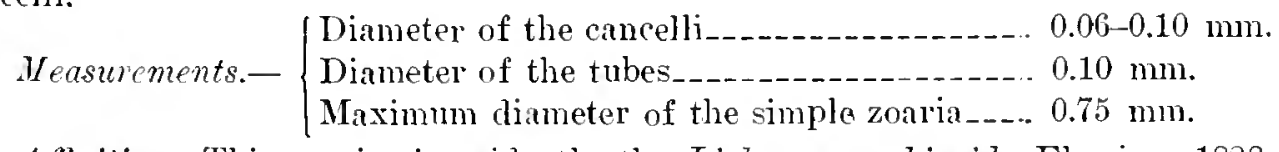

Affinities.-This species is evidently the Lichenopora hispida Fleming, 1828, universally distributed throughout all the seas of the globe. The variations noted in this species are so extraordinary that a rerision of the known specimens appears necessary. The oeciostome figured by Hincks has not been rediscovered; the ovicelled specimens from the Mediterranean have never shown it. The arrangement in quincuns of the tubes on the zoarial margins does not therefore appear as a sufficient specific character if it is not supplemented by the character of the ovicell. the oeciostome, and the cancelli. In adopting the name Lichenopora grignonensis we are certain of having made a good identification, the comparison of the specimens having been made directly. Some subsequent studies will make the synonyms more specific.

The composite zoaria appear to incrust algae, forming a greater or less thickness with many lamellac superposed. Two specimens from Cocoa post office, Choctaw County, Alabama, are hollow and measure 6 by $2 \frac{1}{2}$ centimeters.

Occurrence.-Miclwayan (Chyyton limestone); Luverne. Crenshaw County. Alabama (common); 1 mile west of Fort (raines, Georgia (rare).

Claibonnian: Claiborne, Alabama (very rare).

Jacksonian: Three and one-half miles southeast of shell Bluff post office, Georgia (common).

Lower Jacksonian (Moodys marl): Jackson. Mississippi (common).

Midkle Jacksonian: Wiluingrton. North Carolina (very common); near Lenuds Ferry, Sonth Carolina (very common); Entaw springs. Sunth Carolina (common); 18 miles west of Wrigltsville. .Tolnson County, Georgia, (rare); Rich Hill, $5 \frac{1}{4}$ miles southeast of Knoxville. Craw ford Comnty, (reorrial; $; 1$ miles south of Perry. Georgia (rare). 
Upper Jacksonian (Ocala limestone) : Chipola River, east of Marianna, Jackson Countr. Florida (rare); $1 \frac{1}{2}$ miles above Bainbridge, Georgia (rare).

Tackisonian (Zeuglodon bed): Bluff on south side of Suck Creek, Clarke County, Mississippi (rare) ; Shubuta, Mississippi (rare) ; Pachuta, Clarke County, Mississippi (rare): Cocon post office, Choctaw County, Alabama (rare).

Geological distribution.-Intetian of the environs of Paris (Canu).

Plesiotypes.-Cat. Nos. 65259, 65260, U.S.N.M.

LICHENOPORA GRIGNONENSIS, var. MULTILAMELLOSA. new variety.

Plate 133, figs. 14-17.

We have discovered some multilamellar zonria which offer the aspect of true Ceriopora because they are altered by foscilization. The fascicles are hardly visible, and exact determination is impossible. Nevertheless the cancelli are much smaller than on the similar masses of Lichinopora bolctiformis Reuss, 1869. The superposed lamellae are not alwars intimately joined; in dissecting away a fragment of the upper lamella of a specimen from Rich Hill. Georgia, we have verified on the well-preserved lower lamella the presence of the fascicles and the visors characteristic of Lichenopora grignonensis. This latter species never having been found in all the localities mentioned. we believe it necessary to establish a variety. but this is rery probably only a simple variation analogous to that already mentioned in other composite Lichenopora. The ovicell observed was concave at the center and convex between the fascicles.

Occurrence.-Middle .Tacksonian: One-half mile south of Georgia Kaolin Company's mine, Twiggs County Georgia (rare) : Baldock. Barnwell County, South Carolina (rare); Rich Hill, $5 \frac{1}{4}$ miles southeast of Knoxville, Crawford County, Georgia (common) : 17 miles northeast of Hawkinsville, Georgia.

Cotypes.-Cat. No. 65365, U.S.N.M.

LICHENOPORA PROLIFERA Reuss, I847.

Plate 162, figs. 4-7.

1847. Defrencin prolifera Iisuss, Dje fussilen Folgurien des Wiener Tertiärbeckens, Haidinger's naturwissenschaftliche Abhandlungen, vol. 2, p. 37, pl. 6, fig. 1.

1851. Defrancia prolifera Reuss, Ein Beitrag sur Paleontologie der Tertiarschichten olverschlesens, Zeitsehrift der Deutschen Geologischen Gesellschaft, vol. 3, p. 175.

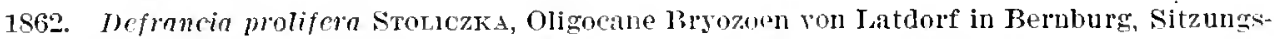
brrichte der k. Akademie der Wissenschaften, Wein, vol. 45, $\mathrm{p}$. 82.

1877. Defrancia prolifera Manzoni, I Brozoi fossili del Mincene d'Anstria ed Ungheria, JI. Denkschriften der k. Akademie der Wissenschaften, Wien, rol. 38, p. 17, il. 15 , fig. $5 \mathrm{~S}$.

1895. Lirhchopora prolifera Neviani, Briozoi fossili delle Farnesina Honte presso Roma, I'alontographia italica, rol. 1, p. 135 (39).

1896. Lichcnopora prolifera Neriaxi, Bliozoi postplioceniei di Spilinga (Calabria), Atti dell'Acaremie Gioenia di Scieuze naturali in Catalina, ser. 4, vol. 9, p. 65.

189s. Lichemopoin prolifera Neviasi, Briozoi neozoici li alcume localita d'Italia, Bohlettino della Societá Romana par gli Studi Zoologici, pt. 4, vol. 7, p. 16; pt. 5, p. 15.

1000. Lichenovora prolifern Nevisx. Brinzoi neogenici delle Calabrie, Ialeontographia italiea, vol. 6, p. 247 (sep. 133).

Description.-The zoarium is simple, very convex, and discoidal or composite. and formed of superposed disks; the lower face in concave with a peduncle hardly 
salient and striated coneentrieally on the basal lamella. The central area is very large. The fascicles are salient, regular, from 18 to 22 in number, continued almost to the zoarial margin, monoserial. The tubes are rectangular, smaller than the cancelli and without visol. The eancelli are large and polygonal.

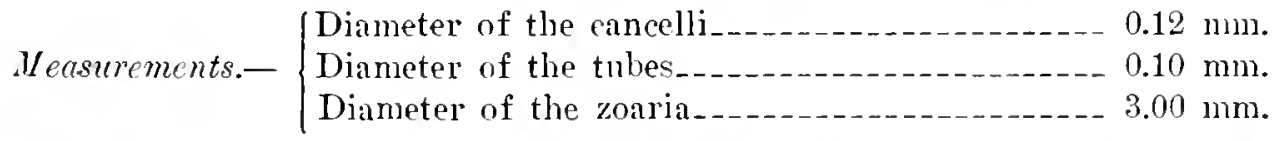

Affinities.-There is in the Oligocene a speeies very elose to Heteroporella deformis Reuss, 1847 , but in which the central area is much smaller. This species was refigured in $187 \mathrm{~T}$ hy Manzoni with very different elaracters from the figure by Reuss, 186t, not cited, noreover, in the synonymy. On the other hand, Stoliezka, 1861. having found the species of Reuss, 187, in the Lower Oligocene of Latdorf, its discovery in the Vicksburgian is not unexpected. Our specimens are much like the figures of Lichenopora protifera by Reuss and Manzoni, and our identification appears to be good.

Neviani cited this species in the Pliocene and in the Quarternary. Perhaps he confused it with Liehenopora radiaia Savigny-Audouin, 1526, although distinction between the two speeies ought to be easy to determine.

Occurrenee-Vicksburgian (Marianna limestone): Salt Mountain, 5 miles south of Jackson, Alabama (rare).

Geological distribution.-Latdorfian of Germany (Stoliczka); Helvetian of Italy (Neviani); Tortonian of Austria-Hungary (Reuss); Astian of Italy (Neviani).

Plesiotypes.-Cat. No. $65 \pm 73$, U.S.N.M.

LICHENOPORA GOLDFUSSI Reuss, 1964.

Plate $16:$, figs. S-20.

1547. Defrancin stclata Retss. Die fossilen folygarien des Wiener Tontïurbekens, IIaidingers' natumissenschaftliche AbhandIungen, vol. 2, p. 3て, pl. 6, fig. 2. 1 Not Goldfuss, 1827.)

1864. Radiopora goldfussi Recss, Zur fauna des dentschen oberoligncins, sitzmugsurelte der k. Akademie der Wissenschaften. Wien, rol. 5, j. 676 (ser. 6.-)

1865. Radiupora goldfussi Recss, Teler die Foraminiferen mu Brymoen des dentshen Septarienthones, Denksoliften der k. Aludemie der Wissenschaften, Wien, vol. "w, P. S4, pl. 10, figs. 11, 12.

1877. Defrannia stellata Manzoni, I Briozoi fossili del Hincene d'Iustria ell Lnghria, Denkschriften der k. Akademie der Wissenschaften, Wien, vol. 3T, p. 16, pl. 16, fis. 03.

Description. - The zoarium is simple, discoidal, rely convex; the lower face is very concare and striated concentrically. The fascicles are salient. regular, triserial, complete almost to the zoarial margins; the central area is small. The tubes are a little smaller than the central cancelli. They are polygonal and deprived of a visor. The cancelli are large, polygonal, and without spinule.
Leusurements.
Diameter of the tubes $0.10 \mathrm{~mm}$. Diameter of the cancelli__._._. Diamcier of the linge zon rial $8.00 \mathrm{~mm}$. Width of the fascicles. $0.30-0.40 \mathrm{~mm}$. 
Affinitics.-In its multiserial fiascicles this species much resembles Lichenopora remucose Philippi. 194\%. It differs from it in the greater width of its fascicles, which are continued almost to the zoarial margins. The orifice of the cancelli is less excarated.

In 1876 Manzoni did not appear to admit the idlentity of the Oligocene species with the Miocene; we do not see, howerer, any essential difference. Our specimens from Monroeville, Alabama, are very well represented by the fignres given for the Niocene form, although generally the central area is much snaller.

Wre have not discorered the ovicell. nor the spinules. The species is perhaps not a Lichenoport, and it will be necessary to await the collection of a large number of specimens before placing it definitely.

Occurrence.-Vicksburgian ( Marianna limestone) : One mile north of Monroeville, Alabana (very abunclant); Salt Mountain, š miles sonth of Jackson, Alabama (common) ; near Claiborne, Monroe Comnty, Alabama (rare).

Geological distribution.-Rupelian of Germany (Renss); Chattian of Germany (Reuss); Tortonian of Austria-Hungary (Reuss).

Plesiotypes.-Cat. No. 6.)-174, U.S.N.M.
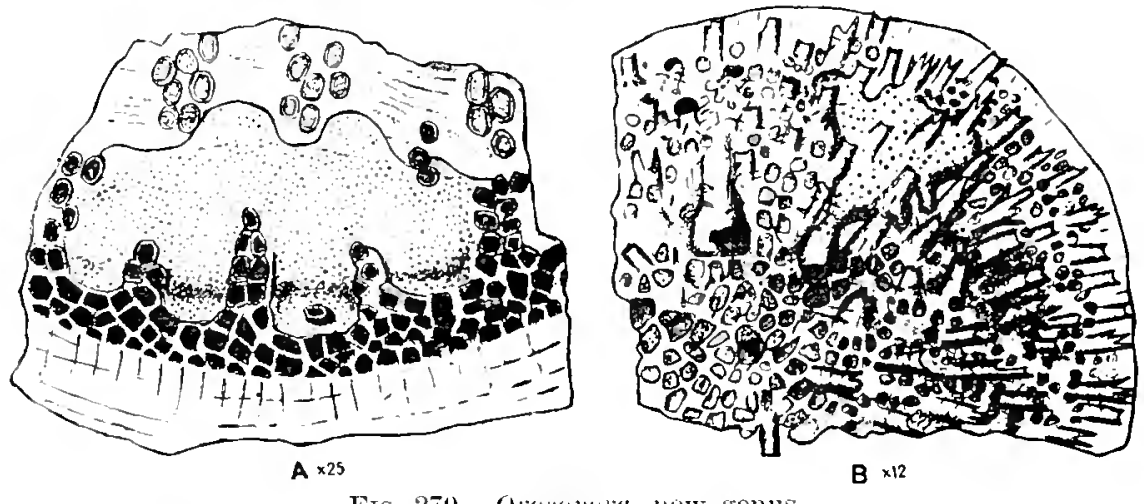

Fig. 270.-0rostmmin, new genus.

A. Ovicelled specimen, $\times-5,5$ of Desmcplaginceia (Lichcnopora) linetata Maccilliviay. (After Waters, 1SsS.) (Introduced by error:)

B. Portion of ovicelled zoarium, $\times 12$, of orosopora (Lichenopora) ciliata Busk, 1575 . (After Waters, 18s7.)

OROSOPORA, new genus.

Greek: oros, signifying borter.

The oricell is placed near the zoarial margin and not at the centel of the zoarium.

Genotype.-Orosopora (Lichenopora) citinta Busk, 1875.

Range.-Recent.

Genus TROCHILIOPORA Gregory, 1909.

1009. Troctiliopra Greons, Catalogue Fossil Rryozoa in Department of Geology, British Musem. Cretaceous IBryozon, vol. I, p. 265.

Lichenoporidae with a single top shape or capitate zoarinm, composed of a constricted stem and expanded head. Apertures in rertical series on the margin of the liearl. (After Gregory.) The lower face bears cancelli.

Genotyle.-Trochitiopora humei Gregory, 1909. Santonian. 
Genus CONOCAVA Calvet, 1911.

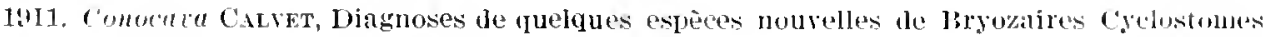
provenant des Campagnes scientifiques accomplies par S.A.S. le Prince de Munaco a bord de la P'rincesse Alice, Bulletin Institut ocranographia Monaco, Ni), 215, p. 8.

Zoarium conieal, fixed to the sulstratum by it enlarged summit and increasing in size at the batse. Lateral surface eccupied in part by salient series of tubular
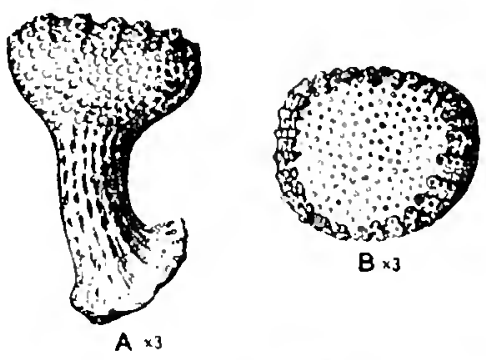

FIG. 271.-Genus Trochiliopora Gregury, 1909.

Side and tup views, $\times 3$, of the type of the genus Trochitiopora humci Glegory, 1909, from the Clatk of Fngland.

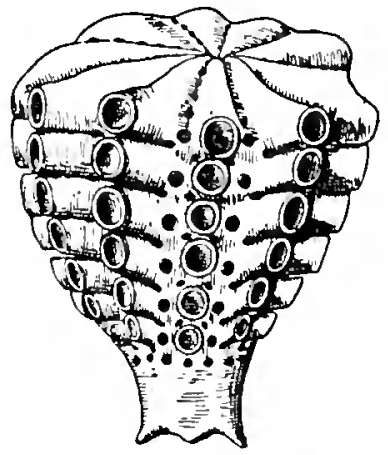

FIg. 2T2.-Genus Conocava Calvet, 1911.

Zoarium of Conocara richardi Calvet, $1911, \times 22$.

zooecia. arranged side by side, and according to as many generatrices of the colonial cone as there are series, these being separated from each other by depressions where the intermediate pores are found. (Calvet.)

Genotype.-Conocava richardi Calvet, 1911.

liange.-Recent.

LEIOSOECIIDAE, new family.

The oricell is a large, orbicular, smooth, salient strelling, clevated above a shallow excaration and obstructing a certain number of tubes.

This fanily otlers the greatest analogy with that of the Plagioeciidae with which it will be necessary to join it if we find intermediate forms. It has only appeared to differ from it in a greater constancy of the orbicular form of the ovicell and in the presence of mesopores. The ovicell of the Ceidae is also rely close. as is that of Entalophoru remossissime D'Orbigny, 1851.

LEIOSOECIA, new genus.

(ireek: leois. smooth, in allusion to the aspect of the oricell.

The tubes are cylindrical. The mesopores ale parietal and regular.

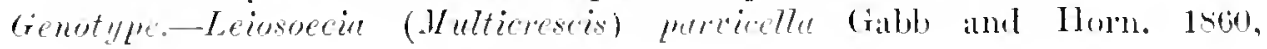
Maastrichten. 


\section{PARLEIOSOECIA, new genus.}

The prefix "par" indicates the presence of club-shaped tubes.

The tubes are club-shaped, bent at right angles at their extremity. The mesopores are numerous with resicular walls.

Genotype.-Parleiosoecia jacksonica, new species. Jacksonian.

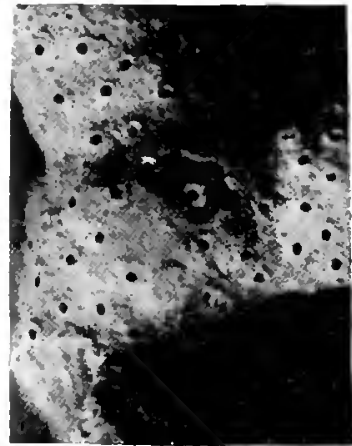

$A \times 12$

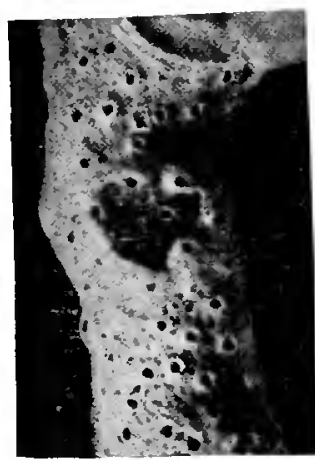

$\mathrm{B} \times 12$

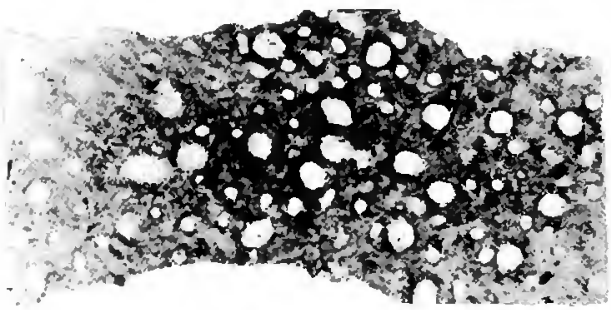

$\mathrm{D} \times 25$

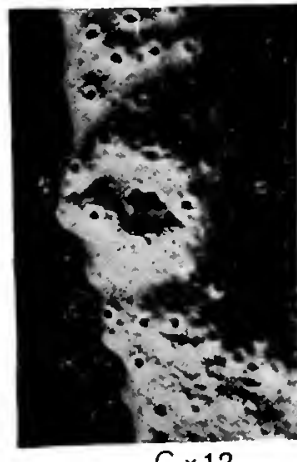

$\mathrm{C} \times 12$

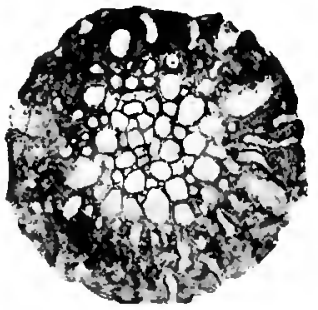

$E \times 25$
$\mathrm{F} \times 25$

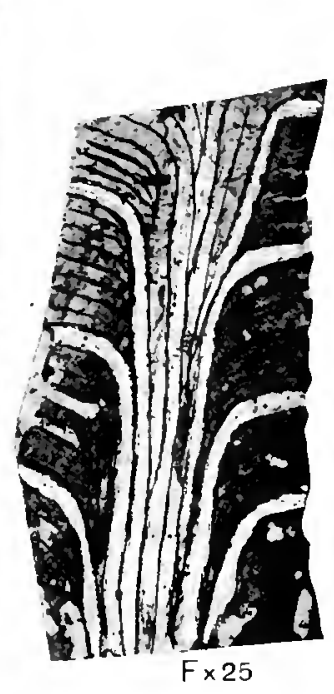

FIt. 273--Leiosuccin, new genus.

A-F. Leiosnecia (Afulticrescis) particella Gabb and Horn, 1860. A-C. Three views of ovicelled specimens, $\times 12$, showing that the ovicell obstructs a nunber of the zooecia. D. Tangential thin section, $\times \mathbf{2 5}$. E. Transverse thin section, $\dot{X} \mathbf{2 5}$. F. Vertical thin section, $\times 25$, showing the cylindrical tubes and the mesopores.

Upper Cretaceous (Vincentown marl) at Vincentown, New Jersey.

PARLEIOSOECIA JACKSONICA, new species.

Plate 148, figs. 1-13.

Description.-The zoarium is free, solid or hollow, irregularly cylindrical and branched; sonctimes clinging to algae or to bryozoa, sometimes attached to the -nkstratum by an expanded base. The tubes are club-shaped in the great part of their length, bent and cylindrical at their extremity (sections); the peristome is orbicular, thin, somewhat salient. The mesopores are numerous, polygonal with resicular walls (section). The oricell is orbicular. globular, very salient. absolutely smooth. 


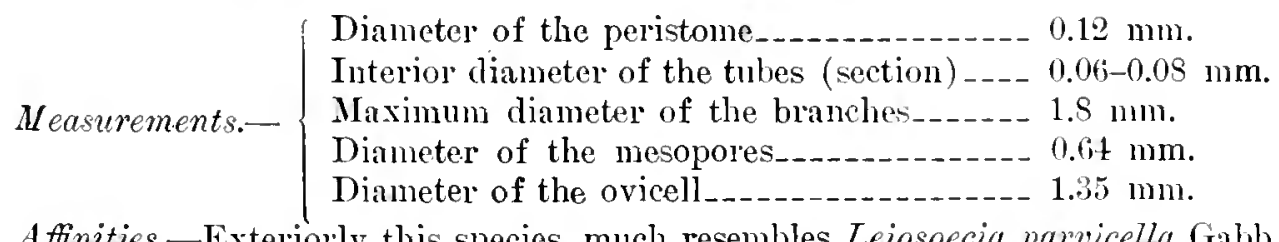

Affinities.-Exteriorly this species, much resembles Leiosoecia parvicella Gabb and Horn, 1860, from the Cretaceous of New Jersey; it differs from it in its clubshaped tubes, its loollow zoarium, and in its larger and more globular ovicell.

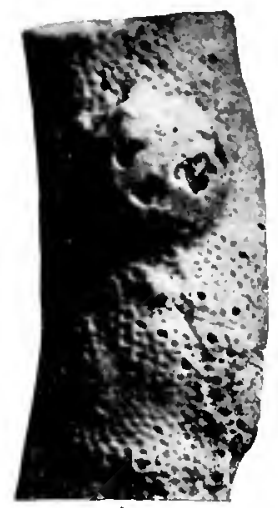

$\mathrm{A} \times 12$

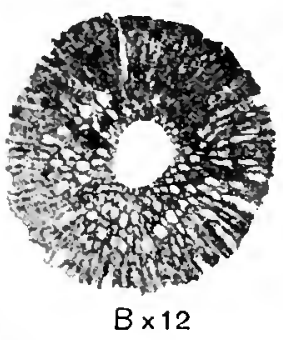

Fig. 274.-Parleiosoeeia, now genus.

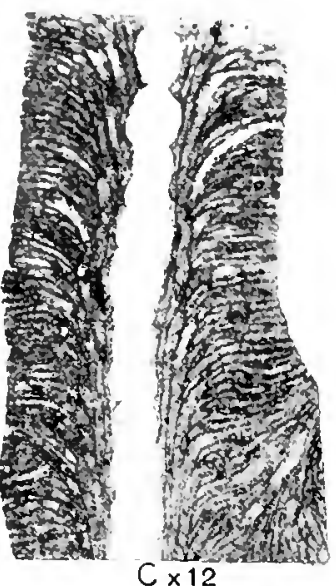

C $\times 12$

1-C. Parlciosoccia jacksonia, new species. A. Ovicelled branch, $\times 12$, showing the smooth ovicell. B. Transverse section, $\times 12$. C. Vertical section, $\times 12$.

Middle Jacksonian of Soutl Carolina.

It appears rather close to Heteropora subreticulata Reuss, 1869. from the Priabonian of Vicentin, but it differs from it in the exterior form of the mesopores. The interior of the branches presents (fig. 13) a successive series of rather regular constrictions, the utility of which is not yet known. They do not correspond to the form of an internal substratum, for the branches are naturally hollow and closed at their extremities. These internal cavities are often traversed by very convex diaphragms (fig. 12).

At the ramifications the walls of the mesopores cease to be vesicular, transforming themselves thus into firmatopores or canals of reinforcement.

Occurrence.-Middle Jacksonian. Wilmington, North Carolina (rare); near Lenuds Ferry, Soutl Carolina (rare); Eutaw Springs. South Carolina (very common); 18 miles west of Wrightsville, Johnston County, Georgia (very rare): Rich Hill, $5 \frac{1}{4}$ miles southeast of Innoxville, Crawford County, Georqia (rare) : 17 miles northeast of Hawkinsville, Georgia (very common).

Cotypes.-Cat. Nos. 654t6-65451, U.S.N.M. 


\section{Family TRETOCYCLOECIIDAE Canu, 1919.}

1919. Tetrocyelocinac (in error for Tretocycloccialne) Caxu, Etudes sur les Ovicelles dex Bryozoaires Cyclostomes (2), Bulletin Société Géologique de France, ser. $t$. vol. 17, 1. 3413 .

The ovicell is orbicular, flat, not salient, smooth. regular, and limited, traversed by tubes and sometimes by mesopores adjacent to the latter.

'This family has a resemblance to the Diaperoeciidae, but differs from it in the flat orbicular and not globular form of the ovicell, and in the presence of the mesopores.

\section{Genus TRETOCYCLOECIA Canu, 1919.}

1019. Tetronyclocciu (in error for Tretocycloccia) Canu, Etudes sur les Oricelles des Bryozoaires Cyclostomes (2), Bulletin sociétẻ Géologique de France, ser. 4, vol. 17 , p. 346.

The tubes are cylindrical. 'The mesopores are irregularly directed; their walls are resicular. The tubes which perforate the oricell are accompanied by the adjacent mesopores.

Genotype.-Tretocycloceia (Heteropora) dichotoma Reuss, 1847 (not Hagenow, 1851).

Range.-Midwayan-Tortonian.

TRETOCYCLOECIA (?) ATTENUATA Ulrich, 1882.

Plate 109, figs. 1-9.

1852. Heteropora attenuatu Ulrich, American Paleozoic Bryozoa, Journal Cincinnati Society Natural Ilistory, vol. 5, p. 144, pl. 6, hig. 12.

1909. Sparsicatea attcnuata Gregors, Catalogue Fossil Bryozoa in Department Geology IBritish Musenm, Cretaceous, rol. 2, p. 302.

Description.-The zoarium is solid, cylindrical. branched, with branches rounded at the summit. The tubes are cylindrical. curred at their extremity (in section). The peristome is smooth, orbicular, not salient, imperfectly visible. The mesopores are rare, rounted, smaller than the tubes, with rery thick walls and in section very short and with vesicular walls.

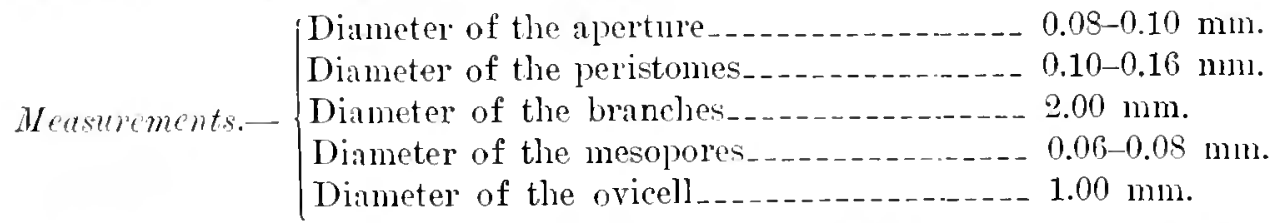

Traintions. - The number of the mesopores surrounding an aperture is rather variable. More often there is only one mesopore between the peristomes; sometimes the mesopores are in groups of six or seren. The branches are sometimes dichotomons and sometimes arborescent. The distance betreen two mesopores is almost always greater than their diameter.

The only oriell diseovered was broken; we are therefore not exactly certain of our generic determination. 
Ittivite. This species exteriorly resembles worn specimens of Aseosuecie prominens: it differs from it in the great thickness of the walls of the mesopores.

It differs from Tretoryelocene mirulata in its branched. nometiculate and smaller zoarium, in its much less mumerous mesopores, and in its alpertures, which are arranged in somewhat regular quincunx.

Oceurrence.-Midwayan (Clayton limestone): Mabelvale, near Little Rock, Arkansas (rare).

Cotypes.-Cat. No. 65056. C.S.N.M.

TRETOCYCLOECIA GRANDIS, new species.

Plate 1 in, tigs. $7-10$.

Description.-The zoarium is flat. cylindrical, branched. The tubes are cylindrical or polrgonal, bent obliquely at their extremity. The peristome is thin, orbicular, salient. The apertura is latec. The mesopores are large polygonal. irregularly grouperl, and almays closed by a calcareous pellicle rather resistant and finely perforated. 'The ovicell is orbicular.

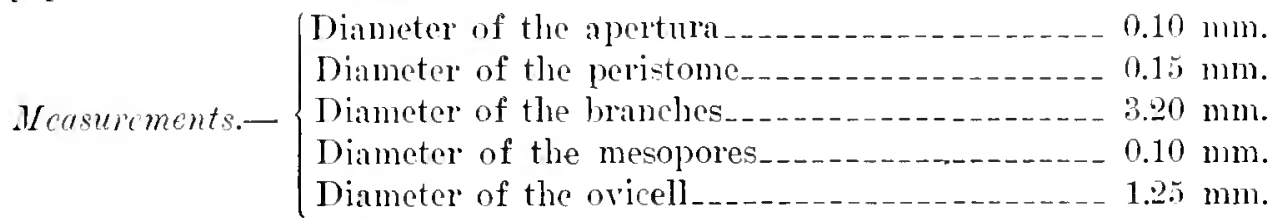

Affinitics.-This species ofler's much the aspect of the Pustulopora (Clanesa) retifere Stoliczka. 1861. of the Latdorfian, the type of which we have not been able to compare. It differs in its mesopores, the dianeter of which never surpasses that of the tubes, and in lar ger apertures $(0.10$ and not $0.06 \mathrm{~mm}$.).

The figured specimen is the only one found. The study of the species is therefore incomplete.

Oecurrence.L_owar .Tacksonian (Moodys marl) : Jackson, Mississippi (rery rare).

Holotype-Cat. No. 6.537.2, U.S.N.M.

TRETOCYCLOECIA RETICULATA, new species.

Plate 149, figs. 1-14.

Jescription.-The zoarium is free, solid, cylindrical, large, reticulate. The tubes are very long, cylindrical, bent at a right angle at their extremity: the apertures are oubicular, crouped in irregular zones (in section). The mespores are exteriorly small, polyonal. with thin walls, grouped in irregular, transversal zones, and of a large diameter in section: the walls are resicular. Diaphragms in the tubes are rare. The ovicell is orbicular. harlly salient.

$$
\begin{aligned}
& \text { Dianeter of the apertura_._._._._._._._. n.12 } \mathrm{mm} \text {. }
\end{aligned}
$$

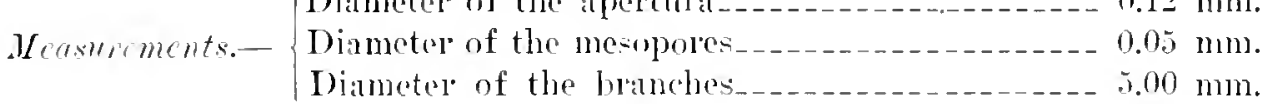




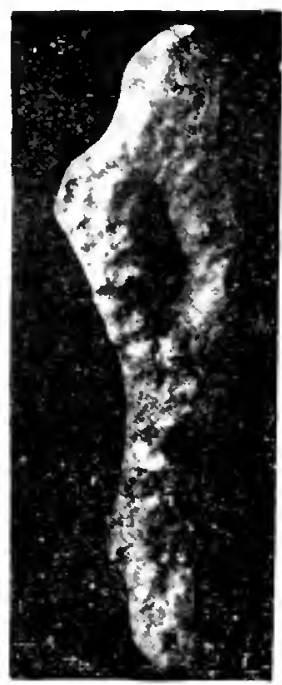

A

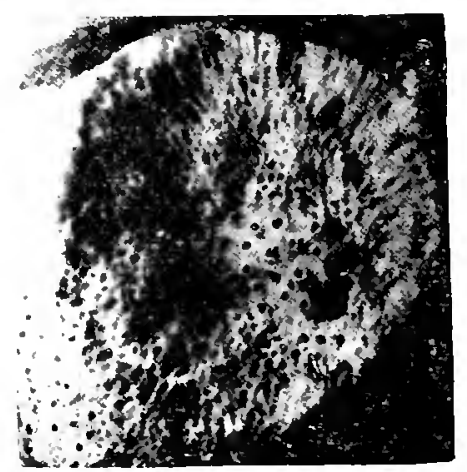

$D \times 12$

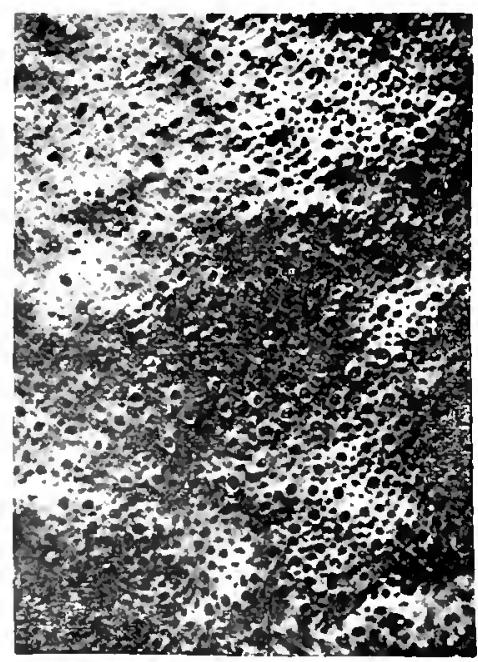

$\mathrm{G} \times 15$

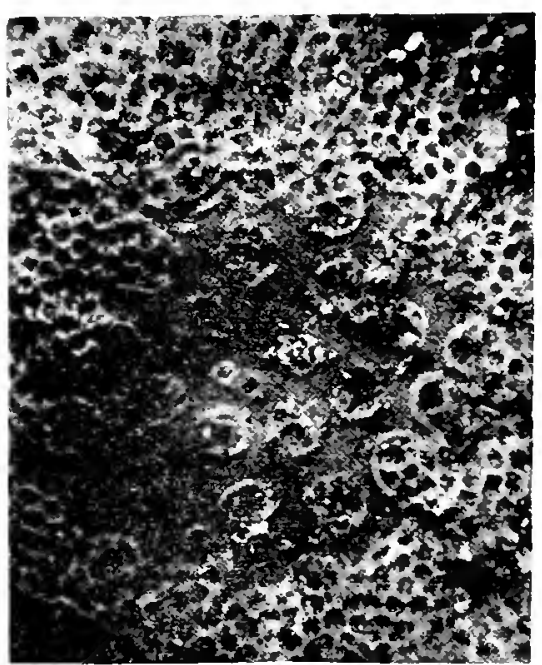

$8 \times 25$

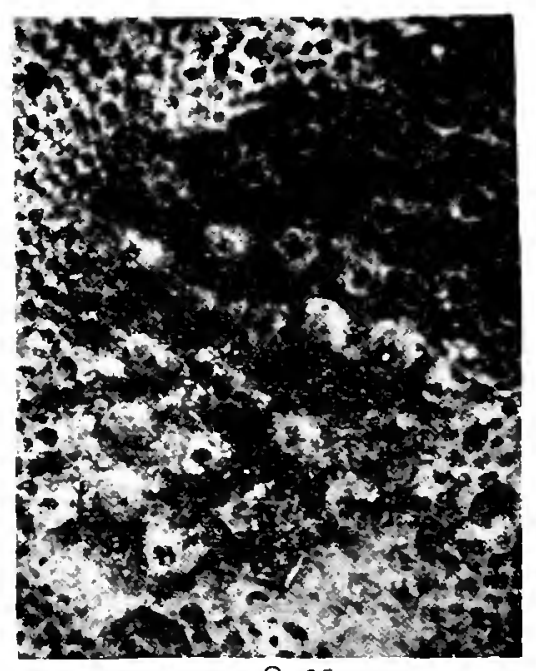

$\mathrm{C} \times 25$

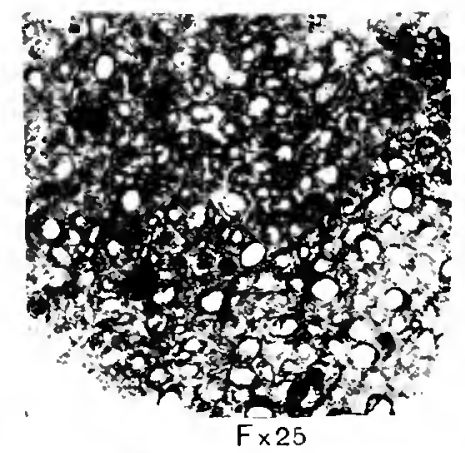

$E \times 12$

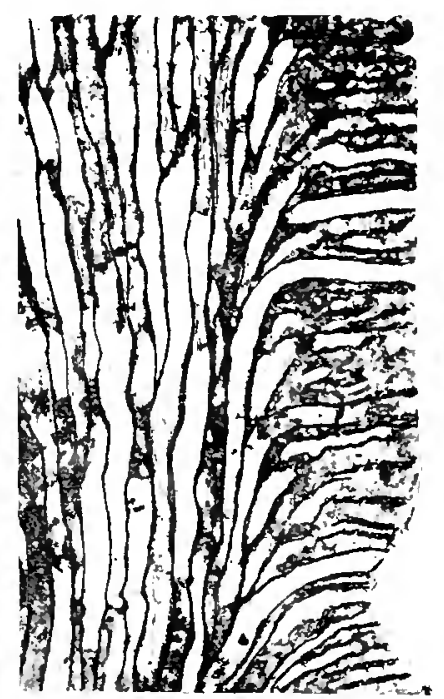

$\mathrm{H} \times 25$
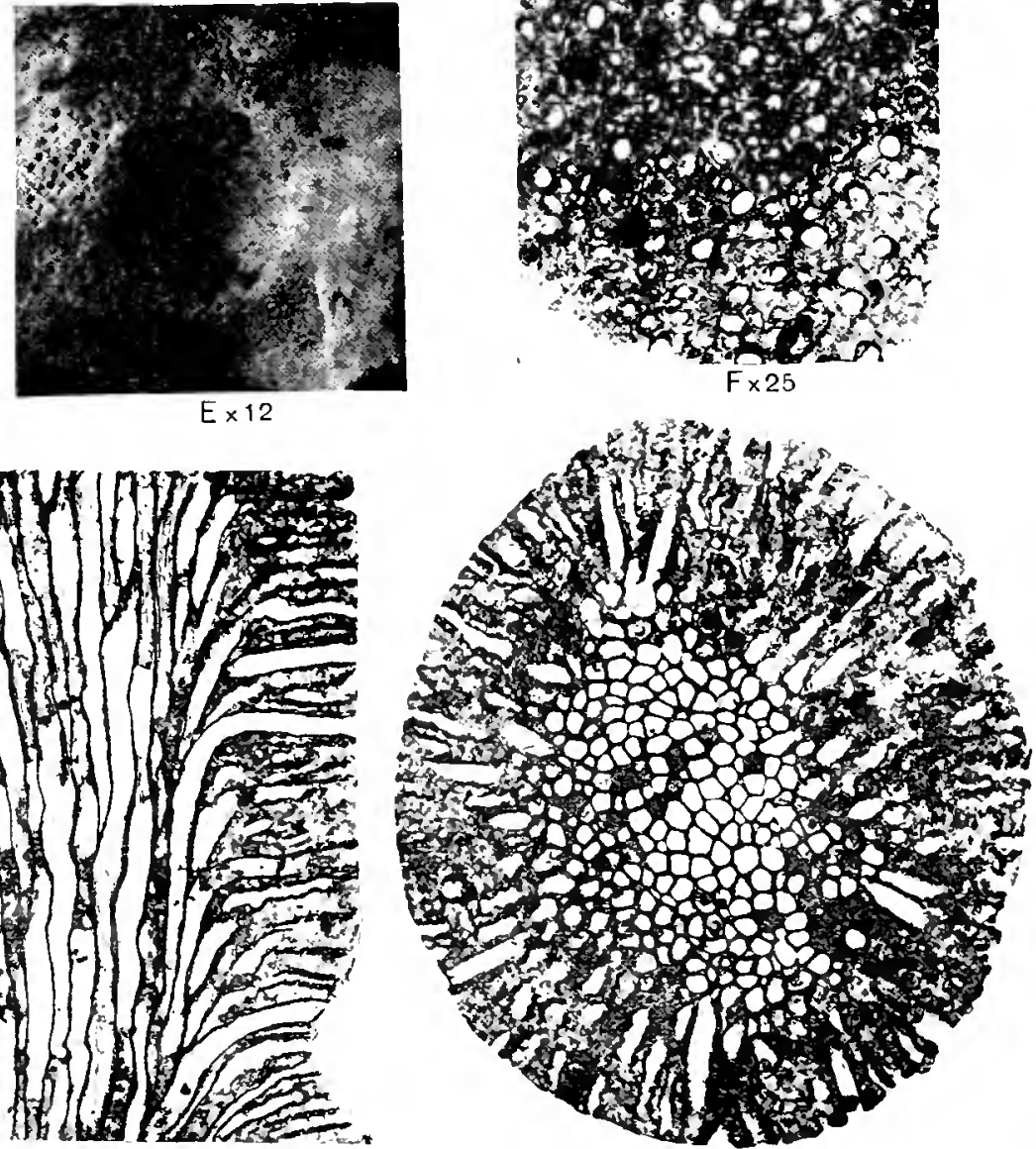

$1 \times 25$ 
Fig. 275.-Genus Tretocycloecia Canu, 1919.

A-I. Tretocycloccin (Hcteropora) dichotoma Reuss, 1S47. A. Zoarium, natulal size. B. Surface, $X \mathbf{2 5}$, slowing ovicell pierced by the tubes with accompanying mesopores. C. Interior of the oricell, $X \mathbf{2 5}$. D. Surface of specimen, $X 12$, showing ovicell covered by a new layer of tubes and made risible by fracture. F. Another example, $\times 12$, showing the interior of the oricell. F. Tangential thin section, $\times 25$. G. Surface of zoarium, $\times 15$. H. Vertical thin section, $\times$ 25. I. Transverse thin section, $X 25$.

Helretian of Done la Fontaine (Maine et Loire) and Mus (Gard), France. 
1 ariutions.-The zoaria are not always reticulate; it is frequent to find branches free, smooth, or spinous. The relative arrangement of the apertura and mesopores is that of sparsicavea; the zones are almost always transversal, but very irregular (fig. 3). The mesopores are sometimes closed by a calcareous lamella.

An excellent longitudinal section permitted us to study the branching of the zoaria (fig. 11). At the center of the zoarimm and quite distant from the bifurcation, two tubes diverge, an axial tube to the left and an axial tube to the right: their successive ramifications diverge necessarily in forming the two zoarial branches.

The mesopores have a diameter almost equal to that of the tubes; this character is not visible in the tangential sections (fig. 13). The zones of mesopores appear to be formed of branched mesopores (figs. 11.12).

Affinities. - In its reticulate zoarium and in the aspect of its surface, this species is identical with Ascosoecia ulrieki; it differs from it in its somewhat larger apertura $(0.12$ and not $0.10 \mathrm{~mm}$.).

Occurrence.-Middle Jacksonian: Near Lenuls Ferry, South Carolina (rare); Eutaw Springs, South Carolina (very common).

Cotypes.-Cat. No. 65374, U.S.N.M.

\section{Genus PARTRETOCYClOECIA Canu, 1919.}

1919. Partetrocyclocia (in error for Partrctocycloceia) Canu. Etudes sur les Oricelles des Pryozonries Cyclostomes (2), Bulletin Socícté Géologique de France, ser. 4, rol. 17 , p. 346.

The tubes are club-shaped.

Genotype.-Partretocycloccia (Cavaria) dumosa Ulrich.

Range--Midwayan-Vicksburgian.

All the known species of this genus have hollow zoaria (Cavaria form of growth). The tubes are short and their club-shaped form does not appear very clearly in transversal sections. It would he preferable to chose a genotype with a solid zoarium.

Another consequence of the contraction is to transform certain mesopores into aborted tubes; that is to say, into dactylethrae.

\section{PARTRETOCYCLOECla DUMOSA Ulrich, 1901.}

Plate 103, figc. 1-14.

1901. Cacaria dumosa Uuricir, Marçand Geological survey, Eocene, p. 208, pl. 59, figs. 4-8.

Description.-The zoarium is free, hollow. hranched, dichotomous. arborescent. The tubes are short, club-shaped, cylindrical. with their extremity bent (in section). The peristomes are orbicular, hardly salient. thin, irregularly distributed in quincunx. The mesopores are smaller, polygonal, hut rounded and (in section) with thick walls. The ovicell is large. smooth. perforated by the tulses; each tube is acconpanied by a single mesopore. 
NORTH AMERICAN EARLY TERTIARY BRYOzOA.

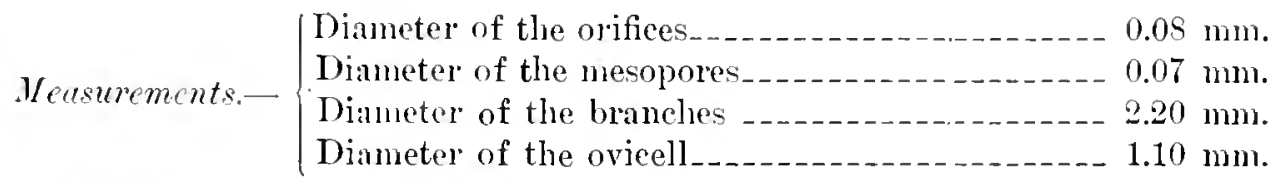

Tariations. -This species has been rery well described hy Uhrich. Even the oricell has been well studied and figured. We have nothing new to add.

The zoarial cavities are irregular and as they are closed we have supposed that they were hydrostatic.

The adrentitions tubes are indeed mesopores and not dactylethrae. for they arise in front of normal tubes and not on their dorsal.

Occurence-CLowest Eocene (Bryozoan bed at base of Arquia formation): Upper Marlboro, Maryland (very common).

Plesiotypes-Cat. No. 65239, U.S.N.M.

PARTRETOCYCLOECIA REPTANS, new species.

Plate 150, figs. 11-14.

Description.-The zoarium creeps over bryozoa. It probably gives rise to free and hollow fronds. The tubes are club-shaped. The peristomes are orbienlar, rery thin, little salient, irregularly arranged. The mesopores are numerous, polygonal, elosed by a caleareons lamella. The ovicell is large, orbienlar, pierced by the tubes, but never by the mesopores.

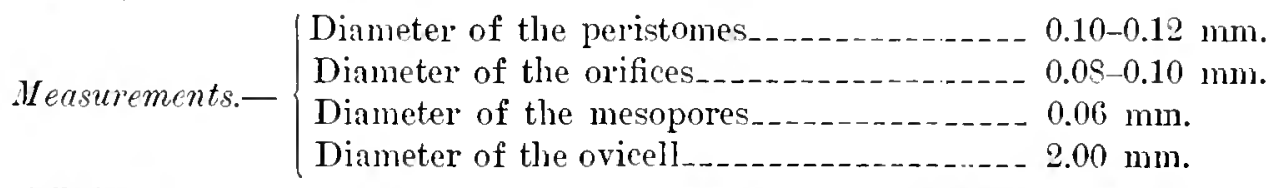

Affinities.-D'Orbigny classified this zoarial form in Reptomulticlansa. The absolute identity of its oricell with the other species of Partretocyctoecia requires its elassifieation here. The figured specimen is the only one found.

Occurrence.-Middle Jacksonian: Near Lenuds Ferry, South Carolina (very rare).

Molotype--Cat. No. 65373, U.S.N.M.

PARTRETOCYCLOECIA POROSA, new speries.

Plate 151, figs. 1-6.

Description-The zoarium is massive, orbicular, formed of many superposed layers. The tubes are very short, club-shaped, bent at their extremity (in section); the peristomes are thin, salient, numerous, elliptical or oval. arranged in quineunx. The mesopores are numerous, polygonal, smaller than the peristomes, with nonresicular walls. The oriecll is very large, orbienlar, perforated by the tubes. but not perforated by the mesopores.

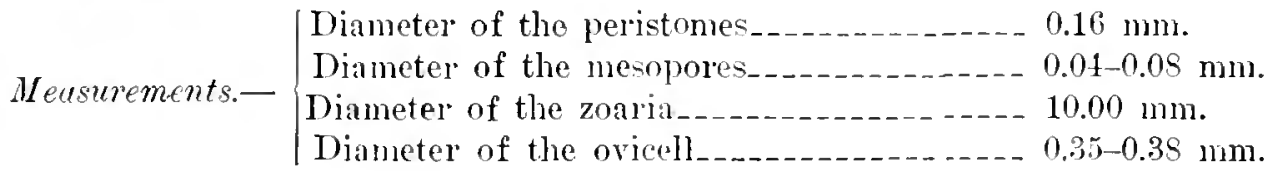



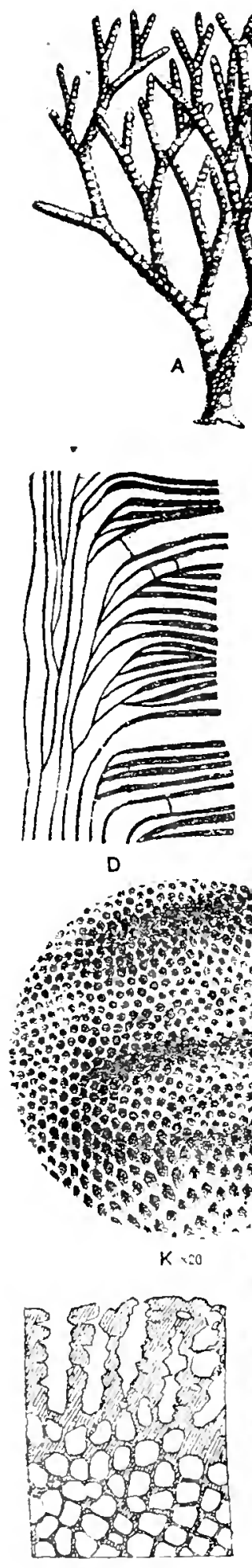

$\mathrm{L} \times 18$
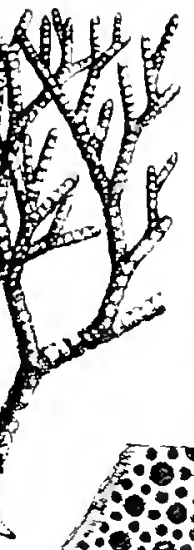

$6000: 0$ -0:80.: -0:8\%.8:0.9

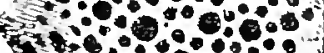
3. $0.0 \%$ 70.00 .95 $400-0$. t+ 0.00 .9 it $0^{\circ} 0^{\circ}: 0$

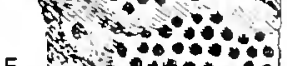

E 5 $E$ in $00 \therefore: \div 8 \div$ $1000: 9: 8: 9: 8:$

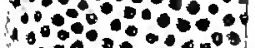
$00: \because 00^{\circ}$ $10: 00$ $\because \because 9 \because \because \div$ -2a $\because \because \because 50 \%: 0$
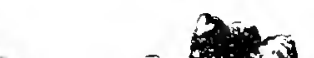

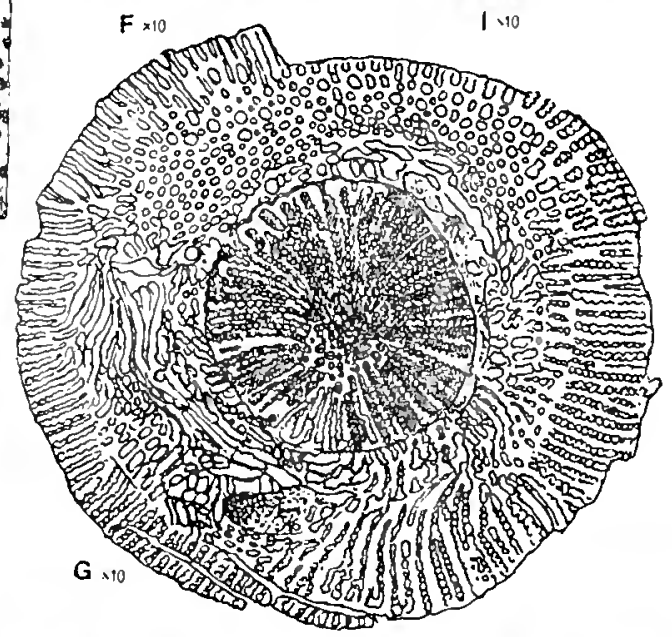

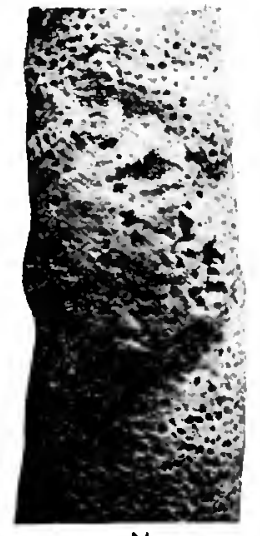

$N \times 12$

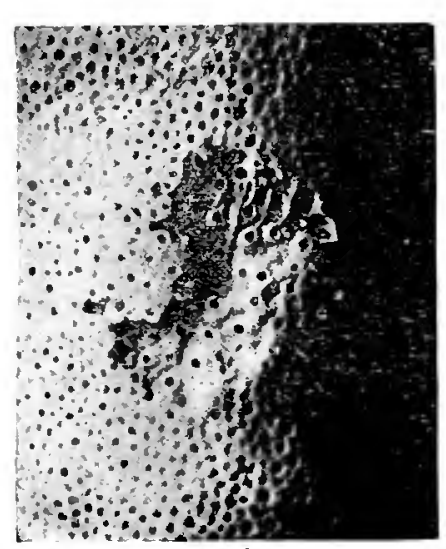

$\mathrm{O} \times 1=$

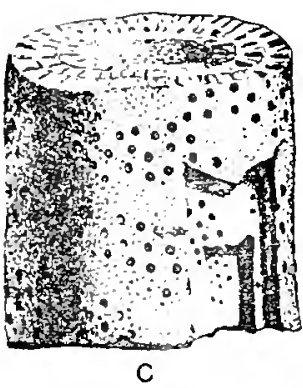

$\left[\begin{array}{llll}0 & 0 & 0 \\ 0 & 0 & 0 \\ 0 & 0 & 0 & 0 \\ 0 & 0 & 0 & 0 \\ 0 & 0 & 0 & 0 \\ 0 & 0 & 0 & 0 \\ 0 & 0 & 0\end{array}\right]$

$\mathrm{H} 、 10$

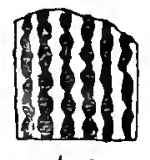

Sos $0=2$

3030 ?

4300

$F \times 10$
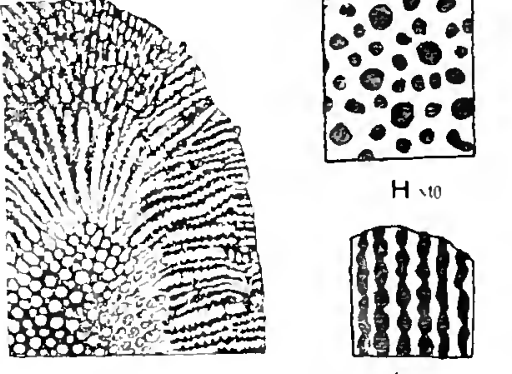
Fig. 276.-Genus Ascosoceia Canu, 1919.

Forma Zemopure Diorbigny, 1854 (=Zonatula Gregory, 1909).

A-I. Ascosoccia (Zonopora) arborea Koch and Dunker, 1537. A. Zoarium restored, natural size, from the Neocomian of France. B. Surface of a well preserved zoarium with salient peristomes. C. Surfice of a worn zoarimm with nonsalient peristomes. (A-C, after Dorbigny, 1S5t.) D. Longitudinat section. (After P'ergens, 18s9.) The walls are vesicular. E. Surfice of a zoarium of the rariety subnolosa, $\times 10$. F. Transverse section of the same variety, $\times 10$. $d$. Transverse section, $X 10$, showing, like the preceding, that the walls of the tubes are vesicular (=moniliform of Gregory). H. A transverse section, $X 10$, showing the apertures and single circle of mesopores. I. I'art of a rertical section, $X] 10$, from the same specimen showing the moniliform walls of the zooccial. (D-I. After Gregory, 1909.)

Ascosoccia (Zonatula) pscudotorquata Iragenow, 1851. J. Zoarium, naturat size, from the Cretaceous at Mastricht. K. Portion of the surface, $X$. 2n. (After Pergens, 1893.)

L. Part of a vertical section, $X 18$, near the edge of a zoarium of var. irregularis showing zooecia cut longitudinally and transwersally, and moniliform distal wills of the outer zonecia.

II. Part of the vertical section, $X 18$, of a long branch, 5 mm. in diameter, of var. ireguluris. (I, II, after Gregurr, 1909.)

Ascosoccia (Zonopora) tigcriensis D'Orbigny, 1\$53. N. Oricell found on a specimen from the Ianstrichtian at Roym, France, $X 12$. O. Interior of ovicell on a specinen from the same locality, $\times 20$.

$$
55999-20-\text { Buhl. } 106-53
$$


Variations.-The great number of peristomes and mesopores which ornament the surface of this bryozoan give it a very characteristic porous aspect. Moreover, the oval peristomes are unique in the genus. The longitudinal sections which we have made are not very clear. They simply indicate the superposition of the multiple layers composing the zoarium. The walls of the tubes and mesopores do not appear recicular.

In its exterior aspect this species much resembles Lichenopora, especially if we olserve the oval form of the peristomes. But the nature of its ovicell does not permit that it be classed with these well-known bryozoa.

Occumence.-Middle Jacksonian : Eutaw Springs, South Carolina (common). Cotypes.-Cat. No. 65368, U.S.N.M.

\section{PARTRETOCYCLOECIA EXILIS, new species.}

Plate 160, tigs, 5-16.

Description.-The zoarium is hollow, eylindrical, bifurcated, with large central cavities and thin walls. The tubes are club-shaped in their lower part and cylindrical where the mesopores are dereloped (in section). The peristomes are thin, orbicular, hardly salient, arranged vaguely in very irregnlar, transrerse rows. The oricell is orbicular, somewhat salient, pierced by tubes each of which is accompanied by a mesopore.

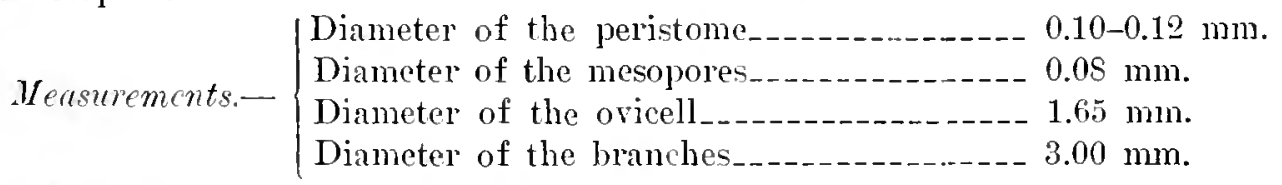

Tariations.-The peristomes are salient (figs. 9, 10) or not (figs. 11, 12). The mesopores are snall (fig. 9), medium (fig. 10), or large and polygonal (fig. 12), according to the clegree of weathering.

In the longitudinal section it is impossible to confirm the nature of the tubes. whether they are cylindrical or club-shaped.

Affinities.-In its exterior aspect this species much resembles Partretocycloecin dumosa Ulrich, 1901. It is distinguished from it only by its micrometric dimensions, in its smaller ovicell, and in its larger internal carities. The size of the latter is in fact very characteristic.

Occurrence-Vicksburgian (Marianna limestone) : One mile north of Monroerille, Alabama (very cominon).

Cotypes.-Cat. No. 65413 , U.S.N.M.

Family ASCOSOECIIDAE Canu, 19 I9.

1910. Ascosocciidae Canu, Etudes sur les Oricelles des Bryozonires Cyclostomes (2), Bulletin Société Géologique de France, ser. 4, vol. 17, p. 346.

The ovicell is a large, elliptical, elongate swelling quite salient and perforated by the tubes: often a median oeciopore is present. 
This family offers the greatest resemblanees to the Diaperoeciulae. It clitlers from it chiefly in the more constant form of the ovicells and in the presence of mesopores.

This family includes a great mumber of zoarial forms classitied by Gregory in his families of Petaloporidae and Zonatulae, in which the ovicell is identical. It inchules also the forma Multirace Dorbigny, 1852. The ovicell of the latter and also that of Zonopore of the same anthor have been discovered by Cann in the French Cretaceous.

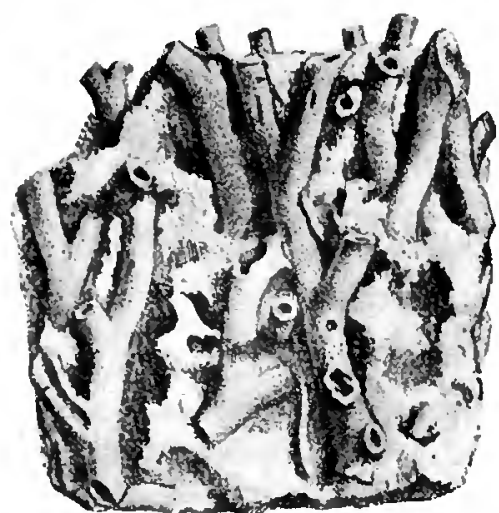

A
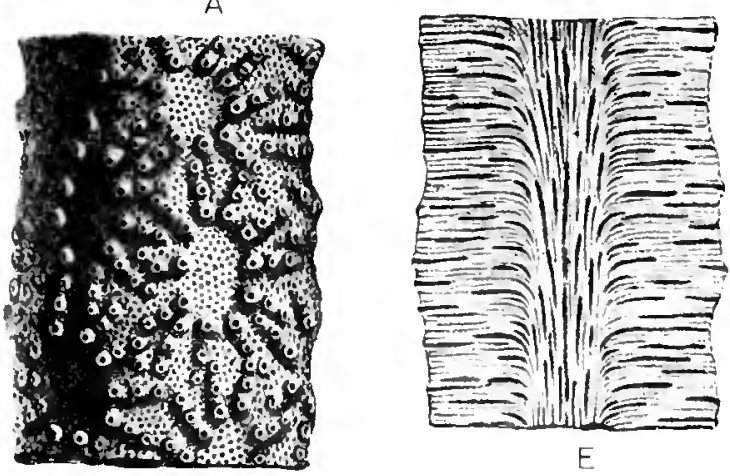

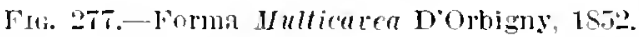
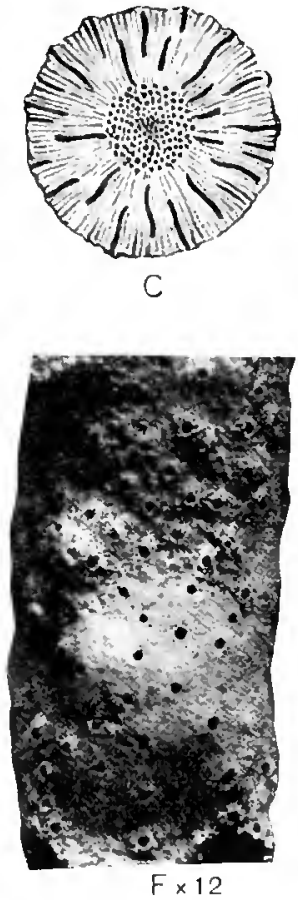

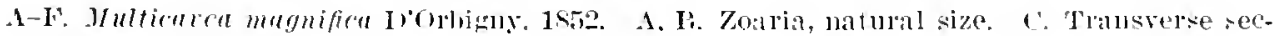
tion of a branch, enlarged. I. Aspect of the zoillial sulface, enlarged. H. Lonsiturinal section. (A-E, after DOrligny, 1552.) F. An ovicelled specimen from the Maastrichtian of Royan, France.

The genera recognized ly Gregory are only zourial forms. Thus the form alled Cururiv. with hollow zon rium. presents ovicells of $\mathbf{\Lambda}$ scosoeciidae (as Paruseosoccia consimilis Trich, 1982), of Leiosoecijale (:L P'arle iosoecin jachsonica. new species), and Tretocycloceidae (as Putrotorycloceid crilis. new species).

Moreover, the zoarial aspect called Zonoporc results simply from the bifurcation of the mesopores: it can therefore ocm withont importance in any family containing adventitous tulies. 
Gregory in 1909 distinguished the genera Petalopora and Sparsicavea by their ovicells. Our new observations show no fundamental difference between the oricells of these two old genera, which appear to be otherwise only zoarial aspects; we have included them in the genus Parascosoccia.

\section{Genus ASCOSOECIA Canu, 1919.}

1919. Ascosoccia Cant, Ftudes sm les Ovicelles ges Firozoniles Cyclostoues (2), Bulletin Société Géologique de France, ser. 4, vol. 17. p. 347.

The tubes are eylindrical. The walls of the mesopores are vesicular.

Crenotype.-1 scosoceia (Zonopora) ligeriensis D'Orbigny, 1852.

Range.-Neocomian-Midwayan.

In this genus it will be necessary to include the forms Zonopora, with bifuleated mesopores (as Z. Tigeriensis D'Orbigny, 1853) and Multicavea, with peristomes arranged in radial rows (as Mutticarea magnifica. D'Orbigny, 1854).

\section{ASCOSOECIA PRonineNs, new species.}

Plate 108, figs. 17-2.).

Description.- I the zoarium is solid, arborescent, bushy, sometimes reticulat: and borne on an expanded base. The tubes are cylindrical, bent horizontally at their extremity (in section). The peristomes are thin, orbicular, salient, irregularly arranged in quineunx. The mesopores are very small and polygonal. The ovicell is glolular, very salicnt, orbienlar.

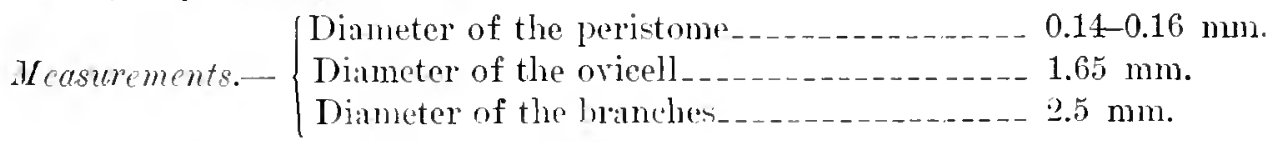

This speeies is quite well charaeterized by its salient peristomes; but this eharacter is easily lessened on the rorn specimens. The number of tubes between the mesopores is irregular. In longitudinal section the mesopores are almost as wide as the tubes; they appear, on the contrary, lum smaller in tangential section. There is probably a thickening of their walls at their extremity. The sections of this species are very diflicult to interpret and its structure is still not clearly understool.

Ifthities.-I scosoecia prominems difler's frou Tutocyctoecia attenuata Ulrich, 18.2., in the thinness of the walls of the mesopores.

Occurarenre--Midwayan (Clayton limestome): Mabelvale, near Little Rock, Arlkansas (common).

rotypes.-Cat. No. 6.5 140 . T.S.X.M.

\section{ASCOSOECIA ? (ZONOPORA) ULRICII, new species.}

Ilate 110. nigs. 1-5.

Description.-The zoarim is free, cylindrical. solirl, bushy, or retienlate. Tha tubes are very long. cylindrieal, bent at their extremity (in section). The peristomes are rather thick, nomsalient. grouped in quincunx in irregular. transrersal zones. 
The meropores are small, polygonal, separated by thick walls. crouped in transreseal zones, altermating with the zones of the peristomes. and (in section) with resiculat walls and often ramified.

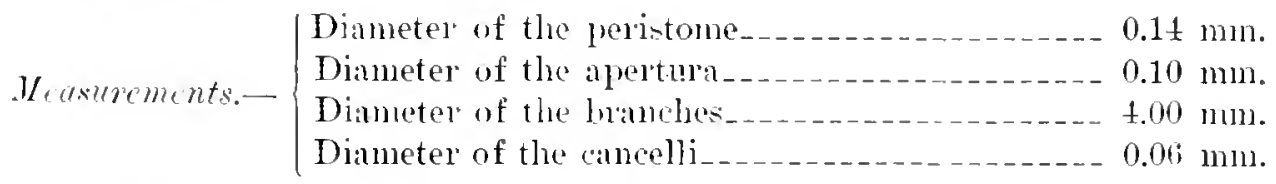

This species was noted in 1850 I hy Chich, who discovered the mature of the tibes and mesopores of Zonopora.

We have not discovered the wicell, so on generic reference is quite doubtful. The reemblanee of this species to Zonopora Tigeriensis Dorbigny, 155\%, has cansed us to classify it provisionally in om new genus.

We lnow that the large zones of nesupores are formed by their branching; but the latter appears to be rather irregular. so that the longitudinal sections are always somewhat confused.

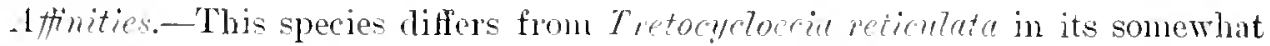
-maller micrometric measmements.

Oceurence.-Midwayan (Clayton limestone): Makelrale, near Little Rock. Artiansas (riare).

Cotyles.-Cat. No. 65201. T.N.X.Mi.

\section{POLYASCOSOECIA, new genus.}

The oricell is globular. salient. spread betreen the fascicles whose length it anguments, placed eceentrically on the frontal. The tubes are crimrical, orienter. short; they ramify into numerous nesopores on the frontal. The dorsal of the zoarimm is thick. with iamellar structure, and perforater ly racmoles bent toward the base.

Genotype.-Polyaseosocia coronopus. new species.

Ranyc.-Eocene-Pliocene.

Further remarks upon this new genus and a deseription of the genotrye are incluked in a stuly of the cyclo-tomatom bryozon now in press.

This genus differs from Plenroned in which the ovicell is placed identically, not only in the different nature of the oricell. but in its eylindrical tubes.

It ditfers from the gems Ekrosonce. efmally provided with pores on the two faces of the zoarinn, in its oricell placed laterally. and in its short ryndrical tubes.

POLYASCOSOECIA JACKSONICA, new spccics.

I'lite $1: 34$, tigs. $1-21$.

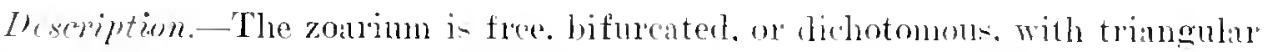
section, often reticulated. The farcicles are very little salient. composed of four tubes, arranged altemately on earls sile of the median crest and quite close to it. 
The tubes are invisible and hidden by the zoarial calcification; the peristome is orhicular or rectingular': the frontal supports two vacuoles at least. The sulci are searcely visible on the dorsal and the vacuoles appear very small and arranged in quincunx. The ovicell is rery large and quite porous. spread orer the median crest and in six interfaseicular spaces.

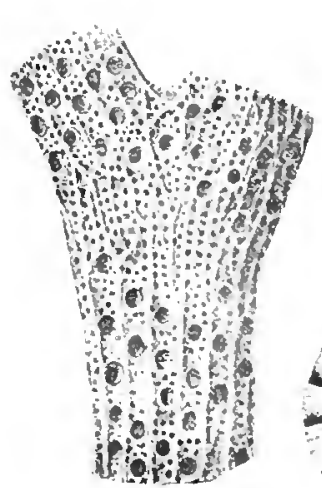

A

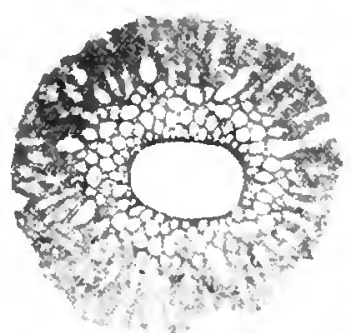

$\mathrm{J} \times 25$

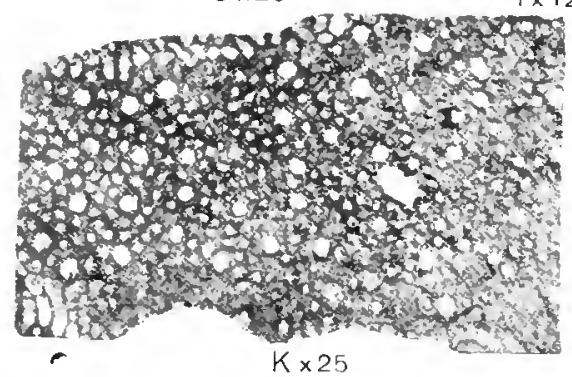

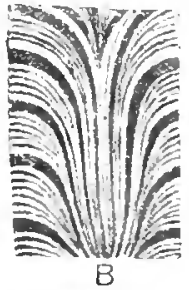

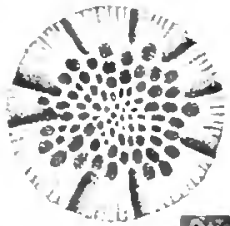

C
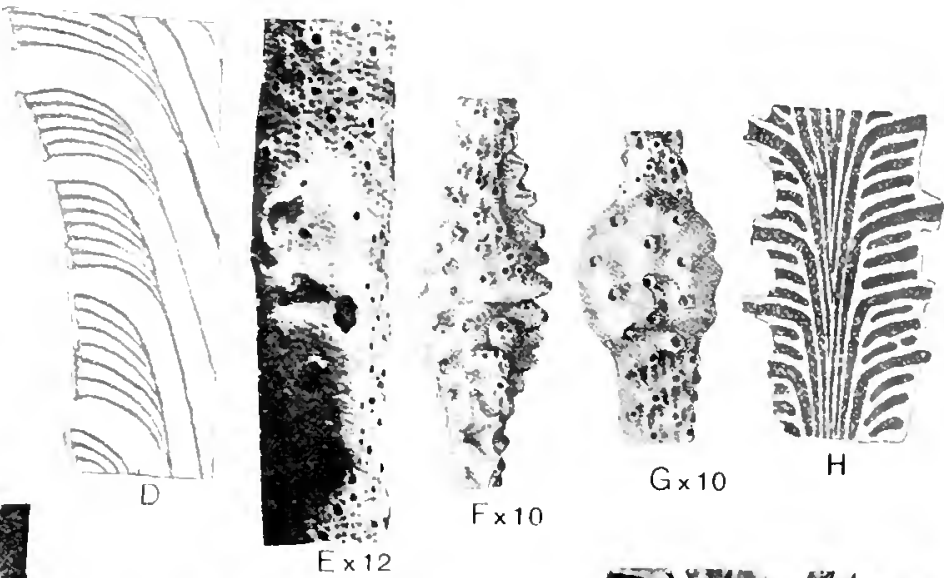

$\mathrm{H}$

$F \times 10$

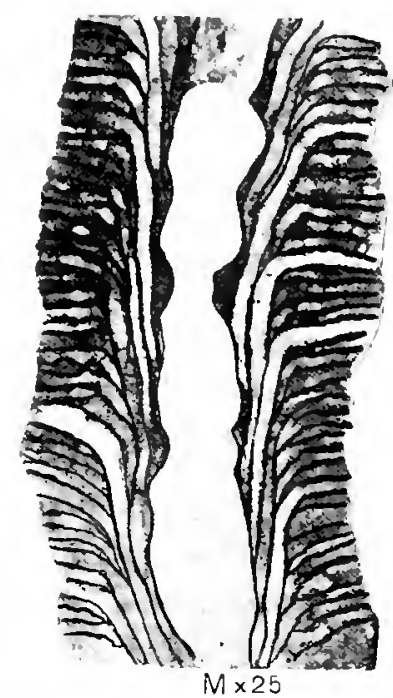

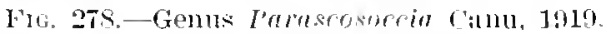

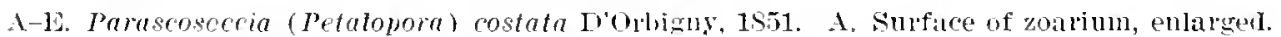
B. C. Longitudinal and transverse section, marnitiel. (A-C. After Novak, 1877.) D. Iongitudinal thin section. (After Porta.) F. Yiew of zoriun, $\times 12$, showing the ovicell pielced by the tulus.

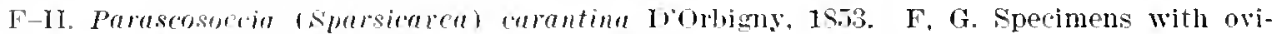
(alls, Y. 10, from Crotafonus of England. H. Longitudinal section, X 1t. (F-H. After Gregory, 1890$.

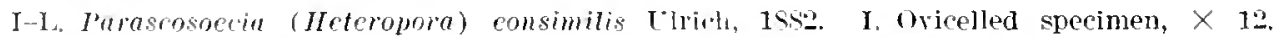
funt the Mirwayn at Mahelvale, Arkansas. J. K. M. Trinsverse, tangential, and longiturinal

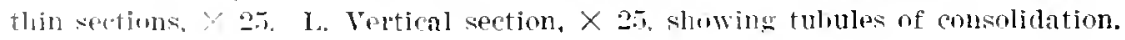




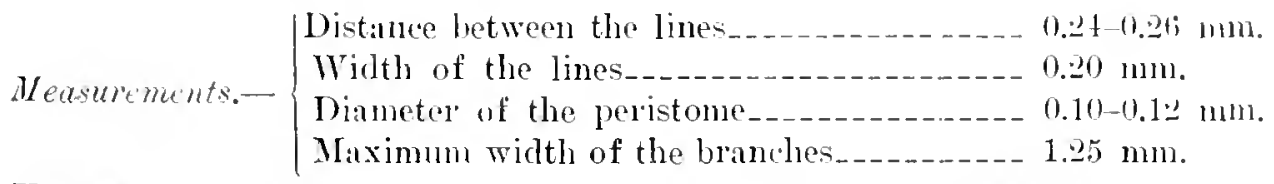

Tariations.-The polymorphism of this species is mprecelenterl. If the number of the specimens found had not permitted the discovery of the intermediate forms, it might have appeared that many new species were represented. In interesting rariation is that shown by the young branches; the tubes lo not bear any racunles: their frontal is eoncave, bordered laterally, and of a microscopic structure analogous to that of the other Cyclostomata.

The longitudinal section shows very numerous racuoles. The successive lamellae have no regularity: they appear to be formed by very thick walls of tergopores irregularly loranched and entangled. This is therefore only one aspect of lamellar structure. In transverse section these psendo-lamellae are still more irregular: they appear to result from the juxtaposition of the tergopores arranged parallel to the basal lamella.

The tangential section of the dorsal shows that the vacnoles perforate a sort of olocyst with large elements.

The abrasion of the clorsal vacnoles and of the basal lamella shows that in the interior the tubes have the fusiform appearance and are arrunged as in the other free Cyclostomati having only one cellular face.

The zoarium is supported by an expanded base. Only a single specimen witl the base has been found and we have not been able to diseover the ancestrula by successive sections.

Aftinitiex.-This species differs from Polyascosopcia cancellato Renss, 1sti (not Goldfuss), in its fascicles which are quite close to the median crest.

It differs from Polyascosoceia foraminosa Reuss. 1865, in its smaller vacuoles and in its fascicles not distant from the median crest.

This may possibly be Polyascosoccia subcancellata Manzoni, 1877, but that author has neglected to figure the anterior face of the zoarium, the aspect of which is mknown to us.

Occurvence.-Middle Jacksonian: Rich Hill, $5 \frac{1}{4}$ nilles southeast of Kinoxille. Crawford County, Georgia (very abmondant); Baldock, Barnwell Comnty, South Carolina (common); 17 miles northeast of Hawkinsville, Georgia (comnnon); $3 \frac{1}{2}$ miles south of Perry, Georgia (very abundant); $3 \frac{1}{2}$ miles north of Grovania, Georgia (common); one-half mile sontheast of Georgia Kaolin Co. mine. Twigas County, Georgia (very common), 12 miles southenst of Marshallville, Georgia (abundant): Eutaw Springs, Sonth Carolina (rare) : 18 miles north of Wrightsville, Johnson County, Georgia (common); 1 miles southeast of Lilly. Dooly County, Georgia (common).

This species exists in almost all the localitics of the middle Jacksomian, although it has not yet been found at this horizon at Wilmington. North Calrolini.

Cotypes.Cat. Nos. 6.i339, 65834, U.S.N.M. 
Plate 141, figs. $28-33$.

Tescription.-The zonrium is free, bifureated, or arborescent. with triangular section. The fascicles are little salient. formed of three or four tubes and arranged alternately on each side of the median crest to which they are almost adjacent. The tubes are invisible and hidden by two or three racuoles. The peristome is quadrangular and more salient in its proximal portion. On the dorsal the longitudinal sulci are little deep. The racuoles are fummel-shaped and close together.

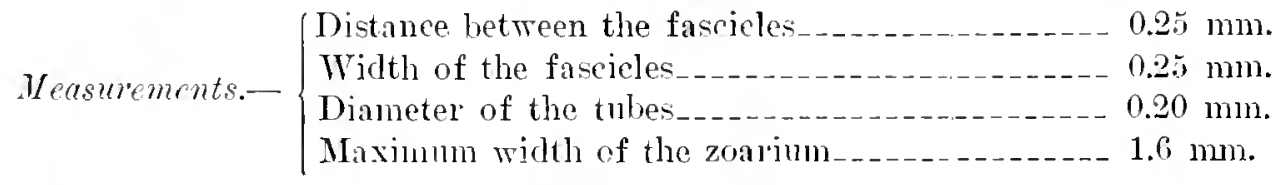

Affnities.-This species is characterized by the special arrangement of the fascicles which appear imbricated one above the other, on account of the saliency of the proximal portion of the peristome.

It diftel's from Potyasensoeria jaclisomira in its wider tubes (0.20 and not 0.12 mm.) and in its large vacuoles.

Occurvener.-Tower Jacksonian (Moodys marl) : Tackson, Mississippi (rare).

Cotypes.-Cat. No. 65342. T.S.N.M.

\section{Genus PARASCOSOECIA Canu, 1919.}

1919. I'arascosoccin Cand, Etudes sur les Ovicelles des Bryozoaires Cyclostomes (2), Bulletin Société Géologique de France, ser. 4, vol. 17, p. 34 i.

The tubes are club-shaped. The mesopores have no resicular walls.

renotype.-Parasrosocria (C'acea) costata D’Orbigny, 1851.

Range.-Cenomanian-Midwayan.

The form Petalopora is characterized by the rery great regularity in the arrangement of the mesopores. The latter are of equal length in sparsicaca. Finally, the hollow forms have been termed cavaria. But all those forms are again found equally in the other families with mesopores.

PARASCOSOECIA CONSIMILIS Utrich, 1882.

Plate 110, figs. 6-15.

18s. Hetcroporn consimilis Thrich. American Paleoznic IBryana, Jomnal Cincinnati Society Natulal History, vol. 5, 1) 144. pl. 6, 1ig. 11.

1!10. Petulopora consimilis Gregonx. Catalogue Fossil Bryuzon in Department Geology Rritish Mlusenum Clestcents, vol. 2, p. 320.

Mrseription.-The zoariun is hollow (Cararia), cylindrical, dichotomous, arborescent. The tubes are short. club-shaped at first, cylindrical and convex at linht anches at thoir extremitios (in section): the peristomes are orlucular. very 
little or not salient. arranged in irregular quincunx. The mesopores are small, polygonal, numerous. closed by a calcareous lamella. The ovicell is rely large, elliptical, as wide as the branehes.

Tariations.-The peristome is rarely risible. The zoarial avities are completely closed; they are often laterally constricted, preceded and followed by firmatopores, their dimensions and their forms are absolutely irregular, and we have not yet discovered the reason for their formation.

Affinities.-This species differs from Ascosoecia prominens in its hollow zoarium and in its club-shaped tuhes.

The oricell is absolutely analogous to that of Cavea costate D'Orbigny, 1851, but the mesopores are irregularly disseminated and not grouped symmetrically on a double row between the peristomes.

This species shows by the form of its ovicell that the generic distinetion made by Gregory between Petatopore, Sparsicavea, and Cavaria is useless.

Occurrence-Midwaym (Clayton limestone): Mabelvale, near Little Rock. Arkansas (very common) : 1 mile west of Fort Gaines, Geor gia (common).

Cotypes.-Cat. No. 65262, U.S.N.M.

\section{Order CTENOSTOMATA Busk.}

Fossil representatives of this order of the Bryozoa are extremely rare compared with those of the other orders. In the Recent seas the Ctenostomata are likewise the least represented group of Bryozoa specifically, althongh some of the -pecies are quite abundant and widespread. But a single form of this order has been discovered so far in the North American Early Tertiary rocks and it is too poorly preserved to merit deseription as a well-defined species.

In the Ctenostomata the zooecia are usually isolated and dereloped loy bukding from the internodes of a distinct tubular stolon or stem. The orifice is terminal and has an operculum of setre. Marsupia are wanting. The zon rimu is horny or membranaceous.

All of the known Paleozoic Ctenostomata have been describer by Ulrich and Bassler in their Revision of the Paleozoic Bryozoa. ${ }^{1}$ Little study has been put upon the Mesozoic and Cenozoic forms but the Recent species have bern the subject of numerons papers.

1904. Ulrich and Passler. Smithsonian Miscellaneous Collections, rol. 45. Iy. 65(i-2!l, 4 pls. 


\section{Family TEREBRIPORIDAE D'Orbigny, 1839.}

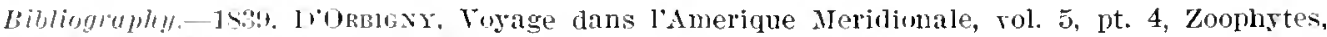
1. 22. 11. 10, figs, 10-19.-1860. Fischer, Étude sur les Rryozoaires perforants de la famille des Terebriporider, Tunvelles Archives du Iuseum d'Histoine Xaturelle, vol. 2, pp. 2!3-313.-

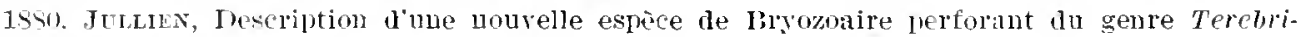
foru Lolligny, linlletín scricté Zoologique de France, vol, 5, p. 5.

Broyozoa perforating very superficially the enamel of shells. The zoarium is a more or less complicated network of small canals in which the zooecia are inserted.

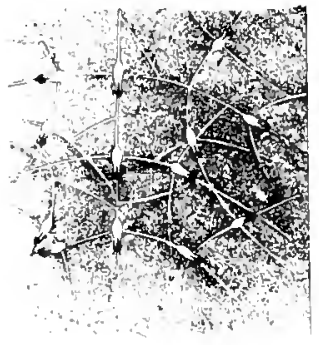

A

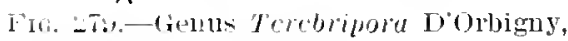
$18: 39$.

A. B. Terebripora ramosu Dorinigny, 15.39, A. \%oarium enlarged; primitive axis longitudinal, secondiry axis transvelse; many small anastomising canals letween the axes of diflerent arders are seen. B. Znoedium much enlarged. 'The small canals leave the sides of the zooe. cium toward its mirlle. I After risher, 1860.)

The zooecia are arranged on the axes of minute canals. which in branching energe from the primary axis at the point of attachment of a zooecium.

Genotype.-Terebripora ramose D Orbigny, 1839.

Range.-Turassic-Recent.

TEREBRIPORA, species undetermined.

Plate 112, fig. 13.

Of this species we have found only a fragment, which is a rather vague imprint not meriting a detailed description. The zooecia are very elongate; their dorsal, which is as usual very thin, is sometimes hroken. The zoarium is very incomplete, but the arrangement of the ramifications leaves no doubt as to the generic determination. It is useless to give a name to such a poor fragment, and the present notice is simply to indicate the presence of the genus in the Midwayn and to call the attention of collector's to it.

Occurrenee.-Milway (Porters Creek formation): Three miles north of - cooba, Kemper Comnty. Mississippi (very rare). 


\section{INDEX.}

\begin{tabular}{|c|c|}
\hline 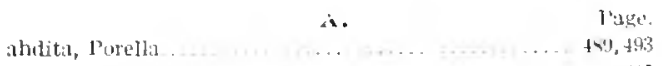 & 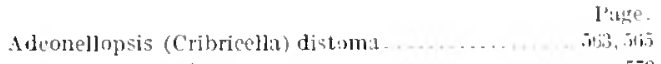 \\
\hline 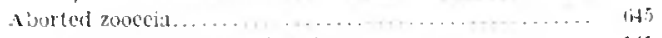 & 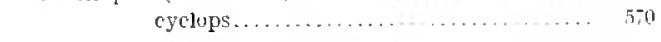 \\
\hline tisa, Mlerina (Membranipora)................ 141 & (Eschara) cascinophora ................ \\
\hline 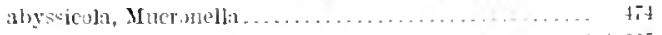 & 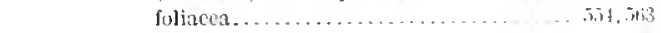 \\
\hline sonittip ro (Vincularia) . . . . . . . . 211, 22.5 & $\ldots \ldots \ldots \ldots \ldots$ \\
\hline 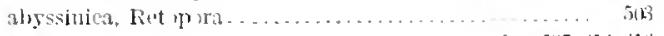 & gramulis. . . . . . . . . . . . . . . . . \\
\hline 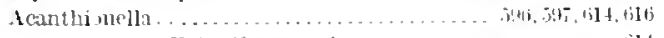 & magniporusil. ........... \\
\hline (Echarifora) typica. . . . . . . . . . . . n & oblicuat. . . . . . . . . . . . . . . \\
\hline 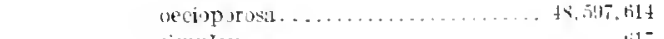 & (Poricella) el ngital............... \\
\hline simplex. . . . . . . . . . . . . . . . . . . . & manomica . . . . . . . . \\
\hline typicin . . . . . . . . . . . . . . . . . & porusa................. \\
\hline 1cantliocell a. . . . . . . . . . . . . . . . . . . . . . . . 2, 2, 304 & 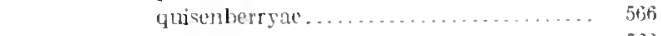 \\
\hline$\ldots \ldots \ldots \ldots \ldots \ldots \ldots \ldots$ & 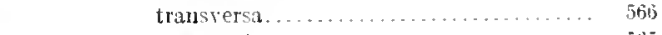 \\
\hline tubulifera. . . . . . . . . . . . . . . . . 23 & wetherelli. . . . . . . . . . . . . . . . . . . \\
\hline 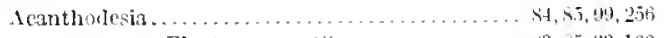 & $\ldots \ldots \ldots \ldots \ldots \ldots, 5.51,532.573$ \\
\hline (Flistra) sa,artii . . . . . . . . . . $\$ 3 . \times 5,99.100$ & a....... \\
\hline cervata, Metroperiella. . . . . . . . . . . . . . & Frobosciula............... \\
\hline Accesury tubes. . . . . . . . . . . . . . . . . . . . . . . . & Adventitious tules. . . . . . . . . . . . . . . . . . \\
\hline 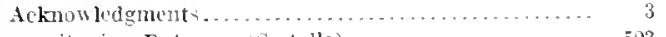 & 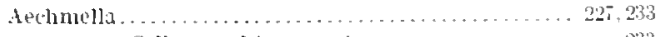 \\
\hline cquitanica, Fotepora (Sctella)................ 503 & (Cellepora) lijppuctelis . . . . . . . . . . . \\
\hline Acropora . . . . . . . . . . . . . . . . . . . . . . . . 317.319 & michaudiana............ \\
\hline (Cellaria) coronata . . . . . . . . . . . . . $31, .319$ & roemeri........ \\
\hline (Entalophora) gratel ou] $\ldots \ldots \ldots \ldots \ldots \ldots \ldots$. 318 & urantia. . . . . . . . . . . . . . \\
\hline (Eschara) gracilis ...................... 31., 319 & santhe............ \\
\hline (Forina) contorta. ....................... 318 & xiphia. ............ \\
\hline (Fustulipora) manuillata . . . . . . . . . . . 314,319 & crassimargo $. . . \ldots \ldots \ldots . . . . .$. \\
\hline saillans . . . . . . . . . . . . . . . . . . . 314,311 & filimargu. . . . . . . . . . . . . . . 227.233,234 \\
\hline trita. . . . . . . . . . . . . . . . $31 \mathbf{n}^{2}$ & (Membranipora) ambigua.................. \\
\hline croporidae. . . . . . . . . . . . . . . . . . . . . . . . . . . & inna...... \\
\hline$\ldots \ldots \ldots \ldots \ldots \ldots \ldots \ldots \ldots \ldots+\cdots$ & depressa. \\
\hline 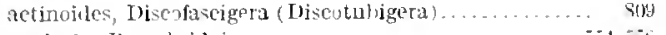 & Attea anguina... \\
\hline 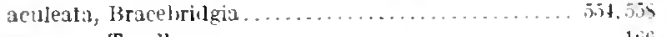 & recta......... \\
\hline 'Tegella................................... 1ili & 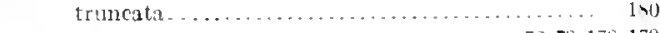 \\
\hline cutirostris, Portlla . . . . . . . . . . . . . . . . . . . . & 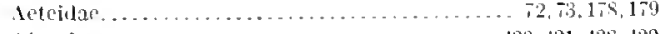 \\
\hline 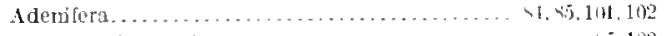 & $\ldots \ldots \ldots \ldots \ldots \ldots \ldots$ \\
\hline inarmata. . . . . . . . . . . . . . . . 102 & anstralis $\ldots \ldots \ldots \ldots \ldots \ldots \ldots$ \\
\hline 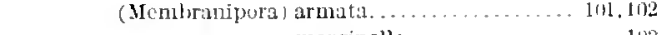 & clavula................ \\
\hline$\ldots \ldots \ldots .1012$ & alata, Schizobrachiella (Schizoportlia) \\
\hline nigrans...... & mbranujora).... \\
\hline$\ldots \ldots \ldots, 102$ & Ellisina (Membranipora) ........... \\
\hline$\ldots \ldots \ldots \ldots \ldots \ldots \ldots$ & albirostris, Holoportla.............. \\
\hline appendiculati......... & allori. Metropericlla (?) . . . . . . . . . . . . . \\
\hline (Cellepora) heckeli ......... & Alderinit........................... \\
\hline grisea................... & (Bıflustra) ovalis ........... \\
\hline violacta.......... & ctassa ................... \\
\hline deonella. . . . . . . . . . . . . . . & (FIustrullario) fr:1n'farla.... \\
\hline Hirn sphocella trit n..... & 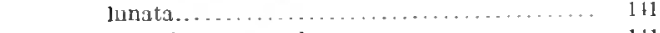 \\
\hline (Eschara) polyst mollib... & (Membranipora) abortiva.... \\
\hline folliculata . . . . . . . . . . . & cumnungsi....... \\
\hline intricaria.......... & mobellis. . . . . . . . \\
\hline 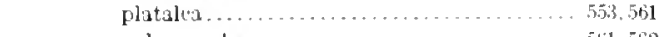 & mrregularis........ \\
\hline polyusorphat..... & 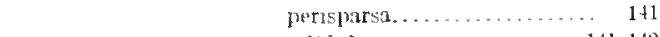 \\
\hline polystomella............ & solidula....... \\
\hline serrata............ & $\ldots \ldots \ldots \times 3,143$ \\
\hline leonellopsis...... & pulcherrima. . \\
\hline cuscinoph yra. & Iriclı, étuopori..... \\
\hline
\end{tabular}




\begin{tabular}{|c|c|}
\hline $\begin{array}{r}\text { Pagt? } \\
\text { itI }\end{array}$ & $\begin{array}{r}\text { Tage } \\
-49,52,461\end{array}$ \\
\hline ifera, 1 Juppomenella. & ngulatum, Rhynchozoon. \\
\hline Peristomella (Eschara).. & scharellina. \\
\hline imentary canal............... & ngulosq, rellepora......... \\
\hline mime, Lumulits (riscoffustrellaria) bouci.. & Membrunipora \\
\hline ormation Names... & Onychocilla.... \\
\hline 662 & angusta, Ellisina (?) ... \\
\hline (charinella) & Membranipora... \\
\hline$\ldots 606,613$ & angustaedes, Hippomenella. \\
\hline$\ldots 641,682$ & ngustata, l'roboscina..... \\
\hline ..... & ..... \\
\hline ..... & bra........ \\
\hline ..... & ......... \\
\hline orat........ & antaretica, Hurnera......... \\
\hline lia) $\ldots . .$. & ra............... \\
\hline riporella)........... & 4.59 \\
\hline mericana, La & 58 \\
\hline ...... & atordes, Amphiblestrum (Mermbranipura). \\
\hline muatophora & ntioja. Eschara.......... \\
\hline$\ldots . . .[4]$ & antiqua, costazzia. \\
\hline mocna, Entalophor & . $633,244,219,220,222$ \\
\hline ......... & .............. \\
\hline Amphiblestrum . . . . . . . . . . . . . . . . . . . . . $84,141,1 \mathrm{si}$ & Stomatopora.......... \\
\hline 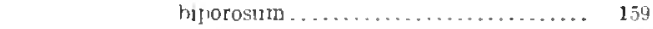 & antropura... \\
\hline 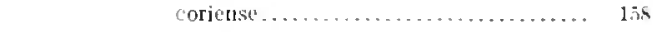 & nipora) granulifera... \\
\hline 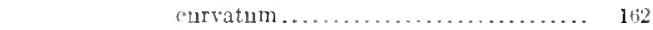 & (.................. \\
\hline , Ramplionotus. & (Lepralia).... \\
\hline .... & ......... \\
\hline$\cdots$ & $\ldots+453,540,640$ \\
\hline ...... & ....638,634 \\
\hline anipora) anteridus, . & apiculata, \\
\hline argentea & $\ldots \ldots$ \\
\hline flemingi. ....... 141, 156-15s & appensia Di. \\
\hline trifolium... & Leprilin.... \\
\hline umbonata.. & ….......................... 803, 809 \\
\hline 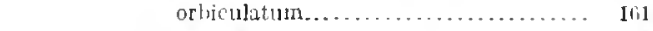 & ..... \\
\hline .......... & $27 \pi$ \\
\hline .... & ........ \\
\hline .... & Butfonella (Sschizoporelta).... \\
\hline a) heteropora. & $\ldots \ldots \ldots \ldots \ldots \ldots 2,311,312$ \\
\hline mpla, $\mathrm{I}$ & inatit... \\
\hline ............ & tonocros............2.2\$3,311,312 \\
\hline …..... $8 \mathrm{s,70}$ & $\ldots \ldots$. \\
\hline$\ldots \ldots \ldots \ldots \ldots \ldots \ldots \ldots+20,121,430$ & 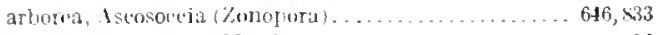 \\
\hline$\ldots \ldots+21.430$ & mbranipora). . . . ................ \\
\hline ............. & . . . \\
\hline ... & 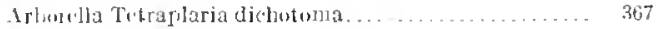 \\
\hline .... & $\ldots$. \\
\hline .. 6998,699 & $\operatorname{ra}($ critepora)............ \\
\hline 739 & 571 \\
\hline .............. & ina. \\
\hline .............. & 708 \\
\hline ........... & arcifera, Uhagh \\
\hline …...... & aretica, Ijplusulen obelia.................. \\
\hline .................... & arenata, Jliprozergusella ....... ................. 373,400 \\
\hline ............. & Id dnonea.................. . \\
\hline $66 i 1$ & $\ldots .47,454$ \\
\hline 56 & 454 \\
\hline $2 \operatorname{tin}$ & inbrantipora). \\
\hline 55 & 335 \\
\hline .... & $\ldots 101.102$ \\
\hline $1 \pi \mathrm{s}$ & 369 \\
\hline … & Arthroporna.......... \\
\hline$\ldots \ldots \ldots \ldots \ldots$, & $\ldots \ldots . .339,35 \mathbf{I}$ \\
\hline ingulata, romalipura. & 351 \\
\hline
\end{tabular}




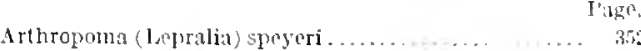

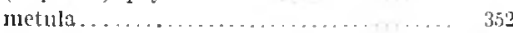
pesunseris........................ 35,1

Iscophora.

Ascopore.

iscosin. mandora. .

Ascosoecia ........................... $\times 32,833, \times 36$ lateralis . . . . . . . . . . . . . . . . . . . . . . prominens..................... $83 t$ (Zonatula) psetudotorquata............. $\$ 33$

(Zonopora) arkorea................. it ti, 833 ligeriensis....................

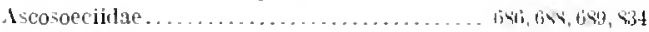
aspera, bathosella......................... 40. . 405 Hucronella...................... 4n. asperrina, Iinpodiplosia (Lepralia)................ 334 asperula, Gastronella........................ $3 ; 21$ Aspidelectra............................. 252,317 nielolontha. .................... 283,317

Aspidostoma................................

flanmulum.................. 254,254

gicuntea, Eschara................. 252-254

globifermm.................... 254

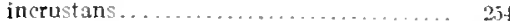

onychoceliferum.................. $25 t$

poriforum ........................ 2is

Aspidostomidae......................... $211,2,2$

asymetrica, Steganoporclla (Gaudryanella).......... 263

asymmetrica, Floritina...................... 224

atlantica, Cellaria................................

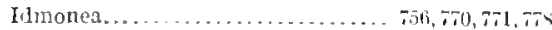

Retepora........................ $5 n^{3}$

Tubnliprora. . . . . . . . . . . . . . . . . 779

atomicula, Filisparsa......................

attenuata, Heteronora.....................

Sparsicavea.................. 820

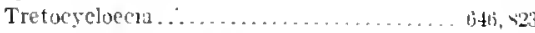

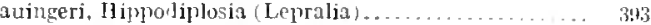

a uriculata, femellinora..................... Schizomavella (Jepralia) . . . . . . . . . . . . 3,30,354 Schizoporella..................... 33,3

aurita, Calopora (Menbranipora) ........... 146, 147,152 Lepralia.

aust raliensis, Haswellia (Mrriozoum)...... 512, jith

australis, 1 imulo 1 ia....................... 421,423

Entalophora..................

Tetraplaria . . . . . . . . . . . . . . . .

tricularia ............................. til

frontal or immersed. .............. it

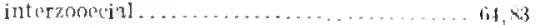

arieularia, litmula. mediun......................... 4. pirot of....

arictlaris, Shlismonora.

Axicularium, st rufeture of.

Axial gemmation.........

axienlata, Hippomencllu

\section{J3}

baceata, Mippodiplosia....

baceatus, Ramplionotic.......

Bactrollaria

Batridium.

Bactridum cllyblem ballii Escharina..........................

Lepralia............................

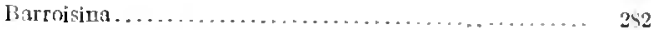

elegantula............................ 243

Basal lamella.................................

system of fixation......................

bassleri, Ramplionotus..................... 103

Bathoselia............................. 403, 404

aspera....................... 4nt, 403

cingerans...................

mudata. . . .................... 400

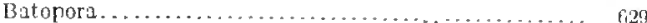

conica........................... 629

multiradiata ...................... 6120

rosula.......................... n

scrobiculata......................

stoliczkai......................... ri2y

lreak........................................... 61,451

beaniana Retepora (Sertelta)............... 499,503

heisseli, Lnnulites....................................

Beisselina.............................. 322,323

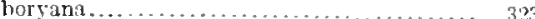

(Eschara) striata.................. 322

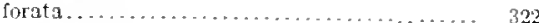

implienta....................... 32

midwayanica........................ 321

striata....................... 323

trulla....................... 318, 324

hellula, Electra (Membranipora)............... if

henemunita, Menipea....................... 18

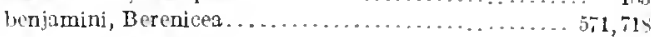

Membraniporina ................

Berenicea...............................

archiari...............................

benjamini..................... 6.

brevissima . . . . ..................6. 671,7

cocciner ........................... $10 . .4$

congesta......................... it

diluviana........................ 708

Diplosolen obcia.....................

folium......................... 70 .

inrondita....................... $672,7 \mathrm{l}$

ingens. . . . . . . . . . . . . . . . .

latomarginata......................

lineata......................... 714

malmula......................... tion, 718

papillos: ...........................

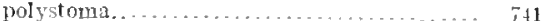

prominens........................

regularjs.......................

sarniensis...........................

stipata......................

suborbicularis.....................

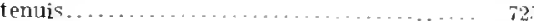

undata............................ 180,717

indulata......................... 70,

beyrichi, Dakaria (Cellaria $\ldots . \ldots \ldots \ldots \ldots \ldots \ldots \ldots \ldots$ 30.

hiajerta, Schizoporella (1.rjoralia).............. 343

Stephanoselta.................... 339,314

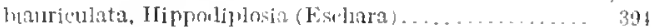

Methbranipura..................... 11

Reptohtstrint...................... 1f

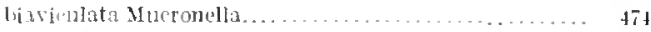

bicollaridae............................. 72,73 
bicolor, Electra (Nembranipora) . . . ..............

bicornigera, Lepralia............................ 410

bicornis, Membranipora.......................... 148

bidens, Gargutua......................... 227, 230

M!mbranipora ......................... 231

bidenticulata, Schismopora...................... 591

hiduplicata, Tesmedinporoecia (Tubulipora)......... 751

bificiatn, cellaria............................... $2-1$

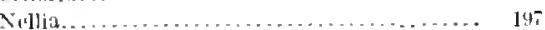

Bitlabellaria................................ apithyi............................ 68 ;

Biflustra fencstrella, stanonocella................. thallata, Memhraniporima................ form of zoarium . . . . . . . . . . . . . . . . . .

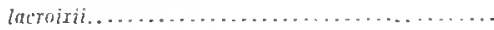
megapora, diranmella.................... ovillis, Alderima.........................

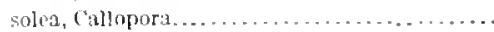
torta Euritina ................................

bifurtati, Oncousnecia (Filisparsa)..............6 657,64 )

ligibuera, Meniseopora......................554,5i;

hiincisa, Murconella..........................

bilamellaria, Rectongehocelia.................... 210

bilaminata, Rlanmphostomella .................. 476

bilola, Hornera.............................. 6914

bimarginata, Floridina (Semieschara).............. 20.

Bimulticarea................................ 817 variabi is............................ 817

bini, Fi isparsa.............................. 695, 702

bioculata, Menbraniporolla.................... $28 \mathrm{f}$

Biparietal gemmation........................... 64 r

biplanata, Metroperiella........................ 36.4

Bipora...................................... 631 untonata.............................. 6i31

biporosa, llippoporina ......................... 37

biporosum, Amphiblestrum . . . . . . . . ............ 159

birostrata, 110 lopuralla..................... 612,613

biseriata, Fi isprarsa ...........................

bispinosa, Puellina............................. 297

Rhynchozoon (lepralia) ................. 50.8

biturrita, Gephyrophora (Schizoporel!a)............. 521

Blind (sealed) zooecium . . . . . . . . . . . . . . . . . .

bo'etiformis, Lichenopora....................... $\$ 13$ Radiopora........................... $\$ 13$

borgana, Beisselina............................ 323

borri, Caberea......................... 65, 191, 193

Proboscina.................................6. $65 \mathrm{k}$

boryi, Crisia ................................. 191

l,oryii, Peristomoecia (1'robuscina) .............. 692,693

bosqueti, Pachytheca.......................... 323

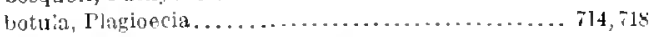

hotulus, Lepralia........................... 371

bouei ulmina, Lunulitess (Discoflustrellaria)........... 1113 concaru, Lunulites (Discoflustrellarin)............. 103 depressa, Lunulite's (Discofustrelluria)............ 1013 duclusif, Lunulites (Discoflustrellaria)............. 103 Lunulites (Discoflustrellarin)................... 103 tisi, Lunulites (Discoflustrelliria)................ 1013

Trochopora.......................... \$5, 103 truncat, Lurulizes (Discollustrellari $)$............ 104

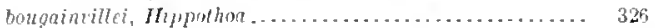
bracebrilgia . . . . . . . . . . . . . . . . . $551,555,557,55 \%$ acu'teata......................... 554 , 5is

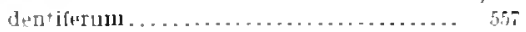

I’age.

Bracebritgia (Eschara) ignobilis .................. 557

polymorpha.............. 557,559

(Meniscopora) subcrenulata.............. 557

po:ymorpha costulata................ 559

(Porella) emendata.................... 557

(I'oricalla) elongata.................. 558

(Porina) subsu?cata................ 557,558

(I'orostoma) clavatum................ 557 polymorphum............ 557

pyriformis........................ 558

brathycephala, Lepraliz ......................... 589

Branching of zoarium........................... 649

brarardi, Conopenm (Membranipora) .............. 86

brendolensis, thamphostome la................. 477

Brettia................................... 200

brevis, Dakaria............................... 360

Desmeplagioecia (Actinojora)............... 720

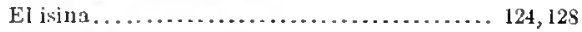

\$ ecynoecia............................ 728

Metracolposa ............................ 305

hrevissima, Berenicea..........................6. 671,717

Micrupora........................ 235

britannica, Cal.opora (Membranipora)................. 147

brongniarti, ("horizopora (Flustra)................ 333

brundidgensis, Plagioecia..................... 71,718

Bryocrptella............................... 496

(Cryptella) torymata..............456, 496

Bryozua, (ieneral Description of .................. 39

lowcenlenta, Metrocrypta.................... 432,450,451

Buffonella .......................... 339, 345, 34!

(Escharella) stylifera................... 349

hexagonalis........................... 349

(Lepralia) incisa....................... 349

pauper..................... 349

nicrostona......................... 350

rhomboidalis......................... 350

ridleyi .......................... 339,34

(schizopurella) arachnoides.............. 349

carinata................ 349

cierici.................. 349

cremu ata................ 340

edwardsiana............... 349

hexagona................ 349

laevigata................ 349

levata.................. 349

Inarsupifera.............. 349

nuda.................. 349

ridleyi................... 348

rimosa ................. 349

rumida.................. 349

simplex................. $34 y$

Buguba avicularia............................... 41

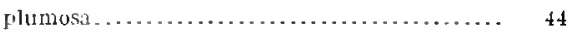

sallatieri............................. 63

turbinata................................. 43

Bugularia................................. 168

Bugulopsis ...................................... 181

buliata, Lichenopura......................... $\$ 15$

nurnsi. Quadricellariat (?) ....................... 279

Łuskii, steganoportila ....................... 261

C.

Caherea. .

$181,191-193$

voryi ........................... $65,191,193$

tlarwini .............................. 193 
Page.

Caberea ellisi.

Caberiella................

calamorpha, Pucllini..

(a)cification. .

Calcified zooecia..

californick, Thalamoporella rozieri................. ${ }_{2} 68$

ealjforuicnsis, Callopora (Memuraniporn) ........... 147

Callopora.

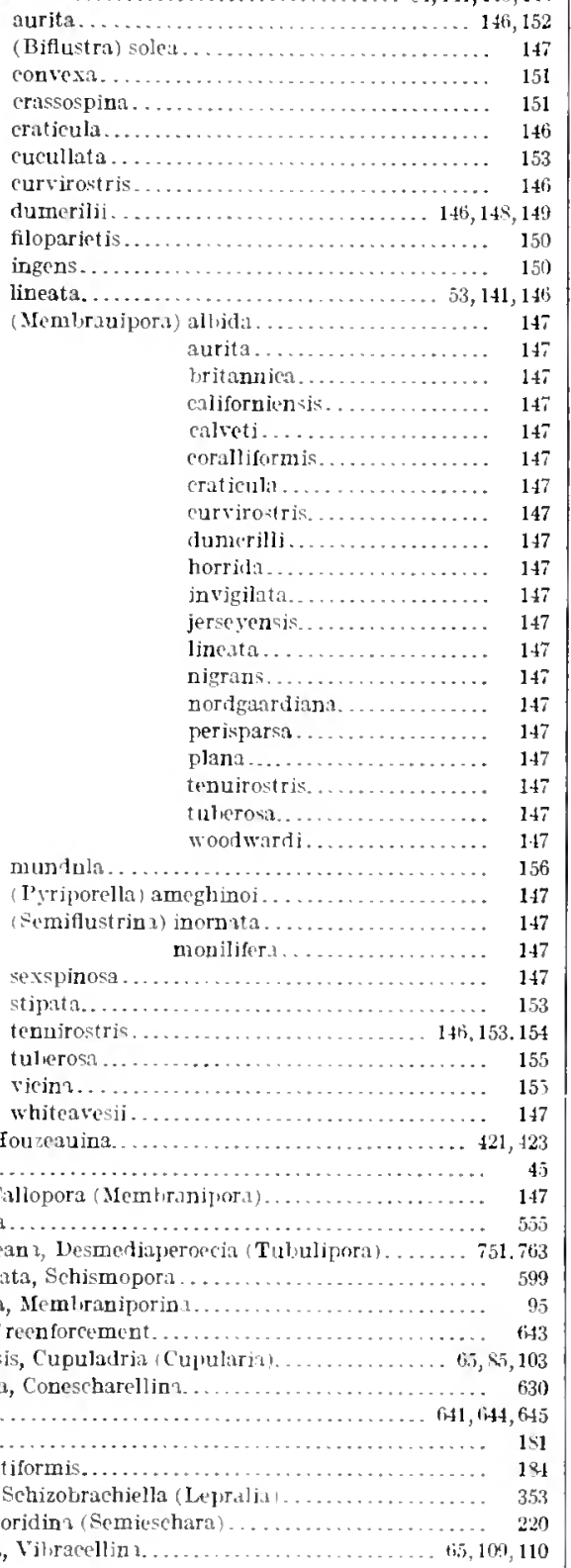

capillata, Lichenolor.

Capillata, Lichenoporia . . $\ldots \ldots \ldots \ldots \ldots . . \ldots 15$

capitata, Entulophora ..... . . . . . . . . . 740

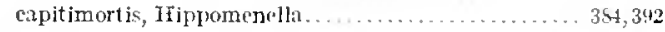

capulns, Lurularia (Liululites) . . . . . . . . . . . 234, 239

carantina, Parascosoecia (Sparsicarea) . . . . . . . . . f6.16, $\$ 38$

Carbasea dissimilis........................ $16, \ldots$

cardelle..............................

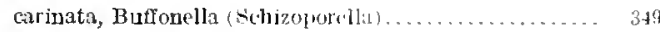

carolinensis radiata, Fuellina . . . . . . . . . . . . . 297

ciksiformis, Tubulipora . . . . . . . . . . . . . . . . . .

Catenicella subseptentrion 1 ls. . . . . . . . . . . . . . . 550

Catenicellidae............................... 550

catenularia, Memliranipora.................

Pyтipora.............

cuudifera, Tetraplaria........................ 3tis

Canloram phus.......................... 4,4174

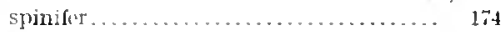

cara, Otionella........................... 10 s

Cavaria ................................ $634, \$ 31$

Partretocycineria rlunzos. . . . . . . . . . . . $\$ 30$

Cavea, Parascosoecia costata .................. $4 \mathbf{4 0}$

Carolini, Lacerna (Schizopordla)................ 340

eecilij, Arthropoma (Flustra) . . . . . . . . . . . . 339, 351

Cellaria............................. ${ }_{272}$

Acropora coronata .................... 318

atlantica . . . . . . . . . . . . . . . . . . .

Jifaciata............................. 27

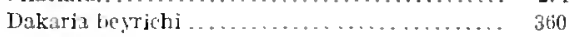

dennanti..........................

dimorpha. . . . . . . . . . . . . . . . .

fistulosa . . . . . . . . . . . . . . . . . 271, 272

rigida. . . . . . . . . . . . . . . . . . . 271

schrejhersi..................... 35.

sinuosa.............................. 272

strictocella . . . . . . . . . . . . . . . . . . . . . 273

Tetraplaria schrejlersi ................. 3ti

Cellariidae ............................ 259-271

allarioiles, Entilophora................... 723

Cellepora.............................. 503,595

angulosa............................. 205

coccinta..............................

coronopus-pumicosil . . . . . . . . . . . . $596^{\circ}$

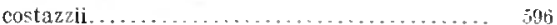

erustulenta, Floriaina. . . . . . . . . . . . 220

cycloris . . . . . . . . . . . . . . . . . . . 5.57

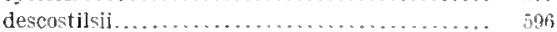

Distansescharella fiamiliaris .............. $\quad 209$

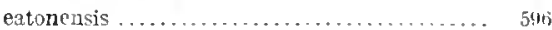

entomasoma......................... 345

form of zoarium .................... lis

glomerata ... . . . . . . . . . . . . . . . . $6 u_{2}^{2}$

hippocrepis, fechnulla................ 233

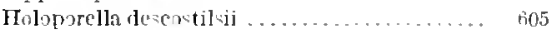

inornata........................ 320

janthina . . . . . . . . . . . . . . . . . . . .

Lepraliclla contigria . . . . . . . . . . . . . . . . 509

megacephala.........................

michaudiana, Acchmella.............. 233

Osthimosia sigtata . . . . . . . . . . . . . . ... 601

ytcroporn . . . . . . . . . . . . . . . . . . $\$ 10$

ramulosa . . . . . . . . . . . . . . . . . . $590^{3}$

roemeri, 1echmellik . . . . . . . . . . . . . . $\$ 33$

rotundora. . . . . . . . . . . . . . . . . . 615

sardonjea . . . . . . . . . . . . . . . . 596,615

Schismopori curonuple................ 599 


\begin{tabular}{|c|c|c|}
\hline \multirow{6}{*}{ Cellepora } & \multicolumn{2}{|l|}{$\begin{array}{l}l^{3}: a g e . \\
599\end{array}$} \\
\hline & scripta. ............. & ra, Semihaswellia.... \\
\hline & tis & kei, Macropora... \\
\hline & n.......... & assification....... \\
\hline & 2333 & of Costulate. \\
\hline & ........... & 70 \\
\hline \multirow{2}{*}{\multicolumn{2}{|c|}{ 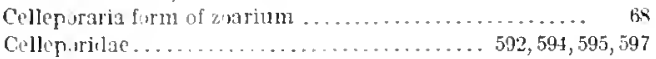 }} & Clausa heteropura.. \\
\hline & & Scrupucellaria. \\
\hline \multirow{2}{*}{\multicolumn{2}{|c|}{$\begin{array}{l}\text { Cellularia } \\
\text { cellulosa, Retepura . . . . . . . . . . . . . . . . . . . . } 490,500,503\end{array}$}} & Lva, Dia \\
\hline & & clavata, 1) \\
\hline \multicolumn{2}{|c|}{ cela, "nyclucella............................ $\quad 207$} & lia). \\
\hline \multirow{2}{*}{\multicolumn{2}{|c|}{ 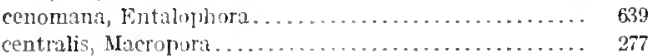 }} & $\sin \ldots \ldots \ldots \ldots \ldots$. \\
\hline & & itio \\
\hline \multicolumn{2}{|c|}{ Centronea........................... $752,756,761$} & vatirar \\
\hline & cropura.............. 756,761 & \\
\hline \multicolumn{2}{|l|}{ Ceriupora. } & st ima) \\
\hline & .......... & 1.25ilor mis, \\
\hline & S01 & 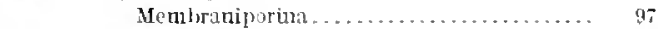 \\
\hline & .......6 678,679 & arioedes, I'lagi \\
\hline & $\ldots \ldots \ldots \ldots \ldots \ldots \ldots 636,679$ & $42 ?$ \\
\hline & ........... & יll.... \\
\hline & ..... & ... \\
\hline & $\ldots 636,679$ & (Ullit).. \\
\hline \multicolumn{2}{|c|}{ ceroides, Tubucellaria......................... 541,542} & liva) ................. 315,316 \\
\hline \multirow{2}{*}{\multicolumn{2}{|c|}{$\begin{array}{r}\text { cervicurnis, Ifiast pora lamell sa................ }{ }^{672} \\
\text { Porella Millep ra. . . . . . . . } 455,456,479,483\end{array}$}} & -.. 596,414 \\
\hline & & .................. \\
\hline & ................. & ....... \\
\hline \multicolumn{2}{|c|}{ Chaperia spinosa .............................. 69} & 109 \\
\hline \multirow{2}{*}{\multicolumn{2}{|c|}{ 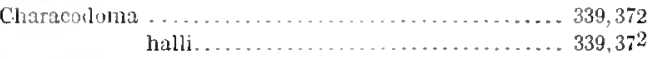 }} & 404 \\
\hline & & 410 \\
\hline \multicolumn{2}{|c|}{ Cheilopora .............................. 524,525} & 409 \\
\hline & .................. & 411 \\
\hline & ..... & 409 \\
\hline & ............ & ............. \\
\hline & ..... & …............ $403,404,409,411$ \\
\hline & ................... & 1 resupin $\_$t...................... \\
\hline & ................... & 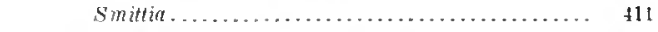 \\
\hline & $\ldots \ldots \ldots 3,525$ & (Defrancia) $\ldots \ldots \ldots \ldots \ldots \ldots$ \\
\hline & ..... & $\ldots \ldots \ldots \ldots \ldots \ldots \ldots$ \\
\hline & ........... & 201 \\
\hline & ..... & $22^{2}$ \\
\hline & ..... & $2 \$ 3$ \\
\hline listom & nata & 308 \\
\hline & ment............. & (iz) .... \\
\hline & …............. & 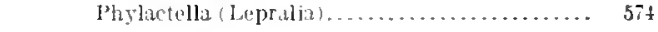 \\
\hline & (n.............. & 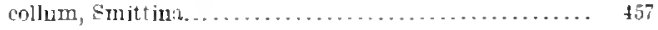 \\
\hline & $\mathrm{i}+\mathbf{n} \ldots \ldots \ldots \ldots . . . .$. & 663 \\
\hline & (................ & .. $\$ 21,425$ \\
\hline & atic classilication of Early Ter- & 194 \\
\hline & & 456 \\
\hline & ........ & \\
\hline & ...... 3319,3 & 510 \\
\hline & $\therefore \ldots \ldots$ & m...... \\
\hline horizule & ..... 325,333 & ........ \\
\hline & 3.3 & mpacta, l)iastopora...................................... \\
\hline Clanotreme & …...27t,275 & ….... 192,493 \\
\hline & $272,274,273$ & $7+6$ \\
\hline & $\$ 3$ & $\ldots 59,314$ \\
\hline & $25+1$ & ... \\
\hline & 405 & \\
\hline & 351 & compressa, D \\
\hline & 25. & 729 \\
\hline 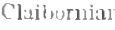 & 19 & pra \\
\hline & (.......... & (יז.1 _ \\
\hline niea & 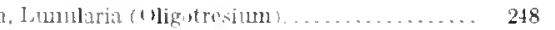 & Nellia... \\
\hline
\end{tabular}




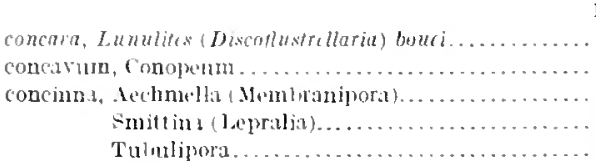

concreta, Plagioncia..................63, $711,717, \pi 1$

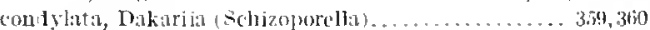

Conescharellina

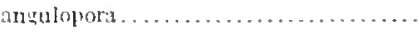

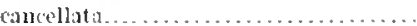

in

philippinensis.

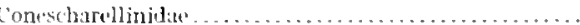

conferta, Hippoporina (Eschara)

confusa, cirmmella $($ Flustrella $) \ldots \ldots \ldots \ldots \ldots \ldots \ldots \ldots$

congesta, bioraniteat

conicib, lithtoporin.

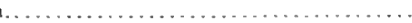

Trochopor:

conifora. Ineteroporit.....

conjuncta, $\mathbf{1}$ แ)

Conocavia............................... 42

conom?unt

richarti...... 423

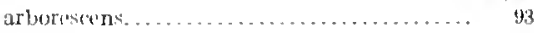

concavim ........................

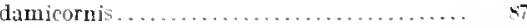

honckiri. . . . . . . . . . .

heroixi..................... $85,86,89$

lamellostum....................... 92

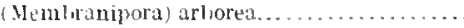

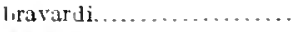

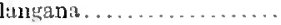

maplest onei

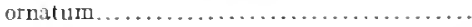

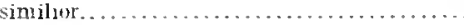

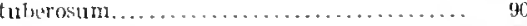

wilcoxianicum................... st

consimilis, Parascosocecin (I feteropora)........ $431,434,84$ )

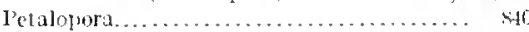

constanti, Heteroport...................... ti3t

contigua, Lepralinla (Cpllepora) ................ 504,511

Lunularia......................... 24

Lunulites.......................... 210

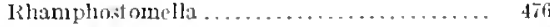

contorta, Lcropora (Porina) .................. 31

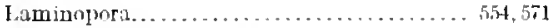

Peristomella Mucronella............... 40.

contortoplicatun, Triphylozoom................ 50 .

contracta, Perigastrella (Lepralia) ............... 576

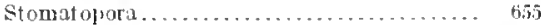

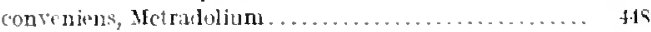

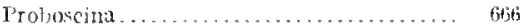

conveva, Callopora........................... 151

Galenpsis.......................... $5 \mathrm{LI}$

1) phytrote........................ 302

Lacerna (schizoporella) ................ $3 \cdot 16$

IRhamphon omella.................. 4is

Schizaropsjs.................... 512,515

Stankmowlla (Flustrella).............. 1 bs

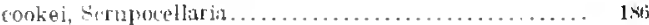

conhul, mittina. . . . . . . . . . . . . . . . . . . . 46.5

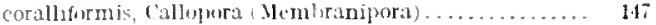

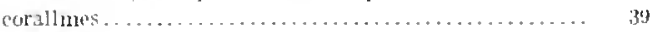

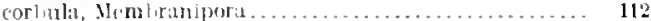

Corbulipura.

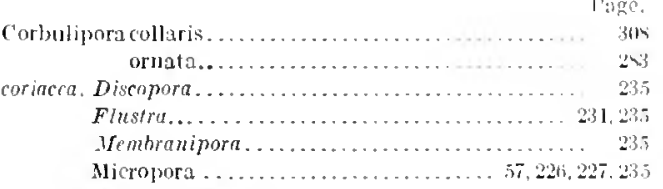

coritnse, Amphiblestrum . . . . . . . . . . . . . . . . 158

Cormiculitera, Hincksima (Mumbrampora)........... 112

corniger, Larnacius (Membranipora).............. 124.141

cornur, stomatopora.........................

cormuta, crisidia............................ 649

(Sertularia)................. $707,70 \mathrm{~m}$

Decurtaria........................

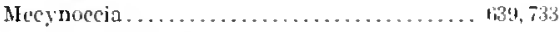

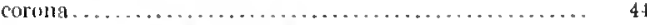

coronata, Acropora (cularia) . . . . . . . . . . . . . 314.31.

Ellisina (Mfembranipora)............. 126

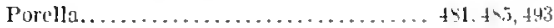

Smittina......................... 4ti

coronopus, Idmidronca (Idmonoa) .......... 642, nivt, Th

Polyascosoecia.................... $44,5,437$

pramicosa, Cellopora.................. $5400^{\circ}$

Schismopora (Collepora). ........... 54\%,544,5y9

corrugatum, Rhynchomom, . . . . . . . . . . . . . . . . 509

cuscinophora, Adeonellopsis (Eschara)............ 5is. sitio Cribricella (Ischara)...................... 5tit

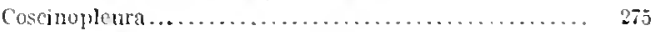
digilata....................... 275

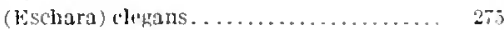

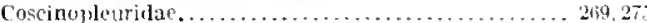

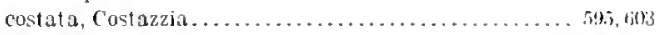

Parascosoccia (Cavea)............... 589, 5.34, $\$ 40$

Parnlumulites. . . . . . . . . . . . . . . . . 2411

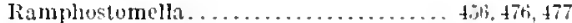

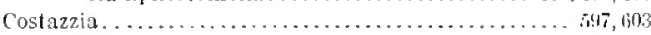

antiqua. . . . . . . . . . . . . . . . . . . .

costata........................ 5145, 503

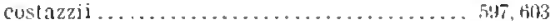

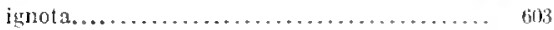

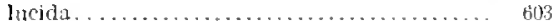

tutulosa . . . . . . . . . . . . . . . . . . 603

costazzii, Cellepora......................... 54

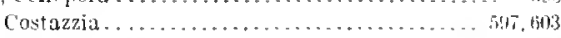

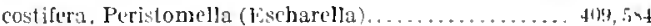

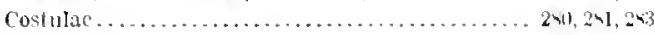

costulata Bracoloridgia polymorpha ................. 5.5 Hippomenel]................... 34, 392

costule interaroslar.......................... tit

costulifera, ltincksina.................... 1 It $1 \mathrm{l}$ -

conchii, Redepura........................ 5103

cranei, Jroboscina.......................... tits

crassa, Alderina............................... 1ti

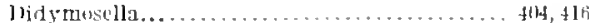

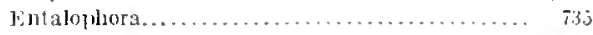

khagasustuma........................ 2it

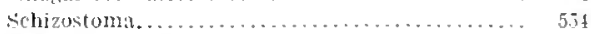

crassatina, nsthimosia ...................... tim

crassicullis, 1 fuplomenulla................... $342,3: 43$

Ifoloperella . . . . . . . . . . . . . . . .

Mrinbranipurella................... $2 \times t^{6}$

sitomachetos(lla................44, 511, 432,433

crassicustulata, Figularia..................... 31 b

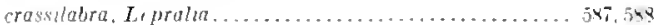

crassilabris, stechojurina................... 624.625 


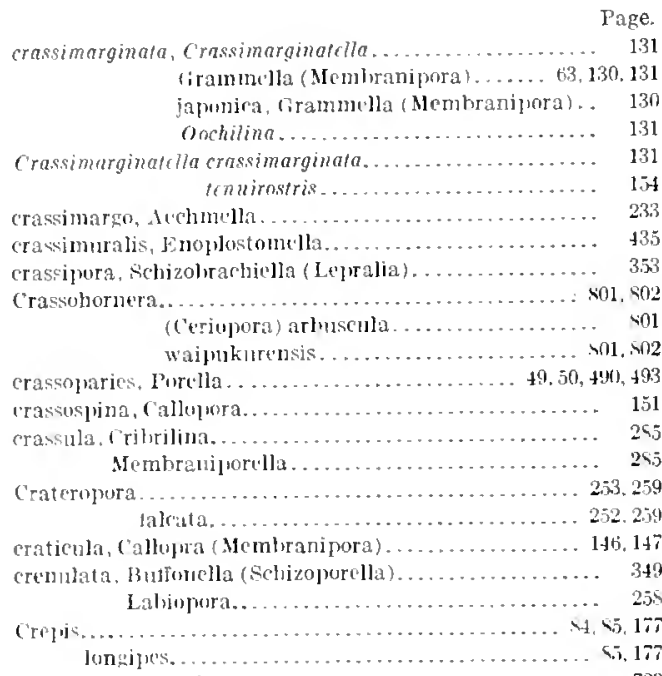

eretacea, Entalophora..

crihraria, ('risia.

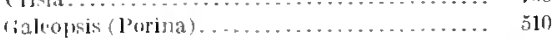

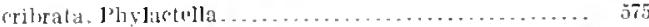

Critrenduecium.............................. 242,310

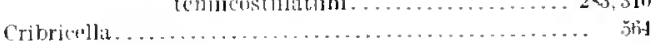
Arlomelopsis distoma.................. 563,564

(Fidiara) cuscinophora................. 5th

Cribrilina

annulata ......................... 291

Mrachnopusia trmilata................ 313

(rassula ............................. 24.5

Figularia clithridiata ........................ 316

uattyae, Pullina.....................

Gephyrutes nitido-punctata............. 300

laticostulata ........................ 292

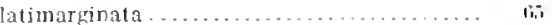

nodw

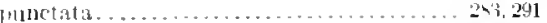

radiata, l'uellina ..................... $2913,241$.

rathlimap ........................... 218

verucowa.......................... 291

Cribrilinilize

cribrusa, collatina............................. 20

Crisia

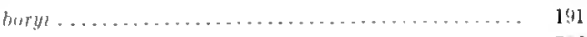

cribrariz ................................

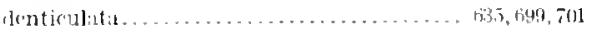

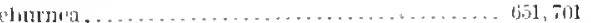

mwardia................................

blwardiana............................ $\quad i 11$

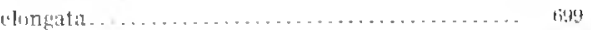

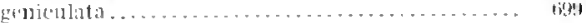

hurnesi ................................. in

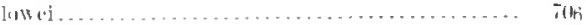

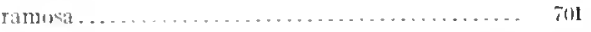

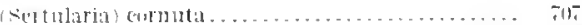

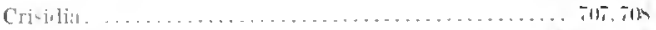

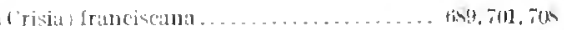

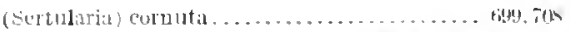

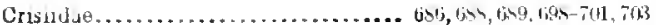

Tage.

Cina normaniana ............................

crispa, Diseocavea .......................... $\mathrm{s} 19$

Lichenopora............................ $\$ 18$

cristata, A piendesia .......................... liastopora.......................... it1

Klejdionella........................ $\quad \mathrm{i} 20$

Crisulipora............................... $74 \$_{, 749}$

flabclata........................... 50

grandipora........................

occilcntalis........................

prominens........................ 719

crozetensis, Mueronella.......................... 475

crustulenta, Floridina (Cellepora) ................. 220

Cryptella................................. 490

Brsoeryptella torruata.................. 496,497

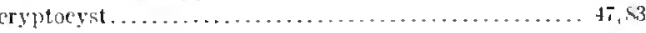

eryptopora, Heteropora ....................... fis var, tenera, 1Icteropora.................. dist

Cryptostomata............................... tl

Ctenostomata............................. $41, s 41$

cucullata, Watersipora, lahiısa..................

(Lepralia) ............... $1,33,53 \mathrm{~s}$

Cucullipora................................. $3 \xi$

tetrasticha.............. $3 ! n$

eumningsi, Alderina (Membranipora)............. 141

Cumulipora angulata............................ thi

cuniformis, Homolıstega...................... $27 s$

cupula, Mamillopora........................ 632

Cupuliulria.......................... $44,15,94,100,103$ (Cupulariu ) canariensis. . . . . . . . . . $55,85,103$

curvatum, $A$ mphillest.rum ................... 1 ti2 curvirostris, Callopora (Membranipora)......... 14ti, 147, 133

cuvieri, Stamenoedla (Eschara).................. 16.

Cvelicopora.......................... $4211,+21,424$

colum......................... $421,42$.

filifera.......................... 427

fissurata......................... +25

Kymella polaris.................... $\$ 2 s$

laticella......................... 427

(Lepralia) longipora ................. +25,524

spongiopsis.......................... +26

Cyclocolposia............................. $421,+31$

prriorata........................ 421,431

Cycloperiella ....................... $421,+21,430$ rubra........................ 421,431

cyelops, Idennellopis.............................

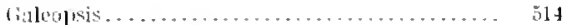

eychoris, (Mllepora l'erigastrella................. $5 \pi$

Cyelostomiata.............................. $4 ., 633$

general consisteration............... 633 s.sitematic descrintions............... 6.31

cylindrica, Mucyuccia....................... $i 27$

Mutraculposa ........................ 307

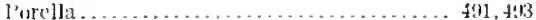

stamenocella........................ 1tis

Cylindrical tubes, structure of .................

cylindriformis, Ranphonotus (Anphiblestrum)....... lik3

Cyphoules compresin....................... vecilentulis................... is

cy)raca, () givalia .......................... 2014

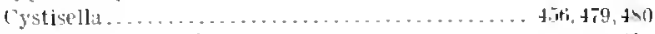

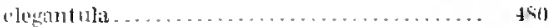
fragilis.............................. tin

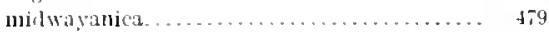

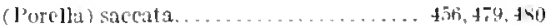

Cytividac ........................................ ting 
D.

$[$ a ryont $]$ h . . . . . . . . . . $27,231,212$ otonaria...

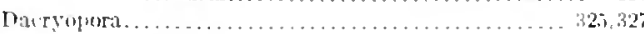
(8)

334

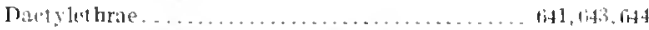

thatylus, Ferlora (1)jovllustrellaria) ............... 1i24

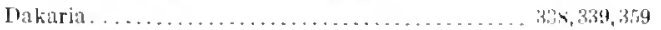
hirris....

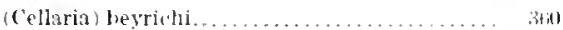

chevreuxi . . . . . . . . . . . . . . . . . . 33:1,354

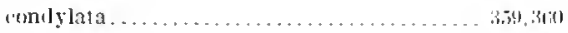

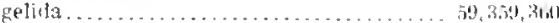

laxata . . . . . . . . .

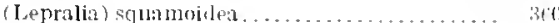

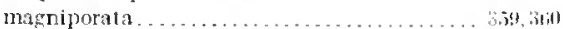

(schizoporella) substuammoirfea.......... 3in

clamiurbis, Conopenm....................... st

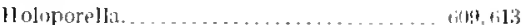

dania, Herpet opora...................... sl

Membranipora. ....... it

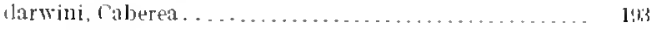

davidsoni, liastonora. ..................... 112,72.

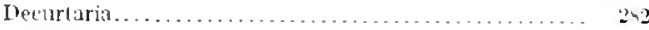

cornuta. . . . 2

defenca, Hincksina (Membranipora) . ............. 112

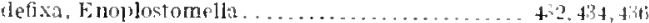

deflexa, Finlalophora. . . . . . . . . . . . . . . . .

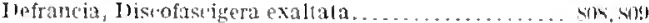

monosticha . . . . .................. 721

prolifera . . . . . . . . . . . . . . . . . . . . . . .

stellata.........................

I teframiopora........ Isil

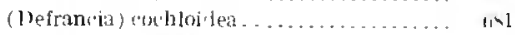

relicata, Ilippoporina (Wsthara) . . . . . . . . . . . . . 374

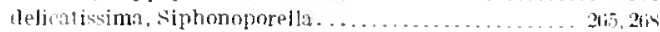

delieatula, kntalophora........................

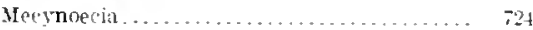

delrauxi, Filisparsa............................ tiat

depiracantha, Tremopura . . . . . . . . . . . . . . 124, 149

4)

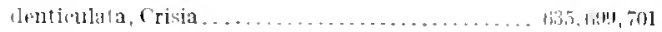

dentivulatum. Triphyllozom . . . . . . . . . . . . . . . .

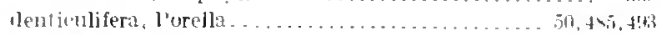

dentiferum, bracetorilgia . . . . . . . . . . . . . . . . .

depressa, lectamella (Membranipora)............ 23i

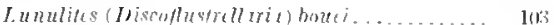

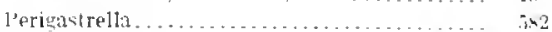

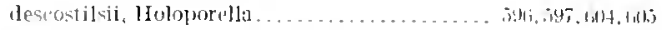
deshayes. Florilinollis (Marginaria) . . . . . . . . . 2.

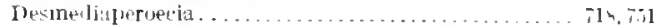

(Tubulipora) bijupliata ......... inl ampiranean . .

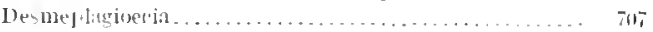

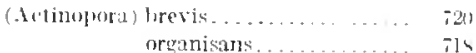

tonuis....

(Borringara) lineata

compreses.

dichotumb.

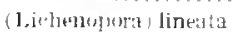

lohuta. . . .

(J'avotuligrara) dimirliata

gambiaremei

inlirata l'age

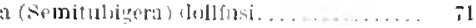

levelopment of Cheilostumata....................... 4

Jarva...................... 4 .

Fialeroeria - ats

(ava . . .

interjuncta.

intrituria . . . . . . . . . . . . . . . . livi, 734, 740

jak konjensis . 742

lolbtata . . . . . . . . . . . . . . .

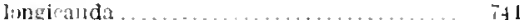

orticulat . . . . . . . . . . . . . . . . . . .

fulcherrima...................... 7334,710

revularis... . . . . . . . . . . . . . . . . . . 5.59

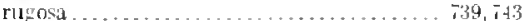

varians.............................. $\mathrm{itl}$

vintricosa . in

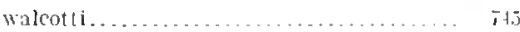

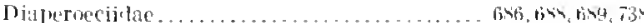

Ant tomy of . . . . . . . . . . . . . . .

diaphand, Ilarmeria....................... b! ,52

Mlucronlulla . . . . . . . . . . . . . . . . . .

[)

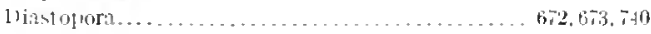

complacta............. its

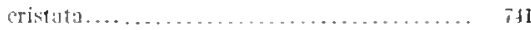

Iavilsmi.........

rolinata........................

ucharimles..............................

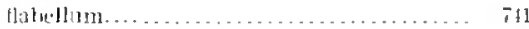

Jacta................. 711

Lamullosi cervicomis. . . . . . . . . . . . . . 672

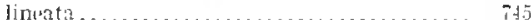

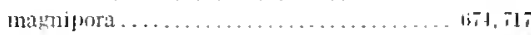

michudini.............................

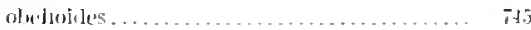

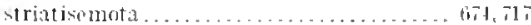

siluorbicularis. .................... $730^{3}$

tonuis. . . . . . . . . . . . . . . . . . . . . . T

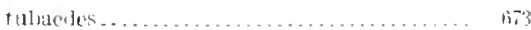

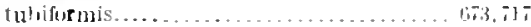

tululus. . . . . . . . . . . . . . . . .

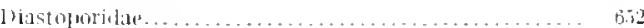

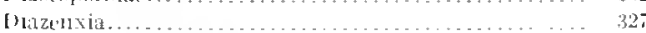

lichotoma, besmeplagionciz ..... it

lakthionia..................... it

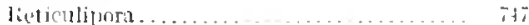

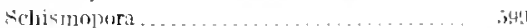

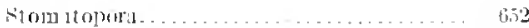

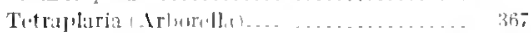

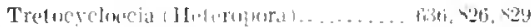

1) (T: l.

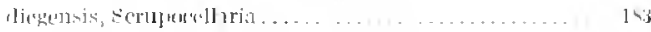

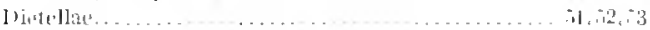

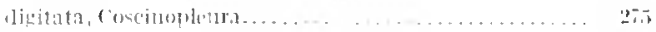

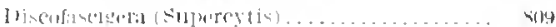

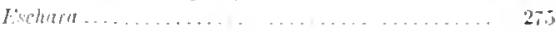

(B)

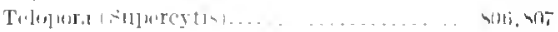

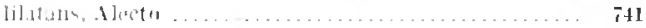

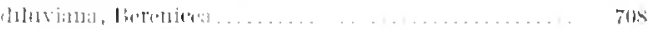

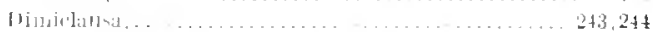

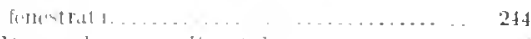

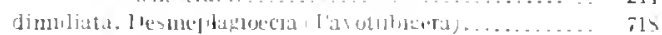




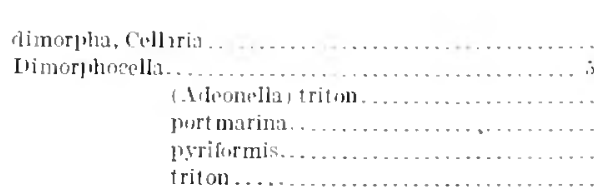

Thiploulesmopora nuposita.

[i]ploplolens.

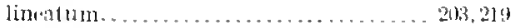

parsuliporum.

sagit tarium...

sagitullerium.

Jiplopora.

biplosulen

compactum...................... 715

intricarial . . ..............

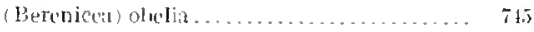

obelia arcticin ....................... 746

planum....... .

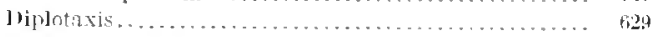

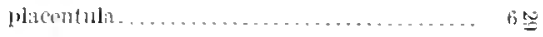

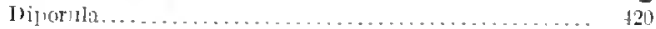

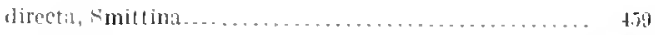

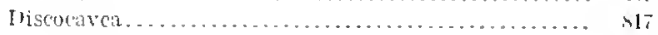

crispa..................... $\$ 10$

elegans.......................

irregularis................... 47

parnensis. . . . . . . . . . 14

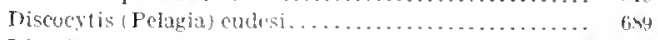

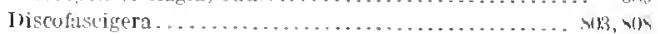

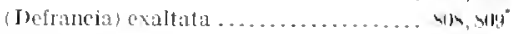

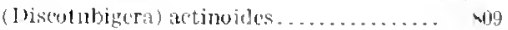

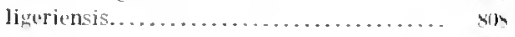

(Sinperchtis) digitata.............. v. vit

Iiscofustrellaria....................... 4,176

bouci, Lunuluts. . . . . . . . . . . . . 10.3

Qlmina, Lianulitos........... 1113

concata, Lunulites............. 1013

depressu, Lunutilis. .......... 1013

duclosn, Lunuluts............ 1133

tiza, Lurulites.............. 1113

truncalu, Lubultus............ 11]4

doma....................... siti

Felota ifactylus . . . . . . . . . .

discoltu, Jlagivecia ...................... 717

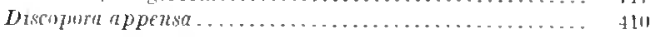

cuccinen...................... 111

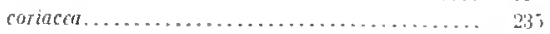

lichenopura hispida............. - 12

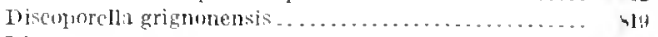

Ibiseo prarsa clypeiformis. . . . . . . .

regularis. . . . . . . . . . .

tontis......................

varians...........................

(1)iscutuhigera) Jiseofuscigera actinuiles.......... wh wh

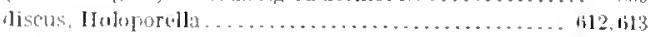

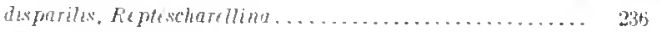

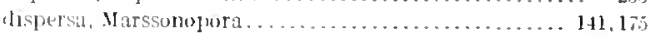

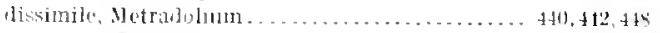

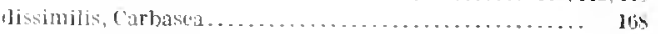

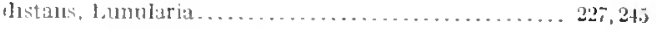
Nembraniporella .....................

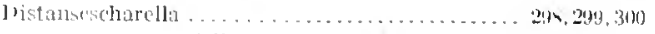

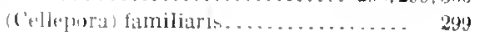

Tistamseacharel page.

distoma, ddesn+llopsis.................... 5i3, s6is

rribricella (Hschara) ................. 504

disturta. Electra (Membranipora)............... i

Hipuozcugosella..................... 349

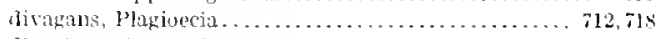

divaricata. Jl ippothoa ....................... 327

disergens, feristomoecia (Stomatopora) ..........642,643

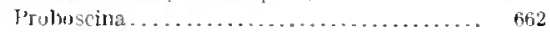

Aivision, IJolostomatous................... 596

schizostomatons...................... 596

dullfusi, luesmeplagioccia (semitubigera).......... its

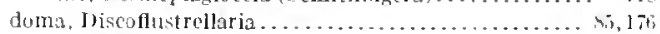

Tomopora diatata ....................... \$17

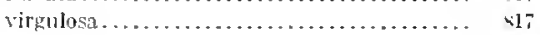

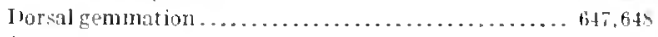

dubia, Scrupucellaria . . . . . . . . . . . . . . . 190

duclusth, Hetractis........................... 103

Lumulates (Discoflustrellatia) bouci.......... 103

dojardini, Fungella ........................ finj

lumerilli, Callopora (Mombranipora)........... 14ij-14y

Flustia .......................... 145

dumosa, Pariritocycloccia (Cavaria)............. \$30

duphx, Menthentocium . ................. 120

duplicuta, faleopsis (Eschara)................... 510

dupliciter, mychocelia..................... 20.5

dut mpleantum, Rhagasostuma. . . . . . . . . . . $5 . \ldots$

dutertru Mastiguphora (Finstra).............

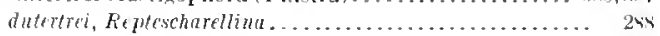

schiroporelli..................... $58 \mathrm{j}$

\section{E.}

Early Stagos in Cheilostomati................ H

Eurly Tertiars Cheilostomata, systematic Clinsificontion

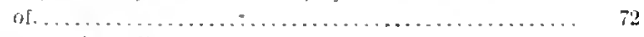

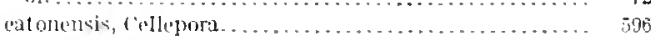

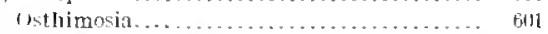

eatoni, Lacerma (Fchizoporolla) ................. 346

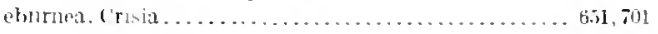

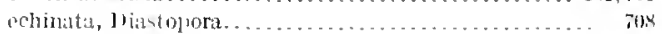

Entalophora . . . . . . $t$.

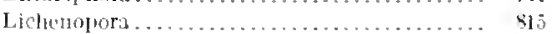

Eetocyt . . . . . . . . . . . . . . . . . . . . $42, \$ 6,634$

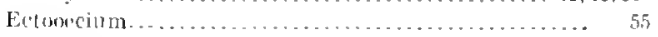

Eetoprocta .............................. so

["] wardsi, ('rinia . . . . . . . . . .

Ftrlora........................ 62, 624

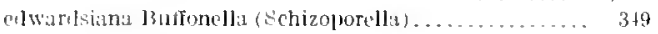

(risit......................... 701

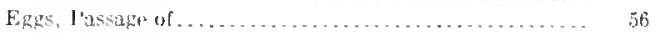

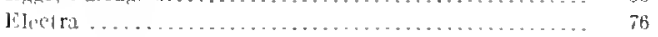

(Flust ra) pilosa $\ldots \ldots \ldots \ldots \ldots \ldots \ldots \ldots \ldots \ldots \ldots$.7 triacanthis ................

(Membranipora) lellula ..............

bicolor . . . .

distorta................. 77

monostadigs................ it

telolliz................... 77

parvimater..................... 77

jilimil . . . . . .

Tendra zosterionta . . . . . . . . . . . .

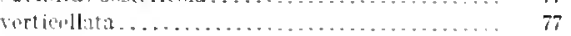

Electrintiar . . . . . . . . .

(logans, Coscinopletura (Fschara) .................. 275 


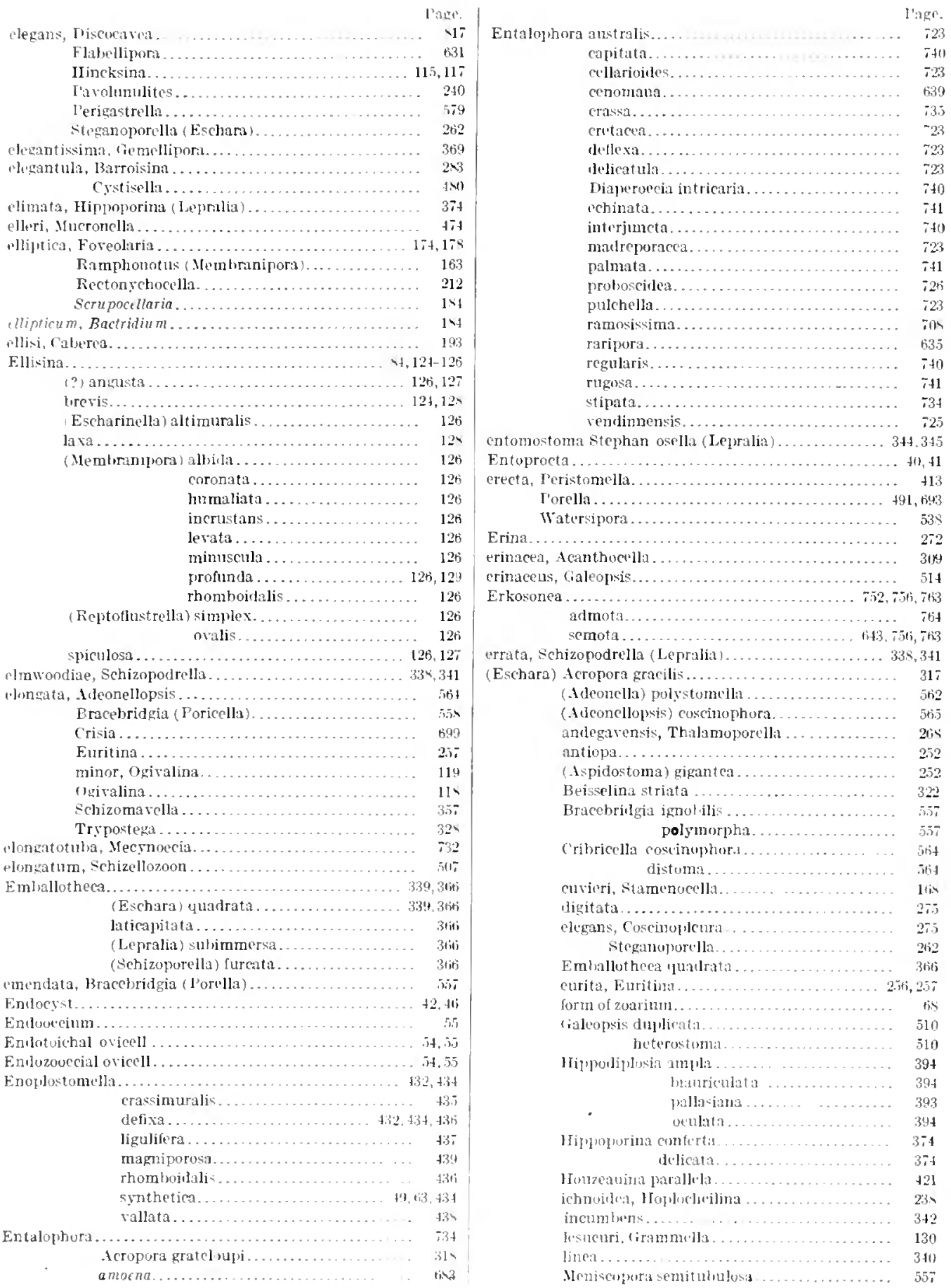


(Eschara) Motrarablotos moniliforum. I'age.

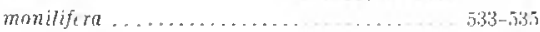
osculifera, Hoplocheriliut.

I'erist ondella alifera.

fllyma1 opur:1

punctata.

radiata

Famploostomallascialit....

schizolavella nhymatopora.

Stylupona sfrongites.....

texta.

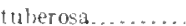

Tulucella mammilluris

viminea...

Fscharella, Butionellastritira.

lerist om lla motifura.

Schizomavella porifera

Escharrlla micripora. . . . . . .

Escharellidau.

Escharidae.

Esharifora, Acanthion"lia tb] dou

Excharina ballii.

$$
\begin{aligned}
& \text { coccinta.... } \\
& \text { hyndmanm. } \\
& \text { prsanseris. }
\end{aligned}
$$

Escliarinella...

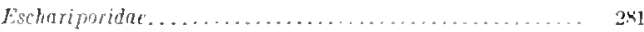

Eschamdes cuccinan .......................... 411 moniliftra................... 5.535

escharoides, liastopora

Escharousis.

Encratea..........

clolata...

Eneratilitac........

endesi, Discoeytis (1'nlaya)

Euginomil.

eurita, Euritina (Esohara)

Euritina..................

(Bitjust ris) turtid

(3ongata.

(Eschara) enrita.

intermedia....

lata.......

lineta....

torta...

(Vincularial gracili.

welselis .

"vexa, wsthimesia.

.......

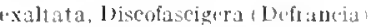

axcarans, ktomatopura

excrlsa, Fedora Kionidellial

cucentrica, 1 rhitulijora.

Excretury and Nervous Systems...

"xigua, l'robuseina.

Siniltina......

silounatopuris.

"xilis, l’artretoevelueclid

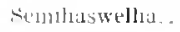

"ximia, Jly lartella (l, prabat

"ximipurat, 1)gisalun: . . .

Fxu[d]

$$
\text { luluata. }
$$

Jongirot

(ricus]us
. 234

414

i. $33,5.34$

$2+4$

$4 i 5$

$3.7 ! 4$

342

$\pm 41$

54

342

4⿻?

3.74

534

$2 \times 1,334$

334

(i)

(1)!

5,57

52.7

$+1$

25

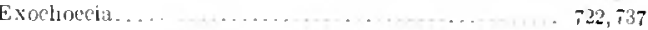

rugua . . . . . . . .

expansa, Probuicina....................... $7+1$

exjatiata, Irotroseina........................

\section{$\mathbf{F}$.}

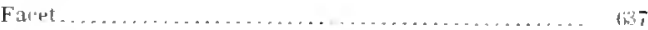

falita, Crateropora . . . . . . . . . . . . . . . . . 252, 259

1al.ifera. Hip rodiplosia....................... 34.

I'eristomela....................... 415

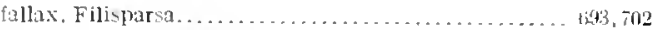

Tubutellaria........................ 543

faniliaris, listansescharella (Cellepora)............ 2y

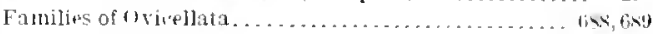

Family, characters of ...................... iI

Farcimin oculutu.............................. 1 . tcrella......................... 19

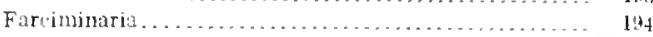

Farviminariblae...................... $72,73,144$

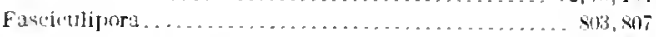
ranısa . . . . . . . . . . . so. surculitera...................... \$18

fasciolata. stomatopora ..................... 158

Fasulpora suloramosa.........................

fayalensis, schizomavella (Schizoporella)........... 354

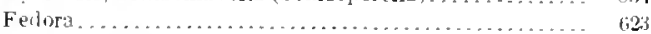

([1scollustrellaria) dactylus............... 1124

(2) wardsi. . . . . . . . . . . . . . . . . . $1 ; 23,1 ; 24$

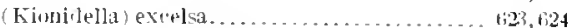

olılıueseriata..............

jusilla . . . . . . . . . . . . . . . . . . . $1 ; 2$

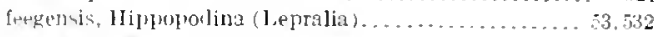

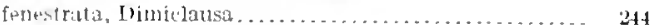

Galeopsis (1liprothoa)................ 511

Gephyrophora (lippothoa)............ 521

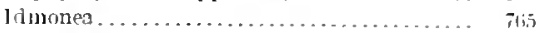

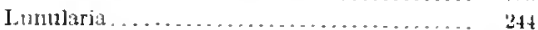

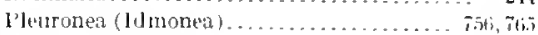

[enestrella, stamenocella (Biflustra) .............. livi

ferox. Membrustega (1, Mralia) . . . . . . . . . . . . . 174,1 it

siruprew llaria........................ 144

fihrosa, l'lenronea . . . . . . . . . . . . . . . . . . . .

Fintluria . . . . . . . . . . . . . . . 282,313.314.315

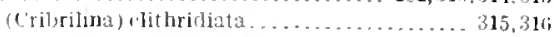

(?) crassiuostulata . . . . . . . . . . . . . . . 31t

(Hemphehara) philomeli............... 310

(Leprilia) foularis...............243.315,311;

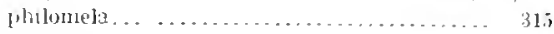

figuliaris, Furtlaria (Lepralia) . . . . . . . . . . 243, 315,316

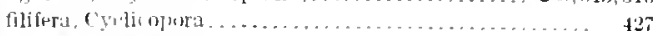

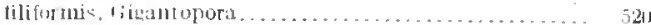

Iolmonea . . . . . . . . . . . . . . . .

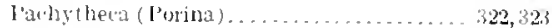

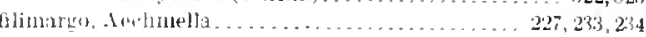

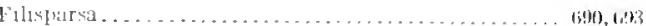
alomiola . . . . . . . . . . . 

hut

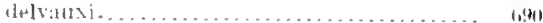

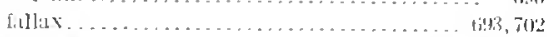

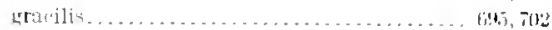
I1) lanilia . . . . . . . . . . . . . . . . . 697,703

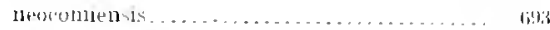

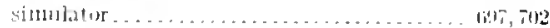

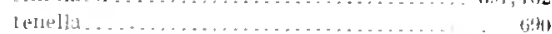


Filicparsa typicu

rarian.

filoparietis, callopors

fiubriata, Lichenofor

firma, steganoporella int tua )

(Lepralia) .

Firmatopores.

fissa, Lacema (s.hizoporella).....

Retepora.....

Fissiparity of primary embryn

f. seurara, Cycliceporil

Holoporellit . . . . . . . . . . . . .

Hornera............................ 79,5

fistulosa. Cellaria . . . . . . . . . . . . . . . . . . 271,272

Fivation, basal systen of.

tif the larva......

flabellaris. Microporella....................... Tululipori ...............6.649, $753,755,757,750$

flatellata, resulspora.

Membrataporina (Bilustra) ...............

Mieroecia . . . . . . .

Flabellipora................................ 631

clegans...............................

tlahelium, Diastopora....................... 711

Flagellum................................. is

fammeum, Amphiblest rimm . . . . . . . . . . . . . 160

flammulum, Aspidostoma................... 251, 259

flemingii, A mphiblest rum (Membranpora) ......... 14l,

$144,154,156,158$

ilexuosa, 1.aterotuligera...................... i23

FIoridina ............................... 20.4, 219

antiqua................ $13,204,219,220,222$

asymmetrica........................ 224

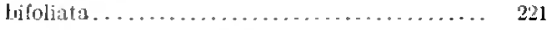

(Cellepora) crustulenta................ 22i)

grantilosa........................ 220

loguncula.......................... 223

onydentata...................... 221

(Eemieschata) bimarginata.............. 220

cantri................... 220

rendonat. .

Floridinella .......................... $22 \pi, 229$

(Marginaria) deshayesi............... 229

(Membranipora) formosa............. 229

vicksburgica . . . . . . . . . . . . . 227,220

Flusl ta, irthropoma cecilii.................. 351

Chorizopora brongniarti.................. 333

coriacen, Micropora................... 234,235

dumerilli ................................. 1 เs

Hippadenclla margaritifera.............. 500

inca, Mimbranuora...................

isabelleana, Menloranipora..............

lacroirit ............................... s.

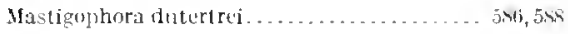

plosa, Electra . . . . . .

rosselii. Rosspliana..................... 22,

sarartii, duanthortesia..................... 14,100

Schizoniavela mont ferratil............. $3 \mathbf{5 1}$

tehuelcha, Jemtranipora................ is

triamantha, Electra....................

tukreulata, Jfmloranipra............... ה7

Filustramorpha........................ 420, 324

Halnligaru..................... 59

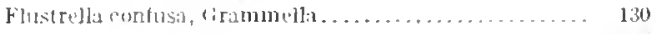

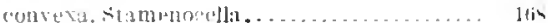

Flustrellaria franqana, Ahlerina.......... l'agu.

Flustridae ................................ 72,73

flustroides, Itincksina (Mentornipora) . . . . . . . 111,112

follacea, Ideonellopsis...................... $551,5 t j 3$

folium Berenicer............................... 位

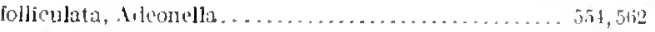

Foraminella................................ 253

forata, Beisselina........................ 322

Form and size of zooec $\$$. . . . . . . . . . . . . . . . . . .

Form of zoaritum......................... 64 .

Formation of skeliton........................ tit

Formations and Station Numbers.............. 15

formosa, Floridinella (Membranipora)............. 223

formosum, Triphyllozoon ................... 5ins

Foreolaria............................. 174,178

Mliptica............................. 17,1 is

fragilis. Cystisella........................ tyt

Vincularia.......................... 198

franciscana, Crisidia (Crisia).............. 659), 701, 708

franyana, Alderina (lilustrellaria)............... 141

Prricarea......................... \$17

frondiculata, Hornera..................... 796,797

Frondjpora . . . . . . . . . . . . . . . . . . . . . . s

interporosa...................... 806

larvigata.......................... 806

verrue osa..................... 1084, 804, 805

Frondiporidae.................... $6515,685,689,803,804$

Frontal ............................... 540

or dependant avicularia .................. 83

immersed avicnlarna................... 64

fuchsii, Lacerna (Lepraha).................... $34 t i$

fulguraus, Peristomella (Lepralia) . .............. 419, 410

Functions of relation ............................ th teproduction ....................... 53

Fungella................................. 645

dujardmi.......................... $\$ \$ \$ 55$

tungl formis, Reptomulticava................. 680

finniculus............................. $\$ 2$

fureata, Emballotheca (Sclizoporelia)..............

Reginella............................ $2 \checkmark 3$

fusiforme, Diplopholeos . . . . . . . . . . . . . . . 2(14,215

fusiforms, Pleuronea....................... iss

Tubucellarm....................... 542

(*.

galeata, Adeonelopsis...................... $5 t^{4}$ Mlurinopsis............................. 343

Schizomavella $($ latralia) .................

Galeopsidae...........................

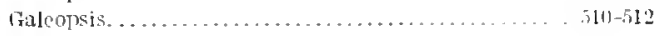

convexa............................. 511

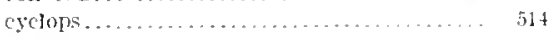

erinasens.......................... $51 t$

(Eschara) duplicata................... 510

heterostomia ............... 510

(H1)

longi(collis ..............................

(Porma) colıumata................... \$11"

tribraria.......................... 510

tux

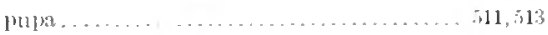

rahidus . . . . . . .

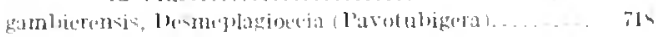

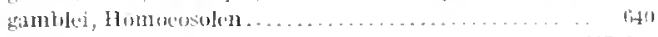

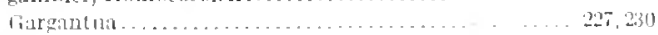


Page.

Frargantua bidens. firma steganoporella. . .

Castropulla ............................... 320 asturuliz .......................... 321 ventricosa . . . . . . . . . . . . . . . . . . $57,314,320$ gattraf, Pupllina (Cribrilina).................293, 244 irandryanella asymetrica, Stegumoporellak . . . . . . . . 262

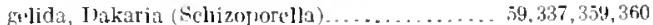
Ilippe]lozoon ......................... 506

Gimullaria

Joricatis......................... 200

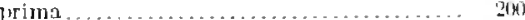

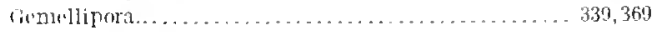
arbuscula ....................... ist arrogata ......................... 369 duriculata...................... $37^{2}$ rl'kintissimia . . . . . . . . . . . . . . . 369 klalira ................... $330,331,339,369$ polita. ....................... $3 \pi^{2}$ grot 11 sid . . . . . . . . . . . . . . . . . 360

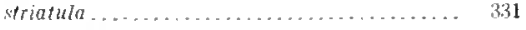
trianguli . 369

fremellipordla. . . . . . . . . . . . . . . . . . . 339, 372 vorax.................... 334,352

geminata, I'rohoseina .................... bit

fiemmation................................... 647

axial nuthots of .................... 6it

ficueral toutomy of the Cheilestomata............ 43

Consideration of tho Cloilostomata......... t6 Cyclostomata............ fí34

Decription of the Bryozon.............. 39 Generje Table of Membranipurae................ it quniculata, Crisia......................... 694 Genus, characters of ............................ il litographic and thologic listribution, I ists......... 17 Feologic Tables of Mesozoic and ('nozole Formations... 12

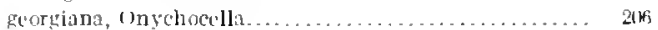
frombtruhora. . . . . . . . . . . . . . . . . . . . $512,520,521$

(Eschara) tuberosa ............... 521

Hipuothoil fonestratia ............ 521

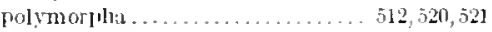
(Schizoporalla) biturritit............ 521

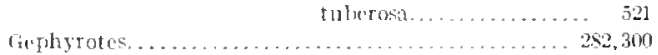
conviva . . . . . . . . . . . . . . . . . . . . . . 302 (Cribrilima ) niticlopunctata............ 3\%

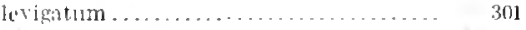
ntide-punctat a...................243,30 juladristrialis sillings. spectabilis.

gibhosi, Tulucella.

gigantea. Cinnotromula.. Exclara ( I spidostomia)

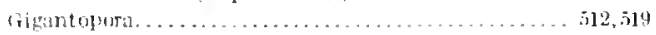

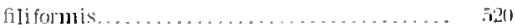

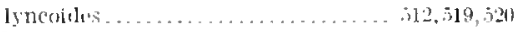

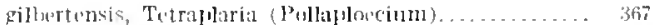

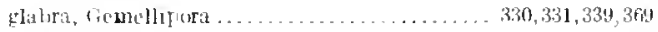
glabrum, Coclophyma....................... int

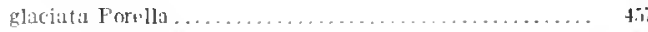
glotilutum, $\Lambda$ spulustoma . . . . . . . . . . . . . . . . .

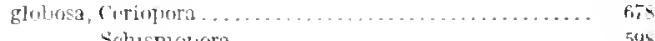
schisnupora ....................... 59 s glubula, Mermoce iis. l'age.

globulifera, Tervia ........................ 791

globulosa, Plagimecia......................... 713

glomerata, Celleporaria......................

Ostbimosia....................... $60_{2}$

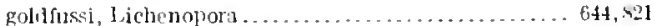

1,unulites. . . . . .................... 240

Radionora ......................... \$21

goniostoma, Schizobrachidila (1,epralia)........... 3.53

gracile, Sipholictyum ..................... \$n2

Tessaradoma (Pustulopora) . . . . . . . . . 512,521

gracilis Acropora (Esclara).................... 317,319

Euritina (Vincularia) . . . . . . . . . . . . . 257

Filismrsa ......................... 695,702

laswellia ........................ $\$ 17$

Mcmbranipora...................... 236

Micropora......................... 236

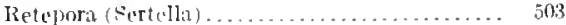

Tervia................................

grallat or, lilmonea .

Grammella......................... $4,124,130$

(Biflustra) meganora................. 130

crassimarginata................663,130,131

(Eschariu lesueuri .................... 130

(Flustrellik) confusa................ 130

(Memlranipora) crassimurginata. . . . . . 130

ja]rnnica... 130

papulifera............. 130

sculpta............... 130 cucullata........ 130

pusilla ..................... 124, 132

trunswersit. . . . . . . . . . . . . . . . . . 132

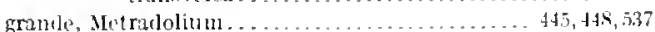

rranlifossia smittina .............. 52,460

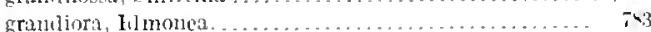

grindipora, Crisulipora . . . . . . . . . . . . . . . . $\quad 50$

lanuliaria?..................... 242

Motroperilla ..................... 362

Timsaruloma..................... 522

granrliporosum, schizorthosweos. . . . . . . . . . . . . $1 ; 27$

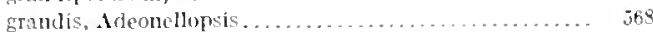

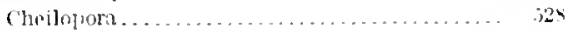

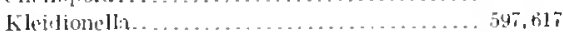

Mntracolprew. . . . . . . . . . . . . . . . . . 243,305

Stamenocella. . . . . . . . . . . . . . . . . . .

Tretucycloecia...................... \$2

grandisuri, Lisusel].......................... 419

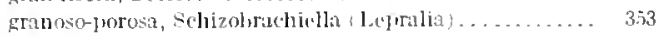

gramulata, Thalnnomurolk .................... 63

tulvifira, Thalamourella.............. 257

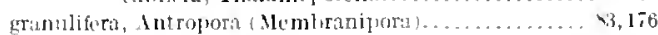

Sehizumiviliz ................... 3.55

granulosa, Floridina....................... 220

Hiplomiplusia ...................... 394

110loporelliz....................... 607,613

Mucronclli2 52,475

l'orvlla . . . . . . . . . . . . . . . . . 444,493

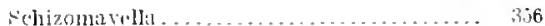

smittina. .

gratulvupi, Acropera (Entalophura)............ 318

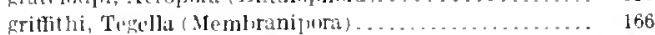

grimonensis, I liseconmralla . . . . . . . . . . . . . . . \$19

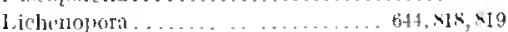

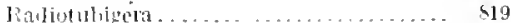

Tubulipura. .................... $\$$. . 19

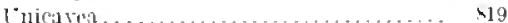




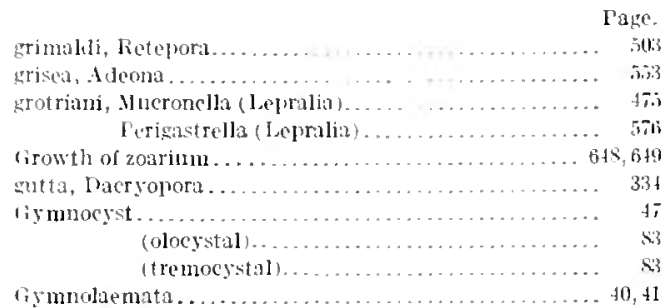

II.

hat .........

Iialitat . . . . . . . . . .

baldoni. Cheilopori. ....................... 52.

hagenowi, ilippozengosella (Bactridiunt) . . . . . . . 39

Lunularia............................ 239

haidngeri, orbitulipori........................ 620

Steganopordla (vincularia) .............. 2fi2

halli, characotoma....................... 339,392

Ilaplopoma. . . . . . . . . . . . . . . . . . . . . . 325, 33: impressum....................... 332

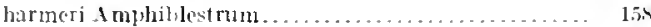

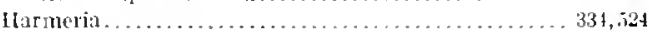
diaphana . . . . . . . . . . . . . . . . . . (Lepralia) seutulatia ................. 334,524

harmsworthi, schizomatella (Echizolorellu)......... 3.54 hast a, schizopodrella (Nehizopordlir) linearis .......... 63

Haswellia.............................512,51h gracilis............................ 517 (Myriozonm) anstralicnsis............ 512,516

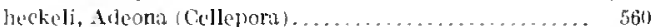

Hlyintoma........................4, $\times 5,91,103$ implicata. . . . . . n . n

(IIemeschara) Fisularia philomela................ 316 Schizobrachiolla sangulneta. ............. 35;

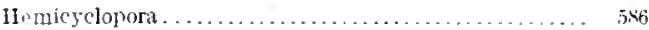
(Lepralia) labiosa . . . . . . . . . . . . . . obeliselus....................... parajuncta.................. $5 \pi_{2}$, ise (Lepralias polita................... 5ne

IIemiscptella........................... $\quad \mid(x)$

Herentia hyndmanni....................... $5 s^{2}$

Herpetoporn............................... in,

danica............................ $\$$

Hefuractis duclusit............................ 103

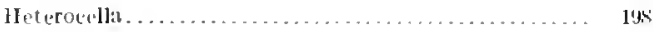

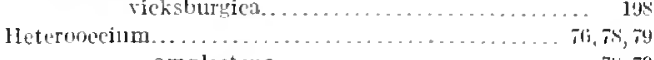

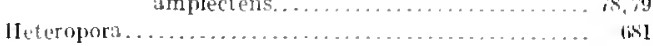
ilveolatz.........................titl, tik2

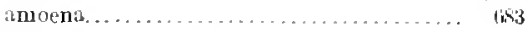
Amphiblestrum (Ruptoflustrullia)......... 15* attenuata....................... \$2

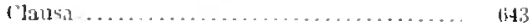
clavifurmis.......................... 67 comifera............................ tis] comsimilis......................... $\mathbf{s}_{11}$ constanti........................... cryptopora tenera................... ts nenzelinica........................

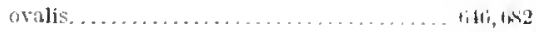
l'urascosoccia consimilis . ................. $83^{4}$ prelliculita . . . . . . . . . . . l'age.

Reptomulticava ..................... 158

tecta.................. 65.2

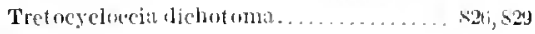

Ileteroporellit verrucosil........................ 818

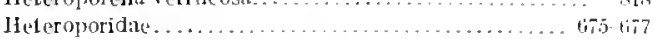

heterostoma (aleopsis (Eschtra) ............... 510

hexagona Butronella (Schizopur(lli) . . ............. 349

Romancheina .......................

hexagonalis, Buffondlit........................ 340

Hippoporinb...................... 38

Lacerna......................... 347

l'erigastrella ..................... 352,587

hexagonum, Rhagessust omil. .................. 230,254

hians, Odontiondla (Menblunipora).............. 256

Hincksina .......................... 109, 111

costulifera................... 11+i,117

elegans............................ 115,117

flustroides......................................

jacksonita. ......................... 113,117

megivicularia................. 1019.114i,117

(Membranipmes) coniculifera ............ 112

defensi. . . . . . .

flustroides............. 112

inarmata.............. 112

maderensis............. 112

minusculit ............ 112

13rmlit................. 112

$\sec \operatorname{let} 0 \mathrm{~s} \ldots \ldots \ldots \ldots \ldots \ldots, 112$

ocalensis........................... 114,117

parraricularit . . . . . . . . . . . . . . 115,117

pyrula............................ 111

reptans......................... 112,117

sceletos............................ 111

smithi........................ 113,117

vicksburgica.......................

Iiippadenella ......................... 373,402

(Flnstra) wargaritifera. . . . . . . $373,49 \%, 300$

Hijpellozoon ......................... 505,5015

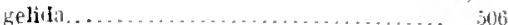

hippucrepis................... 499, 5015

lepralioides..................... $\$ 06$

(Retepora) novezclanditre........... 505, 51

hipnocrepis, techmella (r"elle'mra) . . . . . . . . . . . . 233

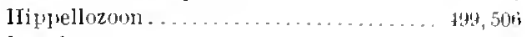

Lyruliz.........................

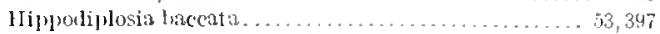

(Eschara) ampla .................. 394

biimuriculat th............... 394

oculatit................ 394

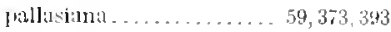

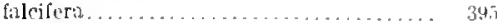

gramulasa..................... 394

(Lepralia) apteti....... 344

a)purrima................ 394

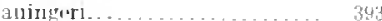

rlavilta.................... 34,3

mexpileta. 394

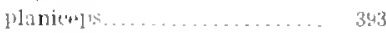

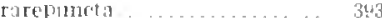

wmierintata. . . . . . . 343

restatid... . .

nuarni]

petioll1s... ..................... 345

strangulata... 
I'are

lippouliplosic vertucesa. respertilato.

Hilpomenelka. . alifera anguxlailos axiculata caplimortiv. $\operatorname{costulatia.....2.~}$ ('Tasisicollis. incoldilia...

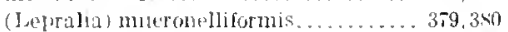

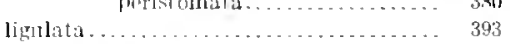
mucromolliformis. . ............. 373 (Mforcomb]la) perforata . . . . . . . . . . 380

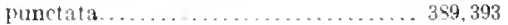
mungens. . . . . . . . . . . . . . . . 358, 393 rablicata ...... . . . . . . . . . 387. 393 rot 11 la . . . . . . . . . . . . 50,52,351, 392 transwersala . . . . . . . . . . . . . . . 382 342 transversora.................. 345,393 t1uberosia . . . . . . . . . . . . . . . . 391, 393

Hippopodina ......................... 524.532 (Lepralia) lepensis............. . 53,532

Hupopodinirlue ...... . . . . . . . . . . . . . 524 Hippoponetla . . $373,379,380$ hilppolus . . . . . . . . . . . . $373,379,380$

Hippoporat. 372 anatomy of . . . . . . . . . . . . . . . 370,371

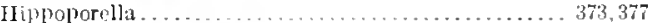

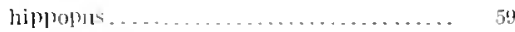
multilamellusa . . . . . . . . . . . . . . 5 59,37s perforata. . . . . . . . . . . . . 373.37

Hilpoporina. biporosa. . . . . . . . . . . . . . . . . (Eschara) conferti. 37 tylicata................... 374 hexpgonalis... ................ 374

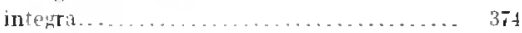
(Iepralia) collars. . . . . . . . ............ 374 elimata................... 374

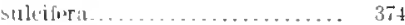
Inrcellinil. . . . . . . . . . .

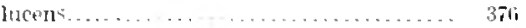
nidwaranica..................... 375 parvilia .......................... 37

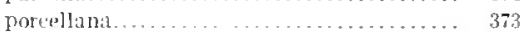

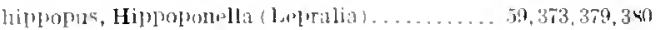
lispot hoa . . . . . . . . . . . . . . . . . . . 325-32 loumainvilun . . . . . . . . . . . . . . . . . 320 (?) colljum il ... . . . . . . . . . . . . . . 327 thraricata. . . . . . . . . . . . . . . . . . 327 tialeopsis, fulevitata................. 511

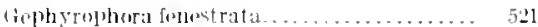

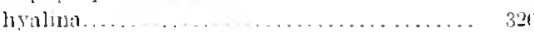

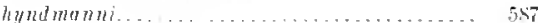
tubcroulum.

Hilluthoilate.

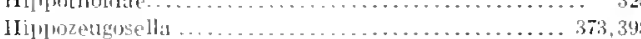
arciata..................... 373,400

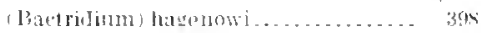
distorti1................. 390

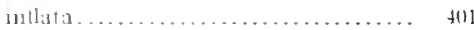
marginalit.................... fil

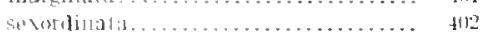

Page.

Hiphozeugosell. t teges. . . . . . . . . . . . . . . 394

hirsuta, Tuhucellaria. ....................... 54 .

hirsutum, Triphyllozonn.................... 50 . . .

Jirta, Microecia................................... 734

Plagiopcia......................... 715, 719

hispida, Lichtmoprara (Discopora)............. 411,\$12, 815

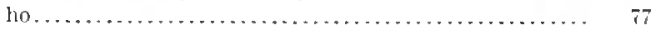
holdswortli, Lichenothora...................... fift, \$15

hole, papilla . . . . . . . . . . . . . . . . . . . . . . .

Holoporella .............................. 596, 59t, nit albirostris........................ 595 altirostris.......................6n 606,613 apiculat a . . . . . . . . . . . . . . . . . 595 hirostrata..................... 612,613 crassicollis......................66 $607,6 \mathbf{l} 3$ damicornis.....................6.601, 613 descostilsii................... 54i, 60 4, fin 5 discus . . ................6. 612,612 fissurata ....................... filli, fil granulosa... . . . . . . . . . . . . . . . fort, 61 micropora. .................... 610,613 orhicollilerat .......................... 60.5, 61 peristomaria....................611,61: nigmentaria ..................................

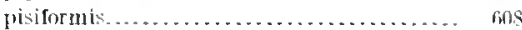
separata.......................... $(0109, b 13$ seposita . . . . . . . . . . . . . . . filo, 613 vermiformis........................... 604

Holostonat ous division . . . . . . . . . . . . . . . . 596

Honialostegra cuniformis.................... 27

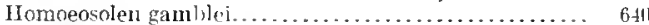
hoockeri, Conopen (Memliranipora) ............

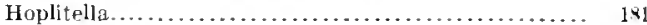
Hoplocheiliua........................ 227, 237 (Eschara) ichnoidea............... 239 osculifera................ 238 (Lepralia) russelli................ 238 (Rept escharellina) prolifera.......... 234 syectahilis................... 22

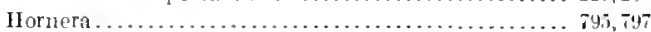

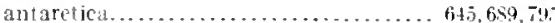
bilola . . . . . . . . . . . . . . . . . . . . concatelita...................... 639.74. fissurata . . . . . . . . . . . . . . . . . . . . . .

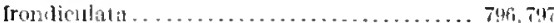
jacksonica ...................... $795,79$. lichenuide... . . . . . . . . . . . . . . . . . .

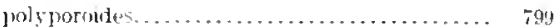
porosa . . . . . . . . . . . . . . . . . . . . . . . . 8010 reteramat.......................... telluiranta ............................ stut

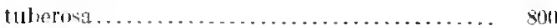
Hormeridae . . . . . . . . . . . . . . . . 686, 688, $689,793,794,745$ Anatonny of ......................

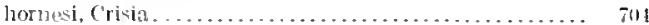
Mutronello ( Jeepralia).................. 47

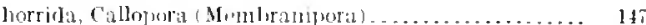

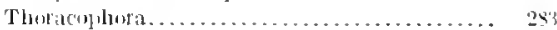

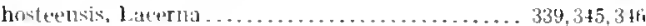
Houzpanina . . . . . . . . . . . . . . . . . . . 120,421 callinil...................... $421,12 n$ ( Fishara) warallela................. t2l libral a..................... $\$ 22$

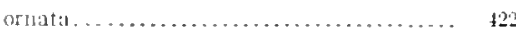




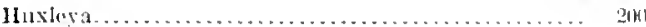
hyadesi, Mcmhinulura....................... is hyalina, llippolloa............................ Megarora.............................

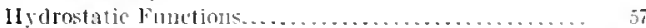
hyndmanmi, Exrharina ......................... in

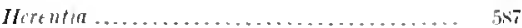
Hiplwhoa.......................... Le pralia ...............................

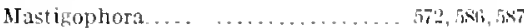
schizupordla........................ is

Ilyperstomial ovicell .......................... it 11 ypostege.

\section{I.}

iehnoirlea, Iloplucheilina (Eschara)................. Idmidronea.....................

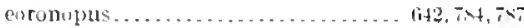
culter..............................

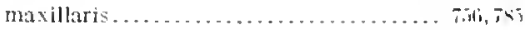
rusacea...........................

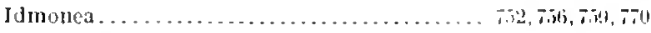
arcuata . . . . . atlant ica.................... commiscens........................... fenestrata.......................... t:lifrrmis................................. grallator . . . . grandisra.............................. (llmilronea) eoronolns................. ist maxillaris.................... in

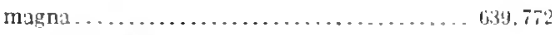

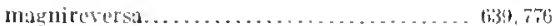
nusillaris.............................. milneana.......................... non reticuln........................... int parsula ...................... botri................................. is

(Pleurone:n) frnestrata.................... riti

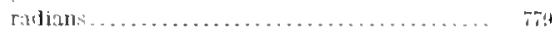

ralicata.............................. $i \neq 1$

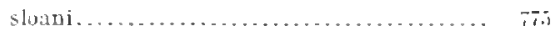

tacti.................................. iil

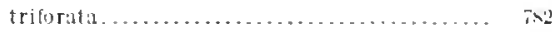

Tubulipura tumida.......................

intmonentes. Proboscina...................... titit

ignohilis, laracebridgia (Eschara) . ................ कin

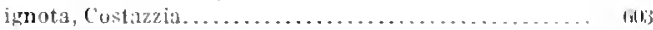

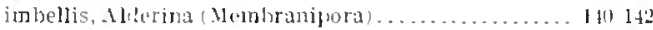

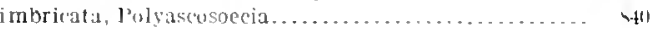

Immatureregion. . . . . . . . . . . . .

Immersed orfrontal arjenluria.................... of

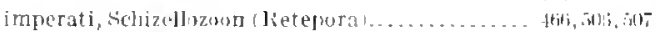
implicata. Beissulma ..........................

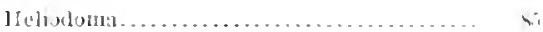

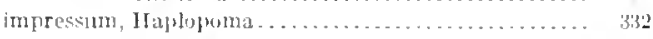

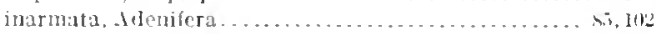
Hincksina Mrmbramiporal . . . . . . . . . 112 linkllina . . . .

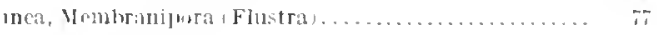

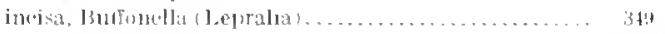
('momerharallinia .

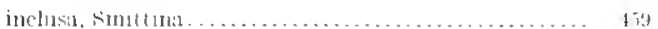

Inromplete zoovium . . . . . . . . . . . . . . . .

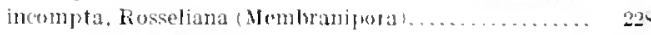

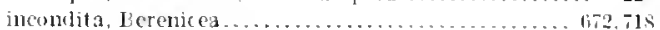

IIipumernella..................... 343,392

incrustans, 1 spirdostoma....................... 254 Ellisina (Nembramipora).............. 1\% Steganoporella........................ 2ris

inevmbens, vischara....................... 342

inferaviculifera, stamenocalla................. 172

inflata, Ifippozetgosella..................... th

infundihulum, lhylactella..................... sit

ingeus, Derenicea ......................... 671,71s

Callopora . . . ........................... 1,ill

Filisparsa ..................... 1i, $1,694,8112$

inhahilis, l'eristomella (Muerondlia) .............. thy

innominat $x$ Lepralit.......................... 24i

Puellina.............................. 294

inornata, Cellepora .......................... $1 \$ 7,329$

inornata, Trypostega . . . ..................... 329

Inovicel ata.....................................

imsignis Lacerna (Schizolrorella) .................. 34

integra, IJippoporina...................... 37

intorarcolar costule......................... $4 . \overline{4}$

int rjuncta, Diaperoecia ...................... 740

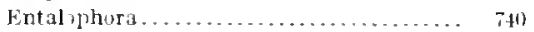

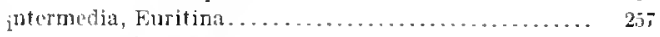

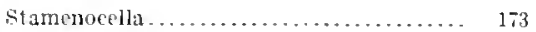

interporosa, Frondipora...................... sn

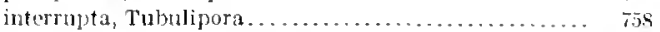

interstilia, Orbitolites (Lunuhtes) .................. 626

Schizorthosecus........................ $620^{\circ}$

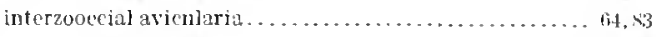

lnt razoarial gemmation....................... b. bits

intricaria, Adeonclia ........................... 561

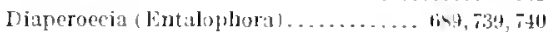
biplosolen .......................... 739 intrata, lieticulipora......................... iti

Introvert..................................

invigilata, Callopora (1) embranipora) ............. 147

irregnuaris, Alderina (Iemlranipora)......... 1:31, 141,142 l)iscocavea............................ Phormopora....................... 4012,4133 Porelliı........................... $4 \backslash 4,493$

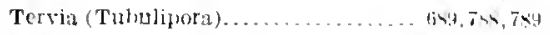

isabelleana, Membranipora (Flustra)...............

. .

jacksonensis, Lacerna....................... 34 .

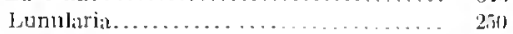

jacksmi, Peristonulla (Amittia) ............. firy

Jacksonian (heilost omatolas [Bryozoil, lisk .......... 20 Cyclostomiluns Bryozun, list ........... 30 locilitie's............................. 1is

jackonica, nistansescharilla.................. $2_{24}$ IJincksina....................... 113,117 Hornera.......................... $71,7,797$

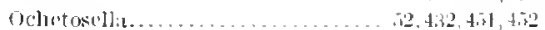

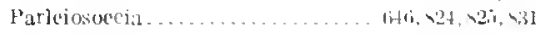

Polyatiscosestial . . . . .

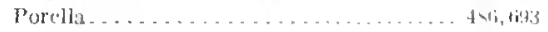

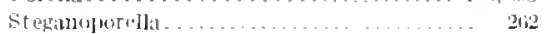

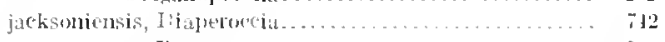

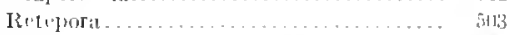

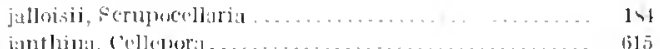


jellyae, Tervia.

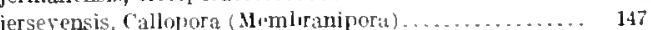

johmstoni, Prohoscina.......................... 741

jousseaumi, fhonicosia....................... 339, 352

\section{K.}

Key to Plagiocia und Berenice.................. 717

Kionidella

$546,597,624$

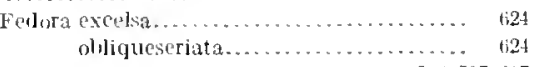
cristata.............................. tigt

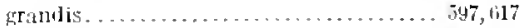

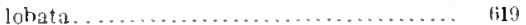
lyasiticia ......................... til9 verrucosa

Fymella........................... $42 t, 421,428$ (Cyclicopora) polaris................ 421, 42,

\section{L.}

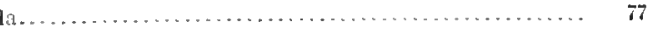

labiata, Mucrontlli......................... tit

Perigastrella (lefralia $) \ldots \ldots \ldots \ldots \ldots \ldots$. niti

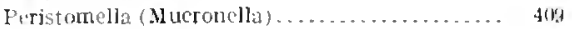

Plylactella.......................... 572

Thalamoporella rozi ri................... 2tis

labiatula, smittina............................ the the

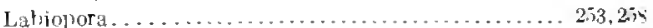

(rimulatia.......................... 25

latriosa, Cheilopora............................. $524 i$

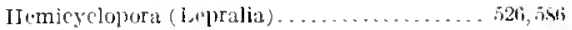

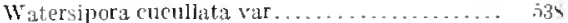

lahratulum, Metradolium..................... 441,44

labrosa, I'hylactelda........................ 572,573

Lacerna.............................. $334,345,341 \mathrm{i}$

hexiunalis . . . . . . . . . . . . . . . . . . 347

hosterensis........................ 33:4, 345,34ti

jacksonensis.......................... 3ti

(Lepralia) fucdesii .................... 3tri

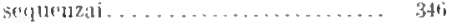

sutsi . . . .

(schizopurollis) cavolitui .................. 3th

convexa.................. $3+t_{i}$

vitmi .................... 346

fissa................... 34 ti

insimis.................... 34 ii

nit

niticlissima ................ 340

orinata.................... 34

ovalis................... 340

laciniata, Peristomella (Lepralia) ................. t(1,

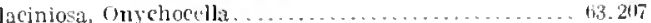

Quadricellaria ........................ 279

Retepora..............................

lacroixii, Buthusta...............................

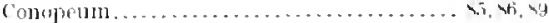

Flustra..............................

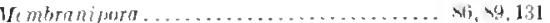

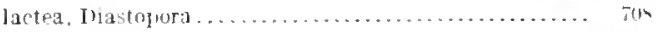
lacuni. ......................................

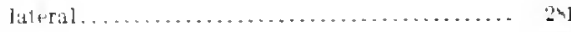

mwdian ............................

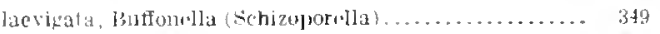

Frondipura lantis, lorella . . .......................... Page.

Lageni americana.......................... 591 socialis . . .

Lagonoecia ................................ $\mathbf{7 \times , 7 9 2}$ lamellifera........................... 792

Japuncula, Floridlina ............................ 223

lamellsfera, Lagonoec1a............................. 792

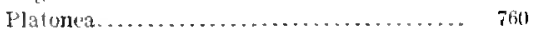

lamellosa cervicornis, I)iastopora.................. $\quad 1772$ Macroecia (I)iastopora)............... $6 \uparrow 9,722,723$

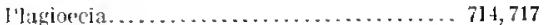

lamellosum, Conopenm......................... 92

Laminopora contorta..................... 5it, 571

lamourouxi, J'eristumoecia ( I'rohoscina) . ............ ti92, 693

Jandroti, Semimulticavea ..................... \$17

landshorovi smittia.............................. 4.77

langana. Conopellm (Membranipura) ............... sit

laguata. Mucronella............................. 474

I arnacius (.Memlranipora) corniger.............. 124, 14n

Larva develumitnt of .......................... 44

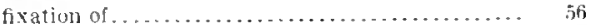

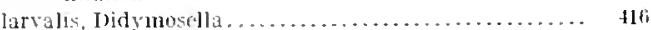

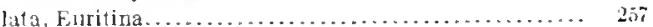

M

Schizonavela (Schizoporella).................. 35.5

latıral lacumae ...................................... $2 \times 1$

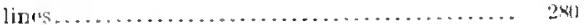

lateralis iscosencia............................. 639 Prosthenoecia (lieptutulvigera) ............ 793 stegraporella........................... 2til

Laterotulipera flexuosa $\ldots \ldots \ldots \ldots \ldots \ldots \ldots \ldots . .723$

micropora.......................... 725

laticapitata. Emballotheca...................... 3 bit

laticedla, cycliculora ........................... 427

IIembraniporidra...................... 135

leristomella .......................... 413

laticustulata, ("ribrilina........................ 292

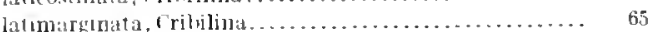

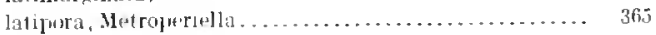

latoliravis, l'rotoscina ......................... 667

1.tontarinata Berenicus 708

l'lagloecia ......................... 1939,749

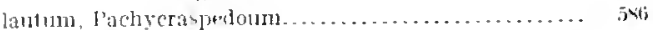

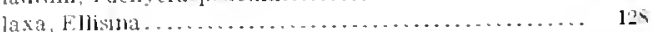

1/e ubranipra........................... 96

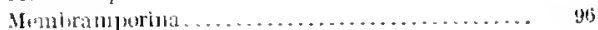

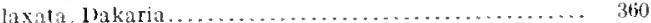
Filistursa............................

Leiose. grandisora............................. 449 orlicularis rostrifera......................... $432,44 x_{y}+49$

lojosmedia Multicrescis) parvicella.............. this, $\times 23, \times 24$ latiosen clidat . .

lukvthimia ................................. $i t 7$ dichotma........................

lenticularrs, (1rintulipura........................

letrialia

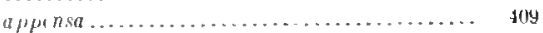
Arachnorisia monoceros................ 311 Arthroj,on: spwyeri .................... 352 


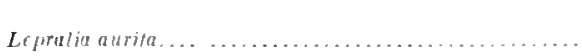

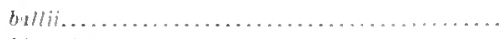

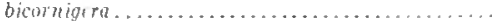

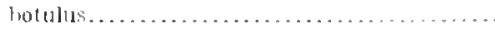

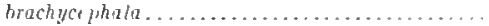

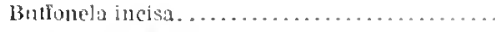
pilper....................... $31 !$

(hrilopora sincera.................... , in

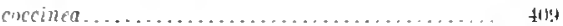

crassilabra........................ is ist

(yclicopora longipora................... 42.5

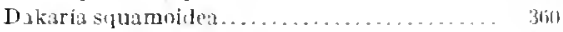

Ëmhallotheca sibbimmersi............... Bit;

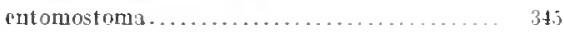

Jerox, Membrostiga..................... 170

Figularia figularis . . . . . . . . . . $316 \ldots \ldots$.

firmx.............................. 262

fulguran. . ........................ 410

IHarmeria settulata .................. 3.34

Hemicyclopora labjosa................. 5. 5i polita.................. $54 \mathrm{i}$

Mippoijiplosia aperta................ auingeri..................... 39.3

asperima............... 394

clizita..................... 343

megalota................ 344

planiceps................. 34

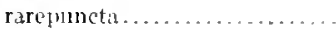

semicristata.................

vestita.................. $; y 3 z$

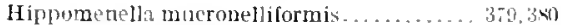
peristomati............... 3\% 340

II ippopo linu fergensis . . . . . . . . . . . . . 532

Iippoponth hippopus................

Hippopurina collaris . . . . . . . . . . . . . . . . . . 374

elimata.................. 374

porcullana................ $; 34$

sulciferia.................... $33^{-1}$

hyndmanni........................... 5ni

innominala. . . . . . . . . . . . . . . . . . . . . . . .

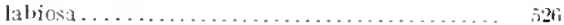

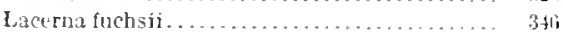

sequenzai................... $3 \mathrm{H}$

swessi....................... 310

nurtyi...........................

(Membraniporulla) nitila . . . . . . . . . . . . $3 \pi$

Metroperiella trigonostoma . . . . . . . . . . . . . 30 .

mombifcra.............................

Mueronella grotrimí....................

hormesi.................... 475

peachi................... 47,475

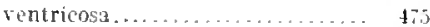

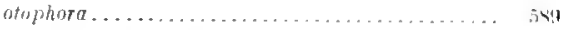

perconat......................... 110

l'erigastrolla contracta. . . . . . . . . . . . . . grotriani................. $5 \pi 6$

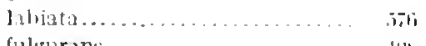

leristomello fulgurans . . . . . . . . . . . . . . the lacinintit. ... $\quad 1 n \ldots \ldots \ldots \ldots \ldots$

mamillata................

peregrina................ the

sirenuis................. Hit

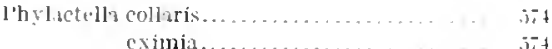

tubiceps............. n. nis

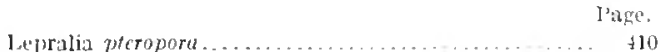

pungens...................... 428

resupinata........................... 410

Rhynclozoon hispinosa . . . . . . . . . . . . 5nt

russedi, Hoplochoilima..................... 234

Schizobrachiella candiula................ -3.33 erassipors ................ $3.3,3$ goninst oma.................... 3.5 franosu-porisid............ 3,3 schjzost oma............. 3.j.

Schizomavella auriculata............... 3.j. galeata.................. $3 i \pi 4$

Schizovorlrelliz erratia.................... 334 linearis................ 3358 micornis................. 338

Schizoporella biapurta ................ 34.3 scripta ......................... 2415 Smittina concimma................ 457 reticulat: ......... t.50

Stephanosella cntomostoma............. 34 seriatil...................... 34

striatula.......................... 3330 strombcki............................ $4 \mathrm{r}^{3}$

tridentata...................... 4 thy

Tubiporclla magnirostris................. 549

vcnusta. . . . . . . . . . . . . . . . . . . . . . 330

Watersipora cucullata................... 533

uondiana........................... 5xe

L.ppraliella. . . . . . . . . . . . . . . . . . . . 5th, 511

(Cellepora) pontigua................ 5 . . . . 511

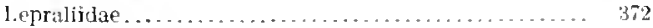

depralioites, Hippellozonn........................

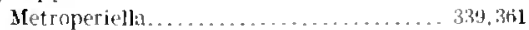

Jesuenri, tirammelh (Eschara ).................. 130

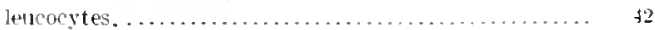

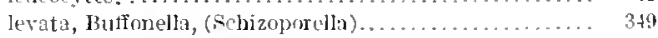

Ellisina (Membranibora).............. 125, 12b

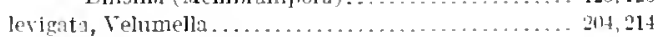

levigatum, fephyrotes....................... 301

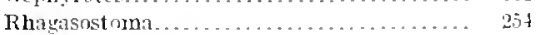

leviuseni, Schizobrachella (Achizoporella).......... 353

velunella (mychocella). .......... 203,213,214

lexis, Muerunella.............................. tit

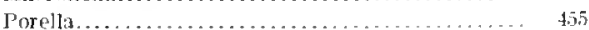

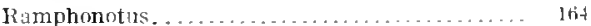

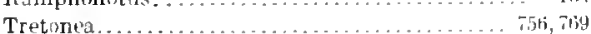

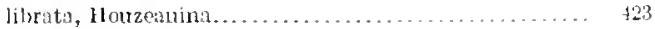

liehenvides, Hornera. . . . . . . . . . . . . . . . . . . . 745

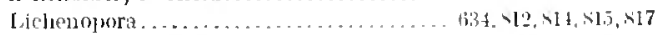
holetiformis . . . . . . . . . . . . . . . . $\$ 13$

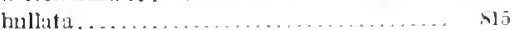

cipillatil....................... \$1

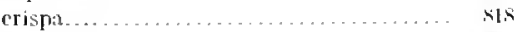

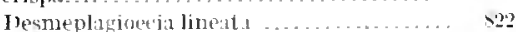

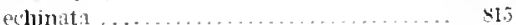

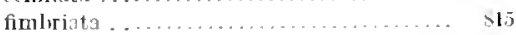

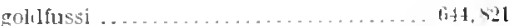

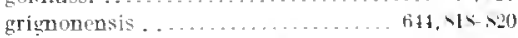

var multilumellusi.......... \$211

(I)

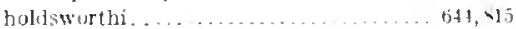

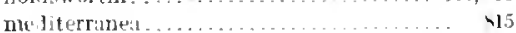

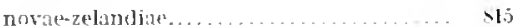

prulifara. . . . . . . . . . . .

radiata ..... 649, 45 
(Lich(nopora) retimlat.1

stenliata.

turhinita.

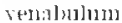

vermicirias

verruensa. . .

zonarial forms of.

Lichenourorilte.

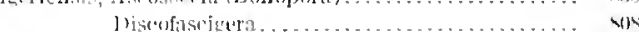

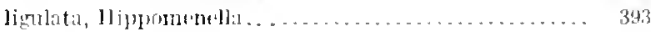

lunnlaria................................. 24:

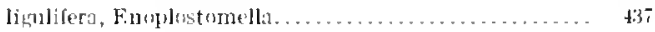

lilimea, "Tublifura.......................... $\$ 53$

limosa, Mrmbinipora.......................

line, limm n....

lineat, Eschiris. . .

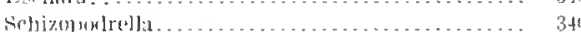

line.uris hastata, bechizopolrella . . . . . . . . . . . . in

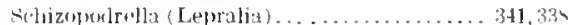

lineata, bermirem......

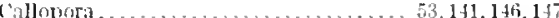

I)esmeplagioeria . . . . . . . . . . . . . . . . . 115,422

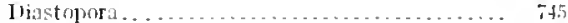

Me mbranipord.......................... 14

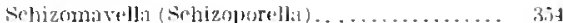

linestum, Iliplopholens . . . . . . . . . . . . . . . . 2003,21!

lines, liaterial. . . . . . .

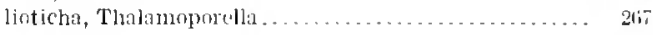

List of Localities............................. 15

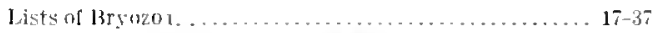

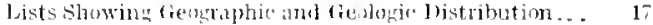

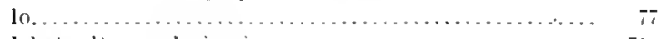

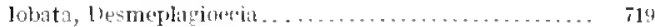

bxachella .......................... 114

Kleidimella...........................

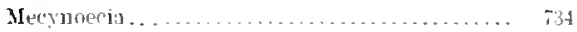

Plitiveria . . . . . . . . . . . . . . . . . . . . . .

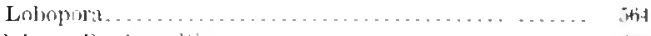

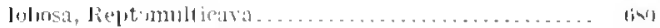

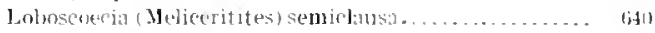

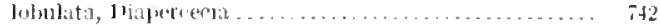

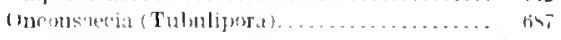

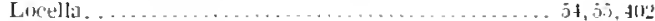

$\operatorname{lon} \operatorname{anc} 1$ lan....

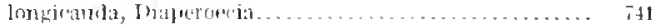

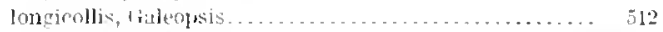

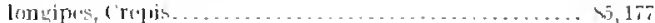

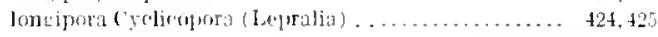

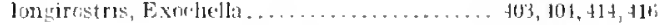

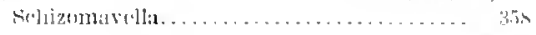

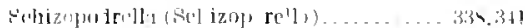

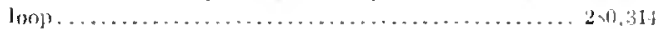

lophothore ....................................

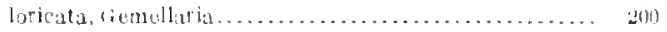

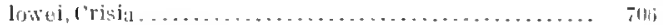

Menthro

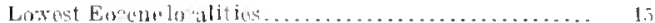

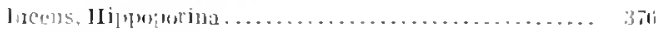

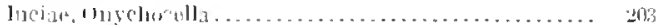

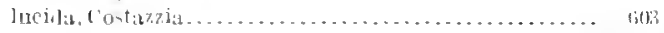

luma . . . . . . . . . . . . . . .

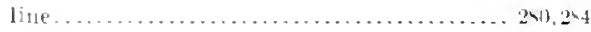

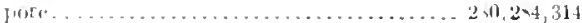

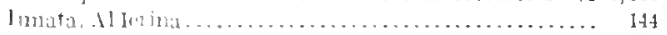

Fage.

lunata, Mocynomia . . . . . . . . . . . . . . . . . 730

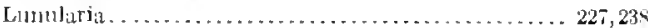

capmlus........................... 239

(oligotresium ) claiboruica .............. 24s

contjuna............................. 247

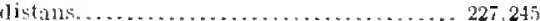

toutrata.......................... 244

arandipura......................... 242

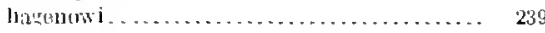

jacksonensis............................ 250

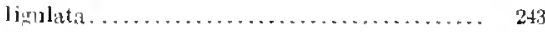

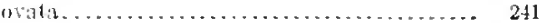

pratellifurmis........................ 239

relund

reversa............................... 240

tintinaluli2. . . . . . . . . . . .

tubifera............................ 245

verrucusa ........................... 242

((1)igotreinun) vickshurensis............ 249

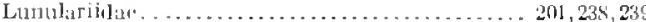

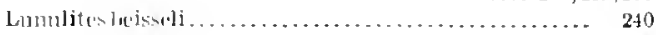

caluluk. ................................ 235

contrgtra.............................. 246

Lunulils (D)wollustrellaria) boudi.................. 103

almint............ 103

cuncara............ 103

depressa............ 103

duclosii............. 103

tiza............... 103

truncatr........... 104

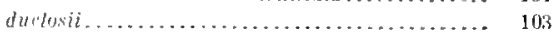

form of zoarium. ......................... fix

Huld lussi.............................. 240

unisstitiq............................ 620

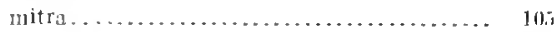

munsturi............................ 240

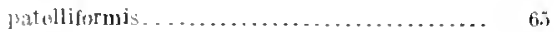

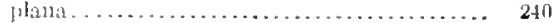

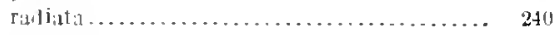

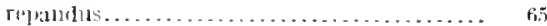

salebrosa............................... 240

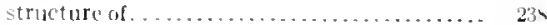

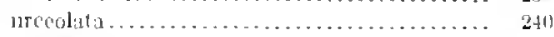

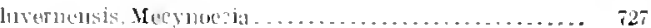

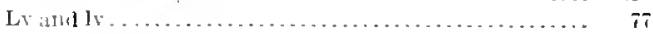

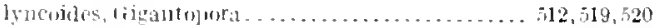

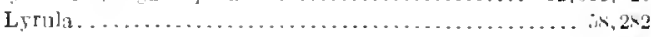

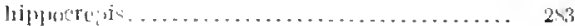

lyтul: . . . . . . . . . . .

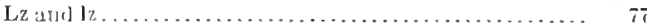

M.

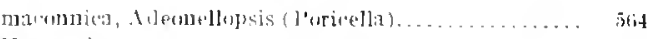

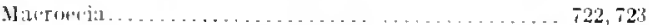

(1 riaglupura) lamellosa . . . . . . . lis:1, 722, 72.

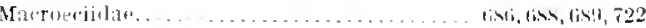

Mracrugra . . . . . . . . . . . . . . . . . . 27i, 277

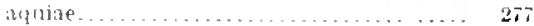

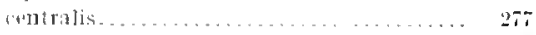

Warkti.................

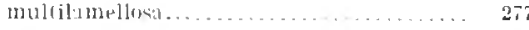

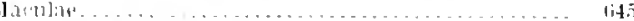

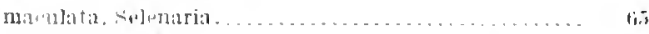

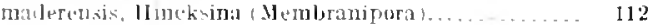

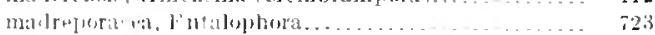




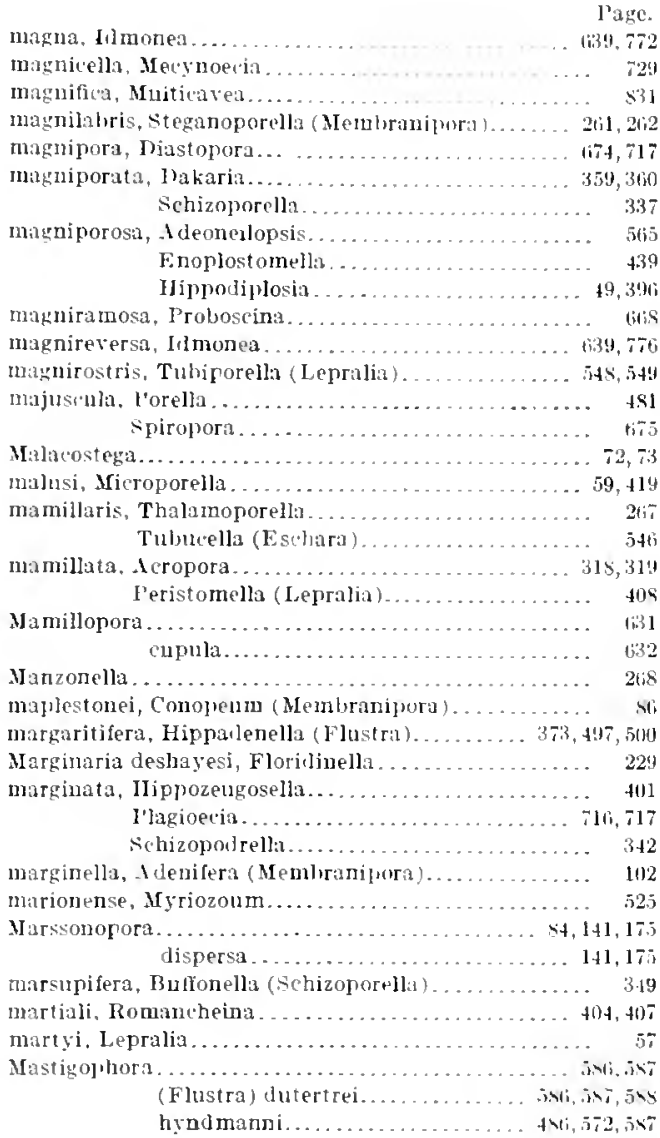

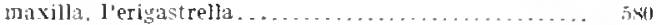

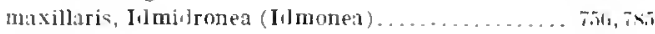
mecalliei, thionella.......................... 106 metuntrina, Mesenteripora. . . . . . . . . . . . . . Me.ynoeria ......................... 722,724 brevis........................ compressa. ...................... cormuta........................ 1.39, 7.3 .3 "ylindricu. . . . . . . . . . . . . . . . 727 delicatula....................... 724 elongatotuba................... 732 globula ......................... 734 lobata $\ldots \ldots \ldots \ldots \ldots \ldots \ldots \ldots \ldots \ldots \ldots$. 734 lunata....................... 730 luvernensis. ...................... magnioella . . . . . . . . . . . . . . . . . . . . . 720 Marvituba.............................

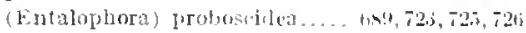
unsilla ..................... yuisenberryae ................... rligosa . . . . . . . . . . . .

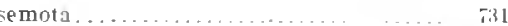

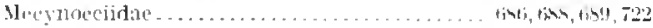
anatomy of . . . . . . F. . . . . . . . . . . . . merlian avioulitim median hanme. T'age.

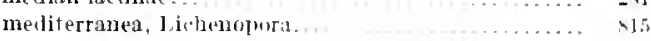

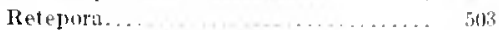

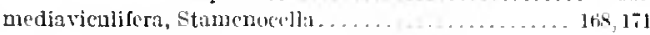
megacephala, colle porm ............. .......... 245 megalota. Hippodiplusia (I.cpralia) ............... 394 Megapora.......................... 141, 170,177

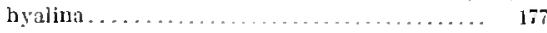
ringens..................... 141,17t,17i megapora, Grammella (lsitlustra) ............. 130 megavicularia, Hincksina. . . . . . . . . . . . . . . 109, 11 Mleberita........................... 272 melolontha, Aspilelectra .................. $2 \$ 3.317$ mewbranacea, Memuranifur: .............. $75,77,74$ Membranicellariilae . . . . . . . . . . . . . . . . . . . 2\$ Mrmbranipora........................ 7 abortiva, I]derint................. 141 albida, callopora................. 147 Ellisina . . . . . . . . . . . . . . . $126^{\circ}$ ambiguu, dechmella .............. 233

lfembranipora angulusa ................. 127,205 anterials, Amphihlestrum ........... 158

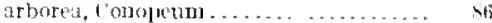
argentea, Amphiluestrum ........... 15s armata . demiferia....................... aurita, (al)oprit................ 147 bellula, Eloctra.................... 77 biaurkulatr..................... 148 bicolır, Electra.................. bidens...................... 230 bicornis.......................... 14s bravardi. comontun . . . . . . . . . . . . . britamica, (alloprora............... 1t califormionsis, callojula ........... 147 calveti. callopwra.................. 14t catemularia ..................... . 5,40 concinna, tuchmilla................ 233 coralliform 1s, callopmrı . . . . . . . . . . . . 14 corbula........................ 1]2 coriacta.......................

Iembranipora corniculifera, Elunck siun . . . . . . . . . . . 2]

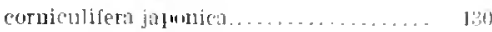
cormiger, Lirmacius... . . . . . . . . . . . . . . ] ] coronatu, Ellisina................ 120

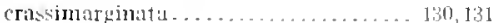

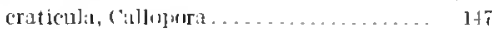

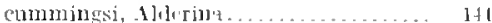
curvirostris, cillobura.............. 1t7 damica . . . . . . . . . . . . . . . . .

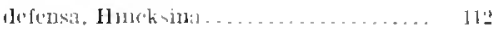

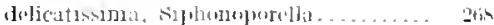

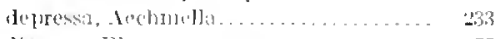
disturtal, Elutrat...... . . . . . . . .

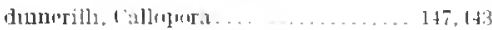
clliptick, limmphumotus . . . . . . . . . . . dtiv

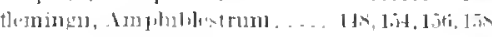
(Flu-tr] incu a.

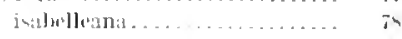

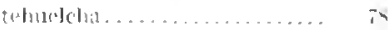
tulureulata ..............

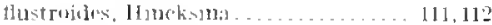
formusa, Flurmbuvila . . . . . . . . . . . 209

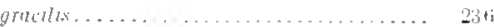

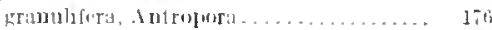

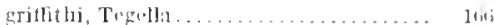




\begin{tabular}{|c|c|c|}
\hline Membranipora & 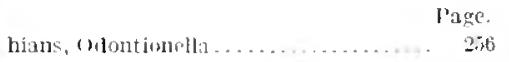 & Mimbraniport lla....................... 2\$1, 242, 244 \\
\hline & hoockeri... & 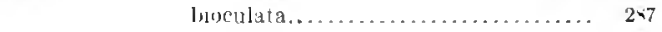 \\
\hline & horrita, callopora.................. & crassicollis........................ \\
\hline & humaliati, Ellisina................. & crassula....................... \\
\hline & 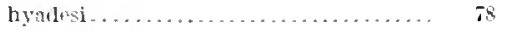 & 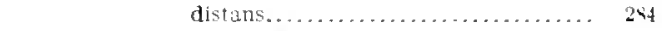 \\
\hline & imbellis, . Aderini . . . . . . . . . . . . . . 140,141 & (Lepralia) nitida................ \\
\hline & jnarmata, Hinckinut............... & $\bmod \operatorname{sia} . . . . . . .$. \\
\hline & incomluta. Rosspliania............... & 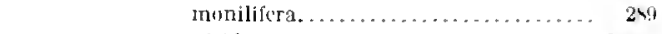 \\
\hline & incrustuns, Ellisina $\ldots . . . \ldots \ldots \ldots \ldots$ & nitida..................... 283,294 \\
\hline & invigilata, Callopora ................. & 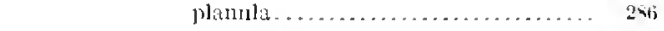 \\
\hline & irregularis, . Hderinta. . . . . . . . . . 131,1+1 & 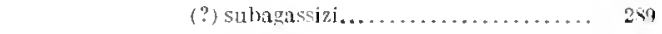 \\
\hline & jersejensis, Callopmin ................ & 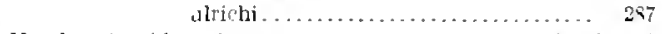 \\
\hline & lacruirii.................. $\$ 6, \$ 9,131$ & Membraniporitla....................... $4,124.133$ \\
\hline & Iangana, Conopenn . . . . . . . . . . & 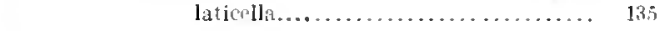 \\
\hline & 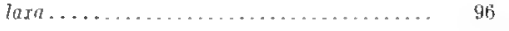 & 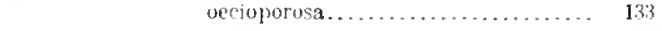 \\
\hline & levata, Ellisina ................ 125,136 & 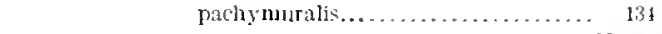 \\
\hline & $\operatorname{limosa} \ldots \ldots \ldots \ldots \ldots \ldots \ldots \ldots$ & perrocta................... 133, 13i \\
\hline & lineata, Callopora................. 147, 14s & 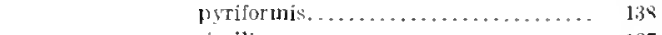 \\
\hline & maderensis, Hinchsina............. 112 & 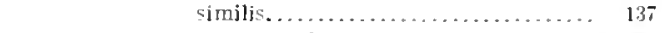 \\
\hline & magnilalisis, staganoporella.......... & spissimuralis.............. 48, 135, 27 \\
\hline & maplestmui, conoperm .............. & trigemma.................. I24, 134 \\
\hline & marginella, Adenifera............... & Membraniporina.......................... 44 \\
\hline & menbrandeca . . . . . . . . . . . & arcana.......... \\
\hline & numusula, Ellisinta . . . . . . . . . . . 12ti & 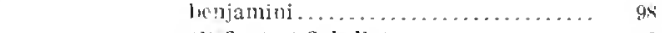 \\
\hline & Hincksinil . .............. & (I'iflustra) flabellatia................ \\
\hline & monostachys, Electra.............. & canalifma...................... \\
\hline & nigrans, Mlonifira................. & 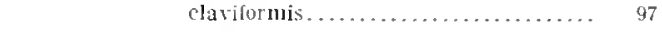 \\
\hline & Callopora $\ldots \ldots \ldots \ldots \ldots \ldots$ T 147 & 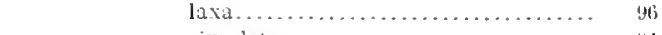 \\
\hline & norluaraliana, callopora........... 147 & 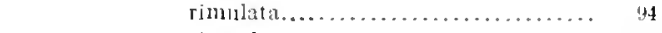 \\
\hline & occulta, Tergolla . . . . . . . . . . . . . . & 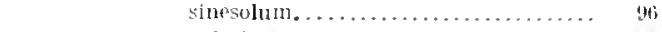 \\
\hline & occultata, (bontionella.............. & 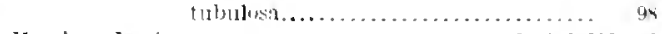 \\
\hline & papulifera, Grammella .............. & Jlembrenduccium................... s4, 1199, 119,120 \\
\hline & 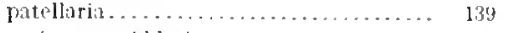 & 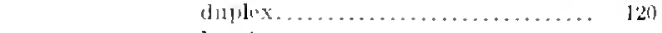 \\
\hline & perisparsa, Aldurina................. & 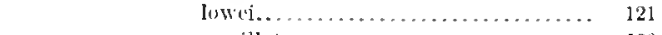 \\
\hline & 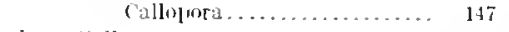 & papillatum................... \\
\hline & plana, (allopura...................... & 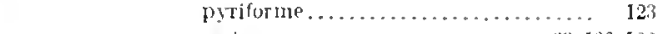 \\
\hline & 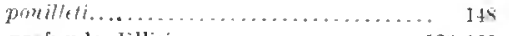 & rectun. . . . . . . . . . . . $69,109,122$ \\
\hline & profunda, Fllisina ............... 126, 129 & transversin $\ldots \ldots \ldots \ldots \ldots \ldots \ldots .120$ \\
\hline & pura............. is & Membrostega............................ 94,174 \\
\hline & lyrula, Ifincksina.................. & (Lepalia) ferox................. 174.17i \\
\hline & renssianda. Rusollana .................. & nendonensis, radiopora............. \\
\hline & rhonalusidalis. F.llisina................ & 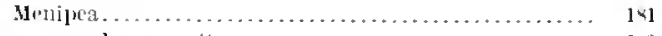 \\
\hline & 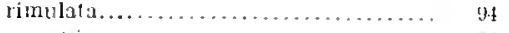 & benemsnita...................... \\
\hline & sarartil. . . . . . . . . . . . . . . . . & Mrniscopora............ \\
\hline & 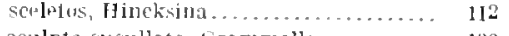 & (Menjscopora) Bracehridria subcremulata............. \\
\hline & sculpta cucullata, firammrlia............ & 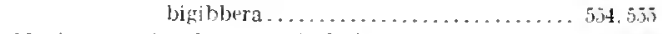 \\
\hline & Giramnullit. . . . . . . . . . . . & Meniscopora (lishara) semitubulosa . . . . . . . . . . . . \\
\hline & sigillata, liamplonuotus............. & simolii ............... \\
\hline & solıdula, 1 liderina.................... & 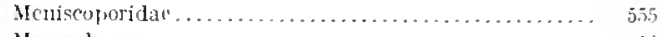 \\
\hline & sophiar", Tegilla........... & 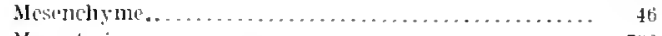 \\
\hline & spiculisil........................ $\quad 127$ & 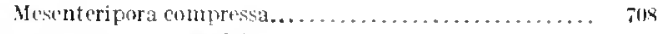 \\
\hline Mumbraniporac & $(\ldots \ldots \ldots \ldots \ldots \ldots \ldots \ldots \ldots, 72,73,72$ & 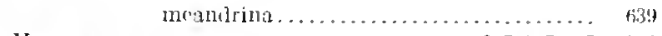 \\
\hline & 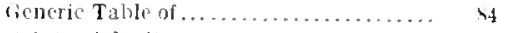 & 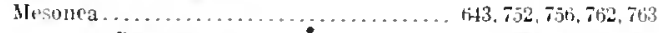 \\
\hline & striati. Adunitira.......... & (Retepora) ratians....... \\
\hline & subpilimargo................ & subpertisa.............. \\
\hline & tenella, linetra....................... & Mesupores...................... \\
\hline & lenuirustris, Callopora.............. 147, 1.54 & Methods of gemmation........... \\
\hline & trjfolinum, Amphiblestrum........... 1js & 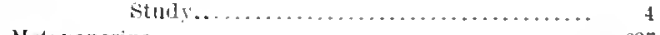 \\
\hline & triminghamensis, Tegrlla............ 1n.th & 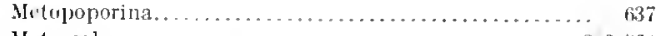 \\
\hline & 1rullit, Beissplinu................ 314,324 & Metracolpusa.................... \\
\hline & rubirosa, callopra. . . . . . . . . . . 147 & bruvis.......... \\
\hline & umbonati. Amplubustrum............. & 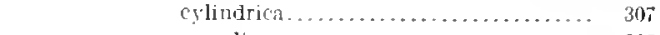 \\
\hline & unjecrlis. Teqgolla . . . . . . . . . . . . . & grandis.......................... 305 \\
\hline & 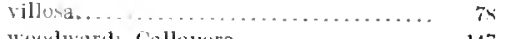 & robusta. . . . . . . . . . . . $2 \times 3,305,30 t i$ \\
\hline & wondward, Callopora ................ 147 & Metradolium,................................ 432,440 \\
\hline
\end{tabular}




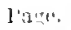

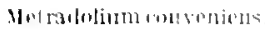
divimuli. [rand . litliatulinm olliefunm ] hascirimulalum. sultifirimi... transiorauth.

\section{Metrarialulutos} grimle .

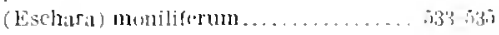

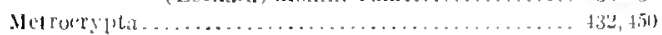
breculenta.................. 4,32, $4,4,1,1$, Metropericla . . . . . . . . . . . . . . . 334, 334,341 acervitit...........................

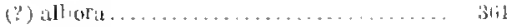

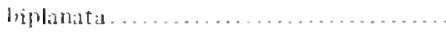
urandipora.

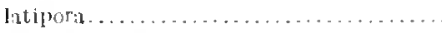
(lepralia) triguntestomit..............

Inpralivides........................

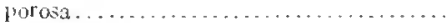

(schizopreteha) lata ................... leveriliuidos..............

metstit, Arthropoma.......................... Mrombic und Cenuznic Fumation Valtes........... 12, 14

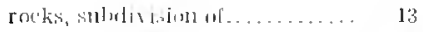

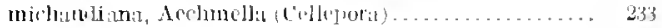
mi.lulini, I'iustopora.....................

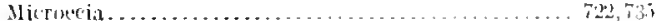
1labellata...................

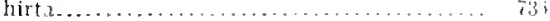
viluin.............................. $73 ;$

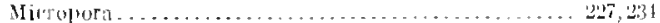

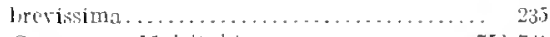

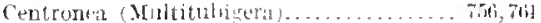

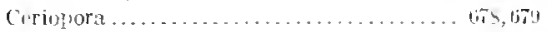

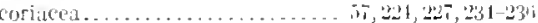

Eschitelli ......................... 531 gractls............................. 23i

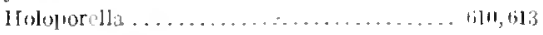

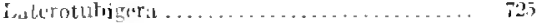
mintuta. . . . . . . .

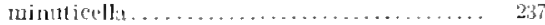
normithi...........................

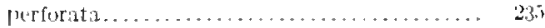

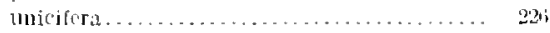

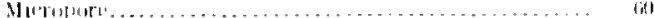

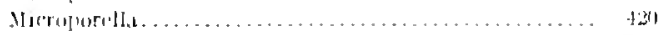

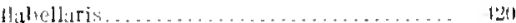

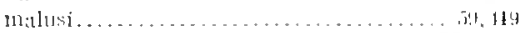

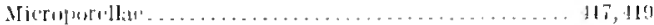

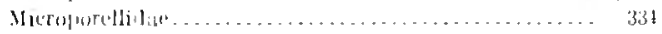

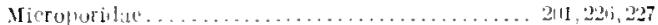

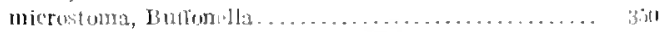

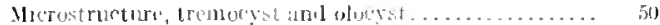

Mjwayn Listi............................. 17 loculities. . . . . . . . . . . . . . . . . . .

mulay

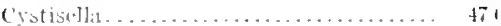
Irippolorint. . . . . . . Nellia....................... smitti]

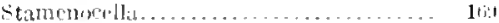
Tulndipor...........................

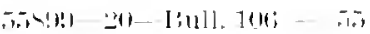

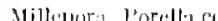
unmetapa

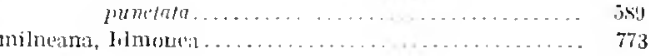

milneri, Fermpocellaria ....................... 1st;

minlax, Ramphonotns..................... 111,163

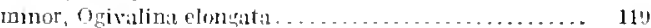

mimulit, Mieropora........................... 235

I'ordia........................... 4 \&I

Stomitoport........................ ti, ti

minusend: Ellisina (Momminipora) ........... 12)

Fincksina (Mombranipora) . . . . . . . . . 112

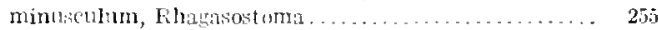

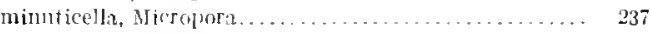

misur, Umbonnl.1........................... 494

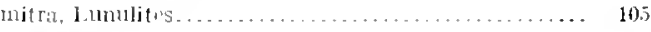

molesta cribrilina . . . . . . . .

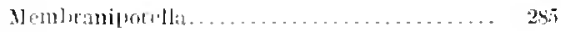

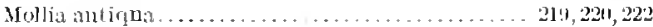
tuburculuta....................... 330 monilifira, Calinjoura ( Eschert............................ . Leprakin.............................. 53,5

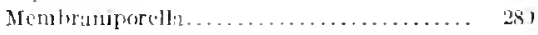
Sichizturellu...................... 5is;

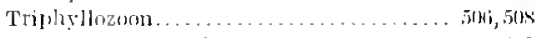
mmbmatil .............. $4 ! 9$

Tulnerlia........................... 517

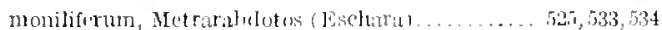

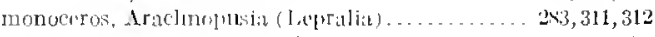

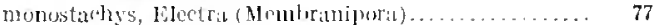
monosticha, Itefrancial....................... 721

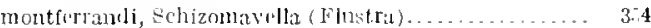
mortisaga, imittistomit..................... 551

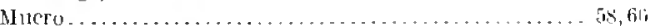

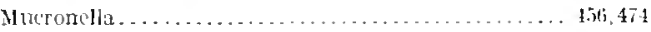
abyssicolat........................ 471 aspera............................ 40.

hiaviculati........................ 471

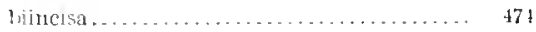
coceina........................... $11 !$

crozphns.......................... diaptana........................ 47

ellrit............................... 471 grantilosit . . . . . . . . . . . . . .

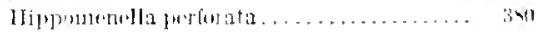

(l ejralia) grotritul. ................ horm

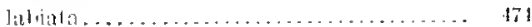

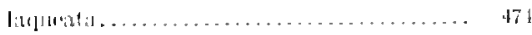

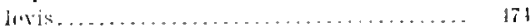

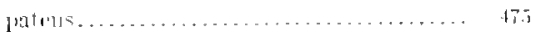

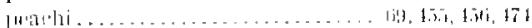

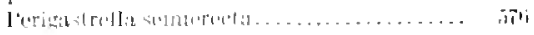

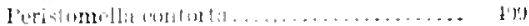

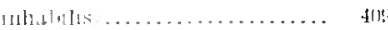

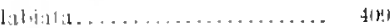

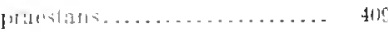

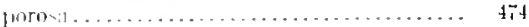

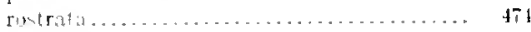
suimststma....................... tit teres............................... 470.

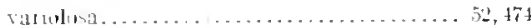

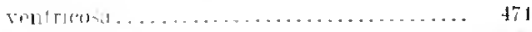

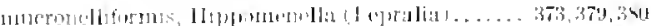

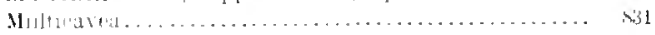




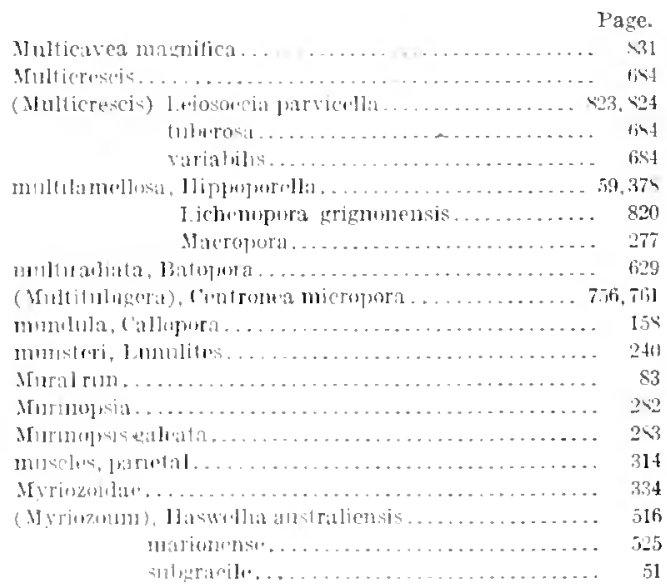

N.

Xatirn. of 11) onicoll

Xulli:

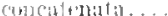

mulwatalutu.

menlata.

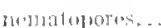

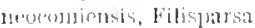

dationomat.

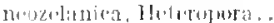

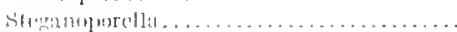

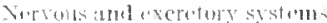

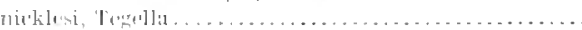

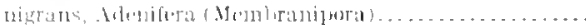

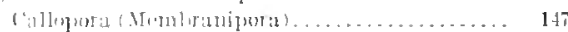

\imla 1 ... 339,37

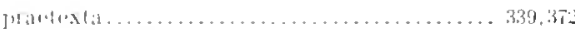

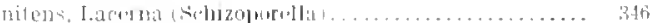

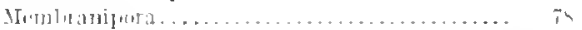

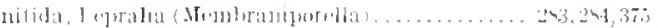

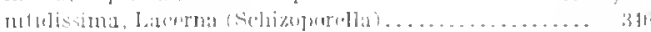

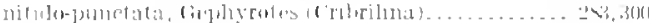

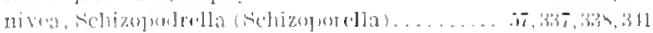

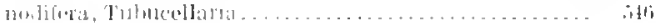

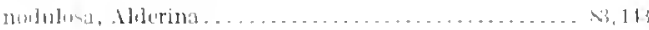

Alnmatophlina ...................... 111

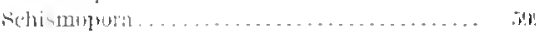

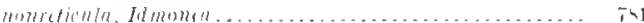

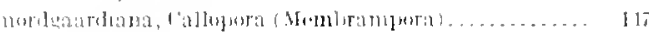

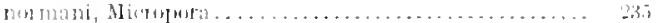

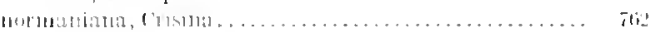

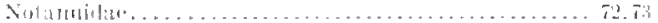

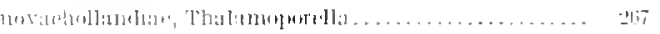

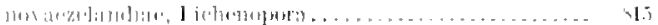

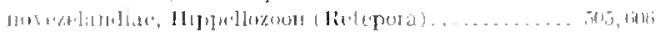

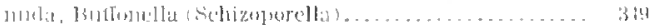

\section{0.}

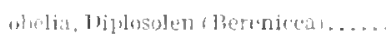

whelintes. Iriastop oria.....

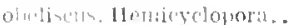

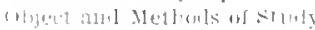

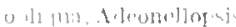

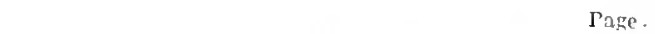

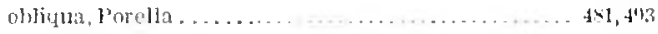

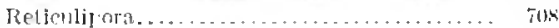

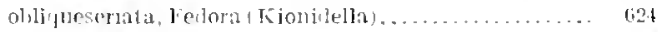

olilitum, Metraklolium............... $42: 4,46,414$

oculpusis, Hinckin ..................... 114,117

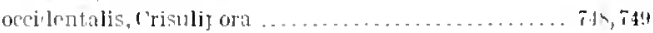

Gyulon:utes........................ Ts

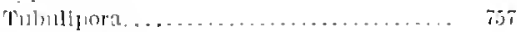

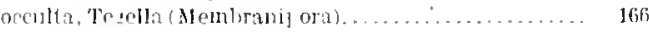

oreultata, \{hlont innella (Membranij ora)............ 251

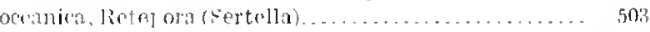

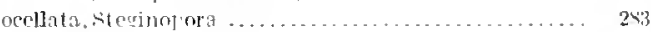

1) jaksulica. . . . . . . . . . .

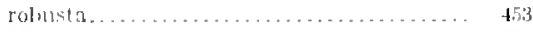

octonaris, locryonelha . . . . . . . . . . . . . . . . 227

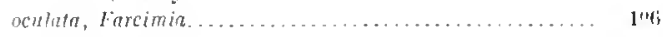

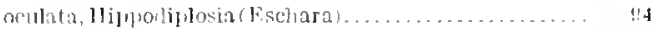

Sellia .........................

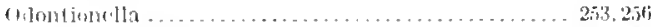

(Memblanipora) hians............. 2iti

occultata............

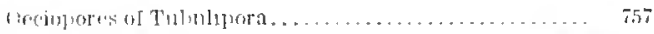

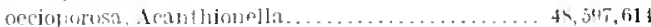

Momimaniporidra................ 133

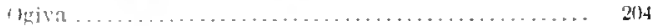

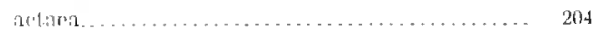

(1)

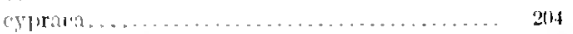

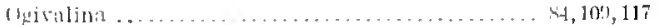

vomenta. . . . 114

var minor . . . . . . . . . . . . . . $11 !$

ovimiport. . . . . . . . . . . . . . . 109,117, 119

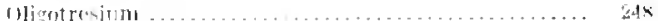

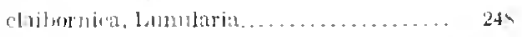

ibls

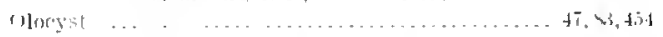

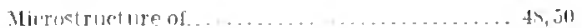

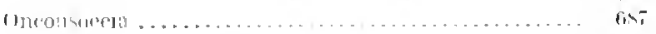

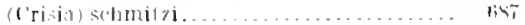

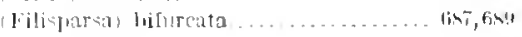

आ1

Tulndipma) wblulata............. lini

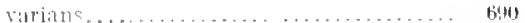

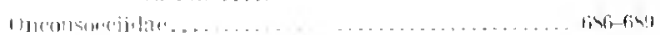

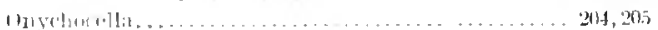

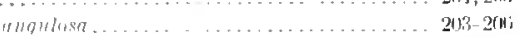

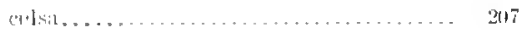

divitat: . . . .

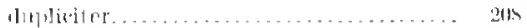

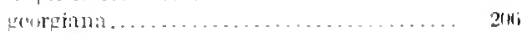

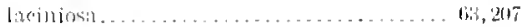

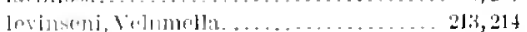

lullat. . 2113

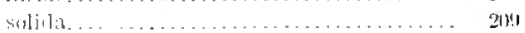

(m)

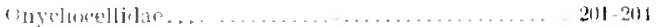

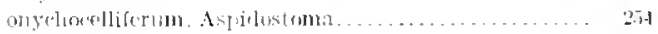

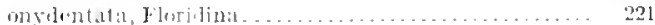

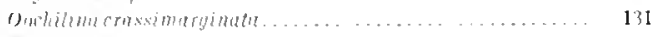

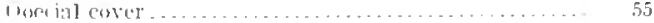

7th 1 "

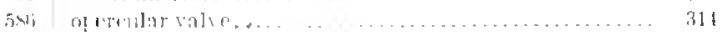

(1)

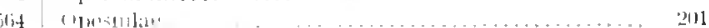




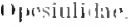

11"millu

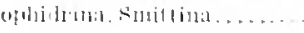

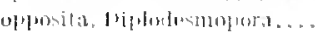

Stomatopota

opulenta, Tematia .....

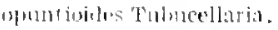

urlua intlaria, smittina.

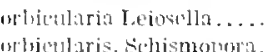

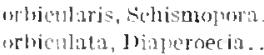

whit latum, Amphilestrum

wrbindifern, Hibloporalla.

orbifera, cheingrora

orintultis intersting.

urhitulijora

ecentrion.

hailingeri.

lentioularis.

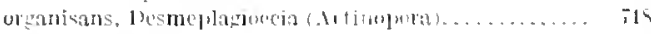

Tubulijura . . . . . . . . . . . . .

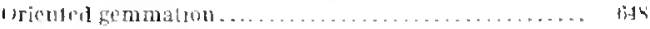
zoviria ............................ 584,505

(rrifice ur apertura ............................. tigh

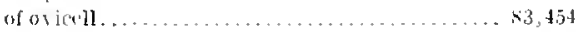

1 rigin of zoarium .......................... 650

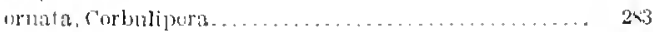

Irmpanina ....................... 422

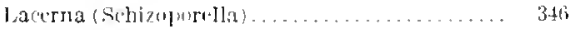

Trsarktoma . . . . . . . . . . . . .

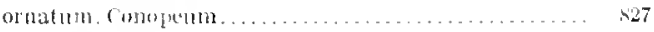

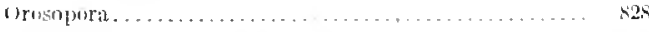

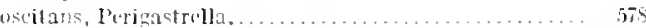

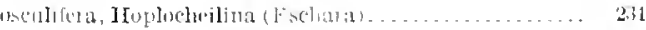

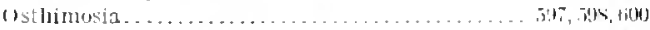

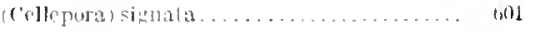
(lavata . . . . . . .

rascatina.......................... bitz

tutonensis. . .

creta....................... is

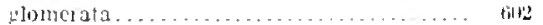

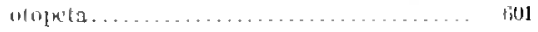

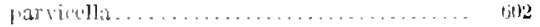

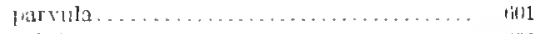

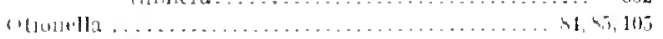
(ava................................ I0s micallipi ............................ $100 \mathrm{n}$

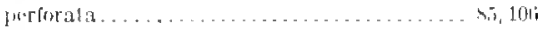

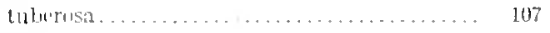

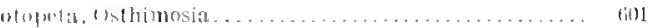

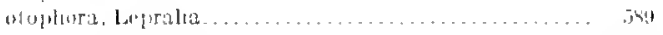

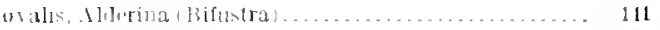

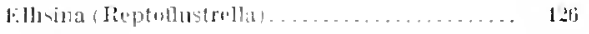

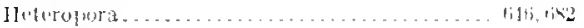

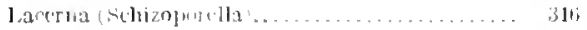

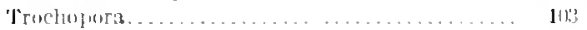

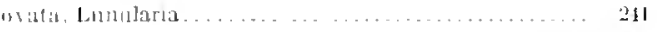

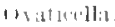

a)

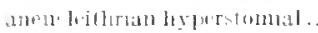

11, $12,5,2,1,1,1,01$

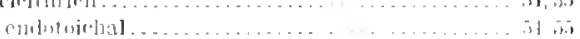

(maluzuncial. . l'age.

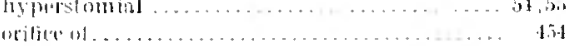

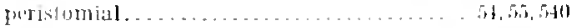

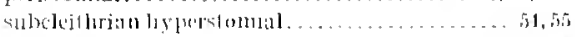

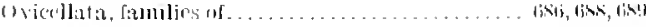

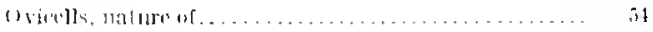

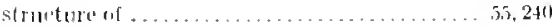

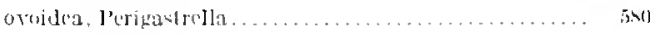

\section{1 .}

Pahyerantolenum lantum . .

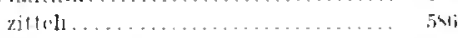

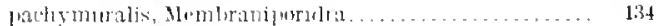

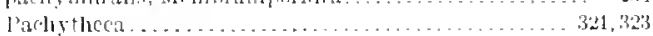

b)

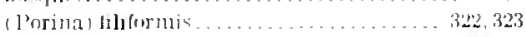

stipata .......................... 314,322

paufic a, Tubıliqura ...........................

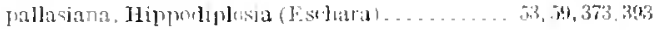

palmata, lentalephwa........................ $i 11$

balmula, berenict'a . . . . . . . . . . . . .

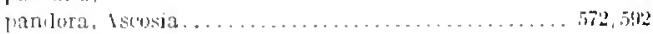



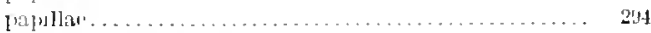

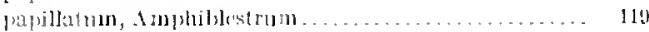

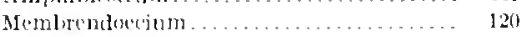

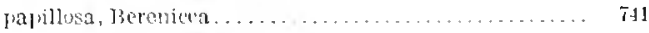

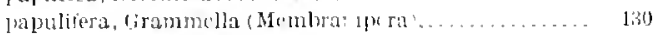

Trypunatria . . . . . . . . . . . .

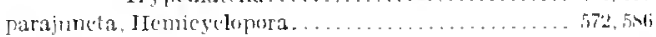

farallela. Houzcanina (leschara) . . . . . . . . . . . . 421

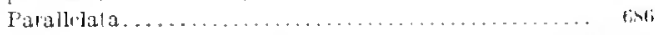

Parascusuccia ................................ 4.84."10

(Cavea) custata .................... the.1. sto

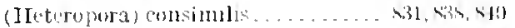

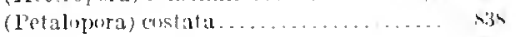

(Aparsicatualarantima.............. \$3.

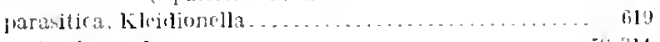

prarintal nullscles. . . . . . . . . . . . . . . . . . . 55,311

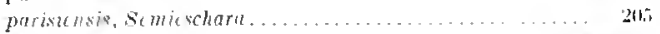

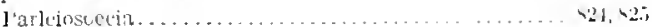

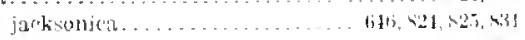

parnonsis, Iriscoeawa . . . . . . .

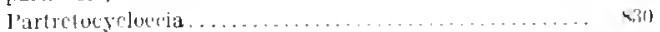

(c)a $a$ in) dommat................ \$30

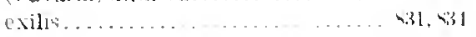

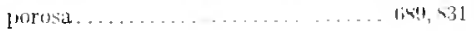

reptans.......................

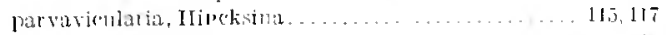

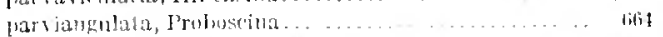

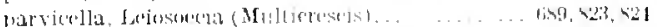

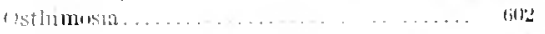

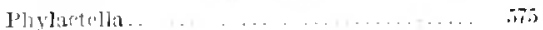

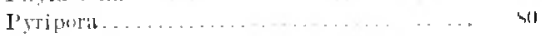

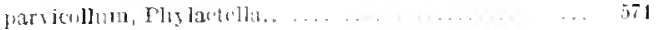

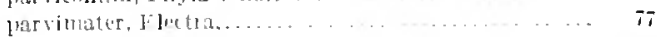

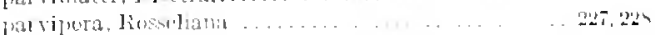

stephame lia ... . . . . . . . . . . 34 t

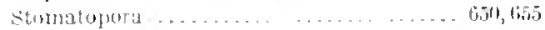

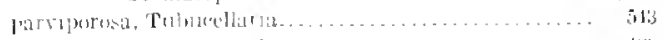

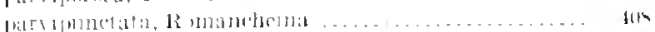

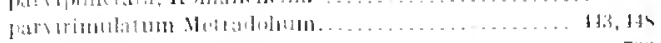

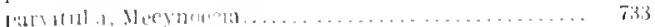

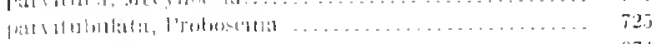

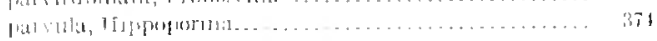




\begin{tabular}{|c|c|c|}
\hline & $\begin{array}{l}\text { age. } \\
7800\end{array}$ & Peristamella (Mucronella) inhalilis.... \\
\hline Osthime & (i) 1 & Jabiala...... \\
\hline Tervia. & 790 & praestans... \\
\hline parvuliporum, 1 piplepluters. ........ & $21 \mathrm{~s}$ & 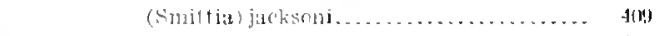 \\
\hline ........ & 56 & 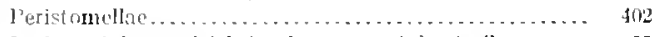 \\
\hline Palellaria, Mema & 139 & I'eristomial ancucheit hrian hyperst imial orirel] ......... \\
\hline Acoluformis, 1 ur & 239 & ovicell............... \\
\hline $1.11101 \mathrm{I} i$ & 15.5 & leustrmiale. \\
\hline alcis, implibl & 1611 & Feristumice....... \\
\hline Mucromellil. & 47.3 & $54,45,3,154,540,6109$ \\
\hline Telopora. & $\sin 7$ & Peristomeria ... \\
\hline 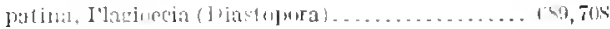 & & (f'robencina) horryii. . \\
\hline ........... & 319 & lamournuxi. \\
\hline avchunuli & 210 & (Stomaternera) diverens. \\
\hline .......... & 240 & 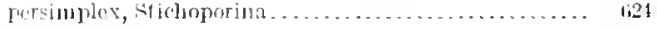 \\
\hline 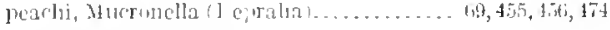 & 475 & 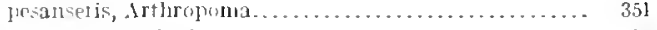 \\
\hline .................... 177 & & 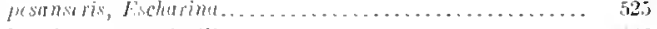 \\
\hline or $\ldots \ldots \ldots \ldots \ldots \ldots \ldots \ldots \ldots \ldots \ldots$ & $231 ;$ & letaluprara comsinilis............. \\
\hline 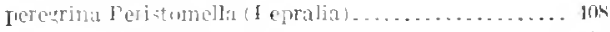 & 110 & 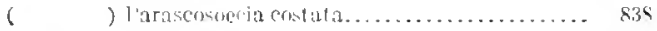 \\
\hline$\ldots \ldots \ldots \ldots \ldots \ldots \ldots \ldots, 121$ & & reliolus, I Iipurdiplasin . ............. \\
\hline 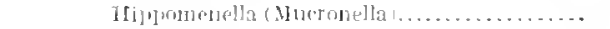 & $3 \times 0$ & Arlsitulijwra...... \\
\hline …........ 373 & & retij, Irmone:a.......... \\
\hline .... & 233 & plajangea, Tulunlipra....... \\
\hline ..........85 & $1 \mathrm{kj}$ & Miliplunensis, Conestharellina..... \\
\hline erigastrulla. & $5 \pi i$ & 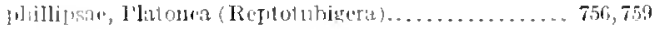 \\
\hline ........ & $571 \%$ & philomela, Fimularia (Ifomeselarid). \\
\hline ........ & 554 & 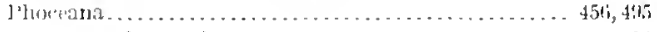 \\
\hline ........... & $57 \bar{i}$ & reltuminas..... \\
\hline .......... & 542 & simulizt or . ................ \\
\hline ............ & $58 \div$ & 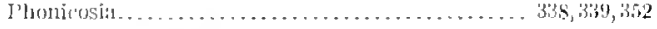 \\
\hline 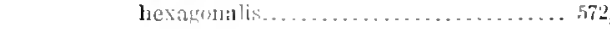 & & jousspaumi.................. \\
\hline ........ & 5710 & sanguinea............ \\
\hline ...... & 570 & l'hormentora.............. \\
\hline Jaliatia. & $5 \pi i$ & irregularis....... \\
\hline ....... & $3 \times 0$ & I'] y.l. \\
\hline 1:a semierecta $\ldots \ldots \ldots \ldots \ldots \ldots$. & $5 \pi \mathrm{i}$ & (wlummaris........... \\
\hline ............... & $52 \sqrt{3}$ & a................... \\
\hline .......... & $5 \%$ & inffind lihnalum .......... . \\
\hline ........... & 5,3 & lalint $1 \ldots \ldots \ldots \ldots \ldots \ldots$ \\
\hline .......... & 192 & l:Itrusis .................. \\
\hline ........... & 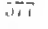 & (1.eprulia) (willuris.......... \\
\hline ........... & Sil & eximia ....................... \\
\hline ................ & & tubsi a pre............ \\
\hline$\ldots \ldots \ldots \ldots \ldots \ldots \ldots+c 17$ & tids & bllit, .............. \\
\hline …..... & 124 & gurvicellum .......... \\
\hline .......ts, 124 & & jurosa. \\
\hline [misil) $\ldots \ldots \ldots \ldots \ldots \ldots$ & 141 & yennentigerin... \\
\hline 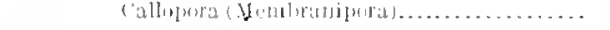 & 117 & lintue. \\
\hline 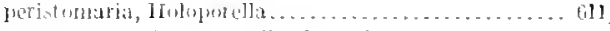 & 1,13 & 1) \\
\hline 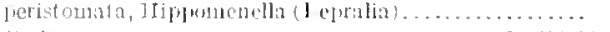 & 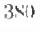 & 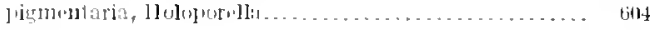 \\
\hline 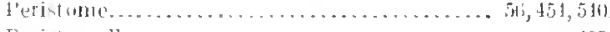 & (6t.9? & 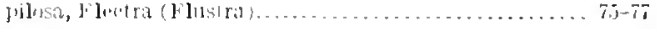 \\
\hline …..... 40.13 & Ain & Juifornis, lIoloporsla................ \\
\hline $\operatorname{coccine} 2, \ldots \ldots \ldots$. & all & $1, \ldots \ldots \ldots \ldots \ldots \ldots$ \\
\hline renupinater. & 412 & liflutaxis............... \\
\hline & 113 & 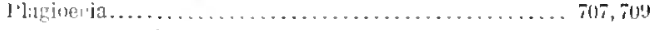 \\
\hline alif & 415 & $\ldots 714,718$ \\
\hline lit) coblifura. & $4+4$ & brumalielewhish . . . . . . . . \\
\hline .. & 415 & 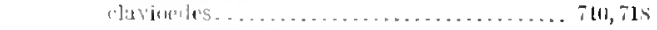 \\
\hline & 413 & $(0,5,71,71,718$ \\
\hline (Leperalia fut & 4us & (1 liastrifora) Latcomarginatil ... \\
\hline & 409 & ratiuki. \\
\hline$m i x$ & 4118 & . \\
\hline$\cdots$ & 4114 & 12,71, \\
\hline$s t r$ & $10 !$ & 10 sil. \\
\hline Hella & 101 & \\
\hline
\end{tabular}


INDEX.

Page. 1

Plagione lamellosi

littomir

lotata............................ $: 10, \pi 17$

mareinala............................ $811, .717$

patina...............................

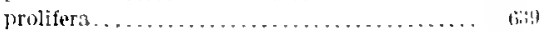

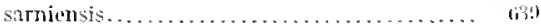

suliramusa........................

superpusita........................

tulifer............................ ה11,

tubondes......................... 717

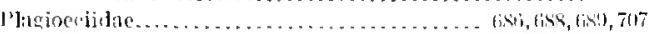

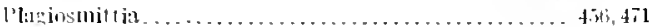
Forellnites.......................... 472 regul:aris........................ $451,471,472$

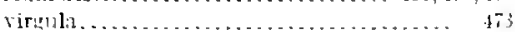

Hlicinstoma, Schizomevella (Sehizoporella)........... 35.

llima, (allopora (Nembratipora) ................ $14 \bar{i}$

L.mulites............................. 240

I'erimast rellit . . . . . . .

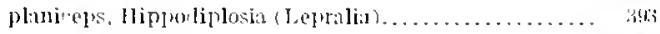

plimula, Memhrmi

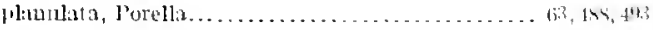

[1:anum, bijlosolm ........................... iti

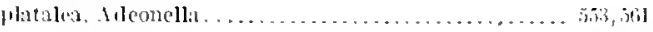

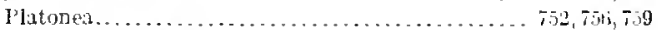

(1arata............................... Tit

lamellifera............................. itio

(Reptotubigera) phillipsaf .............. 7., 7.69

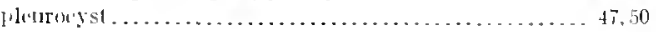

grandia.......................... 4,4

structure of.......................... 52

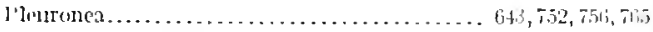

alveolata.............................

fenestrata............................ Titi

fibrosa................................ $i t i$,

fusiformis............................ 768

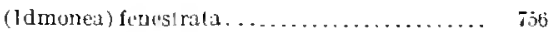

suhpertusa........................... 767

I lir ata, Thesmeflagioecia ........................

Rhamphostoniella...................... 476

Velumella................................. 214

plomosa, Bugula .............................. 44

Tubulipora..........................

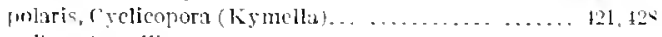

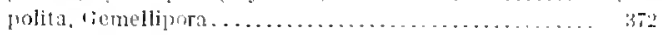

llemicyclopora (Lepralia .................... $5 \$ 6$

l'ollaploecium, Tetraplu ia gilherterusis............. зй

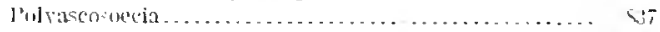
coromopils . . . . . . . . . . . . . . . . . . . . biks 437 jacksonica.......................

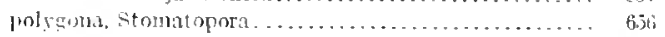

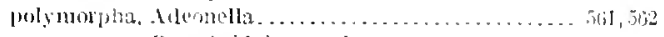
Bracebrulgiz costulati................. 5.30

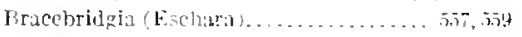

ricphrrophora................... 512,520,521

polspornides. Hornera . . . . . . . . . . . . . . . . .

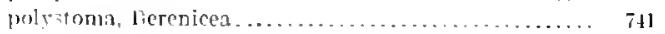

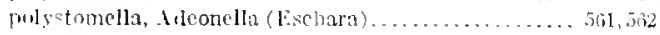

Polyzua................................... 39

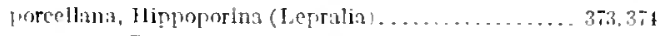

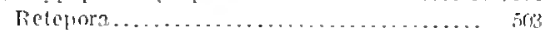

pure, aroblar . . . .

ctramber . . . . . . .

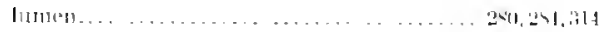

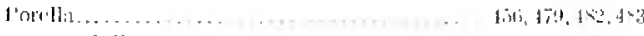

ablitia......... the the

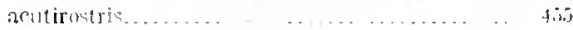

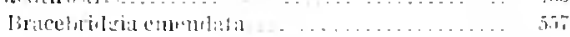

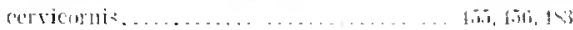

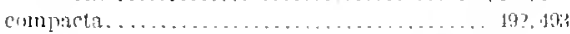

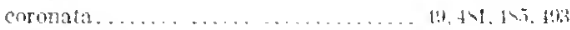

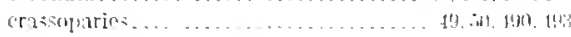

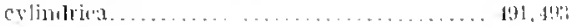

('rati olla saceata . . . . . . . . . . . . . . . . .

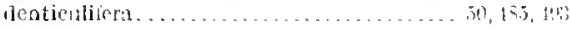

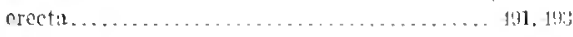

grasiata. . .

granulo:a. . . . . . . . . . . . . . . . . . .

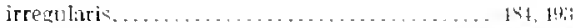

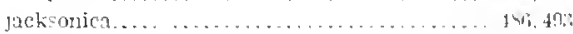

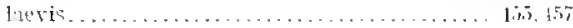

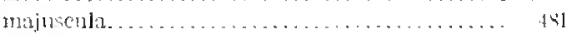

(Millepora) cervienritis.................... tin

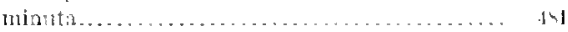

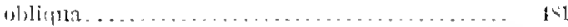

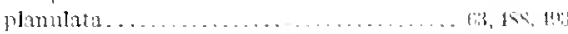

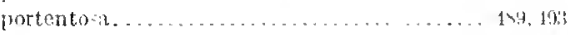

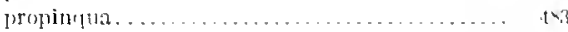

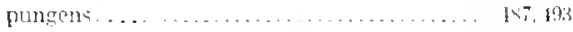

nngniculata. . . . . . . . . . . . . . .

porelluides, Ilasiosmittia . . . . . . . . . . . . . .

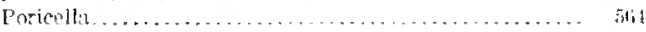

Aleunelope elongatin............... in

macombiria.................

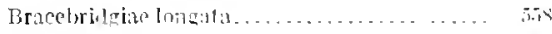

porifera, Schizomarella (Fohardla) . ............. 3.5

porilerum, Arropora pultorta.................... sil

Aspilostoma . . . . . . . . . . .

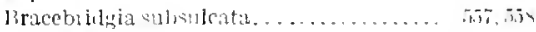

Galempis columata................ 510

cribraria.................. 510

tuberenIn:a ..................

lachrthere filitur mis................. $32 x$

proho:cilea.......................... is

porosa, Aleonellopit........................... sis

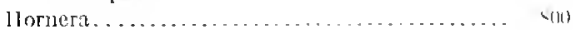

vetroperiella........................

Mucronella............................

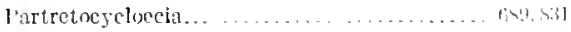

phylactella . . . . . . . . . . . . .

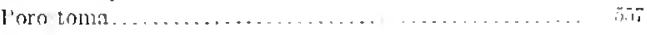

Bracetritgia clavatum ................. ni

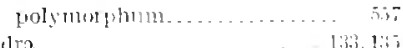

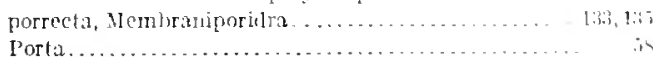

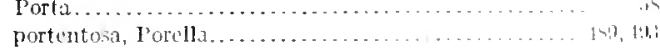

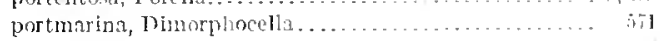

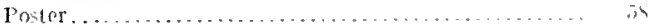

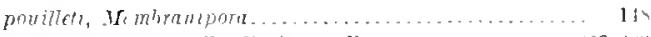

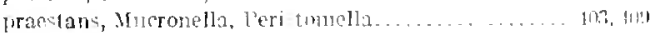

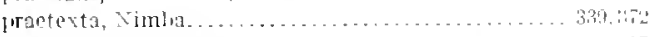

pratti. stumitunorz...........................

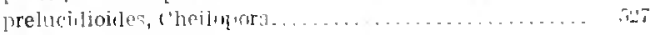

pre:tans, Fomancheina. . . . . . . . .

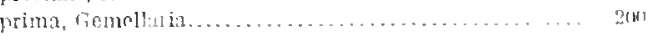

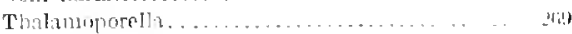

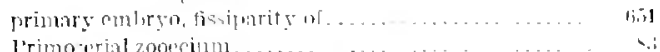

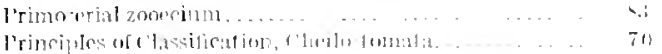




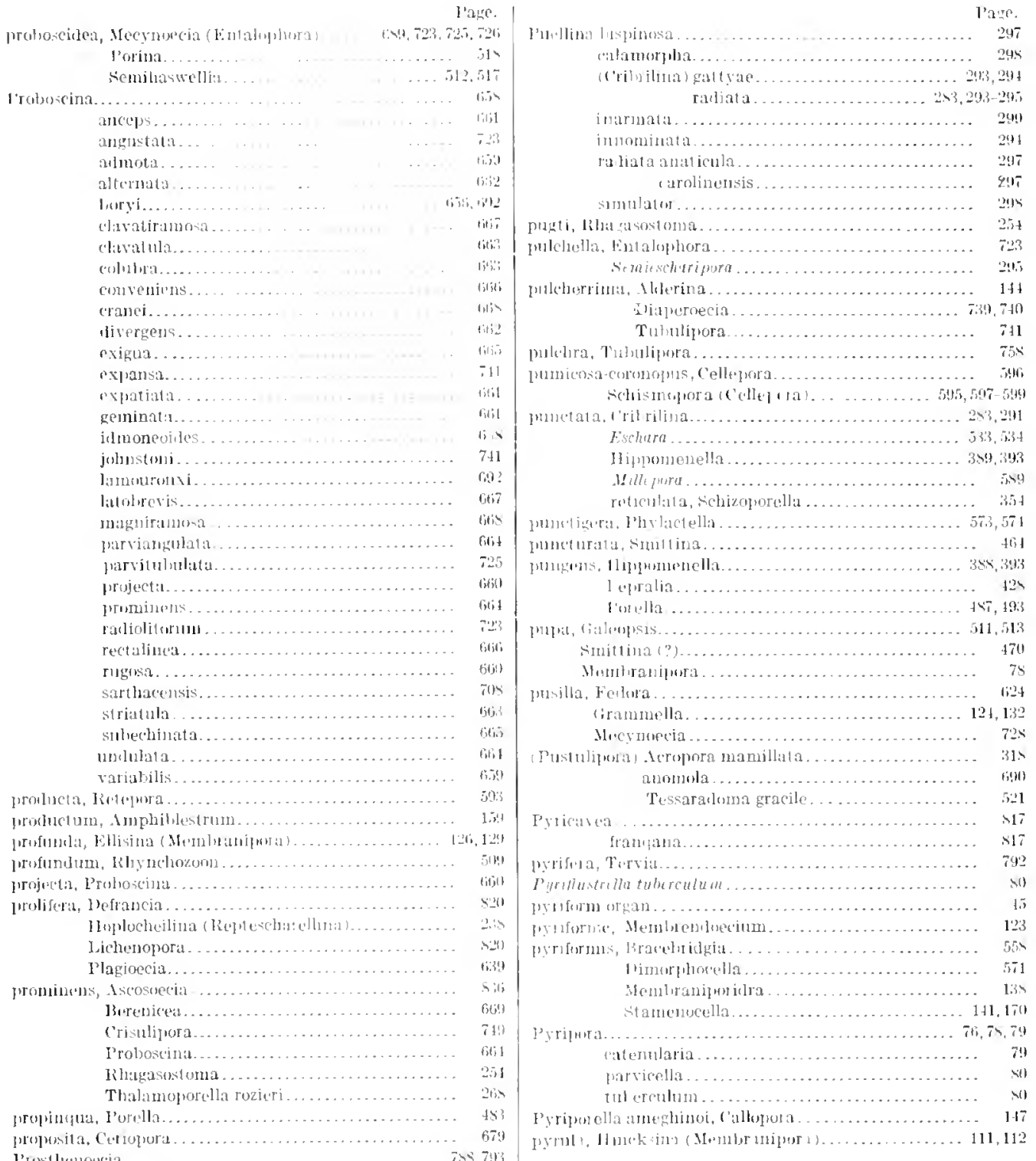

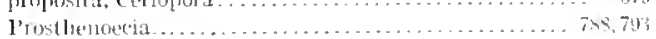

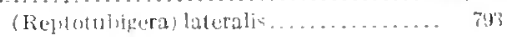

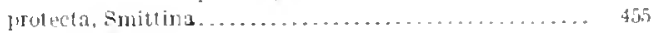

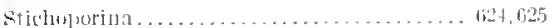

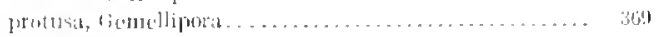

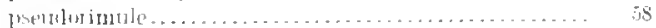

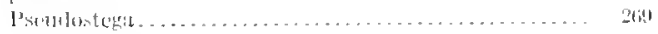

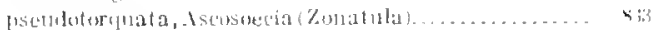

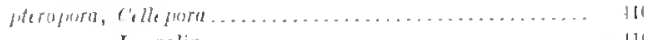

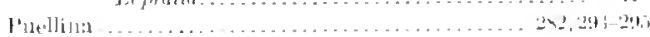

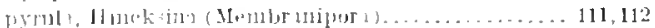

\section{Q.}

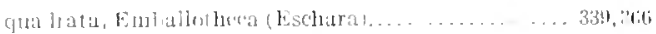

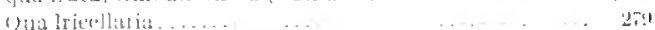
??

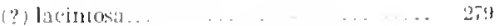

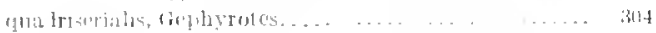

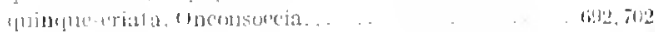

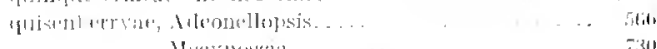


18

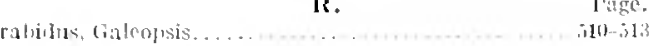

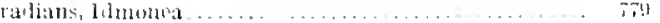

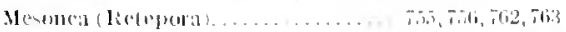

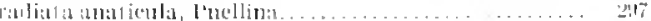

camolineusis, puellina ... . . . . . . . . . . . . .

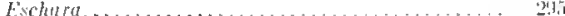

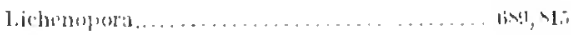

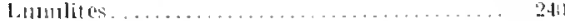

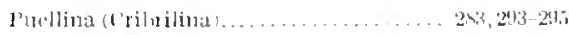

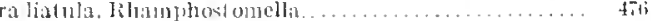

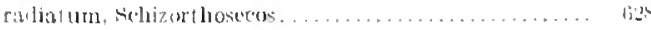

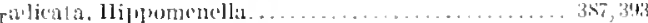

It lnoncit. . . . . . . . . . . . . . . . . . . .

rablicitera, Tremopora. . . . . . . . . . . . . . . . . 13,1

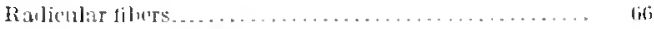

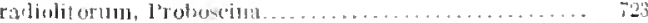

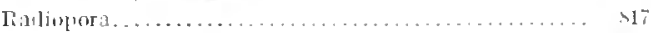

lowniformis. ....................... by

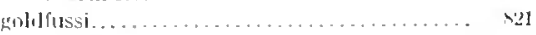

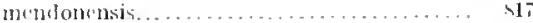

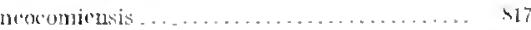

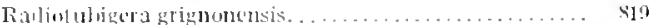

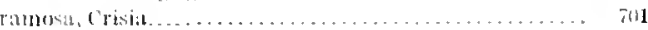

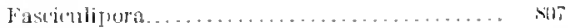

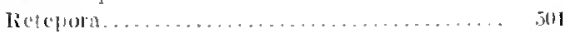

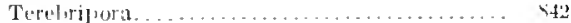

ramusiome, butalophora. ................. The

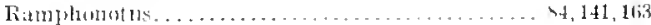
bacentus. .................... 16.

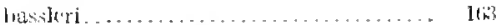

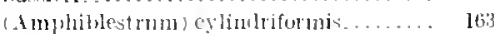

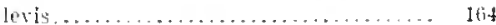

(Hombranipora) elligticet.......... 10, sigillatia........... 10.3

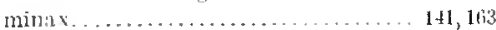

reglalaris. . . . . . . . . . . . . . . 16,7

slo:mi........................ 164

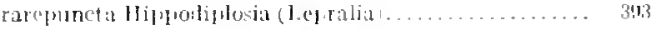

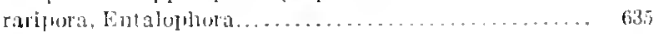

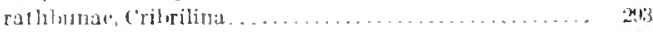

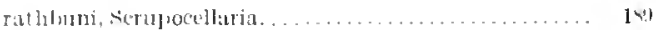

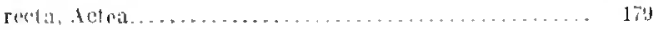

rectaliner, fruboveina....................... dibi

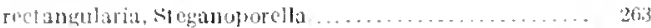

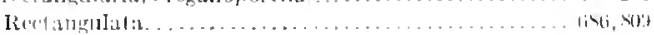

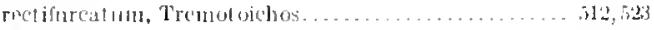

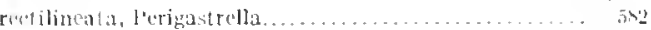

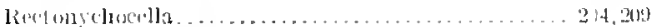

bilamoluriı.................. 210

dlipition . . . . . . . . . . . . . . . . 212

s'milnna.................. 2, 2, 24, 210

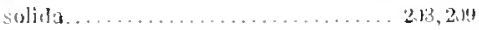

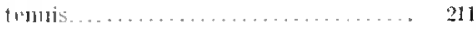

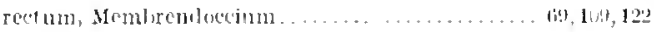

Jerenmlent ovicell. . . . . . . . . . . . . . . . . . 54

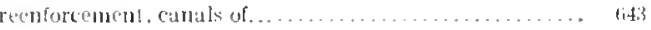

lieferences, stnonymit........................ II)

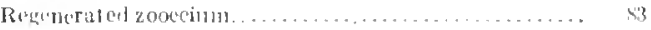

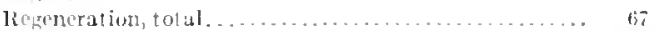

IRegindlla..

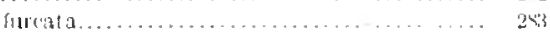

regularis, Bureniena. ........................ Thti

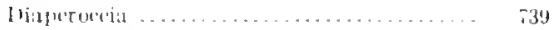

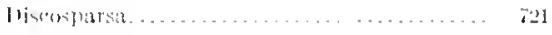

Fintiluphula...................... 710

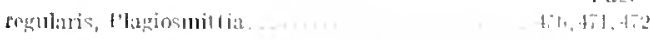

Rotuphomotis.

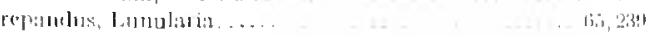

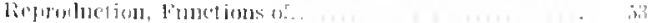

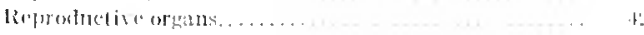

reptatu, Jinukina........ . 112,117

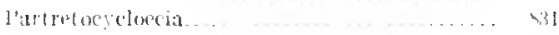

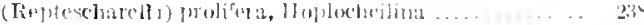

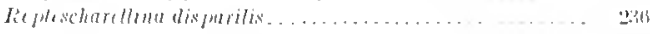

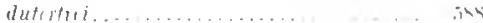

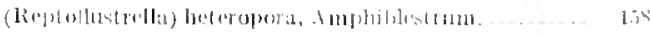
ov:slis, Ellisina . . . . . . . . .

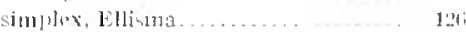

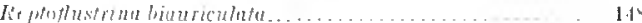

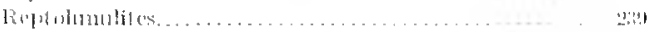

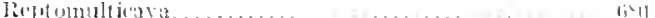

fintrifotmo................ (is)

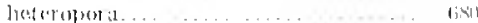

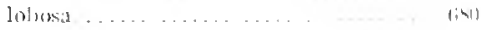

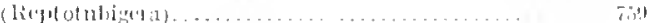

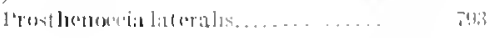

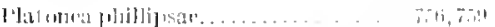

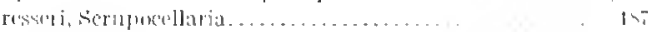

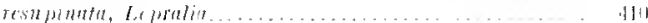

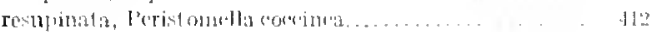

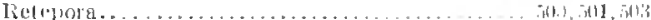

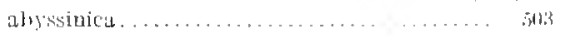

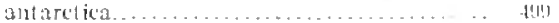
allantica.........................

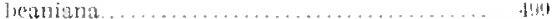

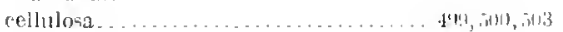

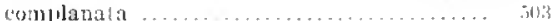

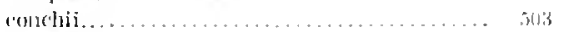

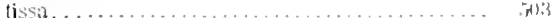

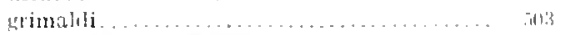

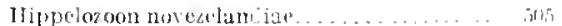

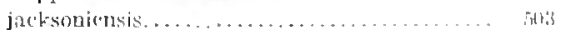

jermanomis

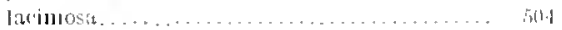

me lit erranos

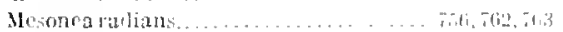

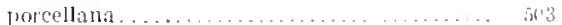

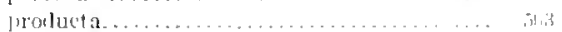

ramosa ......................

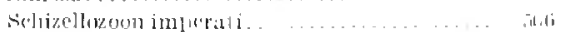

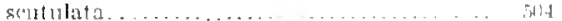

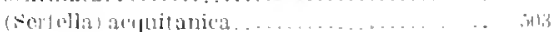

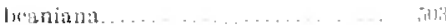

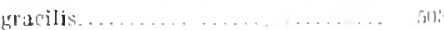

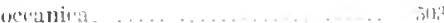

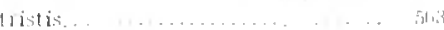

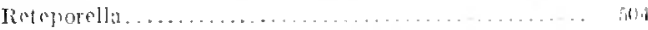

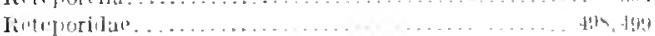

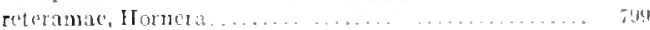

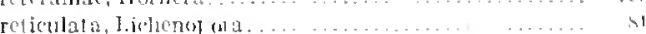

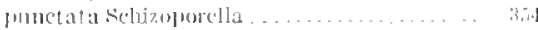

smitia ...................... 4.

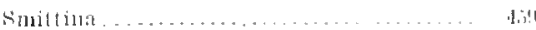

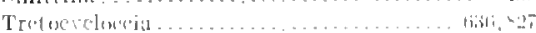

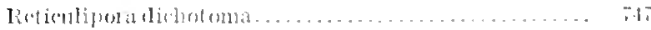

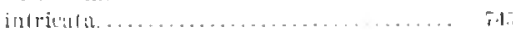

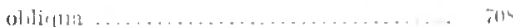

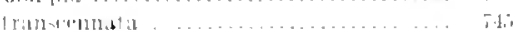

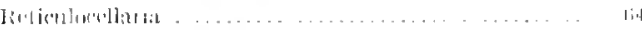

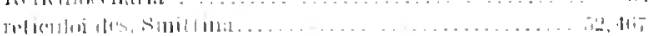


retiformis. Canta

1 'a:ce. relractilo misk rmassi, stichongrina

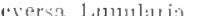

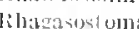

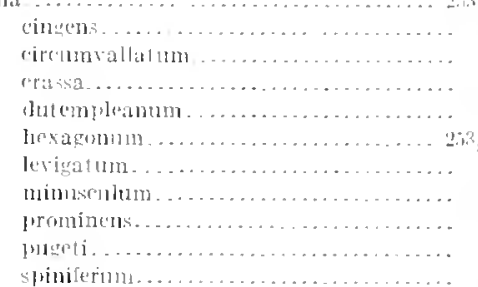

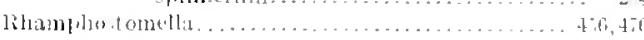
bilaminata . . . . . . . .

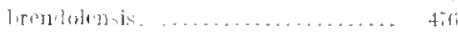

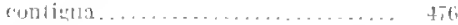

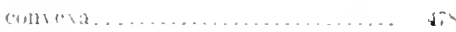

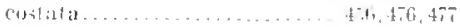

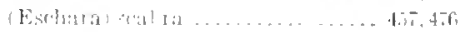

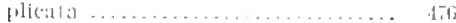

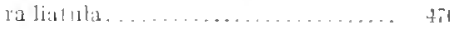
sim] $1 \times x \ldots \ldots \ldots \ldots \ldots \ldots \ldots \ldots \ldots$

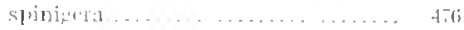

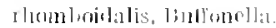
Elli-ina $\$$ Hal ralum Enchlostmont

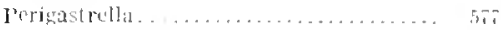

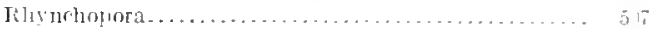

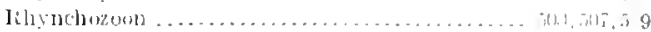
aligntatim . . . .

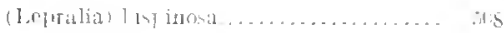

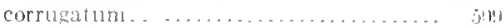

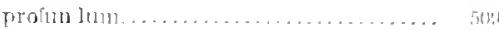

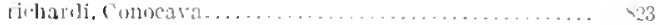

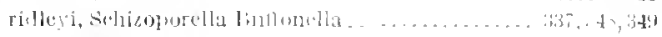
rigidia, rellaria ...............................

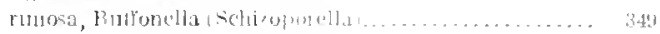

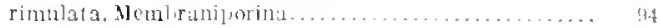

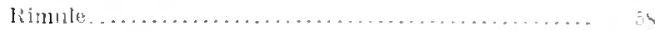
Rimmle-spiramen . . . . . . . .

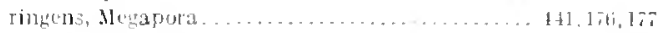

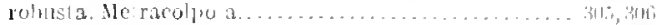

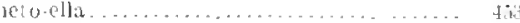

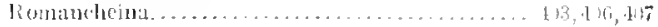
hexagna...................... this

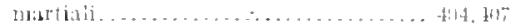

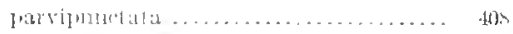

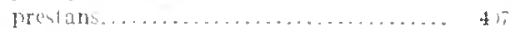

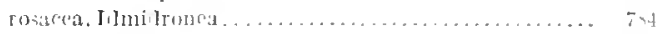
lioweliana........................... 227.228

(Membranipona) ineminta............ parripora........................... 22, 2as

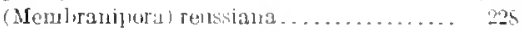
(Flustra) rosselii . . . . . . . $29 . \ldots \ldots \ldots \ldots$ rosselii, Roseliana (ivlustra) .................. 225 Rosette flates............................. 51 ro:trata, Mucronella....................... 174

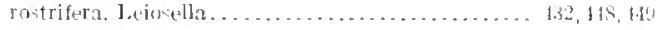

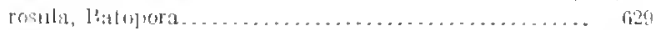
rothla, Hipm

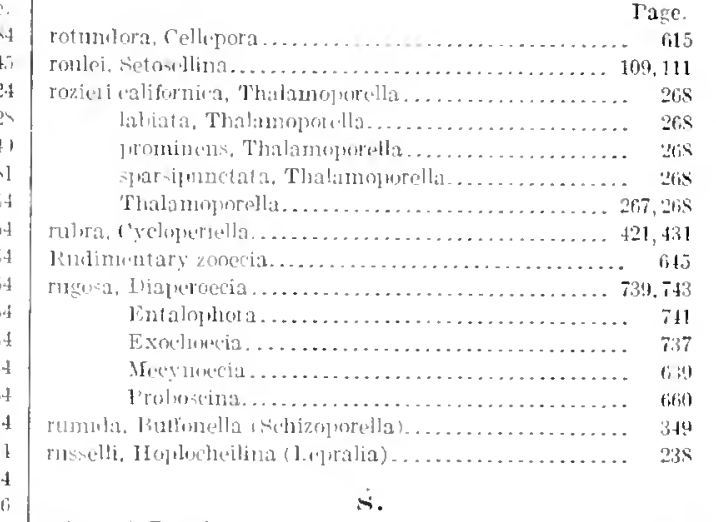

Galalieri. Bry

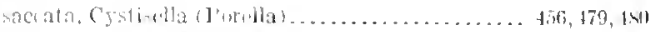

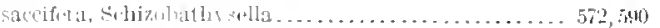

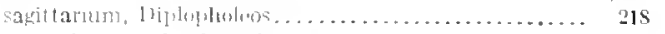

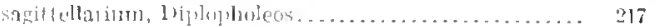

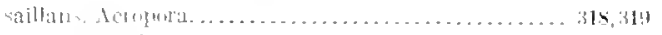

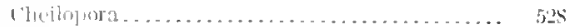

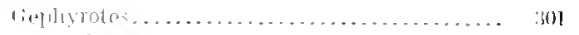

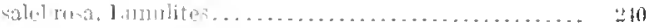

s̆n

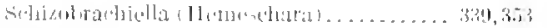

sandonica, (4)

sarnimsic, liernicea............................

Itarisecia........................ mis

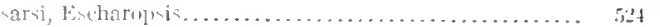

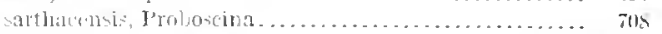

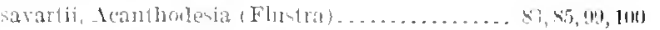

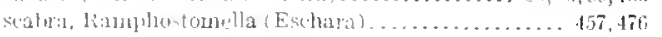

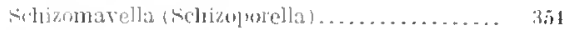

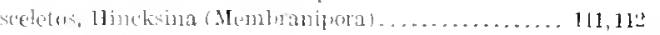

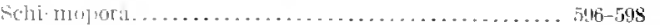

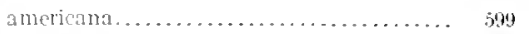
aviculatis..........................

linlenticnlata....................... 5y

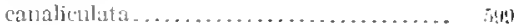

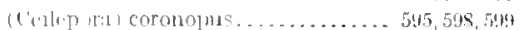
pumicosa.............. 5 sn cerricornis......................... s!n dithutmin . . . . . . . . . . . . . . . . Hol 

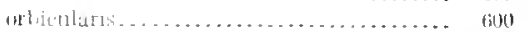
[municusa................... $505,507,594$ mulnmatia......................... 600 ventricosa........................ 5519 zanzil arimsis...................... $\$ 59$

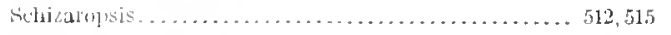
(1)

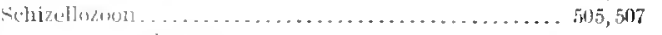

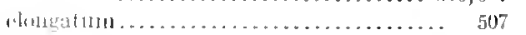

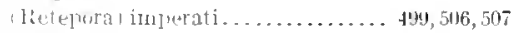
valuderia........................ 499,50\% tessellatm...................... 541

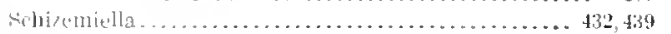
clititurnica.................... 432,414

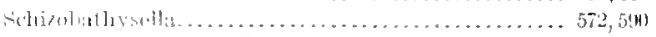
sarciftrit................... 572,590 


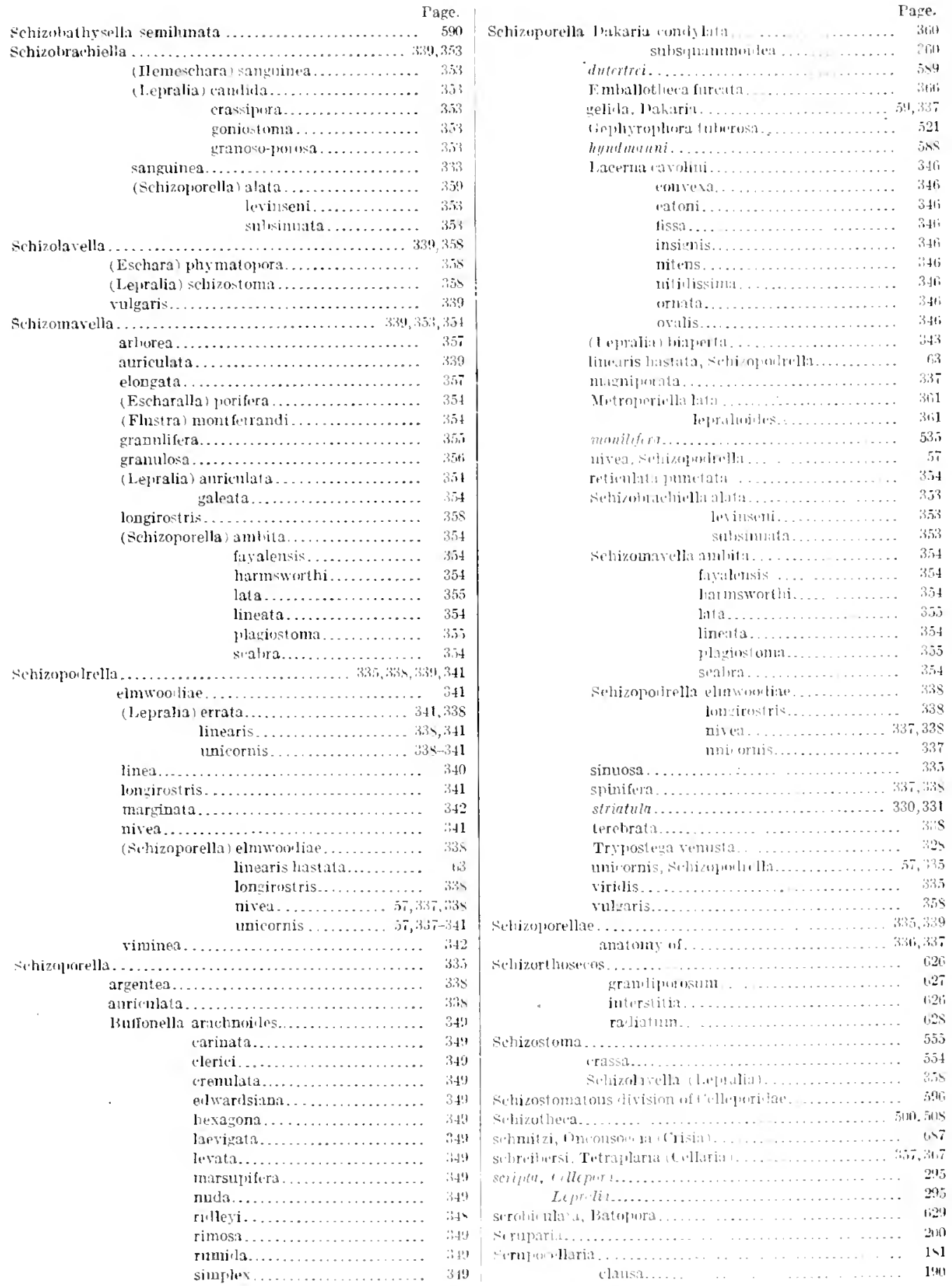




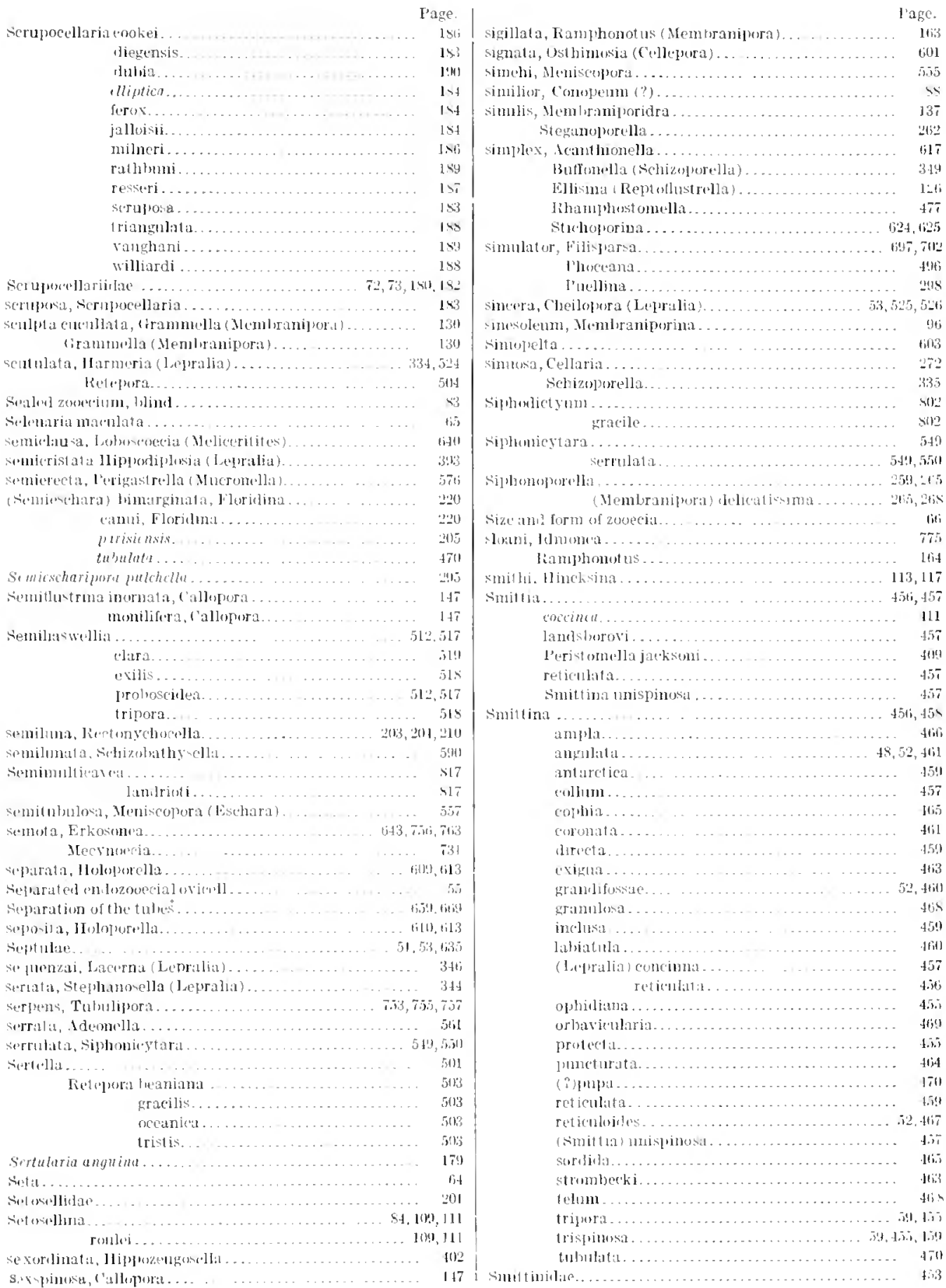




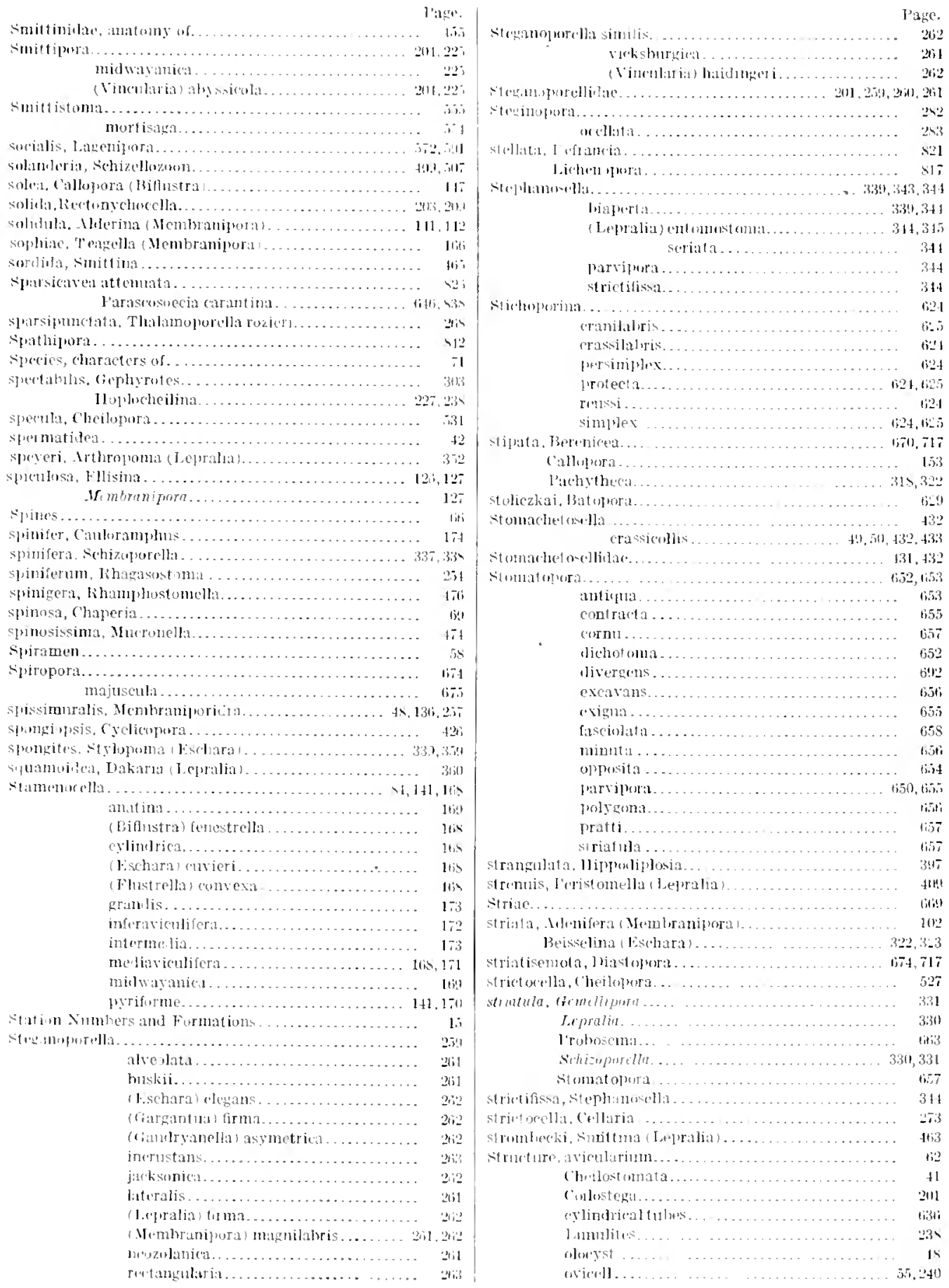




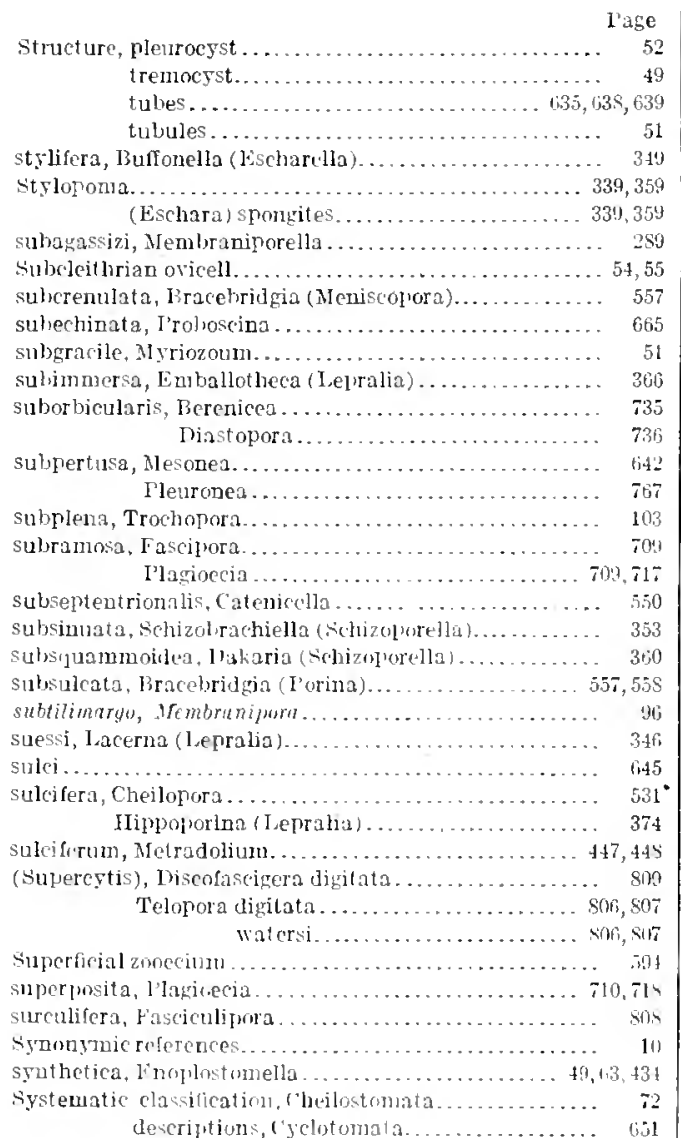

\section{$\mathbf{T}$.}

tacta, lilmonea.........................

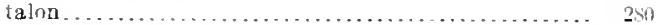

tantilla, Pelipornedia.................... tri, 121, 12i tecta, Euritina ............................ 255 Ilet eropora . . . . . . . . . . . . . . . . . .

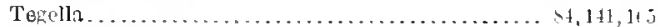

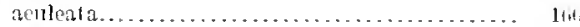
(Membranipria) gullithi ................ 16 afculta................... 160 soljhiae.................... liti

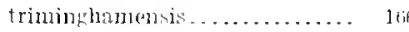
unicornis........................ 110

nicklasi......................... 19. inicornis . . . . . . . . . . . . . . . . . . . . . . . . . .

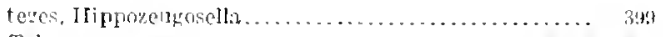

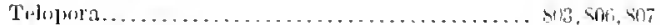
(superegtis) ristata................. vin, sht (sulercytis) watersi..................... soni, sot patms............................ $\$ 17$ telmm, Smittima.......................... 4his T'ena hia . . . . . . . . . . . . . . . .

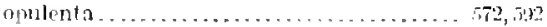

Tembiastericula, libetra............... 77

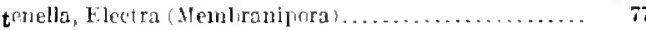

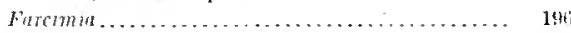

lilisparsa...........................,

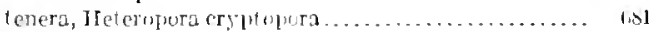

Tentacle sheath.................................... t'

Tentactes...................................... 4:

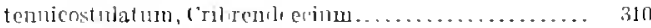

Ienti

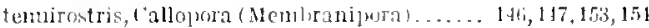

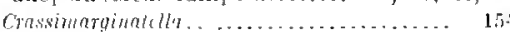

temis, lierenicea............................. 725

bermeplagirecia (Artinopora).............. 721

biastlobora............................ 721

I iscosparsa . . . . . . . . . . . . .

Rectonychocella..................... 211

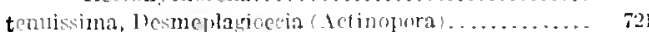

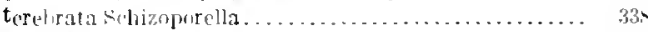

Terusi

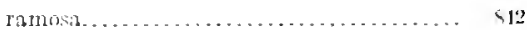

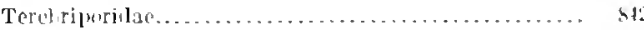

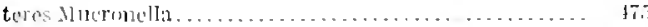

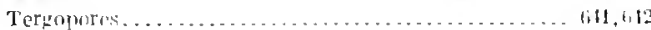

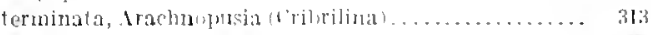

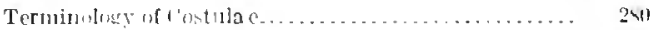

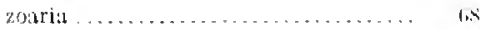

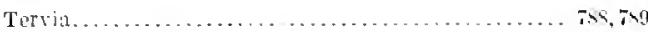

ylolmli[era......................... 791

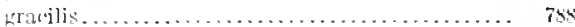

jollyac.................................. 7,9

marvila . . . . . . .

wyrifera............................. 792

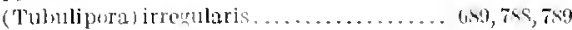

tumita............................... 790

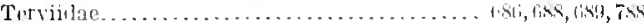

Tessatadoma .......................... 512,521,522

(I'ustulopural kracile.............. 512,521

grandipora...................... 522

urnata...........................

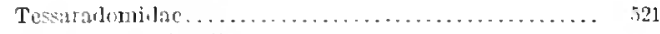

tessellatum, Schizelltwom . . . . . . . . . . . . . .

Tetraplaria ............................. 33!, 34id

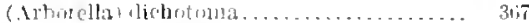

anst ralis......................... 334.347

(1'elliria schuil ersi.................... 3ij

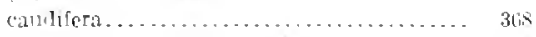

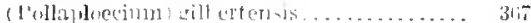

tuliercilata....................... आ

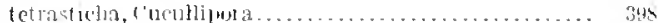

Tetrugcheria .............................

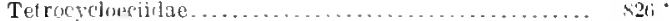

tevta, lisclara............................. 312

Thajmpra................................... 248

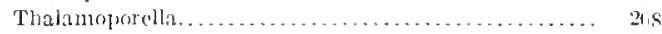

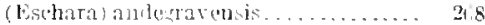

gramulati........................

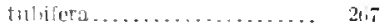

lintidia.......................... 210. mamillaris ...................... 20.7

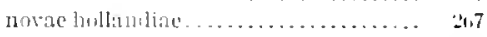

prina........................... 249

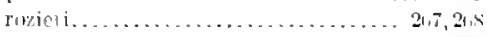

califirnica................. 2t,

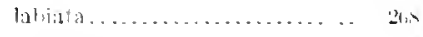

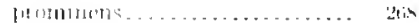

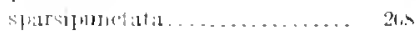


Thalamolurelidac

Tholopora.

t'lioracopliora.....

252

liorrida......................... 293

lintinabula. Lunularia. ......................... 23!1, 2:1

tisu, Lunulites (Discollustrollurin) butui.............. 103

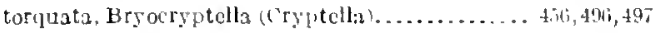

torta. Euritina (Billustra) . . . . . . . . . . . . . . . . 257

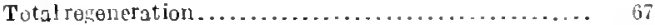

Trace of spine................................ 53

trauscennala, Reticulipora ....................

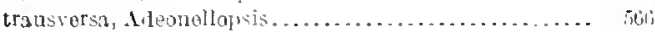

Cheilopora........................ 520

Grammella...................... 132

transversata, Hiproldenella......................342,392

transvorsora, Hippononetla.................... 34,348

trausvorsun, Membrendoocinm.................... 129

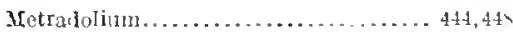

trapezoldea, Terigastrella . . . . . . . . . . . . . . . . . . $5 \$ 1$

Vibracolla........................ 22:

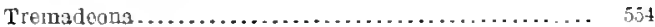

Trewocyst. ................................... 70

Trewuonora.............................. $4,121,139$ deudracantha...................... 124, 139

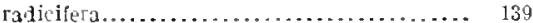

Tremopores................................. 47,49

Tremotoichos............................. 512,523

roctifurcatım................... 512,523

Tropostomata........................... $4 !, 037$

Tropostomatous like C 5 clustomata..............

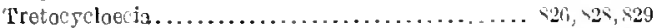

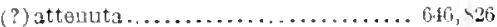
grandis. . ...................... 827 (Heteronora) dichotoma.......... (33ti, 526,529 reticulata.................... 63ti, $<27$

Trotacycloecüdae..................... $646,1,4,6 \times 9,526$

Tretonea.............................

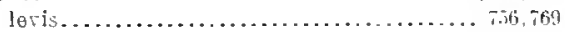

triacantha. Eloctra (Flustra)................... it

triangula, Gemellipora....................... 369

triqnidata, Scrupocellaria ................... 14

tricuspis, Exochella............................. 414

tridendats Leprali. ........................... 109

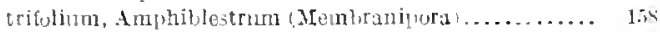

triforata, Idnlonea .......................

tricemma, Me nbraniporiłra.................... 124, 134

trigonutona, Metroneriolla (Lepralia) ............. 361

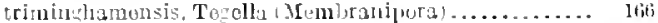

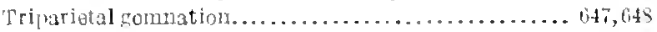

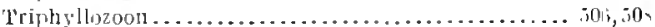

cohnuiforum.................... 50.

dent iculatinn .................... 504

formosuni......................... j0s

hirsutum .................... so

tnonilifera umbonata............... 499

(Fetenora) monilifurum............. st); jos

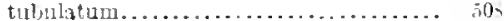

victoricnsis.......................

trinora, senihaswellia....................... 515

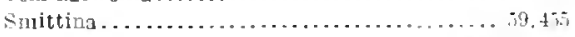

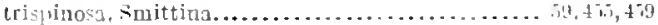

tristis, Rutopora (Sertella).................... ith)

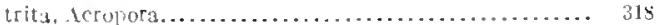

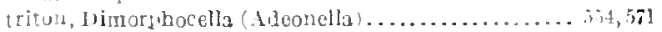

Page.

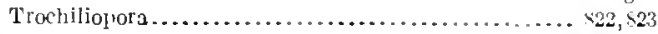

hutnd ....................... $\$ 22,823$

Trochopora............................ $44,5,103$

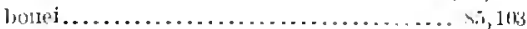
conica......................... 103 ovalis............................... 103 subplena...................... 103 truncati............................ 104

trnlla, Boisselina......................... 319,324

trumcata, seter........................... 1su 1 movinarin............................ 140

Lunulites (Discollustrellatia) bunci........... 103

Trochopora......................... 10 -

Tryjumatella.............................. 404,417 paptidifera.....................404,417

Trypostera . . . . . . . . . . . . . . . . . . . 325,327,324 a clongata........................... 325 inornata......................... 329 undulata....................... 329 venusta......................... $53,329,330$

tubacues, Diastopora. ........................ $6: 3$

tubarculata, Membranipora (Fhistra)............. it Mollir ........................... 330 Totranlaria........................ 367

tulierculosa, ralcopsis (I'orina) . . . . . . . . . . . . . 510

tuberculum, Hippothon......................... 80

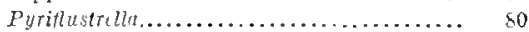
Pyribrora........................ 80

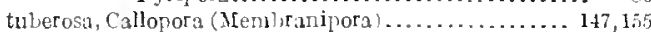
Ceriopora.............................6. 6.8 Eschara............................. 440 Gephyrophora (schizoporolla)............ 521 Hippomenell . . . . . . . . . . . . . . . . . . . 391,393

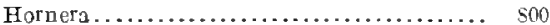
MLulticrescis.......................... 641 otionella............................ $10 \bar{i}$ tuberosum, Cononeum....................... 90

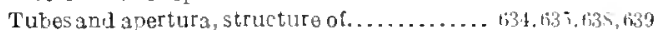
with lacots......................... ti 37,6440 Thomboidal oritice................ 637,640

tubiceps, Phylactella (Lopralia) . . . . . . . . . . . . . . 5.3

tubifer, Plarioocia. . . . . . . . . .

tuliferd, Lunularia........................... $24 \mathrm{j}$

Osthimosia..................... fiv

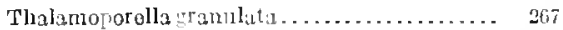

tutifurmis, Diastopora....................... $6.7,717$

Tuhinorella...............................

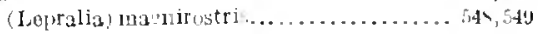

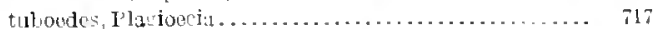

Tu\}ucoll ............................... 546

(Eschara) minnullati.................. $546^{\circ}$

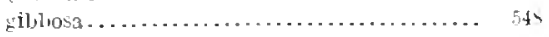

monitiferg.......................... 547

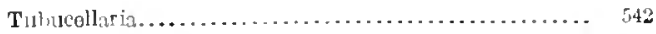

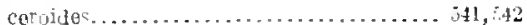

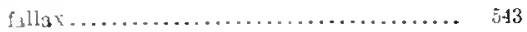

fusifonis....................... $\$ 42$

hirstu......................... 542

modifora....................... 546

opuntiolles........................ it1, $\{42$

parvilurusa...................... 543

vickslureica.................... 544

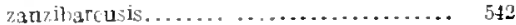

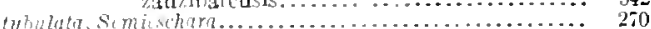




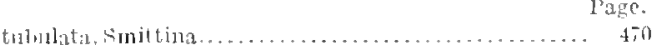

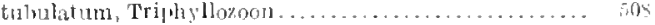

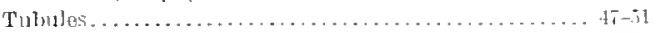

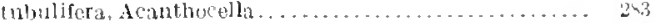

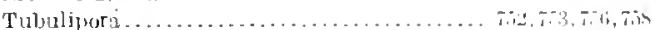
ajertiz...... attantica......................... cimplicheatiz......................... itis

classiformis......................... 7

"omcinna............................

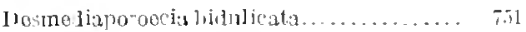
canticlieana .......... ris

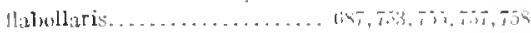
grimnonusis........................ 1

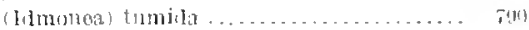

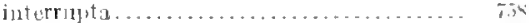

libiacea....................... \%

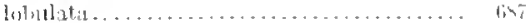

milwaynnica ...................

orilontalis............................

oocingores of..................... T.

orumisans . . . . . . . . .

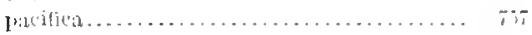

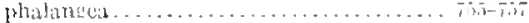

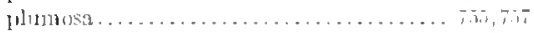

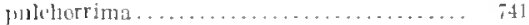

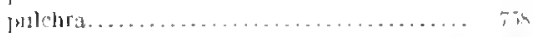
serpons. ......................

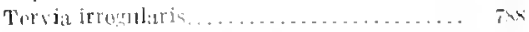

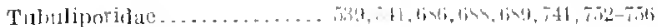

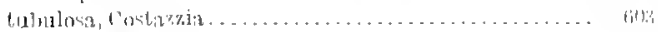

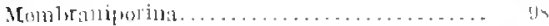

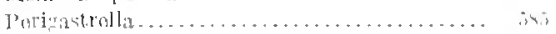

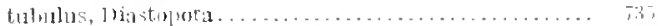

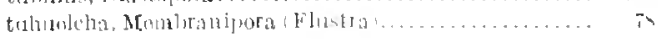

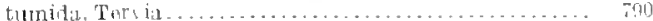

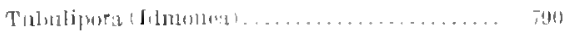

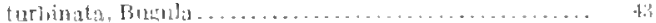

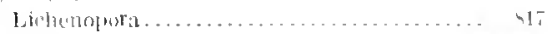

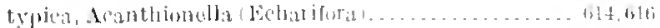

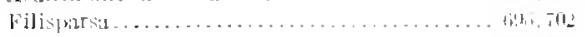

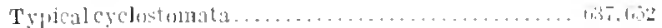

I.

Iliagh ias. areifurid . . . . . . . .

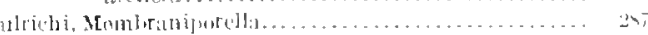

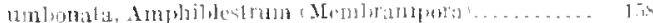

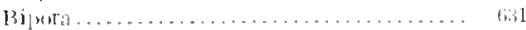

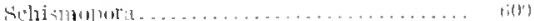

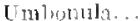

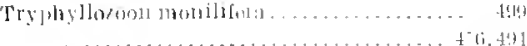

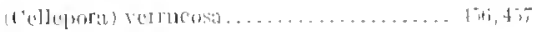
coratomurblat . . . . . . . . . . . . . . .

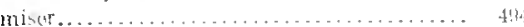

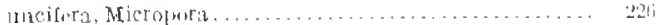

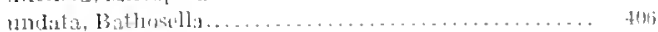

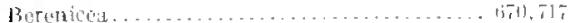

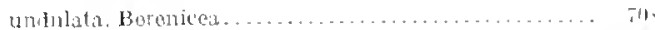

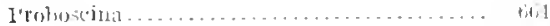

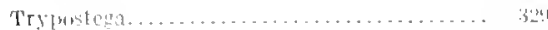

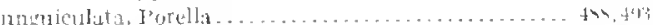

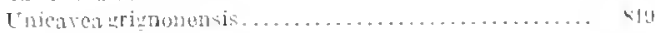

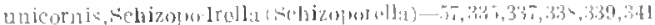

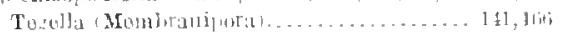

J'agre.

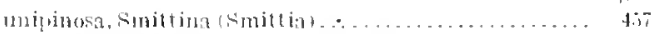

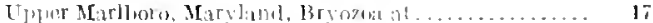

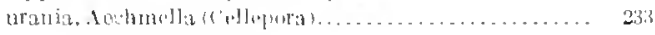

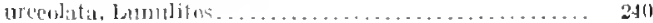

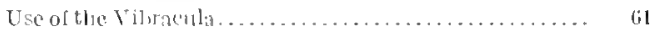

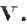

Tit(1)

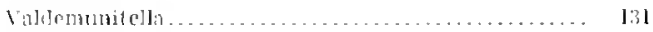

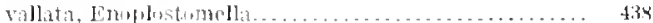

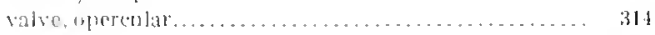

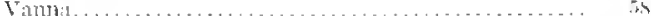

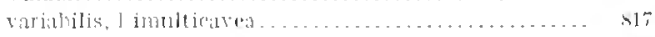

Yultioreseis .

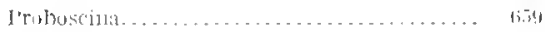

vatians, limeranda.

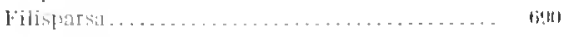

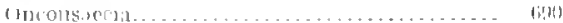

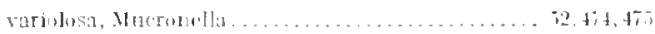

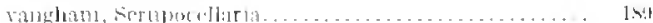

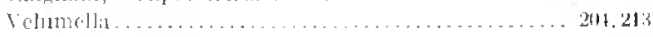

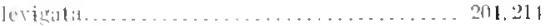

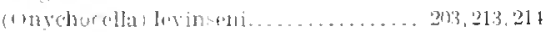

vliritia . . . . . . . . . . . 1

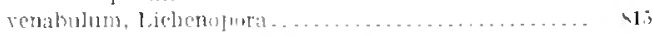

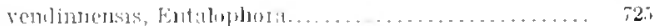

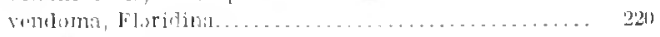

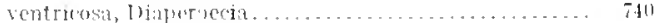

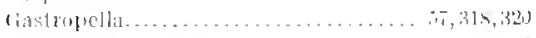

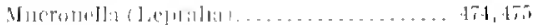

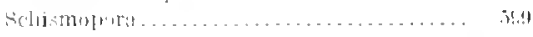

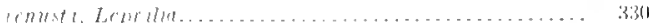

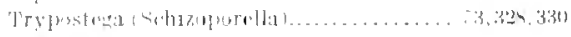

valuf

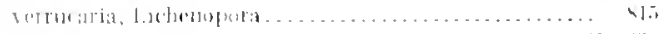

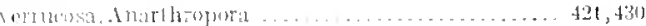

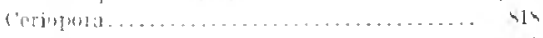

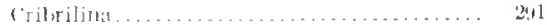

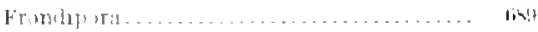

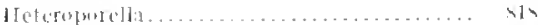

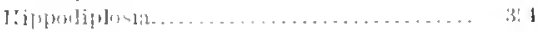

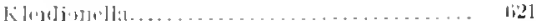

I Hhind

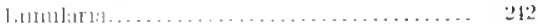

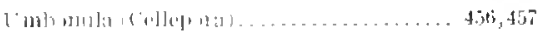

[1164]

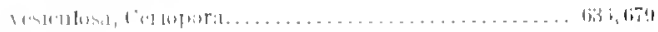

औ"y

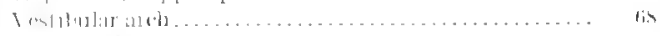

balla, l"

\1

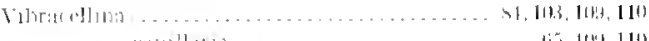

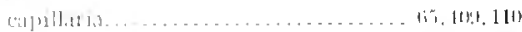

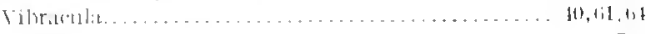

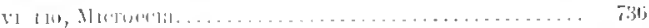

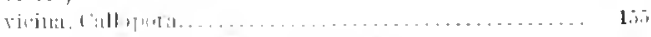

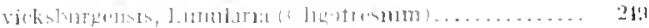

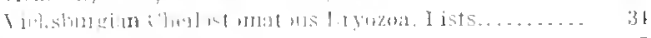

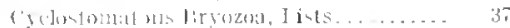

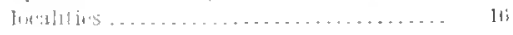

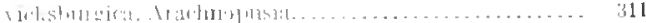

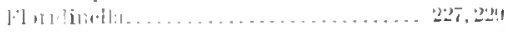

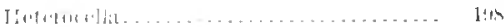

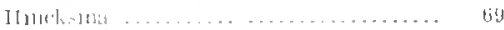


vehhurgica, stegrmupurellix.

Tubusmlintin.

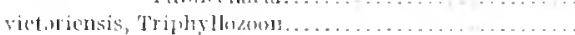

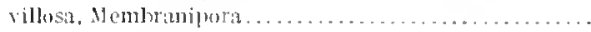

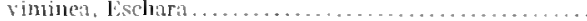

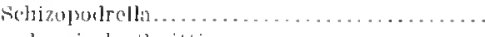

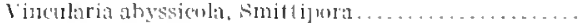

fotm of $z$ tiritm........................

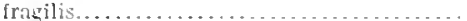

gracilis, Euritina.......................

hailingeri, stertanoporollas

tinlacen, Adeona.

virgulin, l'laciosmittin

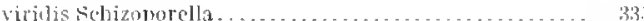

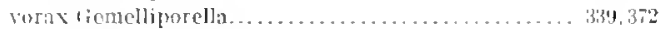

vuliraris, schizolavella

Bchizojorclia ....................... 3is

\section{w.}

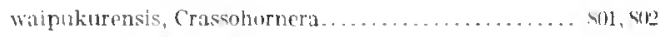

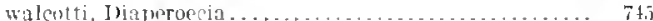

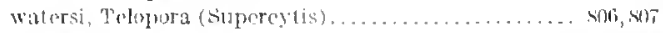

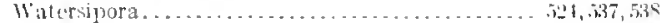
cheullata lationa.................... 538 ерест................................ 539 (lepralia) enchliata................ 598 wolschi, Euritina ................................. 257 wetherelli, hleonelopsis....................... 50.5 Wlup...................................... bt whitedvesii, ('nllopma ........................ 1t7 Wilcuxim localities........................... 15, 14 whlemianicum, Conoperm ...................... w

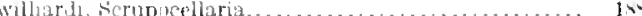
urondiana, Lefratia .............................. 545 Moolipura...................................

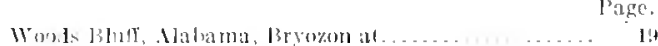

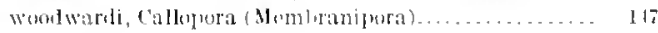

$x$.

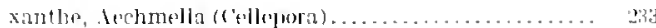

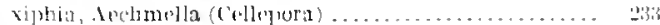

$Z$.

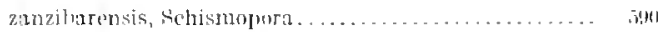

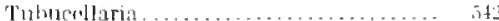

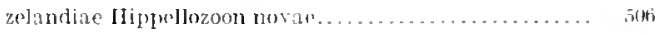

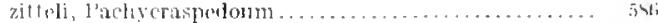

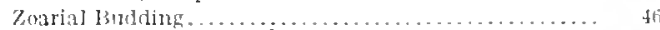
forms of lichemopora.................... Nib,

growth ..................................

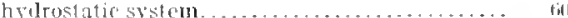

Zoarium .

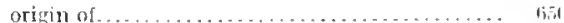
terminology $\ldots \ldots \ldots \ldots \ldots \ldots \ldots \ldots \ldots \ldots$. on

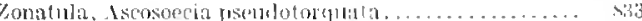

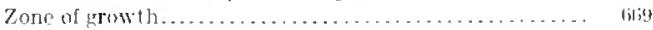

Zonopra Ascosoccia arborta...................... $\$ 33$ ligerimisis........................

Zonecia. calclfied...............................

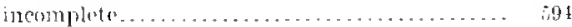

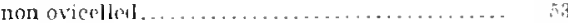

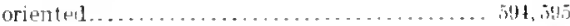
primeserial.................... superficial............................... 591

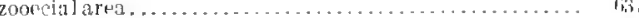

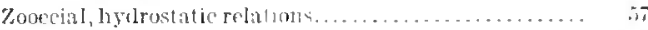
zooid ........................................ 37

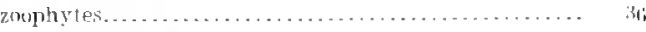

Zustericola, Electra (Tendra $\ldots \ldots \ldots \ldots \ldots \ldots \ldots \ldots$ is 


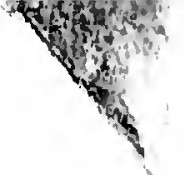


1 

- 


